
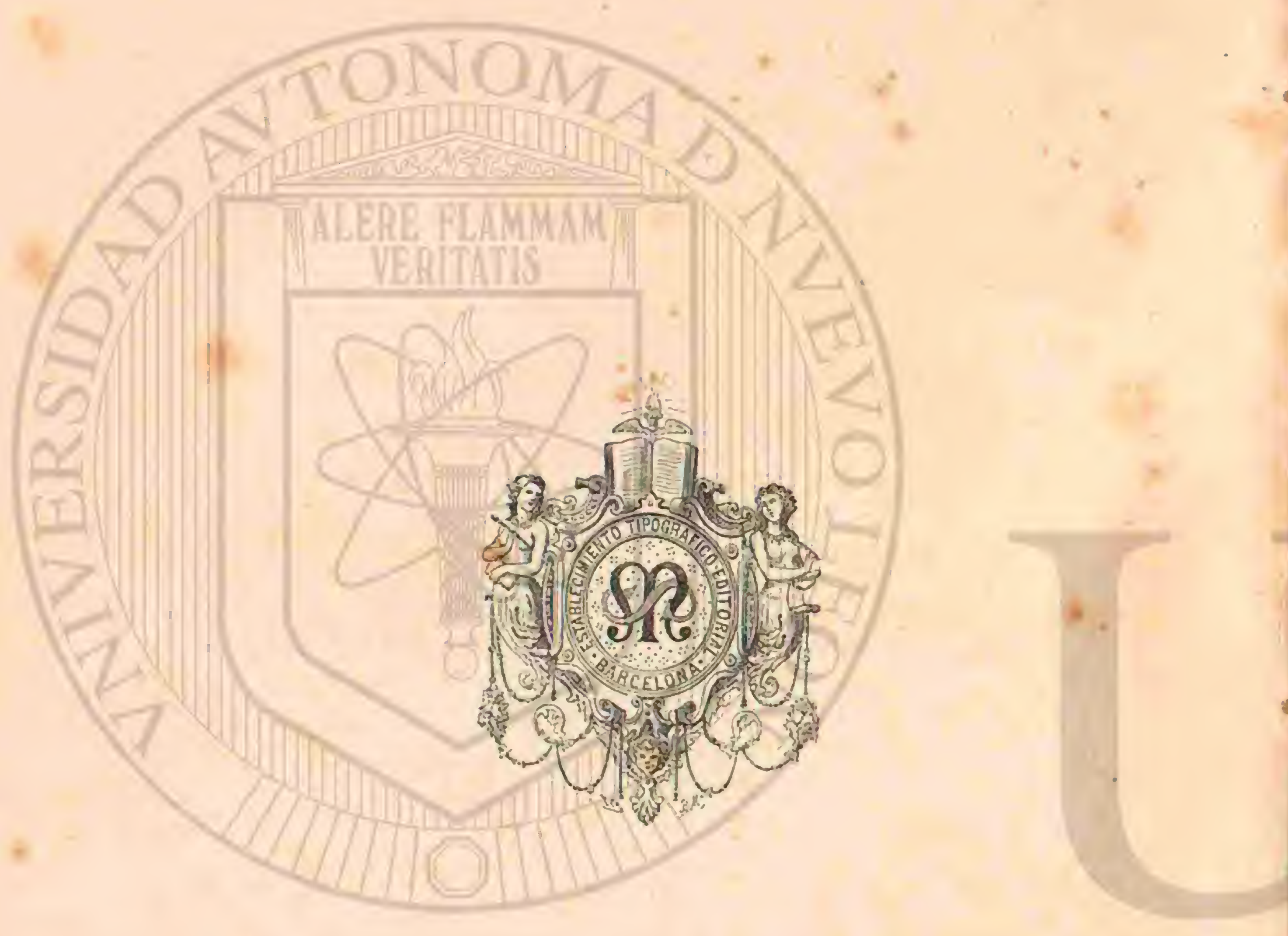

\section{UNIVERSIDAD AUTÓN .}

DIRECCIÓN GENERA 


\title{
LA CREACION
}

\section{HISTORIA NATURAL}

DIVISION DE LA OBRA:

\author{
ZOOLOGIA Ó REINO ANIMAL
}

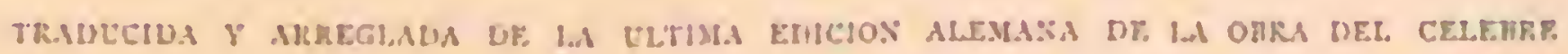

\section{DR. A. E. BREHM}

ANTROPOLOGIA, BOTANICA, MINERALOGIA, GEOLOGLI Y PALIONTOLOGIA

escritas par crutiros autorcs espunoles

con presencia de los may cormpletros y reciustes datos de estas diferentes ranas de la ciencia

TOMO III

\section{A $V$ ES}

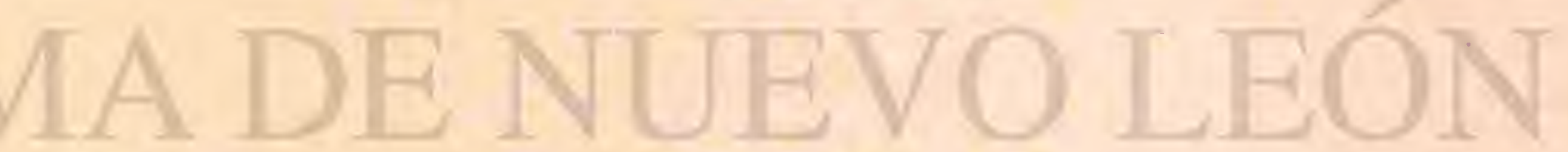

BARCELONA

MONTANER Y SIMON, EDITORES

CALLE DE CASANOTA NUMS 


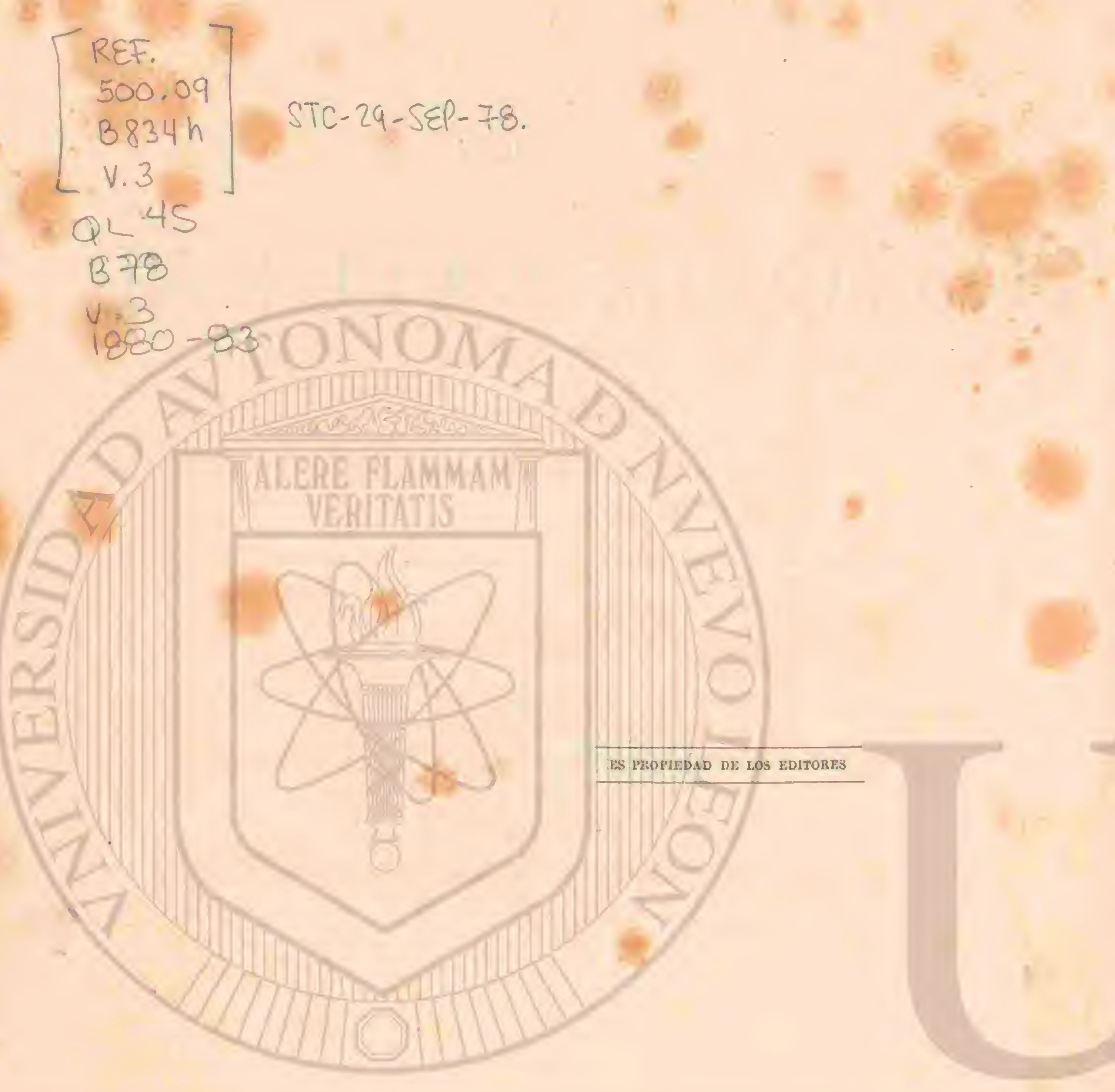

\section{UNIVERSIDAD AUTÓNO}

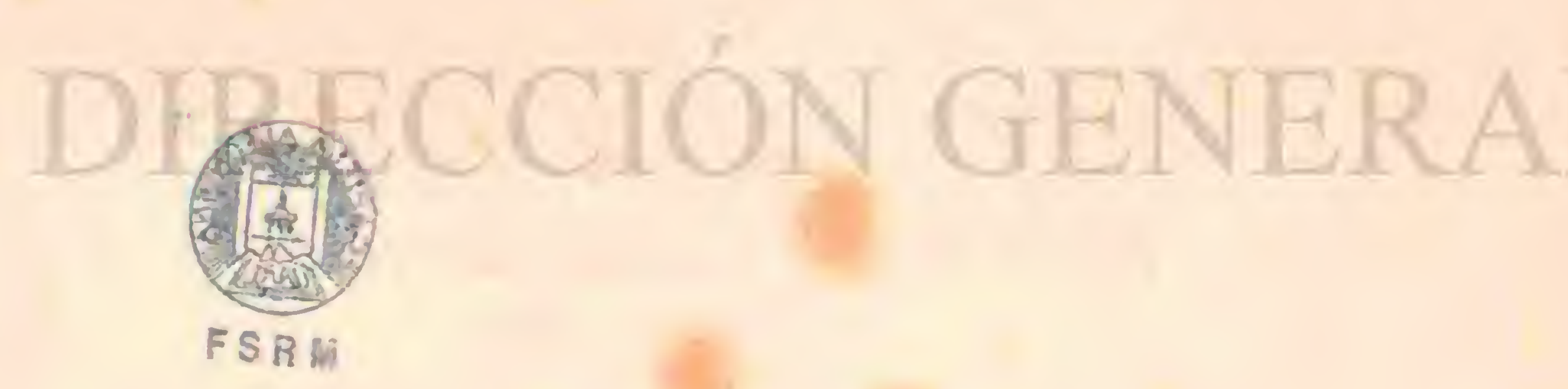




\title{
INTRODUCCION
}

\author{
CONSIDERACIONES GENERALES SOBRE LAS AVES
}

BAl ave por la plumax: asi distingue el pueblo f́ estos séres de los demás vertebrados; pero nosotros, que hemos de dar una definicion de las aves que satisfaga f los naturalistas. añadiremos aun, que en ellas las dos mandibulas se prolon. gan en forma de pico córneo; los miembros anteriores se convierten en alas; no existen, por consiguiente, mas quue dos patas, cujos tarso y metatarso se sueldan en una sola pieza; la calavera se articula por un solo cóndilo occipizal, y la mandibula inferior, compuesta de varias piezas, está suspen. dida del crínco por medio del hueso curdado, móvil casi siempre; por fin, el comzon ticne dos auriculas y dos ventri. rulos, los pulmones comunican con las camaras aérens y aun con los huesos que generalmente contienen aire; el diafng. ma es incompleto $y$ la pélvis no está abierta.

Por extraña que parezca la conformacion de las aves, su esqueleto ofrece aun gran analogia con el de los mamiferos y mayor con el de los repriles, hasta el punto de que no pocos naturalistas ven en estos iltimos los precursorís de los vertebrados con plimmas. 1o de mayor trascenden. cia en la organizacion de las aves es su facultad de volar; en conexion intima con ella aparecen todas las particularidades bien acentuadas de la forma exterior $y$ de la estructura in. terma; por ella sobre todo se explica la trasformacion que las aves, a diferencia de los mamiferos y reptiles, necesitan sufrir para llegar á ser lo que son.

Iit cráneo, muy abovedado, se complone de mrios huesos, cuyos bordes suturales, claramente visibles en las primeras úpocas, se sueldan despues unos con otros tan intimamente, que no queda huella siquiera de la primitiva sepamcion. los huesos pequeños, pero muy alargados, que forman la cara, son los dos maxilares superiores, el bomer y el hueso cuadrado, cl incisivo y el maxilar inferior.

Las órbilas se distinguen por lo grandes: la pared huesosa que las separa es muy ténue y puede ser incomplena algunas veces. Solo hay un cóndilo por delante del agujero occipital. lo cual comunica s la cabeza de las aves una movilidad mucho mas considerable que la de los mamíteros.

Las vértebras cervicales varian de nueve d veinticuatro y son excesivamente movibles unas sobré otras; en cambio las dorsales que liguran en numero de seis a diez, y his lumba. res 6 sacras, que oscilan entre nueve y diez $y$ siete, son todas inmóviles y aparecen soldadas á menudo unas con otras. Fin contmposicion a lo que se observa en los mamiferos, las vér. tebras coxigeas, de ocho á diez generalmente, ó menos, por éceto de soldaduras, cstán siempre mucho mas desarrolla. dos que las de aquellos, la tiltima, sobre todo, ciestinada a sostener las grandes plumas de la cola, afecta la forma de una gran làmina huesosa, triangular ó cuadrada.

l.as costillas, cuyo nímero coincide con el de las vértebras dorsales, son anchas y delgadas, se articulan por un extremo con las vértebras a que corresponden y por el otro con el es. ternon, mediante huesos especiales. Todas ellas, excepto la primera y la última, presentan en su borde posterior una apofisis en forma de gancho que se aplica sobre el borde superior de la costilla inferior inmediata; cstas apófisis con. tribujen esencialmente ả consolidar la cavidad torácica; muy desarrolladas, por consiguiente, en las aves de gran vuelo, se atrofian ó desaparecen por completo en las puramente corredoras. El esternon (fir $2, A$ y B) es compamble à un gran escudo, cuya parte centmal lleva una cresta huesosa ó la guillir. Sus dimensiones y la altura de esta gnardan relacion con los robustos mísculos pectorales que aquil se insertan; viarian, por consiguiente, segun el desarrollo y amplitud del vuelo en las diversas aves. Asi, por ejemplo, en todas las ra. praces la quilla es muy alta y encorvada, al paso cuue falta del todo en las de corto vitelo, y aun hay algunas en que llega hasta a ser hueca interiomente, ocupando entonces su cavidad un saco aúreo.

Ia pelvis difiere de la de los mamiferos, por su longitud sobre todo.

En la cintura cscapular los onoplatos, que son largos $y$ delgados, sc apoyan as uno y otro lado cie la colunana vertebral sobre las costillas y se unen por delante con el hueso Hamado coracoideo, para formar la articulacian de la espalda; por su partc, las claviculas se sucldan por su's extremos an. teriores y constituyen asi la honfillar ó huese furcular. El esquelèto del ala (fig. 2 A) sé compone del brazo o húmero, (gue es largo y neumático, es decir, hueco y lleno de aire; el antebrazo, donde al contrario de lo que ocurre en los mamiferos, está muy desarrollado el cuibito y es muy endetile el radio; dos huesos metacarpianos ó tres à lo mas, y tres dedos, a saber: el pulgar, que \& reces está provisto de una uña cn forma de verdadera garra, oculta debajo de la pluma, ye se compone entonces de dos falanges; el decio grueso con dos falanges tambien, y el pequeño, de una sola $y$ soldada al anterior.

Lans extremidades posteriores comprenden el anca, la pierma, el tarso y el pié propiamente dicho, esto es los dedos (figura 3). En la pierna el perone se atrofia y esta soldado a la tibia, que es robusta; representa al tarso un solo hucso, largo y hueco, con el cual se articulan los dedos. Tres de estos se dirigen por lo comun hícia adelante yo el cuario há- 
cia atrás; en ciertas aves, sin embaigo, el dedo posterior se inclina hácia adelante, en algunas se atrona, en otras se diri. ge hácia atrás uno de los dedos, d externo ó el interno; y hay casos, en fin, en que el pie queda reducido á solo dos dedos aparentes. El pulgar tiene generalmente dos falanges, el primero anterior tres, cuatro el segundo y cinco el externo.

Todo el esqueleto se osifica coa extremada rapides y los huesos son mucho mas compacios y rigidos, y mas blancos tambien que en los mamiferos. Pero lo que distinguc sobre todo, á los huesos de las ares de los de estos, es el que son neumáticos. La médula que existe en los huesos de las aves cuando son jovenes y esta provista de gran riqueza rascular, va resolviéndose gradualmente, con lo cual acaban aquellos por quedarse huecos y en disposicion de llenarse de aire.

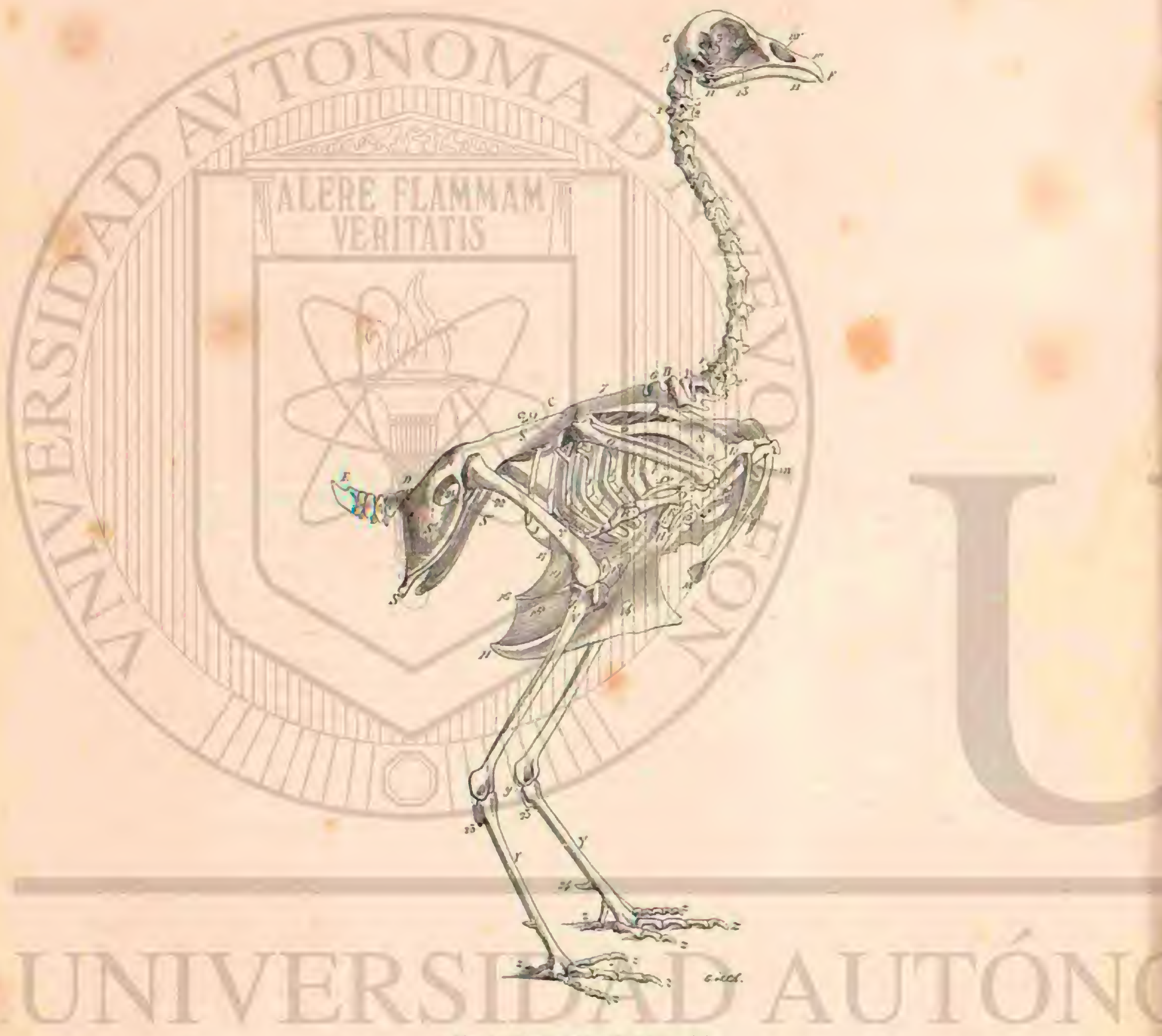

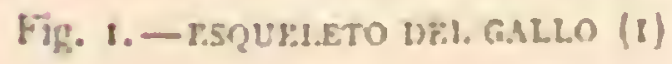

Sistrima muscular - De toüs los músculos, los pecto. rales que mueven el ala, son los que alcanzan mayor desar. rollo, $y$ adyuieren un volumen ge no se observa en ningun

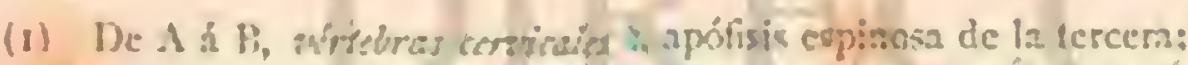

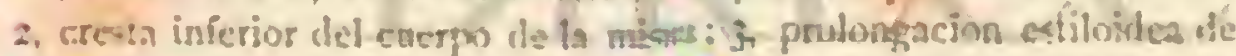

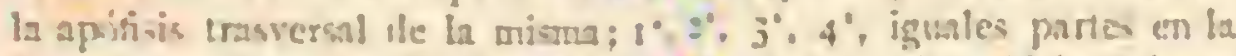
duoulćcima vertchm - De BH a C. :

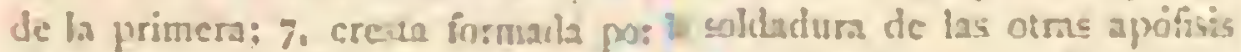

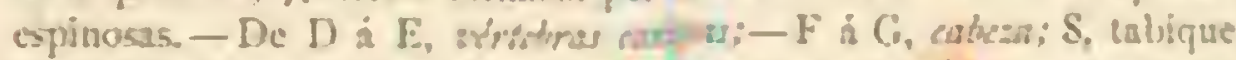

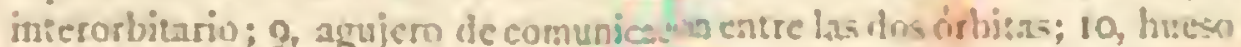
intermaxilat; $10^{\circ}$, alverturse exieriores is L nariz: 1t, massilar: 12, hueso

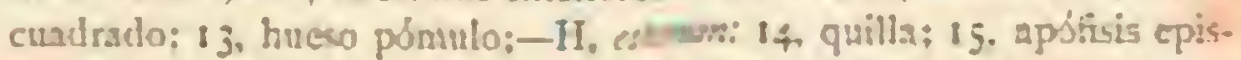
icrnal; 16. apófsis lateral; 17, apuón. Literal cxierma is, membrana otro vertebrado. Los músculos del dorso son, por el contra. rio, endebles; en los mienbros posteriores, solo el anca y la pierna suelen tener músculos robustos: pues solo en aquelias aves cuyas piumas bajan hasta los dedos, se ven aun múscu. 105 i lo largo de los tarsos; en todas las demás solo existen têndones en esta region. l.os músculos del cuello y los cuta: neos tienen considerable desartollo: los de la cara son rudi. meniarios.

siuc cubre la ceso:adura insersa; 19, membrans de la cicoiadura cxics.

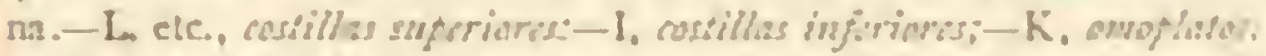

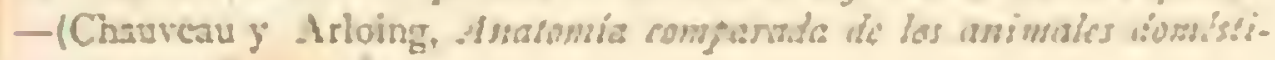
cos. Heris, ISTO.) 
Sisteals NFrryoso.-Ofrece casi la misma disposicion que en los mamiferos; cl encifible aventaja aun en voliumen ad la médula espinal, pero su estructura es mas sencilla; consta de cerebro anterior y pasterior; el primero ofrece los dos hemisferios cerebrales, pero desprovistos de las circunvolucio. nes tan caracteristicas del cerebro de los mamiferos. Ia mé. dula oblongada es bastante grande; la médula espinal, recion. deada y de un espesor unifome en la region cervical, es mas ancha y gruesa en la dorsal, y mas delgada en la region sacra. Los nervios vienen á tener casi la wisma distribucion general que en los mamiferos.
ORGNIOS DE LOS SFNTIDOS - lodos los sentidos existen y bien desarrollados; algunos son á veces rudimentarios, pero jamás se atrofian totalmente.

Organos do. Ia vision. - De todos los sentidos el ojo es el mas perfecto, tanto por su tamaño, que es relativamente muy considerable, como por su estructura interior. Su forma y dimensiones varian mucho; por ejemplo, todas las aves que ven á largas distancias y las nocturnas los tienen muy gran. des, las otras nuy pequeños Son peculiares del ojo de las aves el anillo esclerótio compuesto de doce a treinta lamini. lias huesosas cuadrilateras que se cubren por sus bordes a la

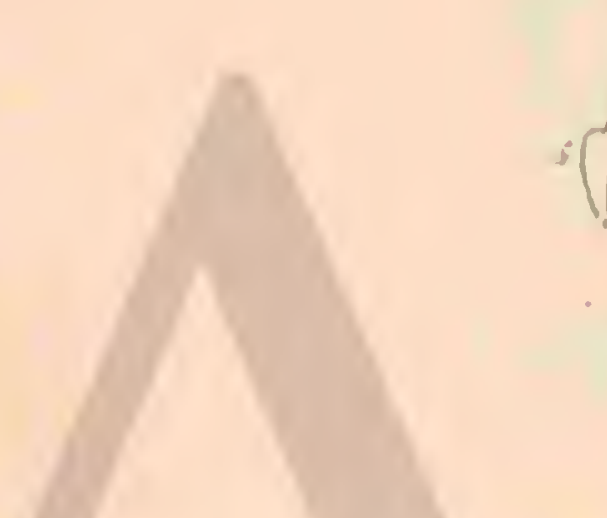

manera cic las icjas de un tejado, variando mucho por lo de. más de forma, robuste? ! tarnaño, y el prine, membrana ple. gada muy vascular, culrierta de un pigmento negro, situada á la entrada del nervio óftico, y gue penctra en el interior del cuerpo vitreo y llega a veces hasta tocar el cristalino. Listos dos órganos permien sin duda que cl ojo de las aves se adap. te a codas las distancias y le comunican á la vez una extraor. dinaria movilidad. Ademảs de los dos pairpados, que siempre exisicn, poscen las aves un iercero semi-irasparente llamado membrans vicfifarle: esia, que se halla siivada en el angulo anterior del ojo, y puece correrse como una cortinilla, sine para preservarlo de una luz demasiado fiseric. Iil iris varia de coloracion segun la esperie, la edad jo ex sexo; general. mente es pardo, pero se observan todos los tonos de este co. lor hasta el rojo, el ammarillo claro ó el gris de plata, y ciesde use al gris claro y al azul; algunas ares tiznen el ojo de colos verde vivo, orras negro azulado.

OkCiasos sutmos- El oido externo no existe: Ins gran. des aberturas del conducto auditivo se hallan detris y á los lados de la cabeza, en la mayor parte de las aves estín ro. deadas ó cubiertas de plumas radiantes, jero que no impiden el paso a las ondas sonorae. Fa èl sitto del pabellon tienen los buhos un repliegue cutáneo muy movible que puede levamear o bajar el animal s voluniad. Ia membromo del lim. fonv estŕ casi a flor de la cabeza; el conducto auditivo es curto y uncinbranoso, y la caja tinzanica cxtensa. los tres hivesecillos del oido medio, quue existen en los mamiferos, estän representados en las aves por un hueso inico, poliédrico, que ofrece alguna semejanza con el martillo, y reemplaza al mismo tiempo al yunque $y$ al estribo.
Orgaxos olfatokios.-Fistin mucho menos ciesarrolla. dos que en los mamiferos: no hay nariz aparente, ni grandes fosas nasales; los agujeros, siruados comunmente en la mandibula superior cerca de la base del pico, se presentan gene. ralmenic redondos, y rara vez desembocan en ellos conductos cómeos de alguna longilud; estan desnudos ó cubiertos ya plar la piel, ya por piumas sedosis. Interiormente la cavi. dad nasal se divide en dos partes, cada una de las cuales presenta trés conchias membranosas, cartilaginosas ó huesosas, por cuya unembrana fittuitaria se distribuye el nervio olfatorio.

OkGaros DE: rezro. - Son raras las aves que parecen cs. tar bien doiadas respecto al gusto: pues la forma de su lengrna solo en algunas sos pernuite inferir que esté destinado este úrgano á representar dicho sentido. Fuera de estas, en la mayor parte está mas ó ménos atrofiada; es corta y rudimen.

(1) A, esicrison y liuesos del ala es el fallo (vihtos puse encima):

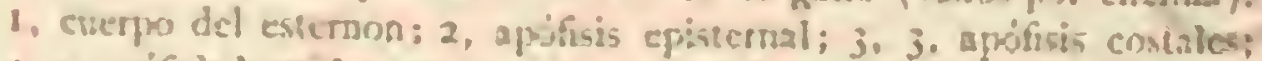

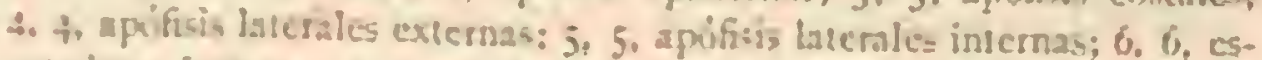
cotaluras iniemas: 7.7 . escotarlura: cutemas: $\$$, ussuplato: 0 clavieula

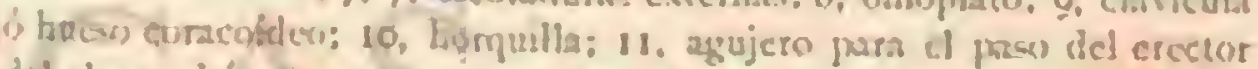

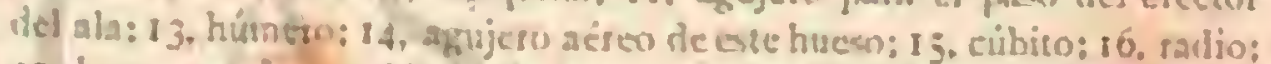

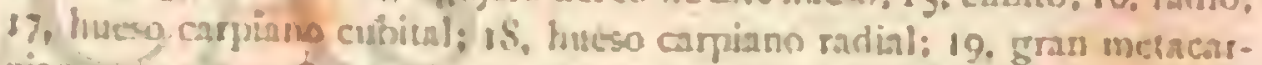

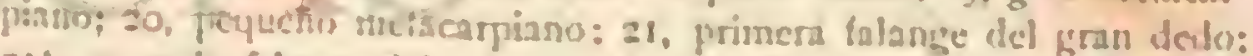

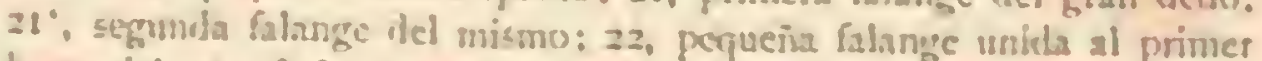

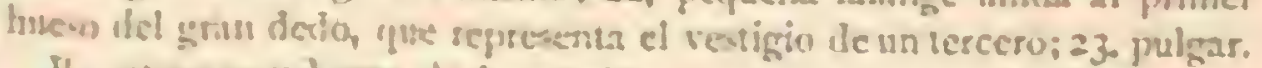

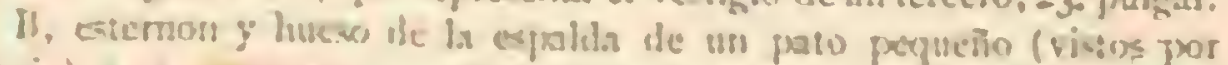
ahajo): 1, 8, colemon: 2, quilha: 3. 3, escovaduras laterale; 4. 4, cors-

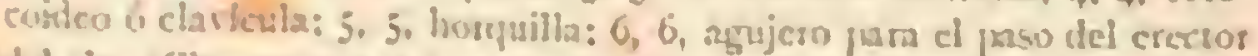

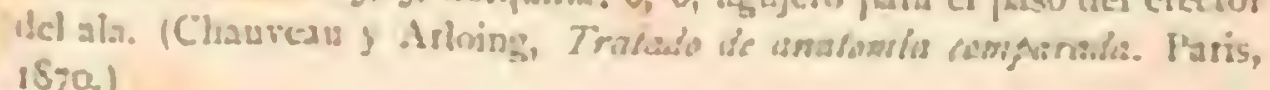


taria, ó se halla cubierta por una merubrana córnea; rara vez es larga y carnosa. En general, la lengua de las aves es mas bien un órgano de tacto que de gusto; en ocasiones les sirve tambien para coger los alimentos.

Orgaxos Dea. T'Acto. - El tacto, lo mismo pasivo que activo, está muy desamollado en las aves; su piel exterior es, en efecto, muy rica en nervios, y á la lengua, que es órgano táctil frecuentemenie, ayuda todavia el pico revestido por una mucosa delicada.
SISTRMA CIRCULATORIO \& RESPIRATORIO. - Son muy perfectos en las ares; cl corazon (fig. 4), con dos auriculas y dos ventrículos, está formado bajo el mismo plan que el de los mamiferos, siquiera sus músculos son mas poderosos. I,os pulmones (fig. 5), situados á derecha é izq̨uierda del cormzon, cuỵo vértice vicne a caer entre los dos lóbulos del higado, se sueldan con las costillas y bajan mas que en los mamiferos; no hay por lo tanto separacion completa entre las cavidades corácica y: abdominal.

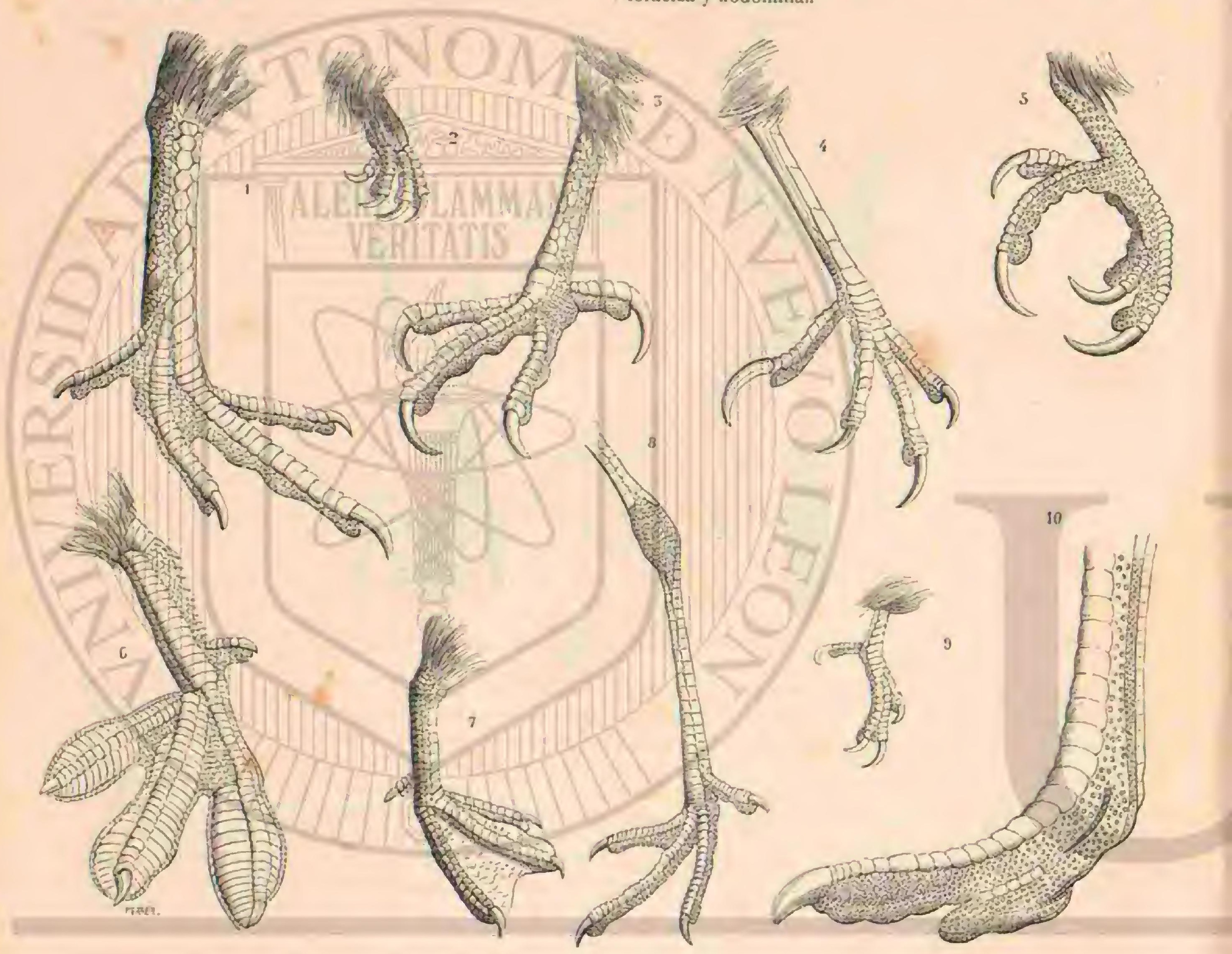

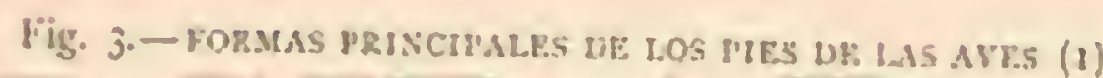

El aire inspirado llena no solo los pulmones, sino tambien una.s bolsas ó recipientes aéreos llamadas sacus de la pleuru, esparcidas por todo el cucrpo: a ellas pasa el aire desde los pulmones y se difunde luego por aquel, penetrando hasta en la mayor parte de los huesos mismos, ya en sus cavidades medulares huecas, ya en las células neumniticas que ademds presentan. Ia triquea, formada por anillos huesosos enlaza. dos por menbranas, tiene dos laringes, una inierior y oin superior. Esta última, cugn forma es casi triangular, esta dc. tris de la base de la lengua y carece de epiglotis: la glotis aparece rodeada de papilas ricas en nervios, y tapiza sus bor. des una menibrana blanda y muscular que puede obstruir completamente su abertura. I a laringe inferior se halla en cl extremo corréspondiente de la tráquica, antes de su bifurca. cion, y en realidad es solo un ensanchamiento del último anillo traqueal. Una especie de puente colocado en el centro de la laringe inferior y que procede de la duplicacion 6 repliegıe de la membrana interna de $1 a$ tráqquen, divide á aqquella en dos incisiones ó hendiduras, cuyos bordes vibran al pasar el aire, y sirven de este modo para la produccion de los sonidos. A cada lado de la laringe inferior hay de uno á cinco músculos; a ellos debe su movilidad hácia muchos la. dos esté aparato, que es propriamente el de la roz en las aves. lin pocas faltan completamente dichos músculos; otras, entre las cuales se crientan la mayoria de las cantoras, poseen cinco pares A derecha ¿ izquierda de la tráluca corren además unos músculos muy larges ugue, partiendo de la laringe infe. rior, llegan algunas veces hasta las orejas, y que al contraerse

(1) I, listia comun: 2, Vencejo; 3. Cemicalo: 4. Vicass o Jarin: 5. Lom: 6, Somormujo: 7 . Palo ó anade; S, Maliza: 9, Marrin pesca. loi: 10. Arestruz. 
hacen disminuir la altura de la tráquea. Lin ciertas aves sigue esta una direccion peculiarisima; no baja directa del cuello al tónax, sino que, segun ya dijimos, se coloca antes sobre la quilla ó da una vuelta mas ó menos profunda sobre los inúsculos peciorales extcriores, encorvindose luego hacia arriba para penetrar al fin en la caja ioricica.

Apakato Dhekstro. - Las aves dificren mucho de los mamiferos en este resprecto, sobre todo porque carecen de dientes tsagan enteros los alimentos; de manern, que si bien existen glándulas salivales, la insalivacion en realidad apenas se verifica en la cavidad bucal, ya que el alimento no es triturado antes de la deglucion. En muchas aves queda retenido desde luego en una dilatacion del esófago, llamada buche, donde sufre una primera digestion; en otras llega inmediatamente al rentriculo subcenturiado. Este, que es tambien un ensan. chamiento de la porcion inferior del esófago, tiene sus paredes muy ricas en glandulas, y mas delgadas siempre que las del estómago propiamente dicho ó molleja, no falta jamís en las aves, y alcanza su major desarrollo en las que carecen de buche. El estómago varia mucho; en las especies principal ó exclusivamente carnivoras sus paredes por lo comun son delgndas; en las que obscrvan un régimen vegetal son, en cambio, sumamente musculosas, y su interior se presenta tapizado por una membrana dura y plegada quue, contrayéndo. se bajo la accion de misculos robustos, funciona á la nuanera de una escofina, triturando y deshaciendo los alimentos jun. tamente con los granos de arena y piedrecitas que el are tra ga con ayuellos. Ein el intestino falta completamente el grueso, excepto en el avestruz que presenta vestigios El recto se ensancha al acabar, formando la cloaca en que desembocan los dos uréleres y los conductos seminiferos ó los oviductos respertivamente. Li bazo es rciativamente pequeño; volumi. noso el páncreas asi coma el higado, que ofrece granulacio. nes duris y está dividido en muchos lóbulos; Ia vesícula biliar es graude tambien y los riñones, por fin, son largos, anclios y lobulados.

Arararo cisitin - Algunas aves tienen un pene precep tible; todas naturalmente testiculos y conductos deferentes. Los primeros, situados en el vientre sobre los riñones, están muy turgentes durante el periodo de la reproduccion, termimado el cual se retraen y yłuedan reducidos a una especie de ovillos apenas visibles. Los conductos deferentes corren re. iorciéndose sobre si nuismos a lo lango del lado externo de los uréteres, por delante de los rinones, y forman antes de terminar pequenas vesiculas El ovario tiene la forma de un racimo, está colocado en la parte superior del rinon ye complone de muchos corpúsculos redoncieados, que son las gemas, cuyo numero oscila próximamente entre 100 y 500 . El oviducto es un mbo largo, en forma de intestino: presenta dos abertums, una en la cavidad abclominal y otra en la cloaca.

'Troturestus; prumas - Kn cuanto a su manera de formarse, la piel de las aves tiene gran semejanza con la de los mamiferos Se distinguen tambien en ella tres capas: la epidermis, la red mucosa y el dermis la primera es fina y muy plegada, si bien en los tarsos y dedos se convierte en esca. mas córneas, y en el pico sufre tambien irasiormacion pare. cida. El dernis varia de espesor: muy tenue en algunas aves, es gruieso y resistente en oiras, pero siempre muy rico cn vasos y nervios; su cara interna suele apojarse muy of menudo sobre una capa muy espesa de grasa.

Las plumas se desarrollan en hundimientos de la piel don. de ran sumergiendose poco a poco las cminencias ố papilas que presen:a la misma on un princjpio. Son estas muy ricas en vasos y están constituidas interiormente por el dermis que el epidermis cubre formando una especie de estuche.
Segun Carus, las parpilas ofrecen en su cara anterior un surco profundo; de él arrancan á derecía è izquierda viros mas superficiales, que unidos as su ver con prequeños surcus laterales rodear la papila, en cuya cara posterior desembocan haciéndose cada ver. mas superficiales. I a epidernis qque ta. piza exteriormente la depresion y la papila con todos sus accidentes, penetra hicia adentro gracias i una prolificacion de sus células, parte de las cuales van haciénduse córneas, y rechnzadas hácia fuera constituyen el rudimento inmediato de la pluma. La forma de esta se determina por los surcos de la papila; el canon corresponde al surco anterior $y$ mas

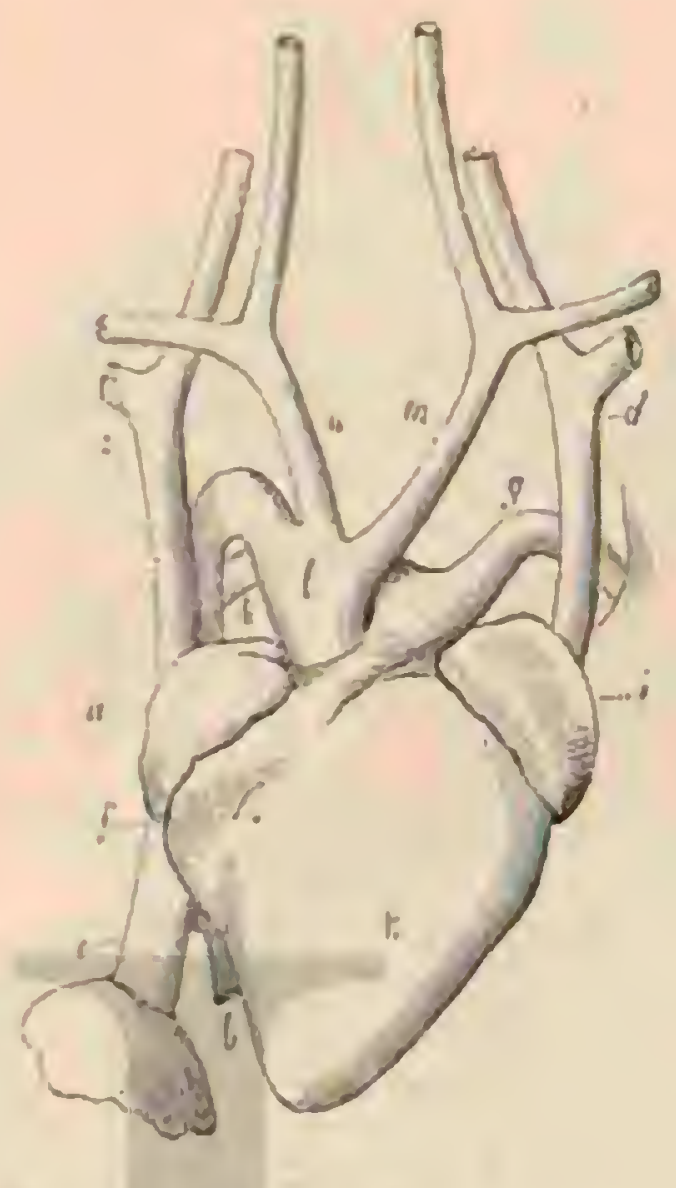

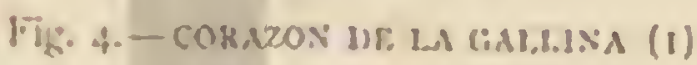

profundo; las barbas a los dos surcos laterales. Cuando In pluma ua á dejar de rececer, desaparecen los surcos: ciérrase formando un tubo la placa destinada á convertirse en canon, y la papila comenida dentro de aquel, muy alargada enton. ces, se seca y muere las plumas son, pues, formaciones epidérmicas; producto del mismo órden que los pelos, las pứas y las escamas de los mamiferos. Varian mucho sezun las es. peries y, aun dentro de cada una, segun las diversis regiones del cuerpo delare Distinguese en cada pluma el tallo 5 las barbas, $y$ en el primero el tallo propiamente dicho ó ríquis y el tubo ó cañon. Este, que es la parte inferior de la pluma, alojada en la jiel, constituye un tubo redondo, hueco, tras. parente, que va haciendose cuadrangular hácia su parte supe. rior, y se llena de midula, mientras que en su parte meudia ofrece una masa celular muy desarrollada en los extremos, y constituida por células que encrjan unas ent utras á modo de cucuruchos y son las encargadas de suministrar las sustan. cias nutritivas necesarias al desarrollo de la pluma. La cara superior del tallo es convexa y cubicrta tambien por una 5 s.5. tancia córnea y lisa; la inicrior está dividida por un canal longitudinal y es menos plana. $A$ lo largo del tallo se hallan dispuestas en dos series las barbas que son unas laminillas córneas delgadas, dirigidas oblicuamente de dentro afuera y provistas en su borde superior de unas fibrillas disjues tas en dos series que a su vez presentan otros apéndices aun de unáforma y disposiciones análogns, merced á los cuales adquueren las plumas la continuidad que á primera viša pa-

(1) C, auricula derecha: L, vena cava interios: 6. vena cara sapprior deresha: 6. rena casa superior isquierda: c, vens porta, cal la cual se ha

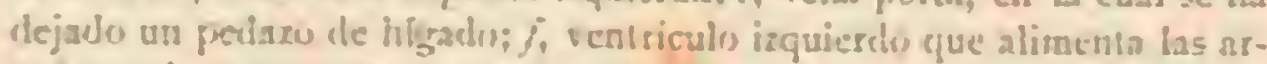

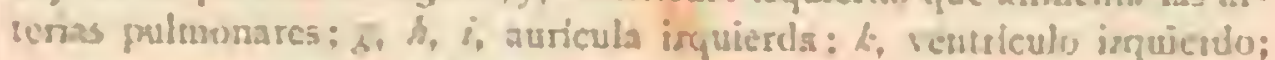
l. acrta; sn, n, lats dess suliciarias, 
rece haber entre las barbas. Además de las plumas descritas llevan las aves otras mas finas que forman el plumon. Entre las primeras se distinguen las rémiges ó remeras, las rectrices $\dot{0}$ timoneras $y$ las tectrices ó cobijas. Las remeras se distribuyen en la mano, el brazo y la espalda. Fo la parte del ala que corresponde il la mano hay generalmentc diez remeras de primer örden ó rémiges primarias, mientras que en el brazo es variable el múmero de remeras de segundo órden o rémiges secundarias: la cola tiene generalmente doce rec. trices, tara ver menos, mas con frecuencia Nuchas plu. mas de las propiamente dichas ofrecen en su raiz, esto es,

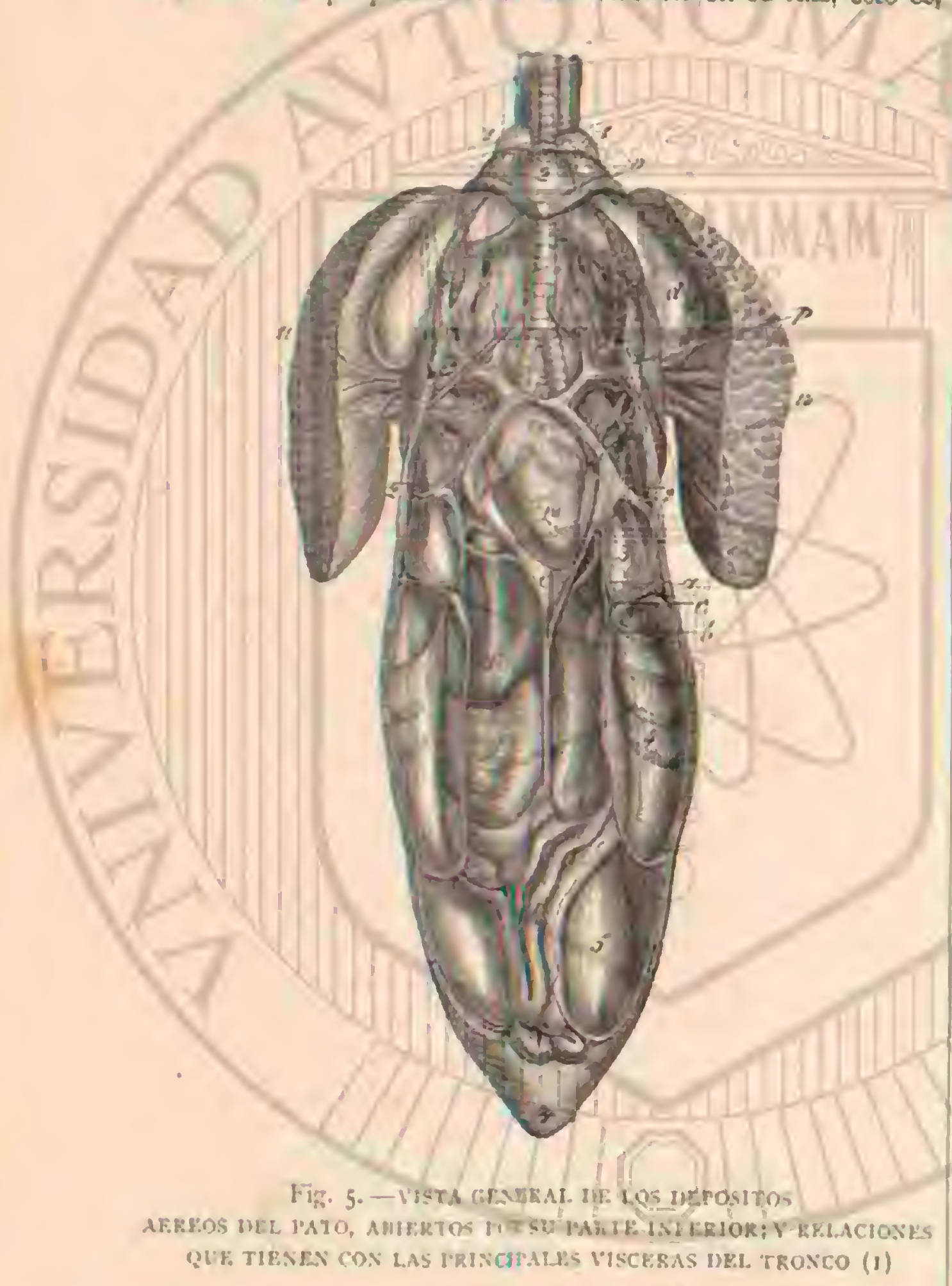

en la base del canal que divide la cara inferior de su tallo, un apendice o hiporaquis ryuc es el rudimento de una pluma accesoria: generalmente se rieeda esta muy pequeña, pero en el casuario llega a tener igusl longitud y desarrollo que la principal. No se distriburen las plumas jor igual sobre todo el cuerpo, sino mas bien ea regiones, por manera que, en realidad, la mavor parte del cuerpo estri desnudo, y el reveslimiento de plunas se limiza á ciertas fajas estrechas sucesivas, cuyo curso difiere segun las especies.

Las aves cuyas plumas se distribuyen por igual sobre toda la superficie del euerpo no pueden volar. Las plumas del tronco se cubren unas a otras como las tejas 6 pizarras de

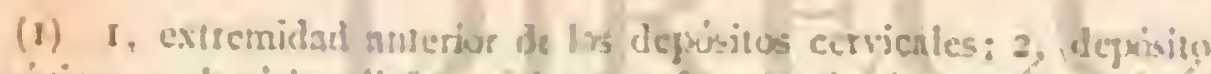

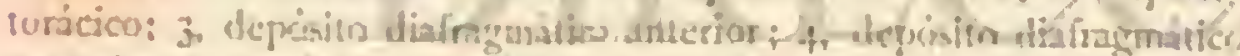

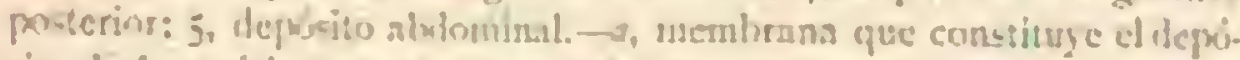

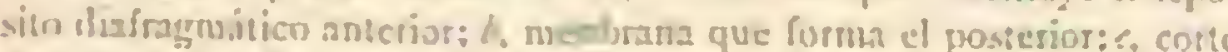

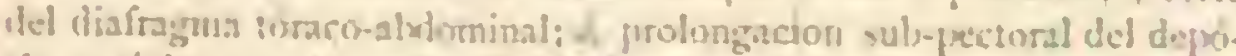

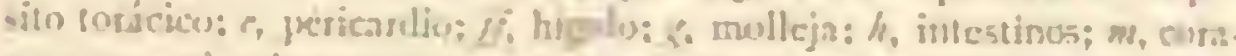

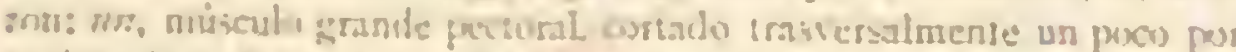

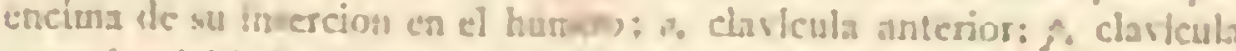

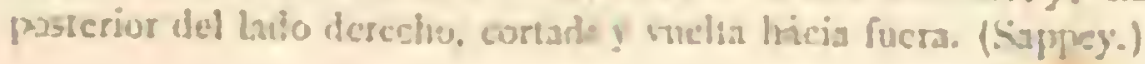

un tejado; las remeras y rectrices aparecen dispuestas en forma de abanico y cubiertas de arriba abajo por las tectri. ces que se dividen en tectrices de la mano y superiores é in. feriores del ala y de la cola, ó en otros térninos, super y sub. alares, super y sub-caudales. Las plumas que constituyen el plumon tienen las harbas mas largas, lacias y Rexioles, des. aparece mas 6 menos la contiguidad de los apéndices de las fibrillas y varia por completo la estructura total de la pluma. Ia diferencia de color de las plumas es tambien correlativa de la de su forma: una misma pluma que presenta distinios colores, puede afectar una estructura diversa, pues su brillo, mas que de la materia colorante peculiar a la pluma, depende de su manera de reflejar la luz. El decolorarse las plumas es frecuente, mas raro el que se oscurezcan; no son pues insólitos y aun se obscrvan en muchas aves fenómenos nota. bles en punio al color.

Para la determinacion de las aves importa conocer exacia. mente las denominaciones usuales de las diversas plumas y de todas las partes del cuerpo: la figura ; puede servir para dar una idea general.

MOVIMIENTOS INTERNOS. - NUTRICION. - Ningun animal se nutre con tanta actividad, ni tiene la sangre tan caliente como las aves. Bien es rerdad que lo uno es consecuencia de lo otro: la gran intensidad de la respiracion es lo que da ¿las aves su mayor actividad y fuerza. Inspiran una cautidad de aire mucha mas considerable que los otros animales; pues además del airc descompuesto, esto es, quimicamente unido á los tejidos, circula por todo su cuerpo una gran cantidad de aire que permanece inalterado, ya yue, segun vimos, se llenan de él no solo los pulmones, sino tambien las bolsas aéreas, los canales y células de los huesos y aun rá veces otras células cutíncas. Su sangre recibe, por tanto, mucho mas oxigeno que en los demás animales; la combustion se hace mas viva y energica, mayor la excitacion que produce en el organismo, mucho mas activa y rípida la circulacion. Por su parte las arterias y venas son relativamente mas fuertes y la sangre mas rica en globulos que en los demis vertebrados. A todo lo cual corresponde necesariamente en las aves una vitalidad sin ejemplo, y como consccuencia del mayor gasto de fuerzas originado por aquella, es la digestion mucho mas activa.

Puede asegurarse que las aves comen proporcionalmente mas que ningun otro animal: muclias hay que no cesan de comer mientras están despiertas; las insectivoras llegan hasta ingerir al dia una cantidad de alimento tan grande, que pesa dos $\delta$ tres veces mas que el cuerpo mismo del ave Las car. ruiroms comen mucho menos, pues el peso de su, comida diaria no llega is la sexta parte ciel de su cuerpo; las que se alimentan de sustancias vegetales no consumen cantidad mayor; pero, con todo, podemos llamar glotonas a unas y L otras comparindolas con los maunficros.

Los alimentos pasan inmediatanente al buche of al ventri. culo sub-centuriado donde sufren una primera digestion; llegados al estómago, se descomponen por completo of se pulverizan triturados como por una piedra.

Muchas aves llenan todo su esórago de alimento hasta la faringe; otras llènan el buche, hasta el punto de comuni. carle el aspecto de un verdadero tumor. Ins rapaces digieren aun Jos huesos duros y las grandes granivoras llegan hasta á hacer cambiar de forma, bajo la accion continua de su estó. mago, los pedazos de hierro que á veces tragan. Unas con. servan en su estómago durante semanas enteras, sin devol. verlas, las sustancias imposibles de digerir; otras, en cambio, las vomitan en forma de bolas apelotonadas; estas viltimas necesitan para crecer tngar sustancins implusibles de digerir; 
cuflaquecen y aun mueren, cuando se las obliga a renunciar totalmente a esta clase de materias, produciéndoseles tambien una hipertrofin en la pared interna del estomago, cu yas excrecencias arrojan entonces de cuando en cuando, en ver. de las bolas apelotonadas que vomitarian en otro caso.

A pesar de la actividad de sus funciones nutritivas, cuando las ares tiemen comida en abundancia, depositase bajo la piel y entre las visceras mucha grasa; pero csta se consume com. pletamente al cabo de muchos dias conserutivos de absti. nencia sin embargo, las aves soportan menos el liambre que los maniferos.

MOVIMIFNTOS VOLUNTARIOS. - VEK.O. - Tam. bien los movimientos voluntarios de las aves son mas rápidos y sostenidos que los de los otros animales; sus músculos, en efecto, mas fuerte's, vigorosos y excitables, producen contrac. ciones mas enérgicas. Sobre el vielo, que es el movimiento caracteristico de estos séres, ya dijumos algo (T. I, phg. $v$ ), E importará recordario frorque se enlaza con lo que vamos å decir. Todos los deinas animales capaces de moverse por el aire, revolotean ó se agitan en êl; solo vuelan las aves, y lo deben á la disposicion de sus alas.

l'odas sus plumas, en efecto, se recubren unas a otras como las tejas de un tejacio, y se encorvan de tal modo ujue comunican al ala una forma abovedada. Cuando el animal se eleva, sepráranse las pennas y puede pasar el aire a trasces de ellas; cuando baja, adhicren unas con otras las barbas de las plunas y oponen al aire una considerable resistcncia: of cacia alctaro se cleva el are, y como este se produce de ade. lante a atris y de arriba á abajo, avamza afjuella al mismo tiempo. I a cola le sirve de timon; para elevarse la dirige un poco hícia arriba, la haja para descender, y la ladea para volverse se comprende rue los aletazos en las aves verd:! deramente voladoras se suceden unas reces inu de prisa, otras déspacio, y en ocasiones se interrunupen del todo; como tambien que las aias esián mas ú menos vucitas y que el borde anterior por lo tanio, está ỵa levautado, ya deprimido, segun yue el are vucla con ligereza ó lentitud, hácia arriba y adclante, se cierne sula ó gira; y no hay que decir que cierra las alas cuando va á precipitarse repentinamente sobra el suelo desde uma aitura considerable. Fil arqueamiento del ala hace tambien neceshrio al ave volar contra el viento; pues Ia corriente de aire que la azota por delante le llena las alas y la lesanta, mientras que la que viene por detrás le separa las plumas y le distiende las alas, entorpeciendo considera. blemente el movimiento. La diversa rapidez del ruelo, su naturaleza y tipo, están en iniina conexion con la forma del ala $y$ la constitucion del plumnje. Ias alas largas, delgadas, puntiagudas, de pennas resistentes fo el plumaje corto sirven para un vuclo rápido: con las que son cortas, anchas y romas y con un plumaje lario, ha de ser el ruclo ionosamente lento. I a cola larga y aneha permite cambios bruscos de direccion; con alas grandes, redondeadas y anchas puede el ave cernerse fácilmente, etc. Fin cuanto $f$ la rapidey del mo. vimiento he dicho que la del ruelo de las aves excede a la de todos los demás animales; tocante à su dumcion, hay que decir yue no cede tamproco el are of ningun animal en este respecto, pues hace cosas yue nos jureren incomprensibles, recorre en pocos dias miles de leguas y an pocas homs imnquea un nncho inat. Lak aves de paso 6 emigrantes vuelan dias enteros casi sin descansar; las que se riernen retozan horns seguidas en el aire, exigiéndose un concurso de cir. cunstancias muy desfavorables para que en realidad se agoten las liserzas del ave en ocasiones señaladas. Parece, y mara. villa por cierio, que el ave ruela con igual velocidad en todas las aluras, cualesquicra que sean las diferencas de presion y la energia que por tanto debe desplegar segun los casns. Hallándose Humboldi cerca de la cima del Chimborazo, vió cernerse todavia un condor is tan inmensa altura, sobre é?, que parecia un punto negro tan solo, pero inoviéndose con

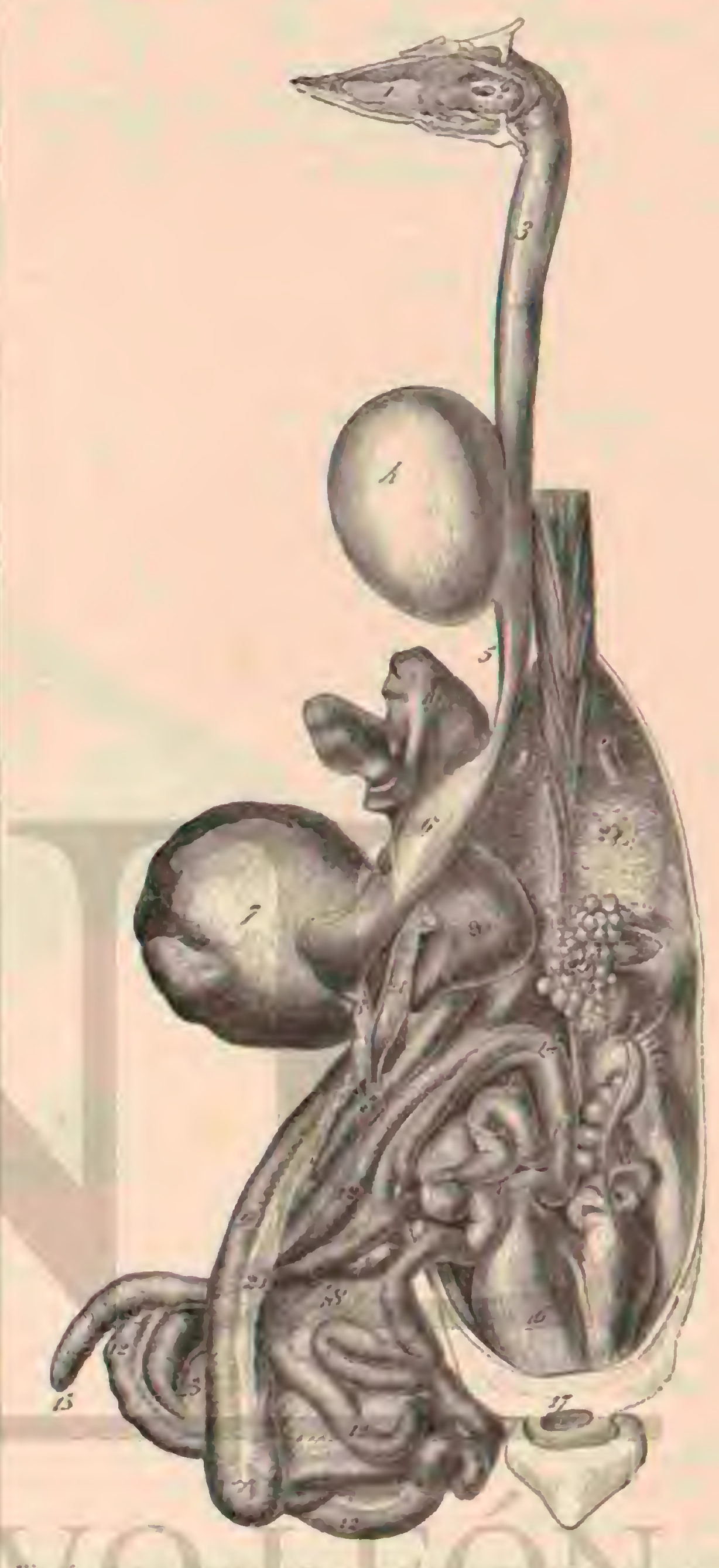

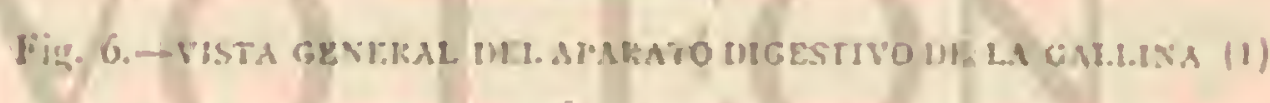

tanta facilidad como pudiera hacerio en las regiones bajas. Con todo no pasa esto siempre, y lo prucban los ensayos hechos por los acronautas que han soltado pralomas á grandes alturas, y observaron que su vuclo era mucho menos seguro rque en las capas inferiores de la atmósiera.

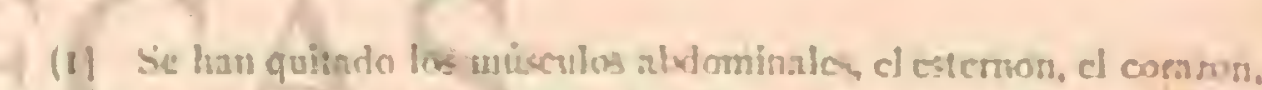

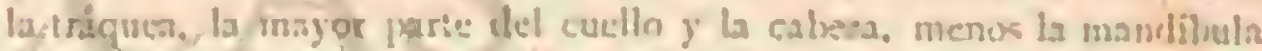

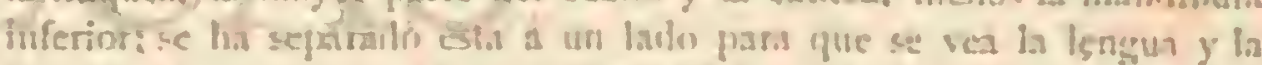

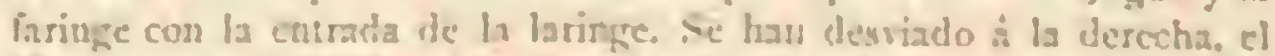

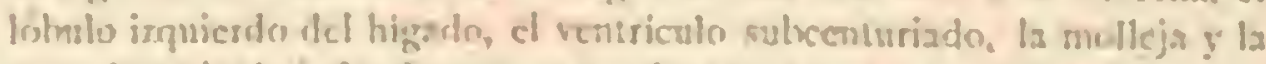

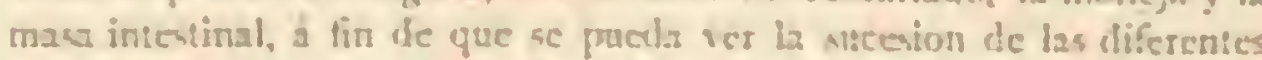
paries bel canal slimentioio, lejamlo al desculjerso el otario $\because$ cl ovi.

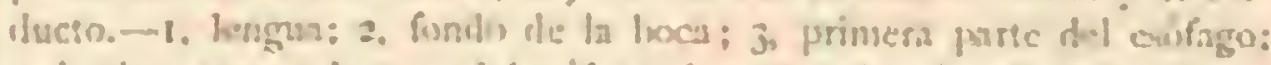
4. inche; 5 segunda parte del esuísgo: 6 , veniriculo subentarialu: 7, mo.

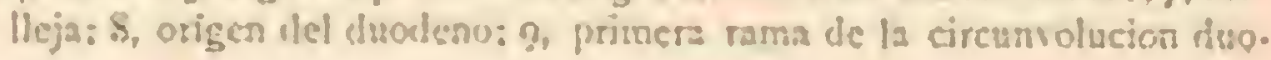


Marcira-Genemlmente las aves que son buenas rolado. ras andan mal: algunas de ellas, siu embargo, corren cun ligereza. In clase entera olrece diferencias muy notables en cuanto a la progresion sobre cl suelo: hay aves urincipainiente corredoras, las hay trotadoras, algunas caminan á saltos, otras marchan simplemente, $y$ las hay, en fin, torpes para andar, que se balancean ó arrastran tan solo. El paso de las aves difiere mucho del nuestro; pero exceptuando algunas especies acuáticas, que casi rastrean, todas las demás ares que andan como el hombre sobre sus dos yiés, se apoyan sobre los de. dos de estos. Aquellis cujo centro de gravedad se halla en medio del cuerpo, son las qque mejor andan, aunque no mas de prisa; las de patas grandes andan bien, aunque a pasos medidos; las de piernas cortas, mal, generalinente á brincos; finalmente, las que tienen sus extremidades posteriores de un largo regular van muy de prisa, y mas bien corren que andan. Las que se tienen nuy erguidas sobre sus patas se mueven pesada y torpemente; casi pasa lo mismo à las de piernas insertas muy atrais y cuerpo inclinado haicia adelante, pues cada paso las obliga á imprimir un movimiento de rotacion á su cuerpo. Algunas aves que son excelentes voladoras, no pueden andar en absoluto; orras que nadan admirablemente,

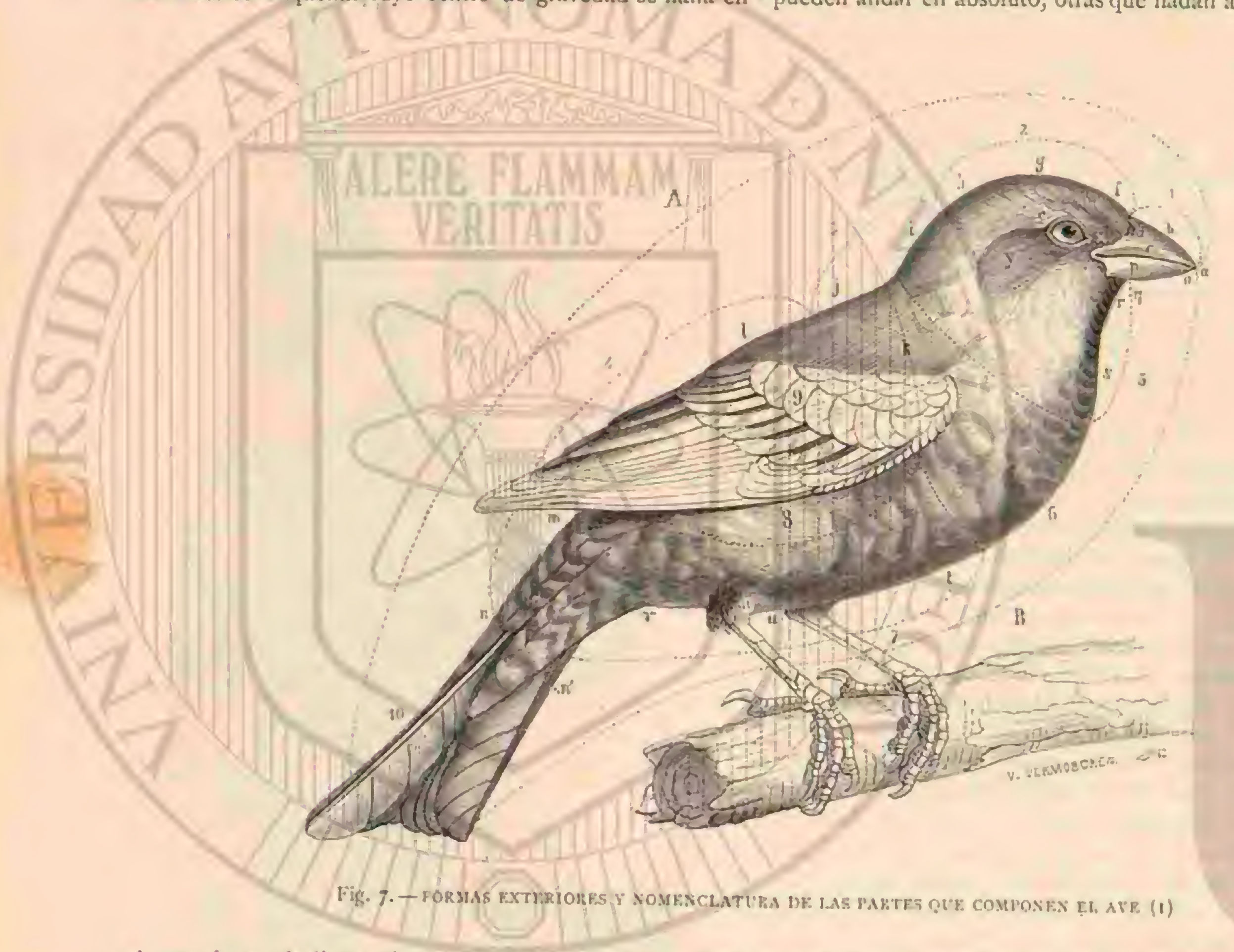

solo consiguen deslixarse of rastrear sobre el suelo; muchas se sirven tambien de las alas para correr mas rápidamente.

Namcion $Y$ sumersior:-Muchas ares se mueven con gran agilidad en el agua : nadan con tal dustreza, que la ma yoria de los actos de su vida los cjecutan nadando, y con la misma ligereza con que bogan por la superficie, se sumergen tambien en el fondo. 'lodas cllas nadan, arrojadas que sean al agua; no es esta facultad patrimonio exclusivo de las aves nadadoras propiamente dichas, En estas, como en general en fodas las aves que viven en cl agun, es el plumaje mas com. pacto que en las demás especies, צr como además está barnizado por una espesa capa aceitosa, tiene cunnto necesita

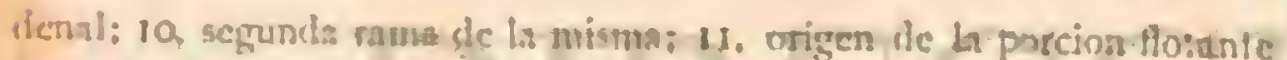

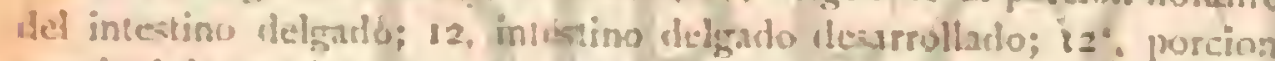

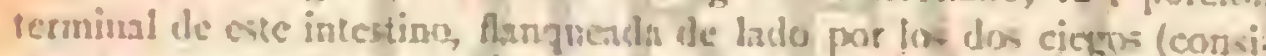

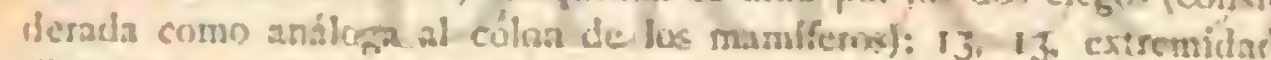

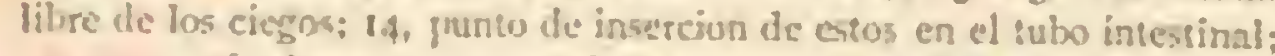
15. recto; 16, cianca: 17, ann; 1\$, mesnterio; 19 , lóbulo izçuierdo de

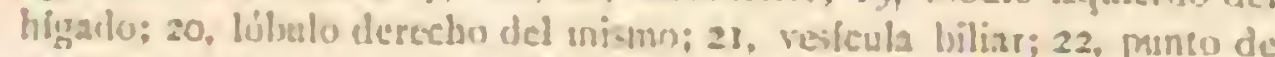
insercion de los canales pancresticos y. uiliares flos dor conducias pancreáticos son lis mas antcriores: el caral hepaitico está en el centro, y ef

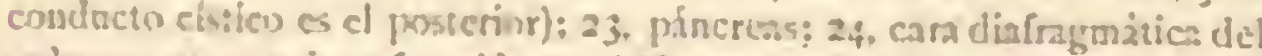
pulunor; 25, nvario; 26 , oviducto. (Chareall y Arloing.) para no mojarse. El ave, cuando flota sobre el agua, guarda el equilibrio sin esfuerzo alguno; y cada golpe de remo quue ejecuta significa un avance de todo el cuerpo, pues las patas no ejecutan movimiento alguno que no sea para la progre. sion. Parn nadar utiliza por lo comun solo los piés, que pri. mero encoge y lleva hácia adchnte para extenderlos-luego, rechazando el agua con fuerzi. Si nada despacio, solo agnita una pata tras la otra; pero en el caso contratio, extiende y encoge las dos á la par generalmente. Parn dirigir el rumbo,

(1) A, care superios: li, cana inferior:-I, pico formanto de la man diluda superios que comprende: i, h puntas; $k$, el lorno is aristn; $c$ los

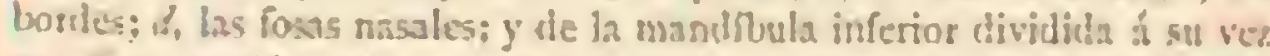

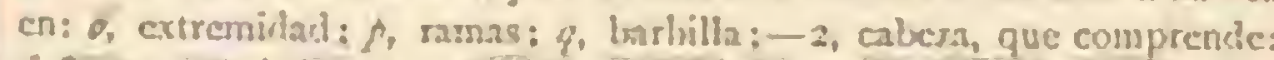
fo freate: $k$. Vérice; $h$, uccipucio. Detajo y a los latin de la abeza dis.

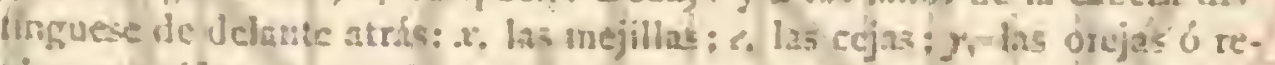

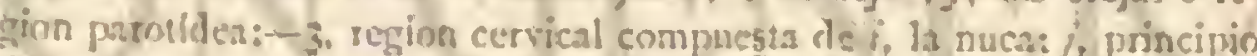

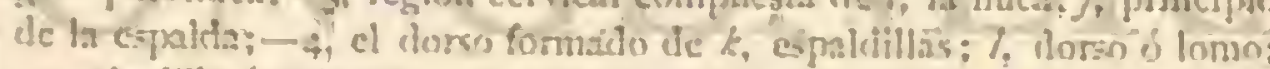
m. rabadilla ú obi-nillo:-5, renion anterior del cuello en la cual se dis. kingue: $r$, la garganta: s, parke inferior die la misma; - 6, prechn;-\%, ah.

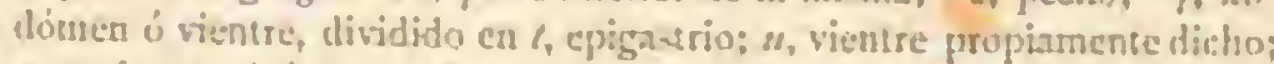
$\because$ region enal ó ann:-S, costados:-9, alz: - 10, cola cubicrin en sil origer por $x$, sujuacaulales, iccirices ó enbijns: $"$ sulucaudales o cohifas inferiore:-11, extremidades paieriores divididas en muslo, piema, tarso y dedos. 
deja una pata atrás con los dedos extendidos y rema con la otra.

Nitucion y sumersion. - Ias aves nadadoras buzan tams. bien generalmente. Muchas nadan entre dos aguas mejor que a la superficie, rivalizando entonces con los peces; otras solo pueden sumergirse precipitandose desde cierta alturn. Cada una de estas dos aptirudes irasciende mucho al modo de vivir las ares. Aquecllas que solo necesitan un pequeño esfucro, un leve salio para sumergirse en el fondo del agus, pueden ser llamadas verdaderos buzos; las que necesitan dejarse caer desde el aire, pudieran recibir el nombre de buzos por impulso. Las primeras son maestras, las seguncins aprendices solo en su artc; aquellas, que se sumergen à su gusio, pueden permanecer dentro del agua largo tiempo; estas, q̨ue solo se hunden impulsadas gracias of la velocidad adyuirida en el aire, vuelven ciertamente contra su voluntad á La superficie del agua que las seriaza a su ver; las unas buscan alli su presa, las orras se ven obligadas a confiscar la gn hecha. lass alas cortas son parrimonio de las que buzan en forma: para liacerlo solo por impulso se necesitan alas largas, porque en las aves que se hallan en este caso el ruejo es lo principal y la sumersion lo accesorio. Lina sola fomilia, la de las procelarideas 6 aves de semplestad, reune hasta cierto punto ambas facultades. Las que son verdaderos buzos se sirven de sus patas. ! las que lo son tan solo por impulso, de sus alas principalmenie; pero las hay entre las primeras, sin embargo, que utilizan á la vecz paias, alas y cola. In profundidad a que descienden las aves nadadoms, la direccion y relocidad que lle:an en su morimiento, y el liempo que permanecen bajo el agua, varian extmordinariamente. Los eiders ( finas mollissima) piseden, como ga dijimos, resistir siete minutos sumergirse, segun Holboell, hasta una profundidad de ciento veinte metros; pero la mayorin no visitan tan grandes honduras, segummente, yal cabo de tres minutos a la sumo de inmersion, vielven a salir a la superficie para respirar el aire. Algunas ares, que no se cuentan entre las verdaderas uadadoras, no solo son capaces de nadar y buzar, sino que pueden correr tambien acd y alla jor ef fondo del agua.

ACCIO: vH. TRERAR. - Es otra de las aptitudes de las aves: murhas de cllas trepan en efecto, $y$, a la verdad, perfecta. mente. Útilizan pasa ello las patas, sobre todo, ayudándose además en ocasiones, del pico y de la cola, y un á reces de las alas tambien. El modo de treprar menos perfecto es el de los loros, que se suspiender con el pico de una rana elevada, aizando el cuerpo despues; el mas completo es en cambio, el que ofrecen los yjicos, que solo se sirven de las patas y la cola. Algunas aves mas bien que trejan revolotean, piles á cada movimiento de ascenso clevan las alas y las recogen luego, comando vuclo realmente para soltar del sitio cil que están oiro mas elevado, donde se fijan de nuevo; asi se conduce el ticoriromo, mientras los ficos aranzan hacia arri. ba sin clevar sensiblemente las alas. Casi lodas las trepadoras suben solo ó corren por la cara superior de las ramas; las hay, con rodo, que pueden en realiciad bajar de cabeza por cl ironco, y otras capaces de marchar por la cara inferior de las ramas.

Vor. - Fis un don especial de las aves su voz sonora, llena y pura. Cierto que existen muchas que solo dejan oir pocas noras, o sonidos desagradables, agudos y chillones; pero la mayor parte tienen 1 na $\mathrm{roz}$ extraodinarianenie fexible y dulce; ninguna es nuda, afónica por completo. Su vor pernite á las avis un rico lenguaje y un canio delicioso. A me. dida que se las observa mas detenidamente, se obtienen nuevos testimonios de que par sentimiento, impresion o concepto tiene el are sonidos esperiales, á que, sin exagera. cion, hay que otorgar valor de palabias, ya que no solo se

Tosio 111 comprenden estos animales unos á otros, sino que además el observador atento llerga á entenderíos. Se liaman 6 reclaman unas á otras; manificstan su alegria ó su amor; se retan à la peler ó se piden auxilio ó alianza: se avisan de la presencia de enemigos $\delta$ de peligros de orm especie; se comunican, en fin, las cosas mas diversas, y saben comprenderse unas á otras no solo las especies afines, sino las mejor $y$ las peor dotadas en cuanto al lenguaje. El pajarillo atiende al aviso de las grandes ares de ribera; la corneja previene a los estoruinos yo otras especies campestres; toda la poblacion alada del bosgue se alarma al oir un grito de angustia cel mirlo. Las mas precaridas se constitujen en centirelas de las otras, que atienden bien á sus indicaciones. En la época de los amores se entreiciencu las ares hablardo y cliariando unas con otras, ajectuosamente las mas veces; las madres, por su marte, hablan i sus hijos con la maycr temura. Unas con. versan en realidad, pues se responden mu:uamente; otras expresan con voces sus sentimientos sin preocuparse de si hallan eco en las demís. A ellas pertenecen las aves canto. ras, las iavoritas de la creacion, que asi debe llamirselas, las que han despertiado en nosoiros el innyor amor liácia la clase de que forman parie. Mientras se trata de comversar, no hay casi diferencia en punto ś facultades entre uno y otro scso; pero el canto es privativo dul uncho, mrisima ve\% llega d aprender la liemlisa of recitar alguna estrola. Todas las aves realmente cantoras tienen los músculos de la laringe interior, sobre poco mas ó menos, igualmenic desarrollados; pero di. fieren muchisims en cuanio á facultades de canto.

las diversas especics poseen entonaciones propias; cada una tiene su peculiar extension de vox, y enlaza à su modo las notas para formar cstrofas que por inucho que se parezcan, se distinguen con todo ficilmente por la amplitud, redondes. te intensidad de sus notas constitutivas. El canto de algunas se cierra en unas noias, ian solo; otras llegan á dominar oc. tavas. L.as hay quc cantan cjecutando una tras otra frases distintas, jerfectamente definidas, discontinuas, como el rui. sehor f el pinzon; haylas, en cambio, que si bien pasan cons. taniemente de una nota i otra diversa, no agrupan estas, sin embargio, cu frases musicales: tal ocurre a la alondra $y$ el jilguero. P’or lo demás, cada uma sabe clar gran variedad i su canto, yue por esto, precisamente, nos impresiona tan visa. unente La localidad ejerce tambien su inulujo, jues la misma are canta de una manera en la montaña y de otra en la llanura, zunģue la drerencia sulo puede apreciaria un oido educado al efecto. Un bien cantor, ja de frases, ya solo de notas sucesirns, puede formar excelentes ciiscipulos: uno malo les harí prerder, én cambio, sis inejores dotes. En las ares ocurre, por deegraciar, que al aprencier lis jóvencs á carlar con las adultas de su especie, adnuieren mas fácilncute sus defoctos que sus buenas cualidades. Algunas hay que no se conientar con el canto propio de su especis, sino que lo mezclan con divergas notás di irasles tomadias de otras ares ó con gritos en que quieren reproducir los sonidos y ruidos sque han llegado á chocarles; tales sou los rurlones, que asi se llama a estos pajjaras, aunque con poca justicia. Aves cantoras en el sentido propio del vocablo, esto es, que no solo tienen en la laringe inierior los músculos destinados al canto, sino que además cantan, realinente abundan, sobre todo en los paises de la zona templaris.

SENTIDOS.-- li indicamos antes que ningun senticio estr atrofiado en las a:es. lista conclusion, que brota del simple evảmen de los órganos, se confirma de lleno por las observa. ciones directas. Toulas las aves ren y ojen mu bien, algunas bienen un deliçado olfato, en oiras el gusto llega á alcanzar cicrto desarrollo aunque bastante limitado, y no falia tacto af zinguna, pasivo a lo meiros. 
Vista-la gran movilidad del ojo exterior é interiormente permite al ave abarcar un ancho campo visual y distrouir dentio de él un objeto con una precision que nos astenluta. A distancias increitules divisan las rapaces los peạueàs ma. miferos, y las insectivoras su presa. El ojo esti en cocinuo moviniento, pues el foco visual ha de variar con el iverso alejamiento de los objetos Es iscil convencerse cie clia con un experimento muy sencillo. Ácerinuese la mano al tjo de una rapas, por ejemplo, de un buitre real, curo iris de color claro facilita la obscrvacion; repariese en el tamato de la pu pila, y se verá que esta se encoge y se ensnncha contantemente a medida que se aproxima ó se aleija la anana Solo asi se explica que estas ares, cuando se ciemen a centusates de metros sobre el stelo, puedar yercibir los paquecios obje 105, ! los vean tawbien con rocin precision cuando fos earan desde cercon

Orso. - Su cxcelescia la inferimos ya del canto mismo, gue no es innato sino ayterdido; peto adurás olsenjulw nes direcias prueban que és muy fino en las ares. Lsi las silves ires solo por el oido advierten en ocrsiones la inminencia de algun peligro; las domésticas atienden al mas leve runer los buhos de grandes orejjas dejen sin duda utidzar, cuania ca. 2an, lo mismo el oido que la risia, nunque no es oosa ha: por hoy demostrada sin embargo, probablemente estas diuras noillegan en delicadeza de oide a donde ciertos mas letos; ailc menos no hay aun observicion alguna que deba hacmos creer que ningun ave vione el oiço un fino como un estric lago, un gato ó un saton.

Ourato. - Sobre el de las aves reina togaria gran vaficuiad

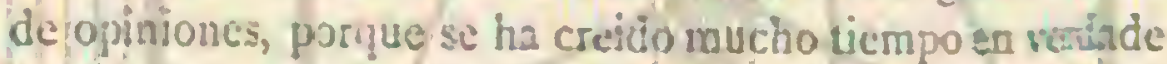
ras tábulas Aun lov dia para muchos cazadores es nusitivo gue el cuerro hucle la póliom en el cañon de la esececta, y muchos naturalistas creen aun que el buitre olta:es ln ance podrida a distancia quizás de legúas, Que lo primero éialso, excusado es decirlo; lo segundo puedo negarlo aporambome en numerosas obscrvaciontes. No pucde negársties, cierta mente; un olfato medianamentc desarrollado, ce cht dan testimonio todas las aves en que tratanos de obctrial puero en cuanto a nlfatent tan' sutiluente como vened basto at los manificos, no hay gue hablar de ello siquiers

Custa - Tambien es inferior at de los últimes. Cieno nue vemos a las ares yteferit unos alimentos á otros ć inicinos qque aqqucllos les saben mejor que es:os; pero recordatio qque los tmgan generalmente sin triturarlos antes, connowderemos el poco fundamenio de semcjanic incuccion La tengua en estos animales es, de seguro, nas bien un órguno düracio que del gusto. Precisaniente er ella tienen muchns reses su palpacion mas delicada; los jicos, los colibris ó pajjans moscas y los dentirostros se valen de clla para regisirit in agu. jerros en que se oculta, su presit, y separas de lo que ian á comer las materias extrainas can que está mezclado. ànogue menos que la lengua, sirfe tamoien de brgano irrita pico, sobre todo; de él se ralen, la chora perdiz, yor ejerpio, ! rambien los denzirostros. En cuanio al pié, casi no tiete $\mathrm{cm}$. pleo en este respecto.

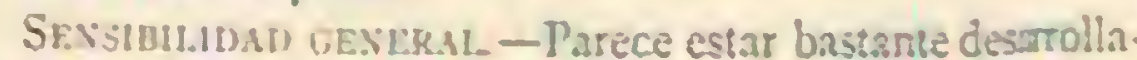
da en las arcs, pues todas ellas se muestran nuup sermibles á los influjos exteriores, ya de la atmósfera, ya de ooms objetok

INTr.dGEsicka. - En punto á la facultad cétedial qué Ha. mamos asi, como en lo relazivo a la naiuraleza iustrirusa de las aves, rale, i mi juicio, cuanio dijimos en igual supecto de los mamiferos; á lo menos no conorco en estos strguna facultad psiquica ni msgo alguno de caraicter que nose ob. serven tambien en aquellas. Largo tiempo se ha afirataco lo contrario, atriouyendo los fenómenos de tal oides en tos ares al inllujo de una fuerza natural inconsciente, el instinlo, que se dice, y aun hoy prevalece esta idea, solo por el hecho, cier. tamente, de no haber observado cada cual por si mismo ó no haber comprendido las observaciones de otros Ya lo lie di. cho en La rida de las dies: en cuestiones de este género no ha de olvidarse que la explicacion que damos hoy a ciertos ínómenos de la vida de las aves se funda casi solo en meras hipótesis. Cuando nos parece comprender mejor al animal, solo llegamos en realidad a un conociniento mup incompleto de su naturaleza misma. Cierto que conseguimos í veces formarnos una idea de sus pensamientos y conciusiones; pero no sabemos hasia qué punto es verdadera ó falsa. Muchos hechos son todavia enigmáticos $\iota^{\circ}$ inexplicables para nosotros sin duda alguna: pror ejemplo, las precauciones que algumas toman en prevision, al parecer, de sucesos futuros, pues emi. gran antes de que comiencen a faltar alimentos con la llemida del invierno, $f$ introducen a veces modificaciones cn la manera habitual de construir sus nidos, y aun de reproducirse, que resultan luego muy aciccuadas a cicrtos fmes $A$ esta misnin categaría corresponden tambien, aunque solo en determinalos limites, los fenónenos q̨ue atribuimos al instinto artistico, como se dice, de las aves, y otros muchos aun. En cuanto ila explicacion de ales hechos, oscuros todavia, en vez de esiorzarnos para dar alguna teoría incompleta, parece mucho mas razonable confesar sin rescria nuestra ignorancia actual. Quedelpara nuevas observaciones ulteriores la expli. cicion de estos misterios aparentes, y sirvanos el negarlos hoy como tales de estimulo para estudiarlos mas à fondo. Es cómodo, pero indigno del espiritu humano, suplir la falta de conocimientos positivos con creencias milagrosas, pues necesariancnte perdemos de vista á la naturaleza desde el mo. unento en que empezamos á divagar por el campo dic lo sc. bromaiural. El que niega á las aves inteligencia, ó no se la concede muy desarrollada y capaz, no las conoce de seguro; it no ser que no quiera conocerlas porque espera salvar así Ia insostenible supremacia de semidios que el hombe se otorga aun á si propio. Olvida ugue son educables; que se las puede adiestrar, acosiumbrarlas à entrar y salir en su jaula 6 en su morada, enseniarlas á hablar ó producir vocablos, si no se quicre concederles palabra; en suma, que es posible obte. ner de ellas lo que no podrian realizar en absoluto si las guiara solo una supuesta fuerza exterior incomprensible, de que no cabe formarse idea siquiera, pues su poder ignoto, a yue deberia el ave obedecer sin saberlo, cesa desde el mo. mento en que cualquiera se ocupa de educarlas.

DISTRIBUCION GEOGRÁFICA. - I Aas aves son cos mopoilitas. Se las halla en toda ia tierra conocida, en los is. lotes polares como en el ecuador, sobre el mar como sobre los vértices de las inas altas monianas, en las regiones fértiles y en el desierto, dentro de los bosyues juimitiros como en los desnudos picos sirgidos ha poco del seno de los mares. Cada rona ticne sus especies particulares. Por regla general obedece tambien la distribucion de las aves sobre el globo à las lejes quue rigen la de los demás animales, pues en las regiones frias son sumamente numerosas, pero corres. ponden á pocas especies, mientms que yendo hácia el ecuador aumenta gradualmente su diversidad, crece el nimero de formas especificas. Fliagua, que es el elemento uniforme, cjerce sobre las aves su natural influjo; asi las especies acué ticas figuran en corto numern $y$-aun son muy afines loa tierra, á su ver, refleja en los séres de esta chase su variedad rịuisima; no solo en cada zona, sino en cada localidad aparecen aves diversas: las que habitan la Tundra boreal, el desierto de agua, difreren de las que animan el desierto de ariona; unas son las que viven en la llanura y otras las que pueblan la montaña, ni son tampoco las mismas las que mo. 
ran en los bosques $y$ las que son naturales de las regiones descubiertas.

Siendo, como son, las aves producios y conseruencias naturales de ha constitucion del suelo y del clima, han de variar forzosamente como su patria y domicilio. En el agua el area de dispersion de las especies es ciertamente mas ex. tensa que en tierra donde un ancho rio, un brazo de mar, ó una inontana pueden oponer ya una barrera; pero con todo, los mares mismos tienen tambien sus limites inferiores pam este efecto. De solo poquisimas aves puede decirse literal. mente que habitan en todas las regiones de la tierra conocicia; son estas un ave terrestre no mas, y algunas acuaticas y de ribera: es cosmopolita en efecto, el bulio de los panta. nos 6 de orejas cortas, que se presenta en las cinco partes del globo; lo es tambien el alcaravan que frecuenta todas las costas de todos los continentes, apareciendo yo pudiendo aparecer lo mismo en el hemisterio occidental que en el oriental, ya que donde quiera encuentra iguales condiciones de vida. Generalmente las especies tienen un área de dis. persion mas extensa en el seniclo de la longitud que en el de la latitud: en las regiones septentrionales viven muchas ares, cuyo número es casi igual en los tres grandes continentes, mientras que algunas leguas mas hácia el sur ofrece ya notables diferencias. Ia facilidad de locomocion de las aves no influge rotablemente en la inagnitud del área de dispersion de las especies: aves de gran vuclo pueden tener una patria mas reducida que oiras peor clotadas. Tampoco contribuyen los viajes periódicos, in emignacion, \& ensan. cinr dichas áreas como luego veremas.

Siguiendo a Sclater se considera generalmente dividida la superficic lerrestre en scis regiones zongraficas. En la primera, que es la septentrional del antiguo continente y rom. prende luropa, el norte del Africa y. del Asia, hasta el 34 " de latitud, viven, segun calcula Sclater, próximamente 650 es. pecies, enire las cuales solo merecen citarse como caractcristicas de la region los ruisconores, las currucas y silvias de cola roja, los pirrocorax de los Alpes, los grajos, los hortelanos y los picogordos ó cocotráustidos. M(uy pocos son los grupos de ares propias de esta masta region que no alcancen cn las oims mayor desarrollo. Tis la mas polure de todas y solo cuenta una cspecie por cada 1,300 millas cuadradas.

En el territorio etiópiro, y $\mathrm{en}$ las islas situadas al sudesie del rontinente africano, Madagascar,-Matricio y Hortuon, nsi como en la parte meridional de la Arabia, habitan sarias fa. milias propias de él, conue) por ejemplo los cólidos, los ann. bólidos, los bufagidos y un gran numero de especies caracieristicas.

Aqui viven los loros, agapornis, tiserinos, viudas, macronix, sirlis, los poliboroideos, el águila de moñe, el elanoides de Riocour, el circacto, las poliornis, el coragipo, el neofron, los macrndipterix, la mayor parte de los saxicólidos, los burlones, el indicador, las pintadas, el avestruy, las mas de las arutardas, los taquidromos, el baleniceps, la grulla curonada y varias palmipedas.

Muy especial es la fauna de Madagascar: aunque pertenerca al territorio etiópico, es tan cxclusiva y cancteristica, que deberíamos considerar á esta isla como continente aishaio si sole quisićramos tomar en consideracion dicha fauna. Ex. tmio es que los animales de Madagascar tengan un tipo asistico mas bien q̨ue-africano, circunstancia que justifica hasta cierto punto la suposicion de qque en ia ćpoca antidiluviana se extenderia un gran continente entre el Africa y la India Si ha llegado á cxistir una el emurias y si es cierto que ese continente desapareció en las profundidades del mar, solo podria considerarse á Madagascar y los grupos de islas innediatos, sobre todo las Msscarenas, Sechelles y Almiran. tes, como los restos de él. «Este es el último refugio, dice Hartlaub, de una poblacion animal de tipo lemúricio, extinguida en todos los alreciedores. No se encuentra en Madagascar ni uno solo de iodos los géneros de aves propios del Africa, Y por lo misino pareceria justo conceder á esta isla singular el nango de terrizorio independiente. Nada menos que cuitro familias de aves se hallan solo en Madagascar y en las islas vecinas. Además de esto, si se bace la comparacion con Africa, remos que los loros, las rapaces diurnas, los cucúlidos. las apivoras, palomas y aves acuaticas, son muy numerosns; mieniras que los fringilidos, los merópidos y estorninos escasean; las familias de los cuervos, de los lánidos, de los túrdidos, de los artámidos, de los muscicinidos y de los craterópidos, tienen alli, por otra parte, tipos verdaderantente citranos. Sclater calcula que el número de todas las especies del tesritorio ctiónico asciende ŝ mil doscicntas cincuenta; de modo que debe contarse una por cada trescientas cincuenta leguas cuadradas geogrificas; el número de las especies de Madagascar, segun Hartlaub, no baja de doscientas vinie, de las cuales al menos ciento cuatro son propias de la isla.

Como icrecr territorio consideramos, como Sclater, el Indico, que comprende toda el Asio, al sur del Himalnya, es decir, Ia India, Ceilan, Birmania, Malaca, el sur de la China, las islas de la Sonda, las liilipinas y las islas inmediatas. Fnire las especies cancteristicas de es:os paises, tan ricos $\mathrm{cn}$ aves, citaré los paleornitidos, los paradoxornis, los martines, menatos, anomalocorax, dendrocites, temias, temnuros, el cuervo respiandeciente, los hicrax, los cspizanctos, acantilis, batracostmmos, pericrorotos, caliopes, las timalins, los ortolo. mos, enicuros, nictiomis, eudinamis, las gallinas, los faisanes, pavos reales, jacanas y diversas palmaipedas.

Calculando el suiniero de las especies propias de este territoria en 1,500 , resulia que en cada 1,jo leguas cuadradas geográficas habita una especic, y que el territorio indico es relativamente el mas rico de todos.

En el territorio de la Ocennia comprendemos la Australia, la Nueva Guinca y demís islas Papurísicas, la Tasmania, la Nueva Zelanda y todas las islas del Pacifico. In fauna ornito. lógica de estos paises debe designarse como relativamente rica y muy especial. En estos paises habitan los cacatias, los es. trigops, los politelis, el platiccrco perueno, la cotorra ondulada, el uimine, los pezoporcs, los sitirostros, los petilorincos, los clamidoros, los sericulos, los paradiscos, los gimnorinos, los despertadores, el uracto, el epilocirco, los dendroquelidones, las salánganas, los egoteles, los podaryos, los íalconcios, los casicanes, los pardalotes, las liras, los ortotomos, aracnoteros, coridones, martines cazadores, tanisifteros, simeos, los di. duncrilades, tos talegallos, el casuario, el apterix y diversas malmipedas

Suponiendo que el número de especies de todo el ierritorio ascienda A mil, resulta una especie por cada 1 So leguas cuadradas geográficas.

In parte sepientrional del Nuero Mundo $b$ el norte de la Anrérica, desde el estrecho de Panamá hasta el mar Artico, no es mucho mas rica en especies que la del antiguo continente. Las aves caracteristicas de esia parte del mundo son los paserculos del Savannah, los sentrófanos, los amodromos, los pavos y otras. Lil nuimero de especies se calcula en 660, de modo que puede contarse una por caida 560 leguas cua. dradas.

La América del sur, en fin, es la parte del mundo mas rica en especics, no solo por su abundancia sino tambicn por la especialidad de las formas; solo por el número de individuos es un poco inferior al territorio indico. Sclater calcula su cj. fra en 2,250 , resultando de aqui una especie por cada 1 ole. 
guas cliadradas. Lo menos ocho $\delta$ nueve iamilias, ricas en su major parte en géneros ó especies, habiran exclusivamente aquel territorio; ý todo un órden, el de los estridoriços, viven con preferencia en él, pues muy pocas de las numerosas espe. cies perienecen i la America del norte, debiénduse por lo tanto considerarle como propro de la Anérica del sur, rica sobre todo en especies caracteristicas.

Viven aqui el crisutis del Amazonas, el pione rojo, los ocropties, los aras, los conuros, los enicognatos, los cocoljo. res, el cardenal, los catamblirincos, los habins, los tangaras, los paseréledos, la urraca azul, los diodones, los seudaetos, la harpia, los ictincos, cimindis, el urubitinga, lus poliboreos, el condor, el urubu, el gathinaco, los foleoptinx, cipselidos, au tróstomos, nictibins, bjataras, tirnos, los mana rodenos, Ins miotereos, los guri-guit, los atmaties, los home. ros, cammefitos, melanerpos, los colapteos, los picummeos, los colibris, prionics, los barbucios, la nayor parte de los curru. ctis, el zanclostonio triste, los crotorigicios, los tucrnes, las palounas emigrantes, los geotrigoneos, los pavos, los odonto. foros, los inncos, los penélopes, los cripturideos, los nandis, los curipiges, los agamis, los palanedeós y un gran numero de palmipedas.

Resultn de lo expuesto, que en el bcmisferio oriental del globo existen unas cuatro mil trescientas especies de aves, y en el occidental unas tres mil. Jistas cifras no son, sin embar. go, del tódo exactas, y de ningun modo están conformes con los cálculos de otros uatumlistas. (xiny ciir on $1 \$$; 1 nada menos due once mil ciento sesenta y dos esprecies, y Wallace cuenta en $19-6$ diez nil doscientas; vero ni el uno ni cl otro pueden responder de la exactitud de sus noticias. Probable. meate exageramos al calcular en nueve mil el múnero de las uspecies hasta ahora conocidas.

HABITACION:- Ia de las avés es muy rariada: sclas ve portodas partes donde no les falte el alimento: desde las orillas del uar, elevanse las especies acunticas a bastante altura en las monahis, particularmente las zancudas; en tierra frrmie se, ven aves yor todas partes, incluso en el desierto, donde en medio de las ârenas mas áridas encuentran aun die que alli. meutarse; pero en general. como se nota en los namiferos, su cxistencin ests/ enlazada sobre todo, siquicrn indirectamen. te, con la presenciá de/los regetales. Sin embargo, en los bosques es donde está clase de séresse ostenta en todo su desarrollo: los que habitan los océanos se cuentan por millo. nes. Durante el periodo del celo se reuner en bandadas in. uunerables en las costas bravas y las islas solitarias; pero segun queda yn indicado, pocas especies lis constituyen. I. tierra, y particularmente en los bosques, se ven bandadas igualmente numerosas, compucstas de las formas mas varia. das, pudiendo observar que ctunto mas se acerca uno al ecuador, mas se multiplican las especies. En los paises tronicales no pueden ser mas diversas las condiciones de evistencin, asi como las desencjanzas en el aspecto del-icrreno. Ia mayor varicdad de especies no se halla en las selsas virgenes, sino en los puntos donde alterman los bosques $\because$ las estepas, las montainas y los valles, los tertenos secos y los pantanos Dondc un rio atraviesa un bospue, ó está rodendo un pantano de árboles, is domina una porcion de la selva los alrededores inundados, alli se deja ver el mayor numero de especies, porque encuentran en medio de aqquellos elementos reunidos un alimento mas aburiciante que en otra parte. De la facilidaci que cacuentran en alimentarse depende la presencia de las ares, como la de todos los demás animales, en ciertas locali. dacles.

Ningun otro animal sabe visitar \& fondo su cominio tan perfectamenie como el ave: inspecciona los sitios mas retirados, todos los escondrijos, y recoge cunnto le conviene. Mu. chas granivoras y palomas por ejemplo, se contentan con los alimentos tal como los encuentran; otras saben perfectamente despojar los granos de sus cubiertas; las gallinas desentierran los tubérculos y raices de que se alimentan. Las frugivoras recogen las bayas y los frutos con su pico, y algunas sc apoderan die ellos al vuelo. Los pijaros insectivoros cogen su presa de todos modos: pican los insectos de las ramas y de las hojas doncie se hallan; los atrapan al vuclo; los sacan del seno de las flores, de las aberturas y grietas donde se esconden, y no los descubren a menudo sino despues de un largo ! penoso imbajo. Fn algunos esta organizada la lengua de tal modo, que pueden sacar los insectos de su e.5. conciite.

Bi alimento de los cuervos es comun à todos ellos; mien. tras por el contrario, cada rapaz tiene su presa. Hay algunos que solo sor inendigos $\delta$ parásitos; parece que la mision de utros consiste en llevarse las inmundicias y restos putrefactos; hasta los haj que se contentan con los hiresos. las mas de estas ares dan caza a los séres vivos, sin despreciar por eso los animales mucrtos; muchas hacen principalmente la giverra á lós grandes insectos, y solo por excepcion acometen los pequeños vertebrados; otras se alimentan sobre todo de estos vilimos; las unas no se apoderan de su presa, sino cuianúb descansa; otras lo hacen a la carrera ó al vuelo; las demás la cazar de cualquier manera.

Lintre las ares acuiticas, las hay que observan un régimen cxcepcionaimente animal, al paso gue otras se alimentan á lia vei de arrimales y vegetales. Estas últimas cogen la presa que ven flotanie en las superficies de las aguas: las primeras la huscan y/persiguen a grandes profundidades algunas ve. ces. Entre, estas, las unas cazan sobre d agua, las otras se dejan caer desde las alturas sobre la presa zue codician.

In resúmen, no exisic en la superficie terrestre un solo punto que no ésté habitado por las aves: cacia una utiliza sus facultades especiales de la manera mas completa, facultades gue estån admimblëmente armonizacias con su organizacion.

DESARROLLO.-El are tiene una corta infancia y una larga juventud. Su creciniento se termina rajpiủamente; algu. nas semanas despues de nacer pucde figurar ya entre sus se. uncjantes; pero necesita algun tiempo para igualarse con sus padres. Sabido es que el ave nace de un huevo, y que para desarrollarse le es indispensable cierto calor, que le propor. ciona la madre, ó bien las sustancias vegetales in fermenta. cion ó el sol.

Cuando llega el momento de la reproduccion, el órulo (fig. 8) que lleva ya en si el gérmen del sér futuro, crece-rí. pidamente; la parte de su contenido, que debe constituir el iriefus, ó la yema, se organiza; luego se abre la cápsula del omario, y llega al oviducio, órgano secretor de la clara ó albú: men. A medida que desciende, bajo la inffuencia de las con. tracciones de que es susceptible el órgano, envuélvese con las capas sucesivas del albumen, las últumas de las cuales, producidas por un compartimiento particular del oviducto, conviértense en membranas del cascaron. Provisto de todos estos elementos, pencira el huevo al in en la porcion del órgano que jroduce la costra caliza; cuando esta se halla compleiamenie formada, las contracciones musculares del oviducto acaban por expeler el huevo, con el extremo mas pequeño hícia adelante, y entonces sale, á traviés de la cloaca, fuera del cuerpo de la madre (tig. 9).

La cstructura y el tamaño del huevo varian mucho; su volimen esta generalmente en relacion con la talla del ave, siquicra sean uumerosas en este concepto las excepciones. La forma mas comun es la oroidea, que presenta d huevo de la gallina; pero este tipo se modifica en muchas especies para ser completamentic oval; tambien se ven huevos esiéri- 
cos, elipticos, ovicónicos $\delta$ piriformes, y algunos son casi cilindricos (fig. 10). En cuanto a los colores, tampoco puede indicarse una regla general: los hueros depositados en cavidades son con mas frecuencia blancos ó unicoloros; los que estan en los nidos al aire libie, manchados Por lo que hace al número, estamos en el mismo caso: varia de t a 24 si bien lo mas comun es que oscile entre 4 y 6 .

La hembra comienza comunmente s enpollar cuando acaba de poner: permanece entonces en el nido como poseida de un acceso febril, y calienta sus hueros con el pascho reempla. zándola a veces el macho en tan penosa tarea. En ciertos casos expone sus huevos al calor del sol, ó al que se desprende de las sustancias regetales que fermentan. Ell periodo de la

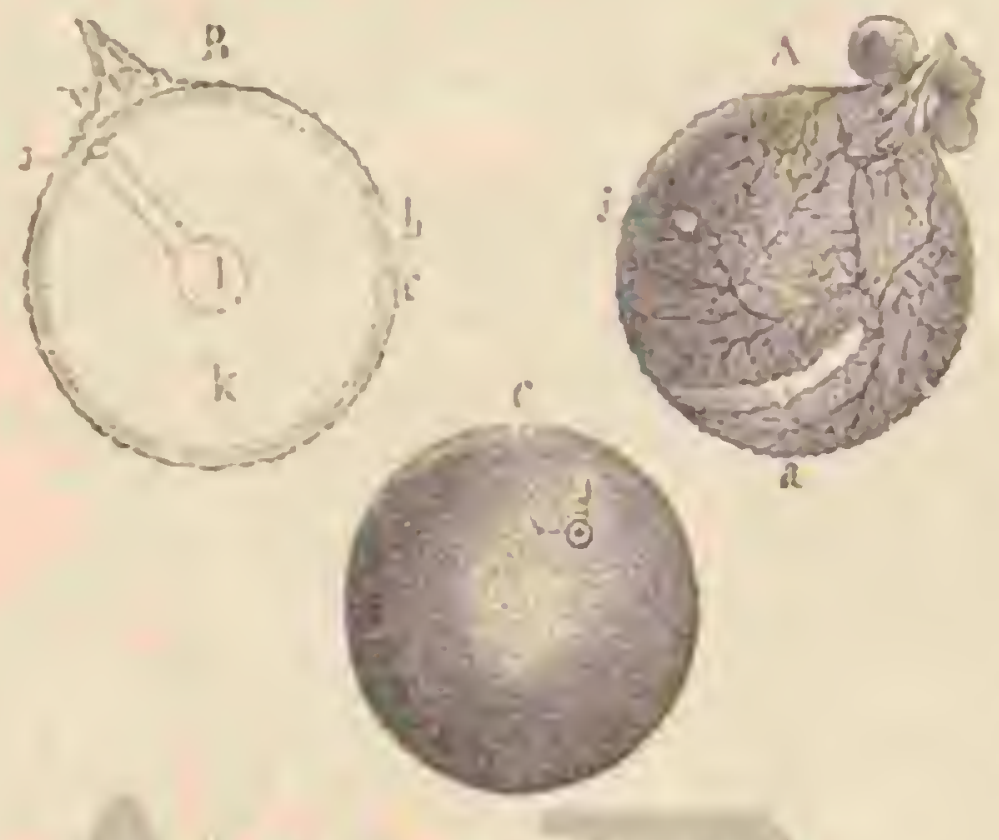

Fig. \&. -

incubacion varia con las circunstancias climatéricas, si bien dentro de límites muy reducidos para una inisma especie Las uriaciones son mucho mas considerables cuando se com. paran especies distintas; asi por ejemplo, el avestruz cutze sus huevos por espacio de 55 o 60 dias, y el coliuri de io a 12: el término medio puede ser de is á 26 . Ijl huero necesita para desarrollarse una temperatura de $30^{\circ}: 3 z^{\circ}$ centigra. dos; no es absolutamente necesario que la produrca la madre, pues se puede obtener artificialmente, hasta cierto punto. Plinio cuenta que Julia Augusta, esposa de l'iberio, consiguió sacar pollos, conservando los hucros en su seno;y hace mules de años que los egipcios sabian prescindir de las gallinas cluecas, sometiendo los huevosa un calorartificial constante. Si se martienen los huevos a una temperatura de $30^{\circ}$ por es. pacio de a 1 dias, se consigue seguramente sacar pollos.

Para desarrollarse necesita el germen respirar; asi es que todo huevo privado de oxigeno se malugra inialiblemente.

Al cabo de poco tiempo se deja scntir la influencia del calor: doce horas despues de comenzar in incubacion de un huero de gallina, ia cicatricula es ya mas visible, y los círcu. los blanquizcos que la rodean se agrandan y multiplican. A los dos dias aparece una pequeña piominencia, en el centro de la cual se designan las primeras lineas del embrion, en forma de pequeno cuerpo prolongado, que presenta el aspec. to de un bizcocho. Hacia el fin del segundo dia déjanse ya ver los clementos de la sangre, como otros tantos puntos rojos pecuucnos, lincas y myas convergentes que se anaszo. mosan formando una red.

Esta, la diferenciacion de los vasos, se muestra clara al ter cer dia; se unen estos en ramos y forman un punto nedio, el

(1) $A$, capsula orárica con un úrulo en la que ee ve la linea exan.

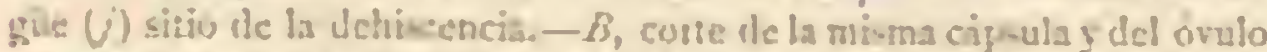

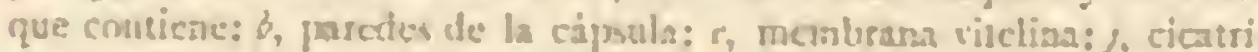
cula \& germen: $;$, redcula germinativa; $k$, yesma: $\ell$, ofera animal do la

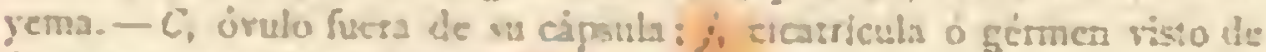
freste; :', sesicula germinativa. corazon, especie de tubo contorneado con tres dilataciones. 1 poco de llegar al término de su formacion comiena á con. tmerse y dilatarse alternatisamente; y entonces la vida no solo se hace perceprible sino que se asegura ciefnitivamente.

L.a cabeza se forma a expensas de tres vesiculas trasparen. tes entre las que se advierte un punto saliente completamen. te incoloro, que es el ojo. De una de ellas baja posteriormente una linea, formada por pequenas masas unidas de dos en dos: este es el esbozo y origen de la columna veriebral. Dos laminillas que sobresalen en su extremidad inferior marcan los contornos del abdómen; y se manifiestan los rudimentos del mesenterio, del estómago y de los intestinos.

Al cuarto dia se halla aumentado el volumen de la yema, ģนe al nismo tiempo se ruelve mas clata y fuida en tanto que la clarn disminuye $\{$ proporcion. Los vasos son ya de major volúmen y los injectos vasculares se multiplican; comiénzanse a distinguir las venas de las arterias; el gérmen se ha encorvado y la cabeza toca la cxirernidad caudal. Ia con. fornuacion del corazon es claramente perceptible; se ven los rasos del cerebro, las mandibulas indicadas, los rudimentos de las patas y de las alas y una masa gelatinosa de un gris rojizo que representa el lighado.

A los cinco dias se han desarrollado mucho los rasos, el comzon y los intestinos; el pecho está casi enteramente cu. bierto por las alas y por una protuberancia que parte de la columna vertebral; al concluir el quinto din se observan las primeras seîales de los pulmones; el corazon se rodea de una bolsa tmasparente y aparece ya clara la médula espinal.

A los seis dias la capa externa del biastoderno forma dos resiculas cerradas de las cuales la exterior constituirá el co. rion $y$ la interior, que abraza el gérmen, el amnios; en el ab. dómen del embrion se percibe un saco que crece por las con-

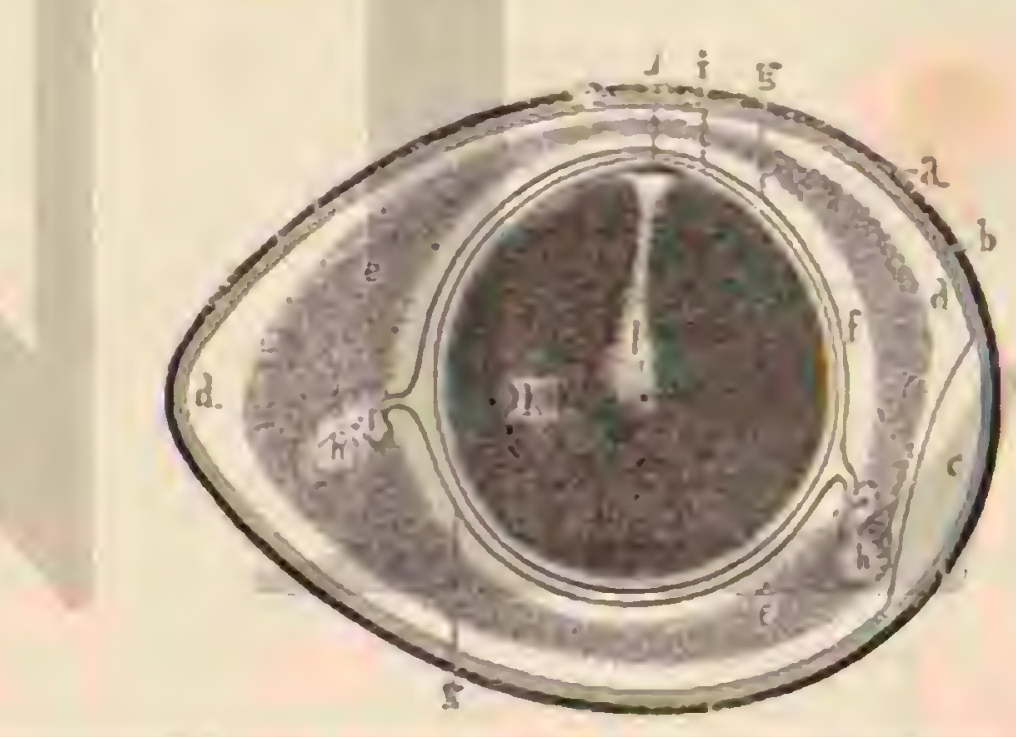

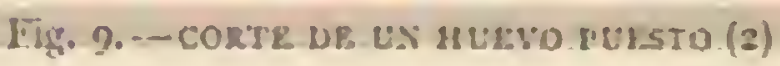

tribuciones de la clara y envia vasos al cuerpo de la pequeña placenta. Jas partes individualizadas ya del nuero organismo se pronuncian mas, y a veces al fin del dia comienza en el enbrion una especic de morimiento.

a los sietce dias nota casi libremente en el liquido amniótico, 5 tiene cerca de dos centimetros de largo; su cabeza es casi tan gruesa como el resto del cuerpo; el cerebro se presenta como una masa blanca y mucosa, pudiendo distinguirse los diversos elementos que han de constituirle Cuerpos gela. tinosos forman la columna veriebral; las costillas aparecen corno líneas pálidas; el esófago, el buche y el estúmago son muy visibles y se puede al menos percibir el bazo y la vejiga de is hiel.

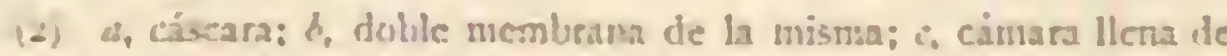

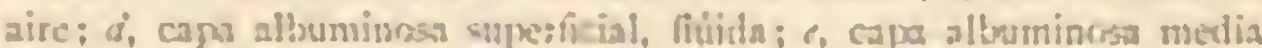

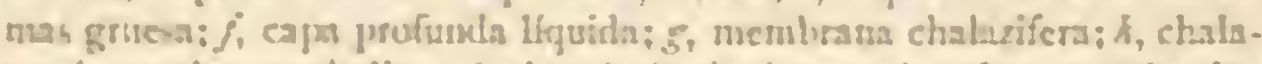

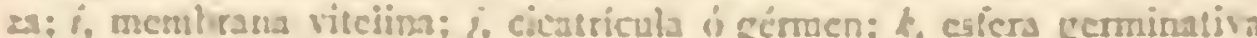
que desarrollinduse se lrz-forma en la eśrera animal $\%$, situaila cerea ile la meabrama situiina. 
Sigue el increniento del embrion durante el octavo dia $y$ se forman las epifisis del estemon; unas lineas blanquircas situadas al rededor de los rudimentos de los huesos, indican los músculos. Al noveno presenta la cabeza una prolongacion que será ia mandibula superior; el ojo muy grande está cubierto de párpados trasparentes; el corazon, ya desarrollado $y$ encerrado en el pericardio, late doce veces por minuto; el cerebro adquiere mas consistencia, y el rudimento de los cartilagros es perceptible.

Durante los dias décimn y undécimo crece el embrion has. ta alcanzar una longitud de cuatro centímetros; la cabeza, mas pequeña proporcionalmente q̨ue antes, está oculta entre las patas, y casi del todo cubierta par las alas; la vejiga de la hiel se llena del liquido que la caracteriza; la piel, muy pas. cular, presenta prominencias a través de las cuales saldrán mas tarde las plumas.

En los dos dias siguientes el embrion alcanza una longitud de cinco centimetros; el plumon apunta en la mbadilla, en el lomo, sobre las alas y en las ancas; designanse los miembros, y los dedos y los tarsos se cubren de tenues escamas blan. quecinas. Fórmase el pico y se endurece; el cerebro presenta casi su volúmen definitivo; el cráneo se osifica; los pulmones aparecen de tamaño proporcionado; reconócense los anillos de la tráquen, los tubos uriníferos, los uréteres, el orario $\mathrm{y}$ el oviducto. I.os músculos son todavia blancos é inconsistentes, pero visibles los tendones mas iuertes; los puntos de osifica. cion aparecen en la mayoria de los huesos.

En los otros dos dias llega el embrion \& una longitud de seis á siete centimctros; el pico y las fálanges mucstran una envoltura córnea y apuntan las plumas de las alas; cuando se hostiga al polluclo abre y cicra el pico.

Desde el décimosexto al décimonoveno dia la piel ocupa toda la superficie interior del huevo; desaparece la clara y la bolsa vitelina se contrae y penetra sucesivamente en la cari. dad del abdómen á través de la abertura umbilical. El plumaje se completa. El embrion está encerrado en la cavidad amniótica, replegado sobre si mismo, con la cabeza a los lá. dos del pecho, cubierta por el ala derecha, y dobladas las patas debajo del vientre. Se mueve con mucháactividad, abre y cierra el pico, aspira el aire, y pia algunas veces débilmente. La cabeza está desarrollada, y el cerebro tiene su forma definitiva. La produccion del calor es escasa rodavia.

En los dos últimos dias es absorbido enteramente el vite. lus en la cavidad abdominal; el ieto liena totalmente el huero; respira, pia y saca la lengua como si se tirase de ella. Algunas horas antes de ver la lua, à los veintiun dias, agitase en todos sentidos: toca la costra caliza con una punta de que se halla provisto el pico, y forma grietas y aberturas haciendo saltas pedacitos del cascaron. Este se rompe al fin, y la pe. q̨ueña ave, estirando las patas, saca la cabeza de debajo del ala 5 abandona su prision.

Pocas aves son tan vigorosas como el pallo de la gallina doméstica al salir del huevo; ni son muchas tampoco las que como él se hallan en estado de tomar por si mismas el alimento $y$ vivir sin ajeno auxilio pocos minutos despues de salir del cascaron. Las que han de estar mejor dotadas en lo sucesivo en punto á fuerza y agilidad son precisamente al nacer las mas desvalidas; aquellas que se construyen un nido aéreo salen al mundo provistas de pluma y de sentidos desarrollados, en tanto que las de nicio ierrestre están entónces desnudas y ciegas; las primeras producen desde su infancia una grata impresion, porque en cierto modo son criaturas completas, asi como las segundas la causan solo de miseria y frialdad.

El desarrollo posterior de las aves hasta la época del vuelo dura mas $\delta$ menos tiempo: las pequerias que fabrican un nido, pueden servirse de sus alas al cabo de tres semanas; las marores á los tres meses, y lay algunas que necesitan varios anos para igualarse con sus padres. La infancia de es. tos séres no se termina, en efecto, cuando cmprenden su ruelo, sino cuando se cubren de su definitivo plumaje. Muchos tienen primero uno completamente distinto del de sus padres; en ocasiones se asemeja este al de la madre y es sus. tituido despues por el propio de su sexo. Algunas rapaces no son adultas hasta despurues de algunos anos.

MUDAS، - Todos los cambios de plumaje resultan del desgaste, de la transformacion de color y de la muda; es decir, de la caida de las plumas y aparicion de otras nuevas.

El desgaste de las plumas aumenta algunas veces su be. lleza, porque las extremidades de estas, á menudo descolori. das, soni eliminadas completamente y entonces la parte media de las mismas, de tintes mas vivos, es la que aparece á la vista.

lin cuanto á los cambios parciales de color en el plumaje, que varios naturalistas han querido negar, es un hecho que no se ha explicado, pero del cual no puede dudarse. Los pequeños pigargos, por ejemplo, tienen un plumaje oscuro bastante uniforme, al paso que en los adultos son blancas la cola por lo menos, y cn ciertas variedades la cabc\%a tam. bien: y sin embargo, ni las pennas caudales, ni las plumas de la cabeza caen con la muda: solo cambian de tinte las pennas rectrices, en las que es fácil la observacion; presentan desde luego puntos blancos que se muitiplican, se agrandan, y confunden finalmente unos con otros, volviéndose las plu. mas totalmente blancas. El cómo tiene lugar en muchas aves el cambio del primer plumaje por una mera mutacion de color 6 por mutacion parcial de color y de plumas, es un fenóineno que no conocemos aun bien; mas la existencia de estos hechos no puede ponerse ya en duda.

La muda se verifica cuando el desgaste, la influencia de la lur, del polro y de la humedad han dejado á las plumas mas 6 inenos incapaces de llenar sus funciones; despues del periodo de la incubacion es cuando principalmente se verifica este cambio, probablemente a consecuencia del estado febril en que se encuentra d ave durante el. Comienza la muda por diferentes regiones del cuerpo, pero se ojera siempre simétricamente en sus dos mitades. En nuchas especies no alcanza la primera muda mas que á las peçueñas plumas del cuerpo y hasta la segunda no cacn las pennas de las alas y de la cola. Para ciertas aves pasan varios años antes que aquellas se renucven por compleio, porque no se desprenden sino dos cadia año; en otras es, por el contrario, la muda tan rópida, que durante cierto tiempo están incapaci. zadas para volar.

De no estar enferma el ave, cada muda le reviste de un plumaje mas brillante que, al contrario de lo que ocurre en otros animales, se embellece cada ve\% mas, á medida que el individuo va envejeciendo. Si la muda se interrumpe, el ave picrde la salud, porque la nueva fase de su plumaje es una condicion necesaria de su vida

EDAD. - El térnino medio de la vida del are cambia con su tamniso y acaso con la duracion de su primera edad de desarrollo. En general puede asegurarse que alcanza una larga existencir Los canarios, bien cuidados, viven tanto como los perros caseros: esto es, doce, quince, diez y ocho años: y en libertad, cuando una circunstancia accidental no acarrea su inuerte, aun se prolonga mas su iejez. Sc cuenta de águilas enjauladas que han vivido mas de un siglo, y de muchos papagayos que alcanzan la vida humana.

ENFERMEDADES، - las ares libres no suelen padecer enfermedades; las mas perecen entre las garras de otras car. nivoras mas poderosas por su tamano of fuerza. Se ha obser. 
vado, no obstante, que ciertasequidemias ocasionan la muerte à los individuos de um misma especie: los sometidos á cau. tividad y las especies ó razas domésticas se hallan sujetos a ciertas eniermedades que son generalmente mortales.

Rara vez se encuentran en el campo cadáreres de aves, y si solo a veces el de alguna de gran talla, que langa sucum. bido de muerte natuml. Muchas perecen sin que sepamos cónde ni cómo; de vez en cuando arroja el mar à la playa los restos de algun ave acuática, \& se encuentran aigunas en los sitios donde acostumbraná pasar la noche; pero los cuer. pos de las mas desaparecen siempre, cual si la naturaleza misma se encargase de sepultarlos.

GENERO DE VIDA.- - Niugun sér, he dicho en mi Vida del äe, despliega lanta actividad como el pájaro en su vida ordinaria; ninguno aprovecha tanto el ticmpo como ćl: el dia mas largo no le basta; la noche mas corta se prolonga demasiado; siempreactivo, no puede pasar la mirad de su existencia durmiendo ó aleturgado; quiere crecer, agitarse, medir alegremente todo el tiempo que se le ha conce. dido.

lodas las aves sc despiertan pronto del corto sucio noc. iurno: las mas no duermen ya cuando los primeros albores de la aurora comienzan á teilir el horizonte. En las regiones polares no hacen diferencia mientras el sol alumbra entre lo que corresponde à dia y noche. He oido el canto del cuclillo a media noche, $y$ á las primeras horas de la maiana contumaba el prijato con la misma actividad, sin upe por cilo descansara despues en todo el dia. Algunas horas de la no. che y pocos minutos mientras brilla el sol, parecen bastarle para su reproso. lis sabido q̨ue nuestras gallinas domésticas entran en su gallinero antes de anochecer; pero no se duermen en seguiday, en cambio, el cacareo que se oye por la mañara nos indica que ires horas de sueno han sido suff. cientes para prepararse a un dia de largas fatigas. Lo mismo sucede en la mayor parte de las aves; únicamente las grandes rapitces, y sobre todo, el buitre, parecen tardar mas en abanconar el sitio de reposo.

Elave, desde que poste voz, saluda con su canto la llegada del dia, al menos en la éryoca del celo, en que el amor ngita su existencia, $y$ arabado su himno busca el alimento. Casj todos los xéres de esta clase comen dos veces al dia, una por la mañana y otra por la tarde y consagran medio dia al reposo y ordenacion de su piumaje. Hay en esta regla ex cepciones en las que aprovechan para su alimento circunstancias farorables. Ians mpaces no hacen casi mas de una comida; las çue entre cllas se alimentan de restos animales y no cogen-por si nismas la presa, no encueniran de comer cuanco quieren, y deben á menudo sufrir hambre durante largas horas. En general el are come al dia lo que encuentra: solo algunas, como el pico y. otras trepadoras, hacen provisiones, guardánciolas en ciertos sirios y. previniéndose al par contra los rigores del invierno.

Despues de tomar su alimento va el ave á beber y a ba. harse: mas para esto le sirve inuchas veces la arena, el polvo o la nicre, en se\% del agua. Eil cuidado de su plumaje, sobre todo, si se halla en desiavorable estado, llev mucho tiempo al ave. Despues del bain le seca sacudiéndole, erizandole, para precipizar la operacion, 5 haciendo sacudir cada una de las plumas; las frosa despues con la grasa que produce la glándula de la cola, y la exriende por su cuerpo con la ayuda del pico, irotando en todos los sitios hasta donde puede alcanzar con dl; para los inaccesibles de esta suerte se vale de la parte posterior de la cabeza. Ordena y extiende una vez. mas cada pluma, cuidando sobre todo de las que le adornan, como las de la cola y las timonerns; sacude de nucivo todo el plumaje, se pone las plumas en su sitio, y se muestra sa- tisfecha cuando lo ha dejado todo en orden. Entrégase despues algun tiempo al descanso, digicre y vuelle á cazar.

Cuando el ave ha tenido la formua de hallar suriciente alimento, se dirige yor la tarde á un sitio determinado donde se reune con otros individuos de su especie. El prajaro canior despliega entonces todos los tesoros de su ruz y luego se entrega al descanso, ya en sociedad o $y$, en el periodo del celo, cerea del nido donde empolla su hembra ó estan sus desvalidos hijuelos, en el caso de no llevarios consigo; pero no se entrega todavia al reposo sin entonar una larga plega. ria, con variados gorjios, gritos de alarma y lamentos, hasia que al tin la fatiga le vence. El mal tiempo interrunipe la regularidad de esta vida apacible, pues las aves se sienten influidas sobremanera por los agentes atmosféricos.

CELO Y REPRODUCCION. - Cuando ia naturaleza se desprierta, has aves lo hacen tambien. In todas partes, en efecto, se declara el periodo del celo en la primavera; en los trópicos ocurre esto al principiar la estacion de las lluvias, que, segun se ha dicho varias veces, corresponde á nuestra primavera y no al invierno. A diferencia, en tal respecto, de otros animales, los de la clase que nos ocupa viven en union conyuggal dusante su vida. Muy pocos se conducen como los maniferos, en los cuales el macho ó vive habizualnente con varias hembras ú ofrece el ejemplo de una poligamia pasajera durante la época del celo. Cada pareja, una vez constituidin, es en las aves un modelo de fidelidad, y muy excepcionalmente se da el caso de que uno de los sexos, poseido de una pasion violenta, quebrante las lejes conjugales. Mas como por lo general las hembras son mas numerosas que los machos, sucede que algunos de estos, viudos ó jóvenes, ronden las hermbras apareadas; y les disculpa qque sus esposos no tienen bastante respeto siempre $\{$ los funes santos del matrimonio y buscan mas bien en sis compañera una especje de novia, que se proponen monopolizar. In consecuencia natural de semejante audacia es ųuc el macho irata vivamente de hacer desistir de sus propósitos al impertinente intruso, y esto en ciertos casos por vias de hecho, dando margen al las peleas que se traban en la época del celo. Pro. bablemente cada marido hace malas partidas y acaso padece su hembra del pecado de la noveleria; en fín, como quiera que sea, él recurre á sus fuerzas para conservar el bien que posce. Su emulacion, su furia implacable, deben disculparse en tales circunstancias. A veces las hembras en presencia del raptor toman parte auxiliando al marido y iuchando con el; pero la mayoria se alejan del camino de la virtud, vien. do solo en su esposo uno de tantos esposos. Se han he. cho en este punto observacionts curiosisimas: hănse visto lrembras que tomaron un nuevo companero a la media hora de haber sido muerto el anterior; perecer igunlmente el se. gundo á mano de un enemigo y aceptar inmediatamente un tercero. Por lo regular, los maclsos maniticstan mas senti. uniento que las hemuras el dia gqué experimentan pérdida se. mejante, probablemente porque les es mas dificil hallar nueva compañera.

Los machos hacen todas las finezas y esfuerzos imagina. bles para cautivar la atencion de las hembras y obtener sus favores; unos canian impacientes y. las llaman, otros salian y vuelan al rededor de ellas desplegando todas sus gracins. A veces las demosiraciones se hncen violentas, y sucede que el macho varsigue a la hembra horas enicras, mientras clia pa. rece rechazarle enojada; pero lo mas frecuente es que no resista largo tiempo y se rinda con completo abandono.

El amor no es menos poderoso para con la hembra que para con el macho, y les domina con el mismo impeiu en la jurentud que en la edad madura. Hermann Muller cuenta el caso de un canario de seis semanas con el que hubian en- 
cerrado á su propia madre con objeto de obtener descen. dencia: esta puso primero en julio un huevo que dió una hembra mestiza de jilguero y canario, y doce años mas tarde incubaba con major celo varios huevos de canarios machos. El mismo profundo y atento observador nota que la tristeza ocasionada por la privacion de los goces de la familia es mas fuerte cuando se hallan aprisionados dos individuos del mismo sexo. Los machos de la clase de las ares aman como los hombres $y$ las hembras como las mujeres; los dos sexos tienden a cambiar su personalidad por la superior que resulta del matrimonio.

En el momento de st:5 amores, busca la pareja para construir su nido un sitio conveniente, donde se estabiece y vuclie los ninos sucesivos; por lo regular le sitúa en el centro del espacio elegido para su dominio, que varia segun las especius. En caso necesario se acomoda i coiocar en cuá. quier parte el templo de sus amores: en lo alto como en lo bajo, sobro el agua como solure la tierra, en el bosque como en el despoblado. En las condiciones normáles, las rapaces forman el suyo a una gran altura y muy rara rez cerca del suelo, donde anidan casi todas las corredoras; los pájaros arboricolas $y$ de los bosgues hacen su nido sobre una rama, eligiendo las altas, en los huecos naturales ó fabricados por ellos, en tierra ó soòre un lecho de rnusgo, ctc; las aves de los pantanos en medio de los juncos y cañayerales, cn el cieno' y yerbas acuaticas, en los pequeños isloies 6 , en fin, flotantes en la superficie del líquido. Las aves marinas anidan en las costas bravas y en las cavidicies que ellas mismas abren. Todo cuanto puede decirse sobre este punto, hablan. do en general, es que el nido esti oculto á los enemigos en sitios donde no le descubre la vista; y que cuando se halla al aire libre ocupa una posicion inaccesible'a menudo, $\delta$ bien está colocado de tal modo que no se le puede divisar fácil. mente. Li forma del nido no es constante en un mismo órden ó ramilia: deprende de la localidad, observíndose en este concépto las mayores diferencias entre los representantes de un mismo grupo.

El hombre iniluye frecuenicmente de una manera pode. rosa en la eleccion que hace el are de los sitios en gue se propone anidar; y esto inconscientemente, construyenda nue. vas moradas ó abandonando las antiguas. Todas las especies de Suabia que incuban en las casas se han acomodado á csto, abandonando la predileccion de sus antepasados por anidar en las rocas y huecos de los árbo!es, y adoptan actualmente piara hacerlo un sitio u otro segun los casos; los gorriones y la silvia roja doméstica, las aves nocturnas, las lechuzas, las espe. cies (que anidan en las torres, los cuervos, el estornimo guar. dian, la upupa y otras muchas se han hecho habitantes de nuestras casas sin invitacion por parte del hombre; asi como el estornino comun y las golondrinas la han aceztado. De otra manera inlluje en estè respecto el trabajo humano cor. tando los árboles anosos ó barrenando las rocas, 10 cual ha obligado á ciertos pojaros a buscarse alojamientos en las cavidades de la tierra.

Los nidos mas sencillos son los de las especies que, sin preparativo alguno, anidan en rierra; siguen á estos los de açuellas que por lo menos practican una pequeña excaracion donde depositan sus huevos; y en tercer término figuran los de las aves que tapizan esta cavidad con materias blandas. Obsérvase la misma gradacion para los pájaros que constru. yen sus nidos en agujeros nque para los que los ponen flotantes, aunq̧ı, como se comprende fúcilmente, estos últimos tienen que fabricar ante todo $y$ en todos los casos un piso sobre que descanse su morada. lin las construcciones de las nue anidan en los árboles se notan tantas diferencias como en las espe. cies inismas que los fabrican: contentanse unas con formar un monton de mmaje seco: las otras levantan una verdadera ar. mazon; aves hay que pmctican excavaciones y algunas de ellas las cubren de ramaje fino, yerbas, raices, pelos y plumas; varias anaden una especie de tejadillo para resguardarse me. jor; y algunas, en fin, hacen la entrada en forma de galería. Entre los hatitantes de las mamas figuran en primer termino las tejedoras quue no se sirven solo de yerbas, sino que tejen verdaderas telas regetales con los filamentos quie encuentran ó preparan jor si mismas. Pero enire todas las ares, los me. jores arquitectos son $\sin$ disputa los siteles, que construyen las sólidas paredes de su nido con esa arcilla grasa llamada lehm, que cieslien en su saliva: unos emplean la arcilla sola, otros la mezclan con sustancias vegetales, musgro, hojas, que salivan de la misma mancra, y otros se sirren exclusivamente de estas úlimas, sin materia mineral, las cuales se endurecen al contacto del aire.

Por reyla general las ares construyen los nidos con el exclusivo objeto de poner los huevos y para que sirvan de cuna y habitacion a ios hijuclos; pero algunas fabricar nidos para su recreo y para habitacion durante el invierno. Tal es lo que sé obsersa en rarios ploceideos, en el petilorinco, el clamidero manchado y en cierta especic de los pantanos, cuyo nido gigantesco esti dividido en un compartimiento destinado a la incubacion y salon de descanso y otro á comer y hacer centinela. Deben igualmente mencionarse en esta categoria los de los fiés, que duermen sicmpre en los huecos de los árboles, y los de los gorriones, que pasan tranquilamenic las noches de invierno en nidos muy abrigndos.

Si bien en general cada especic emplea constaniemente los mismos materiales para sus construcciones, acomodindolos álas circunstancias, se muestran á reces nuulables y capri. chosas en este respecto sin razon especial conocida. Productos del arte humano, que los preducesores de los pajaros que hoy viven nunca aqurovechaban para fabricar sus nidos, son utilizados por estos tiltimos; tales como las enrolturas de algodon, plantas usadas para el embalaje y otros despojos. Los pajaros cautivos prescinden no pocas reces de aquellos ma. teriales dé quue se sirven en el estado cie libertad, yal contra. rio, se aprovechan de otros que en dicho estado jamás utilizan.

La hembra construye su nido secundada con frecuencia por el macho: esta regla general no deja de tener excepciones, por ejemplo en las tejedoras, en que el macho fabrica solo y su compañer contribuye a lo mas a la obra colocán. dose algunas veces en el interior del nido. En las mas de las especies el macho vela por la seguridad de la vivienda, haciendo centinela, y solo en aquellas que visen en poligamia es donde se observa que no se tome el macho sencjante cujdado. Duranie la construccion del nido, cste distrae a la hembra con su charla y sus cantos.

El trabajo de fabricacion de la vivienda requiere la mayor actividad y perseverancia, yen lo posible, el no ser interrum. pido; aveces, por el contrario, debe ser comenzado y aban. donado alternatisamente. Exige la obra por una parte trabajo mental de insentiva, y material de otro para el tmsporte de materiales, $y$ ambos reclaman aislamiento y reposo. Las materias son arrancadas de los árboles con el pico y las patas, ó tomadas del sucloy las aguas; las trasporta despues la hem. bra por el aire; y las talla, pliega é hila con el pico, para de. jarlas, en fin, en el sitio donde deben ser utilizadas. Con la ayucia del macho encorva las ramas que ha arrancado con las patas, $y$ las comprime unas con otras con el pecho.

De una carta que me escribe Hermann. Muller, a cuya larga carrera se deben tantas delicadas observaciones, reproduz$\mathrm{CO}$, en parte extractado y en parie textualmente, el siguiente cuadro sobre el modo cómo las parejas construyen sis vi. viendas. 
Las aves, cuando están tranquilas, echan en la excavacion interior del nido los materiales de que van a construirle, $y$ despues los comprimen, los arregian cuidadosamente con el pico y los guarecen con esmero bajo su clierryo. Sirvense con preferencia de las patas para disiribuir y repartir las ramitas con una habilidad admirab!c, apretindolas para darles firme. 2a. La forma de la cavidad interior la dan con el pecho, to cual ejecuta el ave girando dentro de ella con la cola vertical; por esto el muro del nido es pendiente por la parte superior, donde recibe su forma por el trabajo variable del pecho, parte anterior de las alas y cuello; el borde del mismo es moldeado con la porcion inferior del pico: pero principal. mente mediante un movimiento rápido y de báscula de la cola, y despues alisado por los repliegues de debajo del pico.
Largo tiempo la ocupa el prévio encorvamiento con el pico de las pajitas y escarnas de arcilla que ha de emplear el pequeño arrista en su obra La previsora ave silvestre deja por fueray por dentro del nido algunas pajitas salientes, $y$ de este modo puede agrandarle en caso de hacerse insuficiente, elevando sus muros; una vez dispuesto todo, coloca en él sus huevos.

Ciertas aves fabrican sus nidos en comunidad: las hem. bras colocan los huevos juntos y los cubren alternativamen. te; otras, constituidas en bandadas, forman una vasta construccion, dividida en varios compartimientos para cada familia, y otms en fin fabrican su nido continuo con el de otra especie, a veces debajo de este, anidando en compania de su propietario.

Por lo que se refiere $\mathfrak{a}$ la puesta, Hermann Muller se ha

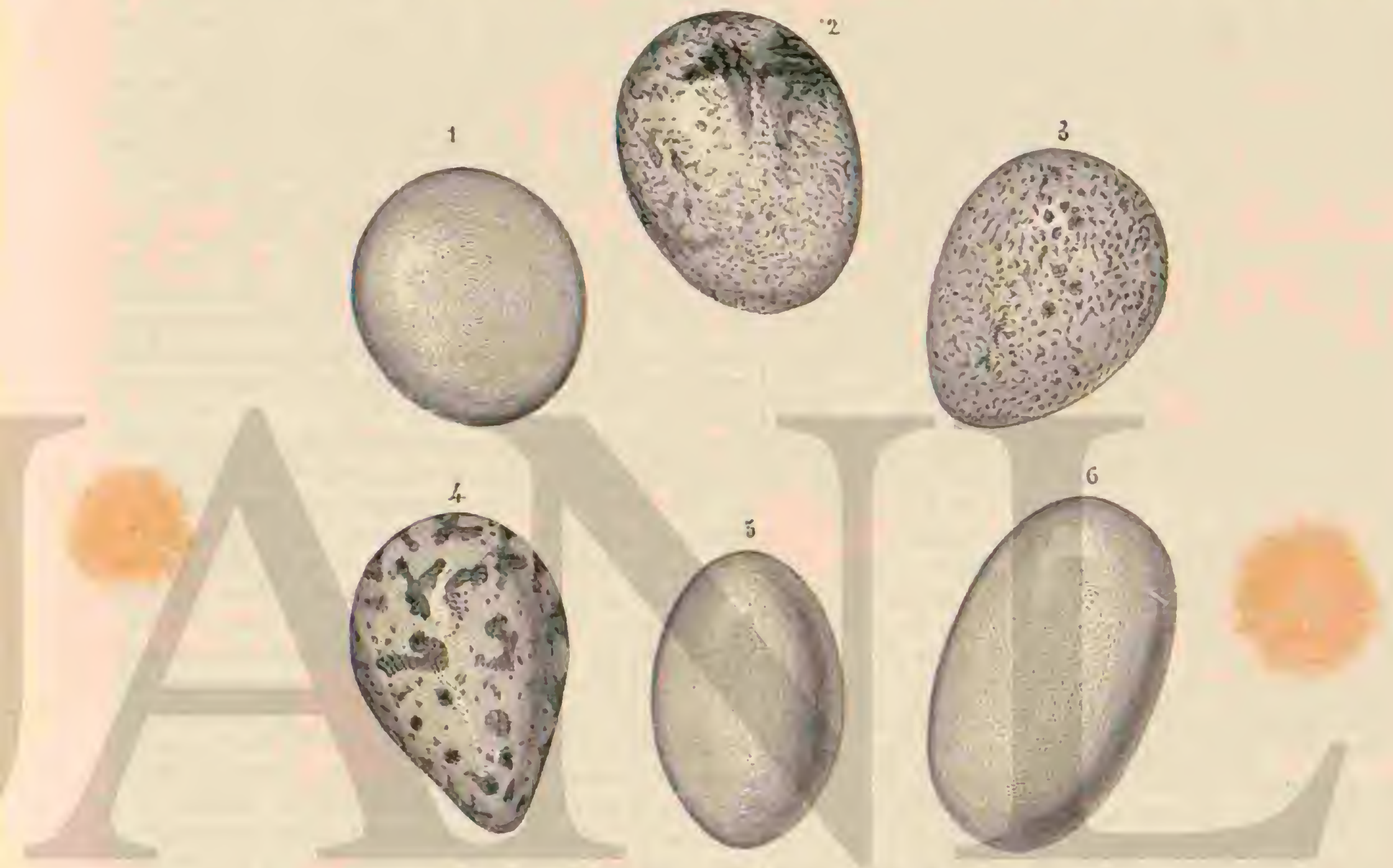

Fig. 10. - rORMAS 8RISCrSALE DE LOS IUEVOS DT. LAS AVES (1)

servido conunicarme observaciones muy escrupulosas y pre. cisas, con destino á uni eVida de los animales. G La mayoria de las aves ponen por la mañana entre las cinco y las nueve y con preferencia a una hora fija Li trabijo de la puesta desde su comienzo hasta que el ave sale del nido ocupa uria media liora, pero no de un mocio tan constante que no pueda este tiempo prolongarse $\delta$ acortarse. Ya durante el dia en que ziene lugar $y$ á reces desde la media noche de la vis. pera se adivina que el ave va á poner por la extraordinaria cantidad que toma de alimento y granitos de arena 6 caliza Movimientos vivos y vuelos inquictos en torno de su morada parecen prepararla para la expulsion del huero. Empieza đá agitarse y se desliza en el nido. Esta agitacion se manifiesta por una respiracion entrecortada con el pica medio cermodo, la elevacion de la parte anterior del cuerpo con movimien. tos tenblorosos y el consiguiente descenso de las alas. Para ejecutar la puesta el pájaro abre mucho el pico, ejerce so. bre el oviducto una compresion visible y el huevo sale al exterior. La agitacion es en este momento corta, pero muy manifiesta, pues el ave en vez de descansar completamente Toso III en el nido, permanece algunos monentos erguida sobre sus patas rigidas, probablemente para no tocar nada con su irritado cuerpo. Pasado este momento, se echa, abandonándose con voluptuosidad en su lecho y comienza a regocijarse. Eista alegria no procede de la cesacion del dalor sino de la satisfacción de ser madre, puesto que se repjite no pocas ve. ces durante la incubacion, cuando ya debe laber olvidado la pasada angustia, y en cambio no riene lugar cuando no incuba su puesta. La pequeijez del huevo no basta para ha. cer variar las manifestaciones del fenómeno fisiológico; por ejemplo, para suprimir la agiracion que le acompañas Des. de que la hembra comienza 1 poner, aumenta el calor de incubacion; entra en una cspecie de estado febril y ninuchos afirman que caen las plumas de dirersas partes del cuerpo, sobre todo las llamadas de incubacion. Ia madre es casi siempre la que toma los principales cuidacios para el des.

(1) I, esférico di globular (huero de lechurs): 2, oral (hucro de ga. vilun f: 3 orsdo (huero de presdiz); \& oriconico (huem de chocha); 5. eliprico (huevo de colimbo); 6, cilindrico (hueso de ganga). 
arrollo de los huevos; no los abandona desde el medio dia hasta la manana del siguiente, en que lo hace solo el tiempo preciso para ir á comer, durante el cual la reemplaza el ma. cho. Algunas veces, no obstante, el trabajo se reparte por igual entre los dos sexos y los avestruces dan el ejemplo único de que el macho sea el que incuba. La ayuda indispensable del espyoso para evitar el enfriamiento nocivo del huevo es tolerada por muchas hembras, pero no vista con compla cencia por ellas a juzgar por su actitud de dlesconfinnza. \$1. gunas distrien su tiempo durante la incubacion con la compañia del macho, que en algunas especies penetra en el nido y vela sin cesar durante este periodo. La mayor parte de los machos se da á conocer por su actitud de defensores de su familia dando de ella incontestables prucbas.

Casi todas las aves, segun dice Hermann Muller, proceden con la mayor precaucion al entrar en el nido y salir de él cuando incuban. « Se acercan §h hurtadillas, detiénense algu nos mómentos junto al borde, miran con atencion lós huevos y su posicion, saltan al hoyo con las piernas y dedos entrc. abiertos, empuian con el pico ó con la barba los huevos para colocarlos debajo del vientre, entran despues completa. mente en el nido, muévense hácin atrás para poner los hue. vos cebajo de las plumas, aranzan de nuevo, erizan las plu. mas sacudiéndose en todos sentidō, extienden las alas y la cola sobre el borde del nido y cubren de este modo cuanto es posible los huevos, para preservarlos de la atmósfera exteribt. D Jas aves acuáticas no olvidan nunca secar cuidadosariente su plumaje cuancio salen del agua para ponerse en el nido. Al hacer el ave el movimiento retrógrado de que antes hroblamos, las huevos cambian por lo regular de posicion, pero segun las observaciones de Hermann Muller, no dan una vuelta sobre st eje, sino que se mueven horizonzalmen. te, y segun parece, esto sucede solo cnsualmente.

* La hembra procura poner los huevos todo lo posible debajo deli plumaje, sin hacer aprecio de su posicion. Al aban. donar cl vido, las aves comienzan por estirar las piernas há cia atrás, arquean el dorso, vuclven el cuello y lá caberá, entreabren las alas, se enderezan, y solo despues saltan lige ramente fucra. Antes do alcjarse las especies cuja plumazon se desprende cuando incuban, cubren con él los huevos: otras lo hacen con tierrió arena, pero las mas no adoptan esta precaucion. Las aves no tienen inteligencia para reconocer lo que contiene su nido y la naturaleza de los huevos, pues cubren los suyos con igual aficion que los de oiras especies, y hasta empollan algun ticmpo anies de poner, objetos extranos, como nueces, bolas, -piedras, etc.

*os huevos medio incubados 6 podridos tienen para ellas el mismo valor; no hacen caso de los que caen del nicio, cunl si supieran que scria en vano incubarlos mas. Ln cambio cuando la colocacion de los huevos se ha desordenado por alguna causa, los van mudando de sitio hasta que los cubren todos nuevamente.

Casi sicmpre se resienten mucho cuando baja la temperatura exterior; se entristecen si el tiempo es frio, y no vuelven á estar alegres hasta que ocurre un cambio favorable. Ei mayor calor del ave durante todo el periodo de la incuba. cion, comienza tres ó cuatro dias despues de la salida del primer polluelo y favorece por lo tanto of menudo à los que nacen mas tarde.

- El desarrollo del feto en una misma incubación no se rerifica siempre con iguales condiciones; : cuando la henbra cubre los huevos regularmente sucede a veces lo contrario, saliendo algunos hijuelos uno ó varios dias mas tarde. De ordinario suclen salir á luz en las horas de la mañana; ma vez sucede lo contrario. Los padres no ajudan á su progenie cuando en el interior de la cáscara trabaja para romperla; no sabemos alun con certeza cómo proceden los polluclo para librarse de su prision; pero lo cierto es quue hacen bas tante ruido en el interios del huevo, como puede observars en uno de gallina. Las madres demuestran que oyen est rumor, jues miran con frecuencia y atencion; pero no pue den prestar auxilio. Cuando se escucha atentamente; parec que el continuo picar del polluelo en la císcara es lo qu produce el ruido. Al fin se rompe esta del modo arriba des crito y regularmente por el sitio en que se halla la membran interior extendida en la cxtremidad obtusa; sin embargo, n sucede asi siempre; algunas veces se abren varios agujeros a rededor de la ć́scara. Eil polluelo, empujando con los piés déjala rota; y en el nismo instante los padres la recogen, par llevársela a veces muy léjos del nido; algunos se la comen co mucho gusto. L.os polluelos que aun estan pegados á cáscara corren peligro de ser arrastrados con ella fuera de nido. Despues de haber limpiado este, la madre ruelve á c colocíndose cuidadosamente: se apoya por derecha é irquic da en las paredes para no comprimir ó hacer daño a su tiemos hijuelos, y comunicales ante todo calor. En los pr meros cuatro á siete dias sepárase de cllos lo menus posib! y sicmpre por muy corto tiempo; trascurrido este término, trasporte de marores cantidades de alimento exige cambio esenciales. Ias especies pequeñas cubren comunmente lo polluelós de dia y de noche hasta que han salido las pluma del dorso. A mediona que los pequeños crecen, la madre can bia de posicion en el nido, poniendo sus piés sobre el lom de asjuellos, pero tan ligeramente que no Jos molesta de ni gun modo.

- Los pequenos mismos, cuando han dejado la cáscara, col can la cabeza en el interior del nido, sirviéndose de los hueve que aun quedan como de cabeccras; y cuando ga no hay ni guno apojan la cabera ó el cuello uno sobre otro; el que es debajo de todos debe estirarse y sacudirse mucho para evit la presion. Los pequeños lináridos son ỵa al cuarto dia de vida bastante robustos para revolversey descansar su cabe en la pared del nido. Cuando tienen demasiado calor ba el pecho de la madre alargan i menudo sus cabecitas, cc los picos num abiertos, fuera del plumaje de aņuella, cual temieran sofocarse. Las madres cuidadosas saben natura mente lo que convicne á sus hijuelos, y no se dejan molest por ellos en sus obligaciones. Una hembra de linárido, obse vada por mi, sujetaba continuamente las roluminosas cabez de las pirrulas que empollaba porque estas, ya al quinto d colocribanlas sobre el borde del nido, con lo cual molestab. tal vez à la madre. Otra hembra jóven é inexperta de la m ma especie, creyendo ver siempre en los picos muy abiert de su primera cria una schal de hambre, llenśbalos de pa lla aunque tenian los buches repletos. Los polluelos prefer: entonces retirar sus cabezas.

- Hasta las arecillas mas pequeñas se agarran con las ui a los materiales del nido cuando sienten que se las qui coger: lo mismo proceden cuando suben por la pared del ni para hacer sus deposiciones, ó cuando cjecutan los prime ejercicios de ruelo: de este modo procuran evitar una cal eventual. Despues de la primera comida sc les ve ya alete poco a poco adquieren inas fuerza, y obtienen al fin graciosa ligereza nue observamos en los gorriones pequeñ - Sienten su primera molestia cuando la madre deja el ni 6 cuando la temperatura baja; entonces tiemblan las ala todo el cuerpo de los polluelos, y quizás aumente por es rápidos movimientos la circulacion de la sangre y el ca interno.

Un canario hace las primeras tentativas sérias para vo al décimosexto dia de su vida. Los polluelos de las espe que jasan los primeros dias de su vida en el nido, son co 
los monos pequeños: el ejemplo induce a la imitacion. Es muy divertido ver á un pequeno cuando empieza á mover sus alas aun desnudas, y cuando inmediatamente despues todos sus hermanitos siguen el ejemplo. Los primeros movimientos para andar no los hacen con los dedos, sino con el talon; si las avecillas tienen prisa, inclinanse hácia adelante, y avanzan valiendose de las alas. No he podido observar cuando comienza la actividad de los piés, á causa del plumaje que sobre ellos se desarrolla. Los lináridos pequeños abren sus ojos al quinto dia de su vida; pero no completamente hasta el décimo.

Inmediatamente despues de haberse secado, los peq̨uchos empiczan a dejar oir su voz. Entre los canarios, jilgueros, espinidos y pirrulas que incubaban en una habitacion, los canarios fueron los jurimeros en gritar, y con bastante fuerza; despues lo hicieron, mas débiimente, los jilgueros y esplinidos: y por último, con voz menos fuerte aun. las pírulas, cual si ya en los primeros sonidos quisieran indicar las facul. tades de canto que mas tarde desarrollan. Hostos sonidos no indican de ningun modo hambre; muy por el contrario, expresan el bienestar, pues callan al punio cuando se levanta la madre y el aire fresco penetra en el nido. Ff desarrollo del cuerpo no gunrda proporcion con el de la voz; los canarios no pian con mas vigor al quinto ó sexto dia que el primero: despues de abrir los ojos grian con mas fuerza, pero solo cunado tienen mucha hambre ó envidia unos de otros. Si se les presenta algo sospechoso, guardan silencio al punto, ochitanse en el nido. En las pirrulas pequeñas se verifica ol cambio de la 10\% en el décimocuarto dia de su vida, los canarios machos indican ya en el nido su sexo por una especic de ronquido; lo mismo hacen los espinidos. Los canarios emiticron sus primeros trinos el décimonoveno dia, y los es. pinidos el vigésimo prinero. Ios hijuelos de la primera de estas especies abandunan su cuna à los catorce ó diez y seis dias, despues de probar la lisera de sus alas en el borde del nido; pero vuelven pronto cuando el tiempo es frio. Algunos salen á los dicr y nueve dias, y a los reintidos son ya del todo independientes. Otros, si bien se alimentan en parte por si mismos, necesitan aun la ayuda de sus padres hasta el dia trigésimo. Los espinidos son por muchos conceptos superiores a los canarios: salen del nido a los catorce ó quince dias, y ya á los dicz y nueve los considera la madre como adultos, es decir, que los rechaza a picotazos cuando quicren accrcarse á clla.

"En los primeros dias, antes que los pequeños aporen sus cabezas an la pared del nicio, los machos no suclen tomar parte directamente en la alimentacion; pero mas tarde reparan este descuido tomando a su cargo casi exclusivo el cuidado de su progenie cuando la madre ya incuba por segunda ver, $y$ alimentando tambien á esta última para gue no tenga que abandonar con demasiada frecuencia los huevos ó los pequeños. Listos obtienen asi dos ventajas: disfrutan del calor continuo de su madre y reciben los alimentos dos veces salivados, lo cual facilita la digestion. Antes de que los padres tomen alimento ó le den à su progenie, limpian de la manera mas cuidadosa sus picos. Jos polluelos salen del cascaron con mucha hambre; tan luego como se han secado levantan sus-voluminosas catezas cual si padeciesen somnolencia y abren tanto el pico, que esic órgano retienbla. Cadacual inten. ta coger al otro el hocado, pues el primero que alarga el cuello és el que antes satisface su ape:ito; solo cuando retira la cabeza llega el turno á sus hermanitos. Esto contribuye mucho a que se atrase el desarrollo de algunos. Gracias al cambio ripuido que. se verilica en su alimentacion, los padres no necesitan instigar á los pequeños à que coman. Mientras están ciegos levantan sus picos muy abiertos al mas leve movimiento de la madre; cuando esta no los satisface en seguida aprictan la punta de su pico contra el pecho de aquella. Cuando alguna verse juresenta el raro caso de que por demasiado satisfechos se havan adormecioio profundamente y no quieren abrir el pico, los padres emplean varios inedios para despertarlos. Comienzan por emitir unos sonidos suaves y dulces; si esto no produce cl resultado apetecido, les tocan primero la base del pico y despues los párpados que son mas sensibles; y si aun asi no consiguen nada, introducen la punta de su pico en la hendidura del de los pequeños para abrirle a la fucrza. Dos hembras de espinidos hacian tragar tanto alimento à sus hijuelos que los atormentaban verdaderamente. Cuando los buches cic estos csiaban demasiado llenos y cuando todas las tenativas para hacerles comer eran inútiles, empujaban con la mayor suavidad las cabezas de los pequenos repetidas veces á derecha éirquierda, ponianselas dercchas, y cogiendo con la punta del pico unos cuatro milimetros del de sus hijuelos, abrian ligeramente este viltimo para hacer entrar con la lengua algun alimento. La papilla que al principio sirve de nutricion es tan espesa como un jarabe, mas a pesar de eso contiene tanto líquido que no se necesita bebida especial para los pequenos Por medio de inclinaciones de cabeza, la madre liace subir del buche una cantidad suficiente de la papilla para tres dó. sis, raras veces para dos ó una; examinala cuidadosamente con la lengua para ver si contiene alguna particula dura, y colócala despues en el paladar de los pequenos, de modo que por su propio peso y sin gran esfuerzo entra en el esófago. Los espinidos tragan enteras las larvas de hormiga, y las expelen en el mismo estado. Cunndo los padres observan que en el paladar ó en la lengua de sus hijuelos quueda todavia una particula de la comida anterior retiranla cuidadosamente, la tragan, y solo despues continúan díndoles alimento. Si cl alimento depositado en uno de los picos es demasiado grande, recogen parte de él. Cuando un macho de espinido expelia algunas larvas de hormiga pegadas casualmente unas á otras la hembra las quitaba una por una y tragábalas despues de haberlas examinado, quiats por miedo de que pudiesen contener ya animales vivos. Todas las partes duras de los insectos en general déjanse siempre cuidadosamente á un lado, porque á los granivoros pequeños les cuesta tanto como a. los vermivoros digcrir las materias córneas.

* Una hembra de espinido picaba con tanta frecuencia en el ángulo del pico de su hijuclo, que trazó pequenas líncas sangrientas. El buche de un pequeño de esta especie se llenó de tal modo una vez, que el ave no pudo cerrar el pico durante mucho tiempo: yel de un canario jóven se infó de tal manera, que nole era posible volver la cabeza para limpiarse el plumaje.

Para las aves peguenas, la limpieza es una condicion in. dispensable; las plumas pegadas al ano son indicio seguro de muerte. Por eso se esfueran los padres, tanto como los hijos, en satisfacer esta primera condicion. Sus instintos se com pletan alternativamente, como se observa dunnte la incubacion y en los primeros dias que los hijuelos pasan en el nido. El intestino, tanto de los adultos como de los pequeños, puede ensancharse mucho: mientras que en circunstancias norniales las deposiciones se verifican a intervalos muy cortos, durante la inculuacion, por ejemplo, retardanse a veces diez y' seis horas completas, llegando entonces los excrementos á menudo al tamaño de los huevos puestos por la hembra. Los polluelos no hacen deposiciones mientras la madre los cubre; cuando esto dura demasiado tiempo indican su necesidad por movimienros inquietos haicia atràs. La hembra se levanta entonces; el macho acude tambien sin prévio aviso, $y$ ambos observan atentamente, con la cabeza inclinada y los ojos fijos en su progenie, los movimientos que hace Los polluclos suben 
agarrándose con las uñas á la pared del nido: detiénense al llegar al punto mas alio; muérense algunas veces de lado, y expelen los excrementos, al parecer á pocos milimetros de distancia del orificio. Esta distancia parece siempre mas grande de lo que es en cfecto, porque las avecillas se deslizan ya otra vez hácia el nido, tan luego como sale la última parte liquida de los excrementos, cual si no quisieran que les tocase.

Ia forma de barco que tiene el bajo vientre de los peque ños impide, aunque se descuidaren alguna vez, tocar la pared de un nido regular con el ano. Sienipre gueda bastante espa. cio para que los padres puedan sacar los excrementos. Cuan. do la posicion lo permite, el macho y la hembra no esperan á que salga la deposicion, sino que introducen él picó en el ano y la sacan. En la escuela nos cnseñaron ya que las ares adultas se llevan los excrementos del nido: y grande fuépor lo tanto mi asombro al observar que mis camarios no confir maban nunca este hecho; aun hoj dudaria de la exactitud del áserto por lo que hace $a$ las aves domésticas, si estas no In hubiesen tamhien confirmacio repeticas reces; y si dos gorriones no hubiesen hecho lo mismo, el uno en mi habitacion y el otro delante de la rentana. A mbos llamaron mi atercion por sus movinientos asqquerosos, despues de los cuales romitaron pequenas particulas que resultaron ser excrementos de aves pequenas. $A$ mis aves, $y$ no a mis obserraciones, podia culparse de que el hecho me hubiera sido desconocido durante mas de veinte arios. En este tiempo he observado un sinnúmero de veces en todas mis aves el procedimiento siguiente gue por lo disimulado era tanto mas dificil de obser. var. Mis aves domesticadas tragaban los excrementos de sus hijuclos; los machos perseguianá las hembras cargadas con tan extraño alimento, se lo quitaban, y volviendo al nido, dában. sclo otra vez á los polluelos; las hemuras procedian del mismo modo, y por lo tanto, estas sustancias circulaban continua. mente. Yo veo en este hecho una prueba evidente de que los excrementos contienen aun sustancias no digeridas, cosa que no puede admirarnos en vista de la rapidez con que se verifica la digestion. Todo esto cambia cuando los polluelos, al sexto, setimo ó noveno dia de su vida, pueden hacer sus deposiciones en el borde del nido ó fuera: los padres no to. can ya tales excrementos, y los mas cuidadosos de ellos pre. fieren cubrirlos con algunas fibras Sin embargo he observado tambien en csto punto excepciones. Algunos espinidos, próximos ya salir del nido, habian dejado caer sus excremen tos desde el borde hasta el interior; cuando la madre observó esto, pasacio algun tiempo, recogió los excrementos yn secos, despedazólos y se los comió. Lo mismo observé mas tarde en un canario.

7odos los polluelos hacen sus deposiciones regularmente al mismo tiempo, tan luego como se ha levantado la madre, dando asi mucho que hacer a los padres. Cuando satisfacen sus necesidades durante la ausencia det macho y la hembra, el daño no es grande, pues los excrementos de los polluclos, como ya se sabe, están envueltos en una membrana gelat:nosa, que se conserva algun tiempo y solo se destruye por la infuencia del aire y del calor. Asi como á los adultos, los parásitos mortifican tambien $\mathbf{a}$ la progenic.

- Varias especies de piojos son una de las peores plagas para tocias las aves perguenas; una docena de estos basta para qui tarles el sueño. En la cabera y las alas es donde mas abun dan, lo cual se reconoce fácilmente por el temblor y loś sacu dimientos de estas partes. Cuando el tormento aflige mucho, las ares rechinan el pico mientras diermen. En un nido que contenga polluelos, los parásitos pueden aumentarse de un modo terrible, porque las aves de la jaula no tienen tant. ocasion de librarse por medio de baños de agua 6 de arena de los molestos huéspedes, y porque ademais incuban varias veces en el mismo nido. Muchas veces se les ve interrumpir su ocupacion, sacudir el pico y cazar con el los abominables insectos. Cuardo se obliga á las aves domesticadas á estar mucho tiempo quietas en un mismo sitio, cubriendo la jaula con un pañuelo, obsérrase que tan luego como se quita este apartan rápidamente y con violencia los hueros para examinar el fondo del nido, mas caliente entorices, y por eso mas propicio para los parisitos; si la jaula no es oscum, las aves practican todos los dias varias veces el mismo procedimiento. Tan luego como los padres se ponen en la parte posterior del nido ó sobre el borde, inclinanse mucho para examinar con detencion el hoyo, y recogen los parásitos que encueniran. I.os polluelos padecen mas que los adultos por efecto de los parásitos que ya desde las primeras horas de su vida comien. zan à mortificarlos; y como no pueden avudarse à si mismos, necesitan toda la vigilancia de la madre.

Muchas reces he observado muy de cerca la vida intima de has aves. Tan luego como los polluelos están secos y han cescansado de los esfuerzos que exige su salida del cascaron, is madre se coloca convenientemente y empieza á buscar parásios. Examina sus hijuelos por todas partes, muévese con la major precaucion para no ahujentar los odiados animali. tos, coge súbitamente uno, se lo come, y acecha de nuevo. Parece que esta caza no gusta mucho á los pequeños, pues los priva del calor y por eso hacen esfuerzos para ponerse debajo de la madre; pero esta se retira hasta que ya no puede seguir. A menudo coge tambien con los insectos la plumazon, cosa que fácilmente puede observarse por los frecuentes mo. vimientos de los polluelos. A veces durnba la caceria de los padres tanto tiempo, que por micdo de que se resfriase su progenie la interrumpia yo tocando con el dedo la jaula. Ia madre cuidadosa no se contenta solo con limpiar la cabera, sino que examina tambien el dorso y los costados, y si es posible, el vientre. Cicrta hembra de espinido dejó una ver. h́ su hijuclo boca arriba, y fué necesario que yo le volviera á sı posicion natural. Para facilitar la caza á mis ares mojé cl borde del nido con algunas gotas de tintura insecticica; a los pocos instantes, los parásitos se ponian en moviniento y con ellos la hembra que continuaba cazando mientras no se la inquietaba. A causa de su pequeñez, los parásitos quedan in. visibles para el obscrvador: pero obsérvase el resultado de la caza por los movimicntos que hacen las aves para tragar sus victimas, lo cual les cuesta mas que á los adultos.

* El desarrollo de las plumas de estas aves en las primeras semanas de su vida es mucho mas lento que en las siguientes; una de las causas que en csto influre es la circunstancia de que la madre abandona el nido desde la segunda semana con unas frecuencia, dando ocasion para que entre el aire y la luz y para que los pequeños puedan limpiar sus plumas. Es cosa diverida ver cómo las torpes arecillas ruclven sus cabe. zas para coger ya los tallos salientes, ya los puntos de la piel por donde deben salir. Una prucba convincente de esto ofrecian los camarios empollados en inviemo; á causa del frio sus padres los cubrian mas de lo que suclen en verano, r el resultado de esto era que los cuerpos se desarrollaban bien, mientras quue las plumas estaban aun muy imperfectas á los doce ó trece dias de su vida: hasta uno de los polluelos, que á los diez y seis habia dejado voluntariamente el nido tenia el plumaje tan poco desarrollado que fué preciso calentarle artificialmente por espacio de varias noches. Al salir del nido sobresalen principalmerte en la cabeza las fibrillas del plumon primitivo; es posible ọue la mayor parte de ellas estén debajo de las tectrices; pero probablemente, los padres arrancan tambien bastantes; obsérvase, por lo menos, que el macho y la hembra miran algun tiempo à sus hijuelos posados en la percha; de repente los pican, $y$ à juzgar por los movimientos 
consulsivos de las arecillas, debe creerse que les han hecho daño. Los canarios pequeños tienen la costumbre de arran. carse alternativamente en otono las plumas del dorso hasta quedar pelados y samgrientos; pero csto resa tan luego como las plumas vuelven $\mathbf{A}$ crecer. El ticmpo que estas aves necesitan para mudar por segunda vez. de plumaje saria segun las especies, pero dura por lo regular algunos meses. I

Las obsermciones anteriores se refieren solamente á los espinidos, canarios y pirrulas; pero debe suponerse que hasta cierto grado pueden generalizarse. Is posible que tambien las otras aves que pasan los primeros dias de su juventud en el nido procedan de un modo análogo; en las especies majores cambian mas ó menos las condiciones.

Los padres de estas especies cubren tambien á sus hijuclos desnudos mientras es preciso; pero su calor es mucho mas considerable que en las pequeñas; muchos de ellos tienen un plumon lanoso, que asi como en las aves de rapiñn, existe ya al salir el pollo del cascaron. Varias especies de las que empollan en huecos de árboles no pueden sacar los excre. mentos de sus hijuelos á causa de la formacion de su pico; $y$ las deposiciones se acumulan entonces de tal modo en el nido, que este se convierte al fin en un verdadero foco de pestilencia. Sin embargo, los hijuelos prosperan tambien como los mejor tratados de las especies descritas. Otros, por ejemplo, los de las aves de rapiña, no necesian el cuidado de sus padres en este concepto, pues levantan sencillamente el ano sobre el borde del nido y expelentsus excrementos liquidos y blancos a larga distancia, ensuciando asi los contornos del nido de una manera desagradable. Las aves de rapina y carnivoras, por ejemplo la garaa real, agregan \& los excre. inentos toda clase de restos de la presa, que en el estado de putrefaccion producen un hedor insoportable, de modo que los nidos de estas aves, y sobre todo de las mas magnificas, son los mas sucios.

Mucho menos se cuidan los padres de las especies que en seguida salen del nido y cuyos penqueños son casi iguales en cuanto i la rapidez del desarrollo que los rumiantes entre los mamíferos. Inmediatamente despues que los pequeños han salido del huero, y no bien se ha secado su espeso plu. mon por ciecto del calor de la madre, alejanse con los pa dres del nido y desde entonces ya son aptos para seguitlos á todas partes, recorticndo las especies terrestres los canmos, $y$ las acuáticas, $\delta$ al menos gran parte de ellas, las corrientes.

Sin cmbargo, ni las unas ni las otras pueden vivir descle luego independientes; anies al contmrio, todavía necesian mucho tiempo los cuidados paternos

El padre y la madre, ó al menos la última, guia å sus hi. juclos, los reune, los abriga y los defiende de muchos peli. gros que les amenaman. Como podemos ver en clialquier ga. llina doméstica, la madre se cuida no solamente de propor. cionarles alimento escarbando la tierra, sino quc tambien sigue comunicándoles el calor de su propio pecho.

Cada nube que cubre el sol le infunde cuidado: uns tem. pestad le causa un miedo mortal. Cúbrelos con su propio cuerpo cuando cae un pedrisco: clige solicita los sitios que parecen mas abundantes en alimento, y raga á mucha dis. tancia por su terriorio. Lo propio que nuestm gallina se portan todas las demás gallinåcens, la mayor parte de las corredoras y tambien las especies acuáticas cuyos polluelos salen en seguida del nido. El macho del cisne y de la oca cuidan con no menor solicitud à sus pequeĩos: la hembra del pato se encarga voluntariamente de este cuidado. Cuando los pe. queños están cansados les presenta su lomo ensanchado un poco por las plumas entreabiertas, como sitio de reposo. Cuando amenaza à los pequeños del somormujo un peligro. los padres los cobijan bajo sus alas y se sumergen con clios it ha profundidad que creen mas segura, ó se remontan con ellos $\{$ los aires, salvindolos murhas veces de las persecucio. nes de sus enemigos. Todas las aves. aun las mas timidas, se distinguen por su valor y astucia, cuando se trata de defender á sus hijos: la macire finge di veces tener herida un ala y aletea con dificultad, imitåndola tambien el padre con objasto de butar al enemigo y distraer su atencion cunndo amenaza a los polluelos; con tal estratagema se hacen persegu'r hasta cierta distancia, incitando la mpacidad de su contrasio con toda clase de ademanes, hasta que se remontan de pronto, alegres del buen éxito de su astucia para volver al lado de los pequeños que mientras tanto han podido encontrar un refugio. Las especics cuyos pequeños abandonan el nido no los descuidan á pesar de ello, y les tienen tanto cariño como aquellas cuyos hijuelos pasan su primera juventud al lado de sus padres.

Pero ni las unas ni las otras los abandonan por completo aun cuando sean tan grandes que puedan buscasse por si mismos el alimento; pues las aves instruyen á sus hijuelos minuciosamente en todos los actos necesarios para la vida. Tan lusego como los polluclos de la golondrina pucden volar. vemos a la madre pasar por las calies de nuestms ciudades. elevarse á las alturas del cielo ó tocar en su vuelo casi a la ticrra; entonces es cuando enseña á sus hijuelos; procura adiestrarlos en el dificil arte del ruelo, cnsenarles á coger su presa sin ayuda de los padres y prepamilos para el próxi. mo viaje.

En todas las buenas roladoras exige tal instruccion bastantc tiempo, y en las especics que volando leben adquirir su alimento, mucho cuidado. Si son halcones, se reuren il macho y la hembra para enscùar á sus hijuelos ci mejor modo de cazar; uno de los padres coge una presa, se remonia por encima de los pequeños y deja caer la victima, que es la recompensa del que pueda cogerla: si ninguno la atmpa, ia recoge el macho, que miraha el espectáculo volando por debajo de los pequeños; remóntase á su vez al aire y renite la operacion. Asi proceden poco mas 6 menos tocins las aves, mostrando de tal modo el infinito carisio que tienen à sus hijuelos. Solo cuando estos se han hecho independientes y cstán bastante instruidos pam alimentarse, el cariño de los padres se convierte muchas reres en indiferencia. I as mismas ares que tan solicitas se mostraban en cuidar à su progenic, la echan entonces fuern del área de su dominio. y yo no la conocen. Los nequeños tienen casi tanto cariño á los padres como estos á cllos, si bien aun en este.caso.se observa el egois. mo propio de casi todos los séres jórenes. Ja mayor parte de ellos obedecen solamente mientras su obediencia se re. compensa por el alimento: tarnpoco dejan de ser en su pri. mera jurentud sobrado voluntariosos, siendo preciso recurrir al castigo para corregirlos; la cxpcriencia propia completa despues la instruccion de los padres, cuyo resultado siemnre puede conocerse.

Con decir por fin que hay algunas especies de aves grue desde el primer dia de su vida pueden prescindir de los cui. dados de sus padres y que esto no obstante, dichas especies. se reproducen, habré irazado à grandes rasgos un hosquejo general de la vida de lás aves jövenes.

EMIGRACIONEs. - Cumplidos los deberes que les im. pone la reproduccion, muchas aves cmprenden un viaje mas 6 menos largo; siendo, no obstante, preciso distinguir entre las que realmente emigran, y aquellas que solo viajan ó va. gan de un punto á otro. Las primeras marchan cada año en la misma época y siguen igual direccion; las segundas no mudan de residencia sino por necesidad, sin época ija ni rumbo señalado de antemano para su viaje, el cual termina 
cuando deja de existir la causa que lo produjo. Las aves errantes recorren una extension muy linitada, y solo abandoman su localidad para trasladarsé á otra, situada a corta distancia.

Para emprender sus emigraciones se alejan de nosotros cada otono las aves cantoras, que vuelven en la primavera; y por la misma causa nos abandonan las aves acuáticas antes que el hielo haya cubierto su dominio. Mas de la miand de las aves de Europa, del norte de Asia y de América, son emi. grantes; todas se dirigen hacia el sur: las del hemisferio orien:al al sudoeste, las del occidental haicia el este, segun la couffiguracion de los paises donde van a pasar el inviermo. I os rios y cuencas de las comarcas que tecurren, Jes sirven de caminos; los valles trufundos, limitados por montañas, son los sitios de jaso y juntos de retsnion. Tas unas viajan aparendís; las otras en banciadas mas ó meros numerosas: si ste exceptrian las especies mas déiblés, que solo viajan duraute La noclie, las demás emigmn de clia. Parters antes gue las acose el hambre; avanan con rapiciez, como impelidas ją una fuctar irresistib!e; notándose que aun aquellas nacidas en jaula, y que sicmpre vivieron cautivas, cxperimentan In misma agitacion en la época de las emigraciones. Estas nos abandonan pronto, aquellas mas tarde; pero todas $\mathrm{cn}$ épocas deterninidas; observandose que las úlimas en ale jarse son tambien las primeras en volver, $y$ las primeras que nos abanidonan regresan mas tarde. Ef martinete negro se va L principios de agosto para no regresar hasta el mes de majo; las litimas emigrantes desaparecen por el mes de no. ricmbre y ruelven por febreto.

Las aves se alejan con frecuencia mucho para invernar, y sun ignoramos hasta dónde avanzan ciertas especies. Muchas van il residir al mediodia de Eurojat un gran numero permanece iemporalmente en el norte de Africa, dusde el $37^{\circ}$ al 24 " de latitud; otras penetran ca las zonas tropicales, y durnite el invierno se dejan ver en las costas del Allántico, en las dei mar Rojo y en el de las Indias. Este último país ylas islas inmiediatas a Birman, Siam y el sur de la China, forman tambien una esthcina de imvierno.

Las ales de la America del norte vanalsur de los Estados. Unidos y h la América central.

In el hemisferio sur se obsurvan tambien emignaciones scmejantes; las aves de America marchan hacia el norte, hasta el Brasil, y las del sur de Austratia en direccion al norte de este continente $y$ de las islas próximas, tales como por ejemp!o, la Nueva Guinea.

Antes cie matchar las aves emigrantes, acostumbran á reu. nirse en ciertos juntos, levantando el vielo cuando su número es suficiente. Algunas se ejercitan antes de emprender su riaje; cusayan sus fuerzas con las de sus companeras, y en cicrtos casos hastit pelcan entre si.

Ias bandadas se conservan mas $\delta$ menos unidas durante - el viaje, $y$ a reces guardan un órden determinado al volar; forman un ángulo, $\dot{0}$ bien dos lineas rectas, que convergen entre si en forma de $V$, con la punta vuelta hácia adelante. Algunas atraviesan los aires en lineas cerradas, otras se agrupar irregularmente. Las ares cmigrantes se mantienen por lo regular a gran altura: a menudo se dejan cacr bruscamente, y ruelan aigun tienipo cercit del stelo para elevarse otra rez. Lis aves débiles no recorren grandes distancias de una ver, y solo vuelan de árbol en írbal ó de bosquie en bosque; las andidoras, cuyo vuclo es penoso, franquean una gran parte del camino ả pié; las aves acuaticas á nado. Si el viento sopla de frente, se hace el viaje con mucha rapidez y si de espalda, es mas lento $y$ hasta se interrumpe poralgunos dias.

Los viajes pueden compararse á las emigraciones en el sentido de que se verifican en cierta época, con mas 6 menos regularidad. Muchas aves del no:te son viajeras; van errantes todo el año en espacios bastante extensos, y solo cuando el invierno es muy riguroso se dirigen hácia el sur, llegando hasta el mediodia de Europa. En tales circunstancias emigran en cierto modo.

Las que podrian llamarse vagabundis ian errantes por docpuiera durante todo el año: en este caso se laallan las grandes rapaces, que buscan continuamente su presa : y tam. bien los machos viudos ó célibes. Parece que otras vagan mas bien por gusto que por necesidad, y recorren extensiones de terreno mas reducidas. En los países tropicales pueden asentejarse algunas reces los pajaros á las espucies emigrantes.

De todos modos, y por largos que sean sus viajes, deveremos considerar sicmpre como patria del ave el pais doncie se reproduce: en este sentido puede decirse que el nido es la casa del ave.

UTILIDAD.-Los mamíteros son animales útiles; las ases sirven ndemás de recreo: aquellos para vivir han de patgar al hombre un tributo; las segundas, por el costrario, me. recen indo su cariuo y benevolencia. Por su gracia, su be lleza, agilidad y yo\% armoniosa, son agradables á nuestros semejantes. Los primeros hombres debicron amar a las aves los saliajes las protegen; los sacerdotes de muchas religiones las considernban como séres sagrados; y los pocias de todos los tiempos las ensalzaron y ensalzan aun en sus composicio. nes. Su género de vida, su camto, su vuelo y continua alcyria ros encantan y seducen; les cuncedemos la hospitaliciad çue rehuramos á los manifcros, y mas aun á los rejutiles, sin es. perar de ellas grandes beneficios; por último, las tomamos por cornuaberas para tenerlas en nuestras habitaciones.

Aun cuinndo las tendemus redes y lazos ó las persegumos a tiros, no se cxungue nuestra inclinacion hácia ellas; antes al contrario, son nuestras favoritas. Su vida tiene una alta significacion para nuestra propiedad y para nuestro bienestar. Las aves forman un eslabon indispersable en la cadena de los séres; merced a ellas se conserva el equilibrio en el reino animal y se oponen a la perniciosa actividad de las utras cla ses, sobre todo de los insectos, que sin ellas convertirian quizàs en un desierto 1 la naturaleza. Ls verdad que la urilidad de las aves no puede calcularse, porųue deben comarse en consideracion cuestiones cuya solucion no se ha hallado todavía. Sin embargo, es casi seguro que esta utiliclad supera con creces el dano que nos causan, por lo cual haccmos bict en cuidarlas y protegerlas. Ia manera cómo hor dia se culti van los campos y los bosques perjudica precisamente $a$ las especies de aves que en major grado merecen nuestra consi deracion; pues las priva de sitios para construir sus nidos las obliga a emigrar y a buscar cn otra parte una patria ma conveniente. En algunas partes el hombre les declara abierta oposicion, exterminándolas con escopetas, redes y hazos; pero la disminucion que sufren las ares por la caza es poco consi derable en comparacion con la gue experimentan a conse cuencia de la roturacion de ticras. Por consiguiente solo podemos proteger y cuidar eficazmente a las aves proporcio nandoles sitios donde pucdan vivir y empollar, ya les arre glemos dichos sitios artificialmente, ó ya conservemos lo existentes. Todas las demảs nedidas propuestas por el senti mentalismo, la inexperiencia y la estupider serán tan imporen tes para poner cuta á la disminucion de varias especies com para favorecer un aumento efectivo en otras. Reputimos qu es indispensable destivarles sitios a propósito para sus ni dos y entonces acudirin espontáneantente á ellos. Solo este sentido recomiendo, como y'a lo he hecho hace anos, toda persona instruida la divisa

¿PROTFCCION A LAS AIFS! 


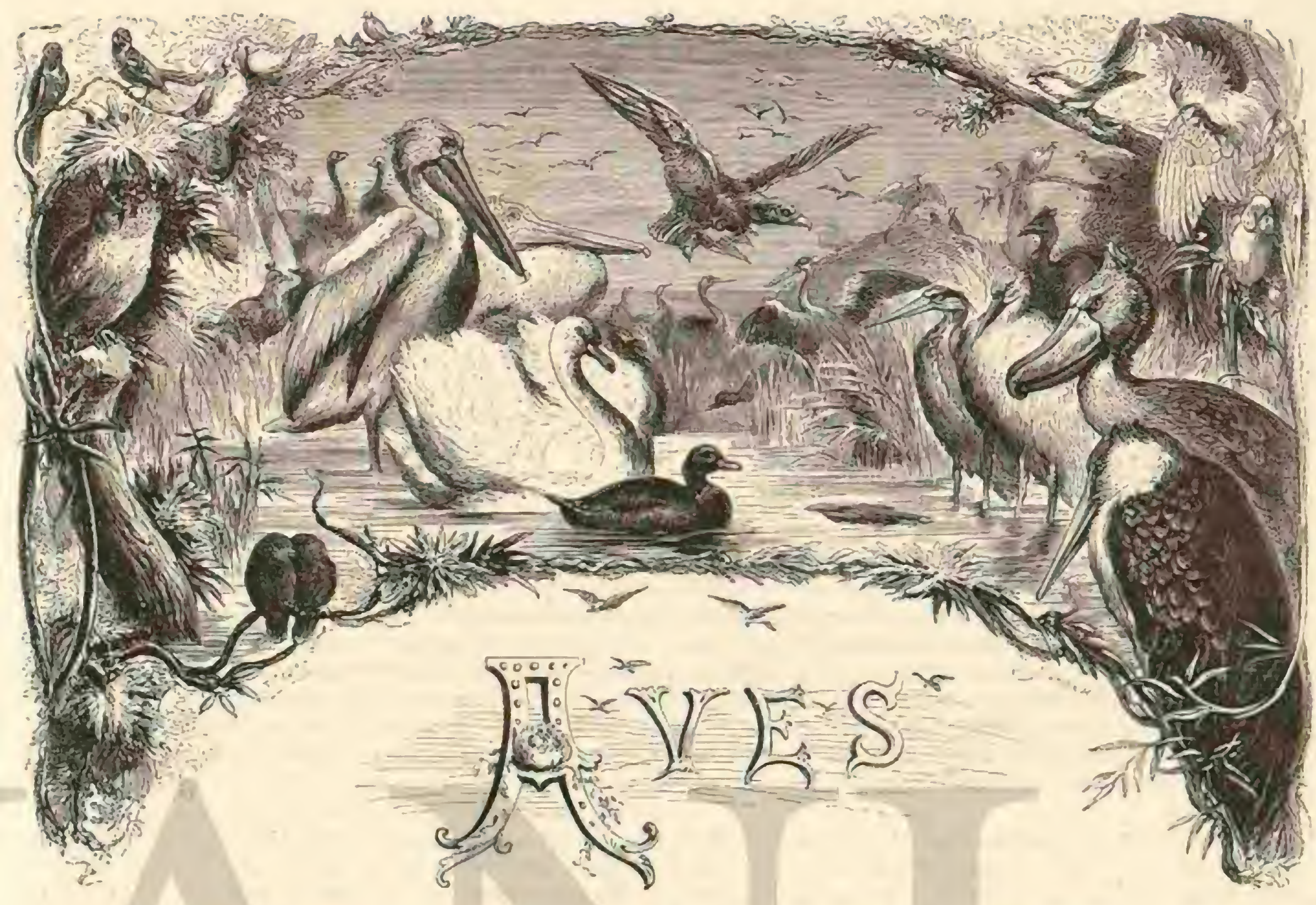

PRIMERA SUB-CLASE-VOLUCRIDOS

PRINIER ORDIEN

LOROS-PSITTAGINI

CONSIDERACIONES GENERALES.-LOS loros SOn monos alados, no solo en opinion del hombre de nundo, sino tambien para el naturalista. Jamás fué mas exacta comparacion alguna entre animales pertenecientes a clases dis. tintas; pero no me apoyaré solo en este paralclo para estable. cer çue los loros son las ares mas superiores, pues todios sus caractéres bastan para asegurarles este lugar.

Si se exceptúan Lacépede, Ulliger, Blainville, Bonaparte, Kaup, Carus, Wallace y otros narumlistas, los demás no ruic. ren asiguar á estos séres sino un rango inferior en la serie; débiendo atribuir esta opinion á que se han fijado principalmente cn un caracier por el cual se asemejan los loros a otras ares, esto es, en la forma del pié. Los loros, los picos, los cuclillos, los tucanes, los curucús, los barbudios y los jacamaras son trepadores, es decir, que tienen en cada pata cuatro dedos, dos hácia delante y dos hácia atrás.

lo creo que para formar idea exacia del pić de las aves trepadoras, débe compararse con la cola prehensil de los mamiferos, pues ambos órganos permiten al animal vivir en los árboles, y cogerse fuertemente à las ramas y troncos. Adviértase, sin embargo, que estos órganos no existen en séres que esién próximos en la seric animal, antes por el contra. rio. en especies muy distintas, siçuiera el género de vida sea idéntico.
Por'otra parte, el pié de las trepadoras no corresponde siempre al mismo tipo, y varia por lo menos, tanto como los demás caractéres que distinguen à estas aves. Iil pié del loro se diferencia completamente del de las o:rns trepadoras, sobre todo por la estructura de los huesos del tarso, que mas que en ninguna otra ave se asemeja al tipo de la mano.

Segun esta opinon establecense entre los loros y otras aves trepadoras limites mas extensos que los que suelen scũalarse para la separacion de varias familias: los loros forman por lo tanto un órden bien marcado.

CARACTÉRES.-Constituyen los loros un órden bien determinado: su caracter esencial consiste en la forma del pico, forma particular que no presenta el de ninguma otra ave. Hé aqui por qué Stande, uno de los muchos autores que han iratado de establecer una clasificacion natural de las as'es, designó â los loros, y no sin razon, con el nombre de globirostros. A primera vista aseméjase su pico al dicl are de rapina, solo que es mas grueso y fuerte, mas alto relativamente, y desarrollado con mas uniformidad. I a miz de la mandibula superior está cubierta por una membrana blanda des. provista de plumas, llamada cera.

Finsch considera con sazon como particularidad mas caracteristica del pico del loro la proporcion entre su altura y su longitud: la primera que en la base es casi doble que la 
anchura, mide poco menos que la longitud, y hasta es a veces mayor. En cuanto a la castructura de este pico, Burmeister dice lo siguiente:

«Sobre la mandibula superior del pico de los loros se observa una prominencia dorsal delgada, aunque bien definida, de la cual descienden las dos caras laterales, que se arquuean regularmente. Por detrís terminan estas dos caras, de una manera insensible, en una membrana corta, cuvierta de algunas plunas erectiles, sobre tocio debajo de las fosas nasa. les, y la cual se prolonga hácia el ángulo de la boca. Las fosas se hallan situadas en la parte superior de dicha menbra. na llamada cera; son redondas y las circuye un ribete alto. Los bordes de la mandibula superior presentan de ordinario en su centro una protuberancia en forma de diente obtuso, sólido, y mas cortante hácia delante que por detrás. Líl extremo de la mandibula es largo, encorvase ell forma de gancho, y esta surcado en su cara interna, que se arquea un poco. La mandibula inferior es mas coria, y gruesa y en forma de canastillo; apenas es mas baja, 6 si se quiere, tan alta como la superior; en su centro suele presentar una ligera costilia longitudimal que corresponde al ángulo de la mandibula A muy corta distancia de esta se observan otras dos jrominencias gure se reunen hácia delante limitando la parte terminal, ancha, alta y cortante, de la mandibula superior. Por delante de estas prominencias presenta el borde su. perior de aquella una escotadura que corresponde con el diente de ia orra mandibula; y á partir de alli se va ensar.chando esta por detrás: sus caras laterales son mas ó menos convexas:

linsch llama la atencion tambien soure la particularidad de que la primera mitad del lado inferior de la mandibula superió está separada de la otra mitad por un ángulo recto.

Los dernas órganos de los loros ofrecen una disposicion menos característica. das patas, añade Burmeister, son gruesas, fúcrtes y carnosas, aunque cortas; el tarso es mas corto que el dedo del centro, y est i cubierto de pequeñas escamas: los dedos, bastante largos, tienen la punta gruesa; el dorso y el tarso cubierto de varias escamas que ran agrandándose hasta cerca de su extremo. İn la última falanje son cortas, pero revisten tambien toda la parte superior del dedo; las Lñas no son largas ni vigotoshs, aunque si nuy encorvadas y bastante agudas. Los dedos inierno y anterior suelen te ner la uña mas peq̧ueña; despues sigue el puigar; en el ex terno y anterior es algo mas larga que en el externo y prosterior.

Las aias y la cola estân, segun Finsch, bien desarrolladas en casi todas las especies; las alas grandes y pumiagudas, tienen rémigres que se distinguen por sus tallos fuertes y anchas barbas y que se estrechan o redondean en la extremidad; su número varia entre diez y nucve y veintidos, pero es re. yularmente de veinte; entre ellas sobresale de las demás la segunda, ó esta con la siguiente, y a veces tambien las tres primeras, ó bien la tercera y cuarta, y hasta cxcepcional. mente la sexta y la sétima; la punta del ala tiene casi siem. pre la misma longitud; en el ingulo del ala hay siempre cuatro plumas; las doce caudales ó timoneras varian mucho, tanto por su forma como por su longitud, y de consiguiente la figura de la cola es mus variada.

El plumon de los loros, relativamente poco espeso, consiste en plurnitas que en la parte exterior presentan ún gran iallo falso, y están mezcladas con otras muy suaves; las exteriores forman como unas placas nuy marcadas, cuya forma varia mucho: la del lomo se civide casi siempre â la altura de los omoplatos, formando una especie de horquilla: la placa infer:or termina noco mas ó menos en el cuello, $y$ la de la espaldilla suele ser doble. I as plumas suares se hallan en la cabeza y el cuello, entre los limites de las placas, y segun reconoce Nitsch, cubren continuamente las plumas exteriores con un polvo blanco 6 azulado, procedente de la piel que rodea al canon.

Esta opinion no esti conforme con mis observaciones, las cuales me inducen s. creer que el citado polvo, fácil de quitar, proviene de las nismas plumas exteriores. Debe advertirse tambien que el plumaje deja descubiertas muchas veces varias partes, sobre todo las mejillas y la region de los ojos.

Por mucha variacion que ofrezca el color del plumaje, no por eso es menos caracteristico: domina el verde, aunque tambien se encuentran loros ce color azul jacinto, púrpura, amarillo de oro y gris. Es muy particular la distribucion de los colores en el plumaje de estas aves: es preciso notar, en lo que pudiera llamarse campo de coloracion, la presencia de los tintes complementarios en las dos caras del cuerpo, $y$ has. ta en la rnisma pluma: la cara superior es azul violeta, azul oscuro ó claro, y verde; la inferior de un amarillo claro, ana. ranjado, rojo y purpura. No menos noiable es lo que se ob. serva en ciertos cacatuas, por ejemplo en los que el color rojo 6 amarillo vivo de la base de las plumas, queda com1) letamente oculto por el tinte blanco del resto del plumaje.

A ubbos scxos tienen por lo regular el mismo color, pero no siempre; los hijuelos difieren comunmente poco de los adultos; si bien se hallan individuos que se diferencian mucho. Los úrganos internos de los loros deben llamar igualmente nuestra atencion: el esqueleto sobre todo, ofrece diversas particularidades interesantes. Eil craneo, segun linsch, es muy grande, ancho, aplanado en su parte superior y redondeado en el occipucio, presentando caractéres especiales que no se observan en toda la clase. Estas particularidades son las siguicutes: la articulacion del maxilar inferior y el hueso timpánico; csic presenta un cóndilo muy prolongado que se articula en una depresion de la cara interna del maxilar; la articulacion entre el maxilar superior y el hueso frontal, articulácion que si bien consiste solo en un ligamento, tiene todas las condiciones de tal; el tamaño extraordinario de los huesos palatinos, anchos, dispuestos verticalmente, y que en su cara anterior se unen como articulacion con la mandibula superior: la altura y longitud extraña de las ramas submaxi. lares, que á menudo sobresalen del occipucio; y en fin, la gran movilidad de las mandibulas. El borde huesoso de la órbita está completamente cerrado en muchas especies, si bien no en todas. La columua vertebral se compone de once á doce vértebras cervicales, de siete \& nueve dorsales, de cinco á seis sacro-coxigeas y de ocho à nueve caudales; el númcro de las costillas vara de ocho á nueve.

El esternon es notable por su alta cresta, angosta al mismo tiempo, por su gran longitud y anchura casi jgual, y por tener la parte posterior redondeada sin rasgadura, alguna; el sacro es plano; la prélvis larga y redondeada en su cara superior: la horquilla falta á menudo, y cuando cxiste esta siempre poco desarrollada; el hueso coracoideo es fuerte y corto; los omoplaros planos y de una anchura regular; el húmero siempre mucho mas corto que el antebrazo; el rádio muy delgado y recto; el cúbito encorvado hácia atrìs y afuera; el hueso carpiano superior es aplanado; el inferior tiene en su cara interior un borde abultado; el metacarpo se distingue por su longitud, y el dedo medio por su anchura. Las piernas se caracterizan sobre todo por. la longitud de la tibia y la brevedad del metatarso; en cuanto à los dedos, el exterior es el mas largo y despues el del centro.

Entre las partes blandas, el órgano mas notable es la lengua, que se presenta gruesa, carnosa, cónica y obrusa; su borde esta provisto algunas veces de dentelladuras ó de púas córneas. lil esófago se encuentra en el buche; un conducto 
liso separa el ventriculo subcenturiado del esiómago tropiamente dicho ó molleja, cuyas paredes son diclgadas y rellosas en su cara interna: no hay vesicula biliar ni ciego; el intestino sucle ser una mitad mas largo que el cuerpo. El pincreas es doble, el bazo perqueño, y el rinon está profundamente trilo. bado. Debe notarse además la presencia de dos arterias ca. rótidas, y la carencia de la glíndula coxigea en ciertos casos. La laringe inferior esta provista de tres pares de músculos.

Coma quiera que consideremos í los loros, no prodremos menos de ver en ellos un grupo bien distinto, que no es dado comprender en ninguna de las otms divisiones generales: $m$. zon que nos obliga á formar con cllos lo que se ha convenido en llamar un órden.

Parece poco esencial hacer de este órden una sola familia, dividirle en sud-familias, $\delta$ dar a estas últimas el rango de familias

DISTRIBUCION GEOGRAFICA. - I.os loros habian todos los continentcs, excepto el de Luropa. We las trescientas cincuenta y cinco especies que linsch contó en 1968 , ciento cuarenta y dos viven en América, ochenta y sinco en las islas de los I'apúes y en las Molucas, sesenta en Austmlia, treinta en la Polinesia, veinticinco en Árica y diez y nueve en el mediodia del Asia, incluso las islas de la Sonda.

Merced á los descubrimientos modernos háse aumentado en mas de veinte el numero de las especies conocidas; pero la proporcion distributiva ha continuado sicndo casi la misma. La gran mayoria pertenece is la \%ona cillida; de las tres. cientas cincuenta especies, solo ocho pasan del trópico de Cáncer, y sesenta y dos del de Capricomio. Una especie americana se extiende por el norte hasta el $\$ 3^{3}$ je latitud; virn se encuenira en el hemisferio meridional hasta los de siertos de la 'liern del Fuego (53" latitud sur): los domice. llas habitan todavia en la isla de Macquari a los $52^{\circ}$ de latitud sur. En el Africa $y$ el . Isia saler poco 6 nada délos limites de la zona cálida y en el Africa occidental del $16^{\circ}$ de latitud nortc: en el este del Africa no se hallan, segun mis observaciones, mas al norte del $85^{\circ}$; mientras que en la mitad meridional se alejan mas del Ecundor; algunas especies habitan én lá zona emplada de Asia

USOS, COSTUMBRES Y RÉGIMEN.-LOS caractéres físicos no es in único que distingue á los loros: diferénciarse además de las niras aves por la manera de vivir, sus costumbris y facultades. Siendo indudable ulue el género de vida de los animales se armoniza perfectamente con su conformacion fisica, resulta qure siendo esta esprecial, debe aquel serlo tambien. In su estudio detenido hallaremos nueros argumentos en pro de la idea de asignar h estas aves el ligar cn que las colocamos.

Opinando con Oken, he designado a los mamiferos como animales dotados de todos los sentidos; $y$ he dicho que el desatrollo igual y uniforma de estos era indicio de una mar. cada superioridad en la escalia de los séres. Aplicando este grincipio al estudio de las aves, resulta que salvas algunas excepciones, se diferencian los loros de los otros animales de la misma clase, precisamente por al desarrollo uniforme de sus sentidos. Ninguno de ellos aparece atrofiado, ni alcanza sampoco un extraordinario desarrollo en detrimento de los demás Fil halcon as notable por su vista pespctranie, el buho por \$u fino oido, El cuerro pror su oliaio, los ámades parecen iener un gusto perfecto; el tacto del pico es muy delicado; y asi podriamos decir de otros muchos; pezo el lora ve, sienie, oye, gusia y toca: todos sus sentidos cstán bien desarrollados. Excusado parece probar que ve y oye; y para convencerse de que está igualmente dotado en cuanto á los demás sentidos, basia la mas minima atencion. Fstornuda despues de respiras el humo: reconoce con una rapidez increible los frutos que

Toso III son buenos: examinese un loro domesticado cuando se le da un terron de azúcar, véasele como toca los objetos con su len. gua; pasadle la mano por las plumas, y no se le podrá negar ni el gusto ni el tacto.

No menos positiva es la inteligencia de estos animales: por ella podemos llamarlos, segun queda indicado, mosos alados. No se reconoce al mono en el loro hasta despulues de apreciar el alcance de sus facultades intelectuales; tiene con efecto rodas las del cuadrumano, con sus pasiones, sus cualidades y defectos; es en suma el ave mas inteligente; es como él caprichoso $i$ inconsiante; es en momentos dados el compañero mas alegre y agradable, y se convierte de pronto en el sír mas insufrible El loro tiene memoria, prudencia, astucia y discernimiento: se comprende a si mismo: es orgulloso, tiene vilor y experimenta afectuoso carino hácia las personas que le amnn; puede decirse que es fiel hasta la mucrie y agrade. cido con conocimiento de causa. Se le puede enseñar y conseguir que obedezca, corno el mono; pero tambien es iracundo, maligno, astuto y falso; recuerda los malos tratamientos y hasta se muestra despiadado con los súres mas débiles. Su carácter es una mexcla de las cualidades y defectus mas opuestos: pero senrejante conjunto indica por si mismo un gran desarrollo de inteligencia.

La descripcion precedente ha sido atacada por un autor muy digno de ser oido, y en su consecuencia no he perdido ocasion de observar cuantos loros me fué posible, sin parcialidad de ninguna especie. Con el tienapo trascurrido entre la publicacion de la primera edicion y de la presente, he vuclto itener centenares déloros a mi disposicion, 6 los he visto en cautiviliad; he fijado tanto mi atencion en los recien cogidos como en los domesticados ya; he hecho todos los esfuerzos imaginables para conocer su carácter; he consultado la opinion de los inteligentes en la unateria; y no lie omitido, en fin, medio alguno para conseguir mi ubjeto: el resulado de mi exímen es que mantengo lo dicho antes, en toda la cx. tension de su sentido.

Léjos de negarlo, confieso que tambièn otras ares tienen una gran inteligencia; pero en ninguma reconozco ianta igualdad de las faculades intelectuales como la que existe en los loros. Fácilmente se comprenderá que no he cerrado los ojos ante las excepciones de la regla; sé muy bien que no todos los loros dan á conocer tan clammente su vida in. telectual como lo hacen las principales especies del órden; tampoco ignoro que algunos cuervos, estorninos y grullas, halcones y buhos, dan pruebas evidentes de una superior inseligencis y que pueden competir muy bien con varios loros; pero no poseen la misma facultad de ajurender y la misma movilidad del espiritu que regularnente se observan en estas aves; y si las tienen, no alcanyan tanto desarrollo, Los ademanes expresiros del loro, su vireza, la facilidad con que comprende, la ternura reciproca del macho y la hembra, su cariño para con el amo y la malicia con que. se defienden contra séres hunannos ó animales aborrecidos, son cosas á que ninguma ave alcanza.

He dirho que ini opinion ha tenido adverearios; pero dcho añadir que tambien mereció por oira parte aprobacion sin reserva si la mayoria, ó mejor ùicho casi todos los individuos det órden de los lorus, tan rico en especies, merece el nombre de muns emnlumaders, me eseribe Emilio Linden, uno de los mas expertos conocedores de ares, esto podria decirse principalmente por su facultad de imitar, por la grotesca manera con que irepan; por su memoria, astucia y precaucion, así como por sus caprichos: y por la malicia y malignidad que precisamente en las especies mas principales se observan. Mis loros me dan todos los dias pruebas de su gran inteligencia y no omitiré citarias mas tasde al hablas de 
las especies. Aqui solo diré, ó mas bien preguntaré: ¿ una prueba de la inteligencia de estas excelentes aves el hecho de que un loro moje un terron de azicar en su vaso de agua, por haber llegado á comprender que en ella se ablandan las golosinas duras? ¿No se creera en esta prueba al observar su admiracion cuando nota qque la golosina se distselve en el agua y desaparece, y al ver que nunca le vuelve d sllceder lo mismo, micntras que jamás deja de mojar el pan? Con razon se repiten las palabras de Scheitlin, que liama al perro un animal humano; pero con la misma merecen los loros el calificativo de aies hismanas. Eil cariño con que alegran y recompensan á su amo, el conocimiento con que se acomodan a los deseos del hombre, sus esfucrzos para

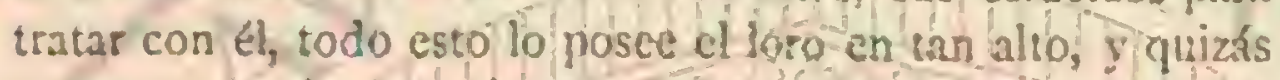
en mayor grado que el perto, pues é are ocipa un lugar mucho mas inferior que este en la clasificacion de los animales. Estay del todo conforme con las palahras de V. Una diversidad tan grande como la observadla en el carrácter y en his faculindes del loro no debe cesconocerse.

Era de esperar que un animal tan bien dotado sacase el mejor partido posible de sus órganos, Se ha querido anteponer otras aves a los loros, porque no eran tan rapidos, for cjemplo, en sus movimientos: cicrto que no vuclan tan bien cono el halcon, ni trepan con is agilidad del pico, ni corren con la ligereza de la gallina, y que no madan con el aplomo del cissic, pero ino podria decirse otro tanto del hombre? Los loros, sin einbargo, son muy ágiles; las grandes especies rucian pesadanente, al parecer, si bien con rapider; las pequeñas sobresalen en este ejercicio; csto me consoló casi de la pérdida de una pequeña cotorra (Melopsitacus uridulatus) qué husó con raudo vuelo de la jaula donde yo"la tenia. Cortaba el aire como un halcon, y hoviase cual una golon. drina. \&Los aras, dice el principe de W'ied, vuelan con lenti. tud, y baten vigorosamentc el aire con sus alas, llevando la cola horizontal; los murmsonas y los frriyuitos vuelan con mas rapidez y atraviesan el aire como una flecha; el vuelo de los loros propiamente díchos es bastante tirdo, dando aletazos repetidos con sus cortas alas para mover su pesado cuerpo.s

A muchos loros parece extranarles el suelo, i saltan mas bien que andan; pero hay especies terrestres cusos individuos corren con tanta rapidé como una zancuda. El nimfico de Australia puede compararse con uria becada por su modo cie andar; Gould habla de un platicerco que corria como un avo fria. Si es dificultoso para los loros saltar de rama en mama, no por esto se mueven menos rápidamente en los árboles, revolotcando ó brincando; la única diferencia que existe entre elios y las demás aves, es que estas solo se sirven de sus patas, mientras que aqquellos se valen al propio tiempo de su pico.

Saben utilizar sus miembros mejor que las demás aves: las patas les sirven de manos; 54 pico es mas movible que el de cualquiera otra especie; ninguna lo maneja tan bien, siendo las únicas aves que se valen de él para trepar.

Su vor es fucrie y chillona, aunque no del todo desagradable, distinguiéndose por su tiexibilidad y expresion.

Cuando las grandes especies viven reunidas en bandadas dejando oir todas a la vez sus gritos, no son nada agradables para el hombre \&Es preciso haber vivido en los cálidos valles de los Andes para comprender cómo los gritos de los aras pueden dominar por completo el mugido de los tor rentes que se precipitan de roca en roca. Tambien los ca. catúas se hacen notar por sus terribles gritos; los de una numerosa bandada de paleórnidos son verdaderamentc in. fernales; el ruido qque produce un grupo de sitáculos podria compararse con el que hacen los herreros cuando forjan hoces. Algunas especies emiten una especie de ladricios; otras silban; estas grtiñen, y aquellas producen sonidos semejantes a la roz de la rana.

Hay ciertas especies, como por ejemplo la pequeĩa cotorm ondulada, rujo macho al enamorar á su compafiera emtona un canto tan agmable, que se le podria clasificar entre las aves cantoras; otras hay que aprenden á silbar ciertos aires mejor que pudiera hacerlo un canario.

Todo el mundo sabe cómo los loros llegan á imitar la vor. y la palabra humanas; arentajan por cllo á todos los demás animales, $y$ hacen en este concepto cosas increibles: no charlan, sino que hablan.

Fäcilmente se comprenderá que no quiero decir con esto que los loros entienden la significacion de las palabras repetidas por ellos, $\delta$ de las que puedan inventar y componer; solo preicndo que saben emplear oportunamente las palabras que se les enseñan; que, por ejemplo, cuancio se les ha ensenado bien, dicen por la mañana buenos dias y 110 buenas noches. Fórmanse por consiguiente una idea de las palabras y frases aprendidas, reteniendo en la memoria la ocasion y la hora del dia en que se las enseñaron, y empleando las mismas paiabras 6 frases en iguales ocasiones.

Precisamente del mismo modo procede un niño cuando aprende á hablar; pero este comyrende con el tiempo toda la significacion de la palabra; mientras que esto no lo conse. guirá nunca el Ioro.

Álgunos aficionados á pájaros, que durante muchos años lan cuidado loros, están completanente conformes conmigo en cuanto á lo anteriormente expuesto. "No siempre el hablar de los loros; dice Linden, es solo una imitacion de jalabras, sino tambien con írecuencia la expresion de un deseo ó de la gratitud por un favor recibido; muchas veces hay cierta ternura en la pronunciacion de palabras ó frases enteras que se acompanan con los gestos corresjondientes. Fi que por espacio de algunos snos ha tenido á su lado loros $y$ ha recibido pruebás del apego y carino de alguno de ellos, crecrá sin dificultad que á menudo he sentido tanto la pérdida de uno if orro de esos animales, como si hubiese muerto un amigo mio. I.os loros, que en su mayor parte son juguctones, pueden contribuir mucho á entretenernos. Nadie negara que el hablar ncrecienta mucho la familiaridad entrc el loro y su amo; en eiecto, esta facultad les hace muy superiores, al menos á mis ojos, á los monos.

\Casi todas las especies del órden tienen la facultad de hablar 6 imitar las voces de otras ares, y hasta el canto, que ejecutan con tanta maestría como los mejores cantores; pero tambien emiten sonidos que hieren aun a los nervios mas fucrtes Estog convencido de que esta facultad de imitar es propia así de las especies grandes como de las pequeñas; mas tambien sé que no todos los individuos de la misma especie cstán igualmente dotados. En casa de mi amigo Stoelker ví un loro de frente dorada que hablaba muy bien; $y$ hace ya mas de veinte aisos que tenia yo un metopsitaco ondulado cn compañia de comarios y espínidos que imitaba con facilidad cl canto de estos del modo mas perfecto. Tambien posci una roselía que initaba magníficamente el canto del mirlo y actualmente conservo un melopsitaco que canta volando como una alondra.

2. No cs posible dar una enseñanza regular a mis loros y tampoco ine gusta enseĩarles palabras sin darles antes ocasion parn formarse una idea de lo que significan. Con el largo tiem. po que paso diariamente con mis favoritos, sc acostumbran estos á mí y me cobran cariño; en ese trato familiar hay natu. ralmente preguntas y contestaciones, y estas últimas me prue. ban que los loros hablan á menudo con pleno conocimiento de lo que dicen.

Por lo regular se desliza la existencia de los loros en los 
bosques, si bien algunas especies viven en las llanuras desjiovistas de árboles y en las estepas; otras se elevan en los Andes mas alla del limite de los árboles, ì 3,600 metros $\$ 0$. bre el nivel del mar. He observado que en el nordeste de Africa no se veian sino donde habia monos; de modo que casi se podria considerar a estos animales como inseparables. Cunnto mayores son los bosques y mas rica la vegeiacion, mas abundan ins lozos. aEn las selins de los trópicos, dice el princine cie Wied, forman la mayor parte de la poblacion alada. Io mismo sucede en Australia, en varios paises de la India y en ciertas partes de Africa, donde son tan comunes como entre nosotros los cuervos y los gorriones.

Donde quiera que habiten llaman la atencion, embeliecen los bosques con su plumaje y los animan con sus gritos \$los loros, dice el principe de Wied, engalanan con sus plumas de brillantes colores las sombrias selvas virgenes de los trópicos. - Es imposible desrribir, dice (iould, el mágico es pecráculo que ofrecen los loros de rojo plumaje, volando en inedio de las acacias de platedadas hojas de la Australia, soire las cuales se destancan los magniricos colores de las pintadas aves. - Los cacatúas, cxelama Mitchell cutusiasmado, tras. forman las alturas donde habitan en un pais de delicias. toQYo los he visto, dice Audubon, cubriendo compretamente las ramas de los árboles, tan compactos y oprimidos como si fueran un solo animal x- $\&$ Por manana y tarde, cuenta Schomburgk, se divisan innunerables handadas de loros que cruzan los aires atronando el espacio con sus gritos: cierta tarde vi a una caer sobre los árboles de la ribera, y las ramas se doblegaban bajo el peso de aquellas aves.? ¿Qué serian sin ellos los grandiosos bosques de los erópicos? Nada... el triste jardin de un cucantador, el dominio del silencio, el desierto: ellos animan la soledad, le dan vida, maravillando á ia vez. la vista y el oido.

liuera del periodo del cclo viven los lorosen sociedades ó bandaclas muy numerosas; eligen su residencia en un sitio del bosque, y' de alli parten todos los dias al cuprender sus excursiones. los individuos de una misma bandada perma. necen fielmente unidos entre si y comparten su buena ó mala suertc. Todos abandonan juntos por la maniana el sitio donde han pasado la noche; se posan sobre un árbol ó en un campo, á fin de comer los frutos; colocan centinelas parn que vigilen por la seguridad de todos, y estain ntentos á sus adveriencias En caso de peligro caprenden la iuga, sosteniérdose mutuamente, y vuelven juntos al sitio acostumbrado: en una palabra, viven continuamente reunidos.

4 A los primeros albores de la brillanteaurora de los srópicos, dice el principe de Wied, pónense en movimiento los loros; secan sus alas humedecidas por el rocio; ejercitanse retozando: se llaman con sonoros gritos; hacen mil havilidades en los árboles, y emprenden despues su rápido ruclo para buscar la comicia. Por las tarde vuelsen todes puntualnente al lugar que les sirve de abrigo.?

'Tschudi ha observado asiunismo en el Peni las cotidianas excursiones de los loros: hasta los indigenas han dado el nombre de jormalera a ura especie que baja regularmente todas las mañanas de la montaña para volver por la tarde.

Le Vaillant refiere quee los lo:os del sudeste de Afriea van en reducidas bandadas á buscar su alimento. Hácia el medio dia acostumiran a bañarse; dunnte las horas de mas calor se ocultan en el foliaje de los árboles; dispérsanse de nuevo; se bañan una vez mas, y vuclven s pasar la noche al mismo sitio de donde salieron por la mañana.

Ell lugar de reposo no es siempre el mismo: unas reces eligen la copa de un árbol, otras la pared de alguna roca agrietada, ó bien un tronco hueco, que es lo que suelen pre. ferir. ila cotorra de la América del rone (comarys carolinerssis), dice Audubon, se alberga en un irbol hueco ó en el nido de un gran pico, abandonado por este. A la hora del crepúsculo se pueden ver bandadas de estas ares, que se reunen al rededor de los añosos sicomoros y de otros árboles huecos:agnipanse i la entrada de la cavidad y penetran en ella una tras otra; si fatia sitio, las que no han podido entrar se suspenden al rededor de la abertura con sus patas y su pico. Dirinse al verlas que este órgano solo sosticne todo el peso del cuerpo; yero mirando con un anteojo de larga vista pude convencerme de lo contrario. 2

En las selvas virgenes $y$ en las orillas del Nilo Azul, he sorprendido con frecuencia, durante la hora del crepúsculo, a los loros que penetraban en los troncos huecos de las adansonias. En las Indias, segun cuenta Layard, el paleornis de collar (folcurnis torquatus) pasa la noche en las espesuras de bambúes. Todos los loros, los grajos y los cuerros de varias millas 1 la redonda, se reunen por la tarde en los bambues, y despues de ponerse el sol, hasta que cierra la noche, y des. de que brilla la aurora hasta la entrada del dia, percibe el oido del vinjero el rumor producido por aquellas ares, semejante al que formarian numerosas mnáquinas de vapor. Algunas bandadas regresan tarde de sus excursiones, y entonces ruelan las aves rasando la tierra, y chocan $t$ menudo contra los cuerpos sólidos que encueatran. Varias noches seguidas se hallaron loros muertos gor haberse estrellado contra las paredes if otros obsticulos.

Layard traza una descripcion muy animada de las costum. bres de la cotorra de Alejandro, muy comun en Ceilan. «In Chilaw, dice, he visto a las cotorras posarse en los cocoteros del mercado, que les servian de refugio, y era tal su nuinicro, que sus gritos dominaban completamente á los de los vendedores. Me habian hablado de aquel especiśculo, y cierta tarde tne puse cn observacion en un puente de los alredcdores para ver si podria calcular el núnero de las aves que llegaban por una sola parte. Hácia las cuatro aparecieron alguras banda. das dispersas que volvian á su retiro; despues llegaron otras cada rez mas numerosas, y al cabo de media horn pasaban de continuo, hasta el punto de ser imposible contar las ban dadas. Elevatuanse algunas en el aire par encima de los árbo. les, dẹindose caer despues verticalmente; otras volahan rasando la tierra, de tal modo que me tocaban varias el rostro con sus alas; pasaban ráuidas como el pensamiento, y brilla. ba su plúmaje á los rayos del sol Permaneci en mi puesto hasta que oscurecio, y aun las oia pasar sin serme posible verlas en medio de las tinicbias. Disparé la escopcia y elevó. se de pronto un sordo rumor, semejante al del viento muy fuerte; comenzaron á revolotear las cotormas, y lanzaron tales gritos, gule no lo olvidaré jamas; su roz pencerante, su conti. nuo sleico, y el frotamiento de las hojas producian tario ruido, que me di por muy contento cuando me encontré en cas. :

Las copas de los espesos áboies son indispensables para los loros como lugar de reposo seguro: y mas bien buscan un biren escondite que un abrigo para prescriarse de la inten. perie; les gusta el calor, mas no temen el frio, ni menos la lluvia. En medio de las terribles tempestades de los trópicos, dice el principe de Wied, que oscurecen a reces el cielo, se ve a los loros innóriles, posados en las ramas mas altas, y deiando oir su alegre cacarco, mientras que el agua chorrea en sus alas. Podrian encontrar cerca un abrigo en el espeso follaje; pero parecen complacerse en recibir la cálida lluvia de la tempestad: cuando esta cesa, apresúranse, no obstanic, á sccar sus plumas.

No sucede lo mismo cuandio hace buen tiempo: crionces buscan el sitio mas sombrio del frool para sustrarse a los ar. 
dores del sol, 6 acaso para ocultarse, conıo lo hacen, cuando les amenaza un peligro. Saben perfectamente yue una espesa copa es el mejor escondite para los séres cuyo plumaje es de! color del bosque, y que dificilmente se les puede ver alli. Se da el caso de que haya cincuenta loros en un àrbol y no se divise ninguno, aunque se sepa que están en él.

Prescindiendo de esto: tambien recurren 1 la astucia, pues no quieren ser vistos: si uno de ellos divisa a cualquier enemigo d tienpo, da la señal de alarma y lodos se callan al ins. tante, retiranse al centro del follaje, trejan silenciosamente, y se dirigen ciel lado opluesto á aquel en que se oyó el ruido; cmprenden entonees su vuelo, y no dejan oir sú vou hasta que se hallan a unos cien pasos de distancia cual si guisieran burlarse des importuno quio los molesto. tsto es lo que tracen geneminente clianda se hatlan en un urbol comiendo los irutos: durante sus exearsiones de merodeo despliegan suas. túcin y prudencia en el mas alto grado.

Los lórós comen principalmenté irutas y gmnos: algunos, no obstnnte, apenas se alimentan unas que del néctar de las flores, del pólen, y acaso tambien de los insectos que habitan el caliz de aquellas a los aras y las cotorras le gustan muclio los retonos de los árboles y los botones de las flores, y ciertos cachtúns no desprecian tampoco las larvas de los insectos Créo, jor otra parte, que las grandes especies observan un rigimen mucho mas animal de lo que se supone; veo una prueba cie ello en la sed de sangre que experimentau ciertos loros, y tambicn en la avider. con que reciben las carnes cuando están cautivos, si se les acostumbra i este régincon. Yo lie tenido loros que se precipitaban sobre sus compnneros: abrian les el cránco y sacaban el cerebro; mas no puedo decir si se lo comian ó no. Un loro al que se dejaba entiar y sadir libre. inente, se complacia, segun me contó siu propictario, en sorprencer á los pajarillos apenas salian delénido; los mataba y desplumaba con mucha limpieza; comia una parte y timba despues los cadáeres a decir verdad, anuel era un animal cautivo, acostumbrado por consiguiente a comer de todo: estos hechos aislados nada prucbar conera la alimentaçion casi exclusivamente rágetal de los loros.

Curioso espectículo es ver à estos animales cuarido van de merodeo y sé dejan caer sobre un árbol frulal ó un cam. po. En tales circunstancias parecen verdaderamente unos monos alados: cada cual déspliega suma astucia, y desde léjos acuden todos presurosos hácin el sitio donde se ve una buena presa. 2 Varios frutos que preficren en particular, dice el principe de Wied, atraen á los tímidos aras å larga distancia del lindero del bosque. Gould ha visto casi sicmpre á los paritguitos de lengua de pincel en los eucaliptos, cuyas fores les ofrecen abundante alimento; jamás los ha encontrado en otros árboles.

Todas las grandes especies dan pruebas de ser muy pradentes cunnoio buscan la convida, haciéndolo asi aunque se hallen en el busque. it Los grandes araras de plumaje verde domdo, que habitan en los Andes, dice P'eppig, se precipitan en bandadas sobre las rojas eritrinas cuyas fiores devoran; lanzan gritos atronadores; pero tienen la prudencia de callarse cuando quieren merodeas en un campo de maiz. Cada indiviuuo reprime entonces su deseo de chillar: solo se oien algunos sordos murmullos, y la obra destructora si gue su curso rápiciamente El cazador y hasta el indio, furioso al ver sus cosechas destruidas, no poeden acercarse ficilmente a las ladromas aves, pues las de mas edad estän de centincla en el árbol mas alto. A la prinera seĩal que dan contesta un grito á media roz; í la segunda cinprende el ruelo toda la bandada, lanzando agudos gritos, y se dirigen a otros sitios para continuar sus depredaciones.

Schomburgh confirma en un todo este relato, y anade que a menudo no se reconoce la presencia de semejante bandada de loros sino por la cubierta de los gramos que al caer sobre las hojas producen un ruido fácil de oir desde léjos. Le Vaillant, que lia visto loros surprendidos en medio de un iestin por la presencia de un enemigo, dice lo siguiente: *lermanecieron inmóviles; no se via nada, y sin embargo habia alli varios miles de loros reunidos. Sonó una deionacion, y al momento se remontó toda la bandada por los ajres, produciendo un gran estrépito.

En los sirios donde saben qque nada tienen que temer del hombre, no sucede lo mismo. In la India, al decir de Jer. don, penetran en las ciudades, y se posan en los tejados de las casas, sin duda para dirigirse desce alli á los campos y jardines.

Los daños que ocasionan son inmensos, y justifican todas las medidas que se han adoptado contra los loros, pues nada está seguro en las localidades cque frecucntan. aLos grandes araras, particularmicute, dice el príncipe de Wied, abren, con su vigoroso pico los frutos y las nueces mas curas. No obs. tante, saben contentarse lo mismo con un fruto jugoso que con un pequeño grano: las ranuras de la mandibula superior les permiten cogerle, por liso y diminuio que sea; y tambien les sirve de mucho yara ello su lengua movible. En un momento gueda abierta la nuez despojada la espiga y descubierto el grano; si no les basta el pico recurren à sus patas.

A semcjanza de los monos, destruyen nucho mas de lo que comen: las bandadas innumerables que caen sobre los árboles ólos campos se atracan cuanto pueden, y no es tanto to yue se llevan para comérselo cómodamente, como lo quue echan ál perder. Al caer sobre un jardin registran cada arbol, isrueban todos los fruins, tiran todos los que no les parecen bastante sabrosos y solo devoran aquellos que mas les con. vienen. De este modo despojan todo un śrbol, comenzando for lasy rmas interiores; y al llegar a la cima, lanzanse sobre orropara repetir la misma operacion. In la América det norte y en Chile, deshojan los árboles antes de que ma. duren los frutos, a fin de saborear la leche que rodea el grano. Segun intormes de Audubon, les gusta mucho el trigo amontonado en los campos; sacan con mucha limpieza el grano de la espiga y dejan esta y la paja para del campesino. Los unos prefieren cierto alimento, y los denris otro; pero por regla general, no hay fruto ni cosecha que no devoren; sicndo esta la razon de la falta de buena armonia entre el homure y estas aves.

Despues de tomar su alimento van los loros á beber $y$ a baurarse: absorben mucho liquido, $y$ hasta toman el agua salobre, segun dicen Audubon y Schomburgh. Acostumbran á baiarse en ias charcas: I.e-Vaillant refiere gue lo hacen de tal modo, que las gotas de agua los rocian á nanera de lluvia: F. Audubon asegura que les gusta restregarse en la arena como hacen las gallinas, cubriéndose tambien las alas de polvo. Al cfecto, se amastran algunas veces hasta el nido ce los grandes martines-pescadores; buscan las tierras impreg. madas de sa!; y esto explica porqué se encuentran sicmpre loros cerca de las corrientes saladas, en el interior de los bosques.

Fistas ares se reproducen en la estacion que corresponde $i$ la primavera de su patria, y en la que precede a la época de la madurez-de los frutos. Parece que las grandes çjuecies no ponen mas que una vez al año, y solo Gos huevos: los phaticercos de Australia y demás loros de larga cola forman exccpcion á esta regla, pues ponen tres ó cuatro: y algunos hasta seis ó nucve liucros, dos ó tres veces al ano, segun ha podido observarse en individuos cautivos. Los paleornis y los cacatías ponen siempre mas de dos hucros, pero una 
sola rez; los de los loros son redondeados, blancos y de cáscara lisa.

Los loros prefieren siempre fabricar su nido en el hueco de um arbol: algunas especies americanas se albergan en las grietas de las rocas; ; las cotorras de la India, al ceecir de Jerdon, en los agujeros cie las casas viejas, de las pagodas y de las tumbas. Los loros ierrestres ponen sus huevos en la tierra desmuda. Audubon asegura que habitan el mismo nido varias hembras, lo cual me parece un error, pero de todos modos, lo cierto es que los loros que forman grandes bandadas anidan unos junio a otros. Molina hablo ya de semejantes reuniones, observadas por él en Chile, y Pappig da de ellas una descripcion muy completa. Este espectáculo, dice, sorprenderá seguramenic do iodo el rue le vea por prjmera vez. Aranza el viajero con gran trabajo hasta la pared vertical de una roca y se cree completamente aislado; a su alredecior reina ese silencio quue en las zonas tropicales de América indica la hora del medio dia; óvese, no obstante, por todos lados una especie de murmullo; pero por mas que se mira, no se ve de dónde procede. De pronto resuena el grito de alarma de un loro; repstese luego, y en un instante se ve rodeado el viajero de nuives de pajjaros, que en com. pacros circulos vuelan i su alrededor, cual si quisieran caer sobre él.

x Por todas las grietas de la roca asoman cabezas de loros, y los que no huyen indican con sus gritos que participan de la emocion general. Cada abertura es la entrada de un nido formado por el are cul las capas de marga que separan las masas roquizas; á veces sề cuentan centenares de ellas; pero siampre situndas fuera del alcance de todo carnicero. En los bosques no se encuentran semejantes asociaciones, porque alli es mucho mas dificil hallar condiciones favorables para In nidibiencion comun. Los loros buscan, sobre rodo, los grandes arboles, cujos troncos ó ramas puresentan huecos cn rarios sitios.

En Africa anidan con preferencia en las adansonias, y en los agujeros mas bien que en el ramaje, cuando el árbol estả fuera del bosque. En las estepars del Kordorahn, vi yo una arboleda aislada de adansonias, y aunque desprovistas de sus hrojas, habiase domiciliado alli una colonia de loros, los cua. les no hubicran elegido skguramente ąquel punto si los árboles no hubiesen estado huecos.

Cuando los loros no encuentran para su nido un díbol preparado, sea por un diestro pico. ó por una feliz casualidad, deben arreglarlo por si, en cuyo caso se ve cómo saben utili. zar su pico. Fil macho y la hembra, en especial esia última, practican un agujero en la corteza: suspéndense del tronco con su acerado ógano, royendo mas bien que cortando, y leramian fibra por fibra hasta formar la abertura. Cierta es que necesitan jarn esto algunas semanas; pero a fueran de constancia consiguen su objeto. I'racticado el agujero, riueda hecho lo principal: algunas ramitas ó astillas bastan para cu. brir el fondo, pues el loro se contenta con un nido muy im. perfecto. "En el blanco ironco de una palmera iremis, dice Paeppig, vi una brillante cola de plumas de color azul celeste: cra un ara amarillo, que se ocumaba en ensanchar con su pico un nido del påjaro de este nombre; y en th poria sus huevos, aunque no le ura posibie introducir la colas

Si no, intervienen circurstancias incsperadas, la pareja virlye todos los aros al mismo nida. Einte los antiguos me. sicanos que traficaban con plumas de loro, lus airboles en que estas aves tenian sus nidos eran, segun Hernandez, propile. dad particular, y pasaban siempre de padre a hija Los loros hacen poco aprecio de la comodidad de su nido; a nuchos les basta el fondo desnudo y casi putrefacio de los huecos de ärboles, yotros se limitan a cubrirle con algunos filamentos de madern. Sin embargo, tambien hay excepciones: los loros cmanos, segun he observado en cautivos, tapizan el hueco de su nido con filamentos muy finos de madera ó de paja, y al. gunas esprecies de cotorras de cola plana hacen un lecho con jerba y plumas.

Macho y hembra suelen cubrir los huevos alternativamente.

Entre las pequeñas especies, como por cjemplo, la cotorra ondulada, la hembra cubre los huevos jor espacio de diez y seis y diez y ocho dias; otros loros emplean diez. yueve, veintitres ó veinticinco: no se sabe cuínto tiempo durn la incubacion para los aras.

Los polluclos salen muy inperfectos; pero se desarrollan rápidamente: aunque no los cubre al principio mas que un escaso plumon, salen a los cinco ó seis dias las primerns plu. mas, y abren los ojos a los ocho o dicz. Las pequenas cotor. ras onduladas abandonan su nido por vez princra á los treinta y ires dias, y dos despues vuelan por los alrededores.

Es de notar yue algunos loros pequenos presentan en el pico yrulongaciones en forma de dientes, las cuales desaparecen mas tarde; caen y son reemplazadas por masas cartilaginosas. Créesc que estos dientes son las extremidades, cu. biertas de papuilas córnens, de msos y nervios que favorecen y regularizan el crecimiento del pico.

El padre y la madre alimentan a sus hijuelos hasta algun liempo despues de abandonar el nido; humedecen en su buche los granos destinados para ellos y los introducen en el pico. Schomburgk ha obscrvicio un par de loros que anidaban cerca de su campamento y ha visto que los hijuelos no recibian su comida mas que dos reces diarias; una of las once de la mañana y otra á las cinco de la tarde \&Cuando llegaban los padres, dice, posábanse sobre una rama cerca de su agujero, y si veian que se les observaba, permanecian inmóviles, esperando una ocasion para desaparecer en el nido sin ser ofservidos.

Los padres prodigan los mayores cuidados a su progenic: en caso de peligro la defiendén con tanto valor como abne. gacion; y si estån cautivos no permiten que se acerque ni aun el amo, por mucho que le conozcan y amen.

Ciertos loros adoptan a los pequeños abandonados y los tratan con el mismo cariso, aunque no pertenezcan á su espe. cic. El cirujano del buque Tritor, con quien hice la travesia de Nueva Holanda i Inglatern, refiere Cunningham, poscia dos loros, uno de los cuales era demasiado pequeño para poder alimentarse por si mismo. El de mas edad, un loro azul, se encargo de cuidarle, $y$ lo hizo con la major ter. nura. la amistad de las dos aves pareció esirecharse con el tiempo; pasaban todo el dia acariciándose; el mas viejo en. lazaba tiernamente al otro con sus alas; hasta tal punto llegaron i ser ruidosas las pruebas que se datan de su afecto, que se resolvió sejararlos para que no tuviesen motivo de queja los pasajeros. İl mas jóven fué trasladado a mi camarote, doncie habia otras rarias aves; pero al cabo de dos meses consiguió escaparse el loro azul, y guiado por la roz de su ahijado, penetró en mi camara y se cogió í la jaula. Entonces volvimos a reunir \& los cos amigos, mas á los quince dias murió el mas jóven, por un accidente imprevisto: el otro se entristeció, no se oyó mas su voz y poco despues dejó de existir.s

Se conocen otros cjemplos análogos. El que tiene muchos loros observaŕ nas ó menos tarde semicjantes rasgos de no. bleza y caridad. Una cotorra de la Carolina, expuesta por Buxton, padeció cie tal modo en el rizuroso imvierno de I\$60, i consecuencia de las heludas, que perdió ambas piernas. Lin toro del Amazonas se compadeció de la poure ave, colocóse a su lado, limpióle las plumas, y défendióla contra los ataques de ottos loros que amenazaban mataria, como asi lo 
hicieron al fin. No podia ser mas vivo el contraste entre la pobre mutilada y su compañero, que brillaba en toda su lozania.

Asi como las cotorras de diferenie especic traban amistad del modo que hemos dicho, de la propia suerte contracu relaciones amorosas, que si bien son al principio formosas hastá cierto punto, consolidanse con el tienpos de tal modo, que no se rompen aunque se dé á las dos aves oportunidad de aparearse con sus sencjantes. Con much frecuencia se apa. reari, sobre todo cacatủas de diversa especie, aunque tambien se observa lo mismo en otras cotorms. Por una casuia. lidad, me escribe Linden, perdi la hembira de una pareja de la Pionsia fuscicolls ; y el macbo se nsoció con una cotorra de Alejandro que aceptú voluntariamente las caricias de! toras. tero. Muchas veces pude otservar el apareamiento de ambos; la heinbra puso inuchos huevos y los cubrio; pero desgraciádaniente no dicron cria. Sin embargo, estos huevos no eran infecundos, pues muchos que yo abri, contenian fetos muy desarrollados Ninguna de las otras cotorsas gue habitaban el mismo recinto con la pareja osó nunca acercarse f la hembra; pues el macho la vigitaba con el mayor celo y se móstraba hostil hasta contra mi cuando la hembra se co. locaba sobre mi hombro para pedir al pedacito de pan que yo solia ofrecerle al repartir in racion dis demás aves: sicmpre compartia con su compañero las golósinas obienidas. Eil macho se encolerizabis cuando yo permitia a la hembra permancect mas de lo acostumbrado solore mi hombro; bajaba a uno de los palos inferiores, y erizundo el plumaje, producia unosisonidos cxtranos. Tambien la hembra me manifestaba sus descos de reunirse con su compañero tirandome suare. mente de la oreja o del cabello. Ln la tarde de un frio dia de invierno se me escapó la hembra, porque ignorando yo qué se habia posado en mi liombro, salió commigo de la jan. la. El ave voló a la copa de un árbol innccesible, sin que los gritos del macho la indujeran \& bajar voluntariamente; solo el frio de la noche la obligó á cllo; de modo que nos fú po sible recobrarla Sin embargo, esta escapatoria le costó una pulmonia, de cuyas resultas murio poco despues El macho la buscaba desjues en todos los nidos, dejando nit sonidos lastimeros. Poca amtes de ocurtir cste percance habia com. prado yo una pareja de cotorns de Alejandro; y una ve? convencido el macho viudo de que en vano buscaria á su difunta companera, fjó su atercion en la hembra de mi nueva pareja. Lista se hallaua en una jaula separada del recinto comun; pero el macho logró roinperla y apoderarse del ave apetecida. Yo no ine opuse i esto, y descle cntonces vivió con la segunda hembra tan familiarmente como con la primera; mientras que el macho legitimo hubo de consolarse solo. Mtuchas veces procuré bacerle volar en el mismo com. partimiento con el pion, pero este, celoso de su dominio, le obligaba siempre \& volver inmediatamente á su jaula. T:unbien se da el caso de que los loros manifiesten enemistad, no solo conira individuos de otra especie, sino contra los de la inisma. Ias cotorras de cola plana de la Australia se distinguen sobre tocio por su mala indole. A menudo se traban encarnizadas luchas entre los machos de la misma ó de diversas especies, luchas que suelen acabar con la muerte del mas débil. La causa de estos sangrientos combates puede ser la envidia por el alimento en unos, los celos en otros; y el despotismo, en fin, en algunos; tambien sucede que uno ú oiro se precipita sin razon conocida sobre indivi. duos mas débiles de su género. Yo mismo he observado cómo una cotorra criada por nosotros, fuć acometida desde luego, al entrar en la jaula comun, por otras de su misma especie, habiéndola maltratado de tal modo, que pereció al poco tiempo. Asi como sucede con otros muchos animales, casi todas las cotorras demuestran un odio profundo contra los individuos mutilados ó enfermos de su misma ó de otra especie. Exicepciones como las indicadas se observan muy mas reces. Eil loro enfermo que ha de compartir la misma jaula cou otros, ó el que. está herido, siempre es victima de sus compañeros.

Los loros se engalanan, por lo regular á los dos anos, de su plumaje definitivo, y son aptos ya para reproducirse: las pequeñas especies no necesitan mas que un año, y â pesar de esta precocidad, viven largo tiempo. Se la podido reco. nocer el hecho en loros cautivos, que sobrevivicron al la fa. milia en cuja compania pasaron su juventud. Cuéntase en una leyenca americana que ciertos loros han visto desapare. cer á todo un pucblo. «s probable, dice Humboldt, que la ihima familia de los Atures tardara en cxtinguirse, pues en el Majpures vive todavia un viejo lorn al gune no entienden los indigenas, porqque. segun dicen, habla la lengua de los Atures.

Is probaúle que los mas de los grandes loros mucran mas bien de vejez que en las manos ó en las garras de sus eneinigos, aunque tambien los sienen, siendo el hombre cl mas temible de todos ellos. Merced a su cautela y perspicacia, consigutn escapar de los carniccros, y tambien saben defen derse contra los nue pueden penetrar hasta su retiro. Ias rapaces y los mamiferos arboricolas que se alimentan de carnc, hacen á menudo presa en las especies pequeinas; pero las̀ grandes luchan con éxito, sirviéndose de su acerado pico como de usi arma poderosa. Contra el hombre no tienen defensa; deiben sucumbir ante su asiucia.

CA\%A.-En todas partes se persigue a los loros; por duquiera se les saza con cierta aficion, ya por la utilidad que pueden repartar, $\delta$ bien para impedir sus destrozos. Esto es necesario en todas las localidades donde las plantaciones se hallan inınediatas á los bosques liabitados por los loros. \$No se crea, dice hudubon, que el propietnio sufre manquilamente los perjuicios «que le ocasionan estas ares; trata de sorprenderlas en sus excursiones, y les hace pagar con la vida su rapacidad. Provisto de su escopeta bien cargada se desliza hasta cerca de ellas, y de un solo tiro hace cacr á ve. ces oclıo ó diez. Las otras se levantan, chillan, revolotean describiendo circulos duranie cinco ó seis minutos; se acercan á los cadáveres de sus compañeras; rodénilos lanzando gritos planideros, y cacn á su vez, victimas de su amistad, liasta que el plantador no las cree ya bastante numcrosas para causar daño en sus cosechas y deja en paz á las que sobieviven. En pocas horas he matado yo asi varios cente nares de loros, llevandome cestos llenos de sus cadiveres: pero los que solo estản heridos se defienden vigorosamente, † con sus cortantes picos ocasionan a veces profundas heri. das. \ Los chilenos esperan a que los loros se hayan posado en un campo, y entonces se lanzan de improviso sobre cllos y los matan as palos; los liabitantes die Alsstralia los asustar cuanco descansan, y disparan sus Rechas contra la bandada que vuela. Algunos cazadores temerarios se deslizan á lo largo de las paredes de roca, donde los loros establecen su morada, y con unos garfios se apoderan de los pequeños que se hallan en los nidos.

Los cazadores de aficion, y tambien los de oficio, procurar sorprenderlos mientras comen. Para coger los pequeños se cortan los árboles cunudio no es posible subir á cllos; asimis mo se emplcan las redes, In liga, eic.

CAUTIVIDAD.- In domesticidad de los loros recuerd: en cierto modo lá de nuestros animales caseros, y data $y$ desde las épocas mas remotas. Fn los antiguos monumento egipcios filtan completamente, al decir de Dunichen, la imágenes de estas aves, y tanıoco la Biblia hace mencion d ellas. 
En la India, empero, Onesicrito, general de Alejandro el Grande, las encontró ya domesticadas, y llevólas vivias a Gré. cia; mas tarde se recibieron á menudo en Roma. Plinio describe sus usos y costumbres con bastante exactitud; pero solo conocia los palcornidos.

\&:Oh desgraciada Roma! exclamaba el rigido Caton el Censor, iá que extremo te ves reducida, cuando las mujeres crian perros en su seno y llevan los hombres loros en la manoly Ponianse estas aves en jaulas de plata, de concha y de marnl, y habia personas encargadis exclusivamente de cuidarlas y enscñarlas, sobre $10 d o$, í pronunciar el nombre de Cisir.

Un loro que hablara costaba a menudo mas que un esclavo: Ovidio no se desdenó de cantar a una de estas aves: Hcliogábalo no crein poder ofrecer í sus conridados un manjar mas raro que un plato de cabezas de loro: en tiempo de Neron no se conocian aun mas que las especies irdias, y hasta mas tarde ro se importaron bs loros de Africa.

En la época de las cruzadas tenian loros los opulentos barones para adornar sus palacios, y se les ensenaba af hablar, segun se deduce de la siguiente cita de Cristian ron Hameln: QQuisiera que pudiese hablar como loro en jaula.

Al llegar á América encontraron los comparieros de Colon loros domesticados en las cabañas de los indigenas.

Cumio los espano!es, mandados por Nicuesa y Ojeda quisieron sorprénder, en 8509 , el pueblo de Yurbaco de los Caribes, situado en el istmo de Darien, los loros que vigrilabaı en las copas de los śrboles delante de las chozas, anunciaron la llegrada del enemigo, de modo que sus dueños pudieron enprender a ticmpo la fuga.

Schomburgk nos dice que en la América del Sur se les deja volar libremente sin cortarles las alas. "Yo he visto at varios, escribió dicho natumlista, reunirse por la mañana con sus congeneres salvajes, nuarcharse con ellos, y volviur por la arde ș la cabaña del amo. \& Cierto dia, añacis, divisamos una arboleda que parceia cubicrta de flores ámarillas; regoci. jảbame yo de haber descubierto un muevo vegetal, cuando reconoci de pronto que las tales Bores se movian cambiando de sitio: eran kessi-kessi (conmms solstitialis) domesticados, que al acercarnos nosotros emprendieron su vuelo con infernal estrépico, dirigiéndose á una cabaña vecina \& De los relatos de Schomburgh se desprende que en los pueblos indios reem. plazan los loros a las gallinas, solo que iniervicnen mas que estas en la sociedad del hombre no deja de ser un heclio curioso la inclinacion gue tienen los monos y los loros hicia los ninos: rara ver he visto jugar á los muchachos indios sin que hubiese entre clios alguno de dichos animales, y’ obsér vase que los loros aprenden muy pronto a imitar codos los sonidos que oyen; el canto del gallo, el ladrido del-perro, y los lloros y risas de los niños.

La destreza de los indios para domesticar los loros en muy pocotiempro, es verdaderamente asombrosa é incomprensible para el europeo. Cuando Bates, en su viaje por cl territorio del rio Amazonas, atravesó el rio Aveyros, cayó súbitamente al agua una cotorra de una 'bandada que en el mismo momento pasaba por encima. El viajero quiso pescar el ave, con la intencion de conservarla en una jaula, puesto que no se habia hecho daño; pero la cotorra estába muy furiosa, intentó morder a todo el mundo, y se negó á tomar alimento: de modo que Bates no sabia qué lancer con su prisionera. Una india anciana, célebre por su habilidad para domesticar loros, se encargó de cuiciar a la pequenena salvaje, y $\{$ los dos dias la presentó completamente mansa. Desde entonces el ave se familiarizó mas de lo que imaginarse pueda; aprendió á hablar, y habia olvidado del todo sus vicios antêriores. Bates no pudo averiguar de qué medio se habia valido la india; pero un conocido le aseguró que aquella mujer domesticaba con tanta facilidad a estas aves dóndolas saliva.

La sterte del loro que vive en Europa es bien triste, si se compara su vida doméstica en ạuellos paises. Las peores horas para él $50 n$ las que pasa antes de llegar á su destino. El indio que le coge para cambiarle por algun producto de Europa, le deja en el pucrto mas próximo en manos de algun marinero, que ni sabe cuidar del animal, ni darle el alimento que le conviene, resultando de aqui que la mitad de los loros embarcados no pueden resistir la travesía, y muchos de los que sobreviven, van di morir en las oscuras y sucias tiendas de los vendedores de pájaros. Solo cuando el loro cncuentra un buen amo mejora su suerte; pero muchas reces se ha vuclto timido, desconfiado $y$ maligno, y no pierde hasta mucho tienpo despues estas malas cualidades.

Sin embargo, el loro es un animal juicioso; sabe acomo. darse a las circunstancias y se acostumbra desde luego a toda especie de régimen. En vez de los frutos sabrosos y de los granos de sus bosques natales, toma los alimentos del hom. bre, que le agradan tamto mas, cuanto mas los va conociendo. Al principio le bastan los canamones y el mijo; pero luego es ya mas delicado: le dan golosinas y llega ś ser tan gloton, que no se contenta con un alimento sencillo. Se le puedo acostumbrar a comer de todo; ó beber café, té, vino y cerveza, y emariágase con los licores espirituosos. Los pequeños platicercos de Australia son los únicos que constituyen una cicepcion, pues solo comen-granos y hojas. Se ha dicho que el régimen animal a que se-somete a los loros les hace contraer la mala costumbre de arrancarse las plumas hasta cl punto de quedarse calvos, si tal puede decirse. Se ocupan en semcjante tarea con muchn ardimiento, $y$ ningun castigo, por mas que sean muy sensibles ¿ lodos, es suficiente para que pierdan semejante costumbre. ¿Debe reconocerse por causa el nuevo régimen? lis muy posible, pues nunca he visto á los loros encolerizarse de ial manera contra si mismos cuando toman un alimento sencillo.

Otros observadores buscan la causa de arrancarse los luros las plumas en el fastidio á que estas aves, tan activas en libertad, se ven condenadas en su cautiverio: aseguran que se puede corregirles de cste vicio tacilitàndoles sicmpre una cantidad suficiente de madera blanca para despedazaria, es decir, dandoles algo en que ocupiarse. Segun mis observacio. nes, cierto es que los loros, por lo general muy aficionados a la destruccion, trabajan de continuo, y con buen exito para destrozar los palitos y otras partes de madera de su jaula; pero nuuca he notado que los individuos que de este modo se ocupaban dejasen de arrancarse sus propias plumas. No puedo reconocer por consiguiente el medio indicado como verdaderamente eficaz.

Tambien Vekemans, direcior muy experto del Jardin zoolúgico de Amberes, y por cuyas manos pasan todos los años miles de loros vivos, está conforme connigo en este parecer, y al preguntarle cómo podria corregirse este vicio en esas aves, coniestóme que solo conocia un medio, cual era el de matarlas. A pesar de todo, no negaré que algun loro ú otro pierda efectivamente su vicio dándole madera blanda, y ademís creo recomendable el medio, aunque solo fuese para ocuprar al ave cautiva. Sin embargo, la eleccion de un alimento conveniente me parece de mucha mayor impor. tancia.

Segun lo que yo he visto por mis propias observaciones, las grandes especies de loros se conservan muy bien cuando se les da de comer cañamones, arroz cocido, avena, maiz, lechuga, coles y frutas; à las peq̨ueñas especies les conviene mejor el mijo, la lechuga y hojas; las almendras amargas $y \mathrm{cl}$ perejil son para todas venenos mortales. 
Segun se nota en tocios los animales superiores, entre los loros los hay que aun siendo de la misma especie, se instru. yen con mas ó menos ficilidad, ó estan mejor ó peor dota. dos. Fstos aprenden mucho y pronto; aquellos poco y muy despacio, $y$ algunos no aprenden nada; pero un buen sis. tema de educacion unroduce por lo regular los mejores resultados.

A los loros les sirve de mucho su excelente memoria, pues recuerdan las cosas durante algunos años; es tau indispensable para ellos como su lengua movible, sin la cual no podrian imitar la voz humana. Se fijan en una idea y retienen la palabra; á esta se agrega una segunda y luego una tercern; y su incultad se desarrolla á medida yue se ejercita mas. Hé aqui cómo el hijo de las sélvas virgenes, puresto en contacto con el horrbre, se amolda nas y mas a su imágen, convirtiéndose en un sér al que no podemos rehusar cierta estimacion.

Ed loro se humaniza en cierto modo por el contacto con el hombre, lo mismo que un perro se instruye, y hasta quijsiera decir llega as civilizarse por la ecucacion. En prueba de ello sé puede alegar la circunstancia de que esta are no solo se aprória los usos y costumbres die la casa de su amo, sino giue no produce sus gritos desagradables con tanta frecuen. cia, sustituýndolos al fin, excepto cuando se halla excitado, con las palabras y canciones que se le enserian. Fsta manera de acomodarse á los deseos del hombre, prueba hasta la evidencia las excelentes cualidades del loro. Su gran inteligencia se demuestra aun de otro modo, y casi podria decirse en todis las ocasiones. No solamente distinguen a los foras. teros de los hombres, las mujeres y los amigos de la casa, conio lo hacen otras nuthas aves, sino que tambien recono. cen a las diferentes personas. Para saber si un loro es maclio 6 hembra, bastará que un hombre y una mujer, acercándose alternativamente á Cl, le acaricien ó le irriten. Cuando acepta sin dificultad las caricias del hombre, el ave es probable. mente hembra, y en caso contrario, macho. Yo no querin creerlo, pero me he convencido al fin de la veracidad del hecho. El loro no se conduce sin embargo siempre de la misma manera conl diferentes personas dei mismo sexo. Casi sicmpre observa antes de juzgar 6 de obrar: á veces nani. fiesta desde luego aversion contra cierta persona, $y$ este sentimiento aumenta con el tiempo en vez de disminuir. Es preciso admirar muchas veces su instinto para conocer a los hombres.

Todo esto debe tomarse en consideracion cuando se quiere enscnar y educar a un loro; asi como cualquier otro animal destinado fs ser instruido por otro sér superior, exige la misma regularidad en la enseñanza y se le ha de tratar con duizura y carino á la par que con firmeza.

Un exceso de afecto es tan nocivo como demasiada severidad: la mujer que vive sola can su loro le convierte en un sćr insoportable, porque le mima demasiado $y$ le atiende mas de lo que debiera. Ia primera condicion consiste en colocarlo en una reducida jaula, a fin de que su amo pueda ocuparse de 6 l conrenientemente; si se le deja en libertad en lugares espaciosos, rara vez se domestica, r menos aprende à hablar; no se le debe dejar libre sino cuando su educacion está casi terminadia.

Los loros exigen ciertas condiciones para llegar á satisfacer uno de los mas viros deseos de los aficionados, cual es elde poner hueros; el hecho es raro en los individuos cautivos, porque no se les tiene en sitio conreniente; pero muchas ob. servaciones prueban, sin embargo, que no es muy dificil que se reproduzcan en nuestras moradas cuando se les da espacio y reposo, y un nido a propósito. Lina vasta pajarera donde puedan pasar todo el año tranquilamente, $y$ un tronco de ärbol de madera blanda, con un agujero bastante grande, son las condiciones esenciales para que pongan los loros: de donde resulia que se contentan, segun se ve, con poco y que saben acomodarse perfectamente á todas las circunstancias.

Conficso francamente que me gusta mas ver á los loros re. unidos en una gran pajarera que en uma estrecha jaula, aun. que hablen en ella perfectamiente.

Hasta ahora, los jardines zoológicos, que por lo dennás tanto contribuyen a aumentar el interés hácia los animales, han descuidado mucho los loros. Se les tenia como en las colecciones ambulantes, sobre armazones de madera, atán. dolos con una cadena, 6 se les colocaba en jaulas uno junto á atro. Es un verdadero tormento para el visitante de una coleccion de loros permanecer largo tiempo en el local donde se hallan, porque ciertas especies, acostumbradas á ver á sus semejantes y a otras ares con cierto órden, producen pritos espantosos apenas ven que este órden sufre alteracion.

De este modo indican al guardian todo incidente que les choca; lanzan gritos capaces de ensordecer el tímpano mas fierte, acompañados de movimicntos muy viros, alctean violentamente inclinan repetidas veces la cabcza para de. mostrar su excitacion. Fixactamente lo nismo se conducen cuando un hombre desconocido entra en su morada; si entonces grita una de las aves, todas las demás hacen coro; en este casó producen un concierto verdaderamente intolerable, y todas las censuras que se hacen contra la cautividad de los loros marecen justificables. Hé aqui por que los departamen. tos de lóros de los jardines zoológicos excitan poco interés. Fu los últinos tiempos, y sobre todo en Inglaterra y Alemania, se han hecho repetidas tentativas para aclimatar los loros en libertad. Iass aves se acostumbraron pronto al clima curo peo: ajaréronse y criaron sus hijucios y sin duda se hubieran propagado muy bien si no les huviese perseguido tanta gente. Bn todas partes donde se ve una de estas aves extranjeras se la mata, desvaneciendo asi toda esperanza de aclimatacion, Ir cual, dicho sea de paso, nos ofrece muchas dudas respecto á sts utilidad.

Las tentativas mas completas y felices para aclimatar loros son debidas á Buxton, quien se propuso el objeto en dos de sus haciendas de Inglaterra. Un crisotis del Amazonas que despues de vivir veinte alros en cautividad se habia hecho célebre como orndoy de primer brden, desperto en Buxton la idea de exponer loros, pues la citada ave, escapada un dia, permaneció casi tres meses en las copas de los airboles de la vecindad, no volviendo á la casa hasta principios del invierno. Su plumaje se habia iesarrollado tan magnificamente durante este tiempo, que Buxton, seducido por la misma sencillez del hecho, resolvió hacer mas tentativas y púsolas en práctica en gran escala. Fligió jacos y crisotis amazonas, cuatro especies de cacatúas, paleórnidos, platicércidos y dos especies de lóridos. Todos volaban libres á su antojo, hacian los ridos en el parqque s bosques de la vecirdad; conducian. se como si estuvieran libres y'sabian esconderse de tal modo, que solo una vista perspicaz podia distinguirlos en la espesura de los gigantescos árboles. Algunos emprendicron largos viajes, de los cuales no volvieron, sin duda por haber sido cazados ó muertos; los demás, manteniéndose mas cerca de la casa de donde habian salido, jresentábanse por la manana y la tarde para recibir su alimento. Cuando se habia puesto sobre un tripode el cesto con el almuerzo de los loros, escribe Buxton, presentábase una pareja de cacatúas blancos que desde un arbol habia observado todos los preparativos para la comida; despues acudia una cotorra de cresta y revo. loteaba algunos minutos casi verticalmente en la misma po. sicion que toman los colibris, es decis, con la cabeza y la cola inclinadas hácia adentro y las alas extendidas. Seguian 
dos ó tres cacatúas sonrosados, qque se agamaban al tripo- mienza por reñir con sus rivales, utilizindose muy bien de su de sin atreverse á tomar parte en el festin, como lo hacian largo pico, y todas las ar'cs se alborotan. Puedo asegum que sus compañeros mas atrevidos. De pronto se acerca uno de los grandes cacatuas de moño amarillo, volando pesadamente y ahuyenta al punto á todos los pequeños; pero estos vuelven a reunirse muy pronto, $y$ un lori, ostentando sus brillantes colores rojo y verde, remóntase por el aire y se coloca un instante despues sobre la punta del tripode, donde contrastan sus vivos tintes con el blanco puro del cacatua. Un grajo alpino, con su plumaje negro aul brillante, con su pico y jiés rojos de coral, compieta el grupro; el recien llegado co. semejante espectáculo, tal como yo lo he visto centenares de veces, tiene un arractivo indecible, sobre todo cuando en una mañana serena de invierno, el suelo esti cubierto de nieve, sobre la cual se destacan mas aun los vivos colores de las aves, que se cuidan poco del írio. Los jacos tienen la pru. dencia de refugiarse ell una casa que a este érecto se han construido; pero todas las demás aves vagan durante todo of año por los bosques. Alun en el invierno de 1867 á 1865 , cuando el termómetro bajó á $6^{\circ}$ bajo cero, todas mis cau.

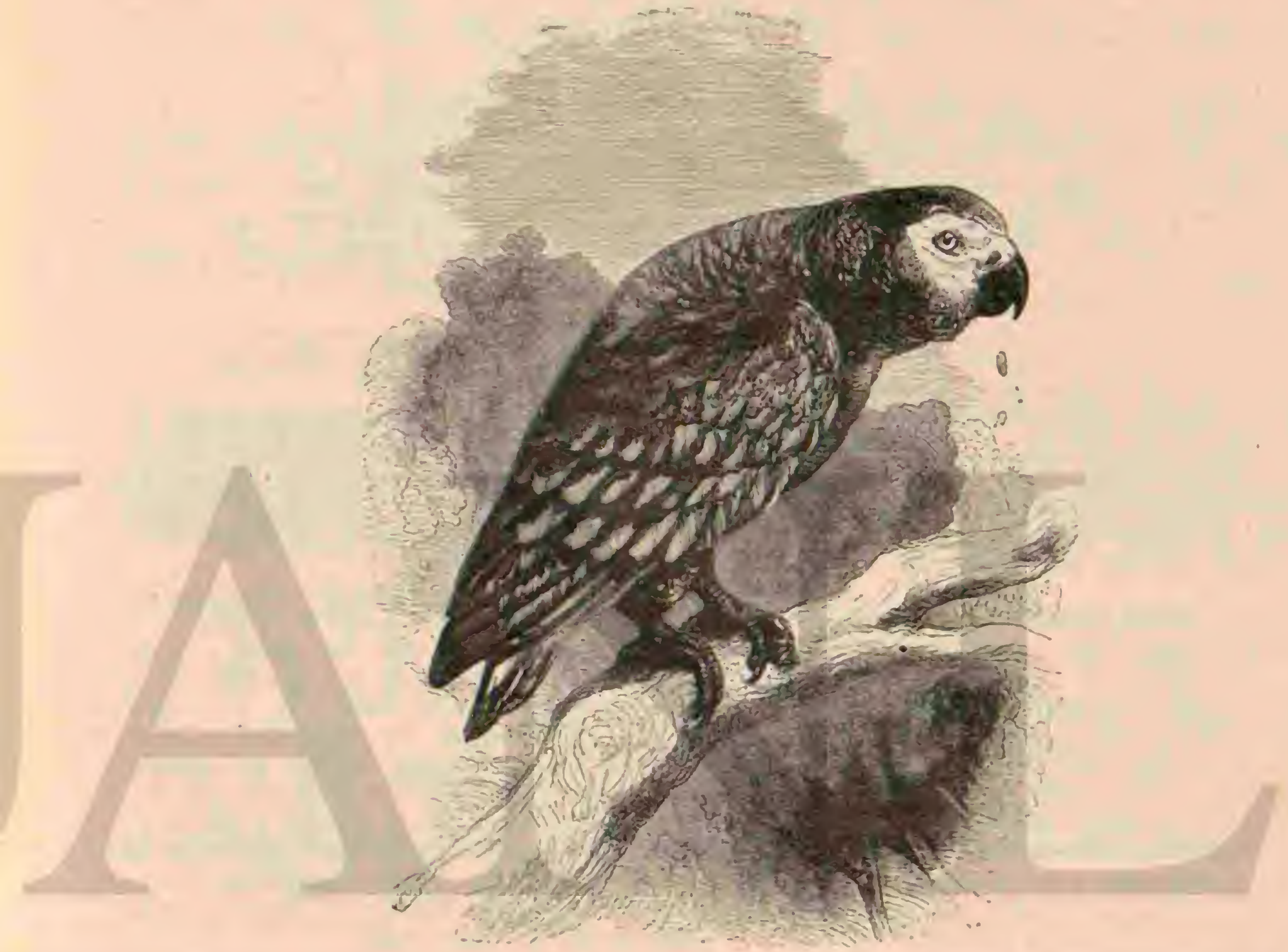

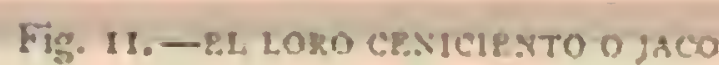

tivas se conservaban tan vivaces y alegres como antes, excepto un cacatún, cuya desaparicion cierto dia no he podido ex. plicarme.

Creo, en efecto. nue el irio no hace dano a estas aves cuaudo están sanas y bien alimentadas; tienen un plumaje ran admirable y una circulacion de sangre tan activa, que raras veces las mata el frio; y si bien no creo (que les agraden las heladas, parécene, sin embargo, bastaute singular que los loros del Africa, las coiorras de la India, y los loris de Fili. pinas, no sufran bajo ia influencia del frio y de las nieres del norte. Mi jardinera asegura que los jacos presienten la tem. pestad de antcmano y buscan muchas veces refugio en los invernaderos antes de que estalle. Foste dato me parece curioso.

* Nada maś cxtrnĩo que el contraste entre el plumaje de los loros recien llegados y el de los que tengo hace algunas semanas en libertad, cuyas plumas adquieren un brillo como el del bronce pulimentado. Asi un cambio mcional en el Tosso III régimen alimenticio, como la limpieza y el ejercicio conve. niente, son cosas de gran importancia para el bienestar de csas aves. I.as quie no pueden volar, $\delta$ que preficren permanecer en la casa, están siempre tristes y son irascibles: mientras que los individuos viraces que vuelan por los alrededores y buscan por si mismos su alimento, muéstranse alegres, contentos y dóciles Proiesan gran carino al jardinero que los cuida, y mras reces se ve a este trabajar sin tener uno o dos cacatias sobre la cabeza 6 los hombros.

Una pareja de estas últimas aves hizo las primeras tentati. ms par construir un nido, intentando inúlilmente colocarle en una de las chimenteas. Antes de cancluir su obra, el nido cayó al suelo, juntaniente con los cacatúas; y como esto su. cedió en verano, no se supo lo ocurrido hasta despues de haber pasado las potares aves un dia y una noclie entre el hollin: mis infelices cacatúas oirecian el mas lastimoso aspecto. Sin embargo, construyeron otro nido en una cajita que al cfecto estaba colgada bajo el techo de la casa; mas a pesar 
de que la hembra puso los heeros, y los cubrio continuamente hasta setiembre, no turo cria. Una pareja de diferentes especies de crisotis amazonas hizo mas tarde su nido en uno de los cajones destimados para la cria, y obturo un hijuelo; frero cuando este pudo salir del nido, uno de los cacatúas le mató. Al ano siguiente, la misma pareja mezclada turo dos peqquenos, $y$ entonces fue un espectífulo verdadernmenie encantador el que ofrecian todos los individuos de la peque. ina familia cunndo volaban juntos, tratándose con el mayor cariño. Desgraciadamente, la madre y uno de los hijuelos fucron muertos. Mas tarde aparéronse un cacatía de mono amarillo con un inca; hicieron por si mismos su nido en ia rama muerta de una acíciajla hembra puso los huevos y crió los pequeños. listos eran nuy bonitos, pero no se pare. cian á los padres; tcnian un mono miy hermoso de color rojo anaranjado, y blanco el piumaje. Los padres estaban tan contentos con el buen éxito de su tentativa que hi repiticton, resultando esta ver tres pequeños. La pequeia familia cons. taba ya de siete individuos; pero desgraciadamente fuć heridó uno de los primogénitos cierto dia de invierno, y desde entonces no le permiticron las otras aves estar con elias, obligándole a vivir aislado en un arbusto cerca de la casa. Un dia lé llcué al jardin con otrós varios cacatúas; pera al. gunos de sus congéneres se precipitaron sobre él y le mataron. Lin 1868 tuvimos la csperanza de nque la misma pareja criaria oita réz pero desgraciadamente, una pareja de jacos ocupo sul nido, no en balde, pues obtuvo dos pequños. Fin por de. más grotesco el interés exagerndo gue se tomaban las otras aves de la inisma especie cuando los jarcos cubrian su nido en la acicia. Casi todo el dia estabin posadas en la rama de un árbol que habia en frente, s apents salia uno de los padres, acompañábale un grupo de sus congéneres lanzando terribles gritos.

Los loros observan tambien en Inglaterta un gencro de vida sistemático, segun se colige del siguiente final del relato de Buston. Mos loros, dice, hacen cierta distribucion de sus horas. Poco despues de rayar la rurora ójense sus gritos des de un bosque alyo distante, donde los mas de ellos duernen despues acuden para recibir su almuerzo; duemen durante las horas del medio dia, buscan mas tarde alimerta, yresén. tanse, en fin, para tomar su cena. Antes de entrógarsieal descanso manifiestan la mayoralegtia, como lo hacen los cuervos. Los loros propiamente dichos describen entonces muchas veces círculos en el aire a gran altura; mientras que los cacatúas revolotean de un árbol en otro, dejando oir su voz, sobre todo cuando ren hombres en el jardin. No puedo negar que algunos de cllos causan á reces darios, particularmente por su aficion á la fruta; pero se les puede dispensar por la disraccion que proporcionan y por la admirable hermosura de su plumaje.

USOS Y PRODUCTOS. - Aunque dura y filamentosa, la carne de los loros es muy apreciada, y sirve sobre todo para hacer un buen caldo, calificado de delicioso por Schomburgh. A los chilenos les gusta muchisino: los incios de América y los salrajes de Australia persiguen actiramente a estas ares para comer su carne.

Mas bien se cazan, sin cmbargo, con el fin de obtener sus hermosas plumas. ANada mas natural, dice el principe de Wied, que este adorno, tan precioso como sencillo, y tan bus. cado por los salvajes; y d-fe que son magníficos los toscos irabajos de pluma que hacen aquellos pucublos incultos, y de los cuales nos hablan los viajeros. Varias tribus indigenas del Brasil se han distinguido particularmente en este arte; $y$ hasta se dice que saben teñir las plumas del loro con sangre de rana, lo cual seguramente es una íbula inrentada por algun natural, y referida por el a un europeo demasiado créciulo.
La marcada aficion que manifiestan los pueblos salvajes á las plumas de loro es muy antigua y está muy generalizada. En los énocas mas remotas, dice Pajpig, los habitantes de los linderos de los bosques llevaban si los incas plumas de aras para adurnar sus paiscios; y los antiguos historiadores del Perí nos cian á conocer que el afan de buscar estas plu. mas y la coca, indujeron á los hombres á penetrar en las ter. ribles selvas virgenes.

Por este concepto ocupan los loros un lugar en la historia del mundo; y no se crea que el hecho que acabamos cle ciiar es aislado, pues en otra circunstancia liguraron estas aves de una manera notable. Por una bandada de loros que volaban se descubrió la América. Pinzon, compañero y segundo de Colon, suplicó à este que cambiara la direccion del buqque, diciéndole: rengo el presentimiento de que debemos nave. pgir por otrn lado. Humbold refiere que un viejo marinero nianifestó al hijo del gran descubridor, que Pinzon turo el presentimiento al ver volar à unos loros, \& los cuales observó por la tarde cuando se dirigian hácia el sudoeste para bus. cár, segun pensó él, tiersa y árboles donde pasar la noche. Casi podria decirse que estas ares promovieron en las colonias del nuevo continente la separacion de las razas latina y gernianas

No es mi nimimo hacer de esta casualidad un mérito para los loros; cito el becho porque creo nue no debia pasarle en silencio.

Esta's aves tienen para nosotros la misma utiliciad que los monos: se come su carne, sirven sus plumas de adorno, y su compania entretielsc. Los a jreciamos á pesar de sus defectos, perdonándolus que nos pinuen las orejas $y$ lo roan todo, incluso el hierro; ros dejamos seducir por su hermosura y nos hace gracía su jurudencia.

CLASIFICACION, - I a clasificacion de los loros es muy dificil tínto á causa del gran número de. sariedades conocidas, como por la sorprendente conformidad de iodos los caractíres esenciales de las mas distintas especies del óden. Como dice muy bien Wallace en su última obra, este órden se halla, bajo el punto de vista zoológico, en un lamentable desónden. Apenas es posible distinguir marcadamente los aiversos grupos principales, por mas que no puedan desconocerse sus tipos caracteristicos. 1)ebemos considerar por lo tanto fí estos grupos principales como sub-familias. Yo clasifico todo el órden en una sola familia, dividiéndala en sub fami. lias; peto no refutaré a los que, con Wallace, las consideran como familias ó cambian elórden.

\section{LOS SITACIIDEOS - PSIT- TAGINE}

CARACTÉRES.-IOS sitacideos deben figurat en primer término, á mi modo de ver, y se distingruen por su cola corta $\delta$ cuando mas de longitud regular, ya cortada 6 ligeramente redondeada en su extremidad.

DISTRIBUCION GEOGRÁFICA.-El área de dispersion de esta familia se extiende por todos los paises chlidos; las especies que la componen se hallan en mayor núme. ro en Anérica y Africa, $y$ con menos frecuencia en Australia: solo faltan en la Polinesia.

\section{LOS LOROS GRISES - PSITTACUS}

CARACTÉRES. - Las especies que formản este género constituyen el tipo originario del órden; sus caractéres distimivos consisten en tener el pico robusto con arista redon. deada; alas largas, cuyas puritas ofrecen bastante desarrollo; 
cola de longitud regular, cortada casi en linea recta, y plumas grandes; las fosas nasales, la piel quue nay alrededor de los ojos, la cera y los circulos oculares están desnudos.

\section{EL JACO-PSITTACUS ERITHACUS}

CARACTÉRES.-Pocas palauras bastan para describir csta especie, pues en rigor solo tiene dos coloras principales en su plumaje. la cola es de un rojo de escarlaia y todas las demás plumas de un gris ceniciento, con el borde menos inienso. En la cabeza y en el cuello este borcie se marca mas, y por eso aquellas regiones parecen mas claras. Cuando cae cl fino polvo que como una gruesa capa suele cubrir las plumas, estas tienen un color negro azul de pizarm. Obsérvanse dilerenies variedades, y muchas de estas presentan unos co. lores magnificos, teniendo algunas plumas de las alas y de otras partes del cuerpo un hermoso brillo rojo; pero saras veces llegan individuos de esta especie a Europa, porque los comerciantes estaulecidos en la costa occidental del Africa, suelen comprar para si estas ares, llamadis alli loros reales. El jaco pequeno se distingue del adulto por su plumaje gris pardusco mas pálido, y por su pupila gris.

a pesar de todos mis esfuerzos, me escribe Reichenow, no he podido averiguar si las plumas caudales de los jacos jóvenes son rojas ó grises. Varias veces he recibido individuos jórenes que tenian el centro de las plumas gris oscuro y los lacios de un pardo rojo sucio, por lo cual podria creerse que el color cambia poco a poco desde la base; pero estas ares procedieron sicmpre de las monianas del interior y pertenecian, segun parece resultar de observaciunes recientes, á la especic del fsilfarus Tinnel, conocida hace mucino ticmpo y congenere muy afine del jaco. La pupila del jaco adulio es anarilla, el pico negro y los piés de un gris de plomo. El macho, un poco mas grande que la hembra, mide $6{ }^{\text {m }}, 31$; la anchum de las alas extendidas es de $\{, 2,05, y$ la longitud de $\left(1^{\prime \prime}, 22 ;\right.$ ! cola tiene (1), os (fig. 11).

DISTRIBUCION GEOGRÁFICA.-El área de dispersion del jaco se exticnde for el oeste del Africa, desde la Senegambia hasta el Benguela, llegando por el este hasta el lago 'Tschad, las fuentes occidentales el Nilo y el lago Nyanza; ocupa casi los mismos territorios que la palmera de aceite. Dentro de este inmenso espacio el are se deja ver casi en rodas partes con suma frecuencia, y por lo mismo debemos extrañar mucho que hasta los útimos tiempos no se hayan obtenido datos sobre su género de vida en libertad. Mis lectores ngradecerán conmigo la amabilidad de Rei. chencsw, el cual ha observado muy exacta y minuciosamente al jaco, poniendo á mi disposicion sus infornes. El citado maturalista dice lo siguiente:

GPor do quiera que se dirija el viajero, en todas pattes oje el grito de los jacos, muy abundanies en el Afrien accidental, sobre todo en la costa de Oro, en el delta del Niger y jünto al Kamerun y Gabon. La naturaleza les ofrecce alqui, en los impenetrables bosques del pais aluvial de las descm. bocaduras de los rios, unos albergues tan ocultos y cómodos q̧ue la persecucion á que cstán expuestos por parte de los indigenas y algunos otros enemigus, no tiene ninguna imfror. tancia. Los inanglares son los-bosques que sirsen priacipalmente a estas aves para criar; buscan los huecos de los árboles y ensánchanlos con su fuerte pico. Durante ia incu. bacion, que se efectua en la estacion lluviosa correspondiente á los sitios respectiros, al sur ó al norte del ecundor, es decir en nuestros meses de verano, $\dot{o}$ en los del invierno del hemisferio ineridional, las parcjas viven unas ó menos aisladas; pero despues de este periodo reunense con sus hi. juelos y otros individuos de la misma especie, formando bandadas que hacen vida comun. Para descansar eligen los árboles mas aitos y todas las noches los ocupan. Al ponerse el sol presénianse por diversos puntos bandaủas mas $\delta$ menos numerosas; de modo que muchas veces se reunen algu. nos centenares de estas aves. l'ácilmentc se descubren estos sitios de repposo, pues à gran distancia se oyen los gritos de las ares que llegan asi como de las que se preparan para descansar: solo al oscurecer guardan todas profundo silencio. A la mañana siguicnte resuenan de nuevo los gritos que anuncian la salida de las bandadas: graznando ruidosamentc, los jacos se dirigen hácia el interior para saquear los cam. pos de maiz que los negros tienen con preferencia en las mesetas. El maiz medio madura constituye el alimento favorito de estas ares, y terribles son los destrozos que causan en los campas. Solo a la hora de ponerse el sol comienzan la reti. rada para volver á reunirse en sus ärboles. En sus expedicio. nes siguen siempre el mismo camino cuando no se las inquicta. Nosotros lo reconocimos muy pronto, y nos aprorechamos de ello para proporcionar provisiones á nuestra cocinera pero nunca podiamos frecuentar mucho tiempo el mismo sitio, porque las astutas ares comprendiendo el peli. gro, evitábanle, dando un rodeo.

El ruelo de los jacos puede calificarse de misero; dando algunos aletazos cortados y rópidos dirigense en linea recta hácia el punto que tratan de alcanzar; y no parece sino que temen caer a cada momento á tierra. Cuando llegamos à la costa y vimos pros primera vez a cierta distancia unos jacos rolando, creimos que cran patos, pues sa vuelo se parecia en un todo al de estas aves. Un tiro basta para dispersar por completo una bandada de jacos; cespues de la deconacion precipitanse a tierma dando verdaderas volteretas, y poco a poco vuelven a clevarse. Sus ruidosos gritos, que por lo re. gular praducen solo cuando ven un ave de rapina, revelan cuál es su terror cuando ocurre algun accidente inusitado.

Reichenow no ha podido hacér observaciones proplias, y por eso doy inas credito à las noticias de Keuleman. En la isla cie los Principes, donde este viajero observó, la incubacion se cfectua en diciembre, despues de la estacion lluviosa. los huecos mas profundos de los, árboles suelen servir de nido; la hembra pone hasta cinco huevos de color blanco puro y forma oralada. No es fícil descubrir los nidos, porque las ares los construyen en lo mas impenetrable de la es. pesurn.

in un espacio muy circunscrito hállanse muchas veces varios centenares de parejas que cubren sus huevos: pero casi nunca se ve mas de un nido cn cada írbol. Los padres saben muy bien defender-su progenic y iodos los comprne. ros les ayudan en este deber; los inoigenas no cogen los pe. queños del nido, por creer que en este hay tanto calor que se quemarian los dedos al tocarlu.

Enire las aves'de rapiña, continua Reichenow, cuéntase en paricular una especie de aguila marina (Cippohierar ar: golensis) que es peligrosa cnenuiga de los jacos. Yo la vi va. rias reces perseguir a estas aves, y pude reconocer cuánio temen à esa rapay. No cabe duda que esa águila, a pesar de no ser muy ágil en su ruelo, alcanza fácilmente a los torpes jacos.

Fista noticia de Reicherow se halla en completa contra. diccion con un aserto de Keuleman, quien asegurn que los jacos son jendencieros y se reunen para atacar $i$ las rapaces, lo cual electuan con buen resultado. No sé si esta noticia se funda en observaciones ciertas, pero yo por mi parte, no creo en la exactitud del hecho, pues todos los loros, cuyo género de vida un libertad conocemos, se conducen del modo indicado por Keichenow.

CAzA.- Keuleman refiere que en la isla de los Princi- 
pes no se cogen los jacos hasta despues de salir por primera rez del nido, porque segun dice, caen fácilmente en lazos de toda clase, descubriéndose entonces por sus gritos. Segun Reichenow, no sucede así en el continente. eNi uno solo de todos los jacos que llegan vivos á Europa, dice al terminar su relato, se coge en la edad adulta; los negros roban todos los pequeños del nido antes de salir de él. En el interior del pais, los jefes ó los notables de los pueblos, recogen las aves pequenas para llevarlas despues en major número a la costa. Mientrns tanto les cortan las alas $y$ las dejan asi en libertad. Hé aqui porqué en todos los pueblos se vé á los loros posados en los techos de paja ó en los árboles que al efecto se planian delante de las chozas, y cuyo conjunto re cuerda en un todo nuestras palomas domésticas, alerrando tanto la vista, que casi se olvida el enojo que causan los gri tos. Cuando los jacos peçueios no necesitan ya la madre, se pueden comprar en la costa por cuatro francos cada uno, en cl intcrior del pais los cambian por mercanciss de mucho nenos valor; mas tarde suben los precios tanto, que en los vapores ingleses se pagan muchás veces de is á 22 francos por un jaço.

I.os individuos adultos, domesticados ya por trna larga cautividad, valen mucho mas que los jórences, y por eso al. gunos negros codiciosos los instruyen y educan en las misiones mucho tiempo, enseiándoles algunas palabras en su lunguaje ó en mal inglés. Cada buque que, sale de la costa occidental del Africa lleva cierto número de jacos. A pesar del poco cuidado que se tiene, mueren mus jocos durante el riaje; pero la monandad es grande cuando llegan a Euro. pa, porque alli se hacen sentir las cunsecuencias del mal tratamiento durante la travesia. I a mayor falta del cuidado consiste en que un error extraño, pero muy general, induce a los naveganies à no dejar beber á los loros durante el viaje. Cono estos no se alimentan sino de galleta dura y les falta cl agua para beber, se presentan indigestiones, y cotno con. secuencia de ellas enfermedades de los intestinos, fl las cuales sucumben la mayor parte de las ares. Fl buque en que yo volvi llevabr unos treinta jacos i bordo; estos recibieron, a consecuencia de mis ruegos, dos reces jor dia hgua para beber, $y$ todos menos uno llegtron sin novedad t Furop. Si se tiene ademas en cuenta/que los jacos libres se alimentan en particular de simientes liarinosas, y si al principio no se les da mas que esto, súprimiendo los cañamones y otras simientes aceitosas, no es probable sucumbieran estas ares que tan facilmente soportan la cautividad.

CAUTIVIDAD. - Alli donde se encuentra el jaco los indigenas le cogen, le domestican y le enseña f hablar, para cambiarle ó venderle despues. Denham, Clapperton y Oud. ney llevaron a Inglaterra jacos vivos del lago Tschad; Heuglin encontró la misma especie en el pais de los nyam-nyam y de los bongos, y livingstore le vió en los alrededores del lago Nyanza en estado de domesticidad. Todos los viajeros que han visitado la costa occidental del Africa halláronle vivo en manos de los indigenas; algunas tribus tenian muchos.

-El jaco, dice Reichenow, es la única ave que desde ia costa occidental del Africa llega con regularidad al mercado europeo de animales, las otras especies de aquellas regiones tan ricas en animales curiosos, no se encuentran siemnre. Este hecho se funda en la indiferencia y reserva de los indi. genas del pais. Los negros de la costa del Africa occiciental son demasiado perezosos para ocuparse en coger aves. I) todo indiferentes á la naturaleza que les rodea, solo las apre. cian para comérselas; y he aqui porqué no encontré en la casa de los habitantes mas inteligentes de la Costa de Oro sino algunas avecillas domesticadas. El jaco, sin cmbargo, es casi en todas plartes una excepcion de la regla.\%
El jaco, una de las aves mas favoritas que se tienen en do. mesticidad, merece en un todo el favor de que goza. porque es dócil, inteligente y carinoso con su amo; en todas las lenguas se habla de El; toda historia natural y todo libro in general que trata de la vida de los animales da noticias de fl. Kefiérense infinidad de historias graciosas relativas a esta ave. Levaillant habla minuciosamente de uno de esos loros, pro. piedad de un comerciante de Amsterdam, y que poseia muy buenas cualidades.

1. Carl, este era su nombre, hablaba tan biens sonto Ciscron: podria yo llenar endo un libro con los discursos que pronunciaba y qque me repitió sin olvidar una silaba. Obediente á todas las órdenes, llevaba á su amo cuanto este le pedia, el gorro de dornir ó las zapatillas; llamaba á la criada si cra necesario y solia estar siempre en la tienda, donde prestaba buenos servicios. Si ausente el dueño, entraba álguien, daba grandes chillidos hasta verle llegas ó à cualquiera otra persona; tenia excelente memoria, yabia decir frases enteras en holandés. Solo álos sesenta aíos de cautiverio comenzaron á debilitarse sus facultades, y cada dia olvidaba alguna cosa de las que aprendió. No decia sino la mitad de una frase; trabucaba lns palabras, y mezclábalas unas con otras. in

Estás pocas palabras de Le Vaillant no dan, sin embargo, una idéa exacta de los méritos de la especie. Se han publi. cado otros muchos relatos, y en todos ellos se reconoce que los loros cenicientos tienen poco mas ó menos las mismas facultades intelectuales, si bien hay algunos que sobresalen por su mayor disposicion. El mas notable acaso fue uno que vivió largó tienpo en Viena.y en Salzburgo, y que llamó la atencion de celosos y entendidos observadores. Varios natumilistas, entre los cuales me cuento, han hablado ya de él en mas de un libro, y' no puedo menos de reproducir aqui algo de lo que sé. Len. tenia mucha razon cuando dijo que desde que eristen aves no se habia visto ninguna que alcanzara el grado de instruccion del citado loro, que tenia por nombre $7 a 0^{2}$

lín $182 \pi$ y a ruegos del canónigo Jose Marchner, de Salzburgo, el consejero ministerial Andrés Mechletar conupróle por 25 florines ( 62 pesetas) a un capitan de buque de Tries. te. En i $S_{30}$, pasó á manos de Haniki, maestro de ceremonias de la catedral, quien le daba dos lecciones diarias, una por la mañana de nueve á dier, y la otra por la noche de diez a once; ocupábase mucho de ê, y desarrolló sus facultades en el mas alto grado. A la muerte de Hanikl fué vendido el loro por 150 florines (375 pesetas); y en 1842 , por 370 (925 pesetas). Un amigo de mi padre, el conde Gourcy. Droitaumont, publicó un artículo sobre este loro, que cxcito el asombro general; y a ruegos de L.enz, el presidente de Klei. mayrn, úlimo propictario de Jaco, compictó los primeros datos del conde Gourcy. Droitaumont, de los cuales he tomado los siguientes apuntes:

Furo estaba atento á todo, y de todo sabia juzgar; contestaba convenientemente á las preguntas; obedecia una órden; saludaba a los recien llegados y á los que se iban; decia buc. uns dias y buenus tardes á las horas oportunas, yedia de comer cuando tenia hambre. Llamaba por su nombre a rodos los individuos de la familia: y manifestaba ciertas preferencias. Cuando queria ver al presidente Kleimayrn, grimba: Ven aqui, papà. \& Hablába, cantaba y silbaba como un hom. bre; parecia a veces un improvisador poseido de énutsiasmo; y hubiérase ciicho al oirie desde léjos, que álguien pronun. ciaba un discurso.

A continuacion doy la lista de todo lo que Furo habla, cania, silba, ctc: «Señor Cura, buenos dias-Senor Cura, déne V. una almendra - ¿Quieres una almendra, quicres una nuer? - Ya te la daré; aqui la tienes. - Dios le guarde, señor 
capitan. - Servidor de V., señora.-iPaleio, ladron, mirchate, márchate á casaì ¿No quieres? la te enseriare jo. - Muen Paperol, eres muy buen chico; te daré una peladilla; ya ic la dare-:Nani, nani:-Senor vecino, déjeme V. tiempo.s Cuando llaman a la puerta grita muy alto cual si fuese un hombre: Adelante, adelante; servidor de V., señor Brau; me alegro de verle, me alegro mucho. Con frecuencia llana tambien él mismo a su jaula, pronunciando las palauras an. teriores, é inita muy bien la voz del cuco. Hé aqui otras de sus frases:- Dame un beso y te daré una alınendra - Mira aqquL - Ven aqui. - Vi querido Paperol. - Braro, bravisimol - Vamos á rezar. - Vamos á comer. - Vamos a la ventana Jerónimo, levintate. - Me marcho, adios. - Viva el emperador, que vira mucho tiempo. - i De dónde vienes?-Perdó. neme su merced; crei que cra V. un pájaro.l Cuando des. truye algo con su pico, dice: $\mathrm{No}$ muerdas, estate quicto. ¿Qué has hecho? Espera, ladron, mal sujeto; espera y te pegaré.- Paperol, ¿cómo lo pasas? - Ya has comido algo.Que aproveche a V. - Bst, bst, buenas noches. - Paperol pue. de salir; ven aijul.-Paperol, tira, tira Paperol. Fintonces imita la detonacion del tiro, gritando ipum: igu, gu! Despues dice: r.Márchate a casa; márchate en seguida-Si no te marchas ahora te pegaré.s Tocando una campanilla que se

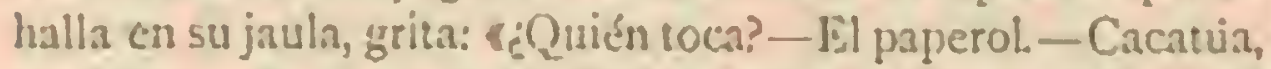
cacatúa_-i Ja, ja, ja, ja!--Espera con $t u$ já, mal sujeto.- E:l perrito está ą̧ui; un perrito muy lindo $Y$ al decir esto lla. ma al animal añadiendo: ¿Cómo habla el perrito? - Ladras Cuando se le manda hacer fuego, grita fum, y despues deja oir las voces de mando militar: $\$$; Alıo! : alto: Alincar. ; Prepa. ren armas; apunten, fuego. -; Pum? : Braso, Lravisimo. A veces se le olvida decir;fuego: $y$ a las palabras apunten armas, anade el fum; pero entonces no grita ; bravo, bravisimo! cual si conociera él mismo su falta - « Dios les guarde, adios. Asi dice cuando se marcha la gente. «Q Qué A mi me quieres enganar, engañarme a mi. " Despues lanza unos grilos muy ruidosos. \$:Qué! á mi me quieres, engahar, mal sujeto; engahar. me á ni. : Ya, ga; esas son cosas del mundo: $Y$ despues rie como un hombre. Si ve que se prepara la mesa, ó cuando lo oge desde una habitacion innediata, grim en seguicia: \& Va. mos á comer, vamos. Cuando su amo almuera en otra ha. bitacion próxima le dice: Q Ya te daré craca.

Cuando la campana de la catedral anunciaba la hora del oficio divino, Furo griaba: kla vay. IId con Dios! I si le acompañaba otra persona, anladia: Dios os guarde a todos. Cuando pasaba la noche en la habitacion de su amo, cstaba silencioso micutras este dormia; pero si le llevaban of otro cuarto, comenzaba al amanecer a cantar, silbar y hablar.

El amo de fraro tenia una perdiz, y cuando esta dejó oir 513 roz for primem ver, volvióse hácia ella el lorn yexclamó: 8:Bravo, pequeña, bravo: Mas tarde se le enseñaron algunas cortas canciones: moduiaba ciertos acordes; silbaba una escala ascendente y descendente y juoducia gorjeos: pero no cantaba ni silbaba siempre en el mismo tono; bajaba y subia de uno à medio, mas no hacia nunca notas falsas. En Vicna se le ensenió á silbar un aire de la Hrarta: su amo bailó delanie de cl, y Touo le imitó, levantando una pata despues de otra y moviendo el cuerpo de la manera mas cómica que imaguarse pueda.

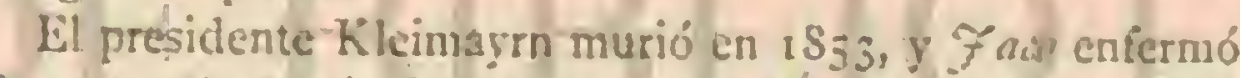
de pena: al año siguiente fuć necusarió haccrle una canita y se le cuidó con el mayor cariño: hablaba aun y repetia a me sudo con voz triste: Jaco estå enierme, muy enfermo. Pronunciando estas palabras exhalo un dia cl último aliento.

De otro jaco the refierc una scriora de alta posicion, lo siguiente:

Q Ell loro del cual quuicro dar algunas noticias, nos fuć rc. galado por un hombre que habia vivido mucho tiempo en la India holandesa; hablaba ja nuucho, aunque solo holandés; muy pronio, sin embargo, aprendió aleman y irancés: en es. tos tres idiomas expresibase como un hombre, y tal em su aiencion que aprendió muchas frases que nunca le habian ensènado, cmpleándolas, con general asombro, en ciertas ocasiones oportunas

8 Hablaba algunas palaluras y frases en holandés, y serviase de paiabras holandesas cuando en aleman le faltaba alguna. Preguntaba $y$ contestaba, pedia y daba las gracias; emplleaba las palabras con conocimiento del tienupo, del lugar y de las personas.

- Paprieli quuiere hacer kiluk, kiluh (es decir beber). Paphisers quicre coiner. Cuanuo entonces no se le daba en seguida lo peàido, gritaba: I Pag hren quiere algo de comer. Y cuando aun no sc hacia su voluntad, revolvia todo cuanto tenia á su alcance para expresar su im.

Blor la mañana saluda diciendo; hir: jous y por la noche: bon soir. Cuando queria ir á dormir pronunciaba las palabras: (Pafilien çuiere acostarse; y al llevarle decia: bon seir, lror: soir.

* Tenia mucho carino a su ama, que regularmente le daba su alimento. Al recibirlo besaba la mano con su pico, diciendo: \$Beso las manos a la sciora. T'omaba parte en todo lo que hacia su ama, y muchas veces, cuando ia vecia ocupada en cualquier cosa, jreguntaba con una gravedad en extremo grotesca: ¿¿Pero qué hace alli la señom?. Cuando csta hubo muerto sentia tambien el animal el dolor de su pérdicia, y costó mucho hacerie tomar alimenio para conscrvarle con vida. Muchas veces despertó de nuevo la tristeza de los pa-

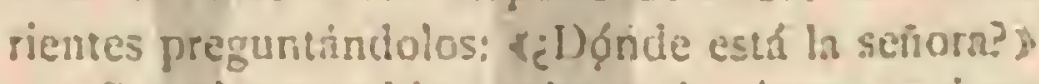

- Cantaba muy bien: sobre todo vierta cancion religiosa. el'upilien debe cantar una vez. - Asi se amonestaba dil mis. mo, empresando en seguida:

\section{Terreguct nigenum, \\ I)

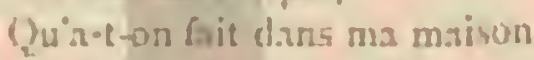 \\ fersdass mon absence?}

- Fin cierta cancion alemana yue empicza con las palabras usin amor $y$ sin vino no poclemos vivir, $\$$ cambiaba á veces ia palabra vino por la francesa maison, $\delta$ decia: un beso sans.facon; lo eque te divertia tanto que jurorumpia en una gran carcajada.

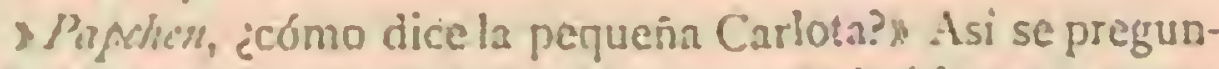
talis a veces, contestandose cual si otro le hubiese pregunta. do: Eh: mi bonito Jiyphies, ven aqui y dame un beso. Y decia esto con ianta ternura en la vo\% como hubiera podido tener la misina Carlota. Para alabarse á sl mismo, decia: «; Ay qué hermoso es el Pigrhen's. pasindose el jiê por el ho. cico.

yern wo era hermoso de ningun modo, pues tenia tam. bien el vicio de quitarse las plumas. l'ara renedio recetarou banos de vino, que fucron propinacios con una regadera muy fina. Estos baños le cran sumamcite desayradables y cuando reia que se hacian preparativos para cllo, comenzaba á suplicar con insistencia, diciendo: No mojar à Paperien; ;ay! del pobre l'ipiren, no mojarles

is No le gusiaban las personas extranias que venian para - oirle hablár, y por lo regular estas no lograban su deseo, sino ocultảndose; mientras estaban presentes cl ave no dejaba oir ni una silaba Con tanta mas vincidad hablaba cuanto mas oculto estada el visitante $\dot{0}$ si se habia marchado de veras; entonces parecia cual si hubiese querido indemnizarse por el tiempo que no habia hablado. Sin embargo, era posiule gran. jearse su carino y gustúbale lablar con gente que le visitaba 
a menudo. Un comandante inisy grueso, al cual conocia muy bien, quiso cierio dia ensenarle algo. KPasa por el baston, Papklben, pasa al baston, dijo el militar. A Papches no le gusto eso é hizo el eniadado; pero subitamente soltaba una gran carcajada diciendo: Comandante, pasa ti al basion, co. mandante?

Hacia mucho tiempo que otro de sus amigos no habia visitado la casa. Se hablaba de eso expresando la esperanza de que Roth, asi se llamaba el amigo, vencria hor. Alli viene Roth, dijo súbitamente Pisphen que mirando por la venta. na, habiale reconocido ya deste léjos.

"Un hijo de la casa, Jorge, era esperado despues de una larga ausencia, y se hablabade esto ertre la lamilia. Torge no llego hasta muy tarde por la noche cuando Pifktien ya cstaba durmiendo en su jauta cubierta deszucs de los primeros saludos, el recien llegacio fjó su aencion en el favo rito de todos, y apenas levantó el pañuelo que cubria la jaula,

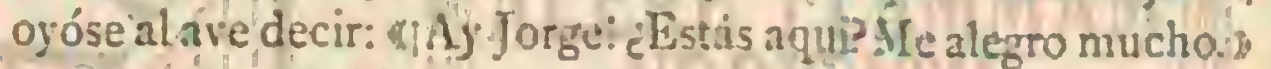
- Fste lozo habia observado que su amo, acercándose á la ventana, llamaba muchas veces al administrador $\delta$ al inspec tor; y descle entonces, apenas le veia dirigirse á ella, pronun cinba cada yez los dos nombres de acquellos empleados, pues no sabia quien se iba a llamar. Es impoșible referir todo lo nue hablaba y hacia este loro: era medio hombre.

I. Papilien murió de un modo deplorable habianle regalado d un ánciano pariente de la casi, que se habia viselto lelo y queria mucho al are; todos llomon cuando se la llevo; Pap ifin no jodia hacerlo tambien, jero tal pesar le causó la se paracion de sus queridos amos que murió pocos dias despues. Podria cilar muchos ejemplos de loros que llegaron a un alto grado de instruccion; pero creo yue do dicho basta para dar una ideh de lo que de estos séres puede obiencrse. Debo observar, no obstante, que la excelente memoria de los loros no duja de ser en cicros casos inconveniente, pues siendo sus primeros amos los marineros, y teniendo mas arcie roce frecuente con los criados, fácil es comprender que con seme jante escucla, el vócabulario que de aquellos apretidan no se distingue por la finura y el bien gusto. Resulta de aqui, que por muy bien que se énseñe al animal, conserna cste el recuerdo de su primera educacion, y mezcla las palabras mas triviales y hasta groseras, con la mas bonita frase. Parece complacurse en imitar los gritos y ruidos mas singulares y desagradables, como el chirrido de una puerta, el ladrido de un perro, el maullido de un gato ó la tos de un viejo. Todo cuanto acabo de referir, y otros muchos cjemplos que podria citar aun, indican hasta la evidencia una faculad intelectual y no un puro instinio.

El loro gris no es tan solo un sér inteligente, sino tambien bondadioso. CLino de mis amigos, retiere Hood, tenia un loro gris que llegó á ser el mas cariūoso protector de los animales abandonados. En el jardin de su dueño habia unos rosales rodeados de una empalizada, que se entrelazaban con varias plantas trepadoras; una pareja de pinzones habia formado alli su rido, y la gente de la casa se complacia en dar!es de comer. Polby, este era el nombre del loro, observó todo aquello y resolvió seguir el ejenuplo: como estaba libre, salióse de la jaula: imito de una manera admirable el grito de llamada del pinzon, y comenzós llenar de conida el pico de los pequeños. Pero anquellas prnebas de amistad debieron parecer demasiado ruidosas is los padres, (pue asuistados al ver aquella grande are que no conocian, se dispersaron, abandonando su progenie al cuidado de Polly. Fl loro no quiso desde entonces habitar en su jaula; permanecia dia y noche junto á sus hijos adoptivos, $y$ tuvo la satisfaccion de criarlos bien. Cuando pudieron volar, posábanse sobre la ca beza y el cuello de su afectuoso padre, que se pascaba gra. vemente muy satisfecho con aquel peso; pero su carino fué pagado con muy poco reconocimiento, pues cuando las alas de los pinzones adquirieron bastante fucra, huycron estos para siempre.

Buxton refiere otro pasaje mas extrano aun en la vida in. telectual del jaco. $\$$ El instinto paternal de una pareja de loros grises, de los que habitaban en mi parque, dice aquel aficionado, adquuirió un caracter en extremo grotesco. Una gata habia parido en uno de los nidos y criado alli sus pequeños. Los loros, que no habian conseguido nunca tener progenie, parecian mirar los gatitos como sus propios hijue. los; vivian en coninua guerra con la gata, y tan luego como esta abandonaba el cajon, uno de los loros se colocaba junio a los gatitos; y aunque la gata estuviesc con cllos, observi. balos atentamente. 3

Raras veces se reproducen los jacos en cautividad; si bien se conocen algunos casos de estas aves que cubrieron los huevos y criaron sus pequeños hasta en una estrecha jaula. Buffon habla de una pareja que cinco $\delta$ seis aios se. guidos tuvo cada vez cuatro huevos y crió regularmente su progenie. Labac cuenta un caso semejante, jo Buxton observó últimamente en sus jacos libres que criaban en el hueco de un árbol tres hijuelos. Úno de cllos murio; pero los oiros dos se asociaron con la bandada de loros, expuesta por Buxton, y presentábanse todas las mañanas para recibir su alimento.

Cuando se les cuida bien, sometiéndoles á un régimen sencillo y arreglado, los jacos viven largo tiempo. El que po. seia el mercader Minnink-Huysen de Amsterdam contaba ya treinta y dos años de cautividad antes de llegar á manos de su últimó proseedor, y aun vivió despues cuarenta y un años mas. Cuatro ó cinco antes de morir comenzó á decaer; debilitáronse sus faculiades fisicas é intelectuales, sobre todo la memoria, segun hemos dicho ya; y en los dos últimos años no podia ya sostenerse en la percha, siẻndole forzoso per. manecer en el suelo. Al fin no le fué posible comer y era necesario darle el alimento; la muda no se verificaba ya bien, y solo cambiaba algunas plumas, que caian luego para no salir unas. Asi murió poco ś poico, agobiado por la edad. Viemos, pues, que hay hechos que justifican efectivamente las palabras de Humboldt, citadas antes.

UsOS Y PRODUcTOS. - Dohru hace elogios de la car. ne del jaco por su excelente gusto; Reichenow, al contrario, no encuentra bueno sino el caldo, y dice de la carne que tie. ne el aspecto de la de buey y que es tan dura que ni á pesar de un cuchillo afilado $y$ de buenos dientes, es posible mascarla. Ios indigenas son de la opinion de Dohru; sin embargo, no podemos fijarnos demasiado en eso, porque los negros, y todos los habitantes del centro del Africa en general, matan à cualquier pajaro de que pueden apodemrse y le echan con piel, plumas é intestinos al fuego, comiéndoselo como gran golosina, tan luego como está asado por fuera Por lo demás se persirue al jaco menos por su carne que por sus rectrices rojas; todos los negros las emplean como ade. rero guerrcro ó tambien en la magia como umedicina.

\section{LOS ECLÉETIDOS - ECLECTUS}

CARACTÉRES. - I as especies de este grupo se distin. guen por su pico muy fuerte, redondeado en la arista y con uma ligera sesgadum dentada; las alas son largas; entre las rémiges primarias, la tercera es la de mas longitud; la punta de las alas es muy saliente; la cola de un largo regular y redondeada; las plumas, duras y anchas, cubren tambien la region al rededor del ojo, las fosas masales y la cera; tienen un magníico color verde $\delta$ rojo brillante. 
Hasta los últimos tiempos se ha creido reconocer siete especies de este grupo, es decir tres verdes y cuatro rojas, cuyos machos yembras tenian el mismo plumaje ó por lo menos muy parecido; los informes sorprendentes q̨ue nos da Adolfo Bernardo Meyer hacen dudar, sin embargo, de la veracidad de este aserto. El citado viajero, al examinar en la isla de . Mnfoor las aves inuertas por él, extranó mucho que todos los ecléctidos verdes fucran machos, y los rojos hembms. Las observaciones que hizo mas tarde minuciosamente, dieron, segun afrrma, el mismo resultado; y al preguntar á los cazadores malayos, estos le contestaron que los ecléctidos verdes y rojos cran de una misma especie. Mejer considera esto como un hecho probado; ve en las tres especies verdes variedades del macho, $y$ en las cuatro rojas, de la hemora; y por lo tanto reune todos los ecléctidos en una sola especie.

DISTRIBUCION GEOGRÁFICA.-Ios ecléctidos habitan en la Nucra Guinea, las Molucas y Filipinas.

A continuacion describiré los dos tipos del género.

\section{EL ECLECTIDO VERDE - ECLECTUS PO- LYCHLORUS}

CARACTÉRES. - Ëste loro es una ave magnifica, mucho mas grande que el jaco y de un color verde muy viro, mas oscuro en la parte superior. En los lados del pecho hay una gran mancha roja escariata; del mismo tinte son las tectrices de los hombros y las inferiores de las aias; la rémige angular $y$ las pequeñas tectrices ai lo largo del antebrazo son de color azul claro; las rémiges de la mano presentan en su parte inferior un borde negro y son de un azul anill; las del brazo verdes hasta la mitad de la base y azul oscuro en el resto; las tres tiltimas rémiges, verdes; las tres rectrices cxteriores, de un azul oscuro de aniil, están bordeadas de ne. gro en su parte interior; la cuarta y quinta solo son azules en la extremidad y verdes en el resto de su extension, como las dos del centro. La pupila es de color amarillo anaranjado; Ia mandibula superior, rojo de coral y amarilla de cera en la punta; la inferior y los pies, negros.

\section{EL ECLÉCTIDO ROJO-ECLECTUS GRANDIS}

CARACTÉRES. - Este segundo tipo de los ecléctidos tiene el plumaje de un rojo escarlata, mas viro en la parte superior de la cabeza y en la nuca; por el dorso se corre una faja transversal; el precho y el vientre son de color azul de ultramar oscuro; el borde de las alas del mismo tinte mas claro; las rémiges de la mano están orilladas de negro interiormente; las tectrices y la rémige angular son de un azul de ariil, y del mismo tinte las puntas de las rémiges del brazo, que son rojas en el resto, con un borde negro; lns tres últimas rémiges tienen un matiz. verde en las barbas interiores; las tectrices del brazo son azules on la base de las barbas interiores y verdes en el resto; las extrenidades de las rectrices superiores $y$ las rectrices inferiores, de un color muy vivo de limon: la base de las primeras es negruzca.

CONSIDERACIONES GENERALES SOBRE $A M-$ BOS TIPOS.-No negaré que los asertos de Meyer parecen justificables, pero debo añadir que no prucban mad.. Stoelker me dice tambien que todos los ecléctidos verdes edaminados por él eran machos, y todos los rojos, hemurns; pero no he podido convencerme aun de que ambos penenercan of la misma especic. La casualidad engaña muchas veces. I a su posicion de Meyer será refutada tau luego como se pueda probar que un solo ecléctido rojo cra del sexo masculino, y uno verde del femenino. \& Es un gran error, escribia Brown a Sclater, pretender que todos los ecléctidos verdes y rojos son machos y hembras de una sola especie. Este punto ros labia llamado la atencion, y yo estoy completamente convencido de que las citadas aves constitujen diversas esnecits. Nosotros hemos matado machos y hembras del ecléctido verde. Utima. mente se recibió en el Museo de Berlin un ecléctido rojo que, segun el cazador, era macho.

DISTRIBUCION GEOGRÁFICA.-No posecmos aun suficientes datos sobre el género de vida en libertad de los ccléctidos en general: pero su area de dispersion se ha podi. do circunscribrir con bastante exactitud. Los dos especies antes descritas se han encontrado en Ternate, Halmatera y Batjan; el ecléctido verde habita además en la Nueva Cuinea, Guebe, Waigiu y Myson.

Usos Y costUmbRES. - Eduarcio de Martens dice que los ecléctidos viren en los bosçues mas bien aislados que en bandadas, de lo ctsal resultaria que estas ares son menos sociables que otras especies. Nada mas se sabe de cierto sobre su genero de vida en libertad, pues lo dicho por un malayo á Meyer sobre que los ecléctidos verdes y rojos cubren alternativamente los huevos, no tiene ninguna importancia en opinion de aquel, de modo que será mejor no to. mata por ahom en consideracion.

CAUTIVIDAD. - Lin poco mejor instruidos estamos sobre los ecléctidos, cautivos. Estas magnificas ares se reciben todavia en nuestro mercado de animales, aurque con menos frecuencia que de diez. á veinte años atrós, pues no son las que ofrecen mas atractivo. El brillo de sus magnificos colores seduce la vista; pero su carícter grave, por no decir triste, no cotrobora de ningun modo la primera impresion. Tambien estas aves se domestican fácilmente, y asi como otms inu. chas, llegan i nuestras manos muy familiariandas ya con el hombre: aunque con frecuencia se pierden tambien sus bre. nas cualidades yor el mal trato durante el viaje. Sin cmbargo, por lo regular miestran cariño a su amo cuando este sabe infundirles confianza, y á veces aprenden á hablar. Son mas débiles, $\delta$ al menos no resisten tan bien la cautividad como otras especies de igual tamano, y por esta causa raras veces viren largo tiempo en tal estado; a menudo mueren súbitamente por causas desconocidas. Hasta ahora nunca se han reproducido en la jaula, al inenos que yo sepa: pero tampoco se ha tenido hasta ahora $\mathrm{en}$ cautividad á la ré el número necesario para hacer tentativas con esie objeto. Varias hem. bras de la especie roja pusieron huevos en la jaula y no se fecundaron yotros han vivido muchos anos juntos, tanto verdes con verdes, como con rojos sin manifestar deseos de reprodu. cirse No se puede tomar en consideracion la conducta que ob. servan unos con otros. Meyer nos dice que un eclécido verde que se habia reunido con uno rojo le acariciaba mucho; pero iambien sucede lo contrario, es decir, gue ambas especies tmbar encarnizadas luchas, cuando se les reune en una jaulia despues de una larga cautividad solitaria. Aunque los indivi. duos de distinta especie que Neyer poseia se hubiesen apareado, puesto huevos y criado su progenie, esto no probaria que ambos eran de una misna especic. Lo mismo sucede con bastante frecuencia, como ya hemos dicho, enire los loros de diferente especie; y hasta se da el caso de aparearse dos hem. bras, poner huevos una de cllas y cubrirlos, aunque naturalmente sin resultado.

\section{LOS CRISOTIS-CHRYSOTIS}

CARACTERES. - Los crisotis, llamados tambien luris amiazoras y lores irertes, constituren uno de los géneros mas numerosos de la sub-familia. Las especies que le componen son ares grandes 6 de tamaño regulär, de formas recogicias, con pico muy fuertc y poco abovedado, curz arista esta se. 
parada marcadamente hicia atris; las alas son de regular longitud; la segunda y tercera de las réniges mas largas; la punta de aquellas no sobresale casi, o por lo manos muy poco; Ia cola es corta, ó de longitud regular, y un poco redondeada; las plumas del tronco, bastante fuertes, son anchas y cortadas en su extremidad; la cera y los circulos oculares no estan por lo regular cubiertos.

Todos los crisotis, de los cuales se han distinguido unas treinta especies, son tan iguales en estructura y color, que Finsch los considera, no solo como el género mas desarrollado de todo el órden, sino como el tipo originario de los loros en genern!. In grin inteligencia de estas aves contirm. semejante opinion, y por eso hago mencion cle ello.

DISTRIBUCION GEOGRÁFICA. - El Áred de dispet. sion del grupo se extiende desde los estados de la Plata hasta el mediodia de México, pudiendase considerar como centro el rio de las Amãzonas. Varias especics habitan las grandes y pequeias Amtillas, dondetienen sus representantes en las diversas islas; el territorio que habital cada especie es tan circunscrito, que se podria considerarlas como varieda. des fijas de una misma forma.

USOS, COSTUMBRES Y REGIMEN.- E! género de vida, los usos y costumbres, \& la manera de ser de todas las especies, no difieren por ningun concepto; lo que se dice de una puede. aplicarse con pocas exceṕciones á todas las demảs.

Por la mañana vuclan, como todos tos loros de cola corta en general, aleteando con fuerza y rajidanente, y produ. ciendo ruidosos gritos; dirigense hácia los bosques ó á las plantaciones de árboles; aliméntanse hasta quedar satisfe. chas, descansan is la hora del medio dia, y por la noche vuclven otra ver a buscar que comer. Firera del periodo de la incubacion reuinense por la tarde en numerosas bandiadas, que producen un ruido infernal anies de elegir los sitios para entregarse al descanso.

\section{EL CRISOTIS DE LAS AMAZONAS-CHRY-} SOTIS AMAZONICA

CARACTÉRES. - Elegimos por tipo del género que nos ocupa el crisotis de las Amazonas, el kurikn y papasm de los brasileños. Esta especie, una de las de tamaño regular del grupo, mide $0^{\circ}, 35$ de largo: la ancilura es de $0^{\circ}, 56$; la longitud de las alas de $0^{\prime \prime}$, s $y^{\mathrm{l}}$ la de la cola de ()$^{m}$, , 0 . El co. lor del plumaje es verde oscuro; las plumas de la parte pos. terior del cuello prescntan en su extremidad posterior un borde negruzco poco marcado; en la frente tiene una faja ancha de color azul lila; la parte superior de la cabeza y las mejillas son de un amarillo vivo; la superior de las alas verde y amarilla en la articulacion de la mano; las réniges de esta última, excepto lí primera que es negra, ofrecen un Linte verde pálido en la base de lis barbas exteriores y des. pues azul de indigo; la segunda, tercera y cuarta rémiges del brazo son verdes en la base, rojas de cinabrio en el centro y azul de índigo en la punta; todas las demís, excepto las dos últimas, gue son verdes, tienen un tinte verde en la parte exterior, r.egro en la interior y azul cn la extremidad; la parte inferior de todas las rémiges es negra, yerde en la mitad de su base; las tectrices inferiores de las alas verdes; las cuatro rectrices exteriores de ambos lados dis un color rojo claro de cinabrio por dentro y verde oscuro por fuem con la punta de un verde amarillento; la quinta rectriz presenta en las barbas interiores, que son vercies, una mancha roja; la segunda y tercera tienen otra igual, aunque mas pálida en la base y junto al canon; cl tinte rojo de las otras esta dividido en el centro por una ancha faja transicrsal verde; las tectrices inferiores de la cola son de un verde anarillo; las plumas caudales vistas por debajo, presentan sobre un fondo rojo de cinabrio una faja transversal verde en el centro y oira mas ancha de un verde amarillo en la estremidad. In pupila es de un rojo cirabrio; el pico amarillo de cuerno, con la punta pardo oscura, y los piés parduscos (figum 12). Los cautivos cambian de color fácilmente, pro. duciendo á veces varicdades muy bonitas

DISTRIBUCION GEOGRÁFICA.-El ârea de disper. sion del crisotis de las Amazonas se catiende desde e! interior del Brasil hasta la Guayana inglesa y la isla de la 'Trinidad, prolongandose por cl oeste hasta Bogota, el Ecuador y Venezuela.

USOS, COSTUMBRES Y RÉGIMEN. - Essta especic, dice el principe de Wied, es una de lns mas comunes en la costa oriental del Brasil: yo la vi muy numerosa en todos los puntos donde las espesas selvas virgenes llegan hasta los pantanos en que crecen los mangles, $\delta$ lasta la embocadura de los rios: anida en ambos puntos, pero con preferencia cer cal de aque!los árboles, por los cuales manifiesta mucha pre. dileccion. Se encucntran ya numerosos loros de esta especie en los bosques de los alrededores de Rio.Janeiro, y tambien los vi mas hácia el norte, cerca de los rios Parahiba, EspirituSanto y Belmonte Por mañana y tarde oia por todos lados su vor penetrante salir del seno de los jarales, cubiertos a mienudo por las altas aguas que representan alli los sauces de nuestros paises, con la diferencia de ser mas elevadas: estos loros anidan en el hueco de los troncos ó de las ramas gruesas.

- Wurante el periodo del celo, remóntanse todas las parejas de lurihas, gritando y llamando á sus semejantes; y en la's otras épocas se reunen en bandadas numerosas. Yo las he visto innumerables en los bosques del Macure, resonando por todas partes sus gritos. Habia alli varias especies reunidas; era necesario mucho tiempo para que toda la bandada deślilase, y no es posible dar una idea del estrépito que ocasionaban, sobre todo cuando un grupo de loros aluuyentaba ¿́ otros individuos de un árbol á fin de tomar posesion de el. Por numerosas que scan estas reuniones, no se las puede comparar, sin embargo, con las que forman las palomas via. jeras de la América del norte.

- De tal modo se armoniza el color de las plumas de estas ares con el del follaje, quue cuando una de las bandadas se posa en un árbol alto y muy poblado, es á menudo imp̧osible verla. Nótase tan solo su presencia por la continua caida de las cubiertas de las semillas; mientras comen permanecen silenciosas: pero cuando se asustan dejan oir su roz penetrante.

¿Se mata un gran número de ellas porque su carne es muy buena: un caldo de popugrajo es, ro solamente en el Brasil, siro tambien en Surinam, un alimento farorito.

Gundlach nos da algunas noticias sobre el gúnero de vida en libertad del crisotis de Cuba (Chrysotis lemecrohnlus), las cuales reproduzco aqui para completar la descripcion anterior. Cunndo estas ares se reunen hallándose libres, suelen producir un estrépito infernal que se oje â gran disıancia, ó bien guardan un profundo silencio, $\dot{o}$ dejan oir, sobre todo cuando descansan en la espesura, unos sonidos suaves pare. cidos á un murmullo. A veces se levantan en gran número delante del obseriador, antes que este hayn advertido su presencia. Agrádales tambien agarrarse á los retoños de las palmeras ó á las ramas desnudas para subir y bajar de ellas. Viren de ordinario pareadas y en su vuclo se las re por lo regular de dos en dos, aunque a menudo forman tambien numerosas bandadas. Su vuelo es recto y rápido, pero a costa de muchos aletaros. Si se mata á uno de ellos, y sobre todo 
cuando se le hiere, muchos de sus companeros acuden para averiguar la causa del accidente, y el cazador aprovecha la ocasion para aumeniar el número de sus victimas.

Todos los crisotis se asemejan probablemente por lo que hace á la reproduccion. Las especies sobre cuyo género de vida tenemos noticins por tal concepto, ponen en la prima. vera de tres a cuatro huevos blancos; los hnecos de los drboles les sirven de nido, $y$ de lecho las mismas fibras leñosas que caen al ensanchar la cavidad del tronco. Cuando no se los inquieta no crian sino una vez al año, es decir, en la primavera de aquellos paises. Los pequeños se domestican con suma facilidad y aprenden á hablar muy bien, cuanco se les coge en el nido. Por eso se encuentran á menudo en las ca. sas brasileinas y se llevan en gran nimero a las ciudades, donde los marinos los compran para llevárselos a Furopa. En el pais figuran entre los loros mas comunes que se co. nocen; son muy dóciles, al menos con su amo ó las personas que mas los atienden; distinguense además por lo mansos y carinosos y merecen los elogios que de ellos se hacen. 'Tambien podrian referirse de estas ares historias análogas á las que circulan sobre el jaco. "Uno de mis crisotis, me escribe Linden, sabe canciones muy bonitas y armoniosas, y siguc

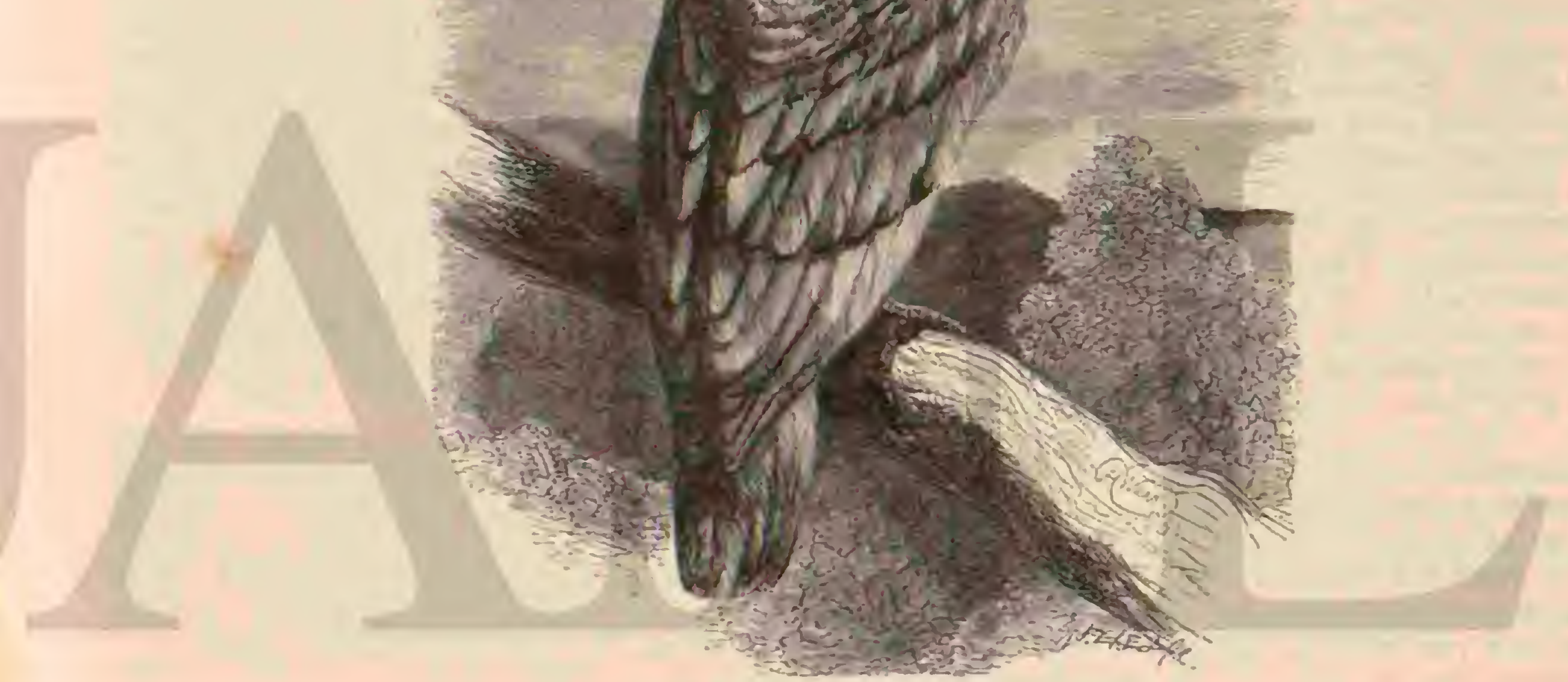

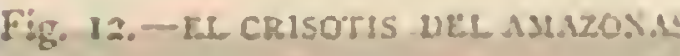

el compss con las alas medio abiertas, recorriendo la percha. Algunos inteligentes que le oyeron cantar, dijéronme que cs. tas canciones eran melociás de los negros del Brasil. Du. rante mas de medio año el ave habia permanecido silenciosa, y solo despues manifestó su habilidad, danda uma prueba evidente de su excelente memoria Oiros crisotis imitan con asombrosa facilidad los sonidos ó palabras que oyen. Uno de mis cautivos canta una bonita cancion alemana y habla muchn, siempre con la misma entonacion que su inaestro. 'ambien imita á las demas aves en cuanto hablan y en la manera de decirlo. Pocos dias despues de haber muerto mi cacatua de casco, el crisotis dijo exactamente como cl, con é mismo tono aunquue con voz.suave: ACacatúa, cacatria, mi querida cacatúa, imitando á la vez sus movimientos. Ahora se coloca siempre junto is un loro de las Molucas cuyas palabras y gestos imita de la manera mas fiel. Cuando se llama a la puerta, dice: adelante; pero no si ore resonar el hierro. Lin crisotis del Amazonas que se le habia es. capado a Buxton permaneció tres meses en el jardin, hasta Tosso III que el frio del invierno le obligó sá volver â la casa; entonces divertia a rodo el mundo al repetir las súplicas que la criada le habia hecho con voz. lastimera para que volviese: era evidence que sabia que aquellas instancias se it dirigieron $a$ é

Mi padre vió un crisotis ámazona que habia cobrado mu. cho afecto of la hija de la casa, manifestándose en cambio maligno con los demis individuos de la familia y personas desconocidas Inutil era hablarle afectuosamente, pues no respondia, ni se cuidaba al parecer de nadic; pero cuando se acercaba su favorita, cambiaba de aspecto. Reconocia su paso y mostrábase muy contento cuando oia á su amiga subir la escalera; corsia a su encuentro apuenas la veia entrar; posábase sobre su hombro: agitíbase de contento y cacareaba cual si quisiera hablarla.

Correspondia a las caricias que se le hacian, acercarido suavemente sus mejillas a las de su ama y produciendo los sonidos nuas dulces. La señozita podia jugar con el sin mic. do; cogia el dedo con el pico, y tambien el labio superior, sin defraudiar nunca csta confianza. Cuando su ama estaba 
ausente, entristeciasc al parecer, permanecia inmóvil en el mismo sitio, rehusaba comer; y en fin, su conducti cam. biaba por completo. Yo he visto varios crisotis del Amazo. nas y tambien he tenido algunos que en lo esencial mostrat. banse tan amables como el anterior. He observado tambien que es muy fácil domesticar individuos salvajes, y puedo recomendar por lo tanto muciso esta especie.

USOS Y PRODUCTOS. - Sc persigue con encarniza. miento á las dos especies parque su carne es muy nutritiv?. Lil caldo de Joro, dice el principe de Wied, es muy busca. do, no solo en el Brasil sino tambien en Surinam.

\section{LOS PIONES-PIONIAS}

CARACTERES.-El genero de los piones 6 forus de ults Jargas se compone de unas cuareata especies, cuyos caractéres comunes son los siguientes: El tamajo varia eatre el de una paloma y el de un grajo; sus formas son recogidas y gruesas; el pico fuerte, con su arista marcadamente sẹparada hácia atris; sus lados son ligeramente abovedados, le hacen parecer algo comprimido, y además tiene un sussco que se marca mas ó menos $\{$ lo largo de la arista. El pié es fuerte; las piernas cortas; los dedos de Inngitud regular; las unas fuertes, $y$ las alas largas; la segunda y tercern rémige tienen mas longitud que las otras; la punta de las alas sobresale mucino, de modo que estas cubren las dos terceras partes de la cola cunndo el ave descansa; la cola es corta, ancha y escotada en su extremidad; sus plumas afectan en la pumta la forma de grapa y raras veces se redonden; las plumas, suaves 6 fuertes, $y$ anchas, forman en el cuello muchas reces una especie de escamas.

DISTRIBUCION GEOGRÁFICA.-LOS piones habitan en trús contimentes. La mitad de las especies pertenece á la América del sur; la mayor parte de las denás habita el Africa, y las menos el Asia.

USOS, COSTUMBRES Y REGIMEN.-El genero de vida de las piones no difiere mucho del de los otros sitacideos. También viven apareados, durante el periodo de la incubacion, en Jos bosques grandes y pequenos, donde eligen los grandes árbóles aislados, por cjemplo las adansonias, que les ofrecen huecos para sus nidos. Despues de criar sus hi. juclos, ragan con ellos por el pais y tambien se reunen a veces con otras familias, formando bandadas mas 6 menos numerosas, que visitan los árboles frutales y•los campos. Distribuyen su tiempo poco mas ó menos como otras especics del órden; siguen ciertos caminos para sus expediciones, y tienen sus horas fijas para comer, banarse 6 descansar. Sus movimientos se asemejan mucho $\{$ los de los crisotis; pero su voz no es tan chillona como la de atros loros. En cuanto a sus facultades intelectuales las opiniones no están conformes; pero creo no engaiarme si los considero en general como bich dotados. El modo de incubar no parece diferir del de los otros loros de cola corta; esto se desprende por lo menos de las pocas noticias que sobre el particular se han obte niclo.

CAZA. - A causa de los grandes perjuicios que los piones ocasionan a los campesinos y plantadores de su patria, se les persigue de continuo, aunque no en todas paries; en algunas regiones los aborrecen con justa rałon y cázanlos á cente nares, empleándose toda clase de meơios para librarse de su presencia: tambien se cogén con lazos y redes para tenerlos en jaulas.

CAUTIVIDAD. - Los piones som los loros menos exi gentes, y no cuesta gran trabajo cuidarlos; se domesticar pronto y en alto grado, y si se cugen pequeños en el nido $y$ se les instruje bien, aprénden tambien á pronunciar palabras.
Sin embargo, existe generalmente la preocupacion de que son menos dóciles que sus congéneres grandes, y por eso se les dispensan raras veces los clogios que yo, segun mis ob. servaciones, no les puedo negar.

Los limites de esta obra no me permiten tomar en consideracion mas que una especie.

\section{EL PION ACCIPITRINO-PIONIAS ACCIPI- TRINUS}

CARACTÉRES. - Esta cspecie, aunque tal vez no !a mas bonita, es sin embargo una de las inas extranas del género, que se ha subdividido en muchos sub-géneros. El plumaje de la parte posterior y de los lados del cuello, toda la parte su. perior y los muslos son de un verde oscuro brillante; la parte anterior y superior de la cabeza, de un amarillo pardusco 6 de café con leche; las sienes, la region de las orejas, los lados de la cabeza, y tambien la barba, de un pardusco pálido, con unas fajas y manclans blanquuizcas; las plumas del occipucio y de la nuca, nuchas, muy prolongadas y erectiles, tienen un colar rojo oscuro de carmin que tira un poco á violcta, y' forman cuando se exticnden una especic de abanico; cada pluma, de un pardo pálido en la base, presenta en la punta un ancho borde azul; toda la parte inferior, á excepcion de las plumas laterales del pecho, ofrece igual color; estas últimas son verdes por fuera; las remiges y tectrices de la mano, negtas; las primeras del brazo negras tan solo en la mitad de la base de las barbas interiores; las tres tiltimas rerdes; este es el tinte de las plumas caudales, asi como tambien el del dorso, y en su parte interior tienen un ancho borde de color regro palido; solo las exteriores de ambos lados son grises interiormente $y$ de un color azul oscuro por fucra; las tectri. ces inferiores de la cola son verdes. I.a pupila es parda; cl [jico, los piés y los circulos oculares carecen de pluma, y parecen de un color pardo oscuro. I.a longitud del are, segun Burmeister, es de $0^{m}, 27$, la de las alas $6^{\circ}, 18, y$ la de la cola $0^{\circ}, 34$.

DISTRIBUCION GEOGRÁFICA.-Segun lo que hasta ahora se sabe, cl papagajo accipitrino habita los bosques de las orillas del Amazonas y de la Gunyana, donde es tan co. mun como los oiros loros. Spix le vió cerca de Villa-Nova, en el Amazonas; Schomburgk no hace mencion de êl mas qृue dos veces en la relacion de su viaje; dice que los encontró cerca del Rupununi, y domesticados algunos en las chozas de los warraus.

Pocas noticias nos da Schomburgk respecto al género de vida de esta especic en su estado libre, por mas que haya tenido ocasion de observar y de rer innumerables bandadas en las palmeras de Sawari. Cuando se encoleriza, dice, y se levantan las brillantes plumas de su nuca, formando un cir. culo alrededor de la cabera, representa uno de los mas her. mosos loros. Los colonos le llaman kia, por imitacion de su grito. El mismo viajero nos dice tambicn que este papagayo busca los bosques mas clevados, inmediatos a las vivicndas; que no es receloso $y$ se domestica fácilmente, pero que no se presta mucho á la instruccion; que anida en los huecos de los árboles y pone á menudo cuntro huevos en ver de dos $\delta$ itcs.

CAUTIVIDAD. Fo ture mucho tiempo un pion acci. iyitrino y he visto orros dos en los jardines \%oológicos: $10 d 05$ tres, sobre todo el mio, eran aves muy graciosas. Mi cautivo se mostraba tan dócil como cualquier otro loro bien domes. ticado; dulce y tranquilo, y si asi se me permite decirlo, sin pasiones, familiarizúse muy pronto; cuanco pasaba junto á su jaula, saludábame con sus movimientos, y parccian agra. darle muclio las caricias que podia laccrle sin temor de que 
me mordicra. No tenia la malicia de otros loros; complaciale que le rascasen por debajo de las plumas, y entonces solia levantar las del occipucio, desplegando poco a poco su hermoso abanico; pero no lo hacia cuando algo le irritaba, como lo cree Schomburgk, sino mas bien cuando estaba de buen humor.

- En cuanto á sus movimientos, diferian mucho de los de todos sus congéneres mas afines que he visto en libertad ó cautivos, y que he cuidado yo mismo. No tenia nada de la inquietud de la mayor parte de los piones; comunmente permanecia inmóvil, mirando fijamente en una misma direccion, mas por la viveza de sus ojos reconociase que lo observaba todo á su alrededor atentamente. Asi como los cacatias, anun. ciaba todo incidente inusitado ó que le pareciera mas extra. ño; agitábase entonces y gritaba Cuando se movia hacialo pausadamente, y al parecer con intencion. Su voz cra muy chillona, pero no correspondia s los sonidos descritos por Schomburgk.

Otro pion accipitrino que yo observé producia unos gritos tan diversos, que me vi obligado is creer quue los habia aprendido; este pion hubiera llegado á pronunciar vocablos, cnsc. ñándole de una manera conveniente. No podia quedarme duda sobre el desarrollo de sus facultades intelectuales: cicrto que no hacia todos esos ademanes expresiros con quue los cacatías, por cjemplo, intentan hacerse comprender: pero distinguia muy bien las personas extrañas de sus conocidos: mostraba grande interés por todo cunnto pasaba a su alrededor; atendia cuando le llamaban sus amigos, y accedia voluntariamente a los deseos de estos. Por sus buenas disposiciones llego \& ser muy pronto uno de mis favoritos.

Desnues de escritas esias lincas, recibi de I incien los siguientes datos sobre un cautiro de esta especie, cuidado liacin nueve años por dicho naturalista: En vista de un grabado de mi primera edicion de esta obra, crei poder deducir que el pion accipitrino figuraba entre las aves malignas; y no me es posiole cxpresar cuánta fuć mi alegria cuando el comerciante de animales Jamrach, de lóndres, me envió uno de estos loros, sin que yo se lo hubiese pedido, por cierto muy barato, atendida la rareza del ave. Cuando la recibi estaba enfermiza, y desesperé de conservarla viva; pero tuve la gran satisinccion de verla recobrar al puco tiempo las fuerzas, y no tardó en desarrollarse todo el brillo de su plumaje. Desde el priner dia me extrañó ya su carácter dócil. Habia creido que Ins plumas crectiles gave no forman penacho, sino un bonito collar en forma de abanico, se erizaban solo cuando el are se irritaba; pero observé que no era asi, y hasta ahora no he podido averiguar por qué erige su abanico en ciertas ocasio. nes. Cierto que muchas reces lo hace cuando se enoja; pero si le irrito para obligarle à levaniar su collar, defiéndese solo con el pico, sin mover las plumas. 1 menuco expresa su alegria desplegando su collar, y csto sucede principalmente cuando imito su voz ordinaria silbando suavemente. No obstante, en este caso todo depende de su caprichio: cuando quicro enseñarle á algun visitante en toda subellez.a, es bien seguro que no querrá desplegar su abanico; mientras que otras veces sin incilarle yo, no se cansa de levantarle. En la comida demuestra tambien que es inuy caprichoso: nuchas veces busca el maiz y desdeña todos los demás granos; otros dias no re. coge sino los del girasol; y se ha dado el caso de no querer esperar á que le dé un pedacito de bixcocho mojado en leche; tá veces no quicre esta golosim, sino un higo ó alguna naranja, que a menudo desprecia tambien durante semanas enteras; los reloños sabrosos del sauce le gustan sin embargo siempre.

- Una tempestad le excita en extremo causándole gran es panto, pues todo su cuerpo se estremece; cuando truena acurrúcase timidamente en un rincon; y aun despues de ha. ber cesado el remporal, demuestra con sus ademanes cuanto le domina el terror. Si se le enseña la lu\% de un farol, des. piértase en seguida sin manifestar la menor exciacion. A pe. sar de nue el crisotis accipitrino no se distingue por su vivacidad, se ha captado no obstante todo mi carino, recompen. sándomclo por su duizura, su familiaridad y el cariño que me demuestra.

\section{LOS SITÁCULOS - PSITTACULA}

Entre los loros propiamente dichos existen además otros que merecen que digamos acerca de ellos almunas palabras: son los que forman el grupa de los sitáculos ó loros enanos, aves las mas bonitas que se conocen, de vistoso plumaje $y$ agradables costumbres. \& Los pocias, dice Schomburgk, ignoraban la tierna amistad que se profesan los dos seros de los loros enanos, por eso eligieron la tórtola como simbolo del amor idflico: ino sabian cuín inferior era al de nuestros 10. ros! Entre el macho y la hembra reina la mas perfecta armo. nia; sus roluntades y sus actos están siempre de acuerdo: si él come, ella tambien; si se baña, le hace compaña; si grita, le contesta; si uno de ellos enferma, es cuidado y alimentado por el otro; y aunque se reuna en el mismo árbol uma nume. rosa bandada, nunca se separan las parejas. \%

Los siticulos nque con mas ó menos reguiaridad pasan á nuestras jaulas, ofreciéndonos ocasion, de observarles minuciosamente, contirman la exactitud de la descripcion de Schomburgk. No sin razon se ha dado a una especie el nombre de inseparable, calificativo n̨ue se aplicó despues a todas las demás; pero cxagérase demasiado cuando se pretende que un individuo de la pareja no sobrevire nunca i la mucrte del otro. Es verdad que sufren mucho por la pérdida del com. panero; pero si utro le sustituye, desvanécese su tristeza, y poco a poco se acostumbran tambien a vivir aislados. Sin embargo, solo en caso de necesidad se tienen solos, por. que nadic se quiere prisar del gracioso espectaculo que ofre. ce la ternura de ambas aves.

CARACTÉRES. - Yodos los sitŕculos son pequeños y de formas recogiclas; tienen el tamaùo del gorrion, ó cuando mas del estornino; y un plumaje brillante, muchas veces abigarrado. El color predominante es un bonito verde; la cabera roja con frecuencia; la rabadilla-azul; la cola casi sicmpre abigarradn, con una faja negra trasrersal I otsa en la punta. Lil pico, relativamente muy fuerte, á veces en extremo grueso, y casi siempre mas alto que largo, se redondea por los lados; ia mandibula superior se encorva un poco y con su larga y gruesa punta traza un arco sobre ia inferior; en la extremidad se ve una sesgadura rectangular ó una ligera curva; la riandibula inferior es casi siempre mas alta que la siperior, Y su borde se arquea marcadamente en la punta; los piés son corios y robustos; las alas largas con la punta muy prolongada; las tres primeras remiges sobresalen de todas las demás; la cola, en fin, es corta y se redondea ligeramente, ó jresenta una cscotaduma imsicrsal.

DISTRIBUCION GEOGRAFICA.-Los sitáculos están mas extendidos que todos los demás géneros del órden, pues habitan cu cuatro continentes: de las veintitres especies que Finsch distingue, once viven en la América del sur, tres en el continente del Aírica, una en Madagascar, sieic en las istas meridiomales del Asia, y una en Australia.

USOS, COSTUMBRES Y REGMMEN.-Parece que to. das las especies son muy comunes donde se las encuentra, y que despues del periodo de la incubacion forman bandadas, con frecuencia innumernbles. Pucblan el bosque y las estepas donde hay mucha espesura; y asi se encuentran en el llano, 
como en las montanas, hasta una altura de 3,000 metros. Solo guardan silencio mientras comen y descansan; en las demús horas producen un estrépito infernal; charlan, silban, y emiten sonidos tan agudos, que aturden cl oido. Sus movimientos son muy vivos y variados: parn volar aletean rápidamente; corren con ligereza, y trepan a intervalos, pero mas de prisa que las demás especies del gíncro. En cuanto á sus facultades intelectuales, son muy inferiores a las de todos los loros grandes, ! lo mismo podemos decir respecto a su carácter; los mas llegan a ser muy pronto tan fastidiosos, como interesantes parecian al principio. Toda clase de frutas y de

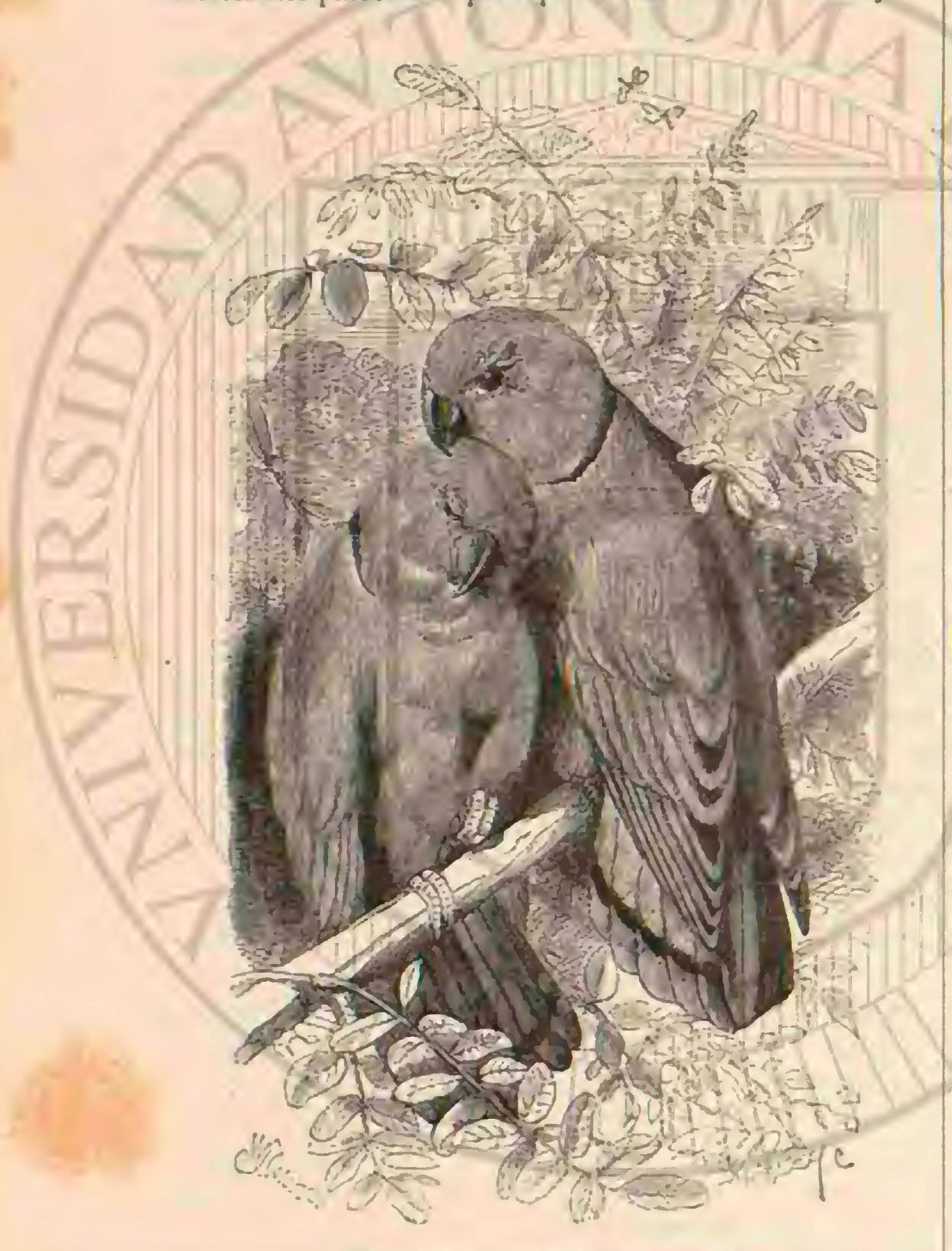

Jig. Ij. - I.L SIT.CULO DE SIMTSDER

simientes constituyen su alimento. Estas aves invaden tambien a veces los campos de trigoy ocasionan en ciertas circunstancias graves perjuicios. Todas las especies incuban en huecos de arboles, pero algunas los tapizan cuidadosamente con materias blandas. las hembras ponen de cuatro á acho hueros, y los machos las ayudan á cubrirlos.

CAUTIVIDAD.- Los sitáculos cautivos exigen mucho cuidado; son muy débiles, y solo excepcionalmenie recompensan el trabajo que ocasionan. Sin umbargo, muchas personas los buscan con preferencia, y hasta tienen partidarios entusiastas.

\section{EL SITÁCULO SONROSADO-PSITTACULA ROSEICOLLIS}

CARACTERES. - Entre todos los sitículos que conozco doy el lugar preferente a esta especie, uma de las mas gran des de su gúnero: su longitud es de $07^{\circ}, 17$; la de las alas $11^{\circ}, 10$, y la de la cola $0^{m}, 05$. En el plumaje predomina un bonito color verde, mas claro en la parte inferior y con un brillo amarillento en los costados; en la frente se ve una faja de color rojo pálido de escarlata; las mcjillas, la region de las orejas y la garganta tienen un tinte muy fino de melocoton ó sonrosido pálido, que en la parte inferior pasa poco al poco al rerde; las plumas inferiores de la cula y las tectrices superiores de la misma son de un azul celeste; las rémiges de un verde yerba por fuera, mas oscums y casi negruzcas en la punta; sus barbas interiores tienen un borde azulado pálido; las dos rectrices del centro son verdes; las otras, del mismo tinte, con puntas de un verde azulado, presentan una faja inasversal negruzca delante de su extremidad, y una mancha de color rojo sinabrio en la mitad de la base. La pupila es de un pardo oscuro; los circulos oculares estrechos y blanąuiz. cos; el pico, amarillo de cera, con la punia verdosa; y los piés de un verde azulado. Ambos sexos tienen los mismos colores; el de los hijuelos es mas oscuro, y no existe aun la faja frontal.

DISTRIBUCION GEOGRÁFICA.- La patria del sitźculo sonrosado es el sudoeste del Africa, sobre todo el pais de los rafres, de los namakas y de los damaras; abunda en Angola; y segun dice Kirk, encuéntrasele tambien en el sudestc, sobre todo en el territorio del Zambeze. Segun las noticias de Orilepp, esta especie es la farorita de los campesinos cie Iimpopo, los cuales la tienen con frecuencia en jaulas.

USOS, COSTUMBRES Y REGIMEN.-Segun tengo entendido, Mnderson es el único que nos ha dado noticias sobre la vida de esas aves en libertad. ¿Este bonito y pequenolo lord, dice, habita en todo el pais de los damaras y' de los namakias, pero tambien se le encuentra en Owakango y junto a) lago Nigami, siempre formando reducidas bandadas, que frecuentan sobre todo las cercanias de los rios a otras corrien. tús, ál, hs cuales van a beber por lo menos una vez diaria. Gracias á esto pueden servir muy bien de guia al viajero se. diento, cuando este tiene bastante experiencia para utilizarse de semejante oportunidad para descubrir los sitios ocultos donde se encuentra el agua.

- El sitáculo sonrosado se distingue por su vuelo en extre. mo rápido; las pequeñas bandacias pasan con la celeridad del rayo cuando van en busca de su alimento ó del agua; pero rara vez franquean grandes distancias sin detenerse. Cuando cruzan los aires emiten sonidos agudos muy continuados $y$ tambien los producen si se les espanta bruscamente. Su ali. mento consiste en bayas y diversas simientes.

3 Listos loros no se construyen sus nidos, sino que ocupan los de otras ares, sobre todo los de cierta especie de gorrion y los dêl canario de Mahali. No puedo decir si expulsan á los propietarios legitimos ó si solo se sirven de nidos abando. uados; pero he visto sitículos sonrosados y gorriones, casi en igual número, al abrigo de un mismo árbol. Los huevos son de un blanco puro y mas largos que los del pico.

CAUTIVIDAD.- Los sitáculos sonrosados que yo cuicée y observé varios años en cautividad excitaban en alto grado mi interes: por sus costumbres y carricter son muy superiores á los otros sitáculos: no cabe duda que estín mejor dotados, y tienen mas desarrollada la inteligencia: y en fin, que poseen todas las cualidades necesarias para cautivar en su favor. Quizás no exngere al decir que pueden figurar dignamente entre los mas graciosos loros en general. Su plumaje esta siempre muy limpio y arreglado: son muy alemres y vivaces: muévense casi de continuo y gritan mucho; pero en cambio se distinguen por su cocilidad, al menos con sus semejantes; el macho y la hembra profesan gran carino a su progenie. lor su manera de trepar se parecen á otros loros de cola coria; pero recuerdan tambien los corilis, porqque, asi como estos, inclinan á veces la caveza y se cuelgan con los pies 
del techo de la jaula. Su voz es demasiado chillona para una habitacion pequeria, pero no incomoda en un espacio nuayor, ni tampoco en una gran jaula; producen un silbido que $a$ veces degenera en trino. La voz ordinaria se podria exuresar por las silabas zick, zichi, die\% o veinte reces repetidas; la voz. de alarma se indicaria por firrirrirnirrif sif bit sit. liel, liet $\delta$ siterifitititie, con un sir ninal. Ei macho se posa a veces lo mas cómodamente posible, con el plumaje erizado, y cierra los ojos, cual si se abismara en sus reflexiones; inmóvil en el mismo sitio, deja oir un canto, cuyos sonidos, si bien iguales a los de la voz de alarma, suavizanse con otros conjuntivos, cuya fuerza y entonacion difiere bastante; de modo que se efectua una variacion agradable.

Por mas que estas avecillas sean interesantes cuando se tienen muchas reunidas, no desplliegan roda su gracia sino cuando se preparan para la incubacion. Ya he dado a cono. cer mis obsermaciones sobre este punto en mis dics rautivins, obra destinadia il los aficionados á las aves, que conticne las

Fig. LG. TL C.ICITLA JIS. MONO AMRRH.

noticias mas exactas y fidedignas sobre la cria die todas, pero las de que ahora tratamos son tan extranas y unicas en su ginero, que casi me veo obligado a repetirlas agui. La ca. sualidad me ha dado a conocer las necesidades de esas aves. Las noticias de Anderson sohre su genero de vida en libertad no ejtaban publicadas aun cuando adquiri los primeros sitáculos sonrosados. No podia imaginarne que su reproduc. cion diuriese tan esencinlmente de la de otros siticulos 6 loros en general: mis cautivos estaban apareados y las parejas se próésaban el major cariño, sin hacer por eso los pre parativos para incubar. Por mas que fuesen pacificos con sus semejantes, no sucedia lo mismo con sus companeros de jaula, uña especie de tejedores; destruian los nidos de estos y cometian otros destrozos. Yo achaque esto a la insolencia acostumbrada de los loros y por lo mismo no me opuse á sus actos. Entraban y salian de las cajitas destinadas para ello; pero considerabanlas al parecer, mas bien como es. condite, que como nidos. Aunque era evidente que deses. ban hacer cria, reconociase tambien al mismo tiempo g̣ue les faltaba algo. Hasta entonces so!o habian comido gra. nos, como mijo, cañamones 5 avena, desjurceiando el alimento mezclado; esto me indujo à creer que mis sitŕculos comerian retobios, $y^{\circ}$ i fin de asegumrme diles ramas verdes de sauce con sus hojas. Pocos minutos despues que estaban posadios sobre ellas, arrancaban rajpidamente el follaje y roian los retoños y la corteza. All princinio me pareció que este irabajo reconocia por causa la inclinacion á destruir; pero al observarlas minuciosamente, vi que mis aves habian encontrado al fin el deseado material para la construccion de su nido. Arrancaban hábilmente un pedazo de corteza de $11^{\circ}, 06$ á 11", ro de longitud; cogianle despues con el pico por una extremidad, crizaban las plumas de la rabadilla parn culocar entre ellas el pedazo de corteza, y alisábanias en seguida De! mismo modo separaron un segundo, iercero $y$ hasta ocho pedazos de corteza, poniéndoselos siempre enire el plumaje: muchos cayeron al suelo, sin que las aves hicieran caso de ello: y tambien retiraron rarios, pero sicmpre que. daban algunos. El loro, levantándose al fin, volaba lemsamente y con cuidado hacia la cajita del nido para dejar alli su carga No sé si los demás sitáculos proceden del mismo 
modo; pero lo creo probable. Mis observaciones, sin embargo, sobre este punto son las únicas que hasta ahara se han hecho. Toda la historia matuml de las aves no registra otro hecho semejante; ninguna de las aves, cuya manera de reproducirse conocemos, sin exceptuar el bolborinco, que construye nidos al aire libre, lleva de igual modo el material para la construccion de los suyos. Mi observacion me colnó por lo tanto de alegria, excitando la admiracion de todos los naturalistas.

Poco despues de haber comenzado la consiruccion del nido, verificóse el apareamiento de una pareja, y.aigunos dias mas tarde el de otra Dificilnente se podria imaginar cosa de mas atractivo que este Intimo y lingo apareamiento de los sexos; las caricias prelimimares, la habil posicion durante el acto mismo, los descos ardicrstes del macho, el olvido ce :oda reserva por parte de la hembra, el contento y satisfaccion cespues de la cópula, y la mutua gratitud de ainbas aves. No puedo decir cuándo se puso el priner huevo, ni cuánto duró la incubacion y la cria de los pequeños, porque no quise mo. lestar á las aves examinando su nido; solo he observado que este se compone de pedazos de cortezay tiene la forma de dós tercerns partes de un hemisferio hineco. El huevo es blanco, muy redondeado y sclativamente grande; los hijuclos, cì número de dos $\{$ cinco, salen a tas diez $u$ once semanas del primer apareamicnto; $y$ al los tres ó cuatro meses revisten el plumaje de los aduitos; las plumas nismas no cambian hasta el octavo mes, mientras que la mandibula superior, ne. gruzca al principio, palidece ya á las primeras tres ó cuatro semanas. Ambos padres alimeniabari a los pequeños, y no solo con veretales, sino tambien con larras, circunstancia por la cual podria suponerse que en libertad se nutren tambien de insectos. Su proceder es igual en un todo al de los padres; tienen su viveza, movilidad y penctracion desde el priner dia de su existencia; pronto aprenden tambien a tener prudencia y suficiente astucia para ocultarse; y desde el quinto mes yn no sc diférencian de los adultos. Inmediatancnic despues de In primera cria, y antes de que los lijuclos de la misma se hayan declarado independientes, el macho $y$ la hembra se aparcan por segunda ve, sin duda la última en cl año.

No he olvidado tampoco hacer todas las observaciones de que pueden ser objeto los loros cuando incuban. Mis áves profesaban el mayor carino i sus propios hijuelos; pero con los otros de su especie mostrábanse muy liostiles y se preci. pitaban sobre ellos, a pesar de haber vivido en la mejor armonia con las pequeñas aves durante la incubacion, cxcep. tuando un poco de celos y desconfianza. Al fin me vi abligado à defender los pequeños contra tales alaques.

Varias hembras sucumbieron al poner los hueves, perdién. dose por lo tanto algunas crias; mas no por ello dejo de creer que csia especie de sitáculo es la mas propia para tenerla en cautividad, y puedo recomendarla mucho por tal concepto.

\section{EL SITÁCULO DE SWINDER-PSITTACULA SWVINDERIANA}

CARACTERES.-Esta especie, que se ha tomado por tipo del género Agropormis, es una de las mas bonitas entre los loros enanos. Tiene cuando mas $0^{n}, 14$ de largo, de los cuales corresponden $1, ", 03$ a la cola, con corta diferencia; sus alas extendidas alcanzan $6 ", 25$; el largo no excede de $6^{\circ}, 0$. El fondo del plumaje es verde; la parte inferior del lomo, la rabadilla y las plumas superiores del ala, arul celeste; la cola corta, apenas redondeada; las pennas que la constituyen, excepto las dos medias cuya superficie es ver. de, son de un rojo oscuro en su mitad basilar y vercies en la terminal, laallandose separados los dos colores por una faja negruzca. La cara, el vientre y las plumas que cubren la cola son de un verde amarillo; cl cuello y el pecho de un amari. llo de ocre verdoso; y adoma la parte superior del cuello un collar negro (fig. 13).

DistRIBUCION GEOGRÁriCA.-Indícase como pa. tria de tan precioso loro el oeste y el centro de América.

USOS, COSTUMBRES Y REGIMEN.-Cirecenos completamente de datos acerca de su estado libre: los pocos individuos que se han visto vivos en Europa tienen las mis. mas costumbres que las otras especies del grupo.

\section{LOS CORILIS-CORYLLIS}

CARACTERES. - Finsch clasifica los corilis entre los si. iacideos, mientras que otros los consideran como lóridos. Las especies que pertenecen á este género son en su maỵor parte mas penqueñas aun que los sitículos; y son las lilipu. tienses del órden, pues el mas pequeño de todos los loros, el sorilly r.tilis, pertenece a este género. Su pico es muy ende. ble, mucho mas largo que alto, y comprimido latcralmente; la mandibula superior forma un ángulo en la arista, que se encorva ligcramente $y$ termina en uma larga punta un poco arqueada; la mandibula inferior es mas baja que la superior, y tiene delarie de la punta una ligera sesgadura; la cera es Doco marcada y se dirige en forma de arco hicia adelante; las fosas nasales son redondas yo están cubiertas de pluma; los piés cortos y robustos: las alas, que durante el reposo cubren mas de la mitad de la cola, son largas; la scgunda ré. mige sobresale de todas las demis; la punta de las alas es muy saliente; la cola un poco redondeada y corta; el plumaje, recio y espeso, sc compone de plumas anchas, cuyas barbas son mus divergentes. El color predominante es verde; en 1a parte superior de la cabca y en la garganta se observan manclas rojas, amarillas y azules; la rabadilla es siempre roja.

DISTRIBUCION GEOGRÁFICA. - Los corilis, curo húincro de especies pasa de doce, habitan en el pais é islas de la Malasin: su área de dispersion se extiende desde Cei. lan hasta Malabar y desde la peninsula de Máalaca hasta Flo. res. Dentro de esta inmensa cxtension se hallan las especies casi siempre muy aisladas; solo en las Filipinas viven cuatro especies, y por consiguiente podenos considerar estas islas como su pairia priucipal.

USOS, COSTUMBRES Y REGTMEN.-Carecemos de noticias exactas sobre el género de vida en libertad de estas ares; solo sabemes que son arboricolas en la verdadera acepcion de la palabia, que se reuren a veces en bandadas in. numerables, y que se alimentan de varias flores de árboles, retonos y simientes. Para descansar se suspenden de los piés comn los murciélagos; vuclan poco, pero con mucha destre. za; su roz cs agradable, y construyen sus nidos en huecos de árboles.

CAUTIVIDAD. - Iôs indigenas del país donde estas aves habitan son muy aficionados a tenerlas cautivas; pero como los corilis se cuentan entre las especies mas débiles, pocas reces llegan á Europa.

\section{EL CORILIS DE CORONILLA AZUL-CORY- LLIS GALGULUS}

CARACTÉRES-He tenido la suerte de poseer mas de dos anos un corilis de coronilla azul, y por eso le elijo como tipo del grupo. lista avecilla, el silindit y silinditum de los indigenas de Iava, el serindil de los de Sumatra, el serendak, sindabir y heisung slinde de los malayos, y el talisol de los dayaks, es una avecilla graciosisima; tiene poco mas ó menos el tamaño de nuestro gorrion; en su plumaje predomina el 
color verde de yerba; en la parte superior de la cabeza se ve una mancha redoncia de color azul oscuro de ultramar; en el dorso otra, de forma triangular y de color amarillo anaran. jado: y una tercera en la garganta, mas grande, trasversal y ovalada; la garganta, la rabadilla y las tectrices de la cola son de un rojo muy vivo de escarlata; una faja tmsiersal estrecina de la parte inferior del lomo, y los bordes de las plumas de la parte inferior de los muslos, tienen un tinte amarillo vivo; las rémiges son negras en las barbas interiores, por debajo como las plumas caudales, azules de mar; las tectrices inferiores, verdes. La pupila es de un pardo oscuro; el pico negro; la cera gris claro; y los piés de un amarillo pardusco. Ël color del macho es mas oscuro que el de la hemira; esta última tiene en vez de la mancha azul, una de color verde cn la parte sujperior de la cabcza, y orra en el dorso mas pequeña, de un tinte verdoso azulado: no existe la mancha de la garganta. El plumaje de los hijuelos es mas oscuro; la manclia de la coronilla está solo indicada, ๖ las del lomo y de la garganta no existen.

DISTRIBUCION GEOGRÁFICA. - Por lo que hasta ahora sabemos, el corilis de coronilla azul vive exclusivamente en Borneo, Sumatra, Banca y la punta meridional de Malacar

USOS, COSTUMBRES Y REGIMEN.-Solo Salomon Muller, que lia podido observar las graciosas avecillas en el sur de Borneo, nos da algunos detalles sobre su género de vida en libertad. Este infatigable y sabio viajero, vió el co. rilis de coronilla azul enjaulado en las casas de los dayaks; segun jarece es su ave favorita, y suelen tener varios individuos cautiros en jaulas redonchas y giratorias de bambú, las cuales se ponen cn movimicnto cuando las ares trepan. El corilis de coronilla arul se alimenta, en su estado liurc, de retoños y fiores de árboles, sobre todo de los eritrinidos; in cautividad se le nutre con arroz cocido, y it veces plátanos crudos, que al parecer le gustan mucho. Por lo demás, dice Muller, solo añadiré que es dif́cil distinguir esta avecilla entre el verde follnje y rojas Rores de los critrinidos. No se sabe nada sobre la reproduccion.

CAUTIVIDAD. - Varias veces he tenido la satisfaccion de adquirir corilis de coronilla azul cautivos; y durante mu. chos anos conservé una pareja cuyos usos y costumbres he descrito en mis Akes cautions. Esta descripcion es la unica, minuciosa y exacta que yo conorco, y de consiguiente me veo obligado á reproducirla. Los corilis de coronilla azul, y quiza todos los corilis en general, son sin duda las especies mas dóciles de su órden; son unas avecillas graciosisimas, en extremo mansas, y ígiles, aunque no impetuosas; charlan cantando. $\delta$ vice-versa, sin molestar con agudos gritos; y ejecutan todos sus movimientos coll -una facilidady gracia extraordinarias. Cuando andan por cl suelo, su paso es presuroso y seguro; sin temor alguno atrévense á dar sal. tos, relativamente muy grandes para sus coras piernecitas; y trepan con rapider, y destreza, valiéndose del pico y de los piés con el mismo aplomo que cunndo suben por la rejilla de la jaula.

Aunque solo he podido observar su vuelo en la jaula grande, y $n 0 \mathrm{cn}$ toda su cxtension, he reconocido que es fácil y nada penoso, it pesar de la rapider con que mueven las alas; nunca les oi jroducir el estrépito que causan los sitáculos al remontarse por los aires.

Durante el rep̧oso generalnente se les ve en la posicion regular; para dormir initan á los murciélagos, colgándose siempre por los piés del techo de la jaula, 6 de una rama; y no solo el tronco sino tambien la cabeza, toman uma posi. cion vertical; de modo que el dorso, el cuello recogido, la coronilla y el pico forman una linea recta; la cola forma una diagonal hácia atrís, sin duda para impedir que el tronco tropiece con otro objeto: el plumaje se criza irregularmente. En esta posicion, las lindas avecillas cambian de aspecto de tal modo, que parecen otra vec tan gruesas como cuando están posidas, y hasta afectan la forma de una esfora. MU. chas veces se agarran so!o con una pierna, acercando tauto la otra al tronco, que apeuas se ven los dedos. Con frecuencia cambian tambien de pierna para que cada una descanse alternativamente. Cuando se les asusta refúgianse siempre en el techo, cunl si crejesen quue colgadas están mas seguras. En esta posicion ocúpanse á veces en cosas de poca in. portancia, como por ejemplo en arreglarse las plunias; mientras tanto emiten algunos sonidos para expresar su satisfaccion. Sin embargo, hacen esto mas á menudo cuando están posadas. Si cl corilis siente la necesidid de hacer sus deposiciones, levanta la cola un poco mas de lo ordinario, arquea un poco el tronco y expele los excrementos, que por lo regular consisten en bolitas cubiertas por una especic de membrana Cuando reposa 6 duerme, esta avecilla dilata su cuerpo mas de lo acostumbrado, y cierra los parpados de modo que solo se ve una estrecha abertura. No es necesario decir que los corilis pueden tomar tambien tocias las demás posiciones posibles para los loros: lo mismo les da estar cabeza arriba que cabeza abajo; pero la posicion de los murciélagos es la que adoptan con mas frecuencin; y por lo mis. mo propondria se llamase a los corilis boros murcielngos, si no me pareciesc este calinicativo menos gracioso que el suyo projio.

Las facultades intelectuales de los corilis parecen ser poco mas o menos iguales á las de los sitículos; los corilis de co. ronilla azul, inofensivos y familiares, llegan a conocer pronto a su amo y a la familia; no se inquietan en lo mas minimo cuando alguno se acerca a la jaula, ni se atemorizan si se lle. va esta de un sitio à otro; permanecen en la misma posicion, colgados del techo. Distinguen al punto á las persomas extra. has, pero tambien se familiarizan con ellas; la presencia de un perro es lo que les excita en allo grado. Sus ademanes no son nunca tan expresivos como los de las especies grandes, y tampoco gritan cuando se los enoja, como lo hacen los sitículos. Su carácter es del todo pacifico y grave; viven, si asi podemos decirlo, tranquilos y contentos de si mismos; macho y hembra conservan la mejor armonia, por mas que al parecer no se acaricien. No he obsersiado nunca que se limpien alternativamente el plumaje ni se cojan el pico, de la manera que lo liacen otros loros. J.os individuos de una numcrosa coleccion que ture ocasion de ver vivian tambien en la mas perfecta armonia; pero cuando puse un macho en la jaula de mi pareja, el otro manifestó inqquietud, aunqque al parecer mas bicn por temor que por celos. Sin cmbargo, he creido observar en este caso la curiosidad propia de esas avecillas. Muy agradable es el canto del macho, al que se oye sin cmbargo con poca frecuencia. Es verdád que no puede compa. rarse con el de los fringilidos, sino que consiste mas bien en una seric de trinos y silbidos, pero producidos con tanta gracia, que sc oyen con mucho gusto. En cuanto á las variaciones, cste canto es quizís un poco inferior al de las cotorms onduladas; pero el conjunto es en mi opinion enteramente igual. Cuando el corilis canta, suelc animarse mucho; prolonga el cuello tanto como le es posible y eriza las plumas rcjas de la garganta, de modo que los movimientos de aquellas reproducen los de los músculos de esta. Cada trino dum de uno $\mathbf{a}$ dos minutos, y despues de un corto intervalo el co. rilis comienza de nuevo á charlar. En invierno sucede a me. nudo que despues de permanecer silencioso muchas horas y de haber dormido un rato, comienza is cantar por la noche, cuando se ha encendido la luz. Ia lrembra inita algunas re- 
ces la llamada del macho, que consiste en un ait agudo; pero en general ove el canto de $5 u$ companero sin excitacion visible $y^{\circ}$ hasta con indiferencia, pues continúa comiendo, sube y baja por la rejilla, se cuelga para descansar, limp̧iase el plumaje, y en una palabra, no hace ningun aprecio. del macho, que segun parece, canta mas bien para entretcherse que para divertir a la hembra.

El alimento de mis corilis era por b regular el mismo que se sucle dar a los canarios, es decir, frutas cortadas en predacitos y larvas irescas de hormiga; con esto se conservaban muy bien, cambiaban el plumnje sin perder nada de su simcidad y sin sufrir alteraciones en su color; peró nunca lle. garon a reproducirse. Otros individuos de la nisma especic adquiridos por mi mas tarde, murieron yoco desplues de su llegada; pero no puedo creêr que en general sean mas débiles que los sitáculos á los płaticércidos; tampoco me conformo con la opinion de que no soportan ln cautividad; y hasta estól convencido de que mis pronto ó mas târde se propaga rán en nuestras jaulas.

\section{LOS CACATÚUDOS - PLYC- TOLOPHINE}

La Nueva Holanda es el garaiso de las aves; los mamile ros son alli súres raquiticos que solo ofrecen una vaga analo gia con los de las otras partes del mundo; las aves, por el contrario, se hallan tan bien representadas como en cualquier otro continente. Examinarenos en la sucesivo muchaśy sin gulares familias propias de aquel pais. mas ninguna de ellas le da un sello particular como los loros. Fin medio del verde follaje de los gomeros se destacan, como otras tantas flores animadas, los cacaulas de brillante plumaje, y sobre las ama rillas acacias, sobresalen las plumas color escarlata de las rosadas cotorras. Al rededor de las flores que contienen el celicado núctar revolotean los loris, mientras que los pequeủos platicercos prestan animacion a las desiertas praderas del interior del territorio. Los loros alli, como entre nosotros las golondrinas, recorren las calles de las ciudades 0 de los jueblos, ó a senuejanza de los gorriones, orupail los caminos y los patios de lás casas, y cuando el colono almacena su cose cha, agrúpanse ante su granja centenares de aquellos para buscar en la paja los granos que quedaron. 1 todos los ria. jeros les seduce semejante espectáculo; pero el cultivador profesa un odio profundo á las aves ladronas, $y$ las mata sin colmpasion.

Entre mas de sesenta especies de loros que habitan en Australia, los cacatúidos ocupan uno de los primeros lugares.

Forman un grupo bastante circunscrito en el úrden y se les considera por eso con razon coino familia independiente, $\delta$ al menos como sub-fnmilia.

CARACTÉRES. - El caricter mas đistintivo consiste en el penacho formado por las plumas de la cabeza, caracter que basta para distinguirlos de todos los demás loros

DISTRIBUCION GEOGRÁFICA. - Los cacatúidos ha. bitan en la Australia, en el pais de los Papues y en algunas islas indico-malayas. Su area de dispersion se extiende desde las Filipinas hasta la Tasmania, jesde limor y lilores hasta las islas de Salomon. Dentro de este circulo casi todos los paises é islas están poblados de cacatuidos; algunas especies se han propagado por vastos territorios 0 islas; mientras que In mayor parte parecen tener un área de dispersion muy circunscrita

USOS, COSTUMBRES Y RÉGIMEN.-Foman bandadas innumerables cstablecidas en los bosquues; parten de alli para tecorrer las llanuras y los campos, y excitan la adm:- racion del viajero que los contempla. eten medio de la oscu ridad que determina la espesura de la selva, dice Mitchel, vuclan los blancos cacatúas semejantes a fantásticas visiones; mientras que otros, con sus alas escarlata y su moño color de fuego, parecen sćres ideales soñados por la imaginacion. Se hace preciso haber experimentado todo el encanto que cjerce en el hombre.del norte la espiéndida vegetacion de los trópicos: es necesario haber conocido hasta qué punto llega cste sentimiento al ver entre otras cosas aquellas pintadas aves, para que no se crean exageradas tales palabras.

Por sus usos y costumbres los cacatúas se parecen à los demas loros, pero son los mas dóciles y familiares de todos. Cuando viren reunidas bandadas de miles de individuos, sus gritos pueden llegar á ser desagradables; pera si se tiene uno solo, muy pronto se le toma cariino. Todos los cacatúas se distinguen por su astucia é inteligencia; pero los mas son graves y dóciles. Sus facuitades intelectuales alcanzan un gran desarrollo; son curiosos; tienen mucha memoria y casi cada individuo revela un carácter especial: apenas se ven dos que se conduzcan del mismo modo. El cacatúa'se familiariza muy furontó con ol hombre: es menos maligno que otros loros; reconoce con gratitud el cariño que se le profesa, y parece solicitarle de codo el mundo en el mismo grado. Solo por el mal trataniento liega a ser irascible y desagradable; y se debe jrocunar no granjearse su mala voluntad, pues el cacatúa, grncins i su excelente memoria, conserva fácilmente por mu. chos años las impresiones recibidas. Dificilmente, ó nunca, olvida una ofensa, $y$ apenas se podria conseguir que recobrase confinza cuando una vez. la ha perdido; hasta sucede a menuda gne el ave ofendicin siente el deseo de vangarse y puede causar dano á quien la maltrató. Este rasgo de su carácter es quizás el único censurable; su cualidad dominante es la ducilidad; quicre profesar cariño y que se le corresponda, lo cual demuestra is su amo de mil maneras. Una rez acostum. brado a la cautividad y familiarizado con un hombre, pronto se deja tocar por cil, y despues por todas las personas; si all. guien desea acariciarle inclina la cabeza y entreabre el plumaje para recibir los halagos. 'Tal vez sienta una impresion agradable cuando le rascan la piel: y con tan buena voluntad recibe las caricias, que parece olvidarse completamente de si mismo, cautivando por esto al observador.

4Yotengo, me escribe Linden, un cacatúa, cuya docilidad y Familiaridad exceden a toda ponderncion. Aunque en el carácter de los loros se observa siempre algo de malignidad, y por mas que deba esperarse de ellos algun picotazo en ciertas circunstancias, por despertar su malicia 6 su cólera, este individuo es una cxcepcion. En los diez años que le tengo, siempre se ha mostrado igualmente cariñoso; permite hacer con et cuanto se quicre, y condúcese como un niño bien educado. Sin embargo, cuando se acaricia demasiado í su compañero, despiértase su envidia, y en este caso se toca con un pié el cuello y la cabeza para manifestar el desco de recibir halagos tambien. D

Pero el cacatúa tiene tambien otras cualidades muy dignas de aprecio: por su gran inteligencia, su excelente 'memoria y su tacilidad para aprender, podria competir con los loros mas favorecidos. Tambien el aprende á hablar-sin dificultad: reu. ne varias palabras en una frase, y las emplea oportunamente; se le pueden enseñar varias habilidades; en nnn, reconócese ẹn tódo su superior inteligencia.

«Ningun género de loros en genernl, dicc Linden, merece tanto como los cacatúas el nombre de mones cmplumudos, esto se conoce sobre todo en su inclinacion a remedar. 'lodo cuanto pasa en una jaula vecina llama su atencion, y cuando pueden lo imitan, tanto los movimientos y ademanes como los sonidos inusitados, bien sean agradables 6 desagradables. 
padre y tia, vicjo.) Las aves que la pronuncian, proceden pues, de los países malayos, ó llegaron a manos de los indi. genas de aquellas regiones cuando eran pequeños. Por esta observacion de Rosenberg ine explico tambien la tierna en. tonacion de la referida palabra: es preciso que las mujeres y los ninos sean los maestros que enserien a las ares recien cogidas.

Asi como otros loros, tambicn los cacatuas libres forman bandadas, que aun durante el periodo de la incubacion ha. cen casi vida comtn. Pasan la noche ocultos en el follaje mas espeso de los árboles altos, y por 12 mañana producen unos gritos que se oyen á larga distancia; despues, remontándose por los aires, iuelan aleteando ligeramente, y'i reces deslizanse sin mover-las alas, cuando se cirigen hacia un campo de trigo ú otro sitio que Jes ofrece alimento: aprove. chanse tanto como pueden de la abundancia en su territorio. Se nutren principalmente de frutas, granos y simientes; tam. bien comen raices y cebolleias, que cxtraen habilmente coll su larga mandibula superior; no desprecian las sctas; y à la manera de las gallinas tragan piedrecillas, sin duda para facilitar la digestion. Fil buche y el estómago contienen siempre los alimeratos mas distintos. Los cacatias pueden causar grandes perjuicios en los sembrados y en los campos de mair. Siempre están en movimiento, excepto a las horas del medio dia; todo cuanto pasa a su alrededor llama su atencion, y gritan apenas ven algo nuevo. Si cuando una bandada acabs de ocupar un sitio acierta á pasar otra jor alli, producese un estrépito infernal, de cuyos sonidos solo pueden formar idea aquellos que hayan oido los gritos de algunos individuos cautivos. Tan luego como una bandada la satisfecho su ape tito vuelve al lugar de reposo en el bosque y permanece al gun tiempo silenciosa mientras acaba de digerir; despues va por segunda rez en busca de alimento, y llegada la noche, se reunen todos los individuos en el sitio acostumbmdo.

De este ino do joco mas 6 menos viven las bandadas liasta la época del celo cntonces dividense en parejas, y cadacual busca un laueco convèniente para su nido. Estese encuentrai, segun las circunstancias, en cavidades de arboles de tocia clase, y sobre todo en ramas huecas, asi como tambien en las grietas de las rocas. Miles de cstas aves visitan todos los años las escarpadas rocas de los rios de la Australia meridional, asi como las gaviotas, mas numerosas aun, frecuentan las rocas de los mares del norte. Preténdese que varios de esos nuros de piedra están completamente agujereados por los loros. y en efecto, el hecho parece creible atendida la fuerza y durea del pico. La hembra suele poner dos hwevos, ó à lo mas tres, aunque esto viltimo es raro; tienen una forma aguda y por el tamaño se parecen à los de una gallina cnana: pero difieren dastante de estos tiltimos por su brillo. No sé cómo se verifica la incubacion ni tampoco de g̣ue manera se crian los pequeños. Buxton, á quieu no faltaria ocasion de hacer observaciones sobre esto en sus aves cautivas, no dice nada sobre el particular.

Con frecucncia contraen amistad los cacatúas de distinta especic, y si los amigos son macho y hembra, prodúcese por lo regular una union amorosa que tarde 6 temprano conduce al apareamiento. Desde teste insianic se les ve siempre uno junto á otro, colmándose de caricias, como lo hacen los sitá. culos. Fin la coleccion de ares de Linden, un gigantesco ca. catúa de mejilla amarilla se la elegido una pequeña hembra de la especie Ducorp y ahora viven apareados. aRepetidas veces, me escribe Linden, he observindo la cópula: la ternu. ra con que se tratan anies y despues es cxtratha: abrízanse formalmente con las alas y se besan como dos cnamorados; pero la hembra.no ha puesto aun huevos, y hasta ahora han destruido en pocas horas todas las cajitas que les puse para construir su nido. Sin embargo ya hemos visto antes que los cacatúns de distinta especic se pueden reproducir tambien con éxito.

CAzA.- A causa de los perjuicios que los cacatúas ocasionan á los campesinos, sobre todo cuando se presentan en gran uúmero, persiguenlos tenazmente en su patria, matán. dose a reces centenares de ellos. Algunos viajeros aseguran que cuando estas aves sufren persecucion comienzan á ser pronto muy prudentes y proceden en sus invasiones de merodeo como otros loros ó como monos, con verdadern astu. cia, siendo entonces dificil ahuventarlos de los campos. Los indigenas cazan estas aves de una manera muy cxtraña. el'al vez no haya, dice el capitan Circy, espectículo mas interesante que la caza del cacatúa en Nueva Holanda. Los habitan. tes de este prais se sirven para clla del arma singular, llamada iumering instrumento falciforme y plano de madera dura, que se lanza con la mano á unos trcinta metros de distancia, y quic trarando circuios al cortar el aire, toca con bastante seguridad cn el blanco á pesar de sus evolıciones. Esta arma cs In misma que los habitantes del Africa central fabrican con madera y lierro. Iil indigema persigue a una uumerosa bandada de cacatúas en el campo ó en el bosque, con prefe. rencia alli donde altosy magnificos árboles rodean un estan. que, porque los cacatías visitan principalmente tales sitios, y alli se les ve á menudo en bandadas innumerables trepando por el ramaje de los árboles donde suclen tambien descansar de nuclie. Fil cazador se acerca a esos estançues deslizandose con toda precaucion de un árbol en otro, de asbusto en arbusto, esforzándose todo lo posible para no ser descubierto por las aves vigilantes; mas por poco ruido que haga, los cacatúas le divisan, y un moviniento general anuncia la presen. cia del tenible enemigo. I as aves conocen que hay Ipeligro: pera no saben aun bien en qué consiste. Asi se acerca el ca. zadoral final aglia y presentase delante de sus victimas: lanzando gritos infernales, remóntase la blanca nube por los nires $y$ en este mismo instante el indigenal arroja su arma. Fil bumerang, girando rápicia y singularmente sobre el ngua, clevase como un arco y jronto alcanza a las ares, mientras que otras dos ó tres armas de la misma especie siguen á la primera En vano procuran las aves salvarse; el vuclo, al parecer irregular, del arma, las jerturba y paraliza su fuga, y las que son tocadas por el bumerang perecen, sea porque el ins. trumento les corte el cuello ó les destroce un ala. Gritando de ciolor y de ira, una de las ares cae en tierra y solo cuando el cazador de picl oscura ha logrado su fin, la bandada se recoge y huye poseida de terror, ó busca refugio ell las copas mas espesas de los àrboles.

CAUTIVIDAD.-Cunado se le cuida bien, el cacatúa soporta algunos anos la cautividad; conócense cjemplos de individuos que han vivido mas de setenta arios en la jaula. Cuesta muy poco mantenerle, porque gradualmente se acos. tumbra á todo lo que come el hombre pero debo recomen. dar que no se le den sino los alimentos mas sencillos, granos de varias clases, arroz cocido y quizas un poco de bircocho, pues cuando recibe la comida con extremada auundancia, fácilmente engorda demasiado y se acostumbra á vicios que despues no se pueden extirpar. Para graniearse su amisiad es menester atenderle mucho, trataric con carino y perdonarle muchos resabios. 'lodo cacaitia se domestica, tarde ó tempra. no, cuando se le cuida bien y entonces recompensa con el mas fiel cariño a su amo. Sin embargo, no ha de creerse que el cacatúa olvida, ni aun en las condiciones mas felices, cl uso de sus alas. a En un cacatia de mejilla amarilla he podido reconocer, me escribe linden, que los loros, aun despues de largos anos de cautividad, y cuando al parecer solo pueden trepar ó saltar, saben lancer uso, en el primer momento de li. 
bertad, de la perfecta fuera de sus alas. Cometi la imprudencia de poner en el jardin una jaula muy grande en que se hallaban el citado cacatúa con su companero; y cierta mañaìa se me escapó por debajo del brazo; un momento despues laallábase ya en la copa del árbol mas"allo del jardin, donde desplegó stis alas, y erizó su casco amarillo, ofreciendo un aspecto magniñco. Llaméle con las mejores palabras, ense. iándole su alimento fivorito; pero no hizo caso de nada, y despues de trepar un poco por el ramaje, remontóse súbitamente con gran ruido por los aires elevándose siempre cada vez mas, de modo çue apenas pude seguirle con la vista; 6 . los pocos momentos dirigiase hácia una lengua de tierra yue

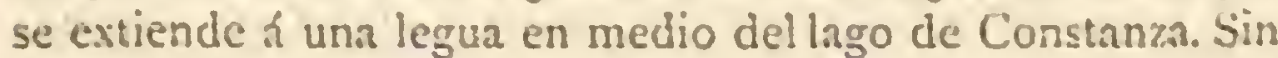
perder tiempo comencé á buscarle, pero en suno examiné todo árbol frutal, los sauces y los álamos a lo largo de la orilla; y llegada la noche perdi la esperanza de recobrarle, figurándome que se habia escapado \& los bosques de la orilla opuesta del lago. No obstante, me puse otra vez en camino á la mañana siguiente antes de rajar el alba y ape. nas hube andado un cuarto de hora, crel oir su vor; avancé un poco y descubri en efecto al ave en un jardin de árboles frutales, donde se divertia en arrancar una considerable cantidad de ramas. Contestó á mis voces, pero cuando habia buscado auxilio y una escolera, por la cual subió un hombre al árbol, refugióse en el inmediato, se clevó súbitamente por cl aire $y$ describiendo una espiral, fus a posarse al fin en la copa del álamo mas alto de la orilla. Parecióme inútil llamarle hallíndose a tanta altura; pero como habia tenido la pre. caucion de llevar su compañero en una pequeña jàsla, púse. la en el suelo junto á otra vacía. Ambas ares se liamaron, contestáronse alternativamente, el fugitivo bajó al ín de sta altura; pero un hombre que jasaba casualmente en aquel momento, ahuyentóle por segunda vez y al punto volvió á. sur sitio anierior. Perdida la paciencia, puse un centincla muy cerca del árbol, y volví sin esperanza i casa; mas apenas habia pasado un cuarto de hora, trajéronme el fugitiro. Su compar. nero le habia llamado y no pudo resistir a la fuerza de la antigua amistad. Descie entonces ya hace múcho tiempo g̨ue está bien encersado y uque vive en la mayor intimidad con su hembrin.

USOS Y PRODUCTOS. - Asegirase que la carne del cacatur es bastante sabrosa, y sobre todo se hacen elogios de su caldo.

Los muclios cacatúas que llegan vivos á Europa demues tran fa facilidad con que se dejan coger. Cuanto mas scncillo es el alimento, mas ficilmente soportan la cautividad, $y$ son por eso muy propios para largos viajes; pero teniendo en cuenta que en Alemania se compra un cacatía de tercera ó cuarta mano por pocos francos, ficilnente podemos deducir que el precio de estas aves debe ser muy bajo en su patria.

LOS CACATÚAS PROPIAMENTE DICHOS - PLICTOLOPHUS

CARACTÉRES.-La descripcion anterior se refiere esen. cialnente á este género: las especies de que se compone son loros grandes ó de tamaio regular, es decir que sus dimen. siones varian cutre las del grajo y del estomino, sicndo las formas muy recogidas. Los caractéres del género, del cual se conocen hasta ahora diez y seis especies, ó segun otros dicz y ocho, son los siguientes: el pico, muy fuerte, ram rez tiene mas altura que longitud, es ligeramente abovedado en los lados y muy conprimido; la arista se redondea, aplanándose un poco hasta la punta, y tiene á veces un pequeño surco longitudinal; la mandibula superior forma un arco muy pro. nunciado y se encorva con la punta hácia adentro, esta últi. ma sobresale y baja á veces mucho, presentando por delante una sesgadura profunda ó reciondeada; la mandibula inferior es mas baja que la superior, estrecha en los lados y ancha por debajo, con los bordes incisivos lisos y arqueados en la extremidad. Las piernas son muy cortas y los piés fuertes, con dedos robustos y provistos de unas falciformes. I.as alas son largas y puntingudas, con la extremidad poco saliente; la tercera ó cuarta rémige sobresale de las otras: la cola ticne una anchura regular y!la punta escotada; el plumaje, que deja descubierto un circulo mas ó menos extenso alrededor de los ojos, se compone de plumas anchas y sedosas, redondeadis en la punta. Ll carácter distintivo consiste en una especic de casco ó mono que varia mucho segun las especies, componiéndose de las plumas prolongadas de la frente y de la co. ronilla. Lil color del plumaje es blanco y el del casco abi. garrado.

Este género comprende lo mas principal de la sub familia. y las especies mas caracteristicas de la misma.

DISTRIBUCION GEOGRAFICA.-Lil área de dispersion de los cacatúas propiamente dichos se extiende por casi todos los paises e islas anies indicadas al hablar de los cacatuidos en general.

USOS Y'COSTUMBRES. - Son los jin descritos en el mismo lugar.

\section{EL CACATUA DE LAS MOLUCAS-PLICTO- LOPHUS MOLUCCENSIS}

CA R A CTERES. - Este cacatuido, el golari de los indios, juntamente con su congénere de Australia, es la especie mas grande. Su color predominante es blanco, con un lustre somrosado hermosisimo; las plumas del mono rojas, sobrepuestas de otras blancas de $\left(1^{m}, 17\right.$ de largo. Ia mitad de la base de las rémiges y de la cola ofrece un tinte amarillento jor debajo; la pupila es de un pardo oscuro; los pequeñus circulos oculares de un gris azul $\delta$ blanco azulado; el pico $y$ los piés negros, con un lustre gris en los individuos cautivos y azul en los libres. Segun me éscribe Rosenberg, el color sonrosado del plumaje se oscurece con la edad en los individuos libres de una manera que no sc observa nunca en los catulivos.

DISTRIBUCION GEOGRÁFICA.-Rosenberg me escribe lo signiente: El cacatua de las Molucas habita casi exchusivamente la isla de Ceram; raras veces pasa a la de Amboina, que esti contigua, y mas al sur. Solo una vez.ob. servé y maté un individuo en esta tiltima. Los habitantes de Amboina y los de Ceram designan á este cacatlía con el nombre de fintalla.

USOS, COSTUMBRES Y REGIMEN. - IEl cacatúa de las Molucas es uno de los tipos mas comunes de su pa. tria. Assi habita en la costa como en el interior, lo nismo en la llanura que en la montana de la isha, donde por logeneral no abundan las ares; y obsérvase que prenere siempre los bosques solitarios. Es curioso espectáculo observar à este ca. catúido, sin duda el mas hermoso del género, en sus usos y costumbres. Su vuelo es ruidoso y fuerte; siempre sigue la linea recta; y si se espamta al ave cuando cruza el espacio, proniere ruidosos gritos. Tan pronto está en el suelo como en la copa de los árboles, sicmpre ocupada y velando por su seguridad. Cierto que fácilmente se la puede sorprender en los bosques solitarios de las montañas; pero en las regiones habitadas, sobre todo alli donde se les persigue mucho, estos cacatúas son muy timidos. Por lo regular se les ve $\mathrm{cn}$ parejas, y despues del periodo de la incubacion en bandadas, las cuales forman siempre cuando se trata de saquear un 
campo de trigo. Segun dicen los indigenas, el macho se man. riene fiel a la hembra toda su vida una vez apareado. Su alimento consiste en trigo, granos y varios frutos.

* Hácia fines de la estacion seca, la hembra busca un hueco de árbol á propósito, artéglale mas 6 menos clidadosamente y pone sobre las ńbras lenosas caidas al ensanchar el hucco, tres $\delta$ cuatro huevos blancos y brillanies de poco mas de (1),04 de longitud. La incubacion dura veinticinco dias. Los hijuelos revisten ya en el nido el plumaje de sus padres. Los indigenas de Australia, buenos trepadores, co. gen con frecuencia los pequeños del nido y los domestican para venderlos. lin Ceram vale dos francos una de estas ares, $\delta$ menos aun, y en Amboina de cuatro i seis. ?

CAUTIVIDAD. Podemos decir ?zue el cacatia de las Molucas cautivo participa de todas las cunlidades de su familia, y sobre todo de su género. Fs un ave magniñca, a la cual se toma tanto mas cariño cuanto mas se la conoce. Casi siem pre llega domesticada a nuesiras manos, y sibien al principio se milestra un poco arisca, acomódase sin embargo muy pronto, gracias á su astucia citrnordinaria, al nucvo géncro de vida; agradece mucho las caricias que se le disızensan, $y$ las recompensa con extremada têrnura. Es un ave muy inte. ligente, vivaz y activa. Aunque esté posada tranquilamente sobre su percha, dice Linden con mucha razon, lesanta y baja de coniinuo su magnifico mono para expresar que ob. serva todo cuanto pasa a su alrededor; cuando se excita eriza no solo las plumas largas de aquel, sino tambien las del fcue1lo, de la nuca y del pecho, que entonces forman como un gran collar; entreabre las alas y desarrolla la cola en figura de abanico, ofreciendo asi un aspecto perdaderamente magnifico. Las plumas rojas del moño parecen brillantes llamas; Ins que hay al rededor de la mandibula inferior toman jel as. pecto de barbas, ! las alas entreabitertas contribujen a que el ave parezca una imagen de la fuera orgullosa a medida que aumenta su excitacion muévese con mayor viveza sin alisar el plumaje, y si entonces se halla en una jaula ancha ó en un espacio mas grande, balancéase sobre su percha, no solo os: tentando todas sus galas, sino tambien haciendo alarde de sus habilidades. Mi cacatua de las Molucas es un ave tan magnifica como gentil, tan soberbia como carnonos, y es pro. bable que esté persuadida de su belleza. Su grito no es nunca tan fuerte como el de los cacatúas de mejilla amarilla $\delta$ de los incas, y en mi opinion es mas bien agradable. Sus facultades oratorias igualan á las de cualquicra otra especie. Con mucha gracia sabe contestar si le dicen alguna cosa; cuando le abro la puerta para acariciarle, acerca el pico á mi rostro, y con la cntonacion mas suave pronuncia las palauras \&cacadú, buen papagayo, muy buen papagayo. si jo tuviera mas paciencia no me seria dificil ensedarle mucho mas. Un mo. vimiento brusco, un rumor desusado, $\delta$ la repentina aparicion de un objeto que no conoce, cáusanle á menudo gran temor; pero se recobra muy pronio y acostumbrase a las cosas nuevas. No se muestra nunca maligno con los demás cacatúas; pero tampoco demasiado amable. Agrádale mucho estar en la puertecilla abieria de su jaula con un crisotis de las Annazonas de frente azul, al que acaricia con frecuencia; pero mas á menudo le provoca à la lucha, sin hacer nunca uso de su mayor fuerza. Solo su insolencia le induce \& jugar de este modo con su congénere; pero pronto le deja tranquilo: este, can. sado ya de la troma, le da por fin un picotazo. Mucho me gustaria dejar estas dos ares juntas; mas el crisotis de las a mazonas se ha encariuado de tal modo con una hembra de arara tan celosa, que es imposible separarlos.

* En cuanto al alimento, el cacarúa de las Molucas es tan poco exigente como cualquiera orro de sus congéneres; pero en cambio pide con mas frecuencia un baño, y al chapuzarse a su antojo en el agua, reconócese cuảnto le gusta; tambien le complace que le mojen abundaniemente por encima. Solo cuando esta chorreando como un perro de aguas sale del baño, y entonces conviene retimrse hasta que se haya sacudido bastante

\section{EL CACATÚA DE MOÑO AMARILLO-CACA- TUA GALERITA}

CARACTERES.-Esta especie es una de las que se ven con frecuencia cautivas; es un ave bastante grande, pues llega a tener f" 45 de largo; el plumaje es blanco brillante. El moño, las plumas que cubren las orejas, el centro del vientre, las alas y la base interna de las pennas caudales son de un amarillo de azufre padido; el pico negro, y las patas de un pardo agrisado (iig. r4).

DISTRIBUCION GEOGRÁFICA.-No se sabe todavia çon certeza si estos cacatúas sc han propagado desde la isla de Van-Diemen por toda la Nueva Holanda, hasta Nueva Guinea, ó si son especies distintas, aunque semejantes por el plumaje, todas las que habitan aquellos diversos paises. Se han notado algunas diferencias en la forma del pico, y csto parece confirmar la segunda opinion.

El cacatúa de la isla de Van-Diemen es el mayor, y el que tiene el pico mas largo; el de la Nueva Guinea es mas pequeño y tiene dicho órgano mas corto y redondeado.

Śgun Gould, el cacatúa de moño amarillo abunda en toda la Australia, excepto en la parte occidental.

Úsos y costúmBRES.-Forma grandes bandadas de varios miles de individuos, y parece preferir las llanuras descubiertas y los bosques de poca espesura a las breñas de las costas.

\section{EL CACATÚA INCA - PLICTOLOPHUS LEAD- BEATERI}

CARACTERES.-Esta especie, el jakkiui de los indige. nas de la Australia, es una de las mas bonitas de aquel continente. Es bianco; pero la parte anterior de la cabeza, la irente, los lados del cuello, el centro de la cara inferior de las alas, la parte media del vientre y la base de la cara interna de las pennas caudales, son de color de rosa: las plu: mas que hay debajo de las alas tienen un bonito tinte rojo carmin, y el moño vivos colores. Las plumas son de un rojo brillante en la base, amarillas en el centro $y$ blancas en el extremo. Cuando el ave inclina su moño, no se re mas que blanco; pero cuando le levanta, aparece el rojo, con una faja que contribuye al adorno de aquella parte. Eliris es pardo claro, el pico color de cuerno claro y los tarsos de un pardo oscuro (fig. 15).

I a hembra se diferencia del macho por los colores menos vivos del vientre, yor lener mas tinte amarillo en cl'moño.

El cacatúa Inca es mas pequeño y esbelto que el de mono amarillo.

DISTRIBUCION GEOGRAFICA. - Dice Gould que este magnifico loro está diseninado en todo el sur de Australia, y prefiere permanecer cerca de los gomeros y en los jarales que bordean las corrientes. Fis muy comun en las márgenes del Darring y del Murray; falta en las costas del norte y noroeste de 1 ustralia.

USOS, COSTUMBRES Y RÉGIMEN.-Durante el periodo del celo se dejan ver estos cacatúas todos los años en sitios fijos, donde se reune un gran numero de indi. viduos.

P'restan mucha animacion á los bosques del interior de las ticrras: su voz es mas planidera que la de sus congéneres y 
no tiene el tono ronco. La presencia de estos loros seduce la vista del viajero que atraviesa los bosques donde viven; $y$ á cilos podrian aplicarse muy bien las palabras de Mitchell, citadas antes.

CAUTIVIDA D.-El cacatúa Inca representa, sin disputa, la mas hermosa especie del género conocida en la actualidad; y por eso es tambien la mas buscada por los aficionados. Constituye uno de los mas preciosos adornos de una coleccion de loros, por muy rica que esta sea. Todo en él, así la belleza de su plumaje como su carácter dulce, contribuje á excitar la adiniracion del observacior; soporta muy bien la cautividad, ja á juzgar por lo nque dicen ciertos autores, es mas dócil y fácil de domesticar que los demás loros.

\section{EL GRAN CACATÚA BLANCO-CACATUA CRISTATUS}

CARACTERES.- Esta ave tiene el tamaño de la gallina

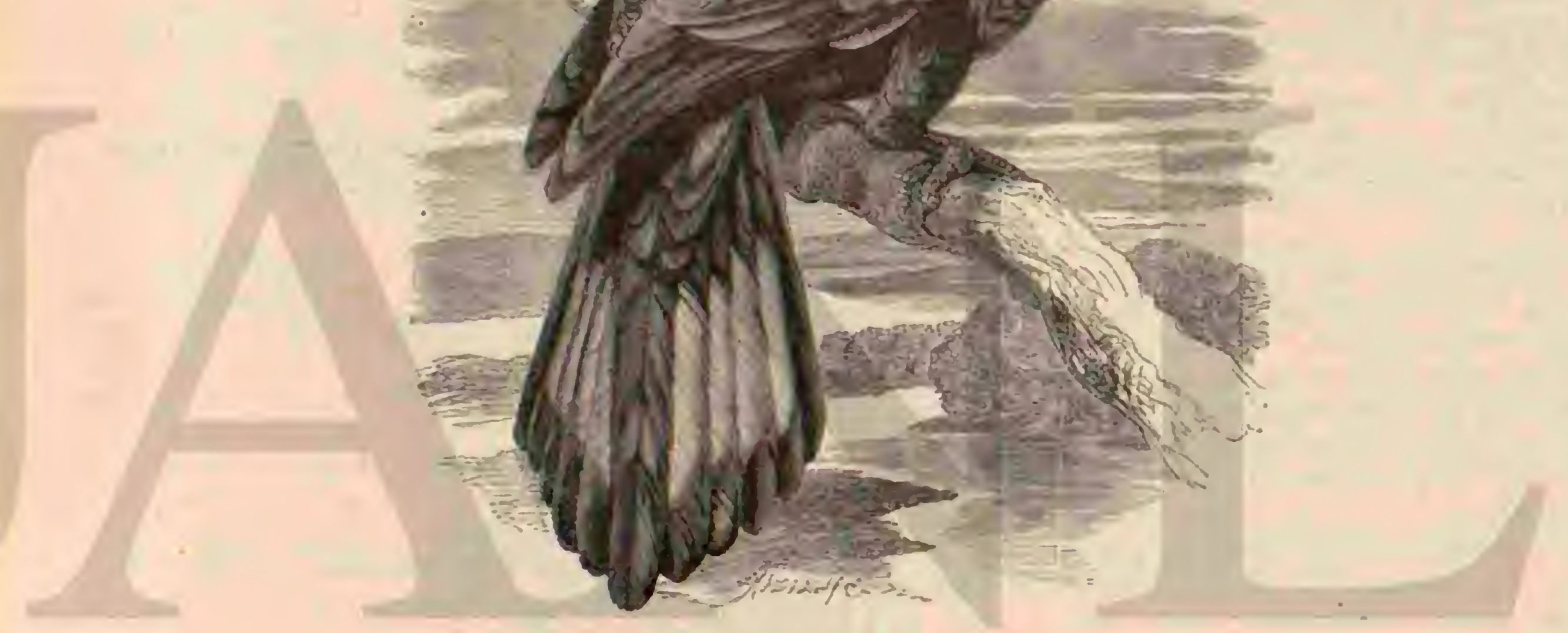

Fig. 16. - E. Cacates ne maxis

vulgar; pero parece mucho mayor, particularmente cuardo se la excita, porque criza todas sus plumas. Distinguese tambien por su magnífico plumaje, que es del todo blanco con un ligero viso rosado; el moino que adorna su cabezn es completamente blanco; el pico negro y las patas del mismo tinte.

DISTRIBUCION GEOGRÁFICA.-El cacatúa blanco habita en la Nueva Guinea y en las islas adyacentes.

USOS, COSTUMBRES Y REGIMEN.-Apenas dificre de los demås cacatuias por sus costumbres y género de vida.

CAUTIVIDAD.-Muchos de los individuos de esta especie se distirguen por la facilidad con que aprenden a repetir las palabias yne oyen, y son muy agtadables para recreo de los aficionados, constitusendo adernás un precioso adorno en las colecciones.

\section{LOS LICMÉTIDOS-LICMETIS}

CARACTÉRES. En este género ó sub gémero relinense dos especies de cacatúidos que se distinguen de las otras por tener el pico muy prolongado y la mandibula superior $\mathrm{cn}$ extremo larga. Reconocemos en ellos las aves no arboricolas de la familia.

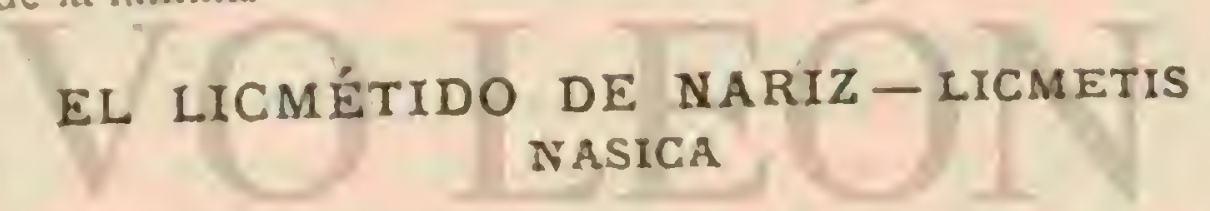

CARÁCTÉRES. - El licmétido ó cacatúa de nari\% tiene tambien el color predominante de sus congúneres y un frequeĩo mono de plumas erectiles en la parte anierior de la cabcar. Su longitud es de $0^{\circ}, 45$, la de las a as $66^{\prime \prime}, 27, y$ la de la cola ff, a 1 : no tengo dato alguno sobre la anchura; el pico mide à lo largo de la arista $0^{\circ}, 05$. Ambos sexos tienen igual color, predominando siempre el blanco; las rémiges y has rectrices son amarilias in la cara inferior de las barbas in. teriores; todas las plumas de la cabeza y del cuello, hasta la parte superior del pecho, y tambien las b!andas, son de un rojo cinabrio en la base y blancas en la punta; roja es tam. bien una faja de la frente que se corre por encima de los ojos en forma de cejas, llegando hasta la mandibula inferior; en 
el pecho hay urra trastersal, del mismo tinte Los ojos, de un pardo oscuro, están rodeados de un circulo azul pizarna el cual está circuido à su vez por las cejas en la parte poste. rior y debajo por una corona de plumas de color rojo amari. llo; el pico es amarillento y los piés de un gris ceniza. 'Todias las plumas de la region de las mejillas son erecriles.

DISTRIBUCioN GEOGRÁFICA. - Gould distingue con razon, dos diferentes especies de caccotuias de nariz, de las cuales una habita en el occidente de Australia y la Nueva (iales, y la otra en Puerto Feline $y$ en la dustralia meridional.

USOS, COSTUMBRES Y REGIMEN.-El cacatía de nariz habita mas bien el interior del pais que las costas: tambien forma considerab!es bandadas que pasan Ia noche y las horas del medio dia en los altos árboles del bosque: pero fuera de eśto, casi siempre andan por tierra aunque con len titud y ásaltitos. Su vuelo, por el contrario, es en extremo rápido y mas veloz que el de otros cacatúas. El alimento consiste en granos y simientes, pero principalmente en raices y cebolletas de varias plantas; sobre todo de las orquideas Lis cuales extraen diestramente con su largo pico. Poco hay que decir sobre la reproduccion: estas aves ponen dos hue vos blancos, semejantes á los del cacatua de mono, sobré un lecho forrado con restos de maderá en los huecos de los grandes gomerus.

CAUTIVIDAD. - El cacatúa de nariz soporta ficilmente la cautividad. En Europa, sobre todo, se le ha importado en los Litimos tiempos con mas frecuencia que anteriormente: pero no es de ningun modo comun en las colecciones. Ciould dice que el cacatúa de nariz cautivo es mas maligno e irritable que sus congéneres, y yo opino del mismo modo. El are se acostumbra dificilmente á su amo \& al principio opone resistencia: corresponde a las caricias con piconzos y ni siquiera permite que se le toque; todo lo inusitado le ex. cita, y a veces enfurécese rerdaderamente. Entonces eriza el penueho penacho de plumas que en forma de herradura adorma su frente; de modo que se descubre por completo el color rojo del fondo; inclina repetidas veces bruscrmente h cabeza; rechina el pico y lahza al fin un grito furioso. In este grito se distinguc tambien la palahm contrdi, pero su entona. cion difiere de la de sus congéneres; estos la pronuncian, como ya sabentos, suavementé y de una vez; mientras que el cacatúa de nariz emite las dos primeras silabas gritando; de modo que suenan mas bien como liai que como $\mathrm{kag}$, solo desprues pronuncia con mas duizura el $d u$.

Extraña es la facilidad con que esta ave puede mover sus pico en todas direcciones. Ningun otro laro tiene igual agilidad en amuas mandibulas: el pico del cacatúa de nariz. es la tenaza natural mas perfeccionada que imaginarse pueda.

Para ser jusio debo añadir que tambien esta especic puede domesticarse mucho y hasta aprender i hablar. Lin anigo mio conoció un individuo que no solo sabia pro. nunciar muchas palabras y frases, sino que tambicn las enpleaba continuamente. En el Jardin 2.00 lógico de Amberes llegó á ser el farorito general de todos los visitantes; pero no se entretenia mucho con ellos; saludaba por lo regular a sus conocidos cuando les veia á lo léjos, sin manifestar nunca con ellos desagrado ó mal humor cuando le acariciaban.

\section{LOS CALIPTORINCOS-CALYP- TORRHINCHUS}

CARÁCTÉRES. - Las especiés mas afines de la anterior son los caliptorincos, cuyo género comprende las muy grandes, desde cl tamaro del cuervo hasta el del estornino; pero á causa de sus largas alas parecen aun mas grandes de lo que son en realidad. El pico, en extremo fuerte y mas alto que largo, se arquea en forma de semicirculo, encorvín. dose su punta hácia adentro: la mandibula superior, ancha y muy abovedada en la base, tiene su arista sumamente aquillada, comprimida lateraimente hácia la punta, y con una sesgadura ligeramente redondeada; la mandibula inferior, que no tiene tanta altura como la superior, es muy anclia y forma un aingulo bastante grande: el borde de los maxilares es recto y se arz̧uea en la punta en forma de gancho. l.os piés son fuertes; las piernas cortas, desnudas y ro. bustas; los dedos están provistos de largas unias falciformes; las alas, largas y agudas, tienen la extremidad muy saliente; la tercera remige es la mas larga; la cola, ancha y larga, se redonder mucho; el plumaje, muy suave, deja descubiertos casi sicmpre un ancho circulo alrededor de los ojos y una parte de los frenillos; compónese de plumas anchas y redondeadas en su extremidad, que se prolongan en el occipucio en forma de moño arqueado hácia atrás, pero raras veces alto. Iil color contrasta con el de los cacatúas, porque piedomina un negro brillante de acero, cortado casi siem. pre por una faja roja ó amarilla en la cola, o bien por una maricha en la oreja de color amarillo vivo. El plumaje de las hembras y de los hijuclos difiere del de los machos por te. trer la parte inferior ondulada de rojizo 6 amarillo, y formada la faja caudal por listas diagonales y manchas; el mono, las mejillas $y$ las tectrices superiores de las alas presentan orras mas pequeñas cn forma de puntos, segun se observa en la mayor parte de las especics.

\section{ELCACATÚA DE CASCO-CALYPTORRHIN- CHUS GALEATUS}

CARACTERES. - Algunos naturalistas consideran esta especie, qué forma el tránsito entre los cacatuas propiamente dichos y el caliptorinco de Banks, como tipo de un subge. nero especial (Calloceplalum). Lista ave, del tamaño de un cacatúa regular, es de color negro oscuro de pizarra, con on. dulaciones trasversales de color mas claro; cadia pluma tiene en su extremidad una estrecha orla de un tinte blanco pardusco claro; la cabeza, la nuca, las mejillas y el casco son de un magnífico rojo de escarlata; las rémiges del brazo están borcieadas exteriormente de un verde oscuro de bronce; las tectrices inferiores y la cara inferior de las ahs y de la cola presentan un gris oscuro. Los ojos son pardo oscuros; el pico blanco de cuerno y los piés negruzcos. El plumaje de los pe. queros, y quizas tambien el cie las licmbras adultas, es de un color pardo gris oscuro de pizarra; ias plumas de la jarte superior presentan en la base y en el centro fajas trasversales blanquizcas, y en la extremidad una orla estrecha de color rojo pálido; las de la parte inferior estín bordeadas en su extremidad de un ligero tinte gris; las plumas de la cola y las rémiges tienen en la mitad de la base fajas trasveràles poco marcadas de un gris claro; la cabeza y el casco son casi de un mismo color, pardo gris de pizarm.

DISTRIBUCION GEOGRAFICA, - Could dice que esta especie habita en los bosques de la costa meridional de Australia y algunas islas vecinas y que tambien se encuentra en las partes septentrionales de la Tierm de Van Diemen; Péron le encontró en la isla del Rey; y el musco de Sidney prosec un individuo de la bahia de Iforeton.

USOS, COSTUMBRES Y RÉGIMEN،-Carecemosaun de datos exactos sobre el género de vida en libertad del ca. catúa de casco. Gould dice tan solo que vive en los árboles mas aitos y que se alimenta de las semillas de varios gomeros.

CaUtividad. - l'ampoco sé gran cosa sobre su modo 
de vivir en cautividad, aunque he visto el ave reperidas veces en casa de los tmicantes y an jardines zoológicos. Rara sez. se la ve en nuestro mercado. Su postura yovimientos, sus usos y costunibres, son los de otros cacatúidos, ó por lo me. nos munca he observado gran diferencia Schmidt la presenta como un ave arisca y desagndable, que solo corresponde i las caricias y if los regalos que se le hacen emitiendo breves sonidos roncos, y'a que no descargando fuertes picotazos sobre los dedos que se le tienden, con tal furia algumas veces, que hace retemblar la jaula. Por lo regular siemure se ve á este cacatia posado tranquilamente en su percha, y con dij. cultad se le induce á ejecutar movimiento alguno; tampoco muestra la menor inclinacion á domesticarsc. Otros aficiona. dos, como por ejemplo Linden, hacen elogios de su familiari. dad, de sus movimientos groiescos y de la suare entonacion con que pronuncia la palabra sncouds. De aqui resuita que esta ave es mas afine de los cacatuas propiamente dichos que ninguna otra especie de !a sub-ianitia.

\section{EL CACATÚA DE BANKS-CALYPTORRHIN- CHUS BANKSI}

CARACTERES. - Si aun no se conoce bien el cacatua de $\mathrm{Casco}_{2}$ en cambio estamos mejor iniormados sobre otras especies del género, cuyo tipo mas caracteristico es el caliptorinco de Banks, el cacntiua sueston de los alemanes y el gering gora de los indigemas de Australia; l'sta ave es mas grande que todos los cacatuidos hasta altora citacios: su longitud total alcanza $2^{\circ}, 70$; la de las alas $0^{\circ}, 4^{2}$ y la de la cola $0^{\circ}, 30$. El plumaje, excepto solamenic las plumas caudales, es en el macho de un negro brillante con lustre verde, y en la hem. bra negro verdusco; en la cabeza, en los lados del cuello y en las tectrices de las alas hay manchas amarillas, y en la parte inferior fajas del mismo tinte, mas pálido. Fi macho tiene en la cola una ancha faja rojo escarlata que se corre por el centro, dejando libres sin embargo las cos recirices del centro y las barbas exteriores de las plumas laterales. Fin la hembra se observan iguales fajas, anchas, de color amarillo salpicado de rojizo: en las tectrices inferiores de la cola se ven iguales matices (fig. 16).

DISTRIBUCION GEOGRÁFICA.-Los caliptorincos, ó jeringueros, segun los liaman vulgarmente, solo habitan en Ia Nueva Holanda, pero se extienden en varias partes de este contineric.

USOS, COSTUMBRES Y REGIMEN.-Gould cuenta seis especies, y pinta con bastante exactitud su manera de vivir. Todas se asemejan mucho en este concepto, y en su consecuencia las examinaremos en globo.

Los caliptorincas son verciaderos loros arboricolas: se ali. menian de los granos de los cucaliptos y de otros árboles de sis pais; y cn algunas ocasiones devoran grandes orugas, cua. lidad que los aparta algun tínto de los demis loros. Forman reducidos grupos de cuatro a ocho individuos, y solo banda das, como los otros racatuidos, cuando viajan.

Cada region de Australia, desde las costas septentrionales hasta la isia de Van.Diemen, ofrece su especie particular: el caliptorinco de Banks pertence a la Nueva Lales del sur, y se encuentra sobre todo $\mathrm{ch}$ la comarca que sc extiende desele la bahia de Moreton hasta Puerto Felipe; no es raro en lis iumediaciones de Sydnery de otras varias ciudades. Su vuelo es pesado; mueve las alas penosamente y pocas veces se re. monta por los aires á gran altura; pero puede recorrer sin descansar una distancia bastante larga, dejando oir entonces sil voz, menos penetrante que la de los otros cacatididos. Ciertas especies producen un grito quue les ha valido el nom. bre con qque las designan aquellos habitantes; o:ras emi. ten sonidos planideros particulares; hay algunas que gritan cuando descansan y grazman como los cuervos. Cuardo andan por el suélo, son pesados, como los denás loros, si bien trepan fácilmente, aunque con lentitud, à la copa de los ár. boles.

Muy poca- cosa nos dice Gould accrca de sus faculiades intelectuales: los inas son tímidos j desconfrados, a causa sin duda de la encarnizada persecucion que suiren; solo cuando van a comer olvidan algumas veces por un momento su pru. dencis.

Muéstranse muy aferıuosos entre si: ruando uno de ellos mucre $\delta$ nqueda herido, no le abandonan sus companeros; re. volotean alrededor de el; se posan en los árboles juróximos lanzando gritos lastimeros, y exponense ślos tiros del caza. dor, que podria aniquilar entonces toda la bandada.

No deja de ser curiosa la manera de comer de los calipta. rincos: algunos tienen la costumbre de cortar las ramitas de los árboles irutales, al parecer para entretencrse, y todos se sirven de su pico vigoroso para extraer los insectos que se al. bergan en la madera. I as grandes orugas que se encuentran en los eucaliptos no bastan siempre para su alimento: guiados probablemente por el olfato, cazan entonces las larvas que roen la madera; levantan hábilmente la corteza y practican agujeros, á menudo muy profundos, hasta que se appoderan de la presa Algunos parecen ser particularmente insectiroros; otros prefieren los granos, sobre todo los de las casuarincis $y$ de las banksias; y aunque desprecian aparentemente los frutos, complf́cense en picarlos y cortarlos antes de su ma. durez, con gran perjuicio de los habitantes.

Los caliptorincos anidan solo en los troncos huecos, y bus. can los mas elevados é inaccesibles, \& los que no puede tre. par el indigena. No fabrican nido; limitanse, cuando mas, á tapizar el fondo de su albergue con astillas que arrancan de las paredes del árbol: la hembra pone de dos a cinco huevos, que miden (1":- 45 de largo por (1"- 040 de ancho.

l.os caliptorincos deben temer, no sols al hombre, sino tam. Lien a las aves de rapina y a los marsupiales carniceros, de los cuales no pueden defenderse á presas de sus poderosas armas

Ca Utridad.-Raras veces se recibe en Europa el cacatúa de Banks, pues dificimente resiste la cautividad. Ia impresion gue su vista produce en el obseriador no es favo. rable; mas tranquuilos que sus congéneres de plumaje claro, parecen tambien mucho menos iavorecidos por todas sus cualidades. Gencralmente se les ve en una posicion casi ho. rizonial; solo cuando ręrosan enderézanse algunas reces; pero aun entonces lo hacen con cicrta rigidez y lorpez. Cuando andan por el suelo ó corren por una rama es cuando despliegan toda su actividad. Sus pasos son presurosos como los de la mayar parte de los loros de Australia, y por lo genemal tan ripidos, que casi corren: en las ramas ejecutan movinien. tos asaz grotescos para estas grandes aves. Cuando trepan se agarran lentamenie, con nucha precaucion, ś una barm de su jaula, ó à una mma con el pico, atraen el cucrpo al parecer trabajosamente, cógense con los piés, y vuelven a buscar con el pico nuevo punto de apoyo. No pueden trejar por varillas lisas, y cuando çuieren bajar al suclo necesitan nuchisimo tiempo, cual si terniesen a cada paso cacr, como lo indica cl hecho de arrastrarse con visible tenor. No hacen ejercicios gimnásticos como los que ejecutan otros cacatúidos, y casi nunca se les re pendientes de una rama con la cabera hácia abajo. Cuando se les tiene en un gran espacio eligen siempre un sitio deierminado como, por cjemplo, una rama a la que rácilmente pueden subir; permanecen en ella mientras no co. men, y cuando mas, hacen algunas piruetas, acompañadas de rápidas inclinaciones de cabeza, todo esto sin perder nunca 
su gravedad caracieristica. Su ocupacion favorita consiste en roer alguna rama, pero fijanse en ella solo, sin tocar las inme. diatas, como lo hacen otros loros. Aunque tengan mucloo espacio para moverse, solo en caso de necesidad se resuelven á volar, y cuando al fin lo hacen suelen caer al suelo, porque no saben calcular la distancia. Esta particularidad parece relacionarse con el hecho de no entreabrir sus alas cuando están excitados, limitándose á erizar las plumas de la cara. Con frecuencin dejan oir su vor, que podria expresarse por la silaba krıss ó grem, pronuncinda con una enionacion ronca; se parece á la conocida voz de la grulla, pero es mucho mas baja I reces se oge tambien un-suave grolels que parece expresar su buen humor. Duermén mas tichpo y se entregan al descanso antes gue otros loros, pero en cambio están des. piertos todó el dia, antes de dormir no gritan, como ló hacen sus congéneres; muy léjos de ello, pernanecen mas siiencio. sos que de costumbre; colocan la cabeza ertro las plumas del hombro y no hacen caso de lo que pasa \& su rededor. No son dóciles con sus semejanics, sino que rinen continuamen. te, aunque son tan cobardes, que cl loro mas pequeño los pondria en fuga. Cuando se acerca uno de ellos levantan la voz un poco mas que de ordinario, inclinan bruscamente la cabeza y huyen con toda la rapidez posible. Muy notable es su poco asco: nunca limpian su plumaje con cuidado sin reparar que se han ensuciado ellos ó que liagan sido ensuciados por otros. Su alimento en la cautividad se reduce \& pocas especies de granos, de los cuales prefieren los caniamones y. Ia avena; esta última les gusta sobre todo cuando se ha quitado la cáscarn; agrádales tambien el maiz cocido; pero rehusan el crudo, cual si temiesen mascarle con sus enormes picos. En cambio codician lasilarvas de los abejorros y los caracoles, â veces tambien gusanós; deroran los primeros y los últimos sin preparativos, pero rompen la concha de los caracoles y extraen cuidadosamenté su conienido.

USOS Y PRODUCTOS.- Parece que los euronens no aprecian mucho ta carnc de este loro, que es un verdadero regalo parn los miscrables indigenas.

\section{EL CACATÚA ARARA-MICROGLOSSUS ATERRIMUS}

CARACTÉRES. - De todas las especies de loros esta es una de las mayores, y ninguna tiene el jico tan poderoso. Este pico gigantesco, cuya longitud excede a la de la cabe2a, es mucho mas largo que alio $y$ muy comprimido lateralmente; la mandibula superior se encorra en forma de semicirculo hácia abajo; su punta es larga y delgada y junto á ella se ve una prominencia rectangular, con la cual toca la cxtremidad de la mandibula inferior; esta última no encaja en la superior, y distinguesc por sus anchos maxilares y su barbilla que forma un rectángulo con ellos. Los piés son ro. bustos, aunque relativamente debiles; las piernas cortas y desnudas hasta la articulacion, $y$ los dedos de longitud regular. Ias alas, bastante largas, tienen las puntas muy cortas; la cuarta rémige es la mas larga de todas. Ia cola, larga y ancha, tiene las plumas redondendas en la extremidad; $\mathrm{el}$ plumaje, bastante suave, se compone tambien de plumas muy anchas; solo las del casco son puntiagudas; este viltimo se arq̨uea hácia arriba y atrás Ia clasificacion del ave se funda principalmente en ia cola, que es corta y cuadrada, y tambien en el moño; la cabeza difiere tambicn mucho por su forma de la de los cacatúidos verdaderos, y el enorme pico recuerda los verdaderos amras. Caracteristica es igual. mente la lengua, basiante larga, carnosa, cilindrica, hueca por arriba, aplanada en la paric anterior de la punta, de co. lor roịo oscuro, cómen en la extremidad y provista de una especie de corteza negra; este órgano puede separarse bastante del pico para emplearle como cuchara; con $6 l$ recoge el ave el alimento triturado por aquel y lo conduce al csúfago. L.os bordes de la lengua son muy moribles y pueden arquearse por izquierda y derecha; de modo que encierran el alimento como en un tubo.

El rasmolus, como le llaman en la Nueva Guinea, aventaja en fuerza a la mayor parte de los araras. Su plumaje es igual. mente regro oscuro con un ligero lustre verdoso, aunque $\mathrm{en}$ general cubierto de un polvillo harinoso. Las mejillas, des. nudas y con répliegues, son de color rojo: el moño está formado por plumas largas y estrechas, cuyo color tira mas al gris que todas las demás (fig. 17).

DISTRIBUCION GEOGRÁ FICA. - Este loro liabita en la Nueva Guinea! las islas vecinas, sobre todo Salawati, Misul, Waigiu y las islas de Aru; tambien se le encuentra en la puntaseptentrional de Australia.

USOS, COSTUMBRES Y RÉGIMEN.-Poco se sabe sobre el género de vida de estas aves en libertad. Mac Gillivray las vió en los alrededores del cabo York con bastante frecuencia y por lo regular en paręias. Viven en los gomeros nias altos yroducen un grito que podria expresarse por las silabas uril, aril; son en extremo tímidas. Ias nueces de co. co constituryen la base de su régimen alimenticio, y tambien tragan pedacitos de piedra.

a Fl cacatúa amra, dice Rosenberg, quien ha dado últimamente algunas noticias sobre los loros de las islas del $\mathrm{Pa}-$ cifico, abunda bastante en IYaigiu, Misul, Salawati y la costa dé la Nueva Caniner.

buelen posarse en las cimas de los mas clevados árboles, están continuamente en movimiento, y cuando descansan 6 cruzan los aires con vigoroso vuelo, dejan oir su voz pene. tranté muy distinta de la del cacatúa blanco. Los indigenas cogén los pequeños en el nido, los crian y los venden á los traficantes.

\Los microglosos cautivos prefieren para su alimento los frutos del ronarium ó calophunion, y saben partir perfécta. mente su cáscara, tan dura conso el hierro. Se domestican muy bien: un labitante de Amboina poseia un individuo que volaba libremente por la ciudad y rolvia siempre á la casa para comer y dormir.

Wiallace le observó y cogió en las islas de Aru. Ein estos parajes, dice, habita los sitios bajos del bosque y vive aishado; pero con mas frecuencia se ven grupos de dos y tres; su vuelo es lento y silencioso; aliméntase de varias clases de frutas y simientes, pero busca con preferencia las de la nuez del canurium, que se encuentra en ciertos árboles mus altos de todas las islas habiindas por él. la manera de comer esta simiente parece indicar una relacion entre la forma del pico y la costumbre del ave, relacion que se debe $\{$ que la nuez del comurium constituje su alimento princips. La cás. cara de esta nuez, bastante triangular $y$ del todo lisa por fuera, es tan duia que solo el martillo puede romperla. El cacatúa arara coge una extremidad con su pico, le sujeta con la lengua y practicacon la mandibula inferior un agujero trans. versal en la misma. Despues coge la nuez con el pié, arranca un pedazo y lo sujeta con la scsgadura profunda de la mandibula superior; una vez descubiertas las fibras, la nuer. no puede escaparse; el are la coge de nuevó, colócala en el borde. de la mandibula inferior, y con poderoso esfuerzo arranca un peda\%o de cáscara. Hecho esto vuelve \& sujetarla con el pié y con la aguda punta del pico estrae su contenido, el cual come á pedaros. Asi vemos que cada particularidad de ia forma y estructura de tan extraño pico tiene su aplica. cion, y fácilmente podemos comprender que los cacatúas arara han sostenido la competencia con sus activos y mas 
numerosos congéneres blancos, gracias á su facultad de servirse de un alimento que ninguna otra are puede sacas de su criscara, dum como la piedra. La voz de este cacatúa se reduce \& un silbicio plañidero.

Wallace hace mencion tambien de la extrana debilidad de la gigantesca ave (que sucumbe in una herida relativamente leve

CAUTIVIDAD. - De Martens vió un rasmoles cautivo en Mahai.

*El cacatún negro, dice, es un sér singular: con su aspecto rigido, su cara roja, su pico cnorme, y su moño levan. tado siempre, parece un viejo gencral, y su fealdad misma produce viva impresion. Es calmoso y arisco; cuando seacercan is el, y aunqure esté contento, deja oir su voz, tan desagradable como penetrante. l.os indigenas, y con ellos los residentes europeos, creen que en este loro la lengua consti. tuye êl principjia del csófago.

Segun Rosenberg, el microgloso negro es bastante comun en Amboina y se puede comprar por jo o bo francos uno. En Europa constituye una rareza en las colecciones: existe actunlmente uno vivo en el Jardin zoológico de Amsterdam; mi colega Westernann, director de aquel notable establecimiento, tuvo á bien comunicarme los siguientes apuntes:

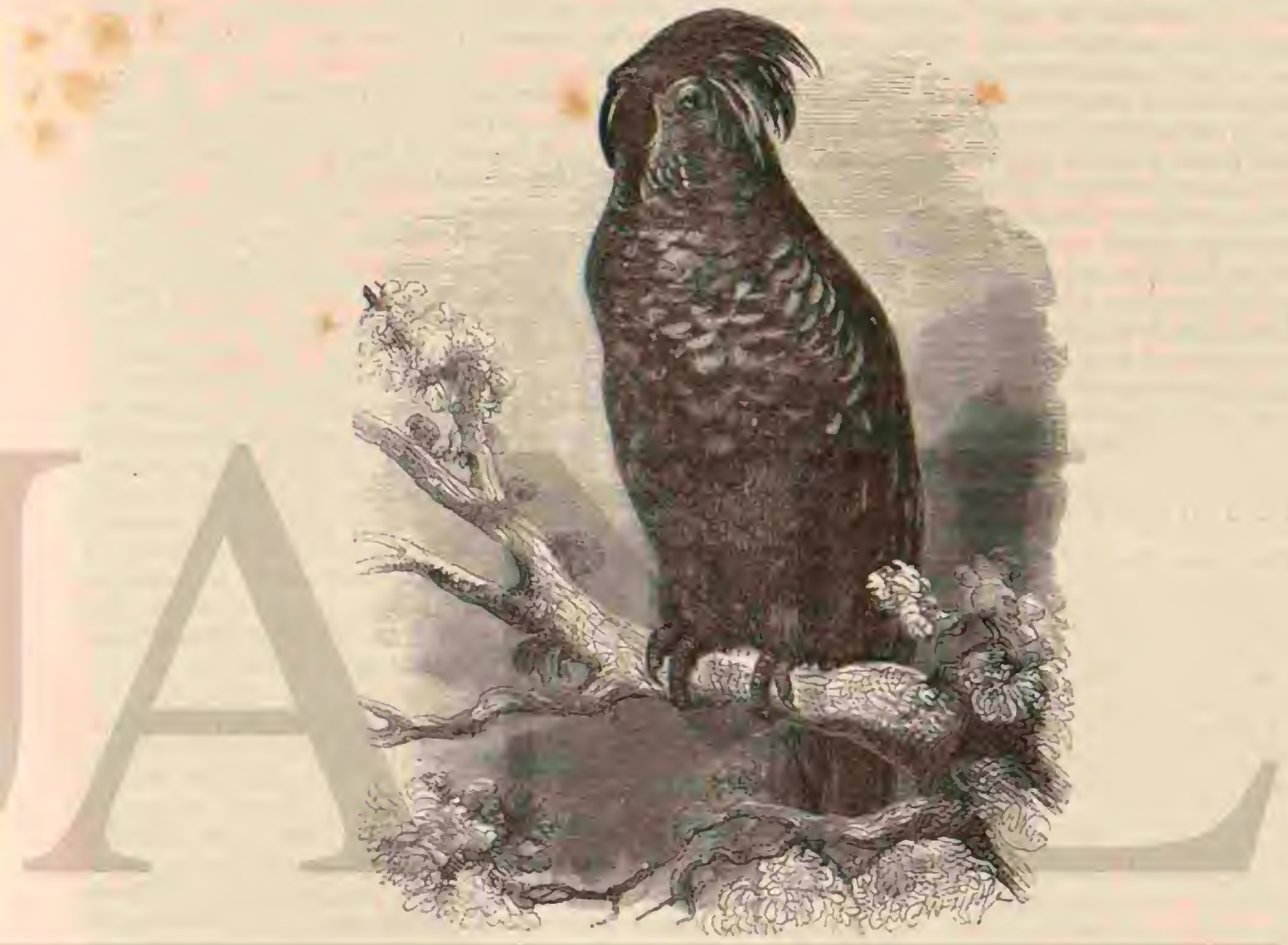

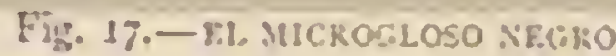

* Poseemos un rasmales desde el a de mayo de 1860 : hemos conseguido á costa de grandes esfuerzos proporcionarie un alimenio conveniente. Cuando este loro está libre, no come al parecer sino frutos de almendra; el nuestro comio durante el viaje granos de cararium, ý poco á poco fué acos. tumbrándose á otro régimen. Ahora le damos cañamones y todos los alimentos del hombre, excepto la came, con lo cual le va muy bien.

\Díerenciándose en esto de todos los demás loros, se vale de ha lengua de la manera nias singular: coge el alimento con la pata, se lo lleva ? la boca para dividirlo yoprime con la pun. ta de aquella, jrovista de una hoja córnea, has particulas que ha desprendido y están pegadas al órgano; entonces recoge la lengua y traga lo que se adhirió á clla. Todo esto lo hace tan despacio, que su comida dum mucho ciempo.s

Tambien Schmidt describe minuciosamente el modo de comer del cacatúa aram. 1 Ambas mandibulas, dice cl citaco naturalista, recogen el alimento, por ejemplo un coñamon, to. Toso III candolo continuamente con la lengua; esta le oprime contra la prominencia dentaria de la mandibula superior, y la infe. rior le abre; csta última y la lengua cogen despues el cariamon, y el diente de la superior saca el contenido de la cáscarn; ambas mandihulas, auxiliadas siempre por la lengua, mascan y trituran cuidadosamenic el grano. Hecho esto la lengua se levanta un poco, y oprime luego el alimento en un surco trasversal que alli se encuentra Entonces retira rápidamente la lengua conduciendo el bocado haicia el pala. dar; y expeliéndole otra vez hácia afuera, déjale en la pri. mera prominoncia trasversal del paladar, desde donde el alimento pisa al esórago por encima de la laringe. Al despe. dazarle, sujétale tambien á veces con el pie. El ave no come nada antes de estar muy triturado 6 en pedazos muy pequeî05, y por eso dura siempre la comida mucho tiempo. Para beber pone el cacatúa arara la parte anterior de la mandibula inferior en el agua, eleva despues la cabeza rípidamente en direccion diagonal hácia adelante $\mathrm{y}$ arriba. Le gusta mucho la 
carne cruda; del arroz y del maiz solo come la parte interior mas tierna; el pan y las frutas son golosinas para él.

Ia voz que expresariamos por el sonido ira $a$, recordaba a Schmidt el rechinamiento de una pucrta. Cuando este so. nido se emite en roz baja parece expresar el buen humor, y si se pronuncia bruscamente, fastidio ó deseo. En tales cir. cunstancias, el rasmalos produce los sonidos rápidamente y repetidas veces, recordando entonces con ellos el de un makal comun. Los daños que este gigantesco cacaura puede ocasionar, para satisfacer su espiritu de destruccion, son ad. mirables. Me asombro, dice Schmidi, al terminar su excelente relato, la fuerza y dureza del pico. Nuestro cautivo se ocupaba con preferencia en romper las vasijas donde tenia el alimento, y los resultados de este capricho cran verdadera. mente increibles. Cierto dia arrancó el borde, de seis mili. metros de alto por quince de grueso, de dos platos de barro cocido; al dia siguiente se le pusieron dos botes de porcelana de igual grueso, y tambien sus bordes desajarecieron al poco rato. Entonces puse vasijas de hicrro fundido; mas al las dos horas el rasmalos habia abierto en la mirgen del uno una sésgadura que llegaba hasta el fondo. Este juego no acabó hasta que hice fabricar vasos pesados de hierro coiado, que no podia ni romper ni volcar. Debo aíndir que no le obliga. ba la necesidad de comer cal á estos excesos; pues no tocaba ni la capa de cal de la pared nininguna otra sustancia caliza. Desgraciadamente murió de tisis el extrano animal despues de hiaber vivido solo tres años enire nosotros. No conozco noticias sobre la reproduccion del cacatúa arara

\section{LOS NASITERNOS-NASITERNA}

CA RACTÉRES.-Asi como el cacatúa arara es el gigan. te de la familia, las especies que componen este género son los pigmeos de la misma. Difjeren no solo de sus congéneres mas afines, sino iambien de todos los loros en general, por su tamano excesisamente pequeno; juntamente con los cori. lis, son las esjecies mas diminutas de todo el órden. Hasta los últimos tiempos se conocian solo dos especies: Salvadori distingue $\mathrm{ch}$ la actuatidad siete

Sobre la clasificacion de estos pigmeos, dice Finsch, no puede haber cluda alguna; son realmente cacntuias en miniatura. Su pico, en un todn igual por su forma al del arara, es muy fuerte, mucho mas alio que largo, bastante corvo y de punta corta, que apenas sobresale de la mandibula inferior; In superior es anclia y abovedada en la base, muy comprimida lateralmente hácia la punta, aquillada en la arista y provista delante de la punta de una sesgadura profunda de ángulo agudo; la inferior es mas alta qlie la superior, aplana. da lateralmente, y distinguense por el angulo ancho y redondeado de la barbilla y por los bordes truncados de los maxilares. Las juicrnas son delgadas, los dedos tienen el doble de largo de cllas y están provistos de unas endebles, poco encorvadas. Las alas, largas y agudas, llegan casi hasta la extremidad de la cola cuando el ave reposa; su purta es muy prolongada; la segunda rémige es la mas larga. La cola, corta y redondeada, es notable sobre todo por sus tallos rígidos, encorvados, agudos y salientes, por cuyo carácter sc considera á esta arecilla como el pico de los loros. El plumaje, bastan. te suave, no forma moino, y distinguese aderuás de otros cacatuidos por predominar el color verde.

\section{EL NASITERNO ENANO - NASITERNA PYGMEA}

CARACTérEs. - lista especie, la mas conocida del género, no es mucho mas grande que nuestros espinidos; tiene el plumaje verde, algo mas claro por debajo, amarillo en la parte superior de la cabeza, y pardusco amarillo en los circulos oculares; las tectrices pequeñas de las alas son negras, bordeadas de rerde; las rémiges de la mano, negras tambien, presenian un borde estrecho de color verde, asi como las del brazo, viendose otro mas anclio en las barbas interiores; las últimas rémiges son verdes del todo; las plumas caudales nogras, $y$ adornadas en la extremidad por una mancha amarilla; las dos rectrices del centro, de un azul de mar: las dos exteriores de cada lado estín bordeadas de verde por fuera; las tectrices inferiores de la cola son amarillas, con mezcla de verdusco hácia la punta; el pico es gris oscuro; y' los piés de un pardo gris. Las hembras no se distinguen por el color.

DISTRIBUGION GEOGRÁFICA.- El hirea de dispersion de esta especie es la misma indicnda para el género.

USOS, COSTUMBRES Y REGIMEN. - Hoco sabe. mos acerca de la manera de vivir de estas aves. La primera pareja que Quoj y Gaimard trajeron alregresar de su largo viaje llegó por casualidad á sus manos; uno de sus companeros habia tirado sobre una ave posada en un arbol, y en vez de tocarla mató dos loros desconocidos. Solo en los últi. mosiarios se enriqueció con varios individuos nuestra coleccion; y mas tarde, Bernstein, Rosenberg, Wallace y Beccari nos han dado algunas noticias sobre su género de vida en libertad. Excepto este uiltimo, todos los viajeros están conformes en qque es muj dificil apoderarse de estas avecillas, yo hasta verlas, no solo a causa de su pequeñez sino por su costumbre de vivir en las copas de los árboles mas altos y frondosos. Solo Beccari dice que cuando una vez se conocen los árboles favoritos del cacatúa enano es fícil encontrarlo y matarle. Valiéndose de su pico, tiene la costumbre de trepar por los troncos y las ramas de los bejucos. Los papues cogen muchas veces individuos vivos sacándolos de los huecos de los árboles donde construyen su nido. Los luevos, segun Allen, se parecen álos del sitáculo americano. Nada mas se sobre esta ave notable.

\section{LOS CALIPSÍTACOS-CALLIPSI- TACUS}

CARACTÉRES.-Este género es uno de los que mas difieren del tipo general de toda la familia de los cacatúidos; distinguese por los caractéres siguientes: el pico es mas cu. deble que el de los cacatúas propiamente dichos, pero en un todo semejante; las piernas cortas; los dedos débiles; las alas en extremo largas y agudas, con la punta extraordinaria. nente prolongada: la segunda rémige es la que tiene mas longitud; la cola, cuyas dos plumas centrales sobresalen mucho de las demás, afecta la forma de cuña; el plumaje es muy suave; su color varía segun el sexo.

\section{EL CACATÚA CORELLA-CALLIPSITACUS NOVA HOLLANDIE}

CARACTÉRES.- Esta es la especic tipo del género que nos ocupa. Iil corella, ó levo cacatía de los colonos de la Nueva Holanda, iene el tamaño de nuestros mirlos mas grandes, aunque parece raucho mayor á causa de su larga cola. El piumaje es muy abigarraco y bonito, precominando un tinte pardo gris accituma oscuro, que en la parte inferior pasa al gris; la parte superior de la cabeza y las mejillas son de un amarillo de paja pílido; las plumas del moño, de igual color, tienen la punta gris; en la region de las orejas se ve una mancha redonda rojo amarillenta, con el borde jos. terior blanquuizco; las réniges de la mano son de un gris de pizarra, con las barbas interiores de un pardo oscuro: las del 
brazo, excepto la última, que es de un pardo muy oscuro, tienen las barbas exteriores blancas $y$ las interiores pardus. cas; las tectrices superiores son de este ifltimo color, las inferiores y la parte inferior de las rémiges, negras; las dos recurices del centro, grises, las otras cenicientas con borde negro en las barbas interiores y con 1 a cara inferior igualmente ne. gra; las tectrices superiores de la cola, cenicientas, $y$ las inferiores de un tinte algo mas oscuro. l.os anillos oculares son de un color pardo muy oscuro; los circulos oculares desnu. dos y grises, el pico gris negruzco con base pardusca; la cera gris; los piés pardo gris. La hembra distinguese del maclıo por tener la parte superior mas clara, la inferior de un color parcio gris rojizo pialido, la mancha de las orejas, anarillo de paja claro; la cabeza y el mono de un amarillo gris sucjo; las rémiges tienen interiormente cuatro of cinco manchas redondas, de un amarillo pálido; las dos rectrices exteriores de cada lado son del mismo matiz, con una faja inasversal jaspeada de negro; mientras q̨ue las oiras ostenian en toda su cara anterior manclias trasversales mas ó menos marcadas. El pequeño, semejanic à la liembra, tiene il plumaje pardo sucio, con un lustre amarillento en la parte inferior; las plumas del moño son igualmente de un pardo sucio y la mancha de la oreja mas oscura ó inas clara, segun el sexo; pero siempre de un amarillo sucio.

DISTRIBUCION GEOGRÁFICA.-Gould, el primero que nos dió á conocer las costumbres de esta especie, la vió muy numerosa en el interior de Australia. Escasea mucho en las costas, al menos comparada con las grandes bandadas que acuden á los estanques del interior; yeven pocos individuos cn la llanura. entre las montains y el mar. Parece ser mas comun en la parte oriental de Australia que en la occidental; en verano habíta las llanuras del valle superior del Hunter, 0 bien las orillas del Peel y de otros rios cuyo curso se dirige haicia el norte.

USOS, COSTUMBRES Y RREGIMEN.-Pasado cl pe tiodo del celo, se recinen los calipsitacos en bandadas innumcrables, que cubren el suelo en una gran extension, ó se josan por centenares en las ramas secas de los gomeros que crecen f́ orillas del agua. En seticubre emprenden sus viajes ýllegan al punto donde se reproducen; en febrero ó marzo viuelven al norte.

Jos calipsitacos de la Nueva Holanda se alimentan de se. millas de gramineas; y como necesitan agua, permanecen siempre cerca de los rios, en cuyas orillas anidan invariable. mente. Son muy ágiles, corren con facilidad por el suelo, tre. pan bien y vuclan con alguna ientitud, aunque con perfeccion I soltura. Fil hombre no los espanta: cuando le ven cerca, los que estån en tierra se limitan â refugiarsc en un átbol próximo y se posan sobre la primera rama que encuentran, volviendo al mismo sitio cuando el peligro la pasado. No son zimidos, razon por la cual se les coge sin dificulad: tienen la carne delicada, y son muy á propósito para énjaularlos.

La hembra pone cinco ó seis liuevos blancos de unos $0^{\circ}, 02$ de largo.

El sénor Engethart, un observidor muy concienzudo que hı vivido muchisimos años en Australia, me facilitó algunas noticias para compleiar las anteriores, $y$ si bien las lie publicado ya en mis dies cumfizas, créome en el deber de reproducirlas en este lugar. "Wl corclla, me escribe el citado observordor, efectua sus viajes con muchisima irregularidad: con frecuencia pasan tres ó cuatro años sin que visite en la Aus. tralia meridional las regiones cultivadas, lo cual sucede siem. pre despues de un buen invierno ye de una primavera húmeda. Fntonces sabe que tambien para él y sus pequcios habrá alimento, el cual consiste en simientes de varias gramineas, por cjemplo de la yerba de kanguro y de la del canarium.
Cuando las espigas del candeal se llenan de granos, gritos penetrantes y reclamos que se oyen å mucha distancia anuncian la llegada de las ares y poco despues obsérvase quue han fijado su residencia en medio de las plantaciones sin mostrarse dificiles en cuanto á los ásboles yue les sirven de vivienda. Muchos años se presentan bandadas innumerables que en un inmenso espacio cubren literalmente el suelo ó los gigan. tescos árboles de goma rojos.

2. Esta ave gora de mucha mas estimacion que las otras, sin exceptuar la cotorra ondulada. Cuando cerca de las planta. ciones construye descuidadamente su nido con restos de ma. dera podrida, prefiriendo siempre el hueco de alguna rama para tener un punto de apoyo, los inuchachos vigilan con cuidado todos sus actos hasta que llega al fin el dia deseado en que pueden coger el nido. Entonces reina gran jubilo en todas partes: cada campesino adquiere muy pronto su pareja de corellas, y cada cual hace todos los esfuerzos posibles para domesticar las dóciles avecillas y ensemarlas alguna cancion, todo lo cual cuesta muy poco trabajo. Tambien se llevan en. tonces á la ciudad, para la venta, centenares y miles de pe. queños, que se expenden $\alpha$ mzon de dos y medio frarcos á tres. A pesar de la persecucion á que se hallan expuestos los corellas, mas de un nido se libra del saqueo, y pronto sc reunen varias fandilins que forman numerosas bandadas. Ciracio. sisimo es el aspecto que ofrecen cstas aves cuando con el mono erguido $y$ alineadas en largas lilas en las ramas de los altos írboles, escuchan ateniamente todos los rumores para emprender rofpidamente la fuga aprenas oyen las pisadas de alguno que se acérca. I a primera incubacion del corella, as! como la de otras muchas aves de la Australia meridional, se efectua en el mes de octubre, és decir en la primarera de aquellas regiones; la segunda un poco antes de Navidad ó aun mas tarde. La hembra pune de seis a ocho liuevos blan. cos, que por lo regular se aprosechan todos; de modo que una familia sucle componerse de seis a ocho individuos. Los padres alimentan a st progenie mucho tiempo despues de haber abandonado el nido. 'ude obscrar esto mu bien una ver, porque una parcja de corellas lanbia fijado su domicilio delan. te de mi ventana: ocupábause ya en hacer el nido para la segunda cria, y sin cmbargo alimentaban aun los bijuelos medio adultos de la primera.

\$A principios de la estacion lluviosa este loro alandona el mediodia de Australia, y formando con sus senejantes in. mensas bandadas, dirigese hácia el norte del continente.

CA UTIVIDad.-De todos los loros de Australia, el co. rella es, exceptuando la cotorm ondulada, el que se recibe con mas frecuencia en nuestro mercado. Cuando se le cuida bien, resiste mejor que ningun otro loro la cautividad, y re. prodícesc fiscilmente en la jaula. Es una de las esprecies me. nos exigentes de todo el órden, pues le basta un poco de gnno, avena, mijo y canamones; tambien come verdura de toda clase, incluso las zanahorias cortadas, y pronio se acos. tumbra al alimento humano cuandose le domestica cuidado. samente y se le ticne en una habitacion. Seria muy agmoiable para todo aficionado a las aves si sus gritos no ofendicran el oido.

\section{LOS ESTRINGOPIDOS- STRINGOPES}

CARACTERES. - Por la misma razon que se han sep̧a. rado los buhos de los halcones, podriamos aislas de los loros el kirkapo, la especie mas notable entre ellos, ave nocturna de la Nucra Holanda, que podriamos considerar como repre. seritante de una sub.familia, o si se quiere, familia indepen. diente. 
El ave recuerda tanto á los buhos, que podria figurar entre ellos à no ser diferente la estructura de los pies. Para came. terizarla basta llamar la atencion sobre el disco racial, semejante al de los buhos. El pico es fuerte y grueso, mas alto que largo; la mandibula superior tan ancha en la base como alta, con arista redondeada, que prolongándose en punta corta y obtusa, tiene sus bordes ligeramente truncados; la mandibula inferior, no tan alta como la superior, tiene los bordes de los maxilares aplanados; el ángulo de la barbilla, en el cual se ven cuatro surcos longitudinales profundos, ele. vase en forma de arco; las piernas son muy robustas, largas $y$ gruesas; los piés tienen dedos prolongacios y gruesos, pro. vistos de uñas muy corvas y agudas; las alas son cortas y redondeadas, con la punta poco saliente; la quinta rémige so. bresale de las demás. La cola, bastante larga, se redondea ligeramente en la extremidad; el plumaje, bastante recio, se compone de anchas plumas, cuya extremidad se redondea; c1l la frente son estrechas. y estan casi divididas, presentando unas prolongaciones semejantes á pelos, que $\mathbf{a}$ manera de radios circuyen la base del pico $y$ forman una especie de velo.

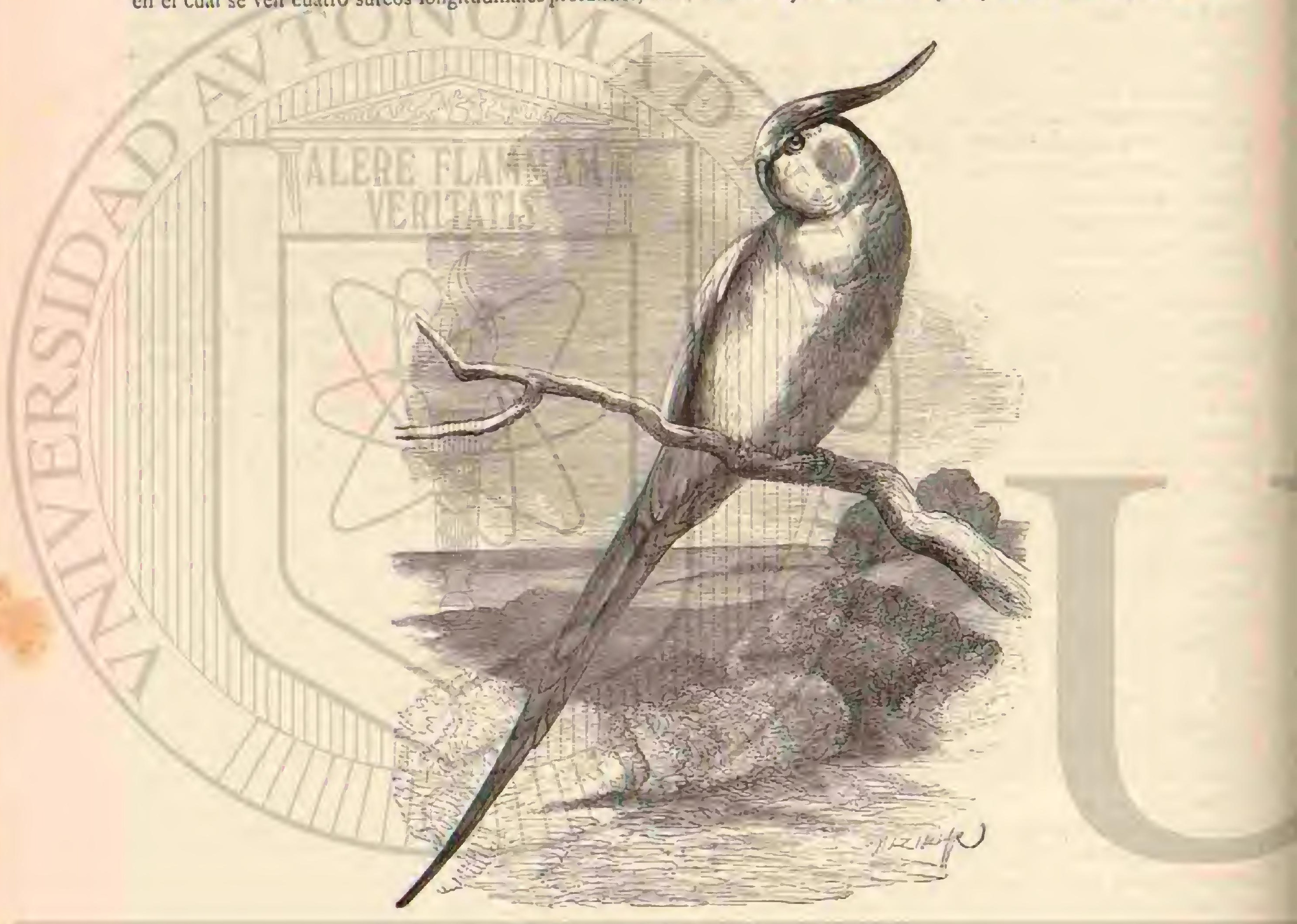

Fig. 1S. - EL CALHPSITICO DE LA NUR.MA HOLANIA

El esqueleto se parece por el crineo al de los cacatúidos, pero difiere del de todos'los loros por el esternon, poco desarrollado $y$ con la quilla mutiada.

\section{EL KAKAPO-STRINGOPS HABROPTILUS}

CARÁCTÉRES. - Esta especie es una de las mas gran. des de los loros en general, é iguala casi en tamaño a un buho de los mas grandes. El macho tienc toda la parte superior de un color verde aceitunado; en la base de las plumas, de ur tinte pardo oscuro, hay muchas fajas trasversales, y en el tallo manchas de color amarillento verdoso: la parte inferior presenta el mismo matiz, y en cada pluma se ven estrechas fajas trasversales de color pardo oscuro. El velo facial, de la misma forma que el de los buhos, cubre la frente y la region de las orejas; este velo y la barba son de un tinte amarillento de paja pálido, y la region de las orejas de un pardusco aceitunado ciaro. Las rémiges tienen las barbas interiores de co. lor pardo oscuro, $y$ las exteriores de un pardo amarillento aceitunado con mézcla de manchas jaspeadas de negro. Las recirices pardo amarillentas, tienen las barbas negras; las tectrices inferiores de la cola no presentan casi mas color que el verde aceituna. El pico es blanquizco; los piés de un pardo gris claro de cuerno. La hembra difiere por tener el color verde de la parte superior mas oscuro; las plumas mas anchas en la base y de un pardo intenso, con manchas ama. rillentas en el tallo, $y$ algunas otras trasversales en las barbas del mismo color. El disco facial es de color pardusco aceituna, porque las plumas tienen solo lineas muy claras y estrechis en los tallos Asi ciescribe Finsch una pareja de estas aves extrañas. En las obras que yo conozco no encuentro medidas cxactas.

DISTRIBUCION GEOGRÁFICA. - La patria de estos loros es la Nucia Zelanda.

CONSIDER ACIONES GENERALES. - A pesar de que conocemos hace ya mucho tiempo la Nueva Zelanda, hasta los títimos tiempos no se descubrió el kakapo ó el larapo de los maoris. El primer individuo que se vió de esta extraña 
especie tenia las plumas verdes, $y$ su cabeza servia de adorno á los indigenas. Asi la natumleza del terreno que habita como su género de vida, permitieron obsermarla, y en 1 \$ 45 recibiose al fin en Europa el primer individuo disecado. En los años trascurridos desde entonces hemos llegado í conocer con bastante exactitud el kakapo; pero al mismo tiempo se nos ha manifestacio el temor de que sufra muy pronto la suerte del dronte, es decir, que se extinga la esprecic. En la Nueva Zelanda es muy reducido actualmente el nimero de estas ares; solo en los lejanos valles de la parte meridional de la isla se las re todavia con frecuencia, mientras que en in septentrional han sido exterminadas ya casi del todo. Esto pa. rece justificar dicho temor; pero no piensa del mismo modo la persona mas conocedora de estas aves, el doctor Iulio Haast. al nue ha estudiado como yo la naturaleza de la Nuera \%elanda, dice, debe saber que aun hay miles de leguas cuadradas de terrenos inhabitados, que se conservarin incultos algunos centenares de anos: solo el naturalista pone alli el pié, y se debe suponer que ia notable especie puede vivir aun tranquilamente largo tiempo. Las esperanzas de con-

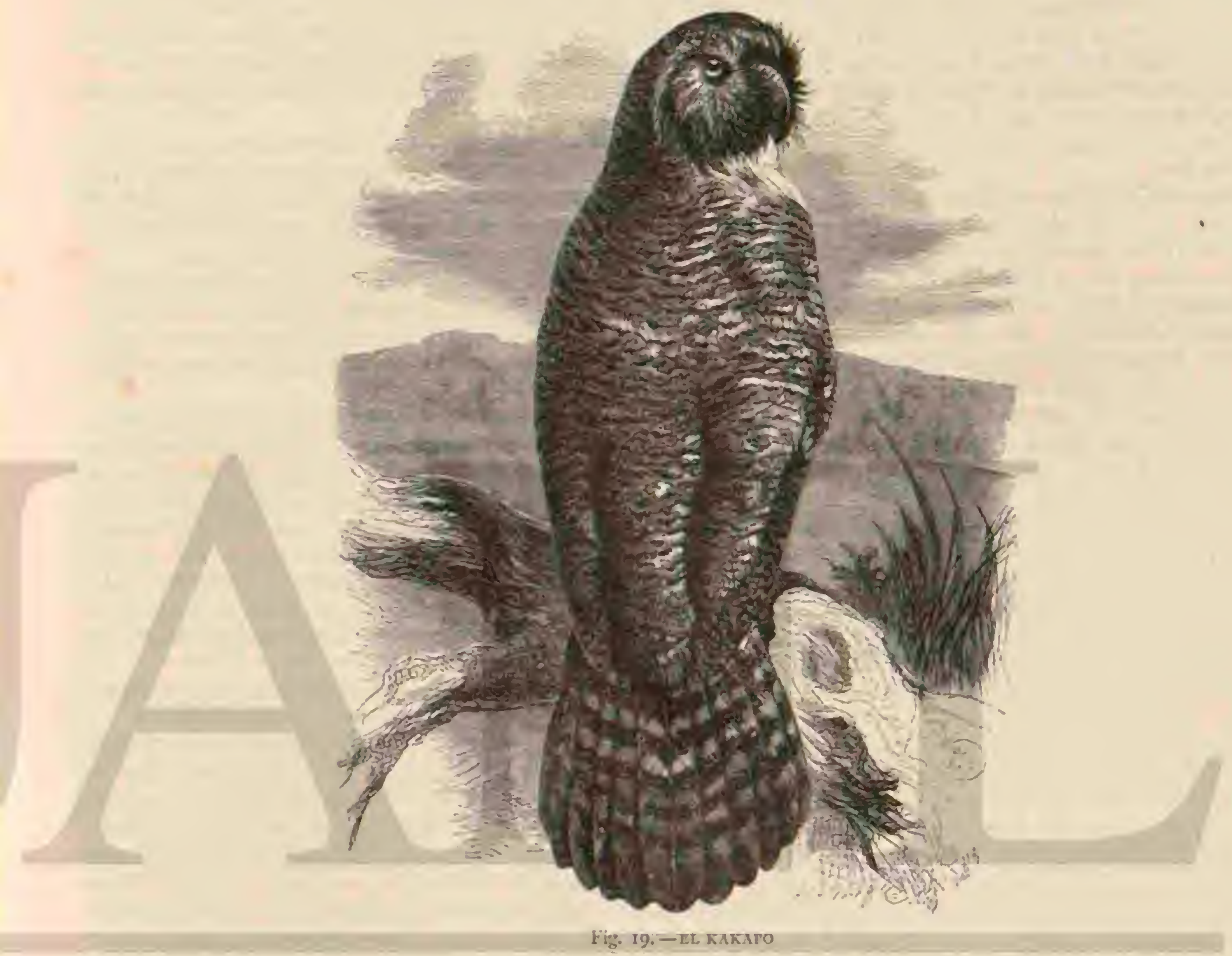

servar la especie parecen tanto mas fundadas cuando refle. xionamos que al kakapo se encuentra desde las orillas del mar hasta una altura de 600 metros sobre el nivel de sus aguas; $y$ aunque se exterminase en lós territorios bajos, las montañas poco-accesiibles le ofrecerian siempre un refugio seguro.

Adents de los datos de Haast, tenemos atros de Lyall y de lorge Giej, los cuales reproducirci aqui en extracto.

2.Aun cuando se supone, dice Lyall, que el kakapo se en. cuentra todavia en las altas montañas del interior de la isla septentrional de Nueva Zelanda, solo lo hemos laallado du. rante nuestro vinje en las costas de estas islas, en la extremidad sur de la isla centri. - En los fiordos que avantan mucho hácia el interior obsérvase todavia un nưmero considerable de estas ares.

USOS, COSTUMBRES Y REGIMEN.-1qui habita las vertientes secas de las colinas 6 la proximidad de los rios, en los parajes donde crecen grandes árboles que no están ro. deados por los helechos ni por las brenas. Vimos por primera vez este loro en un monte situado á unos 1,200 metros sobri el nivel del mar; y mas harde encontramos muchos en la lla. nura, á orillas del rio jo no léjos de aquel.

4 Lis muy noiable, ariade Hast, que no se encuentre el kakapo en ningun punto de la vertiente oriental de los Alpes zclandeses, exceptuando, no obstante, el valle del rio Makiarora, que forma el lago Wanaka:y lo extraño tanto mas, cuan. to que hay en aquel punto grandes bosques. Parece estar confinado en la vertiente occidental de dicha cadena de montanas; solo franquea el desniladero poco alto y cubierto de bosque, que conduce desde las corrientes del rjo de Haast a las del Makarora, y llega asi hasta la embocadura de este, en el lago llanaka, donde por la falia de bosque se limita su área de dispersion. Fis muy comun en el valle de Makarora, aun cuando frecuentan mucho aquellas selvas los leñadores. Cuando acampamos en el lindero del boscque oiamos conti. nuamente los gritos dei estrigope; pero ninguno de los trabnjadores suspechaba la presencia de un ave tan grande, aunque su penetrante voz llamara mas de una vez su atencion. Es 
menos comun en el valle de Hunter, aunque solo está ro. dendo de montanas poco alias y un desiladero bastante bajo, habiendo alli grandes bosques que le ofrecerian cómodo asilo.

En tales sitios, dice Lfall, se reconocen fäcilmente las huellas de este loro, que tienen unos $\|^{ \pm}, 30$ de largo y son regularmente aplanadas hasta el borde, el cual se hunde de $00^{\prime \prime}, 05$ \& $0^{\mathrm{m}}, 07$ en el musgo; se cruzan dichas huellas en àngulo recto, y asenéjanse de una manera singular á las nues. tras, tanto que al principio creimos que habrian pasado por alli algunos indigenas.

y. El kakapo habita en las cavidades practicadas en las rai. ces de los troncos ó en las grietas de las rocas. Como en muchos árboles de la Nuera Zelanda sobresalen ajuellas de la superficie del terreno, enctentra el loro ficilnente donde albergarse; pero nos ha parecido que las cavidades naturales estaban ensanchadas, si bien no vimos en ninguma parte are na extraida.s

Haast, que al parecer no tenia conócimiento de los trabajos de Lyall, opina de! rnismo modo, segun indica el siguiente pirrafo: rlodos los nidos de kakapos que yo examiné se hallaban en cavidades naturales, si bien he visto uno construido artificialmente Fn la orilla narte del rio de Haast, cerca del confluente del Clark, y en un sitio dónde la márgen se clevaba de 6 \& 8 piés, vi varios agujeros redondeados, donde mi purro no podia entrar. Despues de haber olfateado comenzó a escarbar en cierto śstio, desculrió el fondo de la madrigue ra y sacó el loro. Aquel nido era evidentemente artificial, siendo nuy posible que el kakapo tenga la facuitad de escarbar la tierra.

Con trecuencia tienen estos agujerós dos salidas, y los árboles estain huecos por encima en cietta extension.

Durante el dia no se ve el kakapo si no se le ahujenta de. su nido. No pudimos descubrirle, dice Lyall, sin el auxilio de los perros. Fn otro tiempo, cunndo estos no eran conocidos, aun en la isla y abundaba mas el arc, cazábanle los incígenas por la noche con lachas de viento. Ahora existe alli una raza de perros semi-salsajes, que labita el norte de la isla y persigue sin cesnr al kakape, exterminairdole en lós puntos donde se fija, El árca de dispersion de los perrós se halla li mitada hasta ahora por un rio, mas apenas le hasan fran quendo, es de temer que desaparezca el loro, pues á pesar de la vigorosa resistencia que opone con sus unas y su pico, acaba siempre por ser victima de sus enemigos, mucho mas podcrosos: el kakapo esta destinado a sufrir la misma suerte que el dronte

₹Los maris me han asegundo, ainade Hast, que el kin kapo es valeroso, y lucha a veces con exito contra los per. ros, cosa que yo no puedo creer sino suponiendo que estos animales son muy débiles. Con el mio no hubo nunca pelen formal: cierto es que recibia al principio sendos picotazos y aranazos; pero no tardó en aprendèr á sujetar su presa pronto, destrozíndole el cráneo.

Se ha calificado hasta ahora al hakapo de ave nocturna, mas yo creo que no lo es del todo. Solo se oye su roz una hor despues de ponerse el sol, donde reinan las mas pro. fundas tinieblas a causa de la espesura del follaje; entonces comenzaba sus excursiones, $y$ en aquel momento era cuan do, atraido por la luz, se acercaba a nuestras tiendas, dejan. dose coger por los perros. Sin emuargo, dos veces he sor prendido á estos loros durante el dia, cuando iban a comer y vigilaban atentamente. la primera fus por la mañana en un bosque de poca espesura: al regresar de la costa, vimos un kakapo sobre un árbol derribado, no léjos del rio Haast, y al acercarnos, emprendió rápidamente la fuga: pero le cogieron muy pronto los perros. Ia segunda vez fué tambien en pleno dia; atravesábamos un desfiladero, y vimos uno posado sobre un arbusto cujos frutos se comia. Apenas nos vió, precipiróse á tierra y desapareció en medio cie las rocas, siendo lo mas'singular que no abriese las alas para disminuir la violencia de la caida. A fin de saber si este loro po. dria volar, puse en sitio descubierto un katapo cogido por un perro: y lejos de huir, corrió hácia la espesura mas próxima, con una mpidez que no era de esperar, atendidas sus pesadas formas. Yo le veia de lado, y me pareció que tenia las alas aplicadas contra el cuerpo; jero mis compaices, que le observaban por detrás, dijeron que las entreabria li. geramente, aunque sin agitarlas, de lo cual resulta que solo hacia uso de cllas para conservar el equilibrio. Recorre dis. tancias bastante largas, segun pudimos reccnocer por sus huellas, las cuales segui con írecuencia en el espacio de mas de una milla.

Lyall dice haber visto volar mas de una vez á los estrigo. pes. En nuestras cacerias, dice, solo le vimos rolar para su. bir 1 los átboles huecos $\delta$ en busca de un refugio; desde alli se trasladaba á otro menos clerado, y trepaba rápidamentc, ayudandose con su cola, sin mover apenas las alas.

2la yor del kakapo es ronca, y chillona cuando se irrita 6 tiene hambre. los maoris aseguran que hacen \& menudo un ruido que $n$ iurde, cunndo se reunen por el invierno en gran. des bandarias y saludan con sus gritos a los coinpaneros que llegan y a los que se ran.

IEl estómago de los kakajos (̧ue matamos contenia una masa homogénea, de un color verde pálido y algunas veces casi blanca, sin ninguna mercla de fibras. No cabe duda que estos loros se alimentan en parte de raices, de hojas y reto jios. En un sitio donde cran muy numerosos, observamos quue todas las leguminosas que crecian á orillas del rio estaban despojadas de sus retoños; y nuestro piloto, que habia parndo alli varios años, nos aseguró que los kakapos se los comian: casi siempre vimos que su pico estaba cubierto de barro seco.

Haast precisa mas aun, cxpresindose en los siguientes tér. minos:

4Parece que el kakapo necesita el agua de los rios para desleir las pilantas de que llena su estómago: en todos los que matamos, exicepto dos que labian comido bayas, pudimos notar que el buche estaba lleno de musgo muy bien desmenuzado, y en gran cantidad. El ave parece mucho mas pequenิa cuando tiene vacia dicha parte del cuerpo: la gran masa de aquel alimento poco nutritivo, que necesita consu. mir, explica cómo vive en tierra; semejante régimen le per mite tambien subsistir donde no se encuentra ningun otro representante de su fanilia.

* has demás aves tienen la piel forrada de una capa de grasa blanda y aceitosa; pero la del kaliapo es sólida y de co. lo: blanco, sin duda a causa de su ajimentacion vegetal; Ia carne es mejor que la de los otros loros, y hasta puede de cirse que tiene un gusto muy delicado. Constituye un alimento precioso para el viajero que recorre aquellos desiertos paises, y comprendo muy bien que los maoris de las cosias occidentales se relaman cuando se habla delante de ellos del kakiapo.

* En la última quincena de febrero y la primera de marzo, estacion que pasamos en los paises habitacios por aquellos toros, dice lyyall, hallé con frecuencia sus agujeros ocupados por uno ó dos hijuelos; nunca mas. Una vez encontré un peq̨ueño $y$ un huevo podrido: por lo regular, aunņue no siempre, se re á un adulto con su cria, mas no en un nido propiamente dicho, pues el kakapo se limisa á practicar un agujero en medio de la madera carcomida. Los huevos son blancos, del tamaño de los de paloma; los hijuelos que ha. 
llamos cran de diversa edad; los unos tenian todas sus plumas, los otros solo lleviban plumon.

CAUTIVIDAD. - Nos He:aron \& bordo inuchos pequeños siros; pero los mas murieron al cabo de algunos dias, sin duda por no habcirseles cuidado bien: algunos subsisticron sarios meses. Por lo regular se atrofian sus patas á las pocas semanas, ya por falta de espacio 6 por insuficiencia de alimento. Se les daba de comer pan mojado y patatas coci. das: cuando los dejajbamos correr por el jardin, picaban las coles, la yerba y' cuantas hojas verdes encontraban.

y Un kakiapo, que pude llevar felizmente hasta un punto situado á 600 millas inglesas de las costas britanicas, se alimentó durante nuestra permanencia en Sydney, de hojas de lankisia $y$ de cucaliptu; gustábanie las nueces $y$ las almc:ydras, y en toda la travesia no le di apenas orn cosa mas que nueces del Brasil.

* Varias veces le dieron convulsiones, y entonces no pro. baba el alimento en dos ó tres dias: gritaba mucho, y amenazaba con su pico á todo el que se acercaba. Nadie podin fiarse de él, pues á reces daba tales picotazos cuando menos se pensaba, que hacia brotar sangre. Cuando estaba sobre el puente jugueteaba con cuantos objetos reia á su paso, y por lo regular con mis pantalones y mis botas; parecia encaprichado con estas; trepaba sobre ellas y agitaba las alas, mani. festando su contento de todos modos; un accidente me privớ de él.

\$Otro kakapo que el capitan Stolies regaló al Mayor Murmy corria libremente por el jardin; gustábale estar con los ninos y los seguin paso á p.250 como un perro.

Grey, y últimamente Sale, dan tambien pormenores sobre la vida en cautividad del kakapo. \& El kakapo, dice Grey, es un ave dócil y astuta, que se iamiliariza muy pronto con los une la tratan bien. Trepa por el cuerpo de las personas conocidas, restrégast contra ellas, y es muy sociable y jugue. tona. De todas las aves que conozco, esta seria la companera mas recomendable si no fuese tan sucin; su manera de nanifestar carino con sus lialagos es mas propia de un perro que de un ave. Sale, que en is jo llevb el primer kakapo vivo a Inglaterra, estri confurme en lo esencial con lo que acabamos de exponer. Il Jurante todo el tiempo que tuve esta ave, dice el citado viajero, siempre la vialegte y de buen humor, dispuesta á aceptar con agradecimiento las caricias que se la prodigaban. Muy notable es su inclinacion a retozar; corre descle un lado á orro de la habitacion para cogerme la mano con las garras y el pico; revucilcase cono un gatito por el suelo y vuelve ásu sitio jara que la inviten á jugar de nuevo. Sus caricias son a veces demasiado bruscas; pero la mas pequeña reprension basta para que se modere.

\&ista ave tiene singulares caprichos: algunas reces me entretenia en poner un perro $\delta$ un gato delante de su jauln: entonces, entreabriendo las alas, avanzaba ó retrocedia bai. lando, cual si yuisicra parecer fúriosa, y cuando su aspecto inusitado atemorizaba a los animales, manifestaba la mayor alegria, moviéndose de la manera mas grotesca. Lina de sus costumbres consiste en rolver la cabeza hácia atrás cuando anda, levantando el pico, romo si quisiern ver qué aspecto ofrecen las cosas al revés. Muchas veces se complace en acurrucarse en mi mano, crizar las plumas y darme golpeci. ins con las alas; si entonces mueve la cabeza, esto indica que se halla en el colmo de la alegria No creo justificada la acus: sacion de que esta ave es muy sucia; yo diria que no lo es mas que cualquier otro loro. Mucho me sorprendió oir que durante el tiempo que estuvo en el jardin zoológico del Re. gente, raras veces se dejó ver de dia Segtan mis obsermacio nes, siempre hace lo contrario, si bien es cierto q̨ue no mani. fiesta tanta vivacidad de dia como de noche.

\section{LOS SITACINOS SITTA- CIN}

CARACTÉRES.-Esta sub familia comprende los loros de cola larga, caracterizados por su cola prolongada en forma de cuña, que se adelgaza gradualmente hicia la punta.

Casi la mitad de codos los loros conocidos pertenecen à este grupo.

DISTRIBUCION GEOGRÁFICA.-Los sitacinos habitan en todos las continentes; pero donde mas abundan es en la Anérica del sur, en Australia, en las islas del Pacifico y en la jarte metidional del continente asiático, donde se halla el mayor número de especies. Algunos naturalistas modernos han intentado dividir el grupo en varias subdivisiones de igual rango; pero segun mi opinion no hay razones fundadas para ello.

\section{LOS ARARAS-SITTACE}

CARACTÉRES. - Entre los sitacinos, los araras ocupan el primer lugar, porque son las especies mas grandes de la sub-familia. Este género se compone de loros del ramaño de los cuervos $\delta$ de los estorninos, que se distinguen por su pico muy fuerte, en extremo grande, comprimido lateralmente, cou una arista corva, y prolongado en punta muy sa. liente; la parte desnuda de la cabeza comprende los circulos oculares y la parte antcrior de las mejillas; algunas veces se limita tambien \& una membrana con repliegues al rededor de la mandibula inferior; la cola es muy larga. In mandibula superior liene junto ó su extremidad una sesgadura dentada: la inferior, mas estrecha que la superior, se aplana lateral. mente; el ángulo de la barbilla es ancho y forma una curva junto á su extremidad; la parte desnuda de los lados de la cabeza esta cubierta nuchas veces de plumas cortas dispuestas en series muy scparadas; las alas, largas y agudas, tienen la punta mup prolongada; la tercera rémige sobresaic de todas las demás; el la cola, larga y uniforme, las plunas exicriores tienen proco mas ó menos la iercera parte de la longitud de las del centro. El plunaje es recio, de color verde muy viro, rojo ó azul. I a hembra no difiere del macho por el plumaje, y los pegreños muy poco:

DISTRIBUCION GEOGRÁFICA.- - LOS araras, llamados tambien sin mzon aras, se encucutran desde la parte septentrional de México hasta el Brasil meridional y el Para. guay; pero no llegan hasta Chile. Varias especies suben por los Andes hasta la altura de 3.500 metros.

USOS, COSTUMBRLS Y HÉGIMEN.-Ia mayor parte de las especies havita en las selvas virgenes, lejos del hombre; retrocede cada rez mas ante los plantadores, y esca. sea á medida que aumenta la poblacion. 11 contrario de los demás ioros, viren en parejas, í veces aisladas, que no suclen acompañarse de otras; if veces, sin embargo, sobre todo des. jues del periodo del celo, reúnense varias de ellas en reducidas bandadas, que solo excepcionalmente llegan a ser numerosas. Parece que ninguna pareja abandona su residencia ordinaria sino para emprender sus correrias diarias. Iil centro de su recinto es el árbol que contiene el nicio, al cual vuelve la pa. reja todos los arios. Fiste hecho era conocido ya de los antiguos peruanos; y asi como ellos, muchas tribus de indios de la Guayana y del Brasil se utilizan hoy dia de esta circunstancia. Todo árbol donde el ave anidaba, considerábase como una herencia que se trasnitia de padres a hijos. Iil arara necesira que cl hueco del árbol sea muy ancho, y como los que tienen tal condicion escasean mucho en las selras virgenes, las aves se ven obligadas á permanecer en ciertas 
regiones. En cuanto al carácter, los amas se distinguen de los otros loros por cierta tranquila gravedad, sin ser inferiores a ellos por sus facultades. Aliméntanse de varias frutas de los árboles de su patria; pero tambien invaden y saquean los campos, causando grandes destrozos cuando se reune un gran número de individuos. En la primavera de aquellas regiones, la hembra pone dos huevos, y segun parece cliddase jor si sola de cubrirlos: los padres profesan tanto cariño á su pro. genie como à si mismos. Los indios actuales, imitando á los de remotas épocas, cogen los pequeños para criarlos y persiguen $\{$ los adultos pan obtener sus magnificas plimas.

Basta para nuestro objeto describir de. Tas diez y ocho especies de este género la más grande, y la que con mas frecuencia se recibe cautisa en Europa.

\section{EL ARARA JACINTO-SITTACE HYACINTHINA}

CARACTÉRES. - Tanto por su tamaño comol por su belleza particular, esta especie debe higumr í la cabeza de la sub-familia. El aram jacinto se distingte por su pico gigan. tesco, carácter notable que indujo á varios naturalistas á elegir esta especie como tipo único (Andorhynchus). Su color es un azul oscuro de cobalto, mas claro en la cabeza $y$ el cuello: la base de las plumas es gris, $y$ las barbas interiores de las rémiges están bordeadas de negro.-Estas últimas plu. mas. Ins rectrices $y$ las grandes iectrices tienen un tinte negro brillante, lo mismo que sus tallos. Los ojos son cie un pardo oscuro: los circulos oculares, grandes y desnudos, son de un color vivo de naranja; el pico negro, y los pies de un tinte pardo negruzco. La longitud ce esta are, segun Bur. meister, puede sez de un metro; las alas miden 1$)^{\omega}, 4=$ y la cola $(i), 58$.

DISTRIBUCION GEOGRAFICA.-El área de dispersion del amra jacinto se limita 2 las partes sejtentrionales del Brasil central, extendiéndose poco mas 6 menos desda el $16^{\circ}$ de látitud sur hasta el Amazonas. Aur en su misma patria, la especie escasen mucho, y for eso se ve muy taras veces en Europa.

\section{EL ARAKANGA - SITTACE MACAO}

CARACTERES. - Tambien esta especie és bastante gran de, pues mide $\theta^{m}, S 6$ de largo, yor $\theta^{m}, 15$ de ancho, sicado la longitud de las alas de $0^{\circ}, 40$ y la de la cola de $\|^{\circ}, 32$. Las plumas pequeñas son de un rojo escarlata, mas claras en la region de la frente y en la de las orejas; las de la parte pos. terior del dorso y las tectrices se distinguen por su color azul celeste muy bonito; las rémiges de la mano y del brazo, las tectrices y la punta de las alas tienen un tinte azul Prusia; las primeras presentan en las barbas interiores un ancho borde negruzco; las grandes tectrices de las alas $y$ las largas plumas del hombro son de un amarillo anaranjado, adornadas en la punta con manchas verdes; las rémiges de un rojo escarlata y azul celeste en su extremidad; las dos exteriores tienen un matiz azul oscuro; las tectrices inferiores de las alas, y la cara inferior de las rémiges y rectrices, contrastan por su color rojo brillinte de cscarlata. Ios ojos son de un blanco amari. llento; la parte desnuda de las mejillas pardusca; la mandi: bula superior de un blanco de cuerno, adornada en cl borde de su base por una mancha negra triangular; la mandibula inferior es negra, $y$ los piés de un negro pardusco.

DISTRIBUCION GEOGRÁFICA.-FI arakanga habita en los paiscs septentrionales de la América del sur, desde la Bolivia y el norte del Brasil hasta Guatemala y Honduras; tambien se le encuentra en el Perú, y probablemente en México.

\section{EL ARARA DE ALAS VERDES - SITTACE CHLOROPTERA}

CARACTÉRES. - Esta Especie ha sido confundida con la precedente, si bien se distingue de una manera marcada por su plumaje de color oscuro de escarlata y por las tectri. ces verdes de las alas y de los hombros.

DISTRIBUCION GEOGRÁFICA. - Habita en el Brasil central y meridional, pero tambien se extiende hácia el norte, el sur y el oeste.

\section{EL ARARAUNA-SITTACE ARARAUNA}

CARACTERES.-Fita es la última especie de que hare mencion: se reconoce por los siguientes caractéres: 'Toda la parte superior y las tectrices de la cola son de un azul celeste oscuro; los lados del cuello y las regiones inferiores de un color de naranja viro; al rededor de las mejillas y de las barbas se corre una faja negra; el ojo es gris verdoso; las partes desmudas de los lados de la cabeza de un color pardusco de came; él pico negro; los piés de un negro pardusco. Ia longitud es de $0^{\circ}, 97$, las alas miden $0^{\circ}, 40 \mathrm{y}$ la cola $1^{\prime \prime}, 5=$

DISTRIBUCION GEOGRAFICA.-El strea de dispersion de esta especic es la misnı que la del arakanga.

USOS, COSTUMBRES Y REGIMEN DE LOS ARARAS EN GENERAL. - I.os araras solr aves propias de las sclvas virgenes: habitan en los bosques de la llanura cruzados por rios. En épocas anteriores vivian tambien en las inmedia. ciones de las grandes ciudades; pero hace ya mucho tiempo que sé retirtron ante la invasion del hombre, y mas pronto is mas tarde desajparecerain de los puntos donde el plantador comienza if cultivar la selva virgen. Varias especies no se li. mitan al bosque, sino que habitan aun en las regiones secas Y altus, abrasidas por el sol del estio, ast como en las mon. tañas salvinjes y pedregosas de la provincia de Bahia, donde alegran la vista del viajero.

aAl navegar por los rios que atraviesan los bosques por cerca de la costn, refiere el principe de Wied, se ven magnt. ficos loros, que se reconocen por su espléndido plumaje rojo, su larga cola y su voz, cuando batiendo lentamente sus alas cruzar el aire, destacándose sobre el oscuro azul del ciclo. 3 Todos los viajeros hablan en términos entusiastas.y exagera. dos de aquellas apariciones que les sorprenden de improviso: Waterton dice que no hay especticulo como el de una ban. dada de varios miles de araras, cuando se remontan por el es. pacio; pero el principe de Wied y todos los observadores concienzudos aseguran que nadic ha debido ver bandada tan numerosa.

El género de vida de estas aves, continúa el principe de Wied, no difiere del de los otros loros: durante el fuerte calor del medio dia se les ve descansar, posados en las ramas bajas de un copudo irhol; algunas horas despues se animan poco a poco. Cuando no están en celo se asocian para ir a buscar frutos de las palmeras, del sapucnjor, etc, cuya cáscara parten con su vigoroso pico. A semejanza de todos los loros, guardan silencio cuando invaden un ảrbol frutal, mas la caida de las cáscaras descubre su-presencia. En varias localidades, so. bre todo en la estacion fria, los he visto muy ocupados en buscar el fruto de una planta irepadora que llaman spirifir en el pais; suben habilmente por en medio de las lianas, $y$ entonces se les podia cazar fácilmente. Tenian el buchelleno de los granos blancos de dicha planta: en otras estaciones observé que su pico estaba coloreado de azul, á causa de picar cicrtos írutos.

Le Vaillant dice que los araras son loros estúpidos que no temen al cazador: puedo asegurar, por lo gyue yo mismo he 
visto, que en los bosques del Brasil, donde abundan mucho, son los séres mas desconfiados y astuios.

En los individuos cautivos se puede observar cuán justos son los elogios que hacen los brasilunos al hablar de las ia cultades intelectuales de estas aves. Cicrto que carecen de la viracidad de muchos de sus congéneres; pero fuern injusto acisarias de perezosas o torpes. En comparacion con otros loros parecen calnoson, prudentes y graves; mas solo aquel que no los haşa obscrvado podria negar el desarrollo de sus sentidos y de su inteligencia. Tambien los araras saben acomodarse, mas ficilmente quizás que todus los demás loros, í las circunstancias, a los deseos y exigencias del hombre, y toleran todo tratamiento prudente y benigno, sill hacer uso de su gran fuerza mas que cuando se les irrita. Con sus semejantes viven en la mejor inceligencia, y con otras aves of séres inofensiros en la mas envidiable armonia. Como sa he dicho en otro lugar, se hacen agradables por su caracter y dignos de aprecio. No solo son aves dóciles y familiares, sino tambien carinosas con sus semejantes y con el hombre.

Cuando se posan en un árbol y se disponen á comer, todos se callan, y cuando mas, se oye un ligero murmullo, semejan. te al cuchicheo de varias personas. No lanzan gritos mas que cuando vuclan ó se és injuicta, y chillan subre todo si llegat el cazador sin ser visto y los espanta subitamente disparando un tiro. Eutonces lanzan gritos atsonadores, ! puede suceder, como lo ha dicho Humboldi, que dunisiess el mugide de los forrentes.

Su grito es ronco, monosilibico, parecido al graznido del cuervo. Eil principe de Wied dice çue ro se puede traducir por las silabas ara ob arara: Burmecister, por el contrario, ase. gura que jercibió charamente estos sondilos; y por lo yue yo he podido observar en individuos cautivos, me inclino si este parecer.

Su aliuento principal consiste en frutas, nueces y simien. tes de los árboles de la sclva virgen; su poderoso pico les sirve para romper las ciscaras de varias nueces de palnecra, duras como piedras; pero algunas veces invaden las plantaciones del hombre. Asi conso otras muchas aves frugivoras de la selva virgen, ambien los araras buscan fuera del perio. do del celo, las frutas mas maduras, y entones puede suce. der que extiendan sus excursiones mas allá de los limites de sil territorio, para saquear los campos donde abundan las frutas y el trigo. Schomburgk describe estos merodeos de un modo muy exacto. Cuando encuentran un campo donde hay frutas maduras, dice, colocan centinclas al rededor, en los årboles mas furóximos; su voz, por lo regrular tan ruidosa, deja de oirse, $y$ solo a intervalos percibese algun sonido aho. gado. Si se divisa un objeto sospechoso, el centinela que primero le ha visto deja escapar un ligero grito para advertir \& los ladrones, y estos contestan con otro. Cuando el peligroes mas inminente, el centinela se remonta por los aires lanzando un grito sonoro y al mismo tiempo clévase toda In bandada, contestando á su companiero, para buscar su salvacion en la fuga. .

L.os araras son, como los otros loros, nieles entre si. \& Fa enero de $17 S S$, refiere Azara, Manuel Palomares mató una de estas aves a la distancia de una milla de la ciudad del Para. guay, y la ató a la silla de su caballo. El macho que habia perdido asi su hembra, siguió al cazador hasta su casa, pasando por en nucdio de. la ciudad; precipitóse sobre el caciáver, sin querer separarse de é, y estuvo varios dias en el mismo sitio, has:a que se dejo coger, quedindose luego en la casa. o

Otros naturalistas que han observado los araras en libertad, nos dan noticias semejantes. El cariño del macho y la hem. bra es tan firme que podria decirse que una vez apareados solo viver para si y su piogenie Jos famosos sitáculos no pueden ser mas afectuosos entre si que estas grandes ares. Sicmpre se ve al macho con la hembra, y aumpue se reunen varias familias, nunca se separan, como lo hacen tambien otros loros. Este mutuo apego es un hecho tan conocido de

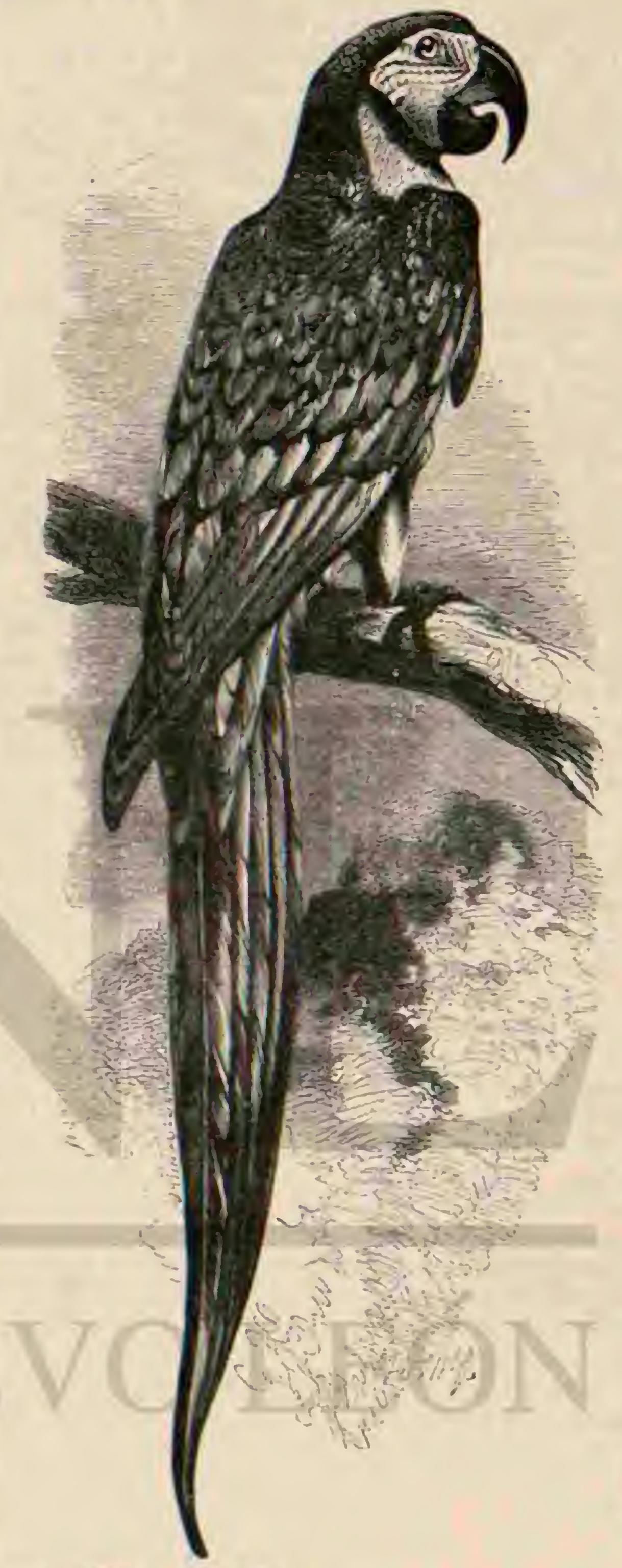

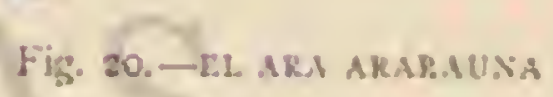

los brasileños que se aprovechan de él para apoderarse de varios individuos de una bandada, pues cuando uno sucumbe de resultas de un tiro, su companern acude al punto para averiguar la causa del accidente, arrajendo a veces con sus gritos á otros de la bandada.

\& Durante la época del apareamiento, dice el principe de Wied, buscan los araras el sitio habitado por ellos anterior 
mente, siempre y cuando no se les haya molestado; asi es que pernanecen fieles varios años a una misma localidad. Para establecer su nido eligen un írbol alto, de follaje espeso, y que tenga una rama hueca ó en parte carcomida; agrandan la cavidad con su pico a fin de acomodarse, y alli es donde la hembra deposita dos huevos blancos.

Los huevos son casi tan grandes como los de la gallina, tienen la punta obtusa y la otra extremidad gruesa, ligera. mente redondeada; la cáscarn es granujienta, con espesos poros redondos, de regular profundidad. No se ha podido averiguar hasta ahora si solo la hembra se ocupa en culrir los huevos, ó si cl macho la ajuda: creoposible esto último, y aun probable.

Segun dice Schomburgk, la prolongada cota de este loro, que sobresale del nido, le descubre con freruencia. Dice trana que los padres no pierden nunca de vista el rido, y que var. alternativamente para dar de comer á sus pequenos: cuando alguien se acerca, se agitan mucho. Los hijuelos no chillan para pedir alimento, sino que golpean con su pico las paredes de.su alberguc. Como los demás loros, nacen nuy imperfec. tos, y aun cuando hayan comenzado a volar, necesian largo tiempo del cuidado de los padres. Los indigenas los cogen antes de que les haya salido toda la plema, í fon de domesricarlos.

CAZA. - l'anto los blancos como los indios cazan acrivamente á los araras, y cl europeo se regocija muclio cuando dispara un tiro y se apodera de estos magnificos animales. ¿El cazador, dice el principe de WVied, oculto por las breñas y los troncos de los árboles, se acerca cautelosamente á una bandada de araras, y de un solo tiro hace cact confrecuencia varios; su voz penctrante llana la atencion de todos. Se le mata con perdigon zorrero, pues comummente se ha de tirar a las copas de los áboles mas alios: una vez herido el anra, sc agarra à la rama con su pico y sus patas, permareciendo largo tiempo en esta posicion.

CAUTIVIDAD Y DOMESTICIDAD.-Parece quelos araras cautivos han sido en todo tiempo las aves favoritas de los indios. Con ámiracion, dice Humboldt, vimos ararás domesticados culas cliozas de los indios, que corrian uor los campos como entre nosotros las palomas. tquellos loros cons. tituyen un verdadero adorno en los cormles indios, pues no les aventajan en bellema los pavos reales, ni los faisanes dorados, ni los hocos. A Cristóbal Colon le chocó ya aquella mancra de criar loros, ares tan distintas de las gallinas; $y^{\circ}$ desde el descubrimiento de América obscrvó que los indios comian con gusto araras ó grandes loros en vez de gallimas.

Es peligroso, no obstante, tener araras cautivos, pues se sirven con harta frecuencia de su pico temible, aunçue hay algunos que se domestican muy bien. Mi padre vió en el gabi. nete del principe de Wied un individuo que corria libremen te por la casa; pero separábase poco. de su amo; se dejaba coger por él y llevar en la mano, y oprimia suavemente su pico contra las mejillas. Miraba a las personas desconocidas con ojos finos y penetrantes, cual si quisiera grabar profun. damente sus facciones en la memoria. En el Jardin zoológico de Hamburgo existen varios araras domesticados, pero solo demuestran afecto á su guardian; con las demás personas son tan maliciosos $y$ hasta malignos como los monos. El guarda hace cuanto quicre con ellos: delante de nosorros, por el contrario, parecian furiosos, erizaban las plumas de la cabeza y agitaban el pico con aire amenazador.

«Una ararauna que yo tengo, me escribe Linden, demuestra lo que se puede hacer con un ave de su especie. Ahora figura entre mis favoritas; pero cuando la recibi era limiday maligna; producia gritos terribles, y debia valerme de la astucia para que no une mordiese al darte el alimento nece sario, pues no quise haccrla pradecer hambre, como aconsejan algunos aficionados inzprudentes. Sabia muy bien que mucho mas lograria con un buen tratamiento. En cfecto, esie proce. der y buenas palnbras han corregido muy pronto todos los vicios de mi ararauna. No le gusta que le toquen las plumas de la cola, pero se deja acariciar en la cabez:a, y i menudo alarga la lengua por un lado del pico, cual si quisiern recom. pensar con clla las caricias. Una vez se resfrió, y como a con. secuencia de csto se le obstruyeron las fosas nasales, limpié. selas con una pluma; cste remedio parecia aliviarie mucho, y lo demostraba del modo acostumbrado entre los loros. Con. linuamente ne hacia alguna jugarreta: habiendo reconocido jue la cerradura de su jaula cra demasiado endebie, y desques de observar cómo se abria la pucrta, consiguió salir muy pron. to de su prision; pascúse por todas partes, y desbarató varias jaulas de imaçera. Alfín, fué necesario cambiar de cerradura, lo cual no mareció agradar al principio á mi arara; jero poco a poco olvido el incidente, llegando à ser tan dócil, çue aho. ra puedo dejarlin pasear libremente sin temer su insolencia. Suclc posarse junto à la puerta de su jaula y cuando le digo: avueliéd tu casa, obedece en seguida: se baña muclas veces en uná vasija llena de agua. Cuando antes le habia presto esta vacia en la jaula la destrozó en seguida, mientras que nuncal lo hiro cuando estaba llena. Para dormir se senaba pocas veces sóbre la perclia, sino que se agarraba con el pico y los piés á las rejas: muchas reces tambien reunia la arena de su jaula echándose sobre ella jara descansar. Al principis crei que le falıba algo, pero enojóse muclio cuando intenté haccrle levantar del suelo; desue entonces dejéle obrar a su aniojo. Su jaula cstá colocada de modo yue puede ver todo el jardin y los caminos, y por eso se ha crigido en centinela de tódos mis loros; cuando un perro ó un gato pasa por los alrededores, lo anuncia en seguida lanzando un grito particular. Sus vecinos, cacatias y crisotis amanonas, repiten el grito, y despues todos guardan durante algunos momentos lin silencio profundo; de modo que se echa de ver que todos há comprendido el significado de la advertencias

El arara no aprende nunca á hablar tan bien como los de. mís loros, pero no carece del todo de semejante facultad. \& El individuo que yo posco, escribia Siedhof á mi padre, ha lle. gado al fin a hablar, merced a las lecciones de una marica que tengo.

3Le tuve cuatro meses sin oir mas que su horrible chillido: cietro dia lo trasladé a otro lugar, colocándole cerca de mi marica, que no deja de charlar un momento; y diez dias des. pucs hablaba el tambien.

* Aloora sabe llanar á todos mis hijos por su nombre; repíte lo que oye, mas siempre habla cuando esta solo.

El citado ararauna apjendió iambion á hablar sin maestro. Linden me refiere sobre este particular lo siguiente: \&uenos diss, aras; son ahora las primeras palabras gue el ave pronuncia cuando me ve por la manann; antes lo repetia durante todo el dia; mas ya no lo lanec sino cunndo es oportuno. A seces dice: a Jacob es un cacacu, no, un loro, un ladron. Polly, Polly, ven, ven aquil. Cuando le doy un higo ó un pedacito de manzana se lo come diciendo: Esto es bueno, ¿no es verdad, Iacob? Pcro si es un terron de azúcar, excla. ma: Esto es muy bueno; y menca la cabeza afurmativamen. te. Al tomar su alimento ordinario no da nunca las gracias sino á reces un picotazo; pero no lo liace así cuando se le ofrecen golosinas. Muchas reces volcaba ó llevaba de una parte a otra la vasija de su alimento, lo cual le prohibi con las

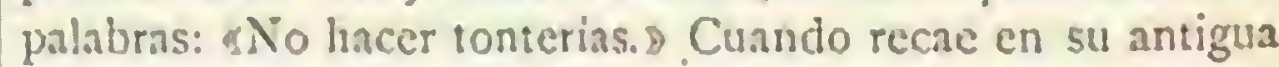
costumbre, él mismo dice: eso son tonterias; y si le qui. to la rasija, consuclase con restregar el pico en la arena, diciendo: Rerdad, tonterias. Del crisotis del Ama\%onas antes 
citado, que pronuncia perfectamente y con muy buena ento. nacion las palabras: \&Laura, tienes ojos como perlas; queri. da, equé quieres mas; ? ha aprendido esta frase, pero confun. de unchas veces las palabras y la construccion.

Los araras resisten largo tienupo la cautividad. Azara habla de uno que despues de haber vivido cuarenta y cuatro años con la misma familia, cayó al fin en el marasmo senil, y no ptido digerir ya mas que mai\% cocido.

Segun dice Bourjot, en i $\mathcal{S}_{1} S_{1}$ una pareja de araraunas cauti. va en Caen se ha propagado tambien.

USOS X PRODUCTOS. - La carne de los amras, dice el principe de Wied, es para el cazador un bocado delicioso: tiene el sabor de la del buey; pero la de los individuos viejos es dura y á inenudo muy gorda, sobre todo durante la estacion de los frios, lo cual no impide que produzca un caldo excelente.

5 Emplíanse las plumas para diversos usos: todo carador gue mata un arara adorma su sombrero con las plumas blancas y rojas de las alas $¥$ de la cola; los brasileños utilizan las pennas de las alas para escribir; los salvajes fabrican con ellas aciornos. Con las rémiges guarnecen sus flechas, $y$ las otras plumas les sirven á muchos para cugalanarse. Fin otro tiempo fabricalan objetos artisticos las tribus un poco civilizadas de Lingoa geral, y conservábanlos en cajas cerradas con cern.

- Ios tupinambos de la costa oriental, que habitan el pais recorrido jor mi, comienzan con mucha ceremonia la fiesta que debe terminar matando y comiéndose un enemigo hecho prisionero en la guerna el verdugo, el que lleva la maza, se cubre el cuerpo con una capa de goma en la ciue san pega. das plumillas del ave, y adorna su cabeza una diadema hecha con las de la cola. Fintre aquella tribu son simboln de la guerra las plumas de los araras, y aun lioy buscan estos adornos: solo a costa de grandes esfuerzos han conseguido los je. suitas extirpar semejante costumbre de algunos salvajes civi. lizados jia.

\section{EL ENICOGNATO LEPTORINCO-HENICOG- NATHUS LEPTORRINGHUS}

CARACTÉRES. - Bil enicognato leptorinco ó loro de fica largo, el ciroroy de los chilenos; ocupa en su familia el mismo lugar que el cacatua de mariz en la suya; es un are terrestre con pico muy prolongadoy de punta larga, que con ra\%on se considero como tino de un género especial (Hemsriguathus).

La estructura de sus alas y la de la cola es casi igual á la del corella; mas por el pico difierc de todos los demás loros en gencral. Este pico, bastante fucrte, es delgado y muy largo; la mandibula superior, doble mas alta que larga, se encorva muy poco, es aplanada lateralmente y rediondéase en-la-arista, que se-prolonga en una punta angosta, la cual sobresale casi horizontalmente, presentando ch su basc una sesgadura dentada; la mandibula inferior, tan alta como la superior, se aplana en los laclos, redondeándose en cl ángulo de la barbilla y arqueándose con los bordes ligeramente. Los piés y los dedos son robustos, estos uiltimos estin provistos de uñas muy corvin; las alas son largas y agudas, con la segunda rémige mas prolongada que las oiras; la cola, larga támbien. puntinguda y cuneiforme, se estrecha gradualmente hácia la punta; las plumas exteriores no llegan ni s la mitad de la longitud de las del centro. El plumaje es recio, predominando el color verde aceituna oscuro; el borde de la frente, las pitumas de la cera y los estrechos circulos oculares son de un rojo purpúreo cobrizo oscuro; las plumas del centro del vientre tienen un lustre de igual color y for man una mancha poco marcada: las plumas de la parte superior de la cabeza presentan una ancha faja uegra en la extremidad; las rémiges de la mano y las tectrices son de un verde azulado por fuera, bordendas de negro en los lados y con la cxtremidad negruzca; las mayores tectrices inferiores de las alas y la cara inferior de las rémiges tienen un tinte gris negruzco, con el horde de has barbas interiores amari. llento aceitunado pilido; las rectrices son de color rojo pur. pureo de cobre oscuro. Eil iris es amarillo de oro: el pico y los piés de un gris azulado. El plumaje de la hembra, mas pálido, tiene la mancha rojiza del vientre mas pequeña. Con bastante frecuencia se encuentra todavia una variedad amarilla llamada por los chilenos rey de choray. La longitud del ave es de $0^{\mathrm{m}}, 3 \mathrm{3}$, las alas nuiden $\left(1^{\mathrm{m}}, 20\right.$ y la cola $0^{\circ}, 17$; este es el mismo tamaño de la marica.

Distribucion GEOGRÁficA.-El cnicognato leptorinco es uno de los tres loros que habitan en Chile, extiéndese por el pais y hảcia el sur hasta el estrecho de Maga. llanes y encuéntrase iambicn en Chiloc.

USOS, COSTUMBRES Y REGIMEN.-Poco se ha dicho hasta ahora sobre el género de vida de esta ave en libertad, pero to bastante para salser qué uso hace de su ex. trano pico. Sobre este particular tenemos datos de Boeck, Gay y uiltimamente tambien de Iandbeck.

Fste loro es muy comun: se encucntran á menuclo bandadas de varios centenares de individuos que lanzan ruidosos gritos.

Es el are mas temible para los campos de trigo y de maiz, porque roba los granos.

Ni tampoco se contenta con esto, sino que saquea tambien los hwertos donde hav irtooles frutales y con preferencia los manzanos, cuyas pepitas le gusian mucho. No podemos adnirarnos por lo tanto de que los chilenos le odien y persigan con sania. I andabeli dice, que al contrario de otro loro de Chile, que practica en tierra agujeros de hasta tres metros de profundidad, el choroy hace su nido en los altos árboles de pellin. Bocel: asegura que los campesinos llevan los po. lluelos a la ciudad y que se crian facilmente. Su carne es muy dura.

CA UTIVIDAD. - Hacc poco tiempo que se recibe á menudo este loro vivo en Europa: yo mismo he tenido algunos y nunca he observado en elius costumbres ó particularidades cxtrañas, tal rez porque tenia los cautivos en una gran jaula comun donde podina ocultarse entre has otras ares. Muctrel me refiere lo siguiente: Hasta ahora habia hecho proco caso del choroy de nuestro jardin roolf́gico; su jaula estaba mal situada, y nunca veia en clla mas que diversos loros con cola uniforme; pero esto cambió cuando reciblencargo de dibujar el ave para la Vida de los arrimales, pues entonces me vi obligado a observarla minuciosamente. Al acercarme is su jaula separóse al punto de la vasija donde tiene el alimento y, me niró de hito è hito; cuando acerqué mi mano a la reja bajó el cuello, alargó horizontalmente la cabeza, erizó las plumas de la frente, de la nuca y de los hombros, clavó en mi su mirada, abrió el pico y precipitóse bruscamente sobre mi de. do, el cual retiré, como ja se comprenderá, lo mas pronto posible. Eil are volvió despues á ocupar su primera posicion, como si esperase oportunidad para renovar su ataque. A fin de hacer mas obsernaciones sobre este proceder extrano puse la mano en el lado opucsto de la jaula : el choroy se precipitó rápidanente sobre clla, volviendo a tomar la misma posicion; y al verme tocar de nuevo en el mismo sitio que la primera ver lanzósc hácia él como una exhalacion. En cada una de st:5 posiciones el are manifestaba la mayor excitacion, pareciendo verdaderamente furiosa cuando repartia picotazos á diestro y siniestro. Su cólera se acrecentó al fin de tal modo, 
que salto hasta la reja sin tomar las precauciones acostum. bradas por los loros, y hasta se caró una vez de la percha. Fin estos bruscos movimientos, que solo puedo comparar con los de un perro en extremo excitado, las alas guardaban la misma posicion; solo la coia manienia cl cguilibrio subiendo y bajando á cada movimiento, $\delta$ dando coletaros.

El choroy ha estado ya mas de medio año en el jardin zoológico, y de consiguiente no se puede suponer que su excitacion sea consecuencia de su estado salvaje ó de la falta de educacion. Sin embargo, nuy pronto se tranquilizó, pues no le habia dado motio para enfurecerse ni molestado en manera alguna, por lo cual me pareció mas extraña ia furia que mostrú al principio de verme. Cuando le alargué tranqui. lamente el lápiz cogióle presuroso. al parecer con ta intencion de reconocer la naturaleza del objeco. Los movimientos que a este efectó hizo con in cabera superan en agilidad a toda cuanto lie visto y recordánone mucho por cste concepto los hatrones y buhos. Vuclie da cabeza alicrnativamenté izquier da y derecha, con tania rapidez que apenas tiene tiempo de rór el óbjeto. Al fin halló el sitio por dorde concric; sujetó. le é intentó arrancarle de ni mano: un pequeno movimiento contrarió bastó jara que se enfureciese de nucro; y con pro vocadara tranuluilidad parecís esperar lan ocasiun para von. gnisc dé mi.

p.l choroy me parece un animal intrúdido y muv peligroso para encrnigos verdaderes Ia solura y agilidad de sus mo. vimientós, la rapiclea en sus resoluciones, y la seguridad con que se sirve de su arma toe admirarun tontu como me uivir tió su furor. En ningun ctro loro habia observido una maiig niỏad tan poco justiticala, y meros aun senejante manera de atacar; pues era la primera vez que vein i un ave de esta ćspecic descargar picotazos como bo hacia el choroys

\section{LAS COTORRAS-CONURUS}

CARACTERES. - I.as cotoras se distingucn por sii picn? muy corro, comprimiclo lateralmentc, y de longitud casi igual i. la altura; la arista, obtusa y estrecha, vicne un ligern surce. Los pies son rolustos; las piermas cortas; los dedos, regulares y provistos de fugrtes unias; las alas largas y agudas; la scgun da y iercera rémiges son las mas largas; ta cola, prolongada cuneitorme, se adelgaza gradualmente hácia la cxtremidad. Iil plumaje es recio, y en su color predomina el verde con los mas variados dibujos y inanchas.

DISTRIBUCION GEOGRÅFICA.-Este género, mas rico en especies que ningun otro, tiene sus representantes en América; su área de dispersion se extiende desde el estrecho de Magallanes hasta el $42^{\circ}$ de latitud norte; pero en la partc septentrional del continente no hay mas que una especie. In mayoria de las cotorras habitan en la parte central de la America del sur, sobre todo en los territorios bajos y humedos del Amaronas y en los inmediatus. Varias especies ocupan vastas regiones; otras, en cambio, parecen limitarse a parajes circunscritos.

USOS, COSTUMBRES Y RÉGIMEN.-Graciss á las excelentes obserraciones del principe de Wied, conocemos bastante bien el género de vida de las cotorras. En todas partes animan estos jreciosos loros los bosques con su pre. sencia, particularmente aquellos donde no ha penetrado aun el hombre: pero en la costa llegan hasta cerca de las vivien. das humanas. Cunnco no estan en celo, las cotorras forman bandadas bastante numerosas; si se las espanta, vuelan con ln rapidez de la flecha lanzando penetrantes gritos, y van a refugiarse en la copa de un árbol. Apenas raya la aurora, cuando se oye ya su voz penetrante y un poco ronca: despues de haber dado la señal de marcha con un grio de llamada, emprenden su vuelo y cren sobre la espesura, mas una rez. alli, se callan, aun cuando no permanecen iranquilas. Muy léjos de esto, se mueren sin cesar, trepan, suben, bajan de rama en rama ayudíndose con su pico; procuran no frotar la cola contra el árbol, y gracias á su color vêrde, escapan á ive. nudo à la vista del cazador. Cuando les amenaza un peligro permanecen silenciosas é inmóviles, y solo se las oye al volar: contriburen mucho a prestar animacion á los bosques, y á menudo es su roz el único rumor que hiere el oido del viajero. Donde las plantaciones están contiguas a los bosques que frecuentan, causan grandes destrozos y devastan los atrozales mas bien que los campos de maiz.

Despues del periodo del celo es cuando mas se dẹian ver en el lindero del bosque, acompainadas de sus hijuelos, álos que siguen alinentando aunque ya estén desarrollados com. pletamente.

Anidarn en los troncos de los árbules huecos, y ponen dos o tres hueros blancos: los hijuelos crecen sin tener nada que temer del liombre, porque es opinion general en el Brasil que las cotorras no se pueden domesticar, ni se consigue que ha. blen nunca ni resisten el cautiveric.

CAUtrvidad.- Hay á pesar de todo ciertas especies que son bastante apreciadas y sa conservan en las casas pmo. que tienen una indole muy pacifica. Segun dice Schomburghk, algunas especics san mul luscadas por los indins, y a clln se dube principalmen:e que se vean en sus puchlos bandadas numerosas de cotorras en estado de clomesticidad.

Los brinsileinos suelen atarlas á un palo, fijo por uno de sus cxiten:os en la pared exicrior de las casas.

No se persigue a estos animales para comer sú carne, porque son demasiado pequeños. Fl naturalista, que tienc otio objeto. los caza sin gran trabjo y maia con fiecuencia mu. chros de un tiro.

Muy á menudo se traen á Europa dirersis especies de co. torras. y muclios aficionados no admiten quie los brasilenos tengan razon en curnto al concepto que de ellas tienen.

\section{LA COTORRA DE LA CAROLINA-CONURUS CAROLINENSIS}

CARACTÉRES. - . 11 género cctorra pestencce el único loro que habita en la América del norte. Su longitud es de $0^{\circ}, 32$ por $0^{\circ}, 55$ de ancho; las alas miden $60^{\circ}, 18 \%$ la cola $6^{\circ}, 15$. El color predominante e's un bonito verde, mas oscuro en el loma y de viso amarillenio en la parte inferior; la frerate, las mejillas, el occipucio, los hombros y las rémiges son de co. lor rojizo anaranjado; la nuca de un amarillo puro de oro. las grandes tectrices de las alas, de color verde aceituna, tiener la punta amarillenta; las remiges son de un verde os. curn en las barbas exteriores y purpúreo en las inicriores; en la mitad de la baso de las últimas rémiges del brazo y de las plumas del hombro se observa una mezcla de verde pardusco nceitunndo; las plumas caudales son de un verde. oscuro, y azules cerca del tallo. Ia pripila es de un pardo gris; el pico blanquizco pálido, y los piés de un tinte amarillento de car. ne. la hembra se distingue por su color mas pálido: los pequeños son del tocio verdes, excepto la parte anterior de la cabera, que riene un tinte anaranjado.

DISTRIBUGION GEOGRAFICA. - Ia cotorra de la Carolina existe en la América del norte basta el $4^{\circ}$ de latitud, y parece poco sensible á las intemperies. Wilson asegura que le sorprendió mucho ver en el mes de febrero, en medio de una tempestad de nieve, una bandada de aquellas que rolaban chillando a lo largo del Ohio. Se encuentran estas cotorras algunas veces hasia mas alla del nortc, en los alrededores de Albany. 
Estas condiciones han cambiado nucho desce entonces. A udubon dice en su excelente obra, publicada en i $\$_{3} 1$, que el numero de cotorras de la Carolina disminuye rápidamen. te, y que spenas se encuentran en regiones donde hace veinticinco anos habiaban en grandes bandachas; anade que el citado ano apcras se vicron en las orillas del Mississippi la mitad de las que alli habitaban quince anos antes. Ia disminucion contirúa sin iregua. \& Todos los inviemos, dice Allen, cógense centerares de estas aves magnificas en la parte superior de las orillas del rio de San Juan, desde donde se envian á las ciudades del norte, y tambien los cazadores las matan a miles sin beneficio ninguro.s Teniendo en cucria cstas inútiles carnicerias, Boardman teme, y con ra. zon, que la cotorn de Carolina se extinguiri muy jronto completamente. Muchos cazadores matan de 40 a 50 indivi. duos con pocos tiros, solo por diverirse, recompensando la fidelidad de las aves con la muerte; inmolan una iras otra a las que acuden en busca de sus companerns, y asi extermi. nan toda la bandada. Sus invasiones en los campos excitan tambicn á los campesinos á perseguir á estas aves.

Así pues, no podemos extrañar que la cotorra de la Carclima haya desaparecido de vastos territorios de los Lstados

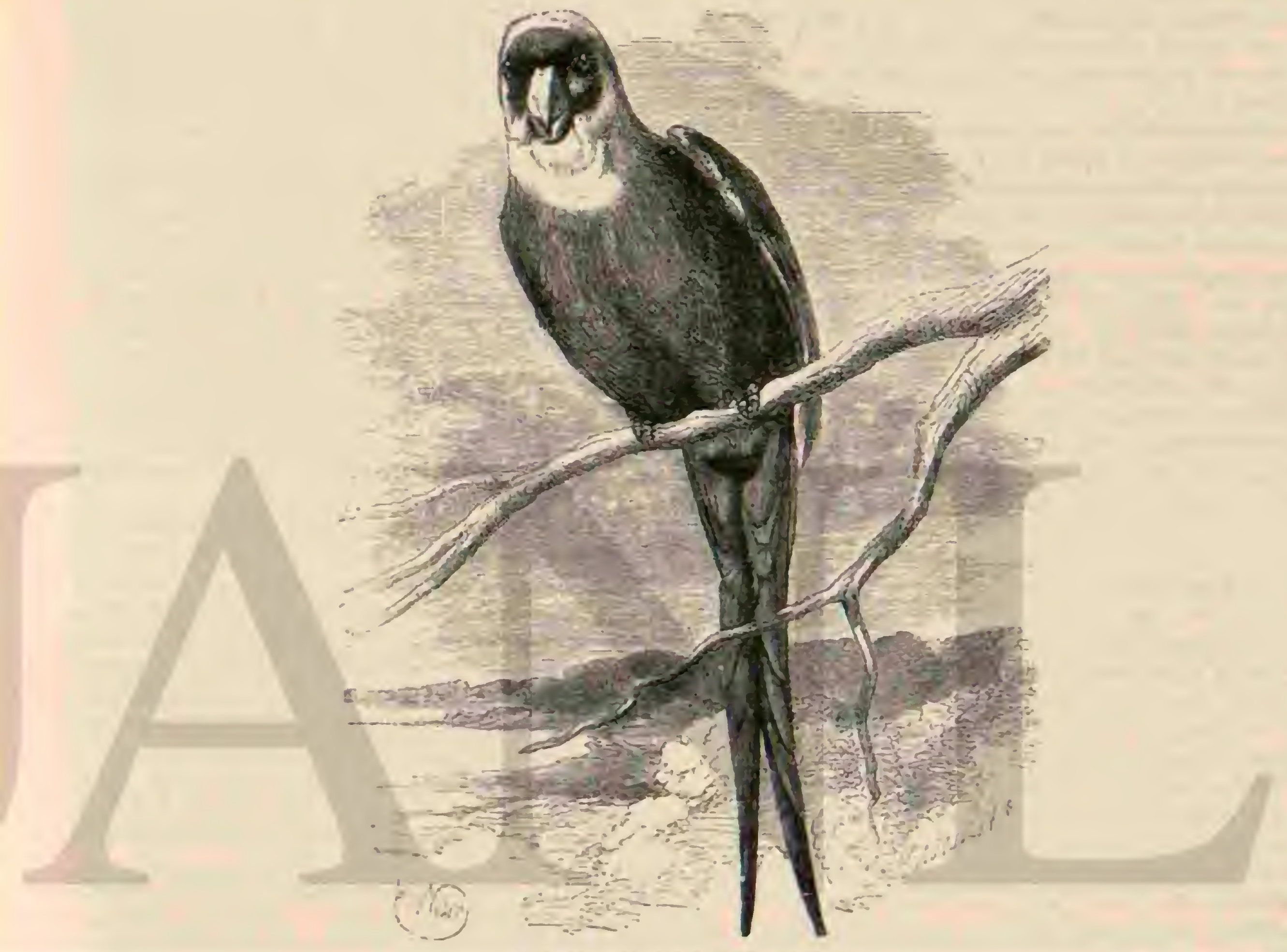

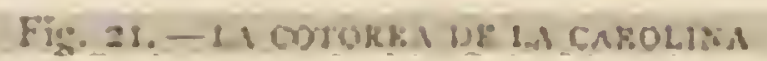

Unidos; el hecho indica con harta evideracia cuál es la suerte reservada al nve para el porvenir: no será otra sino su completo externinio. Sin embargo, aun hay regiones donde la cotoma de ia Carolina vive tranquilamente: encuéntrase todavia en Jorida, Illinois, Arcansas, Kansas, Nebraskia, Michigan y Missouri. Segun los datos recogidos por Hayden, se la re en los espesos bosques de las orillas del Missouri, haicia el norte, hasta el fucrte Leavenworth, y probablemente hasta la descmbocadura del rio Platte, á los $41^{\circ}$ latitud norte. Fire. cuenta los bosçues situados al rededor de los grandes rios de Inciana y de Texas, pero ja no se encuentra en el este de Kansas.

USOS, COSTUMBRES Y REGIMEN. - I.I cutorTa de la Carolina busca los sitios dorde la tierra firtil estra cubicrta de una yerba muy mala, á saber, in bardana rugcosa, cuyos frutos, aunque sijzados de largas espinas, le ofrecen abundante alimento. Invade tambien las plantaciones y ocasiona grandes daños, destruỵcrido mas de lo çue come.
Wiison, Audubon y el principe de Wied, nos han dado á conocer los usos y costumbres de esta especie.

la coiarn de la Carolina, dice Audubon, no se contenta solo con los írutos de la bardana rugosa: come de indos; y por eso es aborrecida en extremo de los planiadores, los campesinos y los jornaleros l.os campos de cercales son visitados a veces por estas aves, que ocupan completamente todo el terreno, pareciendo que se halle cubierto de una snagnifica alfombra; agrupanse alrededor de las gavillas, tiran de la paja, y echan a perder dos veces mas grano del que necesitan para hartare Cacus subre los manzanos y los ciruelos cuando los fruics estín verdes aun, y sacan las pepias: cal los jardines, donde se agrupan tambien por bandadas, destrozan todos los frutales solo para comerse las pepitas, blandas alin y lechosas; desprecian todo lo demás y no dejan un árbol hasta despojarle compleimenic. Los demàs productos de la tierm, si se exceptúa el mait, tampoco sc hallan al abrigo de sus ataques. Inútil parece decir que el plantador 
hace lo posióle para vengar la pérdida de sus cosechas, entablando contra las cotorras rerdaderas batallas: a veces caen de diez à veinte de un solo tiro; pero las demás vuelien al mismo sitio; asi he visio yo matar centenares de ellas en pccas horas. 8

L La cotorra de la Carolina, dice Wilson, es muy sociable, y se muestra sumamente carinosa con sus semejantes. Cuando se tira contra una banciada y se mata alguna, las demśs vuclven, rodean á la victima, lanzando gritos lastimeros, esfuérzanse por prestarle socorro y se posan en el arbol mas próximo. Si el cazador tira de nuevo no huycn; su abnegacion parece excitarse, por el contrario, y se accrcan cada vez mas álos individuos que sucumbictan. A rieces se disperisan las mismas pruebas de láecto que jos inscparables; se rascan, se limpian nutuamente; y las parcjas permanecen siempre unidas.

> Hificil seria hallar contraste mas notable que el que ofrece el vuelo ligero y rápido dé las cotorras de la Carolina y su marcha pesada por las ramas y mas aun por el suelo. Cuando vuelan ofrecen mucha analogia con las palomas: van en columna cerrada, y avanzan con la ligereza del viento lanzando gritos penetrantes: nor lo regular siguen la linca recta; pero a veces describen una ondulada, canibiando bruscamenic de direccion.

y Buscan ante todo los zrances sicomoros y los platanos, cuyos troncos huecos les ofrecen un asilo: freinta ó cuarenta individuos, y mas aun cuando hace frio, se introducen en el mismo escondrijo; suspéndense de la corteza con el pico, y se cosen con este órgano y las unas. Parece que disermen mucho, ó por lo meros, entran varias veces en su nido du. rante el dia, á fin de entregarse al sucno.

y Les gusta mucho la sal: se encuentran siempre numerosos individuos cerca de las salinas, donde cubren el terreno y los árboles, hasta el punto de que à veces no se ve mas que el verde brillanie de su plumaje.

Teniendo en cuenta el laudable celo de los naturalistas norte-americanos que se ocupan de la historia de las aves, 110 podremos menos de extrañar que no se liayan recogído aun ciatos suficientes sobre la reproducción de la cotorm de la Carolima Ridgway, refiriéndose cn este punto a las noticias de llilson y Audubon, dice qque ningun naturalista nore. americano cstá nejor instruido sobre el particular q̨ue los dos citados. Segun las averigunciones de Wilson, cl ave pone sus huevos como otras especies congéneres, en los huecos de los árboles, sin construir nido alguno. Varios observadores dicen que los huevos son blancos; otros aseguran que son moteados. Un aldeano afirmó á Wilson que habia encontrado en el hueco de un áriol cortado, los restos de mas de veinte huevos de loro puestos en un mido de ramaje. De todas estas noticias contrarias, Wilson cree poder deducir que varios loros incuban en un mismo nido; y. Iudubon apoya este aserto evidentemente erróneo. De sus areriguacioncs resulta que la cotorra pone sus dos huevos en el mismo hueco de árbol que la sirve para dormir. Audubon cree igualnzente que varias hembras depositan sus huevos en el mismo nido; pero esto no explica cómo se reproducen estas aves. Parece que para los naturalistas noric-americanos es muy dificil obtener hueros de csta are; asi lo prueba el hecho de que uno de los primeros conocedores en los Estados-Unidos preguntó a Nehrkorn, si no seria posible enviarle hueros de la cotorra de la Carolina, cautiva en Alemania. El Jardin roolúgico de Hannover pudo satisfacer los deseos del americano. De las noticias publicadas sobre la incubacion de la citada especie en el jardin zoológico de mi casa, resulta que en el mes de junio la hembra glone dos huevos en una cajita convenien. temente construida, y sobie fibras leñosas. Iil mayor diáme- tro de estos es de $0^{\circ}, 0,32, \mathrm{y}$ el menor de $0^{m}, 030$; de modo que tienen casi la forma estérica; son blancos como la nieve, muy brillantes, y segun aseguran algunos matumlistas expertos, difieren mucho de los de otros loros.

CAUTIVIDAD.-Sobre la vida en cautividad de la cotorra de la Carolina, Wilson nos da las siguientes noticias:

«Curioso por saber si estas cotorras se domestican fácil. mente, resolvi llevarme una que estaba ligeramente. herida en un ala; mandé construir una especic de jaula en la proa de mi barca y la alimenté con bardana. I.os primeros dias no hizo mas que comer, dormir y picar las varillas de su pri. sion.

- Al saltar á ticrma para recorrer el pais, llevaba nu cotorra en un pañuelo de seda, a pesar de todas las molestias que esto pudiera causarme, pues los caminos estaban muy malos entonces, y cra preciso atravesar à nado rios, torrentes y pantanos en una extension de varins millas. Muchas veces se me escapaba del bolsillo y me era preciso apearme para buscarla entre los árboles y las cañas; de modo qque en nas de uná ocasion esture á punto de abandonarla; pero persisti en mi designio. Cuando acampábamos por la noche en el bośque, dejábala sobre el equipaje, y à la mañana siguiente la lomabn de nuevo. Asi caminé mas de mil leguas, y al lle. gar al territorio de caza de los indios, rodekronme los Pie. les Rojas, hombres, mujeres y niños, los cuales se reian al fer mi extraño companero de viaje. Los chickasaws le lla. ninban en su lengua kilinky, pero cambiaron el calificativo cuándo me overon jronunciar el nombre de Pully. Mi coior. ta fuć mas tarde un medio para trabar amistad con aquellas tribus:

Xuanuo huve llegado a casa de mi amigo Dunbar, bus. qué una jaula y la puse á la puerta de casa. Bien pronto co. menzó a llamar á sus semejantes, y todos los dias rodeaban nuestra vivienda numerosas bandadas de cotorras que charlabar en su lenguaje con Polly. Pude coger una, que tam. bien estaba ligeramente herida en un ala, y la prodigó mil caricias con su pico. A los pocos dias murió ésta y Polly es. tuvo algun tiempo inconsolable; mas habiendo colocado un espejo en el sitio donde solia ponerse la cotorma muerta, Polly. róntempló su imágen y recobrb su alegria; estaba fuera de si de contento; y cra curioso ver cómo apoyaba la cabeza contra el espejo, manifestando su satisfaccion con penetrantes gritos.

No tardó en comprender sunombre, y respondia cuando la llamaban; se subia á mi espalda, colocábase en un hombro y tomaba el alimento de mi boca. Seguramente hubiera completado su educacion á no haber ocurrido un triste accidente: una mañana, cuando yu dormia aun, la pobre $P_{u} / l y$ quiso volar y se ahogó en el golfo de México. \$

Lil principe confirma en lo esencial la ciescripcion anterior. Encontró las aves junto al Mississijpịi en los mescs de prima. vera, muchas reces en bandadas inmensas, a pesar de la persecucion de los plantadores. En la parte mas baja de las orillas del Missouri se vieron tambien algunas; pero $\mathrm{cul}$ la superior no se encontró un solo individuo. Los indios de los alrededores del Fuerte Union llevaban pieles de esta cotorra como adorno para la cabeza.

Las cotorras que el principe de Wied trató de enscinar, co. mieran desde el primer dia 5 se domesticaron rápidamente. Al principio picaban con fuera à cualquiera que las tocase: pero bien pronto se acostumbraron is la socieciad de los hombres Una de ellas murió de una manera muy triste; co. gida en invierno, la puso en una habiracion abrigada; el calor de la chimenea, que buscó en seguida, fue causa de su perdida, determinando una inllamacion del cerebro a la cual su. cumbio. 
En los últimos anos llegaron á Europa tantas cotorras vi. vas de la Carolina que el precio bajó muy pronto á pocos francos. Desde entonces se ven individuos cautivos de esta especie en rodos los jardines zoológicos y en las jaulas de muchos afrcionados. Uno de estos, que escribe mucho pero sin sentido, dice que este loro es tonto y tinuido; pero con esto no prueba sino que le falta toda facultad de observar. Rey se ve obligaco a indicar algo en honor del ave. Hace ya muchos años, dice, que tengo junto à otros loros varias cutorras de la Carolina, las cuales a pesar de sus gritos y de ia costumbre de roer todos los marcos de las ventanns, se han granjeado de tal modo mi carino por otras cualidades, que nunca puedo resolverme d venderlas. $\mathrm{Al}$ poco tiempo se ha. hian acostumbrado ya tanto \& mi persona, que se posaban sobre mi cabeza ó nii mano cuando les ofrecia una nuez gue les gusta mucho. Si al coger el fruto le ocultabu del todo en la mano, las aves permanecian tranquilamente en su sitio; pero al romper la cascara sin dejarla ver acudian presurosas, atmidas por el ruido. Mas tarde, cuando las puse en una jaula, pude estudiar mejor aun sus superiores facultades in. telectuales. Una de sus malas costumures consistia en volcar la vasija del agua apcnas habian satisfecio su sed, 6 hacerla caer por la puertecilla de su jaula al suelo, manifestando el mayor contento cuando se rompia. Todos mis esiuenos para sujetar la rasjia fueron inutiles, pues gracias à su sagacidad, las cotorras comprendian muy pronto cómo podrian burlar mi prevision. Como no podia lograr ni propósito por el medio inciicado, mojaba á las ares con agua cada rez que las sorprendia infraganti. Ofrecian un aspecto por demds grotes. $\mathrm{co}$, cuando para ejecutar su fechoria abrian la puerta de su jaula; as este efecto una de las cotorras colocaba su pico como palanca por delsajo de la puertecilia; mientras que la otra suspendida del techo, sujetábala lasta que su compañera la levantaba lo suficiente para que la vasija pudiese pasar por la shertura. Despues alargaba cl cuello á fin de ver si go es. atba sentado á uri mesa, $y$ una vez convencida de que no obsernaba nada, acercaba cuidadosamente la snsija â la puerta y haciala caer si jo no lo evitaba al punto. Si no me opo. nia á su travesura, ó si me laallaba ausente cuando la ejecıtaban, dábanne á conocer que comprendian su falsa, aprenas me veian llegar.

Lo que mas me gusta en estos loros es la facilidad con que se acostumbran à entrar en la jaula y salir de clla. A veces ragan por el jardin desde las nueve de la mañana hasta el oscurecer, y solo se presentan alguna que otra ver, para descansar ó tomar alimento, en una ventana de mi habita. cion, donde he colocado una percha. Por lo comun vuelan muy poco, y sobre todo durante las horas del medio dia les gusta descansar. Por la manana hacen sus mas largas ex. pediciones, y al oscurecer cusando quicren dormir, acuden á la ventaha de mi cuarto, donde ya hace mucho tiempo está su jaula; si la encuentran cerrada, lanzan unos gritos verda. deramenic atronadores y golpean con su pico en los vidrios; pero si casuatmente no hay nadie y la ventana no se abre, tambien saben cmprender el camino por mi despacho y otras sarias habitaciones, hasta llegar a su dormitorio.

x.Su vuclo es ligero y gacioso. Muchas veces se precipitan casi verticalmente desde su percha of la calle; niras velan por encima de la veniana of se elevan sobre las casas mas altas describiendo anchos circulos, Cuando vuclan solo af corta distancia, aletean mucho; pero en sus grandes expediciones, gute a veces duran de veinte a veinticinco minutos, su suelo es rápido como el myo. Cuando pasan asi con una rapider increible por delante de la ventana y velven como Rechas por la opuesta esquina de la casa, 0 cuando se lanzan rerticalmente de arriba abajo en una pared, me recuerdan siempre el vuelo de nuestro halcon. Si son perseguidos porotras aves, las ahuyentan casi siempre precipitándose sobre ellas, como puscieran hacerlo unas rapaces. Riñen contusuamente con una especie de golondrina. Un gorrion, adnuirado cierto dia al ver aquellas aves abigarradas, siguio mucho tiempo s una: cuando podia, se le acercaba, $\delta$ bien fijaba en ella sus miradas con asumbro chando volvia a la ventana; repitió varias veces la misma operacion, sin notar que un ami. go mio y yo le observábamos desde la ventana.

r. Es natural quec el ruelo de estas aves llame tambien mu. clio la atencion del hombre. A pesar de que al principio se reunian unuchos curiosos delante de mi casa, no faltando el ruido consiguiente, nis aves continuaban iranquuilas sus ejercicios de vuelo sin lincer caso de la mulkitud.

Wl De todos los loros de cola larga que he tenido cautivos í obsersido en otras partes, la cosorra de la Carolina merece el primer lugar en cuanto á las facultades intelectuales. En mi opinion, es hasta superior por este concepto á muchos de los loros de cola corta nejor dotados. Verdad es que nunca se familiariza tanto conno los lóridos y cacatúidos; pues se muestra siempre desconfiado yobre todo muy prudente. Pero la designacion de sonfus y timsidos no se les puede aplicar de ningun modo.

Estoy bastante conforme con Rey en cuanto a su opinion respecto a la inteligencia de las cotorras de la Carolina. No he observado, sin embargo, las aves descritas; pero muchas reces he visto individuos en jaulas grandes $y$ pequeiras $y$ siemure lie encontrado que son uno de los mas astutos de todos los loros. No rabe duda para mi de que se domestican con el tiempo tanto como cualquiera especie de su órden. Es preciso un este caso tratarlas bicn.

\section{LOS PALEÓRNIDOS - PALEORNIS}

CARACTÉRES.-I - DOS paleúrnidos pueden considenrse como uno de los mas bonitos y graciosos loros. El género consta de diez y seis especies, cuyo tamaño varía desde el (iel mirlo hasta del estornino, que habitan principalmente en el Asia meridional, hallándose tambien algunas especies en Africa. Eil pico de los individuos de este género es relativa. mente muy robusto y ian largo como alto; la mandibula superior está dividida en forma de śngulo en la mitad de su base y presenta un ligero surco longituciinal: es ligernmente abovedada por todos lados y muy corra en la extremidad, junio á la'cual se ve una pequena sesgadura dentada; la mandibula inferior forma un ángulo ancho, redondeado en la bar. billa, af cuyolado hay casi siempre una pequenta prominen. cia á manera de iaja; los piés son cortos y robustos; las alas largas y puntiagudas; la segunda rémige sobresale de todas las demás; la cola, uniforme, se adelgaza gradualmente há. cia la punta y se compone de plunias de regular anchura redondcadas en su extremo; distingúcse casi siemure por sobresalir las dos rectrices del centro mucho de las otrns. El plumaje es bastante recio y predomina en ell un bonito rerde de hoja; solo la cabeza y un anillo al redcojor ciel cuello son abigarrados; en ambas mejillas hay una maucha negra. Los sexos no se distinguen, pero los pequeños difieren casi sien. pre de los aduitos.

Pocos géneros de laros tienen especies tan iguales en es. truciura y colores comolos paleórnidos. Parecen, si nsi puede decirse, como fundidos en un mismo moide, y hasta por lo que hace a la distribucion de sus colores podriamos decir lo mismo. En cuanio al género de vida, se asencja de aal modo, que los usns y costumbres del uno dan a conocer en lo esencial los del otro.

DISTRIBUCION GEOGRAFICA.—El áres de disguer. 
sion de los paleórnidos no es mucho mas extensa que la de las cotorras, pues habitan la mayor parte de la zona cilida de Africa y Asia, ó, para decirlo con mas precision, en todas las regiones del Africa desde el $6^{\prime \prime}$ y $17^{\circ}$ de latitud norte, ó sea descle la Senegambia hasta el mar Rojo, y en el Asia la ma. yor paric del continente meridional, esto es, desde ol Indo hasta el sur de la China y deste Cachemira y Ladak hasia Ceilan y las grandes islas de la So:uda. En el mediodia de la Arabia, en Persas y en el Belucichistan no se han observado hasti alıora; cn cambio, Armand David ha densosirado úlit. manente que todos tos veranos se presenta una especie en Chinn, donde peisetra hasia el $30^{\circ}$ de latitud norte. Otras tres habitan en Mludigascar yilas islas vecinas.

USOS, coSTUMBRES X REGIMEN. - IOS p.ácórnidos prefiéren las ragiones lianas y las momtanas de proca altura; en las üliunas suben, $2 !$ menos que se sepa hastano ho.

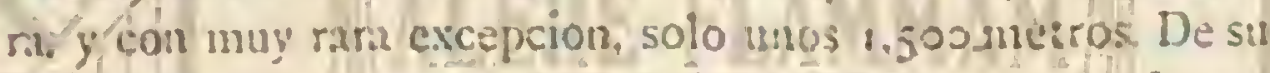
géturo de vida, arreglada, como la de la mayor parte da sus congeneres, puede iurnarse una idea si cunsideramus los usos frostumlres de cualquier especie. Jüra consaguirlo con has. tante exactitud, creo subi:iente publicar a continuacion las mobicins que Bernstein ha dadosubre el paleónnido de d!ejan aro: A D srante el dia, dice, el citado loro vecla por parejasó buifueños grupus por las huertas y bosques de su territorin: pero al declinar la tarde, iodos tos individuos de la espucic disentinados por los alrededores reínense en aigun ärtuol yrande y froadoso, ó tambien cnilis esjesiarss de baubues, donde jrasan comunmente la noche Aifuel citue conoce uno de cstos árboles, y se oculta al uscurecer cerca de él, puede observar un espectículo muy inceresnac. 11 pronerse el sol aciden poco a poco las ares en tochs las direcciones; tan luago como har llegado levantart alegremente su vo\% y cml. piezan una música en que van tomando parte todos los que llegan despues, causando al fin un ruido verdadornmente infernal que no cesa hasta que cicrra la noche. Entonces e! si lencio se hace getieral y sulo a intervalos se interrumpes estid quictud cusódú algun individuo ynte no ha cicontrado buses sitio para dornir se adita, jntentandu ocupar el pucsto de uno de sus companeros ya durmido. lin tal caso, coduśse enfidan corrigiento al perturbador con alyumes jucotazos. As conti. nuan hasil quic h uscuridad es completa. Con ol printer fulgor del alba se dispersa otra ve la handada para rolver de nuevo á la noche siguiente al misuro sitio.

> Durante el periudo del celo, los paleórnidos viven apa. reados, y entonces no se reunen por la noche en bundadas. Construgen sus nidos ea los huecos de los árboles sirviendose muy bien de su fuerte pico para ensancharlos.\$ I a hem bra pone tres ó cuatro hueros que probablemente cubren ambos seros. Los pequeños se desarroilan lentamente, y algun tiempo despues de salir del nido sus padres les enseñan lo necesario, hasta que al fin se conducen como ellos. Todas las especies son muy propias para la cautividad: por la belle. za de sus colores, sus excelentes facultades intelectuales y su familiaridad, son interesantes, y agradables aves para la jaula

\section{EL PALEORNIDO DE COLLAR - PALEORNIS} TORQUATUS

CONSIDERACIONES HISTÓRICAS. - Este loro, dice Plinio, es originario de la India, donde le llaman asis tace. Imia la voz humana, pronuncia írases, saluda al cmperador y aprende las palabras que oye Su cabeza es tan dura como su pico. Para enseñarle s hablar le pegan con una varita de hierro en dicha parte, pues con otro instrumento mas blando no sentiria los golpes. Al bajar al suelo se apoja sobre el pico en ver. de hacerlo con los jies, y aunque se valga de estos, siempre basca un sosten, porque sus piernas son demasiado débiles.

Otros datos del mismo naturalista confirman que las ante. riores palabras se refieren al paleórnido de collar. Desde los tiempos mas remotos esta ave se habia granjeado ya cl carino de todos los aficionados a animales, y aun en la Ldad media se le tenia con preícrencia en las jaulas, consideríndole como objeto muy precioso. Onesicrito, general de Alejandro d Cirnde, le llevó a Grecia despues de su expedicion à la Indin; los romanos le encontraron mas tarde cerca de Tergedum, junto á la parte media del Nilo. Diodoro de Sicilia habla de él como de un loro que se encuentra en los conlines mas lejaruis do los Sirin.

CARACTERES. - Lil palcórnido de collar, el figra ó fir de los bengaleses. el gallar leihar, ragu y kara de otras tribus

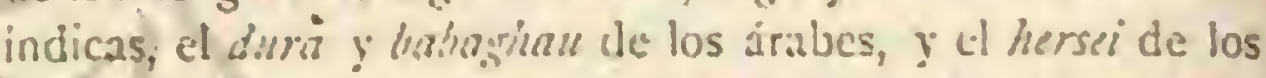
abisinios, es un ave tan graciosa como delicada, y de colores muy ayradables. Es una de las especies de tanano regular de su género; la longitud to:al del macio varia de $1{ }^{\prime \prime}, 3 j$ 1:0",40, la cola mide $1-, 25$ y las alas, ciesde la articulaciun lísta la pumta, solo $1^{*}, 15$. Fil color del plumaje es generalmente un verde de yerba m my vivo con un ligero lustre ama. rillentó en la coronilla, pálido en las partes inferiores y oscuro en lins réniges. Ambos lados del cucllo $y$ la region de las meiillas son de un delicado lila ó azul ccleste; en la garganta so ve una faja negra, y junto à esta otra de un magnilico color rosia

Ins extrimidades de las pennas caudales son de un azul celeste; Ia cara inferior de las alas y de la cola, de un verde amarillento: el pico de un rojo vivo, mas useuro en la punia dóla mandibula superior; las patas grises, y el iris blanco ámarlliento fus anillos de los ojos estrechn' y rojos Ambos siexos $110 \mathrm{se}$ distinguen en el color (iig. 22\%. En los pequenos ol phimaje es verde, menos brillnnte antes de la :muda, y mas chro que el de los individuas que le han cambiado ya.

DISTRIBUCION GEOGRAFICA. - El paleórnido de collar és de iodas las cspecies de su género la que esta mas diseminada, puss ianto se le encuenira en el Asia meridional como en Africa. Cierro que los individuos africaros ditieren de los demás por ser algo mas pequeños, por su color verde anarillento, por la major anchura de la faja de las mejillas, por tener el collar de la nuca cortado en el centro, y en el occipucio un brillo azul; pero todas estas diferencias no pa. recen suficiuntes para justificar la separacion en dos especies, y los naturalistas están contormes en que el paleórnidu de co. llar indio y el africano deben considerarse como una sola. Aun. que sea asi, cebe tomarse sin cmbargo en consideracion que el género de vida de los de la India es tan diferente del de los de Africa como puede serio entre los paleórnidos en general. Tal vez. se deban a las particularidades de anbos territorios estas variaciones, en cuyo caso tendriamos un ejemplo ins. iructivo para la suposicion de que una misma are pueda tener otro género de vida cuando cambian las circunstancias. El paleórnido de collar habita en Asia, la peninsula indica, desde Bengala hasta Nepal y Cachemira, y desde el Indo hasia Tenasserim ó Pegu y la isla de Ceilan. I a roticia de Chesney de que sambien se encuentra en Siria, donde es frecuente durante el verano, está conforme con la de Diodoro Siculo; pero es dudosa, porque ningun otro viajero hace. mencion de un loro que habie tegiones tan sepientrionales. Probablemente serí el Himalaya la frontera septentrional de su área de dispersion. En las islas Andaman fueron expuestas por Tyeler varias parejas poco antes del año $15 ; 0, y$ tal vex se aclimataran alli, como lo han hecho algunos individuos escapados de los alrededores de la ciudad del Cabo, donde actualmente crian. 
En Africa se halla diseminada ia especie desde el 17 hasta el So de latitud norte, en todos los paises del interior. Parece que en el Africa occidental se la ve tambien en la costa; en el norte de este continente la encontré mas al sur del $15^{\circ}$ de latitud norte, en los puntos de la costa de Abisinia visitados por mí

USOS, COSTUMBRES Y REGIMEN.-Dentro del área de dispersion indica este loro es una de las aves mas comunes del pais, donde frecuenta, sobre todo, las llanuras. Segun Blyth prefiere las regiones cultivadas a todas las demâs, y es por consiguiente el único loro ínaico que busca la vecindad del hombre No solo fabrica su nido en jardines y liuertas ó en los árboles que prestan sombra a los caminos y a las calles, sino tambien en los huecos convenientes de los grandes edificios, en los agujeros de paredes y en las grietas. En algunas partes vive léjos de todo bosqque, contentándose con las pocos árboles que el ciudadiano ó campesino plantó para tener frutas y sombra. Fn muchas ciudades de la India se le ve posado en las cimas de los techos como entre nos. otros la monédula; en otras se observa que clige los árboles del mercado como sitio de reunion, al cual vuelven todas las noches sin hacer caso del bullicio de la gente: la descripcion de Layard mas arriba citada se refiere á esta ave. Fin tales circunstancias es preciso que en todas partes cause muchos perjuicios, y solo à la benevolencia con que los indios tratan i los animales en general se puede atribuir que no se le per. siga con tanto encarniramiento como of la cotorra de la Ca. rolina. Saquea los árboles írutales y devasta los campos: coge los frutos sin madurar: arranca el trigo de las espigas antes que adruieran su color de oro, $y$ cuando los cereales han sido ya recolectados, busca en los camnos, i la manera de los palomos, los granos perdidos, ó, imitando da la cotorra de la Carolina, invade los pajares para apoderarse de las es. pigas. Considerables bandadas emprenden á veces expedi. ciones de merodeo a grandes distancias, y cuando semejante legion descubre un árbol frutal, es bien seguro que no pasaró de largo; léjos de esto, describen anchos circulos sobre la copa, y precipitandose despues sobre las frutas despójanle al poco rato. En algunas regiones se reune tambien con otros congéneres y vaga con ellos por el pais.

Como ya hemos dicho, el género de vida de esta especie no es el mismo en Africa; aqui habita, descie la costa occi. dental hasia la parte oriental de la montaia de Abisinia, to. dos los bosques convenientes. No vive siempre en las selvas virgenes que sin interrupcion cubren todos los paises bajos del Africa central, sino que frecuenta tambien los bosques mas circunscritos cuando estos contienen algunos árboles siempre verdes, que ofrecen abrigo en todas las estaciones del año. Extraño me pareció en mi viaje por la Abisinia encontrarle solitario alli donde habia monos. Despues de repe. tidas observaciones nos convencimos al fin de que veriamos estas aves en el mismo territorio donde se hallamn cuadru. manos $y$ vice.versa. Ias grandes selvas que sin interrupcion se cxtienden por los valles cruzados por abundanies corrientes ofrecen a ambas especies de animales cuanto pucden ape. tecer.

Dificil seria para el viajero en aquellas regiones no hacer aprecio de los paleórnidos de collar, pues sus gritos estridentes dominan los mil rumores del bosqque, en razon tambien á que forman siempre numerosas bandadas.

Úna de cstas se fija en un bosquecillo de tamarindos, ó de otros airboles de espeso follaje, y sale de alli todos los dias para recorret su dominio. Yor la mainana están aun bas tante tranq̨uilos, mas apenas sale el sol, emprenden sur ruelo gritando, y se ven las bandadas que amviesan el bosque para ir en busca de alimento. Ias selvas de Africa son poToro III
Ures en irboles frutales; pero las plantas que crecen i la sombra de los grandes árboles contienen abundantes granos, que caen y son recogidos por los paleornis. Solo cuando los pequeños frutos redondos del azufaifo alcanzan toda su ma-

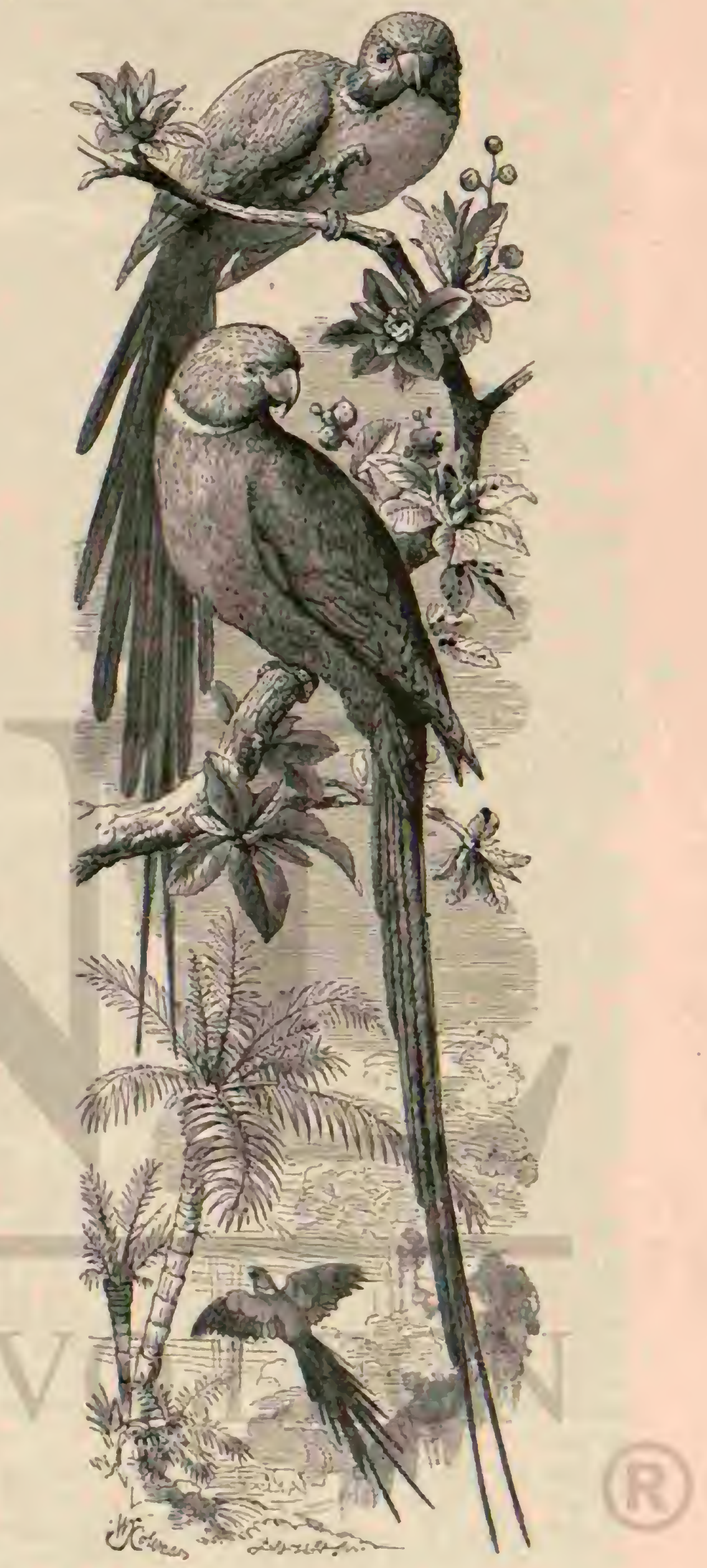

$$
\text { Fig. 12.-Ki. 1'allorsís DE. comax }
$$

dure?, j caen las cáscaras del tamarindo, dejan estos loros de bajar á tiern Es probable que parte de su régimen sea ambien animal; al menos, yo los he visto á menudo ocupa. dos en destruir los nidos de hormigas, of de térmites, y he observado asimismo paleornis cautivos, que eran muy aficio. nados ì la carne. Rara vez se les sorprende en los campos que rodean los bosqques. Aunqque se mantienen iácilmente los 
paleornis cautiros con cereales del pais, parece que prefieren los frutos del bosque.

Hácia la hora del medio dia van á beber, y luego se posan en un árbol para descansar algunas horas: aquel es el momento que destinan a charlar y gritar, y entonces se puede advertir la presencia de una bandada; pero es dificil verla, porque esta oculta en medio del follaje, cuyo tinte se armo niza perfectamente con el de la pluma de aquellos.

Lo que el principe de Wied dice acerca de los loros del sur de América puede aplicarse tambien á estos paleórnidos; se necesita una vista muy perspicaz para distinguir á las verdes ares en el follaje.

Apenas observan, los paleornís algo sospechoso, guardan silencio, ó se aleján prudentemente sin hacer el menor ruido si temen que sé les persiga. Si se detiencel viajero al pié de un árbol, del que partian centenares de voces, todo queda silencióso al monsento, $y$ bien pronto desaparece hasta el último paleornis: todos se van uno tras otro para situarse en un árbol mas lejano, donde se ojen á poco sus gritos de triunfo.

Despues de haber descansado van estos loros á comer y beber por segunda ver; llegada la tarde, reunense en sus árboles favoritos, se acomodan lo mejor posible y grian mas que en todo el dia. En la primavicr, cuando la selva virgen se ostenta én todo su inágico esplendor, refígranse los paleornis en los troncos liuecos; durante la seçuia deben dorinir en las ramas de los árboles verdes, pues los agujeros no son suficientes para que se-alberguen todos los individuos, y lós árboles despajados de su follaje no les ofrecen un abrigo bastante seguro, En tales ocasiones es cuando arman ruidosa griteria y empenadas contiendas, mas animadas que en época otra alguna.

Los paleornis vuclan con rapidez, pero su marcha por el suelo es lenta y pesada, y con dificultad trepan a los arbo. les. Tambien el vuelo debe ser muy iatigoso para ellos, pues aletcan mucho, y se balancean ligeramente cuando quicren bajar. Iamás se remonta por los aires el paleornis pará reto. zar, como hacen otras aves; solo vuela cuando suiere trasladarse de un jumto á otro, y se detiene apenas ha llegado. Su marcha, si tal puede llamarse, consiste en una especie de bamboleo torye y pesado; el loro arrastra penosamente su cuerpo, lesintando la cola para impedir que toguce al suclo, ofreciendo un aspecto grotesco.

Yerdon dice que el paleórnido de collar incuba en la India, desde el mes de enero hasta marzo; en el Africa central el periodo del celo se declara en la estacion lluviosa. Como ya he dicho, no solo los árboles, sina tambien toda clase de huecos, sobre todo los de diversos edificios, sirven alli para fabricar el nido; la especie de Africa anida exclusivamente en los troncos. Despues de la primera lluvia, la gigantesca adansonia se teviste de un espeso follaje y todos los huecos quedan ocultos del modo mas conveniente. Aquí construyen las parejas su nido, y segun me han asegurado, reuinense tambien bandadas cugas parejas viven en la mejor inteligen. cia despues de algunas riñas. La hembra pone de tres a cua tro huevos del todo blancos y algo brillantes, cuyo nayyor diámetro es de $1^{\prime \prime}, 028$ y el menor de $\theta^{\circ}, 022$. En Africa se ven ya á fines de la estacion lluviosa los adultos con sus pequenos, y estas familias se reunen pronto, formando considerables bandadas. Segun las observaciones hechas en individuos cau. tivos, los pequenos necesitan al menos tres años para adquirir el pelaje de los adultos, sobre todo el característico collar rojo. A pesar de sus buenas armas, los paleórnidos de collar sufren mucha persecucion de las grandes ares de rapiña, y se. gun aseguran algunos observadores indios, sirven de presa á las menos ágiles.
Philipps dice que el milano de aquellas regiones se preci. pita á veces sobre ellos cuando están posados en los árboles, y se apodern siempre de alguno; y que tambien los grandes buhos los atacan. Anderson, por el contrario, asegura que el halcon de Schahin (Fralo peregrimafor) es uno de sus ene. migos mas peligrosos «Reducidas bandadas de palcórnidos, dice el citado viajero, se dirigian rápidamente, unas en pos de otras, al lugar de reposo, cuando súbitamente tuve el gus. to de ver a uno de los citados halcones precipitarse sobre uno de aquellos grupos, pasando á corta distancia de la ca. beza de mi caballo. 'Tres reces repitió su ataque y cada una de ellas se comprimian los loros esplantados, y cayeron al campo por donde yo pasaba. Cuando volvieron á elevarsé, el balcon redobló sus esfuerzos, pero faltó otra vez, y poniéndo. se al fin en un árbol, lo maté. En el Africa no he visto tales ataques, pero no abrigo la menor duda de que los halcones de cste jais atacan tambien á los palcórnidos de collar.

CA\%A.- En las partes del Africa que yo he recorrido, el europeo que colecciona es el único que caza el paleornis de collar con arma de fuego. Los indigenas no se toman este trabajo; si alguna vez cogen algunos vivos es porque tienen seguridad de venderlos. Por mucho que abunden estos loros no es fácil tirarles, pues su astucia deja burlado al mas dies. tro cazador, si bien he sabido yo utilizarme de su misma desconfianza para matarlos con mas facilidad. Cuando divisaba una bandada de palcornis, apostábame en el árbol mas próximo y espeso, y enviaba á uno de mis compañeros para que amenazase el árbol donde se habia situado aquella: los loros volaban hácia mi, y podia entonces timr con seguridad.

En el Africa central no se emplea ningun procedimiento particular para cazarlos: se cogen fícilmente los pequeños, y î veces se consigue sorprender á un individuo vicjo en su nido. Jamás se usan las redes, aunque son muy conocidas de los indigenas.

En el Senegal está, por el contrario, tan regularizada la caza, que puede decirse que de alli procedén la mayor parte de los que remos en Europa. Es de creer, por otraparte, que abunden mucho y sea f́cil apoderarse de ellos, porque los que se traen á nuestros paises no alcanzan un precio muy elcrádo.

CaUtividaD.-He tenido bastantes veces durante mi estancia en el Africa paleornis cautivos, $y$ nunca he quedado satisfecho de ellos: en cierta ocasion reuni hasta diez y ocho, à los cuales daba toda la libertad posible, dejándolos én una gran habitacion; los alimentaba bien y hasta abrigué la espe. ranza de conscrvarlos todos, mas no se realizó mi desco, pues pronto se lanzaron unos contra otros, y los mas fuertes mataron à los mas débiles. Abrianles el cráneo y se comian el cerebro, como lo hacen los paros carboneros.

Posteriormente, reconociendo en elios mejores cualidades, les cobré cariño. Por timidos $y$ ariscos que sean los pequeños, mas tarde se amansan y dulcifican cuando se les cuida y están aislados en una jaula. Tambien pierden la costumbre de gritar y aprenden sin gran dificultad á pronunciar palabras, cumpliendo asi con todo lo que puede exigirse de un loro cautivo. Mucho mas bonitos parecen sin embargo en medio de un gran numero de loros. Aqui se aparean muy pronto y entonces granjéase la pareja el carino de todo el inundo. El macho colma a la hembra de todas esas caricias que los lo. ros se prodigan; la besa, la ofrece de comer, la rasca en el plumaje y abrázala verdaderamente; despues entreabre las alas y desplicga la cola, ofreciendo entonces la imaigen del águila heráldica; los celos le inducen á rechazar à los otros loros; y vigila continuamente, sobre todo delante de la entrada del nido, el cual arregla pronto convenientemente. Es muy curioso ver cómo trabaja la hemóra en la cajita y de qué 
modo la llama el macho dando golpecitos con el pico sobre la madera; la hembra saca la cabeza por la entrada, déjase acariciar un momento y ruelve á retirarse, mientras su com. pañero continúa vigilando. Los paleórnidos de collar, cauzivos, no han incubado hasta ahora en ninguna parte, al menos que yo sepa; pero no cabe duda que lo harain cuando se reunan todas las condiciones necesarias para ello.

\section{LOS BROTOQUÉRIDOS-BROTO- QUERYS}

CARACTERES.-Los brotoquéridos, ó loros de pico estrecho, constituyen un genero que solo comprende diez. es. pecies: sus representantes son loros pequeños de cola corta, cuyo tamaño varía entre el del estornino y el de la monédu. la; el pico es delgado; bastante largo, comprimido lateralmen. te, anguloso en la arista y prolongado en una punta muy encorvada hácia abajo; la mandibula superior ticne una profunda sesgadura junto à su extremidad; la inferior es propos. cionalmente estrecha; los piés son bastante endebles; las piernas cortas; las alas largas y puntiagudas; la segunda ré mige es la mas larga; la punta de las alas tiene una longitud regular, asi como la cola; esta última es uniforme, con las plumas del centro un poco salientes y las exteriores mas cortas. El plumaje es suave y de color verde; en la barba hay una mancha de un tinte amarillo anaranjado; las tectrices de las alas son amarillas.

DISTRIBUCION GEOGRAFICA.-Todas las especics hasta ahora conocidas viven en la América del sur; estàn diseminadas con bastante regularidad tanto por el este como por el sur $\mathrm{y}$ el norte, descle el Paraguay hasta Honduras.

USOS Y COSTUMBRES.- El género de vida de las especies es tan anảlogo, que nos bastark describir por este concepto una sola de ellas.

\section{EL BROTOQUERIDO TIRIKA - BROTOQUE- RYS TIRICA}

CARACTÉRES.-Esta especie pertenece a las mayores del género; su color es un bonito verde, algo oscuro cn la parte superior, y mas claro en la frente, en las mejillas y en la parte inferior del cuerpo; las tectrices tienen un tinte amarillento; no existe la mancha de color anaranjado de la barba. Lass tectrices son de un bonito azul oscuro; las rémi. ges bordeadas de negro en las barbas interiores, tienen un matiz verde oscuro en la cam inferior y azul a lo largo del tallo. Ios ojos son de un pardo gris; el pico de color de carne rojizo claro; la cera biancjuizca, y los piés de un pardo claro. La hembra se distingue por su color mas pálido y los pequeños por un color verde gris y por faltarles la mancha azul die las alas.

DISTRIBUCION GEOGRÁFICA.-F! tirika secncuen. tra en la mayor parte oriental de la América del sur, habita todas las selvas de la costa del Brasil y hállase tambien en los bosques de la Guayana.

USOS, COSTUMBRES Y REGIMEN.-El tiriks es uno de los loros mas comunes en el Brasil oriental; vive en bandadas muy numerosas y reúnese a veces con yequeños loros de cola cuneiforme. Vuela con la mpidez de ia necria. desde un extremo del bosque al otro, ó a travies de los cam. jos, dejando oir su agudo grito con mucha frecuencia; cuan. do se reunen en numerosas bandadas producen un ruido verdaderamente infernal. El tirika es un huéspeci temible para las plantaciones de atroz y de maiz, á causa de los graves perjuicios que ocasiona y pro eso le persiguen con tanto en. carnizamiento los campesinos; como es poco-timido, se le mata fácilmente y a menudo pierde la libertad por su caríc. ter carinoso. Se cogen nuchos individuos con el auxilio de un ave que sirve de reclamo, ó bien con liga, y acostúmbrase a guardarlos en jaulas porque los tirikas son muy apreciados de los bmsileños a causa de su carácter dócil y la facilidad con que se domestican; por lo regular se les tiene sujetos con una cadenita en una percha colocada en la pared exterior de la habitacion.

CAUTIVIDAD.- Los tirikas suelen llegar cautivos a Europa, donde tienen muchos aficionados y amigos; y segun mis observaciones, no sin razon. Son ágiles, alegres, gracio. sos, astutos y yoco exigentes; familiarizanse pronto y no des. cansan desde la mañana hasta la noche. Dadas estas excelen. tes cualidades, natural es que los aficionados se complarcan en tenerlos como adomo en sus jaulas. Sus movimientos son rápidos y ágiles; corren con paso corto, pero con una ligereza que admira cuando se rellexiona que son loros; trepan muy fácilmente y vuelan tambien en un espacio pequeño con sin. gular destreza. Se ha observado que viven en la mejor inteli. gencia con aves de las mas distinias especies, y parece que no tienen el carácter pendenciero de otros loros. Son mus poco exigentes en cuanto al alimento y soportan la cautividad hasta en parajes frios.

Ros tirikas y todos los broinquéridos en general, me es. cribe von Schlechtendal, se distingren por la viveza de sus movimientos; hacen mucho ruido, y sobre todo lanzan gritos ierribles cuando se hallan excitados. Con la misma ligereza con que trepan por las perchas de su jaula suben y bajan tambien por la reja; s apenas ven gue me acerco a la jaula con algunas espigas verdes de avena, salúdanme con sus gritos. Al que sea rnuy delicado de oido no le recomendare los brotoquériclos para tencrlos en su habitacion. Aunque los gritos no son tan chillones como los de los sitículos y de va. rias especies de cotorras, producen sin embargo bastante rui. do, sobre todo cuando se reunen algunos individuos. Por otra parte, una coleccion de estas ares en una jaula espaciosa es muchn mas agradable que una pareja sola; y segun mis ob. servaciones, se pueden tener muy bien juntos con las especies pequenans de cotorras. Prescindiendo del ruido que producen, los tirikas tienen muy buenas cualidades; y por sus pocas exigencias soll tambien recomendables para las nersonas inexpertas en aves. Jos conamones, avena mojada, simientes de girasol, trigo medio maduro, maiz, y tambien frutas y bayas sobre todo las del fresno, constituyen el régrimen alimenticio, con el cual se pueden conservar nuchos anos en cautividad. Al principio muestranse por lo regular un poco timidos y asustadizos, sin duda por el mal trato dumnte el viaje; pero cuando se repanen merecen todos los clogios que los aficiomados a las aves les dispensan.

\section{LOS BOLBORINCOS - BOLBO- RHYNCHUS}

CARACTÉRES. - 1.os bolborincos ó loros de pico grmeso son especies cuyo tamaño varia entre el del estornino y el de la monidula; distinguense por la mandibula superior muy fuerte, corta, muy redondeada $y$ ensanchada lateralmente, con punta corta, ancha yo obtusa junto á la cual se ve una ligera sesgadura dentada; Ia mandibula iuferior es alta, ancha y re. dondenda en el ángulo de la barbilla y ligeramente ericos. vada junto á in extremidad; las jiernas son cortas y robus. tas; las alas largas, las tres rémiges primarias, casi iguales entre si, sobresalen de las demás; todas ellas se adelgazan hócia la punıa; la cola es cunciforme y obtusa en la extremi. dad; cl plumaje suave, y su color poco vivo.

DISTRIBUCION GEOGRÄFICA.- Estas especies ha: 
bitan con preferencia en los países de la parte occidental, meridional y ceniral de la América del sur, sobre todo en los Estados de la Plata, en el Paraguay, Uruguay, Bolivia y el Perí.

USOS Y COSTUMBRES. - Los bolborincos difieren por muchos conceptos de todos los demás loros sitacinos y hasta de todos los loros en general; pero en particular por la ma. nera extmina de fabricar sus nidos.

\section{ELBOLBORINCO CALITA-BOLBORHYACHUS} MONACHUS

CARACTÉRES. - La especie mas conocida del género es el loro murje de los alemanes, la ritorra y ralita de los sudamericanos. Esta ave tiene 0,27 de longitud; las alas miden $0^{\mathrm{m}}, 15$ y la cola 0,12 . Fn el plumaje predomina el color verde; el de la region de la nuca es pardusco de aceituna pálido, con mezcla de gris; láfrente, la parte anterior de la cabeza, la linea naso-ocular, las mejillas, el cuello y el pecho de un gris claro; las plumas del buche parduscas, onduladas con estrechos bordes de color gris pálido en sus extremida. des; la parte inferiar del pecho y el vientre son de un gris claro; el bajo vientre, los muslos, la region del ano y las tec. trices inferiores de la cola de color verde amarillo; las rémiges y la punta de las alas son de un azul ináigo, verdes por fuera, y con un ancho borde negruzco interiormente; las tectrices y las rémiges del brazo, ercepto la última, que es verde, tienen un tinte azul de índigo mas oscuro. Ia cara inferior de todas las rémiges presenta un azul de mar oscuro con mezcla de verde, $y$ del mismo color son las grandes tec trices de las alas, mientras que las pequenias de la misma re. gion son verdes; las plumas caudales, en fin, son de un rerde claro én la cara inferior, y azul de mar verdusco por dentro, con un borde verde amarillo. El iris es pardo; el pico gris amarillento, y los piés de un gris pardusco. Los sexos no se distinguen, ni tampoco los pequeños, que desde un principio tienen casi el plumaje de los padres.

DISTRIBUCION GEOGRÁFICA.-Parece que el área de dispersion del bolborinco calita tiene su centró en los Estados de la Plata, extendiéndose desde aqui, por el Paraguay, el Uruguay, la República Argentina, Bolivia; y guizás tambien por la parte sudoeste del Brasil y el oeste, hasta Matto Grosso.

USOS, COSTUMBRES Y REGIMEN. - Carecemos aun de noticias exactas sobre el géncro de vida en libertad de estas especies; pero de la incubacion sabemos mas que de otros muchos loros de las regiones mas conocidas de la América del sur. De los pocos datos obtenidos de los viaje. ros, sobre todo de Rengger y Darwiu, resulta que el calita es en el Paraguay y en la Banda Oriental una de las ares mas comunes; fuera del periodo del celo recorre el pais en bandadas de 50 á 200 individuos, que ocasionan muchos destrozos en los campos de trigo y sobre todo de maiz, por lo cual se hacen objeto de una persecucion mas encarniza. da Rengger describe estos loros diciendo que son tan numerosos é insolentes, que á pesar de haber vigilantes que durante todo el dia recorren los canjpos, no es posible ahuyentarlos del todo. Empléanse toda clase de medios para librarse de estos voraces ladrones alados; aplatase á todos los medios imaginables y se coge un numero asombroso de individuos, los cuales se venden á razon de un tanto por cada docena de cabezas. A Darwin le dijeron que solo en un ano se habian cogido cerca de la Colonia del Sacramento, junto al rio de la Plata, nada menos que 2,500 individuos.

El bolborinco calita es el único loro que fabrica grandes nidos en los árboles. Ia primera noticia que sobre estos tu- vimos procedia de Azara, el cual dice que los nidos son muy grandes, muchas reces de mas de un metro de diámetro, que están cubicrtos por arriba, y tapizados interiormente con yerbas. Añade que en un árbol se encuentran varios, y que algunas hembras hacen uso del mismo nido. Este relato del concienzudo viajero fué para algunos naturalistas tan sorprendente, que se crejeron con derecho para dudar de él; pero otros viajeros confirman en un todo lo dicho por Azara. Darwin encontró en una isla del rio Paraná muchos ni. dos del calita y algunos de ellos tan próximos, que formaban una gran mole de ramas secas. Castelnau observó, como Azara, que varias hembras incuban en el mismo nido; este úlimo, compuesto de pedacitos de madera, tenia cuatro ó cinco aberturas, y estaba habitado por una numerosa ban. dada de estas aves, que abundan mucho en los pantanos de Jarayas, á lo cual se debe que los indigenas de aquellas regiones las llamen Joro de pantasso. Bumeister, que vió tam. bien nidos, nos dice en su Viaje por los Estades de la Plala. A falta de otra ocupacion mas útil observé algunos árboles altos despojados de follaje que yo creia muértos, y vi en ellos unos montoncs de ramaje seco y paja entrelazada, cuyo origen y significacion no supe explicarme, pues eran demasiado grandes para nidos de pajjaro y estaban muy al descubierto. Sin embargo, mis compañeros me aseguraron que cran en efecto, nidos de ave, es decir los del loro verde con garganta gris, llamado en el país calita. Dijéronme, además, que esta ave tiene la costumbre de fabricar sus nidos en sociednd, y que por eso parecian las construcciones tan voluminosas. Luego yi yo mismo tambien entrar y salir las parejas

CAÚrIVIDAD. - Ultimamente hemos tenido ocasion de observar en nuestras jaulas la construccion de los nidos del calita. Azara dice que en la América del sur se acostumbra a tener esta ave enjaulada, y que se debe recomendar para esto á causa de su gracia y gentileza: anade que los indige. nas la dan cl nombre de ariuda jörer. El macho y la hembra se ácarician continuamente del modo mas gracioso, y repro. dúcense fácilmente en cautividad. Todas estas noticias son exactas. En los últimos años se han recibido muchos calitas, hasta entonces bastante escasos; á pesar de sus gritos consiguieron granjearse el favor de mas de un aficionado. Schmidt fué el primero que pudo dar noticias sobre su reproduccion en la jaula El bolborinco calita fue uno de los loros que el citado naturalista eligió para el experimento de hacerlos invernar al aire libre: el resultado de estas tentativas fué en general satisfactorio y hasta muy favorable con respecto al caliia. Cunndo comenzó á sentirse el verdadero frio del in. vierno, Schmidt vió que los calitas sabian preservarse muy bien de él: todas las noches buscaban el nido en la gran jaula, cuya entrada era opuesta á la direccion del viento, y cuando hacia mucho írio, no dejaban durante el dia su nido sino para buscar el alimento. Al principio de la primavera su plumaje era hermosisimo y del todo completo, prueba que Ia vida mas libre al aire fresco habia sido muy conveniente para ellos. En abril emperaron á coger ramas de los arbustos que habia en la jaula y las llevaron, defraudando la esperanza del observador, al interior de la cajita del nido: cubriéronla del todo por dentro, y criaron en ella su progenie, de la cual háblaré mas abajo. Los calitas de otros aficionados procedic. ron del mismo modo, y casi-parecia que tambien ellos bus. caban con preferencia los huecos. En algunas parejas que cuidé yo mismo he observado no obstante lo contrario. Ultimamente se reprodujo una pareja en el Jardin zoológico de Berlin, la misma que Muetzel ha observado minuciosamente durante sus visitas regulares al jardin zoológico. Me refiere sobre el particular lo siguiente: 
In pareja de calitas está en una jaula grande con otros loros de Africa y de Australia, una especie de mirlos (Pefrncincla saxatilis), y dos picos negros pequeños. En un ángulo de la jaula, y a la altura de unos tres metros sobre el suelo, la pareja comenzó \& entrclazar palmitas de escoba con la reja: el guardian los ayudó desde luego fijando tres palos de madera trasversalmente en la red de alambre; y los calitas reconocieron este faror con gratitud, utilizandolos en seguida como base para su nido. Desde entonces tmbajaron afanosos en la construccion; el macho llevaba las tamas y la hembra las ponia en orden, formando desde luego la base redonda y en figun de plato. Despues abovedó el techo, $y$ al mismo tiempo la entrada, formando una especie de tubo comprimido y un poco inclinado hacia adelante. 'Tanio el uno como ln otra parecian al principio de construccion muy ligera y trasparente; pero pronto se aumentó su consistencia con otras ramas puestas encima. Cuanto mas adelantaba el nido tanto mas desaparecia la forma del tubo, y al fin ofreció iocio el aspecto de una gran bola espinosa de mas de un metro de diámetro, en la yue todas las ramas tenian el cabo grueso hácia afuera, viéndose solo una abertura poco regular, que indicaba la existencia del tubo.

\El infatigable macho habia llevado todo el material co. giendo la rama elegida con el pico y trepando despues al nido. La hernbra á su vez se ocupaba en entrelazar las ramas, sir hacer uso de las que no convenian.

- No se crea que este trabajo de la pareja se pudo efectuar con toda comodidad: muy por el contrario, á cada momento debia interrumpir su tarea pam protegerle contra sus compañeros de jaula, que continuamente estorbaban la obra, porque se habia despertado la curiosidad de todos los demás loros. Estos querian ver y admirar; pero como se acercaban demasiaclo al nido, la hembra dejaba su trabajo, revolviase contra los perturbadores y producia ruidosos gritos. A esta senal, el macho dejaba caer en seguida la rama que ya tenia en el pico $y$ precipitándose sobre el enemigo, descargábale picotazos y alctazos con tal fuerza, que podia creerse que iba á matar á su adversario. I a lucha acababa regularmenic con la huida vergonzosa del curioso. Fl calita, temiendo por su nido, mordia, picaba y daba aletazos en la cabeza y el cuerpo de su enemigo, arrancéndole rémiges y tectrices. Una ve\% le vi sacudir as un ave dicz ó doce vices con tal fuerza por la cola, que la pobre no pudo salvarse sin perder sus rectrices.

\$ Los pequerios picos negros molestaban mucho à los cali. tas por su corpeza y timidez; demasiado pequeños aun, no sabian salvarsé á ticmno, y recibian mas de un picotazo de los furiosos loros. $\mathrm{Al}$ fin infundieron estos tal respeto en sus compañeros que ahora solo casualmente se acerca alguno al niclo. Fil macho vigila casi sicmpre, posado en una rama mas gruesa que sobresaic del nido; á cada momento entra en el interior para ver 1 la hembra ó busca alguna rama para perfeccionar la construccion. I a hembra permanece siempre en el interior, pero se ve por la entrada su cabeza, jo á veces asoma tambien al borde de la abertura, cuando el macho tra. baja demasiado tiempo para remenciar el nido.

Sobre la incubacion y la cria de los pequenoos no se habian hecho aun observaciones en esta pareja al publicar ha presenic obra; pero tenemos datos anteriores. A principios de mayo, dice Schunidt, refiriendose a los dos calitas, la hembra se retiró al nido, cuidándose desde entonces el macho de alimeniarla. Este ultimo estaba posado en la percha la mayor parte del dia, delante de la entrada del nido, el cual parecis vigilar, pues tan luego como observaba algo sospechoso, gritaba ruidosamente. El $2 \&$ de mayo encontróse ciebajo del nido la mitad de una cáscara de huevo, de la cual habia sa. lido evidentemente un ave pequeña, pues en su parte inte rior se reconocia muy bien la formacion de las venas. Los padres entraban y salian desde entonces con frecuencia en el nido, y la hembra, sobre todo, permanecia mucho tiempo en este, alargando regularmente la cabeza por la entrada de la cajita. No se observaba mada de la actividad que regularmente es consecuencia de la cria de los polluelos; pero crei no deber dar demasiada importancia á este hecho, porque habia notado que las aves intentaban ocultar lo que hacian.

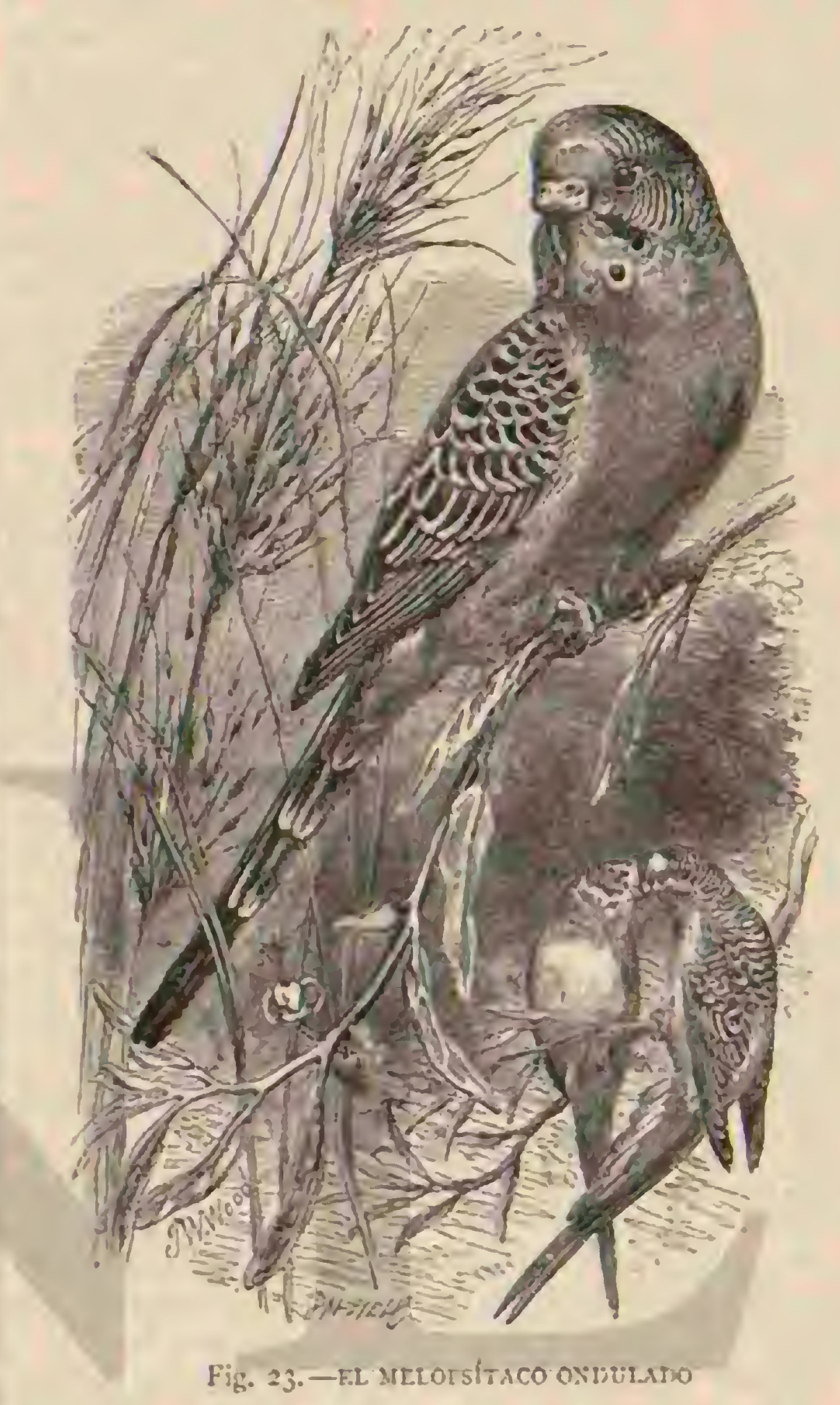

Aun despues de algunas semanas no se vió indicio alguno de cria, lo cunl me indujo is suproner que el hijuclo labia muerto; y pror lo tanto esperé á que los padres incubaran de nuevo.

- A principios de julio eche de menos un cardenal verde que habitaba la misma pajarera con los calitas, y como en ninguna parte se encontró, á pesar de haberle buscado por todos los rincones, supuse que habia entrado en alguna de las cajitas y que estaria muerto alli. Fil guardian procedió entonces a examinar todas las cajitas, y con gran sorpresa nuestra encontró en el nido de los loros un hijuelo, que de. bia haber salido hacia poco, y cuatro huevos blancos. Esta avecilla media dos centimetros de largo y estaba revestida de un plumon de color gris oscuro; el nido, cuidadosamente sapizado de yerba, tenia el fondo completamente cubierto de ramaje. la se comprenderá que al punto volvimos á poner la cajita en su lugar; mas tarde se reconoció que el movimienio no habia jerjudicado la cria.

Pareciame cxiraño que la hembra, que cubria los huevos sola y sin ayuda inmediata del macho, no hubiese incubado con uas tranquilidad y mas continuamente, hecho en que 
no nos habiamos fijado â pesar de nuestra minuciosa obser. vacion. Supuse que el polluelo habia salido hacia poco ticm. po y que podria esperar aun algo de los huevos. Tampoco fué posible ver cómo los padres alimentaban su progenic, porque la hembra se introducia en el interior del nido apenas se creia obsersada, mientras que el macho vigilaba por fuera. Cuando las dos aves nos veian acechar, aunque fuera á cierta distancia, tambien la henibra salia llamada por el macho, y ambos proferian gritos de cólera, que no cesaban hasta que nos retirabamos. La hembra habia colocado verticalmente sf la entrada del nido un pedacito bastante grueso de madera, que iba cmpujando poco á poco hácia el centro, cual si quisiera impedir ḱlos polluelos la salida del nido, $\delta$ dificultar la entrada i las demás aves. No se veian mas cáscaras de huevo debajo del nido, ni oiase tampoco sonido alguno que revelase la presencia de un hijuelo; pero la major cantidad de alimento que los padres consumian hizo suponer que debia haber algunos polluelos en el nido. I a hembra los alimenta ba al principio con preferencia con lechuga de la cual consumia diariamente tres grandes tronchos; mas tarde tomaban tambien paniblanco mojado, $y$ al fin canamones.

\. El z de agosto vi por prinera vez cómo la madre daba de comer a los polluelos. Hizo salir el alimento del buche, in. clinando la/cabeza, cuyo movimiento se comunicó á todo el cuerpo; $y$ aunque la hembra tenia la mayor partc de el dell. tro del nido, crei observar que repartia el alimento á varios hijuclos. Sin duda eran estos ya bastante grandes, pues la hembra podia llegar a sus picos sin entrar en el interior del nido. Iil ro de agosto por la tarde se vieron las cabezas de dos polluelos en la entrada de la cajita, $y$ al dia siguiente salis el primern corriendo alegremente: mas al poco rato pase. ció entristecerse, y permaneció inmóvil en un rincon. Como el tiempo estaba lluvioso, dispuse que le trasladaran al nido, 3 pesar de los gritos de los padres, y entonces se vieron las caberas de otros dos polluelos. El 15 de agosto salió el primero otra vez en compania de uno de sus hermanos, reconociéndose al punto cuál de los dos era el de mas edad, pornque parecia mas robusto y vivaz que el otro, el cual se arrinconó al cabo de una hora cual si turiese frio. Por la noche se te juso en el nido, mientras que cl mayor se retiraba a la parte cubierta de la pajarera, donde desde crtonces ocupó todas las noches su sitio. $\mathrm{El}$ is de agosto salió un polluelo; pero no puedo decir si era el segundo ó el tercer hermano. Su estado era del todo satisfactorio, y no hubimos de tomar medida alguna para cuidarle. El dia 20 salió el último polluclo del nido, y vióse que era muy robusto. Todos tenian completo su plumnje al salir del nido; solo las rémiges y las rectrices no eran aun tan largas como las de los adultos; en el color no se notaba mas diferencia que la de ser el verde menos vivo; las rémiges parecian mas bien verdes que azules, y los bordes claros de las plumas grises de la cabera y del pecho eran me. nos marcados; de modo que el plumaje ofrecia en su cotali. dad un tinte mas pálido y uniforme. El cuerpo tenia casi el taniano del de un ave adulia: la cabeza era relativamente grande, y el pico menos corro. Al principio no manifestaban mucha viveza; permanecian casi todo el dia posados en una rama que á este ejecto se habia puesto en tierra. Cuando los padres se acercaban á ellos pedian, alimento, inclinando la cabear y aleteando. Por lo regular siempre quedaban satisfe. chos: macho y hembra cumplian con cste deber, pará lo cual, cogiendo el pico del polluelo, volvianle la cabeza de lado é introducian despues el alimento cel modo antes descrito. I.os pollucios echaban la cabeza hácia atrís, repitiendo despues los ademanes con que solian expresar su deseo de comer. Al cabo de pocos dias, sin embargo, ya sabian encontrar ellos mismos la vasija del alimento y cominn un poco sin ayuda; pero hasta fines de agosto necesitaron aun el auxilio de los padres. Poco 1 poco adquirieron mas agilidad, y pronto trepa. ron por la reja de la pajarera. Mientras hacian este ejercicio, sus padres les arreglaban el plumaje, trepaban en pos de ellos, pasaban su pico por una pluma despues de oira para limpiar. las y alisarlas, como lo hacian con las suyas propias.

No he podido averiguar en estas primeras observaciones cuánto tiempo dura la incubacion; pero podemos suponer con bastante seguridad que los hijuelos necesitan unos cua. renta dias para poder salir del nido.

\section{LOS MELOPSITTACOS-MELOP- SITACUS}

CARACTERES. - Entre todos los loros que se crian en nuestras jaulas, una pequeña especie de Australia ocupa sin duda el primer lugar, y dificilmente se encontrarí otra que en tan alto grado sea propia para tenerla en la habitacion. Algunos loros cautivan por la belleza de sus colores, pero el melopsitnco gusta mas bien por su gracia y docilidad. Tambien esta ave es muy bonita; pero su caràcter familiar ofrece mas atractivo que la belleza de su plumaje; es un adorno para la habitacion, y se granjea pronto el favor de todos.

\section{EL MELOPSÍTACO ONDULADO - MELOPSI- TACUS UNDULATUS}

CARACTÉRES. - Esta especic es la única representante del gúnero hasta ahora conocida, y tambien de los loros mas pequenios; mas por su larga cola parece mayor de lo que es en realidad. Su longitud varia de $0^{\circ}, 20$ á $0^{\circ}, 22$ por $0^{\circ}, 26$ a $(1), 27$ de anchura con las alas extendidas; estas tienen $1^{\text {m }}, 09$ Y la cola casi $t^{\prime \prime}, 10$ de largo. Sus formas son graciosísimas; el cuerpo enjuto; el pico mas alto que largo yedondeado lateralmente por arriba; la mandibula superior se encorva casi verticalmente; su punta es muy prolongada, y junto ó clla-se observa una profunda sesgadura; la mandibula infe. rior es tan alta como la superior y redondeada en el ángulo de la barbilla; las piernas son delgadas, enjutas y relativa. mente altas; los dedos, bastante largos, estín provistos de un̉as igualmente largas; las alas son prolongadas y puntiagu. das; la segunda rémige es la de mas longitud; la cola, muy larga, se adelgaza gradualmente hácia la punta, de modo que las plumas exteriores solo tienen la tercera parte de la longitud de las del centro; el plumaje, en extremo suave, con dibujos muy bonitos, apenas se distingue por el color en los sexos y no difiere cr nada del de los pequeños. Ia frente, la parte superior de la cabeza, y la region de la mandibula inferior son de un amarillo de azuire, y en sus lados hay cua. tro manchas de un azul viro, de las cuales la de las mejillas es la mayor, mientras que las otras tres tienen la forma de puntos; la region del occipucio, la parte posterior del cuello, Ia nuca, las espaldillas y la mayor parte de las tectrices tienen un color amarillo verdusco; en cada pluma se ven cua. tro lineas trasversales finas y negras, que en las tectrices se reducen á dos, pero mas anchas; la parte posterior del dor. so, la rabadilla y las tectrices superiores de la cola, asi como la parte inferior del tronco, descle la barba, son de un mag. nífico verde; las rémiges de la mano y sus tectrices de un verde nscuro, bordeadas de amarillo exteriormente y negru\%cas por dentro, con manchas cuneiformes amarillentas en el centro; las rémiges del brazo son verdes por fuer, con un angosto borde amarillento, amarillas interiormente y negruz. cas $\mathrm{en} \mathrm{la} \mathrm{base;} \mathrm{las} \mathrm{últimas} \mathrm{rémiges} \mathrm{y}$ las últimas plumas de la espaldilla son de un pardo oscuro, con auchos bordes amarillos; las dos tectrices del centro son de un azul oscuro 
y las otias de un azul verde, con grandes manchas de un amarillo de limon en el centro, las cuales se extienden sobre las barbas; la base de estas tiene anchos bordes negros. I.os ojos son de un amarillo pálido; el pico amarillo de cuerno y gris verde en la base; la cera de un arul oscuro, y los piés verdes azulados. La hembra es un poco mas pequeña y di. fiere del macho por el color verde gris de la cara y por tener las manchas de las mejillas mas pequerias; el hijuelo se reconoce por su color mas oscuro y dibujos mas pálidos, por la extension de las ondas y por carecer, en fin, de las manchas azules de la barta; tambien presentan en el pecho on. dulaciones trasrersales de color oscuro.

DISTRIBUCION GEOGRÁfICA. - Lista especie es propia de la Australia, 10 mismo que sus congéneres.

USOS, COSTUMBRES Y REGIMEN. - Shaw es el primero que ha descrito el melopsitaco ondulado; pero nin. gun naturalista nos dió á conocer su género de vida antes que Could. Hoy sabemos que habitan todo el interior de Austmlia numerosas bandadas de estos loros, los cuales buscan las llanuras ricas en prados, y se alimentan de los gra. nos de las gramineas.

Todos los observadores que los han visto libres, y cuantos aficionados los tuvieron cautivos, hacen a la par su clogio. Cuando d principios de diciembre recorrió Gould las llanu. ras del interior de Australia vióse rodeado de melopsítacos y resolvió permanecer en el mismo punio para observar de. tenidamente sus usos y costumbres.

Aparecen por bandadas de veinte a cien individuos en las inmediaciones de un pequeño estanque, donde apagan ln sed, y emprenden el vuelo hácia la llanum á ciertas horas para buscar los granos de que se alimentan.

Iban can mas frecuencia á beber pror la mañana temprano, y por la tarde antes de caer la noche. Durante el calor per. manecen inmóviles en las cimas de los gomeros, no siendo fácil descubrirlos; pero al emprender su vuelo se agrupan en las ramas secas ó en las que se inclinan sobre la superficie del agua.

Su vuelo es rápido como el del halcon ó de la golondrina; andan bastante bien por el suclo y no son torpes para trepar. Cuando vuclan lanzan gritos peneirantes, $y$ en las horas de descanso producen una especie de gorjeo muy animado que no puede llamarse canto, pues las distintas voces se confun. den formando una discordancia dificil de describir.

Aun dumnte el periodo del celo constituyen los melopsi. tacos numerosas reuniones en las que no se separan nunca los individuos de cada pareja; anidan en los agujeros $y$ huecos de los gomeros, y en el mes de diciembre contiene cada nido de cuatro á seis huevos blancos, bastante redondeados. A fines de diciembre tienen los hijuclos todo su plumaje, y pueden vivir por si solus.

Reúnense entonces con los individuos viejos aisiados, $y$. emprenden lodas sus excursiones Segun se ha podido ab. servar en individuos cautivos, estos loros contracu dos ó tres uniones sucesivas.

Cuando termina la época de la reproduccion comienzan sus viajes las banciadas; dirigense de sur \& norte, y vuelven a su punto de partida cuando maduran los gramos. En toda la Australia del sur aparecen los melopsitacos en la primavera, que es nuestro otono, con tanta regularidad como, en tre nosotrós las aves de paso. Los indigenas dicen que apa recen a reces en paises donde no se les habia visto antes, lo cual parece muy creible.

Los datos de Gould son ahora mas completos merced a un relato que debo a la amabilidad de Engelhart, relato que re. produrco á continuacion, aunque ga le publique en mis fars curvfitas. En la fauna ornitológica de la Australia del sur figu- ra el melopsitaco ondulado, al que los indigenas llaman loro de concha ó loro canario. Lno de los sitios preferidos por estas aves para su incubacion, y en el clan pude hacer mis observaciones, es sin duda Malleeshrub, magnifico bosque de eucalipios que \& lo largo del rio Murray se extiunde desde su desembocadura hasta la primera curra grande. Cuandoen esta region desierta llueve en abundancia despuxs de un in. vieno húmedo, cúbrese la tierra de una yerba espesa y alta; un inmenso espacio de varias leguas cuadradas que en otm estacion ofrece el aspecto de un triste arenal, revistese súbita. mente de una nagnífica aliombra de gramineas, y bajo la in. Rucncia del sol calido de la Australia meridional, las yerbas alcanzan la altum de un metro; las flores se desarrollan rỉyidamente, y á las cinco ó seis semanas las espigas se cuajan de granos. Muchos dias antes de esto, preséntanse innumem. bles bandadas de aquellos graciosos loros, que al punto se ocupan afanosamente en la incubacion. El extraño tronco del mallee, de cuya mir. parten ocho ó diez tallos de seis metros de altura, con escaso follaje, y en los cuales se forman numerosos huecos de ramas, favorece mucho la reproduccion de estas aves. Cada uno de aquellos, cada espacio que ofreacan las ramas utilizase para construir un nido; $y$ en pocas sema. nas toda la region está poblada de melopsitacos. Los abun. dantes granos de las gramineas ofrecen un excelente alimento á los polluclos. Eil que en esta época se cxtraviase en tal re. gion, podria coger fácilmente centenares de aquellos con las manos: numerosas bandadas ałarecen delanic de él, forman. do largas filas en el mmaje desnudo; entreteniéndose con su canto, miran tranquilamente cono el hombre, siempre dis. puesto a matar, toma su escopicia para dirigirles una descar. ga, que a menudo mata docenas s. la vey $\mathrm{Al}$ fin se agotan las provisiones de grano; quizas falta tambien el agua, y las magnificas ares cmprenden entonces sus viajes. Primero se dirigen à los lagos de Alexandrina y Wellington, cruzados ambos por el Murray antes de desembocar este en el mar; éignoro si es porque los pantanos les ofrecen aqui mayor abundancia de gramincas, $\delta$ porque el agua las atrae. De todos modos este es el sirio á donde todos los anos van los caza. dores para colocar sus redes y donde se cogen muchos milla. res de melopsitacos.

- Fista descripcion, como ya he dicho, se refiere solo a los años nุue llueve en abundancia; si hay sequia, parece que ya no existen los melopsitncos. Sin duda se han dirigido entonces al lejano norte, porque aqui, aun en el verano, caen á menudo copiosas lluvias, que como por encanto cubren el desierto de una verde alfombra. Parece que todos los loros cunigrantes saben esto de antenano, pues alli donde la natura. leza les ofrece alimento, ó casi podria decirse, alli cionde lo ofreceró, preséntanse sin falta.

Segun las noticias de otro aleman que ha vivido muchos anos en Australia, se cogen centenares y millares de melopsitacos ondulados al oscurecer, por medio de grandes redes en forma de bolsa; y enciérranse en cajas para entregarlos asi a los iraficantes a Melbourne llevan un númeto increible, y cuando hay muchos en el mercado se compra la pareja por unos tres francos, mientras que al por mayor resultan cuando mas a dos. Pasado el periodo durante el cual se cazan estas aves, llenanse con ellas todos los espacios libres de los buques, y ruas de un capitan cede su címara á estas aves durante la travesia desde Australia \& Europa. Hace apcnas veinte años que los melopsitacos ondulados escaseaban aun en nuestro continente; hoy dia llegan todos los anos en mayor 6 menor nuimero al mercado; la cifra varia segun el resultado de la caza ó segun la suerte que el capitan ha tenido con ellos du. rantc el viaje.

En Australia colocan muchos en una jaula pequeria, cu. 
yas perchas están escalonadas, de modo que se pueda colo. car el mayor numero en el menor espacio posible; y forman asi un agradable conjunto. Toda la bandada aparece en compactas filas; se ven las cabezas unas detrás de otras; sus ojos se fijan á la vez en el espectador y parece como que im. ploran la libertad. Nunca promueven entre si peleas: hasta en el periodo del celo viven juntos, y en la mejor inteligencia, miles de estos loros de ambos sexos. He visto en Londres la enorme paiarera de un traticante que acababa de - recibir un cargamenio de estos loros; habia alli mas de mil parejas $y$ reinaba entre todas la nejor armonia.

El melopsitaco ondulado debe figurar entre las aves lla. madas inseparables, es decir, en el número de las que no so. portan la pérdiáa de su pareja: debe tener compañía, yimejor un individuo de la mismn especie y de distinio sexo. En caso de necesidad se le puede dejar con otro loro pequeño; pero nunca se conducirí con él con tanta ternura como con su semejante. Se debe, pues, adquirir uná pareja si se quiere observar todas sus cualidades. Cuando muerí uno de cllos, lé reempláa otro del mismo sexo y se aparea rápidamente. 1.a sobriedad es una de las ventajas de este loro: ninguna otra ave casera se contenta con un alimento tan sencillo y variado; le damos mijo y cañmones, y esto le basta. Inútil. mente se ha tratado de alimentarle con otros granos: come congusto las hojas verdes decol, de lechuza, etc, y deja las irutas; el azícar yotras golosinas: bebe poco, ya menudo pasa tada una semana sin probar el linuido; pero se debe cuidar de darle siempre agua fresca Resulta, pues, que la facilidad con que se le mantiene contribuye â que sea muy buscado.

Por otra parte, este melopsitaco está dotido de otras cua lidades que le captan la benevolencia del hombre. No cabe ducla de que en cuanio as su imeligencia es inferior á los grandes loros; mas apenas se reconóce esta falta. Por sus movimientos iguala a todos sus congéneres; corre con destreza y rapidamente á pesar de sus cortos pasos; trepa con perfeccion y vucla con la celeriad del rayo. Para poder juz. gar bien de la agilidad de su vuclo, es preciso verle cuando escapa de su prisión. Puede desafiar por este concepto á un halcon; cjecuta las vuelias s circumvalaciones mas graciosas; sabe calcular las mayores distancias y las mas pequeñas, iguala, en una palabra, al ave mas voladora. Por esta agilidad granjéase ya nuestro carino; pero mucho mas nos cautiva su voz. Los loros que saben hablar con su amo no pueden muchas reces reprimir su inclinacion natural de lanzar desagradables gritos, y hay pocos hombres que soporten mucho riempo este defecto de los loros; pero con los melopsitacos ondulados no sucede asi; aunque no les falta la voz, jamás hacen uso de ella de una inanera incómoda, y si sicm. pre agracablemente. No es ninguna exageracion pretender que el macho de estas aves debe figurar entre las cantoras, pues su charla es a menudo un canto muy sencillo, pero agradable. Para mi lo es mucho cl de esta magnifica ave; no solo son de la misma opinion otros aficionados, sino que han reconocido que este melopsitaco aprende é imita los cantos de otros oscinidos; algunos llegan á pronunciar palabras.

Si se cuida convenientemente a una pareja de melopsitacos, no se les molesta, y se les da un nido á propósito, puede tenerse casi la seguridad de verlos reproducirse.

Si no sucede asi, la culpa es regularmente del amo, y no se trata aqui de pequeñas faltas, sino de algunas muy grandes: no se da al ave lo mas necesario y atribujense á ella las consecuencias de ello.

Es preferible, no obstante, poner varios individuos en un gran espacio, pues entonces se excitan los machos entre sí, domina en eilos la pasion de los celos y es mas poderosa la influencia de su amor. Una reducida habitacion, que se puede calentar y rentilar sin molestar á los loros, que tenga el suclo cubierto de arena y las paredes guarnecidas de nidos, es lo mas á propósito para estos séres; y mejor aun, siquiera no indispensable, que aquellos estén rodeados de arbustos y plantas, donde los loros puedan ocultarse para descansar. Al efecto se deben elegir árboles verdes; pero es forzoso reem. plazarlos con frecuencia, pues todo lo picotean los loros. Para los nidos prefieren los troncos huecos de sauce, cuyas cavidades se dividen en varios compartimientos, de modo que se puedan albergar algunos en cada uno. Semejante habitacion satisface todas las condiciones apetecidas.

Basta sin embargo tambien una cajita ordinaria de nido con entrada estrecha para que la hembra se crea segurn; $y$ como esta especic, lo mismo que la major parte de loros, ponè sus huevos sencillamente en tierra, conviene practicar en el suelo un hoyo pequeño y llenarlo de serrin. Las aves se arreglan despues el nido conrenientemente, sacando de 12. cajita el serrin que les parece necesario. Un espacio dispuestó de esta manera para la incubacion, da los resultados mas farorables; pero en la mayor parte de los casos basta una jaula de tamaño regular. El que acostumbra a los me. lonsitacos a volar libremente en su habitacion, puede ahorrarse la compra de una pajarera especial.

No conozco, me escribe de Hinkeldey, ninguna otra ave tan propia como el melopsíaco para dejarla libre en una gran habitacion. Póngase la jaula en cualquier sitio de la estancia, déjese abierta la puertecilla y el alimento dentro, y se observatá que las aves salen muy pronio, pero tambien que vuelven a ella despues de dar algunos paseos. A los pocos dias sé acostumbran a tomar su alimento en la jaula y no se pusan nunca en otro sitio ni ensucian, por consiguiente, la habitacion; divirtiendo sobremanera al observador con su rápido vuelo y la gracia de sus movimientos. Hasta ahora jamás han chocado mis melopsitacos contra los vidrios de la ventana ni se han escapado por la puerta abierta del cuarto. Mi dormitorio comunica con la sala principal por una puerta de dos hojas: se halla siempre abierta y muchas veces tambien la rentana del cuarto ó del salon; pero nunca se me ha escapado un melopsitaco.

sEsta primavera hice la prueba con tres individuos recien llegados en un buque, y se acostumbraron muy pronto al gé. nero de vida descrito. Los quehaceres diarios no incomodan en nada à las aves, pues sus nidos están colgados en la pa. red. Debo hacer constar que no todos los melopsitacos ondulados respetan lo mismo las ventanas abiertas; pero por lo demás, creo que en las citadas especiales circunstancias divierten aun mucho mas de lo ordinario.

Es preciso haber criado uno mismo loros para comprender el entusiasmo con que hablan de ellos los verdaderos aficio. nados; cuanto mas se les conoce mas se les aprecia; ol observar sus costumbres es una verdadera diversion, un agradable pasatiempo. El macho, dice Devon, es modelo de esposos, como la hembra de madres; solo se ocupa de su compañera, sin fijar su atencion en las demas; siempre es celoso y atento con ella; posado sobre una rama á la entrada del nido, le dirige su canto, y mientras cubre los hueros, aliméntala con cuidado. Nunca està triste y taciturno, ni dormita como otros; siempre se le ve alegre, contento $y$ vivaz.

Quien por si propio haya cuidado melopsitacos ondulados estará conforme con las anteriores palabras. Cuanto pueda decirse de la gracia, sociabilidad $\mathrm{y}$ afecto reciproco de los sitáculns, es tambien aplicable, en mucho mas alto grado, à los melopsitacos. El mutuo proceder del macho y la hembra 
es lo mas admirable que imaginarse pueda: cada uno de por si hace todo lo posible para agradar al otro; el macho, sobre todo, se nutustra en extremo solicito cuando pide los favores de la hembra, que raras reces se le niegan.

e Aunque muy ardiente, dice otro observador, no cansa d su hembra como lo hacen otros pajaros, y satisface con pa. ciencia todos sus caprichos hasta que se rinde al fin $a$ sus caricias. Hasta el apareamiento recuerda la fábula de Ieda y del cisne: la hembra humilla la cabeza anie el macho, y este la coge con el pico, enlazindola con sus largas nlas lis infatigable cuando se trata de alimentar a su hembra, j se muestra tan tierno como colosa.

La construccion del nido es obra de la hembra: con su pico practica la abertura hasta que llena sus descos: des. prende de las paredes de la cavidad varias astillas para cubrir el fondo, y a los dos dias pone de cuatro a ocho huevos redondos y blancos, los cuales cubre por espacio de diez y ocho ú veinte dias El macho se cuida de alimentarla durante la incubacion, pues la hembra no abandona el nido sino para satisfacer sus mas urgentes necesidades. Los hijuclos están en aquel de treinta a treinta y cinco dias, y no lo dejan hasta que tienen todas sus plumas.

Mientras dura la educacion se afana mucho la hembra por conservar el nido aseado, y cual macire cuidadosa y diligente, limpia a sus hijos todas las mañanas uno despues de otro; cuando salen del nido comienzan á buscar alimento, y al cabo de pocos dias tienen todas las costumbres de sus pa. dres. En tales circunstancias se necesita cierta prudencia, principalmente si hay en la jaula alguna pareja que cubra, pues los celos del macho se revelan a veces de una manera

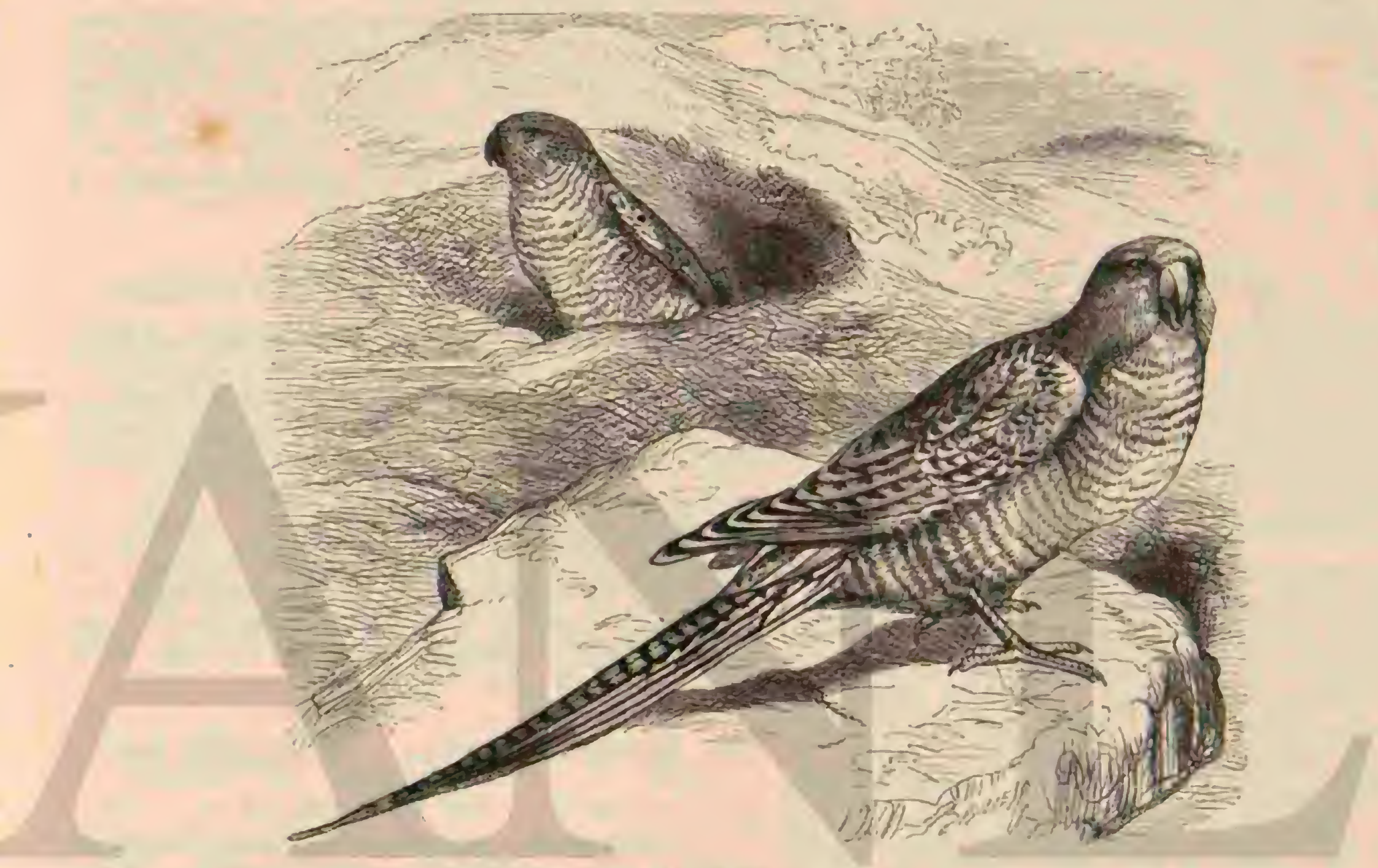

Fig. 24. - T. lizzororo viraz.

terrible: el mismo loro que ha cuidado a su progenie con tanta ternura, cae a menudo de improviso sobre ella y da muerte á iodos sus hijos.

A reces, algunas liembras se nuestran mas duras que los machos con los hijuelos de otras parejas; en tales casos conviene separarlas

Cuando salen los pequeños de la primera puesta, la hembra pone segunda ver. y despues otra y otra: F. Schlegel, director del Jardin zoológico de Breshu, observó una jareja que cubria coninuamente; pero esto es una excepcion: la regla parece ser tres pucsias al año.

Se puede dejar sin temor con sus padres a los hijuelos de la última puesta, y colucar entonces en la jaula los de las precedentes. Estos se muestrnn ai instante tan benévolos como sus padres. Poseidos del mas celoso afan, cuidan y ali. mentan a sus hermanitos; el uno hace lo que ve hacer al otro, y pasan el tiempo en comer, trepar y retozar. A menudo promueven tal algazara, que molestan á los padres, los cuales tratan entonces de imponer silencio. Cuando en una pajarera hay una docena de parejas con sus crias, ofrecen un curioso espectaculo; en tal caso no sucle turbarse la bucua armonia, ni se excitan tampoco los celos del macho, pues no puede fijarse en un solo objeto, sino que se ve obligado a fijarse en muchos.

Vemos por esto cuán necesario es adquirit parejas de melopsitacos, pues cuando se tienen dos del mismo sero y se les da un compañero de otro, se aparean en seguida.

Neubert tenia dos pares de melopsitacos ondulados; mu. ricron los machos, sin que en mucho tiempa pudiera con. seguir otro. las dos hembras viudas habitaron la jaula en paz; estaban alegres y contentas y en la mejor armonia; pero la llegada del nuevo mạcho turbó aquel bienestar. \&las dos hembras, cuenta Neulert, se hallaban una al lado de otra, y en lo mas aleo die la jaula cuando eritó cl macho, al que contemplaron atentamente; este la.5 miró tambien sin mover. se, y lanzó despues un ligero grito de llamada, siendo contestado por una de las hembras. Aquel repitió el grito, $y$ al instante se precipitó á su encuentro ia que habia contestado, como si viera un companero que hubiese estado ausente largo tiempo. La otra hembra miraba tranquilismente; pero cuando 
pasó is su lado la pareja, enfurecióse contra su antigua compañera, suspendióse de su cuello y le arrancó las plumas. Al momento se las scparó, y despues se obtuvo otro macho parn ella; mas por una rara cxcepcion, no quiso aparcarse, $y$ vivió triste $y$ abatidas

Si quisicra citar todas las observaciones que he recogido sobre la reproduccion de los melopsitacos ondulados tendria que llenar varias paiginas; el que desee instruirse con mas minuciosidad rea lo que de ellas digo en mis sives cautivas. Este libro contienc todas las noticias que pueden desearse y tambien instrucciones que no son propias de una obra como la Vida de los amimalis. No obstante, daré á conocer una observacion que yo mismo he hecho en mis melopsitacos.

La primera páreja que ture vivia en muy buena intaligericia, si bien es cierto que no habia llegado aun cl periodo del celo: habitaba en una gran pajarera y parecia estar muy bren. Sin embargo, los rayos del sol, que acariciaban \& los melopsitacos, debieron despertar, sin duda, en ellos el deseo de recobmr la libertad: cierto dia consiguió la hembra ensanchar un hueco, $y$ antes de que pudieramos apercibirnos de ello, escanó por la ventana, lo cual me proporcionó ocasion de estuedar el ave bajo un nuevo punto de vista. Su vuelo me cautrió de tal modo, que casi mé hizo olvidar la pena que me causaba semejante pérdida: el loro remontado por los aires deslizábase con una rapidez y ligcreza admirables; no volaba como los otros representantes del mismo órden, sino como el halcon o la golondrina, y bien pronto desaparecio de mi vista. No obstante, al cabo de algúnos minutos volvió la fugitiva al jardin, atraida sin duda por los gritos de su compranero, que me habia apresurado yo a poner en la ven. irna Contestóle la hembra, y repitiendo sus sonidos, fué á posarse en un ciruelo que habia debajo de ni balcon. Aque lla escena iba i tener un descnlace imprevisto: los aficionadosque hayan poseido esta especie, saben que su grito se aserieja al que jroducen los gorriones, mas yo no me habia fijado en esto entonces: estábamos en el verano y en todos los iejados pululaban numerosos gorriones pequeños. $\mathrm{La}$ presencia del hermoso melopsitnco produjo entre anuellos pajaros mucha impresion; al verle pusado en el árbol, y con. versando con el macho, crejeron los gorriones que los liamalu, y acudieron en masa á pesar de las repetidas advertencias de sus mayores. Estos parecieron tambien admirados, mas to se dejaron engañar y contemplaban desde lęjos al verce habitante de la Australia, mientras que los pequeños por el contrario, le cercaron por todas partes. La hembra no parecia hacer caso de ellos, pero no les conturo esto; cobra ron cada vez mas confianza; saltaban á su lado, mirando con admiracion, y piaban continuamente. Molestado el loro, refugiơse en otro árbol yo á él le siguió toda la pequeria banda. da; sjlo cuando la hembra trazaba algunos atrevidos circulos en el aire, los pesados gorriones, que no podian hacer otro tanto, permaneciar en el suelo estupefactos. Aquel espectáculo duró sobre una hora; ocuparon el jardin todos los gorrions de las cercanias; hasta que por último la hembra cedió al carino del macho; penetró en la habitacion, y habiéndola puesto en la jaula con su companero, recibióla este con vivas mustras de alegria, mientras que los gorriones se dispersaban en todos sentidos.

Debo añadir que algunos mélopsitacos ondulados vivieron liurs largo tiempo en Europa: en la primavera de is6 I sC escanó un par de una pajarera de Bélgica; desapareció en los arboies de un parque, y duranic mucho tiempo no se volvió a saber nada de su paradero. Habian anidado, $y$ debieron criat sus hijuelos, pues su antiguo propictario sorprendió en el 0:0jo una bandada de diez á doce individuos en un cam. po de avena: les atrajo dándoles de comer, y a jrinčupios del invierno se consiguió coger diez.

No cabe duda que los melopsitacos ondulados prosperarian mucho en nuestro pais, y esto explica por qué algunos aficionados han propuesto aclimatarlos en nuestro continente. Pero ¿qué ganariamos con eso? Aun suponiendo que estas aves, acostumbradas a su vida pasajera, permaneciesen du. rante el invierno en un territorio que, pordecirlo asi, habitan forzosamente y que no emprendiesen la fuga hácia el sur: aun admitiendo además que las emiseras escopetas: quo tantu incomodaron a Buxton en sus pruebas, no comenzaran if funcionar: solo adquiririamos con los melopsitacos unas aves muy bonitas, pero á la vez basiante perjudiciales. Por otra parte dariamos motivo para quue murmurasen mas que hunca aquellas personas inexpertas que tanto escriben sobre la utilidad y el daño de las aves.

Hay otra especie à la que se ha llamado melopsitaco de fajas asules, y que apenas difiere de la anterior mas que por el ca. ricier que le da nombre. Aseméjase en un todo al melopsitaco ondulado por sus costumbres y género de vida y en su consecuericia no creemos necesario extendernos en su descripcion. I a límina que se acompaña representa el tipo de esta ave.

\section{LOS PEZOPOROS - PEZOPORUS}

CARACTÉRES.-Este género está represcntado, al menos que sepamos hasta ahora, por dos túnicas especies, cuyos caractéres son los siguientes: pico corto, grueso, redondeado y prolongado en punta saliente y obtusa sin sesgadura den. tada; piernas rolustas relativamente muy altas, con dedos largos, provistos de unas endebles poco encorvadas; alas muy largas y puntiagudas; la segunda rémige y la tercera son las de mas longitud; $y$ todas las plumas, largas en general, son punteadas. Lin ol plumaje, bastante suave, predonina el color verde, observindose en la parte inferior unos extranos dibujos trastersales, y manchas en la superior, I os sexos no se distinguen por el color.

\section{EL PEZOPORO VIVAZ - PEZOPORUS PHOR- Mosus}

CARACTERES. - El pezoporo vivaz tiene el tamaño del mirlo, y un color bastante abigarrado, aunque se mezclan pocos tintes, predominando sicmpre un bonito verde aceituna. Las plumas de la parie superior de la cabca presentan en el centro unas lineas negras que se prolongan á lo largo del tallo; las de la nuca, de las espaldillas y de la parte posterior del lomo, asi como las tecirices de las alas; son negras, con dos $\delta$ tres líneas estrechas trasiersales de color amarilio, y un ancho borde verde. Este último es mas angosto en las tectrices superiores de la colá, por cuya causa parecen mas estrechas. Las plumas de las mejillas, de la barba, de la garganta $y$ del buche son de un verde de accituna, excepto el tallo que es negro; las del pecho, del vientre y de los costados, y tambien las tectrices inferiores de la cola, de un amarillo aceitu. nado, con tres anchas fajas trasversales negras y un estrecho borde verde; por la frente se corre oira faja angosta de color rojo. Las rémiges de la mano y del brazo son de un tinte pardo aceituna oscuro, pero verdes en las barbas exteriores, presentando en su centro las interiores unas manchas de co. lor anırillo pálido cuyo tamaño aumenta de adelante atrás, y que forman desde la cuarta rénige una ancha faja trasversal amarilla; las tectrices de las alas son verdes; las mayores y la cara inferior de las rémiges, de un negro gris; las cuatro tectrices del centro, de un tinte verde oscuro, presentan es. 
trechas fajas trasversales amarillas; las otras de un amarillo verdoso tienen en las barbas interiores fajas anälogas negras, que en las exteriores son mas anchas y verdes. Los ojos son pardos, el pico pardo negruzco, y los piés de color de cuerno (fig. 24).

DISTRIBUCION GEOGRAFICA.- Segun Could, el pezoporo vivaz habita en toda la Australia meridional y en la isla de Van. Diemen; no se le ha encontrado en la parte norte; pero es probable que no falte del todo.

USOS, COSTUMBRES Y RÉGIMEN. - Difieren sUS costumbres de las de todos los demis loros, excepcion hecha del kaliapo. Siemure esta en tierra, y muy rara vex se le ve en los árboles; busca los lugares estériles y arenosos donde no crecen mas que las yerbas cortas, y tambien le gustan los terrenos turbosos, cubiertos de juncos. Vive solo $\delta$ con su hembra, $y$ como hace una vida retirada es dificil encontrarle sin el auxilio de los perros. Corre ian bien como la chocha, y para evitar las miradas sabe agacharse contra el suelo, como lo hacen las galliniceas y las aves de los pantanos; solo cuan. do se le sorprende de improviso se levanta como esias últimas y vuela rápidamente rasando la tierra; describe algunas S S en el aire, baja nuevamente y huye corriendo; pero los perros le paran. Resulta de aqui, que cuando uno de estos se pone de mucstra, no sabe el cazndor si está delante de una chocha ó de un peropioro; pero como la carne de este es delicada, mas tierna que la de la otra, y de un gusto análogo al de la codorniz, lo mismo le da al hombre una pieza que otra.

La hembra pone sus hueros blancos en la tierm desnuda: el macho le presta su auxilio para cuorirlos; y no tardan los hijuelos en adquirir el plumaje de sus padres, declaránciose muy pronto independientes.

Ultimamente se lian ampliado mucho estas noticias de Gould con las observaciones de Muller, director actual del lardin de plantas de Melbourne. Las citadas obserraciones se refieren á la segunda especie del género (Pesoporus ocitdentalis); pero creo que tambien pueden aplicarse al pezopo. ro vivaz. Aquella es un ave nocturna, que pasa el dia en cuevas y solo sale despues de ponerse el sol para ir en busca de su ulimento.

CAUTIVIDAD. - Un individuo cautivo del Jardin zoológico de lóndres pasaba todo el dia tranquilamente en el mismo sitio; no despertaba hasta la hora del crepuisculo, y entonces comia. Los granos constituian su unico alinzento; asi como al kapapo, gustábanle tambien las puntas de las gramineas, por lo cual le díbamos siempre yerba fresca. Nunca se posaba sobre una rama, sino en el suelo, por donde corria con mpidez; su voz era un silbido agudo monótono.

USOS Y PRODUCTOS. - La carne del nezoporo, segun dicen, es excelente y mas tierua que ha de la becada; su sabor es analogo á la de la codornir. de modo que los cazado. res la aprecian tanto como la de cualquiera de estas ares.

\section{LOS EUFÉMIDOS - EUPHEMA}

CARACTÉRES. - Las aves de este género, retresentado solo por seis especies, todas de la Nueva.Holanda, pasan tambien una gran frarie de su vida en el staclo. Los curemidos ticnen el iamaño de nuestros fringilidos, caracierizándose por su pico endeble y corto, redondeado en la arista, con punta muy curva, sin sesgadura dentada; las picmas son de. biles, delgadas y de longitud regular; las alas puntiagudas; la segunda y tercera rémiges son las mas largas; las tectrices muy prolongadas y anchas en la base, acielgázanse mucho hácia la punta y se acortan gradualmente hácia la extrenuidad de la cola. El plumaje es tan abundante, que estas ares parecen mucho majores de lo que son en realidad; su color predominante es el verde aceituna; la frente $y$ las tectrices de las alas suclen ser azules; el vientre $y$ las tectrices exierio. res de un tinte amarillo.

DISTRIBUCION GEOGRÁFICA.-El área de dispersion de cste género se extiende por Australia y Tasmania $\delta$ la tierra de Van Diemen, mas no existen al parecer en el nord. este de aquel contincnte.

\section{EL EUFÉMIDO HERMOSO-EUPHEMA PULCHELLA}

CARACTÉRES.-Fl eufémido hermoso, el turkisin de muestros traficantes de aves, es una de las especies mas co. munes del género. Tuda la cara hasta los ojos, y las tectrices superiores del ala, excepto una mancha parda roja, formada por las tectrices mas pequenas del antebrazo, son de color azul celestc; los hombros, el lomo y las demás regiones su. periores, de un verde de jerba; la parte inferior, desde la barba hasta las tectrices inferiores cie la cola, de un amarillo muy vivo con brillo verdusco en el pecho y los lados del vientre; las rémiges negras, de un azul añil por fucra, y ori. lladas de un estrecho borde verde; las dos tectrices del cen. tro, verdes; las exteriores, de un amarillo vivo, en casi toda su extension, y solo en la base verdes y negras, colores que se extienden hacia el centro. El iris es pardo; el pico negruzco, y los piés de un pardo gris claro.

La-hembra tienc las mejillas, la barba, el buche y el pecho de un verde amarillo, $y$ ln mancha pardo roja del antebrazo menos marcada. Ios polluelos se parecen á la hembra; pero los sevos difieren pronto despues de abandonar el nido.

DISTRIBUCION GEOGRÁFICA.-Esta aie es propia de la Australia

USOS, COSTUMBRES Y REGIMEN.-No tenemos aun datos exactos sobre la vida en libertad de la especie des. crita y sobre la de todos los eufémidos en general. Gould dice que estas ares viven, en bandadas mas ó menos numerosas, en las costas solitarias de iustralia, donde se presentan al prinripio de la primavera para empollar, internaindose despues en aquel continente En circunstancias favorables, sobre todo cuando las simientes de las gramineas dan una buena cosecha, forman numerosas agrupaciones, que recorren una considerable extension de las estepas. Asi como la major parte de los loros de Australia, pasan una gran parte del dia en tierra, octupadas en buscar el alimento: carren con la agiliciad de las pequeñas aves de pantano; su paso es presuroso y rápido; y gracias a la facilidad con que trepan, vencen todos los obstículos del terteno. Su ruclo es rápido como el rayo y regularmente pasari muy cerca del suclo cjecutando las evoluciones mas caprichosas; pero á veces ele. vanse tambien en cl espacio. Cuando se les ahuyenta no saben dirigirse of un árbol, sino que buscan su refugio en tierra. Su vo\% consiste en sonidos agudos, poco agradables Sus facultades intelectuales son anảlogas à las del platicércido y quizás un poco inferiores a las del melopsitaco ondulado. El cufémido hermoso incuba como la mayor parte de sus congéneres en huecos de árboles; una especie, sin embargo, construye sus nidos en las hendiduras y grietas de las rocas La hembra pone unos ocho huevos, y, segun ha observado Fiedler, se cuida elia sola de cubrirlos mientras que el macho no se acerca al nido.

CAUTIVIDAD. - Los cufémidos, asi como los platicércidos, sus congéneres mas aíne, son en exiremo debiles y pertenecen a las especies que mas dificilmente soportan la cautividad. 'Todas las tertativas hechas hasta ahorn para pro- 
porcionarles las condiciones necesarias para su vida, han sido inútiles; se les ha hecho invernar tanto en espacios cálidos como al aire libre; se les ha dado la mayor variedad de alimento, $y$, en fin, se ha hecho todo para ponerles a salvo de las mas diferentes influencias atmosféricas, sin obtener hasta

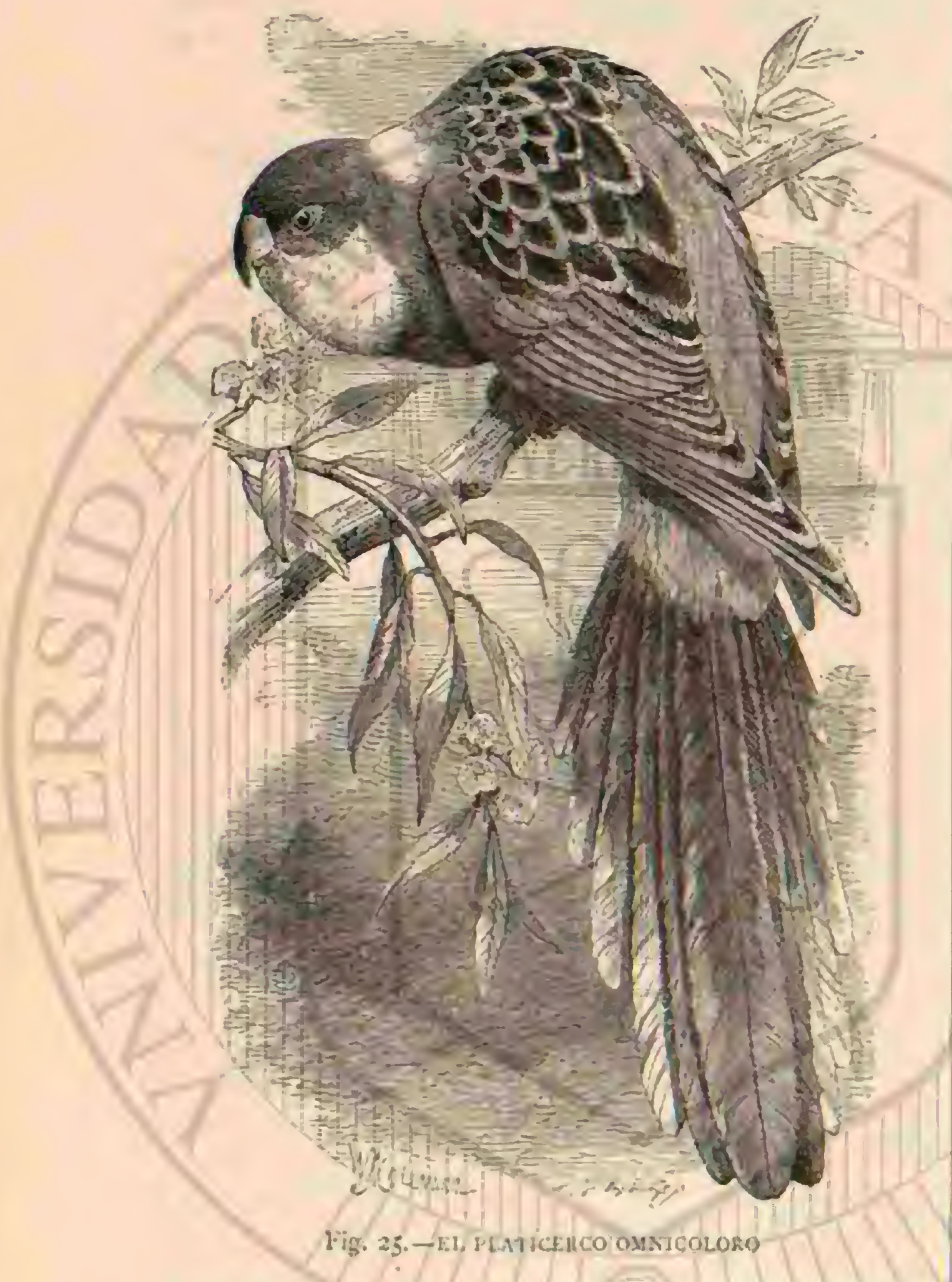

ahora otro resultado que la seguridad de qque no soportan nuestro clima. Su belleza y la gracia de sus movimientos cau. tivan á todo aficionado: pero su debilidad es causa de que pocos se ocupen de estas aves.

\section{LOS PLATICERCIDOS - PLATY- CERCUS}

CARACTÉRES. - El género de loros de la Nueva Ho landa y de la Oceania en general mas rico en especics es el de los platicércidos, que sé compone de aves de color mas ó menos hermoso, y cujo tamaño varia desde el del mirlo hasta el de la corneja. Sus caractéres son los siguientes: pico corto y robusto, casi siempre mas alto que largo, redondeado por arriba lateralmente, con la arista terminada en puntia, $y$ por lo regular muy corta; junto i la extremidad tiene una sesgadura dentada obtusa; la mandibula inferior es de ordinario tan alta como la superior, y forma un ángulo abierto, redondeado en la barbilla, en el cual se ve á reces una pe. queña prominencia en forma cic lista: las piernas son endebles y relativamente altas; las alas largas y puntiagudas, con sus extremidades prolongadas; las rémiges segunda, tercera y cuarta son las mas largas; la cola, casi sicmpre prolongada, adelgázase gradualmente hácia la punta, y se compione de plumas en extremo anchas, redondeadas en la plunta; el plu- maje, en fin, es suave, por lo regular muv abigarrado; pero en algunos individuos no se ven mas colores que el verde $y$ el rojo.

DISTRIBUCION GEOGRÁFICA.-LOs platicércidos, cuyo género se compone de unas cuarenta especies, representan en Australia y en las otras islas de su área de dispersion á los paleórnidos de la. India y del Africa. Finsch considera como cosa notable el hecho de que falten alli donde hay pa. leómidos, y que su área de dispersion conience donie ter. mina la de aquellos Habitan en Timor, Burn, Ceram, cl cste de las Molucas, Nueva Guinea, Australia, Tasmania, las Nuevas Hébridas, la Nueva Caledonia, Nueva Zelanda, las islas de Norfolk y Aukland y algunos grupos de las del Ocḱano meridional, las islas de Fidji, de los 1 migos y de ia Sociedăd. En cambio no se hallan en cl continente de Asia, en las Filipinas, en las Célebes, ni en el grupo que forman las isias de Flores, Sumbawa, Bali y Lombok, grupo que establece la comunicacion entre 'Mimor $y$ las grandes islas de la Sonda. Una de sus especies se extiende hasta las islas de Maquaria, es decir, lasta el $54^{\circ}$ de latitud sur, que constituye el limite mas meridional del área de dispersion de todos los loros.

USO'S, COSTUMBRES Y REGIMEN.-Conocemos aun muy poco el género de vida en libertad de los platicér. cídos, de esas aves que tanto cautivan nuestra atencion por la belleza de sus colores y su gracia. De las observaciones de Gould resulta que tambien las especies de este género viven como casi todas las de Nueva Holanda, es decir, que son con preferencia terrestres. I as vastas llanuras de aquel pais les ofrecen algunos años abundante alimento, mientras que en otros permanecen completamente estériles; en estc caso deben imitar ál los corellas, a los melopsitacos y eufémidos, emprendiendo emigraciones irregulares mas 6 menos largas. Los platicircidos figumn entre las aves mas voladoras, y so. bre todo corren mucho; pero no trepran tan bien como otros de sus congéneres. Su voz es mas agradable que la de la na. yor parte de los loros: raras reces gritan; por lo regular pro. ducen un silbido de dulce entonacion, y i menudo un canto melodioso. Sus facultades intelectuales son inferiores á las de otros loros, aunque sus sentidos alcanzan casi el mismo des. arrollo. Muchas especies son sociables tanto en libertad como en la jaula; otras por el contrario, precipitanse sobre sus semejantes ú otros congéneres y los matan a fuerza de picotazos en la nuca; algunas llegan á devorar sus victimas. En su patria viven hasta en la época del celo en pequeĩos grupos, y cada especie se aisla una de otra, si bien varias habitan el mismo territorio. Estas bandadas vagan con bastante irregu. laridad por el pais, visitan los alrededores de las moradas del hombre, y penctran hasta en medio de las ciudades; pasan las horas de la mañana y de la tarde buscando en tierra su alimento, que consiste en simientes de toda clase de gramineas Poco antes de la época del celo dividense los grupos para buscar los huecos de los árboles, donde las hembras ha. cen su nido, depositando sobre las fibras leñosas que caen al ensanchar la cavidad de cuarro á ocho huevos, y segun cier. tos observadores, hasta doce, blancos y brillantes. Segun pa. rece, la hembra los cubre sin ayuda del macho. Ambos sexos se teunen despues para criar los hijuclos, hasta que estos pueden seguirlos en sus viajes.

CAUtIVIDaD.-Hace unos diex ó doce años que los piaticércidos llegan con bastante frecuencia a Europa y han llamado la arencion de mas de un af́cionado. No obstante, con dificuliad se conservan estas ares en la jaula, pues nin. guna especie de loros es tan débil como ellas, y no sabemos aun cómo se déce cuidarlas. Hay, sin embargo, algunas excepciones de individuos que se conservaron largos años en cautividad, aunque no se les atendia mucho: mas por lo re- 
gular mueren sin causa conocida al poco tiempo. \&ingun otro grupo de loros, dice Linden, de acuerdo conmigo en este punto, comprende especies tan raquiticas como los pla. ticercos. Un individuo sano al parecer por la noche, aparece muerto por la mañana; otro oculta de pronto su cabeza debajo del ala, y a las pocas horas ha dejado de existir. A pesar de todos los cuidados posibles, el resultado viene a ser siempre el mismo.j. Segun las pruebas hechas, las aves soporian muy bien nuestro clima, $y$ hasta parecen estar mejor cuando se las hace invernar al aire libre; pero todas mueren al cabo de poco tiempo, tanto las que se conservan en habitaciones como las que se tienen al aire libre. Algunas especies se han reproducido tambien en nuestras jaulas.

\section{EL PLATICERCO OMNICOLORO-PLATY- CERCUS EXIMIUS}

CARACTÉRES.-Esta especie, una de las mas conocidas del genero, la que los colonos de Australin llaman riselli: y los indigenas de la Nueva Gales del sur bundullock, tiene ul tamaño de un mirlo grande, es decir, una longitud de $1 \%, 32$. La cabera, la garganta, el pecho y las tectrices in. feriores de la cola, son de un vivo rojo escarlata; las plum,s de dichas partes son amarillas en la base; las infuriores del cuello, las de la nuca y de los hombros negras, con un an. cho borde amarillo pálido; las de la parte inferior del pecho $y$ de los lados, de un amarillo vivo, con mancha negra en el centro; las del vientre, del muslo y de la rabadilla, asi como las tectrices superiores de la cola, de un bonito verde claro con viso amarillento; las réniges de un pardo oscuro con las barbas exteriores de un azul intenso; las de la mano de un magnifico lila; las tres ó cuatro últinas del brazo presentan exteriormente un ancho borde verde claro; todas las rémiges tienen la cara inferior de un negro gris; las dos rectrices del centro son de un verde oscuro aceituna y hácia la punta de un verde azulado; las otras de un azul oscuro en la mitad de la base y lila claro en la mitad anterior, con la punta blanra. Desde la mandibula superior hasta la region de las orejas se corre una mancha blanca: otra negra, inas grande, adorna la region del antebrazo. los ojos son de un pardo oscuro, nsi como el pico y los piés (fig. 25). I.a hernbra no difiere nucho del macho, y los polluelos se asemejan tambien bastante á los adultos, diferenciándose solo por sus colores mas pálidos y por tener la parte inferior del pecho de un verde amarillento; la mancha blanca de las incjillas presenta un vivo azulado.

DISTRIBUCION GEOGRÁFICA.-El platicerco om. nicoloro habita en la Nueva (iales del sur y' en la Tasmania: es uno de los loros mas cormunes, pero solo en ciertos punios, y esta como acantonado en algunas localidades, limita. dis á menudo por una pequeña corriente de agua que no iranquea.

USOS, COSTUMBRES Y REGIMEN. - No forman estos platicercos grandes bandadas: solo constituyen reduci. das familias que buscan con preferencia los lugares descu. biertos, las colinas y las llanuras ricas en praderas, sembradas aqui y allá de altos árboles y de algunas breñas. Unos y otras forman en cierto morjo el centro de su dominio en los pu. queubos' prados y los claros del brosque, donde van à buscor su alimento. Se les encuentra en todos los caminos, coma á nuestros gorriones; y á semejanya de estos, solo vuelan hasta el árbol ó el matorral mas próximos cuando se les asustr. Todos los viajeros están contestes en que la aparicion de este loro produce en el hombre del norte una impresion indes. criptible.

El platicerco omnicoloro tiene un vuelo ondulante: bate con rapidez las alas; pèro no se aleja mucho, y parece fatigarse muy pronto. En tierra no es torpe, pues corre con tanta agilidad como el pinzon.

Produce un silbido tan agradable, que casi se le podria considerar como un pájaro cantor.

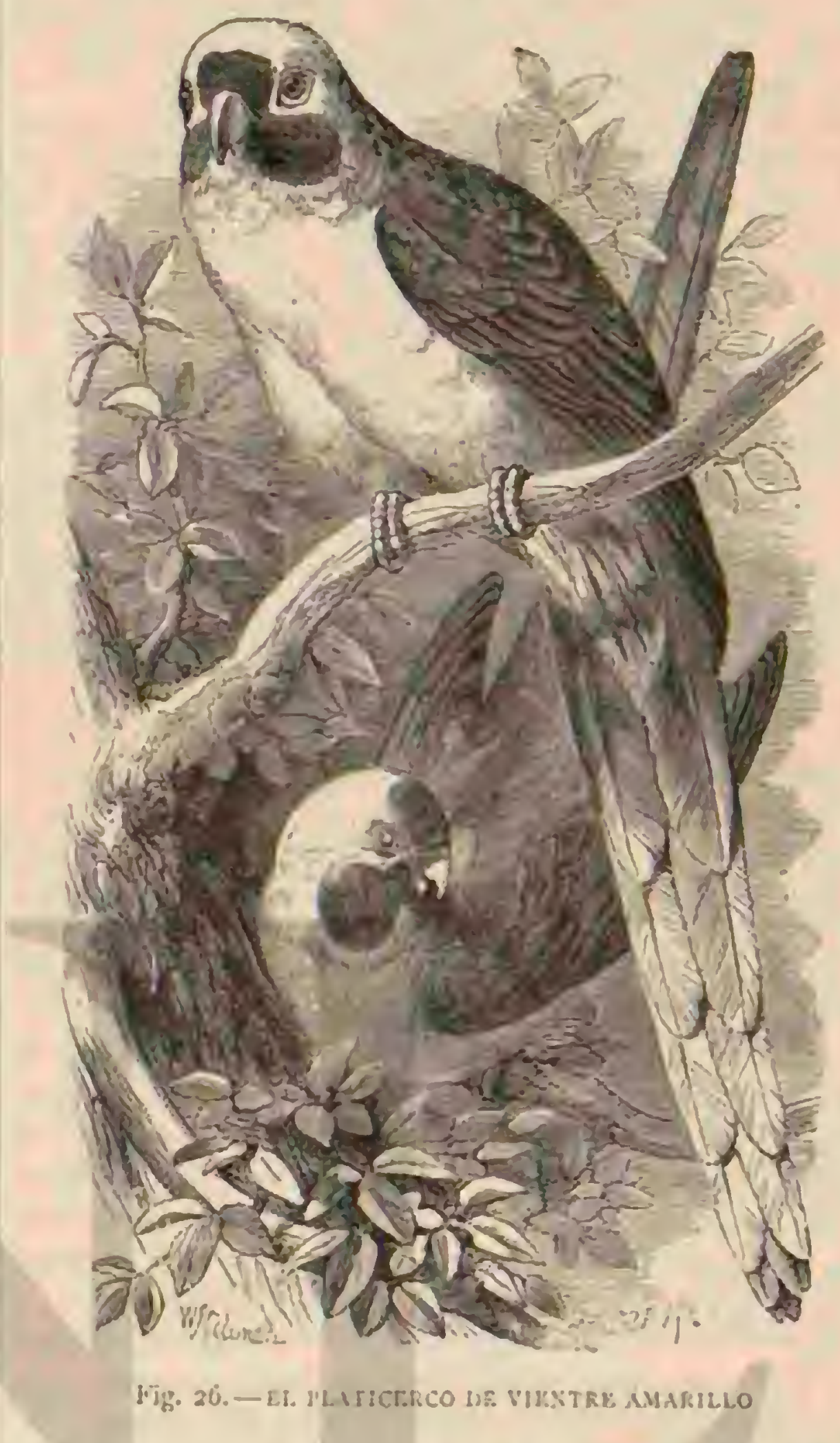

Constituyen su régimen principal los granos de toda espe. cie, pirticularmente los de las graminens; en ciertas ocasiones come tambien insectos.

El periodo del celo se declara en la primavera, es decir, desde el mes de octubre al de enero: la hembra pone de sicte a diez huevos, de un bonito color blanco, los cuales depositi en la rama hueca de un eucalipto 6 de cualquier otro arbol eleviado.

El huevo es corto y tiene las mitades casi iguales, de un color blanco amarillento gris que parece blanco verdoso si en el se reffeja la luz; su longitud es de $11^{\infty}, 025$ por 0 ,0 02 I de ancho. Segun Calay, nunca se encuentran mas de scis polluelas en el nido. Estas aves utilizan todos los huecos de árboles, hasta los mas profundos, y se las ve entrar y salir con la agilidad del oposum.

CAUTIVIDAD. - Eil rosella es una de las especies de su género que con mas frecuencia se recibe en Europa, donde se ha reproducido en diversos puntos. Por ln demis, todo cunnto hemos dicho al hablar del género es aplicable á la especie.

\section{EL PLATICERCO DE VIENTRE AMARILLO- PLATYCERCUS CALEDONICUS}

CARACTERES,-En el hermoso plumaje de este loro 
predominan los colores azul, amarillo, carmin y verde, en toda su purea, y se le conoce desde luego por tener las plumas del lomo terminadas en forma de punta de lanza. La frente es de un hermoso tinte carmin; la garganta y el centro de las alas le tienen azul; el pecho y el abdómen son de un magnifico amarillo de oro: las plumas del lomo son de color negro verdoso oscuro, con un filete del mismo tinte, pero micho mas claro, y estín además moteadas de verde: las cobijas de lás alas presentan algunas manchas rojas, las dos pennas. del centro de la cola son verdes, las demás azules, mas oscu. ras en la base y pálidas en el extremo. Los colores de la hembra son muy parecidos; pero no ian brillantes (fig, 26).

DISTRIBUCION GEOGRÁICA. - Este loro habita en toda la Tierra de Varl. Dienen, y abunda tambien nucho en las islas contiguas.

USOS, COSTUMBRES X REGIMEN.-El platicerco de que hablamos forma reducidas bandadas y vive en los bosques lo mismo que en los lugares descubiertos, y llama la atencion del viajero que recorre aquel cxtraino pals, asi por su familiaridad como por su numero, pues á reces se ven tan abundantes estos loros como los gorriones de nuestro pais. Segun Gould, su carne es muy delicada, y constituye mn plato exquisito.

CAUTIVIDAD. - Es muy á propósito para vivir en jaula y resiste muy bien este género de vida, olvidando pronto la pérdida de su libertad.

\section{LOS LÓRIDOS - TRICHO- GLOSSIN 在}

y dividido en forma de pelos; en la parte superior de la cabe. 22 y posterior del cuello hay a veces unos tallos largos, estre. chos y rigidos, pertenecientes $\$$ las plumas, que en algunas especies forman como un moño; el color es muy brillante, rojo, con dibujos azules, $\delta$ a veces de un solo color negro ó azul; el del pico es de un vivo amarillo anaranjado, ó negro, y el de los piés siempre oscuro.

\section{EL LORI DE LAS DAMAS - DOMYCELLA ATRICAPILLA}

CARACTÉRES.- Elijo para tipo del género una de las cspecies mas conocidas, cual es lori de las damas, el kasforic de los labitantes de Amboina, el luri ó ninrie de los naturales de Ceram, el kala-sira-lori de los bengaleses. Su color predominante es un magnífico rojo de escarlata; la frente y los hombros son de un negro muy oscuro; el occipucio de un tinte violeta oscuro; en el buche se ve una especic de ancha placa que á veces se extiende hasta el pecho, y cuyo color es amarillo inuy vivo. I a parte superior de las alas es azul; cada pluma esta orillada de blanco en la extremidad; las alas son de un verde oscuro de graminea, y pardusco amarillo aceitunado en la region de los hombros; las rémiges primarias de la mano son de un tinte amarillo de azufre por dentro y negras en la punta; las rémiges del brazo, excepto las dos últimas, que se distinguen por su color verde, son del todo amarillas interiormente; las pequeñas tectrices del ala y las plumas de la parte inferior del muslo, azules. Al rededor de la pupila se ve un estrecho circulo amarillo; ol resio del iris es pardo; el pico de un vivo color de naranja, y los piés de un regro gris (fig. 27). Segun Rosenberg, hálianse con frecuencia ráriedádes; nsi, por ejemplo, se ven individuos con una placa sonrosada en la cabeza, y las alas amarillas.

DISTRIBUCION GEOGRÁFICA.- Esta hermosa ave habita exclusivamente en Ceram y Amboina; nunca se cn. cuentra, como otras especies de su género, en Bornen 6 en el continente.

USOS, COSTUMBRES Y REGIMEN.-RStanVe, dice Rosenberg, á cuya amabilidad debo las siguientes noticias, es conuun en su patria; vive tanto en la soledad de las selvas como cerca de las moradas del hombre; pero nunca le vi en las montañas de Ceram. Por lo regular forma con sus semejantes grupos de pequeñns familias, y distinguese por su rápido vuelo. Muchas veces le vi pasas por cncima de la ciu. dad de Amboina, ejecutando las mas caprichosas evoluciones, luciendo el brillo de su plumaje, y dándose 1 conocer por sus gritos. Su alimento consiste, además de la miel vegctal, en frutas arboricolas, gustándole sobre todo las bananas. Tie. ne costumbre de anidar en los huecos de los árboles, doncle la hembra deposita sus huevos, que asi como los de todos los loros, son de un blanco brillante, y poco mayores que los de nuestro mirlo negro.

CAUTIVIDAD. - El lori de las damas es la especic que mas á menudo se ve cautiva en Amboina; apenas lay en la capital una casa ó una choza donde falte. Es el ave favorita de los habitantes, $v$ merece esta distincion tanto por su bellera como por su docilidad; aprende ficilmente $\{$ bablar, y es entonces el orgullo de su ducño. Por menos de ocho ó diez forines ( 17 \&:2 I francos) no se pucde comprar un individuo que sepa hablar; mientras que los otros se dan por tres 6 cuatro. Añadiremos de paso que tambien hay loris tercos y malignos. Se les alimenta con arroz crudo y cocido, salvado mojado y plátanos; asimismo se les da todos los dias agua fresca, porque beben inucho y les gusta bañarse. La palabra lori, que estas aves pronuncian, es tambien ense. ñada, no natural. sobre todo en la extremidad; el plumaje es bastante recio,
particularmente en la nuca, en el cuello y en el dorso, largo 
Con bastante frecuencia se recibe en Europa este lori, y por eso he tenido varias veces ocasion de observarle, asi como â otros individuos de su gúnero. Debo rectificar lo que dije en la primera edicion de esta obra respecto á que son quietos y fastidiosos; cuando escribi aqquellas líneas no cono. cia aun las ares. Los loris parecen, por el contrario, muy vivaces y astutos; estín en continuo movimiento desde la mañana hasta la noche, y son tan ágiles como inteligentes. Todo cuanto pasa \& su alrededor les llama la atencion, y manifiestan su curiosidad inclinando rảpidamente la cabcia. Por su ligereza y solkura para trepar no les aventaja ningun otro loro; sus movimientos son en extremo rápidos y á veces dan grandes saltos. Cuando están de buen humor complácense en bailar grotescamente en la percha. Su vo\% natural se reduce $\hat{\alpha}_{\text {s }}$ un grito desagradable, que segun Linden se podria expresar por avihe wihe wi sui, acompanado de un sil. bido y cloqueo muy extranos. Todos los loris que pudimos observar en cautividad eran sumamente pendencieros. Un lori de las damas cuidado por mi, y del cual he hablado ya detalladamente en mis Aües cautitas, luchó con los mas di. versos compañoros de su pajarera, excitando su ira con extrañas inclinaciones de cabeza, al paso que erizaba las plumas, entreabria las alas y hacia movimientos provocativos; despues alejábase muy contento para buscar otro adversario; pero siempre volvia hácia el primero en que una vez habia fijado su atencion. Al poco tiempo habia subyugado a to das las aves débiles, pero con su adversario principal, un cacatúa de nariz, habia irabado tal enemistad, que pronto le costó la vida: esta ave que habitaba una.jaula separada cscapóse un dia de ella, se precipitó á su vez sobre su ene. migo, y solo por mi intervencion fué posible salvar al lori; pero la excitacion de cste habia sido tan violenta, que murió al dia siguiente. Tampoco los loris viven en buena armonia con sus senejantes, pues hasta las parcjas rinen mu. chas veces. En sus ataques no proceden como las otras es. pecies; cógense con las garras, si es posible por la cabeza y cl pico, y se valen de este último solo para defenderse. Con su amo son afectuosos ó malignos, segun las circunstancias. Varios individuos están ya completamente domesticados cuando llegan á nuestro poder, y entonces son los compa. heros mas anables; déjanse tocar, acariciar y coger sin hacer uso jamás de su pico; otros, por el contrario, son mordedores $y$ desagradables en alto grado. En todo caso, Linden ticne completamente razon cuando dice que son muy superiores á sus congéneres mas afines, los tricoglosos ó loris de cola cunciforme, tanto por su inteligencia como por su docilidad y vigor.

Cuando se les cuida bien, los loris de las damas resisten perfectamente la cautividad, pero no es del todo fácil cuidarlos como se debc. Exigen, ante todo, un espacio abrigado y un alimento conveniente. Por lo general, bistales arroz cocido, zanahorias y otros frutos, con algunas sinicntes $y$ pan blanco; pero una pequeña falta, una golosina que se les ofrezca puede causar su muerte. Iinden observó que sus loris cautivos comian con mucho gusto cerezas negras, mientms que morian inmediatamente despues de haber comico moras. Una condicion principal para su bienestar es el agua, sobre todo para bañarse; de todas las especies de su úrden, esta cs la que mas la necesita; toman un binno, si no diaria. menie, al menos cada dos dias. No se echan al agua como suelen hacerlo otros loros: colocados en el borde de la vasija, se mojan el lomo, el pecho, el vientre, la cola y las alas, pero no la cabeza; imueven las rémiges y las tectrices; sécanse despues el plumaje, y manifiestan con su gran agilidad su buen humor. Es extraño, me escribe Iinden, que ducrman en el fordo de la jaula y se echen en un rincon; susueño es muy ligero, pries les despierta el mas leve rumor, segun lo indican por sus silbidos. En ningun otro género de loros, anade linden, he observado una muda tan marcada y cxtraña como en los domicellas; los cañones de las plumas aparecen blancos y tan rigidos, que al tacto parecen cerdas; la cabeza y el cuello parecen estar erizados.

\# Es poco probable que los domicellas se reproduacan jamás en nuestras jaulas y hasta parece imposible en vista de los defectuosos aparatos que les podemos ofrecer. No cs dado arreglaries una espesa selva virgen, ni tampoco proporcio. narles un alimento que tambien fuese conveniente para los polluelos. Por otra parte, estas aves son demasiado curiosas Einquietas para ocuparse celosamente en la incubacion; pero no negaré que una casualidad puede vencer las dificultades qque hasta ahora nos parecen insuperables.

\section{LOS TRICOGLOSOS-TRIGHO- GLOSSUS}

CARACTRERS. - Los tricoglosos ó loris de cola cunciforme forman el segund género de la sub.familia; son aves cuyo tanaño varia eutre el del gorrion y el de la paloma; el pico, de longitud regular, es comprimido lateralmente $y$ de aristia angulosa, cuya punta, delgada y muy corva, cs trun cacia marcadamente, mientras que los bordes de la mandi bula inferior son rectos; el angulo de la barbilla sube diago. nalmente; los piés son cortos y robustos, con dedos gruesos, provistos de uñas fuertes y corras; las alas son largas y puntiagudas; una de las tres primeras rémiges es la de mayor longitud; las puntas de las alas son largas; la cola cunciforme y gradualmente adelgaxada hiacia la punta; las plumas de la cola son bastante anchas en la base y se estrechan há. cia la cxtremidad, que es redondeada; el plumaje, bastante recio, se compone de plumas anchas y brillantes; cl color predominaute de la region supcrior es verde, y el del penacho rojo; por la suca se corre una faja trasversal mas clara, y en el penacho hay algunas listas mas oscuras.

DISTRIBUCION GEOGRÁFICA.-El área de dispersion de los tricoglosos es casi la misma que la de los plati. cercos, pero se extiende mas hácia el oeste. Su centro se halla en cl continente de Australia; su limite meridional es la 'lierra de Van Diemen y el septentrional las islas Halma. hera y Morotai, del grupo de las Molucas. De las islas del mar meridional solo habitan la Nueva Caledonia, las Nuevas Hébricias y las islas de Salomon, pero en cambio se extienden por la parte occidental hasta Sumbava y flores.

USOS, COSTUMBRES Y REGIMEN.-Sobre el género de vida en libertad de esta ave tencmos noticias exac. tas gracias á las averiguaciones de (jould. El rasgo principal de su carácter es la sociabilidad y asi puede suceder que en un mismo árbol vivan tres $\delta$ cuatro especies en la mejor armonía. Los tricoglosos, asi como casi todos los loros de Australia, emprender viajes, particularmente las especies que empollan en el sur, las cuales van y vienen con cierta regularidad. Para efectuar estas emigracioues reúnense en bandadas innumerables, tan espesas que forman una nube; entonces ejecutan caprichosas evoluciones; sus gritos son verdaderamente infermales; y a mucha distancia llaman ya la atencion del observador.

El vuelo de estos lorós es muy rápido, sobre todo en el momento de lanzarse como una flecha por los aires, y pro. ducen entonces un grito penetranic. In los ärboles trepan con bastante agilidad, pero mas bien como los paros que a la manera de los loros.

$A$ la salida del sol comienzan á buscar su alimento con tal ardor, que no se les puede alejar de los árboles en que se 
han posado. Un tiro no p̧roduce otro efecto qque el de levan. tar una griteria general; lo mas que hacen es abandonar la rama donde ha sido muerto uno de sus compañeros, â fin de ir a comer las flores de otra. Son muy diestros para chupar cl néctar, y si se les levanta por las patas al caer, se ve como fluir aquel del pico, perfectamente limpio.

Apenas sabemos nada acerca de la reproduccion de estos séres: parece que las bandadas no se dispersan durante el periodo del celo, y que solo anidan algunas parejas en el mis- mo árbol. El nido suele estar en el hueco de una rama, y contiene en octubre de dos á cuatro huevos, blancos y prolongados.

USOS Y PRODUCTOS.-La belleza del plumaje de es. tas aves cautiva â los mismos indigenas de Australia, tan indiferentes, segun parece, á la hermosura de la naturaleza y sus productos, pues obsérvase que en algunas regiones con. servan cuidadosamente las cabezas de todos los tricoglosos cazados, á fin de hacer con ellas una especie de collares que

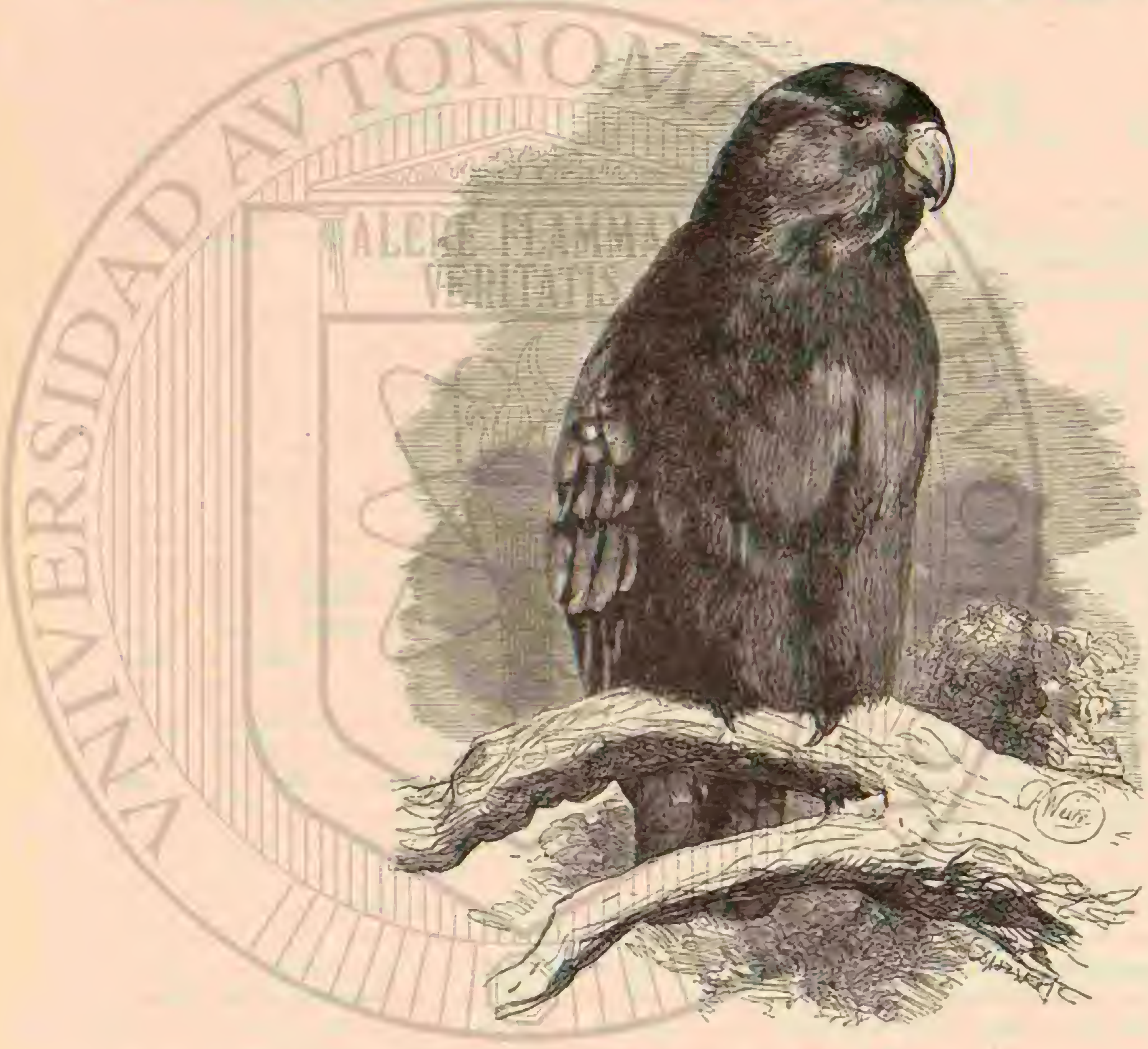

Fig. 27. - F.L L.ORI DE. LAS UAMAS

les sirven de adorno. Los colonos curopeos solo persiguen á estos loris para tenerlos en cautividad. Su carne es dura, y exhala además cierto olor ciesagradable, lo cual es. suficiente para que no les den cazn.

CaUTrVIDAD. - Fistos loros resisten, la cautividad mas fracilmente de lo que se espemba, aunque los viajeros dicen que con preferencia se alimentan de miel regetal y no gustan de las simientes; acostúmbranse sin embargo a estas últimas, conservándose en la cautividad mas que los plati. cercos y otros muchos loros que pasan por granivoros. Una especie ha llegado à reproducirse en Europay varias han puesto huevos.

No aseguraré que se pueda decir esto de rodo el grupo en general, pues de hs reintiscis especies que se conocen, ni aun la mitad han llegado vivas hasta nosotros.

\section{EL LORI OMNICOLORO - TRICHOGLOSSUS NOVAE HOLIANDIAE}

CARACTERES.-Fista especie, el warie de los indigenas de la Nueva Gales del sur, el guril de los naturales de Bota. nybay, el iatpagmu de los bengaleses, es la que con mas frecuencia se ve en nuestras jaulas, y una de las mas grandes del género, pues tiene casi cl tamaño de la coiorra de la Carolina. Ia cabe\%, las incjillas y la garganta son de un azul lila; la parte posterior del cuello, la nuca, la rabadilla y la cola de un verde oscuro de graminea; las plumas de la parte superior del lomo, amarillas en el centro y rojas en la base; las de la nuca, que forman un collar poco marcado, de un verde amarillo; el buche, el pecho y las tectrices inferiores de las alas, de un hermoso rojo cinabrio con lineas trasversales, tan pronto oscuras como claras; los lados del pecho de un amarillo vivo; las plumas del vientre, de un azul oscuro, rojas en la base; las de los lados del vientre rojas, con una mancha azul en la punta; los muslos, la tibia, la region del ano y las tectrices inferiores de la cola, verdes: las demas plumas rojas en la base, amarillas en el centro y verdes en su extremidad; las rémiges, negras en las barbas interiores, tienen en el centro una extensa mancha amarilla; las barbas interiores de las rectrices, de un amarillo de limon, son rojizas en la base. El 
iris es rojo anaranjado; el pico rojo de sangre; la cera de un pardo oscuro, $y$ los piés de un pardo pálido.(fig. 28 \%

DISTRYBUCION GEOGRẮFICA.-Ciould indica solo el sur de la Australia como patria del lori omnicoloro; pero tambien se encuentra, segun las últimas observaciones, en toda la Australia, y hasta en la Tiern de Van Jiemen.

USOS, COSTUMBRES Y REGIMEN.-Esta magni. fica ave puebla en gran número, pero casi exclusivamente, los besques de cucaliptos, que le ofrecen abundante alimen. 10; prefiere los árboles cuyas flores acaban de abrirse, porque tienen mas néctar y pólen. El espectículo nue ofrece un bosque de estos eucaliptos cubierios de flores, y visitado por diversas especies de tricoglosos, no se puede describir con palabras; á menudo se encuentrnn en un mismo árbol tres ó cuatro especies distintas que extraen el contenido de las to. res en la misma rama. Menos aun podria darse idea del es. trépito que produce su continua griteria, sobre todo cuando una bandada abandona un árbol para pasar a otra parte del bosçue. Es preciso haber visto y oido tales bandadas para formarse una idea exacta.

Paseåndose cierta mañana por entre los jarales de los al. rededores de Hunter, Ciould llego á un enorme eucalipto de cerca de 90 metros de alto, que apenas habia comenzado á florecer; miles de loris, atrnicos por las flores, poblaban el ramaje, y veianse alli reunidas las mas diversas especies: en la misma rama mató Gould individuos de las cuatro que ha bitan aquel pais.

Gould no ha podido hacer observaciones propias sobre la reproduccion; pero los indigenas le dijeron que la hembra pone dos huevos en los huecos mas altos de los eucaliptos, cubriendolos desde julio hasta setiembre. Este dato carece tal ve: de exactitud, $\delta$ por lo menos asi resulta del hecho de que las aves cautivas de la misma especic han puesto seis hueros.

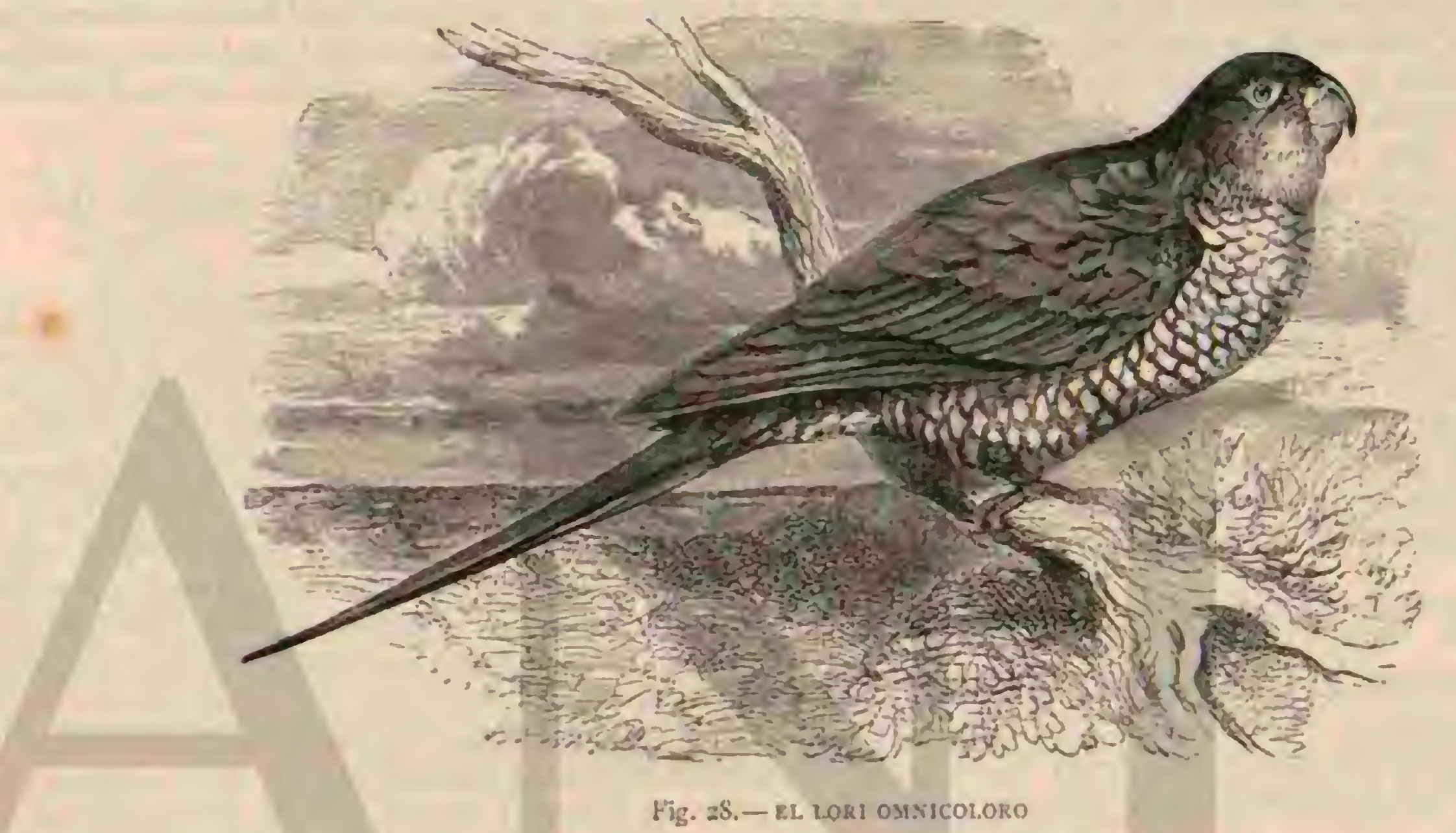

Calay cree que el lori omnicoloro se alimenta exclusiva. mente del néctar de las flores, y que nunca come simientes, siendo por eso muy dificil conservarle. Fista noticia es sin duda talsa, pues como ga he dicho, tiltimamente se recibe este tricogloso con frecuencia, y sicmpre es mas numeroso en nuestras jaulas. Hace diez anos que faltaba aun del todo en nuestro mercado; pero de pronio llegó un número consi. derable de estas avecillas, que se vendieron bajo los nombres mas distintos, akecibi, me escribe linden, una de las primeras parejas, recomendíndosenre que los alimentara solo con mijo y. agua. Al principio segui este consejo; pero al ver que dejaban casi intacto el alimento, diles tambien fniras, las cuales deroraron con ansia: la consecuencia fue que ambas aves sucumbieron a los pocos dias, despues de sufrir terribles convulsiones. Una segunda pareja que adquiri y alimenté principalmente con pan blanco mojado en leche resistio inas tiempo, pero murió tambien con iguales siniomas. E! examen anatómico, tanto de la primera como de la segunda parcja, no me explicó la causa de su muerte. Despues he cuidado otros con mas $\delta$ menos suerte; pero en gencral debo declarar que estas aves.pertenecen a las especies cuya conservacion es mas dificil. No obstante, he oido decir lo contrario, ha. biéndoseme asegurado que se han obienido crias; y hasta me enviaron la pareja de la cual se consiguicron polluelos; pero al morir los dos individuos, resultó que ambos eran hambras.
De este modo se publican y se creen muchas reces noticias falsas. Segun las pocas experiencias que yo he hecho con esta esprecie, debo convenir con linden en upue los iricoglosos son bastante dificiles de conservar, por mas que haỵa excepciones. Asi, por ejemplo, el ministro de Estado Gessler me escribe diciendo ţue ha tenido un lori omnicoloro cinco anos en completa salud, lo cual demosiró el ave poniendo seis huevos. Se alimentaba con mijo, carne de buey desme. nuzada, raspaduras de zanahoria y azúcar, todo esto mercla. do en iguales partes: la voracidad con que el lori se precipi. taba sicmpre sobre este alimento, comiendo hasta la uiltima particula, demostró que convenia à sus inclinaciones. Des. preciaba los insectos que le daban, expeliéndolos cuanda se los introducian en el pico.

«El lori omnicoloro, dice Linden, es mucho mas vivaz que los domiccllas; $y$ hasta podria decirse que es impletuoso. Mis aves csiaban siempre en cierto cstado de excitacion y no podia tenerlas en una pajaresa, porque el ruido que se hacia las espantaba demasiacio facilmente, y porque en este caso suelen ser muchas veces victimas de su excitacion. Vuclan con la rapidez del rajo, produciendo siempre una especie de graznido, y no bajan a tierra sino cuando sienten la ne cesidad de banarse. Su voz, dificil de expresar, consiste en una especie de graznido; pero siempre es chillona s pentetrante. 8 


\section{LOS PIRRODOS - PYRRHODES}

CARACTÉRES.-Los pirrodos 6 sarmosinos de Wagler, psitfaprus de Lesson, se distinguen entre los lóridos por sus formas mas esbeltas; la cola se compone de rectrices escalonadas; las dos medias son mas largas que el cuerpo y se adelgazan gradualmente hasta la punta.

\section{EL PIRRODO DE LOS PAPÚES-PYRRHODES PAPUENSIS}

CARACTERES. - Este lórido tiene un largo total de $0^{\circ}, 45$; de ellos corresponden lo menos flo, 30 ol las rectrices me dias; la extension de las alas abiertas es de 0,39 . Fi plumaje es de colores vivos: sobre un fondo rojo escarlata, se ven sem. bracias varias manchas azules, amarillo de oro y verde claro; la cabeza, la nuca, la parte superior del lomo y el vientre, son de un rojo escarlata, excepto dos fajas azul celeste que bajan a lo largo ide la cabeza. Los lados del pecho y las ancas es. tán manchados de amarillo; la paste inferior del lomo, las plumas que cubren la cola $y$ la cara interna de los musios, son de un azul oscuro; las alas verdes; las pennas medias de in cola, de un verde claro con el extremo amarillo dorado; las otras rectrices son tambien verdes y amarillas, pero de un tinic mas oscuro (fig. 29).

DISTRIBUCION GEOGRÁFICA.-Este loro es propio de la Nieva Guinea: segun tengo entendido, nunca se le ha visto vivo en Europa, ni poscemos tampoco ningun dato acerea de su género de vida.

USOS Y PRODUCTOS. - Los indigenas le dan caza le utilizan para iguales fines que las ares del paraiso, prepanrandole del mismo modo: córtanle las jatas y lo disecan, en cuyo estado se ven con frecuencia en Europa.

\section{LOS NESTORES - NESTOR}

CARACTÉRES.-El género de los nestores $\delta$ loris de cola obtusa comprende cinco especies de las cuales se ham extinguido dos completamente; la primera de estas des. apareció ya s. principios del presente siglo y la segunda a mediados.

Los nestores son loros de forma robusta y recogida, cuyo tamaino varia entre el del estornino y cl del cuervo. Distin. guense por tener el pico muy fuerte $y$ largo, comprimido lateralmente; la mandíbula superior presenta en su arista, estrecha y redondeada, un ligero surco longitudinal que ocu. fla dos tercios desde la base, y en los lados una proninencia ligeramente redondeada en forma de lista; la punta se en. corra en figura de arco plano y es muy prolongada, presen tando junto á su extremidad una ligera prominencia dentada; los surcos de la punta ́altan; los bordes de la mandibula superior son lisos y rectos, y el ángulo de la barbilla, ancho plano; los piés son robustos; las piernas bastante largas; los dedos largos, provistos de unas fuertes y muy corras; las alas, prolongadas y puntiagudas, sobresalen de las iectrices supe riores de la cola cuando el ave descansa; la tercera y cuarta rérniges son las mas largasi la cola, de una longitud regular, es recta y se compone de plumas anchas, cuya punta afecta la forma de doble gancho; el plumaje, abundante, y de color pardo aceitunado ó verde, mas vivo en la nuca y en el vien tre, no difiere en los seros. La lengua en cuya forma se funda la clasificacion de los nestores, como la de los otros loris, es gruesa, segun Potts, aplanada en la cara superior y redon deada en la inferior, en la cual presenta una seric de papilas cortas, rigidas, en figura de cepillo, dispuestas en cierto tno do como el borde de las unas en el dedo humano.
Por este carácter difieren bastante de los otros loris, pero su lengua se asemeja mas á la de estos que á la de ninguna otra especie de loro.

DISTRIBUCION GFOGRÅFICA.-Las tres especies aun existentes labitan en los bosques de las dos islas princi. pales de la Nueva Zelanda, en número an considerable, que se podria asegurar su evistencia para muchos años.

USOS, COSTUMBRES Y REGIMEN.-Mientras que las dos especies extinguidas habitaban solo en las pequenas islas donde fueron exterminadas por los curopeos, las otras viven en los grandes bosques del interior, sobre todo en las montañas inaccesibles; y segun la especie, en los bos. ques de la zona media y en los que forman el limite superior de la vegetacion arbórea. Resulta pues que habitan todas las zonas de las islas situadas al nivel del mar y las que se hallan a dos mil metros de altura. Hasta últimamente no hemos obtenido datos sobre el género de vida de ninguna especie; ahóra contamos con las excelentes observaciones publicadas en su mayor parte á principios y mediados del decenio pa. sado, entre las cuales figuran las de Potts y Buller; de modo que actualmente conocemos los nestores mejor que á mu. chos loros domesticados hace siglos.

\section{EL NESTOR MERIDIONAL-NESTOR MERI- DIONALIS}

CARACTER FS.--El nestor meridional, el kaka de los maoris, tipo el mas conocido del género, tiene una longitud de $10^{\circ}, 47$ por $107, S_{3}$ de anchura de punta a punta de ala; las alas miden $0^{\circ}, 2 \$$ de largo y la cola $0^{\circ}, 1 \$$. El color del plu. maje es muy variable; mas por lo regular, la frente, la coro. nilla y el occipucio son de un gris blanco; los lados de la cabeza y del cuello, la nuca, la barba, la garganta, el buche Y la region superior del pecho, de un pardo oscuro; la region de las oreins de un tinte amarillo: la parte inferior de las mejillas y la garganta de un pardo purpúreo oscuro; la parte posteriot del cuello, cuyas plumas forman una faja trasversal blanca, la rabadilla, las tectrices superiores de la cola y las regiones inferiores, de un pardo purpúrco ascuro; cada pluma es parda en la base y purpúrea en la extremidad; las de la parte posterior del cuello presentan un borde estrecho pardusco anaraujado; las plumas del dorso, asi como las tectrices superiores de las alas, son de un tinte parcio aceitunado con viso verde, y tienen en la extremidad un borde negro muy marcado; las tectrices centrales de las alas están orilladas de un blanco purpúreo; las rémiges dé la mano, de color pardo oscuro, presenian en la mitad de la base de las barbas exteriores un color verde y en el borde de las interiores de cinco a seis manchas puntiagudas de un color rojo pálido de cinabrio; las - tecírices ýlas rémiges del bmzo son de un pardo claro de aceituna; las últimas tienen tambien cinco manchas rojas en el borde de las barbas interiores; sus rectrices son de un pardo oscuro y por fuera de un verde intenso; las plumas del hombro y las pequenas tectrices de la parte inferior del ala, de un rojo oscuro de cinabrio con fajas trasversales pardas, poco marcadas; las tectrices medias de la parte inferjor del ala de un pardo pálido, con grandes inanchas rojas en el borde; las plumas caudales son de un pardo oscuro aceitunado, negras en la punta y de un parda rojizo brillante en la mitad de la base, en las barbas inte. riores y en la cara inferior; la base de aquellas tiene en el borde seis manchas de color rojo cinabrio. Lil iris es pardo oscuro; el pico de un gris azulado intenso; la mandibula inferior pardo amarilla en la base, y los piés de un gris azul. Machos y hembras revisten el mismo plunaje, y los hijuelos se ase. mejan mucho á los adultos, diferencíndose solo por su color 
mas pálido, por teiner poco marcadas las pumtas negras de has plumas, y muy pequenias las manchas rojas del borde de las barbas interiores de las rectrices. No me ocupo de las muchas variedades.

DISTRIBUCION GEOGRẢFICA.-Líl direa de dispersion del kaka se extiende por una gran parie de las montañas occidentales de la Nueva Zelanda, desde la falda de aquellas hasta el limite de la zona de los altos árboles.

\section{EL KEA-NESTOR NOTABILIS}

CARACTERES. - Fi kca de los indigenas ó laro ti los monsfajias de los colonos, es mas grande que su congénere descrito, pues mide ()$^{*}, 50$; las alas tienen $11^{\circ}, 32$ de largo, $y$ la $\operatorname{cola} U^{\circ}, 20$; cl color predominante del plumaje es verde acei. iuna; cada pluma ostenta en la punta una mancha parda en forma de media luna y una linea estrecha parda en el tallo: las plumas de la parte posterior del dorso y las tectrices su. periores de la cola son de un bonito tinte rojo de escarlata pálido en su extremidad; las rémiges de la mano y sus tectrices son pardas, con un borde azul verdoso en la base de las barbas exteriores, y tanto en ellas como en las rémiges del brazo se ven siempre manchas denticuladas de un color amarillo vivo; estas manchas, vistas por debajo, forman tres fajas; las plunas caudales son de un verde pálido; las del lado pardas en las barbas interiores, donde presentan manchas den. ticuladas de color amarillo anamnjado, que forman tres fajas bien distintas; las tectrices de los hombros y las inferiores del ala son de un rojo escarlata con la extremidad parda. El iris es pardo oscuro; el pico pardo antarillento, y los piés de un tinte amarillo de accite.

DISTRIBUCION GFOGRAFICA.- Lil àrea de dispersion del kea se limita á una zona de la Nueva Zelanda situa. da á una altura que varia de 1,500 á 2,000 metros sobre el nivel del mar; solo baja de aquella elevacion cuando el in. vierno es muy riguroso.

\section{EL NESTOR DE PICO LARGO - NESTOR PRO- DUCTUS}

CARACTERES. - Keconvicese la especic por sus varia. dos colores (fig. 3o): la cara superior del cucrio es parda; la cabeza $y$ la nuca están manchadas de gris, pues coda pluma tiene un feston oscuro; cl lomo, el vientre y las plumas infe. riores que cubren la cola son de un rojo oscuro: el jecho, la garganta $y$ las mejillas de un tinte amarillo con visos rojos, sobre todo en aquellas. Las rectrices son de color amarillo anaranjado en su raiz, y orilladas de pardo; las barbas inter. nas de la base de las rémiges de un tinte de orin oscuro, y pardas en su cara interna. Hl circulo que rodea el ojo es de un pardo aceitunado, lo mismo que los tarșos: cl pico pardo, y. el iris de este mismo color, nuy uscuro.

En los pequeios está reenuplazado el color amarillo y rojo por un tinte jardo aceitunado oscuro.

DISTRIBUCION GEOGRÁFICA.-Ia especie de que tratamos habita la pequeũa ish Felipe, que no tiene cinco millas de circuito; segun Gould, personas que han pasado algunos ah̆os en la isla de Norfolk, distante apenas cuatro o cinco millas de la amerior, no le han visto nunca alli.

USOS, COSTUMBRES Y REGIMEN DE LOS NESTORESEN GENERAL. - Fil kea se va retirando á los bos. ques solitarios á medida que el colono arınza mas jo mas, j’ ya escasea bastante en muchas regiones donde antes era muy comun; jero todavia se ven numcrosas bandadas. En el interior de los bosques abundar como siempre, porque el hombre no ha prodido ejercer aun su infuencia en el género de vida del kea; el territorio que habita esta are se halla situado en una altura, a donde solo llegan algunos aventureros para bus. car oro, ó bien los naturalistas para crzar. Montañas salvajes y rios profundos presentan un obstáculo al viajero, ofreciendo al are la mas completa seguridad; encumbradas rocas con inaccesibles muros de pieara, donde abundan las caridades y las grietas, sirvenles para entregarse al reposo 5 construir sus nidos; $y$ las ricas praderas, cuya vegetacion enana se es. malta en verano de preciosas fores, ofrícenles el alimenio en abunciancia. Quizás solo el haicon de la Nueva 7.elanda (Fulio Noice Ziolusndic) penetra en aquel territorio salvaje, que tan bien satisface sus necesidades Esta rapaz no es el mas peligroso enerniga del nestor de pico largo; más debe temer un invierno riguroso. Cuando el frio es muy intenso, cuando iodas las cimis de las montañas quedan sepultadas debajo de la nieve, el nestor se ve obligado á abandonar sus seguras rocas para buscar en los bosques mas bajos su alimento.

l'anto el kea como el nestor meridional emprenden en ciertas estaciones del año cxcursiones mas ó menos regulares; las causâs deben ser las mismas; pero en la segunda especie no se reconoce tanto la necesidad como en la prinera. En el nestor influira solo, tal vez, el deseo de viajar; durante el verano le retienen la incubacion y la cria de sus polluelos; pero tan luego como estos se hacen independientes, empieza á vagar pror el país. Entonces se ven á veces en los bosques bandadas muy numerosas de estas aves, que poco á poco se reunen, atraidas por la abundancia del alimento; pero no viajan nunca en gran numero: Potts ha observado que van aisladas ó cuando mas en grupos de seis á ocho indiriduos. Sin embargo nunca olvidan producir á intervalos su grito, sin duda para reconocer si otras aves de su especie han tomado el mismo camino ó se han reunido en algun paraje. Cuando reciben contestacion, bajan de la altura con vuelo lento, acomprasado y penoso al parecer, descansando á ratos en Las ramas secas de los arboles mas altos. El que observa las aves solo cuando vuelan pausadamente, apenas podrá formarse una idea de la agilidad que demuestran por lo regular. En los hosques que habitan duranti el vemno se ven nuchas veces, segun Potts, numerosas bandadas que se remontan gritando por las regiones aúreas, donde describen anchos circulos, ejecut:ando todit clase de evoluciones, cuyo objeto no es evi. dentemente otro que el de divertirse. 1) pronto se ve á una de estas aves, mas atrevida q̨ue sus compañeras, precipitarse hácia las profundidades con las alas recogidas y casi en direccion vertical, mientms que las otras parecen aplaudirla con sus ruidosos gritos. Iil nestor neridional es un ave arbo. ricola; el kea es esencialniente terrestre. Anquel anda por ol suclo cou tanta pesadez como la mayor parte de los otros loros, saltando á la manera de cueryos, pero muclio inas tor. pernenic; en cambio está muy familiarizado con los árboles, sube y baja con un. agilidad admirable, y balancéase con sorprendenie destreza í to largo de las ramas; el kea, por el contrario, corre con la rapidez del euf́n mido de Australia 6 del cacatua de naria y apenas se le puede llamar ave arbo. ricola.

Las dos especies son sociables, conı la mayor parte de los loros. No solamenie las parejas sino tambien los demás individuos, viven in la nus perfecta armoniz. Fil carador que al pasar por los bosques solo encuentra í intervalos algun nestor nislacio, asombrase cuando al producir este un grito de cspanto, ve llegar por todas partes sus numerosos compañeros. Lin el bosijue, hasta enronces silencioso, resuenan súbitamente los gritos de las ares ! sus movimucutos revelan cuanta compasion les inspira su companiero herido. livera de rales casos, se les ve poco durante el verano; ocúltanse y guardan silencio en las horas de calor, y solo cuando la almósiera refresca, 
salen de sus escondites; al rayar el alba y por la noche dejan oir su vo\% y muchas veces se les ve ir de una parte à otra, á la luz de la luna. Todo lo que tienen de silenciosos cuando descansan, tienen de alborotadores cuando despiertan; por todos los puntos del bosqque se oyen sus extraños gritos, que son la reproduccion de sus nombres: y entonces se les ve en toda su actividad. Los unos trepan por los bejucos $\delta$ se sirven de su fuerte pico para descortezar algun tronco; otros ensanchan un agujero, examinan la madera podrida, ó recosgen bayas; $y$ todos, en fin, ejecutan diversos trabajos, bien para satislacer su apetito, ó ya para destruir. Toda su actividad se emplea para buscar el alimento; son omnivoros en el verdadero sentido de la palabra. Durante la época del celo alimén- tanse con preferencia del pólen de las plantas; pero despues comen casi toda clase de bayas y frutas silvestres; acometen hasta á los grandes animales y no desprecian en caso de necesidad los cadáveres. Su fuerte pico les permite perforar la madera podrida, y cuando han olfateado en ella una presa, abren profundos agujeros en los troncos de los árboles. Potts pondera quizás mas de lo justo la utilidad de estas ares para los bosques de la Nueva Zelanda, donde como se sabe faitan los picos, y parece inclinado \& clasificarlos entre las aves guarda-bosques; dice tambien que por su aficion al néctar vegetal son útiles en otro concepto, pues contribuyen a la fecundacion de las plantas. Estos méritos no serán, en efecto, tan grandes como parecen. Otros observadores hablan en

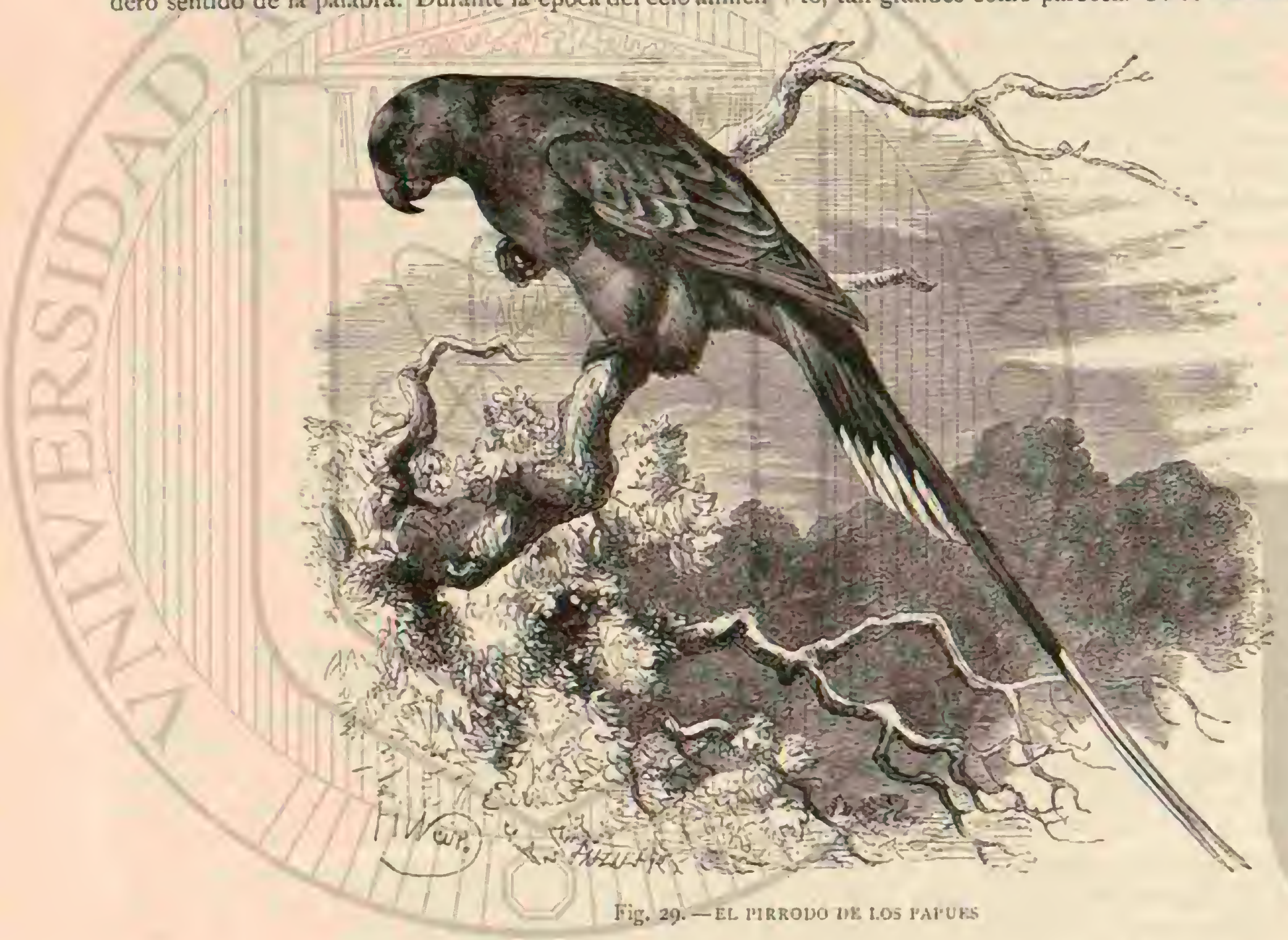

cambio de mucinas fechorias de que se hacen culpables: Potts duda que jamśs ataquen un árbol sano y forido; Buchanan, por el contrario, cogió un nestor que arrancaba la corteza de un árbol completamente sano, solo para recoger la savia.

Peor es aun lo que hace el kea. Esta ave ha perjudicado mucho, segun se dice, á cièrto señor Campbell: observóse que los rebaños de ovejas de dicho colorio tenian sin causa conocida una enfermedad extraña; en varias partes de la piel de estos animales producianse heridas del tamano de una mano, que llegaban hasta los músculos, y echaban á jeerder Ia lama por la sangre, ocasionando á menudo la muerte. Al fin un pastor observó que los loros de la montaña eran los causantes: vió a una de las aves posarse sobre la oveja elegida, y antes que el estúpido animal pudiese librarse de ella, abrirle un agujero en el cuerpo. Advertidos ya los pastores, pudicron presenciar desde entonces ataques análogos. Los keas se presentaban aislados ó en grupos, posábanse sobre el lomo de una oveja, scparaban su lana es inferian al animal una herida, atormentándole hasta que abandonaba el rebaño. Entonces le perseguian y renovaban sus ataques; aturaianle por completo; $y$ cuando al fin, desfallecido ya, se echaba en tierra preservando todo lo posible su lomo contra las aves, estas empezaban á comer por el otro lado del tronco, causando asi muchas reces la muerte. Se añade que estos ataques solo se verificaban en una zona de la montaña situada á los I,600 ó I, 800 metros de altura; que solo se observaron durante el invierno; que los culpables eran siempre individuos aislados; mientras que en otros sitios de la montaña, situados a la misma altitud, no se observaba cosa semejante. Por poco creible que la noticia parezca no puede dudarse de la veracidad del hecho, si se toman en consideracion oiras observa. ciones recogidas por los naturalistas de la Nueva Zelanda respecto a los marcados instintos carniceros del nestor de la montaña. Fn los liftimos años esta ave ha reconocido, segun dice Polts en otro pasaje, que cerca de las colonias tambien suele haber un depósito de carne y no olvida nunca aprovecharse de esta circunstancia. Preséntase con regularidad en los contornos de los mataderos de ovejas para comerse alli los despojos, y sobre todo las caberas de los animales muertos. Gracias a su voracidad disminuyen tambien las provisio. nes de carne de ternera $y$ las de oveja de igual modo, y ni tampoco desprecia las pieles secas. Estos ladrones nocturnos se presentan por lo regular de noche, y no es raro ver tocia una bandada reunida a la vista de una choza de matadero. 
Haast considera al kea como ave en alto grado curiosa, que no puede abstenerse de examinar minuciosamente cuantos objetos encuentra. En uno de sus paseos por la montan̉a habia recogido dicho naturalista con gran trabajo un haz de plantas alpinas, el cual colocó en una roca saliente. Durante su corta auscncia, un kea habia visto el haz y demostrado su inicrés por la botanica precipitándole al abismo. En otra ocasion, un pastor quecó muy sorprendido cuando al volver a su choza despues de una ausencia de dos dias, y habién. dola dejado bien cemaia, oyó en el interior un ruido extraño: produciale un nestor, que habiencio penetrado por la chime- nea, ocupíbase en revolver con su fuerte pico todos los objetos del interior: ropas, cama, pañuelos, todo cunnto no resistia á los picotazos estaba destrozado; las sartenes, puche. ros y platos yacian por tierra; y en una palabra, apenas se veia un objeto que no estuviese roto; ni aun la cruz de la ventana estaba intacts.

Fn la época del celo los nestores se manifiestan el carino recinroco acostumbrado cntre los loros. El macho que se une con una hembra no se separa ya nunca, y cuando esta se dirige á un árbol vecino, siguela de cerca. Cuando se trata de buscar sitio conveniente para el nido y de construirle,

Fig. 30, - E. NESTOR แIE HCO LAKCO

ambas aves cxaminan los árboles cuyo interior estás hueco y podrido y se comunica con el exterior por medio de una abertura mas ó menos grande. Por lo pronto se ensancha y alisa la entrada, trabajo que ocupa toda la atencion cie las ares; y obsérvase que estas son muy exigentes en la eleccion de su vivienda, pues á menudo dejan un nido casi acabado cuando han descubierio otro mejor. Buller encontró el 23 de diciembre en una cavidad dos hijuelos que podrian tener unos diez dias; hallabbase $a$ un metro de alturn del suelo $y$ reduciase il una especie de galeria de $0^{*}, 60$ de longitud por $10^{\circ}, 30$ de diámetro que conducia a un nido de $\|^{\prime \prime}, 40$ de diámetro. Iais paredes del mismo eran lisas, y el fondo estabn cubierto de madem podrida y de algunas corteras, cuyos uil. timos fragmentos habian sido llevados alli por las ares. lil nestor meridional, sin embargo, utiliza tambien las cavidades entre las raices de un árbol $\delta$ las grietas de roca, donde arregla pronto su nido. A principios de noviembre la hembra pone cuatro hueros blancos cuyo mayor diametro es de $0^{n}, 04$ $y$ al menor de $0^{m}, 0_{3}$, los cubre con aficion y ambos padres se cuidan de la cria de los polluelos que salen por Navidad. Potts hace mencion de un ejemulo del gran carino que los padres profesan â sus hijuelos: desputes de un incendio del bosque encontró un ave muerta á la entrada del nido, sin duda porque no habia podido resolverse a abandonar su progenie. Los indigenas, que $\{$ menudo cogen los polluelos en el nido, aseguman que a veces se aparean dos hembras con un macho: el hecho de encontrarse dumnte el periodo del eclo tres aves juntas, parece confirmar en algo esta no. iicia.

La incubacion y cria de los hijuelos ocupa casi todo el verano, y solo hácia el otono de aquellos paises, que es nues. irn primavera, la vida de estas aves comienza á ser mas di. vertida Teniendo muy abundante el alimento engordan mucho, y entonces la carnce es muy buscada. No es tan agradable su vidar en invierno, estacion que debe considerarse como su enemigo mas peligroso. Las ricas selvas se cubren de una 
alfombra de nieve; el alimento escasea; y el ave, que debe buscar con qué satisfacer sus necesidades, permanece posada en un mismo sitio, con el plumaje erizado $y$ silenciosa, cual una verdadera imágen de la tristeza. Entonces ha de aceptar todos los alimentos, mientras que en verano podia elegir las golosinas que le ofrecia la rica naturaleza; come con gusto las simientes mas duras y amargas, y hasta las busca en los jardincs. Así pasa el invierno, y solo cuando la primavera vuclve á lucir sus galas, el ave recobra su alegria y con. tento.

CAzA.-El hombre es para estas aves un enemigo mas cruel aun que el invierno, pues persigue á todas las especies de nestores cón aficion, para comer su carme y criar sus hijuelos. Tanto el nestor meridional como el kea, dejanse co. ger muy fácilmente: el primero con lazos y redes de varias clases, y el otro de un modo que recuerda nuestra manera de coger los espinidos con liga.

El ker es tan descuidado que sin dificuttad se le puede pasar un nudo corredizo por el cuello cuando visita las chozas.

CAUTIVIDA D.-El ave cautiva se acomoda muy pronto asu nueva situacion; no se enfurece ni aletea; permanece tranquila hasta que la quitan el núdo corredizo; pero piensa al principio en la libertad y sabe lograrla nas facilmente de lo que por lo regular se figura el cazador. En mo seria ellcerrarle en una jaula de madera, pues la destruiria en poco tiempo. Tambien sabe escapar de situaciones dificiles: cierto individuo que por falta de una jaula fué puesto debajo de un cubo, descubrio muy prónto que este, a causa del asa, no tocaba por un lado en el suelo: introdujo en el hueco su pico, derribó el cubo y escapóse. Cuesta poco acostumbrarle á cualquier alimento y cuando se le trata bien domesticrse á las pocas semamas; mas fácilmente se consigue aun cou los polluelos que se cogen en el nido, y estos son los que con mas frecuencia se tienen en cautividad, tanto por los indige. nas como por los curopeos. Los primeros se acercan siem. pre con la mayor precaucion al nido de un nestor para no ahuyentar álos padres; y hasta no se atreven \& tocar cl hueco ni á respirar sobre el, pues creen que esto yn basta para obligar à los adultos á dejar el nido, Los hijuelos que están ya algo desarrollados se fueden criar fácilmente, porquè acep. tan todo cuanto el hombre come. $\mathrm{El}$ que aun dude que son omniroros, dice Potts, podra convencerse dejando libre un cautivo donde haya leche á su disposicion; muy pronto verá con qué destreza el ave sabe extraer la parte manteco. sa. Fistos polluelos se acostumbran fácilmente a entrar $y$ salir, y resisten muy bien su cautiverio, tanto mas cuanto mayor es la libertad de que disfrutan. Al europeo no se le puede aconsejar que los deje libres, pues abusarian de este favor cometiendo fechorias que, repetidas muchas veces con conocimiento visible, acabarian con la paciencia del mas indulgente. Para un nestor domesticado que tenga la entrada y salida libre, no hay en la casa ni en el jardin objeto alguno en que no pruebe sus fuerzas para satisfacer su instinto destructor. Buller asegura haber conocido un nestor que en un solo dia cogio miles de flores de peral, destrozando las vides $y$ otras plantas. Cuando se deja una de estas aves libre en una habitacion, todos los objetos sufren los ataques de su poderoso pico. I.os indigenas, que no necesitan resguar. dar nada, aprecian esta ave mas que ninguna otra especie doméstica; su excelente facultad de imitar la permite aprender palabras ; frases de la lengua de los maoris, y por su astucia puede emplearse como reclamo para otras de su es. pecie.

El que posec un nestor que sabe atraer a la red a sus compañeros libres, no vende el ave por ningun dinero. E! nestor cautivo que habla sirve de diversion a la juventud de un pueblo de moris; el ave de reclamo es para su dueño una verdadera fuente de riqueza, y como sus facultades aumentan con los años, no podenos extrañarnos que los indi. genas no vendan tal ave ni por 250 francos.

En visia de lo expuesto paréceme extrano que se reciban en Europa tan pocos nestores cautivos. Solo últimamente han llegado algunas de estas curiosas aves. Finsch vió un nestor vivo en el Jardin zoológico de Lóndres. «Difiere bas. tante por su conducta de todos los demás loros, dice aquel naturalista, pues corre casi siempre rápidamente por el suelo désu jaula; siempre está bastante derecho, y cuando alarga el cuello recuerda mucho á los halcones. Sin embargo, le vi tambien trepar con mucha habilidad, como otros loros, sir. viéndose del pico. No he oido su roz nunca.y Mas tarde re. cibió el Jardin zoológico de Lóndres otros cautivos de la misma especie y últimamente llegó uno al Jardin zoológico de Amsterdan. Ni de unos ni de otros se han publicádo, al menos que yo sepa, detalles minuciosos.

\section{LOS DASIPTILOS - DASYPTILUS}

La especie que ha servido de base á Wagler para formar su género (Dasyfitilus) no es menos singular que la descrita de los nestores, con la cual guarda cieria semejanza. Distinguese de todas las que componen la familia de los cacatúi. dos por caractéres muy marcados; y ofrece tal analogía con las rapaces, que un autor inglés ha dicho, y con razon, que de cada diez personas, nueve la tomarian por un águila.

CARACTERES. - El pico es prolongado y muy comprimico: In mandíbula superior sobresale de la inferior, aunque menos que en los nestores; la cara, el circulo de los ojos y la barba están desnudos; cubren la cabeza algunas sedas erectiles y plunás mus espaciadas, de tallo duro y rigido; las alas son anchas y solo llegan hasta la mitad de la cola, que es mediana y redondeada; las rectrices y las rémiges son suma. mente erectiles; las plumas del cuerpo secas y quebradizas, por lo regular.

DISTRIBUCION GEOGRÁFICA.-No se sabe á punto fijo cuál es su patria: Gould cree que habita en la fiormosa, donde no existe ningun otro loro: es mas probable que sea originario de la Nueva Guinea ó de Salawatti: Rosenberg indica positivamente la primera isla como su verdadera patria. De todos modos, no sabemos con seguridad si escasea ó no, pues aquellos paises no han sido explorados aun; pero la verdad es que en muy pocas colecciones se ha visto este loro.

\section{EL DASIPTILO DE PESQUET - DASYPTILUS PESQUETTI}

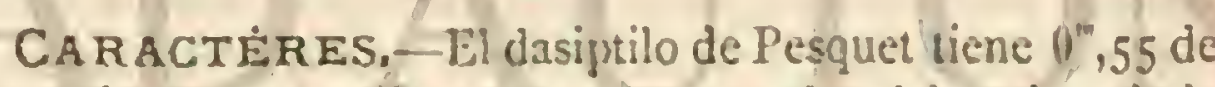
largo, inclusos los $0^{\mathrm{t}}, 16$ que corresponden á la cola; el ala plegada mide f" ${ }^{\prime}, 30$. El plumaje es de color negro brillante, con visos grises en la garganta, en la cabeza y el pecho, visos debidos a una lista de color pardo oscuro que orilla las plumas. Las superiores del ala en la articulacion del carpo, las primeras que cubren las remiges secundarias, las inferiores del ala, las barbas externas de las cinco primeras rémiges secundarias, las plumas axilares, el vientre y la rabadilla, son de un color rojo escarlata; las que cubren inferiormente ia cola mas oscuras; las sub-caudales tienen los extremos de un rojo oscuro, el pico es negro y los tarsos de un pardo oscuro (rigura 31). A pesar de lo mucho que escasea el dasiptilo de Pesquet, podemos reproducir un dibujo copiado del natural: representa un individuo que vivió largo tiempo en la famosa coleccion de lord Derby: 


\section{LEVIROSTROS - LEVIROSTRES}

Este órden comprende ares de formas muy distintas unas de otras, y las especies que constituyen la primera familia difieren tanto de las de la última, que apenas se pueden reco. nocer como congeneres. Si comparamos los levirostros con lus tan matcados grupos de loros, colibris y picos, que yo considero como brdenes independientes, conforme en esto con los naturalistas modernos, veremos que parecen formas un grupo compuesto de los elementos mas heterogéneos. Hé aquil por qué los naturalistas opinan tan diversamente acerca de estas aves; y aun hoy dia la cuestion no estí resuelia Ni siquicn respecto al nombre del b́rden hay acuerdo en las opiniones. Los levirostros son las mismas aves que Huxley designó con el calificativo de cocigonórfidos (Cusejgomer. phac). Yo he preferido el nombre de levirostros, acioptado por Reichenbach, porque me parece mas conveniente.

CARACTERRE. - Las ares que reunimos en este órden difieren tanto unas de otras que es dificil determinar caracteres generales, pues muy pocos son aplicables en todos los casos. Cada parte del cuerpo presenta modificaciones: el tronco es tan pronio recogido como prolongado; el curello corto $\delta$ bastante largo; $\mathrm{cl}$ pico relativamente mas grande que el de cualquiera otra ave, al paso que hay esprecies en las cuales solo constituje un pequeno gancho córneo; is mandi. bula superios, movible y unida con la coronilla como en los loros, est soldada en otros géneros con los huesos frontales, distinguiéndose à menudo por unas extrañas excrecencias cómeas; unas especies la tienen delgada, recta y en forma de lezna, en otras es gruesa y corva, tan pronto redondeada como comprimida lateralmente. I.os piés son por lo regular cortos; la piel de las piernas ofrece la forma de red, 6 se compone de placas; el primer dedo puede ser movible en todas direcciones, dirigiendose hịcia delante o hácia atrás; en algunas especies se obserrin esta particularidad en el segundo tercero. Las alas son generalmente anchas y redondeadas, y por excepcion puntiagudas; el numero de rémiges varia mu. cho; la cola es corta ó prolongada, compuesta de plumas muy anchas y largas ó pequeñas: solo el numero de estas es algo constante, hallindose de ordinario diez ó dowe tectrices, y por excepcion solo ocho; el plumaje difiere en cuanio á su forma, disposicion y color, y lo mismo se observa en el resto de la estructura.

Aunque los levirostros se asemejen poco entre si, pertene cen sin embargo á un solo grupo, bien se dé í esie el rango de órden $\delta$ no. Nadie puede desconocer que las formas mas variadas se enlazan por otras; de modo que ningun levirostro ocupa una posicion tan aislada como el gipogerauno 6 ser pentario dentro del órden de las rapaces. Varas familias se asemejan tanto, que podria creersc que la una es solo repro. duccion de la otra: pero cada cual conserva su independencia y puede distinguirse marcadamente por ciertos caractéres, mientras gue en las especies de la misma familia se necesita at veces el eximen mas detenido para reconocer la diferencia de dos de ellas.

Mas que en su estructura exterior, los levirostros se aseimejan por la interna, sobre rodo en cuanto se refiere al cra- neo. Segun Huxley, pertenecen $\{$ las aves en que las apófisis palatinas de los maxilases superiores se reunen en la linea central, bien inmediatamenie 6 ya por medio del cartilago nasal huesoso, formando de consiguiente un grupo muy con. genérico con el de los loros. 'Todas las especies se asemejan por el carácter de tener el esfenoides imperfecto o nuuy pequeno, y las apófisis palatinas de los maxilares superiores mas 6 menos celulares 1.os cuerpos de los maxilares superiores ocupan a veces mas de la mitad de la lroca: los huesos pala. tinos carecen de placa vertical en su parte posterior y extién. dense en ella por lo regular horizontalmente, prolongandose á menudo su ángulo exturior en forma de una apófisis unas ó imenos marcada. In columna vertebral sc compone de trece vértehras cervicales, siete ri ocho dorsales, nueve á trece sa. cro-coxigeas ý cinco á ocho caudales El esternon tiene gencralmente en ambos lados dos sesgaduras; la pélvis es cor. ia y ancha; la cxtremidad anterior del pubis se prolonga en algunas especies en forma de apofisis obtusa $\delta$ puniinguda. La lengua pucde ser estrecha y larga y lienar todo cl espacio que hay entre las ramas de los maxilares inferiores; otras ve. ces asemájase ds una hoja fibrosa $y$ seca, distinguiéndose por su proca longitud. El esófago se ensancha excepcionalmente en forma de buche; el estómago, musculoso y de piel delgada en unos, es grueso y carmoso en los otros; la vejiga de la bilis y los ciegos faltan en algunas especies; la parte inferior de la laringe viene solo dos, o cuando mas cuatro musculos laterales

DISTRIBUCION GEOGRÁFICA.-I Los levirostros son cosmopolitas, siquiera havitan con preferencia las zonas cálidas; algunos viven en las regiones templadas, y otros no existen sinc en los paises frios. Las altas cadenas de montañas no les convienen; solo se encuentran en los primeros contra. fucrtes. Viven exclusiramente en los bosques, y no hacen mas uzue pasar por los lugares descubiertos Las mas de estas aves son sedentarias; algunas hay errantes y otras emigran. recorriendo extensiones muy considembles de terreno. El arren de dispersion de cada especie varia mucho: pero es coinunmenie muy reducida.

USOS, COSTUMBRES Y RÉGIMEN.-LOS levirostros no observan todos el mismo género de vida, y dificil es formarse en este concepto una idea exacta No son aves parti. cularmente bien dotadas: en tierra se muestran torpes, y en el ramaje no pueden moverse sin el auxilio de las alas; sus patas les sirven cuando mas para cogerse â la rama que a\}. canzan al vuelo y sostenerse en ella; pero no para andar ni saltar. En cambio vuclan todos muy bien, y hasta hay algunos que ritalizan en estc concépto con el halcon y la golondrina. Cuéntase tambien una familia que tiene en cierto modo pror dominio el agua; las aves que de ella forman parte, se sumergen, $\delta$ se dejan caer desde lo alto en la liquida superficie $y$ se remontan agitando con fucrza las alas.

Los levirostros no están bien dotados en cuanto of la roz, ni figumn entre ellos aves canionas Pocos hay, sin embargo, que guarden silencio; muchos por el contmio, compláccnse en lanzar gritos; pero todos, sin excepcion, producen solo 
algunas notas muy poco variadas. Los sentidos de la vista y oido parecen bastante perfectos en estas aves; el gusto y el olfato son imperfectos por no decir rudimentarios. Lin cuanto á la inteligencia no es posible asegurar nada á punto fijo, pues si alcanza gran desarrollo en algunos, parece limitada en los mas, contándose varios que se distinguen por su torpeza y estupider. Hay levirostros que son timidos, y algunos tan osados é indiferentes, que el mayor peligro no les causa impresion.

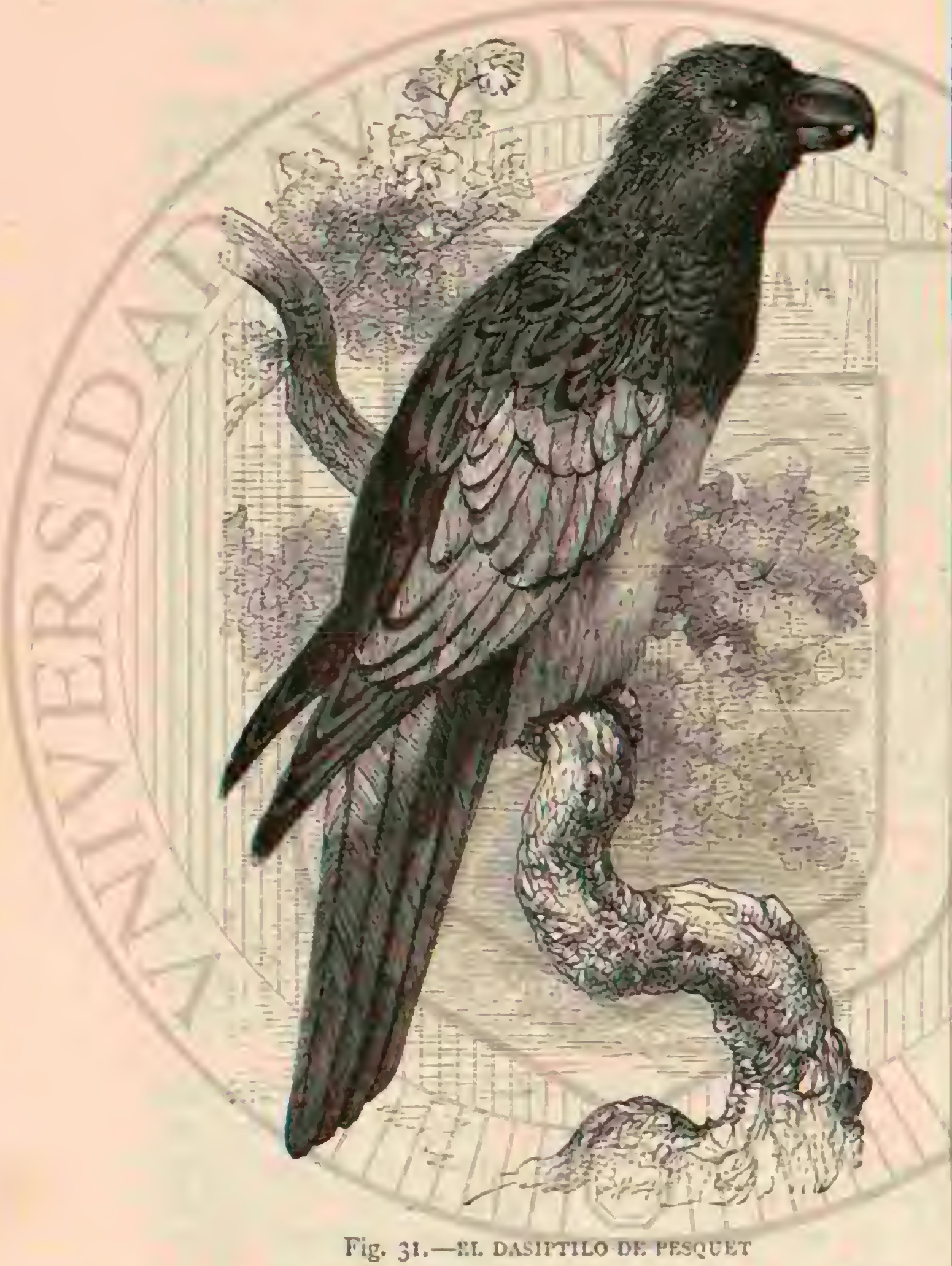

Las costumbres de estas aves ofrecen mas de una particularidad curiosa: muy pocas de elias, las mejor dotadas, son sociables, ó mejor dicho viven reunidas con sus semejantes 6 con otras especies afines. Por lo general, cada una permanece aislada; mientras el amor de familia no cxcitc a un levirostro, jamás se inquieta por sus semcjantes, y trata por el contrario de alejarse de ellos, aunque debe advertirse que no rodos parecen accesibles al amor de la progenic, por mas que el número de estos sea muy reducido. Podenos estable cer, como regla general, que un levirostro, ó una pareja de estas ares, habita cierro dominio, en el que no tolera la presencia de ningun intruso. Posarse silenciosa y tranquilamente sobre la rama de un árbol, acechar su presa, perseguirla, volver al mismo sitio y recorrer su dominio una $\delta$ dos veces al dia, son todas las ocupaciones ordinarias de los leviros tros. Solo algunos, los mas nobles, constituyen una excepcion; retozan largo tiempo con sus semejantes en las regiones aéreas; deslizanse con ellos á través del follaje 6 buscan su alimento en tierra. Ocripanse tambien de to que pasa à su alrededor; persiguen á las rapaces, y anuncian á los otros séres alados su presencia; mientras que las demás especies se cuidan solo de lo que puede inieresarles directa- mente, siendo el amor el único sentimiento que se nanifiesta en sus actos.

La mayor parte de los levirostros se alimenta de pequeños vertebrados, huevos, insectos, moluscos, larvas y gusanos; los denzás comen granos principalmente. Los primeros son muy voraces, cazan todo el dia, digieren rápidamente, y no dejan pasar ante ellos una presa sin atraparla; los que se alimentan sobre todo de frutos parecen menos hambrientos, y en todo caso, quedan satisíechos mas pronto. Los levirostros surcan el aire en todos sentidos para cazar, ó bien se precipitan sobre su presa desde el sitio donde se han posado; otras veces la cogen en tierra, y algunos se apoderan de ella hasta en el agua, dejándose caer desde cierta altura Varios levi. rostros se mantienen, sin peligro alguno, de las larvas que los demás vertebrados no pueden comer impunemente.

Casi todas estas aves anidan en agujeros practicados en tierra, ó en el tronco de un árbol hueco; algunas cons. truyen, al aire libre, nidos muy toscos; y las hay, en fin, que confian su progenic á padres extraños, aunque sin perderla completamente de vista Los huevos de las primeras son generalmente blancos; los de las segundas se asemejan coinunmente, por el rolúmen y el color, á los de las especies que cuidan de ellos: todos los levirostros anidan solo una vez a! año. Isstas aves reportan al hombre muy poca utilidad: algunas le jrestan bastante buenos servicios en ciertas circunstancias; pero por otra parte ocasionan muchos daños directa ó indirectamente; de modo que los unos son una compensación de los otros.

CaUtroidad- Estas ares se prestan poco á la cauti ridad, y hasta hay algunas completamente refractarias. Otras, en canibio, se acostumbran fäcilmente al nuevo réginen, y rarias de ellas son incapaces de alimentarse por si mismas en una estrecha jaula. Las primeras son mas ó menos divertidas en cautividad; las otras muy fastidiosas, y por punto general podemos decir que los !evirostros no nos sirven de $\operatorname{gran} \cos 2$

\section{LOS RAMFASTIDOS- RAMPHASTIDE}

«o criste en el Brasil, dice Burmeister, ningun grupo de animales mejor definido y caracterizado, a primera vista, que el de los ramfastidos. Si militan razones para poner à los loros en parangon con los monos, tambien las hay para com. parar á los ramfastidos con los perezosos, y con tanto mayor motivo, cuanto que este modo de ver conviene con la dis. persion geogrifica de los tipos animales. Los ramíastidos solo habitan en la zona tropical de América; pero en su calidad de ares, déjanse fet aun mas allá de eśte limite. Éncuén. transe en México y en Buenos Aires, donde no existen los perezosos; habitan en la vestiente occidental de las Cordilleras, punto al que tho van tampoco aquellos animales, y no se les ve nunca á mas de 5,000 piés sobre el nivel del mar. To. dos sus movimientos revelan mas ligereza que los del pere zoso, pues al fin $y$ al cabo son aves, y como tales, deben te. ner cierta viveza; pero son estúpidas y sus sentidos obtusos, si bien no tanto como los de aquel manifero.

Debo confesar que no comprendo el paralclo establecido por este ingenioso autor, pues el género de vida de las ares de que hablamos, al menos á juzgar por lo que me consta, no se presta en manera alguna $\mathbf{a}$ tamaña companacion. Ningun otro observador reconoce en dichas aves sentidos obtusos; ninguno encontró en ellas la menor cosa que recuerde a los perezosos; antes por el contrario, encómiase su prudencia, vivacidad y agradables costumbres. 
- La parte mas notable del tucan, continúa Burmeister, es su pico cónico, córneo, grande, corvo, mas ó menos compri. mido lateralmente, an ancho como la cabeza en su base, $y$ casi tan largo como el tronco; está cubierto en todas sus partes de una-ligera capa córnea que llega hasta su naci. miento, y por eso le falta la cera; las fosas nasales se abren por arriba junto 2 la frente, á cada lado de la arista del pico, Y quedan ocultas por las plumas de la cabeza : el pico no es dentado y se encorva mucho en su exiremidad; el borcie de las mandibulas presenta cuancio mas aigunas escotaduras. la region de la cabeza, al rededor de los ojos y de la mandibula superior, desde el ángulo de la boca hasta la frente es regularmente desnuda, y hasta carece de plumas cerdosas; los párpados no tienen tampoco pestañas, carácter de q̨ue participan los loros.

- El plumaje es rico, aunujue no abundante: se compone de plumas poco numerusas, blandas, lacias, anchas, redon. deadis y bastante cortas: las alas son redondeadas tambien

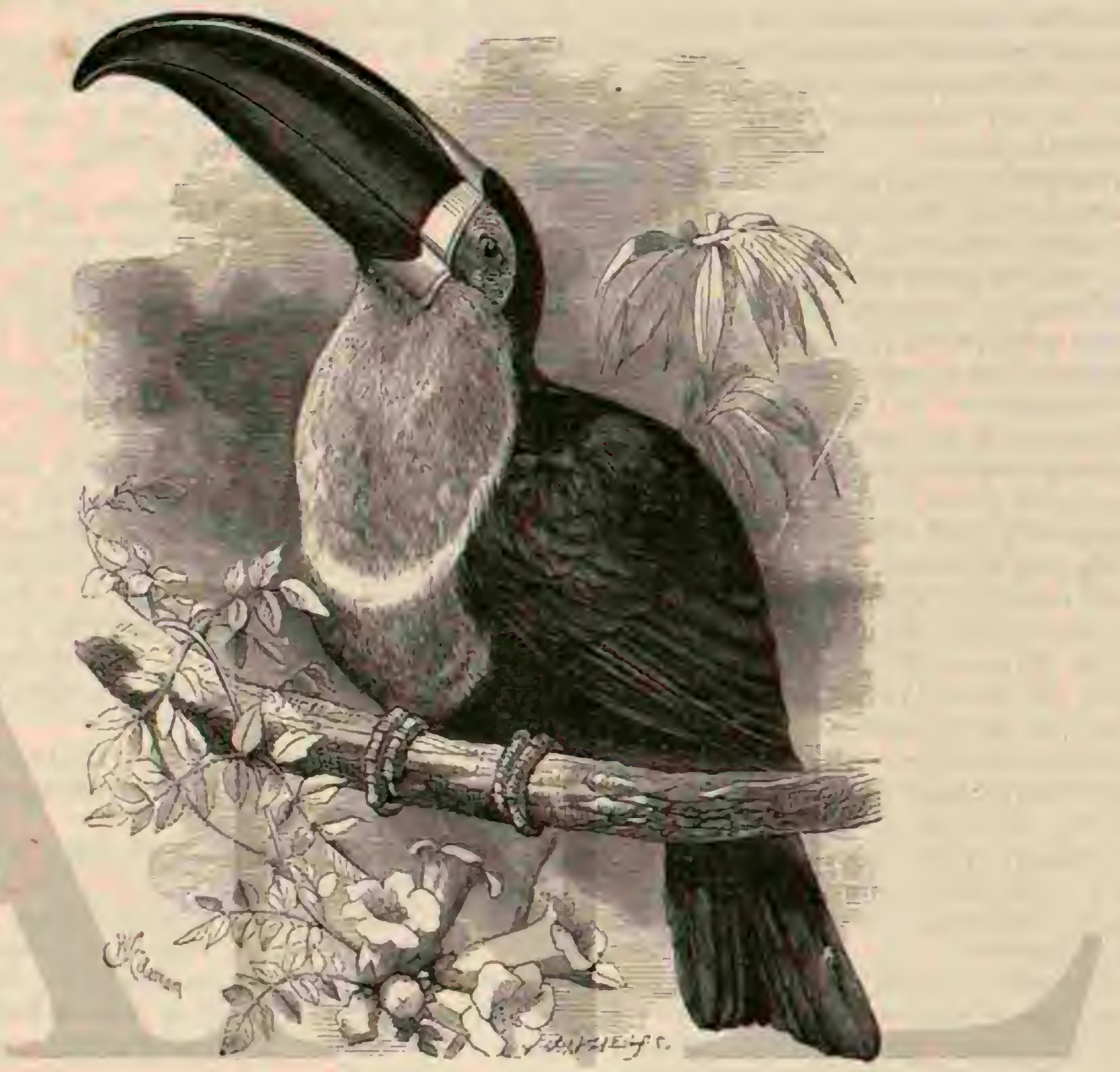

Fig. 3ิ2.-EL TuLAS roco

y no sobresalen del naciniento de la cola; las rémiges secundarias, anchas, grandes y largas, cubren casi por conapleto las primarias, que son mucino mas pequehas y menos exten. sas; la primera rémige es muy corta, la segunda menos; y la cuarta es mas larga por lo regular, atunue sobresale poco de la tercera y la aquinta, sucediendo lo mismo con esta úlcima respecto o la sexta. La cola, grance y ancha, es ả menudo larga, cónica, puntiaguda y escalonada, y se compone de dict pennas. Las patas son grandes y fuertes, prero no mus. culosas; los tarsos, bastante largos y delgados, están cubiertos por delante y detrás, de escamas tubulares, generalmente en número de sicte; por encima de las ariiculaciones de las falanges hay dos, y una sola cubre una de arjuellas. La cara plantar de los dedos es verrugosa; las uizas largas y muy en. corvadas, aunque no robustas; las dos anteriores son algo mas grandes que la postcrior, y presentan un reborde muy saliente en su lado inierno.

- Conocidos son los caractéres esenciales de la estructura interior; el pico, tan grande y pesado al parecer, es hueco y le ocupa un tejido esponjoso, de grandes celulas, a las จุue Tоно III llega el aire por las fosas nasales; estas hállanse representa. das por conductos contorneados en forma de $S$, que bajan desde la frente hasta la faringe. La lengua ofrece el aspecto de una estrectia cinta córnea, recortada en los bordes, algo comrarable con una hoja de gramínea: carece completa. mente de músculos. El buche no cxistc; la túnica musculosa del estómago es gruesa: el higado tiene dos lóbulos; no existe la vesicula hiliar ni los ciegos.

- En el esquelero vemos que los huesos del críneo, del cuello, del tronco, de la pélvis, y los húmeros son los únicos neumáticos: los iémures, los huesos de ha piema y el pié, los del antebrazo y la mano, contienen médula. Existen doce vértebras cervicales, de sicie \& ocho dorsales y ocho caudales. El esternon no presenta un gran desarrollo; es ancho por detrás, y está provisto á cada lado de dos apófisis desiguales. La quilla esternal es poco saliente, sin prolongacion anterior, articulando de un rnodo particular con las dos ramas de la hornuilla, que son independientes una de otra s

DISTRIBUCION GEOGRÁFICA. - Los ramfastidos habitar las selvas virgenes de la América meridional. 
USOS, COSTUMBRES Y RÉGIMEN. - Burmeister asegura quie nadie ha descrito tan bien las costumbres de los ramfastidos como e! principe de lvied, y por lo mismo co. piaremos lo que ell dice:

Sonnini y Azara han trazado una reseña muy exacta de estas singulares aves: las descripciones de ambos autores estain conformes en general; pero en cada una se indican algunas particularidades especiales diversas, sin que por ello desmerezcan en nada el atractivo y la exactitud de los relatos.

- En las selvas virgenes del Brasil, los ramfastidos son, con los loros, las aves mas comunes. En invicrno se matan por todas partes numerosos individuos parn comer su carne; pero ofrecen mas interes para cl extranjero que para el indigena. el cual está muy acostumbrado a ver sus singulares formas y su brillante plumaje.

s Verdad es que estas ares abundan mucho en los bosanes de dicho jais; pero no lo es menos, que ofrece gran dificu! tad, como lo ha observado muy bien Somnini, poder estw. diar a fondo su género de vida y sobre iodo su maneral de reproducirse. Los brasileños me han asegurado que la hem. bra pone dos huevos en el tronco hueco dc un árbol, lo cual es probable, pues la mayor paric cie las ares del pais da el mismo número.

- El régimen de los ramfastidas permanicció ignorado mu cho tiempo: Azara asegura que roban los nidos de las aves, y yo no puedo afirmar lo contrario: pero si diré que en el estómago de los individuos examinndos por mi, solo hallé granos y btras sustancias análogas. Watcron afirma esto y dice que los ramfastidos no son carnivoros. Ocasionan graves danos en las plantaciones porque se comen los pláianos y las guayabas. En catutividad son omnivoros: yo he visto a una de cstas aves devorar carne con avidez, beber firon (coci. miento hecho con harina de yuca y caldo de carne), y comer frutos de diversas especies. Debemos citar tambien una ob servacion de Humboldi, y es haber visto i estas aves comer jeces. Yo no he observado nunca que los raminastidos lanzasen su alimento al hire antes de comerle. I.os salvajes ase guran que se alimentan de frutos cuando viven libre's, $y$ ncaso coman otras sustancias, al menós las que puedan tomar con su endeble pico.

\$os raminstidos son tan curiosos comó las cornejas, cuyo regimen parecen observar; persiguen juntos álas aves de rapina, y se reunen muchos para hostigar á sus enemigos. Yo no puedo decir que vuelan pesadamente: el aserto con trario de Sonnini se refiere sin duda al toco, al que jamás he visto en los aires. El tucana (Ramphastus Temminckii) vuela \&. gran altura, trazanco una linea ligeramente ondulada, sin hacer esfuerzos extraordinarios, y sin un aparato diferente del de las otras aves. Cuando vuelan los ramfastidos, tienden horizontalmente el cuello y el pico, y por lo tanto no llevan la cabcza encogida entre las espaldillas, como lo asegum le Vaillant. Thaterton se engaria tambien al indicar que el pico se inclina hácia tierm por scr excesiramente pesado para las fuerzas del ave: muchas veces, por el contrario, he admirado la ligcreza y rapidez. con que estas aves jugueteaban en el espacio sobre los árboles, para desaparecer bien pronto en medio del follaje. Dudo que el toco constituya una excen. cicn, pues su pico es tan ligero, yue no debe pesarle mas gyue cl de otra ave que le tenga pequeño.

- El grito varia segun Ins especies: Azara expresa por risk el que ha oido: $\mathrm{m}$ me parece que este deo ser el del toco: las otras especies que yo estudié le tenian muy diferente.

USOS Y PRODUCTOS. - I LOS indigenas de América fabrican adornos con las hermosas plumas de estas aves, y al efecto emplean principtlmente las del pecho, que tienen el color de naranja.
En lo siguiente doy á conocer las noticias posterinres so. bre estos animales.

\section{LOS TUCANES - RAMPHASTUS}

CARACTERES.-Los tucanes tienen el pico muy grande y grueso en la base, sumamente comprimido en la punta, y de arista aguda; los tarsos fuertes, altos, cubiertos de grandes escamas planas; los dedos largos: la cola corta y redon deada; las alas cortas y tambien obtusas, con la cuarta $y$ q̨uinta rémiges mas prolongadas.

Jass diversas especies conocidas se asemejan mucho por el plumaje, que es de un magnifico color negro brillante, sobre el cual se destacan el amarillo, el blanco ó el rojo de la garganta, del lomo y de la rabadilla.

\section{EL TUCAN TOCO-RAMPHASTUS TOCO}

CARACTÉRES. - El toco (fig. 32) es el mayor de los tucanes: ticne todo el plumaje negro, excepto la garganta, las mejillas, la parte anterior del cuello, y las cobijas superio. res de la cola, que son blancas, y la rabadilla de un rojo de sangre claro. El pico es muy grande y alto, con algunas escotaciuras en sus bordes; su color es rojo naranja viro; el lomo y la punta de la mandibula inferior de un rojo de fuego; el extremo superior y el borde posterior son negros; unia mancla iriangular delante del ojo amarilla, los anillos oculares azules, el iris verde oscuro, las patas azuladas. El toco mide $11^{*}, 5$, de largo, el ala $0^{*}, 23-y$ la cola $0^{24}, 14$.

DisTRIBUCION GEOGRÁFICA.- Habita las partes altas de la América del sur, desde la Guayana hasta el Paraguay; tambien se encuentra en la América central.

\section{EL TUCAN DE PICO ROJO-RAMPHASTUS ERYTHRORHYNCHUS}

CARACTÉRES.-El tucan de pico rojo, kirimn de los indigenas, es algo mas pequeño y eshelıo que el toco, al que se aseméja mucho. Difierc, no obstante, por el pico, que es menos alto, de color escarlata, amarillo en la base y en la cresta; la garganta es tambien blanca, orillada inferiormente por una ancha Iaja roja; la rabadilla tiene un tinte amarillo.

DISTRIBUCION GEOGRÁFICA.-Habita en la Amé. rica del norte.

\section{EL TUCAN DE TEMMINCK-RAMPHASTUS TEMMINCKII}

CAR AC.TÉRES.-El tucan de Temminck ó tucana, tiene la parte inferior del cuello amarilla, orillada de un filete mas claro; cruza el pecho una faja roja; la rabadilla es de un tinte amarillo; el pico negro, excepto una ancha faja de un amarillo nálido que se nota en la base; el ojo azulado, rodeado de un circulo desnudo rojo intenso; las patas son de un gris plomo. Este tucan mide $10^{n}, 48$ de largo por $1 \|^{*}, 55$ de punta a punta de ala; esta tiene $10^{n}$, is y la cola $11^{\mathrm{m}}, 16$. Los pequeños se distinguen por su pico menos denticulado y por sus colores mas pálidos.

DISTRIBUCION GEOGRÁFICA-Vive en los bósques, á lo' largo de las costas del Brasil.

USOS, COSTUMBRES Y REGIMEN.-De las descripciones de los viajeros que han observado los tucanes en su pais, se desprende que todas las especies observan absolutamente las mismas costumbres; de modo que se les puede aplicar lo que diga de una de ellas.

Eil toco, segun hemos dicho antes, solo habita en los paí- 
ses altos Dice Schomburgh que vive exclusiramente en las sabanas; que se le ve aparendo en los oasis y en los bosnues que bordean las corrientes, 6 bien por reducidas bandadas, las cuales recorren aquellos parajes en busca de frutos naduros.

El tucan de pico rojo, 6 kirimu, es una de las aves silvicolas mas comunes, que solo escasea en la costa misma, abundando principalmente en los grandes bosques.

El tucan de Temminck ó. tucana, representa la especie mas conocida; en los paises recorridos por el principe de Wied se la encuentra, lo mismo que la anterior, en todos los grandes bosques. Los viajeros dicen que los kirimas y los tu. canas viven aparendos descie el periodo del celo hasta el mo. mento de la muda.

Estas lltimas aves se posan en los altos árboles, donde buscan su alimento, saltando de rama en rama, con mas li. gereza de lo que se creeria á primera vista; otras veces repo. san en la extremidad de una mua, y dejan oir su $10 \%$ gruñona ó parecida a un silbicio.

Durante el calor del dia se ocultan entre el follaje en los valles muy cálidos; y segun 'I'schudi, no reaparecen hasta despues de ponerse el sol. Raras veces bajan á tierra, y probablemente no lo hacen sino para beber ó recoger frutas of simicntes caidas. Su locomocion es muy cxtmina; para correr dan grandes saltos, poniendo el tarso en direccion oblicua hácia adelante y prolongando los dedos. Solo en el acto de bajar dan á reces algunos pasns presurosos; mas par lo regular comserian los piés juntos y avanzan comandio un fuerte inipulso. Ia cola se elera entonces miss que las alas, conservando la posicion horizontal y un poro levantada. Fsta posicion y la manera de moverse comunican ó estas aves un aspecto tan extmino, que fícilmente se reconoce que no son terrestres, lo cual se nota mas aun cuando se las ve moverse en las copas de los árboles. Solo aqui despliegan sus facultades fisicas; dan saltos mucho mayores que en el suclo, ya en direccion de las ramas 6 diagonalmente: $a$ menudo dan una vucla en medio del salto: suben y bajan con gran agilidad; y solo entreabren un poco has alas cuando pasan de una rama a otra mas distanie lin este caso toman impulso por un salto; franquean rápidamente la distancia, cambiando a reces de direccion; describen un arco, y al lle. gar delante de la otra rama abren la cola tanto como es po. sible, sin duda con la intencion de intertumpir su movi micnto, y luego agarran la rama con Tos pits y saltan como antes. Su vuclo es relatisamente perfecto; al pasat de un śrbol at otro cruzan el aire ligeramente; pero cuando frun quean grandes distancias vuclan á intervalos, con la cabeza un poco inclinada, probablemente fó causa del ramaño del pico. Azara dice que vuelin en linea recta $y$ horizontaimes. te, agitando sus alas con gran ruido y a ciertos intervalos; pero que avanaan con mas rapidez de in que pudiena creerse al verlos, De este modo franquean en las horas de la marianá y por la noche grancies distancias del boseque, volando de un árbol a otro, para buscar entre el follaje alguma presa; pero muchas reces salian solo para divertirse.

a A veces, dice Bates, se ven cuatro ó cinco individuos que permanecen horas enteras en la copa de un arbol produciendo sus gritos singulares; uno de ellos, situado á mas altura que los demis, parece ser el direcior de orquesta en aquel concierto discordante, y los demás lanzan sus scruidos por turno en diversos tonos. Tambien emiten gritos de llamada cuando están ocultos en medio del follaje; pero les gusia so. bre todo gritar, segun afirman los indios, cuando amenaza lluvia, teniendo el don de pronosticar el cambio de tiempo.

Todos los tucanes, sin cxcepcion alguna, son ágiles, alegics y timidos, aunque sambien curiosos. Huyen del hombre, y es preciso ser muy hábil y experto para sorprenderles; les gusta juguetear con el cazador; à semejanza del grajo, ruelan de. lante de él de trecho en trecho; pero siempre poniéndose fuera del alcance, y teniendo cuidado de elegir un sitio bien oculto. Si se trata de hostigar á una rapaz, como por ejermplo \& un buho, todos acuden al momento. Fijan su atencion en cuamto les roden; son los primeros en divisar al enemigo y munciarle á coda la poblacion alada; y corro tienen vigor y están bien armados, suclen ahurentar a todas las mpaces pequenas. Bates dice que son timidos y desconfiacios cuando forman reducidas familias: pero que pierden toda su pruden. cia apenas llegan a reunirse en gran número. Esto suele suceder principalmente despues de la muda, que se verifica desde el mes de marzo al de junio.

No están de acuerdo los maturalistas respecto á la cuestion de saber cuáles son las sustancias de que se alimentan estas aves. Schomburgk cree que solo comen irutos: Bates dice que estos constituyen el fondo de su régimen, estando per-

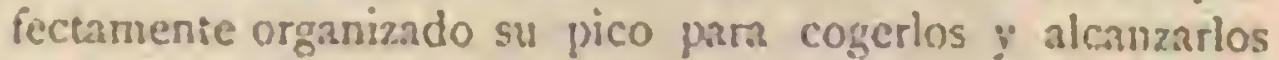
desde léjos. Azasa, por el contrario, asegura que no se limitan f un alimento vegetal, sino quue exterminan muchas aves á las cuales inspiran terror por su enorme pico; que ahuyentan á las pequenas especies y á los mismos araras de sus nidos, para devorar los huevos y las crias; y por último, que en la estacion de las lluvias, cuando se halla inundido de agua el nido del homero, le destrujen a fin de comerse los huevos ó los hijuelos. Humbold: dice, por su parte, quec se alimentan de peces. 'lengo la conviccion de que estos dos últimos autorts estån en lo cierto: los bucerotidos, tan semejantes ì los tuca. nes, son igualmente frugivorns, lo cual no implide que den activa caza a los pequeños vertebradus; además de esto, ob. sérvase que todos los tucanes cautivos se muestran aficionados à las sustancias animales. Tambien persiguen à los verte. brados de escaso tamaño con tal ardor, que es jurtciso admitir yุue les impcle a ello un instinto naturnl. dzara refiere asimismo que lanzan al aire los frutos y pedizos die carne, como lo haria un jugiar, repitiendo la maniobra hasta conseguir coger. los de un modo conveniente para facilitar la deglucion. los ocros naturalisias no han observado el mismo hecho: Schom burgh dice terminanicnicnte que di un are tan singularmente conformacia le es dificil cuger su alimento en tierra; pero que cuando lo consigue, levanta su pico verticalnuente y tragra el pediaro sin lamarle antes al aire.

Despues de muchas y cuidadosas observaciones soy de parecer de Schomburgk. 'Tampoco he visto nunca que un tucan haja jugado con la presa del-nodo indicadn pror Azara, por grande que sea la agilidad con que coge en el aire el ali. mento que se le arroja. Notable me parece su desireza pam recoger con el pico, tan torje al parecer, un objeto pequeño, como por cjemplo un cañamon que está en tierra ; cógele con las puntas del pico, levanta uste verticalmente, y duja caer el grano a la boca. De una manera analoga procede cuando quiere beber.

- Cuancio bebe, dice el sabin naturalista, procede el ave de una manera tmuy singular: los monjes suponen que lace ta señal de la cruz sobre el agua, creencia que ha llegacio is scr popuslar, dando origen al nombre Dios te die con eque los crio. llos designan al tucan. * Segun 'Tschudi este últino nombre és una reproduccion del grito de esta ave, cujo grito puecie compararse inuy bien con las indicadas silabas. Castelnau nos dice que cuando bebe el ave introduce en el agua la punia del pico y aspira con fuerza el liquido; leváutale luego y le invere de derecha á irquierda con movimientos imerrun. pidos.

Debo añadir á esta descripcion, por lo demás exacta, que nunca lie observado los movimientos interrumpidos. El are, 
segun dice Castelnau, llena su pico de agua, pero despues

levanta la cabeza como una gallina que bebe y deja caer el liquido en la garganta.

Carecemos de detalles relativos $\mathbf{a}$ la manera de reproducir se estas aves: unicarnente sabemos que los tucanes anidan en troncos huecos y ponen huevos blancos. Los hijuelos re. visten muy pronto el plumaje de los adultos; pero hasta los dos ó tres años no adquiere su pico el color definitivo.

CAzA.-En el Brasil se persigue muy activamente á los tucanes, tanto para utilizar su carne y sus plumas, como para conservarlos en habitacion. Con frecuencia hemos nuatado varios en un dia, dice el principe de llied, y comido su car. ne, parecida á la de la comejay Burmeistér dice que es nuy delicada, y muy suculenta sise cusece con orroz: Schomburgh se limita a indicar que es comestible. Bates reficre que todos los habitantes de Ega, pueblo de las orillas del Amazonas, se entregan con ardor i la caza de los tucanes cen la época en que sus bandadas se presentan en lós bosques proximos. Estis aves son entonces poco timidas, y caen fácilmente en poder del cazador. \&las gentes que en Figa poseen una escopeta, $\delta$ una simple cerbatana, van al bosque y matan algunos tucanes para variar un poco su comida. Yudiera decirse que en junio y julio no se alimenta ariel pueblo mas que de es. tas ares, pues durante semanas enteras, todas las familias tienen diariamente en su mesa un tucan asado ó cocido. En aquella estacion estan gordos, y su catne es muy delicada y suculentas

Schomburgk senala el uso que los naturales hacen de las plumas; describe una entrevista con los maiongkongs y aniade: SLlevan la cabeza adornada, con mucho grusto, con plumas rojas y amarillas, de las que ilenen los tucanes en el nacimiento de la cola. Además de aquellos indigenas, los guinaus, lós maupes y los panixanas, elaboran con las plu. mas, no solo bonitos adornos, sino verdaderos mantos: si las cacerias que empirenden aquellos salvajes para obiener las plumas fueran tan destructoras como las de los habitantes de Ega, los tucanes habrian desaparecido bien pronto; pero estos naturales se valen de un medio asa ingenioso para su conservacion. Tiran á las aves con flechias muy pequeinas, impregnadas con una ligera dósis de veneno; la herida que infieren es demasiado insignificanté para matar al ave, si bien el tósigo basta para aturdirla. Apenas cae le arrancan las plumas de adorno, abandonándola en seguida; bien pronto emprende el ave su vuelo, acaso para ser cogida otra vez $y$ despiumada de nuevo.

CAUTiVIDAD. - Cuando se cogen los tucanes pequeños para conservarlos son muy agradables. "Esta are, dice Hum. boldt, recucrda el cuervo por su género de vida. Es valerosa, fácil de domesticar, y su pico le sirve de arma defensiva. No tarda en adquuirir su predominio en la casa; roba todo cuanto puede coger; se baña con frecuencia y le gusta pescar a la orilla del agua. El tucan que yo compré era muy jóven; pero durante toda la travesia, complaciase en hacer travesuras contra los ariscos monos nocturnos.

a De todos los animales domesticados que vi en Watu.Ti. caba, refiere Schomburgk, creo que ninguno me causó tanto placer como un tucan, que habia "llegado a set dueno y senoor, no solo de todos los séres alados, sino tanibien de los grandes cuadrúpedos, de tal modo que unos y otros parecian someterse a su dominio. Si surgia alguna disputa entre los agamis, los hocos, los yacus y las otras gailinåceas, terminábala el tirano poniendo en fuga a todos los combatientes, y si alguno de ellos no veia al tucan en lo recio de la pelen, al. gunos vigorosos picotazos le daban as eniender que el sobe rano no toleraba la menor disension intestina entre sus súb ditos: si se tiraban pedazos de pan ó huesos entre aquelios séres, ningun bipedo ni cuadrápedo osaba tocarlo antes que el tucan quedara satisfecho. Si sc presentaba algun perro desconocido, haciale comprender que se hallaba en tierra extrania, descargándole vigorosos picotazos, y le perseguia por todo el pueblo. El dia de mi marcha, cuando los animales iban a verse por fin libres del déspota, llegó un gran perro con su amo, vió unos buesos, y crẹendo tener tanto derecho como el tucan, aproderóse de ellos tranquilamente, sin cuidarse de si desagradaria ó no al tucan. liurioso este, precipitóse sobre el temerario y le picó en la cabeza; el can comenzó á grunir, y como el ave redoblara sus picotazos sin hacer ningun aprecio, revolvióse su enemigo bruscamente y dió á su adverario tal dentellada en la cabeza, que murio muy pronto. Aquad desenlace trágico nos coniristó, pues el ave era muy divertida, sobre todo cuando acometia sin miedo à un perro grande, óllamaba al órden á uno de sus súbditos desobedientes, entre los cuales figuraba un conti.

Baics refiere, que paseandose por un bosque, vió posado en una rama poco alta un tucan, al que cogyió con la mano sin dificultad. El ave estaba sin fuerzas y mecio muerta de hambre; recobróse bien pronto cuando le dieron de comer, y fué uno de los animales mas divertidos que imaginarse pueda. No tenia menos inteligencia que los loros; dejábanla correr libremente por la casa, y bastaba un buen correctivo para gue se alejase de la mesa del trabajo. Comia de todo lo que tomaba su amo, carne, tortuga, pescado, fruta, etc., y llegaba regularmente para ocupar su puesto en la mesa. Su voracidad era extmordinaria; digerialo todo con facilidad sorprendente; sabia cuál era la hora de comer, y al cabo de algunas scmanas, costó trabajo hacerle salir del comedor. Encerraronle una ve\% en un patio rodeado de una empaliza. da bastante alia; pero irepó por encima, acercóse al comedor y se preséntó en la mesa al servir el primer plato. Algun tiemno despues llegó a pasearse por la calle, delante de la casa, mas un dia le robaron: Bates le daba yo por perdido, pero á los dos coins apareció á la hora de costumbre en el co. medor, por haber podido escaparse de manos de su ilegitimo dueño.

Broderip y Vigors tuvieron otro tucan al que sometieron casi exclusivamente à un régimen vegetal, aunque mezclando algunas veces con su acostumbrado alimento pan, arroz, patatas, etc. Gustábanle mucho las frutas, y mostrábase con. tentisimo cuando le ofrecian una manzana, una naranja ó cualquier otra golosina semejante. Despues de coger el pedazo con la punta del pico, y de saborearle con el extremo de la lengua, visiblemente satisfecho, le hacia desaparecer en su faringe, levantando bruscamente aquel órgano. Sin cmbargo, revelábanse en el ave ciertos instintos de rapina respecto á otros animales vivos: si sc aproximaba á su jaula un ave 6 solo una piel disecada, excitábast en el mas alto grado; se lemntaba al punto y crizaba las plumas, lanzando un grito sordo y chillon, semcjante á un grito de alegria, ó mas bien de triunfo; chispeaban sus ojos, y parecia dispuesto á saltar sobre su presa: la vista de un espejo le producia la misma cxcitacion.

Habiendo introducido Broderip en la jaula un gorrion, cogióle el tucan al instante, sin darle apenas tiempo para lanzar un breve grito. Un minuto despues estaba ya muerto, y de tal modo desgarrado, que se veian los intestinos. El tu. can se preparó entonces á desplumarle; rompióle desputes los hucsos de las patas y las alas, y le redujo a una masa informe; al mismo tiempo saltaba entre las ramas, emitiendo sin cesar su extraño grunido, y agitando el pico y las alas. Primero se comió los intestinos, acabando por tragarse toda el ave, incluso el pico $y$ las patas, manifestando en ello la maror satisfaccion. 'lerminada su comida, quitó cuidadosamente 
las piumas que se adhiricton. Broderip dice haberle visto vomitar muchas veces lo que babia comido para devorarlo despues, como lo hacen los perros. Lina vez devolvió asi un pedazo de carne a medio digerir, $y$ al hacerlo produjo una especie de cacarco; habia examinado antés su pitanza, y viendo que solo se componia de pan, qque no le gustaba inucho, guiso sin duda vomitar lo comido, sf fin de tener la satistaccion de comer carne otra vez. Preferia las sustancias animales s las vegetales, y comenzaba siempre por las primeras cuando podia elegir, sin tocar nunca los frutos hasta despues de haberlas devorado.

El tucan de Vigors era muy agradable y aficionado á la sociedad: permitia que jugueiearan con él, comia en la mano; em nuy limpio, alegre y bonito, a pesar de su pico informe; moviase ligeramente y con gracia; tenia siempre el plumaje muy aseado y se bañaba regularmente todos los dias. Si nada le molestaba, sus costumbres eran las mismas todos los dias: a la entrada de la noche comia por última vez; daba la vuelta por su jaula varias veces, y se aplanaba despues sobre la va. rilla mas alta; despues de encoger la cabeza entre las espal. dillas, levantaba la cola verticalmente, y permanecia inmóvil unas dos horas, con los ojos cerrados, como dormitando. En. tonces se le podia tocar fícilnente: tomaba con gusto cual. quiera golosina que le daban, aunque sin cambiar de postura, y si le bajaban la cola, levantábala en seguida. Al cabo de dos homs colocaba lentamente su pico sobre el lomo, ocultíbale entre las pluınas, dejaba colgantes sus alas, y parecia entonces una bala. En invierno variaban sus movimientos; el fuego de la chimenea le ienia largo tiempo despierto.

a.Mis tucanes, me escribe el docto: Bodinus, son ares encantadoras: su magnifico plumaje excita la admiracion de todos; su pico enorme no parece monstruoso, y si un poco singular. El houbre no les intinida; muéstranse vivaces y alegres, fo siempre tienen hambre. Su aseo es tal, clue se ocupan continuanente en limpiar y alisar su plumaje; tambien se distinguen por su sorprendente agilidad, en una palabra, son aves de las mas divertidas.

Segun mis propias observaciones estoy conionne con el experto zoólogo, y' solo quiero añadiralgo sobre el género de vida de los tucanes en cautividad. Estas aves necesitan para desplegar toda su belleza y agilidad, una jaula ancha y alta, donde puedan moverse a 5 su antojo; en esta jaula, y cuando se les preserva cuidadosamente del frio, resisten la cautividad muchos años y domesticanse en alto grado; conocen al guar. dian y le distinguen de otras personas; déjanse tocar por él, o sascar el plumaje, como los loros;y se captan nuestro cariño mas aun por esto que por la belleza de su plumaje, su vivacidad y buen humor. Sin embargo, tambien tienen cualidades que \{ nuestros ojos pueden llegar a ser verdaderos vicios. Prescin. diendo de sus instintos de carricero, que no permiten tener animales mas débiles en su compaña, ni aun entre si viven en buena inteligencia; á menudo pelean unos con otros; for. man partidos y persiguen y atormentan a otro companiero de la especie cuando les disgusta. Si se les pore al mismo tiempo en una jaula vacia, suelen estar en paz; un individuo se arroga la soberania, los otros le obedecen y todos viren en la mejor inteligencia; pero esta se turba al punto cuando llega un compañera nuevo. Al principio le miran con curiosidad y atencion; todos acuden, uno tras otro, para cxamin narle cetenidamente, cual si nunca hubiesen visto tno de sus. semejantes; y los que están posados muy cerca de él vuélvense con lentitud para observar al fomstero de piés á cabeza. El recien llegado sienie poco à poco cierto malestar, pero per manece quicto en su sitio, contemplando a los curiosos que han acudido sucesivamente. Por algun tiempo todo va muy bien; pero tan luego como el recien llegado se acérca al co. medero, todos llegan presurosos para quitarle el bocado de la boca, dispuestos á precipitarse sobre él si continúa comiendo, y sobre rodo si huye ante el ademan amenazador de sus compañeros. Si entonces no es bastante vigoroso para hacer frente a los agresores, estos se precipitan sobre el, descar. gándole piconazos sobre el lomo. Cuando se defiende valero. samente, sus companeros toleran, por lo menos, su companin; pero si huye, persiguenle por todas partes, volviendo sienmpre al ataque; de modo que el pobre procura al fin no acercarse ś ninguno. Un tucan perseguido asi, pierde a menudo todo apego á la vida; y solo cuando logra encontrar un amigo se

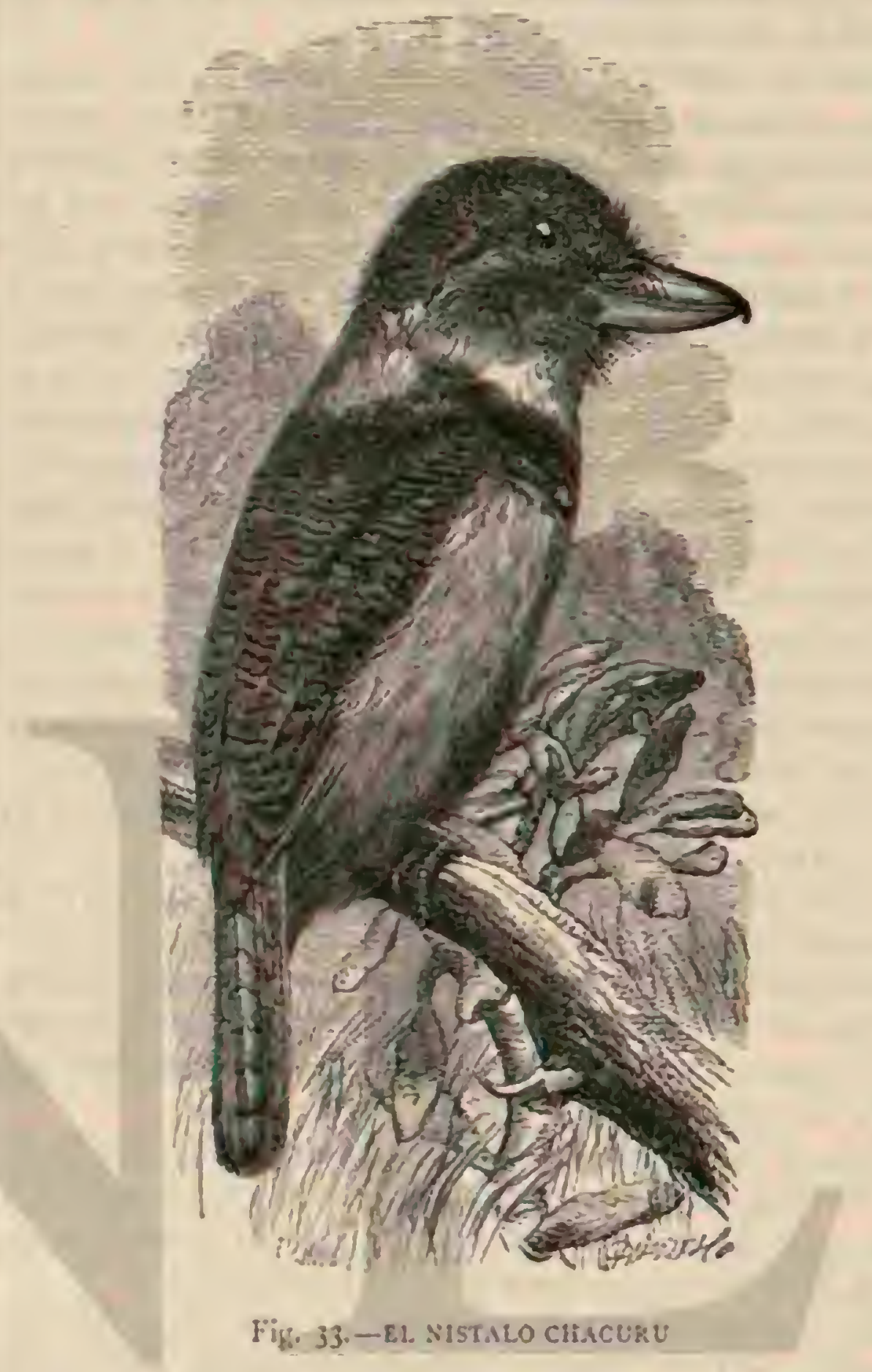

acaban las rinas. Ias condiciones son por consiguiente mas iavorables para las hembras que para los machos, que han de surrir por efecto de la envidia y de los celos de los demás.

\section{LOS TEROGLOSOS - PTEROGLOSSUS}

CARACTERES. - T'eroglosos se llaman las especies de la familia de los ramfástidos que tienen el pico pequeño, á proparcion, largo, redondẹdo, medianamente comprimido hicia la punta, apenas tan alto como la cabeza en su base, de bordes cortantes y mandibulas mas 6 menos escotadas; las fosas nasales se abren en un surco del pico, en am. bos lados de la cresta frontal, que es plana. Tienen las alas cortas, bastante agudas 6 sub-agudas, con la tercera penna más larga; la cóla es largara cónica, terminada en punta y es. calonada El plumaje presenta vivos colores, en los que pre. dominan el verde y el amarillo; la hernbra difiere 1 menudo del macho por este carácter.

\section{EL TEROGLOSO ARACARI - PTEROGLOSSUS ARACARI}

CARACTERES.-El aracari, o arassari de los brasile- 
nos, representa una de las especies mas conocidas. Tiene las partes siperiores de color verde oscuro, con brillo metálico; la cabera y el cuello negros; las mejillas de un pardo violeta oscuro con visos; el pecho $y$ el vientre de un verde amarillo pálido; una faja que ocupa el centro del vientre, y la rabadi. lla, de un tinte rojo; la cola de un verde negro en la cara superior, de un gris verde en la.inferior. El ojo es pardo, rodeado de un espacio desnudo de color negro pizarra; la mandibula superior de un blanco amarillento, excepto la arista, que es negra, asj como el ángulo de la boca y la man. dibula inferior, presentando esta última un filete blanco hícia su base: las patas son de un gris verdoso. El ave mide $00^{\prime \prime}$, de largo, el ala $6, " 16$ y la cola $6,17 \%$

USOS, COSTUMBRES Y REGIMEN.-ZE] aracari, dice el principe de ivicd, habita en todas las sctvas virgenes del Brasil que yo he recorrido, donde es bastante comun y observa el género de vida de los tucanes. Se le ve con trecuencia posado en el extrenio de una rama-seca en la copa de ún alto árbol, lànzando $\alpha$ intervalos su breve grito disilabico, que se puede expresar por kuliz likik. Vive apareado, y en reducidas bandadas cuando no está en celo, las cuales recorren el pais hasta la primavera. Durante la estacion fria y sobre todo cuando maduran los mas de los frutos, abandona con frecuencia los bosijues, y acerćńndose a la costa. llega hasta la inmediacion de las plantaciones. Entonces se matan muchos individuos, pues su carne es buena y gorda en aque. lla estacion. Fil vuclo de estas aves es nndulado é interrum pido, como el del tucan, sin exigir frecuentes aletazos; cuan. do descansan mueven la cabeza como las urracas. Anidan en troncos lueecos, y ponen dos huevos cada vez. Reúnense alrededor de las rapaces, y particularmente de los buhos, a fin de hostigarles sin cesar.

¿Esta especie, dice Schomburgk, es bastante comun en la Guayana inglesa: los aracaris se encuentran en los bosques aparcados $\delta$ en reducidas bandadas; se posan sobre los árbo les que llevan frutos maduros, y parece que el buscar alimento motiva su reunion en un mismo sitio, pues se diseminan por parcjas al emprender su vuelo.

Solo se alimentan de frutos, segun este naturalista; pero Burmeister, que opina !o contrario, se expresa asl: No solo. comen frutos, sino tambien insectos, $y$ hasta colépteros de gran tamaño. Esto me parece lo mas verosimil.

En el diario de viaje de cste último autor se encuentra una descripcion corta, aunque interesante, respecto á los movi. mientos de dichas aves; dice asi: en la copa de un árbol muy grande, hallibase una familia de aracaris, que se ocu. paba en recoger los frutos, curos individuos manifestaban toda su satisfaccion con un continuo cacareo. Yo creia que eran loros, y me extrañaba.no verlos emprender su vuelo lamzando fuertes gritos. Sus movimientos eran, con efecto, del todo semejantes á los de aquellas aves, aunque no tan prudentes. Estaban muy afanadas en su obra; llamábanse de vez en cuanda, y se dejaban observar cómodanante. No po. dria negarse que ofrecen cierta semejanza con los loros; como ellos, viren por parcjas $\delta$ reducidas bandadas; caen juntas sobre un árbol; se comen los frutos, y si se las espanta, cada par se va por su lado

Bates dice, al hablar de olra especie dél mismo género, que no la vió jamás reunirse con sus semejantes en un ảrbol irutal; pero que siempre la encontró por bandadas, saltando entre el ramaje, ú ocultándose en la espesura de árboles poco altos. Por lo que yo sé, añade, el aracari no lanza un grito chillon, como el del tucan; hay una especie que canta como la rana. El mismo autor da cuenta de un hecho singular, presenciado por él mismo. AHabia tirado, dice, contra un aracari que se posó en un elevado árbol de un oscuro bar ranco; solo consegui herirle, $y$ gritaba con todas sus fuerzas cuando iba á cogerle. En el mismo instante, todo el barranco pareció animarse como por arte mágica: eran los compañeros de mi victima, de los cuales no habia visto antes ni uno solo; saltando entre el ramaje Hlegaban hasta mi; suspendianse de las lianas; gritaban todos, batiendo las alas y agitábanse furiosos. Si hubiese tenido un palo largo en la mano, nada mas fácil que matar varias de aquellas aves. Despues de rematar al herido, preparábame á dar cuenta de aquellos importunos, mas apenas cesaron los gritos de la victima, todos sus compañeros se refugiaron en lo mas espeso del follaje, y desapareció hasta el último antes de poder cargar la escopeta.

Layard encontró una pareja de aracaris en compañia de algunos picos; esta pareja tenia probablemente tambien su nido en uno de los agujeros de aquellas aves; pero el viajero no pudo subir al árbol para coger los huevos. No habia des. cubierto la presencia de las aves hasta despues de matar un pico; al resonar la detonacion el aracari alargó con precaucion la cabeza por el agujero para ver lo que pasaba; mas al divi. \$ar al naturalista al pié del arbol, retiróla rápidamente: esto se repitio is cada tiro.

CAUTIVIDAD.-Schomburgk nos dice que los indios cogen muchas veces y crian aracaris, los cuales se domesti. can muy pronto.

USOS Y PRODUCTOS.-Pappig reficre que los indi. genas emplean las raspaduras del pico $y$ de la lengua de los aracaris como remedio infalible contra la opresion y los ca. lambres.

\section{LOS MEGALÉMIDOS- MEGAL压MID压}

CARACTERES. - Los megalémidos 6 nirs barludas, se caracterizan por su tronco cilindrico, un poco pesado y te cogido, y por su pico de longitud regular, grueso, casi cónico, cncorvado, ancho en la base y comprimido hácia la punta lateralmente; sus bordes son ya rectos 6 garchudos desde abajo arriba, $y$ á reces tambien denticulados con surcos que rematan en una especie de diente. Las patas son cortas, pero fuertes y paridigitadas; el dedo pulgar y el exterior se dirigen hácia atrís; las alas redondeadas, de longitud regular $\delta$ cortas; las tecirices de las alas son pequeias; la cola corta, casi siempre cortada rectangularmente ó á veces tambien un poco redondeada, en cuyo caso tiene mas longitud: compóriese de diez plumas. El plumaje es suave, pero está bien arraigado y ostenta los colores mas magníficos; la region del pico se halla cubieria de numerosas cerdas.

DISTRIBUCION GEOGRÁFIC.A.--Esta familia, que cuenta unas ochenta especies conociỏas, habita los paises tropicales de ambos mundos; siquicra esté representada en cada uno por géneros distintos. Es propia principalmente de Africa y Asia: no se ha encontrado aun ninguno de sus representantes en Australia

USOS, COSTUMBRES Y REGIMEN. - LOS megalemidos son en general aves viraces $y$ alegres, sin manifestar jamás aquella indiferencia estúpida propia de algunas de las familias anteriores. Tienen carácter sociable y forman a me. nudo reducidas bandadas que viven juntas. Cazan los insec. tos de que se alimentan en la copa de los árboles, en medio de las breñas; rara vez esperan á que pase uno d su alcance para perseguirle, y recorren durante el dia una extension de bosque mas ó menos considerablc. Ademśs de los insectos, comen tambien bayas y frutos de diversas clases.

Las grandes especies no se contentan con insectos, sino 
que acometen tambien a los pequeños vertebrados, por lo menos en cautividad. Un megalémido que layard conservaba en su gran pajarera, mató poco à poco todos los fringilicos que contenia. Al principio solo cogió los que se le acercaban descuidadamente, ocultíndosc detrás de un arbusto espeso, ó del comedero, donde se apoderó de sodos los pequenos compañeros que se ponian á su alcance; golpeábalos contrn el suclo ó una rania, y los devoraba despues. 1 pesar de esto debemos suproner que los frutos constituyen la base de su régimen alimenticio, segun lo indica el aspecto de las ares observadas en libertad.

El plumaje de estas no sucle estar runca bien alisado: casi siempre tienen sucia una gran parte de él, sobre todo en la region del pico; y esto se debe al jugo de las frutas. Por amor á estas, los megalémidos van desde el bosque á los jar. dines, donde permanecen á veces muchos dias saqueando los àrboles frutales.

Parece qque no se acostumbran à vivir en tierra, $\delta$ por lo menos, yo no he visto una sola especie africana en el suelo. Trepan con bastanie destreza: su ruelo es rípido aunque po. co extenso, y agitan siempre con fierza las alas. Casi rodos tienen la voz sonorn y penetrante, y obsérvase que al reunirse los individuos de ciertas especies forman á manera de un gran concierto

En general el hombre noles inspira ningun temor; diriase que comprenden la seguridad en que se hallan en la cima de los grandes y copudos árboles y cuán dificil es descubrirlos alli. Sin embargo, los que se ponen al descubierto para can. tar dan pruebas de cierta prudencia.

A poca cosa se reduce lo qque se sabe acerca de la repro. duccion de estas aves, pues solo se ha averiguado que anidan en troncos de árboles huecos ó en cavidades practicadas en tierm, y que sus hueros son blancos.

Marshall divide los megalémidos en tres sub.familias, af saber: en pogonorincinos (Pogonorhymringrir), meghléminos (Algabemine), y capitoninos (Copjoinsine); los urineros pertenecen, con excepcion de dos especies, al territorio etió. pico; los segundos, que forman la mayoria, se encuentran en los paises ecuatoriales del antiguo continente; los terceros, en fin, habitan el Nuevo mundo. Las diferencias cntre estos grupos son sin embargo de tan poca importancia, que prefiero no regirme por tal division.

\section{LOS MEGALEMAS-MEGALAMA}

CARACTERES. - Fistas ares tienen el pico corto y aca. nalado lateralmente; las alas bastante puntiagudas, con la tercera, cuara y quinta rémiges mas largas; la cola corta y casi iruncada en angulo recto.

DISTRIBUCION GEOGRÁFICA.-Este género es pro. pio del Asia.

\section{EL MEGALEMA INDIO - MEGALAMA INDICA}

CARACTERES. - El mega!ema indio tiene el lomo verde; el vientre amarillento 6 blanco verdoso: las plumas de lomo y las cobijas superiores del ala orilladas de amarillento las del pecho rayadas longitudinalmente de un tinic verdoso la trente y una mancha que hay en la tegion de la garganta de un rojo escarlata brillante, limitada inferiomente por un fuston amarillo de oro; una faja que rodea el occipucio, otr que cruza el pecho, y una tercera que se nota cerca del pico, son negras; el ojo pardo oscuro; el pico regro, y las patas de un rojo coral. El ave mide $0^{\circ}, 26$ de largo por ()$^{\circ}, 20$ de punta a punta de ala; csta tiene $0^{\circ}, 085$ y la cola $0^{\circ}, 04$.
DISTRIBUCION GEOGRÁFICA.-Segun Jerdon, esta are habita toda la India, hasta la Cochinchina, Ccilan y las islas malayas, sobre todo Sumain y las Filipinas, pero no se le encuentra en el Himalaya ni en el Punjab.

USOS, COSTUMBRES Y REGIMEN.-Abunda don. de quiera que haya árboles; vive en los oquedales, en los brezos y jardines y en los paseos; no es nada timida. adelán. tase hasta cerca de las casas, y muchas veces se posa hasta elr los tejados y paredes. Algunos naturnlistas dicen haberla visto trepar a la manera del pico: pero Jerrion, que no ha observado semejante cosa, duda mucho del hecho. Su grito, bastante fuerte, se puede cxpresar por duk duk, y le procuce comunmente cuando se posa en lo alto de un árbol, incli. nando à cada sílaba la cabea à derechn é izquierda. Sunde. vall dice que un megaiema emite siempre la misma nota; pero que apenas ha encontrado dos individuos que produacar sonidos hlénticos, de ial modo que, cuando se reunen varias de estas aves, forman un concierto mada desagradable.

El megalema indio come frutos é insectos: un individuo cautivo, observado por Blyth, dejaba los alimentos del reiro animal cuando le presentaban frutas.

Un megalémido que yo tenia hacia completamenie lo con. trario, prefiriendo los gusanos de harina á todas las oiras golosinas, sin despreciar sin embargo las frutas. Mi cautivo vivia con todos los companteros de jaula en la mejor inteligencia, o mejor dicho no hacia ningun caso de ellos, perma. neciendo siempre en el sitio que eligib descle el primer dia; no se movia dinnate muchashoras, y solo a intervalos dejaba oir su voz. Tamporo bajaba al suclo sino cuando le obligaba el hambre; pero posábase siempre sobre una rama ó en el borde del comedero; las pocas veces que bajaba \& tierra, saltaba con mas ligereza de la qque podria suponerse.

Sobre la reproduccion del megalema indio no puedo decir apenas nada; solo sabemos que construye el nido en huecos de árbol, sirviendose probablemente del mismo muchos años; la hembra pone dos ó quizás nas huevos.

\section{LOS TRAQUIFONOS - TRACHY- PHONI}

CARACTERES, - Tienen el pico afilado, de mediana extension, arista dorsal ligeramente encorvadis con la puna comprimida; los tarsos son altos, y mas largos que el dedo medio; las alas bastante prolongadas, con in cuarta rémige major, y la cola bastante grande y redondeada.

DISTRIBUCION GEOGRÁFICA. - Este género peric. nece á la fauna africana.

\section{EL TRAQUIFONO ALJOFARADO - TRACHY- PHONUS MARGARITATUS \\ CARACTERES. - El traquifono aljofarado tiene ellomo} de color pardo de tierna de sombra con motas y rayas blan. cas; el vientre amarillo brillante; el pecho con mezcla de rojizo; la frenie $y$ la coronilla negras; la garganta presenta manchas de este último color en ct macho; adorna el pecho un collar formado de otras jequeñas del mismo tinte; la rabadilla es de escarlata oscuro; tl ojo es de un rojo intenso, el pico del propio matiz pero mas claro, $y$ las patas de un gris plomo. El are mide $10^{\circ}$, ig de largo, $y$ su ala $0^{\prime \prime}, 09$.

DISTRIBUCION GEOGRÁFICA. - Fsta are no es rara en todos los puntos del nordeste de Africa recorridos por mi: se la re al sur del $17^{\circ}$ de latizud norte, en los jardines $y$ bos. ques del Sennaar y del Kordofan.

USOS, COSTUMBRES Y REGIMEN.-El traquifono aljofaradio no pasa desapercibido parn el viajero, porque hace 
cuanto puede para llamar la atencion, y es el que anima los jardines situados cerca de los pueblos y los bosques de las estepas. Por lo regular se le encuentra apareado, 6 en reducidas bandadas despues del celo; jands se oculta, como lo hacen los demás capitónidos de Africa, y a ciertas horas, sobre todo, se deja ver en descubierto. Por mañana y tarde se posa en alguna elevada rama, donde el macho y la hern. bra reunidos, entonan un canio muy paricular, que puede expresarse por gukguk, girre, gukguk, segun Hartmann, por tiur tiur; y segun Heuglin por du, du, dui dui dui dui du; las dos roces se confunden, $y$ resulta un canto en que las notas se mezclan tambien, sin poder distinguirlas, produ. ciendo una especie de zumbido, cono lo ha dicho muy bien Hartmann. Este canto, segun dicho autor, es de los mas singulares y característicos que pueden oirse en aquellos paises, y recrea sobre todo por clatan con que el ave le entona. Sin embargo, al traquifono aljofarado no le gusta que le observen los blancos; se calla y huye al acercarse un europeo, siendo por lo tanto difícil observar sus movimientos.

En cuanto à lo demás, csta ave vive como los otros capitónidos: se mueve con lentitud en la copa de los árboles, donde caza insectos, come frutos y recoge los granos. Trepa mal; no vucla nunca léjos; unas véces se cierne y otras agita las alas; es aficionado al reposo, y permanece con tenacidad en el paraje que una vez eligib. 1 pesar de ello, prolonga sus excursiones mas lćjos que las dèmás aves de la familia.

Heuglin ha descrito ol nido de esta especie cn los siguientes términos: El 26 de setiembre encontré un nido de traquifono aljofarado en la orilla arcillosa y escarpada de un torrente formado en la estacion de las lluvias, que conducia al Ain.Saba. Hallíbase á unos nuere metros sobre el fonda del lecho; un agujero circular, de cerca de dos pulgadas de diánetro, daba paso i una galeria algo inclinada hácia la parte superior, que se abria a unas dos pulgadas mas alla, en la pared de una cavidad mayor, redondeada, dirigida hácia abajo, y separada del conducto por una especie de pequeno tabique. En el interior, sobre la tierra desnuda, habia un huevo recien puesto, de tamaño regular, relativamente á la talla del are, ovoideo, bastante obtuso en sus dos puntas, color blanco, con visos somrosados, y cáscara muy fina y luciente. El $\&$ de octubre hallé en un sitio análogo otro nido con cuatro huevos en vias de desarrollo: asemejábase en un todo al primero, solo que aquellos reposaban sobre una capa de granos de malvàcens. Ignoro si el mismo traquifono fabrica el nido.

In la obra que Heuglin publicó mas tarde, añade que nunca encontró aas de cuatro huevos, pero que en cambio ha visto cinco 6 seis polluelos, que sin duda provenian de la misma pareja; supone que esta are empolla mas de uná vez al año.

\section{LOS BUCONIDOS-BUCO- NID死}

CARACTERES. - Los bucónidos, vulgarmente llamados cuclillas harbudos ó niès peresosas, constituyen una familia que comprende sobre cuarenta especies. I.os caracteres de estas son: tronco robusto y grueso; cabera muy voluminosa; pico de longitud variatile, encorvado en la arista, $\delta$ por lo menos en la punta, a veces ganchudo, y siempre sin surcos ó denticulacion; piés endebles; el primero y cuarto dedos se dirigen hácia atrás $y$ los del centro hácia adclanté: las alas son de longitud regular ó cortas, distinguiéndose sobre todo por las numerosas y grandes tectrices; la cola, tambien de longitud regular $\delta$ corta, se compone de doce plumas: el plumaje es en extremo ligtro y suare, de color oscuro: la region del pico está cubierta de cerdas rigidas. Ia estructura interna, segun Burmeister, parece análoga \& la de los cucúlidos.

DISTRIBUCION GEOGRÁFICA.-Esta familia habita exclusivamente la América del sur.

USOS, COSTUMBRES Y REGIMEN.-Todos los buconidos viven en los bosques, solitarios ó en parejas; cuanco mas, se encuentran reducidas familias en ciertas cstaciones. No les agrada la proximidad de las viviendas del hombre y prefieren los bosques mas desiertos. Sus movimientos no tie. nen el menor atractiro: la pereza, la cachaza y la estupidez son sus principales cualidades. Aliménanse de insectos, que atrapan al paso, lanzándose desde el sitio donde se posan. A los unos les gustan las copas de los úrboles, á los otros las ramas bajas, yninguno suele andar por tierra á menudo. A penas sabemos nada acerca de su manera de reproducirse: algunas especies anidan, segun parece, en agujeros que ellas nismas abren en el suelo.

Estas aves no se pueden conservar en jaula: son dificiles de alimentar, y por otra parte no compensan con sus cualicades las molestias que causa tenerlas. Solo se les da caza por su carne, que es muy delicada: por su aspecto tranquilo s majestuoso han sido designadas con cl nombre vulgar de Jivicesldel bosque.

\section{LOS NISTALOS-NYSTALUS}

CARACTERES. - Los nistalos recuerdan á los alcióninos, y aun algunos podrian confundirse perfectamente con ellos si no ruera por sus patas paridigitadas. Tianen el pico casi tan largo como la cabeza, fuerte, recto, comprimido lateralmente, de bordes lisos y punta de la mandibula superior un poco corva; los tarsos bastante cortos y delgados; la cola de'mediana longitud, compuesta de plumas angostas, todas del mismo largo, excepto las dos externas que son un poco mas cortas.

\section{EL NISTALO CHACURU-NYSTALUS CHACURUS}

CARACTERES. - Azara fué el primero que nos dió á conocer esta ave, con el nombre de chacur\%. Tienc la parte superior de la cabeza, el lomo $y$ las alas de un pardo rojizo, con rayas trasvetsales negras; el vientre blanco amarillento; un collarin y una ancha linea naso ocular de un blanco puro las mejillas negras; las rémiges de un gris pardo, con las se cundarias orilladas de rojo pardo, y cubiertas de manchitas trasversales del mismo tinte; las rectrices son de un pardo negruzco oscuro, sembradas de pequeñas manchas angulosas de un amarillo rojizo en los bordes El ojo es pardo castano; el pico de un rojo bermellon sucio, color de carne en su base $y$ gris negro en la punta $y$ la arista: las patas'son pardas. El ave mide $\left(6^{m}, 22\right.$ de largo, y hasta $11^{\prime \prime}, 28$ segun Natterer, $y(1)^{\prime \prime}, 3^{2}$ de punta a punta de ala; esta tienc $0^{\mathrm{m}}, 08 \mathrm{y}$ la cola $0^{\mathrm{m}}, 075$ (figura 33).

USOS, COSTUMBRES Y RÉGIMEN.-Azara dice que siempre encontró á esta ave solitaria, y en réducido número de individuos en los sitios de poco bosque. El principe de Nied la observó en los matorsales que hay cerca de lagoa Santa «solitaria y silenciosa, posada en las ramas descubier tas de las copas de los árboles, donde permiria al viajero acer carse mucho sin hacer un solo movimiento. Permanecia tran quila hasta que nos hallabamos á seis ú ocho pasos de ella, y no volaba si no se agitaba la rama donde se habia posado. Esto conviene perfectamente con las noticias de Azara, que 
califica a esta are de triste, apática y estúpida; dice que se posa á mediana altura en las ramas pequeñas; pero el principe de lVied asegura haberta visto en el suelo.

Burmeister dice que se alimenta de los insectos que atrapa segun van pasando cerca de ella; no trepa á la mancra de los picos, y espera pacientemente á que una buena presa se ponga á su alcance. \$No he podido adquirir su nido, dice aquej naturalista; los brasileños aseguran q̨ue anida en los troncos huecos de los arboles, y que pone varios hueros blancos. Azara nos manifiesia que su nombre guamai de cinaiuru es una oncmatopeya de su grito: pero ni el principe de Wied ni Burmeister han oido la roz del arce.

\section{LOS TRAPISTAS-MONASTA}

CARACTÉrEs. - Se diferencian de los nistalos por su pico pequeño, mas delgado y endeble en la punta, ligeramente corro, sin ser ganchudo; las patas son endebles; las alas mas largas y puntiagudas; la cola medianamente prolon. gada, con rectrices angostas; el plunaje mas blando y lanoso, el ojo está rodeado de un circulo desnudo.

\section{EL TRAPISTA PARDO-MONASTES FUSCA}

CARACrERES. - Esta ave (fig. 34) tiene la cabeza y el lomo de color pardo oscuro, con listas de un amarillo rojo; el vientre gris leonado; una gran mancha que hay en la base del cuello es de un blanco puro, y una faja pectoral negra, las rectrices y las rémiges de un gris pardo intenso, y estas últimas orilladas de pardo rojo en sus barbas externas; el ojo es de este útrimo tinte, $y$ el pico $y$ las patas negros. Los colores de los pequeros son mas oscuros:la mancha blanca del cue-
$1 l o$ presenta en ellos una mezcla de amarillo claro. Fil ave mide $0^{\circ}, 20$ de largura por $0^{m}, 51$ de punta ś punta de ala, esta úlima 0,085 y la cola $00^{\circ}, 085$.

USOS Y costUMBRES. - \&lil irapista pardo, dice el principe de Wied, es una de las ares inas comunes en los bosques del sudoeste del Brasil. Cerea de Rio Jnneirn la en. contré en rodos los matormles espesos, hasta cerca de las casas; suele posarse en alguna rama baja $\delta$ en ticrra, acechando tranquilamente los insectos. Sicmpre la vi inmóvily jamás he oido su vozs

CEn la primavera, añade Burmeister, llega acompaninda de su familia hasta los jardines de los pueblos, y’ se posa a orilla de los caminos; pero permanece en una completa inaccion, $y^{\circ}$ no parece inquictarse de la qque la rodea. Por lo mismo pro duce una singular impresion: desde léjos se distingue su gnr. ganta blanca, destacándose en medio de los matorrales; al acercarse se la te inn:óvil y como dormida, con sus grandes ojos fijos en el viajero, cual si se preguntase qué debe hacer. lodo en su sér revela de tal modo la estupidezy la indiferen. cia, que no se puede motejar a los brasilerios el haber aplicado á esta ave el nombre de Fono cóoibo (Juan el tonto). Bajo el punto de vista ornitológico, es un ave singular, que reune al aspecto del cuclillo, tan osado, tan aturdido é impletuoso, el plumaje oscuro y los perezosos movimientos del chotacauras de silencioso vuclo.

Tovo 11
WNo he visto su nido, ni el principe de Wied habla de êl tampoco.s

En el estómago de una de estas ares encontré, con vesti. gios de otros insectos, una gran mariposa diurna que le lle. naba por completo.

\section{LOS QUELIDÓPTEROS-CHE-}

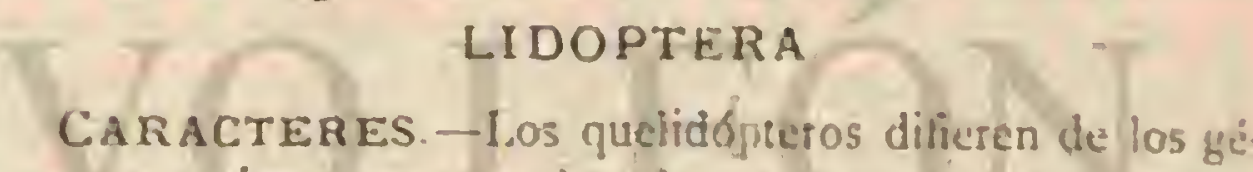
neros anteriores por tener la cula muy conta y el plumaje mas corto y compacto.

\section{EL QUELIDÓPTERO TENEBROSO - CHELI- DOPTERA TENEBROSA}

CARACTERES. - El quuelidóptero tenebroso tiene el plumaje de color negro pizarra con visos azulados; el vientre amarillo rojo; la mbadilla blanca; el ojo pardo oscuro; el pico negro y las patas grises. Mide $11^{\circ}, 22$ de largo por $11^{\circ}, 3 \mathrm{~S}$ de punta a punta de ala, el ala $0^{\prime \prime}, 12$ y la cola $11^{\prime \prime}, 05$ (fig. 35 ).

USOS, COSTUMBRES Y RÉGIMEN.-REn la mayor parte de los cantones cel Brasil, dice el principe de lificd, el quelidóptero tencbroso no es raro, y aun abunda mucho en algunos: se le ve sobre todo donde alternan las selvas virge- 
nes con los lugares descubiertos, y en el lindero de los bos. ques: pero tambien se le halla en el interior de aquellos, donde permanece inmóvil en las ramas secas y altas De vez en cuando se lanza por los aires como el papamoscas, arrapa una presa y vuclve a su sitio; está silencioso y tranquilo, $y^{\circ}$ le gusta situarse á ciesta altura, contrariamente a la costumbre de los otros buconidos. Por su aspecto y plumaje se parece un puco á la golondrina, razon por la cual le aplicaron los brasileños el nombre de golondrina de hosugu. Esta semejanza es sobre todo visible cuando el are se posa en tierra; sus patas están mal confornadas para andar, y se desliza por el suelo como la golondirina: su vaelo es ligero y ondulado. Al posarse sobre una alta rama, deja oir su grito de llamada, que es breve. No tiene nada de tímida, y-yor lo tanto se da puede dar caza con facilidad: si se la hiere produce algunos gritos agudos: alimentase de insectos.s Segun Burmeister, come principalmente hormigas y grandes chinches.
«En las orillas del Rio Grande de Belmonte, en los bos. ques del pais de los botocudos, continúa el principe de Wied, he podido observar los nidos del quelidóptero.tenebroso. En el mes de agosto vi a estas aves penetrar en agujeros redondos, abiertos en la orilla arenosa del rio, y semejantes a los nidos del martin pescador. Dejamos uno al descubierto, $y$ despues de socavar horizontalmente á la profundidad de unos dos piés, encontramos dos huevos de color blanco de leche, sobre una ligera capa de plumas.

\section{LOS GALBULIDOS-GAL- BULIDE}

Los galbulidos, a los que Cabanis llana agromites (aves perezosas), se pueden considerar como representantes de los certidos en el Nuevo Mundo; pero ambien es dable admitir

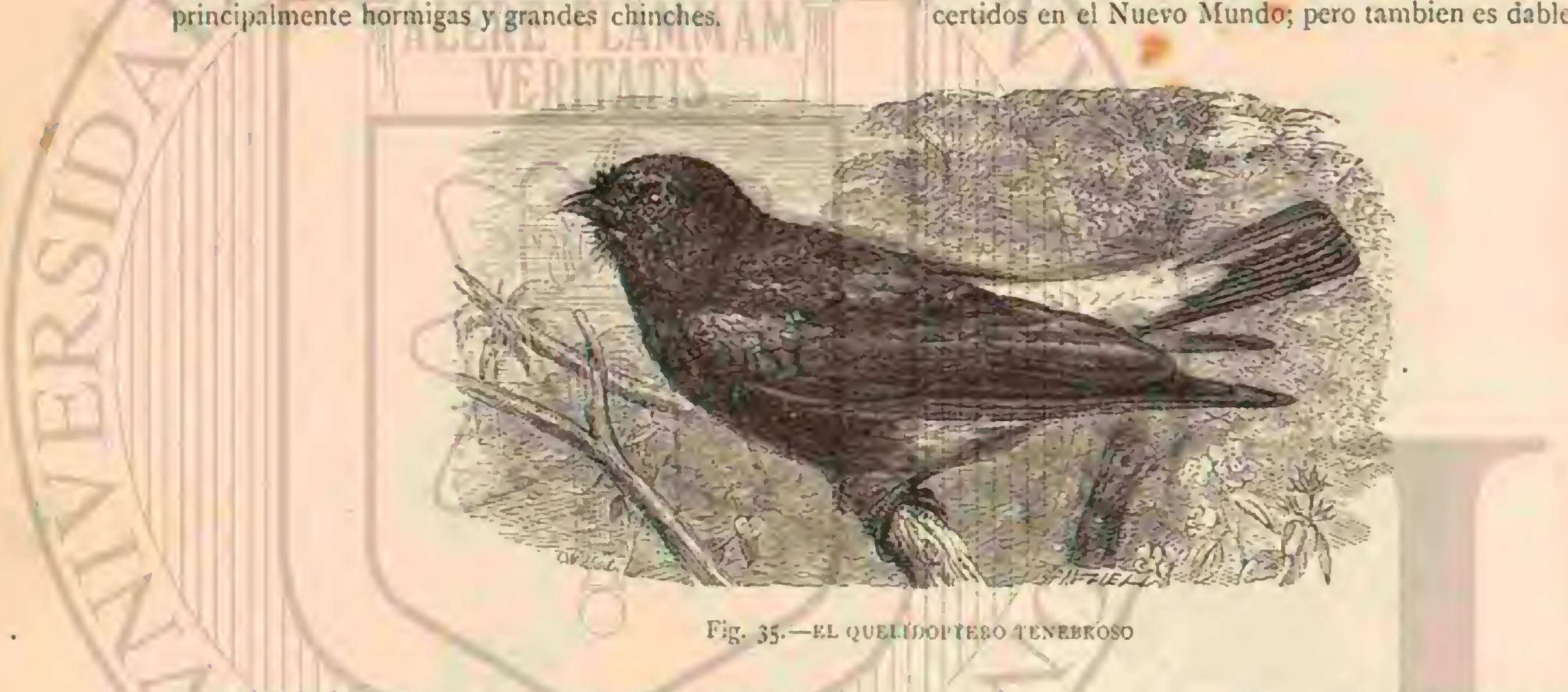

que forman tránsito entre los certidos, los alcedinidos ó los nicionidos $\&$ los buconidos, atendiendo i los muchos cirac léres que presentan, comunes a unos y otros. Reinchenbach los calinica de certidos: Burmeister los mira como una tribu de buconidos, y Cabánis los aproxima á estos últimos.

CARACTÉRES. - Los representantes de esta familia tienen el tronco prolongado; pico largo, casi siempre recto, alto, con ángulos agudos y en forma de lezna; piés endebles y delicados, provistos de cuatro dedos, mas veces de dos; alas cortas, que apenas cubren la base de la cola; la cuarta rémige $\delta$ la quinta son las mas largas; la cola, bastante prolongada, se adelgaza gradualmente hacia su extremidad, y compónese de diez a doce plumas redondeadas en la punta; el plumaje es suave y ligero, con un magnífico brillo de oro; la region del pico está cubierta de sedas. L Los galbulidos se asemejan á los buconidos por tener la piel en extremo fina y las plumas anchas, suaves, de tallo delgado y poco arraigadas. La estruc. tura interior recuerda en todas sus partes la de los cucúlidos.

DISTRIBUCION GEOGRÁFICA.-Los galbulidos, familia que apenas cuenta veinte esnecies conocidas, habitan en la América del sur, pero no se encuentran en el oeste de los Andes; su área de dispersion es por consiguiente inuy li. mitada, y aun en ella recorren cortas distancias, porque viven con preferencia en los parajes húmedos de las selvas virgenes.

USOS, COSTUMBRES Y RÉGIMEN.-Por este concepto no ofrecen nada de notable, y apenas hablan sobre el particular los naturalistas. Los galbulidos son ares pesadas, perezosas, indiferentes, estúpidas; y tienen bien merecido su nombre popular brasileño de Juas el sons?.

Paréceme inútil describir en detalle los diversos géneros que constituren la familia de los galbulidos: me bastará decir que se asemejan, unos a los certidos, otros a los alcedinidos y variosi los troquilidos, y que tienen cuntro dedos, ó solo tres.

\section{LOS IACAMARAS - GALBULA}

CARACTERES.-Los jacamaras tienen el pico largo, delgado, alto, ligeramente corvo y de cresta dorsal cortante; las alas son largas a proporcion, sobresaliendo de las otras la cuarta y quinta rémiges; la cola es-larga tambien, fuerte ! truncada, con las pennas redondeadas en su extremidad, las laterales mas cortas que las medias; los tarsos cortos y endebles; los dos dedos auteriores estąn unidos en casi toda su extension, quedando solo libres en la extremidad; los postc riores son muy cortos; el plumaje sumamente blanco y lacio.

\section{EL JACAMARA VERDE-GALBULA VIRIDIS}

CARACTERES.-Fil jacamara verde (fig. 37) esla es. pecie mas conocida: tiene el lomo y el pecho de un magnifico color verde: el vientre pardo rojo: la garganta blanca en el macho y de un leonado rojo en la hembra; las rectrices laterales pardo rojas, $y$ verdes en la punta; el oja pardu; el pico, la linea naso-ocular y un circulo desnudo que rodea el ojo, de un tinte pardo; las patas de color de carne pardusco. Segun las medidas tomadas por el principe de Wied, esta ave tienc $f^{\circ}, 215$ de largo, la cola $\left(1^{\prime \prime}\right.$, on y el ala $1^{\circ}, 08$.

DISTRIBUCION GEOGRÁFICA. - E! jacamara verde habita los bosques que bordean la costa del Brasil, y no es raro en ninguna parte. 
USOS, COSTUMBRES Y REGLMEN. - El principe de Wied dice que esta preciosa ave ofrece mas de un punto de semejanza con los pájnos moscas, cosa que ha observado hasta los salvajes botocudos, pues la llaman gran colibri. Vire solitaria en los bosques huimedos, en medio de las breinas, $y$ suele estar posada en alguma rama baja, cerca del agua. Su vuelo es rápido, pero poco extenso. Siempre silenciosa, triste y melancólica, parece inspirarle horror el movimiento: espera pacientemente â que se acerque un insecto; atrápale al vuelo y vuclve á su observatorio. Schomburgk asegura que à menudo está homs enterns inmóvil en un mismo sitio. Su grito, sonoro, claro y penetrante, no constituye en modo alguno un ranio agradable, segun dijo Buffon. El jacamara, lo mismo que sus congéneres, anida en un agujero redondeado, abierto en tierra á orilla de una corriente: su nido se parece al del martin pescador vulgar. El principe de Wied nos lo dice asil; pero no ha visto él mismo los nidos.

A esto se reduce todo lo que sabemos de las costumbres del jacamara verde. Pueppig airade, que en las selras virgenes no es dificil reconocer el lugar iavorito de un jacamara. por las alas de mariposas que cubren el suelo, pues el ave no co. me sino el cuerpo. listo puede ser verdad; pero me parece muy problemático, por no decir duduso, que el jacatnara al. cance los insectos de un salto, ó dando algunos aletazos, los

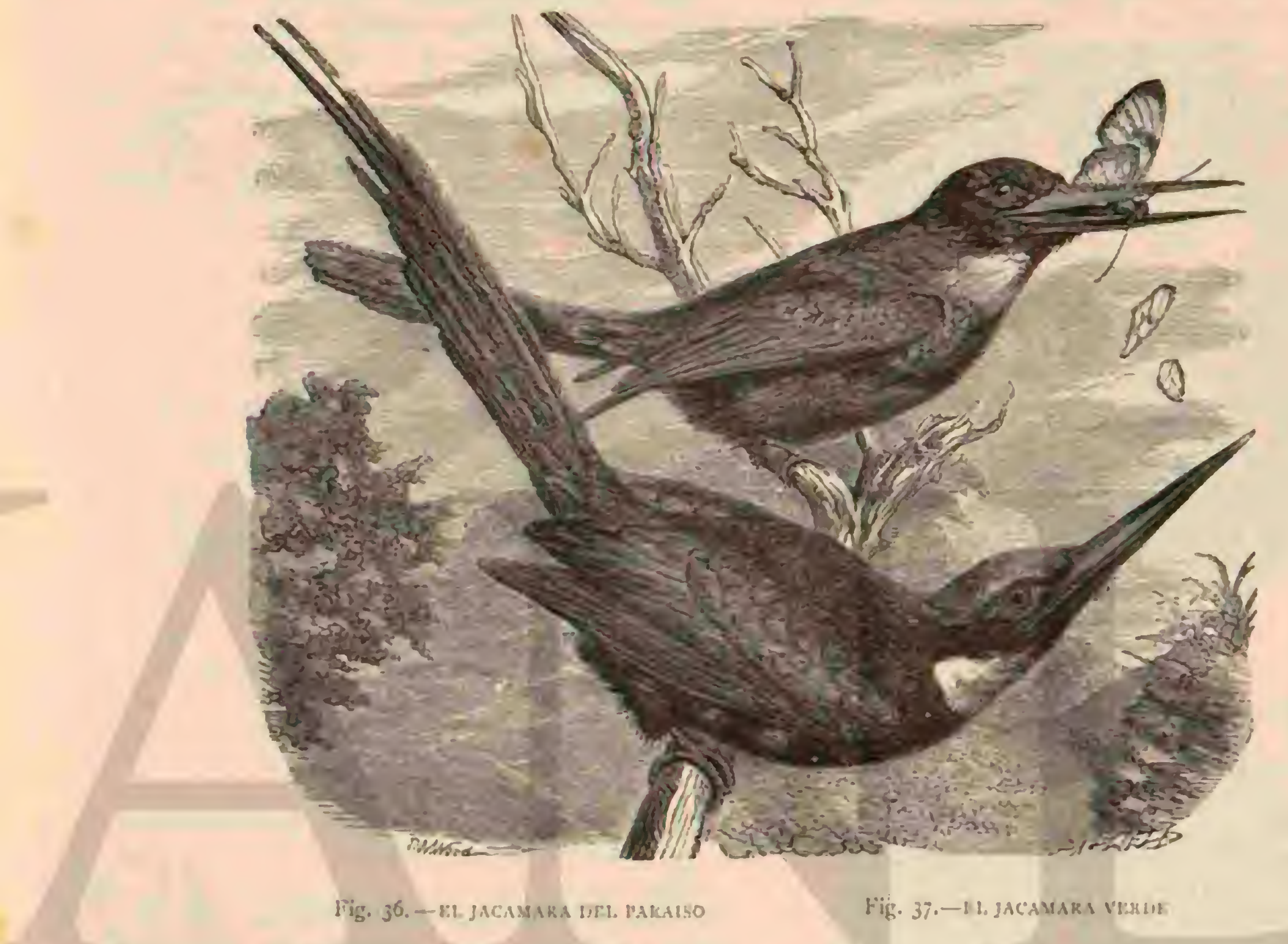

atraviese con su pico y vuelva á comérselos desprues de haberse posado: ignoro cómo lin de hacerlo, y solo puedo ad. mitir que el ave capture su presa como las demås.

\section{EL JACAMARA DEL PARAISO-GALBULA PARADISEA}

CARACTERES.- El jacamara del paraiso (fig. . of) tiene la cabeza parda, con mezcla de un inate violeta; la garganta, el cuello ja algunas de las cobijas de un blanco puro; el lomo, las alas $y$ el resto del cuerpo de un precioso color verde dorado; el pico y los piés negros.

DISTRIBUCION GEOGRÁFICA.-Habita principalmenic en Surinam.

USOS, COSTUMBRES Y REGIMFN. - SC alimenta sobre todo de insectos " no dificre por su género de vida de la especie anterior.

\section{EL JACAMARA TRIDÁCTILO-JACAMARAL- CYON TRIDACTYLA}

CARACTÉRES. - El jacamara tridáctilo (fig. 3 ), mas pequeño que las especies anteriores, no presenta los brillau ies colores que se observan en la mayoria del grupo. Casi todo el plumaje, con raras excepciones, es de un negrooscu.

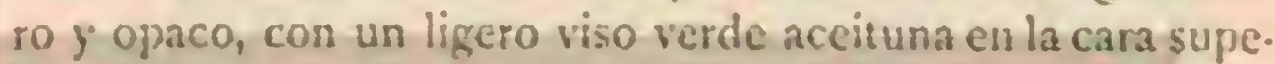
rior del cuerpo y en la cola; en la coronilla tiene dos $\delta$ tres listas de color de chncolate, y otra del mismo tinte que se corre desde el ángulo de la boca hícia la cara superior del cuello; los costados son negros, lo mismo q̨ue el lomo, pero sin el viso verde; la cara inferior de la cola es de un gris pardo.

DISTRIBUCION GEOGRÁFiCA.- Habita en los bos. ques del Bmsil.

\section{EL GRAN JACAMARA - JACAMEROPS GRANDIS}

CARRCTERES. - El gran jacanara (fig. 39) dificte principalmente de las especies anteriores por la extremada anchura de su picn, y por tener encorsado de una mancra muy marcada cl borde de su mandibula superior; la cola es ancha y de un largo regular; il cucllo corto, y lasalas redondendas. Los colores de esta ave se asemejan álos del jacamara verde, con la diferencia de no dominar tanto este tinte

DISTRIBUCION GEOGRÁFICA.-Habira el mismo pais que el jacamara tridactilo. 


\section{LOS TROGONIDOS - TRO- GONID死}

CARACTÉRES.-Ios congéneres mas afines de los bUconidos son los trogonidos ó surucús; las especies compren. didas en esta familia son tambien muy poco vivaces, pero en cambio tienen un plumaje magnífico.

Tienen el cuerpo prolongado; el pico muy corto, ancho, triangular, sumamente combado, de punta ganchuda, bordes roluminosos jor detrás, y a veces dentados, y con la base rodeada de sedas; las patas muy pequeñas y endebles: los tarsos están casi del todo ocultos por las plumas de las nalgas; los dedos, son cortos, y el interno situado junto al pulgar; las alas cortas y cosi redondeadas; las remiges angostas, pun tiagudas, encorvadas en forma de ho\% y con los tallos rigidos: 12 cola, bastante larga, si compone de doce pennas, y de cllas, las tres externas de cada lado son mas cortas que las seis medias, que tienen mas anchura, $\mathfrak{e}$ igual longitud con corta diferencia; el plumaje es muy suave, lacio, lanoso, y presenta un magnifico brillo metálico. I a estructura interna sé asemeja \& la de los cuclillos.

No deja de ser una singularidad el que desaparezca pronto la belleza del plumaje, y quue se pierdan sus bonitos tintes apenas se exponen á la luz. Los trogonidos, dice Cabanis, temen la luz, é influye en cllos tanto mucrtos como viros. Paréceme, no obstante, que el aserto peca de exagerado.

DISTRIBUCION GEOGRÁFICA.-Los trogonidos ha. bitan en iodos los paises tropicales del antiguo y del nuevo continente: se conocen hasta ahora mas de cuarenta especies distinias.

USOS, COSTUMBRES Y REGIMEN. - Ya desde las épocas mas remotas llamó la atencion, tanto de los maturalis. tas como de los aficionados, la belleza del plumaje de estas aves: pero en cambio no ofrecen sus costumbres nada de muy notable. Los trogonidos recuerdan los chotacabras, no solo por su jico muy hendido, sino tambien por sus piés cortos y peciuenos, y por la blandura de su piel y de su plu-
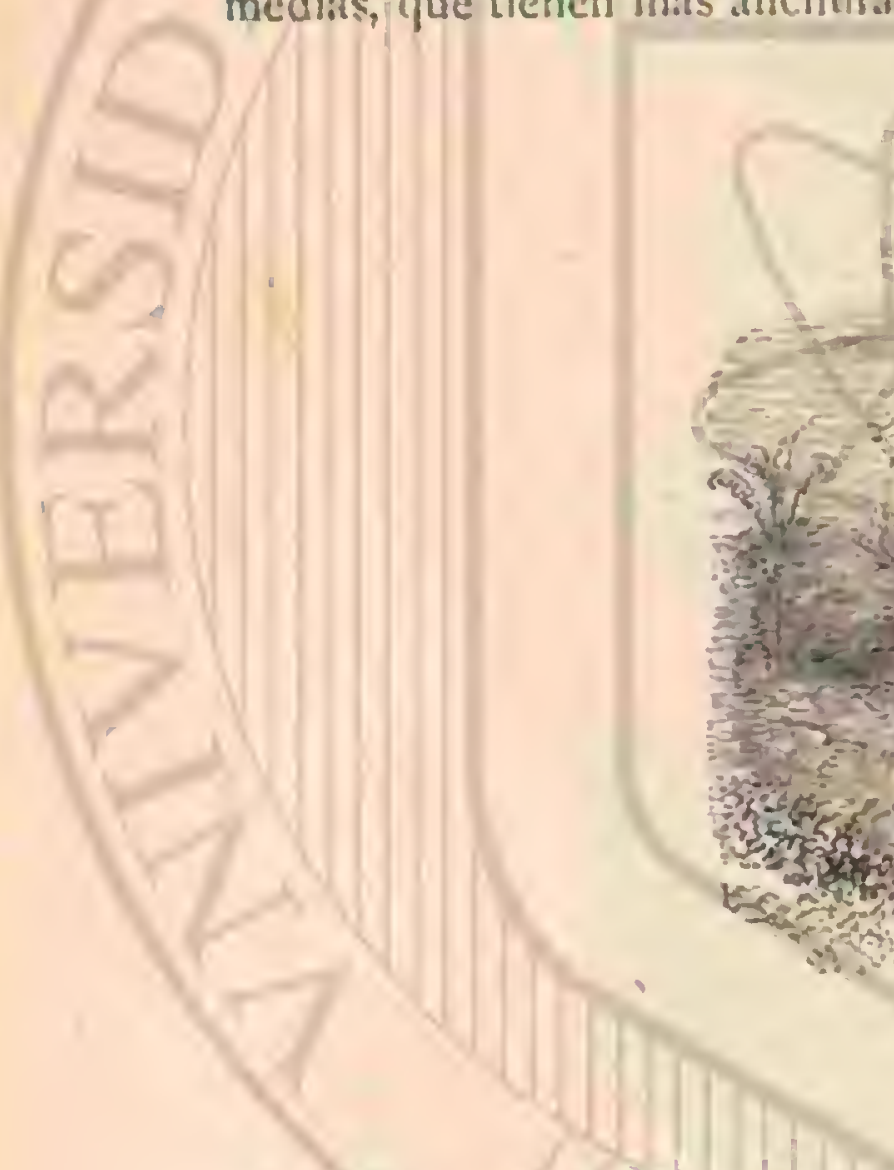

maje. Lo mas notabie es la semejanza de los hijuclos en es tos dos grupos; semejanra que, segun tranzius, puede llegar hasta el punto de inducir a ertor a los mas expertos observadores. No cabe dudá que los trogonidos y los chotacabras deben considerarse hasta cierto punto como congéneres, y asi se explica que algunos naturalistas los hayan clasificado juntos. Sin embargo, difieren esencialmente tanto por su co. lor como por sus costumbres, y estas últimas les comunican tania semejanza con los buconidos y megalemidos, que no podemos seguir el ejemplo de los naturalistas que los reunen con los chotacabras. Arnque bisquen durante el dia su ali. mento, se puede considerar en rigor álos trogonidos como seres crepusculares, pues muy raras reces se les ve fuera de los bosques mas sombrios y espesos, donde no penetran ni aun los rayos perpendiculares del sol. Alli vagan por las ramas bajas, solitarios ó pror parejas, y cuanto mas enmarañada y rica es la selva, mas numerosos aparecen. A veces se cle van en la montaña à considerables alturas. Por su mancra de vivir recuerdan en un todo estas aves á los buconidos. Se las ve posadas sobre una rama, inmóviles, silenciosas é ins. peccionando todos los alrededores; si un insecto pasa cerca de ellas, emprenden su vuclo, persiguiendo su presa con gran agilidad; atrápanla con cicstreza y vuelven á su observatorio. No son absolutamente inscctivaras; comen tambien frutos, y hasta parece que ciertas especies se nutren tan solo de cllos Anidan en troncos de árboles huecos; cada puesta se com pone de dos a cuatro inweros de color claro, por lo regular blancos.
CAUTIVIDas - Extrano es quic hasta ahora no se haya intentado formalmente conservar trogonicios en cautividad. la principal causa de que estas magnificas ares no lleguen vivas a nuestras jaulas se debe atribuir sin duda á la pereza de los americanos y á la indiferencia con que miran la rica fauna de su pais, ó por lo menos los animales que no les per. judican directamente. Asimismo debe influir el poco tacto de los anicricanos para cuidar aies cautivas, f tambien la de. licadera del plumaje es otro impedimento: pero no creo im. posible conservar los trogonidos en la jaula, y hasta me parece que resistirian mejor ta cautividad que muchas otras aves.

\section{LOS HARPACTOS-HARPACTES}

CARACTERES. - Jos harpactos ó surucirs famigeros, tienen el pico fuerte, nuy encorvado y de bordes lisos; los tarsos cubiertos de plumas en la mitad de su longitud; las alas cortas, Ja cola larga, de rectrices laterales anchas y que aumenta de largo desde las externas a las medias.

DISTRIBUCION GEOGRAFICA.-Todas las especies conocidas son propias del Asia meridional $y$ de Malasia.

\section{EL HARPACTO LISTADO-HARPACTES FAS- CIATUS}

CARACTERES.-EI macho de esta especie tiene el lomo pardo castaño, que tira al rojizo; la cabeza y el cuello 
de color negro; las cobijas de las alas listadas de este linte $y$ de blanco; el pecho $y$ el vientre de un rojo escarlata; una faja estrecha de un blanco brillante separa la garganta del pecho; de una oreja á otra se ve un semicirculo rojo, que pasa sobre el occipucio; rodea el ojo un circulo desnudo de un blanco azulado: las rectrices medias son del mismo color del lomo, con las externas listadas de negro y blanco; el ojo es pardo oscuro: el pico de un azul intenso y las patas del mismo tinte aunque mas pálido. Ia hembra no tiene la ca. beza negra; sus rémiges secundarias y las sub-alares presen. tan un angosto filete negro $y$ pardo; cl vientre es de un ama rillo de ocre. Fil are mide $0^{\circ}, 3^{1}$ de largo por $\left(1^{\circ},+1\right.$ de punia a punia de ata, esta tiene $11^{\prime \prime}, 13$ y la cola $11^{\prime \prime}, 15$ (lig. 44).

DISTRIBUCION GEOGRAFICA. - Segun Jerdon se encuentra esta ave en los bosquues de Malabar, desde el ex. tremo sur hasta las montanas de Cihat, asi como en algunas selvas de la India central y de Ceilan, hasta una altitud de 1,000 metros sobre el nivel del mar, si bien suele hallarse con mas frecuencia á la de unos 600 arriba.

USOS, COSTUMBRES Y REGIMEN. - Vive exclusi vamente en los parajes mas sombrios de los bosques, donde se la encuentra i menudo inmóvil sobre una rama. Obser. vándola algun tiempo podria verse cómo abandona por mo mentos su sitio para coger algun insecto; á veces vuetre al mismo punto de donde partió: pern casi sicmpre busca otro, y recorre asi repetidamente una gran parte del bosque. De ordinario está solitaria, aunque en muchas ocasiones se la encuentra tambien por parejias, ! Jerdon ha visto cuatro o cinco harpactos juntos: Layard dice que estas ares se re unen por jecquerios grupos de tres ó cuatro individuos. Als méntase de insectos, sobre codo de coleófuteros, y' segun aqquel naturalista, de langostas y arañas ferdon no recuerda haber oido nunca su roz, y segun entieirdo yo, es una de las aves mas silenciosas que exisien. 'I'ickell, por el rontraric, asegura que lanza un grilo salvaje yo planidede, almo parecido al maullido del gato. El nombre indostínico que se hą dadóa esta ave kuf ni churr (sin cuello), se le aplicó por su costum. bre de tener siempre aquella parte hundida entre las espal. das. Refiriéndose à una especic afine, Jerdon dice que pone dos huevos de color blanco en el hueco de un tronco de árbol.

\section{LOS HAPALODERMOS - HAPALO- DERMA}

CARACTERES. - Til subgénero de los hapalodermos esta representado pot in línica especie de, la familia que se ha encontrado hasta ahora en el Africa. Se caracteriza por tener los bordes de las mandibulas dentadns, y le Vaillant le ha dado el nombre de Nirina, en obseruito á una hermosa hotentote: esta palabra significa fior.

\section{EL HAPALODERMO NARINA - HAPALO- DERMA NARINA}

C ARACTERES. - las narina macho (fig. .;0) icule el lomo de un magnifico color verde dorado, y de igual tinte las plumitas subalares, las rectrices medias, li garganta y el cuello; el pecho y el vientre son de un rosa oscuro; las grandes plumas subalares grises, listadas de negro: las rémigés negras, con los tallos blancos; las rectrices laterales de este último tinte en las barbas externas, y las internas negras. Ia hembra tiene colores mas opacos; la frente y la garganta son de un rojo pardo y las rémiges de un regro pardo.

DISTRIBUCION GEOGRAFICA.- l.e Vaillant descu. brió esta ave en los grandes bosques de la Carreria: mas tarde la observó Ruppell en las selvas quie bordean la cosia de Abisinia; Heuglin la vió en el lossoll y en las márgenes del Nilo Blanco; Ries en Aguapim; du Chaillu en las orillas del Muni; Kirk en el sur de Mozambique, y Monteiro en Benguela. Solo una vez ture yo la suerte de encontrar esta are magnitica en el valle de Mensa, a pocos kilometros de la costa del mar Rojo; paro no creo sea tan rara como supo nen los viajeros.

USOS, COSTUMBRES Y REGIMEN.-I.a Uarina vive en las pendientes escarpadas de las montañas, de muy dificil acceso: Julio Verreaus dice que se encuentra principal niente en el sur de dirican en los grandes bosques situados al este del cabo de Buema Esperanza.

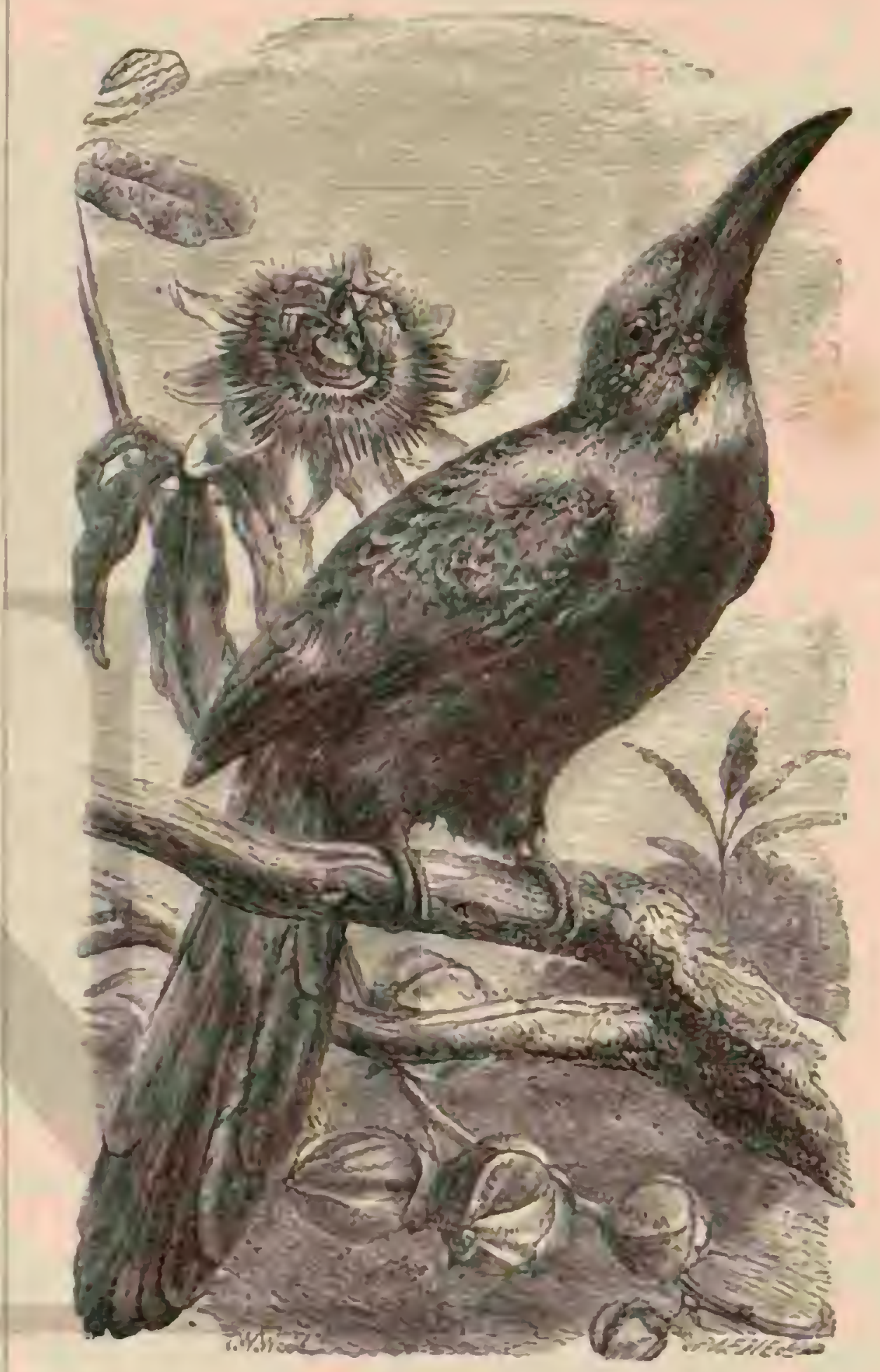

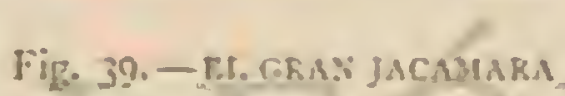

En todo su sćr ofrece la narina aigo de particular que no puede newos de reconocerse l"osada, tiene el cuerpo muy derecho, la rabeza encogida entre las espalutillas y la cola pendiente: su vuelo es silencioso. Ein la éroca del celo. dice Le Vaillant, la narina macho produce unos gritos que parecen expresar el dolor, permaneciendo silenciosa todo el resto del año. I. Verrenux confirma el aserto, calificando de lastincro el grito de esta ave; pero aun psoduce orros so. nidos, pues tiene la cualidad del ventrilocuo. A menudo se la rree bien léjos, cuando estri poẹda en una rama vecina: yo puedo confirmar el hecho porquve oi su roz singular. l.e Paillant asegura que se puede atraer a la narina imitando el grito del buho, ó silbando con una hoja, lo cual concuerda perfectamente con lo que otros naturalistas nos dicen de los trogonicios de la América del sur.

Esta ave se alimenta de mariposas, langostas y moscas. 
$V$ erreaux encontró tambien en su estómago, aunq̨ue pocas reces, restos de coleópteros

Le Vaillant dice que la rarina anida en los troncos hue $\cos$, y que pone cuatro hueros, casi redondos, de color blan$\mathrm{CO}$, aunnque rojizos al parecer cuando están llenos, porque la yema se ve al trasluz. Su numero es de dos, segun Verreaux, rara vez de tres: I incubaceon dura veinte dias; otro tanto necesitan los hijuelos antes de poder volar, y aun entonces permanecen largo tiempo en compañia de sus padres.

\section{LOS SURUCÚS-TROGON}

CARACTÉREj. - I, os sưucís representan \& los trogonidos en América. Ultimamante se han formado varios géne. ros con las muchas especies que habitan este continente; pero los caractéres distintires son de poca importancia Los surucusstienen el pico anch $y$ alto; in mandibula superiur abovedada y en forma de gancho en su extremidad, con los bordes denticulados: las alas cortas y obtusas: la cola, de longitud regular, se adelgaza gradualmente, como en las es. pecies indias; las plumas soil anchas y grandes.

\section{EL SURUCÚ SURUCUA-TROGON SURUCUA}

CARACTERES. - Azara fué el primeto que publicú la descripcion de esta especic: el surucua es un ave de i" 120 de largo por $1^{\prime \prime}, 3 \mathrm{~S}$ de punta a punta de ala, la cola tiene $0^{n}, 09$ y las alas plegadas $\|^{m}, 12$. El plumaje del maclou es magnifico cuando alcanza todo su desarrollo I.a cabeza, cl cuello y el pecho son de un azul negro con brillo metálico; el lomo de un verde luciente; el vientre rojo de sangre; los lados de la cabeza azul de acero, 6 violeta, j los del lomo verdes, ó de un azul dorado; las cobijas superiores del ala, finamente vermiculadas de negro $y$ blanco, presentan un

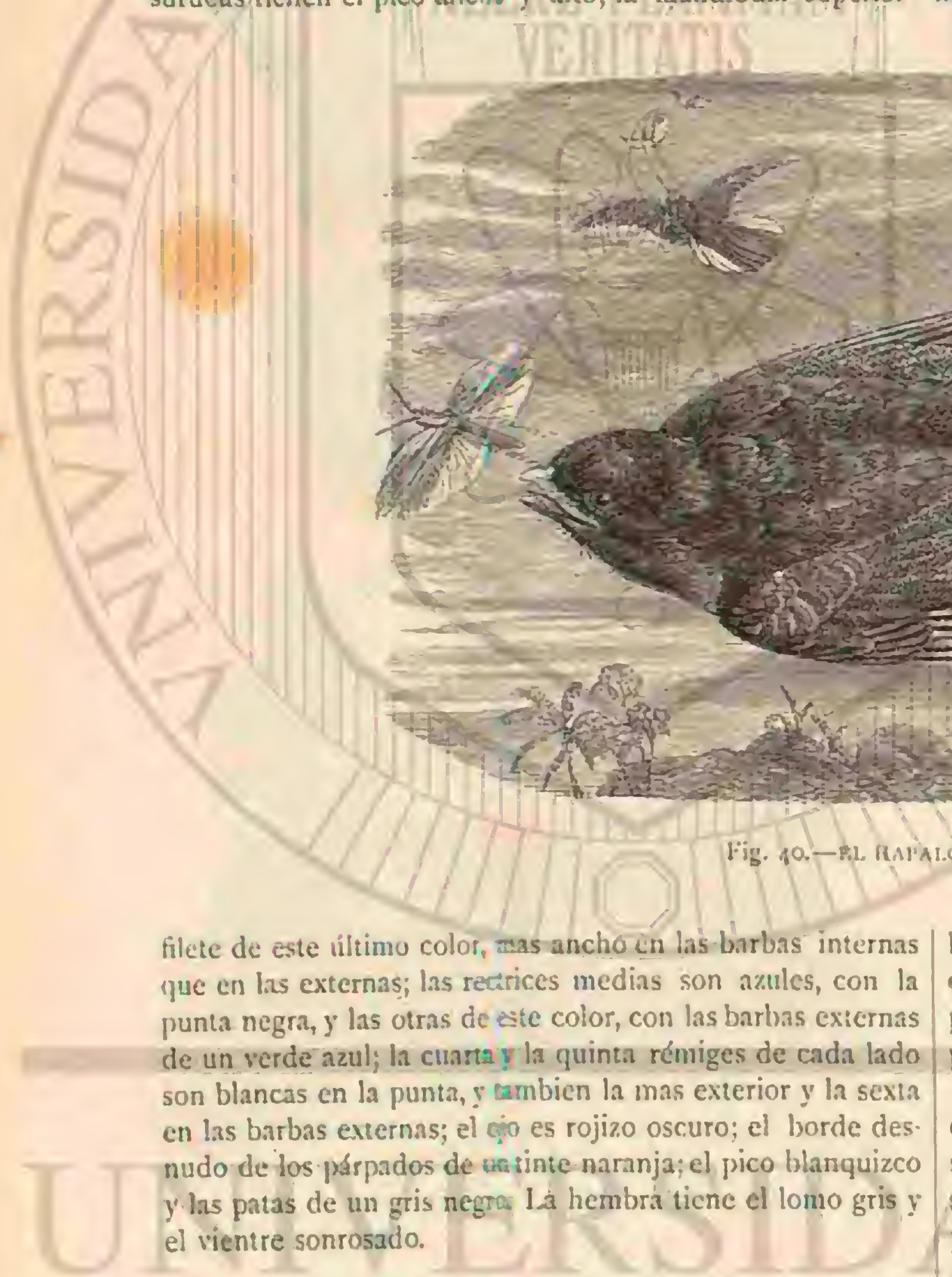

\section{EL SURUCU் POMPEO-TROGON VIRIDI:}

CARACTÉRES.-Ei sancí pompeo tiene la frente, las mejillas $y$ la garganta negras; la parte superior de la cabeza, la nuca, los lados del cuelio y el pecho de un hermoso azul con visos verdes; el lomo, las espaldillas y las rectrices supe riores de las alas de un verde bronce, que tira mas al azulado cuanto mas se aproxima a lomo; el vientre y la rabadilla son de un amarillo vivo; el bosde de las alas y las rémiges de un tinte negro; estas últimas tenen filcies blancos; las rectrices medias son verdes, con un ligero feston hácia la extremidad, $y$ las otras negras, orilladas por fuera de un verde broncea do; las tres externas blancas en las barhas cxteriores y en la punta. La hembra tiene el bmo gris oscuro; el vientre amari
110 claro; las cobijas de las alas cruzadas por listas finas de color blanco. El ojo es pardo, el pico blanco verdoso y las patas negruzcas El surucif pompeo mide $6^{\text {m }}, 32$ de largo por $t^{\prime \prime}, 48$ de punta a punta de ala, la cola $t^{\circ}$, i 3 y el ala $1^{\circ}, 15$.

DISTRIBUCION GEOGRAFICA DE LOS SURUCÚS SURUCUA Y POMPEO. - El surucua habita las selvas sirgenes del sur del Brasil y del norte del Paraguny; el surucú pompeo vive en el norte de estos paises y en la Guayana. Ni uno ni otro son raros; cl pompeo es un ave de las inas comunes en las selvas virgenes, visitadas por el principe de Wied.

USOS, COSTUMBRES Y REGIMEN DE LOS SURUCÚS SURUEUA Y POMPEO. - Ias llanuras y montañas son los pamjes predilectos de estas aves: y se las en. cuentra hasta en las costas, alli donde las selvas virgenes llegan hasta la orilla del mar. Estas aves, dice el principe de Wied, están diseminadas par todos los puntos del Sertong. 10 mismo en los bosqnes catidos f secos del intcrior de-las ticrras, que en aquellas altas selvas, espesas y sombrias, situadas en las costas, mucho mas majestuosas y magnificas que las del centro del Brasil. Abundan todaria mucho mas en los primeros que en las segundas. if

En todos los puntos de aquellas localidades se oye resomar el grito del pompeo, que consiste en un silbido monótono, 
bastante corto y repetido varias veces, aunque siempre en tono mas bajo; este grito es bastante análogo al de la pava, y se expresa, segun Schomburgh, por i's iu. Ėn todas partes se puede ver al are, pues no es nada tumida y deja que se accrque uno bastante. Azara vió matar $\dot{a}$ un surucua de un paio, y al jrincipe de Wied opina que puede suceder lo mis. mo con el pompeo.

Uno y otro estan horas enteras inmoiviles ó segun dice Schomburgk sin cansarse sobre una rama inuerta, a nuy poca altura del suelo, con el cuello encogido, la cola pendiente y acechando los insectos. Pur lo regular se encuentran estas aves solitarias, ó cuando mas de dos en dos: Bates dice, ne oustanis, haber visto reducidas bandadas de media doce- na de individuos. Permanecen, dice este viajero, una $\delta$ dos horas inmóviles sobre alguna rama baja, limitándose tan solo a volver un poco la cabeza cuando pasa un insecto cerca de cllos \$ Si este se pone a su alcance, remóntanse con viclo silencioso, como el del buho, te atrapan y vuclven al mismo sitio. Schomburgk dice que :s menudo se las encuentra en las higueras, cuyo fruto parece gustarles mucho. Natterer encontró en el estómago de un pompeo frutos y granos. Estas aves despliegan mas actividad por la mainana, particularmente al. salir el sol, hora en que resuenan sus gritos por todo el bos. que. El surucú surucua anida en agujeros que abre en medin de las construcciones formadas por los térnites en los árbo. les. SYo vi un nuacho, dice dzara, suspendido de un árbol á

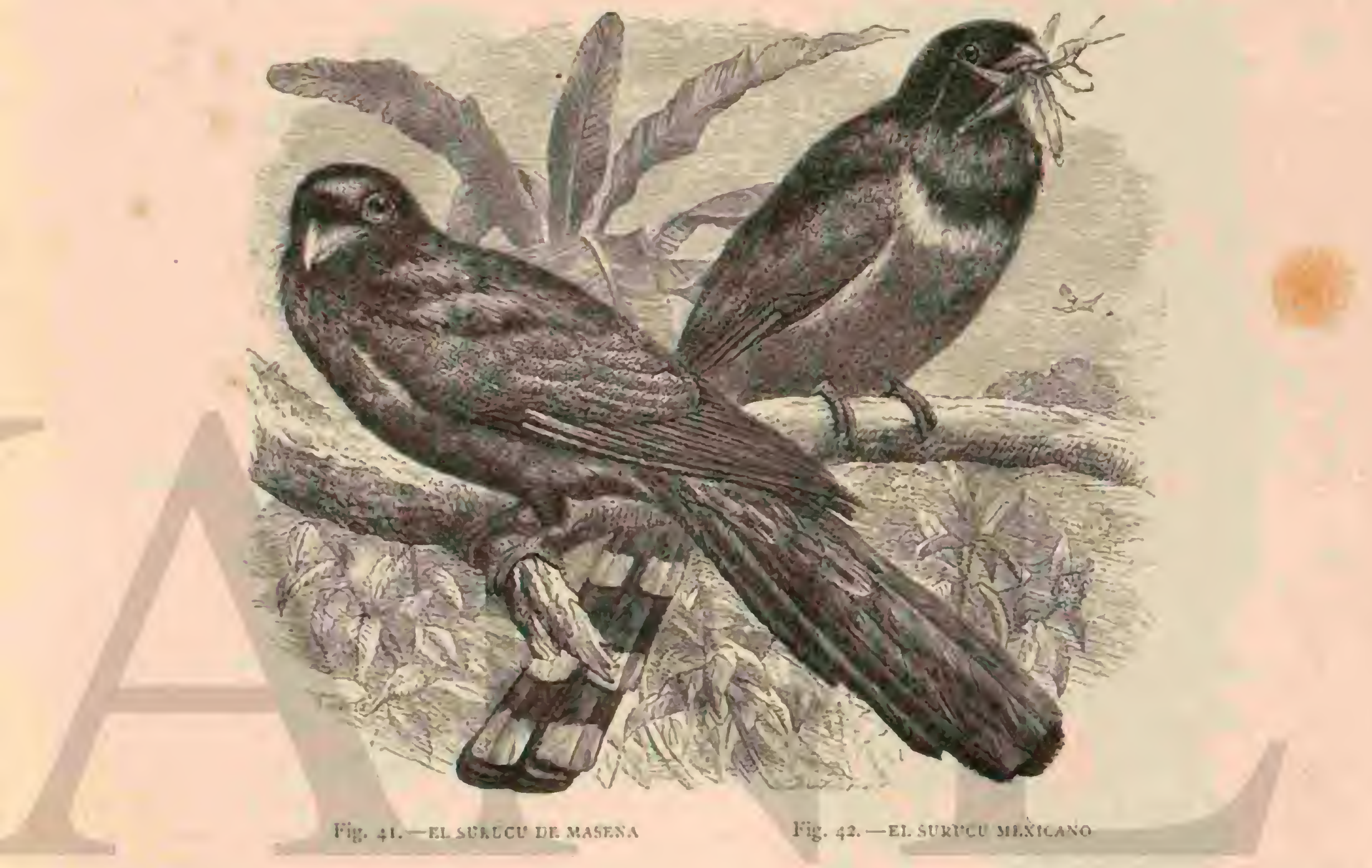

la manera del pico, y ocupado en agrandar su nido á picota zos, mientras que ia hembra permanecia inmóvil sobre un irbol próximo y parecia animarle con sus miradas.y Ein se. tiembre queda terminada la construccion del nido y la hem. bra pone de dos i cuatro liuevos blancos Schomburgk nos ha dado a conocer la manera de reproducirse el pompeo: pero creo que se deben proner en duda sus asertos. Dice que la. especie construye en medio de las ramas un nído sene. jonte al de la paloma zorita; y si el liccho es positivo, el ave de que hablamos diferiria entonces esencialmente por tal roncepto de iodos sus congéneres.

Ningun ave da tanto que harer al naturalista despues de muerta como el surucua. $\$$ No hay animal, dice Schomburgk, que me haya costado tanio trabajo para disecarle como el surucii ; y raro es el caso en que se consigue lesantar la piel sin decreromal for muchas preçaciones yue so rounen. Es tan delicada, que si el are cae y tropieza contra una rama ó una picdra, se desgarra y muila.

C.AZA. - No es dificil matar a cualquiera de estos surucús, pucs aunque no se les rea, se les atrae fácilmente imitando su grito, y enionces llegan á posarsc cerca del cazador. la carne de estas especies es muy delicaóa.

\section{EL SURUCÚ DE MASENA-TROGON MASSEN A.}

CARACTERES.--1 a magnifica are, designada con di cho calificativo en honor al principe de este nombre, se dis. tingue for tener la parte superior de la cabcza, of chello y cl lomo de un color gris intenso, que cantrasta con el tinte ne. gro de los lados de aquella y de la gargania: el pecho y el abdómen son de un precioso escarlata; el color domiunntc del centro de las alas es un ligero gris, con mezcla de rayas negras inuy finas; las remiges son negras, con un filcte blan. co; las plumas de la cola son negras tambien, presentando las dos jel centro matices variables de un verde oscuro y jurpura, y una mancha negra en su extremo; el pico es ama. rillo; las patas negruxcas (fig. ;1).

- L Los colores de la hemora no son tan bonitos: las partes su. periores del cuerpo se cambian en un tinte gris azulado oscu. ro, en vez del bonito color verde del macho, y las alas tienen mezcla de gris en lugar de las rajas negras; el abdómen y el pecho son de un tinte escarlata; el pico tiene un color sin. gular: la mandibula superior es negra y la inferior amarilla.

DISTRIBUCION GEOGRÁFICA.- Eil surucú de Ma- 
sena habita en la América central y se le encuentra en Hon. duras y México.

USOS, COSTUMBRES Y REGIMEN.-No difiere de la especic anterior por su género de vida.

\section{EL SURUCÚ MEXICANO-TROGON MEXICANUS}

CARACTERES. - El macho adulto de esta esprecie (Gigura 42) tiene la cara superior del cuerpo, cuando ostenta su mas rico plumaje, de un magnifico color verde, y parte de la inferior de un escarlata brillante; la garganta y los lados de la cabeza negros, rodeando anuella ura faja blanca; las alas son negras tambien con mezcla de gris, excepto las ré. miges primarias, que son del todo negras; en la cola alterna este uitimo tinte con el blanco y el verde; las dos plumas centrales son de este uiltimo color, moteadas de negro, y las otras de este tinte, con mezcla de blanco; la cabeza es de un amarillo brillante.

DISTRIBUCION GEOGRÁFICA.- Segun lo indica el nombre, esta especie habita en México, "y abunda principalmente enl la parte del norte.

\section{LOS PRIOTELOS-PRIOTELUS}

CARACTERES.-Aunque estas aves tienen el pico, las

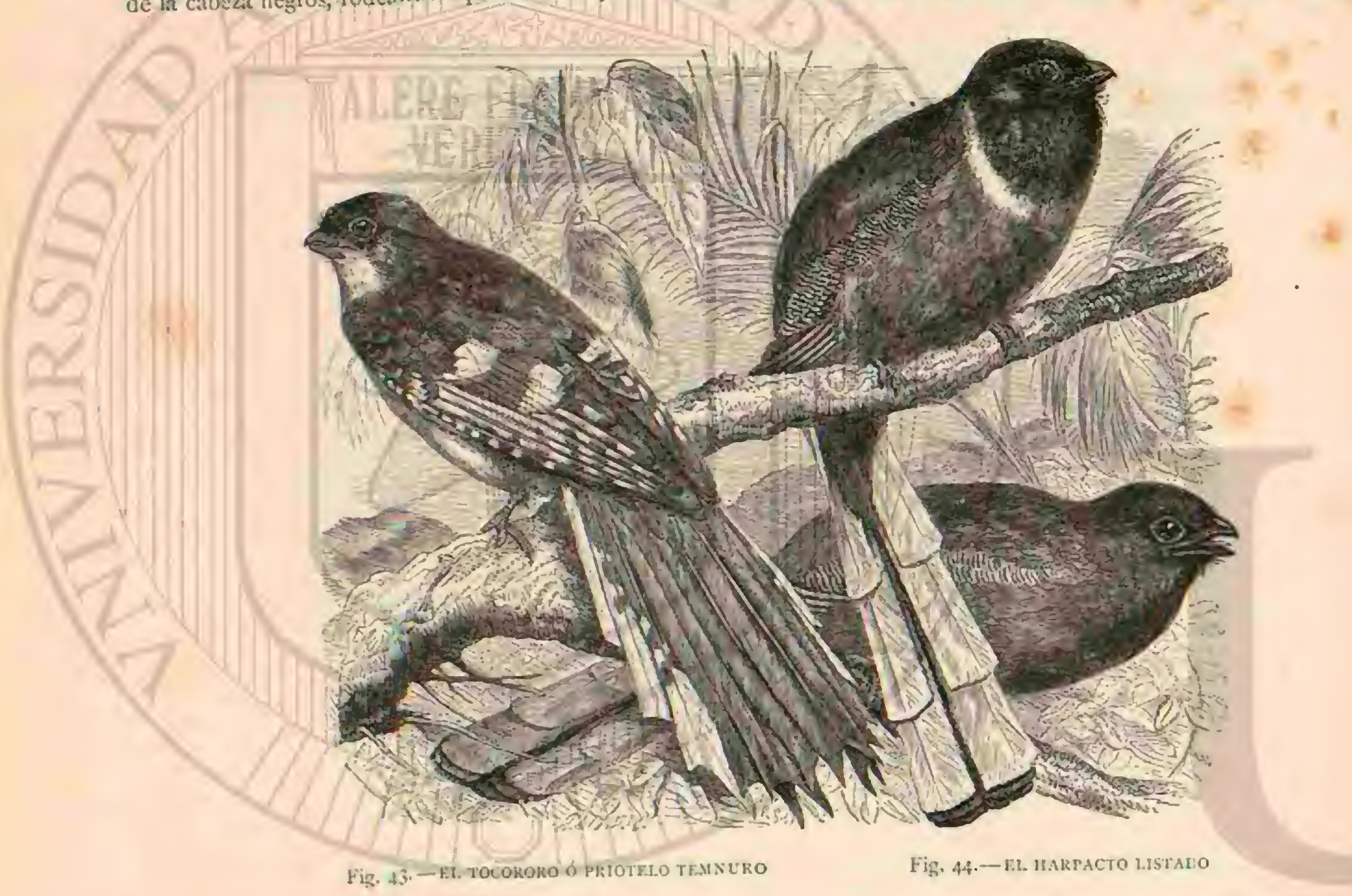

alas y las patas conformadas casi lo mismo que los surucuis, diferéncianse de estos por la forma de la cola, consistiendo en esto su principal carácter genérico. Cada una de las rectrices se ensancha en su extremidad y está recortada en forma de media luna; el talio de la penna es mas corto que las barbas laterales a que da nacimiento, $y$ la linea externa de estas barbas sobresale de la otra formando agıda pun:a.

\section{EL PRIOTELO TEMNURO-PRIOTELUS TEMNURUS}

CARACTERES. - El priotelo temnuro, vulgarmente llamado por los insulares fosurro, es la única especic conocida del género. Tienc la parte superior de lá cabeza, la nuca, el lomo y las sub- scapulares de color verde netálico; los lados de la cabeza a ules ; el cuello y el pecho de un gris ceniciento; el vientre rojo bermellon: las rémiges pardas, lis. tadas de blanco; las grandes sub-alares azules, con una mancha blanca: las rectrices medias de un verde bronce oscuro, - las orras de un arul varde, con las tres internas blancas en la extremidad. El ojo es amarillo rojo; el pico pardo negro; el ángulo de la boca y la mandibula inferior de un rojo coral; las patas pardo negras. El ave mide $0^{m}, 26$ de largo por $0^{m}, 39$ de punta á punta de ala, la cola $t^{5}$, i 3 y 10 mismo el ala plegada (fig. 93 ).

DISTRIBUCION GEOGRÁFiCA. - El priotelo temnuro es muy comun en ciertas partes de la isla de Cuba

USOS, COSTUMBRES Y REGIMEN. - Orbigny' Gundlach han hablado sobre el género de vida de esta ave, Y a este último debemos observacionés minuciosas. El toco roro habita solo en los bosques, y no se encuentra en male7.as, huertas ni cafetales, sino cuando sale del bosque alto; siempre se posa en los árboles mas próximos á este, y no se aleja nunca de su residencia. Asi como toujos sus congéneres de la misma familia, no le inspira temor el hombre; permite que este se le acerque y hasta se posa muchas veces junto a las personas cuando estas no se mueven. Su posicion suele ser insariablemente" la misma: siempre está derecho, con e. cuello recogido y la cola erguida, de modo que una línea trazada desde la cabeza, por el dorso, hasta la extremidad de aquella parte, forma el segmenio de un círculo.

Nunca salta entre el ramaje; permanece quicto on una rama horizontal 6 en un bejuco y vuela desde ạ̣ui à otro sitio. Su alimento consiste en bajas y hores, pero preficre 
todo los insectos. Cuando esta posacio deja oir su roz, que podria expresarse por las silabas po-ropro repetidas dos ó mas veces, $y$ i las cuales debe su nombre; tambien produce otra voz mas suave que suena como tui-rh, y que no se ore á mucha distancia. Su vitelo es rápido, pero cortado y silencioso.

La hembra de esta especic busca un nido abandonado de pico, y deposita en él, sin arreglarle antes con materias biandas, tres $\delta$ cuatro huevos de cáscara muy lisa, ulancos y de un lustre azulado, de $10^{\circ}, 029$ de longitud por $0 ", 023$ de diámetro. Duranic la época del celo, el plumaje exhala un olor de almizcle bastante marcado.

Casi nunca se tiene el tocororo en cautividad, pues su ali. mentacion es difícultosa, porque se niega á comer; no canta ni es vivaz y adcmas se gastan muy pronto sus plumas.

El plumaje se inserta tan ligeramente en la piel, que cae con facilidad; y pasa lograr un individuo bien conservado es preciso muclias veces matar varios, porque las plumas se desprenden ya por la sola caida.

\section{LOS CALUROS - CALURUS}

CARACTLRES. - Los caluros, quue se han distribuido en varios sub.géneros, son los mayores tipos del grupo: tienen la cabeza ancha y plana; el pico tan alto como ancho, delgado, comprimido hacia la punia y muy corro; su plumaje está muy desarrollado, sobre todo en las alas y en la rabadilla; es superior en belleza al de todos los trogonidos y hasta en ioda la clase no se observa otro tan magnifico.

\section{EL CALURO RESPLANDECIENTE-CALURUS RESPLENDENS}

CARACTERES. - El caluro resplandeciente, cl quesal de los indigenas, es el mas nagnífico de tocios sus congéne. res, y se caracteriza por tener una especie decimera de espesas plumas, comprimida iateralmente, alta y de forma hemis férica; las tectrices, muy desarrolladas, penden sobre las alas y la cola; el color predominante del plumaje es un verde es: meralda dorado; el pecho y las regiones inferiores de un rojo vivo de escarlata; las rémiges son negras; las cuatro tectrices del centro tienen el mismo color, pero las otras son blancas. La primera seric de las ectrices superiores de las alas es muy prolóngada, angosta, puntiaguda y de forma de hoja de pal. mera, y asi como las tectrices superiores de la cola, tiene un color verde dondo; las dos rectrices del centro alcanzzn i veces una longitud de 11, , So. Los ojos son de un pardo os. curo; los pírjados negros; el pico amarillo, de un pardo accitunado en la base, y los piés de un pardo amarillo. Ia hembra tiene solo indicada la cimera y las tectrices no pre. sentan tanto desarrollo.

La longitud del ave es de $10^{\prime \prime}, 4^{2} ;$ la anchura de $0^{\circ}, 22$ de punta a punta de ala; la cola mide tambien $11^{m}, 22$. Las tectrices de la cola mas largas sobresalen de las rectrices unos $11 \%, 65$.

DISTRIBUCION GEOGRÁFICA.-El quesal es propio de México y de la América central.

USOS COSTUMBRES Y REGIMEN.-Salvin Y Owen nos han dado ultimamente noricias sobre csta are, que habi. ta con preferencia los bosques de la montaía.

¿El quesal, dice Salvin, vive á una altitud medin de 2,000 metros: en aquella zona se le encuentra en rodos los bosques de altos äboles; esta con preferencin en las ramas del segundo ercio del tronco, y permanece casi completamente inmóvil, limitándose cuando mas â volver con lentitud la cabeza de uno a otro lado, ó a levantar $\varepsilon$ inclinar por momentos su Tosso III larga cola Sin embargo, si divisa un fruto maduro, emprendu su vuclo; está un mo como suspendido en el aire, coge una baya y vuelve al mismo lugar, cjecutando este movimiento

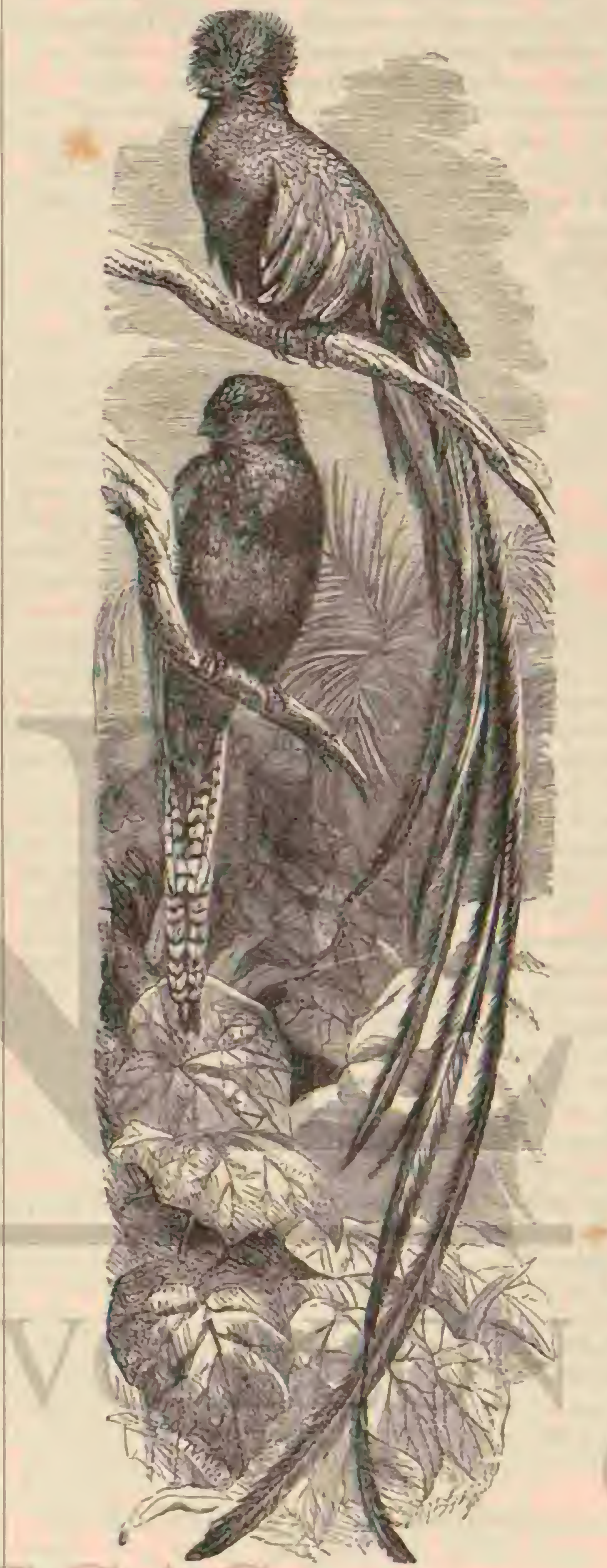

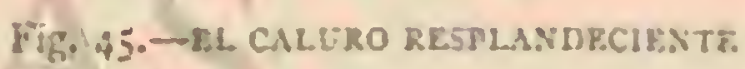

con una gracia indescriptible. Muchas reces he oido a varias personas cxclamar con cnusiasmo al ver colibris disecados: Qué magnifico espectriculo deben ofrecer estas avecillas cuando vuelan! Esto es un error: â veinte metros de distancia no se distinguen ya los colores del colibri; pero no sucede lo mismo con el quesal; su belleza es la misma en cual. 
quier posicion que se halle; ningun are del Nuevo Mundo le izuala por tal concepto, ni tampoco le aventaja ninguna del aniguo continente. Tal es la impresion que me produjo cuando la vi por primera vez

asu ruelo es rápido, y sigue la linea recta, arrastrando el are majestuosamente sus largas plumas.

Produce diversos gritos: el de llamada es disilábico, y se puede expresar por iru iru: comienza por lanuar un ligero silbido, cada re\% mas sonoro, y que termina por un grito fuerte, aunque no deja de ser armonioso. A reces le prolonga, comenzando con lentitud; aumenia luego en sigor y disminuje gradualmente: tambien cmite otros gritos roncos y discordantes.

3El quesal se alimenta sobre todo de frutos, aunque al. gunas veceś se encuentran langostas en su estómago.s.

Al hablar Oven de la manera de reproducirse el caluro resplandeciente, dice lo gue sigue: a En una caceria que se rérificó en la montaña de Santa Cruz, uno de nuestros comghileros me anunció qque habia encontrado un nido de quesal a cosa de una milla de Chilasco, y habiéndose ofrecido a matar lá hembra y traerme los luevos si le proporcionaba algun ayudante, consenti en ello gusioso. Al cabo de algun tempo volvió efectivamente, trayéndome lo prometido, y me ėjo que halló el nido en un tronco de árbol muerto, s unos reintiseis piés de altura sobre al sucto. Ia abertura de entrada cra exactamente de la dimension necesnria para que pu. chicra pasar cl ave, y la cavidad tenia apenas el espacio suficiente para que el quesal se pudiera tevolver: en el agujero to habia nido propiamente dicho. Segun los informes de otros montaneses, esta ave se posesiona cuando le es posible del rido abándonado de un pico.

Ho creo, añade Salvin, que esta noticia basta parn forronrse una idea del nido de esta ave. En mi opinion, el ma cho deja á la hemum el cuidado de cubrir los huevos: dicese cue el त̧ueșat no anida sino en un árbol hueco y perforado do parte a parte, creencia que se funda.en la imposibilidad ce figurarse otro nido en el cual no se deteriorasen las largas plumas del macho. Segun estos detalles, el ave entraria en su rido por una abertura, $y$ saldria por otra, situada en el lado epuesto. Semejante creencia tuvo su origen en Guntemala, conde me han descrito con frecuencia estos nidos; pero jamás encontrí persona alguna que hubiese visto uno por sus propios ojos.

CAzA.-Para quien sepa imitar bien el grito del macho ó de la hembra, es fácil la caza de csta ave: una reproduccion exacta del de la segunda basta para que acudan los machos cร lodo tiempo $\mathrm{y}$ se pongan á tiro; tambien atrae a las hembras: pero solo en el periodo del celo, cuando la pasion las escita - empeñar lucha.

Salvin asegura terminantemente que jatnás turo que espe. rus mucho tiempo: por lo regular llega la hembra primero y se posa sobre el cazador, que sin hacer aprecio, debe contirivar gritando lasta que se presente el macho: rara vee tiran Jos cazadores á las hembras.

\section{EL CALURO MAGNÍFICO-CALURUS ANTI-} SIANUS

CARACTERES. - Esta ave se distingue por tener un zechon de plumas sedosas en la raiz del pico; las cobijas de has alas y de la cola alcanzan mucho desarrollo, aunque sin sir prolongadas. Ios colores del plumaje vienen á ser los zinismos que los de la espuecie anterior, solo que las tres rec. aices externas son enteramente blancas y cl pico amarillento. Esta ave mide $6^{\prime \prime}, 3 \delta$ de largo, las alas $0^{\circ}, 2$ i $y$ la cola $0^{\circ}$, is (Figura 46).
DISTRIBUCION GEOGRÁFICA.-D'Orbigny descubrib el caluro magnifico en Bolivia, en los bosques cálidos y humecos de la provincia de lungas. Escasea, y es dificil de encontrar, porque elige para vivir la inmediacion de las cata. ratas.

\section{LOS CUCÚLIDOS - CUCU- LID压}

CARAGTERES. - Esta familia es muy rica en especies y formas, habiéndose descrito hasta ahora cerca de doscientas especies. Los caractéres del grupo son los siguientes: tronco prolongado; alas bastante largas; la cola larga, compuesta de diez a doce plumas; pico comprimido, ligeramente corvo, á vecesalto, de ángulo agudo, y cuya longitud es poco mas ó menos la de la cabeza; piernas relativamente largas y fuertes, y dedos cortos.

\section{LOS INDICADORIDOS - INDICA- TORINA}

Los indicadoridos son, como dice muy bien Cabanis, las especies de la familia que merecen ocupar el primer rango. Ultimamente se ha emitido tambien otra opinion, segun la cyal se los chnsifica, como lo hace Sundevall, entre los jin. guidos y megalémidos, dando á entender que las citadas aves son las mas congenéricas. Yo creo q̨ue no hay ninguna razon para negar la alinidad de los indicadoridos con los otros cu. cúlidoss, reconocida ya por Cabanis y demostrada adenrás por el heclio de que tanto los indicadores como algunos otros grupos de cuculidos son en cierto modo parásitos.

CARACTERES. - Los indicadores se caracterizan por sus formas relativamente recogidas, alas largas, cola corta, pico grueso $y$ piés cortos. El pico, mas corto que la cabeza, cs casi recto y comprimido lateralmente; la nandibula superior se encorva en su extremidad en forma de gancho, que cae sobre la superior, la cual se arquea a su rez hácia arriba. I os piés son cortos y robustos; las piernas mas cortas que el dedo exterior: los dedos en general largos y bastante fuertes. Las alas, prolongadas y puntiagudas, son sin embargo bastante anchas; de las nueve rémiges de la mano, la tercera es la mas larga, y la cuarta y quinta solo un poco mas cortas. La cola, de regular longitud, se comprone de doce rectrices, es redondeada y se trunca un poco en el centro, porque las dos plumas del centro son un poco mas cortas que las inmediatas, y las cxteriores mucho mas que todas las otras. El plu. maje es abundante, liso y duro; cada pluma se inserta fuertemente en la piel, que es gruesa.

DISTRIBUCION GEOGRÁFICA. - Los indicadores pertenceen principalmente al Africa; hasta ahora, solo se han encontrado dos especies en Sikhim y Borneo.

USOS, COSTUMBRES Y REGIMEN. - Viven en los bosques por parejas, rara ve\% por reducidas bandadas; ruclan de un árbol en otro y dejan oir entonces su voz fuerte y ar. moniosa \& 1 pesar de su escasa talla y de su plumaje oscuro, dice Heuglin, son todos fáciles de reconocer desde léjos por su vuclo singular, asi como por el tinte blanco de sus rectrices externas. Son ares mus jopulares en Africa, y todos las conocen en las regiones que habitan. Los mas antiguos riajeros hacen mencion de ellas, é indican una particularidad que debe serles comun. Parece, en efecto, como si quisieran comunicar á los otros animales, y al hombre mismo, todo cuanto observan de curioso; vuclan al rededor de ellos, y diriase que con sus gritos y movimientos los invitan á seguirles. CTodos los indigenas, desde el Cabo hasta el Senegal y A Aisinia, saben 
que le conducirain ast al sitio donde haya un enjambre de abejas; pero tambien suele darse el caso de que el ave atraiga al hombre junto al cadáver de un animal lleno de larvas de insectos, cuandio no persigue con sus gritos al mismo leon o al leopardo. Barber niega la exactitud de esta uitima noticia, fundindose en sus observaciones. 'lanto él como sus nuere hermanos que todos han nacido y vivido mucho tiempo en Africa, dicen que los indicadores indican solo los enjambres de abejas, sin hacer caso de otros objetos.

Hasta estos ultimos años no hemos llegado a conocer cóno se reproducen los inciicadores: ahora sabemos que son parisi tos, que no se cuidan de su progenie y la confian al cuidado de otras especies.

De los relatos de los viajeros resulta que todos los indica. dores observan esencialmente las mismas costumbres; jpor lo tanto nos bastará la resez̃a de una sola especie.

\section{EL INDICADOR DE SPARMANN - INDICA- TOR SPARMANNI}

CA R ACTERES. - El indicador de Sparmann, el kerkerie y harharief de los abisinios, tiene el plumaje de color pardo gris en su parte superior, gris blanquizco en la inferior y negro en la garganta; en la region de las orejas se ve una inancha blanca pardusca y otra amarilla en los hombros; algumas plu. mas de los muslos presentan lineas longitudinales negras; las rémiges son de un tinte pardusco gris; las tectrices de las alas tienen un ancho borde blanco; las plumas cenirales de la cola son pardas, y las dos siguientes de ambos lidos del nismo color en las barbas exteriores y blancas en las interiores; las tres lilimas de los dos lados son blancas, con la punta parda. El iris tience este último color; los círculos oculares son de un gris de plomo; el pico blanco amarillento y los pies de un gris pardusco. I a longitud de esta are es de ${ }^{\prime}=, 18 ;$ las alas miden $11^{\prime \prime}, 115,8$ la cola $0 \%, 0 ;($ fig. +i $)$.

DISTRIBUCION GEOGRAFICA. - lil indicador de Sparmann está diseminado en toda el Africa, desde el Cabo hasta el $16^{\circ}$ de latitud norte. Parece, no obstante, que solo es ave de paso en ciertos paises del Sudan oriental, y particular. mente en el Habesch: solo la lie visto una vey, y aun entonces no hizo mas que crizar por delante, de manera que no puedo hablar por propias observaciones, al paso que rodos los viajeros que han recorrido el inismo país que yn, han po. dido estudiarla detenidamente. Heuglin cree que habita en el Sudan $y$ ca el Habesch desde el mes de setiembre al de abril, pues jamas rió individuo alguno durante ia sequín. Yo puedo asegurar que ni aun en la estacion de las lluvias tuve la suerte de ver un individuo en las márgenes del Nilo Azul.

Tambicn Ankinori, que despues de Heuglin y de mi, visitú el pais de los bogos, dice que la especie es ma y que no la ha visto sino cuatro veces: $y$ al contrario de Heuglin, en los meses de marro, julio y seticmbre. Respecio á su escaser, este naturalista dice que su reducicio tamano, su sencillo color la costumbre de vivir en árboles frondosos son razones sufi. cientes para que no se la vea fícilmenie, si bien se deja co. nocer, cuando vuela, por los extmnos contornos de la cola, descubriendo su presencia por su conocidu grito. Estas aves son por lo demás tranquilaş é inclinadas a la soledad; irepan lentamente por et ramaje, $\$$ solo se dejan oir cuando algun objeto extraño llama su aiencion, sobre todo si descubren nidos de avispas ó enjambres de abejas.

El viajero Ludolf, cuya historia de Etiopia se publicó en $16 S_{1}$, es el primero que habla del indicador. Sabe pasitiva. mente, aunque no habla por experiencia, gue esta ave indica al hombre cuanto llama su atencion, no solamente los nidos de abcjas, sino tambien los búfalos salvijes, los eleíanies, los tugres y las serpientes; s que conduce al cazador hácia el animal o el objeto que descubre.

Lobo, curo viaje por ibisinia se dió á luz en 1728 , hace mencion tambien de esta ave, expresindose en los siguientes iérminos: eEl morer 6 indicaior de mid tiene la singular propiedad de descubrir los nidos de las abejas. Fn el pais (Abicinia) se ven muchos de estos insectos de diversas especies, algunos de los cuales están domesticados como los nuestros, y hacen su miel en colmenas; otros hay salrajes que depositan la suya, umas veces en el hueco de un árbol y otras en un agujero practicado en tierm, teniendo cuidado de conservar. los muy limpios, y cubriéndolos tan periectamente, que rara rez es posible encontrar estos nidos sin el auxilio del moroc, aunque suelen hallarse en los caminos frecuentados. la miel fabricada debajo de vierm es tan buena como la de nuestras colmenas, si bien me ha parecido un poco mas negra; y me inclino a creer que con esta fire con la yue se alimentó San Juan en el desierto. Cuando el moroc descubre algun nido de abcjas, dirigese al camino; si ve pasar á cualquicra, entona su canto, agita las alas, y por diversos movimicntos invita al viajero í que te siga Apenas observa que le han oido, vuela de un árbol a otro hasta llegar al paraje donde las abejas han uncerrado su tesoro, y entonces comienza 1 cantar melodiosamente. Fil abisinio se apodera de la miel, y siempre deja una parte para el are, en recompensa de su delacion."

A fines del siglo úlimo, Sparmann trazó una descrijucion completa de las costumbres del indicador, y todos los natu. ralistas sucesivos confirmaron su relato. Verdad es que I.c Vaillant pretende que Sparmann no ha visto jamás al indica. dor, y que no hace sino répetir lo referido por lus hotentotes; pero como Le Vaillane no rectifica los asertos de aquel natu. ralista, y si por otra parte se atiende á que los datos facilitados por il accrca de la reproduccion del ave son erróncos, no podemos dar compleio crédito ai sus alegaciones.

Eil curlille descisbribur de lo miel, dice Sparmann, merece con justo motivo un articulo sejanando, y creo q̨ue este es el lugar en que debemos hablar del asunto. El ave no ofrece nada notable por su tamano ni color: á primem vista se la tomaria por un gorrion ordinario, aunque es algo mas grueso $y$ de un tinte mas claro; tiene una manchita de color amari. lio en cada espaldilla, y las plumas de su cola presentan alguna mezcla de blanco.

- Segun he dichn antes, por su propio interés descubre esta ave a los hombres $y$ â los rateles los nidos de abe. jos, pues ella misma es muy aficionada á la miel, y sobre todo á sus huevos; y sabe que todas las veces que se destruge uno de estos nidos, se dermma siempre un poco de la sustancia, siquiera no se la deje el hombre en recompensa de sus servicios.

1.e Vaillant refura con razon este parecer, diciendo que los indicadores que habitan en parajes despoblados no pue. den esperar semejante recompensa por sns servicios, y que sin ernbargo viven; de modo que el are no sirve al hombre con intencion, sino que este se aprovecha de la particularidad de aqquella.

Q El medio, asi continúa Sparmann, que emplea para co. municar su descubrimiento, es tan extraodinario como maravillosamente adecuado al objeto.

* La tarde y la manana son las homs en que el irdicador tience mas âpecito, \& por 10 menos, entonces salc mas comun. mente; $y$ con sus penctranies gritos flerr, sherr, cherr, parece que trata de llamar la atencion de los rateles, de los hoten. tures ó de los colonos Raro es que unos ú otros no acudan al paraje donde se ove el grito; entonces el are, repitiéndole sin cesar, vucla con lentitud de trecho en trecho hàcia el punto donde se halla el enjambre de abejas. Es preciso que 
los que siguen al indicador procuren no asustarle con algun ruido extraordinario ó por llevar demasiada gente; conviene mas bien hacer lo que uno de mis boschesmans, inuy prictico en aquella operacion, el cual contestaba al are con un ligero silbido, como para dar á entender que se atendia á su llamada. He observado que cuando los nidos de abejas están un poco léjos, el indicador franquea largos espacios, y descansa por momentos, esperando a su companero de caza, y animándole con nueros gritos á que le sign. Pero a medida que sc acerca al nido, acorta el espacio de sus estaciones, produce su grito mas á menudo y repitc sus chery con mayor fuerza. He visto tambien, con gran asombro, lo que varias personas me habian asegurado antes, $y$ es, (jue si el ave, impaciente por llegar, deja muy atrís al cazador, retrasado por la des igualdad y obstáculos del terreno, vuelve cerca de él, y con sus recioblados gritos, que revelan mas impaciencia todavia, parece reprenderle su lentitud. Por último, llegado al nido de las abejas, bien se halle en una grieta de roca, en el hueco de un árbol 6 en algun agujero subterráneo, se cierne al mo. mento sobre él durante algunos segundos (yo mismo he sido dos veces testigo del hecho); despues se posa silenciosamente, y suele ocultarse en algun airbol ó matorral próximo, para ver qué sucederá, con la esperanza de obtener su parte de botin. Es probabie que el ave se cierna siempre mas ó menos tiempo sobre el nido de abejas antes de ir á esconderse; pero no siempre se fija en ello la atencion, pues se tiene la segu.

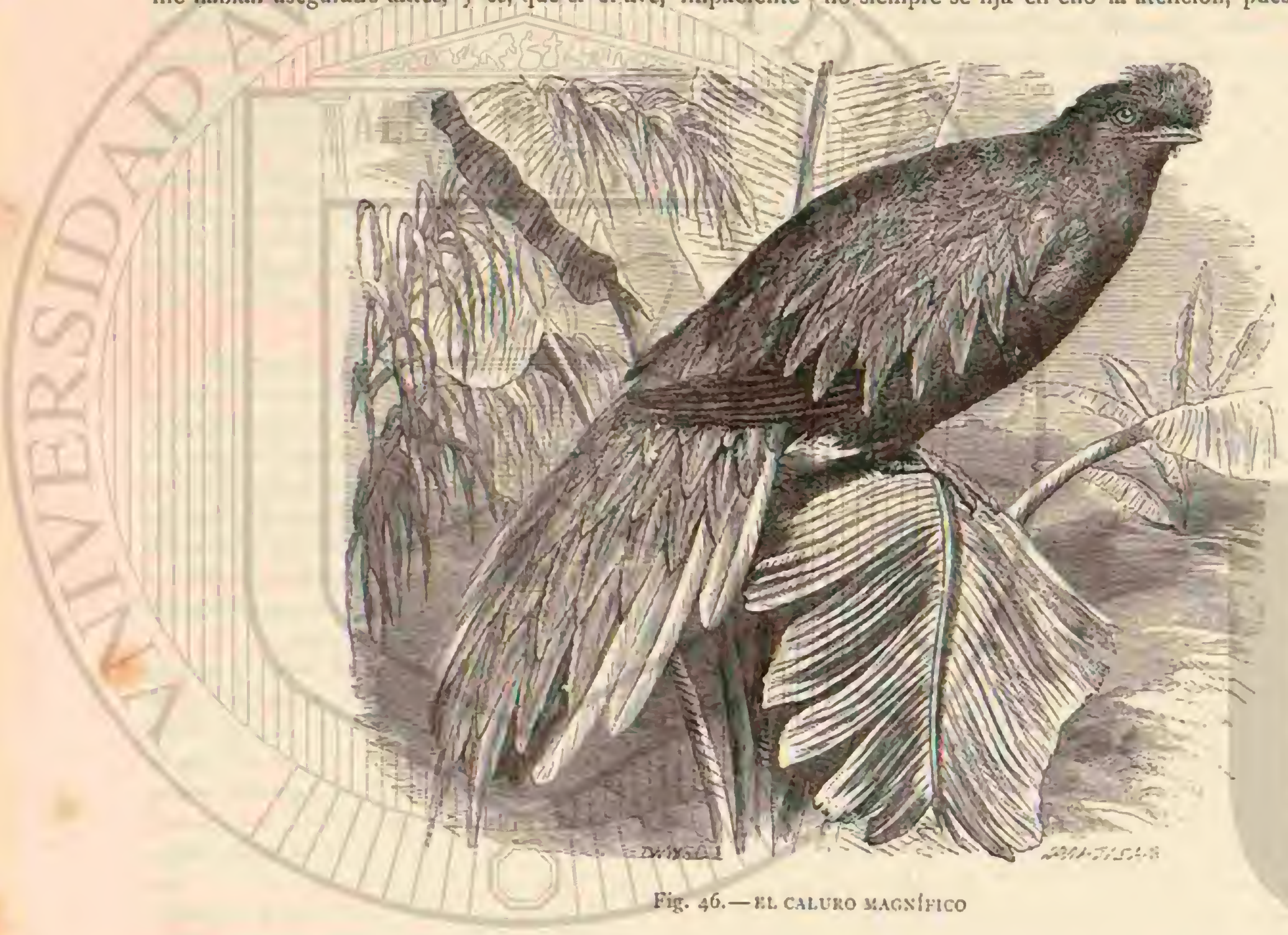

ridad de que el nido no estí léjos cuando, despues de recorrer una parte de camino, se detiene el indicador y deja de gritar.

* En un paraje donde nos detuvimos un par de dias, mis hotentotes fueron guiados por un cuclille de les alicjas, cuyas seỉales parecian dudosas y ambiguas. Hiroles adelantar y retroceder varias veces, llevándoles siempre al mismo sitio; y cntonces, uno de los hombres, mas atento que los otros, co. menzó á buscar con cuidado y halló el nị̣o.

Despues de haber desenterrado ó descubierto los nidos de las abejas, gracias al auxilio del ave, reconocidos los hotentotes, le suelen cejar una buena porcion de aquella parte del panal que contiene los huevos y las crias. Fste pedazo, el peor á nuestros ojos, es probablemente al mas delicado para el indicador, y ni aun los hotentotes le desprecian. Me han dicho que cuando un hombre toma por ocupacion-bus. car nidos de abejas, no debe ser a! principio demasiado generoso con la oficiosa ave, y si dejarle solo una parte suficiente para despertar su apetito, pues la esperanza de obtener mcjor recompensa, le cxcitará á conducirle de nuevo á otro nido, si conoce la existencia de alguno en las inmediaciones.

Aunque en los alrededores del Cabo hay muchas abejas silvestres, no se conocia el ave, ni su propiedad de descubrir la miel. Cuando oi hablar por primera rez del hecho en Groot. vaters.bosch, cstaba muy persuadido de que me contaban fábulas, sobre todo despues de haber visto en aquel punto á un hotentote que corria intitilmente tras de una de estas aves. Debo añadir, sin embargo, que $\mathrm{cl}$ bosque era muy espeso y casi impenetrable, y el ave menos familiar y mas reservada que en los cantones mas lejanos. Mis hotentotes de Buffel jagts-rivicr y de Zwellendam me dijeron que cn cstos dos lugares de su nacimiento habian conocido al ave; pero que escascaba mucho, y que a causa de asustarse fácilmente, no les dirigia hàcia la miel tan pronto ni con tanta seguridad como los indicadores que hallamos en el desierto, cerca de Kautkai ó Vish-rivier.

- Los habitantes de Bruntjes-hoogte llaman á esta ave hat ningreviser (guia de la miel): aunque la vi en aquel punto una ver, y muy a menudo en el desierto, no pude tirar contra una sino á mi vuelta. Disparé el tiro cuando revoloteaba de lante de mí invitándome à que la siguiera; y mis boschesmans llevaron muy a mal mi conducta. Aunque prometi a mis ho tentotes de Zwellendam un buen regalo de iabaco y cuentas de vidrio si querian ayudarme á cazar un indicador, negáronse 
a cllo, pues el ave era demasiado querida para que pensaran en sacrificarla traidoramente.

Cunuming refiere que se enciende yerba fresca a la entrada del nido, sacando luego la miel, de la cual se da una parte al guia; y que si se contesta silbando a su gotjeo, conduce al hombre $\mathfrak{a}$ un segundo $y$ tercer nido. Gurney dice haber en contrado langostas en el estómago de un indicador; pero quue tambien ha visto al ave posarse sobre uma colmena y atrapar al paso las abejas que entraban $\delta$ salian. Conirma asimismo el hecho de que los cafres recompensan los servicios de su guia, y que apenas queda el nido al descubierto, sé acerca el animal para coger los panales que le dejan.

Kirk nos ha dado uiltimamente pormenores minuciosos sobre la manera de conducirse el indicador cuando se un in digena de la région del Zambezé. Revoloteando de rama en rama por los irboles inmediatos al viajero, y proliriendo su grito, el ave llama la atencion de aqquel; cuando el hombre le contesta como suelen hacer los indigenas, silbando y mirando sus piés, toma cierı direccion, se posa á corta distancia y salta de un árbol ó oiro. Si el hombre sigue, avanza mas y mas, y asi le conduce hasta la inmediacion de la colmena; llegado anui, aléjase, pero no indica el enjambre mismo; se necesita cierta experiencia para encontrarle, aunque el ave haya señalado un circulo circunscrito. Kirk ha observado tambien que cuando el hombre, despues de seguir algun tiempo la direccion indicada, se va por otra parte, el ave vuelie para indicar un segundo nido en otro sitio. Lo malo es que a menudo conduce al hombre a un nido de abejas do. mésticas, por la sencilla razon de que estas son las mismas que las silvestres, con la unica diferencia de habitar las musin-

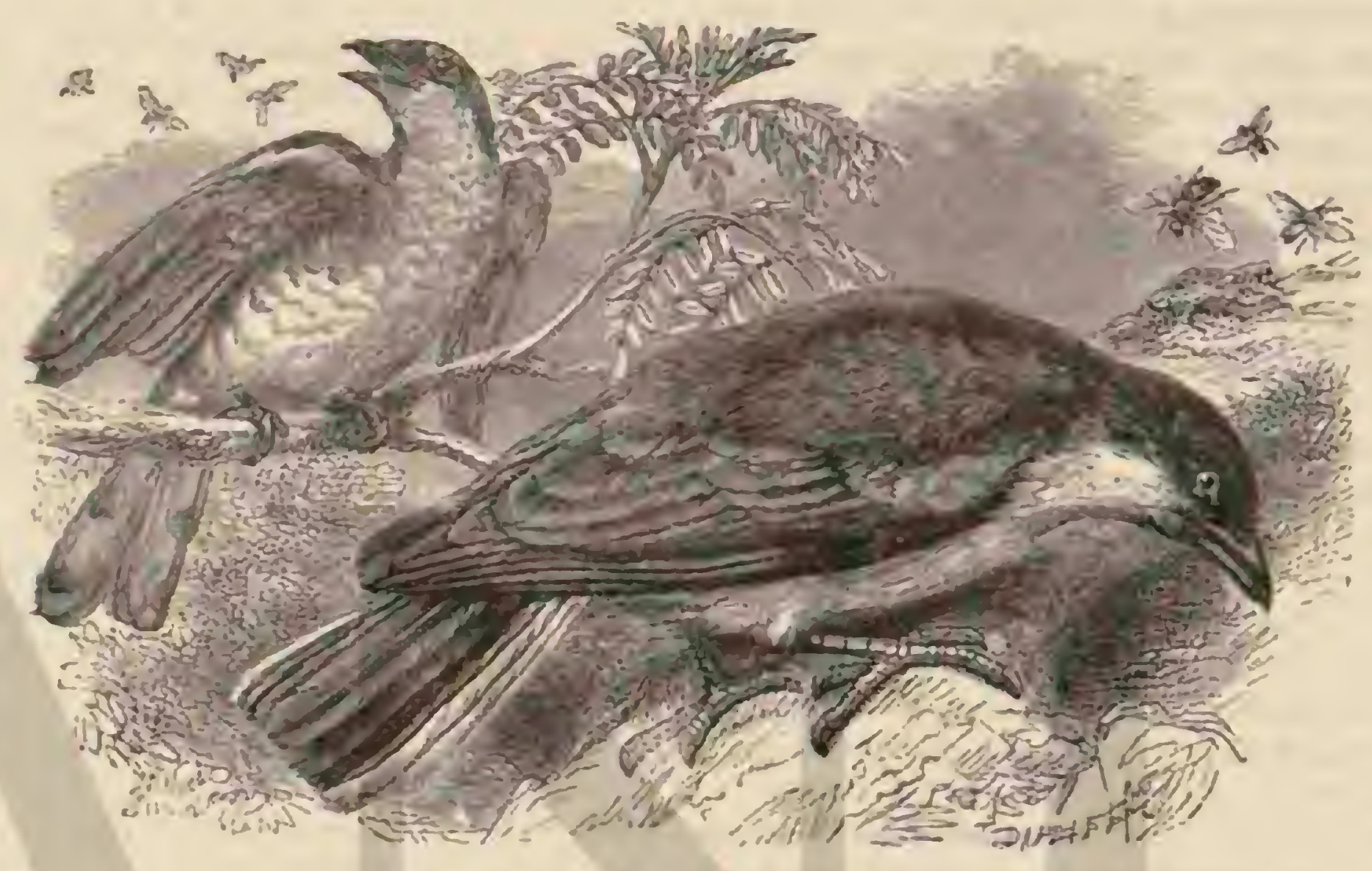

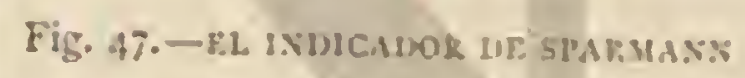

gras ó colmenas que se colocan cerca de los árboles para que los insectos tomen posesion de ellas. $\mathrm{El}$ ave conduce indis. tintamente a los nidos con miel y a los que carecen de ella, y tan satisfecha parece cuando se sacan los panales llenos de larvas como cuando conticnen iniel.

Lin sus expediciones contra las abcjas, su espeso y duro plumaje protege al indicador contrn las picaduras de los in. sectos. Fácilmenie se explica que estos defiendan su cria: pero ninguno de los observadores modernos nos ha dicho que la lucha entre el are y las abejas puede tener un des. enlace funesto para la primen. Solo Levaillant nos habla sobre esta Los indicadores persiguen sin duda, no solo ia las larvas de las abejas y congéneres de la oruga rellosa, sino tambien a otros insectos; y Atmore dice, en contestacion a varias jreguntas de largard, que la especie del grupo indicado ya por Kirk osa acometer á los pájarus pequeños, los cua. les devora con la misma voracidad que los línidos, y que él misıno mató un individuo en el acto de cebarse en un gorrion cogido al vuelo $\{$ la vista del obserindor.

Levaillant asegura que el indicador pone tres ó cuatro hue. vos blancos sobre la madera podrida de las huecos de árbol, Y que ambos sexos se ocupan en cubrirlos. Esta noticia es, sin embargo, inexacta, como lo han demostrado las observa. ciones de Verreaux. Bistos natumalistas encontraron lusevos $y$ polluelos de rarias especies de indicadores en nidos de lánidos, picos, oriólidos y otros; y siento mucho no iener en cste momento a mi disposicion el relato de los citados viaje- ros, pues debo limirarme al extracio dado por Hartlaub. La hembra pone su huevo blanco y brillante en el suelo, y lo lleva con el pico al nido de oira are, del cual saca uno de los que encuentra Cuando el pequeño indicador se ha desarrollado un poca, lo cual sucede al cabo de un mes, segun las observaciones de Verreaux, el macho y la hembra le alimentan, excitandole á abandonar el nido de sus padres adoptivos Verreaux observó que una misma hembra puso sus tres huevos en los nidos de tres diferentes aves pequenas. Tambien Atmore designa al indicador observado por êl como parksito, y dice que deja cubrir sus huevos por un pico ó por un mega. lémido.

\section{LOS CUCULINOS-CUCULINA}

CARACTERRS. - Los cuculinos tienen formas esbeltas; el pico del largo de la cabeas, ligeramente corro, bastante delgadoy ensanchado en la base; patas rortas o medianas; alas largas, estrechas y puntiagudas: la rémige tereera suele ser la mas larga; cola larga, redondeada ó cónica, compuesta de doce pennas; el plumaje, bastantc espeso, no encaja sóli. damente en la picl; sus colores varian, pero segun el sexo, y particularmente la edad.

Resulta de las observaciones de Nitzsch, que la estructura interna de los cuculinos (se toma para estudio el cuclillo de Europa) ofrece las siguientes particularidades: Tienen 12 véstebras cervicales, i dorsales y j coxigens: de los siete pares 
de costillas, solo cinco son huesosos; la parte posterior del esternon se encorva por fuera, y la horquilla se enla\%a con el esternon por una verdadera articulacion. No existe el hueso coracoideo; la pelvis es corta; y todos los huesos son neumá ticos, excepto los ímures. La lengua es córnea, de mediana longitud, bastante ancha, cortante en su parte anterior y cll los bordes; el esófago ancho; el buche no existe; el ventriculo subcenturiado tiene sus paredes cubiertas de glándulas nucosas muy grandes. El estómago puede dilatarse considera blemenie; los dos lóbulos del higado son de igual tamano, ! el baro pequeño.

DISTRIBUCION GEOGRÁFICA.-Los cuculinos, cuya sub-familia se compone de unas noventa especies, habitan todos el antiguo continente y la Nueva Holanda: muy' numerosos en las Indias y en Africa, no estín representados en el norte sino por una sola especic

USOS, COSTUMBRES Y REGIMEN.-Todas estas ares, sin excepcion alguna, habitan los bosques, que rara vez. abandonan; las que viven en el norte emigran: las otras solo son errantes. Los cuculinos se distinguen por su carácter tur. bulento, inquieto y timido. Huyen de la sociedad de sus seme. jantes y de lasotras especics; atraviesan rápidamente un espacio bastante grande, visitando los árboles; se lanzan desde ellos sobre la presa que codician, aunque sin posarse nunca en tierra, y tecorren de este modo su dominio volando, comiendo y gritando todo el dia. Se alimentan casi exclusivamente de insectos, sobre todo de larvis y orugas rellosas, que des precian las demás ares. I.os pelos de esios insectos se adhicren il las paredes del estómago de los cuculinos, comunicando al órgano un aspecto velloso que la incúucido a error $\{$ muchos naturalistas. Dícese que las grandes esyecies comen tambien vertebrados pequeños y reptiles. Todos tos cuculinos sin excepción tienen fama en todas partes, y en mi concepto justamente, de ser ladrones de nidos, que no contentos con arrebatar los huevos, se los comen tambien.

Esto se explica, por otra parte, fácilmente, cuando se considera de qué modo se reproducen. Los cuculinos no cubren sus huevos, sino que los abandoman al cuidado de otras aves, á cuyos nidos los llevan, despues de quitar uno, por lo mernos, de los que alli hay. Se ha negado con frecuencia el hecho, pero numerosas observaciones no permiten ya ponerle en duda. En cuanto a las causas que inducen a lós cuculinos á no cubrir por si mismos, se han inventado muchas hipótesis, sin que ninguna de ellas nos parezca satisfactoria.

¿Son estas aves nocivas 6 útiles? Seguramente nos prestan servicios al descubrir las orugas vellosas, que nunca tocan los otros insectivoros; pero por otra parte ocasionan daño cuando destruyen huevas de otras ares. Un cuclillo pen̨ıeño no crece sin causar la muerte de rodos sus hermanos adoptivos; mas \& esto se puede contestar que un individuo adulto extermina por si solo mas. insectos que cinco ó seis aves cantoras, de lo cual resulta que se debe proteger á los cuculinos.

\section{LOS CUCLILLOS-CUCULUS}

CARACTÉRES. - El género cuclillo presenta los siguien. tes: cuerpo esbclto; pico pequeño, endeble, un poca arquea. do, entero y gradualmente comprimiclo hasta la punta; alas largas, muy obtusas, con la tercera rémige mas extensa; cola muy larga, redondeada; tarsos cortos, cubiertos de pluma en parte; el circulo del ojo no esta muy desnudo; el plumaje es blaindo y de color oscuro.

\section{EL CUCLILLO PROPIAMENTE DICHO- CUCULOS CANORUS}

CARACTERES. - Fl cuclillo macho (fig. 4S) tiene e iomo de color ceniciento azulado ó gris ceniciento oscuro; el vientre gris blanco, cruzado de negro; la garganta, las mejillas y los lados del cuello de un gris ceniciento puro; las alas de un negro plomizo; la cola negra, manchada de blanco; el ojo amarillo vivo; el pico negro, con la base de la mandibula in. ferior amarilla, y las patas de este color. La hembra adulta se asemeja al inacho, y tiene en la nuca y los lados del cue. llo fajas rojizas poco marcadas. En los hijuelos el lomo y el vientre ofrecen ondulaciones trasversales; las hembras jórenes suelen tener el lomo pardo, cruzado de fajas muy marcadas. El cuclillo mide 1$)^{\prime \prime} 3^{2}$ de largo por 11 ", 61 de punta a punta de ali; la cola $0^{n}, 17$ y el ala $0^{\circ}, 19$. La hembra tiene unos dos ó tres centimetros menos de largo y de ancho.

DISTRIBUCION GEOGRÁFICA.-En Europa, Asiay Africa hay pocos paises y regiones donde no se encuentre el cuclillo. Esta ave esti diseminada desde el norte del antiguo continente, desde la China y los paises del Amur hasta la costa de Portugal y desde el cabo Norte hasta Siria, Pales. tina y Argel, $\delta$ las estepas y montañas del Asia central y Persia Emprende sus excursiones; desde la Siberia pasa por la China y llega á las islas de Java, de la Soncia y Ceilan, desde Lìropa se trasiada al mediodia de Africa. En todos los paises del Sudan oriental que he visirado vi tambien el cuclillo pero en ningun punto como ave invernante. Caba. nis considera los cuclillos de la Siberia y del Arrica occiden. tal y meridional como especies independientes; pero fun. dándone en mis propias observaciones debo decir que soy de distinto parecer. lara mi no cabe duda que el cuclillo de la Siberin occidental es en un todo semejante al nuestro; y no creo haber muerto en el mediodia de la Nubia ningun individuo de distinta especic que la nuestra; de modo que debemos considerar á los individuos de las colecciones pro. cedentes del Africa meridional como pertenecientes á nues. tra espécie. No ha de extrañarse que un ave de vuelo tan ágil como el del cuclillo pueda franquear distancias tan grandes como otms aves pasajeras que no saben volar tan bien. Segun mis observaciones y las de otros muchos, viaja rápidamentc, $\delta$ cuando menos no se le ve en el nortc de Africa ó en la Siria mucho antes que en Alemania; solo al llegar mas al norte ra mas despacio, por causas que fácil. mente se comprenden. Iin Alemania se presenta con regula. ridad á mediados de abril, y por excepcion antes, díndose el caso de llegar á veces a principios del mes, sin cuidarse de si el tiempo es ó no favorable. Schacht, excelente ob. servador, oyó su voz el 5 de abril de I \$75, cuando los árbo. les carecian aun de follaje. «Muchas veces veiase por la mañana una espesa alfombra de nieve; pero el cuclillo permanecia firme en su puesto, y cuando el sol salia por fin, de. jaba oir su cusur. Segun las observaciones de Sachse, tambien en el Westit Walt se presenta a menudo á principios de abril. Hucne oyó en Esthland su grito el 3 de mago; en el norte de Noruega, en cambio, no se presenta antes de fines de este mes; y los campesinos de aquellas regiones creen quue es una mala señal para el año que el cuclillo se deje oir antes del deshielo ó antes de retonar las hojas de los árbo. les. Tanto de Alemania como de Escandinavia se marcha en los primeros dias de setiembre y ya el dia 11 del mismo mes se le ha visto en el mediodia de la Nubia. Excepcional. menic le encontré tambien el i\& de julio ceren de Alejan. dria, como ave pasajer. Segun las experiencias de Blanford $y$ de St. Tohn abunda bastante extendido en la Persia oriental, $y$ hasta es muy comun en algunas regiones; en ellas se reproduce, pero probablemente no abandona el pais. Blanford oýó su grito el 18 de febrero y St. John el 25 de encro, es decir en una estacion en que el ave del norte permanece aun en el centro de Alirica. 
En Alemania el cuclillo es bastante comun, en la Europa del sur unucho menos frecuente; pero tambien pone hueros aqui. Ên el mediodía de Portugal le oyó Rey desde el 13 de abril durante algunos dias; pero no mas tarde, y cree que no pone lıuevos en el pais. \&Yo lc observé, por el contrario, en Espara durante el verano, y dudo por consiguiente de la exactitud de Rey. Hácia el norte abunda mas, y en Fscandinavia es una de las aves mas comunes del pais; no recuerdo haber visto en ninguna parte tantos cuclillos como en Noruega Japonia. En la montaña sube hasta el limite de las nieves: en los Alpes de Alemania habita todos los veranos los valles montañosos situados a 1,500 mctros de altura y clévase aun 600 ó 700 metros mas, segun supone Panbamus, fundándose en sus observaciones; en el Altai oí su voz tambien mas arriba de la \%ona vegetal, y no dudo que visita las pra. deras situadas desde 1,800 á 2,300 metros sobre el nivel del unar.

Aunque el cuclillo es ave arboricola, no vive sin cmbargo exclusivamente en el bosque; abunda menos en regiones desprovistas de árboles; pero no falta en cllas del todo. Así, por ejemplo, encuéntrase en islas donde no hay casi ningun árbol, como las de Sylt y Borkum, y en las cstepas de la Siberia meridional, asi como en las altas mesetas de la Persia oriental ó en nuestros Alpes, mas arriba de los limites de la regetacion arbórea. Segun mis observaciones, recogidas en tres continentes, y con preferencia relativas al cuclillo, la primcra condicion que esta are exige en el punto que habita es la abundancia de pequeñas aves, que puedan servir de padres adoptivos para su progenic. Una vez hallado esto, bástanle muy pocos àrboles, algunos arbustos bajos, maleza y cañaverales; y cuando aun falta esto úleimo, conténtase con pedazos de tiern para posarse. En casos excepcionales se deja seducir tambien por la mayor abundancia de alimento; mas por lo régular no abandona un sitio propio para la reproduccion. Siempre se observará que el número de cuclillos aumenta en la misma proporcion que la de los padres adoptivos, y tanto mas cuanto mas abunda una especie de estos ultimos en un espacio circunscrito. Por eso preficre ol cu clillo los bosques donde hay diversas especies vegetales á los que solo contienen una clase de árboles; y por eso se en cuentm mas abundante que en ningun otro sitio en los alre dedores de los pamtanos y de los paises bajos donde hay muclia agua. Quien conozca el cuclillo no pretendera que este tiene una gran preferencia por los bosques de sauco pero el que risite el del Spree, donde no hay apenas otros árboles, se admirará desde luego al ver un inmenso núnero de cuclillos, y solo podra explicarse la gran abundancia de estas aves al observar que aqui un sinmúmero de currucas, de ántidos y de motacilas le ofrecen la mayor facilidad de sacar \& luz su progenic.

Cada parcja ó mas bien cada machó, elige para si, ó con quista un dominio bastante extenso, donde prohibe la entrada a otro rival cualquiera; si le aluujentan, fijase cerea de su enemigo y empeña lucha con ell diariamente. Naumann ha reconocido que esta ave vuelve todos los años al mismo paraje: habia observado $\{$ un individuo que se distinguia de todos.los otros por su vor particular, y por-espacio de vein. titres anos le vió rolver todas las primaveras al mismo punto del bosnue.

Segun las experiencias de Walter, lo mismo puede decirse exactamente respecto á la hembra, segun consta por los hue. ros de un color raro y especial que todos los años se en cuentran en la misma region, y depositados en los uridos de la misma especic de aves. El territorio donde la hembra pone su primer huevo es su patria; pero no permanece en ella tanto tiempo como el macho; este vaga continuamente por su tcrreno y se presenta con cierta regularidad varias veces al dia en determinados irboles. No sucede as! con la hembra, como yo mismo puedo asegurar por mis propias observaciones: mis experiencias con los cuclillos, repetidas cada primavera y en todas las ocasiones, me han denıostrado que el número de las hembras es inucho menor que el de los machos, y el de estos al menos doble que el de aquellas. Mientras que los inachos permanecen siempre en un mismo territorio, la hembra vaga durante todo el verano, 6 todo el periodo del celo, por las regiones donde aquuellos se hallan, aparéndose tan pronto con uno como con otro, y despre. ciando al que acaóa de satisfacer sus deseos para ir en busca de otras aventuras amorosas. Una hembra que se conocia por faltarle una pluma de la cola, y que yo pude observar cerca de Berlin, visitó, mientras yo la pude seguir con la vista, los territorios de cinco machos; pero probablemente extenderia sus expediciones mas aun.

No cabe duda que todas las demás hembras proceden del mismo modo, segun lo han probado hasta la evidencia otras observaciones. Muchas veces he visto, dice Walter, cómo una hembra, acompanada de un macho, fué abandonada por este al pasar a otro territorio, crumando sobre un gran lago; el macho trazó un gran arco y despues una linea recta, diri. giéndose al punto de partida Si la hembra habia depositado en este punto un huevo, rolvia a él al dia siguiente; y solo en el caso de vjue cerca del primer nido no hallara otro, tar. daba mas y no volvia a reces hasta despues de algunos dias. Varias hembras visitan el mismo territorio, y asi es que cada macho puede aparearse al menos con una de ellas. Esta inconstancia de las hembras explica, segun mi opinion, ciertos sucesos en el periodo del celo del modo mas sencillo y suficientc.

Eintre los congéncres que yo conozco del cuclillo no hay minguno que iguale á este por lo roluble, inquieto y vivo; muevese desde la manana hasta la noche, y en Escandinavia aun la mayor parte de esta.

Foxtraña impresion me produjo oir alli, durante mis cacerias nocturnas, el grito del cuclillo despues de las once de la noche, $y$ antes de la una de la madrugada. Holtz asegura haberle oido en la isla de Gottland aun á las doce de la no. che, alternando con el buho, y tal vez no descanse a esta hora, segun se cree. Yo por mi parte obscrvé siempre, du. rante mis repetidos viajes al extremo norte, que cl cuclillo guarda silencio desde las once y media lrasta las doce y media de la noche, lo cual me hizo suponer que duerme á esta hora. Durante sus expediciones come continuamente, porque es tan voras, como activo. Su vuclo, ligero y gracioso, se asemeja al del halcon, pero no iguala en rapidez ni aun al. de la tórtola. Al llegar á alguna rama busca à su alrededor algun alimento; cuando ha descubierto una presa, precipitase sobre ella ejecutando algunas hábiles evoluciones, la coge $y$. vuelve á la misma rama ó vuela á otro árbol. En Escandina. via le gusta mucho posarse sobre las cercas que separan los caminos de los campos, y en general busca mas los alrede. dores de los pueblos.

Por lo demás, el cuclillo solo es hábil para volar; aunque se le clasifica como trepador no sabe trepar, y en tierra anda á saltitos. Mas diestro es para moverse en el ramaje, a pesar de que tambien aqui le gusta permanecer siempre en el sitio que elige, y si se traslada á otro, hácelo por lo re. gular volando. $\Lambda$ s subir á un árbol, en tiempo de primavera, produce su grito muchas veces seguidas; y en el periodo del celo abusa tanto de su vor que se enronquece. Casi en todos los iäiomas, el nombre del cuclillo es una reproduccion de su grito por poco cxacta que parezca; este grito no suena ku-kuck sino uhiu; como en oiras muchas voces de ave fal. 
tan las consonantes del todo, solo porque la primera $"$ se pronuncia con mas fuerza creemos oir gu. El que como jo liama a todo cuclillo imisando su voz, sabe muy bien que no acude ninguno cuando se grita ku-kuk. Naumann dice que se puede imitar la voz del ave tocando en la flauta los tonos fa y re de la octava media; yo hice producir estas dos notas, y debo confesar que se parecen à la voz del cuclillo; pero la entonacion de la flauta es muy diferente y dudo mucho que con ella se pudiera llamar al ave. Puedo asegurar resuelta. mente que en el piano no es dado imitar la yoz del cuclillo, y tampoco es cxacta la reproduccion que hacen de ella nues. iros relojes llamados de cuclillo, por conveniente que parezca emplear dos fautrs distintas.

Cuando llega ú un territorio, el cuclillo no grita mucho al principio; pero durante el periodo del celo, no solo se aye su roz despues de subir al arbol,-sino tambien cuando vuela por la mañana y por la noche, sobre todo cuando amenara lluvia ó ha llovido. Sin embargo, en dicho periodo se oye su grito a todas las horas del dia cuando se le excita imitando su rou $\mathrm{Al}$ gritar inclina las alas, un poco extendidas, levanta la cola sobre la linea horizontal, infla la garganta, produce su gro-grul y repitele de quince a cuarenta y hasta sesenta veces seguidas, posado en li rama, dando así á conocer su nombre en todas las direcciones. Cuando está excitado par un rival duplica la primera silaba, yentonces rodo el grito suena como gu-gu-gurs. Si al gritar-le provoca un ave peque. Ba ó se precipita sobre el mientras infla su garganta, interrumpe bruscamente su grito y suele suprimir la úlcima silaba.

Cuando llega una hembra repite su grk-rub-guhl dos ó cuatro veces, $y$ añade despues algunos sonidos roncos que se han

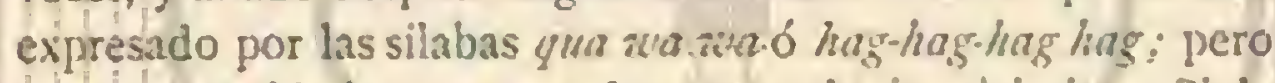
que en realidad no se pueden reproducir ni imitar. Si le enoja la presencia de un rival que nó puede ver aun, produce inmediatamente, antes ó despues de subir al árbol, una nota de dos á cuatro veces repeticia, que se podria comparar con la roz de la rana, expresindose por las silabas quorroumurg; a veces le prosocan denasiado sus companeros, que ja no temen los picota\%os, y entonces lanza un ronco sacrp que se ove tambien cuando yuela. Sin cmbargo, siempre predomina el gu-gult; este sonido se repite cada cinco segundos cuatro veces, pero es raro oirle mas de veinté ó treinta seguidos; porque despues de cada grito mas largo hay cortos intervalos de un segundo a uno y medio mas de duracion que en los gritos regulares Despues de la introduccion siguese un intervalo apenas perceptible para el observador poco experto, intervalo producido probablemente cuando el ave escucha para ver si otro cuclillo le contesta; despues produce su grito, y entre este y el siguiente media igual intervalo, oyendose a veces un tercer grito; solo despues empieza la scgunda parte interrumpida del mismo modo, hasta que al fin el cansancio exige un intervalo mas largo.

Se describe al cuclillo como ave esencialmente pendenciera, mas no puedo conformarme con semejante opinion; solo empeña lucha con sus semejantes y no hace aprecio de las demás aves sino cuando trata de quitarles uno de sus huevos para poner el suyo. Sin embargo, las pequeñas espe. cies, \& las que deja el cuidado de criar su progénie, le cono cen muy bien y le persiguen apenas le divișan Los cuclillos cautivos que se encierran con aves de escaso tamaño, viven con ellas en buena armonia, sin tratar nunca de atormentarlas; pero la vista de un macho de su especie les excita en alto grado. El cuclillo es tan mal padre como apasionado y celoso de su hembra, à la que sigue por todas partes, aun. que no esta bien probado aun si acompaña á una sola 6 si se va con todas las que ve, segun lo aseguran observadores muy concienzudos. Como quiera que sea, parce que el amor le enloquece; re en cada uno de sus semejantes un rival, 6 mejor dicho el mas detestable de todos los séres.

El que efectivamente haya observado el cuclillo no dudará de que entre dos machos de esta especie existe la mayor ri. validad, la cual se revela en todas las ocasiones. El cuclillo que se entretiene en repetir su nombre del modo mas ino fensivo excitase en extremo tan luego como oje la voz de un rival, verdadero ó supuesto. Entonces son mas viros sus mo vimientos; siguense los gritos; mira y escucha atentamente inclinase hacia adelante mas que de costumbre; y despues de cada grito se vuelve á derecha é izquierda para asegurarse de la direccion de donde proceden los gritos del rival. Al prin cipio no abandona su puesto; sino que parece esperar par ver si el corazon del oiro esta dotado del mismo valor que e suyo; deja oir despues varias veces 54 vor y mira y escuch de nuevo: Si no se presenta el rival resuélvese s. buscarle, entonces se debe admirar la seguridad con que reconoce l direccion y la distancia. Cuando en mis pruebas se me ocurri cambiar de puesto, despues de haber despertado los celos de cuclillo, presentábase este al punto en el mismo sitio de don de partió mi primera voz y esto sin seguir la linea recta, pue solia describir un gran arco, sin duda con la intencion de ve al supuesto rival. Llegado anqui, vuelve \& posarse, gritand mas aun que antes, y si no se ve orro cuclillo, produce sonido agradables; los cortos y roncos, son scrial indudable de ira Una ver excitado, persigue al rival imaginario en el espaci de uno ó dos kilómetrns, ó permanece mas de media hor cerca de 61 y si aparece un segundo cuclillo, enganado de misma manera, la lucha comienza al punto. Con mucha razo dice/Naumann, que esta ave no tolera a otro macho en 5 distrito ó cerca de su hembra y que procura ahuyentarla fuerza de picotazos. Yo no he visto esto, y si he observad siempre que ambos rivales se persiguen con rápido vuelo pre cipitándose de vez en cuando uno sobre otro; despues s posan otra vez en una rama, empiezan á gritar, y vuclven la misma persecucion. Sin embargo, otros observadores afi: man tambien lo de los picotazos. "En $\mathrm{I}_{4} \mathrm{~S}$ a tunes de juli me escribe liebe, vi cómo dos machos, despues de habe gritado con mucha excitacion en dos bosques separados p un pequeño claro, dirigí́ronse uno contra otro y trabaro furiosa lucha en el aire. A poco los vi caer, primero lent mente y luego con rapidez, siempre agarrados, f tal cra s furia que pude acercarme â ellos â quince pasos sin que $h$ cieran caso de mi. Entonces observé que se habian cogid con el pico, golpeándose con las alas libres, como los pal mos, aunque no con tanta fuerza: al tin se alejó el uno; otro lo intentó en vano, pues se habia roto el huimero, pr bablemente á consecuencia de la caida El Erito del cuclill segun deriurco de mis observaciones, tiene por primer obje llamar a la hembra: y creo haber observado un sinnúnet de veces que esta acude $\$$ los llamamientos. Mientms le s necesario colocar un huevo, no hace caso del macho; m apenas lo ha puesto, contesta, acércase mucho al macho deja sentir su singular reclamo, algo parecido a una carcaj da. Su voz consiste en los sonidos yikikikickick ó tambi quichirvichavich, que se siguen rápidamente, precediéndol una especie de gorjco muy ligero que se oye solo 1 cor distancia. Fsta voz es melodiosa y parece seducir al mach pues al punto deja su sitio, grita gingwh, gruguguh, gुg repitiendo estas silabas cuando está muy cxcitado, y ana quaisarubur mientras sigue á la hembra. Esta vuelve a in tarle, el cuclillo la contesta; todos los machos que la han oi acuden, y entonces empieza una caceria verdaderamer loca. A mecudo siguen to una sola hembra dos, tres y ha cuatro machos, ella los excita repiticndo gorjeos y al hin 
enloquece de amor. Ejecutancio las mas variadas evoluciones en las copas de los árboles y las espesuras, un macho la sigue de cerca, oiro à cièrta distancia, cada cual dominado del desto de alcanzarla y de ser el agraciado; todos olvidan las aves pequeñas que acompañan a este cortejo nupcial, y hasta la lucha acostumbrada, $\delta$ por lo menos, solo de vez en cuan. do precipitase algun macho sobre su odiado rival, pues nin. guno quiere perder tiempo. la hembra no está menos excitada quie su ś́quito, $y$ sin duda el mas céloso de sus aspimn. tes es el que mas le gusta; su aparente resistencia solo tiene por objeto excitarlos mas aun. Al fin, se abandona á las caricias de cualquier macho, porque no conoce los limites del matrimsonio.

El apareamiento se verifica regularmente en la copa seca de un árbol, ó en otro sitio á propósito; y en las estepas del l'urkestan en el suelo, siempre con mucho ruido, gritos y gorjeos. Hasta ahora no he observado que un macho estorbe a otro en el acto, ni tampoco tendria razon para ello. iEn is;0, me escribe Liebe, oi en un desfiladero, cerca de Gera, el garjeo de una hembra de cuclillo y los gritos de un macho: completamente cubierto por una espesura baja de pinos, deslicéme a hurtadillas por la pendiente y vi un macho volando hácia el oeste y una hembra posada en una rama. Poco despues vino otro macho por el este, gritó mucho en la espesura vecina y cubrió despues å la hembra sin mas preliminares. Apenas hubo concluido apareció un tercer macho, y ahuyentando al segundo, ofrecióse à la hembra, la cual le aceptó sin rodeos. Este lecho, confirmado por un observa. dor experto y fidedigno en todos los conceptos, no necesita por cicrto mas explicacion.

Cuando la hembra se presenta muy tarde por la noche en el sitio donde el macho ducrme, excita tambien á este porque nunca olvida anunciarse; mas por entonces ambos reprimen sus deseos: ni el macho ni la hembra abandonan despues

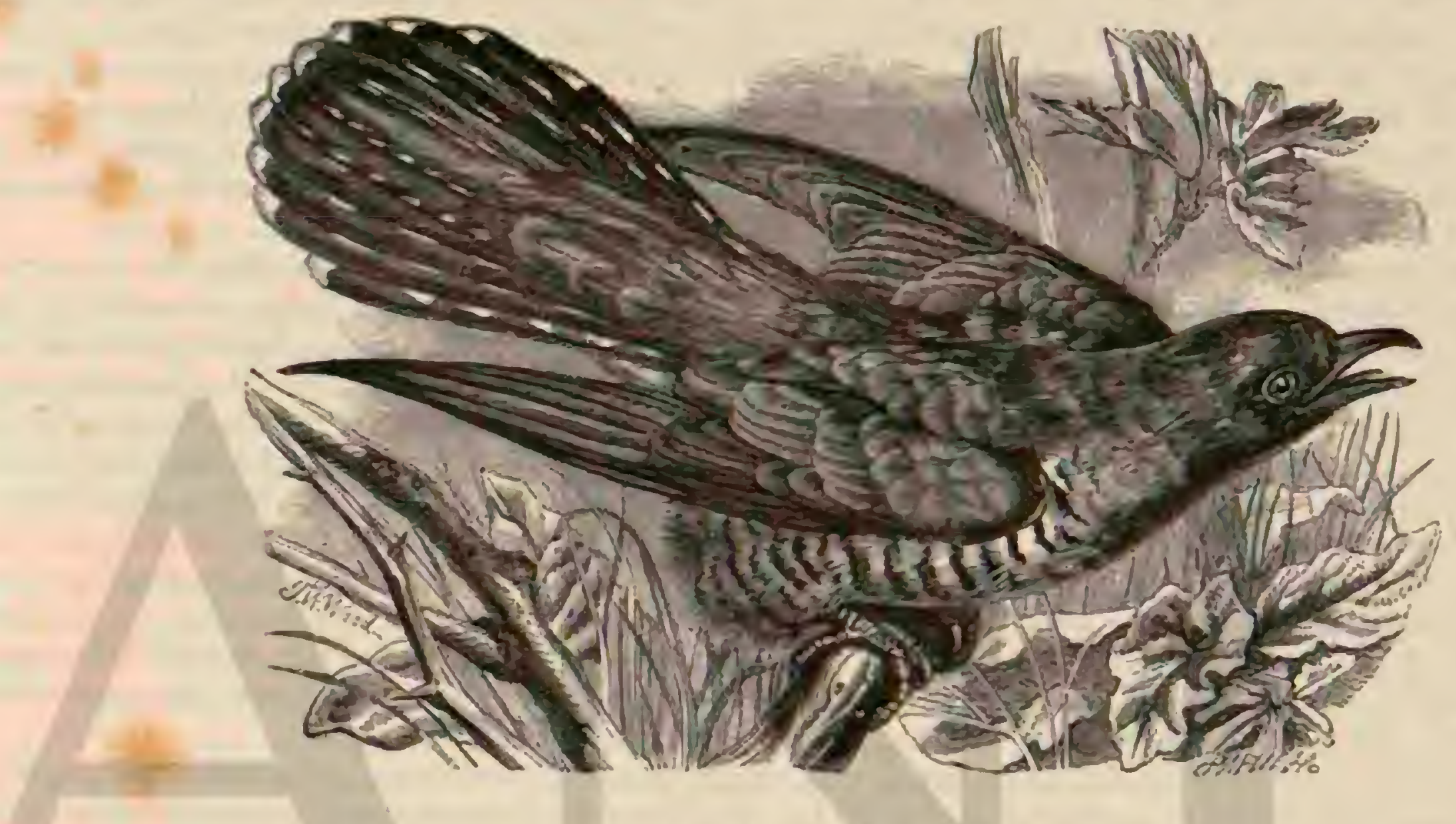

Yig. 4 S. - EL CUCLILLOO CRBS

del crepúsculo su sitio, como tampoco lo hacen por la maña nia antes de salir el sol. A la llamada de la hembra el macho contesta del modo acostumbrado; aquella vuelve a llamarle y asi continúan los gritos y gorjens hasta que el chotacabra deja oir su yoz. Al fin guardan sitencio: ambos se han enten. dido para el dis siguiente.

Si alguno duda de que el cuclillo sea poligamo, podrá convencerse visitando repetidas reces los sitios donde duerme. Hoy se oye la vo\% de In hembra acompañada de la del macho; mañana, solo la del último, porque nquella ofrece sus favores á un rival. Por eso es an dificil formarse una idea exacta de la vida amorosa del cuclillo. Yo le he observido durante unos cuarenta anos; he aniadido una observacion a otra; le he llamado centenares de veces; aun en esta prima. vera the he ocupado dias enteros casi exclusivamente de esta are; $y$ sin embargo, solo he podido averiguar una parte de su viủa.

Los antiguos sabian ya que esta are pone sus hueros en los nidos de otras 4 El huevo del cuclilo, dice Aristóteles, lo cubre el ave en cuyo nido se deposita, la cual se cuida de alimentar al hijuelo cuando sale del cascaron. Dicese que el macho adoptivo rechaza a su propia jrogenie, la echa del nido y la deja morir de hambre mieniras crece el jóven cu. cillo; otros aseguran que llega hasta el punto de matarla para alinentar al intruso, pornque este es tan bonito, que ma-

Tosso 111 cho y hembra desprecian por Il sus propios hijos. Todos estos detalles se han refarido por personas que se decian tesrigos oculares; pero no concuerdan en cunnto \& In nuncra de morir los pequeños del padre adoptivo. Unos dicen que el cuclillo viejo llega parn devorarlos; otros pretenden que como el hijuelo de este íltimo es mayor y tiene mas fuerza que sus hermanos adoptivos, toma para si todo el alimento y los deja mori de hambre; $y$-hasta hay quien asegura que se los come Fil cuclillo hace muy bien en colocar asi sus hijuclos, pues sabe que es muy cobarde para defenderlos, tanto, que las avecillas se complacen en perseguirle y darte caza.

Ya veremos que hay mucho de verdad en esta descripcion de Aristóteles; pero debo confesar que aun hoy no sabemos todo cuanto se refiere à las costumbres de los cuclillos. No me entreterdré aq̨ul en rcferir las diversas conjciuras é hịó tesis emitidas acerca de esta ave, y de que están llenos los tratados de historia natural y los diarios de ornitologia: dire tan solo que ignoramos aun pornue cl cuclillo no cubre sus huevos; y nos atendremos a los hechos positivos que se conocen respecto of la manera de rejuroducirse esta ave.

Aunque no hajamos areriguado porqué los cuclillos no incuban por si mismos sus huevos, el hechoes $\tan$ indudable que no podernos menos de admirarnos en alto grado cuando oimos emitir la opinion contraria; por eso nos parecerá verdaderamente inexplicable que uno de nuestros periódicos 
mas populares haya insertado una noticia, escrita por Adolfo Muller, observador bastante experto, quien asegum que sc ha encontrado un cuclillo cubriendo sus huevos. Seguramen. te se ha tomado un chotacabra por un cuclillo; no de otro modo podria explicarse un error tan craso. Lo positivo, es decir, lo que resulta de diversas observaciones respecto as la reproduccion de nuestra ave, es que el cuclillo deposita sus huevos en un gran número de nidos de aves cantoras para que se los cubran. Actualmente conocemos ya unos setenta padres adoptivos de diversas especies, y no cabe duda que el número aumemará considerablemente á medida que conozcamos con mas exactitud toda el área de dispersion de esta ave extraordinaria.

For mi parte sé que se han encontrado huevos diel cuclillo en nidos de pinzon, ce nevatilla, de jilguero, de verderon, de pardillo, de embcriza anarilla, de cincramo de los cañaverales, de alondra moñuda, comun y de los árboles; de grajo, de urraca, de ruisenoor, de petirojo, de cuello azul, de los dos colirojos, de collalba, de tordo, de mirlo, de curruca de los jatdines, de troglodita, de pipi oscuro, del de los jprados y de los írboles; de agrodromo campestre, de reyezue!o ordinario $y$ de triple faja, de paro carbonero, de tórtola y de pa loma zurita. De todos estos nidos, los de los calamohérpidos, de lás currucas y de las emberizas son los que prefiere el are; otros hay de que no hace uso sino en caso de extrema necesidad, probablemente tambien por equivocacion.

Al enumerar los padres adoptivos del cuclillo, quisiera ad. vertir que no me parece se pueda afirmar con seguridad completa que todos los huevos designados como de cuclillo lo son en efecto. Es muy posible, y hasta prohable, que los mas expertos recolcctores se equivoquen y hasta no exageraria al decir que en ciertos casos es imposible reconocer la diferencia entre un huevo de cuclillo j uno de los padrés adoptiros cuando son iguales en tamaño y color.

Los hueros del cuclillo, muy penueños en proporcion' á las dimensiones del ave, apenas son tan grandes como los del gorrion; difieren muy poco de los de este por la forma y tienen las mitades desiguales; de mocio que su mayor diá metro trasversal se halla mas cerca de la extremidad gruesa, que es ligeramente redondeada, mientras que la mitad mas larga se adelgaza bruscamente; in cáscara es muy tenue, bri llante y fácil de romperse, y/sus poros no se pueden observar sin microscopio; cuando es fresco, su color predominante es un verde amarillo mas ó menos vivo, con mezcla de manchas de un gris violeta ó verdoso pailido, y puntitos pardos muy marcados. Ios huevos, no obstante, pueden ser majores ó menores, de forma y color mas variables que los de ninguna otra especie cuya reproduccion conocemos; pero siempre se parecen mas $\delta$ menos á aquellos junto á los cuales los colo ca, resultando de aqui, que segun las localidades, predomina tan pronio una variedid como otra La hembra no pone mas que un huevo en el mismo nido, ó cuando mas dos, y solo en el caso de haber ya otros. Es probable que no los deposi te sino en los nidos de una misma especie, á menos que no se vea en la precision de hacerlo de otro modo. Este hecho ha sido descubierto primero por Baldamus, por lo cual me he servido casi de sus propias palabras.

Segun las recientes observaciones, estoy conformie en lo esencial con los datos anteriores. Es verdad que se encuentran en muchos nidos huevos que difieren de los de los padres adoptivos, y algunas reces tales que ni siquicra se parecen: en mi concepto proceden de las hembras de cuclillo que no pudiendo encontrar un nido conveniente, y obligadas por la necesidad de poner, hubieron de contentarse con otros. Si se comparan los huevos del cuclillo, no solamente con los de los padres adoptiros, sino tambien con los de to- das las ares pequenas que dentro de una region determinad fueron elegidas para criar los polluelos, se observará segura mente su semejanza con los de alguna de ellas. Esto lo ha dicho Passler hace dos años: fundándose en sus concienzu das experiencias, este naturalista crce que el huevo primitiv se parece á los del nido i que va destinado; pero pueci suceder que la hembra del cuclillo, que produce en el mis mo año solo hueros del mismo color, no encuentre siempr los padres adoptivos convenientes y los deposite por lo tant en nidos de ares cuyos huevos difieren de los suyos Apena. se podria dudar que una hembra de cuclillo elige siempre e cuanto le es posible los nidos de una misma esfrecie de aves y parece por lo menos muy probable que preficra aquella que debe su origen.

8 Las hembras, dice 1 alter, conocen perfectamente el nid donde fueron criadas y saben distinguir sus padres adoptivo de otras aves; pues en la úlima semana de su permanenci en el nido, su inteligencia se ha desarrollado ya tanto com su cuerpo, y las que, por ejemplo, salieron bien del nido un reyezuclo, no tendrán razon para entregar al año siguient su huevo á otra ave. I a bien arreglada vivienda del reze aueló, habiala yrotegido de los temporales y pedriscos, cuan do á principios de junio estalló la tempestad, y natuml que no lo olvide.

Otras observaciones del citado ornitólogo hacen supone que lo mismo sucede, poco mas ó menos, con todas las de más aves Asi, por ejemplo, Walter encontró huevos de clillo de igual color solo en los nicios del calamodo, otro en los del acrocéfnlo y algunos exclusivamente en los de curruca comun, a pesar de que habia en todas partes nume rosos nidos de especies congenéricas. Parece, por lo tanto que la hembra del cuclillo distingue muy bien tentre los d ferentes nidos, y precisamente esto hace suponer lo dich antes. Mis observaciones sobre el paso de una hembra po varios distritos me inducen á creer que su vida es tan vagu binda por necesidad, porque ha de buscar nidos conrenier tes por todos conceptos.

Cuando las condiciones para la reproduccion del cuclil son muy favorables, es decir, cuando encuentra en un mi mo sitio muchos padres adoptivos de la misma especie, observará que los huevos se parecen en general de un mod sorprendente. Sin embargo, se puede asegurar que much hembras de cuclillo visitan un mismo distrito para pone pues á menudo se encuentran en un espacio muy limitad varios huevos de esta ave, tanto de color diferente com igual ó por lo menos parecido, y de idéntico desarrollo, dár dose hasta el caso de hallar dos 6 tres en un mismo nid procedentes sin duda de varias hembras.

Walter encontró en 1876 , en un solo dia, cuatro huevo de cuclillo del todo frescos en una superficie que no exc dia de la cuarta parte de una hectárea, circunstancia por cual supuso con razon que al menos cuatro hembras habria visitado aquel Jugar. Podria demostrarse una analogia entr el color de estos huevos y el de los de cierta especie de p dres adoptivos, no en todos los casos, pero si en los mas; parece cuando nenos posible que la hembra del cuclillo lc ponga semejantes a los de las aves que los adoptaron.

Antes de poner el huevo, la hembra sale a buscar nido el macho no la acompaña, ni tampoco parece hacer caso su progenie. La hembra busca los nidos del modo mas verso, ya volando ó trepando por los arbustos, ó bien obse vando las aves que elige como padres adoptiros. «Dos vec en este año, yuna en el anterior, dice Walter, pude observ á la hembra del cuclillo cuando buscaba los nidos. 1a pra mera vez, hallándome oculto junto al agua, vi llegar al a desde la orilla opuesta $y$ posarse en un álamo negro inm 
diato i mi; muy pronto se dirigió ś un sauce próximo, per. seguida ya en su vuelo por un acrocéfalo, y' tan activamente, que el are hubo de hacer mil evoluciones para evitar los ataques de su enemigo. Con gusto vi el impetu del pequeĩo cantor, q̧ue no renunció à la persecucion al pasar el cuclillo por el primero y despnes por el segundo arbusto. Cinco mi. nutos despues remontósc cl cuclillo y se alejo. Entonces examiné cuidadosamente los arbustos y encontré en el se. gundo un nido del acrocéfalo can dos huevos. Despues de anotar por escrito el resultado en el sitio misino, continué mi camino, y ḋ las nueve de la mañana siguiente busqué otm vez el mismo sitio. En el nido vi dos huevos del acroctínlo y uno de cuclillo; pero en el borde de aq̧uel hallé otro de la primera de dichas aves, roto en parte, y que evidente. mente habia sido arrojado pror el cuclillo. Hice mi segunda observacion en una pradera: tenia la vista fija en un are que en la yerba recogia material para la construccion del nido, y que se alejó con él muy pronto. En el monento de dirigirme al sitio donde el ave se habia posado, me tomó la delantera un cuclillo que habia salido sin duda con la mis. ma intencion que yo, es decir, á buscar nidos del intido. Llegaba el bosque recino en linea recta hacia el sitio donde estaba oculto el ántido; revoloteó corno nunca lo habia visto hasta entonces en un cuclillo, elevindose á varios metros de altum sobre la pradera; posóse y volvio á remontarse en seguida para revolotear otra vez algunos pasos mas allk. El acrocéfalo se elevó despues, y cl cuclillo, bajando al sitio abandonado por él, permaneció un rato entre la yerba, volviendo despues al bosque. Al principio busquué en vano el nido; pero cuando al cabo de media hora se dirigió el ántido al sitio abandonado por el cuclillo, consegui hallar, corriendo rípidamente hácia ell, y por la circunstancia de haberse elevado el ave a jocos pasos de mi, el nido casi acabado y muy oculto. Desgraciadamente, mis negocios no me jermitieron ir los dias siguientes al mismo lugar para cerciorarme de la evistencia de un hucro de cuclillo. Liste viltimo, como hemos risto, habia encontrado el nido mas bien observando que buscando. . Venciendo su timidez, ordinaria, llegan mu chas veces a las inmediaciones de las casas y hasta el inte rior de los edificios, por ejemplo, de los graneros y pajares. las hora de poner sus huevos no es fija; en la mayoria de rasos lo hacen en las horas de la mañana; pero tambien se ha visto que a veces los depositan por la tarde. Si lo permite el sitio \& la construccion del nido, la hembra pone en este, y en caso contrario lo deja en el suelo; cógelo despues con el pico 5 lo lleva asi al nido. Eseste último dato está confir mado por observaciones esencialmente conformes, y entre otras una de Liebe. En i $\$ 71$, me escribe este omitólogo, vi en el sitio ya descrito y muy cómodo para las observaciones, una hembra de cuclillo que estaba posada en el suelo con el plumaje erizado; levintóse despues, recogió algo con el pico $y$ lo llevó á un arbusto de pinos vecino. Alli habia, como reconoci al punto, un nido de currucas, y junto å tres hueros de esta ave vi otro del cuclillo, caliente aun. Era evidente que este último habia puesto su huero en el suelo, llerándole despues en el pico al nido, a pesar de que, ha. llándose este en una especie de nicho natuml, hubiera po. dido mu bien depasitarle en el Por lo demás, era un nido abandondo, y a los quince dias encontre aun los huevos intiacios y frios- Adolfo Muller vió cierto dix conio un cu. clillo se agitaba cerca de un nido de motacilla, inclinando la cabera y moviendo las alas y la cola; de pronto comenzó a temblar, cxtendió las alas un poco, permaneció un rato agachado, recogió despues el huevo puesto con el pico muy abierto, y moviendo de continuo la cabcza, llevóle al nido de los padres adoptivos. Otra observacion de Liebe confirma tambien el hecho de que la hembra de cuclilio pane su huevo en el suelo. En $1 \$ 73$, añade el citado naturalista, vi i las cinco y media de la mañana, en un monton de fiedras del camino, un are de regular tamaño, que erizaba el plu. maje de tal modo, que á pesar del anteojo no pude reconocerla Al llegar á unos ciento cincuenta pasos de distancia alejóse, y entorces vi que era una hembra de cuclillo. Cuan. do llegué al manton de piedras lallé sobre una de estas un huevo de cuclillo roto, que debia haber sido puesto hacia pocos momentos, pues aun se desprendia un ligero vapor. Baldamus, sin duda cl mejor conocedor de esta ave parnisita, ha observado inmbien repetidas reces que ia hembra pone sus huevos en el suelo. Cierto dia sucedió asi hasta en el patio interior de la casa del guarda bosques Versier, en Noorddijk, cerca de Leiden. Un cazador encontró un cu. clillo en el canalizo del patio, y á su parecer enfermo y mo. ribundo; levantóle y fué á presentarsele á su amo q̨ue le toinó para examinarle. A los pocos minutos Verster sintió cn la mano cierto calor, y vió que em producido por un huevo del ave, la cual escapó alegremente, a la vista de los dos hombres, por la ventana abierta. Baldamus posce aun hoy el huevo, cuya ciscara es un poco deprimida. A menudo su. cede que la hembra entra para poner su huevo en huecos por donde no puede pasar sin gran trabajo, y varias se han cogido en tales casos porque no prodian volver \& salir.

Despues de haber depositado el huevo, la hembra rija su atencion en el nido, vuelve repetidas veces a $\mathrm{el}$, y sacn huevos y aun prolluclos; pero nunca los suyos. Walier nicga el hecho. *El cuclillo, dice, tiene mala fana como ladron de nidos, que no solo echa fuera los huevos, sino tambien devorn algu. no de ellos Si se observara bien se veria que cl ave no cs tan bárbara como lo parece, pues no hace mas que las demás aves; todas en general se revuelven al construir el nido, para comprimir el material que sobresale, comunicándole unaforma redondeada; esto lo lincen hasta proco anies de poner el huevo y asinismo procede el cuclillo. Los huerus extranos que hay en el nido no son para él orm cosa sino objetos superfluos: cn su consecuencia oprime el cuerpo contra las paredes, y describiendo un circulo, echa fuem los huevos ó los ajlasta en el fondo del nido. Si uste es denasiado estrecho para poder revolverse, saca los hueros con el pico, lo mismo que otras aves quitarian del nido objetos ajue no las pertene. cen. I os hueros pequeios se rompen muy fácilmente, y si lo mismo sucede al cuclillo con el suyo al llevarle al nido, mas fácilmente aun sucederá con los mas delicados de los padres adoptiros á los cuales no debc, adenvás, consideracion alguna. Cuando se le rompe el huero y su contenido le llena el pico, se lo traga $>$ Walter cita una serie de prucbas en ajoyo de su aserto: asi como otros observidores, tambien ef ha creontra. do repetidas reces nidośnue conteriian un huevo de cuclillo, y junto 1 él habia otro de los padres adoptiros, aplastado en el fondo. Asimismo ha ouservado mas de una rez como el cuclillo se revolvia y además le la visto romper su propio huevo al cogerle con el pico. Paessler y otros, pror el contra rio, aseguran haber visto que la hembra del cuclillo saca del nido un huevo de los padres adopiros, y que mas tarde se lleva hasta los polluelos A esto conicsta Walier, con mucha razon, que no prede haber hijuelos, y que de consiguiente no es posible gue se los lleve, puesto que la hembra del cuclitlo visita diariamente el nido y saca los huevos, sin contar que al volver repetidas veces para robarlos, su nimero debe disminuir, lo cual no sucede, como lo enseria la experiencia. sNunca he observado, dice, al visitar mas arde los nidos que contenian un huero de cuclillo. una disminucion en el mímero de los de los jadres adoptiros, y si muchas reces un aumento. Las aves no suelen poner el número completo 
de huevos cuando el cuclillo ha depositado primero el suyo, porque este ocupa ya bastante lugar. Sin embargo, he encontrado todos los años una $\delta$ dos veces los huevos com. pletos. Despues de haber depositado la hembra del cuclillo su luevo, es decir cuando esta no ha encontrado aun otros, las aves suelen poner tres mas, y los cubren en seguida $\gg$ Bal. damus, que ha revisado mi descripcion del cuclillo, opina, como Walter, que la hembra no saca todos los dias un huevo de In madre adoptivn del nido, $\delta$ que al menos no lo hace con intencion; pero pucde suceder, en su concepto, que $\dot{z}$ causa de rerse molestada por los propietarios del nido continuamente, se rompan uno 6 varios huevos, los cuales echa despues fuer, pues si quedase un hucvo rota en el nido, sus propietarios legitimos lo abandonarian sin duda.

Esto prúcba ya cierto cuidado de la liembra de cuclillo para con su progenic, $y$ las observiciones de Bajdamus lo demuestran además hasta la evidencia. Como este naturalista ha di. cho ya en sus Cuentos de ares, librito muy gracioso, fúndase principalmente en dos observaciones recientes. Cierto dia del mes de junio, a las seis de la tarde, hallándose Baldamus cerca de Halle, en la orilla izquierda del Saple, oculto detrás de un sauce, vió como un cuclillo, llegendo de la orilla opues. ta, cruzó sobre la corriente en direccion a la mairgen opuesta, muy escarpada, y desapareció. Baldamus, fijándose en el si. tio, acercóse á hurtadillas por detrás de la espesurn, se incli. nó y vió al cuclillo en un nido, con el plumaje erizado y cerrados lós ojos, señal de que estaba poniendo el huevo. A los pocos minutos se alisó el plumaje, abrió los ojos, y al ver á Baldamus emprendió el vuelo hácia la orilla opuesta, des. apareciendo en la espesura. Fn el nido de motacilla estaba el huevo del cuclillo, aun caliente, y asemejábase mucho á los de los propietarios del nido. Despues de dudar corto rato sobre si debia tomar el huevo ó aprovecharse de la ocasion para hacer mas observaciones, decidióse por lo último. Baldamus volvió á colocar el bonito huevo en el nido, ocultóse de modo que pudicra divisarle, y á los pocos minutos vió al cuclillo volver; el ave sacó el huevo del nido con el pico y llevólo á la orilla derechn. Tambien el hechá siguiente pruebr el cuidado de las hembras por su progenic. En 1867 , áfines de mayo, Baldamus se hallaba en la Engadina superior para recoger nuevas observaciones. El 6 de junio, el guardabosque Silvaplana le dijo que habia encontrado en un nido de ántido un cuclillo que acababa de salir del cascaron, y que estaba $\therefore$ pocos pasos de una choza, al pié del pico del Piz Monteratsch sobre una pequeña superficie sin nieve y cubierta de larga yerba del año anterior. Baldamus se dirigió al sitio incicado y despues de buscar en rano entró en la choza; pero poco despues vió saltar de un abeto un cuclillo, que fué á posarse en el sitio cubierto de jerbas. Con ayuda de sus buenos anteojos, el naturalista observó muy bien como el cuclillo inclinaba repctidas veces la cabeza, ocupándose en algo, despues de lo cual volvió al abeto para reunirse con el macho, que desde alli le llamaba continuamente. Cuando Baldamus llegó al nido, ya descubierto, encontró un polluclo que á lo mas tendria veinticuatro horas, tres huevos de antido ilesos cerca del nido, y otro mas léjos entre la yerba. Todos los huevos de que salieron los polluelos, ya muy desarrolla. dos, se conservan como pruebas en la coleccion de Baldanus.

Despues de tales observaciones, que no dejar la menor duda, apenas puede negarse el cuidado de las hembras de cuclillo; el que estas le tengan en todos los casos ya es otra cuestion. Así, por ejemplo, no es prueba de gran cuidado el hecho de poner la hembra su huevo en nidos destinados is la incubacion 6 que ya estin abandonados. Casi todos los ornitólogos que observan con atencion, encuentran huevos de cuclillo en nidos abandonados ó no conciuidos: Liebe, $y$ tambien Paessler, reconocieron el hecho en 1 mo de saxicola, y Walter en los qque cl reyezuelo se construye, no para $\mathrm{cm}$ pollar, sino para dormir.

El periodo del celo del cuclillo dura mientras grita, y de. pende por consiguiente, no solo del tiempo sino tambien de la region; así, por ejemplo, en el norte $\delta$ en la montana alta connienza mas tarde; pero se prolonga mas que en el sur y en la llanura. Tambien se rige la reproduccion del cuclillo, como toda su vida, por la de las aves pequenas. Con bastante sorpresa oi à la altura del Riesengebirge, aun á fines de julio, el grito del cuclillo, mientras que i seis ú ochocientos me tros mas abajo permanecia silencioso hacia ya mucho tiempo. En la altura casi desnuda, cubierta solo de abetos enanos, cl ántido acuático ocupábase aun en la segunda cria, razon su. ficiente para que el cuclillo se dirigiese of la altura que los meses anteriores solo habia visitado pocas veces. Me atrevo a deducir de esta obscrvacion que el cuclillo riaja mientras pone sus huevos, para buscar nidos convenientes.

Sobre el liempo que media entre la puesta de uno y otro huevo liay diferentes opiniones. Mientras que los mas calculan de seis a ocho dias, Walter asegura haber observado que dos cuclillos ponian al menos dos huevos por scmana, y alega en pro dé su aserto observaciones que parecen confitmar al hecho. Tambien vió, no obstante, que una hembra necesitó seis dias para poner el segundo huevo, y considera como exacta la observacion de los ornitólogos que calculan el intervalo en scis á ocho dias. Cree sin embargo que un inturvalo tan largo puede resultar del cansancio que se observa en todas las aves cuando ponen. Si pudiese probarse que la hembra del cuclillo pone, en efecto, cada tres ó cuatro dias un huevo, resultaria para todo el periodo de su reproduccion unos veinte á veinticuatro, y solo esta circunstancia daria una explicacion suficiente del hecho de que los cuclillos no cubran por si mismos los huevos, pues ninguna pareja de aves podria criar tantos polluelos, tan voraces ya desde el primer dia de su existencia. Por mucho que pueda alegarse en pro de esta opinion, no está sin embargo demostrada aun tal productividad y parece de consiguiente que no podemos fundar aun en clla la cirada explicacion.

« Ess curioso, dice Bechstein, observar con qué placer ven las aves al la hembra del cuclillo acercarse á su nido: en re?. de abandonar los huevos, como lo hacen cuando aparecen un hombre ó un animal, diriase que experimentan mucha alegria. La hembra del iroglodita, si se halla cubriendo, salta del nido cuando liega la del cuclillo, y la deja lugar para que ponga á su gusto; despues da saltitos alrededor, yá sus alegres gritos llega el macho, que parece enorgullecerse por que un ave tan grande honre su nido.

En otro sitio anade Bechstein lo siguiente: La griteria de las aves pequeñas al ver un cuclillo pudiera deberse á la buena inteligencia que reina entre este y los padres adoptivos, ó mas bien a una expresion de alegria. Quizás le llamen para que les dé á criar algun polluelo. El que comprende el len. guaje de las aves crecrí sin duda esta opinion mas exacta que la de los que suponen que esos sonidos son gritos de terror lanzados por lins aves cuando, enganadas al pronto, creen ver en el cuclillo, a causa de sus alas y de sis vielo, al temible halcon, tan peligroso para ellas.

Todo esto es encantador, pero desgraciadamente no es verdad: todas las aves, que por su mala suerte están destinadas a criar un cuclillo, manificstan gran temor por el peligro que las amenaza, y procuran por todos los medios alejar al ave.

Conocen muy bien al cuclillo y ninguna de ellas le toma por un halcon; esto lo ve hasta el mas inexperto, si observa un poco detenidamente. Cierto que á las aves pequeñas les 
gusta provocar á los halcones profiriendo agudos gritos; pero su manera de proceder es muy distinta, y nunca son tan osadas como en sus ataques contra el cuclillo. He observado un sinnúmero de veces que no solo persiguen a csta ave cuando vuela, sino tambien cuando está posada tranquilamente en un árbol. Sin duda les atrae el bien conocido grito y se precipitan volando hácia ella, haciendo mil evoluciones al emprender sus ataiques; tambien proceden así con los buhos, pero nunca con los halcones. Al obrar asi contra cl cuclillo parecen bien convencidas de su seguridad, y tal es su atrevimiento y pertinacia, que el ave se ve obligadi, no solo á interrumpir sus gritos sino tambien á defenderse. Para esto menudea los picotazos, lanzando el sonido expresacio por saerr; pero rarns veces le sirve su defensa, pues a cada momento se precipitan las aves pequeñas sobre el odiado parásito, en cuyo caso comienza la rerdadera caza. Cuando se acerca el cuclillo \& un nido, sus propietarios demuestran con gritos y movimientos cuánto temen por su cria; por otra parte al cuclillo no le gusta poner en presencia de los padres adoptiros. Llega como un ladron nocturno, deposita su huevo $y$ huye al instante. No es menos curioso ver algunas ares, que no pudiendo sufrir el menor desarreglo en su nido, ni que le toquen siquiera, respetan sin cmbargo el huero del cuclillo, al paso que tiran otros inezclados con los suyos, y siguen cubriendo aunque el parásito les arrebate los que ellas pusieron. Aborrecen al cuclillo, pero no rehusan cuidar de sus huevos y de su progenic.

En el momento de salir del cascaron, el pequeño cuclillo es muy imperfecto; pero se le reconoce iácilmente, segun Naumann, por su gran cabeza, ś la que comunican un aspec. to mas informe los desmesurados ojos; crece rapidamenic, y aparece mas hediondo cuando comienzan á apuntar las plumas en su negruzca piel. Me han diclıo que una ver se creyó á primera vista que un cuclillo recien nacido cra un sapo. Cierto individuo jóven que Paessler encontró el z 1 de junio, tenia ya doble talla el 24 ; estaba cubierto de rudimentos de plumas, su color era azul negruzco, $y$ aun permanecian sus ojos cerracios. 1 l 2 de julio llenaba ya todo el nido; la cabe. za, el cuello y la rabadilla sobresalian del borde; tenia los ojos abiertos; las cobijas de las alas eran pardas y el vientre carecia de plumas. El 5 del mismo mes habia abandonado gat el nido.

Fácilmente se comprende que el desarrollo no se verifica en todos los cuclillos del mismo modo. Il uno necesia mas tiempo, el otro menos; este es qquizis mas feo que el utro, aqquel mas bonito; pero en general se pueden considerar como exactos los anteriores datos de Naumann y Pacssler. Por torpe que sea el ave al salir del cascaron, siempre se distin. gue por su voracidad. Necesita mas alimento del que pueden darle los padres adoptivos, y lo coge, cuando tiene hermanos adoptivos, del nismo pico de estos; si no mueren de hambre o los mata su madre, acaba por ccharlos del nido. Esto explica que siempre se encuentre solo un cuclillo algo desarro. llado. Friderich ha reconocido por sus propias observaciones que el cuclillo arroja intencionalmente a los hijuelos de sus padres adoprivos fuera del nido. Friderich tenia un cuclillo pequeño, casi sin pluma, que solo contaba unos ires dias de edad, y como estabin solo en cl nido, dióle por compañeros unos canarios de ocho dias. La traviesa avecilla no descansó y $\pi$ hasta que hubo puesto uno de aquellos sobre su dorso; despues se irguió, retrocedió bruscamente y echó fuera á uno de los pequeños canarios, procedicndo despues del mismo modo con los otros.

liriderich hizo su segunda prueba con unas bolitas de pa. pel en rez de aves, y aperas puestas en el nido, sufrieron la misma suerte. Los experimentos posteriores con cuclillos de mas edad dieron siempre el mismo resultado. Walter repitió y completó las pruebas de Friderich: colocó un huevo en el nido de un reyezuelo que contenia un pequeño cuclillo; pero con gran sorpresa suya, no fué arrojado, asi como tampoco alguuas bolitas de papel depositarias mas tarde. Cuando el cuclillo tuvo siete dias, Walter le dió por compañero un cnneoctono aun sin pluma y algo mas jóven. El cuclillo se volvió en seguida, puso la parte posterior de la cabeza debajo del enneoctono y arrojólo hábil y segummente fuera del agu. jero. De repeidos experimentos resulta que los huevos pues. tos en el nido no llaman la atencion del ave, mientras que todos los polluelos son arrojados del mismo modo. Cunndo dos cuclillos salen del cascaron en un mismo nido, el mas débil sufre la misma suerte, como en otro caso los hermanos adoptivos. Este proceder se podria considerar como un egoismo hereditario, ó al menos como instinto indispensable para la conservacion del cuclillo; la palabra no cambia el hecho. Noiable es una observacion de Berucklacher: puso un cucli. llo pequeño, cubierto ya de pluma, en el ángulo del pié de una ventana, frente á un nido de cuatro pinzones, que conta. ban solo doce dias. Ei cuclillo permaneció algunas lioras quieto en su rincon, donde se le dió su alimento; pero de pronto procuró moverse, y avanzando poco á poco, dirigiósc en linea recta hácia el nido de pinzones. Una vez llegado empezó á trepar, tomó posesion del borde, avanzó con el pecho, y al cabo de dos horas apoderóse del nido á pesar de la resistencia de los propietarios legítimos. Para lograr su fin no hizo mas movimiento que el de comprimir el pecho contra el nido, alctcando para molestar á los pinzones con el aire; estos se acercaron al borde, y aunque alli se mantuvieron algun ticmipo, cajeron poco á poco. Despues de haber conquistado de este modo el nido, el cuclillo se manturo firme en él. Por poco cortés $\ell$ imperdonable que sea este acto, concluye Berucklacher, débo confesar sin embargo q̨ue habia echado fuera a los propietarios de la manera mas graciosa.

La ternura de las aves pequebas, que en esta ocasion se observa, manifićstase sobre todo en la cria del cuclillo. Con un afecto verdaderamente conmovedor, llevan al yoraz, po. lluclo, que ocupa solo en el nido el lugar de la legitima cria, un abundante alimento; ofrecenle escarabajos, moscas, caracoles, orugas y gusanos y trabajan desde la mañana hasta la noche sin satisfacerle ni poner términoá su continuo y ronco sis, zisis. Cuando sale del nido le siguen aun muchos dias, pues muy pronto vaga a su antojo por los alrededores. A re. ces sucede que no puede salir de la estrecha abertura de un hueco de árbol, y entonces sus padres adoptivos permanecen alli hasta muy entrado el otono, solo para alimentarle. Se han observado hembras de motacila que nutrias aun i sus hijos adoptivos cuando todos sus congéneres habian comenzado ya su viaje hácia el sur. Scmujante ternura no llega sin enbargo hasta el punto cuc ha indicado Bechstein. Cuando sale, dice este autor, pósase sobre un árbol vecino, se cstira varias veces, limpia sus plumas y deja oir por primera vez su ronco grito. Tan luego como el agudo girrte ha resonado algunas reces en los contornos, todas las aves pequeñas acu. den; robéculas, currucas, hipolaidos y taralcidos, le saludan, le miran por todas partes, alégranse de verle y le trnen sodo el alimento posible, de modo que no puede abrir bastantes veces el pico. Is curioso observar como toda ave quicre tener la preferencia en servir a esta desconocida, y cuando pasa de un árbol á otro para ejercitarse en el ruelo, tambien la acompanan las ares y aliméntanle hasta que pueda pres. cindir de su ayuda.

Lo malo es que en todo esto hay mucha exageracion: $\mathrm{mi}$ padre puśo un dia en el tejado de la casa un pequeño cucli. llo hambriento, y varias nevatillas y colirojos que revoloteaban 
por los alrededores le miraron sin darle nada; a otro individuo jóren que fué conducido al mismo sitio, diósele poco de comer, de modo que gritaba continuamente; pero ninguna ave cantora ni nevatilla se compadeció de él. ę. fin de ase. gurarme mas, trasladé el cuclillo desde el tejado a unos maiorrales donde habia numerosas avecillas, $y$ despues de ponerle sobre una rama sin atarle, pues apenas podia volar, esperé largo tiempo. El cuclillo gritaba à cuello tendido, hasta que al fin apareció una curruca con un insecto en el pico; acercóse a mi ave, miróla algun tiempo, y fué á llevar la presa á sus hijuclos, que se hallaban muy cerca de alli: no se acercó ninguna ave mas. Bien vemos que los hechos contradicen las bonitas historias de Bechstein.

Los cuclillos que sé cogen en el nido déjanse criar fáci\}. mente; se contentan con toda clase de alimento conveniente, y solo exigen la abundancia Sin embargo, no tienen nada de recomeadable para la cautividad; son tan voraces, que esto basta para que molesten. Cuando so cogen muy pecqueños domesticanse pronto; pero los aduitos se defienden por miedo cuando se acerca un hombre; levantan las alas como ares de rapina y dan á veces tambien picotazos á la mano que les ofrece alimento. Bechstein y despues de él atros observado. res; califican por eso al cuclillo penueño de pervarso, pero esto es una calumnia.

Yerdad es, dice mi padre, que abre el pico y adelanta la cabeza, pero únicamente lo liace cuando quiere asustar á su enemigo, ó en cl caso de estar hambriento, lo cual ic sucecie siempre. En cuanio á mi, debo decir que todos los individuos que ure cautivos no cran malignos, ni tampoco he obserrado en ellos nada del odio que, segun Naumann, parecen profesar ấ las demás ares. Mi cuclillo vive con loros, picos cruzados, cardenales, alondras, calandrias, abubillas : palomas calradas, "ha estado largo liémpo en una misma jaula con pequeiros fringilos de Africa, sin que haya causado nunca el menor daio ś ninguna de estas aves, al menos que yo sepa. Hasta los cuclillos que se cogen cuando son viejos se domestican bastante pronto. Dehne tujo una hembra que al cabo de tres dias salia al encuentro de su amo cuando le llevaba de comer.

Muy singular cs que el cuclillo cativo no produzca su grito en la jaula; de todos los que yo he cuidado, y cuyo número es bastante considerablé, no he oido ál uno solo, ni tampoco tengo noticia de lo contrario, como no sea la de Brucklacher, quien pretende que deja oir su voz. Sin embargo, este observador añade que su cuclillo domesticado solo pro. ducia una vez el grito caracteristico.

El cuclillo adulto tiene pocos enemigos: la agilidad de su vuelo le pone á salio de la nayor parte de los halcones, y sin duda se escapa siempre de los carniceros trepadores. Debe sufrir, sin embargo, las impertinencias de las ares pequeñas, no solamente de las especies á que confia por lo regular sus huevos, sino tambien de otras. En prinera línea figuran entre ellas las valerosas nevatillas que le acosan del modo dicho tan luego como se deja ver. Además he visto que le acome. tian los oriólidos, los diferentes lánidos, el gran muscicảjido, el hipolais, y en fin, las currucas. Segun las observaciones de Walier, hasta el pico verde le ataca, y por cierto mas sérin. mente que las aves antes citadas. Este excelente volador al. canza al cuclillo fugitivo, y le espanta al fin de tal modo, que el perseguido no sabe qué hacer. Walter vio cierto dir un cuclillo que acosado por un pico verde se refugio en el único árbol que habia en su camino; pero su perseguidor le siguio, obligándole á emprender desde luego la fuga hácia el bosque, distante unos cincuenta pasos da aquel árbol; á los pocos momentos le alcanzó otra ver, y acometióle con tal impetu, que el cuclillo se vió precisado á descender contra su costum. bre al campo raso, lo cual no impidió que el pico le siguiera. Una espesura ocultó á las dos aves á la vista de Walter, que solo vió un bulto en el suelo, y cuando pudo acercarse, ya habian desaparecido. Ademas de tales adversarios y de varios parásitos, el cuclillo adulto sufre la persecucion de las rapaces de vuclo ligero, aunque no tauto como podria suponerse. En cambio tiene muchos enemigos cuando es pequeño $y$ aun en el nido. Los zorros, gatos, inartas, comadrejas, matones, cuer. vos, garrúlidos y otros lacirones de nidos descubren la voraz arecilla mas facilmente aun que los habitantes legitimos del nido, y consideranla como buena jresa. Tambien el hombre se asocia en ciertas regiones, y’a por ignorancia ó supersticion, a tantos enemigos. Segun cierta creencia popular, el cuclillo se trasforma durante el invierno en halcon, y el matar a este parece mas bien un mx́rito que una crueldad. Solo cuando escapa sin contratiempo del nido parece mas asegurada la existencia de esta ave: guardase entonces del hombre, y cs muy dificil enganarla cuando no se sabe imitar perfectamente su voz. Mas dificil aun es apoderarse de un cuclillo adulto vivo; jo no conozco ninguna manena de cogerle, y sill em. bargo debe liaber, pues en Grecia, donde se come y se con. sidera como golosina al cuclillo, se llevan á fines de julio individuos bien gordos al inercado, los cuales se habrín co. gido seguramente viros.

UTILIDAD. - Creo prestar un servicio recomeradando \& todos que protejan al cuclillo gris: no deberia faltar en nin. gun bosque, pues no solo le anima, sino que contribuye no. tablemente a su buena conservacion.

El cornzon nos dice que la primavera no llega hasta que el cuclillo canta; el espiritu nos indica que este grito sonoro tiene un signifrcado mucho mas importance aun. "Dónde csiá cl corazon humano, dice Eugenio de Homerer, que \& no estar joseido del mas abominable egoismo, no se sienta poseido de alegria al oir el grito del cuclilio por primera vez. en la primavera? Iovenes §viejos, pobres y ricos escuchan con igual placer su sonora roz. Si solo se judiera decir del cuclillo que es el verdadero precursor de la primavera, esta sola circunstancia bastaria ya para hacerle digno de la protec. cion humana; pero es tambicn uno de los mas útiles exterminndores de muchos insectos dañinos que no tienen otro enemigo. La roz del cuclillo es la señal de que ruclve uno de los mejores guardianes de nuestros bosques. Se alimenta de insectos de toda especie, y en casos cxcepcionales de frutos, exterminando sobre todo los animales que desprecian los demás insectivoros, cual son las orugas vellosas.

Segun las observaciones de Liebe, prefiere sin embargo las orugas lisas y de tamano regular á las vellosas y grandes; pero en su insaciable voracidad es por lo regular poco exigente. come por lo tanto, las orugas rellosas, dice Liebe, sin reparo alguno: pero siempre le cuesta mucho irabajo $s$ tiempo. Asi como lo hacen otros varios insectivoros, hace pasar por el pico las orugas con mucha habilidad, tinascándolas de continuo hácia atrás y adelante en posicion trasversal, para poder tragarlas mas cómodamente. Sncude las grandes orugas de un modo tan extrano, que á primera vista se pudiera creer este movimiento torpe y pesado, pero es del todo conveniente: alarga la cabeza mucho horizontalmente, coge la oruga por una extremidad y la golpea, no contra el suelo, ni contra la rama donde está posado, sino en el aire, describiencio con el pico una linea que corresponde perfectamente a la que la mano forma al chasquear $\dot{a}$ derecha $E$ izquierda el lárigo. Asi consigue no solo matar y estirar completamente la oruga, sino extraer tambien el contenida acuoso. En un cuclillo cautivo no se pucde observar este procedimiento á poca distancia, porque el are mancha al osservador la cara y la ropas con el lịuido sangriento, aunque no se ensucia a sí propia, 
gracias a la destreza de sus movimientos. Antes de comer la oruga, pásala de diez a quince veces por el pico y la sacude al aire.

A pesar de estos cuidadosos prepamivos come relativamente mucho y se hace por lo mismo muy útil. Sabido es que entre las orugas vellosas hay algunas que ocasionan mucho dano en los hosques y que se multiplican rápidanente; su mas encarnizado, o casi único enemigo cficaz, es el cuclillo, y por su insaciable voracidad deberia apreciarle todo guarda-bosque inteligente, porque esta ave puede hacer mas para el cxterminio de esos insecios daninos, de lo qque jamås haria el hombre.

La siguiente obscrvacion de Fa Homeyer es una prueba de ello.

A principios de julio de 1848 , aparecieron varios cuclillos en un pinar de mas de treinta fanegas de tierra, y algunos dias despues aumentó de tal manera su número, nue Homeyer fijó en el hecho su atencion, pues no habria menos de cien individuos. Aquella reunion era debida á la presencia de una infinidad de orugas de pino (liparis monachus): los cuclillos encontmban alli el alimento en nbundancia, y ha. bian inierrumpido su comenzado viaje para utilizar tan feli\% hallazgo. Cada individuo se ocupaba con afan en buscar su alimento, y en un minuto se tragaba mas de dicz. orugas. \& Calcúlense, dice Hameyer, solo dos or:gas por ave yo por minuto, $y$ tendremos para cien individuos, on un dia de dicz ! seis horas (nes de julio) 112,000 orugas; los cuclillos habian estado quince dias en la localidad, y el número de in. sectos devorados pudo elevarse por consiguiente í 2.SSo,000: la disminucion fue, con efecto, tan notable, gute se hubiera creido que las aves habian exterminado todas las orugas: mas zarde no se vio ya seiral de ellas.

Esta observacion del excelente naturalista 120 es de nin. gun modo aislada. El que observa aleniamente en verano un bosque invadido pur orugras, rerá que los cuclillos, libres ya de sus ocupaciones amorosas, acuden de todas partes para satisfacer su voracidad. Cuando la cria de estos insectos sale del nido, los cuclillos no bastan tampoco para exterminarlos, pern al menos pueden disminuirlos, sin contar el caso de que destruyen los nidos mismos. Por eso es el deber de todo hombre racional dejar al bosngue sus guardianes $y$ à nosotros el heraldo de la primavera; su obligacion es protegerle $y$ cuidarle tanto como le sea posibic, combatiendo siempre en codas partes la falsa opinion de quese esta ave podria hacer daño.

\section{LOS COCCISTIDOS-COCCYSTES}

A principios del siglo, un negociante de Lubben, en el valle del Spree, llamado Muller, recibió noticia de que, no lejos de su casa se habian posado dos aves muy extrañas en un bosque pantanoso. Atendiendo a la indicacion, dirigióse al sitio, y vió efectiramente dos aves muy recelosas y timi. das, semejantes al cuclillo, que volaban de un årbol á oiro gritando con fuerza. Los souvidos no se parecian en nada is los que emie el cuclillo gris y recorcaban mas bien los del pico. El negociante consiguió matar una de aquellas ares, pero asustada la orra por la deconacion, cobró miedo y no pudo ser habida. El ave muerta fue despues presentada $a$ mi padre, quien traró. su descripcion, liamándole cuclillo de obla lorga. Mas tarde se reconoció que habia sido descrita por Linnen con el nombre de aucuins ñlandarius; pero de todos modos, mi padre fué el primero en seralarla en dlemania, y me estaba reservado el dar á conocer su manera de reproducirse.

CARACTÉRES.-ILOS coccistidos tienen el cuerpo pro. longado; el pico del mismo largo que la cabeza, poco mas ó menos, ancho y grueso en la base, muy compruimido lateral. mente y encorvado: las patas iuertes y relativamente largas, cubiertas de plumas por delante hasta debajo de la asticula. cion tibio tarsiana y desnudas por detrís; las alas regulares, con la tercera rémige mas prolongada: la cola mas larga que el cuerpo, cónica, de plumas estrechas, alcanzando apenas las externas el centro de las medias; el plumaje liso, y la ca. beza adornada de una especie de moño. Los dos sexos revis. ien el inismo plumaje, que varis un poco con la edad.

Essa género es uno de los mas ricos de la familia, aurique se hayan separado diversos cuculidos que (jloger agrupó.

DISTRIBUGION GEOGRÁFICA.-LOS coccistidos son propios de Africa.

\section{EL COCCISTES GRAJO-COCCYSTES GLAN- DARIUS}

CARACTERES. - Fil coccistes grajo ó manchado tiene Ia cabezn gris cenicienta; el lomo y el vientre gris pardo; la gargnnta, los lados del cuello y del pecho de un amarillo leo. nado que tira al rojizo: las cobijas de las alas y las rémiges secundarias presentan en su extremidad una extensa mancha blanca triangular; el ojo es pardo oscuro; el pico puírtura; las patas de un gris verdoso. El coccistes grajo mide unos $\left(1^{\prime \prime}\right.$,40 de largo, el ala $\left(0^{\circ}, 21 \text { y la cola } 1\right)^{n}, 225$.

DISTRIBUCION GEOGRÁfICA.- Esta ave es arigimaria de Africa: abunda en ciertos puntos de la Nubia y de Egipto, tampoco escasea en Arabia y Palestina. Fn Persia es muy frecuente en algunos años, nuỵ ram en otros. Se la encuentra en Argel, descie donde pasa a Europa todos las años, mas ó menos regularmente. Anida en Espalin; déjase ver con bastante frecuencia en Italia, y mas raras veces en Grecia; probablemente se la ve en todo el mediodia de Euro. pa. Segun mis observinciones, aprarere anualmente en Ale. jandria durante la época de la emignacion; muy raras veces se presenta en Alemania; hasta ahora solo se conocen dos casos de que se la haya cazado aqui. Tiene costumbre de invernar en las selvas vírgenes del Africa central, donde la he cazado t menudo. Unicamente los individuos q̨ue anidan en Europa emigran tan lejos hácia el sur; los que viven en Egipio no abandonan el pais durante el invierno.

USOS, COSTUMBRES Y REGIMEN. - El coccistes grajo busca en Ëgipto los bosquecillos de mimosas disemi. nados en el valle del Nilo; en uno de un cuario de legua de perimetro, suelen encontrarse hasta ocho y diez parejas de estas aves, mielltras que en otms comarcas se recorren gran. des extensiones de terreno sin ver un solo individuo.

En Palestina, donde el coccistes grajoes casi tan frecuente como en el Eigipto, habita, segun "Tristram, en los bosques escasos, todos de encinas, donde se presenta áfines de rebre. ro, abandonándolos ámediados del otono. En España fija su residencia en puntos análogos, mientras que en el interior del Africa, y sobre codo en el rio de las Gacelas, segun Heuglin, habita vastas llanuras donde abundan las granineas. Evita el desierto y las montañas altas, y tampoco le agradan las estepas desprovistas de árboles; al contrario de nuestro ca. clillo, raras veces se le encuentra aislado.

Ignoro si el periodo del celo ejerce alguna infiuencia en sus costumbres sociales; solo puedo decir que en esta época encontré coccistes reunidos, aunque no vivian pacificaniente entre si. Allen, que ha recorrido el Africa despues que yo, dice que se encuentran comunmente aynreados; Heuglin dice no haberlos visto mas que sulitarios: pero yo opino que viven reunidos por regla general, constituyendo una excep. cion los que permanecen solos. 
En cuanto á los usos y costumbres, el coccistes grajo ape. nas ofrece analogia con el cuclillo; vuela casi como él; pero en todo lo demás difiere notablemente. Habita un dominio mucho menos extenso; vuclve con mucha mas frecuencia al mismo sitio, mas no se le puede comparar en este concepto con el cuclillo. Los machos se persiguen con ardor, gritan fuertemente, $y$ empeĩan luchas encarnizadas aunque sin desplegar nunca la rabia que anima al cuclillo.

El vuelo del grajo es ligero y rápido: el ave pasa con la celeridad del gavilan a través de la mas compacta espesura, sin detenerse un instante, $y$ 'de ordinario no va léjos; solo cuando dos machos se persiguen franquean grandes espacios. Rara vez se posa esta ave en tierra, por lo menos yo no la he visto nunca hacerlo, pere en cambio the presenciado a menudo cóno coge su jrest, volando á ras del suelo. Si la espantan se dirige a un árbol, se interna en el follaje y es. pera al cazador; cuando el peligro se acerca, deslizase silenciosamente entre las ramas y abandoná el árbol por el lado ópuesto, consiguiendo asi desorientar muchas veces al perseguidor.

Su voz, distinta de la del cuclillo, consiste en una especie de carcajada que recuerda el grito de la urraca, y que Allen exprésa por kiau kiau; su grito de llamada, que no he oido, pirece ser kerk kerk. Lo sucle producir con tanta fuerza y tan reperidamente, que se oje desde téjos y no es fácil confundirle con ningun otro.

Fin el estómago de los inaividuos gue jo maté he hallado insectos de toda especie y orugas. Allen encontró principalmente langostas.

Heuglin designa mariposas, orugas, arañas, langostas y es. carabajos como presa ordinaria del ave y añade que á me. nudo el estómago está, como el de nuestro cisclillo, cubierto de una espesa capa de vellos de orugas.

No se sabia á punto fijo si el coccistes grajo anidaba ó po nia sus huevos en los nidos de otras especies. y como la cuestion em importante de resolver, porque determinaba si cl ave era ó no un cuclillo, resolvi estudiarla. Durante largo liempo fueron inúiles mis investigaciones; pero al fin recogi un primer dato el 5 ide marzo de i\$50. En un bosque de mimosas de los alrededores de Siut maté sjete coccistes, en. tre los cuales se contaba una hembra que tenia un huevo formado en el oviducto; desgraciadamente, el plomo rompió este huevo, y solo enconiré los restos; pero bastaron para demostrarme que aquel diferia mucho del que pone el cu. clillo gris. Además de esto, y aquí estaba el punto mas importante, conocia ya la estacion de las puestas, estacion que varia mucho en Africa; mas aun pasaron dos anos antes de saber á qué atenermie.

El a de marzo de I\$52, persegui largo tiempo á un coccis tes en un jardin de los alrededores de Tebas (Alio Egipto); al cabo de media hora le vi deslizarse en un nido situado en un aito árbol. Guardéme bien de molestarle, y como quiera que al cabo de un cuarto de hora se alcjara volanco de los alrededores, subi al árbol y encontré un nido de corneja ce. nicienta con seis huevos, uno de los cuales acababa de ser roto. De estos seis huevos reconoci desde luego dos que se parecian mucho, por el tamaño y cl color, á los de la corne. ja, solo que cran un poco mas pequeiros y no se podian con. fundir con los de ninguna otra ave. Apoderéme de ellos y los trasladé cuidadosamente á mi barca para compararlos con los restos de quue hablé anies, y con gran satisfaccion noté la mas completa semejanza. Tenian, poco mas ó mencs, ol tamaño de un huevo de urraca y la forma de los del cuclillo. « Su color, como lo ha dicho Bazdecher, es verde azulado claro, con manchas apiñadas de un gris ceniciento y par. dusco, que se reunen hácia la punia gruesa, formando como una corona mas ó menos completa. Además de estas manchas hay algunos puntos de color pardo oscuro. Los huevos no se pueden casi comparar, ni menos aun confundir con los de urraca ó de corneja, pues difieren por la forma, por el grano de la cáscara, por el dibujo y el color.y

Este primer descubrimiento bastaba ya para dejar sentado cuál êra el modo de reproducirse el coccistes. El 12 de marzo ture oportunidiad de hacer con este motivo una nueva observacion: en un jardin formado de bosquecillos de árboles, como todos los de Egipto, oi resonar el grito discordante de un are de la especie, kickkiek, kick, kiek; di principio a la caza y maté dos individuos adultos, pero vi un tercero, jóven aun, que era alimentado por dos cornejas cenicientas. A partir de aquel momento, hice registrar todos los nidos de es. tas últimas aves y el ig de marzo encontré otro huero de coccistes.

No me ha causado sorpresa el oir que tal descubrimiento se pusiera en cluda y hasta se negara; pero lo que me ha es. candalizado es que se considerasen estos hechos, referidos con toda exactitud y presenciados por mi, xcomo hipótesis que habria yo buscado fraudulentamente para sostener lo que decia, apoyandome en las charlatanerias inconscientes de un jóven sirio. Por fortuna he hallado mas tarde una nueva confirmacion de esta hipótesis: poco despues de mi llegada Madrid trabé conocimiento con los naturalistas de la capital; en su circulo se hablaba de tales $\delta$ cuales animales, cuando un celoso coleccionista me preguntó si conocia el coccistes grajo, a lo cual contesté afirmativamente. Pero, ¿sabe usted a!go acerca de su manera de reproducirse? - Sí scñor, repuse. - Eso és imposible, replicó, pues yo soy el primero que ha descubierto algo sobre el particular; cqué es lo que sabe usted? Yo conocia las aves de Esparia; podia indicar con mucha probabilidad cuales eran los padres adoptivos del coc. cistes; las corbinas no hacen mas que cruzar por aquel pais; las especies de cornejas faltan por completo; y segun las ob. servaciones hechas por mi en Egipio, solo la urraca podia servir de madre al coccistes, por lo cual la indiqué desde lue. go. Tiene usted razon, se me contestó; pero ¿de dónde sabe usted esto?\$ Referi entonces lo que habia visto, y el coleccionista espanol me dib cuenta de sus observaciones.

Llamó su atencion el hecho de haber hallado en nidos de urraca hueros algo distintos de los suyos, sobre todo mas pequeños: pidió informes á unos excelentes cazadores, y supo que el cucliblo cra el que ponia en los nidos de urraca. El hecho le pareció imposible, pues los huevos que habia visto diferian notablemente de los del cuclillo; comenzó á buscar por si mismo, y descubrió al fin que aquellos eran deposita. dos por el coccistes.

Sin embargo, no le correspondia á él la gloria del descubrimiento, pues ya mucho antes, un antiguo naturalista aleman llamado Mieg, habia observado que los coccistés jóvenes recibian su alimento de las urracas; si bien no dió al hecho la necesaria publicidad. Mi digno interlocutor pociia creerse con derechos de prioridad, y acaso se resintiera su amor propio cuando le dije que ya se habia anunciado el hecho al mundo sabio.

Hoy dia, la cuestion estŕ ya completamente zanjada. Al. gunos años despues de mi viaje á España, Tristram exploró la Argelia, y halló huevos del coccistes grajo, semejantes á los de la urraca de Mauritania (Pia manritanica). Segun dice, esta ave no se limita á poner en el nido de la urraca, sino que cubre tambien sus huevos, pues encontró dos a punto de abrirse en un nido que acababa de abandonar un coccistes: los relatos de los árabes confirman esta opinion, pero sabido es que estos arreglan siempre su contestacion segun la pre. gunta, es decir, segun la opinion que en esta se da á entender. 
En iS6s y i $86 z$, Alien $y$ Cochmne recorricron el Fgipto: ya eran conocidos los padres adoptivos del coccistes grajo, y no les fué dificil encontrar en los nidos de la corneja ceni. cienta huevos é hijuelos de la especie parisita. Allen no ha. $1 / 6$ sino dos de los jrimeros y tres de los segundos, apare. ciendo dos en el mismo nido: pero Cochrane, mas afortumado, descubrió trece huevos y doce hijuelos, todos en los nidos de la corncja cenicienta: en tres de estos habia dos de los primeros, y en uno dos hijuelos del coccistes.

De las observaciones de Allen, resulta qque los individuos jóvenes de la especie se desarrollan mas pronto que sus hermanos adoptivos, pues cuando estes se hallan todavia desnudos, los otros aparecen cubiertos de plumas lemos, pues, que los huevos de coccistes se desarrollan antes que los de la corneja: la opinion de Allen, segun la que no dejposita el coc. cistes sus hueros.sino en un nido de aquella ave, cuya pues. ta se ha completado, no es del todo exacta, segun mis obsermacioncs a Parece, dice Allen, quue el coccistes solo pone en aquellos nidos de corneja, situados en los bosquecillos de mimosas; yo no encontré nunca huevos en los que estaban en árboles altos.

En Palestina, dice Iristram, he visto a las connejas anidar indistintamente en los árboles aislados, en las rocas ó en las ruinas, $y$ he observado iambien al coccistes grajo que de. posita los huevos en sus nidos. Adquiri varios de aquellos y noté que los de corneja estaban á punto de abrirse en un

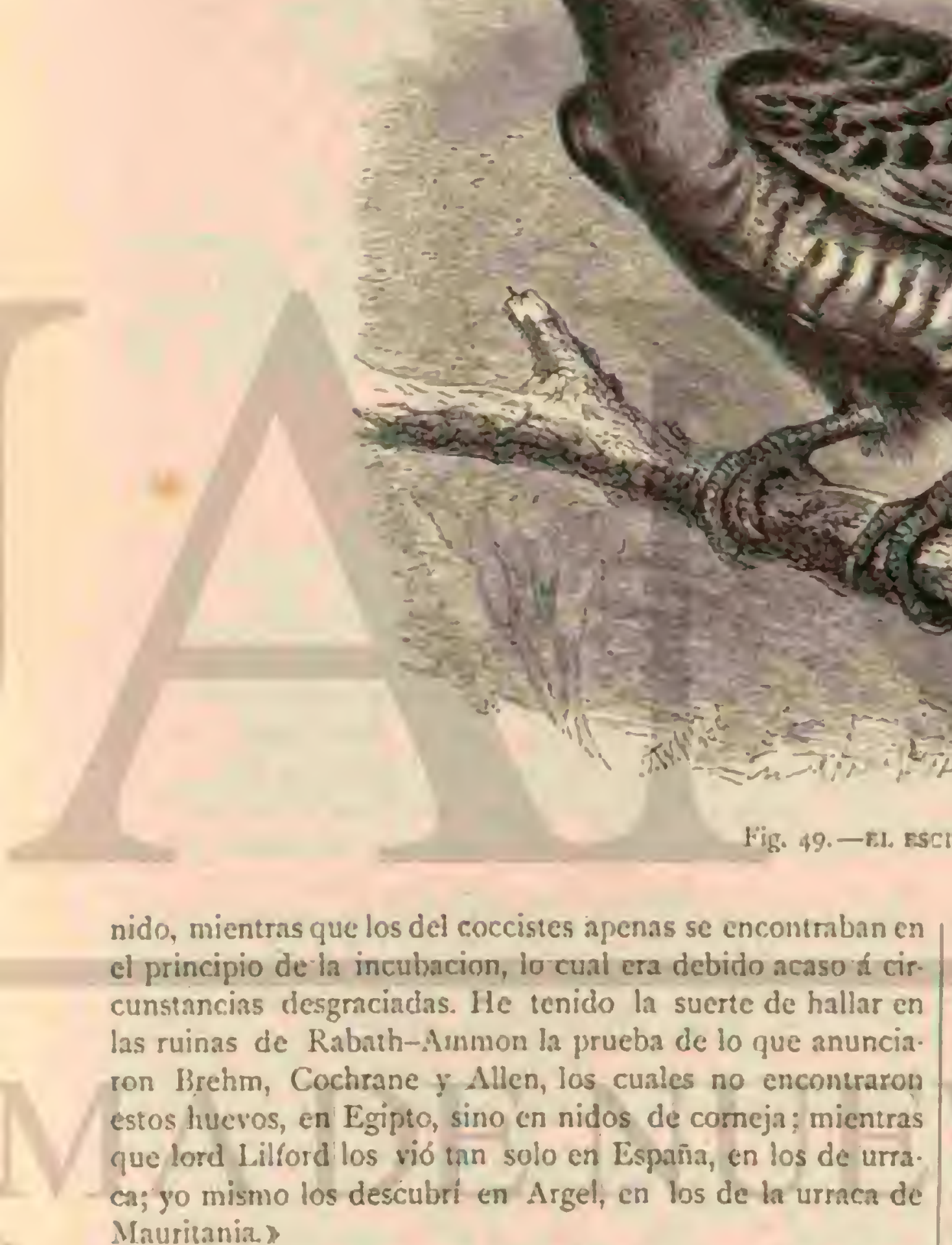

Si añadimos ahora que Liliord encontró en España un huero del coccistes grajo en el nido de un cucrvo, Rey, en Portugal, cuatro en otros tantos de la urraca azui: : que sir John, en fin, fundado en sus propias observaciones hechas en Persia, designa a la urraca como madré adoptiva natural, habremos comptetado la lista úe los padrés adoptivis del ave hasta athóra conocidos, aduciendo una prucba mas para el hecho de que estas parásitas confian sus huevos exclusiva. mente ? varias aves corvinas, sin enypollarlos nunca de por si.

En vista de todas estas experiencias, completamente con. formes, Tristran no ha racilndo, como era de suponer, en sectificar la opinion arriba ciada, declarando an $1 \$ 69$ que no puede haber duda sobre el hecho de que el coccistes grajoes un ave parásita Lin la primcra edicion de esta obra no me referi á esa decharacion por creer que este punto estaba ya completanente resuclto; pero con gran asombro veo ahora que Krueper, observador muy conocido en la Furopa oricntal y.en el Asia Menor, -viene i decirnos nueve anos despues de la citada declaracion de Tristram, que hasta ahora no se sabe nada de cicrto sobre la incubacion de ese cuciilido. En apoyo de su aserto alega que hay dos obscrveciones contra. rias, la mia y la de una sociedad inglesa de viajeros, la rial pretende que el coccistes grajo pone sus huevos en nidos de urraca y los cubre Segun la opinion de Krueper, los ornitólogos deben confirmar la exactirud de una ủ otra observacion. Entre los campesinos griegos circula el cuento de que el coc. cistes grajo pone sus hucros en los nidos de las urracas y los cubre. (Debernos esprerar, sin embargo, niade el cirado na. suralista, una afirmacion terminante, que sin duda no tasdara en darse á luz A continuacion de estos párrafos, Kruepei publica una carta de Gonzenbach, de la cual resulia que un cazador enviado por este último encontró en un nido de urracas dos polluelos de coccistes grajo y tres urmcas prequenas que podian sener unos veinte dias de edad; pero todos habian muerto à consecuencia de un pedrisco. Es posible que esta 
noticia haya despertado en Krueper dudas sobre la exactitud de mis observaciones; evidentemente no se ha fijado en lo dicho por Tristram; a pesar de lo mucho que ha observado sobre la incubacion de las aves, no ha tenido en cuenta la circunstancia de que ningun corvino, bien se llame cuervo, grajo ceniciento, urraca comun ó de Mauritania, apenas permitiria que un coccistes grajo cmpollase en su nido. Repito por consiguiente otra vezque la cuestion está completamente resuelta, y que ninguna opinion, sea de quien fucre, puede cambiar nada en el hecho. Las observaciones posteriores aumentarán nuestros conocimientos sobre la incubacion; pero no harin dudar de lo que actualmente hemos reconocido como exacto.

CAUTIVIDAD. - Allen dice que los coccistes jórenes se acostumbran pronto a la cautividad: crió uno que comia nucha carne, y i pesar de esto, gritaba siempre, pidiendo mas. El individuo de que hablo pudo ser trasladado á Inglaterra; mas no sé cuánto tiempo vivió; Allen dice tan solo haber observado que con el tienpo palidecia el color del plumaje, lo cual prueba que le consersó á lo menos durante algunos meses.

En uno de nuestros jardines zoológicos, no recuerdo en cuál, ni puedo encoutrar tampoco la noticia referente al he. cho, vi un coccistes grajo que se alimentaba de una mercla de carne, pan blanco, zanahorias, larvas de hormiga y otras sus. tancias análogas; se conservaba muy bien. Esto denuestra, en mi opinion, que el coccistes grajo resiste tan fácilmente in cautividad como el cuclillo comun.

\section{LOS EUDINAMIS - EUDYNAMIS}

CAR A CTERES. - Los individuos de este peqqueño grujo de cucúlidos tienen el pico grueso, fuerte, de arista dorsal muy curva y mandibula inferior casi recta; las patas son fuer. tes; las alas medianas, con la cuarta rémige mas larga; la cola prolongada y redondeada; el jumaje blando, de color bas tante uniforme Fil macho es generalmente negro; la hembra un poco inayor y mas ó menos manchada de negró y blanco.

DISTRIBUCIÓN GEOGRÁFICA. L Los cudinamis ha. bitan lás islas de la Occania y el sur de Asia.

\section{EL EUDINAMIS ORIENTAL-EUDYNAMIS ORIENTALIS}

CARACTERES.-Esta ave, vulgarmente llamada coel, el kiril de los indos, el kokic de los bengaleses, el koha de los cingaleses, el kiusil de los malayos, el tuliu y tschuli de los javaneses, representa la especic mas conocida. El macho tiene el plumaje de color negro verdoso brillante; el de la hembra es verde oscuro, con el lomo manchado de blanco; las alas y la cola tienen lístas de este color; el vientre, blanco tambien, prescnta manchas del mismo matiz, prolongadas en el cuello y de forma de corazon en el pecho. El ojo es de color de es. carlata; el pico verdoso claro; las patas de un azul apizarrado. El macho mide $0^{\circ}, 41$ de largo por $\left(1^{m}, 60\right.$ de punta a punta de ala; la hembra $0^{ \pm}, 46$ para la primera de estas dinmensiones, y $\left(1^{\prime \prime}, 63\right.$ para la segunda: el largo del ala varia de $0^{\circ}, 19$ á $0^{\circ}, 21$. yotro tanto tiene la cola.

DISTRIBUGION GEOGRÁFICA. - El eudinamis oriental, dice Jerdon; se encuentra en todas las Indins, desde Ceilan has!a Burmah, en las islas malayas y en Filipinas.

USOS, COSTUMBRES X RÉGIMEN. $\rightarrow$ Habita los jardines, los bosquecillos, las alamedas, los bosques de poca espesura, y se alimenta casi exclusivamente de frutas, sobre todo de higos y plátanos. Aunque no sociable, forma sin embargo reducidas tribus: no es nada tímido; cuando descansa permanece retirndo, está silencioso, pero grita al emprender su vuelo, el cual difiere del del cuclillo en no ser tan regular, pues el ave agita con mas frecuencia las alas. Hácia la época del celo, el eudinamis oriental parece mas excitado: se le ore continuamente, $y$ hasta por la noche, lanzando su bien conocido grito coll, cuel; el macho produce además otro que se puede expresar por humcihu ó hones; cuando siucla lanza un tercero mas sonoro.s

Blyth nos da noticias mas ninuciosas. El coel, si bien se parece en sus hábitos al cuclillo y tiene tambien la cos. tumbre de volar de un árbol á otro, no es muy timido, y permite por lo regular al hombre acercarse, permaneciendo in múvil para no ser observado, sobre todo mientras come. Si un árbol está cargado de frutas y el cazador se coloca debajo, podrí matar tantos que apenas le quede ticmpo para cargan la escopeta. A medida que una ú otra fruta llega á madura el coel cambia de árbol; â falta de ellas alimentase de varias bayns, las cuales devora enteras, y cuyas simientes expele despues por el pico. Para comer se reunen á menudo varios eudinamis; pero no son sociables, como no lo serin quizás tampoco todos los demás cucrilidos. Sin embargo todas estas costumures del ave cambian al acercarse el periodo del cclo entonces grita sin cesar y del modo mas terrible. Los distintos nombres que se le dan en los diversos paises son una repro ducción de su grito, que lanzado como el del cuclillo es agra dabile cuando se oje a cierta distancia; pero al fin cansa por su continua repeticion a todas las horas del dia y de la noche curando menos al curopeo. Los indigenas, sin embargo, sor dé otra opinion, pues admiran al ave principalnsente por $s$ roz; la tienen s menudo en cautividad, y diviérteles tanto como las mejóres cantoras.

Por efecio del buen trato que se le dispensa, el coel cautiv pierde pronto toda timidez y canta lo mismo en la jaula que en libertad.

- La hembra de este cudinanis, refiere Blyth, muy conoci da yopular en las Indias, parece que pone exclusivament los huevos en los nidos del corrus sflemiens y del corrus ar mimntus. Este es un hecho tan comun, que la misma person nos trajo a la vez cinco ó seis hueros cogidos en nidos dife rentes. A veces no se encuentra en el de nuestras corneja mas que uno de eudinamis, de lo cual debemos deducir ņu esta are arroja los que encuentra eu el nido donde pone pero no se sabe aun si el jóren coel tiene el instinto de tira del nido á sus cohabitantes, aunque me inclino á ponerlo e duda. Frith, en cuya experiencia tengo gran confianza, m aseguró no haber hallado nunca mas de un huevo de coele cada nido, ni los vió tampoco sino en el de las dos aves qu acabo de citar. Ha observado con frecuencia que la hembr del anomalocorax aluyjentaba de su yecindad á la del coel: hasta se dió una vez el caso de que al huir esta última de 1 persecucion, se lanzase con tal fuerza contra los vidirios d una ventana que se rompió el pico y cayó á ticrra.

- I mayor Davidson refiere el hecho siguiente: Me halla ba en el arerandal de mi bumgalari, cuando of de pronto us grito en el bosquecillo, y acudi al instante, creyendo que ba bia caido del nido un anomalocorax pequeño; pero en $s$ lugar encontré con asombro un jóver eudinamis. Acerquém y vía la pequena ave, qué gritando, y con movimientos ten blorosos, recibia el alimento que llevaba una comeja U indigena me aseguró que la madre adoptiva cria al hijuel hasta que se halla en estado de bastarse a si mismo.x

* El huevo de eudinanis mide $0^{n}, 030$ de largo y de $0^{n}, 01$ á $\left(0^{\circ}, 022\right.$ de ancho; se asemeja al de cotri (dendrocisto rufin) es de color verde accituna pálido, con manchas regulares pa do rojas, sobre todo hacia la punta gruesa, y representa verdadero tipo del huevo de los cucúlidos. 
Philipps está en contradiccion con el relato del mayor (1). vidson; Al mismo y un indigena muy instruido, acostumbrado \& la obsernacion, notaron que la hembra del coel, despues de haber puesto su huevo en un nido de corncja, se aproxima is menudo para vigilarle, con el fin de ver si lo han tirado a tierra, lo cual sucede cuando el pequeño tiene su abigarrado plumaje Enionces pucde volar, mas no satisfacer sus necesidades por si solo, y su verdadera madre es la que le mantiene en aquel monento. Philipps ha observado varias veces el hecho durante su permanencia en Gwalior: Blyth vio tambien i la hembra del eudinamis alimentar á su hijuelo; era casi adulto y estaba posado sobre una rama mientras su madre le llevaba frutos.

Lo nue parece positivo, dice Blyth en conclusion, es yue el coel pone varios huevos, en el espacio de dos 6 tres dias, lo mismo que el cuclillo, y que cuando los hijuelos son expulsados por sus padres adoptivos, su verdadera madre los alimenta aun durante algun tiempo.p Blyth siente no liaber podido recoger observaciones propias en este concepto y po. demos por lo tanto dejar á un lado las noticias de Philipps.

Ia hembra del eudinamis, niade Jerdon, pone sus huevos casi exclusivamente en el nido del anumalocurir sfiendens, y mas rara vez en el del comous culminatus; por lo regular no deposita sino uno cn cada nido, y generalmente, aunque no siempre, rompe alguno de los que encuentra. Is crecencia popular, cxtendida en la India, que d anomalocorax recono. ce el engano cuando el jóven coel es casi adulto, y que le expulsa entonces del nido; esto no es sin cmbargo la regla, pues con irecuencia he visto anomalocorax que alimentaban ¿ pequeños cudinamis despues de haber dejado el nido.

Swinhoe dice, fundándose en sus últimas observaciones, que el coel no confia exclusiramente sus huevos a las especies citadas, sino tambien à otras, si bien congenéricas de los cuervos, sobre codo de las grículas y mainas. Un roel, ob. servado por Swinhoe, dirigióse à un árbol y fué recibido por la hembra que se habia situado cerca del nido de una grácu. la; el propietario legitimo de aquel se precipito sobre los intrusos, pero le obligaron á cmprender la ruga.

CA UTIVIDAD. - En tna de mis visitas al Jardin zoológico de Londres, vi con gusto uno de Ins cudinanis renitidos por Pabu-Rajendra. Mulik, un indio aficionado a la ornitolo. gía. Esta ave se hallaba en aquella capital hacia dos airos, y en tan perfecta salud, que se podia esperar conservarla todavia mucho tiempo: alimentábanla con arroz cocido y frutas frescas ó secas. Desagraciadamente no tuve tiempo de estudiarla con detencion; me pareció muy vivaz hasta en su cautiverio, y creo que se distingue en este punto del cuclillo de Europa.

\section{LOS CRISOCOXIS-CHRYSOCOCCYX} CARACTERES. - Los crisocusis ó mudilhas dorndos, snn los cucúlidos mas bonitos, siendo su hermosura tal, que nin. gun metal presenia tan espléndidos colores como los de su plumaje; este es uno de sus caractéres mas importantes, y acaso el esencial a la especic. Tienen escasa talla; cuerpo prolongado; pico de mediana extension, bastante endeble, conformado como el del cuclillo: tarsos cortos; dedos largos; alas bastante puntiagudas, con la tercera rémige mas prolon. gada; cola larga, un poco redondeada latcralmente: plumas grandes y poco numerosas.

DISTRIBUCION GEOGRÁFICA. - Habita en las re. giones tropicales de Africa, Asia yueva Holanda.

\section{EL CRISOCOXIS DORADO - CHRYSOCOCCYX} AURATUS

CARACTÉRES. - El crisocoxis dorado, que llaman vul. gamiente didrsk ó iuclillo dorndh, liene el lomo de un color verde mesślico brillante, con refiejos cobrizos, presentando varias plumas en su borde un viso azulado, y otras una $\delta$ dos manchas del mismo color. Por delante del ojo se nota una raya blanca y otra por detrás, y en la frente una mancha del nismo color; el vientre es pardusco claro ó blanco amarillento, pero de un tinte tan delicado, que no aparece en sodo su brillo sino inmediatamente despues de la muda, pues la lur. del sol le blanquea ripidamente, en el propio individuo viro. Los dos costados, las cobijas de la cola $y$ las inferiores de las alas son de color verdoso; las primeras rémiges primarias, las secundarias $y$ las rectrices externas, de un verde oscuro, orilladas de blanco.

El ojo es de un pardo amarillo vivo, en el macho, y rojo cochinilla durante la estacion del cèlo; los párpados de un rojo coral; el pico azul oscuro, y las patas de un gris azul claro. Eil ave inide $1 \|^{\prime}, 95$ de largo por $11^{m}, 33$ de punta à punta de ala, esta tiene 1$)^{\prime \prime}$, is y la cola $11^{\prime \prime}, 085$.

Ia hembra, algo mas vequeña, presenta colores menos vivos, y manchas en el vientre: los hijuclos tienen esta parte sembrada de amarillo, el pecho yo la garganta son de un verde metílico, con pequeñas plumas compactas y sobrepucstas; las del lomo tienen filetes de amarillo rojo, y en las alas hay manchas del mismo color.

DISTRIBUCION GEOGRÁFICA. - 4he visto el didrik, dice T.e Vaillani, en la mayor parte del sur de Africa desde el rio de los Elefantes hasta el pais de los pequeños nama. queses, donde es tan comun, que hubicra podido matar miies de individuos. En mi diario de viaje veo que mi bravo Klazs y yo hemos cazado 210 machos, 183 hembras 1103 pequeños. Esta ave dista mucho de ser tan comun en el Africa rentral, donde la hemosobservado, Ruppell, Heuglin, Antinori y yo; si mal no recuerdo, únicamente la he visto en las selvas virgenes. Mis notas dicen que no se posa sino en los úrboles mas altos y copudos. Heuglin la vió en Abisinia, en las márgenes del Nilo Blanco y del Nilo Azul, en los ra. llados, en los árboles y hasta en los pucblos.

Segun dice el mismo ouservador, en el Habesch se presenta á principios de la estacion lluviosa y abanciona de nuevo su parria con los polluelos, en scticmbre ú octubre. Antinori dice que se le ve en el pais de los bogos al mediados de junio y siempre acompanado de ha hembra.

USOS, COSTUMBRES Y REGIMEN. - Vive con preferencia en la montaña $y$ habita las pendientes cubiertas de bosque, cxpucstas al sol, á la altura de 300 á 2,000 metros sobre el nivel det niar.

El crisocoxis dondo no es dificil de descubrir: el macho se hace notar por sus gritos y peleas con sus semejantes; el sonida que produce es un silbido claro que Le Vaillant ex. presa por doblisididrits y Heuglin por husilhwidhuridi. In hem. bra emite solo uma nota poco sonora, equivalente a nitikuik. con la que contesta al macho, sirviéndose tambien de ella para llamar. lin el periodo del celo, los machos son tan pendencieros y celosos como el cuclillo gris.

4 Cuando un macho deja oir su vor sonora, dice Heuglin, contéstale en seguida otro de las inmediaciones, y a menudo se ve como dus 6 tres de ellos luchan furiosos. Fil deseo de aparearse aumenta la agilidad del ave por todos conceptos. Fischer diee que el ctisocoxis dorado no se deja oir hasta meciiados de abril; quue antes de esta época permanece silencioso y solo se le ve alguna vez en los cocoteros; pero des. pues se le encuentra apareado en todas partes. Siempre inquieto, como todos los cueúlides en general, preséntase aci y allá; tan pronto aparece en la copa de un árbol como en la espesura de un pantano, joiras veces se le ve en las huertas. Su vielo es rápido y r.gil, como el de todos sus congíneres, y 
reconócese por las lineas arqueadas que describe; algunos observadores comparan este vuelo con el de la nevatilla.

En el estómago de los individuos disecados por Fischer se encontraron orugas vellosas bastante grandes, prueba que tambien en este concepto el crisocoxis dorado se parece á sus congéneres. Le Vaillant encontró ochenta y tres huevos de di. cirik en aves insectiroras, observando que la hembra cogia el suyo con el pico para licvarle al nido elegido por ella. $\Lambda$ una mera casualidad debio el descubrimiento de este hecho: ha. biendo matado una hembra, y como quisiera introducirle un tapon en la garganta para impedir que la sangre manchara las plumas, encontró un huevo, que era de color blanco brillante. Heuglin abservó en los ovarios de dos hembras disecadas por él en julio jo setiembre, oriductos casi llenos, y vió un gran número en ria de desarrollo.

Tambien sobre la reproduccion de este cucúlido tenemos parias noticias. Mientras que Le Vaillant y dyres dicen que no cubre el mismo sus huevos, Heuglin, Antinori y Fischer se inclinan a suponer lo contrario. Heuglin no ha podido asegurarse si el crisocoxis dorado y sus congéneres mas próxinos incuban por si mismos 6 no. En el primer caso, dice, y segun mis observaciones, los padres se cuidarian de los pequeños cuanda estos salen del nido, pues en octubre de 186 , he visto varias veces, cerca de Keren, como unos crisodoxis dorados adultos alimentaban á otro que ya jo dia volar un poco y que estaba-posado en la copa de un arbusto bajo; los adultos eran sin duda sus padres: una vez vi hasta dos pequeños juntos, pero de diferente edad. Anti. norino ha podido inacer tales observaciones, pero un criado etiope de Munzinger le dió una noticia segun la cual parece que el ave incuba de por si. Cierto dia se cogió un criso: curis en un cascron que Munzinger utilizaba como cua. dra, y el criado que se cuidaba de los animales aseguró á Antinori que en los años precedentes una pareja de estos cucúlidos, quizas los mismos individuos, habia anidado en la paja del teclao de dicho caseron. Con ambas noticins esta conforme la de Fischer. Este turo ocasion de observar mi. nuciosamente al crisocoxis dorado desnues de haber lia. mado este su atencion con sus gritos Unna parcja de esas aves que visitaba al principio todos los dias un jardinillo situado en medio de la ciudad y circuido por todos lados de muros, anidó mas tarde en los arbustos del citado jardin. 2 lil nido, me escribe Fischer, con Tecina 4 de mayo de $187 \%$ está ya concluido, y espero por consiguiente poder enviar á usted el nido $y$ la puesta de este cucúlido si el propietario del jardin me lo permite Esto probaria que el crisocoxis dorado cubre por si mismo sus huevos.

\section{LOS ESCITROPES-SCYTHROPS}

CARACTÉRES.- - I os escitropes son los mayores cuch lidos que se conocen, distinguiéndose por su pico, por el cual se les considera como un tránsito entre los cuclillos y los tucanes. Dicho órgano, mas largo que la cabeza, es grande, fuerte, grueso, bastante ancho y alio en su raiz, comprimida lateralmente, de cresta dorsal en extremo encorvada y con la punta de las dos manábulas ganchuda; segun la edad, la superior presenta surcos longitudinales, mas ó menos marcados, que terminan hicia el borde maxilar con pequeñas escoiaduras dentadas. Las patas son fuertes; los tarsos cor tos, y los dedos vigorosos aunque no muy largos. Las alas, cuýa tercera rémige es mas prolongada, cubren casi la mitad de la cola, relativamente corta, redondeada y compuesta de doce pennas. El plumaje es abundante, recordando su color al del cuclilio: Ia linea naso ocular $y$ la region ocular carecen de plumas.

\section{EL ESCITROPE GIGANTE-SCXTHROPS NOVAE HOLLANDIAE}

CARACTERES, - El escitrope gigante, 6 de la Nueva Holanda (fig. 49), única especie conocida del género, tiene la cabeza, el cuello y el pecho de color gris; el lomo, las alas y la cola de un verde accituna, terminando cada pluma yor una ancha faja pardo negra; en la rabadilla lleva otms poco marcadas de color gris pardo; las rectrices son de un gris plomo oscuro en su cara dorsal; las cuatro externas blancas en su cxtremidad, con una ancha faja negra por delante del tinte blanco, y surcado el resto de la pluma de rayas finas: el ojo es pardo, rodeado de un círculo desnudo rojo escarlaia; el pico es amarillento y las patas de un pardo aceitunado. La hembra solo se distingue por ser un poco mas peque. ña: el macho mide mas de $0^{\circ}, 6_{j}$ de largo, el ala $0^{\circ}, 34$ y la cola $0^{m}, 26$.

DISTRIBUCION GEOGRÁFICA.-Segun me escribe de Rosenberg, el escitrope gigante no habita solo en la Nueva Holanda, sino tambien en la Nueva Guinea, en las Célebes, Ternate, Ceram y las islas de Aru; Gould le enconiró en la Niueva Gales del sur, donde es ave de paso que se presenta en octubre y desaparece en erero.

USOS, COSTUMBRES Y REGIMEN. - Latham dice que se le ve comunmente por manana y tarde, formando tribus de siete á ocino individuos, y mas á menudo en parejas: por su asjecto, costumbres y movimientos, por el régimen y manera de reproducirse, se ascmeja notablemente al cuclillo gris.

Cuando está posado su aspecto es magnifico, sobre todo al catcuder su larga cola en forma de abanico; su vuelo recuerda ámenudo el de un gran halcon. Fil primer escitrope gignure que Bennett mató en el Jardin de plantas de Sidney parecióle al fironto un halcon. Así como una de estas ares, trazaba circulos en la altura, interrumpiendolos á veces para revolotear muy cerca de las copas altas de los eucaliptos y casuarinos; tambien daba vucltas al rededor de estos árboles, describiendo circulos enteros, ó dirigiéndose de una rama á otra, ocupado siempre en buscar langostas y otros grandes insectos, los cuales cogia de las hojas y hasta del tronco mismo; á veces producia un grito y revoloteaba con las alas tendidas, tal como suclen hacerlo los halcones. Lo mismo grita cuando vuela que en cstado de reposo; pero sobre todo si divisa un halcon ú otra rapaz

Elsey, que observó esta ave en el norte de Australia, dice que sostiene á menudo por espacio de cinco minutos su grito planiidero. A veces, no parecia inquietarse lo mas minimo por nuestra presencia: pero era muy timido comunmente; no se posa jamás en tierra; yo no le he visto nunca sino en la copa de los árboles mas altos.

El estómago del individuo muerto por Bennett contenia una infinidad de escarabajos dorados y grandes langostas. En el estómago de otros escitropes se encontraron ademús frutas y simientes, sobre todo las del cucalipto rojo y las del árbol de la menta.

No conocemos aun bien los detalles relativos á su manera de reproducirse, si bien parece probada gue tambien el esci. trope confia sus huevos al otras ares. Gould vio un pequeño al que alimentaban dos individuos de otra especie: Strange encontró en el oviducto de una hembra muerta por êl, un luevo perfectamente formado; era de color gris con manchas y pumtos de un tinte pardo negruzco.

CAUTIVIDAD.- Un pequeño escitrope, que observó Bennett, lué puesto en la misma jaula con un martin pescador gigante; abrió la boca como si tuviera hambre, y compa. decido sin duda su compañero, cogió un pedazo de carne, 
trabajóle con su pico para ablandaric suficientemente, y se lo dió á su protegido, continuando asi hasta que el pequeño pudo comer por si solo. La primera vez que le vi, dice Bennett, hallábase en lo alto de la jaula; levantóse agitando las alas y se posó de nuevo como lo hacen ciertos halcones, con los cuales ofrece, por otm parte, cierta semejanza. Cuando le llevan de comer por la mañana baja al piso de la jaula, pero vuelve á subir inmediatamente á su lugar. Segun lo que yo observé, inclinome a creer que estas aves se domestican facilmente en cautividad.

\section{LOS FENICOFEINOS-PHGNICO- PHIIINAE}

CARACTÉRES. - Estos cucúlidos tienen el cuerpo pro. longado; cola larga; patas cortas, lo mismo que las alas: pico vigoroso, de mediana longitud; la region ocular suele pre. sentarse desnuda; el plumaje reviste vivos colores; las plumas afectan con frecuencia el aspacto de pelos.

DISTRIBUCION GEOGRÁFICA.-Esta familia está representada principalmente en las Indias é islas adyacentes: solo una especie habita el Africa.

USOS, COSTUMBRES Y REGIMEN. - Poco sabemos acerca del géneto de vida de estas aves: solo ha llegado à nuestro conocimiento que habitan en el seno de los mas es. pesos bosques y lejos de los lugares habitados; que liujen del hombre, que se alimentan sobre todo de insecios, $y$ que probablemente cubren sus huevos.

\section{LOS FENICOFEIDOS-PH@NICO- PHAES}

CARACTERES. - I as ares de este género tienen el pico muy comprimido y las dos manảibulas encorvadas; los tar- sos medianamente largos; los cicdos cortos, de unis punti agudas; las alas cortas y redondeadas, con la cuarta, yunina y sexta rémiges casi iguales ; mas largas que las otras; la cola muy larga y cónica.

\section{EL FENICOFEIDO TRISTE-PHCENICOPHAES TRISTIS}

CARACTÉRES. - El fcnicofeido triste, kokil ó bal: kokil, segun le llaman los bengaleses, es conocido desde que Jer. don publicó su descripcion. Tiene el lomo de coior gris verde oscuro; la cabeza y el cuello de un tinte agrisado; la cola y las alas con visos verdes; las rectrices blancas en la cxtremidad; la garganta y el pecho de un gris claro; el vien. tre $y$ un circulo que rodea la region ocular, blancos; el ojo pardo oscuro, y la parte desnuda que le rodea de un rojo escarlata inienso; el pico verde manzana, y las patas de un azul apizarrado verdoso. Esta ave mide $6^{m}, 60$ de largo, el ala ()$^{2}, 17$ y la cola $6^{n}, 4^{2}$.

DISTRIBUCION GEOGRAFICA.- E El ienicofeido triste, dice Jerdon, se encuentra en Bengala, en la India central, en los valles del Himalaya, en el Assam, Burnah y Malaca, donde es muy comun.

USOS, COSTUMBRES Y RÉGIMEN. - Le he visto comunmente solitario, recorriendo los bosques, y cazando langostas, grillos jo otros insectos. In el Sikin se le encuen. tra solo en los valles cílidos, á unos 1,000 metros solure el nivel del mar.

* Unin vez me dieron dos huevos largos de color blanco muy puro, diciéndome que eran de esta ave; pero jamás he visto su nido, que acaso se compone de ramas y raices. He hallado un huevo semejante en el oviducto de una hembra que mate.

Blyth dice que esta ave revela á menudo su presencia por su monótono grito /scruk, repetidó varias reces.

Al hablar de otra especie, Crould asegura que no le gusta volar, y que no franguea jamás grandes espacios de una sola vicz.

Algunos naturalistas han supuesto que estas aves comen frutos; pero Jerdon dice terminantemente que no lo ha visto nunca.

Hé aqui todo cuanto sabemos accrea del género de vida de los fenicofeidos; 5 yor lo tanto me parece inútil describir otras especies.

\section{LOS COCCICIDOS-COCCYGINA:}

CARACTÉRES. - Los coccicidos tienen el cucrpogrue. so; alas mas ó menos cortas; cola muy larga, compuesta de die pennas, y excepcionalmente de doce; pico bastante vi. 
goroso; tarsos altos, lo suficiente en algunas especies para que puedan vivir en tierra. El plumaje es muy blando: la hembra tiene los mismos colores del macho, y por lo regular es algo mayor. L.os hijuelos apenas difieren de los adultos.

DISTRIBUCION GEOGRAFICA.-Estas aves habitan toda la América, principalmente en la del sur. En la fauna del Nuevo Mundo son los equiralentes de los cucúlidos en la del antiguo.

USOS, COSTUMBRES Y RF́GIMEN.-IOS coccicidos viven en los bosques of en las arboledas: son timidos y aficionados á la soledad; permanecen comunmente en las mas intrincadas espesuras; deslizanse con destreza en medio del ramaje y de vez en cuando bajan i tierra Se alimentan de insectos y frutos; pero comen sobre todo orugas vellosas. Saquean los nidos de las avecillas, ó por lo menos haceir caer los huevos; mas en cambio no malogran ninguna cria pará poner los suyos, pues por lo regular cubren ellos mis. mos, y parece que no depositan sus huevos en nidos de oiras aves si no les obliga dallo la necesidad.

\section{LOS COCIZOS-COCCYZUS}

Se asignan á este género los siguientes caractéres: pico tan largo como la cabeza, endeble, comprimido, ligeramente encorvado y agudo; tarsos cortos; alas largas, muy obtusas, con la tercera rénige mas prolongada; cola larga, cónica, compuesta de diez pennas angostas y redondeadas en el ex. tremo.

\section{EL COCIZO A MERICANO-COCCYZUS AMERI- GANUS}

CA RACTÉRES. - El cocizo americano, llamado vulgarmente cuclillo de Ins llurias, que nos han dado á conocer wil. son, Audubon, Nuttall y otros observadores, tiene todo el lomo de color pardo claro, comprendidas las cobijas de las alas y las rectrices medias; el vientre blanco agrisado; las barbas internas de las primeras réniges orilladas de amarillo naranja, que tira al pardusco; las rectrices, excepto las inedias, son negras con la punia blanca, y las mas laterales de este último color en las barbas externas; el ojo es pardo os. curo; la mandibula superior de un negro pardusco, la inferior amarilla; las patas de un gris plomo. Esta ave mide $0^{m}, 33$ de largo por $U^{m}, 4^{2}$ de punta á punta de ala; esta tiene $6^{n}, 15$ y la cola $6^{\circ}, 175$ (fig. 50).

DISTRIBUCION GEOGRÁ FICA.-Esta ave seextiende sobre todos los Estados Unidos, desde el Canadá hasta la Florida y desde el Atlantico hasta el Pacifico; hallase tambien en el sudoeste de Texas y en todas las grandes Antillas, donde á veces anida. Newton encontró su nido en In isla de San ta Cruz; Gosse, en la Jamaica; Gundlach y Lempeye en Cuba; y Salvin en la América central. El área en que anida se extiende por consiguiente desde el Canadi y Minnesota hasta Florida, y desde Nueva Brunswick hasta Texas. En las partes meridionales, este cucúlido se aleja muy poco de su residencia habitual, mientras que en el norte es are de paso.

USOS, COSTUMBRES Y REGIMEN. - IEI extran. jero que en los meses de mayo y junio recorre los bosques de los Estados Unidos, dice Wilson, ore à veces sonidos guturales y profundos, que parecen cxpresarse por kas kas; comienzan lentamente y acaban por precipiarse de tal modo, que las noias parecen coniundirse. Se ojen estos gritos sin ver al ave que los produce, porque esta es timida, amante de la soledad, y busca siempre la mas enmarañada espesura. Aquel es el imelillo de pico amarillo ó cuilillo de las llsuras, ave de verano en aquel pais. Llega a los Estados del centro á mediados de abril, y á los del norte á fines de este mes, ó \& principios de mayo, permaneciendo alli hasta setiembre. En esta época se reune con sus semejantes, y forma grandes bandadas, que se dirigen todas hảcia la América central para pasar el invierno. Estas bandadas emigrantes son inmensas y se extienden en un vasto espacio; las aves que las forman van unas detrás de otras, pero no les une ningun lazo comun, si estalla un huracan puede suceder que busquen un refugio en las pequeñas islas diel mar de las Antillas, en cuyo caso recorren una considerable distancia. Asi se explica que Hurdis viese á una bandada llegar en el mes de octubre álas Bermudas: formábanla miles de individuos, y parecia impelicia por un fuerte viento del sudoeste, acompanaco de lluvia; los cocizos se posaron en las breñas de la custa meridional de la isla; pero al dia siguiente desaparecian ya, continuando su camino.

En la primavera se encuentra esta ave en toda la América, y cuando se conocen sus costumbres no es dificil observarla, pues abunda muclso en ciertas localidades. Las mas de ellas se fijan en los bosques, aunque un gran número elige tambien las inmediaciones de las casas; penetran en los huertos y jardines, y los machos anuncian bien pronto su presencia con los gritos kou ku kuk ó kuk, repetidas continuamente. «lin tiempo caluroso, dice Nuttall, gritan horas enteras sin parar, y hasta por la noche.

Coues compara el grito con el del buho de las cuevas, y asegura que la semejanza produce fácilmente errores. Segun las observaciones de Cooper, se parece tambien al grito del sapo.

El cocizo americano se desliza mas bien que corre: en las ramas se mueve con tanta ligereza como el paro: rara ree se posa en tierra, y si lo hace, da saltitos con increible torpeza. Vucla rápida y silenciosamente, aunque no suele ir léjos, y se detiene en ol primer árbol cuyo espeso follaje le ofrezca alguna-seguridad. Audubon dice que cuando circula en medio del ramaje, enseña tan pronto el vientre como la espal. dia. Alinéntase de insectos y frutos, sobre todo de mariposas, langostas y orugas velludas; en el otorio come bayas. Se le acusa, y acaso con razon, de robar los nidos de las avecillas.

Coues considera á este cucúlido como ave timida que habita con preferencia el alto bosque, aunque frecuenta tambien los parques grandes $y$ frondosos, por mas que se hallen en medio de las ciudades. Por lo regular se oculta siempre en. tre las ramas; solo cuando persigue á un insecto por los aires se la ve distintamente, pues entonces, el color gris metálico de su plumaje brilia al reflejarse el sol, resaltando vivamente su parte inferior blanca. Mas s menudo se la oye que se la ve, pues cuando pasa de un árbol á otro hácelo con sigilo. Cuando grita permanece inmóvil como una estatua mucho tiempo en el mismo sitio, y del mismo modo procede cuando observa un objeto sospechoso. P'arece que es bastante curiosa, ó por lo menos se la ve mirar á menudo fijamente en el interior de la espesura mas cnmarañada, cual si quisiera reconocerlo todo. Por su costumbre de saquear los nidos es en extremo odiada por todas las aves pequeñas, que la persiguen con tanta saña como a nuestro cuclillo tan luego como se pre senta.

Su manera de reproducirse demuestra que la especie conserva cierto lazo de parentesco con los cuclillos, pues se encuentran $\{$ veces sus huevos cr nidos de otras aves. Nuttall hallo uno en el nido de un burlon, y otro en el de un torcio viajero; pero lo mas curioso es que la hembra cubre al momento el huevo que ha puesto, y por lo tanto no salen á luz todos los hijuelos al mismo tiempo. Su nido, situado en una rama horizontal, sucle estar á la altura del hombre, y se com. 
pone de ramas y verbas; es plano y se asemeja al de la paloma comun. Los huevos, en número de cuatro ó cinco, tie. nen forma prolongada 5 color verde viro.

\&allándome en Charleston a principios de junio de $\mathrm{I}_{37}$, dice Auclubon, suplicóme M. Rheit que fuese a su posesion para ver un nidn: estaba en medio de un airbol de mediana altura, y pudo alcanzarlo fícilmente el hijo de dicho seivor. Un cuclillo adulto que alli habia no abandonó el sitio hasta el momento de it a cogrerle; huyó silenciosamente á otro árbol y entonces se vieron dos hijuclos, quue pudiendo ya volar, sal. taron apresuradamente para trepar por las ramas, donde fue. ron cogidos. Presentáronme el nido despues, y vi que contenia otros tres cuclillos pequeños, aunque de talla distinta: el mas pequeño acababa de salir á luz; el segundo no contaba sino algunos dias; el tercero tenia casi todas sus plumas, y una semana mas tarde hubiera podido volar. Además de esta cria, encontritonse dos huevos: uno de ellos contenia un cmbrion, y el otra acababa de ser depositado. Comparando todos los pequeños, no encontramos dos de la misma talla, y por lo tanto debian haber salido del cascaron en diferentes épocas, reconociéndose que los mayores tenian por lo menos tres semanas mas que los otros. M. Rhett me asegurd haber observado el mismo hecho, refiriéndome que una pareja llegó a poner once huevos y crió otros tantos hijuelos en una sola estacion.

El descubrimiento del citado natumlista fuć confirmado mas tarde por Hrewer. Lla hembra, escribe este último, co. mienza a cubrir apenas pone el primer huevo: he hallado en el mismo nido uno recien depositado, y otro del cual iba salir el pollo. lambien he cogido huevos a punto de abrirse, que se hallaban junto á los pequeños acabados de nacer y con otros que comenzaban a volar.s. Estos hechos son muy interesantes y creo que no se han dado linsia ahora a conocer.

Segun las observaciones de Nuttall, bastante minuciosas, el cocizo americano suele abandonar los huevos cuando los tocan antes de haber comenzado á cubrirlos; en cambio ma nifiesta el mayor cariño \{ su progenic, y acércase tanto al hom bre cuando esie In inquicia en su nido, que se le puede coger casi con la mano. Así como hacen otras aves, el macho 6 la hembra se precipitan en tal caso al suelo, revolotean, revuél. canse, fingen cojear y vilcnse de toda clase de ardides para llamar la atencion del intruso, produciendo al propio tiempo lastimeros sonidos guturales que por lo regular no se oyen. Mientras la hembra empolla, el macho vigila, posado en una raua inmediata y avisa a su companera si ve algun enemigo. Cuando los polluclos saien del cascaron, los padres se ocupan en alimeniar á su romz progenic. Newton confirma las noticias de Nuttall, pero además ha observado un caso de frdelidad conyugal digno de citarse. Habia dispando un tiro á un macho, y cuando este cayoo al suelo gritanda, presentóse a) punto la hemorn y contenzó a revolotear junto al suelo comosi su jrogrenic estuviers en peligro. Lin nido encontra do por este último observador $y$ mal oculto en una rama baja, era tan pequeio, que solo bastaba para coniener los tres huevos, pero no la hembra que los cubria. lista no se levanto hasta que Newton labo parado con su caballo casi delante de clla, tocándola con el lítigo. Nuttall cree que el cocizo americano empolla mas de una vez al ano, pues ha enconirado huevos aun 1 fines de agosto; tambien dice que este cucúlido pone á veces en nidos de otras aves.

Dice que ha encontrado un huevo en el nido del galeos. coses de la Carolina, y otro en el del mirlo migrazorio. Nin. gun otro observador ha referido semejanie cosa.

Como en América no se le da caza, explicase ficilmente que sea muy confiado: por otra parte, comprende bien pronto las intenciones del hombre, y la experiencia le obli- ga a ser prudente. Audubon asegura que suele atraparle el halcon.

\section{LOS SAUROTEROS - SAUROTHERA}

CARACTÉRES. - Se distinguen por la conformacion del pico, mas largo que la cabeza, casi recio, delgado, comprimido lateralmente $y$ de punta ganchuda; los tarsos son cortos y raquiticos; los dedos largos y delgados; las alas de mediana longitud y obiusas, con la cuarta, quinta y sexta rémiges mas largas; la cola, bastante prolongada y sumamenie cónica, se compone de dicz pennas redondeadas en la extre. midad.

\section{EL SAUROTERO VIEJO - SAUROTHERA VETULA}

CARACTERES. - El nie de llwiti, como llaman i este saurotero en la Jamaica, ricne el lomo gris oscuro; la cara inferior del cuerpo de un amarillo leonado que tira al ceni. ciento claro en el pecho yalgo gris amarillento en el vientre; las diez primeras rémiges son de un rojo pardo claro, y pardo amarillento en su extremidad; las dos rectrices medias grises con visos rerdosos; las laterales de un pardo negrurco y blan. cas en la punta. Eil ojo, de color pardo, esiá rodendo de un circulo rojo escarlata; el pico es negruzco y las patas de un negro azulado: los dos sexos tienen el plumaje igta!. El ave mide 0 " 40 de largo por $10^{m}, 36$ de punta a punta de ala; esta tiene $0^{\circ}, 12$ y la cola $0^{2}, 87$ (fig. 51 ).

\section{DISTRIBUCION GEOGRAFICA.-El sauroiero viejo} es propio de Jamaica.

USOS, COSTUMBRES Y RÉGIMEN. - Uno $\delta$ doS dias despues de mi llegada a la Jamaica, refiere Gosse, em. prendi con un jóven una cxcursion a cierta colina cubierta en parte de una espresura poco menos que impenetrable; y al llegar, observé á pocos jasos de nosotros un ave extraña que parecia examinarnos con vivo interés. Mi joren companero me dijo que ern el air de llario ó Timis el loro, segun se le llama por su curiosidad; sin añadir palabra, cogió una piedra y la tiró tan acertadamente, que el ave cayó en tierra y la pude coger.

- Mas tarde he visto con frecuencia \& Tombs el lero, siem. pre saltando de rama en rama y mirando á los que se acercan, sin alejarse mas que algunos pasos cuando le asustan, para repetir luego el mismo ejercicio. Encuéntrase por todas partes en los tallares, segun se colige ya al ver sus alis cortas y cóncarras como las de las gallinas. Vuela poco, y solo para trasladarse de un árbol \& otro: prefiere trepar y saltar en medio del ramaje, y cuanda cstá en los aires, deslizase casi en linea recta sin agitar las alas. A nicnudo se le re posado sobre el ramaje en una postura curiosa, con la cabeza mas baja gute las patas y la cola vertical. Una vez posado, pro. duce á iniervalos un grito bastante sonoro, emitido siempre en el mismo tono, pero con mas 6 menos rapidez, el cual se puede expresar con las silabas tiki tikj fiki, pronunciadas con toda la celeridad posible. Algunas reces grita cuando vuela; con bastante frecuencin se le ve en tiersa, donde se mueve a saltitos, llevando la cabeza baja y la cola un poco levan. tada.s

Esta ave se'alimenta de insectos de toda especie, de pequeños vertebracios tales como ratones y ligartos. Robinson halló en el estómago de un individuo uno de aquellos reptiles, de $10^{*}, 2$ de largo, arrollado de tal suerte, quue la cabeza aparecia hícia la mitad del cuerno. El ave destroza primero la cabeza del lagarto, y se lo traga despues entero, comen. zando por ella. 
Gosse encontró un nido de saurotero en la bifurcacion de una rama; componiase de raíces, musgo y hojas, y conte nia un huevo con manchas sobre fondo claro. Hill le refirió que antes del apareamiento el macho declara su amor con graciosos movimientos; entreabre la cola y las alas y eriza el plumaje.

CAUTIVIDAD. - Los individuos viejos que Hill conser vó enjaulados, vivieron algunas semanas, alimentándose con insectos y carne. $\mathrm{Al}$ jrincipio gritaban continuamente, esta ban furiosos y procuraban dar picotazos.

Segun Gosse, tiene una resistencia vital notable, pues at durns f enas pudo rematar \& un individuo que hirió.

\section{LOS GEOCOCCITES}

\section{- GEOCOCCYX}

CARÁctéRES. - Estos cucullidos, unos de los mas singulares de todos, se distinguen por su gran tamano. El pico, unas largo que la cabeza, y comprimido lateralmente, encór yase en la punta en forma de gancho: las patas son muy largas; los dedos cortos y provistos de grandes unas; los piés cstán cubiertos de placas en su parte anterior; las alas son en extremo cortas $y$ convexas; la quinta, sexia y séptima rémiges son de igual longitud $y /$ sobresalen de todas las deinás; la cola, larga y escalonada, se compone de plumas cstrechas; el plumaje, abundante y-suave, se prolonga en el occipucio en forma de moño; la region que rodea el pico está cúbierta de cerdas.

DISTRIBUCION GEOGRAFICA. - Los geoccocites son exclusivamente propios del mediodia de la Auérica del norte.

\section{EL GEOCOCCITES DE CALIFORNIA} -GEOCOCCYX CALIFORNIANUS

CARACTERES. - Esta especie, una de las mas grandes de la familia, puede alcanzar una longitud de $0^{\circ}, 50$ a $0^{\prime \prime}, 60$, contándose la cola por $\theta^{m}, 31$ á $\theta^{*}, 35$; las alas solo mi den $11^{\prime \prime}, 17$. Fil plumaje es abigarrado, pero de colorés oscu. ros; la parte superior, de la cabeza es negra, presentando cada pluma un ancho borde rojizo; sobre los ojos se corre una faja de color claro, formada por las puntas blanquizcas de las plumas; la nuca es negra, con sus plumas orilladas en los lados de un tinte rojizo; los lados de la cabeza son blanquircos, con una linea poco marcada en la region de las orejas, aunque de color oscuro; el pecho es de un tinte de orin, y el resio de la parte inferior blanquizco; la rabadilla pardo gris. Las rémiges son negras, con brillo metálico ver. doso: las posteriores del brazo ostentan, así como las tectri. ces superiores de las alas, anchos bordes blanquizcos en los lados; las barbas exteriores tienen en el centro $y$ en la cx. tremidad manchas de color blanco, y tambien las puntas de las tectrices de las alas ofrecen el mismo color; estas fajas forman tres lineas trasversales de matiz claro que se cor ren sobre las alas; las plumas caudales son de un color vio líceo azulado de acero, con la extremidad blanca; las dos del centro verdosas y bordeadas de blanco en los lados. El iris es pardo; los circulos oculares desnudos y amarillos: el pico y los piés de un azulado claro.

DISTRIBUCION GEOGRÁFICA.-El geococcites de California habita en las regiones situacias entre el médiodia de California y el centro de 'Texas hasta México.

USOS, COSTUMBRES Y REGIMEN.-Esta ave es muy conocida en su patria, no solo por sus extrainas formas, sino tambien por sus costumbres singulares, $y$ tanto los indigenas como los blancos la designan con diferentes nombres. Estos últimos la llaman en México el campesino ó corredor de caminos: en Texas, gallo de las estepas; en Cali. fornia, en fin, cuclillo lerrestre. Se le encuentra á menudo en todo el norte de Mféxico, en Texas y California, sobre todo en algunas regiones como por ejemplo trizona y Nucro MIExico. Sus alas cortas le obligan á volar lentanjente; pero en cambio sus largas piernas le permiten correr con rapidez en tierra. Es una de esas aves, que solo en caso de apremiante necesidad abandonan un territorio para trasladarse á otro. Poco sociable, siempre vive aislada, vagando por su localidad tan oculta y silenciosamente como le es posible. Cuando no se la inquieta, se la ve pasear tranquilamente con la cola er. guida s la parte anterior del cuerpo un poco inclinada, pero tambien toma otras muchas posiciones. De muy diferente modo se conduce cuando se ve amenazada: en la carrera puede competir casi con un caballo, ó cuando menos ro la aventaja por este concepto ninguna aye norte-americana, pues puede car saltos de tres metros, y franquea de uno solo gran. des espacios, aunque solo extiende las alas un momento para ayudarse. En cuanto a su vuelo, como tiene tan cortas las alas, raras veces se eleva a mas de dos unctros sobre el suelo, Los mexicanos organizan á menudo cacerias que tie. nen por objeto, mas bien lucir la habilidad del jinete en la carrera con un ave tan ágil, que no comer su carne.

El coronel Mac Call refiere que, observando en cierta ocasion uno de estos cucúlidos en un camino llano, habia co. menzado áperseguirle: el ave se hallaba á unos cien metros de distancia delante del caballo, y emprendió la fuga al ver que este la perseguia. Mas de cuatrocientos metros recorrió el jincte detrás del geococcites, que saltaba con la cabeza tendida y las alas un poco entreabiertas; el coronel no pudo alcanzarle, y cuando al fin el ave se refugio en una espesura, no habia perdido mas que cincuenta metros de su ventaja Dresser ascgura haberle cazado muchas veces de igual ma. nera, pero nunca le vió servirse de las alas, ni aun en la fuga maś rípida.

El alimento ordinario del geococcites de California se com. pone de roda clase de insectos y moluscos, sobre todo cara. coles. Sucle llevar estos últimos à ciertos sitios para quitarles la cáscara, y por eso se encuentran muchas reces en los bosques habitados por estos cucúlidios restos de sus comidas. Tambien ataca á los pequeños vertebracios, sobre todo repri. les, á lo cual se debe que los mexicanos le consideren como un útil enemigo de la tan temida y odiada serpiente de cascabel, a la cual vence sin dificultad, por lo menos mientras es jóven. Gracias a su agilidad en saltar, este cucúlido se apodera a menudo tambien de una presa al vuelo; ninguna especie de su familia le iguala en voracidad y en instintos carniceros. La única roz que hasta ahora se ha reconocido en el geococcites de California consiste en un grito débil 6 un arrullo muy semejante al de los palomos; producele muy pocas veces, $y$ cuando lo hace, levanta el mono y la cola.

Carecemos de noticias minuciosas sobre la reproduccion del ave. Hermann encontró un nido hecho i la ligera con ramas en medio del follaje de una cactea, al cual contenia dos grandes hueros blancos.

CAUTIVIDAD. - lil cario que los mexicanos profesan al geococcites de California se explica por la facilidad con que se deja domesticar. Se le tiene á menudo en cautividad, y el are se acomoda al poco tiempo con su nuevo género de vida; no solo se le puede permitir correr à su antöo por la casa, sino tambien pascarse por el patio y el jardin.

Una vez domesticado es de gran utilidad, porque extermina los ratones, las jequeñas serpientes y otros reptiles sectos de toda clase. En varios individuos se ha observado que juegan con su presa como un gato con el raton, derorán. dola despues sin quitar los huesos y el pelaje. Dresser tenia 
un macho cautivo, al que no podia dejar solo, porque robaba toda clase de objetos ó los destrozaba jugando. Proiesaba la mayor aversion á un loro domesticado y erizaba las p!umas tan luego como le dejaban libre; enfureciase en alto grado, ! se retirnba al tin á la casa de un vecino ó á su lugar farorito de descanso.

\section{LOS CROTOFAGIDOS-CROTOPHAG E:}

CARACTERES.-LOS crotofagidos tienen el cuerpo prolongado, y sobre el pico una arista saliente; patas vigorosas; slas medianas; cola larga, ancha, redondeada y compuesta de ocho pennas; el plunnaje, compacto y mas ó menos brillan. te, está formado de plumitas; rodean la raiz del pico algunas sedas; la linea naso ocular y la region ocular aparecen desnu. das. El interior de la mandibula superior esta hueco, $y$ la parte cómea se compone de células de paredes muy deigndas, como en los iucanes y les bucerotidos. Los crotongidos se asemejan tambien á los primeros por su compacto plumaje, que les hace parecer delgados; y establecen en cierto modo un trånsito entre los cuculidos y los tucanes.

DISTRIBUGION GEOGRÁFICA.-- Esta familia poco numerosa habila en la Amćrica ceniral y meridional.

USOS, COSTUMBRES Y RÉGIMEN.-El géneto de vida de los crotofngidos dificre del de los cucúlidos, y arrece mas analogia con el de las urracas y las cornejas, ó de los tucanes. Se les ve siempre reunidos, cerca de las casas y en medio de los bosques de las estepras; preficren el fondo de los valles, en las pmodens humedas, donde pueden estar cerca de los ganados. No les inspira temor el hombre, y hasta demuestran à menudo una imprudencis incomprensible.

La manera de reproducirse no deja de ofrecer alguna sin. gularidad; gencralmente hablando ambos sexos cubren jumtos y hasia se da el caso de que varias hembras ponen en el mis. mo nido; emp̧ollan a la vez y crian sus hijuelos en sociednd.

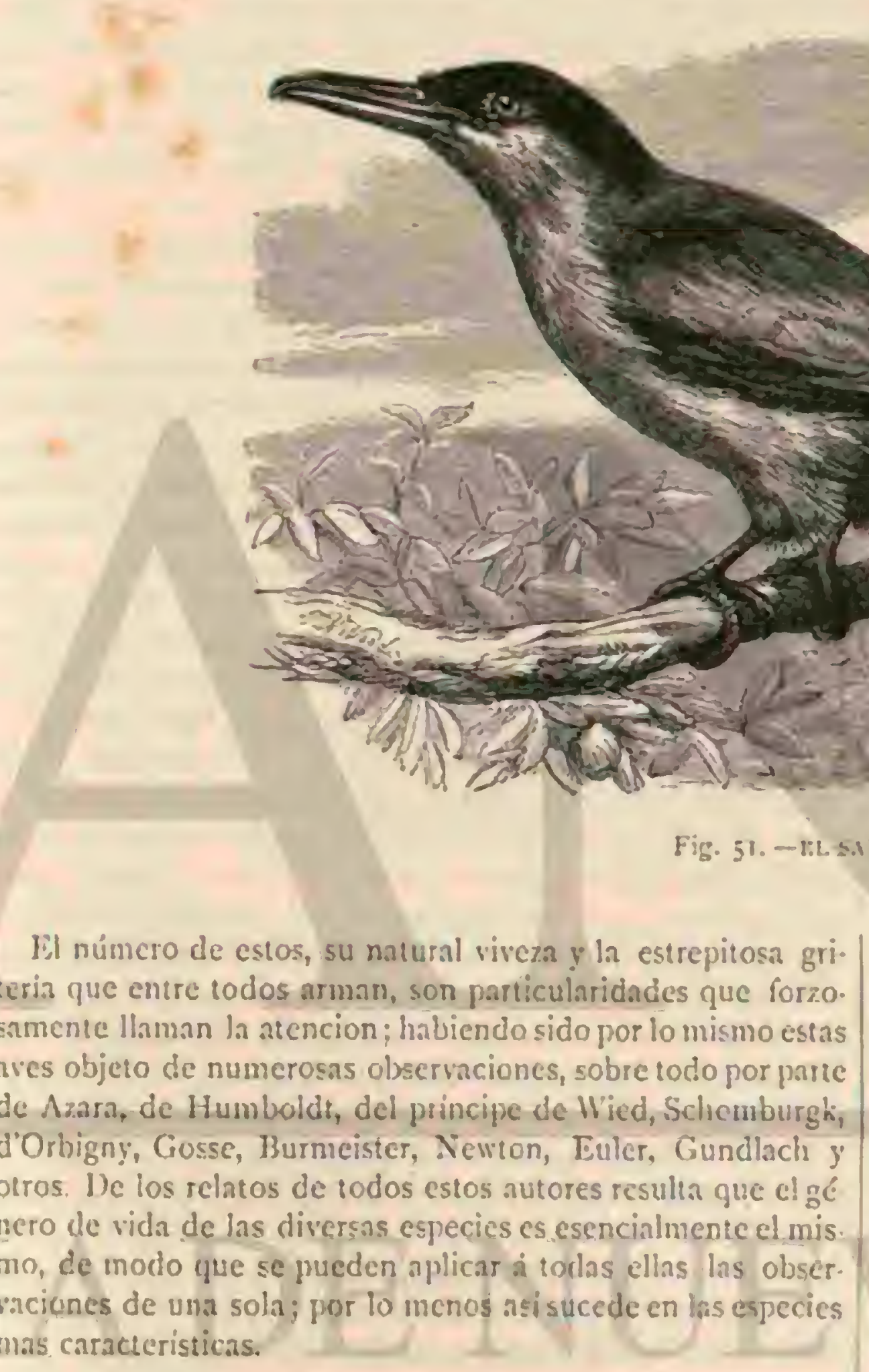

\section{LOS CROTOFAGOS}

CROTOPHAGA

CARACTERES.- I.OS crotofigos ofrecen alguna seme. janza con las urracas : tienen formas esbeltas; cabeas pequeña; pico tán largo como la cola, alto al nivel de su miz, de arista dorsat en forma de cimera, y que se prolonga por la frente; la punta es sumamente encorvada y los bordes maxilares lisos; los tarsos aitos y fucrtes; los dedos anterior y externo dos reces mas largos que el interno; cl segundo igual al pulgar; las alas, bastante prolongadas, cubren al menos la base de la cola, son obtusas, y su cuarta rénige mas larga; la cola lo es tanto como el tronco, con las dos rectrices externas un poco mas separadas que las otras.

DISTRIBUCION GEOGRAFICA.-Tres especies de este género, que difieren principalmente cutre si por la talla y la forma del pico, habitan el Brasil y da América meridional.

\section{EL CROTOFAGIDO ANI - CROTOPHAGA ANI}

CARACTÉRES. - La CSpecic mas conocida y propagada del géneró y de la familia es el ani de los brasileños: mide 10.35 de largo por 10 ", 40 de punta a punta de ala; las alas $0^{m}, 13$ y la cola $6^{\circ}, 17$. A pesar de tener la cola mas larga, el ani no alcanza apenns el tamaño del cuclilio. El plu. maje, de un negro muy oscuro, tiene en las alas y la cola un lustre azul metálico; las plumas de la cabeza y del cuello pre. sentan en su extremidad anchos bordes de un color pardusco bronceacio; las del dorso, de la nuca, del buche y del perho cstán orilladas de un azul oscuro. Eil jicco, cuya arista es alia y sguda, presenta juntó á la cxtrenidad una ligera sesgadura; sus lados son lisos, sin surcos longitudinales: su color negro, como el de las piemis; y el de los ojos pardo gris (fig. \$2).

DISTRIBUCION GEOGRÁFICA.-El ani habita en la mayor parte de la Amírica del sur, y al oeste de los Andes. Su śrea de dispersion se extiende desde el este del Brasil hasta la smérica central, incluso la isha occidental de las Antillas: alguna que otra vez se le obserra tambien en el sur de los Estados Linidos 
En el Brasil se le encuentra en todos los parajes donde los terrenos de barbechn aliernan con los bosqutecillos y mator. rales; pero nunca se le ve en las grandes selvas. Su ronco grito llama la atencion del viajero cn toda la Guayana apemas se aleja de los establecinientos. En la Jamaica se le encuen. tra en todas las llunuras, sobre todo en las estepas y las praderas donde van a pacer los bueyes y los caballos; alli se le ve tan numeroso, que Cosse le considera como el ave mas comun de la isla: tambien aburda, macho en Santa Cruz.

USOS, COSTUMBRES Y REGIMEN. - LAS costum. bres del crotolago anió de las sabanas son muy curiosasy dignas de observarse. Lis una de misares favoritas, dice Hill: las demás tienen cada cual su cstacion; pero los crotofagos se encuentran todo el año en los campos; en las juaderns y en aquellos puntos descubiertos úondé crecen algunos árboles ó matorrales es seguro encontrarles. Son osados; por su aspecto se reconoce que no tienen nada de timidos, mas nunca dejan de anunciar la llegada del hombre con un grito. Despues de la tormenta son los primeros que abandionan la espe sura donde se habian refugiado, a fin de secar su plumaje y volver \& los sitios descubiertos: ni aun el burlon le adelanta en tales casos. Apenas se oje resonar en un matorral próximo el grito cai iotsch cui iolsch, aparece en. seguida una bandada de croiofagos volando; llevan la cola abierta, y se dirigen á un paraje al que presta nueva animacion la humedad, haciendo snlir de la tierra todo un mundo de irsecios. El sol lanza bblicuamenta sus rayos sobre cl suelo; la biisa produce una dulce frescura y se oye el mismo grito resonar en el espacio: un halcon se remonta silenciosamente de en medio de los árboles y se cierne sobre la sabana; pero inucho antes, todos los séres alados han obedecido 1 la señal dealarma que lanzó el crotorngo, y ya no se oye ningungrito ni se agita una sola pluma. burante los dias calidos y abrasadores, cuando se ha secado el rocio y se agostan las plamas, cl crotofago de las sabanas se dirige un poco despues del medio dia hácia las corrientes de agua, y forma reducidas tribus con sus semejantes. Si encuentrau un árbol derribado, en el curso de la corriente, se posau alli, tonando las prosturas mas diversas: los unos, conla cola al aire, beben copiosamente; otros permanecen silenciosos, y como sumidos en sus meditaciones, $y$ varios de ellos alisan su plumaje ó repusan en la arena de la orilla. Estån alli hasta ponerse el sol, y entonces emprenden su vuelo, cuando un individuo de la bandada hace la señal para dirigirse al sitio donde deben entregarse al descanso.

«Son aves que ofrecen mucho interés, escribe Schomburgh, y el observador pasa horas enteras contemplando sus movi. mientos. Saltan alrededor de los bueyes, ó bien se deslizan en la yerba para coger grillos y otros insectos; pero si deben huir, desaparece su agilidad, porque los misculos de sus alas no son bastante fuertes. Con mas frecuencia se encuentran estas aves en los bosques y en los matorrales, a lo largo de los rios que atraviesan las sabanas; vuclan de una breña en otra, lanzando fuertes gritos, y escasean mas en aquellas que en el interior de los bosquies. 3

eGístales posarse por la mañana en los árboles poco altos, para calentarse al sol con las alas extendidas, dice Ciosse, y alli pernanecen largo tiempo innóviles en la misma posi cion. Durante el calor del medio dia van a las hondonadas, y se posan en los vallados y matorrales con el pico abierto, como para aspirar el aire fresco con toda la fuerza de sus pulmones. Entonces parecen olvidar su prudencia y su acostumbma charla: con frecuencia diriase que dos ó tres de ellos juegan al escondice en medio de un espeso matorral, rodeado de lianas y plantas trepadoras, pues con sus gritos singulares parecen invitar á los demás individuos à que los busquen. $\$$
Gundlach, que ha obsersado al ani en Cuba, habla tambien de la sociabilidad del ave y dice quue vaga en fami. lias de un sitio i oiro, pero limitandose siempre á una reducida localidad. Una de ellas hace las reces de centincla y da la señal de alarma en caso de peligro: entunces todas producen su grito antes de emprender la fuga, y esta es la causa principal de que siempre se oiga su voz. Sus gritos pueden distraer mucho a veces; pero tambien molestar en alto grado al cazador, porque dan la señal de alarma á los animales que este busca, induciéndolos á huir.

Los crotofagos no son torpes: en tierra dan saltitos, levan. tando las dos patas simultáneamente, y a reces corren moviendo la una despues de la otra. En los árboles son muy ágiles: se posan en la extremidad de una rama gruesa; tefúgianse luego en medio de la copa, corren rápidamente entre el ramaje para cazar los insectos con la major actividad, y abandonan el árbol por el lado opuesto al en que penetrarun, uno despues de otro ó todos juntos, lanzando luertes gritos. Al volar oirecen un aspecto extraño; forman una sola linea con su cuerpo delgado, su larga cola, su gran cabeza y su vigoroso pico, y agian muy poco las alas, por lo cual se ase. mejan mas bien á un pez que á un avc, segun dijo muy opor. tumimente Gosse.

Ei crotolago de las sabanas y cierta especie de halcon su. fren, segun Newton, continuamente los ataques del tirano, y dificil es decir cuál de estas dos ares agrada mas al obsersador. Cuanda sopla una ligera brisa, aquel apenas tiene fuer. 2as, i causa de la longizud de su cola y de la brevedad de sus alas, y abandonándole en aquel momento su instinto, vula én la direccion del viento en vez de hacerlo en sentido contrario. El rirano aparece entonces y le da tales picotazos, que no le queda oiro remedio sino buscar un refugio en la yetua 6 en el interior de la mas espesa breña espinosa. En táles circunstancias, el plumaje del crotofago se deteriora mucho, particularmente su cola, y por lo mismo es dificil encontrar un, solo individuo que la tenga en buen estado.

El grito del de las sabamas tiene algo de sirigular $y$ de gangoso: Kittliz. le expresa por fris-i tru i; isura por ocai ó aani; el principe de Wied por ani ó a i; yundlach por la palabra y\%dio. Este grito no tiene por cierto nada de agradable y los colonos han dado por eso á esta ave el nombre de zireja bruja. Enn la época del celo, segun Gundlach, óyense otros sonidos que constituyen una especie de canto, ó cosa parecida, cuando resuenan varios à la vez. Estos sonidos son guturales y solo se oyen à corta・distancia.

El régimen de estas aves es muy variado: aliméntanse so. bre todo de reptiles, insectos y gusanos, y hy periodos en que solo comen frutos. En el estómago de las que se han disecado se hallaron langoshas, mariposas, moscas, frutas y bayas Estas aves comen los parásios que atormentan a los animales de cucrnos, y ì ellos se debe que frecuenten los pastos; corren sobre el lomo de los individuos, sin que ma. nifiesten el menor desagrado, y á menudo se ven varios cro. tofagos à la ve\% sobre el lomo de un buey, bien esté andando ó cntregado al descanso. El principe de llied los ha obserrado así, cn compania del caracara blanco; Ciosse notó el ardor con que se ocupan en purgar de los paraisitos á una vaca; y lodos los naturalistas hacen mencion de la amistad que reina entre estas aves y aquellos cuadrúpedos.

'Tambien cazan los insectos al vucio. En el mes de di. ciembre, dice Gosse, vi una reducida bandada de crotoiagos posados en el ramaje, desde donde volaban sin cesar, segu. ramente para coger los insectos que jasaban a su alcance. Un dia del mes de marzo, y otro del de mayo, llamaron mi atencion algunas de estas aves, que perseguian a una mariposa; otra vez vi á un individuo con una libelula en el pico. 
He observado asinismo algunos que perseguian \& los lagar. tos pequeiros.:

Varios autores describen detalladamente la manera de re. producirse el are; pero no todos están completanente de acuerclo sobre este punto. Azara ha risio que los crotofagos anidan juntos, cxceptuando el mayor: Ricardo Schomburgh opina lo contrario, y d'Orbigny es de su pirecer.

Segun dice Burmeister, en todos los puntos del Brasil se encientran nidos del crotofago de las sabanas, en las bresias mas altas, en los bosquucs y hasta cerca de los cdificios. a Fis. tas ares, que viren apareadas, descubren el nido por sus continuas idas y veniobs: las diversas parcjas no se reunen para construir uno comun, de gran tamaño, à causa, sin duda, de las frecuentes pertuibaciones à que se hallan expriestas; fabrican por el contrario uno pequeitn, que sulo contiene, fror lo regular, rinco ó seis hnevos. La descripcion rue dis Azara de las cosiumbres de los croiofagos, cunndo viven juntos cerea de las viviendas humanas, puede aplicarsc a los que habitan parajes donde el hombre no persigue $\mathrm{a}$ la espe. cie: pero en el Brasil no se saise nadia sobre este purin. In no he oido nunca hablar de ello a ningun hatitante de acquel pais, à pesar de que suelen conocer muy bien las costumbres de lns amimales indigenas, $y$ les gusta referir detalles cuando se piden informes sobre el particular. s

Fsto conviene con el relato de Schouburgh', yuien se ex. presa del modo siguiente: a los indios creen que únicamen:e los coroyas construyen un nido comun, al paso pue en las otras dos esprecies, catia pareja hace el stayo Gosse que opina lo contrario, dice: "Toclos los colonos alirman que las croinfagos de las sabauas iabrican un nicis gencral muy gran. de, compuesto de ramas, y situado comusmente en un alto árbol. Hill, cuyo testimonio es digno de $f$, se expresa asi: a Una media docena de crotofagos de las satuanis liacen un solo nide, que es bastante grande para que jucdan caber todos con su progenice. Cubren abunosamente, y mienersis dura la incubacion no abancionan jamás sus hueros sin taparlos antes con hajas. Yo enconré uno solo de cstos nides en el mes de julio: componiase de un gran numero de ramns entrclazadis y cubicrtas de hojas, y contenia orto hure:os, entre los cuales vi restos de las cóśscaras de otres, no solo en el nicio sino tambien al pic del irbol,

Gundlach no duda :ampece que smrias henbras empollen en el unismo nido: dice haber enconirado algunos con muchos lucros, á reces dispuestos en una ó varias capns, cu. biertis de material del nido, llevado por las hembras, que debian iomar parte en la iscubacion la construccion del nid̉o, ó mejar dicho el periodo dela reproduccion, comienza en Cuba en abril y dura hasta octubre, segun las observaciones del mismo naturnissta. Fi nielo esta situncio en los sitios mas frondosos de los árboles, ó en los bambies y bejucos mas ernarañados y consiste en ranmas pentienas y plantins secas. "L.os seis hueros de crotofago, dice por stu parre Turmeis. ter, vienen a tener el volimen de los de la paloma: en el instanie de ser puestos eran de un color blanco purn, yofrecian cierto aspecto cretoso, con un ligero viso verde; la superficic estaba surcada por ranuras cuyo fondo presentaba un mag. nifico tinie verde: el frote con un cuerpo duro les hacia per. der su revestimienio blanco, dejando al descubierto la capa verde inferior. Opino que este revestimiento es una especie de baño que se adticre al huevo, probablemente durante 5 แ permanencia en la cloaca, y yo le compararia con la sustan. cia cretácea de la urea, de que estàn cubicros los excremen. tos de las aves. Cuando se uguita la capa blanca, el huevo, que parecia antes maic y cretáceo, presenta una surperficie pulimentada, con un granillo muy fruo, yes tan pronito verde azulado como verde mar. $y$
Gundiach observó en casi todos los lueveros las linens indicadas por Hurmcister, y no duda n̨ue estas sean producidins por las uñas de las aves, que los arainan cuando los cubren, pues las rayas no se observan sino en la criscara al cabo de algunos dias, al paso que los hmevos recien puestos son de un verde azulado.

- En cl mes de junio, escribe Newton, encontré un nido del crotolngo de las sabanas, en el que vi dos aves, una al lado de otra; estaba apoyado conira el tronco del árbol, sosterido por varias ramitas, il la altura de unos cinco piés. En una tosca construccion de ramas y ramillas, cubierta en parte de hojas secas, en medio de las cuales habia catorce huevos: este nicio parecia ser de propiedad comun. Por lo regular se ven dos ó tres aves juntas, y cuatro ó cinco en las mamas su. periores: los individuos del nido gritnron mientras pernmaneci en los alrededores.

Segun Schomburgk, los hijuclos abandonan el nido antes de poder volar; saltan en medio del ramaje en compania de sus padres, ! parecen tan agiles como cstos. Apenas amenaza un peligro vuelan los viejos lanzando gritos salvajus y los pequeños se precipitan al suelo para ocultarse en medio de las jerbas.

Los crotofagidos se conducen con el hombre de diferente modo: por lo regular no huren de los jinetes, 6 sinicamente lo hacen cuando estos se acercan mucho é se paran; pero $n$ no se mestran ian confialos con los peones. Alli donde ven con proca frecuencia al hombre, su osadia es verdaderanente increilite.

4. la manera de las aves del desicro, dice Humboldt, descontian tan poco de nuestros scmejantes, que un niño podria cogerlos con la mano muchas veces. Ln el valle de Amgua, donde son muy comunes, llegaban á menudo à josarse, en pleno dia, sobre la hamaca donde cstabamos ccha. dos Por lo que dice Sclomburghi, no pueden sufrir los sil. bidos, y cmirrenden d vuelo apenas ojen uno.

Algunos cubanos comen la carne de esta are á juesar de su olor extraño y hasta la recomiendan al los combalecientes, porque, segun diccin, abre el apretito. P'or lo demás, las caza. dores no la persiguen sino cuando quieren vengarse de sus gritos.

I:n cuanto álos çue se matan ó se hicren, no todos caen en proder del cazador, á causa de sa gran resistencia vilal. «Si no se le hiere en la cabeza o el corazon, dice Schom. burgh, el cazador puede estar seguro de nue no le cogerś, pues huye entre las jerbas 6 los maiorrales con una rapidec increible. Dé diez 6 doce yue cerribé á menudo á la ver, apenas pude encontrar uno ó dos al llegar al sitio donde ca. yeran. Al dia siguiente de mi llegada a Zuruma, tiré à un indiriciuo rou bala: el propectit le deegarno in priel abdom:nal, por donde salina los intestinos: á pesar de ecio no le hubiese encontsado a no haberle visto uno de tuis indios a mas de juscientos pastos de distancia, y esto gracias if que los iniestinos se le enredaron en las ramas de un ma. tortal.

\section{LOS CENTROPODIDOS-CENTRO-} PODIN.T:

CARACTERES.- - Jisias ares siguen presentando el as. pecto de los cuclilios; pero denen el pico muy flerte, corto, sumamente cncorvado y comprimido lateralmente; los tarsos altos; los decios cortos a proporcion; el pulgar provisto co. mummente de un espolon puniragudo, mas ó menos largo; las alas muy cortas y redondeadrs; la cola, cónica y compuesta de diez. pennas, es en extremo larga ó de mediana longituci; el plumaje tiene una dureza particular. Los colores varian 
segun el sexo, pero mucho por la edad; hasta los tres años, con corta diferencia, no revisten los pequeños el plursaje de los adultos.

DISTRIBUCION GEOGRÁ FICA.-LOs centropodidos habitan el Africa, la India oricntal, las islas malayas y la Nueva Holanda.

USOS, COSTUMBRES Y RÉGIMEN.-Podemos con. siderar que estas aves ocupan en la fauma del antigno conti. nente el mismo lugar que los coccicidos en la del Nuevo Mundo. Tienen muchas costumbres de estos: hibitan las hondonadas, los matorrales de nucho foliaje, la esuesura de cañaverales y hasta las altas yerbas. Corren por el suclo, deslizándose como ratones en inedio del mas compacto ra. majc, y penetran donde no pueden penetrar otras nves; dan caza ä los grandes insecios, 10 mismo gue a las esculopendras y escorpiones; se atreven hasta con los lagartos y las serpientes; roban los nidos, yarece que no desprecian ninguna presa animal: jamás tocan los alimentos vegetales Como vuelan mal, solo en casos extrenios y apurados hacen uso de sus alas: lanzan gritos bastante singulares, sordos como los de un ventrilocuo. Anidan en los matorrales, en medio de las yerbas $\delta$ de las cañas; su nido está cubierto y provisto de dos aberturas, una para la entrada y otra para la salida. Cada puesta consta de tres a cinco huevos, que niacho y hembra cubren alternativamentc.

Los polluelos tienen un aspecto muy extraño, porque su piel negra está cubierta de plumas cerdosas y su lengua roja es negra en la punta. Bernstein se admiró mucho al ver por primem ve\% el nido de una especic india con polluelos, por. que estas negras avecillas abrieron el pico y alargaron sus rojas lenguas.

\section{EL CENTROPO DE EGIPTO-CENTROPUS EGXPTIACUS}

CARACTERES.-Fista especie, perteneciente al género de los centropos, se caracteriza por tener la cola relativa. inente corta y el plumaje pardo rojizo. La partc superior de

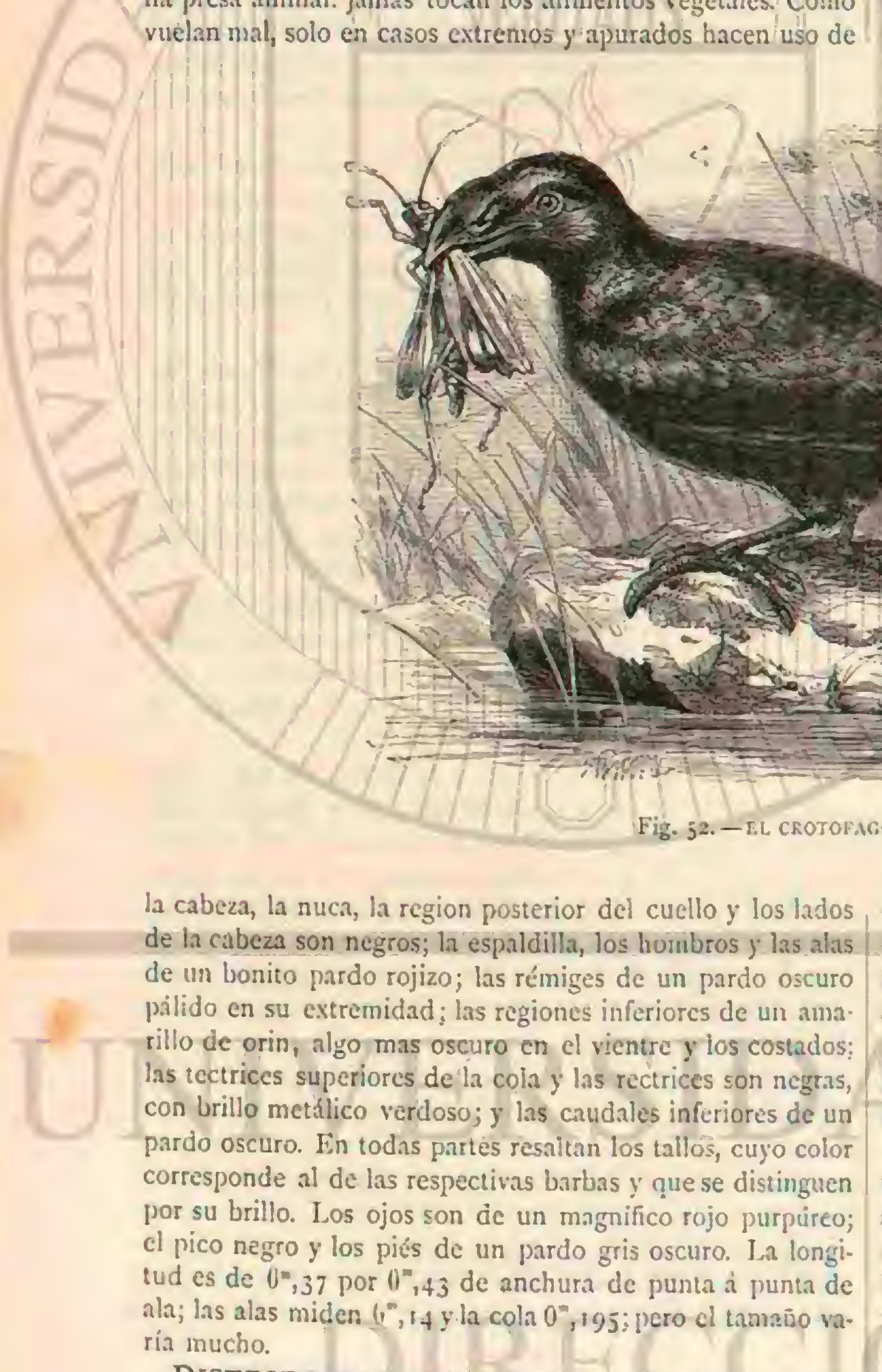

DISTRIBUCION GEOGRÁFICA. - No es Jara esta ave en el nordeste de Africa, y hasta abunda mucho en Jigipto, donde frecuenta casi exclusivamente las grandes extensiones de cañaverales: en el Sudan habita las mas impenetrables espesuras.

USOS, COSTUMBRES Y RÉGIMEN. - Deslizase \& través de las mas enmarañadas plantas espinosas con la lige. reza de una rata; trepa, se arrastra en medio de las ramas, déjase ver de vez en cuando, permanece un instante inmóvil, examinando los alrededores, desaparece de nuevo en las bre: inas, deslizándose por los aires mas bien que agitando las alas, ó ya corriendo por la superficie de la tierra. No ofrecen sus morimientos la menor semejanza con los del cuclillo; permance tranquilo y silencioso, sin llamar la atencion, y no hace nada en pleno dia.

Su alimento consiste en toda clase de insectos, con prefe. rencia hormigas, sobre las cuales se arroja con verdadera ansia. Tal ver coma tambien muchos caracoles y orros animales blandos, que constituyen el alimento favorito de todos los centropodinos. Heuglin asegura no haber encontrado nunca moluscos en el estómago del congénere ya citado, aunque estos abundan a menudo alli donde habita dicho centropodina. Schweiniurth aseguma á su rez que la misma ave come dos especies de caracoles terrestres. A semejanza de las demás aves de la misma familia, los centropos de Egipto viven apareados; al ver un individuo, de seguro se encuentra pronto el otro; únicamente los jơvenes vagan largo ticmpo, acaso años enteros, solitarios y crantes. Yo no he hallado sino un nido, en el Delta, á fines de julio, sobre la copa de un oliro: componiase casi exclusivamente de pajas 
de maiz y contenia cuatro hijuelos medio desarrollados, de los cuales pude conservar uno bastante tiempo. No conozco los hucios de esta ave.

Ignoro qué enemigos puede tener el centropo de Egipto, pues jamas he visto individuo aiguno que iuese perseguido por un ave de rapina. Isis brenas espinosas, donde üja su domicilio, son de todos modos para el ave un buen refugio.

En Egipto no piensa nadie en dar caza al ave, pues se la mira con la misma indiferencia que á las dernas. In el este de Africa ro se la persigue tampoco; se la deja tan tranquila como å uno de sus congéneres, pucs su carne despide un olor iétido yue no permite comerla.

CAUT\&VIDAD.-No recuerdo haber tenido mas que un cautivo de esta especie, y aun muy poco tiempo; pero es fácil domesticarlos, segun lo han demostrado otros cautivos que vivieron en varios jardines zoologicos, y quue se alimen. taban solo de carne cruda El ave no puede dar á conocer todas sus cualidades en la jaula: mas á pesar de esto llama la atencion del observador por su aspecto y la agilidad con que corre, salta, trẹıa y ejecuta diversos ejercicios. Comparado con esta ave, el cuclillo comun es verdaderamente fas. tidioso.

\section{LOS POLOFILOS-POLOPHILUS}

CARACTÉRES.-1.os polofilos, canocidos entre los in gleses que habitan la Australia con el nombre vulyar de cy dillos faisesues de espolon, se caracterizan especialniente por su gran talla, y su pico corto y gruesu, sumamenic inclinado.

DISTRIBUCION GEOGRÁFICA. - Estas aves son proprias de Austrilia.

\section{EL POLOFILO FAISAN-POLOPHILUS PHASIANUS}

CARACTERES. - Eil polofilo faisan, virvilillo firisu): (figu ra 53), tiene el plumaje negro oscuro: las cobijas de las alas de un tiute pardo leomado y negro, presentando cada pluma sobre el tallo una raya clara; la parte inferior del lomo es de un verde oscuro, manchado de negro; has alas de un pardo castano, con dos listas negras; las plumas de la cola de un pardo oscuro, que forma visos verdosos y manchas muy finas, rojas y de un pardo claro; su extremidad es blanca, excepto en las dos medias; el ojo es rojizo; el pico negro $y$ las patas nagras de plomo. Los hijuelos tienen el lomo pardo rojizo, el vientue gris leonado $y$ presentan manchas como los adultos. Esta ave nide $\left(, n, 63\right.$ de largo, el ala $6^{m}, 26$ y $12 \operatorname{cola} \theta^{\circ}, 34$.

USOS, COSTUMBRES Y REGIMEN.-Gould nos ha dado á conocer el género de vidn de csta ave se la en cuentril en los pantanos cubiertos de breñas, yesbas y caina verales; permance casi sicmpre en tierrà, y corre ron suma rapider Solo en uiltimo cxtremo busca refugio en los árboles: se posa primero sobre una rama baja, desde donde se cleva por saltos sucesivos hasta la cima, y hasta llegar al ella no emprende su vuelo para ganar lentamente otro árbol.

Sitúa su nido en medio de una espesa mata: es muj gran. de, I se compone de yerbas secas; por arriba convero y pro. visto de dos aberturas por las cuales saca la hembra, cuando cubre, la cabeza y la cola al veces se encuentra este nido debajo de las hojas de una pandánea; pero mucho menos á menudo que en medio de las jerbas. Cada puesta se compo. ne de cuatro 6 cinco huevos, de forma redondeada, grano tosco, color blanco sucio, y rayados algunos de pardo.

CAUTIVIDAD.- Tambien el polofilo faisan se acos tumbra fácilmente à la cautividad $y$ a un alimento variado que no es dificil ob:ener; soporta muy bien largos viajes por mar, y se ha recibido ya varias veces en Europa, sobre todo en Inglaterra.

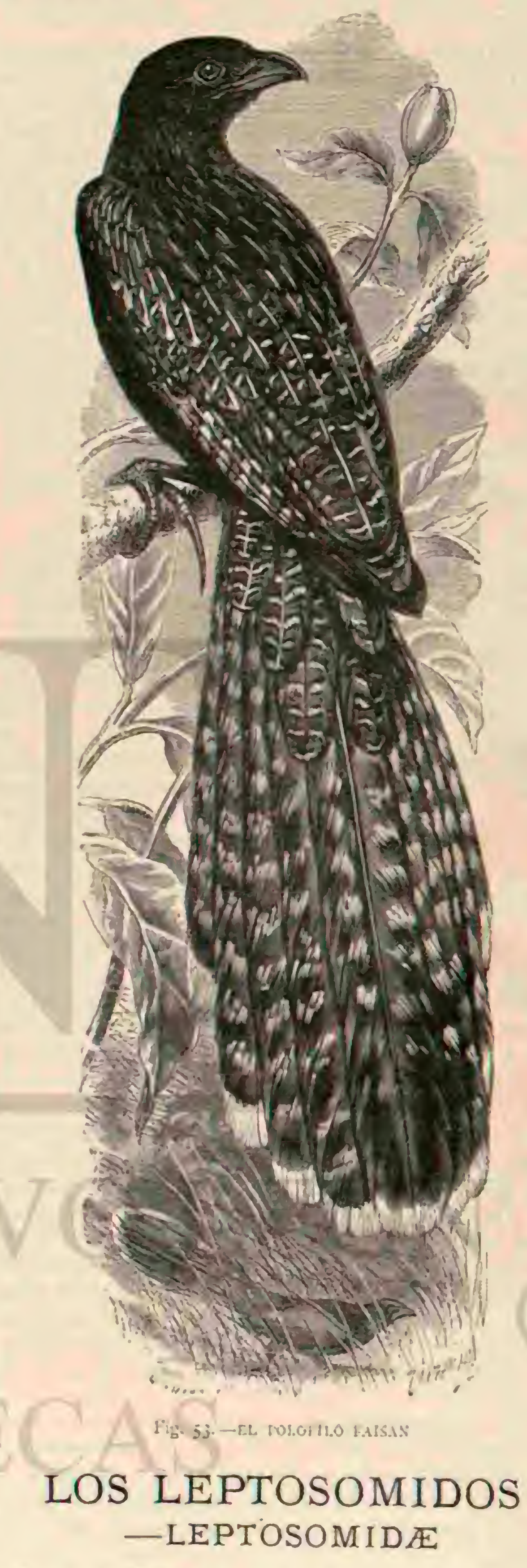

La isla de Madagascar, tan tica en seires extraños de su fauna animal, produce un are, el kurol, que puede conside. rarse como una de las especies mas curiosas. Mucho han 
discusido sobre csta are los naturalistas, clasificandola tan pronto entre los megalénidos como entre los cuctilidos, $y$ aun entre los corscidos; pero al fin se ha formado en su ia. vor una familia independiente, la de los kuroles, ó leptosó. midos.

CARACTERES.- Eil kurol ofrece analogia con todas las ares citadas, $y$ ademis diriase que es congénere de los ram. fístidos. Su fi:co, aunquıe al parecer corto, es largo y grueso, mas ancho en su parte posicrior, muy comprimido hácia adelante, algo corvo en la arista, mareadamente aquillado y deprimido por dos sureos diagonales é irreguhres; el corte de la mandibula sunerior presento una profunda sesgadura junto i su extremidat, has fosas nasales, sikuadas delante de la base del pico, son angostas y estan cubicrtas de una piel chistica, ocultaidolas del todo unas pluass blandas en forma de mechon, nile insartas en amijos latos de la manaibula superior, se arquenn hácia arriba entre sl. I, as pistas, cle lon gitud regular, tienen el tarso corto fr cubiefin de escramas ir. rogulates; el dedo exterior se dirige lizia atris; el fulgar es nuvi péqueno; y las uins, bastanie pasjucias, se encorvan poco; las alas, faue pasan de la mitad de la cola, son notables por el nimero y gran tamais de sus cohijas; las réni. ges iercen y quinia son de igual longitudy sobresalen de todas las demás; la cola, de un largo regular, se compane de doce rectrices de casi igual longiud, redondendas en la cxtremiciad. Fistos son los caractéres priácipales, tanto del ku. rol como del género y do la fimilis, cuyo tipo representa

\section{EL KUROL-LEPTOSOMUS DISCOLOR}

CARACTERES. - Esta especic puede tener una longitud

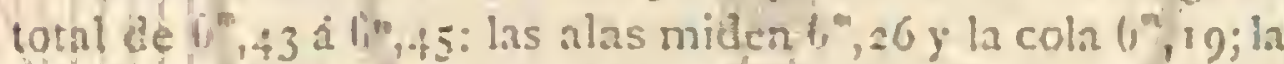
parte anterior de la cabeza, el cucilo; el bische y la region superior del pecho, son de un gris-azul oscuro; la coronilla, que afecta un poco la forma de mono, es negra; el dorso, las tecrices mas pequeñas de las alas y las cscapulares, que tienen un hermoso brillo rojo de coure, son de un verde nietalico; en las grandes rectrices preclomina el rojizo de cobre; la parte inferior ca gris, lexcepto el vientre y la region situada debajo de las plu:nas caudales que se distinguen por su color blanco; las rémiges son de un negro mate, con las barbas interiores blancals ein la base y-las exteriores de un brillo rerdoso metálico; las barbas de las secundarias tienen un viso rojizo de cobre; las rectrices son negruzeas, con lustre verdoso metálico muy marcado. El iris es pardo, el pico ne. gro, y los piés de un amarillo oscuro. - an hembra se distingue por tener la cabeza y el cuello de color pardo roijzo, con bordes negros; las plumas del dorso son pardas, con man. chas pardo rojizas de un lustre ierdoso rojizo de cobre; las tectrices de las alas son negras, manchadas de castano; las Iéniges secundarias, orilladas de pardo rojo, presenian fajas del mismo color $y$ de un brillo rojizo de cobre; las rectrices de un mati\% pardo, son mas oscuras hicia la punta y estän orilladas de rojizo de orin; en la region inferior predomina un rojizo claro de azufre, en el cual resaltan manchas redondeadas de un brillonegro, inmiediatas a la crtremidad de las plumas.

DISTRIBUCION GEOGR AFICA.- Fil liurol habita en Madagascar y en la isla luana, del grupo de las Comores.

USOS, COSTUMBRES Y REGIMEN.-Si extraña es el are por su colory conjunto, no lo es menos jor su géncro de vida, sobre el cual debemos pormenores mas ó menos minuciosos a Cirandidier, Nerton, Roch, Pollen y Dacm. E: kurol no escasea en el norocste y sur de Madagascar; tam bien habita en Marotte, y hallanse algunos individuos en la isla Juana. Los indigenas de Madagascar le han dado varios nombres: en la region de Wetsimarak, por cjemplo, le llaman Cymmbo, yen el territorio de Sakalarse, Trentrie; este último nombre, segun se dice, es una reproduccion de su grito lastimero. En riertas épocas se le re en bandadas de dicz i doce individuos que con meferencia habitan en el lindero de los bosques: á reces llegan á ser considerables en los mismos sitios; y el número de machos es tan superior al de las hembras que Jollen cree poler contar al menos tres de aquellos por cada una de estas.

Ei hurol es un ave extrana por todos concepios, pero no tiene nada de astuta $A$ cada momento se ofe su grito, que pucte expresarse por las silabas lihudifutihn, y cuya fuerya aumenta al lin; á veces resuena tanto por los bosfues, que causa verdadera molestia: al gritar infla tanto la garganta y Ia parie anterior del cuello, que estas partes parecen un saco incndieme. Aung̨ue muy alicionado à gritar, muéstrase estú. pido y perczoso tan luego como se ha josado en una mama; en ella permanece en posicion muy vertical é inmóvil como si caturicse enibalsamado, y 1:o sulo permite al cazador acer carse á tiro, viendo con indiferencia cómo caen sus compa heros und á uno, sino que se deja matar a palos, en la verda der. arencion de la palabra, sin pensar en la fuga. Cuando varioś machos siguen $i$ una benbra, esta se hace de notar: yi si uno cac muerto, el otro no hự, limitándose á saltar cunndo yas de una rama á ctra. De una manera muy dile. rente se condice cuando vuela y se remonta a cierta altum; entonces retoza lo mismo que uuestro coricido azul; vaga alerre por las regiones aéiens; elévase rápida y verticalmente snbre cierto punto del bosque: y Jéjase caer despues cerran. do casi dul todo las aias. Al mismo ticmpo produce un silbicho, tan semejante al grito del śguila, que Roch y Newton dudaron mucho ticinpo si cl ave que cjecuta'sa an magnifi. cas evoluciones en su vuelo, seria el kurol ó una rapaz. Solo desgues de observar repetidas veces cun el nnteojo ricono. cieron que era el kurol; tambien vieron nute otro individuo de la especie, posado tranquilamente en un árbol, le contestaba à menudo.

Segun las experiencias de Pollen, el kurol sce alimenta prin. cipalmente de langostas: pero persigue tambien a los camaleo. nes y lagartos ; la carne de estos tiltimos comunica à la del are un olor desngradable como el que observamos en nuestro cuclillo.

Pollen ro ina podido adquirir informes exactos sobre la reproduccion. Durante su permanencia en Mayoite vió tin kurol que llevaba juncos al liueco de un gran árbol para fas. bricar su nido: pero no prudo averiguar nada mas. lin su concento, el kurol es poligamo; pero esta opinion se funda solo en el hecho de haber visto reunidos mas machos que hem. bras, circunstancia que no prueba nada. Finalmente, se cxplica que un ave tan extraña hnya llamado la atencion de los indigenas; pero dificil es comprender por qué el kurol rejresenta un papel tan importante en los cantos sagrados y en las oraciones de los indigenas de Madagascar.

\section{LOS CÓLIDOS_COLIIDÆ}

Esta familia comprende solo siete esnecies conocidas, tan distintas de las otras aves, que los naturalistás las han cla. sificado del modo mas diverso. Linneo clasificó los cólidos ó aies ralunes entre los fringilidos; mientras que otros ornitólogos no creian fácil señalarles un lugar determinado en el sistema. Swainson fué el primero en designarles el lugar en que casi todos los autores agrupan ahora esas aves, considerindolas como amfiboles. Puesto que estas últimas se asemejan mucho aun à los cucúlidos, debemos clissificar tambien 
i Ios cúlidos entre los kevirostros; pero no puede negarse que su atinidad con otros géneros del órden es muy dudosa.

DISTRIBUCION GEOGRÁFICA.-I.OS Cólidos son ex: clusiramente propios del Africa.

Touas las especies ufue hasta ahora se conocen sc asemejan en tan alto grado, que solo podemos formar con eilas un género, el de los colius.

\section{LOS COLIUS - COLIUS}

CARACTŔRES. - Los representantes de este género se caracterizan par su cuerpo muy prolongado, casi cilindrico y musculoso; el pico, corto, grueso, abaredado y corvo desde in base, se comprime algo en la punta, que sobresale de la mandibula inferior en forma de gancho; las piernas son corras; los dedos largos; las alas breres y muy redowdeadas; la :ola mide mas del doble de la longizud del cuerpo; las réniges cuarta, quinza y sexta sobresalen de todas las demás. Las particularidades mas notables son la forma de los piés y la naturaleza del plumaje: en los primeros, los dedos exteriores son versátiles: en el segundo se observa que la parte que cu. bre el tronco es en exiremo fina, de modo que las plumas se asemejan al pelaje de los manileros; las doce grandes rectri. ces son en cambio mug rigidas, con el tallo mug fuerte, y las barbas de igual anchura, compuestas de fibras recias; las del centro miden al menos cuarro veces la longitud de ins anie. riores, lo cual produce un escalo:ımiento que so se observa en ninguna otra especie de toda la clase. El color predornimanie es un gris azufrado diñcil de describir, y que tira mas ó menos al rojo ó al gris ceniciento; de moda que tambien por este concepio es coracieristico el nomire de rirs infunis.

Durante mi viaje por Africa he observado dos especies de cstas aves extranas; pero notć una conformidad ian grande ea sus usos y costumbres, que me parece suficicule describir una sola, exponiendo en ella todo cunnto se sabe sobre el grupo en general.

\section{EL COLIU DE COLA LARGA-COLIUS MA- CROURUS}

CARACTERES.- Esta esperic alcanza una longitud de 0, 34 , por una anchura de $1,2,29$ con las alas cxtendidas; es. tas miden $11^{\circ}, 10$ y la cola $10^{\circ}$, 24. Li color predominante es un gris rojizo que en la parte superior de la cabeza tira al ama. rillento isabela, en la barba y centro de la gargana al blanco pálido, y en la region inferior del pecho al amasillo gris isa. bela. Fin el centro de la nuca hay una mancha azul celeste: el manto es ceniciento claro; las rémiges y tectrices son de un rojo cancla en la mirad de la base y de un pardo de tierra en el resto. Los ojos son pardo rojos y tienen un ancho circulo desnudo al rededor; la linea naso ocuiar y la base del pico son de un rojo de lacre, y la punta de cste ultimo negra; los pićs de un rojo de coral (fig. 5i). Los sexos no se distin. guen por el color.

DISTRIBUCION GEOGRÁFICA.- Fl trea de dispersion de la especic descrita se extiende en una gran parte del Africa, por el nordeste, desde el mediodia de la Nubia y el pais de los bogos hasia ia region donde nace el Nilo y por el peste desde la Sencgambia hasta el pais de los damaras. Vo le encontré por primera vez on la Bahiuda ineridional, y desde aqui en todos los puntos del Sudan oriental visitados por mi; Heuglin le vió en el pais bajo y en las montanas de $A b i$ sinia hasta la altura de 2,000 metros, pero ya no le hallo en la parte superior del Nilo Blanco, y cree por eso que el ave no se extiende mucho hácia el sur.

Parece que los colidos en general se limitan al Africa, pues no esti contirmada aun la noticia de algunos autores antiguos de que tambien se encuentran en la India Habitan el centro y mediodia de Airica, pero ialian del todo ell el norte, as pesar de que alli abundan sus, árboles favorios; solo al èntrar en las es:epas cubiertas de árboles se encuentran sus bandacias. En algunas partes de las selsas virgenes aburdan mucho y en las ciudades del Africa central ó en los pueblos del Cábo se presentan tambien con regularidad. Algunas especivs yarecen limitarse af un dirca de disprersion muy circunscrita; otras se extienden desde la costa occidental hasta la oriental, y desde el $g b^{3}$ de latitud norte hasta el Cabo. Toủas las esjuecies se encuentran solo alli donde hay árboles y arbustos y una espesura impenetrable para otras ates en el verciadero sentido de la palabra.

Le Vaillant fué el printero que nos div á conocer su género de vida, refiriendo con este motivo liechos sorprendenies, que no merecieron mucho crédio, y que aun ahora no son muy dignos de confianca, por mas quue dicho maturalista tên. ga fama de concienzudo. Despues de observar colius, he erei. do poder desmentir sus asertos; pero otros naturalistas han venido á confirmarlos luego, y de tal manern, que no me atrevo is negar los hechos que nos refieren.

Todos los colius. viven en inarilias 6 reducicias bandadas compuestas generalmente de seis individuos: estatblécense en un jardin ó en una parte del bosquue, y particndo de alli re. corren todos los dias un distrito bastante extenso, eligiendo siempre para albergarse el sitio donde la espesum es mas im. practicable. El que no ha visitado los paises de los trópicos, dificilmente puede formarse una idea de lo que son aquellos parajes. Un espeso frbol, generalenente espinoso, esta cubier. to de plantas paraisitas y de lianas, quue le estrechan y cniazan pur todos lados, de ial modo que con dificultad atraviesa al. guna rama aspella red inextricable; alli no pucden penctrar los hombres ni los nuarmiferos, $y$ a duras penas se consigue practicar alguna abertura con un cuchillo de caza; pero el are se introduce alli y encuentra seguro refugio contra todos sus cnemigos, y hasia contra el plomo del cazador, quien sabe muy bien que no podrí recoger su victima. Las lianas enlazan los árboles unos con otros en una gran extension; forman un recinto donde nadic puede sentar la planta y cuyo interior sera siempre desconocido para nosotros. En tales lugares ha. bitan los colius; à niugun otro pajjaro le es dido penetrar donde ellos se mueven con ngilidad suma, y corten con tansa rapidez. como el manifero que les lia dado el nombre, desli. zíndose por las mas pequerias aberturas. Llega una bandada de colius del limite de una de aquellas espesuras, detiénese un instante, encuentra la entrada, y en un abrir y cerrar de ojos desaparecen todias las aves. Si se da la vuelia por aquel enmaranado laberinto, bien pronto se ve aparecer por el lado opuesto una cabeza, despues un cucrpo y por rikimo todo el animal; resueria un grito; nsanua toda la bandada, y se preci. pita á un tiempo en otro miatorral para desaparecer del mismo modo. ¿Cómo pueden moverse en aquella espesura? Este cs un enigma para el cazador.

Mucho les cuesta à los colius, segun Le Vaillant, determinarse á emprender su vielo, y necesitan prepararse, trepando al extremo de las ramas, desde doncic se lanzan sobre otra brena cercana, pero llegan bajando insensiblemente desde el punto de partida de tal modo que al tocar el pić del nantorral, no parce que sc prasan, sino qque bajan unas despues de otros. Una vez llegados permanecen iranquilos durante ciento tiem. po; despues se les ve asrastratse hácia una de las ramas, tre. par con el auxilio de las platas y del pico, á la mnnera de los loros, y alcanzar asi la cima de los árboles donde ce ve a cacia individuo cogido â la punta de una ramı.

Al volar baten alternativamente las alas y luego se ciemen, 
conservando aquellas muy tendidas, lo mismo que la cola. Le Vaillant compara al coliu que ruela con ha neclıa que cruza los nires: jamais se remontan estas aves a gran altura, $y$ nunca ciscienden tampoco hasta tocar el suelo. Cuando se elevan por el espacio lanza cada individuo un grito vibrante que se puede expresar por kirr kirr ó tri lri, y reuniéndose los sonidos, confúndense y producen un estrépito que no es posible describir.

Estas aves, siempre segun Le Vaillant, se reunen en bandadas en una breña para pasar la noche, $y$ lo que parece singular es que duerman suspendidas de las ramas con la cabeza liácia abajo, oprimiéndose entonces de tal modo unas contra otras, que forman una masa, comparable solo con los enjam. bres de abejas reunidas en peloton, que se suspenden de las ramas del árbol.

lo no he visto nunca nada de esto; pero J. Verreaux cree haber observado que un coliu se cuelga de la rama por una pata, dejando peridiente la otra á esta se coge un segundo, del cual se agarra un tercero, y forman de cste modo una cádena de cinco ó seis individuos. As se confirma plenamen. te lo que nos dice Le Vaillant. Segun lo que yo he visto, el coliu toma para descansar una postura extraña; aplica su cuerpo contra la rama en que sé posa, y como en esta posicion debe doblar mucho las articulaciones de las piemas, diriase que se suspende; pero no es asi. Trepa a las ramas, y se sosticne algunas veces como los paros, con la cabeza hicia abajo, aunque siempre por muy poco tiempo.

Ic Vuillant anade que es muy facil coger colius cuando se descubre el sitio donde decansan: basta is por ia noche of muy de mañana, para apoderarse de grupos cnteros; si hace frio se entorpecen de tal manera, que se les desengancha siu que se escape uno solo.

No puedo aceptar este cuento, ni he visto cosa alguna que me haga suponer una cosa semejante. Cierto que los colius no son recelosos; se puede matar á todos los individuos de una bandada, uno despues de otro, antes que hayan pensado en huir; son confiados cinofensiros, pero no tan estúpidos que se dejen coger con la inano. Viviendo en lugares oculios, al abrigo de las asechanzas, son imprudentes jpero saben distinguir bien entre un amigo y, un adversario: los que frecuen. tan los jardinas inmediatos á las casas están siempre muy alerta. Parece que los colius solo se alimentan de regetales: yo creis que comian tambien insectos: pero durante mi pri. mer viaje no encontré en el estómago de los que maté sino restos regetales, tal como retonos, frutos y granos. En el cen. tro de Africa constituyen su alimento mas frecuente las bayas del azufaio; en los jardines devoran los higos chumbos, las uvas, y segun Hartmann, los limones dulces. Al comer to. man las posturas mas variadas, como lo hacen los paros; se cogen unas reces il fruto mismo y otras á las ramas, dejando pendiente la cabez. En el centro de Africa no se qucja nadie de los daños que ocasionan en los jardines; pero en el Cabo de Buena Esperanza, por el contrario, son nocivos, porque abundan mas que en el inierior. Son una calamidad para los huertos, pues no solo se comen todos los frutos, sino tambien los botones de los árboles y los retonos de todos los granos que comicnzan - ó-gerninar. Inútil es resguardar con maderos los cuadros sembrados; penetran deslizándose por las ramas y lo devoran todo en un inctanie; ningun medio es eficaz pam allejarlos de los irboles que han resuelto des. pojar; por todas partes encuentran una entrada para comer el fruto prohibido.

I. Vaillant, y despues Gurney, Hartmann, Anderson y Heuglin, han descrito el nido del coliu: scgun el primero, tiene la forma cónica, compuesto de rafees de toda especie, encontrándose comunmente varios nidos cstrechados unos contra otros en un matorral de los mas espesos y espinosos. Hartmann dice que se compone de jerbas, cortezas y hojas tomentosas, revestido interiormente con la pelusilla de ciertas plantas. Gurney nos asegura que estít revestido de hojas verdes y frescas, $y$ se pregunta si no scria necesario cierto grado de humedad para la incubacion de los huevos.

Heuglin encontró nidos en ln estacion lluviosa, a fines de setiembre, á unos cuatro ó cinco metros de altura sobre el suelo, en los gramados y vides de los jardines de Cirartom; dice que son pequeinos, planos y de construccion ligera, componiéndose de rerba seca, corteza de àrboles, raices y rama. je. Contienen de dosá tres huevos de $6{ }^{\circ}, 016$ \{ $61^{m}, 01 ;$ de lon. gitud, por $0^{\prime \prime}$, olt de grueso, y de forma obiusa; la críscara. bastante fina, es blanca, con algunas manchas, líneas y ara. bescos bastante marcados de color rojizo. Tambien Anderson indica el númers de tres huevos como regular, o segun dice el, invariable. Por lo demas, carecemos de observaciones so. bre la reproduccion.

CAzA. - En el Cabo de Buena Esperanza se persigue a los cólidos tanto á causa de sus saqueos en las plantaciones como para comer su carne suculenta.

CAUrrvidaD. - En el Cabo se cogen muchas de estas ares rivas; pero segun Le.Vaillant, son muy poco graciosas en la jaula: unas veces se acurrucan en un rincon ó se arras. tran penosamente, y otras se cueigan del techo, permanccienda horas enteras en esta posicion. Algunos observadores modernos parecen creer lo contrario, pues dicen que los cautivos son viraces y divertidos.

\section{LOS MUSOFÁGIDOS- MUSOPHAGID压}

Esta familia cuenta solo unas diez y ocho especies, y sin razon se designan por algunos con el nombre de comedores de flálomis, puesto que dificilmente se alimentan de ellos. No sabemos wún con seguridad si son congéneres de los cuculi. dos; pero me parecen mas afines de estos que de las ares con que se los ha agrupado.

CARACTÉRES. - Los musof́gidos tienen una talla que varia entre la del grajo y la del cuervo. El cuerpo es prolongado; el cuello corto; la cabeza mediana; el pico, fuertey ancho, de arista superior muy encorvada y la inferior algo recogida por dentro, con el corte dentado. Ias alas son de un largo regular y redondendas, con la cuasta ó quinta penna mas prolongada; la cola larga y redondeada; las paras fuertes y bastante altas; los dedos se dirigen uno hácia atrás y tres adelante; el extremo se puede inclinar un peco de lado. El phumaje es blando, y los colores muy vivos á menudo.

DISTRIBUCION GEOGRÁFICA.- I.OS musofágidos habitan los grandes bosques del centro y del sur de Africa: no se encuentra ninguno en los puntos donde no hay ár. boles.

USOS, COSTUMBRES Y REGIMEN. - Viren en grUpos poco numerosos, compuestos de tres á quince individuos: permanecen conuumente en los àrboles, y algunos recorren con cierta regularidad una gran extension de terreno. Su vuelo es bastante fícil: el ave puede cambiar de direccion en todos sentidos cuando cruza los aires; en los úrboles se mueve con gran agilidad. Dificil es asegurar cosa alguna sobre su inteligencia; pern no se ins debe clasificar cutre las aves estupidas: están atentas á todo, son muy cautclosas, y si se las persigue, manifiestan suma desconfianza. l'arece que no hacen caso de las otras aves, pues nunca se las encuen. tra sino con sus senejantes, si bien sucede a veces que los individuos de especies andlogas se reunen por algun tiempo. 
Costa de Oro, mientras que dice Reichenow determinadamente que el musófngo violeta vive siempre aislado $\delta$ en parejas, y mas bien en la espesura baja y en los lincieros de los bosques quue en los altos árboles de las selras virgenes. Aqui vire iranquilamente y oculto, pero cuando el viajero le ha distinguido entre el follaje, los mänisicos colores del ave llaman en alio grado su ntencion. Parece que por el carícter, la voz y el régimen alimenticio difieren poco de sus congé. neres, ó al menos se pucde stiponer ast por los cautivos que alguna rez. recibimos en Europa.

CAUTIVIDAD. - İl musófago violeta escasea mucho aun en las colecciones: pero ultimamente se han obtenido no solo pieles, sino iambien individuos viros.

\section{LOS TURACOS-CORYTHAIX}

Fistas especies, llamadas tambien nits de enso, son mejor conocidas que el géncro anterior: constituyen el grupo mas considerable de la familia, y se extienden portodas las partes del nais antes citado: abundan mucho mas que sus congéne. res, y llaman la atencion alli donde se encuentran.

CARACTERES.- Iil pico es corto, pequeñoy trianguhr; la mandibula superior se encorva en forma de un ligero gan cho sobre la inferior, las fosas nasales éstin cubiertas en parte por las plumas de la frente; las alas son cortas y redondea. dașila quinta rémige es lit mas larga; la colo, de mediana lóngitud : redondeada; al rededor de los ojos se ve un je. çucho circulo cubierio á veces de verrugas carnosas. Fil plu. maje, muy abundante, se prolonga en la cabera en forma de casco; el color predominante es verde, mientras que las rémi. ges se distinguen regularmente por su magnifico rojo purpú reo. Las civersas especies se asemejan en extremo, tanto por la coloracion como por el gúneró de vida.

\section{EL TURACO DEMEJILLAS BLANCAS- CORYTHAIX LEUCOTYS}

CAR ACTÉRES. - Hi turaco (fig. 55) ticne el lomo y las alas de color verde violeta oscuro; la cola de un violeta ne gro con perfuenas líneas irasversales oscuras; el vientre y las nalgas de un gris intenso, y el moño ó casco de un verde mur brillante. Una mancha que hay por delante del ojo, y otra que baja casi verticalmente de la oreja, prolongandose por el cuello, son de un tinie blanco de nieve; las pennas de las alas de un rojo carmin, orilladas circularmente de un tin. te verde puerro. El ojo, de color pardo claro, está rodeado de un circulo de penueñas rugosidades de un rojo bermellon; el pico es rojo de sangre en la punta; la mandibula superior verde hasta las fosas nasales, y las patas de un gris pardo. El ave mide $11^{*}, 45$ de largo $5,6 \%, 57$ de punta á junta de ala; esta plegada $U^{w}, 175$ y la cola $0^{*}, 215$.

Ia hembra es un poco mas pequeña q̨ue el macho; pero ticne el mismo plumaje.

DISTRIBUCION GEOGRÁFICA. - Ista ave es propia de la Abisinia.

USOS, COSTUMBRES Y REGIMEN.- En mis cacerias por el Habcsch tuve varias veces ocasion de observar al turaco: solo sc le encuentra á una altitud bastante grande, en los valles cubiertos de bosque y vien bantados, donde cre. cen las cuiorbiàceas de corona.

Forma bandadas ó reducidas familias, lo mismo que el gmjo. de cuyanctividad participa: vagn todo el dia de un punto a otro, pero vuelve con regularidad á ciertos àrboles, tal como los sicomoros y tamarindos, rodendos de breñas poco elevadas. Aquel es el punto de reunion de la tribu, y de alli parten las aves, cada clial por su lado, para ir á buscar el alimento.
Cuanda se halla uno de dichos ábboles'se puede obscrvar cómodiamente à estas magnificas ares a medio dia y por la tarde. l.laman muy pronto la atencion, ya prorque salian de rama en rama, ó bien porque producen su grito particular. lis un sonido dificil de describir: tiene un timbre sordo, casi de ventrilocuo, y no se juede reconocer á qué distancia se halla el are: el sonido ąue emite se expresaria por iolushaia. yaguga.

El turaco de mejillas blancas pasa casi tocia su vida en los árboles y no desciende á tierra sino alguros momentos, por lo regular en los sitios conde se halla el suelo cubierto de cuforbios poco altos. Solo permanece alli el tiempio necesa. rio para coger alguna presa; luego gana rápidamente el árbol mas próximo, permanece alli algunos instantes, y se traslada fotro; ó vielve á tierra. Los restantes individuos de la ban. dada hacen lo mismo, no juntos, sino separados, exactamen. tè como los grajos: vuelan sin ruido, siguiendo el uno al cira; y comn todos llevan la misma direccion que el primero, con corta diferencia, tardan poco en reunirse.

En los irboles es sumamente figil esta are: salta de una rnna á otra, corre i lo largo de ellas, llega ai su extremo, mira por todas partes,y se lanza despues á otro árbol ó se intro. duce en lo mas espeso del follaje. Su vuclo se parece tanto al del grajo como al del pico: el ave describe una linea on. dulada, aunque bajando poco: bástanle algunos alctazos para clevarse hasta el punto culminante de su carrera: despliega entonces sus alas, y ostentándolas en todo su esplendor, baja ripidamente pars elevarse de nuevo: lleva el cuello tendido, alta la cabeza, y la colu abicrta ú cerrada alternativamente, scgun que bajn ó sube.

In cl estómago de los individuos que yo maté no he hallado mas que sustancias vegetales, bayas y granos: he visto á los turacos posarse con frecuencia en los matorrales cuyos frutos estaban maduros; pero permanecian alli muy poco tiempo. En cierto modo no hacian mas que probar un fruto y refugiarse al momento en medio del follaje.

Heuglin dice que tambien se alimenta de orugas é insectos en general; y Lefebrre asegura haber chcontrado pequeños caracoles de agua dulce en el estómago de los turacos muertos por él.

En el mes de abril naté una hembra en cuyo oviducto si un huero perfectamente desarrollado, de color blanco y del tamaño de los de naloma, notable sobre todo por-la finura y el brillo de la cáscara. Nunca le conseguido descubrir el nido de esta ave, si bien no dudo que anida en los troncos huecos. Hasta en el periodo del celo viven los turacos por tribus, y no por familias, cuando menos los que yo he visto. No he podido hacer observacion alguna acerca de los ene: migos raturales del turaco y de los peligros a que se halla expuesto cuando vire libre; pero puede suponerse que le persiguen los gavilanes y los halcones. La prudencia cie que da pruebas, su costumbre de ocuitarse en medio del mas es. peso follaje y de volar aisladamente, sin permanecer mas que un momento en tierra, indican que nuestra supposicion cs cxacti, aunque no se pueda asegurar nada positivo sobre cste punto.

CazA. - a los abisinios no les ocurre carar al turaco de mejillas blancas, ni tampoco tencrle cautiro, I pot la misma razon no desconfia mucho esta ave del lombre, pero basta que la persigan una vez para hacerse sumamente recelosa. Su continua movilidad hace por demás dificil su caza; toda la tribu se agita delante del cazador y no tarda en desajarecer de sus ojos: poniéndose al acecho cerca de los árboles favoritos de estas aves, se puede tener la seguridad de coger algun individuo.

Q Esta ave, dice Heuglin, se distingue po: su asombrosa 
agilidad al trepar: cuando la rompen un ala de un tiro corre rápidanente hácia el próximo árbol, brepa como un centropo por el tronco y desaparece al punto en el follaje ó entre los bejucos.

CAUTIVIDAD.-Desce la creacion de los jardines roológicos conocemos la vida en caurividad de los turacos; pero tambien posecmos antiguos datos. Mluy á menuda se ve en las grandes colecciones de animales vivos una especie del oeste de Airica, y esta es la que ha descrito Ploss hace cin. cuenta años.

1. Mi ave, dice, es vivazy lista; todo el dia esti cn novi. miento; vuelve la cabeza a derecha é izquierdn, y cada ve\% que come exriende las alas y la cola; está may donesticada, toma el alimento en mi mano, y puedo dejarla correr libremente por la habitacion. Salta i gran distancia, con las alas nuy abiertas, pero sin agitarias, $y$ con el cuelio endido. 1)espues anda varios pasos, conscrvando la misma posicion: su marcha es fácil y rápida, mas no puede trepar, y con tra. bajo se sostiene en el enrejado de su jaula Su grito de llamada es una especie de grminido, que repiec ocho ó dici. veces seguidas, y siempre con mas fuera cuando re un ob. jeto extraño, de mocio quue se le oge a través de varias puer. ias cerradas.

2Si me acerco al ave moviendo los labios, levámise, dilata su garganta y su bucize y arroja algunos alimentos, como para dármelos, lo cual me indica rque nutre is sus pequenos con el contenido de su buche: es probable ngue machn y hembra se ocupen en la cria de su progenie. ldeva continuamente el moño levantado, excepto por la noche, cuando duerne ó cuando le prodigan caricias. Yo le doy de conser pan unoja. do en agua y frutas cortadas en pedacitos; en invierno se alimenta de manzanas y peras; cn las demás estaciones de fresas, cerczas dulces, framblicsas, ciruclas, uras, ctc Necesita frutas para conservarsc bien; traga piedrecillas y arena en bastante canticlad y se baina con gusto. En resúmen, el turaco luri es ficil de conservar, y yo tengo el mio hace ja cerca de cuatro anios.

- El if de junio de i\$25 puso un huevo en su comedero y el 5 de julio otro: en rez de utiizar un nido de palouma que le preparc yo, reciróse al sitio mas oscuro de la jaula antes de poner, de donde lie deducido que cuando el are vive en libertad anida en los troncos ce los úrboles. Al poner enfer. mó, y bebia una extraordinaria cantidnd de agua.

2. E.sta ave muda una vez al año.

He cuidado varios turacos y los cuento entre las aves mas graciosas que los paises iropicales enviau a nuestras jaulas. Solo descansan en las haras del medio dia, pero sodo el res. to de la maiana y de la tarce se mueven continuanente desplegando toda su belicta, de modo que sirven de adorno a toda pajarera grande; subre iodo en las gue se hallan al aire libre su aspecto es magnifico. Son inas vivares en las primerns horas de la mañana $y$ en las últimas de la tarde: cuando el dia es muy claro se rerimn a la oscuridad del fo. Ilaje, ó en un aposènto donde no peneiren los rayos del sol. - Evitan esios úlumos lo mismo que las lluvias fuertes que mojan su plumaje de tal modo que casi son iucapaces de volar. Con sus companicros de jaula visen en períceta armo. - niáo mas bien no liacen caso alguno de ellos. I.os he tenido con tas mas diferentes aves en una misma jaula, sin observar nune que hubiesen-trabado peleas con atgun corripanero. Sunque alguno de estos se ponga al lado de ellos oprimién. dóse conira su cuerpo, se quedan tan inofensivos como antes.

Se alimentan sencillamenic de arroz cocicio mezclado con frutas: necesitan mucho, pero no son delicados en cuanto a las calidad.

Rara vez se ope su voz: por lo regular no producen mas que una cspecie de grunido; cuando se lés cxcita gritan con iverza, emitiendo un sonido cortado que se puecle expresar por krsusk, krusek.

I. Verreaus ha hecho una curiosa ovserracion sobre estas aves: ha visto que las plumas de las alas pierden su hermoso color violeta cuando se mojan, y que desaparece del todo su tiule si se irota entonces con los dedos.

Esto to han podido ver desde entonces todos los que tenian turacos y les daban en vasjoas muy limpias, sobre todo si eran de porcelana blanca, el agua necesaria para bailarse. Lina pareja observada por liuderes comunicó al agua de un vaso de tamaño regular un color tan vivo que parecia tinta roja algo pálida; pero se banaba varias veces al dia, despren. diéndose asi por lo tanto una cantidad considerable de co. lor. Mientras las plumas maban mojadas, su coloracion purpúrca siraba mucho al azul: pero cuando se habian seca. do arlquirian un rojo purpiteo ian inagnifico como antes. IJusante la muda no perdian tanto el color, segun he observado en los suracos cuidados for mi. Despites de morir el ave no disminuye el desprendimiento del color, ó por lo ine. nos asi lo reconocieron W'esterman y Schlugel.

Lin el lardin zoológico de Amsierdan le sobrecogieron á un turac:o convulsiones, $y$ segun se hace en tales casos, ro. cinironle con agua frin. Essturo echado algunas horas í inmó. vil, y murió al lin. Lina parte de su cuerpo quedó seca, y sola siguió mojada la n̨ue tocaba al stelo; cn esta última cambió el color rojo del ala en azul, ỹen la otra consersó su tinte brillante. Fn el plumaje preparado no ejerce el agua ninguna infuencia: es preciso lavarle con agua de jałon 6 una ligera solucion de amoniaco para que pierda su color.

\section{LOS ESQUIZORIS - SCHIZORHIS}

CARACTERES. - En tocio el centro y oeste de Africa cxisten varias especies de amfibólidos, que han sido separados de los otros para reunirlos en un giupo con el nombre genérico de siliseribis. Se caracterizan por su cuerpo prolon. gado, las alas son relativamente largas, con la cuarta penna mas larga; por su pico grueso y fucres, apenas mas alto yuue ancho, de arista muy corva y cortes poco dentados; y ulti. manente por su color oscuro y la naturaleza de las plumas de la cabeza.

\section{EL ESQUIZORIS DE FAJAS-SCHIZORHIS ZONURUS:}

CARACTERES. - En mi últino viaje not Lbisinia pUdC ubservar esta ave (fig. 56 ), que tiene 1$)^{\infty}, 51$ de largo por $6^{\circ}, 75$ de punta a punta de ala; esta plegada mide $66^{m}, 25$ : 0iro tanio la cola; ia hembra es algo mayor que el macho. Cuando son adultos, una y otro tienen el lumo de color pardo oscl. ro, bastantc uniforme; el vientre ! el pecho de un gris ceniciento ciaro, que tira al pardo hácia la linea media. las.plumas del occipucio, largas p puniagudas, se leirantan en forma de mono y estín oxiliadas de blanco. las del lomo son le un gris azul en la parte oculı; las pennas de las alas de un piar. do negro, con una gran mancha euadrilátera blanca en ias barbas externas, pera sola en el macho; las prenuas caudales micdias de un parda claro en toda su extension; las cuatro externas, del mismo time en mas de la mitad de su longitud, blancas luego y icrminadas por una ancha fija negra. Ki ojo es gris pardo; el pico de un veide amarillo y las patas de un gris ceniciento oscura

DISTRIBUCION GEOGRÁFICA.-Elesquizoris de fa. jas parece estar muy diseninado: Ruppell le encontró en varias provincias de Abisinia; yo ic lie visto bastante nume. 
roso en el pais de los Bogos; otros viajeros le hallaron en las márgenes del Nilo Azul, y Heuglin le observó en las corrientes del Nilo Blanco.

Heuglin le ha visto en el territorio del nacimiento del Nilo Blanco y le designa como uno de los amfíboles mas comunes; dice que habita con preferencia en los bosques situados á la altura de 600 a i, 200 metros sobre el nivel del mar, y sobre todo en los àsboles mas elevados de las orillas de las aguas; tambien yo le he visto cerca de los riachuelos que desde la montaña se dirigen al mar.

USOS, COSTUMBRES Y REGIMEN.-A diferencia del turaco que no deja oir mas que una.voz ahogada, el es. quizoris de fajas trata por el contrańo de rivalizar con los monos por sus continuos gritos. Esta ave es la que engaña con frecuencia al cazador, haciéndole creer que una bandada de cercopitecos acaba de descubrir alguna cosa nueva y lo anun. cia con sus gritos. Su voz se asemeja, en efecto, á la de los monos; es sonora y vibrante; se podria traducir por g $z, \xi u$, guk, gri grack, gra girr, firr gruk gai, gr guk, y como todos los individuos de la bandada gritan á la vez, prodúcese un estrć. pito que aturde.

Yo he procurado anotar estos sonidos en el mismo sitio donde los oi y puedo hacerme responsable de su exactitud en cuanto esta es posible; pero reo en las obras de otros na. iuralistas que ni uno solo ha entendido lo mismo que jo. Sin embargo, Hevglin está conforme conmigo: tambien él dice

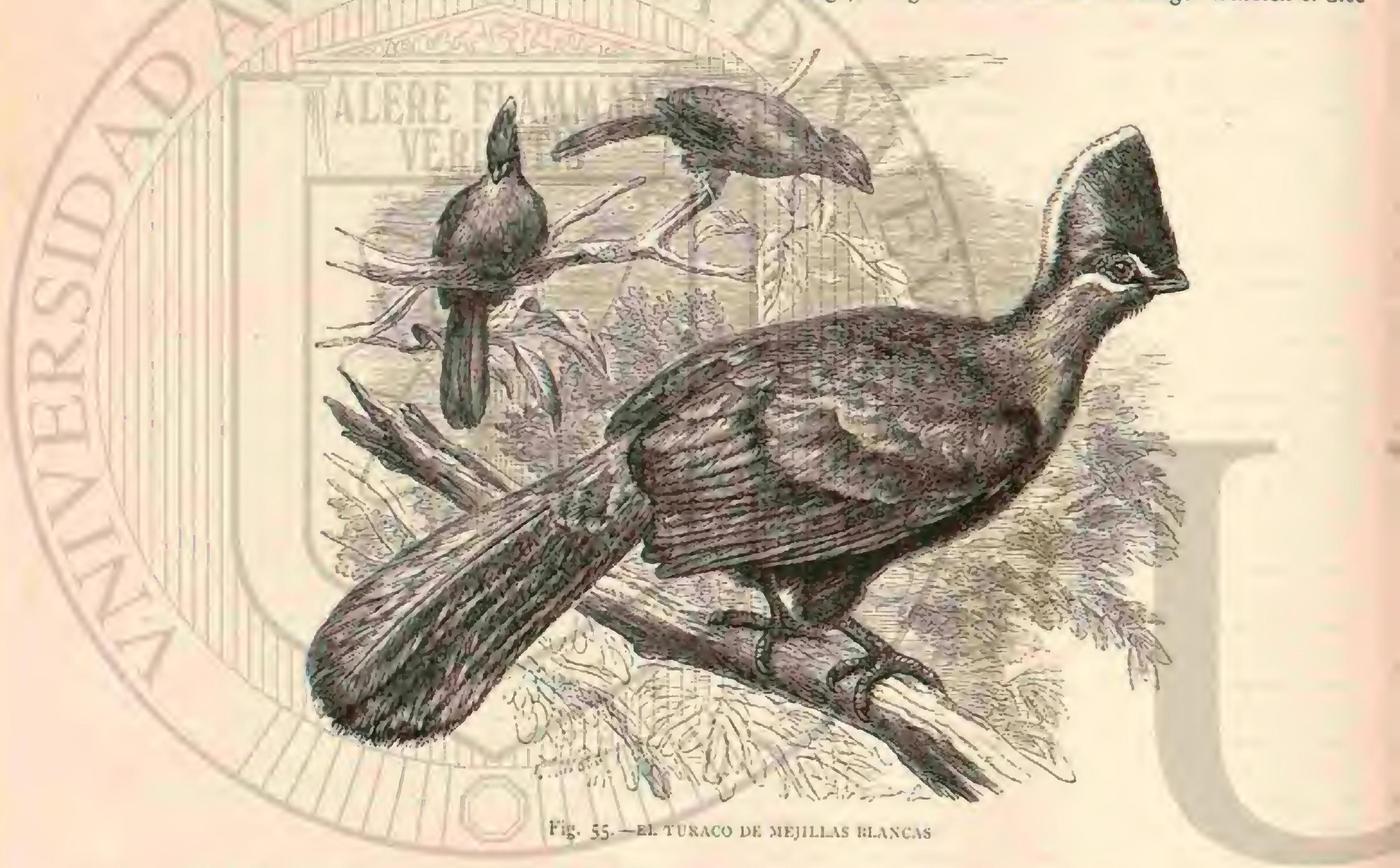

que la roz del esquizoris, nuy ruidosa, se asemeja à una carcajada, ó bien al ladrido ronco del perro ó ya á los gritos de pequeños monos. Tambien recuerdan la voz del tetrao; $y$ á veces arrulla como una tórtola. Antinori dice con razon de esta ave que es la que mas grita en aquella region.

Si se dirige uno hácia el sitio de donde procede, no se tarda en rer á estas singulares aves posadas en un árbol de los mas altos, de dos en dos ó por reducidas familias; $y$ avanzando prudentemente se las puede obscrvar con calma.

El esquizoris de fajas, que se podria llamar tambien ruidoso, por lo mucho que grita, ofrece gran semejanza con el cocal (exrtrofus) y el ani por su género de vida. 'Tiene como este último el vuelo conado; no atraviesa por su gusto un largo espacio, sino que va de árbol en árbol; se posa sobre la rama mas alta, enderézase, mueve la cola y lanza gritos que resuenan en toda la montaila.

Segun Heuglin, los individuos de una bandada retozan $y$ rihen continuamente y se persiguen gritancio de un árbol à otro. Pocas veces se ve el esquizoris posado tranquilamente cn el mismo sitio; muy por el contrario, casi siempre está en movimiento; paséase á menudo con destreza sobre jas ramas inclinando el cucllo y apoderándose de alguna presa; muy pocas reces descansa algunos momentos. Heuglin dice que por lo regular no es timido; pero yo he observido lo contrario $y$ me ha parecido un ave muy cautelosa; de modo que es bastante dificil apoderarse de ella. Solo en la inmediacion de los pueblos es meros desconfiado, acostumbrandose fácil. mente i la presencia del hombre.

Se alimenta de bayas de diversas especies, que recoge por mañana y tarde en las breñas: destina las demás horas al reposo y las pasa en los árboles mas altos; en medio del dia busca en los lugares mas sombrios un refugio contra cl calor.

Antinori le vió renetidas veces rodeado de aves pequeñas que le perseguian como suclen hacerlo los buhos y cuclillos.

\section{LOS BUCERÓTIDOS Ó CA- LAOS - BUCEROTIDA}

Ins calaos ó bucerótidos son para cl antiguo continente lo que los ramfástidos ó tucanes para el nuevo, á pesar de las diferencias esenciales que existen entre ambos gruposy que estoy léjos de desconocer. Rigorosamente hablando, for. man los primeros una familia de ares aislaca que no tiene 
semejanza con ninguna otra, pero en uiltimo extremo mas

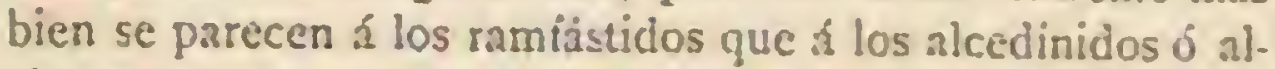
ciones, en los cuales se han geuerido rer sus especies mas afines.

CARACTERES. - IAS aves de esta familia son fáciles de caracierizar: lienen el pico largo, muy grueso, mas ó me. nos encorvado, provisto en su mayor parte de apénudices singulares que simulan un cuerno; pero por muy variada que pucda ser la forma, no es prosib!e confundirle con el de nin. guna otra ave. Distinguense además por tener el cuerpo mus protongado, cuello bastante largo; cabera relativamente pequena; cola medianamente larga, cuando no lo es con exce. so, compuesta de diez rectrices; las alas son cortas y muy redondeadas; las patas cortas; las plumas del lomo pequeñas; las del vicntre desbarbadas y camo vellosas. Muchas especics tienen desnuda la garganta y la region del ojo.

Iin cuanto al las formas, esta familia ofrece una gran mric. dad ce tipus: cacia especie se puede considerar casi ccmo un

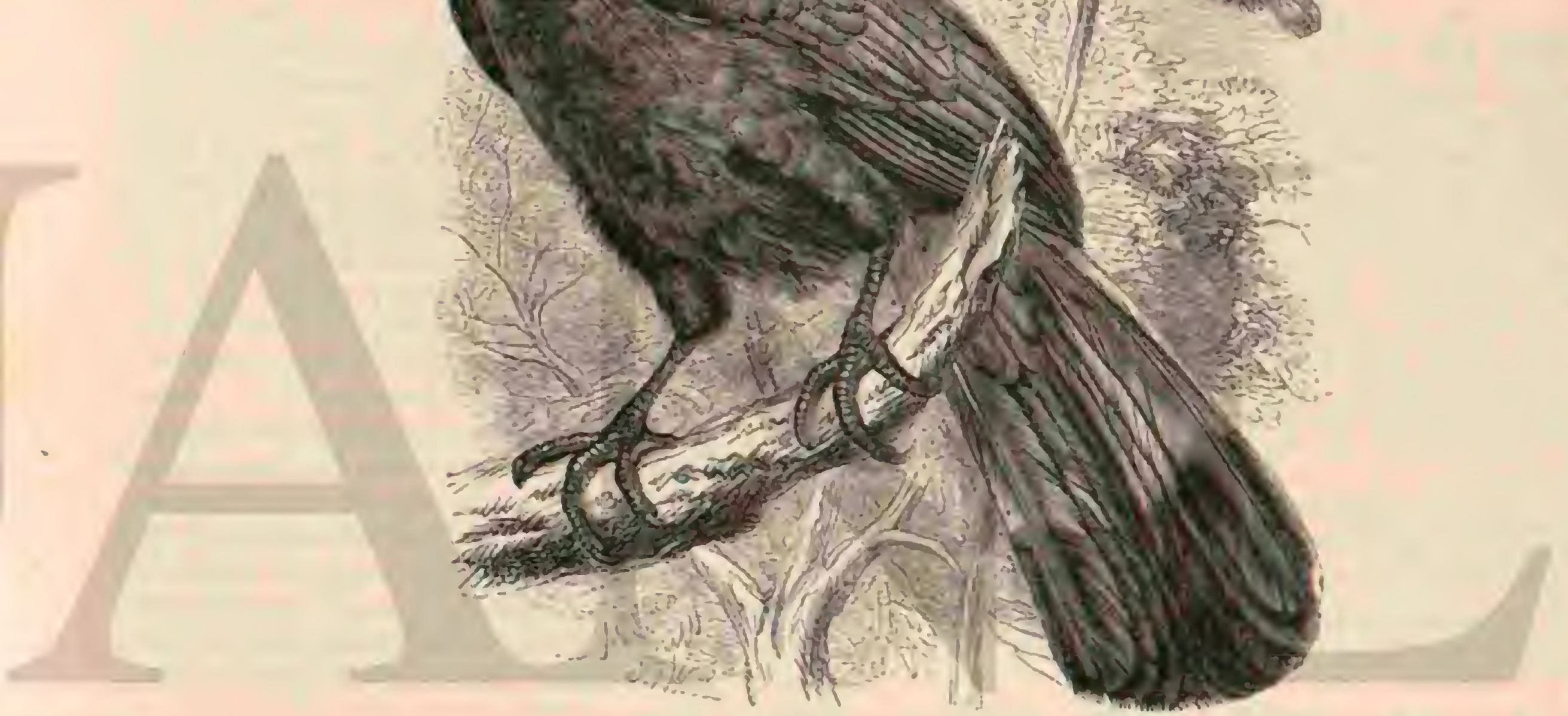

Fig. j6. - EL Es!

género, y en una misma de aquellas difieren considerable. menic los individuos de distinta edad.

Lo mas notable en su organizacion interna es la gran lige rer.a del esquelcto. No solo el pico monstruoso, sino rasi to dos los huesos, se componen de células mu grandes de paredes sumamente delgadas, todas neumáticas. Fil estcrnon se ensancha en su parte posterior y presenta a cada lado una ligera protuberancia; la hornuilla es muy nequena, no se articula con aquel; el esóngo es ancho; el estómago muy mus. culoso; el intestino corto y desprovisto de cicgos. Lin muchas especies, por no decir en todas, el aire puede llegar hasta debajo de la piel, que solo sesdhiere adbilmente 1 los órya. nos subjacentes, y el tejido subcutáneo contiene tambien en variós sirios grandes cétulas llenas de aire.

DISTRIBUCION GEOGRÁFICA. - I OS calaos habian el Asia meridional con las ishas malayas y el Africa central y meridional, componiendo unas cincuenta especies muy se mejantes en forma, coloracion, usos y costumbres. Lil foco de su area de dispersion parece ser el Asia, si bien se hallan representados ambien en Africa por muchas especies.
USOS, COSTUMBRES Y REGIMEN. - Se les er. cuentra desde las orillas del mar hasta una altitud de 3,000 metros, y siempre en grandes bostzues espesos y alios: úniramente las especies pequelias se dejon ver áveces en los matorrales.

'Todos los buceróidôs viven aparcados, sun cunndo son socjables, pues se reunen muchas reces con sus semejantcs, y hasta con especies muy distintas con tal que participen de su género de vida. Como los tucanes, pasan casi toda su vida en los ắrboles: los quie viven en tierra constituyen una excep. cion. Ia mayor parte andan torpemente aunque se muever con agilidad en el ramuje; vuelan mejor de lo que se creeria a prinera vista, y si no iranquean largas distancias, no se debe atribuir á la fatiga que les cause, pues se les ve varias veces juntos, jugucteando horas enteras en los aires. Su vuclo es gereralmente ruidoso; se oye à un bucerótido antes de verle: y hasta dicen algunos observadores concienzudos que el vuelo de cieras especies se percibe á la distancia de una milla inglesa.

El oido y la vista alcanzan bastante desarrollo en estag 
aves; y los démás sentidos lo tienen en mayor ó menor gra. do: Carecemos aun de los detalles precisos para poder apreciar su inteligencia; pero sabemos que todas las especies co. nocidas son prudentes, miedosas y vigilanies Su roz es algun tanto sorda, monositábica ó disilática, la producen con rigor y contribuyen con ella no poco á la animacion de la selva Respecto de esto ciroca lo que dice Ayres, el cual asegura haber oido con la mayor sorpresa un tucan que caniaba agradablemente a la manera del tordo: Al principio creyó equivocarse, pero hubo de convencerse despies de observar largo rato al are posada en la úlrima rana de ua árbol, nues cuando esta ecloó á lolar quedó las selva silenciosa como antes.

Su régimen es variable: la mayor parte comen vertebrados pequenos, insectos y liasta resios putrefictos; todos se ali. men!nn cambien de granos frutos, y ligumos son reatmente onmivóros.

Sú manera de reproducirse, al menos de las especiés indias obscrvadas hasta el dia, es muy singuihr, tanto que ninguna attal especie de aves ofrece una cosa anilloga. lil nido es un calaboro para la macire que permanece asi encernada hasta que los hijuclos salen á luz ú hasta cuando jueden volar, segun dicen cicilos autores. Solo el macho se encarga de ali. mentar a toda la familia, para lo cual debe trabnjar tanto yo esformarse de tal modo, que al fin se gueda reducido a la piel y los huesos. Entre tanto muda la hembra, ó por lo menos pierde sus plumas tan completanenteque queda algun tiempo del todo incapaz de rolar. Puede aduritirse con bastante verosimilitud que todos los ramfástidos obran de un modo antálogo. Anidan en troncos huecosipcro nientras la hembra cubre, el macho tapa ha enirada del nido con tierna húmeda, sin dejar mas que un agujero apenas suficiente para que la cautivi yueda sicar el pico á fin de recibir su alimento.

I.os baccrótidos que viren libres, y sobre todo las grandes especies, no deben tener á muchosenemigos, pues las mas de las ratraces temen su formidable pico, siendo estas las cuuc hatyen de àquellas. İ! liombre no has persigue tampoco, y an hay algumas que se consideran como séres sagrados en algu. nos puntos sin embargo, lodas parecen ver en nuestros semejantes ádyersários temibles y huyen de ellos con cuidacio; pero en caltividad sc homestican muy pronic, encoriñandose con su amo, hasta él punto de poder este dujarlas en libertad sin temor de qure abusen de ella.

\section{LOS RINCACEROS-RHYNCHACEROS}

CARACTÉRES.- IS ian variacia en los unceróticos la estructura del pico, y mas especialmente la de su apéndice, que han tevido que subdividirse los miembros de esta familia nadia menos que en doce géneros, il pesar de la gran concorcancia que presentan en los demís puntos. No entra en el cundro çue ine ise trazado el ocuparme de esios detilles. y me he de contentar con atender solo en segundo lugar a esta nueva division actualnente tan en boga, y segun la cual se reunen en un género ó subgénero especial, al ţue se ha dado el nombre de rincaceros, has especies mas pequeñas del grupo. Su juico es rejativamente peques̆o, aunque bastante grande en sij corro arriba yiabajo, mas ú menos dentado en los bosdes, de cresıa elevada y rortante, á reces sur. cado en los ladós, pero sin prominencia cómea - Los piés soin cortos y débiles; bastante largas las alas con la cuarta ó quinta rúmige mas largas que las otras; y la cola ligeramente redondeacia.

EL TOK Ó'RINCACERO DE PICO ROJO-BUCEROS ERYTHRORHYNCHUS

CARACTÉREs. - Es una de las especies mas pequeñas de la familia, tan fóscil de conocer como dificil de describir con pocas palabras. Toda la parte central de la cabeza es pardo. oscura, la region de la orcja pardisca, una lista en cada lado del cuello es de un pardo negraxco, y otra que corre, entre aquel y la parte superior de la cabeza, blanca. La parse st:perior del cuerpo es tambien de color pardo negruzco, con manchas cuneiformes blancas que se hallan en los extremos de las rémiges secundarias y en las cobijas. Iass rémiges primarius soin negras, las seis primeras con manchas blanens ovales en la cara inferior de las barbas, y desde la segun. da hasta la quinia tambien en la exterior. Lis secundarias, a excepcion de las tres jormeras y de la tiltima, son blancas, ; asi como las primarias, estín salpicadas de manchas y además orladas de blanco. Ias tres prineras y última de Jas secundarias, asi como las coxigeas mayores, son de color pardo negruzco y blancas en la cara inierior junto á la raiz Las grandes covijas de las alas son blancas tambien; las dos rectrices del medio san de color pardo oscuro unido; las otras son negrns cerca de la raiz y blancas en el cxtremo, donde tienen una laja transversal negra que en las uilimas téctrices se reduce insensiblemente à una manclia blanca. El ojo es pardo oscuro, y el pico rojo de sangre, crecpto una mancha oscura en la raiz de la mandibula inferior; el pié es getis tiranda a pardo. Esta are mide $11^{\circ}, 46$ de largo, $6^{10}, 57$ de junta d punta de ala; cada ala $6^{\circ}, 17$ y la cola $6^{\circ}, 105$. La hembra, que viene fi tener los mismos colores que el macho, es mucho mas pequeña que este.

DisTRIBUCION GEOGRÁFICA.-El àrea de disper. sion del rincaceró ó tok se extiende desde los $17^{\circ}$ de la:itud norte lificia el sur por la mayor parte del dirica.

USOS, COSTUMBRES Y KEGIMEN.-El tok es una de lissues que diariamente se oyen y se ven en los bosques de la Abisinia, del Sudan oriental, del Kordolan y en todís has regiones análogas del Alrica central, occidenial y ineridiona. Se le empieza ya a cncontrar, si bien no con tanta frecuencia, en los montes claros de las éstepas; como are comun y numerosa, en ciertos puntos en los terrenos lajos de los rios, con tal que el bosque consista en árboles elerados. En las montanas llega, segun las observaciones de Heu. glin, hasta la altura de dos mil metros sobre el nivel del mar. No es emigrante ó are de paso, perose aleja frecuentemente en compania de algun individuo de raza muy afine á grandes distancias, aproximándose hasta á los recilies y coscrios, aunque por lo conun no se acerca mucho á ellos.

Eltok, como la nuyor parte de los buceróticios, es ave arboricola, es decir que jamás baja á liersa á no ser que la filia absoluta de bayas 4 otras frutas de irbol le obliguen á cllo. Cobra afecto a ciertos árboles de su distrito, y se posa en ellos con predileccion en conpania de otros congénceses con los cuales le gusia reunirse, con la mayor regularidad. lambien es aficionado fí mostrarge da la vista de iodos, y se posa en las puntas mas altas de las ramas que forman la copa de los árboles. Su posiura, cuando está posado, no carece de gracia, aunque contrae el cucllo considerablemente hasta formar una si muy achatada, con la cabeza metida en. tre los hombros y con el cuerpo casi rocando á la rama, mientras que porie la cola rigida. Salta de una rama a otra con basiante torpezarpero cambia de puestón con mucha agilidad en la misma nma que ocupa, Su vuclo se parece en cierta manera al de nuestros jicamaderas, pero estan especial al propio tiernpo, que basta para conocer al tok a cual. quicra distancia. Se cleva prinero de algunos aletazos hasta cierta altura, despues se deja caer en direccion muy inclina. da bajando el pico todo lo posible; despres vuelve a subir para bajar otra ver, dilatando y plegando entre tanto alter. nativamente la cols. Esta ave debe su nombre al grito que 
d.a, el cual consiste en un sulo sonido armonioso que reprite con frecuencia ý muy cortos intervalos. Cada sonido suclto in acompanado de una inclinacion de cabeza, pero como sf medida que grita repite los sonidos mas y mas de prisa, casi no le es posible al fun acompariarios iodos con la mencionada inclinacion, aunque de ninguma manera la omite. Heuglin describe estos sonidos reyetidos con la combinacion: llividiulluicosuthuidiu, cantados en todas las escalas y variaciones, obser vando empern que cuando se espantan estas aves prorumpen en un graznido corto y disprero, y otras veces en una esplecic de cacareo muy vivo. De mi sé derir que sus gritos me han parecido siempre monosilábicos, conplarables con los de cier ins palomas que habitan las uismas selvas.

Los toks son tan curiosos y arisprados como los cuerros. Si'se tira contra una pieza de caza, es seguro verlos llegar; se posan solure aigun árbol próximo, y sus gritos anuncian el descubrimiento í toda la poblacion animal de los alreciedo res. La presencia de algun enemigo, de un carnicero, de una mpaz. o de una serpiente, les excita mas aun; catn sobre el mocinuelo con tanto furor y destreza como los cuervos: son los que auuncian a los demás animales la llegada del leopardo; los que usurpan al indiendor la gloria de sus descutbri. mientos, y senalan i sus demás companeros el sitio donde se desliza la scrpiente. No solo las demás ares, sino tambien los cuadrípedos, prestan atencion álos movimientos del lol:, pues es innegable que esias aves han sabido granjearse po sirtramente cierta consideracion entre los demás animales: el aschistiolio endereza las orejas apenas oje resonar su grito; el antilope cntregado al reposo se lcsanta al punto, las aves acuden, y en una palabra, toda la potslacion cel bosqure se despierta y se agita.

En el estómago de los toks şue yo maté he hallado frutos, granos e insectos: mas no dudo que roban los nidos, cogen de vez en cuando una avecilla, un pequeiso mamifero ó un lagnito.

Acerca de la reproduccion del tok tenemos los datos deta. lladisimos de Livingstone confirmados posicriornente cn un lodo por Kirk y Anderson. Fil célebre viajero se expresa del modo siguiente: Nos tocatsa atravesar dilazados bosques de moganes, y mis gentes cogieron un gran múmero de ares $1 / a$. madas ecorve dentro de sus mismos nidos construidos en los huecos de estos àrboles. El dia 19 de ácurerotopamos con uno de dichos nidos, en el que se ronocia estaba a punto de.anidar !a hembra del iorie. El hueco en donde estaba se hallaba tapiado en ambos extremos con barro, a excepcion de una abertura en forma de corazon y de un diametro cal. culado para dar paso as duras penas al cuerpo de la humbra. El espacio interior se prolongaba hricin arriba en donde el ave trataba de ocultarse cuando fuinus to comeria Encontra mos un huevo blanco semejante a los de paloma, y cuando ya teníanos asida sa la hembra, dejó caer atro. Fin el orario encontré otros cuatro fecundados ya.

\Cuando vi por primera vez esta esfrecic estáiamos en una selva de Kolobeng orupados en conar leira. De pronto uno de los indigenas que me acompañaban gritó: ¿j.Aqui tenemos un nido de corve: Fuí à verlo, pero no note mas q̨ue una rendija de un centimeiro de ancliun y de unos siete i dicz de longitud, jracticada en un hueco poco perceptible de un árbol. Yo creia que la palabm d corve significaba algun pe. queño mamifero, y estaba atento a lo epre el hombre sacaria despues de haber roto y quitado el barro y metido el brazo, cuando vi que sacó un tok adulto. Fil indigena me dijo des. pues que estas aves, una vez alojadas en el nido, tenian ył!e pasar una esprecie de reclusion o confinamiento como las recien paridas. Con este objeto rapia el macho la emirada hasta dejar una pequcila nbertura que solo permite a la hem. bra encerrada sacar el pico para recibir del inacho el alimento necesario. He dijo ademas que la hembra era la que cons. truia el nicio, y que no salia hasia que los polluclos estaban en disposicion de volar. Mientras tanto, es decir, durante dos $\delta$ tres meses, se ve al macho tratajar con afan para mantener á la madie y la cria. Ia primera engoida con este régimen, y constituye un bocado predilecto de los indigenas, mientras que el poure macho enfayuece tan miserablemen. te que a menudo cae exterando del rirbol y mutse, solure todo cuando sobrevicne un cambio brusco de tiempro acom. parado de lluvia. En cunnto i mi, conteso que no he tenido ocasion de comprobar la duncion de este ancicro, pero si diré, que cuando volvi a ver ocho dias despues el corve cn el mismo firbol observé q̨ue la abertura volvia á estar tapjada, lo que me hiro suponer que el anies desdichado viudo se habia ya proporcionado otra esposa. Dejamos a ambos tran. quilos y no me fué posible volver mas tarde al mismo sitio.

- En febrero es cuando la hembra toma posesion del niclo. limos muchos de estos ya concluidos, ó hien 1 medio concluir, y lanto acyui en las cercanins de las poscsiones portu. glaesas conno en las de Colobeng estaban acordes los relatos de los indigenas, en que el ave cautiva no abandona el nidn hasta que los pequciuelos se hallan en estado de rolar, que es liácia la época ell que inalura el irigo, y como esta epoca cae á fines de abril, resulta que la reclusion dura de dos a tres meses. Diren que sucede a veces que la hembra tiene dos puestas sucesivas \& iumediatas uma à otra, de tal manera que la segunda cria rompre el huevo o nace cuando los dos pequenuclos de la primesa puesta estion á punto de volar. En este caso sale la madre con los dos hijos majores, y enton. ces el padre y la nuacire juntos alimentan a los recien naci. dos, se entiende, despues die haber vuelto á tapinr la entrada del nido excepto la rendija mencionada. Varias veces he podido examinar la mana donde se habia posado el nacho, y le visto claramente lis huellas de su prermanencia irecuctutc cn el mismo punto durante el tienypo que habia alimentado á su hembro encerrada."

CAUTIVIDAD. - Kecientemente se han introducido di. ferenes tolis en leurup? y los he visto youservaldo en varios jardiaes zoológicos. No son aver de jaula de las que airaen espectadores, porque se mueven poro y raras vecer dejan oir su voz ni menos gritan con tanto alan como en la época del celo cuando estin en libertad, rie modo que-alli no manifics. ian su verdadera y curiosa indo!e.

\section{LOS DICOCEROS-DICHOCEROS}

CARACTERES. - Fisie sulgennero se caracteriza por una prominencia voluminosa, alta y ancha, que ocupa mas del primer ecrcia del pico, y cubre una parte cansulerible de la parte nuterio de ia cabeza, sienca nchatada hícia atrís. Fil represcriante de esta especic de la familit, propia de la ln. dia, cs

\section{EL DICOCERO BICORNIO-BUCEROS BICORNIS}

CARACTERES. - En cl Nepal llaman á esta ave Him. rai: los habiantes de los busutues de la India meridional la

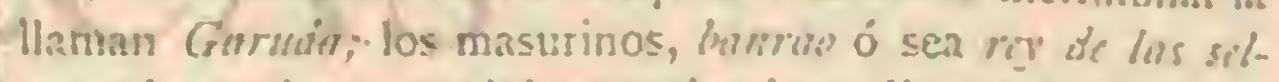

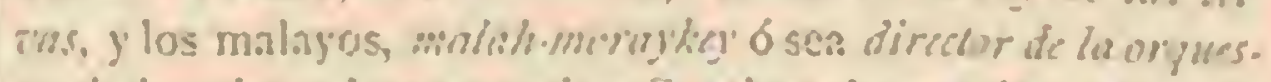

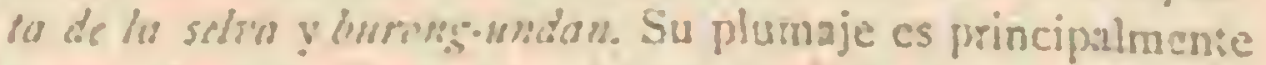
negro; cl cuello, las punias de las tectrices caudales, el vientre, las tectrices sub caudales, una mancha en las alas, is rair. de las rémiges primarias, y finalmente las rectrices son de un blanco mas ó menos puro. A menudo tienen las plumas de! 
cuello y las pennas un tinte amarillento debido â una difusion de la grasa que segrega la glandula coxigea. Fl ojo es ce un tinte cscarlata, la mandibula superior inclusa la pro. minencia son rojas prasando à amarillo de cera; la inferior es amarilla y roja en la punta. Fil espacio comprendido entre el apéndice y el pico es negro en la parte anterior; una lista que recorre el dorso del pico es pardo oscura; la miz del mismo de un negro plomizo, la membrana desmuda del ojo negra y- el pie pardo oscuro. Fl ave mide $I^{m}, 20$ de largo; el

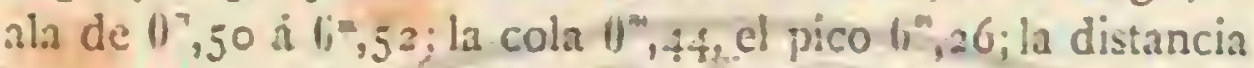
desde la parte posterior de la prominencia hasta la punta del pico es de $0^{m}, 3^{4}$, teniendo dicha prominencia $\|^{*}, 20$ de largo y $66^{\mathrm{m}}, 0 \$_{5}$ de ancho $\left(\tilde{n}_{1}, 5 S\right)$.

DISTRIBUCION GEOGRAEICA.-Fl homrai ó dicoccro bicornio se extiende por tódos los bosques de clevada copa de la India, desde el extremo sur hasta el Himataya, y desde la costa de Malabar liasta Asam, Arracan "l'enaserim, Burma y la peninsula de Malaca. Se le ve tambien en Su
matra.

USOS, COSTUMBRES Y RÉGIMEN. - Jerdon dice que se le encuentra ea la India en los fiancos de las monta. nas hasta la altura de mil (1̧uinientos metros sobre el nivel del mar, pero que raras veces suba tanto, estando casi siempre en las partes bajas. Vire apareado y si alguna vez se le ve en bandadas, cstas 110 son jamás numerosas. Hodgion, a! que debemos una descripcion inodelo tanto por in forma como por el contenido, del aspecto, indole y costumbres de csta ave, dice que habita todas las cercanias poco clevadas del Nepal entre Haridwar á levante y Asam al oeste, y siguiendo siempre las corrientes de los rios penetra en el interior montañoso, quuedíndose empero siempre en las tierras relatiramente bajas sin clevarse nunca á las cúspides de las montainas recinas. Varios indigenas que conocian perfectamente el ave y su género de vida dijeron i Hodgson que
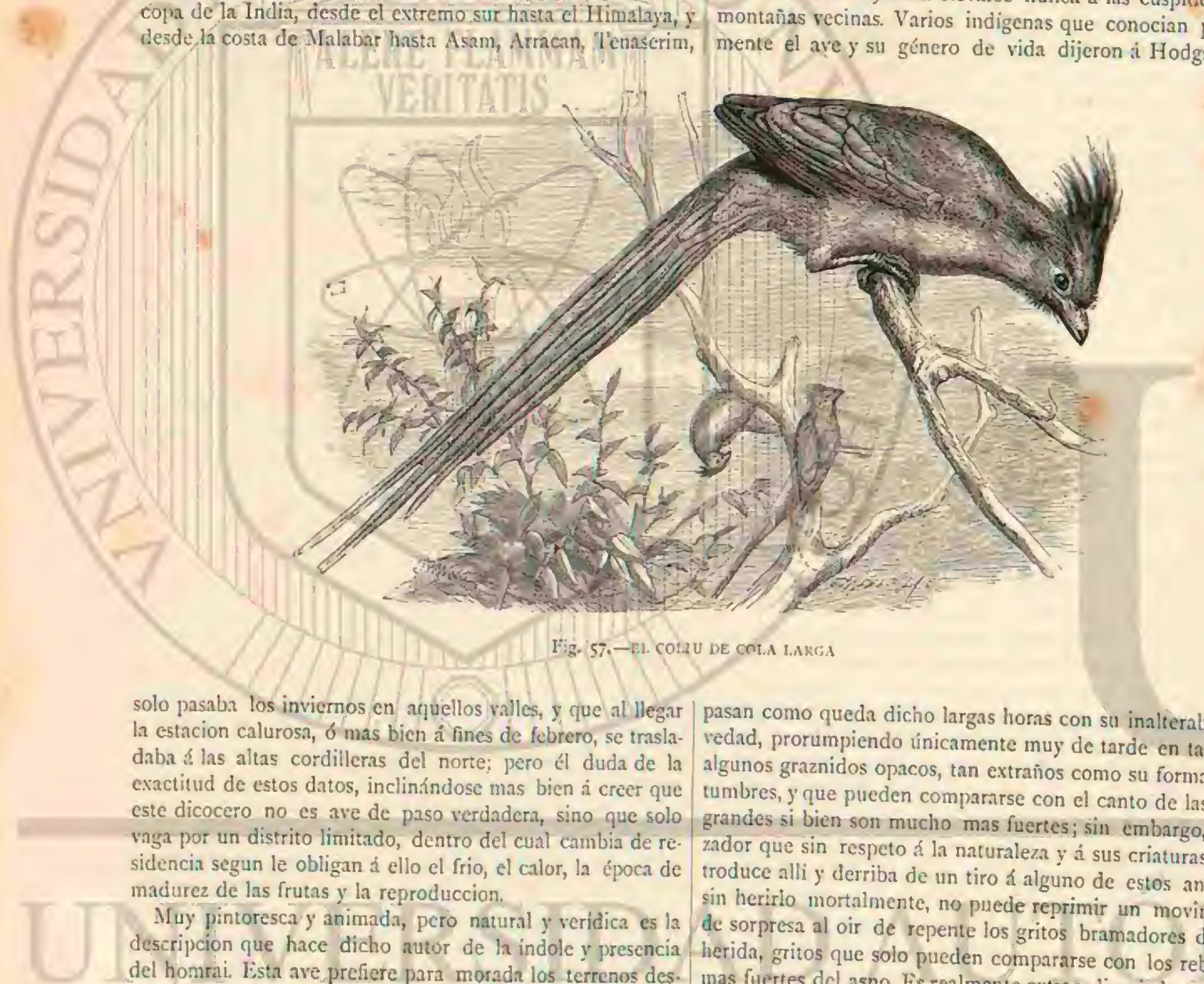

solo pasaba los inviemos $\mathrm{en}$ aquellos valles, g que al llegar la estacion calurosa, $\delta$ mas bien á fines de febrero, se imsladaba : las altas cordilleras del norie: pero él duda de la exactitud de estos datos, inclinándose mas bien a creer que este dicocero no es ave de paso verdadera, sino que solo riga por un distrito limitado, dentro del cual cambia de re. sidencia segun le obligan à ello el frio, el calor, la época de madurez de las frutas y la reproduccion.

Muy pintoresca $y$ animada, pero natural y verídica es la descripcion que hace dicho autor de ha indole y presencia del homrai. Lista ave prefiere para morada los terrenos des. campados en medio de los bosıues y junto à las rios. Es animal sociable que se distingue tanto por sus costumbres serias, tranquilas y sosegadas como por su porte lleno de dignidad $y$ de confianza en si mismo. No es por tanto raro el ver á estr ave extraina y grande sentada tranquila é inmóvil horas enteras en el extremo de la copa de algun árbol alto $\mathrm{y}$ fantástico, con el cuello contraido y casi oculto entre las alas y el cuerpo descansando sobre los pics. De ver en cuando se leranta, por lo regular acomplanada de una ó dos mas, para dar un vuelo corio hàcia la cona de otro árbol ve. cino. Jamás baja á tierta ni se posa siquiera sobre un airbol bajo, por lo menos no lo observó Hodgson. Sicmpre viven en grupos de veinte á treinta, estableciéndose en cada árbol de seis á ocho individuos, si aquel es bastante grande, y alli pasan como quueda dicho largas horas con su inalterable gra. vedad, prorumpiendo únicamente muy de tarde en tarde en algunos graznidos opacos, tan extranios como su forma y cos. tumbres, y que pueden compararse con el canto de las ranas grandes si bien son mucho mas fuertes; sin embargo, el cazador que sin respeto á la maturaleza y a sus crinturas se introduce alli y derriba de un tiro á alguno de estos animales sin heririo mortalmente, no puede reprimir un movimiento de sorpresa al oir de repente los gritos bramadores del are herida, gritos que solo pueden compararse con los rebuznos mas fuertes del asno. Es realmente extraordinaria la potencia de su voz, debida probablemente á lo huesosas que son la laringe $y$ la glotis.

Todos los demis observadores concuerdan en lo mas esencial de esta pintura: solo Jerdon dice que jamas ha visto ni en la India meridional ni en Sikin grupos de estos aninia. les que pasasen de cinco 6 seis individuos, y aun estos grupos eran raros Dice que el dicocero bicornio es un animal taciturno, que solo emite de cuando en cuando un gramnido con vor de bajo, pero no muy fuerte, si bien añade luego que alguna que otra vez, cuando se reunen en cierto número, se les oye otros sonidos desagradables, ásperos y muy fuertes. T:ckell lo confirma diciendo: $\mathrm{La}$ voz que se jroduce como en oiras especies tanto á la inspiracion como á la espiracion despierta los ecos de la selva y al principio cuesta trabajo 
creer que sea la de un ave. Segun las observaciones que lie aletazos pesados, iguales y frecuentes, lo cual consiste en podido hacer en homrais cautivos, comparo estos sonidos stedtos y broncos con el ladrides de un perro de tamaño re. gular y creo joderlos representar por las reces anrok o irel. A cada sonido levanta cl ave el cuello y la cabeza lasta te. ner el pico una posicion rertical, $y$ en seguida los baja.

El homrai, dice Hodgscn, vicela con el cucllo estirado, las piernas contraidas y la cola un tanto extendida. Su vuelo fatigoso describe una linea recta, y el are lo sostiene con que las alas, si bien de respetables dimensiones, parecen carecer de fuerza, probablemente á causa de la poca colésion de la columna vertebral Cada aletazo va acompanado de un ruido silbador tan perceptible que se ore, conforme ase. gurn lerdon, sana milla inglesa de distancia. En ticrn no se halla csta ave en su verdaciero elemento, y es muy iorpe, porque sus piés no estan hechos para andar; pero en cambin los liene admirablemente apropiados parä agarrarse á las ro.

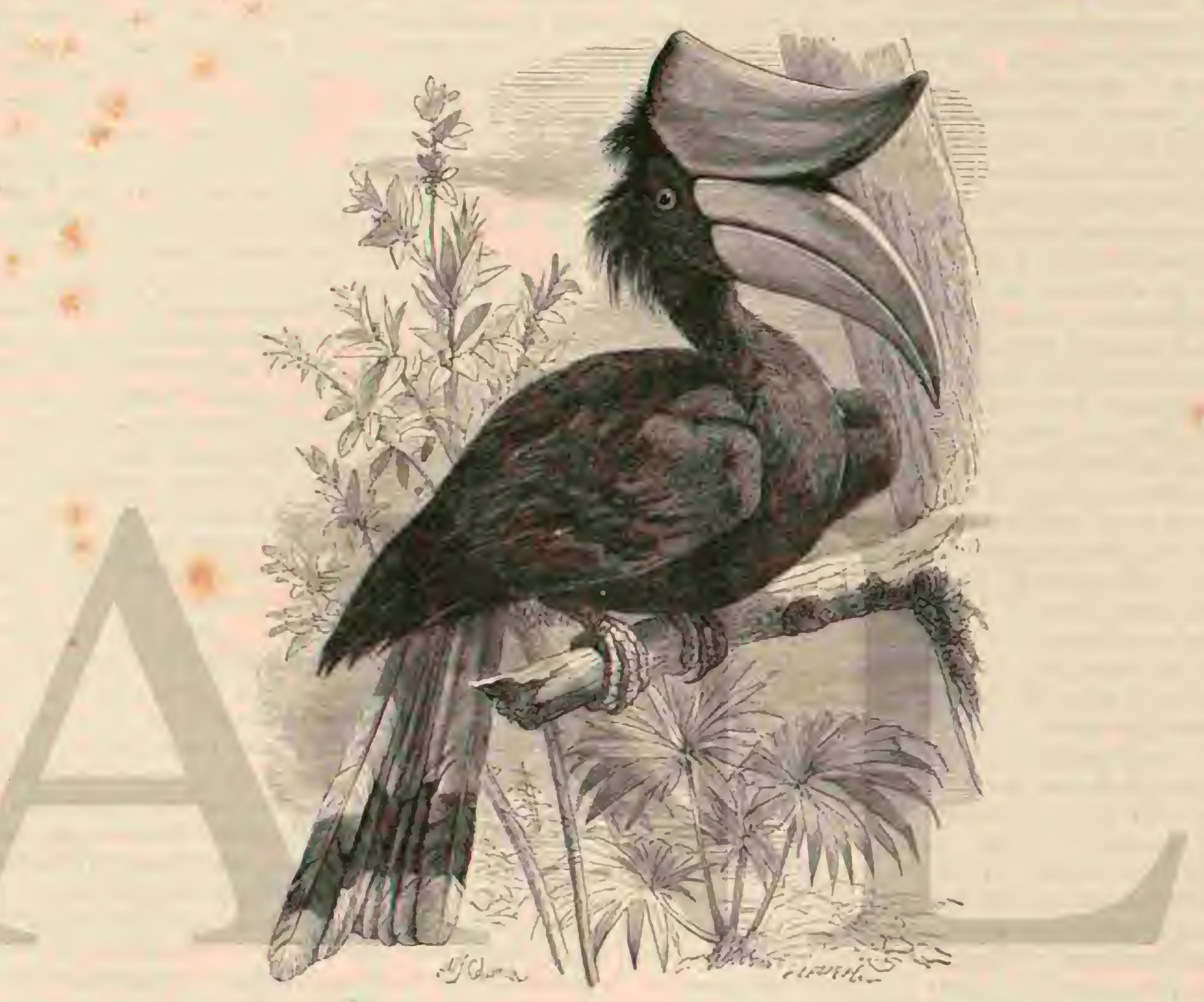

Fig: jS. - H. MICOCERO HCORNIO

mas, if lo cual se agrega, como hace notar Hodgson, que en los árboles encuentra cuanto necesita para su vida: es decir; alimento y reposo, por manera que nada tiene que buscar en el suclo; á pesar de esto de vez en cuando baja alguno yué otro, conforme veremos mas adelante.

Tambien cree Hodgson que los homrais son exclusiva. mente frugivoros. Por lo menos, dice, es cierto que in son en determinadas temporadas; pues los estúmagos de seis ú ocho que maté yexamine en cnero y felrero no contenian nada mas que el fruto de la higuera sagrada. Ia verdad es que prefieren no solo esta fruta sino todos los higns en ge. neral, tanto los siliestres romo los cultivalos, a todas las de más, conforme han observado casi todos los naturalistas que los han visto comer: $\sin$ que por esto formen su alimenio exclusivo, pues varian tambien. Horne dice que estas aves se hacen a veces muy molestas en las plantaciones de fruta. les, como sucedió en la de su propiedad que saquearon los homrais en $186 \%$ en términos de que hubo necesidad de matar una docena de ellos para ahuyentarlos. Los habia en Tosso III todos los árboles a los que trejaban a la manera de loros ayudiandose con el pico. En breve hicieron desaparecer toda la irrata que habia, y cuando el ciueizo inspeccionó los naran. jos que cran de fruto grande, dulce y de picl blanda y poco adherida, vió sodas las maranjas en su juesto, en apasiencjaintactas, pero de hecho completamente raciadas. Claso es que esto da motive para censidernr a estos animaies como exclusivamente frugivoros: pero las observaciones hechas en homrais cautivos no conirman esta suprosicion. En cautividăd no hay duda que cómen toda clase de frutas, fy algunas especies hasta con marcada predileccion y avidez, tanto que pueden calificarse de verdaderas golosinas para cllas; pero además del alimento regetal necesitan tambien sustancias animales, y algunas de ellas dan muestras de ser verdaderas aves de mpina, que atacan y degüellan cuantos animales vi. vos y mas débiles que cllos se ponen a su alcance. En muy poco tiempo despueblan la pajaren donde se los aloja; saben a pesar de su torpe inteligencia apoderarse pronto de sus companicros, acechando tranquilos ; sentados en el mis- 
mo puesto al are distraida, y no bien se halla esta á su alcan. ce la pillan, ỳa estén sentados ó volando, con un movimiento brusco de sı pico, y despues de arrojarla varias veces contra el suelo, la sujetan con una pata y la devoran con tan visible satisfaccion que es imposible atribuirla á un apetito innatural y efecto de la cautividad. Cada uno de los bocados que ar. rancan lo arrojan primero al aire para cogerlo con el pico al vuelo, y tanta es su destreza en este punto que con un poco de ejercicio llegan á atrapar las golosinas que se les arroja con una infalibilidad pasmosa, vengan del lado que quicran. Fuera de esio confirman los homrais cautivos hasta cierto grado otro aserto de Hodgson, el de_que estas aves no beben. No rechazan el agua en absoluto, pero beben solo á grandisimos intervalos; cada quince dias, sisu régimen es exclusivamente regetal, y cada tres o cuatro si es variado.

No faltan observaciones relativas a su reproduccion. Ma son dice: Cunvio la hembra ha jues:o de cinco á seis hue V05, la cmpareda el macho con barro tan completanente que no le queda mas espacio que el indispensable para asomar el pico, y en esta situacion pasa todo el tiempo que dura la incubacion. Su vida correria peligro si tratara de romper la pared de su cárcel. Para hacerle mas llevadera la prérdicia de su libertad se afona el macho por proporcionarle frutas enteras, porque ella rechaza, sin tocarlas siquiera, las que no lo estain. Creo que nodré dispensarme de decir que esta última parte del relato de Mason es una pura invencion, un cuento de In gente del pais que él admitió como moneda corriente. Hé áqui cómo completa Ticheil la relacion que preccde: CEstábamos a 16 de febrero de 18,5 cuando supe por los ha. bitantes de la aldea de Caren, que un dicocero bicornio grande empollaba en el hueco de un árbol alli cercano, y que ya hacia algunos años que una pareja de estas ares se servia del mismo hueco para sacar sus crias. Fui al sitio y vi qque el hueco se hallaba en el tronco de un árbol desprovisto de rmmas hasta la altura de quince metros. El orificio estaba tapadó con una espesa capa de barro, quedando únicamente una pequeria abertura por la cual la hembra solo podia alargar el pico y recibir la racion que el macho le llevaba. Con mucho trabajo se encaramó un hombre del pucblo con cl auxilio de estacas que claró de trecho en trecho en el árbol, y mientras estába ocupacio en romper el barro que cerraba el nido, el macho iba y venia, accreándose casi hasta tocar. nos y despidiendo sonidos roncos, pero nuy fuertes. Me costó trabajo hacerme obedecer de la gente que queria ma. tarle, porque le temian y me aseguraban que los atacaria. Cuando el agujero que đó ya suficientemente agrandado para que el hombre pudiera meter por él un brazo, fué picado por la hembra con tanta furia que le obligó á sacar el brazo mas que de prisa faltando poco que no cajera en ticrra; pero despues de haberse envuelto cl brazo en algunos trapos pudo sacar el ave en estado lastimoso, fea y sucia ; cuando la soltó dejándola en el suelo no podia volar, limitándose ś dar saltitos cortos y á amenazar a los que estaban cerca, hasta que al fin pudo encaramarse à un árbol pequeño donde queció posada, y tan entumecida que le ern imposible servirse de las alas y reunirse con el macho. En el fondo del hueco, a cosa de un metro debajo del agujero de cntrada, habia un solo huevo de color pardo claro sucio, sobre un lectio com. puesto de estiércol, cachicos de corteza y plunas. Iil resto de la cavidad estaba lleno de bayas en putrefaccion. E.l color de la hembra cra amarillo sucio, debido al derrame del accite de la glándula coxigea. $\$$

El mismo autor asegura en otro paraje haber visto cómo el macho tapiaba af la hembra: pero Horne fuć quien tuvo la miejor ocasion de observar á cstas aves mientras construian su niỏo. He aquif lo que dice: En el mes de abril de i $\$ 68$ me avisaron que habia dos nidos en dos distintos algodone. ros huecos, de los que las ares habian ya sacrado con sus picos la madera podrida y eissanchado los huecos lo suficien. te para proceder îla construccion del lecho, puesta y demás. En ambos encontré tres hueros despues que todo habia sido tapizado por las aves al parecer con estiércol tí otro material análogo, lo yue no pude examinar bien a causa de la gma altura il que estaban; y como tenin que hacer cada vez una caminata de unas seis a ocho millas inglesas para visitar el sitio, me faliabz ocasion y tiempo para observar bien la mar. cira de la incubacion. In hembra que hice sacar de uno de estos dos nidos habia perdido muclias plumas que por lo comun no cstán muy adheridas al cuerpo, hallảndose adenuas muy demacracia. A fines del misno mes fui mas fuliz. Cerea de mi ererantiahs (1) se eleriba orgulloso, rodeado de otros árboles, un masnnifico sisu con un hueco en la axila de la priimera rama, cuya posesion era constantemente causa de dis. cordia entre loros y coracias; pero que yo habia deseado siempre ver ocupado por dicoceros bicornios. ¡Cuál no seria mi satisfaccion cuando noté que una pareja de estas aves se decidió á establecerse en él despues de muchas visitas, inspeccion, largas consultas y de la insoportable griteria de los coracias y loros! La cavidad tenia una prorundidad de unos treinta centimetros aproximadamente y ofrecia suficiente espacio para el objeto. Estábamos á 28 de abril; al dia siguiente se metió la hembra dentro para no salir ya, quedán. dole el sitio estrictamente preciso paza meter la cabeza cuando la queria ocultar ó cuando queria echar hácia fuera sus dejecciones. Estaba el hueco á unos tres metros del suclo y cabaimente en frente de mi verandah, de suerte que con un anteujo de larga vista podia yo observarlo todo perfectamente. Luégo que la hembra se hubo instalado en el hueco, desplegó el macho la mayor diligencia para alimentarla, llevando por ló comun el pequeño fruto de la higuera sagrada. El 30 dél mismo mes empezó la hembra à trabajar con ahinco en tapiat la entrada, emspleando en esta operacion como mate. rial principal sus propias degecciones que subia del fondo del hueco para pegarlas a derecha 6 izquierda, alisíndolas y apretándolas con el lado llano de su pico á manera de paleta. El macho se linitaba á buscar y traer alimentos y durantc todo el tiempo no vi jamás fruta alguna arrojada al pić del árbol y solo si muy pocos excrementos que al parecer la hembra misma iba echando desde el momento en que dejó concluida su cárcel. E! macho llegaba á la abertura, se agarraba af la corteza con sus unias y llamaba dando picotazos en ella. Entonces aparecia la hemora para recibir la fruta y el macho volvia a buscar mas. La abertura, que al principio tenia unos quince centimetros de alto por tres ó cuatro de ancho, se iba cerrando mas y mas hasta llegar á ser tan an. gosta quue en el punto mas ancho apenas hubiera podido caber el dedo meñique; pero hay que tener en cuenta que era à manera de rendija, es decir, mas larga que ancha, de suerte que el pico disponia de un espacio de ocho a diez centimetros para abrirse. La operacion de tapiar la abertura labia exigido unos dos ó tres dias, y una vez terminada, la hembra ech6 fuera los excrementos que hasta entonces habian servido \& modo de argamasa. Otro homirai que rondaba por alli ouservaba atentamente todo lo que pasaba, armando de cuando en crundo alguna pendencia con el marido, pero nunca llevó comida a la reclusa. El dia 7 de maso, cuando yo calculaba que la hembra habia tenido suficiente tiempo para completar la puesta, arrimé una escalera de mano al árbol y subi, abri el nido y saqué no sin algun irabajo á la

(1) 1).r este nnmigre en la Indis a los ierrados-mimelores cubiernos

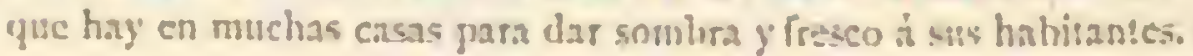


hembra, i la cual hallé en muly buen estado; :odo con el fin de apoderarme de los huevos. Al paincipio apenas podia ve. lar aquella, pero al cabo de algun tiempo lo logró. Ins per. sonas del pais que conocen perfectamente las costumbres do cste animal me dijeron que la lembra romria el barro tan pronto como los pequenuelos pedian su alimento, y no tengo duda que sea asi.

Wallace pudo hacer asimismo observaciones sobre la incubacion de esta ave. Sus cazadores le trajeron un dia un ma. cho que uno de ellos decia haber mucrio mientras daba to la hembra la racion que le lleriba. a Muchas cosas habia yo leido, dice este riajero, resprecto de esta costumbre tan ex. traña de dicha are, y me fui en seguida, acompanado de al. gunos indigenas, al sirin designado. $\mathrm{Nl}$ otro lado de un rioy de un pantano encontramos un grueso árbol inclinado sobre el agua con un agujero en el lado inferior, a la altura de seis metros, en medio de una masa iangosa que scgun me dijeron habia servido para forme la ancha abertura del huero que alli tenia el árbol. No pasó uucho rato cuando oimos un graznido en el interior : observames cómo el ave sacaba la punta blanca del pico. Oírecl una rupia al que quisiena subir y coger el ave con los hueros, pero todos tenian miedo y alegaban que era cosa demasiado dificil; sin embargo al cabo de una hora llamóme la atencion un graznido ronco pero ruidoso que resono ecrea de mi, y que jrovenia de la liembra, la cual me traian jumto con el pequeñuelrs que ha. bian enconirado en el hueco. Este último era un sér sobre. manera cximño, del tamano de una paloma, sin una sola pluma en todo su cucrpo, carnoso, blando s con la piel semi. traslúcida, tanto que el animalito parccia uma mașa gelatinosa con cabera y !)ies anadidos artificialmente mas bien que un ave.

Da costumbre tan estraordinaria del macho de tapiar á la hemora y alimentasla durante la incubacion. hasta el dia en niue pueden rolar los hijos, es uno de los hechos mas ina. mavillosos de historia natnral que puede cuncebir la imagina. cion mas Tantảstica. ?

No parece ser mas activo ci desarrollo ulicrior del jóren dicocero bicomio; pues Hodgson asggura que no concluye antes del cuarto ó quinto año de su existencia; pero d esto contesta Iblyth, fundacio en abservaciones liechas en dicoce. ros cautivos, que bastan ires años para que esta ave adq̨uicra todo su desarrollo.

CAUTIVIDAD. - Tickell nos ha dado s ronocer el gé. nero de vida del dicocero cautivo. Cuando se le coge joven domesticase fácilmente; pero- siempre conserva su innata osadía, y amenaza con su fornidable pico á las personas nue no conoce. Una de estas ares no permitia que la prodigasen caricias, como lotoleran las demás especies mas pequenas de la misma familia: volalsa por el jardin; posíbase sobre los árboles $\delta$ en el tejado de la casa; bajaba algunas reces á tierra, daba saltos, volvin á caer sobre su carpo, y buscaba en la yerba el alimento; una vez cogió una rana, pero la tiró al punto. Al dar sus paseos matinales, mojábase con frecuen. cia las plumas, y en tal caso se ponia al sol con las alas exiendidas para secarse. Otros dos dicoceros parecian aficionadosa la humedad, prues a veces cstaban horas enteras en sitio descubierto cuando llovia con mas fucrza. Nunca lanza. ban gritos agudos; producian solo una especie de gruñido: cran muy voraces y tragaban fícilmente un plátano.

Tambien he visto yo no jocas veces it homrai en pajare. ms espaciosas bajar al stuclo donde se nueve con gran torpe. za: alli se mantenia afiamzaço en la rale del pic y no sobre los dedos, apoyándose además en la cola para conservar el equilibrio; cuando qqueria echar iandar no tenia otro recurso sino haccrio a saltos con ambas patas á la rez, lo cual no basta para que recorra asi distancias muy regulares. En el ramaje es mul diferente su postura; alli se sosticne por lo comun casi horizontal del modo que lo describe Hooggsna, pero cuando quiere descansar bien, deja colgar la cola verti. calmente. Cuando se ha visto mictro tiempo urivado del sol, se levanta de un modo inusitado al primer myo benéfico que le toca; estira todo el cuerpo asi como las alas reperida y altcrnativamente, las alza ianto como puede, y gira en to. das las diracciones para recibir el sol por todos lados. Cuan. do tiene mucho calor alarga el cucllo y al mismo tiempo abre el pico, como lo harcer en igual caso los cuervos y otras ares de nuestro pais.

F.n la actualidad hay varios jardines zoológicos que poseen homrais y he pasado horas enteras contemplíndolos y convenciendome de que si pueden comprararse con alguna ave; es tan solo con los ramfístidos, a los cuales se parecen por sus movimientos, indole y comportamiento; pero son mas tardos, perczosos y mas serios que estos, conforme lo requiere su esinictura mucho mas tosca, lo cual no inspide que tengan gran amalogia con aquellos en su modo de saliar de una rama í oira y en tierra, asi como en el uso que hacen del pico, en su comportamiento en general yobre tocio en la apacidad de que dan sobradas muestras. Despues de todo lo diclio excuso anadir mas sobre su vida en la pajarera solo indicaré que resisten muchos anos y hasta parceen hallarse a su gusto en la cautividad con ial que se les cuide bien y principalmenie cuando se les procura un ralor siem. pre igual. Viven en la mayor armonia entre si, pero no con otras aves mas pequenas que ellos. Jamás vi surgir diferencias y contiendas sérias entre los diferentes dicoceros que observé, y eso que cierto dia uno de ellos cogió un tucan que pasaba volando con la mayor confianza por delante de

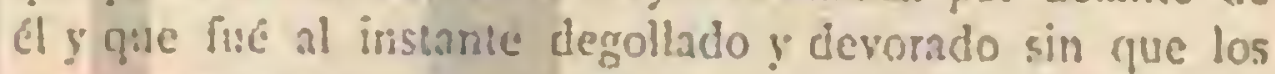
otros se movicsen para disjutar a su compañero la presa. A veces se entretenian dos de ellos rinerdo de un modo muy gracioso. Ambos combatientes se colocaban frente ff frente, y de pronto daban un salco hícia adelarte, chocaban sus pi. cos de modo que se oian los golpes y luego luchaban en toda forma. Habia momentos en que parecia que este juego iba a degenemr en formal pelea, pero luego se conrencia uno del error y que todo ello no cra mas que mero pasatiempo. La inteligencia que reina entre especies distintas se patentiza tambien con los gritos con que se contestan mutunmente.

\section{LOS RITICEROS - RHITICEROS}

CARACTERES. - L̇n los riticeros está recmplazado ol apéndice rostral por una protuberancia rugosa, surcada por pliegues, y dispuesta sobre la mandibula superior. Ias alas son de un largo regular, la cola sumanicnte redondeada, y las patas cortas y vigorosas.

Juzgo conducente \& la mejor inicligencia de lo qque tengo dicho hasia aqui sobre los bucerótidos anadir la cxcelente descripcion que liace Bernstein de la siguiente especie aline y. representante del presente sulgúnero.

\section{EL CALAO DE PROMINENCIA ASURCADA -BUCEROS PLITACUS}

CARACTERES. - Fil riticero de pico asurcado tiene el plumaje negro, excepio la parte superior de la cabeza donde es jardo negruzco; ol cucllo blanco con un ligero matiz gris; el ojo pardo rojizo; el pico de color de cuerno claro; las patas negruzcas, $y$ la cola en ambos sexos blanca. La hembra difiere del macho por el tinte de la parte desnuda de la gar. ganta que es amarillo claro, mientras n̨ue el macho la tiene 
de un color azul indigo sucio. Ios pequeños carecen de prominencia en el pico, la cual no se desarrolla hasta la edad adulta. Como los surcos trasversales varian de número en los

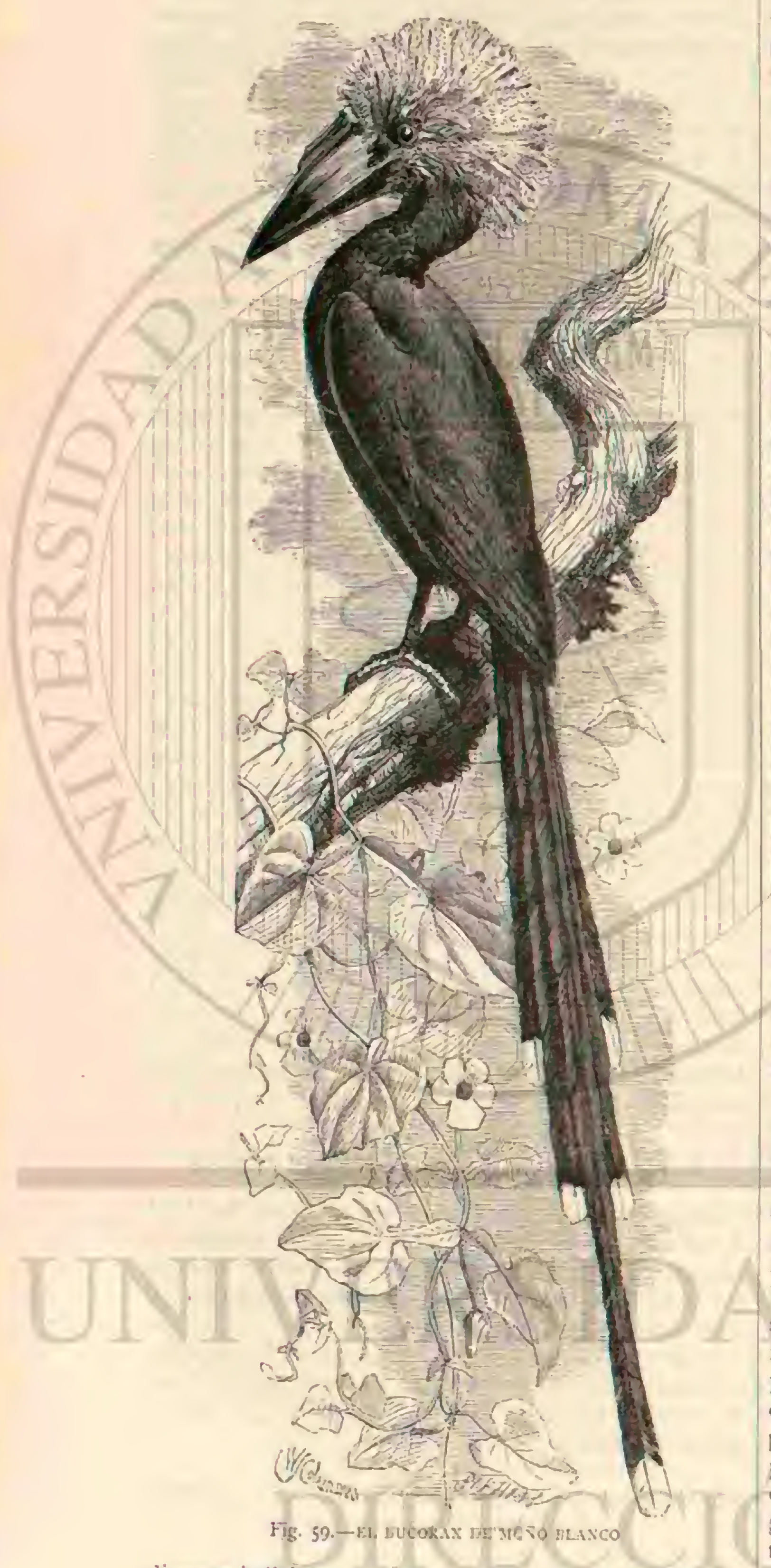

diversos individuos, se suponia antes que se formaba uno cada año, $y$ que se podin reconocer asi la ed̉ad del ave. Esta circunstancia valio á esta el nombre de aral que le dan los europreos que habitan en aquel pais. I.os naturales del pais la llaman djuan, guge y bobosar.

DistribuGion GEOGRAFICA.-Habita en las islas de la Sonda y Malaca.
USOS, COSTUMBRES X REGIMEN. - Sobre este punto dice Bernstein: "Vive en los bosques sombrios. y exten. sos de los terrenos bajos y de las primeras vertientes de las montainas, hasta una altitud de 3,000 inetros sobre el nivel del mar. Escasea mucho en los bosques mas altos, sin duda porque no encuentra los árboles que producen los frutos que tanto parecen gustarle. Recorre á menudo grandes distancias para adquirirlos; muchas veces, sobre todo por la manana, se ve a una pareja de ijultens volar à gran altura sobre el bosque, dirigiéndose cis linea recta al paraje donde maduran los frutos que prefieren. Al volar alargan el pico y la cabeza, produciendo a la rez como un frotamiento, que varía segun la fuerza de los aletazos, y que se oye desde muy léjos; este ruido se percibe sobre todo en el acto de bajar el ala; pero no es aun conocida la causa, $\mathrm{Al}$ agitar el aire con una ala de riticero, se produce cierto ruido, pero no se lo puede com. parar con el que se oye cuando el ave vucla y que acaso es peculiar de todos los bucerótidos. Algunos de estos riticeros jue vivian en una anchurosa pajarera movian frecuentemen. te las alas cuando estaban sentados en los travesanos, pero sim producir su ruido especial, porque en este caso no son los aleinzos de mucho tan vigorosos como cuando vuelan. Yo me inclino i creer que en este ruido desempeña un papel principal la increible dilatacion de los depósitos de aire que como es sabido se hallan entre la piel y la carne muscular, que se continuan hasta en los muslos, la garganta y los extremos de las alas, y que permiten al ave absorber una can. tidad considerable de aire. Lo que si está fuera de duda es que nerced á dicha facultad pueden remontarse con ligereza átanta altura, a despecho de la pequeñe\% relativa de sus alas, y corno el aire encerrado debajo de la piel ha de com. prinirise y cambiar necesaria y continuamenic de puesto por efecto de las fuertes y alternativas contracciones de los músculos, pienso que será tambien la causa del ruido.

Este riticero vive casi siempre apareado, aun fuera de la época del celu, pero nunca le he encontrado formando grandes grupos ó familias. Su alimento consiste en diversas frutas, y como ya he dicho, vuela a menudo hasta larga distancia para buscarlas. He conscrvado varios mucho tiempo con arroz cocido, patatas, plátanos y otras frutas, y como habian sido cogidos jórenes, se domesticaron pronto, tanto que pro. dia dejarlos andar libremente por la casa, si bien teniendo la precaucion de recortarles las alas. L.os que se cogen ya viejos, suelen rehusar todo alimento y se dejan morir de hambie en pocos dias. No he oido la voz de este riticero cuando está en libertad, porque es animal arisco y de consiguiente no es cosa fácil aproximarse à \&̂l para observarlo; pero los que tenia cautivos emitian un fuerte y agudo grujif do cuando se les irritalsa: gruñido ó chillido semejante al de los cerdos cuando están furiosos 6 se los ra á matar. Ia per. sona que lo oje por primera vez cree oir el rugido de una fiera. Tienen en el pico mucha mas fuerza de lo que uno podria suponer atendida su estructura celular y la relativa débilidad de los muisculos elevadores de la mandibula. Pegan picutazos muy dolorosos. Un individuo viejo hizo con el pico un agujero en su jaula formada de bambúes partidos, y elando lo mandé rapar con ama tabia de un centimetro de grueso, volvió á hacer saltar astillas de esta, de suerte que temia continuamenic que se me escapara. Pueden hinchar á voluntad la boisa acrea y desnuda dé la garganta que comu. nica cun la bolsa pectoral stuterior, con lo cual adquieren mucho mas volumen! y asi to hacen generalmente cuando estin posados y descansando.

- La manera de reproducirse el riticero de protuberancia asurcada es muy particular: anikla en un tronco hueco, a bastante altura, $y$ en los juntos mas impenetrables del bos. 
que, por lo cual ofrece dificultad cncontrar los nidos, sin debe examinar cuidadosamente todo el tronco de cada uno contar que estos son casi inabordables. Los Rancos de las montainas donde los fija no presentan sino estrechas aristas, escarpadas y separadas entre si por barrancos profundos, y el piés de los árboles que los cubren estå oculso por una en. maranada espesura de lianas, helechos y plátanos silvestres, de tal modo que solo se podria abrit camino con el hacha. Si se sospecha la existencia de un nido en cualquiera parte del bosulic, es preciso prinuero podér llegar a ella; luego se de estos gigantescos árboles pam descubrir en el extremo de la copa una rendija que podria ser la entrada del nido. A veces orienta el macho con sus idas y venidas; $y$ esto es pre. cisamente lo que sucedió con el único nido que tuve ocasion de observar. Hallábase sobie un rasamala, a unos 20 metros del suela, donde pude reconocer que cra exacto lo que habia dicho Horsfield. Cuando la cavidad del ironco está converientemente dispmesta, en cuya operacion presta excelente

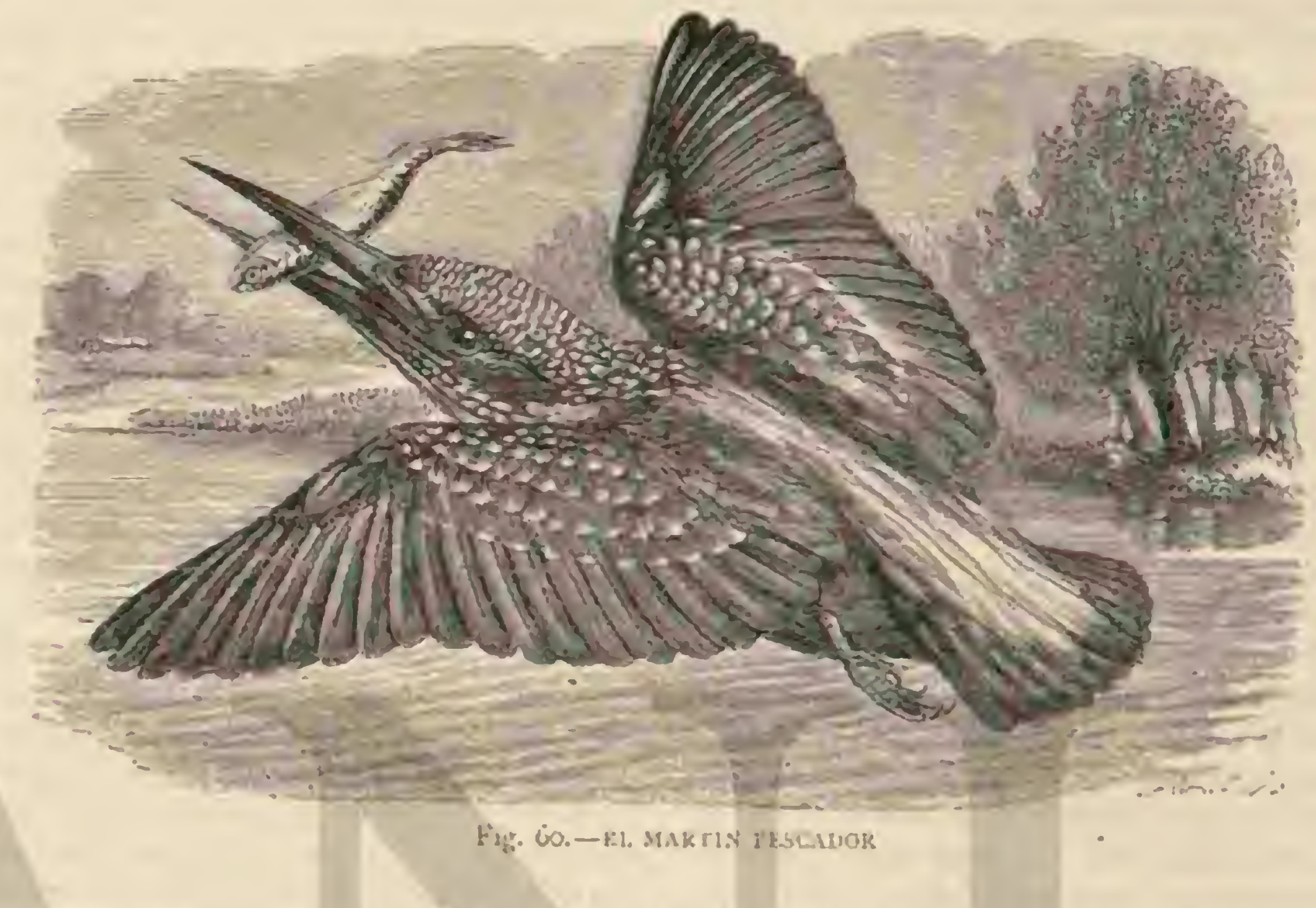

servicio el robusto pico del abe, para recibir los hirevos, y comienza á cubrirlos la hembra, el macho ciern la enrrada del agujero con tiern y madern podtida, cimentudas sis ducia con salivo, no dejando inas que una aberiura para que la henilura puedat sacar el pico. Durante todo el siempo de la iucubacion, el rizicero llesa á su conıpañera abundantes fru. tos, y para encontrar los necesarios, le es preciso muchas veces llegar liasta los paises habitados y cn culcivo, explicin. dose asi que fuese muerto un individuo en un jardin próximo śmi casa. Alrora bien, pregunto yo: epor rué efmpareda el macho $d$ la hembra? ¿Scrá jara evitar has acomeridas de los monos, como supone Horsfield? Esto me parece proco verosíuil, pues.los de Java se guardarian bien de puncrse al al. cance de un arma ian terrible como el pico del ajulass. Ein mi concepto, serian mas de temer las grandes ardillas, pues conózco el caso en que una voladorn, que se hallaba cautiva, se precipitó sobre un halcon que acababan de introducir en su albergue, y habiéndole cogido y matado, le devoró des. pues. Orro hecho hay sobre el que creo deber llamar la aten. cion: la hembra que yo observe habia perdido todas sus pen. nas; quedúbanle solo las dos primeras rúmiges primarias, y en una ala seis y én la otra cuatro secundarias; las demás no conservaban sino la cuarta parte ó la mitad de su largo defi. nitivo. Niada podia indicarme que fuese anpello resultado de mordiscos; en el tronco no habia, sin embargo, ni caitones ni rudimentos de otras; en tal estado no podia el ave clevarse a un pié del suelo, y una rez caida del nido, no le habria sido prosible volver á él. bsto es lo que yo vi por mi mismo: el indigena que halló el agujero me asaguró que la hembra está siempre encerrada asi: que durante el periodo de la in. cubacion se caen sus plumas, sicindole completamente impo. sible volar; yue su impotencia se prolonga hasta el momento en que los hijuelos abandonan el nido para crizar el espacio. Me inclino, pues, \& creer 'que el macho enciersa de este modo a la herubra como medida de precaucion, es decir, para evilar que se caja del uido: esta reservado a otros observadures resolver cste punto.

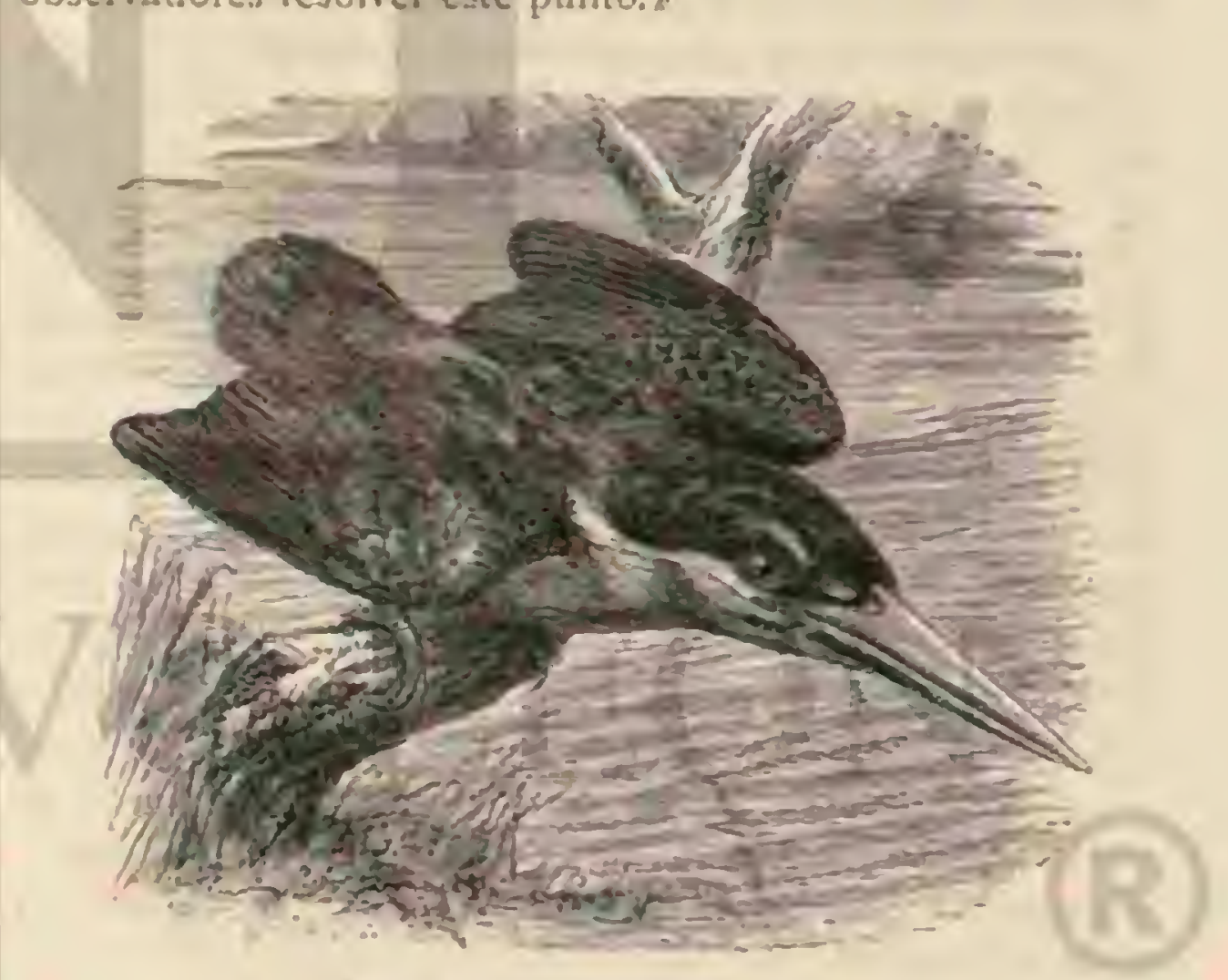

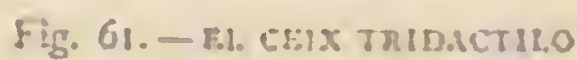

Horsfeld reliere sobre el particular diversas historias, que oyó contarál los indigenas: cree que el macho procede asi flor celos; que vigila if su hembra y la castiga en caso de infideliuad; si al volver de una expedicion cree notar que otro maclio ha cstado cerca del nido, tapa la entrada por completo y la hembra q̨ueda condenada â morir misera é irremisiblemente.

FI nido eflue hallé Bernstein se componia tan solo de una capa seca de astillas y de pocas ranias Junto a un polluelo 
recien nacido: cuyos ojos estaban cerrados aun, habia un huevo muy adelantado en su desarrollo; era pequeño en pro. porcion á la talla del ave, pues solo media $0^{\circ}, 6.4$ de largo pror $11^{\prime \prime}, 43$ en su mayor diámetro trasversal; tenia forma pro. longada, cáscarn blanca, y grano tosco, cubierto de puntos y líneas de color rojo pálido y pardusco poco visibles.

\section{EL TRAGOPAN-TMETOCEROS ABYSSINICUS}

CARACTÉRES. - ES cl mas célebre de todos los buce. róiclos del Africa y una de las marores especies de la familia En Abisinia le dan los nombres de abagambas y ecrcum, en el Sudan el de caba-garn. Es robusta, de alas y cola cortas, pero bastante zancuda. Sir pico es grande, algo corio, aplanado en lós costados, de nunin roma; la promincncia es corta pero alta y arranca desde el centro de la cabeza para ocupar un tercio de la longitud del pico; puede estar abierta ó ceriada por delante, sicndo su forma algo pirecida a un casco encorvado hácia delante, con la parte superior mas ancla que la inferior que se confunde con la raíz del pico. Las piernas son muy robustas y difieren de las de otros buccróticios por la longisud de la tibia que es dob!e que la del dedo medio; ademís por los dedos gruesos éstando el último unido al medio en la ultima articulacion, y este con el interior for una membrana en la penúltina articulacion. La punta del ala en la cual la sexta rémige es la mas larga, sobresale poco de las pennas de la paric hunicral. Ia cola, cupa inngitud vienc \& ser como la mitad de la del ala, tiene las rectrices exteriares casi tan largas como las restanies. I.as regiones del ojo y de la garganta están desnudas y vivanente coloradas. El plumaje es de un negro brillante a excepcion de diez rémiges blancas amarillentas; cl ojo es mardo oscuro, el anillo del rededor, lo mismo que la garganta, de un gris plomizo oscuro, esta tiltima con una orla ancha y encarnada; el pico es negro, exceptuando una mancha en la mandibula superior, cuya mitad superior es roja y la snterior amarilla. La hembra difiere del macho por su menot tamano y por tener la region desnuda de la garganta menos desarrollada que este. De las mediciones hechas por mi mismo restulta que esta ave tiene una longitud de $I^{\circ}, \mathrm{r}, \mathrm{el}$ ancho de punta a punta de ala cs de $I^{\prime \prime}, S_{3}$; la longitud de esta $f^{\circ}, 57$ y la de la cola $6^{\prime \prime}, 35$.

Distribucion GEOGRÁFICA. - El tragopan tie. ne a poca diferencia la misma área de dispersion que el tok, pero no es tan comun como este. Habita toda el Africa central y meridional. Es conocido en Abisinia y en los paises limitrofes, en todo el Sudan meridional, $y$ en la parte occi dental de aquel continente, descie el Senegal hasta la colonia del Cabo, é igualmente en toda la costa sudeste. En la parte que yo he recorrido se presenta descle los $17^{\circ}$ latitud norte hácia el sur, mas ó menos en todas partes, pero no siempre con igual frecuencia porque prefiere las estepas pobladas de bosque y las sicras, a las selvas virgenes y tierras faltas de arbolado. Heuglin dice que en Abisinia sube hasia cuatro mil meiros en las sierras, aunquue solo es frecuente entre mil $y$ dos mil metros.

USOS, COSTUMBRES Y RÉGIMEN.- Pasada la épo ca del celo se reunen á reces varias parejas con sus pequenutelos hasta el número de diez ó doce. Monteiro dice que en el interior del Airica se ven bandadas hasta de cien individuos. Yo no me atrevo á impugnar la veracidad de este dato, pero iampoco quiero admitirla sino considerarla solo como un caso excepcicnal. Por lo comun viven los tragopanes por parejas y separados de sus congéneres; no son aves verdaderamente arboricolas, sino que andan como los cuerros por el suelo donde buscan su alimento, y solo acuden a los árboles cuando tienen miedo ó quieren descansar, prefi. riendo, segun Heuglin, los mas copudos y aislados en los claros, solanas, laderas y otros puntos, descie donde se do. mima un extenso horizonte. asi se acerea un enemigo, dice el mismo autor, que su vista perspicaz descubre luegro, corre i ocultarse entre piedras, matas, cercados ó se levaizta nesadamente, volando hasta una altura moderada en linea recta para posarse un buen irccho mas léjos en el suclo, en una peìa ó rama muerta, y desde alli observar mejor á sus encmigos. Lin estas huidas suele por io comun irse con preferen cia a la ladera opuestia al punto donde cstaba.

Es are tan singular que no hay indigena que no la conozca y no la considere con interés. Cuando el macho estí irritado obra de un modo extraño; extiende la cola y la vuelve á plegar entcramente como los paros; hircha cl saco aéreo de la garganta, roza las alas contra el suelo y se pavonea de un modo arrogante. Su modo de andar es como el de los cuervos, pero con mas balanceo; el vuelo no es de ningun modo débil como dicen alguros, sino por el contrario ligero Y. gracioso, y aun volando a largas distancias sicmpre sucito Yfrexible con tal que esté á cierta elevacion; pero no es ave aficionada a cruzar grandes espacios de una tirado, sino que se vuelve a posar, una vez pasado el miedo que la hiciera levantarse: y si lay árboles á su alcance los prefiere para vi. gilar mejor desde lo alto. Si ve algun objeto sospechoso se pone muy erguida y examina con el pico abierto al intruso. Al primer geito de/uno de ellos se lesanta toda la tribu y ecla a volar! Asustadizo, timido y precavido como es siem. pie, no permite que nadie se acerque of êl y le observe, y aun para conier, escoge con preferencia sitios despejacios desde los cuales pueda dominar con la vista las cercanias.

Iin cl estómago de un abbagamba que yo diseques, habia crire escarabajos peloteros y langostas, gusanos y un camalcon bastante grande. Segun Courney, esta ave se alimenta de li. mazas, Jagartos, ranas, ratas, ratones, langostas, coleúpteros S insectos; Monteiro dice que come reptiles, aves, hueros, insectos, chufas y raices de yuca. Caza principalmente, dice Gourney, en los terrenos donde se ha quemado la jerba; con su vigoroso pico socava el terrcmo, levantando una uube de polvo; coge un insecto, lánzale al aire, le atrapa al cacr y se lo traga Si descubre una serpiente, llama primero en su auxilio á dos ó tres companeros; acércase á su enemigo de lado, desplicga las alas para irritar con cllas al reptil, revuélvese luego súbitamente y en el momento favorable para descargarle un vigoroso picotazo: le opone un ala á guisa de escudo, y renueva los atagues hasta que muere su adversario. Si el reptil procura defenderse, el ave extiende sus dos alas hacia adelante para proteger la cabera $y$ las partes mas indefensas de su cuerpo.s

Antinori fundándose en observaciones directas y en el exámen del estómago de algunos individuos muertos, dice que el abbagamba es omnivoro en toda la extension de la palabra, y que no solamente arranca las planias del suelo, sino çue caza los animales mas diversos, pues encontró en el estómago de un macho una ardilla terrestre con todos los pelos, y en tan buen estado, que se veia quie el ave la habia cogido viva, y la persona que conoce el caracter rabioso y mordedor de estas ardillas, mucho mas grandes que las nucs. tras, no podrá menos de convenir en que esta caza hace niu. cho honor al tragopan. Heuglin lia obsermado que esta ave acude tambien cuando ve una pradera incendiada para apro. vechar los restos de saltones, cscarabajos y otros animales muertos por el elemento vora\%

I.2 voz del tragopan abisinio se reduce á un grito sordo, que se puede expresar por biu ó hu.

4Cuando el macho y la hembra se llaman, dice Heuglin, uno de ellos, probablemente cl macho, lanza un grito sordo, 
aunque sonoro; su companera le responde con otro anälogo, pero una octas:a mas alto, durando aquella especie de colonuio entre ambos esposos cas! inseparables, mas de un cuarto de horn hasta que aigun suceso los interrumpe.) (iourney cita el mismo liecho, andiendo que el macho es el que invaria. blemenic comienza a gritar, y que se le ope con frecuencia a la distancia de cerca de dos millas inglesas.

Al acercarse la época del celo que en el Sudan correspon de à nuestros ineses de otono, gritan los tragopanes con mas frecuencia y excitacion, y se mueven tambien de atra nanera que Heuglin describe asi: \&Los dos, el macho y la hembra, dan vueltas por algun claro del bosque con visible excitacion, hiuchados, derechos y con la garganta llena de aire y bufando, mientras que emiten unos sonidos que parecen salir del inie. rior de una cuba grande.

Mis propias observaciones me han dado a conocer que ef abbagnmba abisinio anida en árboles de troncos lruecos: al decir de Heuglin, las hueros son pequeños, blancos, de grano basto: mas no se sabe aun cúl es su número en cada puesta; ignórase tambien si el maclio encierra á su hembra mientras cubre. Fn el nido que yo encontri, nada indicaba que fuese asi; solo contenia un hijuelo bastante crecido, todo negro, excepto el centro de las alas; su pico no estaba pro. visto todavia de ningun apéndice le deje en su nido, esperando que volverian los padres y los podria cazar; pero no se presentaron.

CAUTIVIDAD. - El hijuelo que yo encontré en el nido, y que me llevé despues de haber esperado inútilmente á los padres, se alimentaba con carne cruda y se domestico muy promo. Cuando le dejé libre en la barca, andaba de un lado ¿ oiro; pero bien pronto eligió un sitio, donde volvia siempre. Contrajo una especie de amistad particular con un cercopitceco. hecho de que ya hice mencion en la historia de los cuadrumanos: aqui solo anadiré q̨ue fué el bucero que mas tarde mantuvo este lazo. En Kharthouin sé le dejó correr libremente por un patio, sin que abusara de su independencia, y nunca olvidaba visitar de vez. en cuando of su antiguo anigo, junto al que pasaba a veces horas enteras a pesar de los malos tratamientos que recibia por 5 parte Aunque habia varios monos encadenados en el patio, el abbagamba conocia muy bien á su compañero, y jamas se equivocó. Gustábale csiar siempre ocupado y divertirse; perseguia á los ibis domesticados, y tambien a los gorriones, que le hacian recorrertodo el patio; trotaba en apariencia sin objeto de una parte $\{$ otra, saltaba, movia la cabeza de infmitas inaneras, y cjecutaba las calriolas mas grotescas que imaginarse puede. Muchas veces irepaba á una de nuestras camas, y echábase alli a su gusto, oculta la cabeza debajo del vientre ó de una de lasalas; nunca manifestó contra nosotros el menor enojo; dejábasc ącariciar y levantar sin dat señales de cólera; y en general, jamás se servia de su terrible pico.

'ambien recibio Antinori un tragopan pequeño sacado del nido, y lo alimentó del mismo modo que cmpleamos nosotros, sobra todo con carne picada y ratones. En proquisimo tiempo se acostumbró cl animal tanto à su amo, que al ins. tante acudia cuando lo llamaba por su nombre Abagamsi para darle su racion, y una vea acostumbrado al la casa corria libremente por ella volando á veces hasta dos ó trescientos pasos de distancia, en cuyo caso obedecia a un niño pequeno que le iba í buscar, volviendo a la casa it zaltitos. Antinori opina que bien puede recomendarse esta ave como anima! doméstico en vista de lo fícil que es mantenerlo, y que seria muy ütil porque limpia la casa de ratones y otras alimañas.

De una relacion de Bodinus resulta que no todos los tra. gopanes cautivos son tan interesantes como el citado, pucs dice en su carta: 4 . Ne das el parabien por tener en mi poder un tragopan, paro lo cierto es que no lo admito, pues para mi, esta ave es una de las mas fastidiosas, por curioso que sea su aspecto á primera vista. Cuando recibiel individuo de que hablo, le puse en una projarera, donde solo habia una paloma doméstica n̨ue tenia las alas paralizadas; y lo primero q̨ue hizo fué caer sobre su companera, a la cual devoró en parte. Cuando yo me escondia, andal)a como una zancuda, lanzando sobre las demás aves ieroces miradas; y de seguro hubieran sufrido la misma suerie de la paloma a no impedirlo el enrejado de la jaula $\mathrm{Al}$ acercarse cualquiern, retirábase al momen:o a un rincon y pernanecia tramquilo, en una in. movilidad tal, que se le hubiera creido disecado si los movimientos de sus ojos no indicaran la vida. Si cl observador se volvia, deslizibase como una flecha dentro de su caseta, y hacia io posible para sustracrse a las miradas; al cabo de algun tiempo volvia para mirar cautelosamente si habia ailguien, y una vez. seguro, levantábase, medio volando y saltando hasta su percha, ó se posaba con mas frecuencia sobre un pequeiro abeto (que habia en la pajarera, el cual se doblegaba bajo el peso del are. Alli permanecia innquilo, sin que yo compren. diese cómo se podia snstener con sus dedos tan cortos. Sus hoscas iniradas se dirigian de un punto á otro constantemente, para ver si álguien se acercaba; en el caso de ponerse junto á él, era preciso estar alerta; pues seguia con los ojos todos los movimientos, abriendo el frico, y si le alargaban el dedo, precipitábase como una Aecla, infriendo con su pico heridas profundas y dolorosas. Los bordes de sus mandibulas eran tan cortantes, que se exponia uno á que le destrozase un dedo, coiriorme me consta por experiencia propia con gran disgusto mio; mas a pesar de todo, era fícil apoderarse del ave: bastaba enseñarle un objcio sobre el cual se fijase su atuncion, y cogerla despues de pronio por el cuello.

Mi abbagn mba no queria comer sino carne; no tocaba el pan ni las frutas: gustibanle sobre todo los ratones, y devoraba hasta ocho, uno despues de otro, con pelos y todo. Ern igualmente aficionado $x$ las aves, ye las comia sin desplu. marlas: de un solo picorazo mataba un gorrion, que sabia coger con la velocidad del rayo: no despreciaba las lom. brices de tiern, que parecian gustarle mucho; pero todo este régimen no le probaba, y creo que en libertad caza con preferencia los repiiles. A pesar de los ratones quie comia, y del abundanie alimento que se le daba, mi abbagamba entlaque. cia mucho, y su garganta, dura y musculosa en otro tiempo, estaba floja y blanda como un simple repliegue cutáneo. lil ave conservaba, sin embargo, su buena salud; comia y digeria bien; tenia el plumaje en buen estado; mas á pesar de rodo, reconocinse por la cxtenuacion del animal, que le faltaba al. guna cosa; $y$ al fin llegó un dia en que le hallamos muerto en su jauit.

\$o compraré mas abuagambas, pues el que le tenido me incomodaba por su excesiva timidez; nunca pude observar sus movimientos, ni se hizo apreciar de nadic.s

Monteiro tuvo tambien un individuo al que sometiót un régimen variado: dióle un dia peces, yue al parecer le gustaron mucho: soltáronle luego en el cortal, y precipitandose en seguida sobre los pollos, mató seis ye se los conió, terminan. do su banquete con algunos huevos.

I.os indigenas no cazan en Africa el tragopan, porifue no utilizan su carne, ni ninguna cosa de el; pero los habitantes de Choas forman una excepcion, porque entre cllos constituyen las plumas de esta ave, segun Heuglin, un adorno muy bliscado para distinguir á los guerreros mas valientes, de modo que las llevan aqquellos que han dado muerte á un enemigo of at alguna fiera. Leíebrre dice que en algunos puntos esta ave es 5agradi, y en Abisinia animal impuro, con acom. partamiento de alguna supersticion ridicula. Fn el Cordóan 
szan el tragopan, segun Kuppell, persiguiéndole á caballo y a la carrera lácia que se rinde cansado sin fucrzas para volar, lo que permitia trármelos viros.

\section{EL BUCORAX DE MON̈O BLANCO-BUCO- RAX ALBOCRISTATUS}

CARACTERES.-Aunque no tan grande como las especies anteriores, este bucorax (fig. 59) es nutable, no solo por su belleza, sino tambien jor el carácter que le da nombre.
El pico es muy ancho en proporcion al tamano del ave; pero no tan prominente cono el de los otros buccrax, y parece menos grotesco gracias al magnifico moño, en forma de aba. nico, que adorma la cabeza. Ia cola, sumamente larga, y de colores muy pronunciados, tiene las plumas negras, con la extremidad de un blanco de nieve; el tinte dominante del cuerpo es un negro intenso, cxcento algunas plumitas blancas que sobresalen en ciertos sitios; el moño es de este último color, con motas negras en su extremidad.
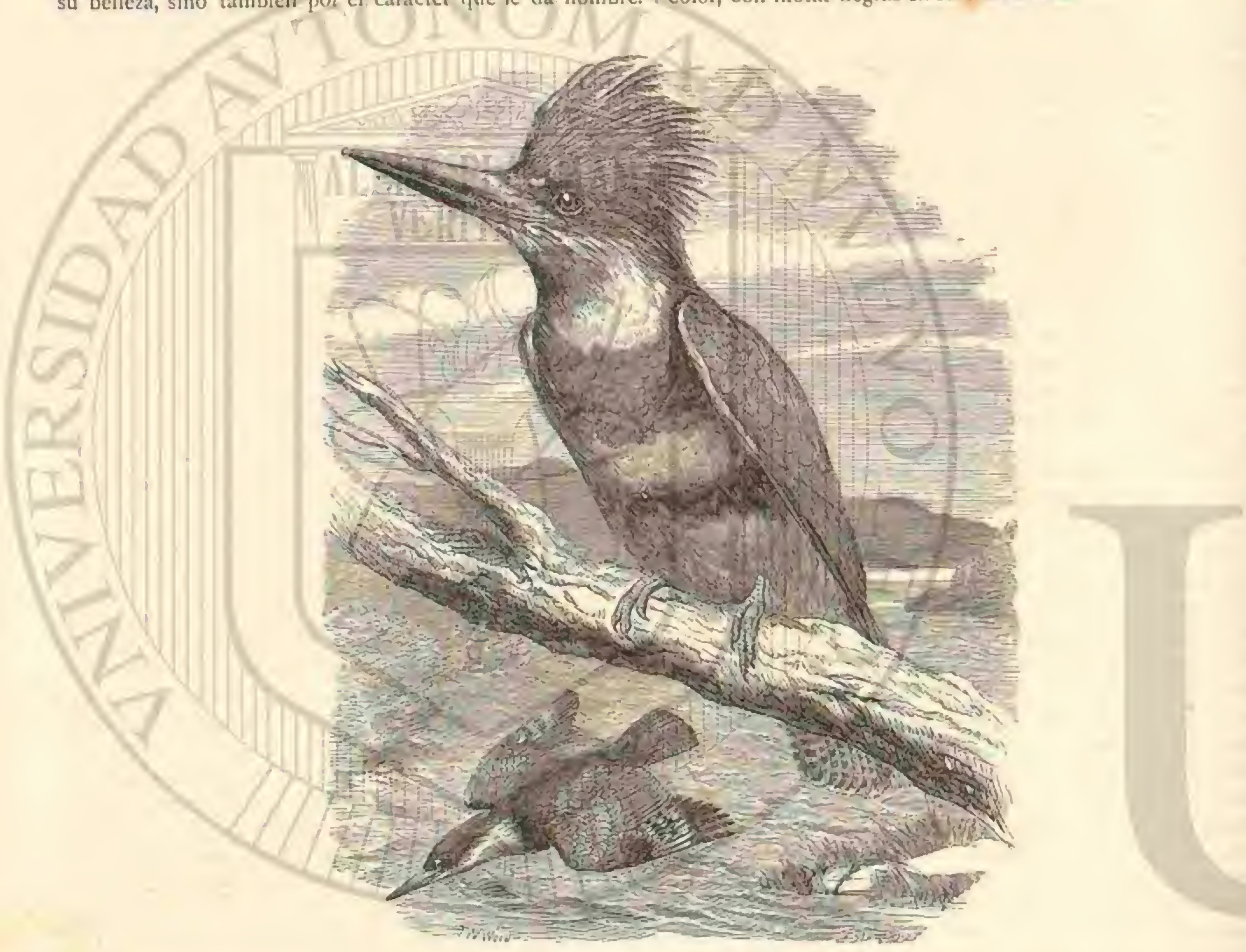

Fig. 62. - E.L. CERII.O 1!CO

DISTRIBUCION GEOGRAFICA.- El bucorax de mono blanco se encuentra en Africa y en Abisinia.

\section{LOS ALCEDINIDOS-AL- CEDINID压}

Los alemanes han dado á esta familia el nombre de ares del hielo ó glariales, porque asi llaman â la especie europea, una de las mas hermosas de nuestro continente y protagonista de muchas fábulas y leyendas. Esta especic es nuestro alcion 6 martin pescador, una de las ciento veinticinco que forman aproximadamente la familia y que cn $5 u$ inmensa ma. yoria habitan las zonas cálidas de nuestro planeta, y mada tienen que ver con el hielo ni con el frio é invierno de los paises septentrionales.

CARACTERES.-I.OS alccdinidos tienen el cuerpo grue. so; cuello corto: cabeza grande; alas cortas ó medianas; cola corta ó de un largo regular; pico muy prolongado, robusto, recto y puntiagudo; patas pequeñas, con tres ó cuatro dedos; plumaje liso, de colores muy vivos á veces, que varian apenas por la edad y menos aun por el sexo.

Véase lo que dice Nitzsch ncerca de la estructura interna, teuiendo presente que ha liecho sus observaciones en la cs. pecie europea. [li] cráreo nfrece cicrta semejanza con el de las garzas reales, y auncyue esta apariencia sea tan solo super. ficial ó ligera, no nos es dado el desconocerla. El lomo del prico y la frente están casi en linea recta: el ave tiere once vértebras cervicales, ocho dursales y sicte caudales: solo las cinco últimas costillas son huesosas; el esternon se asemeja al del are pico. Los miembros posteriores se distinguen, sobre todo, por la brevedad de los tarsos; la lengua, desproporcio. nada con el largo del pico, es menos larga que ancha, casi triangular; los bordes laterales se encorvan por fuera y el postcrior por dentro. Fin el esqueleto de la lengua es de considerar la pequenez del hueso lingual y la anchura del cuerpo del hioides; cl esófago es nncho, aunquue no dilatado en forma de buche; cl ventriculo sub-centuriado muy corto, y el estó. mago membranoso y dilatable: no existen ciegos. 
DISTRIBUCION GEOGRÁ FICA.-LOS alcedinidos es. tán diseminados con bastante uniformidad en toda la super. frcie de la tiersa; pero solo en las regiones callidas aparece esta familia cn toda su plenitud.

USOS, COSTUMBRES Y RÉGIMEN.-Los alcedinidos habitan todo el globo, sibien se encuentran, como queda dicho, en su nayor variedad y número en la zona tórrida.

Todas las especies viven con predileccion cerca del agua, aunque no todas dependan de ella, pues muchas, acaso la mayor parte, son aves silvicolas verdaderas, curo genero de vida apenas conserva alguna analogia con el del resto. Fsie ha sido tambien el motivo, por cierto muy justo, de dividir toda la familia en dos grupos ó subfamilias que comprencen respectivamente los nlicdinsinos ó alciones que cazan buzan$\mathrm{de}_{2}$ y los alcionsinos que son mas silvicolas ó terrestres.

\section{LOS ALCEDINNINOS-ALCEDININE}

CARACTERES. - Su principal rasgo caracteristico con. siste en su pico largo, recto, esbel:o, lateralmente muy com. primido y cuya arista superior forma una linea recta, y en su plumaje grasiento, muj alisado y lustroso.

USOS, COSTUMBRES Y REGIMEN.-Todas las es. pecies de este grupo se establecen en las inmediaciones de las corrientes mientras haya peces en ellas, tanto en las re. giones mas elevadas como junto al mar. Viven solitarios ó

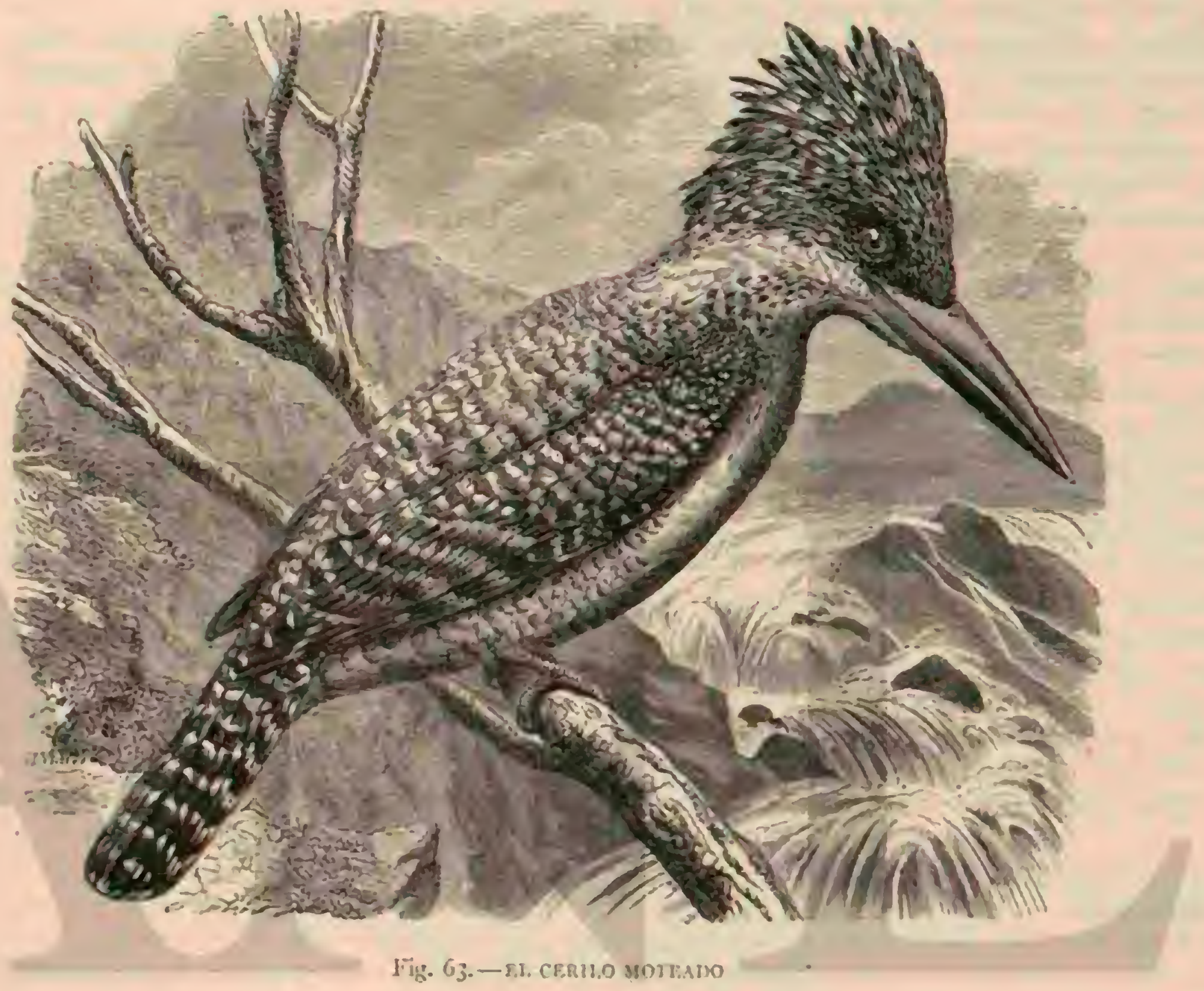

por parejas: como las demás ares pescadoras, guardan sicmpre silencio, son enojosos, dominales la envidia, y huyen de la sociedad de sus semejantes y de la de otras aves, pues en cada sér viviente ven, si no un rival, un vecino molesio. Solo cuando les acupa el cuidado de la progenie permanecen en la misma localidad; en lo resiante del aío andan etrantes, como pescadores que son, siguiendo la corriente del agua; algunas especies recorren asi exiensiones muy conside. rables.

Están singularmente dotados: apenas pueden andar; ruelan torpemente, y no parecen hallarse at su gusto sino en el agua; sumérgense en ella y saben nadar un poco. En cuanto á sus sentidos, la vista es el mas perfecto, y el oido parere bastanie desarrollado: nada podemos asegurar acerca del gusto y el tracio.

Por lo que hace a la inteligencia son bastante inferiores: una desconfianza sin limites parece ser el rasgo distintivo de su carácter, aunque no se distinguen por su pridencia. No carecen sin embargo de toda buena cualidad, pues profesan cuando menos un tierno amor a su progenie.

Su alimento consiste en peces, crustíccos, insectos, etc; siendo mus probable que ni repiles, ni culebras, ni otros Tomo III vertebrados, tan perseguidos por los alcioninos, tengan nada que temer de ellos. Pernanecen inmóviles en una rama que se extienda sobre el agua, 6 bien vuelan rasando la superficie ¿ la manera de las golondrinas y gavioias, con la vista fija en el agua; de repente se precipitan con mas ó menos fucrza sołre el pez que atisban descuidado ó cansado, sumergién. dose un instante para cogerto, 13 dando algunos vigorosos aletazos vuelven á salir y á ocupar otra vez su sitio anterior ú otro donde aguardan que el pez haya muerto, momento que á menudo apresuran golpeando la cabeza de la victima contra una rama, para tragárselo entero, empezando primero por la cabeza, y repetir en seguida la misma operacion.

La multiplicacion de los alcedininos es de bastante consideracion, phes todas las especies tienen una progenie muy numerosa Figigen para anidar las pendientes arcillosas y es. carpadas, donde practican profundas cavidades, cuyo fondo ensanchan para depositar los huevos. No fabrican nido pro. piamente dicho: prero se acumula poco a poco en su albergue tal cantidad de despojos y desechos, compuestos de espinas de pescado, gue forman al in una capa donde el are puede reposar.

Si los alcedininos no son para el hombre de utilidad algu- 
na, en cambio no le ocasionan grandes perjuicios. En efecto, en los paises donde abunda la pesca, la cantidad de alimento que consumen estas aves carece de importancia;y en cuanto á la especie que vive en nuestros paises, tiene tan poca talla, que no merece la pena de hablar de los danos que pueda causarnos.

\section{EL MARTIN PESCADOR Ó ALCION-ALCEDO ISPIDA}

DETALLES HISTÓRICOS. - El alcion (fig. 60) es un ave marina, pór mas que habite tambien las orillas de los rios: los griegros la llamaron asi porque vive en el mar; es poco conocida; jero nada tiere de extraño, pues rara ver. se Ia ve sino en el mes de auril ó á los raros del sol de invierno. Cuando ha rolado una yez al rededor de un buqque, cerca de la costa, alejase al momento y ya no vuelve mas. El mácho de esta especic ha recibido el nombre de cribly ay. Plutarco asegura que el alcion es el mas inteligente y no:able de todos los animales marinos. "¿Que canto de ruiseñor, - dice, puede compararse con el suyo? ¿Qué golondrina vue rila con su ligereza? ¿Qué paloma manifiesta tanto amor à su x companero? ¿Que abeja despliega su actividad? Su nido es suna maravilla de arte $y$ de ingenio, pues el alcion no se vale de nada mas útil yue su pico; le construye en forma de buque, y de tal modo que las olas no pueden sumergirle; en strelaza las espinas de los peces, disponiendo las unas horizontalmente para formar el fondo, y levantando las otma a los lados; encurva las demás en redondo y alarga su nido, s dándole la forma de un esquife de caza. Terminada su yobra, trabaja para consolidar la parte exterior: las olas azoatan los costados y le inundan; pero el ave trabaja sin cesar y le consolida de tal modo, que no se puede romper fácil *mente ni \& pedradas ni a golpes. La abertura del nido es s maravillosa, y está hecha de tal suerte, que solo el alcion xpuede penctrar; para las demas aves es absolutamente invi. ssible, y el agua no puede introducirse porque hat materia tque le forma es susceptible de hincharse como la esponja. - En tal caso se cierra toda lentrada; pero cuando el ave squiere entrar comprime in materia, extrae el liquida yesnetra libremente

\Aristóteles dice que este nido se asemeja á una bola compuesta de flares y de algas; que es de color rojo claro y parecido a un vaso para rentosas con un largo cuello. Este nido es major que una gran esponja, y como tal, está lleno en un sitio y vacio en otro, ofreciendo tal solidez, que apenas se puede romper. Aun no se sabe de qué se compone este nido: crécse que está formado de las espinas de los peces de que se alinienta el are: cuando acaba de construirle, el al. cion ponc sus huevos; algunos pretenden que los deposita en la arena, $\{$ orillas del mar, y que los cubre hasta mediados del invierno: su número es de cinco. Los alciones fabrican su nido en sicte dias, y en los siete siguientes ponen, cubren los huevos y crian los pequeños. El are se multiplica toda su vida, comenzando à la edad de cuatro meses. La hembra profesa un tierno cariño \& su compañero; no se limita á permanecer con él solo durante un periodo del ano, como to hacen las demás aves, sino que está con él siempre, sin unir. se con otro, porque su amor, su amistad y fidelidad son inquebrantables. Cuando en fuerza de la edad llega el macho á ser impotente, y no puede ya satisfícer por si nuismo sus necesidades, su compañera le da de comer, le cuida, no le abandona nunca, le lleva sobre su lomo y le presta sus servi. cios hasta la hora de la muerte. Una vez muerto el macho, la hembra deja de comer y beber, pasa largo tienspo abatida, cual si llevara luto por él, y acaba por sucumbir; pero antes de este instante produce un canto plañidero, cuyas notas se expresan por cey. cy: " que parece el canto de despedida. Repite este grito con frecuencia y liego se calla. Yo no de. seo, ni para mi ni para los otros, oir sonidos semejantes, porque son un presagio de desgracia ó de muerte.

- El alcion y sus hijuelos exhalan un olor agradable, anklogo al del alnizcle: su carne no se descompone despues de su inuerte: créese que el are se despoja rie su piel, ó que por lo menos se saca ella misma los intestinos.

2. Los pañeros conservan cerca de sus télas una piel de esta are, cual si tuviera el privilegio de aluyentar la polilla. Algunos dicen que el rayo no cae en la casa donde hay un nido de alcion, y aseguimse tambien que colocando uno sobre un tesoro, aumenta siempre este último y se evita la po. breza. 2

Hé aqui lo que en su crédula candidez refiere Gesner, compilando todas las historias maravillosas é incomprensibles de los antiguos; pero lo mas curioso es que estas historias se han conservado, al menos en parte, liasta los tiempos modernos, siendo hoy dia una creencia popular. Nucstros antece. sores estaban persuadidos de que aun despues de su muerte, esta are maravillosa alcja el rayo, aumenta los tesoros ocul. tos, comunica gracia y belleza al que la lleva, es garantia de paz y tranquilidad para la casa, asegura la calma en el mar. y atrae $\mathfrak{a}$ los peces, favoreciendo la pesca. Fn nuestros dias existen pueblos asiáticos tales como los tártaros y los ostia. cos, en los que se repiten de boca en boca semejantes histo. rias: para cllos, las plumas de esta ave son un filtro de amor y su pico posec virtudes terapéuticas: para nosotros no tie. nen estas fábulas sino un interés histórico: pero el ave que en ellas se ensalza, no es menos digna de llanar nuestra atencion.

CARACTERES. - l.os martines pescadores tienen el pico largo, delgado y recto; disminuye de espesor desde la base, que es ancha, hasta la punta, de forma cónica o un poco comprimida lateralmente, con los bordes cortantes y algo recogidos por dentro. Las patas son cortas y muy pequeñas; el dedo cxterno y el medio, casi iguales, están unidos en toda la extension de las dos primeras ralanges; el interno y el medio soldados nada mas que hasta la scgurda; el pul. gar es muy pequerio; las alas cortas y sumamente obtusas, con la tercera rémige mas larga; la cola se conpone de doce rectrices pequeñas y cortas; el plumaje abundante, lustroso y alisado, tiene vivos colores, de un brillo metálico por encima del cuerpo y visos sedosos por debajo; las plumas del occipucio se prolongan formando un pequeño moiro. No puede confundirse el martin pescador con ninguna otra ave europlea, pero si con especies de su familia de otros paises. La parte superior de la cabeza y la nuca tienen sobre fondo negro rerdusco fajas irastersales angostas, muy compactas y de co. Lor arul de mar; los hombros, cobijas y parte libre de las ré. miges son de color negro pardusco, con visos de un tono verde mar oscuro, estando las cobijas adenás salpicadas de manchitas redondas de color azul de mar. lil centro del dorso es de un hermoso azu! urqui; pero los costados, asi como una lista debajo del ojo hasta detrás de la region de la oreja, toda la parte inferior, las cabijas inferiores de la cola $y$ de las alas tienen un color vivo de canela rojizo; la garganta y la barba son blancas con viso de amarillo de orin; y funalmente son de color azul de mar oscuro una lista ancha que pasa desde el nacimiento del pico por debajo de la orra color de carela rojizo, los extremos de las plumas en ambos lados del pecho, las cobijas laterales de la cola y las rectri. ces. El iris es pardo oscuro, el pico negro, pero el nacimien. to de la mandibula inferior es rojo, y el pié, pequenito, es rojo de lacre. Esta ave tiene $6 ", 17$ de longitud; de $6{ }^{m}, 27$ 
a $11^{\circ}, 2 S$ de punta a punta de ala; esta plegada $0^{\circ}, 07$ yo la colat $6,0.4$.

DISTRIBUCION GEOGRÁFICA.-Eil martin pescador habita toda la Europa desde Jutlandia, Dinamarea, I.ivonia y Estonia hácin el sur, y la parte occidental del Asia central. Es comun en Esłaña, Grecia y sus islas; asi como il orillas del Jordan, segun las observaciones de Tristram, pero bas. tante raro en Malta; en el Asia orienial le recmplaza una especie mu: afine que algunos naturalistas consideran como variedad. Acaso anide y se reproduzca tambien en el noroes. te del Africa, si bien no se da este caso en la parte nordeste, en la que se presenta puntualmente todos los anos, pero sin hacer cria, sucediendo lo propio, segun se sale de fijo, en las islas Canarias; a decir verdad, tampoco en Grecia se han erconirado hasta hoy hueros ni nido alguno de esta ave por frecuente que alli sen en los meses de invierno. Inliérese de estas apariciones temporales de los martines pescadores del norie, en las regiones neridionales de su šrea de dispersion, que una parte considerab!e, quizás la mayorin de clias cmi. gra, y acaso con la regularidad de las ares de paso. Se pre. senta en Corfis en el mes de agosto y permanece alli en gran numero vagando po: las costas, para desaparecer $d$ principios de abril y faltando completamente en vernno. Es probable que en Egipto suceda lo mismo, puro en Esp̧aña vive todo el año.

USOS, COSTUMBRES Y REGIMEN.-In nUESTrOS paises se encuentra por todis partes esta preciosa are; pero siempre solitaria. Llama la atencion tanto por la belleza de su plumaje como por la singularidad de sus costumbres, aunque se oculia todo lo posible a las miradas del hombre. Permanece $\{$ lo largo de los arroyos of de los perqueños rios de aguas claras y limpidas, aunque se hallen en medio de las sierras hasta unos 1, Soo metros de altura segun Tschudi, $y$ no se le ve sino raras veces cerca de las cenagusas; pre. ficre á todas las demás corricntes las quie atraviesan los bos. ques cuyas orillas estån cubicrtas de sauces. Si augucllas tienen pendientes, tales que no se hielen por completo en el invierno, se queda junto ì cllas, aun durante la inala csta. cion; cuando los lugares son menos favorables, le es preciso enigrar, y entonces llega hasta el norte de Arrica.

Comunmente no se divisa al marin pescador sino cuando pasa camo una flecha sobre la suzerficie del agua; para verle posado es preciso conocer sus costumbres. Si se lialla cerca de los sitios $\delta$ de las casas habitadas escoge un pamje bien oculto, dando pruebas de mucho tacto en la eleccion. Parece inquieio mientras no encuentra un sitio conveniente: los lu gares que prefiere son ficiles de reconocer, pues iodos los martines pescadores que frecuentan las orillas de un rio para descansar, dejan alli sus inmundicias:

e Ein cada canton, dice Naumann, existen varios de estos sitios, situados á menudo a gran distancia unos de otros; rara rez se hallan a mas de dos piés sobre cl nivel del agua, y sicmpre están en lugares retirados. lin los cantones solitarios mas apartados de la morada del hombre, el martin pescador se establece en sitios inas descubiertos, donde se le puede ver á bastante disiancia. P'asa la noche debajo de un resalio en la orilla, y aun dentro de un agujero ó cueva, y solo durante el periodo del celo se posa en las famas clerat das. 3

Cada una de estas aves, ó por lo meros cada pareja, tiene su canton particular en el que prohibe la entrada a sus seme. jantes; solo la nevatilla tiene permiso para participar de su dominio.

Si hay alguna are que merezca el nombre de sedentaria, lo es esta. El martin pescador vulgar permanece á menudo medio dia entero en el mismo sitio, inmóvil, silencioso, y esperando pacientemente a que se deje ver alguna presa. - Parece, dice Naumann, que sus cortas patas solo le permi. ten posarse y no andar; rara vez lo hace, y aun entonces no da mas qque algunos pasos subre una piedra ó una cstaca, nunca por tierra s Si nada le inquieta, solo se mueve para atrapar una presa, j cuando ronsigue su objeto, se queda ha major parte del dia en el mismo sitio. Ún observador paciente pociria verle cómo extiande el cuello, se inclina hácia adelante, con la punia dél pico baja, y se lanza despues șubiramente ai agua sin servirse de sus alas. Por lo regular des. aparece del todo bajo la liquida superficic, bastándole algunos aletazos para salir; entonces se dirige volando á su observatorio, sacude el agua que moja su plumaje, le alisa un poco y. velve a su primera inmovilidad. Si ha lecho varias tenta. tivas inútiles y no ve pez alguno, decidese al fin s cambiar de sitio. Su vuelo es penoso; sus cortas alas no pueden apenas levintar tan pesado cuerpo, y le es preciso agitarlas con tal viracidad, que no es posible distinguir cada alciazo de por st. A pesar, y quires á causa de esto, es su ruelo rapidi. simo, aunque uniforme y monótono, paryue mientras el ava puede, corta el aire en linea recta, manteníndose siempre á igual alesra de ha superficie, y cambiando solo de rumbo cuando cambia la corriente, porrue no le gusta apartarse del rio ó arrojo que recorre, y si lo liace, no se aleja mas allá de quinienios 6 seiscientos pasos. Mientras algun encunigo no le obligue a cllo, no sucla mas que hasta el próximo sitio que cncuentra para posarze. Varias veces, no obstante, el hambre y la necesidad le ob!igan a cjecutar ejercicios de alto

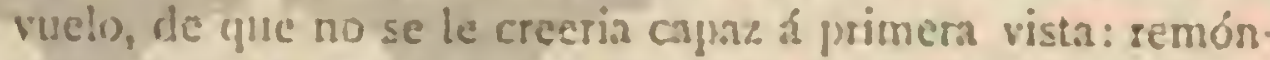
rașe sobre el agua; se mantiene en los aires cemiéndose; examina con cuidado todo cuanto pasa delajo de él, y luego se deja caer de repente para sumergirse en busca de un pez. Por lo regular hace estas evoluciones, muj comunes en otras especics de s!a hamilia, cuando cazas sobre grandes extensiones de agua curas orillas carecen de sitios propios para serviric de atalaya $\delta$ vigia y cuando ha de trabajar para alimentar a su numerosa cria; per mancra que estos esfucrzos parecen ser su ultimo y ubligado recurso; pero hace mas todavia cuando el anor le excita.

Su principal alimento consiste en peces pequeños y en cangrejos, ! de paso en insectos con los que mantiene á sus hijuclos. Fs muy roraz y necesila mas de lo que a primcra vista se cree; como racion diaria apenas le bastan dicz. ó doce pececillos del tamaño de un dedo. No es exigente en cuanto á la clase de pescado y coge cuantos puede, sucedien. do en algunas ocasiones que se apodira de presas bastante grandes Segun dice Naumann, los acecha como el gato á los raiones, y no se apodera de ellos mas nue con el pico, por lo cual se le escapan a menudo, y debe hacer varias ten. tativas antes de conseguir el exito; pero tambien es verdad que una sola presa le basta, si no para tocio cl din, al menos para por la inañan. Su manera de pescer le obliga á elegir un sitio a propósito: no le conviene que haya mup poco fol: do, pues entonces se podria herit, ni tamproco demasiaco profundidad, posugue su presa se le escaparia muy fácilmenie.

Kespecto de esto me comunica liebe los datos que siguen: ه Uno de los sitios predilectos de los martines pescadores es Hirschberg, junto al Saale, por mas que no reuna circuns tancias favorables para las crins. liste rio está encajonado eritre peñas tan escarpadas y altas que no es posible el tránsito po: las orillas ni que se formen sendas 6 reredas. El rio, que es bastante caudaloso y corre sobre multitud de piedras y grandes guijarros, es abundantisimo en peces perqueños. A falia de ramas en donde posarse, se ponen los martines de centincla en alguna piedra, observíndose que las que prefieren para su acecho, están llenas de sus residuos y excrenien- 
tos. Alli he visto con cuánto gusto se comen los cangrejos que á menudo sacan á pesar de la abundancia de peces. Para tragarlos mejor los golpean contra la piedra y no, como al parecer se cree, con la cabeza. Por cierto que alli han de ser los cangrejos su alimento favorito, puesto que los desperdicios de su comida no consisten en otra cosa sino en restos de estos animales.

Las lluvias continuas, que revuelven el agua, le hacen su. frir hambre, y hasta ocasionan su muerte; el invierno es tambien causa de que perezca, pues si los peces desaparecen debajo del hielo 6 en el fondo del agua, debe renunciar á cogerlos. Durante los rigores de la mala estacion le es preci. so contentarse con algunos sitios donde el agua no está helada, y aun allf se da el caso de sumergirse sin poder en. contrar despues el agujero que practico en el hielo. Otras veces muere el martin pescador por haber sido su caza dema. siado faliz; sucumbe ahogado por una presa demasiado grande, que se detiene en su esófngo sin poderla tragar. Vo. mita bolas formadas de espinas y de escamas de peces.

Durante la estacion del celo, el martin pescador está muy
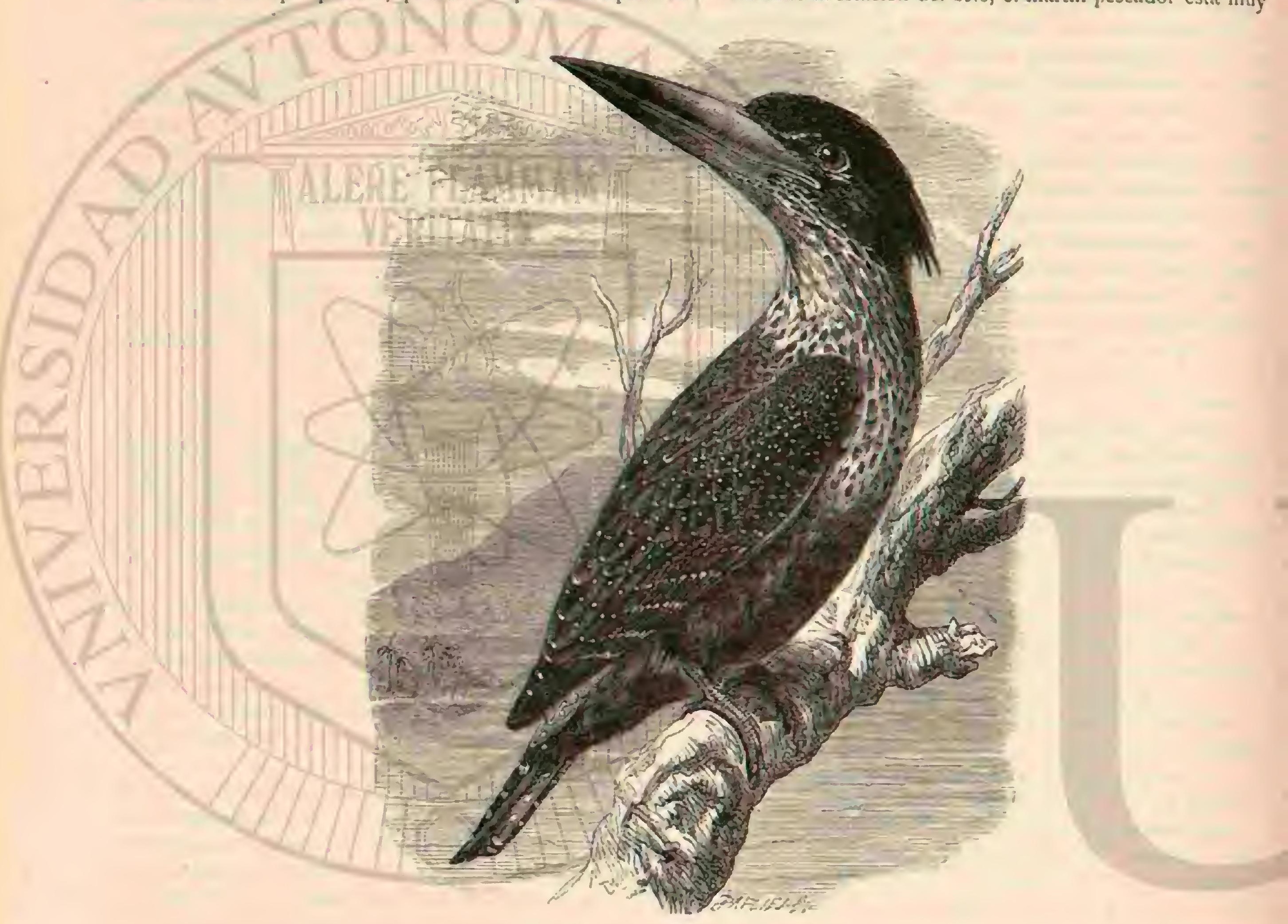

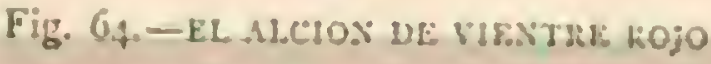

excitado, y lanza con frecuencia su grito, sonoro y penetran. te, fit fil ó si si, grito que repite varias reces, y que no suele dejar oir en ninguna otra ocasion a menos que le domine la cólera: á este sonido acostumbrado, añade el ave además otras notas singulares. El macho, dice mi padre, se posa sobre un ảrbol, í menudo á gran altura, $y$ lanza un grito di. ferente del ordinario; la hembra acude, agasaja al macho y vuela; su compañero la persigue, se posa en otro árbol y vuelve a producir los mismos sonidos hasta que aquella llega de nuevo. Al juguetear asi, estas aves se alejan doscientos o trescientos pasos del agua, y se sitúan, con el cuerpo recto, en un árbol del campo, lo cual no hacen nunca en ninguna

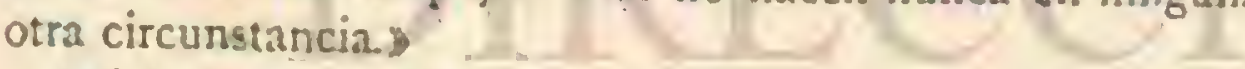

Leisler y mi padre han podido observar la manera de re. producirse este martin pescador, cosa que ignoraba Bechs. tein. 8.Apenas se aparea esta ave, lo cual sucede a fines de marzo ó principios de abril, dice mi padre, busca un sitio propósito para fijar su nido, y elige siempre un ribazo seco $y$ escarpado, completamente desnudo de yerba, donde no pue. den trepar las ratas, las comadrejas ni carnicero alguno. Alli, a jo ó 60 centimeiros bajo el borde superior, el ave practica un agujero redondeado, de unos cinco ó seis centimetros de diảmetro, y de 60 \& 1 metro de profundidad. Esta especic de inadriguera se dirige un poco hácia arriba; la entrada se bifurca y la extremidad opuesta termina por una excavacion redondeada de seis á ocho centímetros de alto y de once á catorce de ancho. El piso esta cubierto de espinas de pesca. dos, es muy seco y la pared superior lisa. Sobre aquel lecho deposita la hembra de scis á sicte huevos, relativamente muy grandes, casi redondos y de color blanco lustroso; cn el momento de ser juestos presentan un tinte amarillento debido ála yema, que se ve al trasluz. Ios huevos que pone esta ave son acaso los mas hermosos que conozco: cuando se va. cian tienen un color blanco brillante, como el esmalte mas puro, y son casi del rolúmen de los de la calandria. No com. prendo cómo pucde el are cubrirlos todos a la vez, con sus plumas duras y cortas.

¿El martin pescador necesita dos ó tres semanas para for. 
mar la madriguera donde se propone depositar sus huevos; si encuentra piedras trata de quitarias, y cuanio no lo con. sigue socava al lado de ellas; á estas piednas se debe nue la galcria sea muchas veces muy tortuosa; si hay deunasiadas, el martin pescador abandona aquel sitio y forma su nido en otm

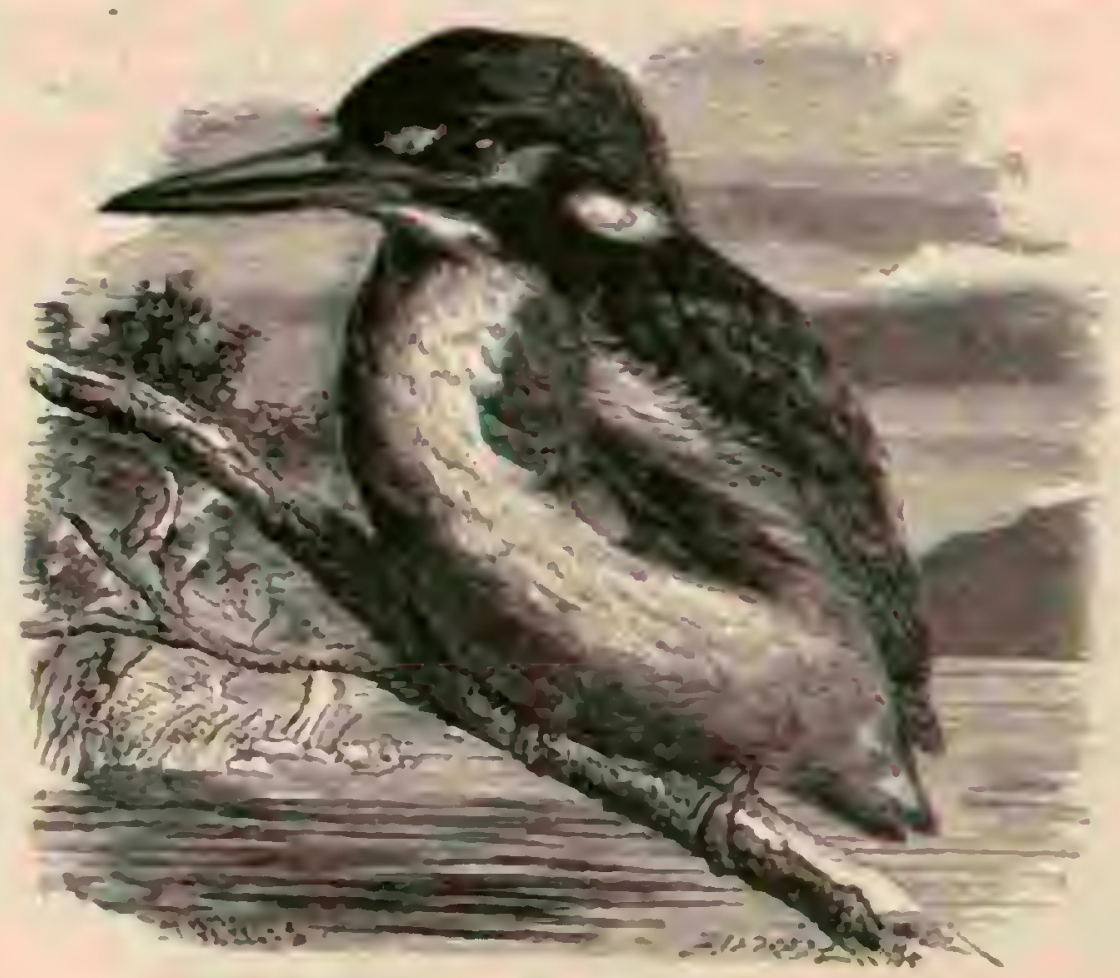

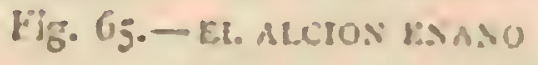

parte. En cuanto da la construccion, aseméjase nuclio á la que practican los picos, con la diferencial de que estos soca. van la madera muerta, y los oiros en tierr. Iil martin pesca. dor habita el mismo nido varios anos, chando no le molesta cosa alguna; pero si la entrada se agranda, no deposita ya sus huevos alli. Fícilmente se reconoce ci que ha sido habi. tado ya, por el mímero de caberas y alas de libelula que están mearladas con las espinas de pescado; cuando el nido es reciente escasean mas estas liltimas, y no se cucucniran restos de dichos insectos antes de salir d liz la cria. I prime. ra vista se distingue el nido de un martin pescador dal agujero de una rata ó de un manrifero, y para saber si esta Iabitado ó no, basta oler la entrada: si cxhala un olor á pes. cado, se puede tener la seguridad de que le habita el ave.

la tenacidad con que el martin permancce sobre sus huevos ó sobre los hijuelos que aun carecen de pluma, es verdaderaniente notable: aungue se descarguen rejpetidos golpes sobre el borde, durante largo ticmpo, no sale de sure. tiro; permanece quieto aun cuando conozca que trabajan para ensanchar la entrada, y no abandona la cria hasta el momento en que le van á coger.

Yo he hallado huevos desde mediados de majo hasta principios de junio.

- El macho se situia i una distancia de ciente á trescientos pasos de su nido, y allá pasa la noche y ura parte dul dia.?

Naumann confirma plenamente lo que dice mi padre, sin anadir mas que algunos datos, cntre atros el de que se en. cuentran a veces hasta once hueros en un solo nido. I. hembra, continúa, cubre sola por espacio de catorce á diez y seis dias; el macho la lleva peces para su alimento y aparta las inmundicias del nido, trabajo que hacen las dos aves cuando los hijuelos han salido à lu\%. En el zmomento de abandonar el cascaron, lus pequeños martines son ficrdade ramente hediondos; no tienen ninguna pluma, y sus ojos permanecen cerrados por espacio de álgunos dias. Su talla difiere mucho; he visto aigunos que no eran la mitad de los otros de la misma prollada; tienen la cabeza graude, el pico corto, $y$ la mandibula inferior sobre $1,0,04$ mas iarga que la superior. Su torpeza es excesiva; mueven a menudo la cabe2a, abriendo nucho el pico: pian un poco cuando lienen hambre y al verlos moverse diria uno que son gusanos ape- lotonados. En aquel periodo les alimentan los padres cou larras de insectos y solure todo con libelulas, á las que arrancan antes la calecza y las alas; mas iarte les dan pececillos. Clando comienzan á echar las plumas parece que están crizados de púas de un color azul negruzco, pues aquellas se hallan encerradas en una especie de vainas muy largas, que tardan bastante en abrirse. Los hijuelos permanecen largo tiempo en el nido antes de poder volar; el criarlos es muy fatigoso para los padres, y entonces despliegan mas activi. dad. Llegado el momento en que la progenie puede ya vo. lar, macho y hembra la conducen á los sitios mas trannuilos, al centro de los matorrales 6 de las raices de un árbol que crece a orillas del agua, $y$ alli se reune asi toda la familia. Si dlguien se acerca, macho $y$ hembra se descubren por su vuelo inquicto y poco extenso, y por sus planideros gritos, mientras que los pequenos se mantienen tmanuilos y silen. ciosos. Si los ahuyentan de su retiro, emprenden el vuelo unos á derecha y otros á izquierda, seguidos siempre de sus padres, que ian pronto acomparian ís los primeros como álos segundos. Los jóvenes necesitan cierto tieupo antes de aprender a pescar.

Naman ha publicado tambien una obsersacion que revela hasta dónde llega el cariuo del martin pescador it su progenie. Deseando adquirit algunos pequeños, dirigióse $\{$ un sitio donde habia visto la entrada de un nido; se aseguró por el olor de la presencia de la f́milia, e hizo sus preparativos para apoderarse de clla. No iba yo solo, dice, y despues de

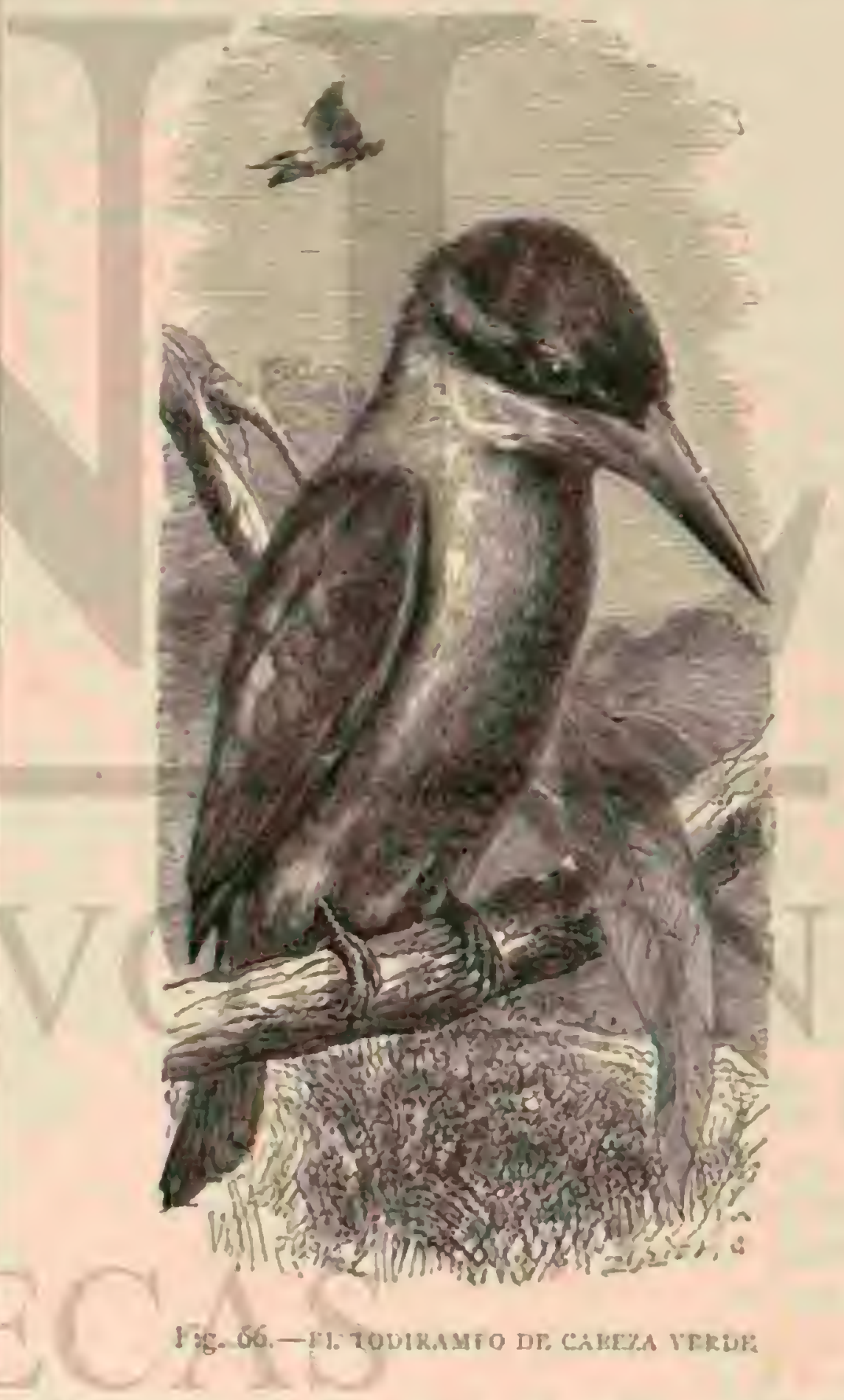

hablar mucho ! de dar con los piés contirues golpes sobre el nido, no vimos salir ninguna are; por lo mismo fué grande mi asombro cuando al iniroducir una vasilla en la entrada se decidió un martin pescador à dejar à sus hijuelos y pasó volando junto a mi. Sin embargn, yo habia resuelto apode. rarme de la fanilin; necesinba tambien uno de los padres; 
y como no teniamos los útiles para el caso, aplazamos la empresa para el dia siguiente, despues de colocar un lazo á la entrada del nido. Toda la perturbacion producida por nues. Ira visita no impidió que la madre procurara acercarse á sus pequeños: al dia siguiente la encontramos colgada del lazo y muerta, y mientras cogiamos los hijos, el macho pasó va rias veces cerca de nosotros lanzando gritos lastimeros.

De las observaciones publicadas posteriormente á las de mi padre y de Naumann, resuita que el periodo del celo para el martin pescador villgar, no está limitado á los meses que ellos indicaron. Así logró Walter en 6 de abril y en otra ocasion a mediados de cste mes sacar crias completas. I): versas circunstancias pueden retardarle: si la yrimavera se retrasa, si los arrojos y los rios siguen crecidos, ó si los uidos se destruyen, ete, el martin pescador debe esperar con diciones mas farorables: $y$ asi sucede que en setiembre se encuentran aun en los agujeros hijuelos sin pluma.

Segun las obscrvaciones concienzudas de Kutter, que lo gró examinar en el trascurso de tres años nada menos que ireinta nidos ocupados por martines pescadores, estos no crian en el mes de seivembre sino en el caso de que las primeras juestas hayan sido destruidas; pues cuando no se molesta al ave no hace mas que una cria al año, de lo cual se pudo convencer el citado naturalista, porque habiendo hecho una scnal con una lima en el pico de las aves que habia cogido enıpo llando en el nido, las pudo reconoccr mas tarde. De sus apun tes, hechos con sumo cuidado, resulıa lo siguiente:

Los martines pescadores constriyen la galeria que con duce al nido invariablemente en las márgenes de los rios cu jos ribazos son empinados y lisos, $\delta$ formando resalto sin que sea preciso que toquen a! agua. I a altura varia segun las condiciones de la orilla, y no lo construyen inmediata uneute debajo del borde sino donde lo hace necesario la calidad de la tierra. Cuando la orilla es muy clevada puede en contrarsela galeria en el centro ó sea á la mitad de la altura lotal yí reces mas abajo. Solo cusindo la hembra principia a poner, proceden estas aves a formar el lecho con las espi nas y escamas que vomitan, porque las madrigneras sin hue ros, aunque sean de construccion reciente y estén acabadas del todo, nunca tienes rastro de despojos, que solo reunen alli los viejós durante la puesta É incubacion hasta que tinal. mente llegan \& formas una capa de un centimetro de grueso. Jamás se hallan los huevos cmpollachos en el suelo de la madriguera, sino invariablemente sobre los citados materiales que como son malos conductores del calórico dificultan el enfriamiento de-aquellos. El número de hueros en las prestas completas encontradas por Kutter fué casi siempre de sicte, major nunca, y menor solo en algun caso raro. Alli donde existen varias de estas madriguems, una cerca de la otra, se encuentra solo una ocupada, y la distancia minima entre dos madrigueras ocupadas es de unos cincuenta pasos. A pesar del trabajo, relativamente colosal para un ave tan pequeña, que representa la cxcavacion de estas cuevas con su galeria correspondiente, lo ejecuta sin embargo en un plazo muy corto, en algunos casos en menos de una semana, de lo cual pudo hutter comvencerse. Como el asiduo picoteo y excavacion en parte en tierra cascajosa ó arenosa desgasta notablenente el pico, en especial la mandibula superior que es la que hace casi todo el trabajo, no es extraño que al concluirlo se haya acortado aquel medio centimetro a causa del desgaste.

Los datos siguientes, que diebo á la amabilidad de Licbe, completarán lo que precede: (He tenido una excelente ocasion de observar unos martines pescadores que durante algunos años han hecho sus crias en la pendiente arcillosa que un desprendimiento de tierra dejó en descubierto, y que fue causado por un pozo ó embudo natural con agua prolunda y fria, donde a falia de peces solo se crian unos pocos articu. lados, y que se halla en el centro de un pequeño matorral junto á un paseo muy concurrido, á unos mil pasos del rio Elster, que alli corre entre espesos matorrales; por manera que las ares tenian que volar mil pasos pasando sobre campos y prados para buscar el alimento para ellas y su cria, con la molestia que debian causarles los paseantes y los trabajadores del campo. A pesar de esto, han vuelto siempre á la pared de arcilla para dormir y hacer sus crias. Otra rez tuve la suerte de observar una hembra que habia elegido para morada un hueco en una raiz carcomida de un árbol. Oia caer continuamente cuerpos pequeños al agua, y acabé por descubrir que eran terroncitos de tierra que salian de aquel agujero estrecho, y que aumentaban a medida que pasaba ticmpo, hasta que por úlímo vi salir la hembra de espaldas, escarbando siem. pre y haciendo toda clase de movimientos, despues de haber hecho caer al agua una gran cantidad de escombros. Al diyisarme voló, pero al cuarto de hora volvió a meterse en cl agujero, del cual salió como la primera ve\%. Mass tarde, cuan. do la galería debió estar suficientemente ensanchada en el interior de la raiz podrida $y$ formada la madriguera en el fondo, salió ya siempre de frente y jamás de espaldas.

Sabido es que ningun carnicero persigue al martin pescador: cuando es adulto, y merced á sus costumbres, cscapa de muchos peligros a que se hallan expuestas otras aves: y rara ver. está su nido dispuesto de tal suerte que puedan llegar á él la rata ó la comadreja. Ni aun el hombre le hace mucho daño, no por sentimientos humanitarios ó aficion á los animales, sino porque el are es esquiva y procura dejar burlados a los cazadores domingueros. Prescindiendo de esto, el qque no estí familiarizado con su género de vida no suele tener ocasion de tirar contra él ni de disponer hábilmente los lazos.

CAUTIVIDAD. - Dificil es acostumbrar al martin pesca. dor a vivir en jaula: los pequeiros que se cogen en el nido pueden conservarse bastante tiempo alimentándoles con pe ces y carne; los adultos son bruscos, salvajes, miedosos; rehusan por lo regular todo alimento, y perecen muy pronto. Sin embargo, no faltan cxcepciones, pues yo mismo he tenido varias veces la suerte de acostumbrar al cautiverio algunas de estas aves ya viejas y de conservarlas mucho tiempo; y lo que es mas, las he perdido siempre por alguna desgracia casual. Jos viejos no rehusan nunca el alimento si se les coge con los-pequeños; el amor á sus hijos les hace olvidar la pérdida de su libertad, y en seguida se aplican á pescar y se acostumı. bran ellos y sus hijos á la jaula y á la racion que se les da Entonces es cuando se hace patente su voracidad pasmosa. Domesticados y colocados en pajareras a propósito son sim contradiccion alguna encantadores.

En el Jardin 7.0ológico de Lóndres se han preparado viviendas especiales parn los martines pescadores y las demás aves acuáticas. Se ha construido una gran jaula, cuyo fondo está ocupado por un estanque bastante profundo, y cuyas paredes ofrecen todo cuanto pueden necesitar estas aves; en las aguas hormiguean infinitos pececillos; por encima hay perchas para el acecho; en suma, todo está dispuesto del mejor modo posible. Los martines se hallan alli mu bien; pucden pescar como cuando viven libres, y asi lo hacen en éecto. Debo decir que me causú sumo placer encontrar á esta ave indigena cautiva, a la que observaba en tal estado por primera vez, placer que no me hubiera proporcionado ninguna otra de tan rica y espléndida coleccion.

\section{LOS CEIX-CEYX}

CARACTÉRES. - Ios ceix son alcedininos que so!o tic- 
nen tres dedos; falta el interno: se clasifican a menudo entre los alcioninos, porque su pico es mas ancho en la base çue el de los otros alcedinidos; pero sus formas generales, su organizacion, particularmente la breredad de sus alas y de su cola, y sus costumbres, los asemejan de tal modo á los martines pescadorés, que no podemos alejarlos.

DISTRIBUCION GEOGRÁFICA.-1.os ceix habitan las Indias, las islas del Archipiclago Malayo, las Filipinas y la Nueva Guinea.

\section{EL CEIX TRIDACTILO-CEYX TRIDACTYLA}

CARACTÉRES.-El ceix tridáctilo representa la mas hermosa especie de este género : la mejor conocida. T'iene el lomo de color naranja, con magnificos visos flor de albérchi. go; los lados del pecho y del cuello varian del pardo rojo al castaño claro; el vientre es de un amarillo azafran; las grandes tectrices superiores del ala de un negro puro; las escapulares y el borde anterior del ala de un pardo castaño; las rémiges pardo negras, orilladas de pardo rojo en sus basbas internas; las rectrices de un rojo de coral y las patas de un rojo claro. Esta ave mide $0^{\circ}, 1$; de largo por $\left(0^{m}, 22\right.$ de punta á punta de ala, la cola $0^{\circ}, 02$ y cl ala $\|^{\circ}, 06$ (fig. 6 ).

DISTRIBUCION GEOGRAFICA.-Ierdon nos diceçue el ceix tridictilo habita en toda la India $y$ en Ceilan, sin ses comun en ninguna parte. Sykes le vió en el Dekan; parcec preferir las costas, y abunda mas en las islas de Malacon eque en las Indias.

USOS, COSTUMBRES Y RTGIMEN.-Se alinema cxclusivamente de pececillos $y$ de animales acuáticos.

\section{LOS CERILOS-CERYLE}

CARACTERES. - Difieren de los martines pescarlores por la estructura de sus alas y de su cola: las primeras son mas largas y puntingudas que en aquellos, con la segunda rémige casi tan larga como la primera, y la cola bastante pro longada $y$ ancha. En otros términos, los órganos del vuelo alcanzan mas desarrollo en los cerilos que en los marrises pescadores; su pico es largo, recto, puntiagudo y comprimi. do lateralmente; el plumaje liso y compacto, pero sin viros colores, y mas ó menos variable, segun el sexo.

DISTRIBUCION GEOGRAFICA.-Fistas aves, con las que se han formado varios géncros, estín diseminadas prin. cipalmente en América, aunque no dejan de tener sus repre. sentantes en Asia y Africa; hasta hay una especie qute se ha presentado varias veces en Europa, donde ha adquirido de recho de ciudadania.

USOS, COSTUMBRES Y REGIMEN.-I. OS cerilos SON los mas fuertes de codos losalcedinidos, asi como los mas ágiles, y por consiguiente los mas voraces: son los tigres the lis pescs, segun ha llamado Cabanis á varios de ellos.

\section{EL CERILO PICO-CERYLE RUDIS}

CARACTERES. - Fs la especic que repetidas veces ha pasado como extraviada desde Egipio y Sisia il Europa. Su colotacion es modesta: tiene el lomo salpicado de negro bianco: la parte inferior del cucrpo es de un blanco juro excepto una ó dos listas pectorales negras y algunas manchas de este mismo color en el pico. Ias plumas negras del occi. pucio y parie superior de la cabeza tienen los bordes de los costados blancos, y las del dorso, de los hombros, de la raba. dilla y las cobijas de las alas, el borde blanco $y$ ancho en el extremo. Ia parte blanca de la cabeza y de los lados del cue llo están intcrrumpidas por una lista regra que nace en el ex. tremo de la abertura bucal, pasa por encima de la orcja jo baja por el cuello. Las rímiges y las cobijas son negras, en la mitad inferior blancas, y las primeras cuatro con bordc de mismo color en la punta; pero las humerales son blancas, $j$, en su extremo exterior negras con una mancha blanca en me. dio. Ias rectrices son blancas con una faja ancha en el extre. mo y en el borde de la faja una mancha blanca. El ojo es pardo oscuro, el pico negro y el pié pardo. Ia longitud es

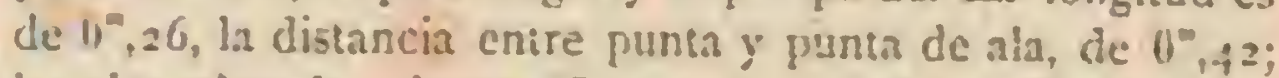
las alas plegadas tiencn $6^{-}, 1,3$ y la cola $0^{\circ}, 05$. La henibra difiere del macho por tener una haja pectoral en lugar de las dos que tiene ayuel. Lista dírerencia fué la causa yue indujo á Swainson a describir los dos sexos como especies diftrentes.

DistribUCION GEOGRÁFICA.-Eil cerilo pico está muy diseminado: se le encuentra en casi coda el Arica, en Siria, Palestina, Persin, en las Indias y en general en el Asia meridional. Lin Europa se le ha visto varias veces, pero solo en (irecia y en Dalmacia; siendo prubable (jue aparezca mas á menudo de lo que se admite generalmente. Es comun en el ralle del Nilo, donde ture numerosas ocasiones de obser. varle.

USOS, COSTUMBRES Y REGTMEN.-Recuerdo sun el asombro çue me causó csta ave en el momento de pisar el afiicaro suelo. En el canal de Mahmoudich, que comunica Alejandria con el Nilo, habia visto ya varias veces un ave grande que rolaba cono la crecerela, cerniéndose en los aires, ó se posaba en las romanias de los poros, sin que pudiese yo reconocer à qués especic pertenecia. Por último consegui ma. tar un individuo, y no jué poca mi satisfaccion al contcmplar un cerilo de pico, que era entonces todavia as mis ojos una gran rareza. Bien pronso, no obstante, dejó de scrlo, y no tardé en reconocer que aunq̨ue aquuella are no era de las mas comunes en Egipto, se la encuenira por todas partes y en todo tiempo, pudiéndose cazar tarto como se quiera.

Comunmente se la ve descansando en las largas prértigas de los pozos, con su blanco pecho vuclto hácia la orilla del rio; si encuentra una palmern ó mimosa en la márgen del Nilo, y le ofrece una de sus ramas sitio conveniente, eligela como obsersintorio. Tambien se posa en el armazon de las ruecias de desagüe, movidas por los buejes, que producen la missia ded . Vibo, tan conocida como maldecida de todos los viajeros.

Ll cerilo pico no es tan receloso como el martin pescador rulgar; sabe que puede conírar en los egipcios, y que nada debe iemer de ello5. Sus cosiumbres ofrecen mas de una particularidad que sorprende al cxtranjero; pero de todas ellas la mas curiosa es su familiaridad con el hombre. Se posa sin la menor inquictud sobre el muchacho quie conduce los buejes que mueven la noria j al alcance de su litigo; permanecetranguilo, como pudiera hacerlo un avedonusticada con su amo y protector, y vucla junto à las mujeres ųue van a sacar agua del Nilo, cual si quisiera alejaslas de alli. Al contrario del martin pescador, tolera en su dominio á las deunas aves, $y$ hasta es sociable; macho y hembra se mantienen fieles a su afecto, y suelen estar posados uno junto a otro. Si Swainson hubiera viajado por ligip:o, habria podido ver, con gran asombro, a su cerilo bicinesa yu cerilo rublis, darse todas las pruebas de cariño que un ticrno esposo es capaz de prodigar a su compancra legitima; y le hubiese sido posible acercarse lo bastanie á estas ares para distinguir los caracteres de una yoira.

El cerilo pico pesca como el martin pescador, cuando este no encuentra bastante alimento con su procedimiento habi. tual; es decir que se cierne sobre el agua, : dejase caer como aquel para coger su jresa. Su vuelo no se asenreja en nada 
al ž̀ martin pescador: mueve las alas rápidamente, mas no de cos manera precipitada, pudiendo distinguirse cada aletazo eze da. Su vuclo no es tan veloz, liace mas recortes cuando riela, y no se desliza directamente como el martin, que rveia como una saeta; tiene casi el movimiento del halcon; reaonntasc, se revuelve, se cierne, va mas léjos y repite la misna maniobra Para coger su presa oprime las alas contra el exerpo: se deja caer en el aglia oblicuamente como una flecta; desaparece bajo el liquido elemento, y se remonta al cabo de un instante á impulso de algunos vigorosos aletazos. Pearson dice, al hablar del cerilo de la India, que permane. ce debajo del agua hasta que se alisan los circulos formados por la caida: Jerdon pone en duda el liecho y yo opino en un todo como él, pues no creo que el ave resista mas de quince ó reinte segundos debajo del agua. Otras reces se su. merge volando bajo un ángulo tan poco marcado, y se remon. ia con tal rapidez, que parece rebotar sobre la superficic liquida. Jerdor no recuerda haber visto jamás á un individuo

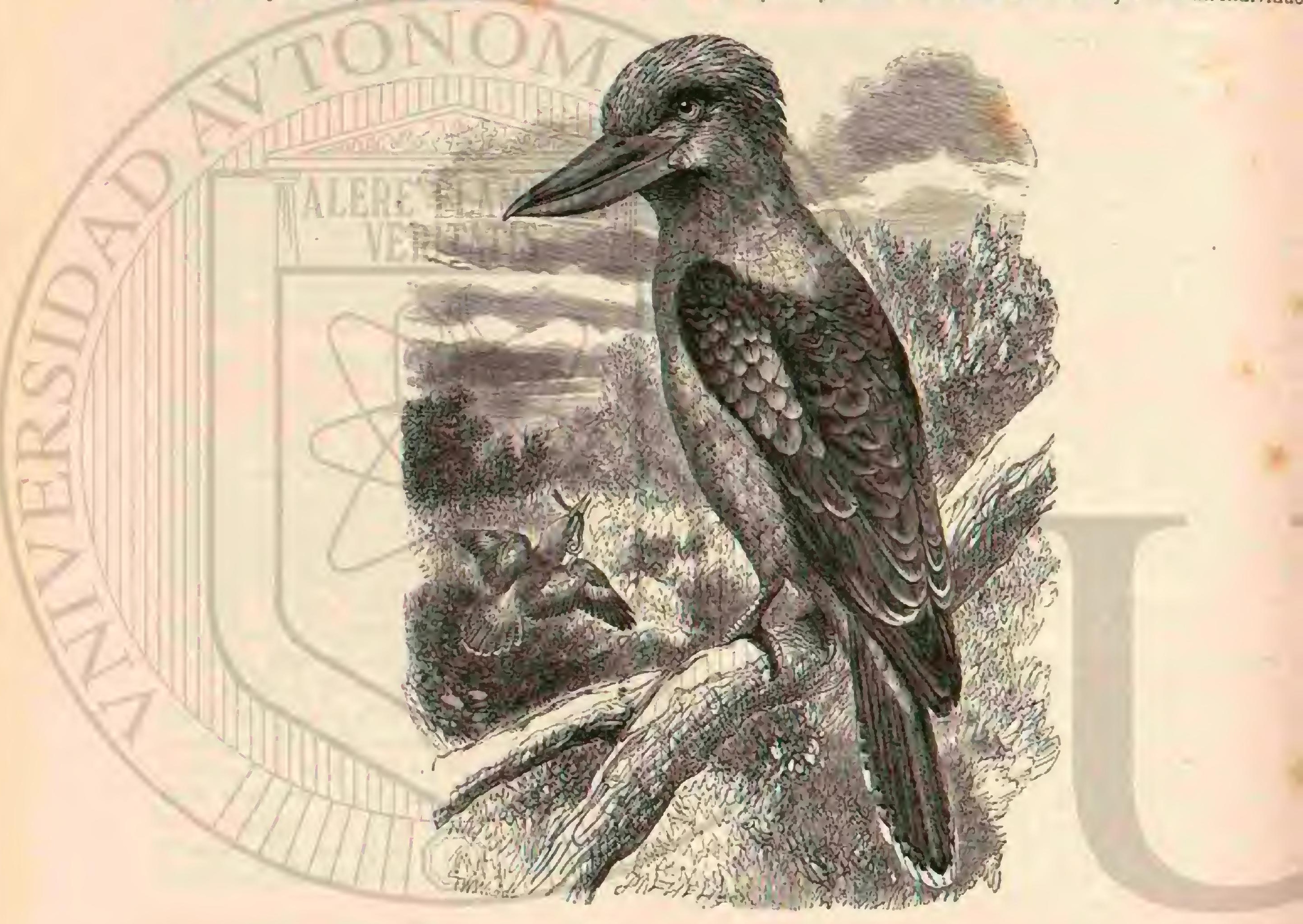

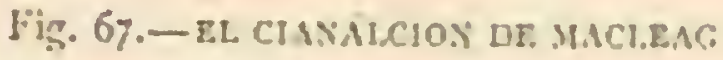

salr del agua sin su presa, pero yo puedo ascgurar que esto surece con frecuencia. Lis posible que el cerilo pịco sea mas dism que el marlin pescador: pero no siempre se apodera de st victima, sin cuda porque no reconoce bien á qué pro. fungidad ha visto madar al pez. Si ntrapa la presa, vuela en sezuda á su percha favorita para comérsela, comunmente desces de haberla golpeado varias veces contra la rama. Si nocaza, se le ve volar irregularmentc, rasando la superficie del sgusa; dirigese en linea recta hácia el sitio donde se quiere pesa, y se remonta de pronto cuando se halla cerca. Dumnte dia permanece tranquilo; i la caida de la tarde manifiesim mas vireza y le gusta retozar. Entonces se oye su vor, que consiste en un grito penetrante, repetido varias veces, $y$ que no se puede expresar fácilmente.

Crando las aguas del Nilo ran crecidas, le es forzuso ale. jass de ellas, porque cstán demasiado turbias para que puedarer los peces; pero los numerosos canales que cruzan el sucis de Fogipto le proporcionan por otra parte suficiente alizento, pues el agua es mas clara y contiene mucha pesca. Aśse explica por qué el ave es mucho mas comun en e]
Delta, donde abundan los canales, que en el Alto Egipto y en la Nubia cuyos recursos se limitan casi á los que ofrece el rio. Las recientes observaciones de 'Tristram nos dan á cono. cer que los cerilos picos aparecen tambien por docenas á orillas del mar, volando sobre las olas, á un centenar de metros de la ribera. En los meses de novienbure y de diciembre vió aquel naturalista un número incalculable en las costas de Palestina, unas veces pescando y otras posados en las rocas.

En Egipto comienza el periodo del celo para csta ave cuan. do las aguas del Nilo están mas bajas, es decir, en marzo y abril. Adams encontró niưos durante el primero de dichos meses, sin duda en otra localidad donde el estado del Nilo tiene poca influencia. Solo una vez recibl un huevo, que me aseguraron ser del cerilo pico; pero desde que lei la relacion de Tristram, dudo de la realidad de lo que me dijeron. Este autor ha visto que en la Palestina anidaban dichas aves por rerdaderas colonias, una de las cuales se habia posesionado de una pendiente arcillosa y cscarpada, en la embocadura del arrojo de Moudawarah, en el lago de Genezareth. La entrada de los nidos se hallaba solo a $0^{\circ}$, ro sobre el agua, $y$ 
apenas se podia llegar sino á nado: de cada abertura partia un conducto, que se hundia á cosa de un metro, ensanchín. dose para formar una simple caridad lateral. Ninguna madri. guera conienia espinas de pescaclos que sirviesen de lecho para deprositar los huevos, ni se encortraban merclados con las immundicias hasta que habia hijuelos: algunas yerbas ia. pizabar el fondo de la graleria. El $2 S$ de abril encontró Bar. lett en un nidocuatro huevos, y seis en otro. Cuanuo I'ristram visitó la misma colonia, en 22 de mayo, vió un gran número de jequeños, capaces ya de volar; otros mas atrasados per- manecian aun en los nidos, y cinco de estos últimos, de los cuales uno habia sido vaciado pror Barles, contenian huevos. Su forma varía mucho: son por lo regulas ovoidéos, y algunos muy prolongados: dicho naturalista no dice nada de su color; pero debo deducir que son de un blanco puro, si bien recuer. do yzue el que me dieron como de cerilo ienia el fondo claro con manchas oscuras.

De una de las madrigueras que registró Tristram, salió una rata con scis pequentos.

Duranie la visita, los padres permanecian prosados en los

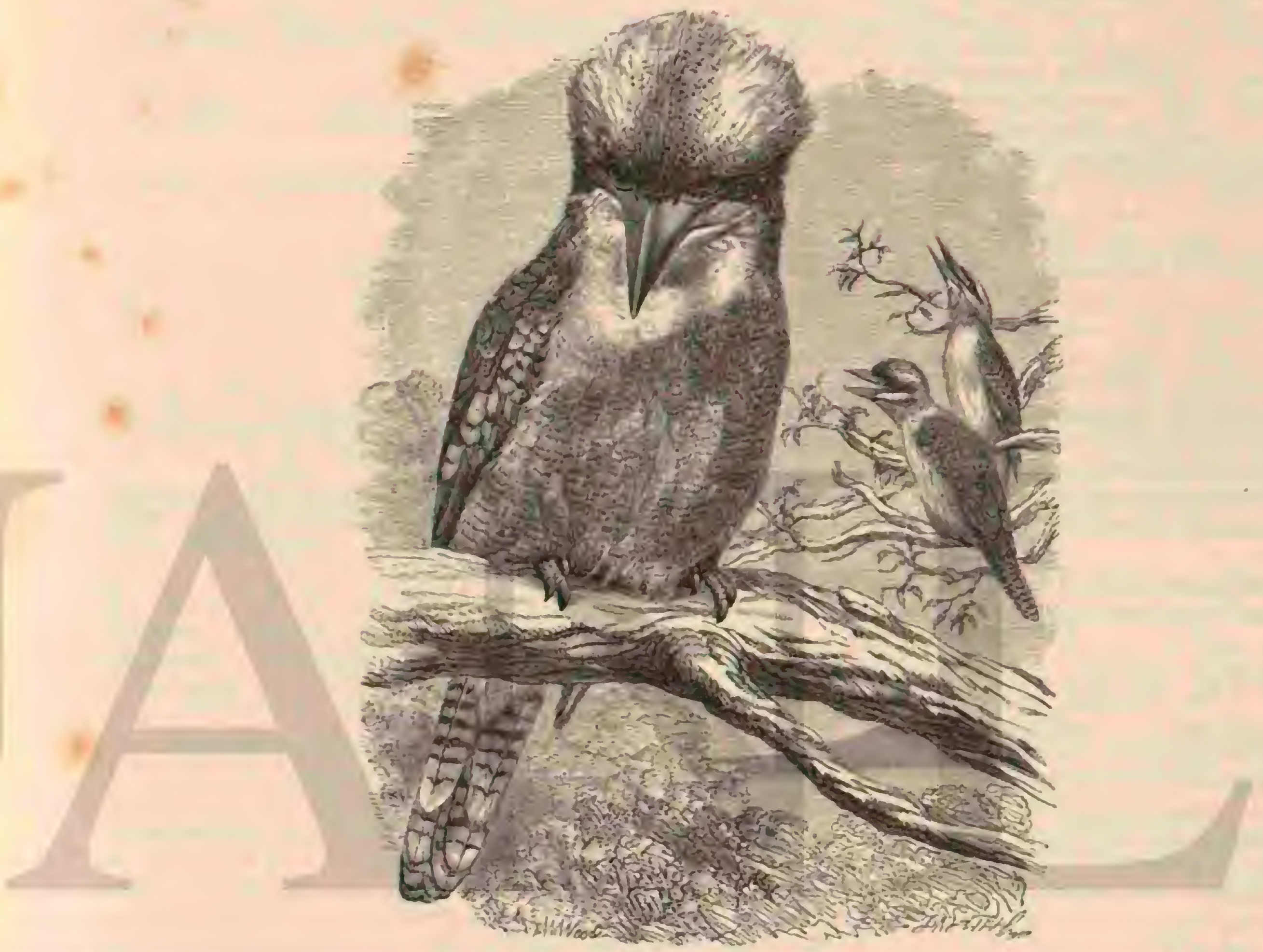

Tig. tS. - EI. P.AKALCION GIGNST:

bosquecillos de laurel rosa, situados en ha orilla, I volaban de un lado a otro lanzando gritos de angustia.

Ignoro cuáles son los enemigos del recrilo pico: jamás he vistô que le acometicra ninguna rapar, y no sé que otros animales pueda temer la especie.

\section{EL CERILO MOTEADO-CERYLE GUTTATA}

CARACTERES. - Esta magnifica ave $\left(f_{i g} \cdot \sigma_{j}\right)$ liene el precho y los lados del cuello de un bonito blanco agrisado, quec paśa á un ligero pálido leonado en el abdómen y en la cara inferior de las cobijas de la cola; el resto del cuerpo ise tre un iondo negro, moteado de numerosas mancinas blaneas. Adoma la cabeza un ancho copreic compuesto de plumas prolongadas de los mismos tintes; algunas manchas negras forman una linea curva entre el pico $y$ la espaldilla, $y$ una faja interrumpida a través del pecho.

DISTRIBUCION GEOGRAFICA. - El cerilo moieado Tose III

habita en fa India y st cncuentre principalmente cerea del Himalaya.

USOS, COSTUMBRES Y REGIMEN. - listh especic se alimenta sobre todo de peces, nunģue numbien come in. sectos. Forma su nido entre las piedras con huesos y yerbns; y la hembra pone cuatro huevos. En cuanto a lo deurás, ajenas difiere del cerilo pico.

\section{LOS ALCIONINOS-HALCYONINE}

A primera vista se diferencian yo de los alcedininos por in conformacion mas perfecta de sus órganos de locomocion aérea. En su conjunto conserva el pico semejanza con los alcedininos, pero es mas ancion, las patas mas fuestes y los tarsos mas altos El plumaje, menos compacto, carece del lustre que presenta el de los martines pescadores, aungque tiene tambien colores muy vivos, $y$ hasta hay algunas espre. cies que pueden figurar entre las mas hermosas aves. Debe 
ráamos considerar á los alcioninos como un iránsito entre los alccdinidos y los bucónidos, pues sus caracteres participan tanto de los de aquellos como de los de estos.

Distribucion GEOGRÁfica. - El Africa, el sur de Asia, Australia y las islas situadas entre estos continentes, son la patria de los alcioninos, que faltan por completo en Eurofra y América.

USOS, COSTUMBRES Y REGIMEN. - Todas cstas aves son mas 6 menos silviculas, y solo algunas manifiestan preferencia á la recindad del agua. Varias de ellas pescan como el nartin, y las mas se asemejan á los barbudos por sus costumbres. Hay especies que viven independientes del agua en los parajes mas secos, pero cubiertos de árboles, los cuales parecen indispensiules para su existencia:

En cuanto á los órganes del vuelo, - los alcioninos son mas perfectos que los alcedininos: vuelan con ligereza, facilidad y grácia, asemejándose por tal concepto álos certidus. Posa dos en alguna aliura, inspeccionan los alrededores con atenta mirada, y cacu sobre su presa apenas la divisan, para rolver despues a ocupar el sitio. No estản á su gusto en tierra. San muy inferiores a la sub-familia que precede por lo que haces la facultad de atrapar la presa en el agua: solo algunas espe cies, y aun estas muy excepcionalmente, se sumergen para coger los peces ú otros animales acuaticos. Su roz es pene trante $y$ bastante singular; sus gritos dificiles de traducir.

Respecto á su inteligencia, no puedo emitir juicio en general; las especies que conseguí observar vivas no me parc. cicron bien dotadas en este concepto:mostraban una confianza y pesadez que no permitian suponer en ellas uma gran dósis de inteligencia, si bien debo confesar que he visto excep. ciones.

Los alcioninos se alimentan de insectos, sobre todo de langostas y coleópteros grandes; las mayores especies comen además crustáceos y vertebrados pequeños. Algunas tienen la fama de exterminar las serpientes, $y$ i otras se les acusa por el contrario, de saqquear los nidos: por su voracidad jue den figurar junto ál los alcedininos.

Su manera de reproducirse difiere de la de las especies de la sub-familia anterior: las mas anidan en troncos de ârboles; algunas en agujeros abiertos naturalmente en tierra ó en la roca, y todas construyen un mido masó menos perfecto. Las pues. tas son poco numerosas, y los huevos de un color blanco brillante como los de los alcedininos.

CAUTIVID \&D. - Ios alcioninos la soportan fácilmente, acostumbrấndose pronto al régimen ả que se les somete; pero es preciso confesar que en jaula son mas extraordinarios que. interesantes; en cambio contraen gran amistad con el hombre y se consigue que maniliesten el mayor carino y entrañable afecto is su dueno.

\section{LOS ALCIONES-HALCYON}

CARACTERES. - Tienen el pico largo, recto, ancho, corvo por arriba en algunas especies; las patas cortas, aunque endebles; alas de mediana largura, y redondeadas, con la ter. cera rémige nas larga, pero sin sobresalir mucho de la cuarta $y$ de la quinta; la cola es relatiramente corta y redondenda.

\section{EL ALCION DE VIENTRE ROJO-HALCYON SEMICCERULEA}

CARACTERES. - Cede poco en tamaño al cerilo pico; pues su longitud es de $10^{m}, 22$, la de las alas $0^{\circ}, 10 \mathrm{y}$ la de la cola $11^{\circ}, 06_{5}$. El plumaje no es tan hermoso como el de mu. chos congéneres suyos; pero los colores son viros y bonitos. La parte superior de la cabeza y el occipucio son de un par- do muy claro: la nuca es mas clara todavia, los lados del cuello y la parte anterior hasta el pecho son blancos, y la parte inferior color de cancla rojizo muy encendicio; el dor. so, los hombros y las rémiges son uegros: estas últimas, enpero, en la parte visible son de un azul de esmalte muy viro y brillante, y el mismo color tienen las cobijas, la rabadilia y la cola. El ojo es pardo y los piés rojos (fig. 64).

DISTRI BUCION GEOGRÁFICA.-El alcion de vientre rojo fú descubierto en el Africa occidental; mas tarde se le senaló en las islas de Cabo Verdey en toda el Af́rica central, y hasta cerca de Abisinia.

Heuglin señala como su área de dispersion en las regiones que recorrimos: las playas del mar Rojo, las mesetas de Abi. sinia hasta 2,000 metros sobre el nivel del mar. Yo lo he visto con frecuencia en los bosques de los rios Azul y Blanco, pero no en las costas del mar Rojo, ni en el pais de los Bogos.

USOS, COSTUMBRES Y REGIMEN. - Si mal no recuerdo, he visto casi siempre solitaria á esta ave singular, aunque á veces hallé muchas en un distrito muy reulucido; generainente me pareció mas comun en los aluviones de los rios que en los bosques de las estepas; pero durante la esta. cion de las lluvias se la veia en todas partes. En ciertos mo. mentós no divisaba ninguna, $y$ de aqui deduzco que debe ser un ave viajera. Acaso ro anide en el Sudan; puede que solo sca alli ave de paso y que marche despues de la muda; todos los individuos yue yo maté a mediados de sctiembre se ha. llaban en el periodo de aquella.

Eil aicion de vientre rojo se asemeja por sus movimientos á los cerridos y muscicápidos: vuela todo el dia, partiendo de una misma rana, y vuelve á ella mientras su caza sea feliz y no le moleste casa alguna: esto no es en el ave indicio de incapacidad, sino mas bien de pereza e indiferentismo. El hombre no la intimida por ningun concepto: contémplale, por el contrario, con la mayor tranquilidad, y por lo mismo no es dificil herisla de un tiro: si se la rerra, limitase ś volar á un árbol vecino.

Parece que se alimenta exclusivamente de langostas 6 por lo menos hay épocas en que dichos insectos constituyen todo su alimento; no desprecia, sin embargo, los coleópteros que vuelan al redecior de las mimosas en for, y atrapa al paso las mariposas que por alli revolotean. Heuglin dice que es mas aficionado á peces que á langostas y escarabajos, pero yo observaré que jamás le he visto pescar, ni siquiera cerca de una corriente en que haya peces. Bolle encontró en el estómago de un alcion de cierta especie afine varios restos de lagarto, lo cual induce á creer que el ave caza tambien los repiles.

J. Verreaux habla de la manera de reproducirse esta are: a decir verdad, sus observaciones se refieren á otra especie; pero creo que se pueden aplicar tambien á la de que hablamos. El periodo del celo corresponde álos meses de octubre yoviembre: el ave anida en un tronco de árbol hueco, y cada puesta consta de tres huevos redondeados, de color blanco brillante; maclio y hembra los cubren alternativamen. te; pero cuando los hijuelos salen á luz, parece que solo el padre se encarga de ellos.

\section{ELALCION ENANO-HALCYONE PUSILLA}

CARACTERES. - El color dominante del plumaje de esta are (fig. 65) es un azul muy oscuro, que muy pocas veces se extiende sobre toda la cara superior del cuerpo; sobre los ojos y debajo de los oidos ticne una mancha blanca; las réniges primarias son de un jardo negruzco y las secundarias azules con un filete verde brillante; la garganta, el pecho y el abdomen son de un hermoso blanco puro, que contrasta 
graciosamente con el tinte azul intenso de las partes supe. riores del cuerpo.

DISTRIBUCION GEOGRÁFICA.-Segun fould, csta especie se encuentra en el norte de Australia y en Nucva Guinea.

\section{LOS TODIRAMFOS-TODIRAMPHUS}

CARACTERES.-Se diferencian de los alciones por iener el pico mas ancho y conto, y las alas mas prolongadas, con la segunda rémige rasi del mismo largo que la tercera.

DISTRIBUCION GEOGRAFICA.-LOS representantes de este género habitan sobre todo en la Ocennia, es decir, en Australia y las grandes islas del sur de Asia: solo algumas raras especies las representan en las Indias.

\section{EL TODIRAMFO DE CABEZA VERDE-TODI- RAMPHUS CHLOROCEPHALUS}

CARACTÉRES.- Eilijo como tipo del género el todiranio de cabeza verde, de cuyas costumbres nus ha dado Bernstcin una excelentc descrijucion. Es una de las mas hermosas aves del grupo: tiene toda la parte superior del cuerpo verde y la inferior blanca; hasta la nuca se extiende una linea naso ocular en forma de collarin; una mancha que hay a los lados de la frente y una lista que marca la nuca, son de un blanco sucio; el ojo amarillento: la mandibula superior neyra, y la inferior del mismo tinte en la punta y blanco ama rillenta en la base El ave mide $0^{-}, 25$ de largo, el ala $10^{\circ}, 12$ $y$ la cola $0^{\circ}, 08$ (fig. 66).

USOS, COSTUMBRES Y REGIMEN.- \& lin inda la parte occidental de lava, dice Berstcin, el todinmío de ca. beza verde representa la especie mas cornun de este género. No hay rio ni arroyo cuyas arillas no sean frectientadas por el ave, siempre y cuando no estén completamentc desprovis. tas de árboles ó breñas. Por lo regular se la ve fija sobre una rania ó una piedra, dominando la superficie del agua, donde espera quue lleguen algunos prececillos ó insectos; aprodérase de estos últimos con mucha destrcza $y$ vuelve a su observa torio para comérsclos. Cuando arraviesa un pais descubierto para trasladarse de un arroyo $\$$ otro, vuela en línea recta batiendo precipitadamente las alas, y se deticne en cual. quier árbol para descansar. Entonces lanza con frecuencia su grito claro y penetranic, que casi se puede expresar por la paiabra kakel, nombre que los malayos han dado á esta ave: por su vuelo y su grito se la puede reconocer desde léjos.

- En los alrededores de Godol se desliza un arroyuelo en el fonito de un barranco de altas y escarpadas paredes, y alli es donde he visto con frecuencia los nidos del todirnmfo de cabera verde. Se hallan con mas frecuencia en uma simple depresion del suelo, prosegidos por la prominencia de alguna picdra, compone de algunas hojas secas y un poco de inusgo, y sobre aquel lecho deposita la heinbra tres ó cuatro hueros blan. cos, poco brillantes, tan cubiertos de lodo por lo regular que solo con el lavado recoturan su color primitivo.

\section{LOS CIANALCIONES-CYANALCYON}

CARACTERES. - Los cianalciones ó abiones usulis. apenas se diferencian de los alciones propiamente dichos sino por la belleza de su plumaje, en el cual predomina el color azul.

\section{EL CIANALCION DE MAC LEAG-CYANAL- CYON MACLEAGI}

CARACTERES.-Fsta ave ciene la parte superior de la cabeza de color arul negro; el lomo azul celeste; las alas y la cola negras, manchadas de azul indigo; toda la cam inferior del cuerpo, la porcion basilar de las rémiges primarias y secundarias, un collar que rodea el cuello y una mancha que se prolonga por detris de las fosas nasales, de color blanco; el ojo es pardo escuro; el pico negro y los tarsos de un gris negruzco. Los colores de la hemura no son tan vivos, ni se continuia su collar blanco. Las aves de esta esprecie miden $0^{\circ}, 19$ de largo; el ala $0^{\circ}, 08$ y la cola cerca de $0^{\circ}, 06$ (fig. 67).

USOS, COSTUMBRES Y REGIMEN.- En toda la Australia, dice Gould, no hay martin pescador ni alcionino comparable con el que lleva el nombre de Mac leag. Su espléndido plumaje parece indicar un clima mas cálido que el de la Nuera Gales del sur, lo cunl parece confirmado por el hecho de que csta ave sé encuentra hasta el extremo norte del continente austral. Como los oiros alcioninos, es rara cerca de las corricntes de agua : busca mas bien los grandes bosques del intcrior del país, y por eso se la conoce en l'uer. to- Essington con el nombre de aie de la selin. Por lo regular se la encuentra apareada, y solitaria algunas veces

\$. Se alimenta de pequenos reptiles, insectos y larvas. Lan. za con fucrza su breve grito, que se puede expresar por fisi.

Se reproduce en noviembre y ciciembre: anida en el hueco de un tronco de arbol, ó en esos hormigueros uque son una de las curiosidades de aguellos paises. El nido es fácil de encontrar, pues apenas se acerca aiguien, el are vucla in. quicta de un lado a viro lanzando lastimeros gritos. Cada puesta se componc de ires ú cuatro huevos de color blanco perlas

\section{LOS PARALCIONES Ó MARTI- NES CAZADORES - PARALGYON}

CAIRACTERES. - I.OS paralciones, llamados martincs casudores (dacelo) y alitones jojyrndes, se distinguen por su gran talla. Tienen el pico voluminoso, largo y grueso, de hase ancha y aplanada, arista dorsal reca, punta comprimi. da lateralmentey algo encorvada en gancho por encima de la mandibula inferior; los tarsos son cortos, pero fuertes; los dedos largos $y$ bastante gruesos: las alas de mediana exten. sion y obtusas, con la segunda rérnige mas corta que la ter. cern, que es la imas prolongada; la cola ảncha y de regular longitud; el plumaje abundante, lácio y de color poco vis. tosa.

\section{EI. PARALCION GIGANTE-PARALCYON GIGAS}

El paralcion, ó martin carador gigante (fig. 68 ), es la es pecie mas conocida de las propias del continente austral. No solo llama desde luego la aterion dicl europeo yque pisa el suclo de la Nueva Holanda, sino que se te ha traido á me. nudo a Europa, y figura hoy dia en todas las colecciones in. portantes.

CARACTERES. - La cabeza, el cuello y todas las parres inferiores son blancas con matiz leonado sucio tirando á orin y como borroso; la frente y parte anterior de la cabeza son pardo oscuras; los muslos cienen listas trasversalcs indecisns y como bormdas: debajo del ojo y encima de la orcja, una inancha ancha en medio de la cabeza y en el occipucio; el dorso, los liombros! las cobijas son todos pardos, pero estas 
últimas, y cuando menos las medias, tienen en la extrenidad mo de la abertura bucal tambien mas pálido. Ell ave mide una delgada orla de color anul berilo: la mbadilla y la segion próxima superior presentan lineas trastersales oscuras casi borradas sobre fondo blanco sucio; otras listas trasversales anchas y negras hay en las rectrices y sus cobijas superiores,

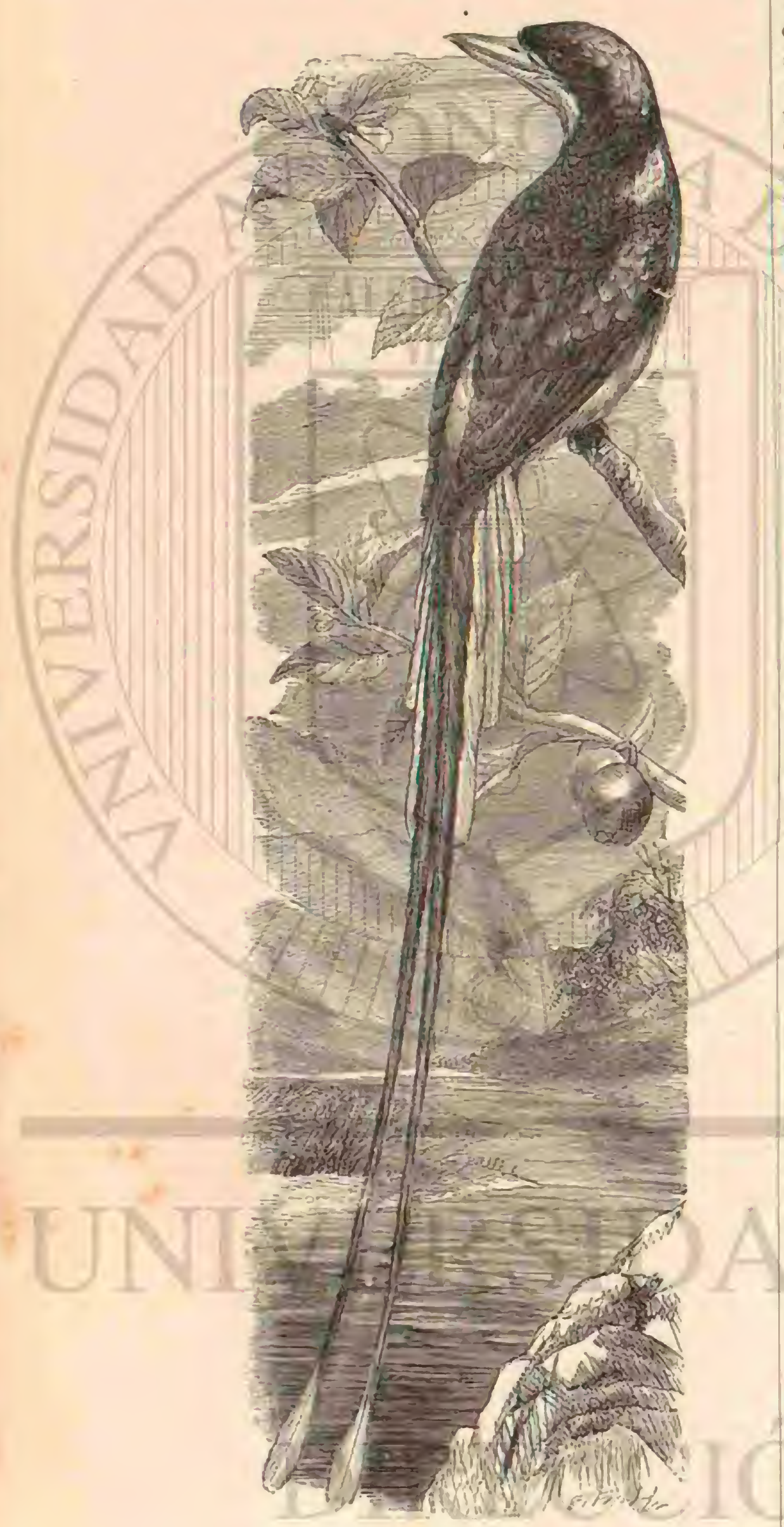

Jig. 69. - H.L roxishrtEko sIl.ru

todas de color pardo rojizo; las primeras están además adornadas en su extremo de una orla ancha y blanca. Hi iris es pardo oscuro, la mandibula superior negra, la inferior amarilla pálida y el pié pardo oscuro. los colores de la hembra son menos vivos y el pardo del centro de la cabeza y del extre. de $0^{\circ}, 45$ a $10^{13}, 47$ de largo y $11^{\circ}, 65$ de ancho de punta ś punta de ala; esia plegada $\|^{\prime \prime}, 21$ y la cola $\theta^{\prime \prime}, 16$.

DISTRIBUCION GEOGRÁFICA. - Gould nos dice que el paralcion gigante no se encuentra en la tierra de Van. Diemen ni en la sustralia occidental; parece que habita exclusivamente al sudeste de la Nueva Holanda, en la tierra situada entre el lago Spencer y la bahia de Moreton.

USOS, COSTUMBRES Y REGIMEN.-LOS primeros naturalistas que visitaron la Australia, senalaron ya la existencia del paralcion gigante; pero únicamente los últimos auto. res, y. Gould, en particular, son los que nos han dado á co. nocer bien su género de vida. Esta ave, dice el citado naturalista, debe ser conocida de todo viajero, 6 de todo habitante de la Nucva Gales del sur. Llama la atencion, no solo por su talla, sino tambien por su voz singular: además de esto, léjos de ser timida, se la ve correr hácia todo aquello que excita su curiosidad. $\alpha$ menudo se posa sobre el árbol á cuyo pié descansa el viajero, desde donde examina gravemente cómo enciende fuego y prepara su comida. Por lo re. gular no se nota su presencia sino cuando deja oir su voz, consistente en una especie de carcajada ronca; siendo este grito tan 'singular, que han hablado de ell cuantos autores escribieron sobre la Nueva Gales del sur. Caley dice que se ove cesde muy léjos, y que por él se ha dado sin duda al ave, el nnmbre popular de Juan al reifor o El grito de esta ave, escritic cl capitan Sturt, parece el de un coro de espiri tus salvajes; espanta al viajero que se cree en peligro, pues diriase que algun genio maléfico se rie de su desgracia.) Fsta singular carcajada, dice à su vez Bennett, comienza por sonidos pocos altos y termina con notas sonoras y elevadas, tanto hure se oye á menudo en toda la colonia Resuenan à Ia hora del crepisculo, $\delta$ cuando el sol se inclina marcadamente al oeste, y parece una despedida á la naturaleza. Un viejo habitante de los bosques se expresa de una manera mas poćtica aun en sus Pascos di un Mafircilisto. \&Una hora antes de salir el sol, despiértanle al cazador unos gritos salrajes, como los que pudiera producir una nuclsedumbre de infernales espiritus, que le rodeasen lanzando clamores y carcajadas: aquel es el canto matinal de Juan el reidar con el que anuncia a sus compañerus la salida de la aurora. $\mathrm{A}$ medio dia se oyen los mismos gritos, y cuando el sol se oculta en el occidente, resuenan de nuevo en el bosque. No olvidaré jamís la primera noche que pasé en Australia al sereno: despues de un sueño agitado, me desperté al rayar el dia; pero necesite algun tiempo para recordar dónde me hallaba, tan grande era la impresion que me produjeron ciertos intssitados rumores. El grito infernal del paralcion gigante se mezclaba con el silbido del pico, con el canto ronco de la gran gallina patuda, con los clamores discordantes de millares de loros, formando todo un conjunto tan extraño que seria imposible describirlo. Despues he oido a menudo el mismo concierto: pero nunca me ha causado igual impre. sion. Funn el reidor es el reloj del habitante de los bosques; nuy léjos de ser timida esta ave, parece gustarle la sociedad, y por eso vive cerca de las iiendas; su dulce carácter, y mas que todo, su afan en perseguir á las serpientes, son cua. lidades que aprecian los indigenas hasta el punto de consi. derar ó esta ave como sagraco.a

Gould dice que se encuentra el paralcion gigante en los intrincados bosques que rodean la costa, asi como en las altas selvas de las montañas. Sin embargo, en ningun punto está nuy extendido; se le ve en todas partes, pero siempre solitario.

Sus alimentos son variados, y los toma todos en el reino animal. Parece preferir los reptiles, los insectos y los crustá- 
ceos; cae con verdadera rabia sobre los lagartos, jo a menudo se le ve volver a su sitio con una culebra en el pico. Una vez, dice el vicjo habitanic de los bosques ri dos de estas aves posadas en la rama muerta de un añoso árbol, y lan. zarse desde alli a tierra de vez en cuando. Habian matado una serpiente, segun pude ver despues, y con su charla y carcajadas manifestaban su satisfaccion. Ignoro si se comen dichos reptiles; pero jamás encontré sino lagartos en el estó. mago de los que yo abri.\& El paralcion gigante caza tambien los pequeños mamiferos; Gould mato cierto dia un individuo para rer que llevaba en el pico, y reconocio que era un marsupial muy raro. la se comprende que no perdonará á los pajarillos que coge en el nicho.

Créese que esta ave puede vivir sin agua: segun he dicho aures, labita en los montes mas áridos, y ni aun los indivi. duos cautivos parecen necesitar agua para beber of banasse.

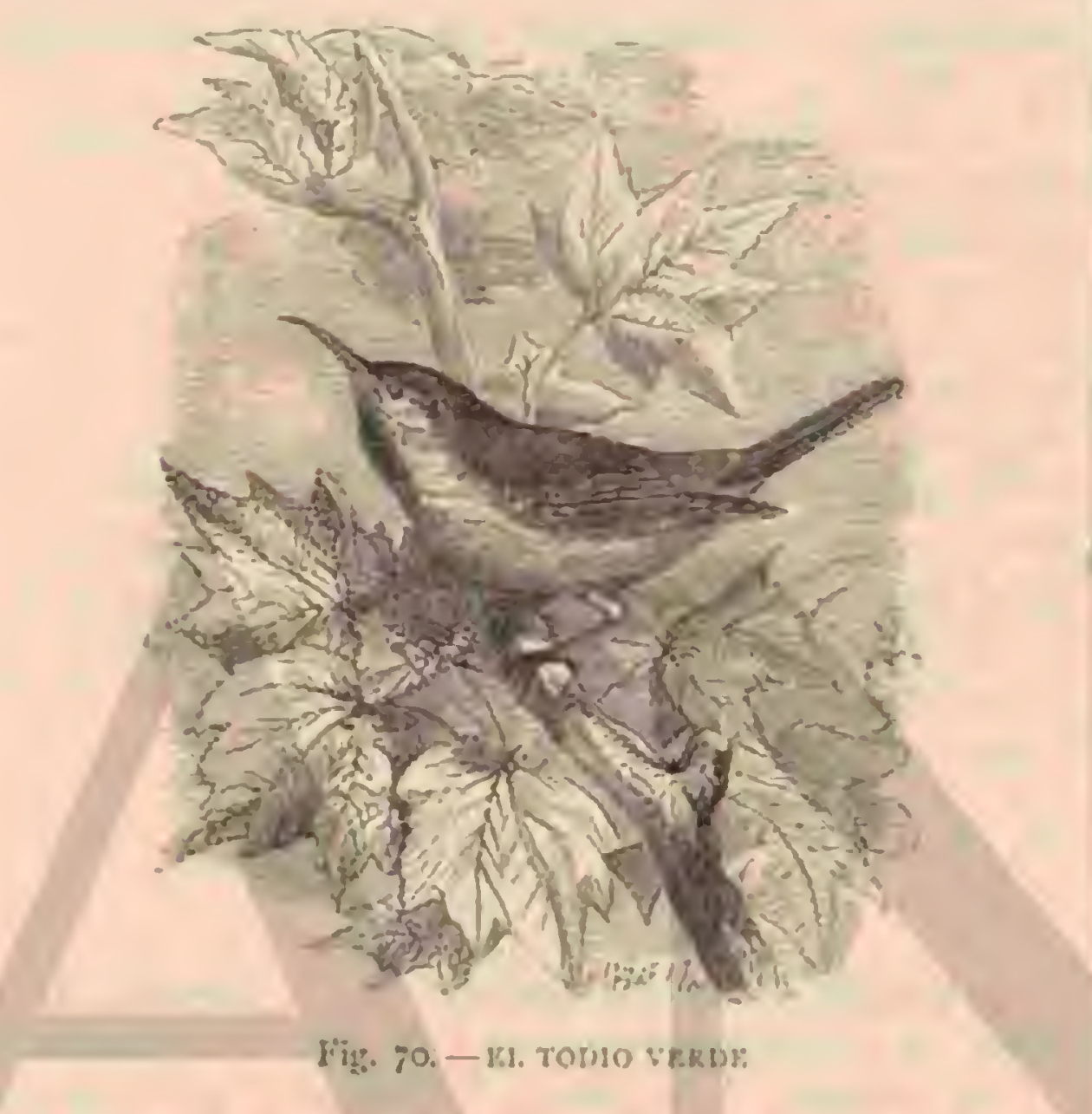

El periodo del celo está comprendido en los meses de agosto y setienibre; macho y hembra buscan para anidar un agujero conveniente en el tronco de algur gomero, y alli pone la segunda los huevos, que son de un color perla mag. nífico. Cuando lian salido á luz los pequeños, sus padres de. fienden valerosamente la eninda de sus albergues; acometen à cualquicra que trate de arrebatar su progenie y le infiercen á menudo peligrosas heridas.

CAUTIVIDAD.- La primera cosa que llamó mi atencion al llegar á Londres, refiere el vicjo habitante de los bos ques, fué un fwan di ridor, encerrado en una pequeía jaula: jamais he visto un sér mas misero ni mas digno de listuna que acuuclla pobre are, que habia trocado el arre libre de sus bosques natales por las espesas nieblas de la moderna Habilonia. la qucja de este naturalista no carece de fundamenro: las ares de la N’ueva Holanda llegan à nuestro pais en muy triste estado: pero su suerte no es luego tan mala como se cree, y una pruedu de clla tenemos en los paralciones cautivos. Estas ares no son difiriles de mantener, prues se contentan con un alimento muy sencillo, que consiste en pe dazos de carne cortados de cualquier modo, mones y peces. Si se ponen en una gran jaula, no iardan en recobrar loda su antigua alegria, y se conducen lo mismo que en su pais. Por lo regular permanecen tranqquilos en el sitio mas conve. niente de su jaula, $y$ si se ponen dos en la misma se les re casi siempre uno junto i otro. Su aspecto es muy singular; la cabeza parece sostenida por las espaldillas, el cucllo está encogido y el plumaje colgante. De rez en cuando, uno de ellos criza las plumas de la cabeza, de tal modo que parece en un doble major de lo que realmente es; en otros instan. ies agitan la cola a pesar de todos estos movimientos, di. riase cque el paralcion es indolente y perezoso; pero esto no pasa de una apariencia: para convericerse de ello basta mirar sus brillanies ujos de astuta mirnda; y obsérvase desde luego que el are inspecciona continuamente todo cuanto puede alcanzar su vista sin que se le escafie la menor cosa.

Aun en cautividad, el paralcion gigante sabe apreciar el tiempo lo mismo que en los bosques de sustralia, y no grikn sino a las horas que hemos indicado anees. Sin enbargo, cuando alguna cosa llama paricularmente su atencion, dcia oir su voz, y una ver acostumbrado í su ano le saluda con su grito.

Los individuos mas domesticados que yo vi, eran los del lardin zoológico de Dresde. Son para la jersona entendida una prueba de la perfecta inteligencia desplegada por mi digno colega y amigo Schecpfi en cuanto se refiere $f$ cuidar los animales. La vista de su amo era para aquelias aves un suce. so, y si estaban descansando tranquilas mostrábanse de pronto vivanente excitadas. a Apenas me presento, dice mi amigo, me saludan con sus gritos, y si entro en la jaula, se posan en mi hombro $y$ en ni mano, siéndome preciso alejarlas id la fuerza yara que me dejen, pues no lo hacen voluntarinmente; si me paseo cerca de la jaula, me siguen volando, aunque no aparente ocuparme de ellas. Para probarme la exacritud de su relato, Schrepfi une condujo a la jaula, y alli pude ver y admirar la familiaridad de los paralciones giganies. Viven con garzas reales, porfirios é ibis, en la mas perfecta armonía, ó mas bien, sin cuidarse de sus compancros de cautividad; pero 110 sucede lo mismo si se tratn de los pajarillos, pues son muy voraces. l'or mucho cariño que se profesen el macho y la hembra de la misma pareja, introdúcese la discordia cuando se trata de apoderntse de alguna victima. Las dos aves cogieron un raton vivo con rabin y le mataron golpeśndole contrn una rama; otro sufrib la misma suerte, y luego, cada uno de los dos paralciones se apoderó de una presa y la trajo hária si violentamente, erizando las plumas de la ca. bera; lanzábanse miraclas feroces, hasta gue al fin se tragó una de ellas el raton, evilando de este modo la discordia.

Para convencerse del afan con que el paralcion come ani. males enteros, es decir, con piel, plumas, escamas ó jelo, basta cnseñarle alguno aunque sea de lejos; apenas io re, f pesar de parecer tan satisfeclio y medrado con los pedacitos de carne que constituyen su racion ustal, cambia al instante de aspecto, eriza el plumaje de la cabeza, los ojos adquieren mayor brillo, menea la cola con fuerza y rapidez, se precipita sobre la presa y expresa su alegria cuando la tiene, con fuertes gritos á los que responde infaliblemente su compa. inero con los suyos Divertidisima es la escena que se presencia al ofrecerles uma serpiente crecida y vira. Fl ave se abalanza sobre clla sin titubear, la agarma como si fuce un raton. y la mata del nisino modo, solo que la resisiencia vi. tal del oidio es mayor y opone grandes obstáculos; asi es que los gritos de jubilo se irasforman en cantos guerreros hasta que el ave logra su objeto mas 6 menos pronto, y que vencida y muerta ha victima se la come, si no del todo, si. quiera en parte y á tropos. No tengo prucbas, pero tampoco dudo de que el paralcion gigante procede de idéntico modo con las serpientes venenusas pequeñas. Noinble es, que par lo regular rechace completamente los peces. Es cazador de las selvas, y no prescador como sus congéneres tan pricticos en la pesca.

Finalmente merece nencionarse que esta especie cria tambien en la jaula. Repelidas veres han puesto y empo. 
llado con gran asiduidad los ejemplares del jardin zoológico de Berlin; pero no han criado los pequeñuelos despues de nacidos.

\section{LOS TANISÍPTEROS-TANY- SIPTERA}

CARACTERES. - Los tanisipteros 6 alciones del farniso se diferencian de los otros alcioninos por tener sus rectrices medias prolongadas. El pico es relativamente corto; pero siempre mas largo que la cabeza, cónico, ancho, aplanado en la base, levinntado en el centro, de arisia dorsal casi recta y mandibula inferior que se encorva por arriba. Ias alas son obtusas, con la cuarta rémige mas larga; la cola prolongada y truncada; $y$ sus dos rectrices médias mucho mas largas que las laterales, provistas de barbas muy cortas, que en ciertas especies aumentan regularmente de longitud \& medida que se acercan lá la punta; en otras no aumentan lás barbas sino desde la última mitad de la pluma.

\section{EL TANISIPTERO SILVIA - TANYSIPTERA SXLVIA}

CARACTERES.- El tanisipiero silvia, representante de la inas bonita especie del gériero, tiene la parte alta de la cabeza de un color azul yivo, to mismo que las alas y las cin co rectrices externas; las mejillas, lá parte posterior del cuello j el lomo, de color negro; entre las dos espaldillas hay una mancha triangular; la rabadilla y las dos largas rectrices medias son de un blanco puro; toda la cara inferior del cuer. po de un rojo canela; el pico y las patas de un tinte rojo. Esta hermosa ave mide $0^{\circ}, 28$ de largo, el ala $0^{\circ}, 10 y$ la cola $(1,08$ (fig. 69).

DistribuCION GEOGRAFICA. - Hasta aqui, dice Gould, no se ha encontrado el tanisiptero silvia sino en las costas norte de la Nueva Holanda. Fil cabo York es la localidad que habita, y alli debe ser abundante, pues con estas últimas épocasise han traido of Europa muchas pieles. Mac fillivray me ha dicho que esta ave era muv comun en todos los bosques de los/alrededores del cabo York, y que vive principalmente en los peçueños claros, ricos en insectos.

Otras especies de cste género, el tanisiptero dea (fanysip fern dea) y el tanisiptero ninfa (tanystptern nympha), viven en la Nueva Guinca, en las Molucas y en Filipinas.

USOS, COSTUMBRES Y REGIMEN. - Llama pronto la atencion por su magnifico plumaje, cuando se lanza fuern del bosque y vuclie a el deslizandose por los aires con la rapidez de la flecha. Jamḱs se posa en tierra: coinunmente se situa sobre una rama horizontal descubierta 6 en una liana; desde alli examina tocios los alrededores; lánzase sobre los insectos que se acercan y vuelve en seguida al mismo

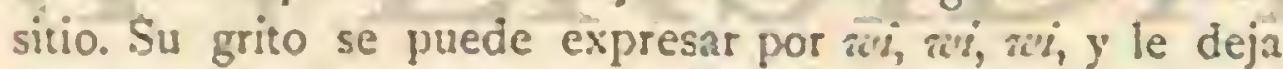
oir de ordinario cuando se posa. Esta ave es timida y rece. losa; asi es que el cazador necesita armarse de paciencia si quiere coger alguna; á menudo es preciso perseguirla durante mas de una hora antes de poderle tirar. Los indigenas dicen que la hembra pone tres hueros blancos en una cavidad que abre en uno de los grandes hormigueros del pais.

\section{LOS TÓDIDOS-TODIDA}

CARACTEREs.-Los tódidos ó platirostros son notabi. lisimos entre todas las aves por la estructura de su pico. Gundlach cree que se les debe considerar como un tránsito entre los alcedinidos y los muscicápidos, con lo cual explica la divergencia de opiniones que hasta hace poco ha existido respecto de estas aves, que por los unos habian sido agregados á los alcedínidos; y por los otros á los muscicápidos Gracias al estudio exacio del esqueleto hecho por Mudie ha podido fijarse definitivamente su afinidad con los platirostros y los momótidos, indicada ya por Nitzsch, y clasificar aque llos enire los levirostros. Ia presente familia consta de un solo genero limitado á cinco especies, cuya área de dispersion se reduce á las Indias occidentales.

\section{LOS TODIS-TODUS}

CARACTÉRES.-Estos platirostros son ares pequeñas, de elegantes formas, pico aplanado y alas y cola cortas. El pico es de un largo regular, recto y tan aplanado, que rigo. rosamente hablando solo está formado de dos laminitas delgadas y romas, ya que la arista superior apenas se distingue Mirado desde arriba presenta el pico la figura de un triángulo prolongado j" truncado delante. La punta de la mandibula superior es recta; esto es, no se encorva hácia abajo; la infe. rior es acliatada; los bordes están finisimamente dentados, y la abertura bucal llega hasta detrás de los ojos. Las jatas son esbeltas y la longitud de los tarsos apenas excede de la del dedo unedia los dedos no van unidos entre si por membra. na alguna; son dulgadisimos, largos y rectos: las uisas son tambien delgadas, de curvatura bastante regular y puntiagu. das. En las alas, cortas y redondeadas, sobresalen las rémiges cuarta, quinta y sexta. La cola, de mediana longitud, es ancha y un poco convexa. El plumaje, bellisimo en ambos sexos, es blando y liso; en el nacimienio del pico hay cerdas. La rair de la lengua es carnosa, y despues traslúcida y seme. jante d' una laminita córnea, ucuteramente como una lámina cortada del cañon de una pluma.y

\section{EL TODI Ó PLATIROSTRO VERDE-TODUS VIRIDIS}

CARACTERES.-La coloracion de este tódidoes de un verde yerba magnífico y lustroso en toda la parte superior del cuerpo coniprendida la cabreza y los lados del cuello, con una orlita roja y angostisina en el borde inferior del ojo. Las plumas de la barba y garganta son de un carmin vivo con un borde estrechisimo blanco de plata en la extremidad. Toda la mancha de la garganta est. circunscrita lateralnente por una rayita estrecha, blanca al principio, es decir, en el extre mo de la comisura de la boca, y de un gris azul delicado en la mitad inferior, completando el circuito una mancha blanca en la parte inferior. lil buche y los dos lados del pecho son verdosos; los lados de los muslos y las cobijas inferiores de las alas y de la cola son amarillos pálidos; cl pectio y el cen. tro del vientre blancos amarillentos, y fnalmente tienen algu. nas plumas que formar como una borla a cada lado de vientre con la punta color de rosa. El iris es gris pálido, el pico de un encarnado de apariencia córnea, y la mandibula inferior tambien amarillenta: los piés son ó bien de un rojo pardo 6 de color de carne pálido. Ina longitud es de $0^{17}, 12, \mathrm{el}$ ancho de punta a punıa de ala de $4^{\text {m }}, 17$; cestas miden $6^{\circ}, 0,45$ y la cola $4^{\circ}, 038$ (fig: 70).

Distribúcion GEOGRÁfICA.-Su irea de disper sion se reduce á la isla de Jamaica.

\section{EL CARTACUBA - TODUS MULTICOLOR}

CARACTÉRFS. - Esta especie reemplaza en Cubs à la anterior, á la cual se parece en cunnto à tamaño y coloracion, a excepcion del color de la listita que limita lateralmente la mancha roja de la garganta, el cual pasa en la parte inferior 
á azul gris, formando una verdadera manchita en los dos lados del cuello.

USOS, COSTUMBRES Y REGIMEN.-Poco se sabia respecto del género de vida de estas dos especies tan nota bles como beliisimas, hasta que recieniemente nos lo dieron a conocer, primero Gosse y despues Gundlach. Todas las especies concucrdan tan completamente en su porte, modos de ser, usos y costumbres, que sin escrúpulo alguno pueden aplicarse los de la una â las demás;-mas á pesar de esto tras cribiré la descripcion de Gosse que se refiere à la especie de Jamaica, y despues la de Gundlach que trata de la carta cuha.

an todos los puntos de Jamaica que he visitado, dice Gosse, es el todi ave muy comun; en todas partes se le encuentra: en las cimas de las montañas de Blucficld á una altura de cosa de mil metros sobre el nivel del mar, y con pre ferencia alli donde el terreno estś cubicrto de impenetrable arboleda. Llama desde luego la atencion por sus plumaje bri llante de verde gerba y la garganta de un rojo atcrciopelado yo huye cunndo se lo acerea el hombre Es ave extraordi nariamente mansa, no por un exceso de confianza, sino mas bien por indiferencia. Si la espantan, vuela s lo sumo hasta la rama mas próxima. I a hemos cogido á menudo con la red de cazar insectos ó herio caer con una ramita, y no es raro que los chicos la cojan con la mano. Essa confianza tan grande ha hecho que se captc el afecto de todo el mundo, buena prueba de ello es el gran numero de sobrenombres cariñosos que le dan los habitantes de la isla.

N Nunca la he visto en cl suelo. Salta en medio de las ra mas y del follaje en busca de pequerios insectos dejando oir su grito, ora quejumbroso, ora sillbadior. Con mas frecuencia se la encuentra posada tranquilamente sobre una rama, con la cabera encogida entre las espaldillas, el pico al aire y eri zado el plumaje, en cuya prosicion partec mas grande de In que es en realidad. Diriase entonces al mirarla, qute unn de los rasigos de su carácter es una torpe candidez; pero esto es apariencia y nada mas, pues si se la observa atentamente se reconoce bien pronto qute sus mimelas se dirigen tan pronto. izquierda como a derecha y que vigila con aterscion. Fil ave vucla tambien de vez en cuando, permanece un momento en el aire, atrapa alguna cosa y ruelve á su rama para devorarla no teniendo fuerza para perseguir á los insectos, esprera á clue se aceryuen y los coge con toda seguridad. Jamás he visto at ningun individuo alimentarse de vegetales, aunque en el es. tómago de los que yo abri, balle a reces pequeiros granos en medic de restos de colcónteros y neurópteros.

sil individuo que vive libre llama la atencion del hombre mas indiferente, y para el europeo es uno de los séres mas agradables cjue se pueden encontrar. Cuando esta posado in medio del follaje, apenas se le distingue, for lo mucho nue se confunde el color de anuel con el de las plumas; pero si cambia de posicion, de modo que se reflejen los rayos del sol en su garganta, brilla como un carbon encendido.

\$. Pl todio verde anida en agujeros abiertos en tierra, como los que practican los alcedinidos: á mi me han énscrado varios, pero jamas hallé nidos ni huevos, debiendo por lo tan to aiencrme \& la descripcion de Hill. + Segun este autor, el ave forma un agujero en una pared vertical de tierra, con el auxilio de su pico y de sus patas; la entrada es tortuosa, la profundidad de $\|^{\circ}, 20$ \& $00^{*}, 30$, y temina por una excancion mas ò menos esférica, cuidadosamente tajuzada con raices, musgo y algodon. Cada puesta consta de cuatro $\delta$ cinco hue ros grises, manchados de pardo: los hijuelos permanecen en aquel albergue subterraineo hasta quue pueden volar.

Ciundlach dice, respecto del cartacuba, que habita los bosques y matorrales, principalmente en las laderas, donde es muy comun y ficil de descubrir si se presta atencion fi su voz y se sigue su direccion. Esta roz, a la cual debe el ave su nombre cientifico, suena como tobofo y ademas, cuando vuela de rama en rama se ope un ruido especial producido for sus aletazos, a causa del cual le ha dado la grente del pais el subrenombre de pedurrera. Nunca salta como los pájaros cantores, sino que esta siempre posado con el pico preparado y atisbando los insectos que pilla al vuelo. No cs nada esquivo ni receloso; no huse cuando se le acerca álguien $y$ hasta se deja coger con redes de cazar mariposas. Nunca cambia de posicion; posado siempre en una ramita horizontal, en una liana ú otra enredadera, extiende las plu. mas laterales a manera de puntales de las alas y da alguna cabezada de cuando en cuando. En su modo de vivir da a conocer las singulares afinidades que tiene con las especies mas variadas. Atrapa las moscas como los muscicápidos y anida en agujeros abiertos en la tierra como el martin pes. cador.

Respecto à su reproduccion debemos â Gundlach los da. tos mas seguros En la prinavera, es decir, en majo, empieza el ave á construir el nido. Gundlach observó una que voló á una pared de tierra yue habia dejado el desmonte de un ca. mino, y donde el animal se puso á tmbajar con el pica A las dos semanas estaba concluido el nido. Una pequeña galeria recta de unos diez centimetros de largo conducia, cam. biando de direccion, a la madriguera interior mucho mas ancha. İn un nido habia tres huevos, y en otro muy próximo cuatro; cran enteramente blancos, fe tenian $10 \% 086 \mathrm{de}$ fargo por $(1 \%, 013$ de ancho en su mavor grosor. Cunndo el ave no encuentra sitio conveniente jara construir su nido en tierra, lo bace en el hueco de un tronco de árbol, segun dicen Ciosse y Cundlach.

Hill tuvo ocasion de poder observar cómodamente la ma. nera de reproducirse esta ave, pues una pareja eligió para anidar un cajon lleno de tierra, yue habia tenido plantas. Un agujero practicado en una de las paredes de arquel, y que servia de entrada á la cavidad que formaron estos animales, ivé sin duda lo que les indujo a fijarse en semejante sitio. Aun cuando no pasaron las aves desapercibidas y se las mo. lestó con frecuencia, no abandonaron su alberguc, y pudie. ron criar felizmente su progenic. Parecian puner mucho empetio en ocultar al hombre el sitio donde se hallaba su nido, y elegian sietmpre, pirn entrar ó salir, tel momenio en que la atencion de los esjectadores se distraia con otra cosa. Cuando los pequeños hubicron comenzado á volar, exami. nóse nejor el cajon, y se vió que los padres habian practicado en la tierra un conducto sinuoso, que llegaba hasta el centro, terminandose en el compartiniento destinado para nido.

CAUTIVIDAD. -No se la puede conservar en jaulas angostas, pero st cuando son espaciosas yodornadas con ar. bolitos verdes, aunque tampoco vive asi mucho tiempo.

* He tenido en jaula, añade Gosse, un individio que se precipitaba con avidez solure los gusanos y los golpeaba vi. gorosamente contra el sucla para despedazarlos y uragarec lus. Cogi orro con una red y le solté en una habitacion: al momento comenzó á dar caza á las moscns y ấ los pentuenos insectos que alli hahia, y continuó esie ejercicio desde por la mañana hasta la caida de la noche Posado en la esquina de una mesa, en una cuerda tendida en el cuarto, ó sobre un inueble, lanmibase desde alli al aire de vez en cuando, y apenas el castaneteo de su pico anuncialoa la captura de una uresa, volvia al misino puesto. Registraba todos los rincones debajo de la mesa para buscar las arañas pequucñas: cazábalas tambien diestramente en las paredes 6 el techo, y como co gia una cada minuen, fácil será comprencier el número de 
insectos que exterminó. En la habitacion donde estaba habia un vaso con agua, $y$ yo vi al ave posarse varias reces en el borde, pero jamás bebió, ni aun cuando introducia su pico en cl liquido. lan vivaz cra para todo aquello que le interesaba como indiferente con nosotros: á veces se posaba sobre la cabeza ó la espalda de alguno, y dejábase acariciar y coger con la mano, aunque no parecia gustarle mucho esto, pues crizaba su plumaje y procuraba escapar. Parecia no desagra. darle la cautividad: murió al fin por un accidente.

* En la Jamaica no hay costumbre de domesticar las aves indigenas, pues de lo contrario, hace mucho tiempo que se buscaria el todi para enjaularle

\section{LOS MOMÓTIDOS-MO- MOTIDA}

CAR ACTÉRES.-Ios individuos que forman esta familia qque podrian llamarse tambien abejarucos dentados ó aserrudos por li gran scmejanza que tienen con estas especies del antiguo continente, constituyen à la rez las especies mas afines de los planirostros. Dífieren de los primeros por su cola mas larga, sus tarsos mas aitus y mayormente por su pico dentado. Este uiltimo es ligeramente encorvado, bastante puntiagudo sin ser ganchudo en el extremo: compri. mida lateralnente y en ambas bordes mandibulares mas o menos aserracio. Guarnecen el borde de la boca plumas cerdosas tiesas pero cortas. Las alas son bastante cortas y algo redondeadas, con la cuarta ó quinta rémige mas larga yque las demás. Complonen la cola, tiesa y robusta, en algunas es pecies diez rectrices y en otras, doce, con las dos medias mas largas, paro comunmente desgastadas en la punta, ó mas arriba Ll plumaje es blando, compacto, compuesto de plumas grandes y lanosas cerca de ia piel, de igual coloracion en ambós sexos y poco variable segun la edad.

Li estructura interma ofrece varias particularidades dignas de atencion: el esqueleto se asemeja al del azulejo y al cel cuclillo. Ticne trece vértebras cervicales, ochó dorsales y otras tantas calidaies; cl esternon es corto y ancho; la hor quilla no se articula con el esternon; ia clavicula y el omo. plato son largos, delgados y cstrechos. Ia lengua tiene alguma semejanza con la de los tucanes, pero es menos larga, y el hueso hioides que la sostiene-muy pequeño; terminase por una sujerficie en forma de lanceta; es bilobada, cómea, y ncupa casi toda la cavidad de la mandibula inferior.

USOS, COSTUMBRES Y REGIMEN.-Se conocen unas diez y siete especies de csta familia, todas silvicolns $y$ habitantes de la América del sud, donde sin ser numerosas se encuentran en todas partes, ya solitarias ya aparendas, pero por lo comun léjos de la morada del hombre. Suelen estar inmóriles sobre una rama baja, si puede ser, junto a un riachuelo, para atisbar desde allí á sus presas, y dejan que se acerquen las personas, fijando en cllas la mirada indife. rente y sin expresion que les es propia. La experiencia no las escarmienta, porque aun alli donde el hombre las persigue í causa de su hermoso plumaje, no se vuelven recelosas, de suerte que en Costarica se les conoce con el apodo de tonsos ó aire londa. No cantan, pero saben gritar y bien. Por la mañana y á la caida de la tarde se ojen sus gritos que se parecen á un simple tono agudo de pauta. Se alimentan de insectos que buscan en tierr.. Algunos viajeros dicen que los cogen al vuelo, pero otros lo niegan. Además de los cscarabajos que deben constituir su principal alimento, atacan igualmente, semejantes en esto a nuestros azulejos y abeja. rucos, i los perqueños vertcbiados, en especial reptiles, y tambien comen irutas. Suclen poner de tres a cuatro huevos de color blanco de leche sucio en huecos de árboles y en los meses que corresponden á nuestra primavera.

CAUTIVIDAD. - Se los puede mantener cautivos con una mezcla de pan, carne cruda y varios vegetales; pero necesitan variar y se precipitan con avidez sobre ratones, pajaritos, lagartos, pequeñas culebras y otros animales por el estilo, que cogen con el pico, y golpean contra el suelo para matarlos, despues de lo cual los despedazan y se los comen.

\section{EL HUTU Ó PRIONITES VULGAR-PRIO- NITES MOMOTA}

CA RACTÉRES.- Fista especie, una de las mas conocidas de la familia, llamada huru por los indigenas, tiene la jarte anterior de la frente $y^{\prime}$ la lista 6 brida que arranca de la comi. sura de la boca, la region de los ojos y una mancha redonda en medio de la cabeza, negras: la primera orlada por delante de anal celeste y por detris de azul ultramar, y la mancha de la oreja por debajo y por detrás, de azul. La parte posterior é inferior del cuello son verdes con vivo pardo canela y orin; las plumas de la nuca son pardo rojizas y forman juntas una mancha; algunas plumas anchas, negras y un tanto largas en el centro de la garganta están orladas de azul celeste. El lomo, has alas y la cola son de color verde jerba oscuro; las pennas interiormente negras; pero las rémiges azul verdoso por fuera: has rectrices tienen en la extremidad una orla ancha azul de mar, algo mas viva, con punta negra en las dos medias. El ojo es pardo rojizo, el pico negro y el pié de un tinte gris pardo de asta. El largo es de $0^{12}, 50$, las alas miden $0^{m}, 17, y$ la cola 0 , 2 \&.

DISTRIBUCION GEOGRÁFICA.-Burmeister dice que esta arc es comun en las selvas del norte del Brasil, y Schiomburgk la ha encontrado a menudo en la Guinea donde tuvo frecuentes ocasiones de observarla.

USOS, COSTUMBRES Y REGIMEN. - KAntes desAlir el sol, dice este último autor, se oye el grito plañidero $y$ melancólico kufu, lashi de los prionites resonar en el seno de la selva virgen, anunciando a la naturaleza, todasia dormida, la vuelta de la aurora. Esta ave singular evita los claros, nunca se aventura en el lindero del bosque, y s pesar de ello no es timida, pues permite al viajero acercarse mucho antes de volar. Cuando esta posada en alguna rama inferior, quees su sitio predilecto, produce su melancólico hufi lustis; levanta la cola à la primera sílaba y la inclina à la segunda, con un movimiento análogo al de nuestra nevatilla: pero cjecutado coil mucha mas gravedad.

D Durante mi permanencia entre los habitantes indigenas de la Guayana, los Hombres sin ligrinsas, reconoci que a nadie podia dirigirme mcjor que a ellos para adquirir datos refe. rentes a estos animales. Pregunte, pues, it mi amigo, el jefe Cabaralli, por qué la cola de este prionites no estaba conformada como la de otras aves. Hombre venido de allende el gran lago, me contestó, ya lo verís mañana $\Lambda$ dia siguien. te, en é́ccto, me condujo al bosque: ena el periodo del celo, y por lo tanto no tardo en hallar un nido con uno que cu. bria; dijome que me ocultase detrás de un árbol y fuć á bus. carle.

d. Para anidar busca esta ave un hoyo redondo ú ovalado en el Alanco de una colina ó en otra euinencia cualquiera Macho $y$ hembra cubren aiternativamente, reemplazándošc con regularidad; pero por graves y mesumdos que sean todos sus movimientos, diriase que el tiempo q̨ue pasa en su nido le parece largo. A los tres ó cuatro minutos de cubrir los huevos, gira varias reces en reciondo; permanece luego tranquilo unos instantes, y se vuelve de nuevo, resultando de es. tos continuos morimienios quue las barbas de las dos largas 
rectrices se enredan ó se desgastan contra los bordes del nido. Apenas le reemplaza su companera, lainzase al macho sobre una rama próxima, y se ocupa ante todo cn arreglar un ploco su plumaje, lo cual no suele conseguir sin quitar por completo las barbas enredadas. Asi es como se produce ese blanco o espacio desnudo, sobre cuyo origen se han hechn tantas hi. pótesis, y que puede servir para reconocer la ediad del ave por su extension. Fin los individuos de mucha edad, la punia de las rectrices aparece desprovista de barbas, mientras que en los jóvenes que no han anidado aun, estan enteras las plu. mas de la colas

Parece poco creible ha relacion de Schomburghi, pero en el fondo está basada en hechos cicrtos, y recientemente la confirma Salvin apoyndo en observaciones pracricadas en estas ares cautivas; por otra parte Bartlett asegura tambien que el hutu se picotea las barbas de las rectrires medias, $y$ tanto es asf que ha podido encontrar en la jaula los restos de las barbas cortadas por estas aves. Esta destruccion de las rectrices no acaba sino cuando el pico del hutu ha perdido su forma primitiva, como les suelc suceder a menu. do á las aves cautivas. Sin embargo, las noticias de Salvin y de Bartlett no dicen nada que pueda poner en claro la causa de tan singular costumbre.

Respecin a la reproduccion, tenemos observaciones de Owen hechas en una especie afine que pone cuatro huevos blanquisimos en el suelo de la madriguera y los emprolla con gran celo y solicitud, pirando i todos los intrusos, mientras que muestra la mas completa indiferencia cuando se saquea otro nido cerca de ella, aunque lo mire, como lo hace en efecto, con aparente interés.

CAUTIVIDAD. - Azara hizo algunas observaciones acerca de la vida del prionites vulgar en cautividad, pues tuvo ires individuos de la especie, à los cuales dejaba correr libreunente por su casa. Dice que es un ave timida y descontiada, aunque curiosa al mismo tiempo; las que है। tenia eran jesa das, $y$ nutabase cicta rigider en todos sus movimientos; in clinaban la cabera hacia delante ó á derecha é izquierda, y saliaban con ligerear estirando las patas como los tucanes. No bajaban de la percha sino para comer; pedian su alimen10 gritando varias veces lis ó fí: romaban pan, ygustábales mucho mas la carne cruda. Antes de tmgar lo que acababan de coger con su pico, golpeátsulo varias veces contra el sue lo, cual si intasen de matar una presa viva . Muy ancionados à los pajarillos, perseguianlos largo tiempo y los mataban golpeándolos: las graudes aves estaban libres de sus acometidis. Jambien cazaban los ratones: a veces comian sandia f maranjas, pero nunca tocaban el maiz pues no les gustaba: dejaban i un lado los pedazos grancles, y janıás los cogian von sus patas. Actuahmente se ven de cuando en cuando prionites ó huties en muestras jaulas, preso en ios jardines zoblógicos son ares todavia rarisimas

\section{LOS ABEJARUCOS Ó ME- ROPIDOS一MEROPIDE}

CARACTERRES. - Los abcjarucos figuran entre las aves mas hermosas del antiguo continente, y ca su orden ocupan un pusesto importanie, yi por su estructura especial ó bien por su bella coloracion te interesante géncro dic vida, oomunes á todos los abejanicos, exceptuando tres especies de las treinta $y$ tantas que se conocen, y que por esta raron forman una sub-familia aparte. Esta analogia es tan grande que lo que se dice de una especie se aplica con insignificantes variaciones th las demás y hace imposible coniundirlas con otras. Tienen el cuerpo prolongado; el prico mas largo que la cabèza, grusc

Touso ill so en la base, puntiagudo, ligeramente curvo, de arista dor. sal aguda, cortes acerados $y$ bordes un poco entrantes; la mandibula superior, mas larga que la inferior, no tiene cur. vatura en la extremidad ni costś escotada cerca de la punta. Las patas son cortas y pequerias; los dedos externo y medio aparecen soldados hasta la tercera falange, como las primerns falanges del dedo interno y del medin; las uiñs son bastante largas, corvins y acerradas, y se hallan provistas por dentro de una arista un poco saliente y cortante; las alas, largas y pun tiagudas, tienen la segunda rimige mas prolongada; la cola, bastante larga, se trunca en ángulo recto, mas ó menos

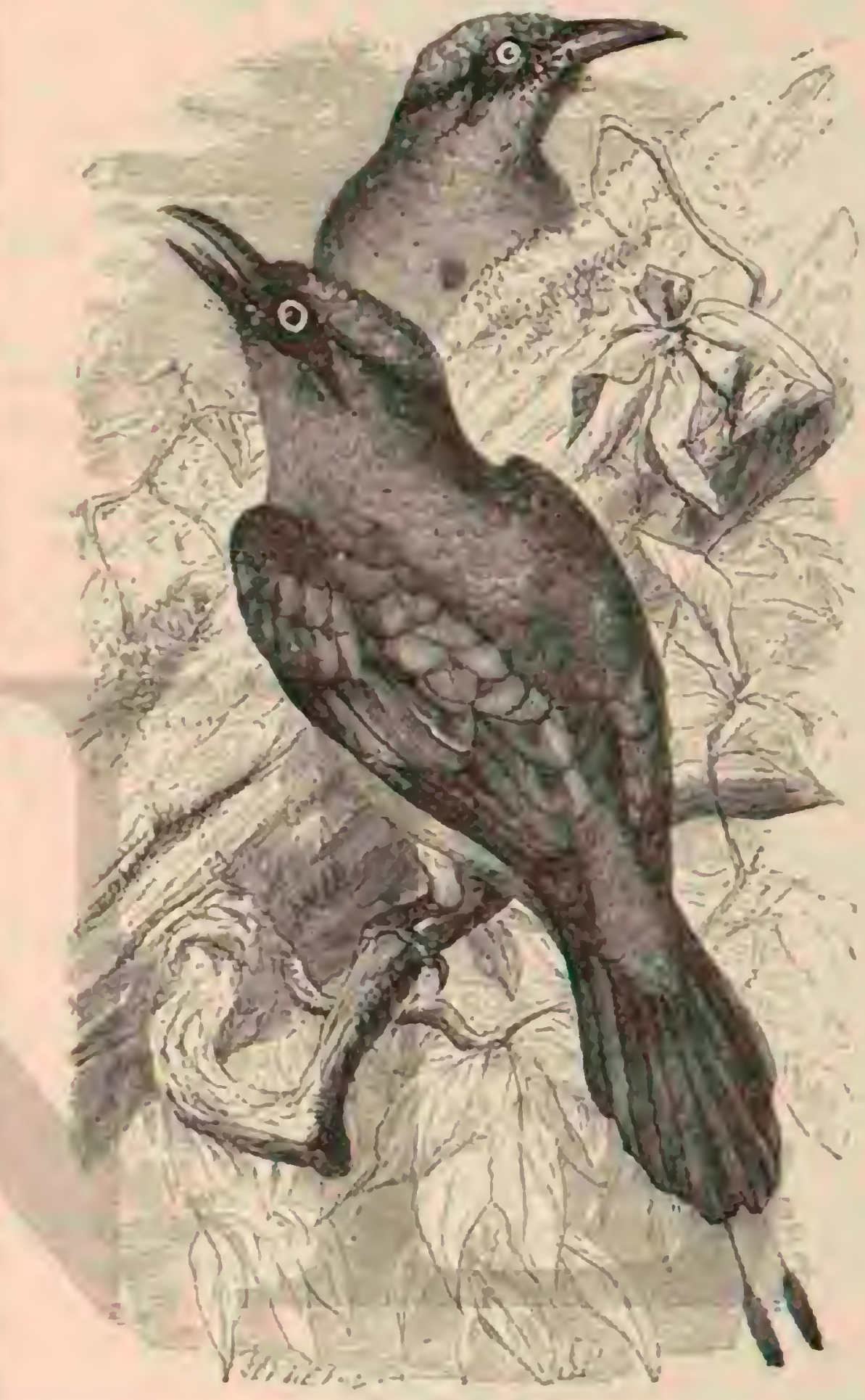

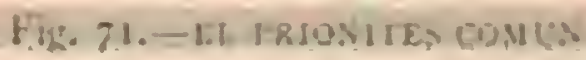

ahorquillada 6 algo redondeada, con las dos rectrices mediae dos veces mas largas que las otras en varias esprecies. Las plumas son cortas y un tanto macizas: los colores vivos y va. riados, formando grandes supurficies l.os sexos dificren muy poen entre si por el plumaje; los peçuefos it tienen mas os. curo, pero á los dos años adquieren los matices de sils padres.

DISTRIBUCION GEOGRÁEICA.-I,OS abejarucos cxis ten en los paises cálidos del antiguo continenie: solo una especic vive en la Nueva Holanda.

USOS, COSTUMBRES Y REGIMEN.-Habitan localidades muy variadas; pero nunca se encuentmn en las des. provistas de arboles: se les ve desde las orillas del mar hasta una aleitud de 2,000 i 2,600 metros; ciertas especies parecen preferir los puntos elevados, yotras las tierras bajas. I,as que viven en el norte emigran con regularidad; las que habitan el sur son cuando mas errantes. Ýa en Egivio cxiste una es. pecie que permanece alli todo el año, durante el cual presen cia dos :eces el paso de especies alines sin que expromulute 
el deseo de emigrar. Las especies del centro de Africa, por el contrario, vagan de un punto a otro; sus correrias dependen de las estaciones; llegan á principio de la lluviosa a los paises donde se proponen anidar, y se marchan al comenzar la se. q̨uía. Todos los abejarucos, sin excepcion, son ares suma. mente pacificas y sociables; hay algunas que se reunen, no solo con sus semejantes, sino tambien con otras de sus con. géneres, formando grandes bandadas, tan intimamente uni. das, que no pueden reconocerse las diversas especies.

Por sus usos y costumbres se ascmejan sobre todo á las golondrinas, recordando asimismo en ciertas particularidades álos papanoscas. Cuando el tiempo es bueno se re à las grandes especies cruzar las alturas en busm de alimento; y si el cielo está nublado ó comienza la época del celo, se posan cn las ramas de los arboles, dispuestas a lanzarse sobre su presa. Rara vez bajan al suelo, y solo para coger el insecto que acechan; pero en cambio rasan a menudo la supericie del agua Pasan la noche en la cima de algun copudo árbol. $\delta$ descansan en el nido durante la estacion del celo.

Los abejarucos llaman necesariamente la atencion, porque animan el pais; es muy curioso ver i una de cstas aves cortando tan pronto el aire, cual si fueso tin halcon, como vo. lando \& la manera de la golondrina.

Cautivan siempre la atencion já se muevan, ó ya descan. sen posadas en el ramiaje ó en tierra; en ambos casos resalta su béllisimo plumaje; pero cuando śe las ve reunidas á cen tenares ó á nillares, como á veces sucede, posadas en algun arbol ó arbusto aislado $\delta$ bien juntitas en tierra, entonces cmbellecen estos sitios de un modo indescriprible. Da gusto verlas volar tan tranquilas, graciosas y ligeras, que no se diria sino que hienden el esplacio sin esfucrzo alguno. 1) rejente dejase caer una verticalmente desde una altura pro digiosa para coger el insecto que atisba; un momento des. pues se la ve de nuevo en las aluras, continuaudo su canino en compania de sus semejantes, y lanzando su grito de lla. mada giirs, giziep. Los abejarucos vuelan iranquilamente; dan algunos aletazos, y se deslizan por los aircs con las alas medio plegadas igualando su rapider á la de una fiecha.

Estas aves no tiench menos atractivo alli donde viven estacionadas, y se las puede olservar de cerca. Se las ve jor parejas, posadas en las ramas lajas: de ver cen cuando llama un individuo al otro con un grito de ternura; su companero vucla rapidamente para coger algun insecto, y el otro espera tranquilo su vuelta. Jamis he visto a dos abejarucos dispu. tarse una presa, ni pelear por un motivo cualquiera; en todas sus relaciones reina la paz y la buena armonia por numerosa que sea la reunion.

Losabcjarucos sealimentan exclusivamente deinsectos, que atrapan al ruelo, rara vezsolure las hojas ó en tiern; y devoran los de aguijon venenoso. Numerosos experimentos han demos. teado que una jicadura de abeja ó de avispa era mortal para la mayor parte de las aves; $y$ se ha observado que casi todas las que comian estos insectos comenzaban por quitarles el agui. jon de que estan armados: los abcjarucos por el contrario se los tragan inmediatamente sin mutilarles en lo mas minimo.

Todas estas aves anidan juntas, fijándose en agujeros abiertos horizontalmente en un terreno cortado á pico; $a$ todas les agrada la snciedad de sus semejanics, y por eso casi sicmpre se encueniran colonias sumamente numerosas. Su morada se reduce á una galerla que desemboca en un compartimicnto mas ancho, pues no construyen nido propiamen. te dicho. Los huevos, curo numero varía entre cuatro y siete, son de un color blanco muy puro; ia hembra los deposita en la tierm desnuda, y poco â poco forman los restos de los insectos que llevan los padres una especie de capa, en la que reposa la progenic.
El dia de Navidad de $1 \$ 50$ atraqué mi bote junto à la co lonia mas numerosa que de esta clase de ares habia vistc to menos sesenta parejas del abcjaruco embridado (Merof frenatus) habian escogido la márgen lisa y resistente de ut ribazo arcilloso del rio Azul para anidar y construir sus gale rias, que ocupaban entre todas i lo mas una superficie d tres ó cuatro metros cuadrados: cstaban una al lado del otra dejando cutre sí una separacion que no pasaba de die á quince centimetros. Las entradas tenian tres centimetro de diámetro, $y$ la galeria una longitud de $1^{\text {" a }} 1^{\prime \prime}, 50$ en d reccion horizontal: el compartimiento del fondo tenia d quince á veinte centímetros de largo, de diez a quince d ancho y de seis a ocho de alto. En ninguno de los nidos qu inspeccionamos encontramos ni lecho, ni huevos, ni cria, á pesar de esto no dejaban las aves de entrar y salir cont nuamente.

Kira interesante verlas tan ocupadas unas veces y otras des cansando en las ramas de los árboles vecinos que adornabar con su presencia de un modo sorprendenie. En cada rama propósito estaba josada una parcja. De cuando en cuand se levantaba uno de los dos esposos para atrapar alguna pre sa y volvia a su puesto despues de haber practicado ilguna evoluciones, 0 se metia en una de las galerias para salir a cabo de un rato bastante largo sin que pudiésemos adivina lo que alli hacia; lo que menos acertabamos á comprende eta tl modo como distingusa cada una su morada en medi de las otras sim equivocarsc, pues delante de las entradas habi un continuo movimiento de ares como el de las abejas ant una colmicna. Siempre habia cierto número de abejaruco que volaban delante de ellas arriba y abajo como para pa sear; pero cuando querian entrar, lo hacian sin titubear; sf paraban un momento y se metian tan de prisa que no queda ba duda de que el hucco era el șujo. Hicia el anochece iba cesando el movimiento y al cerrar la noche ni se oia $n$ se veia ya ningun abcjaruco. la mayor parte, si no todas ia! parejas, se habian retindo al interior de sus nidos para pasal alli la noche. Esto excitó en mi la codicia de coleccionista y resolvi hacerme con un número de estas aves, que enton ces eran muy raras. Mande traer una red enviscada que hice bajar del márgen hasta ponerla exactamente delante do los agujeros. Cuando al dia siguiente al volver de mi primera caceria, fui á inspeccionar la red, hallé cincuenta de estos pobres é inofensiros animales cnredados en sus espresas ma ilas, victimas de mi artería. Asi obtuve un número suficiente de ellos, pero aun hoy al recordarlo me remuerde la con ciencia por haber usado de un proceder de caza tan falaz

CAUTIVIDAD. I Es dificilisimo conservar abejarucos viejos en cautividad; pero los que se cogen pequenos se acos tumbran mas fícilmente de lo que podria suponerse á la pér. dida de su libertad, á su angosta jaula y á la alimentacion artificial; se enticnde empleando, sobre todo al principio, el mas exquisito cuidado y mas tarde una alimentacion mas es. cogida que la que se da á las demis aves domésticas.

\section{EL ABEJARUCO COMUN-MEROPS} APYASTER

CARACTÉRFS.- Es la única especie de la familia que pasa el verano con cxacta regularidad en nuestro continente, $y$ al propio tienapo una de las mayores. Mide 1",26 de largo por ()$^{m}, 45$ de punta a punta de ala; esta tiene $0^{\circ}, 14 y^{\circ}$ la cola de $0^{\circ}, 10$ a $0^{\circ}$, il de largo. La frente es blanca; la parte anterior de la cabeza y una linea al través de los ojos son azul de mar con viso verde: otra lista que corre sobre la linca naso-ocular, pasando por el ojo hasta la region de la oreja, la cual a su vez estí orlada por debajo de otra línea estre- 
cha, blanca í indeterminada que tira a azul, es neugra. La barba y la garganta son de color amarillo encendido, y en la parte inferior están limitados por una fajita trasversal estrecha y negra. la parte superior de la cabeza y el orcipucio son castano oscuro; la posterior del cuello y las cabijas de las alas del mismo culor mas claro que pasa en los hombros, el principio del dorso y la region coxigen, a un amarillo tirando a orin y cancla La parte inferior del cuerpo es de un bellisi. mo azul de mar. Las cobijas caudales superiores son verde azul, excepto las dos medias mas grandes y mas estrechas hácia la punta, que son negras; las rémiges son de color azul verdoso con la punta negra; las pennas del brazo, de castaño timndo á canela, y un poco antes del extremo, arul verdoso, que es cl tinte de las últimas; las pequenas tectrices del codo tienen sinte verde oscuro $y$ las cobijas inferiores color de isa bela timndo á orin. La hembrn no difiere mucho del macho en cuanto á coloracion, y los pequeinuelos además de ser mas pálidos, tienen un viso amarillo en la frente, una pequeña lista trasversal amarilla debajo de la garganta, el lomo verdoso medio borrado, $y$ la parte inferior azul de mar.

El ojo es de un magnifico carmin, el pico negro y las patas rojizas.

DISTRIBUCION GEOGR ŔFICA.-Hay suficientem tivo para considerar al abejaruco comun como ave de la liuropa central, pues se ha dejado ver marias veces, $y$ hasta se le ha visto anidar. Si no se presenta regularmente, no es tampoco muy escasa, sobre todo en el sudeste de. Alemania. Varius veces se indico su aparicion en localialades situadas al norte de su área liabitual de dispersion; ambicn se le encontró en la Alemania del norte, en Dinamarea, Suecia y hasta linlandia; $\{$ veces se presenta en bandadas numero. sas, lo cual no puede menos de llamar la atencion píblica. Asi, por ejemplo, leiase en la Crimice de Lripsig: a Aves ra ras. Año $151 \%$. Hacia la fiesta de San Felipe y Sanriago, se han visto y cogido en Lcipzig aves raras y aun desconocidas, de la talla de la golondrina; tienen el pico largo; la cabcza, el cuello y el lomo de un color pardo oscuro; las alas de un azul intenso; cl cucrpo negro y la garganta amarilla: sus patas eran cortas, y hacian un gran destrozu en las abejas y los pe. ces. Ciessner da un dibnjo del abejaruco, defectuoso por cier10 , pero que permite reconocer al ave, diciendo que se lo man dó un pintor de Estmshurgo donde solia verse este animal, st bien raras veces Desde acjuella época, probablemente la mas rêmota de gue hacen referencia los documentos históri. cos, ha pasado el abejaruco á menudo por Alemania, tanto que en algumos distritos notrascurren diea anos sin verlo. Lo que no suele suceder es que alguna pareja de estas aves em. polle al oiru lado de los Alpes y de los Pirineos, y sin embargo tambien de esto hay ejemplos, pues repetidas reces se han encontrado junto al Danubio mas arriba de Viena, en (2) ลกิ์ 1792 en las márgenes del Olau en Silesia, y recientemente en Bacien. Respecto de este último caso tenemos ia relacion detallada debida a la pluma del caballero Schilling. que adquirió informes en el sitio mismo y da una idea bastantc clara de la inmigracion de dicha are. Resulta de esta rela cion que aparecicron lace algunos años, at últimos de maso poco mas 6 menos, unos cincuenta abejarucos en la sierra de Kaiserstuhl, donde se establecicron muy cerca de la aldea de Birkensolif en un valle pequeño pero fera\% y abierto hacia el sur, y anidaron en la ladera escarpada de una cantera de dolomita, pero otras aves les destruyeron todos los hueros, y en general fueron recibidos los abejarucos de un modo tan poco hospitalario que \& mediados de julio ja no se veia ni una sola de estas agolondrimas africanas, sarias de las cuales habian sido cogidas por algunos labradores que las habian rendido en Colmar y Neubreisach á cinco francos urn, siendo esto suficiente para cxcitar aun mas la codicia de c5. tos cazadores tan miserables como feroces cxrerminadores, que de seguro no habrin tenido ni remotamentc la idea de perdonar a ian infelices aves. Es muy probab!e que aguarde igual suerte al abejaruco en cualyquer distrito de la bendita Alemania donde le ocurriese presentarse, y esta serí una de las mzones capitales de no haber llegrado af ser alli ave de paso regular y puntual. En Espana, Italia, Cirecia, Turquula y en todas las islas del Mediterráneo, asi como en Hungria y en la Rusia meridional, es muy comun, por lo menos en determinados distritos. Pero no hiabita solo en Europa, sino que se extiende tambien por una parte del Asia, pues en P'alestina, isia Menor y Persia es tan frecuente como en la Luropa meridional. Nosotros la hemos encontrado en el 'Turkestan septentrional, $y$ Sewerzow y' otros en el meridional. Adams la vió en gran nuimero en las montañas de Ca. chemira Fin China es sedentaria. P'arece que en sus ernigra. ciones recorre la mitad del $\Lambda$ sia y toda el Aírica. En la Incia se la ve en los sitios a propósito en invierno, y yo la encontré en la época de su paso en Africa, dunde se frresentaba, vol. viendo de Europa a principios de scicalure, volando por en. cima de nosotros hasta mediados de octubre, para volver al norte á principios de abril, y continuando entonces su emi. gracion hasta mediados de mayo. Bil abejaruco no perma. nece durante el invierno en ninguno de los paises recorridos por mi, 5 el dato de Shelley deque se puede ver á esta ave en Egipto todo el año, es cquivocadin: porque ne pasa el in. vierno en todala mitad septentrional del Africa de donde emigra puntualnicnte hácia el uittimo confin sud y sudoeste de a juel continente.

1. Vaillant la encontró cerca de la ciudad del Cabo en tan gran número qque pudo matar mas de trescientas en dos dias. Posibanse á millares en los árboles ocupando con su múnero grandes extensiones de terreno. El mismo autor airade que estas aves tambien crian en el Africa neridional, pero no cabe duda de que esto es un error, prorque jamais he observado una 5ola ave que criam en los paises meridionales que escoge para pasar el invierno. Iayard dice que el mes de agosto es el de su llegada, pero me parece un poco precoz, mientras quue Andetson afirma que ocurre hacia la época de las lluvias en general. E.s probable que no lleguen á su residencia de invierno en realidad antes de fin de seticmbre para volver a abandanarla en marzo. Los dos autores cizados men. cionan además, layard respecto de los paises del Cabo de Buena Esperanza, y Anderson respecio del de llamara, que solo se ve el abcjarnco en Ja época de su emigracion y que se extiende bastante por ioda la anclia zona cque escoge jara pasar el invicmo. I)ebo advertir que los abejarucos viajan, si no siempre, por lo menos con frecuencia en compania de la esprecic afue egipcia (meniş ruejtius), mezclánduse sus isandadae Heuglin niega este dato, pero paral sostenerlo me basta decir que lie muerto ambas especies cuando liraba á una bandada.

\section{EL ABEJARUCO EGIPCIO - MEROPS FGYP- TIUS}

CARACTERES. - El plumaje de esta ave es verde yurba oscuro que en el abdómen pasa á veces a verde malaquira con-viso azul de mar, y en el dorso á pardo amarillento oli. va, ý t pardo mas ó menos marcado en medio de la cabeza y en el occipucio. La frente es blanca, algo amarillenia confusa. Isa parte anterior de la cabeza, una lista ancha al través de los ojos, y otra lista debajo de la linca naso ocular que es negra, son de un azul delicadisimo: la harba es ama. rilla, y el centro de la garganta esti adornado de hermosins 
manchas castañas. Las rémiges y rectrices son verdes tirando á a7ul, aquellas con puntas negras y sus barbas intcriores color pardo cancla; las rectrices medias sobresalen mucho de las otras. El tamaño y el color de los ojos, del pico y de los piés son los mismos q̣ue en el abejaruco comun.

DISTRIBUCION GEOGR ÁFICA. - El área de repro. duccion de esta ave se extiende desde el mar Casuio por la Persia, Asia Menor y el Africa septentrional; pero su área de dispersion comprende toda el Africa y el mediodia de Europa, por cuanto hace viajes dilatadisimos. Una especie muy afine, que algunos consideran la misma, labita la isla de Ma. dagascar.

USOS, COSTUMBRES Y REGIMEN.-LOS USOS, cos. tumbres, alimentacion, riajes y reproduccion, en una pala. bra, todo el género de vida de esta y de la anterior especie se parecen tanto que yo por mi parte jamás he podido advertir la menor diferemcia. Por esta razon bastarí el cuadro que trazaré del género de vida de la prinera especie en las lineas que siguen.

En Grecia aparece el abejaruco en los sitios donde anida á fines de abril 6 á principios de majo siempre en bandadas: y segun Lindermayer á últimos de matzo; aserto que me resisto a creer. Krueper, fundíndose en observaciones conti. nundas por espacio de algunos años, indica como dia de lle gada de los primeros grupos el a de abril, y Drumm para la isla de Corfú el 5 del mismo mes. Ciglioni vió grandes ban. dadas de abejarucos volando en direccion al norte, cerca de Pisa, en los primeros dias de mayo. In la isla de Cerderia los observó Brooke desde el 17 de abril.

A mediados de maro se dispersan un poco las banda.

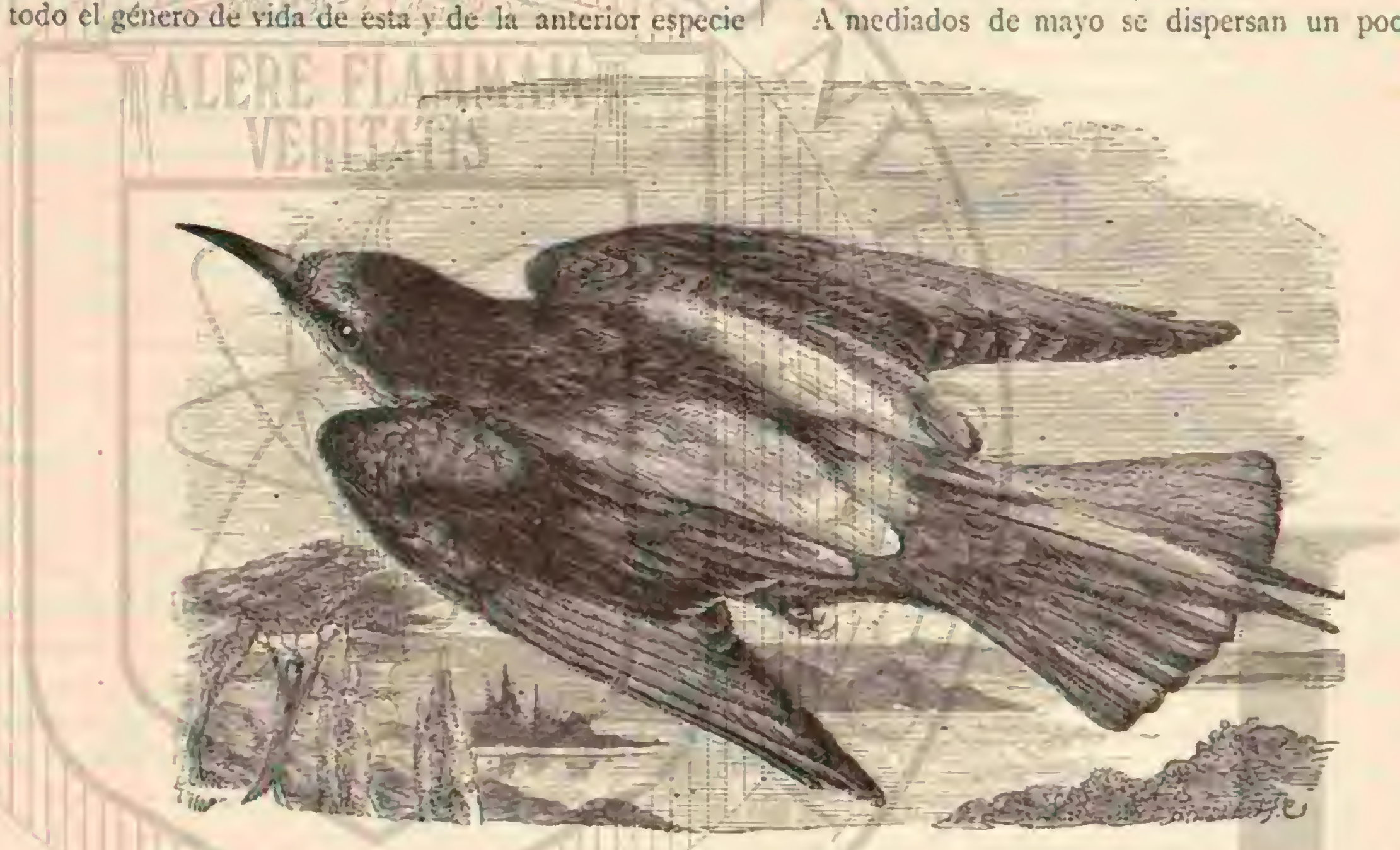

Fig. 72,-Fos skergerve conus

das; pero varios incividuos se tcunen y forman una colonia, compuesta de cincuenta, sesenta parejas, ó aun mas. El nú mero varia segun las localidades: donde los abejarucos en cuentran una pared arcillosa vertical y uny alta, reuinense en gran numero; de lo contrario, cada individuo busca el sitio que mejor pueda convenirle.

En los parajes donde se han eatablecido algunas colonias es donde mejor jueden observarse las costumbres del abeja ruco vulgar. Jass pequeñas especies de esta familia no suelen alejarse de la inmediacion del sitio donde residen; pero los abejarucos de que háblamos pasan horas enteras volando en las aliuras cuando el tiempo es bueno. Aunque su bandada no forma un todo bien compacto, tampoco esta dividida; cada ave ocupa un gran espacio, y sigue siempre exaciamento la misma direccion, llamando continuamente a las otras; de este modo recorren juntas un espacio de varios kilómetros cuadrados, lanzando sin cesar por los aires su grito de llamada sihurr-sihurr, ó suep guep. Hácia la raida de la tarde vuelven a su colonia, separanse por parejas, y hasta la hora del crepúsculo se ocupan activamente en cazar insectos sobre los árboles.

Concluidas las madrigueras es probable que pasen alli la noche, pero hasta aquel momento duermen posados uno al lado del otro en las ramas de matas algo brjas, tan juntos y compactos que á reces se jueden matar if docenas de un solo tiro. Mas numerosos son estos enjambres cuando los pequeriuclos pueden rolar: entonces chando se posan en un sitio arenoso, lo trasforman momentáneamente, con el brillo de sus colores y su gran nimero, en pradera Morida. Cazan con preferencia en terrenos yermos y otros sitios análogós conde acuden mas abejas, porque alli logran mas botin. Ra. ras veces $\delta$ mas bien uunca se acercan á las poblaciones mientras la inclemencia del tiempo no los obligue á ello. Se gun el estado de la atmósfera cambian su sistema de caza. Cuando el ciclo se nubla y cuardo llueve no se remontan grande alturn, como suclen las golondrinas y otros ripséli. dos, sino que cazan desde las ramas ó visitan las inmediaciones de nuestras moradas, donde ocasionan grandes danos en las colmenas, Entonces se les ve posados en una rama 6 junto á una colmena, atrapando las abejas al paso.

I.os abcjarucos son particularmente alicionados á los insectos de aguijon, y asi destrozan las colmenas de las abcjas como los nidos de las avispas y de los zánganos. Cuando cualņuier individuo descubre uno de anuellos, se posa mu: cerca, y en pocas horts atrapa y se come lodos los insectos. No desprecian por eso las langostas, las cigarras, las libélulas, los ábejorros, los mosquitos, las moscas y los coleónteros; devoran todos los insectos que pasan volando á su alcance, y arrojan las alas y otras partes córneas de sus presas.

Para el abejaruco vulgar comienza el perindo del celo à fines de mayo: cuando trata de construir su nido busca la orilla escarpada, arcillosa ó arenosa de una corriente; alli practica un agujero redonúo de $0^{m}, 05$ á $\|^{m}, 06$ de diámetro, -a cuyo éccto se sirre del pico y de las uhas, como no sea 
solo de estas. Del agujero parte una galeria horizontal $\delta$ un poco ascendente que à veces alcanza la prolundidad de 8 ", 30 $\{$ a metros; en su extremo hay un compartimiento de $6 *, 22$ \& $\|^{\circ}, 25$ de largo por $0^{\circ}, 10$ a $0^{\circ}, 15$ de diámetro y $11^{\circ}, 08$ \& $10^{\circ}, 12$ de altura, donde la hembra deposita sus liuevos. La puesta se verifica en el trascurso del mes de junio; consta de cuatro à seis, de color blanco puro y bastante globuloso. Segun Salvin, detrís del primer compartimiento hay à veces otro, enlazado con uma galería de unos $1^{\circ}, 30$ de largo.

A falta de paredes de tierra cortadiss á pion, se decide tambien el abejartico d liacer galerias en el suelo en direc. cion oblicua. Heuglin encontró nidos de esta clase en la Arabia Petrea y en el Figipio central; "T'sistram en Palestina y. Saunders en la Fispara meridional. No aprovechan jroba. blemente los nidos antiguos porque se establecen en ellos lagartos y otros intrusos antipúticos a estas ares. Fis fácil que hagan los huecos exclusivamente con el pico, al igual que los martines pescadores, sirviéndose solo de sus piés pequenosy débiles para echar fuesa la tierra desprendida; pero Lindermayer crec poder inferir de su disposicion que el ave los emplea a manera de paleta de albaniil para hacer correr ba arena debajo del vientre hácin la boca de la galeria. No tengo noticia de que hasta ahora haya sorprendido ningun observador al abejaruco durante su irabajo de excavacion, por lo cual todo se reduce á suposiciones, si bien el ejemplo del martin pescador parece abonar la opinion de Linderma. yer. Algunos antores dicen haber encontrado una capa de musgo y rerbas; pero en los nidos de abejaruco que yo en. contrę, jamás he visto señal algura de estos materiales. Ins alas, las patas de los insectus, y los residuos romitados por los hijuclos 6 los padres, forman una capa sobre la que reposa la progenie. Ignórase si la hembra cubre sola ó si le ayuda el unaclio; solo se sabe guse ambos alimentan y crian á sus hijuelos. A fines de junio comienzan ya estos á volar con sus padres y á recibir sus alimentos lis probable que al principio vuelvan as su nido todas las tardes, ó por lo menos, Powys vió varias veces tres ó cuatro abejarucos que salian de un mismo agujero. Al cabo de algunas semanas se mue ven ya los hijuclos como los mayores, $y$ en el momento de las emigraciones no se diferencian nada por su método de vida.

Jos antiguos referian diversas fábulas acerca del abejaruco vulgar. Esta ave es tan astura, dice (iesner, que traslada á sus hijuclos de un punto a otro $i$ fin de que no se los pue. dan quitar, y vuela tambien por otro lado del yute debe seguir para glue no sc descubra dónde esconde su progenie. Dicese que, a la manera de la cigiieña, prestan los jóvenes grandes servicios a sus padres cuando son vicjos, pues no los dejan salir del nido, les llevan alli su alimento, ó los trasjortan sobre su lomo.

Cierto es que el abejaruco vuigar no puede ser visto en tódas partes con iuenos ojos, jues sus fechorias excitan contra él las iras de los apucultores, que le persiguen sin tregua a pesar de cilo no es timido, sobre codo en los parajes donde espera encontrar abundante presa; las deconaciones no le hacen huir fácilmente, y solo eunndo se le ha perseguida largo tiempo manifiesta alguna desconfianza y dificultả la caza.

CAzA.-Segun Lindermayer, von der Mulle, Kruefrer? y otros, entos últimos meses del verano se matan en (irecia muchos abejarucos; su carne sirve de alimento y es un bo. cado delicioso para los habitanies de aquel pais. Tambien en el mediodia de lispaña, especialmente en Sevilla y Córdoba, venden en la plaza en oiono grandes camtidades de estas aves. En Candía los cogen con anzuclos, como nos lo decia ya Ciesner. asu belleza incita á los muchachos de la isla de Creza a cazarlos con langostas, como lo hacen para las golondrinas; a este tin clavan uno de aquellos insectos en el extremo de una punta de hierro encorvada en forma de anzuelo: la sujetan con un hilo que llevan en la mano, y dejan á la langosta rolar: cuando el abejaruco la ve, se la traga y quedia cogido.s

USOS Y PRODUCTOS.- Dice Gesner que esta ave no es buena para comer, paro quue su carne tiene propiedades terapréuticas muy eficaces. \$No se come el abejaruco, dice, porque su carne es dura é indigesta; pero en cambio es útil

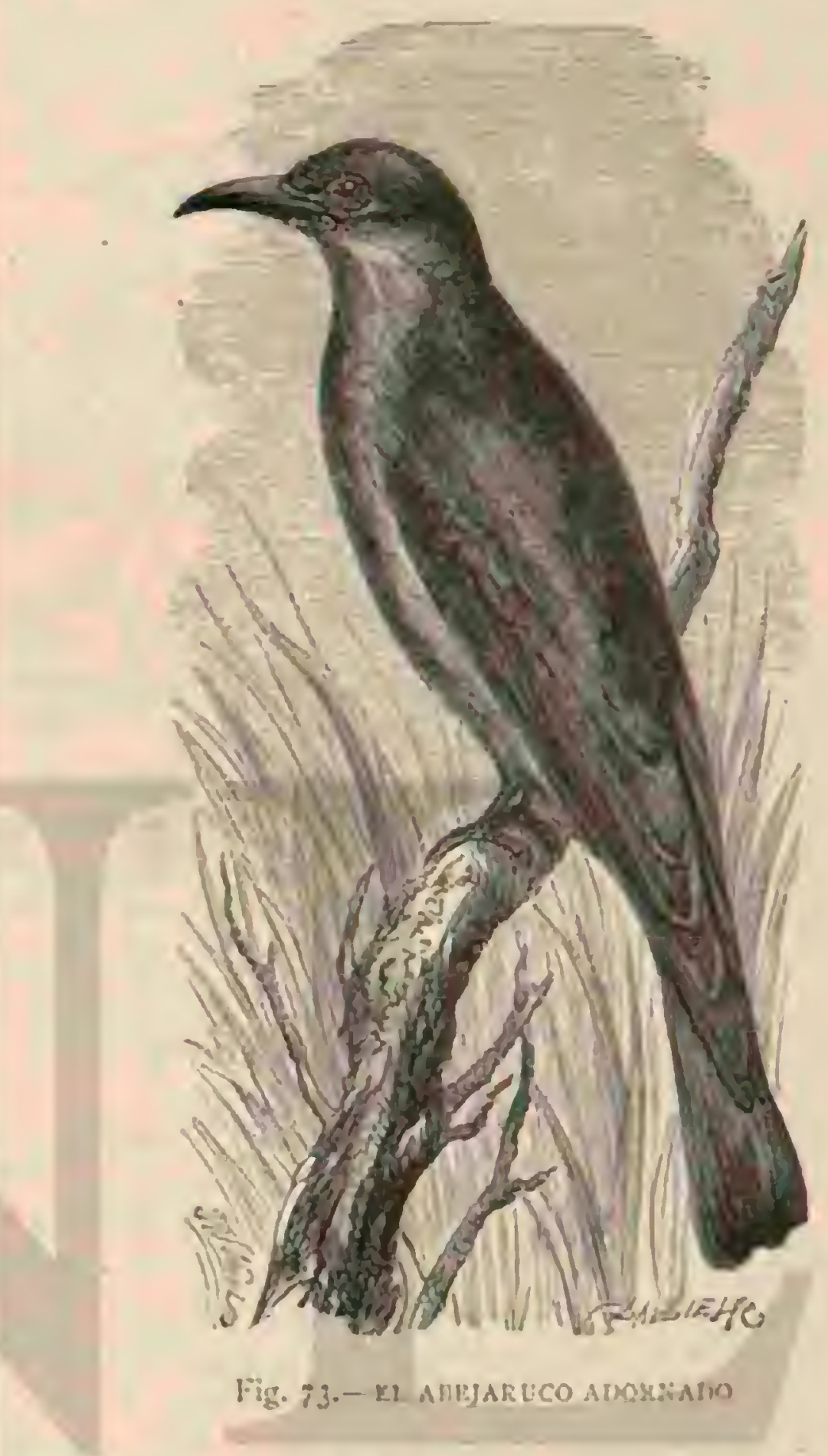

para curar las úlceras. In hiel, merciada con accite y aceitunas verdes, comunica al pelo un magnifico color negro.j

CAUTIVIDAD. - Hasta hace poco tiempo a nadie se lo ocurria tener abejarucos en jaula, porque prevalecia la opinion de que no era prosible; pero recientemente se han hecho algunos ensayos y se ha obtenido el resultado sorprendente de que se conservan mucho micjor de lo give se pensaba. Hasta los individuos vicjos toman el alimento con tal que sea el mismo que comen estando libres; pero rehusan rodos los de. mass. Su roracidad excede á toda ponciencion; comen dinria. mente mas del duble de su propio peso, lo que hace muy costosa su manutencion. Cuando se les coge pequuetios se habituan pronto a la jaula yo is la racion, sibien hay que har. tarlos al principio metiéndoles las bolas de comida en el pico y haciéndoselas tragar a la fuerma. Cobran afecto á in persona que los ouida, la saludan cuando se acerca, reciben el alimento de'su "mano dan miestms de mucha saisfaccion y alcgria.

\section{EL ABEJARUCO NUBIO-MFROPE NUBICUS}

CARACTERES. - Lintre las cspecies africanas merece esta una mencion especial, no porque se la haya elevadótla 
categoria de representante de todo un grupo, género ó sub. género (Melitotheres), sino porque se distingue tanto por su coloracion como por su género de vida. El color dominante de su plumaje es escarlata oscuro, algo mas en las rémiges ? la cola, y mas claro en la cabeza y cl pecho. Ia mbadilla, asi como las tectrices supperiores é inferiores de la cola, son azul turquif; el tinte de la garganta es en la parte inferior de un verde azul oscuro y como borrado, y una faja anclua que hay sobre la linea naso-ocular hasta la region de la oreja, es ne gra Las rémiges tienen puntas negras y anchas, $y$ las prime. ras además antes una faja de verde azulado oscuro, estando todas orladas de color de orin tirando d canela en la raiz de las barbas interiores. El ujo es escariata encendido cono en los demás abejarucos; el jico neyro y el pic gris pardo. Su longi. tud es de $6^{\prime \prime}, 34$, la de las alas 0,15 , la de las rectrices medias ()$^{\circ}, 19 \mathrm{y}$ de las restantes $0^{\prime \prime}, 1,15$.

DistribUCión GEOGRAFICA.-Se lia observadoel abejaruco nubio en los diversos paises de la costa oriental del Africa, unas veces en gran numeroj otras aislado. Yo lo he conocido en el Sudan oriental como ave de paso ó bien er rante. Se presenta en las regiones ģue he recorrido, desule los $15^{\circ}$ latitud norte hácia el sur al principiar la estacion de las lluvias y permanece alli hasta mayo, pero sin la regularidad que se observa en Abisinia; Taca, Kordofan y \& lo largo del Nilo Blanco. Heuglin, que tenia inejor ocasion de observarle, lé encontró cono habitante de todos los distritos cálio dos desde las tierras bajas hasta una altura de 2,000 metros sobre el nivel del mar, a veces en bandadas de mil. Tiene una indole, si es posible, aun mas viva y bulliciosa que sus afines, a. Ins cunles por lo demís se asemeja no solo en su vuclo sino tambicn en todo su carícter, como dice con mucha raron Heuglin. Durante las horas mas calurosas del dia se guarece en las matas y árboles que con frecuencia desapare. cen literalmente bajo su inmenso número, ofreciendo tal muclicdumbre un aspecto sorprendente.

La época del celo cae á principios de las lluvias de verano; y en los paises de poblacion negra colindantes con el Rio Blanco, en marzo y abril; en el Sudan oriental entre junio y agosto. Se encuentran las colónias de uidos tanto en las már genes de los rios como en los/claros de los linderos de los bosques, y aun en los páramos, sibien no tan espesas entonces y á veces formadas solo por algunas parejas Este abcjaruco cava galerias muy hondas, en su mayor parte rectas, y cuya direccion es segun las circunstancias, ya horizontal, ya oblicua. El compartimicnto interior es mas ancho y contiene sobre un

- lecho blando de hojas secas y yerba de tres a cinco huevos de forma ovoidea achatada, ciscara fina y lisa y de color blanco puro, que aparcece rosado por la yema que trasluce al través de la cáscara. Hartmann asegura haber visto en una márgen arcillosa y escarpada mas arribia de Senar; cmuchisi mos miles de estos nidos enteramente inaccesibles y anubes de abejarucos, no meatrevo i contradecirle, pero creo que estos numeros son un tanto cxagerados.

Realizada la cria, se vuelven á seunir los abejarucos nubios en bandadas mas numerosas que antes y que pasan hácia los $16^{\circ}$ latitud norte, cruzando muy jarticularmente los vas. tos paramos que les ofrecer abundante racion. Al alba se ope ya su llamada gutural y peneiranic desde las matas yárboles donde han pasado la noche Toda la tribu se levanta, vaga primero por ach $y$ aculli aguardando que el sol haya secado el rocio y empieza luego la caza de insectos en las yerbas altas a lo largo del agua. Mientras el exuberante monte de jerba que cubre los páramos del Sudan abunde en insectos, encuentran los abejarucos, y con ellos otras muchas aves, facilmente su racion diaria, pres viren casi exclusivamente de langostas.
Con frecuencia, al decir de Heughin, se ve en el Kordofan a los abcjarucos nubios posados sobre los buejes, los asnos y a veces las cigitenas, que se pasean majestuosamente en medio de las yerbas; y desde alli cazan las langostas que van levantando sus singulares monturas. Las atrapan, se las comen rolando, y vuelven despues á su observatorio movible. Yo no recuerdo haber presenciado nunca tan singular espec. táculo; pero si he visto, como Hartmann, al abejaruco nubio coger insectos en tierra, ó extmerlos de las grietas formadas por los ardores del sol; lo mismo que Heuglin, he observado tambien que el incendin de una estepa atraia il cstas aves y a los falcónidos que se alimentan de reptiles, de serpientes y de insectos. Aun jara el que no estudia las costumbres de los animales, êl incendio de una estepa es un especáculo impo. nente, mas para el saturalista tiene un atractivo particular. A riesgo de incurrir en repeticion, no puedo menos de detenerthe un instante sobre este punto al hablar del abejaruco es. carlata.

Cuando la sequia ha destruido toda vida vegetal, cuando las estepas, verdadero paraiso durante la estacion de las lluvias, se trasforman en un inmenso páramo, llega un dia de gran viento en'que el nómada prende fuego a las resecas jerbas. Bien pronto estalla el fuego, violento y terrible; pre. cipitanse las llamas en la llanura con el impetu del huracan; a lo léjos se extiende un mar de fuego; y elévase densa nube de humo. mientrás que el ciclo se enrojece con los vividos resplandores de la confiagracion. El fuego devora las yerbas, chamusca los árboles, destruye las liamas que le ofrecen nue. vo pasto; $\{$ veces alçanza a una selva virgen, cuyos árboles consume, y à menudo llega hasta un pueblo y destruye las cabañas hechas de/rastrojo.

Por rápida'que sea in marcha del incendio, por numero. sos que sean los materiales que le alimentan, jamis el animal ligero en la carrera perece entre las llamas; mas a pesar de esio excita en todos una agitacion y ansiedad sin igual. Dis. persa a cuantos séres pueblan las altas yerbas, y iodos buỵen o medida que se acerca in línea de fuego. En medio de las manadas de los antilopes, poseidos de terror, se ve at los leopardos y otros carniceros, que olvidan ante el peligro co. mun su instintiva ferocidad: el leon se levanta, ruge de cóle. ra y cspanto, y huje tambien como los demís. Los animales que viven bajo del suelo buscan un refugio en sus moradas subterráneas, dejando que pase sobre ellos el abrasado mar de llamas; pero los insectos y los séres que rastrean son pre. sa del fuego; las serpientes no pueden escapar; los escorjuiones, las tarántulas y las escolopendras son desde luego las victimas predestinadas, pues aunque escapen del incendio, encuentran enemigos termibles, atraidos por aquel. $V_{a}$ lie dicho en utro lugar cómo acudian ha rapaces para cazar delante de la linea de llamas; con estas aves se mezclan otras y entre cllas ligura particularmente el abejaruco escarlata. Todos saben que el incendio les proprorciona las presas de que se alimentan, y utilizan tan buena ocasion. Asombra ver su osadia, sobre todo en los mas pequeños: desde las alturas se deja caer el abejaruco en lo mas fuerte del incendio, viela junto à las llamas, remóntase de nuevo, y desaparece un monjento despues en medio de torbellinos de humo. Helglin dice que con frecuencia se nueman las puntas de las alas y de la cola: yo no lo he visio nunca, pudicndo asegurar que vucla roando las llamas y que causa admiracion tanto arro. jo, como el verle volver á elevarse sano y salvo.

\section{EL ABEJARUCO ADORNADO-MEROPJ ORNATUS}

CARACTÉRES. - Fista ave tiene el lomo verde trigo; la parte superior de la cabeza, la nuca y las alas de un rojo par- 
do; la parte alia del lomo y la mbadilla de un tinte azul tur. qui; el vientre verde berilo, la garganta de un amarillo vivo, separado del pecho por una fnja negro oscura; la region anal es azul; la linea naso ocular de un negro satinado, orillada inferiormente de azul celeste. Fsta are mide unos 6-20 de largo, el ala $\theta^{\circ}$, ir y la cola $\theta^{\circ}, 08$ (fig. 73 ).

DISTRIBUCION GEOGRÁFICA.-Debemos à Gould la descripcion de las costumbres de esta ave, descubierta por él en el sur de Australia y en la Nueva Ciales del sur, donde es muy comun, sobre todo en las orillas del rio de los Cisnes.

USOS, COSTUMBRES Y REGIMEN. - Busca los bosques secos y de poca espesura, y está siempre posada sobre una rama muerta, desprovista de hojas, que le sirve de ob. servatorio para la caza. Por la tarde se reune con sus seme. jantes en la orilla del rio, formando grandes bandadas de varios centenares de individuos. Todo es agmable en este alado habitante de los bosques, y por lo mismo se le aprecia universalmente en Australia; la belleza de su plumaje, su aspecto gracioso y. sus airosos movimientos, llaman la atencion de todos. Ademas es un mensajero de la primivera: llega a la Nueva Gales del sur en el mes de agosto para marcharse en marzo, es decir, à la entrada del invierno: entonces se di. rige hácia el norte, y se ven considerables bandadas que recorren el norte de la Australia y las islas inmediatas, con. tándose algunas que anidan alli.

\section{LOS NICTIORNITINOS-NYC- TIORNITHINA}

I. familia de los merópicios se halla representada en la India no solamente por numerosos afines sino tambien por dos especies que dilieren tanto del tipo general, que Cabanis ha creido deber formar con ellas una sub-familia particular.

CARACTERES. - Los nictionis tienen el pico de media. na longitud, ruerte y encorvado, las alas medianas, con la cuarta rémige mas larga que las otras; la cola largn, casi truncada en ángulo recto, $y$ el plumaje blando y bastante rico; el cuello y el pecho están adornados de plumas erectiles de una forma particular.

\section{EL NICTIORNIS DE ATHERTON-NYCTIOR- NYS ATHERTONII}

CARACTERRS. - El nictiornis de Atherton, o sangrok, como le llaman los indios, tiene el lomo verde lorn; el vientre amarillo isabela con rayas longitudinales de un verde accitu. ma, que pasa en las cobijas sub-caudales y sub alares i un tinte orin isabela unido, y á azul de mar muy diáfano en el occipucio. Algunas plumas anchas y bastante largas que na. cen en la region de la garganta son de un azul oscuro con filete mas claro; las del pecho y demás partes inferiores pre. sentan listas longitudinales de color anarillo orin isabela. Ias remeras y rectrices miradas desde abajo son del mismo color por las orlas anchas de su cara inferior; el ojo amarillo inten. so: el pico gris de plomo y negro en la punta; las patas de un verde oscuro. El ave mide $11^{\circ}, 3 j$ de largo por $0^{\circ}, 47$ de punta a punta ce ala; esta tiene $0^{m}, 1$ if y la cola $6^{\circ}, 16$ (fing. 7.9).

DISTRIBUCION GEOGRÁFICA:-Atherton cnvió a Jardine el primer individuo conocido do esta especie, dicién. dole que vivia solitario en los bosques de bambúes del interior de la India, y que sus costumbres eran nocturnas: en presencia de estos datos se le dió el significativo nombre de mitiornis (ner nocturna), nombre cura impropiedad debian demostrar los sucesivos observadores. Sabemos con efecto por Hodgson y tambien por Jerdon, que el sangrok labita en los grandes bosques de las Indins, descie la llanura a una altitud de 1,000 metros sobre el nivel del mar.

USOS, COSTUMBRES Y REGIMEN.-E! nictiornis vive solitario en lo mas sombrio de la selva, donde se le re posado en una rama, desde la cual se lanza sobre los insectos que pasan ásu alcance, para volver al inismo sitio despues. Aliméntase de abejas, de las cuales destruye un gran número, avispas, colcópteros, langostas y otros insectos.

Jamás abandona la oscuridad del bosque, que corresponde perfectamente á su indole tranquila y quieta por no decir adusta. Jerdon dice que jamas ha oido su roz; pero Boys dice que la ticuse muy singular y silvestre.

Al decir de Hodgson, se cogen á menudo individuos vivos en las grandes cacerias que organizan los rajás de las Indias; el ruido gue hacen los cazadores les acurde de tal modo, se. gun dicho autor, que se dejan coger con la mano. Boy's asegura, por el contrario, que es muy dificil sorprenderlo, to porque sea cauto y receloso, sino porque en el bosque, donde establece su morada, abundan las rapaces de todo género. Esto explica la rareza de esta ave en codas las colecciones.

Nada se saber respecto á su reproduccion. Scgun los indigenas anida en f́rboles huecos.

A esto se limitan las noticias que he podido encontrar sobre un ave tan hermosa como rara.

\section{LOS CORACIDOS-CORACII}

Considéranse los corácidos como los mas próximos congéneres de los merópidos; constituyen una reducida familia compuesta de mas de veinte especieș, propias del hemisferio oriental, distinguiéndose por su regular tamaño y por los vi. vos y variados colores de su plumaje.

CARACTÉRES. - LOS corácidos son aves de talla bas. tante axentajada, y revisten un plumaje de vivos y variados colores, flienen el pico bastante largo, fuerte, recto, un poco ènsanchado en la base, comprimido hícia su punta, de bordes cortantes y el extreino corvo; los tarsos son cortos y cndebies: los dedos pequeños; las alas de un largo reguiar y basiante anchas; la cola mediana, unas veces truncada en ángulo recto, $y$ otras un poco redondeada 6 con una ligera escotadura; las dos rectrices externas sobresalen á reces mu. cho de las otras. El plumaje es duro y basto; los tallos de las plumas rigidos y las barbas lisas y desordenadas. Fl verde, el azut, el pardo cancla y el rojo vinoso son los colores predominantes. Las diferencias segun la edad 6 el sexo carecen de importancia.

DISTRIBUCION GEOGRÁFICA.-l.os paises tropica. les del antiguo continente son la verdadera patria de los co. ricidos; hay una especie que habita la Europia: pero las mas viven en la 2011 a ecuatorial. Africa y Asia cuentan con el mismo número de especies, poco mas 6 menos; en la Nueva Holanda se cuentan muy pocas.

USOS, COSTUMBRES Y REGIMEN.-LOS corricidos buscan los parajes secos de las llanuras: son mos en las montañas y en los paises muy fórtiles. No se les puede consi. derar en rigor como aves silvicolas; encuéntranse en los bos. yues de poca espesura de las esiepas de Africa, pero jamis en las selvas virgenes. Buscan ante todo los grandes árboles aislados, las masas de roca y las casas deshabitadas, pues en los primeros pueden abarcar un rasto horizonte, y los aguje. ros ó grietas de las segundas les ofrecen sitios invorables para anidar.

Los corácidos eligen un punto culninante y aislado para posarse, $y$ desde alli examinan todo su dominio. Si algun gran insecto pasa cerca de cllos, le atrapan al momento, como lo hacen los abcjarucos y los papamoscas; cuando un 
raton corre imprtidentemente por el suelo, ó se deja ver un lagarto ú otro reptil cualquicra, caen sobre el y lo arrebatan; tambien se atseven a robar un nido de vez en cuando. Tn ciertas estaciones comen frutas: pero siempre prefieren el régimen animal.

«Todos los corácidos, dice Gloger, son ares inquietas y desagradables: una desconfianza extraordinaria, una prudencia mas que timida, una vivera que no conoce el cansancio, una continuada alegria, una inclinacion parricular á producir ruido y trabar peleas, y en los aclultos una obstinada resistencia i la comesticidad, son los rasgos-mas pronunciados del carácter de estas aves. Nunca permanecen largo tiempo silenciosas; solo se ocultan por temor, jamks por gusto; preficren permanecer en la copa de los árboles ó en la extremi. dad de las ramas secas.

Apenas saltan ni en aquellas ni en tierm, y solo volando se rrasladan de un punto á otro. Su vuelo es vivo, rápido y sumamente fácil; ejecutan mil habilidades notables en los aires: su roz es clura y desagradable. Fl nombre rake que se le da en Alemania es casi una onomatopeya.

Los corảcidos no permanecen fijos en una misma locali. dad simo cuando les retienen los cuidados que deben prodi-

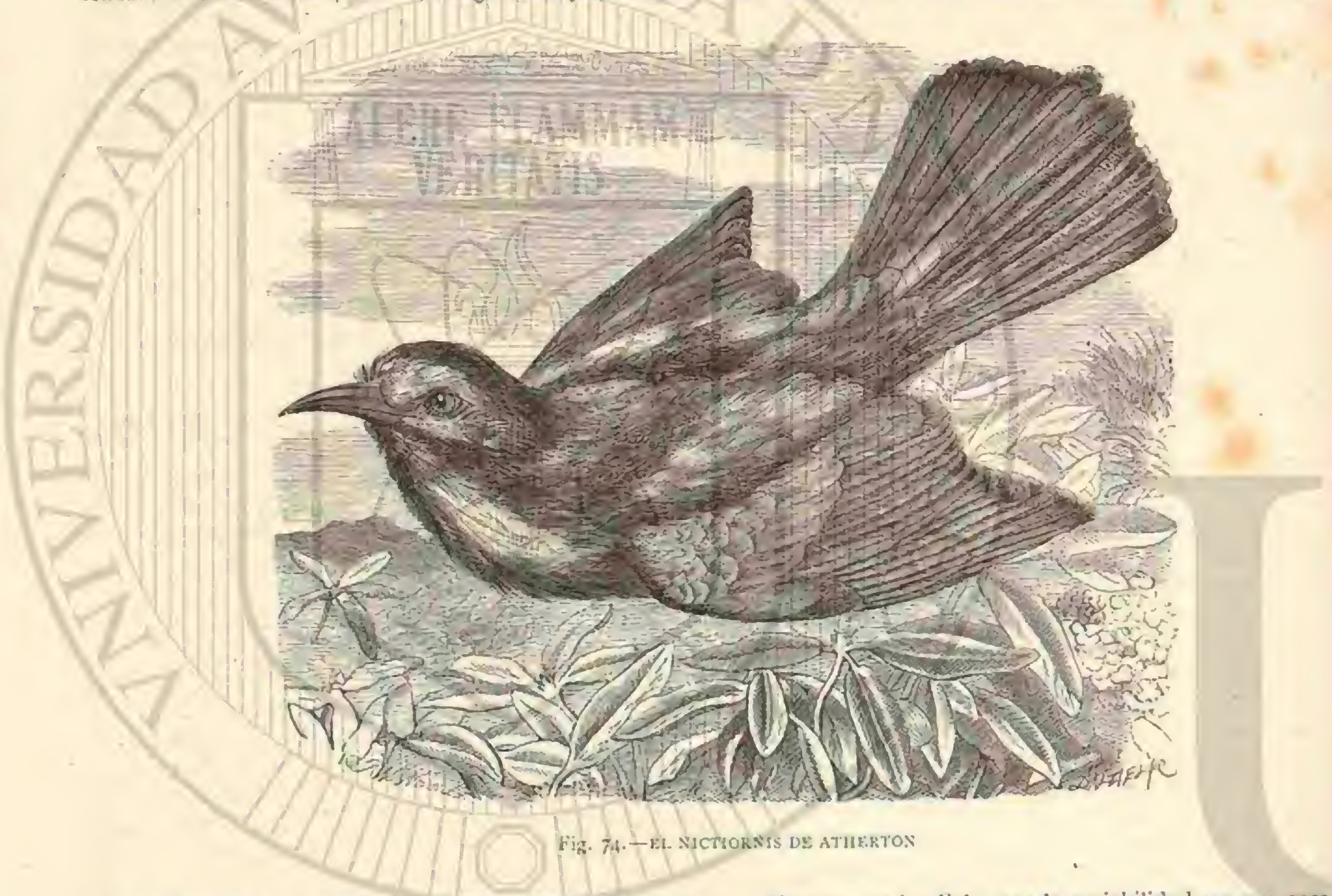

gar à su progeric; en todo el resto del tiempo vagan por el pais. La especie que vive en el norte cmigra todos los años; pero llegado el invierno, en vez de permanecer on un mismo sitio, viaja de continuo y' franguea, sin necesidad aparente, grandes espacios, como lo hacen las especies de los países tropicales. Estas aves construyen su nido en diferentes sitios, pero siempre del mismo modo: en nuestros paises, el vulgar anida en los tronr:os huecos. Se ha visto que todas las clemas aves de la misma farnilia tenian tambien esta costumbre; pero sábesc aliora que utilizan conmas frecuencia, para formar su nido, las grietas de los muros y de las rocas y los agujeros abiertos en los ribazos arcillosos. En cuanto al nido, redícese a una tosca masa de briznas, raices, pelos y plumas. Cada puesta consta de cuatro á cinco huevos cle coler blanco muy puro; macho y hembra los cubren alternativamente, y com. parten la tarea de criar álos hijuelos, desplegando el mayor celo en su cometido, por lo menos mientras no se trate de cubrir los huevos 6 dar de comer á la progenie. De lo demśs 5e cuidan muy poco, y ni siquiera se ocupan ea conservar la limpieza del nido, dejando que se trasforme al fin en una masa de inmundicias. I.os hijuclos no tardan mucho en declararse independientes; poco tiempo despues de haber co. menzado a volar, cada clal marcha por su lado, sin inquic. tarse por sus padres ni por sus semejantes.
Sin razon se ha dicho que la sociabilidad era una cosa $\mathrm{cn}$. teramente desconocida entre los corácidos, pues asi en los que viven en estado libre, como en los cautivos, ha podido obscrvarsc que tan solo rechazan aquello q̨ue se opone á la satisfaccion de sus necesidades. Si bien no puede negarse qué á causa de la imposibilidad de juntarse, traban entre si las diferentes parejas reinidas contiendas en torno de los arrboles ahuccados, no es, sin embargn, menos cierio que estas aves viven en buena armonia y llegan hasta a formar verdaderas colonias en las paredes de los peinascos, tapias, muros viejos, edificios abandonados, clc., donde vinieron á albergarse. En sus emigraciones se reunen tambien en numerosas bandadas, cuyos individuos se diseminatn ocupando una vas. ta extension de territorio para poder asi encontrar mas fícilmente el indispensable alimento. Los coracidos son mas vo. races que los merópidos; de ahi la necesidad de ocupar un área mas extensa donde poder efectuar su caza y saciar su apetito; únense, sin cmbargo, como otras aves de su familia cuando no son un obstáculo para ello el celo ni cl hambre.

Muéstranse aun mas sociables que los merópidos, ya que en aquellos sitios donde se reunen varias especics de coráci. dos, especialinente en la India, juintanse estas unas con oiras, siendo las citadas uniones no menos frecuentes que las que tienen lugar entre nuestros cuervos y cornejas. Aunque 110 
han podido hacerse sobre el particular muclass observaciones, no obstante se ha notado que los mestizos que resultan de tales uniones, muestran claramente su origen, presentando los rasgos carncterísticos de nuestra especie indigena y de dos de las Indins.

CAzA.-Estas aves son objeto de numerosas persecucio. nes á causa de la belleza de su plumaje y de su carne jugo. 5a. En Alemania, todo campesino se cree con derecho if tirar sobre estas singulares aves; en el medicdia de Luropa se organizan contra ellas cacerias regulares. Los corácidos adultos deben temer además las acometidas de los falcónidos de toda especie, y los pequenos las de los carniceros trépadores.

El cultindor que mirn por sus intereses, hace muy bien en protegerlos: podrá ser que de ve\% en cuando se apoderen de alguna avecilla; pero este daño queda suficientemente compensado ron las rentajas que reportan por otra parte, no siendo cierto que destruyan los nidos de otras ares, segun he podido colegir de las observaciones practicadas en individuos que por largos años he mantenido en cautividad en compininia de varios pájaros. Acúsase tambien à los corácidos de comerse el trigo; dícese que se irngan espigas enteras y que por esto se prosan en las hacinas de trigo; pero tampoco es cllo cierto, ya que se colocan en ellas tan solo para poder cbservar mejor los alrededores.

Despues decuanto se ha obscrvado respecto de estas ares, se puede afirmar, sin temor de incurrir en error, que son ani. males útiles y constituyen con el brillante color de su plu. maje el ormato de la region que habitai, no recreando menos la vista del pasajero con las capricho:as evoluciones que describen en el aire, por todo la cual, no solo debiera protegérseles contra la persecucion de los cazadores, sino que se debiera dejar á su disposicion los escasos troncos de árboles huecos, donde pueden hallar abrigo, $y$ hasta procurarles una mora. da, colgando espaciosas cajas, á fin de lograr asi retenerlos en el pais. Se conseguiria indudablemente esto último, si en rez de las cajas que se han construido recieniemente y que a pesar de lo mucho que se las ha elogindo no sirven para el objeto arriba dicho, se prepararan troncos huecos, los cua. les, despues de haberlos sujetado á una altura conveniente á átucles viejos aislados, sirvicran á estas ares para construir en ellos sus niclos.

Si por semejante medio se consigue atracr á los mergos, ¿por qué no podria recabarse otro tanto de los corácidos, los cuales abandonan un pais, que les ofrece condiciones faro. rables, no pot otro motivo sinu purque se les expulsa de sus moradas sin comsideracion alguna? Cualquiera q̧ue haya ob servado de cerca á estas ases, no pucde menos de cobrarles algun carino y hacer aigo en favor de las mismas.

CAUTIVIDAD.-Dificil es, por desgracia, conservar es tas aves cautiras: los adultos no pueden vivir en jaula, y en cuanto a los pequenos, exigen los mas solicitos cuidados para acostumbrarles á la pérdida de su libertad. Por otra paste, no son aves divertidas; permanecen silenciosas en el mismo sitio, cnsucian su plumaje y no saben hacerse querer de su amo, excepcion hecha de las cogidas en su nido cuan. do pequeñns, las cuales se distinguen por su vivera y son en extremo graciosas.

\section{LOS CORACIAS-CORACIAS}

CARACTERES.- Este géncro, al q̨ue pertenecc lin espe cie europea, que consideramos como tipo de la familia, pre senta los siguientes caractéres: el pico es de mediana exten. sion, recto, fuerte, ancho en la base, de arista ligeramente encorvada y la punta ganchuda; los tarsos mas cortos que el Tovn III dedo medio; la segunda rémige es la mas larga de todas, y la cola igual, pues las rectrices externas no se prolongan mas que las otms.

\section{EL AZULEJO-CORACIAS GARRULUUS}

CARAGTERRS.-El coracia vulgar ó azulejo, como vulgarmente se le llama en Castilla (ioracios Ioquax y iridis), tiene un plumaje magnifico. La cabeza, cuello, vienire $y$ cobijas son de un color azul celeste que tirn á verdc; las plumas que aparecen sobre las fosas nasales, en el ángulo de la boca y en la barba, blanquecinas; las pequeñas cobijas del antebrazo y las de la parte superior é inferior de la cola, de azul ultramar oscuro; las del lomo y de las espaldas de un pardo canela; las rémiges posteriores del brazo son del

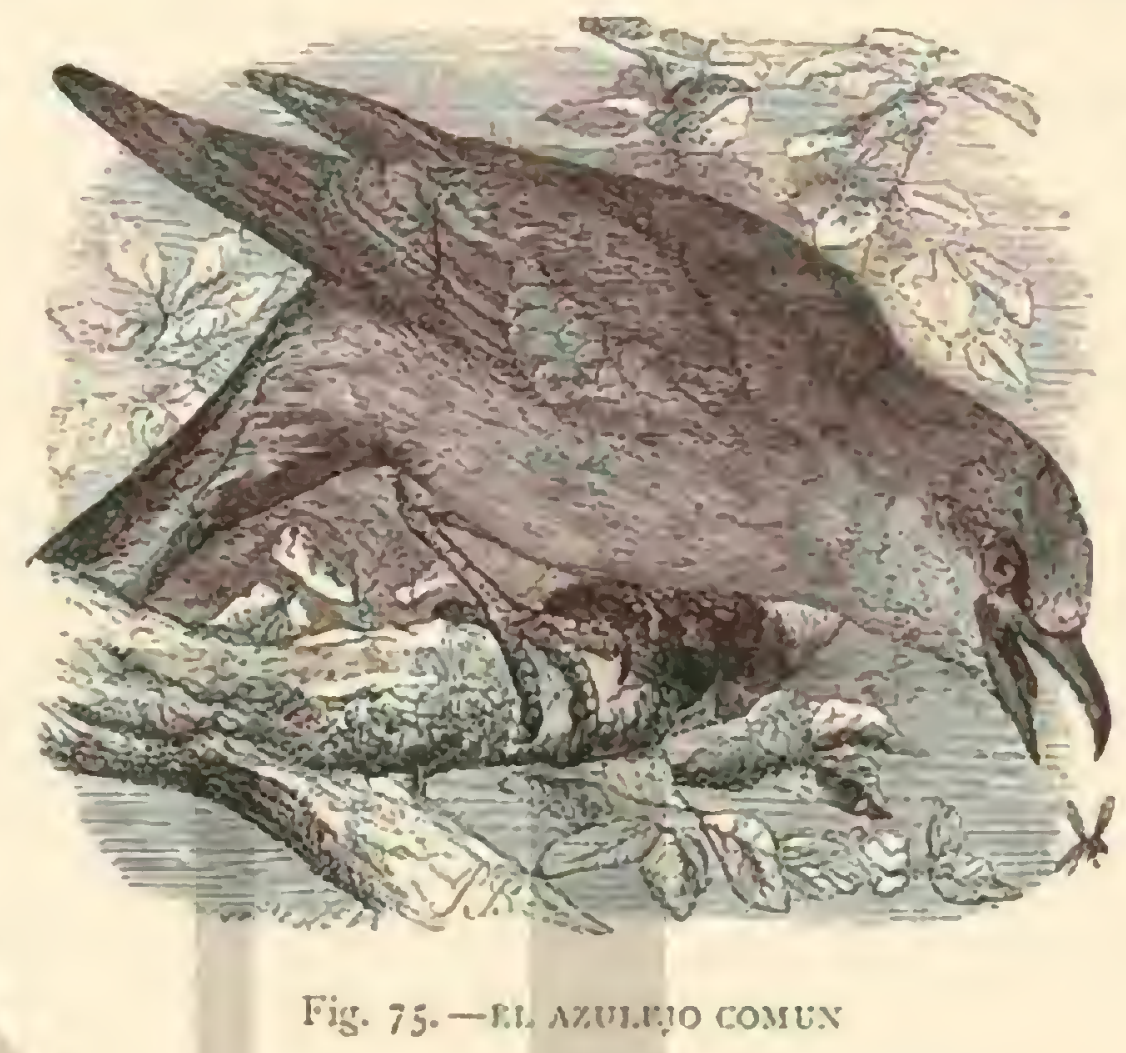

mismo color, mientras las restantes lo tienen negro que tira a azul oscuro, con la mitad basilar de las baruas exteriores de azul celeste; las de la mano ó primarias presentan tam. bien la base de este litimo color, con el resto negro; lis pennas son generalmente de un azul oscuro en su cara inferior; las dos rectrices del centro de un tinte gris pardusco sucio; las demás de un azul celeste oscuro, teniendo las barbas interiores un color azul oscuro en su mitad y un azul claro cerca de la punta. Machos y hembras ofrecen una misma coloracion; esta es menos brillante en los pequeiros, los cuales se distinguen ademas por tener la parte stperior de la cabeza, la nuca y cl vientre de un verde gris: el lomo pardo cancla opaco; la cola de un verde azul pálido, mientras cl resto del plumaje se asemeja al de los padres Esta ave

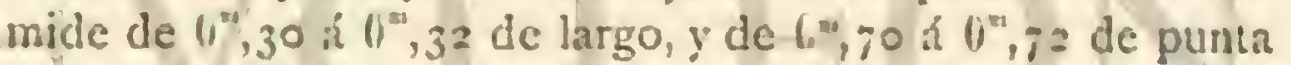
a punta de ala; esta tiene $10^{\circ}, 20$ y la cola $0^{\circ}, 13$.

DISTRIBUCION GEOGRAFICA.-El azulejo se ve en tocos los puntos de Europa al sur de Escandinavia; pero su área de dispersion se exticnde mucho mas alli, pues en sus riajes recorre toda el Africa y todo el sur del Asia. Radde no le encontró en la Siberia oriental: sin embargo se le halla en todo el centro de Asia, desde el sur del Aliai hasta Cachemira y region septentrional de la India, y anida ademfs en el Asia Menor, Persin y noroeste del Africa. No se la ve sino muy raras veces en Inglaterra, Holanda, Succia, Finlan. dia y nore de Rusia: parece que no hace mas que atravesar por la Suiza y el norte de Francia en sus emigraciones.

In Corfif aparece muy abundante en la época de sus emi. graciones; pero las bandadas permanecen alli poco tiempo; solo algunas parcjas anidan en la isla ó en el continente pró. ximo. En Malta es comun durante el otono y la primavera, 
contándose unos pocos individuos qure permanecen alli y se fijan.

En el sur de Rusia, en España, en Grecia, en el Asia Menor y Argel, es muy comun en ciertos puntos: en el tercero de los paises citados, particularnente, se encuentran verdaderas colonias de azulejos, y en España he observado ban. dadas bastante numerosas de estas aves. Segun Jerdon, abundan en el Asia occidental y la ceritral: en las Indias no se las ve sino en las provincias del noroeste.

USOS, COSTUMBRES Y REGIMEN. - LOS azulcjos no aparecen en Alemania de vielta de sus moradas de invierno hasta los últimos dias de abril, y en agosto vuelven á emprender de nuevo sus viajes: conienzan $k$ emigrar primero los pequeños, acompañados de oiros adullos, Jos cuales terminaron ya las tarens de la cria, siguen despues los restantes, y a medindos de setiembre han desaparecido ya todos. A su llegada vuelan de un matorral dotro ó se trasladan de uno a otro bosque; al volverse, no siguen precisamente él mismo camino por donde vinieron; se dispersan mas por el pais que durante la primavera; pasan sin apresturarse de una á otra espesura; pósanse sobre las gavillas de trigo para to. mar algun descanso; hacen aqui su caza $y$ se trasladan fotro funto luego despues de haber saciado su'apetito. Durante la primavera viven reunidos en parejas, y en otono aislados; sin cubargo a veces se les encuentra iambicn formando peque. nass bandadas ó familias, compuestas de varios padres con sus pequeinuelos. Estas aves aparecen en cl sur de Europay en el norie del fírica casi en la nuisma época que cn Alcmania, conduciéndose de igual modo en las tres partes del mundo que acabamos de ciar. Cuando su viaje de primastera, vuelán rápidamente $y$ sin detenerse 2 la patria desenda, al paso que en el de otoño van mas despacio, detienense por todas partes $y$ a leces se paran algunos dias en un nismo sitio, cuando a ello las convida la abundancia de alimento. Durante la travesi se reunen todos los dias muchas de ellas en el valle del Nilo; humenta mas y mas su múmero en las estepas, de modo que alli doncie estas no ofrecen mas que algunos matorrales muy aislados; casi en cada uno de ellos pucde verse posada y atenta a la caza á una de las aves vial jeras. Reúnense los azulejos en numero crecidisimo en aque. llos sitios donde juede hacerse fácil y abundante presa, como, por ejemplo, en los puntós de la estepa invadidos por Ia langosta destructora: yo mismo pude ver handadas com. puestas de unos 50 individuos, $y$ en octubre de 1857 Heu. glin encontró centenares de ellos en los bosques de schora frecuentados por aquel ortóptero. Por mas que las estepas del norte de $A$ frica ofreacan condiciones favorables parn los azulejos, nunca, sin cmbargo, fijan estos su morada en cllas durante el crudo inviemo; prolongan, por el contrario, su viaje mas hácia el sur hasta las costas de Natal y Damara, donde les detience el mar en su marcha. Anderson, que du. rante el iuvierno encontró á nuestras aves en el segundo de los paises iltimamente cirados. se inclina a creer que algu. nas de cllas tienen su morada fija en el sudoeste del Africa; pero es muy probable que aquel viajero confundiera al azu. lejo con alguno de sus congéneres africanos, pues dificilmen. te anida esta ave en la region meridional, limite del icrritorio de sus peregrinaciones.

En Alemania el azulejo huye de la vecindad del hombre: en los paises mas hicia el sur habita tambien con preferencia los sitios despoblados; pero no tiene tanto miedo al hombre. En el mediodia de Furopa esta ave encuentra menos troncos de árboles ś propósito para depositar su nido çue en Alemania: pero en cambio no le faltan ruinas de edificios anti guos y abandonados, $y$ en defecto de estas, paredes arcillo. sas escarpadas como tambien perascos donde pueda hallar un hueco ó grieta para construir en él su nido: este es el motivo por el cual se la encuentra mas á menudo en la Euro. pa meridional que en la central, habitando en la primera de estas regiones sitios que evitaria indudablemente en la se. gunda.

'Tristram hace una descripcion tan exacta como amena acerca de las costumbres del azulejo en Palestina luego despues de su viaje de primarera: nuestra ave llega al citado pais a mediados de abril; a la hom del crepúsculo vespertino pósase en bandadas mas ó menos numerosas encima de los árboles que deben prestarle albergue durante la noche; gorjean, char. lan, gritan y promueven un ruido semejante al que hacen las cornejas de pico blanco. Despues que ha cesado el coro de los alados viajeros, remóntase uno de ellos á las altas regio. nes del aire, donde inframado de amorosos deseos, ejecuta volando los diferentes ejercicios que suelen preceder al acto de la cópula. A los pocos momentos levanta su vuelo toda la bandada; surcan el aire en variadas direcciones; atropéllanse unos a ótrós y eiectuan mil movimientos y juegos, llenos de alegria. Una semana despues desaparecen ya los viajeros re. cien llegados; cncuentranse, sin embargo, como unas veinte is treinta parejas de cllos en alguno de los valles recinos, conde todas las hembras estín afanosamente ocupadas en practicar agujeros al través de alguna pared arcillosa escatpada áfin de fabricar en ellos sus nidus. En adelante no parece ya ningun individuo de la colonia en los árboles a donde con tantaregularidad se les yeia acudir en un princi. pio, por mas que estos leranten su copa muy cerca de sus nidos; los cuidados de la prole absorben toda su actividad y atencion. Encuéntranse tambien arulejos en las inmediacio. nes de las aldeás, mayormente si hay en ellas iglesias $\delta$ mez. quitas arruinadas, de modo que raras veces se visita una de estas, sin encontrar establecidas en las mismas algunas de las bellas aves. Por doquiera se encuentran azulejos, en los minaretes, torrecillas, rocas, piedras y en todos los sitios desde los curles pueden descubrirse fácilmente los alrededores. En las comarcas de Alemania, ocupadas palmo á palmo por el hombre, estas aves no pueden satisfacer sus necésidades con la facilidad que en otros paises. Ya sea por una costun. bre heredada de sus antepasados, ya sea por otra causa, no anidan en Alemania mas que en los huecos de los árboles, circunstancia que bastaria da explicar el porqué son tan poco numerosas. Para que una pareja de azulejos pueda habitar durante el verano en una region cualquiera, es menester que se encuentren en ella huecos de árboles bastante espaciosos para proder contener en su interior el nido juntamente con la hembra que empolla y los pequeñuelos; esta es condicion absolutamente indispensable, en términos que si faltan los árboles en que se vino anidando desde tiempos inmenroria. les, vense forzadas las parejas a abandonar la comarca. En los bosques confiados á la custodia del guarda bosque Hinty, tiempo atrás tres 6 cuatro de cstas venian i anidar todos los anos; y en el término nunicipal de Bublitz hacian lo mismo o:ras diez $\delta$ doce; pero desaparecieron todas ellas, abando. nando el pais, luego despues de haber sido derribadas las viejas encinas que antes les dieran abrigo. Como en todas partes sucede lo propio que en las comarcas citadas, no es de extrañar que vaya menguando de dia en dia en Alemania el número de estas ares, ornato de nuestros bosques 5 cam.
pinas.

Pocas aves animan tanto una comarca como el azulejo; véscle en todas partes. Cuando los cuidados de la progenie no le obligan á permanecer en un mismo sitio, vaga de un punto a otro durante todo el dia; vuela de árbol en árbol, y se posa encima de alguno de ellos, ó en la cxtremidad de una rama seca para acechar su presa descie alli. Cuando hace 
mal tiempo está triste y abatida; si luce el sol vuela por los aires como para divertirse: cjecuta rasios ejercicios; déjase caer verticalmente desde una gran altura, y se remonta des. pues á impulso de vigorosos aletazos, sin que al parecer tengnn objeto determinado todos estos movimientos Sin embar. go, es indudable que lo tienen; tanto el macho como la hembra ejecutan por lo general tales ejercicios con el objeto de agradarse mutuamente, segun parece probarlo la frecuencia de los mismos durante la época del celo; y dichos juegos sirven, asi para satisiacer su afan de moverse y expresar sus particulares afecciones, como para ensayar su habilidad en volar, la cual uo podemos menos de reconocer es extraordinaria. A esta ave no se la ve saltar nunca por las ramas, sino que, como lo hacen casi todos los levirostros, se sirve tan solo de sus alas para moverse; habita en lo posible los terre. nos llanos, aunque á veces los rasa volando, acercándose a ellos lo bastante para poder coger un animal que corra Lin las estepas del lurkestan, en alguno de cuyos puntos se la encuentra con frecuencia, se la ve muchas veces posada encima de un terron ó eminencia que apenas alcanza à diez centimetros de altura.

Hay mucha dirergencia entre los naturalistas y observado. res tocante a las cualidades intelectuales y las costumbres del axu!cjo, si bien todos estän contestes en reconocer el gran desarrollo de sus sentidos. De todas maneras casi no se puede dudar que es un ave cauta y prudente: reconoce distingue el peligro reai del aparente; es mas bien confiada que timida; deja que el hombre se le aproxime en los sitios en que reconoce ser este su amigo, y luye, por el contrario, de la presencia del mismo, tomando grandes urecauciones, en aquuellos donde se ha visto molestada. A la verdad no puede decirse que sean agradables sus costumbres: véscla renir muy á menudo con otras aves $y$ hasta con las de su propia especie. Von der Muhle asegura que el arulcjo de Europa vive en buena armonia con la chova; Naumara dice que hace lo mismo con las otras aves que habitan cerca de 4l: el primer aserto es evacto; en cuanto al scgundo, no se puede admitir sin reserva, pues el azulcjo acomete y persigne con furor, no solo a las rapaces, sino ambien á ios grajos, cuerros y cornejins. Por lo que inira á sus combates con las demás aves de su esprecie, no son ellos tan encarnizados como pudicra crecrse, siendo casi todos ocasionados por la colocacion del nido, los celos y el hambre; de modo que si lay bastantes sitios á propósito para anidar esta ave, descrita por algunos como insocialsle y pendenciera, vive en amistosas relaciones con sus semejantes qu anidan en la misma pareo, del mismo modo que lo hacen los merójidos y otras aves.

Su voz se reduce á un grito penetrante y ronco, que repite i mienudo y que se expresa por mker raker rakir; tol de cótera es un chirrido que se puede expresar por rnek: el de ternura y amor por krael, emitido en tono alto y plañidero. Cuando hace buen tiempo, dice Naumann, remóntase el macho por los aires, ro léjos del sitio donde cubre su hem. bra, y grita rak rak rak; llegado á cicrta altura, dejasc caci dando volteretas, revoloiea de un lado jara otro, y repite va. rias veces seguidas el rach, raeh, mel; despues se posa en la extremidad de una rama seca. Estos gritos, segun parece, ha: cen las reces de cauro.

El azulejo se alimema de insectos de toda especie j de pe. queños reptiles, particularmente de coleópteros, de langostas, gusanos, ranas pequeñas y lagartos. De vez en cuando atrapa un raton ó algun pajarillo. Naumann dice que no le la visto nunca coger un insecto al vuelo; Jcrdon afirma, por su parte, que el azulejo de la India persigue á los insectos volando a cierta distancia, y que caza activamente \{llos térmites alados cuando abandonan su nicio despues de la lluvia.
Naumann dice que los coracias no toman ningun alimento regetal: von der Muhle asegura por el contrario, yque en Girecia ha visto con frecuencia las plumas de la base de su pico untachas del jugo de los higos; Lindermayer afirma que des. pues de abandonar estas aves aquel pais, permanecen aun algun tiempo en las islas antes de continuar su viaje hicia el Africa, y que se detienen alli para devorar un fruto que les gusta mucho, a saber, los ligos. Como quicra que sen, los insectos no constituyen menos la base de su alimento: po. sado en su rama el azulcjo mira alrededor de sí, vuela rápidamente hácia el insecio que columbró,'le coge con su pico, le devora, y velve al mismo lugar donde se hallaba. Come con gusto las pequenas ranas, dice Naumann; yo le he visto cogerlas por las patas posteriores, golpearlas cuntra el suclo hasta que no se moviesen y tragárselas despues, devorando asi tres ó cuatro, una tras otra. Parece que cl azulejo no necesita agua; dicese que no bebe ni sc baña ampoco, lo cual parece verosimil it todos los que han tenido ocasion de observar al ave en las estejas, ó en medio del desierto, don. de no hay una gota de agua.

Nos abstendremos de resolver aqui la cuestion relativa al sitio en que primitivamente consiruia su nido el azulejo, si era aquel el hueco de los árboles y no las grietas de los edi. ficios ni los agujeros practicados por el misıno en paredes arcillosas, 6 al contrario; ínicamente observaremos que cn cl sur de Europa nuestra ave se sirve con mucha menos fre. cuencia del primero de los tres lugares indicados que de los dos restantes Esto es lo q̧ue yo mismo he observado en España, lo que han visto von der. Muhley Lindermayer en Grecia, Porrys y Taylor en Corfí y Malta, Tristmm y Kru. per en el Asia Menor y Palestina. Von der Mluhle encontró en la Maina una colonia de axulejos que liabian formado asi sus nidos ell una costa brava vertical, de 100 metros de al. tura; pero en Negroponto, donde las plantaciones de olivos y los vinedus rodean numerosas casas, los vió anidar en los tejados. Jerdon dice lo mismo de la especie que vive en las Indias. Coebel vió al azulejo anidar en un mismo banco de arena al lado de la chova y o:ms aves, por cjemplo, abejarucos y cipsélidos, lo cual confirma lo que dejamos en otra parte consignado tocante a las amistosas relaciones que mantienen unas con otras. II nido varia segun los paises, si bien se halla siempre tapizado en su interior de raices suaves, ras. trojos, plumas y pelos.

Cada juesta se compone de cuatro a seis huevos de color blanco lustroso; macho $y$ hembra los cubren alternativa. mente, y con tanto aían, que se les puede coger sin que tra. ten de huir. Como los padres no se cuidan de arrojar las inınundicias, dice Naumann, los hijuelos acaban por quedar enterrados en un monton de excrementos y restos de toda especie, exhalando el nikio un olor repugnanie. I i progenie se alimenta de insectos y gusanos; comienza pronto a-rolar, pero permanece aun mucho tiempo con sus padres y em. prende con ellos su excursion. Macho y hembra despliegan la major Urarura para defender á sus hijuelos, yopónense valerosamente à los enemigos que les amerazan, olvidando su propia seguridnd.

CAZA.-La que se da al azulejo es facil, si se elige para acecharle uno de los irboles que el ave prefiere. Mas dificul. tades ofrece cogerie vivo, si bien los pajareros, al menos en Alemania, se cuidan poco de perseguirle. No sucede lo mismo en las Indias, a lo que dice Jerdon: alli se le caza con halcon, y empléanse tambien lazos especiales. Encórvanse unos tallos de caña, que se untan de liga, y bajo el arco que describen se suspende un raton muerto ó cualquier otro cebo. El azulejo procura coger la presa al vuelo; pero toca las cañas con el extremo de sus alas y se queda colgado. 
Ca Utrvida D. - Los péqueñuelos cuidados por mi me proporcionaron muchas y muy gratas distracciones. Despues de algun tiempo de criarlos, no tardaron en acostumbrarse á un régimen alimenticio apropiado; era tal su voracidad que comian mucho y nunca se daban por satisfechos. No bien se les enseñaba algun insecto, abalanzäbanse sobre él con indes. criptible avider; como cada dia yo mismo les propinaba las larvas y saltones, se amansaron luego, como pudiera hacerlo un cuervo cualquiera: saludábanme tan pronto notaban mi presencia; abandonaban al instante sus sitios, y volando gra. ciosamente, venian á posirse encima de mi majo; dejąbanse coger sin oponer la menor resistencia; devorahan lo gue les ofrecia, y volvian á ponerge de nitevo sobre mi mano pocos instantes despues de haberlos soltado. No molestaban lo mas minimo a las otras aves que se hallaban encerradas con ellos

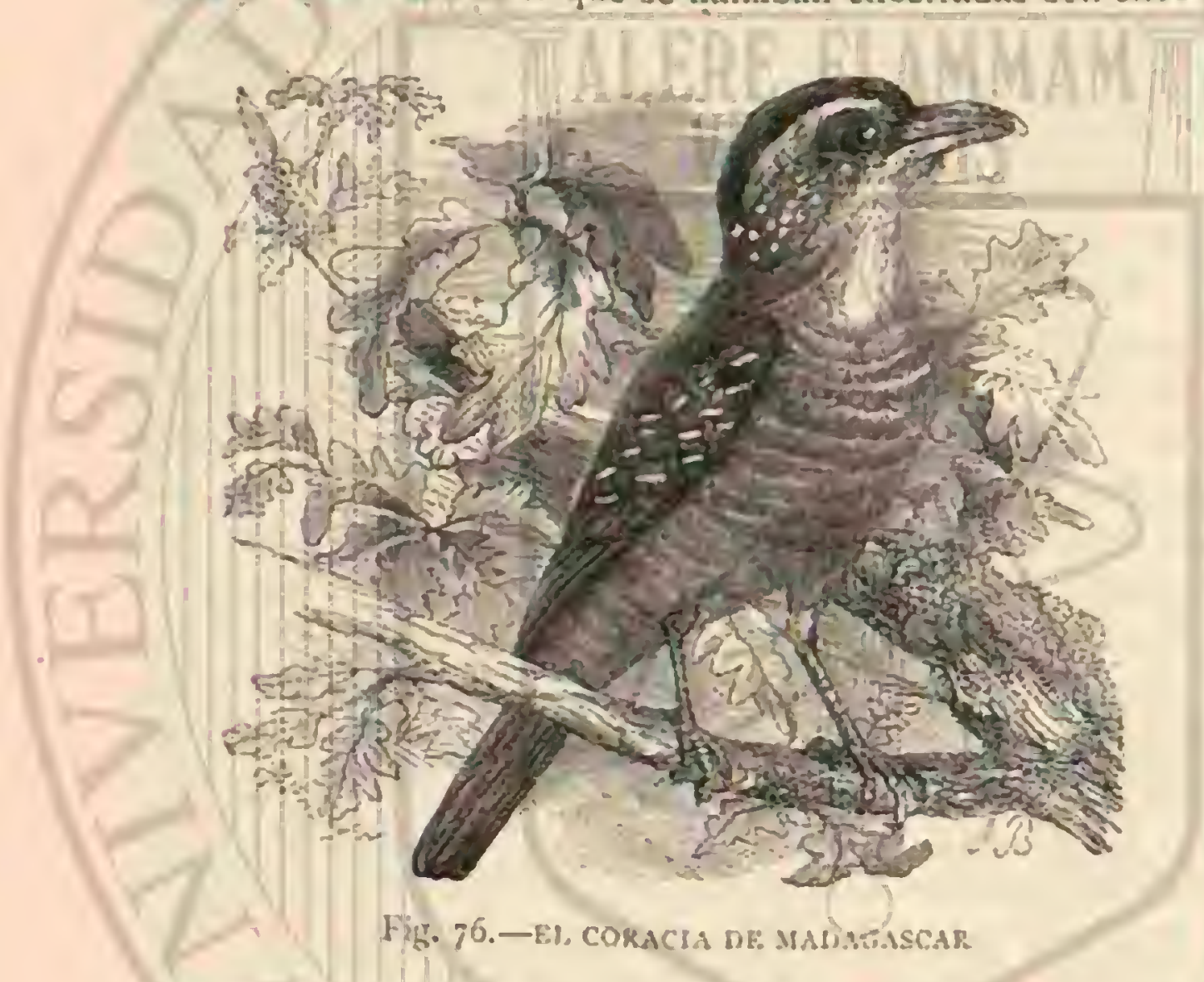

en la misma jaula; por el contrario, si se prescinde de algunas insignilicantes escaramuzas, vivian en buena armonía con todos sus compañeros de encierro.

Por espacio de mucho liempo esture criando estas ares, antes por mi despreciadas, y despues de babetlas observado detenidanente, no pucdo menos de recomendarlas encareci. damente à los aficionados. Cualquierá que pueda proporcio. marlas un encierro bastante espacioso y convenientemente dispuest), como tnabien abundancia de insectos, siquiem no sean mas que tenebrios, no dudo será de nuestra misma opinion y cobrarí por estas aves el mismo interés que nosotros.

\section{EL CORACIA DE MADAGASCAR-BRACHYP- TERACIAS TEPTOSOMUS}

CARACTERES. - Las partes superiores del cuerpo de es. ta ave son de un color pardo castaño con un viso verdoso en el lomo; las alas son pardas tambien, con manchas negras y filetes blancos; las partes inferiores de un gris blanquizco; la garganta presenta una mezcla de pardo, $!$ en el abdúmen hay fajas trasversales del mismo tinte (fig. 76).

DISTRIBUCION GEOGRAFICA.-Segun lo indica el nombre, esta especie es propia de Madagascar.

\section{LOS EURISTOMOS-EURYSTOMUS}

CARACTÉRES, - Los euristomos tienen el pico sumamente encorvado, corto, muy deprimido, ancho á los ladios y de arista redondeada; las patas cortas, con los dedos medio y externo ligeramente soldados, $y$ la cola corta $y$ truncesda en ángulo recto. Las alas son muy largas; la primara rémige tiene la misma largura que la segundia, asemejándose en lo dèmás á los azulejos.

\section{EL EURÍSTOMO DE ORIENTE-EURYSTO- MUS ORIENTALIS}

CARACTÉres. - Esta especie, liamada por los colonos europeos de Australia aiv dollar, y Aions-bafu ó tiongr-lansay por los malayos (nurystomus cyanicollis, fusicicapillus, pacifo. cus, gularis y inlornix, coratias oricmalis, galyulus porificus 1. gularis), es una de las mas conocidas del género. Tiene el mismo tamaño del azulejo, si bien parece mas corto y recogido; mide de $0^{n}, 3^{2}$ á $0^{\circ}, 35$ de largo; el ala $0^{\circ}, 21$ y colla $y, 10$. La cabeza y el cuello son de color aceitunado oscuro; el lomo y la espaldilla de un tinte verde mar mas claro; las alas y el vientre del mismo color, pero mas oscuro; la barba y la garganta presentan una gran mancha de un azul muy yivo. Las rémiges son negras; las rectrices, miradis por la cara inferior, de un azul indigo muy subido, ofreciendo unas $y$ otras en los bordes de las barbas exteriores una raya nuy delgada del mismo color azul; las seis primeras réniges ostentan en su base una mancha blanco azulada. El pico, de punta negra, $y$ las patas son de un color rojizo; hs uñas negras; el ojo pardo oscuro y orillado de rojo. El color es $\mathrm{el}$ mismo, as en el naclio como en la hembra; los peñuenos lo tienen mas oscuro que los padres y no presentan en la garganta la hermosa mancha azul de que "hemos hablado.

DISTRIBUCCION GEOGRÁFIC,A,-Esta are ocupa una area muy extensa: habita toda la India y generalmente el sur del A sia, tanto en el rontinente como en las islas mayores, Ceilan, el archipiélago de las Molucas, Sonda y Filipinas, extendiéndose al este por Siam y la China hasta la cuenca del Amur, $y$ al sur por la Nueva Guinea hasta la region me. ricional de las. Australia.

Sa la encuentra tambien, segun Jerdon, en las faldas del Himalaya, en ia parte inferior de Bengala y Asam, siendo, por el contrario, muy rarn en la region meridional del conti. nente indico; segun Layard, aparece tambien en diversas comarcas de la isla de Ceilan. Fin los demás puntos por donde se extiende su morada, encuéntrasela bastante á nenudo: Gould dice que solo ha visto esta ave en la Nueva Gales del sur; pero Elsey nos comunica que es muy comun en la bahia Victoria. Llega en la primarera á la Nueva Giales, y cuando sus hijuelos están bastante crecidos, se aleja otra vez en direccios al norte.

USOS, COSTUMBRES Y REGIMEN. - Esta ave SE diferencia de los azulejos y de los ciemás de sus congéneres por su gran destreza en volar, asemejándose, sin embargo, á los mismos por lo que respecta a sus costumbres y modo de vivir. Layard pudo obsersar una de estas ares que estaba suspendida de un árbol como un pico, cazando los insectos ocultos en el interior de la madera podrida; los demás ob. servadores dicen que cuando caza, se pone en sitio clevado y que despliega en tal tarea habilidad suma. Al salir y ponerse el sol, ó en los dias en que está el ciclo nublado, es, segun dice Gould, cuando muestra mas actividad esta ave: si hace buen siempo permanece tranquila, posada en alguna rama muerta. Ls valerosa en toda estncion; pero cuando en tra en celo acomete con verdadera furia á cualquiera que se acerque al nido para iurbar su reposo.

Cuando caza se posa comunmente sobre alguna mana muerta cerca de una corriente de agua; alli permanece con el cuerpo derecho, mirando al rededor hasta qุue algun in. secto llama su atencion; entonces cae sobre él, le atrapa y vuclve à posarse en el mismo sitio. A veces se ve a los eu- 
ristomos jugruetear en los aires, en curo caso aparecen comunmente por parejas; vuelan alrededor de la copa de los árboles, y recrean al viajero con la rapidez de sus evoluciones. Mientras vuelan aparecen muy distintamente las manchas plateadas qque tienen en mecio de las alas, de donde les viene el nombre de aecs duros, que vulgarmente se les da. Cuando hace mal tiempo produce esta ave mucho ruido, lanzando su grito vibrante y particular, sobre todu cuando vuela. Se ha dicho quue arrebata à los loros pequenos de sus nidos para matarlos; Gould no confirma en modo alguno esta opinion, pues en el estómago de los que abrió no encontró nunca sino restos de insectos.

La época de ha reproduccion dura desde el mes de se. ticmbre al de diciembre: los huevos, en nuimero de tres ó cuatro por puesta, son de color blanco perla; la hembra los deposita simplemente en el hueco de un tronco de árbol, sin hacer antes en él ningun trabajo preparatorio.

\section{LOS EURILAIMIDOS-EU- RYLAIMI}

Iil pequeño grupo de los curilaimidos nos ofrece un ejem. plo de la insuficiencia de las clasificaciones. Horsfield los reune à los tódidos de América; Swainson á los inuscich́pi. dos; Blyth. Wallace y Sundevall los agru;an con los paradisidos; Van Hlreven los pone al lado de los caprimúlgidos; Gray, Bonaparte y Reichenbach los consideran como afines á los coracidos; y Cabanis, siguiendo su ejemplo, los nira como un trinsito enire los coracidos y los hirundinidos, lo cual le pernite reurirlos con estos dos grupos en una misma familia. ¿Cuál de todos estos autores se acerca mas a la verdad? Fil punto es muy discutible, pues los eurilainidos tienen una conformacion tan singular, que se hace muy dificil com. paratlos con otras aves.

CARACTERES. - Todas las especies actualmente conocidas tienen el cuerpo recogido; el pico mas corto que la cabcra, muy hendido hasta por debajo del ojo, corto, fuerte, deprimido, y muy ancho en la base; adelgazase bruscamente hícia la punta; la mandibula superior, profundamente surcada, remata en gancho, y los bordes se recogen hácia dentro; la boca es casi tan grande como la de las hirundinidos; las patas de largura regular y bastante grwesas; los tarsos un poco mas largos que el dedo del centro; las dos primeras falanges del externo, y solo ha primera del interno, estín sol. dadas con el dedo del medio; las alas son cortas y redondea. das, con la tercera y cuarta rémiges mas largas; la cola, redondeada ótruncada, tiene una ligera escotadura en algunas especies; los-colores del plumaje son viros, y ambos sexos revisten casi el mismo.

DISTRIBUCION GEOGRÁF゙ICA.-Estas aves liabitan en las Indias y en Malaca.

USOS, COSTUMBRES Y RËGIMEN.-Apenas sabe mos nada acerca de este punto: solo hemos podido averiguar que las pocas especies actualmente conocidas habitan en los bosques mas sombrios, sobre todo en aquellos que están alejados de las viviendas humamas.

\section{EL EURILAIMO DE JAVA-EURYLAIMUS}

CARACTERES. - El curilaimo de Java(eurqhimus Hors fieldii), llamado cambien fauplerna litic por los malayos, es en general de un color rojo vinoso agrisado, cl cial se con vierte en negro salpicado de amarillo en el dorso; la parte superior de la cabeza y la garganta son de un gris rojizo, á causa del color gris ceniciento que tienen los extremos de las plumas; la nuca y la parte posterior del cuello tiran á en. carnado: la region anierior de este, el pecho s el vientre al rojo vinoso, en el pecho se nota una peoueria faja negra con reflejos rojizes. El lomo, la espaldilla y el centro de la cola son de color negro; las barbas citeriores de las tectrices de la espaldilla, las interiores de las del centro del dorso hasta la raiz, la punta de las pilumas medias de la cola, el borde de las de la mano, las cohijas de la region posterior é inierior del ala, como tambien una pequera mancha en forma de media luna que se presenta en el borde de las harbas cxteriores de las rémiges secundarias, șon de un amarillo de azitire muy subicio; las rémiges ofrecen por lo demás un color gris pardo negro; las rectrices son tambien negras, si se ex ceptúa una pequeña mancía trastersal que se nota cerca de

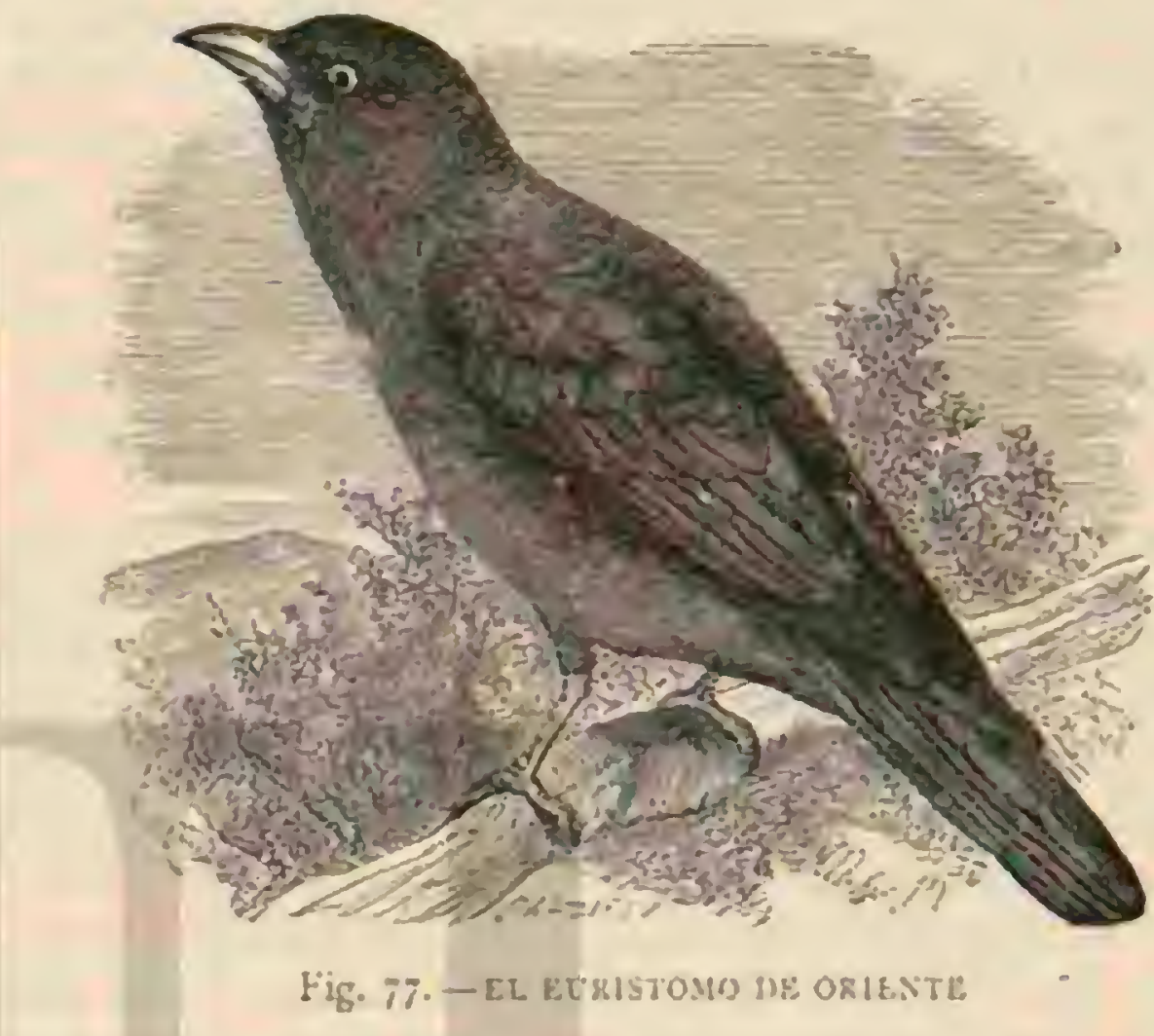

la punta de las barbas interiores y que vista por la parte infe. rior, afecta la forma de una faja; la cirada mancha no se presenta en las dos recerices medias, pudiéndose observar, por el contrario, en las barbas, lanto internas como externas, de las mas exicricures. El pico es de un negro brillante, con los bordes y la arisia de un blanco agrisidu; las patas son de un pardo amarillo. Eil macho y la hemura parecen no dife. renciarse en el color; los pequeios, por el conimrio, tienen el vientre gris salpicado de amarillo y el extremo de las plu. mas de la parte superior del cuerpo negras, con manchas y puncitos irregulares de un amarillo de anufre. Fsta ave mide ii", 22 de largum, el ala $6^{\circ}, 12 y^{\circ}$ la cola $6^{\circ}, 07$.

DISTRIBUCION GEOGIR ÁFICA. - Esta especic es propia de lava, donde la descubrió Horsfield.

USOS, COSTUMBKES X REGIMEN.-Scgun Raties, esta ave smele permanecer cerca do los estamques y de las cotrienics, y se alimenta de gusanos é insectos. Suspende su nido de una rama que pande sobre el agua: Horsicld la en. contró en vastos busques ricos en pantanos y rios.

Helier dice, refiriéndose a una especie afine, quie vive en los árboles mas aleos de los bosques, en bandadas de treinta á cuarenta individuos; $y$ que estas aves son tan confiadas y estúpidas, que se las mata una iras otra sin que huyan.

El currian di Sumatra (ñg. 79) es otra de las especies de esta familia, que solo difiere de la anterior por la cstructura de su pico.

\section{LOS CAPRIMÚLGIDOS -CAPRIMULGID压}

Los fisirostros noctumos ofrecen caractéres tan marcados que no es posible coniundirlos con los demás de sus conge- 
neres; en todas partes lograron atraer la atencion del hombre y han dado lugar a las mas singulares opiniones, como 10 prucban entre otras cosas la multitud y significacion de los nombres que se les han aplicado.

Los caprimúlgidos constituyen una numerosisima familia, compuesta de mas de cien especies, las cuales aunque se distinguen perfectamente por su exterior, no han sidio aun rigo. rosamente clasificadas por los naturalistas.

No es del codo impropia la denominacion de solombrins neslurnas con que se las designa en Alemania, dado que sus caractéres especificos mas generáles son los mismos yuc los de las golondrimas.

CARACTÉRES. I Los caprimúgidos SE distinguen por su especiai aspecto y organizacion, pudiendose notar dite rencias esenciales entre los diversos grupos; aseméranse menos a las golondrinas propiamente dichas que los buhos í los halcones. El tamaño es sumamente vario: algunas especies lo tienen igual al del cuervo, mientras en otras apenas aren taja al de la alondra; el cuerpo es prolongado; el cuello cor to; la cabera muy grande, anclas y plana; los ojos grandes ? bastante coniexos: el pico relativamenic pequcho, sumamente anclio en la parte posterior, corto, aplanado y muy adelgazado hăcia adelante; tiene la punta córnea y delgada, con is mandibula superior encorvada hacia abajo ó a un lado, y la arista obtusa y vuelia un poco hacia atrís; las mandibulas son prolongadas, de lo que resulia que la boca es inas grande que la de las demás aves; jumto a la arista se aburen las fosas nasales, que se presentan tubulares y muy cerca la una de la otra. Ins piernas son regularmente dé. biles; los tarsos muy cortos, con una caliosidad en la parte posterior y generalmente con pequeños escudetes, y cubier. tos con frecuencia de plumas ó sin cllas en la region superior; las dedos son cortos y debiles, excepcion hecha del medio, que se presenta muj desarrollado, está adeniás pro. visto de ura unia larga, dentada y encorvada hácia el lado interior y se enlaza genernlmente con el dedo interno por medio de un empalme; el posterior se dirige hícia atrís y csta enteramente libre, de modo que puede tambien volverse hicia adclante. I.as rúmiges son largas, estrechas y puntia. gudas, siendo la segunda de cllas y no pocas veces la tercera ó la cuarta mas largas que la princra; la cola se compone de dicz plumas, las cuales pueden preseniarse on muy diver sas formas; el plumaje esta compuesto de plumas lacias, grandes y suaves como las del buho; el color es oscuro y poco brillante, formando finos y graciosos dibujos; pero, como podra fícilmente comprenderse, está siempre en conso nancia con la localidad en que viven las dilerentes especies: asi las que moran en los desiertos ó en las estepas, lo tienen de arena; las de los bosques lo présentan parecido al de la corteza de los árboles, que es por otra parte el color do. minante, y ofrece tal uniformidad, que, segun Swainson, anguel que ha visto un caprimúlgido, puede desde luego decir que los la visto todos. Merecen especial mencion las sedas que circundan la boca, asi como tambien las cortas, finas y espesas cejas. En algunas especies preséntanse los machos con especiales adornos, consistentes estos en plumas largas y de forma casi siempre extrania, las cuales se encuentran, no solo en la region de la cola, como en las otras aves, sino tambien en las alas, pudiendosclas considerar como ré. miges de forma especial.

Segun Nizzsch, quien ha estudiado la organizacion interna de la especie europea, el esqueleto del cráneo y de los piés ofrece algunas particularidades en los caprimúlgidos. Los lados del maxilar superior son planos, anchos, neumáticos, como todos los huesos de la caja craneana; cl hueso lagrimal se articula con la parte lateral del maxilar supe- rior; los palatinos son planos y muy ensanchados en su parte posterior; los terigoideos sc articulan por tres superficies con el esfenoides; el hueso cuadrado carece de apólisis. En medio de las ramas del maxilar inferior existe una articulacion que no se observa en ninguna otra ase; y es que la inandibula inferior de los caprimúlgidos se compone, en efecto, de tres piezas uzue no se sueldan jamis entre si. La central, impar, forma la porcion horizontal de la mandibula y la parte anterior de las ramas ascendentes; las dos piezas posteriores representan la porcion terminal de la rama ascendente, se articulan por delante con el hueso cuadrado, y siguen una linea oblicua con la primera pieza: conticinen células aéreas que faitan en esta última.

la porcion pasterior del esternon estí encorvada por abajo, a to cual se debe que el estómago tenga poco lugar para dilatarse; como sucede en el cuclillo. Los diversos huesos del mientbro superior no presentan entre si las mismas relacio. nes que en los cipsélidos: el húmero, que es neunático, es inas largo que el omoplato; cl antebrazo es mas prolongado que el brazo, pero mas tambien que la mano.

1. A lengua es larga y estrecha y no tiene gran superficie, presentando varios resortes en sus bordes y en la cara su. perior. El hueso lingual es cartilaginoso: I laringe inferior no tiene mas que un par de mísculos; el esófago no pre. semta buche ni dilatacion en los caprimúlgidos de! antiguo mundo, al paso que ofrece una en forma de bolsa en varias especies americanas. El ventriculo subeenturiado es pręueino, con paredes gruesas; el estómago es membranoso, con paredes delgandas y muy extensibles. Iil bazo es muy pequeño y prolorigndo, como en cl cuclillo; y los riñones están conformados lo mismo que en las aves cantoras.

DISTRIRUCION GEOGRÁFICA.-I Los cantrimulgidos habitan todas las regiones de la tierra, excepto la zona polar. Existen dos especies en Europa y mas de cuatro en la Ané. rica septentrional: en el norte de Africa, en la América del centro y en las regiones correspondientes de Asia, va su nú mero en aumento considerablemente: en Australia existen tambien varias especies.

USOS, COSTUMBRES Y REGIMEN. - A Anque el érea de dispersion de las varias especies es bastante extensa, habitan tam solo los sitios que les ofrecen condiciones especialmente farorables: la inayor parte de los caprimúlgidos moran en los bosques 6 al menos se retiran al ellos para descansar: sin embargo, algumas especies prefieren las estepas, mientras otras eligen por morada el desicrto 6 las colinas y pendientes pedregosas y demás sitios por el estilo. Las varic. dades que viven en las montañas, suben hasta una gran altiiud: asi el chotacabras de Furopa, segun Tschudi, llega en los Alpes hasta la aitura de 1,500 metros sobre el nivel del mar; una especie que habita el Africa, sube en Habesch, segun dice Heuglin, hasta 4,000 , y Allen atestigua que el halcon nocturno asciende en los montes Colorndos a 3,000 .

Probablemente solo las especies que viven en el ecuador, tienen morada fija; todas las demás están pasando contimuamente de un punto á otro, al paso quue las de las regiones septentrionales emigran generalmente con entera regularidad. A principios de año aparecen ya en su patria, y permanecen en ella hasta los primeros dias de otoño; en sus eunigraciones recorren vastas exterisiones de territorio, de modo que nue:tra especic europea llega hasta el Africa central. No se muesiran sociables, sino cuando riajan; en los demás casos las parejas viven aisladas y se rechnzan mutuamente del lugar de su morada; este suele ser bastante reducido, en términos que alli donde se rcunen muchas de estas aves, á veces en un jardin, viven varias parejas. En el norte de Europa huy'en de la presencia del hombre, oal meros se presentan tan solo 
de noclie y muy raras veces en las inmediaciones de las aldeas; por el contrario, en el mediodia se establecen en el interior de estas 6 en sus inmediaciones, siendo los jardines su habitual morada. La gran mayoria de las especies se afimentan exclusivamente de insectos, los cuales, juntamente con los prequeños animales vertebrados, constituyen la ali. mentacion de algunas: distinguense unas y otras por su extraordinaria voracidad, circunstancia por la que son sumamente úitles en nuestros bosques. Con la destreza propia del halcon ó de la golondrina, ora rosan el suelo volando, ora se remontan á lo alto, describen mil vueltas y rodeos, a cual mas viros y graciosos, al rededor de los matorrales y copas de los árboles, y cogen.al vuelo los insectos que grasan zum. bando cerca de ellas, apoderándose tambien de los que cr. cuentran dormidos sobre las hojas, en los tallos y aun en el suclo. Jas grandes dinensiones de su boca les permiten tra. gar los escarabajos de mayor tamano y especialmente aquellos que son respetados por las otras aves: la especic curopea devora uno tras otro una docena de escarabajos peloteros 0 de dermestos de la grasa, pudiendo asimismo tragar los ma. yores lepidópteros nocturnos, los grillos y las langostas. Para hacer mas facilmente la digestion, las especies que se alimen. tan de insectos, degluten pequenas piedrecilas, que van á recoger en los lugares arenosos. Por punto general comienzan su caza i eso del anocheccr, continuanla por algunas horas y luego la interrumpen para emprenderla de nuevo al des. puntar del dia, y van y’a á descansar aun antes que el sol se levante sobre el liorizonte. Sin embargo hay tambien en ello sus cicepciones: las especies de América cazan muchas reces durante el dia, y no solo en los bosques sombrios, sino tan. bien en sitios despejados, aun brillando el sol en toda su plenitud; las demás suelen estar posadas durame las horas del dia sobre los troncos de los árboles derribados, en el suclo y en las gratas mas oscuras formadas por los peinascos, y se agachan tanto al descinsar, que parecen mucho mas anclias que altas.

Las caprimúlgidas no se muestran como séres dotados de la facultad de moverse, sino cuando vuelan; en tanto que se hallan posados cn las ramas de los árboles, parecen estar como adheridos a ellas, y en el suclo están mas bien acosta. dos que posndos. Su paso es lento, fatigoso y desmayado, y nunca recorren mas que algunos metros; el ruelo, por el contrario, es un término medio entre el de la golondrina y cl del halcon, y se distingue, tanto por su ligerezs y clegan. cia, como por su gracia y facilidad. Raras veces se remontan a las alturas, no por la dificultad 6 imposibilidad de hacerlo, sino porque en las regiones bajas de la atmósfera encuentran mas alimento que en las elevadas; sin cmbargo en sus largas peregrinaciones se les ve a veces subir á una altura considerable, $y$ las especies que vuelan durante el dia, se remontan con frecuencia á las mas altas regiones del espacio.

Su sentido mejor dotado es el de la vista, como lo prueba la magnitud de sus ojos, y siguen lnego en órden á su des. arrollo el oido y el tacto; no sabemos hasta qué punto al. canza la delicadeza del olfato, pero si podemos afirmar que el gusto es en ellos muy imperfecto.

Sus facultades intelectuales están poco desarrolladas, pero no en el grado que generalmente se supone: es verdad que estas aves causan al observador una impresion muy poco favorable cuando están sonolientas, y que las que por casualidad fueron cogidas, no aciestan à defenderse de otro modo que abriendo su descomunal boca y lanzando roncos graznidos; pero no se conducen ciertamente de la misma manera las co. gidas en perfectoestado de vigilia. Muestran por lo conıun una curiosidad necia y una confianza sin limites: pero no tardan en distinguir perfectamente á su enenigo y se valen aun de la astucia para defunderse á si mismos y i su progenie de la persecucion y lazos que este le tiende.

Los caprimúlgidos no construyen verdndero nido; depositan sus hucros en el suelo sin practicar préviamente en él la mas ligera excavacion: el número de estos se limita á dos y las mas de las especies no ponen mas que uno. Lin su excelente tra. tado sobre el modo cómo procrean y se projagan cstas aves, distingue Konig. Warthausen cuatro clases de liueros: los que ponen los chotacabras que viven en el hemisferio septentrional, cspecialmente en la rona temgllada del mundo antiguo, son de un color blanco de leclre ó amarillento, con manchas parduscas ó azuladas cenicientas y algo brillantes; los puestos por los chotacabras del no:te de América son muy resplan. decientes y ofrecen un color verde gris blanquecino, con rayas, manchas y punitos pardos $\delta$ grises colocados mus cerca los unos de los otros; los de los que habitan en la region meridional de la parte del mundo últimamente citada, no tienen brillo alguno, son muy tenues y presentan dibujos de un rojo amarillo of de un gris violeta sobre fondo amarillo de isabsela azulado rojizo ó de un cncarnado muy subido, notín. dose en los mas ligeras nubecillas y raras veces manchas y rayas toscamente trazadas; los de los podargidos é ibijos, por último, no muestran mancha alguna y son de un color blanco mas ó menos puro. Ias hembras son probablemente las únicas qque cubren; esto no obstante, los dos sexos mues. tran el mas viro interés por su nidada y la defienden del mejor modo contra todo ataque. Algunas especies hacen esto sllim:o de una manera especial: segun dice Audubon, toman los huevos, se los meten dentro de su monstruosa boca $y^{\circ}$ los llevan á otro sitio del bosn̨ue gue les parece mas seguro, y alli continuan la incubacion. Los pequeños salen del huero cubiertos de un plumon bastante espeso: al principio parecen muy feos, a causa de su gruesa cabeza y grandes ojos: pero se desarrollan con mucha rapidez. revisten luego el mismo plumaje de los padres. Scegun licmos podido observar, todas las especies cuidan con carinosa solicitud de su progenie, de. fendićndola con todas sus fuerzas.

Los caprimúlgidos cuentan muy pocos enemigos peligro. sos. El hombre que pudo observar y conorcer estas aves, no las persigue nunca, si bien se ha de observar qque el mira. miento ó indulgencia con que se las trata, no es resultado de haber el hombre reconocido los servicios que jrestan, sino mas bien de la circunstancia de haberles considerado como aves de mal agiiero, cuya muerte puede acarrear fatales consecuencias. 'Tal es la opinion de los indios, blancos y negros que viven en la América central, ia cual es tambien comun á los españoles y á varias tribus africanas Los aldeanos y labradores de Alemania miran con aversion a estos séres in. ofensivos, no por otro motivo, sino porque se figuran que sus grandes bocas no sirven para otro objeto sino para chupar la leche á las cabras. No faltan, sin embargo, gentes ignorantes que matan á nuestras aves por el solo placer de matar. Ade. más del hombre, persiguen á estos animales algunos carniceros y las aves de rapiña, asi como tambien las serpientes de mayor tamaño, aunque parece no les causan grandes daños.

CaUtIVIDAD.-Dificil es criar la major parte de los caprimúlgidos; pero no es imposible, si se les coge pequeños en el nido y se les éncicra luego en una sala ó jaula donde al principio estén bien abrigados y se les cuide del modo de. bido: asi se les puede conservar por largo ticmpo. En el ell. cierro no son a la verdad aves muy agradables; pero llegnn indudablemente á serlo aqueltas que pudieron atraerse la aten. cion del aficionado. Las especies que se alimentan, asi de insectos, comso de neqquenos animales vertebrados, se conservan relativamente con mayor facilidad que las otms y viven anos enieros en su encierro. 


\section{LOS PODÁRGIDOS-PODARGINA:}

Los podárgidos difieren mucho de los demás fisirostros, y por 10 mismo se les ha clasificado algunas veces en otros órdenes. Cabanis, por cjemplo, los reune en una misma familia con los coracias y los euriláimidos: no se puede negar que los podárgidos se aseurejan á los segundos por la forma del pico; pero teniendo en cuenta el conjunto de sus caractéres,

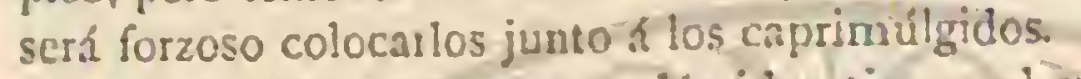

CARACTÉRES. - Los podárgidos lienen el cuerpo prolongado; cuello corto; cabeza aucisa y plana; alas cortas; cola larga: pico grande, plano, nas ó menús liendido, muy ancho en su basc, corro en fa pania, completamente córneo, con mandibulas casi igunles y bordés lizos- las fosns masales es: tín situacias en la base del pico y ocultas en parte por las

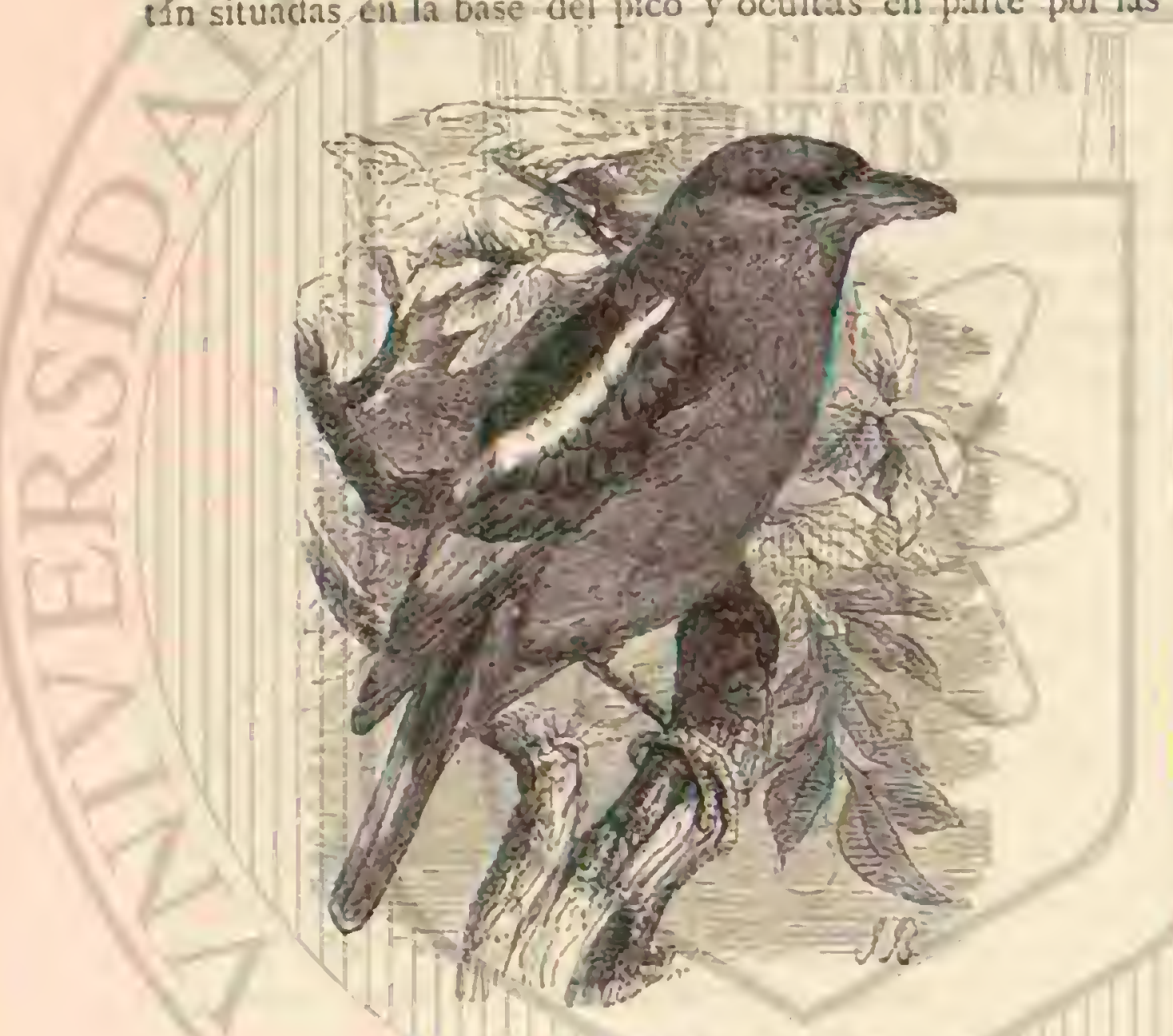

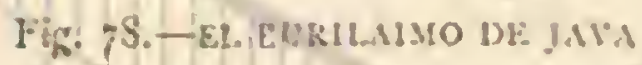

plumas de la frente; los tarsos son cortos, aunrue no tanto como en los caprimulgidos: tienen tres dedos por delante y uno por detrás, no réversible. Sclater cita como un rasgo notable el de tener el dedo externo cinco falanges. El plumaje es abundante, de colores oscuros; las plumas de la base del pico, y en algunas especies las de la region auricular, se tras. forman en scdas.

DISTRIBUCION GEOGRÁFICA. - Todos los podár. gidos conocidos actualmente habitan los bosques del sur de Asia, de la Nueva Holanda y de las islas situadas en aquellos mares.

USOS, COSTUMBRES $\Psi$ RKGIMEN.-Poco conocido es el género de vida de estas aves, nunque se sabe que difiere apenas del de los caprimúlgidos. Además de esto, cada especie tiene costumbres que le son propias, y por lo tanto no podemos generalizar nada sobre esic junto.

\section{LOS PODARGOS - PODARGUS}

CARACTÉRES.-ESte gTupo, que contiene doce especies, se distingue por los siguientes caráctéres: el picó es. corto, ancho, aplamado en los lidos, ercorvado por delante, formando un gancho muy pronunciado, con la arista tambien muy pronunciada; su cortanic borde encrja en la mandibula inferior, que se presenta asimismo aplanada; las fosas nasales y los bordes de la boca se hallan guarnecidos de pelos á ma. nera de sedas; las patas zon muy robustas; el tarso, falto de plumas, presenta en la parte anterior seis placas $\delta$ ešcudetes; las alas son puntiagudas y redondeadas, siendo sus rémiges tercera, cuarta y quinta las mas largas, $y$ la segunda $y$ sexta las mas cortas; la cola es larga y puntiaguda; el plumaje, que es muy abundante, se jresenta blando como el de los buhos y está compuesto de plumas largas y tilamentosas;-solo algunas de estas se trasforman en verdadems sedas en la base del pico.

- DISTRIBUCION GEOGRÁFICA.-Todas las especics de este grupo viven en Australia, Nueva Guinea te islas ad. yacentes.

\section{EL PODARGO HUMERAL-PODARGLS HUMERALIS}

CARACTERES. - El podargo humeral (podargus anstra.

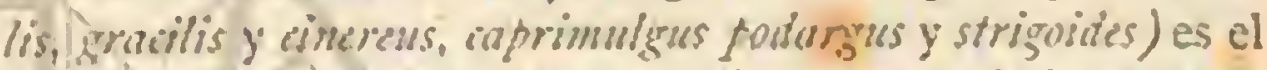
individuo mas notable del grupo: tiene la talla de la corneja; el loma es de un color pardo gris oscuro, salpicado de puntitos blanco agrisados y negros; la regrion de la espaldilla es tambien blanco agrisada, con rayas diagonales en zig zag; ia parte superior de la cabeza y de las alas presentan delgadas rayns negras, sumamente pronunciadas; las pequeñas cobijas del ala, de un pardo oscurn, están salpicadas en la parte curvia de esta de puntitos claros, los cuales se hallan limita. dos interiormente por una seric de manchas blanco agrisadas y punteadas de pardo; las rémiges de la maro ó primarias presentan alternativamenie en las barbas externas fajas dia. gonales negras y gris blanquecinas, salpicadas de puntos de color oscuro; las del brazo ó secundarias y las rectrices estan sembradas de pequeños puntos claros y negros sobre fordo pardo agrisado, con fajas trasversales imperceptibles; las par. tes inferiares, finalmente, son blanco agrisndas, con puntitos y fujas diagonales de un tinte pardo, y rayns negras y delgadas; estas hiltimas forman en los lados del buche varias man. chas de mayores dimensiones, las cuales se hallan limitadas interiormentc por otrns dingonales de un blanco agrisacio elaro; el pico es de un pardo claro con refejos purpuireos; las patas de un pardo accitunado, y cl ojo pardo amarillento. No añadimos mas sobre el color, pues este se ascineja tanto en ias varias especies del grupo, que seria necesario hacer una larga descripcion del mismo para fijar los caractéres diferen. ciales.

DISTRIBUCION GEOGRAFICA.-Esta es una de las aves mas comunes en la Nueva Gales del sur.

USOS, COST UMBRES Y REGIMEN. - Gould y J. Ver reaux nos han dado á conocer las costumbres y género de vida de los podargos, y nos dicen que las diversas especies se ase. mejan de tal modo por su genero de vida, que se puede apli. car $\{$ todas lo que se ha observado en una de ellas.

¿Hay en sustralia, dice Gould, numerosis esjecies que pertenecen a este grupo y parecen destinadas a predominar por su número sobre las langostas. Son séres puesados y ca. chazudos; no cogen su presa al ruelo, sino en los irboles; cuando ro cazan, permanceen en los lugares descubiertos, en los muros, en los tejados y sobre las tumbas de los cementerios. A ello se debe que las gentes supersticiosas los miren como mensajeros de interte, impresion que no disminuye al oir su voz desagradable y ronca. Por lo que hace a la reproduccion, difieren de todos los demás Tisirostros' noctumos; construgen un nido formado de ramitas y le fijan en los ár. boles.

* Esta are es la mas incolente de todas las conocidas; cs dificil despertarla; mientras que el sol ilumina el horizonte permanece dormida sobre una rama, con el cuerpo apoyado en ella, encogido el cuello, oculia la cabeza bajo las plumas de la cspaldilla, y de al modo inmóvil, que mas bien parece 
un nudo del tronco que un ave. Debo advertir tambien que se posa perpendicular $y$ no paralelamenic á la rama; es tal su tranquilidad y tan bien se armoniza el color del plumaje con el de la corteza, que solo le reconoceria una vista ejercitada, aunque acostumbra a posarse en las ramas no guarnecidas de hojas. J

Su sueno es tan profundo, qque cuando dos podargos, macho y hembra, están uno junto a oiro, que es lo mas frecuente, se puede tirar sobre uno, sin que el orro se mueva un ápice. Se les puede tirar piedras y darles de palos sin que se vayan, $y$ hasta es fícil cogerlos con la mano. Aun dacio el caso de que se les despierte, no hacen uso mas que de in fuerza precisa para no caer á tierra; llegan revoloteando $\mathbf{i}$ la rama mas próxima, cógense a ella y se vuelven á dormir. Esta es la regla general; solo por excepcion se ve al podargo franquear un pequeño espacio al vuelo durante el dia.

No sucede otro tanto cuando se acerca la noche; á la lle. gada del crepúsculo, despiérase el ave, se estira, alisa su plumaje y emprende el vuelo; en aquel instante es vivar y activa, distinguiéndose por la rapidez de sus movimientos; remonia por los aires 50 desciende; se prosa cerca de los espesos matorrales; penetra en ellos ayudíndose con la cola y recorre todas las ramas cazando los insectos que se han refugiado alli para pasar la noche. Imitando à las urracas, golpea con su picola corteza para que salgan los séres alli oculios, y persigue a su presa hasta en el interior de los troncos de los árboles huecos. El vuelo de esta ave es defectuoso, corto é interrumpido, como se puede deducir de la pequenez de las alas; pero el animal no tiene nada de torpe, $y$ à veces vucha de rama en rama jugueteando. Cuando cierra la noche cesan sus movi mientos: Gould cree que no se alimenta sino de insectos; Verreaux asegura que se apodera de otros animales.

Durante el invierno estas aves cazan los insectos escondi dos en las grietas y hendiduras de los árboles, y cuando les falta este alimento, comen caracoles y otros pequeiros ani. males acuáticos, que van á buscar i los pantanos. Cuando ponen, son mas carniceros: entonces devoran las avecillas que logran arrebatar de los nidos, jo si la presa us demasiado grande, como, por ejemplo, del tamaño de los alcianes, có. geria con el pico, se la llevan á una rama gruesa, y despues de haberia golpeado varias veces à derecha è izquierda, se la tragan toda entera. Ios podargos no cazan sino á la hora del crepúsculo: cuando acaba de cerrar la noche, permanecen inmóviles en una misma rama, y algunas horas antes de salir el sol emprenden de nuevo su caza, como lo hace el chotacabras.

La voz del macho es fuerte y desagradable, y no deja de causar algun asombro al que la oye por primera vez: asemé. jase, segun Verrcaux, al arrullo de la palona. Como ficilmente podrá comprenderse, los gritos del ave son mas agurios ¿́ intensos durante el periodo del celo: estos suelen ser en tonces la schial del combate; acude luego otro macho, y se emperia una renida lucha, la cual no termina hasta quedar vencedor uno de los dos rivales. La época del celo tiene lugar en los meses de julio y agosto; y el apareamiento sé realiza en la hora del crepúsculo, despues de cuyo acto se retiran machoy henbra à una nisma rama, donde continuan posados el uno junto al otro y en completa inmovilidad hasta que comienza nuevanente su cara. I os dos sexos déspliegan la misma actividad para la construcción de un nido pequeēino y plano, compucsto de pequenas ramas, el cual suelen colocar en la bifurcacion de una rama horizontal á unos dos metros del suelo, de modo nue se puede alcanzar fácilmente con la mano; tapizanio interiormente con algunas briznas y plumas; pero lo hacen tan toscamente, que á través de los materiales que lo componen, se ven brillar lus dos ó cuatro

Tomo III huevos prolongados, biancos como la nieve y parecidos álos de algunas paiomas, que en él deposita la hembra Esta y el macho cubsen alternativamente: la primera suele hacerlo durante el dia, y apenas llega la noche, cede su puesto al segundo, qute no abandona el nido hasta la vieita de su conp̧ariera Continuan ambos del mismo modo hasta que salen á luz los jequeñuelos, despues de lo cual el macho parece cncargarse exclusivamente de alimentar á toda la familia. Cuando el nido esta muy expuesto á los rayos del sol y son los hijuelos demasiado crecidos para que la madre pueda cubrirlos por completo y preservarlos de aquelios, trasládalos la pareja al hueco de algun árbol, hecho tanto mas digno de ser notado cuanto que los padres arrostran impasibles la intemperic en los sitios donde descansan.

los pndargos jóvenes abandonan el nido á principios de

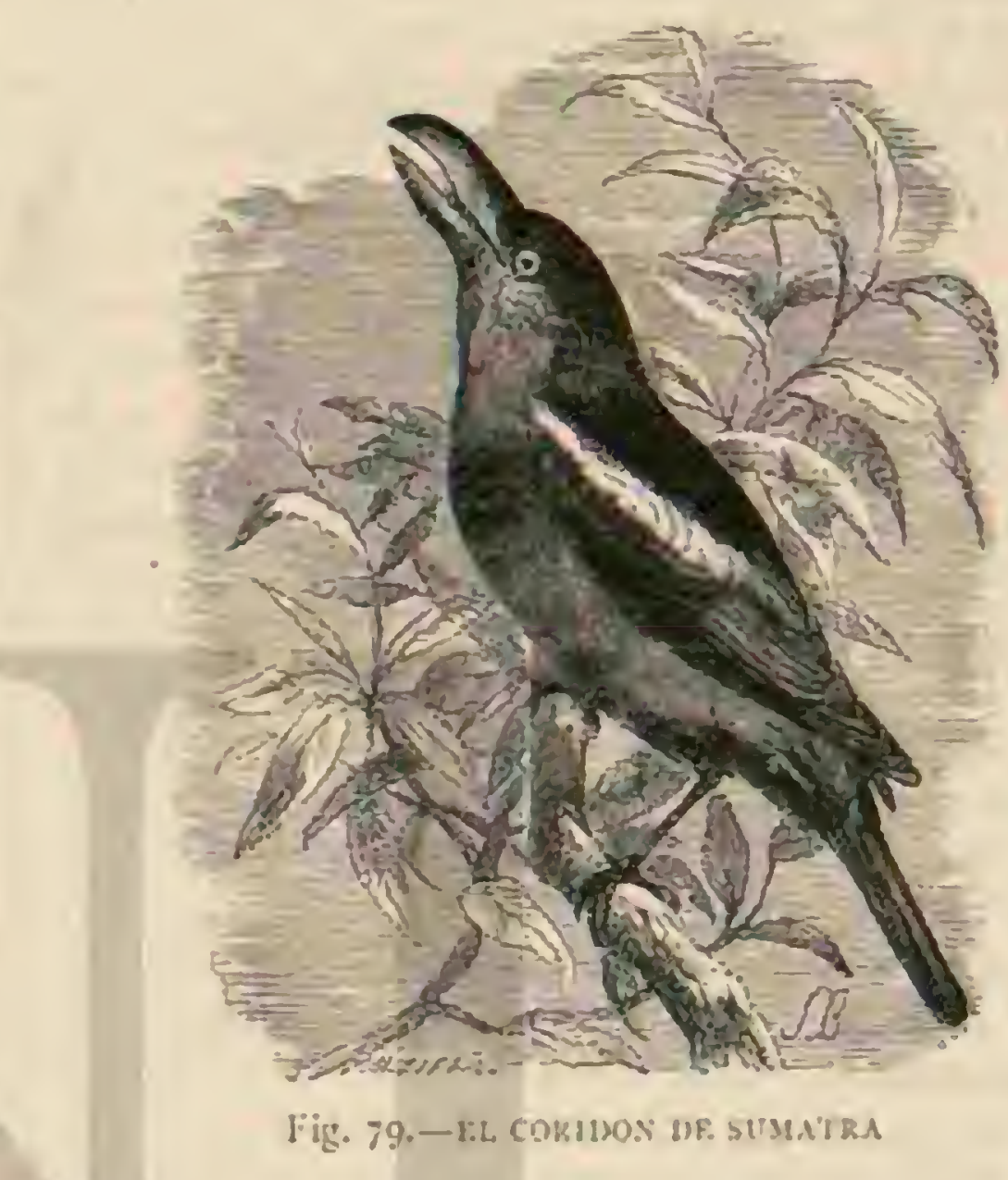

noviembre; pero es probable que continúen todavia por algun tiempo en compania de sus jadres.

Cuando hace frio se encuentran á veces individuos que permanecen varios dias inmóviles en una rama, y como sumidos en un sueno letrirgico del cual no despiertan sino cuando se les toca. Gould es el primero que hizo esta observacion y Verrenur la confirmó plenamente.

- Sin querer asegurar del todo que estas aves tengan un verdadero sueño invernal, dice Ciould, no puedo menos de decir lo que he observado. Las he visto muchas veces reti. rarse a los huecos de los árboles donde permanecieron largo tiempo; y habiendo cogido aigunas, las encontré tan gordas, que no pude preparar las pieles. No veo por qué no podrá iener el ave un stecho invernal análogo al que se observa en los mamiferos, por mas que estos parezcan muj superiorts en organizacion.

A mi modo de ver la opinion de Gould no es admisible, pues el aislamiento y el sucho, aun en el mas alto grado en gue sucle presentarse en los podargos, nada prueba iodavia eri unas aves que, segun se lleva dicho, no salen de su estado de somnolencia ni aun disparando un tiro delante de ellas.

CaUtividad.-Si los podnrgos se cogen pequeños en sus nidos, segun Verreaux, se domestican raipidamente; familiarizanse y reconocen a su ducio ; pósanse á reces sobre su cabeza; llegan á penetrar en su cama, expulsando de ella a otros animales yue tienen la misina costumbre, y mudan de tal modo su caracter, crue llegan à romar su alinento aun en 
pleno dia. Ultimamente se han traido varios podargos vivos á Furopa: en i $\$ 6 z$ llegó el primero álóndres; en $1 \$ G_{3}$ se recibió el segundo en Amsterdam; y algun tiempo despues recibi yo el tercera. En los últimos años he cuidado yo mismo it varios de ellos, y me ha sido además dable observar á otros, de manera que puedo lablar por propia experiencia de las costumbres del ave en cautividad. La primera que tuve en mi poder, era tan mansa, que no solo tomaba el ali. mento de mi mano, sino que tambien se dejaba coger sin oponer la menor resistencia; quedabase posarla sobre aquella y se dejaba llevar de una á otra parte de là sala, sin dar muestra alguna de querer abandonar su pliesio.

lisa una ave tranquila é incolente: dumnte el dia permanece inmóvil en cl mismo sitio, en la posicion descrita por Gould; pero duerme inenos profundamente de lo que dice ei naturalista, pues basta llatmarla para grie se despierte. Al principio no producia mas que un ligero numustlo, algo me lancólico, que se podia expresar por houmm; yo crei que cra su grito de llamada, y habiendo tratado de imitarle para lla mar la atencion del podargo, zuve el gusto de ver, no solo que se levantaba al oirle, sino que nue respondia: siempre que hice la prueba obtuve el mismo resultado. Cuando le presentan un raton ó un pajarillo, se baiancen y grita con mas vigor; fija sus ojos muy abiertos en la presa que codicin, y acaba por precipitarse sobre ella. Asi coge los gusanos; se traga de una rez un raton grande ó un gorrion que tenga las alas cortadas, si bien necesita algun tiempo para ello, pues. media liora despues de haberse engullido el roedor, le sale la cola por la boca. Digiere perfectamente, puesto que rara ver se encuentran en su jaula restos que haya devuelio. Ve. muy bien de dia, aunque sca desde léjos: cerca de su jaula hay un cstanque, y con frecuencia le llaman la atencion las aves acuáticas que habitan en él; parece que los patos son los que mas le interesan. pues los mira fijamente, balanceando la cabeza lo mismo que las lechitas. Despues de ponerse el sol es mayor su vivera, si bien no se mueve mucho. Cuan. do ha comido todo lo que quiere, permanece mas ó menos inmóvil en el mismo sitio: entonces se oje su voz con mas frecuencia, y emite los sonidos con ntievo vigor. Una ver la puse en una pequeña jaula llena de aves, é hizo los mas singulares movimienios, como si recordase que en su pais habia sostenido frecuentes luchas, y que alli era tralada como un buho. Viéndose en tan numerosa companiá, tendió el cuello hácia adelante, de tal modo que la cabe\%a, el cuerpo y la cola Tormaban una linea reça; luego lanzó gritos muy distin. tos con su roz ordinaria, los cuales podian expresarse por krac, krac, kraerae, krackac, kraekae, krackackack; abria y cerraba la boca, y procuraba asustar á sus companeros de cautividad manteniéndose mas bien á la defensiva que a la ofensiva. A un gorrion que se acercó demasiado, cogióle por el pico y le sacudió con fuerza; pero el pdjaro logró escapar.

Encerrada algunos dias con otros gorriones, no los aco. metió: mas il pesar de todo no dudo que devore tambien pá. jaros, como asegura J. Verreaux; y es probable que coja los hijuelos en sus nidos cuando no pueden huir ni defenderse.

\section{LOS BATRACÓSTOMOS - BATRA- CHOSTOMUS}

CAR A CTÉR FS.--Los batracóstomos (boca de rana) son mas pexquenos que los podargos, pero su pico es mas grande, mas ancho y aplanado en su base, su arista se encorva lige. ramente y la punta es ganchuda; la mandibula superior, mas ancha que la inferior, sobresale de ella por todos lados; las fosas nasales son angostas, se hallan $\mathrm{d}$ los lados y cstan cubiertas de pluma; las alas son cortas y redondeadas; la cola corta ú obiusa; las patas cortas y bastante fuertes; los dedos vigorosos y muy movibles; el extremo puede inclinarse completamente liácia atris

DISTRIBUCION GEOGRÁFICA.-Los batracóstomos habitan las Indias y las islas vecinas.

\section{EL BATRACÓSTOMO CORNUDO-BATRA- CHOSTOMUS CORNUTUS}

CARACTÉRES.-El batracóstomo cornudo, ó de Java, (Batiacostomus auritus, podangus anritus y de Fullershonio, bombygstumues fivllersturnii) se distingue por la belleza de su plumaje: en los dos lados de la cabeza, en la region tempo. raly por encima y detrás del ojo nace un mechon de plumas desprovistas de barbas, que cubren completamente los ojos, haciendo que parezca la calseza extraordinariamente grande; el lomo es rojo ciaro, con listas negras y angostas dispues. tas formando $\mathrm{S}$ s: en la nuca laay una faja blanca en forma de media luna; las espaldillas presentan grandes manchas de un blanco azulado, rodeadas de semicirculos negros, y sobre la irente y detrás del ojo hay otras de color amarillo de fue. go. Ia garganta, la parte inferior del cuello y el vientre son blancos, con $\$$ S negras; el pecho es de uri blanco rojo man. chado de negro; la cola de un rojo claro, con siete í ocho frijas oscuras rodeacias de negro y me\%cladas con un gran número de lineas del mismo tinte formando $\mathrm{S} S$; en las alas hay tajas semejantes; el ojo es de color amarillo de azufre; el pico del mismo tinte mas claro y las patas parduscas (figura 8 i).

USOS, COSTUMBRES Y RÉGIMEN.-Bernstein noS dice que esta are habita en las espesuras, especialmente en las de las palnteras de Allangallang, las cuales se encuentran muy abundantes á una altura de mil metros sobre el mar. F. obsertadó citado no la vió nunca en los sitios cultivados, y segun los indigenas, no se encuentra tampoco en la llanura. Bernstein no dice nada tocante á la voz, costumbres y modo de vivir del ave, describiendo en cambio mus detallada. mente su nido. Vió uno, que se encontró casualmente en medio de unas canas en el momento de cortarlas: era de forma oval, plano, un poco ahuecado en su centro, y cubierto por fuera de algunas pequeinas hojas, componićndose el resto de las grises plumas del are: este nido es tan poco consis. tente y pequeño, que apenas puede caber en él el animal cuando empolla. El batracóstomo cornudo que observó Bernstein, estaba posado sobre un tallo de cana que sostuni: e] nido; tenia las dos patas muy cerca la una de la otra y el cuerpo paralelo con aqquella. Cubre los hueros tan solo con el vientre, como lo hacen los klechos; Bernstein no encontró en cl nido mas que uno, 'é ignora si el ave pone mas: es oval $y$ prolongado y se redundea bruscamente en sus dos cxtre. mos; tienc un tinte blanco mate, en el que se destacan manchas y puntitos mas ó menos grandes $e$ irregulares, de color pardo rojo, cuyo número aumenta cerca del extremo grueso, al rededor del cual forman una especie de corona.

\section{LOS EGÓTELOS - EGOTHELES}

CARACTÉRES. - I as estiecies que pertenecen it este género siguen yresentando numerosas relacioncs con los caprimillgidos: su cuerpo es prolongado y robusto; al cuello corto; la cabeza redondenda ó menos plana que en las rés. tantes especies; tiene la cola redondenda y de mediana largura; los tarsos largos, delgados y desnudos; los dedos cortos, raquuiticos y completamente divididos; el pico corio, ancho, grueso, hendido hasta el nivel del ojo, comprimido en la base, adclgazado y en forma de gancho en la punta;

\section{m.}


está provisto en su centro de una especic de rodete que so. bresale, y va desde la punta hácia la frente; en la mandibula inferior hay en el extremo una especic de canal en el que encaja el gaucho de la superior. El plumaje es blando; la frente, las mejillas y la barba tienen las plumas prolongadas y descompuestas que llegan a cubrir el pico y forman una especie de cresta frontal.

\section{EL EGÓTELO DE NUEVA-HOLANDA -AEGOTHELES NOVAE-HOLLANDI}

CARACTERES. - El egótelo de la Nucra. Holanda (ca frimulgns Noire. Hollandive, cristatus, silfalus !' lumsulatus) se asemeja bastante a las pequeñas aves de rapina nocturnas, tanio por su talla, como por sus costumbres. Su largo total es de $1^{\prime \prime}, 25$ y la anchura de sus alas de $0^{\prime \prime}, 30$; tiene el lomo negro pardo, salpicado de pequeños puntos grises, los cuales se hacen mas visibles en los lados del cuello y en el vientre; donde forman fajas transversales de un tinte descolorido pero mas claro; el centro del vientre, las ralgas y las tectrices de la parte superior del ala son blancas; nótasc una mancha de este mismo color, pero algo parda, en la region anterior de la oreja; la parte posterior del cucllo presenta al. gunas plumas puntendas de un color mas claro ó mas oscuro las rémiges son de un color pardo de tierra oscura; las de la mano ó primarias tienen además en sus barbas externas man chas transversales blanquecinas, al paso que las del brazo ó secundarias ofiecen fajas con puntos agrisados; las rectrices, de color pardo negro, cstan adornadas de doce fajas trans versales y delgadas de un pardo gris, con puntitos mas oscu ros, las cuales no se notan nunca en las barbas internas de la segunda y cuarta; el pico es negro y está circundado de largas sedas del mismo color; el íris es pardo de nuez, y las patas de color de carne. La hembra no difiere apenas de macho; 105 jóverses tienen el plumaje mas oscuro que los adultos.

DISTRIBUCION GEOGRAFICA.- Esta are se cn cuentra en todo el sur de la Australia y en la Tasmania: es sedentaria y habita lo mismo las breñas de la costa que los bosquers de poci espesura del interior de las tierras.

USOS, COSTUMBRES Y REGIMEN. - Se asemeja tanto por'sus costumbres \& los buhos cnanos como a los chotacabras. 'Todo el dia permance en el hucco de un árbol, en el eucalipto con mas frecnenrin, y se oculta tan bien, que no es posible divisarla; pero hay una particularidad curiosa que indica su presencia; y es, que cuando se toca el tronco donde se laalla, trepa rajpidamente hasta la entrada del agu. jero para ver quién Hlega a turbar su reposo. Si se cree segura vuelve a su escondrijo y permanece quieta hasta que la rucl. ven á inquictar; solo cuando la molestan mucho vuela hácia otro árbol y se oculia en un nuevo agujero, 6 en las ramas mas espesas. Vuela con bastante lentitud, en linea recta, y sin hacer bruscos. recortes; por su manera de posarse mas bien se parece á los buhos que á los chotacabras, diferen. ciándose de estos últimos por colocarse, no en direccion pa. ralcla a la ramia, sino transversalmente. Cuando se le sorprende, vuelve la cabeza á todos lados, y si se le coge, lanza un silbido á la manera de los buhos.

Ciould dice que el egótelo-pone dos veces al año: en e! pais de Van Diemen se encontraron polluelos recien uacidos en el mes de octubre, y en la Nueva Gales del sur el observador arriba citado logró obtener huevos aun en el mes de enero. Esta ave no construye verdadero nido, sino que deposita sus cuairo ó cinco huevos redondos y enteramente blas: cos entre el polvo de los huccos de los árboles carcomidos, sin haber dispuesto préviamente ninguna yacija.
Cautrurdad.-Carecemos de detalles precisos acerca del género de vida de esta ave en cautividad: Gould ajice haber conservado una pareja durante algun tiempo: cuando se acercaba ailguien erizaban las plunias de la cabeza, silbaban y refugiabanse en un rincon de su jaula.

\section{LOS IBIJOS-NYCTIBIUS}

CARACTERES. - En la América del sur existen unos caprimúlgidos que se diferencian de los que acaba:nos de reschar por tener su pico una forma especial. Es triangular, desmesuradamente ancho en la base, comprimido hácia el extremo, que se dobla y constituye un gancho romo; está hendidu hasta el ángulo posterior del ojo; es en gran parte membranoso, y le cubren plumas pectineas y sedas prolon. giddas; los bordes de la mandibula superior se dilatan en el nacimiento del gancho córneo, y forman un diente saliente y obtuso. A partir de este la mandibula inferior, cuyos bordes son lisos, encajona la superior, mientras que esta se encaja en la otra en todo el resto de su extension. Los ibijos se ca. racterizan ademås por tener el cuerpo grueso; cabcza muy voluminosa; cola proporcionalnente larga y' algo redondeada; plumnje blancio y abundante; alas muy prolongadas y sub. agudas, con la sercera rémige mas larga: tarsos cortus; dedos delgados; unas grandes, corvas y comprinidas, excepto ia del dedo medio, que se dilata en su borde interno, siendo cor. tante y no pectinea.

\section{EL IBIJO GIGANTE-NYYCTIBIUS GRANDIS}

CARACTÉRES.-El ibijo gigante, ó simplemente ibiju, segun le llaman los guaranis, palabra que significa comedor de tierra, es la especie mas grande de este género y de toda ia familia de los caprimúlgidos. Segun el principe de Wied, mide $\left(1 ", 55\right.$ de largo por $1^{m}, 25$ de amplitud de alas; cada una de estas plegada tiene $1^{m}, 40$ y la cola $0^{\mathrm{m}}, 2 \%$. Las tectrices del lomo, de un pardo de orin en sus bordes terminales, presen. tan fajas trasiersales en forma de $\mathrm{S}$ y rayas de color muy oscuro sobre fondo blanquizco leonado; la barba y la garganta son de un pardo rojo de orin, con delgadas rayas tras versales de color negro; la viltima de estas dos partes y cl centro del pecho se presentan salpicados de manclias irregulares de un negro pardo; las subcaudales son blancas, con delgarlas rayas oscuras trasversales y en rig zag; las cobijas colocadas a lo largo del antebrazo, son de un pardo rojo adornado de listas trasversales negras, muy cerca las unas de las otras; las tectrices de la cara inferior del ala son negras, con fajas dingonales de un blanco leonado; las rémiges primarias, de un negro pardo, y las cobijas de la region de la mano presentan en las barbas cxternas listas trasiersales de un gris pardo, colocadas â muy puca distancia las unas de las otras, y en las internas manchas imperceptibles, las cuales constituren dos ó tres fajas trasversales, anchas, grises y pla. teadis, con puntos oscuros en el último tercio de la punta; las rémiges secundarias, de un gris plateado, y las rectrices tienen los bordes de un pardo de orin y fajas diagonales de manchas negras; el pico es de un gris amarillento de cuerno; cl ojo pardo negro y las palas de un gris amarillo.

DISTRIBUCION GEOGRÁ FICA. - El ibijo gignate parece habitar todos los bosques de la América del sur: se han matado algunos individuos en Cayena y en el Paraguay.

USOS, COSTUMBRES Y RÉGIMEN.-Esta ave es acaso menos rara de lo que se admite generalmente; pero ofrece dificultades descubrirla de dia, y no menos observarla de noche. El principe de Wied y Burmeister opinan que mientras luce el sol permanece en la copa de los árboles mas 
aitos y espesos, en la misma posicion que los demás capri. múlgidos, $\delta$ sea con el cuerpo paralelo á la rama donde se posa. Su plumaje color de cortera es su mejor defensa, y su inmovilidad contribuye ambien 1 que pase desapercibida.

Azara describe con el nombre de urutau un chotacabras, que no será probablemente otro sino el ibijo: dice que se posa comunmente en el extremo de una rama rota, de tal modo que sobiesale la cabeza del ave á guisa de prolongacion, y que en tal postura, es muy dificil veria, por lo nucho que se armoniza el colot de su plumaje con el del cuerpo en que se apoya. Cuando los cazadores del Paraguay la sor. prenden posada de este modo, le pasan por el cúelló, sin que trate de huir, un lazo stjeto al extremo de una pértiga, y la atraen hácia asi.

Al hablar de otra especie, el princine de llied reffere que sus gentes mataron un ave á palos; de este modo confirma el relato de Azara, quien dice que el urutan sorprendido durante el dia no huye al acercarse el hombre. Burmcister da cuenta de un hecho análogo: vió un ibijo posado en un árbol Y le disparó varios tiros sin hacerle huir.

Ciosse recibió un urutan ó un form, con cujo nombre se conoce tambien á esta ave en Jamaica, el cual ful derribado del sitio en que estaba posado, pormedio de una pedrada, y mas tarde llegó á su poder otro, el cual se martenia con tanta obstinacion en el sitio de descanso por él escogido, que ni siquiera fijaba su atencion en los transeuntes que pasaban cerca de él, y solo momentos despues de haberle dis. parado un iro, con el que se le hicieron saltar algunas plir. mas, se retiró graznando al interior de! bosque; sin embargo en la noche del siguiente dia apareció otra ver. tranquilanrente
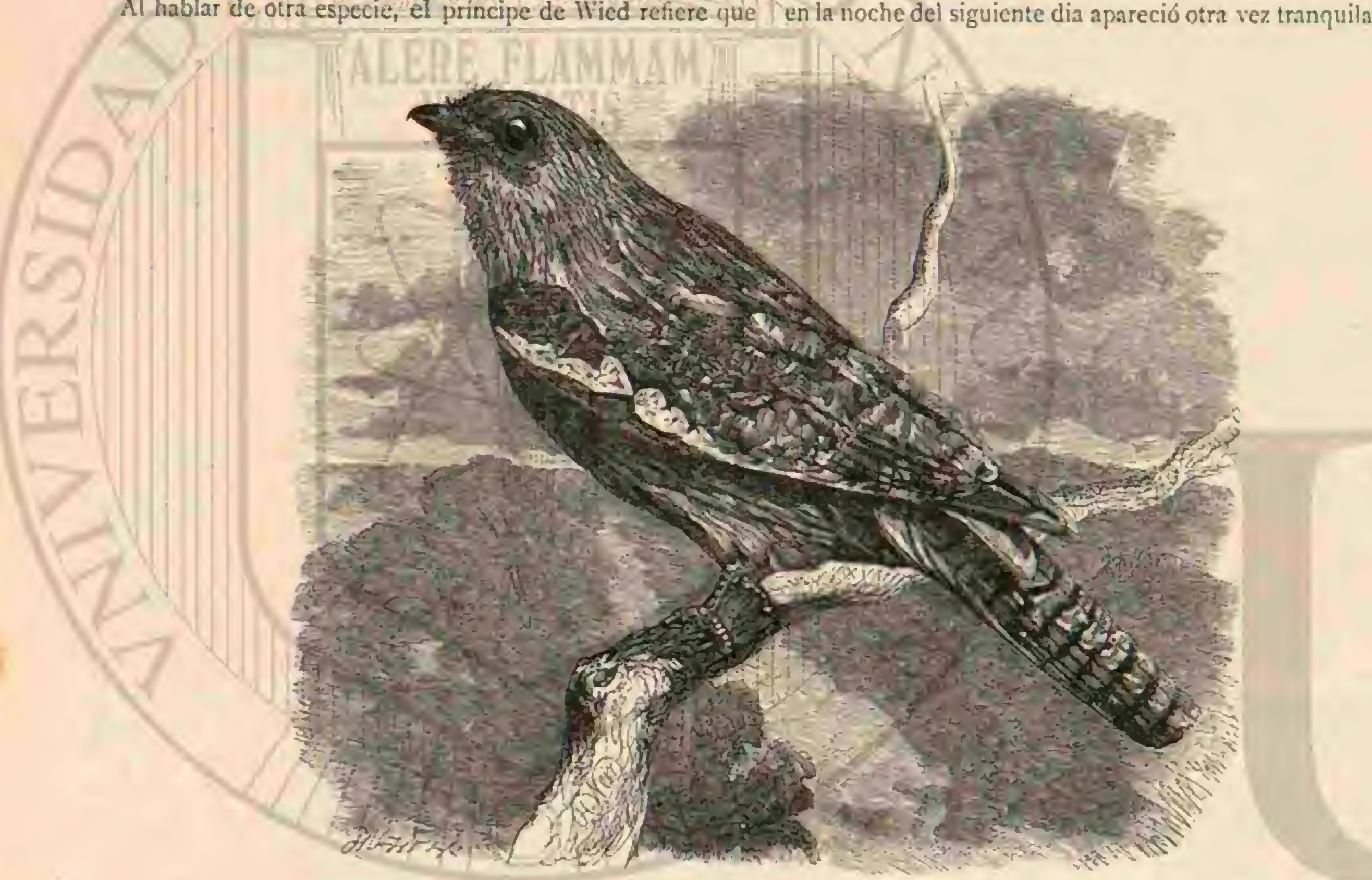

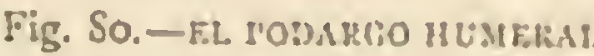

posado en su sitio favorito, y esta por demás decir que pagó su obstinacion con la vida, que le fué arrebatada de un tiro mas certero. Resulta de lo dicho que esta ave, que tiene la talla de un cuervo, seria la mas estupida, to cual se deduce asimismo del examen de su cráneo; pues la masa cere. bral, segun el principe de Wied, no es mayor çue una are. llana.

Sin embargo, llegada la hora del crepúsculo, cambian del todo los movimientos del ibijo, y entonces es tan vivaz. ágil como las especies precedentes. En ninguna parte he hallado la deccripcion detallada de sus costumbres; pero no vacilaria en aplicarle lo quue dice el principe de lWied de una especie muy afine. 4 Las noches de luna de los paises tropji. cales son muy clarns, tanto que el cazador puede yer perfec. tamente á esta are desde léjos; entonces se distingue ibijos que vuelan á tanta altura como las águilas, persiguien. do $\{$ las grandes marjposas nocturnas 6 crepusculares. En el Brasil existe un consicierable número de grandes lepidópte. ros, que no podria tragar sino un animal de boca enorme; el ibijo gigante es su mas terrible cnenigo $y$ derora una infini. dad de estos inscctos, tanto que con frecuencia se encuentra el terrerio de los hosques cubierto de sus alas, únicos restos que deja el arc.

Azara refiere que el ibijo gigante no se posa en tierra du. rante sus cacerias, y que si le dejan en ella abre muchio las alas, se apoya en ellas y en la cola, y no se sostiene con los piés, ni hace uso de ellos. Durante toda la noche produce por intervalos un grito ruidoso, prolongado y melancólico; y es que el macho y la hembra se llaman y se contestan: cuan. do llega la mañana ruelre cada cual à su retiro.

Gosse disecó ás un ibijo y encontró en su estómago los restos de varios escarabajos y de otros insectos de mayor ta. maño; sin embargo no debe por eso creerse que el ave se alimente tan solo de estos animales. Euler supo por un ob. servador digno de sodo crédito que los ibijos cazan tambien de dia, haciéndolo de un modo muy singular: el observador citado encontró á uno de ellos en un pasto; hallábase posa. do sobre el tronco de un árbol y parecia estar completamente inmóvil. Observándole mas de cerca, se apercibió que abria de vez en cuando la boca y se atraia de este modo á las moscas, las cuales se colocaban en gran número sobre la mucosa bañada de espesa saliva. Cuando el numero de estas 
le parecia bastante, cerraba inmediatamente la boca y tragaba la presa que habia cogido: repitió esta operacion muchas veces, permaneciendo siempre con los ojos cerrados, y no abandono el puesto hasta que el observador se le hubo acer. cado lo bastanie para poder tocarle con la mano. Jurante toda la noche, csta ave produce for intermalos un grito pro. longado y melancólico, con el que el macho y la hembia se llaman mutuamente. Ia voz del ibijo se podria expresar, segun Cosse, con las articulaciones hich, las cuales suenan á veces de un rnodo fuerte y ronco y parecen otras salidas del fondo del pecho.

Aunque el citado observador lo ponga cn duda, los indi. genas están quizás en lo cierto cuando dicen que esta ave emite sambien otros sonidos mas penetrantes, como una esjecie de maullidos lastimeros, que, gracios of la supersticiosa interpretacion que de ellos se hace, ponen en constante peligro su vida. Una de estas aves, que recibió Ciosse, fuci mueria únicamente á causa de su modo de gritar lastimero: lá dueña de la casa, cerca de la cualestaba revoloteando, no pudo soportar aqueel grito quejumbroso y rogó à su maricio que matara de un tiro al ave de mal agüero, como asi lo hizo. Fil ibijo, indudablemente á causa de su enorme boca, pasa por uno de los séres mas feos a los ojos de los negros: la magor ofersa que uno de ellos puede inferir á airo, con. siste en estas palabras: "Eres mas foo que un potu.)

Azara dice ademis que el ibijo anida en troncos de árboles huecos, yurmeister asegun que en las ramas un poco socavadas, donde deprosita uno ó dos hucros. Este último naturalista, que pudo adquirir uno, manifiesta que son de forma jrolongada, y apenas mas obtuso un extremo que otro, sin

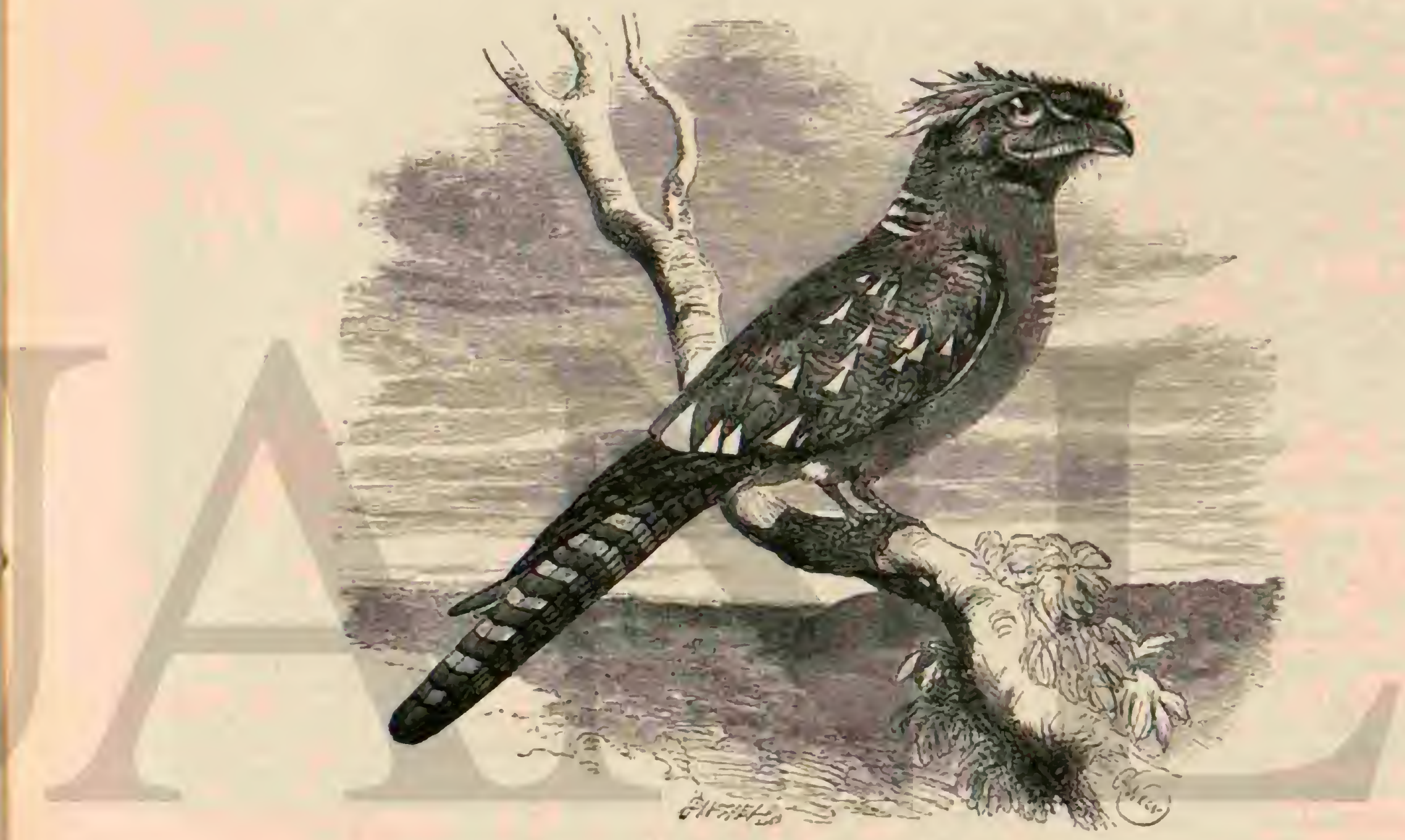

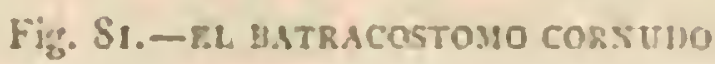

brillo alguno, de color blanco, y cubiertos de puntos grises pardos, pardo amarillos y pardo negros, muy compacios sobre lodo en una de las dos puntas.

CAUTIVIDAD. - Azara y Gosse nos han dado algunos detalles incompletos acerca de la vida de esta especie en cautividad.

A fines de dicicmbre recibió un individuo, cogido mucho tiempo antes, y lo conservó hasia el mes de marzo, alimen. tándole con bolitas de carne cruda y picada. Al comenzar los frios se entristeció, y como estuviera una semana entera sin comer, decidiose Azara á matarle. Aquel ibijo estaba todo el dia inmóril sobre el respaldo de su silla, con los ojos cerrados; en la hora del crepúsculo, por la tarde y la mañana, volaba por el cuarto, y no gritaba sino cuando le cogian. Su voz, fucrte y desagradable, podia expresarse por las articula. ciones kïn, kwr: si ailguien se acercaba a él, abria los ojosy el pico cuanto le era posible.

Gosse crió por muchos dias $\{$ un ibijo, que habia sido hallado en un pantano poblado de árboles y matorrales. Filave se quedaba posada en el mismo sitio donde se la poria, ya encima de un dedo, ya encima de un palo; nunca se colocaba en direccion paralela al punto de apojo, como lo hacen los chotacabras, sino trasversalmente, y con el cuerpo tan levan. tado, que la cabeza y la cola formaban una linea casi vertical. En esta postura permanecia, con cl piumaje algo erizado, la cabeza encogida y los ojos cerrados: si le tocaban, estiraba el cuello para recobrar el equilibrio y abria sus grandes ojos amarillentos y brillantes, con lo que jresentaba un aspecto sumamente cxtrajo. 1)e dia se comportaba por funto general del mismo modo que si estuviera ciego, pues aunque perma. neciese con los ojos abiertos, no le causaban la menor impre sion los objetos uque se le ponian delante; sin embargo, Gosse observó una ó dos veces que despucs de abicrto el ojo se le dilataba la pupila de un modo extraordinario, y que, por el contrario, se contraia instantáneamente hasta quedar reducida a la cuarta parte de su anterior tamaño cuando se movia con rapider la mano ante sus ojos. El mismo observador citado pudo apreciar la extraordinaria movilidad de que estaban estos dotacios, tanto por lo que mira á la dilatabilidad, como por lo yue respecia of la rapidez del movimierivo: si se le po- 
nia una vela encendida á la distancia de un metro poco mas ó menos, ensanchábase su pupila como unos dos centime. tros de modo que ocupaba todo el circulo visible del ojo, y el iris venia a reducirse $a$ un anillo apenas perceptible. Si, por el contrario, se le aproximaba mucho la luz, su pupila se contraia con la misma rapidez con que se le acercaba la luz. hasta quedar reducida á unos cinco milimetros de diámetro.

4. A la entrada de la noche, dice Cosse, esparaba que mi ibijo despertaria; pero quedaron frustradas mis esperanzas, pues el ave no hizo el menor movimiento ni dió señal alguna de vida. En vano la estuve observando de cominuo hasta altas horas de la noche, y en el decurso de esta-penetré sa. rias reces en la sala donde la tenia guardada, para hacer mis observaciones: a las tres de la madrugada la carontré en el mismo sitio y postum en que la Irabia dejado il hs diez de la noche, y como al despuniar del dia no habia cambiadode actitud, crei, no sin. fundamento, que no se habia movido durante el curso de aquella, como tampoco lo hizo en indo el dia șiguiente. Hicele introducir el pico en el agua y dejé crer algunas gotas dentro de su boca, pero rehusó beber. Cogi luego algunos escarabajos y otros insectos para dárse. los; pero fué en vano, no los vela; decidime, por fin, i abrirle el pica cingurgitarle estos últimos, y jos arrojó al momento, sacudiendo con ademan enojado la cabeza. Sin embargo, al anochecer del mismo dia comenzó de repente á animarse; levantó algunas veces el vuclo; iba revoloteando de una parte á otra, ó bien se volvia à su puesto de déscanso. Alrededor de los pájaros disecados que yo guardaba en la sala, revoloteaban varios insectos, y me figuré que cogeria alguno de ellos, pues echaba de vez en cuando una rapida ojeada sobre deterninados objetos y miraba en tarno suro como si qui. siera lanzarse en su persecucion. No es verdad lo que dice Cuvier tocante i la absoluta imposibilidad en que se encuentra el ibijo de levantarse del suclo, pues el mio, a pesar de 10 corto de sus tarsos, levantábase de él sin dificultad algu. na. Cuando conir, tenia las alas por lo comun algo desplegadias, y le llegaban casi al cxtremo de la cola cuando perma. necia posado sobre una rama. Por lo que he podido observar ell esta ave viviendo en cstado libre yen la que jo tuve en cautividad, debo manilestár que á pesar dé ser sus rémiges muy robustas, vuela proco; cara desde un sitio elevadoy vuelve \& su puesto luego después de haber cogido algun insecto nocturno. Como mi ibijo se negaba á tomar alimento, resolvi matarle y enriquecer mi coleccion de aves disecadas con otra nueva: apretéle al efecto fuertemente la tríqquen, y como no pudiera cortarle la respiracion, vime obligado it acabar con él descargándole, muy á pesar mio, unos cuanios golpes sobre la cabeza. A cada uno de estos proferia el ave un corto y ronco grito, s esta fue la primera vez que la oia, pucs lasta entonces habia permanecido completamente inuda. Siempre habia soportido las importunidades ó molestias con la mayor inmasibilidad, y solo despues de haberla excitado, enseñándole repetidas reces un objeto, abria su enorme boca como para asustarme, sin que nunca hubicra mostrado realmente intencion de cogerlo.

\section{LOS ESTEATORNITIDOS-STEA- TORNITHINF:}

CARACTERES.-Asi por su aspecto, como por sus cos. tumbres, estas aves tienen los principales caractéres especificos de los caprinullgidos de major talla; pero como quiera que se distinguen por aigunos que les son peculiares, se for. ma con ellos una subfamilia jarticular, representada por el
gérero siguiente:

\section{EL GUÁCHARO DE CARIPE-STEATORNIS CARIPENSIS}

CARACTERES.-Esta ave (enprimulgus corripressis), llamada por los venezolanos simplemente gusisharo, mide $1^{\prime \prime}: 55$ de largo por I'", 10 de ala a ala: su cuerpo es rnuy esbeito; la cabeza ancha; el pico mas bien largo que ancho y libre, arqueado á lo largo de la arista, de punta encorvada en ganclio y provisto de un diente; la mandibula inferior convexa en la rair, truncada oblicuamente y de punia comprimida; las fosas nasales, que se abren en el centro de este órgano, sun grandes y ovaladas; las patas muy vigorosas; ci tarso, corto, des. nudo y sin escudetes ó escamillas, mide solo la mitad de la largura del dedo medio y la misma de los externos; las alas son muy largas y puntiagudas, sicndo las rémiges cuarta y quinta laśs mas prolongadas, la tercera y sexta muchisimo mas cortas, $y$ la primera, que es de una largura regular, igual \$la séptima; la cola se presenta mucho mas corta que cl ala, muy redondeada y compuesta de plumas rigidas y anchas en el cxtremo, el resto del plumaje es duro é inflexible, irasformándose en sedas en la region que se extiende desde la base del pico hasta los ojos, en términos que la cara se presenta circundada como de un velo, del mismo modo que lo vemos en los buhos; estas sedas guarnecen tambien el párpado $y$ proicyen los ojos, que son grandes y hemisféricos. El plu. maje cs de un magnifico color pardo castaño; el dibujo se compone de puntitos descoloridos apenas visibles en el lomo: de rajas trastersales, estrechas, mas oscuras y poco pronunciadas en la espaldilla y en las rémiges del brazo, y de pe. quenas manchis de color blanco amarillento, en forma de corazon, en la parte superior de la cabeza, en el vientre, en las alas y cn las tectrices supra caudales; estas manchas se tornan mas grandes, semejando gruesas gotas en ias plumas medias de la cobija y en el borde externo de las dos primeras rémiges secundarias. Las barbas internas de las réniges, de un pardo oscuro, muestran de tres a cuatro manclias de un color blanco de orin; las rectrices, de un pardo negro, pre. sentan ocho fajas trasiersales, muy delgadas y del mismo color en la cara superior, con otras tantas muy anchas y de igual tinte en la inferior, y además seis manchas de formas regulares en el borde; las fajas trasversas se reducen á cuatro en las barbas exteriores de la rectriz mas externas. Iil ojo es pardo oscuro; el pico pardo rojizo; las patas de un pardusco amarillento. El macho no difiere de la hembra.

El esófago de los guácharos carece de buche; el estómago es muy carnoso y dotado de gran fuerza muscular; el intes. tino mide doble extension que el cuerpo; debajo de la picl exisic una espesa capa grasosa, la cual rodea por igual las visceras, que parecen estar como encajadas en la grasa.

DISTRIBUCION GEOGRÁFICA. - El guácharo habita las cavernas y los barrancos de la América central: en 1 ;06 le descubrio Alejandro de Humboldt en las grutas de Caripe; otros viajeros le encontraron despues en diversos puntos de la provincia de Bogotá y en varias de las lobregas caver. nas tan numerosas en los Andes.

USOS, COSTUMBRES Y RÉGIMEN.-l'enemos de. talles bastante exactos acerca del género de vida de esta ave singular; pero aun quedan muchos puntos oscuros ca su historia. Lo cicrto es que no se conoce ningun ave que viva como el gurichaso, y de ello puede convencerse cualquiera leyendo los relatos que nos han dejado Humboldt, Junk, Ciross : Goring.

En un pais, dice Humbolat, donde existe tan marcada cendencia á lo maravilloso, una carerna, de la cual brota un torrente y donde viven millares de aves nocturnas, con cuya grasa se guisa entre los misioneros, debe ser naturalmente el 
tema forzado de muchas conversaciones y debe asimismo dar pić á mil entretenidos relatos y controversias. Arrenas un extranjero pone el pié en Cumans, oye ya desde luego hablar hasta la saciedad de la piedsa de ojos de Araya, del labriego de Arenas que amamanió á su hijo, y de la cueva de los guácharos, la cual dicen tiene varias millas de largo. El entusiasmo por los grandes espectáculos y maravillas de la naturaleza ha de ser naturalniente muy grande en una so. ciedad, donde la vida es en extremo monútona y en cuyo seno no ocurren hechos capaces de satislacer al sentimiento de curiosidad innato al hombre.

* La cueva á la cual dan los indigenas la denominacion de cueia de manfera, se encuentra, no en el mismo valle de Ca. ripe, sino á tres millas del monasterio, hácia el sudoeste, y desemboca en un valle lateral que recorre á lo largo de la sierra de Cuácharo. A los 18 de setiembre partimos en di reccion a la mencionada sierra, acompanados de los alcaldes indios y' de un gran número de monjes: recorrimos primero una estrecha serda que conduce hícia el sur, serpenteando en una extension de hora y media por entre risuenas prade. ras, y luego nos dirigimos hácia el oeste, siguiendo el curso de un pequeño rio que sale de la citada cueva Por espacio de tres cuartos de hora continuamos avanzando, ora por en medio del agua, que joor fortuna no era mucha, ora por un terreno pantanoso y resbaladizo, limitado por la corriente del rio y una pared peñascosa. Numerosos montones de tierra desprendida y troncos de árboles, que se hallan por todas partes esparcidos, dificultando el paso á los mulos, hacen en extremo penoso el recorser este irafecto.

- Cuando el viajero llega al pié de la elevada montaña de Cuácharo, is una distancia de cuatrocientos pasos de la cueva, no se descubre aun la entrada de esin. El pequeño rio corre $a$ lo largo de un angosto cauce abicro por las mis. mas aguas y pasa luego por debajo de un peñasco saliente, de manera que el cielo desaparece completamente de la vista; el camino corre paralclo á la corriente, y solo despues de haber doblado el último recodo del mismo, se ve la vasta boca de la gruta. La vista de esta tiene algo de grandioso cimponente aun para aquellos que están familiarizados con los pintorescos paisajes de los Alpes, pues la exuberan. te vegetacion de los trójicos imprime a la abertum de la rueva un aspecto del todo original. la gruta clel Ciuacharo se abre en un peirasco-vertical; su entrada mira al sur y mide 25 metros de ancho por 22 de alto. Encima de ella y sobre la roca crecen árboles de proporciones gigantescas: el manea y la genipa con sus hojas anchas y brillantes, levan. tan al cielo sus atrevidas copas, mientras el curbaril y la eritrina espanden sus ramas y forman una espesa bóveda. El poto, con sus suculentos tallos, el oxílide y unas orqui. deas de forma extraña arraigan y se desarrollan en las hen. diduras mas áridas del peñasco, al paso que varias enreda. deras, constantemente mecidas por el viento, se entre!nzan delante de la entrada de la cuevi, formando, el todo un notable contraste con las grutas de las regiones septentrionales, somibreadas por los abetos y encinas.

\$Esta lujosa vegetacion no adorna tan solo la parte exte. rior de la cueva, sino que penetra hasta en el restibulo de la misma: magnificas heliconias de seis netros de altura, las ho. jas de pisang, las palinas de Praga y los aros arborescentes cubren las márgenes del arroyo hasta debajo de la tiern, de modo que, así en la gruta de Caripe, como en aquellas pro. fundas grietas de las rocas de lo: Andes, en cuyo interior no brilla mas que una debbil luz crepuscular, la regetacion se desarrolla aun a 306 t $t 0$ pasos de profundidad. Fn la gru ta de Caripe penetra la luz solar hasta unos ciento cincuenta metros de profundidad, segun lo acredita el hecho de no ha. ber sido necesario encender antorchas hasta despues de re. corrido este espacio: la forma de la cueva, que constituye un corredor el cual se prolonga en la misma direccion de sud. este \& noroeste, explica perfectamente el por qué se introduce aquella tanto. Donde comienza á desaparecer la luz, óyense los roncos gritos de las aves nocturnas, cuya morada, segun los indigenas, se encuentra tan solo en aquellos antros.

* Es dificil formarse idea del espantoso ruido que produ. cen miles $y$ miles de estas aves en el interior de la sombria caverna: podria tan solo compararse con el que producen nuestras cornejas, que habitan en sociedad los grandes pinares de las regiones septentrionales y anidan en árboles, cuyas copas se entrelazan unas con otras. Los gritos jenetrantes y estridentes de los guf́charos resuenan dentro de la vasta bó. reda, y el eco los reproduce desde la profundidad. Los in. dios nos enseñaron los nidos de las aves, valiéndose al efecto de antorchas sujetas al extremo de largas pértigas: hallábanse estos colocados á una altura de 20 a 23 metros en unos agu. jeros infundibuliformes, de que esta llena la bóreda. Cuanto mas se penetra hácia el interior de la cueva, tanto mayor es el nimero de las aves, que huyen espantadas por la luz. de las aniorchas de resina copal, y tanto mas acrece el ruido, de modo que apenas habian trascurrido unos breves instantes de silencio, resonabar ya á lo léjos los gritos lasimeros de los guácharos que tenian sus nidos en otras dependencias ó ra. mificaciones de aquella.

El guácharo no abandona la cueva hasta que la cerrado la noche, especialmente cuando se halla esta iluminada por la luna: se alimenta de semillas muy duras, y segun los in. dios, no come ui los escarabajos ni las mariposas nocturnas, lo cual debe de ser asi necesariamente, dado que el pico de esta ave está conformado de diferente modo que el de los chotacabras y supone por lo mismo un régimen alimenticio totalmenic distinto.

D La cuesa de Caripe conserva en una extension de cua. trocientos sesenta y dos metros la misma direccion, la misma elevacion y anchura que en la entrada. A duras penas pudimos recabar de los indios que pasaran mas allá del primer departamento, que es el que visitan todos los aỉos para la recoleccion de la manteca; y fué menester todo el ascendiente que sobre ellos ejercen los misioneros, para conseguir que llegaran hasta el punio en que el suelo se elera rápidamente bajo un ángulo de $60^{n}$ y cl riachuelo cae formando una especie de cascada. Cuanto mas se penetraba en el interior de la caverna, tanto mas estridentes eran los gritos de los guácharos; pero al fin tuvinos que pararnos y retrōceder luego, á causa del miedo de nuestros guias, quue se negaron resucltamente $\hat{a}_{\text {dar }}$ un paso mas lácia adelante, haciendo aqui lo propio que casi en todas partes.

*los indigenas atribuyen ideas misticas á dichos antros, habitados siempre por sombras noctumas; creen que las almas de sus antecesores residen en el fondo de la caverna; y dicen que el hombre debe temerlo todo de los lugares ynne no cstán iluminados por el sol ni por la luna. Ir á los parajes donde se hallan los guácharos, es para los indigenas reunirse con sus padres; es la muerte; y por eso los mágicos y los envenenadures hacen sus conjuros nocturnos a la eretrada de la caverna a fin de ahuyentar á Jioroynionoe, jefe de los malos espiritus.

Asi es como se reunen en todos los paises las prime. ras ficciones de los pueblos, sobre iodo aquellas que se refieren a los principios que gobiernan el mundo, a la residencia de las almas despues de la muerte, á la felicidad de los justos y al castigo de los cuipables.. las tinieblas se en. salzan por todas partes con la idea del no ser: la gruta de Caripe es el Tártaro de los griegos; los guácharos qque se 
ciernen sobre el torrente, lanzando plaiideros gritos, recuerdan las ares de la Estigia.

Junk, que ha visitado la misma cueva, nos dice que des. pues de haber cerrado la noche, los guacharos salen del inte. rior de aquella y vinclan de una parte á otra en busca del alimento, lanzando gritos a la manera de los cuervos y chas. queando el pico. Segun el observador citado, se alimentan exclusivmente de frutos; tragan algunos del tamano de un huevo de paloma, y arrojan los hucios. Sus nidos, en forma de copar, cstán compuostos de arcilla: cada puesta consta de dos o cuarro huevos. Hautessier envió a la Academia de $\mathrm{Pa}$ ris un guacharo, juntamente con el nido y los huevos, y se observó que este se componia de los restos de las frutas co. midas por el ave s arrojadas despues en forma de copos de borra. El mismo Hautessiet dice que de guaclarro amasa

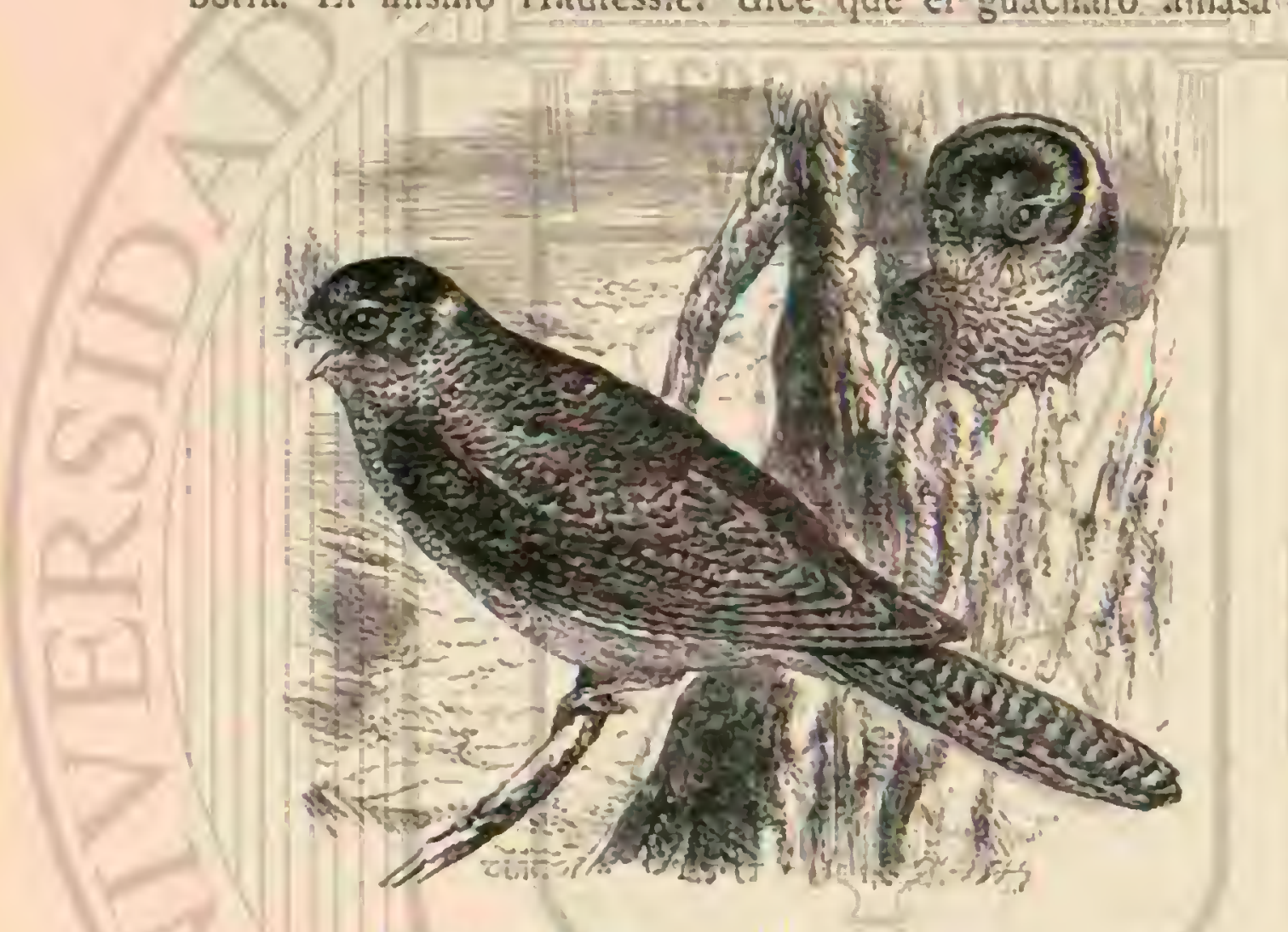

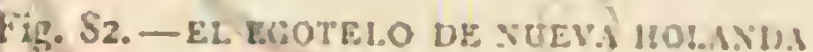

con los piés la / sustancia de su nido, el cual semeja en su conjunto una masa de casca redondeada y es como esta com bustible, a lo que anade otro ubservador que está cubierto dé plumon en los bordes. Konig Warhausen no puede disimu lar sus dudas tocanie á los materiales del niço y al modo de construirlo y concluje dicicndo que las aves, rue habitan a millares en las hendiduras y agujerós de aquellas cuevas, ar rojan, f́la verdad, los mércionados copos, pero que sin cu rar lo mas minimo de estos, depositan los huevos en cual. quier sitio. A fuerza de permanecer el ave continuamente posada sobre el nido, la sustancia de que el mismo se com pone llega 1 adquirir á la larga la misina solidez y consisten cia que si luubiera sido amasada. eSi se separa la capa de plumas que tapiza el nido, dice Konig. Warthausen, el res:o de la masa no parece sino que haya sido préviamente amasa. da; aquellas no cubren los bordes del nido con la regularidad que se nota en el de los ánades, y podria muy bien ser que alli donde aparcen en mayor cantidad, se hubiesen acumu lado casualmente.

Sin embargo, yo vi un nido, que parecia haber sido cons. truido de intento y no hallado ni urilizado por casualidad: te:nia mucho espesor; estaba redondeado exteriormente y algo aliuccado en su centro en forma dé hortera, de modo que parecia un verdadero pastel de casca; notábanse en el muchos residuos de frutos, que debian haber sido arrojados por el ave, pues el análisis quimica no pudo encontrar en su masa el menor vestigio de ácido úrico, y era de formas tan regulares, que no podia dudarse que inbia sido dispuesto propósito. Los huevos tienen aproximadanente el tamaño de los de la paloma doméstica, y al decir de Konig. Warthau. ser, difieren de los del chotacabras propiamente dicho, asi en la forma como en el color: su mayor anchura coincide con la mitad $\delta$ centro del eje longitudinal, desde donde van adelgazándose hácia las puntas mas ó menos pronunciadas, formando una linea bastante inclinada, y se asemejan ś los de los halcones, especialmente a los de aquellos que viven en los canaverales. La cáscara, de mediana resistencia, es de un blanco de cal adornado de manchas parduscas que pro. ceden del nido, y de un verde amarillento por dentro.

Ciross, que visitó en la Nueva Granada el barranco de Icononzo, otra localidad habirada por los guácharos, nos da igualmente detalles que completan los relatos de otros viaje. ros, contradiciéndolos en varios puntos El barranco de Ico. nonzo es una vasta abertura que hay en medio de un banco de arenisca, de cerca de cuatro kilómetros de largo, de nue. ve a rrece de ancho, por ochenta ó noventa de profundidad, y que fornia el lecho de un torrente. En el fondo, tocando casi por er.cima las alborotadas aguas, permanecen siempre los guacharos, y jamás se remontan á bastante altura para que se les pueda observar. Gross quiso que le bajaran con una cuerda, é hixo jié en una ligera saliente de la roca; mas apenas hubo llegado, vióse literalmente acometido por una nube de aquellas aves, que procuraban defender sus nidos. Volaban alrededor de cl, rozándole con las alas, y sus gritos le ensordecian. En menos de una hora mató Ciross unas cua renta, peto los indios apostados a la entrada del barranco no pudieron sacar una sola de las aguas. Mas precavido al año siguiente, dispuso Gross que se tenciera una red en el fondo dul abismo, Uastante grande para recoger las aves que caresen, jo pudo asi adquirir varias. Hé aqui en resumen lo que resulita de sus observaciones.

El guảcharo avanza rípidamente cerniéndose, y extiende las alas y la cola sin agitarlas con frecuencia; es torpe en to. dos sus démás movimientos; no puede andar, y se arrastra penosamente, ayudandose con lns alas. Una rez posado, le. vanta el pecho; pero baja la cabeza, apoyándose comun. mente en sus articulaciones carpianas. Para rastrear levnta un poco la cola, alarga el cuello, y procura conservar el equilibrio imprimiendo a su cabeza los movimientos serpentifor. mes más singulares. Cuancio ruela produce un grito pene. trante, ronco y desagradable por demás. Aliméntase de frutos, pero no arroja los huesos, segun se ha dicho, puesto que salen con sus excrementos. Los hijuelos amontonan es. tos alrededor de los nidos, y acumulan tambien granos, for. mando masas que pueden llegar a $10^{n}, 25$ de altura, y que se asemejan bastante a las paredes de una copa. El guácharo no hace su nido en tierra, ni en ninguna otra materia, pues no construye; la hembra pone sus huevos, que son blancosy piriformes, en una grieta de roca; depositalos sobre la piedra desnuda; el macho y la hembra los cubren alternativamente. Los hijuelos son sumamente imperfecios, y no pueden co. menzar a moverse hasta que su plimaje se desarrolla del 1odo. Su voracidad es increible: cuando estan cxcitados, se lanzan unos contra otros; cogen con el pico todo cuanto en. cuentran, aunque sean sus propias alas ó sus patas, y no sueltan el objeto de que se apoderan.

Gross trató inurilmente de conservar algunos: todos pere. cieron á los pocos dias de cautividad, sin duda porque no pudo darles un alimento conveniente.

Onitimos la tan larga como poco interesante descripcion que nos ha dejado laylor de un sitio habitado por esta are en 'Irinidad, y' reproduciremos a continuacion la que ha he. cho recientemente Goring de varias cuevas visitadas por 61 asi como del carácter del ave. Las noticias que se dan to. canee al guácharo en la Vida de los arimales, me escribe Croring, son excelentes, interesándome en especial las toma. das de Gross; y como estoy convercido de que no puede 
añadirse nada esencial \&ీ lo ỹa expuesto, me limitaró á con. signar lo siguiente. Con razon observa Humboldi que no pirece disminuir el nimero de estas aves, a causa de cubrir se sus bajas con otras procedentes de cavernas inaccesibles para ol liombre, entre las cuales se cuentan las que he visitado con los chacmas con objeio de sacar un cróquis de las mismas.

Estas cuevas se encuentran al sudeste de Caripe, en las montanas de lerezen y Punceres, y el acceso a ellas es en serciad sumamene dificil, á causa de no abrirse ningun sendero a través de la densa selva virger, que con su exube. rante regetacion cubre los montes y sus innumerables barrancos y desfiladeros. al pesar de que la distancia que las separa de Caripe en linea recta, apenas alcanza a seis horas, nosolros, sin embargo, necesitamos dos dias enteros para llegar a las márgenes de! Arcacuar, rio que recoge el agua salida de las citadas cuevas. Hállanse estas situadns en la orilla opuesta del rio, $y$ á la sazon en que visitamos las ca. vernas, habia engrosado tanto la corriente de este con notivo de las lluvias, que tuvimos que hacer altn por espacio de dos dias antes de poder llegar a la otra márgen. Ya al cerrar la primera noche que pasamos en el bosque, oimos los gritos de los guácharos, los cuales salidos poco antes de sus sourbrias moradas, se remoniaron por el aire, sobre las copas de los gigantescos árboles del bosngue. Parecia que en aquella noche, iluminada por clara luna, millares de guácharos habian abandonado sus moradas subierraneas: sus gritos, se mejantes í los de las cornejas, pero mucho mas fuertes y penetrantes, unidos al rápido chasquear de los picos, cran reproducidos de mil diversos modos por los ecos de los salles y barrancos del monte, originándose un ruido tan atronador, que ahogaba las voces de los demás animales nocturnos que habitaban la selva, y no parecia sino que labia estallado una formidable lucha en las regiones ciel aire. Poco a poco fuc menguando el infernal ruido, probablemente i causa de haverse posado las aves en las copas de los árboles para comer sus frutos, pues yo opino que el guácharo no deja oir su roz sino cuando vuela.

- Los nidos cyue he jodido ver, afectan aproximadamente la forma de la boniga seca, de color pardo oscuro, siendo los minteriales de que se componen, tierta porosa cxtraidn del fordo de la cucra y semillas del tamano de huevos de paln. ma, que arrojan otra vez los guácharos Como podra fácilmente comprenderse, la forma del nido viene determinada por la contiguracion de ia gricta, hendidura ó agujero donde el ave lo construyc. Por lo que respecta a los huevos, tan solo he visto dos; pero no dudo de que son exactas las notiTosso III cias yue se dan tocante á los mismos en ala vida de los animales А Аpenas puede formarse una idea de las groseras formas que ofrece el cucrpo de los guácharos pequenios; con decir que son una masa de grasa informe é indescriptible, ya esta dicho todo: son de un color blanco amarillento y muestran so!o indicios de plumaje. He disecado varios de ellos, y encontré ya en su cstómago muchas semillas casi del ta. maño de un huevo de paloma, las cuales estaban envueltas en una sustancia húmeda, de un tinte rosado pślido. 'T'asn. bien he comido algunas de estas avecillas recientemente sa. cadas de su nido, las cuales estaban tan gordas, que solo al. gunos pedazos de su carne fueron bastantes para condimentar la sopa. La carne de los guảcharos jóvenes constituye para los chacmas un riquisimo bocado.

- Mas tarde encontré tambieu el guacharo en las inmedia. ciones de Caracas, como a unas dos homs de distancia al este de la ciudad, y en un sitio hasta ahora no conocido cerca del rio Capaz, provincia de Mérida. Este rio junia. ménte con el Guayra que se halla en Caracas, se abren paso a travis de angostos barrancos, los cunles ofrecen morada farorable y segura para esta ave. Sahido es que el guácharo se halla tambien en la isla Trinidad, por lo que obscrvaré tan solo que esta ave se introduce â veces inmediatamente desde el mar en sus moradas subterríneas abiertas en la mantuosa costa septentrional de la isia. 
USOS Y PRODUCTOS.-Desde tiempo inmemorial utilizan los indigenas la grasa de los guácharos pequeños: glos indios, dice Humboldt, penetran en la ruer'a del guacharn una vez al año, hácia la fiesta de San Juan, armados de pértigas, con las cuales destruyen la mayor parte de los nidos. En dicha época se matan rarios miles de estas aves; para defender los individuos viejos sus crias, revolotean alrededor de los indigenas, !anzando gritos horribles: los pequeños que caen á tierra quedan muertos en el acto. Su peritoneo está muy cargado de grasa; una capa adiposa sc prolonga desde el abdómen hasta el ano, formando una especie de bola en. tre las piernas del ave. Semejante abundancia de grasa en animales frugivoros, no expuestos $\mathrm{h}^{\mathrm{a}} \mathrm{l}$ luz, y que hacen mur pocos movimientos musculares, recuerda lo que se ha ob. servado desde hace mucho tiempo en el arte de cebar las ucas y los buejes. Sabido es cuánto favorecen la operacion la oscuridad y el reposo: las aves nocturnas de Europa estản flacas porque en rez de alimentarse de frutos, como el guá. charo, viven del producto poco abundante de su cax.2 En la época en que se recoge en Caripe lo que alli llaman la co. secha de la manteca, construyen los indios casetas con hojas de palmera cerca de la entrada de la caverna, y en el vestíbulo mismo (nosotros vimos algunos restos de ellas); y en cendiendo all un monton de ramaje, derriten é introducen en vasijas de barro las aves jóvenes recientemente muertas. Fista sustancia cs conocida entre ayuella gente con el nombre de manteca ó aceite de guícharo; es semilliquida, tras. parente é inodora, y de tal pureza, quee se conserva mas de un año sin enranciarse. En el convento de Caripe y en la cocina de los monjes no se emplea mas aceite que el de la caverna, y nunca hemos notado que comunicase a los guisos un gusto il olor desagradables.

*. La cantidad que de este aceite se recoge no está en relacion con la matanza que hacen los indios todos los añus en In gruta, pues parece que solo se obtienen de 150 a 160 botes (de 60 pulgadas cúbicas cada uno) de manteca bien pura; ta que es menos trasparente se conserva en grandes vasijas, de barro. Este rano de la industria de los indigenas re. cuerda la cosecha del aceite de paloma, con el que se llenaban en otro tiempo en la Carolina algunos -miles de pipas, En Caripe se usa desde remotas épocas el aceite de guácha. ro, y los misioneros no han hecho mas que regularizar el método de extraccion.

- Los miembros de una familia india que dicen descender de los primitivos colonizadores del valle, reivindican para si los derechos de propiedad absoluta sobre la cueva; pero desde que se ha introducido en aquella comarca el monaquisıno, aquellos derechos son poco menos que ilusorios, pues los misioneros impronen á los indios 12 obligacion de proveerles del aceite indispensable para alimentar las lámpa. ras que arden delante de los altares, y les compran, segun se dice, el resto.

*a raza de los guácharos habria sido ya hace tiempo ex terminada, si no contribuyeran a su conservacion varias circunstancias, entre las que podrian citarse como principales la supersticion de los indios, la cual impide á estos penetrar muy adentro de la cueva, y en segundo lugar, la de fabricar aquellas aves sü nido en otras grutas recinas, pero inaccesibles para el hombre. Además el sombrio antro va poblándose continuamente de nuevas aves que salen de aquellos pequeños agujeros, pues los misioneros nos aseguraron que las bandadas de guácharos no han sufrido hasta ahora una disminucion notable.

- Aigunos guácharos jóvenes fueron llevados al puerto de Cumand; pero murieron de hambre á los pocos dias, á causa de no gustarles las semillas que se les propinaban. Cuando se abre el buche y el estómago de los guácharos pequeños, encuéntranse en dichos órganos semillas duras y secas, las cuales se designan con el nombre de semilla del guacharn, y constituyen un remedio célebre para combatir las fiebres intermitentes. Estas semillas son traidas por los padres á los pequeñuelos: recógense cuidadosamente y se envian para los enfermos que haya en Caracas y otros puntos de las regiones donde reina la citada enfermedad.

\section{LOS CHOTACABRAS-CAPRIMUL-} GIN.A

CARACTÉRES. - Esta sub.familia se caracteriza por el pico sumamente endeble $y$ por las fuertes sedas que guarne. cen la base del inismo; por sus patas cortas y poco robustas; por el dedo externo, yue consta de cuatro articulaciones, $y$ por el medio, el cual se halla provisto de una larga una dentada y pectinea.

\section{EL CHOTACABRAS EUROPEO.-CAPRIMUL- GUS EUROPAUS}

CARACTERES. LEl chotacabras de Europa ofrece en general los miśmos caractéres de los caprimúlgidos: se dis. tingue por tener el cuerpo prolongado; cl cuello nuy corto; la cabeza grande y ancha; las alas largas, estrechas y agudas, con la segunda penna mas prolongada; la cola truncada casi en ángulo recto, con todas las pennas iguales entre sí, excepto la mas exterior, que es algo mas corta que las demis; el pico corto muy pequeño $y$ ancho, delgado en la raíz y un poco corro en la punta, por delante de las fosas nasales; los tarsos cortos, delgados, y cubiertos de plumas en una mitad, coin el resto cubierto de escamillas; el dedo medio provisto de una uña ensanchada y pectinea, mas largo que los dedos laterales, con los quue se enlaza por un estrecho empalme hasta la primera articulacion; el dedo posterior es pequeno, enteramente libre y dirigido hácia atrás. Las plumas son la. cias, grandes y suaves (fig. $\$ 4$ ).

Esta are tiene 1$)^{\circ}, 26$ de largo, por $0^{\circ}, 55$ de ala à ala; esta plegada mide $0^{\circ}, 19$ y la cola $0^{\mathrm{m}}, 12$. La parte superior del cuerpo es de un gris pardusco sembrado de muchos puntitos mas $\delta$ menos claros, con rayas de color negro sumamente delgadas, las cuales ensanchándose en la parte superior de la cabeza y en el lomo, presentan en su borde externo el aspecto de mancizas a manera de fajas, de un pardo de orin, y forman á lo largo de la coronilla una raya longitudinal oscura, y otras dos iguales en la espaldilla; las tectrices medias de las alas ofrecen una faja trasversal, resultante de las anchas puntas de las mismas, que son de un tinte amarillo de. orin, distinguiéndose de las demás, tas cuales tienen un cotor pardo salpicado de puntos tambien pardos, pero de orin. La region que se extiende desde la base del pico hasta los ojos, junto con la de la orcja, es negra con puntitos pardos de orin, y se halla además, orillada inferiormente por una raya de color amarillento de orin; las tectrices de la parte superior de la cola muestran rayas oscuras en zig-zag sobre fondo gris, al paso que las inferiores del ala, de un tinte de orin, presentan fajas trasversales tambien oscuras; la barba, la garganta y los lados del cuello son de un tinte de orin descolorido y estín adornadas de rayas trasversales negruzcas, las cuales se hacen mas anchas y perceptibles en las demais partes inferiores $y$ van separíndose cada vez mas $y$ mas unas de otras en las cobijas sub-caudales. Fl buche y el pecho son de un pardo negro salpicado de gris, con manchas blanquecinas grandes y redondeadas en los lados; ocupa la parte inferior de la garganta una gran mancha trasversal 
blanco-agrisada con ondas oscuras; destácanse sobre la cara externa de las rémiges, que son de un negro pardo, seis man. chas diagonales, de un amarillo de orin, y en la interna fajas trastersales de este último color; las tres primeras pennas del ala tienen ademass una gran mancha blanca en el centro de las barbas exteriores. Las dos rectrices medias son de un gris pardusco manchado de negro, estando además adornadas con nueve fajas trasversas irregulares tambien de este color; estas fajas, de un gris pardusco nanchado de puntos oscu. ros, se eleran a ocho $\delta$ nueve en las demís rectrices, que son de un pardo negro; las dos rectrices mas exteriores se presentan adornadas de grandes manchas blancas en su ex. tremo. El iris es de un color pasdo oscuro; el párpado rojo: el pico, circundado por las negras sedas de la garganta, es de un negro de cuerno; las patas de un pardo rojizo. La liembra difiere del macho por su color mas oscuro; las bar. bas internas de las tres prinieras pennas del ala y la extremidad de las dos rectrices mas externas presentan manchas mas péqueñas de un amarillento de orin en vez de blancas; los prequeños se distinguen por carecer de tales manchas.

DISTRIBUCION GEOGRÁFICA. - Esta especic se extiende desde el centro de Noruega por toda la Europa y el oeste del Asia, visitando durante el invierno todas las re. giones de Africa y no establece su morada mas que en el sur de esta parte del mundo.

\section{EL CHOTACABRAS DE COLLAR ROJO-CA- PRIMULGUS RUFICOLLIS}

CA RACTÉRES. - La esprecie que acabamos de estudiar, estíl representada en el suroeste de Furopa, especialmente en Espana, por orra de major tamaño, cual es el chotacabras de collar rojo (a)frimulgous rufioriguatus). Esta are tiene $0^{\circ}, 31$ de largo, fror $10^{\circ}, 6 i$ de ala á ala; esta jlegada mide $\left(0^{\circ}, 20\right.$ y la cola $11^{\prime \prime}, 16$. La parte superior de la cabeza es de un gris ceniciento algo salpicado de oscuro, jo at lo largo del centro de la misma aparecen anchas rayas negras, con juntitos de un orin descolorido en los bordes; la region que se extiende desde la base del pico hasta los ojos, y la de la oreja son dé un pardo oscuro de orin; la garganta, de un rojizo de orin, está ribeteada en los lados por una delgada raya blanca, que procede del ángulo de la boca, y en la parte inferior por otras dos grandes, de este úlimo color, las cuales se hallan separadas por otra central y delgada, de un rojizo de orin; la region superior del cuello, cuyas plumas presentan un color algo confuso í causa de tener los lados y los ex tremos orillados de negro, está adornada de una ancha iaja de un rojo de orin; el vientre es de un pardo gris salpicado de un color algo oscuro; con delgadas rayas negras; las tec trices de la cspaldilla tienen las barbas internas ribeteadas de negro, y las extemas de un amarillo de orin, de lo que resulta una ancha raya negra, manchada de este segundo color; las tectrices de la parte superior de las alas son de un tinte pardo de orin y' estàn adornadas de grandes manchas redondas de un color rojizo de orin y de lineas y puntos negros: el pecho presenta varios puntos grises, rayas tras. versales mas oscuras y grandes manchas de un blanquecino de orin sobre fondo rojo tambien de orin; las restantes par. tes inferiores son de un amarillo de orin, con estrechas rayas trasversales oscuras en el vientre y en los costados. Las rte. miges son negras y presentan anchas fajas trasversales de un rojo de orin; notanse cuatro de cstas en las barbas externas de las remiges del brazo, mientras las que ofrecen las rémiges de la mano, se juntan unas con otras en el borde in. terno; las tres primeras pennas del ala tienen en la cara interna la gran mancha blanca comun á la mayoria de los chotacabras; las dos rectrices centrales son de un pardo gris oscuro, con siete fajas tmasversales delgadas; las dos mas externas tienen en el extremo grandes manchas blancas, las cuales son mas delgadas en la tercera; las restantes presentan ocho listas trasversales de un rojo de orin manchado de oscuro sobre fondo pardo negro; cl ojo es pardo oscuro; el pico negro; las patas de un pardo negro sucio.

DISTRIBUCION GEOGRÅFICA.-El área de dispersion de esta ave parece ser algo limitada: habita en la pe. uinsula ibérica y en el noroeste de Árica; llega en sus viajes hasta Mlalta y Francia, y se la ha visto tambien en Inglaterra.

\section{EL ANTROSTOMO VOCINGLERO-ANTROS- TOMUS VOCINGLERUS}

CARACTERES. - Fsta especic (onprimulgus ruiferus y clamator). que los americanos ilaman ihis porervil!, aunque no la mas numerosa, es, sin embargo, la mas generalmente conocida en la América septentrional. Lista ave tiene casi el mismo tamaño que el chotacabras de Europa: su plumaje es de un pardo negro sembando de puntitos de orin $y$ grises, con delgadas manchas negras, las cuales se vuelven mas an. chas en la region superior de la cabeza; la parte posterior y los lados del cuello están adormados de rayas imsiersales negras y de un tinte de orin: las tectrices de la espaldilla y del ala presentan en su borde dos manchas irregulares de este último color; las mejillas y la region de la oreja son de un subido pardo de orin, con rayas negras; la parte superior de la garganta es tambien negra, con estrechas líneas tras. versales de color de orin, y la inferior se halla limitada por una faja trasiersal blanca, que llega casi hasta los lados del cuello; nótanse en la parte superior del pecho listas tmaver. sales negras y pardas de orin; en las otras partes inferiores se presentan tambien fajas tmistersales negras y estrechas so. bre fondo amarillento de orin. Las rémiges, de color negro, muestran cie seis a siete manchas trasversales de un tinte de orin en los bordes, las cuales se convierten en grises tambien de orin salpicado de oscuro en las dos mas centrales; las rectrices medias presentan manchas trasversales negras, y las restanies están adornadas de uma sola de estas, con la mitad terminal blanca y la basilar de color de orin (fig. \$5). Ia hemura se distingue del macho portener la faja de la gar. gania a ie un tinte palido de orin, siete lineas trasversales del mismo color en las rectrices, y los bordes terminales de estas de un amarillo de oritr.

DISTRIBUCION GEOGRAFICA. - Fsta ave habita Ia region oriental de los listados.Únidos \& visita durante el invierno Méjico y la América del Sur.

\section{LOS ESCOTORNIS-SCOTORNIS}

CARACTÉRES.- listas aves se distinguen de sus con. géneres hasta aqui descritas jor el pico, el cual, aunque con. formado casi del mismo modo que el de los cho:acabms, tiene, sin embargo, la punta mas aguda y mucho mas encorvada, con los bordes cortantes muy prolongados hácia el interior de la boca; esta se presenta sumamente hendida; la cola es muy larga y truncada, siendo las dos pennas del cen. tro mucho mas prolongadas que las otras; el tarso esta cubierto dé plumas en la region superior y de cuatro escudeies en el resto; las alas son largas, con la segunda y iercera réiniges unas prolongadas que las otras.

\section{EL ESCOTORNIS CLIMACURO-SCOTORNIS CLIMACURUS}

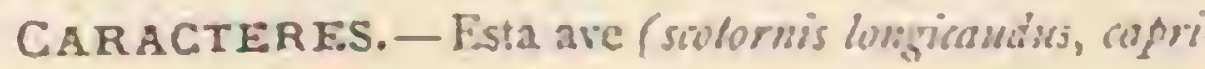


mulgus longionudus, juratns, macrocercus, Boreanii y Wiedersperigii), es de mucho menor tamaño, pero de major largura que el chotacabras de liuropa: mide ()$^{n}, 40$ de largo por ()$^{\infty}, 52$ de ala á ala; esta plegada es de $11^{\circ}, 14$ y la cola de $\left(1^{\circ 1}, 25\right.$. La parte superior del cuerpo es de un pardo gris, sembrado de puntitos mas ó menos oscuros; nótase á lo largo del centro de la cabeza una grande mancha negra y en la parte posterior del cucllo rayas trasversales negras sobre fondo amari llento de orin; la espaldilla es de este color y tambien negra, s causa de ser de un amnrillo de orin, pero negra en el centro, la parte externa de las plumas que cubren esta region del cuerpo: las cobijas medias superiores del ala tienen los bordes terminales blancos, de lo que resulta una faja irastersal. oblicua: Ta barba, de un pardo de orim, presenta una estrecha linea blanca que sale del ángulo de la boca; la garganta están adornada de una gran mancha de este color en forma de es cudo, con el borde inferior negro; la parte superior del pecho es de un pardo de orin salpicado de puntos grises oscuros y algunas manchas blancas; el resto de la region inferior pre. senta estrechas rayas trasversales oscuras sobre fondo ama. rillo de orin. Fixtiéndese una ancha faja blanca irasversa] sobre las barbas internas de la primera y segunda rémiges, asi como sobre las internas y cxternas de la tercera y g̨uinta, mientras las pennas del brazo se hallan adornadas de listas de un amarillo de orin, con el borde terminal blanco; las dos rectrices mas céntricas son de un pardo gris sembrado de varios puntos oscuros; adorna las restantes fajas trasversa. les un color pardusco de orin sobre fondo negro; la rectri\% mas externa, cuyats barbas exteriores son de un blanque. cino de orin, presenta diez fajas trasversales mas oscuras y termina con una gran mancha blanca, la cual no se nota mas que en las tarbas externas de la segunda rectri\%: el iris es pardo: cl pico, circundado de largas sedas, negro; las patas de un pardo amarillo (fig. 86). La hembra difiere del macho

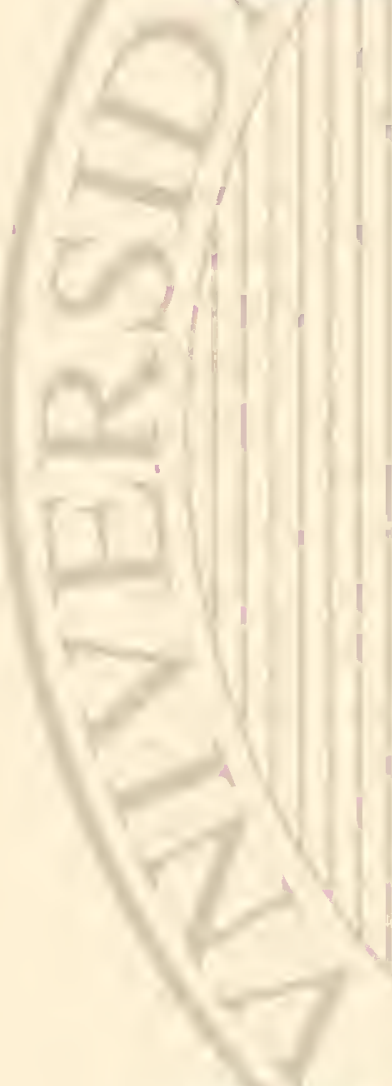

por tener la parte superior del cuerpo de un color gris de orin, las rémiges de un amarillento de orin pálido y una ancha faja trasversal de este último tinte alrededor de los lados y parte postcrior del cuello.

DISTRIBUCION GEOGRAFICA.-Resulta detodas las observaciones hasta el presente practicadas que esta ave habita exclusivamente el Africa desde los $19^{\circ}$ de latitud hácia el sur, la mayor parte de las regiones del oeste $y$ noroeste, asi como tambien todo el centro. Hánse tambien visto algu. nas de estas aves en el mediodia de Luropa, por to que no es de extrañar que se las incluya en el catálogo de las que viven en esta parte del mundo.

\section{LOS HIDROPSALIS - HYDROPSALIS}

CARACTÉRES. - Los hidropsalis tienen la cola suma. mente escotada, si bien este caracter es mas pronunciado en cl macho que $\mathrm{cn}$ la hembra; las alas son largas $\mathrm{y}$ fuertes; ia primera rémige se halla dentada en el borde como se nota en los buhos; el pico es inuy prolongado y relativamente ro. busto en la punta; las patas delicadas y graciosamente contorncadas, cubiertas de plumas en la parte superior $y$ de cscamillas ó escudetes en la inferior.

\section{EL HIDROPSALIS LIRA-HYDROPSALIS FORCXPATA}

CARACTERES. - Jil hidropsalis lira (hydropsalis limba.

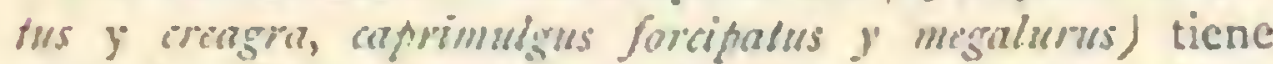

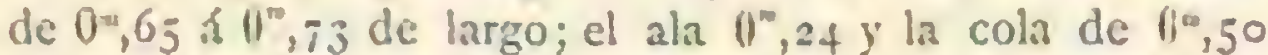
a $10^{\circ}, 55$; la penna caudal mas externa mide tres veces el lar. go del cuerpo. El plumaje tiene, segun Burneister, un color pardo oscuro: nótanse en los lados de la parte superior de la cabeza manchas trasversales de cuales se vuelven mas anchas y descoloridas en la region del ojo, dunde forman una raya mas clara; las iectrices de la nuca tienen los bordes terminales de un amarillo de orin; las del dorso presentan lineas trasversales y ondeadas en zig \%ag: de un amarillo pálido; las escapulares anteriores se hallan adornadas de anchas manchas oblicuas annarillas, con otras de forma oval en los bordes; las de la garganta, cuello, pecho y vientre presentan en los bordes lineas de un amarillo de orin, las cuales se ensanchan en la region del pecho y afectan en la mitad del cuello una mancha de un amarillo pálido, en forma de boca. Las rémiges grandes y fuertes son pardas; las primeras cstín cruzadas interiormente de manchas trasver. sas de un amarillo de orin, las cuales aparecen tambien en las barbas exteriores de las demás; las rectrices centrales son pardas, con los bordes de las barbas interiores ribeiendos de blanco; la externa lleva fajas de un rojo de orin en la base, con los bordes orlados tambien de blanco, formando ondas: las restantes están dibujadas en zig-rag; el iris, el pico y las sedas que guarnecen los bordes de la boca, son de un pardo negro: ins patas de un pardo de carne (fig. $\delta_{i}$ ).

DISTRYBUCION GEOGRAFICA. -Segun Burmeister, el hidropsalis lira parece vivir solitario en lo profundo de los bosques de la américa del sur, sin ser comun en ninguna parte. Dire Azara que algunas especies emigran al Paraguay, viviendo tambien alli en las selvas, y al modo que otros ca. primulegidos, gustan de rasar volando la sumerficic de los arrojos. L
gur
a
de
for
alg
me
ver
E faj: orii pat las

àm

cor

una

rias

me

est: 


\section{LOS COSMETORNIS-COSMETORNIS}

CARACTERES.--Las especies de este grupo se distinguen por el pico sumamente débil, rodeado de sedas cortas is manem de barbas; por las patas bastante largas y el tarso desnudo; por la cola corta y ligeramente escotada, y por la forma especial de las alas, cuyas cinco primeras rémiges son aigo cortas, la sexta mas, la séptima mide el largo de las pri. meras, la octava tiene casi el mismo del ala plegada y la novena es mucho mas larga que todas las otras.

\section{EL COSMETORNIS PORTA-ESTANDARTE- COSMETORNIS VEXILLARIUS}

CARACTERES. - Esta ave (semeiphorus y macrolifientx abvillarius, coprimuly'us Spelici) es de algo nayor tamaño que el chotacabras de liuropa: la parte superior del cuerpo es de un pardo negro, con puntitos de un pardo de orin; la region superior de la cabeza esta adormada de manchas negras, las cuales aparecen mucho mas grandes y al lado de otras termimales de un amarillo de orin en la espaldilla, en las rémiges secundarias posteriores y en las tectrices mas centrales y largas de la cobija superior: los lados de la cabeza son de color oscuro, con fajas trasiersales y manchas de un tinte de orin pálido: las demás partes inferiores del cuerpo se presen. tan blancas y adornadas de delgadas rayas tmssersales oscuras. Las rémiges son negras con la base blanca: las cobijas de la mano regras con el borde terminal del segundo de estos colores; ia segunda liasta la quinta rémiges son de este inismo tinte; la sexta y sćptima del todo negras; la octava y novena de un pardo gris, mas oscuras en la cara externa y blancas en el tallo; las del brazo negras con borde terminal blanco y la base de un amarillo de orin, adornada de dos

\section{(5) \\ fajas tmasversales amarillas; las rectrices de un amarillo de orin, con manchas negras y siete listas trasversales de este último colur; el iris es pardo oscuro; el pico negruzco, y las patas de un pardo claro (fig. 88). \\ DISTRIBUCION GEOGRÁFICA.- Esta especie habita las regiones intertropicales del Africa central. \\ LOS MACRODIPTERIX - MACRO- DIPTERYX}

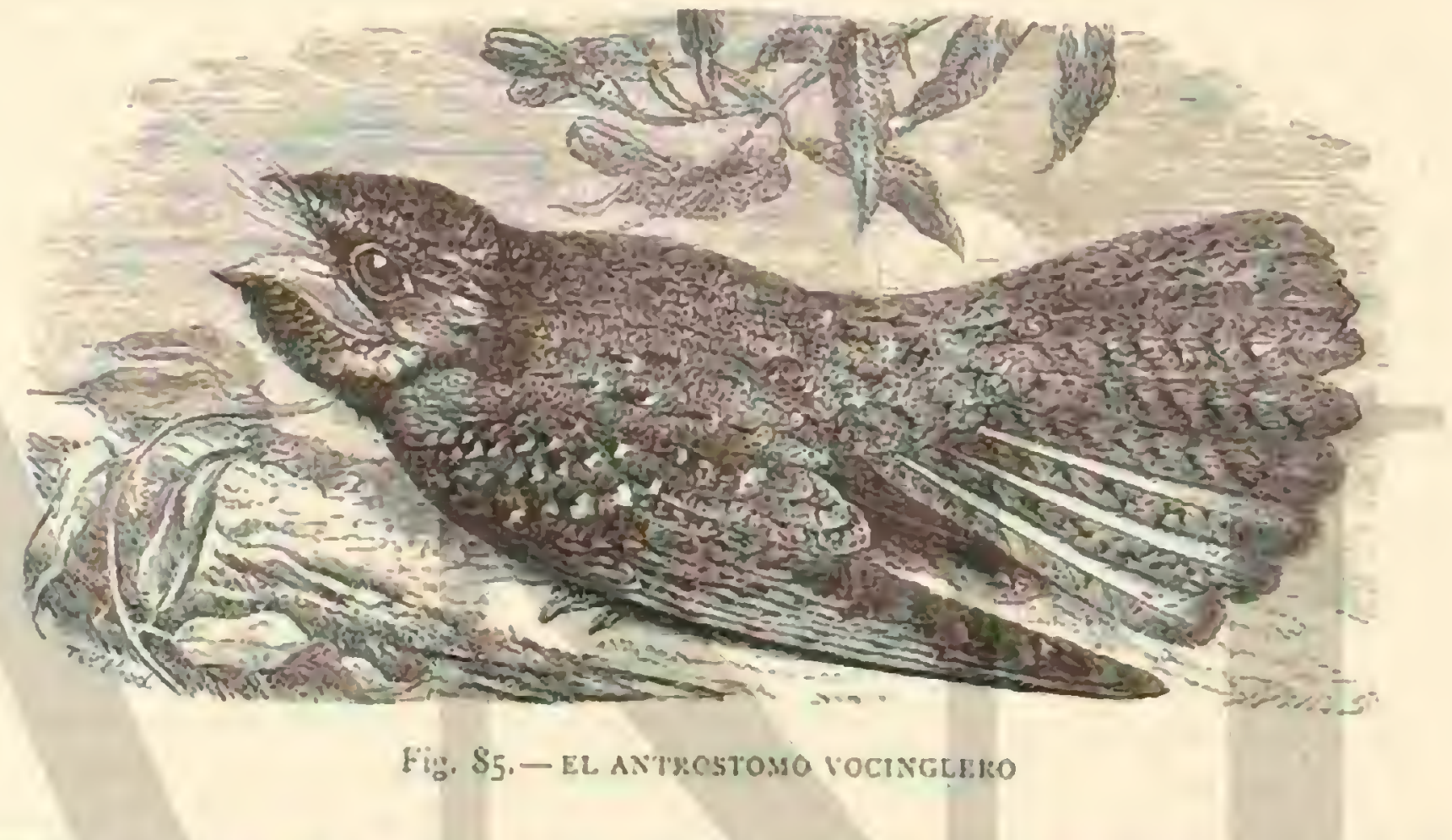

CARACTERES.-Los macrodipterix, llamados por los ámbes aies de cuntro alas, son los mas notables de todos los chotacabras, de los cuales se distinguen mas bien que por la conformacion del pico y de las patas, por la forma de las alas y la cola: esta es muy corta y aquellás llaman la atencion yor una pluma que nace entre las rémiges primarias y secunda rias, mide $0^{\circ}, 47$ de largo y está clesprovista de barbas en la base, al paso que presenta unas largas de $0^{\circ}, 16$ y relativa mente muy anchas en su extremidad, á cada lado del tallo: esta pluma no se nota en la hembra.

\section{EL MACRODIPTERIX LONGIPENO-MA- CRODIPTERYX LONGIPENNIS}

CARACTERES.- Esta ave (mercrocipderix ofricumes y comdvopterus, caproimulgus lonsigennis, maserodipserix y afriatr aus) tiene el plumije bastante oscuro; la parte superior del cucrpo es de un pardo negro; la region superior de la cabeza de un pardo gris, con puntitos pardos de orin; las tectrices de la espaldilia y las de la cobija sunerior están salpicndas de grandes manchas de color de orin mas pronunciadas en las primeras que en las segundas; la barba y la parte su. perior de la garganta son tambien de este víltimo inte, con ondas trasversales negras; $\mathrm{cl}$ buche $y$ el pecho de un pardo ne. gro salpicado de puntos grises, con manchas de orin; las restantes partes inferiores, tambien de este color, se presentan adornadas con listas trasversales oscuras: nótase alrededor del cuello wna ancha lista de un pardo de orin oscuro, ondeadia de negro. Las negras rémiges están cruzadas por cinco fajas trasversales nas claras en las barbas internas; la que nace entre las primarias y secundarias y constituye un adorno en esta ase, muestra en la extremidad de las barbas seis anchas listas trasversas punteadas de gris sobre fondo negro; las dos rectrices centrales son de un pardo gris, con puntos oscuros, $y$ las restantes negras; unns y otras están adomadas de cinco fajas trasversales de color negro las primeras y de un pardo de orin, con manchas oscuras las segundas. Esta ave mide $\left(0^{\circ}, 21\right.$ de largo; cl ala plegada $0^{\circ}, 17$ y bia cola 0 " 10 (fig. Sg).

DISTRIBUCION GEOGRÁICA. - El macrodipterix longipeno habita las regiones central y oecidental de Africa.

USOS, COSTUMBRES $\times$ REGIMEN DE LOS CHOTACABRAS. - Describir los usos y costumbres de los diversos géneros que acabamos de examinar, es volver en cierto mocio á lo que ya hernos dicho antes al habiar de las genemidades de la familia.

La mayor parte de los chotacabras viven en los bosques, y no queremos decir con esto que busquen los mas espesos E impenctrables; encucrntranse sobre todo alli dunde la es\}e. sura alterna con los claros. Las estepas de Africa, clonde 
crecen diseminados los árboles ó los matorrales, mientras que todo el suelo está cubierto de altas retbas, son para cstas aves un verdadero jaraiso:y por lo tanto se encientran alli excesivamente numerosas.

En los bosques del mediodia de Fiuropa, que reunea casi las mismas condiciones, abundan mas que en los del zorte, donde no se encuentran sino en los bosqutes de corifiesas, aunque sean menos ricos en insectos que los otros. Cuindo comienzan sus emigraciones aparecen en todos los sitios donde hay espesura; pero en el norte no anidan sino en los bosques de coniferas.

La especie del mediodia de Europa, el chotacabras de cuello rojo, encuenira excelentes albergues a lo largo de las montanas, donde las rocas alternan con las brenas; y es casi tan comun en Ins arbolodas, subre todo en los olivares.

los chotacabras de color de arena, tales como les de Fgipto, y principalinente el chotacabras isabela (ingripulizus isaliolinus), se oculian en los matorrales nue cubren las ori. lias del Nilo, alli donde el desicrto se limita ante el fro: ó bien se rotiran à las partes cubiertas de résped, imitando en esto á los chotacabras magnificos qué habitan entre las attas yerbas de las estẹpas.

Las especies americanas buscan al parecer localidades se mejantes, aunque los viajeros dicen q̧ue al gunas de ellas furmanecon en las selvas virgenes. Alli se ocultan de dia etr el follaje cazan por la noche en los claros, ito largo de los senderos que atraviesan el bosque, b́ bien por los aires junto \& la copa de los árboles.

Puede admitirse qque las mas de estal aves descansan en el suelo, $y$ en casos raros sobre las ramas; $y$ aur aquellas gre por la noche se posan en los árboles, vuelien á bajar de dia. Esto es fícil de explicar: el chotacabras busca para su reposo un lugar cómodo y seguro, y lo encuentra mas frecussie. mente en tierra que sobre una mma. S'gun he dicho $\mathrm{I}_{2}$ no se coloca trasversalmente sobre esta, sino álo largo, posicion que puede consersar muy bien merced a la uria pectinea de su dedo medioy a su pulgar dirigido hácia dentro; feróriara poder tomarla, necesita una rama bastanie gruesa y desneda en ciera extension, nudosa ó bifurcada.

\&los chotacabras, dice. Jaumann, no encuentmn á reondo lugares muy cónodos pará descansar, asi es que curado se descubre cualquiern de ellos se puede tener la seguriend de verle siempre ocupado. Una rama horizontal de in manzano de mi jardin se dividia formando una horquilla ruy angosta, cuyos dos brazos, igualmente horizontales, texian apenas el grueso de un dedo. Como era un sitio excclers:c para los chotacabras, posíbanse alli, con cada pata sobre eno de los brazos de la horquuilla, apoyada la cola y la parte yosterior del vientre en una parte de la rama unida mas alla de su bifurcacion. Semejante posicion debe ser tan cómod? para estas ares, que en la época de sus emigraciones encontré algunas de ellas posadas en dicho sitio, habiendo conse guido en cierta ocasion matar tres en tres dias consecutios,

Con no menos gusto que el puesto indicado, digen tum bien los chotacabras para descansar y dormir un pedrusco cuya superficie superior sea plana y esté además expuesta ŝ los rayos del sol: cuando no falta una de estas dos circso. tancias, vése siempre posada alguna de estas aves en tues pedruscos. En el Árica y en todos los paises cailidos el ciotacabras evia el calor solar con el mismo cuidadó con qtre lo busca en Lusopa, retiraindose siempre para descansar cerca del tronco de un árbol ó de un matormi.

Cuando dwerme cierra los ojos; pero su oido es tan fro, que advicrte â tiempo el riesgo que le amenaza. Grina como los buhos en la direccion sospechosa, y despues exnprende su vuelo ó se aplana contra la rama óla tierra, espe- rando escapar á las miradas, gracias à su plumaje color de tierra ó corteza.

Naumann pretende que no se ve nunca á los chotacabras andar: el aserto es inexacto, aunque se rehusase admitir que los pocos pasos que da sobre una rania antes de posarse, no es realmente andar: yo he visto á menudo a los chotacabras de Africa recorrer una distancia de varios metros al rededor de un matorral.

Eil chotacabras de Europa no está peor dotado bajo este concepio que su congénere de Africa: véase á este propósito lo que escribe Vielitz. «Cerca de mi casa, sola y rodeada de vastos bosques de coniferas, los chotacabras se presentan en bastante número; asi es que no me han faltado ocasiones fa. rorables para poder observarlos. 11 anochecer de los dias de verano que son serenos y apacibles, revolotean alegremente al rededor del cortijo; se mantienen cerniéndose en el aire, ante la persona que se halla sentada en las inmediaciones de aquel, para mirarla llenos de curiosidad, y desaparecen luego en silencio para reaparecer á los pocos instantes. Si cl hombre permanece inmóvil en el sitio, pósase el ave en al. gun lugar lleno de guijarros; aplánase en el suelo, sin efectuar el menor movimiento, como si fuera un pedazo de cor. teza de árbol; observa atentamente los alrededores, y en el caso de ver que no le amenaza peligro alguno, comienza á ponerse en movimiento con el objeto de recoger algo del pelado suela Por lo comun recorre un espacio de $0^{\infty}, 15$ a (1)", 20 sin interrupcion alguna; detiénese luego; recoge algo del suelo; vuelve a observar nuevamente por breves instan. tes y continua su camino, recorriendo de este modo en todas direcciones, á menudo por espacio de un cunto de hora, los guijarrales, sitios que parecen serle en extremo agradables. Yo he podido observar repetidas veces á esta ave desde el último peldaño de la escalera de mi casa, en tanto que ella estaba posada delante de la misma en un sitio de cuatro a seis metros de cxtension: cl ave recorria este reducido espacio, andando de una parte á otra, y en ciertas ocasiones se me aproximaba ianto, que hasta podia alcanzarla con la mano. Cuando quiere recorrer un espacio de mayores dimensiones, se vale entonces de sus alas, las cuales levanta graciosamente \& fin de poder asi conscrvar el equilibrio. Cuando siente mas vivos descos de moverse, trasladase con sorprendente rapidez á un sitio á propósito, en cuyo caso sube- y baja alternativamente sus alas, pero teniendo siempre apoyados los piés en el suelo.

El vuelo varia segun la hora y el estado de cxcitacion del ave: de dia es vacilante, incierto, irregular y hasta torpe; diriase que el animal es un objeto inanimado, que se balancea en el espacio; pero de noche cambia completamente.

A medida que desaparecen los últimos rayos del sol, despiértase el cliotacabras; alisa su plumaje; mira por todos lados, y despues. se remonta por encima del bosque con fácil y ligero vuclo. Unas veces se cierne como la golondrina; otras se desliza por los aires batiendo precipitadamente las alas; cambia de direccion; inclinase á derecha é izquierda, sube y baja con tanta rapidez como la golondrina rústica. A reces permance en el mismo sitio en los aires, sobre todo cuando alguna cosa despierta su curiosidad; cjecutando :odos estos movimientos hasta que no puede continuar su caza, por haber cerrado la noche. Se traga por docenas insectos relativamente enormes, tal como saliones, escarabajos y esfinges; cuando está satisfecho, se posa y digicre; luego vuelve á cazar dumnte toda la noche, à menos que no sea muy densa la oscuridad ó sople demasiado el viento.

Iass primeras horas de esta y de la mañana son aquellas en que vuela con mayor agilidad; sin embargo, ni una sola vez me ha sido dable ver ni oir á esta ave en la mitad de las 
hermosas y apacibles noches de las regiones ecuatoriales. Durante sus excursiones se aleja con frecuencia mucho el chotacabras de su retiro: en luringia, por cjemplo, llega hasta los pueblos situados cerca del bosque; en lispaña se deja ver en las ciudades; en Madrid anida en los jardines de sus alrededores; en el Africa centmal abandona las estepas y llega hasta las viviendas.

Asi en poblado como en el bosque, visita durante sus ex. cursiones nocturnas determinados sitios con cierta regulari. dad, ya con el objeto de cazar en ellos los insectos que pasan cerca de él zumbando, ya conel de entonar su exiraño canto de amor. Yo pude observar en Alemania a una de estas aves, la cual durante un mes entero acudió todas las noches y casi ia la misma hora á un grupo de tilos que se levantaban á un kilómetro de distancia del bosqzue, donde tenia puesto su nido; volaba al rededor de las copas de aquellos describiendo graciosas evoluciones y espirales, sin duda con el ob. jeto de hacer salir los insectos que estaban ocultos entre las ramas; pasaba luego á un segundo grupo de árboles, de este it un tercero y se volvia en seguida al bosque inmediato. Si se quiere obsermar al chotacabras, basta encontrar el sitio donde suele cantar, pues en el decurso de la moche acude alli varias veces. Si se siente iranguilo, la presencia del hom. bre no le causa la menor turbacion, sino que, por el contra. rio, va y viene conportándose del mismo modo que antes, sin que por esto deje de mirar curiosamente al observador.

Sucede a menudo que un especticulo desusado excita su curiosidad: basta un perro para llamar su atencion largo rato, precipitase sobre él como el halcon, le sigue y acompaña hasta mas allá de los limites de su doninio, y con frecuencia va mucho tiempo detrás de un hombre que acertó a pasar cerea del sitio de su morada, volando alrededor de él hasta que llega al lindero del bosque. No se cuida de las otras aves mas pequeñas, por la sencilla razon de que estas se han ido à descansar cuando comienza á emprender sus excursiones. Sin embargo, no puede negarse que les causa alguna turbacion, siquiera sea pasajera; $y$ lo prueba el hecho de haberse establecido un chotacabras en un jardin de Inglaterm y haberlo abandonado luego asustadas todas las de. más aves que momban en $\mathfrak{d}$, volviendo, no obstante, al mismo á los dos ótres dias, tan pronto como se hubieron cerciorado de que el recien venido era un compañero del todo inoiensivo y por consiguiente, nada-temible.

El amor ejerce tambien su influencia en los chotacabras, por muy pesados é indiferentes que parezcan: los machos se disputan violentamente la posesion de una hembra. 'Iratan ademis de seducirla con sus gracias: despliegan nuevo ardi. mienio, siendo su ruclo entonces mas rápido y atrevido. A la manera de las palomas poscidas de amor, el clio:acabrns recoge bruscamente sus alas y se deja caer desde una gram altura produciendo un ruido particular, $\delta$ bien se ciemey vuela con gracia alrededor de su hembra, que permancece inmóvil. Cada especie manifiesta su pasion de una manera particular: pero las mas notables por tal concepto deben ser los chotacabras de Africa y América, que se distinguen por su plumaje espléndido. Yo no he hallado descrito en ningu. na parte el vuelo del hidropsalis lira, y por la tanto ignoro si los machos de la especie adquieren un aspecto fantástico cuando cruzan los aires; pero recucrdo aun con gusto el agradable espectículo que ofrecian a mi vista en las tardes de primavera los escotornis en celo. Sin cuidarse del hombre ni de sus gestos, las inagnificas aves penetraban en los lugares habitados; volaban al rededor de los árboles con una gracia, una rapider y agilidad seductoras; en las claras no. ches de los trópicos podiamos observar todios sus movimientos y veiamos cómo baxian las alas y recogian ó cnsanchaban su larga cola, cual si puisieran lucir ante nosoiros todas sus gracias. Llegaban hasta los fuegos de nuestro campamento como atridas por aquella luz insólita, y ejecutaban los mas singulares ejercicios.

Con gran sentimiento mio, janirs pude ver los macrodipterix: pero todos los irabes que conocian esta ave, hablaban de su belleza con entusiasmo: por otra parte, las siguicnies lineas de Russeger nos dan á conocer qué efecto produce la aparicion de tan magnifica esprecie eSi yo me hubiese criado en el seno del harem, habria creido en aquel momento en todos los cncantos y artificios: lo que yo veia en el aire era sorjurendente: era un ave que parecia mas bien rodar que volar por el espacio. 'lan pronto creia ver una como dos ó cuatro alas; pero la que yo miraba parecia tener el último numero; en algunos momentos giraba sobre si misma y no era posible distinguir el conjunto, por lo mucho que se con. fundia. Las dos largas plumas eran juguete de la mas leve brisa; disminuian la rapidez del vuelo del ave, ó por otro lado, al flotar en el espacio, comunicábanla un aspecto fantástico, tanto mas cuanto que no se la ve sino á la luz del crepuisculo. 8

Mas detallada que la precedente es la descripcion que del vuclo del ave nos ha dejado Heuglin: No bien cnmienza á brillar en el fondo del firmamento la primera estrella, dice el observador citado, el macrodipterix da principio a su caza; vuela con rapider y en linea recta, siguiendo constantemente el mismo camino, hácia los últimos confines del bosque, donde la regetacion no es tan abundante; recórrelos de una parte a otra persiguiendo las langostas, los cscambajos y las mariprosas nocturnas; remóntase á poca altura, y entonceses su vuelo lento y silencioso. Solo cunndo se para de repente o hace un rápido recorte, se oge un rumor semejante al chasquido causado por un painuelo de seda: si las largas pennas de sus alas, cxecupcion hecha de la extremidad, están desgastadas por el roce, parece, para valerme de la expresion de un indigena, of quien pregunté tocante a las costumbres del macrodipterix, como si este fuera perseguido por otras dos aves mas prequenas, las cuales le empujaran incesantemente y con regularidad de arriba abajo.

La roz de los chatacauras es muy variable: algunas especies producen una especic de grunido, otras emiten sonidos mas ó menos armoniosos. Cuando se asusta de dia cl chota. cabras de Europa, repite con voz débil y ronca dick. dark; si está en peligro bufa y silba como los buhos. Durante el periodo del celo se oye resonar su canto, que consiste en dos notas, ó mejor dicho, dos ruidos, las cuales emite con in. creible ardor: podrian compararse con el ron ron de los gatos Posado sobre una rama, produce primero un sonido bastante fuerte equivalente a oitrorr, al que sigue acto con. tinuo otro mas bajo, que se expresa por orrr; es probable que emita el primero durante la inspiracion y el segundo en la espiracion.

Cuando el chotacabras canta con ardiente entusiasmo, su gorjeo dura de 30 à 300 segundos: una de estas aves que pude observar por breves instantes, reloj en mano, continuó cantando sin interrupcion por espacio de + minutos 45 se. gundos; descansú otros 45 segundos, y aprorechó esic es. jacio de tiempo para volar á otro árbol, donde comenzó otro gorjeo, curn duracion fué de tres minutos 15 segundos. Si el are ocupa un silio cúmodo, como por ejemplo, la bifurca. cion de las ramas de un árbol ó una de estas gruesa, lisa y desnuda de hojas, suele dividir comunmente el periodo principal de su canto en varias partes; emite un gruniido, que se prolonga por uno 6 dos minutos; hace luego una pausa de unos tres segundos de duracion; reanuda pror algunos instantes su canto; vuelve á interrumpirio de nuevo 
por breves momentos ! termina, por tiltimo, con intervalos de tiempo cada vez, mas cortos. Si el observador se apro. xima mucho al ave, advierte que el micmuro principai de su canto acaba con sonidos bajos, semejantes al grunido, pero que se distinguen esencialmenic de los que anies se oian y â los que se pudiem dar en cierto modo el nonbre de suspiros: estos sonidos se podrian expresar por medio de las articulaciones guorre puorre smurre y semejan, á mi modo de ver, los ahogados chirridos de una rana, que se oye desde léjos.

La hembra deja oir á veces un sonido análogo; pero mu. cho mas débit: al volar el macho s: la hembra lanzan un grito
Todos los chotacabras de Africa que yo of producen el mismo ruido que el de Europa; el de collar rojn se distingue por su armoniosa roz, mas suave; emite dos sonidos bas. tante semejantes que podrian traducirse por kluk kluck kluck. siendo uno de ellos mas bajo que el otro. Fl jotan, ob. servado por Radde en las montanas de Bureja, tiene por grito de llamada una especie de cacareo que se puede cxpresar por las silabas dischug ischog, a lo cual se debe que los tungusos dieran á esta ave el nombre de dsondseggrum. El chotacabms de las Indias (iatrimisus imdicus), que se ha confundido a menudo con 4 de Europa, grita tryo, al decir de Jerdon.

Bien vemos cuánto varia la roz entre los chotacabras mup

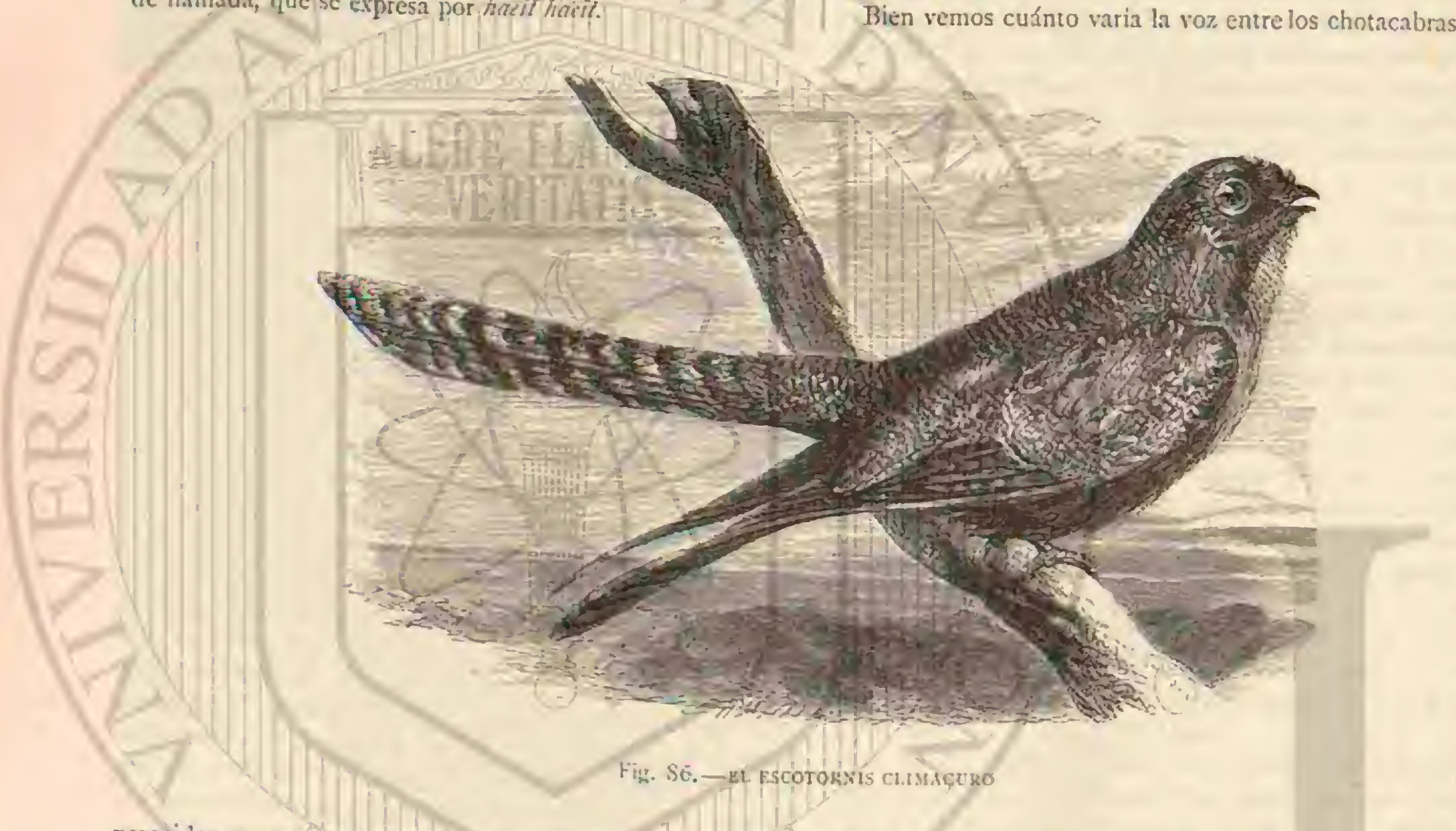

parccidos, y creo que este es carácter bastante para demos tmr que son otras lántas especies independientes unas de otras, y no simples vatiedades de una misma.

El grito de ciertos chotacabras de América debe ser muy singular, pues ha impresionado, nn solo á los salvajes sino tambien a los colonos, hasta el punto de temer a estas aves y darles los nombres mas extranos. Schomburgk ha descrito las voces que resueman en el bosflue cuando cesa el alegre concierto de la poblacion alada, y dice con este motivo: - Percibeuse entonces en medio del silencio de la noche los gritos plañideros de los chotacabras, posados sobre las ra. mas secas que se inclinan en la superficie del rio; estos sonidos son tan siniestros y desagradables, que se comprende el temor inspirado por dichas ares. No hay negro, indio, ni criollo, que se atreva á tirar contra ellas; el segundo las considera como servidoras del cspiritu maléfico Jabahu; los negros creen que son mensajeras de Jumbo, divinidad del mal. y los criollos las miran como mensajeras de muerte. Léase la brillante descripcion que del canto de estas aves hace Waterion en sus a Viajes\%. Pronto resono en mis oidos el plañidero ha-ha-ha-hu-ha-ha-ho, nue parecia provenir de aquellos árboles ó de la próxima orilla y que, oyén. dose al principio clara $y$ distintamente, acababa de conver. tirse poco a poco en una especie de suspiro; seguian luego con angustiosa precipitacion las roces: Who arepres, who. (Ui?) d las cuales se (¿uién cres tú, quién, quién, quién eres enian un ács sucedian inmediatamente estas otras, que

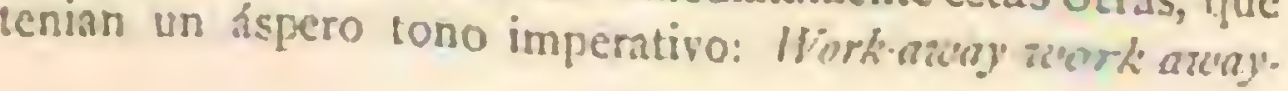

aork-arial ('Trabaja, ca, imbaja, trabaja, trabaja, en'); oiasc pocos momentos despues una roz que, impregnada de pro. fundo tedio, parecin decir: Willy.come conse-gro (Guillermo, ven, vámonos, Ciuillermo, Cuillermo, Guillermo, ven, vámonos:), y resquaba al instante orra no ménos lastimem: ; Whis-poor-Will' Whip-Whip-Whis-Whis. fonr-IVill (Golpea, pobre Guillermo, golpea, golpea, golpea, golpea, pobre (iuillermo), hasta que por uilumo se percibia de repente desde el fondo de la sombria selva el grito penetranie de un mono que se veia turbado en su sueño ó acababa de caer en las garras de un gato-tigre.

Los chotacabrns, mas lentos y pesados que las golondrinas, tienen tambien menos inteligencia que ellas; son res. pecto á estas lo que los buhos con relacion á los halcones. En su vida nocturna les faltan ocasiones para desarrollar sus facultades intelectuales; el hombre, enemigo innato de todos los animales, no los juzga muy favorablemente.

Solo de este modo puedo explicarme la curiosidad de los chotacabras: ya he dicho antes que toda cosa nueva llama su atencion, y que se acercan entonces para reria mas de cerca. En los bosques desiertos van junto al viajero extraviado; vuelan á su alrededor y lé acompañn largo tiempo sin otro fin que el de examinar detenidamente la desusada aparicion; la luz los atrac mucho mas; tocios llegan junto à los fuegos del campamento y comienzan a volar alrededor. Si se dispara un tiro y no cae ninguno, quedan sumamente sorprendidos; detiénense de pronto sin reconocer el riesgo, ye ciernen largo rato en el mismo punto para informarse 
de lo sucedido; pero si uno de cllos mucre, los demás se alnrman, aprorechaindose de la experiencia.

En ninguna parte es tan fícil como en Africa cazar estas aves con escopeta, pues viven alli sin temor, y á nadie se le ocurre ni aun espantarlas. La presencia de un ave de rapinina nocturna les hace cambiar de movimiento; conocen ásu ene. migo y emprenden la fuga al instante.

El chotacabras revela tener astucia: en Espania le dan el nombre de engañaphastores, solo porque estos son los que le ven con mas frecuencia. Ia llegada de un ganado basta para poner en movimiento al chotacabras; el pastor le divisa; di. rigese hácia el sitio donde se ha refugiado; cree poder cogerle sin diñcultad; adelantase y alarga la mano; pero en el misıno instante emprende su vielo el ave Lira que observaba con atencion todos los movimientos de su enemigo, ye fingia dormida, para escapar en el mamento oportuno. No se crea que refiero aqui una fábula inventada por puro capricho. Cierto dia, dice Naumann, ayudaba yo á tender una red para las alondras, cuando muy cerca de mi, sobre un tronco derribado, divisé un chotacabras que jarecia profundamente dormido. Resuelto á cogerle, puse la red de manera que cubriese el tronco, y despues de haber cerrado asi toda salida al ave, hicimos ruido para ahuyentarla hícia el centro, donde pensábamos cogerla mas fácilmente. Entonces vimos que estaba despierta, si bien trataba de engañarnos fingiéndose dormida; para acercarme, hube de pasar por debajo de la red, y no volo hasta el momento en que alargaba yo la mano para cogerla, quedando luego sujeta entre las mallas.

Iodas las especies de la sub.fimilia que viven en las regio. nes seprentrionales del globo, y aun quizis aquellas que mo. ran en paises donde las estaciones cambian de un modo brusco, abancionan durante los meses mas rigurosos del ano los sitios en que anidan, y emigran con mas ó menos regula. ridad a otras comarcas. El chotacabras de Europa no se pre. senta en su patria hasta fines de abril, raras veces á media. dos de este mes, estando su aparicion relaciomada con la abundancia y naturaleza de los alimentos que necesita; en las regiones montuosas 6 en el norte suele aparecer á principios de nayo, y nos va sucesiramente dejando no hien el mes de octubre toca á su fin. A diferencia de los cipsélidos, anda despacio y sin cansarse, por mas que, gracias a su lia. bilidad en volar, recorra fácilmente grandes extensiones de territorio y hasta mases, al parccer, sin necesidad. Durante la prinavera los chotacabras emigrantes ran casi siempre ais. lados y a lo mas por parejas; en otono, por el contrario, cons. tituyen bandadas mas 6 menos numcrosas, las cuales van engrosándose constantemente à medida que avanzan mas hácia el sur. Asi en la Europa meridional, como en el norte de Africa y en la Arabia l'étrea, hánse observado tales ban. dadas desde tiltimos de agosto hasta los meses de setiembre y. octubre. Los primeros en partir son probablemente aque. llos que no puadicron completar la educacion de su prole sino muy tarde, ó se detuvieron en su marcha, á causa del abundante alimento con que les brindara una determinada comarca.

Cualquier sitio que durante su viaje pueda proporcionarles algun abrigo para descansar de dia, parece ser del gusto de estas avcs; sin embargo preñeren para ello los lugares pobia. dos de árboles 6 al menos de matorales; y en caso apurado no descicuan tampoco las colinas pedregosas y desprovistas de toda regetacion, los desiertos y las estenas.

Si por un motivo cualquiera les urge partir, 6 bien las $\mathrm{co}$. marcas que cruzan no les ofrecen el alimento necesario, en. tonces ruelan de dia, aun contra su costumbre: Heuglin pudo observar uno que en el decurso de este vino á posarse sobre un buque á fin de entregarse al descanso, hecho que se ve

Toso III repetido con alguna frecuencia por lns chotacabras que en sus emigraciones atravicsan el mar. En el norocste del Africa siguen el mismo camino çue casi todas las aves emigrantes,

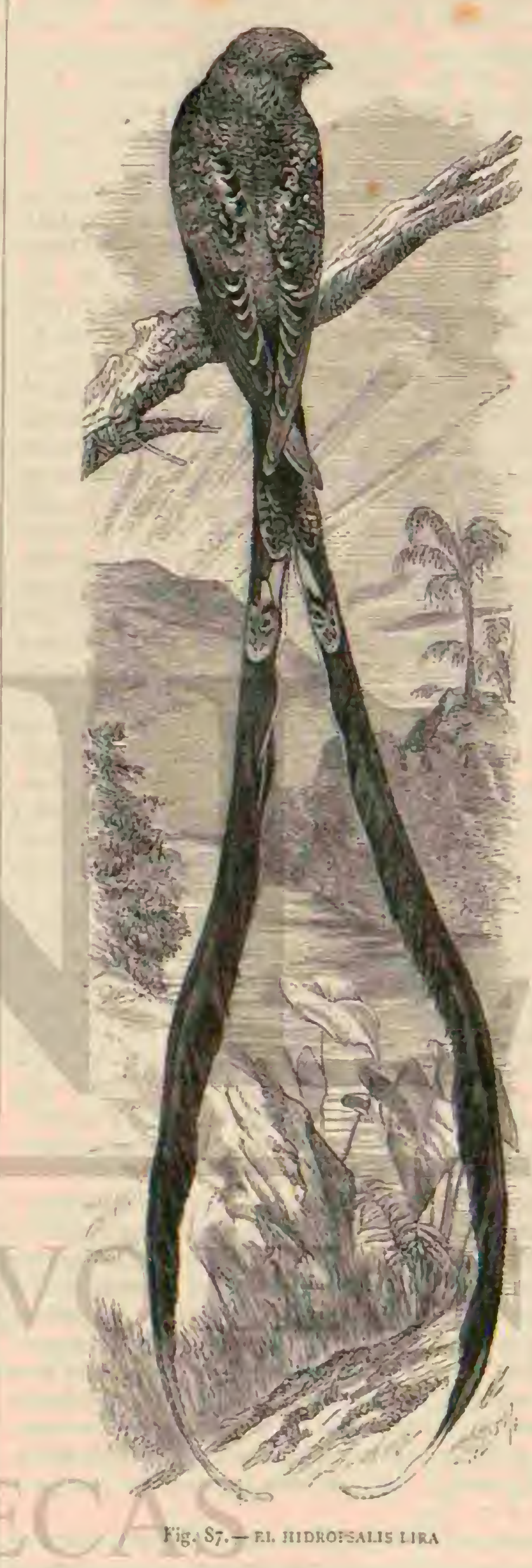

es decir, el valle del Nilo; sin embargo, segun lo observado por Heuglin, aranzan tambien it lo largo de las costas del mar Rojo, en cujo caso podria atribuirse este cambio de itinerario á los frecuentes extravios que padecen al airaresar el desierto, falto de árboles

El citado obserndor encontró đlas ares viajerns en las cos- 
tas de Danakil y Somali, en las tierras de los Bogos, Habesch Y Kordofan; yo los hallé en los bosques que se extienden á una fotra margen de los principales afluentes del Nilo. De¿iénense alli, precisamente en los mismos sitios habitados por las especies propias del pais; pero no traban con estas relacion alguna, $y$ al modo que las golondrinas, se alejan sin recordarse lo mas minimo de ellas. No podemos decir con entera certeza cuál sen el punto limite de sus viajes, pero si observaremos que raras veces se encuentra esta ave en las regiones mas al sur del Africa.

Cuando los clrotacabras vuelien, ya á fines de mayo aparecen en Egipto, pero aislados, y en numerosas bandadas á principios de abril; preséntanse poco desjues en Girecia, donde, asi como en el Asia Henor y en el Ailas, tan solamente anidan: y acelernado desde este momento su vuclo, Ulegan un poco mas tarde $\mathbf{1}$ las contarcas de Alemania Ast el chotacabras de Europa como otras especies de la subra. milia, traspasan en sus viajes los limites de su dominio, se gun lo prueba el hecho de haberse encontrado el escotornis climacuro en Provenza y cl chotacabras de los desiertos en Helgoland. Parece que los chotacabras no ponen mas que una vez, al airo: el periodo del celo variz segun los paises; pero coincide siempre con la primavera. El macho trata de cautivar a la hembra, y parn ello despliega todas sus gracias. Su ron ran y su grito son cantos de amor: despues del apa. irenmiento, deposita la hembra dos huevos en tierra, en algun sitio oculto debajo de un matorral, cuyas ramas toquen el s suelo, sobre un tronco de árbol cubierto de musgo ó en una mata de yerba. Nunca fabrican nido los chotacabras, ni se toman siguiera el trabajo de arreglar un poco la capa donde depositan los huevos; macho y hembra los cubren alternatiramente, y manifiestan el mayor cariñoa su progenic. Cuando le amenaza un peligro, levántase la madre que cubre, y huye volando, como paralizada; arrástrase por el suelo; re móntase despues por los aires y desaparece volando con las, alas tendidas.

Si el observador permanece silencioso é inmóvil juntó 'á los hueros hallados, no tarda en ver a la hembra, que se acerca; párase á alguna distancia de aquellos; mira en derredor con mucha jrecaucion y recelo, y si nota h presencia del observador que está espiando, mirale cie hito à hito; parece como que rellexiona ! se pone lyego en movimiento. VAse aproximando siempre mas y mas, dando cortos pasos a la manera de los ánades, y cuando se halla ya muy cerca, hinchase de repente y bufa con el objeto de espantar y ahujentar al perturbador de su tranquilidad.

La conducta del are en semejante caso es tan interesante y diverticia, que Eugenio de Homeyer, á quien soy deudor de estas noticias, nunca se descuidaba de cnsenar a aquellos de sus amigos que lo eran a su vez de los animales, el nido de un chotacabras que se habia establecido en su jardin, á fin de hacerles gozar del encantador espectáculo: icuán grande no debe ser el amor del ave hácia su futura prole para que en medio de su pequenez y debilidad ose acercarse de este modo al hombre formidable y casi siempre cruel para con los animales! Si se aproximan à su nido durante la noche, inquiétase en cxtremo la liembra "y grita como para pedir socorro al macho.

Estas aves recurren tambien á otro medio para librar á su progenie de los ataques de cualquier enemigo: Audubon ha observado una especie que trasportaba sus huevos, y hasta sus hijuclos a sitio mans seguro en el caso de haberse des. cubierto su nido, y no tengo por imposible que hagan lo nismo las demás especies. Durante mucho tiempo, dice, procuré averiguar cómo procede el choiacabras para llevar su cria i otm parte, y gracias al excelente olfato de un perro, pude reconocer por de pronto que la conduce nuy léjos. I.os negros, que observan bien, por lo general, las costumbres de los animales, me dijeron que los chotacabras empujaban of hacian rodar sus huevos con el pico; algunos campesinos á quiencs interrogué, creian que se los llevaban debajo del ala, y habiendo resuclto ascgurarme de la verdad, hé aquí lo que averigüe. Cuando una de estas aves, ya sea el macho ó la hembre, observa que han sido tocados sus huevos, eriza su plumaje, y permanece algunos minutos profundamente abatida; produce despues un ligero murmullo, y su compañero llega al instante, rasando de tal modo cl suelo que debe tocarle con sus patas. Despues de cmitir algunos gritos, coge la hem. bra un huevo con su pico ligcramente abierto, el macho hace otro tanto; ambos vuelan despacio y con prudencia, muy cerca del suelo y desaparecen en el ramaje. No se llevan asi los huevos sino cuando los ha tocado el hombre; y no los abandonan si este descubre el nido y se retira sin poner la mano en él.s

Macho y hembra permanecen todo el dia sobre sus hijue. los que acaban de salir á luz. Mi padre vió á uno de los cho. tacaltas ocultar sụ progenic, aunqque estaba ya completainente desarrollada. Los peņueños no reciben su alimento sino por la noche; sus padres comienzan por darles insectos blandos, efimeras y mariposas; luego les llevan otros mas duros, y acaban por ensenarles á cazar y a que busquen de comer por si nismos.

Rènetidas reces se ha tomado al chotacabras, cn el mo. mento de estar cubriendo sus hueros, por el cuclillo, y háse sostenido en su consecuencia que este ultimo tambien empo. llaba: á la verdad no acertamos á explicarnos el por qué de tal confusion, pues si se exceptúa el color gris del plumaje, en nada absolutamente se parecen las dos aves.

ENEMIGOS,-1.o son del chotacabras algunos carnice. ros y las rapaces. Fn el sur de Europa, donde se sacrifican toda clase de animales, especialmente comestibles, á las exi. gencias del apetito, se caza al ave para aprovechąr su carne; los griegos é italianos la consideran como un bocado muy exguisito y por este motivo la persiguen sin tregua ni descanso durante la época de sus emigraciones; en Alemania la acechan tan solo los naturalistas y los cazadores furtivos. El chotacabras como todas sus especies son aves de reconocida utilidad, como asi lo prucban sus costumbres y régimen, y se hacen, por lo tanto, acreedoras à toda nuestra proteccion y simpatia. Tan solo los necios y cuantos rinden culto \& lo maravilloso, pueden dar crédito \& las fábulas ridiculas

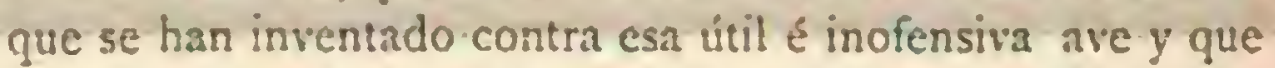
no son mas que monstruoso engendro de la ignorancia y del fanatismo. En esto sucede lo que siempre: aquello que no puede comprenderse, exalta la imaginacion de los ignorantes y les incita á urdir absurdas consejas y relatos inverosimiles, los cuales son luego aceptados como maneda corriente entre cierta clase de gentes. Por ridiculo que parezca, ello es cierto que todavia hay personas que toman el nombre de chotacabras al pié de la letray creen que esta ave va á chupar la leche de las cabras y de otros aninuales; y no faltan quienes se ia reptesentan bajo la forma de un sombrio fantasma ó de una hechicera dotada de inágico poder. Pero aquel que, como yo, pudo casi todas las noches observar al ave en el interior del Africa; quien tuvo la dicha de set risitado por ella junto á la hoguera que ardia durante la noche en medio del desierto; quien, rinalmente, al cerrar esta y cuando aca. baba de terminarse el alegre concierto de las ares diurnas, oyó resonar en sus oidos el canto ó grito de la misma á manera de cordial bienvenida, aquel y solo aquel puede amarla con verdadera pasion y proiegerla contra la torpe maledicen. cia y toda clase de persecuciones. 
CAUTIVIDAD.-Dificil es criar los chotacabras que se cogen en el nido; pero no imposible. Mi padre lo intentó varias veces y pudo consegurio dándoles coleópteros y mariposas nocturnas; pero morian muy pronto si se les alimen. taba con moscas: un pequeño que iuro mi padre devoraba de 360 a 480 en un solo dir.

Si se les alimenta bien, crecen muy pronto los individuos jórenes aunque estén cautivos, y no tardan en adquirir las costumbres de sus padres; se aplanan contra el suelo si se acerca un hombre á cllos; encolerizanse y bufan silbando.

Les gusia el calor, pero buscan la sombra: cuando mi padre ponia los suyos al sol, mstreaban para colocarse debajo de los barrotes de la ventana. 'l'schudi turo un chotacabras que hacia lo mismo y al referirse $d$ él decia lo siguiente: هicntras escribo estas lineas se pasea un chotacabras por mi cuarto; hace ya nucho tiempo que le tengo ye alimenta de insectos y gusanos: pero nunca come con gusto. Aunque es un are nocturna está muy avispado duraiste el dia; cuando hace sol sale de sis rincon, se echa en el sitio mas caliente, ensancha la cola y medio cierra los ojos; mas apemas desaparece el astro del dia, vuclve a su sitio y descansa de ordinario con el vientre appoşado en el sucio. No le gusta volar; da saltitos torpemente; se cae de lado a cada monen. to, $y$ permanece en tal posicion hasta que le levantas, aun. que está perfectamente bueno y conserva toda su fuer\%. Se ha domesticado muchn: pero si se accrca una persona des. conocida, produce un ligero grunirio. Le gusta estar en la mano, y mira a la gente con sus grandes ojos negros, que revelan la mayor confianza: c5 el favorito de toda mi fatilitis.

E:a los uiltimos tiempos he cuidado varios circtacaliras, y tanto por los datos que he podido recoger por experiencia propia, como pror los que se me han facilitado por otras personas, debo confesar que son aves de jaula un verdad poro atracivas, sin cmbargo de que merecen llamar la atencion por sus extranias costumbres. P'ara aquellos que saben tratar debidamente ares torpes y desmianadas, no es nada difficil criar las de que uos vecupamos: es verdad que debe alimen. tarse a los peryenos, ingurgitandoles al alimento, y que con respecto á los ya casi adulos, hay tambien necesidad de presentarselo í poca distancia; pero no lo es menos que sc puede acostumbrar á algunas de estas ares á cazar la presa que vuela en el interior de su encierro, $y$ a alinentarse por sí solas. Friderich nos refiere una anécdota verdaderamente conmoredora tocante a un chotacabras cautivo. Cogida el ave en su nido cuando jóren, y criada siempre con el mayor cuidado, llegt i hacerse en extremo mansa; - pero como su ducño tuvicra algunas dificultades para procurarle el alimen. 10, tomó la resolucion de dejar abierta la puertecita de la jaula y facilitarle de este modo la fuga. No queriendo el are aprovechar la favorable coyuntura yne se le ofrecia de reco. brar su libertad, á eso del anochecer el duero la arrojó al aire en medio de la campina; alejóse aquella volando, pero al cabo de un cuarto de hora volvió á casa del que la cuidabr.

Como se repitien mrins reces el ensayo, el chotacabras adnuirio la costumbre de irse volando adonde y cuando queria: pero a las primeras horas de la manama volvia sicm: pre á su antigua morada. A fin de habituarla por completo ¿ la libertad antes de que llegara la época de emigrar, é irnpedir de este modo que volviese, friderich llevo al ave as un lugar muy lejano y la soltó; pero al año siguiente, mientras se estaba arreglando el aposento en que habitara un dia, se hallaron sus restos desecados en un escondrijo: la pobre are, ya fuera por carisio á su primitivo dueno, ya instigada por el hambre, habia ruelto á la casa de este, y inurió sin que aa. dic se aparcibiera de elio.

\section{LOS PODAGEROS - PODAGER}

CARACTERES. - Se caracterizan por tener el cuerpo grueso; cabeza muy ancha; pico bastante fuerte, ligeramenie encorvado en la punta, con bordes un poco levantadosy cubiertos de sedas erectiles y cortas. I as fosas nasales se abren en la base de la mandibula superior; las alas son largas y agudas, con la segunda y tercera peunas mas largas; la cola corta, ligeramenie redondeada y compuesta de pen. mas anchas; los tarsos largos, desnudos y gruesos, asi como los dedos; la una del dedo medio es dentada, y el plumaje crectil.

\section{EL PODAGERO NACUNDA-PODAGER NA- CUNDA}

CARACTERES. - Las ares de esta especic, it ia que llaman los brasileños crenngo ó corrisngy. tienen el lomo par. do negro, con motas muj finas de amarillo rojo, la cabeza mas oscum que el centro de aquel: la espaldilla adornada de grandes mancinas parlo negras; las rectrices, moteadas tambien, presentan de seis á ocho fajas necrras, orilladas de blanco en el macho; la garganta, la linea que va del pico al ojo, las orejas y la parte anierior del cuello son de un amarillo rojo un poco manchado. Entre las dos orejas se ex. tiende una faja blanca; el vientre, las nalgas y las cobijas in. feriores de la cola son de este úlimo color; el ojo muy grande, de un tinte pardo claro: el pico gris pardo con la punta negruzca; las patas de color de carne con visos de un gris pardo. De las medidas tomadas por el principe de Wied, resulta que el nacunda ticne ()$^{\circ}, 2 S$ de largo por $0^{\circ}, 27$ de amplitud de alas; el ala p!egada mide 1$)^{\prime \prime}, 23$ y la cola $11^{\prime \prime} 10$ (figura 90).

DISTRIBUCION GEOGRÁFICA.- Por lo que dicen - Izara, el princine de Wied. Schomburgli y Burmeister, encuéntrase el nacunda en casi toda la América del sur, sobre todo en las estepas.

USOS, COSTUMBRES Y RÉGIMEN.- Esta especic evita los espesos bosques, asi como los lugares del todo des. cubiertos, y busca los sitios donde abundan las breñas. Dice Burmeiser que se la ve cerca de los pueblas, donde es bien conocida de todos con el nombre de rriangu.

El nacunda se disingue por sus costumbres diurnas y su sociabiliciad. Azara dice que caza los insectos de dia, y que se remonta par los aires a mucha mayor alturn que los demás caprimuilgidos, sin posarse nunca. Otros observadores asegu. rant que ruando se le espanta vucla solo a corta distancia, se posa luego en tiern, $y$ se oculta entre las yerbas a tres 6 cliatro pasos del observador.

So no le of mas que una vez durante mis viajes, dice el principe de Wied: en un cetcnso pasto, situado en el inieror de la provincia de Bahia, divisé un gran número de estas ares al medio dia, cuando era mas fuerte el calor del mes de febrero; inostrábanse vivaces y activas; volabar en medio de los bueyes y de los caballos; posábanse á menudo en tierra, y un monxento despues volvian i revoloicar alrededor del ganado, como hacen las golondrinas.

Dice Sclromburgk que el nacunda hace los morimientos de las pequeinas especies de rapaces nocturnas: cuando se acerca un hombre, levanta la cabeza y se oculta luego, es. perando una ocasion farorable para volar. Los indios han deducido del hecho que el ave tenia ojos en el lomo.

Al acercarse la noche se oje con frecuencia un grito pla. ĩidero, que se dice ser el del nacunda. Tarlor vió bandadas, que en su opinion constaban de varios centenares de indi- 
viduos, los cuales cazaban ruidosamente insectos, así en los claros del bosque como en el interior. Volaban con la mayor agilidad, tan ripidamente como los mas ägiles halcones; pero a la manera de las golondrinas. Cuando se posaban en tierra no se las pociia distinguir.

Burmeister ha descrito el huevo de esta arc, pues recibió a fines de octubre uno que fur hallado en medio de las yerbas, cerca de un maturral. Eira de forma cilincirica, y de color blanco, algo amarillo, cubierto de rayas trasversales de un gris parduseo, pardo rojo y pardo negro: la extremi. dad mas obtusa estaba nenosllistada que el resto del huevo. Azara dice que el ave prone gensaramente dos.

\section{LOS CORDEILOS-CHORDEILES}

Los corckeilos difieren ejancialmente de las especies anteriormente descritas, asi en su organizacion interna, como en su modo de vivir, que parece ser un término media entre el de los caprimúlgidos y el de los cipsélidos: estas diferencins son de tal importancia, que aigunos naturalistas los han clevado a la categoria de una sub familia particular.

CARACTERES.-Este grupo se distingue por tener el pico sumamenic pequeño y casi del todo cubierto por las plumas de la cabeza; por las rigidas sedas que guarnecen la

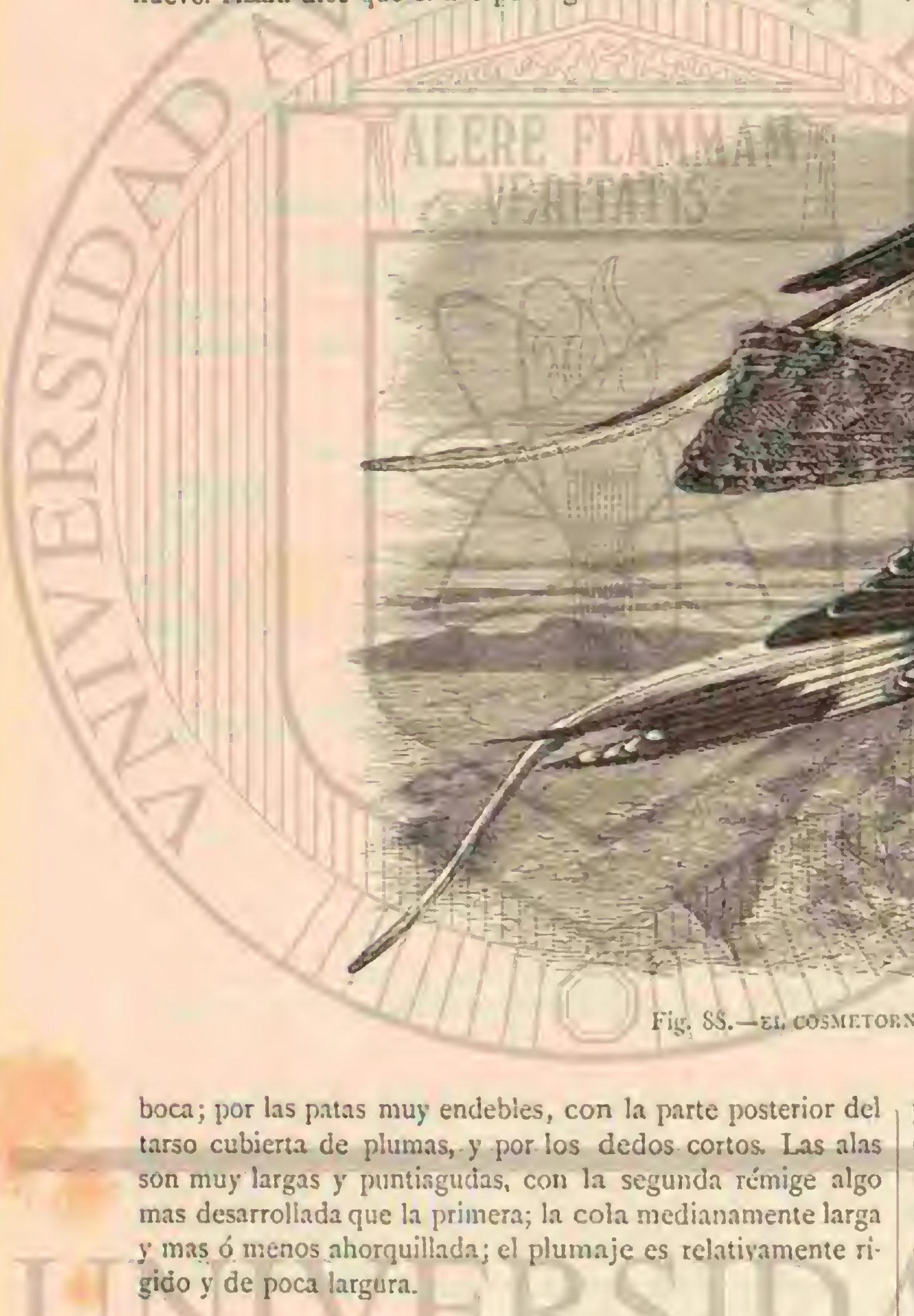

\section{EL CORDEILO DE VIRGINIA-CHORDEILES VIRGINIANUS}

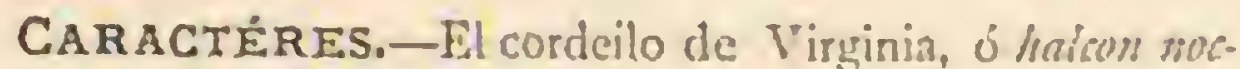
turnw, segun le llanan los americanos (Caprimsigus fopotuc, (mmericanus yo àrginianus) es la especie mas conocida del gru. po. Su tamaño es aproximadamente el mismo del chotacabras de Luropa: tiene $11^{\prime \prime}, 22$ de largo por $\|^{\infty}, 55$ de ala á ala; esta plegada mide 6,20 y la cola. 10,11 . El lomo es negro pas. dusco; las plumas de la parte superior de la cabeza y de la espaldilla presentan los bordes manchados de color de orin; Las sienes y la cabeza están cruzadas de fajas trasversales de un amarillo pálido; las mejillas, la cabeza y los lados del cuello son de un rojo de orin, con manchas negras; el án. gulo de la barba y los lados de la garganta presentan man. chas trasversales negras sobse fondo de orin; ei buche y el

pecho son negro pardos, adormados con manchas de color de orin; el resto del vienire es de este último tinte y se halla surcado de listas irasversales negras; nóiase en la garganta una mancia blanca, en forma de escudo, que se ra estrechando hacia los lados del cuello. Las rémiges son negras: las barbas internas de la primera y segunda, como tambien las internas $y$ externas de la tercera, cuarta yo quinia, muestran en el centro, una mancha trasversal blanca; la cara in; terna de las secundarias ó del brazo la presentan de color de orin pálido: las rectrices son negras y están cruzadas por seis fajas trasversales de un gris pardusco, las cuales se vuelven mas anchas y oscuras en las dos centrales que en las restantes; las dos mas exteriores llevan una lista trasversal blarier en la parte inferior de las barbas internas; el iris es pardo; el pico negro; los bordés de la boca amarillos, $y$ las patas de un amarillento de cuerno (fig. gi).

DISTRIBUCION GEOGRÁFICA, - Segun las investi. gaciones practicadas por algunos naturalistas y observadores americanos, esta ave se extiende por todos los Estados.Unidos desde Florida y Texas hasta las mas altas latitudes septentrionales y desde las costas del Atlantico hasta las del Pacifico: anida tambien en las Indias occidentaies, $y$ en sus peregrinaciones llega hasta la América del sur. Audubon la 
encontró en las regiones mas hácia el norte, en Nueva-Bruns. wick y Nueva. Fscocia.

USOS, COSTUMBRES Y RÉGIMEN.-Wilson. AU dubon, el principe de llied, Ridgway y otros naturalistas nos han dado á conocer detalladanente las costumbres de esta ave. Hacia primeros de abril, dice el segundo ke los observadores citados, aparece el halcon nocturno en la Luisiana y se aleja mas en direccion del este, pues ninguno se queda en dicho listado, ni tampoco en el del Mlississippi, para anidar. Cruza con tal rapidez las dos comarcas citadas, que pocos dias despues de habérsele visto, no se le encuentra ya: por el contmrio, cuando su viaje de otono, se detiene con frecuen. cia semanas enicras en los Fstados meridionales, donde se le puede ver deste mediados de agosto hasta el mes de octubre. Duranie este largo viaje pasa sobre nuestras ciudades y pueblos; pósase en los árboles que adornan las calles yo pocas veces en las chinieneas, desde donde lanza gritos penetrantes, con singular regocijo o admiracion por parte de las gentes que le escuchan. \$

Desde los tiempos de Audubon han cambiado radical. mente las costumbres de esta are, puesto que se ha establecido hasta en las ciudades mas populosas. Segun Ridgwaj, acrece cada año de un modo considerable el número de los halcones nocturnos ruuc habitan en Boston; y en los meses

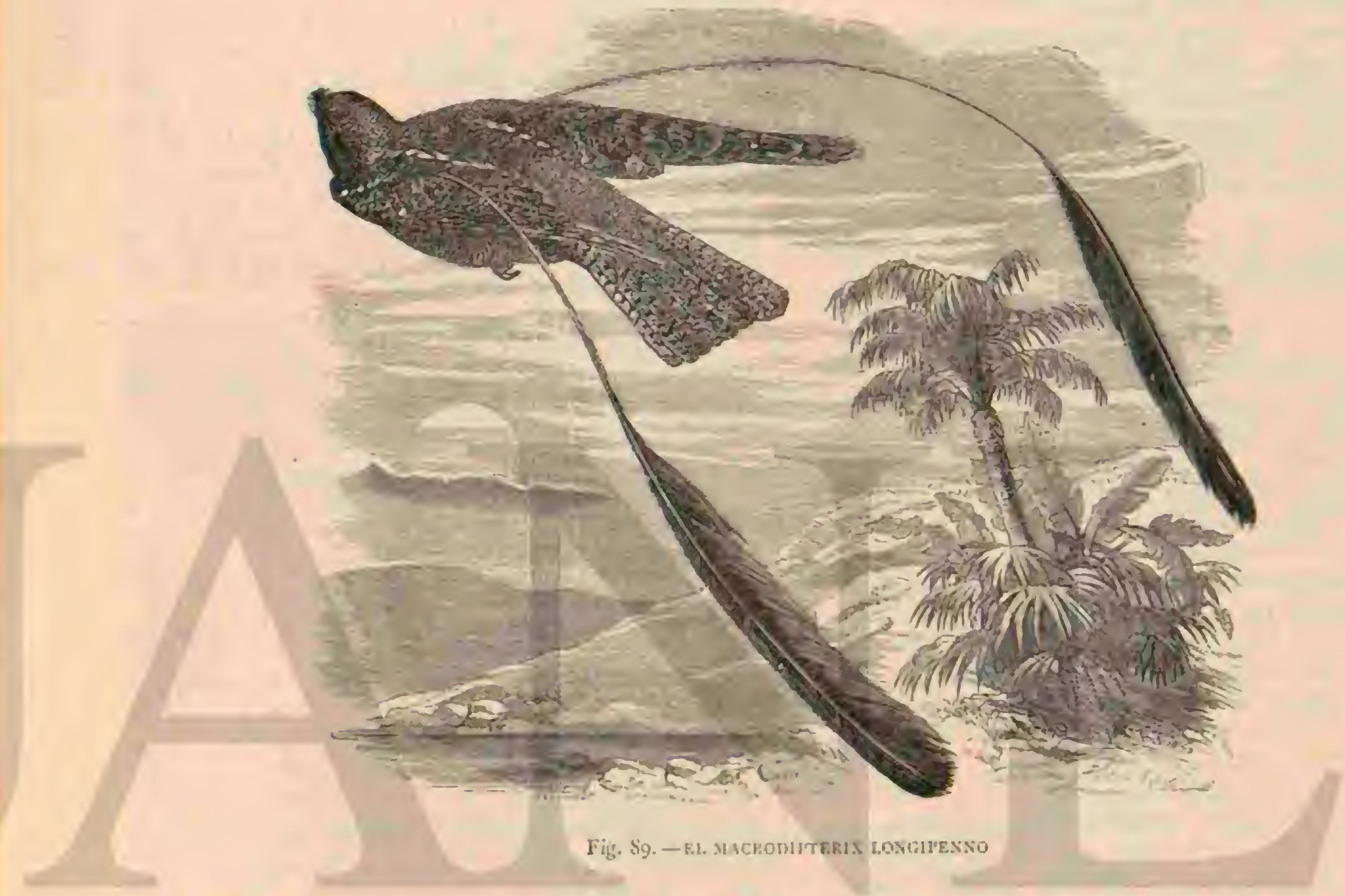

de junio julio se les ve cazar durante todas las horas de! dia, especialmente por la iarde, en las mas elevadas regiones de la atmósfera, como si fueran cipsélidos de pura raza. Los numerosos insectos que, segun el obsersador vilimamenic cirado, pululan en las grandes ciudades, tal rez á causa de los muchos jardines que las rodean, como tambien las azoteas, pueden haber contribuido á detener al alado habitante de las selvas.

Cuando se dirigen al norte, afrarecen en los Jistados del centro hácia primeros de mayo, y no llegan á anzuel punto hasia principios de junio; a urimeros de scticmbre, y a mas tardar a fines de este mes, abandonan ya las comarcas a donde vinieron a anidar. Segun Gundlach, se dirigen desde el sur á Cuba, y en abrit aparecen ya en esin isla; pueblan en numero considerable todas las estepas; pero en agosto 0$\}$ pincipios de setiembre van desapareciendo gradualmente para unsiadarse a Jamaica, donde pasan el invieno. Eligen por morada sitios muy diversos: comareas poco pobladas de árboles, estepas, campinas, ciudiades y aldeas, llanos y montanias, elevándose en estas i unos 3.500 metros sobic el nivel del mar.

Se notan diferencias tales entre el modo de vivir del halcon nocturno y el de los caprimuigidos, que Kidgway extraina se haya incluido el urro en el grupo de los otros. El cordeilo de Virginia no inerece en rigor el nombre que se le ha dado, pues no es ave nocturna, y si apenas crepuscular, recorcando sus costumbres mas bien á los cipsélidos que á los caprimiigidos. Vésele cazar por la mañana y en las primeras horas de la noche, y persigue en sus excursiones una presa muy diferente de la que persiguen estos viltimos: no bien ha cerrado la noche, da por terminada su cazn y el ave se retira á descansar. Audubon 1105 ha dado noticjas parecidas a las que acabamos de aptantar tocante á esta ave, si bien no acertó á crponerias en iodas sus consecuercias.

EFil vielo icl corduilo de Virginia, dice Audubon, es \$scil, ligero y sostenido: cuando hace mal tiempo se. le puede obscrmar de dia y se ve que sus movimientos son por demás graciosos. I)eslizase por los aires con incrcible rapiciez; se remonta de pronto $\delta$ se cierne a cierta aliura, cual si tratara de caer sobre una juresa, y vuclve a ejecutar un instante des. pues su primer movirnicnio. Produce á la vez griros pere. trantes; unas veces sube y otras baja; rasa la sujerticie del agua, y de repente se le re rozar los árboles mas altosy franquear las montainas.

y En el periodo del celo es cuando despliega principalmente todas sus habilidacies: el macho procura seducir ${ }^{\circ}$ la 
hembra con su gracia y distinguirse de sus rivales: de repente se eleva a varios centenares de metros lanzando su grito, tanto mas sonoro " frecuente cuanto mas se remonta el ave; y Juego, medio replegadas las alas, céjase caer oblicuanente. Creeriase que ha de cstrellarse contra el suelo: pero ensan. chando at tiempo sus alas y su cola, vuela mas léjos.

Cuando se deja caer asi, produce un ruido singular, resultante, segun (iundlach, de las vibraciones de las pennas de las alas $y$ de la cola.

• Es un espectáculo curioso, continúa Audubon, ver algunos machos reunidos, rivalizando en gracia y agilidad delante de una heinbra; pero la lucha no es larga, pues una vez que aquella elige compañero, este se preciyjin sobre sus rivalcs y los ahuyenta fuera de su dominio.

r. Cuando se acerca la noche y sojla fuerte viento, se apro. sima mas el ave á tjerra; entonces ruela con mas rapidez é irregularidind, y persigue a los insectos; por último, al cerrar la noche del todo, se posa sobre un árbol ó un icjado, valli permanece hasta el otro dia A semejanza de los otros câjri. múlgidos, apoya su pecho sobre el objeto donde se posa. Su gritu putede expresarse por las silabas fickictek.

- Aliméntase de insectos muy pequeños, principalmente de mpscis, de las cuales extermina un número increible.

3. Si se abre una de estas aves, dice el principe de Wied, encuentrase su garganta llena de una masa pastosa, que solo ise compone de moscas x

Tanto por lo que se acaba de expraner como por su mano ra del cazar, el hialcon nocturno se comporta del mismo modo que los cilsélidos, y merece, por cousiguiente, asi porsu for ma comn por su régimen y costumbres, ocupar un lugar in termedio centre estos últimos y los caprimúlgidos.

El jeriodo del celo comienza en los úlumos dias de mayo: la hembri deposita en el suelo, sin haber preparado deantemano ninguna yacija, dos huevos de color gris, sembrados de puntos y inanchas de un pardo verdoso y gris vio!eta. In la campinia, da hembra escoge para ello cualquier sitio á propó sito, ora se halle este en los campos y en la verde pradera, ora en los bosques y otros lugares parecidos; en las ciudades anida tan solo en las ozotens que se encuentran poro fre cuentadas por el hombre. La hembra es ta unica que cubre los huevos, y en cáso de peligró, no solo muestra un valor toda prueba, sino que tambien sibe cmylear la astucia y cl disimulo para alejar a los encmigos de su amada prole.

Los hijuelos nacen cubiertos de un plumon pardo oscuro: los pacires los crian cuidadosamente, y en caso de peligro los deínende la madre con valor, ó trata de llamar sobre si la atencion del enemigo. Cuando los hijuelos son un poco ma. yores todos los individuos de la familia permanecen uno al lado de otro, silenciosos, inmoviles; y en lugares tan bien elegidos, que es dificil dar con ellos.

CAzs.-Poco á poco va comprendiéndose en América que los cordeilos de Virginia son, como todos sus congéneres, aves útiles, y es por cierto de lamentar que se les persiga sin mas objeto que el de ejercitarse en el tiro. Audubon asegura que su carne es excelente, sobre todo en el otono, en cuya enoca están muy gordos. Nada dificil es csta caza, ni tampo co lo es matar un individuo al vuelo, pues se deja aproxinar
i tiro de fusil.

\section{LOS CIPSÉLIDOS-CIPSELI}

CARACTERES. - Véase, por lo demás, cuailes sol los caractéres que distinguen á los cipsćlidos: estas ares timen pequeña ó mediana talla; el cuerpo prolongado; el cuello corto; la cabeza ancha y poco convexa; el pico pequeño, cor to, endeble, trianguhar, muy ancho en la base, comprimido lateralmente hácia la punta, y con la abertura bucal enorme. Lass alas son angostas, encorvadas y en forma de sable; las pennas de la mano ó primarias ascienden á diez, y la prime. ra es por lo regular mas larga; en algunas especies algo mas corta que la segunda; las pennas del brazo 6 secundarins no pasan de siete ú ocho; son anchas, redondeadas y un poco escotadas en su cxiremo. La cola varia; tan pronto es corta como larga, mas ó menos escotada y compuesta solo de diez pennas. Los tarsos son cortos y gruesos; los dedos cortos tambien, provistos de uñas comprimidas lateralmente, muy cornas y aceradas. Ins plumas, pequenas por lo general, tienen un color oscuro, y rara vez brillo metálico.

Segun Nitzsch, đlos cipsélidos, ó por lo menos el martine. te negro, se asemejan \& las golondrinas, asi por las formas exteriores como por ciertos detalles de organizacion, a saber, por la estructura del esqueleto del cráneo, paráicularmente la de los husesos palatinos y por las dimensiones del brazo y de la mano. Aseméjanse asimismo a los hirundinidos y á muchas aves cantoras por la presencia de los huesos neuma. icos, por la forma de las bolsas aćreas y la del ligado, y por la preșencia de dos páncreas: pero tienen además caractéres que les son propios y por los que difieren, asi de las ares citadas como de todas las demás.

En los cipsélidos el esternon es grande, mas largo que an. cho, mas ancho por detrás que por delante, sin porcion mem. branosa, y con la quilla grande y alta. El himero es mas corto y neumútico, presentando tres apófisis casi ganciudas: su largo no excede del de la segunda falange del dedo mavor los huesos de la mano son mas largos que en los hirundínidos. KUnicamente los colibris tienen un brazo tan paqueno con uma mano lan larga: los dedos de las patas presentan tambien curiosas particularidades: mientras que en las ciemśs aves tienc dos falanges el pulgar, el dedo inter. ilo tres, el unedio cuatro y el extremo cinco, en los cipsélicios éstán representados estos nuimcros por dos, tres, tres y tres: al dedo medio parece asi tener una falange encogida, y el externo dos. (Burmeister observa que este caracter no se aplica sino a los martinetes propiamente dichos.) I a laringe inferior no tiene mas que un par de musculos bastante ende. bles; la lengua es casi tan plana, ancha y aguda por delante como la de los hirundinidos; el buche no existe; el ventriculo subcenturiado es pequeño; el estómago ligeramente muscu.

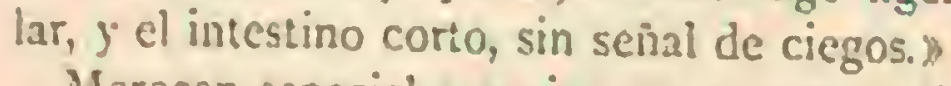

Merecen especial mencion por su extraordinario desarrollo las glindulas salivales, merced á las que pueden consiruir nidos de-natumleza especial. Segun las observaciones de Girtanner, hay en los dos lados del frenillo de la lengua dos grandes aglomeraciones de glóndulas salimales, que alojadas en la inucosa de la cavidad bucal, se extienden desde la punta de la mandibula inferior, siguiendo en la direccion de las ramas del maxilar tambien inferior, hasta la glotis: cada una de cstas agrapaciones glandulosas se divide y subdivide en otras varias. Durante la Epoca del celo, dichas glándulas están muy turgescentes y sẹgregan una saliva tan abundante y' viscosa, que estas aves pueden enplearia perfectamente para aglutinar los materiaics de sus nidos.

DISTRIBUCION GEOGRÁFICn.-1.os cipsélidos es. tán diseminados en toda la superficie de la tiern; se les en. cuentra en todas las \%onas, exceptuados los paises polares, y en todas las altitudes, desde las orillas del mar hasta el limite de las nieves eternas.

USOS, COSTUMBRES Y RÉGIMEN.-Se encuentran los cipsélidos lo mismo en los bosques que en los lugares descubiertos, siquiera habiten con preferencia las montañas las ciudades, porque se encuentran en los muros y las pare. des de roca excelentes sisios para anidar. 
Estas ares son esencialmente aéreas. Descie que lucen los primeros rayos de ia aurora hasta que se pone el sol, están en continuo movimiento; nunca parecen cansadas; bástanles pocas horas de sueĩo: recorren sin futiga centenares de leguas, y algunas especies se remontan a tal altura, qque desaparecen de la vista. Por el vuelo se las reconoce de téjos: sus alas extendidas, semejantes a una media luna, se mueven con tal rapidez, que parecen las alas de un insecto ó de un colibri. $A$ reces están largo tiempo sin agitarlas; cambian de direccion inclinándolas ligeramente de un lado î otro, y moviendo la cola de una manera tan iraperceptible, que no podemos notarlo. No obstante, cortan el aire con la rapidez de una saeta; giran y se revuelven de todos lados; pero sus movimientos son menos graciosos que los de los hirundinidos. En tierra se mueven con mucha torpeza: no pueden andar, $y$ apenas se arrastran penosamente; pero en cambio trepan bastante bien por los muros ó las paredes de roca.

Atendida su incesante agilidad, gastan mucha fuerza, y necesitan por consiguiente un alinzento muy abundante. $A$ esto se debe que los cipsélidos sean mas voraces que todos los hirundinidos; exterminan por lo tanto un considerable numero de insectos, devorando principalmente los que en. cuentran en las mas altas regiones de la atmósfera, para nosotros casi del todo desconocidos. No podriamos decir cuánto come al dia un martinete del tamaño del tordo; pero no cabe duda de que el número debe ser inmenso, poryue estas aves comen siempre que vuelan, y están en los aires casi todo el dia.

La vista está muy desarrollada en los cipsélidos: el ojo es grande y carece de pestanas; en segundo lugar figura el oido: si bien nada podemos asegurar acerca de los deruás sentidos. La inteligencia parece ser muy escasa.

I.os cipsélidos son sociables, aunque turbulentos y pen. dencicros; siempre están en lucha, ya sea entre sí ó con las otras ares; no son prudentes ni aun astutos; tienen carácter violento y exponen su vida aturdidamente.

Todos los que habitan las zonas templadas son emigran. tes; los que viven bajo los trópicos solo viajan dentro de reducidos limites. Muchos emignan con notable regularidad; llegan y se van en un dia fijo: pero la duracion de su fverma. nencia en un pais es muy variable, sin que se haja recono. cido la causa. Las especies que habitan el centro de Africa abandonan en ciertos momentos los lugares donde fijaron sus nidos, y segun he observado, vuelven mas tarde. Io mismo sucede, dicen los autores, con las que viven en cl sur de Asia y en la América meridional.

los cipsélidos cmigrantes permanecen tan pocotiempoen su pais, que apenas llegados se apresuran a construir sus nidos: persiguense los machos lanzando gritos; jelean furiosa. mente en los aires, $y$ tratan de ahurentar de su nido of los individuos que lo tienen hecho. Ia construccion de aquel difiere de la que tienen los de todas las demás aves: solo al. gunos hacen los suyos mas ó menos semejantes á los de los hirundinidos; muchos se contentan con amontonar en el fondo de la cavidad que eligen una porcion de heno, paja, retama, etc, la cual entrelazan torpemente. Sean cuales fueren los materiales de que se forma el nido, están aglutina dos por la saliva del are, ! tambien hay algunas especies que hacen el suyo con ha sustancia viscosa solamente.

La hembra pone un reducido numero de liueros, por lo regular cilindricos y de color blanco, y ella sola se encarga de cubrirlos. Los padres alimentan a sus hijuelos y los enseñan: cada pareja anida una y à lo mas dos veces al año.

I.os cipsélidos tienen tambien sus enemigos, si bien poco numerosos. Gracias â su ruela rápido, escapan con frecuen- cia del peligro; únicamente los halcones mas ligeros son capaces de alcanzar al martinete cuando ruela. I,os hijuelos estín expuestos á las acometidas de todos los pequeños carniceros trepadores: y hay, en fin, ciertas especies que son perseguidas por el hombre.

CAUTIVIDA D. - - hos cipsélidos no son ares que soporten fácilmente la cautividad; no es, sin embargo, imposible criar hasta la edad adulta aquellos que fueron cogidos pe. quenoos en su nido, con tal que se les ponga al principio el alimento dentro del pico para acostumbrarlos paulatinamente á comer solos. Ios cogidos cuando viejos, no pueden en maner alguna acostumbrarse al encierro: unas reces yacen inmóviles en el suelo; otras les da por trepar inecsantemente a lo largo de las paredes; rchusan toda clase de alimento y acaban por perecer, victimas de sus impetuosos arrebatos ó del hambre. Como no es posible ofrecer d́ estas aves un recinto bastanic cajar. para poder en él desarrollar sus facultades mas notables, se conducen siempre de una manera torpe y desmaỉnda. No propercionan ningun placer ni distraccion al que las cria, si bien logran por lo extrañas cauti. var la atencion del observador.

\section{LOS DENDROQUELIDONES -DENDROCHELIDON}

CARACTERES. - Los dendroquelidones, ó marfinetes de lus dibioles, se caracterizan por tener el cuerpo prolongado, el pico pequerio y la cola larga y sumamente ahorquillada. fas rémiges son muy largas, teniendo las dos primeras casi la misma largura que las otras; los piés estair conformados como los de las golondrinas. Los dendroquelidones se distinguen tambien por tener las plumas occipitales prolongadas en forma de moño; el esqueleto ofrece asinismo algumas particularidades y: llaman especialmente la atencion por una resicula biliar de que carecen los inartinetes.

DISTRIBUCION GEOGRÁFICA.- Todas las especies pertenecientes a este grupo habitan las Indias y las islas ad. yacentes, asi como la Australia y el Africa.

\section{EL DENDROQUELIDON KLECHO-DEN- DROCHELIDON KLECHO}

CARACTERES.-El klecho, llamado por los mainjos

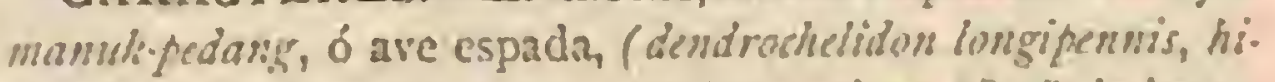
rundo, opsselus marroglergat y pallestre) tiene 11", 8 de largo; el ala plegada mide $" 1,15$ y la cola $1 ", 0 S$. Las anchas plumas del mono, la parte superior de la cabeza, el lomo, la espaldilla y la cobija son de un color verde negro oscuro, con reficjos metálicos poco brillantes: la extremidad de las tectrices del ala son del mismo tinte, pero tornasoladas de azul de acero; las mejillas y la region que se extiende debajo de! ojo, son negras; la rabadilla y las cobijas supracaudales de un gris de moho claro; las rémiges y las tectrices de 12 mano son negras, con visos azules de este último color; las del brazo, de un gris de moho, y las posteriores de 3.2 mano presentan cambiantes verdes de acero; las cobijas mas largas de la espaldilla son blancas, lo mismo que el vientre. La barba, la gargania, el buche, el cuello y los lados del cuerpo son de un gris de moho; las plumas de la carn infe. fior del ala de un verde negro: las rectrices, que se presentan sumamente escoladas, son negras, con reltejos verdes en la base $y$ azulado negros en la punta; el ojo es de un pardo subido; el pico negro; las patas de un gris de cuerno. El ma. cho tiene en la region de la oreja una mancha de un rojo de orin oscuro, la cual no existe en la hembra (fig. 92).

DISTRIBUCION GEOGRÁFICA،-El úrea de disper. 
sion de esta especie se extiende por las grandes islas de la Son. da, Java, Sumatra, Borneo, Banca y la peninsula de Malaca.

USOS, COSTUMBRES Y RÉGIMEN.-Todas estas aves difieren notablemente de las demás de la misma familia por lo que hace á los usos y costumbres: habitan en los jun. cales y en las espesuras, especialmente en las que se hallan en cl llano; gustan de posarse en las copas de los árboles, por mas que su habilidad en trepar sea escasa.

Segun Jerdon, encuéntrause en las Indias bandadas muy numcrosas a veces; pero reducidas por lo regular á unos cunntos individuos, que ian pronto se posan en los irboles secos, desnudos de hoja, como cortan el airc con rápido

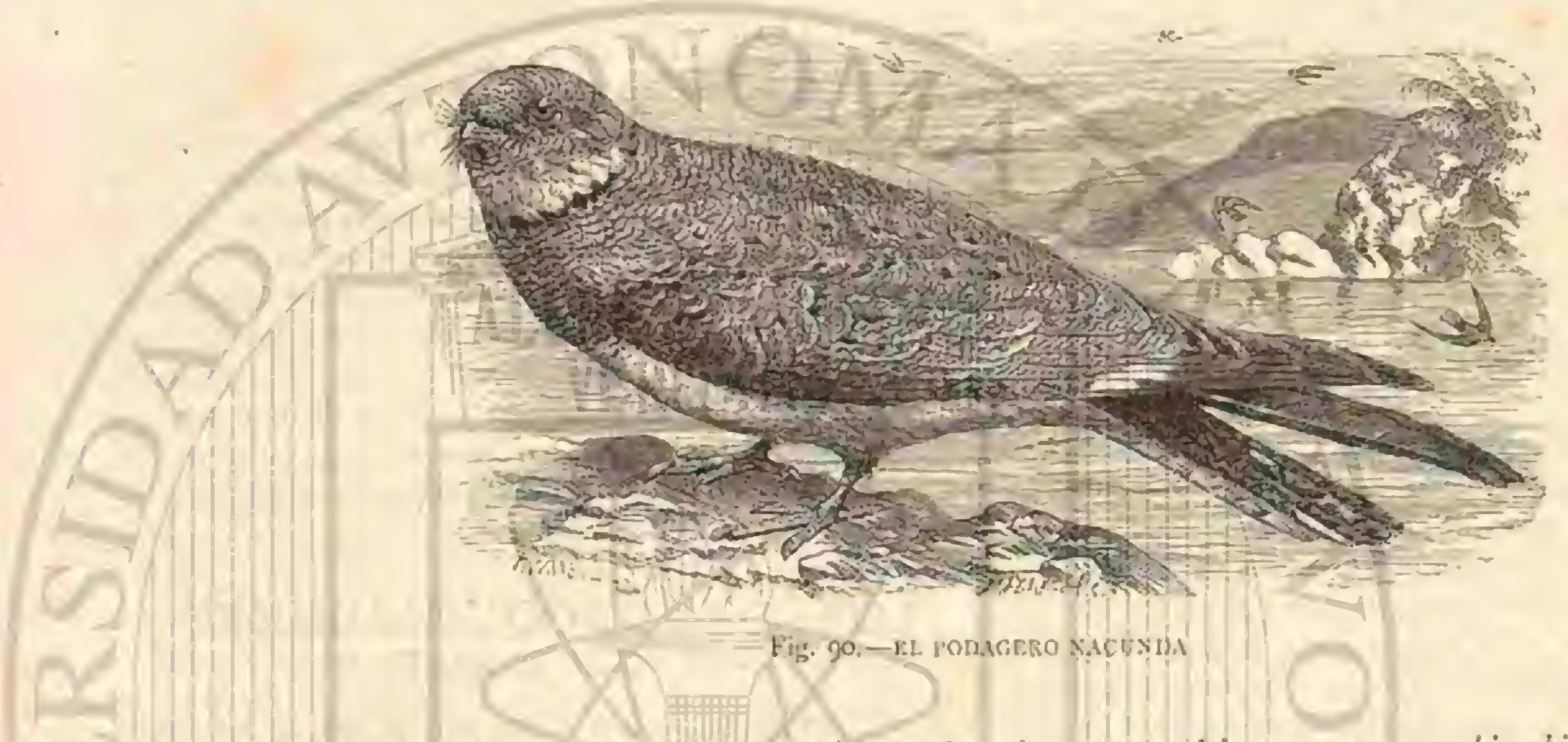

vuclo, inanteniéndose siempre cerca de las corrientes de agua. Cuando descansan enderezan su cucrpo, bajando continuamente su moño: al volar producen un grito penetrante, parecido al del papagaro, que indica desde léjos su presen. cia, y que podria expresarse por kia, kia, kia; y si están posados entonan un breve canto, que se ha procurado traducir con las silabas tichiffel tichaffel kleko kleko, y del que han re. cibido su nombré.

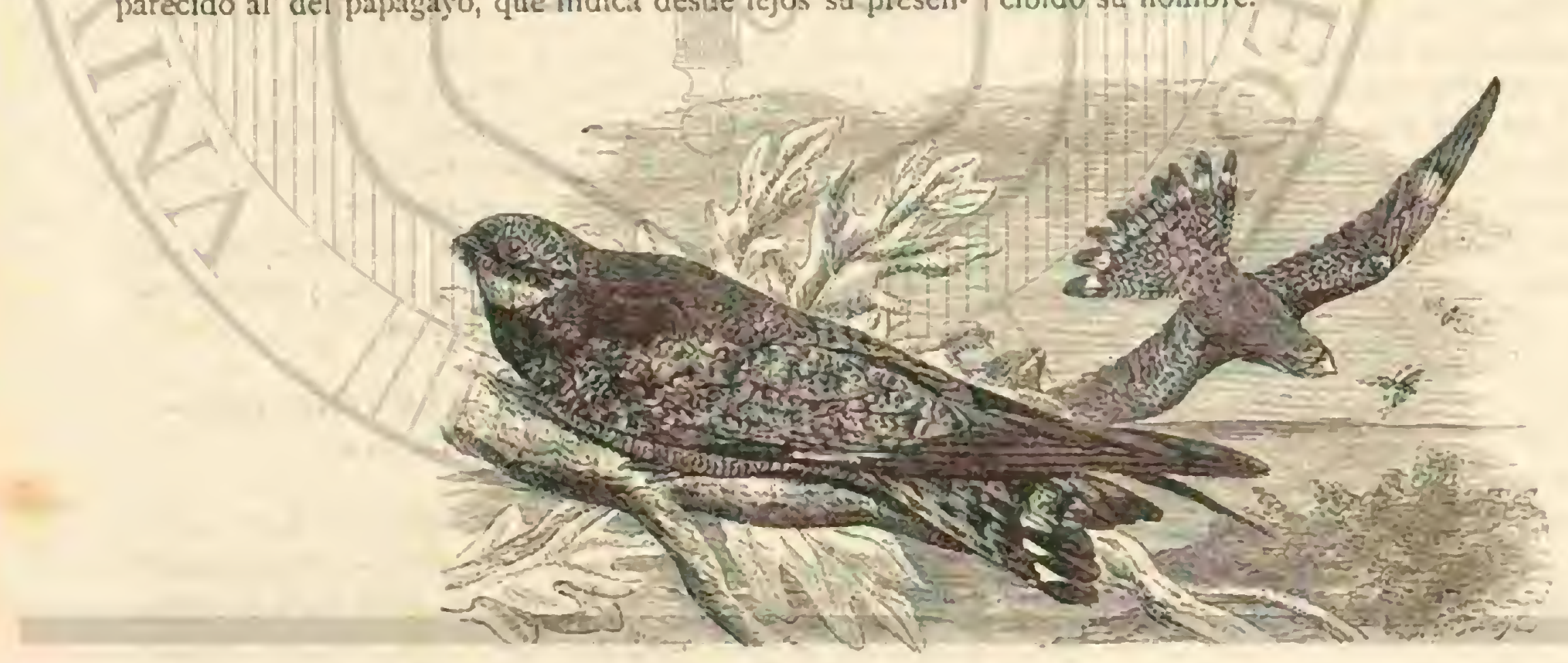

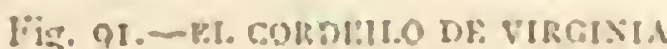

Bernstein nos ha dado detalles muy interesantes acerca del modo de reproducirse el kilecho. «ista ave, dice, construye su nido de una manera particular: mientras que las demás aves anidan a lo largo de las rocas $\delta$ de los paredo. nes, en aberturas y grietas, ella lo hace en las. ramas mas altas; por su forma hemisférica y por la manera con que cstán dispuestos los materiales, aseméjase bastante su nido al de la salángana, si bien - es mucho mas pequeño y merios profundo. Todos los que yo examiné no tenian mas que to milimetros de profundidad $y$ de 30 á to de diámetro: este nido, fjado en una penqueña rama horizontal, de unos 1,",oz de espesor, que constituye la pared posterior de aquel, parece asi una pequeña copa, y apenas puede conterer un huevo. Las paredes son tan delgadas, que se podrian comparar á una hoja de pergamino; se componen de plumas, liquenes y cortezas, enlazado el todo por una materia vis. cosa, probablemente la salisa, pues adviertese que en el pe. riodo del celo llegan â cstar muy turgescentes las glándulas salivales de estas aves. El nido es tan pequeño y frágil, que no pudiendo el ave sostenerse en él, se posa sobre la rama y cubre con su vientre el único huevo que pone. Este último tienc 25 milimetros de largo, y 19 en su mayor anchura; es de forma ovalada muy regular, y no se distingue el extremo grueso, del delgado: su color es azul celeste, mas claro cuando se racia - Segun mis observaciones, esta nve anida dos reces al año: la primera en mayo 6 junio, y la segunda paco despues; solo raras veces el mismo nido sirve para las dos puestas.

- Esta desproporcion aparente entre la talla del ave, el grandor de su nido y el de su huevo, excitó mi curiosidad por observar al hijnelo; era cvidente que poco despues de salir á lu\%, no podria permanecer en el nido; y en efecto, habiendo dejado á una pareja de estas aves cubrir tranquilamente, algunos dias despues de nacer el pequeño, llenaba.

\section{co}


completamente el espacio en que se hallaba. Entonces aban donó el nido y tomó la postura que tenia la hembra al cubrir, es decir, se posó sobre la rama apoyando el vientre en el nido. En tal estado, seria el avecilla ficil presa de todas las rapaces si no se valiera de un artificio para cscapar a sus miradas No abandona su posicion antes de estar completa. mente desarrollada; mas apenas divisa algo sospechoso, levanta el cuello, eriza todas las plumas, inclinase hácia adelante de modo que las patas quedan invisibles; y como permancec completamente inmóvil, y se armoniza lan bien su plumaje, moteado de pardo y negro, con el color de las ramas cubiertas de liquenes blanquizcos, es muy difícil divisarla. Mas tarde, cuando llegó a ser el hijuclo mayor, mandé cortar la rania, con el nido que estaba sujeto á ella, y el avecilla se condujo del mismo modo, permaneciendo inmóvil. Hizo pues lo contrario de lo que hacen las demás aves pequeñas, álas que vemos alargar sus picos, muy abier. tos, hácia las personas que se acercan, lanzando gritos las timeros.

\section{LOS VENCEUOS - GYPSELUS}

CARACTERES.-El género vencejo, que se puede con. siderar como el tipo de la familia, se distingue de sus congéneres por tener su primera rémige casi la misma largura de la segunda $y$ por su cola ligeramente ahorquillada; las patas son gruesas y vigorosas, cubiertas de plumas en la parte an. terior $y$ desnudas en la posterior.

DISTRIBUCION GEOGRÁFICA.-En Europa viven dos especics de este grupo: la una en todas las regiones de la misma, y la otra, que es la de mayor tamaño de la familia, tan solo en las comarcas montañosas del sur; las dos, sin embargo, se encuentran en Alemania.

\section{EL VENCEJO ALPINO -- CYPSELUS MELBA}

CARACTERES.- El rencejo alpino (rypselus alpirus, falluralis, gularis y Layardi, hirundo melba y alpina, upus y micropus melio ) es mas grande que sus congéneres: tiene $0^{\mathrm{m}}, 22$ de largo $y$ de $U^{\prime \prime}, 55$ á $0^{\circ}, 56$ de ala a ala; esta plegada mide $0^{\prime \prime}, 20$ y la cola de $\|^{\prime \prime}$, oS a ()$^{\prime \prime}, 09$. Li parte superior del cuerpo, los lados de la cabera y las tectrices sub-caudales son de un pardo de humo oscuro; las pennas tienen los bordes termina. les de un color pardusco de acero; la barba, la garganta, el pecho, el vientre y la region de las nalgas son blancos; en la parte superior del pecho se nota una faja de color pardo, la cual abarcando por uno $y$ otro lado el espacio comprendido entre la base del pico y la espaldilla, se estrecha considera. blemente en el centro de aquel. Las rémiges son de un negro pardo mas oscuro que las plumas de la cobija superior y se distinguen por reflejos de un verde bronceado; Ja cobija infe. rior, asi como ta de las rectrices son de un pardo gris bri llante; el ojo es pardo oscuro; el pico negro; las patas desnu das y de este último color.

DISTRIBUCION GEOGRÁFICA._El centro de disper sion de esta magnifica ave se encuentra en la cuenca de Mediterraineo: desde este mas extiendese por un lado hácia las costas de Portugal, los Pirineos y los Alpes, y por el otro hácia el Atlas y las elevadas cordilletas del Asia Menor, corrićndose desde es:a punta a lo largo de la costa del mar Caspio y del lago Aral, se dirige hácia el este y llega hasta la region septentrional del Himalaya. Infiérese de lo dicho que el vencejo alpino habita tocias las cordilleras de Espana que le ofrecen condiciones favorables, especialmente las de la costa del Mediterráneo, las igualnente apropiadas de la pe ninsula de los Balcanes, varios sitios de los Alpes, las mas al TOMO III tas montañas de Italia y de todas las islas del mar citado, los - Alpes de Transilvania, las paredes de los escarpados peỉascos de Crimea, del sur de los Urales y de las sierras del Turkes. tan hasta Cachemira, algunos puntos de la Persia, y la mayor parte del Asia Menor, de Siria y Palestina; anida, por tíltimo, en el Atlas y va tambien 2 veces à cfectuarlo mas allá de los limites de este vasto dominio que acabamos de fijar.

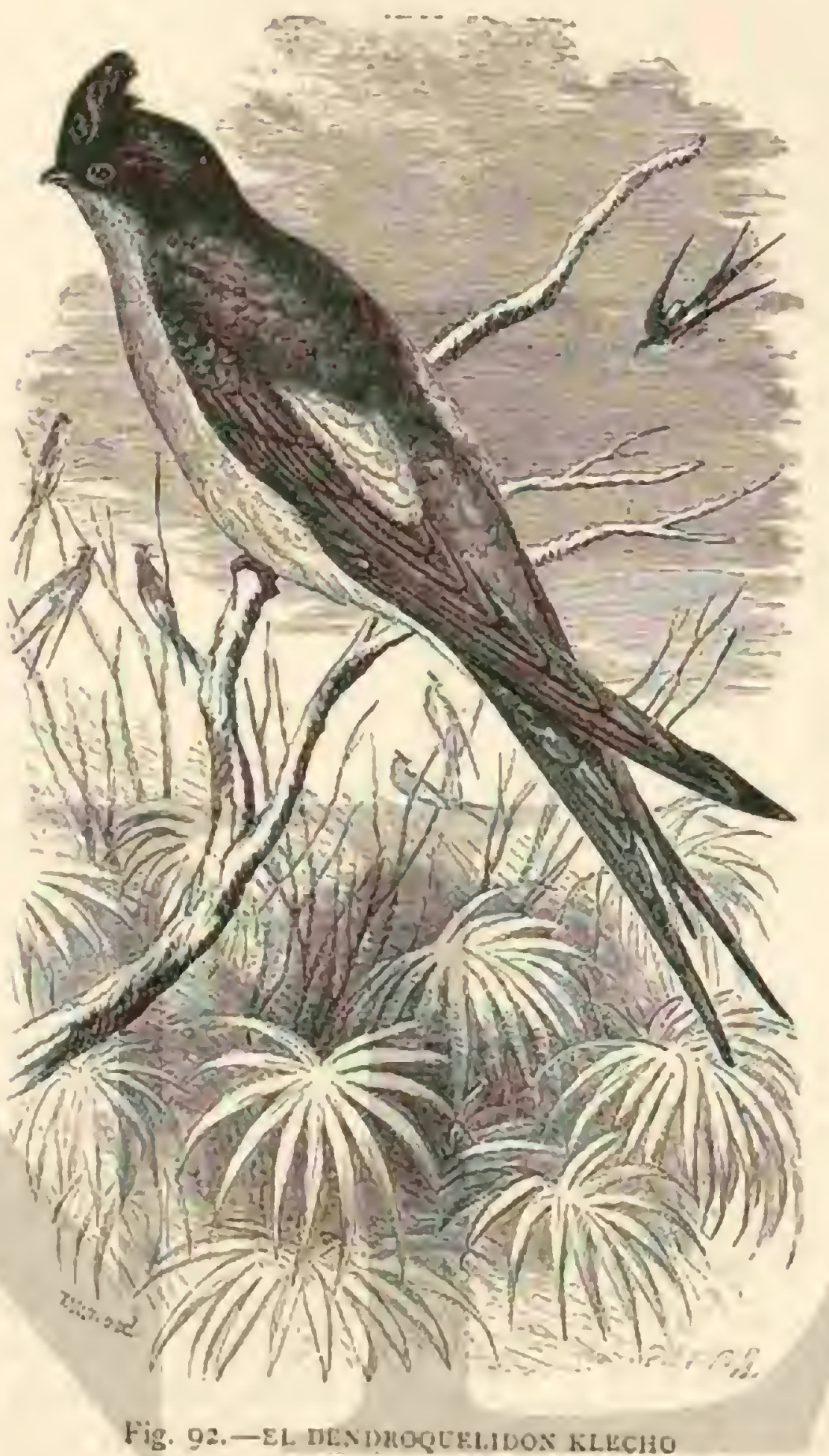

Segun lo observado por Heuglin, esta ave va á hacer su nido en las sierras del Habesch, especialmente en las pare. des de las rocas de basalto verticales y del todo inaccesibles que se hallan en Tenta, en Woro Heimano; y al decir de Jerdon, en diversos puntos de las Indias orientales, en aque. llos muros penascosos que satisfacen sus deseos. Debe, sin enbargo, notarse que en ninguno de los sitios indicados es el venccjo alpino ave de morada fija: en cl norte de su do. minio emigra por el contrario, con regularidad, y en los puntos restantes es quizás simple ave de paso.

USOS, COSTUMBRES Y REGIMEN. - El renccjo alpino aparece mucho mas temprano que el comun en la costa meridional del Mediterräneo; segun Tristram, ya à.me. diados de febrero se presenta en Siria, $y$ segun ha observado Krueper, a fines de marzo en Grecia y no mucho mas tarde en Suiza. I.a época de su aparicion en el último de los paises citados, fluctúa entre los ültimos dias de marzo y media. dos de abril, adclantándose 6 retardindose segun la tempe. ratura reinante. El veridico Reinhard, guardian mayor de la torre de la catedral de Berma, comunicó à Girtanner que en la primavera se presentan primero dos 6 tres de estas aves, describen, lanzando penetrantes gritos, unas cuantas vueltas al redecoor de su vieja morada, y luego, como si se lubbieran 
cerciorado de que ella cxistia aun y era asimismo habitable, desaparecian para volver despues en major número, hasta que á los ocho dias llegaba toda la bandada, compuesta de unos 150 individuos. Apenas es menester observar que muchas de estas aves perecen si despues de su vuclta, como no pocas veces sucede, cl frio se recrudece aun por algunos dias, ó bien cae una nerada copiosa. Reinhard asegura que áfines de abril de! año 1 S6o habia podido recoger unos 23 vencejos alpinos que halló muertos despues de una abundante nevada en las galerias y maderámen de la torre de la catedral de Berna; pero que no podia naturalmente precisar el número de aquellos que perecieron de hambre y de frio en escondrijos del todo inaccesibles, asi como tampoco el de los otros que, caídos desde las mas eleyadas regiones de la atmósfera, habian ido ámorir léjos de la citada catedral.

Hace algunos anos, Girtanner encontró a principios del verano én el monte Rosa, cerca de San Gall, un vencejo alpino que yacia en el suelo sumamente rendido y demacrado: pro. bablemente el ave habia subido á aquellas àlturas en busca de alimento desde los Alpes de Appenzell, cubiertos de una ś́bana de nieve recien caida. Ia epoca de la partida de estas aves lácia el sur, es determinada, lo propio que su vueita en primavera, por las condiciones atmós!ericas y alimenticias, y cae entre nuediados de setiembre y principios de octubre. En el año 1866 abandonaron la catedral de Berna á prineros del úlimo mes citado, y en el de $1 \$ 6 \hat{\gamma}$ á del mismo; por el contrario, en el 12 de octubre del sigujentenno, se encontra. ban aun estas aves en la citada catedral, por mas que hubicran padecido tanto á causa de la nieve y del frio, que otra vez volvieron â hallarse muchas de cllas muertas de hambre. En una carta que en fecha 13 octubre de 1860 dirigió a Cirtanner y que este turo la amabilidad de cejarme leer, Reimhard describe del siguiente modo la partida de las aves: a las siete de la marana del dia 7 de estemes, los vencejos alpinos emprendicron su viaje al Africa. Unos cuantos dias antes de marcharse, todas las mañanas y casi á la misma hora se les rein abandonar la torre y remontarse a tal altura, que no era posible divisarlos sino con el auxilio del anteojo; reunianse en aquellas elevadas regiones formando circulo y no cesaban de revolotear hasta la puesta del sol, en cuyia hora descendian otra vez para descansar y dormir. Durante estos dias, á diferencia de lo que antes acontecia, pasaban la noche en profunda tranquilidad y silencio, sicndo ello motivado, sin duda, por el cansancio que naturalmente debia seguirse á tan continuado vuclo. En los años anteriores algunos de ellos continuaban aun revoloteando al rededor de la torre despues que la mayor parte habian ya marchado; pero en el presente no ha sucedido lo mismo, habiendo desaparecido todos el $;$ de octubre, sin que se hubien viclto í ver ningun otro en lo sucesivo.

Durante sus peregrinaciones, el vencejo alpino traspasa con frecuencia los limites septentrionales de su dominio, pues se le ha visto repeticas reces en el norte de Alemania, en Dinamarca y en las islas Británicas. Fi dia $S$ de junio de 1791 , Bechstein le vió en la floresta de Turingia; el profesor Bro. mirshi pudo cogerlo en la corre de Wittstock cl 22 de marzo de 1811 ; el 15 de setiembre de 1849 , se le mató de un tiro en las inmediaciones de la ciudad de Coburgo; uno fué ar. rancado de las garras de un halcon emigrante, que fué mucr. to cerca de la cueva de San Blas, y finalmente otro que, segun Eugenio de Honejer, se conservaba antes en el museo de Rostock y que fué destruido por la polilla, habia sido matado en Mecklenburgo. Vorggreve duda, aunque sin fundarse en razon alguna, que el vencejo de los Alpes apa. reaca en los citados lugares, admitiendo únicamente que pu. diera laber sucedido así tas solo en casos raros: pero nó cabe duda que el observador citado no ha recorrido aṇuellas comarcas. Las noticias dadas por Bechstein son tan precisas, que no se puede menos de dar crédito á lo que nos dice este excelente observador $\lesseqgtr$ que à continuacion reprociu. cimos.

هlas tres aves (los vencejos alpinos) continuaron volando á mi airededor à tan corta distancia y por tan largo tiempo, dice Bechstein, que pude distinguir con bastante precision, así su tamaño como su color, y cra, por consiguiente, impo. sible que las confundiera con el rencejo comun. iLástima qุue no tuviera en aquellos momentos una escopeta en mi poder? La yoz de las tales aves consistia en un siri seri claro, vibranie y sonoro; desde entonces no las pude ya ver mas." No son menos positivas las demás noticias que sobre el parti. cular poscemos, y solo parece no serlo la que nos da Cloger tocante al vencejo alpino en la cordillera de los Cigaries, coniundiéndolo probablensente con el vencejo comun, que, segun mis observaciones, anida en las hendiduras de los pe. ñascos de aquellas montainas. El vencejo alpino fué tambien muerto en Helgoland, y es probable que, sin ser notado, cruce volando la Alemania mucho mas i menudo de lo que pudieran suponer los ornitólogos. Durante su viaje de invierno va mucho mas léjos que cuando se dirige al norte: como su congénere atraviesa toda el Africa; encuentrasele en las regiones del sur y del sudoeste, lo mismo en el cabo de Buena Esperanza que en el pais de los namaqueses, y revolotea tan alegremente en la montaña de la Tabla como sobre los mas altos picos de la cordillera de Santis. lerdon halló millares de estas aves, que se habian establecido cerca de las cataratas de Gairsoppa en unos peñascos que se le. vantan como á 300 metros de altura sobre el nivel del valle; al decir del citado observador, todos los vencejos qué van errantes sin tregua ni descanso por el sur de la India, reñnense en este sitio para pasar la noche.

Tan creidos están los habitantes de la isla de Capri, dice Bolle, de que el rencejo alpino pasa el invierno en los barrancos de la isla, en.lugar de cruzar el mar, como lo hacen otras aves, que nadie seria bastante á convencerles de lo con. trario; pues á no ser verdadera su antiquisima creencia, dicen aquellos buenos islẹnos, quienes en punto á zoologia saben tanto como Aristóteles, que esta ave no cazaria durante el dia tan crecido número de moscas para llevarlas á las grietas de los penascos, aun despues que estas fieron ya abandonadas por sus pequeños. Lo inismo opinan los habi. tantes de Montserrat, los cuales hacen cabal distincion entre el vencejo alpino, al que dan el nombre de falsia blansan, $y$ el negro ó comun que denominan falsín negra; y sostienen que el primero mora durante todo el verano en las paredes de las perias de dicha montania, mientras el segundo emigra con perfecta regularidad. Tales y tan preciosas indicaciones me hicieron aquellos habitantes tocante, a la particha y llega. da del vencejo comun, que á la verdad me parece deben ser tendidas en consideracion las concernientes al vencejo al. pino. No es cicrtamente imposible que este pase el invierno en Lspana, pues en ella permanece durante la citada esta. cion el cotilo de las rocas (entule rupestris), que comparte á menudo su morada con el vencejo alpino, y como tendré oca. sion de notar mas tarde, aun en el mes de noviembre observé el comun en el sur del pais. Si los datos de los moradores de Montserrat íueran ciertos, entonces quuizas se referirian, no á los vencejos alpinos que durante el verano anidaron en las paredes de las rocas de aquel monte, sino í otros que llegados del norte, vinieron a buscar abrigo en las quebradu. ras de aquellas, cuando las habian ya abandonado los primeros para trasladarse á las regiones meridionales del Africa.

No nos faltan motivos para dar á nuestra ave el nombre 
de vencejo alpino, por mas que en ningun sitio de los Alpes sea tan contun como en las comarcas del sur, en algunos de curos puntos se reune á reces en numerosisimas bandadas, al paso que en aquella cordillera es en todas partes mucho menos numeroso. Girtanner enumern una serie de lugares á donde $v$ á anidar regularmente esta ave: segun su opinion, en todas y cada una de las mas clevadas sierras de Suiza se cuentran establecidas algunas colonias; pero donde se pre. senta en mayor número, es en la region meridional de los Alpes, especialmente en el Valais. Conócense varios sitios donde fabrican estas aves sus nidos, en el Hasli superior, en Gemmi, en Pletschberg, en los periascos del Entlibuch, en los del valle de Urbach, en el canton de Berna, y en va. rios desiertos pedregosos del valle de Heremance. Los ven. cejos alpinos se encuentran menos frecuentenente en cl este de Suiza que en el oeste y en el centro; sin embargo vénse tambien algunos en el canton de los Grisones y en los mon. tes de Appenzell. En el lirol y en la Carintia anidan tan solo en algunos sitios; pero no lo lacen, que jo seja, en las mas elevadas montañas de Baviern, y se agita muclio la cuestion acerca de si es verdad que se les haya encontrado em. pollando en Alemania. Además de las paredes de las rocas, entre las que prefiere aquellas que se hallan á orillas del mar o en sus inmediaciones, habita tambien nuestra are los edificios elevados, a donde ruelie todos los anos con la cons. tarcia y terquedaci propia de todos los cipselidos, despues de haberse establecido una sola rez, en cilos. Entre los sirios escogidos para construir el nido, citaremos como principales las iglesias de Ierna, Friburgo y Burgdorf, las torres de Portugal, especialmente las de la provincia de los Algarbes, las mezquitas de Constantinopla y algunos monasterios construidos en puntos eleriados en Crimea.

Aunque los usos y costumbres del vencejo alpino se asemejan en lo esencial a los del comun, sin embargo difieren notablemente de los de este bajo diversos puntos de vista. Muchas son las noticias que, sobre todo en los últimos ticm. pos, nos lan facilitado varios naturalistas alemanes, ingleses ¿ italianos, respecto del modo de vivir de esta ave, sicndo las mas inieresantes entre todas cllas las contenidas en dos pre. ciosisimas descripciones que nos han dejado Bolle y Girtan. ner y de las que extractamos lo siguiente:

Luego despues de su llegadzal pais donde acostumbran hacer cria, dice el perspicaz observador últimamente citado, los rencejos alpinos comienzan a construir nidos nuevos ó ås restaurar los que antes tenian. Como les es dificil levantarse nuemmente del suelo en que nunca se posan sino de mala gana, recugen los materiales para su nido en las regiones del aire: estos consisten en paja, heno, hojarasca y demís objeros que fotan en la atmóstera á merced del viento, b’ que estas aves atrapan al ruelo. Procúranse tambien otros nuateriales, volando rapidamente hasta rasar la superficic del suelo y del agua, ó agarrándose a los muros donde es posible recoger algo. I a argamasa con que unen todos estos matcriales para formar su nido, no han de sacarla del suelo, como sus congéneres las golondrinas; llérnnla consiantemente consigo, $y$ consiste en una sustancia viscosa, semi-liquida y semejante á una solucjon de goma saturada, la cual segrcgan sus grandes glánduhas salivales. A pesar de mis esiuerzos para obtener uno de estos nidos, que fuera sacado de la montana, no me fué dable conseguirlo, de modo que todo cuanto sé resjecto de ellos y de su formacion, lo debo al cxímen comparativo de los seis que tiene en su coleccion el Dr. Stolker, proce. dentes de la torre de la catedral de Berma.

Lo primero que llama verdadcramente la atencion en tales nidos, es su extraordinaria pequeiter, atendido el tamano del ave: afectan por lo comun la forma de una taza redonda, de $0^{\circ}, 10 \leqslant 0^{\circ}, 12$ de diámetro en el borde superior, de $0^{\circ}, 04 x^{\circ}$ $1^{\circ}, 06$ de altura y $0^{\infty}, 0,3$ de prolundidad ó hueco. Para ņue se acomoden perfectamente i nuestra are, es preciso que ape. nas tengan hueco, de lo contrario esta, con sus largas alas y cortas patas, no podria posarse convenientemente en ellos ni alcanzar al fondo de los mismos. Son tan penueños, que lle. gan á desaparecer por completo de la vista, cuando contienen un su cavidad al macho y a la hembra 6 a los varios hijuelos de eslos. Sin embargo, a pesar de su poca capacidad, lienen casi la suficiente para poder albergar un ave de tan escaso tamaio como es el vencejo alpino, y por cira pate, tanio los viejos como los júvenes saben cogerse perfectamente con las unias a los nidos para evitar el caerse. Deshaciendo con cuidado uno de ellos, se viene á conocer que están cons. truidos del modo siguiente: despues de haberse extendido una capa de saliva sobre la superficie de la viga, hueco del muro, hendidura de la peña, ètco, en que debe construirse el nido, colócanse encima de dicha capa hojas, paja, yerba seca y otros matcriales parecidos, y se hallan estos tan fuertemente adheridos a la saliva viscosa, que cuando se saca el nido, siguen ambien con él perqueños frngmentos de la viga corrompida. Ias hojas, briznas y demás de que se compone el nido, están dispuestas, parte en forma circular, y parte entretejidas; el borde inferior se compone de tallos fuertes y estrechamente entrelazados; pero como debe ser propor. cionado a la capacidad del agujero donde el nido se consiruye, el ave se ve con frecuencia obligada á abancionar la forma original redonda de este para darle otra diferente. Sobic estos materiales asi dispuesios y pegados å la saliva, va continuando el are la construccion de su nido. Cuando esic se halla apoyado solo por uno de sus lados, se adhiere tambien á la sustancia viscosa; pero en este caso, á juzgar por los nidos que tengo it la vista, se compone exclusivamente de tallos de yerba, brảcteas y plumas de vencejo alpino unidas por un entretejido sumamente espeso: muy raras veces con. ticne pedazos de papel, rasces y otros materiales parecidos. Fl borde superior consisie en tallos de jerba y plumas dispuestas en forma circular, semicircular ó angulosa, segun las circunstancias, y no se descubre nada que tapice la cara intcrna ó hueco. Cuando loz citados elenentos constitutivos del nido no están sólidamente unidos unos con otros, enire. lázase con ellos una pluma de rencejo alpino y se aglutina el todacon la susodicha saliva. Lista se aplica principalmente \& los bordes superior é inferior y á toda la superficie del borde interno de la cavidad, y como se solidifica rapida. mente. en contacto con el aire, liniendo á convertirse en una masa dura y brillante, el nido adquiere de cste modo una extraordinaria consistencia.

- En la base de uno de estos nicios se halla empotrado, cxcepucion hecha de las alas, un penueño vencejo alpino, cuyo cadáver se adhiere tan perfectamente a la masa mucilaginosa, que aun se ve su boca, en extremo abierta, cblar rellena de heno, jaja, etc. Fste hecho no se explica, sino teniéndese en cuenta que una avecilla de uno de los años anteriores cayó de un nido, y habiéndose quedado muerta y disecadia en el mismo sitio donde mas tarde quisieron anidar otras ares, vino á constimir la parte mas inferior del nido de estas. Fatio ha podido observar que el vencejo alpino, para complctar la construccion de su nido, utiliza con frecuencia las puestas de los gorriones que anidan en las cercanias, $y$ lo prueba el he. cho de haberse enconirado uno cubiesto en algunos puntos de su parte extcrior de una capa amarilla y de grandes frag. menios de cáscaras de hucros de aquellas aves. ?

Yo quiero obsersar aqui que el vencejo comun guarda muy poco miramicnto a las nidadas de otras aves, por lo que no seria nada extraño que el alpino hiciera lo mismo, es decir, 
que se apropiara el nido construido por un gorrion, lo tapi. zara de una capa de saliva, y en el acto de aglutinar los materiales, rompiera los huevos, sin necesidad de sacarlos de ningun nicio vecino.

Gencralmente á principios de junio, ya á menudo antes de esta fecha, cl rencajo alpino tiene ya casi terminado su nido, y la hembra comienza á poner desde luego un huero cada dos dias, hasta llegar al númern de irés ó cuatro. Estos hue. ros, segun Girtnnner, son siempre de un color blanico de le. che, sin brillo alguno, y asi a la vista como al tacto parecen como modelados en yeso. Su estructura es medianamente fina: nótanse en su exiremo mas grueso capas calcáreas mas gro. seras que las del resto, $y$ presentan por todas partes un regular número de poros Sou de forma prolongada, hasta ter. minar en punta, ó casi del todo oval: diéz que Girtanner escogió y midió entre cuarenta, tcnian de 0",029 å 0, 033 de largo pot 1$)^{\prime \prime}, 019$ a $11^{m}, 022$ de aucho: $y$ como un dirinetro aumenia en la proporcion que el otro disminuye, resulta que el contenidoy peso del huevo son casi sicmpre iguales. El vencejo alpino no pone mas que una vezal año, al modo q̨ue lo hace su congénere el comun.

Ningun observador despreocupado puede dejar de experi. mentar una impresion profunda al ver el vencejo alpino al aire libre, impresion quue se acrecienta considerablemente á causa de la grandiosidad y magnificencia del sitio, que constituye la morada habitual de esta ave de incansable ruclo. Léase la tan poética como interesante descripcion que nos hace Bolle de su encuentro con el magnifico cinsélido en la

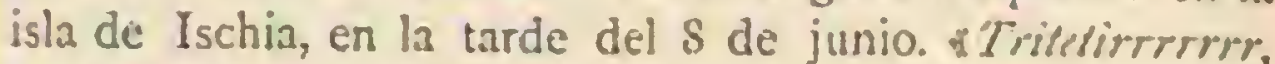
dice है, resonó sobre mi cabeza en las serenas regiones del aire, y divisé luego una pareja de vencejos alpinos que allá er el fondo azul del firmamento se entretenian en perseguirse mutuaniente.

Era imposible desconocer al ave: el lugar, como tambien el tamaño y blanco vientre de la misma, me la dieron á co. nocer bien pronto. Sin cambiar de sitio, no tardé en ver otras varias: estas aves habitan en número considerable el peủascoso monte, cuỵa cima se halla coronada por el cas.

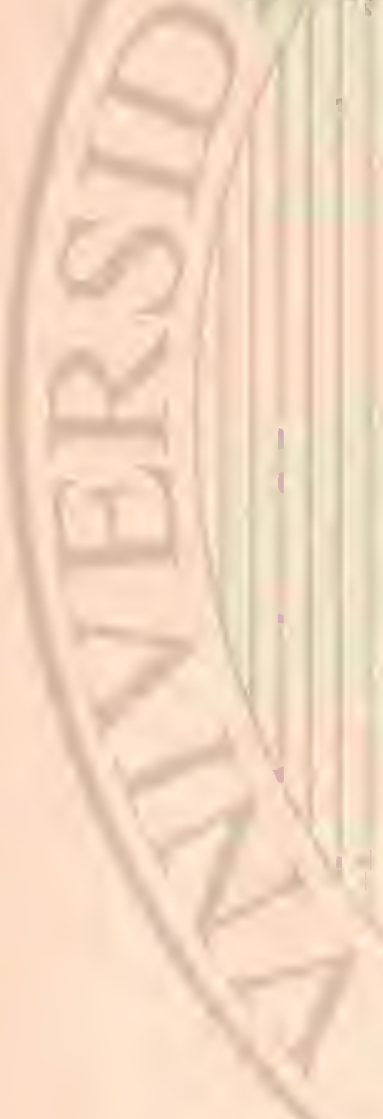

tillo du la ciudad de Ischia, y es posible que se hayan establecido en todos los cabos de la isla. Colocado en la cima de la Punta del Ensteridor, que forma el escollo de la parte occidental de la isla, en este sitio admirable por sus espumo. sas rompientes, atestado de restos de lava, desde el cual se descubre á lo lejes el cabo Circe y las islas Ponza, esiaba contemplando extasiado las bandadas de vencejos alpinos que rasaban volando la tersa supurficie de las aguas. No sé si à causa de una ilusion óptica, esto es, porque la luz se refractara de un modo especial al través de su plumaje ó bien porque volando oblicuamente, presentasen la parte inferior de su cuerpo algo suelta hácia arriba, lo cierto es que al levantarse sobre el azul oscuro de las ondas, me parecian ser de un color blanco de plata. Mas tarde volvi á encontrat en la isla de Capri á las aladas hijas del aire, las cuales saludé como á antiguas amigas; pues ellas fueron mi única compa. nia en las horas de soledad que pasć en aquel sitio. Ora se marche por el estrecho borde de los gigantescos peñascos, ora se bogrue junto a su pić azotado de continuo por las olas, en todas nartes se ve uno rucleado de bandadas de estas aves, las cuales forman numerosas colonias alrededor de la isla. No una ver sino muclias, he pasado largas horas sen. tado en el escollo oriental de la isla, que con las ruinas del palacio imperial croca en la memoria el solitario y sombrio fantasma de Tiberio; y cuando desde aqui apastaba la mirada del sereno y lejano horizonte, en cuyo fonco se destacaban el Vesubio y el Somma, junto con el cabo de Minerva y el golín de Salerno, que se pierde á lo léjos mas allá de las Sirenas, y apoyado sobre la pendiente buscaba, lleno de roluptuoso horror, el fondo del insondable abismo, sin acertar a ver otra cosa que la centelleante superficie del mar azulado, sobre la cual se deslizaba lentamente, cono un punto impercepible, una gaviota; entonces eran siempre los vencejos alpinos, los que me alegraban con sus gritos en aquuel paraje solitario: ellos eran los quue uniéndose debajo del peñasco, llamado el Salto de Tibério, de unos 400 me. tros de altura, parecian burlarse de la ley de la gravedad.

Tambien he visto yo al vencejo alpino en un pais de im. pollente y' grandioso aspecto, en la montaña de Montserrat, en Cataluña. El MIontserrat es una montana aishda que se levanta á unos $1,5 \mathrm{co}$ metros sobre el nivel del suclo que la rodea; está compuesta de millares de rocas de forma cónica y de la naturaleza mas cxtraña, las cuales colocadins unas so. bre otras, se elevan por último, cual potentes obeliscos, estas al lado de aquellas y dejan entre si abiertas profundas gargantas y espaniosos precipicios. Desde lo alto del monte es. páciase la mirada sobre una tan vasta como rica extension de territorio, hasta que el alma q̨ueda absorta ế la conten:placion del sublime espectŕculo. Allk en los últimes confines del norte se ren brillar con fúlgido resplandor los alsos pi:cachos de los Pirineos cubictos de nieve: hácia el este piér. dese la mirada en el azul oscuro del Mediterráneo, sobre cuya superficie se levantan á lo léjos las islas Baleares, cn. vuclias en un velo de trasparente bruma; y hacja las restan. tes partes descubren los ojos innunierables sierras y quebra. dos montes. Fn uno de anuellos altos obeliscos han estable. 
cido una colonia los vencejos alpinos, los cuales comparten aqui gustosos su morada con los comunes. Ninguno de los expedicionarios y aficionados á las aves, que à la sazon me acompañaban, pudieron resistir al deseo de carar á nuesiras aves, que lanzando penetrantes gritos, rolaban al rededor del Cinoll biernat, nombre con que designa el pueblo un pedrusco tallado á manera de columna. Sus nidos se hallan construidos en una especie de enorme torreon que se le. vanta a una regular altura sobre el pié de la pared escarpada del peñasco. Con el objeto de carar á los vencejos, puse mis piés sobre el mencionado pedrusco, que unido al resto de la montaña por medio de una estrecha piedra colo. cada á modo de puente, se levanta como una isla en el mar, ó como la torre angular de una gigantesca fortaleza; y miraba desde aqui el fondo del inmenso abismo, que abrienciose debajo de mis piés, parecia venir á terminarse en el pe dregoso valle atravesado por la ruidosa corriente del Llo. bregat.

En mi vida he sufrido vahidos, pero af pesar de esto no me atrevi a volver mis ojos a la otra parte del sitio en que me encontraba: la sima me infundia horror. Era ian profunda, que una piedra arrojada desde lo alto necesitaba largo rato para llegar al fondo, pues hasta despues de tras. curridos unos nueve segundos no se percibia el ruido ocasio. nado por el choque. A pesar de ser innumerables los rencejos alpinos que atravesaban volando uno tras otro el estrecho paso, no me fué posible matar uno solo de ellos: las enormes dimensiones de las masas nque me rodeaban, impredian. me apuntar con seguridad, ya que me privaban de todo punto de comparacion para medir las distancias. Despues de algunas infructuosas tentativas, me senté, puse la escopeta en el suelo, y contentéme con mirar á las magnificas aves, hasta que, por último, sintiendo renacer en mi interior los descos de volar, largo tiempo comprimidos, mis labios pro. nunciaron maquinalmente aquelias paiabras del pceta: Ay? dificilmente el cuerpo llegara un dia á tener alas para poder volar como el espiritu!

El vencejo alpino no se atreve à penetrar mar adentro,

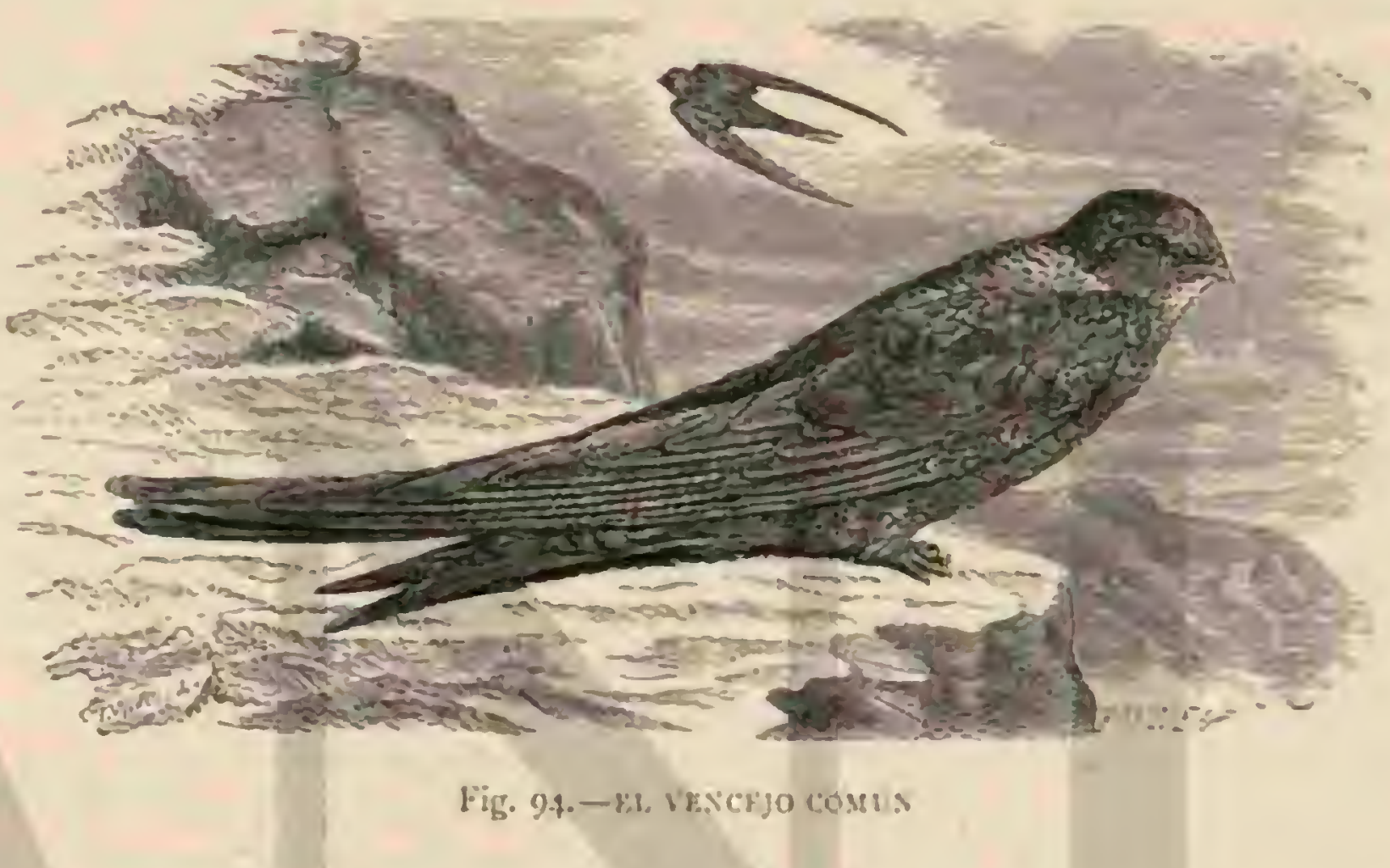

cx́cepto en la época de sus emigraciones. Bolle asegura haber pasado muchas veces por mar cerca de la gran peninsula peiascosa del monte Argentaro, en el sur de la Toscana, sin que á pesar de ser alli muy comun, hubicra parecido una sola ver revoloteando en torno del buque. Sin embargo esta ave nerece el nombre de rondone maritso, ó vencejo de mar, con que se le conoce en Toscana, pues habita con preferencia en los peñascos que se levantan i orilias del mismo, y en Italia no se le re nunca en el interior de las cilidndes como acontece en Suiza y Poriugal. En el primcro de los paises citados penetra con frecuencia dentro de las grutas bajas y levanta liego su vuelo á través de las espumosas olas.

- Cuando el vencejo alpino se cierne en lo alto, su vuelo se asemeja bastante al del halcon: vuela durante iargo mto, sin apenas mover las alas, y siguen luego dos vigorosos aletazos interrumpidos por rópidas bajadas en linea recła $y$ oblicua. Ias aves que componen la bandada, unas veces se dispersan y otras ruelven á juntarse, no siendo raro que se separe una pareja para remontarse jugando à major altum. Permanecen en continuo movimiento hasta cerrar por com. pleto la nocire; pero llegada esta hora, trasládanse luego á otro sitio y se eniregan a otro género de tarcas: véselas cortar el aire con reposado y bajo ruelo, al modo de las golondrinas, sobre todas las granjas y los terrenos cultivados que se hallan cerca de la costa, especialmente sobre las huertas y vinedos: cada una caza por su propia cuenta, $y$ sin juguetear ya con sus compañeros, corren afanosa y silenciosa. mente detrás de los insectos nocturnos, por los que sienten marcada predileccion. Condúcense bajo este concepto de muy distinto modo ņue los vencejos comunes, los cunles ca. zan tambien a la misma hora. pero reunidos en bandadas y lanzando penetrantes gritos i no ser su tamaño, las largas y puntiagudasalas y la region superior del pecho, de un tinte mas oscuro, pudiera tomarseles por golondrinas domésticas, á causa del color claro del vientre; ejecutan ejercicios, á la verdad, sorprendentes en el aire; páranse para coger la presa y no pocas veces se les ve cemerse: cuấn inferior no parece, comparado con estas aves de raudo ivelo, el pequeno murciélago, que, tanto aquí como en las calles de Nápoles, revelotea muy á menudo durante las últimas horas de la tarde $y$ á reces en pleno dia.

Ningun ave es en cambio mas torpe para moverse en la superficie plana del suelo, f́ cionde caiga por casualidad, segun se desprende de las observaciones hechas por Girtanner. Llevado el vencejo aipino muy cerca del techo en una espaciosa sala, déjase caer; extiende luego rápidamente las alas, y se acerca á poca distancia del suelo, describiendo un arco bastante pronuncindo; vuelve poco à poco á levantarse; describe unos cuaritos circulcs, y de pronto, como si pare. ciera faltarle el espacio indispensable jara remontar su vuelo, se cuelga en cualquier punta. Repetido el experimento en una estancia de menores dimensiones, pudo notarse que el are alcanzaba la pared opucsta antes de que pudicra elcrar por segunda rez el vuelo; chocaba y caia siempre en tierra, desde la que no podin.nunca levantarse. Azotaba el suelo 
con las alas extendidas y las patas apreladas contra el vienire; arrastrábase penosamente hảcia la pared, ýá pesar de las desigualdades que esta presentaba en su superficie, nunca le era dable trepar a lo largo de la misma. Nio cabe duda, dice Girtanner, que nuestra are bace lo mismo cuando cae al suclo en estado libre. Si tiene la suerte de caer sobre el techo de una casa ó en la superficie de una roca, se arrastra del modo descrito hasta llegar al borde, y desde aqui no hace mas que echarse abajo para liego emprender el ruelo; pero si por desgracia cae cn un recinto cercado de muros verticales, ó en otro sitio al extremo de cuya pendiente no pucde llegar con facilidad a causa de su vasta extension, en tonces está irremisiblementè perdida.

Aseguraseque cuando el vencejo alpino yace en el suelo, sin ser bastante á levantarse de el: vuelan inmediatamente en su auxitio sus demás compañeros, como lo hace el ven cejo comun, logrando con frecuencia levantarle y hacerier cobrar el vuelo. No dudo de la posibilidad del hecho, ma. yormente cuando recuerdo con viva satisfaccion otro análogo acontecido entre unas chovas: una de estas ares corria de una parte $i$ otra, sin poder remontarsé á causa de iener las alas sumanente recortadas; acerto a ver i su desdichada compañera una bandada que estaba viajando; arrojósc in mediatamente sobre ella, y cogiéndola con el pico por las alas, despues de perseverantes esiuerzos, consiguio levantarla a considerable altura : aquellas aves no renunciaron à su ge nernso intento, ni se alejaron del sitio hasta despues de haberse convencido de la inutilidad de sus esfuerzos. Por mi prite no negaré que asi sepan socörcrse imutuamente los vencejos alpinos en caso apurado; fiero en manera alguria puedo conformarne con la opinion de Girtanner cuando afirma que estas aves caidas al sticlo, no pueden ya levantar se de nuevo y están, pot tanto, condenadas á perecer. Sin duda en semejantc caso se conducirán/como el vencejo comun y se servirán de iguales medios que este; pero salta \& la vista que para coinprobar la verdad de nuestro aserto, se ha de colocar el ave no en los estrechos limites de una sala, sino en sitio despejado y abierto, desde el cual pueda descubrir un vasto horizonté y recobrar asi el valor que le falta para remontar el vuelo.

4Si se halian reunicios vários venccjos alpirios, observa Bolle, su grito se parce á un jrollongado trino, en ol que se percibe clara y distintamente una $r$, acompañada del sonido de $i$ al principio y al fin. Este es un sonido natural, que armoniza perfectamente con el aspecto agreste, pero claro $y$ sereno, que suelen presentar los sitios de la costa labitados por estas ares, sonido que va aumentando ó bien perdiendo en intensidad, segun la distancia á que las mismas se hallen respecto del observador; sin embargo, siempre vuelve á resonar de la misma manera en los oidos de este, y solo se hace mas perceptible al causa de su larga duracion y mono. tonia. Los que vuclan solos y aislados, eniten unos sonidos que podrian expresarse por las sílabas siep, aiep; con ellos llaman indudablemente à sus compañeros, que, sin embargo, se ven siempre à muy corta distancia.

No menos que su presencia, son tambien interesantes las costumbres y régimen del vencejo alpino, como puedeverse por el siguiente fragmento de Girtanner. \&ótase siempre una animacion extraordinaria, dice el citado observador, en las inmediaciones de la vieja torre y de la cordillera que sirven de morada á esias aves sociables, pero sumamente pendencicras, turbulentas y aturdidas. $\mathrm{Ni}$ un momento siquiera duranie la noche, cesan las riinas y el iumulto en el interior de las grietns, donde tienen íbricados sus nidos, en lérminos que dificilmente se comprende cómo pueden gozar de un reposo, nue parece serles del todo indisjensable, dada su incesante actividad. Essta, sin embargo, sube de punto, no bien los primeros rayos de la luz del dia penetran dentro de las sombrias hendiduras, á cuya hora se disponen i salir de ellas sus alados moradores: con el pecho aplanado contra el suelo y auxiliándose eficazmente con sus alas, arrástranse con sumo trabajo à lo largo de las grietas hasta llegar al borde de las mismas, $y$ conseguido su intento, no tienen ya que temer para el resto del dia mas penalidades ni latigas.

-Sale entonces la bandada de misteriosas sombras; remóntanse á través del fresco y límpido aire de la manana, lanzando penetrantes gritos, que terminándose de vez en cuando en un agudo gorieo, resuenan alegremente en medio del silencio del crepúsculo y llevan la animacion al fondo de los barran. cos del bosque y de las ciudades, aun envueltos en tinicblas. Sin desplegar las infatigables alas mas que en el momento de descender, remóntanse, formando circulos, á tan considerable altura, que ya no es posible descubrirlas á la simple vista, y parecen por un momento haber traspuesto los límites de su dominio. Sin embango, no tardan el aparecer de nuevo: allá en las regiones etéreas vénse centellear, como copos de nieve heridos por los rayos del sol naciente, sus brillantes alas y su blanco vientre sin mancilla. Asi pasan toda la mañana, ora cazando, ora jugueteando, pero siempre con estrépito, al re dedor de sus inoradas. Si ya entrado el dia les molesta el calor, réiranse á descansar en el interior de sus frescas y sonbrias habitaciones, donde prefieren pasar las horas cuan. do aquel es muy intenso. Este es el momento en que todas se entregan al sueño: al menos permanecen tranquilas y con las alas plegadas, y no se oye el menor ruido. Al declinar el dia despiertase de nuevo la agitacion $y$ la vida entre las in. quictas avés; cortan lentamente el airc describiendo grandes circulos y cruzandose las unas con las otras; la algazara y el tumulto sin limires no cesan hasta haber cerrado la noche, y aun en esta hora se las ve revolotear alegremente en las calles yor desicrtas de la ciudad $y^{\circ}$ en los pastos de los Alpes abandonados por los rebaños. Cuando el tiempo es malo ó lluvioso, indudablemente nuestras aves se quedarian gustosas dentro de sus moradas; pero el hambre las fuerza a salir de ellas: en tales ocasiones cada una va por su camino, persi. guiendo con afan los insectos á tmvés de los pastos de los Alpes, 6 recorre silenciosamente la corriente de un arroyo, donde puecia encontrar algunas libelulas if otros insectos parecidos: y el altivo morador de las montañas está satisiecho y contento, si rasando ahora en su vielo la superficic del valle, puede hallar algo con que aplacar su hambre. Sien las mas elevadas zonas de los Alpes baja mucho ha temperatura ó estalla de súbito una de aquellas espantosas tempestades que suelen desencadenarse en aquellas alturas, estas aves desciendert tambien al valle. Despues de una ienaz sequia, acogen regocijadas la templada lluvia; entonces beben, se banan, sacuidense los molestos parásitos, vuclan encima de sus moradas, y hasta aquellas que están cmpollando, abandonan sus nidos para entregarse á este dulce pasatiempo.

\$Este modo de vivir libre y regocijado continua hasta lle. gado el periodo de la incubacion. Terminada esta, el ave no piensa en otra cosa que en procurarse el alimento indispen. sable, tanto para ella como para sus hijuelos: con frenético aian, con la boca sumamente abierta, vuela ahora con ason. brosa rapidez en todas direcciones, y no hay insecto que a] cruzarse en su camino, no se quede instantaneamente pegado á su viscoso paladar. Fl ave no da por terminada la furiosa caza hasta haber acumulado una gran cantidad de insectos dentro de su garganta: vuelve ahora rápidamente al nicio $y$ da la presa al mas hambriento de sus hijuelos Esta tarea ocupa á nuestra ave por espracio de siete ll ocho semanas, lo que no puedic menos de ser asi, dado ajue los pequcịnuclos 
no pucden abandonar el nido hasta tiallarse lo bastante des. arrollados para poder desde luego, y sin prévio ensayo, sos. tenerse en medio del espacio. Macho y irembra se encargan de cubrir los huevos, y tres semanas dospues de puesto el uiltimo de estos, tiene lugar la eclosion. Los pequeños vienen al mundo con el cuerpo enteramente cubierto de plumon gris, al modo de pequeñas rapaces; solo se descubren indicios de plumas en la cabeza, en las alas y en la cola; aquellas es. tán ribeteadas de blanco; las patas, del todo desnudas, son de color rosado. Aun cuando la puesta se compone al prin. cipio de cuntro huevos, sin embargo no se encuentran á me. nudo mas que tres pequenuclos, sea prorque los padres en sus movimientos siempre impetuosos hayan aplastado uno de aquellos, sca que uno de estos haya sido expulsado del reducido nido por sus hermanitos. Se desarrollan con mucisa lentitud, a causa de lo dificil que es para los padres procu. rarles el suficiente alimento; pero dejan ya el nido mucho tiempo antes de emprender el primer vuelo. Cógense con las unas á las paredes de las hendiduras mas espaciosas; perma. necen con frecuencia largas horas en esta postura, y los vic. jos se encargan de llevarles comida. Comienzan a volar $\alpha$ fines, y cuando mas pronto, á mediacios de agosto, y llegada la éroca de emigrar, despliegan ya en el ruclo la misma des. treza de los padres.

ENEMIGOS. - Tanto por el sitio donde construye su nido, como por su costumbre de permanecer constantemen. te en las mas elevadas regiones del aire y la mpidez de st. vuelo, el vencejo alpino goza de una sida bastante segura 5 tmnquila: solo le alcanzan el hambre y los rigores del frio, q̨ue diezman á veces colonias enteras. Al modo que su con. génere el comun, traba encarnizadas luchas con sus seme. jantes; cógeșe por las uinas con tanta fuera a su adversario, que á mérudo cae con él al suelo, y lá pèlea termina las mas veces con la mucrle de los dos coniendientes. A presar de que en Capri vive literalmente al lado del halcon emi. grante, y por mas que Bolle crea qque no debe apenas temer de su vecino, no puede, sin embargo, negarse que es algunas reces victima del ave de rapiria, como lo atestigua el hecho que en otra parte dejamos consignado. Tiene tambien por enemigos á diferentes clases de parásitos, los cuales le mo. lestan bastante, especialmente en la época del celo.

CAzA.-En Suiza, nadic piensa en perseguir al rencejo alpino, si no es por fines cientificos; pero no-sucede lo propio en Italia $y$ en Grecia, donde aun como en los ticmpos de Gessner, se le coge con anzuclo. A reces, dice Bolle, se ve en Italia un muchacho que iendido en el borde de un escarpado cscollo ó del tejado de una casa y ocultándose lo mas posible, se entretiene en cazar el rencejo alpino. Sirvese para cllo de una caña ó pértiga, á uno de cuyos ca. bos esta sujeto un hilo de color arul celeste, el cual tieneásu vez en el extremo un anzuclo oculto entre algodon y plu. mas; múrese el anzuelo, junto con varias plunitas que Ho. tan casualmente esparcidas a su alrededor, al impulso del viento, y en él queda cogida el ave en el momento de ir á recoger materiales para la construccion de su nido. En Por. tugal se caza tambien al ave de la misma manera, segun re. fiere Rey. En Grecia, segun dice de . Jühle, se colocan entre dos puntos elevados y opuestos varios cordones, de los que se hallan suspendidos pequeños anzuelos provistos de crines de caballo y plumon, y en ellos son cogidos los vencejos al. pinos cuando están ocupados cu reunir materiales para fa. bricar su nido. Acéchase tambien à las aves desde lo alto de una roca, donde sopla de continuo una corriente de viento; se les tira y caen muertas al fondo del ribazo, f donde sc pasa luego á recogerias para llevarias al mercado, en el que son bastante estimadas.
CAUTMIDAD. - Aunquue era ya de presumir que seria muy dificil criar al vencejo alpino en el encierro, sin em. bargo Girtanner quiso hacer el ensajo. Los cogidos en edad avanzada se mostraban huraños y rebeldes; echábanse con. tra las paredes del cncierro, lanzando á cada choque un penetrante grito; sc acurrucaban en el angulo mas oscuro de la sala y permanccian alli, sin moverse en lo mas minimo, hasta que se les sacaba de dicho sitio. Kepetidas veces lo gmron hincar sus aceradas uñas en la mano del que los cui. daba; asi es que este creyó oportuno ponerse unos guantes de piel siempre que debia cogerlos para darles comida. Ina hembra perecio a los cinco dias de haber sido cogida, á causa de rehusar ó arrojar constantemente el alimento que se le daba; el macho se dejo alimentar, pero con muchas dificuitades; fué enflaqueciendo mas y mas cada dia y murio tres scmanas mas tarde: esta pareja tenia completamente descuidados a sus hijuelos, que habian sido cogidlos con ella, a causa sin duda de la imposibilidad de ali. mentarlos. Girtanner judo comprobar asimismo lo ya obscr vado por Fatio, á saber, que los adultos no tragaban penqueños bocados, sino que aguardaban hasta haberse acumulado en la garganta una gran cantidad de comida, la que deglutian luego, haciendo un violento esfuerzo.

Los cuatro pequeñuclos que componian la nidada, tenian en el momento de ser cogidos, de cinco al scis semanas de edad ye parecian ya muchisimo á los padres; en febrero del año próximn desaparecieron por completo los bordes blancos de sus plumas, y luego empezó la muda del plu. mon. Su vida en el encicrro cra en extremo monótona, y solo parecian mostrar algun ap̣ego á su nido, consistente en uma peqqueía cesta llena de musgo. Hácia fines de agosto comenzaron a ensayarse en el vuelo; pero fueron inútiles todos sus esfuerzos, y no pudieron nunca remontarse á pesar de ser muy robustos ! bastante viraces. No bien habian conseguido levantarse un poco, volvian luego of caer al suelo; arrastrábanse penosamente hasta el rincon mas próximo, y alli se quedalaan por largo rato, con las cabezas apretadas unos contra otros, viniendo á formar una especie de estrella.

Cunndo se colgaban de una pared, nunca pensaban en abandonar el sitio, y caian á tiersa lucgo despues de haberlo inientado. A los tres meses aprendieron a beber y lo hacian a menudo y de igual modo que las otras ares; en cambio Girtanner nunca pudo conseguir que tomaran por si misnos el alimento, debiendo este scrles ingurgitado, de lo contrario jermanecian sentados y con la boca abierta, sin comer nada. Cuando se hizo ya sentir el frio, fué preciso encerrarlos en una espaciosa jaula, a lo largo de cuyas paredes irepabar afanosamente, promoviendo gran ruido: si uno tocaba a otro sin necesidad ó motivo explicable, echabanse todos à dar brincos y á proierir incesantes gritos Como á partir de viltimos de noviemure no ema de esperar un mayor desarrolio fisico ni intelectual, Cirtanner se decidió à dấ nuerte á tres de ellos, y solo continuó criando el cuarto hasta primeros de mayo: devolverles la libertad valia tanto como entregarlos de imtento á una muerte segura é inevitable. KHasta cl vencejo alpino, así concluye Cirtanner, es suscepible de conservarse en cautividad, aun dentro de una jaula; pero me remorderia In conciencia de aconsejar a nadie yue lo eligiera por com. pañero en una estancia: es mejor dejarle abandonado á los locos arrebatos de una libertad sin limites.

USOS Y PŔODUCTOS. - \&No se puede negar, dice Cirtanner, que cs muy poca la utilidad que reporta el renccjo alpino en la economia de la naturaleza; pero tampoco puede afirmarse que cause el menor perjuicio: su grito no es, á la verdad, nada agradable, y es su carne tan poco sabrosa, que no vale la pena de darle caza No debe, sin embargo, olvi. 
darse que destruye un extraodinario numero de insectos; que anima con sus alegres gritos los escollos mas tristes $y$ las montañas mas desiertas $y$ que, por viltimo, causa una impre. sion en extremo agradable ver brillar á los rajos del sol en las cumbres de los montes una bandada de estas aves. contemplar sus juegos y combates, sus interesantes costum. bres y modo de vivir.

\section{EL VENCEJO COMUN - CYPSELUS APUS}

CARACTÉRES.-El vencejo comun, que tantas-veces hemos citado, tiene $(1$, , 8 de largo por 10 , 4o de ala a ala; esta plegada mide $t^{m}, 1$ y y la cola 0 " 08 . El plumaje es de un color negro pardo de hollin con visos de un verde negro de bronce, los cuales se hácen mas pronunciados en el lomo y en la espaldilla; la barba y la garganta se presentan adornadas de una mancha blanca redondeada; el ojo es pardo oscuro; el pico negro y las patas de un tinte pardusco claro. To se nota diferencia alguna entre los dos séxos; los individuos jóvenes difieren de los adultos por tener el plumaje de un color mas claro y los bordes terminales de las plumas orlados de una delgada linea de un blanco pálido.

Eil vencejo comun es recmplazado en Egipto por el múri. do, el cual fué descrito primeramente por mi padre y por mi bajo el nombre de ojpselus muringis, y: 15 años mas tarde por Shelley bajo el de grpsclus fallidus, y se distingue de sus congúnerés por el color gris de raton de su plumaje y por la mancha blanca de su garganta. En China vive una especie muy seniejante al vencejo múrido, ála cual se da la deno. minacion de opsichs primeusis.

DISTRIBUCION GEOGRAFICA.- Fista es el ave que vemos volar por las calles desde el 1.0 de majo al mes de agosto, y tambicn al rededor de los campanarios de nuestras iglesias, lanzando penetrantes gritos. Estí muy diseminada: yo la he visto de Drontheim a Málaga en todos los paises de Europa gue he recorrido; otros abservadores la han ericon. trado en una gran parte del Asia central y septentrional; en ciertos puntos de Persin es muy conun durante el verano, en otros, especialmente en los alrededores de Schiras, anida en número considerable. Durante sus emigraciones atraviesa toda el Africa, y ha sido observada tambien en el extremo sur de ceta parte del globo.

USOS, COSTUMBRES Y REGIMEN. - El vencejo comun llega a nuestros paises con una regularidad notable; aparece el 1.0 ó el a de mayo y nos abandona el 1.0 de agos. to, a mas tardar. I os individuos que se ren despues de esta epoca son los que se fijaron en los paises mas septentrionales, ó que retrasados en la cria á causa del mal tiempo, tienen aun hijuelos que no pueden emprender un largo viaje. A fines de agosto encontre todavia algunos de estos rezagados en Alemania y en el Dorrefjeld.

En los sitios donde anidar muchas de estas aves, es mas dificil observar la época de su llegada y de su vuelta; es por cl contrario fácil fijarla donde crian jocas. Asi en el año 18 i pude notar que la línica pareja que habitaba on el cam panario de la iglesia de la aldea donde naci, habia desapa recido ga a 26 de julio, y desde esta fecha hasta medizdos de agosto, continuaron pasando varias de estas aves, solas ó reunidas en parejas y familias; daban unas cuantas vueltas al rededor del citado campanario y volvian luego á alejarse: en este mismo año no compareció ninguna otra desde el 13 de agosto en adelante. Eugenio de Homeyer observó banda das emigrantes muy rezagadas en los dias $S$ y 9 de setiembre. A Espaina llega el vencejo negro en igual época que á Alemania, y abandona el princro de los citados paises al mismo tiempo que el segundo; sin embargo no sucede lo misıno por lo que toca á Grecia, segun observaciones por mí practicadas: aqui aparece mas temprano y emigra mas tarde a las regiones del sur. Segun los datos de Lindermayer, que a la verdadi tengo por algo dudosos, se presenta en este último pais mas pronto que el vencejo alpino, esto $\mathrm{es}_{\text {, }}$ a fines de marzo; pero segun las observaciones de Krueper, lo hace en igual época que su congénere, á mediados de abril, y ra. ras veces a principios, y se marcha tambien temprano como este. En el centro de la Persia se le ve casi en la misma época que en Grecia, al paso que en el sur aparece ya en febrero: pero al decir de Saint-Iohn, permanece en aquel pais liasta fines de octubre.

Pocos dias despues aparece en el interior de Africa; el 3 de agosto le vi yo sobre los minaretes de la mezquita de Kartum. En el alto Egipto se hallan con frecuencia, sobre todo en los meses de fébrêro marzo, numerosas bandadas de estas aves; y es probable que algunas pasen alli el invier. no, aunque la gran masa llega hasta el cabo de Buena. Esperanza. Sin embargo, durante mi residencia en Malaga, vicon admiracion, del i 3 al 28 de octubre, gran número de ellos, que volabar al rededor de los campanarios. Me inclino a creer que cran aves que volvian de Africa, pues segun todas las observaciones, abandonan al mismo tiempo el sur y norte de Espalia, es decir, en los primeros dias de agosto, sin que se encuentren luego mas que algunos individuos rezagados. Estos últimos, por causas todavia desconocidas, se pueden ver tambien mucho mas tarde mas hácia al norte: asi Dowell hace mencion de un vencejo negro aislado, el cual fué visto en Inglaterra/en compañia de varias golondrinas durante el mes de octubre; y Collett nos habla de otro, el cual aun en noviembre revoloteaba en la comarca de Waranget Fjordsy fué halladó muerto de hambre en 15 del mismo mes.

Parece que los vencejos negros emigran siempre en grandes bandadas: con frecuencia se ven docenas y hasta cente. nares de ellos donde la vispera no se divisaba uno solo; viajan de noche, abandonando todos à la vez una determinada ciudad: Naumann dice que á la mitad de aq̧uella es cuando emprenden la marcha.

El vencejo negro habitaba primitivamenic solo en los peinascos; con el tiempo vino a morar entre los hombres, y poco á poco ha llegado a convertirse en ave de ciudady aldea. Al principio esiablecia su morada cn edificios antiguos y de alguna elevacion, especialmente en las torres, y solo cuando no bastaron los agujeros ó grietas que habia en los citados sitios, se vió precisado á anidar en los huccos de los árboles, viniendo asi á convertirse en habitante de los. bosquues. Esta ave pertenece al número de aquellas que van multiplicándose cada dia mas en Alemania, por lo que no es de extranar que en muchas localidades y, aun en comarcas enteras de este pais comience a sentit la escasez de mora. dis donde fijarse. Como antes, habita tambien hoy en pemascos que le ofrezcan condiciones favorables, y sube en la montaña hasta unos 2,000 metros de altura.

Nada dificil es distinguir el vencejo negro de los hirundi. nidos, pues sus movimientos y su género de vida difieren mucho de los de las golondrinas. Como estas es sumamente vivaz y activo; el aire constituje su verdadero dominio, y all es donde pasa toda su vida; desde que lucen los primeros albores de la aurora hasta que cierra la noche, caza y vuela a grandes alturas, y solo por la tarde, $\delta$ cuando hace mal tiempo, se acerca à la tierra.

No puede precisarse hasta qué punto se remonia en el lla. no, pero si es posible, cunndo se le observa desde lo alto de las montaias; desde las cumbres del Montserrat y de la cor. aillera de los Gigantes, vile elevarse sobre el llano á tanta altura, á cuanta pude alcanzar con el anteojo, de modo que 
llega a traspasar las capas de aire que se encuentran io mas de 1,000 metros de elevacion. Esta are vuela mas o me. nostiempo, segun sea la duracion del dia: en el solsticio de verano prolonga su vuclo desde las tres $y$ diez minutos de la madrugada hasta las ocho y cincuenia minutos de la noche, al parecer, sin interrupcion.

En nuestros paises despliega su actividad hasta en pleno medio dia, y en los meriuionales pasa esta hora ocula en el fondo de un agujero. In Cannsias, por cjemplo, segun nos refiere Bolle, los vencejos desaparecen hícia las die\% de la mainana, y no se dejan ver hasta la tarde.

No conozco en nuestros paises ningun ave que vuele con tanta rapidez: su vuelo es facil, ligern y siempre sostenido; no puede cambiar bruscamente de direccion, como lo hace la golondrina; pero corta el aire con mas ligereza; sus estrechas alas, en forma de hoz, se agitan con tal rapidez, que la vista no puede seguir sus movimientos; luego las extiende el ave de pronto y se cierne, inmóvil al parecer.

De tal modo atrac su vuelo, que por él se echa en olvido cuanto tiene el ave de desagradable, y se la contempla siem. pre con creciente entusiasmo cuando se cierne en lo alto del espacio. Sostiénese en este de cualquier modo y en iodas las posturas: sube con la misma facilidad ąue baja; se vuclve $y$ gira con sorprendente rapidez; describe los grandes circulos con la misna seguridad que los pequeños; vésela por un momento volar masando la superficie de las aguas, y a los pocos momentos desaparece, remontándose a una inmentsa altura.

Ningun ave es en cambio mas torpe para moverse en tierra; no puede andar, y lo mas que hace es arrastmrse penosa. mente; se ha dicho que es incapaz de tomar impulso cuando se le pone sobre un terreno muy llano; pero esto es un error. Fil vencejo que esta en tierra extiende las alas; de un vigo. roso empuje se lanza por los aires y emprende su vuclo, sien do de advertir que tambien puede hacer uso de sus patas, de las cunlés se sirve para trepar por las paredes verticales defenderse.

Fil vencejo grita y no canta: su vor consiste en un sonido penctrante que se puede expresar por las silabas spi, ssio $k$ tri; cuando el ave está excitada, se la oye cominuanente produ. cir estos sonidos, y si se reunen varias, hacen un ruido que aturde. Al volver à sus nidos todos gorjean, lo nismo los jóvenes que los viejos.

De todos sus sentidos, el oido y la vista son-los mas per fectos; el olfato, el gusto y el tacto parecen bastante obtusos.

Bajo el punto de vista de la inteligencia, el vencejo ocupa un lugar bastante inicrior; es pendencicro, violento y aturdi do; no rive en $123 \%$ con ningun ave, ni aun con sus semcjan tes, y siempre se le ve luchar dias enteros cerca de su nido. Dus machos dominados por la pasion de lus celos se precipitan uno sobre otro; se cogen por las unias y caen a tierr. rodando; los golpes que se dan no son siempre inofensivos, pues a mi padre le presentaron algunos vencejos quue caycron muertos á tierra, y que tenian el pecho completamente des. trozado. Acometen tambien a otras aves: Naumann vió á un individuo perseguir sin motivo alyuno á un gorrion que buscaba gusanos; cayó sobre él varias veces como lo hubiera hecho un halcon, ye espantó de tal modo al pobre pájaro, que este fué a buscar refugio a los piés de los labradores que tra bajaban en un campo. El vencejo negro no manifiesta tener buenos senimientos sino con su progenic. lorma su nido en diferentes parajes, segun la localidad: en Alemania comun mente lo hace en las grietas de los nuros de los campanarios y de los grandes edificios ó en los huecos de los árboles, raras veces en los agujeros de las paredes arcillosas escarpadas. A menudo aliuyenta a los estorninos y los gorriones die los nidos artificiales que se preparan para ellos, sin que baste i contenerle la presencia de la hembra que cabre. Acosala de tal modo, que ln obliga al fin á dejar el nido.

En el caso de verse sériamente resistido, recurre á sus ar. mas naturales y lucha desesperadamente con el objeto de alcanzar un sitio donde anidar. Léase á este propósito lo que me escribe Liebe UUn estornino, dice, que defendia valcro. samente su nido contra los ataques de un vencejo negro, fué gravemente herido por este, en términos que cuando el jardinero acudió en su auxilio, estaba ya inuerto: la pobre ave ienia el ala y el lomo profundamente desgarsados, y en algu. nas partes de la cabeza la piel estaba del rodo desprendida. Es inposible que el vencejo regro infiera tales heridas con

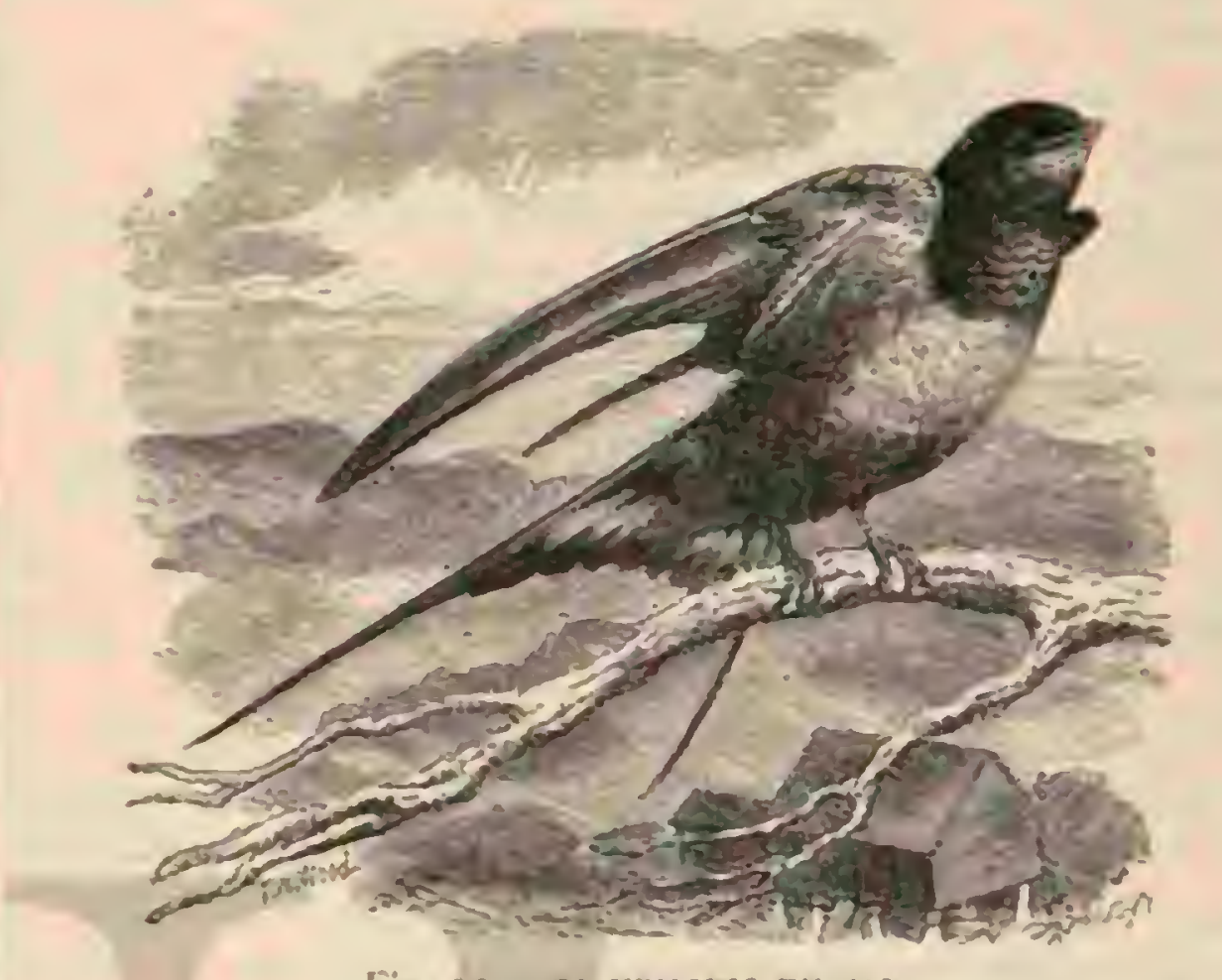

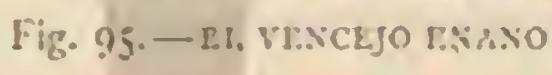

su Rexible y poco tesistente pico, por lo que se puede suponer fundadamente que en la lucha se vale de sus fuertes y acera. das uñas, ruando no le bastan ni las alas ni el pico. Nada riene, pues, de particular que hasta el fuerte estornino se vea obligadoá ceder ante un tan violento como peligroso adver. sario. Fste hace caso omiso de las quejas de las affigidas aves a las cuales arrebatara el nido; echa plumas, trapos y cuanto atraja al vuelo sobre los hucros ó los pequeisuelos: aplasta a los prinieros, ahoga a los segundos, y despues de haber amasado el todo con saliva, yone a su ve\%

El serior Daumerlang, quien ha estado observando por lasgos años las luchas entre los estorninos y los vencejos negros, las describe del siguiente modo en una carta que me escribe. rEn la ventana de la buhardilla que se abre sobre mi despacho se halla colocada una caja para los estorninos, la cual, a causa de su farorable situacion, se encuentra regularmente habitada, si no por estas aves, por gorriones, y durante el verano por rencejos comunes. Un las luchas que sostienen los estorninos con los gorriones, quedan siempire vencedores los últimos; pero no succde cictamente lo mismo en las que traban con los vencejos negros. Estos no se dejan amedrentar por nada. y todo lo arrostran con tal de poder apoderarse de la caja donde ya á su llegada está incubando el estornino, y tener asi un sitio para poder anidar. Si jo no tercio en la pelea, los estorninos son siempre expulsados de la caja despues de lar. gas y encarnizadas lucias, y los vencejos, sin laacer caso al. guno de los picotazos de los expulsados, toman posesion de aquella, rompiendo luego los huevos ó destrozando ì los pe. queñuclós con sus accradas unas.

- Como siento especial simparia por los vencejos negros, á causa de su vigor é incansable actividad, coloque una caja particular para ellos al lado de la de los estorninos; pero bien pronto noté que no hacian uso de ella, no por otro motivo sino porque no contenia en su interior nido alguno, pues la prosesion de este parece ser lo único que codiciun. 
\$ A fin de alejar a las pendencieras aves, me aposté junto a la ya citada ventana y fui echándolas de la caja, una por una, cogiéndolas con la mano, à medida que se acercaban rolando; pues se ha de observar que son tan osadas, que no reconocen uingun peligro, ni temen en lo mas minimo la presencia del hombre. A reces en pocas horas lograba apo. derarme de cuatro ó seis de ellas; pero otras tantas se esca. paban a nis asechanzas, pues ya no se posaban en la caja. Para ver si escarmentaban con la pérdida de su libertad, encerrélas por algun tiempo y les pintaba - ła cabeza ó las alas de color blanco al bleo; sin enibargo no por esto se enmen. daron; por el cóntrario, en tanto que los pequeños estorninos no habian acabado de desarrollarse completamente, no de. sistian de su intento de apoderarse del nido de estos, hasta que, por último, agotada mi paciencia, puse un cabezon de carton a una hembra, la mas terca de todas. No tardó, sin embargo, la incorregíble ave en librarse del importuno dije y penétró de nuevo en la caja de los estorninos: en rano el macho de estos la opuso valerosa resistencia; abalanzóse con tanta furia sobre el agresor que los dos se cogieron por las uñas y vinieron rodando al suelo. Bien acudi yo en auxilio del esforzado defensor de su familia, arrojando punados de arena ílos demás vencejos negros que se aproximaban; pero fueron inutiles nuestros comunes esfuerzos. El estornino ha. bia comprendido perfectamente mi buena intencion, asi es que no se asustó por lo de la granizáda de arena; pero el réncejo négro hizo tan poco caso de ella como de los ata ques del dueño del nido. No bien éste 6 yo nos descuidába mos, volvia siempre la misma hembra á penetrar dentro du la codiciada caja, al paso que otras de su especie se conten taban con acercarse á clla, agarrarse al agujero y observar desde all el interior del nido, absteniéndose de todo ataque en el caso de ver en él pequeñuelós. Cuando los estorninos jóvenes estaban ya casi del todo crecidos, la importuna hem. bra no trataba de matarlos, pero si de arrojarlos fuera del nido, por lo que se trababa una nueva lucha cacia vey que én semejantes casos llegaban los viejos. Tomé, por último una resolucion suprema; hice un cabezon maror que el primero; lo endosé en/a cabeza de la molesta ave, y sucedió lo que era ya de prever; la carga era demasiado pesada y dió con la terca hembra en el fio Pegnitu cuyns aguas se deslizaban por delante de mi casa Corri yo mismo al punto á salvarla, y la saqué del agua cuando estaba ya próxima á ahogarse: recobró luego sus fuerzas, fué puesta en libertad y nunca ja. más volvió.

Ta extraordinaria terquedad del are no podia, á mi modo de ver, provenir de otra cosa, sino de que, habiendo echado á los estorninos fuera de su nido y arrebatádoles la cria en los años anteriores, sin que yo lo hubiera impedido, ahorn se creia con derecho a ocupar la mencionada caja. No me fue dificil amedrentar á los demis vencejos negros; esta hembra fué la ínica que no pudo ser ahurentada hasta despues de largos dias de resistencia, ýa ella, en mi opinion, se debe que de once años á esta parte ninguna pareja de estorninos hayia puesto dos veces.

In las montañas elevadas, donde franquea el limite supe rior del bosque, llegando en los hermosos dias de verano hasta la zona mas alta, desprecia el vencejo negro los viejos edificios y los huecos de los árboles, I pasa á establecer su nido en las innumerables grietas y hendiduras de los peñas. cos mas altos, que le ofrecen lugar mas favorable; prefiere enire estas las mas secas y espaciosas, y con frecuencia habitan en ellas a centenares. Lleno de indiferencia para con las demás aves, establécesc entre cllas sin ninguma clase de re. paro: en Espana le encontramos entre los cernicalos, los gorriones comunes $\mathrm{y}$ los colirojos; Alejandro de Homever le obscrvó en las Baleares en medio de bandadas de palomas (columbir lrezia) y de papamoscas; en el sur de Rusia Gobel le vió entre los abejarucos y los azulejos; en la Pomemnia interior Eugenio de Homejer le encontró anidando en la misma pared arcillosa al tado de las golondrinas de ribera, de cuyos nidos se habia apoderado. Donde viven las dos es. pecies europeas, como en Suiza y en España, se fijan juntas en el mismo sitio.

Cuando una pareja ha tomado posesion de su nido, vuelve

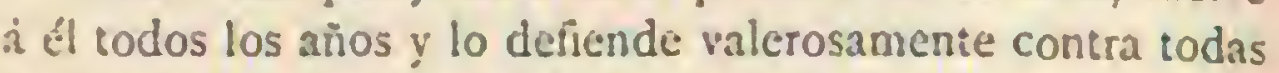
las demás ares que intentan ocuparle. Este nido se compone de rastrojo, heno, hojamsca, trapos y plumas, materiales quue coge el ave en los nidos de gorriones, ó que atrapa al vuelo. Rata vez los recoge por tierra ó los arranca de los árboles; los acumula sin órden, aglutinandolos despues con su saliva viscosa, que se solidifica rapidamente.

Cada puesta consta de dos huevos, de forma casi cilindrica, prolongados, y obtusos en sus dos extremos: solo cubre la hembra, y entre tanto es alimentada por su compañero; al menos cuando mo hace mal tiempo. Si llueve, no puede el macho encontrar suficiente alimento para él y su hembra, y esta debe por lo tanto abandonar sus huevos para cazar. Ios padres crian á sus hijuelos, que crecen muy poco á poco, no pudiendo emprender su vuelo hasta trascurridas algunas semanas. No se encuentran huevos hasta fines de mayo, lo mas pronto los hijuelos salen á luz en julio, y comienzan á Volar a fin de dicho mes.

E! rencejo comun se alimenta de insectos muy pequeños, cuyas especies no es iácil determinar, dado que en el estómago del ave muerta, la presa se halla ya por lo comun di. gerida ó al menos tan triturada, que es punto menos que imposible reconocerla. De todos modos, las especies que constitujen la parte principal de su alimento, deben de volar en las mas clevadas capas de la atmósfera y solo despues que ha principiado el buen tiempo: únicamente en virtud de esta circunstancia puede explicarse la llegada mas ó me1105 tardia del ave à determinados sitios, como tambien si mas 6 menos larga permanencia en los mismos. Sabemos a punto fijo que el rencejo negro, al modo que sus congéne. res, se alimenta de muy diversas especies de insectos, como son tíbanos, escarabajos, mariposas de escaso tamaño, mos. cas, mosquitos, libélulas y efimeras, segun lo prueban los restos de estos animalitos, encontrados en las stistancias yo. mitadas por el ave. Sin embargo, no deben de constituir los insectos citados la base de la alimentacion del vencejo comun, pues de ser asi, no tendria este necesidad de perma. necer en el extranjero hasta el mes de mayo y de volver a abandonar la patria en agosto. En el sur de su dominio, los insectos que el are caza deben naturalmente aparecer mas temprano que en el norte $y$ volar en uno $y$ otro punto mas ticmpo que en Alemania; y solo asi se comprencic la distinta época de su llegada fo de su partida. Dado su con. tinuo ejercicio y el enorme consumo que hace de su fuerza, ci vencejo negro necesita, como todas las especies de su fa. milia, una considerable cantidad de alimento.

Varios observadores creen que no bebe, pero esto no es exacto, y lo puedo asegurar por-mis propias observaciones. Lo cierto es que no se baña sino cuando llueve, y que no se sumerge en el agua conio las golondrinas. Atendice a que siempre estí en movimiento, necesita comer inuchio, si bien puede resistir un prolongado ayuno: se han visto vencejos cautivos que vivieron scis semanas sin tomar alimento.

listas ares tienen pocos enemigos: entre nosotros no le da caza sino el gerifalte; en otros paises debe temer á varias especies de halcones. De vez en cuando perecen los hijuelos entre los dientes de los lirones y de otros rocdores que tre- 
pan, aunque no se da semejante caso sino cuando estas aves anidan en troncos huecos $\delta$ en cajas de estorninos.

CAzA.-En nuestros paises no persigue el hombre al rencejo negro sino cuando llega á ser peligroso ó molesto å. los estorninos; y creo quue se obraria muy cuerdamente, si, como aconseja Licbe, se dispusieran para habitacion de esta are pequerias cajas de unos $10^{\circ}, 50$ de largo por $11^{\circ}, 15$ de ancho y 11,07 de alto, con un agujero circular de $\left(0^{\circ}, 05\right.$ en la cara anterior 5 con algunos materiales dentro para la cons. truccion del nido; pues de este modo se daria 1 la ver pro teccion á ella y al estornino, puesto por la misma en constante peligro.

No sucede lo mismo en el mediodia de Eurnpa y sobre todo en Italia. Segun Savi, los vencejos jövenes tienen una carne excelente y muy apreciada: para adquirirla se practican en lo mas alto de las paredes de las casas, de una torre $\delta$ de un palomar, varios agujeros que se puedan registrar desde adentro; alli anidan aquellos, y es fácil apoderarse de los hijuelos. Sin embargo, no se deben coger todos: y para que se conserve la especie, solo se toma uno de cada nido. Savi nos dice además, que en Massa, cerca de Cartara, se ha construicio en una roca una torre destimada exclusiramente a la nidificacion de estas aves.

\section{LOS VENCEIOS ENANOS- CYPSIURUS}

CARACTÉRES. - lin los últimos tiempos han sido se. paradas del grupo de los vencejos, $a$ mi entender sin motivo suficiente, bajo el nombre de oypsiurus, varias especies pe queñas que solo tienen por caractéres distintivos su reducido tamaño y la rectriz mas extrema terminada en una larga pun ta. Hago mencion de estas avecillas solo á causa de la espe cial construccion de su nido.

\section{EL VENCEJO ENANO-CYPSELUS PARVUS}

CARACTÉRES - Fil vencejo enano, llamado por los in dios futte deuli, y tambien habassia ó aie del sicsuo por los habitantes de Bengala, es muchn mas pequeño que el co. mun: tiene $0^{\mathrm{m}}, 15$ de largo por $0^{\circ}, 23$ de ala á ala; esta plegada mide $0^{\prime \prime}, 12 \mathrm{y}$ la cola, sumamente escotada, $1^{\circ}, \mathrm{oS}$. Tience el plumaje de un pardo de humo, con visos de brance poco pronunciados; la garganta de un tinte algo mas claro, á causa de presentar las plumas de esta parte los bordes laterales ribeteados de un color blanquecino pálido; el ojo es pardo oscuro; el pico y las patas de un color negro (fig. 95).

DISTRIBUCION GEOGRÁFICA. - Solo se encuentra al rencejo enano en el interior del Africa, en el seno de las selvas virgenes con mas frecuencia que en otros puntos. Mis observaciones no concuerdan con los dalos de Heuglin, guien afirma que en el sur del Figinto es ave de morada fija, si bien es posible que algunas de estas aves penetren hácia el norte. No se le encuentra como morador habitunl del pais mas que en el sur de la Nubia $y$ en número mas crecido a lo largo de ias márgenes de los rios Blanco $j$ Azul, asi como tambien en todos los sitios donde hay palmeras. Habi La, además de los territurios bañados por el Nilo, loda el Africa central desde las costas occidentales hasta las orien. tales. Todaria no se sabe á punto fjo si el pequeño vencejo que se ve en Madagascar, pertenece da la especie del enano ó atra muy parecida, pues Harlaub, en su ultima obra sobre las aves que viren en la citada isla, deja la cuestion sin resolver; sin embargo pudiera creerse ser el mismo, si se considera que nuestra ave, ademis de habitar el Africa, se extiende tambien por una gran parte del sur del Asia. Solo cuando no esta en celo, vaga de un lado a otro sin objeto fijo ni direccion determinada; llegada dicha época recorre una zona muy reducida.

USOS, COSTUMBRES Y RÉGIMEN. - Al venccjo enano no le aventajan en agilidad los demás cipsélidos: no conozco are alguna cuyo ruclo sea mas ráplido.

Durante un viaje por el Nilo Azul, vi en el mes de seticm bre algunas palmeras que sobresalian de los demás árboles, y que debian tener gran atractivo para los vencejos, pues mas de cincuenta parejas revoloteaban al rededor. Iban de un lacio á otro, lanzando gritos penetrantes: pero volvian siempre hacia dichos àbboles despues de haberse alejado á alguna distancia Excitada mi curiosidad, acerqueme y vi que de vez en cuando se posaban aquellas aves en las hojas de pal. mera; observando luego varios puntos blancos que se desta. caban sobre el verde follaje, y ciescoso de saber lo que cra aquello, subi al átbol, y halle, no sin sorpresa, que dichus puntos eran nidos de vencejos cnanos.

Su estructura es muy singulas: como la hoja de palmera pesa demasiado para su pedículo, encórvase y rende rerti. calmente; el limbo forma adenis con ạuel un àngulo agu. do, y el centro de la hoja tiene una especie de gotern. En clla es donde el vencejo enano forma su nido, que se compone de fitras de algodon, aglutinadas con saliva y pegadas entre si y á la hoja; podria compararse con una cucha. ra redondeada, con una profunda excavacion y perpendicular en el mango. El foncio del nido tiene unos $0^{\circ}, 05$ de dímetro y está relleno de plumas blancas pegadas igualmente contra las paredes. Cada puesta no suele constar de mas que de dos huevos.

Eil rencejo enano toma sus precauciones para que no se puedan caer del nido los huevos 6 los peçueños. Cuando sopla el viento con fuerza, la hoja que los sostiene se agita violentamente, y para que no sea lanzada fuera su progenic, el are pega los huevos y los pequeños con su saliva. Los huevos son cilindricos y de color blanco; tienen unos $0^{\prime \prime}, 02$ de largo, y no ocupan la misma posicion que los de otras aves, sino nue se adhieren al nido por una de sus puntas. He hallado hijuelos bastante crecidos, que todavia estaban pegados al nido. y creo que tales medidas de precaucion son inútiles cuando los peņueños han revestido sus primeras plu. mas y pueden ya cogerse á las paredes de su albergue.

Heuglin confirma lo dicho, y observa que los pequeñuelos cuando están senii-desarrollados, se agarran firmemente âlas paredes del nido. Hil rencejo enano que vive en la India, escoge por morada las palmeras de laalmira y los cocoteros, y a falta de algodon, utiliza para tapizar el fondo del nido jerbas, plumas y otros materiales parecidos.

\section{LAS SALÁNGANAS-COLLOCALIA}

CARACTḱRES.- las salínganas son aquellas aves, célebres desde hace mucho tiempo, pero aun joco conocidas, cuyos nidos se comen. Iil género a que pertenccen presenta los siguientes caractéres: talla pequeía; pico muy pequeño y ganchudo; alas bastante prolongadas y agudas, con la segunda rémige mas larga: cola mediana, truncada en ángulo recto ó ligeramente escoiada; pico pequeĩo, en extremo curvo: tarsos desnudos, cortos y robustos a proporcion; dedos anteriores casi iguales; pulgat dirigudo hácia atrás, jo no versáil; plumaje bastante erectil y colores muy sencillos.

Los órganos internos ofrecen como particularidad el exce. sivo desarrollo de las glándulas salivales.

\section{LA SALÁngana PROPIAMENTE DICHA- COLLOCALIA NIDIFICA}

CARACTÉRES. - La especie tipo del grupo, la salánga- 
"na (collocalia unicolor, coniolor y breigrostris, hirunds) esculesha y maritima, ippselus esculenfus) llamada sarms-burong y lajong por los malayos, lazuet por los naturales de Java y Femirl y Jeriku por los del Japon, apenas aventaja en tamaho á nuestra golondrina de mar: tiene $0^{\circ}, 13$ de largo por $11^{\prime \prime}, 3^{\circ}$ de ala á ala; esta plegada $0^{\circ}, 12$ y la cola $0^{\circ}, 06$. L.a parte superior del cuerpo es de un pardo negro ahumado oscuro, con visos bronceados; la inferior de un pardo gris de humo; las pennas de la cola, que se presenta muy poco ahorquillada, son algo mas oscuras que las tectrices del lomo y de color negro; el ojo es pardo oscuro; el pico y las patas negras (fig. 96).

DISTRIBUCION GEOGRÁFICA. Antes se creia que la salángrana propiamente dicha no habitaba sino en las islas de la Sonda: pero últimamente se la ha encontrado tambien

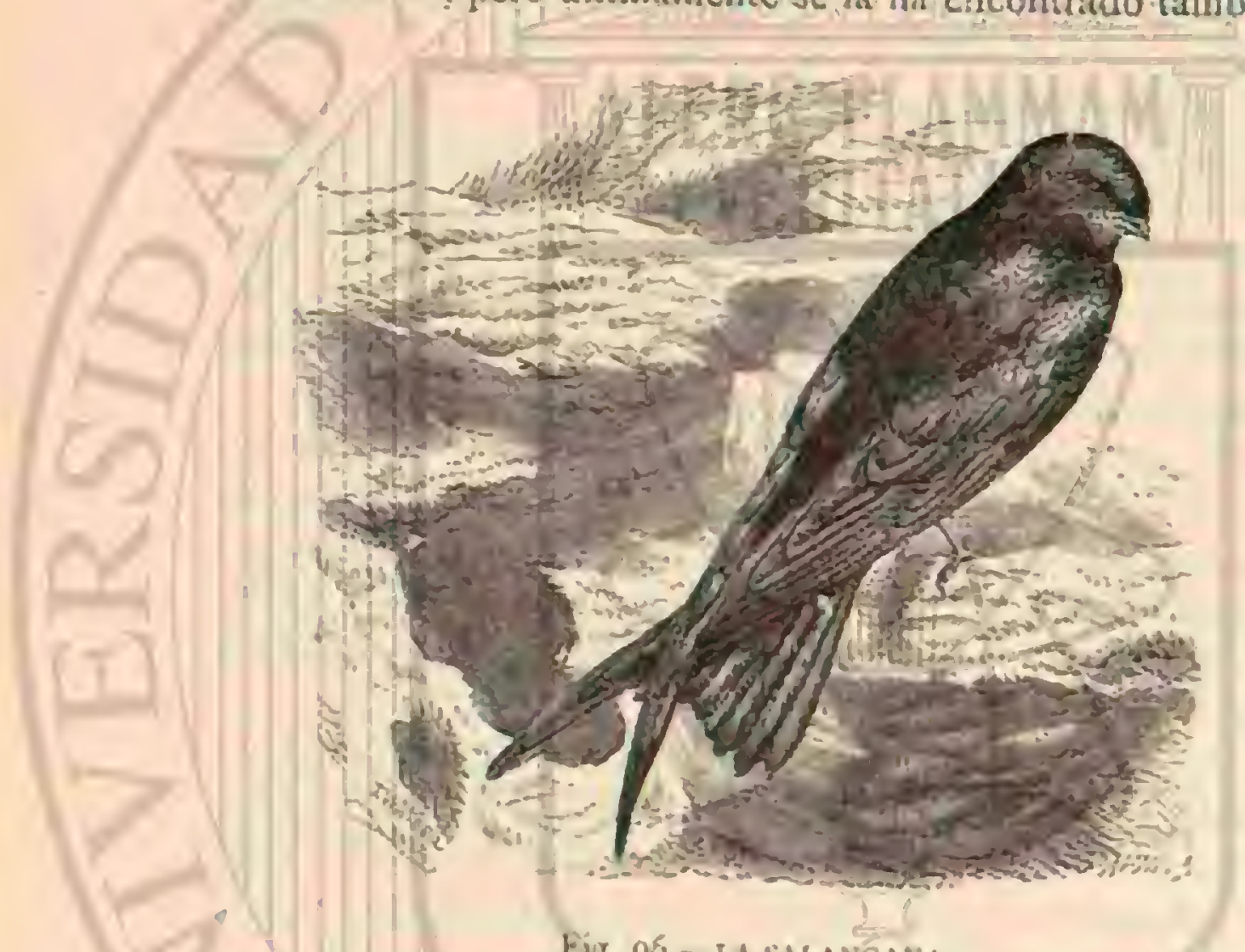

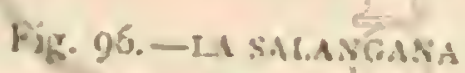

en Arrakan, á lo largo de la costa oriental del golfo de Ben gala, en Siam, Cochinchina, Ceilan, en las islas Nicubar y Andaman.

USOS, COSTUMBRES Y REGIMEN,-LaS noticias que tenemos acerca/del genero de vida de las salínganas, no $50 m$ tan detalladas como las relativas a sus celebrados nidos, cuyos elèmentos constitutivos conocemos exactamente ta mas circunstanciada descripcion que poseemos tocante á las costumbres y régimen del ave, es la de lunghuhn; pero es fuerza confesar que en ella se da a conocer mas bien la mo. rada que el modo de vivir del ave. Oigannos en prueba de ello las propias palabras del observador. \& las escarpadas costas del sur de Java, dice Junghuhn, ofrecen una vista en extremo pintoresca: la soberbia y cxuberante vegetacion que cubre la isha, se desarrolla y penetra hasta los extremos confines de la misma, en términos que hasta los pandanos ó bancas llegan à arraigar en las paredes escarpadas y extienden á millares sus ramas desde el borde del peñascoso muro subre cl abismo. El mar, que en aquella parte es muy profundo $y$ está en incesante movimiento, bate de continuo los piés del calcáren periasco, y con el decurso de los siglos ha consegui. do abrit en el seno de este rastas y profundas hendiduras que forman una esprecic de bahia muy abovedada. En estos sitios, especialmente en los en que el mar agitándose con mayor furia ha socavado mas la roca, se ven revolotear de una parte á otra bandadias enteras de estas pequeiras aves; cortan de intento en su vuelo la densa espuma que levantan las olas al estrellarse contra el peirasco, sin duda porque en ella encuentran el alimento que necesitan, probablemente diminutos animales acuáticos ó restos de aquellos que fueron es. trellados contra los escollos por el furioso impetu del oleaje.
Si el observador ó viajero se traslada al cabo peñascoso que se levanta al este de Rongliap, y se sienta al borde del muro, no tarda en ver la entrada de una caverna abierta en el pie de la pared de esie lado. Siguiendo con la mirada el movi. miento del mar, cuyas aguas están siempre subiendo y ba. jando, se nota que la boca de la cueva se halla unas veces enteramente oculta por las olas y otras al descubicrto, aprovechando en este último caso las salánganas la ocasion que se les presenta para entrar y salir del interior de aquella con la mpider del rayo.

Las aves tienen fijados sus nidos en la bóveda oscura y sumamente cóncaria del fondo de la caverna; conocen perfectamente el momento favorable en que la entrada de esta se halla libre, y no hay que decir que saben aprovecharlo oportumamente antes que otra montaña de agua vuclva cubrirla ó cermarla de nuevo. Cada vez que se acerca una grande ula, el mar penetra con el estruendo del trueno den. tro de la cueva, cierra la entrada de esta, y entonces tiene lugar un fenómeno que pone de manifiesto la fuerza expansiva del aire contenido en el interior de la caverna: comprimido y encerrado este por aquella en un pequchio espacio, ejerce presion en sentido contrario al del agua, y no bien esta empieza á bajar de nuevo, formando una especie de va. lle al pié del peñascoso muro, sale silbando con fuerza de dentro de la cueva, al propio tiempo que se lcranta de la boca de la inisma una columna de menudas gotas de agua, que semejan el humo que sale del cañon de un arma de riuego despues de descargada; y la ola, que aun no ha cesado en su movimiento de avance, libre de la resistencia que an. tes le oponia daire, se introduce con impetu y en direccion horizontal hasta, 100 metros dentro de la caverna, cuya entrada queda luego otra vez oculta por una nueva ola que avanza. Mientras á alguna distancia de la costa el mar permanece tranquilo $y$ su azulada superficie se presenta limpida y brillante como un espejo, óyese aqui al pié de la roca d hervor incesante, el continuo batir de las olas; la luz del sol se refracta con adminable claridad en cada una de ellas al momento de disolverse, y el arco iris despliega su brillante manto de colores al través de las columnas de finisimas gotas de agua que salen del interior de la caverna.

Unos sitios que presentan tan grandioso é imponente aspecto, unos sitios en que se realizan sorprendentes fenó. menos, en que hay antros que silban y humean $y$ doude los colores del arco iris aparecen y desaparecen sin interrupcion sobre las olas del mar agitado, necesariamente deben de estar habitados por séres sobrenaturales, por espiritus invisibles. $Y$ asi es en efecto: si se interroga sobre el particular á los javanesés, se obticne por loda contestacion que aquella caverna está habitada por la reina Loro, la cual impera sobre cl proceloso mar y extiende su dominio por toda la costa. Esta diosa es objeto de la mayor veneracion entre los natu. rales de Java, de manera que en Ronghap, en el interior de un bosque de palmeras que se extiende sobre la costa brava. hay una hermosa casa construida de palmas dọnde no mora ningun mortal, y nadic pasa por delante de csta morada sin llevarse las manos á la cabeza en señal de respetuoso saludo. Quien quiera que se atreviese ś cntrar en la citada casa, pagaria con su vida tamaño atrevimiento: clla pertenece à Ia reina Loro, la cual sale á veces del seno del mar ó abandona la cueva peñascosa y se introduce de un modo invisible ell esta morada donde la picdad y devocion del pueblo le tiene preparados muebles, camas y lrermosos trajes, de los que puede usar la deidad como y cuando le acomode. Solo el jefe de los que recogen los nidos de nuestras aves, el cual reviste el carácter de una especie de sacerdote, entra de vez en cuando en la mansion del espiritu para limpiarla del polvo 
q̧ue la cubre, levantíndose mientras tanto delante de la puerta de la misma, en guisa de piadosa órenda, el humo perfumado del incienso. Durante esta operacion no profieren una sola palabra ni el sacerdute, ni los demás javaneses que se hallan postrados de hinojos y llenos de medroso y devoto recogrimiento ante la sagrada mansion. Cuando ha llegado el dia de la cosecha de los nidos, se celebra un solemne ban. quete: extiéndense al clecto sobre el césped que alfombra el suclo y entre los matorrales que crecen delante de la casa de la dinsa, unas esierillas sumamente limpias; colócanse sobre ellas varios manjares y se invoca luego a la divinidad â fin de que venga tambien á ocupar su puesto en el convite. Termimada esta plegaria, échanse de bruces rodos los comensales con el objeto de dar tiempo à la reina para probar las vian. das ó á lo menos susustancia, en el caso de ser este su gus. to, $y$ luego comen el resto de los manjares, ahora mas sucú. lentos, en tauto que el gamelan hace resonar allá á lo léjos sus armoniosos acordes y anima la fiesta la mas cordialy sincera alegrias

Ademis de estos sitios tan notables por su gmndiosidad como por la abundancia de nidos que en ellos se recogen, las salinganas habitan tambien otros muchos en el interior de lava. La cueva arriba mencionada se encuentra en la resi. dencia de Bagalen; pero la colonia de las aves se halla esta. blecida en medio de la isla, en las montanas calizas que se levantan en la regencia de Perange á una altura de 600 á 800 metros, casi á igual distancia de la costa septentrional. In estas montanas hay seis cavernas habitadas por salánganas y en Karang Balong nueve. La caverna de Cieda se halla abierta en é muro de la costa, el cual se eleva á 25 meiros de alti. tud sobre el nivel del mar cuando este esta en su reflujo: dicho muro está tambien excarado, formando bóveda, y á una altura de ocho metros sobre la superficie de las aguas, presenta una especie de resalto, hasta el cual llega una es. calera que pende verticalmente del borde del muro, com puesta de dos cuerdas de rotang unidas entre si por made ros colocados trasversalmente â distancia de $0^{\circ}, 15$ unos de otros. Sulo una distancia de tres metros separa el techo de la entrada de la cueva del nivel del mar, cuyas aguas, aun en el periodo del reflujo, cubren por completo todo el pavimento de esta, mientras que durante el hujo queda cuteramente oculta por las olas. Despréndesce, pues, de lo dicho que los cazadores de nidos no pueden penetrar en el interior de la caverna, sino cuando las aguas están muy bajas y tranquilas, y aun asi seria ello imposible, si la peña de la bóveda no estuviera agujereada $y$ hendida por mil partes. En estos agujeros y en los puntos mas salientes de la peria se mantiene firmemente sujeto con las manos el mas vigoroso y atrevido de los caza.

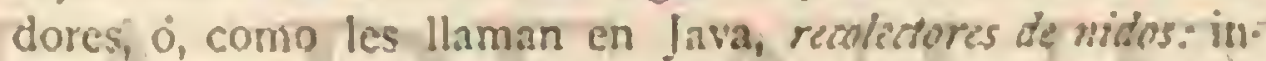
troducese primero trepando, y ata al nismo tiempo á las ci. tadas puntas pequeñas cuerdas de rotang, las cuales cuelgan desde el techo de la caverna hasta $t^{m}, 50$ o $2^{m}$. A los estrenos de estas cuerdas se sujetan otras iguales muy largas, las cuales corren en direccion horizontal bajo el techo; siguen, ora subiendo, ora bajando, codas las desigualdades del mis. mo: se extienden á manera de puente colgante á lo largo de la cueva, la cual mide cincuenta, metros de ancho, y en el interior de esta, donde baja la bóveda, se hallan colocadas a ocho metros de altura sobre la superficie del agua. La caver. na de Dahar tience quince metros de ancho por ciento cin. cuenta de largo; ábrese su intrada á cuatro metros de altura sobre el nivel del mar, cuyas aguas penetran en el interior lassta unos veinte metros y cubren asimismo su suclo.

Antes de colgar las escaleras y bajar al espumoso abismo para ir à recoger los nidos, los cazadores dirigen una solemne plesaria à la ya mencionada diosa Loro, á la cual se dan di. versos nombres en los distintos puntos de la isla; sin embar. go esta diosa no es otra que Durga, la esposa del dios Siva, simbolo de la fuerza creadora, de la vida y de la fecundidad inagotable para los actuales habirantes de Java, quienes á pesar de profesar el islamismo, tributan aun á aquella disi. nidad el mismo culto que anies.

\$A fines de diciembre de $1 \$ 46$, refiere Jerdon, visité una caverna de la isla de los Yichones, cerca de Honoro; mi guia me aseguró que las aves llegaban entre ocho y nueve de la

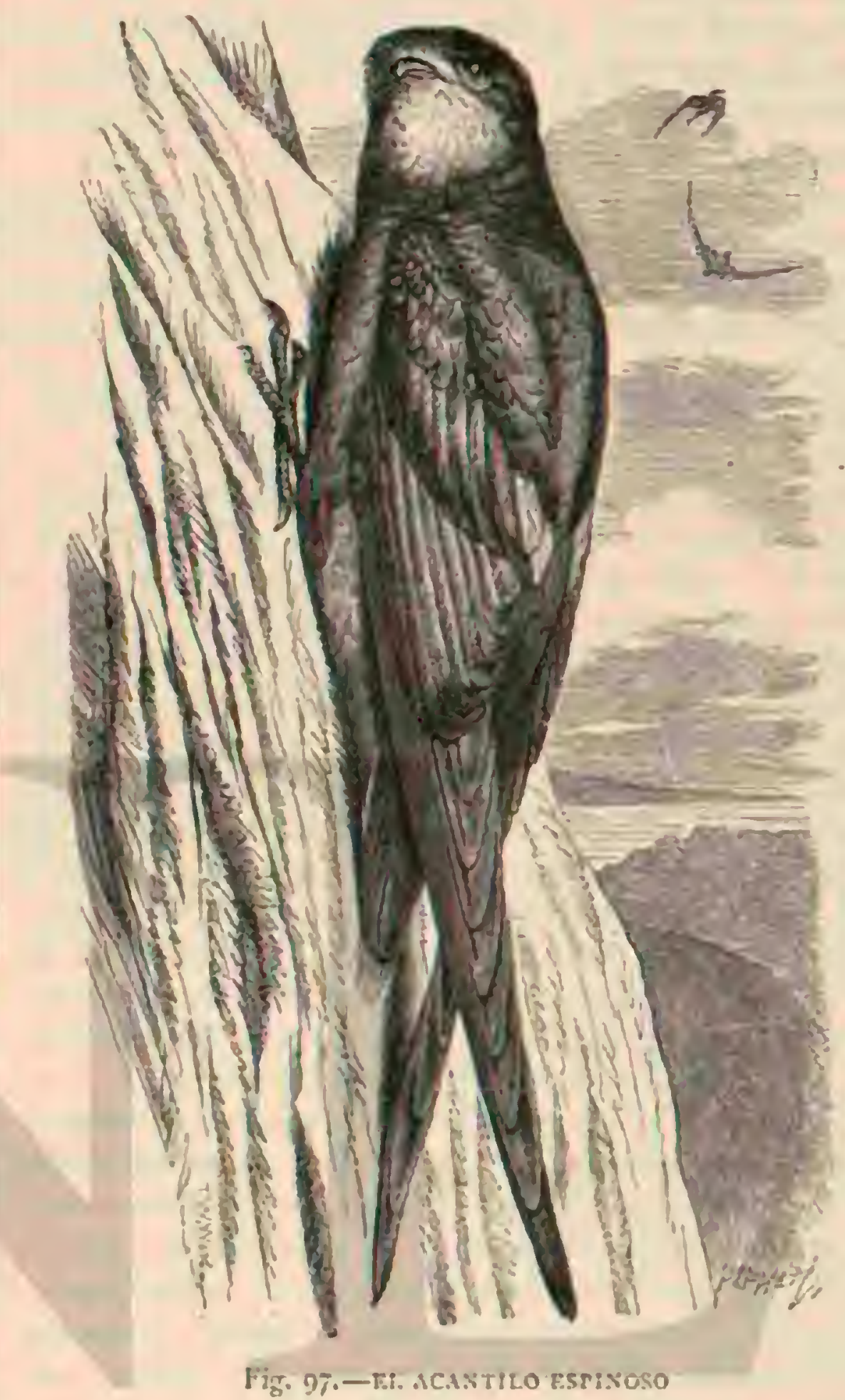

noche; y habiéndole encargado que me cogiese algunas, vol. vió al dia siguiente y me trajo varias salínganas vivas que cogib en un nido a las nueve de la noche.

En otra caverna que visité en el mes de marzo vi de cin. cuenta á cien nidos, algunos de los cuales contenian huevos; los mas de aquellos eran de coristruccion reciente, y hallabarse alli unas veinte parejas de salánganas.

- Cerca de Darjiling aparecen á menudo estas atves muy numerosas: segun dice Tickel, se presentan en agosto, dirigiendose hácia el sudoeste: yo he visto con frecuencia gran. des bandadas que se posaban sobre el suelo y volaban sicmpre con una rapidez cxtmordinaria."

Hé aqui lo que sobre el régimen y costumbres de las salánganas nos dice lunghulın, fundado en las observaciones de los ancianos y experimentados cazadores de nidos y en las suyás propias. Estas aves habitan, si no anidan, en las cuevas ya citadas; si no las retienen dentro de ellas los cui. dados de la prole, lánzanse fuera en mumerosas landadas, no bien comienzan a brillar los primeros myos del sol, y se dispersan de tal modo, que duranie el dia no se ve siquiera una sola de ellas ni sobre los matormles ni sobre los estanques y arroyos. Solo á eso del anochecer, cuando los mur- 
ciélagos se disponen â salir de sus escondrijos, vuelven d aparecer de nuevo las bandadas juntas para pasar la noche dentro de la caverna; deslizanse con la rapidez de la flecha, sin chocar nunca á pesar de la densa oscuridad que las enruelve, por las angostas aberturas y rendijas de aquella y se retiran en las cavidades mas elevadas al lado de los inurcié. lagos, sin causarse mutuamente la menor molestia. Estos duermen de dia en tanto que sus convecinas han abandonado sus agujeros para ir en busca del alimento; salen á su vez cuando estas regresan á la entrada de la noché y no vuelven á parecer hasta la manana del siguiente dia, cuando las salánganas abandonan otra vez la cueva: dé este modo viven juntos y $\sin$ molestarse en lo mas minimo estos animales tan diferentes por sus costumbres, pues la mitad de ellos se sia cuando viene la otra mitad, y vuélvese esta cuando llega aquella otra vez Mientras unos pocos cazadores de ridos afrrman que las salánganas, al modo que sus congéneres, se alimentan de pequeños insectos, especialmente de mosquitos, la mayor parte de aquellos, por el contrario, suposten que van à caza de varios animales acuáticos y restos de los mis. mos, por lo que anaden que aquellas de estas aves que ani. dan en el interior de la isla, se ven precisadas al recorrer al menos dos reces cada dia una distancin de yo kil. para póder pasar de th caverna, donde crian, al mar y vice.versa: Iunghuhn parece asentir a la opinion de los indigenas, ya que la consigna sin la menor observacion en contra. En las cuevas de Bandong, segun aseguran los cazadores de nidos, las aves empollan cuatro veces en el decurso del año, permaneciendo la mitad de cllas dentro de la caverna durante la época de la cria; macho y hembra cubren seis horns por turno, $y$ todas Ins parejas estan ocupadas a un mismo tiempo en las lareas de la cria con solo una diferencia de diez dias. Jas salánganas nunca utilizan dos veces un mismo nido, sino que, por el contrario, se fabrican otro nuevo para cada puesta, por mas que esto les exija un mes de trabajo: el nido viejo comienza á despedir mial olor y se descompone luego.

Las salánganas son conocidas y ceiebradas desde remotos tiempos, principalmente por sus nidos, abundando sobre este asunto las historias. En la costa de China, dice Bontius, se ven avecillas del género detas golondrinas, que lle. gan del interior del pais para anidar en las costas bravas, a lo largo del mar; recogen en la espuma de las olas una ma. teria gelatinosa, probablemente esterma de ballena, ó ver. dadera freza de pescado, y con ella construyen sus nidos. Los chinos los cogen en las costas hravas y se los llevan a las Indias, donde los venden â un subido précio. Estos nidos. se cuecen con caldo de gallina ó de carnero, formando un plato nuy apreciado de los gastrónomos. .

Hasta últimamente se atribuyó a estos nidos cl mismo origen y todos los viajeros estaban contestes en que la salángana cogia en el mar los materiales de que forma su nido. Kampfer refiere que unos pescaciores chinos le aseguraron que se compone solo de la carne de un pulpo grande, que prepara antes el ave de cierto modo: Rumph describe una pequeña planta, blanda y como cartilaginosa, medio traspa. rente, viscosa, lisa y de color bianco y rojo, que crece en las orillas del mar, en las rocas y entre las conchas; $y^{\circ}$ dice que la salángana se sirve de ella para construir su nido. Sin em. bargo, ef mismo pone en duda su aserto y cree probable que los animales lo fabriquen con uno de los productos de secrecion. Poivre escribió á Buffon manifestandole haber observado que entre Java y Cochinchina, $y$ entre Sumatra y Nueva Guinea, estaba cubierta la superficie del mar de una sustancia semejante á la cola luerte, medio desleida, sustan. cia que al congularse se parecia en un todo à la materia de los nidos de la salíngana. Raflles, participando de la opinion de Rumph, la considera como un producto de secrecion, y dice que son tales los esfuerzos del animal para emitirla, que está mezclada con sangre. Habiendo abierto Home el estómago de una salángana, encontró muy desarrollados los conductos excretores de las glándulas estomacales, y provistos de una abertura iubular dividida cir varios lóbulos, como los pétalos de una tor. Segun él, estos tiltimos segregarian el musus que forma la construccion. Fil análisis quimico de los nidos de salảngana ha demostrado a Marsdien que la sustan. cia que las compone guarda un término medio entre la albú. mina y la gelatina; que resiste largo tiempo a la accion diel agua en ebullicion, hinchandose al cabo de algunas horas; $y$ que al secarse vuelve á ser dura, pero quebradiza Por níl. timo, gracias á Bernstein, sabenos cómo se forman estos ni. dos comestibles.

\&o debemos extranar, dice, que se hayan emitido opj.

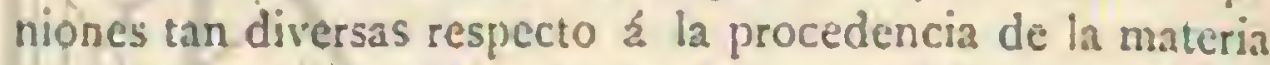
que compone los nidos de la salángana. Mientras solo se creyó en los relatos de indigenas ignorantes y supersticio. sos, y cuando se tenia por suficiente la simple comparacion de los caractéres exteriores de esta sustancia con los de otras materias completamente distintas, no era de esperar que sc hiciese luz sobre este punto; ni se podia llegar á lo cierto sino observando a las aves en vida. A decir verdad, esto es dificil. pues anidan en cavernas lóbregas, mas ó menos im. practicables, donde apenas penetra la claridad del dia. fisiste por fórtuna una especie semejante que habita en Java, conocida con el nombre de kusappi, y a la cual se puede observar fácilmente, pues anida cn sitios abordables, bién í la entrada de las cavernas ó a lo largo de las costas bravas. Viarias veces he podido verla construir su nido, cosa que nunca conseguí con la verdadera salángana.

Nucho tiempo hace que es conocida la forma de los nidos comestibles (los de la salángana propiamente dicha): asemejanse $\dot{a}$ un cuarto de cascara de huevo, siguiendo su gran diámetro; estón abiertos por arriba; la roca conira la cual se aplican los cierra por detris. Las paredes son muy delgadas; el horde superior se prolonga y forma á cacia lado una especie de ala bastante fuerte, que sostiene la construc. ción aplicada contra la roca. lil nido se compone de una materia traslúcida, blanquizca ó pardusca, y presenta tres estrias trasversales onduladas, dispuestas mas ó menos para. lelamente entre si. Lista es la única organizacion que ofre. cen: los nidos oscuros y parduscos, que tienen menos valor. son en mi concepto nidos antiguos donde se han criado hijuelos; los blancos valen mas y son de mas reciente construccion. Otros observadores atribuyen a dos especies dis. tintas los nidos diferentes; pero como yo no he podido adquirir ningun ave cogida en un nido pardo, no me aventuraré á resolver la cuestion, prescindiendo de que se encuentran todos los grados intermedios entre los nidos blancos y los pardos, presentando todos la misma disposicion, lo cual me hace creer que pertenecen realmente \& una sola especic. Hállanse nidos cuga cara interna afecta una disposicion reticulada, resultante de la desecacion y contraccion de la sustancia empleada; á menudo se encueniran tambien plu. mas adheridas á las paredes.

- En estos nidos es donde la salángaria pone dos huevos, rara veztres, de color blanco brillante, que miclen 17 , ozo en su diámetro longitudinal, y $0^{\prime \prime}$, ot $\mathrm{cn}$ el mayor dímetro trasversal.

3. El nido del kusappi o salángana fucifaga (collocalia fu. ishogar se asemeja exteriormente al de la salängana propia. mente dicha, difiriendo sobre todo en que se compone de tallos de yerbas; la materia gelatinosa no sirve mas que para enlazarlos entre si y fjjar el nido contra la roca: por eso es 
mas abundante en la parte posterior, y en particular en los dos aleros qué prolongan por detris el borde superior. listos aleros no cxisten muchas veces, sobre todo cuando el nido es de sólida constraccion. Yo poseo muchos de kusappi que se hallaron en el tejado de un edificio público de Batavia: se componen de tallos de yerba y de crines de caballo dispues. tas unas sobre otras sin enlace alguno, aglutinadas por la masa gelatinosa, mas abundante en la pared posterior. En contré otros tres nidos que se componian de sustancias ve getales mas Aexibles y cntrelazadas; como en ellos era la materia gelatinosa menos indispensable, solo estaba en la parte posterior, donde servia para sostener el nido contra la ruca.

Volviendo luego Bernstein a las antiguas leyendas, dice haber obserrado kusappis que fabricaban sus nidos; asegura que tuvo varios cautivos, y disécó un gran nummero de ellos, convenciéndose asi de que la matcria era evidentemente producto de una secrecion. En sus primeras comunicaciones insistió sobre el gran desarrollo de las glandulas salivales, particularmente de las sub-linguales, y emite la hipótesis de que podrian ser muy bien los órganos de secrecion de la sustaricia que forma el nido. Despues adquirió una prueba de ello al ver que durante el periodo del celo estaban las glán. dulas muy turgescentes, disminuyendo de volímen despues de poner la hembra.

a Estas glandulas segregan considerable cantidad de un mucus espeso $;$ viscoso, que se amasa en la parte anterior de la cavidad bucal, liquido bastante parecido an una solucion saturada de goma arábiga. Si se saca un hilo de la boca y se arrolla al rededor de un palito, se puede extraer toda la sa. liva, y hasta los conductos excretores; sécase muy pronto, y sc asemeja por completo á la sustancia gue compone los ni. dos. Exnminada con el microscopio, presenta el mismo aspecto: si se pone entre dos hojas de papel, las pega como si fuese una solucion de goma.

Cuando el are comienza a construir su nido, vueha hácia el sitio que eligió, y con el extreno de la lengua aplica su saliva sobre In roca, repitiendo la operacion diez 0 veinte veces, sin alejarse nunca muclio. De este modo tmza un sc micirculo $\delta$ una especic de herradura; la salina se seca rápi damente: y queda formada una base soilida sobre la cual se apoyará el nido. El kusappi emplea diversas sustancias vege. tales une aglutina con su saliva; la salángana propiamente di. cha no se sirve sino de esta tiltima: se posa sobre el armazon de su nido, é inclinando alternativamente la cabeza de dere. cha a izquierda, levanta las paredes, formando asi las lineas estratificadas de que hemos hablado antes: en el momento del trabajo pueden quedar pegadas algunas plumas por la saliva. Es posible tambien que la irritacion cansada por el aumento fisiológico de las giảndulas induzca á las aves a ́ra. ciarlas, oprimiéndolas o frotándolas; por lo tanto pueden producirse lesiones, mezclíndose algunas gotas de sangre con la saliva. La secrecion de esta se halla en relacion con el régimen del ave: cuando daba yo á mis salanganas durante algunos dias mucho alimento, la secrecion salival era tnuy abundante, y disminuia, por el contrario, si las aves paciecian hambre. Esto explica por qué en ciertas ocasiones constru. yen las salinganas sus nidos con mas prontitud yue en oiras; en el primer caso tieneu abundante alimento, y en el segundo éscasea mucho.

USOS Y PRODUCTOS.- En las cuevas de Baudong, hácese la recoleccion de los nidos ires ó cuatro veces durante el año: la primera en abril 6 mayo, la segunda en julio. 6 agosto y la tercera en noviembre ó diciembre. Cliando co. mienzan ấ recogerse los nidos, encuéntranse todavia la miind de ellos con huevos ó pequenuelos sin alas, mientras estos han abandonado ya la otra mitad: cómense los primcros, tiranse los segundos, y échase á perder de este modo en cada recoleccion la mitad de la cria. No se vaya á creer por esto que disminuya el número de las salánganas; pero no va tam poco en aumento donde no se recogen los nidos inas qque tres veces al año, dejando escapar una cria entera. En las cucvas últimamente mencionadas considérase la primera ro secha conso la peor, la segunda como la mejor, y como re. gular la tercera. las primera recoleccion empieza cuando la gean majoria de los nidos tienen polluelos ya revestidos de pequeias plumas, y hasta esta época, que se llama de la madurez, bajan cada dia i la cueva algunos cazadores para ver en qué estado se encuentran los nidos, juntamente con su corrienido. Los que de estos abrigan pequeños con plumas nacientes, son de primera calidad; los que los contienen com. pletamente desnucios, de segunda, y son, por último, de iercera clase aquellos que tienen aun huevos en su interior: los nidos que albergan pequeños enteramente cubiertos de plumas, son de color negro y mada valen.

Las seis cueras de Baudong dan anualmente por término medio 13,530 nidos, ó sea 3,3 So en cada recoleccion, de lo cual se desprende que deben estar habitados por 6,760 salinganas. Fil número de los que se recogen en Karang-Bolong, se calcula en unos 500,000 , los cuales divididos en tres re. colecciones, suponen una poblacion de mas de 33:000 de estas aves en cada una de las nueve cavernns que existen en ayuel sitio. Ahora bien: si se tiene en cuenta que cien nidos constituyen por térnino medio un kati, y cien katis un pikol, resulta que se recogen al año de aq a 50 fikoles, los cuales pagados por los clsinos de + á 5,000 florines, ó a un florin cada dos ó dos y medio nidos, vienen a arrojar anualmente, deducidos 10,000 Rorines de gastos, un producto liquido de 2 4,000 florines poco mas ó menos a favor de cada una de las nucve cavernas citadas. los datos precedentes fueron recogidos en i\$ $\$$ i por Junghuhn de boca de varios cazadores de nidos, especialmente del encargado de la cus. todia de las mencionadas cavernas de Karang.Bolong, en cuya localidad constitujen los recolectores de nidos una cas. ta particular, cuya profesion se trasmite de padres á hijos por herencia.

I'rescindiendo de Jara, se recogen tambien nidos de salánganas en otros varios puntos, especialmente en todo el archipucélago Indio, de modo que, at decir de los viajeros, todos los anos se introducen en China varios millones de ellos, viniendo a representar la cantidad total de los recogi. dos una suma de seis millones de marcos aproximadamente.

\section{LOS ACANTILOS-ACANTHYLIS}

CARACTERES.-I os acantilos se caracterizan por te. ner rectrices cuyos tallos sobresalen de las barbas en forma de espinas ó puias, por lo cual se les ha dado a veces el nombra de martivites estincesas. T'ienen además tarsos prclongados; dedos mediananente largos, y un pu!gar muy fuerte, dirigido hácia atrás y no reversible. Su plumaje es bastante espeso.

DISTRIBUCION GEOGRÁFICA.-LOS acantilos son propios del Asia, de Africa, de América y de Australia

\section{EL ACANTILO ESPINOSO-ACANTHYLIS} ACAUDACUTA

CARACTÉRES. - El acantilo espinoso (fig. 9i) tienc $10^{\circ}, 23$ de largo por $10^{\circ}, 55$ de amplitud de alas; esta $)$ ! egada mide $0^{\circ}, 22$ y la cola $0^{\circ}, 06$. La cabeza, la parte superior del cuello, las cobijas superiores de la cola, los costados, las re. 
miges y las rectrices son de un color negro oscuro, con visos de un azul verdoso; el lomo y la espaldilla de un pardo ce. niciento: Ia barba, el pecho y la nuca de un tinte blanco; cl vientre de un pardo de sebo; las sub caudales y una lista que desciende sobre la parte posterior y lateral de la nalga blancas, con mezcla de algunas plumas de un azul negro muy brillante; las barbas internas de las penmas del brazo son blancas; el pico negro; las patas color de plomo y el ojo pardo oscuro.

DISTRIBUCION GEOGRÁFICA.-Segun Jerdon, esta ave habita la parte sur del Hinalaya, el Nepaul, el Sitkim y cl Boukiars.

USOS, COSTUMBRES Y REGIMEN. - Se reconoce fácilmente esta ave por la ligereza y rapidez de todos sus mo. vimientos: anida en colonias, á lo largo de las rocas escarpidas, un poco mas abajo del limite de las nieves. Despues de aniciar recorre el país sin direccion fija, y parece que rara vez está dos ó tres dias en el mismo punto. Sin duda le sirve para trepar su espinosa cola.

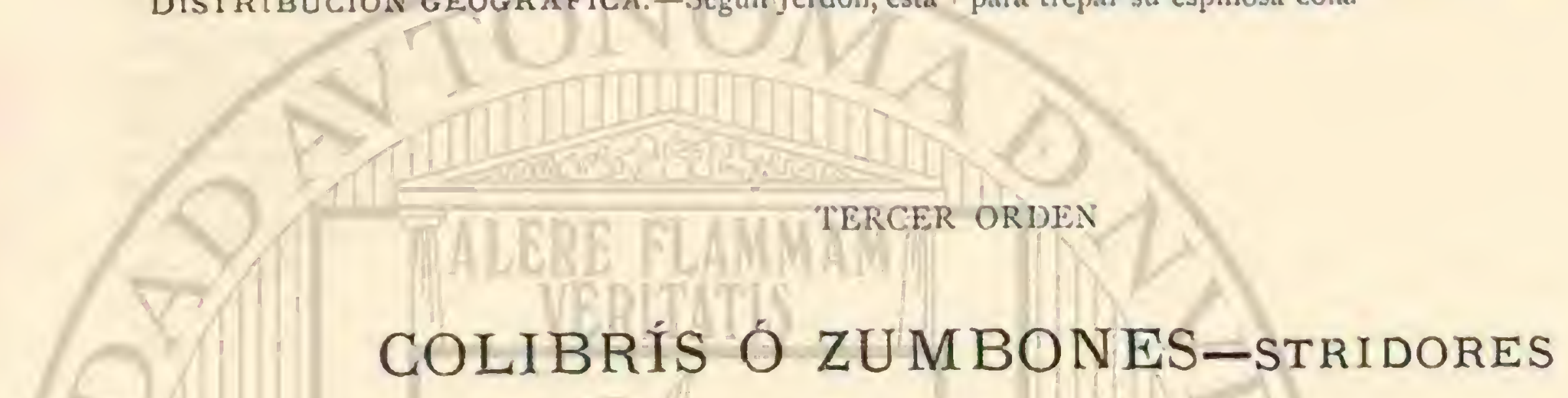

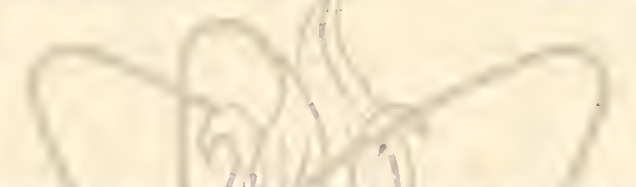

-De todos los séres animados, hé aqui los mas graciosos por sus bellas formas y por lo espléndido de tos colores. Las piedras preciosas y los metales pulimentados por los mas distinguidos artistas no son comparables con esta joya de la naturaleza; colocados por esta en el órden de los pájaros, pero en viltimo término de la escala en cuanto al tamaño, maxime mirama is: mininis. Su obra macstra es el ditninuto pajaro mosca, al que ha colmado de todos los clones que se limitó á repartir cntre otras aves; ligereza, rapider, agilidad, gracia s ricos adornos, todo pertenece à este pequeño favo. rito. Irrillan en su plumaje los matices de la esmeralda, del rubi y del topacio, y jamis le ensucia con el polvo de la ticra; en su vida, exclusivamente aérea, apenas se le ve toyar la yerba jur momentos; siempre está en los aires, vuela entre las flores; participa de su frescura y de su brillo; ali. méntase de su néctar, y no habita sino los climas donde aquellas se renuevan sin cesar.

- En los paises mas cálidós del Nuevo Nundo es donde se encuentran todas las especies de pájaros moscas. Sun bas. tante numerosas, y parecen estar confimadas entre los dos trópicos; las que avanzan en verano por las zonas templadas se ausentan por muy poco tiempo; parecen seguir al sol, avanzar y retirarse con cl, y volar en alas del céfiro en pos de una primavera cterna.x

En cstos términos describió Buffon, con su encantador estilo, los pajaros moscas; y todos los naturalistas, incluso los mas graves, no ensalzarán nunca demasiado su belleza. «éuién no se detendrá nudo de asombro, dice Audubon, al ver uno de esos encantadores séres cortar los aires, soste niéndose como por encanto, volar de for en Hor y resplan. acerer cual otro rayo desprendido del arco iris, brillando como la luz misma? - El colibri, dice Waterton, es la verdadera ave del paraiso: $5 e$ la ve hender los aires con la rapidez del pensamiento; roza el semblante del viajero, $y$ al momento desaparece para volver en seguida of volar de flor en hor; tan pronio parece un rubl como un topacio, una es. meralda ó una brillante lentejuela de oro. No Noxiste en la tierra, escribe Burmeister, atve de aspecto mas gracioso, ni de colores mas vivos que estos singuiares habitantes de la América; es preciso haberlos visto viros y en su pais matal, para comprender hasta qué punto se mostró pródiga la na. turaleza con ellos al dotarles de belleza tanta.y

Pero si todos lus naturalistas están unánimes en adınirar A los colibris, no sucede lo mismo cuando se trata del lugar que debe asignárseles en el sistema; y aun no se ha resuelto universalmente si forman una sola familia 6 constituyen un órden.

No puede negarse que los colibris se asemejan en varios puntos $\$$ otras aves, pero en realidad no se pueden colocar en ninguno de los órdenes establecidos. Al considerar la suma de sus caractéres se ve la necesidad de formar con ellos un grupo aparé.

El tipo que rejresentan es especial y sus costumbres difieren totalmente de las de los otros volátiles. Los colibris entre las aves representan en cierto modo á los insectos; sus movimientos, su alimentacion, todo su sér, en fin, ofrece unalogias innegables con los de algunos de aquellos séres, particularmente con las mariposas. Los colibris son aves cuando se posan, insectos cuando se mueven. Se les ha co. locado junto $\{$ las especies de alto vuelo, sin que se asemejen a ellas sino por la estructura del ala; se les ha presentado como tenuirostros, y particularmente como nectarinidos; pero difieren de ellos casi por todos conceptos Tambien se hubiera podido reunirlos con los picos, toda vez que su lengua esta conformada lo inismo que la de los picidos: cualquiera que sea el lugar que se les asigne, siempre se podrín hacer objecioncs: cstán aislados en medio del reino de las ares. No cometeré, pues, ninguna falta al formar con ellos un órden aparte, sin contar que otros naturalistas han participado de la misma opinion. El órden de los zum. bones (stridores), creado por Cabanis, comprende; además de los colibris, los chotacubras, los martinetes, los turacos y los colius; hallar alguna semejanza entre estos últimos y los colibrís es para ini imposible; ni aun puedo descubrir sus afi. midades con los chosacabras y los turacos.

CARACTERES. - I os colibrís varian mucho en cuanto á la talla: los hay que son tan grandes como las pequeñas especics de los merópidos, al paso que otros tienen las dimensiones de una mosca del mayor tamaño. Su cuerpo es prolongado, ó cuando menos lo parece, pues tienen la cola comunmente larga; en aigunas especies en que es corta y ru. dimentaria, se ve que el cuerpo es en cambio vigoroso y fornido. El pico, ñno, largo, aleznado, recto ó ligeramente corvo, es unas veces tan largo como la cabeza y otras inucho mas; en algumos individuos ofrece casi tanta longitud como la mitad del cuerpo. Ia vaina córnea que le cubre es bas. tante delgada; su punta recta; el borde tiene una ligera esco. tadura en los unos y está finamente dentado en su extreni- 
dad; en otros es entcro; los hay que tienen las nandibulas profundamente surcadas, abrazando la superior completa. mente la inferior, con la cual forma un tubo en el que se alọ̣a la lengua. Por detrás constiture la arista ciorsal una protuberancia plana, y presenta una ligera excavacion, que se puede considerar como la nasal, aun cunndo no se abran en ella las fosas; estas se hallan colocadas mas afuern, inme. diatamente al lado del pico, y aparecen bajo la forma de aberturas estrechas $y$ largas.

Las patas de los colibris son notablemente pequeñas y delicadisimas; los tarsos están cubiertos de plumas, mas a menucio erizadas que alisadas; los dedos, completamente se. parados ó un poco reunidos en su base, se hallan cuibiertos de escamas cortas y tubulares; las uinas, muy acerndas y juntiagudas, igualan à los dedos en longitud ó sobresalen. I.as alas son largas, angostas, encorradas ligeramente en forma de ho\%; la primera rémige se prolonga siempre mas y su tallo es mas fuerte que el de las otras; muchas especies tienen Ia primera mitad muy ancha. Por lo regular se cuentan diez, y. á reces nueve rémiges primarias y scis secundarias; de estas, las cuatro primeras son iguales entre si, y las dos últimas cortas y cscalonadas; la última primaria es mas larga que las secundarias. La cola se compone siempre de diez. rectrices, pero oirece muy diversa conformacion: muchas especies la tienen alrorquillada, pues las rectrices externas sob:esalen mas $\delta$ menos de las otras, y presentan en varias de ellas hasta scis veces la longitud de las mas cortas. Sus barbas son iguales en toda la extension de la pluma, ó bien desapa. recen casi completanente lácia el tercio del raquis para de. jarse ver de nuevo en la junta, donde se ensanchan de ma.

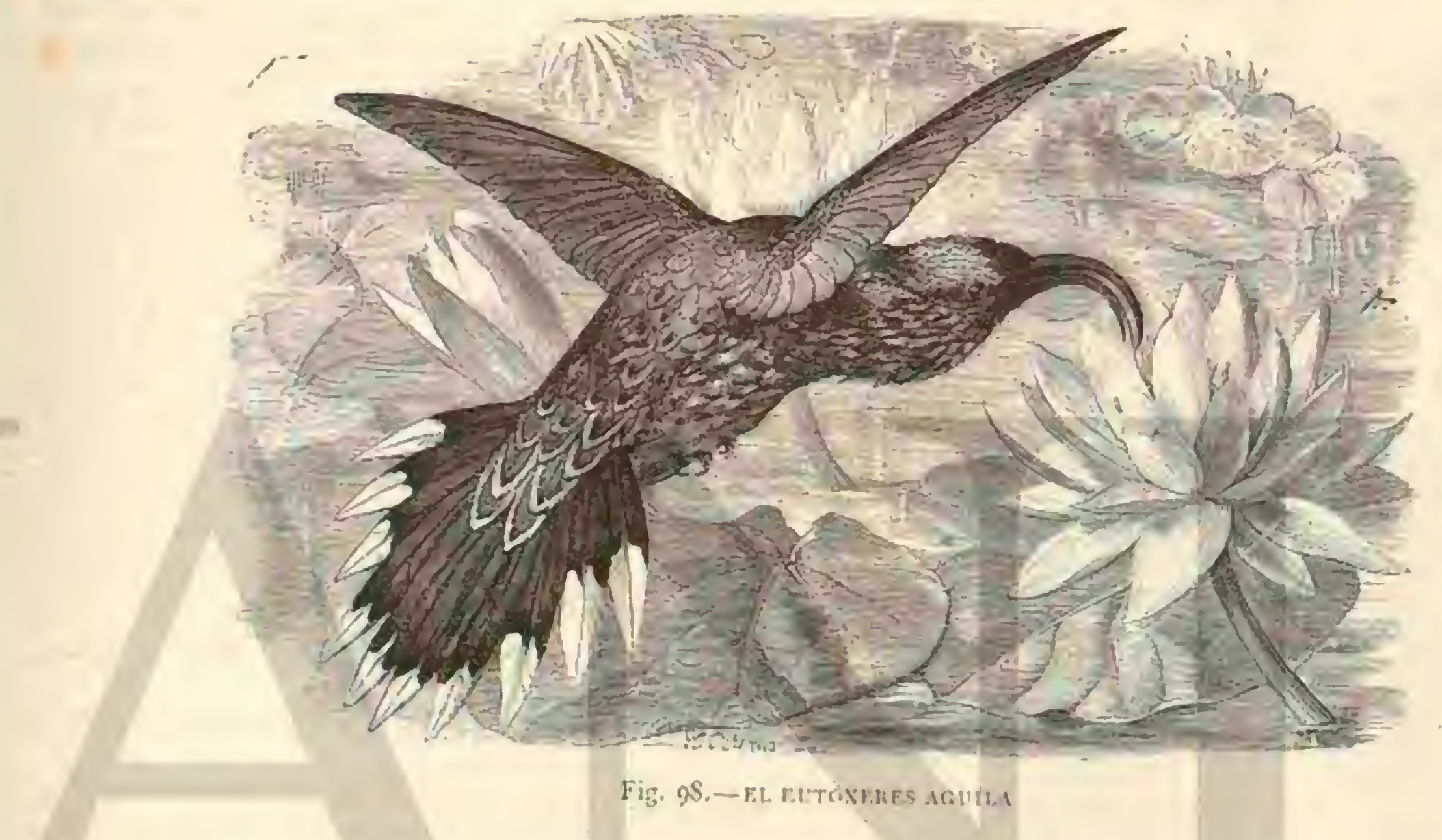

nera que forman una especic de paleta redondeada. En algunas especirs las barbas son muy nequeñas y la pluma parece quedar reducida solo $\mathrm{al}$ tallo. A veces se atrofran las rectrices, conservándose como rudimentarias, en curo caso parecen mas bien aguijones que plumas; sucede tambien que la cula es ahorguillada, pero redondeada por fuera, de tal sucrte que al abrirse forman las extremidades de las rec. trices una linea curva. Algunas especies, en fin, tienen la cola simplemente redondeadi, $y$ entonces son mas largas las rec trices medias.

Fil plumaje es bastante erectil y abundante, en proporcion á la talla del ave, $y$ no uniforme en todas las partes a del cuer po. Asi vemos que ciertos colibris tienen la cabeza adornada de un moino mas ó menos largo, mienras que otros presen. tan un collarin en forma de abanico altededor del pecho, of manojiros de plumas que simulan una barba. Iil plumaje va ria mas ó menos segun la edad ó cl sexo: no se sabe aun de cierto si los colibris mudan una ó dos veces al año. Roden el ojo un circulo desuudo, bastante ancho.

QEl esqueleto de los colibris, dice Burmeister, es muy raquítico, y casí todos los huesos del tronco, neumáticos: las órbitas muy gmandes, y el tabique interorbitario parece per. forado. Cuéntanse doce ó trece sértebras ccrvicales y ocho dorsales. Ia horquilla, corta y cstrecha, no se articula con el esternon, que es nuy ancho en su parte posterior, redondeado y sin escoiaduras ni cavidades. La quilla es suma. mente alta y muy salienic por colante: la pélvis, corta y an rown III cha, se asemeja mas á la de los picos y de los cuclillos qque a la de las aves cantoras. Las vértebras caudales figuran en numero de cinco of sicte, segur que las primeras están sol. dadas 6 no á la pélvis. El miembro superior ofrece como particularidades un omoplato largo, un luximero y antebrazo muj cortos, al paso que la mano es muy larga. Los huesos del miembro inferior son muy raquiticos y cortos, pero los dedos tienen, no obstanie, el mímero ordinario de articula. ciones.

Lil aparato lingual se asemeja al del pico, pues los largos cuernos del hueso hibides se encorvan, staten por detrils $y$ sobre la cabeza, llegan a la irente, y alcanzan al borde del pico hasta en el acto del réposo. Isa lengua se compone de dos cilindros soldados ell su basc, y se termina por una su. perficie aplanada, casi membranosa, y menudamente dentada en los lados. Fistos cilindros son huecos, y no parecen contener sino aire: por lo menos, nunca encontré nada en su interior: por detràs estan soldados uno à otro, y en csta porcion ocupa su cavidad un tejido celular lacio. La lengua es algo mas gruesa por detrás, y la terminan dos superficies lisas un poco divergentes; esta parte del órgano es tan larga como el pico; por detras de las dos superficies es ja mus. culosa, y simula un corto pediculo cuya superficic esta cu. bierta de surcos. Este pediculo, que corresponde al cuerpo del hioides, se va engrosando hasta el nivel de la laringe; alli se divide en dos ramas, que abrazan aquella, pasan al lado de los bronquios de la mandibula inferior y suben las. 
cia el occipucio. Ins cuernos del hueso hioides, en los cuales se inserta un par de misculos divididos, son los que de. terminan los movimientos de la lengua; el mas fuerte de ellos está colocado detrás del hioides y le bordea hasta el nivel del órgano; él es el que determina la salida de la porcion cilindrica en el acto de contracrse. En este movimiento, la vaina del pediculo de la lengua se extiende desde su raiz hasta la laringe, y su longitud se cuadruplica, y hasta se sextuplica El segundo misculo, inserto sobre el cuerno del hioides, al nivel de str articulacion inedia, se corre por este cuerno, pasa por encima de la cabeza, sobre la frente, y se

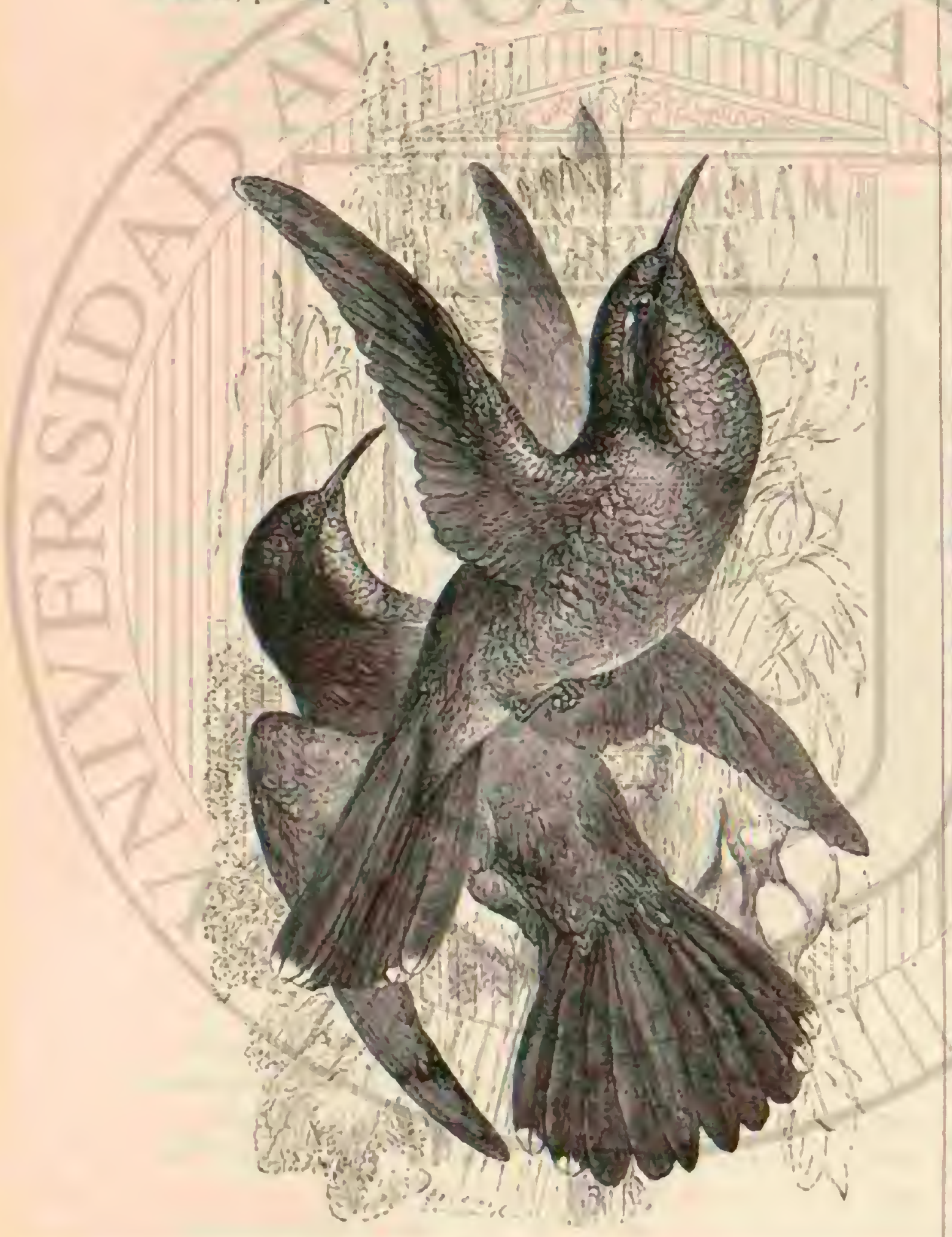

Fig. 99.-EL. R.AMFOnON MANCHADO

enlaza con la raiz del pico; al contraerse tira de la lengua hícia atris, y cncoge la mina entre la base de la lengua y la laringe.

2. He disecado las partes blandas de rarias especies de colibris, yo encontré nada de particular digno de mencionarse. En el cueilo presenta el esóingo una dilatacion oblonga, situada sobre la horquilla, como en los picos y los cucli. llos; despues se acorta este órgano y se comunica por una angosta abertura con el ventriculo subcenturiado. Este último es corto; el estómago muy pequeio, rudondo y poco musculoso: el primero tienc la superficic interna cubierta de glàndulas dispuestas en forma de red; la superficie interna del segundo es lisá, $y$ la mucosa carece de epitelium. No se encuentran en los colibris ni ciego ni vesicula biliar; su higado es muy grande y bilobado, el lóbulo derecho mucho mayor que el izquierdo. La trånquea se bifura por encima de la horquilla, y al nivel de esta bifurcacion existe una laringe inferior globulosa, cuya cara inferior está cubiêtia ś cada lado por dos músculos, uno fino y cl otro filiforme. Los ló. bulos pulmonares son muy pequeños: pero en cambio el corazon es muy voluminoso, y tres veces mas grueso que el estómago. El oviducto, que baja por el costado izquicrdo, es muy grande $y$ ancho, lo cual está en relacion con el extra. ordinario volúmen de los huevos de esta ave. El ovario y los testiculos son peiqueños y dificiles de encontrar: los músculos pectorales alcanzan un desarrollo sumamente notable.

Conocemos demasiado poco las costumbres de estas aves para poder decir en que difieren por tal concepto las diversas especies; lo que sabemas se reficte mas bien á todas en ge. neral que a cada una en particular. Por consiguiente voy a tratar de reunir los datos conocidos para formar un solo cua. dro; pero antes quiero describir detalladamente, por lo me. nos, algunas especies; hacerlo con todas scria imposib?e, pues no sc cuentan menos de cuatrocientas, distribuidas en setenta géneros. A los leciores que quieran estudiar cada una de las especies conocidas, les recomiendo la magnifica obra de Gould ó la de Reichenbach, sobre todo la primera, donde todas están, no solo descritas, sino figuradas.

Para hacer una clasificacion de los colibris fácil de enten. der, tropiézase con varias dificultades: no solamente el número extraordinario de las especies y el conocimiento insufi. ciente que de ellas tenemos, sobre todo en cuanto a las diferencias del sexo y de la edad, sino tambien el escaso tamaño de esas aves, lacen casi imposible una separacion de la genernlidad $y$ una division conveniente en familias y éspecies. Las diferencias de los sexos son tan considerables, que algunos naturalistas han clasificado el macho y la hem. bra de unn misma especie en gérieros distintos y hasta en sub familias. No debe cxtranarnos, pues, encontrar aun hoj dia en libros y escritos zoológicos, opiniones muy diversas sobre el valor de los diferentes grupos. Yo tomaré por guia a Cabanis, conservando su clasificacion de los órdenes y familias, y por lo tanto, solo hablo de sub familias.

\section{LOS POLITMÍNIDOS-POLYTMINE}

CARACTERES.--Ios politminidos son los representantes de esta sub-familia; las especies que comprende, bastante grandes, tienen formas recogidas: pico de longitud regular, fuerte, poco corro ó muy ganchudo, y denticulado en los bordes de ambas mandibulas junto á la punta: dedos cortos; unas largas; alas anchas y algo arquendas; cola grande, un poco mas larga que las alas cuando cl ave reposa, y redion. deada, por ser mas cortas las dos últimas rectrices de cada lado. El plumaje no tiene colores muy vivos; las partes superiores suelen ser verdosas ó de un tinte bronceado; las infe. riores parduscas por lo regular, a menudio con manchas longitudinales en los costados; las rectrices laterales son de color ciaro en la punta; los sexos difieren poco.

\section{EL EUTOXERES ÁGUILA-EUTOXERES AQUILA}

CARACTÉRES.- Este colibri y sus congéneres se distinguen principalmente por su pico fuerte $y$ encorrado en forma de hoz, y por su cola cuneiforme. Ias partes superio. res son de un negro gris brillante, y las inferiores de un negro pardusco, con manchas longitudinales de un gris amarillo oscuro en la garganta, 5 blanquizcas en el pecho; el plumaje de la cabeza y un pequeño mono de plumas son de un negro pardusco; las primeras $y$ las de la rabadilla, están orilladas de pardusco; las remiges son de un pardo purpúreo; las últi. mas secundarias tienen manchas blancas en la punta; las rectrices son de un gris oscuro brillante, oscuras hácia la extremidad $y$ blancas en esta misma, color qque se extiende 
por ambos lados. La mandibula superior es negra, y la inie. rior amarillenta hasta la punta (fig. gS).

DISTRIBUCION GEOGRÁFICA.- La patria de este colibri es Bogotí.

\section{LOS RAMFODONES-GRYPHUS}

CARACTERES. - Fistas aves tierien el pico de mediana largura, grueso y ligeramente corvo; los dedos cortos; las unas largas; las alas anchas, medianamente encorvadas; la cola, ancha tambien, sobresalc un poco de las alas cuando el ave descansa; las dos rectrices externas de cada lado son cortas.

\section{EL RAMFODON MANCHADO-GRYPHUS NEVIUS}

CARACTERES.-TiEne el lomo verde broncendo, con visos cobrizos; la frente y la parte alta de la cabeza de un pardo oscuro; tocins las plumas del lomo, excepto las sub. alares, tienen filetes amarilio rojos; los lados del cuello son rojizos, y tiran al amarillento; una faja estrecha que baja por delante del cuello, el pecho, el vientre y la rabadilla son de un gris amarillento, con manchas longitudinales negras. Por encima del ojo hay dos rajas, la inferior de un tinte rojizo claro y la superior negra; las rémiges son de este color, con visos violeta en las mas externas; las rectrices medias de un verde bronceado y de un amarillo rojo en su extremidad; el ojo pardo oscuro; la mandibula superior regra y la inferior de un blanco amarillento, con la punta del tinie de la prime. ra; las patas son de color de carne. El ave mide $(1 ", 16$ de largo: el ala $0^{n}$, os y la cola $6^{n}, 0.4$ (fig. 99).

DISTRIBUCION GEOGRÁFICA.- Es originaria del Brasil y se le encuentra principalmenie en los valles de las montanas, cubiertos de bosques.

\section{LOS FAETORNITIDOS-PHAETOR- NINA:}

CARACTERES. - Estos colibris, llamados tambien ermi laño, tienen el pico grueso, al:o, comprimido lateralmente y los bordes no denticulados cerca de la punta; las alas son ancisas y se distinguen fyor los tallos en extremo gruesos de las [rimeras rémiges; la cola es larga, escotada ó redondeada, las plumas del centro se prolongan mucho.

\section{LOS FAETONES-PHAETORNIS}

CARACTERES.-Este género es uno de los mas ricos en especies de la sub-familia, $y$ se caracteriza por su pico endeble y ligeramente corro, sin escotadura ch la punta, grande y largo; las patas son bien formadas y pequeñas; los tarsos cstán cubiertos de algumas plumas, y los dedos pro. vistos de unies muy grandes; la cola es cuneiforme y larga; y las rectrices del centro sobresalen por lo regular de todas las uiras. Ei color es bastante oscuro: los sexos difieren poco en cuanto a la coloracion, pero regularmente por una formacion distinta de la cola.

\section{EL FAETON DE CEJAS-PHAETORNIS SU-} PERCILIOSUS

CARACTERES. - Aigunos autores han lianado tambien á esta ave ermilario (fig. 1 co): es uno de los mayores paja. ros moscas; mide 6 ", 10 de largo total, el ala $6 \%, 005 \mathrm{y}$ la cola ()$^{\infty}, 0 \%$. Tiene el lomo de color verde metálico opaco; cl vien. tre de un gris rojizo uniforme: las plumas del lomo orilladas de amarillo rojo; por encima y debajo del ojo se ve una raya de un tinte rojo amarillento pảlido; las rémiges son pardas con visos violeta; las rectrices de un verde bronceado en la cara superior, agrisadas en la inferior, negras en la extremidad, con un filcte amarillo rojo $y$ la punta blanca; la mandi. bula superior es negra, la inferior de un amarillo claro y las matas color de carne.

Ia hembra tiene la cola corta y apenas cónica, pues las rectrices medias son muy poco mas largas que ias otras; mide unos $6^{\prime \prime}, 05$ menos que el macho, y su plumaje es mas oscuro.

DISTRIBUCION GEOGRÁFICA.-Habita el norte del Brasil y de la Guayana y frecuenta sobre todo los lugares donde los espacios descubiertos alternan con las brehas.

\section{LOS LAMPORNITIDOS-LAMPOR- NITHIN.F}

CARACTERES. - Los lampornitidos, ó mingos deles bes. ques, tienen el pico un poco mas largo que la cabcra, recto ó ligeramente encorvado, ancho en la base $y$ un poco escotado por detrais de la punta; los dedos son largos; las unas cortins, altas, puntiagudas y muy corvas; las alas angostas; la cola bastante ancha, obtusa, redondeada, ó algo ahorquillada. Los dos sexos tienen el plumaje muy distinto.

\section{LOS LAMPORNIS-LAMPORNIS}

CARACTERES. - liste genero se cancteriza esencial. mente por téner un pico bastante largo, corvo, ancho, apla. nado en toda su longitud; y por su cola corta y redondeada.

Ia siguiente especie se puede considerar como tipo, no solo del género, sino tambien de la inmilia.

\section{EL LAMPORNIS MANGO-LAMPORNIS MANGUS}

CARACTERES. - Fsta ave tiene el lomo verde broncea. do, con visos cobrizos; las rémiges de un gris negro y visos violeta; las dos rectrices medias del mismo color que las ré. miges en su cara superior; la inferior y las dos de las otras rectrices son de un rojo violeta, que tira al purpura, ý presen. tan un filete negro con visos de un azul metálico; la garganta, el cuello, el pecho $y^{\text {la }}$ parte superior del vientre de un negro aterciopelado y filetes azules á los lados; la parte baja del vientre verde bronceada; el pico negro, y pardo en los peique. ños; las patas negras (fig. 102).

La lrembra tiene el lomo mas claro que el macho; el vientre blanco, con rayas longitudinales negras. Fil lampornis mango mide $0^{m}, 105$ de largo por $0^{m}, 20$ de punta á punta de ala; esta tiene $6^{\circ}, 07$ y la cola $6^{\circ}, 04$.

DISTRIBUCION GEOGRÁlCA.-Habita en casitodo el Brasil; tambien se le ve en el Paraguay, en la Guayana, en las Antillas $y$ hasta en la Florida.

\section{LOS CRISOLAM POS CHRYSOLAMPIS}

CARACTÉRES.- Segun Burmeister, este género presenta los siguicntes: pico mas largo que la cabeza, plano, li. geramente corro, de punta recta, precedida de una escota. dura; las alas son angosins; cola ancha y redondeada; dedos largos; unias cortas, altas, puntiagudas y sumamente corvas.

\section{EL CRISOLAMPO NINFA-- CHRYSOLAMPIS MOSCHITA}

CARACTERES.-EI crisolampo ninla es el mas bonito 
de todos los colibris del Brasil, en concepto de Burneister. 'Tiene la parte superior de la cabeza parda; la garganta de un rojo rubi y rojo aurora dondo, con espléndidos visos; los de las alas son violados; la cola de in rojo castaño claro, con un filete negro en cada pluma; esta especie micle $\|^{* 0}, 1$ de largo por $\left(6^{m}, 1+\text { de punta a punta de ala; esta tiene } 1\right)^{\circ,}$, $6 \mathrm{y}$ la cola $11^{\prime \prime}, 03$. En la hembra y los hijuelos cl lomo es verde broncea. do $y$ el vientre gris (íg. 103).

DISTRIBUCION GEOGRÁFICA. - La ninfa de los bosques habita en el este de la América dél sur: es uno de los pájaros moscas mas comunes en anguella parte de! mundo.

\section{LOS CAMPILOPTERINOS-CAM- TYLOPIHRTN}

El género inas conocido de csta sub-familia es el de los orcobriquilidos.
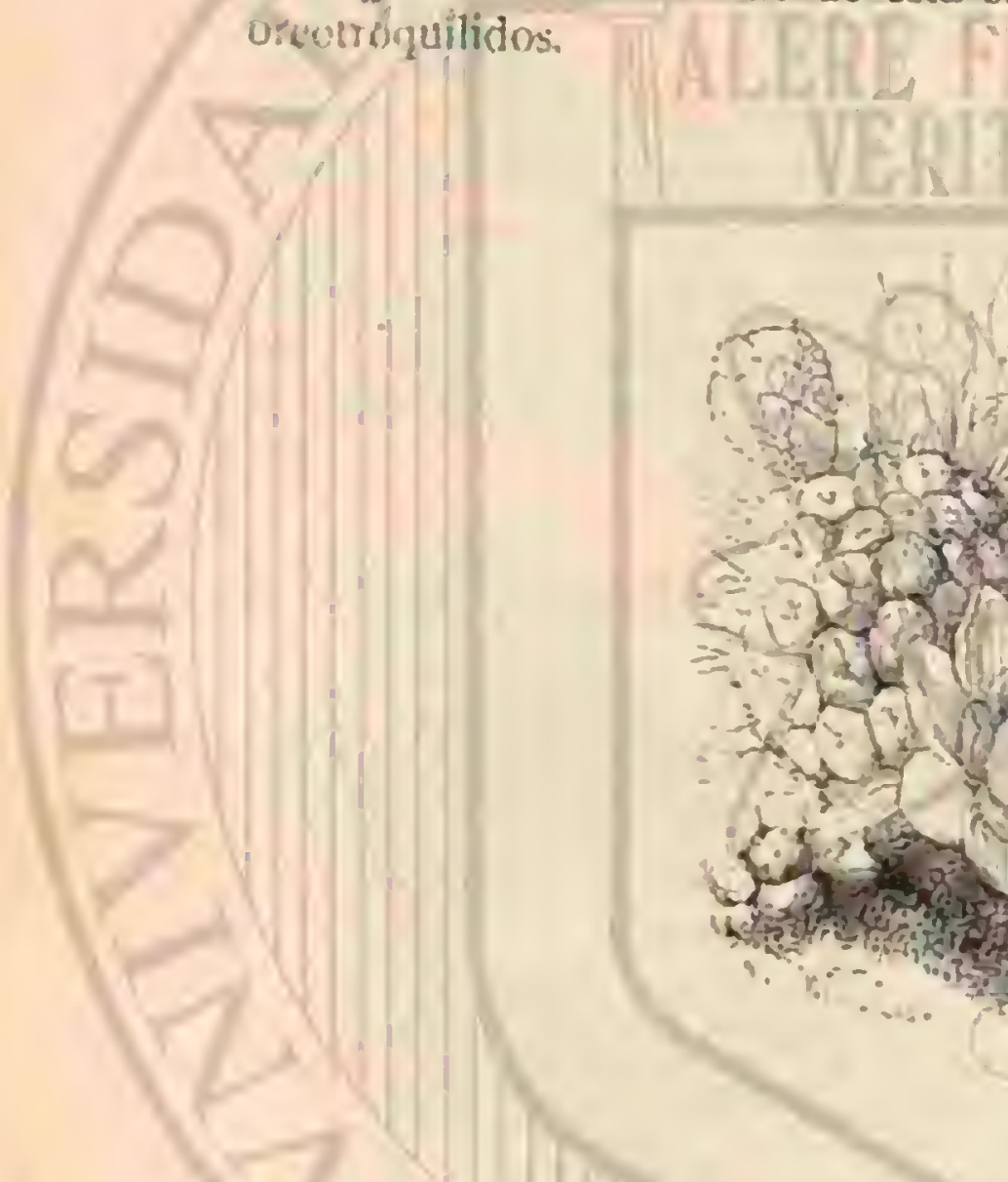

garganta de un color azul violeta brillante; el lomo pardo aceitunado; el vientre blanco y los costados de un parcó aceituma. En niedio de la gargania hay una mancha triangu. lar, de color verde brillante, separada del pecho y del vien tre por una faja de un negro satinado las alas son de un pardo puirpura; las dos rectrices medias de un verde oscuro l.25 otras de un negro verdoso cn las barbas externas y blan co en las internas; el pico $y$ las patas de un tinte negro (figura 104).

La hembra tiene el lomo de color verde aceituna; cl vien tre pardo aceituma, con las plumas orilladas de un tinte mas claro: el pecho blanco, con la punta de cada pluma de um pardo aceituma; las rectrices medias de un verde oscuro bri. llante y. las otras de un pardo verdoso claro, excepto en su parte basilar, que es blanca; las tres externas presentan una mancha de este viltimo color en sus barbis internas, ccrcat de su extremidad. El are mide 6,125 de largo, de los que corresponden $\left(i^{m}, 06\right.$ a la cola.

DISTRIBUCION GEOGRÁFICA.-Esta especie justi. fica bien el nombre con que se la designó, pues no se ha encontrado hasta aqui sino en el Chimborazo, a una altitud de,+ 000 \& 5,000 metros sobre el nivel del mar. Oiras espe. cies afines habitan las demás cimas de los Andes.

\section{LOS PLATISTILOPTEROS -PLATYSTYLOPTERUS}

CARACTERES.-COn dicho nombre ha descrito Rei. chenbach algunas especies que se asemejan álos nectarinidos: son colibris grandes yigorosos que tienen los inllos de

\section{LOS OREOTROQUÍLIDOS -OREOTROCHILI}

CARACTERES. - El pico de estos colibris, llamados tambien ninfus de lu mmsaîu, es de regular longitud, grueso, alto, y sin escotaduras en los lados de la junta; la cola, corta y truncada casi en ángulo recto, solo se redondea un las rectrices exteriores. El plumaje, brillante en el lomo, es casi siempre azul $\delta$ rerde, y en las regiones inferiores de co. lor mas claro; en la garganta brillan los colores metálicos mas magnificos. Los sexos suelen diferir mucho por su color.

\section{EL OREOTROQUILO DEL CHIMBORAZO- OREOTROCHILUS CHIMBORAZO}

CARACTERES. - Lista ave representa una de las mas hermósas especies del grupo: el mache tiene la cabera y la

\section{EL PLATISTILOPTERO ROJO-PLATYSTY- LOPTERUS RUFUS}

CARACTÉRES. - El platistiloptero rojo, ó de alas en. corvadas, tiene unos $6^{m}, 15$ de largo por $6^{\circ}, 20$ de punta is punta de ala. Eil lomo es verde bronceado: el vientre ama. rillo pardusco: las rectrices medias tienen el color del lomo y las otras el del vicntre, presentando todas una mancha blanca cerca de'su extremidiad (irg. 10j).

DISTRIBUCION GEOGRÁFICA.-Tsta are habita en Ciuatemala.

\section{LOS TOPACIOS-TOPAZA}

CARACTERES,- Estos colibris se asemejan aun a los oreotroquilidos cu cuanto a las formas y las alas, si bien las rémiges primarias no son tan anchas. El pico es corto, gruese ! ligeramente-corro; los piés pequeños; las ahas tan largas, que en estacio de reposo llegan á la extremiỏad de la cola: esta última es redondenda, pero distinguese por las recirices del centro, que muy estrechas y corvins se cruzan entre si.

\section{EL TOPACIO COMUN-TOPAZA PELLA}

CARACTERES. - Ei topacio (tig. 106) puede rivalizar en belleza con todos los dernás colibris: la parte superior de la cabera y una faja que rodea la garganta son de un negro 
aterciopelado; cl tronco de un color cobrizo, que tira al mjo (mente besa fiores (fig. 109), representa la espiecie mas conoci. granate, con visos dorados: las cobijas de la cola son verdes; la garganta dorada, con matices verde esmeraida ó amarillo topacio,-segun la incidencia de la luz; las réniges primarias de un pardo rojo, $y$ las secundarias de un rojo de orin; las rectrices medias verdes, y el par siguiente, que sobresale de todas las demis en unos $10^{\circ}, 08$, de un pardo casiaño; las otras son de un rojo pardo. La hembra tiene el plumaje ver. de, con la garganta roja, y sus tintes son menos vistosos que los del macho. Eista ave mide mas de $\theta^{\circ}, 20$, comprendidas las largas plumas de su cola.

DISTRIBUCION GEOGRAFICA.-Li topacio parece ser propio de la Guayana: habita las mas enmarañadas espe suras a orilla de las corrienies. En el valle superior del Ima zonas existe otra especie muy atine.

\section{LOS AITUROS - AITHURUS}

CARACTERES.-Fstas aves tienen el pico corto, fuerte, encorvado en la punta; alas largas y angostas; cola corta, poco ahorquillada, sobresaliendo la segunda rectriz externa de las otras en unos $\|^{\prime \prime}, 16$. Los machos tienen $i$ cada lado de la cabeza, en la region auricular, un mono bastante largo.

\section{EL AITURO DE CAPUCHA-AITHURUS POLYTMUS}

CARACTERES. - El aituro de capucha tiene la parte superior de la cabezar de color negro oscuro; el lomo verde; ia parte anterior del cuello, los lados, y el pecho de un her. moso verde esmeralda; el vientre y las cobijas inferiores de la coln de un aul negro; las rémiges de un negro purpura; las rectrices de un negro oscuro, con visos verdes en su parte basilar, el ojo pardo intenso; el pico rojo cornl, con la punta negra; las patas [mardas. Esta ave mide 1,, 28 de largo por $11^{\circ}, 17$ de punta a punta de ala; esta tiene $10^{\circ}, 08 !$ la cola $b^{\text {min }}, 20($ fig. 107$)$.

El lomo de la hembra es de un tinte verde bronceado, el vientre blanco; los costados están cubiertos de manchas rerdes. Mide $11^{n}, 13$ de largo, el ala plegada $1 ", 08$ y la $\operatorname{col}(1) ", 05$

DistRIBUCION GEOGRÁFICA.-Eata especic habita en la Jamaica.

\section{LOS HELIOTRICINOS-HELIOTRI- CHIS.I}

CARACTERES. - Las especies de esta familia, llamadas tambien uiufas de los flures, tienen casi todas formas robus tas, aunque bastante agraciadas; las alas. son de la misnia longitud que la cola, la cual cubren completamente cuando el we descansa; tambien el pico es grueso, sin ninguna esco: tadura El plumaje difiere mas ó menos en los dos seros.

\section{LOS HELIOTRIX Ó JACOBINOS -HELIOTHRIX}

CARACTÉRFS.- Jos helionix tienen el pico recto, ancho, plano, delgado y de punia prolongada; las pantas rayuilicas y endebles; los dedos están soldados en su basc: las unas son cortas, planas y ligeramente corvas; cónica je plumas estrecinas: en la hombra es redondeadia, $y$ de rectrices anchas.

\section{EL HELIOTRIX OREJUDO - HELIOTHRIX A URICULATA}

CARACTERES. - Fil heliotrix orejudo, Hamado v'uIgasda del género. El lomo y los ladus del ruello son de color verde bronce, con reflejos durados, al menos en los adultos; las rémiges de un tinte negrnaco con visos violeta; el vientre Wlanco; las tres rectrices externas del mismo color, y las me. dias de un bonito azul con matices cobrizos. Por debajo del ojo arranca una raja de un negro aterciopelado, que se en-

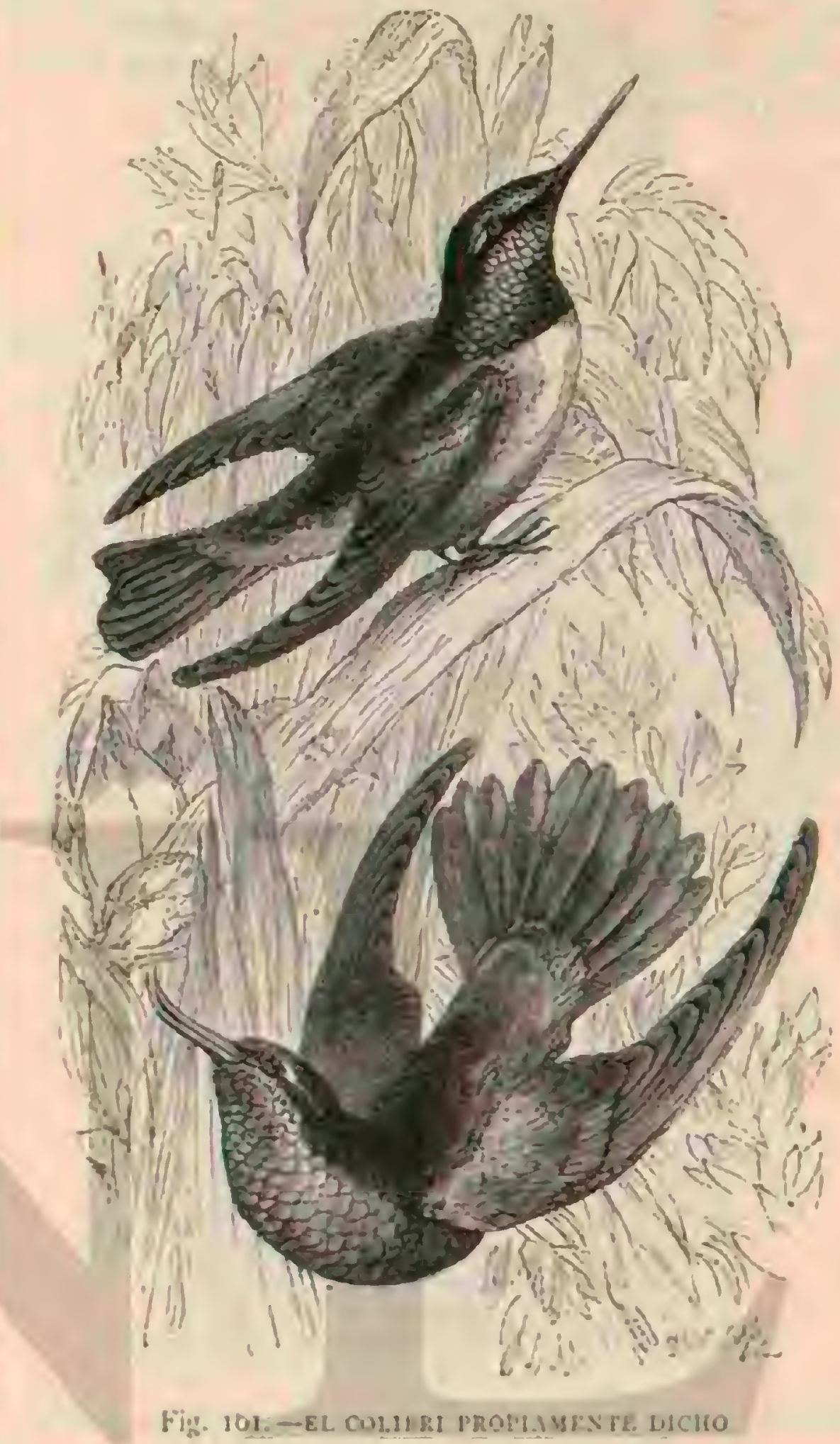

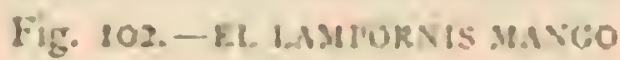

sancha dirigiendose hicin auss, y termina por una faja azul de acero. lil macho tiene la cola larga y las rectrices externas muy cortas; la de la hemirn es corka, ancha é igual: el primero mide $11^{\circ}, 15$ de largo; la hemira $0^{\circ}, 1 \%$, de los cuales corresponden $(1,065$ y 6,028 respectivmente a dicha parte.

DISTRIBUCION GEOGRAFICA. - El principe de Vied asegura que ol besa fitores escasua bastante en el Brasil; Burmeister dice que habita los bosques de la costa oriental de Ia América del sur, hasta Rio lanciro En la Guayana le re. presenta uma especie nfine; las demis del género habilan el oeste de la América del sur.

\section{LOS CHUPAFLORES Ó LIBA- FLORES-FLORISUG}

CARACTŕRES.-- Fistas aves difieren de las del género anterior por iener el pico fuerte y recto, aplanado solo en la base, mas alto que ancio en la punta y ligeramente comba. do; patas furrtes; tarsos cubiertos de pluma; unas un poco corras; alas bargas y estreclass; cola ancha yalgo escotada. 


\section{EL CHUPAFLORES NEGRO-FLORISUGA ATRA}

CARACTERES. - Representa una de las especies mas bonitas del grupo: todo su cuerpo es de color negro atercio. pelado, excepio la rabadilla y las patas; las cobijas de las alas de un verde broncendo, $y$ las remiges negruzcas con visos violeta; las dos rectrices medias negras, con visos azul violeta: las cuatro externas b!ancas, orithadas de negro en su extremidad. lista are mide $0^{\circ}, 12$ de largo, clala plegada $\left(0^{\circ}, 07\right.$ y la cola $0^{\circ}, 04$ (ig. I11).

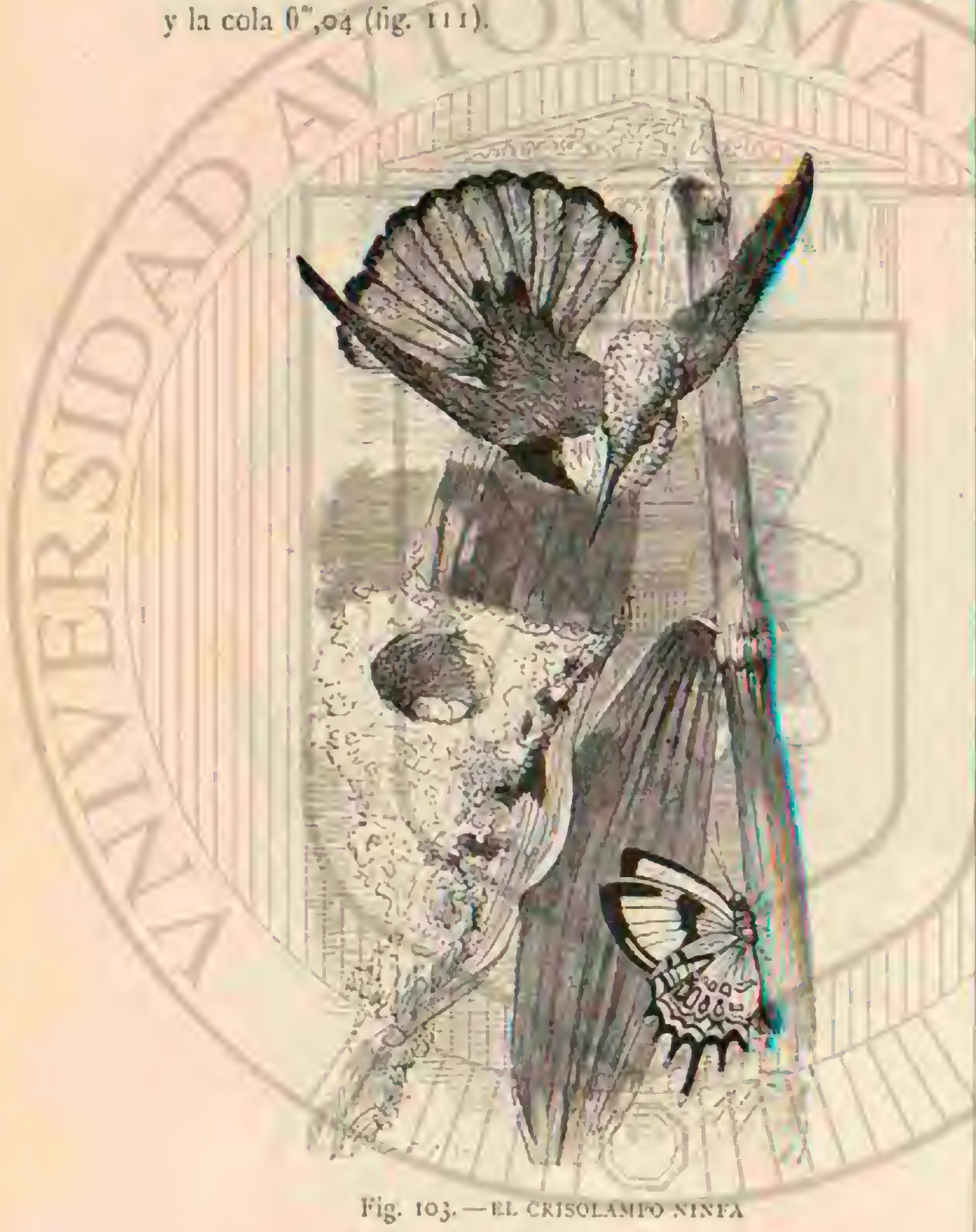

La hembra presenta colores mas opacos; las mejillas son rojizas, y las plunıs del lomo están orilladas de amarillo. Iil pico y las patas son de un negro oscuro en ambos sexos.

DISTRIBUCION GEOGRÁFICA. - Esta especie es muy conum en el Brisil; le gusta habitar las amayores alti. tudes.

\section{EL CHUPAFLORES ENANO-MILISUGA MINIMA}

CARACTERES.- El color dominante de esta bonita are (fig. 113) es verde brillante $y$ metálico, con las alas de un pardo puirpura $y$ ta cola de un negro intenso; a garganta y la barba son blancas, moteadas de negro; el pecho y el ab. dómen de un blanco puro, y los costados de us verde meta lico, casi tan brillante como el del lomo. Las co bujas inferiores de la cola son blancas, con algunas manchitas de un verde pálido.

Los colores de la hembra son mas ojacos quae los del ma. clio, y el calor verde presenta una mezcla de amarillo; la primern mitad de la cola es de un amarillento verdoso.

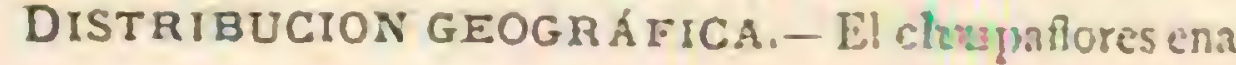

no habita en la India occidental, y se le encuentra principal. mente en Jamaica.

\section{LOS TROQUILINOS - TROQUILIN.E}

Esta subfamilia representa en cierto modo el tipo primitivo de todo el órden. Eil grupo se distingue por la gran varie dad de formas en las especies que lo complonen, y jor eso es dificil describir con pocas palabras los caractéres genera. les; pero poco mas ó imenos son los siguientes: el pico es muy variable en longitud, aunque siempre delgado, redondo y puntiagudo, un poco aplanado junto à la extremidad y casi siempre con bordes lisos y rectos. Eil plumaje se distingue por el hermoso brillo y por la belleza de sus colores, obser. vindose en el formaciones extrañas, tal como moños, plumas mas largas en las orejas y la cola, los tarsos cubiertos de me. chones, etc; las plumas de la garganta figuran una especic de escudo escamoso: y este y oiros adornos contribujen á que las especies de la subfamilia sean mas hermosas que tridos los demás colibris.

Se ha dado tambien a los troquilinos el nombre de elfis.

\section{LOS COLIBRIS-TROCHILUS}

CARACTERES. - Eil pico, mas largo que la cabeza, es liso, la cola muy truncada; las rectrices exteriores no tan largas como las otras; las alas estrechas; las piernas cortas, endebles y enjutas.

\section{EL COLIBRI PROPIAMENTE DICHO--TRO- CHILUS COLUBRIS}

CARACTERES.-El dorso de esta especie es de color rerde oscuro bronceado; la barba y la garganta, hasta los lados del cuello, de un rojo cobri\%o muy vivo, con un ligero viso verde; las regiones inferiores de un blanco sucio; los costados se distinguen por su brillo rerdoso metálico; las rémiges y las rectrices exteriores son de un pardo oscuro luciente. El ojo es pardo, el pico negro y los piés parduscos (fig. 101).

DISTRIBUCION GEOGRÁFICA.- Lil colibri habita en el este de los listados de la América del norte, desde los $57^{\circ}$ hasta el sur, $y$ desde las costas del Atlantico lasta las del Pacifico; cncuéntrase tambien en la América central y en las islas de la India occidental.

\section{LOS CALOTORAX Ó LUCIFEROS - CALOTHORAX}

CARACTÉRES. - El macho de este género tiene la cola de una forma especial; las rectrices cortas, cstrechas, ctectiles, Y aquella ahorquillada en su conjunto. En algunas csjecies se verifica la bifurcacion con cierta regularidad, siendo las rectrices extermas mas largas y las medias menos; en otras, las rectrices citadas se reducen á una especie de munones cortos, casi desprovistos de barbas, y solo la tercera comienza á formar parte de la horquilla. En la heinbra, todas las rectrices son jguales entre si y de nediana extension. Lil pico es pro. longado, fno y ligeramente corro.

\section{EL CALOTORAX DE MULSANT-CALOTHO- RAX MULSANTI}

CARACTERES.- Una de las mas hermosas especies de cste género es la que ha sido dedicada a Mulsant. El macho tiene el lomo y los costados de color verde oscuro, con magnificos visos; la barba, una estrecha linea que va del 
pico al ojo, el cuello, una lista que baja sobre la parte ine. dis del pecho, y el vientre son de un tinte blanco: la barba forma visos violeta (fig. i15).

El lomo de la hembra es mas claro que el del macho; el vientre blanco; los costados y las cobijas superiores de la cola de un pardo rojizo. Por los lados del cuello baja una linea de color verde aceituna oscuro; la cola es pardo clara con una linea negra en la extremidad.

DISTRIBUCION GEOGRAFICA. - lista esprecie habita en Colombia y Bolivia.

\section{LOS CEFALEPIS-CEPHALEPIS}

CARACTERES. - Tienen el pico poco menos largo que la cabeza, puntiagudo, con el extremo de la mandibula su perior algo combado; los dedos cortos; las uñas largas, del. gadas y estrechas; las alas bastante cortas; Ia cola relativa. mente larga, con rémiges anchas. Eil macho lleva en la cabeza un moño, cuya punta estí formada por lima sola pluma.

\section{EL CEFALEPIS DE DELALANDE-CEPHA- LOEPIS DELALANDII}

CARACTERES. - El macho de esta especic (fig. 386) es uno de los mas hermosos colibris que se conocen: cl lomoy las dos rectrices medias son de un bonito color verde bronce mate; la cabeza del mismo tinte muy claroy vivo; las tres largas plumas que constituren el copete, y los lados de la cabeza, de un verde mas nate y oscuro, que se cambia en azul de acero en los individuos de mucha edad. La cara in. ferior del cuerpo es gris cenicienta; el pecho y el centro del vientre, azul celeste; las alas parduscis con reflejos violeta; las rectrices laterales negruycas, y las inas externas oriliadas de blanco; el pico negro y las patas de un pardo negro. La hembra y los pequenos carecen de mono, y su vientre no es de color azul celeste. L.as ares de esta especie miden $0^{m}, 10$ de largo, el ala $11^{\prime \prime}, 06$, la cola $1^{\circ}$, oS y el mono $0^{\circ}, 0.45$.

DISTRIBUCION GEOGRÁFICA. - Burmeisier dice que el cefalepis de Delalande vive solo en los bosques ó en su lindero y que jamas penetra en los jardines. Solo existe en el sur del Brasil, viéndosele apenas al norte de Rio Janeiro.

\section{LOS LOFORNÍS-LOPHORNIS}

CARACTERES. - l. Los lofornis, elfes magnifrees ó roguedas de algunos autores, son unas aves preciosas. El macho idene el cuello adornacio de un collarin compuesto de major $\delta$ menor número de plumas estrechas, largas, de magnificos colores, que el ase puede recoger $\delta$ extender à su antojo; d menudo adorna su cabeza una especie de copete; el pico es fino, puntiagudo, algo grueso cerca de su cxtremidad, y del largo dé la cabeza poco mas ó menos; las alas son pequeñas y estrechas, mas cortas que la cola; las rectrices anchas y todas ellas vienen a tener igual longitud.

\section{EL LOFORNISS ESPLÉN DIDO - LOPHORNIS ORNATA}

CARACTERES.-Dificil parece decir cuál es la mas hermosa de las especies de lofornis, por cuanto todas rivalizan en bellea.a y brillo. El de que tratamos ahora (fig. 11 ) ilene las plumas del tronco de color verde bronce; el moño que adorna la cabeza de un rojo pardusco; una estrecha faja que cruza la parte inferior del lomo, blanca; la cara verde, con magnificos risos; cl collarin de plumas de un pardo rojo claro, con una mancha verde brillante en su extremidad; las rémiges de un pardo púrpura oscuro; el pico de un rojo color de carne, con la punta parda.

La hembra no tienc tintes tan vivos; carece de moño y de collarin, y sa cara no presenta los brillanics visos de la del macho.

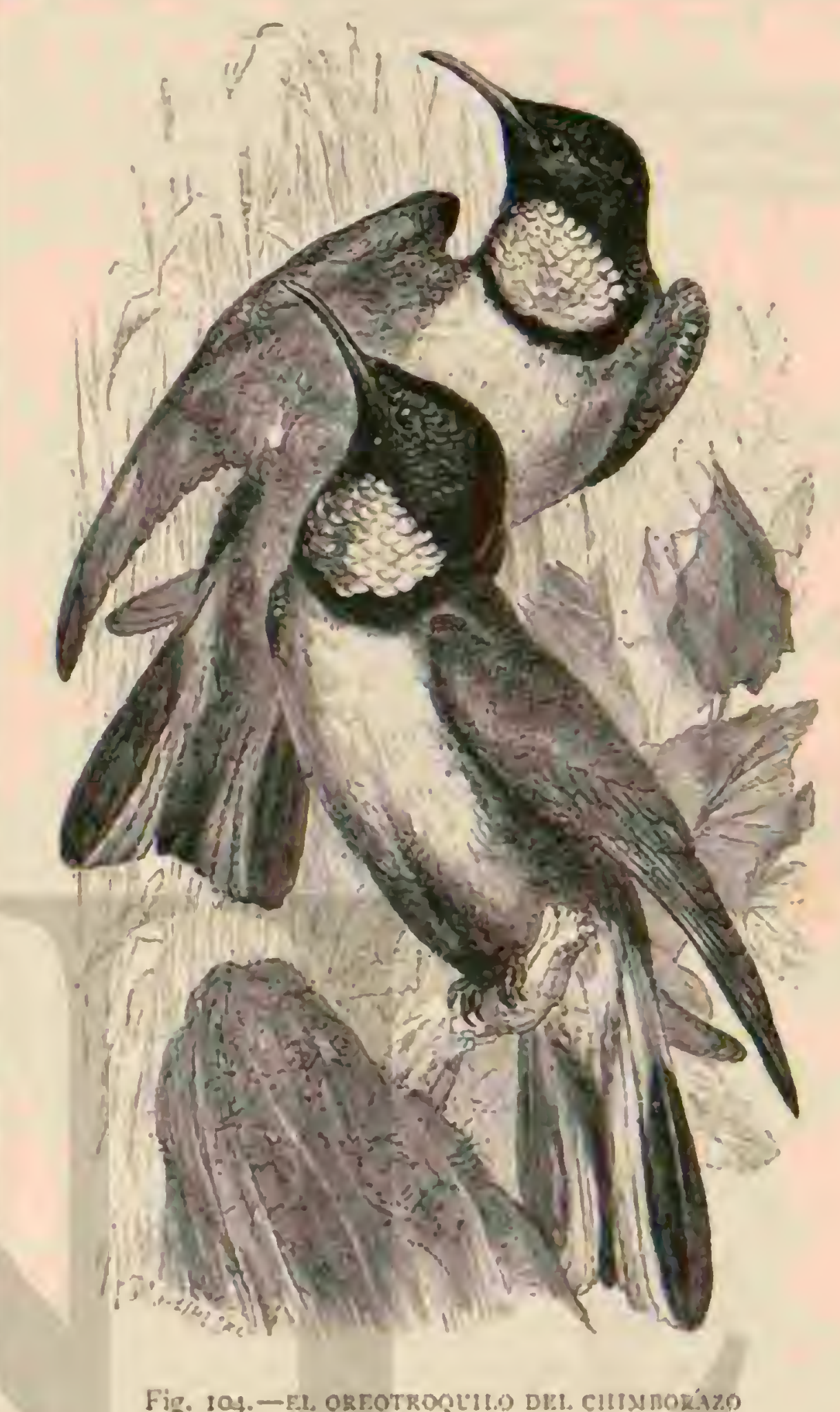

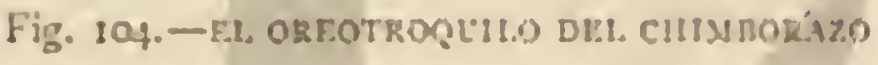

DISTRIBUCION GEOGRÁ FICA.- Esta ayc habita en la Guayama.

\section{LOS BELATRIX-BELLATRIX}

CARACTERES. - Tienen el collarin mas pequeno que los lofornis, pero mas desarrollado el moño.

\section{EL BELATRIX REAL - BELLATRIX REGINAE}

CARACTÉRES.- El belatrix real se asemeja mucho por el plumaje al lofornis espléndido: tiene el cuerpo de color verde bronce: la parte inferior del lomo está cruzada por una faja blanca; la cola es parda; las alas de un pardo pirpura; las plumas del collarin verde esmeralda, manchindas de rojo. Ei mono se compone de plumas largas y angostas de un tinte rojizo muy vivo con una mancha verde bronce oscuro cerca de la puma (fig. 112 ).

\section{LOS HELIACTINOS-HELIACTINUS}

CARACTÉRES. - Los heliactinos ó elies de cola larga se caracterizan por esta última. El pico es mas largo que la cabeza y un poco mas grueso junto á la punta; los piés pe- 
queños; los dedos cortos y provistos de unas bastante grandes y fuertes. El macho tiene las plumas de la cabeza prolongadas; las alas largas y estrechas; la cola uniforme, muy escalonada; las rectrices estrechas y punzingudas.

\section{EL HELIACTINO CORNUDO-HELIACTINUS CORNUTUS}

CARACTERES. El heliactino cornudo (fig. 118) tiene el plumaje de color verde bronce, poco brillante. Ia cubera del macho es de un tinte azul de acero; el collarin violeta.

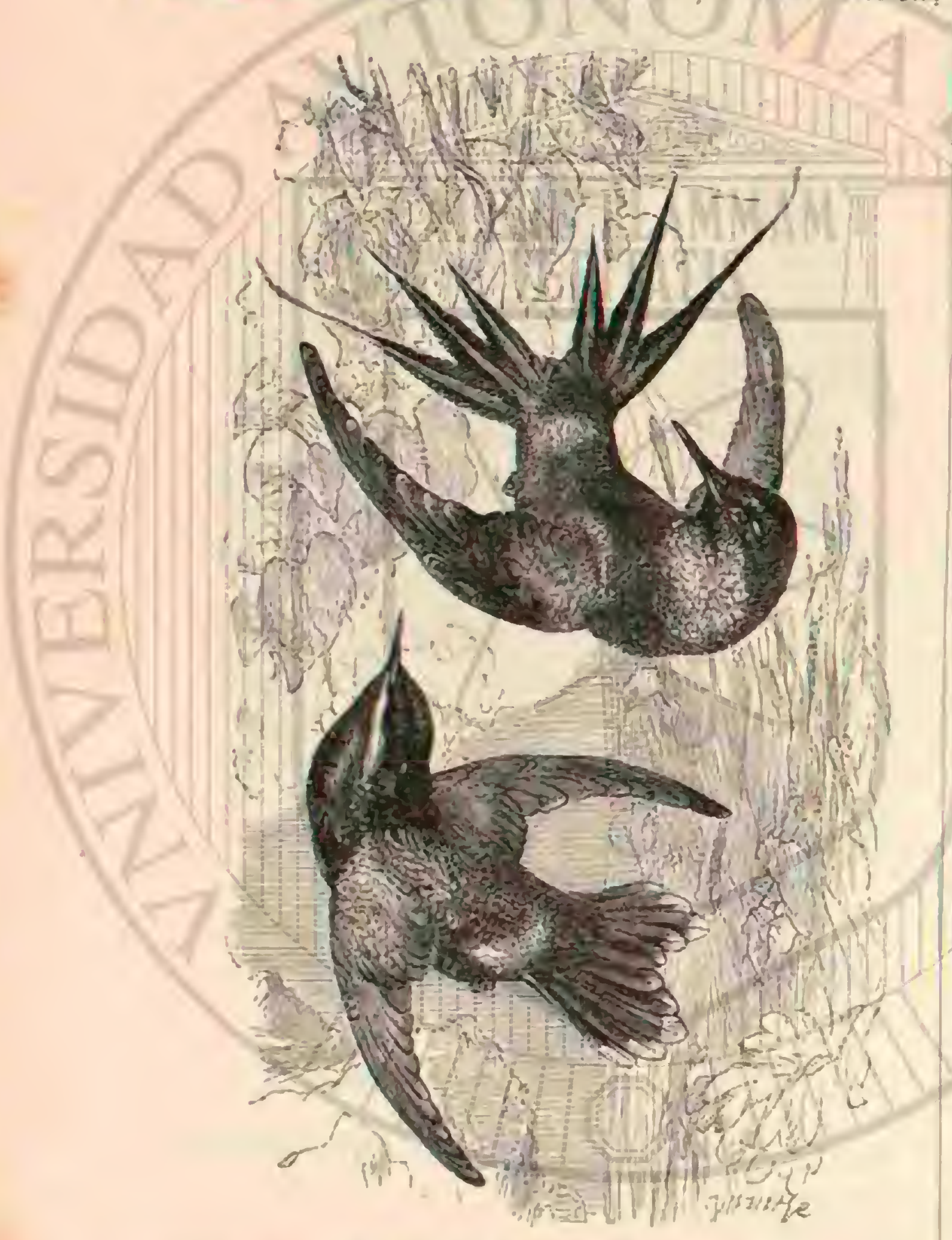

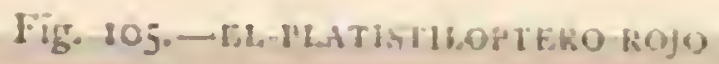

verde amarillo, naranja y rojo sucesivamente, confundién dose estos colores de una manera insensible unos con otros; la garganta, la parte anterior del cucllo $y$ las mejillas son de un negro aterciopelado oscuro; la parte superior del pecho, el centro del vientre, la rabadilla y las rectrices laterales blancas; las rémiges grises; el pico negro. Esta ave mide (1", 12 de largo, el ala plegada $11^{\circ}, 053$ y la cola de $0^{\circ}, 05$ a 0 , o6.

La hembra carece de copete y de cullarin; tiene la gar. ganta amarillo roja, $y$ las rectrices externas listadas de ne. gro en el centro de su longitud.

DISTRIBUCION GEOGRÁFICA.-Segun Burmeister, este colibri parece ser uno de los mas ábundantes en los campos descubiertos en el interior de Minas Geraes.

\section{EL HELIACTINO CORA-HELIACTINUS CORE}

CARACTERES. - Esta bonita ave (fig. 199), cuyo carác. er principal reside en la cola, que afecta la forma de una tijera, tiene la catbeza y las partes superiores del cuerpo de un color verde dorado, a excepcion de las alas que son de un púrpura pardo; la gargania ofrece un tinte violeta, que se cambia en un carmesi meiálico, y las partes inferiores del cuerpo son de un gris blanco. Las dos plumas centrales de la cola son doblemente largas que el siguiente par, y las ntras san graduándose con regularidad, siendo la exterior la mas corta. Solo cl macho ofrece este carácter particular: In cola de la hembra es de un largo regular.

DISTRIBUCION GEOGRÅFICA.-Esta especie habita en el Perú, y abunda mucho entre el Callao y lima; el valle de los Andes es tambien su favorita residencia.

\section{LOS ESTEGANUROS-STEGANURUS}

CARACTÉRES. - LOS esteganuros, ó siifos estandartes, tienen las dos rectrices cxternas muy largas, sin barbas en su lítima mitad, excepto la punta, en la que vuelven a pro. longarse mucho; el pico es corto, casi recto; las patas pe. gueñas y cubiertas de un plumon espeso.

\section{EL ESTEGANURO DE UNDERWOOD - STE. GANURUS UNDERWOODI}

CARACTERES. - Este esteganuro (fig. 1 20) tiene el lomo, el ricntre, los costados y las sub caudales de color verde bronce; el pecho y cl cuelio de un verde brillante; las alas de un pardo púrpura; la cola parda; las barbas terminales de las rectrices externas negras, con visos verdes. Esta ave mide $0^{\circ}, 15$ de largo, el ala $0^{\circ}, 0.45$ y la cola $\left(1^{\circ}, 00\right.$.

In hembra tiene el lomo de color verde bronce; el vientre blanco, con visos verdosos; las sub caudales parduscas; las rectrices de igual largo: poco mas ó menos, son blancas en la crtremidad.

DISTRIBUCION GEOGRÁFICA.-Esta hermosa ave habita en el norte de la América del sur, descie el Prasil hasta Venezuela; $y$ asi frecuema las montanas altas como las de la costa; en las primeras elévase á una altura de 2,000 metros.

\section{EL ESTEGANURO DE VIENTRE COBRIZO - STEGANURUS CUPRIVENTRIS}

CARACTERES. - El macho adulto de esta especic (fig. 121) tiene la parte superior de la cabeza y los lados del cuello de un verde bronceado, excepto en la cara superior de las cobijas de la cola, cuyo tinte es mas puro y tiene brillo metálico; las alas son de un pardo puirpura; la cola negra, con visos de aquel color; la garganta de un bonita verde; el pecho $y$ las partes inferiores del cuerpo, de un verde dorado, excepto el abdómen que tiene un viso cobrizo. La cola de esta especie es muy corta.

DISTRIBUCION GEOGRAFICA. - Habita en Santa Fe de Bogotá y frecuenta principalmente los distritos mon. tañosos.

\section{LOS ESPARGANUROS -SPARGA- NURA}

CARACTERES. - Estas awes difieren principalmente de los esteganuros por la forma de su cola: las rectrices van alargándose de deniro af fuera; las externas tienen por lo menos cinco veces la longitud de las medias y las barbas presentan el inismo largo en toda la extension de la pluma. 


\section{EL ESPARGANURO SAFO-SPARGANURA SAPHO}

CARACTÉRES. - El șióo (ñg. I I rojo escariata; la cabeca y el vientre de un verde metálico; la garganta de un tinte inuy claro y brillante; el bajo vientre es pardo pálido; las alas de un pardo púrpura; las rectrices de un amarillo naranja brillante en la raiz y de un pardo negro oscuro en la extremidad.

Ia hembra tiene el lomo verde; el vientre manchado de yris; Ia cola mas corta y de un rojo claro.

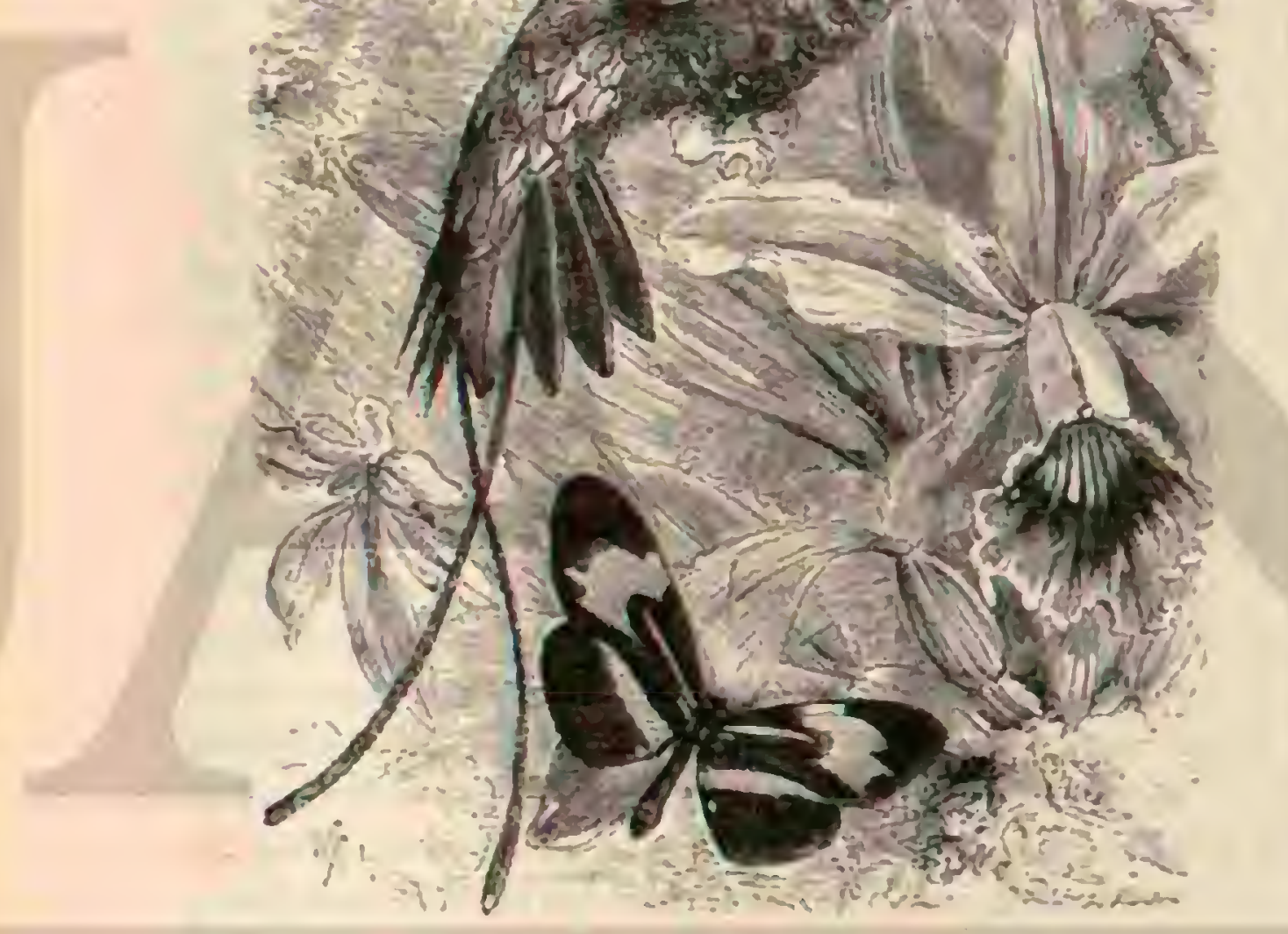

DISTRIBUCION GEOGRÁFICA. - Esta especic existe en Bolivia.

\section{EL ESPARGANURO DE DUPONT - SPARGANURA DUPONTII}

CARACTÉRES. - El macho de esta especie (fig. I10) es de un color verde bronce $\mathrm{cu}$ la parte superior del cuerpo, con mezcla de blanco; la garganta es de un bonito azul me. tálico y de un aegro aterciopelado cuando se refleja de cierio modo la luz, porque cada pluma es de este último color en la base y del orro en la punia; al rededor dél cuello se corre una faja blanca, y toda la cara inferior del cuerpo es de un color verde bronceado, excepto las cobijas inferiores, que están ornadas de una faja blanca. La cola de curiosa forma, presenta muchos colores, y no es fácil describirla: las dos plumas centrales son de un bonito verde lustroso, la siguien. te de un vêrde bronceado, la de mas allá de un pardo oscuro, con dos manchas triangulares blancas en la cara interior, una

Tosio III cerca del centro y la otra en la punta; estas plumas estain ornadas además de tres fajas longitudinales, rojiza la primeזa, blanca la sergunda y parda la tercera, siendo la extremidad blanca.

El plunaje de la hembra es de un hermoso color verde broncendo en la cara superior del cuerpo; tiene la cola corta, y de un tinte negro púrpura bronceado en la base; la cara inferior del cuerpo es de un rojo oscuro.

DISTRIBUCION GEOGRÁFICA. - Esta ave es propia de Méjico, y abunda mucho en Guatemala, donde parece muy familiar $y$ confiada, pues visita todos los jardines $y$ lu. gares habitados.

\section{LOS RAMFOMICRONES- RAMPHOMICRON}

CARACTERES. - En estas aves el pico es delgado, corto, semejante a una espina; las alas medianamente largas $y$ bastante estrechas; Ia cola ancha y en extremo ahorquillada.

\section{EL RAMFOMICRON PICO DE ESPINA-RAM- PHOMICRON HETEROPOGON}

CARACTÉRES. - Las aves de esta especie tienen el lo. mo de color verde bronce; la parte anterior de la cabeza de un verde uriliante; las plumas de la garganta prolongadas en forma de collarin, de un verde metálico en la parte media de la garganta, y de un amarillo naranja en las partes latera. les 6 inferiores: el bajo vientre de un blanco agrisado; las rémiges de un pardo purpura y la cola de un pardo broncea. do (fig. 122).

DISTRIBUCION GEOGRAFICA. - Esta ave es originaria de Santa Fe de Bogota.

\section{LOS HIPERMETROS-HYPER- METRA}

CARACTERES.-Lil pico de las especies que constitu. yen este géncro, muy largo, recto ó aplanado, encórvase tan pronto hácia arriba como hácin abajo, $y$ bien se adelgaza há. cia la punta ó es mas grueso junto à ella; los pićs son relatiramente largos; las alas de algunas especies muy prolongadas y estrechas, y en otras mas cortas y anchas; la cola de longitud regular $y$ truncada en el centro. El plumaje no presenta colores muy visos.

\section{EL HIPERMETRO GIGANTE-HYPERME-}

CARACT teRES. - El hipermetro gigante (ing. 12.3) es una especie de la talla del quelidon de las paredes. Tiene el lomo pardo pálido, con visos verdes; el vientre pardo rojizo; da rabadilla gris amarillenta; la cabeza, lo parte alta del pechoy el lomo adornados de rayas finas de un tinte mas oscuro; las alas son de un pardo intenşo, 10 mismo que la cola, que pre. senta visos verdosos. Esta ave mide (1), es de largo.

DISTRIBUCION GEOGRÁFICA.-Habita una gran parte del oeste de la America del sur: es de paso en cl extremo sur, cuyo punto visita y abandona en épocas regulares.

Se le ha encontrado hasta una altitud de 4,000 á 5,000 metros sobre el nivel del mar.

\section{LOS DOCIMASTES-DOCIMASTES}

CARACTERES.-De tocios los colibris, los docimastes 
son los de pico mas largo: este órgano, que no permite jamás confundirlos con otras especies, tiene la misma longitud que el tronco del ave; esta ligeramente lemntado, y presenta un pequeño aumento de grueso po: detrás de la punta; las alas son relativamente cortas y anchas; la cola de mediana longitud y marcadamente alorquillada.

\section{EL DOCIMASTE PORTA-ESPADA-DOCI- MASTES ENSIFER}

CARACTERES.-- Esta notable especie (igg. 10\$) tiene el lomo y la cabeza de color de cobre; el vientre, la garganta y el centro del pecho de un verde bronceado; la cabeza de co. lor de cobre; los costados presentan visos de un verde pálido: por detrás del ojo tiene una manchita blanca: las atas son de un pardo oscuro ron visos metálicos; el pico pardo amarillento. Esta are mide (1: 22 de largo, de los que corresponden 0,10 al pico; el ala tiene $17,08 \mathrm{y}$ la cola $0^{2}, 06$.

Fil lomo de la hembra es de un tinte mas oscuro, y el vientre está manchado de b!nnco y pardo; los costados pre. sentan solo un ligero brillo metíico: mide $0^{m}, 17$ de largo $y$ el pico 6,08 .

DISTRIBUCION GEOGRÁFICA. Tiste colibri habita en las montañas de Quito y Venezuela En las últimas le en contró Garing, asi como en los bosques bajos, y á una altura de dos ó tres mil metros sobre el nivel del mar.

\section{LOS OXIPOGONES - OXIPOGON}

CARACTÉRES. - Se distinguen por tencr la cabeza adormada de un copete en forma de cimera, por lo cual se les ha dado nlgunas reces el nombre de coithris dé coson; su cola es recta y truncada; las alas anchas, el plumajc opaco y el pico muy, corto.

\section{EL OXIPOGON DE LINDEN-OXYPOGON LINDENI}

CARACTERES. - Esta especic, llamada porilós indige. nas chitito de lás firamas, 6 cabrito de los parramos, tiene el lomo y la region inferior de un color verde pardusco metali. co; la cabeza negra, excepto las gímas blancas del centro del mono; las inferiores de este viltino son verdes; las de la garganta se prolongan ell forma de barbas y son blancas, presentando en su extremidad puntos negros; las rémiges son pardas con lustre rojizo violáceo: las rectrices, cuyos tallos son blan. cos, tienen un tinte pardusco violeta cn su cara inferior. Ia hembra, un poco mas pequena, carece de moño y barbas. Ia longitud es de l,", r 4 ; las alas miden $0^{\circ}, 08$ y la cola $0^{m}, 0 ;$

DISTRIBUCION GEOGRAFICA.- Linden descubrí este singular colibri en la Sierra Nevada de Mérida en Co. lombia, hana aititud de $\$, 000$ á 5,400 metros sobre el nivel del mar. Goring. á quien debemos una imágen del ave de su patria, observóla en la misma montaña del standioso paisaje representado en su cuadro.

Alli habita la graciosa avecilla, á la vista del gügantesco pico de la Concha, que se cleva á mas cie 4.500 metros so. bre el nivel del mar, yá esta alura contribuye mueho a dar vida á la solitaria montaña.

USOS, COSTUMBRES Y RÉGIMEN DE LOS COIIBRIS.-Los colibris son exclusiramentc propios de Ame rica, y mas caracteristicos que ningun otro,vertebrado alado de la fauna de esta parte del mundo. Se encuentran en toda la extension del continente americano, donde la tierra produce fores, desde Sitka hasta el cabo de Hornos.

El colibri propiamente dicho, ó de la América ciel norte, fué hallado en el Labracior; otra especie, que le rẹpresenta en el ceste, existe en las orillas del rio Colombia; por otra parte, se han descubierto tambien algunas de estas aves en la Tierra del Fuego. Elévanse igualmente à gran altura sohre la cima de la cadena de los Andes; se las ve debajo de los limites de las nieves perpetuas, of una altirud de t,000 i 5,000 metros sobre el nivel del nar; y hasta visitan los cro. teres de los volcanes no apagados aun, sitics donde no $0 \leqslant$. ria aventurarse ningun otro vertebrado superior. El nalurn. lista a quien el amor a la ciencia impele á trepar a las allos cimas, los ha risto anidiar en las regiones asoladas por las tempestades de nieve, alli donde no era de esperar que se viese mas que algun condor.

Se puede decir que cada pais, y hasta cada localidad tiene sus especies propias. Ios oreotroquilidos no abandonan las montanas donde riven, $y$ lo mas que hacen es bajar hasta el limite inferior de la region montaiosa, cuando el mal tiempon les obliga a ello. Otras especies, que pueblan los valles cáli. dos $y$ abrasadores en los que nunca sopla el mas leve céfiro. no los dejan sino para renontarse a las alturas; de modo, que 10 mismo las monianas que los valles, los bosques comn las estepas; tiener sus colibris especiales. I a vida de estas joyas de la naturaleza deperde, mas que la de todas las demas aves, de la presencia de ciertas tores; estan en la mas intima relacion con el mundo vegetal. 'l'al fior, que sirse á una especie de alimento, no es visitada nunca por otra: de la forma del pico se deduce ya que algunas no viven sin cicras fores, y que no pueden nutrirse de las demàs.

Grering the dice que el oxipogon se presenta en los para. mos de la Sierra Nevada tan luego como se abren las ama. rillas flores de cierta especie de plantas alpinas, llamadas por el pueblo monjes gigrantes, y canacterissicas de la region, desapareciendo tan pronto como vuelven a cerrarse; otras aves van y vienen de igual modo á medida que sus Pores se abren ó marchitan.

La diferente estructura del pico induce i suponer que ciertas especies examinan solo determinadas flores, no pudiendo hacerlo con utras.

No deja de haber algunas, sin embargo, que parecen poco delicadas en este concepto; Wilson cree que la mitad de las fiores de su patria, por lo menos, son tributarias del colibri de la América del norte; especies tay, en fín, que no buscan sino algunos árboles deterninados, ni visitan tanzpoco mas que las ramas situadas a cicta altura. Unas prefieren las fores de las ramas mas elcracias; otras las de las mas bajas, y varias de cllas solo buscan el follaje. Segun (iosse, el colibri enano se alimenta solo de las flores de las pequeñas plantas que se desarrollan al ras del suelo. Bates dice que los faeto. nes se posar muy pocas veces en las escasas flores que cré. cen en los espesos bosques donde habitan; buscan mas bien en las hojas los insectos de que se alimentan y se inucven con increible agilidad en el follaje examiníndole $\mathrm{cn}$ todos sentidos. En una palabra, no es posible negar la dependen. cia en que se hallan estas aves respecto de ciertas plantas; $y$ por lo tanto, no debe extranarnos que varias islas tengan sus colibris propios. La isla de Juan Fernandez, por ejemplo, posee dos especies, que no se hallan en las islas proximas; el colibri enano, que habita en la Iamaica, no se ha trasladado jamás á Cuba Es de notar, no obstante, que estas aves podrian emprender largas expediciones, pues nada se lo impide; ahi tenemos, si no, varias especies, que nos darian una prucba cridente de cllo.

Lo que acabamos de decir no se aplica á todos los colibris en general, pues las especies a que nos referimos existen en una milad de América.

Dependiendo esercialmente de la regetacion la existencia 
de los colibris, claro estí que las regiones tropicales deben ser las mas ricas en especics.

De las 390 especies contadas por Wallace, 275 habitan en los paises tropicales de la Anérica del sur; 100 (parte de ellas las mismas) en los de la América del roric: 15 en la zona templada de la parte meridional del mismo comsinente, 12 en la propia zona de la parte septentriomal, y 15 en las Antillas.

Seria, no obstante, un error creer que los loosques de las tierras bajas, donde la vegetacion alcanza su mas alto desarrollo, constituyen el paraiso de los colibris; y no poręue estos desprecien las magnificas flores que crecen en aquellas re. giones, pues léjos de ello, vuelan á su alreciedor ! las exa minan: lo que determina la riqueza de especies de estas aves en un pais, no es el número de flores, sino su varicdad. Fin el estado actual de nuestros conocimientos, podemos admi tir yue las montanas de la América del sur y de la central, son has que alimentan major numero de estas ares; $y$ en efecto, alli es donde se presentan bajo aspectos mas va. riados.

Es verdaderamente agradable, me escribe Cictring, observar al gracioso oxipogon cuando en las solitarias alturas de la grandiosa montaña se balancen al rededor de las fiores de los monjes giganies, picando aqui una Aor, ó posándose algunos momentos en utra. 'lan rípidu es el vielo de estas aves en medio de estas plores de la extraña planta, que ape. nas se puede seguirlas con la vista, $y$ sin embargo, $\mathrm{cl}$ magnifico espectaculo llama siempre de nuevo nuestra atencion. Esta avecilla es la unica que en aquella altura representa su género.

México parece ser en este sentido uno de los paises mas privilegiados: es la patria de la quinta parte de codos los co. libris actualmente conocidos, y probablemenie se descuuriran todavia bastantes inas cuando se explore mejor el antiguo imperio de los Mctezumas; verdad es que México es el pais mas variado de toda la América central, jues se encuentran alli todas las altitudes, y al mismo iiempo todas las esincio. nes, ó mas bien todos los grados de temperatura. El natura lista se ve rodeado poi do quiera de aquellas aves de vistosos colores; encuéntralas lo mismo en las tierras cálidas que sobre las mesctas donde reina un frio glacial; asi en los parajes en que una humedad continua desarrolla la espléndida vergetacion de los trópicos, como en los puntos donde solo el cáctus cominua creciendo en las llanuras abrasadas por los rayos del sol, 6 en los flancos de los volcanes surcados por corrientes de ardiente lava. wLlevan la animacion y la alegria, dice Gould, al centro de las ruinas volcanicas, pres. tando vida $a$ unos paises donde jamás sienta el hombre su planta; y turban el silencio de! płramo con su dulce voz ?

Su norada mas favorita son sin duda las praderas esmaita das de flores, los arbustos horicios de las estepas y los jardi. nes; en tales sitios, se las re pasar rasando el suelo, balancearse de fior en flor y cazar muchas veces en union con las abejas y las marifosas.

No es cosa bien averiguada todavia hasta que punto se puede considerar como aves sedentarias a los colibris que no emigran. lo cierto es que ninguno permanece toda el año en la misma localidad: segun las estaciones, ó mejor dicho, los periodos de la florescencia, tal especie se deja ver tan pronto aulu cono alla; $y$ hasta pouria ser qque errase continuamente excepto en el perfodo del celo. Todos los observadores que han permanecido largo tiempo en un mismo punto, reconocen que solo en épocas lijas se dejan ver ciertas especies: Bullock, por ejemplo, dice que algunas de Mé. xico no se presentan hasta principios del icrano. Varias hay que en mayo y junio llegan en gran numero al Jardin bota nico de México, siendo entonces fácil adquirit algunas; mientras que en otras estaciones no se ve ya un solo indivi. duo. Recies hace idéntica observacion para Rio Janciro;

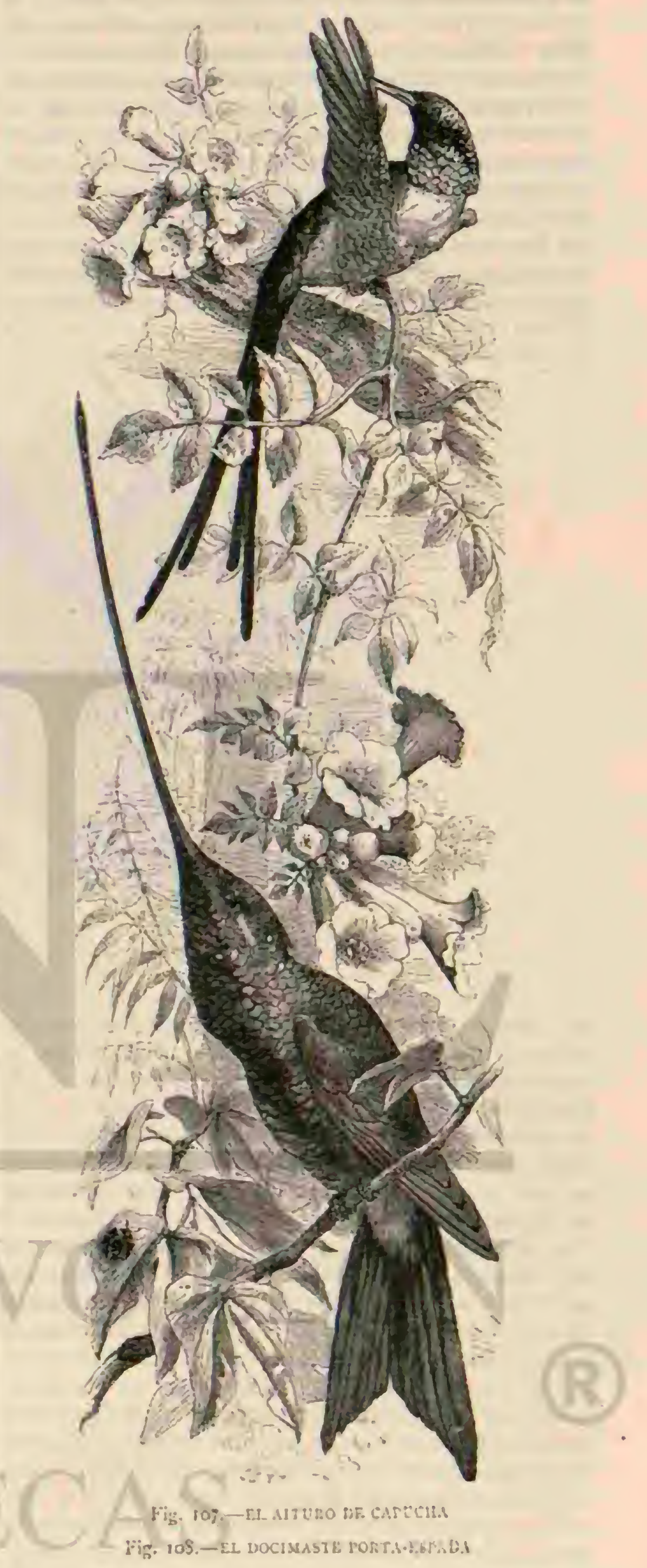

Bates para las orillas del Amazonas, donde residió once años; y lo mismo dicen todos los naturalistas que estudiaron largo tiempo las costumbres de estas ares noiables. Probable es que todas las especies de colib:is sern mas ó menos errn!. ies: las quue habitan las aliuras se ven preciesdas á bajar a los 
valles en ciertas estaciones; y aun aquellas que viven en los parajes donde reina una primavera eterna, donde se renueva diariamente la vegetacion y se encuentran todo el ano árboles y plantas en flor, aun aquellas, repito, deben pasar de un punto a otro para buscar las flores que mejor puedan convenirles. Sabido es que los colibrís acuden en gran número á ciertos árboles en flor, al paso que no parecen conocerlos en otras estaciones: obsérvase que aparecen por bandadas in. numerables apenas comienza a florecer un árbol, como lo hacen los insectos que viven del néctar de las flores; enton. ces llegan de tados los puntos del horizonte y se dirigen al árbol mientras está en flor. Semejantes excutsiones no pue. den llantarse viajes: solo las especies que habitan la zona templada ártica ó austral, son las que cmigran realmenie: liegan á su pais con tanta regularidad como a los nuestros ta golondrina; alli viven y anidan, y apenas se acerca la esta. cion fria, dirigense de nuevo hácia los paises cálidos.

Segun Audubon, el colibri de la América del norte (Tro. chilus colubris), se presenta muy raras veces en la Luisiana antes del 10 de marzo; en los Estados del centro antes del 15 Ge abril, y sucede å menudo que no aparece hasta principios de mayo, permaneciendo hasta setiembre: de la Florida no se va antes de noviembre.

En Cuba es esencialmente are pasajera: (jundlach no la vió sino en los primeros dias de abril, y solo en la parte occidental de la isla; nunca la pudo encontrar en otras regiones á pesar de sus minuciosas pesfruisas. eNo puedo adivinar, dice el citado viajero, quué camino toma esta especie en otoño para dirigirse mas al sur de Cuba, pues en abril llega del mediodía y abunda entonces bastante cerca de la Habana y

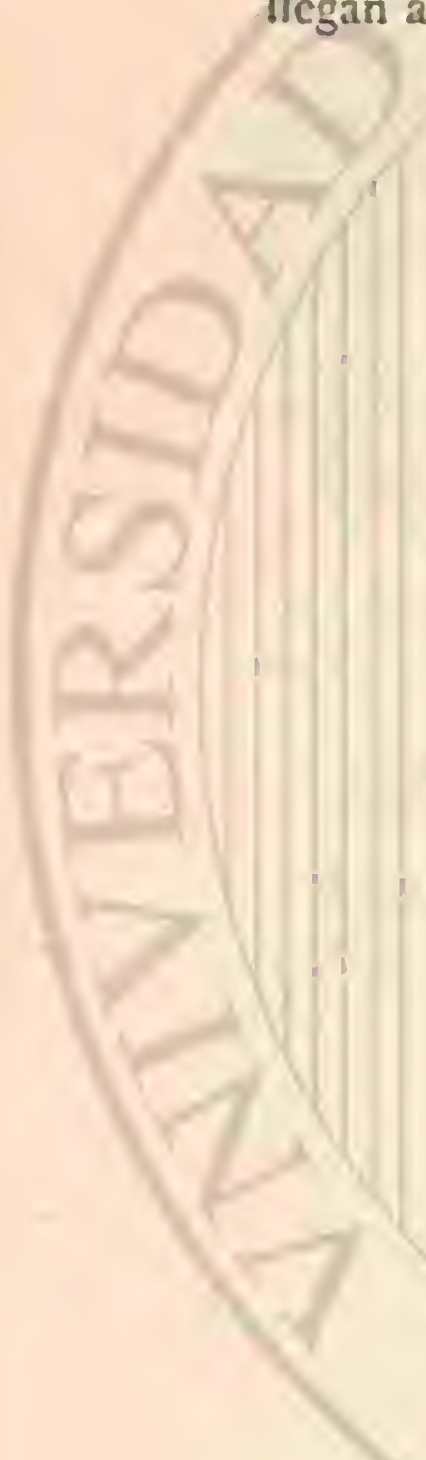

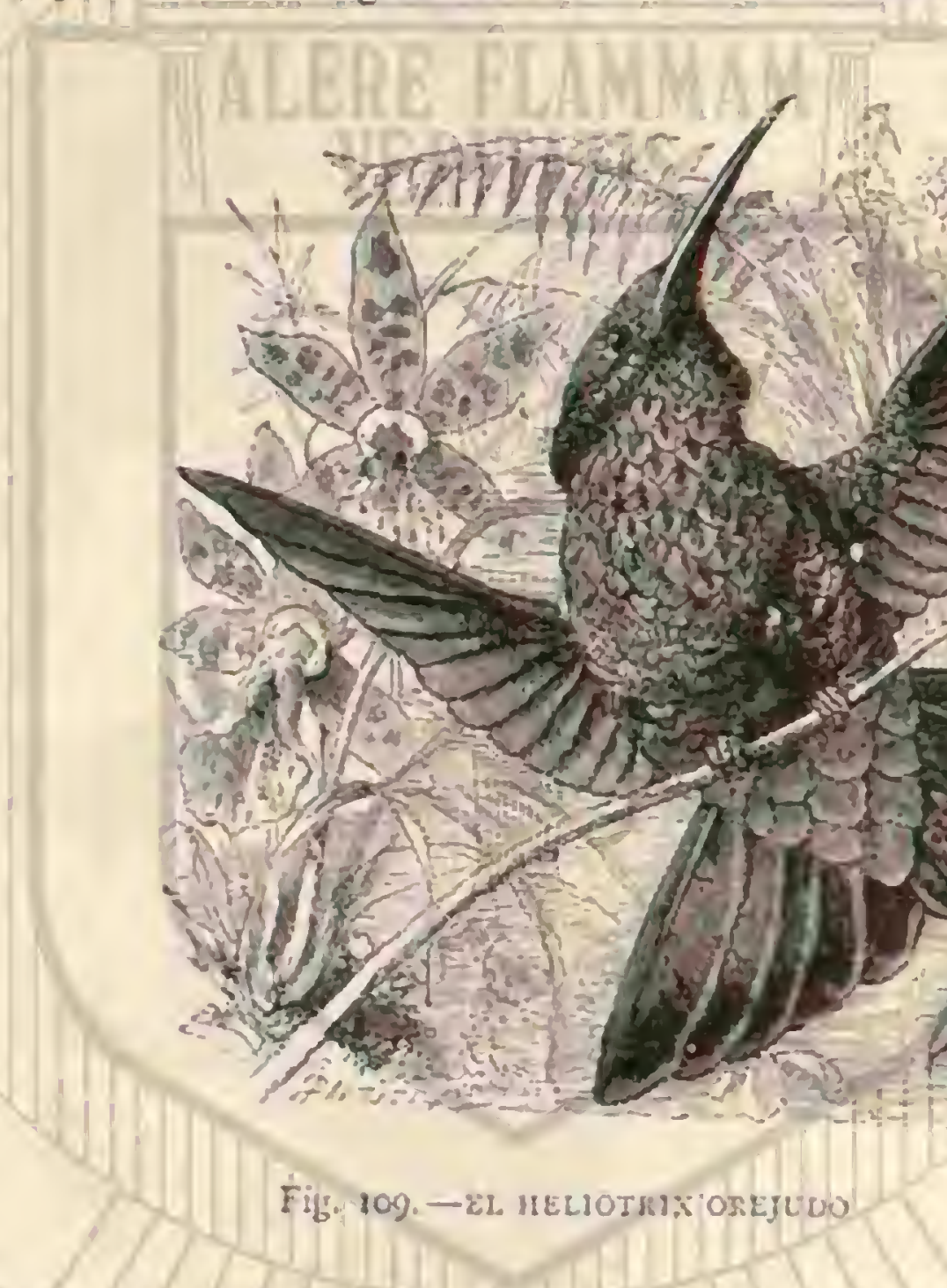

de Cárdenas; nunca la he visto cerca de Matanzans, ni tampoco anida en la isla. Ia especie que habita cl oeste de la América del norte (Selasshorus rufus) lliega, segun Nutall, á principios de abril; en setiembre se dirige hácia el sur, va á pasar el invierno en Mléjico. El colibri de King (Eustephamus galeritus), que habita ia 'Tiern del Fuego, y que se encuentra á la largo de la costa occidental de la América del sur en uma extension de 3,000 kilómetros, no se presenta en Chile hasia principios de da prinavera. Otras dos especies que habitan el mismo pais son tambien aves emigrantes: lle. gan en octubre, yara dirigirse de nuevo, hácia mediados de marzo, á los países tropicales: ciertas especies, no obstante, deber pasar todo el año en el sur, como lo hacen otros colibris en el norte.

Audubon cree que estas aves viajan de noche; pero natu. ralmente, nada puede precisarse sobre el hecho, $y$ digo naturalmente, porque es difficil observar á los colibris en sus viajes. Se puede seguir á las otras aves viajeras con la vista ó el oido, pero no sucede lo mismo con los colibris; el ojo mas perspicaz los pierde de vista muy pronto, sin que sea dado distinguirlos, y el oido no puede reconocer con exactitud la direccion que siguen ni la distancia á que se hallan.

El colibri produce siempre cierta sorpresa, pues se cree ver en êl un sér encantado: ap̧arece sin que se sepa de dónde ha venido y un momento despues no se le ve ya. Apenas se divisa uno en la América del norte, no se tarda en hallar otros por todas partes: un naturalista á quicn debemos datos muy precisos se desp̣ertó una mañana con motivo de haberle Ilevado la noticia de que nealnban de llerar los coliviris; viólos primero sobre un tulipero en lor, y poco despues los encon. tró por todas partes en abundancia, pero bien pronto cisminuyó su número rápidamentc. \$Al cabo de algunos cias, dice, apenas se columbraba uno de vez en cuando, aunque en la ciudad oimos hablar aun de algunos indiviouos gue se acababan de ver. Me parece que los colibrís cmigran por grancies bandadas, y penetran en las ciudades y jardines; lle. gan como una ola, que atraviésa el pais del sur al norte, dejando en todos los puntos algunos individuos aislados. No obstante, de otro modo se podria explicar el hecho: si los primeros dias vimos tantos individuos sobre un tulipero, seria porque este årbol, gracias à su posicion favorable, habia fio. recido antes que todos los demás, mientras que pasados al. gunos dias, y habiendo ya flores por todas partes, los colibris reunidos en un solo punto, se diseminarian en una vasta su. perficic, y parecieron muclio menos numerosos por el hecho mismo de su dispersion.

Para comprender la vida de los colibrís es preciso estudiar antes su vuelo; porque á él deben estas aves ser lo que son; ninguna otra vuela como ellos, y por lo tanto, con ninguna se les puede comparar.

CAntes de verios, dice Saussure, no hubiera podido figurarme ęue a un ave le fuese posible nover las alas con tanta 
rapidez como lo hacen los colibris; cruzan los aires con la celeridad del rayo, ó revolotean algun tiempo en el mismo sitio. Vuelan de dos maneras: $\delta$ bien pasan rápidamente siguiendo la linea recta, ó ya se balancean en un mismo sitio. Claro es que este último movimiento exige mas esfuerzos. pues para mantener el equilibrio, el colibri debe agitar las alas con igual vigor hácia arriba y hácia abajo: y esto lo efectuan con tal ligereza, que al tin no se distinguen ya.»

«En todo su ser, en todos sus actos, caractcrizanse por el apresuramiento. Viven mas y con major actividad que cualquicr oiro animal de nuestro giobo, anade Saussure; desde la manana hasta la noche pasan cruzanco los aires en busca del néctar de las flores: se les ve llegar como el rayo, colo. carse verticalmente delante de una ffor, sustenerse sin apoyo ninguno, extender la cola en forma de abanico, é introducir repeidas veces la lengua en el cóliz. Nunca se posan en una Mor, y diriase que én su precipitacion ni siquiera les queda tiempo para cllo. Acuden con la velocidad del pensamiento, detiénense bruscamente, descansan cuando mas algunos se. gundos en una ramita, y velven á marchar con tanta ligereza que apenas son notados. En el mismo sentido hablan todos los demás observadores.

qi Qué admirable mecanismo, exclama Gould. debe ser el que produce los movimientos vitratorios de las alas del coli. bri, tan largo tiempo sostcnidos! Yo no puedo compararlos con nada; diriase que se deben a una maiquima ingeniosa movida por un resorte poderoso. La primera ve: que obscrié este ruclo, causóme una impresion de las mas singulares; era todo lo contrario de lo que yo esperaba ver. El colibri no corta los aires como una flecha del mismo modo que la go. londrina; pero ya sea para vagne de fior en flor, franquear una corriente ó pasar sobre un írbol, siempre agita sus alas un inovimiento vibratorio. Detiénese por instantes ante un obje10, conservando el requilibrio, y los alctazos se suceden en.

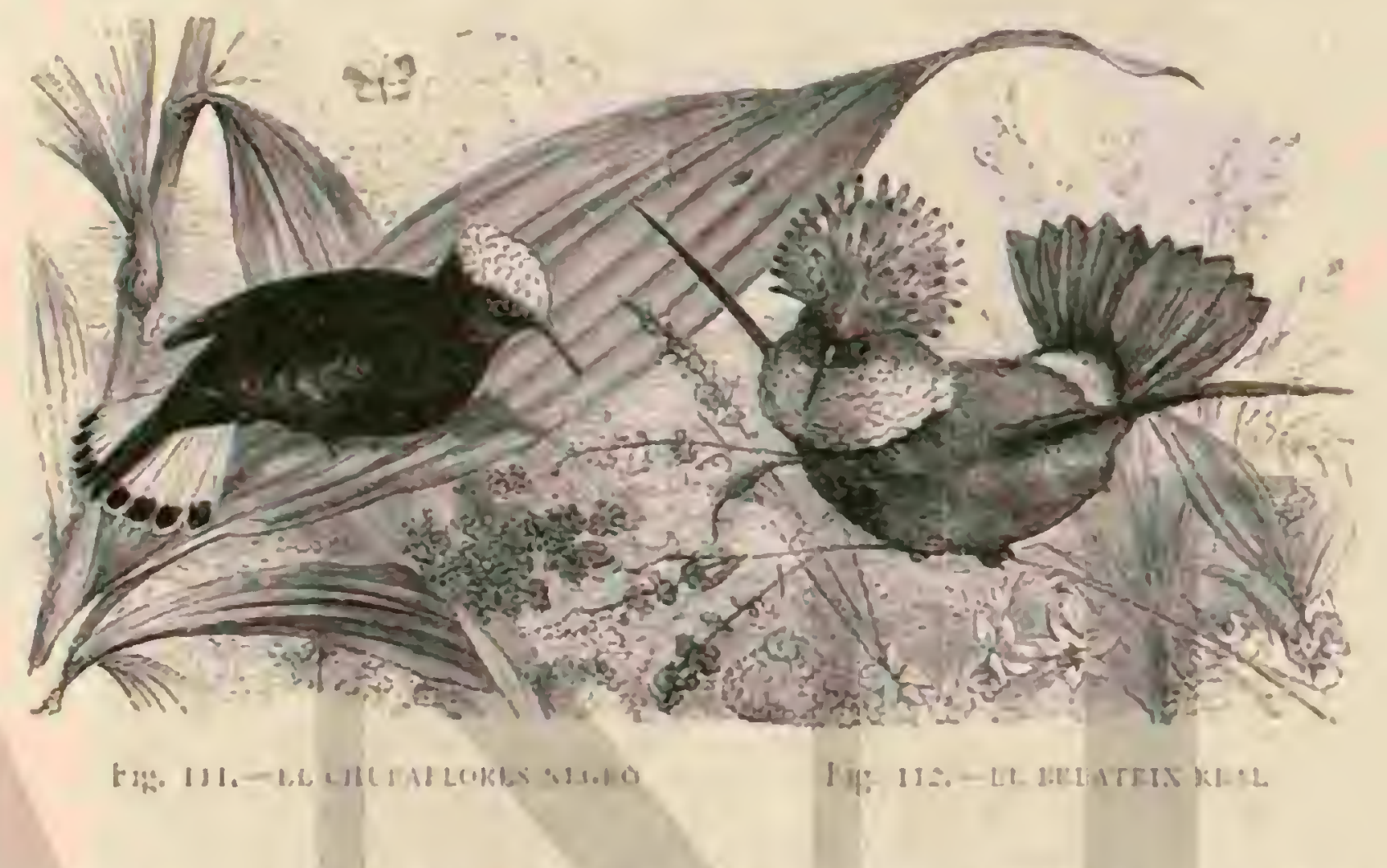

sonces con tal rapidiz, que la vista no puede seguirlos; todo cuanio se nota es un semicirculo confuso al rededor de cada lado del cuerpo. \$s

81.l ruelo de estas arecillas, dice á su vez Kittlity, tiene algo de singular; casi se creeria que son insectos; vuelan de un árbol á otro con tal rapidez, que apenas se pueden distín. guir; pero se detienen ante todo objeto que llarna su atencion; sostiénense en cl aire con el cuerpo lesantado, y agitan de tal modo sus alas, que solo se ven sus reflejos. ?

Mas minuciosa es aun la descripcion de Newton sobre su aparicion y desaparicion. Preséntase, dice, de una manera tan diferente de la acostumbrada, que anguel que no liaya cruzado el Atlántico no podrï formarse una idea exacta del vuclo de los colibris, ni aun haciendo la comparacion con la esinge volante: Lstanios parados, contemplando con admiracion una flor, cuando de pronio aparece entre esia y nues. tros ojos un pequeño objeio oscuro, que por su asprecto parece. estar pendiente de cuatro alambres dispuestos en cruz. Por un momento se le ve delante de la flor; algunos segundos despues detiénese; el espacio entre cada jar de alambres parece invadido por una niebla gris; á paco brilla un rayo como de esmeralda, y el objeto desaparece con $t a l$ rapider, que la vista no puede seguirle, ni el espiritu darse cuenta de su desaparicion. El primero que intentó represen. tar una imigen del colibri cuando vuela fué un hombre atre. vido ó un ignorante, pues ningun lápiz, ningun pircel pucde reproducir asi al ave. Solo se ve que la posicion del tronco es vertical, y que cada una de las alas forma un semicirculo en sus movimientos.\$ Con estas palabras están conformes rodos los observadores concienzudos; pero ahora sibemos ya que no todas las especies vuclan del mismo modo. Eil colibri propio de Cuba, segun Gundiach, difiere óstante de sus congéneres por este concepto. Para examinar la flor acércase mucho á ella, alctea algunós momentos en el mismo sitio, introduce la lengua en el ciliz, retirala vivamente, permancee un instante inmóvil, haciendo un brusco movimiento dirj. gese à otra hor. Hé aqui por qué el ruelo parece cortado é irregular, contribuyendo a la ilusion los continuos movimien. tos de la cola, bastante larga, que el ave ciera y abre de continuo. El colibri norte-americano, por el contratio, tiene sienipre un ruelo casi igual.

Encontramos un magnifico tulipero cubierto de fiores, dice otro observador, $y$ al poco tiempo vimos los colibris, que ocupaban todas las ramas. 'Trazaban circulos sobre la copa; giraban al rededor de las ramas mas inieriores, unas veces desapareciendo en la sombra del follaje, y ostentando otras al sol sus vivos colores. Hubierase dicho desde lejos que aquello cra un enjambre de abejas ú otros insectos; baten las alas tan precipitadamente como los abejorros, y de tal mocio que aquellas llegan à ser casi invisibles y parecen solo un confuso velo. Esto se observa paricularmente cuando las aves se detienen ante la corola de una for para uwscar su alimento.) Mientras el prijaro mosca permanece en un mismo lugar no se oye el ruido que hacen sus alas; pero cuando vuela con rapidez de un punto á viro, produce un rumor pé netrante, muy paricular, sariable segun las especies, mas sordo en las grandes que en las pequeñas, y ian cancteristico en algunas, que basta oirle para saber á cuál de aquellas per. tenece. Nadie se ha explicado aun la causa exacta y piecisa de semejante ruido. 
Puedé suponerse cuando mas glue el ave al franquear gran. des distancias mueve sus alas aun con mas rajidez y vigor que cuando permanece en el mismo sitio, pues cur este últino caso no produce ruido.

En el acto de volar los coliurís producen una corriente de aire muy sensible. \&He ooservado, dice Salvin, un indi viduo que penetró en una habitacion y volaba sobre un pe. dazo de algodon en rama, cuya superficie se agitaba mu cho. Rociefort refiere que cuando un colibri pasa cerca de una persona, le parece $\{$ esta oir el silbido del viento.

No es posible deterninar la direccion del vuelo de estas aves ni las lineas que describe: sus movimientos son tar rá. pidos y tan dininusa su talla, que sc hace imposible observarlas. Audubon asegura que el colibri de in Américi del storte corta los aires trazando lineas extensamente ond:taJas; elévase bajo un ángulo de unos to grados, para bajar describiendo una curva; pero anade que es immosible seguir al colibrí en un espacio da mas de unos cuarenta metros, aunque se apele al auxilio de un instrumento óptico. Poip. pig, á quien no han faltado ocasiones de observar los coli. bris, cree qua lá forma de sus alas, uncorvadas en forma de hoz, les permite cortar los aires con mucha rapidez en linea recta, aunquue sin poder elevarse; y por lo mismo dice, qque los colibris vuselan gor lo rezular horizontalmente. Sin em. bargo, este aserto 5 e contradice de una manera tan marcada con el de los demís autores, que no pademos darle crédito. Gould asegura que los psjaros moscas vuelan con mucha facilidad en todas direcciones; que à menudo se temontan por los aires verticalmente; que retroceden y giran en cir. culo; que vuelan, $\delta$ mas bien bailan de flor en flor $\delta$ de rama en rama; suben, bajan, temóntanse sobre los árboles mas altos y desaparecen de pronto como una exhalacion. Linas veces permanecen junto á las forecillas que crecen á ras del suelo; otras se les ve sobre la yerba, y subitamente fran-

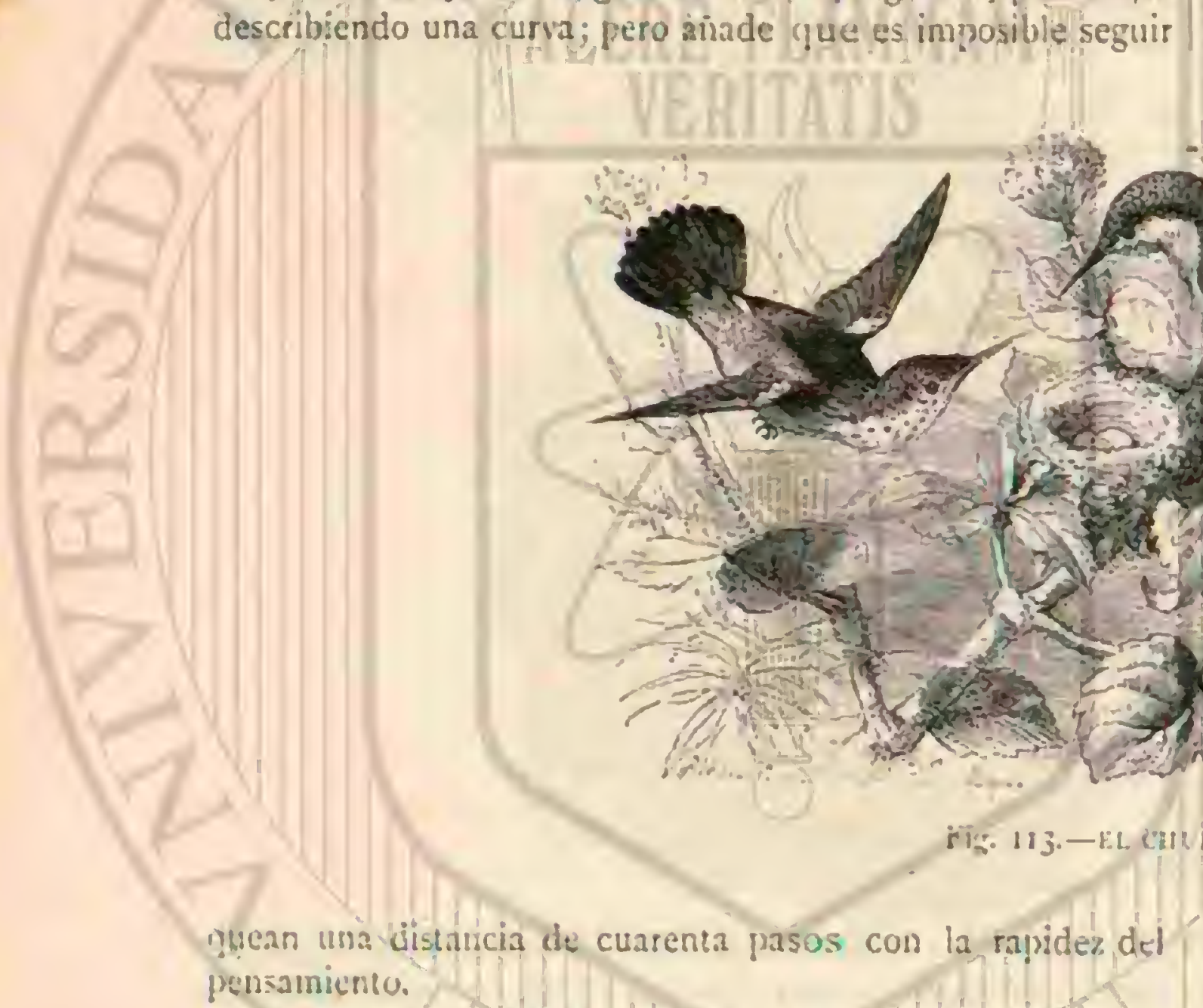

tensimicnto.

"Fistas aves, continúa Audubon, se nueven con una viveza é impetuosidad sin igual: permanecen un instante tan inmúviles en el mismo sitio, que se las creeria fijas alli, en el aire; $y$ de repente se apartan á un lado con la rapidez de una saeta; describen un semicirculo alrededor del árbol y ma á risitar otra hor. A menudo se lanza uno de estos peyueños súres desde la cima de una copa hácia el cielo, cual si le impeliese un poderoso resorte.

De todos modos nos vemos siempre obligados á considerar el colibri como una mariposa emplumada, y esto no debe contenderse en sentido figurndo sino al pié de la tetra.

4. Hl dar el primer paso en las sabanas de la lamaica, dice Eurique de Saussire, vi un brillante insecto verdè, de rápidio vuelo, çue-llegaba repetidas veces á deslizarse entre las ramillas de un arbusto. Admirábame su extraordinaria destreza para escarar de una red, y cuando al in pude cogerle, cuál no seria mi usombro al encontrar ea el fondo de nquella, no un irsecto sino un are. $Y$ es que los colibris no tienen so:o la talla de los insectos, siro tambien sus-movimientos. A Gould le costó mucho el convencer â una persona de que habia visto en Inglaterra macroglosos estrellados (MAcro Flassar skellatarumis) in no cólibris; Bates asegura que solo despues de largas observaciones pudo reconocer la diferencia entre una mariposa de las orillas del Amazonas, el macroglosu titan (.Macroglassa Titan) y ciertos colibris; y que una vez llegó á tirar á una de cátas mariposas creyendo que era un pájaro mosca. Unas y otros, en efecto, vuelan del mismo uodu y se suspenden de una manera idéntica ante las fio- res. Las indios, los negros, $y$ hasta los blancos, consideran al titan y al colibri como un mismo sér; saben que una oruga paede convertirse en mariposa, y no tienen por impo. sible la trasformacion de esta en ave.

Sin embargo, es bastante singular que hasta los colibris parezcan ver en las mariposas séres que les molestan en sus qquehacercs. Segun las observaciones de Saussure, traban ver. dacieras luchas con ellas; persiguenlas de flor en flor, de rama en rama y se precipitan sobre esos insectos hasta que los ahuyentan, llegando a menudo á destrozarles las alas. Hstos ataques se deben evidenicinente al celo, 6 quizás à la envi. dia; pero son en alto grado caracteristicos, tanto para los perseguidores como para los perseguidos. Algunos obsurva. dores concienzudos creen que tambien los sentidos y lis fi. cultades intelectuales de los colibris y de las mainosas ticuen poco mas o menos el mismo desarrollo, error en que incur. rieron sin duda al fijarse en la expresion inocente de los ojos dél ave y en la confianza que manifiesta.

Gracias a su agilidad, su destreza y rapidez, obsérvase en sus actos un aplomo que verdaderamenie asomura. oCuando se ye un coibri, dice Burmeister, no se cansa uno de admirar sus ojos claros y limpidos y la tranquilidad perfecta con que coniempla al observador, al menos mientras este permanece tranquilo, pues apenas noia un movimicnto, desaparece en seguida

Ciertos viajcros hablan del magnífico efecto de los coiores que presenta el phumaje de los colibris en el acto de volar: paro sus relatos carecen de la debida exactitud. Cuando cruzan los aires no se ve nada de ese brillo propio de estas tan celebracins joyas de la naturalen; no se disaingue sino cuan. 
do reposan, ya estén delante de una flor, sin mover mas paric cie su cuerpo que las alas, ó bien situadas en el ramaje. pronto, dice Scinomburgh, se ve una for solitaria; adviértese luego que brilla en ella un topacio, sin que se sepa de dónde y cómo ha venido. Los ojos se fijan en todas partes y vuel. ven ia ver la misma cosa; agqui divisan un rubi de vivos colo res, allá una lentejuela de oro ó un brillante zafiro, que parece despedir mil rayos luminosos; luego se reunen ayuellas joyas, formando espléndida corona, la cual se rompe subitamente para presentar á pocosu forma primitiva.
Hay sin cmbargo algunas cuyos colures brillan tambicn cuando ruelan. E El colibri safo, me escribe Garing, parece una chispa de fuego al refiejarse en su plunaje la luz del sol, y sorprende aun á los que han obseriado nuchas aves de su especie. Cuando la princra de es:as chispas viras se ba. lancé à mi vista en el aire, cautiró de tal modo mi atencion, que olvidé apuntarle con la esconeta si los colibris se cansan de volar, buscan en el follaje un sitio á propósito para el reposo, y prefieren al efecto ramitas muy delgadas y secas, o con pocas hojas; sicmure vuclien a la misına ramita, y con tal

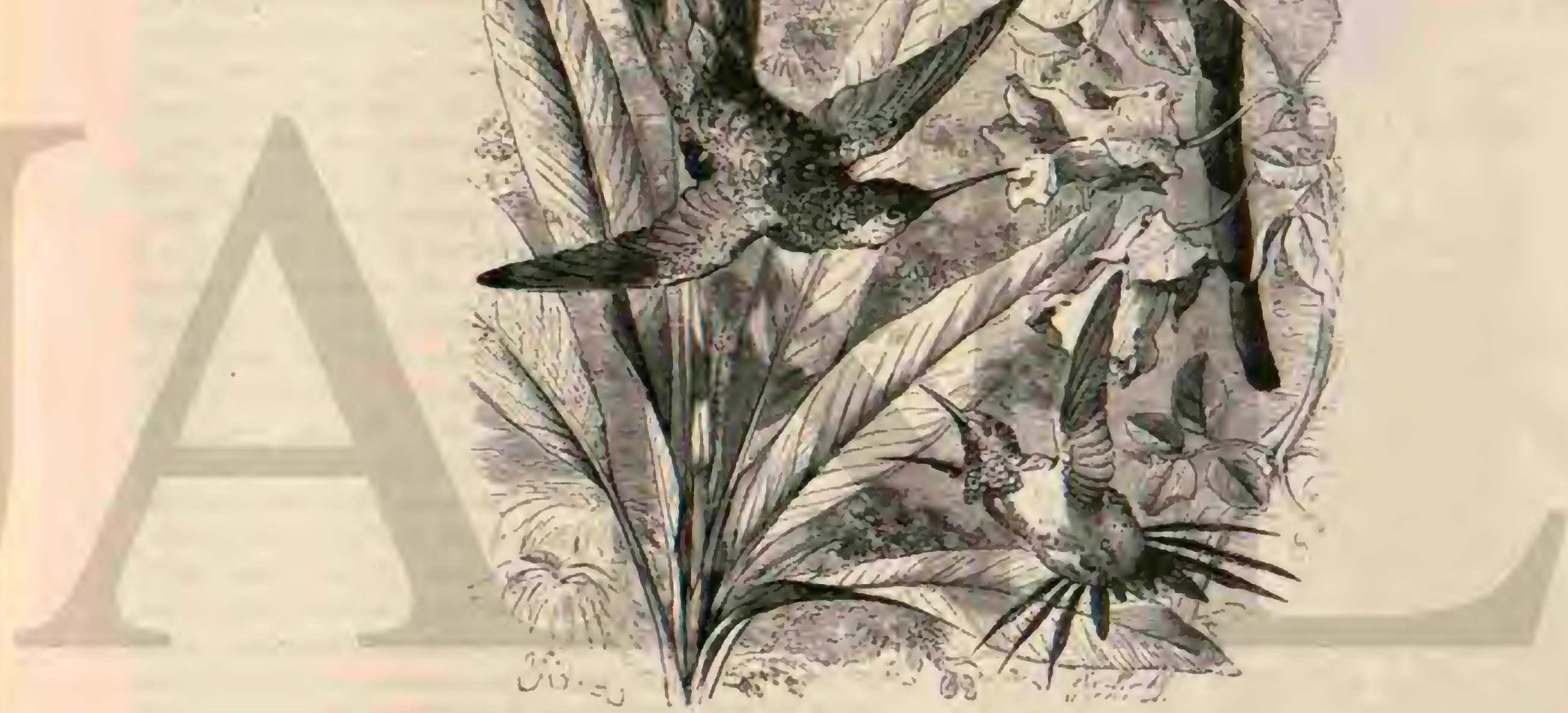

regularidad que, segun Cundlach, solo se necesita permanceer algun tiempo cerca del sitio para poder ver y ubservar las aves. Suelen aprovechar el breve rato de reposo para porer en óden su piumajey limpiarse el pico: pero ni entonces estan quietos, pues cuando menos mueven continuamente las alas y la cola. Apenas arregladas sus plumas vuelven is rolar, balanceándose alrededor de las flores.

La tierm es tan extraña para ellos como para el quuclidon de las paredes, de tal modo que no pueden andar. aCicrto dia, dice Kittliz, heri ligeramente en el ala a una de esas aves, aunque lo bastanie para que no pudiese volar: cajo a tierra, mas no pudo moverse del sitin donde se hallaba, pues sus patas son impropias para saltar 6 andar. Sin embargo, los colibris se posan aigunas reces en tiern, como por cjem. plo, para beber.

Se ha dicho hace mucho tiempo que ningun pảjaro mosca cantaba; esto cs rerdad en general; pero hay varias observaciones que jorman excepcion a la regla. Ia voz de los colibris, dice el principe de Wied, es débil é insignificante; pero lac oido algun individuo cuyo grito de llamada era breve y linormeister dice a su vez: ELos pajaros moscas no son mudos, pues cuando se posan en alguna rama baja para des. cansar, producen de ver. en cuando un grito debil y iemblo. roso. Con frecuencia los he oido; he obscrvado a menudo algun individuo que se posaba en el Rollaje, y he visto como despues de lanzar su grito sacaba del pico tres centimetros de lengua, por to menos. L Los mas de los orros naturalistas dicen que esias aves no producen mas que sonidos torcos y chillones, los cuales se cerpresan pou tirr firr tirr ó so6k: sosk sark.

Segun Salvin, el citado sonido agudo, n̨ue él cxpresa por sihirik, es el griro general de casi lodos los colibris, "se oye sobre todo cuando se les persigue rolando ó se exciran por otsa causá.

Algunos, como Lesson, aindén que por lo regular pernanecen los calibris silenciosus, y gue se puede exiar horas $\mathrm{en}$. teras cechjo del árbol conde sc hallan sin oir su voz. Otros ria. 
turalistas, en cambio; aseguran que ciertas especies cantan. \& El colibri enano, dice Gosse, es el único que canta real. mente: en ia primavera, y apenas amanece, se le ve posado en la mas alta rama de un mangle ó de un naranjo, y alli se le oye entonar su canto débil y poco variado, aunque armo. nioso, el cual repite por espacio de diez minutos.

"Pude acercarme a una de estas pequeñas aves, dice (iundlacir al hablar de otra especie el Orfhnrifyritus Bothi), hasta una distancia de cuatro piés, para observar y escuchar su canto, bastante variado, suave y armonioso. Al entonarle, remúntase el macho à menuclo verticalmente hasta una gran

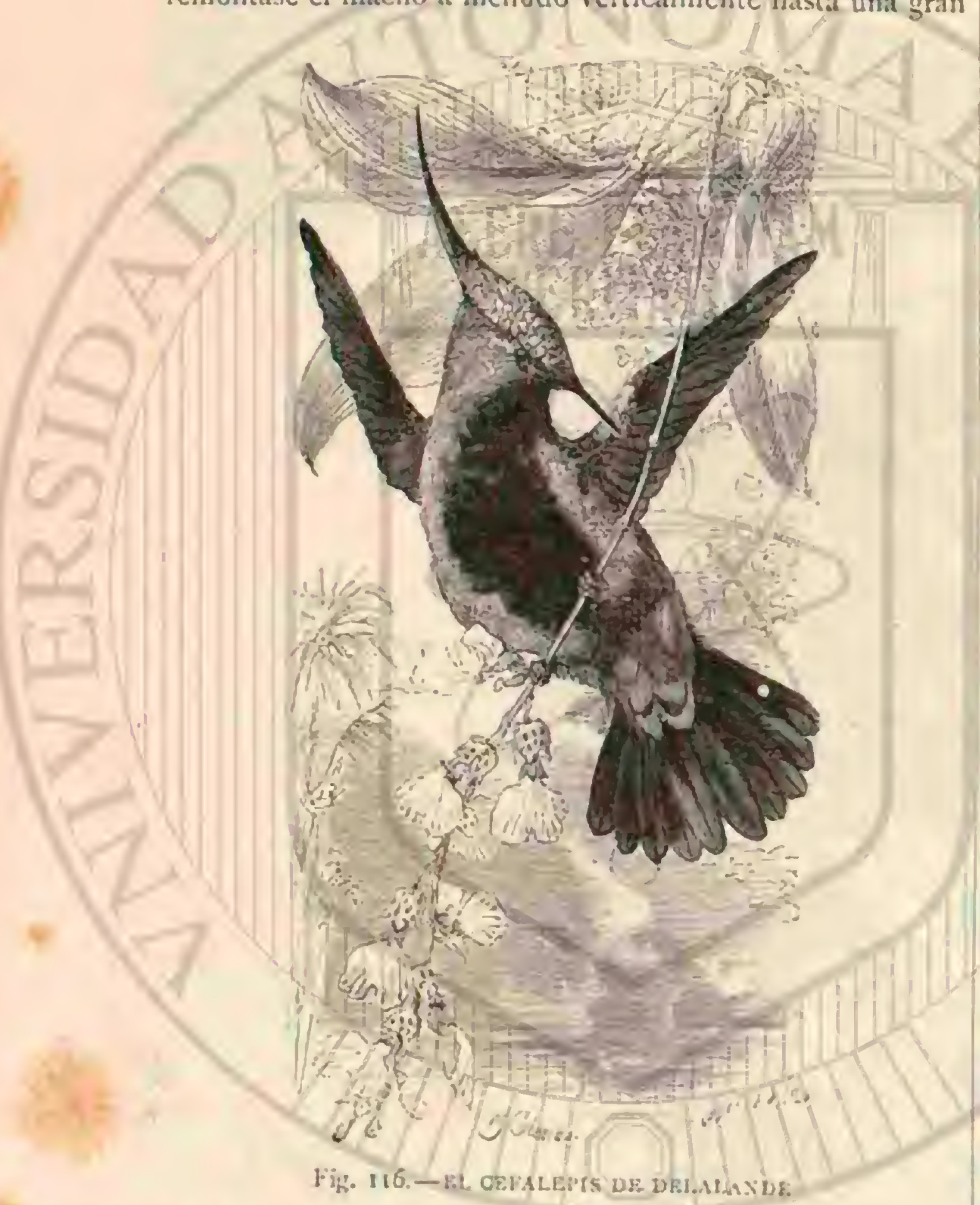

altura, y produce un ligero gorjeo sobre una sola nota. Al cantar mueven, segun dice (jundlach en otro sitio, las lar. gas plumas de la garganta y brillan entonces de un modo magnifico.

"Un colibri dorado, refiere Kittlitz, que se hallaba en una rama con las alas medio extendidas, dejaba oir un canto bastante sonoro y armonioso, canto que me sedujo ianto mas, cuanto que los colioris no producen sino notas chillo

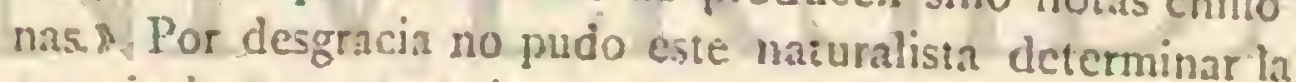
especie à que pertenecia el are.

En mi concepto bastan estas tres citas para dejar sentado que los colibris pueden cantar; y no dudo que se harán semejantes observaciones en otras especies, cuando se comience a estudiar las costumbres de cada una particularmente. Hasta ahora nos hallamos en el mismo caso del naturalista que solo ha residido poco tiempo en América... All llegar á Guatemala, dice Salvin, parecióme que todos iós colibris ob servaban los mismos usos y costumbres y tenian idéntica roz; pero repetidas observaciones durante algun tiempo me dieron ś conocer que cada especic ofrece sus particularidades, $y$ bien pronto pude reconocerlas por su grito y el ruido de su vuelo. Cierto que estas diferencias son dificiles de plicar; paro pueden observarse.
Parece que los colibris tienen sentidos muy sutiles, é igualmente desarroliados, poco mas ó menos, resultando evider. temente de todas las observaciones que la vista es en extremo penetrante, lo cual se reconoce desde luego por su manera de moverse cuando vielan. Es probable que al cruzar los ai. res atrapen insectos completamente invisibles para nuestras ojos, pero que ellos pueden ver: su oido no es menos perfecto que el de las otras aves; y esto es cosa que se puede admitir, aunque carezcamos de observaciones precisas sobre el particular. El tacto alcanza en ellos gran desarrollo, pues de no ser asi, no podrian extraer del interior de las flores la mayor parte de su alimento. No saben, dice muy bien Burmeister, si la flor les oculta ó no una presa; permanecen ante ella, suspendidos en el aire, hundiendo su lengua en la co. rola; agitan continuamente las alas, y continuan en el mismo sitio hasta que han examinado interiormente la flor: sirvense de su lengua como los picos; ningun retiro es para ellos im. penctrable. Su delicado tacto les jermite reconocer la presa; y el inismo órgano que la descubre sirve para cogerla.s En los colibris existe el senticio del gusto; esto se revela por su aficion á las sustancias azucaradas; en cuanto à su olfato, difi. cil es decir cosa alguna; pero se puede suponer, cuando me nos, que no es rudimentario.

1) Ia forma combada y regular de su críneo hay motivo para deducir que sus facultades intelectuales están inuy des. arrolladas. Sin embargo, mas que en las otras aves, los observadores podrian engaharse soure este punto, y por consiguiente no se debe extrahar que scan tan diversas las opiniones acerca del particular. Cuando los colibris se mueven libre. mente, no es posible conocerlos bien; su agiacion y petulan. cia continuas, la ligereza de sus movimientos, su pequeñez y su número son otrás tantas circunstancias que contribuyen á dificultar las observaciones, siquicra no las imposibiliten. Vótase, sin embargo, que saben. distinguir los amigos de los enenigos, entre lo útil y lo nocivo; y que alli donde se les respéta son muy confiados, al paso que se muestran timidos y miedosos en los sitios en que se les da caza. Verdad es que por lo regular llega su confianza á tal punto, que suele serles funesta; pero esto no es sino resuliado de su increible agilidad. Comprenden, si me es pernirido expresarme asi, que pueden escapar á tiempo de todo peligro; y en efecto, mientras solo se trate de sus enemigos naturales, semejante cunfianza se justifica; pero tratándose del hombre, cujos medios destructores no conocen bastante, su seguridad les pierde á menudo, 5 muchos de cllos son victimas en las ca. cerias.

El réginen es el que determina el género de vida de los colibriș Sabido es cuinto se han falseado las opiniones de los naturalistas sobre este punto, y cuảnto se falsean aun, habiéndose creidn que los pajaros moscas se alimentaban solo, ó casi exclusivanente, del néctar de las flores. Es muy natural, dice el principe de Wied; que encontremos en los relatos de los viajeros mil descripciones de estas pequeñas y cranntadoras aves; pero tambien es muy extraño que al. gunas de sus costunubres sean para nosotros casi descono. cidas, sobre todo su régimen. Al ver estas preciosas aves liundir su largo y delicado pico en la corola de las flores, se atribuyo naturalmente un régimen relacionado hasta cierto punto con su belleza, creyendose que se alimentaban del néctar. Considerábase su larga lengua como un cilindro hue. co, y se supuso que debian aspirar con ella los azucarados jugos de las plantas; este es el régimen que les han supuesto muchos autores modernos. El concienzudo naturalista Azara nó observó por si mismo una parte tan csencial de la histo. ria de tan pequeños séres, y participó de las erróncas opi. niones que entonces circulaban. Hallábase no obstante en la 
mejor situacion para njjarnos sobre este punto, y por lo mis. mo, se le peede censurar muy justamente por haberse ate. nido â la descripcion de ios caractéres exteriores de los coli.

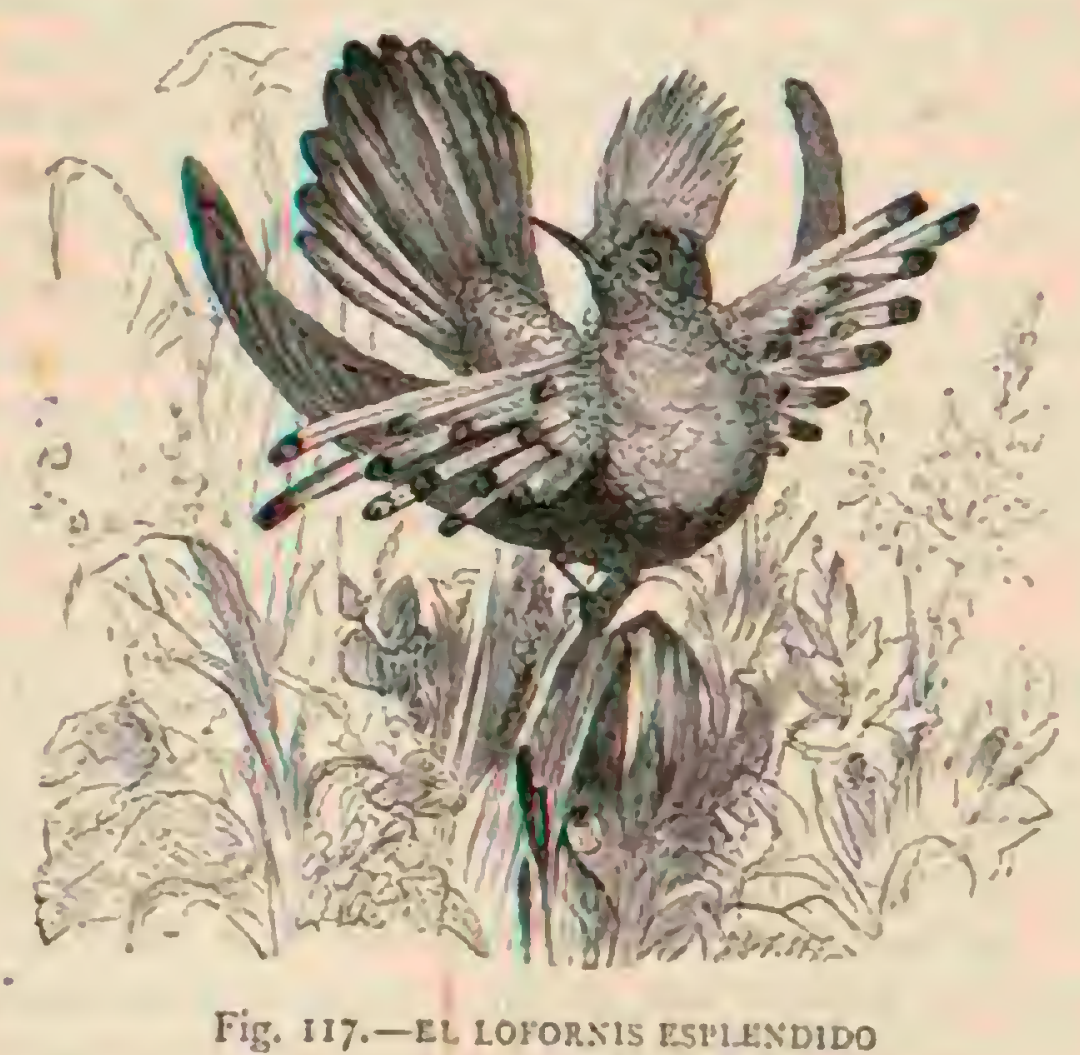

bris. Sin embargo, otros naturalistas rectificaron el error en que incurrian sus predecesores, y entre ellos debemos citar á Badier, el primero en descubrir que los colibris se alimenta. ban de insectos. Ln 17jS nos hizo saber este autor que se habian muerio muy pronto todos los colibris que se trató de alimentar con agua azucarada 6 jarabe: consistia esto en que cuando viven libres no toman sino accidentalmente el néctar de las flores, yse alimentan de pequeños insectos, sobre todo de los que viven en el interior de aquellas para nutrirse de su jugo. Habiendo disecado varios individuos, lallo en todos restos de insectos y de aranas: durante seis semanas, ali. mentó dos con jarabe y bizcocho; pero débilitáronse poco 1 poco y murieson; al abrirlos, vió que su intestino estaba acorchado y contenia azúcar cristalizado. Hácia la misma Epoca, Brandes tradujo la historia natural de Chile, escriia por Molina, é hizo las mismas observaciones que Badier.

En isıo, Wilson díb sobre el particular mas amplios detalles. Hasta ahora, dice, se ha creido que los colibris se alimentaban de miel y de flores; solo uno $\delta$ dos observado. res modernos indicaron que su estómago contenia fragmentos de insectos, que en opinion de los naturalisias debieron ser tragados por casualidad. Los europeos no han tenido muchas ocasiones de observar los hechos por si mismos y disecar algunas de estas aves, debiéndose á cllo que el error haya subsistido tanto tiempo. En cuanto á mi, puedo com. batirlo resueltamente, pues en las hermosas tardes de rerano he observado durante horas enteras á un colibri que cazaba insectos pequeños; cogialos como los papamuscas, pero con una agilidad inuctio mas notable. He disecado tambien gnn número de individuos, y cxaminando con el microscopio el contenido de su estómago, reconoci que de cuatro, en ires por lo menos, habia restos de insectos; á menudo hallé asi. mismo coleópteros muy diminutos, todavia enteros. Varios demis amigos han hecho las mismas observaciones; sabido es que lós colibris buscan princinalmente las flores de corola tubular, y precisamente en estas es donde se introducen con preferencia los insectos pequerios.

\&5 muy probable, escribia Bullock en $1 \$ 25$, que todos los pájaros-moscas se alimenten de insectos; el hecho es po. sitivo para muchos, y yo los he observado muy aientamente cuando cazaban su presa en el Jardin de Plantas de México, como tambien en el patio de una casa de Tehunntepec En aquel șitio un colibri se habia posesionado de un namnjo en

Towo III fior, y rodo el dia estaba cazando las moscas pequeñas que se posaban en las flores. Muchas veces he visto a dichas - vies atrapar al ruelo estos insectos y otros; y al disccarlas, encontré en su estómago los restos. In el Jardin de Jalapa admiré à menudo la destreza con que cazaban los colibris en medio de las innumerables telas de araña; acercábanse a ellas prudentemente para recoger las moscas que estaban cogidas; pero sucedia con frecuencia que las grandes aranias no se dejabar arrebatar fácilmente la presa, y entonces cra. les forzoso retirnrse. Al llegar daban una $\delta$ dos vueltas por el jardin, como para reconocer su terreno de caza; luego comenzaban sus acometidas, volando con prucencia por debajo de una tela de arana, y al fin lanzábanse stubitamente sobre alguna pequeria mosca cogida en la tela. Sus movimientos exigian una gran habilidad, pues i menudo no tenian apenas el espacio sufrciente para mover sus alas, siendo preciso mu. cho cuidado para no quedar prendidos ellos mismos en las telas de araña Por otra parte, no podian cazar sino en las de las pequeñas especies, pues las grandes llegaban al punto, dispuestas á defender su dominio, apenas vecian al colibri acercarse, $y$ al momento huia este con la rapidez de una sacta. Por lo regular duraba la caza unos dica minutos.\$

« Sin saber aun lo que se habia escrito respecto al régimen insectivoro de los colibris, dice el principe de llied, hab!e de ello, en 18zr, en el relato de mi viaje al Brosil, y en

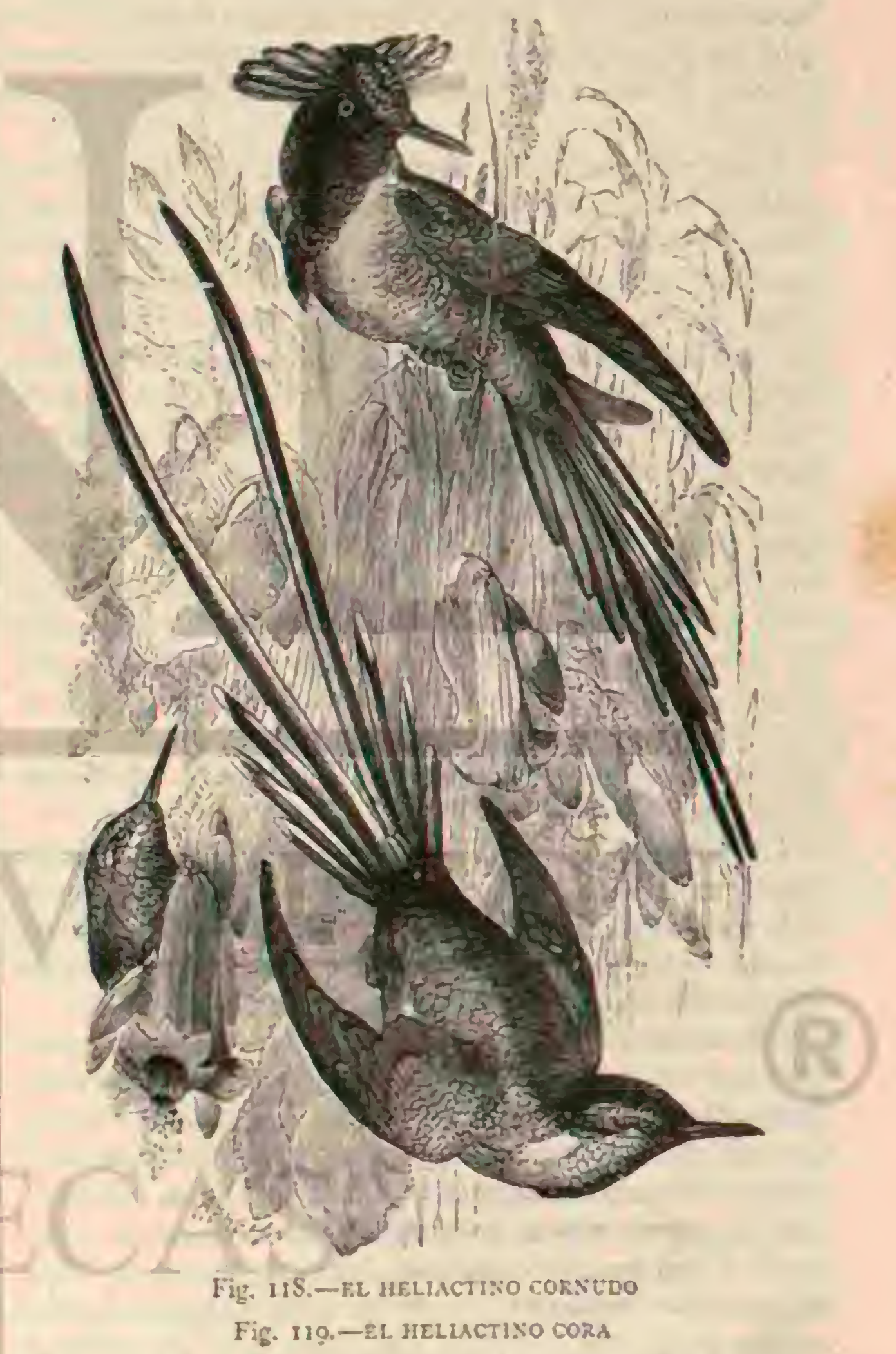

1822, en el Isis. Estoy perfectamente convencido del hecho, pues aun en los mas pequeños colibrís obscrvé que el esto. mago estaba lleno de restos de ineectos, nunca de miel. Es. tas ares se alimentan de pequeños coleópteros, arañas youtros 
insectos; su lengua no es en manera alguna un cilindro hueco en forma de chupador; las dos puntas membranosas que la terminan están muy bien dispuestas para tocar, coger y llevar al pico los insectos sumamente diminutos que habitan el interior de las flores. Al abrir una de estas ares se reco. noce hasta la evidencia la verdad de lo que digo; á menudo he visto individuos cuyo estómago estaba completamente lleno, atestado de restos de insectos de escaso tamaño. Les. son asegura quue se ha tratado de alimentar á los colibris con miel y jugos vegetales; pero aun cuando se hubiese consegui. do conservarlos, esto no probaria de modo alguno que tal sea su régimen en el estado libre; de mi opinion participa tambien aquel sabio. El inglís Rennie se pronuncir on el mismo sentido respecto al régimen de lós colibrís, y todo cuanto dice está muy en su lugar.x

En $1 \delta_{3}$ r se publicó la cxcelente obra de Audubon, en la que dice lo siguiente: "Los colibris se alimentan de insectos, principalmente de coleópteros, cujos restos se encuentran en su estómago, con moscas pequeñas; cogen los primeros en las flores y las segundas al ruelo. Podriamos, pues, conside. rar al colibri como un papamoscas: el néctar y la miel no bastan para alimentarle; cuando mas le pueden servir para apagar su sed. Se han conserrado cautims muchas de estas aves, nutriéndolas con miel 6 azícar; pero fué corta su vida, y murieron todas escuálidas y consumidas; otras, por $\mathrm{cl}$ contrario, á las cuales se daban dosieces diarias flores cogidas en los bosques ó en los jardines, y cuya jaula estaba prote. gida porgasas que permitian el paso a pequeños insectos, vivieron asi mas de un año y se les puso en libertad des. pues.

Gosse y Rurmeister son aun mas explicitos Los colibris, decia el primero en ${ } S_{4} 7$, se alimentan casi exclusiramente de insectos: quiero admitir que tomén adcmàs el néctar de las flores, frues no ignoro que se han conservado individuos cierto tiempo alimentandolos con micl y azicar; pero niego que con semejante régimen hayan conservado sus fuerzas y vivido largo tiempo. Jo disequé varios de los que habitan la Jamaica, y en todos vi que el estómago estaba lléno de luna masa negra complezamente igual a la que se halla en el de las cantoras, y formada de restos de insectos. He visto a the nudo \& cstas aves coger moscas al vuclo, comolo dice Wilson del colibri de la América del norte; he observado cómo i la caida de la noche volaba el lampornis mango al rededor de los árboles que no forecian aun; y por la direccion del vuelo pude conocer que cazaban insectos. Al observar un colibri desde muy cerca pude ver tambien las pequeñas mos. cas que perseguia, $y$ varias veces oi el chasquido que produ. cin al cerrar su pico. $\$$

Lord observó cerca de las Montañas Pedregosas un colibri que en union de otros de su especic se ocupaba en extraer toda clase de insectos del jugo pegnjoso de un árbol. Fistos insectos se habian pegado alli y las avecillas se aprovechaban de la ocasion para coger su presa con toda comodidad.

Intencionalmente he reunido todos estos comprobantes; pero aun me queda una cuestion r̨ue aclarar. Creo que nadic pensará ya que los pájaros moscas se alimentan de néctar y de miel, mas á pesar de ello, me parece que debe tenerse cn cuenta el ascrto de Burmeister. Este autor cree, en efecto, que los pájaros muscas ro atrapan nunca insectos al vuclo, como lo han asegurado algunos obserradores; repite lo que Bullock dice respecto a las arañas; pero rechaza todos los asertos de los demás autores. comer moscas pequeñas cogidas en las telas de araña; permanecen delante de ellas, como ante las fores, $y$ he podido observar perfectamente de que manera cogian un insecto despues de otro, avanzando y retrocediendo alternativamen. ie. Rara vez les molestan las arañas; pero los pequeĩos coli. brís parece que temen quedar cogidos ellos mismos. Que estas aves se alimentan de insectos es cosa que no admite duda; pero nunca los cogen al ruelo, porque no pueden ha. cerlo asi, y por esta razon los extraen de las flores. Que un poco de miel se adhicra a su lengua, esto no significa nada: y no debe creerse que introducen dicho b́rgano en el interior de las flores para libar el néctar. El nombre poético que les han dado los brasilenos, Beija flores (besa Bores), no es del todo exacto, pues el colibri hace mas que besar la fior, pues. to que solo con ella vive. Fácil es explicar por qué estas ares no cogen su presa al vuelo: para ello basta comparar su pico largo, delgado, y de aberturn bucal estrecha, con el pico corto y la ancha boca de la golondrina. Todas las ares que cogen los insectos en el aire tienen aquel órgano corto $y$ aplanado, la abertura bucal considerable, el ángulo de la boca provisto de largas sedas en forma de barbas; y estos caractéres están sicmpre en relacion con la talla de los insec. tos de que se alimentan, con su major ó menor facilidad para cogerlos. Un ave cuyos caractéres sean precisamente opuestos á los que indico, no puede coger insectos al vúelo, no le es posible atraparlos sino cuando esián quietos, bien los retire de los agujeros y de las grietas de la corteza del árbol, como lo hace el pico, ó ya los busque en el interior de las flores, si la manera del colibri.

De todo Jo que indica aqui Burmeister no resulta sino una cosa cierta, y es que rio ha visto a los colibris coger insectos al vuelo: sin embargo, Wilson, Audubon y Cosse son obser. vadores demasiado concienzudos y dignos de crédito, para que podamos negar lo que ellos afirman de comun acuerdo. El pais, el sitio, In variedad de las fores que les juroporcionan su alimento y otras condiciones citeriores, ejercen una gran influencia en el género de vida de los colibris; pero las diversas especies ofrecen entre si numerosas desemejan. zas en este punto. Casi todos los pảjaros moscas son diurnos. Les agrada cl calor y no buscan la sombra, mas en cambio padecen mucho por el frio. Algunos viajeros han pretendido lo contrário, pero Saussure asegura no haberlos visto nunca, al menos en México, en bosques oscuros y frondosos, sino siempre al mediodia y al calor del sol, en parajes donde es. casean los arbustos floridos. Cuando la agava de candelas está en plena florescencia, las ramas del poderoso tallo, quéa mucha altura sobre el suelo ostenta su hermosa y brillante for, hállanse rodeadas de infinidad de colibris en las horas mas calurosas del dia; apenas florece el maiz, se puede ver i ciertas horas todo el canipo lleno de esas avecillas, y por do quiera se oye el zumbido de sus alas 6 su fina roz. Sin em. bargo, hay algunas especies que pueden considerarse como ares nocturnas, porque solo cazan en las primeras horas de la mañana y en las últimas de la tarde, descansando duranté el dia en la oscura sombra de los árboles.

- Waterton, y despues de él Schomburgh, dicen que el topa. cio no se deja ver hasta el momento de refrescar cl ambiente, y que evita con cuidado los raỵos del sol; el principe de Wied solo ha visto por la mañana a una especie en el ac:o de secar su plumaje humedecido por el rocio.

El colibri enano de-la Jamaica revolotea como un zángano alrededor de las piantas mas bajas, y-solo excepcionalmente se remonta á considerable altura, llegando al punto donde el patagon gigante permanece con preferencia. Un árbol en for puede atraer especies muy diversas, y basta ponerse de observacion en lugar conveniente para ver llegar y desaparecer en una hora la mayor parte de los individuos que habitan el pais. Ciertos viajeros, entre otros Spix y Martius, hablan de bandadas de colibris; al paso que otros afirman que estas aves llegan aishadas. Mi experiencia, dice el principe de 
Wied, me ha dado a conocer que los primeros y los segundos están en lo cierto: muchas veces, hallándome cerca de un arbol en flor, hemos tirado en pocos minutos conirs un gran numero de colibris de la misma especie, siendo asi que solo aparecen aislados comunmente. Stedmann dice haber visto volar tantos colibris á la vez alrededor de un árbol, que pro. ducian un ruicio semejante al de un enjambre de abejas. Rochl, cónsul de Hamburgo en Caracas, que residio mas de veinie años en Venezuela, me refirió el mismo hecho; pero anade explicitamente que estas agrupaciones no se rerifican sino al principio de la florescencia, cuando se abren muchas flores simultáneamente en el mismo árbol. Por lo reguiar llega un individuo despues de otro, y cada cual se queda un instante en el mismo sitio. «S impaciencia es demasiado grande, dice Azara, para que puedan examinar un árbol por completa. - Recucrdan un poco \& las abejas. an̉adia el cónsul Roehl; pero hay entre unos y otras notable diferencia. La abeja es inágen del celo y de la actividad; aunque no vaya muy cargada, vuelis con lenitud en medio de las flores, las examina con cuidado, se hunde en su corola, sale cubier. ta de néctar y de pólen, é indica quue es a la vez artista y obrera. El colibri parece mas bien un alegre compañero que se complace en vingar de un punto d otro locamente. Bates dice mas $\delta$ manos la misma cosa.

4 En marzo, abril y mayo, refiere Cosse, el colibri de capu. cha es muy comun: muchas reces he visto llegar al misno sitio centenares de individuos unos tras otros, en la misma tarde. Sin embargo, no ha de creerse por esto qque son aves sociables, pues aunque tres $\delta$ cuatro estén reroloteando alrededor de las flores de una breña, no existe entre ellas ningun lazo; cada cual obedece su capricho y solo se cuida de si. En ciertas ocasiones no se ven inas que machos; en orras aparecen los dos sexos igualmente numerosos, pero solo en los alrededores de su nido se observa entre ellos cierta union. Dos machos de una misma esperie no puecien vivir en paz; apenas se atisban, comienza la lucha; los hay que acometen á cuantos colibris se acercan á ellos, y aun à otras aves dis. tintas.

- Háse hablado con frecuencia de su caraicter pendencicro, y parece que dos individuos de la misma especie no pueden visitar a la vez las fores de un matornl. El lampornis man. go persigue a todos los colibris que se acercan a 6 6?: yo presencié cierto dia una de estas luchas, mas ardiente y prolon. gada que de costumbre, y que ocurrió en un jardin donce habia dos árboles en fror. Varios dias hacia que un mango llegaba regularmente para visitar uno de aquellos: cierta ma. nana apareció otro individuo al mismo ticmpo, y los dos comenzaron inmediatamente af perseguirse en medio del ramaje y de las Pores, precinitándose furiosos uno contro otro. Oinse el ruido de sus alas: revoloteaban, giraban rasando el suclo; y eran todos sus movimientos tan rapidos, que no podia seguirlos con la vista. Al fin, se cogieron por el pico y cayeron los dos; despues de haberse soltado, el uno persi. guió a su enemigo en un corto trecho, y satisiecho luego de su victoria, rolvió al árbol, se posó en una tama y dejó oir su voz: pero ¿ los pocos minutos volviósu enemigo, lanzan. do gritos, ỳ se renovó la contienda. Estoy seguro que obraban asi por enemistad; uno de cllos parecia evidentemente temer al otro; apelaba ô in fuga cuando era perseguido, mas no queria abandonar el campo. En los iniervalos de reposo veia yo al are posada abrir su pico cual si tmatara de aspirar el aire: de ve\% en cunndo se interrumpian las hostilidades; los combatientes visitaban algunas fores, y rolvian a la pelea. Un pequeno pitpit (erslisoliz fiacesla). que saltaba pacificamente en medio del ramaje, parecia mirar a los dos colibris con admiracion; pero cuando uno de ellos ponia en fuga à su adversario, precipitábase ambien contra él para hostigarle. Esta lucha duró una hora entera Salvin asegura que ciertos colibris molestan mucho al cazador, obligando a em. prender la fuga a los demás que tratan de acercarse á cllos. rParece, dice este autor, que las contiendas son su clemento; apenas uno de ellos hunde su largo pico en la corola de una Bor, quiere otro ocupar su puesto, $p$ comienza en seguida la pelea: \& veces se remontan a tania altura en los aires, que desaparecen de fa vista, siempre luchancio.

Atendido su diminuto tamaño, pecan de impetuosos é irritables; no se creen de ningun modo débiles; y muy léjos de ello, confian tanto en su fuera, son tan atrevidos é inclinados á atacar, que acometen a cuantos animales se les antoja. Precipitanse contra los buhos pequeños y hasia se lanzan contra los grandes halcones, osando tambien amenazar al hombre a pocos centimetros de distancia. Desde la inmediacion de su nido elévanse a gran altura y se precipitan sobre el objeio de su ira, produciendo un extrano silbido con sus alas, sin duda con la intencion de asustarle, lo cual osan hacer al fin, valiéndose de su fino pico con toda la fuerza posible. Bullock, que habla tambien de tales ataques contra halcones, crte que dirigen el afilado pico como una aguja contra los ojos de otras aves, obligándolas á emprender rápi. damente la fuga cuanto antes. I.o cierto será que llegan á intimidar al halcon, porque este, no pudiendo divisarlos, y á pesar de sus proderosas armas, se ve obligado á reconocer su impotencia ante estos pigmeos. Debe ser muy gracioso ver al gigante emprender la fuga ante encmigos tan diminutos. Con el hombre se muestran los pájaros moscas muy confiados; no son nada timidos; permiten que se acerque uno micho; vuelan sin temor delante de quien los observa, y to manifiestan la menor desconfianiza mientras no se haga ningun movimienio. Gosse dice que son muy curiosos, y que acriden cuando algun objeto llama su atencion. Audubon y Bumeister aseguran que penetran a menudo en las habitaciones, airaidos por los ramos de flores; Salvin cuenta que un macho que se ocupaba cn la construccion de su nido, le arrebató una hebra de algodon casi de la mano. El principe de Wied vió una pareja à la que se dejó fabricar tranquilamenic su nido en una habitacion.

No se sabe aun si el nuchoy la hembra permanecen juntos todo el año, ó si solo se reunen durante el periodo del celo. Esta Epoca raría mucho segun las localidades: para las ę. pecies emigrantes comienza con la primavera; para las que habitan la America central coincide con la época de la fic. rescencia. Parece que algunas especies no tienen época de. terminada; Gosse asegura muy cxplicitamente que en toda estacion encontro nidos recientes del colibri de capucha. 1 Segun mis observaciones, dice, los mas anjdan en junio.» Hill indicú el mes de encro como periodo del celo. Lis juro. bable que la mayor parte de las especies aniden dos veces al año.

El amor ejerce tambien su influencia en los prjaros mos. cas, pues se observa que hácia la época del apareamiento son mas vivaces y pendencieros que de costumbre. $\mathrm{Nada}$ puede igualar í su ardor, dice Bullock, cuanco en al periodo del celo se acerca un macho al nido de una pareja de la misma especie; la pasion excita álos machos, y pelcan hasta que uno de los dos rivales cae á tierra inerte. Yo he presen. ciado una de estas luchas en el momento de llover lo bas. tante, segun yo crei, para que cayeran al suelo ambos adversarios,

\$Quisiern, dice sudubon, que oiros hubieran paricipado del placer que yo experimenté al observar algunas de estas encaniadoras aves cuando se manifestaban mutuamente su pasion. El macho etiza su plumaje, dilata la garganta, dauza 
apoyándose en las alas, gira al rededor de su compañera y vuela rảpidamante hícia una flor; luego vuclve con el pico lleno para dar alimento a su compañera; muésirase con clla

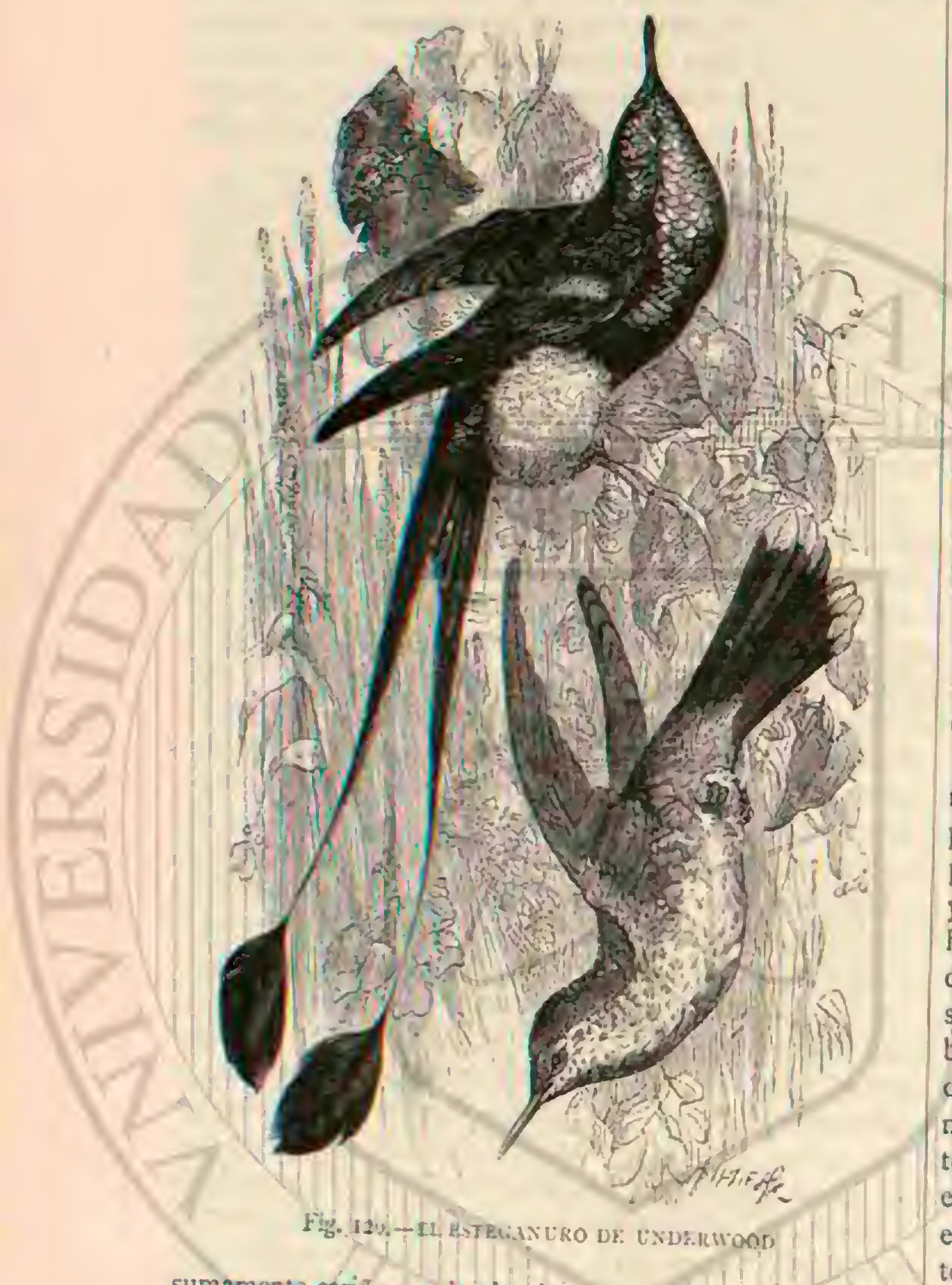

sumamenie carifioso, s ia abanica, permitaseme la frase, con sus pequeuss alas la hemibn recibe agradecida tantas prue bas de ternura; cl valor y la solicitud del macho aumentan entonces; emperia el combate con un rival, persigue á la go londrina purpúrea lasta su mismo nido; y luego, siempre zumbando, vuelvealegre á posarse al lado de su compañera. Todos estos testimonios de ternura, de amor, de fidelidad de valentia, prodigados por el macho à su hembra, son cosas que se pueden ier s admirar, pero que es imposible des cribir. $\$$

Los nidos de las disersas especies de colibrís no dificren mucho unos de otros, ! las puestas se componen solo de dos huevos blanquecinos, prolongados y muy grandes, relativamente ấ la talla del are ? Todos estos nidos, dice Burmeister, ofrecen tal semcjanza, çuc creo inútil describir cada uno de ellos en particular, a jesar de las ligeras diferencias que re. sultan de la eleccion ce los materiales. Estas diferencias se deben considerar coso puramente locales, y estan simple. mente en relacion con la clase de material que encuentra el ave para sus construcciones.

- El fondo del nido se compone de una capa de sustancia algodonosa, mezclada con liquenes, briznas de yerbas secas y escamas de belechos Todas estas materias se encuentran en el mismo nido y a reces no se ve mas que una sola: los liquenes son de especias variadas, y cada colibri parece pre. ferit alguns

. El nido mas curioso es el del faetomis (fliciforuis iur). nome): remata inferiormente en una larga punta, y se com. pone de briznas.de musgo enlazadas entre si por el liquen orchilla del Brasil, sin ninguna sustancia algodonosa. El nido ofrece un vonito aspecto, con la particularidad de que bajo la influencia del calor desarrollado por la incubacion, Jos liquenes 'desprenden su materia colorante, y los huevos se tiinen de un precioso rojo carmin. Este color los cubre ente. ramente con una regularidad notable, de tal modo que no se percibe la mas ligera mancha ni viso; y sin embargo, los liquenes no los rodean del todo, pues están dispuestos hori. zontalmente en medio de los musgos, tocándolos tan solo por una cara.

El nido del colibri de cuello blanco (agtrtria albicollis) es digno tambien de fijar nuestra atencion; esta formado de liquen de un magnifico color gris verdoso, que cubre la cima como un tejadillo; las escamas de los helechos, fijadas de modo que una de sus mitades queda libre, penden alrededor del nìdo, comunicándole un aspecto velloso y un color pardo castaño; solo forman un circulo compacto en el borde de la abertura.

- Encuéntranse tambien en estos nidos muchas sustancias vegetales secas ó marchitas, pequenos tallos y hojias; pero nunca se observa en su colocacion tanta regularidad como en los liquenes y escamas de helecho.

4 Los nidos están situados tamoien de muy distinta mane. ra, pues ciertas especies tienen preferencias bien marcadas por determinados sitios. El colibri de cuello blanco, por ejem. plo, anida en los jardines de los arrabales de Rio Taneiro, y construye siempre su nido en la bifurcacion de unia rama horizontal, de tal modo que esti como enclavado entre los dos brazos de aquella. Yo encontre varios y creo haber ob. servado que el áve tiene un cuidado especial en elegir el ár. bol en que se fja. Otra especie no anida sino en medio de las frondes gigantescas de los helechos que crecen en las montañas, en los terrenos áridos, y que cubren grandes ex. tensiones; en la cara inferior de estas frondes, y cerca de su extremidad, acostumbra la pequeira ave á consiruir su nido, enlazando súlidamente entre si las partes de las hojas que se ocan. Ia mayor parte de los colibris fijan su nido en los ras. trojos ó pequenas ramas verticales: yo tengo varios que hallé

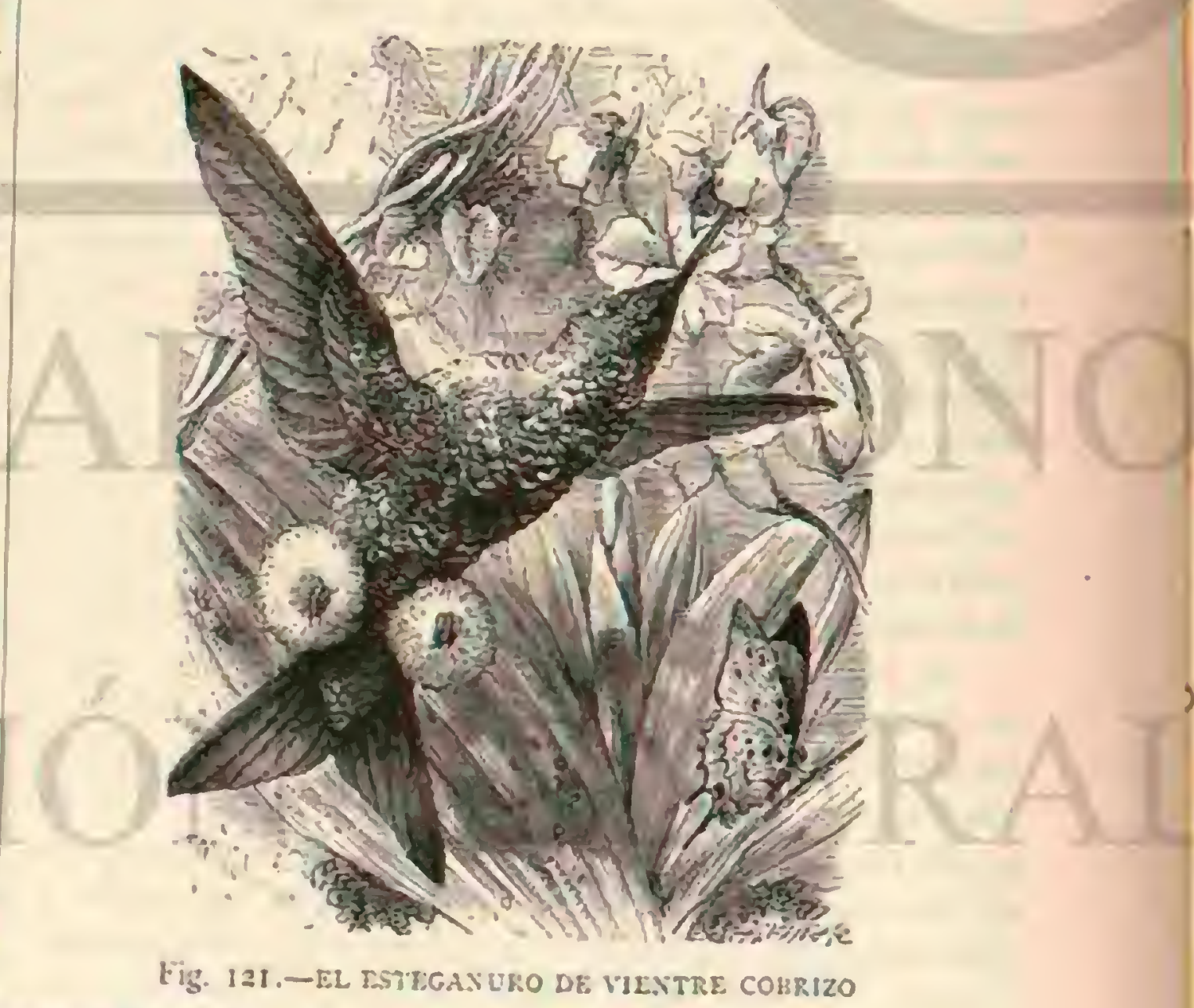

en medio de las cañas, y en algunos hay tallos de yerbas que les sirven de sosten ó apoyo; otros son de construccion muy endeble, y' me costó mucho trabajo conservarlos en su estado 
primitivo. Hay una especie que apenas cmplea mas que raicillas para la construccion, cuyo tejido es menos compacto que el de las otras.

Schomburgk dice que el topacio establece su nido en la bi. furcacion de una pequena rama inclinada sobre el agua, $\delta$ en medio de las lianas colgantes. Hé aqui cómo lo describe: $₫$ In. teriormente tiene el color del cuero curtido ye parece bas. tante á la yesca: para que el viento no pueda balancearle, haciendo caer los huevos, el macho y la heinbra tienen la precaucion de guarnecet la abertura con un ancho reborde recogido por dentro.

Salvin nos dice que en ciertas especies, por lo menos, el macho soma parte en la construccion del nido; pero general. mente, la hembra es la que carga con el mayor trabajo: Gos. se nos lo asegura asi por sus propias observacioncs. Este na. turalista se ocupaba en buscar nidos, cuando oyó á un colibri zumbar, y vió á una hembra con el pico lleno de pelusilla. Espantada al verme, dice, refugióse en una rama situada a pocos pasos: pero como me ocultase detris de una roca, per. maneciendo silencioso é inmóvil, volvió $\$$ los pocos instantes, y desapareció detrás de una piedra, para dejarse ver de nuevo y volar otra vez. Examiné aquel paraje, y con gran contento hallé un nido en via de construccion, situado de modo que se podia observar desde léjos. Esperé un rato, y a poco llegó la hembra y se sostuvo en el aire delante del nido; pero habiéndome divisado dirigióse hácia mi, y roló junto á mi cara, à la distancia de un pié cuando mas. Yo permaneci inmósil; el colibri se posó entonces sobre una rama, alisó su jlumaje, limpió su pico para quitar la pelusilla que habia quedado, $y$ dirigióse despues à una roca cubierta de fino musgo, del cual arrancó lo suficiente para llenar su pico. Hecho esto volvió a su nido, en cuyas paredes trató de introducir el musgo, à la rez que redondeaba la cavidad, volviéndose a todos lados y apoyando el pecho. Mi presencia no la inquietaba, pero al fin emprendió el vuelo, y yo tambien me alejé del sitio. Volvi el $S$ de abril; el nido estaba acabado y contenia dos huevos El 1." de majo envié un hombre para que me rrajese el nido fo la hembra; hallóla cubriendo; la cogió sin trabajo y me la presentó con el nido. Yo la puse en una jaula, pero parecia muy triste; abandonó los hucros, permaneció inmóvil en su percha, y of la mañana siguiente estaba mucrta.y

Audubon dice que la incubacion no dura mas de seis dins; que en una semana crecen los pequeños, y que durante otm mas les alimentan sus padres. Esto no me parece del todo exacto: algunos naturalistas nos aseguran que los pajjaros moscas nacen desnudos y ciegos; que son muy cudebles; que apenas pueden abrir el pico para recibir el alimento; que al dia siguiente de salir á luz se cubre su cuerpo de un plumon agrisado, y que las plumas del lomo salen mas tarde Scgun Burmeister, los pequeños dejan el cascaron á los diez y seis dias: abien los ojos quince despues, y toman su alimenio à las cuatro semanas. Hasta entonces permanecen en su nicio, que la bembra ensancha \& medida que los hijuelos crecen. lodos estos datos no parecen fundarse en observaciones per. sonales: pero no podria decirse lo mismo de los de Salvin, quue se expresa en los términos siguientes: Solo 1 la hembra in. cumbe el cuidado de criar $\mathrm{i}$ sus hijos, ó al menos, yo no he visto nunca al macho cerca del nido, ni sun en el jardin donde se lallaba. Cuando la hembra cubria se pnoia yasar cerca de ella, y hasta coger la rama en que se habia situado sin que emprendiese su vuelo; para esto era preciso, no obs. tante, que hiciese sol, pues si llovia ó hacia mal tiempo, no me era dado acercarme á mas de cinco pasos. Cuando espantaba $\{$ la hembra, permanecia yo á reces cerca del nido. es. perando su vuelta, y la veia siempre aparecer con una brizna de liquen, que fijaba por fuera desplies de instalarse a su gusto. El are hacia todo esto sin ningun temor aparente; hubiérase dicho que queria indicarme que se habia alejado solo para buscar el liquen y no por miedo. Los hijuelos recien nacidos ofrecian el aspecto de una pequera masa negra é informe, con un cuello largo ! un sudimento de pico; crecie. ron muy pronto y no tardaron en llenar el nido completamente. Desde aquel momento, jamás ví î la hembra apoyada en el pecho y sobre su progenic; los hijuelos quedaron aban. donados sin defensa á los rayos del sol y á la liuvia. Para

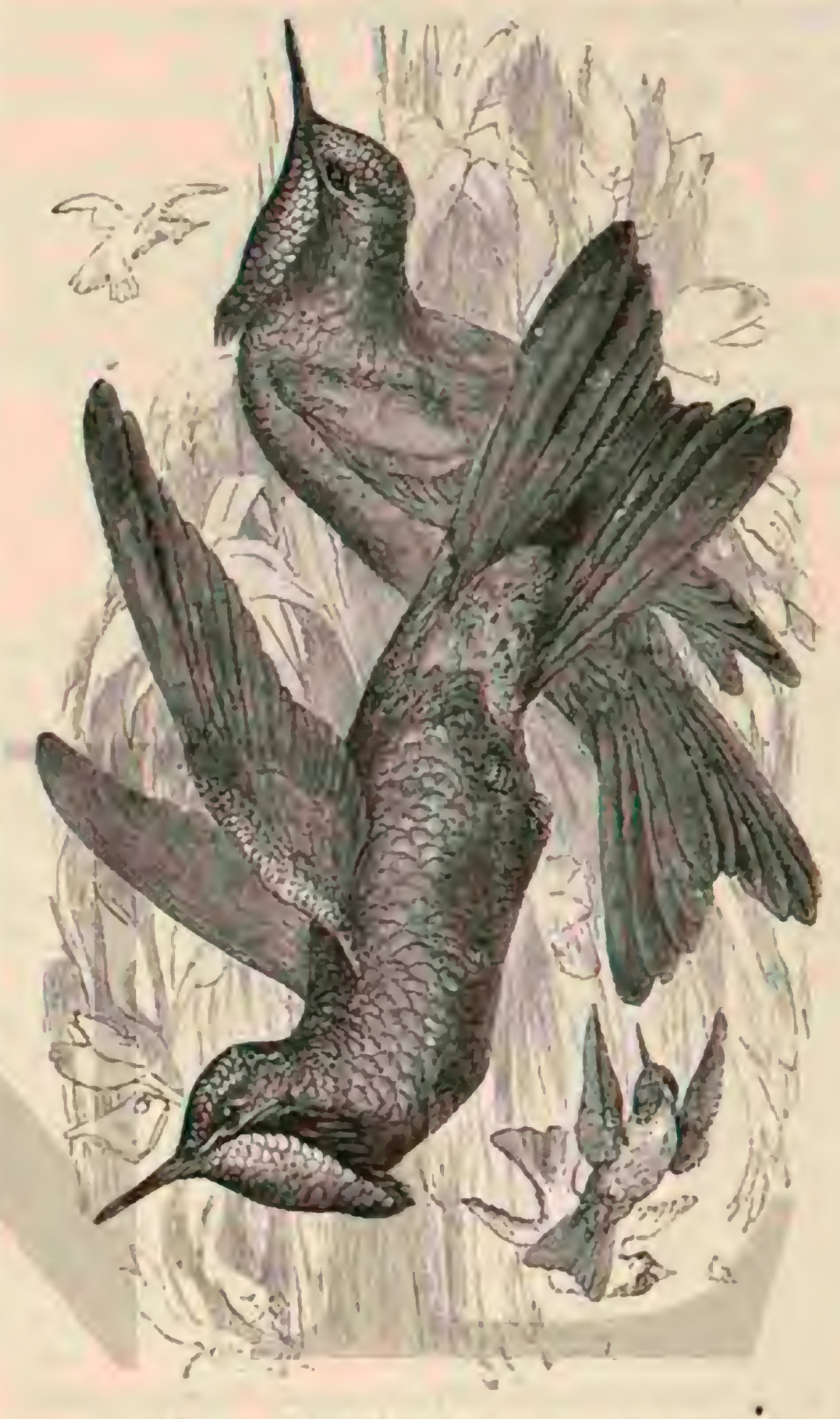

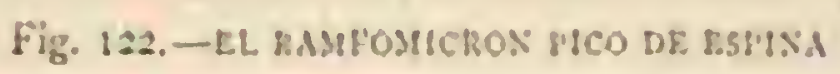

darles de comer se posaba la madre sobre el borde del nido, con el cuerpo muy levaniado. Uno de los pequenos empren. dió su vuelo el is de octubre; pero se cayó en medio de las Hores; yo le puse en el nido, y le abandonó á poco por se. gunda vez, aunque con mejor suerte. La misma tarde vi á la madre que le llevaba de comer; voló despues hicia o:ro àr. bol, y desapareció para siempre: el segundo hijuelo abandonó el nido dos dias mas tarde.

Ei principe de Wied ha hecho una singular observacion: vió en un nido dos pequeños complletamente desnudos de pluma, al rededor de los cuales hormigueaban tanios gusa. nos, que las aves estaban casi completaniente cubicras por cllos. IIgnoro, dice, cómo habrian llegado aquellas larras hasta alli; pero asegúrase que se las encuentra a menudo junto à los colibris pequeños. Burmeister cree que no son las aves mismas las que atraen los gusanos, y si sus excre. mentos, en cuyocaso serian necesarios para conservar la lim. pieza del nido; pero semejante explicacion no prueba nada, pues no podemos admitir que ciertos colibris limpien su albergue, ฤ qu:e otros dejen á sus hijuelos entre las inmun. 
dicias, como lo hace la abubilla. Por otra parte, no es tan comun como lo creen los brasileños encontrar gusanos en los nidos de colibri, toda vez que ningun observador re. ciente hace mencion del hecho.

Audubon ha observado que poco despues de emprender su vuelo se reunen los pequeños; y cree que viajan separa. dos de sus padres, pues ha visto con frecuencia reinte 6 treinta colibris jóvenes, en medio de los cuales iba un solo individuo adulto. No trataré de areriguar hasta qué punto es fundado este aserto.

Exceptuando cl hombre, los colibris no tienen apenas ene-

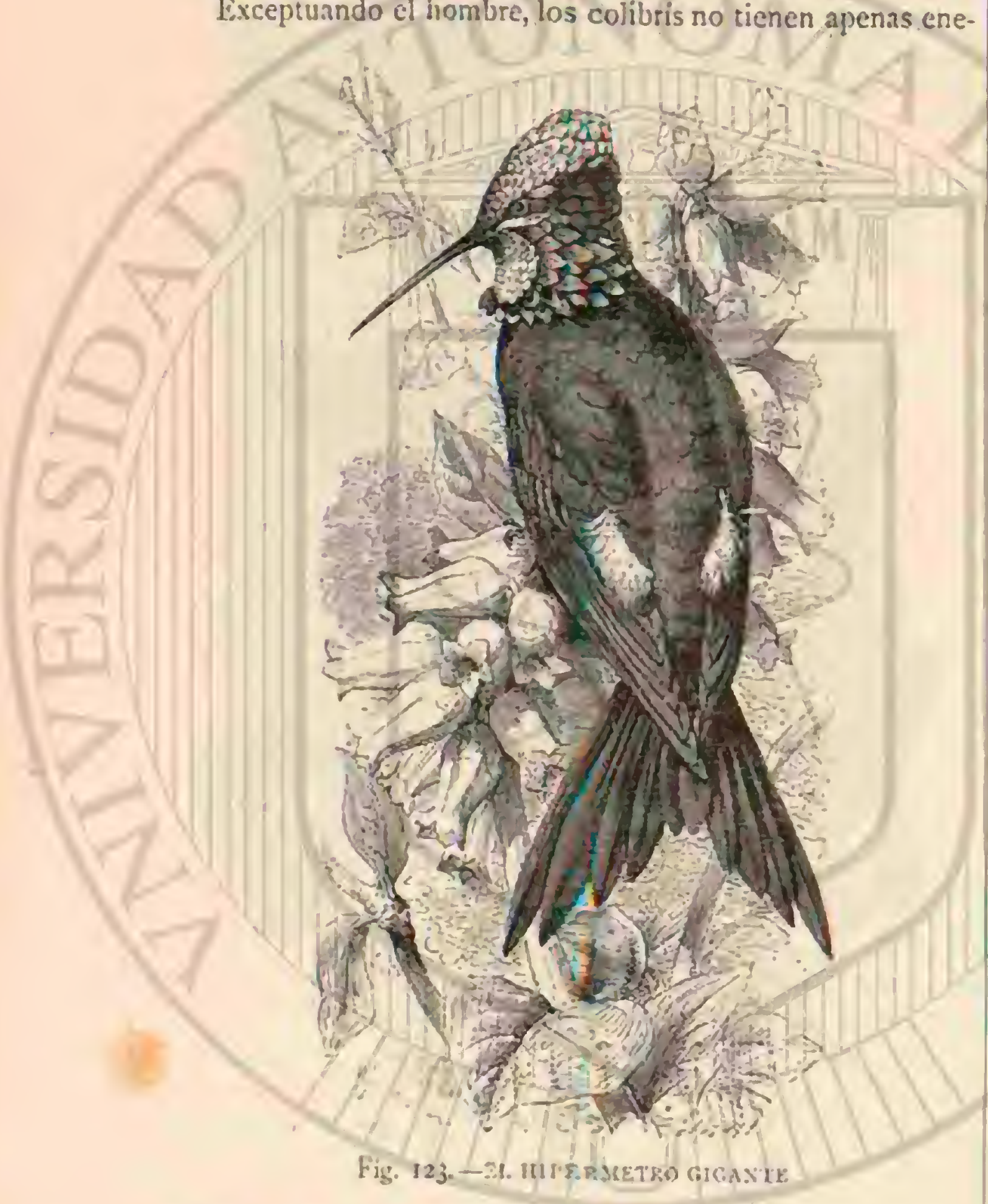

migos que temer; su agilidad les permite librarse de las aco metidas de las rapaces ó de los carniccros; pero las crias pueder ser presa de los que trepan ó de las aves que arrebatan los nidos. Esto explica el iuror con que los colibrís acometen â sus eremigos. A pesar de todo, pocos son los peli. gros que amenazan a estos preciosos séres, y prueba de ello es su número considerable, atendida su escasa multiplicacion. Debe advertirse, no obstante, que en otro tiempo se les suponian enemigos fábulosos, diciéndose entre otras co. sas que las grandes arañas los cogian en sus telas y les aho gaban. Lo que sabemos hoy acerca de las costumbres de estas ares, nos permite poner en duda las historias referidas por la señora Merian y Palisot de Beauvois, aunque admiti remos que seria posible que un colibri pequeño quedase co gido en la rela de una gran araña y fuera devorado por el insecto. De todos modos, estas aves no son tan torpes como los dos pequehos pinzones que Bates encontro un dia cogidos en una tela de arana: conocen el peligro, segun lo prueban las observaciones de Bullock, y saben evitarle perfectamente.

CAZA. - A su gracia y belleza deben los colibris e! ajuecio de los americanos, que no les dan cazn sino cuando al gun coleccionista europeo necesita individuos.
En los antiguos relatos de viajeros se dice que se puede tirar a estas aves con arena ó con agua; Audubon hizo la prueba y vió que si se carga la escopeta con el liquido, se ensucia el arma sin conseguir el objeto. Conso quiera que sea, la caza de estas aves no ofrece la menor dificultad: con perdigon menudo se puede matar muy bien un colibri, bastando ponerse al acecho cerca de un árbol en fior, y elegir bien el momento para tirar. Resulta de aqui que en una ma. hana se pueden cazar tantos como se quiera; pero tambien es verdad, que una ver muerto cl colibri no puede ser útil sino para el naturalista. Huyeron ya aquellos tiempos en que los nobles mexicanos adornaban sus trajes con los despojos del pajaro mosca; hoy dia, por lo menos en la América del sur, estas aves no sirven ya para engalanarse.

CA UTIVIDAD. - Tenemos varias observaciones sobre ha vida de los colibris en cautividad, y como el objeto es de interés general doy á conocerá continuacion las masimportantes.

\&Ciertas personas, refiere Azara, han tenido individuos cautivos: don Pedro Melo, gobernador del Paraguay, poseyó algunos durante unos cuatro meses; rolaban libremente por I. habitacion; aprendieron muy pronto á conocer á su amo: acariciábanle, y volaban al rededor de él para que les dicse alimento. Melo cogia entonces un vaso de jarabe, y los coli. bris humedecian én él su lengua; de vez, en cuando les daba Hores; $y$ de este modo estaban aquellas encantadoras ares tan alegres como en libertad: perecieron por descuido de un criado.

*Muchas personas, dice Wilson, han intentado criar \& es. tas arecillas y acostumbrarlas a la cauividad: Coffer, que ha estudiado muy detenidamente las costumbres de nuestros colibris indigenas, me refirió que habia conservado durante varios meses dos colibris en una jaula, alimentándolos con miel desleida en agua. Esie liquido atraia á las moscas peque has, que eran cazadas ávidamente por las avecillas. Pcale rrió dos pájaros moscas, que volaban libremente por la habi. tacion c iban à posarse en el hombro de su amo cuando tenian gana de comer: al penetmr el sol en el cuarto cogian pequenos insectos, como hacen los papamoscas.

- En ISo $_{3}$ me trajeron un nido con pequeños, que estaban a punto de volar: uno se dirigió á la ventana y se mató; el otro no quiso comer, y al dia siguiente estaba moribundo. Cogióle una señora, le guardó en su seno, y para alimentarle desleia azúcar en su boca, haciéndosela tragar. Asi le crió hasta que se le pudo poner en jaula, y yo le conservé mas de tres meses, dándole agua con azúcar y todos los jugos de las Rores frescas. Era alegre y vivaz y estaba lleno de vida; vo. laba de for en flor, como en libertad, y cuando le llevaban algunas recientes, manifestaba su alegria con sus movimien. tos y silbidos. Adopté todas las precauciones necesarias para poderle conservar durante el invierno; pero desgraciada. mente, escapóse de la jaula, voló por el cuarto, se infirió una herida y murió.

هe llegado à iener enjaulados, dice Bullock, hasta serenta colibris, que conservé varias semanas á merced de ciertos cuidados, y no dudo que si hubiese podido consagrarles todo mi tiempo, los hubiera llevado vivos á Europa. No son salvajes 6 indomables, como se ha dicho, ni es cierto tampoco que se maien ellos mismos en cautividad: muy léjos de ello, ninguna ave se resigna tan fácilmente con su suerte. Jamás se precipitan contra las varillas de su jaula ó las ventanas; permanecen en el aire, ocupando un espacio apenas suficiente para mover las alas, y están horas enteras inmóviles, al parecer. En cada jaula ponia un rasito medio lleno de agua con azúcar, muy concentrada, y en él colocaba flores, que eran risitadas continuamente por mis diminutos cautivos. 
b la sabemos que los colibris en libertad son muy penden. cieros: pero jamás los he visto pelear cuando estan cautivos; antes por el contrario, los pequeños se permiticron muchas familiaridades con los grandes; postbanse en su pico, por cjemplo, y permanecian sobre él varios minutos sin ser ahtu. yentados.

«Hil z.j de febrero, refiere Bumeister, Bercheste me envio un colibri (aggrtrica althirallis), que era muy virar y volaba al rededor de mi habitacion: sus movimientos eran tan rápidos como cuando vivia libre; lanzábase con fuerza contra las pa. redes y rentanas, cayendo al suelo aturdido. Busqué una rama florida ý se la presenté; acudió al momenio, y volando alegremente al rededor de las flores, hundia su lengua en el interior de las corolas. Aunque apenas me hallaba a dos pasos de distancia, no daba senales de temor mientras yo permanecia quieto, mas apenas me movia, alejábase volando. A la caida de la tarde pareció mas tranquila, y acabó por caer I tierra sin fucrzas. Pude cogerle sin que se moviese; sus ojos estaban abiertos y llenos ce vida; latia 54 corazon vio. lentamente; apoyabase sobre sus alas medio abiertas, y para que descansase le coloqué sobre un almohadon muy blando: al dia siguiente le encontré muerto en la misma posicion: habiase dormido para no despertar mas.

Todos estos relatos, no obstante, son muy incompletos al lado del de Crosse Al abandonar Inglaterra, dice este au. 10:, ine prometi trner vivas a Europa algunas de estas pre. ciosas aves, si me era posible; varias observaciones que hice en cl colibri de capucha me indujeron à creer que esta espe. cie se prestaria mejor á la realizacion de ini deseo. Mis es peranzas, no obstante, quedaron frustradas; pero en cambio tuve ocasion de observar perfectamente los usos y costum. bres de estas aves. Cogi muclias con el auxilio de mis cria. dos, valiendome de una red para mariposas, pues los otros aparatos descritos por ciertos naturalistas me parecen mejor en tcoria que para la práctica. Con frecuencia observé que en estas aves predomina la curiosidad sobrc la timidez: pre. paraba mi red, y léjos de huir, alargaban el cuello para exa. minar aquel objeto desconocido, con lo cual me facilitaban su capiura; si se cscapaba alguna, rolvia hácia mi, y sosteniéndose en el aire sobre mi cabeza, contemplábame con una confianza increible. Pero si era fácil coger estas ares, no sucedia lo mismo cuando se trataba de llevarlas a casa, pues perecian comunmente-antes de llegar, aunque no estuviesen heridas, $y$ las que se conservaban en buena salud aparente morian por lo regular al otro dia. Al principio me apresuraba a ponerlas en jaula; pero perecian siemprc; caian de repente al suelo y permanecian inmóviles con los ojos cermdos; si se les cogin con la mano parecinn recobrar la vida por algunos instantes, echiaban la cabera hàcia atrás, agitabanla à derecha é izquierda, como aquejadas por el dolor, extendian las alas, abrian los ojos, erizaban las plumas del pecho, y morian sin convuisiones. Tales fueron los resultados de mis prineras tentativas.

- En el otoño cogi dos machos jóvenes y los puse, no en una jaula, sino en mi habitacion, cuidando antes de cerrar puertas y ventanas. Eran muy vivos s nada salvajes; gustábales juguetear; se mostraban confiados conmigo; sin temor alguno posábanse sobre mi dedo. Cuando les lleré fiores las examinaron al punto, y no tardé en reconocer que despre. ciaban algunas de ellas para registrar las oiras con gran cuidado. Desdé entonces busqué bastante numero de las que preferian, y tuve el gusto de ver cómo las examinaban mien. tras vo ienia el ramo en la mano, volando a una pulgada de mi semblante. Puse las fores en varios rasos, $y$ entoncers comenzaron á registrarlas todas sucesiraniente; de rez en cuando retozaban entre si, 6 posábanse sobre diversos ohje. tos. Se acercaban á la ventana, mas no para volar: mientras permanecian en el aire, oia yo con írecuencia el castantetco de su pico, siendo probable que lo produjeran en cl instante de atrapar algun pequerio insecto. Al cabo de algun ticmpo, uno de ellos cayó á tiersa en un rincon y murió, pero el segundo conservó toda su viveza. Temi que hubieran agotado el contenido de las flores, y en su consecuencia llene un va. sito de agua azucarada, que tape con un corcho, por el cual introduje el cañon de una pluma, y sobre este puse una gran flor cuyo tallo cortado llegaba al fondo. Aquello pareció agradar al colibri; estuvo algun tiempo delante del vasito, y cuando volo, el caion de la pluma quedaba vacio. Bien pronto volvió, aunquc habia quitado la flor, y en el trascurso del dia liegó à comprender perfectamente dónde encontraria aquel rucvo alimento. Al ponerse el sol, buscó un sitio para dormir; al dia siguiente conservaba toda su viveza, y apuró por completo su provision de agua azucarada. Algunas horas despues roló por una puerta, que tuve el descuido de no cerrar, y desapareció, con garan sentimiento mio.

\En el mes de abril otrus tres machos que obtuve pare. cicron acostumbrarse al inomento a su nueva momdin Uno de ellos divisó casi en seguida un vaso lleno de jarabe y bebió varias vecez; otro nurió, y los demás se domesticaron de tal modo, que antes de acabar el dia, volaba uno rozán. dome el rostro; posábase sobre mis labios $\delta$ mi barba, ह in. troducia su pico en mi boca para libar la saliva Llegó hasta ser importuno por tanto atrevimiento, pues hundia su lengua protractil entre mis encias y los dientes. Para atracrle me ponia un poco de jarabe en la boca, y llamaba al ave con un ligero grito, que aprendio a conocer muy pronto. Nio parecian atrnerle mucho las flores frescas; llevé à mi cuarto algunas de noringa, que son para estas aves las preferidas cuando viven libres; registrólas un instante y luego las aban. donó. Cada cual de mis colibris eligió su sitio en una cuerda que tendi á través de mi cuarto, y alli se posaba regularmente; además buscaron uno ó dos parajes cónodos para descansar algunos instantes. Si se les ahujentaba volvian siempre, con tanta regularidad como lo hacen cuando viven libres.

- El mas atrevido de mis colibris era muy Uatallador: aco. metia a cada momento i su companero, que mas pacifico, huia siempre; posábase despues, lanzando su grito de con. tento skris, pero al calo de dos ó tres dias, el vencido se cansó de aquella impertinencia. Quiso ser déspota a su vez, y no pernitió al otro colibri que se acercase al vaso donde estaba el jarabe. Veinte veces seguidas trató de aprosimarse; pero apenas llegaba y sacaba su lengua, caia el otro soure él con una rapidez increible y le ahujentaba. Fl vencido se re. fugiaba entonces en un riucon, y cada ver que intentaba acercarse de nuevo al vaso, renovabase la lucha. En cuanto al otro, bebia muy á su gusto; con el valor recobrúla $102, y$ lós dos individuos lanzaban su skr ris casi continuantente.

y Una ver. acostumbrados i su nueva moradn, manifesta. ron mis cautivos una viracidad sin igunl; tomaban las pos. turas mas diversas, volvianse de todos lados y dejaban rer todas las bellezas y variaciones de su plumaje bajo los dife. rentes juegos de luz. Volaban a derecha é izquicrda, balan. cetbanse en los aires de la manera mas graciosa, y ejecutaban todos sus movimientos con tal prontitud, que era impo. sible seguiries con la vista. Tan pronto en un lado como en otro, oíase de continuo el zumbido de sus alas invisibles, 6 bien rozaban el semblante del espectador antes de que este viera por dónde venia el ave.

* Hasta fines de mayo recibi unos veinticinco colibris mas, casi todos machos; los unos habian sido cazados con redes y los otras con liga. Apenas cogidos, los metian en una cesta: 
זcchos perecieron muy pronto, cosa que yo no me explico aier, pues aunque se posaban en las paredes internas de aczellas no se podian herir, siendo probable que la pena de resse cautivos les ocasionara la muerte. Varios de los que ase. presentaron estaban ya moribundos, y los mas de los otrus perecieron en las primeras veinticuatro horas. No ha. ciar caso alguno de las perclias donde se posaban sus com paeresos, y se daban golpes contra las paredes. Revoloteaban bastante tiempo delante de ellas; luego bajaban lentamente, agiando las alas, y caian al fin sin fuerzas, pero se levanta bar pronio para volar de nuevo junto á la pared: á veces

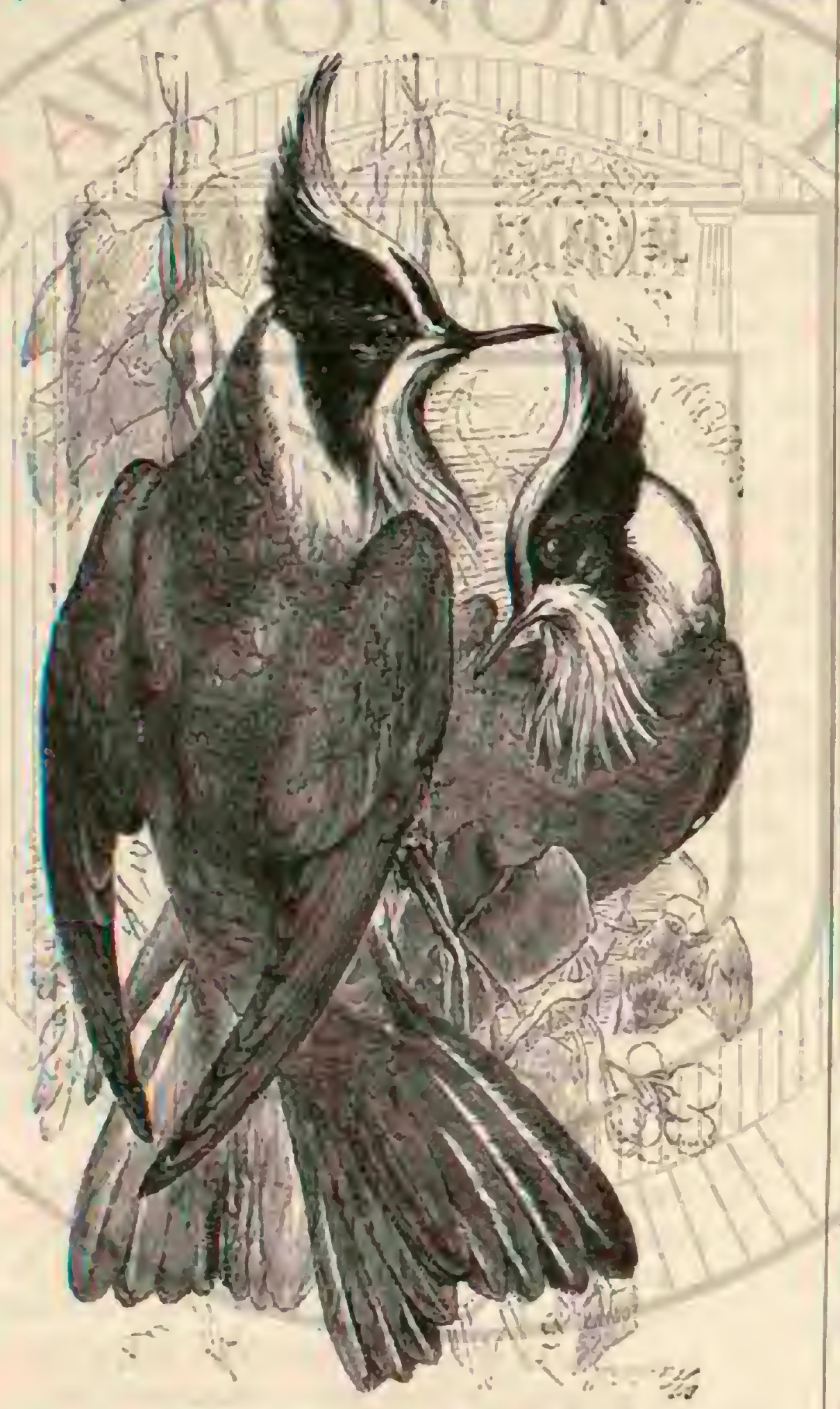

Fig. 124.-EL OXIFOCON Dะ LINDE.N

caian detrís de los cofres $\delta$ cajas que habia en la habita. cios s no teniendo alli espacio suficiente para remontarse, maren sin auxilio. Tal fué la suerte de muchos; asi es, que de los reinticinco colibris que me presentaron, solo pude consertar sicte.

3Debo advertir que estas aves difieren en cuanto al carác ter: i⿺s unas estaban tristes y melancólicas; otras manifesta. ban sucha timidez, y las demás mostrábause dóciles y alegres desds los primeros momentos de su cautividad.

Addopic un plan muy sencillo para acostumbrarlas i la habizicion y enscriarles el vaso que contenia el jarabe. Cuan. do se abria la cesta donde las llevaban, solian rolar hàcia el tecta, rara vez a la rentana; al cabo de pocos instantes co menzaban á rozar las paredes con el pecho ó el pico; y fijan do ta poco la atencion, era fácil reconocer cuảndo comenza ban á cansarse. En aquel momento, dejasbanse coger, por lo reguiar, ye les podia colocar sobre el dedo. Entonces me poris un poco de azúcar en la boca, E introducia su pico entre mis labios. Algunos comenzaban a chupar desde luego pero con mas frecuencia era preciso excitarles repetidamente, si bien se acostumbraban todos al poco tiempo. Conseguido esto, colocaba el colibri sobre la percha, y si tenia buen ca. raicter, quedábase en ella; despues le presentaba un vasolleno de jarabe, y bastábale probarlo una $\delta$ dos reces para saber buscarle luego, pudiéndose considerar ya como domesticado. A partir de aquel instante, el colibri no hacia ya mas que volar por la habitacion, descansando por momentos en su percha. A reces se perseguian dos individuos mutuamente: parecióme que lo hacian por divertirse; pero una observacion mas minuciosa me demostró que solo volaban para cazar in. sectos invisibles á nuestra vista; ì menudo oi cómo chasquea. ban su pico, y una ó dos veces observé q̨ue cogian moscas, bastante grandes para poderse ver. Por lo regular no volaban largo tiempo sin descansar un poco; solo franqueaban una distancia de dos piés, y volvian despues a su sitio, como lo hacen los papamoscas. Por lo demás, los colibris se pueden considerar como papamoscas muy perfectos; yo cal. culo, tomando las cifras mas bajas, que una de estas aves coge al menos ires insectos por minuto, casi sin interrupcion, desde las primeras horas de la mañana lasta la tarde. En el estado libre, sus cacerias, sobre todo las que practican de esta suerte, son tal vez menos fructuosas, y por eso se ali. mentan principalmente de los insectos pequeños que encuen. tran en el interior de las flores; pero sus movinientos en tales casos son los mismos que los del colibri crutivo. Mis ares volaban tambien af veces junto \& las paredes $y$ recogian las moscas prendidas en las telas de araña.

- Su manera de beber era muy curiosa: no rolaban direc. tamente hácia el vaso del jarabe, sino que describian sobre el de doce á yeinte vueltas en espiral, una mas baja que la otra; bebian con frecuencia, pero muy poco á la vez, lo cual no era obstáculo para que cinco individuos apurasen en un dia un cortadillo; sus excrementos eran líquidos y de la mis. ma consistencia que el jarabe que bebian.

* Hasta una hora bastante avanzada de la tarde no se en. tregaban al descanso; á la del crepúsculo seguian cazando todavia; y ni aun por la noche estaban tranquilos, bastando la menor cosa para excitarlos. Si se ertraba en la habitacion con una luz, despertábanse uno ó dos; parecian entonces tan salvajes como en el momento de cogerlos en el campo; ro. laban contra la pared, y si no se tenia cuidado, morianse de miedo.

2Una vez acostumbrados mis colibris á su habitacion. puse cinco en una gran jaula, uno de cuyos.lados estaba provisto de una red metálica. Inspirábame algun temor este cambio, y por lo mismo no hice la prueba hasta la tarde, esperando que la noche los calmaria. Antes de esto, habiales acostumbrado poco a poco ś ir á beber jarabe á la jaula, de modo que no debia ser para ellos un albergue desconocido. Cuando cerré la puctecilla revolotearon un poco por todos lados; pero al dia siguiente tuve el gusto de verlos a todos posados en sus perchas, y bebiendo en el vasito del jarabe. Poco des. pues iniroduje en la jaula otros dos machos, y mas tarde una hembra: al otro dia se habia acercado esta á un colibri de larga cola, que ocupaba él solo una de las perchas, y esforzá. base por despertar su amor. Saltaba sobre el palito tan cerca del macho, que le tocaba siempre; provocábale con sus juegos, agitaba las alas, volaba por encima de el, y hacia ademan de posarse sobre su lomo. Con gran sentimiento m:o, el macho

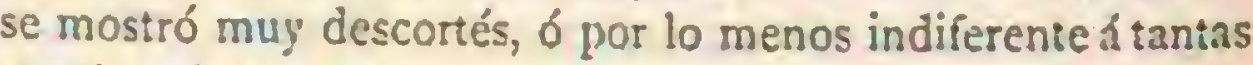
pruebas de ternura.

Esperaba poder llevar mis colibris á Inglatern, y creique estaban rencidas las mayores dificultades: pero mis ilusiones debian desvanecerse. Apenas habian estado una semana en jaula, comenzaron las desgracias: perdi dos cada dia; a la se. 
mana siguiente, solo me quedaba un individuo, y aun este debia seguir bien pronto la suerte de sus companieros. Pro. curé adquirir mas, aunq̨ue inútilmente, pues habia pasado ya Ia estacion de la caza. In imposibilidad de hallar bastante número de insectos lué, á no dudarlo, causa de la muerte de mis cautivos: bebian jarabe; pero esto no bastaba jara con. servarlos. Todos muricron muy enfiaquecidos, y su estómago estaba tan acorchndo que apenas se podia reconocer: en una habitacion habiian podido cazar algunos insectos; $\mathrm{en}$ una estrecha jaula no tuvicron ya este recurso. o

Yarsell cree que seria posible acostumbrar a los colibris prequerios quce se cogen en el nido á que se alimentaran con jarabe: al decir esto solo prueba una cosa, y es yue no ha visto nunca individuos vivos. A los perros se les puede nutrir algun tiempo con azúcar; pero solo se consigue con esto pre. pararlos para la muerte. A mí no me cabe duda que es completamente imposible conservar colibris sin darles mas que miel y azúcar, aunque se les podria acostumirar a otro régimen.

Al principio seria necesario darles larvas de hormiga, que se reemplazarian mas arde con bircorho meaclado co: yena de hucro; para hacérselo comer seria preciso recurrir al medio indicado por Gosse; en rerano convendria darles hores frescas, De este modo creo que se podrian traer colibris vivos â Eurogna, y conservarlos, por lo menos algun tiempo. El experimento de Gould viene i probar la posibilidad de lu que ahora digo.

₹.Mis colibris de América, dice este autor, estaban muy domesticados: los ienia en una jaula de doce pulgadas de largo por siete de ancho, y ocho de altura; en el interior habia una ramita de árbol de la que pendia un írasco de vidrio, el cual llenaba yo todos los dias de jarabe y yema de huevo. Este alimento parecia convenir perfectamente á mis cautivos, al menos mientras recortiamos la costa de América, y cuando atravesábamos el Atlantico; mas apenas hubieron de sufrir la influencia del clima de Europara, y al llegar á la altura de la costa occidental de Irlanda, presentaron sintomas irrecusa. bles de extenuacion, y no se recobraron mas. Consegui, no obstante, llevar uno vivo á lóndres; pero murio al siguiente dia de su llegada.

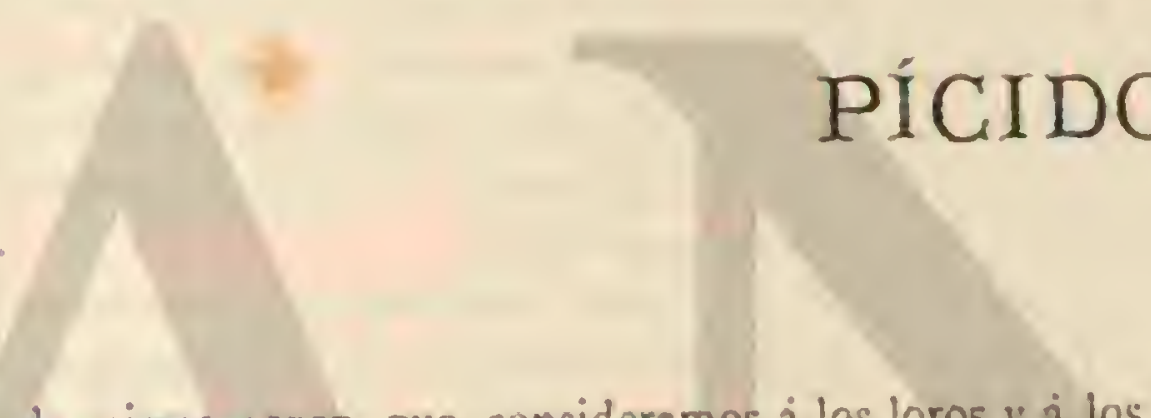

Por la misma razon que consideramos a los loros y a los colibris como ordenes especiales, formaremos tambien otro indeprendiente con la generalidad de los picidos. La mayor parte de los ornitólogos no son de este parecer, jues agrupan los loros con los pícidos y una gran parte de los levirostros; si bien parece que la opinion de que los loros, picidos y cucú. lidos tienen poco de comun ra ganando cada vez mas y mas terreno. Fin efecto, los picidos forman un grupo tan distinto de-los dentis, que no creemos incurrir en error al clevar este grupo al rango de órden. Si los examinamos de cerca, los pícidos ofrecen una estructura tan especial, jp por lo tanto un género de vida tan diferente, que no pueden clasificarse con otras aves trepadoras.

CARACTÉRES. - Los pícidos tienen el cuerpo prolongado; el pico fuerte, recto: cónico, de arista dorsal aguda y punta acerada; las patas cortas, robustas y vuclias liacia den. tro; los dedos largos y opuestos dos a dos, con los dos anterio res soldados éntre si, hasta la mitad de su primera falange. Fon estas aves, el dedo anterior externo, que es el mas largo, estả inclinado hácia atrás, y situado junto al verdadero dedo pos. terior, mucho mas pequeno que el otro, pudiendo suceder que este sea rudimentario, en cuyo caso solo tienen tres dedos, provistos todos de unas muy grandes, iuertes, aceradas encorvidas en semicirculo l.as alas, de mediana cextension y un poco redondeadas, tienen las diez remiges primarias angostas y puntingudas; las nueve ó doce secundarias mas anchas, y un poco mas cortas; la primera rémige es muy peque ña, la segunda meciana, $y$ la tercera ó la cuarta mas larya que las otras. Ia cola se compone de rectrices mny fiexibles y elåsticas, de bardas apretadas, aglutiradas entre si en su mitad basilar, con barbas mas espests, libres en su mitad terminal, é inclinadas hacia abajo, de manera que comunican
A la pluma el aspecto de un tejadillo, representando el tallo la arista. Debajo está la segunda rectriz media, cuya confor. macion es la misma; y mas inferiormente se halla la tercera: a esta útima se parece la cuarta rectriz de cada lado; pero la quinta presenta la forma ordinaria de estas plumas, y la sexta tiene una estructura particular.

En el plumaje inlta casi del todo el plumon, y de consiguiente uredominan las plumas exteriores, que se distinguen por su escaso tallo; son pequcinas en la cabera, ovales y prolon. gadas a menudo en forma de mono. divididas á manera de cahellera y mux espesas; en el ironco son anchas, cortas y escasas, dispuestas en varias placas, entre las cuales la mas notable es la que casi siempre se extiende sin division alguna hasta los omoplatos, donde a menudo forma dos campos laterales Una de las placas ocupa por lo regular el centro de los hombros: cesde in base del frico hasta el nccipucio corre una linea desprovista de plumas.

En inedio de todas las variaciones de plumaje, manifiéstase ell clerta uniformidad: los sexos se disinguen generaimente por la coloracion de la cabeza Mrjor que en toda orn limi. lia, es posible dividir los picidos en varios grupos, segun su color; siendo ya antigua y conocida la clasificacion en picos negros, verdes, abigarrados, etc.

l.os órganos internos de estas aves presentan tantas partiCularidades como los cxternos. El esqueleto es de graciosa forma el cráneo de samaño regular; la coronilla muy aboredada; descle los huesos nasales corre por ambos lados há cia atras una especie de faja, en cuya parte exterior hay un surco que recoge las extremidades del liueso de la lengua; el cartilago de las órbitas solo presenta una nbertura el es. fenoides se compone de dos huesecitos colocados uno junio a otro $b$ separaitos. el palatino se estrecha en ambos lados 
hácia atrás hasta la articulacion del esfenoides, y por delante esti soldado con los maxilares superiores; el hueso cuadrado es en extremo corto. Los omoplatos son cortos y se ensan. chan en su extremidad en forma de lóbulos; la liorquilla es endeble; las claviculas miy iuertes; el esternon mas ancho por detrás que por delante, y con prof́ndas escotaduras en los lados; su quilla es apenas deprimida en el borde externo.

Cuéntanse doce vértebras cervicales, siete ú ocho dorsales y ocho caudales; la última es muy grande y fuerte; su super. ficie superior, en extremo ancha, provista de apófisis espino. sas largas y fuertes.

La lengua mérece njjar uuestra atencion: es pequenia, cór nea, muy af́lada, y provista ch cada uno de sus bordes de cinco 6 seis sedas ó aguijones, cortos y rigidos, que se incli. nan hácia arrás como los ganchos de la punta de una flecha (iggura 125). \&sta pequeña lengua, cice Hurmeister, se inserta en un hueso hioides, recto, del largo del pico, y del cual parten, dirigiéndose hácia atrás, dos apúfisis, compuesta cada una de dos piezas que tienen doble longitud de la del ccierpo del huseso. El hioides estíl encermado en un estuche élástico cubierio de papilas, y oculio en la boca, asemeján. dosé an resoric ó muelle susceptible de extenderse en linea recta. Cuanco el ave descansa, lós dos cuernos del hueso hioides roduan el occipucio y se dirigen hicia la frente, donde se trasforman en subcutineos; sus extremidades llegan á la vaina córnea del pico, prasan de las fosas nasales y se alo. jan en una canal especial. Si el are saca la lengua, descienden i la vaina elística del hueso hioides, saliendo asi aquella del pico yarias pulgadas 1 ^ esta conformacion del aparato lingual corresponde un desarrollo considerable de un par de glándulas mucosas, qৃue se cextiendein a los lados de la man. dibula inferior, hasta por debajo del conducto auditivo, y segregan un línuido viscoso que humedece la lengua: disposicion análoga à la que presentan los hormigueros. Los picidos carecen de buche; su ventriculo subcenturiadoes largo y el estómago musculoso. Ios ciegos faltan ó son rudimenta. rios, en cambio existe la vesícula biliar.

Fis evidente que con tales órganos estin conformados los picidos admirablemente para ciertos actos, Sus aceradas uñas se cogen a úna superficie ancina, pernititéndoles sostenerse sin trabajo en tróncos verticales; y st cola les sirve de apoyo, impidiéndoles deslizarse ó escurrirse. No solo las extremidaces de las ocho grandes rectrices, sino las de todas las otras plumas y las barbas de las tres rectrices medias de cada lado, se aplican contra el tronco, y hallan en la menor desigualdad un punto de apoyo excelente. El pico, vigornso y cortante, es muy á propósito para partir la corteza; la cola sirve a la vez de palanca y de resorte La lengua puede penetrar en los mas estrechos agujeros, y gracias á su movilidad, le es dado seguir rodos los contornos de la galeria que recorre un insecto.

DISTRIBUCION GEOGRAFICA.-LOS picidos estin representados en todas las partes de la tierra excepto en la Nueva Holanda, la Oceania y Madagascar. Segun Gloger, su número aumenta en razon directa de la extension que ocu. jan los bosques. Ha área de dispersion de una especie es bastante limitada: los continentes y aun en ellos sus diversas comarcas poscen no solo especies sino tambien géneros y aun tribus propins; una misma especie puede encontrarse en Asia y en Europa: pero las del antiguo continente difieren de las del Nuevo Mundo.

USOS, COSTUMBRES Y REGIMEN.-Las enormes selvas virgenes de los paises tropicales, g particularmente de las Indias y de la América del sur, representan para estas aves un verdadero paraiso. El Aírica alimenia pocas especies, y casi todas de penqueña talla: en los bosques del Brasil figu. ran los picidos en el número de las ares mas comunes y extendidas.

\& En todas partes, dice el principe de llied, encuentran troncos de árboles carcomidos; por do quiera ha!lan en abun. dancia los insectos que les sirven de pasto. En el centro del Brasil, alli donde ninguna voz humana interrumpe el silencio del desierto, se puede tener la seguridad de oir resonar el grito de alguna de estas aves; pero no es solo en las selvas virgenes donde están confiuadas; animan tambien los bosque cillos, los matorrales y hasta los lugares descubiertos.l

Dificil seria explicar el por qué no existen los picos en cicros cantones.

Gloger suprone que evitan los árboles de corteza sólida y madera dura; pero esto no armoniza con el hecho que seriala. mos, toda rez que en los bosques de aquellos paises existen muchos śrboles que no llenan tales condiciones, y jor oira parte, hay trepadores que, mas aun que los picos, tienen una órganizacion poco á propósito, al parecer, para vivir en los árboles de madera dura.

In la Europa cintral frecuentan los bosques, plantios y jardines, pero siempre aislados, pues tambien son poco so. ciables con sus semejantes. Sin embargo, se les encuentra á veces en companiá de otras pequeñas aves del bosque, a las cuales sirven entonces de guia; pero muy raras veces se les ve reinidos con atros de su órden ó de su familia. Puede suceder, no obstante, que se hallen en un mismo ảrbol dos $\checkmark$ tres diferentes especies de picidos, mas no hacen aprecio una de otrn. Reunense, sin embargo, a menudo muchos in. dividuos de una o de varias especies, cuando hay abuncian. cia de alimento en cierto sitio; tambien se ven en la época de sus viajes numerosos grupos, y segun aseguran algunos observadores, grandes bandadas.

El área de dispersion de cada especie puede ser bastante limitada, ó por el contrario, muy extensa. Iass especies ale. manas con la única excepcion del pico menor, habitan en casi toda la Europa y tambien en el norte del Africa central; otras, en cambio, tienen una patria muy limitada. Cada con. tinente posee sus especies propias y hasta sus grupos, los cuales, sin emoargo, apenas representan géneros, y menos aun sub-familias, a causa de su gran uniformidad.

Ciertas condiciones mas ó menos uniformes farorecen la propagacion de algunas especies, como sucede en casi lodas las aves; los bosquues compuestos de varias clases de árbo?es aseguran la existencia de otras en un mismo ierritorio. Ios picos dependen mas que la maror parte de las aves de deter. minados árboles: cierto que varios de ellos anidan en los bosques de abetos asi como en los de árboles frondosos, pero prefieren siempre los unos y faltan del todo en regiones donde predominan los otros, ó por lo menos los visitan solo de paso.

Mas dependen aun de la naturaleza de los árboles por las condiciones que ofrecen para anidar; y aunque por esie concepto parezcan mas independientes que otras aves que anidan en huccos, puesto que ellas mismas los abren, no sucede asi. No todos los picos encuentran en un exienso bosque un árbol conveniente, como le necesitan para construir su nido, $y$ hé aqui porqué se alejan de muchos. Se sirven de los huccos, no solamente para la incubacion sino tambien para dornir, y por eso no les conviene habitar en un territo. rio muy exienso, pues todas las noches deben volver al centro del mismo, es decir, à su nido. En su consecuencia so!o visitan de paso los bosques que no les ofrecen la conveniencia necesaria, y no se les re en cllos ciertos meses del ano. Cuando cambian las condiciones, es decir, cuando un solo árbol adquiere las cualidades apetecibles para poder servir de nido, el hecho no pasa desapercibido para el ave, y la nis- 
ma especie que ialtaba hacia mas de cuarenta años, vuclve a presentarse, con gran alegria del observador. Solo asi se explica la disminucion de algunas especies 6 el aumento de otras en ciertas regiones vigiladas por expertos obsermiores.

Todos los picidos obserwan esencialmente el mismo género de vida: casi siempre estan trepando ó durmiendo; per. manecen cogidos a las paredes de su albergue en la misma postura que cuando están despiertos; rara vez bajan á tierra, y en caso de hacerlo, dan saltitos torpemente. No les gusta rolar a larga distancia, y no porijue tal ejercicio les fatigue, sino porque no pasan por delante de un árbol sin posarse, á lin de buscar los insectos (que puedan estar ocultos.

Los picidos describen una linea muy ondulada cuando vuelan: al remontarse aletean ruidosa y piecipitadamente; de pronto recogen las alas, dejándose caer oblicuamente para elevarse de nuevo. Al llegar cerca de un airbol, dirigense ha. ria el pié, se cogen al tronco y trepan rápidamente; á menudo suben trazando una espiral: rara vez avanzan por ramas horizontales; algunas veces bajan un poco por el tronco, pero siempre de espalda y nunca de cabeza, la cual inclinan muy hácia atrís, lo mismo que el cuello y e! pecho, cuando estan cogidos: al saltar parn remontarse, mueven la cabeza Su pico funciona à la vez como tijera ó martillo; con el ausilio de este órgano desprenden pedazos de corieza mas $\delta$ menos grandes, descubriendo asi los insectos en su retiro; los co. gen con su lengua ye los tragan.

No he podido explicarme aun bien cómo se verifica esto, á pesar de repetidas observaciones en individuos domestica. dos. Cuando se ticne un pico cautivo en una jaula de techo sólido y se periora este en diferentes sitios, poniendo encima algun alinento favorito, se podràn ver muj bien los movi. mientos de la lengua; pero por mas que el observador se es fucre en explicirselos, nunca obtendrá un conocimiento exacto; siempre quedan dudas. Puede suponerse desde luego que las ramas opuestas en la dura punta córnea de la lengua prestan sus servicios, extrayendo mas de una larva de su es. condite; pero absérrase tambien que objetos de alimento. por ejemplo larvas de hormiga, introduce al pico sin que el are se sirva para eso de la punta de la lengua. Esta última, que tiene la forma de un gusano, se alarga por el agujero del techo, dúblase y se vuelve con incomparable agilidad en to. das las direcciones, hasta que encuentra la larva de hormiga $\delta$ un gusano de harina. En muchos casos recogen la pressa traspasindola con la punta de la lengua; otras veces, sin em. bargo, se observan algunos movimientos serpentinos de aquella, y la larva desaparece con el órgano tan ripidanen. te, que no es posible ver si quedó pegada ó sujeta por medio de una circunvolucion. Gracias á esta ligereza y elasticidad de la lengua el pico puede recorrer con ella los agujeros mas laberinticos de un insecto que destruye la maderal, y sacarle dic su escondite para devorarlo. Por este concepto debemos considerar al ave como un guardabosque de primera clase.

La mayor parte de los picidos se alimentan con preferen. cia de varias clases de insectos en todos los estados de su desarrollo, pero principalmente de los que viven ocultos en los árboles, dentro ó debajo de la corteza, ó ya en la madera misma ; ajgunos comen tambien diferentes bayas! simientes y hasta recogen provisiones de estas últimas para el invierno. Se acusa a varias especies americanas de que en ciertos casos saquean algun nido de ave para derorar los huevos y la cria 6 alimentar con ellos a su progenie: y segun veremos des. pues, se ha dicho lo mismo de nuestras especies: los in formes que en este concepio se han ob:enido no parecen confirmados en manera alguna, $y$ aun deberain hacerse ob. servaciones exactas sobre el particular.
El carácter de los picidos es grave al parecer; pero alegre in realiuad. Esto lo demuestran todas las especies que se tienen en cautividad, domesticadas hasta el punto de haberse faniliarizado completamente con su ama El que los conoce no podra negar que son aves astutas, y el que los conserva mucho ilempo en cautividad, ya en la habitacion ó en la jaula, sabe tambien que tienen algo de grotesco. A d decir verdad, cscribe Liebe, no juede esperarse de ellos mucha finura; sus costumbres son las de los habitantes del bosque, de los carboneros, de los leiladores y otra gente de esta clase \$l la çue no se admite en los salones. Sin embargo, su modo de conducirse agrada inucho al que los mira sin preocupacion. Lo mismo debe decirse de los picidos en liberad. ¿Quién desearial ver nuestros bosques sin estos pequenos carpinteros? Su roz alegra ya al observador, y sobre todo sus gritos, tan semejantes $\alpha$ una carcajada; se oyen desdc muy léjos, asi en busques como en campos, y tan claramente revelan la alegria, que sin duda debemos contar a los picidos entre las aves mas favorecioias.

El rumor que producen con sus picos cuando se cuelgan de una rama seca para perforaria es muy particular, asemejándose en cierto modo al rogue de! tambor, al rechinar de! torno ó al ruido que hacen los carpinseros al dar golpes con el mazo. Segun el tamario de la rama, este ruicio es mas $\delta$ menos fuerte; pero sienure se oye á mucha distancia. Wiese supone que esta extruia música tiene relacion con cl tiempo, pues crec que los picidos pronostican como ningun otro sér los cambios de temperatura: ! anbien opina que pueden producir a reces el ruida para hacer salir los insectos de la rama: pero esto es sin duda errónco, pues todas las observa. ciones inducen i suponer que el macho ejecuta su tamborileo en honor de la heubra. No se sabe aun de cierto si esta expresa sus sentimientos lo mismo yue el macho; pero si es $\cos a$ averiguada que el pico excina con su tamborileo a los individiuos de su especie, los cunles acteden para aceptar la lucha l'ambien se sabe gque initando ese rumor se puede atraer á los picos. Esias aves se sirven, pues, en cierto modo de su órgano mas infuortante para expresar sus senti. micnios.

Los picidos anidan siempre en el agujero de un tronco de árbol del cual desprenden algunas astillas para formar una especie de leclio. Cacia puesta consta de tres a ocho huevos de color blanco puro, y lustroso, los cuales cubren aliernati. vamente el macho y la hembra. Fin el momento de nacer los hijuclos son hediondos $y$ apenas se asemejan en nada $\{$ los padres; trepan muy pronto, y aun antes de echar toda la pluma Cuando comienzan á volar, permanecen aun con sus jrogenitores algun tiempo: pero muy luego los ahuyenian. UTILIDAD. - Nunca se repeiríl bastante que los picos no pueden inenos de sernos útues y que no nos causan daño alguno. Bernstein es el primer naturalista que abogó por cllos, pues reperidas observaciones, durante varios anos, le permitieron reconocer que estas aves no rienen defectos los maturalistas posteriores han confirmadotal opinion, ya pesar de todo, existen hoy todavia personas bastante ignorantes para pretender que el pico perjudica á los árboles Koentig, autor de un smado de agricultura, ha ienido atrevimiento de formular semejante acusacion contra dichas aves.

Alium nu se deciara en faror de los adversarios de nues. ims ares; pero considerándolas bajo otro punto de vista, acusa á los picos primripalmente de tres cosas. En su opinion prerjuaican los bosques al externuinar las útiles hormigas, y al devorar las simientes; los agujeros yue practican en los árboles dan lugar á la prociuccion de setas destructoms; y pror viltimo, perjudican los árboles jơvenes al desconterarios.

Yo puedo aumentar aun esta lista de sus fechorias, añ- 
diendo nุez a reces causan dano cuando destruyen la madera podrida de las edificios o paredes; y tambien al visitar las colmenas, cras paredes perforan, derorando un considerable número dé las habitantes dornidos. 'lodas estas acusaciones no significas nada en comparacion con la gran utilidad que reportan a aestros bosılues y verjeles. Cierto que algumas especies, sctre todo el pico negro y el pico verde, se alimen. ian con fréerencia de hormigas ó de sus larvas, y á menudo casi exclusionente; tampoco se puede negar que otras, en particulir tzestro pico abigarrado, y quizis algunos que no pertenecen a nuestro continente, devoran muchas simientes cuando mat:an; pero las especies de hormigas abundan tanto en r..satos bosques, y los árboles producen cierios años tal cartiad de simientes, yue no podemos dar ninguna improrincia al daño causa do por este concepto. Sin descono. cer la utilida de las hormigas, creo sin embargo deber recordar que bs mas útiles de ellas, las gmandes especics silvesties, se seproducen al lado de los picos, y a pesar de ellos en todar los bosques que les ofrecen las condiciones necesarias para su existencia, sin contar que no se ha demos. trado aun en ninguna parte que los picos impioian el aumento de esos insectos. Confieso que en los puntos donde los pin. res tienen pocos àrbcles como en la provincia de Branden. burgo y en el norte de Alemania en general, el pico abigar. rado puede perjudicar la cosecha de los piniones: pero tambien sostengo sin vacilar que alli donde el pino alcanza su verda. dero desarrollo, todos los picos abigarrados del pais no po. drian perjudicar seriamente el producto de este árbol. Mucho mas caño hacen las ardillas, como dice muy bien Eugenio de Homeyar, y sin embargo, se perdonan todas sus fechorias á causa de su gracia. De menos consideracion es aun el daño que los picos causan por sus trabajos de carpintero. Iodos los guarda bosques y ornitólogos que examinaron agujeros de jicos están conformes connigo en que estas ares eligen solo para la construccion de su nido árboles cuyo interior está podrido aunque parezcan sanos por fuern. Es muy posible que alli donde escasean estos aiboles se vea al pico servirse de los troncos buenos de madera blanda, sobre todo

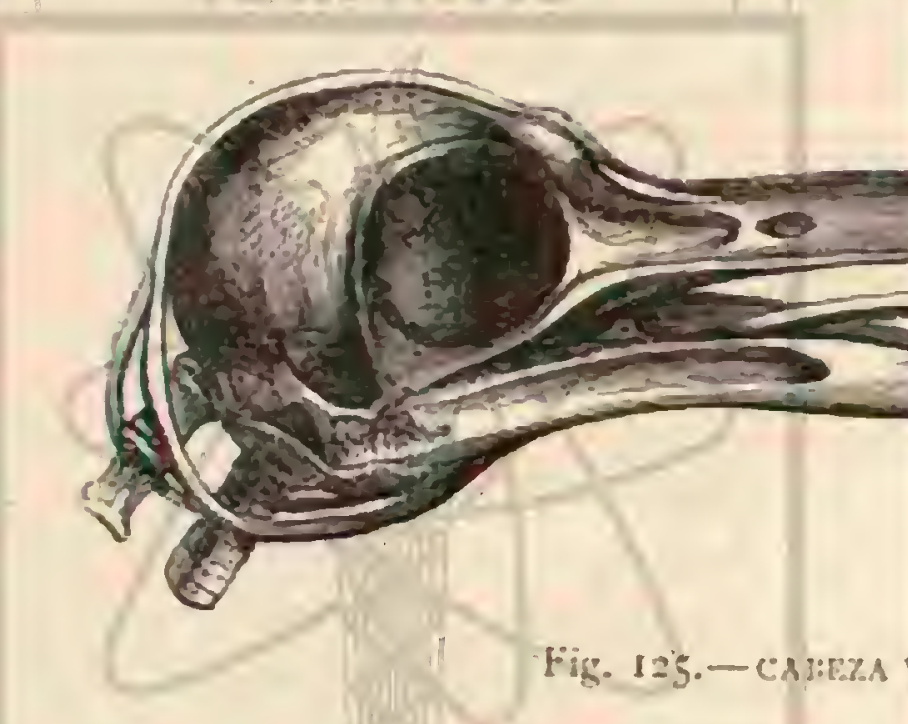

los halawos ó sauces: pero dunde quiera que abunden los otros como sucede for ejemplo, en algunas regiones de la Rusia ó de la Silveria el ave no toca los que están sanos. Fil pico no es la causa de que se pudran los arboles como dice Ho meyer; solo trdica los que están podridos. No he podido hacer hasta aboas observaciones propias en los arbolillos que los picos cescrezan, y joor lo tanto debo atencrme d lo que dice mi aprocole amigo Homeyer.

(Al examizer las diversas localidades no seri dificil en. contrar ciesto aumero de estos irboles, y podrin serinstruc. tivo para todos los que se dedican i-lá selvicultura formar una coleccion de fragmentos, pero no debemos esperar que se enclienirea ea todo bosque á docenas ó centenares. En la mayor parte \& los bosques de la Pomerania, mas alla del Oder, escasean mucho, y en el que yo poseo. cuya superficic es de unas 4 : hectareas, no he podido encontrar ni uno solo á pesar ce haberlos buscado hace muchos años. Puedc ser que en orro regiones suceda lo mismo con mas freciencia, y sobre tobes bastante probable que los picos elijan con preferencia paz sis trabajos las especies de árboles por elios desconocidas: jero los grandes daños de que habla Altum, son tan raros apenas pueden tener importancia para juzgar sobre lazilidad y los perjuicios ocasionados por estas ares. Si las pioas armincan la cortean de árboles sanos, y si repiten diariaorste la operacion en uno mismo, como lo hacen en ciecas sin tocar nunca los inmediatos, esto se debe sin duda ơ แaz cusa particular, y para averiguarla conven drá observas es is iuturo sin preocupaciones, sin contentarse con una explaracion insuficiente para dar por terminado todo exímen. La asunto de ciencia no se deben considerar nunca cromo rereltas las cuestiones dudosas; pero sea cual fuere la explicanesn que nos dernos del hecho, no se podrá demostrar que lis picos ocasionan un daño corsiderable en tos ârboles: pes iérmino medio apenas se encontrarie eutre miles de ellos uno descortezado por estas aves. En la mayo. ria de casos, el daño mismo es tan insignificanie que de ningun modo podria tomarse en consideracion.) Casi lo misno sucede con los destrozos que los picos causan en edificios: muy pocos son los picos que pueden pencirar en el interior de las casas de labranza, y es bien ficil ahuyentarlos cuando molestan. Por últimn, las fechorias de que el pico se hace culpable alguna vez en las colmenas, pueden evitarse sin dificultad: basta un poco de vigilancia.

Si se cxaminan concienzudamente, tanto la utilidad como los perjuicios que causa el pico, la sentencia no puede ser dudosa. Tal rez molesten algunas de estas aves al hombre egoista; quizás le causen tambien algun daño de poca monta, pero asi lo uno como lo otro está fuera de toda proporcion con la extraordinaria utilidad que nos reportan los picidos. H. que cree que solo devoran iusectos que causan pocos des. trozos en los bosques se convencerśs de to contrario cuando el nocivo bóstrico (Bustroikus siphegraphisus) se propaga en demasia: entonces acuden de todas partes los picos para ex terminar miles de insectos de esa dañna especie, que si bien es la mas destructora para el bosque, tiene en nuestra ave su mas encarnizacio enemigo. La utilidad que por esto reportan a nuestros bosques no puede calcularse ni siquiera aproxinuadamente.

Son útiles, no solo al destruir insectos nocivos, sino tam. bien indirectanente, como lo ha dicho muy bien Glogery Io ha repetido el guarda-bosque Wiese, puesto que los picos construyen los albergues donde anidan tantas aies útiles. Por desgracia, no se quiere creer que un árbol viejo y hueco que ha quedado en pić en el bosque, reporta mas beneficio dejándole para que sirva de refugio á las aves, que cortán. dole para leña Gioger asegura que en un año forma el pico ai menos una docena de albergues muy à propósito para utras esfrecies; y que cacia pareja de estus alados carpinteros, 
permitaseme la cxpresion, íbrica en cada primarera una nueva morada, sin utilizarse jamis de la antigua. listo no es del rodo cxacto, pues mi padre y yo hemos observado lo contrario; pero es prositivo que durante sus excursiones prac. tican los picos un agujero fara pasar la noche donde se quedan algun tiempo, y en este trabajo se reconoce cierio capricho. Comienzan por abrir un agujero que abandonan bien pronto sin concluirlo, pero le dejan basanic avanzado para que puedan alojarse otras aves: y por lo mismo, ne asocio enteramente å lis voros de Wiese, que pide se respete á los picos, conserwindolos todos, grandes y pequeños, negros, verdes y abigarrados, pues son huéspedes preciosos para los bosqnes lis verdad que descortezan los árboles; pero los daños yue puedan causar con estu no admiten parangon con los servicios que prestan. Lus progresos del cultivo disminuyern su reprodurcion, y no debe activarse su exterminio dándoles caza. Los árboles donde jueden fijarse escasean cada vez mas, y ya seria tiempo de conservar algunos para evitar

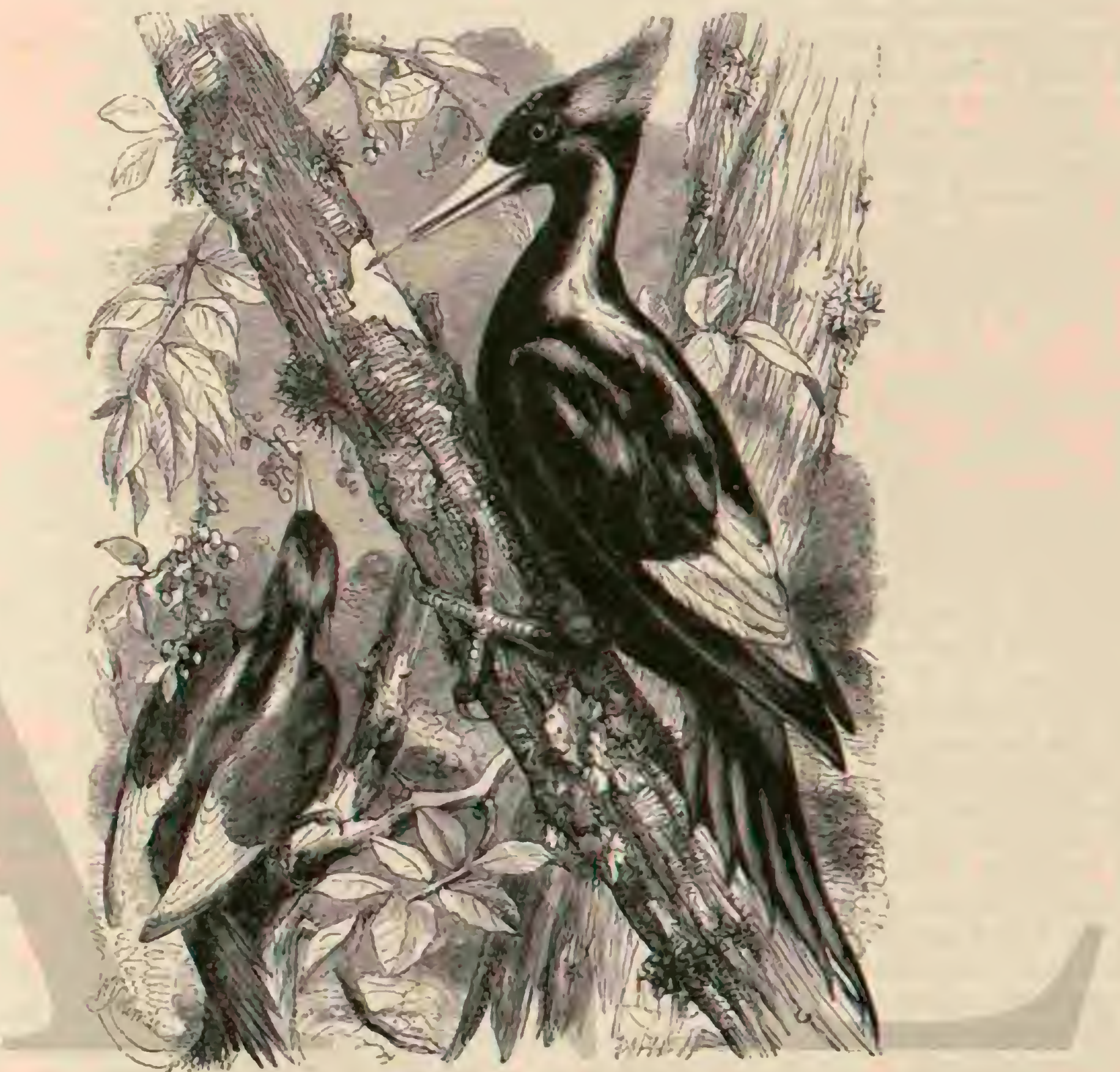

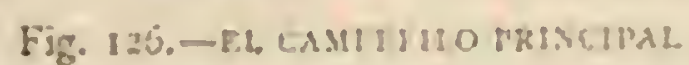

que los picos desaparezcan. Estoy seguro que los propietarios y guarda bosfiues no perderian nada en ello; por lo tanzo, préstese proteccion y amparo á estas aves, tas masui les é indispensables de todos los alados habitantes de nues tros bosques, pues tienen bastantes enenigos.

No solamente les persiguen los carniceros, unamiteros y seres alados, sino tambien los hombres ignorantes y sobre todo los cayadores de aficion. Por otra parte, hallanse cxpuestos a muchos accidentes: hace poco tiempo que Altum describió el sitio donde habian perecido muchas de es:as ares Al cortar un árbol viejo se encontró una cavidand de unos tres metros de largo por $(0)$, , po de ancho en forma de un pilon de azúcar invertido, cuyo lueco estaba en comuni. cacion con el exterior por dos agujeros, uno en el tucho $y$ otro practicado por los picos: el priner agujero se llenaba de agua despues de cada lluvia hasta la altura de $2^{\circ}, 30, y$ en 6 murieron muchos picos 5 esiorninos que por la noche habian buscado alli un albergue. El guarda-bosque Hochhaensler examinó minuciosamentc el hueco y enconiró ciento cinco craneos que aun no estaban del todo en esiado de putrefac. cion. Segun su cálculo, debian haber muerto todos los años al menos doce picos verdes. Muchos se libraron sin duda, del agua, pero los demás no prodrian escapar del elcmento tmidor.

Fil órden de los picidos se divide en dos familias, una de las cuales cuenta trescientas veinte especies y Ia otra solo cinco; la primera es la de los picos propiamente dichos.

\section{LOS PICOS-PICIDE}

Los omirólogos modernos har dividido esta familia en vatios arupos con el fango de sub-familias: In uniformidad del conjunto es sin embargo tan grande, que bien mirado solo pueden formarse dos sub.familias; pero tendre en cuenta la opinion comun y citaré las llamadas sub familias.

\section{LOS DRIOCÓPIDOS-DRYOCOPINAE}

CARACTERES. - Los driocópidos ó picos en cujo plu. maje domina el color negro, forman el primer grupo de los 
picidos, grupo que hasta se podria considerar como una fa. milia. Son los mas grandes y vigorosos de todos los picidos; predonina en ellos el color negro segun acabamos de decir, y muchas veces adorna su cabeza un moño.

DISTRIBUCION GEOGRÁ F́lCA.-Parece que la Amé. rica es su verdadera patria: se les encuentra en todas las zo. nas, al paso que no están represcntados en el aniguo conti. nente simo por una especie europea y. algunas indias.

\section{LOS DRIOCOPOS - DRYOCOPUS}

CARACTÉRES. - Esste gérero ofrecelos siguientes: pico mas largo que la cabeza, fuerte, y mas ancho que alto, de arista dorsal recta angulosa fas alas, ruva yuinta rémige es mas larga, ocuján los dos tercios de la cola, geue se prolonga bastante; los tarson- están cubiertos de plumas en casi toda su extension, y son mas largos que el dedo dei medio, ú dedo anterior externo, compréndida la แñ.

\section{EL DRIOCOPO NEGRO-DRYOCOPUS} MARTIUS

CARACTERES.-Esta ave, !amada tambien fico, negro por la mayor parte de los ornitologistas, idene el plumaje de di. cho color, pero maze. En el macho es de un tinte rojo carmesi la parte superior de la cabera, y la liembra tiene solo una parte del accipucio de dicho color. El ojo es amarillo oscuro de azutre; el pico gris perla, con la punta de un azul pizsrm, sin lustre las patas gris de plomo. Los hijuclos revisten casi el mismo plumaje que los padres El are riene de $0^{m}, .47$ á $0^{m}: 50$ de largo y, de $\left(1,72\right.$ a $0^{\star}, 75$ de punta á punta de ala; la ex. tension de la cola (1), 18 .

DISTRIBUCION GEOGRÁFICA.-Todas las regiones de Tiropa cubiertas de bosque y tambien el Asia, hasta la parte septentrional del Himilayn, son la patria del pico ne: gro. En Alemania habita actuaimente los Alpes y todas Ihs montanas eentrales, sobre todo el Boehmer Wald, Riesen gebirge, Erzgebirge, Fichtelgebirge, el Franken Whid, IIhue ringer Wald, el khon, el Harz, Spessert, Taunus, Ia Selv Negra y los Vosgos, pero kambien se halla en todos los bosques grandes de las llanums del Norte Borggreve designa el Eiba como limite occidental de su irea de dispersion en la Alemania del Norte: pero este dato carece de cxactitud. Vo mismo he recibido polluelos de los alredores de Celle, y tengo noticias fidedignas de la existencia del pico negro en el Oldenburgo meridional, es decir, mas alli aun del Weser. El referido autor solo cita de paso cl Thueringer, y precisa. mente aqui se han hecio las observaciones mas minuciosas sobre los usos y costumbres de! pico negro; aun ahora se en. cuentran estas ares alli con bastante rrecuencia. En el sud. oeste de Alemania, asi como en el este, el pico negro no falta en mingun bosque grande. Para diar noticiss exactas diré que el pico negro habita actualmente, segun Schalow, en todos los grandes bosques de la Marka aunque no abun da, y en los alrededores de Berlin. Ton Mererinck dice que se encuentran en la pradera de Scizlilgen, en la Selva de Rheinharty en todos los pinares de la Pomerania occidental. Eugenio von Homeyer señala como su residencia los bosques de la Pomerania mas allá del Oder: Wiese, todos los bos ques de ambas provincias de-prusia; - Alejandro von Home ger, el bosque de la ciudad de Goerlidz: y Liebe, los grandes bosques del distrito oricntal de Alicnburgo. Segun mis propias observaciones hallase tambien en los bosques ducales del distrito oriental de Altenburgo, y acemás, en escaso número, en toda la 'luringia. En Holanda no le han visto hasta ahora, al menos que yo sepa; en Inglaterra falta del todo, y tampoco visita el norte de Francia, porque no bay bosques a propósito para él. En cambio se cncuentra en el sur y este de aquel pais, asi como en las tres peninsulas me. ridionales de Europa. Sin embargo, en el sur escasea, \& pesar de que en la pendiente meridional de los Alpes se le ve en todas partes. Segun Lessoma y Salvador, abunda en el media dia del Tirol y de Suiza. Tambien vive en los Pirineos y en Espana, al meros en la sierra de Gundarrama; visita la Grecia: Krueper dice que frecuenta los bosquesy las montanas altas del Parnaso, Veluchi y Olimpo. Habita aciemás en todos los bosuques del Balkan, los Carparos y los Alpes de la Transilvania, y descle aqui se dirige hácia cl este de toda la Rusia, Siberia y el norte de la China; se le encuentra hasia en la isla de Sachalien y en el Japon. El circulo polar, por e] norte, y el 6z" en Asia, constituyen el limite de su árén de dispersion; por el mediodia no suele traspasar los linites indicados. No puedo decir si vive en el Ć́ucaso. Lo diclio por algunos ornitólogos antiguos de que el pico negro puede contarse entre las ares de la Persia parece inexacto, segun las averiguaciones de Blandfordy St. Iohn.

USOS, COSTUMBRES Y REGGLEN. - El pico negro necesita grandes bosques, poco visitados por el hombre y provistós al menos de algunos úrboles corpulentos y altos. Como su alimento iavorito es la gran hormiga, prefiere los bosques de ábetos, pinos, etc. à los árboles frondosos; pero no falta tampoco en estos. Cuanto mas salvaje es el bosque tanto mas le gusta; si está bien ordenado repuignale anidar en él, aungue tambien esta regla tiene sus excepciones. Los bosques altos de los. Alpes, ś causa de su situacion no se pireden ar. reglar con remularidad, y los vastos hosques de la Escandinavia, Rusia y Siberia, en los quie las tempestades y el fuego chusan mayores destrozos que il hombre, constituyen su morada favotita.

Asi en el norte como en el slir de Europa evita al hombre, y' solo execpcionalmente se acerca á las poblaciones. Sin en. bargo, reconoce tambien con agradecimienio la proteccion que se le dispensa y hasta familiarizase en cierto modo con las personas que le quieren bien. Segua me refiere Liebe, en la parte de la selva de los Francos, que pertenece al Princi. pado de Reuss, no solo se protege a estas aves por órden del principe, sino que tambien se las cuicla, conservando para ellas algunos árboles vicjos, solbre todo plátanos yabetos. I:n el solitario castillo de Taegersruch, siuado en medio del magnífico bosque antiguo, habiraba un guarda bosque que sabia llamar á los picos negros con un silbido perfectamente imitado; las aves acudian y alimentabalas sobre el techo de un establo con gusanos de harina, larvas, etc. El que conoce el pico sabrá que semejante familiaridad es muy rara: In misma ave que en casi todas partes huye timidamente del hoinbre, conoce al punto cuando se la protege y acércase en. tonces a las inmediaciones de crificios habitados.

El pico negro padece mas que todos sus congéneres por la escaser. de árboles propios para sus nidos y por eso no se le encuentra ya hoy dia en regiones donde antes abundaba. No hace mas de diezy ocho años que empollaba, segun Liebe, en los grandes bosques situados cerca de. Gera: jero aciualmente ha abandonado del todo esta regiun. Un solo arbol hueco basta para retenerle en cierta lccalidad; verotan luego como se corta este árbol emigra En cambio vuelve tan proniso como los árbôles han adquirido basiante fuema para que pueda construir un nido conveniente. Cerca de Riethendorf, mi pueblo natal, desapareció ya el pico negro, poco antes de! año $1 \$ 40$, de un bosque nue yo conorco muy bien desde mi juventud, y durante casi cuarenta años no se vió alli ningun individuo de la especie, ó cuando mas solo de paso. Hace ahora unos cinco años que ha vuelto al mismo 
bos ujue con gran contento mio, y en él hizo mi padre sus excelentes obsernaciones sobre el pico; los árboles lian lle. gado á la edad necesiria para que el ave pueda consiruir en ellos sus nidos.

Fin todos los bosques donde el pico negro anida, se le ve todos los aủos habitar la misma reducida localidad: seis kils. metros cuadrados le bastan para sus exigencias; pero la pareja que habita un distrito no tolera la presencia de otra, y hasta expulsa, como lo hacen todos los picidos, a los mismos pe. queños, que abligados á emigrar, vuelven a poblar los bosques donde habia sido exterminada la especie Al principio vaga la nucia pareja por una gran extension, jkto limitase mas ! mas con el tiempo, conteniandose a veces con un distrito de 100 a 150 lectarcess cuadradas de superficic.

Mi padre es el primero que ha trazado la descripcion exac ta de las costumbres del arc, y por él me guio al escribir las siguientes lineas, puesto que en los úlrimos sesenta años ape. nas se ha sabido algo de nuevo.

Esta are es muy ágil y alegre: pero timida y desconfiada al mismo tienıpo. Tan pronto está en un punto como en otro; en un instante recorre todo su dominio, y es läcil reconocerla, pues en algunos minutos se aje resonar su grito en varios sitios diferentes. Al volar pronuncia el sonido kirr kirr ó liluck kluck; cuando estri posada emite una sola silaba, fene. trante y lánguida, que se puecie imitar por kliha klibac klice: mientras está en su nido, produce otras wotas.

Su vuclo difiere mucho del de los demás picidos: no vuela por sacudidas; sube y baja alternativamente; traza una linca casi recta, algo onduladia; cnsancina mucho las alas, agitán. dolas con fucrza, y parece que las puntas se encorvan. Di. riase que vuela con mas facilidad que los otros picidos, 6 sin hatigarse santo, pues hace menos ruido, y solo produce un ligero frotamiento, que se oye principalmente, segun Nau. mann, cuando el tiempo es sombrio y húmedo. Iil vuclo no suele terer mucha extension; pero sucede en algunas ocasiones que el ave franiquea de una vez un espacio de dos ki. lómeiros, 6 mas.

Magnífico es el aspecio del pico negro cuando baja volan. do de la altura de la moniaña á uno de los valles profundios Eritonces demuestrn el ave todo el vigor de su vuelo, interrumpido solo en su rapidez por algunos ligeros aletazos que parecen tener mas bic:a por objeto alejarle en direccion horizontal de las copas de los arboles, que no elevarle otra veza la altura de uno de los arcos que traza en su vuelo. Cunndo mis amigos de la Carintia me acompaiaron à las Kiartivannkis, y cuando en la cumbre de la montaña contemplamos desde una casita el magnifico paisaje que se extendia á nuestros piés, vimas dos picos negros que lanzando grios de jú. bilo subian y bajaban por los aires, despiegando una agilidad en suruelo que nunca hubiera supuesto en estas aves.

En tierra da saltitos con torjeza, mas no pror esto deja de bajar à menudo para cazal hormigas. De todos los picidos de Luropa, el driocopo negro es el mas diestro para trepary desprender los fragmentos de corteza: al ejecuiar anquel ejercicio siempré pone las dos patas á la ree, como lo hacen los otros picidos: asi corre a lo largo del árbol, haciéndolo con tanta fiserza, que se ofe el ruido producido por sus uñas al tocar el tranco. Aparta el pecho del árbol por donde trepa, y echa al nismo tiempro el cuello hacia atrís. Dliméntase de grandes especies de hormigas, de las larras y de todos-tos insectos que existen en los pinares. He abierto varios, dice mi padre, y siempre hallé su estómago lleno de hormigas; les gustan sobre todo las larvas de las grandes avispas, como lo justifican los que he disecado yu cujo estómago solo contenia restos de aquellas. En otros encontré gusanos de harina, à menudo en cantidad increible, insectos de los bosques! hormigas rojas. El driocopo regto es para los baskirs un sér molesto, pues como ellos, caza las abejas silvestres, y las impidi frjarse en los agujeros de los árboles. Bernstein cree que come tambien pinones, nueces y bayas: pero observadores mas recientes no han confirmado el aserio. Para descubrir las larvas é insectos de que se alimenta, desprende grandes pedazos de corteza: yen cuanto a has hormigas, las coge con su lengua, cubierta de una sushancia viscosa, utilizándola como el hormigueio.

Segun la estacion mas ó menos farorable, verificase el apareamiento en la primera ó en la segunda mitad de marzo. eEl macho persigue a la hembra durante algun tiempo, y cuando le rinde la ratiga se posa en alguna rama seca, donde comienza i tamborilear; elige siempre la que mejor suena, levanta la cola, y comienza á golpear repretidamente con su pico. Ojese entonces un ruido que se jrodiria expresar por crrpr: en aquel monento el driocopo negro es menostimido que en ninguna otra circunstancis. Muchas veces he perna. necido debajo del árbol donde tamborileaba asi, y he podido observarle a mi gusto. Llegaba la hembra, atraida por el ru. mor; a menudo contestaba con las frases kluk, kluk, liluk; y aun despues de estar esta viltina algunos dias cubriendo los huevos, continua el macho haciendo lo mismo.

h principios deabril es cuando el driocopo negro comien za á fabricar su nido, el cual fija en un árbol carcomicio ya interiormente, donde halla un agujero 6 una rama despren. dida del tronco. I a hembra comienza su trabajo abriendo y ensanchando la abertura, de modo que pueda pasar fácil. mente, luegro forma con afan el compartimiento donde sé pro. pone deprositar los hucros; pero siempre se le of́recen ciertas dificultales que vencer, pases con frecuencia le falta tel espacio necesario para moverse fácilmente. Yo he padido observaria $\{$ menudo, y he visto que a veces se halla tan compiimida que apenas le quedan dos centimetros de sitio para mover el pico. Los golpes que da resuenan entonecs sordamente; las astillas que arranca son muy pequeñas, y solo cuando ha practicado un hueco de cierta extension, puede desprender ingrnentos ma.5 voluminosns. Yo he visto un pico negro que formaba su construccion en un pino algo carco. mido, ! las mayores astillas que desprendia eran de $0^{\circ}, 15$ de largo por $0^{*}, 03$ de ancho, y no $0^{\circ} .30$ pror $0^{\circ}, 03$, resjuccivate; como dice Bernstein. Necesitiridose ya una fuerza considerable para arrancar semejantes astillas. ¿cuales no habrian de ser la talla y el vigor del ave frara separar pedazos del volúmen indicado por el citado autor?

1 La hembra solo trabaja en su nido pror la mañana: por la tarde busca su alimento. Al cabo de diez ó quince dias cque. da formado ef hojo, que mide $0^{\infty}, 40$ de profundidad por $0 \%$;5 de dímetro, hallandose su interior perfectamente unido y como apisonado; el fondu tiene la iorma de un segmento de esfern; está cubierto de astillas finas, y sobre cllas deposita ia hembra tres of cuatro huevos, rnm ver cinco, y me nos seis. Tienen $n^{m}, 030: 211^{\circ}, 0,0$ de largo por $11^{\circ}, 0303^{\circ}, 03^{2}$ de ancho; son de forma prolongada, y muy redondeados en la punta gruesa, puntiagudos en la opuesta y voluminososer el centro: la ciscara es muy lisa, de color blanco brillante, como el esmalte.

- El driocopo negro situ generalmente su nido á gran .al. tura: los he visto a 15 y 25 metros, y solo una rez a 7 meiros sobre cl-sucio; todos ellos en hayas of pinos de tronco liso. Un mismo nido sirve para varios años, aun cuando se haya malogrado alguna puesia; pero cada ver. le repara el ave cuando le ha de ocupar; quita las innundicias y pone una nueva capa de astillas. Construir uno nuevo seria para ella dermasiado fatigoso, y jor oira parte, encuentra pocos árboles a propósito para cambiar anualmenie de sitio. Keconócese 
con facilidad el árbol donde se acaba de construir un nido, pues al rededor, $y$ en el radio de mas de un metro, aparece la tierra cubierta de astillas: cuando el nido es antiguo se en. cuentran tambien; pero no en tanta cantidad.

\o mismo sucede con todos los pícidos, y por lo tanto basta buscar los puntos donde el terreno está cubierto así de restos de madera Bechstein dice que se encuentra con seguridad el nido del pico, buscando los árboles huecos en el pais donde se oye gritar en el mes de mareo á dos de estas aves. Creo que esto no daria buen resultado siempre: en el periodo del celo he oido con frecuencia a los picos gritar, á media legua del punto donde anidaban, y jamás lallésus nidos sino guiandome por las astillas que se encuemiran al pié de los átboles.

'Tschusi, que observó el pico negro en la Austria baja confirma en lo esencial mis observaciones, pero añade que ha encontrado tambien nidos ála altum de apenas dos me. tros sobre el suelo; mientras que cuatro ó cinco son la altura reguhar. El cirado observador hallo en varios árboles cinco y mas agujeros de nido, circunstancia de la cual deduce, aun. que probablenente sin razon, que el pico negro pranctica cada primavera un agujero nuevo. $Y$ o por mi parte añadiré que las hayas y los pinos son en todas partes de Alemania los árboles en que el pico negro anida con preferencia: pero no exclusivamente.

Von Meyerinck encontró tambien un nido en una encina, y Dypowski dice que en Siberia se suelen ver en los alerces. La entrada ciel nido es siempre tan estrecha que dificil. mente se comprendecómo pueden entrar y salir las aves sin dañar su plumaje.

E! macho cubre hácia la mitad del dia, y la hembra, por la mañana, la tarde y toda la noche; esto és por lo menos lo que se puede decir de una manerá general, pues las horas a que cubren uno y otra están muy sujetas a variaciones.

De una observacion notable de l'schusi se desprencie que la hembra cubre los huevos con mucha aficion. «Hace pocos años que en un bosque de la baja Austria se debia cortar un haya vicja en la que una heinbra de pico negro cubra sus huevos, Los lenadores no podian hacerla salir á pesar de dar fuertes golpes en el tronco, y el ave no escapd hasta gue hubo caido el árbol. Es un hecho bastante conocida que se puede coger el ave sobre lós huevos si se le robal la pri. mera puesta, empolla sin embargo en el mismo nido, si no se ensancha la entrada, y segun reconocio Palssler, se pueden encontrar ya à los quince dias otros huevos en el mismo hueco. Los recien nacidos soa hediondos é informes, y solo tienen el lomo cubierto de un escaso plumon negruzco; la cabeza parece muy grande $y$ el pico presenta un grueso desproporcionado. "Si se ahuventa del nido al macho ó la hembra, los hijuclos lanzan un grito particular que no tiene comparacion con el de ninguna otra ave, y que es dificil de describir: cuando son mayores guardan siencio. Los padres parecen muy inquieios cuando älguien se acerca á su jro. genie y lanzan gritos angustiosos, aunque sean como las de. mís aves, menos timidos que de costumbre cuando anidan, y no atiendan á su propia seguridad, por evitar el peligro que amenaza a sus hijuelos. Segun las observaciones de mi pa. dre, alimentan a su progenic con larvas de hormiga. He disecaco, dice, varios driocopos negros adultos, muertos cerca de su nido, y encontré lodo su esúlago lleno de aquéllos insectos. Si no se molesta á los hijuelos, no abandonan el nido hasta que pueden volar perfect:mente; a menudo trepan á lo largo de las paredes de su albergue, y miran hácia fuera sacando su calseza por la abertura. La hembra queda de noche con ellos; el macho duerme en el nido del ano anterior
CAUTIVIDAD. - Se pueden conservar largo tiempo los driocopos negros cuando se cogen pequeños y se cuidan bien. El verano último recibi tres de estas aves, que tenian ya casi lodas sus plumas; una murió al cabo de pocos dias; alimenté á las otras dos, y bien pronto pudieron comer so. las. No tardaron en aprender á coger larvas de hormigas, y pude observar toda la movilidad de su lengua; al ver este órgano doblarse en todos sentidos y recorrer la tela metálica donde habia depositado yo las larvas de hormigas, hubiérase crcido que cra un gusano de los más ágiles. Apenas veian una larva, doblaban la lengua, extendianla sobre la presa con la punta hacia adelante, y la cogian infaliblemente.

Cuando supieron comer bien, los puse en una jaula donde habia ya picos dorados y de otra especie; no dejé de sentir alguna inquietud; pero mis driocopos negros se mostraron bastante sociables; no contrajeron amistad con ninguno de sus compañeros cautivos, si bien no los maltrataron tam. poco, ni les hicieron el menor daño, permaneciendo del todo indiferentes con cllos. Cada cual se cuidaba de si sin inquietarse de los demás; todo lo que hicieron fué apoderarse del cajon donde estaban los picos dorados y permanecer alli; la abertura era un poco estrecha para ellos; pero agrandáronla en pocos dias, arreglándola perfectamente para sus necesidades. Todas las tardes penetraban en la caja y se dormian, cogiéndose cada uno á una pared vertical. Yo habia observado ya que lus picos no dormian sino en aquella posicion, y por lo tanto ture antes cuidado de disponer que se clava. sen cortezas á los lados de la caja; parecieron reconocidos por aquella atencion, pues mientras se complacian en des. truir toda la inadera de su alleergue, las varillas y la corteza clavada en las paredes externas de si caja, respetaron siempre in qque se hallaba en el interior.

Mis driocopos negros se mantenian al principio muy silen. ciosos; pero hácia el otoño se oyó á menudio su voz armo. niosa s penetrante.

Por desgracia no reunia su jaula todas las condiciones apetecidas, y no se hallaba bastante al abrigo de las corrientes de aire: mis driocopos negros tuvieron frio, fueron presa de cunvulsiones, cayeron á tierra, permanecieron varios minu. cos rígidos te inmóriles y acabaron por morir: los habia conservado siete meses.

\section{LOS CAMPEFILOS - CAMPEPHILUS}

CARACTERES. - Liste género comprende las especies mas grandes del órden y de la familia Los campefilos se caracterizan por su cabeza muy gruesa; cuello largo y delga. do; el píco prolongado, recto y fucrte; las patas muy sólidas y corias, cuyo último dedo exterior es el mas largo; alas proinngadas y puntingudas; la tercera, cuarta y quimta réniges, casi de igual longitud, sobresalen de las demás; la cola muy larga y escalonada, tiene las plumas del centro casi tres veces mas largas que las exteriores.

\section{EL CAMPEFILO IMPERIAL - PICUS IMPE- RIALIS}

CARACTÉRES. Fista especic es la mas grande de das; es un ave verdaderamente colosal; tiene el plumaje ne gro, con una estrecha faja sobre la espaldilla; la última mitad de las rémiges posteriores es de color blannuizco; las sub). alares del mismo tinte, manchadas de negro junto á su bordc exterior; el macho presenta un moño rojo escarlata en el occipucio; el de la hembra es negro. Esta ave mide mas de $11^{\prime \prime}, 70$ de largo; el ala recogida $1^{m}, 33$, y la cola $0^{\prime \prime}, 25$.

DISTRIBUCION GEOGRÁFICA. - Habita en las mon.

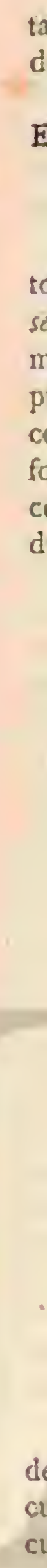

(1)

co

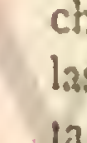

\section{ta}

\section{do}

\section{oj}

\section{ne}

to

pa

ch

$\mathrm{pr}$ 
tañas Pedregosas del norte de California lasta las fronteras de México.

\section{EL CAMPEFILO PRINCIPAL - PICUS PRIN- CIPALIS}

CARACTERES. - Este campeñlo es el mas conocido de todo el género; los anericanos le llaman tambien pico de los seriores ó piro de maryil. Mas grande aun que el pico negro, mide ()$^{\prime \prime}, 55$ de longitud, por $11^{\prime \prime}, 80$ de anchura de punta á punta de ala; las alas $0^{\circ}, 2 S$ y la cola $0^{\circ}, 19$. El plumaje es de color negro brillante, presenta algunas plumitas sobre las fosas nasales, adornándole una estrecha faja que partc del centro de las mejillas, corriéndose por los lados del cuello y de los hombros; las rémiges primarias posteriores y las secun. darias son blancas; las sienes, el moño largo y puntiagudo del occipucio y la nuca son de un rojo inuy vivo de escarla. ta; el iris anarillo; el pico blanco de cuerno; y los piés de un gris oscuro de plomo: la hembra tiene el mono negro (fig. 126).

Varios ornitólogos separan el pico principal de Cuba, con el nombre de ficus Buirdi, de la especie norte-americana; mas parece yue solo es una variedad.

DISTRIBUCION GEOGRÁFICA.-Fl área de disper. sion del pico principal se limiza al sur de los Estados Unidos y a la isla de Cuba. En la América del Norte habita la Carolina, la Georgia, el norie de la Florida, Alabama, Luisiana, el Mississipuji, y tambien los bosques del rio Arkansas y el este del Texas; en Cuba, segun Gundlach, se le ve en el sur, el oeste y el este, sobre todo en los grandes bosques lindantes con la estepa; tanto aqui como alli disminuye el núurcro

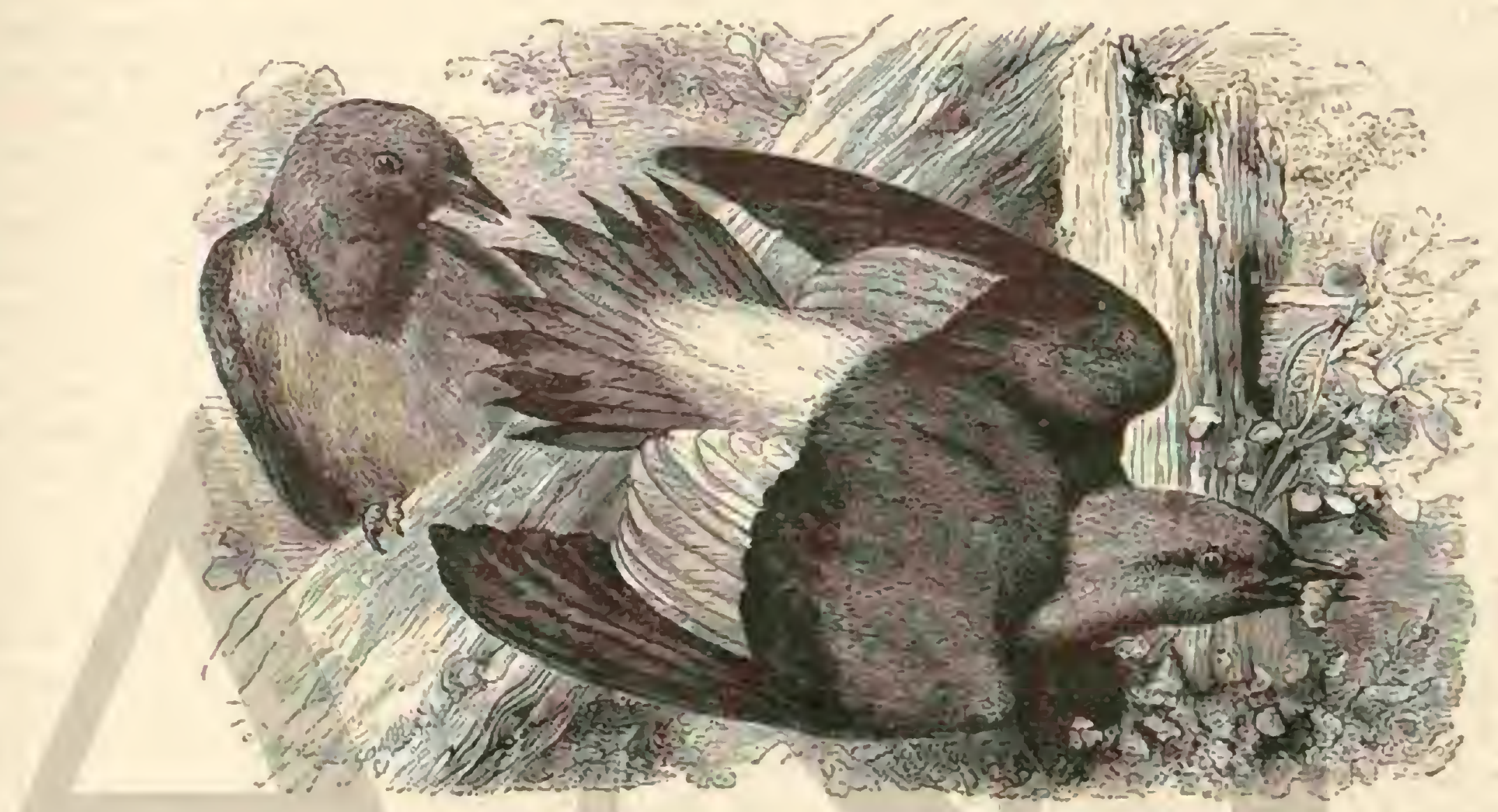

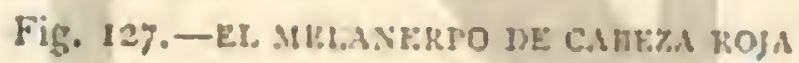

de estas aves de año en año, no solo por los progresos del cultivo de las grandes selvas, sino por la injustificable perse. cucion de los cazndores.

USOS, COSTUMBRES Y REGIMEN.-Audubon nos ha informado sobre el género de vida de la especic libre, y Wilson sobre la cautividad de estas dos especies

En el tono y la distribucion de los colores, que prestan al plumaje tan notable belleza, he hallado siempre alguna cosa que me recordaba el estilo del gran Van Dyck. La mu. cha extension del cucrpo y de la cola, de color negro lustroso; las grandes manchas blancas quie tan graciosamente se des. tacan sobre las alas: el cucllo y pico, realzados por el rico carmin del moño, que en el macho pende airosamente por detrás de la cabeza; y por último, el brillante amarillo de los ojos, son todos caractéres que siempre han evocado en mi el recuerdo de alguna de las mas atrevidas y nobles produccio. nes del inimitable artista. Y esta idea se grabó con tal inssis. tencia en mi espiritu at medida que iba conociendo mejor al nve, que cada vez que la veia volar de uno á otro árbol, no podia menos de exclamar: 1 Ah: ; hé ahi a Van Dick: listo parecerá cextraño, y hasta si se quiere pueril, pero es un he. cho, del que podri jurgarse por la lámina donde yo he re. presentado á este gran pico, indudablemente el primero de su tribu.

* Esta ave limita sus excursiones á una parte comparatiramente reducida de los Estados.Unidos; no se le ha visto nunca frecuentar los del centro, y parece por lo tanto, que Toun III en ninguna parte de estos distritos conviene la naturaleza de los bosques á sus singulares costumbres.

\$Bajando por el Ohio solo empieza a verse en lá contluen. cin de este con el Mississippri, y despues, siguiendo el último rio, bien sea pur abijo ó hácia el mar, 6 remontando en la direccion del Missouri, aparece ya la magnifica ave con mas frecuencia. En las costas del Atlíntico, no pasa de la Caro. lima del norte, aunque se ven algunos individuos en Maryland, pero al oeste ciel Mississippi, y aun mas allá de la pendiente de las Montanas Pedregosas, se encuentra en todos los espe. sos bosques, a orilla de las grandes corrientes que llevan su caudal de aguas al majestuoso tio. Las partes bajas de las dos Carolinas, de la Georgia, de Alabama, de la Luisiana y del Mississippi, constituyen sus retiros favoritos: reside cons. tantemente en dichos Estados; alli cria sus hijuelos, y pasa la vida tranquila y feliz, con sobrado alimento, en medio de aquellos pantanos sombrios y profundos, que comunican al paisaje un aspecto éspecial.

- Eil vuclo de cste pico es particularmente gracioso, pero es nuy raro que recorra un espacio de mas de cien varas de una vez, i no ser que deba cruzar algun gran rio. Entonces iraza profuncias curvas; las alas se exiienden en roda su an. chura, y luego las recoge á fin de repetir bien pronto el pri. mer esfuerzo de impulsion. Para pasar de un árbol \& otro, aunque la distancia sea de mas de cien pasos, solo cjecuta un movimiento, $y$ son sus ondulaciones tan graciosas, que no parece sino que el are se balancea entre las dos copas. En 
aquel momento es cuando ostenta el plumaje cn toda su belleza; al volat ro lanza ningun grito, como no sea en el jueriodo del celo; pero en todo tiempo se oye su roz notable tan pronto como se posa lrepando por el tronco del árbol $\delta$ de las ramas, a cuyo extremo llega siempre, avanza as saltitos, acompaniando cada uno de una nota clara y aguda, aunque bastanic plañidera, que se percibe á veces á la distancia de media milla y resuena como el falsete de un clarinete. Fis una especie de fast, fail, forit, repretido comunmente tres veces seguidas, y tan á menudo, que apenas calla el ave un mo. mento en todo el dia Semejante costumbre le es funesta, porque indica a sus cuemigos dónde se halla; y si se trata de darle muerte, no.es, como se supone, porque destrusa los árboles, sino por su precioso plumaje, y porque la bonita piel que le cubre el cráneo constituye un ajorno para el taje de guerrá de nuestros indios y el saco de municiones de los cazadores. Los viajeros de todos los paises buscan tambien con afan la parte superior de la cabeza y el pico del macho: cuando un vapor se detiene en uno de aquellos parajes, que en el pais llaman siuraing places (depósito de maderas), no es raro ver á los extranjeros dar médin duro por los ó tres cabezas de este pico. A menudo lie podico admirar los ta. halis de los jefes indios, compleramente cubiertos de picos y moños, lo cual me ha dado una idea clara de la grande estima en que los tienen.

- En la primavera estas ares son las primeras de su tribu que dan principio a la nidificacion: yo las he visto ocupadas en practicar su agujero desde principios de marzo, y por lo que he podido observar, siempre le abren en el tronco de un áthal vivo (por lo regular un fresno), á gran altura sobre el suelo. Los picos tienen buen cuidado de cxaminar la situacion particular del árbol y la inclinación del ironco; primero, porque prefieren un lugar setirado, $y$ despues porqque tratan de preservar la abertura del alcance de las aguas durante las lluvias. Al efecto comienzan generalmente á socavar desde luego por debajo de la bifurcacion de una gruesa rama. El agujero sigue primero la direccion horizontal, en la extension de varias pulgadas; f partir de alli, dirigese hácia abajo, mas no en espiral, como lo creen algunas gentes. Segun los casos, la cavidad es mas ó menos profunda: unas veces no pasa de diez pulgadas, $y$ ofras, por cl contrario, alcanza cerca de tres piés. He pensado que estas diferencias pueden relacionarse con la necesidad mas ó menos apremiante que experimenta In hembra, de poner sus huevos; tambien he creido recono. cer que cuanto mas vicja era el are, mas profundo era el agujero en el interior del árbol. El diámetro de los quue yo examiné podria ser de siete pulgadas, aunque la abertura, completamente redonda, no tuviese sino la anchurn suficien. te para dar paso al ave.

Macho y hembra trabajan sin descanso en la formacion del agujero; el uno permance fuern para excitar á la otra mientras trabaja y reemplazarla cuando se fatiga. Algunas veces me acerque á varios árboles donde los picos estaban ocupados en su trabajo, y apoyando mi cabeza, podia percibir fácilmente el ruido de cada picotazo: en dos ocasiones les asustó mi presencia; huyeron volando y no volvieron mas.

* La primera puesta consta por lo general de seis huevos, de color blanco puro, los cuales deposita la hembra sobre unas menudas astillas que amontona en el fondo de la cavi. dad. Los hijuelos se acostumbran á irepar por fuern, lo me. nos quince dias antes de volar à otro árbol: los de la segunda puesta salen ŝl luz à mediados de agosto.

En Kentucky é Indiana no suelen poner mas que una sola vez en cada estacion: los hijuelos revisten desde un principio el plumaje de la hembra; carccen del moño; pero crece pronto, $y$ hácia el otoño está muy marcado, sobre todo en las hembras.

- En. la nusma época no tienen los machos sino una ligera linea roja en la cabeza, $y$ hasta la primavera no se ostenta toda la belleza de su plumaje; su crecimiento no se completa hasta el segundo año; pero aun entonces se reconoce con facilidad á los individuos mas vicjos.

$\$$ Su alimento consiste principalmente en saltones, larvas y gusanos gruesos; pero tan pronto como maduran las uvas en nuestros bosques, precipitanse sobre ellas aividamente. Vo he visto a estas ares suspendidas por las unas de las cepas, en la posicion en que se halla tan à menudo el paro; con el cuerpo tendido hácia abajo, estirábanse todo lo posible, y partcian alcanzar el racimo con mucha satisfaccion. Tambien se las ve á menudo en las guyacanas, pero solo cuando sus irutos hall madurado completamente.

- Estas aves no ocasionan el menor daño en los irigos ni en los irutos de las huertas, aunque en las plantaciones jóve. nes caen á reces sobre los árboles protegidos por una cubierta y los descortezan. Rara vez. se acercan ś tierna, prefi. riendo en todo tiempo las copas de los mas altos árboles; si descubren algun grueso tronco muerto, medio derribado 6 partido, déjanse caer sobre él, y trabajan con tal vigor que á los pocos dins le derriban del todo. Yo he visto los restes de algunos de estos añosos gigantes de nuestros bosques mina. dos de una manera tan singular, que el ironco vacilante $y$ destrozado, no parecia sostenido sino por el enorme monion de astillas que rodeaba su base. Fi pico de estas aves es tan poderoso, y golnean con tal fuerza, que de un solo tiron ar' rancan pedazos de corteza de siete \& ocho pulgadas de largo; y coinenzando por la extremidad de una rama seca, pueden despojarla en una extension de reinte à treinta piés en el es. pacio de algumas horas. Durante todo este tiempo no dejan de dar saltitos, bajando poco á poco, con la cabeza alta, y volviéndola de derecha á izquierda, $\delta$ bien aplicándola con. tra la corteza para reconocer dónde se hallan ocultos los girsanos. Hecho esto, vuelven á cavar afanosamente, y a cada picotazo se oye su grito sonoro, que parece indicar la satis. faccion con que trabajan.

Cuando los pequeños abandonan á sus padres, suelen vivir estos apareados: la hembra es siempre mas ruidosa que el macho y menos timida; su mutuo carino dura mientras viven. Excepto el caso en que practican su agujero para poner, no tocan casi nunca los árboles vivos sino cuando buscan su alimento, despojánclolos á la vez de los insectos nocivos. Varias veces he visto al macho y a la hembra retirarse juntos para pasar la noche en el mismo huecu donde mucho tiempo antes habian criado sus hijuelos: llegaban co. munmente algunos instantes despues de ponerse el sol.

- Si una de estas aves cac á ticrra herida, gana inmediala. mente ol árbol mas próximo, trepa con toda la ligereza posi. ble, y no se detiene lasta las tiltimas ramas, donde consigue por lo regular ocultarse muy bien. Sube por el arbol trazando una línea espiral, s produciendo siempre su sonoro fel fit; pero permanece silenciosa en el momento de hallar un sitio donde se cree segura. Algunas veces se coge con tal vigor á la corieza, que permanece como clavada horas enteras aun despues de inorir. Cuando se quiere coger á un individuo con la mano, lo cual no deja de ofrecer peligro, golpea con fuerza, hirjendo cruelnente con su pico s sus uñas, que son muy agudas $y$ poderosas. Al defenderse asi, lamza un grito lastimero que inspira serciaderamente compasion.

CAUTIVIDAD. - Wilson guiso conservar un campefilo principal cautivo; pero halló que la cosa ofrecia sus dificuliades. Err un individuo viejo, al que se pudo coger despues de haberle herido; lanzata gritos como una criatura, los 
cuales espantaron de tal modo al caballo que anuel montaba, que llegó \& ver amenazada su existencia. Al cruzar las calles de Wilmington, todas las mujeres se asomaron a las ventanas para saber de dónde provenia aquel espantoso ruido, y nuestro naturalista fué asaltado á preguntas à la puerta de su posada. Dejo el ave en su cuarto para ir á cuj. dar del caballo, y al volver, una hora despues, encontró al campefiln trabajando áanosannente. Despues de trepar a la veniana, habia perforado casi los inontantes; yueriendo Wilson cvitar que se escapase, porque se proponia sacar un dibujo, atóle con una cadena á una mesa muy iuerte de mas. goni. Luego salió un instante para buscar de comer, y en el momento de ir \& entrar oyó descle fuera que el ave trabajab. de nuevo: penetró en la habitacion y vió que la mesa no se sostenia ya mas que sobre tres piés. Mientras IVilson sacaba un dibujo del ave, esta le hirio varias veces, mostrindose tan feroz y amante de libertad, que el ilustre naturalista estuvo tentado de llevarla al bosque: rehusó todo alimento y murio al cabo de tres dias.

\section{LOS MELANÉRPInOS-M Mlanetpi}

CARACTERES. - I.os melanérpidos ó picus grajus, son menos notables por su talla qque por la belleza del plumaje. 'lienen el cuerpo robusto, la cabeza fuerte y el cucllo corto. Iil rojo y el negro, ó el rojo y blanco, son los colores domi. nantes del plumaje.

DISTRIBUCION GEOGRÁFICA.-Todas las especies que pertenecen á este grupo habitan las dos Americas.

\section{LOS MELANERPOS-MELANERPES}

CARACTERES. - Tiencn el pico recto, mas ancho yue alto en la base, de arista dorsal cucomada, bordes muy entrantes, provistos de cuatro protuberancias paralclas, que na. cen encima : dejajo de las fosas nasales, términan hácia el centro de su longitud, y están separacins unas de otras por mnuras; los tarsos son del largo del decio medio, comprendida la uña; la cuarta y quinta rémiges iguales entre sí las plumas largas y la cola redondeadn: el ojo presenta un circulo sin pluma.

\section{EL MELANERPO DE CABEZA ROJA- MELANERPES ERYTHROCEPHALUS}

CARACTÉRES. - lil melanerpo de cabezà roja (fig. 12\%) representa la especie mas conocida del ginero. Tiene in cobeza y el cuello de color rojo vivo: el lomo, las alas y la cola de un negro oscuro; las rémiges secundarias, la rabadilia y el vientre de un blanco briliante; el ojo pardo; el pico y las patas de un negro azulado. La hemira es un poco mas pe queña y riene colores menos vivos que el macho. En los hijuelos la cabeza es de un tinte de ocre pardo, lo mismo que el cuello, el lomo y el pecho, presentando todas estas partes manchas circulares de un pardo negro. Las rémiges primarias son de este uiltimo tinte, las secundarias blanco rojizas, con un filcte pardo negro hácin su extrernidad: las rectrices de un pardo negro oscuro. Esta ave mide 6,24 de largo por 6 , fit de punta a punta de ala; esta tiene $11^{\circ, 12}$ ! la cola 4,06 .

DiSTRIBUCION GEOGRÁFICA.- Esta ave habita todo el norte de América.

USOS, COSTUMBRES Y REGIMEN.- WO haY en roda la América del norte, segun creo, dice Wiison, ningun ave que sea mejor conocida que el melanerpo. Por su plu. maje tricolor, sus costumbres destructorns y su abundancia, ha llegado a ser familiar para ocos los niños. Segun el princine de Wied, se la ve posada en iodas las cercas, sus. pendida de las ramas de los árboles ó de los troncos, o ya irepando al rededor de las raices en busca de insectos.

Se la puede considerar, dice Audubon, como are seden. taria en los Estados Linidos: se la encuentra durante todo el invierno en los Estados del sur, donde anida en verano; pero la mayor parte de los melanerpos nos abandonan en seticmbre y viajan por la noche. Vuclan á bastante altura por encima de los árboles, y en numerosas bandadas, siendo de advertir que cada individuo obra á su aniojo, como sucede. ria dó los soldados de un ejército que huyerse disperso. Lanzan grilos penetrantes, cual si quisicran excitarse mutuamente; apenas asoma la aurora se posan en la copa de los árboles muertos, alrededor de las plantaciones, i permanecen alli hasta ponerse el sol, ocupados en buscar su alimento. Lle. gada la hora, emprenden su vuclo uno despues de otro y continuan el viaje.

- Exceptuando el burlon, no conozco are mas alegre y ju. guetona que el melanerpo. Toda su vida es un continuo recreo; en cualquiera parte encuentra alimento abundante $y$ sitios á propósito para fijar su nido. Ins ligeras molestias que se toma son para el otro pasatiempo: no trabaja sino cuando busca alguna golosina bien apecitosa, $\delta$ construje el albergue donde debe depositar sus huevos y criar á sus hijuclos. Aunque el hombre sea su mas tenible enemigo, no le teme: cuando se posa en una empalizada, en la orilla de un camino ó cerca de una plantacion, y se aproxima álguien, tmsládase lentamente al lado opues:o, se oculta y mira con prudencia, como para cvilar que le descubran. En el caso de que la persona pase tranquilamente, vuelve á dejarse ver, y canta como para Feliciarse por el buen éxito de su astucis. Cuando se dirigen directamente hàcia él, línzase à una pértiga ó rama próxima, canta de nuevo y parece provocar à su adversario. Acércase á menudo á las casas, irepia por las paredes, golpea las vigas, lanza un grito, baja al jardin y recoge los frutos mas sabrosos que pucde encontrar.

* No aconsejaré a radie guc olere en una huerta la pre. sancia de los melanerpos, no solo porque se comen los frutos, sino porque destruyen muchos de ellos. Apenas comienzan á enrojecerse las cereras, acuden ya de todus los puntos, desde varias millas â la redonda, y despojan un átbol conjpletamente. I.lega uno de ellos; ve una cereza; lanza su griro de llamada, muera la cola, baja la cabeza y se apodera del fruto. Cuando ha comido lo bastanie, coge una ó dos mas en cl pico para lievirselas à sus hijuclos.

- Imposib!e seria calcular el nimero de ares de esta especie que se ven durante un verano; pero puedo ascgurar haber matado en un solo dia un centenar de individuos en el mis. mo cerero. No solo se comen las guindas, sino tambien las peras, los albérchigos, las manzanas, los higos, las moras y hasta los guisantes. P'asarce en silencio los destrozos que oca. sionan en las casas, pres ma quiero recargar mucho ol acta de acusacion, toda rez que tienen ambien sus buenas cuali. dades. Coren las manzanas de una manera singular; hunden con fuerza en el fruto su pico abierto, le cierran, y vuelan despues á un árbol ó á una cnipalizada, para partirle y comérse. le cúmodamente. Tienen además otro defecto, y es que dero. ran los huevos de los pajarillos; visitan los nidos artificiales preparados para los cipsélidos y las golondrinas azules, y jenetran hasta en-los palomares.

3. En medio de todo, nunca pierden su alegria: si no han satisfecho su hambre, rexinense en reduciỏas bandadas en la cxiremidad de las ramas de algun arbol carcomido y dan cara i los insectos; déjanse cact sobre ellos desde una altura de ocho á doce brazas; ejecuian los mas atrevidos movinientos, y una rez cogida la presa, vuelven á su sitio, lanzando 
un alegre grio de triunfo. Con frecuencia se persiguen dos de ellos de la zanera mas divertida: trazando en el aire curvas graciosas caduladas, ostentan su hermoso plumaje que seduce la rista del espectador; para pasar de un airbol á otro no dan mas que un salto; abren las alas, bajan oblicuamente y llegados al traco elévanse muy despacio. Al trepar suben y bajan, svanrar de lado sin dificultad aparente; pero rara vez desciences de cabeza, como lo hacen los otros picidos. Cuando ran de un árbol to otro, muchas veces es, al jarecer, con la intencioa de acometer a uno de sus semcjantes; pero merced is su agjlidad sabe este cvitar stempre if su adversario, dando vuteas al rededor del arbol con increible rapider.

- Raro es excontrar un nido acabado de construir, pues comunmente u:ìizan éstas aves los antiguns, ensanchaindolos ligeramente. Aadjan estas ares en troncos de árboles muertos; mucbas vecs se encuentran de dier. a doce en el mismo, algunos comeraidos apenas, otros algo profundos y varios concluidos Jaels he visto un nido de melanerpo en un ár. bol todaría verb́t. En la Luisiana y en Kentucliy pone esta are dos reces 2 lano, y solo una en los listados del rentro. Ia hembra depusita de dos a seis hueros, blancos y traslúci. dos, en la caricid de su nido, que se halla unas veces a seis piés escasos de aitura, y otras lo mas elerado posible.

Segun Wilson los melanerpos josvenes ticnen un terrible encrnigo en la calebra negra (coriphindun cunstrictor): esia scrpicnte trepa 1 los átboles mas altos, penetra en el nido del are, $y$ deroa los huevos ó los hijuelos sin defensa, á la vista misma de ess padres $y$ a pesar de sus gritos de angus. tia. Para digerid despues lo que come, el reptil se echa mue llemente en el zido y se enrosca. Sucede à menucio que un mucliacho trepa dí árbol á ricsgo de roinperse el cuello para apoderarse de ea cria: f́acil será comprender su espanto cuando al meter la mano en el nido, coge, no unas in ofensivas arecilza sino el cucrpo viscoso de la terrible ser pientel

\section{EL MELANERPO HORMIGUERO-PICUS PHORMICIVORUS}

CARACTERES. - Esta ave, llamada tamóien evirclor, tiene poco mas menos el tamaño de nuestro pico abigarrado; su longitud es de $0^{\circ}, 25$; las alas miden $11^{\circ}, 16$ y la cola $11^{\circ}$, 10. Elborde ce la frenté, la linea naso-ocular, la barba, las partes superiores un estrecho borde al rededor de los ojos, las sienes, la refion de las orejas y una ancha faja en los la. dos del cuello, san de color negro; la parte anterior de la cabeza de un blazo amarillento; la coronillay el occipucio rojos escariata; la mejillas hasta la region de las orejas, los lados del cueilos la parte inferior de ia garganta, blancos; el buche y el pechs pegros, con manchas longitudinales blan. cas: cl resto de les partes inferiores, blanco: en los costados y en las tectrice inferiores de la cola hay lineas negras que se corren $\mathbf{1}$ lo la de los iallos; la rabadilla y las tecirices superiores de la coia, asi como las rémiges primarias, desde la segunda, son blancas en la base. Ios ojos, pardos; el pico negro de cuerno t los piés de un gris amarillento. En la hen. bra se obserma ee occipucio una faja trasversal ancha de color sojo escartin

DISTRIBUCZON GEOGRÁFICA.-El area de dispersion del melane: hormiguero se halla en los Estados de la costa del Pacífon desde California hasta . lléxico y la América central

USOS, COSTHMBRES Y RÉGIMEN. - EI melaner. po hormiguero, coce Hermann, es el mas alborosador $y$ co. mun de tocios los picidos que se encuentran en California. Se le ve posado anguilamente sobre una de las ramas mas altas de un àrbol, desde donde se lanza de pronto para per. seguir a un insecto; le atrapa, vuelve al sitio que dejó, y comienza un instante despues la misma maniobra. En el otono emplea una gran parte del tiempo en practicar agujeros en las cortezas de los pinos y de las encinas; en cada uno de cllos introduce una bellota, y la encaja tan bien, que se necesita hacer algun esfuerzo para sacarla. Sucede a menudo que despues de terminar semejante trabajo, todo el tronco de la corpulenta conifera aparece como cubicrto de clavos de bronce: estas bellotas sirven de alimento al ave durante el invierno; tambien las utilizan las ardillas, los ratones y los gmjos que descubren tales escondites.

Kelly confirma en un todo este relato y dice lo siguiente: 4Al levaniar la corteza de un árbol observé que estaba acribillada de agujeros cuyo diámetro excedia del que forma una bala de carabina; guardaban entre si tanta regularidad como si. se hubiesen hecho con un compis; algunos estaban llenos de bellotas. Yo habia observado ya varias veces la misma cosa en otros árboles; pero creyendo que seria obra de algun in. secto, no fijéla atencion; aquella vez, no obstante, la presencia de las bel!otas, que no podian haber sido introducidas alli por el viento, me indujo a buscar la causa. Un anigo mio me señaló una bandada de melanerpos que se ocupaban ca recoger sus provisiones de invierno; pliseme en observacion, y vi que pasaban el verano recogiendo alimento para la esta. cion fria; unas veces los veia volando y otras trepando; note que daban vuchas al rededor de un śrbol, y admiré en mas de una ocasion cóma trataban de introducir la bellota. Co. gianla varias veces hasta encontrar un agujero de la dimen. sion apetecida; encajaban el fruto por su extremo delgado, humdianle despues a picotazos, y volaban para ir a buscar orro. En este trabajo revelan un tacto asombroso; no eligen sino las bellotas sanas y de buena calidad: el hombre que las recoge con el objeto de asarlas, se lleva siempre algunas hue. cas ó małas; nuy á menudo están roidas por un gusano las que parecen mejores;y hasta el indio, a pesar de toda su práctica, se engaña muchas ieces; pero en iodas las que yo encontré encajadas en los árboles no habia una sola que con. tuviese el menor gérmen de destruccion.

Cuando los melanerpos hormigueros recogen bellotas con mucho afan, se puede predecir que ncrari muy pronto; nien. tra no sucede esto no tocan a sus provisiones; únicamente lo hacen cuando la ticra se cubre de una blanca alformbra. En. conces comen las bellotas que han reunido, contentándose conabrir la cáscara sin sacarlas del agujero donde se hallan. Se ha juzgado de modo muy diferente esta prevision del pico, tanto mas cuanto que si se reconoció bien en el sur de su area de dispersion la necesidad de hacer provisiones para los dias de escascz, no fuéasi en el norte. P'rescindo de todas las suposiciones que en este concepio se han hecho, $y$ solo aĩado que, si bien no se sabe aun de fijo, es, sin embargo, nuy probable que el melanerpo hormiguero apele en caso de necesidad ás sus provisiones ye las coma.

\section{LOS PICOS-PICI}

CARACTERRES. - Estas aves pucden considerarse como los trepadores mas perfectos: son fornidas, de pequeña ó mediana talla; el pico es poco mas ó menos del largo de la ca. bera; algunas especies solo ticnen tres dedos y su plumaje es negro, manchado de blanco, con rojo ó amarillo en ciertas partes.

Tienen el pico recto, de mediana extension, tan alto como ancho en la base, de arista muy anculosa y surcos laterales, mas próximos a los bordes de las mandibulas que á la parte superior del pico; las alas son obtusas, con la tercera rémige 
mas larga; los tarsos cortos, en parte cubiertos de pluma; la cola larga y cuneiforme, y la cabeza esta desprovista de moño.

DISTRIBUCION GEOGRAFICA.-Habitan en toda la superficie de la tierra, excepto en el centro y sud de Africa.

USOS, COSTUMBRES Y REGIMEN. - Viven casi exclusivamente en los árboles, yo ma vez bajan á tierra

\section{EL PICO MAYOR-PICUS MAJOR}

CARACTÉRES, - Eil pico mayor, fico de fojous, sico rojo, piro norigarrado ó fico de cscaudo, es la especic mas conocida de este grupo, $y$ merece en un todo sus nombres, pues su plumaje es en extremo abigarrado. La parte superior de la cabeza y del lomo, la estrecha linea naso ocular que desde la hendidura del pico corre hácia atrás ensanchándose hacia el cuello, y el pecho, son de color negro; los lados de la cabeza, excepto las sienes, una mancha longitudinal en los lados del cuello, y otra mas grande en los hombros, son de un tinte blanco, lo mismo quue las partes inferiores, cuyo matiz no suele ser tan puro; una mancha grande en el occipucio, la region del ano y las tectrices inferiores de la cola son de un rojo vivo de escarlata; las rémiges primarias pre. sentan cinco fajas trastersales y las secundarias tres; las rectrices exteriores tienen la extremidad blanca, con dos fajas negras, mientras que la tercera de ambos lados presenta solo una. La hembra carece del color rojo del occipu. cio y los pequeños tienen la coronilla de un tinie carmineo. Los ojos son pardos rojizos; el pico de un color claro de plomo; los piés de un gris verdoso. In longitud es de $0^{\circ}, 23$ in $11^{\circ}, 25$; la anchura de punta á punta de ala de $0^{\circ}, 4^{6}$ a $0^{n} 445$; las alas miden $0^{n}, 16 \mathrm{y}$ la cola $10^{\circ}, 08_{5}$.

\section{EL PICO DE LA MAURITANIA - PICUS MAURITANICUS}

CARACTERES, - Esta especie difiere considerablet mente del pico abigarrado por su menor tamaño sp por tener menos desarrolladas las fajas negras de los lados del cuello, que sin embargo se enlazan por una trasversal en la parte inferior de la garganta, presentando un magnifico color rojo viro con borde negro en los individuos adulios, y manchitas del mismo color en los pequeños.

DISTRIBUCION GEOGRÁFICA. - Jiste pico habita en el noroeste del Africa.

En Siria, Palestina, Persia, China y el Himalaya habitan otros congéneres de nuestro pico abigarrado, que los natu. ralistas consideran como especies independientes, ó solo va riedades. En esta linea ígura tambien el pico de la Mauri. tania, del cual he querido hacer mencion porque, segun yo mismo he visto, se le ha encontrado en Espana, y tambien alguna vez en el distrito de Manchester.

DISTRIBUCION GEOGRAFICA DEL PICO MÁYOR EN GENERAL. - Toda la Europa y la Siberia hasta el Kamschatki, juniamente con el Japon, son la patria del pico mayor $\delta$ abigarmdo, que puede considerarse como la especie mas comun entre sus congeneres de Europa y de la Siberia. Yo le he visto en cuantos paises de nuestro con tinente visité, es decis, en todas partes donde hay bosquites ercepto en los Alpes: habita en escaso numero en Laponia: pero frecuenta el mediodia de 12 Escandinavia $y$ de lin. landia; en todo el resto de Europa no es raro, si bien esca. sea en España muclio mas que en Alemania, por no haber ianto bosque Lo mismo podemos decir de Cirecia, pero no de Italia, donde se le ve en los mas diferentes bosquues tan á menudo como en Alemania. En Ilurquia y en toda la Rusia, incluso e! Cáucaso, abunda bastante: en Siberia habita todas las regiones cubiertas de bosque, y a menudo las altas estepas desprovistas de él pero aqui, solo las cercas ó las edificios de madera le ofrecen proporcion para trepar. Cuando en la estepa se establece una plantacion, esta ave se. gun Kadde, es la primera que anida alli. No se sabe aun de cicrto hasta dónde se extiende en el mediodia de Asia; pero es cosa areriguada que traspasa naucho los limites de liu. ropa y que se le encuentm, por ejemplo, en el Asia menor y probablemente tambien en .Marruecos.

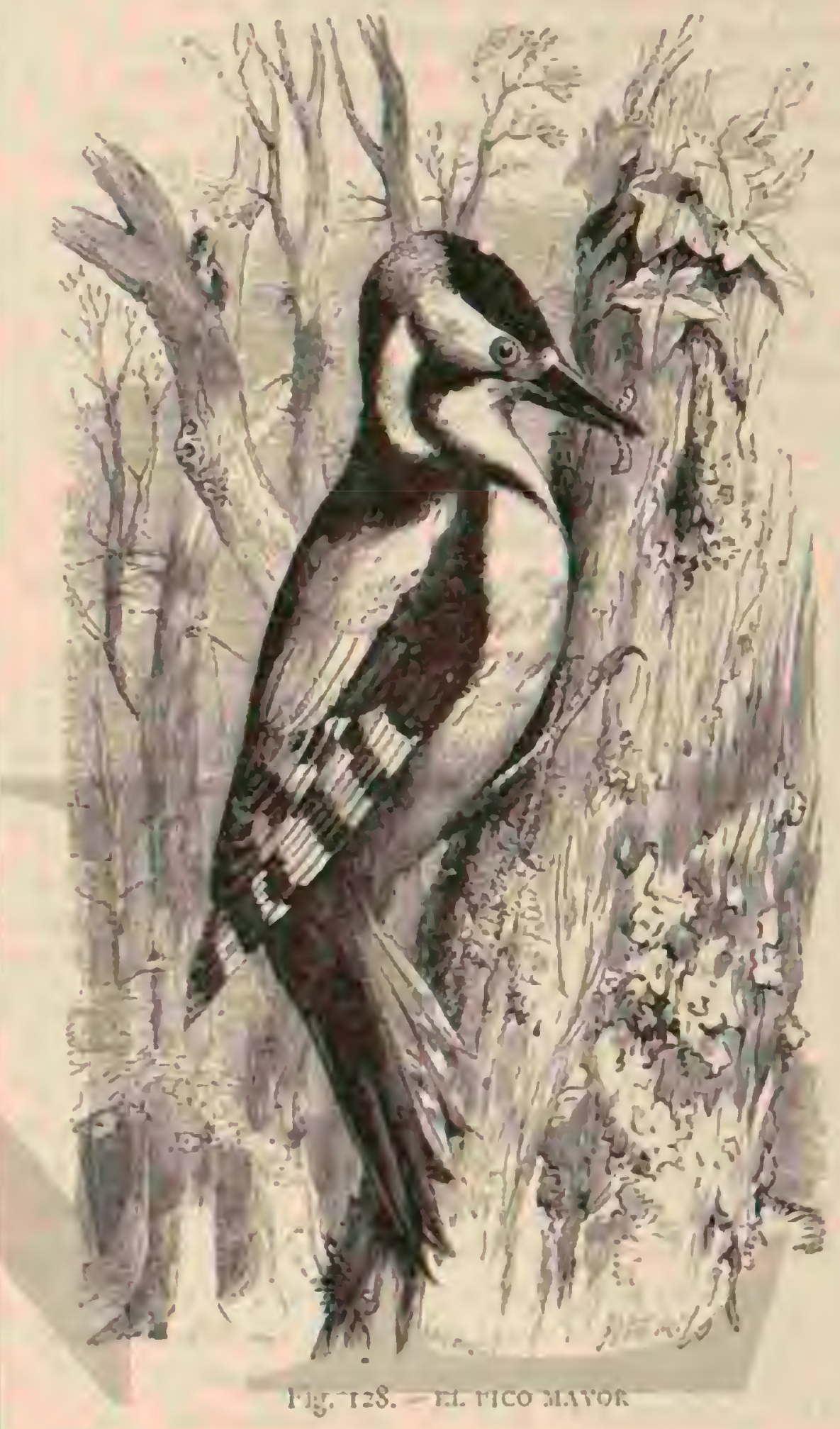

USOS, COSTUMBRES Y REGIMEN.-Mi padre, y despues de él Naumann nos han dado descripciones tan minuciosas del género de vida del pico mayor, que desde entonces apenas se ha saluido rada nuevo de esta ave. Siguiendo mi costumbre de respetar siempre el derecho del primer observador, me regiré por la descripcion de los dos naturalistas citados. Busca los grañdes bosques, pcro se le encuentra rambien en las arboledas j en medio de los campos; en invierno llega hasta los jardines. Preficte los pinares a to. dos los demás sitios: durante el verano vive en un espacio bastante reducido: en oioño y en invierno ensancha el cir. culo de sus peregrinaciones y se reune enionces con los trepadores, los paros y los rejezuelos. llegado el verano no tolera a ninguno de sus semejantes cerca, y apenas oye uno en las jnmediaciones, acude al momento para ahuyentarle. Durante sus viajes permanece siempre en los árboles, y pro. cura no franquear al vuclo espracios descubicrtos.

El pico mayor, como lo ha dicho Naumann, es fuerte, vigoroso, igil y atrevido, reunicndo a estas cualidades ia belle7a. rWurante el buen ticmpo gusta mucho verlos perseguirse de árbol en árbol, trepar por las ramas y calentarse al sol, 
á cuyos rayos brillan mas los colores del plumaje. Casi sien. pre están en moviuniento, y animan admirablemente los sombríos bosqques de pinos. Su vuelo es cortado, ruidoso y bas. tante rápido, aunque solo suclen franquear de una vez cortas distancias. A menudo se posan en la rama mas alta de un árbol y lanzan un grito, equivalente a fick pick 6 kik kik. $\Lambda$ semejanza de todos los demás picidos, pasan la noche en los troncos huecos, $y$ en ellos se refugian tambien cuando cstan heridos. No se llevan bien con sus semejantes, y aunque se les encuentm á menudo en compañia de otras aves, no se puede decir que son sociables, ni siquiera contraen amistad con los trepadores, los paros y los rejezuelos; parece que les sirven de guins, pero en realidad se muestran con cllos indiferentes. No pueden tolerar que se les dispute el alimento: entre todos los picidos, estas son las aves mas fáciles de atraer si se imita el ruido que hacen al golpear los árboles. En la primavera particularmente es seguro verlos acudir, pues entonces les anima la pasion del celo; pero en el verano y el otono llegan igualmeñic hasta cerea del cazador que imita aquel ruido, trepan a las ramas y buscan por todas partes $\alpha$ su rival. Las hembras se condicen en este punto como los machos, prueba evidente de que les impulsa, no solo el celo, sino el deseo de conservar parn sí solos su territorio de caza Schacht sin embargo vió una vez las tres especies europeas de este género en un mismo ábol.

El pica mayor se alimenta de insectos, de sus huevos y larvas, de irutos duros y de bayas. Mi padre, y-despues de él Nauniann, fundados ell sus observaciones, aseguran que no come hormigas ni alimenta s. los hijuelos con sus larvas; Gloger, por el contrario, dice haber matado en invierno un pico mayor cuyo estómago estaba lleno de grandes hornigas de los bosques. Segun mi padre es el mas temible adversario del escarabajo del pino, y para apoderarse de él descorteza los árboles. He observado esto con frecuencia, dice: trepa al rededor de los troncos cuya cortera se resquebraja; hunde su pico y su lengua debajo de ella, ó bien la parte cuando no puede llegar de otro moda il los insectos que oculta. Muchas veces examiné los pedazos de corteza desprendidos, y yi que estaban minados por los insectos. Tambica come muchas orugas nocivas para los arboles: es un excetente guardian de los bosques, al que se deberia proteger todo lo posible.

¿Cuando golpeá sobre una peoueña rama, dice Naumann, se le ve á veces correr al momento por d otro lado para atrapar los insectos que hujen al oir los picotazos; estos sé. res bacen lo mismo que las lombrices de tierra cuando es. carba el topo, y conocen como ellas que se acerca su encmi. go mortal. A Algunas veces, sin embargo, comete esta ave algunos desperfectos: asi, por ejemplo, Wiese asegura que en 1874 tiró contra una de estas aves a fin de sauer qué llevaba en el pico para sus hijuelos", y viú que cra un paro pequeño que aun no habia cchado la pluma. Esto debe ser, no obstante, un caso muy raro, pues el pico mayor se alimenta mu. chas reces de simientes, sobre todo de las del pino, y tambicn de avellanas, que recoge $y$ las coloca en un agujero practica. do expresamente en un árbol tapándolo despues. A menudo se le ve suspendido de una piña, muy ocupado en destrozarla; pe. ro es mas frecuente llevársela a una rama para extraer tranqui. laniente los piñones. Cuando los quiere comer, ciice mi pa. dre, practica en la cara superior de una rama un agujero donde pueda colocarse la mitad de una pina; despues vucla al árbol, coge el fruto por su tallo, lo parte y coloca en la cavidad con el vértice hácia arriba; despues le sujeta con sus dedos ante. riores, descarga sobre el extremo repetidos picotazos a fin de hacer saltar las escamas, y ste apodera de los pinoncs. En tres 6 cuatro minutos los devora, yendo en seguida en busca de otra piria, $y$ hasta que la trac no arroja los restos de la pri- mera. Es de notar que nunca se come todos los granos, ni despoja el cono tan completamente como lo hace el pico cruzado; pero repite la operacion varias veces al dia, y en el mismo árbol. Hay en mi bosque un pino donde suele permanecer un pico mayor durante varias semanas; hảcia meciiados de agosto comienza á comer granos, aun cuando no estén codavia maduros, y en invierno son casi su único alinento; su pico estä cubicrto entonces de resina, mientras que en otras especies se suele ver manchado á menudo de tierra.

Fil pico mayor no da pruebas de tener mucha perseveran. cia cuando construye su nido: comienza varios amies de ter. minar uno; no siendo raro el que se sirva de otro cualquiera abandonado. La cntrada es estrecha y esta es lo suficiente para que el ave pueda entrar y salir; la excavacion tiene generalmente $0^{n}$ ' 33 de profundidad; el espacio donde la hem. bra deposita los huevos es de paredes muy alisadas y el fondo esta cubierto de astillas. Al apareamiento preceden largas contiendas, pues comunnente se disputan dos machos la misma hembra. \&an vueltas sobre los árboles, dice mi ja. dre, trazando grandes circulos: cuando el uno se cansa, se posa sobre alguna rama seca y deja oir su voz; apenas se calla, comienza el orro, durando esto horas enteras. 'lan pronto como uno de ellos divisa la hembra, corre hácia ella, y los dós machos se persiguen gritando kueck kneck kaeck, kick kick. Si algun otro macho los oye llega tambien al punto, en cuyo caso aumentan los gritos; los rivales siguen à la hembra ó se acometen, hasta que uno de ellos queda vencedor $y$ ahuyenta a los denas.

Cada puesia consta de cuatro ó cinco huevos, ram vez de seis; son pequerios, prolongados, de cáscara delgada, grano fino $y$ color blanco lustroso. Macho y hembra cubren alter. mativamente por espacio de catorce ó dice y seis dias: los hijuclos salen à luz enteramente desurovistos de pluma, y son tán feos como iniormes. Sus padres les cuidan cariño. samente; Janzan gritos de angustia si algun peligro les ame. naza y no se alejan del nido jamás. Despues de haber comenzado á volar los pequeños, permanecen aun con el maclio y la henibra, quue los alimentan hasta que pueden mantenerse por si solos

CAUTIVIDAD. - Los picos abigarrados en cautividad son muy divertidos, y no es dificil acostumbrarlos a un ali. mento que se armoniza poco con el que acostumbran á to. mar cuando están libres. Yo les he mantenido muchos meses con el que regularmente se da é los mirlos. Viven en la mejor inteligencia con las mas distintas aves pequeñas que se hallen en su compania; pero no con otras de su especie, pues son pendencieros, como lo demuestran ya en la primera juventud. 2Dos hermanos, me escribe liebe, que el dia anterior salieron del nido y no pueden aun volar, precipitanse ya con tal furia uno sobre otro que es preciso separarlos para evitar heridas graves, sobre todo en la cabeza ó en la lengua. Si prescindimos de este caraicter pendencicro, diviesten por lo demás mucho á su amo por la gracia y agilidad de sus movimientos, su vo\% alegre y clara y su bonito aspecto.

Licbe me envió en otro tiempo una descripcion tan exce. lente sobre la vida en cautividad de este pico, que creo conveniente reproducirła aqui. Eil pico rojo es un sér magnifico que se familiariza con el hombre tanto como las aves canto. ras de mas desarrollo. Mi abuelo labia acostumbrado de tal modo á un individuo libre á posarse en su veniana, que tan luego como esta se abria llegaba para tomar nueces, etc., que se le ofrecian en una cuchara. Cuando se le coge pequeño en el nido familiarizase pronto con su amo y hasta le conoce por su paso; un individun que tengo ahora me saluda consu alegre kick kick cliando subo por la escalera á mi cuarto; y aun sale á recibirme hasta donde se lo permite su jaula; opri. 
me su bonito pico contra la reja y deja oir una especie de carcajada apenas me acerco. Grande es su alegria cuando te presento una avellana abierta en la punta de mi cuchillo; yo la sujeto con los dedos y él acaba de romperla sin hacerme daño, comiéndose despues el contenido. Cuando parto del todo In fruta con los dientes expresa a menudo su agradeci. miento cjecutando un tamborileo en la caja de hoja de lata que está en el suelo de su jaula, con lo cual demuestra que lo hace en mi obseguio. Jos picos abigarrados son en gene ral ares astutas, cuyos ojos brillantes exjresan marcadamenic cierta reflexion y curiosidad, á la par que insolencia: su modo de proceder tiene algo de interesante y grotesco. Tambien estas saltan, pero torpemente y no ianto como lus gorriones: condicense como muchachas graciosas quue andan en zuccos y se rien ellas mismas de su poca ligereza. Sus movinientos extraños y bruscos, todo su sér, su alegria. las inclinaciones de cabera que tan pronto indican curiosidad como timida precaucion son cosas que seducen al observador. Aunque se les despierte en medio de su sueño conservan su amabilidad y acuden á la luz de la limpara para ver qué sucede. Todo lo quieren examinar minuciosamente, primero con la lengua y despues á picotazos, cada ve\% mas fuertes; cualidad algo desagradable por un concepto, pues cuando una persona acerca demasiado la cara 6 la mano á la jaula, su curiosidad suele ser algo dolorosa; pero manteniéndose a distancia con. renicnte divierte mucho ver cómo el ave toca con su larga lengua la punta de la narizá rebusca en ia barba del hombre.

- Cuando se les deja libres en la habitacion molestan á ve. ces por su curiosidad en los momentos en que no se les vigila: pero sus ademanes grotescos divierten mucho en cam bio. Fs muy curioso verlos cuando encuentran un libro abier. to: vuelven primero con la lengua alguras hojas y despues le echan i un lado a picotazos, cual si la materia de que trata no iuese de su gusto. Por la observacion siguiente se colige cuínta es la astucia de estas aves, a pesar de las grandes $\$$ cudidas á que esta expucsto su cerebro. A reces quedan cógidas con un dedo en una de las estrechas mailas de alambre de la red de su jaula, y entonces no revolotean con vinlencia, sino que miran cuidadosamente el sitio donde se engancharon y extracn la paia con ayuda del pico.

- Por muchas que sean las buenas cualidades del pica rojo. no puedo negar sin enbargo que tambien puede hacerse desagradable. Cuando se-te deja salir de la janla para observar mejor todos sus movinientos, trepa a menudo por las piermas, sin reparar que sus garras hacen daño; y si se jueg? con él es preciso tener sicmpre urecaucion, porjue sus picotazos causan á veces bastante dolor; si los dirige as su anno, hácelo solo para jugar, procediendo como las aves de rapina domes. ticadas, que roen $\&$ veces los dedos con su jicn: pero nunca lo hacen po: ira, porque este es un sentimiento del rodo des. conocido para ćl. Si otra ave se posa sobre su jaula parece alegrarse por tener una ocasion de entretenerse con otro ob jeto, pero nunca se obsersa envidia ó malicia. Diriase que Ia diversion es una necesidad jarn esta ave, aunque no se crea asi al ver a los individuos libres ragar aislados por bos. ques y jardines. Su agradecimiento es evidente cuando su amo le cuida bien, y de mil maneras expresa su desco de que este lo haga.

l'or el siguiente informe de Girtanner se deducirá hasta qué punto pueden familiarizarse los picos mayores. mis cautivos, dice el citado ornitólogo, que se habia hecho del todo independiente y que tambien sabia buscar los gusa. nos, las larvas, las arañas y otros insectos, cstaba destinado por mi á ser puesto en libertad. l.e lleve al inierior de un bosque alto $y$ dejéle volar; al instante trepó alegre por un abeto, pero volviendo continuamente la cabeza hácia mi.
Cuando quise alejarme comenzó á llamar, siguióme y se agarró á mi ropa. Por mucho que hice para dejarle, siempre supo encontrarme, y no me quedó mas remedio que volver a llevarle á casa. Otro individuo se habia domesticado de al modo, que entraba y salia à su antojo sin pensar jamás en la fuga: veiase con mas frecuencia en los árboles de los paseos puiblicos yue en mi casa. Contestaba siempre cuando se le llamaba con un silbido, acudia presuroso, y recibia entonces por recompensa algunas larvas de abejorro. Sabia tambien encontrarme en un jardin público situado á corta distancia de mi casa; buscábame alli con regularidad; pedia cualquier golosina, como escarabajos, nueces of frutas; dirigiase al árbol inmediato, la depositaba en una hendidura y la devoraba.

Los picos mayores son a reces presa de los gavilanes yo de los azores: pero en el bosq̨ue escapan de estos enemigos por la rapider. con que trepan á los árboles y se ocultan en los agujeros. Ias comadrejas y las ardilihas devoran a menudo la progenie. Cuando los padres ven á estos animales acercarse al nido, dice Naumann, los persiguen lanzando gritos de angustia.s

\section{EL PICO MEDIO-PYCUS MEDIUS}

CARACTERES. - Fil pico medio, llamacio tambien giro

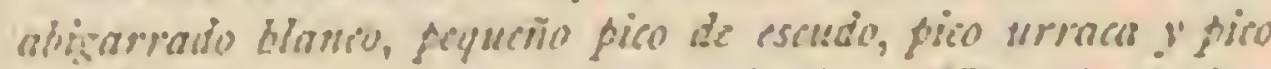
ficinder, es un ave de $0^{n}, 21$ de longritud por $0^{\circ}, 40$ de anchu. ra de punta a punta de las alas; cstas micien $6^{\prime \prime}, 1$, y la cola 11" os. I a frente y parte anterior de la cabean son de un blanquizco rojizo; la coronilla y el occipucio rojo escarlata; la nuca y parte posterior del cuello y cl resto de las partes superiores, negras; los lados de la cabeza y del cuello, las sienes $y$ la parte inferior hasta cl vientre, blancos, con un li. gero viso amarillo rojizo en el centro del pecho; el vientre, el ano y las tectrices inferiores de la cola, de un escarlaza claro; los lados del vientre y de los muslos, asi como los del pecho, presentan estrechas lineas aegras â lo largo de los tallos; de bajo de las orejas hay una mancha negra longitudinal quese reune con una faja mas estrecha, corriéndose hasta el pecho; en los hombros hay grandes manchas blancas. Las rémiges primarias son negras, con cinco grandes manchas blancas trasversales, las secundarias tienen tres; las tectrices son blancas en su extremidad, de modo que el aia plegada presenta seis fajas tmaversales de este color. Las dos rectrices de ambos lados son blancas en la mitad cxtrema, con dos fajas trastersales oscuras, que en las barbas interiores de la segun. da se reduce a una sola. Los ojos son rojos; el pico de un negro azulado de cuerno, y los pices de un negruzco gris. I hembra se parece al macho; pero el rojo de la parte superior de la cabeza y de la inferior del vientre es mas claro, y tanto aquella como ef pecho ticnen un lustre amarillo rojizo mas marcado. Los polluelos se distinguen por el rojo sucio de la parte superior de la cabera y por las tecrices inferiores de la cola, que son de un zojo pálido.

DISTRIBUCION GEOGRÁFICA. - Fil pico medio es una de las pocas aves que salen de los limites de nuestro continente, pero solo en algunos puntos. Su área de disper. sion se extiende por el norte hasta el centro de la Suecia; en el sudeste hasta ol Asia . Ienor; en el este hasia la Besara. bia; en el sur hasta la Cirecia, Italia y Espaina, y en el oeste hasta la costa de! Atlántico.

Lin Alemania y Francia se presenta solo en algunos pun. tos, y con preferencia en varios bosques frondosos. Segun las observaciones de.Schalow, se le encuentm con bastante frecuencia en la Marca; anida en las inmediaciones de Berlin, en el lardin zoolúgico, $y$ hasta entra en los jardines del interior de la ciudac. Segun Nauman es tan comun en Anlati 
como el pico mayor, y en los bosques frondosos abunda mas. Otros observadores, entre ellos Borggreve, dicen que está confinado en todo el norte de Alemania; pero este aserto es crróneo, al menos en parte, porque este pico vaga a bastante distancia, visitando regiones donde no vive en orro tiempo. Altum le encontró en todos los encinares de Alemania, noti cia que considero como la mas cxacta, puesto que habita en los bosques grandes. En Turingia falta en grandes espacios, sin duda porqque evita los bosquues de abetos. Abunda en los de Dinamarca, pero falta del todo en Ingtaterra; en Holanda se le ve alguna vez cerca de la frontern alemana; en Bélgica no visita sino los encinares de las Ardenas; es mas frecuente en el mediodia que en cl norte de Francia, donde abunda en varios puntos, al paso que falta del todo en otros. Segun dicen los urnitólogos de fispaūa es mas recuenté en algunas regiones de este pais que el pico major; en Portugal se le considera como are comun, micntras que escasea cn Italia y en Grecia, donde Krueper lo observó durante el invierno en los olivares de la Arcadia y en las montañas de Taygetos y de Veluchi. Abunda por el contrario en Macedonia y la Bulgaria, pero se ve muy poco en Besarabia y en Crimea; en el resto de la Rusia solo se le encucritra en las provincias occi. dentales, segun Pallas.

USOS, COSTUMBRES Y REGIMEN.-Debemos á Naumann, que ha tenido muchas-ocasionics, de observar e] are, la descripcion mas minuciosa de su genero de vida, de la cual ne serviré principalmente ahora. Asi como lá mayor parte de las aves que permanecen continuaniente en la mis ma localidad, ó se alejan/solo a corta cistancia, el pico me dio abandona ya en agosto, ó à mas tardar en setiemure, su residencia ordinaria; viga de bosquie ch. bosque y vuelve en marzo. MLuchos de estos picos permanecen todo et invierno en Alctmania, algunos en las inmediaciones de su nido; y otros invernan en regiones meridionales. Viajan aisiados, yendo los pequeños a la cabeza, tal vé en compania de los padres; pero nunca se ven mas de tres jumtos. Ya se com. prenderá que solo ruelan de dia; aproiechan sobre lodol in hors del creplisculo matutino, siguiendo regnlarmente los bosques $\delta$ las lineas de drboles, y no tcuen franquear gran des distancias por el campo libre. Cuando en sus expedicio nes pasa mucho tiempo sin encontrar bosques frondosos, permanecen algun tiempo en los plantios de abetos, pero prefieren siempre la espesura. Tano en verano como en invierno visitan con frecuencia los bosques de las orillas del libiba, que se componen principalmente de encinas, aunņue tambien contienen muchos olmos, fresnos, hayas y otras especies de írboles. En el otono recorren los bosques pequeños, los plantios de sauces, y tambien los jardines donde hay frutas, en los cuales se quedan á reces muchas semanas Esic pico trepa por los troncos, bien cerca del suclo, $\delta$ ya en medio de las ramas y hasta en las altas copas, sin fijarse en que los ár. boles sear viejos o jóvenes; tambien se aventura en las pun. tas de las ramas mas delgadas, como todos los picidos, y ran ге\% baja á tierra, donde permanece muy poco tiempo. Cuando en invierno se halla en una region donde le falta un hueco de áriol para pasar en él la noche, muy pronto abre uno, y con frecuencia se le ve debajo de una rama podrida horizontal. El pico medio se distingue entre sus congéneres por su belleza, contrastando agradablentente sus colores blanco y negro con el magnifico rojo. Es mas alegre que casi todas las especies; sus movimientos son mas rápidos y ágiles que los del pico mayor, y cuando este les ataca sabe defenderse muy bien merced s la movilidad de sus eroluciones. Poco sociable, como todos los picidos, tambien él lucha continuamente con sus semejantes; y á menudo se ven dos que peleando en los aires caen agarrados en tierra. Para que se traben tales pendencias basta que un individuo trepe al mis. mo tiempo que otro por un árbol. Sin embargo, á pesar de su carkcter pendenciero, muchas veces vagan algunos indi. viduos juntos por el bosque; asi como el pico abigarrado, réunese con los régulos, sitas y certidos; en sus viajes se le ve casi siempre muy acompañado, y hasta es una cxcep. cion que no suceda asi. Asi como las otras especies de su ia. milin, tambien es inquicto y precipitado; solo cuando quicre extraer una presa de la madera se detiene algun tiempo en el mismo sitio, pero muy poco; no siendo esie caso, siempre esta en movimiento. Demuestra su agilidad cuando trepa $y$ vuela; en el suelo da saltitos con los tarsos muy arqueados, pero no es mucha su pesadez Por lo que lase á trepar, dificilmente le igualara otro pico europeo. En su vuclo traza una gran linea en forma de arco, y es aun mas ligero y rájuido que el pico abigarrado: aseméjasc á estè por la vor, pero su kivll o fich cs mas alto y se sigue nas apresuradamente. En la primavera gritan mucho los picos medios y llegado el período del celo, los machos se posan en la copa de un árbol, donde repiten su kick un sinnúmero de veces con una rapi. dez/ extraorỏinaria El grito tiene por objeto llamar i la hembra, y tambien á otros machos, pero entonces sirve de reto, pues a menudo se presenta alguno y da principio la lu. cha, persiguiéndose uno a otro a lo largo de las ramas. La pelea es á feces formal, y solo cuando ambos se han cansado se cueigan uno junto a otro en un arbol y gritan á mas no poder; pero entonces su ro\% es chillona.' Jespues de eri. zar las bonitas plumas de su cabeza, toman por breves momentos una posicion amenazadora y vuelven á precipitarse uno sobre otro. Durante la época del celo, el macho persigue á la hembra de una manera semejante; jero diviértense adémás, como el pico abigarrado, tocando el tambor sobre las ramas secas, lo cual comunica mucha animacion á los encinares.

El alimento del pico medio es casi el mismo que el del pico abigarrado, con la diferencia de preferir los insectos: solo por excepcion come algunas clases de simientes siliestres. l'ara buscar su alimento diario trepa por los troncos y pica en ellos de continuo, cogiendo tados los insecios que encuentra en las hendiduras de la corteza ó en la madera po. cirida. Varias clases de escarabajos en todas las fases de su vida, arañas, huevos de insectos y orugas le sirven de pasto, y desce la maniana hasta muy tarde se le ve trabajar para apodcrarse de su presa. Nu desprecia tampoco las avellanas, las bellotas y frutos del lanya: asi como el pico mayor, y á menudo en compañia de éste, visita los cerezos, coge la fruta madura, parte el hueso y se come su contenido. Tambien le gusta la simiente del abeto, la cual abre como el pico abigar. rado: mas al parecer no lo hace sino cuando le falta comida mejor.

A fines de marzo, ó en abril, comienza a experimentar los deseos amorosos, y entonces resuenan en el bosque los gritos de este pico. Despues de continuas luchas con otros rliales, el macho conquista al fin una hembra, y procede en. tonces a formar un hueco para el nido, si es que no hay alguno en la localidad. Raras veces se halla este hueco fímenos altura que la de seis metros: péro muchas veces encuéntrase a reinie, ya en un tronco, ó en una gruesa rama. Li entrada es redonda y tan estrecha que apenas puede pasar el ave: el hueco mísmo, igualmente redondo, mide $11^{\circ}, 1 \$$ i $11^{\circ}, 25$ de profundidad, raras veces mas. Ia puesta se compone de circo a siete huevos, cortos, de forma oval, del todo blancos, orillantes, lisos y de grano fino. J a hembra los coloca sobre algunas fibras finas del fondo y cubrelos dumnte quince dias, alternando con el macho. Los polluelos son feos y torpes has. ta que su plumaje se desarrolla, y tienen la cabeza tan volu- 
minosa como las de todas las ciemás especies de picidos: crecen con bastante lentitud y no abandonan el nico tasta que pueden volar perfectamente. Ambos padres profesan tiemo cariño ì sus hijuelos: déjanse coger sobre los huevos, y mas tarde se exponen sin reparo a peligros que en ciro caso evitarian.

Las martas, las comadrejas, el halcon de las gallinas y el nisido comun persiguen y cogen al pico medio: las coumdre. jas $\mathrm{y}$ otros carniceros pequenos amenazan las crias: y el hom. bre, en su imprudencia, apodérase de los adultos y de los nidos. El pico medio no es timido, se deja engañar fácilmente por la imiacion de su tamborilco, y tambien se le coge con lazos si se le cuida bien soporta probablemente la cautividad, lo mismo que el pico mayor. Io no he tenido ninguno, ni tampoco le he visto en cautividad: pero no dudo yue su tratamiento es tan fácil como el de los picos mayor y menor.

\section{EL PICO MENOR-PICUS MINOR}

CaRaCTERES. - Esta especie es el enano entre los picidos europeos y uno de los tipos mas pequeños de la familia en general. La parte anterior de su cabeza es de color

Fig. 1:2.-E1. IICO Mesos

blanquizco rojizo; la coronilla de un escariata vivo; el occijucio, una estrecha faja longitudinal de la parte posterior del cuello, otra que se corre desde el pico por debajo y de trås de la region de las orejas, donde se ensancha, y todo el resto de las partes inferiores, son de color negro; en el dorso, los hombros y la region superior de la rabadilla, predomina el blanco con tres ó cuatro fajas trasversales negras; la linea masa.ocular, las sienes, el buche $y$ los lados del cueilo son de un blanco sucio: las plumas del buche presenian linens anchas; en los lados del pecho las hay mas estrechas á lo largo de los tallos; las fectrices inferiores de la cola están adornadas de fajas trasversales negras; las rémiges primarias son tambien de este color y tiencen exteriormente cuatro ó cinco pequeñas manchas blancas; en las secundarias hay dos mas grandes; las grandes tecirices del ala $y$ las rémiges secundarias están orilladas del mismo color; de modo que el ala recogida presenta cinco fajas trasversales blancas; las rec-

trices exteriotes son de igual tinte, con tres fajas trísversales negras; la segunda de cada lado es del iodo blanca en las barbas exteriores y en la extremidad de lis interiures, donde hay otras fajas negras; en la tercera de cada lado, en fin, el blanco se limita à la extremidad. Los ojos son rojizos: el pico de un negro azulado de cuerno y los piés de un gris de plomo.

La hembra carece de rojo en la coronilla; esta y la parte anterior de la cabeza son de un blanco pardusce. Los pequeños se distinguen de la madre por el color blanco pardusco rójizo sucio de las regiones inferiores, y no solamente los machos jóvenes sino tambien las hembras, tienen una mancha roja en la coronilla, siendo inagor en los primeros que en las segundas. Estas manchas disminuyen de เamaño de dia en dia en las hembras, y al tin desaparecen del todo al cabo de cuatro semanas, conservindose solo en los ma. chos. 
La longitud del ave es de $0^{\infty}, 16$ por $\|^{*}, 30$ de anchura de punta a punta de ala; estas últimas miden $0^{\prime \prime,}, 07$ y la cola $0^{n}, 06$.

DISTRIBUCION GEOGRÁFICA.-El trea de dispersion de esta ave es al menos tan extensa como la del pico mayor, pues habita toda la Europa desde la Iaponia hasta el extremo sur, y tambien el Asia central hasta los paises del Amur; al contrario del pico abigarrado, encuéntrase aun en los bosques del noroeste del Africa. Algunos naturalistas consideran al pico menor de la Siberia oriental como especie independiente, porqque el blanco del lomo suele extenderse mas que en los individuos europeos; pero lo mismo sucede con todas las aves de la Siberia en general; y dificilmente se justificaria una separacion de los citados picidos. El árbol favorito del pico menor es el stuce, y por consiguiente, ha bita todas las regiones donde se encuentra, sobre todo las islas de los rios; Elioes dice en conformidad con esto, que ese pico es el mas comun en Ta Macedonia, hallandose en todos los bosques pantanosos de alerces y sauces. En nuestro virje por la Siberia occidenial hemos observado la exactitud del hecho. Alli donde el caudaloso Obi se divide en un número infinito de brazos, formando con ellos islas cubiertas de stuces, cl pico menor abunda mas que ninguno de sus congéneres, y hasta en alguno de aquellos sitios se le puede con. siderat como una de las aves mas comunes. In efecto, los sauces y otros árboles de madera blanda, convienen mejor á sus débiles fuerzas; en las hayas j los troncos de madera fuere, no construje sus nidos sino cunndo los írboles se pudren.

Esto explica su poca frecuencia en Europa.

En Alemania abunda basiante en las regiones donde hay sauces y hayas, mas por lo regular no se fija la atencion en el ave. Eugenio de Homeger me refiere que un amigo del guarda.bosque superior Seeling rogó á este que le enviara picos menores. Dicho empleado habia creido hasta entonces que esta especie de aves cra muy rara en su distrito, porque pocas reces ]a habia visto; pero encargo á sus guarda-bosques que observaran el pico y sus nidos; y a los dos dias se le cn. tregaron veinte individuos de la especie. Is posible que su. ceda lo mismo tambien en otros grandes bosques de las 113. nuras de la Alemania del norte.

No se la pucde considerar como viajon, pues se la ve todo el año en el pais donde se la reproducido; pero es crrante, y desciende hasta las regiones bajas de las montañas. Estas mudanzas se verifican en otoño y primavera, desde el mes de setiembre ú octubre hasta el de abril. Se alcja de los bosques compuestos exclusiramente de coniferas: una vez esta. blecida en cierto dominio le recorre todo varias reces al dia, lo cual se reconoce particularmente durante el invierno, cuando la caida de la hoja permite ver nejor al ave. Ei centro de su dominio está indicado por algun tronco hueco, donde el-ave pasa ia noche: en sus peregrinaciones evita aventurarse en sitios donde no encuentra semejante refugio. Segun Naumann, muchas veces desaloja violentamente i los paros ó gorriones que se introducen antes que ella en sus agujeros, pues como se entrega al descanso mas tarde, en. cuentra tales albergues ocupados, y no puede penetrar sin lucha.

El pico menor, dice Saumann, es uno de los mas vivaces y ágiles: trepa con ligereza por los árboles, da vucltas al rededor de los troncos, y hasta baja algunos pasos, pero siem. pre con la cabeza erguida; corre por las ramas que apenas tienen un dedo de grueso 6 se suspende de su cara inferior. Golpea los árboles, y es tan diestro como sus congéneres para pracicar agujeros á propósito para la nidificacion; busca no obstante para ello los sitios donde la madera es mas blanda, prefiriendo las encinas viejas, en las que anida bastante á menudo en cavidades que presenta la cara inferior de ramas casi horizontales. A veces se posa á través de una jequeña rama, como las otras ares, y en tal caso encoge mucho las patas. De un natural muy pendencicro, no permite que ninguno de sus semejantes permanezca cerca de él. Se le ve, lo mismo que à sus congéneres, acompañado á menudo de los trepadores, los paros y los repezuelos, que suelen seguirle, sin que parezca inquietarse de su presencia. No teme al hombre, y le permite acercarse mucho antes de huir. Su grito puecie imitarse por kick kgrck: la nota es alta ó baja y lánguida; a reces la repite seguidamente, sobre todo cuando se posa en un árbol; grita mucho si hace mal riempo, y mas en la época de la puesta: el macho ronca, como los otros picos, aunque con menos fuerza y en rono mas alto.

Durante el periodo del celo, que comierza en el mes de mayo, se distingue esta ave por sus gritos y su continua agitacion; es una época de luchas, entre dos machos quue se disputan una hembra, ó entre dos parejas nue tratan de ocu. par el mismo agujero. Anida á bastante altura, con preferencia en los altos y viejos sauces, chopos, allamos, hayas y en caso de necesidad tambien en encinas; no desprecia tam. poco lós árboles frutales; en Pomerania anida siempre, se. gun Eugenio de Homeyer, en hayas secas y podridas, situa. das en los linderos de bosques claros.

1.a construccion le cansa mucho, y por eso clige siempre una rama rota y carcomida en su interior; la abertura del nido es circular; no tiene mas de $11^{\mathrm{m}}, 04$ de diámetro, y con. duce a un hoyo de $1^{\circ}, 10$ a $0^{\circ}, 12$ de ancho ye de $0^{\circ}, 15 \leqslant 0^{\circ}, 17$ de profunaidad. Il pico menor comienza varius nidos antes de acabar uno, por lo cual es mas dificil encontrar los hue. vos. Para conseguirlo se debe seguir el consejo de Paessler, es decir, acechar al macho cuando lleva el alimenio a la hembra. Cada puesta consta de cinco ì siete huevos, peque. ños, de color blanco lustroso, cubiertos algunas veces de puntitos rojos. El macho y la hembra cubren alternativa. mente po: espacio de catorce dias; ambos se cuidan de criar a los hijuelos, y los conservan consigo mucho tiempo despues de baber comenzado á volar.

El pico menor se alimenta exclusivamente de insectos, $y$ hasta en invierno está su estómago lleno de sus restos. Extermina gran número de hormigas, arairas, coleópteros y sus huevos. Presta grandes servicios, dice Naumann, no solo en los bosques sino inmbien en los huertos. D Trepa continuamente á los árboles, golpea sus ramas y está comiendo siempre: cuando se abre su estónago se le ve siempre repleto de un número increible de animales nocivos.

Felizmente se halla menos expuesto este pico que los otros â ser victima de la rabia destructora de ciertas gentes; no llama tanto la atencion, y el que llega i conocerle no puede menos de cobrarle arecto. Sin embargo, su confranza le conduce á mas de un peligro: tambien acude cliando se imita el ruicio que hace al golpear los árboles: pero es pre. ciso saber hacerlo muy bien para atraer al ave por este medio.

CAUTIVIDAD. - Los picos menores cautivos son aves graciosisimas. Inofensivos y familiares, alegres y en exiremo ágiles, son del todo propios para la jaula; pero exigen un espacio en que puedan picar á su antojo, si se quiere que den a conocer rodas sus particularidades. Como ya he dicho en mis Azes caufiatas, se les puede tener sin reparo con los péridos y régulos, pues vivén en perfecta armonia. Es un es. pectáculo gracioso formar en tales jaulas el conocido cuadro de la vida en libertad de nuestras ares silvestres en miniatu. ra, pues asi como en la selva, concúdese pronto á la linda avecilla la soberania sobre todos los habitantes de la jaula. 
Waiter está en un todo conforme con mis elogios del trepa. dor enano. El pico menor, me escribe dicho ornitólogo, es un are astuta, siempre alegre, familias é inclinada al retoro; tanto, que el pico abigarrado parece del todo estúpido a st lado. No contento con jugar solo, de la manera mas gracio. sa, excita tambien a menudo a su amo aे divertirse con है. Cuardo enionces se mueve un brazo ó un paruelo, todas las aves se alegran, comenzando á ejecutar las evoluciones mas grotescas; se persiguen unas á oiras y irepan alrededor ciel tronco como los monos. Una se oculta con las alas levanta. das casi verticalmente, otra la descubre y entonces corren ambas como bailando alrededor del árbol, siempre provocándose y persiguiéndose. Muchas veces debi accrcarme a las jaulas para trannuilizará mis ares, y entonces acudia toda la familia a la reja para exaninar cuidadosamente mi mano.s

El mismo observador refiere el caso siguienic: 2 Para reco. nocer tanto el exterior como las facultades intelectuales de esta are, habia sacado del nido cinco ņolluelos que ya tenian algunas plumas, á fin de reunirlos con un pico abigarrado de la misma edad. Alimentaba á los seis con larvas de hormiga y aunque no sabian recogerlas aun del suelo, las cogian des. pues de algunos ejercicios de un papel que se les tendia por delante del pico. A los cuatro dias los cinco picos menores abandonaron uno despues de otro el nido arreglado para ellos; treparon por el trónco del árbol que al efecto habia puesto en la jaula, y recogieron tambien su alimento del suelo. Apenas se acostumbraron a comer solos, atrapaban la larva de horniga, corrian con elia hácia el pico abigarrado, que aun estaba en el nido y se la daban. Antes de que el quinto hubiese entregado la suya, el primero volvia con otra y asi continuaron hasta que el pico grande abigarndo pareció satisfecho; pero tan luego como manifestaba tener gana re. petiase el nismo ejercicio hasta que al cabo de algunos dias el pico mayor pudo comer solo.

Como debia emprender un largo viaje no pude conservar las lindas avecillas, y resolvi devolverles su libertad despues de tenerlas dos meses en la jaula; llevélas al jardin zoológico de Berlin y las puse en un troncode encina algo distante del carnino. Todas comenzaron al punto $\{$ irabajar en el con su pico, ocupacion que al parecer les hizo olvidar todo cuan. to pasaba a su alrededor; mas apenas quise alejarme, acudic. ron y se posaron en mi precho y en los hombros. No me quedó mas remedio que cortar una fuerte rama y ahuyentar con ella á las avecillas que se intimidaron. Si no lo hubiera hecho asi, alguno las habria cogido y quizás muerto al poco rato. Dos picos menores que yo tenia habian sido criados para mi por unos amigos, nque acostumbraban a darles larvas de hormiga; conservatonse en buena salud, mientrns pude proporcionarles este alimento fresco; pero despues murieron anbas uno despues de otro, sin poderme explicar la causa, como lo hizo despues IValter. Estas ares tienen los órganos digestivos tan débiles que no pueden formar la pelota; cuan do se les da un alimento dificil de digerir, como insectos con alas duras, piés, etc., enferman y mueren pronto de la eisis. Esta circunstancia es el mayor obsiáculo para conservarlos mucho icmpo en la jaula.

Los mismos enemigos que tienen los demás picidos persi. guen tambien al pico menor y mas de cuatro de estas aveci llas perecen entre sus garras; jero muchas tambien se escapan gracias á su agilidad incomparable. - En cambio su caracter inofensivo ys sumiliaridad les exponen á los mayozes peli. gros por parte de los cazadores. Sin embargo no prodria decirse que su numero disninuye, pues afortunadamente el invicr. no no es tan malo para ellas como para los picidos terrestres, y iambien sus nidos están mas ocultos a la vista de los llamados coleccionadores de huevos, que escudados con la ciencia, son los mayores enemigos del mundo alado, pues no solo saquean los nidos, sino quue los destruyen, causando entre los picos mayores destrozos que los mas peligrosos carniceros

\section{EL PICO BLANCO-PICUS LEOCONOTUS}

CARACTERES. - El pico blanco, llamado ambien fiu urraca, y fico ahigarrade de lomo blanso, es el mas raro de lodos los pícidos europecas. Mucho nayor que el jico abigarrado, es muy poco mas peçucio que el pico gris, pues tiene una longitud de $4^{\circ}, 26$ \& $0^{\circ}, 2 S$, por $10^{\circ}, 47$ if $11^{\prime \prime}, 50$ de anchura de punta á punta de las alas; estas miden $0^{\circ}, 16$ y la cola $U^{*}, 10$. Ia frente y parte anterior de la cabeza son bian. cas, con un viso rojiro pálido; la coronilla y el occipucio rojos de escarlata, debiendo noiarse que la base de las plu. mas de esta region es gris, color qque se mezcla algo con el anterior; la nuca, la parte posterior del cuello y la superior del rronco, asi como una faja que desde el ángulo de la boca se corre por los lados del cuello, reuniéndose aqui con otra mas ancha, situada entre la region de las orejas y los lados del iuche, son negras; la region posterior del dorso y la de los hombros, blancas, con aigunas estrechas lineas trasversales negras; la linea naso-ocular, las sienes, los lados de la cabera y del cuello y las partes inferiores son blancas; los lados de los muslos, el vientre y la region del ano, negros; las tectrices inferiores de la cola de un escarlata vivo; los lados del pecho y del vientre presentan estrechas lineas: en las rérniges primarias se observan en las barbas exteriores cuatro anchas fajas trasversales blancas, y en las secundarias dos; las tec. trices del brazo y las mayores de la parte superior de las alas tienen en su extremidad anclios bordes blancos, de modo que el ala recogida forma seis anchas fajas trasversales blancas. Las dos rectrices exteriores son negras en la base y blancas en el resto de su extension, con dos fajas trasversales oscuras que en la segunda solo se notan en las barbas interiores; la tercera rectrix, blanca en su extremidad, tiene oira faja semejante. El iris es rojo amarillo ó pardo; el pico azul oscuro con pumta negra, y los piés de un gris de plomo. La hembia tiene la coronilla negra; en los polluclos, segun dice Altum, no se marca todavia el color. Las pulumas de la coronilla son negras y presentan hasta la mitad de la cabeza puntos de un rojo sucio, de modo que la paric anierior de aquellas parere negra. Las regiones inferiores son de un blanco pálido, $y$ solo las últimas plumas del vientre $y$ las tectrices inferiores de la cola tienen un viso de escarlata, observándose, como en los adultos, las manchas de los lados del pecho y del vientre, que desaparecen poco a poco de la cols.

DISTRIBUCION GEOGRÁFICA.-El drea de disper. sion del pico blanco se extiende jor el norte y nordeste de Furopa, y por toda la Siberia meridional hasta los paises del Amur. Litimamente se ha sabido que esta ave anida en Ale. mania; pero como solo se presenta muj aislada, podria decirse que lo hace excepcionalmente. No la han visto aun, al menos que yo sepa, en Esparia, Italia, Francia, Bélgica, Holanda, Dinamarca é Inglaterra; pero en cambio abunda bastante en el sur de la Escandinavia. Scgun Collet, anida en los paises bajos de las provincias de Cristiania y Hamar, y en varios puntos de aquella region se ven muchos individuos: perofrecuentan mas nun el norte y cl sur de la provincia de Trondjem; en Ocrkedal ! Surendal es el mas comun de todos los picidos. En Suecia, segun Nilsson, se le ve aisladamente en algunos sitios; pero mas a menudo en el norte que en el sur, aunque no parcec extenderse hasta las partes mas septentrionales de Escandinavia. La Finlandia forma el enlace de su área de dispersion con Kusia, incluso las provincias de 
Báltico y la Polonia, cuyos paises pueden considerarse quizás como la verdadera patria de este pico en Europa Segun Radde, habita en todos los territorios cubiertos de bosque de la Siberia meridiònal, y anida con frecuencia en la montaña de Bureja. Yo creo que todos los picos blancos que se han encontrado en Alemania, es decir, en ambas provincias de Prusia, en Silesia, en la Marca, en Mecklemburgo y en Baviera, asi como los que se han visto en Bohemia, en el Aus. tria superior y en los Pirineos, solo pueden considerarse como individuos errantes, que habiendo salido por casualidad de los limites de su verdaclera área de dispersion, anidaron fuera de clla.

Lin frecia y el Asia Menor se encuentra un congénere del pico blanco, que líltimamente se ha reconocido como esprecie independiente: es el pico de Grecin (fricus Jilfordi). que difiere del pico blanco por el color oscuro de escariata de la coronilla y del occipucio, y por los hombros y el manto, en los cuales se ven anchas fijas trastersales blancas y inegras; las, regiones inferiores son de un color algo mas vivo.

USOS, COSTUMBRES Y REGIMEN.-Solo Taczanowski nos ha dado noticias minuciosas sobre la vida en liber. tod de esta ave. «El pico blanco, se encuentra por todas pirtes en Polonia, pero nunca en gran número; escasea por el contrario mas que el pico medio, y hrabita principalmente en los bosques frondosos, sobre toda en añuellos donde abun. dan las encinas y álamos; no se le encuentra nunca en los de abetos Distinguese de los otros prícidos por su caricter tran. quilo: nótase mas lentitud en sus movimientos, y su voz se oye con menos frecuencia. $A$ veces se le ve horas enteras en un mismo árbol; pero despues irepa de vez en cunndo bas. tante rápidamente al rededor del tronco para buscar su alimento. A pesar de tener el pico mas grueso, no produce con a tanto ruido como las demás especies; trabaja tran. quilamente $y$ busca, en cuanto le és posible, los árboles mas podridos; pero aun en estos solo arranca la corteza. En in. vierno se le ye á menudo en los jardines y en los pueblos, donde suele permanecer á veces todo el dia: limitase á buscar su alimento en algunos árboles ó arbustos, y no hace aprecio del hombre En la cpoca del celo produce un tamborileo ó manera de otros picos abigarrados, pero tan poco ruidoso, que solo se le oye à corta distancia

DSu alimento consiste exclusivamente en insectos. Algunos dias antes que el pico negro, casí siemprc á principios de abril, comienza á construir su nido, y à mediados de mayo salen $\dot{a}$ luz pequeños. El nido se construye en un árbol muy podrido, con preferencia en fresnos y álamos, raras veces en encinas, y casi siempre en el tronco, $a$ unos cuatro $\delta$ seis metros de altura. Le gusian tanto los árboles podridos, que aun los clige cuando solo la cortera impíde su caida Uno de estos troncos, que contenia un nido con polluelos y habia kervido ya algunos años para anidar, cayó en pedazos, en of verdadero sentido de la palabra, cuando le sacudi. Un observador experto puede reconocer fácilmente el nido del pıco blanco, no solo por los grandes pedazos de madera que hay debajo de cl, sino tambien por su entrada circular, que en las otras especies suele ser oral. El hueco es mas espacioso que el del pico mayor, $y$ ś veces ian ancho y profundo como el del pico verde. El número de huevos no suele pasar de tres; solo conozco un ejemplo de haberse encontrado cuatro. Asermejanse mucho á los del pico mayor; pero varian bastante por la forma, siendo unos muy prolongados $y$ otros muy re. dondos.

Entre las demás observaciones que se han publicado sobre el pico blanco citaré tambien las siguientes. Nilsson estấ conforme con Tacianowski en que esta ave prefiere los bosques de árboles muy prodridos; dice que tambien se encuentra en los de abetos, $y$ anade que no es muy tímida; que examina en los árboles siempre las partes superiores; que en verano vive apareado $y$ en invierno en familia algunas veces.

Collet dice quue se la coge todos los otoños en los lazos dispuestos para los torcos, lo cual prueba que no desprecia del todo el alimento vegetal. Altum, en fin, nos da noticias muj curiosas sobre su incubacion en Alemania. Conocianse solo dos casos de haberse reproducido el pico blanco en este pais, una en el distrito de Munich y otra en Silesia; pero en concepto de Altum, estos casos son mas frecuentes de lo que se suponia. El citado naturalista cree que hace ya muchos años que anida en la Marca. Una hembra que se conserva en la coleccion de la Escuela de selvicultura de Eberswalde fué muerta durante el periodo del celo en el bosque de Liep y en junio de 1847 se cogió un macho. El 29 de mayo de $18 ; 2$, Altum obturo una prueba segura de que el pico blanco anida en Alemania: Shesse, jóven empleado en la administracion de bosques, le llevo un macho adulto que habia muerto el dia anterior en el distrito de Liep, mientras se ocupaba en alimentar a su pequeño; $y$ de consiguiente no se puede dudar que el ave anida tambien en Alemania.

\section{LOS GECINOS- GECINUS}

Ciloger fué el primer naturalista que fundåndose en dos especies de Alemania separó de la familia los gecinos ó nicos verdes, grupo que comprende unas doce especies. Ahora se reunen estos pícidos en un género independiente, que nosotros consideramos como subgénero.

CARACTERES. - Los gecinos, llamados tambien cloro. picos ú picus revdes, tienen bastante talla, cuerpo esbelto, pico algo cónico, de cuatro caras poco marcadas, y cresta dorsal ligeramente corva; las patas son fuertes y con cuatro dedos: las alas sedondeadas, con la cuarta y quinta rémiges mas largas nue las otras: la lengua muy larga. El plumaje, generalmente verde, presenta en el vientre un viso inas claro; las plumas de la cabeza tienen un color vivo y'se prolongan á menudo en forma de moño.

Segun Reichenbach, los gecinos tienen el esqueleto ende. ble, lo cual indica poca fuerza: su cráneo es mas prolongado que el de los otros pícidos; las vértebras dorsales presentan apófisis espinosas superiores anchas y oprimidas entre si. El carácter de la uniformidad mas ó menos completa del plumaje, se conserva, sin embargo, como lo mas pronunciado, pues á decir verdad los gecinos no constituyen por sí un grupo bien limitado.

\section{EL GECINO VERDE-GECINUS VIRIDIS}

CARACTERES.-Esta especie, el pico verde propiamente dicho, llamado tambien relinciador, leñador y carpin. fero; es la mas conocida de los gecinos. La parte superior de la cabeza, la nuca, y una cxtensa mancha en el ángulo de la boca, orillada de negro, son de color escarlata; en la coronilla, la base de las plumas es de color gris lustroso; las plumitas de la nariz y la linea naso.ocular son de un negro de humo; las regiones superiores de un verde aceitunado; las alas tienen un viso pardusco; la rabadilla y lastectrices superiores de la cola son de un amarillo brillante; la region de las orejas, la barba y la garganta, biancas, con un viso ver. doso sucio; los lados del cuello de un color blanco verdoso amarillo; los muslos y las tectrices inferiores de la cola tienen fajas trasversales oscuras; las rémiges primarias presen. tan en las barbas exteriores de seis á siete manchas trasversales de color blanco rojizo; las barbas interiores de todas las rémiges están bordeadas de manchas blanquizcas anchas: 
en las rectrices, que son negras, hay de cinco á sirte fajas trasversales de un color pardo aceitunario pálida. La hem. bra se distingue del macho por tener la mancha diel ingulo de la boca negra; en el individuo jóren las partes inferiores están adornadas de fajas trastersales negras; la parte superior de la cabeza y el occipucio son de un gris oscero con puntos rojos; las manchas de las mejillas solo estín indica. das por bordes negros en las plumas; y en los lados del cuello se ren lineas longitudinales de color oscuro. Los ojos del adulto son de un color blanco azulado, y los del joiven de un gris oscuro; el pico tiene un tinte sucio gris de plomo y negruzco en la punta; los piés son de un gris de plomo verdoso. La longitud es de $11^{\circ}, j^{1}$ por $0^{\infty}, 52$ de anchura de punta a punta de las alas; estas miden $0^{\circ}, 18$ y la cona $0^{\circ}, 12$.

DISTRIBUCION GEOGRÁfICA.-El gecino verde figura tambien entre las especies cuya àrea de disfersion es mas extensa. Excepto Espain ! la l'undra, se le escuentra con mas 6 menos frecuencia en toda Europa. Blandiord le vió hasta en Persia; no vive en Egifto, por mas g̨ue crean lo contrario mi padre, Naumann, Gloger y otros autores. Hícia el norte se extiende hasta la Laponia En España habita una especie afine (Gecinus Sharapi), que solo ditiere por tener la linea naso.ocular y los circulos oculares de color gris de pizarra en vez de negro: la faja roja de las inejillas no está orillada de negro.

USOS, COSTUMBRES Y REGIMEN.-En muchas régiones de Alemania el pico rerde es un ave muy conocida, mientras no se le encuenirn en otras, viéndose cuando mas individuos errantes durante el invierno. Mas hatcia el oeste, y sobri: todo en Rusin, escasia mucho mas que cl yico gris. En las montanas sube regularmente hasta la aleura de mil quinientos metros; Baldamus encontró un nido en !a Engadina. Durante el periodo del celo habita un territorio mas 6 menos extenso, pero en general no nuy grande; en otoño se alcjan prinero los individuos jóvenes, y cuando el frio es muy riguroso ó la nieve muy abundante, iambien las adultos. Apenas llegan los pequeños á declararse independientes comienza para ellos una vida vagabunda, que dura hasta la primavera siguiente, cuando se acerca el período del celo. Sus cxcursiones no son sin cmbargo regulares, ni iampoco se extienden à ciertos puntos: muchos inviernos perma. necen en su distrito, pero durante otros vagan a bastante distancia del pais; dirigense tambien hacia el sur, y llegan á veces hasta los limites de nuestro continente. Iin Macedo. nia, segun dicen, se han observado mas picos verdes en in. vierno que en verano, A la manera de sus congúneres, el gecino verde viaja tambien aislado, aunque á veces se reune en grupos. Schacht observó una vez por Navidad uno de ocho individuos en una pradera, donde saltaban en busca de su alimento; pero emprendieron la fuga tan luego como el ob. servador se acercó. Oberndeesler, conocedor experto de las aves propias de Alemania, dice haber visto una bandada de mas de cien individuos, cuyas tres cuartas partes se compo nian de picos verdes y el resto de picos grises; esa bandada se habia reunido en el espacio de una cuarta parte de liectárea

No se puede decir que el gecino verde sea un ave forestal; muy escaso en los bosques de coniferas, abunda mas en aquellos donde predoninan otras esencias, prefiriendo los sitios donde las arboledas alteman con los lugares descubiertos. Duranie el periodo del celo no se aparta mucho del lugar donde tiene el nido; en el inviemo, cuando abandona el pais, recorre un distrito bastante extenso; pero todas las tardes busca un agujero para pasar la noche. Entonces se le ve habitar vario nueses los jardines situados cerca de las casas y vagar por entre ellas. He observado largo tiempo á un individuo que pasaba todas las noches en el campanario de la iglesia de mi pueblo; otro se habia fijado en un nido artificinl preparado en nuestro jardin para los estorninos. El gecino verde es tan alegre y visaz, tan astuto y prudente como los otros yicidos, y dado como ellos al continuo movimiento; trepa con igual destreza y anda mucho mejor. Con frecuencia se le ve en tierra dando saltitos rípidos: su vuelo es ruidoso y muy onclulado, distinguiéndose en esto del de los otros picidos: tiene 10\% clara y sonora; su griro, equivalente

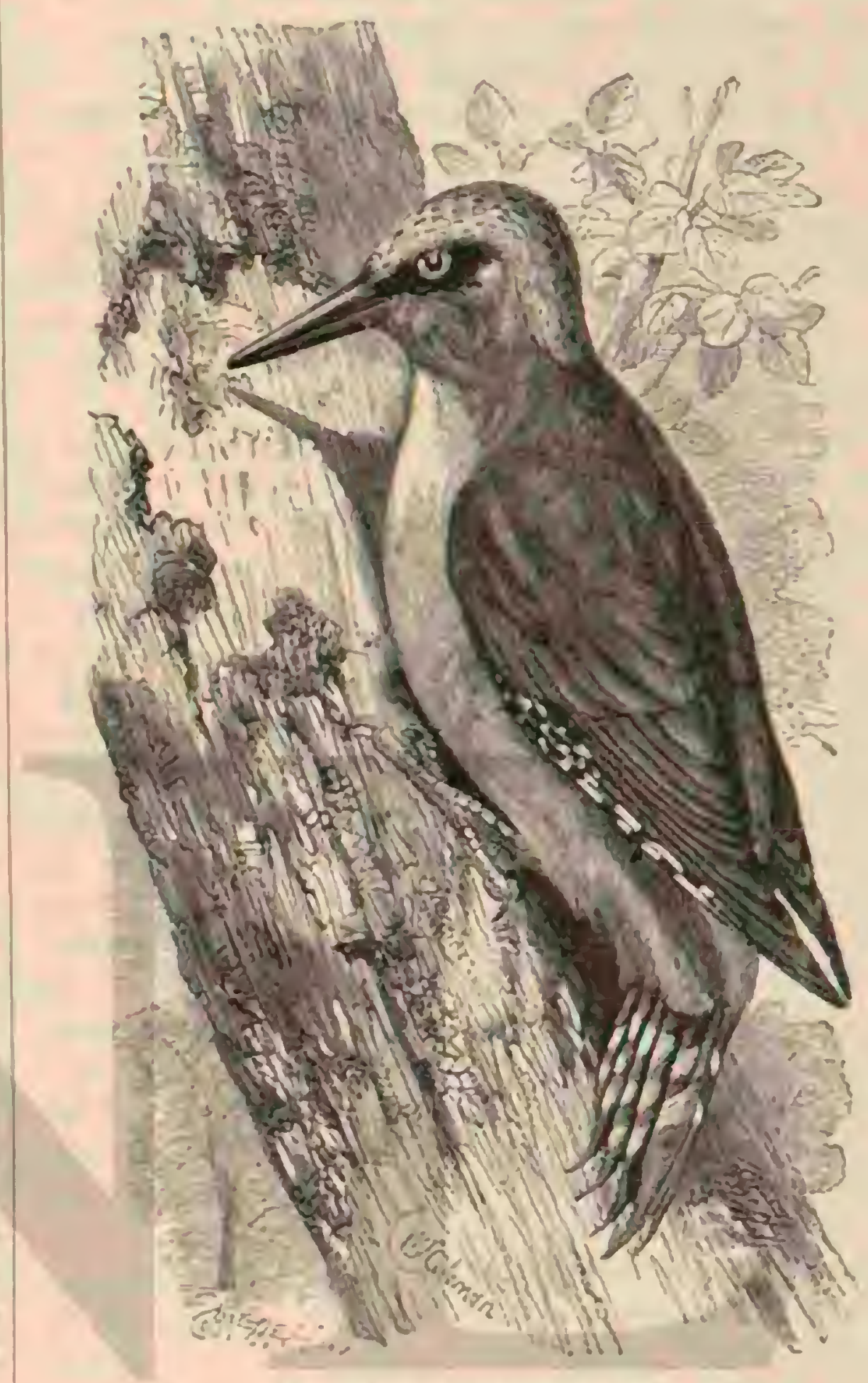

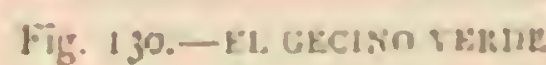

á gluck, que repite varias veces, se asemeja d una car cajada, el grito de ternura es guck gaces. ó lisps; el de angustia es ronco y desagradable. No tamborilea, como lo hacen los demás picos; tanto mi padré como Naumann aseguran no ha. berle oido nunca.

Su género de vida se asenreja en un todo al de sus congéneres: apjenas comienza i desaparecer el rocio de la manana, abandona su ręiro y empieza à recorrer su doninio: mientras no le inquiete el celo se cuida poco de su companera; vaga solitario de un árbol å otro con tanta regularidad que no es dificil alcanzarle al paso. Visita los árboles, comen zando por el pié, y sube á lo largo del tronco; rara vez llega á las ramas. Si álguien se acerca al sitio donde estó, deslizase rápidamente por el lado opuesto al del ouservador; alarga luego la cabeza de vez en cuando y mira; si cree que le ob. servan trepa a mayor altura, emprende el vuelo de reprente, y viéndose entonces seguro, maniñesta su satisfaccion con un grito claro y alegre Su actividad es mucha hasta el mediodia, poco mas ó menos: en una sola mañana visita mas de cien árboles y caza en varios homnigueros. (jolpea los troncos menos que los atros picidos; pero en cambio practica 
a menudo profundos agujeros en ol armazon de las casas y en las paredes de arcilla. En el verano, despues de la siega, corre por el suelo dancio caza á los gusanos y larvas; en in. vierno vucla por las cuestas donde el sol ha derretido la nieve, para buscar los insectos que alli se ocultan. No es delicado en la eleccion del alimento, si bien prefiere á todo las hormigas rojas, aventurändose á menudo $\mathfrak{a}$ gran distancia por los campos para encontrarlas. No le gustan mucho las sustancias regetales, aunque come serbas, segun dice Snell. Su destreza para coger hormigas es aun mas notaule que la de los otros picidos; tiene la lengua mas larga y viscosa, y se sirve de ella como el horniguero.

- En los bosques situados cerca de Wetalar, ne escribe von Rejchenau, donde abundan los nidos de hormigas, he podido reconocer cuśn aficionados son los picos verdes á estos insectos y sus larras. los montones de madera podrida, muy ligcros al principio, llezan a ser tan compactos por su propio lesso, asi como por la putrefaccion y el agua de las lluvias, que el gecino verde se ve obligado 2 abrir paso con su pico puntiagudo para llegar á su alimento favorito.

2. En invierno las hormigas ahondan muclio sus agujeros, y el pico se ve entonces obligndo a practicarlos á $0 \%, 30$ de pro fundidai para obtener los insectos medio rigidos de frio. Fista ocupacion le limita naturalmente la facultad de observar óle impide ver lo gue pasa a su alrededor; el hambre le hace olvidar su precaucion ordinaria, y entonces puede ser fácilmente presa de un camicero; Wieber, mi antiguo compañero de caza, cogió una vez con ia mano un ave de esta especie, complèiamente sana, que estaba ocupada del modo indicado. Lo mismo refieren otros observadores, por extrano que parezca que un ave tan astuta se deje coger de tal modo. Ademís de las hormigas, el pico verde come tambien muchas clases de larvas de escarabajo y de mariposa, sobre todo las del capricornio y del cosso (cussus lismiperda), asi como, segun nos dice Halter, de los grillorálpidos, los cuales traspasa verdaderamente con la punta de su lengua, extra. yéndolos de sús agujeros y escondites. Acosiumbra ál visitar en invierno los pucblos y las casas de labranza, y entonces puede suceder que cause tambien destrozos en la propiedad, prescindiendo de que cuando busea insectos perjudica con su pico las paredes de barró y lós techos de paja; algunas reces se abre camino en una colmena y ocasiona grandes destrozos entre estos insectos dormidos. No desprecia tampoco del todo el alimento vegetal: Schacht le ha visto comer los frutos del fresno, y Haller observó un gecino verde que todos los inviernos visitaba un jardin donde abundaba la vid silvestre, cuyas bayas comin con ansia.

A fines de febrero se dirige a la localidad donde piensa reproducirse; pero hasta el mes de abril no comienza la hem. bra a construir su nido. En marzo se reunen los dos sexos y se manifiesta en el macho una gran excitacion. Posado en la cima de un elevado árbol, grita a menudo con fuerza, ó per. sigue á la hembra de un tronco en otro; la pareja se muestra muy celosa de su dominio $y$ acomete a cualujuier otra que trate de fijarse en el mismo punto. El gecino verde elige para anidar un ärbol hueco, cuyo interior esté carcomido: macho y hembra practican un agujero, terminándole en menos de quince dias; la abertura es redonda, yo tiene mas que el diánctro precisamente necesario para que pucda pasar el ave; el interior mide $\|^{*}, 250$ ó $11^{*}, 50$ de profundidad, y de $0^{*}, 15$ i $11 \%, 20$ de diámetro. Si al socavar encuentra el gecino madera dura, abandona el sitio, y antes que comenzar otra ver. el trabajo, apodérase de cualquier agujero que haya abandonado alguno de sus semejantes.

Cada puesta consta de seis á ocho huevos, oblongos, volu. minosos en el cxtremo grueso, de cáscara lisa y color blanco lustroso. Macho y hembra cubren alternativamente yor espa. cio de diez y seis ó diez y ocho dias; el primero desde las diez de la manana á las tres ó las cuatro de la tarde, y la hembra el resto del dia: los dos alimentan á sus hijuelos. Is. tos son tan feos al nacer con: todos los demás picidos, y crecen rápidamente: á las tres semanas llegan ya a la entrada del nido, mas tarde trepan por el áibol, y al fín aconupanan á los padres en sus correrias; pero vuelven diariamente al nido. Las excursiones se van alargando cada vez mas, hasta que al fin se reunc la familia para volver a su amtiguo alber. gue, pasando la noche en el primer retiro conveniente que encuentra. En octubre pueden ya vivir por si solos los hijue. los, y se dispersan, dirigiéndose cada cual por su lado.

CAzA. - Dificil es apoderarse del pico verde, y solo por casualidad se coge alguno en una trampa: como mejor se con. sigue es colocando un lazo \& la enirada de un agujero. En nii bosque, dice Naumann, se habia fijado un pico verde en el agujero de un viejo álamo; trepé por una escalera de mano y puse un lazo en la abertura. Oculto en una choza de follaje, vi al pico llegar á la hora del crepúsculo, mirar mis preparatiyos con aire receloso, abandonar el árbol y volver rarias reces antes de aventurarse à penetrar en su albergue. Al fin se introdujo en su agujero: al sentir el lazo alrededor de su cuello quiso volar; pero cayó gritando al pié del árbol: estaba cogido. I.e solté al dia siguiente, pero desconfió largo tiempo del árbol donde se le atrapó, aunque pasadas algunas semanas comenzó á volver todas las tardes a su antigua resi. dencia

CAUTIVIDAD. - \&El pico verde es tan vivaz E impetun. so, continúa Naumann, que no se puede pensar en domesti. carle cuando es adulto. Inútilmente se ha tratado de hacerlo, pues el desgraciado cautivo sucumbe muy pronto; jor otra parte, con sus vigorosos picotazos rompe bien pronto la jau. la de madera donde se le encierra, y si se le pone en una habitacion, irepa por todas partes y estropea todo lo ijue encuentra. Acaso se podria domesticar álos pequeños, mas no connzco ningun cjemplo de ello.

Estimulado por cl buen éxito en la cria de picos negros, lice tambien la misma prueba con gecinos verdes: pero no puedo decir que me divirtieron mucho: procedian en general como el citado congénere y observé en ellos la misma inclinacion á destruir. Mis cautivos no llegaron uunca í ser del todo alegres, á pesar de quue les ofrecia cuantas larvas de hormiga les era posible comer. Tambien liebe ha observado lo mismo que yo; a pesar de su solicitud, ningun gecino verde. llegó a mucha edad.

De todas nuestras aves solo el asturiỏo de las zoritas es el que amenaza mas sériamente á este pico; para librarse de los halcones propiamente dichos, que como se sabe solo cogen su presa al vuelo, utilizase de los troncos de árbol, en los cuales busca su refugio ran luego convo ve una de esias rapaces; entonces trepa con tanta rapidez alrededor del tron. $\mathrm{co}$, que un ave menos ágil que el astúrido de las zoritas no podria cogerle; pero este ejecuta en su ruclo evoluciones tan bruscas que sin dificultad consigue apoderarse del pico ver. de. Asi lo hacen suponer los gritos de ecrror que el pico lan. za al ver á la terrible majaz Otras grandes aves salvajes, como por ejemplo las cornejas, provocan tambien á vecesá nuestro pico, pero nunca iraban luchas sérias. En cambio, se jro. mueven á veces peleas cuando practica una cntrada en un hormiguero. Adolío Muller vió cierto dia cómo un grajo, despues de haber observado á un pico verde ocupado de la manera indicada, acercóse poco i poco y provocó bruscamente al ave. Los dos se atacaron y defendieron con igual destreza hasta que el grajo, buscando refuerzo, ahuyentó al pico con ayuda de otros cinco de su especie. 
E! hombre no persigue à este picido mas que à otros, à pesar de que excita á veces la cólera del campesino cuyas colmenas destroza: pero tiene en el invierno el mas peligroso enemigo. Cuando una espresa capa de nieve cubre el suelo, pronto comienza la escasez, y solo alli donde hay grandes arboles vicjos que le ofrecen insectos ocultos en su madera podrida, le es posible soportar sin detrimento in rigurosa es iacion. Cuando el frio comienza súbitamente con una gran nevada, encuentrase $\{$ menudo $\{$ cste pico en los viejos bos. ques altos, $y$ í veres en numerosos grupos. Snell observó que en el inviemo de $1 \$ 60$ a $\$ \$ 61$ casi todos los picidos de los alrededores se habian reunido en un encinar muy antiguo. aEn aquellos dias, dice el citado observador, se oyeron desdo Ia mañana hasta la norhe los picotazos, di ruido y los gritos de aquellas aves, de tal modo que hasta los campesinos mas estúpidas que pasaban yor el camino hubicron de fijar su atencion en el bosque. 3 Ln las regiones donde no hay tales selvas se nota despues de un invierno riguroso una disminucion visible de estos picos. "lo rnismo he encontrado, dice Liebe, picos verdes y grises muertos en tales inviernos, tambien me trajeron á casa varias reces radiveres de estos picidos. Cuando en los últimos meses del invierno las hor migas se retiran a sus agujeros, y apenas ha nieve cubre las praderas, los picos verdes se ven reducidos á comer larvas de la matiera y otros insectos de esta clase; pero nuestra admi. nistracion de busques no suele perdonar los átboles que po. drian contener alimento para aquellas ares. Los picos verdes y los grises, las pequeñas especies del pico abigarndo y los picos negros, se extinguirain entre nosotros, carno los Pieles tojas, anuyentados jor el cultivo.

\section{EL GECINO GRIS-PICUS CANUS}

CARACTRRES. - Fista especic es solo un poco mas pe. queña que la anterior; su longitud no pasa de $11^{\equiv}: j \circ$, y gu anchura de $0^{\circ}, 50$ de punta a punta de las alas; estas miden 11", 15 y la cola 6 (11. Ia parte anterior de la cabeza y el centro de la coronilla son de un rojo escarlata; al borde de la frente yna estrecha faja sobre la linea waso-ocular, que es negra, tienen un mariz gris oscuro; los lados de la cabeza son un poco mas claros; el occipucio y la nuca de un viso verdoso; el resto de las partes superiores de un vercie aceituna; las tectrices superiores de la cola de un amarillo acei. tunado brillantc; la barba y la garganta de un gris sucio, se. parado de las mejillas por una faja muy angosia negra, que particndo de !a base de la mandibula inferior llega hasta las orejas; las mejillas son grises; el pecho y las demis regiones inícriores de III verdoso gris sucio; las rémiges primarias presentan en sus barbas exteriores de seisá sicte manclias trasversnles estrechas y bianquizcas, y todas las rémiges tienen en las inieriores otras anílogas; las recirices son de un pardo oscuro "las dos dol centro ofrecen á lo largo del tallo un viso gris parciusco. El iris, pardo rojizo en los individuos jóvenes, es rojo sonrosado en los adultos: el pico de un negro pardusco de cuerno, y los piés de un negro de pizarm. La hembra se parece al macho, pero casece de la mancha roja en la coronilla.

DISTRIBUCION GEOGRÁFICA.- El śrea de dispersion del gecino gris es inucho mas evtensa que la de su con. gencre, que sin embargo es mas conocido: exceptuando Inglaterra, habita en la mayor parte de la Furopa y en toda la Siberia hasta el Japon; por el sur se le ve hasta en Persin.

USOS, COSTUMBRES Y RÉGIMEN.-En Alemania no abunda esta especic ianto como el pico verde, pero habita joco mas ó menos en los mismos lugares que cste; en algunas partes falta del todo: en oims ce le ve aislado, al menos. en los sitios proprios para él. Esta especie parece destinada a sufrir la misma suerte que el pico negro ! el gecino verde, pues su numero disminuye de aho en ano à medida que el cultivo progresa Cuando yo en jóven auundaba en Turingia tanto como en el periodo comprencido descle $1 \$: 0$ i $1 \$ 30$, curante cuyo tiempo mi padte tuvo ocasion de hacer excelentes obsesvaciones; ahora solo sa le ve alguna que otra ve\%, sin que pueda decirse por qué el número ha disminuido tan visiblemente. Secun dice mi padre, agradale el lindero de los bosquez o estos mismos cuando se hallan situados en medio del campo, asi como los valles cubicrios de arboles frondo. sos: solo elige los bosrues de abctos cuando lindan con el campo; los valles de los rios de Turingia le ofrecen de consiguiente todas las condiciones necesarias para vivir cómoda. mante, y a jesar de esto escasea cada vez mas Tal ve\% no suceda asi en otras regiones de Alemania; prero en greneral se observa que mi opinion es exacta Borggreve dice que el gecino gris permanere con preferencia en la zoma cubierta de hajas, situada à la altura de joo á $\$ 00$ metros sobre el nivel del mar, y Ciloger pretende que algunos suben en verano bosgures mas altos que los Alper; yo, por mi parte, debo ana. dir que nunca le he visto en las montañas clemdas, ý solo raras veces en las aitums indicadas por Horggreve; muy por el conirario, siempre le halle en los paises bajos, sobre todo donde abundan las colinas. Sin cmbargo, tambien Baldamus le encontró en los altos valles de los Aipes. Segun mis obser. raciones, podria casi decir que es un ave propin de los grandes plantios de árboles frutales; si algunos de estos son anosos y están huecos, se la ve con mas frecuencia que en parte algunn, $y^{\circ}$ en sus viajes visita con regularidad tales sitios.

Cuando los inviernos no son rigurosos, las parejas permanecen uno y otro año en la localidad donde auidaron, aunnque tambien emprendell cortas expediciones. Los inviernos rigu. rosos, fror el contrario, obligan al pjico gris á emigrar á puntos lejanos por las inismas razones que su congencre mayor. listas expediciones ie conducen, no solamente al mediodia de Ale. mania, sino tambien mas allí de los Mpes, de los Pirineos y. de los Balkanes; pero por lo regular limitanlas zodo lo posib!e. Solo en octubre comienza a viajar, y en los primeros dias je marzo vtelve puntualmente al distrito donde anida, por dificil g̨ue aun le sea vivir en ćl. Gloger prescnde que está en guerra abierta con el pico verde, ! que este no le sufre en su territorio: la moticia no es exacta sinn en el caso de qque el pico verde, mas fuerte que él, le expulse de un distrito donde falia lugar. Por lo demás, viven en tan perfecta nrmonia como pueden hacerto los picidos de diferente esfecie en-general;y yo mismo conozco distritos bastante reducidos donde amias se rejproducen todos los vesanes. Durante sus viajes se reunen, segun dice Snell, con bastanic frecuencia; buscan su alinento en los mismos sitios, y cuando se les ahujenta vuclan juntos 6. cierta distancia.

Lin sus usos y su carácter el pico gris se parece tanto â su congénere mas afine, que se necesita una gran experiencia para distinguirlos. Segun dice mi pardre, ciene la vivacidad y alegría del pico verde; su destreza en el arte de trepar. sus inanera de buscar el alimento; da como él saltitos cuando anda, ye le parece tambien en el ruclo, solo que en este no coma tanto impett, ni projuce ianto runor. I gusta mucho trepar por las partes inieriores de los árboles; cuando se le ahujenta sube da cupa del mas alto y se coloca casi siem. pre de manera que el ironco 6 una mama le protejan conira e! tiro del cazador. Al huir del hombre, siempre se coge cn el lado del árbol opuesto al enemigo, y solo á veces alarga la cabeza para carse cuenta del peligro. De este modo se le puede perseguir mucho tiempo sin alcanzarle. He notado una particularidad, propia tambien del gecino verde, y es 
que en oioño, $\delta$ al comenzar el inviemo, tiene cierto distrito que visita con regularidad todos los dias. Entonces se pre. senta casi todas las mañanas a la misma hora en el jardin, como dice mi padre y yo mismo he observado en mi juventud; agirrase á cierto ảrbol, vuela desde alli a otro, y todos los dias repite la misma operacion; aparece en el mismo sitio y aléjase de igual manera. En el suelo se le ve con ianta frecuencia como al pico verde $y^{\circ}$ en otoño se presenta con regularidad en las praderas rasas. Su voz recuerda la del gecino verde; pero es un poco mas alta y clara: su grito se podria expresar por las silabas jeck greck gick gcick; alguna ve\% se oje un claro pick, que ambos sexos producen; en el periodo del celo dejan oir, tanto el macho como la hembra, un silbido muy sonoto y fuerte, que suena como kli klis klis klui kivi y va bajando hasta el fin. Segun Naumann, cuando el pico verde grita se posa siempre en la copa de un árbol alto - por eso se oye su magnifica vor. á mucha distancir Los sonidos tienen cierta analogía con los del gecino verde, pero son mas suaves y menos agudos, distinguiéndose por la circunstancia de que los últimos son mas bajos, pudiendo reconocerlos al punto un oido atento. Sin duda sirven para llamarse entre si los sesos. Cuando entonces se encuentra una paraja, comienzan á retozar y á perseguirse. El macho sigue a la hembra entonces horas enteras; grita repetidas ve. ces del modo indicado; revoloten y trepa con ella alrededor del tronco de un árbol; llamala de ver, en cuando con su tierno gicle grek gick gich, y hasta se excita de tal manem, que se agarsa a una rama seca y ejecuta un tamborileo á ma nera de los picós negro y abigarrado mientras que el gecino verde no hace nunca esto, segun parece.

'l'ánbien el gecino gris se alimenta preferentemente de hormigas y persigue sobre todo d las especies amarilla (Phormica xeunuca) y parda (Phermica fusca). Alli donde no abunda la primera, ningun pico verde permanece en verano; y tambien la persigue con preferencia durante el in rierno. No es de consiguiente extraño que una espesa capa de nieve le obligue a cmigrar, porque entonces no puede al: canzar su alimento favorito. Cuando trabaja en los árboles extrae todos los insectos y larvas de que puede anoderarse, y si en veranó encuentm orugas lisas no las desprecia tam. poco. En lós ríltimas meses de osonio y en invierno sc alimenta tambien de materias vegetales; mi padre encontr 6 en sis estómago bayas del satíco, y Snell la fruta del serbal silvestre.

la época del celo cmpieza para el pico gris un poco mas tarde que para el gecino verde; pero los dos construjen su nido de un modo semejante; practica por si mismo un agu. jero, y revela en este trabajo una gran resistencia contra las fatigas. Lin pico abigarrado que mi padre observaba empezó a trabajar en un haya en que habia roto uni rama seca; pero pronto dejó el trabajo, porque le era demasiado dificil. En la primavera siguiente mi padre vió pedazos de madera debajo del árbol y oyó que un pico trabajaba en su interior: entonces dió algunos golpes contra el tronco y al punto salió un pico gris, el cual anidó mas tarde en aquel hueco; pero pronto fué presa de un rarnicero. La entrada que el pico gris abre es tan estrecha que un gecino verde apenas puede pasar por ella; el interiot, por el contrario, tiene á veces $0^{*}, 30$ ó cuando menos $0^{\circ}, 25$ de profundidad por $\theta^{+}, 120^{\circ}, 20$ de diaimetro; sus paredes son muy lisas. Mi padre ha visto su nido en pinos, tilos, liayas y alisos. Naumann en pinos lisos y encinas y yo mismo le encontré cierto dia en un manzano. La puesta consiste en cinco ó seis huevos, rara vez siete ú ocho: son brillantes, de un blanco puro, con una extremidad bastante puntinguda, mientras gue la opuesta se redondea obtusamente; la cáscara es fina, tierna y delgada: estos hue. ros se parecen en un todo $\{$ los del pico verde, solo que son mas pequeños. La hembra los pone, como las de la mayor parte de los picidos, sobre un lecho de finas fibras leñosas, en el fondo del hueco, cubriéndolos alternativamente con el ma. cho. Los padres alimentan a los polluelos casi exciusivamente con las larvas de las dos especies de hormigas citadas. Estos permanecen en el nido, cuando no se les inquieta, hasta que pueden volar; pero ya trepan antes por el interior del hueco, alargan á menudo su cabeza por la entrada y saludan á sus padres con gritos extraños apenas los ven llegar; aun despues de salir del nido los padres los alimentan mucho tiempo, manifestandoles el mayor carino; cubren los huevos con tan. ta aficion, que a menudo se les puede coger en el nido; si se mata a uno de ellos, el otro se encarga de criar los hijuelos, que son bastante exigentes.

Además del hombre, el pico gris tiene por enemigos å las grandes especies de halcones, sobre todo el astúrido de las zoritas y al nisido comun. Este último se precipita sobre el gecino gris, pero no creo que pucda matarle; el astúrido, por el contrario, le degüella sin que pueda resistir por bien armado que esté. \$Hace poco tiempo, me escribe Snell, pude observar este caso, por haber llamado mi atencion los gritos delterror del pico gris. Un astúrido de las zoritas habia ahuventado al pico de un àrbol, persiguiéndole con empeño; las dos aves cruzaron huertos y jardines en todas direcciones 4. lo largo del rio; los gritos del pico se debilitaron á medida que aunientó su cansaucio, al fin no sc ojeron yis, y poco despues fué victima de su perseguidor. Un invierno riguroso es aun nas temible que el astúrido para cl pico gris; y aunque por lo regular le salva la emigracion, sucede sin em. bargo con bastanie frecuencia que una nevada súbita y continua le impide emprender la fuga a tiempo. In tales casos se encuentran à menudo vicos grises y gecinos verdes muer. tos de hambre en los si us donde habian buscado su último refugio

\section{LOS COLAPTOS-COLAPTES}

Mientras que los grupos de picidos hasta ahora descritos sc ascmejan tan esencialmente que cuando mas solo sc les podria considerar como sub.géneros, los colaptos deben ele. varse al rango de género.

CARACTERES. - Los representantes de este género tie. nen el jico bastanic delgado, marcadamente corvo, no muy largo y con arista aguda; las pequerias protuberancias que por lo regular rodean las fosas nasales, son tan lisas que apenas se reconoce una línea muy fina; la mandibula superior es. mucho mas larga que la inferior; el tarso fuerte y alto: los dedos de longitud regular y carnosos, y las garras mucho mas endebles y finas que en otros pícidos del mismo tamaño. Jas alas son cortas y obtusas, y solo cubren la base de la cola cunndo el ave descansa; la quinta rẻmige sobresale de tocias las demás. La cola se compone de plumas puntiagudas, un poco rigidas, yes menos escalonada que en sus congéneres.

\section{EL COLAPTO DORADO--COLAPTES AURATUS}

CARACTERES. - Fl colapto dorado, la especie mas hermosa del género, es un poco mas pequeño que nuestro pico gris. la parte anterior de la cabeza y posterior del cue. llo son de un gris ceniciento; la linea naso-ocular, unas fajas de la region de los ojos, las sienes, los lados de la cabeza! del cuello, la barba y la garganta, son de un color rojizo de vino; una faja grande que hay en las mejillas y otra ancha en forma de media luna en el buche, son negras; las partes superiores de un pardo isabela, con fajas trasversales negras; 
la rabadilla blanca; iss recirices superiores de la cola tienen tambien anchas fajas irastersales negras; las regiones inferiores blancas desde la mancha negra del buche, con un viso de rino rojizo y grandes puntos negros en el pecho y los costados; en la nuca se re una mancha en forma de herradura, de color rojo vivo; las rémiges son negms y piesentan en las barbas exteriores de cuatro a cinco grandes manchas trasver. sales de color pardo que forman verdaderas injas; en las barbas interiores se observa en la mitad de la base un borde ancho de color blanco amarillento; los tallos de las rémiges son de un amarillo anaranjado; los de las rectrices del mismo color en la mitad de la base y negros en el resto; las dos rectrices citeriores son blancas en la punta, presentando la primera en cada lado tres manchas clams en el borde; la cara infrior de las rémiges y rectrices es de un amarillo aceitunado oscuro brillanie, pero negro en el úlimo iercio de estas. los ojos son de un pardo claro; el pico pardo por arriba y azulado por debajo; los piés de un azul gris. La hembra ca. rece de la linea naso ocular negra: los pequeños, de un color mas sucio, ticnen mas estrecia la faja roja pálida de ia nuen. la longiud del ave es de $0^{\prime \prime}, 3=$, por $6^{\prime \prime}, 4^{2}$ de anchura de punta a punta de ala; cstas miden $1{ }^{*}, 16$ y la cola $11^{*}, 12$.

DISTRIBUCION GEOGRÁFICA.- Lil colapto darado habita en Texas, todo el este de los Listados Unidos de la América del Norte hasta la punta extrema septentrional de Nueva Escocia. Segun dicen, se le ha visto en Grocnlandia.

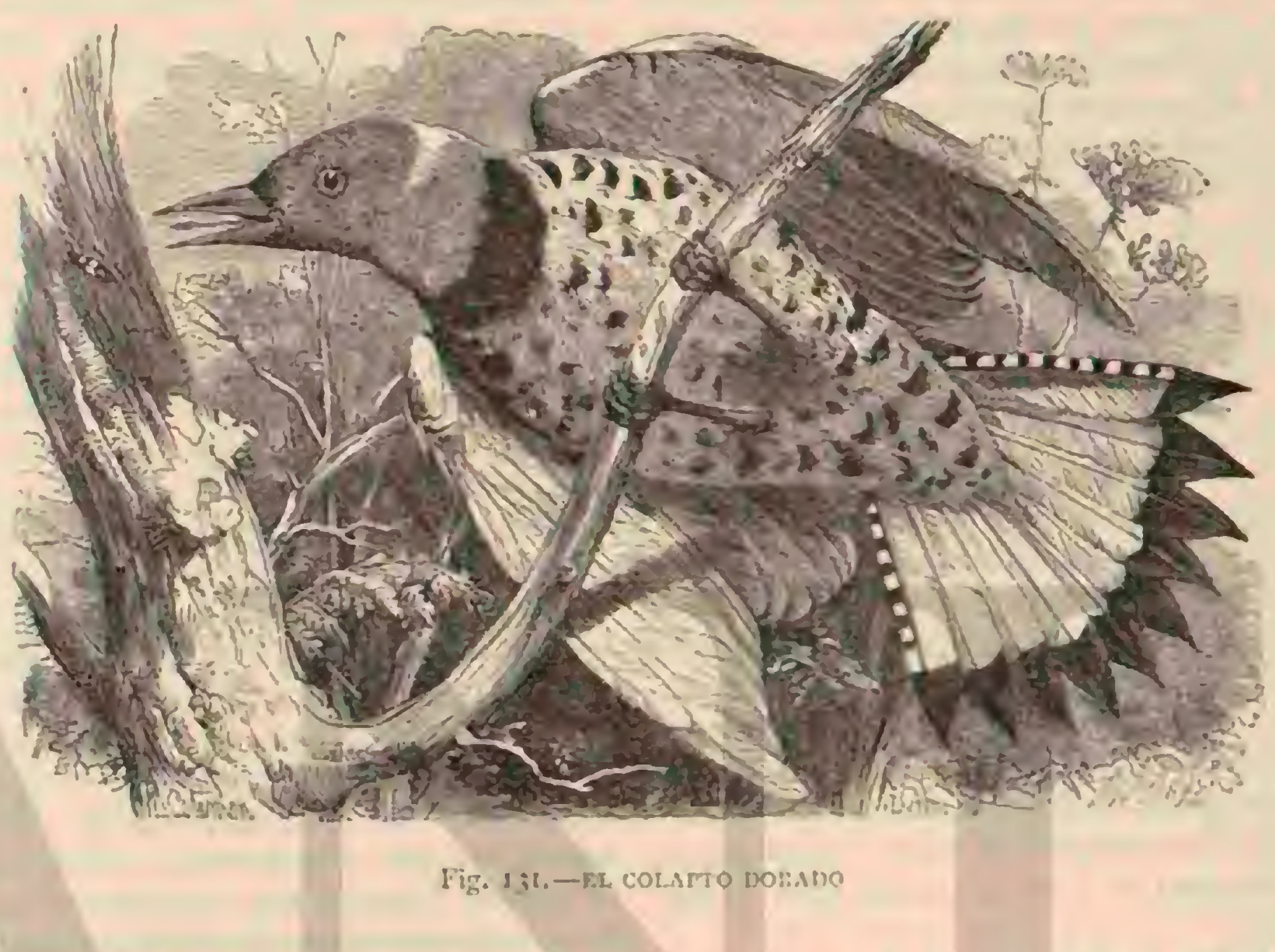

USOS, COSTUMBRES Y REGIMEN.- En los Esir dos Unidos meridionales, esta ave vive siempre en ciertos distritos, ó cuando mns emprende cortos viajes. En los Essa. dos del norte, por el contrario, es pasajera; preséniase alli, segun la situacion mas ineridional ó septentrional del punto dunde anida, en marzo ó en abril, formando considerables bandadas, y ruelve if marchar en setiembre ú octubre. Segun asegura Audubon, viaja de noche, como se puede reconocer fácilmente por los gritos que entonces dejan oir ó por el ex iraño rumor de las alas. Alli donde se encuentra el colapto dondo preséntase en un núntero extraordinario, tanto que se le podria considerar, si no como la especie mas abundante, al menos comó la mas diseminada de todos los jicidos de la América del norte.

Witson y Audubon nos han dado a conocer las costumbres del colapto dorado: cl segundo de estos naturalistas se expresa en los siguientes térninos: a Apenas los primeros dias de la primavera imponen á las aves los dulces deberes de la reproduccion, óyese resonar en la copa de los árboles la voz del colapto dorado, que anuncia la llegada de la feliz. estacion. Su grito expresa bien el placer, es una especie de carcajada que se prolonga, tan sorora como alegre. Varios machos persiguen ô la hembra, acércanse á ella, bajan' la ca. beza, ensanchan la cola, avanzan, retroceden, toman las pos. :uras mas diversas, y hacen rodos los esfuerzos posibles jara conrencerla de la sinceridad y rehemencia de su amor. La hembra ruela a otro airbol; pero seguida de uno, dos $y$ algunas veces hasia de media docena de machos, los cuales re. piten a porfia sus carinosas demostraciones. No luchan entre

Tosso 111 si, ni siquiera parecen cclosos, y cuando la hembra indica cuśl da la preferencia, abandonan los demás â la pareja icliz. y ran a buscar oira companera. A esto se debe que todos los colaptos estín bien ajareados; eada pareja comienza desde luego à horada: un trbol af fin de concruir un alber. rue a propósito para ella y su progenic; maclio y hembra trabajan con ardimicnto, y hasta con placer; mientras que el primero socava, la segunda se prone á su lado y le felicita por cada astilla que va desprendiendo. Cuando deseansa, diriase que le habla con ternura, y si cstá fatigado le presta su auxilio. De este modo queda bien pronto formada la cavidad; entonces se acarician mutuamente las dos aves; trepan con verdadera alegria por los troncos; tamborilean con su pico soure las ramas muertas; ahuycnian á los melanerpos que inientan acercarse: defienden su nido conira los estorninos purpúreos, y dejan oir sus gritos y sus risas. Al cabo de dos semanas pone la hembra cuarro ó scis huevos, y parece com. placida al ver su blancura y trasparencia: cuando todo es farorable puede criar una numerosa progenic, pues anida dos reces al año.

Esta útima noticia, si es exacta, solo puede aplicarse al sur de los Fstados-Únidos, pues en el norte de este pais, y sobre fodo en los rastos dominios ingleses de la Anuérica del norte, donde vive ambien, apenas seria el verano bastante largo para que pudiera tener dos crias. A fin de completar el relato de $A$ uddubon, debo aniadir que Paine scrnala el so de abril como dia de la llegada de esic pico; micntras que Au. dubon asegura que á mediados de mayo conienza la cons. truccion de su nido; dice tambien que la puesta se efectua 
en los últimos dias de mavo ó en los primeros de junio, y que consta de siete huevos. Paine no ha encontrado nunca nidos del colapto dorado en el interior de los bosques, pero sí en el lindero de los mismos, y tampoco observó que una pareja emplease dos veces el mismo hueco, lo que sin em. bargo podrí suponerse casi con seguridad. Al contrario de la mayor parte de sus congéneres, el colapto dorado es muy ti mido cuando se halla cerca del nido, ó mejor dicho, aproximase a este con tal cautela que es bastante dificil encontrar un nido. Cuando se inquieta a una pareja, hallandose en él, machn y hembra vuelan al rededor del artrol, produciendo gritos y sonidos guturales. 1.os poltuclos observados por Paine abandonaron el nido tan lentamente urio despues de otro, que el mas pequeno fué hallado unos quince dias despues del primero. Antes de salir del nido, uresantábrse cada uno de ellos en la entrada, descubriéndose por sus gritos cuando álguien se acercaba al árbol. lian luego como supi ron hacer uso de sus alas comenzaron á revolotear hácia el in. terior del bosque acompañados de sus padres, que despues los alimentaron todavia algun ticrupo instruyéndolos en lo necesario.

《El vuelo de esta ave, continúa Audubon, es rápido y sos. tenido, aunque cortado, si se compara con el de otras aves de la misma familia Para pasar de un árbol à otro, dirigese en linea recta; cuando estí á varias brazas del punto de llegada, se baja, se posa al pié del tronco y trepa rípidamente. Si se sitúa sobre una rama, inclina la cabitra, y en et caso de creerse scgura, lanzal su bien conocicio grito fiker. Trepa muy bien, en todas las posturas que toman los demás picidos; baja muchas veces a tierra, donde da saltitos ilgilmente: pero no sucle hacerlo sino con el fin de recoger alguna baya, una langosta, un hiseso de fruta, ó bien para cazar las hormigas y los demás pequeños insectos que se alojan en has raices. Gústanle todas las irutas, manzanas, peras, albérchigos, ctc; parece tambien que le agradan particularmente ciertas bayas que maduran en los bosques: no desprecia los cereales tiernos, y en invierno visita los graneros.

Algunas de estas aves pasan todo cl año en los Estados Unidos; otras emigran en invierno, dirigiendose hícia el sur; viajan de noche, reconociéndose el paso de las bandadas por el ruido particular que hacen frotando las alas, asi como por los gritos que lanzan de vez en cuando.

\El procion lavador y la serpiente negra son los mas temibles enemigos del colapto dorado: muchas veces, el primero in. troduce en el nido una de sus patas anterioresy, si no es de. masiado profundo, saca los huevos, que abre $y$ sorbe con avidez; r. menudo se apodera hasta de los adulros cuando ccbren. La serpiente negra devora tambien los huevos y las crias. Diversas especics de falcónidos persiguen al colapto dorado al vuclo; pero este consigue escapar con frecuencia, refugiándose en algun agujero. Ls muy agradable ver cl asombro del halcon cuando la presa desaparece súbitamente de su vista, precisamente en el momento mismo en que la iba á coger. Si cl colapto no encuentra un agujero para refugiarse, se lanza en seguida á un årbol, y comienza á describir espirales al rededor del ironco, con tal rapidez, que burla á me. nudo los esfuerzos de la rapaz.

2. Muchos caradores aprecian en extremo la carne del co. lapto dorado, sobre todo en los Estados del centro. Algunas reces se ven estas aves en los mercados de Nueva. York y Filadelfia: yo confieso que me parece muy desagradable, á causa del olor á hormigas que exhala.

CAUTIVIDAD.-Ninguno de los picidos que conozco soporta tan fácilmente la cautividad como el colapto dorado, que con bastante frecuencia se ve en nuestras jaulas.

No es diñcil alimentarle ó por lo menos no lo es mas que mantener á otro insectivoro; conténtase con la pasta de los tordos; pero es necesario añadir larvas de hormigas en gran número. Nuestros colaptos se mostraron desde el principio muy domesticados: no tardaron en conocer á su guardian, y acudian cuardo les liamaba para darles de corner. Para el aficionado, dice mi hermano, este colapto es una de las aves mas divertidas que se puedan tener en jaula. Obsérvanse tn ella todus los acnstumbrados movimientos de los picidos; se ve con (zué rapidey y agilidad trepa por las ramas colocadas en su jaula; con gué vigor parte la corteza; con qué seguridad se agarra; y hasta se puede estudiar su vuelo, pues muchas veces trata de remontarse. He visto algunas de estas aves, que hasta durmiendo tomaban su posicion favorita. Sabia por inis observaciones en los picos indigenas, que estos pasaban la noche en troncos huecos, y por lo mismo me sorprendio ver que los colapios dorados no se posaban simplemente en el fondo del agujero, sino que se cogian a las paredes, en la misma postura que toman para trepar: de donde inferi que semejante posicion es en ellos la mas natural.

Fin 1865 se reprodujeron nuestros colapros, prueba de que podian soportar la cautividad tan bien como cualquier otra ave. La primavera no dejo de ejercer sobre ellos cierta infuencia: el macho manifestaba los sentimientos que le animan por medio de gritos y del tamborileo caracteristico; el grito de llamada era el mismo indicado por Audubon; prod:grba caricias a su hemura, y jugueteaba con ella de mil di. versos modos. Cierta mañana encontró el guardian un huevo en el fondo de la jaula, 5 á los pocos dias otro; pero no se renlizó mi esperanza de ver los hijuclos, pues la hembra enfermó y murió, lo cual fué debido, sin duda, á una puesta muy precipizada. Era conmovedor ver entonces al macho; duranie todo el dia no dejaba de llamar á su hembra, y tan. borileába para manifestar su sentimiento, asi como lo hacia algun tiempo antes para indicar su amor. Niaun por la noche descansaba; pero poco á poco se calmó, aunque sin recubrar su antigua alegria; cuando todos sus companeros habian muerto. permanecia completamente silenciuso.

En los últimos años he cuidado otros colaptos dorados $s$ los lie visto en varios jardines zoológicos; pero ninguno se apareó ni comenzó la construccion de un nido.

\section{EL COLAPTO DE MÉXICO-COLAPTES MEXICANUS}

CARACTERAES.-Fn el sur de los Estados Línidos, en Texas y en México vive con el colapio dorado una especie muy afine que lleva el nombre de estc último pais y se llama tambien fico colrizo. Su plumaje se asemeja mucho al de la especic anterior: pero los colores son mas oscuros, y tiene los tallos de las rémiges de un tinte rojo naranja en re\% de amarillo de oro. La frente y la parie superior de da cabeza son de color pardo leonado, que tira à rojizo; el lomo gris pardo con listas negras trastersales y su parte anicrior blanca; las rectrices pardas, con los tallos de un rojo naranja; la barba, la gargania y el cuello, de un gris rojizo claro; el pe. cho y el vientre de un blanco rojizo, sembrados de manchas redondas negras; cl occipucio roju bermellon; cruza la parte mas alta del pecho una faja negra, y por los lados de la cara ¿ del cuello baja una Jinea enćarnada. Esta are tiene la talla del colapto dorado, con corta diferencia.

DISTRIBUCION GEOGRÁFICA.-EI área de disper. sion del colapto mexicano linda con la de su congéncte el colapio dorado, y ocupa todo el ocste de los Estrdos Linidos, desde las Montanas Pedregosas hasta el Pacifico, y desde el estrecho de Fuca hasta el mediocia de Mćxico. Alli donde se tocan ambos territorios, las dos especies viven juntas EI 
observador, dice el principe de Wied, se extraña cuando poco despues de haber muerto al colapto dorado se levanta súbi tamente delante de él otra ave parecida en la cual el color amarillo de algunas partes se ha trasformado en un magni. fico rojo de naranja. Solo poco á poco se reconoce que esta ave persenece à otra especie parecida, pero diferente.

Todos los autores norte-americanos que han observado al colanto mexicano dentro de los limites de su patria, aseguran que sus usos y costumbres, su carkcter, su voz y su alimento, asi como su manera de reproducirse, se asemejan en un todo a los del colapto dorado: y por eso nos parecen mas extra ỉs las observaciones que Saussure ha hecho en México sobre la misma ave.

बDespues de haber bajado del Cofre de Perote, visite el antiguo volcan que llaman Pizarro: esta singular montaña cónica á manera de pilon de azúcar, que se destaca de la llanura de Perote, cual orra isha elevándose del seno del mar, admira á todos los viajeros por la regularidad y gracia de sus contornos: pero cuando el viajero se acerca ! comienza á trepar por las áridas pendientes de anquella pirámide de lasa, sorprende al pronto el aspecto de la curiosa regetacion que tapiza el escoriado suélo. Aquella pálicia verdura, que desde léjos se creia ser la de los bosques, se reduce a! una cantidad asombrosa de pequerias pitas, cuya fur estrellada verde solo mide dos ó tres piés, y los pedúnculos dos ó tres puilgadas de diametro: aparte de estas especies de enormes alcacho. fas, de que parecen esmaltadas aquellas blanquizcas arenas, una gran juca proyecta sobre las azuladas uaquitas de la montain una sombra insuficiente, y hace las veces de ario. leda en un pais donde aquella prodiccion natural adq̨uiere el carácter de fenómeno raro. Alquella soledad seca y arida, que no parecia animada por ningun sér viviente, comenzaba á impresionarme al contemplar su aspecto ligubre y silen cioso; pero al avanzar por aquel desierto crizado de espinas, lanóme subitamente la atencion un gran nimero de picos, exclusivos habitantes de aquellos parajes desolados. Nunca se deja de experimeniar cierto placer cuando se encuentra In vida despures de laber recorrido inanimados desiertos, y hacia ya largo tienupo que no tenia esta satisfaccion. Bien pronto reconoci que el colaples ruliricalus, tan notable por el brillo rojizo de sus alas, era el rey de aquellos lugares; q̧ue aunque existieran alli otras especies, consermaba incontesta blemente la superjoridad por su-aventajada talla y por el nu. mero de sus representantes. Todas aquellas aves, grandes ó pequeñas, jugucteaban sin descanso; reinaba en el bosque de los flloes una agitarion poco natural, una inusitada actividad. Por ntra parte, la reunion de un gran número de picos ell el mismo paraje tenia ya en si algo de insólito: porque la natu. raleza asigni à estas aves costumbres mas solitarias y-un género de vida que les prohibe vivir jumas, so pena de pa decer liambre. léjos de turiar á los alados habirantes de la sabana con una intempestiva detonacion. oculteme bajo ha sombra poco hospitałaria de una yuca, y cual oiro curioso indiscreto, observé, sin decir palahra, lo que debia suceder en medio de aquella república rolatil.

No pasó mucho tiemıpo sin penetrar el misterio: los picos iban y verian, visitando un momento cada planta, y liego emprendian su vuelo. Fij:tbanse sabre todo en los tallos de los álocs: trabajaban un instante, golpeando repeiduniente la madera con sus agudos picos; rolaban despues ślas yucas para continuar su trabajo, y dirigianse otra vez a los áloes para repetir la operacion. Entonces me acerque a las pitas, examiné sus tallos y vi que estaban acribillados de agujeros, dispuestos irregularmente unos encina de orros, los cuales correspondian á no dudarlo ì un vacio interior; apresuréme a cortar uno, a fin de examinar lo gue pudiera haber en el rentro, y no fuć pora mi sorpresa al verle convertido en verdadero almacen de viveres.

3 La sagacidad que cesplicga la industriosa are en la elec. cion de anquel depósito y el arte con que le llena, son cosas que merecen describirse. Despues de haber florecido la plan. ia de la pira, muere y se seca, pero permanece aun mucho tiempo fija en el suelo; al tallo ó estipite forma una percha rertical, cuya capa exteriar se endurece al secarse, mientras que el tejido interno se destruye gradualmente, dejando asi en el centro de anuel tallo uma cavidad que ocupa toda su lon. girud, eligiéndola los picos para guardar sus jrovisiones. Estas últimas llaman asimismo la atencion por lo que representan; no son insecios. ni larvas if otros alimentos animales parecidos á los que las aves trep̧adoras buscan debajo de las cortezas; nada de esio: pertenecen exclusivaniente al dominio vegetal: son bellotas que almacenan mestras aves para el invierno en sus graneros naturales. l.a cavidad central del tallo de las pitas ofrece un diámetro precisamente exacto para que pueda pasar uno de estos frutos, segun su menor diancetro, de modo que se colocan los unos a continuacion de los otros a manera de las cuentas de un tosario; de tal modo tue cuando se parte el tallo longitudinalmente se ve toda la cavidad ocupada por una scrie de bellotas. Sin em. bargo, el órden no es siempre perfecio: en las pitas de gran. des dimensiones el conducto es mas ancho, y los frutos se disponen con menos regularidad.

- Pero ¿cómo procede el ave para llenar su almacen, que esta naturalmente cerrado por todas partes? En la solucion de este uroblema es en to que parece mas maravilloso su instinto. Perfora ś picotazos la parte inferior del tallo, prac. ticando en la corteza un agujerito redondo, que llega hasta la cavidad central, y aprorecha la abertura para introducir bellotas hasta llenar la parte de aguella sisuada debajo del agujera El pico forma entonces otro en un punto mas alto, - por el llena el espacio hueco centml situado entre los dos orificios: despues abre un tercero mas arriba, y continúa de este modo llenando su almacen, hasta que, subiendo poco á poco alcanza el punto donde el conducto se estrecha de tal modo que no pueden pasar ya las belloias. Debe advertirse, no oustante, que la caviủad no es bastante ancha. ni cstá suficieniemente expedita para que los frutos puedan recorrerla, cayendo por la sola intluencia de su peso. Eil ave debe empujarlos, y a pesar de su gran destreza, apernas consigue llenar mas que un espacio de una 6 dos pulgadas del vacio central, lo cual le obliga a estrechar las distancias que sepa ran los agujeros si quiere que se llene por completo la cavi. dad descle la base hasta el extremo.

- Iista obra no se hace siempre con la misma regularidad; verdad es que lay allos cuyr médula. casi intacta, apenas ofrece un vacio rentral; debiendo advertir que la parte superior se encuentra casi siempre ocupada por su propio icjido. Entonces necesitan los picos desplegar muciaa mas mara para introducir sus provisiones de bellota, pues no hallando cavidades suricientes donde poder amontonarlas, de. ben abrirlas por si mismos. A este fin practican un agujero para cada bellota que introdueen en el centro mismo de la médula, en la que han abierto una cavidad suficiente para contenerla. Por lo mismo se encuentran muchos tallos en que los írutos no aparecen acumulados en un hueco central, sino purestos cada urio en el fondo de uno de estos agujeros, que acribillan la superficie del talio.

- Liste trabajo es rudo y hace sudar mucho al ave; nece. sita gran destreza para almaccnar tales provisiones; pero tambien debe anadirse que ln explozacion de sus graneros es mucho mas fícil despues. El pico no necesita buscar su ali. menio debajo de capas de madera que se parten laboriosa- 
mente; bistale hundir su pico afilado en los orificios que practicó para encontrar la comida, puciendo en vista de todo lo que precede decirse que la próvida naturaleza dotó à nuesira ave de aquel órgano sólido, no tanto para buscar su necesario alimento \& través de los bosques, como para ocultarle siempré.

Las costumbres del colaphes ruliricalus, aunque muy dis. tintas de las de otros picos, exigen, sin enabargo, que el ave tenga el pico idéntico al suyo, porque el tejido periférico de los bohordos de los áloes es sumaurente duro, y no se puede perionar simo con un instrumento sólido. Y no es lo mas notable la paciencia de estos séres para llenar sus dépósitos: su perseverancia para adquirir las bellotas es mas asombrosa todavia. En efecto: clévase el Pizatro én medio de un de sierto de arena y de corrientes de lava que no sostienen encina alguna y por lo tanio no pude comprender-dínde to maban las aves sus viveres preciso era ir a buscarlos á varias leguas de distancia, quiźs a la vertiente de la Cordillera. Tal es el ingenioso procedimiento de que se vale la natura. léa, siempre próvida, para preservar á los picos de los hor. rores del hambre dumne los seis meses de invierno, en un pais irido, donde el ciclo, sicmpre sereno, lo reseca toda. Esto produce alli la mlierte de toda vegetacion, como entre nosotros el frio: asi es que las plantas córiáceas de las sabanas, que son la sequedad misma, no puedert alimentar los insectos necesarios para la subsistencia de los picos. Sin el recurso con que cuentan, estas aves no tendrian mas rensedio que emigrar ó morirse de hambre.

2. Corria entonces el mes de abril, es decir, el quinto 6 sexto mes de la estacion muerta, y los picos se ocupaban en retirar las bellotas de sus graneros. Todo me induce á creer que se alimentan exclusivamente de estos frutos y no de las meaquinas larvas que pueden cncerrar; su manera de proce. der entonces es tan digna de atención como lo demás. In bellota, lisa y redondeadn, no puede ser cogida ficilmente por los piés demasiado grandes del pico, y por lo tanto. a fin de sujetarla lo bastante para poderla partir, apela el ave un procedimiento de los mas ingeniosos. Practica en la es pecic de corteźa seca que rodea el ástil de las yucas un ngu jero lo bastante grande para encajar ia bellota por la punta estrecha, pero no tanto que pueda pasar todo el fruto: 10 introduce luego alli $y$ lo hunde con su pico á manera de cuña en la madcra. Asi sujeia la bellota, el ave la parte á picota. zos con gran facilidad, y á cada golpe se hunde mas la bellota y se fija mejor. Hé aqui por qué los tallos de muchas jucas estaban acribillados de agujeros como los bohordos de las pitas. Cuando esios árboles mueren, la corteza que los cubre se desprende del tronco, y entonces deja entre ella la madera un intersticio muy extenso, que tambien puede servir para depósito como el vaclo ceninal de los bohordos de las pitas. Nuestras aves, bastante previsoras para aprove char tal circunstancia, cubren de agujeros las cortezas mucr. tas é introducen tambien bellotas entre ellas y la madera del árool. Sin embargo, scmejante recurso no parece convenirias mucho, lo cual se comprende fácilmente, pues siendo el granero demasiado vasto, los frutos caen al fondo cie aqquella bolsa natural, y los picos no saben ya cómo sacarlos. Asi se explica que al levantar las cortezas agujercadas no haya en contrado yo por lo regular sino restos de las bellotas que cayeron: cuando los picos las despedazabal en los agujeros practicados por fuera escascaban mucho las bellotas in

- Los procedimientos que acabamos de describir son harto notables. iHé aqui un ave que almacena viveres para el in. vierno! Recorre una gran distancia para buscar un alimento que no parece propio de su raza, y le trasporta á otras re. giones donde crece la planta que le sirve de almacen. No le oculta en los hucecos de los árboles, en las grietas de las ro. cas, en hoyos pracicados en tierra, ni en sitio alguno, en suma, que pudiern presentarse naturalmente a su vista: un instinto poderoso le revela la existencia de un espacio exi. guo, oculto en el centro del tallo de una planta; penetra en él rompiendo la madera que le ciern por todas partes, y acumula alli sus viveres con un órden perfecto. De este modo los preserva de la humediad, en las condiciones mas favorables para su conservacion, al abrigo de las ratas y de las denás ares frugivoras, cuyos medios mecánicos son in. suficientes para perforar la inadera que los cubre.

xNo dudo que estos hechos se juzgarin dignos de llamar la atencion de los ornitologistas, y recomiendo á los vinjeros que los estudien y completen las observaciones, procurando averiguar á qué punto van los picos á recoger las bellotas. Apenas crecen cacinas sino en la rertiente de las Cordilleras ; pero como hay cerca de diez leguas desde esta vertiente al Pizarro, se me resiste creer que estos picos vayan s buscar sus viveres á una distancia tan grande. Seria preciso obser. var la pperacion de llenar el depósito, seguir despues al ave, y procurar saber si cada pico conserva la propiedad de los álós que preparó, ó si mutuos robos ocasionan contiendas entre los propictarios respectivos.

- Varios picos pertenecientes a especies mas débiles habi. tan tambien la sabana de Pizarro; pero no he podido reco. nocer si procedian del mismo modo. En una parte de la montaña estaban trasformados en graneros los innumerables bobordos de pitas secas, y á este depósito general era debida In aluencia de picos en aquel punto. Fis probable que du. rante la estacion/seca se reunan dichas ares en los sitios abrie abundan las citadas plantas, por tener alli preparado su alimento, y que al comenzar las lluvias del verano se dis. persen por los campos para buscar los insectos que la naturileza les ofrece entonces en abundancias

\section{LOS GEOCOLAPTOS-GEOCOLAPTES}

CARACTRERS. - Mientras que la mayor parte de los picidos viven casi siempre en los årboles, ó por lo menos no suclen cazar sino en ellos, hay algunos, tales como los gec. colaptos ó ficus terrestres, que buscan su alimento en tierra.

listas aves tienen el pico del largo de la cabeza, algo comprimido lateralmente, un poco encorvado, de arista an. gulosa, con el borde de la mandibula superior algo abultado hícia la base; las alas, bastante poderosas, son largas, pun. tiagudas y obiusas, con la cuarta penna mas prolongada; la cola fuerte y puntiaguda; los tarsos altos y sus dedos relati. vamente endebles.

\section{EL GEOCOLAPTO CAMPESTRE-GEOCOLAP- TES CAMPESTRIS}

CARACTERES. - El geocolapto campestre tiene un plumaje variado, pero de colores poco vivos. La parte supe. rior de la cabera y la garganta son negras; las mejillas, el chello y la parte superior del pecho de un amarillo dorado: el lomo y las alas de un amarillo pálido, con rayas pardo negras; la parte inferior de aquel, el pecho y el vientre de un tinte amarillo blanquizco claro, presentando las plumas va. rias listas negras trasversales; las rémiges pardas, con los tallos de un amarillo dorado: las barbas internas y externas de las secundarias tienen rayas blancas: las rectrices son de un pardo negro: las barbas externas de las intcrmedias y las internas de las tres medias están rayadas de amarillo: el ojo es cie un tinte rojizo cereza oscuro; el pico negruzco y las 
patas de un gris sucio. Los dos sexos difieren poco uno de otro: pero la hembra tiene colores menos viros que los del macho: los pequenos presentan rayas mas anchas que los adultos La longitud es de $0^{\circ}, 32$ por $0^{\prime \prime},+7$ de anchura de punta a punta de ala; cstas miden $0^{\circ}, 145$ y la cola $10^{\circ}, 3$.

DISTRIBUCION GEOGRAFICA.- Parece que esta especie habita la masor parte del interior de la América del sur.

USOS, COSTUMBRES Y REGIMEN.-LI geocolag. to campestre, dice el principe de Wied, difiere de todas las demás especies por su habitat; no se encuentra sino en los lugares descubiertos, completamente desprovistos de bosque, r donde solo crecen algunas breñas aisladas. Jamis le he visto en las grandes sclins cercanas \& la cosia ; y si únicamente ell las áridas landas, abrasadas por el sol, en el interior de Sertongs, en las provincias de Bahia y de Minas Azrra le ouservó en el Paraguay.

Burmeister asegura por su parte, que el geocolapto cam. pestre habita en los lugares descubicrtos, cerca de los nidos de térmites. El En la vertiente de una elernda mescia, dice, fué donde vi los primeros: una bandada de ocho a diez in. dividuos se ocupaba en golpear un grueso árbol; de rez en cuando se posaba uno de cllos en tierra, andaba como una comeja y volvia despues al árbol. Fin de creer que hubiesen encontrado alli un excelente alimento; sin duda habian sor. jrendidu durante su viaje una colonia de zérmites. Aquellas aves no podian menos de llamarme la atencion: un pien gri tando y corriendo por el suelo era para mi una cosa extraor. dinaria; dije á mi hijo que timse conzra uno, hizolo asi y cayeo el ave: al txaminar el cuerpo. convencime de que habia pe. neirado en el Campo, pues solo alli se encuentra este pico singular.

Lid geocolapto campestre, añade el principe de Wied, se alimenta principalmente de los térniles y hormigas que laaibi. tan estas llanuras por bandadas innumerables. Lincuentranse en las landas y en los bosques altoranos cónicos formados de una arcilla amarillenta, çue tienen à ménudo dos metros de altura, obra de los térmies; pero en los lugares descukiertos, son aquellos un poco aplanados, por lo regular. De las ramas mas fuertes de los árboles perden otros nidos de for ma redondeada y color pardo negto, viélidose en cada tronco de cactus por lo menos uno. Alii es donde el geocolapto acostumbra á posarse para cazar, y es are muy útil porque destruye los iusectos nocivos, verdadera calamidad para los colonos del Irrasil. Estos voraces séres construyen sus nidos, lo mismo encima que debajo de tiema; los sitúan igualmente cerca de las viviendas humanas: pero en todas partes tienen numerosos enemigos quie los cazan encamizadamente. Los hormigueros, diversos picidos, los tordos homigueros y otras muchas aves, son preciosos auxiliares para el planiador en la lucha que debe sostenci contra los devastadores insectos.?

De esta cita del principe de Wied resul:a evidentementc que Azara y Spix incurrieron en crror al creer que el geoco lapso no tiepaba á los árboles, si bien es cierto que no lo hace lanto cono los oiros picidos. Sus arsos, muy largos, le con vienen mas para saltar y andar, aunque tambien se le ve tre par como a los picos. Sube por-los troncos de los cacius; salta con cl cuerpo recto sobre las ramas horizontales; pero en tierra es donde está casi siempre.

Hudson, que muy sin razon conbate un aserto de Darwin sobre cste picicio, esta coniorme en lo esencial con las nuticias anieriores; dice terminantemente que esta ave trepa à la manera de otros picidos, sirviéndose de su endeble cola, y que asi como estos pica la corteza y la madera podrida. Con frecuencia baja al suclo, y il veces se le halla d varios kiló metros de distancia de todos los árboles, ocupacio en coger hormigas y toda clase de larwas; pero cste es un caso excep. cional, pues solo sucede cuando quiere volar de un grupro de árboles á otro. Estas excursiones se vicetuan a cortos intervalos, pues raras veces se determina el are $\mathbf{a}$ un vuclo largo.

Comunmente se le encuentra apareado: es probable yue la bundada de que habla Burmeister fuese una familia, es decir, el macho, la hembra y lus lijuelos. En cuanto i lo demás, el geacolapto se asenveja a los otros picidos: vitula y grita lo mismo que el gecino verde de Europa.

\$Su nido, dice Burmeister, deve estar perfectamente oculto, pues no es conocido aun: no me parece probab!e quue le construya en tietra.

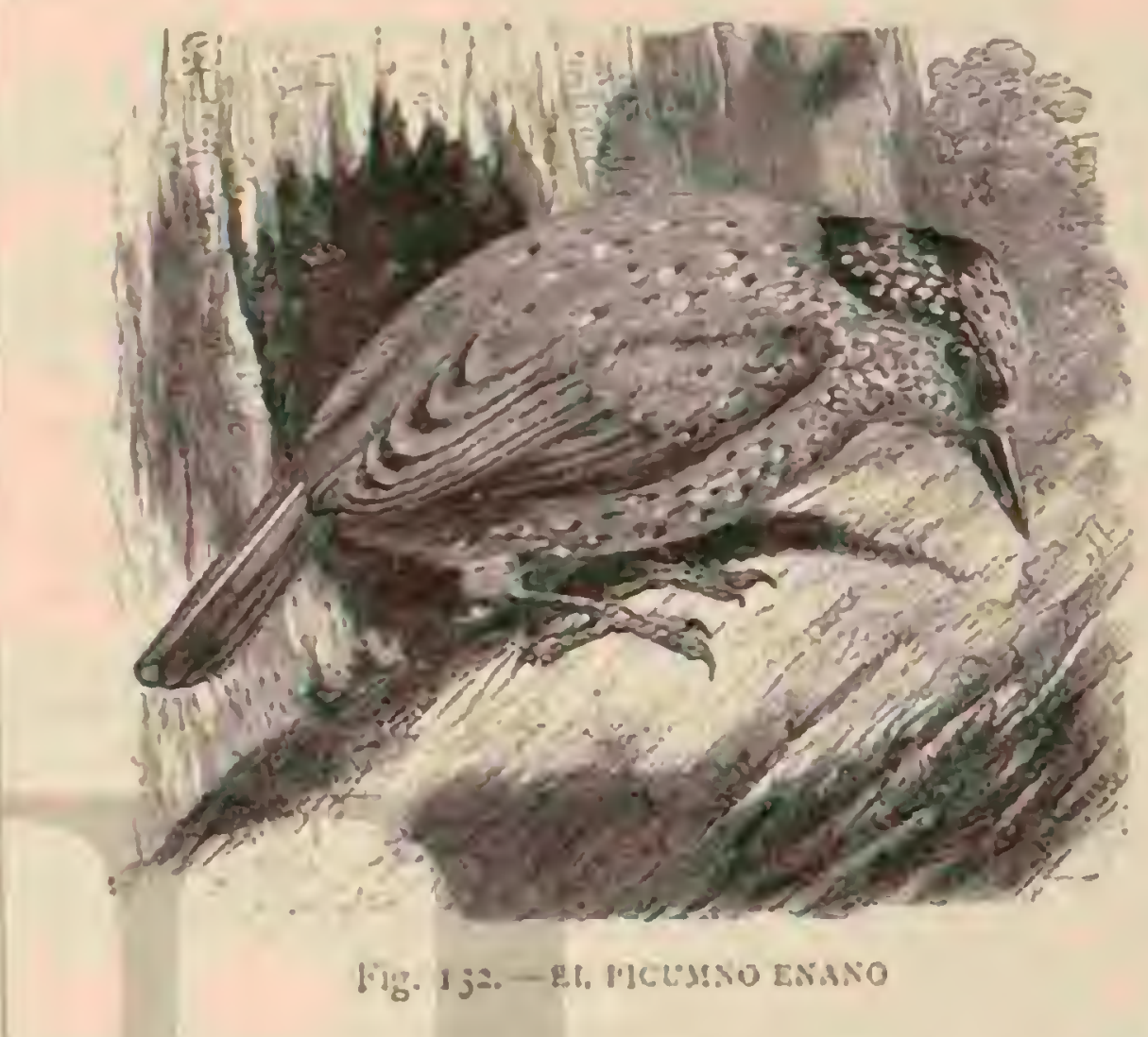

Hodson confirma la exactirud de la suposicion de Burmeister pur el hecho de que colaptos campesires obeervados por el en Bucnos-Aires, anidan con preferencia en los árboles llamados cmabu, fabricandulus ellos mismos en los huecos como ciros picidos. El amba tiene una madera nuy blanda, y por eso puede el colapno camplestre practicar un agujero aunųue el ártol sea sano y verde.

La aberum de ia enirada se elssa en el interior, segun dice, if unos $11^{\mathrm{m}}$,20 antes de llegar al nido mismo.

\section{LOS PICOIDEOS - PICOIDES}

CARACTERES.-- El Úlitino género de picidos de que haré mencion son los jicoídeos, picos abigarrados con patas provistas de ires ciedos: el pico es casi tan largo como la ca. bexa, recin, ancho, elevado en la arista en forma de quilla y sesgado hácia la punia; los tarsos son largos; los dos dedos anteriores tienen casi igual longitud y son un poco mas cor. tos y̧ue el último posterior.

\section{EL PICOIDEO TRIDÁCTILO-PICOIDES TRI- DALTYLUS}

CARACTERES. - El lipo aleman del grupo de los picoideos es pl picoideo tridłctilo: esta are, casi igual en tamaño a nuestro pico abigarrado, no tiene los colores tan vivos, pero no se mexclan merios. I as ylumitas yue cubren la nariz son blancas con puntas negras; las de la parte anterior de la cabeza, blancas tambien con lineas negras en los tallas, y las de la coronilla de un amarillo vivo de limon. Eil occipucio, una faja ancha que se corre sobre los ojos, por la region de las orejas y en los lados del cuello, bordeada por atra entre la parte superior y por debajo por una mas ancha de color 
blanco, ofrecen un tinte negro; del mismo color es una faja gue parriendo de la base de la mandibula superior, se corre desde anqui hácia la parte posterior del cuello, componién. dose solo en parte de lineas negras en los tallos; la barba, la garganta y el centro de la region inferior son blancas: las plumas del buche y de los lados del pecion tienen manchas negras en los tallos; el vientre, los lados de los muslos, el ano y las tecrices inferiores de la cola presentan fajas tras. versales negras: las regiones superiores, incluso las alas y ex cepto una ancha faja lungirudinal blanca que baja de la parte posterior del cuello hasta las tectrices superiores de la cola, son nugras: cn las alas y las plumas de los hombros hay manchas longitudinales blancas; las rémiges primarias tienen en las barbas exteriores cinco manchas trastersales blancas, y las serunciarias tres: Ias secundarias presentan además en el borde de las barbas interiores ouras mas grandes del mismó tinte, de modo que en el ala recogida se ren seis fajas trasversales estrecinas de color blanco: en las dos rectrices inferiores de cada lado, bordeadas de binnco en la punta, hay otras dos hajas del mismo tinte: en la tercera de cada lado|solo se ve una: los ojos son blancos; el pico azul de plo. mo. En la hembra, la coronilla es blanca con lineas longitu. dinales negras.

DISTHIBUCION GEOCRÁFicA.- Fil frea de dispersion del picoideo tridactilo ofrece la particularidad de limiar. sc, en el centro y mediouia de Europa, a las montanas altas; extiéndese en cambio por todo el liorte de nuestro continente y tambien por el Asia central hasta cl Kamschatảa y Sachalien: en el norte llega hasta donde hay árboles, y en el sur hasta la montasia de Tianschan. El área de ciospersion de este picido se asemeja, pues, a la del lagopo alpino, el cual se encuentra tambien en nuestros Alpes.

El picoideo tridaictilo es una verdadera ave montanesa y solo visita los paises bajos ó la llanura alli donde estos ofrecen el tipo de las montanas alias, como sucede en los bosques del alio norte, en los cuales comienza ya la Tundra. Dentro de ks limites de Alemania solo se ha encontrado su nido en los Alpes de Baviera: pero puede suponerse que hisladamente anida tambien en las montanas centrales de la Silesia y en la selvá de Bohemia, aunque ninguno de los observadores que lo creen asi haya enconirado hasta ahoral su nicio en tales parajes. En cambió se puede asegurar que el pico tridác. cilo habita continuamente en los $\mathrm{h}$ /pes, iallándose disemi. nado hasta los promontorios mas orientales de este, los Cárpatos. donde, segun llodxicki, es el mas comun de todos los picidos. 'Tambien vive en los Alpes de la Transilvania, el Cáucaso y todas las montanas de la Fscandinavia, desde el punto mas meridional de este pais, hasta los $70^{\circ}$ de latitud norke; no falia tampoco en el norte de la Rusia, en el Ural y en todas las montañas y bosques ya citados del norte y centro del Asia. Parece que en ninguna parte abunda, pues cada pareja habita un territorio bastante extenso: pero debo anadir que los bosques clegidos por esta ave dificultan mu. cho un exámen minucioso. In nuestros Alpes habita exclu. sivamente los bosques de abetos, pinares, etc., y en el norte le agradan, segun parece, los olivares.

Cuando un incendio en los bosques destrure vastas superficies cubicrtas de abetos, liegando á ser los árboles presa de los insectos, preséntase tambien aqui el ave para aprovecharse de la ocasion, y entonces puede succder que el observador encuentre un número inesperado de estos picidos. Sin em bargo, en el nortc le placen tal vez mas los bosques de alisos, probablemenic por la sencilla razon de que el color de su plumaje es exaciamente el de los troncos centenarios de los alisos del unite. Despues del periodo del celo, el picoideo tridáctilo vaga por el pais, de preferencia en compaisia de los mirlos, con los cuales se le coge á menudo en los lazos ten. didos para los tordos, y entonces sale á veces de los limites de su territorio ordinario, encontraindosele por esta causa en regiones de Alemania que no pueden gustarle. Asi, por ejem. plo, en Anlaalt se cazó, segun Naumann, un individuo qque estaba en una encina y lo mismo se ha hechocon otros varias veces en los promontorios de los Alpes de Baviera. Quizas abunde en Alemania mas de lo que pudiera suponerse por las observaciones hechas hasta ahora.

USOS, COSTUMBRES Y RFGIMEN.-Fil caríctery las costumbres del picoideo tridáciilo se asemejan mucho is las del pico abigarrado, ó por lo menos yo no he vistn dife. rencia alguna en cuantos individuos pude observar en laponia s. Siberia. Es igrualmente alegre, ágil, atrevido é inquieto; se le parece en el vuelo y en la vor, solo que esta úlima, segun Girtanner, es mucho mas sonora; produce un tamborileo ruando codicia el alimento de otra ave: acude tambien cuan. do se imitan stis picotazos: y en fin, parécese al picn abigar. rado en todas sus particularidacies. Su alimento consiste en insectos $y$ materias vegetales. Parece que en los Alpes se nutre preferentemente, segun Girtanner, de las huevos y larwas del Gastropitiar y además de algunos otros insectos des. conocidos; inmbien come vegetales, probablemente piñones; en los bosques de las montanias centrales, su alimento es el mismo que el del pico abigarrado, y en las del norte se le ve coger toda clase de insectos de los airboles, a curo efecto arranca pedazos de la corteza, practicando agujeros profun. dós en la madera poudrida. Collet examinó los estómagos de tres de estos picidos y vió que contenian las larvas de un ce. cidónidio y del gran capricornio, uno de los mas perjudiciales para el bosque, y algunos otros insectos, sobre tocio maripo. sas En otoño se nutre tambien sin duda de materias vegeta. les, solire todo de bayas del plátano, pues si asi nofuere, no podria explicarse por qué se le coge en los lazos iendidos á los tordos. Sobre su manera de reproducirse tenemos muy pocas noticins.

Segun Wodzicki, es muy prudente cuando construje su nido; forma de veinte á treinta huecos, y tan pronto pasa la noche en uno como en otro, hasta que al rin lo fabrica en un hueco nuevo. Por eso no se suele descubrir su nido sino cuando lleva el alimento \& sus pequeños. Lin hueco exz. minado por Girtanner se encontró en un ateto alto y enfermizo de un bosque de Graubunden, situado a unos 1,600 metros sobre cl nivel del mar; pero á una altura tan considerable que fué preciso cortar el árbol para llegar á los pe. queños. Tales huecos se abren por-las mismas ares y no se distinguen de los de nuestro pico abigarrado. La puesta se compone de cinco hisevos blancos y brillantes, cuyo diáme-

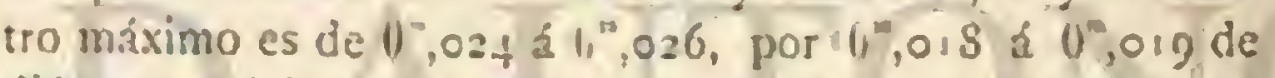
diámetro minimo; la hembra pone los huevos á principios de junio y probablemente los cubren ambos padres alternativa. mente, lo mismo que ambos se cuidan de la alimentacion de sus pequeños.

CACTIVIDAD. - Algunos picoideos tridaictilos cogidos pequeños del nido y cuidados por Girtanner aceptaron, dis. putando y gritando continuamente, las larvas de hormiga que se les dieron, y se destrrollaron muy bien: de modo que casi podian empear i volar cuando una manana se les encontró muertos sin causa explicable: parece por consiguienic que no es fácil tenerlos en cautividad.

\section{LOS PICUMNIDOS - PICUMNI}

CARACTERES.-Los picumnidos ó pions de colit blandis son muy afines i los picos propiamente dichos: Reichenbach 
considera que representan a los nlcedinidos entre los picos: Calannis los agrupa entre esios y los torce cuellos 'Jienen el aspecto del pico: pero su cola no les puede servir de punto de aproyo; su talla es muy escasa; apenas son un poco mayo. res que el troglodita.

DISIRIBUCION GEOGRÁFICA. - LOS picumnidos, que para algunos autores constikujen solo una sub familia, aunquue su cola flexible los distingue perfectamente de los picidos, peritenecen sobre todo á la América del sur. Se conocen además tres especies propias de las Indias y una de Africa.

USOS, COSTUMBRES Y RÉGIMEN. - Nada sabe. mos con seguridad acerca de las costumbres de estas aves, pues los datos que nos suministran los diversos autores no estan nada conformes.

\section{LOS PICUMNOS - PICUMNUS}

CARACTÉRES. - Tienen el pico prolongado, cónico, recto, puntiagucio, y sin atista bien pronunciada; las patas, conformadas exactamente como las de los picus, no son endebles ni pequeñas, aicridida la talla del ave; las unas se encorvan marcadamente en forma de hoz; las alas son cortas, obtusas y redondeadas, con la cuarta y quinta rémiges mas largas que las otras; la cola se compone de doce pennas, cortas, blandas y redondeadas; las dos externas son muy pequeñas; el plumaje muy blando y las plumas poco numerosas.

\section{EL PICUMNO ENANO-PICUMNUS MINUTUS}

CARACTERES. - Esta ave ha sido tambien llamada fico erano por algunos autores. Tiene el lomo gris pardo; el vientre crużado por rayas blancas y negras: la parte superior de la cabera de esta último color con puncitos blancus; la frente roja en el macho, y con mutas blancas en la beinbra. las rémiges son de un pardo negro, orilladas de amarillo; has sub) alares del mismo color, con filete claro; las rectrices negras, adornadas de anchas fajas blancas, las laterales en lis barbas externas $y$ las medianas en las intermas. lil ojo es pardo; la raiz del pico de color de ploino, con la arista y la punta negras; las patas gris de plomo tambien. Esta ave mide $11^{\circ}, 06$ de largo por 11,15 de punta a punia de ala, la cola $11^{m}, 025$ y el ala $(1 ", 048$ (figura 132).

DISTRI OUCION ‘EOGR + FICA.-El picumno enano se encuenira á menudo en todos los bosques de las costas, desde la Guayana hasta el Paraguay. Se le ve tambien cerca de las casas.

USOS, COSTUMBRES Y RÉGIMEN.-Vive por pa. rejas en el verano, y dumnte el inviemo en reducidas ban dadas, que recorren un prais bastante extenso. Segun el principe de llied, tiene todas las costumbries de los ycos, trepando como ellos à loz troncos parn cazar insectos y larins. Bur. meister, opmando de distinta manera, dice que esta are se astmeja por sus usos al rę̣eruelo; pero ningun otro de esios autores confirma los ascrtos de Azara, quien asegura que el ave liepra por los troncos y salta de rama en rama

Schomburgk encontró sicmpre el picumno criano niezclado conoras aves, recorriendo el bosyue en su compañia è in. troduciendose a nenucio en los jardines y plantaciones. Di. visó cierta pareja que acudia con regularidad á una rama hueca, en la cual salia y eniraba; pero no parece que haya observado el nido. Una especic afine habita el Perú, y sabe. mos por 'l'schudi que pone cuatro reces al ano.

Hé anquí tudos los datos qque he podido recoger acerca de estas cncantadoras ares.

\section{LOS TORQUILIDOS- JYNGID死}

CARACTERES. - I.OS torquilidos son las aves menos perfectas de la seccion de las trepadoras, y constituyen en cierto modo un trónsito entre los picidos y los cucúlidos. Prerier el cuerpo pralongado; el cuello largo. Ia cabeza bas. tante peçuena; el chello desprovisto de surcos laterales; la cula redondeada y compuesta de pennas anchas y flexibles que no pueden servir de punto de apoyo.

Segun Niicsch, los órganos internos presentan la misma confurmacion que en los picos: la lengua es muy protractil y filiforme, y su punta no está guarnecida de ganchos.

DISTMIBUCION GEOHRAFICA. - Esta familia está basada en un género único, que tiene rẹresentantis en Eu. ropa, Asia y Airica.

\section{LOS TORCE-CUELLOS - JYNX}

CARACTERES.-Los torce cuellos tienen el pico corro, recto, cónico, puntiagudo, algo comprimido, y con plumas en la base; las alas medianas, muy obtusas, con la tercera rémige mas larga: la cola prolongada, ancha y de pennas blandas; los tarsos fuertes y escamosos, y el plumaje blando.

\section{EL TORCE-CUELLO VERTICILO - JYNX TURQUILLA}

CARACTERES.-Fil torce.cuello verticilo ó vulgar (figura 133 ) tiene el lomo gris ceniciento claro, con puntes muy diminutos, y ondulado de gris oscuro; el vientre blanco, cun manchas discminadas triangulares c intensas: Ia garganta y el cuello de color amarille, con rayas trasversales; una lista negruzca baja de la parre superior de la cabeza hasta el lomo; cl resio de este úlimo catá sembradu de inanchas negrurcas, paruo rojas ó de un purdo claro. las rémiges prcsentan rayas pardo rojas y pardo negras; las recirices estin cubiertas de motas de este culor. y adornadas además de cinco listins cur. vas y estrechas. El ojo is pardo amarillo; cel pico y las patas de un amarillo verdoso. Los tintes de los hijuelos son mas opacos y menos juros, y los ojus pardos. Eil ave mide 10 ".18 de largo por $t^{2}, 29$ a $1 \%, 30$ de punta a punta de ala; es!a tiene $0^{*}$, co y la cola $\left({ }^{\circ}, 00_{5}\right.$.

DITIRIGUCION GEOGRAFrCA. - Fil torce.cuello vul. gar habita la mitad del globo; pero su verdadera patria is a en el norte, en el centro de Europla y en . Asia Lin Alemania se le encuentra casi cur todas partes menos en las altas montakias y en los bosquits mas espesos y sombrios. Por el norte llega hasta el centro de Escandinavia, y por cl este se extien. de su área de dispersion hasta el salle del ria Amor.

Er el centro y mediodia de la Rusin le vi con frecuencia en todas partes $y$ aun en las estcpas es bastante comun; en la Dauria escasea innto como en Europa.

Ls raso en el sur de Europia: segun mis olsernaciones, no anida en las llanuras de Lspaña, ni tampoco en Grecia:

Yo creo que la causa de esto es la escaser. de árbules en Esparia y Crecia, por mas que se opronga a sal suposicion la presencia del torce-cuellos en las estepas. Sin enbargo, como la pobiacion escasea en estas, los pocos airboles de los valles le ofrecen moradas tan seguras, que puecie vivir muy fácil. mente alli con las mismas condiciones que en Espaina y Gre. cia impiden su existencia. Fin Italia se cuenta, segun l.esso. na Y Salvadori, encre las ares comunes del pais, preséntase con regularidad en la primavera, cria su progenie y vuelve a emigrar en otono. 
Durante sus viajes atravicsa todo el Egipto $y$ la Nubia, y se dirige a tomar cuarteles de invierno en el Sudan oriental. Segun Gerdon, se le encuentra en tocias las partes de la India, aunque solo en invierno.

Lindermayer dice que sucle invernar en Grecia, donde se le observia a menudo desde octubre nasta marzo en los oliva. res. Krueper confirma el hecho fundado en sus observacio. nes. Asi, por ejemplo, un torce cuello que se conserva en el Musco de Alenas fué muerto et 3 de enero de 1863 en Arica; ctro se cazó el 5 de febrero de 1874 cerca de Atenas, despues de una nevada; y en el invierno de 1 so hasta se encontró una de estas aves muerta en la nieve. Lessona y Salvadori dicen tambinn en su excelente traduccion de ta primera edicion de «Ia vida de los animales que en el centroy nedí: dia de Italia se observar con alguna frecuencia torce-cuellos que pasan alli el invierno.

USOS, COSTUMBRES Y REGIMEN.AEn Alemania no se presenta el torce-cuello hasta que la primavera está algo adelantada, $y$ abandona el pais antes de terminar el verano. Cuanco el ticmpo es muy propicio llega ya desde el 10 al is de abril; pero mas á menudo del zo al 30, y aun á veces en los primeros dias de mayo; pernanece en el sitio donde ani. da liasta principios de agosto, rarás veces mas. Entonces co mienzan sus cortos viajes, y si mas tarde, hasta mediados de setiembre, se ven todavia algunos individuos de su especic, debemos suponer que lian aridado en el norte y que se diri gen hícia el mediodia ; viaja siempre de noche. Hácia el oto. no forma reducidas bandajas, que emigtan de concierto; pero al regresa lo hace cada individuo scolo, si bien se da el caso de que en la primavera se vean en ciertas localidades, como por cjemplo en Egipto y España, varias de cestas ares juntas.

Li torce-cuello verticilo busca los parajes en que predomiuan los bosques, pero donde encuentra tambien grandes y numerosos claros. Ias arboledas, los matorrales y las huertas son los lugares que parece preferir. No teme al hombre, pues se fija cerca de las casas, en los jardines, y alli donde un árbol le ofrezca un ngujero en que poder practicar su nido.

Ilama bien pronto lá atencion, particularmente en la primavera cuando se halla en el círculo de su dominio; su voz le descubre mas, cuántó que la hembra contesta con regula. ridad al llamamiento del macho. Repite-vente veces segui. das su grito acrii id, atii id: si se dirige álguien hácia el sitio donde percibe el sonido, no tardará nutho en ver al ave; se posa en las ramas de un àrbol; se agarra á un tronco, ó biẹn se guueda en tierra tranquilo, aunque sin permanecer inmóvil. No es pesado ni torpe, pero si perezoso, pues solo se mueve cuando no puede hacer otra cosa; nada tiene cie la vivacidad ni de la petulancin de los picos y de los otros trepadores. Sus dedos opuestos le permiren cogerse perfectamente a las tron. cos de los árboles; pero no treja. En ticrra da saltitos con bastante pesadez: solo vuela al árbol mas proximo; sube has ta la copa: déjase caer casi hasta el suelo; vuela un instante, aleteando precipitadamente, y se remonta despues describien do una larga curva.

Lo mas particular en esta ave es la facilidad que ticne de volver la cabeza en todas direcciones: i cacia cosa inusitada que ve hace varios gestos, que aumentan en razon directa del cspanto que le produce. Alarga su cuello, dice Naumann, eriza las plunas de la cabean en forma de mono: abre su cola como un abanico; enderézase varias veces lentamentc, ó bien se contrae; extiende su cuello hícia adelante, vuelve los ojos, dilata la garganta como una rana, y produce al mismo tiempo un ronquido sordo y gutural Cuando le domina la cólera, está herido ó queda preso en un lazo, y se le quiere coger con la mano, hace tales gestos, que aquel que lo ve por primera ver, se queda estupefacto, si no atemorizado. Con las plumas de la cabeza erizadas y los ojos medio cerrados, alarga el cuello, le vuelue despacio a todas partes, cual pudiern hacer. lo una serpiente: parece trazar varios circulos con su cabeza, y dirige su pico tan pronto hácia adelante como hácia atrás Diriase que con esta maniobra trata el ave de asustar á su enemigo; su plumaje, cuyos tintes se confunden con los de la correza de los árboles, ó con el de la tierra, contribuye it la ilusion, haciendo creer que podria espantar, imitando los movimientos de la serpiente, tan temida de casi todos los animales. Y esto no es una cosa instintiva, sino aprendida, pues solo los torce.cuellos adultos laacen eso.

Una hermosa mañana de verano, Grill se paseaba con su petro en un pargue, cuando el animal comenzó de prontos. ladrar, parindose delante de una pequeña espesura. Al acercarse Grill, vió un torce-cucllo que, echado al suelo, hacia movimientos extraños; extendia la cola y las alas, alargaba el cuello, movia su cabera como las serpienies, revolvia los ojos en las órbitis, erizaba las plumas de la cabeza, cic. Fi obser. rador, alejando el perro, que casi tocó al ave, apoderóse de esta, la llevó a casa y pisola en una jaula. Lin el mismo instante tomó su posicion natural, j cuando mas tarde se la dejó en libertad, nlejóse muy alegre, rcconociéndose asi q̨ue cstaba del todo sana. Los cautivos demuestran siempre que solo ejecutan sus movimientos extrairos para asustar à los se. res que les parecen peligrosos.

Kara vez se bye á esta ave producir mas grito que zuid id. ¿aij ift; cuando está poseido de cólera, el macho grita zused, הard; si tiere miedo, tanto él como la hembra pronuncian la frase scracke, in segunda sillsa como una serpiente cuando la irritán : los pequeinós cuando están en el nido producen cl mismo rumar que las langostas.

Con razon aplicaron los espanoles al torce-cuello el $110 \mathrm{~m}$. bre de $/ m$ miguen, 6 comedor de hormigas, pues efectivamente, constivuyen estos insectos la base de su alimentacion. Se coba cn todas las pequenias especies; prefiere las larvas a los adultos; pero come tambien las de otros insectos y las orugas. Sulengua, mas protráctil que la de ningun ctro pi. cido, le sirve de mucho en este caso: como los hormigueros, introduce su lengua a través de las grietas, $y$ hasta en el in. terior de los agujeros: espera á que las hormigas se hayan cogido con sus mandibulas ó adhieran á la saliva viscosa, y juego la retira de pronto para introducirla en su boca. Coolpea las larvas con la punta del pico, como lo vió ya el viejo Gessner. $\& \mathrm{E}$ torce-cuello traspasa rápidamente las hormigas con su lengua, lo musmo que los niños atraviesan las ranas con puntas de hierro; luego se las traga, pero sin tocarlas con el pico, como tienen costumbre de hacer otras aves para comérselas.

Algo se debe añadir sobre este particular. Repetidas veces me esforcé, pero sienipre en vano, para reconocer cómo coge su presa el torce cuel!o que tengo en cautividad, y por el cual me intereso mucho. He visto que abre un poco el pi. co, saca la lengua, la mueve algunos momertos entrc las larvas, y retirala rápidamentc; pero no se observa de qué modo queda fija la presa en aquel órgano, aunque se mire al ave á pocos centimetros de distancia

Ei torce-cuello comun puede encontrar, sin buscar mucho, un sitio á propósito parn ábricar su nido: bástale un agujero de abertura bastante angosta, que no pueda das paso á un carnicero. Poco le importa la altura en que se halla: si un ár. bol presenta varios orificios, deja comunmente los mas ele vados para los gorriones, los paros, los colirojos y otras aves, con las que no gusta de trabar pendencia ; se fija en los mas bajos y vive entonces en buena armonia con sus vecinos.

Cunncio le falta lugar ś propósito para fabricar su nido, 
muéstrase menos pacifico de lo que dice Niumann. En el este de la I'uringia clige, segun Licbe, las cajitas de estornino, porque los árboles vicjos desaparecen rápidamente, micntras los picos que suelen construirle sus viviendas escasean cada vez mas; y en ellas deposita los huevos sin el me. nor preparativo sobre las materias medio podridas, en las cuales anidaron el año anterior los gorriones ó estorninos. Cuando encuentra estas cajitas ocupadas, 6 las que se han puesto para otras aves, intenta, obligado por la tsecesidal, penetrar en cilas á la fuerza, en cuyo caso puede ser perjudi. cial en los jardines provistos de tales cajitas, ya que no des. truya algunos nidos. En cl viltimo caso liace su vido en el lueco de algun tronco de sauce viejo; de ordinario le limpia un poco, formando en el fondo con la madera podrida una especie de lecho bastante blando.

Alli tes donde á fines de mayo pone la hembra de siete á once huevos, pequenonos, obtusos, de ciscara lisa y delgada $y$ color blanco; los cubre par espacio de catorce dias, y no la reemplaza sa companero mas que un rato, á eso del medio dia. La hembra permanece sobre los hucros con tanto afan como persistencia: segun mis observaciones, es muy dificil hacérselos abandonar; cuando se golpea el ärbol, no se muc. ve, como hacen las demás aves que anidan en agujeros; aunque se mire por la abertura de su nido permanece quicta, limitándose a silbar como una serpiente.

Èn el momento de salir á luz los hijuelos, solo algunas partes de su cuerpo estín cubiertas de un escaso plumon agrisado: crecen rảpidamente; sus padres les llevan alimento en abundancia: y no abandoman el nido hasta que ya pueden volar muy bien. Por muy solícitos que se muestren los padres en todo cuanto se refiere á su progenie, hay una cosa que descuidan mucho, y es su limpieza. Se censura tambien esic defecto á la abubilla, pero el torce cuello corre parejas con aquella en este punto, de tal modo que su nido acaba por no ser mas que un monton de inmundicias. Cuando los hijuelos han comenzado a volar, los padres viven aun largo tiempo en su compaña y les ensenan a luchar contra las dificuliades de su existencia. Hasta mediados de junio no se disperean

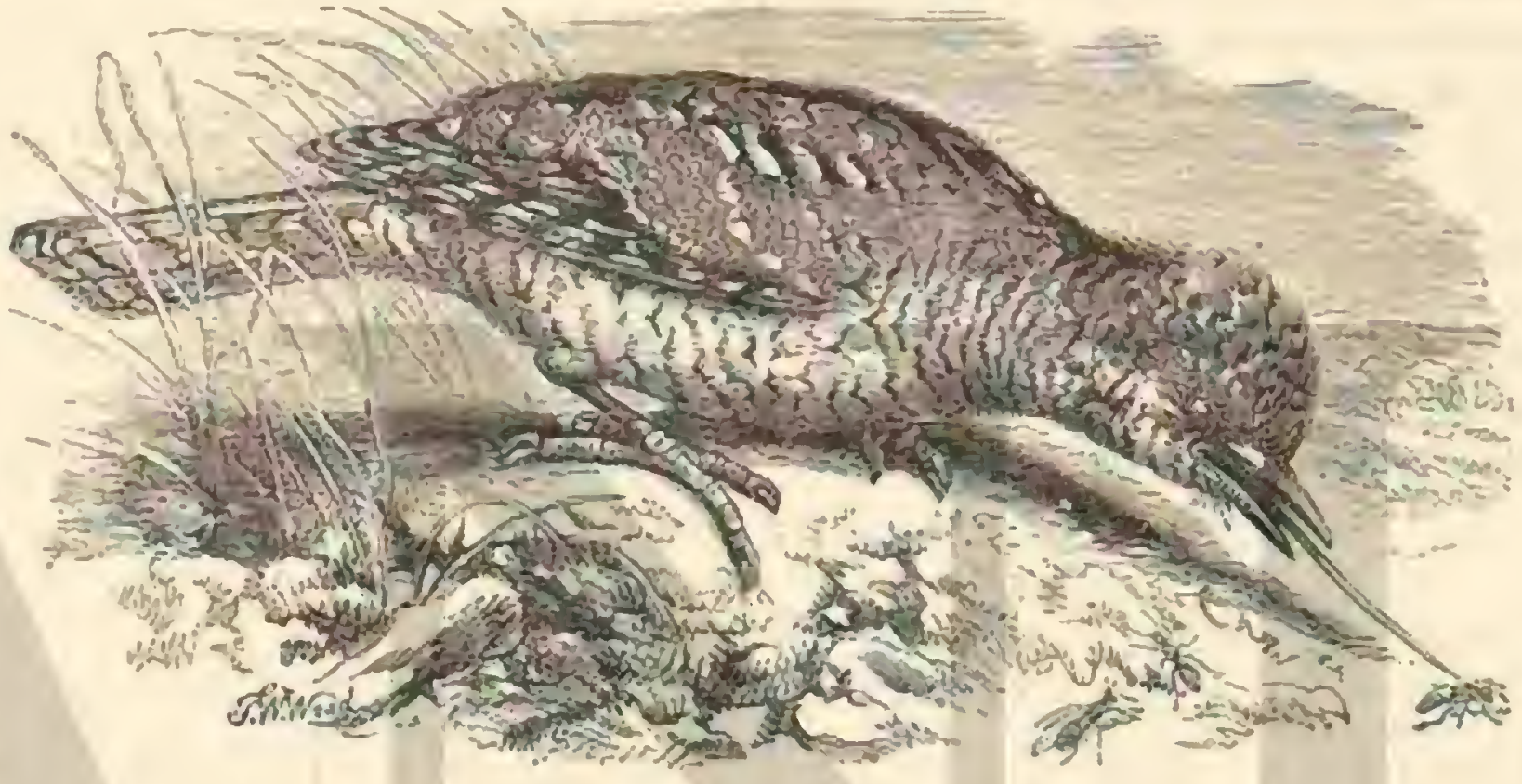

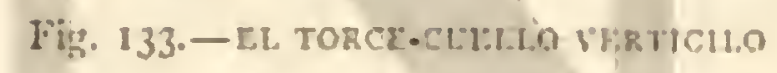

las familias, para ir cada individuo \& vivir solitario $\mathrm{cts}$ tanto que llega el dia de la marcha.

El torce-cucllo verticilo se halla expuesto por desgracia con demasiada frecuencia á los tiros de los cascadoris dominisueros, que dominados por su rabia destructora \& ignorante, exterminnn muchos individuos. El gavilan y las otras rapaces, la urraca, el grajo, el gato, la marta y la comadreja, son tam bicn otros tantos cnemigos terribles para esa inocente ave. Indudablemente que su carne es tierna y sabrosa; pero con un individuo no bay mas que para un bocado, y por lo tanto no justifica en manera alguna la encarnizada guerra de que es victima. Por otra parte el ave es de todo punto inofensiva; nos presta, por el contrario, sus servicios, $y$ aun cuando no fuese mas que por un semtimiento de gratitud, se la deberia respetar.

CAUTIVIDAD. - No es dificil acostumbrar \& este torcecuelto al régimen de la cautividad, aunque hay individuos que no quieren comer sino huevos de hormiga. Naumaun tuvo uno que prenirió pasar hambre antes que tocax maripo. sas, orugas, coleópteros, larvas, libelulas, moscas y araủas, que le ofrecian en abundancia; pero cuando le dieron larvas de hormiga, precipitose sobre ellas y las cogió ávidamente con su lengua, como con un tenedor. Sin embargo, los torce. cuellos se acostumbran comunmente poco a poco at otro alimento, ó por lo menos, ași sucedió con los que yo tuve, y con otro cuva historia reficre Franenfeld. Dicho autor ascgura que el ave se domestica perfectamente y aprende a conocer a su amo, aurqque al principio gesticula mucho en todas oca.

Toso III siones. He tenido un individuo, dice Gessner, que no volaba al acercarse un hombre; encolcrizábase, levantaba la cabeza $y$ daba picotazos, pero sin hacer daño; a menudo volvia su pico hácia atrás y luego hácia adelante, dando ń conocer de este modo su enojo; al mismo ticmpo erizaba todas las plu. mas del cucllo levantando la cola \$ Segun Frauenfeld, el torce cuello comun no hace tantos gestos sino para insyiras temor á los demás animales: aquel naturalista dejaba volar libremente por su habitacion sa un toree.cuello y a dos picos; si uno de estos se acercaba demasiado a su compañero aquel comenzaba a gesticular al momento, y conseguia asustar a las aves, que huian apenas imitaba el silbido de la serpiente. Al principio hacia to mismo con su amo; pero bien pronto $\mathrm{cm}$ pezó a conocerle y no le amenazó ya mas. eSc pone á la defensiva, añade Frauenfeld: agáchase, aเanza, alargando al propio tiempo el cuello; ensancha la cola, eriza las plumas. de la cabeza, y de repente la echa hácia atrais, repitien. do este movimiento tres' $\delta$ cuatro veces seguidas hasta que su adversario se alcja. Es particularmente curioso verle fuera de la jaula: en tales circunstancias busca un escondite, donde se acurruca de tal modo, que muchas reces cuesta irabajo encontrarle; mientras no se cree descubierto, perma. nece tranquilo, siguiendo con la vista a quien le busca; y cuando reconoce que le han divisado, comienza sus movi. mientos para asustar al enemigo. Si se le sorprende hallán. dose fuera de 5u jaula, se estira, aplánase contra el suelo y permanece inmóvil; cuando dejan de observarle se levanta y continúa recorriendo la habitacion. Solo cunndo algunas per. 
sonas entran à la vez donde mi torce-cuello se halia, vuela atemorizado para posarse en algun objeto alto.

Cuando se crian los polluclos de un nido, divierter mas aun gute las ares adultas. Los gritos que producen estas avecillas cuando tienen hambre, dice Girtanner, son los so nidos mas extruios que pueden eirse, y sorprenden sobre todo cuando proceden del interior de una cajita cerrada cuyo conicrido no se pueda reconocer por fuera: basta tocarla ligeramente para oir un zumbido extraio, que se podria iniar mu bien con un tamboril y que convierte en cierto modo la cajita en un reloj de música. Cußl no es entonces el asombro de los observadores inexperios cuando al abrir la cajita aparece stibitamente el peyueno grupo que se agita grotescimente. Los pejucios mas desarrollados muever sus lengras serpentinas, ias tevuciven como un tayo entre las larras de hormiga y tragan cun asomtiosa rapide\% lo gue han recogido. Fstos polluelos se amansan tanto co mo los animales domésticos y contribuyen mucho à divertir á suramo. Con otras ares suelen vivir siempre en la mejor inteligancia y pueden recomendarse tambien por este con. cépto. El pobre é inafiasivo torce cuello tiene enenigos mus péligrosos, tales como el nisido comun, las urracas y grajos, los gatos, martas y comadrejas; no pocos son victimas de estos animales, y tambien, demasiado á menudo, de la escopeta de los caradores de aficion. Desde que se ha intentado desacreditar al torce cuello, ni sifunerit le protege la opinion de los zoólogos, que no le consideran como ste tutil. Yo, por mil parte, me inclino rusueltamente en su favor. Sé muy bicn que se alimenta sobre todo de hormigas, que en general nos son útiles, pero el número de estos insectos es tan enorme, que $n o$ pueden tomarse en consideracion los que come el turce.cuello: esta ave no se debe considerar de ningun modo como danina por tal concepto. 'Tambien sé que al buscar su albergue estorba à una ú cotra de las aves que anidan en huecos, yo que tal ver. las expulsa de su nido: pero seria una locura comprenderla por eso en la lista de las aves perjudi. ciales. Cuando el torec-aitello molesta en este sentido, no hay nada mas sencillo para poner coto il sus desmanes que colo. car algunas cajitas ancias, con una estrecha abertura, a pro. pósito para esta ave, en los árboles que de preferencia elige. Es realmente una injusticia matarla; y en cuanto á lo dé considerar sus mo:imiemtos convulsivos y sus muecas como priebas evidentes de su mala indole, segun to ha hecho Gredler, esto no se puede tomar sino como uma broma. aun. que algo pesada, porque podria interpretarse mal. En nues. tro tiempo, cuando tantos jgnorantes toman la pluma para imsladar al papel con atrevida mano los suenos y creaciones fantasticas de su cervoro, como resultados de una obserra. cion fiel y de un examen concienzudo, paréceme doblemente peligroso sentenciar á un ave tan apreciabie. Dirinse que cuantos se interesan por los animales de nuestra patria están póseidos de la mania de ver en cada uno de ellos un enemi. go que nós perjudica, $\delta$ de considerar como crimenes algunas pequentas fechorias de que se hacen culpables.

Harto se sabe que el hombre ignorante es mas aficionado al cxicrminio que á la conservacion, y por eso tales acusa. ciones solo pueden producir efectos perniciosos. Por esta razon me creo oblizado á defender tambien al torce-cuello y áreducir las acusaciones lanzadas conzra el a su rerdadero valor, es decir, à declararias injustas y sin importancia alguna.

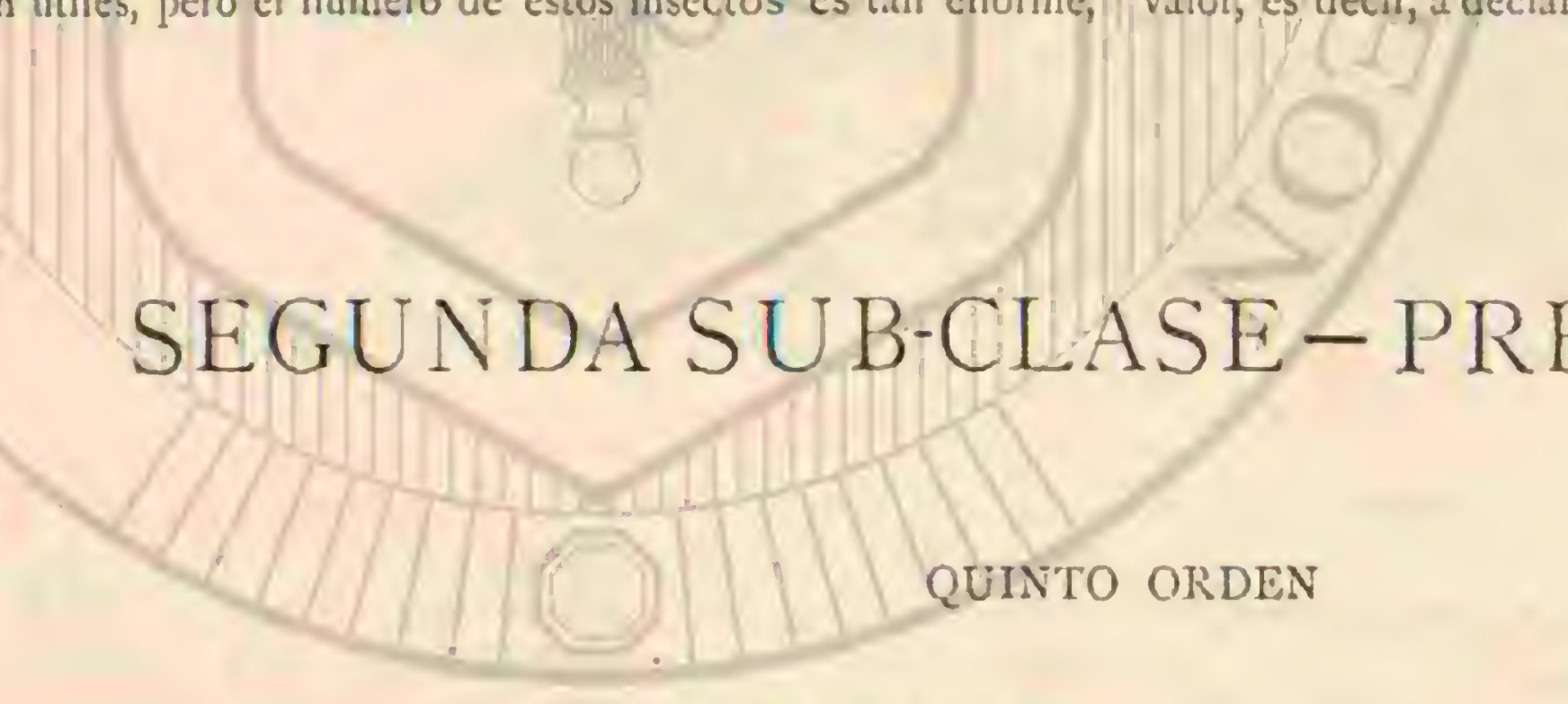

\section{RAPACES-ACCIPITRES}

Si procedienda to mismo que en los mamiferos quisiéra. mos separar de las otras aves a las que se alimentan de presa, no hallariamos un solo órden que no correspondiese a esta clase. La existencia de familias y órdenes, cuyos re. presentantes se alimentan exclusivamente de vegetales, es uno de los caractéres distintivos de los mamiferos, y mada semejante observamos en las demas clases de los vertebrados. Casi todas las ares son predatoras, y aun acjuellas que parecen mas inofensivas, tales como las cantoras, se alimentan casi exclusivamente de otros animales, y no comen frutas ni raices sinu como accesorio.

No se admite por lo general mas que un solo órden de aves carniceras, y bajo esta derominacion no van comprendidas las marinas y de ribera, que sin embargo no suelen alimentarse mas que de vertebrados.

En ciertas grandes divisiones de la clase de las aves, divi. siones que consideramos como otros tantos órdenes, se ma. nifiesta con caractéres nuy pronunciados el régirnen animal, consistente sobre todo en presas vivas. Todas estas aves se nutren casi exclusivamente de otros animales, persiguen ásu presa con encarnizamiento, lo mismo en el aire que por tiern, asi en el follaje de los árboles como en el seno de las aguas; la matan despues de haberla cogido, ó se conientan con los cadáveres que hallan; proceden por consiguitute del mismo modo que los mamileros carniceros. A estas aies llamamos rapaces.

CARACTERES. - La talla de las rapaces es variable: ha de algunas alcanza casi ad la de las mayures zancudas, ó a la de algunas aves acuáticas, y otras no son mas grandes que la alondra, figurando entre estos dos extremos iodos los térrminos posibles. A pesar de estas diferencias considerables, se reconoce siempre el lipo del ave sapaz.

No es dificil reseñar los caractéres generales del brden de que tratamos: el cuerpo se asemeja nucho al de los loros: es fornicio y con el pecho ancho, auneque á menudo de una lon. gitud casi desproporcionada; la cabeza grande, redondeada, y prolongacia en casos raros; el cuello grueso, a menudo corto, y largo á veces; el tronco corto y roousto, como los 
1 miemiros superiores é inferiores. Se puede por ln tantn reconocer un ave rapaz aunçue carezca de sus armas ofensivas : de su jlumaje; pero las unas y el otro las caracterizan en realidad.

Eil pico se parece mucho al del loro: es corto, con la arista de la mandibula superior muy convesa y encorvada en gan cho en la punta: la base está cubierta de una membrana llamada cera, pero el frico no es glubuluso como en los loros; sino comprimido lateralmente, y mas alto que ancho. Ia mandibula superior es inmovil y cubre completamente la in. ferior; sus bordes son mas cortantes, su gancho mas aguza do, y'con frecuencia esti provista la primera de un diente agudo.

L.as patas se asemejan tambien á las del loro: son cortns y fucrtes, con los dedos muy largos en proporcion á los tarsos: uno de los anteriores puede dirigirse hácia atras hasta cierto punto; pero lo mas caracteristico en los pit's son las urias. que constituyen una garn. Son muy corras y aceradas, rara vez. planas y romas; rienen la cara superior convexa y la in ferior ligeramente concava, limitada por dos bordes casi cor tan:es.

El plumaje presenta notables diferencias, segun las fami lias y los géneros; las plumas son en general blandas y esca sas, pero en los halcones suceçe lo conirario. Las águilas pescadoras, los buitres del muevo continente y las buhos carecen de tallos falsos; en los buitres, yirersas rapaces diurnas, ef plumon cubre unas reces rodas las partes del cuerpo, y atras es mas abundante en el cuello ó en fajas qute se corren sobre las placas de las plumas exteriores, y que en ciertas especies ocupan el lugar de estas ultimas. Las plumas faltan á veces en varias panes de la cabexa, con írecuencia en la linea naso ocular, y como en muchos loros, al rededor de los ojos; en algunas esprecies, por el contrario. observase que precisanente los cijos están rndeacios de una corona de plunas dispuestas en furma de radios, como el dicco que remos en el kakapo. Lo mismo que en los luros y los levirostros, la placa de flumas de las espraldillas se divide en medio de los onroplatos, siendo el plumaje mas escaso en la parie inferior: ias dos ramas laternles de la placa mas baja estan muy sepanradas a veces y se ensanchan en su parte anterior ramificindose casi siempec otra ver en la region superior de los hombros.

Lans pennas de las alas y de la cola son muy grandes, y su número consinnte: diš en la mano, doce, yencralmente de trece a diez y seis en el brazo, y uiras doce caudales dispucstas por pares. Asi como se observa en los loros de organiza cion superior, las rapaces mas.perfecias tienen plumas pe quenis: en muchas especies, y' esto es característico en las ares de que hablamos, los a arsos, y hasta los dedos, cstán cubiertos de plunias y las de la notga son muy prolongadas à inenudo.

El plumaje es por lo regular de color oscuro, amnque no desagradable a la vista, y aun hay alguizas especics que se distinguen por la belleza de los matices. 1.25 paries de la cabeza desprovistas de plumas, los apéndices del pico de algu. nas de estas ares, la region oculo nasal, el pico, las jatas y los ojos tienen à menudo vivos colores. En cuanto a la estructum interior, debo de aniadir algunos detalles, guilndome por lo que dice Carus. El cringeo ca fos lo regular muy ancho, comparativamente can su longitud, los lagrimales, unas reces libres, y otras soldados con los ironta
les, sun largos y forman el borde superior de las órbitas, cuyo cartilago divisorio sucle estar cerndo en las aves adiltas; los maxilares supreriores constiruyen solo una pequeña parte del paladar: delante del csfenoides, que se prolonğa en punia, hállase sicmpre una formacion huesosa en el cartilago de las fosas nasales, fornacion que en la mayor parte de los gére. ros y de las especies alcan ea un gran desarrallo: las apóśsis palatinas de lus masilares siaperiores se enlazan entre si en las aves de rapina diurnas y ambas con el cartllago nasal, mientras en los buhos forman una esfecic de masas tspronjosas que si bien se aproximan untcho entre si, solo se reunen con el cartilago nasil: en los buitr's del nuevo continente se presentan como hojas delgadas, corras y huesosas, estrechas y horizontales en el borde intericur de los palatinus y no soldadas: la superlicic articular del hueso cuadrado se prolonga trasrersalmente.

El númaro de las vériebras, muy recogidas, y á reces tan anchas como largas, varia mucho. Cuentanse de nueve á trèce cervicales, siete a diez dorsales, diez ì catorce sacro coxigeas y sicte i nueve caudales. Fil esternon es casi siempre un poco mas estrecho por delante que en su parte prosterior, unas veces cuadrado yotras mas largo que ancho; la quilla es alia y aburedida por detris: en los buhas y los buitres serpentarios oldsérvase una ap̧ólisis lateral en la parte poste. rior, apófisis muy poco desarrollada ó mutilada en las rapaces diurnas; en estas se ensancha la extremidad anterior de las claviculas, encórvase hacia airás y es hueca en la superticie cxtcrior de fa apófisis de los coracoideos: en los huesos sóli. dos de las alas, aplanados en las partes de la mano, se ven unas frijitas musculosas muy desarrolladas; ten la cara anterior de los hueses de las piemas son por lo regular cortos y aplanados y solo largos en los buitres serpentarios; se encuentra en las aguilas pescadoras y en los buhos en el tarso una es. vecic dr ptiente huesoso yuc da paso à los tendones. Casi cerios los huesos carecen de médula, de modo pue las cavdades huesosas pueden llenarse de aire. Los pulmones y las bulsas aéreas, que llegan hasta la cavidad del vientre, llénarsse por medio de los pulurones y facilitan ef vielo au. mentando su iuerza. Lil coófago puede ensancharse mucho y liene en su intcrior muchas veces numerosos repliegues; en la marnia de las esprecies se diata en forma de buche la panza se distingue yor sus muchas giándulas; la parte princi. pal del estómang es grande y tiene la forma de saco el intes. tino raria inucho; la lengua, larga y redondeada por delante, es denticulada en su parte posterior.

Entre los órganos de los sentidos, el ojo merccesobre todo fijar nuestra alconcion: cs grande, especialmente en las rajaces mucturnas, $\vee$ tienc movimientos interiores muy completos, dererninados por la jrescncia del peine. De aquil resulta una acomodacion de la vista igualmente buena para distancins muy distintas: accrcando la mano al ojo de un buitre y retirindola luego, se pueden uhservar muy ficilmente las mriaciones del dirimeiro de la fupila.

7 los órganos del oide estín bien desarsollados en las ra. paces, sobre todo en los buhos, cuyas orcjas describircmos despues.

Los órganos olfatorios son en cambio ridimentarios hasta cicro punto, aunyte algunos no lo crean asi, al merros por lo que hace á los buitus.

El tacto es mas perlecto en estas ares que el gusto y clut fíto; el segundo, no obstante, parece proco desarrollado; si bien no se puede negar que las aves de rap̧iisa eligen uno ! otro alimenio y en cierto modo sun golosas.

DISTRIBU .ION GEOGRÁFICA.-Las rapaces habitan coda la tierra; se las encuenira en todas las latiquies.

USOS, COSTUMBRES Y RÉ;IMEN.-Las facultades inielectuales de las rapaces estan muy desarrolladas; pues aunque algumas parezcan estúpidas, por lo commn dan pruebas de inteligencia Hotadas de gran valor. parece que comprenden su poder, g hasta se obseiva en ellas cierta grandeza; pero al mismo iicmpo son crueles, feroces y astu- 
tas. No obran sin reflexion; conciben proyectos y los ejecutan; son fieles a sus companeras, $y$ acometen alrevidamente á sus enemigos. Ios halcones, sobre todo, nos demuestran hasta qué punto puede llegar a desarrollarse su inteligencia.

Las rapaces carecen de una cualidad peculiar de los pája ros; su voz no es en general muy agradable; algunas solo producen dos of tres notas distintas, y aun estas nuy discor dantes. No queremos decir que no existan algunas rapaces cuya voz deje de ser agradable ai oido humano.

las mas de cstas aves son arboricolas y viven en los bosques; pero sin evitar las montnuas y el desierto. Asi se las encuentra en las mas pequeñas isias del Océano como en las cinas de las montánas mas elevadas tan pronto se ciernen sobre los bancos de hielo de (iroenlandia y del spitzberg como sobre las llanuras menosas, abrasadas por los ardientes rayos del sol del desierto: 10 mismo habitan las impenetrables espesuras de las selvas wrgenes que los edincios delas ciudades. Cáa especie tiene un área de dispersion muy extensa, aunque no proporcionada con sus facultades locomotrices; alyunas solo habitan una localidad muy reducida: otras no rcconocen limite alguno recorren toda la tierra.

Varias rapaces emigran: cuando el invierno deja desnudo su dominio, dirigense hácia el sur, siguiendo a los pajaros pequeños; las especies que viven mas al norte no emigran: limitanse a vagar errantes en un espacio bastante limitado. Al enjprender sus emigraciones, se reunen à reces por numerosas bandadas, y se aislan inego, hácia la primavera se forman las parejas; cada cual vuclve entonces a su antiguo canton, y no tarda en reproducirse.

Todas las rapaces anidan a principios de la primavera, y soln una rezal año si no se las persigue: su nido es muy variable; por lo regular esti situado sobre un irbol, en algun cinto de roca, álo largo de una páred impracticable, ó en la grieta de un muro; rara vez en el húeco de un árbol, y me. nos aun en tierr. Todos los nidos que se hallan en árboles ó rocas son de sólida estructura, anchos y bajos, $\dot{a}$ menos que hayan servido mischas veces, en cuyo caso los repara el ave cada ano; chinterior es poco profundo: macho y hembra coadjuran á su construccion. I.as grandes especies no pueden adquirit sin dificultad los materiales necesarios: Tschudi nos dice que el águila leonada se deja caer desde las alturas sobre la rama nue necesita; la coge con sus garras, despues de romperla por el impulso de su caida, y se remonta con ella; las pocas rapaces que anidan en agujeros se contentan con depositar los huevos en el fondo de un ironco hueco, en tierra ó sobre una piedra desnuda.

Es probable que las especies que fabrican por si sus nidos figuren en el menor número; los halcones pequeños se sirven con preferencia de los de otras ares, sobre todo de las cor. vinas, de varias rapaces y quizis tambicn de la garza real y de las cigüeñas negras; a falta de ellos buscan un hueco de árbol. Segun las observaciones de Eugenio Hometer, el buzardo fabrica en Alemania los nidos para las especies grandes; la cormeja cenicienta ó corvina, raras veces la comun ó la urraca, construye los de las pequeñas. Muchas rapaces diurnas, como por ejemplo las grandes águilas, tienen dos nidos, los cuales ocupan alternativamentc, y que á causa de su tamaño deben construir por si mismas: al pequeno ha!con emigrante le agrada mucho utilizar estos nidos criando te es posible. De este modo puede suceder que el águila marina ó pescadora ocupe un año su nido y sea reemplazada en el al siguiente por el iralcon emigrante. Homejer encontró en nidos que primeramente debieron ser de buzardos, águilas rusas, milanos reales, halcones emigrantes, gavilanes, buhos y mochuelos salrajes.

Al apateamiento preceden varios ejercicios que sirven de diversion á estas aves: el macho vuela airosamente y sé ba. lancea en los aires; algunos emiten sonidos particulares muy dulces, qque forman una especie de canto. Tambiea los celos ejercen su influencia en estos séres; cada intruso es acome. tido y ahujentado, no permitiendo nunca el macho en su vecindad a otro, aunque sea de distinta especie. Ias luclas que empenan no dejan de tener cierta grandeza: son retira. das súbitas, ataques rápidos, defensas brillantes, mutuas persecuciones y resistencias vigorosas. Los dos adversarios se cogen fuertemente, se oprimen; : no pudiendo entonces servirse de sus alas, caen á tierra con la violencia de un tor. bellino. En tierra cesa la lucha, mas para volrer á comenzar a los pocos momentos en medio de los aires; despues cie una prolongada pelea, retínse el vencido, perseguido siempre por el vencedor hasta mas alla de los limites de su dominio; pero no se restablece con esto la paz Renuévase la contienda al otro dia y en los siguientes, y es preciso que el mas fuerte alcance varias victorias para poder disfrutar de slis primeras ventajas. Sin embargo, por muy encarnizadas que sean estas luchas, mroes que terminen con la muerte de uno de los combatientes: la hembra observa aquellas peleas con interés. aunque sin tomar parte; $y$ despues de la derrota de uno de los dos rivales, se rinde al vencedor.

Isos huevos son redondendos, de cáscara rugosa, por lo re. gular, y color completamente blanco, agrisado, amarillento, ó sembrado de punios oscuros: el número de huevos varia de uno á siete. Lo mas frecuente es que la hembra cubra sola: únicamente en algunas especies la reemplaza el macho de rez en cuando: la incubacion dura de tres á seis semanas. En los primeros dias, los hijuelos son unos pequeños séres, dul todó redondos, de cabeza voluminosa y njos muy abir. tos, ocultos por un plumon gris blanquizco; crecen rapida. mente, y no tardan en aparecer las plumas del lomo. Los jadres manifiestan el mas tierno cariño i su progenie, jamis la abandonan, y expónense por ella al peligro, $\delta$ á la muerte si no ticnen suficientes fuerzas para defenderla. En tales cir. cunstancias son pocas las rapaces que demuestran cobardia; muy lejos de ello, las mas despliegan un atrevimiento $y$ te. meridad que admiran, y hay varias que trasladan as sus hijuelos á otro lugar donde puedan estar mas segurns. No es me. nor la acrividad de los padres para criar a su progenie; le llevan mas alimento del que puede consumir; $y$ si se la pes. sigue $\delta$ le amenaza un riesgo, dejan caer desde lo alto su presa sobre el nido. $A l$ principio les dan el alimento a medio digerir y despues les jresentan las presas despedazadas: liay algunas especies en que solo la hembra se cuida de preparar los alimentos convenientemente. Aun despues de haber em. prendido su vuelo permanecen largo tiempo los hijuelos con sus padres, que les enscinan á cacar y buscar su comida, ve. lando siempre por su seguridad.

Los vertebrados de todas clases, los insectos, los huevos, los gusanos y moluscos, el excremento humano, y por excepcion los frutos, constituyen en parte el régimen de las rapaces; arpodéranse de los animales vivos; arrebatan su presa á oiras carniceras, 6 se conientan con recoger los restos que encuentran.

Cogen su presa con las garras y ia despedazan con el pico.

Su digestion es muy rapida: en las especies que tienen buche permanecen los alimentos algun tiempo en este órga. no, quedando sometidos a la accion de la saliva, y luego son digeridos por el jugo gístrico. Los huesos, los tendones $y$ los ligamentos se reducen á una especie de papilla; los pelos y las fllumas forman pelotillas que romitan las aves de vez en cuando. Los excrementos constituyen una sustaricia bastante líquida, sumamente calcirea. 'Todas las rapaces pueden 
comer mucho de una vez y soportar una abstinencia muy prolongada.

Cuanto mejor cazan estas aves mas superioridad tienen para nosotros, y por mas nolles las consideramos, si bien hay excepciones en la reyla.

Exceptuando el hombre, pocos enemigos tienen las rapaces: su fuerza y agilidad son su salvaruardia; pero en cambio les atormentan los parisitos, que forman en su plumaje numerosas colonias. Como quiern que sea, viven libres y fe. lices, mientras no las persiguce el hombre.

UTILIDAD. - Segun que las rapaces acometan álos séres que son para nosotros nociros ó útiles, debemos conside. rarlas como aliadas o enemigas. Ahom bien, salvo algunas especies, a las que debemos perseguir inexorablemente, por los muchos destrozos que ocasionan entre otros animales be neficiosos para nosotros, las rayaces nos prestan, en general, grandes servicios.

l'ocas hay que scan de una utilidad immediata; ya no sc adiestran para la caza, como antes: ya a los ojos de muchas personas, no sirven de nada las que se enjaulan; pero éno se han de reconocer los servicios que nos prestan inediatamente exterminando cuanto es posible esa funcsta raza de roedores $y$ de insectos? Y no debemos considerar solo como sagrados al serpentario (इyprneraumus serpentarius). que tritura la cabean del culira capellor, y al buitre, que se encarga de sanear las calles de las ciudades de Africa y del sur de Asia, sino tambien á otras rapaces que habitan nuestros campos y merecen e mayor aprecio. Nuestro deber seria proiegerlas y dejarlas cumplit su mision en paz

Prescindiendo de estos inmensos servicios, las veniajas que nos pueden reportar además ciertas rapaces, son harto insig. nirscantes. I a carne del mayor numero de ellas no es comes. tible; tinicamente los mogoles y los indios de América aprc. cian las plumas del aguila; en cautividad no puede servir de mucho uno de estos téres. Mejor nas conviene que viran del todo libres.

Clasificacion, - Las rapaces se dividen en grupos bien naturales, y en lodo tiempo admitidos. Basta dirigit una ojeada sobre el conjunto de cate órden para reconocer tres formas claramente definidas, por mas que ciertas especies parezcan establecer un tránsito de la una da la otra. De aqui la division de las rapaces en falcónidos ó halcones, en vultú. ridos 6 buitres, en estrigidos ó buhos. Es indudable que los filcónidos deben figurar en primera linea; pero ¿deberemos colocar a los vultúridos antes de los estrigidos ó posponerlos a cllos? Estos son inas rapaces, y anuellos están niss desarto. Ilndos por lo que hace ó los sentidos y á la inteligencia; yor lo ianto les asignaremos el segundo lugar.

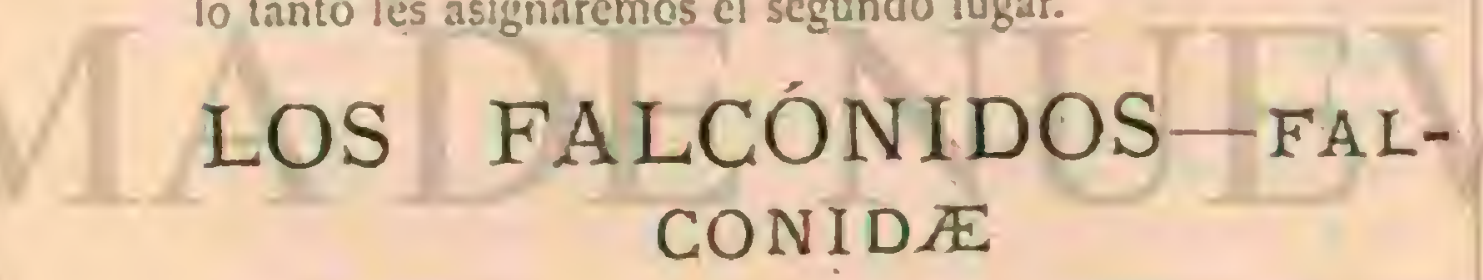

CARACTERES. - Los de los falcónidos, que constitu. yen la maroria de todas las aves de rapina, son los siguien. tes: tronco robusto y recogido, excepcionalmente enjuto; ca. beza de tamaño regular; cuclto corto; ujos regulares, pero en extremo vivos': pica relativamentc corto; ia cera siempre visible, es decir, desprovista de plumas: la mandibula superion encorvada en forma de gancho agudo sobre la inferior, y mu. chas veces con prominencias deniiculadas en sus bordes; los piés son tan pronto cortos $y$ fuertes como largos y endebles. Las alas, grandes y por lo regular puntiagudas, tienen en este caso mas larga la segunda ó teicera rérnige; raras veces las alas son redondeadas, y cuando tienen esta forma, la tercera ó cuarta rémige se prolonga mas la cola es tan pronto corta como larga y reciondeada; unas especies la tienen escalonada o cortada en rectángulo; en otras alecta la furma de horquilia Eil plumaje, que no solo cubre el tronco, sino tambien la cabeza y el cuello, y á menuojo hasta los piés, no suele dejar visible mas que una parte de las mejillas, y es por lo regular recio y rigido, solo por excepcion suave y sedoso; pero sien. pre abundante El buche existe, aunque nunca en forma de saco, sino de jorobil.

DISTRIBUCION GEOGRÁFICA.-Los falcónidos se encuentran en toda el frea de dispersion del órden, y ha. bitan por consiguiente todas las.zonas de la misma latitud y longitud, si bien nunca se clevan tanto por los aires como Las águilas y los buitres.

USOS, COSTUMBRES Y RÉGIMEN. - F.stas rapaces viven en las regiones mas diversas; irectientan las llanuras $y$ montañas, los paises provistos de hosque y los que carecen de él, desde la costa del mar hasta la region de los abetos enanos, pero dependen, como todas las aves de rapiña cazadoras, de la presa que constituge su alimento; y hé aqui por qué se presentan con mas frecuencia alli donde abunda, aun. quise no evitan del todo las regiones en que escasea. Muchos de ellos abandonan su residencia y siguen á las aves pasaje. ras à los paises cálidos; otros permanecen rodo el año en su territorio, à pesar del riguroso invierno que la mayor parte del año reina en el pais; cuando mas cmprenden viajes dentro de limites muy circunscritos. La extraordinaria facilidad que tienen para volar parece relacionasse con la extension del área de dispersion de las especies; jero puede suceder en esie concepto lo contrario.

l'ocas especies de falcónidos vielan lentamente; la nuayor parte de ellos son los voladores mas rápidos quec conocemos; peta en cambio muevense con torpera en el suelo y aun en el ramaje de los árboles. Lo que antes hemos dicho de las aves de rapiña en general puede aplicarse tambien á lus falcónidos, solo que estos no se distinguen tanto por las malas cualidades en el carricter de las especies de esteórden tan numeroso. Cierto que algunos se alimentan tambien de cadáceses y materias putrefactas; pero la gmn majoria se nu. tre exclusivamente de presa adquirida por sus propios isfuerzos, ô la cual persigue mientras corre ó vuela, ó cuando nada en la superficic del agur. Su instrumento de ataque es sicmpre el pié; rara voz sirve para la defensa el pico, mucho mas endeble que los piés, los cuales estån provistos de poderosas garras. De ellas se vale el halcon para estrangular á su victi. ma; el pico no le sirve mas que para despedazarla anies de comérsela. Sin cuidarse de sí el animal vive aun ó está y̧a muerto, comienza á desplumarle y destrozarle, eligiendo por to regular las jartes blandas y carnosas. Rams veces da muerte a su vicima de un pricotaro en la cabeza; devora los huesos pequeños, pelo, plumas y escamas; yen la gran ma. yoria de especies, estas materias lorman una parte tan necesaria para su alimento que el ave enícrma cuando no puede comerlas y formar con ellas unas balas que expele por el pico.

A causa de su gran facilidad para digerir, estas aves neresitan tanto alimento, que las especies inas grandes de la fa. milia pueden causar verdaderos destrozos entre los animales pequeños de su territorio; y precisamente por esto podemos calcular el daño y la utilidad que nos reportan estas rapaces. Sluchas de ellas son tan daninas como dignas otras de nues. ira proteccion.

En cuanto á la reproduccion, nada tenemos que añadir å lo ya dicho.

\section{LOS FALCONINOS-FALCONINE}

Los naturalistas no están aun acorcies sobre la division de los ialcónidos en rarios grupos; nosotros vemos en ellos una 
familia rica en formas y especies, y los sutdividiremos en grupos con el rango de sub.familias, siendo el primero el de los falconinos.

CARACTÉRES. - LOS falconinos 6 halcenes propiamen. te dichos son rapaces pequeñas 6 cuando asas de tamaño regular y de estructura robusta; la cabeza es grande, el cuello corto y el plumaje liso; la mandibula supxirer. relativamente corra y muy redoncieada en la arista, forma en la punta un gancho puntiagudo, con una sesgadura-denticulada; la man. dibula inferior es corta y truncada; los larses breves ó de langitud regular; los dedos largosi lasalas prolangadas yo pur:tiagudas: la segunda remige sueie ser la más turga; la cola es de longitud regular y mas ó incnos rejondeadz

\section{LOS HALCONES-FALCO}

Los halcones deben ocupar aqui el primer lugar, pues son entre las rapaices lo que los felinos entre los carniceros. es decir, los séres mejor doandos en el órden. Sis facultades intelectuales guardan perfecta armonia con las fisicas: son rapaces en ioda la extension de la paiabra: La riterza, la agilidad, el valor, la pasion por ia cara, el niajestuoso aspecto Y hasta la nobleza, si tal pucde, decirse, scn oisas tantas cualidadus que no podemos menos de reconoceries.

CAMACTERES. - LOS halicones repureserian el ipo de his raprices en roda su perfuccion: tienen el cuerpo recogido, la cabeza grande, el cucllo corto y las alas lergas y agudas, sienda la segunda rémige la mas larga, y exeepcionalmente La tescera. El pico es relacivamente corto, aurguve vigoroso, con la mandibula superior mas ganchuda, provista en sus bordes de un diente mas ó menos saliente; la inferior es corta, con bordes inuy cortantes y una esco:sujura que corresjonde con dicho diente. Las garras son af proplotcion mas grances $y$ fucrtes que en ninguna dira rapaz; las nalgas grue. sas y musculosas y los tarsos cortos. Rodca el oino un espacio desnudo de color viro, que facilita à este órgano importante 1. mayor libertad de movimiento.

Dificil es describir en general el color dd flumaje: mu. chos halcones, sin embargo, tienen el lomo gis azul claro. la cara inferior del cucrpo de un gris pálido atuarilio teonado ó blanco, y cruzadas las inejillis por una faja tegra, 6 barba. In los verdaderos halcones, ó intresies nos/cs d macho es mucho mas pequeno que la hembra, y en los faliones rino bles esiá coloreado el plumaje de diverso modo. Los peque. ũos vificren de los padres, y hasta los dos 0 ires años no revisten las plurnas de ios adultos.

DISTRIBUCION GEOGRÁFICA.- Dos halcones habitan todas las partes de la tierra: se les encuertra desdc las costas hasta las mas altas montanins.

USOS, COSTUMBRES Y REGIMEN.-Prefieren vivir en los bosques; á menudo habitan anjbien en las rocas y las ruinas; lo mismo se les encuentra en los lugare mas desier. tos que en medio de las ciudades. Cada cspecie tieneun d́rea de dispersion bastante extensa; muchas de esias aves son emigranies, al paso que otras no hacen mas que vagar de un punto a otro sin emprender verdaderos vinjes

Todos los halcones son séres adinirablemante dotados para la locomocion: distinguense sobtc todo por su vueto notahle, rípido y muy sostenido: recorren cos una ligerezn increible espacios inrnensos; para lanzarse sobre su presa se dejan caer desde una aleura prodigiosa, y con ma celeridad tal, que la vista no puede reconocer $\$$ furma

El vuelo varia segun las especies: Ios halecres llamados nobles aletcan rápidamente y rara vez, se dejas deslizar un instante en el aire cerniéndose; Ios inrobiles vuetan con mas lentirud, se ciernen mas, y con frecuencia perranecen en un mismn sitio del espacio agitando continuamente las alas. Durante la estacion del celo, elévause por las regiones aéreas hasta unin altura prodigiosa; se ciernen largo tiempo, trazando circulos majestuosos, y tratan de cautivar asi a sus compa. neras. Por lo regular se mantienen a una elevacion de go á 120 metros sobre el suelo.

Cuando descansan y se posan permanecen muy erguidos; al andar llevan el cuerpo horizontal; pero debemos anadir que son mug torpes en tierra, y que solo avanzan andando de una manera exirana y ayudándose con las alas.

Los halcones nobles se alimentan de vertebrados, particularmente de pajaros; los imobles de insectos; los primeros se apodcran de su presa al vuclo, y muchos son capaces de sorprender al ave posada: los segundos atrapan los insectos en el aire ú a la carrera. Ninguno se alimenta de restos pu. trefactos, al menos cuando vive libre: rara vez, devoran la presa donde la cogieron; la irasporian por lo regular â un sitio mas conveniente desde el cual pueden observar todo el horizonte; la despluman, la despedazan en parte y se la comen.

Lós halcones cazan por mañana y tarde: al medio dia suelen permanecer inmóviles en lugar tranquilo, con las plu. mas erizadas y sumidos en la especie de letargo ugue les pro. duce la digestion. Duermen bastante tiempo; pero ya es tarde cuando se entregnn al reposo, y hay algunos que cazan sun is la hora del creprisculo.

Jistas aves son sociables hasta cierto punto: en verano viben Lor parejas, y cada cual en un dominio parricular, del que ahuyentan á las demás rapaces. Liegada la hora de empren. der sus excursiones, forman bandadas, muy numerosas it reces, que permanecen reunidas durante algunas semanas y hasta meses. Manifiestan un odio violeuro hacia las aguilas y los buhos, y no desperdician la ocasion de acometer \& unas y otros.

Los halcones anidan en las grietas de las paredes de las rocas muy escarpadas, en ediricios altos y en la cima de los mas grandes árboles; no faltan algunos que lo hacen en tierra ó en algún tronco hueco. Con frecuencia se apoderan de los nidos de otros grandes pájaros, principalmente de los dul cuerro. Eil que hacen los halcones es de rosca construc. cion, bastante plano, y con el interior giarnecido de algunas menudas raices. Los huevos, cuyo nimero varia entre tre: siete, son redondos, de cáscara rugosa, y por lo general de un color pardo rojizo pálido, sembrados de punios oscuros. Solo cubre la hembra; durante h incubacion, ef macho le da su alimento, y la entretienc, cjecutando delante de ella sus ejercicios aéreos. Los padres cuidan de su progenie con mucha iernura i la denenden contra todos sus encmigos, excepto el homise.

Los halcones fuertes no obstante, figuran por desgracia en el número de las aves mas dainosas de nuestros bosques, yn se pueden tolerar; ni aun las pequeiras especies son uti. les. Estas últmas se hallan expuestas a las acometidas de sus congeineres mas fuertes, las cuales notienen por su parte, mas enemigas que el hombre. Puede suponerse tambien que los carniceros trepadores devoran los huevos y las crias; pero et hecho merece confirmacion.

EMPLEO DE LOS HALCONES EN LA CAZA.Desde las épocas mas remotas los halcones tian sido em. pleados por el hombre y siguen sirviendole aun hoy dia en varios paises de Asia y Africa; ellus son los halcones de nuestros poetas y ellos los que se adiestraban para la caza de la garaa real.

l.enr, quue ha reunico iodos los datos referentes á este punto, nos dice que hácia ef ano .16 antes de lesucristo, Cicsins vió halcones entre los indios: y está probado tambiè 
que en el primer siglo de nuestra era, en el ano 75 despues de Tesucristo, caraban con halcon los habitantes de la Tra. cia. En 3jo. Julio Firmicus Maternus, de Sicilia, habló de

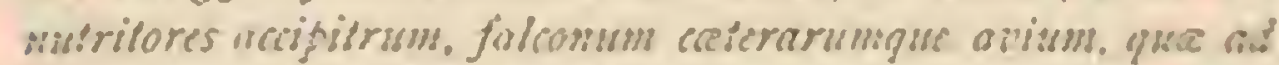

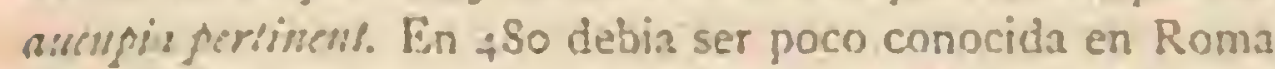
esta caceria, pues Sidonio A polinario cina al Edicius, hijo del empendor ivito, como el primero que caró con halcon. Sin embargo, bien pronto se fué propagando, y de tal modo, q̨ue en el airo 506 prohibió el concilio de Agda \& los eclesísti cos que tuvicran halcones y persos de caza, renovóndose la órden inútilmente en los concilios de Epaon, en $51 \%$ y de Macon, en 585 . En el sighn vmi, el rey Lstelberto escribió á Bunifacio, arzobiepo de Maguncia, acerca de un par de hal. conses para cazar las grullas; y en el año $\$ 00$ decretó Cảro Mngno la ley siguiente: xilquel que robe ó inate un halcon zutil para cazar las grullas, ưebe dar otro tan lueno yogar \$ seis dineros: y abonará tres por un halcon que cace los npajiaros en el aire. - Eil que mate 6 robe un gavilan $u_{\text {otra }}$ bave de las que se llevan en el paño, debe dar otro an bueno sy pagar un dincro.s

El emperador Federico Barbaroja adiestraba á mismo halcones, caballos y perros: segun Bandullus, Reynaldo, maryuús de Este, nantenia a gran cosio unos ciento cir cuenta halcones: el emperador linrique VI. hijo de Federico Barbaroja, cra sumamente afrcionado of la cetreria, segun nos dice Collenuccio; el emperador Féderico II tenia fama de ser el mas habil halconero de su trenupo, y tan apasionacio por este gencro de caza, que se dedicaba â ella en presencia del cncrnigo. Escribió sobre el asunto un tratado, g̨ut fute impreso en Augaburgo en 1596, y curo manuscrito hatia sido anotado por su hijo Manfredo, rey de Siclia. En el sitio de Accon, el rey de Francia, Felipe Augusto, ofreció en vano álos turcos mil monedas de oro for un magnifico halcon que se le habia escapado. Demetrio, probablemente médico del emperador Miguel Paleólogo, escribió en 1 270 un tra. tado de cetreria en griego, el cual fue impreso en 1612: cn esta obrita se daban detalles acerca de la pasion con q̨i:e las damas de la Edad Media se dedicaban a la cerreria. En 1396 fundó en Prusia una escuela de halconeros el gran maestre Conracio de Jungingen. Fuduardo III de Inglaterra castigaba de muerte el robo de un halcon, y condenaba á prision for un año y un dia al que se apoderase de un nido de estas aves. Cuando en 1396 hizo pristonero Bayaceio al duyue de Nevers y a otros muchos caballeros, en la batalla de Nicoipo. lis, reluusó aquel monarca tudos los rescates que le prome tieron: pern como et dutgue de Borgona le otreciese doce halcones blancos, canjeó al instantc todos sus prisioneros. Francisco I, apellidado el padre de los cazadores, grastaba mucho en sus halcones: el superinendente de la cetreria, $\delta$ gra: halconero, recibia anualurente t,000 libras de sueldo, suma enurme para aquella época liste funcionario tenia a sus órdentes quince ubaileros, a cada tmo de los cuales le corrospondian 500 ó 600 lihras, ! se contaban cincuenta halconeros con is sueldo de 200 . El superintendente tenia trescientos halcones, podia cazar donde le pareciese bien, y percibia ademais un impresto sobre el comercio de estas aves El cmperador Cartos V cedió la isla de M!alta i los calna Héros expuisados de Rodas, con la condicion de que todos losínios le dieran un halcon blanco, en reconoximiento de aquel hecho. Cuando se hubo cumplido la lẹ que prohibia á los eclesiásticos tener halcones, los barones pretendieson conservar el derecho de poner los suyos sobre el aliar du. sante el uficio divina.

Los emperadores : los principes alemanes llegaron a im. poner a los conventos la obligacion de mantener sus hal. concs.
Fil landgrave Luis IV de Hesse, reficte el doctor Landau, prohibio bajo las penas mas severas, por una ley del 5 de mayo rie $157 \%$, glse se cogieran los aidos de estas ares E.n una carta del is de noviembre de $16 \geq 9$, dirigida al landgrave Guillermo V de Hesse, se dice de qué manera se adiestran los halcones, valiendose de las garzas rèles: estas debinn tener la punta del pico cubierta con una vaina de corteza de satico, de manern que no pudiuse herir a los halcones; se les guarnecia el cuello con una esjecie de collar de tela para que no fuesen heridas en aquella parte, y por uiltimo se les ataba á las patas unos pesos á fin de que no pudieran volar. Fin el reinado del landgrave Je elipe de Hesse, todos los dueios de palonares estaban obligados a dar un pichon de cada diez para los haleones del principe.

هDeste hace varios siglos, la mejor escuela de cetrerí, unica que existc aun, se halla en Falkenwerth, en Flandes. Como en los alrededores no se cogen bastantes halcones, van los cazadores hasta Noruega é Islandia; de este vileimo pals son los mejores. Segun dice Th. Schmide, los halconeros holandeses cazan en Pomemnia duranic el otono un gran número de halcones, que llergan del norte fatigados y sin fuerzas por haber atravesado el mar. Para volver a Holanda atan las ares a unas pertigas que llevan sobre el hombro, y â fin de alimentar á las aves mas fácilmente, van pidiendo perros por los pucblos que recorren.

3 Iil general holandes Ardesch nos da detalles sobre el es. tado actual de la cerreria en Falkenwerth, $y$ dice que aun existen alli mrias personas édicadas a la enseñana de hal. cones Este puchlo está situado en medio de una landa des. cubierta, yocupa por lo tanto una posicion muy conveniente: en otonio es cuandio se rogen las aves: pur lo general no se corrservan sino las hembras, subre todo las que son del mismo ano, y en caso de necesidad las de dos, que aun se pheden adiestrar: los demàs individuos 5 e dejan libres. Hé arqui ahora cómo se cazan: un halconero, perfeciamente ccul10, tience en la mano un bramante de unas cien varas de largo, en curo extremo se surjeta un pichon; di unos cuarenta pasos del hombre, atraviesa el cordel por un amillo junto al cual hay una red de la que parte una cuerda cujo extremo sujeta tambien el halconero. Cisando aparece una de estas ares, ol hombre sacude el bramante que retiene al pichon; este agita las alas, y apenas le divisa ct halcon, cae snbre él y le coge. Fin cl minmo momento atrac el cazador al halcon y a su presa, stjeta entre las poderosas garras de aquel. hasta que tocan el anillo; baja entonces la red y el halcon queda cogido. Importa mucho saber en que momento aparece anjuel, y al éfecro se vale el cazador de un centincla vigilante, esto es, de la prega reborda gris, á la cual se sujeta junto al firclion, y que no deja de lanzar un grito penetrante apenas aparece el ave de rapiria - Wurante los tres primeros dias no se da mada de comer al prisionero, se le pone una cajucha, Y se le lleva en la mano lo mas ámenudo posible. En la pri. mavera siguiente debe haber ierminado la cnschanza delave: entonces van los halconeros de lialkenverth is Ingtaterrs, y alyuilan sus aves por cierto ticmpo al duque de Bhedford. Sucede con frecuencia que durante la caceria se matan los hatennes of se hieren, pues no les detiene ningun obstáculo; asi es ufue rara vez, dura mas de tres nños una de estas ases. > Jiv el siglo surn se habia perdido ya casi del todo la costumbre de carne con halion, y hoy no se conserva sino en alguras localidades. Cuando yo era muchacho corroci en Vieimar un halconero que practicalsa su artc con eniusiasmo, y en Merningen habia otro. Segran iengo enicndido solo se caza actualnerute con halion en los puntos siguientes: en Bedford, en las posesiones del duque de este nombre; en el condado de Nurfolk, y en las tierras de lord Barnars. Cada 
otoino llegan à Bedford y á Didlington-Hall los halconeros de lialkenwerth, que llevan sus halcones y se vuelven en invierno. En Didlington hay criadero de garzas, donde anidan es. tas aves en gran numero: en Loo se cazó activamente con halcon en 18 \& .

\$ Los útiles necesarios para esta clase de caceria son los siguientes: una corerisa de cuero bastante ancha lateralmente para que los ojos no estén oprimicios; dos correas de cue. ro, ó bridas, una corta y la otra de unos cinco piés de largo, con las cuales se sujetan las patas del halcon: un feador, 6 cordelito de unos veinte metros: un armadijo, ó especie de maniqui cubierto de plumas, que sirve primcro para adicstrar al are, y luego para tlámásla yor último, unos grangles grue. sos, como los que usan los halconeros, para no herirse con las garras dul hatcon.

- Para adiestrar al ave debe empezarse por encapucharla, y no se la da de comer durante veinticuatro horas, cuidando de sujetarla bien; pasado este tiempo, se la coloca en cl puno, se le quita la capreruza y se le ofrece un pajaro. Si no lo come se la vuclse a cncapuchar por espacio de veinticuatro horas, y asi se furosigue sometiéndola al ay uno hasta cinco dias consecutiros. Cuanto mas se repitan las tentativas, mas pronto se domesticará y comerá en el puño, que es loesencial. Conseguido esto, comienza la verdadera instruccion, consistente en una serie de ejercicios, antes de los cuales se la descubre, llevándola mucho tiempo en el puno; terminada la leccion, se la cubre de nuevo y se la ata, a fín de que jueda meditar sobre lo que se exige de ella.

- En el primer ejercicio se coloca el halcon en el respaldo de una silla, y cebe apreader a saltar desde alli al puno del halconeto para tomar su alimento; cada vez que se repite está leccion se debe alejar uno mas del ave, y cuando está bien acostumbrada a semejante maniobra, se repite al aire libre, teniendo sicmpre sujeto al lialcon por el hilo atado i la larga correa de cuero, que se colocara de modo que el animal vuele contra cl vicnto.

Obtenido este primer resultado, se coloca al ave, que debe tener puestala caperuza, en una especie de aro oscilante, y se balancea toda la noclze de modo que no pueda dormir; á la manana siguiente se repiten los ejercicios, dêndole siempre de comer eri el purio; se practica la operacion del aro dos noches mas, y i la cuarta se le deja dormir en par.

NAl dia siguiente se suelta el halcon sin bramante y dejan. do solo la correa: para comer debe volar siempre hasta ef puno; si trata de escaparse, acércase el halconero y le llama hasta que llega; repitese el ejercicio en libertad; se le enseña a volar sobre el puño del cazador montado, y á que no tema a los hombres ni a los perros.

2. Al fin llega el momento de adiestrarle para la caza: al cfecto se sujeta al ave a una larga cuerda, y se tira al aire un pichon muerto para que le coja, dejando que le despedace la primera vez; despıes que se haya encarnizado con su presa, se le quita para darle de comer en el puino. Ll ejercicio se repite luego con pajjaros vivos, cuyas alas se cortan: cuando el halcon sabe ya mas se le lleva al campo con un perro de muestra para cazar una perdia; tan pronto como aquel se detiene, se quita la caperuza al ase de rapiña, que cae sobre la presa en el momento de ensprendier su vuelo: si se le esca. ja se atrae al are rapaz tirando de la correa, ó con una palo ma cuyas alas están cortadas.

"Para criscinaráa un halcon à que acometa à las aves grandes, como las grullas y las garaas reales, se le lanza primeramente contra individios jơvenes ó viejos, $\{$ los que se cortan pré. viamente las alas, cubriéndoles la punta del pico: si esto no es posible, debe cazar en comprinia de un halcon vicjo, bien amaestrado. A fin de que las garzas no mueran muy pronto se protege su cuello con un collar de cuero blando. En estas cacerias, el halcon traia de elevarse rápidamente sobre la garza para acometerla por arriba; y esta f su vez. sube masy mas presentando siempre a su adversario la punta del pico, y esforzindose por traspasarle. Sin cmbargo, por tin alcanza el halcon ả su enemigo, le coge y caun ambos á tierra. El cazador acude presuroso cntonces, separa el are de rapina de su victima, le da de comer, despoja os la garza de sus mas hermosas plumas, le pone en uno de los tarsos un anillo inctílico, donde estí grabada la fecha y el lugar de la captu. ra, y la deja en libertad. Con frecuencia se da è caso de que una misma garza sea cazada repetidas reces y lleve va. rios anillos.

- Si se quiere adiestrar el halcon para la caza de la liebre, se rellena la piel de este animal con heno 6 hilaza, y sobre su lomo se fija un jedizzo de carne, destinada a servir de alimento al ave de rapina. La liebre simulada se coloca sobre unas ruedas, y es artastracia por el hombre, primero muy despacio, y luego rápidamente, hasta que el halcon aprenda a cógerla: despues se repite el ejercicio á caballo. I a caceria de la liebre con halcon $n o$ se puede verificar mas que en una llanura ciesprovista de árboles.

In el Asia central es donde se ha cazado en todo tiempo con halcon, y en vista escala. \& En el mes de mar\%o, cuenta Marco Polo, Kublai.Kiban sale de Cambalu; lleva consigo diez nil halconeros y pajareros, los cuales se diseminan por el pais en cuadrillas de doscientos a trescientos; y todo cuan. to matan debe ser cutregado al Klian. La escolta de este sa compone de otros diez nil hombres, cada uno de los cuales lleva un silbato, y cuando cazan, forman un vasto circulo, vigilando i los lialcones que suelta el Kinan para cogerlos y presentarlos de nuevo. Cada una de las aves que pertenece al soberano, ó á uno de los grandes señores, lleva en la pata una placa de plata en la que están grabados el nombre del propictario y el del halconero; $y$ hay tambien un empleado especial á quien se entregan los halcones curo dueño no se presenta inmediatamente. Durante toda la caceria va el Kihan montado en un elefante, y lleva siempre consigo los mejores halcones: 1 su lado cabalgan muchos hombres que observan el espacio y avisan al Khan tan pronto como aparece un are. En toda la extension del reino se vela cuidadosamente sobre la caza de pelo y pluma, a fin de que sea sicmpre abundante en las cacerias del Khan.

Tavernier, que residió varios anos en Persia, nos dia sobre cl particular los siguientes detalles: El rey de Persia conser. va para si mas de ochocientos halcones adiestrados, unos para cazar los jabalies, los asnos salvajes, los antilopes y los zorros, y otros para las grullas, las garzas, las ocas y las per dices.

- Para adiestrarlos en la caza de cuacrípedos, se toma un animal disecado, se le pone carne en la parte donde están los ojos, y se hace de modo que el halcon se la coma alli icuan. do ya está acostumbrado, colócase el cuadrúpedo sobre cua. tro ruedas y se tira de él mientras el ave va devorando su jitanza. Despues se sujeia el maniqui un caballo, que debe correr con toda la rapider posible, en ianto que el ave de rapina come: de la misma manera se enseria à los cuervos. Chardin, que viajó por Persia algunos años désinties que Tavernier, refiere que cuando el halcon acomete 4 los grandes cuadrúpedos, y se coge a su cabeza, se acude prontamente en su auxilio con los perros; anade que á principios del siglo vil se habian adiestrado estas ares para acometer á los hombres y sacarles los ojos.

En Persia no se ha renuncindo â la caza con halcon; véase lo que en $1 S_{2}$; nos referia Juan Malcolm: Se caza a caballo, 
con halcones y lebreles; apenas se levanta un antilope huye con la rapidez del viento, y en seguida se sueltan los halcones y los perros; los primeros vuelan rasando el suelo, alcan. zan al animal y se posan sobre su cabeza; mientras que los segundos llegan á poco y sujetan la presa. No se sueltan los halcones contra los antilopes machos vicjos, porque se hieren ficilmente con los cuernos. M Malcolm, que tomó parte en una caceria de avutardas, dice que esta ave se deliende vigorosa. mente con el pico y las alas, obligando á menudo a los halcones à emprender la fuga.
Posteriormente vió $\mathrm{C}$. de Hugel que el rajả de Bajauri ca. zaba perdices con halcon entre Iahore y Cachemira. En 1 S 20 encontró Murawiew en toda la China halcones adiestrados, con los cuales se perseguia a las cabras salvajes; y liman los halló tambien entre los baschkirs y los kirghises, en i $\$ 2$ S.

Fn I $S_{5}=$ vio asimismo Erman que los baschkirs tenin águilas leonadas, milanos y gavilanes adiestndos para la cazn. Atkinson hizo un dibujo, que representa à Beck, sulian de los kirghises, en el momento de dar de comer á su aguila favorita

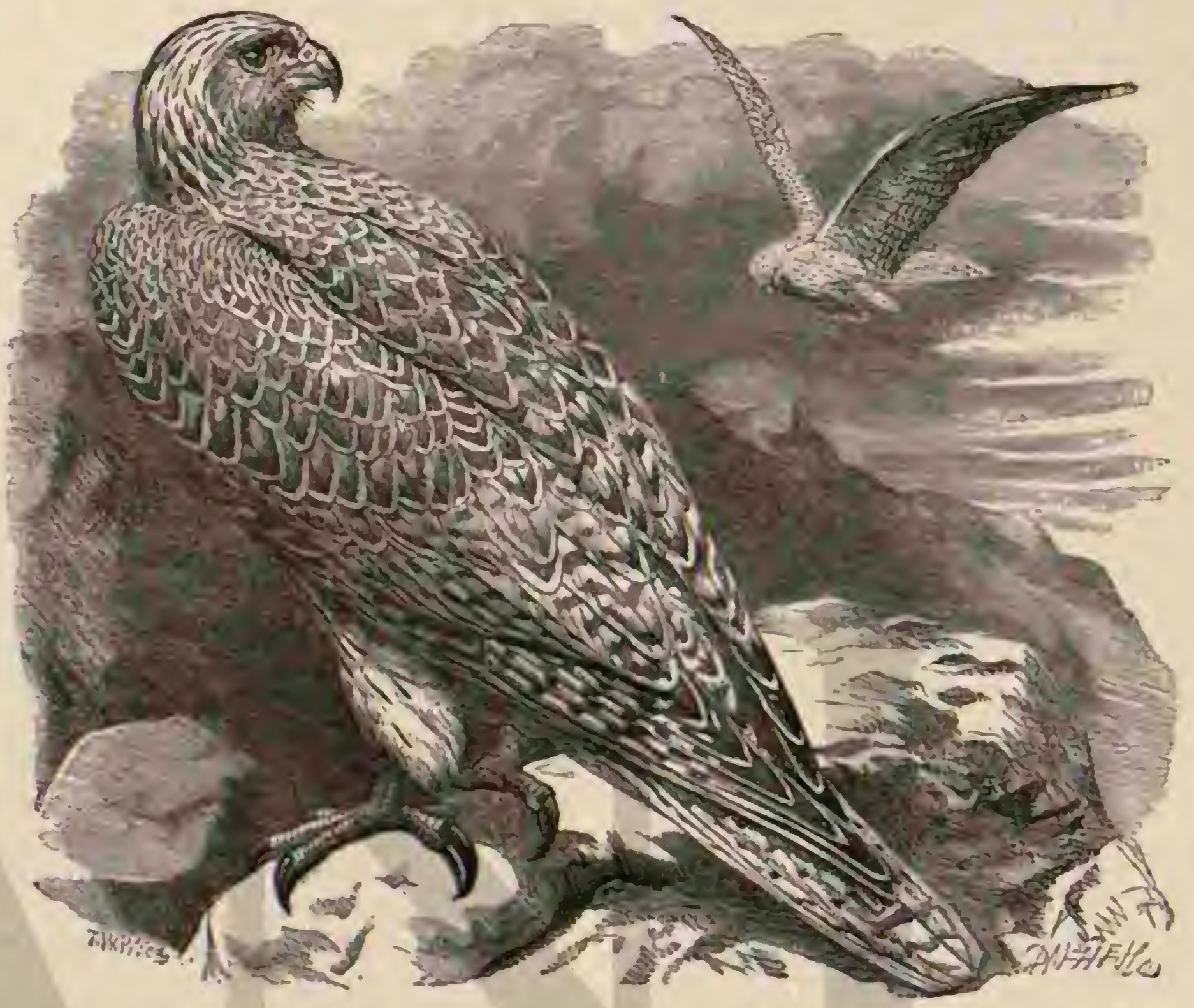

Fig. 13:-E1. GE.KIFALTE UR: SORUEG

Debo añadir que en Inglaterra se cultiva aun hoy tan no. ble arte. El principe imperial Rodolfo de Austria vió en Alexandra-Hall, cerca de Lóndres, halcones emigrantes y azores, aves pertenecientes a una sociedad de cazadores que ron cllas cazaban en Holanda, Normancia y Bretaña c princine mismo colocó los halcones sobre su puño y lanzó uno en persecucion de una paioma, que pronto fué alcanzada, á pesar de que Ioóndres estaba muy cerca.

Los ámbes, y sobre todo los beduinos del Sahara, que en aquella tribu constituyen la nobleza, los persas, los indios, varios pueblos del Cáucaso y del Asia central, los chinos y los mogoles practican aun hoy dia la caza con halcon. I.os primeros se sirven perferentemente del halcon comun del sudeste de Europa, especie llamada por ellos swhis; este halcon inverna en el norte de Africa y se importa de Siria, del Asia menor, de Crimea y de Persia: Jos individuos bien adies. trádos se pagan á precios verdaderanente exorbitantes. Por casualidad no he visto yo misno la halconeria de los árabes; pero Heuglin nos ha dejado una descripcion tan exacta como minuciosa para darnos a conocer cómo ese pueblo adiestra y utiliza los halcones. ¿Los halconeros árabes, dice este naturalista muerto demasiado pronto para la ciencia, cogen el sukitir con trampas de hierro, cuyos arcos están forrados de pedazos de lienzo á fin de que no lastimen los piés del ave. Estas trampas se colocan en el sitio donde el halcon sucle томо 111 pasar la noche, $\mathrm{g}$ tienen un inccanismo que se inclina cuando salia el muelle; de modo que el halcon cogido queda pendiente en el aire sin hacerse el menor dano, $y$ á disposicion del cazador. Se necesita inucho cuidado, paciencia y habilidad de parte del halconero para adiestrar al sulkr para la caza de gacelas. El cazador ata en seguida al cautivo y le pone una caperuza de cucro, que prorista de una abertura para el pico, se puede sujetar en la nuca por medio de una tirilla de piel; despues se encierra al ave en un aposento oscuro, colocindola sobre una percha de madem ó una vasija llena de arena seca. Los primeros dias se le hace sufrir hambre, y despues no se le da el alimento sino sobre el guante del halconero, quitàndole la caperuza; de este modo se acostumbra muy pronto al guante, y aun a los movimientos del bra. r.o; por lo regular se alimenta al ave con higado, pero sicmpre en escasa cantidad. El halconero procura acostumunar á su discipulo a posarse sobre el guante; al principio en casa y mas tarde al aire libre, teniéndole atado con una cuerda que poco á poco se alarga. Despues de darle el alimento se le debe poner otra vez la caperuza Para acabar de adiestrar. le se le ata d una cuerda de bastante longitud, presentándole el pellejo embalsamado de un gacela, cuyas órbitas se llenan de carnc. Al hablar de la gacela ya hemos indicado la manera de perfeccionar la enseñanza del hajcon, y creo por lo tanto inútil una repeticion de este relato. 
Jerdon descixe de un modo muy interesante el procedi. miento de los halconeros indios para cazar.

«En rarios gantos de las Indias se adiestra el haicon viajero: se le cogeen las orillas del mar y se vende por dos ó diez rupias i lø halconeros, quienes le adiestran para la caza de la grulla, de la cigiieña, de la garza real, del pico abierto, del oder y de a avutarda. Debo observar aqui que los halconeros indigeas, mucho mas expertos que los primeros de Europa, han sconocido unánimemente que la garza real procura atratess a su adversario con el pico. Aunque el halcon deje caer sa presa en tierra, aun no puede contarse por seguro, á ments que la coja por la nuca; lo cual hace siem. pre todo indivituo vicjo. En la caza del culun (grus airgo), el halcon se neguarda de la una interna, acerada y corva, de esta are, que le puede herir gravemente.

Mas aprecisa nun los indios el scisalin, 6 halcon real, que el viajero, pues le tienen por el mejor. Todos los años se co. gen machisimas con cañas de bambú untadas de liga, en las que se ponen gor cebo algunos pajarillos. Este halcon se adiestra para a género de caza particular á la que dan los balconeros el zombre de casa a pif firme: no se suelta el ave sobre la presa, sino que se la dejà cernerse sobre el halconero hasta que se leranta el animal, en cuyo caso cae sobre él con una rapider seprendente.

- Nada ofrec tanto atractivo como ver $a$ un halcon acometer á una pesudiz. ó una avutarda: apenas divisa su presa, desciende y se remonta dos ó tres veces; y luego con las alas medio cerradas cae sobre ella con la, rapidez de la flecha. Lista nanera de cazar es muy segura : pero no puede compa. rarse con la de imicon viajero que se lanza contra una grulla óun tbis.

Vamos á ertar ahora en el estudio de las especies mas importantes y conocidas de la familia de los falcónidos.

\section{LOS GERIFALTES-HIEROFALCO}

CARACIEAES.-Ios gerifaltes son las aves mas nobles de la familia: cracterizanse por su gran talla y pico robusto, voluminoso y tus corro; los tarsos están cubiertos de plu. mas en las dostercerás partes de su longitud; la cola es larga, ancha, cas tectilinea, $y$ sobreśale un poco de las alas. Al envejecer blangetea el plumaje; pero este no es un carácter exclusivamen: gropio, segun se ha dicho.

DISTRIBCCION GEOGRÁ EICA.-Estas aves habitan el extremo nete de los dos continentes.

Los naturafatas no estín aun acordes respecto á si hay dos ó tres especies de gerifaltes.

Yo, por mi parte, creo que se pueden reconocer dos espe. cies, aunqute a niego la posibilidad de que todas resulten al fin variedrdes cé una misma. No obstante, nos es dado dis. tinguirlas con alguna certéza, y los adultos con perfecta se. guridad, pues terece que difieren tambien un poco por las proporciones.

\section{EL HALCON O GERIFALTE ÁRTICO- FAICO ARTICUS}

CARACTERES. - El plumaje del halcon àrtico es de un blanco puro, cen mayor ó menor número de manchas de color pardo inteeso, que á veces pueden faltar; tienen la forma de motas do de puntas de flechn, $y$ hállanse en la extremidad de las plumas sequeñas. Los ojos, de color pardo, están circuidos de un =illo desnudo amarillo verdoso; el pico es azul amarillento er los adultos, mas oscuro en la punta; la cera amarilla: los rijás pajizos en los adultos y azules en los pe. queños.
Los halcones de este color y de estos dibujos anidan exclusivanente en las latitudes mas altas, es decir, en el norte de Groculandia y en la Nueva Zembla, y solo se acercan á estos paises durante el invierno, visitando entonces tambien la parte occidental del Asia oriental y del extremo norte de América. Esta especie ha sido designada principalmente con el nombre de halcon ártico, separándosela de las que se en. cuentran en Islandia, al mediodia de la Groenlandia y en Labrador, á las cuales se considera como independientes, aunque su estructura es en un todo igual. Holboell, que ha pasado algunos años en Grocnlandia, fijando mucho su atencion en la fauna alada de aquel pais, dice terminantemente que el halcon es en Groenlandia la especie mas comun de su familia, tan abundante en el mediodia como en el norte, pero muy distinto por su color, que varia desde el blanco con motas oscuras hasta el sencillo gris azulado intenso. Sin duda, dice el citado viajero, la edad infure en estas varia. ciones, puesto que no se encuentra casi ningun polluelo blan. co. No obstante, las diferencias de color se notan no solo en los pequeños del nido sino tambien en los adultos, y de estos úteimos debe suponerse que conservan el mismo tinte toda su vida. Yo he visto varias parcjas cuyos individuos eran, uno de color claro y otro oscuro, y tambien he muerto ma. chos que ofrecian la misma diferencia. Cierto dia recibi un nido de halcon con cuatro polluelos, de los cuales uno era gris azul, casi sin manchas; y los otros, por el contrario, muy claros, con fajas de color pardusco. Tambien he cazado muchos halcones pequeños que ofrecian la misma sariedad en el tinte, tanto los machos como las hembras.

Las pocas obseraciones que he podido hacer sobre este punto me inducen a creer que en el norte de Groenlandia predomina el color blanco, y en el mediodia el oscuro.y Yo creo que esta suposicion de Holboell resuelve completamen. te el problema, al parecer tan complicado: los individuos blancos serán aves adultas del cxtremo norte; los que tienen la region superior de un azul de pizarra claro con manchas mas oscuras, $y$ la inferior blanca con manchas longitudinales en el pecho y fajas trasversales en el cuello, provienen sin duda de latitudes mas meridionales, siendo de notar que los dibujos formados por las manchas longitudinales y tnasversa. les pueden hallarse tanto en los primeros como en los últimos. Es posible tambien que algunos de los halcones de los paises meridionales se vuelvan blancos; mas por lo regular solo los individuos procedentes del extremo norte tienen este color, $y$ en ellos desaparecen al fin del todo las fajas y manchas oscuras que en los pequeños comunican as toda la parte superior un aspecto moteado, formando en la cola fajas tras. versales. En los individuos jóvenes, tanto de los halcones septentrionales como meridionales, el color predominante del lomo es pardo gris ó gris oscuro y los dibujos se reducen a manchas longitudinales y trasversales muy marcadas. Ia coronilla puede ser mas clara ó mas oscura, y liene á veces los tallos de las plumas negros. Las alas y la cola presentan sicmpre muchas fajas.

Homejer, que opina del mismo modo, me escribe lo siguiente: «En cuanto a las tres especies de halcon artico, cuya existencia se supone en general, no me es posible distinguir. las, ni siquiera reconocer la diferencia entre los polluelos del gerialte $\mathrm{g}$ los del halcon frtico propiamente dicho, á pesar de haber examinado minuciosamente un gran número de ellos. El color mas 6 menos blanco del halcon ártico se debe en mi opinion, á la mayor ó menor edad, y tal vez al paraje que el ave habita: pero las manchas longitudinales $y$ las tras. versales dependen evidentemente solo de la edad. Los huevos depositados por las hembras de las tres supuestas especies no se pucảen distinguir tampoco, y por eso creo tambien que 
no podemos reconocer sino una sola especie de halcon årtico. A pesar de estos informes sin duda muj importantes, describiré ahora el gerifaite del continente europeo, dando despues oiros detalles por separado.

\section{EL GERIFALTE DE NORUEGA-FALCO GYREALCO}

CARACTERES.-Fl gerifalte de Noruega es, por decirlo en dos palabras, un halcon peregrino grande, que se ca. racteriza por tener las regiones superiores de un azul gris oscuro, negro en el lomn; la coln, del mismo tinte, provista de rajas mas oscuras; las alas son de un pardo intenso; las paries inferiores parduscas $\delta$ de un blanco amarillento, con fajas longitudinales oscuras, que en los costados y el plu. maje de los piés se trasforman en manchas trasversales. En los polluelos predomina en el lamo el pardo oscuro, mientras que las regiones inferiores son de un amarillento gris claro con manchas longitudinales. Los hijuelos del gerifalie no se distinguen apenas de los del halcon peregrino cuando están en el nidio.

El tamaño de todos los gerifaltes viene á ser el mismo, aunque la especie de Noruega parece mas pequeña. Segun yo misino he visto, la longitud de la hembra es de $0^{\circ}, 60$, por $1^{\circ}, 26$ de punta á punta de las alas; estas miden $0^{n}, 40 \mathrm{y}$ la cola $(1 ", 24($ fig. I 34$)$.

DISTRIBUCION GEOGRÁFICA, - Fil área de dispersion del gerifalte de Noruega se limita, por lo que se sabe hasta ahorn, al norte de la Escandiuavia y á la Rusia septentrional: y si Middendorf ha observado bien, al este de la Siberia. Segun he podido reconocer, es el único gerifalte que anida en I aponia. Un individuo pequeño, muerto en el oesie de la Siberia, y que yo he visto cn una coleccion de l'jumen, no cra el gerifalce de Noruega, sino el halcon ártico.

USOS, COSTUMBRES Y REGIMEN.- Haremos un estudio general de las costumbres de estas ares, reuniendo las observaciones particulares que se han podido practicar en las diversas especies.

Aunque no evitan los bosques, los gerifaltes no eligen los sitios que otros falcónidos: habitan las costas bravas á orillas del mar, y se fijan con preferencia donde anidan en verano miles de aves marinas. He notado que nunca faltaban los ge rifaltes en semejantes localidades.

I.os individuos jórencs que no se han apareado aun se in. teman bastante por el pais, y encuéniranse con bastante fre cuericia en los Alpes esccandinavos; mientras que los adultos no abandonan las costas bravas.

Son tambien por lo tanto halcones árticos pequeños que I veces traspasan los fimites de su verdadera área de dispersion, en cujo caso llegan al norte de Escandimavia, á las islas de Feroe, â la Ciran Bretaña, à Dinamarca y Alemania, asi como bajan desde el norte de Rusia hasta los puntos meridionales del pais, $y$ desde la Nueva Zembla, a lo largo del Obi, hasta el mediodia del Ural, ó por lo menos la region de Tjumen. No trataré de averiguar si los gerifaltes obsersndos por Middendorf y Radde en la Siberia oriental eran en efecto la especic de Noruega; pero me parece mas creible que el halcon ártico habitc, no solo en la Nueva Zembla, sino tambien en otras islas ó partes del Asia septenirional, desde donde emigrará en invierno hícia el mediodia.

Parece que anida asimismo en el norte de América, desde la bahia de Baftin hasta el estrecho de Behring; pero segun se asegura, hánse recibido individuos de la especie nornega del occidente de la América inglesa, y por lo tanto es posible que su área de dispersion se extienda desde el norte de la Escandinavia á lo largo de las costas maritimas hasta América, de lo cual resultaria nue tambien esta ave debe considerarse como variedad meridional del halcon ártico.

Debo anadir aun que, segun mis observaciones, Collett confunde en sus Noticias sobre las aies de Nirmega el gerifalte de este pais con el halcon peregrino, diciendo del uno lo que deberia decir del otro.

Cada pareja permanece en el punto que una vez eligió; si le abandona pronto, se presenta otr. Desde tiempo inme. morial habitan los gerifaltes ciertas rocas de Laponia; Nordvi. negociante y muy buen ornitologista, pudo, por lo tanto, indicarnos en el liarangerfjord un sitio donde encontraria seguramente gerifaltes de Noruega, á pesar de no haber visitado en muchos años aqquel punio, ni tenido noticia de èl.

Por su manera de ser se asemejan mucho los gerifaltes al halcon comun: su vuelo es menos rápido, su roz no tan so. nora, siendo esta la única diferencia que yo note despues de olsservar á estas aves libres y cautivas. T'odo lo que diremos mas adelante del halcon comun podria aplicarse á las espe. cies quie nos ocupan.

Los gerifaltes se alimentan en verano de aves marinas, y en invierno de lagópedos; tambien cazan la liebre, y dumante varios meses, segun dice Radde, solo se nutren de ardillas. Fn el Nyten, costa brava de Nornega, habitada por las ares marinas, observé duranic los tres dias que pasé alli, una pa. reja de gerifalies de Noruega que iban con regularidad á las diez de la mañana y á las cuatro de la tarde á buscar su presa. Su caceria no duraba mucho tiemp̨o: llegaban al sitio, trazaban uno $\delta$ dos circulos al rededor de la costa brava, y luego caian sobre la bandada de aves, lleviondose uma cada vez: nunca les vi errar el golpe. Holboell dice haber observado un gerifalte de (iroenlandia que se apoderó á un'tiempo de dos gaviotas tridśctilas, y otro dia de dos becadas marinas. Faber encontró un nido de halcon abundantemente provisto de pingüinos, somormujos y mancos. Los gerifaltes no son menos peligrosos para las palomas, si bien, dice Holboell, que a él no le arrebataron nunca mas que las jorenes, pue's las adultas escapan tícilmente del ave rapaz, gracias of su rápido vuelo.

Despues del periodo del celo llegan los gerifaltes hasta cerca de las viviendas humanas; inuéstranse poco recelosos y se dejan coger fảcilmente con un lagópedo $\delta$ cualquier otra ave. En invierno abandonan las costas yara seguir hasta las montatias a los lagópedos, los cuales temen muclisimo al gerifalte, porque es su mas terrible encmigo. Apenas le divisan, se hunden en la nieve con una rapidez sorprendente y sepultanse en ella por completo: Schrader obscrvó un he. cho semejante. Las aves marinas procuran tambien ponerse al abrigo de las acometidas del gerifalte, pero están reunidas en baridadas tan numerosas, que no se pueden observar los movimientos del indiviciuo cazndo: solo se ve á las de. mís dispersarse, como to hacen las palomas al aparecer el halcon.

Ia dependencia en que vive el halcon ártico de las aves marinas nos explica el que no emigre con tanta irregularidad como el halcon peregrino y el enano, los cuales habitan tam. bien en el extremo norte. Para esa especie el invierno de aquellas regiones no tiene gran importancia, pues desde alli hasta donde se extiende el Gulf-stream (corriente del golfo) el mar esti libre de hielo, y aunque las costas que cl ave habita estén rodcadas de moles de hielo, siempre quedan parajes despejados donde se reunen las aves que sirven de pasto at la rapaz. Los paises mas septentrionales $;$ las islas de aquellas regiones están poblados tambien todo el año de lagópedos blancos, y de este modo, hasta el continente le facilita su alimento. Fin otros paises, la caza es probable. 
mente para este halcon mucho mas penosa que en su patria, y á veces se verá obligado á contentarse alli con animales quıe nunca persigue aqui.

"En medio de las intrincadas espesuras de los bosques de las montañas de Bureja, refiere Radde, no podria el gerifalte perseguir a las ardillas, que constituyen su acostum. brada presa, y por lo mismo las acecha pacientemente; pero al mismo tiempo siempre está alerta, y no permite que se acerque ningun cazador á tiro de fusil: el mismo naturalista vió un gerifalte posado sobre un pino, muy cerca de una bandada de ortegas, y era indudable que acechaba.

Segun Faber, los gerifaltes construyen un nido ancho, aunque poco elevado, eligiendo al efecto la grieta de una pared roquiza impracticable, situada cerca del mar. Dice Nordvi que el gerifalte de Noruega busca el nido del cuervo 6 dc otra ave, âla que ahurenta con sus ataques.

En este caso, el halcon cubre solo el nido con algunas ramas secas y delgadas que lleva en las garras, tapizando la cavidad con fragmentos de ramas verdes de sauce y yerba; mas tarde, sin embargo, los restos de la comida de los po. lluelos cubren completamente el fondo. Cuando esta rapaz construye por si misma su nido, sirvese de unas estacas muy gruesas, tales como no las empleán ni aun los cuervos ni los buzardos, y pone en la cavidad un poco de yerba seca. Mac Farlanc asegura haber encontrado en los contomos de la fortaleza de Anderson, y a orillas del rio del mismo nombre, tanios nidos del gerifalte de Noruega, que pudo trepar $a$ diez y ocho de ellos; dos se haliaban, por excepcion, en las copas de pinos lisos 6 de otros árboles, á una altura de tres a ocho metros sobre el suclo; algunos se encontraron en la punta misma del árbol, y otros en el ramaje mas bajo, junto al tronco. I'odos ellos se habian hecho con ramas gruesas y delgadas; musgo, yerba seca, pelos de ciervo, y otras materias blandas. Solo se halló en uná roca, un nido de cons truccion muy ligera, y otro en tierra, junto a una colina alta y escabrosa.

Segun Holboell, la hembra del halcon ártico pone en Groenlandia sus huevos en junio; Nordvi, por el contrario, me dijo que el gerifalic de Norvega comenzaba a reprodu. cirse en abril, y me regaló, cuatro polluelos disecados que cogió del nido en junio. A principios de julio, yo mismo encontré una pareja de gerifaltes de Noruega en el nido, pero no pude averiguar si este contenia polluelos.

Los informes de Wolley, que en I aponia examinó nidos de esta ave, estan completamente conformes con lo dicho. Tambien él encontró huevos recien puestos á principios de mayo y recibió crias que á fines de abril eran completas. En esta época, el país que el are habita está cubierto aun de una espesa capa de nieve. In la Nueva Zembla, y quizás tambien en otras regiones árticas del área de dispersion de los gerifaltes en general, el perfodo del celo se declara pro. bablemente en los últimos meses del año. Cuando el conde de Wilcgek se ocupaba en la Nueva-Zembla en fotografiar, vió el 25 de agosto un halcon ártico, blanco como la nicve, y visible á mucha distancia; como el ave volaba directamente hảcia el conde, este le disparó un tiro con perdigones; pero el halcon empezó à perseguirle resueltamente $y$ atacóle de continuo durante cuatro ó cinco horas. Gmcias a esto, Wilcgek descubrió al fin el nido, en el cual estaba la hembra cubriendo tres huevos. El are se condujo lo mismo que el halcon peregrino cuando defiende su nido; precipitóse á po. cos pasos del viajero y expuso su vida a pesar de hallarse herido; de tal modo que Wilcgek pudo al fin matarle ocultándose cerca del nido. Holboell compara los cuatro huevos con los del lagópedo; pero son doble mas grandes y mas obtusos; si el color no difiere en todos, la forma varia en cambio bastante. Un huero, que recibi de Nordvi, es blanco amarillento con vetas como las del mairmol, manchas y pun. tos de color rojizo.

El gobierno dinamarqués enviaba antes a Islandia todos los años un buque especial, llamado de los halcones, para bus. car alli estas aves, á las cuales daban caza los halconeros que acompañaban á la cxpedicion. Los gastos de la compra y alimentacion de estas rapaces, del salario de los tripulantes, etcétera, eran bastante considerables; pero como la caza se efectuaba segun ciertas reglas, el precio de un halcon no excedia de nueve a diez thalers dinamarqueses. Desde Co. penhague llegaban las ares á mano de los halconeros ó enviábanse como preciosos regalos a varias cortes extranjeras. Hoy dia, el gobierno ha dejado de ocuparse de esta caza, como fácilmente se comprende; pero el buque va todos los veranos á Islandia, y casi siempre se reciben varios halcones vivos en Dinamarca, desde donde se envia alguno à nuestros jardines zoológicos.

En Laponia y Escandinavia nadie caza el gerifalte de No. ruega mas que los naturalistas, á pesar de los daños que oca. siona. Son, sin embargo, tan numerosas las bandadas de aves marinas que pueblan las costas bravas, y abundan de tal manera los lagópedos en las montañas, que los perjuicios son insignificantes: los noruegos aseguran que los ingleses, impelidos tan solo por su aficion à la caza, llegan al pais todos los años y destruyen muchas mas aves que los mismos gerifaltes. En Islandia y Groenlandia por el contrario, donde son mas comunes estos últimos, y se acercan cada invierno á las casas, se les persigue sin tregua ni descanso: en todo el norte de Asia se apoderan de ellos para enseñarlos a cazar.

Asi, por ejemplo, los kirguises de Bivar, que conocen mus bien el ave, cuentan que en otro tiempo los empleados y co: merciantes ricos del celeste imperio tenian halcones adiestra. dos para la caza o para luchar con el águila; pero que hoy dia no se les permite ya. Los pueblos nómadas de la Siberia oriental practican aun hoy dia este método de caza, y por eso aprecian mucho el halcon àrtico.

Despurs del hombre no ticne el gerifalic otro adversario tan digno de él como el cuervo; Faber y Holboell dicen que con frecuencia se ve luchar a estas dos aves.

C.AUTIVIDAD. - Segun mis observaciones, el halcon artico se conduce en cautividad lo mismo que el halcon pe. regrino; se le ha de cuidar de igual manera; pero raras veces alcanza en la jaula \& mucha edad. La historia de estas aves nos dice que algunos halcones han vivido veinte años; pero no sucede asi en nuestros jardines zoológicos, y ya es mucho cuando un individuo llega aqui fa la edad en que reviste el plumaje de los adultos. A decir verdad, parece muy dificil prodigarlos tan solícitos cuidados como los que recibian del halconero, segun los autores antiguos. El arte de estos últimos consistia no solamente en adiestrar las aves, sino tam. bien en proporcionarles el alimento conveniente y en curar sus enfermedades. \&Un halconcro experto, dice Gessner, ha de fijar su atencion en nutrir el ave a tiempo y de la manera debida; debe dairsele un alimento análogo al que toma en libertad y sobre todo carne facil de digerir, aun caliente, que conserve el olor de la sangre. Tambien debe procurar que el ave no engorde en demasia ni enflaquezca con exceso, pues en este último caso enferma y pierde su valor; grita sin ce. sar, y sobre todo cuando el halconero la lanza por los aires y en persecucion de alguna presa. Cuando engorda con es. ceso comienza á ser perezosa, y por lo tanto se ha de guar. dar el término medio, arreglandose de modo quue el ave tome su alimento con gana natural. Esto se consigue no dándole de comer antes que haya digerido su alimento anterior. Además debe tomarse en consideracion la naturaleza 
de tales ares segun el sexo $\mathrm{g}$ la especie: a las de color negro, cuyo carícter parece ser melancólico, conviene darles la mayor parte del alimento caliente $y$ húmedo, como gallinas, palo. mas y carne de cabrito. Los halcones blancos, de naturaleza flemática, yllenos de humedad rociva, necesitan un alimento seco y caliente, como carne de macho cabrio, de perro ó de mulo, urracas, gorriones, etc. Las especies de plumaje rojo, que tienen la sangre mucho mas caliente, deben alimentarse de cosas frias $y$ húmedas, tal como carne de gallina, de aves acuáticas y de cangrejo.s Como quiera que sea, de la des. cripcion anterior resulta que se tenia el major cuidado para la conservacion de los halcones y jara darles el alimento tan fresco y bueno como la experiencia lo aconsejaba. En nuestros jardines zoológicos no se pueden soportar tales gastos, y esta será la razon de obtenerse résultados tan desfarora. bles. Si quisicramos dar a nuestros halcones uno $\delta$ dos palo. mos, gallinas, perdices, patos li otras aves, si posible fuera vivas, sin duda los conservariamos tanto tiempo como antes los halconeros.

\section{EL HALCON LANARIO-FALCO LANARIUS}

CARACTÉRES. - Este gerifalte, casi tan aprecindo en otro tiempo como el halcon ártico, es un are de magnifico aspecto, que tiene $0^{\circ}, 5+$ de longitud por $1^{\circ}$, , 0 de anchum de punta a punta de las alas; estas miden $1{ }^{\prime \prime},+1, y$ la cola (1), 20 ; por su color se parece bastante a un halcon peregrino jóren, at lo cual se debe que se le haya confundido muchas veces con 6. La faja de las mejillas es poco marcada; las plumas de la coronilla son rojizas, con manchas Iongitudinales de color pardo oscuro, que reuniéndose en la nucr, forman oira mas grande y oscura; en ln frente, que es amarilla, y en las plumas de las mejillas, hay unas lineas mas oscums; la nuca es blanca, con fajas y manchas longitudinales de color pardo pálido; toda la parte superior, incluso las rémiges se. cundarias, son de este último tinte; cada pluma es gris en la punta, orillada en los lados de rojizo y con el tailo oscuro; la gargania y la barba son de un bianco amarillento; toda la re gion inferior es de un blanco rojizo, aciornada de grandes inanchas longitudinales de color oscuro, y que hácia la punta aumentan de tamaño. Las rémiges primarias, de un blanco oscuro pálido, tienen en sus barbas interiores grandes manchas ovales, blancas por fuera y rojizas cerca del tallo; las rectrices del centro son de un color pardo leonado; todas las demás presentan en las barbas exteriores de siete á ocho manchas redondas, $y$ en las interiores otras de un blanco ro. jizo, visibles tambien en la cara inferior; la mandibula supe. rior es gris de cuerno; la inferior amarillenta; la cera de color dé carne, $y$ los piés verdosos $\delta$ de un tinte amarillo. Los po. lluelos se distinguen de los adultos por su color mas oscuro; las manchas de la parte inferior son mas grandes; la cora, los circulos oculares y los piés, azules.

\section{EL HALCON DE FELDEGG-FALCO TANYP- TERUS}

CARACTERES:- Esta cspecie se parece tanto a la anterios, que algunos ornitólogos solo la consideran como varie. dad de la misma; pero es mucho mas pequeria, de color rojizo de orin, ornada solo de estrechas lineas negras en el occipu. cio, que tambien puede ser de un solo color; las barbas son mas fuertes: los bordes de las plumas del lomo mas anchos y de color azul; la cola tiene fajas en rez de manchas; la parte inferior resalta por su lustre amarillento claro, $y$ las manchas son mas pequeỉas.

DISTRIBUCION GEOGRÁFICA DE LAS DOS ES-
PECIFs. - El halcon lamario no anida en Alemania; esta diseminado por el sudeste de nuestro continente, sobre todo por el Austria inferior, la Galitzis, Polonia, Hungria, los paises bajos del Danubio, el sur de Rusia y la provincia del Balkan; encuentrase adenuis en varios puntos del Asia central hasta la China; en Armenia, en el Asis Mlenor y probablemente en Persia; emigra en invierno hasta la India y el Egipto cen. tral; pero no anida en tstos dos últimos paises. Puede ser que á menudo se presenten individuos errantes en Alemania;

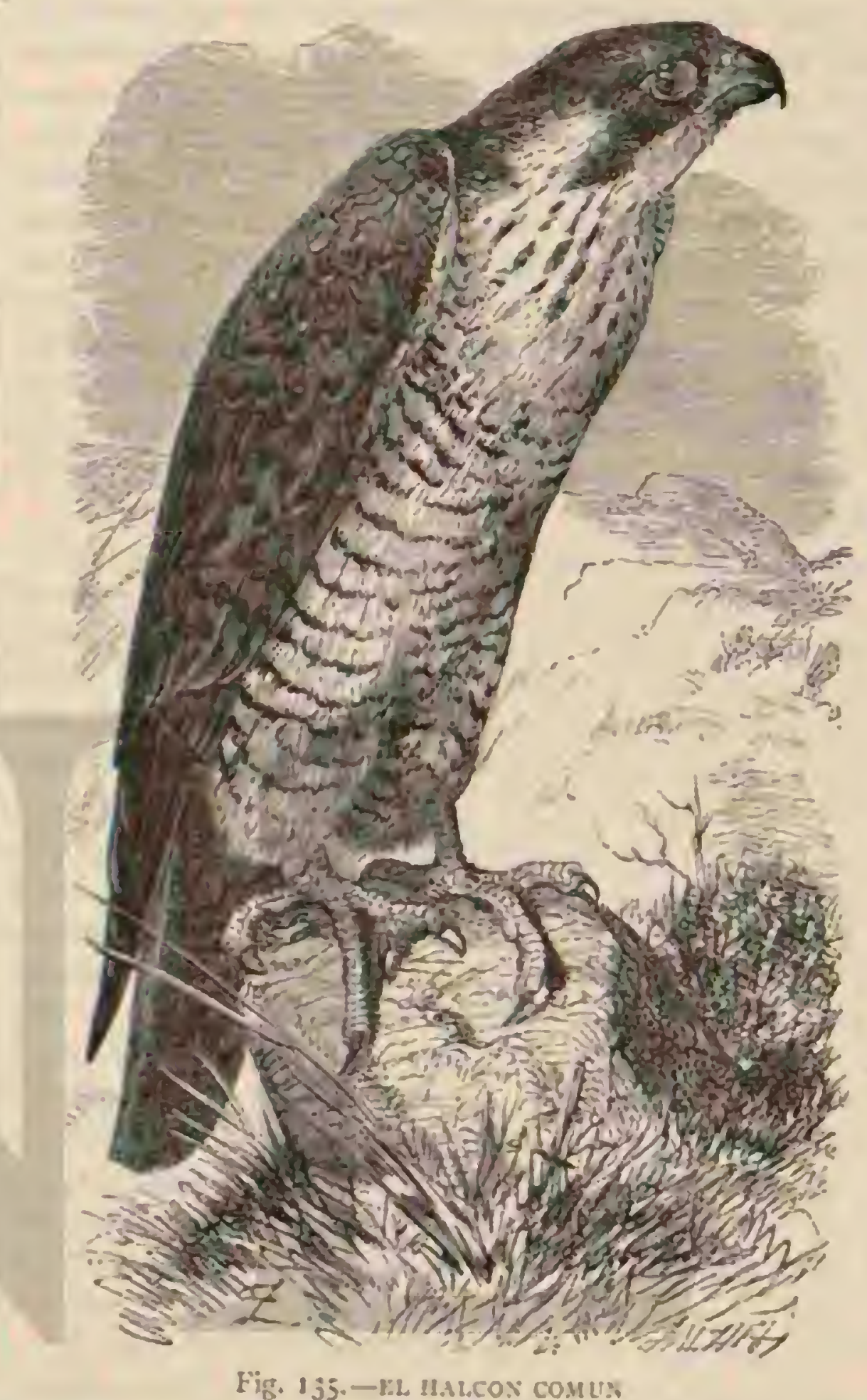

pero no conozco ningun caso cierto de que se haya visto aqui. Fuera de los límites de este imperio ha anidado en Bohemia: en un bosque de las islas del Danubio, cerca de Viena, el principe imperial, Rodolfo de ztustria, mató el $=0$ de abril de $1 S_{i} S$, a presencia de Eugenio Homejer $j$ de la mia, un macho que estaba junto al nido; á los cuatro dias se cazó otro, lo cual prueba que el are no es rara en el Austria inierior.

Fil halcon de lecldegg represenia al halcon lanario en Dal. macia y con mas irecuencia en Egipto, en el norte del $\Lambda$ frica, en el Sudan oriental yen Abisinia.

USOS, COSTUMBRES Y REGIMEN.-Fil haicon la. nario se parece por sus usos y costumbres al peregrino; pero los halconeros árabes le distinguen de su congénere atribuyén. dole cualidades que, segun ellos aseguran, no posce este. Segun he reconocido, esos halconeros tienen razon. En una cacera del principe imperial, archiduque Rodolfo de Austria en Hungria, á la cual hubimos de asistir Eugenio de Ho. meyer \& yo, obsermamus varias reces el halcon lanario, y si bien nos faltaba tiempo para ocuparnos detenidamente de el, pudimos sin embargo reconocer diferencias esenciales entre él §al halcon peregrino. Su vuelo se distingre ga d 
primera vista del de esta especie; su cuerpo prolongado, en comparacion con el del halcon peregrino; ia cola mas larga, las alas mas puntiagudas, mas anchas en el hombro y en el húmero y de consiguiente muy corras, son caractéres suficientes para reconocerle con seguridad. Vuela con mayor rapidez que su congénere, y mejor que el halcon arboricola; mueve con mucha ligereza y vigor las alas, para lanzarse despues de algunos aletazos por las regiones aéreas, y describe sobre su nido anchos circulos con una facilidad admirable, sosteniéndose mucho tiempo sin mover las alas. El macho que vimos en la caceria nos dió una prueba de su rapacidad: de Dombororrski, ayudante de guardabosque, que nos acompañaha, llamó / algunas palomas silvestres â la isla del Danubio, donde nos hallatbamos, imitando su voz. Apenas se levantaran estas aves, cuando el halcon se preci. pitó en medio de ellas. Poseidas de terror, y olvidando toda pridencia, se refugiaron en las copas de los ärboles inmedia tos, y un momento despues pasó el halcon por en medio de ellas. Kápido como el rayo era entonces su vuelo, y distintamente oimos el rumor que producian sus alas; pero por grande que fuese la rapidez con que cruzaba los aires, el plo. mo seguro del principe le alcanzo, liaciendole pagar con la vida su atrevimiento.

Woborzil fué el primero que nos dió noticias sobre la reproduccion de esta ave; pero últimamente nos han informado tambien sobre este punzo Gocbel y Holtz; Woborzil encontró el ave anidando s orillas del Moldau. En el distrito de Euman, en la Rusia meridional, donde Goebel observó el halcon lanario, este abunda muclio mas que el peregrino, y cuéntase entre las aves que bastanic a menudo pasan el verano en aguel pais. Su nido se encuentra alli siempre en árboles y no en rocas; elige con preferencia las encinas, y excepcionalmen. te tambien los tilos situados en los linderos de los bosques circuidos de campos; construye el nido a unos 16 metros sobre el suelo, formando la base con ramas gruesas y delgadas; el rmaje mas fino y las hojas sirven para cubrir las pa:redes. Ia hembra pone cinco huevos, raras veces cuatro ó seis, completándose el número á mediados de abril; así como los de todos los halcones, los de una misma puesta varian considerablemente en tamaño, forma y color; su mayor dia. metro es de $6^{67}, 051 / 0^{\circ}, 056$ y el menor de $U^{\circ}, 040$ \& $0^{\circ}, 042$; el color es amarillento ó blanquizco; en el primer caso, los dibujos consisten en manchas muy oscuras de color pardo rojo, que formando como unas grandes nubes, dejan libre en algunos sitios el color predominante; en el scgundo caso, las manchas son uniformes en todo el huevo y apenas permiten ver el color blanquizco. Así como todos los halcones, los padres profesan un carino excesivo à su cria. Ia hembra permanece inmóvil sobre los huevos hasta que ve al cazador trepar por el árbol, y á menudo no se levanta sino cuando el hombre está muy cerca del nido; entonces describe círculos sobre él, manteniéndose siempre, sin embargo, di respetable distancia. Holtr. está conforme con Goebel en que el halcon lanario es un are poco timida. El primero dice: Yo le he visto muchas veces en la época del celo posado tranquilamen. te en el borde del nido; limpiśbase el plumaje y no manifestaba la menor timidezo Goebel añade: \&El halcon Tanario es un ave de rapiña muy confiada y no pertenece ad las especies timidas: yo me he acercado a él en dias de primavera hasta colocarme debajo del mismo árbol donde se hallaba, desprovisto aun de follaje; de modo que pude matar a la rapaz ficilmente.

En el Austria inferior y Hungria hemos visto tambien el halcon lanario durante el periodo del celo, siempre aislado en los bosques: anidaba en los mas inmediatos a Viena, com. puestos principalmente de álamos y sauces, y solia situarse en medio de un grupo de nidos de la gara real. Repetidas veces le observamos en las islas del Danubio y de Hungria en iguales circunstancias; y tampoco faltaba en los preciosos bosques montañosos de la Fruschkagora. Debo añadir que construye él mismo su nido, ó por lo menos le perfecciona; la hembra de la pareja que anidaba cerca de Viena llevaba ramas secas al nido. A principios de mayo, y en cumplimien. to de una órden del principe imperial, Rodolfo, registróse una encina en un bosque de la Hungría meridional, y en ella se encontraron cuatro polluelos cubiertos de plumon blanco, cuyas rémiges y rectrices apuntaban ya.

Heuglin describe de un modo muy pintoresco el género de vida del halcon lanario dumnte el invierno. 8 Cuando lle. gan las aves acuaticas que pasan el invierno en las lagunas pantanosas del Delta del Nilo, se reunen al mismo tienupo nu. merosos halcones y águilas, que aqui encuentran siempre presa buena y fresca. Con estas rapaces se presenta tambien algunas reces el sukhr, que pronto busca sitio en un sicomo. to, palmera 6 acacia aislada, desde donde puede observar un gran esnacio. Al amanecer, cuando comienza á oirse el estré. pito atronador de millares de ocas, patos y tringidos, reunidos en bandadas que se precipitan sobre las islas cubiertas de cañaverales, en las lagunas 6 en el agua libre, el halcon lanario abandona tambien su albergue; un espeso velo de niebla cubre todavia la liquida superficie, pero esto no impide ála rapaz consumar su obra. Sin trazar grandes circulos y elevandose poco sobre el suelo, dirigese en linea recta y sobre una bandada de patos que retoran alegremente; siguese un momento de silencio profundo; las gallináceas acuáticas y otms malns voladoras se acurrucan y sumérgense al punto; mientras que los patos, confiados en su destreza en el vuelo, reinóntanse por los aires buscando su salvacion on la fuga. Eutonces se eleva tambien el halcon; rápido como la flecha despedida del arco, precipirase sobre la victima elegida y có gela con una agilidad asombrosa; perseguido por milanos y otros halcones, que atruenan el espacio con sus gritos, y sin hacer aprecio de estas aves, lleva su presa a la altura mas próxinu, y alli la destroma en pocos momentos. A veces describe tambien circulos a mucha elevacion y precipitasc retozando sobre una bandada de aves de pantano, sin ajpresurar su vuelo hasta que se fija bien en su víctima; rams veces se le escapa, á pesar de que este halcon no caza tan de prisa ni con tanta impetuosidad como sus congéneres. En las horas del calor descansa en la copa de algun árbol, y por la noche dirígese con pausado $y$ tranquilo vuelo hàcis su albergue. Nada tengo que oponer a esta descripcion, puesto que está conforme en un todo con mis observaciones sobre la vida invernal del halcon peregrino.

\$Solo el halcon lanario, continúa Heuglin, se utiliza para cazar las gacelas; los demás halcones se precipitan en general con demasiada violencia y acaban por matarse unos á otros destrozandose el esternon. Hé aqui por qué se pagan los halcones lanarios bien adiestrados á precios muy subidos.

Tambien nuestros halconeros apreciaban mucho el halcon lanario, casi tanto como el gerifalte de Noruega. Gessner le describe bajo el nombre de sneker ó kup filano, manifestando su descripcion que yá á mediados del siglo xur turo el ave la mala suerte de figurar bajo diferentes nombres: eEntre los haicones nobles se, llama al primero phalce brifanicus y sacir, aelius y aeriphilus, dándosele otras varias dominaciones. Hemos sabido últimamente, continúa nuestro antiguo amigo, que el emperador Maximiliano ha enviado varias personas de su servidumbre á los útimos limites de Polonia para traerle halcones de esta especie, cogidos en sus propios nidos; los encargados hallaron algunos en árboles bajos, por lo cual se comprende fäcilmente que estos halcones no persi- 
guen \& las aves pequenas y si solo \& las grandes. - Tardinus dice que hay tres géneros de halcon sacker: el primero lla. mado sepri por los asirios y babilonios, habita en el occidente de Egipto y en Babilonia, y caza liebres y cervatillos; el segundo que se llama semy; persigue á los corzos pequerios; y el tercero ha recibido el nombre de hynaion 6 strushling, porque no se sabe de donde proviene. Todos los años cmigra hacia el mediodia; se le coge en las islas de Oriente, tal como en las islas de Chipre, Creta y Rodas; pero tambien le recibi. mos de Rusia y 'lartaria Los individuos de color rojo ó gris, y de formas parecidas á las del halcon con lengua gruesa y pirs anchos, caractéres que raramente se encuentran en el halcon sacker, considéranse como los mas nobles. Esta ave es entre todas las de rapiña la mas propia para la caza, la mas familiar y dócil; y digiere fícilmente alimentos duros. Apoderase de las aves grandes, tal como ocas salvajes, grullas, garzas reales, y tambien de inuchos cuadrúpedos, como corzos pequeños y otros. Todo esto prueba por lo menos, que los autores de cuyas obras tomó Gessner sus noticias solo hablan del halcon lanario. Schlegel ha dado por eso al ave el nombre de falio sacer, y varios ornitólogos modernos siguen su ejemplo, por poco conforme q̧ue sea este proceder con la laudable costumbre de conservar el derecho at la primera descripcion. Esta es la ce Pallas, que dió á la especic el nombre de falce lanarius, única denominacion que debemos respetar.

\section{EL HALCON-FALCO}

CARACTERES. - El halcon ofrece grandes semejanzas con los gerifaltes: difiere, sin embargo, por tener menos talla, el pico mas peq̨ueno y encorvadoy menos voluminoso; los tarsos cstán cubiertos de plumas, pero en la tercern parie de su longitud: la cola es mas corta, y las alas alcanzan su cxtremo ó sobresalen de él.

\section{EL HALCON COMUN-FALCO PEREGRINUS}

CARACTERES. - El halcon comun ó viajero, haicon foregrino de algunos maturalistas, representa la especie mas extendida (fig. 135). El individuo adulto tiene of lomo gris pizarra claro, sembrado de manchas triangulares de este úl. timo tinte, pero mas oscuro, dişuestas en forma de fajas, la frente es gris; las mejillas negras; tiene un hargo mostacho de este color, que se prolonga á los lados del cuello; la cola está señalada de un gris ceniciento claro. Ias pennas de las alas son de un negro pizarm, amarillentas en el extremo, $y$ con manchas de un amarillo de orin en las barbas internas; la garganta, la parte anterior del cuello y la mas alta del pe. cho de un amarillo blanquizco; la inferior y el vientre de un amarillo rojizo, presentando la primera listas y manchas cordiformes de un amarillo pardusco, $y$ la segunda manchas tsasversales oscuras, sumamente marcadas, cerca del ano $y$ en las naigas. El iris es pardo oscuro; la cera, el ángulo bu. cal y el circulo desnudo que rodea el ojo, de un tinte amarillo; el pico azul claro, con la punta negra, y los piés amarillos. En vida del ave parece esiar cubierto el plumaje de un plumon-agrisado.

Los colores de la hembra son mas puros que los del macho.

Los pequeños tienen el lomo gris negro, siendo el tallo de las plumas de un amarillo de orin; la garganta y la parte su. perior del pecho, de un tinte blanquirco ó gris amarillento; el vientre blanquizco, sembrado de manchas longitudinales de color pardo claro ú oscuro; el pico azulado claro; la cera y las partes desnudas de la cabeza de un azul verdoso, $y$ las patas azuladas ó amarillo verdosas.
El macho adulto tiene de $0^{\circ}, t^{2} \times 6^{\circ}, 47$ de largo, y de $0^{\circ}, 8_{4}<1^{m}, 04$ de anchura de alas; estas tienen $0^{\circ}, 3^{6}$ y la cola $0^{\circ}, 20 ;$ la hembra, notablemente mayor, tiene de $0 \%, 47$ á $0^{\circ}, 52$ de largo, y de $1 \%, 10$ \& : ${ }^{\circ}, 20$ de punta a punta de ala; esta plegada mide $0^{\circ}, 82$ y la cola $0 \%, 20$ :

DISTRIBUCION GEOGRÁFICA.-El halcon peregri. no merece muy bien su nombre, pues vaga casi por todo el mundo. Su extraordinaria diseminacion se explica muy bien por el hecho de habitar no solo en la zona icmplada, sino tambien en la septentrional fria; hasta en las regiones del polo es una especie abundante, aunque todos los inviemos deba abandonarlas, por mas que anide en ellas, para buscar paises mas meridionales. Entonces pasa portodos los paises septentrionales de Furopa, de Asia y Amésica; en Europa llega hasta el extremo sur, y aun cruzs el Meditermineo, persiguien. do a las aves de paso hasta el mediodia de la Nubia y el este del Sudan. En Asia llega hasta el Japon, China y la India; tambien recorre las Américas. Segun mis observaciones y las de otros naturalistas, las hembras son las qque prolongan inas sus riajes hácia el sur; mientras qque los machos se quedan hácia el norte. Muchas de estas aves, tanto de un sexo como de otro, invernan tambien en Alemania; y como el frea de dispersion donde anidan se extiende por toda liuropa, exceptuando quizás la punta meridional de ia peninsula Ibírica y las partes septentrionales de América, no podemos asombrarnos de que el halcon viajero se encuentre en casi toda la tierra. Ia opinion de que los tres tipos de que haremos mencion solo son variedades constantes de una misma especie, prarece por lo tanto algo fundada. Los individuos que anidan en Alemania ó se encuentran de paso en este pais, varian tambien unucho en tamaño y color; en toda coleccion que posee un gran número de ellos, se encuentran algunos que se parecen mucho fas las citadas variedades, $y$ aun podria decirse que se asemejan en un todo. Fste hecho confirma la opjinion de que todas las llamadas especies análogas a nuestro halcon, deben agruparse con él. Como quiera que sea, el halcon pe. regrino tiene la facultad reconocida de acomodarse álas con. diciones mas diversas. En el nordeste del Africa habita en invierno todos los lagos de la costa y las orillas det Nilo hasta la Nubia central, y encuentra en todas partes sitios conve. nientes, tanto por el alimento como por la seguridad. Lo mismo sucede en el mediodia del Asia.

kEl halcon viajera, dice Jerdon, se encuentra en todas las Indias, desde el Himalaya hasta el cabo de Comorin; pero solo durante la estacion fria. Abunda sobre todo á lo largo de las costas y en las orillas de los grandes rios; no anida ni en las Indias ni en Hinalaya; solo es un ave de paso que apa. rece en los primeros dias de octubre y vuelve i marchar en abril.

Tambien por América viaja muy hácia el sur. Ignoro si se le encuentra en el Brasil; pero pucdo asegurar que cruza el golfo de México. Los viajes de mil kilómetros sor pascos para cli tengo la conviccion de que sin hacer grandes usfuerzos puede franquear en un solo dia el Mediterránco.

En el oeste y sur del Africa el halcon virjero está represen. tado por el halcon meroor (Falio minor); en la India por el mas grande y mas negro schahir: (Falco ferggrinater); y en la Australia por el halcon de smejillas negris (Fubo melareaye. ny's) i no sc sabe aun, sin embargo, si estas tres formas son especies independientes. En el norte de Africa y el nordeste del Asia haillase el foicun: de Berheria (Folco tarbarms), que se distingue por su menor tamaño, por las manchas de un rojo de orin en la nuca, y por no tener tantas manchas en la region inferior. No cabe duda qque esta ave representa una especie independiente. En cuarto \& sus usos y costumbres, esta bonita are es una reproduccion fiel del halcon peregrino. 
Segun parece, habita en toda la costa meridional del Mediterráneo, desde donde se disemina mucho por el interior del Africa y por la India hasta Persia. Muy á menudo se encuentran tambien individuos ermntes en Espana, donde los he visto en colecciones, habiendo obtenido alli algunos los naturalistas ingleses.

USOS, COSTUMBRES Y RÉGIMEN.-El halcon viajero habita en Alemania los bosques extensos, prefriendo aquellos donde hay escabrosas pendientes pedregosas. Con frecuencia se le re asimismo en montañas desprovistas de bos. que y liasta en medio de grandes poblaciones. Yo mismo le observé en las torres de las iglesias de Berlin, en la de San Estéfano de Viena y en las catedrales de Colonia y Aquisgran; sé por informes fidedignos, que habita otros edificios altos cun regularidad. En Berlin se le ve no solo en invierno sino tambien con frecuencia enverano, $y$ si hasta ahora no se ha encontrado su nido en ninguna de las torres altas, esto no prueba que no anide en ellas. Jos sitios farorables, sobre todo las rocas inaccesibles, lé sirven de mórada con tánta re. gularidad como las montañas del norte á los gerifaltes. La Roca de los lalianes, en la selva de Turingia, tiene por lo mismo su nombre muy bien aplicado, pues en ella anida una pareja de halcones viajeros desde tiempo inmemorial. Sin embargo, ni los árboles, ni las rocas, ni los edificios altos son condiciones precisas para su bienestar, pues casi con mayor frecuencia que en Alemania se le encuentra en la Tundra, como ya hemos dicho. Cicrto que no le hallé muchas veces en Laponia; pero en cambio le he visto i menudo durante mi último viaje por el noroeste de Siberia. En la Tundra de la peninsula de los samojedos le faltan casi del todo las ro. cas; pero tambien encuentra aqui sitios convenientes para construir su nido, y por eso se le ve con regularidad todos los veranos.

El halcon viajero, dice Naumann, es fucte, valeroso, agil y de aventajado tamano; sus brillantes ojos revelan a primera vista todas las cualidades del-are.

$\$$ No le armótan bien la naturaiera inútilmente, s por tal concepto rivaliza con las especies de los generos vecinos Su vuclo es rápido bate con frecuencia las alas; rara vez se cicrne, y acércase por lo regular a corta distancia de tierra. Al remontarse despliega la cola, y vucla antes algun sicmpo, rasando el suelo; solo en la primarera se le ve de rez en cuando cerniéndose à considerable altura.

Es receloso y prudente, y para mayor seguridad pasa la noche en los grandes bosques de coniferas; si no los encuentra próximos, permanece en los lugares descubiertos posado sobre una piedra. Solo en casos excepcionales permanece durante la noche en un pequerio bosque donde haya otros ár. boles; en tales circunstancias no se entrega al sueño hasta una hora avanzada; por la tarde se posa en las ramas mas fuertes de las altas copas. En las grandes selvas elige los inayores árboles aislados en medio de los claros, y comienza a buscar un sitio al. ponerse el sol. Durante el dia no le gusta estar en los árboles. Cuando descansa encoge el cuello de modo que la cabeza parece apoyarse directamente en los hombros: se le reconoce desde luego por su garganta blanca que resalta mas con el color negro de las mejillas. En el vuelo se le distingue por sus esbeltas formas, su estrecha cola, y sus alas largas, anchas y puntiagudas. Su voz es fuerte y sonora y suena como las silabas Kiak, Kigiak ó Kajak, Kajaki, pero fucra del periodo del celo se le oye pocas veces.

Lo que dice Naumann respecto á la timidez y cautela del halcon viajero es exacto en nuestros bosques: pero no en to dos los demás parajes. In el desierto de Tundra, esta ave evita con precaucion al cazador; pero en las grandes ciudades no hace aprecio del hombre y hasta demuestra á menudo una osadia que contrasta singularmente con su conducta ordinaria, à no ser que haya fijado su atencion en alguna presa. Mas nos admiramos aun cuando lo vemos en al nordeste del Africa, sobre todo en el Egipto, posado en nuedio de los pueblos sobre algunas palmeras ó un sicomoro del mercado, 6 ya en ruinas de templos, en casas y palomares, desde don. de emprende sus expediciones de merodeo. Vemos pues que su conducta se acomoda siempre y en rodas paries á la lo. calidad, utilizándose de su experiencia para sacar el mejor partido posible.

Parece que el halcon comun no se alimenta mas que de aves: es el terror de todos los séres alados, desde la oca sal. vaje hasta la alondra; causa grandes destrozos en las banda. das de perdices y de palomas; persigue a las ocas sin descan. so, y hasta es temible para las cornejas aisladas, que le sirven de pasto durante semanas enteras.

Asi como sus congéneres afines, apodérase por lo regular de los séres alados cuando vuelan, aunque no vacila en hacer lo mismo con las aves que reposan en los árboles. No procede sin embargo lo mismo con las que se hallan en tierra ó en la superficie liquida: en estos casos la caza le ofrece dificultades casi invencibles y hasta peligrosas, a causa de su vuelo inpetuoso y precipitado. \&El halcon viajero, me escribe Eugenio de Homeyer, fundaindose en sus observaciones de muchos anos, se ve en la completa imposibilidad de atrapar un ave en el suelo ó en el agua. El ọbservador que asegura haber visto tal cosa se ha engairado, pues puede suceder que un ave espantada por el ataque del halcon, haga una tentativa imprudente para huir, elevándose un poco sobre el suelo ó el agua, $y$ entonces precisamente es cuando la rapaz se apodera de ella. Una vez, he visto, a la distancia de doscientos pasos, cómo un halcon viajero se precipito mas de cincuenta veces sobre una palona posada en tierra; pero siempre en vano. En otra ocasion, hallándome oculto en un canaveral junto al Pequeño Haff, de Ueckermunde, divisé un halcon viajero que, jersigusiendo â un tringido alpino, se dirigia hácia mi; á unos cuarenta pasos de distancia, el tringido se precipitó al agua, donde la raplaz le atacó varias veces sin poder atra. parle, hasta que al fin, pareciéndole sin duda la caza dema. siado enojosa, se alejo. El tringido, remontándose al punto, emprendió la fuga en direccion opuesta, pero á los pocos segundos, como el halcon volviese, el tringido se lanzó de uue. vo al agua. Su enemigo le atacó algunas veces en rano, y desistiendo pronto de su empeño desapareció. En un viaje desde Stralsund á Hidensoe observé el tercer caso: era un hermoso dia, y el barco avanzaba ligeramente, impelido por el viento y por las olas. Un halcon viajero, persiguiendo á una paloma arul estaba á punto de cogerla, cuando esta se arrojó al agua; el halcon intentó obligarla á elevarse atacán. dola de continuo, pero todo fué intítil. Al fin, se alcjó la ra. paz, y asi como en el caso anterior, la paloma sc dió dema. siada prisa para huir del enemigo peligroso.

Apenas se hubo elevado sobre el agua, su enemigo volvió a la persecucion, obligindola á buscar de nuevo refugio en el mar. De este modo continuó la caza mientras pude verla desde el barco, que poco á poco se alcjaba. Esto me demostró evidentemente que el halcon viajero no puede coger un ave en el agua, $y$ que esto no sucede cuando aquella se eleva sobre la superficic. Dados estos informes tan icrminantes del excelente obserrador, creo muy posible que jo tambien me haya engainado cuando en el Egipto septentrional crei verá un halcon viajero coger varins veces patos en cl agua, porque estas aves se encuentran alli en tal muititud que uma equirocacion es muy fácil. Sin embargo, debo anadir que las repetidas tentativas del halcon hacen suponer que sus esfuerzos pueden tener excepcionalmente buen exito. Ya sabemos 
que se le coge tambien en las trampas colocadas para los arores, lo cual seria imposible si no acometiese á su presa en el suelo, donde esta sujeto cl cebo, que es por lo regular una paloma. Cuando sus ataques contra un ave posada no producen buen resultado, apela á la astucia. stlli donde se re a la mpaz posada en tierra, en medio del campo, dice Nau mann, hallase por lo regular una bandada de perdices, de las cuales coge una tan luego como se remontan, sin poder hacerles daño mientras pernanecen quietas El halcon acecha largo tiempo, hasta que las perdices creen que se ha alejado; estas se remontan entonces, y la rapazz logra su fin. Ni aun las aves de mas rápido vuelo consiguen escapar muchas veces. «as palomas domésticas aleccionadas ya por la experiencia, dice Naumann, no conocen otro medio de salvacion que el de emprender la ruga lo mas rápidamente posible oprimiéndose una contra otra. El halcon se precipita al punto contra la que se desvia de la bandada; asi su ataque es inuitil: la primera vez, ha paloma trata de ganar la altura, y si lo consigue, sucede algunas veces que el halcon se cansa $y$ se retira. Altum ha observado sus cacerias de palomas durante tres años en Berlin y las describe del modo siguiente:

QAqui solia posarse la hembra del halcon por la mañana, permaneciendo innóvil y acurrucada en una saliente del techo de la iglesia militar. Bandadas de palomas cruzan los aires; la rapar despierta $y$ las sigue con la vista; esto dura unos cinco minutos, y despues se reinonta. Aun no le han visto las palomas; pero al los pocos segundos se acerca tanto i ellas, que su ligero vuelo comienza a ser vacilante y precipitado; con una rapidez. casi increible, el halcon las alcanza, elevándose á unos dicz metros sobre cllas; entonces despliega toda su agilidad y rapidez; con la celeridad del rajo precipitase diagonalmente sobre una de las palomas mas jróximas, $y$ tan bien calculado es su ataque, que sigue todas las evoluciones desespendas del ruelo de su victima; pero en el momento que quiere cogerla se le escapa por debajo. Con el mismo impulso que llevaba para el ataque vuelve â rerrontarse sin aletear; revolotea algunos motnentos en el mismo sitio, y antes de haber pasado diez segundos alcanya de nuevo à la paloma; elévase sobre ella; precipitase luego como un rayo con las alas recogidas; y un momento despues Ia victima sangrienta se agita convulsiramente entre las garmas de la rapaz. Lista se aleja con su presa en direccion horizontal, y pronto desaparece del horizonte Algunas palomas vagan aun aisladamente casi i la altura de las nubes; mientras que las otras han buscado su refugio en los palomares.

Mi padre habla de un halcon viajero que persiguiendo à las palomas penetró hasta el interior del palomar, donde fué cogido.

Lebo anadir que el caso referido por Homejer no es àislado, pues tambien Naumann vió à una palona doméstica salvarse zambulléndusc en el agua.

Despues de las perdices y palomas, tanto domésticas como salrajes, el vanélido de mono es, segun las observaciones de Altum, el ave mas expuesta a los ataques del halcon peregrino. Tanto en la Pomerania como en la Marca, los bos. ques donde se halla su nido estrín llenos de plumas de esarave.

'Todas las aves que el halcon viajero ataca le conocen muy bien y buscan en primer lugar su salmacion en la fuga; ni siquicra las valientes cornejas le amenazan: léjos de ello, huyen con toda la rapidez posible apenas le divisan, pues aunque atacan y persiguen a todos los demás halcones, no se atreven con este; saben que las desprecia y que si le aco. metiesen se lanzaria sobre ellas desde las alturas para des. trozarlas inialiblemente.

Por mi propia observacion solo conozco un ave que ata Tomo III ca con buen éxito s. la rapaz y que sicmpre la expulsa de su territorio; esta ave es la gaviota parásita. Aunque rapaz. a su vez, en extremo ágil y valerosa, todo halcon viajero la iniunde ternor por su cria, y por eso le acomete con la ma. yor saña tan luego como le divisa desde léjos. Con mucho gusto he presenciado el hecho en la peninsula de los samo. yedos. El halcon se dirigia en linea recta hácia su nido, utue evidentemente estaba léjos, cuando llanú la atencion de una gaviota parásita; esta se remonto al punto lanzando furiosos

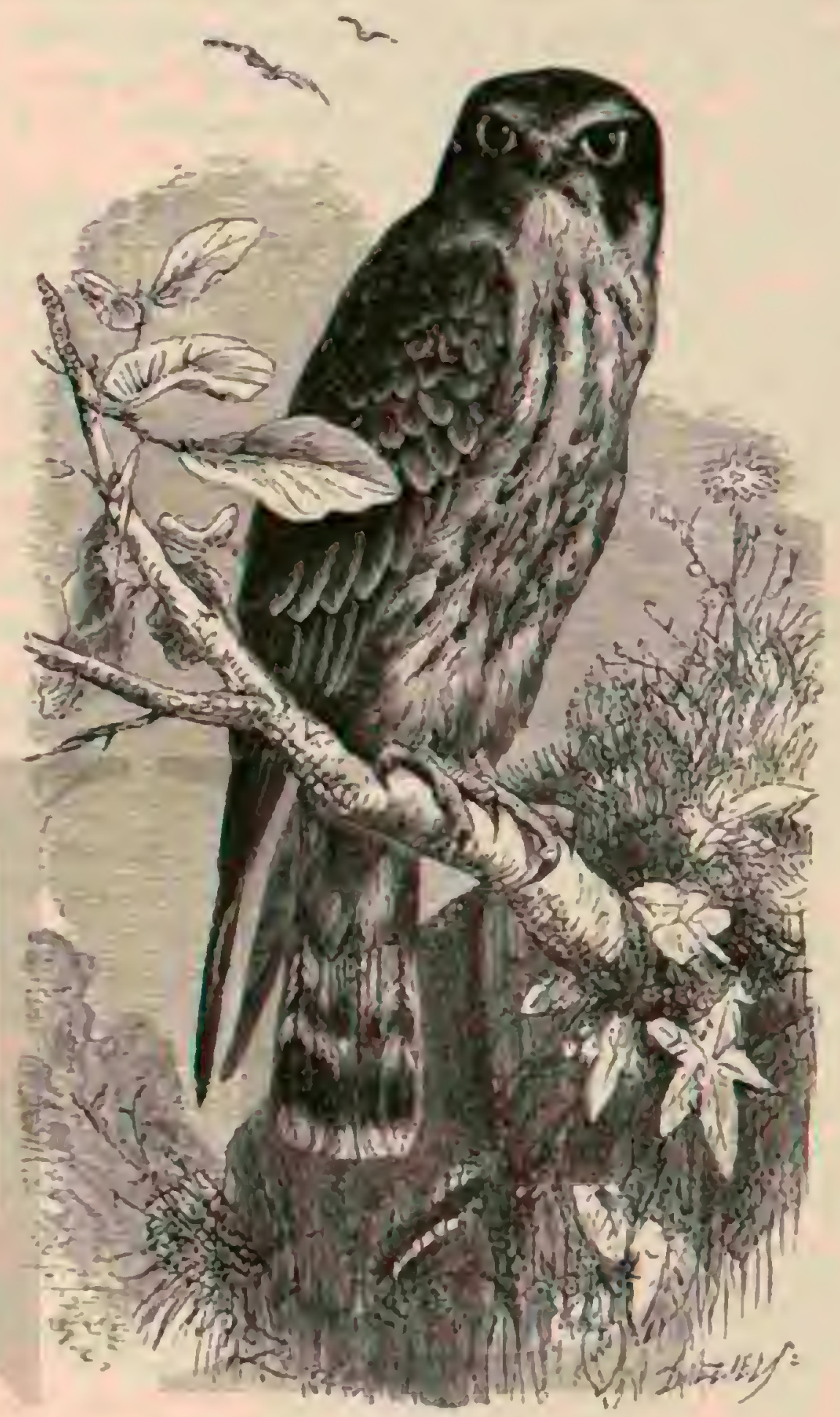

Fig: 136. - EL ABtruciso cons:

gritos; en poco tienıpo dió alcance á la rapaza, y molestóla continuamente desde entonces con los mas violentos ata. ques. Graciosa y ligera, y desplegando una agilidad inimita. ble, elevóse de continuo solve el adversario, acometiéndole desde arriba. Eil halcon hizo todo lo que pudo para evitar los ataques sin defenderse, y continuó su marcha tan rápida. mente como le fué posible, perseguido siempre por la infatigable gaviota Asi pasaron las dos aves sobre la liundra hasta que se perdieron de vista

Cuando el halcon viajero coge una presa, suele matarla ja en el aire; si es demasiado pesada para llevársela, si se trata por ejemplo. de una ortega ó de una oca salvaje, cógese a ella, la fauga y la rinde hasta que cae á tierr. Persigue a su victina con una rapidez tal, que la vista no le puede seguir; se oje un ruido, se re una cosa que cae por los aires, pero no se puede decir lo que es sin duda por la impetuosidad de su ataque es por lo que no le conviene al halcon acome. ler $a$ las ares posadas ó que se hallen en tierm, porque se expone a matarse al chocar contra un objcto resistente. Se citan ejemplos de halcones que se estrellaron contra las ra. mas de los árboles: Pallas asegura tambien que se ahogan á 
menudo al perseguir a los patos, pues la celeridad adquirida es tal, que se hunden is gran profundidad en el agua y no pueden volver i la superficic. Rara vez se le escapa al hal. con su presa; la coge con una facilidad asombrosa.

Como conoce muy bien la agilidad de su ruelo, muestrase muchas reces en extremo atrevido en sus cacerias, daindose hasta el caso de robar al cazador el ave que hirio al vuelo, y esto $\{$ sus propios ojos $y$ antes que la victima caiga en tierra; pero í veces paga su imprudencia con la vida.

Una vez cogida la traslada a un sitio descubierto para comérsela, y si es demasiado grande la devora en el sitio mismo; comienza siempre por desplumarla, al menos en parte; y cuando son pajarillos se los traga con las entrañas, cosa que no hace con las aves de mayor tamaño.

El halcon viajero que anida en Alemania prefiere las cavidades de las rocas mas inaccesibles; pero en caso de necesidad elige los altos árboles del bosque. Parece que solo muy raras veces construye él mismo su nido; utilizase mas bien de los de otras rapaces, como por ejemplo el del águila marina y el del milano, y tambien ocupa los que las cornejas abandonan de grado 6 por fuerza Agrádale soure todo fijar su domicilio en medio de una colonia de garzas reales y has. ta ocupa uno de sus nidos, pues los polluelos que encuentra le sirven de alimento, sin mas trabajo que cogerlos alli, y con ellos puede nutrir tambien á su progenie. Tres nidos hallados en la Tundra nos ofrecieron la prueba de que la maz crec supérfluo llevar material de construccion; faltảndole aqui del todo las rocas, conténtinse con moles de tierra salientes y escabrosas, al menos por un lado, y en caso de necesidad bás. tale una sola piedra ó una gran masa de barro lavado en parte por la lluria. Ia hembra pone entonces los huevos en tiêrta sitn mas preparativos. Los tres nidos encontrados por nosoiros se hallaban en linderos allos de valles 6 en depresiones del suelo; solo vimos uno en cicrto sitio que por un lado presentaba una piedra bastante alta, dificil de escalar; mientras que por el otm se podia llegar fúcimente al nido, pues el terreno era llano. Hubiérase dicho que la rapaz eligió aquel sitio'solo para salvar las apariencias, haciendo creet que la posicion era inexpuguable. Alli mismo, acurrucados junto d la picdra, y enteramente al aite libre vimos en julio y agosto los peque nos cubiertos de plumon, y al parecer tan descuidados como si en la Tundra no hubiese zorros polares ni lobos. En Ale mania no se encuentra hasta abril ó mayo, y á reces junio, In puesta completa, que consiste en tres huevos 6 cuando mas cuatro, de forma redondeada y color amarillo rojizo con mancins pardas I a hembra los cubre sola mientras el macho la divierte del modo ya descriio. Los padres profesan el mayor carino a su progenie é intentan ahuyentar con bruscos atrques á todo enemigo que se acerca al nido. Así lo obser vamos, por lo menos en la Iundra y en Siberia: á larga dis. tancia llamaron los halcónes viajeros nuestra atencion desde el nido; vimosles dirigirse à nuestro encuentro gritando rui dosamente y describiendo circulos en el aire; bajaban \& medida que $n$ os accrcábamos al nido, y nos atacaron repetidas veces. El especí́culo que ofrecen los halcones en tales casos ofrece mucho atractivo, pues lucen todas sus habilidades en el vuelo. Entonces se les ve trazar sus circulos a uni altura a que no llega el tiro; despues recogen sus alas, precipitanse hícia el suclo, pasan a pocos metros del observador, y llegados a cicrto punto hacen uso de sus rectrices para elevarse sin aletaros hasta donde la fuerza del empuje los impulsa luego vuelien á remontarse í la altura anterior para describir otra vez sus circulos y atacarnos de nuevo. Sin embargo, no osan hacerlo forma?mente ni se acercan nunca tanto como los azores y gaviotas en iguales casos.

Alimentan álos polluelos al principio con came medio di. gerida, la cual expelen del buche; mas tarde les llevan en abundancia aves de las mas diferentes; y despues de salir del nido los instruyen en todo lo necesario, sin abandonarlos hasta que aprenden perfectamente. $\$$ En $1 \$_{72}$, me escribe Liebe, vi una pareja de halcones viajeros que trazaba sus círculos al rededor de un bosquecillo en el valle del Elster, y así el macho como la hembra fueron pronto el terror de todas las cormejas del contorno. Cuando me ocupaba en mis trabajos geométricos visité casi diariamente la region y vi al cabo de ocho dias que uno de los halcones iba todas las noches al bosquecillo; posábase por espacio de un cuarto de liora en un árbol, y pasaba despues á intervalos por encima del valle. Mi suposicion de que la hembra habria muerto no se confirmó, pues al poco tiempo fué con el macho al bosquecillo \& la hora acostumbrada, entre seis y siete de la tarde, acompariada de dos hijuelos tan torpes aun que al posarse en una rama no encontraban pronto el equilibrio. Al poco tiempo remontáronse los adultos para retozar, vo. lando contra el viento, espectáculo admirable que ya labia visto una rez en Noruega. El macho se alejó pronto, mien. tras que la hembra continuó sus magnificas evolucioncs, acercándose mas y mas á los hijuelos, hasta que al fin obligó a uno a dejar la rama precipitándose sobre el y tocándole, nó sé si con el ala ó el pecho, pues mi escondite estaba de. masiado léjus y mis anteojos no alcanzaban. De grado ó por fuerza, el hijuelo tenia que volar é imitaba con bastante torpéza los inovinientos de la madre. Poco despues, la hembra procedió del mismo modo con el otro haciéndole volar como al prinicto. Despues de reposar breve rato, obiigó á los dos pequenos a lanzarse en el espacio; dirigióse diagonalmente contra el viento, cruzó cierta distancia por el aire, precijptóse casi verticalmente hácia abajo describiendo un arco magnifico, volvió á elevarse en linea diagonal y ejecutó en fin todas aquellas habilidades que forman parte de sus ejer. cícios aéreos. Los pequeños, intentando acompañar al la madre, imitaron con bastante torpeza sus evoluciones. Al poco se presentó el macho con una corneja en las garras; pero la familia, molestada sin duda por algun objeto, se alejó.

En nuestros paises es peligrosa la presencia del lialcon co. mun, porque ocasiona destrozos considerables. Si se contentase con matar lo que necesita para su alimento propio, se podria en rigor dejarle en paz; pero la cuestion es que man. tiene á toda una bandada de parásitos. Es un hecho curioso que todos los halcones nobles abandonan su presa cuando se les acomete, y esto lo saben muy bien las rapaces que van á caza de restos.

Estas aves perezosas é inhábiles, dice Naumann, están posadas en los postes y puntos cuiminantes del terreno; observan al halcon, y al ver que lleva una presa, persiguenle y se la quitan. Cuando el halcon ve llegar a las hambrientas rapaces, y por mas que sea generalmente muy valeroso y atrevido, abandona su botin, y repitiendo el griro kiah, frials, remóntase por los aires. Eil mismo milano negro (hyalroictinio atra), al que ahuyenta una gallina que defiende a sus polluclos, se atreve a robarle su presa. lin el noroeste de Africa viven á costa del halcon los milanos parásitos: yo ví cierto dia un viajero que en pocos mimutos se apoderó de tres ánades, y hubo de abandonarlas á sus atrevidos perse. guidores, consiguiendo solo alejarse con la cuasta.

Se han hecho esfuerzos para explicar este modo de jroce. der del halcon viajero y al efecto se tuvieron en cuenta varias suposiciones. Segun el parecer de unos, el halcon abandona su presa a esos parásitos para evitar que la contienda llame inutilmente la atencion general; y segun opinan otros, se cree demasiado débil frente à antos enemigos. Riesenthal, que apoya esta última opginion, asegura haber visto que los 
parásitos no osaban nunca atacar á un halcon viajero mien tras volaba con su presa, al paso que lo hacian cuando, po sado en tierra, comenzaba da desgarrar su victima. Yo, por mi jarte, solo puedo decir que no conozco la razon del proceder de un ave tan fuerte $y$ soberbia: pero he visto muy á menudo, al contrario de Riesenthal, cómo el ave volanco con su presa, arrojábala á los mendigos que la perseguian. Si se me pide una explicacion del hecho, deberé suponer como probable que el proceder de sus congéneres parásitos le molesta demasiado y que por esta razon, conociendo ademas su gran agilidad fara robar, les cede la presa fäcilmente adquirida, en la seguridad de obtener pronto otra. A decir verdad, esto haria suponer cierto orgullo por parte del halcon; seria un acto comparable al de un hombre que se cree superior a sus semejantes y da con desden la limosna à un mendigo. Tal suposicion no estaria sin embargo encontra. diccion con el carácter dominante del halcon viajero.

No se puede negar que esia ave es perjudicial: hasta se le niega toda utilidad, y asi los cazadores como los dueños de palomares ven en ella su peor enemigo, juzgando que todos los medios son buenos para exterminarla. Sin embargo, no quisiern yo, ni tampoco los que han observado una vez á esıa ave nragnifica, que dejase de existir, porque es un adomo de nuestros bosques y campos. Fin ella se reune la fuerza $y$ la agilidad con el valor $y$ la energia; y asi posada como vo. lando cautiva la atencion del observador. Si quisiern reco. mendarla para que se la perdonasen sus fechorias, tendria por enemigo a todos los cazadores y aficionados á palomas, pero debo llamar la atencion de los primeros soure la cir cunstancia de que en Inglaterra se comienza a mirar este halcon con ojos nias favombles que antes. Taunbien alli los cazadores la perseguian, empleándose lodos los medios posibles jara exterminarla, desde la trampa de hicro colocada en el nido hasta la chora de acecho, deste la carabina liasta el lazo; y asi se consiguió ahuyentarla de algunos territorios de caza al menos durante la epoca del celo. Sin embargo, desde entances se observó una enfermedad epidénica en las perdices y los tetránidos y creyúse que este mal descono. cido hasta entonces, podria ser consecnencia del exterminio del halcon viajero. l'or la destruccion de este último se faci. litó á estas aves la lucha por la existencia; contáronse smu. chos individuos débiles que por lo regular eran las primeras victimas de la rapaz, y estos individuos produjeron por su aparcamiento una progenie mas raquitica todavia, predis. puesta a toda clase de enfermedades. Tomando en conside. racion estas circunstancias, algunos grandes propietarios de Inglaterra no persiguen ya al halcon viajero, esperando de esta medida, si no un aumento de caza, por lo menos mejores condiciones. Nada diré en pro ni en contra de esta opinion; pero creo que conrenória llamar la atencion de los cazadores sobre el hecho. En cuanto al daño que el halcon viajero causa à nuestros aficionados á palornas, esto es dis tinto: tienen razon por todos conceptos para odiar y perseguir á un uve ante la cual se ven tan débiles, hasta haber sido necesario, como sucedió en Berlin, pedir auxilio â las autoridades contra la rapnaz de los aires. No sé si se habrá accedido á la demanda; pero aunque asi fuese, los municipales no hubieran podido ahuyentar al halcon viajero. A este le ofrecen aun nuestros bosques y montañas un refugio seguro, yaunque se le exterminara aum, volveria a preseniarse entre nosotros por el norte.

CAUTIVIDAD. - Si se cuida bien el halcon peregrino puede vivir en pajarera varios años: pero es preciso darle carne fresca y en suficiente cantidad.

Yo conserve un halcon dunnte mas de un año, dice Naunann, y estaba en una gran jaula; en dos dias se comia แл zorto, y en uno tres corncjas; pero podia pasar mas de una semara sin tomar alimento alguno. Cogia á menudo seis gorriones á la vez, tres en cada garm; poninse derecho, les abria sucesivamente el crineo y dejábalos á un lado. Cost bale mucho trabajo dominar a una corneja o un buhn: cuan. do me veia llegar con una de estas úlimas aves viva, incli. nábase para comenzar la lucha, subiéndose á la percha mas alta. Apenas penetraba en la jaula el buho, echábase de es. paldas con las garms al aire, manteniéndose â la defensiva, y siluaba de cólera. El halcon acometia desde lo alto hasta que hallaba ocasion de coger a su victima por el cuello; de pie sobre el buho, aparaba las alas, lanzaba furiosamente su grito de triunfo, y abria a jicotazos la garganta de su enemi. ga. Tambien comia ratones; pero no tocaba a los topos ni a los hamsters.

En nuestros jardines zoologicos se alimenta el halcon viajero conares, en cuanto es posible; pero con preferencia, como a las otras ares de rapiña, con carne de caballo, y fácilmen. te se explica que no pueda conservarse mucho con tal ali. mento. La experiencia enseña que esta especie no debe estar sino con sus semejantes en una misma jaula, y aun asi no conviene poner mas que dos individuos, pues derora las iapaces pequeñas: mientras que las grandes le amenazan a su ve\% Sobre todo no se debe reunirla con un azor, porque este es mas fuerte y con seguridad le devomrá tarde 6 temprano.

\section{EL HALCON CHIQUERA-FALCO CHIQUERA}

CARACTERES-Fista especic es quiras la mas bella entre todos los halcones, y por lo unismo merece ser mencionada en esta obra; tiene la cabeza y la nuca de color rojo de orin, con mezcla de listas mas oscuras en el zallo de las plumas; el lomo de un gris ceniza oscuro, con visos de azul claro y fajas traswersales negras muy pronunciadas; el pliegue del ala de un amarillo de orin claro: in cola del mismo tintce, con ocho ó die fajas oscuras, siendo la terminal ancha y orillada de blanco; la garganta de este tiltimo color; la parte anterior del cuello $y$ del pecho de un rojo de orin pálido; los costados. el bajo vientre y las malgas de un amarillo rojizo claro, con fajas grises oscuras y muy unidas. Sobre el rjo llera una lista angosta y negra; los lados del cuello son del mismo tinte; el ojo pardo oscuro; el pico amarillo verdoso en la base y azul de cucmo en la punta; las paras de un annarillo narauja. EI macho tiene $\left(0^{n}, 29\right.$ de largo, por $00^{n}, 5 \mathrm{~S}$ de punta a punta de ala; la hembra $0^{\circ} .34 y^{\circ} 11^{\prime \prime}, 68$ respectivamenic; el ala plegada mide en el macho $61^{\circ}, 185$ y en la hembra $6^{\prime \prime}, 22 ;$ la cola $\left(1^{\prime \prime}, 81\right.$ en el primero y $0^{\circ}, 145 \mathrm{em}$ h segunda.

Algunos naturalistas distinguen al halcon chiquera ó halcon de cuello rojo del furwidi, considerándoios como especies independientes; pero es probable que tambien en este caso se podrón admitir las mismas observaciones que para las especies del halcon viajero en gemeral.

USOS, COSTUMBRES Y REGIMEN. - Segun misob. servaciones, este magnifico halcon no se cricuentrn sino al sur del $16^{*}$ de latitud norte, y solo se le ve en las palmeras duleb, cuyar soberbia copa descuella sobre las de los demás árboles, $y$ cuyas hojas, en forma de abanico, le ofrecen el sitio mas convenienic para formar su nido. Se puede tener la seguridad de encontrar ś esia ave donde cxiste una de dichas palmeras. Solo una vez vi al halcon chiçuera en un hosque de palmeras de boveda, cerca de Roseeres, siendo de advertir que á larga distancia de aguel punto no habia ninguna palmera du. leb. Heuglin hiro la misma observacion en el Africa central; - es probable que en la costa occidental no anide este halcon tampoco sino en las palmeras de anchas trujas. Uno de aque. 
llos árboles basta para que una pareja se encariñe con una localidad: desde alli emprenden su vuelo para posarse en la copa de un ásbol del pan, y se fijan en la rama mas alta, inspeccionando desde aquel observatorio todo su dominio. Si aparece una bandada de tiserinos, precipitase el ave rapaz. como una Recha, y rara vez deja de hacer una victima, pues su agilidad es extmordinaria, y excede á la de todos los demás halcones. Debajo de su nido encontré una vez el cadáver de un martinete (cyselus parius), y mas tarde vi dos halcones que perseguian. y acabaron por atrapar, á una de estas ares, las cuales figuran entre las de ruelo mas rápido. Las aves pequeñas, los pajaros, y sobre todo los tiserinos, parecen constituir el exclusivo alimento del hatcon de cuello rojo. No acomete \& los animales mayores que el. \& por lo menos, esto es lo que se deduce de la siguiente particularidad, que con frecuencia he observado. En el mismo árbol; y al lado del halcon, anida la paloma de Guinea (colusnba gainca), y yo he visto varias veces i las dos aves, que estando una junto d otra, parecian vivir en la mas perfecta inteligencia Jamás pude coger un nido de estos halcones, parque es imposible trepar à uma palnera duleb.

La rapidez $y$ agilidad aseguran f esta hermosa ave una vida feliz; pero tambien tiene sus enemigos: las rapaces de mayor talla le hacen la guerra, y una jrueba de ello tuve en cierta selva virgen, donde encontré los restos de un halcon chique. ra, consistentes en la cabeza.y las alas.

Segun las observaciones de Jerdon, esta ave se halla dise minada en sodas las Indias, desde el sur al ñorte. «Escasea no obstante, dice aquel naturalista, en los janajes montaño. sos, y prefiere los descubiertos a la vecindad de las casas y de los jardines. Con frecuencia se la ve posada en un árbol solitario que se eleva en medio de la llanura: parte desde alli rasando con increible rapider las breñas, 125 cercas y las orillas de los estanques; y de repente cae sobre una alondra, una oropéndola $\delta$ cualquiera otra ave. Caza en compañía de su hembra, y prefiere apoderarse de las pequeñas especies, tal como las alondras calandrinas, los pluviales y algunos roe dores de escaso tamaño.

- El halcon chiquera anida en los árboles altos; los lauevos, en número de cuatro, son de color pardo amarillento con manclıas pardas. Los hijuclos comienzan a volar á fines de marzo of principios de abril; los padres se muestran muy carinosos con ellos, y lanzando gritos penetrantes ahuyentan a las cornejas, á los milanos y a la misura águila, cuando intentan apoderarse de la cria.

CAUTIVIDAD. - Algunas veces se coge el halcon para enscintrle a cazar las rodornices y perdices, los minos y sobre todo los gálgulos, en cuyo ejercicio despliega la mayor perspicacia; el gálgulo trata de escapar, á cuyo cfecto vuela ubli. cuamente; dejase caer de pronto; avanza y busca refugio en la copa de un árbol. Sin embargo, no está seguro alli; el hal con le persigue de rama en rama y le ahuyenta, hasta que cansado ya, es presa de la infatigable rapaz. He conocido hal coneros que llegaron á conseguir que sus aves cazaran por bandadas.

\section{LOS AGUILUCHOS-HYPOTRIOR- CHIS}

CARACTERES. - Los aguiluchos 6 Jalcones arhoricolns, constituyen tambien un sub-género independiente, cuyas especies se caracterizan por tener el cuerpo pequeño y prolongado, $y$ alas relativamente largas y falciformes, que llegan hasta la extremidad de la cola ó sobresalen de ella. En mi concepto, csta are es un halcon tan caracterizado, que me parce inadmisible semejante separacion

\section{EL AGUILUCHO COMUN-HYPOTRIORCHIS} SUBBUTEO

C.ARACTERES. - El aguilucho comun (fig. 136) mide $0^{n}, 3$ r de largo por $0^{n}, 7^{8}$ de ala á ala; esta plegada tie. ne ()$^{\prime \prime}, 25$ y la cola $0^{\prime \prime}, 16$; la hembra mide unos $00^{m}, 0,4$ mas de largo, y $0 " 05$ a $0^{\circ}$, 08 mas de anchum de alas. El macho adulto tienc la parte superior del cuerpo de color azul ne. gro, la cabeza gris, y en la nuca una gran mancha blanquizca. Las rémiges y las rectrices son negras, y estas últimas, excepto las dos medias, presentan en sus barbas internas ocho manchas de un rojn de orin, reunidas en forma de fajas trasversales. La cara inferior del cuerpo es blanca ó de un blanco amarillento, con mancinas negras longitudinales; las nalgas, la rabadilla $y$ las cobijas inferiores de la cola, de un rojo de orin; el mostacho, muy marcado, es pardo regro; el ojo pardo oscuro, rodeado de un circulo desnudo del mismo color; la cera y las patas amarillas; el pico azul claro en la base, y del mismo tinte, mas oscuro, cn la punta.

En los pequeños lás plumas del lomo son de un gris azul oscuro, orilladas de amarillo de orin; la mancha de la nuca es mayor y mas amarillenta que en los adultos; la cara inferior del cucrpo de un blanco amarillento, manchada longitudinalmente de negro; las cobijas inferiores de la cola, las plumas del bajo vientre $y$ las nalgas amarillentas, con los tallos négruzcos.

En las islas griegas el aguilucho comun estå representado por otro halcon que se le asemeja mucho, aunque es muy distinto: me refiero at la especie llamada habcon de Leonor (Phaleo Eleororo). Esta are es una quinta parte mas grande y de color mas oscuro que el aguilucho comun; y en las regiones inferiores, cuyo fondo es pardo claro, tiene varias manchas negras.

DISTRIBUCION GFOGRÁFICA.-El aguilucho comun, superior á todos los halcones por la rapidez del vuelo, anida en Europa, desde la Escandinavia, el sur de Finlandia y el norte de Rusia, hasta Grecia y España; tambien habita toda el Asia central hasta el Ural y el Amur; pero escasea hácia el mediodia; hasta ahora no lo han visto anidar en Italia; en Grecia y en España se encuentra solo aislado durante el verano; y asi vemos que los linites del territorio donde esta especie anida solo excepcionalmente pasan de los Balkanes, de los Alpes y de los Pirineos.

Rara vez prolonga sus emigraciones hasta el Africa; pero en cambio es bastante comun todos los inviernos en las In. dias; segun Eversmann, aparece muy numeroso en las estepas recinas del Ural.

USOS, COSTUMBRES Y REGIMEN.- Ei aguilucho habita en nuestros paises los bosques poco espesos $y$ no hace mas que atravesar las grandes selvas.

No solo evita estos bosques, sino tambien las montañas, ó por lo menos las visita muy raras veces, sin que pueda de. cirse por eso en general que abunda $\delta$ escasea. İn las llanuras del norte de Alemania se la encuentra con regularidad, sobre todo en los parajes donde hay inuchas colinas: pero siempre en escaso numero; de modo que el nido de una pareja suele estar separado del de otra muchos kilómctros. En Alemania se presenta en el mes de abril, y vuelse á marchar con regularidad en setiembre ú octubre.

Por su manera de proceder, el aguilucho comun difiere bastante de otros halcones.

«Esta rapaz, dice mi padre, es un are en extremo alegre, atrevida y ágil, que por la rapider de su vuelo puede com petir con cualquier otra; aseméjase mucho al de las golon. drinas, pues asi como estas, lleva casi siempre sus alas en forma de hoz y exicude muy poco la cola, pareciéndose en 
un todo por su aspecto al cipsélido de los muros. Cuando abandona un śrbol franquea í menudo un buen trecho, tres. cientos \& cuatrociertos pasos, sin mover una sola vez las alas; y no lentamente, como los buzardos ó los cernicalos, sino con notable rapider. Cuando se acerca demasiado a tierra, lo cual le sucede siempre al cruzar de ese modo los aires, algunos aletazos le bastan para remontarse de nuevo á las alturas. De esta manera continía su magnifico vuelo, y á poco desaparece del horizonte. Causa verdadero asombro ver al aguilucho perscguir as un ave: disparado como una fecha lánzase en pos de la golondrina, que puede darse por perdida si la rapaz la persigue en camıo raso. A poca distancia abservamos una vez el ataque de un macho adulto: este habia ganado la altura d su presa, un ave pequeña, to mando el impulso necesario para el ataque por medio de un alctazo; despues recogió las alas, y precipitándose desde una elevacion de diez metros en direccion diagonal, bastóle un momento para apoderarse de su víctima. Un pico verde que en aquel instante pasó por debajo del halcon, cspantóse de tal modo, que lanzando agudos gritos fué á ocultarse presuroso a la espesura ccrcana. En tales cacerias, la rapaz, ol. vida todo temor al hombre, persigue sin reparo á las aves, pencira á veces en las casas, y hasta en un coche en movi. miento, cuando la presa busca alli su salvacion. En su vuelo, cjecuta las mas bonitas evoluciones con la mayor facilidad; raras reces se posa en tierra; prefiere quedarse en los árbo. les; pero lo mismo devora su presa en una parte que en otra.

El macho y la hembra son muy fieles entre si, y emigran juntos en el otoño; cazan de concierto; pero llegan át tenes cierta envidia uno de otro que los desune por algun tiempo. $\varangle$ Dos agtsiluchos, cuenta mi padre, cazaban en companiin; uno atrapó una golondrina, dejóla caer, y volvió á cogerla casi en el mismo momento en que llegaba su compañero. Este reclamó su parte de presa; el otro rehuso; diéronse al. gunos picotazos; $y$ habiendo caido á tierra, apoderóse el vencedor de la golondrina, y huyó a vuelo tendido, antes que su conirario se recobrase de su sorpresa. En estas con. tiendas sucedie a menudo que el ave prisionera encuentra oportunidad de escapar. A pesar de tales discordias conyu. gales, macho y hemlora se conservan lieles uno á otro; están siempre juntos y esfuéranse por distraerse mutuamente.

El grito del aguilucho es penetrante, aunque no desagra. dable: se puede expresar por gacth, gaeth, gacth; en el periodo del celo se convierte en gick.

El aguilucho comun es tímido y receloso; no se posa para dormir hasta que lia cerrado la noche, y evita con cuidado la presencia del hombre; todo en su conducta denota una gran inteligencia.

Por lo que dice Naumann, el aguilucho es el terror de las alondras, mas ro perdona tampoco a las otras aves, y es peligroso hasta para la ligera golondrina. hlas temerarias golonirinas, escribe aquel naturalista, que siguen de ordinario à las rapaces, y las molestan con sus gritos burlones, temen muchisino al aguilucho y emprenden la fuga apenas lo divisan. Yo he visto varias reces á una de estas rapaces caer sobre una bandada de aquellas aves, y espantarlas de tal morio, que muclas caian a ticrra como muertas, siéndome fícil cogerlas: permanecian mucho tiempo en mi mano antes de atreverse á volas de nuevo.

Ylas alondras no temen menos á su enemigo; apenas le ven se refugian al lado del hombre; corren entre las piernas de los campesinos y de los ciballos, y es tal su terror que se dejan coger con la mano. Comunmente vuela el aguilucho rasando el suelo: cuando las alondras le divisan i lo léjos, elévanse rápidamente å una altura à que no puede seguirlas
In vista, y una vez alli, dejan oir su cancion, porque saben que cstán seguras. El aguilucho no puede coger su presa sino de arriba abajo, y nunca se atreve á remontarse á scmejantc altura. Las golondrinas, por su parte, lanzan agudos gritos al divisar á su enemigo; recógese la bandada y se eleva por los aires. El aguilucho persigue à las que se quedan aisladas cerca de la tierra, y suele cogerlas siempre despues de cuatro ó seis tentativas; si se le escapan, se cansa y se aleja.y

Snell, observador concienzudo y muy distinguido, cree que

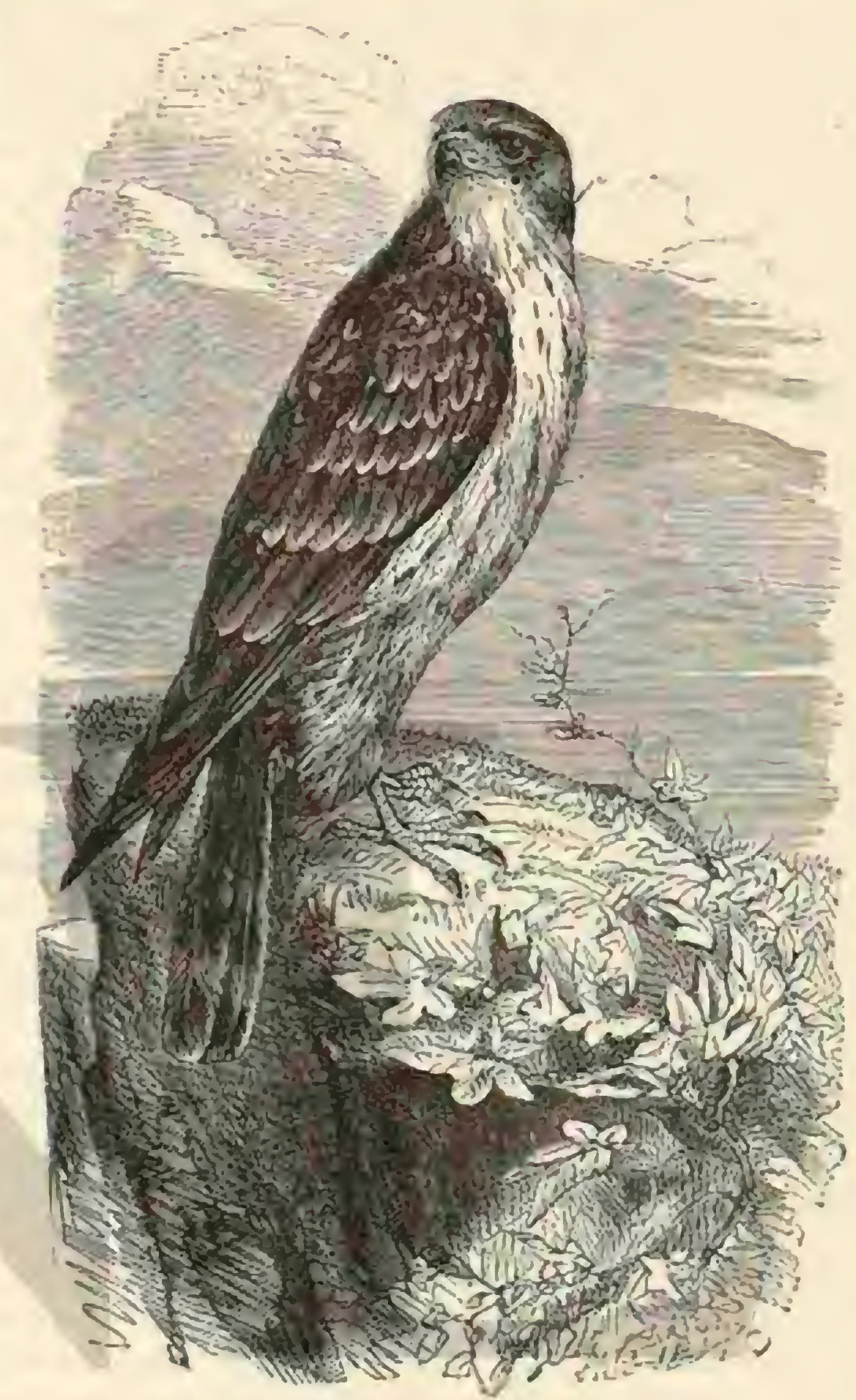

Fig. 137.-T.L IHACON ENANO

el aguilucho no caza sino las golondrinas de ventana, pero que no puede apoderarse de las de chimenea 6 rústicas. " He observado bien, dice, cómo se conducen estas aves; apenas se deja ver la rapar, todas emprenden la fuga; pero las de ventana se elevan mucho mas por los aires, formando un grupo; solo las mas atrevidas se destacan de 61 , y hacen ademan de acometer á su enemigo; pero siempre con mucha prudencia y desplegando la mayor rapidez"

Segun las observaciones modernas, debo declararme partidario de la opinion de Snell. Tambien yo he visto en los úl. timos años golondrinas de chimenea persiguiendo al aguilucho, y lo mismo me escriben Lugenio de Homejer y W. de Reichenau. En el periodo de la enigracion del otoño, me refiere el último, vi en la quinta de Litzelnau, situada en las montaủas de la Baviera alta, à la sazon propiedad mia, una docena de mirlos que pasaron rápidamente a poca altura del suelo por debajo de un plantel de árboles frutales: esto me llamró la atencion, y buscando la causa del espanto de aquellas ares, descubri en $\mathrm{cl}$ aire un aguilucho comun que al poco rato se precipitó hácia la tierra. Estorbado por las 
ramas extendidas de los árboles se vió obligado â suspender su descenso y se puso á revolotear sobre el árbol; pero divisándolo en aquel momento las golondrinas de chimenea que anidaban en la casa, se precipitaron al punto sobre el hal. con, Lanzando clamorosos gritos, y seguidas de sus hijuelos formando un grupo de unas veinte Azotada continuamente la rapaz por las puntas de las alas de sus pequeños adversa. rios y casi aturdida por los gritos de estos, no solo desistió de su caza sino que retrocedí́, posándose en una rama baja de un peral de unos scis metros de altura que se hallaba cerca de ni y en cuyo follaje se refugió. Cuando me vió, se remontó rolando rápidamente por encitina de los árboles frutales. Cuando enjrende sus escursiones de caza penetra no solo en los pueblos sina tambien en las ciudades pasando a veces por las callés a poca altura del suelo, para espantar á las golondrinas; si coge una de estas se retira; si no logra su objeto por sorpresa, se vile de su incomparable rapidez. Scidensacher vió ciertas golondrinas perseguidas por el halcon ocultarse en su terror en un arbusto, escapandose asi de su enenigo. Este desistió en apariencia de lá persecucion, trazó sus circulos sobre el arbusto, elevóse, mass y mas, y se alejó al fin á alguna distancia para describir de nuevo sus espirales. Pero no bien abandonaron $\mathrm{cl}$ arbusto las golondrinas, reanimadás ya á causa de su ausencia, cuando el aguilúcho se precipitó de nuevo entre ellas. Su caza de golondri. nas ófrece un espectículo magníico. Regularmente se reunen los individuos que forman una pareja, y mieniras unu pro. cura remontarse mas que las golondrinas, el otro permance debajo de estas; si bien alternan ambos en este proceder durante la caza y apelan a artíicios tan sorprendentes como los de las espantadas golondrinas. Algunas veces inmolan tantas de lestas aves, que se reconoce maxcadamente la disminucion; pro los destrozos que causan entre ellas no son sin duda tan grandes como los que ocasionan en las alon dras.

Miontras que las golondrinas tienen al aguilucho por el mayor enemigo, los cidsclidos de los muros no parecen ha. cer ningun aprecio de éL \& $\mathrm{E}$ n un distrito de la Prusia occjdental, dice Riesenthal cu sus lies de rupina de Alrmania, libro excelente dedicado a los colzadores y d los naturalistas, anidaba una pareja del aguiluchó comun en las inmediaciones de los nidos del cipsélido de los muros, reuniéndose por lo tanio alli los voladores inas rápidos y agiles. Los haicones no molestaban cn nada á las golondrinas, que muy cerca de su nido entraban y salian en sus agujeros situados en viejos

pinos. Solo alguna vez veiase al aguilucho perseguir á una de estas avecillas negras, y cuando le ganaba la delantera, como sucedia siempre, linitábase á cantar victoria con su alegre kirck kirck kirck. lis muy propio del carácter de los cipséli. dos no dejarse molestar por tal vecindad, y por otra pane esta presa no es siempre la mas facil para el halcon, aunque está probado quue tambien puede atrapar â esas inpetuosas golondrinas.

Es la única ave de rapina, dice Cloger, que ha cogido mas de uno de los rápidos cipsélidos de los muros. Altum asegura haberle visto atrapar una vez una de estas golon. drinas.

Pácilmente se comprenderá que el aguilucho no se limita á dar caza a las golondrinas de chimenca y rústicas, á los cipsélidos de los muros y a las alondras campestres; tambien persigue á la especie de moño, $y$ en el mediodia de Rusia, asi como en las estepas, a las alondras de T'ariaria, de alas blancas, a las de Siberia, á las calandrias, $y$ a todas las espe. cies de la familia. No se conicnta tampoco con una presa tan pequeña; apodérase igualmente de aves del iamano de la co. dorniz y de la tórtola, y ataca à las perdices y grullas. Todos cuantos observaron a esta rapaz duranic el invierno, dicen que se presenta con las codornices y no se aleja hasta que estas aves se van. Sanchse encontró cierta mañana de verano, despues de una copiosa lluvia, un macho jóven que habia cogido una tórtola; pero estaba tan mojado que no pudo re. montarse y fué cogido. El gran montero de Meyerinck, ob. servador tan concienzudo como prácrico, me dice que lia visto repetidas veces a esa rapaz atacar a las perdicés. "Yo he observado á menudo, dice, cómo perseguia en otono á las perdices; en setiembre de $18 ; 6$ maté dos de estas aves de una bandada, y mientras miraba para ver qué direccion seguian las demis, apareció súbitamente un aguilucho, que atacando dos veces a las perdices, aunque en vano, obligólas al fin a refugiarse en un nidal. Continuando mi cacería, fije: al mismo tiempo la vista en el halcon, $y$ como el coche que the conducia levantase casualmente otra unnaada de perdices, estas ayes jasaron bastante cerca de ui, pero de tal modo que no jide tirar. Entonces precipitóse el halcon oim vez desde bastante altura sobre la cara para probar suerte; pero acerté f matarle de un tiro a gran distancis. De esta y otras repetidas obsermaciones resulta que el aguilucho caza tambien perdices. b Itsta uiltima suposicion no es quizás exacta del rodo, pues teneinos infornes por los cuales se prueba que la valerosa y atrevida rapaz molesta tambien for pura insolencia il otras aves que evidentemente no puede vencer. \& El aguilicho comun, dice el profesor Nordmam, se complace al parecer en perseguir aves mucho mayores, aunque no puede causarlas daño; lo mas que lace es molestarlas : las grullas señoritas son principalmente blanco de su malicia. Iin Crimea observé una parcja de estos halcones que por pura insolencia atacaron á una bandada de esas aves cuando retozaban alegremente; dirigiéronse contra una y oira, pero harto se reconocia que lo hacian por broma.

Esto se confirma por una observacion de Ginger, quien dice que támbien atraca á las ardillas. Si el informe es exacto, debel suponerse que tambien en este caso la insolencia es el móril del halcon, pues para él serian demasiado fuertes esos animales Yo creo que por igual motivo se complace en estantar $\{$ una bandada de perdices, pues dudo que pueda matarlàs cuando son adulas. Como quien que sea, obsérmse que siempre prefiere dar caya á las arecillas. Pocas veces coge un raton, pues asi como el halcon viajero, no puede atrapar su presa en tierra. En cambio coge unuy bien los in. sectos al vuelo, sobre todo las langostas, y hasta las hormigas cuando se elevan por el aire. Se lian matado varics indivi. duos cuyos buches contenian solamente insectos. Las observaciones de mi padre prueban que recoge los cscarabajos con el pico y no con las garras. UUn macho persiguió as presen. cin nuestra un pelotero, i la hora del crepuisculo vespertino, $\checkmark$ con tal afan, que se acercó a veinte metros de distancia de nosotros, revoloteando como un chotacabras; pero la corriente del aire producida por el impetu del aguilucho desvió al escrabajo de su camino, de modo que el halcon cerró en vano el pico cuando trató de cogerle; la mpaz. revoloteaba al rededor del escarabajo, mas este se apartó casualmente á un lado, y el ave se vió al fin obligada í desistir de su persecucion. Con esto se reconoció clarameme que la rapaz ca. rece de las cualidades necesarias para coger insectos, es decir, de una boca grande y un ruclo que no, produza fucrte corsriente de aire: a un chotacabras no se le hubiera escapado tan ficilmente el escarabajo.s Como el aguilucho no encuentra el alinento con la abuncancia que exige la voracidad de sus hijuelos hasta los uiltimos meses de primavera, of los pri. meros de rerano, que es cuando abandonan el nido las aves pequeñas, no empieza antes de medindos de mayo, 6 con mas frecuencia hasta fines de julio, la construccion del nido. 
Por lo regular le fabrica el írboles, sobre todo en la monta. na. $y$ tambien se utiliza de las rocas; las lienbras que se hallan en la estepa ponen sin duda en el suelo. Fin el primer caso, el aguilucho suele buscar un nido de corneja abando. nado, que le sirve de base; pero tambien sabe hacer uno con ramaje seco, tapizado interiormente con pelos, cerdas y mus. go. Tos cuatro $\delta$ cinco huevos que la hembra pone tienen una forma longitudinal, rara vez redondeada, y miden $0^{m}, 0,0$ $\left\{0^{m}, 0\left\{j\right.\right.$ de largo, por $\left.1^{m}, 0\right\} 2$ \& $\left.1^{*}, 0\right\} 3$ de ancho; el color predominante es ulanquizco ó rojizo, en el cual se destacan unas manchas muy finas algo marcidas de color rojizo ama. rillo, mas 6 menos numerosas, cubiertas por otras mas espaciadas de un tinte pardusco rojo; estas manchas se acumulan á veces de tal modo que los huevos parecen de un color rojo ladrillo ó pardo gris. Difieren de los huevos del cernicalo por su inayor tamaño, asi como por tener la cáscara mas dura y manos brillante. La hembra los cubre por espacio de tres sêmanas, cuidandose el macho de alimentarla.

aCuando ese llega con un ave ó escarabajo á la inmedia. cion del nido, dice mi padre, la hembra deja oir su voz y vuela al encuentro del macho, devorando despues la presa en el nido. 5 Si al principio del periodo del celo se mata al macho, la hembra sale en seguida para aparearse con otro, y por lo regular consigue su fin á los primeros dias. Stevenson nos habla de una hembra que no llegó á criar hasta despues de haber perdido tres veces su macho, viéndose obligada al fin á unirse con uno que no habia llegado á la edad adulta. Los padres profesan gran cariño sa su progenie: no la abandonan nunca; y no solo defienden cl nido contra todo enemigo, sino que osan atacar al hombre cuando este irata de robarle, acercindose $\dot{a}$ un metro de distancia de tan poderoso enemigo. «Cierto dia, dice Naumann, vimos el polluclo de una cria atrasada, que antes de poder volar habia caido del nido y es. taba posadio al pié de un árbol; los padres le nutrian alli, ! no dejaron de llevarle alimento despues que le hubimos puesto varias veces en el nido, aunque en vano. Pór los datos siguientes se reconoce cuínto es el carino que los padres pro. fusan á sus hijuelos. Cuando Briggs subió a un nido de agui lucho para apoderarse de la cria, nacho $y$ hembra le recibie. ron por lo pronto á gritos, atacándole despues de la manera indicada. Al tocar en licrra, el cazador resolvió matar á los adultos, y al efecto, colocando a su lado á los polluelos, pre paróse á tirar. Apenas oyeron los padres el grito de su pro. genie, precipitáronse de nuevo para atacar otra vez al cazador; sero hicićronlo desde una altura tan considerable y con una rapidez tan extraordinaria, nue Briggs no llegú a tirar. Cuan. do se molesta varias veces à los aguiluchos mientras anidan, obsérvasé que, asi como los cuervos, alimenian á su progenie con una asticia y cautcla singulares, sin exponterse of una muerte inevitable. Se presentan con el ave cogida en sus gar. ras, describen sus circulos, detiénense un momentó y dejan caer la presa sobre el nicjo. Si se maia a la hembra, el macho se cncarga de crinr á los hijuelos, y llevarles sin cansarse, desde la mañana hasta la noche, abundante alimento. Los pequeños aguiluchos reciben al principio casi exclusivamente insectos, sobre todo langostas y uscarabajos blandos, y mas tarde aves pequeñas de diversas especies, en particular alon. dras y golondinas. Al principio no saben aun bien cómo ar. reglarse con esta presa, y la dejan caer á menudo desde los altos arboles donde comen; pero mas tarde la destrozan y devoran tan diestra como rápidamenic. Cuando tienen bas. tante fucrza para salir del nido ragan por los alrededores, ejercitancio sus alas; despues de volar un mto reposan en el borde del nido 6 en los árboles vecinos, y tambien empiezan a perseguir a las langostas $\delta$ las avecilias; pero los padres les alimentan aun mucho tiempo Con su penetrante vista obser- van desde el árbol los actos de sus padres, y por los gritos de alegria de estos, sonidos que conocen muy bien, comprenden que han sido afortunados en su caza: entonces contestan al punto, elévanse por el aire y vuclan al encuentro de los adul. tos. Cuando el que lleva la presa se toca ya con el hijuclo. que antes se aproxima, $\operatorname{cog} c$ con el pico la victima que sus garras sujetan y alírgasela al pequeño aguilucho; este la toma primero con el pico y despues con las garras, para volar a! árbol conde la devorará. El macho suele acompañarle; pero pronto continua su caceria para buscar otra presa. Fsto dura algunas veces hasta cerca de la noche, pues cuando el dia comicnza a declinar despiertan los insectos, y entonces es fácil para los aguiluchos adultos coger caza pequeña; si los hijuelos están bastante adelantados en cl vuelo para poder seguir á sus padres á mas distancia, estos empiezan a ense. narles de la manera descrita ya en la introduccion de este capitulo, para prepararlos å la inciependencia.

Dejando oir sus gritos de llamada, los padres cruzan el aire, sicmpre seguidos de su progenie: su vuelo es al principio lento y sencillo; pero pronto comienzan da cjecutar toda clase de evoluciones; los hijuelos, torpes al principio, adquicren poco à poco una destreza que aumenta de dia en dia, y pronto llegan á coger rápidamente una presa con ayuda del macho $\delta$ de la hembra. Si uno de estos hace una victima, clévase sobre los hijuelos y la deja caer; los pequenos aguiluchos se precipitan gritando para cogerla; y el que lo consigue llévasela á la rama de un árbol para devorarla, perseguido a veces por sus hermanos. Si ninguno de los pequeños acierta á coger la presa, el adulto que vuela por debajo de su proge. nie se precipita sobre la víctima, cógela y se eleva á su vez sobre los pequentos para repetir la misma maniobra. La en. serianza dura de ocho á quince dias, y hasta tres semanas, hasta que los aguiluchos se laan ejercitado lo bastante para buscar su alimento diario. Mientras ranto llega el dia de retirarse hácia sus cuarteles de inviemo, y padres é lijos emprenden la marcha para volver separados en la primavera siguiente.

El aguilucho comun es un animal nocivo: Ienz calcula que uno solo extermina al ano 3,095 aves por lo menos.

CAUTIVIDAD. - En otro tiempo se adiestraba al agui. lucho para la caza, y aum hoy es el mas agradable de todos los falcónidos para conservarle cautivo. jJamás me agradó ave alguna como mi aguilucho, dice mi pacire: si jasaba por delante de la cuadra donde le tenia, gritaba antes de verme; acercábase a la pucrta y cogia el alimento que yo le daba. Al entrar en la cuadra, posibase sobre mi puño y gustábale que le acaricinse. Llevábale luego â mi cuarto; le ponia sobre la mesa, donde permanecia inmóvil; y lasta cn presencia de las personas desconocidas, comiase con mucla limpieza el pája. ro que le dábamos. Si le irritaba ó se queria quitarle su presa, amenazaba con el pico; pero nunca hirió a nadie. Cual. quicra que veia el aguilucho se encarinaba con el y no podia menos de acariciarle. Ninguno se arrepentirá de tener uno de estos séres; conoce á su amo, ajprecia sus bondades, y parece darle gracias por sus halagos.

No puedo menos de contirmar las palabras de mi padre, pues todos los aguiluchos que yo ture me recrearon en ex. tremo.

* Con lo que ha dicho Brehm padre sobre el aguilucho comun, añade Liebe a lo anterior, ha dado a conocer la opinion de todos los naturalistas que alguna vez se tomaron el trabajo de criar un aguilucho peryeño. Esta rapaz tiene un plunaje recio y limpio, mas que el de cualquicra otra ave de rapiña diurna, y tanto por csto como porque se amansa hasta el punto de perder en apariencia su carácter de carniccro, se puede ienerla cautiva. Si no fuese tan dificil conservarla en 
buena salud, seria mas propia para ello que ninguna otra especie de sus congéneres de la Europa central.

Cuando en la cria de un aguilucho pequeño se quiere menos la domesticacion completa que un gran desarsollo, no se le debesacar del nido hasta que el crecimiento de las alas pueda preservarle de las consecuencias de una caida, y tambien se le ha de car toda la libertad posible, alimentandole de aves pequeñas en parte desplumadas. Pero si se desea solo tener un are inolensiva para la habitacion, se le ha de

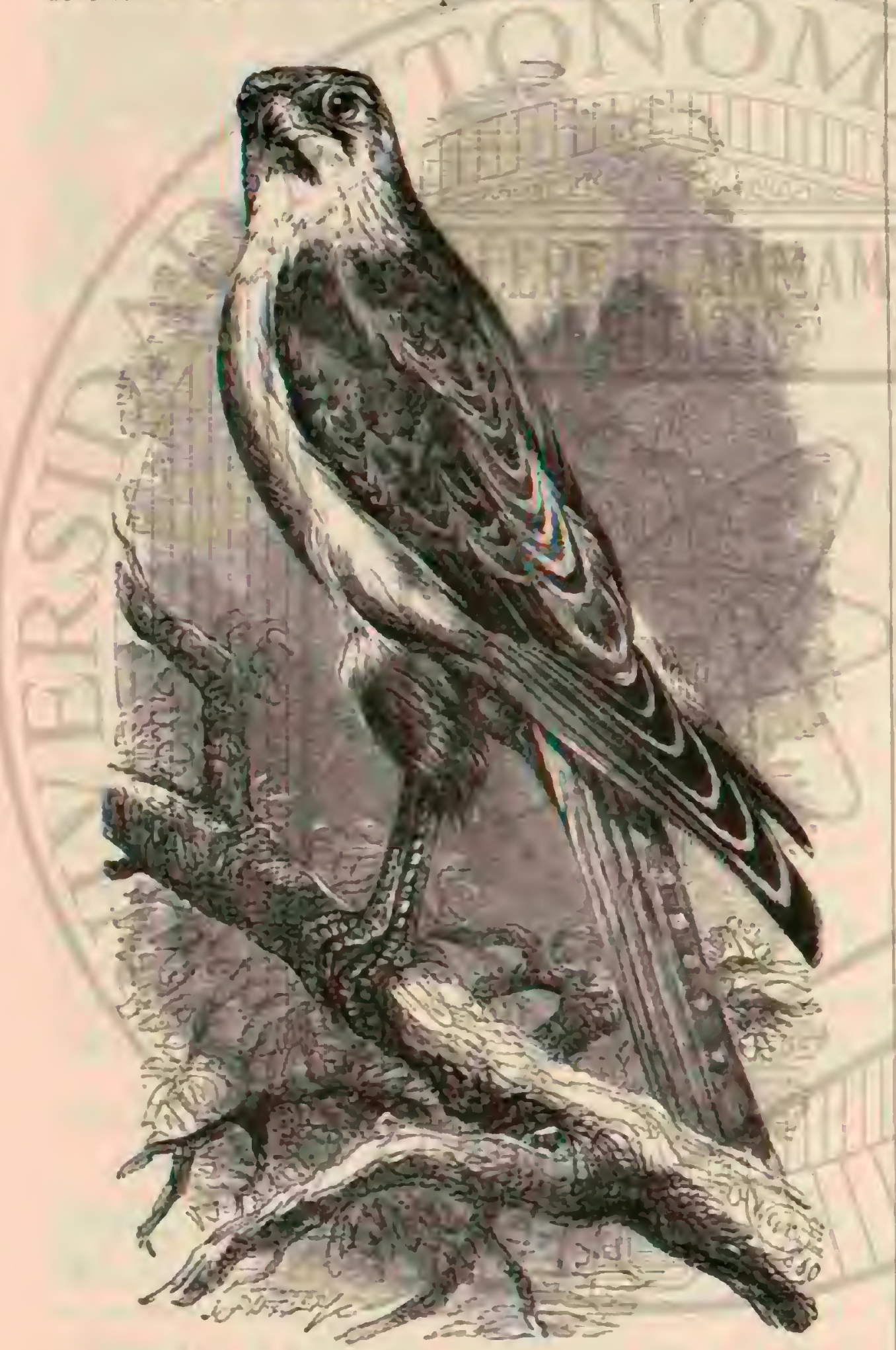

Fig. 13S.-2.1. VEXACILO DERICOR.

sacar mucho antes del nido, y precisamente esto hace dificil un buen desarrollo Su alimento diario, que se le debe dar tres veces, se compone de carne de vaca cortada en pedaci. tos, alternando con grillos, langostas y otros insectos, a los que se quitan antes las piemas, la cabeza y las alas; tambien come larvas de harina, y solo en caso de necesidad las de hormigas: necesita sobre todo huesos blandos machacados y plumitas. No conviene dar al aguilucho demasiado alimento, y se le ha de preservar de toda corriente de aire. A pesar del mayor cuidado, siempre enferman algunos individuos, sobre todo de los pulmones; pero otros en cambio prosperan muy bien, se robustecen y llegan á ser en extremo mansos y dóci. les. Para conservarlos en buena salud, y à fin deque no pierdan su facultad de volar, es menester dejarlos ejercitarse todos los dias en una gran habitacion, \& lo cual se les obliga, en caso de necesidad, colocíndolos sobre el puño y moviendo este rípidamente hácia abajo, sin temor de que hagan uso de sus garras. Se conducen siempre muy bien y no hieren nunca á su amo, porque saben distinguirle de las demás personas, $y$ acuden desde léjos a'su encuentro cuando tienen hambre 6 quieren que se les acaricic. Y'o he llevado algunas de estas aves, puestas sobre el puño, al jardin y á las reunio. nes, $y$ hasta de noche para presentarlas al pronunciar mis discursos, sin que nunca intentaran liuir aunque podian volar muy bien. Paseábanse bastante á inenudo, tanto de dia como de noche, en medio de las numerosas aves pequenas que yo tenia, y posábanse a veces sobre una jaula sin demostrar nunca las inclinaciones de rapaz. Debo advertir, no obstante, que cuando ya podian volar las alimentaba siempre en la mano con pedacitos de carne, sin permitir nunca que destrozaran ratones ni avecillas. Solo les daba los insectos enteros. Grotesco por demas es el aspecto que ofrecen estos rápidos voladores cuando se precipitan sobre una langosta; cógenla primero con una garra. segun todas las reglas del arte, por en medio del cuerpo y comienzan por comer la cabeza, despues devoran el pecho y al fín el vientre, como verdaderos golo. sos, lamiendo de un modo extmino con la lengua; nunca tocan las piernas ni las alas. En cuanto sa sus facultades inte. leciuales, son algo inferiores, segun he observado, $a$ las de otros halcones, $y$ no llegan con mucho a las de los buhos. Para probar esto bastará decir que una gota de lacre sobre Ia mesa les parece sicmpre un pedacito de carne, sin que lleguen áreconocct, por repetidas experiencias, que aquello no es nada para su galoso pico. Un solo error de este género basta para que el buho, de cualquiera especie que sea, no vuclva f enganarse en toda su vida.

Cuando la cara con lialcones habia llegado á su apogeo, adiestrábase al aguilucho para perseguir á las codornices y otras aves penueñas, y scgun dicen, algunos halconeros lograron ensinarle a das caza a las ocas salvajes, cogerlas por el cuello y atorinentarlas hasta que caian á ticrra; mas no parece que esa rapaz haya figurado mucho en la liajconeria; mas bien se ha tenido para observar la gran agilidad de su vuelo que para la verdadera caza. «bil aguilucho, dice nues. tro antiguo ánigo Gessner, es un ave del todo noble, y aunque a causa de su pequenez y de su poca fuerza no se le emplea mucho para la caza, es sin embargo muy manso y dócil, tanto que vuelve en busca de su amo cuando se le deja volar libre por el campo ó en los bosques. lis un espec. táculo muy divertido verle luchar con las ocas salvajes:

\section{EL HALCON ENANO-FALCO ESALON}

CARACTÉRES. - Este halcon, llamado tambien merlin smirill, sitmerl, etc, es en opinion de varios naturalistas el tipo de un género independiente; yo le considero como representante de un sub-género (asaion), cuyos individuos se caracterizan por tener las alas cortas, de tal modu que recogidas solo llegan á las dos tercerns partes de la longitud de la cola; la faja de las barbas se marca muy poco, y los dos sexos diñeren en el color.

La longitud del halcon enano es de $10^{\circ}, 32$ por 1,56 de anchura de punta a punta de las alas; estas últimas miden $0^{\circ}, 20$ y la cola $0^{\circ}, 13$, la hembra tiene $0^{\circ}, 02$ mas de largo por $0^{\circ}, 03$ a $0^{\prime \prime}, 04$ menos de ancho. Ia frente $y$ las mejillas del macho son de un blanco amarillento: la coronilla, la parte anterior de la cabeza y-toda la superior, de un ceniciento azulado oscuro; la garganta de un bianco puro; una faja que se corre sobre los ojos, otra muy ancha en la nuca, los lados del cuello y del centro de las partes interiores, in cluso los costados y muslos, son de un amarillo de orin, unas reces mas claro, y otras mas oscuro. Todas las plumas, excepto las de la garganta, están adornadas de manchas negras, onduladas en la parte superior, y longitudinales, en forma de lanceta, en la extremidad inferior, por debajo del cuérpo; las rémiges, de un pardo oscuro están orilladas en su extre- 
nidad de un blanco suciu, presentando en sus barbas interiores manchas blancas trasversales, que aumentan en tamaño hácia la base, prolongandose hasta el tallo; las rectrices, de un color ceniciento arulado, tienen los tallos negros, y en su extremo una ancha faja negra, orillada de blanco, con inanchas trasversales negras inas ó menos marcadas. Los ojos son de un pardo oscuro: los pairpados y la cera amarillo de limon; el pico de color violácen claro sucio y verde amarillento en In base, y los piés de un amarillo anaranjado. La hembra adulta ticise la frente blanca, asi como una iaja que se corre sobre los ojos, las nejillas y la garganta; en esta última no se ven linens, pero todas las demás plumas tienen varias en el tallo; las de la region de las orejas y de la coronilla pre. sentan tambien algunas de color pardo rojizo oscuro; en las de la nuca hay manchas de color pardo gris 6 rojizo; las plu mas de las demás regiones superiores son de un gris pardo intenso, orilladas de leonado claro, con lineas negras longiiudinales; las de la rabadilla resaltan por su brillo metálico azul claro; las de las partes inferiores son de un pardo de orin pálido ó de un blanco amarillento de orin, distinguién dose por sus tallos negros y unas grandes manchas redondendas de color pardo oscuro; las rémiges son pardas y tienen en sus barbas interiores manchas trasiersales rojizas que blanquean hácia el tallo; las rectrices, de un pardo oscuro con viso gris, presentan seis fajas trasversales angostas de co. Ior blanco pardusco. En algunas hembras se observa un tinte mas azul de pizarra, sobre todo en las fajas de la cola. Los polluclos se parecen á la hembra; pero tienen el dorso pardo claro, una faja muy mareada en la nuca, y sobre los ojos una especie de cejas amarillentas.

DISTRIBUCION GEOGRÁFICA.- Este gracioso hatcon pasa todos los otoños por la Alemania para invernar en el sur de Europa 5 en el norte de Africa, y suelve en pri. mavera á los territorios donde anida.

Bechstein y de Pacssler han asegurado repetidas veces que el lalcon enano anida en Alemania. Bechstein dice haberle visto durante el periodo del celo en la selva de l'uringia: Gloger en la Montaña de los (jigantes, y 'Tobias en la Tau. sitz. El primero de estos naturalistas describe tambien el nido. al parecer por sus propias observaciones, y Paessler compren. de esta especie entre las aves que anidan en Anialt, perque en el tercer decenio de nuestro siglo encontró él mismo su nido, habiendosele dicho además que el ave le fabricaba varins reces en el mismo territorio. No podemos dudar, por lo tanto, que dicho halcon anida por-excepcion en-Nlemania: pern el punto donde lo hace con seguriuad es en el extremo norte de Europa, sobre todo en la "I'uncira y' los bosquues situados al mediadia de este desierto, hasta la latirud de la is!a de Ciothland; en el norte de Escandinavia. en Finlandia $y$ las islas de Feroe, el halcon enano figura entre las aves que anidan con regularidad en el pais; en la Siberia hatita desde la Nueva Zembla en todos los parajes convenientes, pero penetra mas al sur qque en Europa, segun la naturaleza de los bosques, $y$ hasta se le encuentra durante el rerano, segun Eversmann, en las estepas mas meridionales. No le hemos observado aquí con seguridad hasta mas allá del $50^{\circ}$, es ciecir, en Obdorsk, pueblo situado á orillas del cibi, casi citbajo del circulo polar, y otra en la Schtschutschja, que se halla dos grados mas al norte. Parece que hícia el este se le encuentra en todas partes hasta el Amur inferior, ó por lo menos le hallaron Pallas, Middendorf $y$ Kadde en todos sus viajes jor aquelias regiones. No se sabe aun si habita tambien la lundra de Anérica, porque el halcon enano (Fulcis columbarjirs), que alli se encuentra, considerase por la mavor parte de los maturalistas coma especie independiente, siendo poros los que la tienen por variedad de su conginere euro. peo. Teniendo en cuenta las variaciones constantes observa. das en otros halcones que anidan al rededor del polo, incli. nome en faror de la última opinion, y creo iambien que el halcon enano, asi como el gerifaltey el halcon viajero no representan sino una sola especie. El primero de estos, que se alinenta casi exclusivamente de aves de la familia de los gorriones, se ve obligado, asi como el halcon viajero que no caza las aves marinas, a emigrar al principio del invierno hácia el sur; con este motivo le es iorzoso tocar en los paises

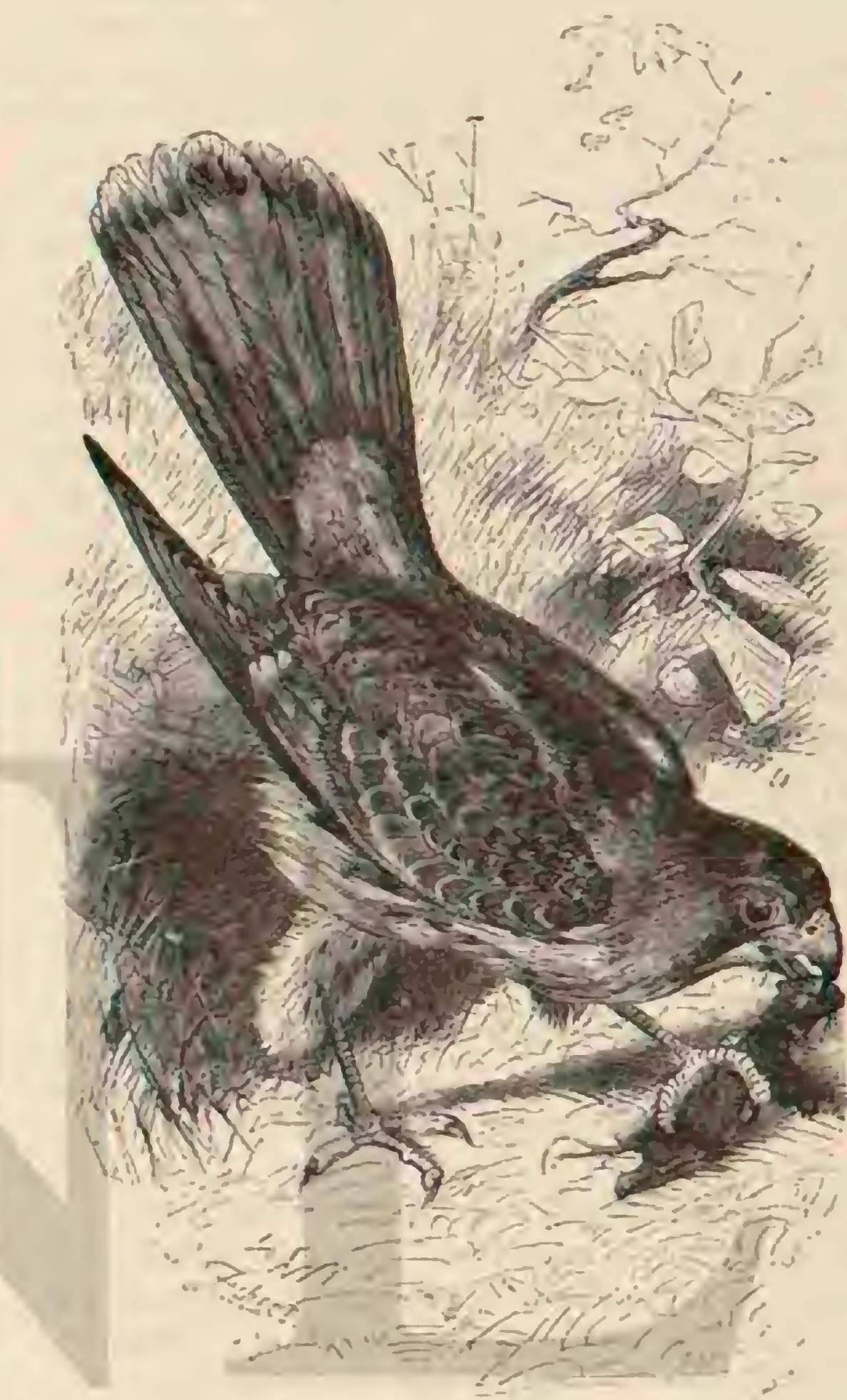

Fig. 139.-EL crRxicaLO COML:

situados entre su patria y las regiones donde inverna; debe franquear en el Asia hasta montañas de $\$, 000$ metros de al. tura, pudiéndosele observar en sus viajes de otoño é invier. no. Si esto nn sucede con regularidad, debe atribuirsé al pequeno tamaño del halcon cnano. i su rápido vuclo y à su género de vida. En Eurapa invérnan todos los años muchi. simos individuos en las tres peninsulas meridionales: pero en mayor número aun en el norte del Africa, sobre todio en Egipto, donde á veces se presenta, contra la costumbre de estas aves, formando considerables grupos; yo mismo encon. iré cierto dia una bandada de diez. individuos, y Snelley ase. gura haber visto en una sola vez en los bosques situados cer. ca de Beni.Suef, al menos treinta individuos: tambien se explica esto teniendo en cuenta que el territorio propio para ese halcon en Figipto se reduce al angosto valle del Nilo ýa sus pocos bosques. En el Asia prolonga sus viajes hasta los limites septentrionales de la peninsula indica; pero hállase con mas irecuencia en el mediodia de la China No hablo de la América porque no se ha demostrado aun que ambus halcones sean de la misma especic.

USOS, COSTUMBRES Y REGIMEN. - A pesar de 
su escaso tamaño, el halcon enano tiene tanta destreza, tanto valor y atrevimiento como cualesquicra de sus congéneres Su vuclo no es tan perfecto como el del aguilucho: recuerda mas bien el del gavilan, $y$ de tal manera, que pude discu. tir con Finscl sobre si el halcon que visitaba todos los dias Obdorsk era un halcon enano o un gavilan. Atendida la brevedad de sus alas el halcon cnano puede ejecutar sus evoluciones con la misma facilidad que dicho astúrido, pèro le aventaja mucho en la rapidez de sus movimientos y complácese á menudo, como el aguilucho, en trazar espirales y circulos semejantes por su gracia á los de esta rapaz Merced á estas facultades es en alto grado propio para in cazal de las aves pequeiras, a las cuales espanta tanto como el aguilucho ó el azor. Cierto dia que me hallaba en la aluura de Obdorsk. admirando el paisaje, en $\$ 4$ mayor paric inundado, que se extendia ante mis ojos, apareció de pronto, à un metro escaso de distancia, un halcon enano que iba persiguiendo á un cuello azul; al verme retrocedió, conteniendo sa vuelo con algu. nos aletazos, camibió de direccion, y pocos segundos despues desaparecia de mi vista, mientras que la tierna arecilla, sal. vada por mi, buscó su refugio en un monton de madera. 'lodas las aves pequeñas de la Tundra sirren de alimento al hakcon cnano. Los cuellos rojos, los centrófanos de Layonia, los antidos, buitidos, prridos y filoscónidós, sufren mucho la persecucion de esa rapaz asi como tambien los tringidos y toda clase de péquenas aves, incluso los mirlós, Con igual ralor que el aguilucho ataca a las aves que le igualan y hasta le superan en tamaño. (iray asegura haber visto) que los hal. cones cranos que visitaban el interior de la ciudad de Glasgow preicrian las palomas para an alimento: y lillort reco. noció cierto dia que una de estas pequenas rapaces le habia robado en una hora nada menos que cinco becadias lieridas. En la isla de Faer se le coge á menudo, ségun Muller, cuando persigue a los estorninos hasta el interior de las casas. Si una bandada de estas aves se ve perseguida por la rapaz, procum siempre gannr la mayor aliura posible hasta que apenas se la ve y asi se salsani todas cllas con bastante ire cuencia; pero cuando uno dé los estorninos se separa de la bandada cac sin remedio en poder dél haicon. Salvin to Bro. drick han observado que caza las golondrinas lo mismo que el aguilucho, imitando con ina agilidad incomparable todos sus inovimientos. Mis propias obserraciones me hacen supo. ner que, al contrario de otros haicones, puede coger su presa sin dificultad en cl suelo ó en el agua. He visto repetidas veces que, asi como el azor, trazaba sus circulos tan ceica de unas espesuras aisladas, que sus alas tocaban casi el Tollaje; y por eso le creo capaz de imitar todas las habilidades de aquel. Confirma mi opinion una noticia de Collett, quien dice que en el verano de is 72 el halcun enano se presentaba con mucha mas irecuencia que antes, 1 causa de una gran emigracion de lemings. Asi como el gavilan, tience la cos. tumbre de elegir siempre para posarse las ramas interiores y mas próximas al tronco.

Lo mismo que sus congéneres, el halcon enano anida, segun las condiciones del sitio, en las regiones montanosas del norte, por lo regular entre las rocas, en los parajes cubiertos de bosque y en árboles; en la Tundra elige la inmediacion de los pantanos. Fundaindose en el aserto de naturalistas que viajaron por el extremn norte, Naumann dice que el nido, hecho con ramas secas y jerba, sin arte ninguno, se suele encontrar en alguna saliente de roca escarpada, á major $\delta$ nenor altura, pero siempre en sitio poco accesible. Collett confirma esta noticia, pero anadiendo que en los Fjelds meridionales elige comunmente el nido abandonado de una corneja cenicienta, cuyo interior taģiza con un poco de musgo. El nido encontrado por Paessler se hallaba en un haya muy frondosa; pero el observador no dice que habia pertenecido a una corneja En los pantanos del Yorkshire meridional y del Derbyshire septentrional, donde el halcon enano se presenta a principios de marzo ó últimos de abril, causando grandes perjuicios enire las perdices de los pequeños panta. nos, anida por lo regular en el suelo, cligiendo para la cons. truccion del nido cualquier horo, el cual arregla descuida. damente con algunas ramitas y yerba seca. A mediados ó a fines de majo hâllanse en él de cuatro à seis huevos de forma prolongada ó redondeada, de color blanquizco ó rojo oscuro de ladrillo, con manchas muy finas y otras mas gran. des de un turte rojizo pardo ó negruzco; en raros casos se encuentran algunos con manchas pardo oscuras sobre un fondo de color de chocolate, que se asemejan á menudo á tos del cernicalo. En el extremo norte, el periodo de la incu. bacion comienza sin duda mas tarde. Los prequeños salen del cascaron al cabo de unas tres semamas; los padres se cuidan de la cria, jrofésanles gran cariño, los defienden con valor, y sill duda los instruyen tambien como los aguiluchos. A fines de agośto, jóvencs y adultos abandonan el territorio donde anidan para buscar su residencia de invierno.

1 pesar de que el haicon enano se alimenta principal. mente de ares pequeñas, el dano que causa no es apenas sensible, pues en sú patria abundan tanto los animales de que se alimenta, que apenas se observa disminucion entre ellos El daño que hace entre las perdices de los pantanos no será tampoco an importante como dicen los guarda-bos. ques. Cierto que éste graciaso halcon no nos es útil, pues ya pasó cl tienipo en que le adiestraban para la caza; pero su malor undomabley su gran agilidad le hacen muy propio para perseguir sodos lós animales pequeños. Fra el halcon favorito de las danas aficionadas a la caza, y sobre rodo de la emperatriz Catalina 11, para cuyo uso se cogian todos los años muchos individuos, los cuales se adiestraban para las cacerias, devolviéndoles su libertad en los uiltimos meses del otoño.

Comprendo muy bien por qué esta are se captaba el cariho de cuantos la poseian. In Alemania se coge tambien alguna, fo con frecuencia con los lazos tendidos para los tordos, gracias a lo cual obtenemos varios individuos para nuestras jaulas. Yo mismo he cuidado uno mucho tiempo, y puedo decir que su aspecto es bastante agradable. Como verdadero halcon esta siempre muy erguido y se distingue por su limpieza. Merced á sus movimientos, ian graciosos como ágiles, sabe volar en un espacio tan pequerio, de tal modo que no Se rozan sus alas; iamiliarizase pronto con su guardian, y cuando este se ocupa á menudo de él, se amansa tanto como otra are de su familia. Un conocido mio tenir uno de estos halcones, al que trataba como un papagayo; labia perdido todo temor á su amo, y tomaba iranquilamente sobre su percha el gorrion 6 el raton que se le tendia con la mano.

\section{LOS YERÁCIDOS - HIERACIDEA}

CARACTÉRES. - Los yericidos que se encuentran en la Nuem Holanda, establecen el trónsito entre los verdaderos halcones, 6 halcones nobles, y los llamados innobles. Tienen el asplecto y el pico de las esplecies que acabamos de examinar; pero sus alas, de menos-exiension, son súb agudas, con la tercen rémige mas larga; los tarsos largos y del. gados; los dedos endebles y mas corios, ! las unias menos poderosas y ganchudas.

\section{EL YERÁCIDO BERÍGORA-HIERACIDEA BERIGORA}

CARACTERES. - El macho mide $(1 "$, it de largo: ia

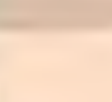

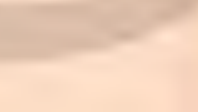

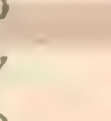


hemura es algo mayor. Los individuos adultos ienen la parte staperior de la cabera de color pardo de orin con mez. cla de rayas negras, el centro del lomo pardo rojizo; ia cspaldilla, las cobijas superiores del ala y las plumas de la cola, parcias, orilladas de rojo de orin, con manchas del mismo tinte: la garganta, el pecho, el centro del vientre y las tectrices inferiores de la cola, son de un leonado pálicio con una lista estrecha y parda á cada lado del tallo de las plumas. los costados son de color de orin, presentando cada pluma una mancha blanco leonada; las plumas de las nalgas de un pardo oscuro con manchas rojizas; y las rémiges secundarias de un pardo negruz.co, con grandes manchas leonadas sobre las barbas internas. Ia cera! el contorno del ojo son de un azulado pálido; ci pico color de plomo en la base y negro en la punta; las patas tienen el primero de estos dos tintes, y el ojo pardo oscuro (îg. 13\$).

DISTRIBUCION GEOGRÁFICA.-El berigora habita la isla de Van Diemen y la Nueva Gales del sur.

USOS, COSTUMBRES Y REGIMEN. - Vive aparea. do durante el periodo del celo, y mas tarde forma con sus semejantes handadas de centenares de individuos. Se alimenta sobre todo de reptiles $e^{\prime}$ insectos; acomete á las aves pe. queñas y a los mamiferos de escaso tamano; y en caso de necesidad devora los restos en descomposicion. Los colonos le consideran como una de las plagas del pais, porque de vez en cuando !es roba algun pollo; pero por orra parte les presta grandes servicios, exterminando los insectos y las orugas. Fin octubre y noviembre construye su nido en los eucaliptos mas altos: cada puesta es de dos $\delta$ ires huevos, cuyo color varia mucho; son por lo regular de un blanco lconado, con manchas mas ó menos confluentes de un pardo rojizo.

\section{LOS IERAX - HIERAX}

CARACTÉRES. - Se llama tambien à estas aves halcones enanos, porque son del tamano de la alondra, mas no for eso tiemen menos valor y osadía çuc los demís falcóni. dos. Se caracterizan por su pico corto, vigoroso, de mandibula superior provista de un diente agudo, y que presenta, lo mismo que la inferior, una escotadurn, debiéndose á ello el haberse creido inuchas veces que el tre tenia dos dientes. Las alas son cortas, con la segunda y teccera pennas mas largas que todas las otras; la cola muy corta, iruncada en ángulo recto; los tarsos cortos 5 gruesos; los dedos provistos de unas muy fucrtes; y el del centro no mucho mas largo que los ciemás.

DISTRIBUCION GEOGRÁFICA. - Fistos pequeños y bonitos falcónidos, de los que se conocen unas seis especies, son propios de las Indias y del pais de los malayos.

\section{EL IERAX AZULADO-HIERAX CCERU- LESCENS}

CARACTÉRES. - Fstr especic, cl muli de los indios, ó alop, como le llaman en Java, es la mas conocida de tan di. minuto género. El individuo pequeño tiene cuando mas $\|^{\text {n }}$, in de largo; la cola mide 15,10 y' el aia plegada 07,06. La parte superior de la cabeza, la nucn, la cola, $j$ las plumas larges y secosas de las nalgas, son de un negro azulado; la parte an terior de la cabeza, la garganta, el pecho y una línea que baja del angulo del pico ála espaldilla, de un blanco rojizo; el vientre rojo de orin; el iris pardo oscuro, y el pico y las patas de un negto azul.

DISTRIBUCION GEOGRAFICA. - Fil mufi esti diseminado en todo el sur de Asia.

USOS, COSTUMBRLS Y REGIMEN.—POCa cosa se sabe acerca de los usos de este falcónido y de los de sus congénerés; y ni aun Jerdon nos dice nada de importante. Dicese que los icrax son vivaces y ralerosos; que dan caza á todas las demás aves y no rehusan la lucha con especies mucho mayores.

CAZA AL VUELO. - Los indios, grandes cazadores, han sabido utilizar las cualidades de este pequeño falcóniclo. lil muti significa puño, y se designa con él al ave; porque en las cacerins se la lleva en el hueco de la mano para lanzarla como una piedra sobre la caza.

Segun Mundy, empléase sobre todo para cazar las calan. drias: este autor asegura, por haberlo visto, que semcjante caceria es de las mas divertidas.

Se lleva el ave en la mano cerrada, de modo que la cabeza sale por un lado $y$ la cola por otro: á veinte ó treinta pa. sos de la pieza levantada, lanza el halconero al ave como una piedra: al momento extiende el halcon las alas, y cae sobre su presi lo mismo que el azor.

Otros naturalistas, y con ellos Jerdon, ponen en duaia estos hechos; pero la descripcion de Mundy no permite apenas dudar de su veracidad, sin contar que autores mas antiguos hablaron ya de ello.

\section{LOS CERNICALOS - TINNUNCULUS}

CARACTÉRES. - Los cernicalos forman un género es. pecial y siguen asemejándose á sus congéneres mas nobles por la fuerza del pico, de las alas y de la cola. Dírieren, no obstante, por tener el plumaje mas manchado, alas de pen. nas menos resistentes, cola mas larga a proporcion, patas mas iuertes, dedos mas cortos, ! colores variables segun el scio.

USOS, COSTUMBRES Y REGIMEN.-I.OS cernicalos se asemejan muchisimo bajo el punto de vista de sus usos 5 costumbres; aunque se ve desde luego que no se hallan tan bien dotados como los halcones nobles. Su vuelo es tambien ligero y rảpido, pero no se puede comparar con el de los verdaderos lalcones. - Los cernicalos vuelan por lo regular a poca elevacion; apenas divisan una presa se detienen de pronto, agitan strs alas, y caen luego sobre el aye que codician. Sin embargo, se remontan á gran altura por los aires, ejecutando los mas graciosos giros, sobre todo en los hermo. sos dias de vérano; cuando descansan se nota en ellos mas abandono que en los halcones nobles, y parecen por lo mismo mas grandes de lo que son realmente En tierra dan prisebas de mayor destreza, pues sus largos tarsos les permiten andar con bastante facilidad; sus sentidos no alcanzan menos desarrolio que los de otros falcónidos: pero distinguense sobre lodo por sus costumbres. Son vivaces, alegres, osados y bur. lones, y con frecuencia molestan mucho a las grandes mpa. ces; compiácense particularmente en hostigar al buho, y hasta con el hombre despliegan $\{$ veces un vaior admirable. Aunque se despiertan muy temprano, no se entregan al sucho hasta bastante tarde: à la hora del crepuísculo se les ve toda. via por los aires.

Su grito, sonoro y alegre, que se puede expresar por las sitabas kli, klb, kil, varia de tono segun que exprese el dolor o la angustia; cuando están encolerizados emiten un sibbido ronco, $y$ se conducen con el hombre de muy diverso modo, segun las circunstanciss. Entre nosotros son timidos, y hasta muy prudentes cuando saben que se les da caza; en el sur, por el contrario, viven con el hombre en la mejor inteligen cia, y no temen habitar bajo su mismo techo.

La vida de invierno de los cernicalos ofrece muchas par ticularidades interesantes: se reunen por tribus cuyos individuos no se sepraran nunca mientras dura su permanencia en 
pais extrano: Jerdon $y$ otros naturalistas nos anuncian que son comunes en Asia todos los inviernos; j en cuanto a mi, puedo decir que he hallado numerosas bandadas en el inte. rior de Africa. Sin cuidarse de las de sus semejantes, que viven todo cl año en Egipto, llegan hasta debajo de los tró. picos, y permanecen en las estepas ó las selvas virgenes. Io que necesitan es un alimento abundante, y por eso se las en. cuentra siempre detrás de las nubes de langosta. Quien no ha visto las bandadas de estos insectos no se puede formar una idea de ellas: en bosques enteros, tocios los ironcos y las manas de los árboles se cubren de langostas, y si se les es. panta, oscurícese el aire cuando vuelan. Sin embargo, estos séres van perseguidos por otros animales que los exterminan. y en primera linea figura el cerricalo. Contenares de estas aves se hallan alli posadas en las ramas mas altas de las mi inosas, donde rciolotean y se cicrnen sobre la masa devasta. dora: mientras que las laxigostas permanecen cogidas a las ramas, las largas espinas de los arboles impicen $a$ las aves acometerlas; jero apenas vuelan, el cernicalo se precipita en lo mas éspeso de la bandada, y coge en sus igarras uno de aquellós insectos, que se defiende $y$ tratr inutilmente de morder las yatas de su enemign, Despues de trisum la cabe. za al ínsecto de un picotazo, el cernicalo \% arranca las alas sin perder tiempo ye lo come rolando. Todo esto es asunto dédos minutos; la rapaz se lanza de nuevo a buscar una segunda y tercera presa. Este espectaculo tenia para nosotros cierio atractivo: hos complaciamos en sacudir lis ramas $\$$ fin de espantar a las langostas, y en pago cazaban a nuestra vista los cemicalos Parcec, no obstante, que las bandadas de aquellos insectos reconocen á su enenigo, pues se dispersan cuando el ave rapaz cae sobre ellos

Solo por esto conviene abstenesnos de perseguir ia la hermosa raplaz, defendiéndola por el contrario; es comummente sobria y de formas graciosas; " como en todos nuestros pue. blos tho deja de ser muy útil, cada cual deberia protegerla por cuantos medios estén a sij alcance.

\section{EL CERNÍCALO COMUN-TINNUNCULUS ALAUDARIUS}

CARACTÉRES. - El cernicalo comun (L̂g: 139) es una magnifica ave de $0^{\infty}, 33$ de largo pror $0^{\circ}, 70$ de amplitud de alas; esta plegada mide $0^{m}, 24$ y la cola $\theta^{*}, 16$. El macho adulto tiene la cabeza, la nuca y la cola de un gris cenicien. to, con una faja azul negra orillada de blanco en la punta; cl lomo es de un rojo de orin, y cada pluma jresenta una man cha triangular blanca La garganta es de un amarillo blanquizco; el pecho y el rientre gris rojo 6 amarillo pálido, llerando cada pluma una mancha longitudinal negra Las pennas de las alas son de este tinte, y presentan de seis a doce manchas triangulares blanquizcas, ó rojo de orin sobre las barbas internas, con un flete claro en la punta; el iris es pardo oscuro; el jico pardo; la cera y cl circulo desnudo que rodea el ojo de un amarillo de limon, y oscura una lista que baja sobre las mejillas.

La hembra adulta tiene el lomo de color rojo ladrillo, $5 \mathrm{em}$. brado de manchas longitudinales negras en la mitad superior y trastersales en la inferior: la cola es gris rojiza, recorrida por fajas, enire las cuiales es mas ancha la inferior; la raba. dilla de un gris ceniciento. Ia cara inferior del cuerpo pre. senta en la hemora los mismos dibujos que en el macho.

los pequeños se parecen à la madre.

DistribUCION GEOGRAFICA.-Desde Laponia hasta el sur de España, $y$ desde los paises del Anur hasta la costa occidental de Portugal, cl cernicalo no falia en ningun pais, en ninguna region de Europa; habita las llanuras y las montarias, tanto las que están cubiertas de bosques como las que carecen de ellos, y lo mismo anida en las selras que en las rocas. Abunda mas en el sur de nuestro continente que en el norte, donde sin embargo no falta. Middendorf le caró en Siberia, hasta of $71^{\circ}$ de latitud norte, y Collett indica los $69^{\circ} 40^{\circ}$ como el punto mas septentrional en que se le ha observado hasta ahora en Escandinavia. Anida con regularidad desde estas latitudes hasta la Persia y el norte del Africa, incluso Madera y las Canarias. En sus viajes cruza el mar Negro y el Medictraneo; durante las tempestades se sefugia a veces en los palos de los buques donde descansa algunas horas y quizás muclıos dias, continuando despues su camino hácia el mediodia del $\Lambda$ sia ó el centro del Africa. A pesar de eso inverna bastante a menudo en Alemaria, con mas irecuencia en el mediodia de este pais ó en Austria, por ejem. plo en Silzkamuzergut; $y$ todos los anos se le ve con regularidad en el mediodia del lirol y en las tres peninsulas meridionales de nuestro continente. Vuelve muchas veces en fubrero, ó unas tardar en marzo, y cuando el oiono es invorable no permanece solo hasta í fines de octubre en el terriiorio donde anida, sino tambien muchos dias de noviembre. En la nzontana se le encuentra aun d dos mil metros sobre el nivel del mar, en el caso de que haya algunos centenares de metros inas abajo un sitio conveniente para su nido. Por mas que le agraden tales parajes, no puede considerarse sin embargo coma are de la alta montaù, porque prefiere los promontorios y el monte bajo y aun abunda mas en todas las partes de las llanuras. Aqui habila en los pequeños bos. ques rodeados de campos, $\delta$ ya en los mas grancles, y, anida en uno de los árboles mas, altos, ó sobre una roca. En las regiones meridionales se utiliza de los edificios vicjos; raras reces falti en los castillos antiguos medio ruinosos, y iam. vien se le encuentra en la mayor parte de las ciudades; yo le he observido en todás aquellas cuyas torres, iglesias y otros edificios altos le ofrecen sitio conveniente. Anida en la torre de San Estéfano de Viena, en la catedral de Colonia, y en muchas de las iglesias antiguas de la Marca, construidas con ladrillos; tambien habita con regularidad en tocios los parajes convenientes de lat Europa meridional. A veces vive, al menos tempomimente, en la misma localidad que el hal. con viajero, y no ne parece improbable que ambos aniden en las cavidades de una misma roca $\delta$ de un mismo edilicio ruinoso. A decir verdad, recuerdo haber leido en alguna parte que el cernicalo abandona su nido tan luego como un halcon viajero anida en las inmediaciones; pera no sé si se citaba un hecho veridico ó solo se hacia suposicion. El cernicalo anida con tanta regularidad entre las monédulas y ja lomas como en el campo entre las cornejas o en rncdio de una colonia de garzas reales.

El cernicalo figura seguramente entre los halcones mas agradables de Alemania. Su gran diseminacion y la irecuen. cia con que en algunas partes se le ve permiten a todo el mundo observarle, lo cual basta para que se le tome ca. riño. Desde las primeras horas de la inaniana hasta muy en. trada la noche manifiesta mucha actividad; se le ve volar solo ó apareacio por todo su territorio; en cl piono forma grupos mas ó menos numerosos ó bien se reune solo en fami. lias que vagan por el campo ó revolotean en un mismo pun. to. Fi cernicalo observa cuidadosamente su domivio, y apenas su penetrante vista descubre un raton, una langosta, un grillo u otro grande insecto, jrecipitase sobre él con las alas reco. gidas; extiéndelas despues un poco cuando se acerca al sue. lo, fija otra vez su vista en la presa, cógela con las garras, remóntase y la devora rolando; si el insecto es denasiado grande, llérale a un sitio mas comodo para comérselo. Si la 
hembra esta cubriendo los huevos, anuncia su llegada por un grito muy prolongado, diferente del ordinario, el cual indica tambien buena suerte en la caza. Cuando esta rodeado de sus inerpertos hijuelos, todo es algazara en torno de los p.2. dres, pues cada uno de cllos se esfuerza para ser el primero en recibir la presa. Este cuadro de familia ofrece un aspecto muy agradable, por el gran cariño que e! macho y la hembra profesan a su progenic.

Lil periodo del celo comienza para el cernicalo mas $o$ menos tarde, segun el tiempo; rara vez, acaba la henbra de po. ner antes de principios de mayo, y con frecuencia antes de los primeros dias de junio: en el mediodia de Europa lo hace mucho mas pronto. Por lo regular se utiliza de un nido de corneja $\delta$ busca un hueco conveniente en rocas ó editicios; en Alemania ocupa los nidos ahandoriados de cuervos 6 de cornejas, en el norte de este pais, y tambien los de la urraca; en los bosques muy antiguos le convienen tambien los huecos de árbales. Sociable como todos los halcones de sangre impum, forma á veces tambien verdaderas colonins de nidos: conócense ejénplos de que veinte ó treinta parejas anidaran pacificamente una al lado de otra en un pequeño bosq̨ue. Si no tiene motivos para temer is su mayor enemigo, el liombre imprudente, hace poco caso de él; y asi como fabrica su nido cratre el bullicio de las ciudades, constrúgele tambien á veces sobre árboles situados á orilla de los caminos. lin al medio. dia de liuropa se acerca mas aun al senor de la tierra; aqui elige i menudo como su congénere el cernicalo crecerina, las casas de los pueblos 6 ciudades, por poco propios que sean tales sitios para auidar; pero inuchas reces debe trabar encarnizadas luchas con las ares cuyos nidos ocupa, pues ninguna pareja de cornejas ni de urracas se deja expulsar sin resistencin; rencido algunas reces, como se ha obserrado litimamente, debe contentarse con la parte superior del nido de la urraca para bacer el suyo. La cavidad de este es bastante plana y difiere poco de la de otms aves de rapiña: cl cernicalo la rellena de raices, paja ó musgo y pclos de ani males. La puesta se compone de cuatro á nueve lusevos, de forma redondenda y color blanco of amarillo de orin, con manchas y puntos rojo.grardos en todas partes; varian mucho por su tamaño y forma, siendo su mayor diàmetro de $0^{\circ}, 036$

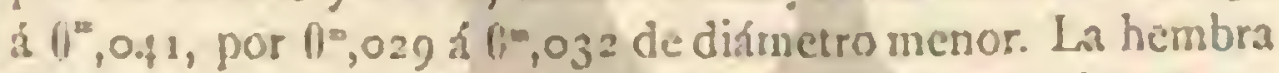
se ocupa principalmente de la incubacion, pero tambien el ma. cho toma á veces parte en ella, cuidíndose por lo regular de nutrir á su companera. Mi padre ha observado yue un macho cubria los polluelos viviendo aun la laembra. Cuando eota pereció, el macho dejó morir as sus hijuelos. Asi como la mayor parle de las demás ares de rapina, puede llevar \& su -progenic abundante presa, aunque no desmenuzaria bien para sus tiernos hijuelos, ni prepararla antes en el buche; pero cuando la progenic es bastante fuerte para salir del nido, el macho ctample frelmente con sus obligaciones de padre, aun. que la hembra liaya nuerto por alguna casualidad. Machoy hembra profesan \& su cria el unismo carino de todas las aves de rapina, demostrando un valor extraordinario frente al hombre. Una vez que mi padre, á la edad de diez anos, subió á un nido de cernícalo para coger los hucvos, los adultos le pasaron tan cerca de la cabeza, que apenas pudo defen. derse contra clios: á piro muchacho de doce años que inten. tó lo mismo, la hembra le arrebató la gorra de la cabeza y se la llevó sin que se pudiera encontrarla despues.

El alimento preferido del cernicalo son los ratones, $;$ ade. más come insectos. Se ha probacio tambien que derora las aves pequeñas cuando puede cogerlas, y tal vez se lleve la cria de aiguna pareja de alondras ó tntidos para nutrir á su progenic. No creo tampoco imposible que devore aiguna licbre recien nacida, sobre todo al recordar el siguiente he. cho citado por mi padre: un cernicalo perseguia á una liebre adulta que corria, precipitándose sobre ella desde una altura lo menos de veinte metros $r$ atacóla dos veces con tal furia que arrancó mucho pelo al cuadrúpedo. A pesar de todo esto, es tan injusto como imprudente comprender al cerni. calo entre las aves daninas, y perseguirle en vez de protegerle. A cuantos le observan detenidamente debe parecerles extraño que Otto de Krieger, el cual conoce muy bien nues. tras rapaces, siente por principio que no protege í ninguna, y que persigue al cernicalo como a las demas aves de rapiña, porque le ha visto coger alondras, nevatillas y robéculas para llevársclas â su nido. Semejonte opinion no se puede emitir cuando se conoce bien el carácter, los usos y costumbres de nuestro cernicalo; no puede fundarse tampoco en el cálculo sobre la utilidad y perjuicios que reporta, ni menos en la consideracion que se debe tener con nuestra selvicultura. Otto de Krieger encontrará no obstante partidarios de su opginion entre los cazadores, que quizás consideran el exterminio de las ares de rapiña como la cosa mas noble de su oficio; pro nunca tendrá de su parte à los naturalistas y agricultores.

Quien conoce al cernicalo le considera como una de nues. tras aves mas útiles, y sabe que es benéficu para lus campos, aunque alguna rez sustraiga al cazador una pequeña liebre ó una perdiz. Yo he subido á muchos nidos del cernicalo, he observado al ave por espacio de cuarenta anos en tres continentes, y me creo por lo tanto bastante autorizado para juzgarle yo mismo. Sin embargo, no soy yo el único que piensa asi, pues todos los observadores concienzucios son del mismo parecer. El daño es insignificante, dice mi padre, pues devora pocas avecillas, y en cambio es muy grande la utiliaad que nos reporta exterminando los ratones. Del mismo modo se explica Naumanu. Eil cernicalo, dice, des. truje muchas crias de las aves pequeñas, sobre todo de alondras, pero devora un número mucho mayor de ratones campestres, y por tal concepto es muy titil; tambien come muchos insectos, como por ejemplo langostas, grillos, etc. Gloger se expresa en iggual sentido, si bien cnumera concienzudamente las fechorias del cernicalo, acusándole entre otras cosas de robar hueves. a Su alimento es tal, dice, que causa muy pocos perjuicios entre los animales, siendo en cambio de gran utilidad para el hombre. Con mucha encr. gia le dentende lugenio de Honejer. El cernicalo, escribe, es una de las ares mas útiles, pues se alimenta exclusiramente, por lo que yo he visto, de ratones, escarabajos, langostas, etc: en ninguna de mis numerosas excursiones, en las cuales he tenido muchas ocasiones de observar al cerni. calo, jamás le vi coger ni siquiera perseguir a un ave. Ascgú. rase que lo hace algunas veces; pero esto es una excepcion tan rara que no se debe tomar en corsidencion.

l'reen examinó las bolas que se hallaron debajo de los nidos de una colonia formada por unos veinte cernicalos, y pudo ver que se componian exclusivamente de pelos $y$ huesos de ratones. Paréceme supérfino citar aun mas testimonios para. dar a conocer el verdadero carácter del cernicalo; si he hecho mencion de tantos es porque atravesamos una ćpoca en que todo el munda se cree con derecho para juzgar sobre la uti. lidad ó el perjuicio de los animales; porque ha llegado un periodó en que se paga a buen precio la caza contra el in. ofensivo cernicalo; $y$ porque, en fin, nos hallamos en un tiem. po en que la major parte de los aficionados á la caza podràn ser buenos tiradores, pero jamás hombres que se interesen por ella. Riesenthal ha contraido un mérito al dar gran im. portancia en sus s.Ares de rapiña de Alemanias á la utilidad del cernicalo. \&los jórenes locos, dice, que solo caran por el aran de gastar pólvora, noostrándose siempre dispuestos â ma. 
tar todo para salrar á sus perdices y liebres, han difamado tam. bien a este halcon como danino para la caza, sosteniendo qque se le debe exterminar. ¿Con qué razon? Poruue han oido decir á alguno, ó quizás lo han visto una vez, que el cernicalo per. seguia a una bandada de perdices, que se precivitaba contra allas, ó que, en fin, habia rogido una. No podemos adinirarnos de esta ligereza en la manera de jnzgar cuando se tiene en cuenta que últimamente se ha llamado la atencion sobre el topo. acusándule de enemigo de la caza. Es posible que el cernicalo coja un perdigon enfermo ó alcjudo de su madre: pero el que ha visto á la galiina ó el gallo ahuyentará raguces mas fuertes, como por ejemplo.et nillaro de las gathinas, no creerá que el cernicalo pueda destrozar en condiciones nor males una bandada de perdices. Por otra pante, euando los pierden sus padres tanbien perecen. Observaciones comola. que he citado vienen a tener al fin el mismo valor que ciertas colecciones de huevos, cuyos fropictarjos hacen saquear por cuatro perdidos regiones y hasta provincias enteras, y escriben los infortnes enviados por tales picaros, publicandolas despues como observaciones propias, muy persuadidos de que trabajan en favor de la ciencia. Asi podemos admirar el colmo de la sencillez si leunos en periódicos científicos noticias como la siguiente: a liste año $n 0$ se ha presentado, destraciadamennie, mas que una pareja de cernicalns; recibilos huevos $\mathrm{cl} . . .$. D(sigue lalfecha). s Segun esto, vemos que el coleccionador, i pesar de la escasez de la inofensiva ave, y aunque toda la puesta de huevos solo vale algunos eéntimos, no vaciló en tomarla, por supuesto, en favor de la cienciat.

- El cernicalo es muy uiril para exterminar los ratones é in. sectos; y en las regiones donde hay bandidas de langostas, que un acercindose a nosotros, los benclicios que reporta son tales, que debemos conseriar el cernicalo aunque solo seit en fuvor de aquellos paises donde se le proiegc, si en ciertas localidades le condenan los hechos, se podró proceder segun jarezca conveniente: pero debemos guardarnos de juzgar la generalidad de estas aves por unas pocas observacio nes no confirmadas, $U_{n}$ jefe de guardabosques, instruido cientilicamente, un cazatior en el verdadero sentido de la pa. labra, que despues de pasar su vida en las selvis escribió una cxcelente obra sobre las aves derajuiñ de Alemania, es cl yut trazó las anteriores lineas: mi lector, que no tiene oportuni. dad de hacer estudios en la libre naturaleza, juzgars si debe creer al observador que ipor principio no protege ni perdona á ningun are de rapisia, ơ a mi padre, Naumann, Gloger, Eugenio de Homeyer, Riesenthal y yo.

CAUTIVIDAD. - EI cernicalo, me escribe licbe, conforme en todo conmiga, es un agradable conpuñero de casa y propio para la habiacion. Distinguese de sus con. gencres por su gran asen; cuando se cubre con musgo el suelo de su jaula no se desarrolla ningun mal olor, pues deja caer sencillamentic sus excrementos por un lado y no los despide contra las paredes y la reja de la jaula, como lo hacen los gavilanes. Por otra parte, parece que sus deposiciones tardun en descomponerse secándose muy pronto. Los cernicalos tienen el plumaje mejor arreglado yue todas las demás ares de rapiña yon en extremo lim. pios. Cuando beben suelen pasarse repetidas veces el pico mojado por el plumaje, el cual se alisan despues cuida. dosanente. Facil es acostumbmrlos a dejarsc raciar de sez en cuando con agua, $y$ hasta diriase que esto los complace mientras que á ciertas aves de rapiña les desagrada evidente. mente El plumaje es muy blando; los tallos de las plumas no se rompen fícilmentc, y por eso se conserva la bonita y larga cola muy bien en la jaula los movimientos del cerni. calo, suaves y ligeros, no son an impetuosos como los de sus congéneres, y por lo tanto se le plicele sacar todos los dias una ver de la jaula para dejarle volar en la habitacion, como yo lo hice siempre. Las aves pequeñas que le ven no le temen tanto como al gavilan. Cierto que los primeros dias revolotean tímidamente en sus jaulas, pero pronto se acos. tumbran á ver á su señor, $y$ al ploco tiempo no se asustan ya en lo mas minimo. Una vez puse una hembra de pinzon adulta en la jaula de un cernicalo de la misma edad, prara ver si el ave de mpina la aceptaria por compañera y poder observar su conducta. Con gran asombro mio, el pinzon no manifestó temor y fué \& posarse en la percha del halcon: cinco dias estuvieron las dos aves juntas, sin nue el cernicalo hiciera el menor dano a su companera ; si bien es verdad gue se le dió el alimento necesario.

lara la domesticacion lo mejor es coger el ave en el nido, cuanda sus rímiges y tectrices sobresalen 10 mas un cen. limetro del flumon; pero entonces se ha de tener el nuyyr cuidados en la cria. Conviene ablandar la carne de ternera $\delta$ de cerdo nie se les da golpeándola con el cuchillo, para cortarla despues en pedacitos, los cuales se mezclan dos ó tres veces a la semama con polvos de huesos. No he dado nunca á lós halcones perueinos con el alimenta pelos y plu. mas, como lo hacia con los buhos desde el principio. Es preciso sacar al ornicaio tocios los dias unar vec de la jaula, ponerle en al dedo y obligatle i sostenerse asi, pues de lo contrario quedan afbiles de las articulaciones de las garms y se crian individuos mutilados, que no pudiendo senerse dercelios en la perchi, se acurrucan en un rincon, apoyín. dose en el tarso. licostúmbranse pronto af colocarse en el dedo y cogidos a él cjercian sus alas agitandolas de conti. nuo. Bustante conocido es su afecto al amo: yo tuve en mi juventud una henibm que entraba y salia por la ventana abieria ae In habitacion, posindose subre mis hombros cuanco me paseaba por la calle con mis compañeros. Cuando estas aves son viejas cuesta mucho domesticarlas, y no meyos dérputes de salir del nido. Mas pronto se consigue, hasta cierto punto, con los individuos adultos cogidos en la réd ó heridos.

VLas heridas causadas por arma de fuego se curan muy pronto en cl cernicalo. Una vez me entregaron una hembra adulta á la cual habian roto de un tiro el himero y los dos antelurazos. Como los músculos y la piel no estaban muy des. trozacios, sujetć las alas al tronco con anchas fajas, proniendo al ave sobre una gran percha en una jaula. Alli se mantuvo posada en la misma posicion por espacio de cinro dias du. rante los cuales rehusó todo alimento, Jimitindose a beber tuna sola vea un poco de agua que le ofrecf. Al terminar cl quuinto dia aceptó con ansia un pedacito de carne y desde entonces tornó alinento diariamente. Al décinotercero las iajas se habian aliojado aunque se hallaban antes bien suje. tas; entorices saqué el ave de la jaula, retiré con cuidado las fajas y el ave voló, con gran asombro mio, por roda la habitacion, hasta el inarco de la ventana; el ala destrozada se habia curado y solo parecia un poco mas baja que la oiras

Wuestnei publica una observacion notable sobre un cerni. calo catutivo: habiendo caido el are del nido, fuć cogida, y como suele suceder siempre, pronto frerdió toda timidez; cogia el alimento de la mano, pero desagradábalé cuue mirasun su comida, por lo cual cubria con las alas extendidas y con el cuerpo inclinado hácia adelante el piednzo di carne, dejando escapar continuamente gritos de ira. Eista desconfianza, que quizás era debida a provocaciones anteriores, couvirtióse muy pronto en la mayor furia Fintonces la pusieron delante un espejo, y cono creyese ver un semejante en su inágen refiejada y le pareciera peligroso, acometió en seguida al supuesto rival con pico y garras, repitiendo sus atangues á pesar de la inutilidad de los golpes en la suptricie lisa del espejo. 
Cuando hubo gastado en rano sus fuerzas, y comprendiendo que no jodia penetrar por el obstáculo que le separaba de su - enemigo supuesto, ocurrióle la idea de atacar a esic en su verdadero sitio, y dirigióse de jronto por detrós del espejo. Era muy diverticio obsernor su gran asombro: su exciacion se calmó entonces de pronto; los gritos cesaron y permaneció inmóvil, con la cabeza tendida, observando el espacio racio. Mucho tiempo se manturo en esta situacion, hasta que al in lanzó de nuevo un furioso grito cual si quisiera provocar al adversario oculto. Una vuclta que dió por el es. pejo la hizo comprender que aquel no habia desaparecido del todo, lo cual excitó de nuevo su cólera Despues de haber interrumpido varias reces su comida con el espejo, este fuć siempre ya para el cernicalo un objeto tan sospechoso, que se excitaba al punto y proferia gritos cunudo conocia la intencion de tomar el espejo de la pared, ó veia a cualquicra acercarse à él.

\section{EL CERNICALO CRECERINA - IINNUN- CULUS CENCHRIS}

CARACTÉRES. - Iil cernicalo crecerina, ó cernicalo rojo, es algo mas jucqueño que la especie anterior: el macho mide 1$)^{m}, 32$ de largo, por $0^{n}, 6 S$ de punta a punta de ala; la hembra $11^{\prime \prime}, 34$ y $10^{\circ}, 73$ respectivamente; cl ala plegada $10^{\prime \prime}, 26$ y la cola $11 \%, 14$.

F.l macho adulto tiene la cabeza de un gris ceniciento azu. lado, y del inismo color las grandes cobijas superiores del ala, el extremo de las réniges secundarias y la cola; ell lomo de un rojo ladrillo unjorme: el pecho rojo amarillento con perqueñas manchas, apenas visibles algunas veces; la cola ostenta en su extremo una faja negra. El ojo, el pico y las patas presentan los mismos colores que en cl cernicalo ordinario, solo yque las uinas, en vez de ser negras, tienen un tinte bianco amarillento.

La hembra se asemeja mucho $a$ la de la especie anterior. de la cual solo se diferencia por sus colores mas claros, por tener la cola de un blanco azulado y las unas blanquizcas.

Los hijue!os revisten el mismo plunaje que la madre.

Distribucion GEOGRAFICA. - El mediodia de Europa, es decir Espana y sus islas, dialta, el sur de Iralia y sobre todo Grecin y los paises situados hácia el este son la patria verdadera del cernicalo crecerina. En el mediodia y centro de España, en Sicilia y en Grecia se le encuentra mas á menudo. al paso que escasea en Turquia; en las estepas meridionales de Rusia, en las de Siberia y del Turkestan es, juntanente con el kobez vesperrino, la mas comun de todas las aves de rapina que alli habitan. Su área de dispersion no se extiende por el norte muy léjus de los limites aje los paises indicados. Raras veces cruza los Pitincos y los Alpes, pero segun una observacion de Hucher, extiéndese por el este de los segundos todos los arios mas y mas, y actualmente anicia, no solo en la provincia de Krain, sino tambien en Ca rintia y la listiria meridional, hallandose asimismo en alguuos punios de la Croacia. De estos últimos parses provienen probablemente los cernicalos creccrinas que à veces, 6 qui. zás con mas trecuencia de lo que creemos, visitan la Alemania Segun mis propias observaciones, en el ocste de la Siberia la estepa constituye el limite del territorio donde anida, y en el este del Asia sucedera probablemente lo mismo. Hácia el sur se extiende solo por . Marruecos, Argelia y Túnez: segun dice Heuglin, anida aisiadamente en las fortificaciones de Alejandria; hállase con regularidad en Palestina, Siria y el Ası Menor, y es en extremo romun en el mediodia de Per sia 'Podos los inviernos visita el Africa y al Asia meridional, partiendo de los puntos septentrionales de su extensa patria
Yo mismo le he observado entre las aves mas comunes que inverman en las estepas del interior; con estas se disemina por la mayor parte del Africa hasta los limites mas meridionales, siendo tndos los años mas abundante en el Cabo y en el país de Damaras, donde se reune con su fiel companero el kobez respertino, cuya sociedad le falta en el sudoeste y mediodia de Europa En España prefiere las grandes ciudades, Ma. drid, Sevilla, Cimnıda, etc.; en (irecia sucede lo mismo, y tambien risita los pueblos de la lianura, sobre todo los que estàn situados en las orillas de los rios. Asi en Espaina como en Cirecia preséntase en la última mitad de marzo, poco mas ó menos como en Persia; jecto en las estepas de la Siburia occidental no aparece antes de lines de abril ó principios de mayo, inmediatamente despues del deshielo, y cuando los rios quedan libres de su cristalina capa. Cuando viaja sigue siempre los valles. Durnnte el verano permanece en su patria y vuelve á emigrar en agosto ó cuando mas tarde en setiembre.

USOS, COSTUMBRES Y REGIMEN. - LOS USOS $Y$ costumbres, asi como el carácter de este halcon son en un todo los de nuestro cernicalo; pero aun se asemejan mas á los del hobez respertino, con el cual tiene muchisimos puntess de contacto. Me refiero á la descripcion que haré de esta última especie y solo dire aqui que el cernicalo creceri. na se cuenta sin dudia entre las aves mas graciosas de toda Ia familia. Merced a su sociabilidad y su buena inteligencia con el kobez vespertino y el cernicalo comun, solo por excepcian se le ve en parejas, pues por lo regular forma ban. dadas Estos halcones, tan bellos por sus colores como f́giles é incansables en su vuelo, dirigense juntos hácia los sitios que les prometen alimento, $\delta$ les sirven para el reposo nocturno, y alli anidan.

Fin las innediaciones de la Acrópolis de Aienas yalrededor de las torres de Madrid les he visto ejecutar sus magnificas evoluciones, y si durante mi estancia en Granada no los encontré en la Alhambra, ese castillo morisco que tanto ha cntusiasmacio a los poetas, fué sin duda porque ustábamos en invierno; durante el verano rodean tambien aqui en gran numero la magnifica fortaleza; pero no se limitan, como lo hacen regularmente nuestros cernicalos, a elegir edificios grandes; se contentan aun con la mas pequeria clioza, pues en el mediodia de Iuropa nadie piensa en perseguirlos por principio, y á los ojos de los turcos y rusos pasan por aves sagradas. Tanto en Oriente como en el mediodia de Rusia y Siberia se ha reconocido muy bien su utilidad: alli se les considera como un auxilio enviado del cielo contra la plaga de las langostas; los habitantes se complacen además en ver. los, porque les agrada su viracidad y caricter alegre, y los tienen por un elemento de vidin de la solitaria estepa Cuando se pasa á caballo ó en coclie por el vasto territorio, divicrte mucho ahijyentarlos de su sitio de reposo y de sus nidos, obligíndolos i retirarse mas y mas. Estas ares son insectivoras en mas alto grado aun que el cernicalo comun, y proba. blemente los enemigos mas encarnizados de los insectos. A pesar de ello no desprecian un raton, uma torpe avecilla ó un lagarto, cuando pueden cogerlo5; pero en general buscan el mismo alimento que el kobez vespertino y el cer. nicalo comun.

Et péríodo del celo del cernicalo crecerina comienza, al menos en Cirecia y España, en los últimos dias de abril o primeros de mayo. Aqui como alli, el nido suele estar regu. larmente en los huecos de muros o en los tejados de las casas, tanto solitarias como habitadas; muchos edificios contienen rarios nidos, ! en las ruinas antiguas hay á reces muchos. En Atenas los vi, no solo en ia Acrópolis, ocupa. dos en la construccion del nido, sino tambien en los tejados 
de las casas; en España se posésionan de la parte mas alta de las torres. En los demás paises de su área de dispersion y donde les faltan los edificios, anidan en rocas ó en huecos de árboles, y a menudo en sociedad con el cernicalo comun. Is de esmintr, pues, que Hucber asegure que el cernicalo crecerina ocupa en Carintia los nidos de la especie comun despres de ahuyentarla. El nido, de tosca y ligera construccion, ocnpa el interior de un hueco, yalli deposita la hembra los huevos, sin formar apenas un lecho de-ramaje. Ia puesta se comprone de cuarro, taras veces de cinco 6 seis huevos, y difieren de los del cernicalo comun por su menor tamano. Parece supérfiro decir mas sobre la reproduccion; ta hembra es la que se ocupa juncipalmente de la cria de los peñue. ros, pero algunas yeces asifdala el snacho, cuidandose tam. bien de alimentarla y relevandola en el nido cuando asi comviene, para cubrir los huevos. En Sicilia se llama a los. po:luelos habusejios di iralla, porque los caballeros de Malia ofrecian al ré de Sicilia con gran jompa uno de estos hal. cones como tributo, jara significar la dependencia de la reducidal pero valerosa hueste, que tenia por jefe al señor de la is ha

Saumcers nos ha dado una noticia sorprendente, aunque no increible, al decirnos que en ciertos casos sé aparean el cernicalo ootnun y el crecerina, produciendo mestizos á su vez fecundos. Esate aserto se funda sin embargo solo en el tamaño extaprdinario de algunos huevos, mayores que los del cernicalo connan, y por lo ianto deberia confirmarse con pruebas CAUTIVIDAD. - Los cernícalos creccrinas cautivos di. fieren meco en la jaula de sus compañeros del norte; su modo de condurirse es en lo esencial el mismo; mas por su bellexa se recomiendan mucho, $y$ liasta llaman la atencion de los indiferentes. Esta ave graciosisima es sumamente limpia; tiene su pluniaje inuy bien arreglado, y su aspecto; en cierto modo altivo, es siempre tan interesante, yue pronto se la toma carino. Ácostúmbrase fácilmente á su amo; vive en perfecta armonia con sus semcjantes, exigiendo solo un poco mas de cuidado que nuezeros halcones pari conservarse bien, prosperar $y$ vi vir contesta en la jaúla Este cuidado consiste ante todo en la eleccion del alimento, pues í los halcones pegueños que cazan insectos sc les debe tratar tambien como insctivoros La carne cruda sin mezcla con otra sustancia Ins mata con seguridad; las avecillas con plumas y los pequenos mamiferos no bastan tampoco, porque no se pueden obtener todos los dias; y por lo tanto es preciso buscar un alimento que se acomode flas descos y necesidades del ave Yo di í mis cautivos, 10 mismo que of los buhros pequeños, un alimento mez. clado, anflogo al que toman los insectivoros, y con el se conservadan las avecillas tan bien como pudiera desearlo. El cernimlo crecerina, asi como todos los congéneres proceden tes del ser, es muy sensible al frio, del cual se le debe pire. servar; ef fresco de los dias de otono les perjudica ya, y el hielo los mata sin remedio. Tan luego como la tem. peratura comienza \& refrescar muéstranse ariscos, erizan el plumaje, pierden la gana de comer y de banarse, enferman, y alacados al fin de convulsiones, caen muertos de la percha. Si el tiempo es favorable, por el contrario, y sobre todo cuando en las horas de la mañana se-siente el calor benefico dé los rayos del sol, nuésimnse siempre alegres y ticnen los ojos tan claros, que ficilmente se reconoce que se hallan bien. Gritan mucho, y a menudo en la misma jaula; mas por lo regular dejan oir solo el furolongado sonido jrrii, grrii, grrii, y no el mas claro y fuerte $k l i, k l i, k l i$; ambas voces se aseme. jan mucto al grito del cernicalo comun. El cernicalo crecerina saluda á sus conocidos lo mismo que su congénere del norte, siempre con el juimer grito.

Comn esta especie puede resistir bastante tiempo el ham. bre y solo alguna vez corre peligros al cruzar los mares, y atendido además que en su residencia de invierno encuentra siempre abundante alimento, su número aumenta visiblemente en tados los puntos donde su peor enemigo, el hombre, no la molesta ni persigue en sus nicos. Si el informe de Hucber resulta exacto, podemos esperar que no tardará en emprender su emigracion lácia Alemania; quiyas se presente mas pronto de lo que se cree, persiguiendo a la langosta viajera, que hace poco tiempo ha invadido este pais. Enton. ces deberemos dispensarle la hospitalidad que merece por sus útiles servicios; esta es una esperanza que quisicra ver realizada; pero se le perseguirá tanto cumo in nuestro cerni. calo, matandole con la misma crueldad que al kobez ves. irertino, el cual trataba de anidar en Bohemia. Despues de lo dicho sobre el cernicalo comun, inuitil es dar mas expli. caciones acerca de lo injusto é imprudente de tal proceder: pero atyui debo declarar que apruebo en un todo las pala. bras de Rieśnthal cuando dice: "Si nosotros nos quejamos en nuestros territorios de que en otros paises se persiga con excesoá las aves agradables y útiles para nosotros, y si por la via internacional buscamos remedio para esto, tambien deberiamos proteger en cuanto fuese posible a las aves que para aquellos paises no solo son títiles y agtadables, sino del todo indispensables.

\section{EL KOBEZ VESPERTINO-FALCO VES- PERTINUS}

Esta ave de rapiña insectivora, propia de la Europa meridional, muy afine de los cernicalos, y sobre tudo del creceri. na, es uno de los mas hermosos halcones en general. Mi nadre le ha separado de los cernicalos, tomándole por tipo

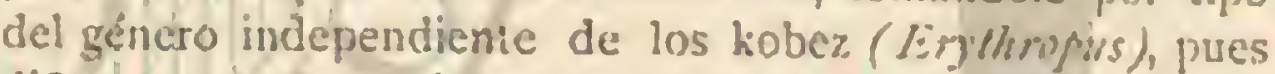
difiere por tener el pico mas corto, por las proporciones de las alas, por su cola mas corta, y en fin, por el color, que varalno solo segun el sero sino tambien segun la edad. "Todos estos caractéres distintivos no tienen suficiente imprortancia, ch nuestra opinion, para que podamos formar, dados los xdelantos actuales, un grupo independiente.

CARACTERES.-El kobez respertiro ticne la talla del cernicalo comun, con corta diferencia, ó sea $\|^{2}$, j I de largo por $1^{\prime \prime}, 7^{S}$ de ala á ala, $0^{\prime \prime}, 22$ esta, $y \|^{\prime \prime}, 1+$ la cola; la hembra mide $0^{\circ}, 03$ mas en la primera de estas dimensiones y $\|^{*}, 04$ a 0,05 en la segunda.

El macho adulto no puede confundirse con ningun otro halcon: el bajo vientre, las nalgas y las cobijas inferiores de la cola son de un rojo de orin oscuro; el resto del plunaje de un azul pizarra uniforme; solo la cola es un poco mas os. cura. La cera, el circulo desnudo que rodea el ojo, y las patas, son de un rojo ladrillo; e? pico amarillento con la punta azuladi.

La hembra tiene la cabeza y la nuca de orin claro; el lomo y la cola gris azul, con fajas oscuras: cl cuello blanco; el mostacho negro; la cara inferior del cuerpo de un rojo de orin, con algunas rayas pardas; la cem, el circulo de los ojos y las patas de un rojo naranja.

En los pequenos el lomo es pardo oscuro, presentando cáda pluma un filcte amarillo de orin; la cola de esté último tinte, y ornada de once ó doce listas trasversales oscuras; la garganta bianca: el pecho y el vientre de un blanco arnarillento con listas anchas de un color oscuro. Jas partes nue carecen de pluma son mas claras aun que en la hembra; el iris es pardo.

DISTRIBUCYON GEOGRÁFICA. - El kobe\% vespertino es propio del sudeste de Europa y del Asia central; solo á orillas del Amur y en China se halia representado por un 
congénere afine, el halcon del Amur (Falou amurensis). Escasea en el oeste de nuestro continente, pero se le observi á veces durante sus viajes; entonces se le ha cazado reperidas veces en varias régiones de Alcmania, en Helgoland, Inglaterra $y$ hasta Suecia. Mas a menudo cruza por. Francia $\delta$ Suiza, suele pasar todas las primaveras y otoños por Cirecia ¿ Italia, presentándose del 15 al 25 de abril y del 2 al $\mathrm{I}_{4} \mathrm{de}$ octubre en el primero de estos paises, y en el segundo en mayo; en Sicilin y Malta se le re al mismo tiempo que en
Grecia, y en la campiña de Roma durante su paso, á veces en bandadas muy numerosas, porque es uno de los halcones mas sociables. En las orillas del Bósforo es en la misma épeca tan comun como cualquiera de sus congéneres. En todos los paises citados no se ha encontrado nunca su nido, aunque Eugenio de Homeyer recibio de la Prusia oriental algunos polluelos que evidentemente contaban pocos dias de existencia; y segun refiere liehe, hratzsch encontró hace pocos años una pareja (que anidata en el distrito de Muec.
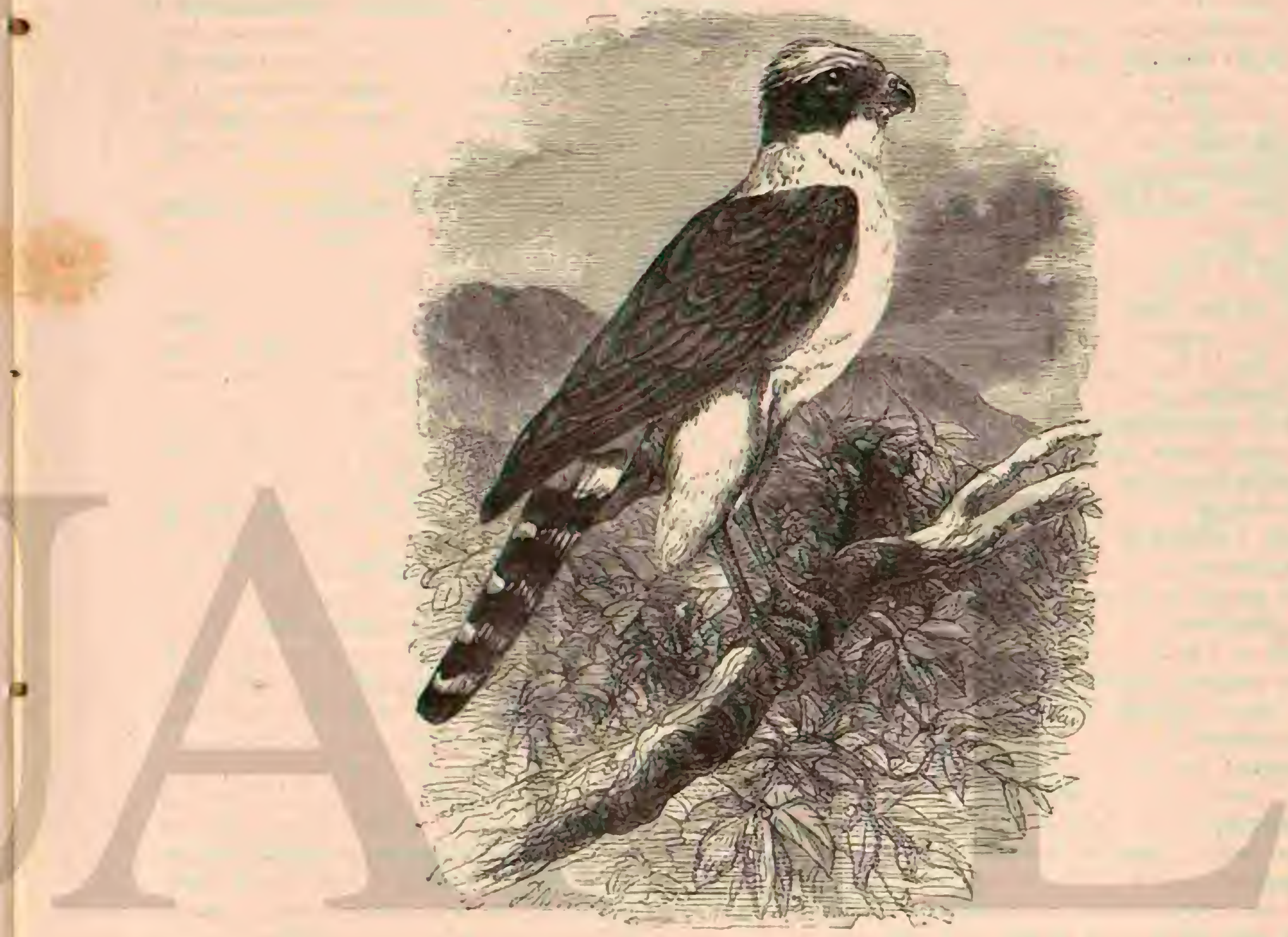

Fig. 1."1, - EL 3ACACUA BL:B2.0N

ker, ducado de Altenburgo. Aunque el hecho pruebe que la graciosa ave ha anidado dentro de los limites de Alemania, esto no pasará de ser una cxcepcion muy rara. El halcon de que se trata es en el verdadero sentido de la palabra un are propia de la csteja, en la cual habita desde Hungria, por el inediodia de Rusia y todo el centro del Asia, hasta las fron. teras de China, de modo que debe emprender preferentemente sus viajes á la India y no al Aírica. En este continente se la encuentra tambien en los paises del Nilo, pero siempre aislada; solo por el Sudeste se la ve con mas frecuencia, y es probable que lleguc desde la India y el sur de la Arabia.

USOS, COSTUMBRES Y RÉGIMEN.-En las estepas del mediodia de la Siberia occidental, visitadas por mi, $y$ en el norte del Turkestan, el kober. vespertino se encisentra con tanta regularidad como las nubecillas blancas en el cielo. Muy raras veces le he visto aislado: casi siempre iba $\mathrm{en}$ ban. dadas con el cernicalo creccrino, cuyo género de vida es completamente igual. Estos dos graciosos halcones son com. parierns fieles casi en todas partes, y lo que se ve en uno se observará tambien en el orro. Alli donde la estepa les ofrece sitios para el reposo, alli donde hay una linea telegráfica y el camino está señalado por pértigas, cestos cỏni. cos llenos de tierra, $\delta$ palos con dos 6 tres ramas cortadas de cierto modo, seguro es que se verí a esos halcones, posados en todos los puntos que pueden servirles de observasorio para examinar su dominio y buscar con la vista alguna presa. Apenas oyen el ruido del coche que se acerca ó la campanilla de los caballos, remóntanse y empiezan al cazar sugun costumbre. A impulso de algunos aletazos ágiles y ripicios como el rayo, que por muchos conceptos recuerdan i los halcones verdaderos, franquean cierta distancia, revolotean en todos sentidos, detiénense en algun punto moviendo ape. nas las alas; aranzan despues $y$ repiten sucesivamente los mismos movimientos gue antes. A memudo se ven dier, veinte ó treinta individuos de ambas especies nque cruzan el aire sobre la estepa al mismo tiempo; otras veces se presenta uno despues de otro, cual si quisieran relevarse en la ins. peccion de su territorio. Un momento despues precipitanse a tierm, donde permanecen un instante para recoger un insecto, por lo regular algun escarabajo, y clévanse de nuevo 
a la altura, donde comienzan fa retozar como antes. Comple. tamente seguros de que el observador no les molestará en lo mas minimo, ejecutan habilidades sobre sa cabeza, preci. pitanse al suelo junto a él, y hasta se acercan a una hoguera Solo cuando descansan en los hilos telegráficos ó en los postes no esperan siempre la llegada del hombre; huyen á menudo hasta hallarse a respetable distancia, y comienzan de nuevo a cazar, sin hacer ya caso del mismo hombre de quien antes huian. Muchas horas he pasado entretenido ob. servando a estas aves; algunas reces les apumaba con ni escopeta para ver si cuando rciolotean permanecen efectivamente en un mismo sitio, $\mathrm{g}$ conrenciame de que era cierto: despues no las molestaba mas, porque todo in ellas me interesada en alto grado.

Debo anadir que estas ares no sé éncuentran en todas las partes de la estepa con la misina frecuencia, y que en sus viajes sigueń marcadamente los grandes rios, ó por lo menos se les observa junto á ellos en el periodo de sus viajes mucho mas a menudo que en las estepas. Ias especies que aqui habitan se diseminan inas porque no encuentran en todas partes sitios á propósito para sus nidos. Yó creo que prefieren las ligeras pendientes de las colinas, $y$ hasta las vertientes mas escarpadas de las montaỉas, mejor que la lianura despejada, aunque tanpoco faltan aqui del todo. Esta preferencia se explica probablemente por la circunstancia de que en las cercanias de tales pendientes ó vertientes hay tambien algunas rocas propias para los nidos, las cuales pueden servir de punto central de reunion. Si en tal sitio hay algunos airboles altos, fórmase alli á veces una verdadern colonia, donde por 1a. manana, $y$ sobre todo por la noche, reunense todos los halcones. Tambien se les ve juntos á la hora del medio dia, formando grupos de veinte, treinta y mas individuos, posa. dos uno junto : otro en los árboles, donde reposan, espernn. do la caida de la tarde, propicia para la caza. En tales casos pucde ser que uno de aquellos árboles sea insuficiente para ofrecer á toda la bandada un punto de descanso, y que las aves, tan pacificas en general, se disputen los puestos, segun lo ha observado Nordmann. Su gran inclinacion da la sociab: lidad les impide, a pesar de esto, posarse en otros árboles, cual si creyesen que han de hacer todós lo mismo que parece bien á uno solo. Si una de las ares abandona el árbol donde reposa, siguenla dos ó tres para ponerse a su lado, y muy pronto llegan todas las demás por distintas direcciones para colocarse precisamente en el mismo árbol. Nordmann ase. gura haberlas visto is veces tan oprimidas, que de un solo tiro mató una docena, sin contar las que hirió ligeramente y no cayeron en su poder. Tan luego como la multitud de insec. tos comienza á moverse, elévanse las aves y vuelan en todas direcciones de la estepa, dando caza \& las langostas, hormigas aladas, mariposas y escarabajos; no reparan en su estado de desarrollo, pero prefieren los adultos, sobre rodo si son escarabajos, los cuales constituyen la base de su régimen alimenticio. Raras veces pueden apoderarse de una avecilla torpe, de un ratoncillo o de un lagarto pequeño. Asombrosa es la destreza con que recogen los escarabajos del suelo, sujetándolos entre sus garras para comérselos volando. Mu. chas reces los insectos son tan pequeños que no se pueden distinguir, à pesar de que el halcon los recoge á pocas me. tros de distancia del observador; solo se reconoce el buen éxito de la caza al ver que el ave devora la presa al vielo, para lo cual adelania ambas garras y la coge del pico. Cuan. do se acerca la noche tanto mas ágiles son sus movimientos, porque i la ho:a del crepúsculo salen mas y mas insectos de sus escondites para vagar por el aire. Por eso se ven á menudo balcones aun mucho despues de poncrse el sol; pero despues se retiran a su albergue. Si el tiempo es nebuloso, pósanse en el suelo, ó ruelan í poca altura, segun Robson, para atrapar algun insecto; mas apenas aclara el tiempo y el sol brilla en todo su esplendor, tambien las aves recobran toda su agilidad.

Llegado el periodo del celo, las bandadas que vivian reunidas en la residencia de invierno y regresaban juntas a su patria, disuélvense en parejas, y entonces se ve á los machos ejecutar roda clase de habilidades en honor de la hembra. Sin embargo, los kobez vespertinos, por lo que yo he podido observar, retozan mucho menos que los lialcones y milanos, aunque pasan la mitad de su vida ejercitándose en el vuelo. Con gran sentimiento mio no he podido hacer obser. vaciones propias sobre la reproduccion, y debo atenerme por lo tanto á lo que han dicho otros naturalistas, sobre tocio Radde y Nordmann. Segun los informes del primero, fabrican su rido en mayo sobre los árboles, y con preferencia en sauces altos; cl scgundo dice que ś menudo buscan un nido de urraca. Esta ave no lo cede voluntariamente, y asi es que la parcja de haliones debe trabar encarnizadas luchas para obtener su fin, liamando á veces en su auxilio otros de su especie. Se ha pretendido que el kobez vespertino anida con preferencia en huecos de árboles, lo cual me parece bastante probable. La puesta se compone de cuatro á cinco huevos muy pequeños y redondos, con cáscara granujienta muy fina, de color blanco amarillento, cubiertos de puntos y man. chas pardo-rojas mas ó menos oscuras. A primeros de agosto, los polluelos salen ya del nido, y sus padres les enseñan cuidadosamente cuanto es necesario. Cuando han ajrendido a cazar, periueños y adultos emprenden la marcha hácia sus cuarteles de invierno.

Es muy fácil coger al kobez respertino con los inzos mas toscos; ningun otro halcon, excepto quizís su congénere mas afine, se deja engainar tan fácilmente. Basta ponet á su vista un grillo, una langosta ú otro insecto grande, rodeando este cebo con liga, para cogerle con seguridad: su plumaje queda pegado en aquella sustancia, y no puede volar cuando coge la codiciada presa.

CAUTIVIDAD.-Fácilmente se acostumbra el kobez res. pertino á la cautividad, ó cuando menos asi me lo hacen su. poner los que yo mismo he cuidado y los que he visto en jardines zoológicos. Sobrada razon tengo para decir que una jaula habitada por kobez vespertinos debe parecer interesante y graciosa á todo observador. Poscen todas las buenas cualidades del halcon, y además su belleza; su modo de colo. carse es gracioso, su carácter pacifico y su rapacidad relativa. mente escasa. Agradecen el cuidado y el cariño que se les dispensa; conocen muy bien a sus amigos y les saludan al verlos con alegres gritos. Sin reparo alguno se les puede tener rcunidos en la jaula, y hasta con el cernicalo crecerino: yo creo que tambien vivirian en buena inteligencia con buhos pequeños. Parece que les cuesta mucho trabajo matar una avecilla, aunque la acometen al punto. Yo alimenté mis cal1tivos con lo que comian los mirlos, y al parecer les sentaba muy bien; habianse acostumbrado muj pronso $\{$ la mezcla, mostrándose muy hábiles para cogerla. A decir verdad, es curioso espectáculo ver á un halcon entreteniéndose con una mezcla de carne picada, pan rascado, zanahorias y larvas, de hormiga.

\section{LOS ASTURIDOS-ACCIPITRINA-}

Los astúridos son las ares que mas se asemejan á los falcónidos, y las mejor dotadas entre las rapaces: aventajan á los mismos halcones, pero carecen de la nobleza que distingue á estos.

CARACTÉRES. - I Los astúridos cienen el cuerpo recogi 
do, el cuello largo, la cabeza pequeña, las nlas cortas y rédondeadas, fa cola muy larga, los tarsos altos y las garras grandes ó pequeñas. El pico es menos convexo que en los falcónidos y mas comprimido lateralmente; el diente de la mandibula superior no se marca tanto y esta mas atrais, aunque en este carácter se observan numerosas varicdades. Salvo raras excepciones, no está rodeado el ojo de un circulo desnudo: el plumaje es bastante espeso y blando, y su color varia segun la edad; pero no por el sexo.

DISTRIBUCION GEOGRAFICA.-Esta subfamilia, que cuenta unas ochenta especies, está diseminada en rodas las partes del mundo, y hasta hay ciertos géneros que se hallan representados por do quiera Los mas tienen un àrea de dis. persion muy extensa, y la de los menos es limitada.

USOS, COSTUMBRES : REGIMEN. - Los astúridos habitan casi exclusiramente los grandes bosques y se ocultan en los sitios de mas espesura. Están muy bien dotados y nada tienen que desear por lo que hace á sus cualidades fisicas: su vuelo es fácil y rápido; cambian instantáneamente de direccion, y se deslizan con la mayor facilidad á través de la mas intrincada espesura; vuelan casi rasando el suelo, y por tierra andan bien, aunque ayudaindose con sus alas; en medio de los árboles mas espesos se mueven con la mayor agilidad.

Son enemigos temibles para todos los animales pequeños; dan caza á los mamiferos como à las aves y reptiles; lo mismo se appoderan de su presa al vuelo que à la carrera, á nado como estando posada; y la persiguen sin tregua ni descanso. Tal es su sed de sangre que se olvidan de atender á su propia seguridad; acometen $\mathbf{a}$ los animales grandes, $y$ las mas de las veces alcanzan la victoria; pero hay ocasiones en que pagan con la vida su temeridad.

Estas aves se inanifiestan tan poco afectuosas entre si como con los otros animales: el amor parece ser entre ellas un sen. tinivento desconocido; la hembra se come al macho; el padre 6 la madre devoran da sus hijuelos, y cuando estos llegan a ser bastante fuertes, acomeien a los que les dicron el sér: solo cuando están todos hartos reina la paz entre los individuos de una misma familia.

Los astúridos se multiplican, por desgracia, rápidamente, pues cada puesta consta de un regular nimero de huevos. Estas aves anidan en los ärboles, y construyen por sí mismas su albergue; algunas especies adornan vistosamente los nidos con ramas verdes, que renuevan á niedida que se van secan do. Defiendén con valor á su progenie, aunque sea contra el hombre.

Todos los astúridos son animales daninos álos que se debe perseguir sin tregua: los falcónidos merecen hasta cierto pun. to que se les defienda y proteja; pero hacerlo con los astifri dos scria un crimen. Aunque es cierto que se adiestran algu nos para la caza, tampoco se les puede clogiar por este concepto, porque son aves tan caprichosas, que con dificultad se las enseña, y rara vez encuentra uno la compensacion de sus molestias.

CAUTIVIDAD.-Los astúridos son desagradab!es cuan do estån cautivos, y dificiles tambien de mantener, por causa de su roracidad y sed de sangre. En cuanto á ponerlos con otras aves, no hay que pensar en ello; y cuanto mas se les co. noce nas se les aborrece.

\section{LOS MACAGUAS - HERPETOTHERES}

CARACTERES. - Los macaguas constituren en cierto modo el tránsito de los falcónidos á los astúridos. Tienen el cuerpo vigoroso; la cabeza grande; las alas, medianamente largas, alcanzan 12 mitad de la cola, y se componen de rémi. ges angostas y puntiagudas, siendo la tercera y cuarta las mas largas. La cola es medinna, un poco reciondeada; lus tarsos de un largo regular y gruesos; los dedos pequeños; las uñas cortas y gruesas; el pico alto, muy comprinido lateralmente; la mandibula superior en extremo ganchuda y la inferior baja y roma. El cuerpo esti cubierto enteramente de plumas largas y puntiagudas, de tallos rígidos; el contorno del ojo aparece desnudo.

\section{EL MACAGUA BURLON-HERPETOTHERES CACHINNANS}

CARACTÉRES.-El macagua burlon, llamado asi por su voz sonora $y$ penetrante, que ofrece cierta semejanza con una carcajada, tiene casi la talla del azor de Europa; perosu cabeza es mas voluminosa y su cuerpo menos grueso. El plumaje de aquella es de color anarillo pálido, ; negro el tallo de cada pluma; las mejillas y la nuca negras; las piumas del lomo pardas, con un angosto filete claro; la cara inferior del cuerpo y una faja de la nuca blancas; el pecho y las nalgas de un blanco rojizo; la cara superior cle la cola negra y la inferior de un amarillo blanquizco, con seis ó siete fajas grises y una blanquizca terminal. Ias rémiges son pardas en las barbas externas, $y$ de un amarillo naranja ó blancas en las iniernas, que presentan estrechas fajas trasversales pardas. El ojo es de un amarillo rojizo, el pico negro y la cera amarilla, lo mismo que las patas. Esta ave mide $10^{\circ}, 55$ de largo; la cola $\left(1^{\prime \prime}, 23\right.$ y la altura de los tarsos es de $\|^{\prime \prime, 07}$ (fig. 140).

DISTRIBUCION GEOGRÁFICA.-Fi macagua es propio de las partes cálidas de la América del sur.

USOS, COSTUMBRES Y REGIMEN.-Azam, Orbigny y Schomburgk no5 han dado a conocer el género de vida del macagua. Dicen que está diseminado en una vasta extension de la América del sur; que se encuentra en tocias partes sin ser comun en ninguna, y que escasea en las costas. Segun d'Orbigny se le ve principalmente en el lindero de los bosques y a lo largo de los rios.

Posado en un viejo árbol muerto, deja oir su grito, semejante a una especie de carcajada, y que por esta particularidrid ha llamado mucho la atencion de los indios. Sus movimientos son los del ave yerezosa, que poco aficionada if volar, nunca va léjos y se limita a pasar de un árbol á otro. Schomburgk dice, lo mismo que d'Orbigny, que no le ha visto nunca cerniéndose en el aire.

Se alimenta principalmente de reptiles, aunque no desprecia las ares, y caza tambien los pequeños maniferos: d:Or bigny opina que come asimismo peces.

Segun Schomburgk, construye su nido en árboles poco elevados.

En todo el l'arnguay estín persuadidos los indios de que el grito del azor anuncia la llegada de una gran caravana; 5 tambien los españoles tienen la misma creencia

\section{LOS DIODONTES - HARPAGÚS}

CARACTF̊.RES. - Estas aves son astúridos de pequeña talla, alns cortas y cola larga y ancha. Distinguense por su pico, cuya mandibula superior, apenas mas larga que la inferior, tiene los bordes muy festoneados y provistos de dos dientes graduados que sobresalen; la mandibula inferior es roma, y tienc cerca de su punta dos dientes agudos; las alas son sub-agudas, los tarsos cortos y del mismo largo que el dedo del centro.

DISTRIBUCION GEOGRÁFICA.-Este género solo habita en la América del sur: esti representado por dos espe. cies que los brasileños confunden con el nombre de garioo, y los indios de la mortaìa con el de zmos. 


\section{EL DIODONTE BIDENTADO-HARPAGUS} BIDENTATUS

CARACTERES. El diodonte bidentado mide $\theta^{\circ}, 37 \mathrm{de}$

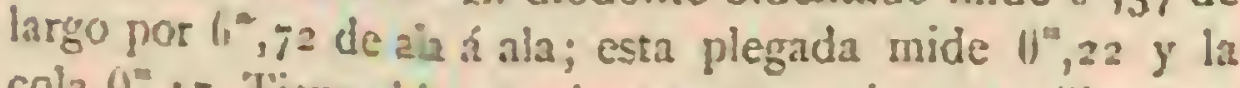
cola $(1), 17$. Thene el lomo gris negro con visos metálicos; el vicnire pardo rojo; ałorna la garganta una faja blanca y es. trecha; la raiadilla es de este color; las rémiges negras, con fajas trastersales de en pardo claro y blancas en las barbas

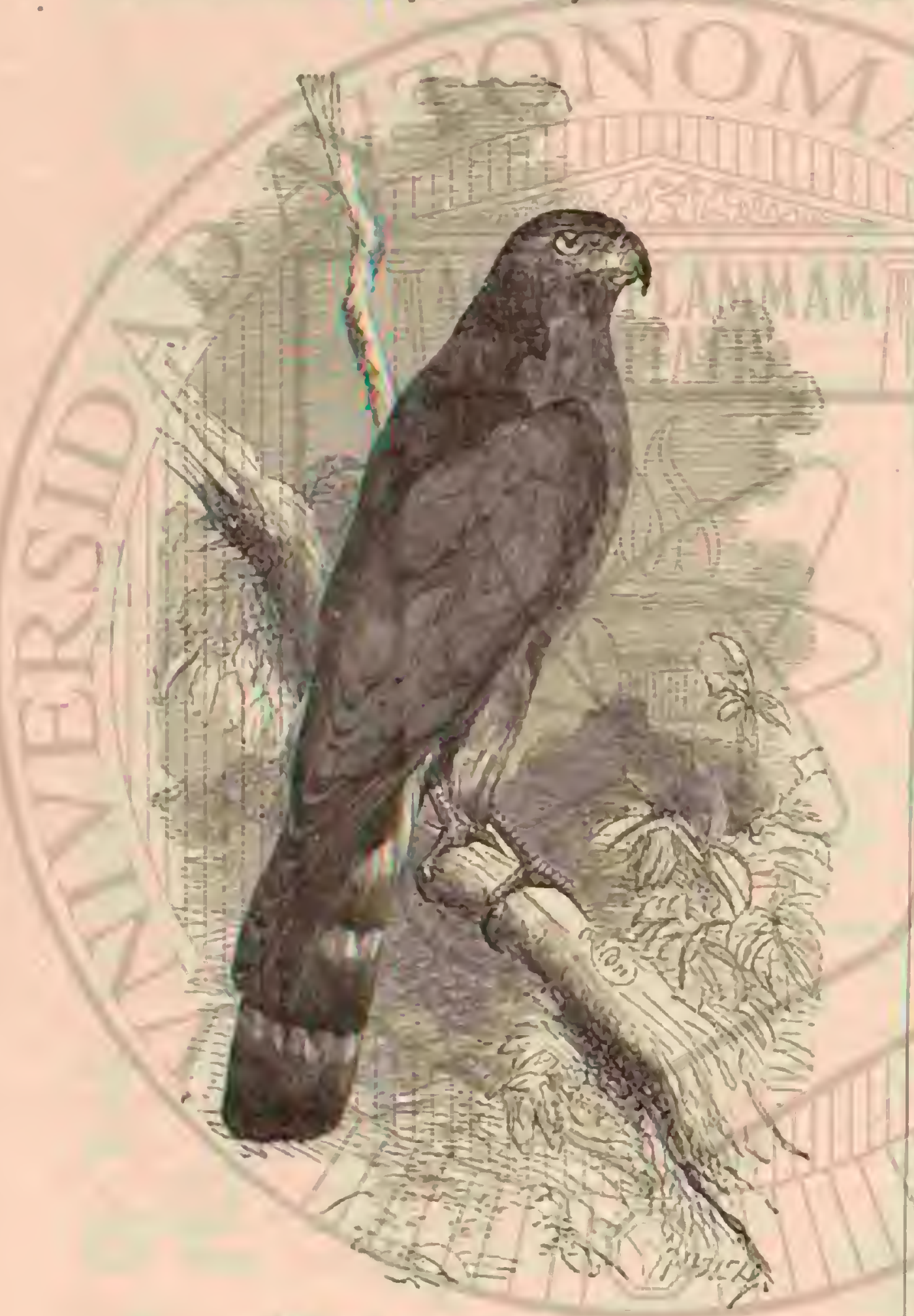

Fig. I41, - EL DIONONTE. EIUI:STA1O

internas: las rectrices negras cn la cara dorsal, parduscas en la ventral, y cruzadas por tres anchas listas grises; el ojo de un tinic carmin claro; la cera amarillo verdosa; el pico gris negro $y$ las patas de un rojo amarillo (fig. 141 ).

Los pequeños tienen el lomo pardo $y^{\circ}$ el vientre blanco, ondulado de pardo claro ó rojo pardo.

DISTRIBUCION GEOGRÁ FICA.-Esta ave es bastan. te comun en los bosques de casi toda la América del sur.

USOS, COSTUMBRES Y REGIMEN.-A semejanza de los demás astúridos, permanece solitario en la copa de un espeso árbol, acechando a las aves, a las que persigue activa. mente. Segun T'schudi, es atrevido y valeroso, y no le arredra acometer á olros animaies mas grandes por lo cual le iemen los indios. Caza las aves de corral, y no se aleja de los alre. dedores de una granja sin haber deiorado la última gallina. Es prudente y astuto, como el azor de Europa, y casi sienpre escapa del cazador. In caso de necesidad, conténtase con insectos; y segun Burmeister, este es el alimento de los jx. qutños que no pueden aun cazar.

Se encuentra el nido del diodonte bidentado en los altos úrboles: los huevos, en número de tres ó cuatro, están cubicr. tos de puntos de color rojo pardo, y se asemejan mucho á los del gerifalte.

\section{LOS GAVILANES - NISUS}

CARACTERES.-Tamos á cxaminar ahora el gavilan, representante europeo de un género extendido sobre toda la superficic de la tierra. Un cuerpo prolongado, cabeza jeque. ทั., pico delgado, sumamente ganchudo; alas cortas; cola larga y truncada en ángulo recto; tarsos endebles y largos; de. dos delgadios y prolongados, y uñas muy aceradas, son los principales caraciéres de los gavilanes. El plumaje varía muy poco.

De todas las aves de rapina congeneres, los gavilanes son las mas ágiles y atrevidas, poseyendo además todas las cualidades de los géneros superiores de csta familia.

\section{EL GAVILAN COMUN-NISUS COMMUNIS}

CARACTERES. - Il gavilan comun, llamado tamuien gavilan de golondrinas, de grorriones, etc, es una de las peque. nas aves de la farmitia. Su longitud no pasa de $0^{\circ}, 32$ por $0^{\prime \prime}, 64$ de anchura de punta á punta de las alas, que miden ()$^{\circ}, 20 \%$ la cola $11^{\circ}, 25$. La hembra es de $0^{\circ}, 08$ a $0^{\circ}, 09$ mas larga $y$ (1) $, 1=300^{\circ}, 15$ mas ancha (fig. 1.4 2).

Los adultos tienen el lomo de color gris ceniciento ne. gruzco, el vientre blanco, con mezcla de rojo de orin, mas marcado en el macho que en la hembra; la cola tiene cinco 6 seis fajas negras y es blancr en el extremo; el pico azulado, la cem amarilla, el iris de un amarillo de oro y los piés de un tinte amarillo pálido.

los gavilanes jóvenes tienen la cara superior del cuerpo gris parda y la parte inferior blanca con manchas pardas, longitudinales en la garganta y el cuello, y irastersales en el vientre y el pecho.

En la perrinsula del Balkian, asi como en el interior de Kusia, existe otro congénere, asociacio con el gavilan conun \& bien representindole: es el gavilan brevipedo (Nisus liresipes.) que dificre por tener el pico y garras mas fuertes; tarsos y dedos mas cortos: plumaje mas oscuro, a\%ul de pizarra en In parte superior y con mayor número de manchas en la in. ferior, sobre todo en la region del buche; las fajas de la cola son mas estrechas y graciosas, y las alas, de un solo color, mas puntiagudas que las de nuestra especie.

DISTRIBUCION GEOGRAFICA. - Parece que el gavilan no falta en ningun punto de Furopa; segun parece, anida y vire en la mayor parte del Asia central. Se le en. cuentra en Laponia y el norte de Escandiuavia en general, así como en Grecia. Desde el Amur se disemina par toda el Asia central y la Europa hasta Madera, hallindose por lo tanto en el norte del territorio del antiguo continente. Segun la naturaleza de los bosques abunda mas en Furopa que en Asia, pero tampoco aqui falta en ningun territorio que en algo corresponda a sus necesidades. En oivio emprende tambien viajes durante los cuales persigue mas bien á los fringilidos que á las alondras, llegando hasta el norte de Africa y en el Asin hasta la India. In los paises del Nilo ex. tiende sus correrias, segun Rueppell, hasta el Kordotan; yo no le he visto sin embargo mas alla del sur de la Nubia cen. tral. Fin Egipto, Argelia y Marruecos, asi como tambien en las peninsulas meridionales de Europa, se le encuentra á menudo dumnte todo el invierno; desaparece del nordeste de Africa a principios de la primavera : pero scgun dicen, anida en Argelia y en las islas Canarias. Asegúrase que tambien lo hace en el Asia Menory en Persin; en el norte de este último pais parece ser conocido de todo el muncio. Fn la India se 
presenta con regularidad todos los imviernos, segun Jerdon à principios de octubre, desapareciendo á primeros de febrero ó marzo.

USOS, COSTUMBRES Y REGIMEN. - El gavilan comun habiti en bosques de toda clase, sobre todo en los que lindan con los campos, y con preferencia en regiones montanosas. Sin embargo, no teme al hombre; léjos de ello, anida en las inmediaciones de pueblos y ciudades, los cuales visita en invierno con regularidad, $y$ hasta busca su presa en los jardines situados en medio de las grandes poblaciones. Cuardo ha tenido la suerte de coger una presa en tal paraje, visitale todos los dias a la misma hora, y ni siquiera tiene la precaucion de llevarse su victima á mucha distancia; mátala en cualquicr sitio oculto en la inmediacion de edificios habitados, $y$ alli la derora.

aEl gavilan, dice ni padre, està todo el dia oculto y no se deja ver sino cuando caza. A pesar de sus pequeñas alas, vuela ficil y ligeramente; pero es en cambio torpe para andar y avanza is saltitos.

- T'an receloso como atrevido, no tene a las ares mayores que 61. Bechstein dice que el macho es mas valeroso que la hemina, y Namann opina lo contrario; yo creo que los dos se engañan, pues ambos sexos se distinguen igualmente por su arrojo, aunque debo añadir que la hembra es mas vigoro. sa y pucde sostener una lucha en la que sucumbiria el ma. cho. Cierto dia vi un ejemplo de ello: un gavilan hembra habia cogido un gorrion y se lo llevó detrás de una cerca, á unos diez. pasos de mi casa, pana devorarle tranquilamente. In el momenio de comenzar su comida, llegó una corneja para quitarle la presa. El gavilan la cubrió con sus alas, y como su enemigo le acometiese varias veces, cmprendió el vuelo, llevándose al gorrion en una garn; volvióse despues con notable agilidad, tocando casi con su espalda el suclo, y descargó tan violento golpe con la garra libre sobre la corлeja, que esta huyó presurosa. El macho no es menos osado que la hembra, é introdúcese como ella en el interior de los pueblos.s)

El gavilan comun se distingue no solo por su osadia, sino tambien por su gran presencia de ánimo y su astucia; es la imágen riel de un ladron vagabundo ó de un bandolero, y difiere en su sér esencialmente de todos los demás halcones europeos, exceptuando tan solo su congénere brevipedo y el azor. Sus movimientos, que guardan proporcion con sus cor. tas alas y larga cola, permiten reconoccrie con seguridad desde léjos. Solo cuando quiere pasar de un bosque à otro, cruzando el campo libre, vuela a impulso de algunos aletazos rápidos, 5 despues se sostiene con las alas extendicias en linea reca; mas por lo regular sigue el lindero del bosque ó de una espesura, cjecutando continuamente las evolucio. nes mas diversas. En los bosques se le ve muchas veces en las copas de los arboles, pero con mas frecuencia debajo ó en medio de ellos. Costea las espesuras ó las cercas a fin de acechar mejor á poca distancia del suelo; da súbitamente media vucla en el ramaje para mirar por el otro lado del bosque; pasa rozando las copas de los árboles: da otra vuelta y aparece de este modo siempre, en el momento menos pen. sado, junto a las aves posadas en el ramaje: entonces se remonta bruscamente \& la altura y precipitase con la rapidez del rayo sobre su presa. Se vale de la astucia mas que cual quiera otra ave de rapiña. Naumann dice que \& veces imita el vuclo del grajo para cnganar a las aves pequeñas; $y$ Eugenio de Homejer ha observado lo misnn: I Un ave, dice, aparecio de pronto à lo último de una larga hilera de encinas, y voló à la manera del grajo, lentamente y de àrbol en árbol, permaneciendo un instante en cada uno de ellos.y. Esta maniobra se parecia tanto á las del grajo, que
Homeyer fijó solo su atencion en el ave porque las bellotas no estaban maduras aun, no habiendo de consiguiente razon para que un grajo examinase el follaje de las encinas: solo entonces reconoció con mucha sorpresa que era un gavilan. La rapaz, acercíndose poco á poco á la tíltima encina, donde se hallaba un grupo de avecillas, diuse á conocer al fin con su vercadero carácter; se precipitó como un rayo sobre aquellas, y un momento despues alejóse con una victima sangricnta entre sus garras.

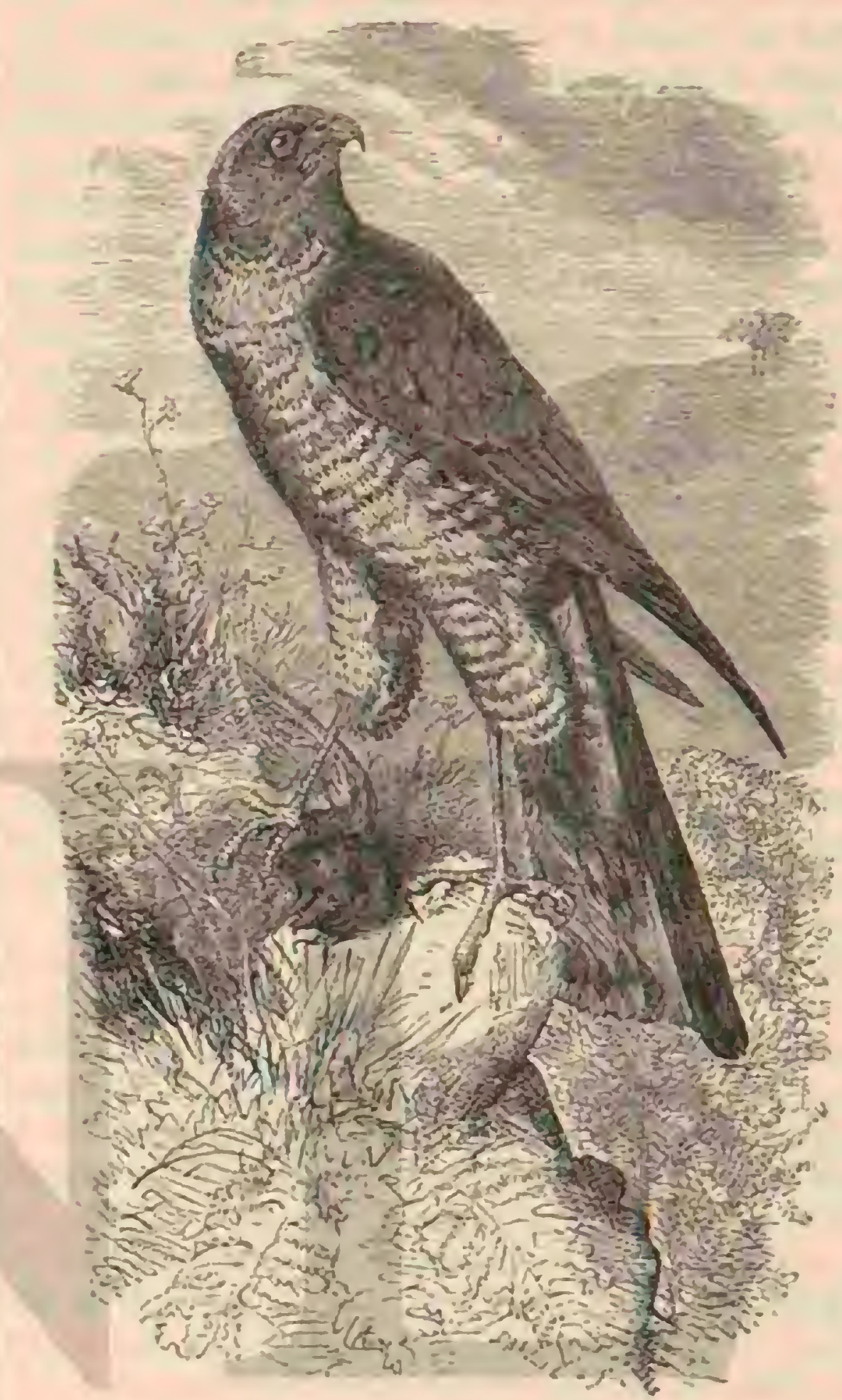

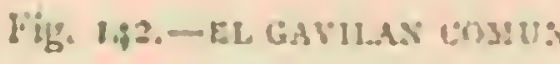

Una vez despertada la rapacidad del gavilan, olvida todo 2 su alrededor, sin hacer caso ni del hombre, ni de los perros ó gatos; solo se fija en la presa qque ha llamado su aten. cion; precipitase como una Becha por encima del hombre, tocando casi su cabeza con las alas, coge su victima con segura gatra, y desaparece al punto antes de nue el observador sepa lo que pasa. Muchas reces se han cogido gavilanes en el interior de las casas, y hasta en coches que iban á la carrera, pornue habian perseguido su presa con tanta voraci dad que olvidaban toda prudencia.

Ultimamente se ha referido que un gavilan, nersiguiendo a un are entró en un coche de un tren en marcha y apoderóse de su presa. I as aves cautivas en la jaula, puesta en una ven. tana dentro ó fuera, no estón mas seguras contra sus ataques que las libres. Sin hacer caso del obstáculo, precipitase sobre los vidrios con peligro de su vida; rómpelos por la fuerza del choque de su cuerpo, y dirigese contra el ave à pesar de los gritos de los moradores de la casa. Una vez, dice Schacht en su Founa ormitolizica de la selin de Teuetolurgo, libro recien escrito y recomendable porque solo cita observaciones propias, tenia yo una jaula con varias aves de reclamo colo- 
cada en el jardin junto a la cerca. Cierto dia me acerqué para tomar un ave, y cuando iba á coger la liga, precipitóse bruscamente un gavilan sobre la avecilla, dando rapidas vueltas al rededor de la jaul.. Nunca habia visto tal atrevimiento y como no tenia otra arma en la mano arrojé la liga sobre el ladron. Desgraciadamente no le tocó y pudo escapar. $\gg$ sun cuando se le dispare un tiro no ceja en su empeño de robar. Rohweder disparó su escopeta, cargada de perdigones gruesós, contra un gavilan que volaba, el cual revolviéndose sobre si mismo y con las alas exiendidas, precipitóse hácia abajo, cayendo en la rama de un arbol á cinco metros sobre el sue. lo; cogido á clla con el pico, permaneció unos dos minutos con la cabeza liácia abajo y las alas extendidas, al parecer sin aliento. Cuando lcvanió cespues la cabeza $y$ agitó las alas, dice el citado cazador, crel que estos movimientos eran el principjo de la agonia ; ccliéne pues la escopeta al hombro y alargué el sombrero para secibir la rapaz al cacr. En el mișmo instante abrió las garms, jero en vez de caer, tendió las alas y escapóse antes que pudien prepararme para tirar. De pronto aparece un estomino, la rapaz le atrapa, y aléjase triunfante con su presa cual si nada hubiese sucedido. Pro. bablemente uno de los perdigones habia socado en el pico y aturdido a la rapaz sin herirla A menuido coge las aves heridas à la vista del cazador; Taczanowski llega a suponer que basta un tiro para atmerla, y yo tambien debo decir que muchas veces he visto llegar un gavilan despues de resonar el tiro; pero nunca hice tal suposicion en semejante caso.

El gavilan comun es el mas terrible enemigo de todas las ares prequeñas: descle la perdiz hasia el reyezuelo, ninguna esta segura; su osadia es exiremada, y hasta se le ha visto acometer i los gallos $y$ is las liebres. En este último caso parece mas bien divertirse, asustando al timido roedor.

Algunos obscrvadores que conocen muy bien esta rapa\% y su indole han querido negar que coge palomas y perdices. Sncll sobre todo asegura no haber visto nunca yjue un gavilan atacase a las palomas. Es verdad, dice, que estas aves huyen tan luego como un gavilan se dirige hácia ellas; pero por mas que he observado, solo he visto que la ranaz pasaba siempre delante de las palomas, para precipitarse sobre los gorriones que se hallaban en el patio ó on la cerea del jardin. Una ver, hasta vi uno posació á pocos metros de la entrada de mi pa. lomar; pero convencime de que solo la persecucion contra los gorriones le habia conducido alli.n Por regla general, esio puede ser exacto; pero sé de casos en que los gavilanes, y sobre todo hembras, cogieron palomas y perdices; Alejandro de Homejer está conforme con esto ullimo, pero no Zittwitz; Tobias habla de los ataques del gavilan contra pequeñas ga. llinas domésticas inglesas.

- Mi padre, me escribe de Reichenau, consiguió en una de sus cacerias apoderarse de una perdiz sin necesidad del perro y sin gastar pólvora ni plomo; á la distancia de algunos centenares de pasos levantóse una bandada de perdices y casi al mismo tiempo se precipitó sobre ellas una hembra de gavilan; cogió la mas cercana y huyjo con $5 u$ victima $\{$ una pradera, donde la degolló. Mi padre esperó tranquilamente hasta que la perdiz estuvo nucrta, yoculto por un declive acercose á hurtadillas hasta el sitio donde debia estar el ga. vilan, cogió una piedra y arrojóla gritando al mismo tiempo ruidosamente, con lo cual asustó a la rapaz de tal modo, que dejó la perdiz y huyo. In oira ocasion impedi a oira hembra de gavilan solo con mis gritos, apoderarse de una paloma que ya habia alcanzado.y Ia verdad es que al gavi. lan no le falta ralor ni rapacidad para atacar cunlquicra caza cuando espera rencerla, y hasta se atreve al parecer con animales mas fuertes.

\&Paseåndorne un dia por el bosque, dice Naumann, vi una garza real que rolaba tranquilamente rasando la copa de los árboles. De repente salio un gavilan de la espesura, cogio por el cuello al ave sorprendida, y cayeron las dos lanzando agudos gritos. Yo acudi presuroso, mas por desgracia me divisó el gavilan demasiado pronto, soltó la presa y huró. Hubierame gustado ver el desenlace de aquella lucha desigual, y si la temeraria rapaz habria concluido por vencer á la garza y ahogarla.

Suponiendo que el gavilan, al acometer á grandes mamiferos, solo se propone asustarlos, debemos creer sin embar. go que coge los pequeños, como por ejemplo la ardilla, solo para nutrirse de su carne. Cárlos Müller observo, ocultaindo. se durante mucho tiempo, cómo un gavilan atacó repetidas veces 2 una ardilla, poniéndola en el mayor peligro.

Las aves pequenas, sobre todo los fringilidos, gorriones, estorrinos 5 mirlos, son las mas cxpuestas a caer en las gar. ras del gavilan, porque sorprendiendolas siempre las impide salsarse, sin contar que las coge volando y hasta las persigue corriendo.

To vi un dia, dice mi padre, un gavilan que iba persiguiendo d un gorrion por una cerca; conociendo este último que si apelaba al vuelo estaba perdido, corria siempre \& través del rallado y de un lado á otro, y la rapaz le seguia en cuanto le era posible; pero cansada al fin de aquella caza infructuosa, fué á posarse sobre un ciruelo próximo, donde la disparé un tiro.

Todas las aves pequeñas conocen y temen à su poderoso adversario: al verle los gorriones, se refugian, segun dice Nordmann, en los agujeros de los ratones, $y$ las oiras aves buscan cualquier escondrijo. Muchas dan una prueba de su perspicacia trazando circulos nuy cerrados alrededor de las ramas del los árboles, $y$ como el gavilan no puede seguirlas con bastanié ligereza, alcanzan cicrta ventaja sobre él y des. aparecen luego en lo mas compacto de la espesura; otras se dejan caer á tierra, permaneciendo inmóviles; y con esta ma. niobra se salvan a menudo. Las mas aigiles las siguen lanzando gritos, y avisan con ellosá sus companeras; las golondrinas de chitnenea, particularmente, le molestan en sus cacerias, y la rapaz parece comprenderlo; cuando comienzan á seguirle, elévase en los aires, describe algunos circulos y huye hácia el bosịue, furioso sin duda contra las f́giles ares.

Rara vez se escapa al gavilan comun su presa, y á menudo coge dos de una vez: conduce su victima a un sitio oculto, le arranca las grandes plumas y la devora, arrojando luego los huesos y demás restos; las avecillas que se hallan en el nido todavia, son para él una golosina, sin despreciar tampoco los huevos. $* E l=9$ de mayo, refiere Hintz, vino un pastor á de. cirme que habia encontrado la vispera un nido de perdices con veintidos huevos; que ya no quedaban sino veinte, $y$ que acalaba de observar â un gavilan pequeño que volaba cerca del nido. Acudi al momento, y como ya no encontrase mas que diez y nueve, oculteme para observar; aun no hacia un cuarto de hora que me hallaba al acecho, cuando viá un ga. vilan llegar al nido y alejarse despues; reconoci entonces que faliaba oiro liuevo, y mas tarde volvió por un tercero; no pude ver cómo se los llevaba, si en las garras ó en el pico.

Rara vez se oye la voz del gavilan: su grito-se expresa por las silabas ki, ki, ki, repetidas varias reces, 6 kack, kack, pronunciadas lentamente: las primeras parecen set su grito de aviso.

El gavilan anida en las espesuras, generalmenie a poca distancia del suelo, y cuando puede, en una conifera, cerca del tronco. Lin Escandinavia, segun dicen, anida alguna ve\% en las rocas, y segun otra no:icia, tambien en huecos de arboles: ni lo uno ni lo otro me parece exacto, porque esto no se aviene con el carácter del gavilan, que siempre está posa- 
do en árboles $\delta$ en el suelo. En aquellas regiones, donde los bosques y los campos aiternan, elige una espesura situada lo mas cerca posible de estos últimos, para construirse en ella su nido aunque sea en la inmediacion de los pueblos; la hem. bra empolla alli muchas veces, $y$ hasta dos al año cuando le roban los huevos.

El nido varia segun la naturaleza del sitio; à veces consiste solo en mamas secas de pinos, abctos 6 abedules y está cons. truido tan ligeramente, que mas bien parece el de una paloma silvestre que el de una rapaz; otras reces en cambio, esta compuesto de los materiales citados, de musgo, hojas secas y tierra, rellenado por dentro con ramitas, raices y pelos, ó tambien con plumon de la hembra, en cuyo caso tienc un aspecto muy bonito.

A fines de mayo se encuentran de tres á cinco huevos, bastante grandes, de cáscara lisa y gruesa, y'cuya forma, co. lor y tamaño varian mucho. Son generalmente blancos, agrisados 6 verdosos, sembrados de puntos mas 6 menos grandes y compactos, de un tinte pardo rojo 6 rojo gris azul. Solo cubre la hembra: jamis abandona sus huevos y los defiende con valor: los padres llevan á sus hijuelos el alimento; pero solo la hembra lo prepara convenientemente. Se ha visto morir de hambre a unos gavilanes pequeños, cuya ma. dre habia sucumbido, aunque tenian a su lado un abundante alimento que les llevaba el macho, pero que no sabia prepa. rar. Despues de emprender su vuelo permanecen los peque. nos largo tiempo con sus padres, que los guian, cuidan y en. senian.

Las grandes especies de falcónidos y el azor de las zuritas devoran al gavilan sin escrúpulo cuando pueden apoderarse de el; las pequerias manifiestan todo el aborrecimiento que les inspira, persiguiéndole juntas. El gavilan liene un enemigo cncrinizado en el hombre, sobre todo en aquellos pun. tos donde se observan los daños que ocasiona; esta rapaz no merece perdon, pues donde se encuentra no hace mas que exterminar, y por lo tanto es justo que se la persiga sin tregua

CaUtrvidaD. - A pesar de todo, el gavilan no es ub jeto de reprobacion universal, pues en varios pueblos de Asia le aprecian mucho. "Lin el sur del Liral, dice Evers. mann, es el ave mas usada, principalmente para la caza de calandrias: se adiestran los individuos jórenes en verano $y$ en otoño; utilizanse para dicho objeto y se les deja despues en libertad; no es nadas ventajoso alimentarlos todo el invierno, pues en verano se pueden coger tantos pequeños como se quiera: solo las hembras grandes se adiestran para la caza, porque los machos no son á propósito.

Lo mismo que en el Ural, se adiestran tambien los gavi. lanes con buen éxito en Persia y la India En Persia, dice St. John, la caza de los gorriones es uno de los recreos fa. voritos durante el verano, sobre todo cuando el calor es de. masiado sofocanic para excursiones penosas. Se cazan estas aves pequeñas con preferencia en las orillas de los canales de riego, y se sueita al halcon antes de que hayan llegado a un refugio seguro. El gavilan coge casi siempre su presa y persigue a los gorriones con tal aficion, aun en los agujeros de los muros y otras cavidades, que á menudo es dificil sacarle; de modo que a veces se pierden individuos preciosos de esta nancra. Un buen gavilan atrapa de quince a seinte gorrio: nes en una hora; su docilidad es admirable; 1 los ocho dias de haberle cogido se le puede emplear para la caza, aunque atado con una larga cuerda; muy pronto se domestica tanto, que aun sin ligarle vuelve en busca de su dueño cunndo este le llama Para la caza de perdices se emplea preferentenente la hembra. Jerdon nos dice que el gavilan, y su congennere el besra (Nisus aingaluss), es muy apreciado por todos los halconeros indios. Ambos se cogen a menudo sin redes $y$ adiéstranse para la caza de perdices, codornices, becadas y palomos, jero sobre todo de mainas; prestan cxcelentes servicios particularmente en los cañaverales, recompensando asi el trabajo que cuesta la enseñanza. Radde refiere una his. toria muy curiosa. En el mediodia del Cáucaso, en el territorio de las fuentes del Eufrates, habitaba en la montana una tribu de kurdos, que aun hoy dia se sirve de los halco. nes para la caza, y cuyo jefe enipleaba azores, gavilanes y águilas muy bien adiestradas. En la casa de este cacique Radde vió una ave de rapina cuyo color y formas eran los del gavilan, pero la cola semejante a la del cernicalo comun. No pudiendo suponerse que ambas especies se hubiesen apareado, la existencia de unas formas tan extminas solo te. nia una explicacion natural, la misma que se dio Radde. El gavilan se habia desgastado de tal manera la cola, que ya no podia hacer uso de ella en la caza; entonces le ocurrió al ca. cique la previsom iojea de dotar á su ave de una cola artifi. cial de rectrices de cernicalo. Cortáronse las plumas caudales gastadas por el centro del carion é insertíronse las nuevas, untadas con una especie de jarabe de azúcar muy pegajoso, en la abertura de los cañones. La cola artificial prestó al gavilan en su caza todos los servicios necesarios.

El que ha tenido gavilanes cautivos podrá reconocer la habilidad de los halconeros asiáticos, porque estas aves no son nada agradables en la cautividad, sino verdaderamente repugnantes por su timider, salvajismo y roracidad. Lenz. refiere un cjemplo del cual hago mencion, porque es canc. teristico del ave:

\$Hace algunos aios, dice, recibi un gavilan hembra; fuć cogido en ocasion de perseguir a una oropéndola en un ma. torral espinoso, con tal furia, que se enredó en medio del ramaje Le atć las alas y le puse en una habitacion en pre. sencia de once personas, á quienes miraba con ojos brillantes de cólera; luego cogi seis gorriones, y dejế á uno libre; el gavilan se precipitó sobre él, cogióle por el cuello, le ahogó entre sus garras, y mirando á los espectadores, permaneció sobre su presa, á la que estrechaba fuertemente entre sus ace. radas uñas. Como no queria comer, salimos fuera, y al volvér diez minutos despues vimos que el gorrion habia sido devo. rado. I.o mismo hizo con otros dos (que solté; en cuanto al cuarto, cogióle y le mató como á los primeros, pero á los diez minutos no se habia comido sino la mitad, lo cual no impidió que diese muerte al quinto y al sexto, aunque sin devorarlos, pues estaba ya harto.

De igual modo procedió tambien un gavilan recien cogido. -Cierto dia, me escribe Liebe, me trajeron un gavilan, cogido con liga al atacar un ave. Mi scñora, que habia recibidio el ave ciel cazador, tuvo poca precaucion y recibió un picotazo de la furiosa rapaz, con lo cual se asustó tanto que la soltó; pero el gavilan, léjos de escaparse por la ventana, cogióse á una de mis jaulas con tanta furia que pude cogerle.

Yo he tenido muchas veces mas $\delta$ menos tiempo gavilanes cautivos, pero nunca he podido profesarles cariño. Debo decir, no obstante, ąue no le creo tan cruel con su propia familia como el azor, aunque tambien es verdad que siempre ture mas individuos reunidos de esia especie que de la otra. Sin embargo, no creo ser injusto al suponerle tan maligno, tan sanguinario e indiferente á los sagrados vinculos de la fami. lia como su congénere el azor. Ias dos aves son afines tanto por sus facultades intelectuales como por sus formas, $y$ am. bas se conducen de una manera muy aníloga en la cautivi dad. Supérfluo me parece decir que mas dificil es tener al gavilan caurivo que al azor, porque es una de las rapaces mas golosas: la carne de caballo que en los jardines zoológicos constituye el alimento casi exclusivo de los carniceros, cua. drupedos y aves, repugna en alto grado al gavilan, y aunnque 
le acose el hambre y se le obligue á tomar un alimento tan desusado, limpiase el pico despues de cada bocado, cual si quisiera expresar que la came jugosa de los pequeños fringilidos, alondras y aves cantoras tiene un gusto mucho mas exquisito que la del nobie corcel. No prodemos admirarnos por consiguiente de que esta ave de rapiña no prospere con tal alimento, y uque nuera urde ó temprano a consecuencia de el, si no se destroza antes el críneo en la reja No conorco, sin embargo, ni un solo soólogo aleman quue sintiera la pérdida de semejante rapar: todos aprecian aun demasiado los gorriones para sactificante st strnejante vagabundo. Alguno podrá entusiasmarse po: los grandes seirores, qque asi como los caballeros de la Fidac media, ponian a contribucion cusn. to estaba á su áicance; pero los tandoléros son despreciados por todo u munto.

\section{LOS AZORES-ASTUR}

Dos axures, tipro de lasưnamilia de los astúridos, se aseniejan mucho ha los gavilanes; slo difieren por tener el cuerpo mas recogido, el pico mas lareo, cola reclondenda, patas mas fuertes y cortas y pluniaje que raría segun la edad.

\section{EL AZOR DE LAS ZURITAS - ASTUR PALUM-} 3ARIUS

CARACTERES. - E azor de las zuritas ó vulgar (figu. ra' 143) es una mpaz de gran tamaño, que mide $0^{\circ}, 55$ de largo por $r$, ro de punta a punta de ala esta plegada tie. ne $0^{*}, 31 y^{\prime \prime}$ la cola $0^{\circ}, 22:$ la hembra cuenta $0^{\circ}, 70$ de largo y 1,25 de amplitud de 25 alas. En el individuo adulto el lomo es gris pardo negruco con visos mas 6 menos grises cenicientos; el vientre birsco, con los tallos de las plumas de un pardo negruzco, lo rismo gue unas pequerias lineas on. duladas; el pico negro; La cera de un amarillo claro; el ojo amarillo vivo y las patas amarillas.

Ios, hijuelos tienen cl homo parcio y manchada cada pluma de un tinte de amarillo de otin; en el vientre se mezclari unas manchas longitudinales fardas sobre un fondo rojo de orin, que se cambia mas tarde en blanco rojizo; el pico, el ojo, las patas y la membrana que cubre ia cera són de color mas cla. ro que en los adultos.

DISTRIBUCION GEOGRAFICA.-EI Área de disper. sion del azor se extiende por la mayor parte de Furopa y del Asia central; pero dentro de los limites de estos paises no se encuentra en todas partes con la misma abundancia. Fn Inglaterra escasea tanto, que los pocos casos en que se le ha visto estan inscritos cuidudosamente en las obras zoológicas. Falta del todo en. Fintendia y en las jslas Feroc; pero en cambio anida en los besugues de la Escandinavia, en Dina. marca, Holanda, ilennaia, Francin, Austria, los paises infe. riores del Danubio, Rusidesde el norte hasta el sur, en el Asia Menor, en el norie de la Persia y, en fin, en el norte $y$ centro de Esspana Sin smbargo, abunda mucho mas ell Alemania que en los peises meridionales. Fn el norte de América está represenizio por un ave muj congenérica, el azor de cabeza negra (fisur atriertillus).

USOS, COSTUMBRES Y REGIMEN.-En Alemania babita con frecuencia las regioncs cubiertas ac bosques, y aumenta mas bien-que ćminuye en los distritos donde no se cuida la caza, mientras que en otras regiones sucede lo contrario. Asf, por ejemplo, cscasea en la Marca mas que amtes, al paso que en el esce de la 'Turingia abunda inas que hace treinta aios. En neriembre da principio su vidi erran. te; pero puede consideriscle como una verdadera ave de paso, por mas que cxtienia sus viajes hasta el norte de Egip. to. Sin embargo, no lo hace con regularidad y ni aun en las peninsulas meridionales se presenta todos los inviernos. No puedo decir si, como sucede con las otras rapaces, un sexo tiene mas apego á la patria que el otro; pero si afirmare que en Alemania se cncuentran y matan en invierno tantos ma. chos como hembras: lo mismo podemos decir del Asia, donde se le ve en el mediodia, segun Jerdon, aunque sicmpre aislado; rara vez se le encuentra en las llanuras. Alli donde el azor establece una vez su nido, dificil es expulsarle, si las condiciones del pais le favorecen un poco. Agrádanle los bosques espesos, donde pueda descansar y perseguir facilmente su presa. No tiene preferencia por los árboles; pero si busca siempre los bosquues que alternan con campos y praderas.

Creo que no se ha publicado hasta ahora ninguna descripción mejor que la que dió mi padre, hace cuarenta años, acerca de las costumbres del azor; y en su consecuencia la tomaré como guia, contentándome con anacir los resuitados de observaciones mas recientes.

$\mathrm{El}$ azor es un ave solitaria, nada sociable, y que ni aun vive con su henibra, sino en el periodo del celo. Es feror, salvaje, osado, activo, vigoroso y perspicaz; vuela con rapide\% y ruidosamente; se cierne con frecuencia, y despliega entonces la cola!

El observidor álgo experto le distingue fácilmente desde lejos de todas las demás rapaces que en Alemania se en. cuentran, excepto quizás de una hembra de gavilan; pues sus cortas alas y la larga cola que la hacen parecer en el ruelo una paloma silvestre, son, además de su gran tamaño, señales caracteristicas. Cuando pasa de un bosqque á otro, sobre todo en regiones montañosas, vuela de una altura a otra, eleván. dose á veces a unos cuatrocientos metros sobre el stuelo; mas por lo regular su vuelo es bajo, sigue por los linderos de los bosques las espesuna, cruza muchas veces los árboles y arbustos, ó pasa sobre las copas. Casi ninguna otra mpar tiene movimientos tan variados como el azor, que a la ranidez de sus bruscas evoluciones reune una agilidad asombrosa en un ave tan grande; elévase con rapidez, mantiénese como inmóvil un momento, dejase caer, vucla con la mayor seguridad en medio de la mas intrincada espesura, sube y baja con ligereza: en tierra es torpe y solo avanza á saltitos. Para descansar elige sicmpre las ramas mas bajas y cercanas al tronco: nunca le he visio posado en rocas ó muros; pero segun se dice se posa a veces sobre las casas de los pueblos.

Su voz, que rara vez. se oye, es fuerte, sonora y desagra. dable: cuando al azor le domina la cólera, produce un so. nido semejante á iarbrk; si está contento por haber cogido alguna presa, cambiase aquel en fưvac, hiuric; al verificarse el apareamiento, su grito es gacck, gacek, gacik, gick, gich, gick, sílabas à que siguen rápidamente las de kiak, kiuk, repetidas virias veces; si se asusta produce los sonigos sirine, ruinc, ILis, wiis.

El azor caza todo el dia, aun en aquellas horas que las otras rapaces dedican al reposo; recorre casi con regularidad un dominio bastanic extenso, y vuelve con frecuencia al sitio donde su caza ha sido feliz. Su insaciable roracidad no le permite entregarse al descanso: siempre desea una nueva victima, siempre está sediento de sangre Acomete $\{$ todas las aves, desde la avutarda y la ortega hasta los mas peque. nos pájaros; y tambien a todos los inamíferos ique cret mas débiles que él. Cae sobre las liebres; arrebata a la coma. dreja del suelo; sorprende á la ardilla en su albergue, y con la misma facilidad se apodera de su presa al vuelo que cuando está posada; lo mismo atrapa al ave acuática que al mamifero.

Basta su presencia para atemorizar å otro animal; y como 
dice Naumann, \&queda cogido y corre su sangre entre las garras de la rapaz antes que haya pensado en huir ó aplanarse contra cl suelo. Su voracidad no puede igúalarse sino con su osadia; pero sobre las das cualiảndes domina la sed de matanza: nada perdona el azor.

Dedicase sobre todo á la caza de palomas; bastan dos azores para exterminar en pocos meses los individuos del palomar mejor poblado. Apenas divisan aquellas aves a su enemigo, emprenden la fuga; pero el azor cae sobre ellas con la celeridad del rayo y trata de separar á una; parece que no agita las alas; las tiene un poco recogidas, y tiende las gar. ras hácia adelante; lanzándose con tal rapidez, que el ruido de su vuelo se puede percibir á ciento ó ciento cincuenta pasos de distancia. «Cierto dia, refiere mi padre, hallábane en el campo y vi á un azor cerniéndose sobre una montana: à un cuarto de legua, divisábase en el valle una bandada de palomas que buscaban tranquilamente su alimento. Apenas las hubo visto el azor, dejóse caer oblicuamente desde una altura de mil brazas al menos; pero las palomas le advirticron á tiempon, y huyeron á vuelo tendido hácia su palomar. En su primera acometida habia bajado la rapaz mas que las palomas; pero elevóse de nuevo, persiguiỏlas y alcanzó at una, la cual, no obstante, practicó un hábil rodeo $y$ pudo escapar de su perseguicior, llegando à su vivienda \$

Cuando el azor no consigue apoderarse de las palomas al vuelo, se vale de la astucia. \&En mi cominio de Podolia, rcfiere el conde Wodzicki, se criaban muchas palomas, y su número llamú pronto la atencion de todos los azores y hal. cones de las cercanias; de tal modo que mis palomas se vie. ron al fin tan perseguidas, que no se atrevieron á recorrer ef campo, y buscaron su alimento cerca de las habitaciones Rara rez abandonaban su palomar, y no se alejaban nunca del patio: esto ciuró mas de una semana:

2. Las aves de rapina abandonaron aquellos parajes; quedìronse solo dos azores; $y$ se daban mana para adquirir su alimento cotidiano. Uno de ellos permanecia horas enteras oculto por un cejadillo de paja, con las plumas crizadas y el cuello encogido, en cuya postuma asenejábase del todo a un buho. Las palomas cobraron confianza, posironse tambien en el tejado, y el ave de rapina no se unovió; pero cuando aquellas comenzaron á entrar y salir sin temor en el palo. mar, cayó sobre ellas, cogió una y llevósela al jardin, pues conocia que alli no le dispararian ningun tiro, porque estaba rodeado de casas. El segundo azor se mostró mas astuto y osado: cada dia llegaba á la misma hora; obligaba da las palornas á entrar en el palomar, y posándose luego sobre este, golpeaba con sus alas repetidas reces, hasta que saliendo una de las aves, se lamzaba al momento sojre ella.s

Fácilmente puede explicarse el terror que se apodera de todas las aves amenazadas por êl cuando se presenta; tan luego como aparece, aunque sea a larga distancia, prodúcese un tumuto en todo el mundo alado. Las palomas ó gallinas que cogidas por la rapaz fueron salvadas, permanecen inmó. viles en el suelo y déjanse coger por el hombre ó se refugian en cualquier escondire, $y$ no olvidan el susto en muchos dias o aun semanas. Las gallinas robustas corren por el inte. rior de la casa con todas. sus juerzas cuando la rapaz se ha cogido en su dorso, cual si quisieran implorar la proteccion del hombre; solo las cornejas, que tambien sufren mucho la persecucion del azör, intentan vengarse.

Esta maja no persigue con menos ardimiento à los mami feros.

Apodérase läcilmente de los lebratos, dice mi padre, y en cuanto á los individuos viejos, observa cierto método. La liebre busca su salvacion en la fuga: el azor se lanza contra ella varias veces para descargarle fuertes picotazos, y despues de haberla herido y' cansado, acaba por cogerla entre sus garras y ahogarla. Semejante caceria dura con frecuencia mucho tiempo; yo vi á una liebre luchar asi largo rato con un azor. Rodaron por el suelo uno sobre otro, y á pesar de esto el ave de rapinina no soltó presa. Un amigo mio, en đ̧uien tengo plena confianza, mató de un solo tiro una liebre y un azor que se habia posado sobre ella.s

En el norte, y sobre todo en Escandinavia, roba mas mamiferos que en el mediodia; $y$ tambien persigue a las manadas de lemings porque le ofrecen fácil presa

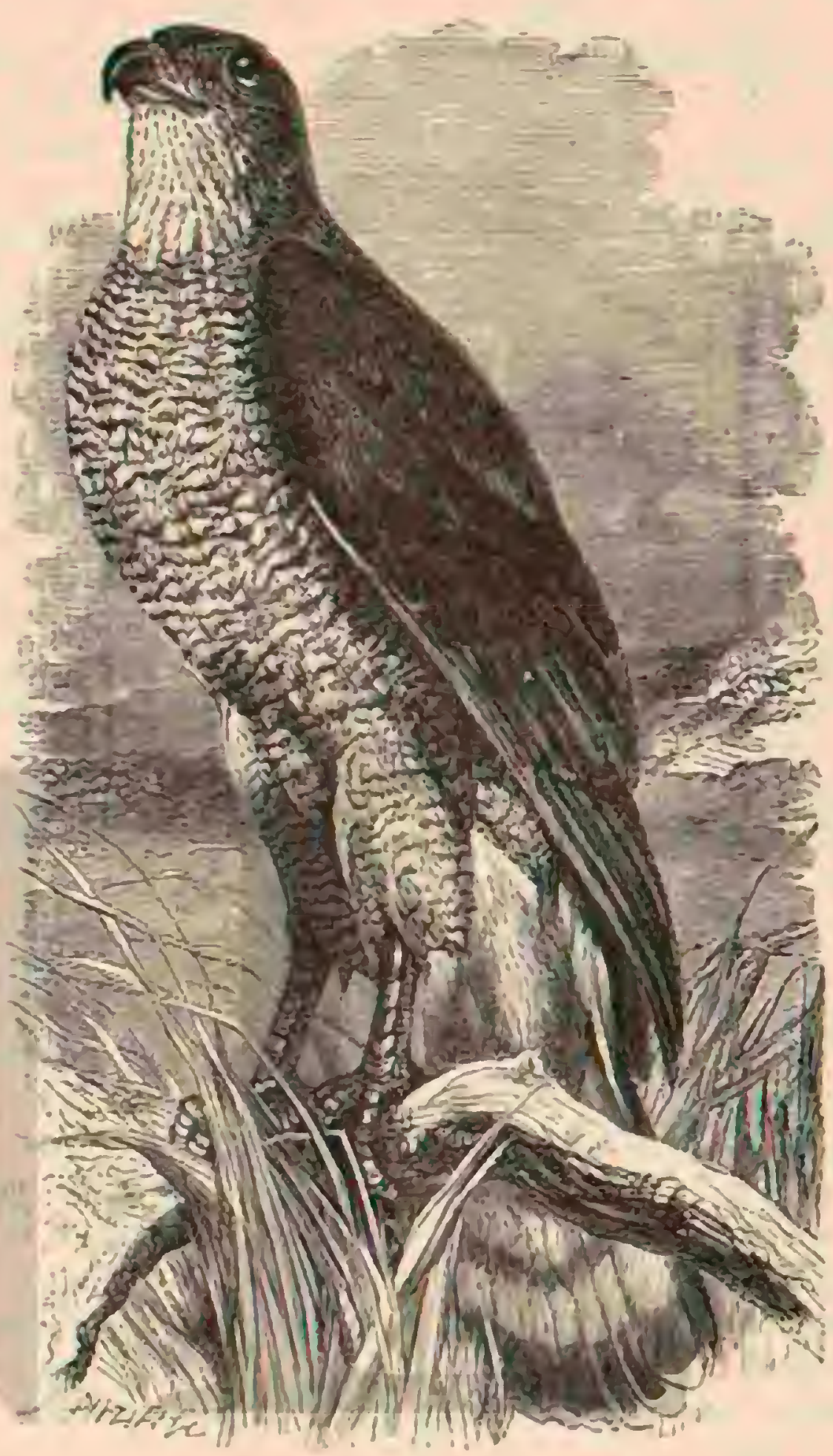

Fig. 143.-EL A\%OR DE LoIS zU.HTAS

El azor no se contenta con una sola ave, coge tantas como le es posible; las mata y devóralas despues tranquilamente. Asi, por ejemplo, Riesenthal rió como un solo azor cogió en una hora cinco cornejas que estaban a punto de salir del nido, â pesar de la defensa de las adultas, que acudieron en gran múmero. A una rapacidad insaciable, agségase en este bandido alado el atrevimiento y la gula. Siempre visita de nuevo la casa de labranza donde una vez hizo una victima, sin hacer aprecio de los preparatisos del hombre para reci. birle. Ninguna ave de rapiña evita con mas astucia las persecuciones; merced á sus repentinas apariciones, no solo ase. gura la presa sino tambien la impunidad. "En poco tiempo, dice Riesenthal, me ha robado en mi solitaria casa del bosque sesenta pollos y gallinas, cogiéndolos á mi vista en el patio cercado, cuando hallándome sin escopeta veiame reducido à tirar piedras y palos conira el ladron; nunca llego mientras tuve el arma al lado.

- Inútil era acecharle horas enteras: mas apenas entraba en casa, el ruido en el gallinero me anunciaba un nuevo robo, y entonces podia ver cómo el ladron se alejaba con un po. 
lluelo. Sin duda me habia observado desde el cercano bos. que. No sé si esta última suposicion es exacta, pero tambien creo porter asegurar que la rapaz observa muy bien al hom. bre y sabe distinguir perfectamente el cazador peligroso del carnpesino.

Todo su proceder es el de un ladron que espera el mo. mento oportuno para ejecutar su intento, que se acerca á hurtadillas a una propicdad, varias veces visitada ya por él, confiando en su astucia y agilidad, ó en su incomparable presencia de ánimo. Conviene con esto su marcada preferencia por los animales mas débiles, como por cjemplo los pollos, y tambien su costumbre, segun asegun Nltum. de elegir siempre en un grapo de aves las que mas se dis. linguen por sus colores mas vives Initando a los halcones, tambien sucle dirigir sus ataques contra has aves que se separan de la bandada. Cuando tiene hambre í está excitado por una larga persecucion 6 quizas poscido de cólera por no haber logrado algun robo, olvida toda firccaucion, persigue a su victima hasta el interior de una casa, $s$ hastá en la ventana coge al ave de la jaula, ó se llever esta lítima, como lo ha observado Nordmann en Finlandia, para sacar la victima despues de alejarse algunos centenares de pasos. En las casas de labranza se le ha cogido con la mano cuando habia hecho presa en una gallina, $\delta$ bien cubriéndole con un cesto: algunas veces le ahuyentan á palos. Iil azor es un verdadero gastrónomo, pues alli donde puede clegir siémpre escogerá In çaza mas sabrosa lin las regiones en guc ésta abunda, y solure todo alli donde hay muchos faisanes y percices, la rapax no se deja coger ell la trampa, segun me escribe de Mejerinct, si se pone como cebo una paloma, mientras que cac muy pronto en el lazo si se coloca una gallina domésti. ca, un faisan ó una perdiz. Alli donde hay palomas persigue destas mas que a las gallinas, aunque no le es tan fácil cogerlas; lo harí sin duda porque le gusia mas su carne.

A la inextinguible sed de sangre gue domina i esta rapaz se debe atribuir que no sen mas sociable; y una pruceba de ello tenemos en los individuos cautivos. Hace algunos anos, cuenta mi hermano, dispuse que se adquiriese para un jardin zoologico un azor herribra con sus dos hijuelos. Por la mañana los puse en una gran jaula, $y$ cuando fut a darles de comer por la tarde, vi que la madre se habia hartado ya, devorando la mitad de uno de sus hijuclos despues de haber matado al otro. Algunos dias despues recibi una pareja de azores con dos pequenos; esta vez los puse aisladamente en una jaula, diles abundante alimento y los envie is su destino. Una re\% llegados, introdujéronlos en la misma jaula con uno de sus semejantes, que estaba cautivo hacia ya un año: pero este úliinso acometió $\{$ los dos individuos jovenes, dióles muerte, y precipitándose despues sobre los majores se los comió, siendo él nismo devorado mas tarde por un nuevo azor que recibimos. Un guarda-bosque amigo mio me refirió que habia encerrado juntos a catorce nzores do las zuritas; dábales alimento en abundancia, $y$ á pesar de esto se devoraban entre si. Yo puedo decir que en cautividad, siempre se come el individuo mas fuerte al mas débil, bien sca su hijo, su padre 6 su compañero; is inútil parece decir que proceden lo mismo con las otras rapaces. Derora todos los animales que puede digerir, ó los mata, por lo menos; ssi es que apenas se deja ver, los demás pajjaros manifiestan todo el odio que les inspira. Las cornejas, sobre todo, no se carsan de pertseguirle y acometerle, sin cuidarse de su propia vida. \&Un azor, dice mi padrc, iba perseguido por țes cornejas; varias veces trató de darles caza; pero sabian evitarle hábilmente, y no consi. guió herir a una sola. Aquella maniobra habia durado cierto tiemno, cuando cl are de rapiña divisó, is unos trescientós pasos de distancia, a varias palomas posadas en un tejado; lanzóse al momento en aquella direccion, dejảndose caer desde una altura de mas de cien brazas; pero volvió sin presa alguna las comejas parecian haberse quedado estupefactas al ver semejante rapide\%: mientras cstuvo cerniondose, pudieron seguirle fácilmente, mas no fue capaz ninguna de se. guirle en su caida. Al elevarse de nuevo por las altas regiones volvió a comenzar la persecucion: el azor cayó por segunda ver. sobre las palomas y judo coger una, la cual se llevó; y corno las cornejas le siguieron mejor aquella vez, estrech ronle tan de cerca, que le fué forzoso abandonar su victina y alejarse de aquel sitio.

las corncjas son las únicas ares que demuestran en toda ocasion su odio mortal contra el azor, díndo!e mucho que hacer. Tan luego como se deja ver rodéale una bandada de cllas; al oir los gritos acuden siempre mas en su auxilio, y asi puede suceder que las cornejas le cierren el paso, sobre todo cuando se aleja con una presa en las garras $\delta$ quuiere devorarla en el suelo. Las aves enemigas olvidan entonces reces todo lo que pinsa á su alrededor: asi sucedió, por ejem plo, con un azor atacado por comejas y que el guarda-bosņue Mueller de Hermannsgruen mató con su cuchillo el in de mayo de 1 S6S. Miraido jor los gritos de las corncjas, Mueller creyó que joudria saluar alguna licbre pecjucña; acereósc cau. telosamente al sitio y vió una gran rapar, tan acosada por las cornejas, que pudo acercarse a unos dic pasos de distancia y arrojar su cuchillo al ladron en el momenso de emprender la fugá por castralidad el arma tocó la cabera del ave, que cayendo aturdida, quedo en poder del guarda-bosque. Fi ca. zador Hraun, a quién debo la noticia de cste liecho natable. encontró a Mucllet despues del sucesn, y pudo ver par si mismo al azor. Ńáumann dice que el azor consigue algunas veces apodenarse de una de las cornejas que le persiguen: yo creo que debe ser un caso raro, porqque estas aves proceden siempre con la mayor prudencia. los halcones no aborrecen menos la sangrienta rapan y las golondrinas se complacen en seguirle, aturdiéndole con sus penetrantes gritos.

Fista ave de rapiña construye su nido en los árboles mas altos, y por lo regular muy cerca del tronco: es grande y pla. no, su base estaf formada de ramas secas sobre las que se ex tiende una capa de oiras verdes de pinos y abetos, las cuales reemplaza cl azor à medicla que se van secando. La cavidad del nido esti rellena de plumas y plumon: terminada la cons. truccion, la misma pareja de azores se utiliza de ella varios años, y $\{$ vecestiene tres $\delta$ cuatro nidos, que ocupan las aves alternativamente y se hallan cercaros uno de otro. Cada año los_repara el azor, ensanchándolos mas, y los guarnece de nuevas ramas. En los buenos dias de marzo se remontan por los aires el macho y la hembra como para manifestarse su cariuo. La puesta se verifica en la segunda mitad de abril; el número de los hueros es de dos a cuatro; tienen la forma prolongada; son anchos en el centro, de cáscara rugosa y gruesa y de color verde blanguizco, con puntos amarillos, algo escasos. Ia hembra los cubre con la mayor solicitud, sin abandonarlos nunca, aunque se la dispare un tiro, y tanto ella como el macho defienden á su progenie con el major arrojo, mostrándose a veces temerarios. Se ha visto a estas aves acometer á los hombres que trepaban por cl árbol.donde esiaba su cria; y hasta se cita el caso de un azor, que sin excitacion alguna, se lanzó contra un hombre ó un caballo.

Los hijuelos crecen rápidamente; comen tanto, que los padres se ven algo apurados para dejarlos satisfechos. El nido sa convierte entonces en una especie de matadero: el padre Y la madre llevan todo cuanto encuentran, incluso nidos cnteros con sus crias, particularmente los de tordos y mirlos. Es probable que los pequeños mas fuertes acumetan y devo. ren á sus hermanos mas débiles cuando les acosa el hambre. 
CazA.-El azor ocasiona tantos destrozos, que se le persigue yor todas partes con encarnizamiento, aunque nunca lo bastante, pues no se trabaja mucho para descubrir los nidos, if fin de exterminas en su gérmen esta raza sanguinaria; ni se caznn tampoco con bastante actividad los individuos adultos. A decir verdad, no es fácil apoderarse de ellos, atendida su perspicacia y astucia: en rarias localidades se saca partido de In aversion que inspira el buho al azor; se le atrae con una de estas aves, y se puede entonces tirar sobre eil tícilmente.

Aunque no le agrada ser molestado por otras aves, complácese en atacar con violencia al buho; aleteando de un modo extraño, acércase à la odiada are, is pocos centimetros de distancia; y asi es que muchas reces no se le puede tirar por temor de herir al buho; pero como alguna vez se pone sobre las pértigas delante de la choza, se le puede timr alli fácil. mente. Iambien se mata sin mucho trabajo à la hembra que cubre, y se cogen bastantes en los lazos.

CAUTIVIDA D. - Fil azor noes menos desagradable cuan do está cautivo: por su salrajismo, su malignidad y su sed de sangre se convierte en un sér insufrible.

Cierto que nunca he visto un azor domesticado, y si solo individuos feroces y arrebatados, que al acercarse un hombre se enfurecian, precipitándose tan violentamente conira las rejas, que se herian las alas, arrancindose plumas de la frion. ie. Los halconeros antiguos nos han demostrado la posibilidad de domesticar esta rajaz, ! los asiáticos nos la prueban aun todos los dias; pero no sé cómo se debe proceder para lograrlo. A pesar de todos mis esfucrzos tanto en adultos como en pequeños, y á pesar del buen trato que les dispense, solo he obtenido por recompensa la mas vil ingratitud. Cualquie ra otra ave de rapiña acostúmbrase al fin, si no á la pérdida de su libertad, por lo menos al alimento que se le da; pero el azor no está nunca contento, por bueno que sea lo que se le ofrezca. Sicmpre grunendo, descontento de si mismo y de todo cuanto ve, permanece acurrucado en un rincon de la jaula, moviendo sus amarillos ojos en las órbitas, apoyado contra la pared y la cola en el suelo, siempre pronto á coger en sus garras cuanto se le acerque, y esperando al parecer una oportunidad para demostrar toda su furia. Ll azor es un ave abominable, tanto en la jaula como en $t . l$ bosque, tan fic roz como maliciosa, y que jamás renuncia a sus fechorias; no se le puede tener con ninguna otra are, por fuerte que sea, en la inisma jaula; todo buzardo, milano $\delta$ buho, esta per dido cuando se le pone en la misma jaula que el azor, por. que este le mata y derora tarde $\sigma$ temprano. A reces se con cibe la esperanza de que no suceda esto, pucs pasan muchos dias sin çue haya faltado ninguno de los compañeros del asesino; pero súbitamente se despierta su naturaleza sanguinaria, y uno de los habitantes de la jaula muere en las garras de la rapaz. Si una vez jirueba la sangre, inmola todós los séres cue se hallan en su compania, miata por cl afan de ma tá, y asi como la marta, cmbriágase con la sangre de sus vic timas.

Puede considerarse como un triunfo en el arte de domes. icar animales conseguir este resultado con el azor. Nuestros antiguos halconeros le apreciaban mucho; y tambien los asiáticos, que cazan aun con are. Segun Jerdon, en las In. dias es el are mas buscada para dicho objeto.

4. Fl bas, segun le llaman ellos, se adiestra paira la caza de arutardas, de milanos, buitres, patos, garzas reales, ibis, hal cones, etc. Para perseguir à la liebre se cubren las patas ded azor con unas fundas de cuero, a fin de evitar que se hiera con las espinas, pues el roedor arrastra siempre consigo al ave durante algun tiempo. La rapaz no le sujeta mas que con una garra, y con la otra procura cogerse a las ramas, a las yerbas y a las raices para detener á la fugitiva. Vuela en li. nea recta sobre su presa: pero si no la tiene a distancia con. veniente, como por ejemplo a ciento 6 doscientas brazas, abandona la cazn; vuelve hácia el halconero y se poosa en un árbol vecino ó en tierra. Uina hembra de azor bien ensenada vale de 20 à 25 rupias y un macho de 10 à jo.

Thompson nos ha dado últimamente noticias minuciosas sobre la manera de coger y emplear el azor en la India: en su opinion, solamente los indios indigenas pueden adiestrayle completamente. El are se caza por lo regular en octubre y noviembre, con unas redes extrañas, en las cuales se pone por cebo una paloma. Los halconeros nagan por las hembras jórenes de cuarenta á sesenta rupias; las adultas valen mas, v los machos algo menos. Una vez. adiestrado, el azor se considera convo el mas excelente de todos los halcones de alas cortas, tanto por su rapidez y atrevimiento como por su vigor infatigable; cuanto mas tiempo se le emplea, tanto mas se desarrollan sus buenas cualidades. Acostúmbrase por lo re. gular nuy pronto al hombre, a los perros y a otros objetos que le espantaban al principio; su docilidad en manos de un buen halconero es verdaderamente asombrosa. $y$ su inteli. gencia casi igual á la del perro. Thompson asegura haber poseido individuos tan mansos y astutos, que bastaba alargar la mano para que se posasen en ella: a otros se les podia dejar libres delante de las tiendas; revoloteaban cuando los cazadores salian, pasando de un árbol á oiro, y asi seguian á la gente por bosques y claros, sin quedarse nunca atrís, hasta que se encontraba una presa, en cuyo caso comenzaban á trabajar. kEra un espectáculo magnífico, dice el citado autor, ver al ave llamada Sulbuun precipitarse como una llecha en persecucion de una gallina silvestre y degollarla antes que viéramos de qué especie era. A veces presenciábamos una carrem de las dos aves; la gallina iba delante perseguida por Sultana; y una yotra corrian á cual mas, hasta que el halcon lograba coger la presa. En una region cubierta de gramineas que no impidan ver, semejante cacería ofrece un espectaculo veruaderamente grandioso. Tambicn es muy interesante cuan. do el halcon persigue a los francolines en las altas yerbas. Algunos elefantes levantan la caza; el francolin se eleva y el halcon le persigue en linea horizontal hasta que le vec caer $y$ le cage precipirándose casi verticalmente sobre la presa.s los azores bien adiestrados se pueden emplear, segun Thompson, en la caza de todas las cspecies de gallinaceas, desde el paro real hasta la perdiz: á menudo coge en una hora mas de una docena. El citado autor ha visto cómo mataron paros reales $y$ liebres sin llevar cuero en las piernas. En la caza de patos, en regiones donde abundan los árboles, el azor sucle ponerse de acecho en un airbol hasta çue lus batidores levantan las aves acuáticas; entonces las persigue y' se precipita sobre cllas ajenas se remonta la bandada.

Lin l'ersia, el azor es el halcon que mas à menudo se adiestra, y muchas veces se pagan hasta quinienios francos por uno. Varias de estas aves se cogen en las colinas del sur y del oeste, cubiertas de bosque, pero las mas de ellas proceden de los boscuues situados al rededor del mar Caspio. Empléase el farhin, asíllaman al azor en l'ersia, para la caza de los cacábidos y francolines. La variedad blanca originaria de la Siberia no se aprecia mas que la comun. Fin el mediodia del Linl y en las cstepas limitrofes este halcon es tambien el que se adiestra mas á menudo, ya porque se le encuentra fácilmente en todas partes, ó bien por reunir mejores condiciones para el objeto.

\section{LOS MELIERAX - MELIERAX}

CARACTERES.-Los melierax, que se han llamado tambien asares cuntoris", se diferencian de los azores propia- 
mente dichos por tener las formas mas esbelias, el pico mas endeble, las alis mas largas, la cola redondeada, los tarsos mas alios y fuertes y las unias mas cortas.

DISTRIBUCION GEOGRÁRICA.-Estosastúridos son propios del africa.

\section{EL MELIERAX LISTADO-MELIERAX POLIZONUS}

EL MELIERAX CANTOR-MELIERAX MUSICUS

CARACTÉRES. - El melienx listado tiene el lomo de color gris pizarra, lo mismo que la gargania y la parte supe-

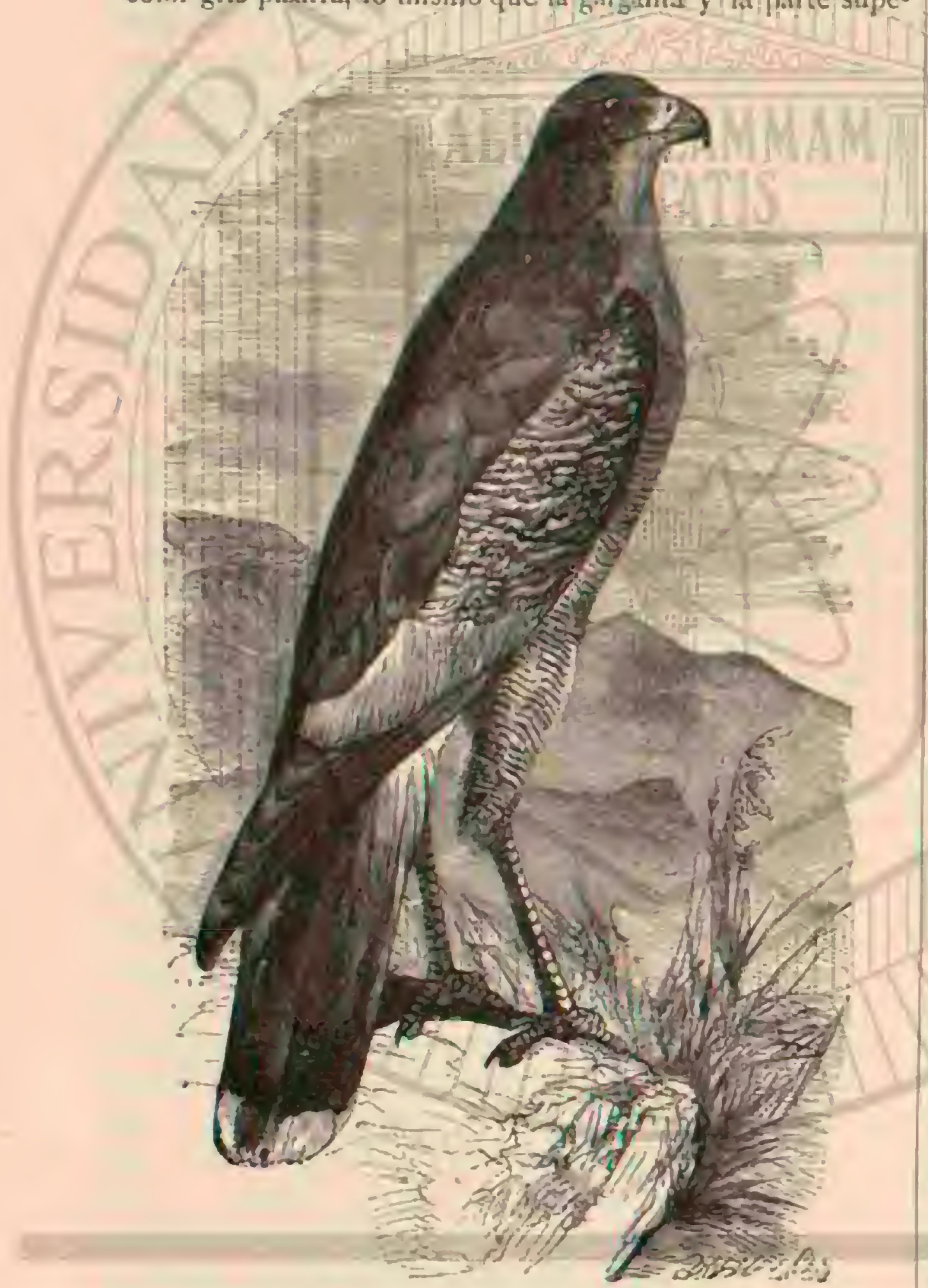

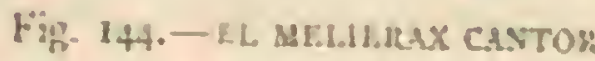

rior del pecho; el rientre, la rabadilla, las nalgas y las gran. des cobijas superiores del ala blancas, con listas angostas formando $S S$, de un tinte gris ceniciento; ins rémiges pardo negras; las rectrices del mismo color, aunque mas claro, con ires anchas fajas trasversales oscuras $y$ su extremidad blanca; el iris pardo; el pico de un azul oscuro; la cern y las patas de un naranja vivo.

El macho mice $0^{\circ}, 50$ de largo por $0^{\circ}, 29$ de punta á punta de ala; csta plegadia alcanza $11 \%, 30$ y la cola $11^{\circ}, 22$. Ia hem. bra es mayor; riene unos $\|^{\circ}, 04$ mas largo y $\|^{\circ}, 05 u^{\circ}, 06$ de amplitud de ains.

En las pequeños el lomo es pardo, el vientre blanco, con fajas trasversales; y del nismo tinte los lados de la cabeza y otra ancha faja pectoral.

El melierax cantor (iig. 144) presenta los mismos colores, poco mas ó menos; pero su talla ordinaria y la cola miden unos $0^{\circ}, 06$ mas de largo.
DISTRIBUCION GEOGRÁFICA.-Estc astúrido habita la Nubia, la Abisinia, el Kordofan, y segun se dice, el Senegal: en el Africa meridional le representa el melierax cantor. Le Vaillant vió á este último bastante numeroso en la Capreria y los paises circunvecinos.

USOS, COSTUMBRES Y REGIMEN.-El mismo via. jero refiere que el melierax cantor permanece en los árboles aislados; que caza liebres, perdices, calandrias, ratas y rato. nes; que construye un nido bastante grande, y que en él de. posita la hembra cuatro huevos redondos, enteramente blan. cos. Le Vaillant anade que el macho merece su nombre à causa del canto que deja oir durante horas enteras. Como no conozco ninguna otra descripcion de esta ave, no puedo asegumr que el relato de Le Vaillant sea exacto: en cuanto \& la especie que habita el centro de Africa, nunca la oi cantar; lo mas que hace es producir un silbido prolongado.

El ave de gure hablamos es muy comun en todas las este. pas cubiertas de bosque, situadas al sur de los $17^{\circ}$ de latitud septentrional: escasen mas en las selvas vírgenes.

Heuglin le observó tambien á cos grados mas al norte que yo, y en los países de los bogos, asi como en Abisinia, á la altura de 1,500 is 2,000 metros sobre el nivel del mar; se le ha visto igualmente en la parte superior del Nilo Blanco, aunque aislado; Spele le mató en los paises de los somalis, Hemrich y Fihenberg le encontraron tambien en Arabia.

USOS, COSTUMBRES Y RÉGIMEN.-Esta aVe no viaja; cris siempre vive apareada, con preferencia en las es. tepas bajas donde ábundan los árboles, y sin hacer caso del hombre: prefieric los árboles aislados de las estepas, desde donde puede ibarcar vastos horizontes; y allf permanece casi todo el dia. Su dominio es bastante limitado; en aquellos lu. gares, cada parcja habita una cerca de otra, y deben conten. tarse con una extension muy reducida.

Los melierax no se asemejan à sus congéncres de Europa sino por su aspecto fisico, siendo distintos en su manem de ser. Indolentes por naturaleza, nada tienen de la osadia que convierte á nuestro azor en terrible encmigo de todos los pe. queios animales: la pereza constiture el fondo de su carác. ter, $y$ se les ve horas enteras en el mismo sitio. Su vuelo ca. rece de la rapidez que distingue al del azor; agitan con lentitud sus alas contas y redondeadas; las tienen bastanic ticmpo extendidas, deslizándose en cierto modo por cl aire, y luego aletean otra vez. Cuando están posados se mantie. nen bastante rectos, con la cabera cncogida y fija la mirada.

Ruppel dice n̨ue el melierax listado se alimenta principalmente de palomas y pajarillos; pero se equivoca en esto; ó si su aserto se apoya en las observaciones que hizo, ha in. currido en un error por una coincidencia fortuita.

Fista ave come sobre todo insectos, reptiles y pequeños mamiferos: por lo que yo he visto se alimenta en geneml, si no exclusivamente, de langostas; raza tambien los pequenos roedores, y de ellos se encuentran casi siempre restos en su estómago. Hartmann le ha visto comer lagartos, y yo tain. bien hice la inisma observacion; parece que no acomcte a las aves sino cuando pasan delanie de él bandadas nuncrosas, $y$ he notado asimismo que rara vez se apodera de alguna.

Fs demasiado cachazudo para poder atraparias al vuelo: jamás se le ve, cumo al azor ó al garilan, perseguir largo ticmpo a las palomas, tan numerosas en aquellos paises. Hasta los roedores de escaso tamaño están seguros delante de él; y vive en perfecta armonia con las ardillas.

Segun Heuglin, sus nidos, situados á mucha altura en árboles frondosos, se componen de ramas secas. Parece que el citado viajero no ha recogido observaciones sobre los hue. vos y la reproduccion en general; y en cuanto a mi, solo 
puedo decir que he visto á principios de la estacion lluviosa, es decir en agosto y setiembre, polluelos que acababan de salir del nido.

CAUTIVIDAD. - El melierax listado cautivo es precisa. mente lo contrario del tipo aleman de su familia: tmanquiloy pacifico, se posa como los halcones verdacieros horas enteras en el mismo sitio; conoce pronto á su amo y hasta se fami. liariza mucho con él al cabo de algun tiempo; tona sin resistencia el alimento; pero no soporta fácilmente nuestro clima.

\section{LOS POLIBOROIDES-POLYBO- ROIDES}

CARACTÉRES. - Estas aves tienen el cuerpo pequeño:

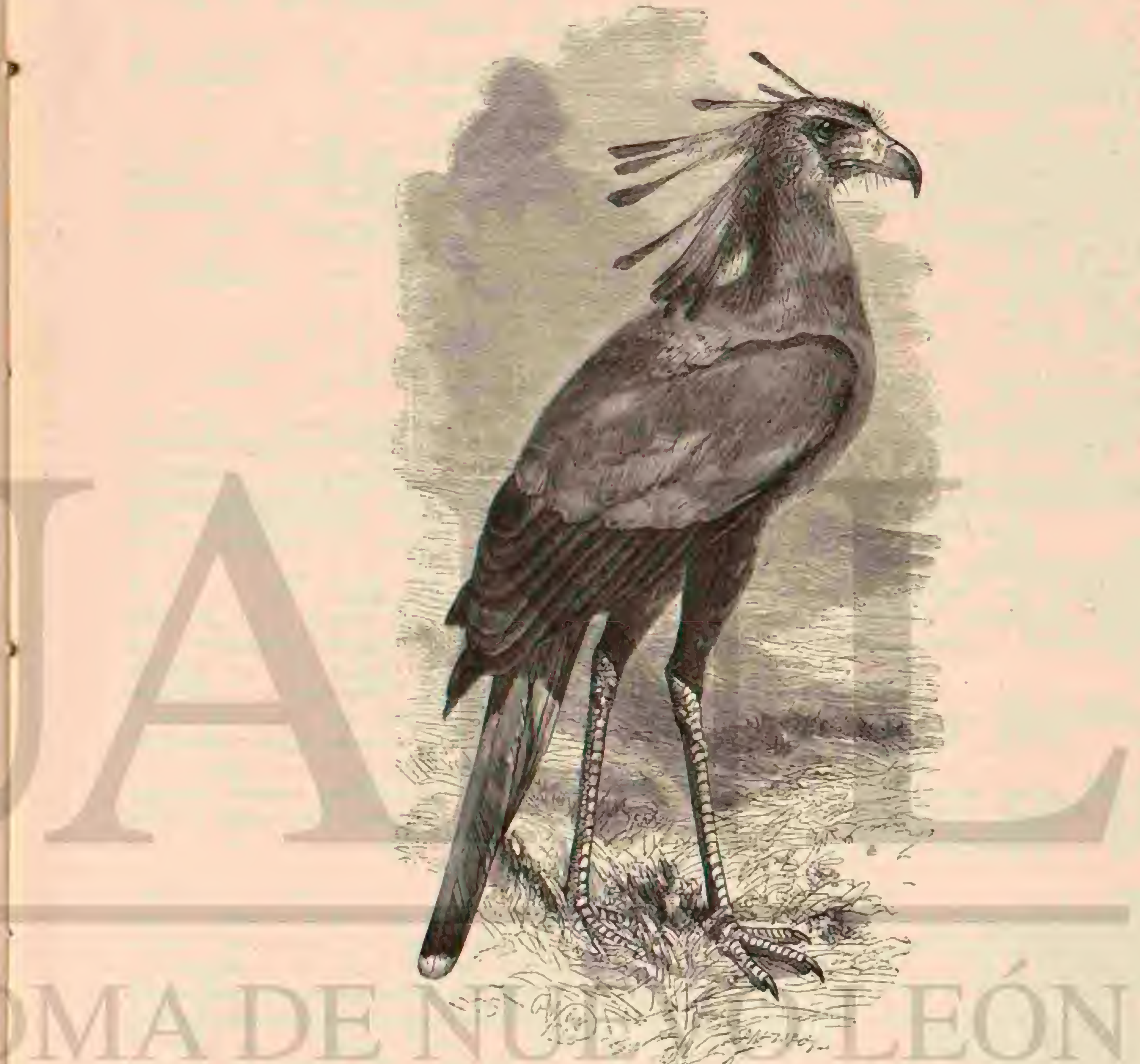

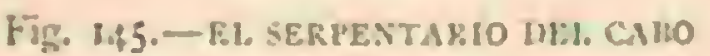

cabeza mediana, con las mejillas desnudas; el pico ende ble; alas cnornes, largas y anchas; cola prolongada, ancha y redondeada: tarsos altos $y$ delgados $y$ dedos relativamente cortos.

\section{EL POLIBOROIDE TIPO-POLYBOROIDES TYPICUS}

CARACTERES. - El poliboroide tipo ó listado tiene el lomo azul ceniciento oscuro, $y$ del mismo color la parte anterior del cuello y el pecho; las rémiges primarias son negras, $y$ las secundarias grises, con una mancha reoionda y negra cerca de su extremidad; las rectrices negras, con la punta blanca, y una ancha faja trasversal del nismo tinte en la mitad de su extcusion; el vientre, las nalgas y las cobijas de la cola blancas, con rayas negras muy finas; el ojo pardo; el pico negro; Tas patas de un amarillo limon; la cera y el circulo de los ojos amarillo claros. Un macho que yo medi te. na $f^{m}, 54$ de largo por $1^{\prime \prime}, 3^{6}$ de punta a punta de ala; esta plegada $6^{\prime \prime}, 42$, la cola $0^{\prime \prime}, 29$, el tarso $1 ", 09$ y el deco del me. dio 11 ". 0.4 .

DISTHIBUCION GEOGRÁFICA.-El área de dispersion del poliboroide tipo se extiende, considerando $\hat{s}$ su congénere de Madagascar como especie diferente, por toda el 
Africa central, descle la costa oriental hasta la occidental, $y$ adcinás por el sur de este continente. Se le ha cazado tantas reces a orillas del Cambia ó Gabun como del Zambezé, en la Cafreria lo inismo que en Habesch y en el oeste del Su. dan. En la parte oriental de este pais, visitada por mi, esca. sea bastante.

USOS, COSTUMBRES Y REGIMEN.-- Esta are se encuentra a veces en los bosques de poca espesura, y munca léjos del agua. Cuando vucla seria fácil confundirla con un dguila; sus alas le permiten sostenerse fácilmente on el aire; y moviéndolas un poco perezosamente pasa de un árbol á otro. Es prudente y timida, y parece observar la vida suli. taria de las otras aves que se atimentar de reptites. Yo di muerte á una en cuyo estómago no encontré mas que dos lagartos; otros naturalistas dicen que caza tambien las ranas.

Sugun J. Verreaux, da pruebas de una agiliclad sin igual: sus tarsos son movib!es en su articulacion tibio-tarsiana, no solo de atrís adelante, sino de deiante atris, y esta conformacion es muy uitil al poliboroide para cazar los reptiles. Hunde sus patas en los pantanos y las agita en todos sentidos con gtan agilidad, hasta que coge su presa; sus dedos cortos pueden penetrar en las mas estrechas aberturas para coger las ranas y los lagartos que en cllas se refugian. J. Verreaux ha observado ademas que el poliboroide tipo se come sin escrúpulo los pajarillos y pequeños mamiferos que habi. tan en la recindad de los pantanos. Esto es lodo cuanto sabemos acerca de las costumbres de un ave tan singular.

\section{LOS SAGITARINIDOS-SAGITA- RINAE}

Creó que se debe colocar aqui un ave de rapiña conside rada por algunos como astúriclo y por otros como tipo de una familia independiente. En efecto, tiene una estructura tan especial, gue por lo menos podemos darle el rango de sub-familia.

\section{EL GIPOGERANO SERPENTARIO-GXPOGE- IRANUUS/SERPENTARIUS}

Esta especie llamada tambien initre de las gribllas, secre. fario y aie de la suevte, difiere de todas has ciemás rajaces por la longitud extraordinaria de sus tarsos, á lo cual se debe que sus picrnas se asemejen á las de las verdaderas aves pantanosas.

CAKACTERES.-Los serpentarios tienen las alas largas, truncadas en ánculo recto, con las cinco primeras pennas de igual longitud; en su articulacion radio-carpiana hay una apoblisis hivesosa en forma cie espolon romo; la cola es muz" larga y cónica; las dos pennas medias sobresalen mucho de las utras; los tarsos son excesivamente prolongados; los dedos corvos; las uñas poco corvas, de un largo regular y romas, pero fuertes; el cuello largo, la cabeza pequena y ancha, y la frente un poco plana. El pico, mas corto que la cabeza, es fuerte, grueso, encorvado desde su base, convexo lateral. mente, comprimido hácia la punta, terminado por un gancho muy agudo con bordes rectos y cortantes, sin dientes ni es cotaduras. La cera se extiende por un lado casi hasta el centro de la mandibula superior, y por el otro hasta debajo del ojo. Las plumas son grandes y abundantes; adorna el occipucio un moño compuesto de doce de aquellas, que el ave suele tener caidas, pudiendo levantarlas a su antojo.

El macho ndulio (fig. 145) tiene la parte superior de la cabeza negra, lo mismo que el moño, la nuca, las rémiges y las rectrices, excepto las dos medias, que tienen las extremidades blancas; el vientre está listado de negro y gris claro; las nalgas de negro y pardo; las dos pennas caudales medias son de un gris azul, con el extremo blanco y manchadas de negro; las cobijas inferiores de la cola de un pardo rojo cla ro. lil ojo es pardo agrisado; el pico de color de cuerno os curo y negro en la punta; la cera de un amarillo oscuro y los tarsos de un tinte naranja.

La hembra y los pequeños difierel del macho por tener el mono mas corto $y$ las pennas caudales menos largas; el plumaje es inas claro; las nalgas listadas de pardo y blanco y el vientre de este viltimo color.

El macho tiene de $1^{12}, 15$ \& $1^{\mathrm{m}}, 25$ de largo; ol ala mide l,",62; la cola $11^{\circ}, 68$ y los tarsos mas de ()$^{\mathrm{m}}$, 29; la hembra es algo mas yrande que el macho.

DISTRIBUCION GEOGRÁFICA.-Eil gipogerano serpentario habita en una gran parte del Africa. Se le ha en contraldo desde el Cabo lassta les $16^{\circ}$ Iatitud norie, y desde la costa del Mar kojo hasta el Sencgal; su årea de dispersion comprende por lo tanto el Cabo, la Cafreria, cl pais de los namaqueses, Natal, el Africa oriental hastaSamhara en el norte de Abisinia, el Ifrica occidental hasta el Gambia y zodo el centró del continente.

USOS, COSTUMBRES Y REGIMEN. - I A estrurtura singular de esta ave hace suponer desde luego que solo vive en aquellas vastas llanuras semcjantes \& las estepas, que se extieiden por la mayor parte del Africa central. Un ave de rapiña formada como el gipogerano serpentario debe vivir con frécerencia en el suclo, siéndole mas ó menos extrañas las regiones aéreas. Segun las observaciones de Heuglin, en Abisinia sube tambien por la montaña lassta la altura de 2,500 inctros; pero aqui habita casi exclusivamente las lla. nuras. No solo se aleja del bosque sino tambien de las inne. diaciones de los árboles altos; su territorio de cáz está en las estcpas, lo mismo en las superficies húmedas que en las arenas secas; en las praderas, y quizás en los campos cubiertos de escasa vegetacion, pero nunca en las espesuras.

(usí como el avestruz, los ótidos y el corredor del desierto, dice Heugin, tambien el serpentario es $11 \mathrm{na}$ verdadera ave de la estepa que solo raras veces vuela á poca altura y con no poca torpeza, pero en cambio cruza su territorio corriendo con bastante rapidez. Su andar y sus posturas no de jan de tener gracia; erguido el cuello y levantada li cabera, mueve estas partes uniformemente hácia adelante y atrás, avanzando unas veces presuroso y otras con lento paso en busca de su presa.

En cuanto á su modo de andar, cstor completamente conforme con mi difunto amigo, pero so en cuanto al vuelo. El gipogerano serpentario ofrece en su marcha un aspecto noble y altivo, pero en el vuelo no se puede desconocer el género á que pertenece, aunque no ser comparable con el de un halcon, águila ó buitre. En cambio, sus largos tarsos le permiten andar con mucha mas ligereza y inejor que ninguna otra are de rapiña: puede françuear muchas leguas andando sin cansarse. Cuando caza corre casi con tanta ligereza como una avutarda, y no le gusta servirse de sus alas. Antes de emprender su vuelo tuma su impulso, y parece que le cuesta trabajo remontarse; pero una vez Hegado á cierta altura se cierne largo tiempo sin dar un solo aletazo. A semejanza de la ciguiena, extiende sus patás hicia atrás y el cuello hácia adchante, siendo su asjecto entonces tan caracteristico, que no se puede confundir con ninguna otra rapaz.

Puede ser que cace con preferencia a la carrera y que ape. nas se remonte a grandes alturas cunndo se le ahuyenta; pero puedo ascegurat por mi propia experiencia que sabe hacer bastante bien lo último.

Todos los observadores estín conformes en que el gipogrerano serpentario vive apareado y habita en territorios bas. 
tante extensos. No aburda cn ninguna parte, pero se en. cuentra en todas las regiones de su área de dispersion. Solo algunas veces se reune cierto número de estas aves extrnñas, como, por ejemplo, cuando se pega fuego á las yerbas de la estepa antes de la estacion lluviosa y $\mathrm{cl}$ incendin se propaga en una extension de muchas leguas, ahuyentando a todos los animales. Fintonces se presenta por lo regular tambien el gi. pogerano serpentario, y seguro de encontrar presa en abundancia, corre y vuela horas enteras por delanie de las llamas que rápidamente avanzan. Por lo demís, solo se le encuentra solitario ó apareado, y no siempre tan fácilmente como podria suponerse por su gran tamaño. A veces caza horas en. teras en la espesura de las altas yerbas que cubren las este. pas y la ocultan á las miradas; y de pronto se lemanta ante el hombre, que no podia sospéclar su presencia. Cuando cstá harto de comer se dirige á un lugar descubierto y permanece inmóvil en el mismo sitio, haciendo la digestion. No deja por esto de vigilar continuamente; esta siemure en guardia ante el hombre, y en cada viajero ve un enemigo de quien debe huir.

Cuando se cree perseguido, segun ha visto Heuglin, pro. cura conscrvarse siempre á la misma distancia de su ene. migo $\delta$ gamar terreno; otras reces vuela algunos miles de pasos, déjase caer en las altas yerbas y huye á la carrera, si es posible en otra direccion.

Esta rapaz, se alimenta principalmente de reptiles, pero no desprecia los otros vertebrados; en ciertas épocas apenas se nutre mas que de los primcros. Sil roracidad es increible; nunca estí satisfecha. Ie Vaillant, mató un individuo que teria en su buche veintiuna pequeñas tortugas enteras; hallo además once lagarios y tres serpientes. Además de estos animales vió tambien una multitud de langostas y otros in sectos, $y$ en el ancho estómago del ave una bola del tanaño de un huevo, compuesta de vértebras de dichos reptiles, es. camas de tortugas, alas y patas de langosta y restos de varios escarabajos que probablemente hubiera arrojado mas tarde. Heuglin cree tambien que extermina mas mamiferos que reptiles; pero otros naturalistas opjinan lo contrario, y parece que tuas tarde tambien Heuglin se ha convencido de ello.

En las Épocas mas remotas se celcbraban las luchas del serpentario. OSa acometer, añade Le V'aillan, $\{$ un enemigo tan temible como la serpiente; si hure, la persigue; dirlase cue vuela rasando la tierra. No extiende, $\sin \mathrm{em}$ bargo, sus alas para hacilitar la carrera, cono se ha dicho del avestruz, sino que las reserva para el combate, empleándolas entonces como armas ofensivas y defensivas. Sorprendicio el reptil, si está léjos de su agujero, detiénese, endereza st cuerpo, y trata de intimidar al ave dilatando extraordinaria. mente la cabera y produciendo un agudo silbido. En aquel instante es cuando la rapaz despliega una de sus alas, á guisa de escudo, y cubre con ella las piernas y la parte inferior del cluerpo. Acometida la serpiente, se lanza furiosa; cl ave salta, descarga un golpe, retrocede, gira en todos sentidos, de una manera verdaderamente cómica para el espectador, v vuclve al ataque, presentando siempre al diente venenoso de su ad. versario el extremo de su ala defensiva. Mientras que la ser. piente agota incitilmente su veneno, mordiendo las pennas insensibles de la rapaz, esta le descarga con la otra ala vigorosos golpes, cuya fuerza aumentan las prominencias y dure. zas de que antes hablé.

* Aturdido al fin el reptil por algun aletazo, vacila y rucda por el polvo; el serpentario le coge con destreza y le lanza por los aires varias veces, hasta que sin fuerzas ya, le des. troza el crineo à picotazos, y se traga el cuerpo entero, si no es demasiado grueso, en cuyo caso le despedaza sujetándole entre sus garras.
Julio Verreaux describe de un modo análogo la manera de cazar el secretario las serpientes; pero su descripcion es mas detallada que la de Le Viillant. "Esta ave tan gentil y majes. tuosa, dice el citado viajero, parece mas interesante aun cuando se prepara para la lucha con una serpiente. Entonces despliega toda su prudencia y se acerca al réptil con la ma. yor precaucion; criza las plumas del mono y de la nuca, pre. cipitase de un poderoso salto sobre la serpiente, descárgala un terrible golpe con su garra y muchas veces la hace rodar por el suelo al primer ataque. Si no sucede asi, enderézase el reptil y la obliga á retroceder de un salto; pero no lo hace sino para esperar el momento conveniente y acometer segunda vez. Con la cabeza erguida, el reptil silba y saca la lengua para espantar al enemigo; pero este cobra mas valor á medi. da que aumenta el peligro. Entreabriendo las alas, aranza de nuevo contra el reptil, y secunda los golpes de sus garms con tal fuerza que muy pronto queda vencida la serpiente é inca. paz de resistir. Cuando el reprtil acomete al ave como lo hemos visto varias veces, el secretario sabe muy ủien evitar sus mordeduras, ya preservíndose con las alas extendidas, $\sigma$ bien saltando a un lado ui otro. Agrotadas sus fuerzas, la serpiente cae al fin al suelo; el ave redobla entonces sus esfuerzos; rompe con sus garras la columina vertebral de su enemigo privandole asi de la posibiliciad de moverse, y por tíltimo la coge con la rapidez del rayo por la nuca. Sin mas preparativos empieza su comida, y en pocos momentos devora una serpiente de casi dos metros de longitud, excepto la cabezan la cual destroza á picotazos: despues üirigese lentamente hácia su retiro, oculta la cabeza entre el plumaje y permanece inmóvil algunas horas, haciendo la digestion.

1)rayson asegura que se re al serpentario cazar tambien su presa volando. «Una de estas rapaces, dice, se cierne á unos sesenta metros sobre el suelo; de pronto se detiene, baja, corre contra la presa que lsa visto y acométela sin vacilar. Lo que dice Drayson confirma plenamente cuanto nos ha referi. do I.e Vaillant.

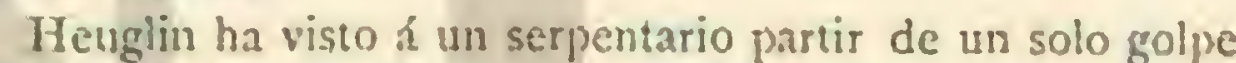
de garm la concha de una tortuga del desierto; y es probable que proceda lo mismo con las serpientes. Algunos autores antiguos refieren que la rapaz arrebata por los aires al dichos reptiles para dejarlos caer y que se hagan pedazos al tocar en tierra; los líltimos viajeros no han visto nada de cato; pero el hecho no es inverosiuil, por cuanto sabemos que otras rapaces apelan al mismo ardid.

Aun no está suficientemente demostrado si la rapar. sucumbe a- la mordedura de una scrpiente venenosa 6 si es refractaria á ella: de todos modos, el hecho es que se traga los reptiles con sus dientes venenosos, exponiéndose sin temor alguno á una peligrosa herida.

Varios autores han hablado y lodos en el mismo sentido, acerca del modo de reproducirse el serpentario: pero á le Vaillant, I. Verreaux y Heuglin es a quien debemos los de. talles mas precisos. İ́n junio ó julio empeñan los machos encarnizadas luchas para disputarse la hembra; esta se rinde al vencedor, y ambos comienzan á construir su nido desde luego. Suelen situarle casi siempre en lo alto de un espeso sirbol, generalmente de una mimosa; el fondo se compone de ramas, enlazadas con barro; la excavincion es poco profun. da, $y$ está cubierta de plumas y de otras sustancias blandas. El mismo nido sirve para varios años; reconócese su edad por el número de capas de que se compone, pues el ave aña. de una cada año. Sucede a menudo que vegetan las ramas que forman el armazon, y rodean entonces el nidó complctamente.

"odas las noches la pareja se dirige al nido para descansar. No permite que otra pareja habite el territorio ocupado por 
ella; en cambio deja, lo mismo que otras aves de rajina, que pequeiras granivoras establezcan su residencia en las inme. diaciones ó en las mismas ramas del nido. Solo en agosto pone la hembra de tres a cuatro huevos, de forma redondea. da y del volúmen de los de una oca, entemmente blancos ó sembrados de algunos puntos rojizos. Despues de una incu. bacion de seis semanas, durante la cual el macho alimenta 1 su compa:iera, salen los hijuelos à luz, cubiertos de un plu. mon blanco: son en extremo torpes, tienen las patas muy endebles r hasta los seis meses no sueler abandonar el nido. Cuando se les quita del mismo, se ouserra que no conienzan á correr siro cinco ó seis meses despues, y aun asi, tienen que descansar a menudo sobre sus tarsos.

CAZA. - La del serpentario ofrece sus dificultades, cuesta murho descubrir al ave y mucho mas ponerse á tiro de ella Hẹuglin y Anderson aseguran que persiguiéndole a caballo se le puecie coger ficilmente. El ave intenta escapar \& la car: rera y al ruelo insta que rendidi de cansancio por la larga persecucion, cae victima del cazador. Heuglin recibió en dos dias nada menos que seis individuos de esta especie, cogidos de la manén descrita.

CAUtrvida D. - Cuando se les cuida bien, los serpentarios se comestican pronto y divierten \& su amo por su modo de piesentarse; por la nobleza de su aspecto, por su marcha arrogante, por sus ojos herrnosos y vivos y por la manera como levantan y bajan las plumas de la nuca; sin cabnarg, segun experimentó Heughin, no siempre reprinen sus inclinaciones a la rapiña; hiscense af menudo peligrosos parm las aves domésticas y hasta se atreven à atacar álos perros y los gatos, dirigiéndoles siempre \{1 la cabeza fuertes gol. pes con su garra que a menudo producen heridas graves. Conténtanse con toda clase de alimento conveniente, pero son en ertienio voraces: tragan pedazos de un tamano extra. ordinario f raras veces se toman la inolestia de desgarrar una presa cón el pico.

Es muy ráro ver al serpentarjo en nuestros jardines zooló gicos, pero siempre cicita la admiracion de todos los con cirrentes. Dicese que en tiempos anteriores se le ha tenidd como are de corral en el Cabo de Buena Esperanza, donde exterminabs toda clase de parśsitos, sin que se mostrara agresivo hàcia sus companeros. Puede convenirse en que son muy vitiles por la caza que dan a las serpientes, ratas, tato nes y otros animales dañinos, pero me resisto á crear que vivan en baena armonía con las aves de corral.

En el Cabo está prohibido bajo las penas mas severas matar a un serpentario: se ha querido aclimataric en la Mfar tinica, a fon de exterminar las servientes de hierro de lanza, verdadera calanidad de aquella isla; esta tentativa no lia se nido resultado, no porque el serpentario no hubiera soportado el clima, sino porque los cazadores de añcion le persiguieron desde un pincipio. haciendo inposible su aclimatacion.

Esta rapaz se ha designado tambien con los rombres de sagilario yecratario, cuya segunda denominacion se le dió á causa de su moño, que se ha comparado con la pluma que lleva el secretario en la oreja. Los nombres que le han dado los árabes son mas poéticos; pero mas inverosimiles aun: en el Sudan oriental se le llama caballo del dibhlo, y en el este, aice de la fortuma. Cada indigena tiene alguna historia que referir acerea de la rapaz; pero todas son del dominio de la fábula y no tienen importancia para el naturálista. Jamás he podido explicarme qué tendria que ver el ave con el destino, cosa tan importante para todo mahometano; y ni aun en las legendas he hallado cosa alguna que me lo dé á eniēnder.

\section{LOS AQUIILIDOS - AQULAE}

Los aıyuilidos son las marores de todas las rapaces que se alimentan de presa viva, y excepcionalmente de restos ani. males en descomposicion. Aplicase este nombre a ciertas aves muy diversas, con las cuales se podrian constituir fun. dadamente varias familias; pero por otra parte, los distintos tipos que vemos entre cllas se enlazan entre si de una manera tan manifiesta, que no se puede desconocer el parentesco que las une a todas.

CARACTERES. - Los aquilidos son grandes aves de cuerpo recogido, cabeza mediana, enteramente cubierta de plumas; pico vigoroso, recto en la base y encorvado en la punta, y mandibula superior sin diente, con una sencilla escotadura en cambio: sus tarsos son de un largo regular, muy gruesos y mas ó menos cubiertos de pluma; los dedos fieries, generalmente largos, y armados siempre de uñas aceradas; las alas, obtusas y mas $\delta$ menos largas, cubren toda la cola en algunos, y solo la base en otros; la cola es ancha, larga, redondeada 6 truncada en ángulo recto. El plumaje es siemnre abundante; a veces muy blando, y por excepcion tosco y recio. Un rasgo característico de las íguilas consiste en que las plumas de la nuca y del occipucio son 6 muy puntingudas ó prolongadas formando como un moño; el ojo es grande y vivar, y el arco cigomático muy prominente, lo cual comunica a estas ares un aire majestuoso.

Para que se pueda formar idea mas exacta de la estructura interna de estas aves, rejoresentamos en la figura 1,40 el es. queleto del águila.

DISTRIBUCION GEOGRÁFICA.-I_os aquilidos habitan toda la tierril, aunque hay algunos sub-géneros limitados a ciertos paises:

USOS, COSTUMBRES Y REGIMEN.-No tienen todas cstas ares la misma residencia: las mas viven en los bos. ques; algunas en las móntañas y las rocas, y utras no se en. cuentrán sino en las costas ó en las orillas de los lagos y de los rios, contandose, en fin, varias que tienen su morada en las estepas. Rara ver se fijan cerca del hombre: buscan los lúgares donde no se las inquieta; abandonan el sitio en que residen, para emprender excursiones hasta la inmediacion de las ciudaces, y si no se las ahujenta, arrebatan su presa a nuestra vista.

Las especies del norte son emigrantes en la mayor partc, ó por lo menos, recorren el pais fuera del periodo del celo, y. habitan segun las circunstancias en su juventud distritos y paises bien diferentes $y$ distantes de los en que viven las pa. rejas que crian y de cierta edad.

A los aquilidos no les gusta la sociedad de sus semejantes; en verano no toleran que otro se fije cerca de su dominio; no se reunen unos con otros hasta el momento de emprender sus emigraciones iuvernales, ó bien cuando encuentran una presa suficiente para varios individuos, como por ejemplo, el cadiver de un gran mamifero; hasta en sus viajes no se conservan muy unidas las sociedades que forman. La casualidad es la que reune a esias aves en las localidides donde encuen. tran abundante alimento; todas se conducen lo mismo, y podria creerse que son sociables; mientras que, a decir ver. dad, cada individuo cuida solo de si. El macho y la hembra de una misma pareja son los únicos que forman excepcion en este caso, pues se manifiestan un mutuo carino, y no cabe duda que su union dura toda la vida. Tampoco se reunen los ayuulidos con las oiras ares; podrán encontrarse por casupli. dad con buitres, buhos ó milanos; pero no traban amistad con ellos: buscan su alimento en el mismo punto, siendo esto lo único que hay entre elios de comun.

Parece que algunos permiten $\mathfrak{1}$ los pequeños parásitos como llamaria yo á ciertas aves, establecerse debajo de su nido, tolerancia que es en cierto modo involuntaria: la gran rapaz consiente que e! pajaro se fije cerca, porque compluen- 
de que no puede apoderarse de él; la agilidad del pequeño sér es su salroconducto.

No queremos negar, sin embargo, que los aquilidos mani. fresten á veces cierta grandeza, como la del leon: los masso. ciables no estàn dominados por la sed de sangre del azor; son rapaces, pero nobles y alivos, y si arrebatan algo es porque tienen precision de hacerlo.

Io contrario sucede en los aquuilidos innobles: algunos hay que no en vano llevan el nombre de águilas-azores (psesudac. los), porque se asemejan a los astúridos, asi por sus costum. bres como por su fisonomia.

Los aquilidos son realmente animales nobles en general: entre las rapaces hay pocas, si se exceptúan los falconidos nobles, que estén mejor dotadas que ellos. Igualmente favo. recidos bajo el punto de vista físico e intelectual, no les aren. tajan en ligerera los falcónidos y los astúridos; pero su vuelo es magnifico y majestuoso, y no se observa en él esa especie de vacilacion que se revela en las dos familias de que acabamos de hablar. Para remontarse extiende el aquilido sus alas, bate con fuerza el aire, aunque con lentitud, y llegado á cierta altura, avanza rápidamente cerniéndose, y muy iendidas las alas. No se le ve dar un solo aletazo, y sin embargo, desajarece de la vista: cuando traza círculos cambia de direccion, volviendo la cola $\hat{a}$ derecha $\mathfrak{E}$ izquierda, levantándola y ba. júndola; sube cerniendose contra el viento y baja siguiendo su direccion. Para coger la presa, precipitase ruidosamente con una rapidez sin igual; un ave muy bien dotada se le pue. de escapar; pero cae con bastante ligereza para apoderarse de una paloma con seguridad.

Ios aquilidos andan por tierra torpemente; dan saltitos de una manera singular, moviendo una pata despues de otra y ayudandose con sus alas; pero cuando están posados, tienen cierto aspecto de noble majestad; su cuerpo permanece dere. cho, y su ademan es sin disputa gracioso. En semejante acti. tud parecen verdaderamente la imảgen de la iuerza.

De todos sus sentidos, la vista es el mas perfecto, y des. pues el oido: los aquilidos ojen muy bien, y parece que les desagradan mucho los ruidos estrepitosos. Se ha hablado nucho de su olfato; pero estoj seguro de que se ha incurrido en exageracion: sin negar este sentido, puede afirmarse que estå muy léjos de alcanzar el desarrollo que sc le atribuye. El tacto es muy fino, y en todo individuo cautivo se puede reconocer la existencia del gusto.

Dificil es formar un juicio general acerca de su inteligen cia, aunque puede asegurarse que alcanza bastante desarrollo. Los aquilidos que viven libres se muestran desconfiados-y circunspectos donde se les ha perseguido; y son por el contrario atrevidos é imprudentes en los parajes en que secreen seguros. Con frecuencia dan pruebas de astucia y de una comprension notables: en cautividad tardan poco en aficio. narse al hombre, siquiera no sea esto una prueba de creerse inferiores, pues aunque el águila esté encadenada, conoce su fuerza y noteme al que intente maltratarla Diariamente veia pruebas de ello en las águilas del Jardin zoológico de Ham. burgo: apenas me divisaban, saludibanme con gritos de ale. gria; me permitian entrar en sus jaulas; pero no toleraban ningun mal tratamiento. Io mismo se conducian con su guardian: en cuanto a las personas desconocidas, no hacian caso de ellas, 6 las rechazaban si cran importunas.

Debe advertirse que los aquilidos q̨ue llamamos nobles, deben considerarse como los que lo son mas: esta califica. cion ha sido aplicada por el aspecto que ofrecen á primera vista, y que está en armonia con sus costumbres: en estos sé. res se ven desarrolladas sobre todo las grandes y nobles cua. lidades.

Los aquuilidos libres se alimentan principalmente de los Toso III animales que cogen por si mismos, y sobre todo de los vertebrados, si bien no conozco ninguno que desprecie los restos putrefactos; es un error creer que solo el hambre puede im. peler à un águila á tomar semejante alimento. Cierto es que prefieren los animales viros, mas no tienen escrúpulo en co. mer los restos que encuentran; no desdeñan alimento alguno, pudiendo decirse que todos los vertebrados superiores son buenos para la rapaz, salvo algunas excepciones. Los aquilidos parecen nuy aficionados á los peces; pocos son los que acometen á los reptiles; arrebatan su presa, ya se halle inmó. vil, corriendo ó volando, y la conducen á un paraje donde puedan devorarla tranquilamentc. $\mathrm{Al}$ acometer despliegan toda su fuerza, y llegan á un grado tal de exciacion, gue puede degenerar en rabia. La resistencia que encuentran no les hace desistir del plan que lian concebido: todo cuanto resuelven lo eje.

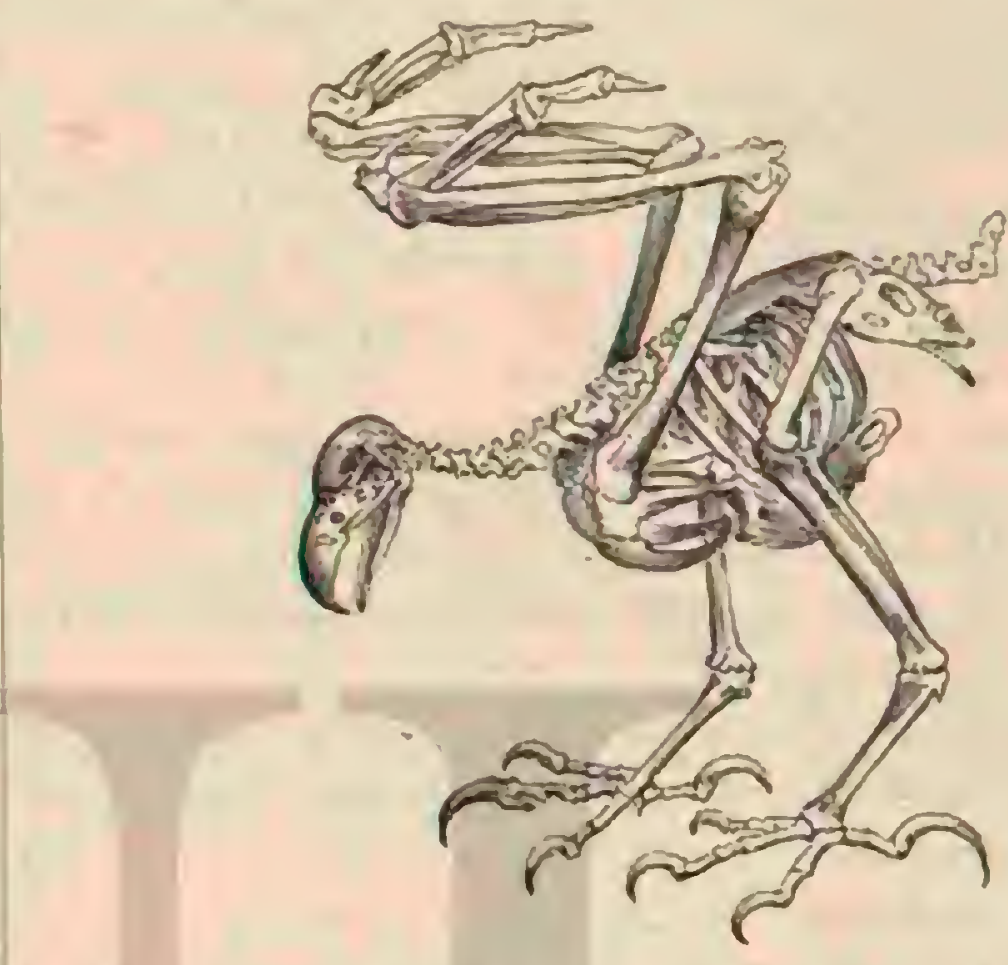

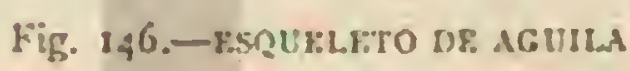

cutan con temeridad; acometen valerosamente á los animales grandes $\delta$ se contentan con apoderarse de alguna débil presa. Su aparicion, dice Naumann, es una señal de muerte para todos los séres que no tienen suficiente fuerza parn resistir $\delta$ bastante ligereza para cscapar. Los mayores aquilidos arrebatan de ticrra á un zorro; apodéranse en los árboles de la narta, á pesar de su vigorosa resistencia; y si el águila estuviera adiestrada, cacria sobre el avestruz y le dejaria sin vida; las que viren libres se atreven hasta con el hombre.

Los aquilicios del norte se reproducen en los primeros me. ses del año; inas pronto los que tienen residencia fija que las especies viajeras, las cuales no llegan hasta el mes de mayo at nuestros climas. Su nido es una construccion cnorme, que guarda proporcion con la talla de estas aves: es bajo, pero ancho, y con la cavidad interior plana; el armazon se compo. ne de ramas secas, del grueso del brazo algunas veces; por encima hay una capa de ramaje mas fino, y el interior está relleno de sustancias mas blandas. Los aquilidos utilizan varios años el mismo nido, aunque reparándole y ensanchín. do!e cada vez que lo necesitan. Suele hallarse sobre los árbo. les $\delta$ cn una roca inaccesible; en caso de necesidad lo cons. truye el ave sencillamente en tierra. Cada puesta es de un huevo 6 dos, rara vez de tres; solo cubre la hembra.

Antes del apareamiento entretienense las aquilidos con sus ejercicios de alto vuelo, ejecutados por el macho mientras que la hembra cubre. Los padres se encargan de criar a sus pequeños; no les dejan carecer de nada, y recorren á veces un espacio de varias leguas para llevarles de comer. Cuando comienzan á volar, permanecen algun ticmpo con sus padres que les enseñan cuidadosamente; pero despues los lanzan al mundo, literalmente hablando, $y$ desde entonces andan erran- 
tes durante varios años, hasta que se aparean y construjen su nido.

Si exceptuamos al hombre, no tienen las águilas ningun enemigo peligroso, aunque si rivales ó adversarios: los pe. queños falcónidos, los cuervos, las golondirinas y las nevitillas, las odian en el mas alto grado; y aunque son impotentes las acometidas con que demuestran su aborrecimiento, mo. lestan \& las altivas rapaces hasta el punto de que se alejan para librarse de una persecucion importuna.

El hombre es enemigo de los aruilidos y debe scrlo, pues los mas le ocasionan graves perjuicios: algunas especies, no obstante, le son vítiles, y debe dispensarles su proteccion.

\section{LAS ÁGUILAS - AQUILA}

CARACTERES. - El género águila se caracteriza por tener el cuerpo vigoroso; la cabeza grande y bien conformada; las alas, anchas y'largas, con la cuarta penna mas prolon. gada, cubren enteramente la cola, que es truncada en ángúlo recto $y$ ancha; los tarsos fuertes, de altura regular y del todo cubiertos de pluma; el pico largo y grande, con bordes cortantes, mandibula superior muy ganchuda y profundamente escotada; el ojo grande y hundidó bajo el arco de la ceja que es muy saliente; los dedos fuertes, de incdiana extension; las unias grandes, aceradas y sumamente corvas. El plumaje es compacto y espeso, las plumas puntiagudas; las de la nuca y del occipiucio, sobre tocio, son bastante delgadas y largas y cubren hasia los dedos.

El águila leonada, el àguila dorada y el kguila imperial son las tres especies en que debemos fijarnos desde luego, pues habitan nuestros paises; son las mas cétebres y las que mas comummente se designan con el nombre de águilas.

No es fácil caracterizar las águilas en breves palabras precisando perfectamente las especies, tańto mas cuanto que los mismos naturalistas estản aun hoy dia en desacuerdo rêspec to de muchas. Cuando estas soberbias aves están vivas, es bastante fícil hacer las debidas distinciones, pero no sucede lo mismo al examinar las picles de águilas muertas.

\section{EL ÁGUILA COMUN Ó LEONADA - AQUILA FULVA}

CARACTÉRES. - Entre las cespecies del genero que mas comunmente se designan lisa y llanamente con el nombre de águila es esta la de mayor tamaño, la mas vigorosa y mas ro. busta. Es el ave de cazı domesticada de todas las tribus del interior del $\mathrm{Asia}$ que pasan la vida montadas en sus caballos; es la protagonista de las fäbulas, el tipo primitivo del animal

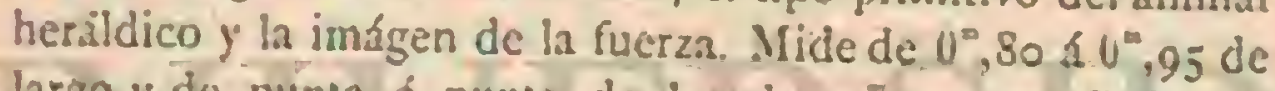
largo y de punta á punta de las alas 2 y mas. Cada ala ticne de $0^{\circ}, 5^{8}$ a $0^{\circ}, 64$ y la cola de $0^{\infty}, 31$ \{ $0^{\infty}, 36$. Las cirras mayores se refieren al macho $y$ las nenores a la hembra. La coloración es en las viejas un pardo que tira á rojo de orin en la nuca, inclusive la parte posterior del cuello; lo restante del plumaje es blanco en las dos terceras partes in. feriores de las plumas y pardo uniforme en la parte de la punta; en la cola es solo blanca la tercera parte de las plumas correspondiente $\hat{a}$ la base, despues se torna listada o man. chada de negro y la mitad extrema, ó sea la punta, negm. Los muslos son pardos, y las cobijas inferiores de la cola blancas. En los aguiluchos es el tinte del plumaje mas claro, y la parte mas clara de la nuca se extiende hasta la superior de la cabeza y \& los lados del cucllo; el ala presenta una mancha grande blanca; la cola es negra en su último tercio y todo el resto de un blanco ceniciento; las ancas son muy
claras y con frecuencia blancas.
En lo que precede nos referimos a la coloracion mas co. mun, pero debemos añadir que el plumaje de esta especie está sujeto a muchisima variacion. Hay individuos viejos que son uniformemente pardo-oscuros; otros pardos con visos dorados; otros presentan en la region del buche y en el vientre este color pardo dorado mientras que el resto es pardo oscurn; los hay que couservan hasta muy viejos la gran man. cha blanca de las alas, y muchos osientan con las alas bonitas listas, etc. Ahora, si todas estas variaciones corresponden solo a una $\delta$ a varias especies, es cosa que hasta la fecha no se ha decidido aun.

\section{EL AGUILA REAL Ó DORADA - AQUILA CHRYSAETOS}

CARACTÉRES. - Naumann, $y$ antes de este Pallas y tambièn mi padre separan de la especic anterior el águila real ó dprada, mientras que los naturalistas modernos se inclinan a considerar ambas especies como simples variedades, ya rijas, ya solo debidas a diferentes edades. Pero yo, despues de haber analizado y compando entre si, en compañia de Eugenio de Homeyer, unos ochenta individuos de estas dos especies de águilas a excitacion del principe imperial Rodolfo de Austria, no puedo menos de ponerme de parte de los primeros Añadire que mi padre hace muchos anos de. signó instantánesinente como águila dorada à ura que tuve a mi cargo juntó con otras de la primera especie. Hé aqui porqué ine parcce muy justo considerar ambas águilas como especies distintas mientras no se aduzcan pruebas convincentes de lo contrario. No puede negarse, por otro lado, que ambas aves son muy afines y que los caractéres distintivos son tanto mas dificiles de encontrar, en cuanto el plumaje de una y otra es poco menos que idéntico cuando son peque. uas, y poco diferente en las vicjas. Las investigacionęs citadis no están concluidas, de suerte que hoy por hoy no puedo todavia decir fijamente que el águila dorada es, segun nues. tms observaciones, notablemente mas perjucina y mas esbelta que la leonada 6 comun, y que ademas difiere de esta por las plumas de la nuca mucho mas anchas, la cola decidida. mente truncada y por las plumas menures casi sin excepcion de color oscuro en su parte inferior. I a coloracion es en gé. neral mas clara, el tinte mas semejante á orin que en la es. pecie comun, diferencia que es mucho mas notable en el pecho, las ancas y las cobijas inferiores de la cola. El hom. bro ó espaldilla presenta una mancha blanca bastante mas marcaida que en la especie leonada, la cual tiene-i lo sumo en dicha region algunas plumas blancas on su edad mas provecta. La cola lleva, sobre fondo entre pardo y ceniciento, fajas 6 listas negras, trastersales, anchas, irregulares, forman. do como dientes, sin que se observe el color bianco en la parte inferior de las plumas. La faja ó lista negra del extremo da la cola es ademas notablemente mas estrecha que en el águila comun.

\section{EL ÁGUUlla CANADENSE-AQUILA Gana- DENSIS}

DISTRIBUCION GEOGRÁFICA. Esta especie susti. tuye en la América del norte á las anteriores, de las que es muy arine, especialmente de la primera.

DISTRIBUCION GEOGRÁFICA DE LAS ÁGUILAS. - El aguila comun habita las cordilleras mas elevadas y los bosques de mayor extension de Europa y de Asia, y pasa accidentaimente, segun Heuglin, aunque raras veces, hasta el norte de Africa En Alemania anida, á lo que yo sepa, solo en las sierras de la Baviera alta y en los dilatados 
montes del Estado en la parte sudeste de la Prusta oriental y de Pomerania. De ver en cuando recorre alguna que otra el resto de Alemania, pero es rarisimo que anide; y si por acaso sucede, suele pagarlo la pareja con la vida y cuando menos cors la pérdida de la puesta 6 de la cria, atendida la exquisita vigilancia de nuestro personal de montes No sucedia sin embargo asi hace algunos decenios, pues entonces todavia era el águila comun ave que anidaba regularmente en la Alemania occidental, oriental y del sur. Mas comun que en Alemania es este soberbio animal en Austria y Hun. gria, especialmente en los Alpes de Estiria, 'Tirol, Carintiay Carniola, donde lo he observado repetidas reces; ni es de ningun modo raro en los monies Karpatos ni en los Alpes de Transilvania, como tampoco en casi ioda la Hungria y parte meridional del imperio austriaco, siendo hasta probable que anide de cuando en cuando alguna pareja en los montes de Bohemia, como dicen se ha visto unos quince años atrás en la cordillera del Riesengebirge. Adernás se extiende esta ave por la Suiza, la Europa meridional, los paises del Atlas, la Escandinavia (?), toda la Rusia (?), en cuanio está cubierta de bosques ó montanas, cl Asia Menor, la Persia septentrional y el Asia central, desde el Liral hasta China, y desde la zona de bosques de la Siberia hasta el Himalaya Es mucho mas rara en la Europa occidental, sobre todo en Francia y Bélgica, que en la parte oriental y meridional. En la Giran Bretaña se presenta 10 mas como ave errante; en Suiza, si bien no es rara, tampoco es frecuente; en el me. diodia de Rusia se la ve con regularidad, y en las montañas del Asia central es animal comun. En cambio parece que el águila dorada solo se presenta de paso en Alemania cuando es jóven, y que su verdadera patria es la Escandinavia, Polonia, Rusia y la Siberia oriental. Entre todas las águilas muertas en Austria.Hungria, no pudimos distinguir ni una sola dorada, mientras que para nosotros lo eran casi todas las que procedentes de los paises anieriormenie citados pudimos examinar con detenimiento.

USOS, COSTUMBRES Y REGIMEN. - Sin alcjarse precisamente de los grandes bosques, anida el águila, como llanaremos en gracia de la brevedad á una y otra, con pre. ferencia en las altas sierms $y$ en sitios de dificil acceso, $y$ sobre todo en picos enteramente inaccesibles.

La pareja, cuando se ha decidido por un distrito, muestra un apego extraordinario al misno, y ni siquiera lo abando. na en invierno, mientras lo consienta la abundancia de la caza, y en todo caso hace repetidas visitas a su nido, como para dar fe de su derecho de propiedad. Es muy probable yue las viejas no emigren ni vaguen errantes si no se las obliga á ello; pero no asi las jóvenes, que por esta razon son las únicas que se matan en Alemania; y hay que tener presente que estas aves necesitan muchos años, quizás seis, achso tambien diey y aun más, antes que pueda llamárselas verdaderamente adultas, es decir, capaces de reproducirse, y que hasta esta época son nómadas y recorren jrobablemente áreas mucho mayores de lo que nos figuramos.

Solo cuando se ha aparcado y se prepara para proceder á la construccion del nido es cuando se hace sedentaria con domicilio fijo, dilatadisimo por supuesto como puede inferirse de la considerable cantidad de alimento que necesia este aninal para manienerse. Desdé su nidal emprende la pareja sus excursiones diarias, por lo regular en una misma direccion, saliendo cuando el sol ya está alto y recorriendo a considerable altura su distrito, en el cual suele seguir las sierras á manera de ruta, rasíndolas cuando son eleradas relativamente á poca altura, distante apenas un tiro de escopeta. \&o he visto 6 menudo, dice Cirtanner, una pareja de aguilas comunes registrar distritos casi enteros de los $\mathrm{Al}$. pes tan escrupulosamente que me ha parecido imposible que pueda escaparse ni una sola pluma it sus cuatro ojos de águila con un procedimiento tan sistemático y preneditado. Macho y hembra echaban á volar casi á un mismo tiempo desde un pico próximo al nido que tenian en una elevada peña; bajaban desde alli rápidamente \& la profundidad, atra. lesaban el valle y seguian despues a poca altura, horizontal. mente y con lentitud, á lo largo de la cordillera opuesta; los dos cónyuges volaban á un mismo nivel; pero á cierta dis. tancia uno de otro, de manera que si algo escapaba á la pe. netrante vista del primero lo veia el segundo, y si aquel levantaba alguna caza, el otro se apresuraba a atraparla. Cuando habian llegado de esta manera al confin de su distrito se elevaban un centenar de metros y volando á esta altura retrocedian á lo largo de la falda de la cadena de montañas, para volver á levantarse al llegar á su confín y seguir de nuevo la misma linea, registrando cuidadosamente todas las sinuosidades de las montañas. i Ay del animal que uno de aquellos cuatro ojos atisba! Si no es muy veloz 6 no lo salva una casualidad, su suerte es fatalmente irrevocable.

El macho y la hembra cazan jumos y se auxilian en caso de peligro: en el momento de comer, se interrumpe no obs. tante la buena armonia; una presa apetitosa es como la manzana de la discordia que indispone à las parcjas mas unidas.

Hácia el medio dia vuelve el águila á su nido, ó se posa en algun lugar tranquilo para descansar, sobre todo cuando la caza ha sido feliz Permanece inmóvil, con el buche hácia adelante y pendientes las plumas; digiere con calma, aunque velando siempre por su seguridad; terminada su comida, se dirige s una corriente para beber. Se ha dicho que la sangre de la víctima bastaba al íguila para aplacar su sed, pero obsérvase todo lo contrario en el individuo cautivo, que belse mucho y experimenta la necesidad de sumergirse en el agua. En los dias calurosos es raro que no se bañe al menos una vez al dia; y cuando ha bebido lo bastante y se ha refrescado \& su gusto, vuelve á cazar. Llegada la tarde, entretiénese en cruzar los aires, y al acercarse la hora del crepúsculo, dirigese con prudencia silenciosamente hácia el sitio donde debe pasar la noche, escogido siempre con la major prevision. Tal es, en pocas palabras, el cuadro de la vida diaria de esta ave.

El águila solo es hermosa cuando estí posada ó cuando vuela: cuando corre es tan torpe que causa risa. Si anda pausadamente se mantiene casi horizontal moviendo una pierna tras otra con gran cachaza, pero cuando se apresura, bien porque estando imposibilitada de volar quiere huir á pié, 6 bien porqque obedezca á otra excitacion, da salios muy grotescos y grandes ayudíndose de las alas, y tan de prisa que cuesta trabajo alcanzarla, si bien mueve á lástima ver sus movimientos torpes E irregulares. Para levantarse del suelo empieza de la misma manera dando saltos acompañados de aletazos pausados y vigorosos; pero una vez llegada-á cierta altura es capaz de sostenerse un cuarto de hora sin dar un solo aletazo, y de cruzar rápidamente los aires, si bien perdiendo un poco de altura; despues volviéndose conira el viento, sube otra vez y llega á la altura primera; todo esto sin mover las alas, salvo en algun caso excepcional en que aletea con gran pausa.

Al igual del buitre, el iguila extiende ianto las alas cuando vuela, que las pennas quedan separadas una de la otra, mientras que las rectrices no cesan de cubrirse; pero a pesar de csto es imposible confundir á una rapaz con otra gracias a la cola cortada en linea recta de la segunda. Algunos bábiles observadores saben distinguir por el ruelo el águila leonada de la dorada; porque esta última es mas esbelta, lo que, unido it su cola menos rectamente recortada, lace que du- 
rante el vuelo resalte mas la diferencia entre ambas. Una y otra proceden, segun las circunstancias, de diferente manera para cacr sobre su presa Cuando describiendo sus circulos en las regiones elevadas atisba el ave una presa, suele abatir un tanto el vuelo como para inspeccionar mejor el objeto; de repente pliega las alas y con las garras abiertas hiende el aire oblicuamente, con un ruido muy perceptible, y se precipita sobre su victima hundiéndole las uiras en el cuerpo. Si esta es un animal inofensivo, no mira como lo coge, pero si es uno que puede causarla daño, no deja nunca de clavarle una de las garras en la cabeza para cegarlo y desarmarlo á la vez. Mi padre ha observado muchas veces el modo de atacar de un aguila dorada que tenia cautiva, y copiaré aqui su excelente descripcion siquiera en extracto.

¿Al coger su presa, dice, el águila clava sus garras con ta! violencia, que se oye perfectamente el ruido, y parece que sus dedos se crispan convulsivamente; coge a los gatos por el cuello, impidiéndoles respirar, y los devora antes que ha-
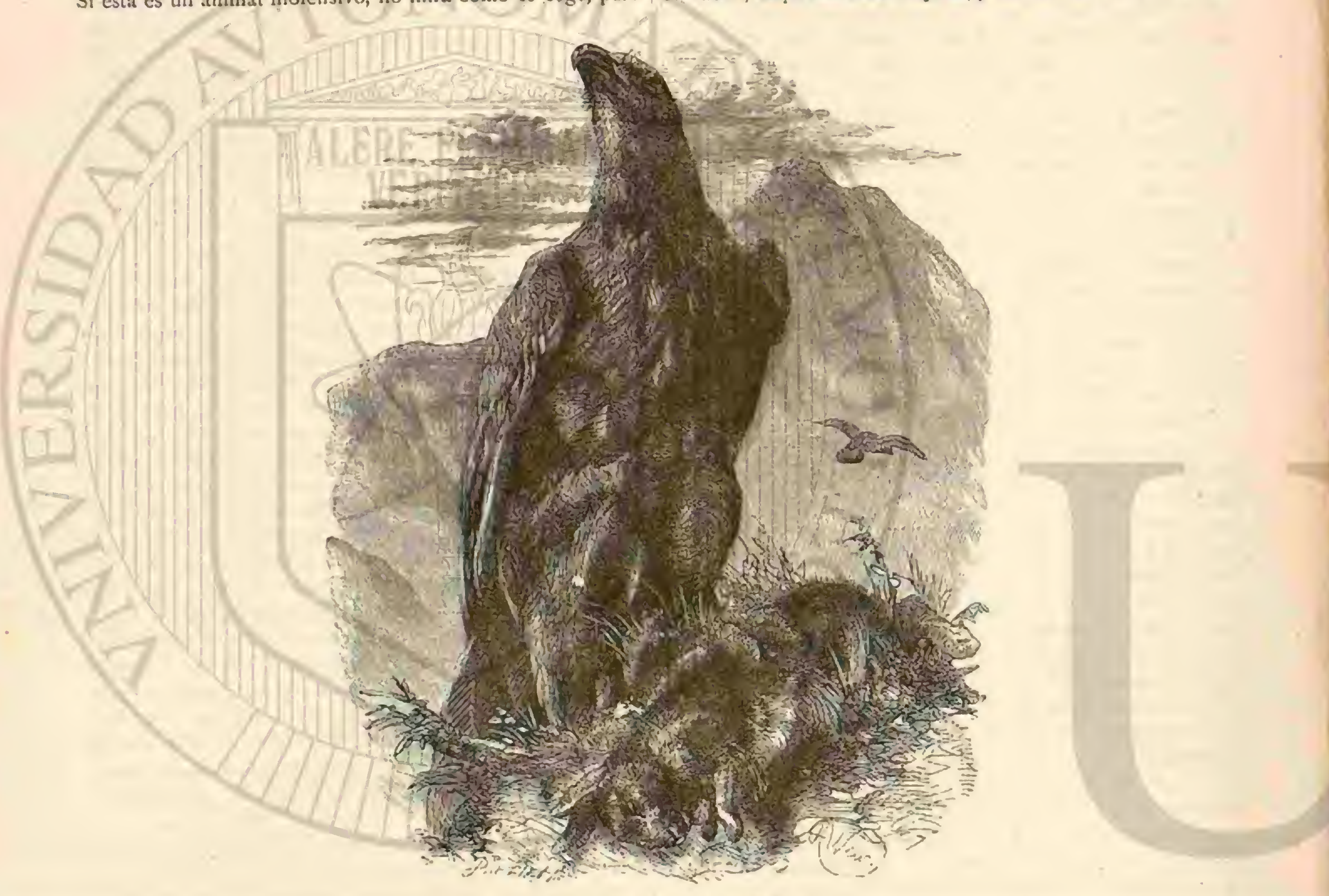

Fig. I47-EL ACUHA BOMAI

yan muerto del todo. Por lo regular sujeta con una de sus garras la cabeza de la victima: á un gato que le eché le reventó un ojo con una de sus uñas; los dedos anteriores mantenian inmóvil la mandíbula izquierda de tal modo, que el animal no podia entreabrir-la boca; la otra garra se habia hundido en el pecho. Para conservar el equilibrio, el águila extendió sus alas, apoyaindose sobre la cola: sus ojos se in. yectaron de sangre y parecian mayores que de ordinario, tenia todas las plumas recogidas, el pico muy abierto y cotgante la lengua; reconociase en aquel momento en el águila una rabia increible, y desplegada toda su fueria. Inútiles cran todos los desesperados esfuerzos del gato para escapar de su terrible enemigo; retorciase como una serpiente $y$ extendia las patas, mas no le cra posible hacer uso de las uñas y de los dientes; el animal maulló, y' entonces hirióle la rapaz en otro sitio del pecho, sujetándole siempre la boca con una garra, y sin hacer uso de su pico. Pasaron tres cuar. tos de hora antes que el gato muriese, $y$ durante todo este ticmpo habia permanecido el iguila sobre él con las garras contraidas y abiertas las alas; luego abandonó el cadáver y se posó en su perclia. Aquel largo tormento me causó tal impresion, que ya no le di ningun gato para que lo matrse. Otros animales perecen tambien entre las poderosas uñas de estas rapaces, y resisten mucho menos que el gato. Las iguilas no temen tampoco acometer a otros animales mas fuertes: se han visto aigunas que arrebataron zorros. \&Pobre zorra, dice á su vez Girtanner con mucha razon, cuya caza nocturna ha sido infructuosa, y que vagando hambrienta sin ver la pareja de águilas que la ha atisbado, observa, arras. trándose con atencion concentrada, una familia de distraidas gallinas; i pobre zorra cuando la reina de tos aires con las alas plegadas, pero ábiertas las garras, baja como una saeta para echarse sobre ella! Aun no ha trascurrido un segundo cuando ya el ave le ha clavado una garra en el hocico, im: pidiéndole hacer uso de sus dientes afilados, micntras yue hincándole las uñas de la otra en el cuerpo, la oprime contra el suelo. Para conserwar el equilibrio da algunos aletazos, y sin aguardar la muerte de la pobre zorra, empicza á destro. zarla en vida. Xa hemos visto en el primer tomo, pág $3^{6}$, que no siempre salc victoriosa el águila de semejante $\mathrm{em}$. 
presa, pero no puede dudarse de que se atreve á acometerla, dando asi pruebas de valor $y$ de confianza en su fuerza, que nunca se ve mojor quee cuando el animal, con la mirada chis. peante, las plumas de la nuca crizadas y las alas medio levantadas, tiene sujeta á su victima, prorumpiendo en un verdadero grito de triunfo. En tales mumentos revela su aspecto tanta arrogancia y tan imponente fucrza que impre. siona à cualquiera. La persuasion en que está de su vigor la arrastra ś veces á acometer hasta al mismo señor de la tierra, al hombre; siendo cierto $y$ positivo que ha atacado crinturas y llevadolas á su nido; no faltando casos auténticos de haber acomctiơ á hombres adulios.

Recibi un dia, dice Nordmann, un águila leonada cuya historia es bastante singular. Hambrienta el ave, precipitóse en medio de cierto pueblo, donde hizo presa de un cerdo muy gordo; como el animal comenzase á chillar, acudieron los habitautes, y un campesino ahuyentó al àguila. Abando. nando con sentimiento su presa, cayó la rapaz sobre un gato

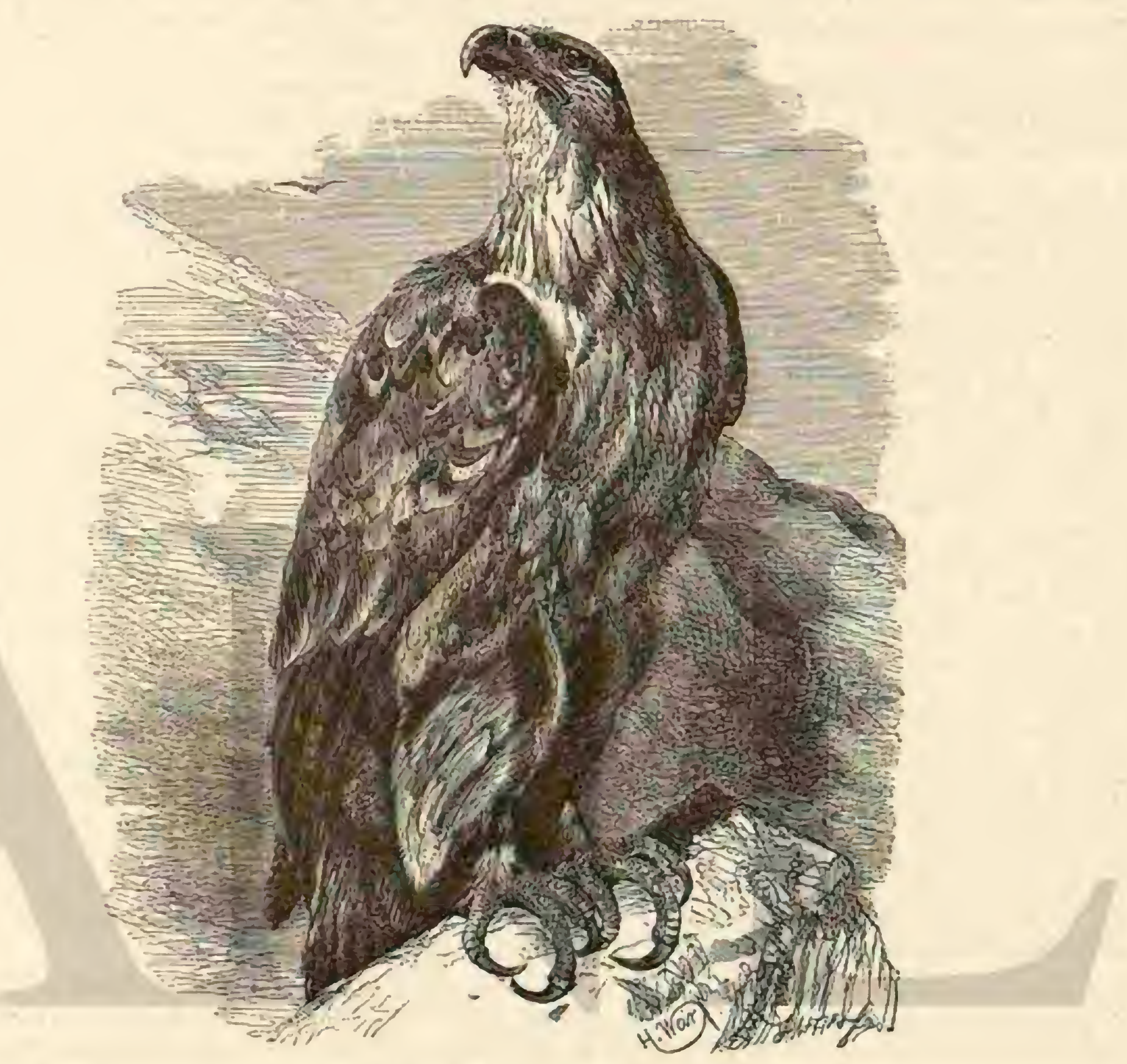

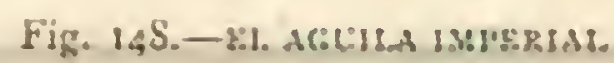

y se lo llevó á una cerca para devorarle: el cerdo herido y el feiino ensangrentado formaron entonces un duo espantoso con sus dolientes quejas. El campesino quiso salvar tambien al gato; pero no osando acometer de frente á su terrible enemigo, fué á busear la escopeta. Cuando el águila le vió volver, solió su victima para lanzarse contra el hombre, y entonces comenzaron à gritar los tres, el desgraciado cazador, el cerdo y el gato. Acudieron al momento otros cam. pesinos, sujetaron al ave, atíronla y me la presentaron.s

Fos muy probable que la mayor parte de los destrozos atri. buidos al gipaeto, ra gue no todos, scan ocasionados por el águila leonada y șus congéneres. En España se habla mucho de la osadia de esta ave, y yo mismo he visto un ejemplo que confirma cuanto se ha dicho.

Delante de la casa donde estábamos cayó un águila soire un gran pavo, y felizmente se llego á tiempo para salvar á la infeliz ave, mas mucrta que vir. Entonces comprendi por qué se conducen de cierto modo las gallinas que viven en todas las moniañas del pais: las acometidas del águila leonada y del azor las han espantado de tal modo, que apenas aparece la mas pequeña rapar, como por ejenplo, el cernicalo, precipitanse aturdidas en las casas buscando un refugio hasta en la habitacion del amo.

En todas las regiones montañosas habitadas por el águila corre continuos y graves peligros el ganado menor; porque á pesar de la mas exquisita vigilancia de los pastores, se pre. cipita la rapaz a su vista, acosada por el hambre, sobre los corderillos y cabritos y se remonta á los aires con ellos. Asi es que para los ganaderos suizos y de ioda la Europa meri. dional no hay ave mas odiada q̧ue el águila; y les sobra la razon; porque ningun otro animal causa tanto daño como ella, y no se limita solo á robar los corderillos de nuestros rebaños, sino que, como ya dije en otro lugar, se atreve tambien con los carneros silvestres. No hay que decir que para la caza menor es peor una pareja de águilas que el mas cruel invierno.

Mucho deberiamos extendernos si se tratara de enumerar todos los animales que son presa del iguila. Podemos decir que en nuestros paises, las otras rapaces, las golondrinas, las aves cantoras y todas las mas rápidas; los grandes rumiantes, 
los solipedos y los ungulados, entre los mamiferos, son los únicos séres que se hallan libres de las acometidas del águila; y aun de estos, solo escapan los individuos adultos, pues la rapsz. no teme perseguir á los jóvenes. $\mathrm{Al}$ lado del nido de estas águilas, y principalmente de la imperial, llegan á fijarse varios pảjaros, que no parecen molestados por su terrible vecino, aun cuando este no desprecia nunca una presa pequeña, segun remos en las siguientes palabras de Radde, que fué testigo del hecho. Las alondras y calandrias, dice, la siguieron apenas se remontó, $y$ al verla posarse en un montecillo, bajaron átierra, sin manifestar la menor desconfianza; pero de repente se lanzó la rapaz sobre ellas y co. gió una:y

Mi padre vió á un águila apoderarse de un crimo á pesar de sus puias: sin que tampoco le valga fla tortuga su concha dura como el hierro. eEl caso de la muerte de Esquilo causada por una tortuga gue, segun Plinio, habia dejado cacr un águila sobre la cabeza calva del poeta, dice ron der Muehle, no es de ninguna manera inverosimil, porque suce. de ámenudo que esta are coge una tortuga terrestre y la lemnta al aire para dejarla caer sobre una peña; trabajo que repite hasta que se rompe la concha del animal; entonces se pósa á su lado y se la come. Hasta los mismos animales que parecen estar al abrigo de sus acometidas en el centro que hibitan, acaban por ser presa suya, por lo mucho que les cansal con su continua persecucion. AjJ es como se apro. dera de las aves acuáticas: estas se sumergen; pero las aco. mete de nucvo repetidas veces, hasta cjue perdidas las fuer. zas, no pueden ya refugiarse en el agaa, y son arrebatadas por eliguila. Otras rapaces trabajan tambien para ella, y con frecuencia se da el caso de que el halcon viajero se ver en in precision de abandonarle la presa, que el águila, of pesar de su innegable orgullo, está léjos de despreciar. A veces roba la taza a la vista del mismo cazador yue la acaba de matar. Habitaba una pareja de águilas comunes en un punto inaccesible de las peñas cerca de Astros en Grecia, pareja que von der Muehle pudo observar cuatro años seguidos. A poca distancia del ptreblo hay un gran pantano cuyo centro viene á ser un lágo que en inviemo sirve de residencia á un sinnúmero de aves acuáticas. A.lli, dice el citado autor, iba yo á menudo á cazar, sucćdiéndomé muchas veces que una ú otra pieza nuerta quedaba en el lago á tal distancia que mis perros no podian ir a buscarla y que siempre acababa por servir de pasto á las águilas, las cuales, no bien oian un tiro, abandonaban el picacho en que estaban posadas para describir circulos al rededor del lago, y muchas veces se apoderaban a mi vista con un atrevimiento increible de la pieza que acababa de derribar, sin que jamás me hubiera sido posible matarias a ellas. Este hecho es ya una prueba de que el aguila no desprecia las presas que otros han muerio; $y$ il esto debo añadir que tambien devora la carne en descomposicion. No cabe duda de que prefiere animales recien muertos a los que se hallen ya en estado de putrefaccion, pero la verdad es que no desprecia nada, ni siquiera regetales, segun sean las circunstancias y quizís cuando el hambre le atormenta, porque Reichenau encontró en su estónago patatas.

Antes de comerse el ave que acaba de coger, ha despluma el águila toscamente; le parte el cráneo y la devora, comenrando por la cabeza, sin dejar mas que el pico si son aves grandes; despues se come el cuello y lo demás del cuerpo. No roca álos intestinos, y como los halcones y los azores, toma pedazos pequeños cada vez; de modo que necesita unos veinte minuzos para despedazar a medias una corneja; come con mucha prudencia, y de vez en cuando mira á su alrededor. Al menor ruido se detiene, mira largo tiempo hå cia el lado de donde procede, y no vuelve à.comer hasta que todo queda tranquilo. Terminada su comida se limpia cuidadosamente el pico; y parece que necesita tragar plumas y pelos para hacer lo mismo en el estómago. Cuando ha hecho la digestion, los pelos y plumas forman una especie de bola que expele el águila una vez cada cinco ú ocho dias; si no la ha formado, traga heno y paja, y la arroja del mismo modo: come los huesos con gusto $y$ los digicre completamente.

El àguila aniđa á principios del año, ó sea à nrediados ó á fin de marzo. Construye su nido en las montañas, con pre. ferencia en sitios espaciosos y cubiertos; y cuando no, en resaltos anchos de peñas inaccesibles. Lin los grandes bosques se establece en las últimas rarnas de los árboles mas altos; de modo que varia segun la localidad. Cuando construye su nido en un árbol, forma primero una armazon volu. minosa de ramas muy gruesas que recoge del suelo ó bien las desgaja del árbol precipitándose desde gran altura sobre las ramas secas, á las que se ase con las garras en el momento opartuno. Sobre esta base coloca ramas mas delgadas, despues ramitas, y finalmente alfombra el espacio interior $y$ muy llamo de liquenes. Estos nidos suelen tener un diámetro de $t^{m}, 30$ hasta 2 metros, y el hneco del nido de $0^{*}, 70$ \& $0^{\circ}$, SO, pero como la pareja lo hace servir varios años, va creciendo con el tiempo en altura cuando no en circunferencia, por manera que á menudo suele llegar á ser una construccion imponente. No emplea tanto trabajo el ave en los huecos de las peñas. Verdad es que tambien suc!c reunir una base de robustas rumas, y hacer el resto del modo indicado, pero se. gun las circunstancias le bastan tambien ramitas. Un nido de águilas que examinó Girtanner en el Canton de los Grisonés consistia simplemente en un enorme monton de ramitas delgadas de pinabctes y de arces, y tenia un metro de alto, ires de largo y dos de ancho. lil hueco donde estaba colocado debia su origen al desprendimiento de una gran masa de la peina y estaba tan resguardado por arriba y por los lados que con dificultad se habria podido introducir en él una bala y mucho ménos el pié del hombre; pues por delanie habia dejado el águila solo el sitio mas preciso para poner las patas, y el monton que formaba el nido sobresalia de la peña, quedando solo en el fondo del hueco un sitio hondo para la puesta, la madre y la cria.

l'ara nada necesita el águila tal monton de ramas, dice el citado autor, pero anie todo procura preservar lós huevos colocados en el fondo de los efectos de la intemperie y evitar despues que los aguiluchos caigan al abismo cuando están solos, pues no es presumible que intenten rebasar un balunte tan alto y lleno de espinas; de paso abriga á la hembra, que esto no obstante, debe sufrir no poco frio, nieve y ventadas, puesto que cmpieza a cubrir en época tan temprana. I Ios huevos, relativamente pequeños, son casi esféricos, ásperos al tacto y de color blanquizco ó gris verdoso, salpicados ir regularmente de manchas y puntos de diferente tamaño de color gris y pardo y bastante mezclados. Suelen encontrarse de dos a tres, pero raras reces salen mas de dos aguiluchos, y por lo comun solo uno. La hembra los cubre unas cinco semanas. Los pequeños, que suelen nacer en los primeros dias de mayo, están como otras ares de rapina, cubiertos de un vello lanudo cenicicnto y crecen con mucha lentitud, por manera que raras veces empiezan a volar antes de mediados de julio, y por lo regular hasta últimos de esie mes. En la primera época de su vida descansan tan inmóviles sobre sus tarsos, que a no verlos mover muy de tarde en arde la cabe. 2a, se dudaria si están vivos ó muenos. Mas tarde se enderezan alguna que orm vez, y hurgonean mucho con su pico el naciente plumaje, que probablemente les causa jicazon à medida que crece; empiesan a estirar y á morer las alas casi 
desnudas como si quisieran ensayarlas; despues prueban a levantarse sobre los dedos; van y vienen; se acercan al borde y dirigen miradas curiosas al abismo sin fondo, $\delta$ bien al aire para ver si vienen sus padres; hasta que finalmente abandonan el nido $y$ se remontan al espacio. Ambos progenitores los cuidan con indecible ternura, pero la madre es la que especialmente se dedica con mayor afan as satisfacer sus necesidades. Apenas abandona el nido inientras sus aguiluchos son pequenos; los calienta frotảndolos ligeramente con su cuerpo, y como Cirtanner ha visto con sus propios ojos, les lleva cada dia ramas frescas de arce para reemplazar las que están húmedas $\delta$ qุue los peq̧ueños han ensuciado; y finalmente, les trae en compañia del macho provisiones de sobra para alimentarlos con abundancia En su primera edad los mantiene la madre con los alimentos medio digeridos en su buche; despues parte en pedacitos la carne que trae para dársela, $y$ últimamente ambos les entregan presas enteras, de jando que se arreglen como puedan, para acostumbrar!os paulatinamente \& la independencia. Esto explica por qué los viejos, por lo menos la hembra, pasan al urincipio tanto ticrn. po en el nido, y que a medida que sus aguiluchos medran estén mas tiempo ausentes y se alejen á distancias siempre mayores, hasta que al fin, cuando saben que su cria tiene suficiente provision, pasan dias enteros sin acercarse al nido. Entonces es tambien cuando este parece un matadero lleno de huesos y pilirafas, porque si los vicjos se muestran muy solfcitos en renorar el material del nido, no lo son respecto a los restos infectos de las victimas que llevan para alimentar su cria, ni hacen el menor caso de las innumerables sabandi. jas que alli se crian ó acuden, dejando i sus aguiluchos con la mayor indiferencia cu medio de tanta y tan hedionda porqueria.

Bechstein da una idea del número de victimas que han de perecer para que vivan dos aguiluchos. Dice que se encontraron al rededor de un nido los restos de cuarenta licbres y de trescientos patos. Ser tal vez exagerado, pero no deja de ser cierto que una pareja de águilas causa terribles destrozos entre los animales de la comarca en que vive; debiendo entenderse por comarca un área nuuy considerable, puesto que se ha observado que iban a buscar garzas á veinte y treinta kilómeiros de distancia para llerarlas a sus pequeảuelos.

En otro nido que inspeccionó el cazador Ragg, haciendose bajar á este efecto desde la cresta de una peria con una clerda, encontró un chotito de gamuza entero, del cual quedaba solo una cuarta parte, y además los restos de una zorra, de una marmota y de cinco licbres alpinas. Para el ganado menor es el águila una verdadera plaga en la época de su cria, y no es extraño que los ganaderos hagan cuanto pueden por exterminar tan terribles ladronas.

CAzA. - Es menester șer excelente trepador de montaña y tirador consumado para cázar al águila comun, porque esta ave solo se deja acercar y sorprender en sitios donde no ha sido atacada todavia, y este caso es muy raro. Casi siemure es recelosa y en extremo precavida desde sus primeros anos, cualidades que aumentan con la edad y la mayor inteligen. cia Distingue muy bicn al cazador del individuo inolensivo, porrque huye del hombre armado apenas le columbra á gran distancia, mientras que roba tranquilamente ol rebaño á la vista del pastor; si bien prefiere por lo regular no exponerse ni frarse de una seguridad incierta s por lo mismo frecuente. mente engañadom, salvándose siempre á ticmpo. Ni olvida ser cauta en el mismo nido, y cuando se le ha matado la pareja, puede decirse que ya no hay medio capaz de alcanzarla. El mejor modo de cogerla es atraeria con carnada, solo que se necesita mucha paciencia para pasar largo tiempo accechándola en una choza vecina y bien disimulada. Prefiere la caza muerta à toja otra carne. Si se coloca junto á este cebo un buho vivo y el cazador aguarda en acecho bien oculto, puede contarse con mucha seguridad con que el águila se pondráa tiro. Asi me lo ha aseverado el principe heredero Rodolfo de Austria uno de los cazadores de águilas comunes mas apasionados y mas felices, cuya experiencia en este punto excede a la de muchos cazadores encanecidos; pero con todo, es siem. pre mas fácil coger el águila con armadijos y trampas, pues un hierro bien cebado es casi infalible, $y$ tambien se saca buen partido de la red, que es el medio usado en China para coger estos animales.

CAUTIVIDAD. - I as águilas se domestican muy pronto cuando son pequenas: acostúmbranse \& su amo; manifiestan impaciencia cuando están mucho tiempo sin verle, y le salu. dan con gritos de alegría cuando llega, sin ser nunca peli. grosas para 6 .

Por lo general suelen tambien portarse bastante bien en compania de otras de su especie, al igual de otras aves grandes de rapina, con ral que estén convencidas de que aque. llas no las temen. Sin embargo no hay nunca que fiarse de ellas como tampoco de oira ave de rapiña cualquiera; sobre todo no pueden dejarse juntas encerradas en estrecho espa. cio $y$ sin vigilancia cuando son jóvenes, puesto que les falta el conocimiento y.jodrian por pura ignorancia atacarse mutuamente y si una sucumbe comérsela la otra; caso que no es tan de temer entre las viejas aunque se les agreguen otras ares de rapina mas pequeñas, siempre que tengan espacio suriciente, porque las salva á estas su mayor agilidad de cualquiern agresion que pudicra proceder de aquellas. I.os mejores conınañeros de las águilas son sin duda los buitres, cuya torpeza permite a aquellas apoderarse a tiempo de los mejores bocados, mientras que su fuerza imponente les causa desde el principio el respeto debido. Poca mella lace en estas rapaces la intemperie, pero no obstante necesitan à la larga un albergue formal si han de vivir cómodamente, y al cual puedan retirarse cuando les parezca. Verdad es que se las ve posadas en las ramas mas altas del árbol quue hay en la pajartra, aun haciendo el frio mas rigoroso $y$ hallándose expuestas al viento mas violento, pern tambien se obscrva que otras veces se esconden para ponerse al abrigo de las inclemencias de la atmósićn.

Su comportamiento indica bastante cuán desagradable les es el tiempo frio, húmedo y lluvioso, pues al paso que se mueven y gritan mucho y á menudo cuando hace sol, per. manecen cuando llueve largo rato inmóviles en un mismo sitio, con visible expresion de mal humor. En cuanto à su alimenio no son dificiles; toda clase de carne les conviene, y lo mismo devoran caza de pelo que de pluma; lo que si necesitan es abundancia de agua pura para beber y mas aun para bañarse, porque son aves muy limpias que no soporan porqueria alguna ni en su pico ni en su plumaje, çue arreglan continuamenic.

Cuando se cuida bien a estas ares soportan la cautividad durante varios años. En el castillo imperial de Viena, cuenta Fitzinger, se conservan águilas vivas, obedeciendo á una costumbre antigua de la casa de Hapsburgo: un águila dorada vivió desde 1615 a $1719, y$ en 1809 murió en Schambrun otra que habia estado cautiva cerca de ochenta años. 2

USOS Y PRODUCTOS.-Pallas y Eversmann nos dicen que los baschkirs adiestran águilas comunes y doradas para cazar; yo mismo las he visto en mi viaje á Siberia y "Turkestan y oido de boca de los kirguises, que son los que mas las emplean, respecto d sus usos y enscrianza lo que sigue: Los cazadores kirguises que se sirven del águila para cazar, la sacan tan jóren como sea posible del nido y la educan 
con la mayor solicitud y esmero. El halconero es el unico que da de comer al ave desde el primer dia con una mano mientras la tiene posada en la otra, á fin de que se acostumbre à su amo. Mas tarde, pero antes de que eche todas sus plumas, la cubre la cabeza despues de cada consida. Toda la enseñanza se limita luego ó acostumbrar al ave à tenerse sobre el puño yj obedecer cuando se la llama; el hábito hereditario ha de hacer lo restante. Cuando el are sabe hacer perfecto uso de sus alas, la lleva el kirguis à la estepa para lanzarla primero sobre caza menor, como bobacs y espermó filos.

No siendo su peso nada leve cansaria el ł́guila muy jron. to el puño del jinete, prótegido por un guante grueso; par cuya razon llevan en la silla 6 tambien en el estribo una especie de apoyó donde descansa-el antebrazo. Gracias a la habilidad con que todos saben jasar con su monitura por los puntos mas dificiles, no tarda el halconero en llegar i un sitio desde el cual domina una gran extension de terreno. Alli quita al àguila su caperuza y la arroja al aire tan luego como pasa una presa. El animal es al principio muy torpe, pero no iarda en adquirir ia habilidad necesaria para coger una marmota antes que esta pueda meterse en su madriguer.

Cuando ha adquirido cierta práctica en esta caza, se la aplica á la de zorros; los auxiliares del-cazador, que por supuesto van tambien montados, levantan la picza y procuran hacerla pasar por delante del halconero, que en el momento oportuno arroja sobre ella el ave. Fsta se lcvanta, describe uno $\delta$ dos circulos, se arroja desde to alto en linea oblicua sobre el zorro, fo le clava sus garras en el cuarto trasero. El 7.orro, al sentirse herido, se agazapa pam dar à su enemigo uno de sus mordiscos mortales, pero el ave aprovecha este moviniento para cogerle la cabeza y si le es posible hunditle las unas en los ojos. El zorro no por esto se rinde ni se da por perdido; al contrario, se echa reperitinamente de espaldas arrastrando consigo el águila é impidiendo asi nuevos ataques: pero los jinetes se acercan y el cuadrúpedo al oirios. se acobarda Por otra parte, el àguila, convencida de habér. selas con un adversario muy temible, saca sus gatras del cuerpo de su victima cuando esta se ha tendido boca arriba y se cierne otra vez, cual negrn nube sobre la pabre, siempre pronta á volverle á clavar sus terribles garras en la cabeza Viéndose el zorro continuamente atacacio, amenazado, heri. do s perseguido, se cansa y desanima mas pronto de lo que podria presumirse, y se deja coger sin ofrecer ya mas resis. tencia a su enemigo aćrco.

Entre tanto se acercan los cazadores, excitando desde léjos con sus gritos al ave, y se apresuran al llegar á poner in á los sufrimientos de la victima de un garrotazo hábil. mente asestado. Cuando el águila ha adquirido suficiente präctica en este género de caza, su amo la enseina à perseguir al lobo, al que levantan los ojeadores del mismo nodo que âs su congénere.

No todas las águilas se atreven á atacar á esta fiera, relativa. mente mas fuerte que ellus, pero las que estån adiestradas lo hacen siempre; con mas precaucion si, pero de la misma manera que para cazar el zorro. El águila scria incapar. de dañar sériamente al lobo, como sucede á menudo con el zorro, sin el auxilio de los cazadores, que acuden celosos en el momento crítico, dando fin con el lobo atacado por el ave

Un águila que caza lobos no tiene precio para los kirguises; porque entonces ya se la puede emplear para perseguir antilopes y cualquiera otra caza; una buena aguila, mediana cazadora, vale en aquel pais tanto como tres ó cuatro yeguas. No puede cazarse con dos àguilas, porqque entonces las excita tanto la envidia que se atacan una a otm y no cejan hasta que alguna de las dos queda muerta.
A pesar de lo expuesto, se saca menos utiliciad del águila viva que de la muerta. En el Tirol y en la Baviera superior se consideran ciertas partes del cuerpo del águila como adornos de grandisimo mérito: en primera linea figuran los vedredones de águila ó sean las cobijas inferiores de la cola que se pagan d dos $y$ hasta cinco fiorines una ( 5 i $12 \%$ pe. setas); en segundo lugar vienen las unas, que se usan como dijes de reloj mucho inas preciados que las puntas de asta de ciervo, los colmillos de la zorra y las garras del azor $\delta$ del buho. Pero aun se aprecian de distinto modo las unas de la misma águila. In de mas valor es la trasera, despues las dos mas largas y mas robustas anteriores, y en último grado la una débil del dedo mas pequeño. Por la primera pagan aquellos montaneses con mucho gusto hasta quince pesetas, de suerte que entre todo se saca de un águila comun muerta, sesenta maxcos y a menudo ochenta ( 75 hasta 100 pesetas). La cabeza y las garras pasan en China por remedios de grandisima virtud y las pennas sirven para abanicos y guar. niciones de Alechas. Tambien alcanzan mucho precio las pennas y rectrices en el pais de los burietas (Asia), y los mogoles las ofrecen como sacrificio á sus dioses. Esta costumbre tiene relacion con una supersticion muy general en tre estas gentes, que segun Radde no matan a las águilas; pero si una dé estas aves es cazada ó queda herida, la deben rematar al instante a fin de no excitar la cólera de los espirius malúficos.

No deja de ser singular que existan las mismas creencias entre los indios de América. vian á buscar los nidos de las grandes águilas, dice el principe de Wied; cuidan de los hi. juelos y les quitan las pennas caudales, que tienen á sus ojos mucho valor, Lunto que no venden una por menos de un duro. Lntre los pieles rojas de la América del norte son estas plumas el distintivo de algun acto honroso, y/los mas de los indios llevan tantas como enemigos matan.

sUná pluara de águila teñida de rojo, y aciornada en su extremo con un cascabel de crótalo, indica una accion ho. norifica, aunque solo para los indios, pues consiste en el robo de caballos. Con estas plumas fabrican los naturales adornos; las tjian perpendicularmente por hileras en una faja de tela roja, que se sujeta en una especie de gorro guarnecido tambien de plumas; y cuando se cubren la cabeza con 6l, forma la faja una especie de cresta, la cual pencie por la espalda hasta tocar al suelo. Los indios mandans llaman s. este adorno de gran ceremonia, mahelisi-acoul hasckha; única. mente álos guerreros mas nombrados les asiste el derecho de ponurselo; tiene muciro valor, y su dueño no le cede nunca sino por un buen caballo. En los dibujos de Batlin, demasiado fantasticos, se representa a los indios que van a la caza del bisonte engalanados con aquel adorno; pero se falta $\{$ la exacritud, pues aquellos indigenas van a la caza con el mis. mo traje de guerra, sin adorno alguno, y llevando solo sus talismanes. Un jefe de nombradia ostentará tal ver su toca de plumas en una gran batalla, ó en caso de un duelo con. venido; pero nunca para cazar. Los indios suelen poner tam. bien plumas de águila en sus armas; adornan con ellas sus cabellos, y hacen asimismo abanicos.

Las dos especies siguientes de águilas de gran tamano, una de las cuales se ha cazado reperiojas reces en Alemania donde se asegura que ha anidado; pertenecen al strieste, mediodia y sudoeste de Europa

\section{EL AGUILA IMPERIAL-AQUILA MOGILNIK}

CARACTFRES.-- Esta especie (fig. I.q $\delta$ ) es mucho mas pequena que la comun y la dorada; tiene solo $0^{\circ}, 80$ a $66^{\prime \prime}, 86$ de largo, segun el sexo: de ${ }^{\prime \prime}, 90$ á $2^{\prime \prime}, 20$ de punta a punta 
de ala; esta mide de $0^{m}, 60$ á $\left(6^{m}, 63\right.$, y la cola de $6^{\circ}, 27$ á $6^{\circ}, 29$. Se ve pues que la hembm no llega al tamaño del macho de la especic comun : el cuerpo es recogido, la cola corta, y las alas, bastante largas, llegan al extremo de aquella. El ave adulta tiene el color pardo oscuro uniforme, con la cabeza y la nuca de un amarillo de orin; en la espaldilla hay una gran mancha blanca cuyo color tienen las últimas pennas; la cola es de un gris ceniciento con lisias negras y una faja terminal estrecha. Cuando jóven se distingue el águila imperial por su plumaje pardo amarillento con manchas longitudinales parco oscuras producidas por los bordes de sus plumas, pudiendo acaso confundirse con su congénere mas próximo, pero jamás con el águila comun jóven.

\section{EL AGUILA ADALBERTO-AQUILA ADALBERTI}

CARACTÉRES. - Mi hermano Reinaldo descubrio esıa

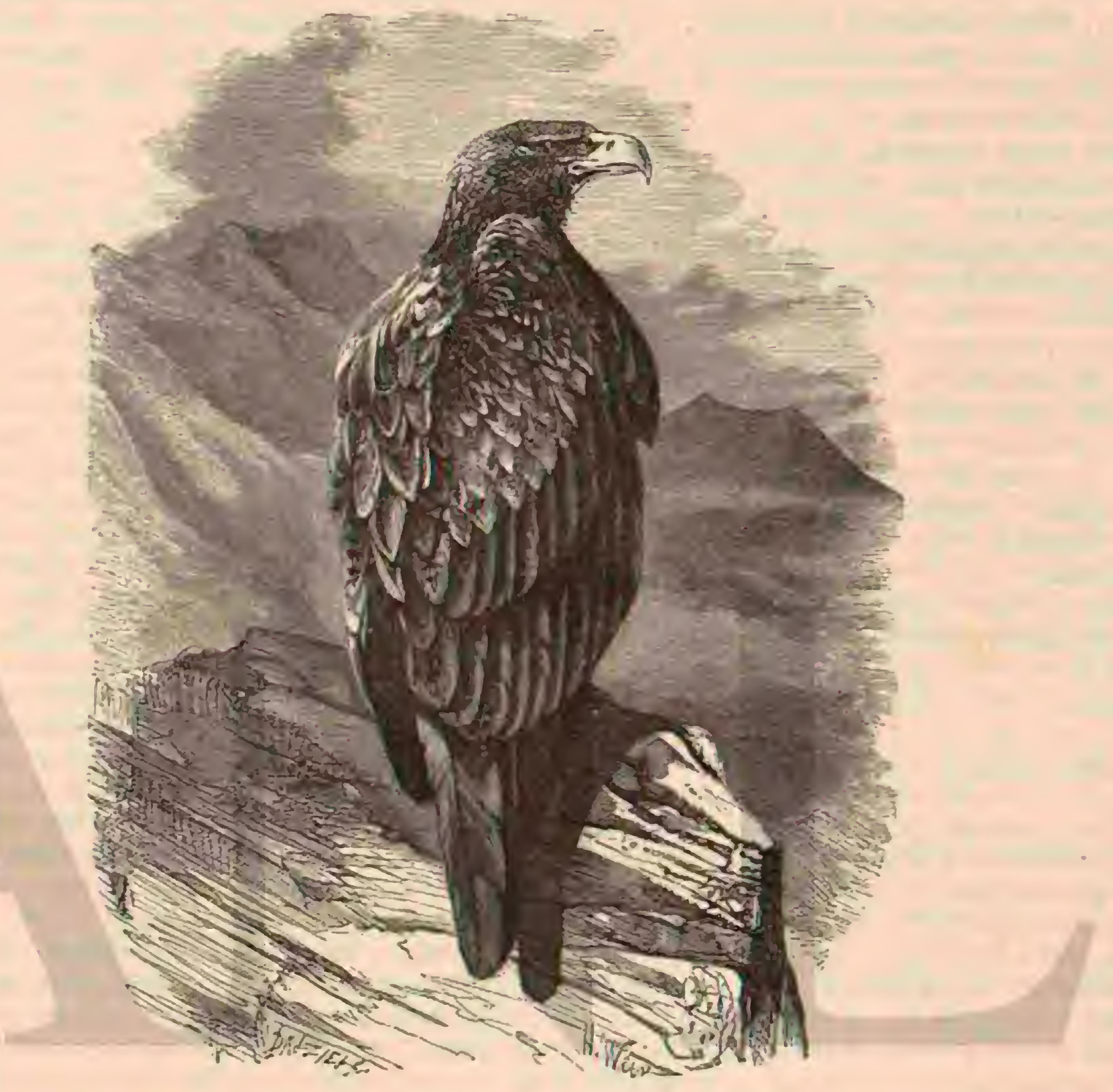

Fig. 349. - EL AGUILA ALDAY

especie en España en el año $1 \$ 60$. Es la mas arine de la anterior de la cual difiere cuando adulta por la gran extension de la mancha blanca de la espaldilla, que se prolonga en forma de faja bastante ancha á lo largo del huimero y antebrazo, el cocio inclusive, asi como por el resto del plumaje en general mas oscuro, $y$ en los jovenes por las listas menos visibles en las partes inferiores.

DISTRIBUCION GEOGRÁFICA.-El árca de dispersion del águila imperial es dilatadisima, plues se extiende desde Hungria 3. China. En Alemania es ave muy rara, pero quizás atraviese el pais mas á menudo de lo que nos figuramos. Luehder dice que la ha visto anidar, pero sus observaciones carecen de base suficiente para admitirlas. De los datos mas recientes resulta que esta águila anida en Hungria, Galitzia (austriaca), Transilvania, Rusia, en los paises del BajoDanubio y la peninsula del Balcan, con sus islas, en los páramos del Asia central desde el Lira! hasta el mar de China, y finalmente en la Trascaucasia y el Asia Menor. Algunas parejas sueltas han anidado á veces en la parte baja del Toso III
Austria, y tambien puede suceder que en Asia traspasen los limites de la region de los paramos $\delta$ estepas; pero esto son excepciones.

En rigor es esta águila un ave de estęas, sin que con esto quiera decir que se aleja de los bosques de lós llanos y las sjerras. Cuando se acerca el invierno, abandona el distrito que habita, sea en Europa ó en Asia, con la regularidad del ave de paso, y no vuelve hasta que la nieve ha desaparccido. Este dato empero no es exacto respecto de los paises meri. dionales, donde Krueper encontró ya en los primeros dias de abril huevos en el nido. Al contrario de otras ares de paso, no se aleja el águila imperial mas que lo estrictamente necesario. Alleon dice que en los alrededores de Constantinopla es ya ave perenne, y en cuanto yo he observado, visita cada invierno el Bajo Egipto, donde se la encuentra regularmente desde octubre á mano, siendo en ciertos distrios hasta co. mun. Los lagos grandes del Delta la atraen especialmente. Algunas siguen el Nilo arriba y se establecen junto al lago Moeris y aun mas allá hasta la primera catarata. En la Nubia 
meridional en abisinia y Kordofan. Recorre tambien desde el Asia central la Persia, Belutchistan, la India y el mediodia de China, por manera que se la debe inallar asimismo en invierno en Anam y Siam. Segun Jerdon anida en el Decan, aun cuando podria ser que la hubiera confundido con el águila de las estepas.

En la peninsula ibérica la representa la otra especie, el águila Adalberto, que probablemente serả la que vive en los paises del Atlas y mas al sur en la costa occidental del Africa.

USOS, COSTUMBRES Y RÉGIMEN. - Ia comarca que habita el aguila imperial durante el periodo del celo puede ser mucho mas sariada que la que necesita la especic comun. Lo que la atrac a la estepa es, segun mi modo de ver, el es. permófilo, porqué cuando mi último viaje f́ Siberia siempre encontré esta íguila con gran frecuencia alli donce ábundan estos roedores. I. mismó poco nas ó menos pasa en Hungria y en general en las tierns del Bajo Danubio. Cuando la caceria del princine imperial Rodolfo en Hungria mencionada amtes, observamos en Sirmia y Eslavonia que el águila imperial anidaba alli y cabalmente abunda en éstos paises el espermófilo. En nquellos mismos distritos es dicha águila decidi. damente silvicola, pero anida mas en los robledales de la lla. nura que en los preciosos montes altos y copudos de la Frus. cagora De todas las observaciones publicadas hasta ahora que se refieren a la residencia habitual de esta ave, resulta que la elige segun las circunstancias que preciominan en las diferentes partes de su área de dispersion, y se establece tan pronio en un bosque, como en un grupo aislado de árboles, y hasta en un árbol solitario, del propio módo que en algun peñasco de las sierras. In lo que si difiere completamente de las especies comun y dorada por lo que hace á sus costumbres, es en que se establece y aun anida muy cerca de las poblaciones, alli donde puede contar con la indiferenciay acaso con la proteccion de los habitanies.

slgunos ornitólogos pretenden que el águila imperial no iguala con muclio ála comun y dorada en nobleza, valor:y aptitud para la rapiña; pero esto no hay que tomarlo en absoluto, porque en proporcion á su merior tamaño es poco mas 6 menos igual a las demis. Segun donde se ha criado y tiene su domicilio es mas ó menos aficionada á emigrar. Si ha vi. vido junto á aldeas, se deja sorprender-fácilmenie por los cazadores, lo cual induce á creer que es menos inteligente que la orgullosa águila comun; pero yo me he convencido por experiencia de que su conducta es hija de las circuns. tancias. En los płramos del sưdoeste de Siberia pertenecien. tes á los dominios de la corona, que ahora se van colonizando y donde se presenta esta are en ciertos puntos con gran frecuencia, era tan poco arisca que muchas veces no se mo. via siquiera de lós postes indicadores del camino cuando pasíbamos por delante en nuestro carruaje tirado por tres caballos llenos de cascabeles y de campanillas, y en las aldeas la veiamos descansando en árboles altos y aislados sin hacer caso alguno del movimiento que debian observar á sus piés; pero en los puntos no frecuentados por el hombre, vivia mucho mas precavida, y en ciertos sitios del Egipto y Hungria la he encontrado hasta recelosisima. Algunos paises del Bajo Danubio, como por ejemplo la Dobrucha, reunen circunstancias muy análogas a los de Siberia, lo que hace que el ave muestre allí tambien, segun ri, idéntica confianza. Cuando ha sido perseguida, cambia de conoucta y obra en consecuencia. Yo por mi parte jumnis he podido observar diferencia alguna notable entre esta ave cuando ruela $y$ sus congéneres de mayores dimensiones. Es positivo que persigue mas que el águila comun i la caza pequeña, y me parece muy probable que rara vez 6 jamás embista a ani. males que pueden defenderse en las estepas, donde los espermófilos son tan numerosos que le ofrecen un alimento abundanté y fácil; pero tambien estoy convencido de que cuando la atormenta el hambre no cede en arrojo sá ningum individuo de su familia. En mi concepto es injusto presentar esta especie simplemente como un gloton innoble y como un milano grande, segun lo ha hecho Hume tinicamente porque no se abalanza siempre sobre el hombre cuando se acerca a su nido, y porque se deja perseguir por las cornejas y se atraca de carne muerta en caso necesario; pues todo esto puede decirse tambien del águila comun. Muchas observaciones han probado que caza todos los animales que su tamaño y fuerza le permiten atacar con éxito, desde la liebre y la mar. mota de las estepas hasta el raton, y desde la avutarda medio idulta hasta el gorrion.

Su nido se parece al del águila comun, y lo construye en los árboles, donde los hay, aunque no sean altos; pero donde faitan, como en las estepas, lo forma en el suelo, y en las sierras en una cavidad 6 sobre algun resalto $\delta$ comisa de peñascos. En las estepas del sur del Ural, como tambien en la Dobrucha, se encuentran los nidos muy cerca de los pue. blos, en lí copal de los árboles, sobre todo en los chopos, ślamos blancos y sauces; en Hungria y en la Rusia meridional casil siempre en bosuuecillos, y en Grecia, Macedonia y Asia Menor lo mismo en los bosques que en las rocas de las montañas. Hudieśtone describe un nido que halló sobre un árbol desmochado a solo tres metros de elevacion. Tenia un diámetro de 17,60 y se componia de ramas gruesas y delgadas con un hueco relleno de lama, pera casi plano. Otros nidos que examinó Farman eran tambien una especic de pila orrande, perollana, de un dímetro de $3^{10}, 3^{\circ}$ y una altum de $0^{\circ}, 50,07,70$ y mas; se componian de ramaje basto y mas ó menos bien guarnecidos de yerba secca, lana, trapos y cosas por él estilo. Los cinco nidos que el principe imperial Rodólfo de Austria y el principe Lcopoldo de Baviera vieron en la Hungria meridional, estaban casi todos colocados sobre las ramas medias mas elcradas de unos robles, y no diferian mucho, en cuanto pudicron examinarlos desde abajo, de los que construye el bornl (haibiatus allivilla, aquilis maritima y lacustre) que tambien anida en Hungria; se hallaban ocupados y muj poblados todos en su base de gorriones campestres. Tambien es probable que cada pareja de aguilas imperiales conserve siempre un mismo nido mientras no se la moleste, porque se ha observado que apenas llegan estas aves en la primavera, se alojan en el suyo respectivo y lo defienden con brio contra todas las aves que pretenden ocuparlo 6 que intentan acercarse a él. Segun Farman, se puede encontrar el macho continuamente de ceninela durante todo el tiempo de cria, entreteniéndose en describir graciosos circulos encima del nido, ó bien posado en un árbol próximo; pero apenas advierte el menor asomo de peligro, echa a volar y avisa á la hembra con un graznido áspero. Al oirlo esta, abandona el nido y los dos describen círculos al rededor. Apenas se acerca otra aguila imperial ó cualquier otra ave de rapiña, se presenta el macho y empieza un combate a muerte. Dos águilas que en cierta ocasion combatian asi á una altura de cien metros poco mas ó menos, llamaron la atencion de Farman con sus penetrantes grazni dos y gritos roncos. El duelo, que duró lo menos reinie mi. nutos, emperó describiendo cada are circulos al rededor de Ia otra, pero á cierta distancia. Luego se arremetieron alternativamente, abalanzindose una sobre otra desde mayor altura; la atacada se apartaba con destreza y atacaba à su vez. Estas acometidas duraron largo rato, pasado el cual se separaron los dos combatientes hasta cierta distancia; pero pronto se revolvió el uno lleno de coraje para precipitarse 
sobre su contrario, que por su parte le recibió con sus ier. ribles armas. Entonces ambas águilas se movian y esgrimian sus garras, pico y alas con tanta rapidez y luria, que el ob. servador no veia mas que una masa confusa cubierta de plumas, imposible de describir, la cual rodaba por los aires de una parte á otra. Por último, ambas se clavaron sus garras con tal fuerza que, impotentes ya para morer las alas, bajaron tambaleaindose unos treinta ó cuarenta metros. Asi acabó el primer acto. El segundo empezó poco mas 6 inenos como el primero, es decir con ataques simulados por ambas partes; pero luego cambiaron de táctica, pues mientras reducian sus circulos, procuraban clevarse una por encima de la otra, hasta que una de ellas lo logro y pudo precipitarse con todo su peso y fuerza sobre su contrario, que, rolviéndose al punto de espaldas, la recibió con sus garras abiertas. Aferradas una \& la otra, volvieron á caer unos cien metros, lle. gando cerca del suelo; á tan escasa altura pudieron desprenderse, para renovar sus ataques, hasta que dando una de ellas una furiosa arremetida á cien metros próximamente del suelo, logro asirse de nuevo á su adversaria, que la hizo frente con valor y le claró sus unas en el cuerpo; entonces cayeron ambas a tierra pesadamente y apenas a diez metros del observador. Al verlas asi, saltó Farman del caballo para coger á las dos, pero cuando tenia ya las manos extendidas para asirlas, se soltaron repentinamente, iruvendo en distin. tas direcciones y dejando en tierra charcos de sangre que no daban lugar á duda sobre lo encarnizado de su contienda.

REPRODUCCION. - En los primeros dias de abril, generalmente el i y el $S$ de este mes, y en Rusia y Sibcria un mes mas tarde, suele quedar completada la puesta que consiste en dos, rara ver, en tres huevos, notablemente mas pe. quenos que los del águila comun y que además varian en forma y color. Miden de $0^{\mathrm{m}}, 070$ i $0^{\circ}, 0 \mathrm{~S}_{2}$ de largo y de $0^{\mathrm{m}}, 054$ à $0^{\circ}, 060$ de grueso; el color es blanco salpicado espesamente de puntos y manchas de un verde mondo, púrpura pálido 0 pardo claro: alguna que otra vez faltan las manchas. A la hembra incumbe, como es regular, la mayor parte del srabajo de incubacion; pero el maclıo la releva á fin de que ella pue. da buscarse alimento $\{$ su gusto. Tambien sucede que ambos salen juntos á cazar dejando el nido con los hucvos bastante tiempo abandonado. Al volver proceden con mucha precaucion, y en lugar de describir circulos al rededor, acuden con rapidez y se introducen en él sin entretenerse fuera. Si se las espanta, se trasladan á un árbol cercano, por lo comun á aquel donde suele vigilar el macho. Alli continuan largo rato y no vuelven al nido sino cuando creen que ha pasado el peligro. Los polluelos que salen al cabo de un mes, en los primeros dias de mayo en Hungria, están cubiertos de un plumon blanco y espeso; los alimentan los viejos, del mismo modo que los del águila comun, y pueden ya volar á media. dos de julio, si bien algo mas tarde en el norte de su área de dispersion.

No siendo el águila imperial tan arisca y montaraz. como las especies comun y dorada, resulta que cuesta mucho me. nos dispararle un tiro; pero las viejas son siempre cautas y á menudo tan dificiles de matar como sus congéncres. Para herirlas nortalmente, se necesita poner una consjderable car. ga en la escopeta, siendo realmente pasmosa su resistercia vital. Mi difunto amigo Herklotz tenia un águila imperial que le entregaron muerta al parecer de una perdigonada por un aficionado á la caza, para que la disecara y preparara. Hacia ya mas de dos dias que el ave estaba debajo de un cajon con la cabeza atravesada por los perdigones, cuando el médico oyó un ruido que le llamó la atencion, viendo luego que el animal a quien creia muerto, se habia incorporado, darido schales evidentes de no tener ganas de abandonar este valle de lágrimas. Fl humanitario médico le turo Iśstima y el ave se salró. Fi tiro la habia dejado ciega, y se mostraba comple. tamente indiferente \& toda influencia exterjor; no se movia ni conia por propio impulso; en una palabra, se comportaba en un todo como aquellas aves á las que se han sacado artificialmente los sesos, posada inmóvil en un tronco sin hacer caso ni del sol, ni de la luz, ni de la lluvia, ni de la tempes. tad. Maquinalmenic cambiaba de puesto si se la obligaba á ello. Mi amigo se tomaba un gran trabajo para alimeniarla y hacerla vivir, embuchándola los pedacitos de carne \& la fuer22, descoso de saber cuanto tiempo viviria. El ave siguió siempre de la nisma manera todo un aino; al cabo de este tiempo obserró Herklotz que empezaba a dar algunas leves muestras de interesarse por algo. El oido iue el primer sentido que empezó a desarrollarse, porque el animal iba conociendo por el ruido de los pasos cuando su amo se acercaba á él extendia las alas, las sacudia, se movia por su propia vo. luntad, conduciéndose en general como quien se despierta de un profundo sueño. Estos movimientos fueron poco á poco haciéndose mas rápidos y vigorosos, si bien era todavia preciso alimentar al ave artificialmente; hasta que a los cuatro años empezó á comer sola, emitiendo tambien con gran sorpresa del médico su cau, cau, grito habitual de estas águilas; y al cabo de otro medio año obraba ya en un todo, salvo su ceguera, como las demás de su especie.

CA UTIVIDAD. - Ins íguilas se domestican muy pronto cuando son pequeiras; pero segun opinion unánime de los kirguises y mogoles no prestan ni con mucho los servicios del águila comun. \&En mi infancia, me escribió el conde Lazar, tuve largo tiempo un águila imperial viva: al principio arrebataba de vez en cuando una gallina; pero los golpes que recibió por aquellos hurtos la enseñaron á no reincidir, $y$ acostumbróse al fin a correr por el pratio y el huerto sin hacer daño alguno à nuestros animales domésticos. Conociane muy bien; acudia cuando la llamaba por su nombre de Pluton, que era el que le habiamos dado: no podia sufrir a las per. sonas extrañas ni á los perros; lanzábase contra las primeras si se acercaban demasiado, y procuraba siempre alejar \& los segundos. Aun cuandio no eran peligrosos los golpes que des. cargaba sobre los hombres, no dejaban de causar bastantc daño: serviase de sus garras, pero daba tambien aletazos, bastante vigorosos parn producir equimosis. Esta ave pereció desgraciadamente: introdujose cierto dia en el jardin de un campesino doncle cometió no sé qué desperfecto, por cl cual fué duramente castigada; el águila rolvió á casa muy abatida; no quiso probar alimento-alguno-desde -aţuel momento y murió al cabo de diez dias. Al abrir su cuerpo no se halló ninguna lesion interna que pudiera explicar el hecho: sin duda fue victina de la pena que le causó haber sidotan maltra. tada.

\section{EL ÁGUILA CHILLONA-AQUILA NAVIA}

CARACTÉRES.- Esta águila, mucho mas pequeña que la comun y la imperial, pero la mas frecuente de iodas las grandes águilas quue viven en Alemania, mide de $0^{\circ}, 6_{j}$ a $10^{\circ}, 70$

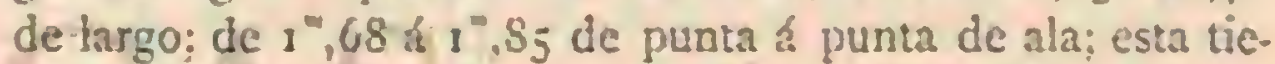
ne de $0^{\circ},+8$ a $0^{\circ}, 52$ y la cola de $6^{\circ}, 24$ a $1^{\circ}, 26$. El color que predomina es pardo cafe un tanto lustroso y liso, que palidece cn la primavera y verano hasta pasar a pardo terroso sin lustre y que se vuelve mas claro en la nuca Las tectrices pequeñas y medianas superiores de las alas son en la prima. vera algo mas claras que el dorso, y las plumas del vientre tambien mas que las del lomo. Las rémiges son de un negro mate 6 tirando a pardo, con listas mas oscuras, pero poco visibles; las posteriores apenas mas oscuras que las cobijas; 
las rectrices un poco mas claras quue las pennas de las alas, cos listas leonadas pálidas; las cobijas sub-caudales color de tierra pálido con las puntas mas claras; los tarsos tienen este misno color. El íris es amarillo con algunos puntos pardos en al macho, y en la hembra amarillo de oro con puntos rojes. La piel de la base del pico es amarilla, y este de un azul cómeo con la punta negra; el piédonde no tiené plumas es anarillo. Las aves jórenes son sensiblemente mas oscuras quelas viejas; las plumas de la nuca tienen manchitas de rojo orin en la punta; las del dorso son color de tierra pardo cos brillo cobrizo: las tectrices pequeñas y medianas superio. res de las alas son mucho mas claras; las cobijas grandes de las alas ostentan manchas mas anchias hácia la parte inferior y que forman dos listas de color de orin claro; cstas manchias se ven tambien en las plumas del buche, mientras que las derás de la parte inferior son de un pardo terroso sin brilto, y las cobijas sub caudales mucho mas claras y adomadas de mascins largas lconadas en el tallo y en la barba.

LISTRIBUCION GEOGRAFICA. - Por lo que se sabe hasa hoy de cierto, habita cl águila chillona, como ave que anit, además de la Alemania del norte, la Polonia, Ja Rusia oct Jiental, Hungria, Galitzia (austriaca), la Turquia europea $y$ la firecia, visitando cuando va de paso, y en individuos aislolos, alguna que otra vez la Alemania occidental, Fran. cia, J̄uiza, Italia, acaso tambien el nordeste del Africa, extraviastose a menudo por Holanda, la Gran Bretaua ó Suecia; pero iala completamente en Espana. Bn la Europa oriental is. riengilánn otras dos especies, el iguila clanga y la de las cscons.

\section{EL ÁGUILA CLANGA-AQUILA CLANGA}

CARACTÉRES. - Esta especie es algomas grande y mas eba $-\lambda$ que la chillona; cl ala plegada, que alcanza y aun paes de la extremidad de la cola, excedé i la de aquella es. pecic a lo menos de $11^{\circ}, 05, y$ la cola de $11^{\circ, 02}$ a $11^{\circ}, 03$; al paso que carso es bastante mas alto y las garmas mas robustas. Lil pumaje es casi unicoloro, sin manchas de orin en la nuca, pariz superior del lomo y del pecho; pero si en la parte infe. ror a panir del buche; la parte inferior del tarso es por lo comn blanca. En las aves jóvenes se observa quue las man. chas de las cobijas superiores de las alas están mucho mas exicelidas que en la especie chillona, puesto que en algunas pluras ocupan todo el borde; pero su coloracion tira siempre a gro en lugar de ser color de orin verdadero. La parte posterio del dorso presenta sobre fondo orin algunas manchas uscumas en los tallos; la parte inferior, á excepxion del cuello y repon del buche que son unicoloros, es negruzea, con el cenis de las plumas de color gris pardo tirando á orin con mankas de este último color poco visibles en el tallo, las cobjase sub caudales son muy claras, por lo regular blancas del tudo ó bien blancas amarillentas; los tarsos son pardo. negracos con muchas manchas grandes de igual color que las dé vientre.

DISTRIBUCION GEOGRÁFICA.-Fl árez de dispersion de esta ave se encuentra al este de la de su congénere chilina, probablemente con exclusion de todas las regiones de ceepas Como ave que anida se la encuentra desde las orilta septentrionales del mar Caspio al través de tocia la Siberia meridional hasta el pais del Amur, $y$ tambien en los bosçes del Ural meridional. En invierno emigra á ia India, y en feneral al sudoeste del Asia y á Egipto, donde es la espor mas numerosa de todas las águilas en los lagọ de la costa y en todo el Delta. En la época de su paso visita con mas fecuencia que la especie chillona la Alemania meridional, S.iza, Francia E Italia, siendo en cambio en la Alemania del Eate una de las aves mas ratas.

\section{EL ÁGUILA DE LAS ESTEPAS-AQUILA NIPALENSIS}

CARACTÉRES.-Esta especic es la mayor del grupo de las chillonas é iguala en tamaño a la imperial. Se caracteriza y diferencia de todas sus congéneres por tener colocadas las fosas nasales al travís, y además por el dibujo de las manchas. La coloracion autumna! de su plumaje se parece mucho a la de la especie anterior en la misma época, solo que es mas clara; existe á veces una mancha color de orin en la nuca; pero lo que distingue á esta especie son las manchas grandes que ocupan toda la extremidad de las cobijas primarias y secundarias de las alas, las cuales forman fajas anchas, majores y mas visibles en las jórenes que en las viejas, ademís de otra quue aparcce en las exiremidades color de orin de las rémiges del antebrazo, asi como presentan tambien las rectrices en la juventud extremidades anchas del nismo color algo mas rojizo.

DISTRIBUCION GEOGRÁFICA.-El águila de las es. tepas habita una gran parte de la Europa oriental y del Asia central, y como ave que anida, positivamente las regiones que indica su nombre, especialmente las estepas del Volga, Akmolinsks, la parte meridional del gobierno de Perm, del Turkestan y de Dauria, el Gobi aito, etc, y hacia el este hasta China y la India, si bien parece queá veces puede tam. bien anidar mug hacia occidente, conforme se infiere de un águila pequeina, que ap̧enas podia volar, y que mataron hace poca en la Pomerania oriental; pero en cuanto á la Europa verdademmente occidental, hay que creer que no pasa por ella en sus emigraciones; por lo menos no se ha cogido to. davia alli.

USOS, cOSTUMBRES Y REGIMEN. - El águila chillona, à cusal especie me limito en lo que sigue, busca los lugares humedos y pantanosos, y habita con preferencia en los bósqués, cerca de las corrientes. No es rara en ciertas selvas de Brunswick, de Hannover y de Meklemburgo; abun. da en Pomerania, sin que se la encuentre indistintamente en cualquier bosque, porque elige sus domicilios, segun se observa, guiada tan pronto por el capricho como por las circunstancias; en cuanto á Alemania, no cabe duda que alli prefiere los hayales á todo otro monte, viéndose rarisima vez en bos. ques de abetos. Cada pareja tiene un solo dominio, bastante reducido; pero por lo mismo se aficiona mas â ell: una ver fija en un paraje, el águila chillona no le abandona ya fícilmentc, $y$ aunque le arrebaten sus huevos ó su cria, vuelve $d$ su nico, $\delta$ bien construira uno nuevo af varios centenares de pasos mas léjos. A parece temprano, generalmente en abril, á veces a iftumos de mayo, y permance en el pais hasta fines de setiembre, si bien empieza su época de emigracion en agosto, prolongándola hasta la época indicada, to cual no impide que se hayan visto tambien individuos sueltos en invierno.-

Está mucho peor dotada que sus congéneres, y es el àguila mas cobarde é inofensiva que yo he conocido; sus costumbres son pacificas, mucho mas semejantes á las del buzo que a las del aguila leonada, como lo indica ya su aspecto. Cuando se posa parece una rapaz innoble; pero por el vuelo es una verdadera íguila; remóntase a gran altura por los aires y se cierne horas enteras, trazando majestuosos circulos. Su voz es penetrante $y$ "pucde expresarse por las silabas yef, yef; mani. fiesta su contento con notas bastante agradables, que ofrecen cierta semejanza con una especie de campanilleo, segun dice Naumann.

En cautividad algunas gritan mucho, tanto como cuando estan en libertad, y otras permanecen siempre calladas.

Su alimento consiste en pequeños vertebrados. En nuestra 
region caza principalmente ranas, y quizís otros anfibios, repriles y pequeños roedores; pero aquellas figuran en primera linca, lo que explica suficientemente su frecuencia ó ausencia completa en tal $\delta$ cual distrio. Lugenio de Homeyer encontró en el estómago de un águila chillona restos de un lucion, lo que prueba que come tambien peces cuando le vicnen à mano, auneque no aseguraré si vivos 6 muertos. Mas que peces busca reptiles, lagartos, culebras, y acaso viboras, y si llega a ser peligrosa para animales superiores, será a lo sumo en el úlimo periodo de la cria, porqque á medida que sus polluelos medran s exigen mayor cantidad de alimento, roba cuanto puede, y entonces es muy probable que no sola. mente cace tordos y mirlos, sino tambien liebres pequerias; pero no es presumible que ni en este caso haga tanto daño como el buzo. Se la ve, como ś este último, posada en árbo. les aislados, piedras ó estacas, acechando su presa Apenas divisa usa, se precipita con rapidez a tierra para cogerla, y en caso necesario da saltos ó grandes pasos tras ella á la manera de las corneias, y como no los da, que yo sepa, ninguna otra águila de las llaniadas nobles en lenguaje de montería No puedo decir si caza aves acuśticas, conforme nüuchos preten den; pero lo que puedo asegurar es que con frecuencia arre. bata su presa al halcon viajero, y devora como un buitre toda ciase de animales.

$\mathrm{D}$ z todas las águilas alemanas, la chillona es la mas silvi. cola y la que solo visita orros distritos cuando las circunstan. rias la obligan á ello. En el bosque muestra decidida prefe. rencia por determinados puntos. Eugenio de Homeyer tuvo la sumabilidad de hacerme saber que esta águila establece su nido invariablemente junto à un pequeño claro para que el ramaje no la estoroc en sa vuelo cuando sale del mismo, y si el terreno es accidentado $\mathbf{a}$ ondulado, élige siempre los sitios despejados para poder remontarse libremente. Rara vez anida en pequeñas arboledas, pero le gustan los bosques circuidos de urados, porque facilitan su caza. Pan colocar su nido necesita árboles vicjos y robustos, prefiriendo á todas las es. pecies las hayas y robles; es un caso rarisimo verla establecerse en una conifera, siendo mas fácil que se contente con un abedul ó álamo. Con dificultad se resuelve á construir ella misma su nido, s solo lo hace cuando no tiene a mano otro de algun buzo $\delta$ azor para apropiárselo; $y$ si puede tener dos, lo prefiere, pues le gusta criar un anio en uno y otro en oiro. Antes de proceder a la puesta, nunca deja de añadir aigunas ramas, y durante la incubacion adorna el nido como lo hacen otras águilas con ramas verdes, ya sea para cubrir y ocultar los pequeños ó bien para mayor limpieza; el lecho es qque. consecuencia de esta costumbre adquieren los nidos de las águilas chillonas con el trascurso de los años una altura con. siderable. En los primeros dias de mayo, y alguna que otra vez $\mathbf{s}$ fines de abril, pone la hembra en el espacio de dos $\delta$ tres dias los dos hueros que suelen constituir su puesta. Si no se encuentra mas que un huevo, es señal de que la parcja ha sido molestada; una puesta de tres huevos es un caso rarisimo. I a forma, el color y dibujo de estos son muy variables; los hay oroideos, mas 6 menos esféricos y oblongos; las manchas de gris azulado pálido que hay sobre el fondo blan. co pueden ser mas ó menos visibles, tirar á amarillo ó sa rojizo y pardusco ó formar como un circulo de manchas en el cen. 
tro, etc Macho y liembra se ayudan y relevan en la incubacion; apenas se separan de los huevos, y profesan gran cariño 3. su cria, por cuya razon no suelen espantarse cuando divi. san al hombre, $a$ no ser que se las haya escarmentado anies repetidas veces Si se las espanta y se las hace huir, vuelven muy pronto cuando cubren. Al acercarse una persona al sitio donde tiene el nido, se levanta el águila con mucha calma y $\{$ menudo deja pasar un buen rato antes de resolverse $\mathbf{a}$ huir; otras veces queda tan inmóvil en el nido que para levantarla es incnester hasta golpearlo repetidas veces. Para volar procede esta ave de un modo pasticular; pues se echa de un lado al otro como balanceándose hasta que ha logrado desplegar sus alas en toda su extension, lo gue hace que aun los mejores tiradores se equivoquen y yerren el tiro cuando la disparan al salir del nido. Al abandorario, describe primero por encima de las copas de los árboles algunos circulos, se posa despues muchas reces soure el árbol mas proximo y se pione á gritar con acento triste. Cuando le rodan los liuevos, stuele abandonar, aunque no siempre, eĺnido. Eugenio de Homeyer me contó que un dia se dió muerte á una hembra junto al nido y los cazadores construycron una choza para aguar. dar y ver si podian ambien tirar-al macho. Este llegó; se posó en el nido, miró los huevos largo rato y despues les dió dos fuertes picotazos. Homeyer mató al ave é hizo que se bajarán los hueros, los cuales cncontraron rotos. No cabia duda de q̨ue el águila, çuizás en el primer-impulso de deses peracion por haber perdido su pareja, habia destruido su pro pia cria, porque Homeyer no abandonó el sitio ni vió acercarse ningun otro animal, y además notó nuuy bien los picota ros sospechosos del macho. Con todo, no dejan de ser muy raros los casos como el descrito, porque el macho acostum tra por regla general a sustituir ála madre cuando esta falta. Hiablase dado muerte a la hembra de otro nido observado tambien por Honeyer. Al cabo de algunos dias volvió este I ver lo yuue sucedia y vió que un ágnila huia del nido; le hi cieron fuegu y la hirjeron en una pierna, en terminos de que colgaba sin movimiento, mas á pesar de esto volvio el are repetidas veces. aunque sienpre de modo que era imposible alcanzarla. Homejer coloó al dia siguiente un buho próximo al nido $y$ al punto se precipitó el ́rguila sobre el, lo guve le costó la vida. Eira un inacho, el herido del dia anterior. La pata estaba ya en via de curácion y a los pocos dias el ave podria haber vuelto a servirse de ella En el nido habia hue. vos incubados.

Los padres proveen al sustento de sus aguiluchos con tanta abundancia como les es posible, constituyendo los reptiles el principal alimento de unos y otros. Mechlenburg dice que es frecuente ver \& los vicjos llevar culebras al nido.

CA UTIVIDAD. - El águila chillona se domestica cuan do se la coge pequeña, con igual facilidad que cualquiera otra ave de rapina. Eugenio de Homeyer conservó cinco años una tan mansa, que podia sacarla $F$ dejarla pasear libremente. Cuando llegaba la hora de darla su racion se le abria su jaula, Homeyer se presentaba en el patio y aguardaba junto as un poste que el águila acudiese volando $y$ se posara en el poste para tomar la racion de su mano. Én cierta ocasion sc paró el águila en el tejado de un granero y fué preciso arrinar una escalera de mano para irla á buscar, a lo cual no opuso la menor resistencia. Distinguia perfectamente á su amo de otras personas, à las que miraba con re celo y hasta se apartaba de las que veia por primera vez. $A 1$ cabo de los cinco años apenas habia variado su coloracion, es decir las manchas que distinguen las águilas chillonas pequeinas de las adultas; lo que prueba suficientemente que esta especie necesita, como las otras, cierto número de años para llegar á todo su desarrollo y ser capaz de reproducirse.
ENEMIGOS. - A excepcion de las ares de rapilia mas fuertes que ella y que se apropian su nido, de los parásitos que viven en sus entrañas y en su piel, y de los cuerros y corncjos que la persiguen con sus gritos, no tiene el águila chillona que temer de ningun animal; sus enemigos mas crueles y desalmados son los cazadores que se deleitan en tirar y matar, asi como los coleccionistas de huevos.

Iéjos estoy de negar la utilidad de una coleccion de hue. vos rica y ordenada cientificamente; pero mucho mayor que Ia utilidad es el daño que causa en su distrito y en el mundo alado uno de estos bárbaros coleccionistas vulgares que, 50 pretexto de servir á la ciencia, recorren todo el pais para sa. quear cuantos nidos encuentran. No hay animal feroz mas destructor que ellos, que solo ven en los huevos que roban el dinero que pueden valerles y no los progresos de la ciencia. El f́guila chillona está mas expuesta à la rapacidad de esos merodeadores por la facilidad con que se descubre su nido, y gracias a ellos ha desaparecido ahora completamente de muchisimos bosques, con gran sentimiento de todas las personas que se complacian en poder ver y observar á esta ave tan grande, tan inofensiva $y$ tan poco perjudicial al hombre.

CazA. - Nó es dificil apoderarse de esta águila, pues no se muestra timida y recelosa sino cuando se la ha perseguido varias veces: Se la puede cazar con carabina y hasta con es. copeia cargada con perdigon: pero creo que conviene mas no perseguirla, pues parece mas útil que nociva. De vez en cuando arrebata alguna liebre ó perdiz: pero compensa tales da. nos exterminando con actividad los pequeños roedores $y$ las serpientes.

\section{EL ÁGUILA ENANA Ó CALZADA-RQUILA PENNATA}

Fin la Turingia oriental, á cosa de dos leguas de Renthendorf, mi pueblo natal, mataron en 7 de octubre de 1810 un águila pequeña, tan distinta por su coloracion de la única especic afine que entonces se conocia, que mi padre se decidió á describirla como especie nueva con el nombre de ignila enarua (ayuila mirusar). Yo crei hasta hace muy poco tiempo, que debia conservar estas diferencias, con tanta mas razon cuanio que habia muerto en Egipto varias aguilas de igual coloracion y de cuyo exámen resultó q̨ue el color os. curo que las distingue no tiene nada que ver ni con la edad ni con el sexo, siendo igual en todos los casos. En los uilti. mos anos, empero, se ha visto en virtud de varias observaciones cque nuestra águila enara oscura se aparen con la tan conocida especie calaada (Agrsilo peruratus) y que entre los pequeños de una misma nidada los hay de coloracion clara y oscura; en vista de esta prueba irrefutable fute preciso reconocer en arabas una misma y sola especie.

CARACTERES. - Esta especie, elevada por Kaup à rC. presentante de un subgénero particular (Hieraefus), es quizás la mas bonita de todo el grupo. El macho mide $10^{\circ}, 47$ de largo: $1^{10}, 13$ de punta a punta de ala; esta útima plegada $11^{\prime \prime}, \hat{3}^{6}$ y $0^{\circ}, 19$ la cola. La hembra excede al macho en longi tud en $11^{\circ}, 04$ y en anchura total en $11^{\prime \prime}, 08$. En la variedad calzada (Agurilat femata) son la frentey la linea naso.ocular de color blanco ceniciento; la region maxilar y de la oreja, asi como el centro de la cabeza, pardo oscuro; todas las plumas son blancas en la raíz con una mancha longitudinal os. cura en el centro; el manto 5 las alas son pardo negruzcos con brillo cobrizo y visos mas claros, prociucidos por los bordes de color menos oscuro, formando en las alas dos listas poco marcadas; las rémiges primarias son negro parduscas y las secundarias pardo oscuras con tres listas trasversales poco 
pronunciadas en la cara inferior de las barbas, y un borde de color pardo terroso: las rectrices son pardo oscuras en la parte superior con borde mas claro en la punta, y gris claro en la inferior; en la mitad inferior 6 de la raí hay manchas pardas longitudinales y céntricas á lo largo del tallo sobre fondo amarillo claro; son mas espesas en la garganta y el pe. cho que en la parte abdominal; faltan en parte en las ancas y en los individuos vicjos ocupan un espacio muy reducido de? pecho. Una mancha blanca realza la espaldilla. El ojo tiene color de bronce claro; el pico es en el nacimiento azul claro y negro en la punta; la pata amarillo de azufre y la cera amarillo pajizo. Cuando jóven se distingue esta ave por el color de orin rojizo claro de la region inferior, siendo en todo lo demás igual á los viejos; los aguiluchos de nido son pardos en la parte superior, amarillos de orin en la inferior sin manchas largas en el centro y no tienen las manchas blancas en la espaldilla.

En la segunda variedad enana (Adquila miruta) es la cabeza y la nuca de color pardo rojo, con manchas longitudinales negruzacas, muy pronunciadas sobre todo en la frente; el lomo es pardo oscuro; las largas plumas de la espaldilla de un pardo negro y las de la cara superior del cuerpo de un tinte de ocre pardo; la cola de un pardo opaco, con tres ó cuatro fajas negras bien marcadas, que tienen la punta pallida; la cara inferior del cuerpo es de un pardo oscuro, con rayas poco visibles: rodea el ojo un circulo oscuro; las ancas, los tarsos y las cobijas sub-caudales son algo menos pardos que el resto de la parte inferior del cuerpo. En la espaldilla hay una mancha blanca; el ojo es pardo; el pico azulado en la base y negro en la punta; y las patas de un amarillo limon.

I.os individuos jóvenes presentan tintes menos oscuros; la cabeza es de un rojo pálido, con el negro de la frente mas pronunciado: las tectrices superiores del ala y las pennas caudales mas claras; la cara inferior del cuerpo de color café con leche y lineas bien marcadas y bastante anchas; las fajas de la cola son poco distintas.

DisTRIBUCION GEOGRAFICA.-El águila cnana se extiende por una gran parte del sudoeste y sucleste de Luropa y del Asia. Su área de dispersion empieza, contando desde Alemania hacia el este, en el Austria meridional y Polonia y se cxtiende desde alli por la Galizia austriaca, la Transilvania, Hungria, los paises del Bajo Danubio, la Turquía europea, Grecia y todo el mediodia de Rusia. En el oeste de Europa anida en varios departamentos franceses y es nunerosa en coda la peninsula ibérica, mientras que escasea muchisimo en Italia, sin que para esta anomalia se pueda indicar una razon plausible No es rara en los bosques del Ural meridional, $y \mathrm{cn}$ las montauias de Tian. Chan y en general en el sudoeste del Turkestan es una de las aves de rapiña mas comunes. En la India y Ceilan anida todavia. Hácia el oeste habita los bosques de Persia y del Asia Me. nor, y aun se establece en toda la costa septentrional del Africa en las localidades á propósito. Es are veraniega en todos estos paises, a cxcepcion de la India, y segun parece de Argelia, permanceiendo todo el mes de abril en su nido y marchándose a fines de setiembre. Ea sus viajes atraviesa literalmente toda el Africa hasta que el mar le intercepta el camino. Se reune en verdaderas bandadas que siguen, lo mismo que otras aves de paso, rutas fijas, como por ejemplo a To largo del Bósforo y del valle del Nilo, hasta qque llegada à sus cuarteles de invierno, se vuelve á establecer aislada. mentc. Esto es, por lo menos, lo que he podido observar en Egipto y en el interior del Africa donde la he risio con fre. cuencia A fincs de marzo de $1 \$_{52}$ encontré bandadas tan considerables, que pude matar veinte de estas águilas en tres dias: en el Sennaar no las he visto sino en invierno.
USOS, COSTUMBRES Y REGIMEN. - El águila enana es por su indole y costumbres un iguila noble verdadera, que difiere de sus congéneres mayores, segun mi opi. nion, solo por dos cualidades particulares: su mayor agilidad y su menor cautela. Su vuelo es rápido, vigoroso y ligero, pudiendo cernerse lango rato, y precipitándose como una Recha sobre su presa. Sorprende cuando Dresser la compara con el buzo, pues por mi parte aseguro que le sobrepuja en todos conceptos, y que ni en el porte y movimientos, ni en la indole y comportamiento debe comparírsela con aquel. Concuerdan completamente conmigo otros naturalistas, como recienientente Goebel que ha podido observarla con mucha frecuencia. Hé aqui lo que dice: Fil àguila enana caza jugando una pequeria parte del dia, inquicta á toda otra are de rapina que prasa, como el borni (hadiaclus), la chilloua y otras, y esta en eterna guerra con el halcon lanario, con el cual se bate apenas le ve, desplegando entonces ambas aves toda su destreza y habilidad y dando un espectáculo intere. santisimo.) Esta es la pura verdad; a mi me encanta tambien el modo de proceder del águila emana. Con frecuencia se las ve trazar en los aires circulos cruzados solo por distraerse; complacense en ascender a una gran altura; pero cuando cazan se mantienen á poca distancia del suelo, $\delta$ segun dice Lazar, sostiénense en el aire batiendo las alas como el cer. nicalo.

No se posan en las ramas mas altas de los árboles, sino en las bajas, y alli permanecen inmóviles con el cuerpo dere. cho, vigilando atentamente los alrededores para descubrir 6 acceirar su presa.

El macho y la hembra no se scparan nunca, aunque via. jen: jamas ví en Africa un águila calzada sola; siempre esta. Uan aparcadas ó por famiiias.

Su vor. es variable: Wodzicki la expresa con las onomato. peyas: coj, coj, sai, cai; Lazar con siud, riud y compara estos sonidos á un silbido claro y penetrante. Krucper y Gocbel afirman lo dicho por Lazar, y el primero, muy práctico en las voces de las ares curopeas, dice: «Cualquiera que oyera el grito de flamada del águila enana en la primavera cuando esta en celo, sin divisar al ave, podria creer que proviene de una especie de totánido, porque percibirå muy claranente dos, y hasta tres veces un sonoro tiv, lim, liu. Lo que menos le ocurrirá será que provienen de un águila, sobre todo si compara estos silluidos con los gritos roncos de las aguilas imperial, comun, chillona, borni y pandion, ó con los de cualquiera otra ave de rapiūa. El citado grito es el único que produce en la época del ceio y de la cria y que repise mas 6 menos segun las circunstancias y segun el estado alegre ó angustiado de su ánimo; mas apenas han concluido la cria, ! los padres pasean, enscian y adiestran á sus aguiluchos, cambian tambien la voz, siendo la de los pequeños tan sorda que es dificil reconocer en ella el grito primaveral de la es. pecic.s

El águila enana es una verdadera rapaz; su principal caza son los pájaros. Lazar dice que se alimentan de aguza-nicves, alondras, emberizas, pinzones, codornices y perdices. Whad. zichi menciona ademis paros y estorninos; yo he encontrado en su estómago tórtolas; pero además de sus presas favoritas, caza tambien pequeños mamiferos, particularmente ratones, que Gocbel encontró en gran número en los buches de estas aves; tampoco desprecian los reptiles: y mi hermano dice que en Fsparia forma el lagarto perlado su alimento principal. Dresser, apoyándose en sus observaciones, duda que esta aguila pueda coger una paloma al vuelo, pero yo, basado en las mias, puedo afirmarlo. Es muy probable que no ceda en nada al azor y que cace con igual destreza, ya al vuelo ó ya posada. 
-Grades bandadas de estorninos, reficre Wodzichi, esta. ban cera de un pantano ocupadas en buscar su alimento, y no tarezaron en atraer á un águila calzada que habitaba el bosque recino. La rapaz se cernió sobre aquellas ares, que rolaber continuamente para posarse; pero cansada al fin de aquelis evoluciones, y queriendo sin duda ver á toda la bandač por el aire a fin de atrapar mas fácilmente una vic. tima, dejóse caer verticalmente sobre los estorninos como un relámfego. Las pequeñas aves buscaron un refugio en los árboles mas próximos; pero antes de que los alcanzasen que dó cogisa una de cllias. La fabulosa rapidez, de su vuelo produs entonces un verdadero sibibido al hender el aire El agruila sat à posarse despues solure el tejado de una birnaca, sin in atetarse del cazador ni del perro; inspeccionó pru. dentenerte los álrededores, y preparóse as desplumar su vic. tima. Is operacion duro mas de un cuarto de hora, y cuando al tr maté á la rapaz, el estornino estaba tan bien pelado como síle hubiese desplumado al cocinero mas diestro. " "

In e bosque es donde mas le gusta al águila calzada cazar, y lo hace como el azor. In Egiuto encuentra con abundancia has tórtolas, de las cuales se alimenta, principalmente en los zosques de palmeras; esta peruueña águila es despues del hajan el enemigo mas terrible de hiquellas aves. Las npaces furasitas conocen bien sus cualidades y costumbres, y I. hositan como al halcon; tan pronto como ven los milanos que el zquila calzada ha cogido algun ave, comienzan à perseguirl inssa obligarla á que les abandone su presa

Rripioduccion. - Respecto \& la reproduccion de estas are tenemos datos de diferenies autores que concuerdán ea to mas esencial, siendo entre cllos los de Holus y Goebe bs mas notables. El aguila enana prefiere los bosques frccéosos, y si puede ser los que se hallan próximos ả grance: rios, sin que por esto rehuya completamente las espesuras de coniferas. En el parque imperial de Schconbrunn anidan cada año una ó dos parejas. Iazar no ha encontrado nunca e la Transilvania un nido de estas arés en las montañas y gor esto duda que esta aguila suba durante la cria a aliuras en poco regulares. En cambio Serrertzon asegura que anin \& la altura de dos mil metros sobre el nivel del mar calas montañas de Pian-Chan. Como no construye su nido sirs cuando nó encuentra otro que pueda apropiarse, no ocura siempre sitios determinados, pues se ha de conteniar cas aquellos que eligicron las aves cuyo nido usurpa, lo que explica tambien que a veces se hallen varias parejas dentro de un circuiio limitado. Utiliza como el aguila chillona toon nido que le parece bueno, segun Holiz los del borni, Eazo, milano y cuerro, y segun Goebel hasta el de la garza, lixirándose por su parte à recomplonerlos y arteglarios un poca Scgun observó mi hermano, en Espana anida con preferescia en olmos y pinos, y siempre en el extremo de una rama que recibe la sombra de otra mas alta. Holtzy Goebel encontraron en Rusia los nidos de esta águila en diferenter especies de árboles de follaje, como tilos, robles, hayas tincas y otros por el estilo, á una altura media de doce metros sobre el suelo, y con mas frecuencia en las bifurcacicas del tronco que en las secundarias. El diametro exterio: del nido media setenta centimetros, el interior cuarenta; ls altura exterior sesenta, $y$ la interior diez y ocho. La base se componia de ramas gruesas y secas y de otras mas delgadas, el interior de cortezas de tilo, yerba, múrdago, hojas y lana. I.os nidos registrados por mi hermano y lazar estabar in excepcion adomados con hojas verdes. A principios de aayo queda completada la puesta que solo se com. pone dedos huevos que miden por término medio $1 ", 056$, a lo mas $0^{\circ}, 059$ y cuando menos $0=, 052$ de largo, y $6^{*}, 045$, á lo mas $6^{\circ}, 0.47$ y nunca meros de $0^{m}, 043$ de dianetro. Su forma oscila entre la puramente ovoidea hasta piriforme $y$ casi esférica; la cáscara puede ser gruesa ó deigada, de grano basto $\delta$ fino, y de dibujo variado tambien.

Por lo regular iienen puntos y manchas de color de orin rojizo of amarillo, irregularmente distribuidos sobre un fondo amarillento 6 verdoso blanquizco. Todos los que han observaco el aguila enana en la época de la cria no saben cómo alabarla. El macho y la hembra se profesan mucho cariijo: Wodzicki los ha visto cogerse del pico como las palomas. Cuando la hembra cubre, permanece el macho horas enteras en el mismo árbol y ocupa el lugar de la hembra varias ve. ces al dia.

Segun Wodzicki, el águila calzada tiene una manera particular de acercarse â su nido: posada sobre una rama, haja la cabeza, hincha el buche y avanza lentamente cómo lo ha. cen las palomas hasta llegar al borde: una vez alli lan\%a su grito de vai, cai, cai, senrejante al sonido de la flauta.

No procede siempre de la misma manera cuando ve que el hombre amenaza su nido, pero por lo regular permanece firne en su puesto, y solo á fuerza de golpear el árbol se lo. gra espantarla y hacerla huir, si bien no deja de volver varias veces con visible inquietud, posándose ff cada momento en las copas de los árboles mas próximos, olvidando su propia seguridad y prorumpiendo en gritos aflictivos cuando ve cómo le roban los huevos; pero sin atreverse á atacar á las personas, segun se ha podido observar. Cuando pasa un ave de rapina de otra especie, sea águila ó halcon, ya es otra cosa; entonces es siempre atrevida $y$ ataca con admirable arrojo y visible furia á todas las rapaces mayores que en la Época de la cria pasan cerca de su nido. «Cerca del nido de un pigargo, refiere Wodzicki, habia fijado su residencia una pareja dé águilas cranas, las cuales dieron á su vecino tales prucbas de valor, que no se atrevió este á dirigirse por su lado. Nada mas interesante que las luchas que empeñaban: aperias se dejaba ver el pigargo à corta distancia, lanzaba su grito melancólico de llamada una de las águilas enanas; la otra acudia al momento, $y$ ambas acometian a su recino, caian sobre el, golpcándole con las garras y el pico, con tal destreza, que el pigargo no podia defenderse. Mas tarde, cuando cubrió la hembra, el macho solo se encargó de pro. teger á su compnnera y a su progenie: tambien daban caza á los milanos y azores,

Los padres proveen juntos à su progenie de alimentos, como antes compartian el trabajo de incubacion. Ios pequerios salen a lu\% a las cuatro sernanas de la puesta, generalmente en la segunda quincena de junio, y cubiertos de un plumon largo, sedoso, de color claro y en la cabeza ama. rillento; pero no tarda en salirles el plumaje descrito mas arriba. Su desarrollo es muy lento, por manera que hasta fin de agosto no pueden volar. Allidonde el hombre no molesta á estas aves, vuelan los viejos con sus aguiluchos sin iemor por los alrededores de su nido; pero apenas ven las viejas que se las persigue, cambian completamente de sistema. QDurante mis excursiones por el Olimpo, dice Krueper, observé un águila enana que á los pocos dias venia seguida de otra mas jóven. Persegui á ambas con el fin de coger la segunda, pero su madre supo dirigirla con tal cautela que fué imposible acercarse \& ella, y a últimos de setiembre desapa. recieron una y otra por baber emprendido su emigracion hácia el sur.

El buho es el ave que mas aversion inspira al àguila cal. zada. Deseaba yo, me escribia Lazar, apoderarme de algunas águilas chillonas; puse como cebo un buho y ocultéme deirás de un almear de heno. De pronto of a una pequenia rapaz de color pardo, caer con tal rapidez sobre el ave, que apenas ture tiempo de coger la carabina; era un águila cal- 
2ada; precipitóse soure el buho, y disparé, mas no con acierto. La rapaz, sin embargo, no se alejó mucho, remonlóse $\{$ unos 160 metros y se cernió largo rato sobre la presa. Al fin cayó sobre ella por segunda vez; hice fuego y crre tambien el tiro: crei toda esperanza perdida; pero á los diee minutos bajo de nuevo el ágruilon, yo aquella vez la maté,

CAzA. - Ya vemos que la caza del águila enana no es dificil, al meros cuando no se las ha perseguido demasiado; el cariño que se profesan el macho y la hembra suele serles funesto, pues casi siempre se da muerte á los dios.

CAUTIVIDAD. - Las aguilas enanas se domestican lo mismo que las otras águilas cuando se las saca pequeñas del nido y se las cuida convenientemente. Una sola vez me fué dado ver una reunion de estas bonitas ares en cautividad, pero como no pude observarlas detenidamente, me limitaré a decir que mi hermano y Lazar, que cuidaron bastante ticm. po ares de esta especie, convienen en que son tan graciosas como agradables, $y$ alaban su inteligencia $y$ la facilidad con que se domestican.

En España adiestran á veces esta ave para un oficio muy singular. Un individuo ingenioso tuvo la idea de emplearla á modo de zahori. Con este objeto se colocaba en sitios publicos con algunas de estas águilas sobre una caja, é invitaba à las personas que pasaban á que se hiciesen sacar por una de dichas aves números favorables de la loteria primitiva, pues las tenia enseiradas á que, cuando se les presentaba una cajiia con los noventa numeros, sacasen los que se deseaba con el pico y se los diesen à la persona que los pedia. Sin duda debian creer que de esta manera bajaba la fortuna realmente del cielo.

\section{LOS URAETOS - UROAETUS}

CARACTERES.- In Australia existe un águila no menos notable que la dorada ó la leonada, considerada por Kaup como representante de su género Uronclus. El aspecto y plumaje de esta rapaz recuerdan las especies anteriores; pero tiene el pico mas fuerte, aunque muy ablongo, larga la cola y muy truncada y escalonada: las plumas de la nuca $50 \mathrm{n}$ muy largas, por todos cuyos caractéres se diferencia de las demás iguilas.

\section{EL ÁGUILA AUDAZ - AQUILA AUDAX}

CARACTÉRES. - Esta águila mide $0^{\infty}, 98$ hasta $1^{\text {" de }}$ largo, y como :", 30 de punta á punta de ala. Ia cabeza, la gar. ganta y las caras dorsal y ventral del cuerpo son de un pardo negruzco; las plumas de estas partes, particularmente las co. bijas de las alas y de la cola, tienen un filete y la punta pardo claro: la parte superior y los lados del cuello son de un tinte rojo; el ojo pardo, el circulo que le rodea y la cera, de un blanco amarillento; el pico de este último tinte en la base y ama rillo en la punta; las patas de igual color, mas claro (fig. 149).

No se conoce aun mas que una especie de este género, aunque parece qque existen dos, una de cuerpo mas fornido, con plumaje mas oscuro, y otra de formas mas esbeltas y tinte mas pátido: la primera especie, ó variedad, segun qujera llamirscle, escasea mas quue la segunda, bien que ocupe la mișma área.

DISTRIBUCION GFOGRÁFICA.- Esta sapaz habita toda la Australia y no es rara en ninguna parte.

USOS, COSTUMBRES Y RÉGIMEN. - Encuéntrase por do quiera, asi en los bosques nuas espesos como en las llanuras, y vive apareada ó en familias: se la ve muy numerosa en los puntos donde viren los kanguros y alli pudo of lïgio del hesigue matar en un invierno mas de una docena

Toso III
- Todo lo que refieren los autores, dice Couid, respecto al valor, la fucrza y ferocidad del aguila leonada conviene exactamente al uraeto audaz. Arrebata todas las especies pequeias de kanguros que habitan la llanura ó las colinas; persigue a la arutarcia, y es el mas terrible enemigo de los rebarios de carneros en los cuales causa horribles destrozos. * No puede apoderarse de los kanguros grandes; pero devora álos hijuelos ý se los lleva, aunque se hallen en la bolsa de la madre. sierto dia, dice el Viejo del hosgue, vi á un àguila persiguien.

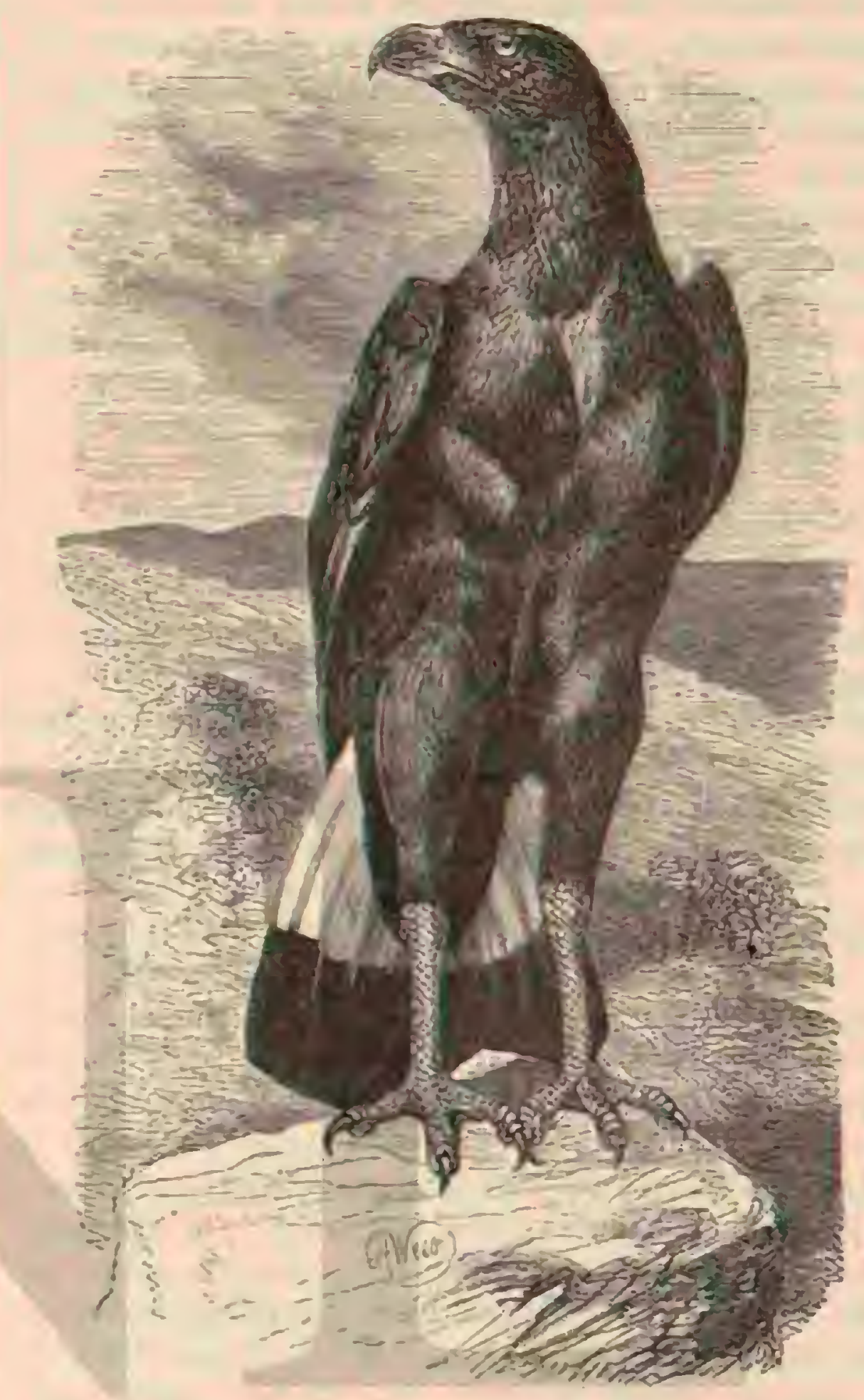

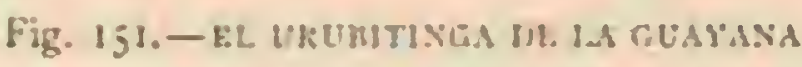

do d́ una hembra de kanguro, que llevaba su cria en la bo'sa; la rapaz no osaba acometer; pern sabia que cuando estuviese cansada la madre, abandonaria su hịuelo.

Los machos se precipitan ansiosos sobre los restos animales, y por este concepto sustituyen periectamented los buitres, que no existen en Australia: Gould vió hasia treinta y cua. renta reunidos al rededor del cadáver de un buey: aigunos de ellos, hartos ya, descansaban en los irboles jứximos, y los demás se disponian a devorar su parte.

Esta Sguila sigue durante dias enteros a los cazadores de kanguros, pues la experiencia le ha criseñado que en tales encerias redunda siempre algo en su bencficio. Fil urneto audaz es el terror dol bosque y de la llanuma, y todos los garaderos le temen como á una calamidad.

Forma su nido en uno de los árboles mas inaccesibles, con frecuencia á poca altura del suelo; pero siempre fuera de al. cance; sus dimensiones varian mucho; y parece quue la parcja lo utiliza varios años, no sin repararlo en cada cstacion, ensanchándolo convenientemenic. El armazon se compone de ramas gruesas sobre las cuales se extiende una capn formada por otras mas delgadas, y el intcrior esti guarnecicio de yer- 
bas y ramitas. Segun Ramsay, el periodo del celo comienza a fin de nuestro verano; en agosto se suelen encontrar en el nido dos huevos redondeados, de cáscara rugosa, que miden unos $\left(1^{\prime \prime}\right.$, oS de largo por $0^{*}$, of de ancho; son de color blanco, y están sembrados de puntos mas ó menos numerosos, rojos, pardos, de un amarillento claro y azul rojo. En varios bosques se encuentra un gran numero de nidos abandonados, que indican cuanto abundaban las rapaces antes que los europeos pusieran el pié en nquel pais.

CAzA. - Fácil es tirar sobre el uracto, atmyéndole con restos animales, y aun es imas sencillo cogerle con trampa. Los indigenas. se apoderan con frecuencia de los hijuelos en los nidos y los llevan s los fuertes, desde donde se remiten s Europa.

CAUTIVIDAD. - Jsia especie no esrura en los jardines zoológicos. Su precio es tan reducido que no se comprende cómo compensa el gasto del alimento que el águila necesita en el trasporte á Europa Bn nuestros climas soportá fácilmente la cautividad: Gurnay habla de una pareja cuya hembra puso y cubrió huevos.

\section{LOS NISAETOS-NISAETUS}

CARACTERES.-Estas aguilns ticnen el cuerpo esbelto alas relativamente cortas, las cuales no cubren del todo is cola, que no es larga: patas prolongrdas; revesticias de plu mas hasta los dedos; tarsos altos; garns grandes y vigorosas con unins largas y poco corvas y pico largo y sólido. Tales son los caractéres de este género, que en el sur de Europa está representado por una especic digna de sus congéneres.

\section{EL ÁGUILA-AZOR - NISAETUS FASCIATUS}

CARACTF́RES. - Alcanza aproximadamente el tamaño del águila clanga: mide $11^{m}, 70$ de largo y $1^{\prime \prime}, 45$ de punta punta de ala; esta piegada $0^{m}, 45$, y la cola 1$)^{m}, 26$. La hembra excede al macho en unos $11 \%$, oS en longitud, y algo mas de (1), 10 en el ancho total. Fi ave adulta tiene In frente bianca lo mismo que una lista que hay sobre el ojo; la parte supe. rior de la cabea y la nuca son pardas con myás oscuras; el lomo y parte inferior del cuelio blancos, marichados de pardo negro en los bordes de las plumas; la cara superior de las alas de un pardo oscuro; la parte inferior del loma pardo negra, Y la superior de la cola bianca con mezcla de negro; la garganta, el pecho y el centro del vientre blancos, manchados de negro; las nalgas presentan anchas fajas de un color denso, dispuestas en forma de $\mathrm{S} S$; la cara interna de aquellas y los tarsos son de un pardo rojo de orin ondenda de gris con manchas negras longitudinales; has pennas pardo negruzcas, con un ligero viso de púrpura; las rémiges primarias son blancas en la raiz con listas pardo oscuras; las secundarias en la parte interior manchadas 5 onduladas de gris; la cara dorsal de la cola excepto las rectrices medias casi uniformemente pardas, es de un gris pardo, orillada de blanco en el extremo,y adornada de siete fajas angostas y oscuras; la cara ventral de un blanco amarillento con puntos de gris pardo.

Los pequenos tienen la cabeza de color rojo claro, leonado en la nuca; el lomo de un pardo pálido: en cada pluma existe un filete amarillo leonado; la cara dorsal de la cola es de un gris ceniciento con nueve ó diez fajas trasversales, y blanca en la extremidad; la cara ventral es de un pardo amarillento claro con myas oscuras; el vientre de un blanco rojizo sucio, sin manchas; el ojo de un amarillo de bronce, el pico azulado, la cera de un amarillo sucio y las patas de amarillo gris

DISTRIBUCION GEOGRÁFICA.-El águila azor habita en Espana, en el sur de Italia, Francia, Crecia, Turquia, el norocste de Arrica, probablemente el Turkestan s todas las Indias, desde el Himalaya hasta las costas meridionales. No es rara en Grecia y en el sur de Italia; es el águila mas comun en Espana y Argelia.

USOS, COSTUMBRES Y REGIMEN.-Vive en las montailas desprovistas de bosque, donde hay peñas cortadas á plomo y escarpadas; en las Indias se encuentra principal. mente en las colinas cubiertas de juncales. No es ave emigrante; pero durante el período del celo vaga por el pais con otras de su especic: mi hernano vió un dia una bandada compuesta de unos veinte individuos, que cruzaban por el Pardo, cerca de Madrid. Cuando está en su nido, esta ave no permite que se fije cerca de ella ninguno de sus semejantes, ui aunque sea otra rapaz, en lo cual se asemeja â los demás angulidos.

Et águila azor es un ave muy ágil, valerosa, atrevida y hasta desicrgonzada; tiene todas las cualidades del azor, mas por lo que hace \& lo físico, está mucho mejor dotada que él. Su vuelo se asemeja mas al del halcon que al del águila leo. nada; se manticne en los aires como esia, trazando varios circulos; pero, cuando suela son sus aletazos mucho mas repetidos, y por lo mismo cruza el espacio con mas rapidez que las demis especies. Para atrapar una presa se deja caer cortanda el aire: cuando se posa para descansar, su aspecto no es tán majestuosín como el de las otras águilas; toma una po. sicion casi horizontal, con el cuerpo inclinado hacia delante, aungue algunas yeces se pone derecha, y es entonces su as. pecto imuchó mas altivo. Sus ojos, nuy vivosy brillanics, expresan una rabia y ferocidad increibles; y a fe yue su mirada está muy en armonia con la conducta del ave Esta águila reune al vigor del halcon la agilidad del gavilan, el valor dé los demás séres de su especie y la ferocidad del azor; no teme 2 ninguna otra ave, y acomete á todas las que $5 \Omega$ acercan al sitio donde ella vive. Mi hermano vió cierto dia do una de estas águilas luchar furiosamente contra un gipaeto; Kruper obsersó otra que acometia intrépidamente à un ad. versario mas temible aun, cual es el pigargo: en cuanto á mi, he presenciado sus peleas con el buitre ceniciento y el águila leonada, y he reconocido que no vive en buena armonia con ninguna otra rapaz.

Caza por lo menos tantos animales como el águila lconada. Temminck dice que solo se alimenta de aves acuaticas; pero debo añadir que su régirnen dista mucho de ser tan limitado. En Espana es el mas temible enemigo de las gallinas; las ar. rebata á la vista misma del hombre, y las persigue con tal tenacidad, que en las granjas aisladas es completamente im posible tener aves. Nio caza menos acivamente las palomas, y hasta los mamíferos de la talla de la liebre y menores, no se libran de sus acometidas.

LUna vez, cuenta laczanowski, vimos junto al bosque de Sada, en la provincia de Constantina, cómo una hembra de esta especic se precipitaba sobre una liebre, matandola del primer golpe. El macho acudió, pero ella no le permitió par. ticipar del botin. En otra ocasion, cayando avutardas con halcon, observamos que nuestras aves rehusaban echarse so. bre la caza, y cra por la aparicion de un aguila azor que repentinamente habia bajado de las elevadas regiones y que se llevó la avutarcia. \%

Segun Jerdon, perșigue en las Indias a las licbres, ilas gallinus de los juncales (gollus Stanleyii), a las garzas, a los palos y à los ibis: yaseguran los halconeros indigenas que se atreve con los mismos halcones adiestrados. En el Nilgherri vió lerdon á una de estas rapaces caer sucesiramente sobre una licbre, una gallina de los juncales y un paro real, auncue siempre en vano, pues el animal perseguido podia refugiarse en lo mas espeso de un canaveral. Observó tambien una pa. 
reja que todos los dias llegaba á un pueblo para coger gallinas. Elliot dice haber observiado dos de estas águilas que se apoderaron casi de un pavo real. Una pareja de estas aves, dice Jerdon, saqueaba los palomares en el Nilgherri, llegando á destruir dos de ellos completamente. Cuando las palo nus vuelan, me decian varios testigos oculares, una de las śguilas las acomete, y procura mas bien ponerse por debajo de ellas que alcanzarlas, mientras que su compañera, apro vechándose del momento de confusion ocasionado por aque Ila maniobm, precipitase a su vez y arrebata con seguridad la presa; la segunda águila se remonia entre tanto por los aires y se apodera ambien de la suya

Todos los animales conocen á esta aguila y procuran evi tar su encuentro. 4 Cuando estaba oculto en los canaverales, dice Powys, a la orilla de los lagos de Albania, donde me ponia al acecho para cazar las pollas de agua, observé con frecuencia el efecto que causaba la aparicion de esta rapaz. I as aves acuáticas no se inquietaban mucho por los milanos que rondaban en las inmediaciones, y apenas levantaban la cabeza cuando se dejaba ver un águila chillona; pero tan pronto como aparecia aquel águila, precipitábanse las pollas de agua en los cañaverales; los patos se echaban en el agua con el cuello tendido; oianse por todas partes gritos de an gustia, y no cesaban hasta que se perdia de vista la peligrosa rapaz. I)os veces se precipitó csta àguila sobre unas aves que yo habia herido, mas nunca se me puso d tiro.\%

El nido del águila azor se encuentra on las grietas de las rocas mas inaccesibles, y segun tengo entendido, solo Kruper lia hecho su descripcion, pues encontró uno en el hueco de una roca en las montanas de Grecia. Contenia dos huevos, y componiase de ramitas de acebuche y de hojas de encina espinosa; el interior estaba cubicrto de plumas. Los dos hue. vos diferian mucho; pero reconociase el tipo del de los aqui. lidos; el uno carecia de manchas y era de un blanco sucio; el otro de un blanco puro, sembrado de manchitas apenas visibles. Este nido se hallaba situado al mediodia y estaba por consiguiente sumamente caldeado por el sol. Durante muchos años seguidos observó el comandante Irby la única pareja que anida en las perias de Cibraliar, y se convenció de que esta especie gusta tambien variar de nido; pues en los años 1860 y 187 i se servian de uno situado i cosa de 100 metros de elevacion desde el pié de la peña, yen $1 \$ 70$ y 1872 de otro situado á major altura. En 1873 no pudo observarlas el comandante por hallarsenusenie, pero en 18 if las encontró en un nido enieramente nuevo. Poco trabajo invierten en su construccion, pero no dejan de adomarlo en la parte suprerior con ramas frescas y vercles de olivo. Irlay no llegó á descubrir cómo las rompian del d́rbol, pero algunas que en. contró al pié de la roca estaban roidas como si las hubiese cortado una rata. Generalmente empiezan por Navidad á testaurar el nido, si bien la hembra no pone antes de princi. pios de febrero. En I 87 puso la hembra el primer huevo en 5 de este més, y los peq̨ueños salieron el if de marzo, de modoque la incubacion dura cuarenta dias. Macho y hembra cubren alternativamente y á veces juntos. Vuclven los huevos con el pico y de aqui proceden las rayas que se ob. serian en los hueros en incubacion. Algunos huevos que el comandante hizo sacar del nido en $1 S_{73}$ y $187+$ tenian un magnifico dibujo de puntos ylineas encarnados, y tan seme. jantes uno al otro que era forzoso reconocerlos como procedenies de una misma hembra. No todos los nidos examinados por Irby ocupaban puestos elerados e inaccesibles, pues varios podian alcanzarse sin gran trabajo. Tambien anida el aguila azor en las peñas en la India. P'ara defender á sn progenie demuestran esias águilas tanto valor como in las demás circunstancias, aunque no parece que acometan al hombre.
CAUTIVIDaD. - Durante mi permanencia en España pude adquirir dos de estas rapaces vivas, una vicia y otra jó. ven: la primera quedó sujeta én unas varetas de liga que la habian embadurnado todo el plumaje, pero los que la iabian cogido la maitmataron de tal modo, que sucumbió al cabo de algunas horas; la segunda habia sido cogida en el nido y tenia todas sus plumas. La puse en una jaula donde habia en. cerrado ya un águila leonada, un buitre, un gipaeto y una chora. Hasta entonces habia reinado la mejor armonia en aquella reunion tan variada; pero interrumpióse tan pronto como introduje al águila azor. Esta parecia estar furiosa; corria por la jaula, provocando i sus companeros, y si se le acometia, eclábase de espalda, descargando vigorosos golpes con sus garras. La chova, tan alegre y vivaz, fué su primera víctima; aun no hacia una hora gue estaba con clla, cuando ya la habia deromdo; con nosotros no se manifestaba mas mansa; acomeiia á cuantos se acercaban; en una palabra, sus costumbres se aseniejaban en un todo a las del azor.

Jerdon cree, y probablemente no se engaña, que se podria adiestrar esta águila para la caza del antílope, de la liebre, de la avutarda y de otros grandes animales. El individuo de que acabo de hablar se mostró luego inuy manso y dumesticado en e! Jardin zoológico de Francfort.

\section{LAS ÁGUILAS MOŃUDAS- SPIZAETUS}

CARACTÉRES. - l.as águilas moñudas que forman el genero mas afine al anterior tienen el cuerpo esbelto; sus alas relativamente cortas, cubren, cuando mas, la tercera parte de la cola, ruue es larga; los tarsos son altos y gruesos. Se distinguen sobre todo estas f́guilas por tener un mono mas ó menos juronunciaco en el occipucio.

\section{EL ÁGUILA MOÑUdA BELICOSA - SPIZEE- TUS BELLICOSUS}

CARACTERRES. - Esta especie, la mayor y mas vignrosa del presente grupo, mide de $11^{\mathrm{m}}$, So a $0^{\prime \prime}, 86$ de largo; el ala plegada de $0^{\circ}, 60$ id ()$^{*}, 65, y$ la cola de $0^{\circ}, 31$ \& $0^{-1}, 3$ t. Ignoro el ancho de punta a punta de ala.

El lomo es pardo ó gris pardo; la cabera de un pardo mezclado de pardo regro, como dibujo longítudinal medio de cada plama; las grandes tectrices superiores del ala son mas claras en la cxtremidad, formíndose asi una faja trasversal; por encima del ojo hay o:ra de color blanco, que se cirige hácia el occipucio; el vientre es del mismo tinte, con visos azulados y casi desprovistos de manchas; la cola de un gris ceniciento, mas oscuro en la cara dorsal que en la rentral, con seis fajas trasversales oscuras; las barbas externas de las réniges son negras, las internas alternativamente claras y os. curas; las cobijas inferiores del ala, de un blanco puro; las rectrices son por encima de color ceniciento oscuro, y por debajo ceniciento pardo, con seis fajas mas oscuras trasversales; el iris pardo gris, la cen azul verdosa, $y$ las garras de un gris de plomo.

Los pequeños son tambien pardo negruzcos en la parte superior. $y$ en la inferior blancos con numerosas manchas pardas que van desapareciendo poco a poco en los primeros cuatro años §a medida que cl lomo se vuelve mas claro (6. gura $150 \%$.

DISTRIBUCION GEOGRAFICA. - la primera descripcion del pizaeto belicoso iué publicada por Le Vaillant en su cxcelente obra sobre las aves del Africa neridional con el nombre de Grifolda. Fste naturalista descubrio el ave en el país de los Grandes Namaqueses, desde el $23^{\circ}$ de latitud 
ste hasta cerca del centro del Africa; mas tarde se le encontró ctuel Africa occidental; yo le he visto en las inontaitas de Abisinia.

USOS, COSTUMBRES Y RÉGIMEN. - Ln POCO que satemos acerca del género de vida de tan magniî́ca rapaz. es 2̌ebido en gran parte á le Vaillant; veamos lo que dice: - Hobe observado que la grifalda elige con picferencia un árbol aisido para su domicilio, porz̨ue es muy receloso y le gusta obsorvar cuanto pasa á su alrededor. 3 Desde alli emprende st ruelo para recorrer un extenso dominio en el que tno permize la presencia de ninguna otra rapaz; si se presenta alguna, acométela en seguida, obligándola \& que se aleje. \&uceste con frecuencia, dice Le Vaillan, que se iorman bandadas de buirres y de cuerros con el ubjeto de aproveche un momento fnuorable para apoderarse del animal que attopa esta águila; pero su aspecto intrépido y fero cuando gurda la presa, bastal para imponerse á la legion de cami. vows.

Dásuila moñuda belicosa cara principaimente por la ma. ñàn y tarde, rara vez con mal éxito.

this Jiebres y los pequeños antilopes constituyen la base de cillalimiento, sin perdonar iampaco á las aves. Todo en su sppecto indica que es un enemigo tan terrible para los aricales de Africa cono el águila leonada para los de nues. tros paises. En todo el sur de tring no hay ninguna ragraz que le aventaje en fuera y cruejdad. Seegun acabamos de deci, no comparte con ninguna otra especie su dominio; su fueany bravura son el terror de tocos tos a nimales indefen. sos, su vuclo, semejante al del águila, es aun mas ligero y rákido, y sul vor penetrante y aguala 6 baja y ronca.

Forma su nido en la copra de los mayores arboles ó entre tocas escarpadas é inaccesibles: reconócense en él tres capas; una inferior, farmada de mmas gruesas; una mediana de ra. mius, musgo y hojas secas, y la úitima comįuesta de ramaje, sote la cual deposita los huevos. Este nido tiene un diáme. trode $t^{\prime \prime}, 50, \mathrm{i}^{2}$, y es tal su solidez, que ur hombre pue. de apojarse en él sin teinor de hundirse. Cuando está cons. truth sobre una prominencia 0 cinto de roca, falta la capa inizior. Le Vaillant cree que una pareja se sirve del nismo nicoo toda la vida.

Ins huevos tienen como $11^{\circ}$, os de largo; son casi redandos $y$ exeramente blancos.

8.Mientras que la hembra cubre, cuntinua le Vaillant, cuidu el macho de atender á las necesidades comunes; lleva el amento al nido y cara para toda la familia, hasta que los hijelos pueden permanecer solos en el nido sin peligro al. gum, pues cuando son mas grandes necesitan tan conside. rabl: cantidad de alimento, g̨ue apenas pueden los padres satisacer su voracidad, $y$ deben cazar juntos á fin de aplacar 3 desmesurado apecito de los aguiluchos.s Tanto es lo que comen, que varios hotentores, segun afirmaron ellos miscos á Le Vaillant, pudieron alineentarse cerca de dos meses con lo que iban á buscar cada dia al nido de las dos águlas, situado cerca de su vivienda, y en el espacio al re-
dedor.

Astes que los hijuelos comiencen at volar, queda comple. tamente cubicrto el nido de montones de huesos.

Cautrvidad. - He conservado largo tieinpo, dice 1. Vartant, una de estas águilas, á la que solo rompi el extre mo edel ala de un tiro. Estuvo tres dias sin querer probar ab. solusmente nada, á pesar de haberla ofrecido de todo; pero tan pronto como se acostumbró á tomar alimento, no habia con q̨ué satisfacerla. Eniureciase si le enseñaban un pedazo de arne; se tragaba enteros los trozos que pesaban cerca de una tubra, y no rehusaba jarnás, aunque tenia el buche tan llemaigunas reces, que le era preciso devolver una parte, la cual devoraba luego. Toda especie de carne era die su gusto, incluso la de otras aves de rapina, y hasta le agradaron los restos de oira grifalda que yo habia disecado.

Paréceme que hay en esto algo de exageracion: en el Jar. din zoológico de Hamburgo existe desde hace un año una águila belicosa que fué cazada en los alrededores de Zan. zibar y nos remitieron directamente. «Esta rapaza, dice mi hermano, sabe cautivar en el mas alto grado la atencion de los espectadores, y parece que ha perdido todo su salvajismo. Es mansa, dócil, y diriase que ba cobrado afecto al hombre; contesta cuando se la llama, y su voz. dulce y agra. dable contrasta singularmente con los destemplados gritos de otros aquilidos: el sonido que produce se puede expresar por las silabas gliuk, gliuk.

- El águila belicosa permanece derecha por lo regular, con el moĩo levantado: su mirada es altiva, aunq̨ue no feroz, $y$ la fija con ciesta expresion de dulzura en laspersonas á quie nes conoce. Coge con su pico el alimento, sin herir nunca da mano que se lo ofrece; si entra álguien en su jaula y se di. rige hácia ella, se pone à la deiensiva; abre sus anchas alas, levanta una de las garras y baja al mismo tiempo su moño. Cuando está en tierra inclina el cuerpo hácia adelante, aun. que no tanto como los otros aquílidos. Como su jaula es bastante grande para que pueda extender bien las alas, $y$ aun volar, se la ve con frecuencia abandonat la percha donde se halla y clevarse hasta la mas alta.

* Parece que no le inquietan sus vecinos, al paso que mira atentanente a todas las personas, y tambien al los ciervos, cuyo recinto se lialla cerca de su jaula.

Añadiré que ésta rapaz ha soportado frios bastante inten. sos, aunque no sin resentirse un poco: durante el invierno solia permanecer silenciosa en su percha, y tiritaba de frio algunas veces. Sin emubargo, estaba mucho mejor al aire libre que encerrada en los recintos caldeados de la casa, donde fuécol:ducida al fin.

\section{EL AGUILA DE PENACHO-SPIZAETUS OCCIPITALIS}

CARACTÉRES. - Essta especic, mucho mas perqueña que la anterior aunque por lo cemás muy afine, habita los mis. mos paises qque clla, y debe su nombre al largo penacho que la distingue. Es muy fornida, de ala y cola cortas, tarsos altos y coloracion bastante unifornse Un parcio mus oscuro es el color dominante; el vientre es mas oscuro y el pecho mas claro que el tinte general. La cara interior de los muslos es blanquizca, el tarso blanco sucio, $y$ la parte superior tiene un refejo entre pardo, cobrizo y purpúreo. Las rémiges primarias son en ia parte inferior del lado de la raiz biarcas $y$. por fuera de un blanco pardusco sucio; en la mitad del ex. remo pardo oscuras. las penuas secunciarias son blancas cr la raiz y tienen dos fajas trasversales en las barbas; la cara exterior de la barba es parda en las recerices y la interior casi blanca con dos fajas anchas de color pardo negruzco y una faja del mismo color en el extremo; las pequeñas cobijas de las alas á lo largo de la nano son blancas y las demás inferiores pardo negruzcas. El ojo es de un amarillo subido; el pico de un azul córneo, mas oscuro en la punta y mas claro en la base; la cera es arnarillo claro y la pata amarillo pajizo. La longitud es de $0^{n}, 50$ a $0^{\circ}, 52$, el anctio de punta á punta deala $i^{\prime \prime}, 20$ hasta $\imath^{\prime \prime}, 30$, el ala plegada de 1$)^{\prime \prime}, 31$ hasta $0^{\prime \prime}, 35$. y la cola de $11^{\circ}$, is a $0^{\circ}, 20$.

DISTRIBUCION GEOGRÁFICA.- Entre todas las águilas moñud̉as del Africa es esta especie la mas extendida, encontraindose desde los $17^{\circ}$ latitud norte hasia el cabo de Buena Esperanza, y desde el Senegal hasta la costa del mar 
Rojo, como tambien en la isla de Madagascar, lo mismo en las tierras llanas que en las montanas con tal que haya bosque. A los páramos y estepas solo acude cuando hay pocos ó muchos árboles, así como á los sitios donde una espesura de mimosas entretejidas de enredaderas guarnece el márgen de algun torrenie que temporalmente lleva agua. Es ave muy comun en los montes altos de la cuenca del Nilo superior.

USOS, COSTUMBRES Y REGIMEN.- En el Alto Egipto se puede ver \& nuestra aguila posada en una gran rama de nimosa, no lejos del tronco, donde sucle entretenerse en juguetear gravemente con sli moño. Por monientos lo ensancha, frunce el entrecejo, cierra los ojos á medias, y criza su penacho hasta ponerlo vertical y tambien todo su plumaje, $\delta$ bien recoge sus plumas, y entorces le cae el moño soure el lomo. Permanece horas enteras inmóvil, indiferente al parecer á iodo cuanto le rodea, y semejante á la estatua de la pereza; pero de repente cambia su aspecto: si apjarece un raton, una rata, una ardilla, alguna paloma, una bandida

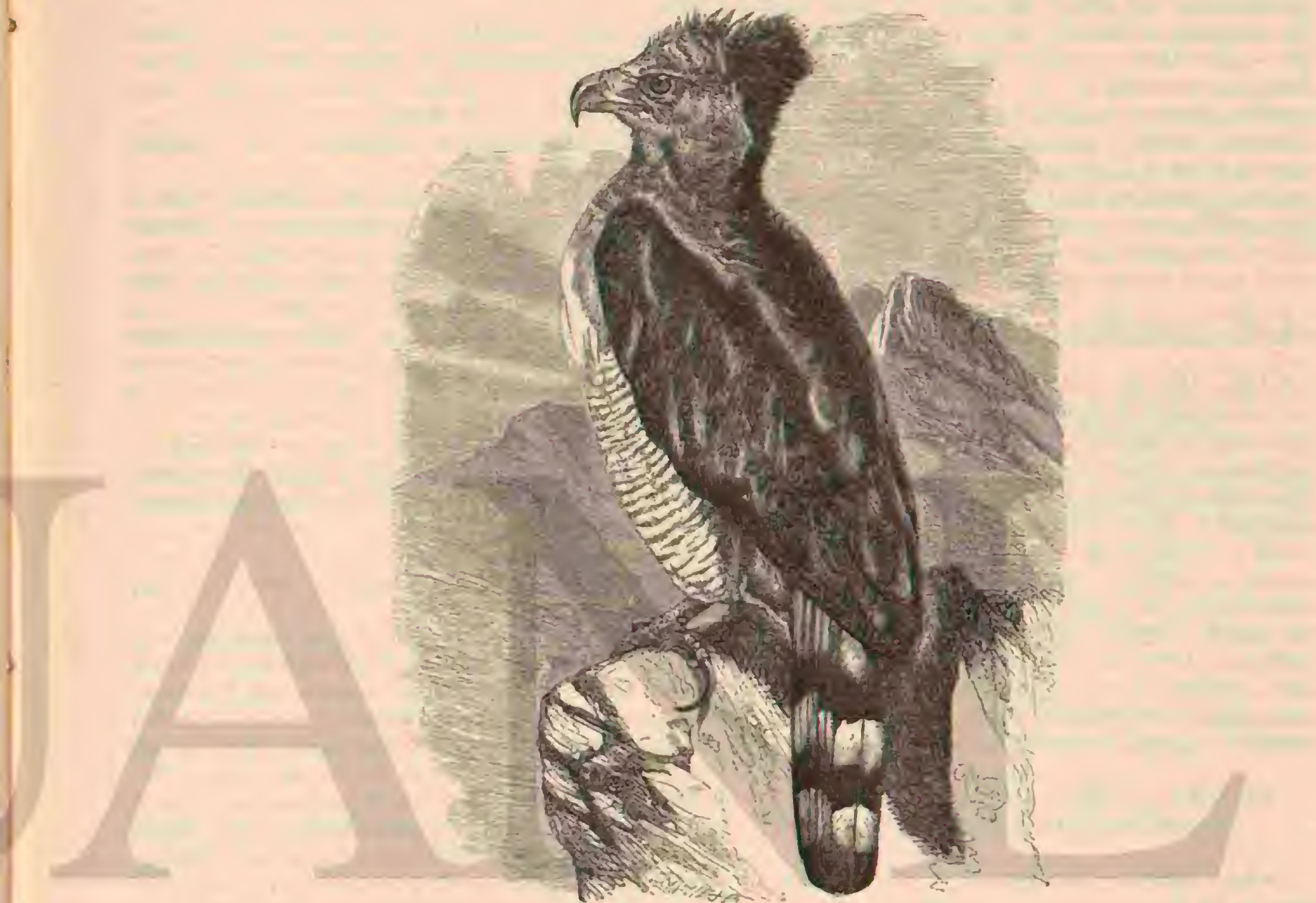

Fig. 152.- IA HAXPIA 18.02

de tiserinos, ó cualquier presa en ín, lảnzase sobre ella como un rayo y se agitan sus alas rápidamente. A la inanera del azor, deslizase á través de los matormales y espesuras mas impenctrables; por todas partes sigue la caza y al fin se apo dera de clla.

No se le puede comparar sino con el azor: es tan atrevi. do, tan impudente y feroz como él; y atendida su talla, es de todas las rapaces la mas cruel y temible. A semejanza de todos los aquilidos del hemisferio oriental, no osa acomerer á los monos; no tiene suficiente valor para habérselas con acqueltos animales ágiles cuyos miembros se prestan un mus. tuo apoyo en caso de peligro. Ya he dicho en la primem parte de esta obra cuál era la sucrte de las águilas que trataban de hacer presa en los cuadrumanos, y por lo tantó no necesito repetirio aquui. Segun Heuglin, caza tambien reptiles y peces, y acaso anfibios. En caso de necesidad se harta de carrona, como ya observa le Vaillant. Heuglin la ha visto cerca de los matadéros, posada en los árioles como los cuer. vos para caer sobre los desperdicios y mondar los huesos arrojados. No he podido obsernar por mi mismo cómo se re. produce el águila de penacho: Le Vaillant dice que anida en los árboles, y que el interior de su nido está cubierto de lana y plumas. La hembra pone dos huevos de color pálido con manchas pardo-rojizas.

CAUTIVIDA D. - El aguila de penacho, qque ja no es en Europa un ave cxcesivamente rara, vive muchos anos en jaula si se la cuida convenientemente, porqutes ruda y poco sensible â las influencias climatéricas. Yo las he renido ă ni cuidado repetidas veces, $y$ tambien las he observado en otras partes. Puede decirse que es uno de los aquilidos mas á pro. pósito jara llamar la atencion: su largo mono flotante, que cuando reposa el cuerpo está casi siempre enhiesto, su plumaje oscuro, y sus ojos vivaces $y$ ardientes, producen una impresión extratia en los espectadores.

Mi águila de penacho es muy vivaz, sobre todo por in mahana y la tarde, en cuyas horas grita mucho; su roz es muy variada: comunmente se compone de sonidos bajos y corta. dos, a los que siguen pronto varias notas mas prolongadas, que en mi concepto podrian expresarse por las silabas micir,

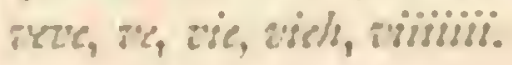


Este aquílido no se la encariñado aun con su guardian; pues si bien se nota que hace un movimiento como para saludarle cuando no le ha visto en mucho tiempo, no es menos cierto que rechaza todas las caricias que se le quieren pro. digar. No sé cómo se conduciria con sus congéneres, aunque opino que no les iria muy bien. Cuando se introducen en su jaula pequenos mamiferos, los mira primero atentamente, alisa su plumaje, recoge su mono, patalea en su percha y vuelve la cabeza de todos lados, como to hace el buho. Sa. tisfecha su curiosidad, déjase caer í tierra, avanza sobre su presa y la coge con una de sus garras; si el mamifero hace un movimiento, retrocede al instante; pero se enardece luego poco á poco. Dista mucho de dar pruebas de ese-furor in. domable que caracteriza \& los otros aquilidos nobles, y por garo lado, es mucho mas torpe que ellos; reflexiona antes de atreverse á repetir un ataque, y no do hace nunca sin cierta pesadez. Acaso depende esto de no ser, su jaula bastante es. paciosa, y pudiera ser que se condujese de otro modo si le fuera posible acometer ás su presa al vuelo, como lo hace en libertad, aunque creo que carece de esa inteligencia que permite \& los aquilidos nobles vencer todos los obstáculos.

\section{LOS URUBITINGAS MORPHNUS}

CARACTERES. - Estas rapaces, qृue algunos naturalistas colocan entre las águilas, y otros entre las azores, viven en los bosques del Brasil, lo mismo qua los ternuros que re. presentari en la América del sur ó las f́guilis moñudas. 'lie nen la talla, la fuerza $y$ el arrogante aspecto de las águilas, asemejándose por su conjunto al azor; el cuerpo es grueso, ta cabeza voluminosa, las alas bastante cortas, la cola ancha y larga; los tarsos son por 10 menos dos veces tan largos como el dedo del centro, y están cubiertos de plumas en una pequeña extension sobre la articulacion tibio-tarsiana, hallíndose el resto protegido por cscamas dispuestas en circulos; los dedos son cortos, pero fuertes; las uñas vigorosis y aceradas; el pico prolongado, poco alto y endeb!e, con la mandibula superior, ganchuda y ligeramente escotada.

\section{EL URUBITINGA DE LA GUAYANA- MORPHNUS GUIANENSIS}

Caractéres. - Fista especie, la mas conocida del grupo, mide $0^{\circ}, 70$ de largo, $1^{\prime \prime}, 50$ hasta $1^{\circ}, 54$ de punta d́ punta de ala; esta plegada $1^{\prime \prime}, 40$ hasta $0^{m}, 42$ y la cola $6^{\prime \prime}, 30$. Su plumaje, que llama la atencion por lo lacio y por ser bastante parecido at de la lechuza, se prolonga en el occipucio formando un plumero de $\|^{\prime \prime}, 15$ de largo. La coloracion varia segun la edad del ave: segun el principe de Wied tiene la cabeza blanca, y del mismo tinte el cuello, el pecho, el vien. tre, la rabadilla y las nalgas, con algunos visos de un ama. rillo sucio; las plumas del lomo, de la espaldilla y las cobijas superiores del ala son de un gris rojizo claro, presentando cada pluma varias manchas y puntos de color gris rojizo: las rémiges son de un pardo negro, con fajas trasversales angostas de un gris rojo; las rectrices ostentan un dibujo seme. jante (ïg. 151).

Pelzeln cree que tal es el plumaje de los individuos jóve. nes, y que los adultos tienen colores mas oscuros: segun dice, su cabeza es cie un color pardo oscúro, lo mismo que la garganta; la nuca, el lonso, las alas, el cuello y el pecho de un negro verdoso; las sub.caudales están orilladas de blanco en su extremidad, y cruzadas por fajas irregulares del mismo tinte.

DISTRIBUCION GEOGRAFICA. - Segun to que nos dicen el principe de Wied, Scloomburgk o. Burmeister, el urubitinga de la Guayana esta diseminado en la mayor parte de la América del sur; se le encuentra en los bosques de las orillas del mar, lo mismo qque en los oasis y en medio de las estepas; pero es mas comun á lo largo de las corrientes.

USOS, COSTUMBRES Y REGIMEN. - Se le ve tr2. zar circulos en los aires y se le reconoce con facilidad por su plumaje blanco brillante, que se destaca sobre el azul oscuro del cielo, $y$ segun Schomburgk por su voz, penetrante.

Se posa sobre las ramas secas de los mas altos árboles, y permanece horas enteras inmóvil, levantando sta magnifico moño.

Su alimento consiste en aves y maniferas: el principe de Wied mató una de estas águilas en cuyo estómago habia res. tos de marsupiales; los cazadores le aseguraron que la rapaz. perseguia sobre todo á los monos.

Dice Schomburgk que construye su nido en los árboles poco elevados.

CAZA.-Es dificil apoderarse del urubitinga, porque se posa siempre á gran altura: los cazadores que man provistos de carabina pueden alcanzarle no obstante; tampoco escapa dé las flechas de los indios «Dos robustos indigenas, refiere el principe de Wied, mataron un urubitinga, no léjos de la orilla del rio, atravesándole de un leechazo cuando estaba posado en su nido, en medio de las mas altas samas de un corpulento árbol. El arma penetró por la garganta; pero aun cstaba completamente vivo cuando me le trajeron. Debe ser un are vigorosa y osada, pues á pesar de su herida se defendia valerosamente con las unias y el pico. Por desgracia no sé pudo llegar á su nido, pues nadie quiso aventurarse it seincjante empresa.

\section{LA HARPIA FEROZ - HARPYIA DESTRUCTOR}

CARACTERES. - Esta águila, la mas imponente de todas las que habitan la América del sur, tiene cierta semejan. za con los urubitingas Es águila azor en toda la acepcion de la palabra. Tiene el cuerpo robusto; la cabeza voluminosa; las garras y el pico extraordinariamente vigorosos; este sobremanera alto y robusto, con el dorso muy redondeado y bordes afilados, escotados debajo de la fosa nasal, detrás de un diente romo. Los tarsos, mas robustos que en ninguna otra rapaz, solo están cubiertos de pluma en la mitad superior de su cara anterior, $y$ de grandes escamas tabulares en el resto de su cxtension; las garras son muy grandes; los dedos largos, terminados por uñas enormes, fuertes y robustas; las alas, que cuando están plegadas no llegan á la mitad de la cola, son, como esta, redondeadas con la quinta rénige mas larga que las demás; el plumaje suare y espeso, bastante parecido al de la lechuza; adoma ia nuca un nono largo y ancho que puede levantar el ave a voluntad. Tiene la cabeza $y$ el cuello de color gris; el moño, el lomo, las alas, la cola, la parte superior del pecho y los costados de un negro pizarra; la cola presenta tres fajas blancas; la parte inferior del pecho y la rabadilla son de este tinie, lo mismo que el vientre, que está manchado de negro. Cuanto mas avanza en edad el ave, mas puros son sus colores. El píco y las uñas son negros, las piernas amarillas y el ojo amarillo rojizo. Cuando cl ave es jóven son menos pronunciados los colores; tione las plumas del lomo listadas de gris, $y$ las del pecho $y$ ciel vien. tre mnnchadas de negro. Segun l'schudi, la harpia mide un metro de largo, el ala plegada $0^{\circ}, 55$ y la cola $0^{\circ}, 34$. Burmeister nos da dintensiones mucho masores. El dedo medio mide $0^{n}, 0 S$ de largo y el posterior $11^{\circ}, 04$, aunque debe tenerse en cuenta que están jrovistos de uñas, las cuales cienen por su curvatura, la del primer dedo 1$)^{m}, 0$, $y$ la del pulgar $0^{-1}, 08$ (fig. 152). 
DISTRIBUCION GEOGRÁFICA.-Parece que la harpia feroz criste en todos los grandes bosq̨ues de la América del sur, desde Mérico hasta el centro del Brasil, y desde la costa del Atlántico hasta la del Pacífico. En las monianas, sin embargo, no habita mas que los valles, y no sube a las alturas.

USOS, COSTUMBRES Y RÉGIMEN, - En los paises donde vive la harpia, ha sido venerada desde tiempo inmemorial, y circulan mil fábulas acerca de sus costumbres. Los primeros autores que han escrito sobre América hacen mencion de la rapaz, y cada cual cucnta sus historias, a cual mas inverosimil. Fernandez dice que es tan grande como un car nero; que aun domesticada, acomete al hombre por el mas ligero motivo; que es siempre maligna y feroz; pero que se la puede adiestrar fícilmente para la caza. Monduyt asegura que de un solo picotazo parte la harpia el cráneo de un hombre; y deja entrever que á menudo hace uso de su fuerza.

Estaba reservado : los observadores modernos, d'Orbigny, 'Tschudi y Pourlamayue, darnos á conocer las costumbres de la harpia y reducir tales exageraciones á su jus:o valor. Nos dicen estos naturalistas que la harpia habita los bosques húmedos de la América del sur, ye sencuentra sobre todo en la inmediacion de los rios, alredecior de los cuales se agrupa toda la vida de aquellas regiones. D'Orbigny manifiesta que no la encontró jamiss en el interior de los bosques, es decir, léjos de las corrientes: esta rapaz se halla en todas partes sin ser comun en ninguna, y puede ser causa de ello la circuns tancia de que los indios han considerado en todo tiempo sus plumas como un adorno precioso, $y$ persiguen al animal sin tregua ni descrnso. A juzgas por lo que dice d'Orbigny, siempre se ve á la harpia solitaria cuando no está en el pe ríodo del celo. A semejanza del azor, rara vez se posa en los árboles altos, y prefiere permanecer á poca altura. Disdi alli parte como una flecha, remóntase verticalmente por los aires, iraza varios circulos, y apenas divisa una presa cae so. bre ella impetuosamente. No es recelosa, pues permite al hombre acercarse mucho, aunque solo ocurre esto en los bosques donde no ha tenido frecuentes ocasiones de encon. trarse con su mas temible cuando no ínico enenigo.

Para la harpia es buen alimento todo vertebrado superior, siempre que pueda dominarle: algunos observadores creen que solo se alimenta de mamiferos, principalmente de monos y perezosos; 'l'schudi la vió cazar aves. Ninguna rapaz. es tan icmida de los indios como la harpia, al decir de anguel naturalista; su talla, su valor y su atrevimiento, la convierten en uno de los enemigos mas peligrosos de los plantadores del Perú, y por lo mismo se le da caza sin compasion. En varios pueblos no pueden los indios criar aves de ninguna especie ni tener perritos, porque son presa de la insaciable rapay. T'schudi ha visto is una harpia arrebatar una gallina at ires pasos de un indio: en los bosques encuentra abundante ali. mento a expensas de los penélopes y de los cripturideos, y extcrmina además un considerable nimero de ardillas, de oposums y de monos. Cunudo una tribu de estos últimos, so. bre todo si son capuchinos, atisba a una harpia, los individuos que la componen lanzan gritos plañideros; refúgianse en un árbol y se ocultan en 10 mas espeso del follaje, pues las probres animales no tienen oira defensa que sus lastimeros gritos contra su enemigo natural. Los makusis han asegurado \& Schomburgk que la harpia es la mayor exterminadora de monos aulladores: que arrebata corzos 5 hasta niños; que persigue á los perezosos y los armnca à pedazos de la rama s que se agarran. Me parece que este último aserio necesitaria confirmarse.

Segun Schomburgh, el nido de la harpia feroztiene el mis. mo tamaño que el del chabirú y está construido cn los mas altos árboles: dicen los indios que el ave le utiliza mrios años: no se conocen sus huevos.

CAUTIVIDAD. - Varias reces se han visto en Europa harpias viras, particularmente en Lóndres, Berlin y Amsterdam, y siempre atraen la atencion general, pues son, con efecto, aves de aspecto fiero y majestuoso. Tenemos algunos detalles acerca de su vida en cautividad: véase lo que dice Peepig, que ha tomado sin duda las noiicias de escritos in. gleses.

Cuantos visitan el Jardin zoolbgica de Ióndres experimentan cierto temor al ver una harpia adulta quue alli existe, y se abstienen de hacer ciertas excitaciones, que se permiten hasia con el tigre, protegidos como están yor los barrotes de las jaulas. lan fija 5 amenazadora es la mirada de aquella rapaz, tanta osadia y rabia concentrada revelan sus brillantes ojos, que aunque permanece derecha é inmóvil como una cstatua, inspira temor a los mas valerosos; parece inaccesible al miedo, y diriase que desprecia todo cuanio la roden; péro su aspecto es rerrible cuando le echan un animal en la jaula. Precipitase sobre su presa con tan ciego furor, que no se la puede resistir, y le destroza la cabeza con sus garras. De un soio golpe deja sin vida al gato mas vigoroso: del segundo le abre los costados y le desgarra el corazon; siendo de advertir que nunca se sirve del pico. La rapidez y seguridad de su ataque, y la idea de que podria ser moral para el hombre, contribuyen á infundir temor à los espectadores. \$

Al hacer Poppig esta descripcion hubiera debido recordar que todas las grandes rapaces se conducen poco mas 6 menos lo mismo; y habria sido mejor dejar las exageraciones i los autores que quieren lucir las galas de su estilo, y que perdi. dos en el terreno de la listoria natural, no encuentran munca nada bastante espantoso y conmovedor. Masius nos da una prueba de lo que puede la imaginacion, jurs junto á su rela to parece pálido el cie Puppig; vénse lo que dice: ulin esta rapaz ha reunido natura la ferocidad y la fuerza: areniaja por su talla al condor y al gipacto; sus huesos y sus tarsos son doblemente gruesos, y sus uñas una mitad mas largns que las del śguila leonada: todo el esqueleto es macizo, y el pico tan acerado y robusto, que le bastan aigunos golpes para romper el cráneo de un corro. Un monio negro, que levanta el animal cuando se encoleriza, contribuye aun á comunicarle un aspecto nus temible. Solo la vista de esta ave cuando descansa, inmovil como una estatua, inspira pavor, y nadie con. templa sin miedo aquelios ojos tan abiertos, de mirada fija j. amenazadora. Pero lo que mas espanta es ver la expresion de la rapaz cuando divisa una presa, $y$ deja de ser una cstatua para precipitarse furiosa solre su victima. Un golpe en la cabeza, otro en el cornzon, y el animal deja de existir; y ad. vièrtase que el ave descarga estos golpes con tal rapidez y acierto, que al momento sa reconoce que el mismo houbre no podria resistir á semejante acometida. En efecto, nuas de un viajero, perdido en nuedio de los desicrtos bosques que habita la terrible rapaz, debe morir entre sus garras, por mas que la harpia se alimente sobre todo de mamiferos, cor. zos, etc.y Es una fortuna que no se alberguen semejantes monstruos en los bosques de los alrededores de Leipzig, y que el muy śensible autor de este púrrafo no se halle al alcan. ce de un sér tan podcroso y feroz.

Tomaremos tambien de Pourlamaque algunas observacio. nes que ha podido hacer en un individuo cautivo. \&il museo de Rio-Janeiro, dice, recibió una jóven harpia de las orillas del Amazonas; apenas podia entonces rolar, y ahora ha cumplido ocho años y tiene la talla de un pavo. Está con frecuencia en su jaula completamente inmóvil, con la cabeza alta y la mirada fija: su aspecto es en aquellos instantes verdadera. mente majestuoso. A menudo salta continuamente de una 
percha á otra, y si pasa un are rolando cerca de su jaula, adquicren sus ojos una singular expresion de ferocidad; agi. tase y grita Cuando la enfurecen tiene bastanie fuerza para doblar las barmas de hierro de su jaula. A pesar de su largo cautiverio no se ha domesticado nada, ni manifiesta el menor apego à su guardian; léjos de esto, le ha herido una vez gravemente en la espalda: es muy maligna con las personas extranas, y todos cuantos se acercan imprudentemente se expo. nen á sus ataques; no permite que la loquen con bastones 6 sombrillas, al momente coge estos objetos y los destroza.

-Con los otras animales es feroz: una perra preñada se acercó un día imprucentemente á su jaula, y cogiéndola al instante, atrájola hácia si y da derorój mas tarde sufrio un puerco cspin la misma suette. Tanipoco respeta si sus I seme jantes: una vez dierón joor companera a la rapaz otra harpín y apenas estuvicron de irente preparironse \$ la lucha.

- La primera saltó a la percas mas alta, abriendo las alas; la segunda hizo lo mismo; entonces arrojo el guardian una gallina en la jaula, y como h recien venidn se precipitase sobre la presa, cayó al mometio la oira sobre su rival, arrancóle la victima y voló à su percha; la primera lanzó un grito, vaciló un poco, lanzando por é pico, una cspuma sanguino. lenta y cayó sin vida: su rival te habia traspasado el corazon.

- Nuestra harpia es insaciabis: acomete a todos los animales, ja sean aves 6 cuadrupectes, siempre que los puede ven. cer, y se come la carne y los huesos; nceesita inuchisimo alimenio: cuando era perueria devoraba en un solo dia un cochinillo de leche, un paro, una gallina $\%$ un pedazo de va. ca. Prefiere los animales yivos á los muertos; $y$ si lo que le dan de comer estí sucio ó podrido, lo echa en el agua para lararlo. A pesar de su vigor, no acomete á su presa sin pre. caucion; coge á las aves grandes por el pico y se lo sujeta de modo quie, no puedan defenderse. Al comer chilla y bate las alas: su grịto es tan penetrante que cási aturde; cuando está excitada pía como un pollo, y sopla si ticue hambre. Despues de comer se limpia el pico y las patas, y arroja léjos de silos excrementos sin mancharse.

Otservaremos de paso que esta rapaz muda todó el año.

UsOS Y PRODUCTOS. DOObigny refiere que los in. dios cogen con frecuencia harjus pequeñas en los nidos, $y$ que las crian y conservan cauiras para obtcner mas facil. mente las plumas: iodo el que tienc una de estas àes viva es muy apreciado por sus companeros. Las mujeres son las encargadas de cuidar de las crias y llevarlas dumnte los via. jes. Cuando las rapaces han mudado comienza su inrmento, pues el propiciario les arranca cos veces anualmente las plusmas de las alas y de la cola pata preparar algun adorno 6 guarnecer sus flechas. Fistas plemas son objeto de un gran comercio entre los indigenas; hay cjertas tribus que se distinguen por su destreza en la caza de harpias, y que adquicren por este medio todo lo que ticce para el indio algun valor: cn el Perú recibe además el cazador afortunado una recompensa particular.

4Cuando un indio, dice 'Tschudi, mata una harpia, recorre con ella todas las cabarias, y cobra una especic de inpusesto, consistente en luevos, gallinas, mair, etco Los indios y los europreos cstablecidos a orillas del Ama\%onas, segun indica Pourlamaque, consiủeran la came, la grasa y la lijel de la harpia como remedios soberancs.

\section{LOS PIGARGOS-haliaEtus}

CARACTERES. - I.OS pigargos constituren entre los aquilidos un género perfectamente separado; son grandes ra. jaces de pico muy robusto y sumamen:e corvo on su parte anterior; los tarsos son fuertes y solo estin cubicrtos de plu. ma en una mitad; las garras grandes; los dedos separados; las unas largas, accradas, y muy corvas; las alas, grandes y sub. agudas, cubren casi cnteramente la cola, que es de un largo regular, ancha y mas $\delta$ menos redondeada. El plumaje es bastante compacto; las plumas de la cabeza y de la nuca puntiagudas, aurque no muy largas y afiladas. El color domi. nante es un gris mas ó menos oscuro y vivo; la cola suele tener un tinte blanco, lo mismo que la cabeza.

\section{EL PIGARGO VULGAR Ó BORNÍ-HALIAE- TUS ALBICILLA}

CARACTERES. - El borni es bastante frecuente en todats las costas europeas. Is un águila imponente, de tamairo variable segun el pais y distrito que habita; pero de coloracion bastante constantc. Mide de $0^{=}, S_{5}$ a $\left(1^{m}, 95\right.$ de largo, casi 2 ",50 de punta á punta de ala; esta plegada tiene de $0^{2}, 65$ a 1) $=, 70, y$ la cola de $0^{\circ}, 30 \leq 0^{\circ}, 32$. La coloracion del ave adul. ta es en la cabeza, nuca, garganta y parte superior del cuello un amarillo ceniciento tirando á leonado claro, con manchas lar. gas poco marcadas producidas por el color pardo oscuro de las raíces de lás plumas y las manchas largas y oscuras del iallo. El manto y lomo son color de tierra oscuro; todas las plumas tienen cl borde amarillo ceniciento leonado claro con manchas laggas pardo oscuras en el centro. El extremo inferior del dorso Yel vientre son de color de tierra jardusco, algo mas intenso hícia lá cola. I as rémiges son pardo negruzcas con los tallos blanquizcos, siendo mas claras las secundarias; las piumas de la cola, un tanio recondeada, son blancas. Antes de la muda suele ser todo cl plumaje deslucido y reducido á un gris ama. rillento como leonadó. El anillo que rodea el ojo, cl pico, la cera y las patas son amarillentos. Las aves jóvenes se distin. guen de las viejas por su cabeza y cola oscuras; asi como por las manchás listadas yroducidas por los extremos pardo oscuros de las plumas menores de color pardo gris claro. El iris es amarillo pkardusco, el pico tiene un tinte azulado córneo y el pié amarillo verdoso (fig. 153).

DisTRIBUCION GEOGRÁFICA,-EI borni tiene la misma área de dispersion que el \{́guila comun. Esta ave ha. bira toda la Europa, y anida positivamente en Nlemania, es. pecialmente en la l'rusia oricntal y Potnerania, acaso tambien en la Marca y el Meklenburgo, y además en Escucia, Escandinavia, en la Rusia meridional y septentrional, Rungria, Transilvania, los paises del Bajo Danubio, Turqußa, Grecia, Italia, Asia menor, Palestina y Egipto, y hácia el este en roda la Siberia septentriomal y central A lo largo del Obi no parece que anide hácia el sur mas alla de la parte septentrional del Altai, porque en el Irtich superior ya le reenplaza el pi. gargo de cabeza blanca (lewcerifualo). Yo le observé hácin el norte liasta donde corre el Obi entre bosques, y tambien re. petidas veces en la Tundra de la peninsula samojeda al nortc del Liml, de lo que puede inferirse que iambien se hallar. $\mathrm{cu}$ las costas sepientrionales de la misma peninsula, puesto que se encuentra en Islandia, Spizberg, Nueva Zembla y por otro lado en Ciroenlandia; Middendorf le observó à los $75^{\circ}$ latitud norte, á orillas del Taimir. lis frecuente en el norte de China y junto al Amur, como que su área de dispersion comprende las islas del Japon. Su presencia en el continente sepientrional americano es cuestionable, jues en cuanto yo sepa, no se le ha cazado alli todavia.

\section{EL PIGARGO DE COLA BLANCA - HALIAE- TUS LEUCORYFHUS}

CARACTÉRES. - Esta especic, mencionada ya mas arri. ba, representa ai borní en la region de las estepas uralo cás. 
pias, en el Irtich superior, $y$ probablemente en todo el Turkestan meridional, puesto que Eversmann la cnconitró en su viaje a Bolkara Tambien vive en Europa, en el pais del Volga inferior, en Crimea y Bulgaria, y por esto menciono esta aguila que difiere del pigargo comun por su menor talla, por tener la parie superior del cuerpo pardo oscura, y la in. ferior pardo ciara, cabeza y nuca pardo orin leonado, garganta y parte superior del cuello color isabela rojizo y cola blanca con una ancha faja negra en la punta.

\section{EL PIGARGO DE CABEZA BLANCA-HA- LIAETUS LEUCOCEPHALUS}

CARACTÉRES.-Menciono esta especie, primeramente porqque representa á la curopea en América, y además porque se pretende que ha pasado repetidas veces a Europa y hasta que se la ha muerto en Alemaniay Turingia. Es algo mas pequcna que el borni; mide $\left(1^{\prime \prime}, 72\right.$ y $0^{\prime \prime}, 85$ de largo segun sca inacho ó hembra, $1^{m}, 90$ a $2^{\prime \prime}, 11$ de punta á punta de ala; esta

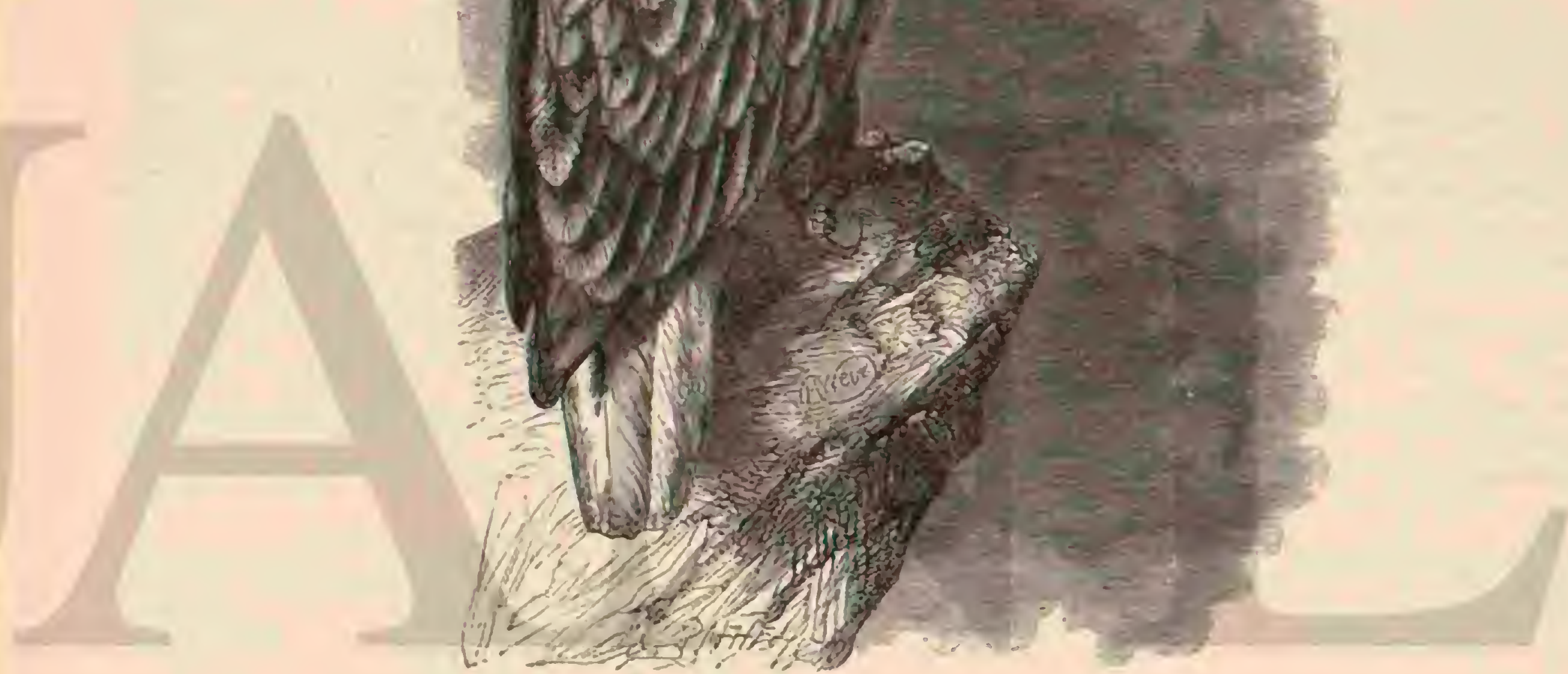

Fig. 15j.-EL PIGARCO PULCAR

plegada $0^{\circ}, 52$ a $0^{\circ}, 5 ;, y^{\circ}$ la cola $0^{\circ}, 27$ i $0^{\circ}, 30$. El plumaje de las aves adultas es de un co!or pardo oscuro uniforme en el tronco, teniendo cada pluma el borde mas claro; la cabeza, parte superior del cuello y la cola son blanquisimas; las rimiges negras; el ojo, la cera, el pico y las patas, un pocó mas claros que en su congénere europea. Cuando jóven, es casi coio pardo negruzco, mas oscuro, casi del todo negro en la cabeza, cuello y nuca, y mas claro en el lomo, alas y pecho, a causa de los bordes claros de las plumas; el pico es oscuro, la cera amarillo verdosa, el ojo pardo y las garmas amarillas

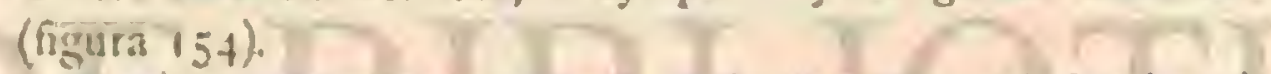

USÓS, COSTUMBRES Y RÉGIMEN.--Todos los pigargos se asemejan notablemente por lo que hace á sus usos y costumbres: son rapaces perczosas; pero fuertes, obstinadas y peligrosisimas. Audubon cscribió una interesentc historia del pigargo leucocéralo; creo lo mas oportuno reproducirla aqui.

\$Para daros una idea de la indole de esta ave, dicc, permitidme, querido lector, irasportaros al Mississippi. Dejad que vuestm barca hote, suavemente impelida por las ondas, Toso III mientras que con los primeros dias del invierno aranzan à impulso de sus ligeras alas bandadas de aves acuáticas, que abandonando los paises del norte, buscan una estacion mas benigna en las latitudes templadas. Contempilad el paisaje: alli, tucando in orilla del anchuroso rio, esta el aguila posada sobre la copa del mas elevado árbol; brilla en sus ojos un fuego sombrio; domina con la vista una vasta extension; escucha, su oido sutil percibe los lejanos rumores; y de vez en cuando dirige su vista â la ticrra, por temor de que se deslice sin ser notado el ligero halcon. La hembra está posada en la orilla opuesta, y si reina la tranquilidad y el silencio, advierte con un grito á su compariero, como si le aconscjara la paciencia a esta seiral bien conocida, el macho abre en parte sus alas inmensas; inclina ligeramente su cuerpo hácia abajo, y contesta con otro grito, semejante á una carcajada histéri. ca; despues vuelve á tomar su primera posicion, y reina de nuevo el silencio. Por delante del águila jasan rápidamente bandadas de patos de toda especie, de fulgas, cercelas y oiras: pero la rapaz no se digna fijar en ellas su atencion. De re. pente, y semejante al ronco sonido del clarin, resuena la voz 
de un cisne, distante aun, pero que se acerca poco á poco: un grito penctrante atraviesa el rio; es el del águila hembra, que no esta menos alerta que su macho; este sacude con fuerza todo el cuerpo, y solo con algunos picotazos, y gracias a la accion de los músculos de la piel, arregla en un momento su plumaje. A poco se ve llegar al blanco viajero; lleva iendido hácia delante su largo y nevado cuello; sus innuietos ojos vigilan tanto como los de su enemigo;y sus anchas alas parecen soportar con dificultad ol peso de su cuerpo, por mas que las agite incesantemente. El aninial parece tan tatigado por sus movimientos, que hasta lleva las piernas iendidas debajo de la cola para faciliar el vuelo. Acércase sin embargo: el aguila ha observado su presa, y en el momanto on que el cisne pasa entre lás embosidas rapaces, el niacho, prepa. rado ya para la cara, se lanza sobre él, dejando oir un grito formidable Hl cisne le percibe, y restaen en sus oidos, mas siniestro que la detonacion de la inortifera carabina.

W. Aquel es el mómento para apreciar todo el pocterio, del aguila clesilzase à través de los aires, semejante á la estrella que cae; y rápida como el rélámpago, hace presa en su tem. blorosa victima, que en la agonia de su desesperacion, cjecu. ta diversás evoluciones para librarse de las garras de su terrible enemigo. Iil cisne sube, gira en lodos sentidos, y quisiera sumergirse en la corriente; pero el águila sc lo impidé, jues sabe muy bien que por ayuel medio podria escaparse, y obliga a su victima a sostenerse con las alas para herirle en el vientre. Bien pronto pierde el ave toda esperanza de sal. vacion, dcbilitase poco a poco y desfallece al ver la bravura y energia de su enunigo. Intenta, por diltimo, un supremo esfuerzo y trata de huir; pero el \{gui! a encarnizada le golpea fuertenente por debajo de las alas, é impeliéndole con irresistible fuerza, le precipita ubliruamente âla orilla mas cer. cana.

N ahora, lector, podreis juzgar de la ferocidad de aquel adversario, in temible para los habitantes del airc: vedte alli triunfante sobire su presa, respirando con mas ralnan; sus gat ras poderosas juisotean el cadảver; hunde su acerado pico cin lo mas profundo del corazon y de hs entranas del cisne mo ribuncio; grita con satisfaccion, saboreando las últimas can vulsiones de su victima, /y parece complácerse en aumentar todos los horrores de su agónia. I a hembra, entre tanto ha seguido con atencion todos los movimicntas de su compañe ro, y si no le ha secundado en la caceria, no es por falia de buena voluntad, sino porque esti segura de que la fueras y el valor del macho son suficientes para semcjanie empresa. Sin embargo, cogida ya la presa, vuela en busca del âguila que la llama, y cuando ha llegado, comienzan las dos rapaces á destrozar al pobre cisne, bebiendo con avidez. su sangre.

Al trazzr este poético cuadro, no ha incurrido seguramente Audubon en exageraciones; no ha hecho mas que reproducir con su florido estilo todo lo que vió: ha hecho una verdadera pintura de la naturalcza.

'lodos los pigargos merecen muy bien el nombre de diynsins de mar con que se les designa. Habitan con preferencia nuestro hemisfurio y no se alejan nunca de las corricntes; en el interior de las tierras no se ren pigargos viejos sino a orillas de los grandes rios ó de los lagos: los jórenes suelen hallarse léjos del mar. Desde el dia en que emprenden su vuclo hasta aquel en que se aparean, es decir, durante varios aios, viagan sin objeto por todo el pais y se internan mucho por las tierras

listos viajes pasan en su mayor parte desapercibidos, porque los pigargos suelen volar á gran altura en sus emigraciones, y si acaso bajan un tanto, es cuando pasan por cncima de grandes bosques. Es indudable que muchos deben atravesar la Alemania, particularmenie á viltimos de otoño y en la primavera, porque à no ser asi no se explicaria la apari cion de tantos en los sitios donde encuentran abundante presa. Sobre esto me escribe Meyerinch: $\ll$ En los diez y seis anos, desde $1 \$_{43}$ a $1 \$_{59}$, que ture á mi cargo la direccion de las grandes cacerias de la corte en el monte de Letzling, aparecieron cada año uno 6 dos dias despues de la caceria, de seis hasta doce pigargos comunes para devorar las entra. nas de las cuatrocientas ó quinientas reses majores mucrtas, entre jabalies y cierros, y buscar las piezas heridas y extra. viadas, con cuyo objeto permanecian en aquel distrito, dis. tante mas de seiscientos kilómetros de las orilins del Báltico, ínico punto de donde podian haber renido, para saciarse con los restos de la caza que solia efectuarse invariablemente entre el 28 de octubre y el 20 de noviembre. A pesar de es. tar yo todos los dias del año y á todas horas en el monte, jamás obserpec alli pigargo alguno iuem de la citada época. No me atrevo a indicar positivamente lo que atraia $\{$ las ánuilas con tanta puntualidad, pero la que si puedo asegu. rar es que su llegada no era efecto del acaso, por cuanto se iba revitiendo cada año con la mayor regularidad. En la familia que alli se rcunia iabia siempre algunos viejos con la cábeza casi blanca, el cuello muy claro y las rectrices blancasy

Yo no admito la suposicion de Mejerinck de que ias águilas acuciteran crpresamente desde las costas del Bältico parm aplacar su voraz apetito en el monte de Letaling; mas bien opino que se encontraban en aquella estacion de paso, y que atisbando desde su altura la abundante presa, se iban reunicndo sucesivamente en el sitio, is la manera de los bui. tres en circunstancios análogas. Es vercuad que el invierno no obliga siémpre á estas aves a abandonar nuestras costas, pero si a has que anidan junto al mar Glacial, al este del Warangefjord, en Laponia y en el norte de Rusia, cuyas re giones se cubren de hiclo y de espesa nieve, siendo estos pigargos los que en parte pasan cerca de las costas y ca parte cruzan el pais á lo largo de las corrientes para reunirse en el rnediodia de Europa y en el norte de Africa, con sus congeneres que viven todo el año en las costas de estas co. marcas.

Por lo que toca a Grecia, consta por observaciones minuciosas que los pigargos son alli mas nunerosos en invier. no que en verano. los viejos, empero, no se resuclven tan fácilmente como los jóvenes a emigrar, por cuanto sc encariñan mas con su distrito y han adquirido major práctica en su vida de rapiủa, de modo que ni siquiera emigran pun. tualmente de Rusia y otros paises interiores del norte, prefi. riencio acercarse en invierno a las poblaciones en cuyos alre. dedores accchan y ayunan hasta que recogen algo, ora sea el cadiver de algun animal doméstico, ó bien un perro, gato, gorrinillo, choto, gallina, paro, ganso ó pato descuidados. Cuando se deciden a abandonar los bosques de la costa, acuden ál los grandes lagos del interior de nuestro país, donde se dedican con mucho ahinco á la pesca y ála caza de ares acuáticas, hasia que la superficie del agua queda helada. Entonces se van, yero no sin volver otra vez para cerciorarse de si aun queda algo, y en caso neggativo, y cuando ninguno de sus distritos acostumbrados ofrece esperanzas de botin, se resuelren i cmprender viajos mas largos: pero a donde quicra que rayan, jamás se separan de los rios y de toda corriente sino en último extremo, siendo, segun mis noticias, un caso raro el matar una de estas aves, vieja 6 jóven, en terrenos que carezcan de grandes rios ó lagos, lo mismo que en las montanas; si bien no cabe duda de que en sus viajes las han de traş̧asar. Mas rarn ha de ser todavia que una pareja de pigargos anide en el interior, estableciendo su morada en alguno de los arboles mas altos de los 
bosques situados léjos de las corrientes. Con todo no rehuye los pámmos, puesto que hasta establece su nido en las este. pas de la Rusia meridional, pero en este caso busca siempre la proximidad de algun rio.

Cuando no estån en celo, forman los pigargos tribus ó re. ducidas bandadas, mas bien como los buitres, que como las aguilas. Un bosque ó una roca les sirven de punto de re. union: en medio del verano suelen pasar la noche en peque. inas islas, ó bien sobre un alto arbol a la orilla del agua, posándose en las ramas elevadas del centro para cstar ente. ramenic ocultos. Si en los alrededores abunda la caza, cobran el inismo apego á estos sitios que á su nido; cada noche acuden a él con la mayor puntualidad, sin abandonarlo aun. que se les moleste repretidas veces. Se retiran tarde a descan. sar, y' por la manana temprano, por lo comun antes de salir el sol, empiezan \& recorrer su distrito. Si la caza ha sido felia, comen hasta saciarse y despues de haber bebido y limpirdose el nico, descansan durante las horns de medio dia, alisindose el plumaje y durmiendo un rato. P'or ia tarde hacen otm excursion hasta la hora de dormir.

El pigargo caza, lo mismo que el àguila comun, todos los animales de que puede apoderarse y sabe ademas hacer ex. celente uso de sus garras desnudas, muy á propósito para pescar. No le valen al erizo sus púas ni i la zorra su afilada dentadura, ni al pato silvestre su prudencia, ni tampoco al alcion su destreza en zambullirse. En la costa caza diferentes aves acuáticas, especialmente patos y alciones, como tambien peces ó mamiferos acuáticos. Si hemos de creer at Wallengren, las aves y los mamiferos buros se hallan mas expuesios aun a las acometidas de la rapaz que los que no se sumer. gen; estos uiltimos huyen volando cuando llega su terrible enemigo, y suelen escapar: los que buscan un refugio debajo del agua, se sumergen apenas divisan al pigargo; pero el ave permanece alli, acechando el momento en que debeis volver á la superficic. Podran escapar una, dos 0 ires veces, mas á la cuarta, cuando salen á la superficic para tomar aliento, son arrebatados por su enemigo. He observado con frecuencia al pigargo rulgar en Noruega, y ambien en las orillas del lago Mensaleh, en el Bajo Egipto,y siempre he visto, que todos los demais animales, incluso las rapaces, temen la presencia de su terrible enenigo, que arrebata su presa al busardo, y no dudo que devora tambien al ave.

A su osadia, y \& su fucra, que el mismo reconoce, reure el pigargo la mayor tenacidad. A. de Homejer vió á uno acometer varias veces a un zorro, muy capaz de defender su piel, y varios testigos oculares, dignos de crédito, han asegu. rado á dicho autor que en tales circunstancias mata cas! siempre la rapaz al zorro; le acomete de continuo, evita con destreza sus dentelladas $y$ le impide-buscar un asito en el bosque. locios saben que el ganado menor no esta libre de los ataques del ave, yes ciertro qute arrebata tambien los ninos.

Nordmann cita el casn de un pigargo que en cierta oca. sion se dejó caer en Laponia sobre la catreza de un pescador calvo, arrancándole la piel, y el de otro que se llevo una merluza de una lancha mientras el pescador que estaba al lado se ocupaba en arreglar la red.

El pigargo fija su residencia cerca de todas las costas uravas del norte, donde anidan numerosas aves, y alli las arre. bata de sus nidos; caza los eiders, se lleva ias focas peque. nas que se hallan al lado de su madre; persiguc a los peces hasta por debajo del agua, y se sumerge en su seguimiento. Algunas veces, no obstante, le cuestan caras semejantes ten. rativas: los naturales del Kamtschatka han referido a Kit. tlit\%, que con frecuencia es arrastrado el pigargo vulgar á las profundidades del agua por algun dellin en el que ha hecho presa Un pigargo que volaba por encima del Havel, segun refrere Lenz, divisó un esturion, y precipitóse sobre bl al momento: pero habia presumido demasiado de su fuerza, pues el pez pesaba mucho, y no le fué posible sacarle. Por otra parte no tenia el animal bastante fuerza para arrastrar la rapax, y por lo tanto comenzó á cortar el agua como una sacta; el águila se mantenia sobre el agarrada con fierza y muy abiertas las alas, de tal modo qque parecia un barco sin velas. Algunas personas que disfrutaron de tan singular esperiáculo, saltaron al momento en una canoa, y acercíndose al sirio, cogieron á la rez al esturion y al ave, cuyas gyarras estaban r.lavadas tan profundamente en el cuerpo de la victima, que no se podian desprender. Semejantes hechos de. ben reproducirse con mas irecuencia de lo que se cree.

Ein las estepas de la Rusia meridional es donde el pigargo se ha de contentar á menudo con las presas mas miscrables, sobre todo cuando caza léjos de las corrientes, pues entonces todo se reduce, segun Nordmann, a mamiferos y aves pequeras. Posado en invierno en los postes miliarios ó en los mojones de tierra que sirven fjara indicar el camino, y lo mas cerca posible de las habitaciones del hombre, acecha los espermónlos y lagartos $\delta$ topos que sabe atrapar con gran destresa en el moniento en que asoman \& la superficie en algun punto de sus excavaciones subterráneas. En ninguno de los pigargos que Nordmann mató en las estepas, y cuyo numero pasaba de una docena, encontró este naturalista res. tos de jreces, sino invariablemente los mamiferos indicados, aves y alguna cinc otra vez lagartos. lin cunnto á coner carne muerta apenas cede el pigargo á los buitres: y hasta en las costas constitujen la mayor parte de su alimento los peces muertos que las olas arrojan à la orilla; mientras que en el interior jamás deja de acudir donde laya el cadiver de algun animal. Nada menos que ocho pigargos encontre hartindose de carne de varios cabalios muertos en un bosque próximo á la ciudad de Jalutaroffsk junto al Tobol, siendo probable que se hallaran reunidos alli hacia algunas semanas. Verdad es que entonces el Tobol estaba helado y el pescado escaseaba. Sin embargo, la habilidad con que descubren has. ta cadiveres cubiertos de nieve ú otra materia es asombrosa, por cuya razon cree Mejerinck que estas aves deben icner un olfato finisimo, y en su aprojo me escribe lo siguiente: «si se expone el cadaver de un caballo en una esjesura jara arract jabalies y zorras, cubriéndolo empero con tierra y m. mas para que no lo devoren de una vez, se observa que las aguilas lo atisban en breve y que acuden a hartarse, aun cuando no es posible que lo divisen desde la altura á que ruclan. Yo no admito esta consecuencia y crco mas bien que el pigargo conoce donde hay carraza, como el buitre, nierced a la multitud de cuervos que se reunen al rededor de la presa oculta. A pesar de todo esto, y de las invasiones y otros pecados de que se hace culpable esta gallarda rapaz, constituyen siempre su principal alimento 'os peces, á cllos persigue subre todo, y si se establece y anida en las costas del inar asi comn en las cercanias de los rios y lagos, es crelusivamente a causa de ellos. Nunca deja de acudir a las pes. querias mal organizadas y explotacins, donde, si no se le perșigue, se vuelve an atrevidio que se planta junto á las cho. zas de los pescadores para ver desde alli si queda algo para él.

En cuanto a las cualidades fisicas, el pigargo es en mucho inferior a las aguilas propiamente dichas, aunque mas dies. tro en tierra y en el agua; su vuelo no tiene la elegancia ni destreza que tanto distinguen al de todis las aguilas nobles: siendo ian diferente su aspecto cunndo suela que con dificultad se confundiri a esta especie con aquallas, pues al punio se le conoce por su cuello corto y jor su cola redon. 
deada 5 corta tambien en proporcion de las alas, que son largas pero de poca y casi igual anchura en su extension. A esto se agrega que vucla con mas lentitud, dando aletazos ఇৃue, sin đejar de ser rápidos, son mas pausados que los de añuellas, $\bar{\gamma}$ merced a los cuales corta los aires en línea recta 6 describe circulos sin mover apenas las alas. En cambio tienen los riggargos una ventaja sobre las águilas citadas, yes su dominio del agua, porque son buzos como el busardo y el buitre fescador, y dignos émulos de las gaviotas y golon. drinas; tanto que se posan à veces para descansar sobre el mar como si fueran aves acuáticas, y permanecen sobre las olas todo el tiempo que les conviene, segun manifestó al naturalista sueco Nilsson un excelente obscrvador. Despues cuando quieren remontarse de nuevo levantan las alas casi verticalmente y se separan del agua de un solo aletazo.

Sus sentidos alcanzan bastante desarrollo; pero no se halla tan bien dotado por lo que hace à la inteligencia. Carece tambien de la nobleza y de la majestad del águila leonada,

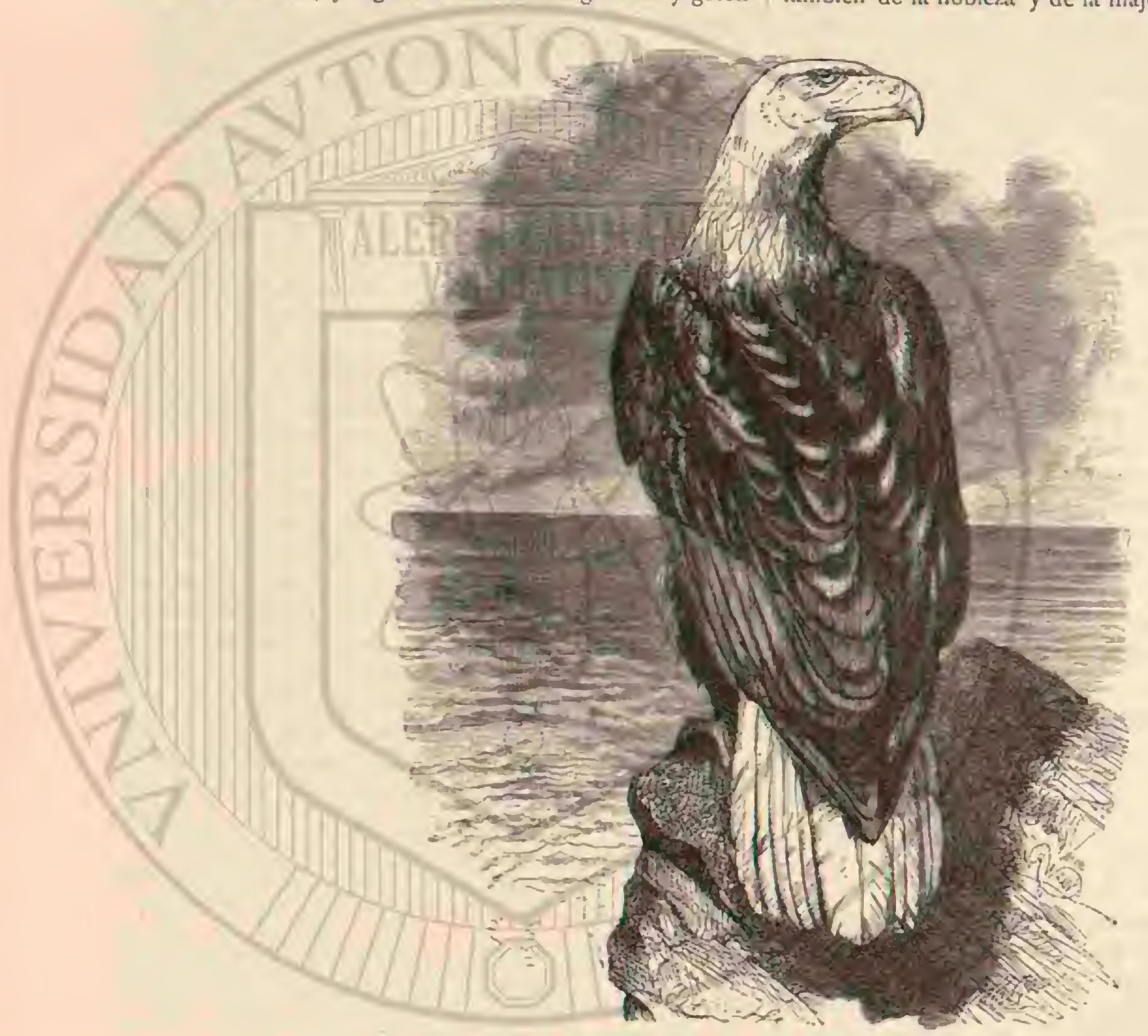

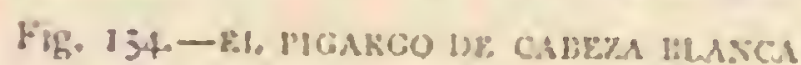

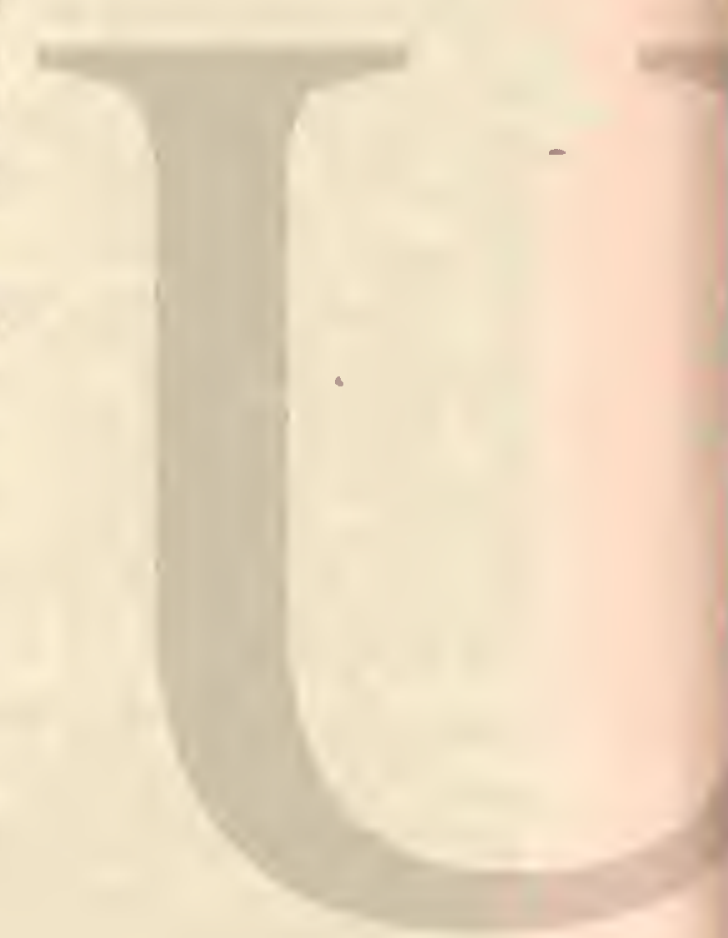

pero se distingue en cambio por su valor y bravura lio he visto dos buzos encerrados en una misma jaula con un águila leomada, la cual soportaba su presencia como el leon la del perrito; mas habiendo puesto estos dos buzos con un pigargo, fueron derorados á los pocos minutos.

Dehne vio tambien â una de estas rajaces domesticada despedazsi en un momento a un balbusardo que le dieron por compåero. Los pigargos diel Jardin zoológico de Ham. burgo están en continua lucha con los buitres; pero por for. tuna estos saben defenderse vigorosamente.

Los pigargos se reproducen por el mes de marzo: es pro bable que contraigan lazos indisolubles para toda la vida, aunque siene el macho rivales con los que debe sostener rudas luchas; y si es vencido puede perder su compañem. ¿Dos machos que observe largo tiempo, escribe el conde de lYodzicki, peleaban continuaniente: descargábanse picotazos y golpes de garras; caian a tierra juntos; volvianse á levantar pam luchar de nuevo, cubriendo el suelo de plumas y de sangre. La hembra presenciaba la pelea, sin tomar parte, y dispuesta a rendirse al vencecior, como asi lo hizo. Ios dos machos eran de edad difurente, y se les reconocia con facili. dad. Ayuella lucha sangrienta duró unos quince dias, $y$ las rapaces se cxcitaron de tal modo, que no pensaban en conter: por la noche se posaban en dos árboles: la hembra y el rencedor en uno, y el rival en otro. Al cabo de un mes se halló en el bosque un nido de pigargo: algunas semanas nas tarde se cogieron los hijuelos, $y$ a poco volvieron los padres al lugar donde se habian unido. Habiéndose presentado un nuevo macho, comenzaron otra vez las luchas: cierto dia se acometicron los dos rivales en los aires y cayeron juntos á tierra; el uno derribó á su adversario, dióle varios picotazos con toda su fuerza, salio sobre el, y cogiéndole por la garganta con una de sus garras, le clavó la otra en el vientre. Bl vencido se conzó á la pata y al ala de su enemigo; un lentador sor. prendió á los combatientes en aquel momento, y acercándo. se á ellos, mató á uno de un palo; cl otro, iodo cubierto de sangre, se enderezó sobre el cadáver de su rival, y frjó en el hombre una mirada con tal expresion de ferocidad, que aquel retrocedió espantado. Solo al cabo de un instante compren. dió el ave el peligro que le amenazaba y se remontó con 
lentitud: si el hombre no hubiese tenido micdo, hubiera ma. tado segurnmente a las dos rapaces.

- Se puede colegir que el tercer pigargo habia estado entre tanto solitario, progectando su venganza como los corsos, dispuesto à utilizar la primern ocasion para llevarla a cabo.

En Hungria me contaron tambien que no era raro ver lu. char a los pigargos, muy comunes alli, en las altas regiones del aire; y una vez cayeron al Danubio, segun me refirib el ayudante de montes Ruzsovitz, dos machos tan agarmdos y con las uñas tan clavadas uno en el cuerpo del otro, que flotaron en la corriente bastante mto como un confuso é informe monton de plumas.

Segun las circunstancias eligen los pigargos para su nido, ya un sitio, ya otro. Alli donde forman la orilla del mar es. carpadas rocas encuentran estas iguilas sitios á propósito; si $a$ lo largo de la costa ó de anchas corrientes hay bosques eligen un árbol alto; donde estos faltan y hay abundancia de pescado se suelen contentar con matas miscrables que con

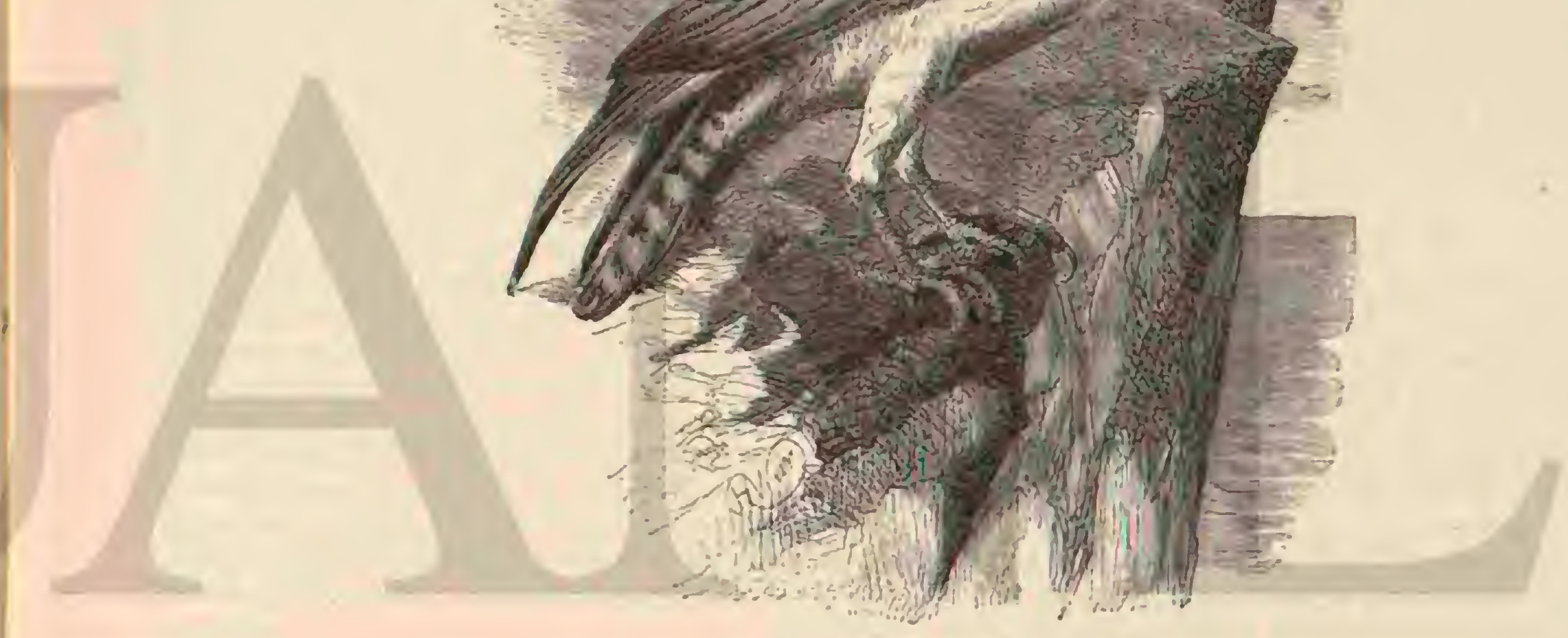

FIg. $1550-86$ 11A1.RL518110 T'ESCALOR

trabajo sostienen la balumba de su nido; y á falta de matorral lo construyen hasta en canaverales, donde son mas espe sos 5 impenetrables. A este efecto rumpen en un gran cir cuito las cañas hasta que formen un leclio bastante resistente sobre el cual reunen los materiales hasta la altura de un metro sobre el nivel del agua. En las estepas se arteglan del mejor modo que pucden; probablemente en cañizares si hay lagos, y en caso necesario simplemente en el suclo. Fin toda la costa del Báltico eligen para el nido, segun Hottz, árboles altos, especialmente pinos, y despues hayas y robles desde donde pueden dominar con la vista ya el próximo bosque, ya los prados y aguas. Ei nido es en todos los casos una cons. iruccion imponente de $1^{\prime \prime}, 50$ \& 2 metros de diámetro por $4 ", 30$ hasta un metro de altura, pues tambien sirve a la pareja para muchas crias, a cada una de las cuales lo aumentan y perfeccionan. Ramas del grueso de un brazo forman la base; sobre esta colocan otras mas delgadas, y ei nido propiamente dicho lo forman con ramias tiernas cubiertas de yerba seca, liquenes, musgos y otros materiales por el estilo. Durante la excursion de caza del principe imperial Rodolfo, mencionada repetidas veces, exploramos diez y nueve nidos de pigargos; seis de los cuales estabar sobre robles, otros tantos en chopos negros, cinco en chopos blancos y dos en hayas, casi todos en las islas del Danubio, algunos en los magríficos bosques de la Fruscrgora á cuntro ó cinco kilómetros del rio en línea rec. ta. Dos de estos nidos se hallaban construidos en las ramas mas altas del centro, tres en ramas secundarias, y los demás en las bifurcaciones junto al tronco. La base de seis de estos nidos consistia en palos gruesos, y la de los demás en ramias que apenas tenian una pulgada de diámetre. I.os menos eran nidos de grandes dimensiones á pesar de que algunos servian ya diez y seis años sin interrupcion para las crias de los pi. gargos mas vicjos; siendo la mayoria hasta relativamente pe. queños, y 1 excepcion de dos, rodos alurigaban numerosas colonias de gorriones del campo.

Hacia in de marzo, rara vez antes y casi siempre algo mas tarde, qqueda terminada la puesta, consistiendo en dos, y lo mas en ires hucros relativamente pequerios, pues miden solo de $0^{m}, 67$ a $0^{m}, 73$ de largo $y^{\circ}$ de $0^{m}, 53$ a $10^{\circ}, 57$ de grueso, de forma y color variables. Ia ciscara es gruesa, aspera y de 
grano basto, y en cuanto á coloacion, los hay blancos como la cal, sin ninguna mancha, y otros que sobre igual fondo jresentan manchas rojizas, pardas ó pardo.oscuras. No se sabe todavia de fijo el tiempo exacto que dum la incubacion; pero si que el macho ayuda a la hembra ś cubrir, y que se posa a cierta distancia del nido en una peña ó risco que le sirve de atalaya para acudir en auxilio de su compañera al menor indicio de peligro.

Fin vista de un hecho que observe he de creer que tam bien auxilia a la hembra materialmente en caso necesario, pues habiendo herido gravemenie en la fruscagora son pigargo hembra, encargué á uno de los monteros del principe que me acompañaban que la buscase en el forido del ralle, a donde habia ido revoloieando. Poco despues oigo encima, al lado y debajo de mi un estruenda como de uma rifagr de viento huracanado y veo pasar como un rayo por delante de mi choza una ave de gran tamaio. Mas tarde me contólel montero que un pignargo se habia casi precipitado sobre él, por to cunl turo que guarecerse rippidanente detrás de un arbol cuando el ave cstaba ya con sus garras aliertas y echadas hricia delante, solo a medio tiro de su escopeta. Como en iodo el contorno no habia mas que una pareja de cstas águilas, es de presumir que arquelln are fuese el macho, que iba a tomar venganza de la imicion de gue su parcja liabia sido victima. Jamás se han obseriado atajues como este junto al nido, al menos que yo sepa, porque alli se muestran los pigargos siempre cautos y recelosos. Cuando la hembra cưbre no está excesivamente aferraủa al nido como otras fyuilas, pues lo abandona ajuras se da un golpe en el; tam. poco suele rolver al poco rato, sino déspues de liaber des. crito muchos circulos sobre el árbol donde dicho nido se halla. Iracho y hembra llevan a sus aguiluchos, al igual de otras especies de la familia, increible abundancia de alimentos, y á medida que los pequeños medran se vuetven los viejos mas atrevidos y van trasformando el nido en un ver. dadero matadero donde pueden encontrarse restos de toda clase de animales, peto principalmente de peces y de aves acuáticas. Apenas han atrapado algo dirigense con su botin al nido sin perder momento, atravesando distancias de cua. tro á cinco kilómetros con hal rapidez que llegran con el pez todavia vivo, segun pudo comprobar el conde de Bombelles que formaba paste de nuestra comitiva de caza en Hungria. Cuando van cargados de botin descuidan los pigargos todas sus precauciones acostumbradas, no describen círculos so bre el nido, sino que se lanzan sobre el mismo en direccion oblicua como una piedra y con tal relocidad que el mejor $t i$. rador no riene tiempo de apuntar siquiera. Si uno de los polluclos cae del nidoy no sucumbe á consecuencia del golpe, lo alimentan los viejos en tierra lo mismo que si estuviera en aquel; cuando perecela hembra se encarga el macho del cuidado de sus hijos, los cuales necesitan en circunstancias favorables de diez á catorce semanas para empezar á volar, aun entonces no se alejan del nido. Hasta el otono no se separan los jóvenes de sus padres.

Cuando sê roba á una pareja de pigargos la primera pues. ia, se resuelve d reces, aunque no siempre, á hacer otra, pero en este caso la limita la hembra casi siempre á un huevo que pone por lo comun en el mismo nido, al cuai tienen estas como las demás águilas grandisimo apego. La pareja no abandona la comarca aungue se la moleste de cóntinuo, y aun pasa el invierno, por poco que sea algo benigno, en las inmediaciones de su nido, ype viene à ser como el centro de su distrito.

Si el pigargo causa menos dano que el águila comun es solo porujue saca una gran parte de su alimento del agua. lin Hungria se oyen pocas quejas respecto á esta ave: alli no hacen caso de los peces que saca del Danubio y de sus afluentes, ni dan gran importancia á tal cual otra cxtralimiiacion mas sensible de la rapa\%, sucediendo otro tanto en Rusia y Siberia No solo no cede el pigargo al aguila comun en rapacidad y en los perjuicios que causa al humbre en su hacienda, sino que i ser posible la supera alli donde establece su nido próximo á lugares poblados; caza en los campos y aun en los mismos corrales de los caserios, causando estragos entre las aves domésticas, por cuanto solo saben escapar de sus uñas los palomos de diestro vuelo, cuando no escóge alguna pieza de entre los cuadrúpedos domésticos jóvenes ó pequeños, cosa quue sucede con bastante frecuencia; todo esto sin contar el daño que causa en la cáza. Alli, por sujuesto, persiguen al pigargo con la mayor diligencia, solo que cl ave, merced a su destreza, pocas reces se deja coger, pues, es. quiva y recelosa siempre, no se deja acercar ni sorprender, sobre todo si ha sido ya perseguida. Siempre se levania antes que sea posible tenerle a tiro, tanto si estí en el suelo como posada en un árbol.

CAYA. - El modo mas fácil de tirar al pigargo con buen évito es desde la choza si el carador no pierde la paciencia, pues, esta ave particija del odio que todas las de mpina diurnas sienten hácia el buho. A falta de este útido acuden tambien ála carnaza expuesta el aire libre, pero que puede tambien servir de cebo en un armadijo de hierro colocado en un sirio visible y despejado, el cual da un resultado mas seguro yue la escopleta, ahorrando tambien tiempo. Cada año se cogen algunos pigargos en trampas cebadas para zorras, de modo que su yista penetrante hasta les permic divisar un cebo tan insignificantie como este. Tales percances no son los tinicos í que los expone su rayncidad, pues en una casa de labranza cérca de Torchlein cogieron y mataron en 28 de diciembre de 1853 un pigargo jóven que hacia tiempo rondaba por aquel distrito. En Noruega se oculta el cazador en una pegureña choua formada con picdras, poniendo á corta distancia un pedazo de carne sujeto á una larga cuerda, cuyo extremo libre tiene el hombic en su mano. Cuando el pigargo hace presa, el cazador atrae hácia sí la carne, y como la rapaz no suelia lo que una vez ha cogido, acércase lo bastante para poderle tirar 6 atraparla viva. lin este uiltimo caso es preciso obrar con mucha prudencia, porque el pigargo conoce sus fueras, y en caso de peligro se sirve de sus armas naturales. Esta ave se aleja del hombre todo lo que puede, y ni nun ataca al que le arrebata su cria; pero si cae viva en poder del cazador, defiéndese valerosamente y puede ser tan peligrosa como la harpia.

UTILIDAD. - En nuestro pais lo único que se hace con el pigargo muerto es disccarle, pero no sucecie lo mismo en la Italia meridional, ó cuando inenos en Sicilia; pues alli co. men s1! carnc.

CaUTIVIDAD. - los pigargos caurivos son al principio indomables, y acometen á su guardian; pero no tardan en domesticarse y en cobrar afecto al hombre. Por esta cualidad son apreciados de todos los directores de los jardines zoolo. gicos: cuando la rapar ve á su amo, salúdale con gritos ale. gres y penetranies, distinguiéndole entre otras personas. Con el tiempo se acostumbran estas ares a su nueva vida, hasta el punto de olvidar su perdida independencia. Hace algun tiempo que se escapó uno de nuestros pigargos á los alrededores: pero iba diariamente al jardin, atraido sin duda por los gritos de sus compraneros, hasta que al fin se le cogió, hallíndose posado sobre su pajarera. Cuidándolos convenien. temente viren mucho tiempo en cautiviciad tanto como cual. quier otro congénerc suyo: citanse casos en que estas aves vivieron cuarenta anos en jaula, habiéndose observado que no echaron su plumaje de adulıs sino á los diez ó doce 
anos. Ha labido otros en que hasta pusieron liueros; entre otros el de una hembra que tuvo Panier, la cual ponia cada año un hucvo, gque defendia de todo el mundo con sus terri. bies armas. Esto prueba que los pigargos criarian sin dificul. tad en cautividad una vez acostumbrodos á ella y en pajarems basiante espaciosas cionde no se los molestara.

\section{EL PIGARGO MARINO - HALIAETUS PELA- GICUS}

CARACTÉRES. - Es el mayor de todos los pigargos y habita el Asia oriental.

\section{EL PIGARGO VOCINGLERO - HALYAETUS VOCIFER}

CARACTERES.-Esta especic es la mas hermosa del género y en general de todas las especies de aves de rapi. na; tanto que embellece positivamente el pais que habita. Los individuos adultos tienen de un blanco deslumbrador la cabeza, cl cuello, la nuca, la parte anterior del pecho y la cola. El lomo y las pennas de las alas son negros azulados. El borde de las alas, es decir, todas las tectrices pequeñas y superiores desde el codo hasta la mano son como el abdó. men de un tinte rojo pardusco magnifico. Lil circulo ocular, la carn y las patas son amarillo claros; y las dos mandibulas negro-azuladas. En los pequeños son las plumas de la parte superior de la cabeza de un color entere pardo, gris y negro mezclado de blanco; la parie postcrior del cuello y la nuca son blancos con mezcla de gris pardusco; el dorso es pardo negruzco; la espaidilla y la parte inferior del lomo, blancas con manchas negro parduscas en la punta de las plumas; la parte anterior del cuello y la superior del pecho tienen manchas longitudinales sobre fondo blanco; tel resto de la parte inferior del cuerpo es blanco; en la anterior del perho se ven cu algunos punios rayas céntricas longitudinales parduscas ó manchas pardas; las rémiges son pardas, en la raiz blancas, y finalmente las rectrices son blanquizcas salpicadas de pardo y con las puntas del mismo color. El plumaje de los indivi. duos jórenes no se trasiorma sino despues de muchas mu. das y como es probable, sucesivamente, segun sucede con el pigargo de la América del norte I.a longitud de esta ave es de $0^{\circ}, 68$ hasta $0^{\circ}, 7^{\circ}$; el ala plegada mide $0^{\circ}, 50, y$ la coln $1 \|^{\prime \prime}, 15$.

DISTRIBUCION GEOGRÁFICA.-EI pigargo rocin glero fué descubierto por Le Vaillant en el sur de Africa; mas tarde se le encontró en el Airrica occidental, y otros viajeros y yo le hemos observado á menudo en el interior de aquel continente.

Su área de dispersion se extiende por la mayor parte de la region ecuatorial del Africa, ó mejor dicho, desde los $\imath S^{\natural}$ de latirud norte á poca diferencia hasta el pais del Cabo, en don de habita y anida como en toda el Africa oriental hasta la confuencia del Atbara con el Nilo; desde alli en las orillas de todas las corrientes y lagos del interior, y despues desde el Senegal otra vez hasta el Cabo.

USOS, GOSTUMBRES Y REGIMEN.-Dice Le Vaillant que se encuentra esta rapaz a lo largo de lis costas, y excepcionalmente en las orillas de los grandes rios; yo no la vi sino en las del Nilo Azul y del Nilo Blanco, y jarnás en las costas, ni del mar Rojo ni del golfo de Aden. Heuglin con. cuerda conmigo ! completa mis observaciones diciendo que estas águilas se encuentran á reces en lechos medio secos de aguas pluriales con tal que al rededor haya monte alto. F.s basiante comun al sur de la conRuencia de los dos Nilos, y rara vez se deja ver mas al norte: habiea las selvas virgentes del Surian, donde se le debe ver pama admirar toda su beileza. Una pareja de estos pigargos, posada en un árbol que se inclina sobre el agua en medio de una espesura impracti. cable de lianas, ofrece un curioso especticulo, y por muy acostumbrado que esté el naturalista á ver en aņuellas ricas regiones aves de plumaje mas espléndido, el aspecto de esta magnifica rapaz. le causa verdadera admiracion.

Este pigargo se asemeja mucho à sus congéneres en cuanto á los usos y costumbres: vive casi siempre por parcjas, y cada una de cllas ejerce su do:ninio en un terreno de treskilóne. tros de extension. Por ia mañana vagan de un punto ś otro; hácia el medio dia se remontan por los aires y trazan circulos lanzando gritos penetrantes que se pueden oir desde muy léjos.

(La po:encia rocal de esta ave, dice Schweinfurth, que habla con entusiasmo de los pigargos vocingleros, no tiene igual en el mundo alado. Sus gritos, que la superficic del agua lleva á grandes distancias, resuenan siempre cuando menos se piensa. Al oirlos, crecriase que son chillidos de mujeres espantadas, y otras veces se parecen a la alegre griteria de una multitud de chiquillos juguetones quse salen repentina. mente de un escondrijo y' llenan el aire con su bulliciosa al. gazara; tan completa es la ilusion que me ha engariado siem. pre, y he vuclto involuntariamente la cabeza para ver à las personas que asi gritaban. Como los gritos constitujen el carácter principal de los vocingleros, los llaman los sudaneses enquié, que significa esacerdote. Sus movimientos, cuando vuelan, llegan á ser muchas veces a violentos, que no parece sino que a cada paso han de dar bruscas volteretas. Al medio dia y hácia la tarde descansan en la copa de un árbol ó sobre un tronco arrojado por las aguas a la orilla, permaneciendo juntos el macho y la hembra, oprimidos uno contra otro. Si divisan alguna cosa nueva, el primeto que la ve lanza un grito, echa la cabeza hícia atrats, ensancla la cola en forma de abanico. la levanta jor encima de Las alas y produce sus gritos chillones y penetrantes con toda su fuerza. Cada pareja liene su lugar farorito, y una vez descubierto se puede volver a encontrar con seguridad: para pasar la noche se retira el pigargo vocinglero a los parajes mas sombrios del bosque, donde los loros, que tambien habitan aquelios sitios, le adormecen con su voceria desentonada. Dice l.e Vaillant que es sagaz y tínido, mas yo he observado todo lo contrario, pues en el Sudan no se le cazat nunca, y por eso no le inspiran temor los hombres, ó cuando mas se admira de su presencia; solo cuando ha sufrido alguna persecucion comienza a ser receloso: pero yo he visto un pigargo que permanecio inmóvil despues de silbar una bala en sus oidos, lo cual me permitio enviarle una segunda, que puso fin á su vida.

Esta rapaz se alimenta de peces o de restos animales: procediendio com? el balbusardo, déjase cacr desde lo alto sobre los primeros, o pesca los que flotan, sumergiindose profun. damente y remontando luego con algunos aletazos pesados. Tambien come los restos, que encuentra en ticrra. Los sudaneses dijeron a Hartman: que saci conchas grancies del agua y las quicbra contra las piedras. Traslada sicmpre su presa a las pecuenas islas $y$ la devora a orillas del agua. Po he visto \{ uno de esios pigargos perseguir á una garza real;y observé á oiro que devoraba un milano cazado por mí pero no creo que acometa a otros vertebrados majores como supone Le Vaillant, quien halló osmmentas de gacela en los restos de su comida.

Con las demás rapaces no se muestra el pigargo vocinglero nada benévolo: acomete principalmente a los buitrés con furor; su agilidad y destreza le asegruran siempre la victoria. No sufre competidores en su distrito. Heuglin vió cómo un vacingleto acometió con grandes gritos a otra ave de rapina, 
obligándola á abandonarle el pez que llevaba. Livingstone le observó repetidas veces arremetiendo i los pelicanos hasta que le arrojaban los peces que tenian en el esólago; pero en cambio no falta quien se aprovecha i su vez de sus presas.

Cierto dia vi una hembra de este pigargo que despues de haber cogido un gran pez se disponia a derorarlo sobre un banco de arena, á orillas del Nilo Azul. Con el auxilio de un buen anteojo de larga vista me era fácil seguir todos sus mo. vimientus, y observé que arrancó la piel á su victima, devo. rárdola lıego con mucha limpieza. Nientras estaba ocupado asi pareció un avisador del crocodilo (Hyas agriptincus) y aproximándose d la rapaz, tomó parte en su comida Era muy curioso observar los movimientos de aquel váliente y peque. no parísito: llegaba como una flechá; cogia mipidanénte al. gunos pedazos, é iba da comérsetos á corta distancia: de ver. en cuando dirigiale la rapaz una mirada casi benś:ola, y no intentaba acometerle Circo, no obstante, que el avisador del crocodilo no debió su salvacionisino al la rapidez de sus movimientos Las funciónes que desemperta cerca del saurio, le habian enseñado sin duda lo que se debe hacer para partici. par del banquete de los animales ternibles.

Ls probable nue anide en el Sudan á principios de la estacion de las lluvias, época en que tió hemos podido reconocer las selvas virgenes.

Mas tarde, ó sea en los últimos meses del ano, no encontramos ninguna de estas aves anidando, y por lo tanto no me es posible decir nada por mis propias betservaciones acerca de su manera de reproducirse. Le Vaillant dice que cons. truyen su nido en la copa de los f́rbóles mas altos ó sobre una raca, y que sus hueros, en núniero de dos 6 tres, tienen un color blanco puro. Heuglin supone, contra lo yue yo opino, que la época del celo cae en los meses de lébrero y marzo, por cuanto entonces se oyen resonar con mas fre cuencia fior las selvas vírgenes los gritos de llamada del ma. cho. Antinori dice que los vocingleros efectuan la cópula rolando ; y Heuglin tha visto quue juguetean picándose y persiguiéndose, oralal través del espeso ramaje de los árboles, ora remontándose \& las altas regiones aćrcas, ó licen precipi. tíndose casi hasta tocar la superficie del agua donde roltean y ruedan un rato para remontarse ntra vez y empezar de nuevo el mismo juego. Hé aqui todo lo qué sé respecto á su rejroduccion.

CAUTIVIDAD. - Este pigargo se conduce lo mismo que sus congéneres cuando está cautivo: domesticase rápidamente $y$ lanza un grito penetrante cuando ve a su amo. Parece que resiste sin dificultad los rigores de nuestro clima, pues en los jardines zoológicos viven estas rapaces todo el año al aire libre.

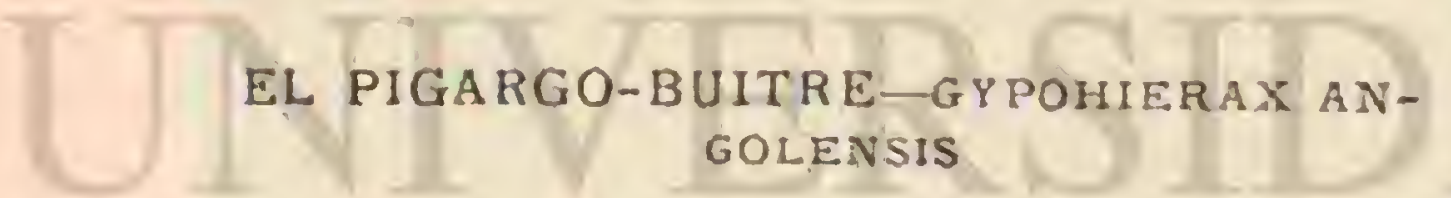

CARACTÉRES. - Se me resiste dar aqui cabida a esta rapaz, que los naturalistas modemos agregan fo las iguilas,

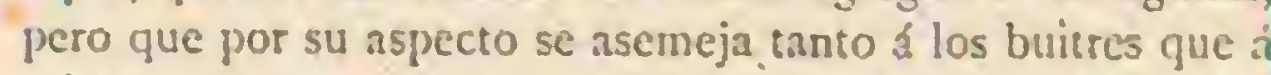
primera vista cualquiera la colocaria entre estos últimos. Del águila solo tiene la estructura de Ja paia y el género de vida. lil pico es rolusio, pero prolongado y muy angosto; la mandibula superior es suavemente encorvada, corta, formando un ganclio romo y desprovista de dientes en lus bordes; la inferior es robusta, dos tercios mas alta que la primera, con la cern hasta la mitad de su longitud; las fosas nasales forman una hendidura ancha y algo oblicua de delante atrás; la linea naso-ocular esti desnuda: la pata es débil, el tarso cubierto de pequeñas placas córncas exagonales, y las garras armadas de uñas medianamente grandes y corvas. $\mathrm{El}$ ala, con la terce. ra, cuarta y quinta rémigges mas largas que las dentas, es larga y puntinguda, y la cola, formada de doce rectrices, es bastan. te corta y un tanto redondeada. El plumaje del ave adulta es de un blanco puro, excepto las puntas de las rémiges primarias, las secundarias, las plumas de la espaldilla y una faja ancha, que son todas negras. El tinte del ojo es anaranjado claro, el pico gris azulado, la cera de un amarillo sucio, la linea maso-ocular anaranjada 6 amarillo rojiza y las patas color de carne. Cuando jóven es el plumaje uniformemente pardo oscuro y el ojo pardo. Para la trasformacion completa del plumaje del individuo jóven se necesitan por lo meros de tres \& cuatro años, efectuŕndose el cambio paulatina y parcialmente en cada muda, segun ha observado Reichenow; de lo cual resulta que se encuentran muchas águilas buitres manchadas de blanco y pardo, predominando, segun la edad del animal, ya el uno, ya el otro de estos dos colores, hasta que en la uiltima fase del plumaje del jóven se presentan las plumas blancas oriadas de pardo amarillo, lo que da al ave un aspecto sucio como si se hubiese revolcado en el barro. Esta especie mide $11^{\circ}, 60$ de largo, el ala plegada $1^{m}, 40$ y la colin $(1), z 0$.

Hnsta epoca muy reciente poco era lo que se sabia sobre esta ave conócida ya de un siglo atrass. A Reichenow debemos un conocimiento mas exacto de ella y hé aqui lo que ha énida la bondad de escriluir para la presente obra:

DISTRIBUC.CION GEOGRÁFICA. - El aguila buitre es comun en los países ecuatoriales del Africa occidental, mientras que éri la parte oriental, es decir en la isla de Pem. bai, al norie de Zanzibar, solo se ha cazado una hasta ahor?. Hin las cóstas necidentales del Africa, y dentro de los límites indicados, es esta especie una de las mas frecuentes entre las aves de rapisa. Desde la Costa de Oro hasta el Gation la he encontrado en todas partes donde era posible que existicra.

USOS, COSTUMBRES Y RFGIMEN.-W Ictióago ante todo, su existencia depende del agua, ๖por consiguiente no se aleja dé las costas del mar y de los rios; tan raro es en las mesetas altas y en las montañas como nuestro pigargo en cl interior de Europa. Los lugares mas propicios para esta especie son los terrenos pantanosos próximos á los rios, y nuy particularmente las descmbocaduras de estos, donde las incalculables masas de lama que arrastran las grandes corrientes del Africa occidental enturbian el agua hasta muchas leguas mar adentro $y$ forman deltas y alfaques, á menu. do de extension muy considerable. Estas ticrnas pantanosas, cuya regetacion consiste principalmente en inanglares, pero que producen tambien la palmera vinifera y el pandano espinoso, se hallan cruzadas por estrechos canalizos, y junto á ellos planta sus reales el águila-buitre, siencio tan comun olli que puede decirse que, junto con el escopo, caracteriza el pais. Alli se les ve ya posadas en la copa de un árbol solas ópor parejas, descansando y digeriendo, ya jugando y describiendo círculos en el aire y a gran alturn, ó bien rasando la superficie del agua en busca de botin. Posada parece esta are positivamente un buitre, a pesar de su posicion bastante er. guida, pues lo que mas se destaca, dandole tal parecido, es el flico $y$ la cara desnuda, de modo que solo se reconoce que es aiguila cuando remonta el vueto. En ciertos detalles de su modo de ser se asemeja támbien á nuestro pizaryo, solo que sus movimientos son mas lentos; cuando vuela es mas ma. niliesta su semejanza; entonces, proceciendo como el pigargo, se solaza revoloteando a gran altura: de pronto desciende un buen irecho, ciérnese tranquilamente en el espacio y vuclve á remontarse, sin agitar casi las alas. Esia ave difiere del pigargo por su modo de cazar que se parece mas al de los mi. lanos. Se cierne á poca altura sobre la superficie del agua, y cuando atisba un per baja con cicrta indolencia describiendo 
un arco, para cogerlo. Jamas la vi precipitarse como el rayo sobre su victima acuática. Parcce que aparte de los peces se alimenta tambien de conchas y aun podria ser que alguna que otra vez sorprenda algun mamifero ó are. Varias veces la he visto perseguir loros grises, que huian de ella con visible angustia, y lanzando penetrantes graznidos. Al principio pareciame qque lo hacia a manera de juego, pero desde que Uisher vio un águila-buitre precipitarse sobre un cabrito, creo probable que persiga en realidad a los loros jacos. Lo que no creo es que coma dítiles, conforme asegura Pel.

> En esta ave llama la atencion su taciturnidad, pues jamás la he oido emitir un solo grito, y eso que la observé por espacio de seis meses casi diariamente en las tierras bajas de Camerun.

\$ Los nidos que vi estaban invariablemente en el árbol mas alto del distrito une recorria cada pareja. En la época del celo suclen abandonar estas àguilas las tierras próximas a las desembocaduras para subir rio arriba y establecer sus nidos en los gigrantescos baobabs, mas propios que los bajos man. gles. Tambien utilizan el mismo nido una serie de años, por lo cual suele adquirir dimensiones considerables. Dos huevos componen al parecer la puesta: y digo al parecer, porque des. graciadamente no me fué posible cerciorarme de ello ni menos hacerme con los huevos, a causa de lo inaccesible de los nidos establecidos sienupre ó en la clíspide del árbol 6 en las bifurcaciones de las ramas. Sin embargo, los negros saben arreglarse para saquear estos nidos, pues de otro modo no se explicaria cómo pueden remitirse á Europar aguiluchos vivos de esta especie, cosa q̨ue sucede como es sabido.

He visto estas aves en diferentes jardines zoológicos, y aun he podido observar algunas por espacio de bastante tiempo. Las que se ven suelen ser jóvenes, de lo que puede inferirse que las águilas-buitres cautivas perecen en su mayor parte en los primeros años. Sin cmbargo, en el jardin zoológico de Lóndres, que posee la coleccion de animales mas rica del mundo, vive acaso todavia una de estas ares que en el mismo jardin llegó á su edad adulta. A pesar do todos mis esfuerzos, no he podido observar nada en las águilasbuitres cautivas que pudiera venir en apoyo de la preten. sion de agregnt estas ares á las águilas. Yor su aspecto siem. jre me parecieron buitres pequeĩos. Si algun atractivo 6 interés ofrecen es únicamente para el especialista; pues hasta las personas legas, pero amantes de los animales, las miran con la mayor indiferencia. Siempre se las ve como clavadas en el mismo sitio, por lo comun en el suelo de su jaula, sin hacer el menor-caso de lo que pasa á su alrededor, aun cuando no dejan de observarlo todo con atencion; tampoco se nota en ellas la menor emocion cuando se les echa su comida. Se aproximan lentamente a coger la carne que seles da, la asen con una de sús garras of la roen mas bien que la destrozan, enternmente como los buitres. Ia única ocu. pacion a que se dedican sin descanso, consiste en alisar su plunaje, y á pesar de esto parecen siempre sucias y desarregladas. En una palabra, son las aves de rapina mas fastidiosas que pueden tenerse cautisas.

\section{EL BALBUSARDO PESCADOR - PANDION} HALIAETUS

CARACTERES.-Los balbusardos constituyen el último género de la familia de los aquilidos: difieren mucho de las otras especies, pudiendo considerarse como el tránsito de aquellos a los milvidos y como una sub fanilia particular (Pandionina). Son relativamente de pequeña talla, pero muy robustos; se distinguen por los siguientes caracteres genéricos: cabeza de tamaño regular; pico bastante corto, Toso III encorvado desde la cera, y en exiremo ganchudo; alas muy largas, con la tercera rémige mas larga que las demás, y que sobresalen mucho de la cola, que no es corta; tarsosfuertes, apenas cubiertos de pluma por debajo de la articulacion tibio-tarsiana, y protegidos, asi como los dedos, muy robus. tos, por escamas reticuladas, pequeñas y gruesas; los dedos son relativamente cortos, provistos de unas fuertes y aceradas, pudiendo inclinarse el externo hácia adclante ó atrás: el plumaje caracteristico en estas ares es liso y aceitoso. Esta

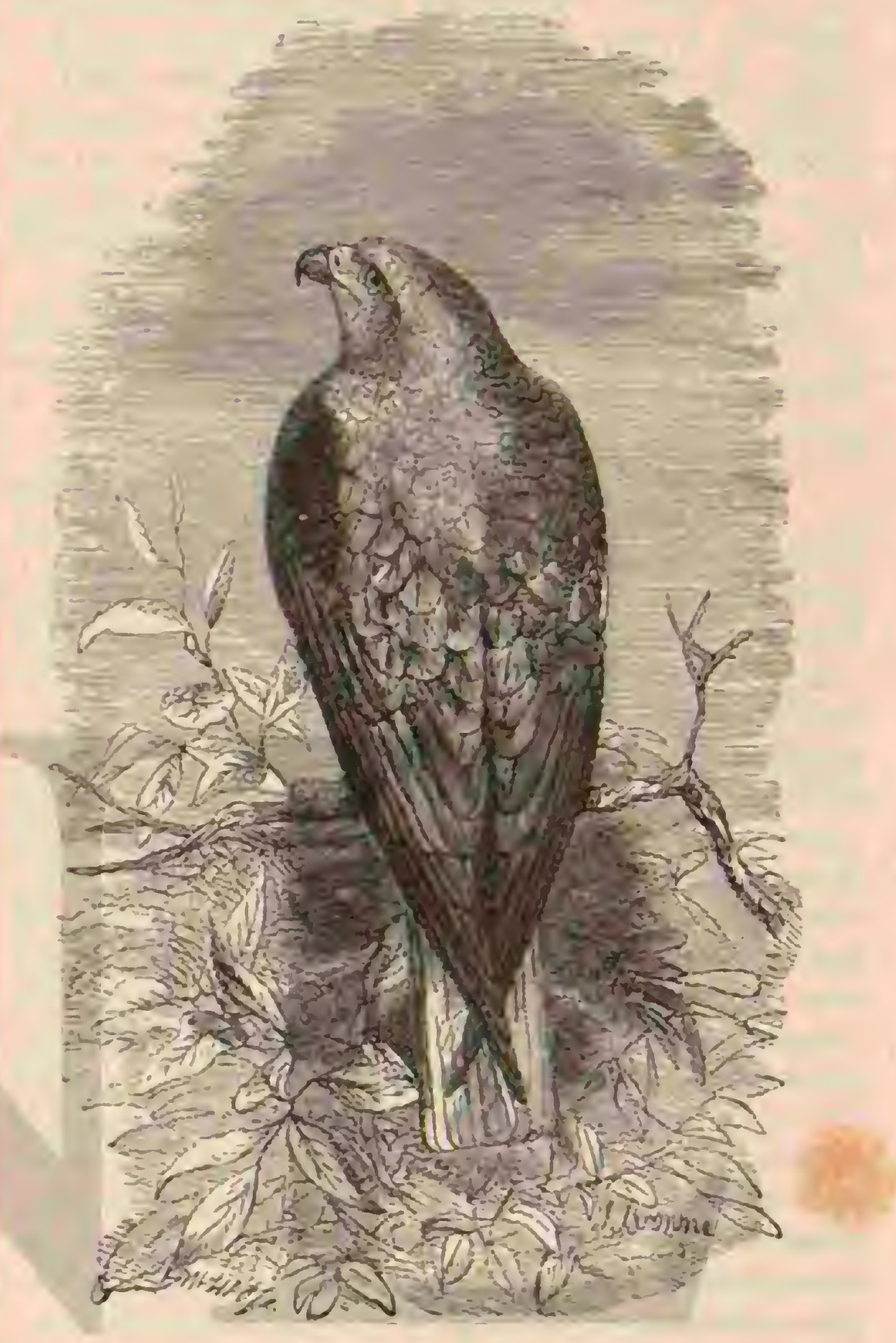

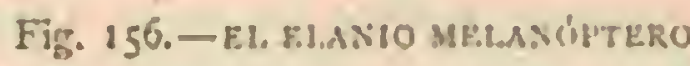

rapaz tiene las plumas de la cabeza y de la nuca muy adel. gazadas, de color blanco amarillento con rayas longitudina. les de un pardo negro: el lomo es pardo, con un filete pálido en cada pluma; la cola está listada de pardo y negro, el vien. tre es blanco ó blanco amarillenio. En el pecho hay una mancha parda, en forma de escudo 6 de collar, rnuy marcada unas veces, apenas visible otras; desde el ojo, qque es amarillo oscuro, corre hasta el ceniro del cuello una faja de color mas oscuro; la cera y las patas son de un tinie gris de plomo, y el pico y las uñas de un negro brillante (fig. 155).

Ia longitud es de $10^{*}, 5 \hat{A}\{(=, 56 ;$ cl ancho de punta $i$ punta de ala de $1 ", 56$ \& $1^{\circ}, 64$, esta plegada mide de $0^{\circ}, 50$ à $l, m, 52$, y la cola de $0 \%$, is á $11^{\prime}, 10$.

DISTRIBUCION GEOGRÁFICA. - El balbusardo pescador es una de las pocas ares que están diseminadas literalmente por toda la tierra. Se ha tratado de hacer distinciones y separaciones entre los balbusardos americanos, asiáticos, oceánicos y el nuestro de Europa: pero de la comparacion de un gran número de pieles de balbusardos resulta que es. tas diferencias no están bastante justificadas. Los balbusardos de los diferentes paises presentan todos los caractéres que, 
juntos con la identidad de su género de vida ca las circuns. tancias mas variadas, prueban paladinamente la unidad de la especic. El balbusardo anida en todos los paises de Eu. ropa desde Iaponia, Finlandia y Rusia septentrional hasta el punto mas meridional, en las islas $y$ aun en los islotes mas pequerios del mar. En Asia habita junto á todos los rios $y$ lagos tanio en el norte como en el mediodia durante todo el año, como igualmente en muchas partes del Africa. En este último continente, en tanto que hasta hoy se ha recorrido y esiudiado, aparece el balbusardo en todos los sitios i propósito, siquiera temporalmentc; y en América se le ha observado desde los puntos mas septentrionaies donde las aguas yuedan algun tiempo deshelintas hasta el Brasil me. ridional. Finalmente, en Australia no talta esta ave en ninguna parte donde las condiciones del terreno le son propiciss. En el norte es el balbusardo are de paso ó scia de verano, $f$ en el mediodia il parecer errante.

USOS, COSTUMBRES Y REGIMEN, - Su género de caza limitado \& una especialidad, la pesca, es el factor que determina su mocio de vivir, pues se alimenta casi exclusiva. mente de peces, y solo en casos apurados de anfibios.

Se comprende pues la causa de que esta are de rapina, tan odiada como perseguida, se esiáblezca solo en comarcas donde abundan las aguas; pero en sus emigraciones lo recorre todio, 5 hasta el estanque mas insignificante la atrae. Ian luego cojo ha llegado a nuestras regiones, que suele ser cuando: la primavera esta ya bastante adelantada, es decir nunca antes de fin de marzo, empieza el balbusardo su géne. to de vida veraniega y procede a recomponer su nido ó á construir uno nuevo que viene á ser su verdadero domicilio y que establece siempre en árboles desde los cuales pueda dominar con la vista los contornos 0 cicrta parte de ellos, como el campo, prados ó un claro de bosque; à cujo efecto lo insiala siempre á una altura considerable, esto es, a unos quince ó yeinte metros del suelo, en las ramas de la cuspide y nunica en las hatcrales. Como el balbusardo se construye por si mismo el nido pescando la mayor parte del material en el agua, es fácil distinguirlo del de las otras águilas. for. ma la base con palos de tres a cuatro centímetros de grueso que suele encontrar acarreados por la corriente; sobre estos coloca ramas mas delgadas, y para guarncecer el interior, $\delta$ mejor dicho, la parté superior, porque apenas ofrece una li. gera concavidad, emplea espadanias, [raja, musgo y líqquenes que arranca de los árboles. Desde léjos se conoce si el nido es de un balbusardo, ya por estar colocado en lo mas alto del árbol, ja por ser redondeado en su base. Suele tener un metro de dismetro, poco mas 6 menos; pero la altura varia segun la antigüedad del nido entre uno y dos y medio metros, puesin que cada año acarrea el balbusardo nuevos materiales acrecentando su obra hasta llegar á has dimensiones citadas \& Solo cuando alguna tempestad causa desperfectos considerab!es en el nido, ó cuando la crin del año anterior la sido repetidas veces molestada, se resuelve la pareja á construir o:ro nido nuevo lo mas cerca posible del viejo, pero maclio $y$ hembra se sirven alternativamente del primitivo para descansar. Esto me escribe Grunack que de reinte años á esia parte viene registrando unos ocho a diez nidos de balbusardo en el monte Dubrow cerca de Berlin, con el objeio de recoger los huevos ó ia crir la copa del árbol donde existe uno de estos nidos suele secarse y morir al cabo de mas ó menos tiempo, probablemente á causa de las deyecciones acres $y$ corrosivas que las aves arrojan en toda la parte superior. Alguna ver, si bien es caso rarísimo, se han observado en nuestro pais hasta dos nidos de baluusardo en
un mismo árbol.

La lecmitra empieza la puesta por lo regular entre el 24
Y 30 de abril, segun sea el tiempo, poniendo cada dos dias un huevo hasta el número de tres, rara vez cuatro, y no pa. saudo muchas veces de dos huevos. Estos son oblongos, de cascara dura y casi desprovista de lustre; su longitud es de $0^{\circ}, 059$ \& $11^{m}, 070$ yel mayor grueso de $0^{m}, 04.420^{\circ}, 052$. El fondo es, segun Paessler, blanco claro con manchas color gris azulado pizarroso y otras de orin. Los hucvos mas her mosos son los que tienen manchas rojas, color de sangre, que se confunden en uno de los dos extremos, y que además es. tán con frecuencia atravesadas de venas negras. Hay huevos cuyas manchas son de un hermoso color castano, de choco. late, de orin, ó simplemente gris; los hay con manchas gran. des yotros salpicados de puntitos, y fimalmente se encuentran iveces algunos cuyas manchas forman una especic de anillo. Grunack, que ha examinado mas de cien hueros, asegura que estos varian casi siempre, ya se hayan sacado de un mis. mo nicio en diferentes años, ya sean de una misma puesta. Lit hembra enjpieza a cubrir no bien ha puesto el primer huevo, y toda la incubacion dura de veintidos a veintiseis dias, repartiendose al parecer este trabajo, el macho y la hembra. Rara vez pacen mas de dos polluelos, que como todas las íguilas son verdaderos monstruos de voracidad, pero a los que llevan los padres el alimento en tanta abur. dancia que el nido está literalmente cubierto de peces frescos aperias medío comidos del lado de la cabeza, aparte de los que llenan iodo el sitio en estado de putrefaccion, à no ser que una pareja de milanos se aproveche de esta circunstan. cia y establezca su nido junto al otro manteniendo su cria en gran parte con los restos de la inesa de sus poderosos y opulentos vecinos. Los pequeños balbusardos necesitan por to menos ocho, y hasta diez semanas para empezar á volar. Entonces abandonan el nido guiados por sus progeniiores que les enserian a pescar, hasta que, finalinente, en scticmbre, octubre 5 lo mas tarde en noviembre parten para el me. diodia.

Cuindo los vientos destruyen el nido, ó el árbol donde está cae bajo el hacha del lenador, sucle abandonar el bal. busardo por regla general todo el bosque, pero no si única. mente le roban los huevos, pues entonces vuclve al año siguiente al mismo nido. Si hay una corriente ó lago donde abundan los peces, en las cercanias de un monte alto, suelen establecerse varias parejas de balbusardos una cerca de la otra; pero por lo regular se apropia cada pareja una comarca muy dilatada donde domina sola, y si puede ser con prefe. rencia junto à la costa.

Tal como acabamos de describir la construccion de los nidos y la reproduccion de los balbusardos se refiere á Alema. nia; pero en otras regiones varia una y otra. En Noruega y Laponia le cuesta trabajo al ave encontrar un átrbol á pro. pósito para construir el nido, y en este caso ha de establecerlo forzosamente en alguna roca. En las inmediaciones de los rios que atraviesan las estepas no le queda al balbusardo otro recurso que hacer su nido en el suelo; y en el mar Rojo, donde solo hay islas con arboleda en la parte meridional, le es preciso construirlo en isiotes madrepóricos ó periascosos que á lo sumo se levantan unos dos metros sobre el nivel de! mar, y como alli le faltan ademis los materiales usuales, se ha de arreglar con los que le ofrece el mar, como algas, conchas, quizás restos coralinos y de otros moluscos, con todo lo cual levanta una pila cónica de unos $0=, 60$ de altura en cuyo plano superior, un tanto ahuecado, pone los huevos. Mientras haya árboles los prefiere, y a falta de cllos elige una mata de mimosa si la hay, of de sihora, sobre las que construye entonces su nido con palos, empleando de paso algas; y en último extremo se contenta con establecerlo so. bre una alberca, $\delta$ en el tejado de una barraca de pescado. 
res abandonada $\delta$ en algun coificio ruinoso. Fn la América del Norte, donde anida en los árboles como en nuestro pais, difiere del balbusardo de Europa, segun Ridgray, en que alli forma colonias de trescientas parejas en una sola islita; esto suponiendo reridica la relacion. No hay duda de que esta ave anida tambien en nuestro pais con preferencia donde viven otras de su especie, pero rara vez tan cerca; en un mismo arbol ó en colonias como las citadas jamais se han encontrado en ninguna otra parte del mundo. Segun el naturalista americano, es el balbusarcio un modelo de virtudes entre las aves de rapiña, tanto que hasta ayuda á otras en la construccion de su nido; pero á decir verdad, no doy crédito á este aserto.

Ia vida diaria del balbusardo es muy sistemática. Macho y liembra abandonan uno tras otro el nido bastante entrado el dia, y vuelan, siguiendo con gran exactitud una ruta de. terminada, hácia el agua à veces muy distante, para dedicarse à la pesca.

Las largas alas de esta rapaz le permiten franquear fácil. rrente grandes espacios; elévase $a$ una altura prodigiosa; se cierne algun siempo; baja despues; $y$ rasando la superficic del agua, da principio \& la pesca No se deja ver mientras se desprenden las nieblas de las corrientes; solo aparece al me. dio dia; entonces traza circulos para reconocer si le amenaza algun peligro: luego baja y se mantiene á unos veinte metros sobre la liquida superficic. Fn ciertos momentos permanece inmóvil en el mismo sitio, como el cernicalo; acecha un pez, y de repente se lanza con las garras tendidas: desaparece de. bajo del agua, aunque solo por un instante; sale luego á im. pulso de algunos vigorosos aletazos, y se sacude rápidamente las gotas adheridas í su plumaje. Si su ataque ha sido infructuoso no se desanima por cllo, y prosigue su caza; cuando alcanza una presa le hunde las garras en el lomo, y con tal vigor que no puede desprenderlas inmediatamente. Por tal particularidad llaman las baschkirs a esa rapaz garris ide bronce. El balbusardo expone con frecuencia su vida, y muchas reces sucumbe en las olas; como acontece, cuando siendo el pez muy grande, le arrastra y alhoga. Se ha observado que cogia siempre su presa poniendo dos dedos á un lado del lomo y dos al otro: si puede arrebatarla fácilmente, remóntase y se la lleva léjos, con preferencia a un bosque, para poder devoraria tranquilamente: cuando el pescado pesa mucho, contentase con arrastrarlc a la orilla.

Solo come los mejores pedizos de su victima y abandona lo demás; se traga varias escamas; pero no parece que le gusten los intestinos.

Solo en el mayor apuro se resuelve á acometer otras pre. sas, segun me manifiesta Licbe, el cual dice que coge ranas de estanques cuando, escarmentado por repetidas persecucio. nes, no se atrere ya á pescar en aguas en que abundan los peces.

El balbusardo vive en la mejor armonia con otras ares de su especie, sin cuidarse en lo mas minimo de las de distinto orden y dandose por satisfecho con que no le molesten. Deja que las pequeñas se establezcan en los huecos de su nido, estando estas por su parte tan conrencidas de la bondad del propictario, que no temen anidar y hacer sus crias alli, lo gue serin en evtremo peligrcso si esta rapaz ian vigorosa pensase en molestarlas. En nuestro país no suele darse este caso, pero en el mar Rojo es algo comun, aprovecliándose alli particu. larmente de este permiso una especie de milano; en América es tan frecuente que los Quisalus furpuress trencen y te jan sus nidos colgantes y aćrios entre los palos del nido del balbusardo, que este tiltimo se distingue cabalmente desde léjos por aquellos apéndices f́abricados por dichas aves. Wi]. son encontró nada menos que cuatro de estos nidos de bolsa en uno de balbusardo. Esto por si soloprueba ya el carácier bonachon de la rapaz ó mejor dicho su indiferencia y carácter exclusivamente ictib́ago; pero mas la patentiza todavia el comportamiento de las aves acuáticas respecto â él.

'Todas cllas conocen al balbusardo y no le temen; diriase que le consideran como it uno de sus semejantes, ? permiten que se mezcle con ellas Cerca del lago de Mensaleh, en el Bajo Egipto, donde llegan todos los inviernos centenares de balbusardos, los he visto con frecuencia en medio de los patos, sin que les inquietara su presencia.

En cambio es muy perseguida esta ave por las otras rapaces: entre nosotros le hostigan sin cesar las comejas, las golondrinas y las oropéndolas, aunque no le hacen mucho dano; pero donde hay pigargos, trabaja muchas veces para estos. El pigargo leucocé́lalo, sobre todo, esta en continua guerra con él; le acomete apenas se apodera de una presa y le persigue hasta conseguir quitarsela Con frecuencia le hos. tigan tambien los milanos parásitos, cuervos y cornejas, para arrebatarle el pez que se lleva. Tambien se aloja la marta en los nidos mas vicjos y de consiguiente mas voluminosos; y bien podria suceder que fuese ella quien deja caer las cásca. ras de los huevos de balbusardo que se encuentran á veces al pié del árbol, despues de haberlos vaciado.

Despues de la nutria es el balbusardo el mayor enemigo y el principal oustáculo de una exploiacion sistematica de cria de peces en estanques y viveros naturales, como en general de toda pesqueria. Ln las cercanias de Peitz, donde se cria en grande escala la carpa en setenta y dos estanques que ocupan una superficic de mas de mil licctáreas, amidan, segun Schalow, cada ano unas veinticinco à treinta parejas de balbusardos que causan tantos perjuicios al arrendatario de dichos cstanques, que este paga ocho pesctas por cada ba!busardo que le presentan. En Ámérica, todavia no se da cré. dito á la importancia de los daños que causa esta rapaz; muy al contrario, alli prevalece aun la supersticion de que una pareja de cllas da suerte al labrador en cuyo terreno anida.

CA\% A. - En nuestro pais son en extremo recelosas y cau. tas las f́guilas pescadoras, atendida la persecucion que su. fren; de suerte que si esta ave no olvida por descuido un momento su seguridad cuando se halla junto al nido, es difi. cil cazarla, pues sus excursiones sobre una muy dilatada $\mathrm{ex}$ tension de agua la salvan casi siempre de las balas que se la tiran; pero en paises meridionales donde no se la tiene tanto odio, no es dificil sorprenderla cuando se posa en algun árbol $\delta$ en sus frecuentes inerodeos. Mas ficil todavia es apoderar. se de ella con una trampa de hierro cebada con un pez y colocada debajo de la superficie del agua. De este modo se cogen cada año muchas en la Alemauja del norte, $y$ á veces llegan virns á las jaulas; pero con todo, esta ave es un hués. ped raro hasta en los jardines zoológicos mas ricos. Yo las he cuidado viejas y recien sacacias del nido, pero nunca he podido amansarlas En cuanto á los balbusardos viejos, ja. más se acostumbran á la jaula; pasan dias enteros en un mismo sitio, y si álguien se acérca ó entra en aquella, dan evidentes muestras de espanto $y$ azoramiento, sin hacerse jamás dóciles para con las personas que los cuidan; decaen visiblemente, enfiaquecen de dia en dia, y cuando menos se piensa se los encuentra nuertos en la jaula sin que se pueda averiguar la causa de este percance. I.os que se cogen jóre. nes en el nido no resisten tampgoco la cautividad; con dificultad se acostumbran à comer solos, y desfallecen mas ó menos pronto, aunque se les dé bastante alimento.

$$
\text { LOS MILVIDOS-MHVINE }
$$

Son tan numerosas las especies gaue comprendemos en la 
familia de los milvidos, y ofrecen entre si tales diferencias, que es dificil asignarles caractéres comunes; pero por otra parte, el tránsito de una i otra se verifica por tantos tipos intermedios, que todo nos conduce a reconocer que forman un grupo muy natural.

CARACTRRES. - Los milvidos tienen formas esbeltas, cuello corto, cabeza mediana y alas largas, mas $\delta$ menos estrechas y agudas; la cola, excepcionalmente corta, con frecuencia mediana, $y$ de ordinario muy larga, es ganchuda y escotada, los tarsos cortos y gruesos; los dedos siempre cortos; el pico entero, encorvado desde la base y muy ganchu do, las unas redondeadas y aceradas. En los milvidos predo-

minan los tonos claros $\mathrm{y}$ yisos en el plumaje
DISTRIBUCION GEOGRAFICA. - Esta familia tiene representantés en todas las partes del globo.

USOS, COSTUMBRES Y REGIMEN. Todos tos milvidos vuelan perfectamente, pero no como las otras rapaces: su vuelo no es rápido y precipitado como el dél halcon, ni se observan en él cambios bruscos y súbitos de direccion; cl ave se cierne mas bien tranquilamente sin agitar las alas, y se ba. lancea en el aire. El aspecto particular que ofréce entonces, resulta de que las extremidades de sus alas están mas altas que el cuerpo; en tierra se mueven algunos milvidos con mucha destreza y agilidad; otros, por el contrario, son muy torpes.

La vista esti muy desarrollada en todas estas aves, y el oido es bastante perfecto, sobre todo en aquellas que tienen un disco de plumas faciales. Parece que en todas el tacto es bastante fino: nada podemos decir respecto al gusto y al olfato.

Los milvidos no tienen tanta inteligencia como las rapa ces que acabamos de examinar: son astutos, curiosos y des. confiados, mas no prudentes; voraces y no valerosos, cobardes y atrevidos al mismo tiempo. Esperan á que otras rapaces

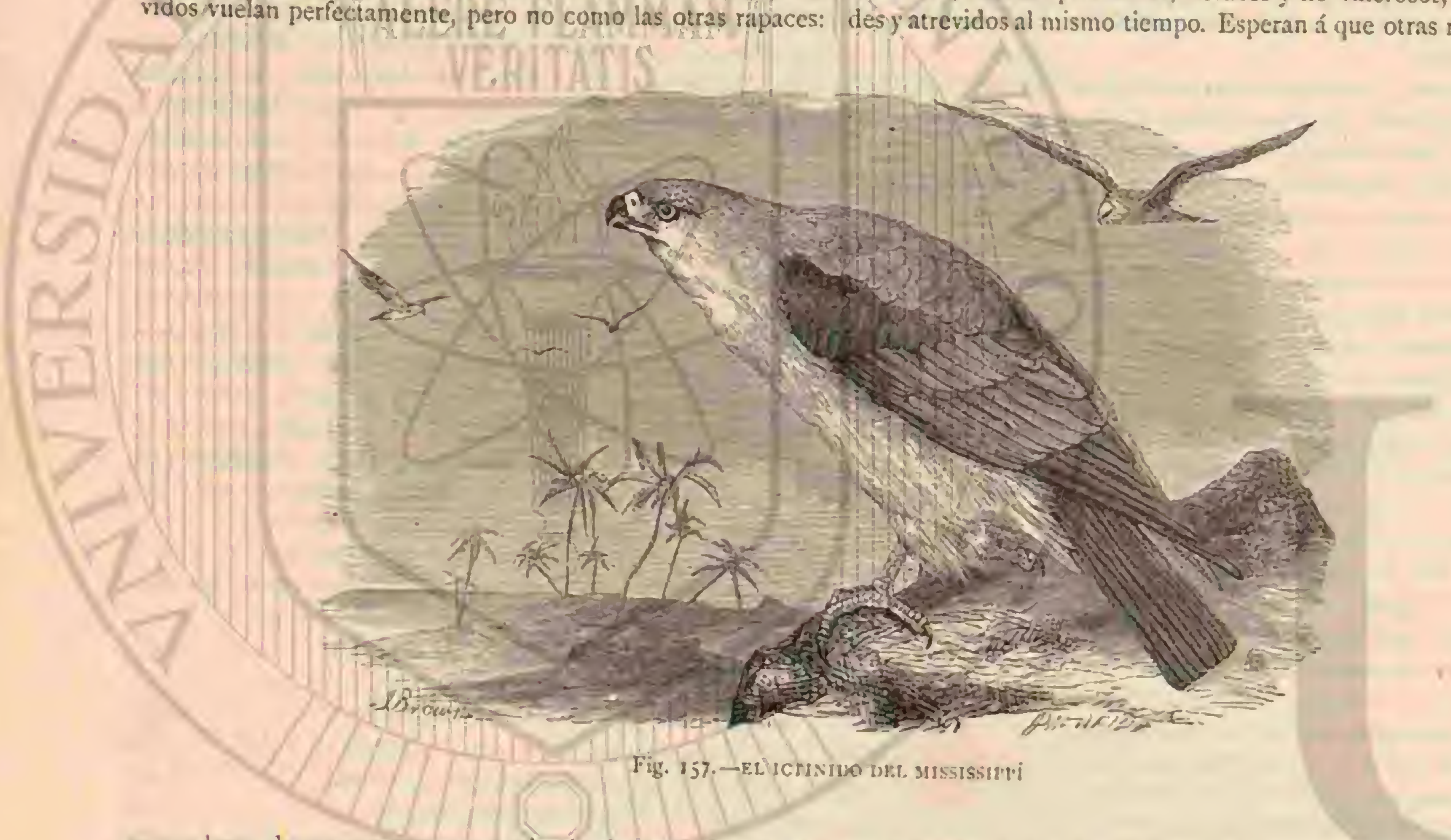

se apoderen de una presa para arrebatárselai son aves rateras, no ladronas.

Solo las especies que mendigan su alimento se inquietan de lo que pasa á su alrededor, y de lo que hacen las otras rapaces, á las que consideran como sus abastecedoras. I tos mas de los milvidos viven apareados: otros forman grandes bandadas, y se manifiestan el mas vivo cariño.

Sienipre se distinguen por su acrividad, desde que raya la aurora hasta que cierra la noche; poco es lo que descansan en medio del dia. Se les ve aislados, volando lentamente por encima de las estepas, de los campos, de los prados, de los estanques y de las corrientes; apodéranse de una presa y siguen su camino. De vez en cuando se remontan por los aires, ejecutando mil ejercicios de alto ruelo, hasta que una nueva presa los atrac otra vez á tierra. Entosces descienden con lentitud, viéndoseles caer bruscamente sobre el objeto que codician; jamás emplean mucho tiempo en la caza.

Ciertos milvidos, insectivoros por su manera de cazar, se asemejan mas $\dot{a}$ las golondrinas que d las rapaces: por lo ge neral se alimentan de pequeños mamíeros, pajarillos, reptiles, peces $\varepsilon^{2}$ insectos; solo algunos comen restos animales. Hay milvidos mas nocivos que uitiles; pero la mavot parte prestan ai hombre considerables servicios

Fistas aves anidan en rocas, en las grietas de los edificios

ruinosos, en los campanarios, en los árboles, en las breñas, y hasta sobre la tierra. El número de sus huevos baria de uno d cinco; los dos sexos cubren alternativamente, y profe. san a sus hijuelos el mas viro amor, cuidindose anbos de enseñarlos.

CAUTIVIDAD. - Todos los milvidos sa donestican fi. cilmente cunndo estan cautivos; algunos cobran carin̄o à su amo; pero los mas son fastidiosos, y aun hay algunos que no se pucien tener en jaula.

Entre nosotros no se adiestra ninguna de estas especies; los baschkirs, por el conirario, utilizan varias para la caza.

\section{LOS HELOTARSOS-HELOTARSUS}

En toda el Africa, desde el $16^{\circ}$-de latitud norte hasta el Cabo de Buena Esperanza, inalita una de las rapaces mas singulares, que con razon se ha elegido para ipo de un género particular designado con el nombre de helofarso. Ias aves que le constituyen siguen conservando muchas relacio. nes con los aquilidos; parecen formar el tränsito de estos a los milvidos, y por lo ianto las colocamos en primer término.

Le Vaillant ha dado à csta ave cl nombre caracteristico de latelero ó juylar, y Smith ha formado con ella, no sin razon, un género independiente, que es el de que nos ocupamos. 
CARACTÉRES. - Se caracterizan estas aves por su cuerpo recogido 5 vigoroso; tienen el cuello corto, cabeza volu. minosa; alas muy prolongadas y agudas, siendo la segunda perna la mas larga: cola muy corta; tarsos cortos tambien, gruesos y cubiertos de escamas sólidas: dedos proporcionados y unas poco encorvadas y obtusas. El plumaje es muy abundante, sobre todo en la cabeza, y las plumas grandes y anchas.

\section{EL HELOTARSO BATELERO-HELOTARSUS ECAUDATUS}

CARACTÉRES. - El color y los dibujos de esta ave son tan notables como sus formas; ticne la cabeza de un magni. fico color negro mate cuando es adulta, y del mismo tinte el cuello y toda su parte anterior e inferior; el lomo, las rectrices y las cobijas superiores de la cola son de un rojo oscuro; el borde del ala y las pequeñas tectrices superiores de un rojo pardo claro ó amarillo isabela; las rémiges primarias negras y las secundarias de un gris ceniciento, con el extremo negro, tormándose asi sobre el ala una ancha faja. la cara inferior de aquella es de un blanco de plata; el ojo de un hermoso pardo darado; el pico amarillo, rojo en la base y arul en la punta. Ja cera y un círculo desnudo que rodea el ojo, de color de sangre, con manchas de un amarillo rojizo; el párpado inferior blanquizco ! las patas de un amarillo rojo.

El plumaje de los individuos jóvenes tiene un tinte pardo oscuro; algunas plumas del vientre presentan un filete gris pardusco, por lo cual parece esta region mas clara que el lomo. La garganta y la frente son de un pardo claro; las pen. nas del brazo de un pardo gris; el ojo rojo pardo; el pico, la cera y las mejillas azules, y las patas azuladas, con visos rojizos.

La hembra mide $1 ", 5^{\circ}$ de largo por $1^{\circ}, \$_{3}$ de punta á pun. ta de ala; esta plegada $1^{\circ}, 5^{\circ}$ y la cola $11^{m}, 13$ : el macho es un poco ñıs pequeno.

DISTRIUUCION GEOGRAFICA.- Lsta ave se halla diseminada en el Africa, escepto el norte: se la encuentra por todas partes, desde el Senegal á la costa del mar Rojo y el Cabo de Buena Esperanza. Le gustan las montanas, aunque no habita en ellas ciclusivamente; creo poder asegurar que abunda mas en las estepas que en los paises montañosos.

Heuglin no le ha observado en las montanas mas altas de Abisinia, pero si con regularidad en todos los montes pedre gosos que, en su mayor parte independientes de otras montanas, se elevan en las Ilanuras del Sudan; tambien le ha visto en los terrenos bajos situados a orillas del rio Blanco $y$ del de las Gacelas.

USOS, COSTUMBRES Y REGIMEN.-Se le ve con mucha frecuencia, pero rara ve\% se le puede observar bien; por lo regular no se le divisa sino cuando vucla, y entonces permanece as una gran aliura, fuera del alcance de la esco. peta.

Heugiin reconoció que abandona is la hora del alba los al. tos arboles donde ha pernoctado, y que entonces comienza a revolotear en su dominio, trazando circulos continuamente, yo no le hallé nunca tan temprano, y ram vez le vi trazar circulos en los aires: muy por el contrario, he rotado casi siem. pre que vuela en linea recta sin detenerse, à no ser que quiera rétozar o haya descubicrto una presa.

Hácia el medio dia se acerca al agua, y despues de estar junto á ella algun tiempo, ocúltase en un árbol próximo para descansar. Llegada la tarde vuelve á cazar, y no se enirega al descanso hasta que cierra la noche. Le Vaillant dice que ol macho y la hembra no se separan nunca, y que rara vez se encuentra al uno sin la otra; pero yo he observado lo con. trario, y siempre los he visto solos. Parece que cada pareja habita un vasto dominio; pero muy pocas veces parmanecen unidas las parejas fuera del periodo del celo.

Reconócese al batelero á primera vista por sus formas ca. racteristicas; y aun ha dado motivo para mil fảbulas su fiso. nomia particular. Segun Spele, se cree que su sombra es la de un mortal, y por lo mismo se profesa cierto respeto al ave en el interior del Africa; se la considera tambien como midi. co, que va muy léjos en busca de raices dotadas de propieda. des maravillosas. Los misinos le llaman mono del cielu, mientras quie los pesados campesinos holandeses del Cabo de

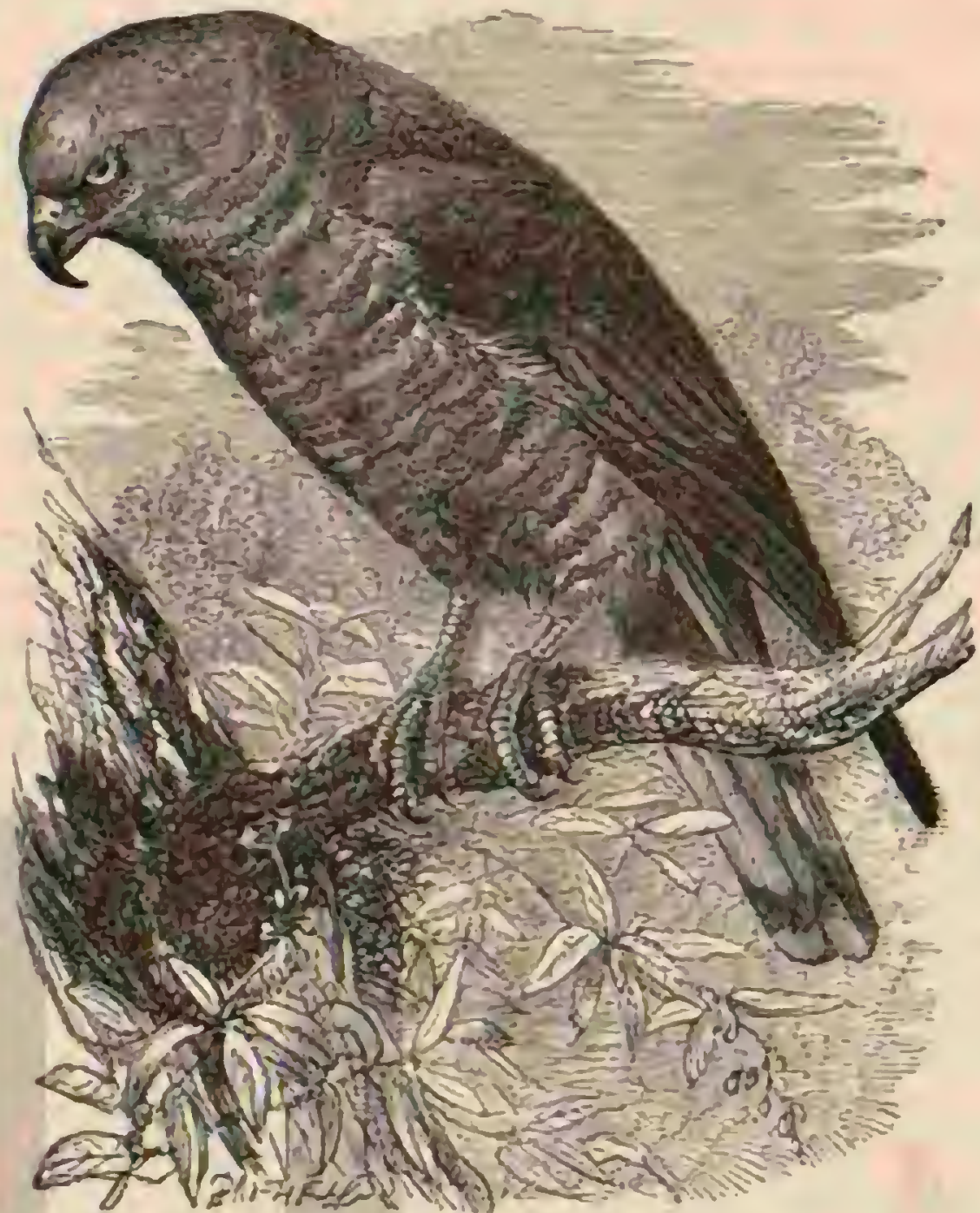

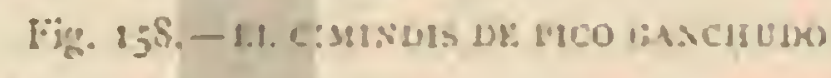

Buera Esperanza no lian enconirado otro nombre mas á propósio que el de gablo de monhañ (Berg-hahn). lia he referido las diversas fábulas que circulan acerca de esta ave singular, que no creo oportuno reproducir aqqui.

Fl vuelo del batelero es particular, y-no anduro desacertado l.e Vaillant al aplicarle semejante nombre. Parece que se divierte él solo; sube y baja, y se cierne por momentos; diriase quue es un barqquero que hace sjercicios de fuerza para entretener a los espectadores. Con frecuencin recoge de pronto las alas y desciende cierto trecho, agitando el aire con elias, de tal modo que no parece sino que se ha roto una, y que cae st tierm. Fs completamente imposible describir su manera de volar: á menudo le he visto dar en el aire verdaderos saltos; a veces levanta las alas subre el cuerpo, perma. nece inmóvil un instante, y las recoge luego de pronto con violencia, produciendo luego un ruido particular que se oye desde léjos. Solo cuancio está en el aire se reconoce toda la gracia y gentileza del ave: en el momento de prosarse para descansar ofrece un aspecto muy extrano: dilata su cuerpo, eriza su plamaje, sobre todo el del cuello $y$ la cabeza; vuelve esta $\mathrm{d}$ un lado y otro, la levanta y la baja lo mismo que el buho. Si alguna cosa despierta su atencion, extiende las alas y muere la cabeza con mas vivacidad.

De todos sus sentidos, la vista es el mas perfecto, como ya lo indica el tamaño de sus ojos; no esta menos favorecida pror lo que hace al oido; el tacto es bastante delicado: no puedo asegurar nada respecto á los demás sentidos.

Sus costumbres no son menos singulares: no puede asegu- 
rarse que se distinga por su valor, aunque sostiene con fre. cuencia peligrosas luchas: es mas bien cobarde y berévola. Cuando está libre se muestra muy tímida; huye ante todo lo que le parece sospechoso 6 no ha visto nunca: pero no sabe distinguir entre los hombres que pueden serle peligrosos $y$ aquellos de quienes no tiene nada que temer. En caurividad, por el contrario, se domestica muy pronto, y hasta se puede jugar con ella como con un loro. $A$ las rapaces no les agrada por lo general que las acaricien: el helotarso batelero, yor el contrario, parece experimentar un vivo placer cuando le sas. can ó le pasan los dedos entre las plumas del cuello, Como quiera que sea, no tolera tales pruebas de cariño del primer llegado, ni las permite sino de lás personas bien conocidas. Con las otras aves se muesira mur dócily no maia nuraca de molestarlas. 'Iodó lo que liene de vivaz cuaudo ruela, parti. cipa de tranquilo y pacifico al posarse: rara rez se oye-su roz; los sonidos que produce se pueden expresar por lina, cua, y mas rara vez por rok, cak ó rom: cuando vuel por ran, nienudo un grito andilogo al del buzo que traduciremos por Militis hishis.

Le Vaillant dice quue el batelero se hítraca de toda especic de restos animales, como lo bacen los buitres, lo cual no im. fide que acorneta muchas veces a las gacelas jóvenes; vaga por los alrededores de las viviendas, donde trata de surprender á las ovejas ó carncros enfermos; los avesinuces pequeños s: clen servirles tambien de pasto.3 Heuglin ha visto al batelero coger liebres: por mi parte nunca le vi aconseter a los mamifuros grandes. Se alimenta de reptiles, y sobre todo de serpientes y lagartos, viéndosele rolar algunas veces con uno de estos animales en el pico. De aquú la fabula de que bice mencion anıs: los árabes, segun parece, creian que apuellas culebras eran raices maravillosas. A sencjanza de todas las demis rapaces del Africa central, quelse alimentan de repti. les, cuando un incendio devora la yerba de las estepas, acude el batelero desde muy lejos, sigue la línea del fuego, vuel en medio del humo, y apodérase de los reptiles que las 11 a mas obligan a salir de su retiro. En cicrtas ocasiones se ali. menta tambien de restos animales; Kirk obturo un individu que habia comido carne cavenenada, vomitada por una hiena

Le Vaillant dice gue el bateléro construye su nido en los árboles, y que la hembra pone tres ó cuatro luevos blancos; Speke opjina que sulo deposita uno; a mi me parece que la rerdad está entre los dos extremios. Heuglin encontró dos pequeños en un mismo nido. El periodo del celo se declara al principio de la senuia; en cuya época es mas fácil para d tonces se.ocultan-los animales bajo una espesa alfombra qu verdura.

CAUTIVIDAD. - Ultimamente se han vistacon frecuencia en Europa batcleros vivos; ahora los hay en todos los jardines zoológicos, aunque siguen siendo ares muy buscadas y que se pagan á subicio precio. Por ntra parte, ninguna rapaz es tan a propósito como esta para cautivar la atencion de sus por la belleza de su plumaje, sino por la singularidad de sus costumbres. Resiste muy bien las variaciones conside rables de temperatura, $y$ si el invierno no es demasiado $r$ guroso, se la puede dejar al aire libre 'Se acoinoda fácil mente con el régimen ordinario de las aves de rapina Segun mis propias observaciones, considero al helutarso de cola corta como una de las rapaces mas agradables en cautividád.

\section{LOS ELANIOS-ELANUS}

Los elanios constituyen un géncro que está diseminado en toda la superficie de la tierra, excepto Europa, donde solo
se ha dejado ver una especie algunas reces.
CARACTERES. - Las cuatro que constituren este género se asemejan muciro: tienen el cuerpo recogido, cl plu. maje compacto, las alas, largas y agudas, sobresalen de la cola, que es corta y tiene una ligera escotadura; los tarsos, cortos y gruesos, están cubiertos de plumas en la mitad de su cara anterior; el dedo del centro es mas largo que los tarsos; las uñas muy aceradas y ganchudas; el pico corto, alto, sumamente corvo y muy ganchudo; los hordes de la mandibula superior están ligeramente escotados; el plumaje es tan fino y suave como el del buho.

\section{EL ELANIO MELANÓPTERO-ELANUS ME- LANOPTERUS}

CARACTERES.-Esta ave tiene las partes superiores de un bonito color ceniciento azul; las inferiores $y$ la frente blancas; las tectrices de las alas y los hombros negros; delan. te de los ojos hay una mancha de este color que se prolonga en forma de linea angosta hasta las sienes; las réniges pri. marias, excepto la uiltima, son de un ceniciento oscuro, blancas en la base de las barbas interiores y de un pardo intenso en las puntas; ias secundarias, de un ceniciento gris, y blan. cas'en las barbas interiores hasta cerca de la punta; ias dos rectrices del centro son cenicientas, las otras blancas y orjlladas de gris en las barbas exteriores; estas uiltimas se distinguen' por su color blanco puro en ambos lados; los ojos de un rojo vivo;"el pico negro, la cera y las patas de un amarillo naranja. Lil macho mide $11^{\circ}, 35$ de largo por $0^{\circ}, i^{\prime \prime} 8$ de anchura de alas, el ala plegada $11^{m}, 30 \mathrm{y}$ la cola $0^{m}, 1+$ (fig. 156). La hembra es algo mas grande.

Los pequenios son de color gris pardusco con el vientre de un amarillo claro, cubierto de listas longitudinales parduscas; las mas de las plumas tienen filetes blancos: el ojo es amarillo.

DiSTRIBUCION GEOGRÁFICA.- Eil elanio melanóptero abunda bastante en Siria y es muy comun en el Figipto. Desde aqui se exticnde por toda el Africa y el mediodia del Asia; con alguna frecuencia llega tambien to Europa donde se le ba cazndo, no solo en Espanana, en el sur de Italia, en Grecia y Dalmacia, sino tambien muchas veces en Alemania, Handes y la Gran Bretana.

USOS, COSTUMBRES Y REGIMEN.-Por lo que yo he podido reconocer, esta ave busca las localidades donde ajternan los bosques y los campos; en el nordeste de Africa evita las grandes selvas, por mas que J. Verreaux haya encontracio en ellas su nido. Escasea mucho en los bosques virgenes del Sudan oriental, y es en cambio muy comun en los bosquecillos y jardines de Egipto.

Vive siempre emparejada y no se asocia nunca con sus semcjantes; pero como las parejas habitan unas cerca de otras, se pueden ver ocho $\delta$ diez individuos de la especie remontarse juntos por los aires.

Por sus usos y costumbres ofrece esta mpaz. tantos puntos de semejanza con el buro, como con el milano y el buho. Caza curante las horas de la mañana y de la tarde, y tambien en la del crepúsculo, cuando las otras rapaces diurnas se han entregado ja al reposo. Bien esté posada ó volancio, no se la puede desconocer; al cruzar los aires lleva las alas levantadas de ial manera, que la punta sobresale mucho del cuerpo; al posarse se distingue por su vistoso plumaje, que brilla a los rayoos del sol. En Egipto descansa en las vigas de las norias, y de ahi el nombre de halcon de las norias, que se le aplica en aquel pais. En la Nubia se le ve en un elevado árbol, descie donde puede abarcar un vasto horizonte: si divisa una presa, $\delta$ le aqueja el hambre, se cierne algun tiempo, casi sin agitar las alas, recorriendo un corto trecho; apenas ve un 
perqueno roedor ó uma langosta, quekdase intnóvil algun tiempo; luego recoge las alas; déjase caer sobre su presa, y se la lleva a su punto de observacion pata devorarla. Con frecuen. cia atrapa las langostas al vuelo, $y$ traslada sienpre los roedores á los árboles. Un campo poco extenso le proporciona todo el alimento necesario: los roedores pequeños constitu. yen la base de sta régimen; solo come las langosias acciden. talmente.

Naturalmenie no desprecia tampoco las ares pequeỉas que coge en el nido; segun Heuglin, devora tambien los lagartos \$ hasta se apodera de algun murciélago, que por lo demás no tienen otro enemigo que el buho.

Esta rapaz es muy agradable. En Egipro no le inspira te. mor el hombre, pues sabe que no le inquietari. Vuela en medio de los trabajadores del campo: anida en los naranjos, cujo fruto recoge todas las semanas el jardinero; pero una vez que llega á conocer à los europeos, muéstrase muy recelosa y nunca se pone st tiro de fusil.

El macho profesa gran carino á su hembra: las ares ino. fensivas no llaman su atencion; pero persigue á las grandes especies de rapaces, lanzando penetrantes gritos. Su voz se asemeja mucho a la del gerifalte, solo que las notas son mas prolongadas y agudas y se pueden reconocer desde muy léjos.

En Egipto comienza el periodo del celo en la primavera; en la Nubia s principios de la estacion lluviosa. Yo encontré el 4 de marzo en un limonero el nido de una de estas rapaces, con tres hijuelos cubiertos de plumon; el 13 vi otro con tres huevos en un azufaifo, y el i 8 del mismo mes descubri un tercero en el que habia cinco hijuclos. Los huevos son de color blanco gris, sembrados de manchas y rayas pardas, muy irregulares: tienen unos $11^{\circ}, 04$ de largo y $11^{\circ}, 03$ en su mayor diánetro. Jerdon dice que son blancos, lo cualinduce a crect que hay grandes variaciones.

'Todos los nidos que yo vi se hallaban en árboles bajos y de espeso follaje, a una altura de siete metros del suelo, cuando nas: estabin poco excavados, rellenos interiormente de pequenas raices y yerbas, fo formada la base con ramitas; los yue contenian hijuelos aparecian completanente cubiertós de pelos de pequeños roedores.

CAUTIVIDAD. - Los polluelos que se cogen en el nido se domestican tanto como el gerifalte ó el cernicalo; tambien se obtiene el mismo resultado aunque sean viejos. No hacen nunca uso de sus armas naturalés con el amo; cuando mas, le amenazan con el pico; pero no le hacen el menor dano. Al cabo de pocos dias toman su alimento en la mano; acostúmbranse muy pronto a estar en una habitacion, y no pare. ce que echen de menos su libertad. Sin embargo, no pueden vivir con otras aves: jo encerré un individuo en la jaula de un hoplóptero arnado, y al dia siguiente se lo habia cornido.

Ls jreciso además tener algun cuidado con estas aves cuando se enjaulan: si se les da carne cruda, perecen bion pronto; necesitan, como los buhos, alimentos cuyos restos puedan devolver.

\section{LOS ICTINIDOS-ICTINIA}

CARACTÉRES.-Estas aves, de estructura robusta, tienen el pico corto, muy corro por arriba y menos corvo por abajo, de gancho recogido con bordes denticulados irregu. larmente; la cera es angosta y las tosas nasales pequenas y redondas; los piés cortas y robustos, cubierios en su cara anterior de placas anchas; el dedo medio, casi tan largo como el tarso; las garras cortas, puntiagudas, muy corvas y algo cóncavas en su cara inferior; las alas son largas, con la tercera rénige unas prolongada; la cola, de longitud regular, es un proco truncada; las plumas pequeñas y suares.
DISTRIBUCION GEOGRÁFICA.- Las dos especics de ictinidos que se conocen son propias de América.

\section{EL ICTINIDO DEL MISSISSIPPI-ICTINIA MISSISSIPPIENSIS}

Caracteres. - El ictinido del Mississippi tiene una longitud de $11 ", 37$ por $11^{\circ}, 95$ de punta á punta de las alas; estas miden $0^{ \pm}, 29$ y la cola $11^{\prime \prime}, 13$. La cabeza, el cucllo, las rémiges secundarias y toda la paric inferior son de color de plomo, debiendo notarse sin embargo que la frente $y$ las puntas de las citadas rémiges son de un blanco de plata; la linea naso-ocular y los párpados snn negros; en las otras partes predomina un color gris de plomo oscuro, que en las pequeñas tectrices del himero, en las de la cola, en las rémiges primarias y en las rectrices pasa i un tinte gris mas intenso; las plumas de la cabeza, del cuello, de los hom. bros, del peclio y del vientre, tienen su base blanca, por lo cual se observan manchas irregulares cuando se descompone el plumaje; las barbas de las rérniges primarias presentan exteriormente uma faja parda, y por dentro grandes manchas del mismo color. En la hembra, los tintes claros son mas oscuros; en los polluelos, que se parecen a la madre, mas turbios que en el macho. Los ojos tienen un color rojo de sangre; el pico es negro; los piés de un rojo carmin (fig. 157).

DISTRIBUCION GEOGRÁFICA.-El área de dispersion del ictinido del dississipni se limita al extremo sur y sud. oeste de los Fstados de la Ainćrica del norte que se tocan con la corriente del golfo. En la Carolina meridional se han visto individuos errantes, y otros hasta en el Mississippi mas al norte; tambien se han cazado varios en otras partes del pais: su verdadera patria, sin embargo, es lexas y México.

USOS, COSTUMBRES Y REGIMEN. - \&uando llega la primavera, dice Audubon, aparece el ictinido en el valle del padre de los rios y remonta las orillas hasta Menfis. En la Luisiana se le ve llegar hácia mediados de abril en reducidas bandadas de cinco o secis individuos; se fija en el bosque, á lo largo de los rios, sin amnar hácia cl interior de las ticrras, y buscando sobre todo las nuevas plantaciones situadas cerca de las corrientes. Su vuelo es vigoroso y muy sostenido: el ictinido se remonta muchas veces á una altum, donde solo es capaz de seguirle el nauclero de la Carolisa; á menudo se cirrne en el aire sin hacer un solo movimiento, trazando majestuosos circulos; en otras ocasiones cierra bruscamente las alas, y se deja caer con sin igual rapidez hasta la rama donde ha-visto un pequerio lagarto ó un insecto. A veces vuela alrededor del tronco de un árbol, en persecucion de una presa, 6 bien describe $S$ como si huyera de algun enemigo peligroso; tambien se deja caer lo mismo que la paloma En sus viajes vuela en línea recta, seguido comun. mente de una nube de golondrinas; en otros momentos se le divisa a una gran aliura entre una bandada de cornejas o de buitres, ó asociado con el milano golondrina. Complácese en hostigar al buitre y le obliga á emprender la fuga. Cuando cae sobre un insecto ó un réptil, se inclina un poco de lado: extiende las patas, abre las garras, apodérase de su presa y se la come volando, con tanta facilidad como si estuviese posada. Mientras conserva buena salud no baja jamás at ticra; ni tiene costumbie de atacar nunca á los mamiferos, aunque le divierte á veces perseguir á un zorro gritando, y haciendo el ademan de caer sobre él: tampoco ocasiona el menor daño a las aves. \&

Ia base de su régimen alimenticio consiste, segun Ridg. way, en varios grillos y langostas; y a reces devora tambien pequenas serpientes. No coge siempre su presa con las garras; con frecuencia se sirve del pico. 
El ictinido anida siempre en las mas altas ramas de un árbol muy clevado: se fija con preferencia en las magnolias ó las encinas blancas, csus magnificos árboles de los bosq̨ues del sur; su nido se parece al de la corneja; consa de ramas toscamente entrclazadas, cubiertas de musgo, de corteza y. hojarasca. I a hembra pone dos ó tres huevos redondeados, negruzcos, con nurnerosos puntos negros y de un color pardo chocolate. Un huevo esaminado por Ridgway tiene mas de $0^{\circ}, 040$ de largo por $f^{\prime \prime}, 035$ de grueso y carece de manchas.

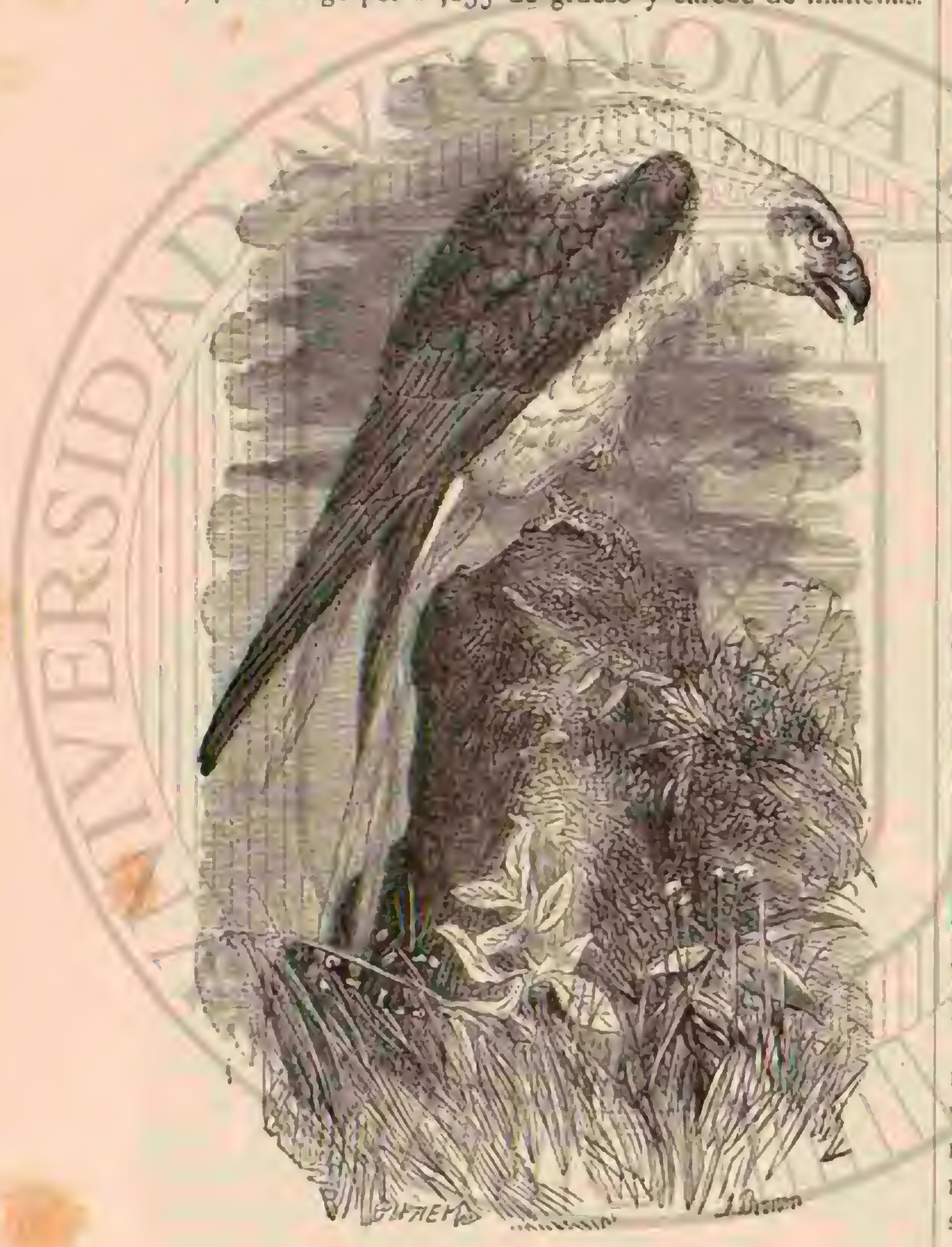

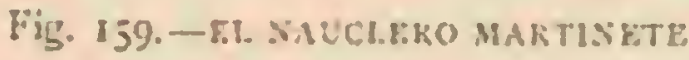

Macho y liembra cubren alternativamente; manifiestan a su progenie el mas tierno cariño, y la defienden contra todos sus enemigos, incluso el hombre. Audubon vió á esta rapaz. acometer varias veces a un negro que intemiaba destruir su nido. Los hijuclos se asemejan muy pronto at los padres, y adquieren su plumaje definitivo antes de la época de la emi. gracion.

CAzA. - El ictinido del Mississippi no es timido, $y$ una rez. posado, permite que cualquiera se acerque. Sin embargo, no deja de ofrecer dificultad su caza, pues no se le suele ver sino cuando vuela, y entonces no está a tiro. Solo suele posarse en las ramas mas altas, necesitándose una buena cara. bina para alcanzarle; si no se hace mas que herirle, procura defenderse aun.

\section{LOS CIMINDIS-CYMINDIS}

CARACTÉRES. - Estas rapaces se ascmejan casi tanto á los milanos, como ai abejaruco; tienen formas esbeltas, alas muy largas; cola larga y ancha, ligeramente redondeada; tarsos cortos, delgados y cubiertos de plumas en una parte de su cara anterior; dedos endebles, de mediana extension uñas delgadas, largas y poco corvas: pico alto, angosto, comprimido lateralmente, de bordes rectos, no escotado ni den. tado, y con mandibula superior muy ganchuda, que sobre. sale mucho de la inferior.

\section{EL CIMINDIS DE PICO GANCHUDO - CYMINDIS UNCINATUS}

CARACTERES. - Esta ave mide $6^{*}, 44$ de largo por 6",9r de ala á ala ; esia plegada $1, " 30$ y la cola $4 ", 19$. El macho adulto tiene el plumaje de un color negro uniforme, con visos azulados; el vientre un poco mas claro que el lomo; las pennas de las alas $y$ de la cola de un gris claro, con listas del propio tinte pero mas oscuro; en la base de la cola hay una ancha faja trasversal; el ojo es gris perla; la mandibula superior negra y la inferior de un blanco amarillento: la cera, la linea que va del pico al ojo, y una mancha que hay alrededor de este, de un gris rerdoso; el borde bucal amarillo, $y$ las patas de un tinte naranja (fig. 158).

La hemora tiene el plumaje gris claro, con las pennas caudales onduladas de gris y negro; el vientre cruzado de líneas blancas; por debajo de la ancha faja blanca de la cola existe una negra, seguida de una gris y otra negra.

In los pequenos el lomo es gris pardo, orilladas de rojo las plumas; la cara inferior del cuerpo de color amarillo rojo claro, con fajas trasversales de un rojo de orin; las rémiges primarias delun pardo negro con fajas claras y filetes blan. quizcos; la cola cortada por dos fajas de un gris amarillento por encima, y otras de un amarillo rojizo por debajo, una de las cuales ocupa el extremo de la cola.

DISTRIBLiCION GEOGRÁFICA.-Segun las observaciones, del principe de Wied, de Schomburgh, de Burmeister y de otros viajeros, esta rapaz liabita la mayor parte de la América del sur; es tan comun en los bosques die las cos. tas como en los de las estepas; pero se la encuentra principalmente en el lindero de aquellos, no léjos de las viviendas.

USOS, COSTUMBRES Y REGIMEN. - EES una hermosn ave, dice el principe de Wied, que se distingue por su vivacidad; sus largas alas le permiten volar fácilmente y con rapider. No es rara en ninguna parte: mis cazadores mataron muchas, y encontré en su estómago insectos y moiuscos; se alimenta de aves y otros pequeños animales; y es osada y salvaje.

Anida en árboles inaccesibles.

\section{LOS NAUCLEROS - NAUCLERUS}

CARACT f́RES. - Los naucleros, 6 milanos golondrinas, son los mas notables de todos los milvidos. Tienen el cuerpo robusto; el cuello corto; la cabeza pequeña, pero larga : la cola muy escotada, conso la de la golondrina, con las pennas externas doblemente mas largas que las medias; cl pico es muy hendido, bastante largo, pero bajo, corvo desde la base, con gancho acerado y bordes rectos sin dientes ni escuta. dura: los tarsos, cortos y pequeños, son bastante gruesos; los dedos cortos; las uñas muy aceradas y en extremo corvas; las plumas grandes y suaves.

\section{EL NAUCLERO MARTINETE-NAUCLERUS FURCATUS}

CARACTÉRES. - El nauclero martincte tiene la cabeza, el cuello, el pecho $\mathrm{sel}$ vientre de un hermoso blanco de nieve; el lomo, las alas y la cola de un tinte negro con visos azules 9 verdes; el pico negro, la cera azulada; las patas 
de un rerdoso claro; el iris pardo rojizo ó pardo oscuro, y las uñas de un gris claro. Esta rapaz mide $(1 ", 60$ de largo por $1{ }^{\circ}, 30$ de punta á punta de ala: esta plegada $0^{\circ}, 40$ á $0^{\circ}, 45$; la mas larga de las rectrices (1), 30 . Hi macho, algo mas peq̨ueño que la hembra, tiene colores mas puros (fig. 159).

En los pequeños son negros los tallos de las plumas que cubren la nuca y el occipucio; el plumaje del lomo de un color gris sin brillo; las cobijas de un tinte gris en la punta; las últimas pennas secundarias completamente blancas.

DISTRIBUCION GEOGR ÁFICA.-EI nauclero marti. nete existe en toda la América meridional, desde el mediodia del Brasil hasta el sur de los Estados-Unidos; en este último pais solo se le encuentra en el verano. Segun Audubon, preséntase en la Luisiana y en el Mississippi á principios de abril y algunos dias de setiembre; algunos individuos aislados avanzan mas, dejándose ver en la Pensilvania, en el Estado de Nuera.York, $y$ hasta se ha natado alguno en Europa; pero esta ave no es sedentaria sino en el sur de la América del norte, en México y en el Brasil.

USOS, COSTUMBRES Y REGIMEN.-Esta rapaz es bien conocida, y aunque asi no fuera, las particularidades que ofrece son muy á propósito para fijar la atencion de la persona mas indiferente. Es raro ver un nauclero solitario, ni rampoco apareado, pues acostumbra a formar bandadas compuestas de un gran número de individuos, los cuales se remontan por los aires ó se posan en algun airbol parn descansar. Estas bandadas constan a menudo de veinte á doscientos individuos; el árbol doncie se posan ofrece un curioso espectáculo. El vuclo del nauclero, dice Audubon, es hermoso y sostenido: esta rapaz se mucve en las elevadas regiones con una ligereza y una gracia que no se cansa uno de adnirar; remóntase á una altura increible, cerniéndose $y$ trazando grandes circulos, sin mover mas que la cola, que le sirve de timon; de repente, déjase caer como un rajo, re. móntase, vucla y desaparece bien pronio. Otras reces se ve una bandada de estas aves rodeando un árbol, cruzar rápida. mente entre las ramas, y coger al paso los lagartos é insectos de que se alimentan. I.os movimientos de estas rapaces son notablemente vivos: la facilidad con que cortan el aire, y la rapidez con que cambian bruscamente de direccion seducen al espectador que las observas

El nauclero martinete se alimenta especial, ya que no exclusivamente de insectos; Audubon y Ridgway dicen que devorn tambien las serpientes y los lagartos, pero todos los demás naturalistas le consideran como insectivoro. Caza los insectos del mismo modo que las golondrinas, con la dife. rencia de que no coge su presa con el pico, sino con las patas. 4 Al atravesar las montanas, dice $\mathrm{R}$. Owen, vimos de repente una bandada de naucleros que rolaban rasando el suelo y siguiendo la misma direccion que nosotros: muchos individuos distaban solo cuatro metros del suelo, y todos se mantenian unidos, lo cual the recordó los martinetes cuando vuclan de concierto al rededor de ruestros mas altos edificios. Estas aves llevaban las alas muy abiertas y la cola extendida: no volaban con mucha rapidez, pero si largo tiempo, y parecin que no agitaban las alas. Nuestra presencia no les asustó lo mas minimo, y no les inquietaron tampoco los gritos de admiracion de mi compañero de viaje y sus ademanes violentos. Algunos individuos pasaban á menos de cinco pa. sos de nosotros, como para dejarse ver mejor; de rez en cuando inclinaba uno lentamente la cabera, y entonces acer. caba al pico la pata con la que acababa de coger algun obje. 20. Esto no duró mas que un instante: el are abria el pico, tragábase la victima y levantaba la cabcza, siendo de notar que todos ejecutaban los mismos movimicntos. Bien pronto comprendimos la razon de tales maniobras: aquellas aves Tомо III cazaban una magnifica especie de abeja, que por desgracia no pude reconocer.

No son únicamente los naturalistas los que tienen al nauclero por insectivoro, sino ambien los animales, y por eso le aborrecen algunos de ellos, pues les perjudica en sus cacerías. Cicrto dia, dice Burmeister, vi un nauclero perseguido por un tirano (saumphogus sulphuratus), que le acosaba furioso. Este último no coge su presa sino al vuelo, sin tocar á los insectos posados en las ramas; y alaimparlos el nauclero

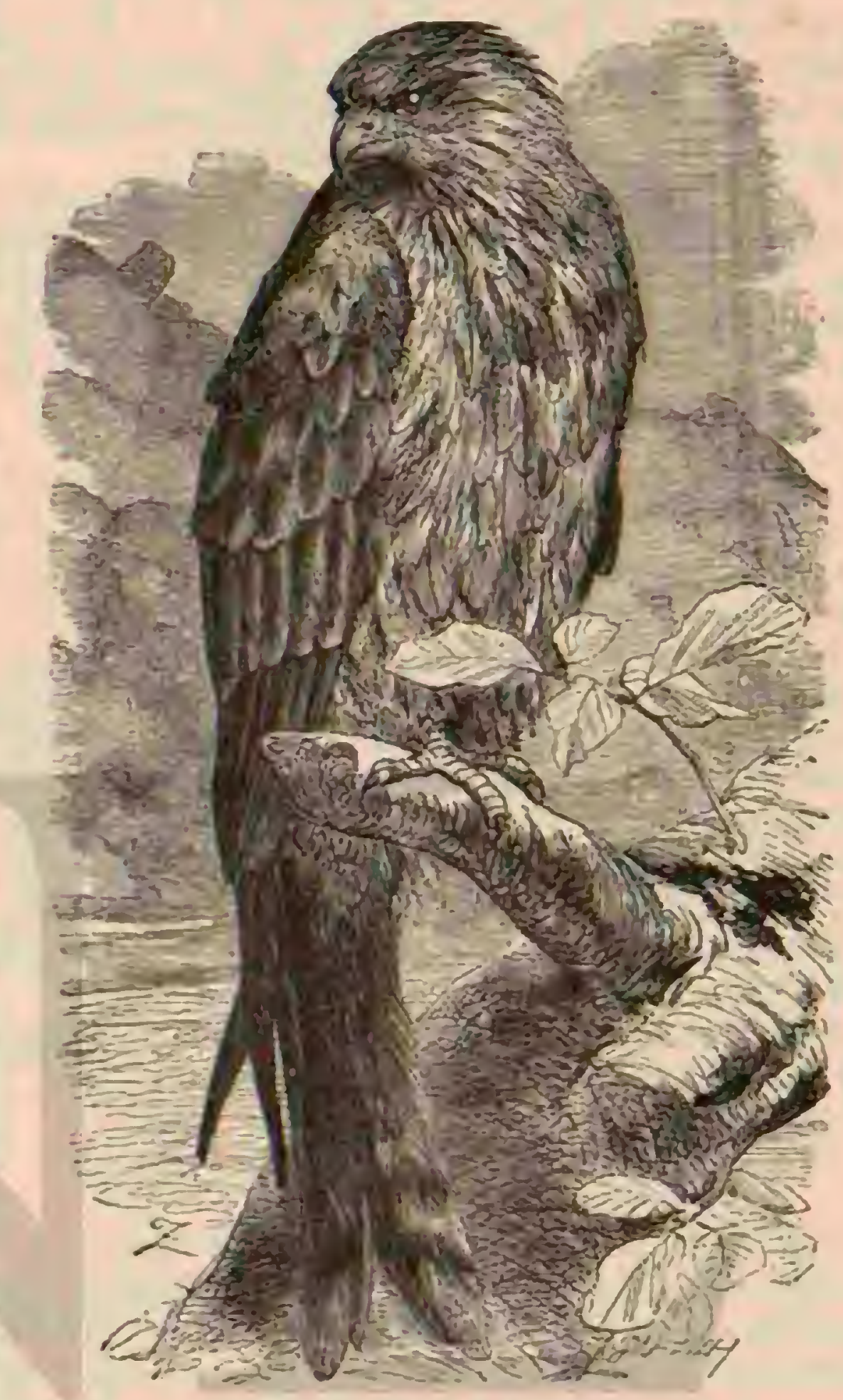

fig. 160.-EL MHANO REAL.

debajo de las hojas y cl ramaje, quitabale en cierto modo el alimento del pico, lo cual irritaba al ave.

a Cuando el tiempo es hermoso y tranquilo, añade Audubon, el nauclero se remonta á una gran alura, persiguiendo al mesyariro halcon, insecio de gran talla, y entonces luce toda su habilidad. Aliméntase principalmente de grandes langos. tas, de orugas, de pequeñas serpientes, lagartos y ranas. Se remonta a poca altura; detiénese un instante, se deja caer, coge una serpiente por el cuello, elévase y la desgarra volando. En aquel monento no ofreceria dificuliad acercarse; pero en todas las demás circunstancias es muy recelosa el ave. Cuando se ha matado a un nauclero llegan lodos los demas cual si quisieran llevarse su cadírer; de este modo he podido tirar varias veces sobre ellos, disparando rápidamente y volviendo á cargar lo mas pronto posible.

- Durante el dia vuelan á gran altura, y por la noche se posan en los pinos y cipreses mas altos, a orilla de los lagos y de los rios.) Azara añade que uno de sus amigos mandó hacer un reclamo parecido á un nauclero; lo lanzo por los aires, y atrajo asi las rapaces á tiro de fusil.

E! nauclero, asl concluye Audubon, se aphrea apenas ha 
llegado à los Estados del sur, procurando antes cautivar á la hembra con sus ejercicios de alto vue!a. Su nido se halla en la cúspide de una encina 6 de un pino muy alto, á orillas de un rio 6 de una laguna, $y$ se asemeja bastante al de la corneja: la parte exterior se compone de ramas secas, mezcla das con musgo de España, y está relleno de yerbas y plumas. Los cinco 6 seis huevos que pone la hembra cada vez, son de color blanco verdoso, con manchas irregulares de un tinte pardo oscuro en el extremo grueso. El macho y la hembra cubren alternativamente, y se alimentan uno $\mathbf{a}$ otro. En el momento de salir a luz los hijuclos estân cubiertos de un plumon amarillento, mas no tardan en adquirir sus primeras plumas; en el otoño se asemejan ya mucho a sus padres, y en la primavera tienen sú plumaje definitivo.

CA UTIVID A D. Hasta agui no ha sido posible conse: var largo tiempo a esta liermosa ave cautiva: un individuo que turo Audubon varios dias, rehusó comer, y hasta vomicó todo cuanto contenia su estómago. Permanecia inmóvil, con las plumas erizadas, y solo cuando le cogian por las alas tra. tabáa de hacer uso de sus ủnas: murió de aniquilamiento.

\section{LOS MILANOS-MILVUS}

CARACTERES. - LOS milanos son rapaces de tamano regular y formas esbeltas; el pico es endeble y relativamente pequerio, algo corvo en la base, con gancho bastante largo, muy hendido y sin escotaduras en el borde; los tarsos son cortos y estin cubiertos en su cara antetior de un escaso pluniaje hasta la region de los talones; los dedos, de regular tamino, tienen garras poco corvas; las alas son relativamenic rnuy grandes y largns; la cuarta rémige es la que se prolonga inas: Ia cola, de bastante longitud, se bifurca mas ó menos las jlumas son grandes, poco compactas y erizadas; las de la cabeza largas y puntiagudas, como las del pecho.

DISTRIBUCION GEOGRAFICA. - IAs seis especies que se han distinguido habitan el antiguo mundo.

\section{EL MILANO REAL-MILVUS REGALIS}

CARACTER ES. - El miláno real, llamado tambien mi lano rojo, milidido bifurendo, rojiso, milato de las gallinas, etc. y considerado por variós ornitólógos como tipo de un sub. género independiente, es un ave de rapióa magnifica, dc $0^{*}, 6_{5}$ a $1^{*}, 67$ de longitud por $8^{\circ}, 40$ a $\gamma^{\circ}, 50$ de punta a punta de las alas: estas miden $0^{2}, 50$ y la cola $0^{10}, 38$. Distinguese de sus congéneres europeos y de todos los milanos en general por su cola bifurcada hasta unos $1 \%$, 10 de la extrenidad. En el macho adulio, la cabeza y la garganta son blancas: todas las plumas presentan en el tallo una línea angosta de color pardo oscuro; las de la cabeza tienen un brillo rojizo claro; la parte posterior del cuello, la nuca y la anterior del pecho son de un rojo de orin; las plumas del corso y de los hom bros de un pardo oscuro en el centro y urilladas de rojizo; el vientre, el resto del pecho y el plumaje de los piés de un bonito rojo de orin, con linens negras de regular anchura en el tallo de las plumas; las rémiges primarias son negras, con la base blanca; las secundarias, negras tambien y de brillo metálico pardo rojizo y con cstrechas fajas trasversales oscu. ras; las pequeñas tecirices de la parte inferior de las alas son rojiaas, con manchas negras; las grandes de este úitimo tinte, orilladas de rojizo; las rectrices del centro son de un rojo de orin; las exteriores negruzcas, con lustre pardo hácia la punrectrices son bin angosto borde blanco sucio; las rémiges jas trasversales negras cn la cara inferior, con estrechas faoscura; el dorso de un oscura; cl dorso de un pardo mas igual; el color rojizo suele ser mas claro: las manchas negras y los bordes de las plumas mas estrechos y oscuros que en el macho. Los ojos son de color de plata; el iris de un amarillo pálido en los adultos; el pico amarillo en la base, azulado en los individuos de me. diana edad y siempre negro en la punta; la cera y los piés son amarillos (fig. 160). En los pequeños todos los colores son mas claros y sucios; las líneas de los tallos merios marcadas; la mayor parte de las plumas tienen anchos bordes amarillos; la pupila es parda; el pico negro; la cera y los piés de un amarillo pilido.

DISTRIBUCION GEOGRÁFICA.-Las llanuras de Europa desde el mediodia de Suecia hasta Espania, y desde aqui hasta la Siberia, son la patria de esta ave rapaz. que Schiller ha designado con el titulo de rey de los aires. Dentro de esta área de dispersion, bastante extensa para semejante especie, el milano real no se encuentra en todas partes, ni siempre tampoco en regiones análogas à otras que habita. En el sur de la Escandinavia abunda mas de lo que podria suponerse y hasta es comun en algunas partes; en Dinamarca está dise. minado en todas las islas, mientras que en Holanda y Bélgi. ca solo se le ve de paso; anida en Francia, Portugal y Espa. n̉a, lo mismo que en todos los parajes convenientes del sur y centro de Italia; por Grecia no pasa sino cuando emprende sus viajes, pero en canbio se le observa en todas las llanuras del Danubio, y con bastante regularidad en las de Polonia; en el mediodia de Rusia solo anida por casualidad; en Ale. mania lo hace en la parte llana de la Turingia, en la Marca, Sajonia, Brunswick, Hannover, Prusia Rhenana, Mecklea. burgo, Pomerania, Posen, y en las provincias de la Prusia occidental y oriental. En todos estos paises habita continuamente los sitios convenientes, mientras que parece faltas en algunas regiones de Westfalia y de la Silesia superior; en Baviera solo se encuentra en las vastas lianuras, y en el sudoeste de Alemania está representado por sus congéneres.

No visita las regiones montañosas de estc pais sino durante sus viajes; preséntase regularmente a primeros de marzo permanece hasta principios de octubre: en los inviernos poco rigorosos se quedan algunos en el pais, cuando creen que no les faltara el alimento. En sus viajes se reunen á veces numerosas bandadas de cincuenta á sesenta individuos, que al parecer viven juntas durante todo el invierno. Cerca de "loledo vimos en medio del invierno una bandada de al menos ochenta individuos, que caraban juntos durante el dia y pa saban la noche en un bosquecillo situado à orillas del 'Tajo. En verano solo suelen verse en la misma region algunas parejas del milano real. En sus viajes por el noroeste de Africa hasta las islas de Cabo Verde, muchos individuos cruzan todos los años repetidas veces por el estrecho de Gibraltar. Algunos permanecen en los paises donde se hallaban, aumentando asi el número de los que desde hace mucho tiempo habitan la region del Atlas y las islas Canarias.

En otro tiempo figuraba esta rapaz en algunas ciuciades de Europa, como actualmente el milano parásito y el govinda en Africa y la India. En tiempo del rey Enrique VIII, dice Pennant, se vieron en las calles de Londres muchos milanos atraidos por los restos de toda clase que se arrojaban en la via pública; cran tan poco timidos, que iban a coger su pre sa en medio de la multitud; y estaba prohibido matarlos. El bohemio Schaschek, que visitó Inglaterra en 1461 , dice que nunca ha visto mayor número de milanos reales que en Lóndres, y Belon asegura no haber encontrado diferencia entre el Cairo y Lóndres en cuanto à los milanos que alli habitan. Hoy dia, las condiciones han cambiado; esta ave, antes tan comun en toda la Gran Bretania, ha sido exterminada en este pais, y solo anida en algunos puntos de Escocia. A pesar de su nombre, este milano no tiene nada de rcal: 
es perezoso, bastante pesado y asaz cobarde; su vuelo es lenio, pero muy sostenido, y no parece sino que nada en los aires; algumas reces está un cuarto de hora sin dar un solo aletazo, guiaindose entonces tan solo por los movimientos de su cola. Tan pronto se remonta á una altura donde apenas le puede seguir la vista, como ruela rasando el suelo, sin hacer esfuerzo alguno.

Su marcha eś defectuosa; mas bien salta que anda; cuando está posado en un árbol recoge el cuello todo lo posible y entonces parece que la cabeza está entre los hombros; no deja colgar la cola en línea recta, sino que la inclina un poco hácia adelante, \& lo cual se debe que sus formas, vistas de lado, presenten un perfil singular. De todos los sentidos, la vista es evidentemente el mas desarrollado, como ya lo de. muestran los hermosos ojos, pero mas aun el proceder del ave cuando volando á inmensa altura distingue cualquier presa $\delta$ un grande buho; el oido, y quizás tambien el tacto, son despues los mas perfectos, mientras que el gusto y el ol. fato parecen tener poco desarrollo. En cuanto á inteligencia puede conpetir con todos los halcones que habitan en Alemania; y mejor que cualquiera de estas aves sabe acomodarse $\{$ las circunstancias. Distingue con gran seguridad al caza. dor del campesino, y alejase de los pueblos donde ha sufrido persecucion, presentandose en otros con tanto atrevimiento como sus congéneres. Un milano real observado por Stoclker examinó todos los dias el pucblo posándose en árboles bajos en medio de las casas. Al rer esta familiaridad, Stoelker empezó á darle alimento, y turo la satisfaccion de verle llevarse la carne y las aves desplumadas, pucsta solo á die\% pa. sos de distancia de la casa. Una vez que se le colocó una trampa describió sus circulos muy cerca de esta, lanzó un grito y alejóse; cuando se le acechaba no parecia, y de este modo salió siempre ileso. Otro individuo visitaba con regu. laridad las fuentes parn buscar alli las entranas de pescado 6 los despojos de la carne; no hacia caso de la gente, ni tam. poco le espantaban los tiros que se le dirigian. Ell milano real revela tambien su inteligencia cerca del nido ó en cautividad. Su roz, poco agradable, es muy sostenida; tiene algo seme. jante á una risotada y al balido de la cabra, pudiendo expre sarse poco mas $\delta$ menos con las silabas jikikinarae; en el periodo del celo deja oir unas extrañas triolas. Se alimenta de mamíferos pequenos, de pajarillos que no pueden aun vo. lar, de lagartos, serpientes, ranas, sapos, langostas y lombrices de tierra; en las granjas arrebata los pollos, dando mucho que hacer a los que guardan las ocas; es perjudicial á las ca. cerias, porque extermina los lebratos y las perdices. A fuerza de hostigar a los halcones, consigue tambien quitarles su pre. 5a. Sin embargo, a pesar de todos sus defectos, el milano real es una de las aves mas útiles de nuestros paises por la infati gable actividad con que persigue á las nubes de arvicolas que devastan nuestros campos. Diariamente extermina un considerable número para su propio alimento ó el de sus hijuelos; y cuando se considera cuántos insectos y roedores nociros devora, inclinase uno a perdonarle que arrebate algun animal. Si no fuera tan impudente $y$ mendigo, y no obligase á los halcones á cazar mas de lo que necesitan para si mismos, le asignariamos un lugar honroso entre los protectores de la agricultura.

Entre los cazadores pasa por un hecho indisputable que el milano real es en extremo perjudicial para la caza y todo el mundo se cree por consiguiente obligado à externinar los adultos y las crias cuando es posible. A decir verdad, es una de las mas inofensivas de todas nuestras aves rapaces; el in dividuo que Stoelker observo, por ejemplo, no espantaba ni at las gallinas ni a las palomas del pueblo que visitaba, manifestando mas aficion a las ares muertas que $a$ las vivas
Tambien su pesca, que efectúa con bastante regularidad y a cuyo efecto recorre á veces distancias de 25 à 30 kilómetros, parece mas peligrosa de lo que es en realidad, prescindiendo de que raras veces tiene la suerte de apoderarse de un pece. cillo; sus esiuerzos tienen por objeto mas bien coger ranas que devorar los escamosos habitantes de las aguas. Solo en la época del celo es verdaderamente perjudicial para las ares domésticas y para la caza.

Poco despues de su llegada, en la primavera, el milano real comienza ya los preparativos para la reproduccion. Cuando le es posible, fabrica su nido en el mismo sitio del año anterior, pero no siempre se sirve del que ccupó antes; si encuentra uno de comeja $\delta$ halcon, conténtase con él, $y$ de lo contrario construge uno nuevo. Despues de haberse divertido mucho tiempo retozando en los aires por encima del bosque elegido, la pareja escoge al fin cierto árbol, que generalmente es el mas alto, aunque á reces no les conviene por ningun concepto: nunca distinguen entre los árboles irondosos y las coníferas. El nido, siruado tan pronto en las ramas de la copa, como en una rama lateral, tiene proco mas ó menos un metro de diámetro; su construccion no di. fiere mucho de la de un nido de buzardo ú otra rapaz., pero el milano real tapiza la cavidad con trapos y papel, y no elige siempre para esto el material mas limpio. Kounig. Warthausen asegura que el exánen del nido puede ser á veces muy desagradable, porque este milano recoge muchas veces el papel mas sucio, segun lo han reconocido otros ob. servadores; y en cuanto \& los trajos, procedentes por lo re. gular de cualquier monton de estiércol de los campos, no son por lo tanto menos repugnantes. Algunas parejas del milano real han llevado á su nido todo un monigote que se habia puesto para ahuyentar à los pájaros; otras robaron å la lavandera la ropa tendida en la cuerda, para rellenar con ella su nido. La puesta se compone de dos á tres huevos, raras veces de cuatro, en extremo semejantes a los del bu. zardo comun, con la única diferencia de ser por lo regular un poco mas grandes. Su diametro longitudinal es de 11,059 a $1,, 062$, y el trasversal de $0^{\circ}, 045$ à $11^{m}, 04 \%$. En la cáscara, de grano fino pero sin lustre, predomina el color blanco ver. doso, con manchas y lineas de un pardo rojo oscuro. Parece que solo la hembra incuba, pues mientras cubre los huevos siempre se ve al macho ocupado en buscar para su compa. niera el alimento necesario. A las cuatro semanas los polluelos saicn del cascaron y ambos padres les llevan abundante alimento. Su roracidad iguala a la de otras ares de rapina y obliga \& los adultos á cazar casi continuamente, siendo la causa de la mayor parte de sus fechorias. Ina hembra em. polla con tanta aficion que a menudo es menester dar varios golpes en el árbol antes de que abandone al nido; pero cuando los polluelos están mas desarrollados y no necesitan tanto la ayuda de los padres, estós toman mas precauciones; huyen á tiempo apenas se acerca un hombre, y no se ponen jamás á tiro aunque les llamen sus hijuelos; limitanse 2 dejar caer el alimento desde la altura. Stoclker pudo reco. nocer con cuánta inteligencia ayudan a sus hijuelos: habiendo hecho subir \& un hombre \& un nido del milano real, los aduitos lanzaron al aire al hijuelo mas pequeño, qque no queria seguir a sus hermanitos, auxiliándole despues en la fuga; de modo que cuando el hombrellegó al nido, ya cstaba desocupado.

CAUTIVIDAD. - El milano real cautiro se domestica pronto si se le cuida bien. Si se le coge adulto, segun la ob. servacion de Stoelker, suele conducirse de una manera muy extraña en presencia de un hombre: finge estar muerto, échase en tierra permaneciendo inmóvil; déjase caer de la percha con las alas y la cola pendientes; abre el pico g hasta 
enseña la lengua, sin dar la menor señal de vida; déjase le vantar por un pié y se mantiene despues en la misma posicion sin moverse, aunque se le vuelva a colocar en el suelo. Esto lo hace mucho tiempo, pero despues mas raras veces; no ninge ya estar muerto, sino moribundo, y cuando re que todo es inuitil, renuncia á sus tentativas, cobra mas y mas confianza, y demuestra al fin el mayor cariño à su amo. Jas aves de esta especie que yo cuidé me saludaban siempre apenas me veian llegar, reconociéndome desde léjos, aunque

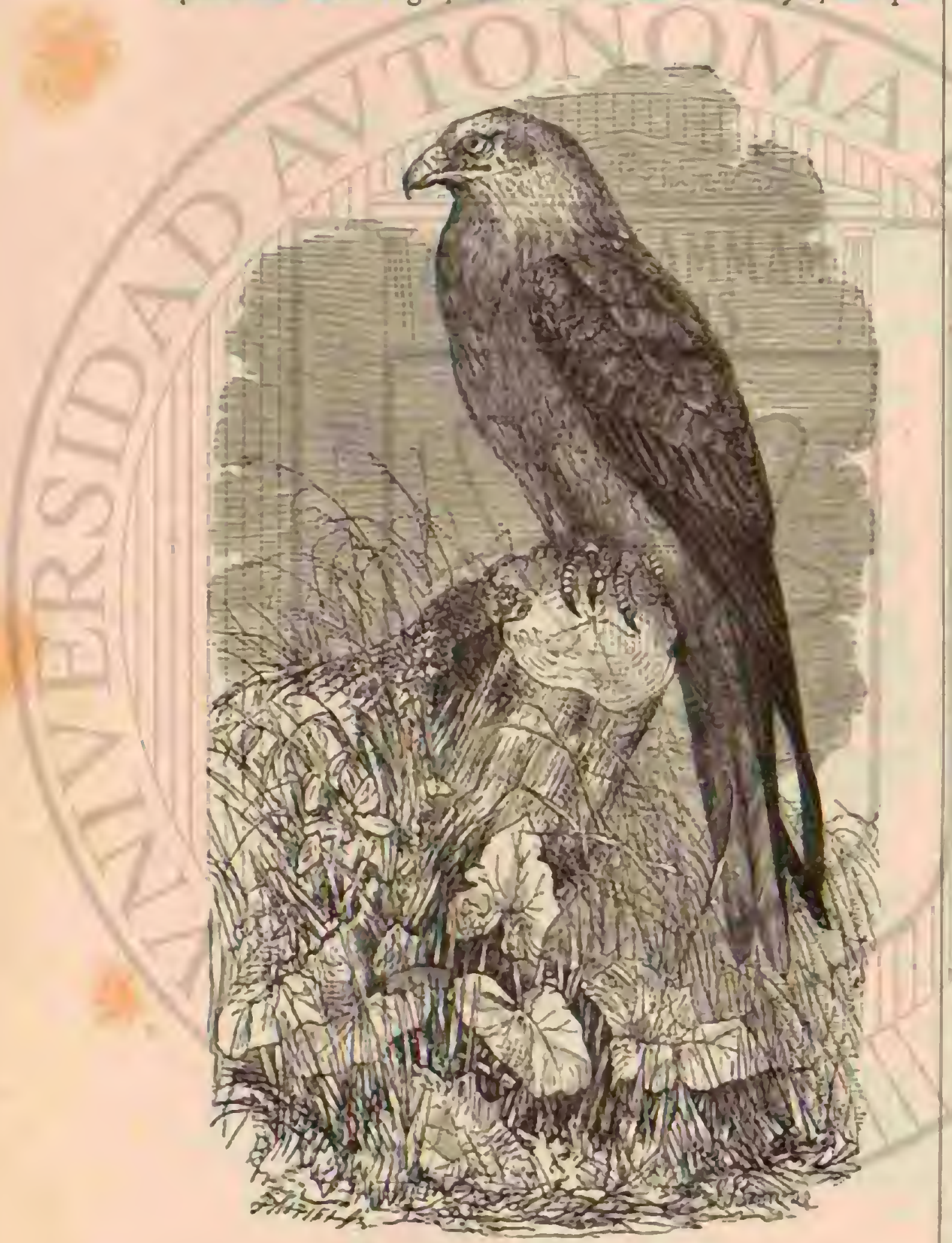

Fig. 161.-E1. MLAsio constsu

me hallara entre nuchas personas. Loj milanos reales se contentan muy fácilmente en cuanto à su alimento: viven en perfecta armonia con otras aves, y pueden designarse por lo tanto como rapaces de buena indole En cuanto is su docilidad con otros animales, obsérvanse algunas excep. ciones.

- Dumnie largo tiempo, refiere Berge, tuve un milano en un granero; mas tarde me fué preciso encerrar con él dos gatos medio adultos. $\mathrm{Al}$ principio no pareció fijar la atencion el ave en sus companeros; pero bien pronio tomó la costum. bre de ahuyentarlos del sitio donde comian; al cabo de poco tiemspo no quiso tomar la carne que le daban, $y$ vaciaba en cambio dos veces diarias el plato de sopa de leche destinado para los gatos, tanto que fué preciso trasladarlos a otro sitio para que no se muriesen de hambre. Mientras que estuvieron en el granero no comió el milano carne, pero tampoco dejó que la tocasen los gatos.

Otras de estas rapaces se han conducido mejor en circunstancias distintas. eUno de mis amigos, dice Lenz, turo mucho ticmpo una hembra de milano real, cuyas alas estaban paralizadas, y por lo mismo se le dejaba recorrer libremente el jardin. Constrayó un nido, puso cios hueros, los cubrió con mucho afan, é hizo lo mismo al año siguiente. Entonces se le echaron tres huevos de gallina y los cubrió tambien: cuando salieron los polluelos, los sujetaba con su pico, si trataban de alejarse, y los colocaba debajo de su cuerpo, procurando alimentarlos con pedazos de carne; pero muric. ron muy pronto. 8

No es el único un cjemplo de esta clase El guardabosq̨ue Girardi cuidó veintitres anos un milano real que se cogió antes de salir del nido, tratándosele como á otras aves de rapina.

Hamatz, asi sellamaba, acudia cuando su amo le llamaba para comer, y muchas veces entraba en la habitacion a fin de coger lo que se le ofrecia en la mano; conduciase como las gallinas: incubaba todos los anos durante mucho tiempo los hueros de aquellas y cuidaba los polluelos, que salian con una facilidad admirable. Curioso cra ver cómo los poiluelos cogian la carne de las garras $\delta$ del pico para comér. scla Desgraciadamente, Hamata, que tambien era mug apreciado porque anunciaba los cambios de temperatura, murio à consecuencia de las mordeduras de un perro de caza.

\section{EL MILANO NEGRO-MILVUS ATER}

CARACTERES. - El milano negro, llamado tambien builve del bosque y laifron de gallinas, es, en opinion de Kaup, el ripo de un sub-género independiente del de los milanos acuáticos (Hidroictinia). Mucho mas pequeño que el milano real, su longitud varia de $6^{\prime \prime}, 55$ a $11^{m}, 5 \$$, por $8^{*}, 36$ a $1^{\prime \prime}, 45$ de nnchura de punta a punta de las alas; estas miden de

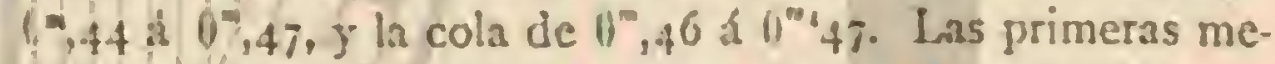
didas son las del macho y las segundas las de la hembra.

El plumaje es en todas sus partes micho mas oscuro que el del milano real, por lo que se le llama con razon milano negro, para significar el contraste con el milano real ó rojo. La cabeza, la nuca, la barba y la gargania son de un gris blanco con líneas de color pardo oscuro, de anchura desigual, $y$ las plumas del manto de un pardo de tierra con un borde mas claro; las de la region del buche, del mismo tinte, presentan lineas bastante anclas en el tallo; las del pecho son de un gris rojizo; las del vientre $y$ las tectrices inferiores de la cola de un pardo de orin mas 6 menos oscuro, con un ligero viso gris y angostas lineas longitudinales negras; las rémiges, de un pardo oscuro, tienen lustre cobrizo; las tectri. ces de la parte superior de las alns de un gris de lierm con bordes mas claros; las rectrices de un pardo oscuro con ocho ó doce fajas pálidas, pero regulares, y un borde gris palido en la extremidad; los circulos oculares son de un gris pálido; el pico negro de cuerno; la cera amarilla y los piés rie un amarillo de naranja.

Los sexos no difieren por el color; los poliuelos tienen la cabeza y parte inferior de un pardo rojizo; todas las plumas presentan en la punta manchas de color amarillo blanquizco claro y líneas oscuras en los tallos; las tectrices del manto, de un pardo oscuro, están orilladas de leonado; las tectrices de las alas, de un ligero gris de ticrn y mas oscuras en el centro, tienen tallos negros y bordes de rojizo claro; las de la garganta son muchas veces de un solo color, leonado claro.

DISTRIBUCION GEOGRAFICA.-El area de dispersion del milano negro es bastante limitada, como la de todos sus congéneres. En el centro de Alemania pertenece à las aves raras; mas á menudo se la ve en la Marca, sobre todo cerca de los lagos del Havil, en Pomerania, Mecklemburgo, en la parte superior del Rhin y en la inferior del Main, sobre todo en la Hesse Rhenana y en Baden. Anida con regularjdad en el Austria inferior, en Hungria, en los paises bajos 
del Danubio, en una gran parte de Rusia y tamuien en Italia y Esmaña; en los sitios farorables de estos paises abunda mu. cho y hasta anida en sociedad. En Alemania se la ve solo en verano; llega en marzo y desaparece en octubre, porque pasa el invierno en el mediodia de Europa; pero algunos in. diviluos prolongan su viaje aun hasta el Africa. Entonces vaga por todo este continente, llegando hasta el sur y sudoeste del mismo; no visita el pais de los damaras y nama. quas, segun Anderson, hasta fines de agosto, y con mas regularidad en octubre ó noviembre $y$ hasta en diciembre alguna vez Al principio se ven pocos de su especie, pero algunos dias despues su numero es tan considerable que puede designarsele como una de las aves mas frecuentes que inver. nan en aquel pais.

USOS, COSTUMBRES Y REGIMEN.-Inmediatamente despues de su llegada, en la primavera, el milano se dirige al sitio donde anidó el ano anterior y da principio su vida de verano. Debo al principe imperial, archiduque Rodolfo de Austria, una descripcion tan excelente y exacta sobre el particular, que creo lo mas conveniente reproducirla aqui, intercalando alguna observacion de otros naturalistas. aEl milano negro es bastante comun en Hungria, y le he ob. servado aqui con regularidad; mientras que en el Austria in. ferior solo se encuentra en algunas regiones. Habita con preferencia los bosques situados a orillas de los grandes rios, en cuyas inmediaciones hay pantanos; los árboles altos son los únicos que elige para anidar $\delta$ dormir; y durante el dia vaga continuamente entre ellos, costeando por lo regular las corricntes. Su género de vida exige un pais llano con mucha agua, y por eso le gustan sobre todo nuestras praderas del Danubio. Fi que conozca esta ave no la considerará nunca como habitante de las montañas, pues jamás se la encuentra en cllas, ni ampoco en las mesetas; y hasta crita los bos. ques que lindan con extensas praderas y campos. El limite de los lugares que habita es muy reducido, lo cual se reco. noce por el hecho de que abundando mucho en las praderas cruzadas por el Danubio, ya no se le ve a una legua de dis. tancia, como por ejemplo en los linderos del bosque de Viena. Tengo la costumbre de visitar con frecuencia este sitio, y ni una sola ver. encontré un milano negro, mientras que el milano real anida alli todos los años. La especie negra es sociable, pues alli donde vive, siempre se encuentra en número considerable de individuos, que buscan la compania de otros congéneres; pero el milano real vive siempre aislado en las moniañas cubiertas de bosque, 6 se retira $\{$ los sitios mas silenciosos de las praderas. El milano negro no evita en el Austria inferior las inmediaciones de los pueblos, y menos aun en Hungria, donde visita hasta las ciudades, incluso la capital en cuyo interior vaga á menudo mucho tiempo.

3. En rigor no es fácil ubservar esta ave sino en el periodo del celo; y por otra parte su género de vida es tan vagabun. do, que pocas veces puede acercarse el hombre 3 la rapaz Cuando se penetra en las praderas del Danubio, vénse primero algunos milanos que volando sobre la maleza baja en los linderos de los campos, dirigense en todos sentidos para buscar su presa. Cuanto mas se penetra en el bosque, tanto mayor es el número de los individuos que se encuentran,y si se pasa a un barco para recorrer un brazo aislado del rio, se verá á los machos describir sus circulos al rededor de los árboles, en las pequenas islas, mientras que en el interior de estas la hembra reposa en el nicio. De vez, en cuando obsérvase como estas aves, una despues de otra, se dirigen desde las islas al brazo principal del rio, hácia las praderas de la orilla opuesta, a menudo sin hacer ningun aprecio de la embarcacion.

s. El vuelo de esta are es magnifico, sobre todo cuando se balancea sobre la superficie de las grandes corrientes, como suele hacerlo durante largo rato; pero solo en la primavera se puede formar una idea exacta de su agilidad. Excitada por el amor, la parcja se remonta á gran altura por los aires para trazar sus circulos; de ręente déjase caer el macho ó la hembra con las alas recogidas hasta poca distancia de la superficie del agua, franquea un corto trecho con la rapidez del rayo, describiendo lineas curvas; vuela despues en sentido inverso; revolotea como el cernicalo y ejecuta los movimientos mas maravillosos en todas direcciones.

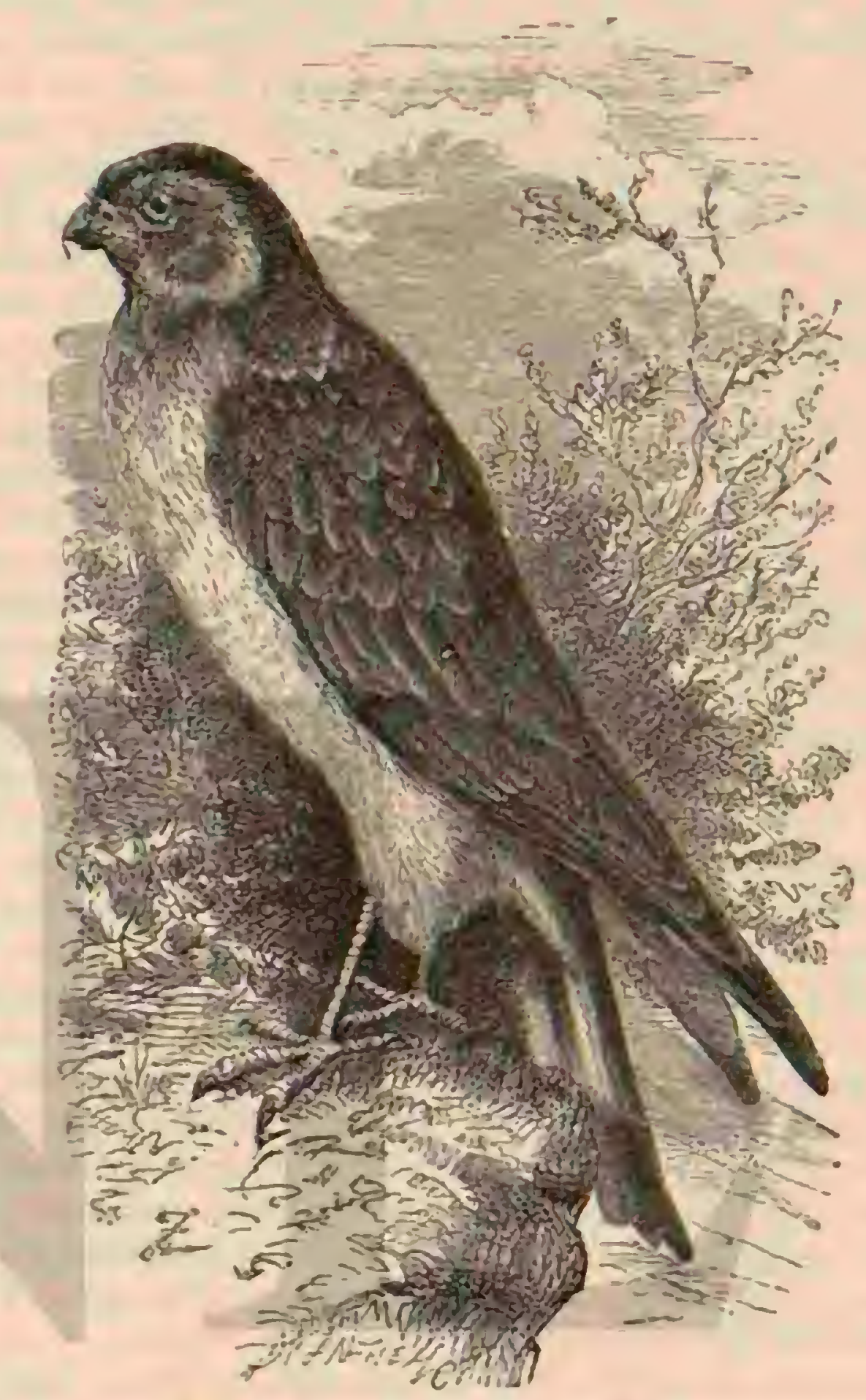

Fig. 162.-8.1. cincino A\%.rtar110

En las islas mas solitarias, donde raras veces se presenta el hombre, es donde se debe buscar el sencillo nido, que se halla hácia la mitad del tronco de un árbol, en la bifurca. cion de alguna rama gruesa. Se componc de ramas secas, ligeramente entrelazadas, y ya desảe léjos se ve la cola de la hembra, que sobresale del nido. El milano negro no sucle fabricar este último. busca los que la garza real abandona, y así sucede que á menudo apenas se reconoce el suyo pro. pio. En las is!as donde se hallan las colonias de la garn. real y de los íalacro corácidos es donde encontre el mayor número de nidos; duranie el periodo del celo no los ví nunca donde anidaban el buzardo, el milano real y las gran. des especies de halcones. Fl periodo de la incubacion varia mucho: á fines de abril visité nidos en que las hembras estaban ya cubriendo los huevos, mientras que otras parejas se ocupaban aun de la construccion del nido y hasta algunas vagaban en busca de un sitio conreniente. En la mayor parte de los nidos las hembras estaban incubando a media. dos de mayo.

xEl que observa al milano negro debe notar que le agrada 
mucho la sociedad de las aves acuáticas y puede conside. rarse como una prueba de su carácter inofensivo la buena armonia en que vive con ellas. Cierto dia encontré un nido en la orilla de una gran isla, y á cien pasos mas allá todos los árboles estaban ocupados por otros de la garza real, mezclados con los del cernicalo y del aguilucho. Todos los habitantes de aquella colonia se cruzaban en su vuelo con la mejor armonia, y el macho del milano ejecutaba sus evoluciones en medio de las garzas reales. En otro sitio encontré dos nidos de milano entre los de las garzas reales y de los falacro-corácioios. El uno se hallaba apenas \& tres metros de aitura sobre el suclo, en una rama gruesa, y encima lí cuatro 6 cinco del falacro corácido; el segundo estaba en un árbol corpulento, tambien a pocr alium del suelo, $y$ s un metro mas arriba hallé dos nidos de garzas reales; las tiem bras de ambas especies ocupábanse en cubrir los huevos, mientras los machos estaban posados uno junto \& otro én la misma rama. Ambos nidos de miano se hallaban en los ár. boles mas exteriores de la isla, uno en el lindero de un bosque pantanoso, y el otro en el lado opuesto de la isla, en la orilla de un ancho brazo del Danubio. En otra pequeña isla habia otro nido de milano, y f poca distancia de este pero separado par un estrecho brazzo del rio, anidaban un buzardo; un halcon lamario y algunos aguiluchos; ambien encontré aqui un gran nido del águila acuática, aunque abandonado al parecer. Yo creo gue la causa principal de reunirse asi las garzas reales y falacro corácidos con los milanos debe atribuirse á la gran voracidad de estos últimos y a su pereya para cazar. Su alimento favorito consiste en peces, y fácilmente pueden satisfacer su apetito al lado de las gar. zas reales, porque estas dejan caer ruuchos grandes peces de su nido, de los cuales se apoderan centonces otros parásitos. El milano negro es sin cmbargo bastante hibil en la pesca, pero sin duda le parece mas cómodo mendigar. Tambien sabe molestar con su impertinencia à las grandes aves acuáticas y al águila de. los rios para que le abandonen su presa comn lo hace su congénere el milano real en el bosque con las iguilas, los buzardos y los halcones. Además de los pe ces, el milano negro se alimenta de lebratos, hamsters, ra tones, y sobre todo ranas. Para los gallineros es peligroso por su gran atrevimiento; roba en zodos los pueblos los po. llitos y los patos pequeños á la vista de sus padres, y solo el arma de fuego puede impedir sus fechorias. Una ver. vi en un prueblo, siruado a orillas de la pradera, un milano negro que cazaba revoloteando sobre una casa de labranza o la altura de la chimenea y buscando una presa á la manera de
los cernícalos.

En cuanto á la reproduccion de este milano, debo añadir que su nido, asi como el del nilano real, suele estar relleno de trapos, delantales viejos, camisetas; masas de pelo de ina. mirero, estopa y de materias análogas: por esto pueden dis. tinguirse fácilmente de los nidos de todas las demás rapaces que habitan en nuestras regiones. Los trapos $y$ los pedazos de estopa que se encuentran en el borde del nido 6 en las ramas próximas indican por lo regular, segun Blasius, que el nido esta ocupado. La puesta, que suele completarse à fines de abril, se compone de tres a cuatro huevos, en citremo semejantes á los del milano real, de color amarillento 6 gris blanquizco, con espesas manchas pardas. Segun parece, solo la hembra empolla, ó al menos asi lo indica una observacion de von Preen, que estando en acecho cerca del nido, notó que un milano, probablemente el macho, dejaba caer peces en el nido desde una altura considerable, y csto cuando solo habia dos huevos. Ia hembra suele cubrir la puesta con tanto afan, que solo huye cuando resuena un tiro. Eugenio de Homejer y yo nos hemos esforzado varias veces, cuando ibamos a cazar con el principe Rodolfo, para obligar al milano á levantarse, y no lo conseguiamos con nuestras voces y el ruido que se hacia. Cuando al fin el ave se resolvia á levantarse, alejábase con suma rapidez, y no hácia un paraje descubierto sino á través de la enramada mas espesa; de modo que el cazador no podia apuntar bien. Cuando no se ha inolestado antes \& la hembra, esta suele volver al nido poco despues de haberla ahuyentado, mientras que el macho deja pasar á veces horas enteras. Si se inquieta á la pareja continuamente y se mata porfin d la hembra, pucdesuceder que el macho, como lo ha observado Preen, acabe por romper los huevos.

Los polluelos saien del cascaron al cabo de tres semanas poco mas 6 menos: al nacer estan cubiertos de un plumon blanco, con un ligero viso de rojo en el occipucio, pardo por detrás de los ojos y de un pardo gris claro en toda la parte superior; este plumon difiere mucho, segun Blasius, del de todas las denás aves de rapina que hay en Alemania, sobre todo por su gran longitud y blandura. Ios padres alimentan. al principio á su progenie con carme, ranas y peces medio digeridos ya en el buche de los adultos. EDificilmente podrian encontrarse, dice Blasius, dos especies de aves tan congenéricas como el milano negro y el real, y que tanto difieran por el tipo. Lo nismo que el milano negro adulto se parece en su vuelo y en su aspecto en algo al águila, tambien en su primera jurentud recuerda al águila rusa. Antes de que pueda sosterierse con los piés, ya tiene la cabeza erguida, $y$ con ademan tránquilo y sin temor, mira fijamente todo cuanto' se le acerca. Por la regular abandona el nido antes de que las rémiges y/rectrices hayan llegado a su completo desarroIlo, yi entonces se le puede coger fácilmente durante la estacion lluviosa en el suelo ó en los árboles bajos. El milano real, por el contrario, es tímido en su jurentud, y suele per. manecer echado en el nido, con la cabeza apoyada en el suclo. Aungue esté completamente desarrollado, solo por fuerza abandona el nido, y dejase coger hasta con la mano cuando ya puede volar perfectamente. Una sola mirada sobre el nido ocupado por los polluelos basta, pues, para reconocer a que especie de milano pertenecen los padres. El milano negro, en cambio, necesita aun mucho tiempo despues de salir del nido la ayuda de los adultos, que continuan con su progenie aun rarias semanas; y el observador atento podria ver entonces fácilmente cómo los padres instruyen á sus hijos, no solo en todas las artes del vuelo sino tambien en la manera de mendigar el alimento, lo cual importa mucho para su vida futura. Solo 1 fines del verano sepárase la farni. lia, y cada individuo comienza la vida independiente, hasta que en otoño se rêunen en grupos, y despues en bandadas, que en sociedad emprenden su viaje hácia el sur.

El milano se considera generalmente como una de nuestras rapaces mas dañinas; yo, por mi parte, creo que los perjuicios causados por esta ave en las regiones donde ha. bita con preferencia no son muy considerables. Iil mayor daño de que se hace culpable redúcese sin duda á molestar a otras aves de rapiña hasta que las obliga á dejarle su pre. sa y á robar por consiguiente mas de lo que necesitarian en otro caso. Cierto es tambien que coge cuanto pucde alcanzar y que perjudica bastante asilá los animales domésticos como á los libres, pero esto es solo en los últimos dias del periodo de su reproduccion. Si ponemos en la balanza sus fechorias y la utilidad que nos produce, seguramente sc mantendrá en el fiel. Cierto que es mas dañino que el mi. lano real, pero no tan perjudicial como se pretende, prescin. diendo de los casos excepcionales, por ejemplo, cuando uno de su especie se acostumbra a cazar en los pueblos los po. lluelos de las aves domésticas; senuejante malhechor no des. 
miente la cobardia propia de todo su género, pues basta una clueca valiente para ahuyentarle; mas á presar de eso coge mas de un patito ó pollo. Algunos individuos se dedican znas de lo regular á la pesca, y entonces ocasionan perjuicios en uno ú otro estanque de carpas; pero en rigor, su pesca es tan poco considerable como su caza de lebratos ó su robo de aves domésticas. Los ratones y las ranas, juntamente con los peces que durante el periodo del celo recoge casi siem. pre debajo de los nidos de la garza, constituyen su alimento principal, y por lo tanto no puede calificarse de muy consi. derable el dano que causa. Yo creo que no se le deben hacer tantos cargos. El que le perdone con benevolencia no le mo. lestará; el que en cambio lo mira con ojus desiarorables en todo cuanto hace le perseguira siempre, como $y$ donde pue. da. Harto siento no poder absolverlo del todo; pero si me atreveré a pedir para el la gracia de todos aquellos que como yo se interesen por un ave tan bella, complaciéndose en ad. mirar su vuelo, que reanima las monótonas regiones habitadas por esa especie.

El milano negro, como dice tambien el archiduque Ro. dolfo, es un gran enemigo del buho, pero no le ataca tan violentamente como otros halcones. En un espeso bosque separado de los campos por una corriente de agua, y que se halla a orillas de la pradera, dice el archiduque, puse mi buho en un sitio descubierto, ocultandome entre el follaje para matar algumos estrigiceps azulados. Apenas hubieron comenzado estos su ataque, ví aparecer dos milanos, atraidos sin duda por el rumor; las rapaces comenzaron á trazar sus circulos sobrc el buho: pero mantuvieronse siempre á la misma altura, fuen del alcance de mi escopeta; no atacaron el buho, ni tampoco pude obligarlos a remontarse á nayor altura, a pesar de haberles disparado algunos tiros: a los diez ininutos abandonaron el sitio por el mismo punto por donde habian llegado.

CaUTIVIDAD. - Esta rapaz es bastante agradable en una pajarera y no ocasiona mucha molestia; resignase muy pronto con la pérdida de su libertad; se encarina con su amo, lanza un grito de alegria cuando le ve, y procura darle diariamente nuevas pruebas de afecto. Vive en buena armo. nia con las otras rapaces de su talla; pero no te causa la menor repugnancia devorar el cadaver de auguellas con las que ha vivido durante varios años en la mejor armonia.

\section{EL MILANO PARÁSITO-MILVUS PARA-} SITICUS

CARACTÉRES. - Esta especie se asemeja tanto á. la anterior que algunos naturalistas dudan de su independen. cia; y en efecto, solo dificre a primera vista por el pico, siempre amarillo en vez de negro; pero examinándola mas de cerca, hállanse tambien otros caractêres bastante distin.

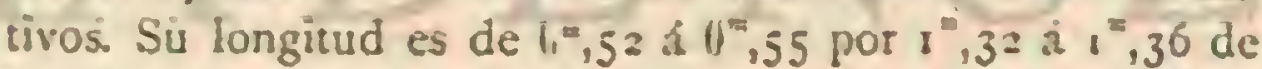
anchura de punta a punta de las alas; estas miden de $U^{*}, 43$ a $6^{\circ}, 45$ y la cola de $4^{\circ}, 20$ á $6^{\circ}, 22$; las primeras medidas corresponden al macho y las segundas á la hembra la ca. beza, el cuello y la parte inferior son de un pardo rojizo; el plumaje de los piés, de las sectrices inferiores y de la cola es de color rojo de orin; la region de la linea naso.ocular y la barba tiran á blanco; todas las plumas presentan en los tallos angostas lineas de color pardo oscuro; el manto, los hombros y el resto de la parte superior son pardos, de un tinte nas pálido en la punta, y con tallos negros; las remiges son de un pardo intenso; las primarias un poco nuas claras por dentro, con manchas oscuras; las secundarias tienen cinco fajas trastersales poco marcadas; las rectrices son pardas en su cara superior; las exteriores mas oscuras, todas orilla das de un tinte claro en las barbas interiores y ornadas de ocho á nueve fajas trasversales de color oscuro; la cara inierior de las barbas interiores es de un blanco pardusco; los ojos de un pardo claro; el pico amarillo de cuerno $y$ los piés amarillo de paja.

DISTRIBUCION GEOGRÁfICA.-El árer de dispersion del milano parásito comprende toda el Africa, ercepto los paises del Atlas; habita además en Madagascar, Palesti. ma, Siria, el Asia Menor, y probablemente hasta en la Turquia curopea: no me parece seguro aun que la especie que anida en las mezquitas de Constantinopla sea en ciecto el milano negro y no el parásito. En el nordeste del Africa se puede designar a este último como una de las rapaces mas comunes; es esencialmente caracteristico de los paises del Nilo y del mar Rojo, y la primera ave terrestre del Egipto que se observa al llegar á este pais: á menudo se la ve trazar sus circulos sobre las selvas virgenes del Nilo superior. El milano parásito ha elegido casi exclusimamente al hombre para que le alimente, y por eso le profesa una amistad que, nuy provechosa por lo regular, puede ser molesta algunas veces.

USOS, COSTUMBRES Y RÉGIMEN.-El milano parásito es el are nıs impertinente que conozco; ningun ani. mal puede merecer mejor su nombre. Solo se ocupa en mendigar, y por eso habita de preferencia en los mismos pueblos; preséntase diariamente en las casas de labranza, y asi anida en las copas de las palmeras del jardin como en las cimas de los minaretes. Precisamenic es incómodo por hallarse en todas partes, y hasta da lugar a que se le odie. Nada se escapa á su vista penctrante; observa con atencion todos los actos del hon bre, y gracias à su intimidad con él ha logrado adquirir un conocimiento tal de las cosas huma. nas, que pocas ares ó aniniales le igualarian por este concepto. No dejara de seguir al cordero que se conduce á la muerte, unientras que no hace caso de los pastores; vucla al encuentro del pescador apenas llega, pero ni siquiera le mira cuando sale á la pesca; aparece sobre el barco si se mata al. gun animal, y describe sus circulos al rededor del cocinero apenas se presenta, importándole poco que la casa flotante esté ancladia 6 en movimiento; es, en fin, el primer visitante de los campamentos, el primer parásito que se presenta so. bre el cadiver de un animal caido. Contra el no hay seguri. dad para ningun pedazo de carne, pues a la agilidad del halcon reune la insolencia, con la roracidad y el conoci. miento de las costumbres humanas.

Con aparente indifurencia esti- posado en un árbol cerca del matadero, 6 en la arista de la próxima casa 6 de la tienda del carnicero; parece que apenas hace caso de lo que ve; mas apenas llaga el comprador, abandona su observatorio y empieza a trazar circulos sobre su cabeza. ity del impru. dente que, segun costumbre, lleve la carne en un cesso sobre la cabeza! Sin duda habrá gastado inútilmente su dinero. Yo mismo he visto, no sin rcirme mucho, cómo un milano parásito arrebató de un cesto todo el pedazo de carne, de mas de un kilógramo de peso, que el comprador llevaba. Hallándonos en Abisinia, nuestro cocinero cortó en pedazos una liebre sobre una caja colocada en el patio; como se le Llamara de juronio y iolviese la cabeza, vió desaparecer en el mismo instante un cuarto de liebre en las garras del mila. no ladron, que no habia dejado escapar la oportunidad favo. rable He visto al ave coger los peces de las barcas de pes. cadores, a pesar de que los propiezarios se esforzaron bas. tante para ahuyentar al insolente koba los objetos, en cl verdadero sentido de la palabra, de la mano del hombre.

No es solo el hombre el que proporcioma alimento á esta ave, pues el milano parásito no se limita á observar las cos. 
tumbres de aquel; estudia tambien las de los animales. Ape. ras el halcon ó el águila ha hecho una presa, rodéales una multitud de estos parásitos, que gritando y acometiéndoles con violencia les persiguen sin descanso; y cuanto mas rápidamente cruzan los aires, tanto mas aumenta el número de los mendigos. Eil peso que el halcon lleva en las garras impidele volar con ianta celeridad como de costumbre, y asi no puede evitas que ios perezosos milanos le acosen siempre de cerca.

Demasiado orgulloso para soportar mas tiempo tanta insolencia, suele abandonar su presa á los miseros bandoleros, que al punto comienzan a disputirsela; yuelve al sitio donde hay caza para escoger otra victima. El milano parásito molesta tambien mucho a los buitres: siempre los acosa con el mayor atrevimiento, cruza entre ellos y hábilmente recoge todo pedazo de carne que las grandes rapaces arrancan de su press.

Los perros gruñen e intentan morderle apenas se pre. senta, pues tambien saben que lleva intencion de robiarles la carne adquirida con harto trabajo. Raras veces se resuel. ve á cazar por si mismo, si bien es bastante hábil y sabe apoderarse perfectamente de las pequemas aves domésticas, inclúso los palomos, sin contar los ratones, reptiles y jeces, que constituyen su alimento preferico.

El milano parasito forma por Jo regular nunterosas ban. dadas: pero solo se le ve en parejas cerca del nido. Sobre los mataderos de las grandes ciudades obsérvanse á veces considerables grupos de cincuenta a sesenta individuos. El nido de esta rapaz suele estar en las palmeras, yó menudo en los altos minaretes de las mezçuitas. La puesta se compone de tres á cinco huevos, cuyo diámietro longitudinal es

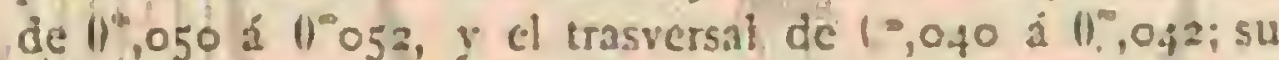
forma es perfectamente oval, un poco mas obtusa en el lado superior que en el inferior: la criscara, bastante lisa y sin briHo, tiene un color blanco de cal, con manchas pardo rojiaas mas claras í oscuras, que à veces se agrupan en la extremidad obtusa. Ia hembra pone en los primeros meses del año, desce febrern hasta abril, y el macho le ayuda a cubrir. En la época del celo, la ósadía de esta rajar aumenta natu. ralmente, y tambien hace mucho mas ruido que de ordina. rio, pues profesa un carino cxccsivo a sus hijuclos y les lieva tanto alimento como es posible; sicmpre teme un peligro para ellos y ataca con gran valor al enemigo que los amena. 22. A fines de mayo la cria cstá bastante adelantada para poder salir del nido; pero continúa llamando á los padres durante mucho tiempo, y hasta el otono no vive independiente.

El nombre àrabe del milano parásito, irifaie, puede servir para expresar su roz y se parece bastante al grito ordinario del are, que comienza con la silaba lif y termina con un sostenido y tembloroso hehaichaehac. En sus movimientos, cua. lidades y facultades intelectuales el milano parásito se parece en un todo af sus congeneres alemanes.

I.os indigenas considernn á esta ave como un compañero muy molesto é impertinente; mas á pesar de esto no se la persigue, crejendo que tambien para el sér alado deben respetarse las lejes de la cortesia y la hospitalidad. Se cuentan anćcdotas muy curiosas sobre su carácter familiar y tambien figura en algunas iradiciones.

\section{EL MILANO GOVINDA-MILVUS (HYDROIC- TINIA) GOVINDA}

CARACTERES.-El govinda ticne la parte superior de la cabeza, el cuello, el pecho y el vientre de color pardo cho. colate, con manchas de un amarillo lconado; la garganta y los lados de la cabeza de un rojo pálido; desde las mejillas il la region de la cabeza se extiende una gran mancha negruzca; las sub.caudales son de un rojo pálido; el lomo y las cobijas superiores de las alas pardas con manchas terminales lconadas; las alas son de aquel mismo tinte; la cola parda por encima, gris por debajo, cortada por fajas un joco mas oscuras, y orillada de leonado en la extremidad; el pico y las unas de color negro; la cera azulada; las patas de un gris azulado y el iris de un gris oscuro. Fsta ave mide $6 ", 59$ de largo total, el ala plegada $\left(1^{m}, 48\right.$ y la cola $[", 31$ (fig. 161).

DISTRIBUCION GEOGRÁFICA.-El govinda representa al milano negro en las Indias.

USOS, COSTUMBRES Y REGIMEN.- Teróon nos ha dado á conocer las costumbres de esta ave en los siguientés términos:

Está diseminada en todas las Indias, y es una de las mpaces mas comunes desde las orillas del mar hasta una altitud de dos mil seiscientos metros. Prefiere la inmediacion de las ciudades y lugares habitados para fijar su residencia; sigue a los viajeros: coge su alimento a la vista del hombre; arrebata su presa á las otras rapaces, y aun à sus semejantes, y de rez en cuando atrapa alguna gallina ú otra ave hericia. Philipps dice que es muy astuta, que acomete á los loros y gallinas; pero que teme á las aves de rapina y á las cornejas, permitiendo que estas se repartan entre si un pedazo de carne sin reclamar su parte. Las noticias de aquel autor no convienen con mis observaciones: el govinda vive en bastante buena inteligencia con las cornejas; pero tambien le he visto perseguirlas y obligarlas a que le abandonen su presa: y hasta sé que algunas personas, dignas de crédito, han asegurado å Blight que las devoraba; tambien ellas persiguen al govinda, aunque sólo por puro pasatiempo. Blight añade que estos milanos forman a menudo grandes bandadas; yo mismo he risto \& los de todo un pais acudir al misno punto, cual si tratasen de celebrar una especie de conscjo. Dicese que du. rante la estacion de las lluvins abandonan á Calcuta pror es pacio de tres 6 cuatro meses; mas yo no he visto nada de esto en otras localidades. Aparéanse por Navidad y cubren desde el mes de enero al de abril. Su nido se compone de troncos gruesos y ramas y el interior suele estar relleno de trapos; el milano le forma en un árbo!, rara ve\% en una roca; y en el deposita la hembra tres ó cuatro huevos.

\section{LOS CÍRCIDOS-CIRCUS}

CARACTERES. - LOS circidos 6 miluidos campestres son aves de rapiña de formas esbeltas $y$ tamaño regular; tienen el tronco pequeño y delicado; pico endeble, muy corvo, ganchudo, largo y con denticulacion obtusa; pies prolongados y enjutos, con dedos cortos; alas largis, grandes y bastante angostas; la cola ancha, de longitud regular; y el pluinaje blando y sedoso. La tercera y cuarta rémiges sobresalen de todas las demás; la primera en cambio es en extremo corta: el plumaje de la cara forma una especic de disco.

\section{EL CÍRCIDO AZULADO-CIRCUS CYANEUS}

CARACTERES.-El circicio azulado, llamado tambien halcon blarro y asul, gazilan blarco, etc, es uno de los halco. nes mas bonitos de nuestro continente, y scgun algunos ornitólogos, el tipo de un sub-género independiente, el de los estrigiceps (Strigieps): mide 1) ${ }^{m}, 6$ de largo, de los que corresponden ()$^{\prime \prime} .21$ a la cola, $y^{*}, 1, j$ de anchura de alas; la plega. da $0^{\circ}, 36$. En el macho adulto el lomo es de color ceniciento claro; el vientre blanco; la garganta listada de pardo y blanco; la primera penna del ala de un gris negro, las cinco si- 
guientes del mismo color, pero grises $\delta$ blancas en la base; las otras de un gris ceniciento; la cola lleva varias fajas oscuras trasversales; el iris, la cera y las patas son de un amarillo limon; el pico négro (fig. 162).

La hembra adulta tiene el lomo pardo leonado; por en:cima del ojo existe una lista blanca; las plumas del occipucio y de la nuca y las cobijas superiores del ala presentan un filete amarillo rojo; en la cola hay listas alternadas de pardo y rojizo; la cara interior es rojiza ambien, con manchas pardas longitudimales

Los pequeños se asemejan á la hembra.

\section{EL CÍRCIDO DE LAS ESTEPAS-CIRCUS SWAINSONII}

CARACTERES. - Wl macho adulto difiere de la especie anterior por tener el color mas pálido ó gris de plomo $y$ blanco en el dorso; las plumas de la rabadilla y de la cola presentan fajas cenicientas y las puntas de las alas son ne. gras. La hembra tiene las plumas del lomo y del pecho pardas, orilladas de rojizo claro; $y$ las de la parte inferior de un amarillo rojo, con inanchas longitudinales de color de orin. Los polluelos se distinguen de la hembra por tener estas úlimas plumas amarillas sin manchas. Adenass de esto, el cír. cido azulado tiene la cuarta rémige mas larga; mientras que en la especie de las estepas lo es la tercera: en esta ave, el horde ex. terior de las alas se estrecha solo hasta la cuarta rémige en forma de arco y no hasta la quinta como en su congenere azulado; solo las tres rémiges primeras se cortan en śngulo obtuso en las barbas interiores y no la cuarta, como sucede en la otra especie; y en fin, la escoiadura interior de la primera rémige se halla por delante y no por debajo de la punta de las tec. trices superiores de las alas.

DISTRIBUCION GEOGRÁFICA DE AMBAS ESPECIES.-El área de dispersion del circido azulado es bas. tante extensa. Habita toda la Europa central y tambicn una gran parte del centro del Asia, llegando en sus viajes á lodos los paises del norte del Africa hasta la region del ecuador; tambien se encuenira en todos los ierritorios del Asia meridional. Por el norte, el $55^{\circ}$ de latitud forma el limite de su área de dispersion; an el mediodia de Europa solo se presen. ta, segun parece, durante sus viajes. En Alemania se le ve en todos los parajes farorables de Prusia, Posen, Silesia inferior, Pomerania, Brandeburgo, Sajonia, Mechlemburgo, Hannover y la parte llana de lVestfalia, asi como en Baviera; además habita aislado en el ouste de Turingia, en Hesse y en los paises del Rhin; pero en cambio falia completamente en 10. das las regiones montañosas, ; escasea en los puntos donde hay muchas colinas. Tambien evita los bosques gmandes. Asi como iodas las especies de su género, que yo conozco, es un ave caracteristica de las llanuras, sobre todo de aquellas en que los campos alternán con las praderas y corrientes de agua.

El circido de las esteyas habita el mediodia de Rusia. los paises bajos del Uanubio, 'Turquia, Grecia, el sur del Asia central y el norte de Africo Vive casi en las mismas condi. ciones, y segun parece tambien en algunos de los mismos paises, pero siempre muy aisladanente. Algunos observado. res fidedignos han hallado su nido en Alemania, por ejemplo en Westfalia. Sin embargo, solo anida con remularidad en los citados paises de la liuropa meridional, sobre todo en la Dobrudscha.

USOS, COSTUMBRES Y REGIMEN.-lil género de vida de ambas especies no difiere apenas, como no sea por algunas pequenas diferencias; y por lo tanto the limitarć a describir el del circido azulado. Cuando esta ave llega á nues tro pais, á fines de marzo, y toma posesion de su dominio, observa un genero de vida tan metódico que seria dificil no reparar en clla. Su dominio, en el cual admite tambien \& otras aves de su especie, suele ser bastante extenso; pero vaga por él todo al dia, siguiendo siempre poco mas ó menos los mismos caminos; de modo que es preciso que todo observador algo atento la vea. Apenas el rocío de la maniana se ha secado en los arbustos, gramineas y campos de trigo, el circido azu. lado emprende sus cxcursiones de merodeo y cara hasta que

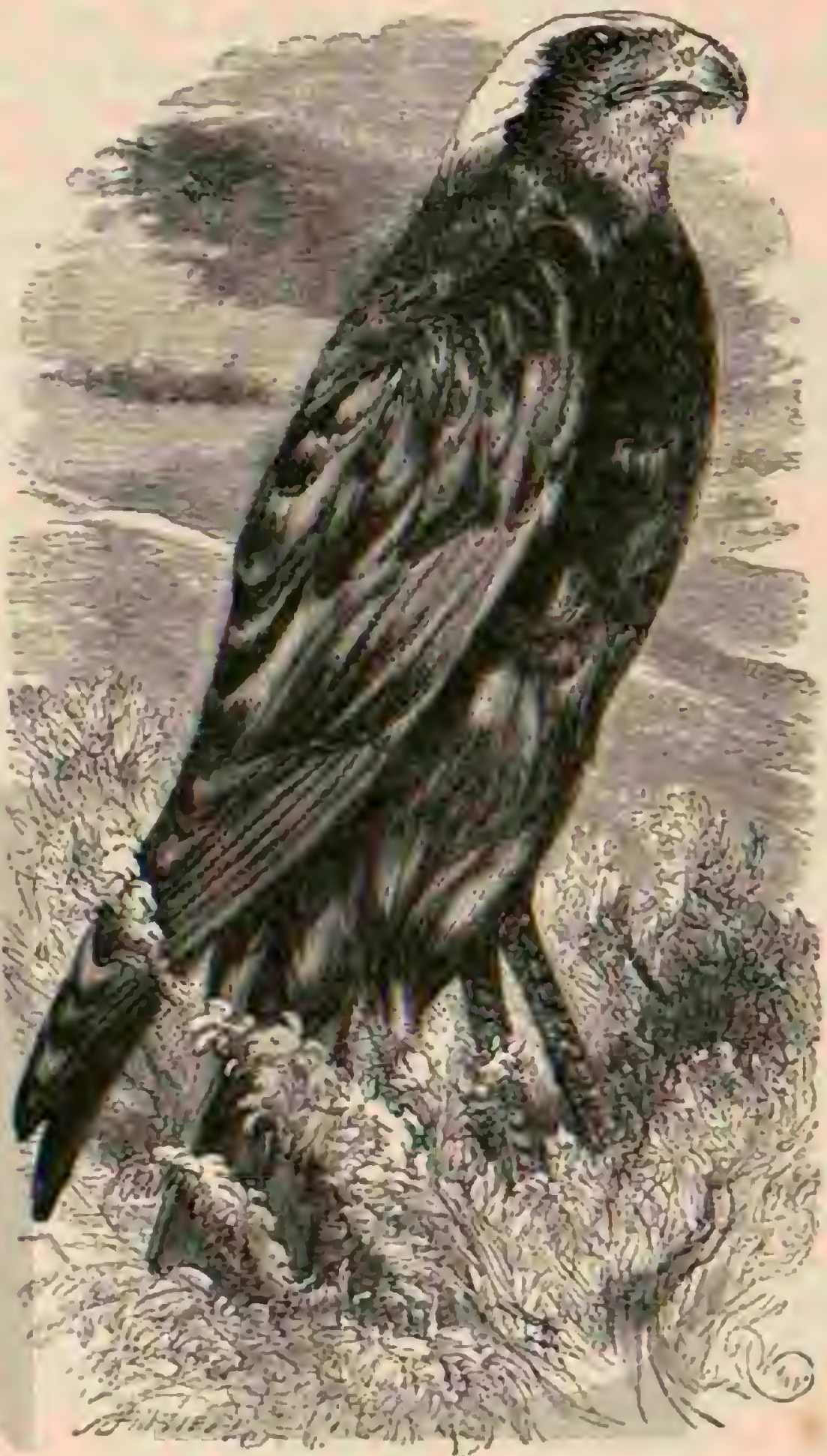

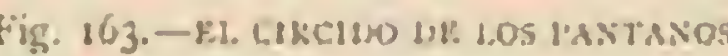

coge alguna juesa, despues descansa mas $\delta$ menos vierupo; vuelve á salir y continua asi hasta la hora del crepusculo vespertino. Balanceándose de continuo, y con inseguro vue. lo al parecer, unas veces avanza con las alas mas altas yue el cuerpo, á poca distancia de tierra, y otras se limita a dar aletazos, siguiendo con preferencia los contornos de una espesum ó las orillas de un riachuclo; á veces interrumpe su marcha en líner recia para desviarse af derecha ó izquier. da; describe varios círculos en un mismo sitio, preciputase repetidas veces a la profundidad como para coger una presa, aunque casi siempre se remonta sin mada; y continuia su vuelo como anies; despues da vueltas al rededor de la copa de un árbol, cruza una esfresura, pasando tan pronto por un lado como por otro: dirigese por el centro de una pra. dera ó campo de trigo, $y$ vuelve en fin, trazando un gran arco, hácia el punto de partida. El que obserra ininuciosa. mente una pareja conocida, rera que una de las dos ases, sobre todo el macho, exnmina ciertos sirios siempre de igual manera, pero no a las mismas horas del dia, sino por la ma. niana, por la tarde ó por la noche. la caceria puede durar hasta hora y media; el ave se entrega despues al descanso un 
cuarto de hora $\delta$ algo mas, $\delta$ por lo menos algunos minutos, para lo cual elige una pę̧ueña eninencia ó un punto firme en la yerba ó entrc el trigo, donde permanece algunos minutos inmóvil, sin olvidarse por eso de vigilar en todas direcciones: entre tanto se alisa y limpia el plumaje. Esto to hace con tanta regularidad, que en tiempo de la muda se puede reconocer su sitio de descanso por las plumas dispersadas en él. Nunca le he visto posado en árboles, mientras que el circido de las estepas suele descansar siempre en ellos.

Muy distinto es el género de vida de esta are en la época del celo, pues tambien á clla le excita nucho el amor. Mien. tras que por lo regular solo el macho ó la hembea cazan, ob. sérvase ahora á los dos juntos, volando á veces tan cerca uno de otro, que no parece sino que se quirercnayudar en la caza: con frecuencia describen tambien sus ćrculos, que se confun. den muchas vecus en ol nismo sitio De pronto clérase el macho, casi verticalmente por las alturas, con una rapider que jamís podria suponerse en cl; da una voltereta y precipitase con ha alas recogidas hácia cl'suclo; traza un circulo'y se renonta de nucvo para repetir la misma maniobra; a veces continúa asi un buen rato, $y$ ejecuta diez $\sigma$ doce veces la misma evolucion en media hora Tambien la hembra imita estas hábilidades en el vuelo, pero siempre con mas moderacion que el macho, segun he observado.

El nido del círcido azulado es muy mexupino y se en. cuentra siempre en el suelo, ya en un arbusto bajo, en bos. ques nuevos ó entre el trigo, en las altas yerbas de prade. ras pantanosas, y hasta en los cariaverates. En rigor no es otra cosa sino un monion irregular de ramas secas, tallos de jerba, cañas y patatas, restos de estiércol y otros materia. les ańlólogos, que recoge con las garras y coloca en su sitio juntándolos casi sin ayuda del pico; la, cavidad está ligeramente tapizada de musgo, pelos, plumas y otras materias blandas Solo cuando la hembra incuiba obsérvase cierto órden en el interior del niclo cual si no hubiese tenido liempo de arreglarlo antes. Como el círcido azulado no puede empezar la incubacion antes de que la yerba y el trigo cstén bastante altos para ocultar ed nido, maras veces se encuentra la prestí completa hasta mediados de mago. Los huevos cujo numero. varia de cualro á cinco, pasando raras veces de seis, tienén

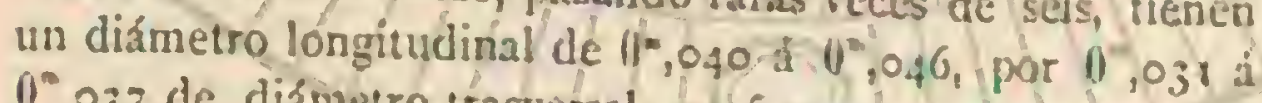
$0^{\circ}, 0,37$ de diámetro trastersal; su forma es tan pronto pro. longada como redondeáda, $y$ casi siempre parecida i la de los huevos del buho, es decir un poco ventruda; la cáscara, de grano ino, sin brillo, y de color blanco verdoso mate, no suele tener manchas; si estas existen, son muy pequenins y escasas, de color gris rojizo ó pardo amarillento. Segun mis observaciones, la henbra se encarga sola de culbrir los huevos, pues solo he visto durante el periodo de la incubacion al macho, ocupado en la caza, debiendo supponer, por lo tanto, que la hembra se ajaja alimentar por él. Cubre los huevos con mucha aficion y no los ábandona sino cuando un enemi go llega muy cerca del nido; pero entonces sabe alejarse con mucha habilidad. Nopuedo decir cuánto dura la incubacion: Naurann asegura que tres sernanas, $y$ tal rez esta noticia sea exacta. Los polluelos son séres graciosisimos, cubiertos de un espeso plunon gris: acurrícanse en el nido con las cabezas unidas y oprimense contra ul suelo al acercarse un sér cxira. no, permaneciendo en esta posicion, cual si esturicran muertos, hasta que el enemigo los coge ó se aleja; guardan tambien profundo silencio, aunque tienen costumbre de piar continuamente. Por lo general permanecen mucho tiempo en cl nicio y no se les ve volar antes de mediados de julio, o mas seguramente á fines de este mes. Al principio cazan aun reunidos con sus padres, que los adiestran convenientemen. te; pero pronto se despierta en ellos el deseo de obtener sa independencia y antes de tres semanas se conducen ya lo mismo que los adultos, sin evitar por eso su compañia. Des. de agosto empiezan á vagar por cl pass, y vuelven alguna quue otra vez al territorio donde se criaron, pero extienden despues sus exprediciones mas y mas, emprendiendo al fin en setien. bre su viaje hácia el sur. Alguno que otro individuo permanece tambien mas largo tiempo en su patria; $;$ si el tiempo es fa. vorable, tal vez algun círcido azulado se quuedarà todo el invierno en el pais.

Congran pesar mio no me es posible defender la cons. ducta de esta ave No puede negarse que es un adorno de la llanura, sobre todo en primavera, cuando su bonito plumaje azul se balancer sobre los verdes campos; tampoco se des. conocerá que nos es útil porque extermina los ratones é insectos, en particular langostas, y que al menos no nos causa daño cuando coge lagartos y ranas, que despues de los ratones constitusen su principal alimento; pero se hace culpable de muchis fechorias, por las cuales no es digna de la proteccion del hombre. A pesar de su debilidad aparente, es un enemigo tan comible como peligroso de todos los animales de que puede apoderarse. Desde el espermófilo al lebrato, $y$ desde el faisan á la perdiz medio adulta, todos los pequeños mamife. ros y ares pequenas perecen entre las garras de la ladrona cuando se hallian en el nido. Cierto que no le es dado coger las ares cuando están provistas de todo su plumaje ó son adultas; pero sabe apoderarse en ciertos casos con mucha habilidad de una hembra que empolle en el suelo asi como de las medio aduitas, y tambien roba los huevos. Los obser. vadores atentos han visto que efectivamente coge los faisanes jóvenes.

W En setiembre de i8;6, me escribe de Meyerinck, maté un circido azulado que pasando por encima de un campo de patatas se precipito suibitamente hácia el suelo cn actitud de ataque. Habíase apoderado de un faisan medio adulto $y$ acrababa de sacarle las entrañas, por cuyo crimen le di el castigo merecido. Varias veces he observado casos análogos. \$ Segun Naumann espanta mucho as las perdices, y como no puede hacerlas daño cuando vuelan, emprenden la fuga tan luego como te sen llegar, ocultándose en los trigos, en la malcza $\delta$ enl los campos de coles. Sin embargo, nada escapa á la vista penetrante del temible ladron; acude al punto, examina minuciosamente los escondites, revolotea de continuo, precipitase muchas veces hácia el suelo, cual si cogiese algo, $\$$ prosigue esta maniobra hasta que logra coger una de las aves.

Q ${ }^{\prime}$ 'anto la perdiz macho como la hembra, dice de Rie. senthal, defienden muchas veces unidos su progenie: mas á pesar de esto se pierde casi siempre uno ú otro de los po. Huelos. nel mismo modo se apodera de otras aves que a las pocas horas de nacer saien del nido, por ejemplo de los pollos de la becada y de otras aves pantanosas y acuáticas; y hasta sabe sorprender perfectamente a las aves que están cubriendo los huevos en el nido, gracias á su destreza para contener de pronto el vuelo y precipitarse rápidamente hácia abajo. Hé aqui todos los perjuicios que nos causa el circido azulado, y estos terminan con el fin del periodo de la repro. duccion de las aves pequeizas. Si consideramos, por consiguiente, sin preocupaciones la utilidad y el danjo çue produ. ce el ave, resulta que solo durante una tempomda del año, relativamente corta, pone en peligro las especies que nos son útiles, mientras que en el resto del ticmpo destruye animales dañinos y no nos molesta ya con sus fechorias.

El círcido azulado vive en continua guerra con las corne. jas; las mas valcrosas aves pequerias, sobre todo las golon. drinas y nevatillas, le molestan mucho, asi como tambien los parásitos que viven en su plumaje y sus entrañas. Entre los 
hombruts, los coleccionistas son sus mas peligrosos enemigos, pucs casi siempre sabe escaparse del cazador. Con buho no suelen dejarse engañar mas que los individuos pequenos, cuando se le coloca cerca del nido, y por lo regular tampoco las trampas producen efecto, à no ser que estén ocultas cui. dadosamente y bien cevadas; de modo que ioda la caza depende en rigor de ia casualidad. El que no pierde la paciencia en el acecho pucde matarle cuando se oculta cerca de su camino, reconocido solo despues de una larga observacion. Muerto un individuo, fácil es apoderarse tambien del otro, para lo cual basta arrojar al aire el cadárer, pues no tardará en llegar su companicero: todos los milvidos y circidos azulados son en extremo curiosos y acuden en seruida cuan. do vén caer al suclo un ave de su especie.

CAUTIVIDAD. - El circido azulado, aun cogido en edad adulta, se conduce en la cautividad mucho mas pacifica. mente que cualquiera otra ave de rapiña de las que conozco, excepto sus congéneres mas afines. Acomódase ficilmente á sı nuevo estado, mira con indiferencia a las personas que se detienen delante de su jaula, paséase con tranquilidad en ella y toma posiciones tan extrañas, que en rigor solo entonces puede formarse una idea de su verdadero aspecto. Sin escrúpulo alguno precipitase sobre el alimento y come de todo ruanto se le da; pero solo cuando aquel es muy bueno se podra conservar largo tiempo el ave. A este efecto es menester darle las nas diferentes especies de animales peq̨ue. ños; y para criar los pollos se debe cortar además la comida en pedacitos.

Hé aqui porgucic solo se ven raras veces en uno ú otro jardin zoológico estas interesanies aves.

\section{EL CIRCIDO CENICIENTO-CIRCUS CINE- RACEUS}

CARACTÉRES. - El circido ceniciento, llamado tam bien miluido de las proderas, se considera por algunos naturalistas como tipo de un sub.género independiente (Glan. cop(ery. $x^{2}$; pero tiene todas las condiciones y caraster de un verdadero milvido. Su longitud es de $0^{-}, 4+4$, por $8^{\prime \prime}, 25$ de anchura de punta a punta de alas; estas miden $0^{\mathrm{m}}, 4 \delta$ y la cola $0^{m}, 23$. El macho adulto, que es el mas bonito de todos nuestros milvidos, tiene la cabeza, la nuca, el dorso y la parte superior del pecho de un color ceniciento azulado, mas oscuro en la nuca y el dorso a causa de tener las plumas y bordes oscuros muy marcados; la parte inferior del pecho, el vientre y el plumaje de los piés son blancos; en los tallos de las plumas se ven angostas lineas de color rojo de orin. Iats rémiges primarias son negras, las secundarias de un ceniciento azulado, con una haja negra; las rémiges postériores del brazo de un gris pardo; las dos plumas del centro de la cola cenicientas y las otras inas claras; el color de las barbas in. teriores se comunica poco á poco á las exteriores, de modo que las tectrices de los lados parecen casi blancas, excepto las últimas que son parduscas; todas las rectrices presentan jajas negras. Las tectrices medias de la parte inferior de las alas tienen tambien lineas rojizas en los tallos; las mas peque nas son blancas; en las mas inferiores se ven fajas irregulares grises, y en las de la articulacion del corlo hay otras de color pardo rojizo. Tanto en ha hembra adulta como en la muy júven, cuyo plumaje se asemeja, el color predominante de la parte superior es gris pardo, y el de la inferior blanco, salpicado de pequeñas manchas rojizas poco marcadas; en la coronilla se ven mrias fajas rojizas que alternan con otras negras. Los individuos jóvenes tienen la region inferior de color de orin, sin manchas; las plumas de la superior son de un gris pardo oscuro, orilladas de rojizo. Sobre el ojo se ve una mancha blanca y debajo de este, en las mejillas, una gran faja de color pardo oscuro; la rabadilla es blanca; las rémiges y las rectrices presentan manchas trasversales pardooscuras. El iris de los individuos adultos es de un amarillo muy vivo, y en los pequeisos pardo; el pico, negro azulado; la cera amarilla; y los piés, muy largos y delgados, de color amarillo pálido.

DISTRIBUCION GEOGRÁFICA.-El àrea de dispersion del circido ceniciento es lan extensa como la de sus dos congéneres descritos; pero esta are pertenece mas al este que al oeste del territorio septentrional del antiguo coninente. En Memania se cuenta entre las especies mas raras del género, pero no falta en los sitios iavorables. Hauita en vastas praderas, $y$ durante el verano en inmensas extensiones de pantanos secos; de modo que anida con preferencia en las orillas de los rios y sobre todo en los terrenos bajos que en imvierno suelen inundarse. Se encuentra en Alemania, principalmente en la gran llanura del norte, desde la Prusia orien. tal hasta la Prusia Rhenana. Con mas frecuencia se le observa en el Austria inferior, en las tierras bajas de Hungria, en los paises meridionales del Danubio y en algunas partes de Ru. sia. I as estepas de la Siberia y del Turkestan septentrional constituyen por lo regular el centro de suárea de dispersion. Ln todas las estepas situadas alrededor del Altai y en el sud. este hasta el Alatau. las cuales he visitado en compañia de Finnch $y$ del conde de Waldburg.Zeil, encontramos al circido ceniciento como especie predominante: pero tambien le vimos en la Tundra del territorio inferior del Ohi, á los $68^{\circ} \mathrm{de}$ latitud, es decir, mas al norte que ningun otro milvido de los que yo conozco. Lin el este se extiende su área de dispersion hasta China Con motivo de sus viajes pasa en el otoño y la primavera por toda la Europa meridiosal, la mayor parte del Asia meridional y del Airica. Durante el invierno, muchos individuos permanecen en los sitios iavorables de la India. El circido ceniciento llega hasta el territorio de las estepas del Africa central; y segur Anderson, tambien visita el jais de los damaras. Heuglin dice yue sube á las montañas mas altas de Abisinia.

USOS, COSTUMBRES Y REGIMEN. - A pesar de que el circido ceniciento no difiere mucho por su género de vida de las dos especies anteriores, creo conveniente ahadir aqui noticias que debo i la pluma del principe imperial Rodolfo de Austria La descripcion del ave es tan interesante, y ademis tan fiel y exacta, que no colrozco oira incjor. En el Austria inferior, me escribe el archiduque, el circido ceniciento anida hasta en las inmediaciones de Viena; pero asi como la mayor parte de sus congéncres muestrase nuy exigente en la eleccion de su domicilio. Habita en las grandes y vastas llanuras llenas de maleza, donde las praderas y los campos alternan con algunas aguas. Es el ave característica de lianura baja y no se encuentrá en las montañas ni en regiones cubiertas de bosque. No tiene tanto apego des dadas como el circido de los pantanos; pero tampoco le agrada abandonar su patria y cmprender largos viajes. I.e gustan mucho los campos y las prnderas, sobre todo cstas cuando estín un poco huimedas y tambien los bosques bajos : los linderos de las selras situadas á orillas de grandes rios, principalmente cuando están en las inmediaciones de las grandes llanuras descubiertas. En el Austria inferior se reco. noce muy bien que nuestro pais se halla en los limites de su área de dispersion, pucsto que en gencral su número escasea y solo se le ve en sitios muy favorables.

Debo añadir en este lugar que en las estcpas citadas el ave busca tambien con jureferencia los sitios cruzados por un rio ú un riachuclo, descle donde emprende sus viajes á las estepas mas secas. Al contrario de lo que hace en otras par. 
tes, este circido sube a mucha altura en las inonianas de aquella region, y no teme pasar tambien por pezueños bos ques, si bien suele quedarse en las pendientes que alin en la altura ofrecen el carácter de la estepa.

El circido ceniciento, continúa el archiduque, es un ver dadero halcon terrestre que pasa toda su vida en el suelo ó muy cerca de él. Solo en el periodo del celo la pareja se re. monta \& menudo is la altura para ejecutar sus evoluciones, que sin embargo no son tan notables como las del circido

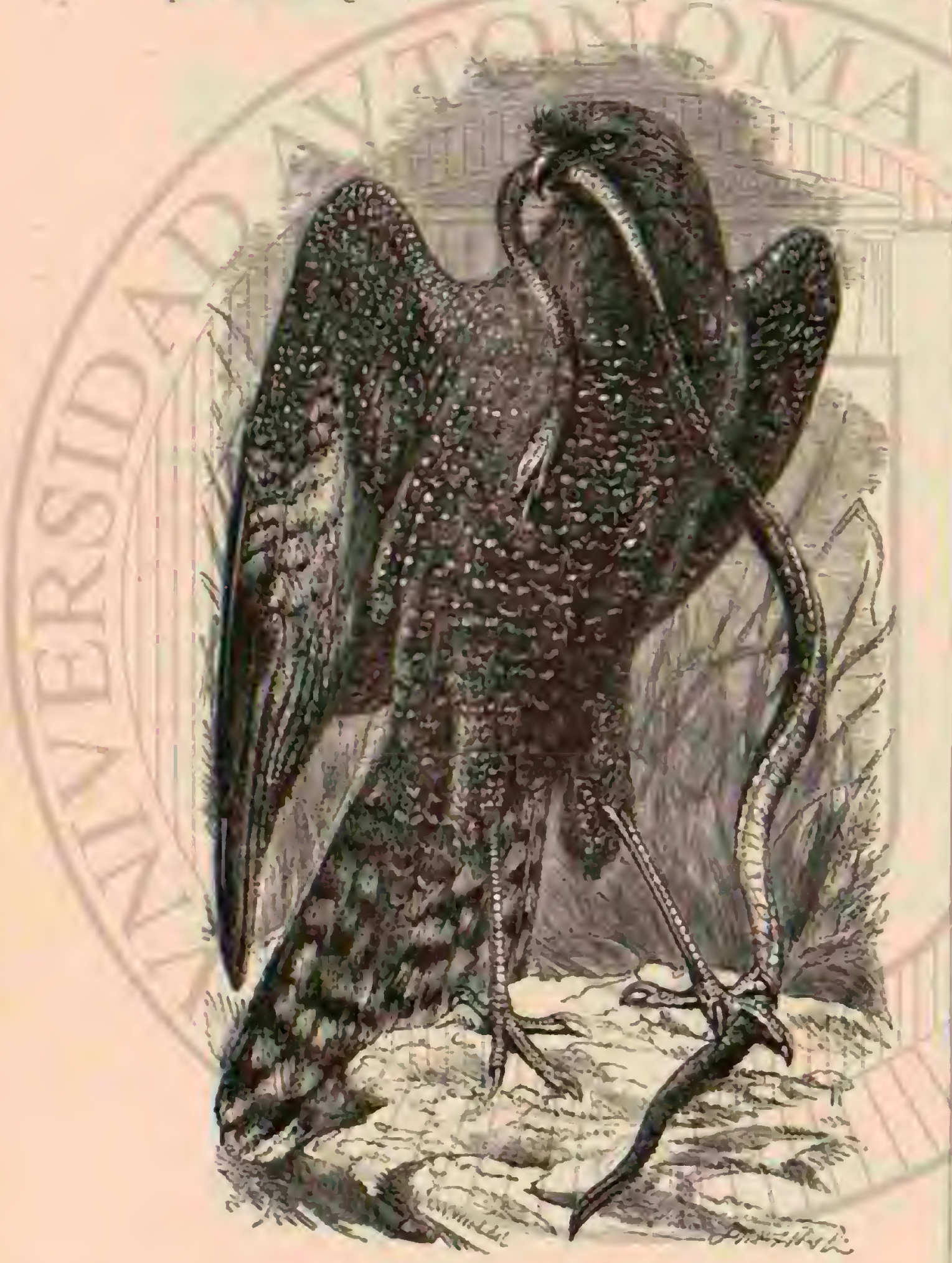

Fig. 164. - EL ESIM.OCIRCO IVE JARDINE

de los pantanos, aunque esa especie es en rigor mas rajpida y ligera en los aires que su congénere mayor. Su vuelo di. fiere tanto del de la mayor parte de las demás rapaces, que podria compararse con el de las golondrinas y et de las ga. viotas, con las cuales le confunden muchis reces los cazadores mas expertos. Cuando el circido ceniciento se re. monta a poca altura, su vuelo ofrece ś menudo una rara semejanza con el de nuestro chotacabras. El circido ceniciento se caracterima sobre todo por su caracter inquicto: desde el amanceer hasta que se pone el sol está en continuo moviniento, y casi siempre dentro de los limites de un distrito bastante reducido. Muchas reces se le ve pa. sar con las alas extendidas sin aletéar, por encima de los campos de trigo; franquea cierta distancia trazando lineas curvas a poca cievacion sobre los campos y las praderns; re. móntase despues verticalmente á la altura para revolotear á la manera de los halcones ó describir por corto tiempo sus circulos, y precipitase otra rez verticalmente hácia el suclo sobre un campo de trigo $\delta$ en las yerbas, donde descansa al gunos momentos para repetir despues la misma maniobra. Las hembras observan un género de vida mas tranquilo que los machos, y durante el periodo de la incubacion viven con preferencia en el suclo; son aves de un aspecto bastante comun que el hombre inexperto no reconoce en la mayoria de casos, confundiéndolas con otras aves de rapina EI macho, por el contrario, es una de las aves mas bonitas y graciosas de nuestro pais: gracias á su carácter alegre y vi. vaz, anima en alto grado la llanura monótona: y cuando esta ave esbelta, cuyo plumaje brilla á los rayos del sol, des. pidiendo plateados reflejos, vaga sobre los campos de trigo, cuyas espigas de oro se mecen bajo el soplo del céfiro, asom. bra é interesa a cuantos están acostumbrados à ver solo en los paises de la Europa central especies de color oscuro del grupo de las aves de rapina. El circido ceniciento pasa la noche en los campos de trigo, en las praderas de altas yerbas, en la espesura de la malez.a ó eu los cañaverales, ýa menudo tambien sobre los mojones, palos, imágeres, etc.; pero siem. pre 1 poca altura del suelo. Evita los bosques de dia, y mas aun de noche. Nunca le vi posado en un árbol; pero si he reconocido que no solo se aleja de los bosques, sino tambien de los árboles que se hallan al descubierto; alli donde anida no se posa tampoco nunca en los arbustos. Tanto le agrada vagar en los alrededores de las praderas situadas i orillas del rio como le disgusta permanecer en el interior de los bosq̨ues. Pasa por los linderos de las selvas altas, pero no penetra nunca en ellas. Muchas veces se le ve volando á la manera de las gaviotas, a lo largo de los brazos del rio, y solo una vez, obseríc que, espantado por la embarcacion que cruzaba en acyuel moinento, dirigióse hácia un bosque alto.

\$Sociable como otras aves de su género, busca aun en la primavera corńpania para anidar en sociedad y recorrer el pais. A menudo se ven varios machos reunidos que cazan en la llanura y pasan de vez en cuando al brazo del rio mas in. mediato. Con frecuencia vuelan en medio de los circidos de los pantanos y de los milanos, en las orillas del I)anubio, $\delta$ retozán con estas aves en el aire. A semejanza de todas las aves de su género, el círcido ceniciento es iambien un ave timida que huye de todo el mundo \& mucha distancia, sin demustrar empero la astucia y prudencia de los halcones. Sin reparar en si el sér que tiene delanie es un cazador $\delta$ un campesino, hombre $\delta$ mujer, como lo hacen otras aves de rapina, emprende la fuga en el acto, siguiendo á menudo con la nayor obstinacion las curvas de su camino, del cual se desvia muy poco. Cuando pasa á mucha altura sobre Jos campos, de modo que pueda ver al hombre áticmpo, seguro es que no se pondrá á tiro; con frecuencia, sin embargo, vucla por los senderos á través de campos y praderas á poca altura del suelo y entonces puede suceder muy bien que por falta de perspectiva se presente á pocos pasos del cazador, a quien serí entonces fícil matarle. Ls menos tínido cuando está posado en el suelo; cntonces itata de escapar oculián. dose; y si se halla en la maleza deja pasar al hombre tran: quilamente, ó se levanta á pucos pasos delante de él.

-El nido del circido ceniciento es de construccion muy sencilla, componiéndose de ramas secas, etc., bastante com. pactas; encuéntrase siempre en el suelo, en la espesura de la maleza, en los trigos ó en las altas vierbas, $y$ hasta en los ca. ñaverales. Esta ave es en genrenal mucho nus previsora que el círcido de los pantanos en la cleccion del sitio para hacer su nido, s siempre evita que esté al descubierto. Segun la temperatura, la hembra acaba de poner en la segunda mitad de mayo, pero nunca antes; entonces se hallarán en su nido de cuatro á cinco hucvos, raras veces seis; tienen poco mas ó menos $0^{n}, 042$ de longitud por $0^{\circ}, 032$ de inayor diametro trasvicrsal, la cascara es blanca, raras veces manchada, sin brillo $y$ de grano fino. por lo cual se parecen algo it los del buho, si bicn difieren marcadamente por el bonito color verde. 
claro de su interior: aseméjanse tanto á los del circido azulado, que es muy posible se hayan confundido á menudo con ellos. El circido ceniciento profesa á su progenie mas cariño del que disperisan á la suya las demàs especies congéneres, y no solo la hembra, sino tambien el macho, expónense á iodo por salvarla; si amenaza un preligto, acuden tambien otras parejas y describen sus circulos con los padres sobre la cabeza del intruso, lanzando ruidosos gritos. Debo adrertir que siempre anidan algunas parejas en el mismo sitio, donde además se encuentran los individuos viejos ó los que aun no están apareados. Mientras las hembras están cubriendo los huevos, los machos vagan coninuamente por los alrededores y visitan de vez en cuando á su compañera parn descansar; despues empiezan de nuevo à volar, abandonando por algun rato el sitio donde se halla el nido para ir en busca de alimento. Cierto dia encontré dos nidos del circido ceniciento en un bosquecillo que forma el limite meridional del Danubio, cerca de Emannswoerth, al este de Viena. El citado bosque tiene cuando menos un kilómetro de longitud por qui. nientos ó seiscientos pasos de anchura; linda en la parte septentrional con altos bosques de la pradera y está separado en el sur de los campos inmediatos por un brazo del rio; el bosque mismo era muy espeso, mas aperas tenia un metro de altura, y en algunos parajes descubierlos hallábanse aun los restos de los troncos cortados. Ambos nidos estaban en el centro de este bosque, a cincuenta pasos uno de otro. $\mathrm{Al}$ cruzar con mi embarcacion el brazo del rio vi cuatro maclios y una hembra que trazaban sus circulos al rededor del bosque; pero solo zuando me hube acercado it un paso de dis tancia de los nidos me convenci de la presencia de las hembras, que esaaban cubriendo los huevos. Ambas se alejaron entonces presurosas, elevindose verticalmente sobre la espesura y huvendo á la manera de los halcones, de un mado muy distinto del que se observa en el circido de los pantanos en casos análogos. A pesar de que me habia colocado mily cerca de los nidos, volvieron en seguida à ellos; pero tambien los machos sagaban continuamente en las inmediaciones, girando en circulos sobre el bosque alto $\delta$ siguiendo el rio, sobre cuya superficie retozaban. Cuando todos se hubieron familiarizado con mi presencia extendieron su vuelo tambien a los campos, pero siempre volvian muy pronto. Entonces puse mi buho en un paraje descubierto, cerca de los nidos, ocultándome en una espesura vecina. Los milvidos atacaron al punto con violencia al odiado adversario; y' era un curioso espectículo ver al ave con su brillo de plata tender las alas, crizar el plumaje, alargar con sin igual furia las largas garras para el ataque, y precipitarse de vez en cuando sobre el buho. A intervalos deja oir un silbido agudo, mientras que en el ataque solo emite una toz apenas perceptible. El buho, as st] ves, reconoce al punto la debilidad de su enemigo, y no hace caso de él. Ni los tiros ni la muerte de un compañero bastan para ahuventar á los circidos entonces; algunos de cllos lle. gan hasta posarse cerca del buho en la espesura, cual si qui. sieran descansar para repexir sus ataquues. A la media hora disminuyó la iuria de los circidos, y describiendo sus circulos siempre mas anchos, reciráronse al fin á espesuras mas leja nas. Sin einbargo, no abandonaron el sitio del zodo, y cuanda puse el buho en el lado opuesto del bosque, empezaron de nuevo sus ataques.

- El circido ceniciento se alimenta de animales que cogeá la carrera ó posados, perto no al vuelo: prefiere los hamsters, ratones y ranas; pero además coge avecillas que no pueden aun volar, y algunas veces tambien liebres, codornices y verdices muy pequeñas. En mi opinion, el poco daño que causa no tiene importancia ninguna, si se compara con la utilidad que nos reporta por la destruccion de los roedores daninos.

\section{EL CIRCIDO DE LOS PANTANOS-CIRCUS AERUGINOSUS}

CARACTÉRES. - El plumaje de esta are raria no solo segun el sexo y la edad, sino tarnbien segun la estacion. En el macho adulto, las plumas de la frente y de la coronilla están orilladas de amarillo pardo; las del resto de la parte superior son de un tinte pardo de cafe; las de las mejullas y de la garganta de un amarillo pálido con los tallos mas os-

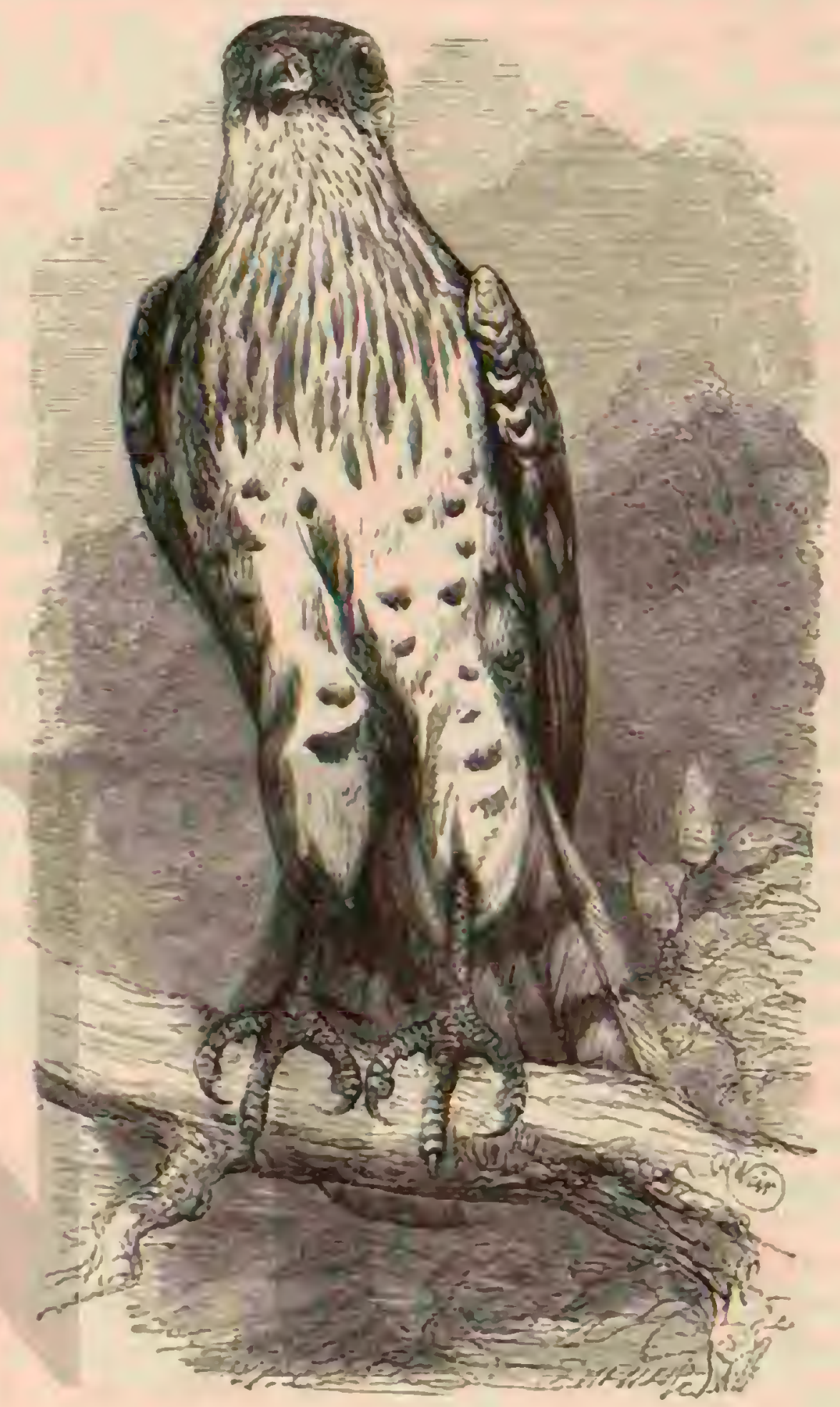

Fig. 165.-E.1. c1rcakto JUiN-1.1.M1.1.NC

curos; las de la parte anterior del cucllo y de la superior del pecho tienen manchas longitudinales de un pardo amarillo, y las de las otras regiones inferiores son de un rojo de orin, con las puntas mas claras; las réniges jirimarias de un pardo oscura, una parte de las secundarias y las grandés tectrices de las alas de un bonito color gris ceniciento las rectrices de un gris mas claro, viso rojizo y blanquizcas en la cara infe. rior. En la hembra cl color es siempre menos viro y mas igual, sobre todo el ceniciento del ala y de la cola, rarns reces bien marcado; la cola es de un pardo gris en su cara supe. rior; la cabeza blanca amarillenta, con lineas mas oscuras en los talios; una mancha que hay en ambos lados de la nuca, los hombros, el disco y el jecho son igualinenic de un color mas claro. En el individuo jóven, que en general se parece á la hembra, predomina un color pardo oscuro; la parte su. perior de la cabeza, la nuca y la garganta son de un blanco amarillenio, ó al menos muy claro, con lineas mas $\delta$ menos oscuras en los tallos. I a longitud del are es de $11^{\prime \prime}, 55$, por $1^{11}, 3^{6}$ de anchura de punta á punta de las alas: estas miden $11^{\infty}, 43 y$ la cola $0^{n}, 24$ (fig. 163 ). La liembra tiene tres ó cuatro centinctros mas de largo y de siete á nueve mas de ancho. 
DISTRIBUCION GEOGRÁFICA.-Desde el $57^{\circ}$ de la. titud norte hácia el sur el circido de los pantanos no falta en ningun pais ni region de Furopa, cuando el punto reune las condiciones que el ave necesita. Además se la encuentra en todo el oeste del Asia, desde la latitud del Altai; pero escasea mas y mas hácia el Oriente, donde solo se la ve á orillas del Amur, en China muy aisladamenie. Cuando cmprende sus viajes pasa por el continente del Asia meridional $\because$ tambien por una gran parte del-Africa. Mas que todo otro milvido depende de las llanuras bajas; pués los pantanos y el agua son condiciones tan necesarias para su existencia que puede asegurarse que nunca se alcja de tales sitios. En Alemania solo se le ve como ave de pasa que se presenta en la primavera, es decir por marzo o abril, ya en agosto empieza a emigrar, y en octebre, cuando mas, desaparecen los áltimos individuos. Enel sur de Europa, sobre todo en Grecia y España, pero tambien en el rote del Africa y principalmen. te én el Ligipio, en Persia y las Indias, se le encuentra durante todo el año.

USOS, COSTUMBRES Y RÉGIMEN, - Sociable como todos los círcidos, esta ceppecie busca en sus viajes la compañin de sus semejantes, y se reune temporalmente hasta con bizardos y gavilanes, en cuya sociedad vaga por el pais cazando, sin perder por eso nunca sus propiedades particulares. Aunque he observado at circido de los pantanos en tres continentes, $y$ alguna ver en considerable númer o, prefiero ceder el uso de la palabra al archiduque Rodolfo, in tercalando las obsersaciones notables de otros naturalistas y mins:

4 En los vastos pantanos de Hungrin, dice el archiduque; el circido de los pantanos abunda tal vez mas aun que en la Ilanura baja de la Alemania septentrional ó en las praderas pautanosas de Schleswig y Holanda; en los demàs palses del Austria, por el contrario, ó no se le encuentra, ó su dominio es muy límitado, como por ejemplo en el Austria inferior, donde los grandes bosques alternan con distritos mas secos trasformados en campos, y donde el ave se limita álos sitios pantanosos de los bosques, de las praderas y de las orillas del Danubio. Esto se obsirva tanto mas marcadamente cuanto que el circido de los pantanos-se ve tan pbligado como otras especies de su género a emprender largas expediciones. Siempre procura no abandonar su territorio, y nunca se le encontrarí en el bosque $\delta$ en la montaña; tambien se aleja de los campos de trigo secos, y nunca lo he visto hasta ahora alli donde abundan las colinas. Hasta falta en aquellos bosques que distan cuando mas diez kilómetros del sitio en que anida y esto sucede lo mismo en el periodo de sus viajes que en la época de la reproduccion. En las praderas del Danubio, donde todos los años se hatla un número bastante considerable de estas aves, limitase tambien á sitios determinados; extraño es que nunca se le observe en los bosques altos, aunque apenas distan at menudo mas que al. gunos centenares de pasos de su nido.

$>$ El género de vida y el carècter del circido de los panta. nos comunicanle el caracter de ave de rapiña innoble, que no de aves. Su poca fuerza solo le permite cazar animales débi. les, a los cuales asesina, en el verdadero sentido de la pala. bra, en el suelo ó en sus escondites de los pantanos. Evita timidamente al hombre, $y$ sabe sustracrse a la persecticion con mucha destreza, ocultándose en los cañaverales 6 en los puntos inaccesibles de las charcas Fuera de la época del celo no se ve esta grande ave de rapiña con tanta frecuencia como podria suponerse. Durante el dia permanece en los canaverales y caza silenciosamente, sin duda con bastante buen resul. tado, sobre todo cuando tiene su alluergue en grandes panta. nos, en aguas estancadas ó en charcos. Aqqui se posa de dia en las cañas, en los pedazos flotantes de madera, ó en las estacas que sobresalen del agua, etc., pero siempre á la mayor distancia posible de la orilla. Si un barco cruza por los cañaverales, $\delta$ un perro que busca la caza nadanđo, déjalos acercarse, cual si confiase en los colores oscuros de su pluma. je para pasar desapercibida, y solo despues se levanta; pero no it la manera de otras aves de rapina, que procuran alejarse lo mas rápidamente posiblé de su perseguidor, sino aleteando pesadamente á poca altura sobre las cañas En los primeros momentos despues de remontarse, $\delta$ cuando solo quiere franquear una corta distancia, lleva pendientes sus largos piés, y entonces, el cazador mas experto podria confundirla fácilmente con una garza real purpưrea. Al ahuyen. tarle por primera vez no busca su salvacion en la fuga; déjase caer al suelo è seguida é intenta ocultarse. En las orillas del lago de Neusiedel vi una vez. levantarse muy cerca de nuestro barco una pareja del circido de los pantanos, que saliendo de lo mas espeso del cañaveral que rodea las orillas, describió largo tiempo sus círculos muy cerca de nosotros, á poca altura sobre las cañas. Ambas aves se mantuvieron á la precisa distancia para que un tiro de perdigones no las pudiese alcanzar; bajaban de vez en cuando, volvian à remontarse y continuaron esta maniobra mientras duró mi caceria, sin hacer aprecio de los tiros que disparaba contra las gaviotas y los patos. El circido de los pantanos se conduce de muy distinta manera en los sitios en que no se siente seguro con. tra las persecuciones del hombre, como por ejemplo en las praderas del Danubio, donde tiene su nido en los cañaverales situados en aguas estancadas 6 en pequeños brazos del rio en medio de las praderas, y donde hasta se ve obligado á anidar en espesos bosques bajos, en la alta yerba ó en los arbustos de ias islas, sitios fácilmente accesibles para el hombre. Aquil se mucstra mucho mas prudenie que en los pantanos y por eso no se le ve tan á menudo.

\$El periodo del celo es la única época en que, diesechando su perezosa lentitud, sale del pantano y de los cañaverales para retozar y describir sus circulos en las alturas, cual si quisiera demostrar sa habilidad en el vuelo. Una pareja de estas aves, que en casi todo el año no se oeja ver, puede reanimar en el mes de abril todo un distrito. Antes de que la hembra haya puesto los huevos, es decir en el periodo del apareamiento, la pareja suele remontarse a menudo á las ré. giones mas altas del aire, ejecutando unas evoluciones mas dificiles aun que las de los milanos, consistiendo la principal de ellas en precipitarse de vez en cuando desde grande altura al suelo; vuelven á elevarse y empiezan de nuevo á retozar, como lo hacen tambien ofros circidos. En las orillas del Danubio vénse en abril con frecuencia cuatro $\delta$ cinco, ő aun mas circidos de los pantanos que en sociedad cjecutan sus habilidades por los aires; despues pasan desde una orilla à otra, rasando la superficie, y describen tambien sus circulos en medio de las gaviotas. Cuando se reunen con ellos mila. nos $\delta$ circidos cenicientos, como suele suceder, alguna de estas aves ejecuta tambien sus evoluciones, y entonces ofrecen las praderas un animado paisaje de primavera.

va principios de mayo no se ve ya nada de esto, pues las hembras están cubriendo ya sus huevos y únicannente los niachos se divierten alguna que otra rez por los aires. Cuan. do se les ve describir sus circulos siempre en el mismo sitio, puede suponerse con seguridad que el nido está cerca, y por lo misino no es dificil hallarle. Se encuentra regularmenic en aguas estancadas, en canaverales y en pantanos, en la yerba de alguna prominencia que sobresale de la superficie del agua, ó cerca de la orilla en ios juncos, y hasta algunas veces en el trigo, cuando los campos lindan con las orillas habita- 
das por el ave Si no hay otro paraje, 6 cuando todo el pantano tiene poco fondo, el nido, semejanie al de las ares acuáticas, está en nedio de las altas cañas sobre el agua, en cuyo caso Hota en la superficie. En las praderas sé le encuen. tra con mas frecuencia en los cañaverales de las aguas estan. cadas y en los brazos de rio angostos; tambien se halla mu. chas veces en bosques bajos situados a corta distancia de la orilla. Alguna ver he observado tambien que varios nidos se hallan á bastanic distancia del agua, en terreno completa. mente seco. En este caso suelen componerse de ramas y yerhas, que en un diámezro bastante grande estan dispuesta.s como un plato en el suelo; mientras que en los pantanos y caliaverales las aves le construyen por lo regular con cañas, juncos y otras plantas acuaticas, que la hembra lleva en las garras, á menudo desde muy léjos. Úna de las condiciones para la eleccion del lugar donde se ha de construir el nido es que no haya obstáculos para la entrada y salida del ave; por eso vemos que en el bosque bajo, donde las espesas ramas no permiten al ave moverse con comodidad a causa de sus largas alas, se halla siempre el nido en pequeños claros. Aun despues de haber puesto algunos huevos, la hembra continua la construccion del nido, y no le cree acabado hasta que comienza å empollar. Ia puesta no se completa antes de los últimos dias de abril, ó mas bien hasta principios de mayo, componiéndose de cuatro huevos, raras veces de cinco 6 seis; su mayor diainetro es de $0^{\prime \prime}, 0,020^{\circ}, 046$, por $0^{\circ}, 031$ á $0^{\circ}, 037$ de grueso; lienen la cáscara granujienta, gruesa y sin lustre, de color blanco verdoso: el interior es de un verde vivo.

X. Los circidos de los pantanos son los padres mas cariño. sos que imaginarse pueda. Mientras que todas las demás aves de rapiña tardan mas ó menos tiempo en volver al nido cuando se las ahujenta, el circido de los pantanos vuelve siempre aunque se le espante reperidas reces, y hasta osa acercarse á su adversario. In hembra empolla sin ayuda del macho, como la de todos los círcidos: cuando el nido está al descubierto procura esconderse acurrucindose, y solo se levanta con gran ruido cuando el cazador se halla a dos ó tres pasos; pero en ve\% de huir con rapidez, como las otras ares de rapiña, clévase lentamente á poca altura del suelo, fran. (juea de este modo unos cien pasos, y se remonta vertical. mente trazando un arco alreciedor del nido, para volver por el otro lado. Si enionces re al intruso cerca de su cria, vaga pror los contornos lanzando griros lastimeros; mas apenas se aleja el hombre cien pasos, precipitase verticalmente sobre el nido. En un canareral de las praderas del Danubio encontré cicrto dia un nido; la hembra, espantada por el rumor, nose alejó hasta que esture â un paso; de modo que me lué fácil matarla en el acto. El macho, que vagaba por los contornos, acudió al punto atraido por la detonacion, y describió sus circulos sobre mi cabeza, siempre mas y mas estrechos, a pe. sar de hallarme del todo al descubierto en medio de un claro; pero al fin le ahuyenté de un tiro. En otro nido que encontré en un bosque cubierto de una espesa regetacion, y situado á mucha distancia del Danubio, la licmbra se levantó á pocos pasos por delante de nosotros y se le dirigieron tres tiros, pero sin resultado. El ave se dirigió lentanente hácia un bosque donde desaparció: mas à los pocos momentos presentóse en el lindero opuesto. Entonces nos alejamos á una distancia de doscientos pasos, y apenas lo hubimos hecho, cl ave se aproximb de nuevo al nido bajando rápidamente. Yo avancé algunos pasos $y$ la maté de un tiro cuando quiso huir otra vez Si es f́cil matar á estos circidos cerca del nido, en cambio cuesta mucho apoderarse de ellos en otra parte. No se deja engañar con el buho; aunquue se le acerca rápida. mente, limitase ả pasar una ó dos veces sobre su cabeza y emprende despues la fuga.»
Fl circido mas perjudicial es sin duda alguna el de los pantanos, pues se alimenta casi exclusivamente de aves acuáticas y pantanosas y de su cria ó de los huevos. Solocuando estos le faltan, se contenta con anfibios, peces é insectos. Caza casi del unismo modo que sus congéneres, pero persi. gue con mas afan la cria de las ares haciéndose culpab!e por este concepto de mas fechorias que ninguna otra ave de rapina; mientras que sus congéneres, los demás circidos, exterminan muchos pequeiros roedores é insectos. Iin el campo, dice Naumann, busca los nidos de alondras y de otras aves, y tanto le gustan los huevos como los pollos. Sabe sacar muy bien el contenido de los huevos grandes, y devora los pequeños con la císcara, por lo cual ocasiona un daño inmenso tanto en los nidos de las aves del campo, como en los de las ocas silvestres y de los patos. Mientras dura el periodo de la incubacion no se alimenta de otra cosa. Ias ares adultas saben muy bien cuán peligroso es tal enemigo para su cria, y de consiguiente procuran alejarle de sus nidos por todos los medios posibles, persiguiéndole con lastimeros gritos y i picotazos. Las ocas silvestres, los patos y otras aves acuáticas cubren sus huevos con el material del nido cuando se ven obligadas á dejarlos por algun tiempo, y esto solo por temor á la rapaz; si no lo hacen asi, el primer circido de los pantanos que los vea los devorara al punto.

\$Parece que las cáscaras de los huevos del cisne son de. masiado duras para su pico, pues le he visto trabajar en ellas sin obiener resuliado. Las pequeinas aves nadadoras estín tambien cxpuestas à sus garras; para coger su cria, las ahuventa del nido. Despues del periodo de la incubacion persi. gue á los polluelos de las ocas, de los patos, de las gallinas acuáticas, etc.; y luego se alimenta preferentemente de estas últimas, las cuales, cuando ren llegar á la rapaz buscan un refugio en los cañaverales, y si las persigue tambien aqui, vuelven al agua descubierta para buscar su salvacion sumergiéndose, pues entre las canias las caza fácilmente, saltando en pos de ellas hasta quue atrapa una. No ataca a los patos adultos, y si la hembra está presente tampoco se atreve con los polluelos; pues tan luego como la rapaz demuestra intencion de precipitarse sobre la progenie, la madre rucla al encuentro de su enemiga y acométela á picotazos, mientras que las avecillas se oprimen unas contra otras al amparo de su madre. Nehrliorn observó cuintos periuicios causa el circido de los pantanos entre las ares que con él habitan el estanque de Riddagshausen, cerca de Brunswick, y pudo reconocer tambien, con gran pesar suyo, que la proteccion cragerada solo es perjudicial. Para retener á los circidos de los pantanos yue en los anios anteriores habian anidado alguna que otra vez, aunque no con regularidad, en uno de los estanques, Nehrkorn dispuso se hiciera todo lo posible para que una pareja criase; y al año siguiente tuvo la satisfaccion de ver anidar dos, que desde entonces siguieron haciéndolo puntualmente. A in de proder enviar los polluelos al jardin zoo. lógico de Berlin, dirigióse en $15 ; 6$ al sitio donde se liallaba el nido, y entonces pudo ver cómo se habian portado sus protegidos. A pesar de que sabia muy bien, dice el citado naturalista, que los circidos de los pantanos son ladrones perversos y que saquean los nidos de las gallinas acuáticas mientras el estanque no esté cubierto de cañas, no me habia formado aun idea exacta de su proceder. Cerca del nido, en el espacio de unos cuarenta nuctros cuadrados, vi entre los juncos plumas de la cabeza y hasta restos de pequeñas ga. llinas acuáticas y de patos, en tal cantidad, que pude expli. carme la disminucion de las citadas ares. Mientras que otras veces centenares de gallinas acuáticas poblaban los cstan. ques, en este año apenas se contaban diez. pares, $\mathfrak{E}$ igual disminucion observé tambien entre los diferentes podicipe- 
dos. Parece que los círcidos no han causado perjuicios entre los acrocéfalos, pues el número de estos es aun inmenso; mas quiero acabar pronto con aquellos y proteger solo á las aves que se limitan a robarme alguna vez un pececillo, sin abusar de tal modo de mi proteccion.

\section{LOS ESPILOCIRCOS-SPILOCIRCUS}

En la Nueva Holanda habitan rapaces semejantes â las anteriores, que han sido sepparidas de cllas, aun cuando no ofrecen mas diferencin que la que resulta de la coloracion.

\section{EL ESPILOCIRCO DE JARDINE-SPI-} LOGIRCUS IARDINII

CARACTERES.-FI espilocirco de Jandine 6 manchado, iéne la talla del circido de los pantanos, poco mas ó menós. La parte superior de la cabeza, las mejillas y el pabellon de la oreja son de un pardo oscuro, con listas de pardo negro; la carn, el lomo y el pecho de un gris denso; la parte infurior de las alas, el vientre y las ancas de un pardo castanio; la mayor parte de las plumas inferiores del lomo y de la espaldilla, y todas las del vientre, ticnen manchas re dondas y blancas á cada lado dél tállo; las pennas de las alas son de un pardn oscuro, y las de la cola listadas aliernativa ménte de pardo oscuro ye gris; el pico es de este úitimo tinte en la base y negro en la punta; las patas amarillas y el ojo de un amarillo naranja (fig. 164).

I.os pequeños tienen el lomo de un pardo oscuro unifor. me, y el vientre listado, pero sin mairchas.

Distribucion GEOGRÁFICA. - El naturalista Gould dice que el espilocirco de Jardine es comun en toda la Nueva Gales del sur.

USOS, COSTUMBRES Y REGMIEN.-POT SUS LSOS no difiere de los circidos y de los estrígiceps: aliméntase de pequeños mamiferos, de pájaros, lagartos y serpientes; anida esta ave en tierra.

\section{LOS BUTEONIDOS - BUTEONES}

CARACTERES, L I As rapaces que constituyen esta fa. milia tienen la talla srande 0 mediana y pesadas formas, que recuerdan todavia las de las águilas, de las cuales difieren sin embargo por sus costumbres innobles. Tienen el cuerpo bastanic grueso; la cabea voluminosa, ancha y plana; el pico corto, corvo desde la base, comprimido lateral. mente; con el corte sin dientes; el cuello corto; las alas largas y redondeadas, con la cuarta penna mas larga que las otras: la cola de una extension regular; los tarsos cortos; los dedos endebies, y ias unas puntiagudas y muy encorvadas. El plumaje, en el que predominan los colores oscuros, es abundante y mas $\delta$ menos lacio; las plumas grandes, largis $y$ anchas, y las de la cabeza, angostas y puntiagudas, no for man mono sino excepcionalmente.

DISTRIBUCION GEOGRÁFICA. - Los buteonidos, de los que se conocen unas cincuenta especies, están diseminados en casi todas las zonas de ambos hemisterios.

USOS, COSTUMBRES Y RÉGIMFN. - listas rapaces habitan la llamura y la montaria; buscan sobre todo los pe queños bosqques sembrados de rocas ó rodeados de campos sin cultivo; durante el periodo del celo se fija cada pareja en un dominio bastante extenso que linda con el de la orra. Sin embargo los butconidos son bastante pacificos y solo impiden la jresencia de otra rapaz cuando se acerea demasiado á su nido. Ias especies del norte amigran, $\delta$ son porlo menos viajeras; las del sur permanecen todo el año en el mismo canton.
Los buteonidos vuclan con lentitud largo rato; se ciernen á menudo, y mas bien á la manera de las aguilas que como los milanos.

Cuando han divisado una presa, están algun tiempo sobre ella, como los pequenos falcónidos, y despues se dejan caer oblicuamente y con bastante lentitud. Muchas veces cazan al acecho: posados sobre un śrbol ó una eminencia, exami. nan el terreno al rededor, y si se mueve algun animal ó se deja ver, abandonan su observatorio y caen sobre la presa.

En tierra son bastante torpes, y saltan mas bien que an. dan: la vista es el mas perfecto de sus sentidos; nada tienen que envidiar al aguila en este concento.

Su inteligencia parece mas obtusa de lo que realmente es; estas rapaces son mas cautas que la major parte de los mil. vidos, aunque algunas veces obran con bastante aturdimiento; no tardan en distinguir lo peligroso para ellas y lo que no lo $\mathrm{ks}, y$ una vez que se las ha perseguido, muéstranse muy circunspectas, sin que se pueda decir que son astutas. Todo lo hacen pesadamente; se las tacha de perezosas poi. que permanecen horas en un mismo sitio; pero semejante acusacion no es merecida, pues su reposo aparente tiene por objeto cazar mejor; están al acecho, y no por eso dejan de vigilar los altrededores.

In los buteonidos no vemos la violencia ni la sed de san. gre de otras rapaces; comen mucho, pero una vez hartos, no siguen cazando. Si exceptuamos al gran duque, que les ins. pira la major aversion, sus relaciones con las demas aves de rapina son generalmente buenas, lo cual no impide que les acometan con irecuencia las pequeñas rapaces; los grajos y los rípidos halcones son los que se complacen principal. mente cn atormentarlos.

Los buteonidos se alimentan de pequeños vertebrados, insectos, gusanos, orugas, $y$ hasta de sustancias vegetales. Son para nosotros auxiliares útiles, porque exterminan los mus. gaños, los arvicolas, las serpientes y otros muchos animales nócivos para nuestras cosechas.

Estas rapaces anidan en los árboles mas altos, y constru. yen su nido toscamente: la puesta es por lo régular de tres ó cuatro huevos, y de uno solo en casos raros. Los padres contribuyen á ensenará á sus hijuelos; los cuidan con cariino, los defienden valerosanente, y permanecen largo tiempo con ellos para guiarlos.

CAUTIVIDAD.- Los pequeños se domestican rápidamente y se les puede ensenar á salir de su jaula y volver á ella; hasta los individuos viejos se resignan pronto con la pérdida de su libertad y cobran afecto á-su amo.

\section{LOS CIRCAETOS-CIRCAETUS}

CARACTERES. - Los circactos constituren el tránsito entre las águilas y los buzos propiamente dichos; son aves grandes, de cuerpo esbêlio, pero vigoroso; cuello corto y cabeza voluminosa; tienen el pico fuerte, encorvado desde su base, algo comprimido lateralmenie, con gancho inuy lar. go $y$ bordes rectos; las alas son prolongadas, anchas, obtu. 5as, ó con la tercera ó cuarta penna mas larga; la cola, de una longitud regular, es ancha y cuadrada; los tarsos alios, cubiertos de una verdadera coraza de escanias; los dedos muy cortos: las uñas cortas tambien, encorvadas y agudas; las plumas grandes y largas; las de la cabeza y de la nuca afila. das como en las águilas.

\section{EL CIRCAETO JUAN LE BLANC-CIRCAETUS GALLICUS}

CARACTERES. - Esta rapaz (fig. $16_{j}$ ) tiene $\left(1^{\text {to }}, 70\right.$ de largo, y $1^{\prime \prime}$, So de punta a punta de ala; esta plegada 
$0^{\circ}, 5^{6}$ y la cola $0^{\circ}, 3^{\circ}$. I.a cara superior del cuerpo es parda: las plumas agudas de la cabeza y de la nuca de un pardo mate, con un filcte claro; las del lomo y de la espal. dilla, ๖ las pequeñas cobijas superiores del ala de un pardo oscuro, con el tallo claro: las pennas de las alas de un pardo negru, orilladas del mismo tinte mas claro, con tallos blancos y rayas trasversales negras: las pennas de la cola de un pardo oscuro con tres anchas fajas trasversales negras, y terminadas por ctra blanca; la frente, la garganta y las meji. llas blanquizcas con rayas muy finas de color pardo; la parte superior del pecho y el buche de este mismo tinte mas palido; el resto de la cara inferior del cuerpo blanco, con algunas manchas de un pardo claro, dispuestas trasversalmente. El ojo es amarillo, el pico negro azulado, la cera y las patas de un pardo claro.
Los individuos jóvenes se diferencian poco de los adultos. DISTRIBUCION GEOGRÁFICA. - A principios del siglo aun nose conocia bien esta ave, y se la confundia con los individuos claros del buzo, pudiendo decirse que su historia no ha quedado completada hasta los ulltimos años, cuando se fijó la atencion en el animal.

Desde esta época se le ha visto anidar en todo el pais de Alemania, sobre todo en Prusia, Pomerania, Silesia, Brandenburgo, Mecklemburgo, el Westerwald y el Palatinado. Con mas regularioad se le observa en el mediodia de Austria, en el sur de Rusia, en Turquia, Grecia, y ambien en Italia, Irancia y España; en la Gran Bretaña y Escandinavia no se le ha cazado aun, al menos cque yo sepa, ni creo que se le haya visto en Holanda tampoco. En Alemania sc presenta á principios de mayo y desaparece en setiembre para ir á inver-

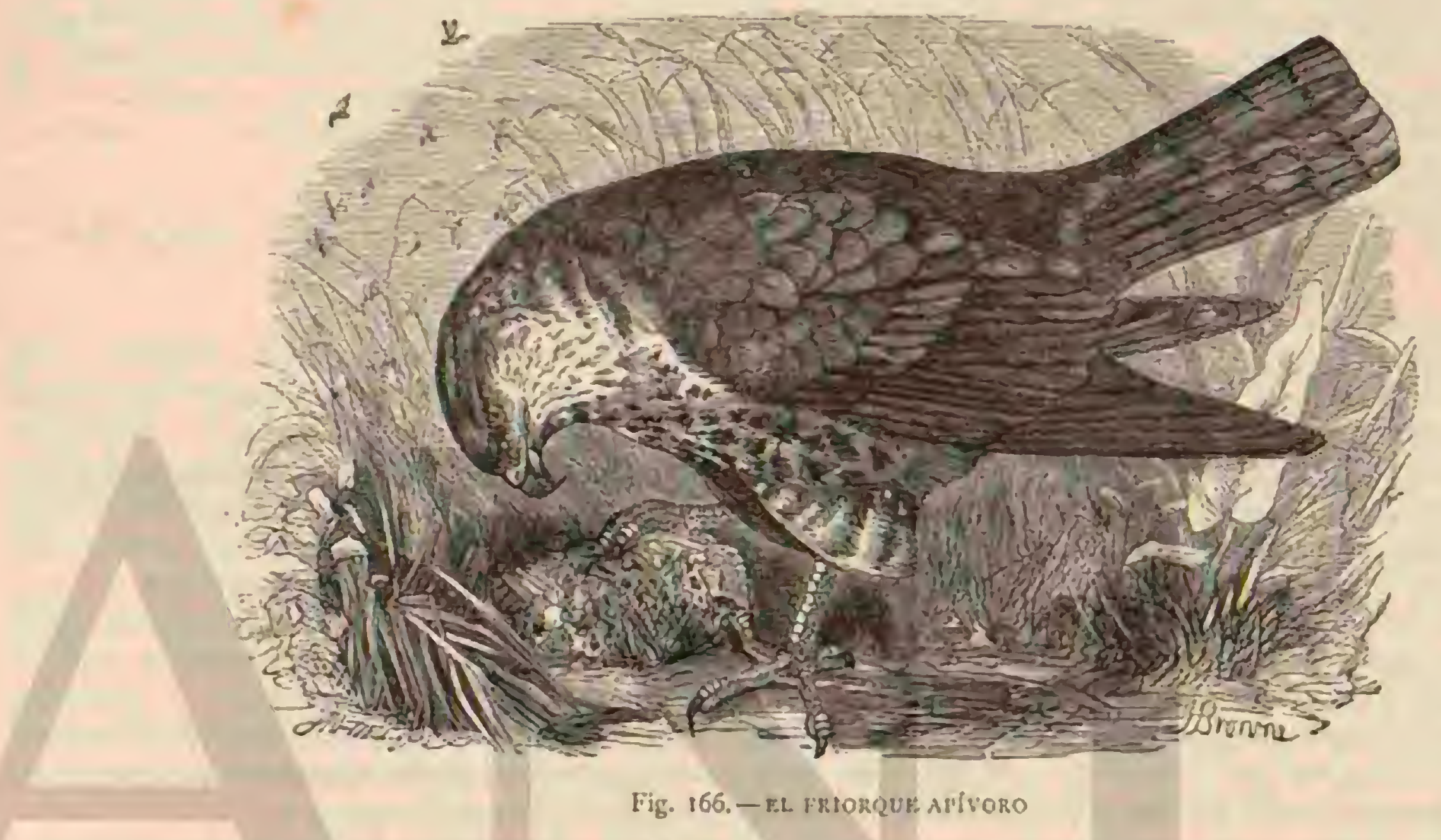

nar en el Africa central y en el Asia meridional, acompañada de los de su especie que alli anidan.

USOS, COSTUMBRES X REGIMEN. - Habita los grandes bosques solitarios, donde vive silencioso y retirado: en las Indias se fija menos en los bosques y juncales que en las llanuras y en medio del pais habitado. En el norte de Aírica se le ve principalmente en invierno, por reducidas bandadas de seis a ocho individuos, los cuales se posan en una roca cerca de algun rio; y con mas frecuencia todavia en las estepas, a varias leguas de toda corriente de agua

Por sus usos y costumbres se asemeja mas al buzo que \{ las águilas: es un ave pacifica é indolente, que no se cuida sino de los animales que han de servirle de alimento.

Dicen todos los observadores que cuando esta cerca de su nido es prudente y recelosa; y segun Jerdon, lanza frecuentes gritos. En Africa no he oido jamás su vor, y sicmpre me pareció una de las rapaces mas confiadas. Posada en un árbol, contempla al cazador, s no se le ocurre alejarse; casi rodos los individuos que yo maté me dejaron acercar hasta el pié del árbol donde se haliaban.

Solo se la ve posada por maniana y tarde: durante las de. mis horas se ocupa en cazar, y lo hace con una lentitudy una placider sin igual; se cieme irazando circulos sobre la llanura, 6 bien se mantiene inmóvil â orillas del agua, ace. chando su presa; cuando vuela permanece á menudo en el mismo sitio, lo mismo que el buzo, pero es mas torpe que el.

Para acometer a los vertebrados de que se alimenta, baja Toso III con lentitud hácia el suclo, luego vucla algun tiempo rasando la tierra, y por último extiende las garras para caer sobre el animal que ha visto: con frecuencia penetra en el agua a fin de coger alguna presa. Mirn con ojo envidioso á sus seme. jantes, y los acomete cuando han sido mas felices que ella: si un individuo coge una serpiente ó un lagarto y lo ve otro, la lucha es segura; al apoderarse el primero de la presa, llega un segundo y se la coge; los dos adversarios se sujeian entonces con las garras, y à menudo caen á tierra; luego se levantan, apírtanse algunos pasos, y se remontan en pos de su victima, que se les ha escapado, aprovechando aquella discordia.

Hácia el medio dia se dirige el circacto a los bancos de arena que hay a orillas de los rios, donde apaga su sed; salta y ruela de un lado a otro, y se ra luego muy despacio. Du. rante los grandes calores se posa a menudo despues de beber, y permanece horas enterns inmóvil en apiariencia, con el cuerpo en una posicion casi vertical. Pasa la noche en un árbol aislado, desde donde puede abarcar con la vista un vasto horizonte; pero aun alli permite al hombre acercarse mucho.

El circaeto se dedica sobre todo a la caza de serpientes: coge además lagartos, ranas y peces; y scgun Jerdon, ratas, pajaritos, cangrejos, grandes insectos y miriápodos. Aunque este ha visto que arrebataba licbres y patos heridos, sin cmbargo, los reptiles forman la base de su alimento, cazándolos con destreza suma a Mijơven circaeto domesticado, escribió 
Mechlenburg á Lenz, cae como un rayo sobre las serpientes, por grandes y malignas que sean; con una de sus garras las coge por detrais de la cabeza, con la otra les sujeta el lomo, lanzando grandes gritos y agitando las alas; con el pico corta los tendones y ligamentos çue enlazan la cabeza al tronco, $y$ el reptil queda sin defensa. Algunos instantes despues comienza á devorarle por la cabeza, y á cada bocado descarga un picotazo en la columna vertebral de su victima. En una mañana se comió tres grandes culebras, una de las cuales media mas de un metro de largo; acostumbra a devolver las escamas. Las serpientes son su presa favorita; le he dado á la vez estos reptiles, ratas, pájaros y ranas, y siempte se lanzó con preferencia sobre las primeris.

Elliot dice haber visto un circaeto enlazado por una serpiente; pero la rapaz sujetaba su cabeza con tal vigor, que eran inútiles los esfuerzos del reptil: la destreza del ave y su espeso plumaje, constituyen su línica defensa contra el veneno de su enemigo. El circaeto no es réractario, como se ha creido: á instancias de Lenz, Mechlenburg dejó que una vi. bora mordicse á su ave; al momento perdis esta su alegria murió a los tres dias.

Ei nido suele estar en altos árboles frondosos, a muy diversa elevacion, y alguna vez entre rocas. La pareja le cons. truye á principios de junio ó repara el que le sirvió el año anterior, pues aunque se le quiten los huevos, vuelve muchos años con regularidad al mismo sitio para anidar. Segun las minuciosas observaciones de Seidensacher, se presenta en Estria fodiados de marzo, acompañado rergularmente de uno 6 dos de su especie, y elévase primero á mucha altura sobre el sitio elegido para anidar.

Despues de algunos dias disuélvese el grupo, y desde entonces solo se ve la pareja que gira continuamente en los aires sin mover casi las alas, dejando oir á menudo su aguda roz, la cual podria cxpresarse por his, his. En seguida cmpieza a reparar si nido, y si se le han cogido varias veces los hue vos 6 molestado de algun tnodo, elige otro ó construye uno nuevo. El nido, no mayor que el del buzo, se compone de ramas secas, y la cavidad está cubierta tambien de este material ó de hojas y ramitas verdes, con las cuales forman una especie de tejadillo. Asegurase que la hembra pone dos hueros, pero nunca se ha encóntrado mas de uno en los prime. ros dias de mayo; ciene la forma oval, $y$ es relativamente muy grande; la cáscara, delgada y muy granujienta, es de color blanco azulado. Segun Tristram, al apareamiento precede:1 muchas maniobras por los aires: el macho y la hembra se persiguen con grandes gritos; clévanse ś mucha altura, describen circulos y precipitanse despues súbitamente d la profundidad. La hembra empolla y el macho vigila.

Asegura Mechlenburg que la incubacion dura veintiocho dias; el machio y la hembra cubren alternativamente, y aunbos se cuidan de alimentar y enseñar a su progenic. En caso de peligro trasportan á sus hijuelos á otro nido, observacion he cha por el conde Wodzicki y el principe de Wied.

CAUTIVIDAD.-Los circaetos pequeños se domestican perfectamente siempre que se cuide mucho de cllos: cuando comen se conducen de una manera singular, segun refiere Eugenio de Homeyer: precipitanse sobre la carne que se les da; échanse encima con tas alas abiertas, lanzando un grito penetrante que puede traducirse por $b l i, b l i ; y$ miran al rededor con desconfianza, cual si temiesen que otra ave les quí-
siera arsebatar la pitanza.

Desgraciadamente no es muy fácil adquirir uno de estos circaetos. Yo no he podido observar mas que dos en cauti. vidad, $y$ solo he cuidado uno que estaba herido, por lo cual no me es posible jurgar de un ave tan rara como extraña. Mi cautivo se posaba tranquila y silenciosamente en un mismo sitio, mirando con sus grandes ojos amarillos á cuantos se acercaban, aunque sin hacerles caso; parecióme por esto un ave de poca inteligencia. Algunos circaetos cautivos demues. tran lo contrario. Un individuo de esta especie cogido pequeño del nido, y al gue Seidensacher pudo observar repetidas reces, era en extremo manso, tanto que se le podia permitir correr por el patio sin cortarle las alas; dejábase tocar por todo el mundo, y no molestaba á las gallinas domés. ticas; en cambio cogia ratones y ratas, llevábalas algun tiempo $y$ las devoraba á veces; tambien dejaba oir à menudo su vor.

\section{LOS FRIORQUES - PERNIS}

CARAGTERES. - Los friorques enlazan á los buzos con los milanos: tienen el cuerpo mas prolongado que los otros buteonidos; las orejas y la cola largas; el pico prolongado, bajo endeble y solamente encorvado cerca de la punta; los tarsos cortos; los dedos medianos; las uñas largas, endebles y corvas; las mejillas guarnecidas de plumitas compactas y escainosas.

\section{EL FRIORQUE APÍVORO-PERNIS API- VORUS}

CARACTERES. - Esta ave tiene de $6^{\circ}, 59\left\{6^{\circ}, 6 z\right.$ de largo, y de $1^{4}, 35 z^{2}$, 40 de punta á punta de ala; esta ple. gada mide $(1,40 \text { y la cola })^{\circ}, 23$. El plumaje es muy variable, aunque dice Behrend que algunas variedades se conservan hereditariamente. Dificil es describir en general el color del ave: unas beces tiene el plumaje de un tinte pardo unifor. me, excepto tres grandes fajas y varias pequeñas rayas del mismo color, que adornan la cola; otras la cabeza es de un gris azul en el macho. Con frecuencia el lomo es pardo, el vientre azulado con manchas blancas, ó bien de este último tinte con manchas pardas; el ojo es de un blanco de plata ó amarillo de oro; la cera amarilla tambien; el pico negro $y$ las patas de un amarillo de limon (fig. 166).

DISTRIBUCION GEOGRAFICA. - Toda la Europa, excepto los paises mas septentrionales, son la patria del friorque apivoro, que habita tambien en una paste de la Escan. dinavia $y$ en Finlandia; no falta en ninguna parte, pero siempre se le encuentra muy aisladamente, y solo en ciertos sitios. En las llanuras de Noruega se le observa á veces en gran número y en verano con regularidad, sobre todo en la costa de este pais; en Suecia estí diseminado hasta la fron. tera de Laponia, y en Rusia figura entre las aves de rapiña comunes; en Dinamarca se presenta cuando viaja, pero tambien anida en algunas partes. En Alemania prefiere el oeste, sin faltar por eso en cl este. Abunda mas en las llanuras bajas que en la montaña, donde no se eleva, segun parece, a mas de mil metros. En Holanda anida cerca de la frontera alèmana; en Bélgica lo hace principalmente en las Ardenas; en Francia abunda mucho mas en el sud $y$ sudeste que en el norte; en España, Italia y Grecia, por el contrario, anida muy aisladamente y parece mas bien que solo visita estos países durante sus viajes; evita mas ó menos los bosques frondosos; segun Altum, parece que te agtadan mas los de hayas que los encinares. Muy entrada la primavera, por lo regular á fines del mes de abril, preséntase entre nosotros, $y$ aun á fines de mayo se ven individuos que viajan hácia los distritos septentrionales, y que ya en agosto continuan su marcha hácia el interior y mediodía del Árica. Por lo regu. lar viaja aislado en pequeños grupos, pero puede suceder que en un solo dia se vean centenares siguiendo el mismo camino. «Desde que estoy aqui, dice Brueggman, he observado 
casi todos los años, á fines de mayo, un grupo de estas ares que siempre se dirigia sobre Kniphausen; la bandada se componia algunas veces de treinta á cuarenta individuos. Ias aves viajaban siempre en linea recta desde el este hácia el oeste, y nunca á mas altura que la de los árboles; nunca les vi describir circulos ni posarse en una rama ó en el suelo. Este año $(18 ; 5)$ he visto á las cuatro de la tarde del 26 de mayo los primeros friorques apivoros, es decir un grupo de unos cincuenta individuos. Estas aves trazaban circulos as una altura de treinta metros cerca de Kniphausen, dirigién. dose siempre desde el oeste al este. Al primer grupo siguie. ron oiros, formando como un cortejo continuo, que siempre seguia la misma direccion, pero ninguno describia circulos ni se elevaba a gran altura. Muchos individuos se posaron tambien en el jardin de Kiniphausen. El paso duró hasta las ocho, y supongo que mas tarde cruzaron otros grupos; pues $a ́$ la manana siguiente se encontraron unos treinta individuos en tierra labrada. Calculo el numero de las aves que han pasado por aqui en mas de mil. En Wilhelmshaven, donde se obserió el 26 de mayo la misma procesion, me refirieron exactamente lo nismo. Esta are habita en todo el norte de Alemania, pero solo aisladamente, $₫$ por lo tanto no se ex. plica de dónde vienen estas ares ni á dónde van. Gaetke ha recogido en Helgoland observaciones iguales: me ha di. cho que, durante el viaje del otono, \& la hora del medio dia, y dirigiéncose al oriente, pasaron grupos de friorques agi. vorns, compuestos de cinco a sicte individuos; por la tarde aumentó el numero de los grupos, que avanzaban con la mayor rapidez, siguiendoles desde las dos de la tarde hasta cerrar la noche tantas bandadas de veinte á treinta indivi. duos, que Gaetke no pudo explicarse su procedencia. En mi opinion estas aves llegaban del lejano este de la Rusia, di. rigiéndose hácia el Africa occidental. Fs notable la exactitud con que los friorques apivoros siguen su linen general, es decir desde el esnordeste al oesudoeste y vice-versa. En al nordeste del Africa. Heuglin y yo no hemos observado nunca ninguaa de estas aves, que muy raras se ven alli en corto numero; mientras que en España, Mlarruecos y el Africa occidental se presentan con regularidad todos los inviernos por numerosas bandadas, pudiéndose presenciar la ida y la vuelta cuando cruzan el estrecho de Cibraliar.

USOS, COSTUMBRES Y REGIMEN.-REI iriorque apivoro, dice Naumann, es un ave tan cobarde como inno. ble, en cuyo concepto se diferencia de todas nuestras rapaces indigenas. Es timida, estúpida y bonachona; ruela con len. titud y pesadez, en general ro se eleva mucho sobre el suelo. Para volar mueve las alas lentamente, y hace sus evoluciones con bastante torpeza; franquea s menudo alguna dis. tancia sin aletear y gira entonces con mas facilidad; su vuelo es generalmente mas ligero, pero mas perczoso que el dé los otros buteónidos. El aspecto que esta are ofrece en su ruelo se distingue 1 primer vista del de su congéncre ale. man; soda el ave parece mucho mas prolongada que el buzo, y aunque presenta la forma triangular propia de todos los buteónidos, se la reconoce muy pronto por sus alas mas lar. gas y angostas y por su cola. En la época del celo ejecuta tambien admirables evoluciones aéreas.

uTodo su sèr, continúa Naumann, indica la mayor percza: se la ve posada horas enteras sobre un poste ó un árbol ais. lado, desde donde acecha su presa; anda bastante bien, y a menudo caza los insectos à la carrera.

x Cuando anda con la cabeza erguida parcceria bastante un águila pequeña si no se distinguiera a prinera vista por su modo de andar, semejante al de las cornejas: su grito se expresa por liki kik, repetido varias reces seguidas.)

Con razon se llama a esta ave apirora, pues su alimento se compone principalmente de avispas y abejas: el friorque apiroro coge los nidos de esos insectos de las ramas, y para obtener los que se hallan debajo de tierra practica varias aberturas LUna vez vi, me escribe Liebe, una pareja de estas aves ocupada en extraer un nido de abejorros que se ha. llaba en el lindero de un campo. La hembra cogió con la garra terrones de tierra, arrancándolos poco á poco, para lo cual serviase del pico algunas veces. El macho la relevaba ś intervalos por poco tiempo, y al cabo de un cuarto de liora terminó el trabajo. Cuando el ave ha descubierto un nido de arispas no es fácil ahuyentarla de él.

El régimen de esta ave difiere del de todas las demás tapaces de Europa; y no en vano se la la dado el nombre que lleva, pues las avispas constituyen su principal alimento; pero solo come aquellas que no están aun completa. mente desarrolladas, y de las cuales no debe temerse cl aguijon. En una mañana de julio, refiere Behrends, un cam pesino obserró á una de estas ares, que se disponia å dejar al descubierto un nido de avispas, y aunque el hombre la espantó varias veces, no por eso dejó de proseguir su trabajo: al medio dia la maté de un tiro antes que llevase a cabo su proyecto. En su estómago no encontré mas que restos de co. leópteros y ni una sola avispa, à pesar de que estos insectos habian rolado i su alrededor por espacio de seis horas, du rante las cuales no hizo mas quue alejarlas sacudiendo la cabezar El hecho despertó uni atencion: poco despues adquiri un individuo herido ligeramente, y cuando le dabn una avispa, apartábala de sí sin quererla comer, limitándose cuando mas á darle un picotazo. Siempre obtuve el mismo resultado sin conseguir que comiera estos insectos.

Behrends, cuya opinion refutaré despues, añade que el friorque devom, además de las avispas y abejas, langostas, escarabajos, orugas, ranas'y lagartos; el citado natumlista encontró en el buche, aunque muy rara vez, restos de animales de sangre calienie, nunica abejorros, ni tampoco fiores de abedules y coniferas, como dice Naumann; pero si hojas de mirtilos.

Este ultimo naturalista considera al friorque como uno de los mas terribles destructores de nidos, $y$ asegura cque no se contenta con acomeier \& los musgaños, a las ratas y a los hamsters, sino tambien a los lebratos. Con frecuencia arte. bata una parte de su alinento al buitre, ó mejor dicho, sigue á esta rapaz para alimentarse de los réstos de sus comidas: en verano conic inirtilos, frambuesas y otras bayas.

- El buche sucle estar lleno, dice Altum, de orugas grandes y pequeñas, de crias de avispas y sobre todo de los abejorros, de restos de ranas, y hasta de avecillas sacadas del nido; entre estas últimas parece preferir sobre todo las del mirlo. No encontré nunca ratones, pero no cabe duda que tambien los devora. Parece que su alimento principal consiste en insectos, particularmente escarabajos, larvas de abe. jorro, orugas de diferentes clases y sobre todo ranas.

Todos los observadores que examinaron los insecios del buche y estomago del friorque apivoro, excepto Behrends, convienen en que el ave no se olvida nunca de quitar el aguijon á las abejas, avispas y abejorros antes de comer. Segun dice Naumann, sabe coger estos insectos con tal des. treza, que al cerrar el pico los coloca tmasversalmente; opri. miendo con rapidez las mandíbulas coria algunos milímetros de la punta del vientre que contiene el aguijon y deja caer el pedacito, guardandose muy bien de tocarle, pues si se le comiera, podria herirla mortalmente en la boea ó en el esó. fago. Mutila todos los insectos de este modo, y nunca se ha encontrado en su buche un aguijon; en la caza misma presérvale de las picaduras su recio plumaje y las fuertes placas de los piés. 
Inmediatamente despues de llegar a su patria, el friorque apivoro da principio a la construccion 6 arreglo de su nido, para lo cual prefiere los bosques frondosos que lindan con campos y praderas. Solo en caso de necesidad se resuelve á iabricar una nuevo, pues agradale mas servirse del nido abandonado de un buzo, de un milano $\delta$ de una corneja, el cual arregla scgun lo jurga necesario, rellenándole sobre todo, aunnque no en todos los casos, de mmas verdes. Cuando se ve obligado á construir él mismo su nido, hácelo con tor

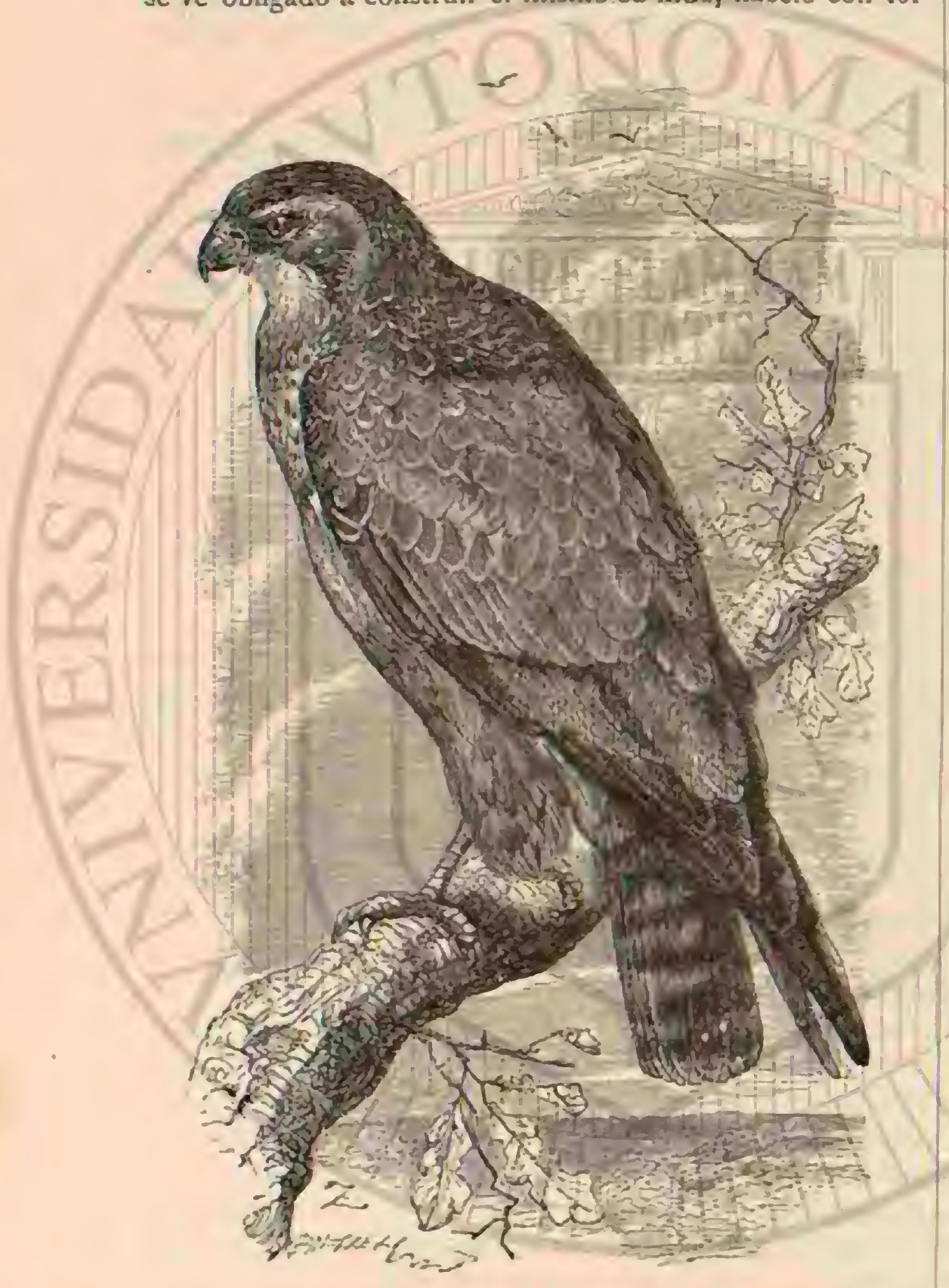

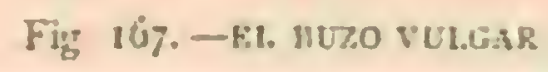

peza y ligeramente: en este caso se compone solo de ramas delgadas, reunidas con mucho descuido, y á veces tan cla. ras, que desde abajo se pueden ver los huevos. En la época del apareamiento la pareja se divierte á la manera de otras aves de rapina, sobre todo de los buzardos, retozando ś mu. cha altura en el aire; : entonces agrada mucho ver has evoluciones de estas aves sobre el lugar donde se halla el nido: la pareja se remonta trazando sus circulos, sube mas y mas en espiral, y el macho 1 mucha mayor altura que la hembra; despues bajan con las alas levantadas casi verticalmente; vuelven á elevarse y repiten la misma erolucion durante mucho tiempo.

Macho $r$ hembra ocupan el nido muchó antes de efectunr. se la puesta: Sachse, que en el Westerwald examinó, en el es. pacio de doce á catorce años, nada menos que treinta y un nidos de esia especie, tan rara en otras regiones, observó que ya el it de mayo llevaban las aves ramas verdes, a pesar de que no se vieron huevos en el nido antes del 4 de junio. La puesta se compone de dos, muy variables por su forma y color; tan pronto son redondeados, como ovales, de cáscara mas 6 menos brillante y color blanco amarillo ó pardo rojo, con dibujos mas claros ó mas oscuros. Segun ha observado Sachse, la hembra no pone hasta fines de mayo, lo mas pronto, y con intervalos de tres á cinco dias. Macho y hembra empollan alternativamente, alimentándose uno á otro de la cria de abejorros, que llevan en los pamales, re. uniendo á reces abundante provision en el nido. Fixtraña es la poca timidez que estas ares demuestran cuando cubren los hueros. $\mathrm{KE} 6$ de junio de $\$ \$ 70$, dice Sachse, supuse que habria huevos en un nido visitado antes por mi varias veces. La hembra estaba cubriéndolos, y aunque di en la encina varios golpes con el baston, no se movio; solo despues de repetirlos muchas veces púsose en el borde del nido, erizó el plumaje, miróme furiosamente, se sacudio y volvió a cubrir los huevos. Cuando hube llegado al sitio mismo donde estaba, levantóse al inn, y avanzando lentamente á lo largo de la rama en que tenia el nido, emprendio la fuga. Perseguida por cornejas y aves pequeñas, describió algun tiempo sus circulos alredector del árbol y fué á posarse en una rama, á cincuenta pasos de distancia. Los dos huevos estaban incubados de cuntro a cinco dins Los polluelos se alimentan al principio de orugas, moscas y otros insectos, que los padres les dan expeliéndolos del buche; mas tarde les llevan panales enteros llenos de crias de larvas y nidos de avispas, y al fin ranas pequenas, aves, etc. Despues de salir del nido, los polluelos se sirven de él algun tiempo para pasar la noche; mas tarde comicnian d vagar por los contornos; pero probablemente vuelien tambien enionces cerca del lugar donde nacieron. Bajo la direccion de sus padres pronto aprenden á alimen. tarse sin ayuda de ellos; pero aun siguen algun tiempo bajo la dependencia de los adultos.

CAUTIVIDAD. - El friorque es ave que interesa mucho cuando está cautiva, si hemos de juzgar por lo que dice Hehrends; hé aqui lo que refiere sobre el particular: «Cogi un jóven macho que acababa de abandonar el nido, $y$ al cabo de) algunas semanas manifest6 la mayor confianza con las personas conocidas y con mis perros, pareciendo que me profesaba mucho cariño; pero si veia un perro extrano, poniase a la defensiva, erizaba las plumas y avanzaba contra él. Mostrábase sumamente afectuoso con cierto perrito, entre cuyas piemas se colocaba cuando el animal se echaba á dormir; retozaba con él, y peinábale el pelaje con su pico; solo cuando se trataba de comer ahuyentaba \& los animales, que no le oponian ninguna resistencia, $\mathrm{s}$ tenia delante la comida mucho tiempo sin tocarla.

Corria por toda la casa y salia de ella libremente; si la puerta estaba cerrada, chillaba para que se la abriesen. En verano iba todos los dias of un jardin público situado cerca de mi casa, donde era muj bien recibido y le daban sicmpre algo de comer. En el otoño chillaba durante horas enteras: cizando por los campos desprovistos de sus mieses. Com. prendia su nombre de Hans, pero no acudia cuando le llamaban si no le aguijoneaba el hambre, ni obedecia tampoco siempre. En momentos de buen humor saltaba sobre la falda de las señoras; abria un ala para que le rascasen, $y$ la expresion de su mirada indicaba su contento; posábase otras veces sobre el hombro é introducia el pico entre los cabellos, pro. duciendo un sonido como si piara. Si alguna persona le hacia dano, acordábase de ello y la cvitaba durante mucho tiempo. Cuando tenia hambre corria detrás de la criada por toda la casa, chillaba y cogiase de su ropa, lanzando agudos gritos y poniéndose á la defensiva si aquella trataba de alejarle. Gus. tábale sobre todo el pan blanco y la leche, aunque tambien comia carne, sustancias harinosas, patatas, y un pajarillo de vez en cuando. Miraba con indiferencia los nidos de avispa, y alejaba con varios movimientos de cabeza s. los insectos 
que volaban demasiado cerca de êl. Si le presentaban uno le mataba, mas no le queria comer.

No quiero deducir de aqui, sin embargo, que no coman nunca avispas, pues sabido es que las aves que se crian cautivas pierden su natural: el individuo que yo tenia era un ejemylo de ello: no tocaba el manjar favorito de sus semejantes, que consiste en larras de avispa.

$\rightarrow$ Mi friorque era muy sensible al frio: en invierno se ocul taba debajo de la estufa y permanecia muy tranquilo para no descubrir su presencia, pues no le permitian estar en el cuarto. En resúmen, pareciase mas por su manera de ser á uma corneja que a una rapaz, aunque sus inovimientos eran mas nesurados; andaba sin saltar, y solo apelaba à esto último cuancio le perseguian: murió al cabo de tres años.

Mas tarde tuve una hembra adulta, de la que ya he ha- blado antes, y se condujo del mismo modo, con la diferencia de gustarle mucho los nidos de avispas; si le presentaban uno, mostrábase muy excitada, saltaba encima y se lo comia, arrancando grandes pedazos: desgarraba los que estaban vacios para buscar larras. El pan blanco, mojado en leche, era uno de sus manjares favoritos; gustábanle tambien las ranas, no tocaba á las aves muertas, y se comia los abejorros, aunque no cra muy golosa. Vivia en muy buena inteligencia con los oiros animales domésticos: nada me complacia tanto como verla comer en la rnisma vasija con dos conejillos de la India, un estornino, un pluvial dorado y dos calandrias; ninguno de estos animales la temia; y muchas veces el cstor. nino le daba un picotazo ó le arrojaba leche en la cara, y entonces adelantábase gravemente y dirigia una nirada altiva á sus compañeros. Cierro dia puse con ella una tórtola que

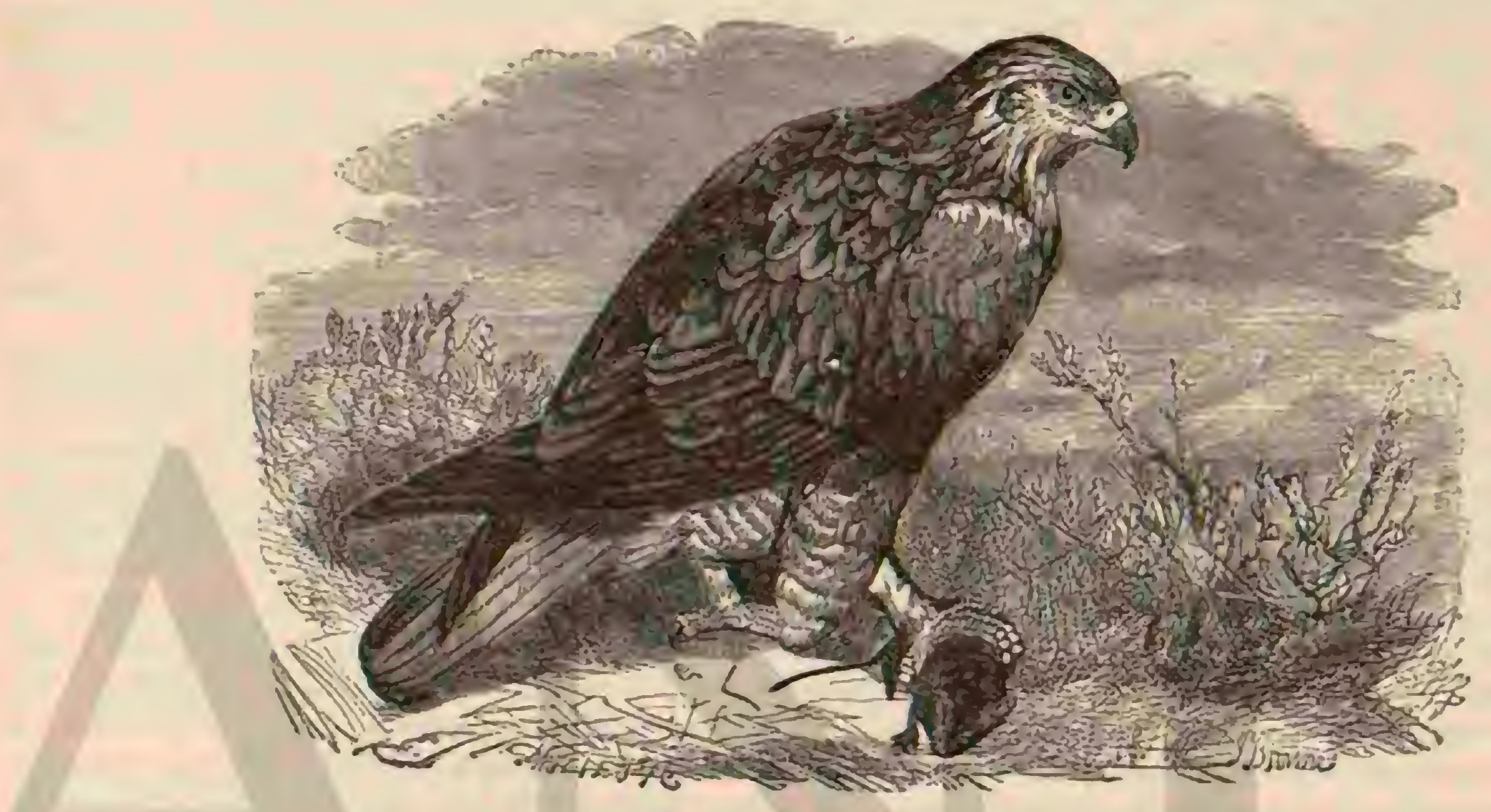

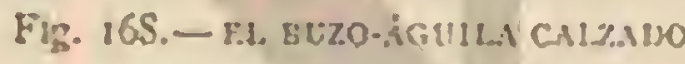

no podia volar, y con gran asombro mio acercóse sin temor á la rapaz, oprimiéndose contra ella; diéronse pruebas de carino las dos aves, y no se separaron ya; la tórtola saltaba de la percha, donde permanecia siempre al lado de la rapaz, e iba a buscar su alimento: pero como no podia volar, corria siempre al pié de la percha, hasta que la ponian junto is su companera; si esta no estaba tranquila le daba picotazos, quıe eran recibidos con la major calma.

Dero asi como la rapaz se mostraba dócil con los amigos y los animales quc acabo de citar, asi se enfurecia en cambio cuando se acercaba un perro; caia sobre él con la rapidez de una saeta, cogiase á su cabeza, dábale aletazos y picotazos, erizaba su plumaje y bufaba como el gato. Todos los perros, hasta los mas grandes y malignos, tenian miedo y se aleja ban: pero aun despues de haber desajparecido, era necesario que pasara algun tiempo para que se calmase la rabia de la rapiz y dejara de dar picotazos á cuanios se acercaban.

- A esta ave le gustaba el sol: to menudo permanecia inmó vil, con las alas extendidas y el pico abierto, cerca de la ventana, desde donde volaba á los tejados inmediatos. I a lluvia le inolestaba: si la sorprendia un chaparron, oculiábasce en el primer sitio que encontraba; cra muy sensible al frio, $y$ haciase preciso tenerla durante el invierno en las habitaciones

Natumal es que se ponciere la utilidad del friorque apivoro, segun dice Altum, cuando solo se coma en consideracion las orugas, avispas, grillos y otros insectos que devora, sin tener en cuenta que las ranas y los abejorros no son animales da. niinos, y que destroza muchas crias de aves. Esto explica, como dice muy bien Sachse, que le persigan todas las aves, tanto grandes como pequenas, con el mayor empeno apenas le ven, mientras que no hacen el inenor caso de su congéne. re, el buzo vulgar. Inas palabras anteriores bastan para saber à qué atenernos: si se hace un balance exacto de los perjuicios y utilidades que esta especie nos presta por la destruc. cion de insectos dañinos, tendremos por resultado que merece proteccion y no persecucion. El que quiera hacerla respon. sable de todo nido de ave destruido y de todo polluelo de perdir. devorado, solo verá en ella una rapaz peligrosa, olvidando su útil actividad. No es posible discutir este punto con los cazadores que solo sirven para gastar pólvora, porque estos nunca podrán juzgar sobre el asunto sin preocupacion.

\section{LOS BUZOS-BUTEO}

CARACTÉRES. - El buzo vulgar, tipo de la familia de los buteónidos y del género de los buzos, se carnctcriza por su pico pequeño, angosto y muy corvo; los tarsos carecen de plumas; las alas son anchas; las rémiges tercera, cuarta y quinta sobresalen de todas las demás; la cola, breve, ó cuan. do mas de longitud regular, se corta en forma de rectángulo y queda cubierta por las alas Esta especie ditiere además marcadamente del friorque apivoro por tener unas plumitas finas y blandas, en forma de pelos, que partiendo del centro como radios cubren la linea naso-ocular y la region del pico. 
EL BUZO VULGAR - BUTEO VULGARIS

CARACTERES.-E! buro vulgar (fig $16 \%$ ) tiene de $0^{m}, 50$ a $11^{m}, 56$ de largo, $y^{\circ}$ de $1^{\circ}, 20$ i $1^{m}, 25$ de anchura de a las; estas miden $\left(1 \%, 38\right.$ á $10^{\circ}, 40$ ! la cola $0^{\circ}, 26$. Dificil es describir su color en general, pues rara vez se encuentran dos individuos semejantes. Los unos son de un pardo negro unifarme, ex. cepto la cola, que es listada; otros tienen el lomo, el pecho y las nalgas de un tinte pardo, y el resto del cuerpo de un gris pardo claro, con manchas trasversales: algunos hay cuyo plumaje es de un parẻs pálido con manchas longitudinales; otros le tienen blanco amarillento, con las pennas de las alas Y de la cola oscuras y e pecho manchado, ctc los ojos del individuo jóven son de un pardo gris: más tarde de un pardo rojizo, y por último griass; la ceta tiene el color amarilloleo. nado; los piés son de es amarillo claro; el pico azulado en la base y negruzco en la punta.

DISTRIBUCION GEOGRAFICA.- Et area de dispersion del buzo no se exuiende mucho fuera de los limites de Europa. En las estepas de la Rusia meridional se encuentra en su lugar el buzo ágüa (Buteo ferox), ave mucho mas grande y fuerte, que tiene la piernas mas largas, y que si bien varia múcho, se la recozoce fácilmente por su cola de color claro casi blanco. En Siberia, en el Asia Menor y en el nord. este del Africa le representa el buzo de las estepas (Buico discrisursm), que al cosirario de la especic anterior es mucho mas pequeño que el baso vulgar; ticne el plumaje en su ma. yor parte rojizo y la ocia de este color; parécese tanto á nuestro buzo qua es fál tomar uno por atro. Esta última especie pasa tambien por Alemania cuando emprende sus viajes. Se ha visto al boro vulgar fuera de Luropa, en el fur. kestan, y durante el itrierno en el norte de Africa. Casi exterminado en la Gras Bretaña, encuéntrascle ahora en el mediodia de Escandinara, en el nórte y centro de la Rusia, en Dinamarca, Alemania, Austria y Hungria, siendo la mas comun de las ares de repiña; en Holanda parece estar confinado a los distritos osientales; en Bélgica y. Francia anida mans veces, $f$-solo se le re mas a menudo como ive de paso; en las ires penínsulas meridionales se presenta con regularidad rodos los inviernos En el mediodia de Alemania suele permanecer de otdinario durante el invierno, mientras que en el norte emigrán cas todos los individuos; en otorio, o sea en setiembre y octube, el buzo vulgar abandona los pai. ses frios para volver en aarzo ó en abril.

USOS, COSTUMBRES Y RÉGIMEN. - Cuando el buzo emprende sus viajes jorma bandadas de veinte á cien individuos, que vuelan bodos en la misma direccion, sin for. mar gru!̣os compactos; dispérsanse á veces sobre una superficie de varios kilórnetros, se remontan a bastante altura por el aire, y suelen describiz sus espirales durante largo tiempo. Al regresar de su viaje arśdales permanecer algunos dias en los sitios que les prometer alimento, despues continuan su
marcha.

Ia pareja elige para domicilio cualquier bosqque, pero con preferencia los que ziternan con campos y praderas; sin embargo, no falta tampeco en las grandes selvas y sube á mucha altura en las moetains.

Una vista cjercitada reconoce al momento al buzo, bien esté posado ó cruzando ios ajres: es un ave cachazuda y tor. pe; por lo regular se la $=$ con las alas recogidas, apoyándose en una sola pata, doblaca ia otra y oculia debajo del pluma. je, en cuya posicion permanece horas enteras inmóvil, aunque no inactiva. La piedra, e monton de tierra, ó el árbol donde se posa, le sirven de observatorio; examina su dominio y na. $y$ sin hacer ruido.
Cuando el buzo vulgar caza, detiénese à menudo mucho tiempo revoloteando en el mismo sitio pam examinarle del modo mas minucioso, $a$ fin de ver si hay algun animal. Cuan. do trata de atacar precipitase con las alas muy recogidas, extiéndelas á poca altura del suelo, franquea á veces alguna distancia, y coge con las garras su victima. En la caza raras veces se cleva á una gran altura; pero en la primavera, y sobre todo en el periodo del celo, remóntase mucho, desplegando una destreza que apenas se supondria en esta ave. (Alli donde anida, dice Altum con mucha mzon, constituye un verdadero adorno para el paisaje, y es un hermoso espec. táculo el que ofrecen ambas aves cuando en los dias serenos de la primavera, $\delta$ aun mas tarde, se balancean sobre el bosque largo tiempo dejando oir su agudo y sonoro himeh. Cuando se cansan de hacer evoluciones en las regiones aúreas, una de las dos aves recoge ambas alas, y produciendo un zumbido precipitase sobre el bosque, seguida de su compa. ñera \ Su grito se asemeja bastante al maullido del gato. La rista es de todos sus sentidos el mas perfecto; el oido fino, el tacto delicado, el gusto existe cvidentemente, y el olfato alcanza mas desarrollo tal vez de lo que se cree.

E) buro vulgar está bastante bien dotado en cunnto á la inteligencia: solo le tachará de estupido quien no le haya observado; tanto libre como cautivo da pruebas de perspica. cia, astucia y comprension.

A lines de abril ó principios de mayo, el buzo prepara el nido que le sirvió el año anterior ó fabrica uno nuevo, a cuyo efecto elige un árbol conveniente en los bosques; este nido se halla siempre a poca altura del suelo, por lo regular muy céra de la base del tronco, en el punto donde sobresale alguna rama ahorquillada; el nido es casi siempre grande y aumenta cada año en circunferencia. El ave se sirve a me. nudo tambien de un nido de cuervo 6 de corneja. En la mayor parie de los casos, el buzo no fabrica solo para sí, sino para otras muchas aves de rapiña de Alemania. El nido tiene unos $11^{m}, 60$ ó cuando mas $0^{m}$, So de diámetro y se compone de ramas gruesas en el fondo y delgadas en la parte superior, elegidas con gran cuidado. El buro tapiza tambien la cavidad algunas veces con musgo, pelos de animales y otras materias blandas. La puesta se compone de tres á cuatro huevos de color blanco verdoso, con manchas de un pardo clara Parece que la hembra los cubre sola, pero el macho presta despues su ayuda para alimentar á los hijuelos.

Al buzo le sucede poco mas 6 menos lo que á la zorra: cada una de sus fechorias se nota con miradas desfavorables, mientras que generaimente se menosprecia su agilidad útil. Todos los cazadores le consideran como la mas dañina de todas las aves de rapiña de nuestro pais y le persiguen con el minyor encarnizamiento. Lus campesinos aficionados a la caza no se permiten juzgarle por si mismos, pero esto no les impide imitar \& los cazadores de oficio. CSolamente los bu. 705 , dice liebe, tuvieron en $1 S_{4} S$ muy mala suerte, mientras que todas las demas aves de rapina mejoraron en su situacion. En el citado ano y en los siguientes, los campesi. nos mataron un gran número de estas rapaces, muy poco daninas, ya junto al nido ó bien al acecho, clavindolas des. pues con gran ostentacion á las puertas de sus graneros, solo porque las pobres aves eran demasiado grandes para pasar desapercibidas, demasiado confradas para recelar del cam. pesino que hasta entonces no las habia perseguido y demasiado torpes y lentas para evitar los tiros. $D$ Lo que se dice de los campesinos es aplicable tambien à otros aficionados á gastar púlvora: yo creo que muy yocos de estos se han formado una idea de las condiciones del buzo, fundada en observaciones propias. Fntre los cazadores que condenan sin consideracion al buzo figura tambien M. Meyerinch, jefe de 
guarda-oosques muy experto: aDesde hace cincuenia sños, me escribe, he observado mucho al buro en las regiones de Alemania donde mas abunda la caza, y puedo pernitirme por lo tanto emitir un juicio exacto sobre la utilidad de esta are y los daños que ocasiona Asi esta especie como sı congéne. re el buzo águila calzado, liguran sin duda cntre las rapaces mas dañinas, y los perjuicios que causan a la caza no guardan ninguna proporcion con la utilidad que prestan á la selvicul. tura. Los buzos roban los corzos pequeños y los lebratos, atreviéndose tambien con las liebres; y no solo cazan faisanes en todas las estaciones del año, sino tambien perdices. Esto lo puedo probar con centenares de ejemplos, y todos los ca. zadores de las regiones donde abunda la cazas serín de mi parecer. En estos distritos, los buzos persiguen a los ratones solo por necesidad, lo mismo que el zorro cuando no tiene mejor presa a su disposicion. Yo vivo actualmente en Silesia: en esta primavera se halla en nuestros campos un número asaz considerable de ratones, tanio que dos hombres han cogido y entregado en el mes de abril, semanalmente, de quinientos á seiscientos de estos roedores, procedentes de campos de trigo de una superficie de trescientas hectáreas. In toda la primavera no he visto codavia ningun buzo en el campo, pero si en los bosques $y$ en sus linderos, donde hay pocos miones.

\$ Aqui, en el distrito de Neumarkt, y solo en quince dias, se han dado ya cuatro casos de liaberse conido á los buzos liebres pequenas en parte devoradas. Dos de estas aves fueron muertas, y en su estómago solo se encontraron restos de liebres pequeñas sin el menor vestigio de miones. In los distritos vecinos se ha hecho la misma observacion, reconocien. dose que los buzos no devoraban solo lebratos, sino tambien faisanes adultos. Un guarda-bosque habia tendido hacia poco tiempo una red, poniendo por cebo una paloma, para coger un azor, oculto en la espesura, á unos ciento cincuenta pa sos de distancia; aguardó a!gun tiempo, pero en vez del azor esperado, presentose un buzo, que cajendo verticalmente sobre el ave, arrebatóla de la red sin que esta se cerrara. Al dia siguiente, la red estaba en el mismo sitio, y otra ver se presentó la rapaz, probablemente la misma, que se llevó la segunda paloma sin quedar cogida. Al tercer dia, en fin, habiéndose puesto en la parte superior de la red unos hilos dispuestos en cruz, púdóse coger á la astuta rapaz, en cuyo estómago no se hallaron tampoco restos de ratones. En el otoño de $\mathbf{S}_{34}$ hubo una gran plaga de ratones, tanto que en los plantios del distrito de Ledderritz, donde estos roe. cozes causaron un daño inmenso, cogiéronse todos los dias unos mil en las trampas preparadas. Esta vez se observó tambien que los buzos, cuyo número era bastante considerable, solo cazaban pequeños faisanes, cogiendo muj pocos rato nes. Las rapaces muertas desde el acectio no tenian en el estómago rnas que carne de aves, y raras veces restos de ra tores. En tales casos, es decir, cuando esos rocdores se presentan en tan inmenso número, los que las rapaces matan apenas disminuyen la cifra, y el hombre puede alcanzar en poco tiempo cien veces mas resuliado. Varias reces pude matar buzos que se habian apoderado de corzos pequeños. Hace muchos años que, siempre en la época del celo de los corzos, me he puesto al acecho imitando la voz de estos cua. drúpedos, á fin de atraer á las rapaces. En varias ocasiones, despues de tocar algunas reces el reclamo, los buzos aparecieron á ocho ó diez pasos de distancia, con las alas exten dicas y dirigiendo furiosas miradas a su alrededor, con la esperanza de poder apoderarse de un pequeño corzo. Los empleados que me acompanaban en la caza habian hecho varias reces la misma prueba. Debo añadir que nunca habia risto un buzo cerca de mi antes de tocar el reclamo; de modo que em preciso que le oyeran cuando mas a tres pasos de distancia. Todos los cazadores de los distritos donde hay perdices y faisanes pueden afirmar que los buzos cogen muchas de las primeras en invierno, cuando hay nieve; $y$ los últimos en los sitios donde se les alimenta. Podria citar un sinnúmero de ejemplos que prueban el carácter danino del buzo; pero me extenderin demasiado. Despues de todo lo expuesto, no puedo conformarme con la opinion expresada en la primern edicion de la Vida de los ssimales, donde se dice que los buzos son mas útiles que dañinos. He re. producido aqui todo lo dicho por el excelente cazador, cuya experiencia aprecio en alto grado; mas á pesar de esto, debo declarar que no me he convencido de que esa rapaz ocasione un gran dano. En cuanto á las fechorias que comete, confiesolas hoy tan claramente como lo hice en la primera edicion de la Vida de los animales; y hasta quiero dar mas prebas de los perjuicios que ocasiona temporalmente, se. gun mis propias observaciones y las de otros. Es verdad que el buzo devora lebratus, ó mata liebres adultas, enfermas ó heridas, lo mismo que ratones, ratas, hamsters, serpientes, ranas, insectos y gusanos; ciento es además que se apodera a reces de perdices, $y$ hasta es posible que tenga bastante destreza para coger en verano y en otono individuos adultos y faisanes; tambien esta probado que lleva á sus polluelos, además de los animales citados, lopos, pájaros, alondras, mirlos y otras aves pequenas; y no se puede negar tampoco que, á semejanza de los circidos, devora en ciertas circunstancias hasta los huevos de paros y otras aves: pero á pesar de todo, el alimento del buzo consiste principalmente en ratones, ratas, hamisters, ranas, langostas y otros insectos, es decir, animales que nos perjudican de un modo sensible, ó que, como las ranas, son tan numerosos, que el exterminio de algunos no merece apreciarse. Blasius ha encontrado en el estómago de un solo buzo treinta ratones; y Martin, que abrió centenares de estas aves para embalsamarlas, solo haIIo restos de ratones en los buches de todas. Mal vez. sea falsa la suposicion de Lenz, segun la cual un buzo que coma diariamente treinta ratones, extermina unos diez mil de estos rocdores; pero está reconocido, y lo estará sienıpre, que el buzo en general es mis titil por el exterminio de los ratones que perjudicial por los daños que causa en algunas especies de caza.

Esta ave se acomoda, sin embargo, como todas las rapn. ces, á las condiciones del pais, y es natural que en las regiones en que abunde la caza cause mas daño que alli donde escasea, pues aqui la persecucion de ciertos animales es mas penosa que la de los quue constituyen el alimento ordinario del ave. Debe tomarse además en consideracion que es parti. cularmente perjudicial en el periodo de la cria, o en invierno, cuando le aguijonea el hambre. I as siguientes palabras del conde de Kospoth prueban que no todos los cazadores son del parecer de Mejerinck. aAlli donde hay muchos ratones, escribe Rospoth á Riesenthal, el buzo llega desde muy léjos. Cuando en i\$79 se declaro entre nosotros la plaga de ratones, zuve los primeros de estos enemigos de la agricultura en un campo de alfalfa de cinco hectáreas de exiension. To. dos los dias vi desde enionces doce buzos que cazaban ratores con afan, sin hacer caso de los lebratos $y$ perdices. Lurante todo el dia estaban reunidos en el mismo campo, hasta que la plaga se extendió mas y se diseminaron por varias partes. En el invierno de is it à 1875 , por el contrario, el buzo llegó á ser muy jeligroso, por impedirle una espesa capa de nieve buscar su alimento ordinario. Mi cazador de iaisanes cogió en esta iemporada siete buzos en la irampa, y cada uno de ellos habia devorado antes una gallina i no ser por la vigilancia, estos siete buzos hubieran causado in- 
menso destrozo entre mis faisanes. Por eso opino que se jebe dejar vivir al buzo en verano, matándole en invierno, donde se le encuentre) Esto pudiera ser exacto segun las miras del cazador; pero el agricultor tiene sin duda mas derecho para juzgar sobre la utilidad y el perjuicio de un animal. Cuando se hace esto sin preocupaciones, sin tener en cuenta la cara, la utilidad del buzo se reconoce evidentemente, y como el naturalista está en el deber de ponerse al lado de aquel que procura obtener toda la utilidad posible del suclo, opino aun hoy como siempre, considerando como un acto indigno que el representante de la roologia en la capital de uno de nuestros pequeños Estados, haya muerto diariamente de catorce a yuince buzos desde la choza de acecho, vanagloriandose en priblice de esta hazaña y diciendo con orgullo que en una sola expedicion se han exterminado cuatrocientas de estas aves de rapiina.

- A pesar cie que no me parece proliable que el buzo coja un carzo pequeiso, intenta por lo menos hacerlo; pero debo hacer presente que esta ave se precipita a veces sobre ani. males de que sabe muy bien que no puede apoderarse. $\uparrow$ Fn I $\$ 6_{3}$, me escribe Licbe, un buzo vulgar se precipitó, cierto dia de otono, cerca de Hohenlauben, sobre un buey de tiro, agarrándose de tal modo al lomo del espantado animal, que el campesino pudo matarle con el mango del látigo. El citado buzo estaba sin duda loco de hambre, pues el ejemplo ya referido del gavilan prueba que aquella influye de un modo extrafo en las aves de rap̧iña.s

A fin de proporcionar algunos amigos mas \& los buros, aves quue no quisiera ver desaparecer de nuestros campos, debo añadir que son las exterminadoras mas eficaces de las culebras. Lenz ha hecho pruebas en gran escala frara con. vencerse de ello, y no sabe elogiar bastante al buzo.

Los buzos, sin embargo, no son refractarios a la accion del veneno de la vibora, y sucumben cuando les toca una parte vascular. Verdad es que esto sucede mas veces; pero siempre hay casos en que perecen algunos individuos $\{$ con. secuencia de sus luchas con las viboras. Un guarda bosque, digno de crédito, refirió á Holland una historia verdadera. mente conmovedóra; dicho empleado trepó cierto dia s un árbol donde habia un nido de buzo, del que no se movia el ave que lo ocupaba; al llegar vió que la rajaz estaba muerta; levantóla, y no sin espanto, vió debajó de ella una víbora visa. La rapaz llevaria el reptil á su nido, y en el murió à conse. cuencia de una mordedura.

\section{LOS BUZOS ÁGULLAS-ARCHIBUTEO}

CARACTÉRES.-Este buzo se distingue sobre todo por tener los tarsos cubiertos de plumas: atendido este caricter, mi padre ha considerado esta especie como tipo de un género independiente.

\section{EL BUZO ÁGUILA CALZADO-ARCHIBUTEO LAGOPUS}

CAR ACTERES. - Esta ave tiene el pico pequeño y angosto, muy corro y ganchudo; las alas son grandes; las re. miges tercera 6 cuarta sobresalen de las demás; la cola es larga y redondeada; el plumaje, algo lacio, forma en la region de la garganta una especie de cerda; las plumas son grandes y largas; las de la cabeza y la nuca de regular longitud, redondeadas. El color varia mucho, ofreciendo una mezcla de blanco, amarillento gris rojizo, pardo negro y pardo. Esta especic mide ()$^{\circ}, 65$ por $t^{\prime \prime}, 50$ de anchura de punia á punta de las alas; estas tienen $6^{n}, 45 \mathrm{~s}$ la cola $0^{\circ}, 24$.

DISTRIBUCION GEOGRÁFICA. - Aunque se ha di. cho que el buzo águila calzado habita en varias partes de Alemania, sobre todo en Buegen, en la Prusia occidental, en Sansitz, en 'luringia y en el Taunus, nuestro pais se halla sin embargo fuera de los limites del verdadero territorio de su réproduccion.

Sabido es que esta ave anida igualmente en el norte de la Gran Bretaña, sobre todo en Escocia, pero probablemente solo en los sitios que se asemejan a la l'undra. Fiácilmente se explica que extienda sus correrias tambien hácia los bosques situados mas al sur, para anidar en ellos; durante el verano habita principalmente en Escandinavia y el norte de Rusia; en Siberia solo la hemos visto en la parte septentrional de la rona de los bosques, pero con mucha mas frecuencia en la verdadera Tundra. Fin el norte de América, donde tambien vive, deben regir las mismas condiciones. Aun en los parajes en que anida inas al sur, por ejemplo en Escandinavia, suele elegir para su morada los sitios análogos á la Tundra, aunque estén rodeados por todas partes de bosques, como por ejemplo los fjeld's desnudos de la montaña.

El buro dguila calzado llega à Alemania procedente del norte, d mediados de octubre, raras veces antes, y jermanece en el pais hasta marzo ó abril. En algunos inviernos extiende sus viajes mas hácia el sur, pero escasea bastante en el norte de Francia y mediodia de Italia. Tambien se le ha visto en Turquia y Grecia, mas no en Españ. Desde el notte de Rusia visita las partes meridionales de este pais o llega hrasta las orillas del mar Negro; desde la Siberia se dirige hácia las estepas del íluthestan.

USOS, COSTUMBRES Y REGIMEN.-Un Observa. dor experto puede distinguir muy bien al buzo águila calzado entre lís otras rapaces de Alemania, sobre todo por el ruelo, que difiere bastante del de su congénere el buzo; re conócese asimismo en sus alas mas largas, en las manchas negras, en la articulacion de la mano y en la extraña combi. nacion de los colores de la cola. Ambas aves difieren tam. bien por sus morimientos, pues el buzo águila calzado mueve las alas mas hácia abajo y suele franquear alguna distancia en linea recta despues de aletear dos 6 ires veces.

Por lo que hace al géncro de vida de estas dos rapaces durante el invierno, es tan análogo, que lo que se dice de una puede aplicarse \& la otra. Mas determinadas son las diferencias de las dos especies tan congenéricas en su vida de verano.

Cuando se viaja por la Tundra se suele ver en las prime. ras horas 6 dias de camino una pareia del buzo águila cal. zacio, ya cerniéndose a mucha altura 6 bien muy cerca del suelo; de vez en cuando revoloten; ayanza un buen trecho y se detiene como para buscar algun leming en el suelo. Cuando el hombre penetra en la Tundra íltimos de julio, esta ave se dirige hacia el apenas le re para demostrarle con grandes gritos el temor de que visite su nido. En esta época los buzos se ocupan solo de su cria. Los huevos, cuyo nímero varía de cuatro i cinco, apenas se distinguen de los de nuestra especie. El nido se halla en la Tundra casi siempre en un sitio a que se puede llegar sin gran trabajo. Tambien el buzo águila calzado se sirve de árboles 6 rocas para anidar, pero en muchos distritos de su area de dispersion no tiene oportunidad para ello; el país le ofrece abundante ali. mento, pero no àrboles ó rocas, y por lo tanto le es preciso anidar en el suelo. Al contrario del halcon viajero, no elige los parajes que lindan con pendientes, sino la cumbre de una colina, importándole poco que esta se elere á treinta ó cuarenta metros ó solo à dos ó tres.

El nido, que en las regiones descubiertas apenas se distingue del de nuestro buzo, difiere en la Tundra por su cons. truccion, componiéndose exclusivamente de ramas delgadas, 
que los buches estaban casi ciclusivamente llenos de matones campestres. Solo $t$ fines del invierno, cuaudo caen grandes nevadas, parece que caza alguna perdiz

El harnbre cxcita tambien al buzo á cometer fechorias que nuestros cazadores no quieren perdonarle zCuando no estaba la tierra cubierta de nieve, dice Eugenio de Homeser, he obserrado al ave en Pomernia todos los inviernos desde hace ochenta años, pudiendo reconocer asi que apenas caya otra cosa sino ratones, aunque le guste tomar parte en cl botin del halcon y el gavilan. Tambien tiene la costumbre de seguir de cerca al cazador y los perros, y varias veces se ha dadoel caso de que robara una perdiz herida a poca distancia de nosotros. Cierto dia ocurrió un inciđente curioso, á principios del invierno: iba yo con un amigo mio en coche por en inedio de los campos cubiertos de nieve, y habiendo disparado ayuel un tiro sobre una bandada de perdices, una de estas aves cayó i la distancia de trescientos pasos. Fon el mismo instante precipitóse sobre ella un buzo, pero de pronto atacóle otroindividuo de su especie, y mientras peleaban sobre la perdiz, presentóse un tercero. Cuando la capa de nicie es muy espesa, este buzo pone en gran peligro a las perdices, y hasta conozco el caso de haber ido una de estas rapaces tocios los dias á robar una paloma de una casa de labranza, hasta que al fin la mató un cazador. Sin embargo, el buzo águila calzado es mucho mas útilique danino, aunque á yeces conviene deshacerse de el.j.

Estos en un todo conforme con las palabras de mi amigo; pero reçhazo enérgicanente la pretensión de algunos cazadores que quieren que se extermine á ista ave en todos los casos, asi como á su congünere aleman. El agricultor es, en todo caso, segun creo, mas atendible que los arrendadores de la cazs

\section{LOS POLIBORINOS}

$S-\mathrm{PO}$

OLYBORINAE

CARACTERES.-LOS poliborinos, ó halcones vultúri dos, constituyen la última subfamilia del grupo: son rapaces de pico bastante largo, recto en la base, poco encorvado é la punta, sin escotadura y ligeramente ganchuda Los polibo. rinos tienen tarsos altos y delgados; dedos de longitud' regular y endebles; garras poco corvas y puntiagudas; alas cortas; côla larga y ancha, y plumaje duro, que deja descubierta la linea naso-ocular, y a veces tambien la garganta y la parte anterior de la frente.

DISTRIBUCION GEOGRÁFICA.-Estas aves reppresentan en su patria no solamente los buitres, sino ianbien á los cuervos, las comejas y las urracas; son propias de la América del sur desde la orilla del mar hasta las aitas montañas de los Andes.

USOS, COSTUMBRES Y REGIMEN. - El principe de Wied, d'Orbigny, Darwin, Schomburgh, 'Tschudi, $\Lambda$ udubon y Burmeister, nos han dado a conocer los usos y costumbres de estas aves singulares, que segun dice Darwin, «admiran pór su numero, su osadia, ! sus costumbres repugnantes \& cualquiera que no conozca mas que las aves de Europa.

4 Los poliborinos, dice d'Orbigny, son los parásitos mas molestos para el hombre en todos los grados de la civiliza cion. Compañeros fieles del viajero salvaje, siguenle desde un bosque a otro, a lo largo de las orillas de los rios ó por la llánura, deteniéndose so!o donde él sequeda. Siempre que el viajero se para en el camino ó arma su tienda, el poliborino se presenta para posarse en ella, cual si quisiera ser el primero en tomar posesion, para recoger los restos del alimento del solitario vinjero. Cuando el hombre funda un pueblo, el ave le sigue tambien alli, fija su residencia en los contornos, raga continuamente en medio de las casas que le puecien proporcionar alimento en abundancia. Cuando se comienza a labrar la tierra y se reune un gran numero de animales domésticos, la actividad incansable del poliborino parece au. mentar mas aun; y desde este momento, su existencia parece astgumda, pues tiene bastante atrevimiento para apoderarse de algun polluelo ó de los pedazos de carne que se ponen á secar. Asi como los buitres, esta ave se ocupa en remediar el descuido de los habitantes de los pueblos y ciudades, devo. rando los cadireres y excrementos. Dos especies de esta familia estan siempre a las pucrias de las casas, en la llanura o cerca de los bosques, otras rodean los caserios de la mon. tana; las hay que viren en las vastas selvas, y varias recorren las costas. No constituyen su alimento exclusivo los restos animales; comen todo lo que pueden encontrar sin mucho trabajo, y hasta hay una especie que se nutre de frutos. Los restos en descomposicion constituyen, no obstante, su alimento principal, siendo seguro encontrarlas donde haya un cadiver.

Los poliborinos se reconocen desde luego por su vuelo: sus alas parecen cuadrilateras; tieren la cola nuy extendida; no hacen mas que cemerse a muy poca altura del suelo; pero tambien prieden volar con mucha rapider. Por tierra andan fácilinente, aunque con lento paso, lo mismo que los vulú. ridos, y no como los falcónidos: hay una especie que no se pasa nunca en los árboles sino en los peñascos, á la manera de los buitres.

Su vista es cxcelente; su oido no menos bueno, su olfato parece bastante desarrollado; las fosas nasales, pur lo menos, están siempre húnedas, como las del buitre.

En sus costumbres se nota una mezcla de atrevimiento y cobardia, de sociabilidad y aislamiento: no se les puede negar la inteligencia; pero. son pór demás desagradables: su vor es penctrante e insoportable; déjanla oir sobre todo cuando per. ciben alguna presa.

Anidan tan á menudo por tierra como por los árboles: el nümero de huevos que pone la hembm varia de dos a seis, y son de formá redondeada, con manchas. Parece que cubren los dos seros.

\section{LOS MILVAGOS - MILVAGO}

CARACTÉRES. - Las especies que constituren este género se reconocen por los siguientes caractéres distintivos. El pico, prolongado, endeble y ligeramente ganchudo, no liene escotadura en la mandibula sujerior; la cera, bastante ancha, se trunca junto á las fosis nasales, gue son redondas $y$ tienen bordes prominentes; los piés son de regular longitud delgados; en los tarsos hay pocas plumas; los dedos, de longitud regular, están provistos de garras bastante fuctes y corvas; las alas son puntiagudas, siendo la cuarta rémige la mas larga; la cola, de longitud regular, se redondea un poco; el plumaje es poco abundante en la region de la garganta.

\section{EL MILVAGO CHİMACHIMA-MILVAGO CHIMACHIMA}

CARACTÉRES. - El chimachima ó chimango, segun le llaman tambien los brasilerios, representa una de las especies mas extendidas. Fl are adulta tiene las alas y el lomo se dirige descle el ojo hácia mismo que la cola y una faja que réniges esian moteadas de blanco encio; las cuatro primeras si en su centro, formándose de un blanco una iaja clara y trasversal; las otras rémiges son de laja listadas de negro en el centro y de un pardo negro en su extremidad; las rectrices blanquizcas, con rayas muy finas de color pardo negro, y del 
mismo tinte en la punta; el ojo es gris pardo; el pico de un blanco azulado en la base, mas claro en su extrenidad; la cera, la linea desnuda que va del pico al ojo, y la barba, son de color amarillo naranja; las patas dic un azulado claro.

La hembra difiere del macho pror sus colores mas sucios y mas anchas las listas de la cola; las rémiges están orilladas en su extrema

Los pequeños tienen la parte superior de la cabeza y las mejillas de un pardo oscuro; los lados $y$ la parte posterior del ruello de un blanco amarillento, manchado de pardo oscuro; el lomo de este tinte con algunas plumas orilladas de rojo: las cobijas superiores de las alas listadas trasversalmente de pardo rojo y de pardo negro; la garganta de un pardo sucio; el pecho de pardo negruzco, presentando calda pluma en su centro listas longitudinales de un tinte amarillo: el vientre es amarillento.

Eil macho mide $0^{\infty},{ }_{3} \delta$ de largo por $0^{\infty}, 81$ de anchum de alas, el ala $0^{\circ}, 25$ y la coln $0^{\circ}, 16$ s $11^{\circ}, 17$; la hembra es un poco mas ancha $y$ larga.

DISTRIBUCION GEOGR ÁFICA. - il mivago chimachima está diseminado en una gran parte de la América del sur: es comun en todo el Brasil, en Chile, en las estepas de la Guayana, y sobre todo en los pantanos secos; se le ve muy numeroso en Chiloé, tambien en las costas de la Patagonia en la Tierra del Fuego.

USOS, COSTUMBRES Y RÉGIMEN.-El chimachima vive en las llanuras descubiertas; busca preferentemente los pastos, y donde no se le persigue llega hasta muy cerca de las casas. Dice Boeck, que en Chilot seven bandadas en los tejados ó siguiendo á los labradores; no falta en ninguna costa, y en las montañas no se eleva mas que á cierta altura

Anda por tierra con paso seguro; su inirada es altiva, y no revela costumbres tan innobles como las que liene el ave; su vuclo es lento, y no se cierne largo rato sin agitar las alas Jamís se remonia mucho el chimachima, ni traya circulos como las rapaces nobles. No se le ve volar nunca sino en linea recta de un punto a otro, dice el principe de Wied; por lo regular le acompaña su hembra, y algunas veces va solo pero jamás en compañia de otros de sus semejanies.

Es un ave pendenciera en el mas alto grado, que pelea de continuo, ya con los individuos de su especie ó con otras ra. paces; pero vive en buena armonia con las aves de los demás órdenes.

Ninguna rapaz observa un régimen an variado como el del chimachima: come de todo, incluso los restos de pan que halla en 105 montones de basura, y las patatas que sabe desenterrar; es el último que abandona cl cadáver de un animal y con frecuencia se le ve en el interior del cuerpo de una vaca ó de un caballo. Guistanle los gusanos y los insectos, $y$ se posa en el lomo de las reses para comerse los piojos g de. más parásitos. In los pantanos caza los moluscos y los reptiles; en la playa se alimenia de todos los animales que arrojan las olas, si bien parece que no persigue á las aves y los ma. mícros. Jamis se han hallado en su estómago sino restos de gusanos, de insectos, moluscos y peces. Es insoportable por la osadia con que lo arrebata todo; y sus gritos espantosos contribuyen aun mas a que sez odiada esta ave; produce sil bidós penetrantes y repeticios que aturden, sobre todo cuan. do gritan \& la ver. varios individuos.

Eil perfodo del celo comienza para el chimachima en se tiembre y octubre: aléjase entonces un poco de las casas para construir su nido en un árbol conveniente, nido de gran tamaño, pero poco alto, y que se compone de ramas y raices. Segun d'Orbigny, la hembra pone cinco ó scis huevos redon deados, cubiertos de puntos rojos, de color pardo oscuro, rnas compactos hacia el extremo grueso. Durante la época del celo parece el chimachima algo mas sociable que en las otras estaciones; tolera mejor la vecindad de sus semejantes y se maniriesta mug carinoso con su progenie; pero tan pronto como los hijuelos comienzan a volar, vuclve a sus costumbres.

\section{LOS BUZOS CHILLONES- IBYCTER}

CARACTÉRES.-IAs esprecies que perienecen á este género 6 subgénero tienen el pico largo, estrecho y ligeramente encorvado hácia la punta; el gancho es endeble y no hay escoiadura: los piés, delgados y de longitud regular, es. tán cubiertos de plumas par debajo de los talones; los dedos son largos; las alas prolongadas y puntiagudas; las rémiges tercera, cuarta y yuinta son las mas largas; la cola tiene las plumas cortas y anchas.

\section{EL BUZO CHILLON AUSTRAL - IBYCTER AUSTRALIS}

CARACTÉRES. - Ia talla de esta rapaz viene as ser la misma que la del águila chillona: el ave adulta tiene el co. lor negro oscuro, con las plumas del cuello, dellomo y del pecho cubiertas de lisias blancas longitudinales; las nalgas son de un rojo vivo; las pennas de las alas, biancas en la base, y las de la cola en el extremo; el pico de color de cuerno claro, y la cera y las patas de un amarillo naranja (figu. ra 169).

Los pequeiros difieren de los adultos por la carencia de las listas claras en el cuello y el jecho; las plumas están manchadas de rojo y blanco rojiro; las pennas de las alas son de este último color en la base, y las de la cola de un pardo negruzco; el pico oscuro y las patas de un anarillo pardo.

DISTRIBUCION GEOGRÁFICR.-Lsta especie habita en la América del sur, y abunda sobre todo en las islas Falkland, que pueden considerarse como centro de su írea de dispersion.

USOS, COSTUMBRES Y REGIMEN. - Darwin 5 Abbor nos han dado á conocer los usos y costumbres del buzo chillon austral. Eista rapaz, dice Inarwin, se asemeja nucho \& otras varias especies de la inisna familia: mantiénese de cadáveres y de animales marinos, y cn ciertas islas le da el mar su alimento. I.éjos de ser timida, distínguese al contrario por una osadia sin igual, liegando hasta las casas para escarbar los basureros. Apenas matan los cazadores alguna pieza, llega una bandada de estas ares y esperan pacientemente su iurno para tomat parte en el festin; acometen a los animales hericios: yo he visto arios individuas caer sobre un cormoran, que tocado por una bala, se habia refugindo en la ribera, donde le remataron á picotazos. Los oficiales de un buque de guerra que pasó el invierno en las islas liaikland, han citado varios ejemplos de la osadia y descaro delos buzos chillones. Una vez acometieron á un perro que dormia muy cerca de ellos; ! en las cacerias arrebaiaban casi todas las ocas que mataban los cazadores. Tenian costumbre de ponerse al acccho varios individuos á la entrada de una ma. driguera de conejo para caer sobre el al salir. Volaban con. tinwamente-al-rededor del buque, y era necesario vigilar atentamente para impedirles que desgarrasen los objetos de cueroy arrebataran las provisiones.

Abbot vió buzos chillones que mataban y devoraban á sus compañeros heridos a Son vivaces y muy curiosos, dice; reco. gen iodo lo que encuentran: cierto dia se llevaron á una legua de distancia un gran sombrero negro barnizado y un 
par de lazos de los que se emplean para cazar bueves. Cuando M. Usborne se disponia a medir la costa, le quita. ron un compás pequeño con el estuche conde estaba, y se lo llevaron a un sitio donde no se pudo encontrar. Además de esto, son excesivamente pendencieros, y tan rabiosos, que en sus accesos de furia arrancan a menudo la yerba con el pico

Sin embargo, cuando un animal es hastante valeroso pram hacerles irente, muéstranse cobardes: Abbot vió à un ostrero

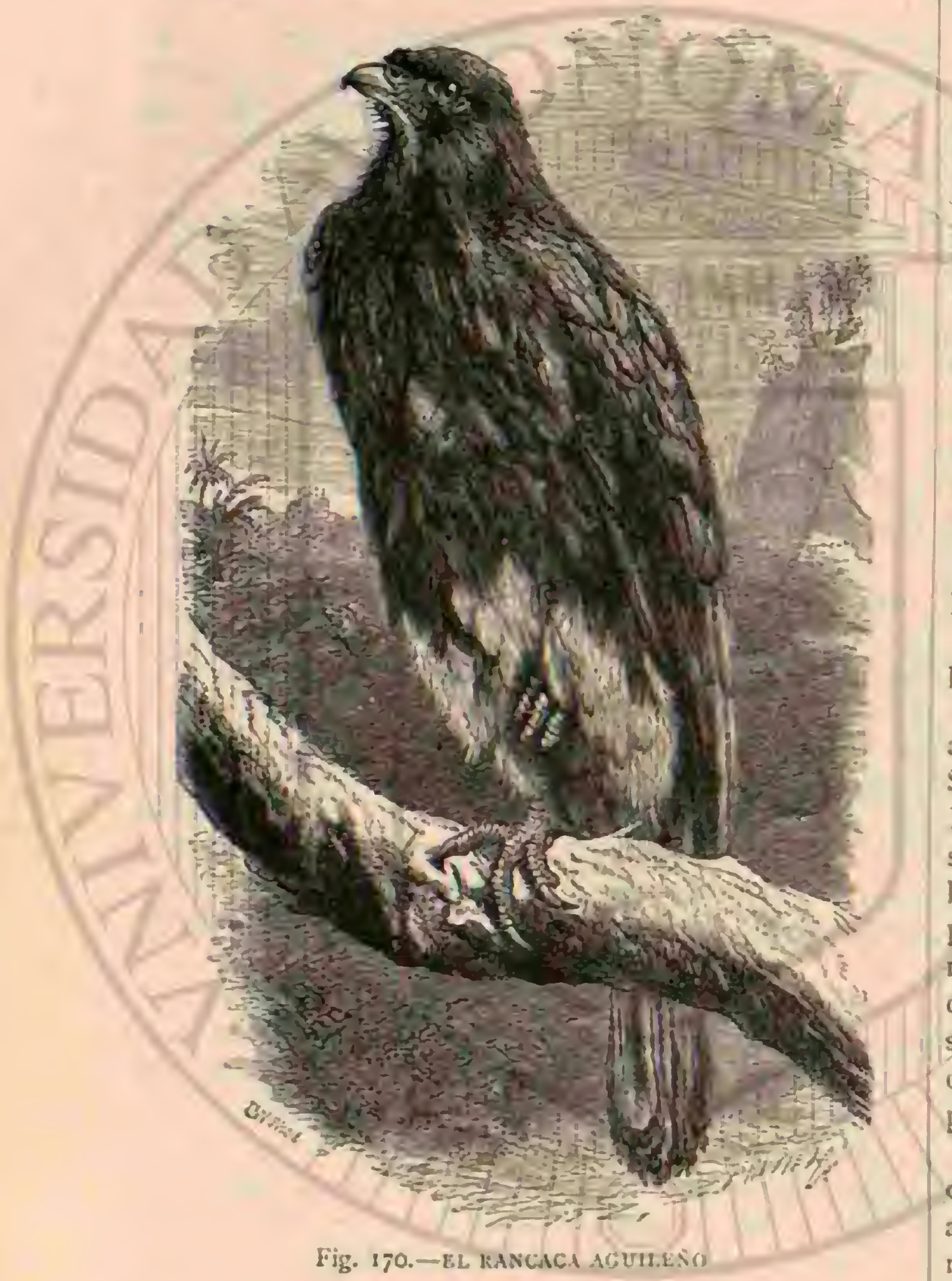

(hawntropus ostraligus) poner en fuga df un buzo chillon austral q̧ue trataba de robarle sus huevos.

En tierra corren con inucha ligereza estas aves, casi tan bien como los faisanes; cuando están posadas no es su aspecto tan noble, y mucho menos alin si acaban de hartarse y tienen la cabera muy inclinada hácia adelante.

Su vuelo es pesado y torpe, mzon por la cual no les gusta remontarse por los aires.

Son muy chillonas; su vor. se parece mucho a la de la cor. neja y es desagradable al oido; para gritar tienen la costum. bre de echar la cabeza hácia atrás.

Anidan en las costas bravis pedregosas, á orillas del mar; su nido se compone de tallos secos de tusacia: el interior está relleno con frecuencia de lana. A principios de noviem. bre deposita la hembra dos huevos, rara vé tres: son redondeados, con el fondo de culor pardo, y cubiertos de manchas y rayas oscuras. Segun dbbot, no adiquieren los hijuclus su plumaje detinitivo liasta la edad de dos años.

\section{LOS RANCACAS - IBICTER}

CARACTÉRES.- Este género se caracteriza por sus formas esbeltas, cola prolongada, cubierta por las alas en mas de la mitad de su longitud; tarsos regulares del mismo largo que el dedo medio: pico prolongado, delgado, de gan. cho endeble $y$ bordes festoneados, pern sin diente. I as mejillas y la garganta están desnudas: solo la parte anterior de la línea nasc-jcular se halla cubierta de espesas sedas.

\section{EL RANCACA AGUILEŃO - IBICTER AQUI- LINUS}

CARACTERES.- Fil rancaca aguileno (fig. 1;0), que Se ha llamado tambien rancsiat de ruellu desnubo, ronecoin americaru y vulgarmente garga, tiene $0^{\prime \prime}, 69$ de largo, y de $0^{\circ}, 15$ á $0^{\circ}, 24$ de punta á punta de ala; esta plegada mide $4^{\circ}, 43$ y la cola $\left(1^{\prime \prime}, 26\right.$. Iin los adulios es de color negro la caber.a el cuello, ellomo, las alas, la cola, el pecho y los costados de la parte superior del vientre, con visos de un verde metálico; el bajo vientre y las nalgas son de un blanco gris; el ojo de un rojizo vivo; la cera, el extremo del angulo bucal y la base de la manaibula inferior de un hermoso azul de cielo; las partes desnudas de la cara de un rojo cinabrio; el pico de un amarillo verdoso claro, con la punta algo mas oscura que la base; las patas de un rojo naranja.

En los pequeños los colores son mas oscuros; tiener las plumas orilladas de pardo y el ojo de este color.

DISTRIBUCION GEOGRÁRICA. - Esta especic es propia de la America meridional.

USOS, COSTUMBRES Y REGIMEN. - El rancaca aguileño es el ave nienos conocida de esta familia. Solo Schomburgk y el principe de lied le han descrito. En el Irasil, dice este, parece que el ganga no habita sino en las selvas virgenes mas desiertas, y le gustan los sitias mas desolados. Caminando en direccion al sur no le encontré hasta pasado el $15^{\circ}$ de latitud meridional, penetrando mucho en inedio de los bosques, entre los rios lleos y Pardo. Alli es donde por primera vez of resonar su voz en medio de las soledades: mas tarde pude observar a estas rapaces, ya solas ó por parcjas, ó bien por bandadas numerosas, despues del periodo del celo.

> El ganga habita los bosques, porque encuentra en cllos con abundancia avispas, abejas y otros insectos de que se alimenta: con frecuencia he hallado su esiómago completamente lleno de restos de avispas. Vucla de una rama en otra gritando, y se posa en las mas secas de los árboles altos: $\hat{a}$ menudo se oye su voz que consiste en una especie de gama ascendente ó descendente, fi la que sigue como un cacareo parecido al de la gallina que cubre sus huevos. En el valle de Rio Pardo vi una numerosa bandada de estas aves en una selva virgen situada en ta vertiente de un wille profundo; volaban de un árbol en otro, y rétozaban por los aires lanzando agudos gritos. Sonnini dice que acompanan á los tucanes: pero esto es una fíbula inventada por los iridige. nas: en cuanto à mi, jamás he visto á estas aves juntas.

Schomburgk anade que el rancaca es una de las aves de rapina mas comunes en la Ciuavana, y que forma siempre bandadas: confirma además las obserraciones de Sonnini y de Mauduyt, puestas en duda por el principe de Wied, y por las cuales se aseguraba que esta ave se alimentaba de frutos y bayas. Eil primer individuo que yo heri, dict, co. menzó á vomitar una cantidad cousiderable de frutos rojos, que reconoci ser los de un malphigir; el hecho me parceció extraurdinario, y por lo mismo abri todas las ares muertas despues, encontrando sicmpre en su estómago frutos y bayas. No debe ponerse en cuda que el ganga come tambien repriles, aunquue los frutos constituyen su principal alimento.8 
Nada se sabe acerca de la manera de reproducirse el ran caca aguileiro, ni se conocen sus costumbres en cautividad.

\section{LOS CARACARAS - POLYBORUS}

CARACTERRE. - I os caracaras tienen el cuerpo prolongado; alas largas y vigorosas que cubren casi enteramente la cola, cuya sercera penma sohresale de las demás; fa cola es bastante larga y tiene las pennas desgastadas en la extremidad, como se observia en los buitres: las patas son altas y delgadas; los dedos bastante contos: las uñas fuertes y aceradas, pern poco encorvadas; el pico grande, alto, ligeramente ganchudo, recro en la base y sin diente. El plumaje es opa co: las plumas de la cabeza, del cucllo y del pecho angostas; las del lomo anchas y redondeadas; la línea que va del pico al njo, la barba y la garganta están cubiertas tan solo por algunas plumas cortas en forma de sedas.

\section{EL CARACARA DEL BRASIL-POLYBORUS BRASILIENSIS}

CARACTÉRES. - El caracara del Brasil ó caracara vulgar, carancio ó araro de los brasilenos (fig. 171), es la especic mas comun de la fannilia de los polibóriclos. El principe de Wied dice que mide $1 ", 70$ de larga y mas de $1 ", 25$ de ala ś ain : esta plegada $l^{\infty}, 3^{S}$ y la cola $U^{\text {ma }}, 20$.

Las plumas del sincipucio y del occipucio forman una especic de moño de un color negro pardusco oscuro: el macho adulto riene el lomo pardo negro con listas blancas trasrersales; las grandes cobijas posteriores del ala están aciorna das de otras de un tinte mas pálido, tambien trasversales; las mejillas, la garganta y la parte inferior del cuello son blancins, of de un blanco amarillento; los lados del pecho Y del cuello, asi como el lomo, están listacios de blancoy pardo oscuro; el vientre, las nalgas; la rabadilla, la basc y ul extremo de las rémiges de un pardo negro. Fistas ulituas son blancas en el centro, con rayas trasversales angostas en las barbas extermas, y puntos y manclias triangulares de co. lor oscuro; las rectrices blancas, cruzadas de rayas muy finas de un tinte pardo claro, y de pardo negro en la extremidad; el ojo es gris ó pardo rojo: la cera, la linea que va del pico al ojo, y el contorno de este, de un amarillo blan. quizco; el pico azulado claro! las patas de un amarillo na. ranja.

La hembar es algo nayor gue cl macho y su plumaje mas oscuro.

Los pequeños tienen todas las plumas de la parte superior del cuerpo adornadas de un filete pailido: las plumas de la parte superior de la cabeza son de un negro pardusco leona. do; la cern de un rojo claro, $y$ las patas de un azul agrisado palido.

DISTRIBUCION GEOGRÁFICA.-Azara, el príncipe de Wied, Marwin, d'Orbigny, Audubon, Schomburgk, 'T'schudi, Boeck, Owen, Hermann y otros naturalisias nos han dado descripciones exactas sobre el caracara; esta ave es propia de la imérica del sur.

USOS, COSTUMBRES Y REGIMEN. - El caracara del Brasil frecuenta los bosques de poca espesura, el llaroyo las estepas: abunda sobre todo en los pantanos, y no se le ve ni en las selvas vïrgenes ni cu las montanas.

4. Aqui se encuentran, dice el principe, muchas de estas ares de rapina, que se pasean por las jraderas ó vuelan ro zando las espesuras; en el suelo tlenen un aspecio muy gra. cioso. porque andan erguidas! ligeranente, pues sus altos talones, sus cortos dedos y las garras algo corras faciliton la locomocion., Eil mechon de plumas les cominica, segun
Boeck, un aspecto innjestuoso, y su atrevimiento. parece confirmar la idea que se forma de cllos a primem vista.

Su alimento consiste en sustancias animales de toda es. pecie. En las estepas cazan, à la inanera de nuestros buzos, ratones, aves pequeinas, lagartos, caracoles é insectos; en las orilias del mar recogen los restos que las olas arrojan a la playa. El principe encontró en el estómago de varios individuos insectos, y sobre todo langostas, de la especie que ha. bita en la costa del Brasil; Boeck los vió á menudo en com.

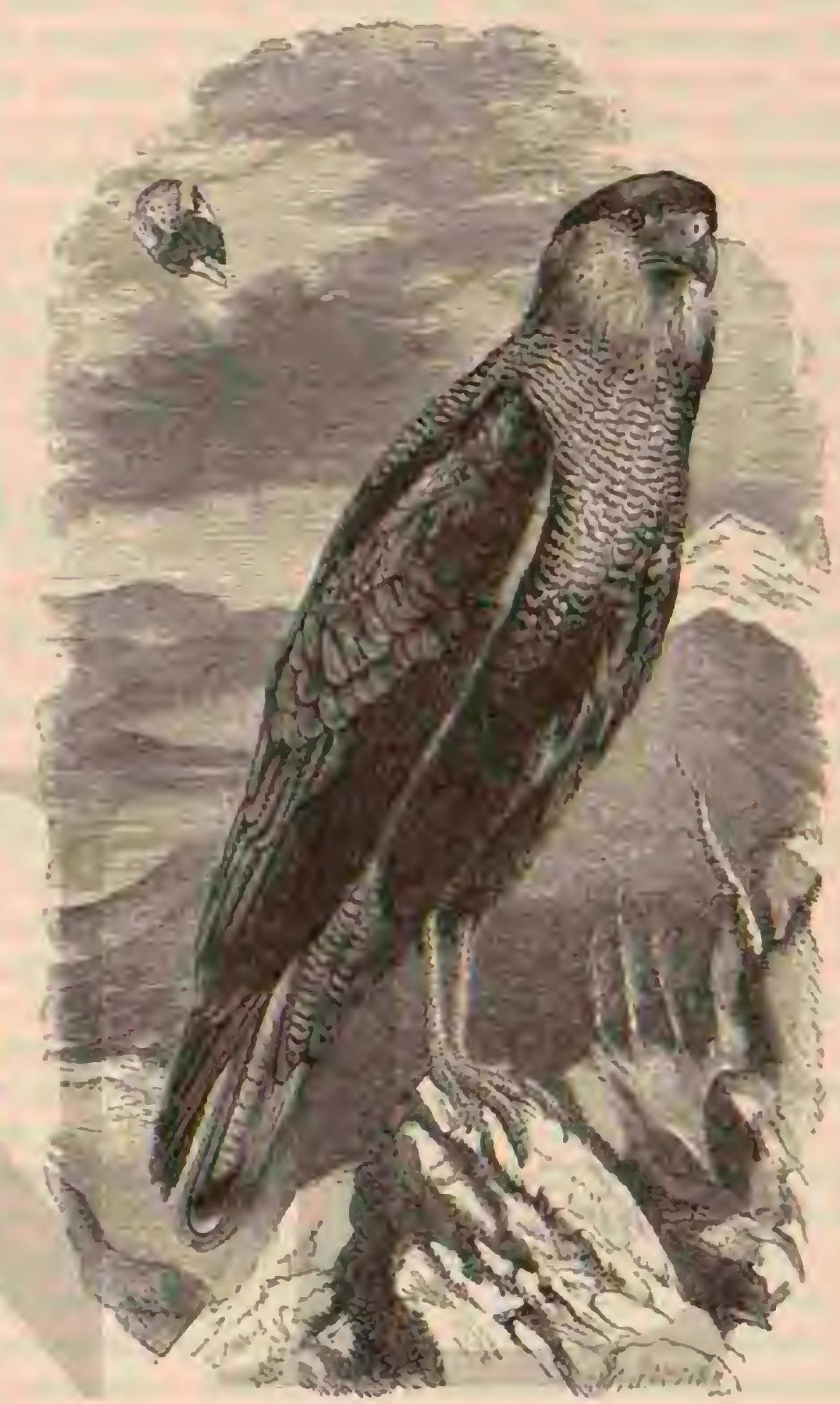

Fif. 1j1.-EL CARACAKA UR, IBASIL

painia de los cerdos, devorando como cllos gusanos y larvas; Azara los considera como enenigos del avestruz americano, de los corderos y de los cervatillos. aCuando una manada de corderos, dice el citado viajero, no estŕ vigilada por un buen perro, puede suceder que el caracara se precipite sobre los recien nacidos! los devore vivos ó les arranque los in. testinos; si cree que no puede vencer su presa, liama á cua. tro ó cinco companicros, y entonces puede llegar i ser un ladron muy peligroso.

Donde hay un resto futrefacto es seguro encontrar cara: cams: cuando mucre un animal, dice Darwin, comienza el gallinaso el festin, y el caransho acaba de limpiar los huesos: a lo largo de los caminos y en medio de los desiertos de la latagonia se ve un gran número de estas ares, que se alimentan de los cadáveres de los animales que han muerto de sed $\delta$ de hambre.

Lil carancho es aborrecido por todas partes por su rapacidad: roba la carne que se pone á secar: J para variar mas sus comidas, acomeic á las ares de corral yarrebata sus hue vos, segun dice Darwin. Con frecuencia se le ve posado en el lumo de las caballos y los mulas, comiéndose sus parai. 
siros, pero á menudo picoien tambien las heridas, y el pobre animal permanece inmóvil, con las orejas bajas y el lomo arqueado, sin poder librarse del ave.

No cabe duda que esta ave devora tambien cadáveres humanos, á juzgar por su manera de proceder cuando ven un hombre dormido en alguna de aquelias soledades. Al despertar, dice Darwin, vense en la colina inmediata una 6 varias de estas aves, yute vigilan al viajero con paciência

Algunas de estas aves siguen a los carndores, y les arre. batan i menudo las piezas a su propia yista; las hay tambien que acompañan i las demas carniceras para cogerles su piesa; persiguen a las grandes cigieñas que han tragado un pedazo de carne, y no las dejan un momento de reposo hasta que lo vuelven y ahandonan: pero en cambio son tambien perseguidas á su 3 ie. par nutues de olras ates.

Ias especies mas afines estan en continua guerra unas con otras: asi el cararara, dice Darwin, está tranquilamente po sado en un árbol, el chimango vuela ásu alrededor, s, pro curn darle picolazos que el caracarn cvita en lo posible A esta rajaz le alormentan los piojos mas que a ninguna otra; tiene tantos, que es casi imposible desplumarla.)

Cuando el caracara grita pone la cabeza sobre las estraldas - deja oir un sonido que algunós viajeros expresaron por "raga, seguido de roo, pronuncjada con ronca voz: y se le ha comparado con el rumor que prodiciria el frote de dos leños rugosos.

Desde la manana a la tarde está cl carancho en continuo movimicnto: hacia la puesta del sol se reune con algunos de sus semejantes, y con sus fieles compañeros, los pernóptcros; todos juntos van á posarse en la rama de un árbol aislado en mecio de las estepas para entregarse al descanso. Se réa estas aves acudir de cinco ó seis leguas' a la redonda, y si no encuentran árbol conveniente, se poisan en las breñas, en las rocas ó solure los nidos de térmites.

El unacho y la hembra viven todo el año en la mas per. fecta union: se les reconoce siempre, aunque varios indivi duos formen una bandada. El periodo del celo varía segun las localidades; corresponde a la primavera en la Americá central. y al otoño en el Paraguay.

El nido se compone de rarias stcas y está rellenado en su interior de raices, yerba y musgo; es muy espacioso, $y$ encuéntrase lo mismo en lós árboles alios que en los bajos. I.os huevos, cuyo número es de tres, 6 cuando inas cuatro, tienen forma de pera, pero son mas prolongados; miden 1)",045 de largo por 0":035 de grueso; el color de los dibujos raria mucho; la ciscara es por lo regular amaritlenta, parda $\delta$ de un rojo de sangre.

los hijuelos salen cubiertos de plumon, y adquieren el plumaje de sus jadres en el nido. Fil macho y la hembra los cuidan tiemamente y los acompanan largo tiempo; pero cuando ya no necesitan nada los rechazan, tratándolos con indifcrencia.

CAUTIVIDAD.--No tenemos muchos detalles acerca de la vida del caracara.

Audution habla de una pareja que cogio Strobel en los al rededores de Charleston. El macho era muy déspota con su compañera y no dejaba escapar nunca la ocasion de maliratarla, de tal modo algunas veres, que la pobre ave estaba algunos minutos echada de espaldas para defenderse con sus patas. Ninguna de estas rapaces manifestaba el inenor afecto por su guardian: cuando se las cogia se defendian tan vigorosamente con el pico $y$ las linias, que era preciso soliarlas. Devoraban los animales muertos y vivos, las ratas, los rato. nes $y$ las gallinas, $y$ eran tan diestras como los halcones $y$ las águilas para arrebatar una presa en sus garras. Sujetaban su presa con las unas, y hacianla pedazos, rragándosé la carne con pelo : pluma. Comian mucho de una vez; pero tambicn podian ayunar largo tiempo; y el agua les cra de tocio punto necesaria. A los dos años tenian ya el plunnaje de los adultos: pero hasta mas tarde no pareció en todo su esplendor.

Un caracara que tenemos en el Jardin zoológico de Ham. burgo no nos ha ofrecido todavia ningun hecho interesante, si bien es rerdad que fué preciso ponerle en una estrecha jaula donde no se puede mover cómodamente. No mani. fiesta el menor apego a su guardian, y parece indiferente á todo. Se le ve horas enteras en el mismo sitio, completa. mente inmóvil; lo mas que hace es levantar y encoger de vez en cuando su moño; por lo regular se posa en la percha mas alta de su jaula; á menucio esta en tierra. La carne es su alimento farorito, si bien no rehusa las sustancias vegeta. les; parece que le gustan sobre todo las patatas; su voz se oje con nucha frecuencia.

\section{LOS VULTÚRIDOS- VULTURID屟}

CARACTÉRFS.- Estas aves que constituirán para nos. otros una familia, son las mayores de lodas las rapaces. El pica, mas largo que la cabeza, ó por lo menos tanto, es recto, $y$ sólo ganchudo junto á la punta de la mandibula superior; mas alto que ancho, tiene los bordes afilados; la cera ócupa una tércera parte de la longitud, y en las especies mas pequerias hasta la mitad. Casi siempre falta una verdadera es. cotadura; pero sustitujela una prominericia de los bordes de In mandibula superior. En algunas especies se observan ensanchamientos de la piel, que en la mayoría de casos forman crestas/soure el pico. Los piés son fuertes, pero los dedos endebles, con uñas cortas, poco corras y siempre obtusas, de modo que las garras no sirven de mucho como armas ofensivas. Ias alas, en exiremo grandes, anchas y muy re. dondeadas, suelen tener la cuarta rémige mas larga. Ia cola, de longitud regular, redondeada ó escalonada, tiene las plumas rigidas. En cuanto á la estructura interna, los buitres ofrecen todos los caractéres distintivos esenciales de los halco. nes, solo que en algunas especies se cuentan mas vertebras cervicales. Ias caudales son inas anchas; el esternon relativamente mas bajo: los huesos del brazo mas largos; el eso. fago se ensancha en forma de buche de considerable tama. no, que sobresale como un saco del cirello cuando esiá lleno; el estómago glanduloso es grande.

OBSER VACIONES GENERALES. - Tenemos á los vulturidos por aves innobles, porque no las consideramos mas ique bajo un punio de vista; pero no se les puede aplicar semejante calificativo en absoluto; antes por el contra. rio, debemos mirarios como muy superiores en ciertos concepios: tienen el páso cachazudo; llevan las alas sepa. radas, y rara ve\% está ordenado su plumaje; su marcha ciertamente no es graciosa, pero en cambio andan ficil. mente, mucho mejor que los mas de los inlcónidos, y paso paso sin saltar. Si iienen el vuelo lento, y no rápido como el del halcon, es no obstante muy sostenido, y puede el ave doninar el vicnto.

Sus sentidos alcanzan tanto desarrollo como los de las otras rapaces; por lo que hace a la vista, sobre todo, nada tienen que envidiar al águila ni al halcon, pues vuelan a una distancia que no podemos apreciar nosotros sin hacer uso de nuestros mas poderosos instrumentos. Su oido es bueno: el olfato mas sutil que el de las otras rapaces, aunque no tanto como se ha supuesto; el gusto bastante bueno; sin poderles negar el tacto. Su inteligencia es en cambio me- 
diana: por tal concepto se hallan muy por debajo de los aquilidos y de los falcónidos, $y$ hasta de los estrígidos, las mas estúpidas de todas las rapaces. Son miedosos, y rara ver. prudentes; pendencieros y coléricos, pero poco audaces y nada valerosos; sociables y no pacificos, malignos y cobardes; y su inteligencia no raya ni sig̨uiera hasta la astu. cia. Aprenden poco a poco 6 conocer $a$ las gentes $y$ à los animales que les pueden hacer ciaño, $y$ con frecuencia los distinguen de aryuellos de que no deben temer nada. Rara vè proiesan afecto á otros séres; en todo sun rudos y estúpidos, y se nota en ellos una curiosa obstinacion en cjecutar lo que han propectado. Los tachamos de perezosos porque los vemos permanecer horas enteras inmóviles en el mismo sitio; pero deberiamos reconocerles la cualidad opuesta cuando pasan casi codo un dia volaudo por los aires. Ln su manera de vivir se observa una mezcla de las facultades mas diversas y contradictorias al parecer; inclinase uno a mirarlos como ares calmosas y pacírcas; mientras que si se observa con atencion, aparecen como las mas violentas die todas las rapaces.

Solo cuando se sabe cuál es el régimen de los vultúridos se puede llegar i conocerlos: la palabra rapaz pierde su sig. nificado en ellos, pues son muy pocos, y aun estos excepcio. nalinente, los que acometen á los animales vivos, observíndose que to hacen de una manera especial. Por lo regular se contentan con lo que la casualidad les proporciona; se hartan con los cadiveres que encuentran; comen las innundicias que descubren, y para esto no necesitan mucha inteligencia, pues les basta la vista. Sin embargo, no siempre les favorece la casualidad; algunas reces se hallan expuestos $\$$ padecer hambre, $y$ hé aqui porque al encontrar una presa procuran compensar sus dias de ayuno, preparándose para el porvenir.

Las aves que se alimentan de este modo no pueden vivir sino en la zona tropical, ó cuando mas en la templada, pues en los paises glaciales, cada sér se ve ubligado á cazar su presa. I a naturaleza del sur es generosa, y proporciona tanto á los vultúridos, que no han de inquietarse mucho para satisfacer sus necesidades.

DISTRIBUCION GEOGRÁFICA.-Los vultúridos habitan todos los paises del globo, excepto la Nucva Holanda: el antiguo continente us mas rico en especies que el nuevo; cada una de estas tiene un àrea de dispersion menos limirada. Algunas son casi tan numerosas en Europa comoen Asia $y$ en ifrica.

USOS, COSTUMBRES Y RËGIMEN. - Encuéntranse los vultưridos en todas las tocalidades, lo mismo en las llanu. ras mas cálidas, abrasadas por el sol de los trópicos, que en los altos picos de las montanas mas elevadas. Entre todas las aves son los que mas se remontan por los aires; tstando además organizados para soportar las variaciones mas consi. derables de presion atmosfírica. Solu algunas especies pare. cen confinadas a ciertas localidacies; asi es que no remos á unas mas quie en las montanas, al paso que otras solo se en. cuentran en la llanura.

No se puede asignar à los vultúridos una residencia pro. pianente dicha: su régimen les obliga á franquear espacios considerables, y pueden hacerlo con el auxilio de sus enor. mes alas.

Solo en la época del celo les retienen en el mismo punio los deberes de la reproduccion y el cuidado de las crias; viajan todo el resto del año, y puede decirse que se hallan á la vez en iodas partes y en ninguna. A parecen repentinamente, y en gran número, en un pais donde durante mucho tiempo no se habia visto un solo individuo, $y$ desajarecen luego sin dejar rastro ni vestigio de su procedencia. Los que viren en las inontanas ienen al parecer una residencia mas fija, pues se les ve en los mismos parajes, aun despues del periodo del celo. Solo algunos cvitan la vecindad del hombre; otros se fijan en los lugares habitados, donde encueneran su coidiano alimento unas fácilmente que en las regiones desiertas. Fin todas las ciudades del Africa y del sur de Asia y de la Amé rica del sur estas aves son tipos caracteristicos.

A los vultúridos se les debe ver sobre todo cuando traba. jan; solo entonces, $y$ hablo por experiencia persomal, se ma. nifiestan realmente tal como son.

Sucumbe un camello en los confines del desierto, rendido de las fatigas de viaje, y agotadas sus fuerzas por los ardores del simoun; cl camellero despoja de su carga al pobre animal que no debe volver á ver las fertiles mârrgenes del Nilo, y continuia la marcha con sus compañeros, abandonando el cuerpo, porque su religion le prohibe tocarle.

Al dia siguiente el cadảer se halla todavia intacto sobre la arena que le ha servido de lecho de muerte, dado caso que no haya llegado alguna hiena de los alrededores: ja descomposicion comienza su oura, y á primera hora de la mañana aparece un cuetvo en la colina próxima. Desde léjos divisa ą̣uel rico pasto; lanza un grito, acércase al cadáver y le contempla largo tiempa. Otros cuervos le imitan, y revinense en gran número, seguidos de diversas rapaces, que acuden luego al sirio. No iardan en dejarse ver el milano parásito y el pernóptero, trazando sus circulos en los aires; acércase un aguila, y varios marabús vuelan por todas partes describiendo espirales extensas sobre la presa codiciada.

Pero la gran dificultad es comenzar: las primeras avés que han llegado hacen inutiles esfuerzos para riesgarrar la piel del animal, denasiado dura para sus débiles fucrzas; y lo mas que consigue algun pernóntero es sacar uno de los ojos de su órbita luega por in la hora de las diez: aquel es el momento en que se despiertan los grandes vulturidos, y van abandonando uno tras oiro el sitio donde han pasado la no. che; costean la montaha sin encontrar cosa alguna y remón tanse por los aires i una prodigiosa elevacion, trazando sus circulos, y siguiéndose unos á oiros con la vista. Si el uno desciende of sube, imitanle los demảs, dirigiéndose con êl hícia el mismo lado. A cierta altura descubren un horizonte inmenso, pues su vista es tan penetranie, que nada se les es. capa: â lo léjos divisa el buirte varias aves que se apinan en un mismo punto, y ya comprende yue alli puede tomar par. te en algun festin: baja tapidamente un centenar de metros, E inspecciona mejor los lugares. De pronto ciern las ajas; fiandose solo en su pesadez, déjasc caer desde una altura inmensa y se despedazaria conera el suclo si no abriera oportunamente las alas para disminuir el impulso y cambiar de direccion. All llegar cerca de tierra, los vulturidos mas pesados extienden sus patas, mientras que los de largo cuello y cuer. po mas ligero, sutxen $y$ bajan oblicuanente con tanta rapidez como el halcon. Lin açuel imomento no parecen las aves pe. rezosas ni torpes, y desplicgan una habilidad de que no se las crecria capaces.

Apenas da uno de ellos el ejempio, siguenle todos los demás sin vacilar, porque saben que les espera una buena pitanza, $y$ acuden por todos lacios. $A$ cada inomento se oye \{ un individuo posarse con gran ruido, $y$ en distintas direccio. nes se ven aparecer los vultúridos, que un minuto antes se divisaban apenas como un punto negro en las altas regiones. Nada puede ya contenerlos; ya no reconocen el peligro, ni aun la presencia del cazador podria atemorizarles. Llegados a ticrra, corren con el cuclla tendido, la cola levantada y las alas entreabicrtas, precipitándose sin racilar sobre el ca. déver.

Las aves mas débiles les abren pasn; pero con las de igual fuerza comienza entonces una serie de luchas: el tumulto, los 
grios y las contiendas que se promueven en anguel momento son indescriptibles, y se necesita verlo para formarse una idea de lo que es.

Dos ó tres picotazos han bastadio para desgarrar la piel: las especies de pico sólido se precipitan entonces sobre los músculos, mientras que las mas débiles introducen cuanto pueden su largo cuello para sacar los intestinos. Empújanse y se rechazan mutuamente con rabia: cl higado y los pulmones son devorados en el acto: los intestinos están ya fuera, y es pre ciso que la rapaz sostenga rudas peleas antes de llevarse un pedazo. Otras aves se van presentando continuamente para reclamar su parte, y a cada-momento se renuevan las luchas rel tumulto acrece-alejündose aun de mala gana los que ya estän hartos. Jas rapaces mas debiles se mantienen \& cierta distancia, pero dispuestas álanzarse 1 la primern oprortunidad para coger algun nedažo. Sobre ellas se ciernen las águilas y los milanos, que caen uronto en medio de los combatientes, arrebatándoles un trozo de carne, con cl cual desaparecen antes que los sulturidos hayan tenido tiempo de castigar su temeridad.

Fn pocos minutos queda completamente devorado un pequeño mamífero, y trataindose de un buey o un camello, tam. poco tienen mas que para una sola comida. Aun despues de hartas, no emprenden su vuelo gusiosas tas rapaces innobles.

Estos banquetes de vultúridos no se, veritican siempre del mismo modo; pues ya en el mediodia de Europa y en toda cl Africa, ilegan à reclamar su parte en el festin otros anima. les hambrientos. En casi toỏos los paises del sur no se ali. mentan los juerros mas que de restos putrefactos; en el Africa central, los marabús, esas grandes zancudas de pico vigoroso, exigen tambien que se comparta con cllos la presa, y los buitres than de sostener rudas luchas pero como el hambre les aguijonca, conviértense en adversarios temibles. Inútil es que los perros gruñan y enseñen los dientes, pues á pesar de todo, les obligan a emprender la fuga, y nada pueden apenas contra las ntrevidas rapaces; solo consigucn alcanzar con sus dientes alguna vez. el extremo del ala de su enenigo, mientras que el ave les ocasiona una profunda herida a coda jicutazo. No sucede lo mismo con los matrabús, los cuales no se dejà ahuyentar por los vultúridos: luchan a dentís con armas igua. les, y saben hacerse lugar, disiribuyendo á derecha é izguierda vigorosos picotazos.

En ciertos casos les cuesta mucho á los vultúridos asegurarse el alimento: en una comunicacion verbal de Behn, documento confirmado por Jerdon, los vultúridos son en las Indias una especic de sepultureros. El indio demasindo pobre para costear una pira, se contenta con extender el cadáver de uno de los suyos sobre una capa de paja, á la cual prendefuego, á fin de que el difunto no quede privado de la llama purificadora; hecho esto, Te arroja is las aguas sagradas del Gianges A miedida que el cuerpo se descom. pone, sube a la superficie de la corriente, I no tarda en llegar un buitre; con las alas tendidas, la rapaz procura mantener el equilibrio y comienza a devorar aquuellos restos mortales. Dice Behn que con frecuencia se sirve de sus alas como de una vela para enipujar el cadiver hácia un banco de arena y comer mas cómodamente: pero entonces llegan otros vulturidos á reclamar su parte, y los marabús se pre. sentan á exigir su racion.

Jerdon vió una vez en medio del Ganges un buitre que habia sido ahuyentado sin duda de un cadáver, y que ba. tiendo las alas trataba de ganar la orilla.

Cuando les aqueja el hambre, los rultúridos osan acome. ter algunas veces á los animales viros, sobre todo los qque están enfermos, por mas que no sean rafaces en la verdadera acepcion de la palabra. Ni aun se puede considerar comotal el gipacto, que es el mas noble de ellos, jor mucho que digan las historias referidas acerca de él: cuando no tiene mucha hambre, tampoco se alimenta mas q̨ue de restos putrefactos. Todus los vultúridos parecen preférir á cualquier otro cadàer el del mamifero, maś no desprecian por eso los de las aves y reptiles: yo los he visto devorar un crocodilo; tambien comen peces.

Las pequeñas especies son mas sobrias qute las grandes: parece que algunas pueden abstenerse de comer carne, al menos durante algun tiempo, alimentindose de los excrementos del hombre, ó del de los animales y de los insectos.

Terminada la comida, los vulturidos no sealejan de buena gana del sitio, segun hemós dicho antes; permanecen en los alrededores para hacer la digestion, y mas tarde apagan la sed. Beben mucho y les gusta bañarse: y a fe que ninguna ave lo necesita tanto como ellos, porque despues de cada comida quedan tan sucios qque inspiran asco. Apenas limpios entréganse al reposo; para ello apóyanse sobre sus patas, con las alas extendidas para calentarse al sol, ó bien se echan sóbre la arena coino las zancudas y las palmipedas. Hasta la tarde no vuelven al sitio donde pasan la noche.

Cuando se asusta súbitamente 1 un vultúrido poco después de comer, acostumbra à vomitar una parte de lo que ha devorado antés de emprender su vuelo; lo propio hace cuando está herido. He ouservacio con frecuencia este hecho en bui. tres catutiros, y he visto además que volvian á comer lo que habian devuelto.

Eis cl momento de remontarse dan los vulturidos varios saltós muy/seguidos, y algunos alctazos; cuando llegan á cierta altura se nueven casi sin agitar las alas, limitandose a cambiar la inclinacion, ja subiendo ó bajando en direccion del viento. Llegan sin esfuerzos aparentes á unas alturas pro. digiosas; vuelan largo ticmpo, y recurren de una vez trayectos de varias leguns, con mucha rapide\% y sin fatigarse.

P'asan la noche en los árboles ó en cintos de roca, segun las especies.

Creinse en otro tiempo que los vultúriclos se guiaban prin. cipalmente por el olfato; pero las observaciones de muchos naturalistas, confirmadas por mi, demuestran todo lo contra. rio. Un cadáver en completa descomposicion, cuyo olor infecto sé extiende á cierta distancia, atrac a los vulturidos; este es un hecho que no se pruede negar, pero el caso no es comun. Créase que estas rapaces jercibian los miasnas a una distancia de varias leguas. y hasta que les atraia el olor del moribundo; mas lee Vaillant ha obsersado, y go lo reco noci despues de él, que fos buitres acuden á- los cadáveres frescos, que no exhalan todavia olor alguno. Yo los he visto llegar en todas direcciones, cualquiera que fucse el viento que soplase, y observé asimismo, lo mismo que Le Vaillant, guc no aparecian junto á unos restos ocullos, sino cuando habian sido descubiertos y señalados por los cuervos. Creo, pues, poder afirmar que la vista es el sentido mas perfecto de estas rapaces, y que siempre se guian por ella.

Los vultúridos se reproducen al principio de la primavera en todos los paises donde habitan: únicamente las especies raras anidan solas; las otras forman sociedad. Unas sitúan su nido en los arboles, otras entre las rocas, y varias en tierra: las has tambien que suportan ja presencia de aves extraijas en sus colonins, como por cjeruplo, de la cigien.

Cuando los vultúridos anidan en los àrboles, su nido es enorme; pero no difiere del de las otras rapaces. El armazon se compone de ramas fuertes, dei grueso del brazo, á las que siguen otras mas pequenas, formindose la excavacion de ramaje y raices; el interior sucle estar relleno de pelos: cuando el nido se apoga en las rocas $\delta$ en tierra, apenas se le puede dar el nombre de tal. 
En todos aq̣uellos puntos donde son perseguidas estas rapaces, no se fijan sino en las rocas $\delta$ árboles inaccesibles: pero no hacen lo misino en los parajes en que se creen se. guras. En el interior de Africa, por ejemplo, se encuentran a menudo sus nidos en śrboles muy bajos ó en verdaderos matorrales.

Los hueros, cuyo número es de dos ơ rres en cada puesta, tienen generalmente la forma oval, cáscara rugosa, y fondo gris ó amarillento, con manchas, puntos y rayas de un tinte oscuro. Es probable que el macho y la hembra los cubran alternativamente, ó por lo menos esto es lo que sucede con ciertas especies: no se sabe aun à punto fijo cuánto dura la incubacion.

Los hijuelos nacen completamenie cubiertos de un plumon mas $\delta$ menos espeso: durante largo tiempo no pueden satis. facer sus necesidades por si mismos, y solo al cabo de algunos meses comienzan à volar.

Los padres se muestran muy carinosos con su progenie, $y$

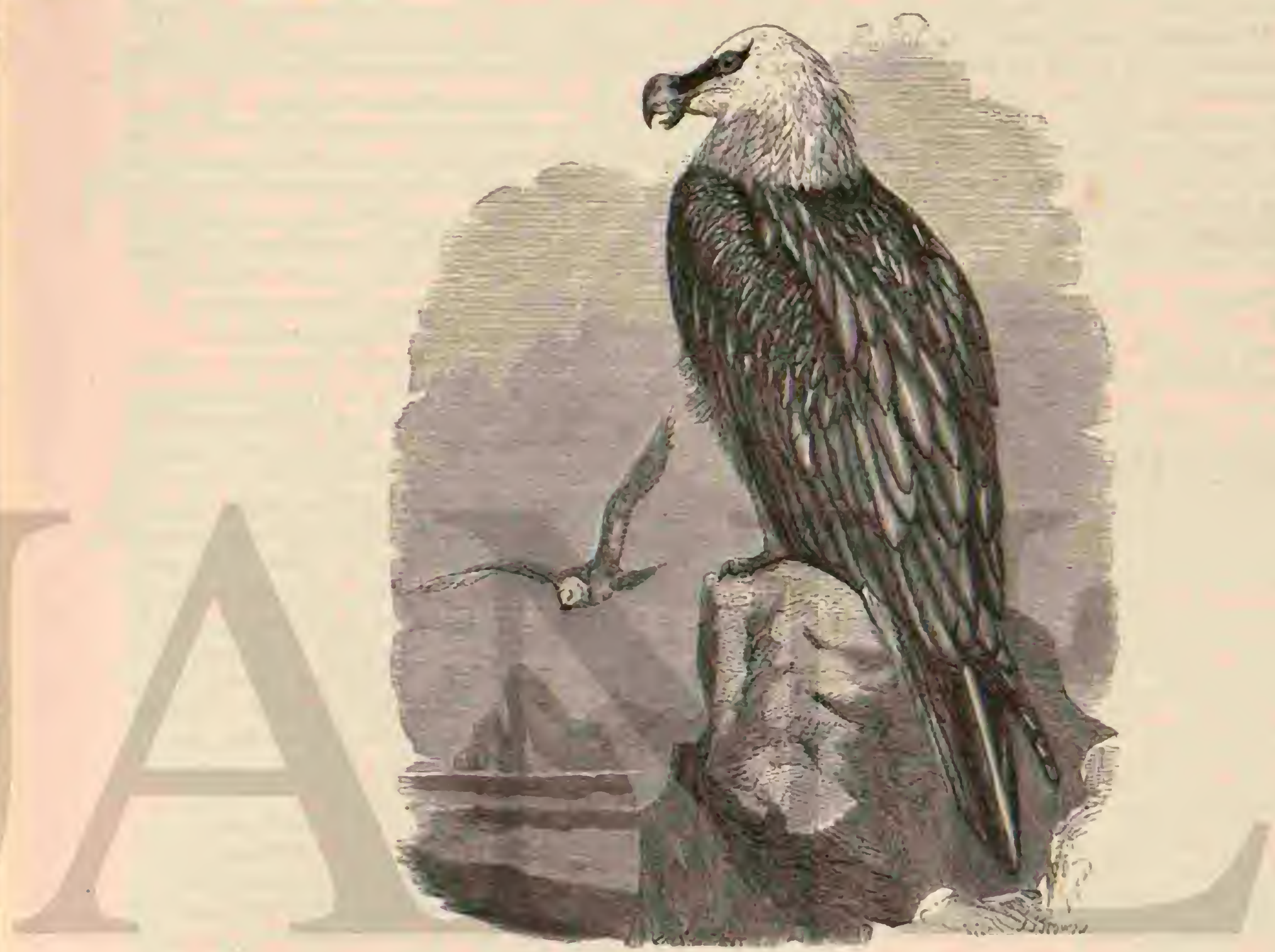

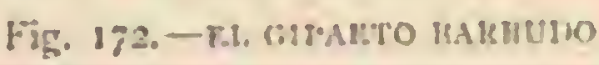

la defienden en caso de peligro, mas no contra el hombre. Al principio reciben los hijuclos sus alimentos descompuestos y a medio digerir; mas tarde se les da una comida mas sólida; pero es dificil satisfacerlos, porque siempre es inayor el hambre gue los domina. Aun despies de volar necesitan durante algunas semanas los cuidados del padre y la madre: bien pronto, sin embargo, aprenden á bastarse á si mismos, y entonces se revelan todos los instintos de su raza.

I.os vultúridos tienen numerosos rivales, pero pocos ene. migos: los parásitos los atormentan; las águilas, los haicones $y$ las cornejas los persiguen e inquictan sin cesar, y los perros y lós marabús les disputar el alinento. El hombre reconoce ios servicios que le prestan, y no les da caza sino cuandn se permiten acometer á los rebaios, en vez de contribuir á la desaparicion de los cadáveres. El gipacto y el condor son los dos infelices súres destinados á expiar todas las faltas de que son culpables las demás rapaces. Las otras cspecies, por el contrario, son objeto de un terror supersticioso; no se las aprecia, ni van comprendidas en los legados de los mahometanos ricos y bienhechores. El indio ve en estas ares, que Tosio III devoran sus muertos, unos séres sagrados á los cuales no puede perseguir; el indigena del interior de Africa las deja obrar libremente, aunque no las absuelva de todo por los daños que ocasionan.

CA UTIVIDAD. - Todos los vultúridos soportan fácilmen. te la cautividad; son duros $y$ mur capaces de resistir el frio; bien es verdad que en su estado libre sufren alternatisamenre bruscos cambios de temperatura al remontarse y bajar po: las regiones aéreas. Conténtanse con el alimento mas vulgar, y cuando están hartos, pueden guardar ayuno por espacio de semanas enteras.-

Domesticanse tnuy pronto: merced s su indiferencia, se sobreponen a las muchas miserias que sufren desgraciadamente durante la cautividad; aunque hay aigunos que constituren cxcepcion y ven solo en su amo un enemigo al que tratan de hacer comprender su fuerza.

Los vultúridos solo interesan cuando se les pone en una vasta jaula en companila de otras grandes rapaces. Permanecen pacíficos casi todo el dia; pero en ciertos momentos, ! sobre todo à la hora de comer, reina la mayor agitacion en 
el seno de aquella socicdad, promoviéndose el mismo tumul to que cuando están las aves libres alrededor de un cadáver Cada cual lucha $y$ hace uso de todas sus armas para apoderarse del mejor pedazo; pónense en juego la fuerza y ln astu cia, pero de todos modos se confirma al fin aquel proverbio de que el derecho del mas iuerte es siempre el mujor. El buitre leonado se distingue sobre todo por sus movimientos: erizado el plumaje, encogido el cuello y chispeantes los ojos, permanece inmóvil junto í la carne que sele arroja, sin tocar á ella, siguiera resuelto á impedir que se la quiten. Llueven los picotazos d́ derecha é izquierda, y ninguno de sus compa. neros es bastante osado para acercarse mucho: aseméjase en aquel momento a una serpiente que trata de morder; siendo csia semeiara tanto mas cabal, cuanto gque la rapaz produce un silbido en un todo anślogo al del reptil. Su atrevimiento y egoismo initan a los demas compañeros de cautividad, y de aqui resultan encamizadas peleas, en las que cada cual debe tomar parte si quiere participar del banquete. Fnton. ces no se oyen mas que silbidos, gritos, cacareos, aletazos, y en fin, un estépito infernal que la piuma no puede describir.

En los últrmos años se la visto varias veces álos vulturi. dos anidar en la jaula; incubaron con gran aficion uno ó dos huevos, pero sus puestas no dieron resultado alguno; sin embargo podemos esperar que mas tarde sucederá lo con. trario.

\section{LOS GIPAETIDOS - GY - PAETID瓜}

Los gipátidos son los mas nobles entre los vultúridos y diferen no solamente de las otras especies del grupo sino tambien da las otras rapaces tanto por sus caractéres fisicos, comu por sus costumbres: lo cual autoriza plenamente el formar con ellos una familia separada.

CARACTÉRES. - Los giphetos tienen el cuerpo grucso y prolongåoo; la cabeza grande, larga, aplanada en su parte anterior, y un poco abombada postcriormente; el cuello es corto; las alas muy largas y sub-agudas, con In tercera penna algo mas prolongada que la segunda y la cuarta, y mucho mas que la prinera; la cola, larga y cónica, se campone de doce pennas; el pico, largo y/fuerte, tiene una escotadura en la base de la mandibula superior, que aumenta de volú men en la punta y forma un gancho muy corvo; las patas son cortas y relativamente endebles; los dedos de un largo regular y débiles; las uñas vigorosas, poco corvas y romas las plumas del cuerpo grandes y abundantes, mientras que las de la cabeza son angostas. La cabeza está completamente cubierta de plumas, así como el cuello; ocultan la cera largas sedas dirigidas hácia delante y alisadas sobre cl pico: los tarsos tienea tambien plumas hasta los dedos.

Los gipaétidos ofrecen algunas particularidades organicas dignas de notar; tienen trece vértebras cervicales, ocho dor. sales y siete caudales; el esternon es largo y ancho; la quilla muy alta; el húmero y el omoplato en extremo fuctes; la clavicula grucsa, muy aproximada al esternon; los huesos de los miembros inferiores son endebles; el cráneo aplanado, angosto en la parte superior, y muy ancho inferiormente; las dos articulaciones de la mandibula inferior separadas yor una distancia de $0^{\circ}, S_{\text {; }}$ - las-mancibulas mu plexibles y la cavidad craneana estrecha.

l.a lengua es corta y ancha; el paladar está cubierto de papilas córneas El esóngo, muy ancho, plegado y suscép. tible de dilatirse considerablemente, no constiture en reali. dad, descle la laringe al estómago, mas que una sola bolsa, en la que la region esofagica propiamente dicha, el buche y el estómago, están separados línicamente por unas prominencias poco pronunciadas. Este últino, de forma cilin. drica, plegada y muy extensible, contiene un gran numero de glándulas que segregan un jugo gástrico, ácido y de olor desagradable.

El largo del intestino es regular: el páncreas muy grande. Los misculos peciorales están mucho mas desarrollados que en las otras rapaces; los de la mandibula y las piemas son endebles.

El ojo tiene una conformacion muy particular: en las demás aves no está descubierto mas que el íris; en los gipaetos es aparente la esclerótica, y forma alrededor de aquel una especie de ribete circular de unos $0^{\circ}, \mathrm{co}_{4}$ de grueso, de color muy viro. Las fosas nasales son muy grandes, y están provistas de largas conchas doblemente contorneadas.

La oreja es bastante perfecta, lo cual da a entender que el oido, juntamente con la vista, son los sentidos mas des. arrollados.

Iil cerebro es pequeño, y solo el cerebelo presenta surcos profunáos.

No se sabe aun si todos los gipactos pertenecen ó no a la misma especie; pero no cabe duda de:que los que habitan el Asia y el Arica difieren notablemente de los que viven en los Alpes. En cuanto á sus usos y costumbres, cualquiera que sêa cl pais donde residen, son los mismos para todos, segun veremos mas adelante.

\section{EL GIPAETO BARBUDO-GYPAETUS BAR- BATUS}

CARACTERES. - Segun he reconocido yo mismo en individuos procedentes de Espana, la longitud de esta es. pecie varia de 1 metro $\& 14,15$ de largo, por $2 ", 40$ a $2 ", 67$ de ancho de punta a punta de las alas; estas miden de $6{ }^{\mathrm{m}}, 79$ 1 $6^{\mathrm{m}}, 82$ y la cola de $0^{\circ}, 48$ a $6^{\circ}, 55$; las primeras medidas corresponden al macho y las segundas a la hembra; pero asi como en lodas las especies grandes, obsérvanse muchas va riaciones.

El individuo adulto tiene la frente de color blanco ama. rillento, lo mismo que la parte superior de la cabeza y los iados, cubiertas estas jartes de plumas sedosas mas oscuras; el occipucio y la nuca son de un amarillo de orin; las plu. mas del Jomo y de la rabadilla, y las cobijas superiores del ala $y$ de la cola, de un negro oscuro, con el tallo blanquirco y la extremidad manchada de amarillento; las pennas de las alas y de la cola, negras en - las barbas externas, de un gris ceniciento en las internas, y con el tallo blanquizco. Toda la cara inferior del cucrpo es de un amarillo de orin, mas oscuro en la garganta que en las otras partes; en los lados del pecho $y$ en las nalgas hay algunas manchas pardas; adorna el pecho una especic de collar de plumas blanco amarillentas, con manchas negras: una linea de este color, yue parte del pico, se dirige hácia el ojo, encorvaindose des. pues hácia el occipucio, pero sin reunirse con la del lado llan esclerótica de un rojo berme. llon; la cera de un negro azulado; el pico gris con la punta negra, y las patas de un gris plomo. (fig. 172 ).

Los individuos jórenes tienen el ojo de un gris ceniciento; prista y la punta de la mandibula inferior mas oscuras que el resto; las patas de un verde pślido sucio, con viso azulado, y la cera de un negro azulado.

Los gipaetos muy pequeños tienen el lomo de color pardo negruzco, con algunas plumas manchadas de blanco; el cuello y la cabeza de un tinte negro y la cera inferior de un pardo rojo claro. No adquieren su plumaje definitivo hasta despues de haber mudado varias veces. 
Los gipaetos de Espana, Cerdeña y del sur de Africa son mas oscuros: los de los Pirineos y del Himalaya mas claros que los que habitan los Alpes suiros; Meves ha descubierto por otra parte, ąue el tinte pardo de sus plumas puede desapare. cer por el lavado y diversos agentes quimicos. Se ha querido deducir de aqui que dicho color no era propio del ave, y que no lo adquiria sino despues de largos baños en las aguas fer. ruginosas; y hasta se ha querido dudar ó negar la independencia del gipacto barbudo como especie, pretendiendo que el plumaje mas claro ó mas oscuro depende sencillamente de haberse bañado of no el gipaeto. No podemos dat ninguna importancia ś este aserto, por la sencilla mron de que, como es sabido, en ninguna montana alta faltan aguas ferruginosas; muy léjos de ello, son tan abundanies, que ningun gipacto dejará de utilizarlas, adquiriendo asi su rico plumaje un bonito color de oro. Con la quimica no podemos hacer nada en este caso, tanto menos cuanto que los experimentos efectuados por órden de Meres no son aun bastante exactos para que se pueda resolver sobre la cuestion principal. No incurriremos pues en error, por ahora, al suponer aun la existencia de varias, o por lo menos de dos especies de gipae. tos, fundándonos en que la de piés desnudos (Gipretus nudipes) se distingue siempre de su congénere de los Alpes: a este últino se referirín los mas de los datos siguientes.

DISTRIBUCION GEOGRÁFICA.-El airea de dispersion del gipaeto barbudo es muy extensa. En Europa habita los Aipes de Suiza, las montañas altas de Transilvania, los Balkanes, aunque con menos frecuencia, los Pirineos, todas las grandes montañas de las tres peninsulas meridionales y el Cáucaso. En Asia esia diseminado por las que se encuentran desde el Altai hasta los promontorios de la China y el Sinaí. Tambien se encuentra en las montanins de la Arabia meri dional y hasta en el Himalaya En Suiza, donde su número ha disminuido mucho actualmente, velase anies el gipaeto con mas ó menos regularidad, segun Girtanner, hasta en las montañas mas altas de Berna, Graubuendin, Tesino y Va. lais.

Se ha reconocido que anida en Graubuendin, y probable. mente tambien en Berna y Tesino; mientras que cla el Valais solo se presenta, al parecer, cuando emprende expediciones de merodeo. In los Alpes de Alemania y en Austria se le ha exterminado del todo, ó por lo menos no se ha visto ninguna de estas aves desde hace cuarenta anos; pero es posible gue visite todavia alguna vez varias montañas del Tirol meridional. En la peninsula del Balkan no falta en ninguna montaña alta; en Italia se le encuentra todavia, aunque en corto nú. mero, en los Aipes y en rodos los puntos de Cerdeña, pero no abunda mucho. El gipneto barbudo es tan comun en Es. paña, excepto Galicia y Leon, que este pais puede conside rarse actualmente como su verdadera patria en Europa. En Asia habita todavia en gran número las regiones del sud. oeste, nientras que en el Alat y en el Celeste Imperio se le ve muy pocas veces. Abunda tanto en el liurkestan, en el Asia Menor, Palestina, Persia, Arabia y el Himalaya, desde Niepal hasta Cachemira y desde Salt hasta Suliman, q̨ue seria dificil no verle. Fn Africa, su ảrea de dispersion se limita i la parte septentrional de esie continente, sobre todn al tilas y Djebel, Ataka y sus comtornos. Muy raras veces se le veen las montanas del Nilo, y menos aun en el valle mismo de este rio. Adams, que le conoció durante sus cacerias en el Himalaya, y que dificilmente le tomaria por otra ave, le ha visto en las puntas de las pirámides; y Hartmann le observó cerca de las cataratas de Wiadi Halra Yo, por mi parte, no le he hallado ni en Figipto ni en Nubia, por frecuente que parezca ser en las montañas de ambos lados del mar Rojo. El gipacto que se encuentra en el este y mediodia de Africa sobre todo en Abisinia y en el pais del Cabo, no es nuestro gipaeto barbudo, sino el de piés desnudos.

USOS, COSTUMBRES Y REGIMEN.-Ningun ave de rapina de las que visitan la Alemania, sin exceptuar el águila, ha sido descrita tan minuciosamente como el gipacto barbudo; y sin embargo, podemos yretender que no hace mucho ticinpo que conocemos bien la historia natural de esta rapaz: despues de haberla observado á menudo en la Arabia Pétrea y en España, fui uno de los primeros que la presentaron bajo su verdadern faz. Actualinente poseemos numerosos datos acerca del ave.

Teremos informes mas ó menos minuciosos de lerdon, Adams, Hodgson, Irby. Heuglin, Gurney, Krueper, Hudles. tone, Hume, Salvin, mi hermano y otros, que todos están conformes, menos en lo que han dicho algunos naturalistas antiguos y modernos, entrc otros el excelente Girtanner, sobre el gipacto barbudo de Suiza. Haré por lo tanto pri. mero un resúmen de mis propias observaciones $y$ de las no. ticias de los citados naturalistas que estén conformes con ellas, anadiendo despues, aunque no sin interponer un veto, los informes de los natumlistas suiros que me parecen mas importanies.

El gipaeto barbudo habita las altas zonas de las montañas, mas aun qque ninguma otra especie de su familia, exceptuando quizás el condor; si bien no huje por eso de los valles. Las tempestades, el hielo y la nieve no le molestan, asi como tampoco el calor que suele reinar en las regiones bajas de has montañas meridionales, tanto menos cuanto que en su táspido vuelo hasta los aires calientes le refrescan, y prescin. diendo de que sa todas horas puede huir del enojoso calor para bañar su pecho en el eter puro de las frias alturas Alli donde en los valles encuentra su alimento sin trabajo y sin que le inquieten los hombres, anida tambien en las regiones bajas de las montanas, por mas que no le agrade abandonar las cimas mas altas cubicrtas de hielo y de nieve. En España se le encuentra con bastante frecuencia en todas las montahas altas, pero tambien anida en las de $200 \leqslant 300$ metros de altura, como sucede en Persia En Suiza, por el contrario, vive tanto como le es posible en los puntos mas altos 6 inac. cesibles de la montana, donde pocos le pueden ver. Solo cuando las tempestades mas violentas del invierno pasan fu. riosamente sobre las elevadas cimas, cubriéndolas de nieve y de hiclo, mientras que en el interior de la montaña el viento del sur agita hasta en sus cimientos las chozas; solo cuando el huracan desencadenado troncha ruidosamente los árboles mas -venerables del bosque con su irresistible impetu, y cuando toda vida parece extinguirse en la lucha tremenda de los elementos, solo entonces el cazador cxperto de las montanas podrá mirar hácia las alturas con la esperanza de ver algun gipaeto barbudo cerniéridose subre el pucblo, pues sabe muy bien que aquel trastorno pasajero de la naturaleza, asi como el aguijon del hambre, obligan al gipaeto a descen. der de su alıa guarida para acercarse á la morada del hom. bre Si logra encontrar algo que comer, repite pronto su risita; pero si la suerte no le es favorable, aléjase al punto, quizis parn no volver jamás; va y viene como un ave extraña de paises lejanos y desconocidos. En otro tiempo, abando. nando las cimas de las montañas de Kur, llegaba à las orillas del tago de Wallen, hasta Quinten yethlis, buscaba una presa fo elevíbase otra vez of considerable altura tan luego como habia satisfecho su hambre; aun hoj, segun las noticias del consejero Brunner de Meiringen, acércase a los pucblos montaneses del Oberhasli, Kandersteg, Iauterbrunn y Grindelwald, en Graubuendin, donde se presenta delante de las casas: y tambien se le ve dunnte mucho tiempo en los valles del Maggia y de Livin. Segun mis observaciones, 
solo suele formar pequeños grupos; yo he visto at este gipacto casi siempre aislado ó por parejas, y uunca mas dic cinco individuos juntos. Cada pareja habita un territorio se. parado del de otra por una distancia de muchos kilómetros, y como le recorre todos los dias con cierta regularidad, difi. cilmente pasa desapercibida en el dominio que habita.

Es mrover a un gipaeto por la mañana, pues aun despues de salir el sol permanece largo tiempo en el mismo sitio donde ha pasado la noche, no poniéndose en movimiento hasta horn y media despues. Iit macho y la hembra vuelan at corta distancia uno de otra, siguiendo los desfiladeros de las montahns sin elevarse apenas a mas de 50 metros sobre el suelo. El gipacto sigue la cadena de montañas en el sentido de su longitud; cuándo encuentra un pico elesado, da la vuelta por él para explorar las dus vertientes, y si cortan dos valles la cadena principal, tos atraviesa sin bajar el vuelo; en los valles que forman una especie de llanura redonảeada suele vérsele cerniéndose durante largo tiempo. Si su penetrante vista no columbra ninguna presa, el gipacto se remon!a \& mas altura para examinar del mismo modo las cimas de las montañas y las mesetas; y cuando aqui no encuéntra nada tampoco, extiende su expedicion lasia la lla nuta.

Al cruzar asi los aires, no es ícil apartar al gipacto de la linea que siguc: yo he visto a uno volar tan cerca de una er mita, que se le hubiera podido tirar con perdigon; no tiene miedo alguno del hombre, $y$ he observado individuos que pasaban cerca de ini.

El gipaeto avanza con una gran rapidez sin agitar las alas; sus movimientos son graciosos, y no se le puede confundir con un águila ó un buitre. Yo in inubiera tomado mas bien désde léjos por un halcon; pero este se reconoce por su frecuente aleteo, lo cual no impide qué otros se hayan equirocado. Su vuelo, dice Gurney, se asemeja de tal modo al de los grandes halcones, que me causó no poca admiracion reconocer un vultúrido en el primer gipaeto que maté.

Cuando ruela esia rapaz, mira a todos lados hasta descu! brir algo que la atrae; entonces traza espirales; sc une con él su compañera, y los dos permanecen á menudo largo rato en el mismo sitio, antes de continuar-su marchat Si la presa que divisan vale la pena, bajan í tierra, y corrén en su scgui. miento como los cuervos: el gipaeto nó devora su victima sino en sitios altos, con preferencia en la cima de una roca: parece que le es dificil emprender su vuclo, y prefiere hallarse à cierta altura, desde donde pucda lanzarse sin esfuer. zo. Cuando se cierne, la brisa mas ligera le basta para remontarse á las mas elevadas regiones.

In la montana alta del Habesch sube á veces st tanta al. tura, segun Heuglin, que aun la vista mas penetrante solo le distingue como pequeño punto en el éter azul. En las rocas que lo permiten suele estar en posicion bastante crguida, pero gencralmente en sentido horizontal, como lo exige su larga cola Su andar es relativamente fácil; avanza siempre sin sal. tar. Aunque al parecer no busca la sociedad de sus semejantes, no evita, sin embargo, la de otms grandes aves de rapina, por mas que no haga ningun caso de ellas: prosigue su mar. cha cual si no existiesen; y aunque anide en medio de esas aves, no se pone nunca en contacto con ellas. Hasta con el águila real vive en buena armonia, ó mejor dicho, hace tan poco caso de lareina de los aires como de cuálquiera otra especie del órden, y aunque algunas rapaces impertinentes la ataquen, continúa su vuelo sin defenderse ni vengarse.

Con las observaciones anteriores cstån conformes las que Girtanner la luecho en los Alpes sobre esta ave. Tanto en Graubuendin como en el Tesino asegurase que el gipaeto barbudo no comiciza su vida activa lassia algun tiempo des pues de salir el sol. \&Abandonando el nido ó la escarpada roca donde ha pasado la noche, si es verano, $\delta$ bien el valle cubierso de bosque y preservado del frio, si es invierno, cmprende una expedicion, solo ó con la hembra, segun la época del ano, para recorrer las regiones visitadas por las gamuzas y las manadas de cabras y carneros; ó bien se dirjge hàcia una colonia de marmotas, donde busca las liebres alpinas para satisfacer su hambre de cualquier manera. Cuando ha conseguido su objeto retirasc durante una parte del dia á su sitio favorito, que es por lo regular una roca solitaria, donde bace la digestion y descansa, para emprender mas tarde otra excursion o apurar los restos de una presa. Hasta mucho liempo despues de ponerse el sal, el carador del Tesino no ve al ave dirigirse hácia su guarida. A Algunos testigos ocula. res han asegurado á Girtanner ųue el vuelo de esta especie es muy distinto segun la intencion que lleva Cuando el gi. paeto barbudo se dirige hácia un sitio determinado, su vuelo es verdaderamente rápido y sostenido; el ave sigue entonces la direccion mas recta posible, pasando á igual altura sobre los valles y muy cerca de las cimas de las montañas ó á lo largo de ellas. De todas las observaciones resulta que al gipaeto no le agrada entonces cambiar de direccion ni de altu. r.a, aunque encuentre viviendas humanas ú hombres en su camino. Muchas veces pasa tan cerca y tan lenta y ciescuida. damente sobre las personas que en ciertos casos no se sabe si será preciso defenderse del ave que no conoce el peligro, $\delta$ que le desprecia cuando tiene intencion de acometer. Todos los naturalistas que han podido obsermar el ave cuando cruza los aires tranquilamente, aseguran que su vuelo es ligero y sostenido, y que traza grandes espirales. El gipacto barbu. do vusela de muy distinto modo cuando caza: Hold dice que se le ve avanzas con pesadez y lentitud al parecer, aieteando estrepitosamente muy cerca del suelo, y que despues se eleva cjecutando graciosas evoluciones para volar al rededor de algunas rocas solitarias. Pero si grande es la destreza de sus movimientos en el aire, cuéstale en cambio mucho irabajo remontarse desde el suelo, a causa de la Iongitud de las alas y la cortedad de las piernas. Solo por necesidad se posa en superficies planas: un cazador del 'Tesino quedo muy admi. rado cierto dia al divisar un gipacto en una planicie; apenas le vió el ave, dirigióse rápicłamente hácia una eminencia, donde se dispuso á emprender el vuelo. Un incividuo que Sallis vió, con no poco asombro, posado en una pendiente d unos quince naetros de altura, dio algunos saltos muy grotes. cos para emprender el vuelo y alejóse despues ligera y orgu. llosamente, pasando sobre la cabeza del sorprendido - observador. Al bajar por los aires, el gipaeto lleva pendientes los pies, y aunque se halle a mucha altura del sueto, trata de moderar la caida elevando las alas, y al posarse en tierra sucle dar algunos pasos ránidos para restablecer el equilibrio.

Si preguntais as un cazador espariol, asi lo he dicho en : 858 , digno de crédito (jué come el gipacto, léjos de referiros alguna de esas historias espantables en que los suizos hacen figu. rar s. esta rapaz, os dirá sencillamente que el quebrasta huesos se alimenta de restos animales, liebres, conejos, pequeños mamiteros, y sobre todo huesos, los cuales parte dejándolos caer de una gran altura Nadie en Espana, ni cazador ni naturalista, os representara al gipaeto como la raphz. mas terri. ble: cada ver que yo he preguntado cual era cl ave que arre. batiba las cabras, los carneros, los perros y los niños, me han dicho que el aguila leonada, y no el gipacto; solo de aquella he oido referir historias análogas á las que se cuentan del lammergeier de los Alpes. En resúmen, el gipaeto está considerado en España como un ave inofensiva, ó por lo menos poco peligrosa ; ningun pastor le teme; ningun cortijero se queja de sus rapinas, antes por el contrario, todos están 
acordes en que, à la manera de los buitres, arrebata los restos putréáctos y deja caer los huesos desde las alturas para romperlos. Yo mismo he visto en Sierra Nevada a un gipaeto clevarse varias veces sobre una roca; bajar y coger alguna cosa, remontandose por los aires para descender de nuevo; y no he hallado en el hecho explicacion mas plausible que la que dan los españoles. Por oira parte, no hay razon alguna para dudar que rompa los huesos de tal modo: segun dicen naturalistas muy dignos de fe, los pigargos, los cuervos y las gaviotas, hacen exactamente lo mismo.

En $1 \$ 69$, Heuglin escribió sobre el gipacto barbudo de Abisinia lo siguiente: Ruestros sabios, los que observan la naturaleza desde su gabinete, pintan al gipacto barbudo como una rapaz feroz, que con sin igual intrepidez. ataca á los ma. miferos y hasta al hombre, procurando precipitarlos en algun abismo. Hemos tenido ocasion de observar esta ave todos los dias, durante largo tiempo y muy de cerca; hemos muerto muchas docenas de individuos; y al examinar sus cadáveres, se ha reconocido con asombro qque su alimento consiste casi exclusivamente en huesos y otros despojos de los mataderos; el gipaeto devora cadáveres animales y humanos; pero soio en caso de necesidad caza él mismo, pues muy raras veces consigue apoderarse de una liebre ó de una cabra perdida. $A$ veces se le ve andar como un cicro, dando tambien saltitos, sobre la verde alfombra de las praderas del pais alto, donde ace. cha las ratas, muy abundantes alli. Sus posturas no tienen la menor analogia con las de los verdaderos rultúridos; mas bien se ascincjan á las de los pernópteros, sobre todo cuando se mueven en el suelo. Por la mañana, al rayar el alba, el gipacto abandona las rocas donde descansa, y franquea una gran extension por campos, praderas y pueblos en direccion al valle, á menudo con tanta rapidez, que se oje distintamentc el ruido casi metálico de sus alas; otras veces se le ve cerniéndose sobre los mataderos, ó siguiendo á otras muchas aves parásitas a los campamentos donde hay trop̧as. $A$ si, por cjemplo, en los primeros meses de nuestra estancia en el país de los bogos no vimos el gipaeto hasta la llegada de las tropas abisinias, con las cuales desapareció tambien. Durante la campaña del rey leodoro contra los galas, presentíronse docenas de estas aves, fieles companeeras del ejército.

Krueper, que observó esta ave en Grecia, se expresa en los términos siguientes: «Cuando se oje pronunciar el nombre de lammergeier, represéntase uno desde luego al ave de rapina mas valerosa, mas osada y mas temible de todas; pero ¿merce realmente semejante reputacion? ¿Debe inspirar un justo temor \& los hombres y al ganado, 6 -se le atribuirán semejantes cualidades sin moivos plausibles? En la Arcadia donde las montañas no son muy altas, comienza su dominio á orillas del mar. ¿Qué puede arrebatar en la llanura? ¿De. rora cabras, carncros ó terneros? Se la ve cernerse sobre la vertiente cubierta de bosqque de una colina; traza circulos con la cabeza inclinada y la vista fija; de repente se deja cacr y desaparece: es que ha cogido una presa, probablemente una cabra; pero no, es una tortuga, que le ha de servir para aplacar su hambre 6 la de sus hijuelos. A fin de poderse comer su carne, arrebátala por los aires y la deja caer sobre una roca, donde se hace pedazos; yo no he presenciado hasta ahora semejante hecho; pero Simpson, que observó al gipaeto en Argelia, me aseguró que era positivo. Refirióme c̨ue cada una de estas rapaces tenia para sí una roca destinada a romper las tortugas, y aseguró haberlas visto el mismo. El 14 de marzo de isGi examiné el nido de un gipacto, y al pié de la roca donde se ballaba, encontré muchas osamentas y es. camas de toriugas

Rlos huesos bien rellenos de médula, dice Simpson, son una golosina que busca el gipacto avidamente; si los otros buitres devoran un animal, preséntase al fin de la comida arrebata los huesos, los rompe y se traga los pedazos. Sin duda fué una de estas aves la que mató á Esquilo dejando cacr una tortuga sobre su cabeza El ave es muy voraz: al rededor de su nido se hallan muchos huesos de tortuga y otras sustancias semejantes, lo cual no quiere decir que se alimente solo de ellas, pues de vez en cuando devora un cor. dero, una liebre 6 una gallina, por mas que su pico y sus garras no tengan bastante vigor, ni puedan desgarmar la presa como lo hacen el águila y el buitre. Fn cambio se opera la deglucion con nucha facilidad: los griegos creen quue pueden tragarlo y digerirlo todo, y refieren sobre el particular historias tan fantásticas, que no puedo repetir aqui. Cierto dia vi á un gipaeto viejo, que habiendo tragado un hueso ú otro objeto dificil de digerir, estaba muy apurado, de tal modo que para facilitar la deglucion, tenia que apoyarse en las largas pennas de su cola.s

Los restos animales, decia Irby, parecen ser el alimento casi exclusiro del gipaeto.

\&.sia ave, dice Gurney, traga huesos muy grandes; todas las que yo maté en la costa sudeste de Africa, tenian el estómago lleno de ellos; habian sido tragados completamente mondados; $y$ he visto a una de estas rapaces comerse un hue. so seco. 'Tambien hallé con aquellos una gran cantidad de pelos de aschkoko, lo cual prueba que el gipacto se alimenta tambien de los animales que arrebata cuando salen á tomar el sol á la boca de sus madrigueras.

¿El gipacto, refiere Adams, al hablar del que habita en Himalaya, coge muchas marmotas; pero no se alimenta exclusivamente de la presa viva; con frecuencia se le ve cer. nerse sobre las montañas, buscando algun cadáver que devo. rar. En las montanias de Cachemira mate un gipacio, en cuyo estómago hallé varios huesos grandes y una pezuña de revezo.

Hutton asegura que el gipaeto de Asia se alimenta sobre todo de restos putrefactos, y que rara vez se apodera de algun animal viro mayor que una gallina. Hodgson es del inismo parecer, y Hume añade que la rapaz come en ciertas circunstancias hasta excrementos humanos.

\&u alimento, me escribe mi hermano Reinaldo, que le ha observado reintidos años en España, consiste en huesos, carne putrefacta $y$ animales vivos. Nunca le he visto posarse sobre cadáveres recientes; limitábase à pasar-á poca altura sobre ellos sin fijar siquiera su atencion en los cuervos, milanos y buitres que ya estaban comiendo. F.n tales casos cerniase algunas veces sobre el cadiver sin tomar parte en el festin. En mis cacerias de buitres he podido observarle todos lus dias: con f́recuencia pasaba solo á seis ú ocho merros de altura sobre el cadíver cerniéndose tres ó cuatro veces, pero runca bajaba hasta tocarle, ni tampoco se posaba en una roca próxima. Cuatro ó cinco dias seguidos le aceché desde la mañana hasta la tarde, absteniéndome de tirar sobre los bui. tres $\delta$ las águilas que se presentaban para no ahuyentar $a !$ gipaeto: pero siempre observe lo mismo. En las montañas del centro de España, como por ejemplo en la sierra de Guadarrama y en la de Avila, se le considera como una ra. par poderosa; pero yo no la he visto nunca coger un animal vivo, y si he observado que pasaba sobre los rebaños de cabras sin mostrar la intencion de atacar â un cabrito. No me he detenido a inquirir si hay algo de cierto en las noticias de alguros cazadores de la España meridional, los cuales aseguraron á Lilford que el gipacto barbucio precipita \& los capricornios en los abismos para alimentarse de sus huesos, despues de haber devorado la carne los buitres. En su nido he hallado carneros cubiertos aun de lana y piernas de cordero, lo cunl induce s. suponer que cogió estos animales vi- 
vos, pues el pastor español no sucle abandonar un animal á los buitres sin quitarle antes la piel.y

En vista de tantos datos conformes en casi todos los puntos, diricil es aceptar como veraces los cuentos que los natu. ralistas suizos han propagado sobre la fuerza, el atrevimiento y rapacidad del gipaeto. Por el estilo de esos cuentos son las. historias de Steinmueller, quien dice que un gipaeto barbudo intentó precipitar á un buey desde una roca; que otro se llevó un cabrito de un año por los aires á pesar de los esfuer. zos del amo, cuyos ataques rechazó; que un tercero dejó caer desde las rcegiones aéreas una cabra que pesaba quince libras; un cuarto se llevó una trampa de hierro de veintisiete libras de peso á una montana muy alta; un quinto fué muerto en el aire por una zorra que habia atrapado; un sexto arrebató un niño á presencia de sus padres; y un séptimo, en - fin, ar. rastró una niña de ire's años, Ana Zurbuchan, á una distancia de cuatrocientos pasos, y solo la llegada de un hombre, atraido por los gritos de la criatura, inipidió que la devorase, perro la victima quedó herida en el brazo izquierdo y en la mano.

Si Girtanner no hubiese referido hiltimamente el caso de haber acometido un gipaeto barbudo $h$ um muchacho de cier. ta edad, no tendria ningun reparo en calificar de fabulas todas estas historias, considerando al gipaeto barbúdo como un pernóptero de mayor tamaño, es decir unave de rapiña sin fuerza, cobarde y mal dotada, tanto fisica como intelectualmente, un ave que solo en ciertas ocasiones coge un vertebrado vivo cuando es débil, pero que por lo regular se ali. menta de huesos y otros despojos animales Sin embargo, como aprecio mucho al citado naturalista y le tengo por un observador concienzudo, no debo pasar en silencio su des. cripcion, por dificil que me sea creer en su exactitud.

QI cuestion sobre el régimen alimenticio del gipaeto bar. budo de los Alpes, dice Girtanner, cuyas noticias reproduzco en extracto, tanto por lo que hace a la clase de las sustancias de que se alimenta como á la manera de apoderarse de ellas, es el capitulo mas discutido de su historia natural. Consta que devora cadáveres en putrefaccion: en esto resultan conformes todas las noticias; y la prueba mas evidente, si no queremos hacer deducciones de su conducta en cautividad para aplicarlas a su vida libre, es que las trarnjas siempre tienen por cebo carne podrida, yue se ha ericontrado muchas veces al ave sobre cadáveres en putrefaccion. Un caza. dor de Graubuendin mató un individuo viejo posado sobre una ternera muerta que estaba al pié de una roca escarpada; ia rapaz habia arrancado ya los ojos, ocupábase en abrir el vientre del animal con toda la fuerza de su ganchudo pico, cuando la bala le tendió muerto sobre el cadáver. En cuanto á la ternera, habianla visto parer poco antes en-la superficie de aquella roca. Varios gipaetos han sido muertos sobre ca. dáveres de gamuzas, llevándose el cazador como buena pre. sa el cuadrípedo y el ave. El gipacto libre comienza siempre á destrozar por la nuca los mamíferos pequeños que coge: despedázalos con su pico $y$ los sujeta con uno $\delta$ los dos piés; si los animales son grandes procede como ya hemos in. dicado.

DEl hecho de que deja caer los grandes huesos ciesde una altura considerable para romperlos sobre las rocas, hecho de cuya veracidad se dudó mucho, ha sido, confirmacio repetidas veces del modo mas evidente en Graubuendin. Solo cuando el gipaeto barbudo de los Ajpes no consigue coger una presa visa vuelve en busca de los animales que mató o de los cuerpos hallados antes, los cuales devora completa. mente.h Nuestro cazador del Tesino vió en invierno como un gipacto fué à buscar al cabo de ocho dias un animal muerto, puesto como cebo, al qque se dirigió en linea recta desde muy léjos, guiado por el olfato ú por la memoria que conservaba del sitio. Una vez sobre el cadáver, al que no se acerca sin adoptar ciertas precauciones, cébase en él, seguro de no ser molestado; pero si es tan cauteloso tratándose de un cuerpo putrefacto, muéstrase en cambio muy atrevido cuando e! hambre o la necesidad le apuran. «Asi, por ejemplo, me escribe Manin, cicrto dia, durante una furiosa tempestad de nieve, ví á un gipaeto viejo saltar en medio del camino cuando solo me hallaba á quince pasos de distancia El sitio donde sucedió esto hallábase inmediato á una casa en que el mismo dia se habia matado un animal doméstico, y donde el ave encontró probablemente huesos, intestinos ú otros despojos. En nuestras regiones prefiere los cuadrúpedos pequeños muertos por fl mismo, como por ejermplo liebres, marmotas, gamuzas y cabras recien nacidas ó pequehis, corderos y cochinillos: en general agrádanle mas los animales salvajes que los domésticos. Cuando encuentra ta. les mamiferos, cuya caza no le cuesta muchos esfuerzos, con. téntase con satisfacer su apetito como mejor le parece; mas si no lo consigue, ni tarnpoco encuentra un cadáver, cl hambre y el instinto de propia conservacion le obligan à atncar y vencer animales vivos de mayor tamaño, como carneros, cabras, gamuzas, zorros, terneras, etc. Todas las noticias que sobre este punto he obtenido de observadores concien. zudos están demasiado conformes para que yo pueda po. ner en duita el hecho. Los mismos observadores convienen tambien en que el gipacto barbudo de los Alpes no podria nantenerse exclusivamente de cadáveres y mamiferos peque. nós. De las liébres se apodera ahuyentandolas de la maleza o de los abetos enanos para cogerlas en terreno descubierto, ya volando sobre ellas $\delta$ bien aturdićndolas antes de un alctazo. Segun la seguridad que ofrezca el sitio, devora la presa en seguida ó la lleva á su nido ó al lugar que elige para el descanso. En la caza de las gamuzas, de los corderos, etc, adultos se sirve primeramente de sus alas $y$ no de las garras. El águila, recogiendo las alas, precipitase como una bomba desde la altura soure su victima, se coge á ella con sus garras y la mata por sofocacion; pero el gipaeto barbudo suele atacar siempre muy de cerca. Nuestro ob. servador del Tesino dice lo siguiente, refiriéndose á sus propias observaciones: "Cuando el gipaeto barbudo distingue, con su penetrante vista, un animal en el suelo, $y$ le parece á propósito para devorarlo, no se precipita como una piedra desde las alturas, á la manera del águila real, sino que se acerca describiendo anchos círculos. Muchas reces se posa primero en un airbol ó en una roca, y no comienza el ataque hasta despues de haberse remontado otra vez á poca altura. Cuando ve gente por los contornos produce ruidosos graznidos y se aleja. No ataca nunca á los animales qque pacen en el valle, léjos de precipicios; pero si observa una gamuza que se halla cerca de un barranco, acúrcase rápidamente por detrás, y ahuyéntala con poderosos aletazos hasta que, atur. dida del todo, huye hácia la pendiente. Solo cuando ha logrado este fin acumula todas sus fuerzas en las alas: por ambos lados, las duras rémiges golpean con gran estrépito á la victima espantada y casi ciega, que en sano intenta defenderse con sus cuernos del asesino. A1 fin se atreve a saltar $\delta$ da un paso en falso: precipítase à la profundidad ó cae exhausta y rueda moribunda al precipicio. El gipaeto barbudo sigue Jen. tamente á su víctima, la remata en caso de necesidad con las alas y no con el pico y comienza en seguida a destrozar el cadáver aun caliente. Cuando un carnero ú otro animal se. mejante, $\delta$ bien un perro de caza se encuentra en un sitio muy escarpado sin echar de ver â la rapaz que se acerca por detrás, la lucha dura regularmente muy poco tiempo. Dando algunos fuertes alctazos, dirigese en linea recta hácia la vic. 
tima sorprendida y la echa al primer choque a la profundidad ó la arranca volando con el pico ó con las garras por fuera de la márgen de las rocas, la deja caer y destrozarse en el precipicio. Conforme con esto Baldenstein, me escribe lo siguiente: «Cierto dia, despues de cazar, hallábame conver. sando por la tarde con un pastor, cuando su perro comenzó à olfatear cerca del precipicio que se hallaba á poca distancia. De repente resonó un aullido del perro, y en el mismo mo. mento vimos al fiel vigilante de las manadas en el aire encima del precipicio, mientras que su asesino, un vicjo gipaeto barbudo, cerniase triunfante sobre su victima. Poco antes no habiamos fijado nuestra atencion en el perro ni lampoco en el ginaeto, hasta que el extraño grito del noble animal nos hizo mirar hácia aquel sitio. Sin aquella voz de terror, habria des. aparecido de un modo misterioso, sin que nos fuese dado explicar el hecho, aunque seguramente hubieramos sospe. chado la causa de su muerte.

\$ El vultúrido descendió rápidamente sobre su presa y desapareció con ella por delante de nosotros. Todo esto sw. cedió con mas rapidex de la que se necesita para contarlo. No puedo decir si el ave precipitó á su victima en el abismo mas por la fuerza de sus aletazos que por la de sus picoiazos, pues segun he dicho, el perro se hallaba ya en el aire cuando su aullido llamó nuestra atencion. En cambio, sé con seguridad que aquel gipaeto no atacó á ninguno de mis perros mientras, léjos del precipicio, buscaban en terreno llano, si bien se le vió cerniéndose sobre ellos. El gipaeto barbudo no acomete to mismo que el águila. Saratz tuvo ocasion de ver por sus propios ojos cómo este gipacto ataca y vénce á las gamuzas, aun à las adultas. aCierto dia, dice, en oca. sion de hallarme observando desde mi casa las gamuzas en su marcha, vi de pronto cómo un poderoso gipacto, precipitándose sobre las ancas de uno de aquellos cuadrúpedos, descargóle algunos rápidos aletazos que le derribaron por tierra, donde en seguida comenzó à destrozarle á picotaros. En una de mis cacerias vi una vez un pequelio grupo de ga. muzas que aranaando á lo largo de un angosto témpano de hielo, y conducidas por la hembra de mas edad, dirigianse hâ. cia la cima de la montana. La hembra se detiene de pronto; todas las demás gamuzas la imitan, y en un momento forman circulo, poniendo las cabezas en el centro. Lina mirada hicia la altura me reveló la causa de can brusea detencion, pues vi que sobre ellas se balanceaba algo en el aire; un anteojo me permitió reconocer que era un gipaeto barbudo. El ave se precipitó en linea diagonal por detràs de las ganuzas; pero estas la recibieron con sus cuemos, obligíndola à desistir de su ataque. Cuatro veces repitió su acometida, y â la quinta elevóse á una gran altura, hasta que solo se la vió como un punto perdido en el cielo; solo entonces dispersá. ronse los cuadrúpedos asustados, dirigiéndose a la castera a una roca saliente, bajo la cual se refugiaron, fijando sus miradas en los aires. En esta posicion permanecieron hasta que el crepúsculo vespertino las tranquilizó del todo. Otro cazador de Graubuendin refiere que una vez un gipacto barbudo que á poca distancia de 4 se precipitó sobre una gamuza, hizo inútiles teniativas para desperiarla \& fuerza de aletazos; su ataque ordinario tuvo esta vez mal éxiro, porque el astuto cuadrúpedo, en vez de huir hácia la pendiente, dió algunos saltos atrevidos á ticmpo, refugiándose en la ca. vidad de una roca, donde rechazó valerosamente con los cuernos todos los ataques, sin abandonar su segura posicion. Un caso del todo semejante ocurrió en el Tesino. Todas estas noticias provienen de los montaneses del territorio de los Alpes, donde el gipaeto barbudo vive aun continuamente: de hombres que no saben distinguirle perfectamente del aguila rêal, y á los cuales no se inducirk nunca á dejar de creer lo que ellos mismos han visto en pleno dia con sus propios ojos. Desde hace mucho tiempo se ha creido que el gipaeto barbudo osa tambien atacar al hombre con la inten. cion de matarle: este aserto se calificó generalmente de iabula; pero algunos le consideraron como un hecho positivo, o por lo menos posible. Los ejemplos de haber sido arrebatados ninos pequeños por grandes aves de rapiña, que solo podrian ser en nuestros Alpes el aguila real ó el gipaeto, han sido confirmados con demasiada seguridad para que se pueda dudar de la exactitud de los hechos;y no comprendo muy bien porqué el culpable lia de ser siempre el águila real, ni me explico tampoco porques el gipaeto barbudo no lua de cometer las mismas fechorias. Sabido es que se atreve con las gamuzas aduitas, mas capaces de resistirse que una criatura, y puesto que las vence casi siempre, mas fácil le seri apoderarse de un débil sér cuando se le ofrece la ocasion de precipitarse desde las rocas, donde con harta frecuencia se permite jugar a los niños de la montaña. Sin temor de enga. narnos podriamos acusar de tales fechorias a las dos rapaces, pues tambien el gipacto barbudo intenta llevarse la presa cuando por cualquiera razon no puede comérsela en el mis. mo sitio donde la cogió. Cuando el peso de la victima es superior á su fuerza, á causa de su tamaño, sicmpre le queda el recurso de dejarla caer, como se ha observado muchas veces. Mas fundada y mas comprensible es la duda sobre el hecho de que nuestro gipaeto barbudo se atreve tambien con hombres medio adultos, intentando matarlos de uno 6 de otro modo. Se conocen muy pocos ejemplons de tales ataques, con 6 sin ningun Exito, que no diesen lugar à las du. das mas justificadas; sin embargo, la veracidad de aquel caso ocurrido en los alrededores de la Silbernalps, donde, segun se dice, un gipaeto barbudo precipitó a un pequeno pastor desde una roca al abismo y comenzó á devorarle, pa. rece muy posible, por haberse confirmado últimamente un suceso análogo en el pais superior de Berna. Este último caso del ataque de un gipacto barbudo contra un hombre casi adulto aconteció en el ano corriente, y por lo mismo no es ninguna historia anticuada; he practicado todas las diligencias posibles para obtener la confirmacion del hecho ó probar que la noticia es una invencion.

e En junio de 18 ;o se pudo leer en varios diarios suizos que cerca de Reichenbach, en el canton de Berna, un niño habia sido atacado por un gipacto barbudo y que seguramen. te hubiera muerto á no haberse logrado ahuyentar á tiempo al ave. Al principio hice poco caso de esta noticia, esperando que el gipaeto barbudo se transformaria pronto en un águila 6 en un gavilan y el niño atacado ẹn un polluelo; pero esia vez no se desmintió el heclio, y como el asunto tenia bastan. te interes para mi, dirigime al señor Haller, cura protestante en Kandergrund, cuya amabilidad me era ya conocidas lil naturalista refiere a continuacion cómo el citado cura le diri. gió à otro colega, cl senor Blaser, quien despues de algunas dilaciones le refirió el caso siguiente: $4 \mathrm{El}$ a de junio de $18 \% 0$, ś eso de las cuatro de la tarde, el muchacho en cuestion, Juan Betschen, jóven alegre, de catorce años de edad, pequeño aun, pero de estructura robusta, se dirigió desde Kien hácia Aris Kien esta situado en el fondo del valle, cerca de Rei. chenbach, en el ángulo que forman los rios Kander y Kien; Aris se halla a unos 150 metros de altura en una grada de la pendiente. El camino que el muchacho seguia condújole \& unas praderas recien segadas, y cuando hubo llegado a un pequeño pasto a mil pasos de distancia de las casas, fue aco. metido de pronto, cuando menos podia esperarlo. El ave se precipitó con una fuerza terrible por detràs del muchacho, envolvióle la cabcza con ambas alas, lo cual le produjo una impresion como si le tocasen dos hoces, y ya el primer golpe 
le derribó aturdido en tierra. Al caer, volvióse el muchacho para ver quién le tapaba tan bruscamente la cabeza; pero fué acometido por segunda vez con ambas alas que casi al mismo tiempo produjeron un zumbido á izquierda y derecha de la cabeza, privénciole casi del conocimiento. El muchacho pudo reconocer entonces el ave enorme, que por tercera vez se precipitó sobre él, clavándole las garras en el costado y en el pecho; con sus répetidos aletazos privóle casi del aliento, y comenzó en seguida á golpearle la cabeza con el pico. A pesar de los movinientos de las picrnas y de todas las evoluciones del cuerpo, el muchacho no logró ahuyentar al ave; concenirando toda su fuerza en los puños, procuró parar con uno de ellos los picotazos, mientras que con el otro golpeaba á su enemigo. Esto debió producir su efecto, pues el ave se elevó súbitamente sobre el niño, quizás para repeír el ata. que; mientras que aquel comenzó á gritar con todas sus fuerzas. No se sabe si estos gritos retrajeron a la rapaz de renovar el ataque, ó si la presencia de una mujer que acudia, atraida por los gritos, haria desistir al ave de su empeño; pero el caso es que en vez de precipitarse de nuevo sobre su victimn, desapareció rápidamente por detrás de un declive. El muchacho estaba tan desfallecido y atolonúrado por el miedo y el terror, que apenas podia moverse; la mujer se acercó cuando se levantaba aturdido y sangriento del suelo, y ya no vió al ave. A pesar de todo, podria dudarse de la exactitud del hecho; pero yo le tengo por veridico. Juan Betschen, que nunca habia oido hablar de semejantes aves, no pudo inventar y describir minuciosamente tal lucha, cuyos detalles refirió a su salvadora, asi como \& las personas que, ya cerca de las casas, le lavaron y vendaron las heridas. Tanto el muchacho como su familia me merecen entero crédito; y en ruanto á las heridas, que so mismo examine poco despues, consistian en tres considerables rasgunos en el occipucio, que penetraron hasta el cránco; en el peclio y en los costados vi marcadamente señales ayuladas y sangrientas producidas por las garras; y la pérdida de sangre habia sido considerable, tanto que el muchacho estuvo muy débil du rante ocho dias. En mi opinion no se puede dudar de la exactitud del relato y de la reracidad del hecho. Pero zeóno - averiguar del niño, que nunca habia visto tales aves, y sobre todo despues del espanto que le infundió la lucha, si suagre. sor fué un águila real 6 un gipaeto barbudo? Comencé $\{$ in turrogarle y me contestó lo mejor posible. Recordaba particularmentc el terrible pico corvo, en el cual vió, al elevarse el ave, algunos de sus cabellos y su sangre; parecióle que tenia tambien un anillo al rededor del cuello, $y$ lns alas man. chadas de puntos blancos, chocandole sobre todo unas cerdas crizadas debajo del pico.

El cura sometió al muchacho á un exámen, del cual nos habla Girtanner brevemente. Despues de enseñársele varios grabados, resolvióse ir con ál á Berna; y conducico al primer museo, no reconoció en el aguila real a su adversario; pero al ver un gipaeto barbudo jóven comenzó \& vacilar, porqque el ave le parcció semejante á su enemigo, por la forma y el tamaño del pico, asi como por las cerdas, pero no por el co. lor de las plumas. Cuando al fin se le condujo ante un gipae. to barbudo aduito, exclamó apenas le vió: Este sí que es! Reconozco el pico, las manchas blancas, el anillo al rededor del cuello, y tambien las cerdas. El muchacho no dudó ya que un gipacto barbudo, de cuello, pecho $y$ vientre amarillo, habia sido su adversario.

"Yor pocos que sean, afortunadamente, los casos en que el gipaeto barbudo ataca al hombre en general, y sobre todo á los niños, continúa Girtanner, no dudo, por lo menos, que estos ataques ocurren, y cada cual puede creer en este punto lo que quiera; pero no consta ningun caso de que el gipacto barbudo haya atacado tambien á los hombres adultos con la esperanza de vencerlos, ó los haya precipitado en un abismo 6 dado muerte de otro modo. Sin embargo, los cazadores, viajeros y pastores que estando en un sitio peligroso de la montaña oyeron de pronto los aletazos de la poderosa ave, que con la rapidez del rayo pasó por encima de ellos en di. reccion al precipicio, no quieren creer tampoco que solo la casualidad condujo al ave por tal sitio. Podria citar datos que me han dado hombres como Baldenstein, verdadero cazador montañés y además observador concienzudo, refrriendo inci. dentes en que se describe de un modo conforme lo terrible de semejante situacion en los parajes solitarios; pero como ya he dicho, faltan ejemplos de haber ocurrido desgracias debidas verdaderamente á tal causa. A pesar de esto, aun los mas propensos a la duda no se atreverán á considerar el mal éxito de los ataques repetidos del ave como consecuencia de su debilidad y estupidez.

Nuestros conocimientos sobre la reproduccion del gipaeto barbudo se han ampliado estos últimos años con las noticias de varios observadores. 'lodos están bastante conformes en que esta ave, asi como otras especies de su órden, incuba repretidas reces en el mismo nido y tambien en medio de otros vultúridos. Un nido visitado por Lilford en España habia servido desde tiempo innemorial, segun aseguraban los habitantes de los pueblos inmediatos. El gipacto barbu. do, 'lo mismo que otras aves de rapina, suele clegir una es. paciosa cavidad de la roca, en un punto casi siempre inacce. sible; pero segun dice mi hermano, puede suceder tambien que anide apenas á diez metros de altura sobre el suelo. Hasta ahora no se sabe si esa rapaz construye por si misma el nido, S si ocupa solo el de otra ave de rapina; ni tampoco hemos averiguado con seguridad si la pareja ocupa todos los anos el mismo nido 6 si cambia entre varios. Segun las observa. ciones de Girtanner, en Suiza elige una roca inaccesible y desprovista de vegetacion, situada à bastante altura en la montaña, prefiriendo las que tengan una saliente que pueda servir de techo á una cavidad espaciosa. Un cazador de quien hace mencion Girtanner, aseguraba haber encontrado un nido sobre tres encinas mutiladas que esiaban muy próximas y junto à una gran roca $\mathrm{Ya}$ en los últimos meses del año el ave visita con regularidad su nido, pues en enero, ó mas tarde en los primeros dias de febrero, empieza la incu. bacion. La major parte de los casos conocidos demuesiran que la hembra pone regularmente un solo huero; pero Saratz dice que en el nido situado cerca de Camogask se vieron desde la roca opuesta, primero uno, y despues dos polluelos, con $10^{\circ}$ cual está conforme una noticia de Adams, de que mas tarde hare mencion. I.os huevos son grandes, redondeados, muy granujicntos, de color blançuirco sucio, con man. chas mas ó menos extensas, a veces de color ceniciento ó gris rojo, mezcladas con otras amarillas, $\delta$ rojo pardas, mas espesas por debajo, $\delta$ al rededor del centro del huevo. No se sabe cuánto tiempo dura la incubacion; los polluelos se ven á primeros de marzo, ó lo mas tarde en abril, tanto en Suiza como en el mediodia de España $y$ en el norte de Africa.

Creo que mi hermano es cl primer naturalista que pudo examinar un nido de gipneto: hallabase situado en un cinto pedregoso protegido contra lós ravos del sol por una roca saliente, fo unas cincuenta brazas del suelo; pero se podia llegar fảcilmente. El nido cra muy grande; su dímeiro scria de $I^{2}, 60$ y su altura de I metro; la excavacion central media $11^{\prime \prime}, 60$ de dímetro y $\left(1^{\infty}, 14\right.$ de profundidad. El armazon se componia de ramas largas cuyo grueso variaba entre el dedo pulgar y el brazo de un niño; seguia luego una delgada capa de ramitas en las que estaba formada la crcavacion ceniral, 
cubierta de fibras de corteza, pelos de raca y crines de caballo. Ios alrededores de la roca estaban cubiertos de una espesa capa de excrementos de color blanco de nieve.

Simpson visito otro nido en Grecia: Krueper nos dice que se compunia de fuertes ramas, que era plano y estaba rellero de pelos de cabra: en el centro habia un gipacto de tres semanas, rodeado de una gran cantidad de huesos, de un pié de asno entero y de abunoantes tortugas. l.os padres se acercaron luego; lanaaron sibidos semejantes á los de los pastores, y estaban sumamente agitados; pero no osaron aco. meter á Simpson, ó por lo menos, no dice Krueper nada de cllo.

$\checkmark$ ease ahora lo que refiere Adams acerca de un tercer nido que halló: En Himalaya, dice, anida el gipaeto sobre las rocas, en lugares inaccesibles: el periodo del celo comienza en abril ó mayo. En los alrededores de Simla vi un nido con dos hijuelos en la caverna de una roca á pico; alrededor habia una gran cantidad de huesos de carnero y de otros ani-
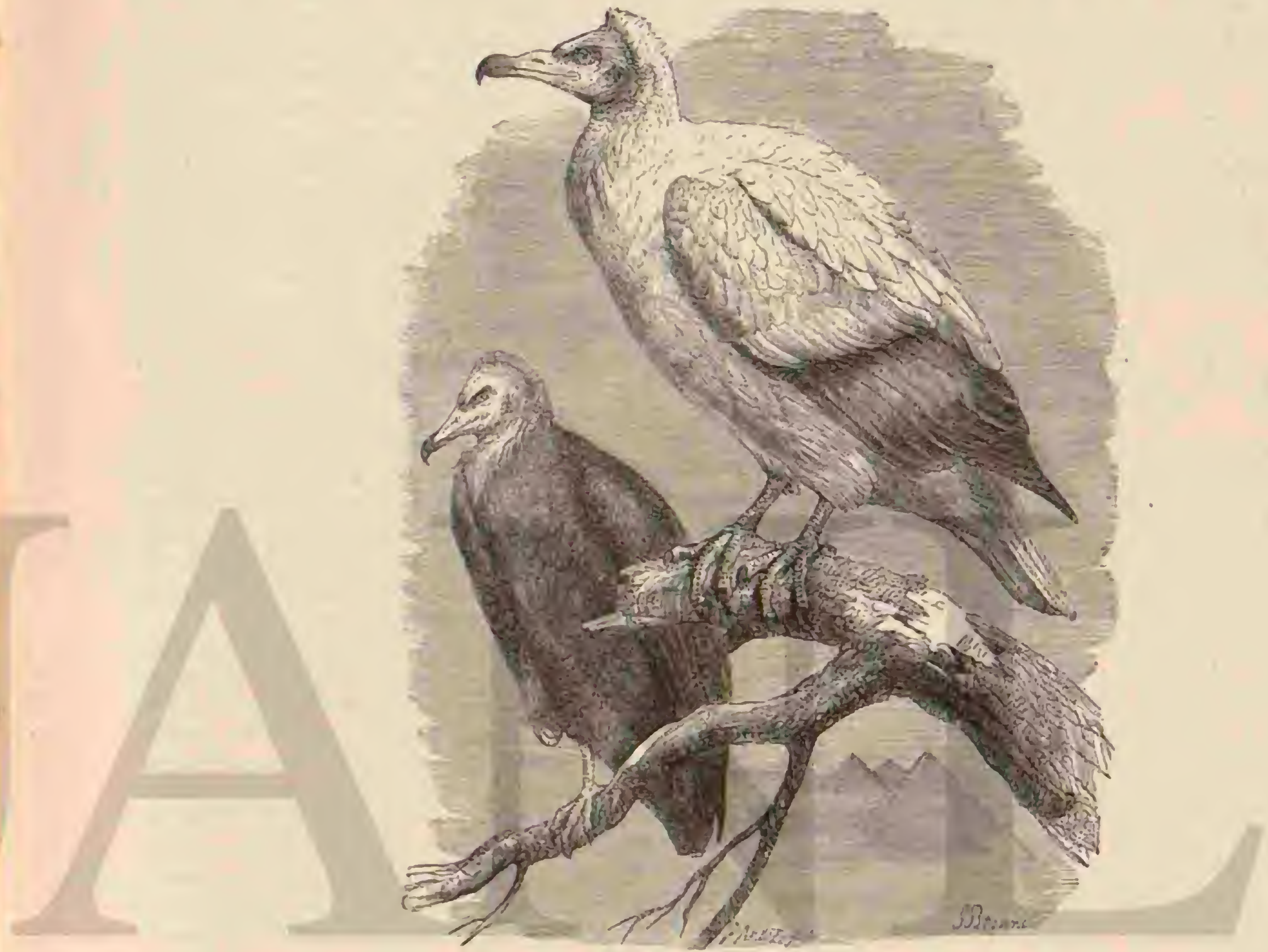

Fig. 173. - EL NEOFROX SHONge

males; cran restos procedentes de un establecimiento euro. peo situado á pocas millas de alli.

Exceptuado el hombre, el gipacto tiene pocos enemigos; pero le atormentan muchos animales. Mi hermano vió un dia á varios seudactos perseguir á una de estas rapaces; segun fdams, el govinda y el anomalocorax son los que mas le hos. tigan: Simpson anade que los pequeizos halcones le acometen y ascdian á menudo.

CA Z.A. - Ya se comprenderś que la de esta ave es de las mas dificiles: á no mediar una feliz casualidad, no se puede tirar sobre ella sino al acecho. situándose cerca de su nicio ó de algun resto animal que sirva de cebo; en Suiza vierten sangre sobre la nieve pam atract à la rapaz Úna vez herido, no intenta nunca el gipaeto decenderse contra el hombre; li. mitase s. erizar las plumas y abrir el pico, y aun trata de coger L su adversario; pero se le domina mur pronto. Tiene mu. cha resistencia vital, y se necesita un tiro muy certero para matarle. Yo disparé una ve\% sobre un individuo, y la bala le destrozó el higado saliendo por la region lumbar: el ave cayó átierra, y sobrcivió aun treinta y seis horas à su herida. Tasso III
Tambien se puede coger á esta rapaz por medio de trampas, con cebo de carne.

CAUTIVIDAD. - Se ha observado á menudo al gipaeto cautivo, y se ha visto que se conduce lo mismo que cuando está libre: a principios de narzo de $1 \$ 57$ recibió mi hemano un individuo jóven; habianle cogióo dos pastores, que se lo dieron á un carnicero para que lo alimentase; al ayode. rasse de el, comenzaron á volar los padres alrededor; pero no acometieron, bastaron algunas pedradas para ponerles en iuga.

Cuando le vi por primera vez, dice mi hermano, era muy torpe; no podia tenerse en pis, y para levantarse tenia que apoyarse desde luego sobre los tarsos, ó sobre el vienire. To. maba con el pico los pedazos de carne que le daban; Jan. zábalos al aire, los recogia con mucha destresa y se los tra. gaba. Si se le introducian por fuerza en el buche hucsos puntiagudos ó de ángulos salientes, hacia esfuerzos para vomitar, hasta que lograba expelerlos.

》 Ie deje aun cierto tiempo en casa de su antiguo propietario; jero como todas las semanas me llamaban al pue. 
blo mis deberes de médico, no dejaba de visitarle á ne. nudo.

\& Habianle puesto en un patio pequeño y mostrabase ale. gre cada ver. que su amo le hacia una visita, manifestando su satisfaccion con ruidosos gritos. J)uranie d dia le ponian al sol: gustábale entonces extender las alas y la cola; se echa. ba apoyado en el rientre, alargaba las patas y permanecia inmóvil asi durante horas enieras, dando seinales de la nayor satisfaccion.

$\$$ Al cabo dé un més pudo ténerse un pié y comenzó á beber; con una pata sujetaba fuertemente la vasija que le daban; sumergia su pico en el agua, echaba viramente la cabeza hacia atris, lanzaba de su garganta una gran cantidad de liquido, y cermar el pico despues, lebja como los buitres y los avestruces, bastándóe cuatro ó scis sortios para ajugar su sed.

* En aquel mornemto procuraba dar picotazos en las nua nos y los piés de cuantas personas le rodeatan; pero nunca hizo daño alguno álsu amo. All cabo de un mes le llevé Murcia: tenia entonces todas sus plumas: las del collarin co menzaban a crecer; tenia la cola bien formada, pero no al canzaba aun todo su largo. Le puse en una gran jaula, a la que se acostumbró fácilmente; pero en los dos primeros dias no comió ni bebió mas que agun: al cabo de este tiempo tuvo hambre, y aunque le di hucsos y restos de gallina, no tocó nada. Entonces quise introducirle por fucra un hueso en la gargania, y lo vomiso en seguida; hasta mucho despues no quiso comerlos. 'Tragaba con avidec la carne fresca de carncto y de vaca, Despuses de haber comido la primera vez en su nireva jaula, echóse sobre la arena para descansar y calentarse al sol.

- Algunos dias le bastaron para llegar á conocerme como a su amo: me contestaba, acudia á mi llamamiento, y dejábasc acaricjar y coger por mi, mieniras que erizaba su plu. maje si se acercaba alguna persona desconocida Parecia que protesalua un odio particular it los campesinos que llevaban el rraje del pais: cicro dia se precipitó gritando sobre un' muchacho a quien habia dado yo el encargo ie liuiptar la jaula, obligándole á retirarse if fueria de picotazos; otra vez desgarró la chaqueta y el-pantalon de un labrador que entró en mi cuarro. Cuando se acercaban un gato ó un perro, erizaba sus plumas lanzando gritos de colera; mas apenas oia ıni voz, se ajuroxinaba ál enrejado y manifestaba su con. tento de diversos modos; pasaba el pico. por las varillas y jugueteaba con mis dedos, sin hacerme nunca dano, aunque se los introdujera en la boca. Cuando le dejaba salir, mani. festaba una gran alegria, y paseándose alrededor del patio, alisaba sus piumas, tratando de volar.

3 De ver en cuando le limpiaba la extremidad de las pennas, porque las ensuciaba continuamente. $\Lambda$ efecto, le in. troducia eñ un cubo y le ragaba, bario yue le era muy desagradable, pues cada ver que se repuetia, agitíbase como un furioso. No tardó en reconocer el cuboy temerle. Cuasdo su plumaje estaba seco, parecia hallarse mas aे su gusto, y agradabalc que le ayudasen à poner sus plumas en órden.

$\$$ Vivió así hasta fin de mayo: comia solo carne $y$ huesos, mas no pajaros: le di palomas, gallinas, perdices, patos, tor dos y chovas, y no tocó jamis a ninguna de esias especies, por mucha hambre que tuviése. Si le introducia por fuerza carne de pajaros en el piico, con y siu las plumas, la romi. taba al momento; pero en cambio, devoraba la de toda es. pecie de mamiferos: estc ensayo, repeticio varias veces, me dió siempre los mismos resultados.

A fines de mayo proporcione a mi farorito, pues ya lo era, un companero de cautividad: un campesino me envió á decir que habia cazado un riguila real, que tenia el ala rota y que me la venderia si deseaba comprarla lo rehusé porque me bastaba un ave de rapiña; pero el campesino volvió y me trajo la madre de mi gipaeto; preguntéle cómo pudo cogerla y me contestó que su hija le dijo dias antes, que detrás de la casa, y sobre una roca, habia un hombre embozado en una capa negra, el cual permanecia inmóril. El buen hombre cogió la escopeta, dirigióse al sitio, y á cien jasos de distancia vió el gipaeto en una caverna, piotegida contra los rayos del sol; hizo fuego sobre él, y de un balazo le rompió un ala por la arriculacion del carpo. Herida el ave, echóse sobre el lado sano, y manifestaba su cólera abriendo el pico y erizando las plumas del cuello. Si se acercaba aiguno, se guia con la vista todos sus movimientos, tratando de dar picotazos; y sujetaba iuertemente lo que una vez habia cogido.

Comencé por cortar el ala al ave herida, operacion que la enfureció; mordia todo lo que alcamzaba, y serviase de sus unias con destreza. Despues la puse con el gipaeto jóven, y al momento se echó sobre el suelo de la jaula. El pequeño dió vueltas a su alrededor, sin conseguir llamar su atencion; luegro le presentamos carne y no tocó a ella; a la mañana siguiente se sostenia ya sobre sus patas, $¥$ al otro dia solté a las dos aves en el patio. El gipacto viejo andaba con mesu. rado paso, pendientes las plumas de las nalgas, levantada la cola y el pico abierto, sin fijar al parecer su atencion en todo la yue lel rodeaba. Habiéndole dado agua, acudió cl mas jóren y comenzó á beber, y al verio el otro, dirigióse tambien hácia la vasija, y apagó su sed con visible compla. cencia. Poco despues estaba ya mas contento, y tragó la carne upe le/pusieron en el pico, y que no habia querido antes; mas no tocó la de las aves, ni se pudo conseguir munca que comiese el mas pequeno pedazo.

- Bren pronto se disipó su cólera: eligió en la jaula una prominencia dée lá pared y fijó alli su domicilio. Esstaba todo el din en el mismo lugar, sin hacer caso de lo que pasaba a su alrededor, ; cuando se le ponia en el patio, ajresu. rábase á volver al su.sitio: al cabo de pocos oias pude acariciarle.

r. Poco tiempo despues proporcioné à los dos gipaetos la compania de una chova: no hicicron aprecio al parecer del recien llegado, y este no tardó en cobrar confianza y envalen. tonarse: rechazaba à jicutazos \& los gipactos cuando se acercaban á su abrevadero, sin permitirles llegar hasta que habia apagado su sed; tambier les quitaba los pedazos de carne que iban á comer. Las dos rapaces se sometian a tales exigencias, y esperaban, mirando con estujudos ojos, hasta que la chova acabase de beber, avanzando luego timidamente para hacer lo mismo. Parecia que aunuellos gipaeios eran de indole nuy afable: cuando estaban sobre'ta percha mas cle. rada de su jaula, podia yo pasar por deuajo de ellos, sin que tratasen de lacerme daño, y aun el mas jóven se bajaba para prodigarme una caricia.

\$Algunos dias despues recibi un aguila leonada jóven, que tenia casi bastante fuerza para volar, y con ella dos pernópic. ros. Los gipaeios parecieron admirarse de ver á los recien renidos; pero no les hicieron ningun dano, y el jóren llegó á permitir, cuando se exiendió en la arena, que uno de los pernópteros se posara sobre su lomo. Introduje luego entre ellos un seudaeto Bonelli, s desde aquel momento, quedó turbada la buena armonia para siempre.

Sin embargo, esta última rapaz. iba a tener un adversario digno de ella: trajeronme otro pernóptero y un gran duque; estc último buscó al momento el rincon mas oscuro y tran. quilo; sus compaineros le miraron largo tiempo con curiosidad, y acercándose el jóven gipacto, contemplóle detenida. mente, y quiso tocar con el pico el plumaje de su taciturno 
compañero. El gran duque le descargó tan vigoroso golpe con su garsa, que le dejó estupefacio, y la rapaz, se retiró como adminda de aquel recibiniento tan brutal.

2Por la tarde se reunian todas aquellas aves en la percha: colocábase primero el iguila leonada; á su lado el gran duque y el gipraeto jóven; despues el permóntero, y en último término el gipaeto vicjo: el seudaeto Bonelli no se posó nunca. Mientras yo estaba en la jaula, permanecian tranquilos, mas apenas salia, el gipaeto jóven comenzaba a molestar a gran duque, recibiendo fuertes golpes á mda tentativa cie agtesion. Sin embargo, no renunciaba á sus atanues hasta que el gran duque se resolvia á posarse en el suelo de la jaula, donde encontraba al seudacto Bonelli. Entonces daba principio la lucha entre los dos prisioneros, los cuales se araniaban y armacaban las plumas, mieniras que las demás aves per. manecian iranquilas contemiplando la pelea

¿lil color rojo no impresiona \& los gipaeios, segun he po dido asegurarme varias veces. Velamme $\{$ menudo con una bata iorrada de colorado, y nunca parecian irritasse. Tampoco manifestaban ninguna inclinacion particular hácia los niōos, como dice Crespon al hablar del gipaeto de Cerdeña. Cuan do andaban sueltos por el patio pasahan à menudo cerca de los niños que jugaban, sin tocarlos nunca, ni dirigiries siquiera ına miradia. Solo cuando se les irriaba se ponian furiosos; el jóven, sobre todo, era menos sufrido; pero su cólera se desen. cadenaba lo mismo contra las personas mayores que contra los niños.

\$Por destracia se hallaba expuesta la jaula á los abrasadores rayos del sol de lispana. á lo cual se debió probable. mente que el gijneto vicjo enfernase y acabara por inorir de una infamacion de los pulmones: el jósen, los ires pernópte. ros y el seudacto, conservaron su sailud, y pude enviarlos á Alemania. En el camino padeció mucho el gipaeto por el calor, pues estaba siempre con el pico abierto, cual si necesi. tara aire frescu y agua; cada ve\% que sc detenia el coche, pa saba la cabeza por entre las rarillas de su jaula, como pidien do de beber, y cuando satisfaciames su deseo, nos dirigia una mirada de reconocimiento.

¿En la travesia se granjeó muy pronto el rarino de tocios los marineros, y recibió un alimento abundante de la cocina del bunque. Se le dejó á menudo libre en el puente, y nunca hizo ademan de probar la fuerza de sus alas

De otros informes sobre la vida en cautividad del gipaeto barbudo, el de Girtanner es el mas instructivo, por lo cual le reproduaco á continuacion en extracto. A fines de mayo de 1569 , el individuo cuidado por mi amigo duranic algunos meses fué cogido en cl canton del 'Tesino en una trampa de zorra. El hierro se habia clavado en la pierna por el tarso, aplastando completamente el iendon del dedo posterior, y como no se hizo la curacion cuidadosamente, este dedo se habia doblado Lácia adelante, de modo nue el pič quedỏ cojo en parte Fl ave, sana por lo demás, llegó al cabo de cos meses a manos de Cirtanner y excitó bastante interés en una exposicion muy bien arreglada de ares vivas de Suiza, que yo visité. La rapaz, se hallaba libre sobre un cajon acolchonado, y como todos los dias iban a veria centenares de visitantes, que ha inquietaban y espantaban á cada momento, vivia en continuo sobresalto; no tomaba alimento delante de foraste ros, respiraba ripiciamente con el pico abierto, dejaba pen. dientes las alas y la cola de un mudo poco agradable, y parecia por todo un ave enferma. Al principio erguiase al punto cuando se presentaba su guardian, cual si se preparase para la lucha; pero mas tarde no hacia ya caso de aquel.

A. princinio, dice Girtanner, crizaba contra mi las plumas de la nuca, presentando como una corona de rajos alreciedor de la angosta cabeza; mirabame furiosamente, corrienco con ternor 6 con ira de una parte of otra y adelantaha las alas con la iricncion de dar picotazos, cada liz que me acercaba á poca distancia ó hacia ademan de tocarla, creyendo sin duda que debia déienderse. Pronto perdió, sin embarge, su desconfinnza, gracias a un buen tratamiento; ya no erizó las plumas del cucllo, y reconoció en mi su guar. dian. Oprimiendo mucho las plumas del cucllo, de modo que este y la cabera parerian muy pequeños, hasta dejó tocarse las plumas del cuello ! del pecho. Entonces pude examinar la pierna herida, y el ave tambien lo permitio, pero cuando el tmtamiento le causaba dolor, dirigia algun picotazo s. la mano, aunque sin herir. Sin embargo, solo consintió que Girtanner le curase; rechazaba \& las personas extrañas apenas reconocia su intencion de tocarle el pié. Aun quince dias despues de estar en la exposicion conoció muy bien á su primer amo, tolerando de él todo cuanto permitia s Girtanner. Cuando estaba de muy buen humar dejaba â sus amigos rascarle la cabera, inclinábaia un pocoy miraba hácia arriba con los ojos entreabiertos, producicndo un ligero silbido.

Muy pronto se establecio entre el ave y su amo una gran confianza y familiaridad. Solo cuando Cirtanncr asustaba al ave inflamabanse sus ojos; los anillos oculares adquirian un colo: rojo de sangre, aumentando de volúmen, y levantaba tambien las alas con ademan amenazador, al paso que pre. paraba el pico prara descargar lin fucte golpe; pero algunas palabras cariiosas bastaban para tranquilizarle. Sin embargo, Girtanner luyo ocasion de conocer la fucrza poderusa de sus diferentes armas. Fil examen y el inatamionto ciel pié he. rido exigian á veces colocar al ave de cspalda; pero esio era decididamente lo que menos le ayradaba. Tan luego como veia hacer los preparativos necesarios para ello, su buen humor se convertia en furia mezclada de temor, y el naturalista y su auxiliar se veian obligados á deienderse con los puños de las garras y el fuerte pico. Al ierobrar de nuevo su liber. tad, el ave abria las alas y el pico, distriburendo ciegamente picotazos cn rodas direcciones; pero al fin rolvia a iranyuilizarse. Otra vey diú una prueba dé su fuera sin tener malas intericiones Girtanner y su auxiliar estaban ocupados en fijar en el suelo una fuerte rama corva destinada a servir de percha, cuando súbiamente se oyó el ruido de sus alas y en el mismo momento los dos hombres recibicton un golpe de los ingulos de las alas que lies hizo reiroceder algunos pasos. Cuando ambos se hubieron recobrado, riendose de su iemor, vieron con asombro al ave posada en el mismo sitio donde se queria clavar la rama. Solo una vez y parn defenderse alacó á su mismo amo, que al cxaminar la herida tocó probablemente alguna paric muy sensible. Con la rapjidez del raýa, y produciondo un agudo sillidio, dió un salio al aire, cesplegó las alas y dirigió un fuerte golpe hácia la cara de su guardian, comunicando at sus duras rémiges un poderoso empuje \&'or suerte, dice Girtanner, no hizo uso de su pico ni de las garras, lo que tambien le era dirici! en su posicion; on cambio, toda mi persona quedó cubierta por las plumas, que me rasparon la cabeza: entonces pucie figtrarme cudl habria sido mi sisuacion si en al momento me hubiese halindo en un sitio peligroso de la montana, cerca de un preci. picio, donde mi adversario hubiera podido emplear loda su fuera y su agilidad y donde el bambre le exciraria a repetidos ataques. En aquel instante no vi ni oi, y solo inienté porerme lo mas pronto posible fuera del alcance del furioso. Ahora estoy bastante convencico de la fuerza de sus alas; conozco el zumbido aterrador y los pinchazos de las rémiges.

Como sin duda estaha triste en su solizaria prision, alegrá. base mucho y visiblemente al presentarse su amo, al que por 
lo regular saludaba con un ligero silbido. Cuando se hallaba en el suelo elevibase en seguida á su percha para estar á la misma altura de su amo; tocaba con el pico la cadena del rełoj, empujándola de un lado å otro; examinaba á suamigo, y manifestaba de mil maneras su buen humor. Si se le pre. sentaba una paja, sujetándola con los dedos, tiraba de clla alegremente: agradábale mucho destrozar las cuerdas, y acu. dia jresurosa apenas veia is su guardian hacer los preparativos parn extenderlas entre las manos. Sabia servirse con mucha destreza de su pico, al parecer tan torpe: érale fácil, por cjemplo, recoger pédacitos de hueso ó de tuétano, del tamaño de un guisante, poniendo el pico de lado en el suelo; cogia los granos por las puntas y arrojábalos hácia la boca. Desgarraba en todos sentidos el fuerteacolchado de su cajón, sacaba la paja y entreteniase continuamente con ella.

No terniá á los perros, ni tampoco estos all ave; pero cuando se lo acercaban mas de lo qu ue creia convéniente, dirigiales algunos aletazos y picotazos. En cuantó á los gatos, prociedia con ellos exactamente del mismo modo indicado yá por Scheitlin. Girtanner tuvo la curiosidad de hacer él mismo la prueba. a.li fin, dice, entró uno de estos félinos en su apo. sentó, cuya puerta cerré al punto sin dcjornie ver. Apenas el gato diviśó á su enemigo, del cual éstabà no obstante se. parado por la reja, comenzó á maullar como nunca lo habia bido antes, manifestando un terror mortal; casi paralizado por el cspanio, arrastróse d hurtadillas por el suelo, hasta que, al fin, atreviéndose à dar un poderoso salto hácia una ventana alierta que se hallaba á bastante altura, desapareció sin volver la cabeza.

Cuando ya no le dolió el pié, el gipaetó preferia las piedras al acolchado para posarse. Muchas veces permanecia largo tiempo inmovil, en posicion muy incomoda al parecer, con el cuerpo inclinado y la cabeza recogida, $\delta$ echada hácia atrás, ó bien iendida, en cuyo caso formába una linea recta con el trónco y la colin Girtanner habia notado que le agra. daba echarse de noche sobre la paja y por eso le puso una caja llena de este material; apenas la hubo colocado en la jaula el ave acudió presurosa y se acomodó con gran contento en el interior. Desde entonces descansaba todas las noches en la caja, apoyándose completamente en cl esternon y los talones; colocaba la cabeza sobre el borde y dejabia la cola fuera. Cuando su amo quueria trashadarle a otro aposento, seguiale de cerca, $y$ si despues volvia á llamarla, acudia presurosa silbando alegremente. Delante de personas extrañas no se mostraba nunca tan familiar con su guardian. Bebia muchisima agua, y tambien-procuraba bañarse, pero no le cra po. sible lograr su fin, pues queria echarse del todo en el bebe. dero y su construccion no se lo permitia. Girtanner le mojaba de vez en cuando con una regadera, lo cual le agradaba mucho al parecer, pues extendia completamente sus alas, dejandolas luego secar al sol, mientras limpiaba y arreglaba su plumaje. Su alimento consistia principalmente en carne cruda de vaca, bastándole media libra para un dia. Algunas veces se le daban conejos, gatos, marsopas, etc. Despreciaba siempre las aves; para matar los conejos poniales un pié en. cima, colocaba lentamente su pico en la cabeza y cerrábale dejando al pequeño animal sin vida. En todo estó procedia con la mayor tranquilidad sin mostrar instintos voraces ni sanguinarios. Siempre comenzaba á comer por detrás de las orejas; separaba despues el cuerpo de la piel y devoraba lo que le parecia, dejando siempre una parte. No se acercaba á la carne podrida; los huesos parecian serle tan necesarios como la carne, pero à todo preferia el tuétano. Devoraba pe. dazos de hueso casi del tamaño de un puño, cuando estaban llenos de esta sustancia, sin reparar que podia atragantarse; pero los despreciaba si estaban vacios. Cuando tenia hambre se atracaba tambien de huesos cocidos y secos, sin que los bordes afilados de las puiras le molestasen en lo mas minimo. Cuando el buche estaba lleno al parecer, el ave hacia algunos violentos esfuerzos para tragar, revolviendo la cabeza, y entonces se podia oir distintamente el ruido que producian los huesos en el esiómago glanduloso. Apenas se explicaba que sus delgadas paredes no se perforasen con las agudas pun. tas de los huesos. Despues de tal comida el ave se posaba tranquilamente; su estómago repleto sobresalia mucho, y á menu. do respiraba penosamente con el pico abierto, mieniras hacia la digestion. Algunos movimientos que hacia de vez en cuan. do durante la deglucion, facilitaban el paso de los huesos, bastante descompuestos y reblandecidos, desde el estómago glanduloso al musculoso. Si por la noche habia comido huesos, ô la mañana siguiente arrojaba ya masas de cal bastante grandes, en parte compactas, de color amarillo gris; despues de comer carne, los excrementos eran liquidos, blancos, mez. clados con una bilis negra y verde Cuando habia tragado muchos pelos, estos solian encontrarse en los excrementos de la siguiente comida de huesos, no digeridos, pero tampoco apelotonados, sino disjulusios en forma de anillo en medio de los excrementos. Solo una vez, en el irascurso de medio año, y despues de haber derorado un gato, arrojó una bola. Cuando por comer demasiado aprisa se le atravesaban algunos huesos agudos en el esólago, arrojábalos sin tardanza, a menudo con grandes esfinerzos que le arrancaban gritos de dolor, y expeliendo por el pico una cantidad bastante considerable del jugo digestivo, casi incoloro y de un olor des. agraditule. Despues tragaba los pedazos nas cuidadosamente, y allas pocas horas tenia ya el buche blando; una libra 6 libra y inedia de carne bastaba para llenarlo del todo.

A los bchó meses de cautividad, el gipacto enfermó; apenas comia ya, y sus excrementos se reducian á una bilis de color verdé oscuro; debiliruse cada vez mas; siempre estaba mustio; los ojos perdian su vireza; los anillos oculares pali. decieron, presentando al fin manchas y fajas de un tinte ama rillo rojizo, y a los quince dias de su enfermedad murió. Al examinarle resultó haber sido la plétora la causa de su muerre.

Comparandu las observaciones de Girtanner con las que se hicieron en otros gipactos barbudos de Suiza, resulia que los individuos que se cogen pequeños se distinguen muy ventajosamente de los adultos. Estos últimos se muestran pere. zosos, estripidos y tercos, y nunca se familiarizan con el hombre; mientras que los júrenes son, tro solo mucho mas agiles, sino tambien mas inteligentes; familiarizanse antes con su amo, y por lo mismo se pueden hacer suposiciones mucho uns exactas sobre su manera de conducirse en liberiad. Un individuo que Baldenstein cuidó durante siete meses conduciase puco mas ó menos como el de Girtanner, y cobró el mismo cariño a su amo. Asi, por cjemplo, sabia indicar muy bien sus descos de bañarse; nadaba con las alas y movia la cola en el suelo imitando ian bien tódos los movimientos del ave que se baña, que Baldenstein buscó al punto una bainera llena de agua, donde el are se precipitó en seguida, moviéndose en el fluido como antes lo habia hecho en seco; sumergiase completamentc en su baño y se mojaba del todo. Cuando Baldenstein provocaba demasiado-á su ave, esta se preparaba para el ataque, por grande que iucra sı familiari. dad con el amo, y aunque reconociese que era su bienhechor. Cuando estaba sobre una mesa tenia la cabeza à la misma altura que la de su amo y los dos se divertian. El gipaeto rascaba á su amo con el pico en las patillas $\delta$ cubriale con la punta de su ala las mangas de la levita, dejando oir su fami. liar gici. Baldenstein á su vez podia acariciarle tanto conzo queria sin que jamńs mostrase desconfianza. Con las personas extrañas conduciase de una manera muy distinta. 
Otro individuo pequeño que Amstein cuidaba, colocóse sobre los hombros de sir amo cuando este hizo sus preparativos para pintaric, y acariciảbale con el pico, porque com. prendia que se descaba hacer algo con él, sin saber quué. Salis ha reconocido tambien que algunos gipaetos, al parecer muy dóciles, se irritan á veces: tenia un individuo cautivo, que habia estado algun tiempo con un gavilan; y como este últi. mo q̨uisiera disputarle una vez un pedazo de carne, infiamá. ronse sus ojos, erizó las plumas, dilatúse su cuello, y clavan. do una garra en el pecho del gavilan, tendióle moribundo á su lado, sin dejar por eso de seguir comiendo tranquilamente, cual si nada nubiera pasado.

El daño que el gipaeto barbudo libre ocasiona al hombre es de poca importancia $\delta$ al menos no debe compararse con el que nos ocasiona el águila real. Allí donde los cadiveres, huesos, tortugas y otros animaies pequeños le ofrecen alimen. to sin trabajo, solo por excepcion se permite ataques sobre la propiedad hurana; y en Suiza ha llegado á escasear tanto

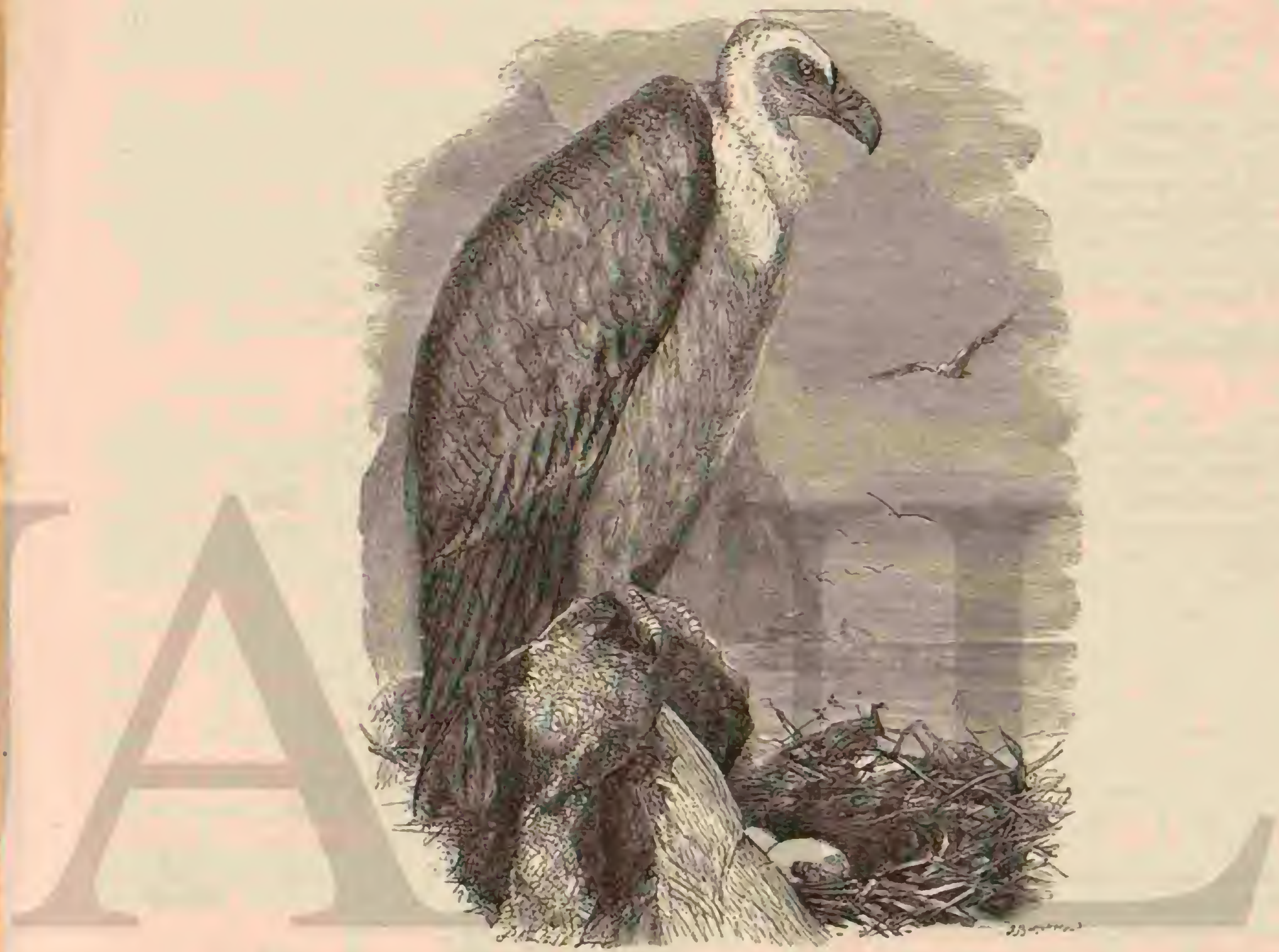

Fig. 174. - EL Girs L.rosida

que sus fechorias no son de gran consideracion. Cierto que tampoco podemos decir que tiene zran utilidad, como no sea pata los tuaregs, que matan esta ave, muy comun entre ellos, para comer su carne, utilizando la grasa cono remedio contra la mordedura de las serpientes venenosas. Alli donde el gipacto barbudo abunda, 'su vida es bastante cómoda y no corre ningun peligro, pues no se le persigue mas que por afi. cion a la caza. A pesar de esto, el hombre es su peor enemigo, pues ocupa mas y mas los territorios donde el ave era antes el único soberano ó donde podia vivir libremente. Tambien las aves de rapiña pequenas, sobre todo el gavilan, los halcones pequeños y las cornejas le prorocan y molestan mucho, y asinismo le atormentan toda clase de parásitos, pero todos estos enemigos juntos no pueden acosarle séria. mente. Solo el señor de la tierra le rechaza mas y mas, ahu. yentándole en algunas partes completamente de su área de dispersion.

Respecto \& su caza, poco hay que decir. Cuando la casualidad no favorece al hombre ó este no encuentra un nido, debe ponerse al acecho muchos dias cerca de un cadáver, como lo hemos hecho inútilinente en Espania; es preciso permanecer muchas semanas seguidas en ciertos puntos de la montaña con la esperanza de matar un gipacto barbudo al paso. Mejor sirve quizis una trampa bien colorada, pero es menester atarla muy bien para que el ave no la arranque y se la lleve. La caza no ofrece ningun peligro, putes ni aun el gipaeto herido intenta defenderse contra el hombre, comolo hacen regularmenie los pernópteros. Segun he observacio so mismo, erizan las plumas de la nuca y abren el pico tanto como pueden, intentando tambien coger con êl í su adversario, pero es facil dominarlos. Su resistencia vital es notable; solo una bala muy certera los mata en el acto. Vo tiré a un individuo al vuelo, con tan buena suerie, que la bala penetró por el vientre, y destruzando el diafragma y el higado, salib por el lado de las rértebras lumbares; el ave cayó en seguida al suelo, pero aun vivió treinta y seis horas.

\section{LOS VULTURINOS-VULTURINA}

CARACTÉRES. - Los vulturinos ó buitrés del antiguo 
continente, forman una segunda saj familia, 6 segun otros, una farnilia independiente; las espacies que la constituyen

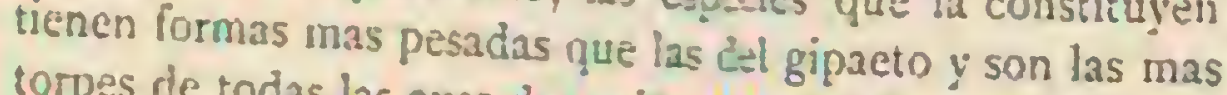
torpes de todas las ares de rapiña es general.

I:l cuerpo es grueso; el pecho suamente ancho: las alas largas, anchas y un poco redondeacis: las pennas erectiles; los tarsos fuertes y de regular alima, desnudos á partir de los talones; los dedos largos y fuertes, sin ser prensiles; las beza, joco mas ú menos yomas; el pico tan largo como la ca que ancho, mêrte, reat muy corvo, mas alio rado, v bordes cortantes, un largo mediaro, bastante ace son mul rece por complet dargas y anchas; ta parte del cuerpo camente de unalo de allas y esta desnuda, ó cubieria sola. mente de una especie de plumón folloso, mas ó menos mal derinidos extráno: las partes gue aigunos rutididos le tienen mu són grandes yoxpresiros yresenta colores vivos, los ojos mente dispuestas Las y las fos nasales están diversa. los sentidos nas desarrollados. 1. sentidos nas desarrollados.

\section{EL NEOFRONTE PERNOPTERO-NEOPHRON PERCNOPTERTS}

Esta especie, que ha recibicio los diversos nombres de

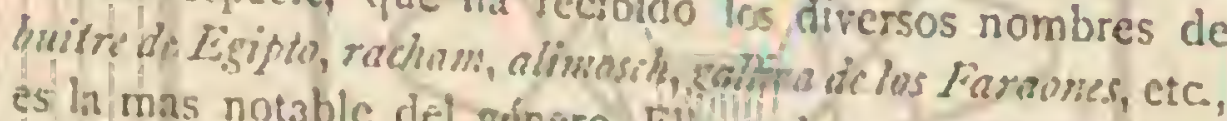
es la mas notable del género. Filia es !a que está renresenotra época objeto de un cumentos ejcios, y la que fué en amor paternal: aun hoy culto tehigaso como simbolo de?

CARACTÉRES L es bastanie apreciada.

catártidios por sus alas prolongaderis difieren de los otros mediana y cunciforme. por la cera en mas de icnen of piro muy largo, cubierto son mediarios, apenas mis prolonge extension; los tarsos iro, $y$ las uinas de un las piolongades que el dedo del cenplumas son abundantes, grandes feramente corras. Las sobre todo, muy prolcne grandes !' lazgas, y las de la nuca, man ura especie de de la cabeza están desnudas a soloia cara y una parte. la edad, pero no segun el sexolot plumaje varía con el plumaje de un color blanco Los intividuos viejos tienen curo en cl cuello y la parte superior a tira al amarillo os. vientre son de un blanco puro dor pecho; el lomo y el las escapulares grises; el iro: las rénies primarias negras; amarillo bronceado claro; cl pico, exeede el pardo rojo al azulada, la cabera yo unico, excepto la punta, que es de un amarillo naranja viro la que hay en el buche, son que el borde de la mandita gargania un poco mas clam

Fin los pequeños es de un inferior, la frente y la cabeza. dilla, las cobijas superiotes tinte gris de hierro la cspal. pecho y el vientre sobre la linea ena raja jue cruza el dilla $y$ las cxtremidades sub couderia, el collar, la raba. los costados y las rémiges, son de el cucllo, el pecho, mas de las nalgas manchadas de un pardo negro: las plu. plumas lanosas del collar y las rectrices camo tinte y gris; las de los lados del cuello, pardas ectrices caudales, grises: las cara, la cera, 5 la cabeza de un en el twilo yel extremo; lá oscuro; el pico negro y la un gris cexiciento; el ojo pardó

La hembra tiene y las patas de un gris claro.

esta plegada mide $0^{\circ}, 00$ de largo, $5,0,60$ de ala a ala;

DISTRIBUCIO $150 \mathrm{y}$ la cola $(1), 26$.

es muy raro en Suiza, segun RAFICA.- El pernóptero no netura ha anidado una parej refiere pa Gessner; cerca de Gi. mayor abundancia. No anida en el modiodia de Francia, pero visita este pais con bastante frecuencia; en Italia se li miza al promontorio de Argentaro y a los contornos de Niza, pareciendo muy extrano que no se encuentre en Cer deña, donde otros vultúridos habitan con preferencia. En Es pana se le ve en todas partes, aunque no abunda; en Cirecia, en la provincia del Balkan, está diseminado por todo el pais. Aqui se presenta, segun Krueper, con mas ó rsenos regulari dad, en los primeros dias de la primavera, y por eso los pas. tores consideran que dicha estacion no comienza hasta que se efectúa su llegadia; tambien le llaman calublo del evblillo, porque creen que este uiltimo hace sobre su dorso su viaje de invierno. Algunas veces se deja ver ya el 12 de marzo on el pais, pero tambien puede suceder que no se lé observe hasta fines de este mes ó primeros de abril. Desde esta época permanece en aquellas regiones hasta setiembre di octubre, y entonces emprende su viaje de invierno. En las Cicladas suele quedar siempre algun individuo durante la estacion friz, y lo mismo sucede en Esparia, donde observamos á este vulturido aun en noviembre y diciembre, en Andalucia, y en enero en los contornos de loledo. Suele abandonar tn. dós Ins inviernos la Crimea y el mediodia de Rusia, doncie igualmente anida; pero en cambio permanece continuancnte en Asia, excepto quizás en los paises de la costa occidental, y una gran parte de! Asia central y meridional. Desde el centro de Egipto hasta el mediodia abunda mucho, y en la Nubia es una de las aves de mpiña mas comunes. Lo mismo pódriamos decir del centro y mediodia de Arrica; pero debe advertirse que el pernóptero es muy aficionado á las cos. tumbres orientales. Tanto abunda en todos los runtos donde el oriental habita, como escaser en otras regiones. En efecto, vive en a ada el Africa desde los limites septentrionales hasta el extremo sur, con la única excepcion quiaras como ya he. mos dicho, de los rerritorios de la costa occidental, donde lrasta ahora solo se le ha encontrado en las islas de Cabo Verde. Sin embargo, no solantente en las costas del mar Rojo, sino tambien mas en el interior de todas las partes donde habitan los negros, el ave no es muy rara; pero evita los grandes bosquues, visitados por su congénere el pernóp. tero negro. En el oeste y mediocia del Asia, habita el Asia Menor, Siria, Palestina, Arabia, Persia, Nepal, Afghanistan, los paises del Himalaya y el norte y centro de la India: en cambio falta del todo en el inediodia del pais y tambien mas Isácia el este, sobre todo en China.

USOS, COSTUMBRES Y REGIMEN.-Ia inmundicia en medio de la cual vive esta ave formosamente a causa de su régimen, ha sido causa de que varios de nuestros na. turalistas, y aun los mas distinguidos, hayan mirado al per. noptero con prevencion. Dificilmente se encontraria un are, dice Naumann, cuyo aspecto hediondo corresponda tan exactamente á su género de vida: su cara desnuda, su cabera pequeña, su buche pelado y prominerite, las espesas plumas que cubren el cuello, su plumaje sicmpre sucio, y sus grue. sas patas, que no lo están menos, son otras tantas circunstancias que contribuyen á que el aspecto de la rapaz sea por demás desagradable para el espectador. Del pico gotea casi continuamentc un liquico sucio; todo el cuerpo cxhala un olor repugnanie; que conserva la piel, aun cuando esté disecada: es rerdaderamente un ave hedionda $x$ Estoy seguro que Naumann habria modificado su opinion si hubiera te. nido tantas oportunidades como yo para examinar at pernoptero en vida. No niego que sus costumbres son en realidad re. pugnantes; no pretendo tampoco presentarle como un are hermosa; pero no tiene nacia de desagradable, $y$ le prefiero sin disputa á todos los grancies vultúridos.

Solo en el mediodia de Europa se muestra el pernóptero timido y desconfiado: en roda el Africa, por lo menos alli 
donde no le han perseguido los europeos, no le inspira te. mor alguno el hombre. No tiene mada de estúpido; sabe re. conocer perfectamente el peligro, y despliega a veces cierta astucia para apoderarse de su presa colidiana. Seria un error creer que es pesado y perezoso: antes por el contrario, casi siempre está en movimiento, y entrétiénese en cruzar los aires dumnte horas entern. Vercad es que cunndo se harta de comer, permanece largo ticmp̨o inmóvil en el mis. mo sitio, laciendo la digestion, y eatonces no se reconocen todas sus cualiơdades; pero ¿no se oùserva acaso la misma cosa en los halcones? Anda como el cuervo, con el cual tiene tambien mas de un punto de semejanza; al volar, se parece á la cigüeña, segun dice Bolle, y hasta cierto punto al gipaeto, aunque su vuelo es menos ripido $y$ airoso que el de esta última rapaz De un solo salto, elérase sobre el suelo; da lentamente algunos aletazos, y vuela luego con bastante rapidez sin agitar las alas. Si el tiempo es bueno, remóntase á una altura de 1,000 \& 1,300 metros: se posa sobre las rocas, evitando hacerlo en los árboles; no sa interna nunca en los grandes bosques. Muy á menudo descansa en los antiguos edificios; en el norte de Africa, en la Arabia y en las Indias, se le ve sobre los templos, las mezquiras, las tumbas y las casas.

A semejanza de los otros representantes de la familia, es muy sociable: unuy rara ver. se ve a un pernoptero solo; mas a menudo se encuentran parejas: pero por lo general forman estas aves bandadas mas o menos numerosas. A reces se reunen con otros vultúridos, aunqque por poco lienzpo, pues no lo hacen sino por necesidad. Convencido de su paca fuerza, el pernoptero es manso y pacifico; pero no tanto como supone Gesner. as tinido y' miedoso, dice este natu. ralista, hasta el punto de que los cuervos y las demás ares semejantes, le maltratan, le ahuyentan y le dominan, porque es pesado y perenoso.y

En el Bajo Eyipto y en el sur de la Nubia se ven con frecuencia numerosas bandadas de pernópteros, que retozan en lós aires; ruelsen juntos á los sitios donde pasan la noche, y marchan desde alli á buscar alimento, sin que se promueva nunca entre ellos la menor contienda.

Cuando están con los grandes vultúridos, condícense es. tas rapraces de distinto modo; mantiénense separadas, mirando timidamente a sus cornpaneros.

El pernóptero no desprécia ningun alimento; come todo lo ngue se puede comer; es el prinicro que llega junto al cadaver de un animal para tomar su parte; devora los ojos y los intestinos cuando le es posible; d menudo se contenta con los restos que le dejan los grances ruluiridos.

Los grandes rios 6 las costas del mar se prestan mas sus necesidades, porque alli las olas arrojan á la orilla toda clase de cadiveres, 6 cuando menos pects muertos, procu. råndole además muchas uspecies marimas pequeñas; tambien se alimenta a veces de mias, manes, avecillas, lagartos y otros repriles; saquea los nidos y coge habilmente las lan. gostas en las praderas. Mi hermano pudo observar un pernoptero que precipitandose sobre - las aves domesticadas, las persiguió, apoderóse de una emberiza, cióle muerie de un solo picotazo y sujetandola la devoró en un momento. Don Lorenzo Maurel refirió á Bolle que con dificultad le era posible criar pavos reales, porque los pernópteros cogian los huevos con la mayor impertinencia y hasta perseguian a las gallinas á cada paso para hacer lo mismo. Sin cmbargo, sus fechorias no son de ninguna importancia para su alimentacion, pues afortunadamente sabe arreglarse de otro modo. En tocia el Africa y hasta cl mediodia de Espanta forman los excrementos humanos stu principal alimento. Casi toda la poblacion sce re obligada a buscar ciertos sitios para satisfacer sus necesidades, y tanto para el upupa como para los pernóp. ieros sirven de puntos de reunion á donde acuden sin hacer aprecio del hombre, que si bien desprecia la actividad del are, reconoce sin embargo en clla un bienhechor. Jerdon nos dice que en la India sucede precisamente lo mismo.

En todas las grandes ciudades del Airica se ven pernópteros en los mataderos, que se hallan por lo regular fuera de las ciudades; circulan en medio de la gente, acechando la ocasion de coger un pedazo de pieló de carne, y se apoderan con avidez de los intestinos que les echan. En caso de siecesidad comen la tierna impregnada de sanure, y de ver en cuando se tragan las sustancias mas indigestas, como por ejemplo, irapos mojados en aquel líquido.

Me ha entretenido siempre observar al pernopiero cuando comia: es menos voraz que los vultúridos, y d pesar de los lugares donde busca su alimento, está siempre bastante limpio. La proteccion que el hombre parece dispensarle, $\delta$ me. jor dicho, la general indiferencia de que es objeto, le inspira tal confianza, que se pasea delante de las puertas de las casas, donde busca de comer tan tranquilamente como las aves domésticas. Cuando desplumaba yo paijaros en mi ienda, accrćbase hasta la entrada, me miraba atentamente, y de. romba a mi vista los pedazos que le itra dando. Fin mis viajes y a través del desierto acabé por cobrarle cariño: seguia dias cuteros a la caravana, y juntamente con el cuervo, cra la primer ale cque se dejaba ver entre nosotros y la últina cis abandonarnos.

Hasta hace poco no se ha llegado á conocer bien cómo se reproducen los pernóptcros. Krueper examinó varios nidos en Grecia: segun 6l, raya ve\% anidan estas aves unas cerca de otras en la misma pared de rexa; pero Hulle, por el con. trario, ha visto cinco ó seis nidos juntos en el mismo peñasco. "Los jernópteros, dice, parecen complacerse en anidar en compania: alli donde una pared rojiza y encarmada les ofrece un asilo conveniente, se nijan desde luego, sin cuicharse de su situacion mas o menos meridional. Por la cantidad de excre. tnentos que se amontonan alrededor de los nidos, se pueden reconocer desde léjos: parece que estas ares no buscan los lugares bien oculıos; para su seguridad les basta fijarse en un punto inaccesible

En España son tan poco numerosos que no es dado ob servar sus colonias. Fin Eigipto se ren sus nidos en las rocas calizas escarpadas, en las riberas del Nilo; a menudo se divisan varios, unos cerca de otros; pero siempre en sitios tales, que no se puede llegar sino deslixándose de arriba abajo con una larga cuerda, cosa qué yo no intenté nunca.

Heuglin indica las piramides como el paraje donde se hallan sus nidos; segun parece, los ha examinado él mismo y dice que el ave los construye, que son bastante grandes y: espesos, y que se componen de ramas secas y de tallos de! durah; pero Harmann asegurn que los hace con perba y irn. pos. El pernoptero anida tambien en la India, tanoo en las rocas como en grandes edificios, pagodas, mezuuitas, sepulcros y hasta algunas veces en arboles, donde fabrica el nido con ramas y coda clase de despojos, rellenando a veces la cavidad con trapos vicjos. Parece que tambien anida con pre. ferencia, segun Alleon, en la ciudad de Constantinopla, pero solo en la parte habitada por los urcos, y no en Pem, donde viven los extranjeros. Alli rabrica su nido ianto en los cipre. ses como en las mezquitas, y en numero tan considerable que el citado naturalista calcula en mil el número de los polluelos que nacen todos los años. En Egipto el tiempo de la incubacion acontece en los meses de febrero hasta abril; cn Grecia, segun Krueper, à mediados de este ullumo mes. Fil citado viajero recibió sin embargo huevos frescos aun à fines de abril $y$ i principios de mayo. Encuéntranse por lo regu. 
lar dos huevos; Krueper no vio en tres veces mas que uno solo: jamás tres ó cuatro: su forma es prolongada y su color varis mucho; son comunmente de un blanco amarillento, con manchas y rayas de un tinte de ocre $\delta$ pardo rojo; algu. nos están sembrados de manchas negruzcas, mas compactas unas veces en el extremo grueso y otras en el pequeño. No se sabe cuśnto tiempo dura la incubacion, ni tampoco si el macho ayuda \& la hembra ó cubrir: esta última no abandona fricimente sus hueros. Los hijuelos salen à luz cubiertos de un plumon blanco agrisado; los padres les dan al principio los alimentos medio aigeridos. Tardan mucho en emprender su vuelo, y aun despues de haber abandonacio el nicio, perinanecen varios meses con sus padres.

CA UTIVIDAD. - Los pernópicros se domestican en alto grado cuando se cogen pequeños; siguen al fin is sumo como un perro y le saludan con gritos de alegria apenas le ven. Tambien los adultos se acomodan pronto a su nueva situacion y consérvanse muchos años en la cautividad.

\section{EL NEOFRON MONJE- NEOPHRON PI- LEATUS}

CARACTÉRES. - Esta especie difiere de-la anterior por tener el pico mas corto, alas mas anchas, y coln mas corta truncada en angulo recto. Tienen la cábeza y el cuello desnudós en su mayor cxtension; el conducto auditivo rodcado de una especic de pabellon, y la parte anterior del cuello cubierta de verrugosidades.

L,as ares de esta especic tienen el plumaje de color pardo de chocolate uniforme: el plumon uque cubre la nuca es de un gris leonado claro; el pico azul, mas oscuro en la punta; las patas de un gris de plomo claro: la cera de un violcta vivo; las partes desnudas de la cabeza rojo azulacias, $y$ las de la garganta de un tinte mas páliỏo (fig. 173 ).

Los jóvenes tienen la parte posterior del cuelio pardo oscura, la oreja cxterna menos marcada, la piel del cucllo lisa, y los colores menos vivos que en los adultos.

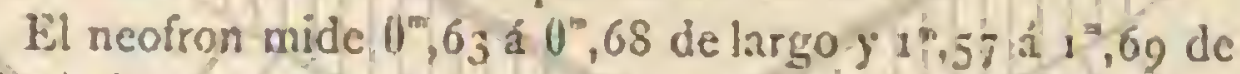
ala a ala: esta plegada ticne $0^{\circ}, 45$ a $13^{2}, 50$, y la cola $0^{*}, 23$ a $(1)^{m}, 25$ i las primeras inedidas son las del macho, las últimas las de la hembra.

DISTRIBUCION. GEOGRAFICA. - Iil neofron mon. je habita en casi todas las partes del Africa central y meridional, pero no se le ha encontrado ni en el norte de este continente, ni en Asia ni Europa. Por lo que se sabe hasta ahora, es el único vultúrido que habita la cosia del Africa occidental; en Abisinia abunda mucho mas que todos sus congéneres, $\delta$ al menos su numero es inucho mayor que el del pernóptero egipcio. En Massaua se le ve posado en los tejados de las casas; en los pueblos de la costa de Abisinia se presenta por la manana cerca de las viviendas del hombre, donde permanece todo el dia, y solo al ponerse el sol se dirige hácia los sitios donde reposa. Mas en el interior repre. serta al pernóptero egripcio, que alejándose del desierto parece buscar mas la compania de los orientales; mientras que el otro, apartado tambien del hombre, lucha por su existencia.

USOS, COSTUMBRES Y REGIMEN.-Se puede considerar al neofron monje como un ave medio doméstica; es tan atrevido como la corncja, y casi tanto como el gorrion; se le ve pasearse sin temor delante de las puertas y acercar. se à la entrada de las cocinas, cligiendo para descansar el arbol mas próximo. Arrebata todas las inmundicias à medida que se deposian, y ayuda asi al pernópiero á conservar la limpieza de los lugares donde se halla: su presencia en todos los mataderos llega muchas veces a ser molesta para el car nicero.
El hombre alimenta al neofron, y este le manifiesta su reconocimiento prestándole ligeros servicios: nunca se lleva nada; jamás arrebata un polluelo ni animal alguno doméstico, y se alimenta casi exclusivamente de las inmundicias y restos de las cocinas. Con frecuencia no come mas que excrementos durante semanas enteras; este es tambien el alimento de sus hijuelos.

Para descansar de noche elige siempre árboles que se ha. llen todo lo léjos posible de las viviendas humanas Cerca de Massaua duerme en las mimosas aisladas de los valles solita. rios de la Samhara, ó en las espesuras de las islas. Suele volar primeramente algun ticmpo sobre cstos sitios; despues se precipita hácia el suelo con las alas reccgidas y se posa con otras aves en el árbol de costumbre.

El neofron ó neofronte monje ofrece cl aspecto de una hermosa ave y de un verdadero buitre: cuando vucla es hasta dificil algunas veces distinguirle de las grandes especies; mientras que al pernóptero se le reconoce desde léjos por sus alas puntiagudas y su cola cónica. I as partes desnudas de la cabera y del cuello contribusen á su belleza, pues cuando el ave está viva, presentan todas las variaciones de color que observamos en la cresta del pavo.

Es mas sociable que los otros vultúridos, y no manifiesta hácia el pernóptero tanta aversion como dice Heuglin: á menudo se le ve en su compañia aun despues de una co. mida

En los primeros meses del año abandona el neofronte los lugares habitados y se dirige a los bosques parit anidar. En el mes de enero vi en una gran sclva de mimosas que bordeala el/Nilo toda una colonia de estas rapaces; sus nidos estaban situados en los altos árboles, apoyados $\mathrm{en}$ una bifur. cacion ó en una gruesa rama cerca del tronco.

Cerca de Massaua, en la pequeña isla del Jeque Said, cuya vegetacion se compone de schoas, avicenias y rizb́foros, existe una colonia mucho mas numerosa Aqui vimos, y des. pues de nosotros Heuglin y. Antinori, grandes extensiones de los espesos matorrales literalmente cubiertas de nidos que se hallan á unos seis metros de altura, y segun la naturaleza del sitio, aislados ó juntos; tambien sirven de morada á los mi. lanos parásitos y a dos especies de garzas reales.

los nidos del neofron, relativamente pequeños, tienen apenas $0^{\circ}, 60$ de diámetro; son planos y se componen de ramas sólidamente entrelazadas, con la excavacion tan peque. ìn que apenas se puede colocar el hijuelo. He examinado mas de veinte nidos, y jamás encontré mas de un huevo en cada uno: su forma es redondeada; la cáscara presenta un grano tosco; el color es blanco gris, con manchas de ocre rojo en el extremo grueso, aunque hay muchas variedades. Los padres cubren alternativamente; el macho durante el medio dia $y$ la hembra en las demás horas. Al deshacer un nido, encontré en medio de las ramas que formaban el arma. zon una inninidad de chinches y oiros insectos, y tambien un liron que habia establecido alli su domicilio.

En la costa meridional del mar Rojo halle en el mes de abril hijuelos medio desarrollados en cada nido. La incubacion, pues, parece ser muy larga, y el crecimiento bastante lento. Heuglin nos dice que abandonan el nido antes de poder volar: vagan entonces por las orillas del mar, ye alimentan de cangrcjos, peces y ratas, que arrojan las olas a la playa.

CAUTividaD.-Como el neofronte es tan poco perseguido como los demás sultúridos, no tiene iemor alguno del hombre y es muy fácil cogerlo vivo. Durante mucho tiempo tuve yo uno que me sirvió de mucho recreo: aprendió muy pronio a conocerme, y cada ver que me veia manifestaba el major contento; pero desgraciadamente se escapó durante 
mi permanencia en Egipto. No he visto ningun otro indivi. duo cautivo.

\section{LOS GIPS - GYPS}

CARACTERES.-Los gips, ó imitres neas, se caracterizan por sus formas relativamente esbeltas; las alas son bastante angostas; la cola de un largo regular; las patas corlas, y la cabeza, sobre todo, muy larga; semejante á la de la oca, se continuia insensiblemente con el cuello, y está cubierta de algunas espesas sedas lanosas. El pico es endeble y largo: las plumas grandes, muy variables segun la edad; los jóvenes se reconocen fácilmente por las plumas largas y flotantes que forman el collar, mientras que este se compone en los viejos de plumas cortas, sin barbas, y semejantes mas bien a los velos. Tambien el color del plumaje varia mas ó menos, sobre todo en el collar, que en los individuos jórenes suele ser de un color pardo pálido oscuro y en los adultos blanco ó blan. co amarillento.

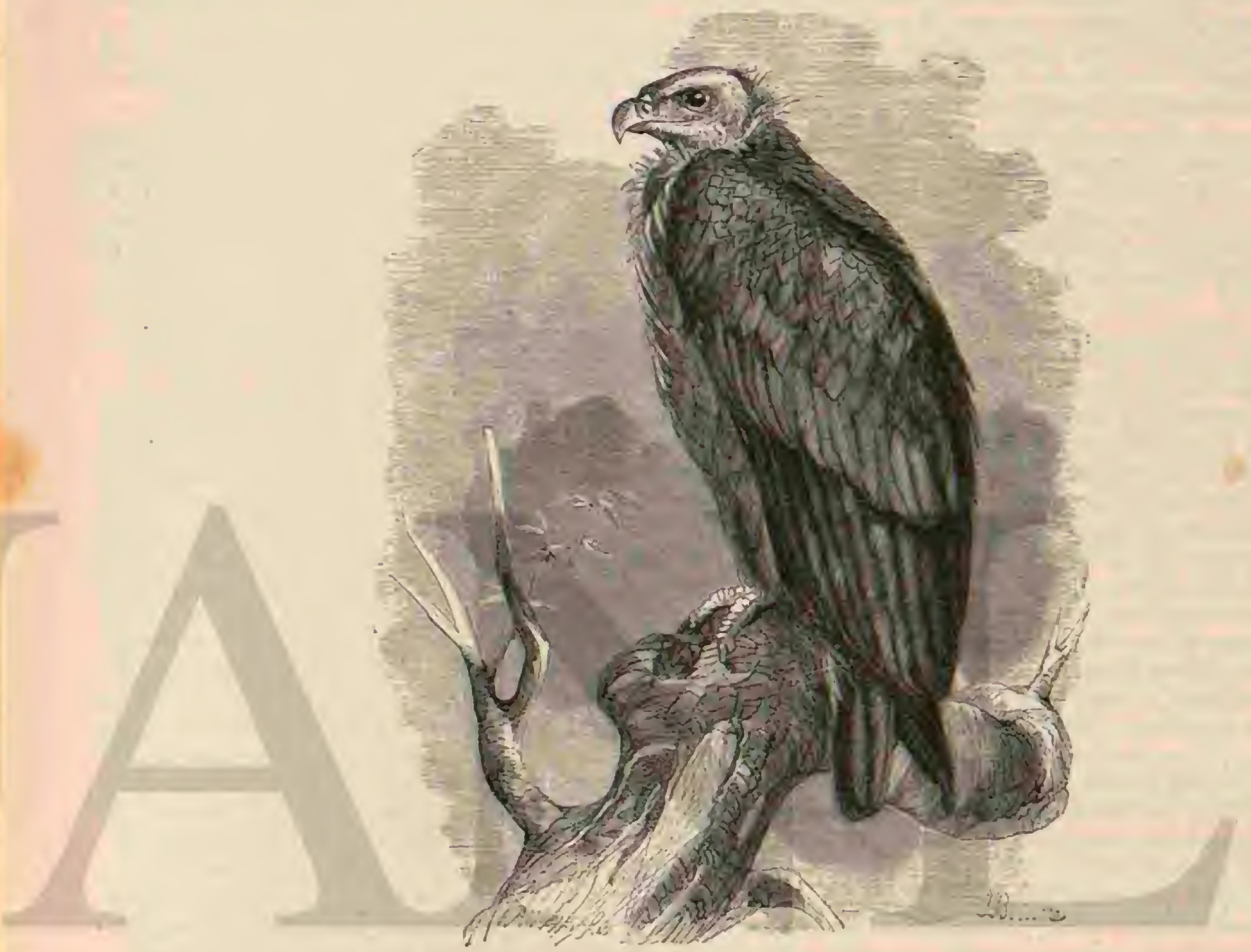

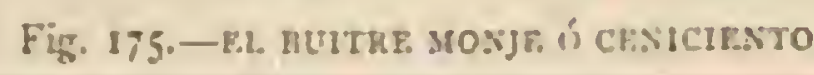

\section{EL GIPS COMUN Ó LEONADO-GYPS VULGARIS}

CARACTERES. - Estn ave puede Hegar 'ó tener $1^{\prime \prime}$ is de langitud por 2,56 de anchura de punta a punta de las alas; estas miden $0^{-}, 68$ y la cola $0^{\circ} ; 30$. El plumaje, de un pardo pálido, mas oscuro en la parte inferior que en la supe. rior, tiene los tallos mas claros. Las tectrices mayores de las alas, anchas y orilladas de blanco, forman una faja ancha y clara en la parte superior; las rémiges primarias y las recrir. ces son negras: las secundarias de un pardo gris, con un an cho borde pálida en las barbas exteriores. Los ojos son de un pardo claro; la cera de un gris de plomo oscuro; el pico de color de orin, y los piés de un gris pardusco claro. En los individuos jövenes resaltan mas las lineas de los tallos; tocio su plumaje es mas oscuro, $y$ las plumas largas y estrechas del collar son iguaimente pardas.

DISTRIBUCION GEOGRÁFICA. - Bi gips vulgar abun. da en la Transilvania, en el mediodia de Hungria y en toda la peninsula del Balkan; en el este, centro y sur de lispa. ña; en Cerdeña y en Sicilia. En la peninsula Itálica, por el Tosso 111 contrario, escasea de tal modo que rasas veces se le ve; pero en cambio se extiende mas y mas por Carintia y el Salzkin. mergut, donde ocupa poco á poco el lugar del gipaeto bar Iudo. Con bastante frecuencia visita tambien la Alemania. Iil punto mas meridional donde anida son al parecer los Alpes de Salzburgo. Con mas frecuencia que en Transilvania habita en todo el Egipto, en el norte de la Nubia, en Trines, Argelia y Marruecos. Tambien se le encuentra en el noroeste del Asia hasta el Himalaya.

\section{EL GIPS DE RUPPELL - GYPS RUPPELII}

CA RACTÉRES. - El gipss de kuppell, que se ha llamado algunas veces brivre-gravilan, representa la mas hermosa es. pecie de! género: es un are de a metro de largo por $2^{\prime \prime}, 25 \mathrm{de}$ punta a punta de ala; esta plegada mide $t^{2}, 63$ y la cola 1$)^{\circ}, 25$. Todas las plumas del adulto, excepio las rémiges $y$ las rectrices, son de un color pardo gris oscuro, y presentan en su extremo un filete mas ó menos ancho, semicircular, de un blanco sucio; cubren escasamente el cuello algunas plumas 
diseminadas, de un tinte gris azul, que pasa al rojo color de carne \& los lados de la garganta; las partes desnudas de la espaldilla son de ur. gris ceniciento, orilladas de rojo color de carne; el ojo gris de plata; el pico amarillo en la raiz y de un tinte de plomo en la punta; la eera negra y las patas de un gris plomo oscuro: el collar se comprone de plumas cortas y blancas, semejantes á pelos.

Los individuos jóvenes tienen las plumas de un tinte gris pardo oscuro, con los tallos de un amarillo pardusco, lo mis. mo que el filete; las pennas de las alas ye da cola son de un pardo negro; el ojo pardo rojizo claro; el pico enteramente negro, excepto sus bordes, que son azulacos; las patas de un gris verdoso.

DISTRIBUCION GEOGRAFICA.-EI gijs de Ruppel! existe en todo el centro del Xfrica.

USOS, COSTUMBRES Y RÉGIMEN, - PRTEC qUO todos los gips habitan las rocas, y. solo alli se encueviran sus nidus, por lo cual se les halla sobre todo cerca de las monta. vias escarpadas. Solo en la Fruschkagora vi al gips leonacio posado en un árbal: pero el de Rupixil suele pasar en ellos in noche.

Las costumbres de los gips son miy análogas à las de los otros vulturidos, si bien ofrecen algunas diferencias inmor. tantes. Muevense con mas rapider y' clégancia que los otros vulúridos del antiguo continente; cunda se dejan caer, 50. bre todo, despliegan casi tanta ligereza como los halcanes, y cambian Asilmente de direccion, mientras que los otros des cienden casi verticalmene hasta cl soelo: por tierra andan con la suficiente ligereza para que le sea dificil as un hombre alcanzarlos a la carrera.

Son los mas astutos, coléricos y violentos de todos los vuitúridos; su inteligencia es limiada, y parece que solo están desarrolladas en ellos las mas bajas cualidades.

Forman grandes lazndadas; anidan por colonias, y se re. unen if menudo con otros buitres, pero siempre son los primeros en promover la discordia y no tazdán en dominar a las otras especies Avanzan con resolucion contra el que los acomete; si están heridos, defiéndense con rałjial precjuitấn. dose hasta conira el hombre; dan salios de medio metro de altura, chasqutean el pico, y dirigen-sicmpre los golpes i la cara de su adversario. Si se les acomete, buren al principio corriendo; pero tan pron: como se les acosa de cerca, revuélrense súbitamente, silban lo nirisno que los buhos, y despiden sus ojos rayos de cólera. Aunque se consiga cogerlos. defiéndense con sus garras, y por poco aceradas que sean, no causan menos peligrosas heridas.

en una caceria en la Sierra de (iladarrama, dice mi hermano, vi por los aires, á gran elevacion, dos gips que se aco metieron de pronto, agarrándose mutuamente; y como ya no podian volar, cayeron á tierm dando rueitas cual una masa inerte. No por esto se enfrió su ardor, y cominuaron la pelea sin minar lo que les rodeaba. Lin pastor quiso apoderarse de ellos y se precipitó sobre las aves con un palo; pero hubo de dar muchos golpes antes que las rapaces comprendiesen que les convenia mas alejarse, suspendiendo su duelo hasta otro dia, concluyendo por separarse cada cual por su lado con las alas caidias. If

P'roceden de una manera csprecial cuando se ceban en un cadâver: se comen principalmente los brganos contenidos en las cavidades, y les bastan algunos picotazos para abrir en la pared aisdominal una brecha suficiente por donde introducir su largo cuello. Sus estremecimientos indican con qué ardor trabajan: se tragan las visceras, lo mistso que el cornzon y el higado, sin saca: la cabeza de la cavidad aboiominal; en cuan. to a los intestinos, los sacan primero del cuerpo, los cortan de un picotazo y se los tragan à pedazos. Tienen entonces la cabeza y el cuello cubiertos de sangre y restos del cadf́rer. ofreciendo un aspecto hediondo. Yo no sé si acometen real. mente á los animales enfermos ó moribundos: pero los ára. bes y los pastores de las montañas del sur de Hungria lo han isegurado.

Segun mis observaciones, los gips duermen mucho durante el dia: no comienzan a cazar hasta algunas hotas antes del medio dia, y á esta tiltima hora toman su alimento; pero cuando tienen crias muestran mas actividad. Lazar, for lo menos, me escribió haber visto den aquella época ئ los gips ponerse en movimiento al rayar el alba, y recorrer desde lue go, durante cerca de una hora, los alrededores de la roca donde se habian domiciliado. Elevándose despues pocoà poco, trazaban circulos cada vez. mayores, y acababan por desapja. recer à lo léjos. Hácia el medio dia regresan cada cual por su lado; reúnense cerca de su colonia y comienzan á dar vueltas al rededor de la roca. Despues de este cjercicio se posan sobre un cinto 6 una arista de roca y reposan durante algunas ho. ras. Entre dos y tres de la tarde se remontan de nuevo con gran ruido: giran algunas veces al rededor de su albergue, y marchan en busea de alimento; pero entonces vuelven mas pronto. Algunas horas antes de ponerse el sol se hallan va en el lugar donde han fijado su domicilio.

Haldamus, Kneper, Simpson, Heuglin y mi hermano nos han dado á conocer últimanente cómo se reproduce el gips leonado, y ine parece lo mas oportuno citar textualmente la descripción del uítimo autor, que es la mas completa y con. cisa.

LEn Espana entra en celo el gijs leonado en la segunda mitad de félorero, ó a principios de marzo: construye el nido en una grieta de roca ó debajo de una cornisa natural que la cubre, y se compone de una capa ligera de ramas de escaso volúmén. La hemúa no pone mas que un huevo, tan grande como el de ia oca: cl macho le cubre por la mañana y en las primeras horas de la tarde, y su companera el resio del dia. El gips leonado no anida nunca en los árboles: cuando el si. tio es conveniente, encuéntranse siempre varios nidos distan. tes uno de otro de ciento a doscientos jasos; las colonias no se componen exclusivamente de cstas rapaces; se ven con ellas gipaetos, seudaetos Bonelli y hasta ciguerias negras.

* Ios gips leonados no abandonan jor su voluntad los hue. ros; se necesita hacer mucho ruido para que salgan de sus escondrijos; en este tíltimo caso jermanecen á la entrada, mirando por todos lados pam ver quién habrá turiado sure poso; y nunca emprenden el vuelo hasta estar bien convencidos del peligro. En mis cacerias por los alrcdedores del Es. corial me entretenia algunas veces en hacer levantar a los gips que cubrian sus huevos; cada vez que yo gritaba, pre. sentábanse mirando por todos lados; y no pudiendo verme, volvíanse á su nido. Una detonacion les hacia huir á todos apresuradamente, y era neccsario esperar mucho ticmpo para verlos volver, por lo menos media hora. Cada cual visitaba los alrededores de su nido; despues se posaba sobre la roca, seguia mirando por todas partes y desaparecia al fin en el fondo de la grieta. Se ha dicho y repetido con frecuencia quue estos vulturidos acometian valerosamente al cazador que inrentaba apoderarse de sus hijuelos: por lo que yo he tenido ocasion de ver, el aserto carece de todo fundamento.

Ignórase aún cuánto dura la incubacion; solo se sabe que a lines de marzo han salido los hijuclos á lu\% Estas ares no exhalan un olor muy agradable: el huevo recien puesto despide ya un olor de almizcle tan insoportable, que solo un apasionado naturalista tendria valor para vaciar uno, y aun asi, nunca lo haria sin repugnancia.

Los hijuelos parecen al principio una bola de lana; los padres los cuidan con mucho cariño; comienzan por alimen- 
tarlos con carne completamente putrefacta, y despues les dan otra mas sólida, pero siempre en las mismas condiciones. Ya se comprenderà que semejante régimen no es el mas á pro. pósito para que desaparezca el iredor innato de cstas aves. Cincias á la inmensa cantidad de alimento que devoran, crecen los pequeiros rápidamente; pero hasta los tres meses no pueden emprender el vuelo.s

CAUTIVIDAD. - Baldamus tuvo un gips leonado, que se cogió en el nido: su talla era la de un gallo grande; estaba cubierto de un plumon espeeso y lanoso, de color blanco su. cio; cxhalaba, sobre todo por las fosas nasales, un olor repug. nante; su voracidad era extremada. Apenas le cugieron se conió dos torcios y un cuclillo; al dia siguiente un milano, una carpa de mediana talia y los intestinos de varias aves: tres semanas despues 110 era casi posiule dejarle satisfechn. En reinticuatro horas devoró las viscuras de dos iemeros, tragíndose luego cuanto pudo cucontrar, incluso la madera y la tierra, sin contar que los pasajeros del vapor le dicros iambien algunos alimentos. Si le presentaban algun animal cntero, trataba siempre de abrir el vientre primcro; mas tarde $n o$ tocó nunca los restos de un cadiver sin haber vaciado antes conipletanuente el abdómen.

"Su vomcidad era tal, dice Baldanus, que cuando tne veia eutrar en el recinto donde se hallaba sin llevarle cosa alguna, comenzaba á gritar y á sacudir In cabera; precipitabase sub: ca mi y me murdia los pies y la ropa: bien pronto aprendio s. reconoctrme enire oiras personas.

Un gips leonado es una cosa exeepcional cuando se consigue domesticarle. "No aventuro mucho, dic ni licrmano, co asegurar que sigue siendu peligroso sicunpe hasta ciesto punio. Solo una rez he visto un gijs verdaderanente domes ticalo, en una posada de Bayona, y a pesar de esto le tonian sirjero con unia larga cadena, que entorpecia mucho sus mo vimientos. Alugel gips acudia cuando le llamaba su amo; acercábase á él, se dejaba coger y acariciar la cabera, cl cue llo, y el lomo: vivia en la mejor inteligencia con los perros de la posada.s

Intanr dice que el gips leonado es hipócsita y arisco, y le compara con los melancólicos malignos Añarle que no ha visto mas que dos individuos domesticacios, uno de los cuales seguia á sts amo como un perro; emprerdia à veces pequeñas excursiones que duraban uno 6 dos dias y regresaba luego. Eil scgundo cra de un carnicero, uguien le conservó varios años, y vivia en la mejor inteligencia con un perro vicjo. Cuando este murió, arrojaron su cadáver á la rapaz,; pero auncuce tenia mucha hambre no tocó el cuerpo de susantiguo amigo; entristecióse despues, rehusando todo alimento, y murió al cabo de ocho dias.

USOS X ProdUCTOS. - En Egypro se utilizan las plu unas del gips leonado para diversos usos. Las jenuas de las alas y de la cola sirven principalmente para preparar adornos y diversos utensilios. En la isla de Creta y en Arábia se venden las pieles de buitre a los manguiteros para hacer abrigos.

\section{LOS BUITRES-VULTUR}

- CARACTÉR ES- Los buitres propiamenie dichos dilicren de los gins por tener el cuerpo mas grueso: el cuellu mas corto y fuerte; la cabeza niryor, y el fico mas vigoroso, ofre ciendo alguna analogì con el del ágivila leonada. Las alas soln mucho mas anchas; cl plumaje es tambien mas suave y compncto; la cabeza está cubierta de un plumon corto, lano. so y cresijo, que forma en el occipucio una especie de morro: la nuca y algunas partes de la gargania estan desnudas; el collar se compane de plumas cortas y anchas, apenas descom puestas y de color oscuro.
EL BUITRE MONJE Ó CENICIENTO-VULTUR CINEREUS

CARACTERES - Di! butre ceniciento, hilre monje ó yan Uritre, como le llamaba Buffon (fig. 155 ), es la mayor de las aves de Europa. "[iene $1 "$ ", 10 de largo por $2^{2}, 22$ de ala a ala; esta flegada 1$)^{\circ}, 7$ ( $y$ la cola $0^{\circ}, 40$ : la liembra mide de $11^{\prime \prime}, 04$ a $11^{\circ}, 06$ mas en la primera de estas dimensiones y de $0^{\circ}, 06$ ai $v^{\circ}$, on en la segunda. Fista rapaz tiente, pues, la talla del condoi con corta diferencia: su plumaje es de color pardo oscuro uniforme; el ojo pardo; el pico azul en la base, rojizo en ciertos sitios. y de un violeta vivo y azul en la punta; las patas blancas ó de color de carne con visos violeta; las partes desnudas del cuello de un gris de plomo claro, el circulo desnudo que rodea el ojo dic un tinte violeta

En los peyución el plumaje es anas oscuro que en los adul. tos, y tiene snas brillo; el plumon de la cabeza es de un parco yris sucia

DISTRIBUCION GEOGRÁFICA. - El buitre monje anida en España y Cerdena, y en lodas las monianas de la peninsula del Ballian, asi como en Eslavonia, Croncia y los paises bajos del Daububio. Por el norte llega hasta la Fruschka. gora, y segun las noticias de Wodzicki, hasta los Carjatos. Desde aqui se extiende por una gran parte del Asia basta Chima y la India. Hace venticinco anos que aun escaseaba mucho en el sur del Lira, mientras que ahora se encuentra alli muy á menudo. La continua epidemia del gamado que hace años reina en aquellas regiones le propo:cioma bastante alimento. En los paises bajos del Danubio, en Cerdeija, Armenia, Siria y Palestiua se le observa con frecuencia, pero rara ve\% en Persia. En el Africa no habita siro los paises del Atlas y una parte de la costa occidental, pero algunas veces se presenta tambion en la parte septentrional del valle del Nilo. L'ur el norte se han encontrado indiviuuos errantes basia con Dinamarca, y cn . Memania se le ha cazado á monu. do. Ciracias fo la agilidad de su vuclo, no le es dificil truslatlarse desde este pais a Humgria.

USOS, COSTUMBRES Y RERGMEN. - Segun las bloservaciones de varios autores, y tambien las mias, los bui. tres cenirientos son menos numirosos que los leanados; en lispaña se les ve únicamente solitarios, o formardo reducidas familias de treś á cinco individuos. En union de los gips se ceban sobre los cadaiveres de los animales, aunque se condurcen con mas dignidad que sus compaiseros; sus costumbres están en perfecta armonia con su estatura mas aventajada; sus movinientos, cuando vuelan, son menos bruscos y mas sostenidos y regulares que los del gips lea nacin.

Aun in figura que le representa volando difiere de la del grips monje, ya por sus alas relativamente mas anchas y un puco puntianudas, y la cola mas larga, que le hacen parecerGa al aguila, ya porque lleva las puntas de las alas un poco arqueadas hicia arriba, micnitas que el gijus comun las tiene rectas.

Su aspecto es mas noble y recuerda el de las afguilas; los ojos no ienen la expresion hipócrita y maligna del gius, y obsérvase en ellos algo de ardiente y caureloso a la vez los buitres cenicientos se alincentan sobic todo de la carne de los animales, y solo comen los iniestinos cuando no pueden elegir otm cosa: tambien se tragan los huesos I azar me dijo que los cazadores de 'Transilvania le aseguraron que esta ra. jaz acomete y mata á los mamiferos.

Puedo citar una serie de pruebas que confirman esta nn. ticia. Uno de los cinco individuos de esta especie que el arcliduqque Rodolfo de Austria, el jurincije I exopoldo de Ba. viera, el conde de Bonbrelles y yo pudimos natar en la Fruscir. 
kagora, tenia en su buche una marmota y otro un lagarto, animales que dificilmente cogerian aquellos buitrés como cadáveres. Heuglin vió en Grecia seis ú ocho gips monjes comiendo; acercóse á hurtadillas á la distancia de treinta pasns, y grande fué su asombro al ver que se disputaban la posesion de varias tortugas terrestres bastante grandes. El "Ino sujetó uno de aquellos animales con las garras, descar. gando poderosos picotazos sobre su escudo dorsal; los demás tenian ya una tortuga abierta y habian sacado su cuerpo del escudo; otra estaba perlorada en las junturas de las placas, y tan gravemente herida, que perdia mucha sangre. Mejerinck refiere que en $186 \%$, año en que varios individuos de csta especie visitaron la Alemania, un gips monje cogio en el do. minio fendal de Helmsclorf una liebre, gracias a lo cual se pudo cazarle. Una prueba mas evidente resulta de una ob servacion de mi hermano, quien me escribe lo siguiente: Acababa de atar un cabrito para atraer a los gipaetos barbu. dos, cuando de pronto vi al cuadrúpedo saliar como un loco
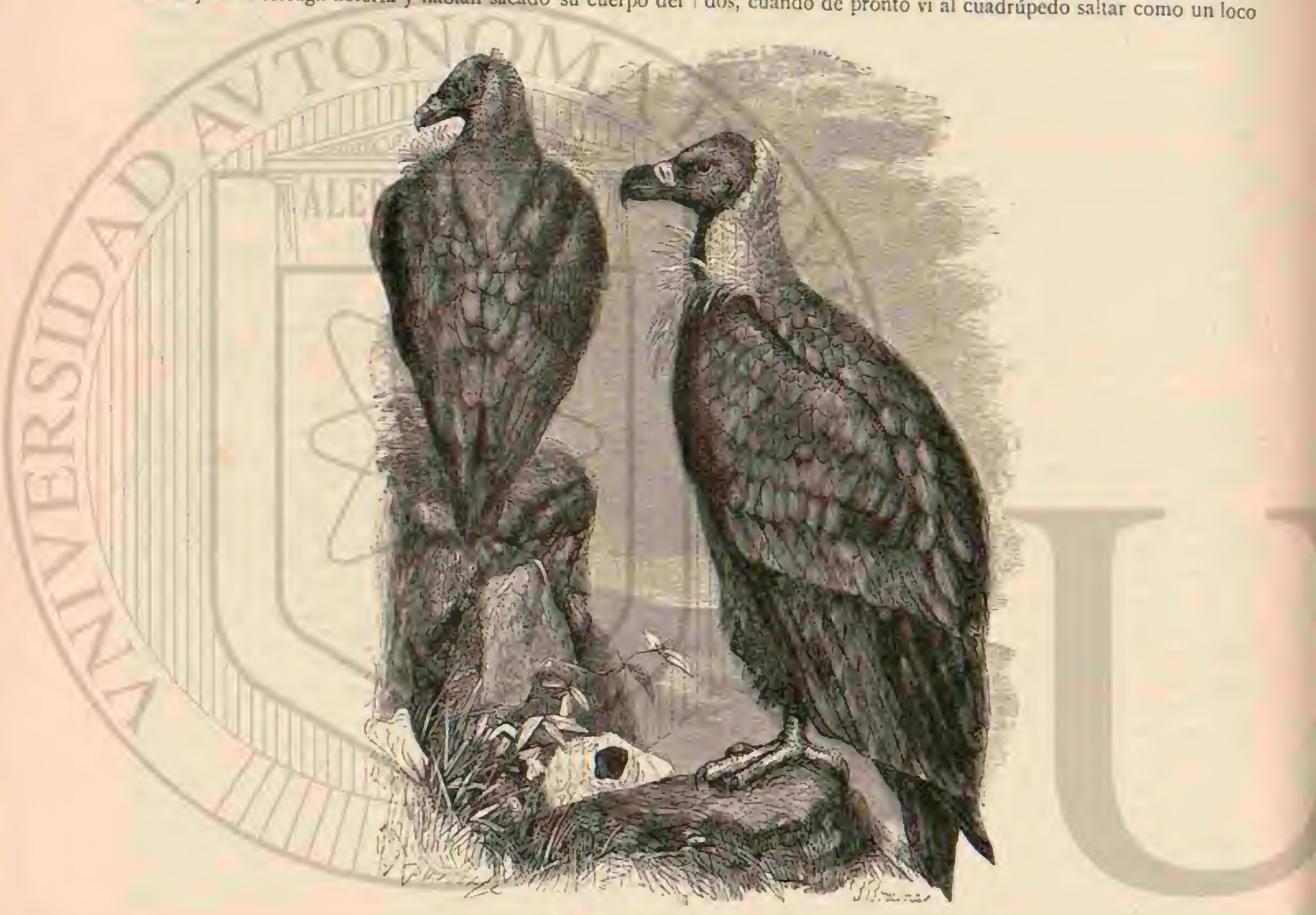

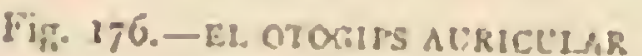

en cuanto se lo permitia la cuerda. Despues oigo un fuerte zumbido en el aire, y ya pensaba tener un gipacto barbudo delante de mi: pero con grande asombro observé que era un gips monje, el cual con las garras extendidas pasó rápida. mente a poca distancia del suelo y ataco al cabrizo. Enton ces salgo presuroso de mi escondite y llego á tiempo para impedir que el buitre me arrebate el espantado animal.

"El buitre ceniciento, dice mi hermano, no anida por co lonias, como el leonado; cada pareja vive solizaria, y no se fija mas que ér los árboles, al menos en Espana. Forma su rido en la rama gruesa de un pino, o en medio de la cspesa copa de una verde encina; pero nunca á mas de acho $d$ die piés del suelo; el armazon se compone de troncos del grueso del brazo, en los cuales se apoỹa una segundá capa de ra inas inas pequeinas; despues aparece la excavacion, que es poco proiunda y está cubierta de mmitas secas. 1 fines de febrero deposita la hembra un huevo blanco, de casscara gruesa, mas pequeño que el del gijos leonado. Dicese que se encuentran s veces dos, que suelen tener manchas: por mi prarte no he visto nunca mas de uno, y todos los cazadores espanoles a quienes interrogué sobre el particular no han hallado nunca mas.

* En el momento de salir á luz el pequeño buitre, está cubierto de un plumon compacto, bianco y lanoso, no em prendiendo el ruelo hasta los cuatro meses. Los padres le alimentan de restos putrefactos; pero nunca le defienden va lerosamente, como se ha diclio y repetido.

- Si se acerca el cazador á un nido donde hay un hijuelo, rodéanle los buitres, pero desde léjos, y poniéndose siem. pre fuera de alcance. Cerca de la Granja encuentran estas rapaces magnificos sitios para albergarse, en medio de los espesos pinares que rodean el pucblo; sus nidos no distan alli un cuarto de legua uno de otro. Cierto dia vi uno de buitres cenicientos muy cerca de una colonia de gips leona. dos, bien es verdad yue el arbol donde se inallabi era el único que habia en los alrededores, y esto era probablemente la causa de que las rapaces anidasen tan cerca de sus congé neres.

Con motivo de una caceria del principe imperial Rodolio de Atsstria en la Hungria sneridional, visitamos en la Frusch. 
kagora seis ú ocho nidos del gips monje, ć hicimos entonces observaciones muy notables. I.os nidos se hallaban exclusi. vamente en árboles, los mas de ellos encinas, hayas y tilos añosos, situados en lo mas espeso de los hosques, pero siempre de modo que el are tenia la salida libre, es decir, casi sin excepcion en la parte superior de las pendientes. I.cs buitres habian elegido por lo regular las fuertes ramas superiores de la copa, rara rez las que estaban secas ó sobresalian mucho; estas últimas servian casi siempre al macho para descansar. Eil nido, á reces oculto en medio del ramaje, es tan grande que no se puede ver á lá hembra cuando empo. lia, componiendose de estacas mas $\delta$ menos fuertes, pero por lo regular no muy gruesas, ! de ramas grandes ó peq̨uer̃as; segun dijeron los hombres que trepaban á los árboles, no está relleno interiornente. I a hembra cubre los huevos con mucho aian, prero suele huir cuando se dan golpes contra el árbol; algunas reces se levanta antes de eniprender la fugi, cual si quisiera reconocer la causa del ruido; despues des.

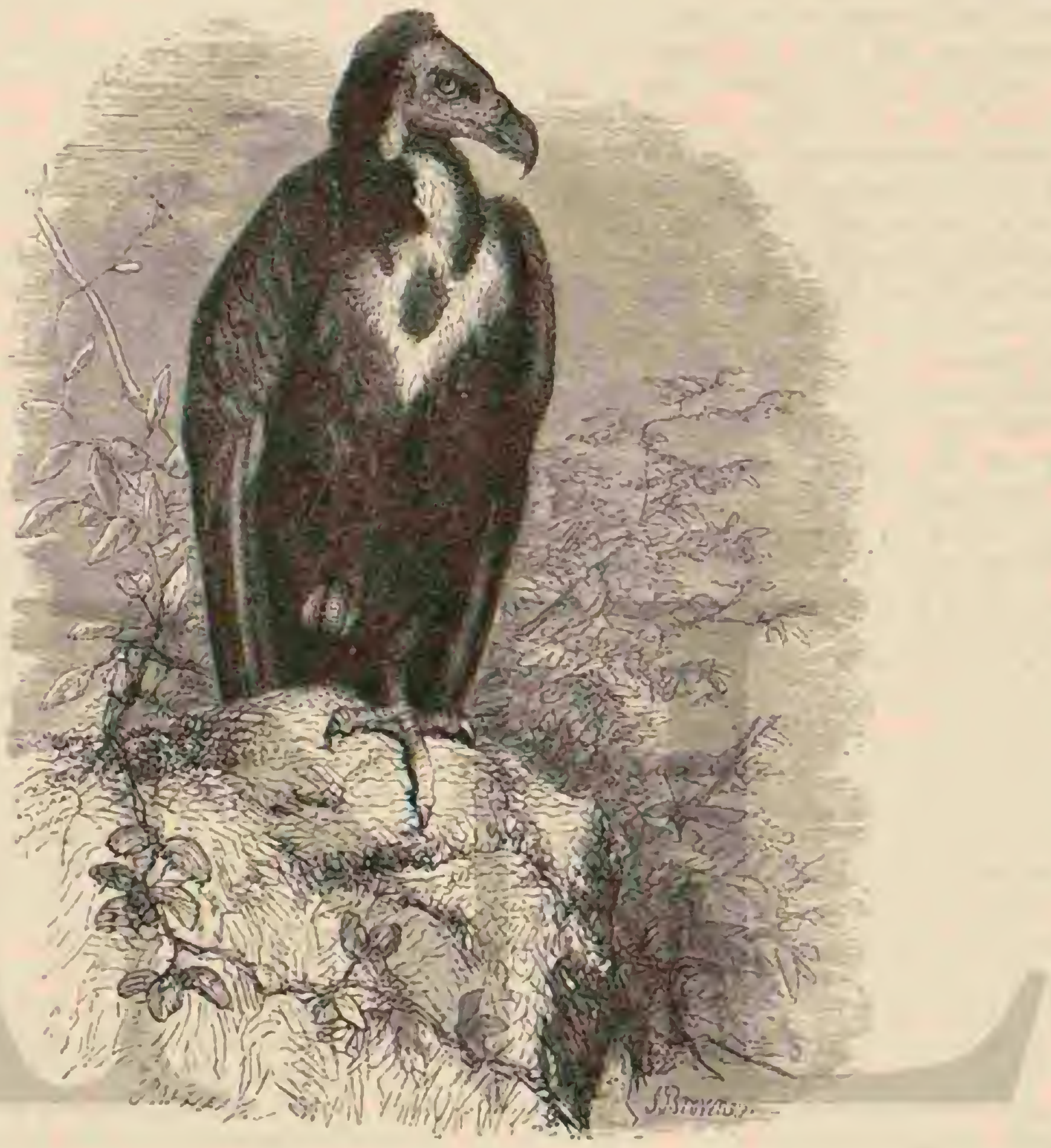

Fig. $17 \%$ - E. orontm CALro

pliega las alas en toda su extension y aléjase con vuelo sos. tenido sin aletear. Si no se la intuieta repetidas veces vuclve muy pronto, pósase subre una rama inmediata al nido y salta desde alli al interior. Despues de curnerse mucho tiempo vuelve siempre en compania de su macho, y ambos se pre. sentan entonces al mismo tiempo sobre id nido; segun he observado, tambien bajan a la vez de las alturas y se posan uno junto a otro en el árbol donde se halla el nido. Parece que ambos toman parte en la incubacion. Un macho me dió una prueba conmoredom del carino que estas ares profesan a la hembra Hallabame hacia mucho tiempo en acecho debajo de uno de los nidos y ya habia duscargado mi esco. peta sin resultado, por no laber podido ier bien la hembra, oculta por el ramaje. Macho y hembra, esprameados por la detonacion, tomaron mas precauciones; pero la llegada de la noche obligó á la segunda al fin á volvet al nido, y cuando se colocó junto al macho, recibió la bala mortal, que la hizo cacr cxánime en el nido. El macho se remontó otra vezy y trazando algunos círculos, volvió a los pocos minuros, sin duda por haber visto á la hembra tendida en el fondo del nido. Mi guia, que llegaba en aquel momento, le ahugentó, y entonces mandé al hombre que subiem al nido; pero antes de que pudiera llegar d la altura, el macho, que se habia ale. jado, volvió al vernos y se poșó en el árbol, pagando esta vez. con la vida su carino di la hembra. Durante nuestra caceria en la Fruschkagora, es decir en los primeros dias de mayo, todas las hembras estabian aun cubriendo los hucvos. In Transilvania se ha observado, segun dicen, que uno de los padres coge al polluelo con las garras, exponiéndose muchó, y se le lleva.

Enotra ocasion reconocimos que el gips monje, á pesar de su carścter pacífico, tiene tambien adversarios que le mo. lestan mucho. El archiduque Rodolfo, uque estaba de acecho debajo del nido de una pareja de estos vultúridos, vió dos grandes aves de rapiña que, agitåndose en los aires, se agar. raron al fin y vinieron a caer en el nido. Entonces se separaron, y el principe imperial reconoció con asombro que los combatientes no eran de la misma especie, sino un gips monje y un iguila real. Nadie se explicó porqqué razon el águila habia atacado al pacifico gips monje. Estc último 
ticne poco que sufrir por parte del hombre, ó al menos no se le persigue con regularidad. El conde de Chotek, que le protege, se queja de que muchos mueren por comer en invierno la carne que se destina para los lobos, aunque se pone de. bajo de un coberizo de muy poca altura.

CA UTIVIDsD. - Un gips monje cuidado por Leisler, era al principio muy dócil pero mas tarde se mosiso ma. ligno, y atacaba con pico y garmas a cuantos se le acercaban excepto á su guardian.

Devoraba con gusto los gatos muertos; pero si se ataba uno con una cuerda y se movia de un lado á otro, su primer movimiento era huir: volvia no obstante al cabo de un momento, daba un ficcorazo al cadảyer. alejáluse de nuevo, y repetia la misna operacion varias veces hasta convencerse de que el animal estaba sin vida Para matar este buitre se le dieron doce granos de arsénico (6o centigramos): al cabo de uma hora le sobrecogieron estremecimientos; pomito la carne envenenadx, aunque para comerla de nuevo, y una hora despures estaba-curado; thismo dia se te propinaron dos dracmas mas (S gramos) del mismo tósigo, repitiéndose los estremecimientos y los sómitos, nas no murió.

O:ro se mostró arisco y laciturno lodo el tiempo que es tuvo cnjaulado, pero desde que andina libre, cstaba mu conténto, y hasta disertido. Comptacese, me escribe Lazar, cn asustar a las gallinas, aun cuando no las acomele jamás; coge a los cerdos por la cola, corre detrás de los perros, y es tan atrevido, que las personas desconocidas delxert estar allerta ruatuda se hallan delante de él. Es precisq que mi criado sé cuidel muclio de que la rapaz no le arrebnte la carne destinada á las otras ares. Esic buitre penetra en la casa, y mu. chas veces lo encuentro á la puerra de mi cuarto cuando salgg de el. Mientras no se le irrita, vive en buena inteligen. cia con tocios, $y$ hasta los ninos pueden acercarse a el sin temor pero si se le atormenta, defiéndese valerosamente y da vigorosos jicutazos. Cuando cstá encolerizado tiene un aire muy grotesco; deja colgar las alas medio abiertas; criza las largas plumas del lomo: se mantiene con el cuerpo horizon tal, avanza el cuello, patalca y salta de una manera tan sin. gular, que no puede uno nienos de reirse. Its lun varaz como el girys leonado, mas no puede ayunar tanto tiempo; yo le doy de comer dos veces diarias, y ademas basiante agua, pues bebe muclio y suele banarse con frecuencia. P'efiere los mamiferos a los pajaros: jamis toca á los peces, por mucha hambre que tenga.

E En mi juventud, dice cl conde Rodolfo de Choteh, re. cibi un gips monje que iué extraido con el plumaje mojado de las olas del Danubio, y al que se cuido durante dos airos en la casa del párroco. Yo me le llevé a Korompa, donde vivió treirta mas; y despies le regalé al principe de Lam berg, quien le trasladó á Stejer y le puso en el foso del cas tillo. Aqui viviria probablemente aun hoy si no le hubiese muerto un ciervo que con if habitaba el mismo recinto. Este buitre, una hembra que repetidas veces ponia huevos, habia trabado intima amistad con una jóven gallina que habia penetrado por la reja de su gran jaula. De noche, $\delta$ cuando el ticmpo era lluvioso, esta gallina sicmpre estab? con su companera que la vigilaba y cubria con el mayor carino. No recuctdo qué se hizo despues de la gallina, solo sé que ul buitre no la mató.s

\section{LOS OTOGIPS - OTOGYPS}

CARACTERES. - Estas rapaces son los gigantes de la familia: stis dimensiones no ciceden de jas de los demás grandes vultiridos: pero su cuerpo es mas grueso que el de ninguna oira especic. 'lienen la cabeza enorme; el pico largo y vigoroso; alas muy grandes y anchas, un poco redondea. das; cola relativamente corta, y tarsos altos. La cara inferior del cuerpo, las nalgas y las piernas están cubiertas de plumon, entre el cual sobresalen algunas plumas largas y delga. das, en fo:ma de espadas. I a cabeza, la mitad de la mucr, y toda la parte anterior del cuello, están desnudas; solo cuuren la barba algunos pelos erectiles.

\section{EL OTOGIPS AURICULAR-OTOGIPS AURI- CULAR!S}

CARACTERES. - Fista especie es la mas conocida del genero (fig. 1 -6). I a longitud del macho varia de $\mathrm{I}^{\mathrm{m}}$, s. $\mathrm{I}^{\circ}, 05$, por 2,70 di 2 , So de anchura de punta á punta de las alas; esias

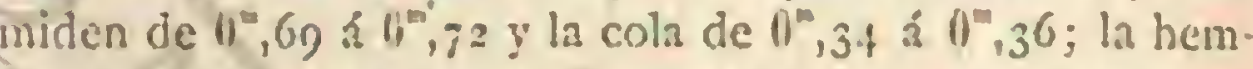
bra es mucho mas grande. El plumaje es de un color pardo de sepbo mas $\delta$ menos pronunciado, con un filete oscuro en las barbas cxternas de las rémiges y de las rectrices, y otro mas claro en las grandes cobijas superiores del ala : el ojo es de un pardo oscuro; el pico color de cuerno en los lados, con la parte mas alta de la mandibula superior oscurn, lo tmismo que la inferior; las patas son de un gris de plomo claro: las partes desnudas del cuello grises y las mejillas de un tinte violeta. Cinndo el ave está muy irritada, todas las partés desnudas det cuello y de la cabeza, excepto la coronilla, adquieren un tinte rojo.

Mluchus individuos tienen en el lomo y la nuea algunas plunas de un leonado prálicio o blanco amarillento.

Fon los pequenos los colores son mas oscurro, y las plu. maş de las partes inferiores mas anchas.

DISTRI EUCION GEOGRÁA1CA. - İl Oingips auricu lar se exticnde desde el Egipto superior por toda el Africa y sube en las montañas hasta la altura de 4,000 metros. No es tan comun como sus rongéneres, pero se le encuentra en todás pantes. Segun dicen, se lan hallado repetidas veces individuos errantes en toda Europa.

\section{EL OTOGIPS CALVO-OTOGYPS CALVUS}

CARACTERES. - Fista especie, cl selsumi de los incos, puede alcanzar, segun Jerdon, una longizud de $11^{\mathrm{m}}, 9 \mathrm{r}$; las alas cxiendidas iniden $0^{\circ}, 60$ y la cola $0^{\circ}, 25$; de modo que esta are es mucho mas pequeña que cl otogips alricular. Ia cabera, exceptuando solo la region de las orejas, está cubierta de plumas cerdosas y escasas; la barba, la garganta, los la. dos de la parte anterior del cuello y un espacio en la interior de los muslos, son desnudos; la region superior del buche, así como el centro del cuello, están revestidos de plumas vellosas, que en la inferior forman una mancha ex. tensa, la cual se prolonga hasta los hombros: la parte supe. rior de los musios y los costados tienen una especie de plu. mon lanoso; las plumas del collar no son rigidas mas que en la nuca; los lóbulos, las orejas y los repliegues de la garganta ofrecen un gran desarrollo; el manto, las tectrices medias de las alas y todas las partes inferiores son de un negro pardusco; las plumas de las alas y de las espaldillas de un pardo pálido, con rarias lineas trasversaics y finas de un tinte oscuro: las pequenas tectrices de las alas son del mismo color; las rémiges secundarias de un pardo claro gris con puntas pardo negras, por lo cual se forma una ancha faja en las alas; las rémiges primarias y las rectrices tienen un tinte negro pardo oscuro. 'Todas las partes desnudas, de un rojo carnin, adquieren un color de sangre cuando el ave se excita. El iris es de un pardo oscuro; el pico, negro de cuerno, la cera de un rojo de carmin oscuro; y los piés del mismo color, mas claro. 
DISTRIBUCION GEOGRÁFICA. - Bl airea de dispersion de esta especie se extiende por toda la India hasta Burna.

USOS, COSTUMBRES Y RÉGIMEN. - LS raro no encontmar el oricu cerca de los cadiveres de los animales grandes, en todos los paises situados al sur de la Nubia. No teme al hombre, y peneira en los pueblos, acercinudose á los mataderos, aunque no es tan confiado como el pernóptero. Cuando se halla junto á una presa es el verdadero amo, pues ahuyenta á todos los dernäs buitres, excepto el gips leonado, y sabe hacerse respetar de los perros.

In especie india se conduce del mismo modo. «Los naturalistas, dice Jerdon, llaman al sictumi rey de los buitres, porgue todos le temen y le ceden el puesto apenas se pre. senta.

De todos los miembros de la familin, el otogips auricular ú oricu es el mas voraz.

El otogips oricu no está dominado, sin embargo, por esa baja avidez que se observa en las especies de largo cuello. Come rápidamente: en cinco minutos devoran un perro grande cuatro ó cinco de estas rapaces, sin dejar mas que el cráneo y los huesos de las patas. He visto con frecuencia cuanta es la fuerza del oricu: un solo picotazo le basta para cortar la piel de un animal grande, y algunos mass para dejar descubiertos los músculos en una gran extension. Yo vi á uno coger una cabra con su pico y matarla fácilmente.

Despues de comer se dirige siempre el oricu hácia la corriente de agua mas próxima; apaga su sed, se limpia y des. cansa como las gallinas; introdúcese en la arena y se calienta al sol; luego cmprende su vuelo; describe grandes círculos en los aires; se cièrne y vuelve al sitio donde pasó ln noche. Ja más te he visto dormir sobre una roca; los árboles son los que le sirven de lugar de reposo, aurque no siempre escoge los mas altos; bistale el primero que encuentra, y con freciencia le hallé en matorrales de mimosas quue apenas tenian tres inetros de clevacion. Mantiénese con el cuerpo casi perpendicular, la cabeza encogida entre las espaldillas y la cola colgante.

Por la mañana permanece inmóvil lo menos dos horas despues de haber salido el sol, en el mismo sitio donde ha pa. sado la noche, siendo entonces tan poco receloso, que el cayador podria acercarse al pié del arbol y matarle con per. digones. Al volver de Mensa, sorprendi en un valle que atra viesa el crmino, un grupo de ocho, los cuales se preparaban á dormir, pudinos jasar junto al úrbol donde se hallaban, sin yue hiciesen ningun movimiento, y solo hureron cuando hube matado un individuo; pero estaban aun tan entorpeci. dos por el sueño, que se posaron de nuevo à unos quinientos pasos ce alli.

El oricu no se presentá junto \&los restos animaies antes de las dier de la mañana, y se retira á las cuatso ó las cinco de la tarde, cuando mas se le pliede reconocer desde léjos por su vielo tranquuilo y majestuoso: cuando divisa una pre. sa, se deja cacr verticalmente desde una altura de un centenar de metros; abre luego las patas y se dirige en linea oblicua hácia el objeto que ha visto. A la manera del gips leonado, alimúntase principatmente de la carne muscular, y parece despreciar las visceras.

Wo he podido lincer ninguna observacion acerca del modo de rejuroducirse esta ave, y por lo tanto dictoo limitarme i copiar á Le Vaillant. E. El buitre occipital, dice el iiustre naturalista, anida en las cavernas de las rocas; la hembra no pone mas que dus huevos blancos, g rara vez. tres. En octubre es cuando comienza el periodo del celo para estas aves, y en enero han salicio á luz todos los hijuelos. Atendido a que forman inmensas bandadas, una sola montaña contiene à ve- ces tantos nidos como sitios hay a propósito para formarlos; y es de notar que jamás anidan los buitres en un árbol, al menos en Africa; me enganaria mucho si no sucediera la misma cosa en todos los buitres del mundo. Parece qure viven en muy buena inteligencia entre si, pues yo he visto en la mis. ina caverna algunas veces hasta tres nicos, que estaban uno al lado de otro. Con el auxilio de mis hotentotes he franqueado a!gunas veces todos los obstículos, exponiendo mi vida, para examinar los nidos de estas aves, cuyo albergue es una verdadera cloaca, repugnante é infecta, que despide un olor insoportable. Fis tanto mas arriesgado aproximarse a estos oscuros antros, cuanto que la entradia está cubierta de un excremento siempre liquido, por la humedad que producen las aguas que filtran continuanente de las rocas. De aqui el grave riesgo de escurrirse en las cirnas y caer en abismos espantosos, sobre los cuales se rijan los buitres con preferencia. He probado los huevos del oricu, asi como los del buitre ceniciento, y me han parecico bastante buenos para utilizar. los Al nacer el pequeño oricu está cubicrto de un phumaje blanquizco.x

En pro de lo primero tencmos un relato de Gurney, quien tenia una hembra cautiva que puso cuatro años seguidos, siempre en febrero, un solo huevo de color blanco con manchas rojizas mas espesas en la exiremidad ob:usa. Sobre esto último no es menester añadir algo. para los que alguna ver. han olido un huevo de buitre recien puesto.

Esta rapaz es mas desprecinda aun por lus indigenas que todos los demis vulúridos. Considérnnla como un anirnal impuro y peligroso: dicen que acomete a las personas dormidas y las mata; pero estoy seguro de que esto es una calumnia, atunque no diré qque no ataque munca á un animal viro, pues yo he visto lo contrario.

Chza. - Dusante mi permanencia en Kiharthoum fui a cazar buitres todos los dias durnnte un mes; y los atraia arrojándoles restos putrefactos. Traspiortados estos á la llanura, los colocábamos en una peçueña eminencia y nos poniamos a unos veinte pasos: varias veces me ha sucedido matar cuatro buitres, uno tras otro, $y$ hasta derribar el mismo número de un solo tiro en cierta ocasion; serviame ademís de trampas; las mas toscas eran suficientes para coger a las rapaces. En poco tiempo tuve asi un gran número de buitres, entrc los cuales habia varios oricus.

CAUTIVIDAD. - I.as rapaces de esta útima especie soportaron tranquilamente la cautividad, y parecian muy confiadas, al contrario de los gips leonados; las até con una correa. y ninguna trató de cortaria Al tercer dia de ser cogidos, el primer oricu comenzó a beber: al cuarto devoró un gato imuerto, al que no habia tocado hasta entonces; al quinto comió delante de mi, y desde entonces se condujo siempre como si yo no estuviera celante, y hasta llegó á tomar el ali. mento de mi mano.

Cuando el otogins come tiene el cuerpo horizontal, extendidas las patas y recogidas las plumas. Sujeta con sus garras la racion de carne y la despedaza a picosazos; no iraga mis que los trozos pequeños, y roe los hucsos con cuidado. ill agua le es absolutamente necesaria; bebe mucho $y$ le gusta banarse. Cuando se enfurece eriza las plumas y silba cono el buho; en tal momento se enrojece mucho la mancha desnuda que tience en el occipucio; si está sobrexcitado vomita la carne que contiene su buche; tambien lo hace á menudo cuando descansa, como se observa en los perros. Si se le pone en una gran pajarera permanece lan tranquilo como cuando está libre; comprende cuainta es su fuerza y no se deja mo. lestar, pero tampoco acomete nunca.

Parece que soporia ficilmente nuestro clima, sunque ic gusta mucho el calor. En nuestros jardines zoológicos tene- 
mos a los oricus al aire libre todo el ano: cuando el frio es riguroso itritan; pero se les da entonces mas de comer que en verano, y soportan así los rigores del invierno.

\section{LOOS CA'TARINOS - CATHARINAE}

CARACTERES. - El carácter mas distintivo de los vulturidos del nuevo continente consiste en las grandes fosas nasales de forma oval, carácter que se considera de bastante importancia para fundar en él una familia especial. Nosotros iomaremos en cuenta esta opinion, reuniendo los buitres del nuevo continente en una sub-fanilia. Además de lo dicho, estas aves se caracterizan por su pico mas 8 micros prolonga do, cubierto en la base de la mandibula superior de una cera blandx; estréchase junto á esta, y es muy corro cn la panta; los piés son robustos; los tarsos gruesos; las alas largas y puntiagudas; la cola bastante larga; la cabezacy la parte su perior del cuello son desnudos y suelen tener, en la mayoria dé casos, unas protubernncias membranosas en forma de cresta, que ocupan la base del pico y la frente, presentando además unos repliegues de colores mus vivos. En la estructura interna obsérvanse diferencias notables, si se compara con la de los vultúridos del antigúo continente y sobre todo $\operatorname{con}$ la del gipacto barlutido.

\section{LOS SARCORAMFOS - SARCO- RAMPHUS}

CARACTERES. - Debe considerarse á estas rapaces como los mas nobles de iodos los vultúridos: tienen el cuer po medianamente prolongado; las alas largas y delgadias; la cola larga tambien, asi como los dedos; los tarsos altos; e cucllo mediano; la cabeza pequeña ; el pico largo, redondea do, comprimido lateralmente, en exiremo ganchudo, adorna do en el macho de una especie de cresta, y rodeado en la region de lá barba de un lóbulo cutáneo. las losas nisales no estín separadas por un tabique. Las plumas son inas an. gostas que las de los otros vultúridos, pero de culores mas vivos; ciertas partes carecen completamente de cllas. El macho es mayor que la hembra.

\section{EL CONDOR - SARCORAMPHUS GRYPHUS}

CARACTÉRES. - Tambien al condor le ha cabido ha suerte del gipacto barbudo; tambien á él se le ha desconoci. do y difunado, propalāndo las fŕbülas mas naravillosas.

Hasta el presente siglo no ha quedacio bien averiguada la verdadera historia matural del condor, siq̨uiera recientemente no haynn faltado maturalistas que tomaron bajo su responsa bilidad algunos asertos, evidentemente falsos. No obstante, Humboldt, Darwin, d'Orbigny y 1. J. de Tschudi nos han dado á corrocer bien al ave, antes de cllos f́abulosa, poseyen do ya la descripcion completa y exacta de su género de vida

El condor adulto tiene el plumaje negro, con ligeros visos de un azul de acero: las rémiges primarias de un negro mate, $y$ las secundarias de un negro agrisado, orilladas exterior. mente de blanco; las grandes cobijas del segundo órden son de un tinte blanco sobre las barbas externas; el occipucio, la cara y la garganta de un gris negruzco; el cuelio de un color de carne livido, y la region del buche de un rojo pálido. Un lóbulo cutáneo, que pende de la gyarganta, y los dos pliegues verrugosos de los lados del cuello, son de un rojo vivo; adorna la parte inferior del cuello un collar de plumas, bastante largas y blancas; el ojo es de un tinte carmin subido; el pico color de cuerno y las natas de un pardo oscuro.

La hembra carece de cresta; la piel desnuda de la cabeza es pardusca, y todo el plumaje de un pardo negro uniforme, con tintes cenicientos en las alas.

Segun Humboldt, el macho ticne $\mathrm{z}^{\prime \prime}, 02$ de largo por $2^{4}, 75$ de punta a punta de ala; esta plegada $1^{\prime \prime}, 15$ y la cola $0^{\circ}, 37$ : una hembra que midió dicho naturalista, tenia ()$^{\prime \prime}, 03$ menos de largo por 0 ", 25 de desarrollo de las alas.

DISTRIBUCION GEOGRÁFICA.- Ei condor habita en las altas montanas de la América del sur: se le encuentra desde Quito hasta $\mathrm{el} 45^{\circ}$ de latitud sur; en los Andes vive particularmente en una zona de 2 á 500 metros sobre el nivel del mar; en el estrecho de Magallanes y en Patagonia, llega hasta la orilla del mar, y anida en las costas bravas escarpadas, cuyo pié bañan las olas. En el Perú y en Bolivia baja muchas veces hasta las costas; dice 'Tschudi que abunda dicz reces mas en las áfturas que en el liano; $y$ admitese general. mente que es de todas las aves la que mas se eleva por los aires. Segun Humboldt, se la ve con frecuencia cerniéndose sobre la cima del Chimborazo, scis veces mas allá de la region de las nubes, y is un elevacion que se calcula exceder de 7,000 metros.

USOS, COSTUMBRES Y REGIMEN.- Todo cuanto vemos en los usos y costumbres del condor de los Andes nos representa al verciadero buitre: es sociable y forma bandadas compuestas de cincuenta ó sesenta individuos, los cuales se diseminan a la llegada del periodo del celo para aparcarse. Culda una de estas bandadas se fija en alguna pared de roca, y aili permanece de continuo, recorricndo por la mañana una extension de la que dificilmente se puece formar iden: elévarise primero los condores lestamente as impulso de algunos aletazos: ý despues á semejanza de los grandes vultúridos, comienzan á cernerse sin agitar las alas. Cuando uno de ellos divisa una presa, déjase caer y le siguen todos los demás. an menos de un cuarto de hora, dice 'Tschudi, caen nubes de condóres sobre el cadáver abandonado de un animal, siendo asi que un momento antes no hubiera podido descu. brir un solo individuo la vista mas penctrante. Si la caza ha sido feliz, welven á eso del medio dia á su roca para descan. sar algunas horas; y por la tarde comienzan á buscar de nuevo su alimento.

El condor, asi como otros vultúridos, se alimenta princifalmente de cadiveres. Humboldt dice que dos de estas aves atacan no solo al ciervo de los Andes y á la vicuña, sino tambien al guanaco $y$ à las terneras, at las cuales persiguen y acosan hasta que caen sin aliento. T'schudi afirma que los condores siguen á las manadas domésticas y salvajes, precipitíndose al punto sobre los animales mucrtos.

Algunas veces tambien acometen â los corderillos recien nacidos, ó á los caballos enfermos, cuyas heridas agrandar á picotazos, y á los que rematan abriéndoles el pecho. Siguen continuamente $\$$ los cazadores: cuando estos desucllan una vicuña ó un ciervo de lus Andes, se ven á menudo rodeados de banciadas de condores, que se precipitan conavidez sohre los intestinos, sin manilestar ningun ten:or al hombre. Acom. pañan al puma en sus excursiones para devorar las sobras de sll comida. \&Cuando estas rapaces se dejan cacr y remontan luego súbitamente, dice Darwin, el chileno sabe que hay alli un puma, velando sabre su presa, que las aluyenta.

Cuando las ovejas tienen ya sus hijuelos, el condor vigila las manadas y aprovecha la ocasion para robar cabritos ó corderos. I as vacas que se hallan en el túltimo periodo de la preñe\%, dice T'schudi, deben encerrarse sicmpre en un corral, cerca de las habitaciones, rodeándole de un muro, y aun asi es menester vigilarlos cuidadosamente, pues tan luego como una vaca pare acuden sin tardanza estas ares gigantescas para apoderarse de la ternera, la cual es arrebatada si no se la defiende enérgicamente. 
Se enscia i los perros dè ganado á currer alrededor de las reses mientras se halle el encuigo id la vista, y a mirar siem. pre hácia las alturas, ladrando vigorosamente si se divisa aiguna de las rapaces.

En las orillas del mar se alimentan de grandes mamiferos marinos, arrojacios por las olas á la playa; evitan la proximidad de las casas, por mas que no les inspire temor el hom. bre. No acometen á los niiros, ó por lo menos no se conoce ejemplo de ello: dice Humboldt çue con frecuencia duermen los muchachos al aire libre, mientras que sus padres recogen la nieve para ir al renderia al llano, y que no temen nada de? condor. Ios indios, por su parte, ascguran que el are no es peligrosa para el hombre.

Estas rapaces despedazan su presa como los otros vultúrjdos. Comienzan, dice 'Tschudi, por separar las partes que ofrecen menos resistencia, lal como los ojos, las orejas, la lengua y los pedazos blandos que hay al rededor del ano, donde practican un gran agujero å fin de penetrar en la ca.

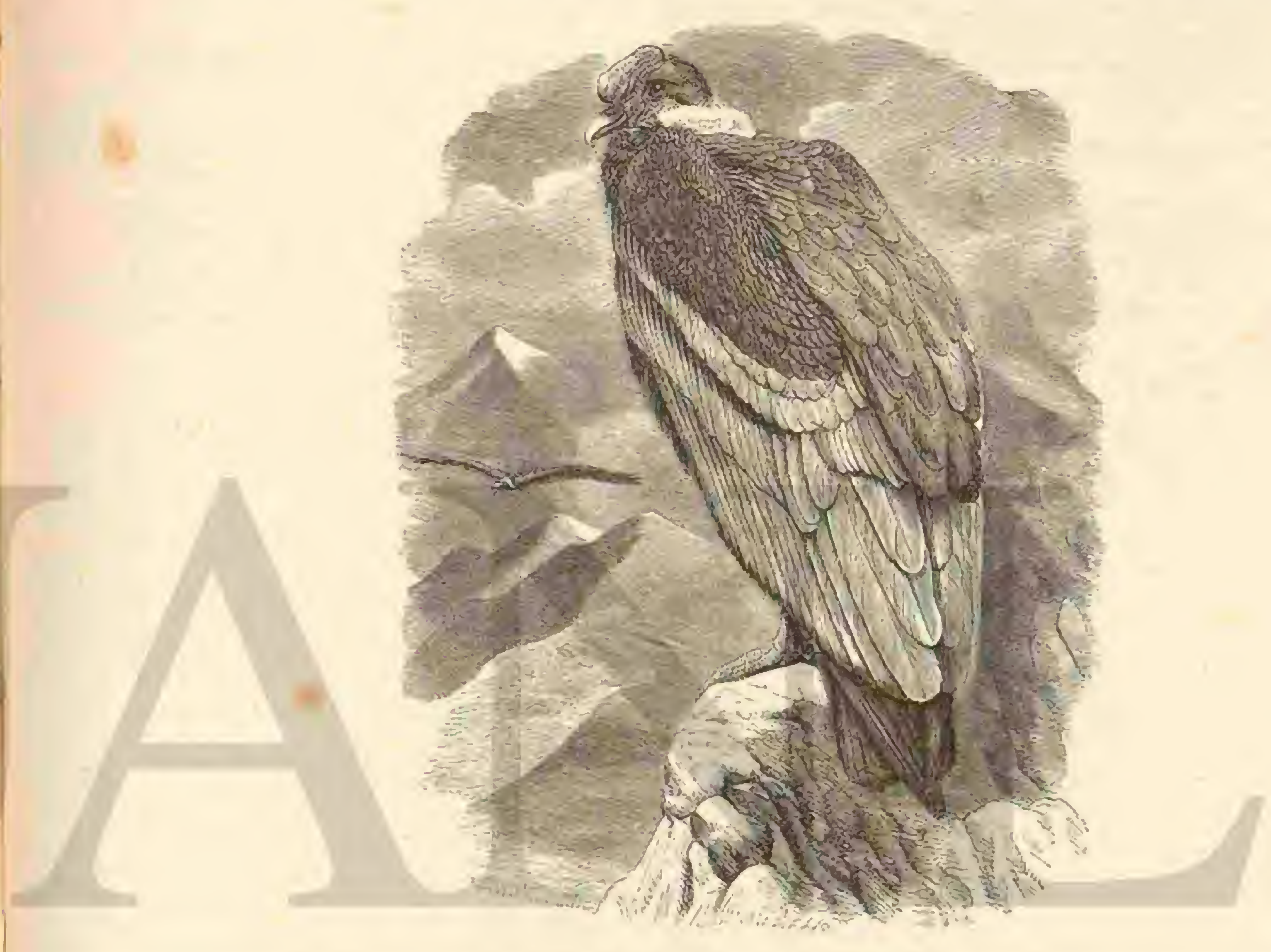

Fig. I7S.-EI. SARCORAMHO CONDOR

vidad abdominal. Cuando se reunen varios individuos alre. dedor de un cadáver, no les bastan ya los orificios naturales para comer bastante de prisa, y practican aberturas en el pe. cho 6 en el vientre. Los indios pretenden que la rapaz sabe perfectamente dónde está el corazon, y quue siempre es el ór gano que primcro busca.

Una ve\% harto, el condor es pesado y perezoso; si se le obliga \& emprender el vuclo romita los alimentos que llenan su buche.

Ail condor es un ave fiera y majestwosa, cuando con las alas extendidas casi inmóviles, se balancea en los aires, $\delta$ cuando irguiéndose sobre una punta de toca saliente observa con su penetrante vista el pais en busca de alguna presa. Pero si la vemos al precipitarse con voracidad indecible sobre su victima, cuando devora grandes pedazos de carne putrefacta, y cuando despues de atracarse aprenas puede moverse y se posa junto á los restos de su comida, que infecta los contor nos, entonces no es mas que un buitre cuja manera de alimentarse nos repugria.

La época del celo del condor puede ser en nutestros mescs Tомо III de invierno ó de primavera; y al apareamiento preceden manifestaciones amorosas muy extrañas por parte del macho, como he observado en individuos cautivos. Macho y hembra se conducen verdaderamente a la manera de los gallos silvestres para expresar sus sentimientos. A intermlos mas 6 menos largos extienden las alas, inclinan el cuello, antes tendido, dilítanle un poco, de modo yue la punta del pico toca casi el buche, y produccn unos sonidos sumamente cstrepitosos, algo semejantes a un tamborileo. Para esto hacen visibles esfuerzos castaneteando la lengua de tal modo que la gar ganta y el vientre se agitan a la ver; luego dan algunos pasos vacilartes, moviendo las alas por espacio de dos ó tres minutos; producen un resoplido, reteniendo antes el aliento; tecogen el cuclloy las alas, sacuden su plumaje, lanzan tam. bien á veces sus excrementos, y vuelven a tomar su posicion anterior. Fi:l otro esposo de la pareja se acerca á veces al excitado, le acaricia con el pico y con la rabeza, le abraza verdaderamente y recibe de él iguales caricias. Todo esto dura poco mas ó menos un minuto. pero se repite en una hora dicz of veinte veces. 
Su niòn, si tal nombre puede dársele, está situado en las rocas mas inaccesibles de las cimas de las Cordilleras; con frecuencia jone la hembra en la tierra desnuda dos huevos, que tienen un color b́lanco amarillento con manchas pardas. Los pequeños nacen cubiertos de un plumon agrisado; crecen lentamente 5 no emprenden su vuelo hasta mucho tiempo despues de haber salido á luz, permaneciendo largo tiempo bajo la tutela de sus padres, que los defienden valerosamente en caso de peligro. En mayo de 1841 , refiere Tschudi, nos perdimos en una escarpada crestá, persiguiendo á un ciervo herido, $y$ divisamos, a menos de cuatro piés, debajo de nos. otros, tres hemuras que se preparaban á cubrir. Nos recibie ron con espontosos gritos amenazadones, y pudimos temer que nos precipitaran yor la cresta donde nos hallabamos, la cual tenia apenas dos piés de anchura. Solo retisandonos prontamente un sitio mas espacioso conseguimos evitar el peligro.

CAzA.-Los indios cogen muchos condores, y parece nue se complacen en maltratarlos. Lilenan el vientre de un animal de yerbas narcóticas; despues de atracarse de ellas, e condor vacila y titubea, como si estuviese embriagado; y en tonces se le atrapa fäcilmente. Otras veces se tira en la llanum un pedaro de carne de modo que se balle en un recinto cercado, y se espera as que las aves, se atráquen; despues se lanzan sobre ellas varios jinetes, y las cogen con el lazo. Mo. lina nos habla de otro géneto de caza, y su relato ha sido confirmado par T'schuadi, por mas qutue parezca inverosimzil; helo aqui: tFxtiendese sobre el suelo una piet de buey, que conserva todaria algunos restos de carne, y debajo de ella se oculta un indio, provisto de lazos. - Cunndo se posa una de Las rapaces, el hombre levanta la piel envolviendo con ella la pata del condor, como si la pusiera un guante; sujctala luego, y cuando algunos individuos están aprisionados asi, alćjase rastreando Otros cazadores, que acuden despues, arrojan va. rias inantas subre las avés y se las llevan a los puebris, donde deben figutar en las corridas de toros. Ocho dins antes de la fiesta no se da nada de comer a los condores, y el dia fijado se ata uno de eiloś en el lomo de cada toro. á los que se hiere antes con alguinas lanzidas; el ave hambrienta agranda la herida, é irrita de este nodd al cuadrúpedo con gran con. tento de los indios.

DEn la eleruủa meseta de la provincia de Huarochirin hay un sitio donde se matan fácilmente muchos condores: es una especie de embudo natural, de unos sesenta piés de profundidad, que es el mismo diámetro de su abertura. Se pone á la orilla el caciaver de un mulo ó de una llama, y bien pron. to llegan los condores. Disputando entre si, y tirando cada cual por su lacio, acaban por hacer rodar el cuerpo al fondo del agujero, y le siguen alli para devorar la presa; pero una rez hartos, es zal' su pesadez, que no pueden salir de aquel embudo. Fn aquel instante aparecen los indios, que provistos de largos palos, matan fícilmente á las abes. I'schudi ajade que asistió á uma caceria por el estilo, en la que se mataron veintiocho condores,

CAUTIVIDAD. - Se han hecho observaciones muy diferentes en los condores cautivos: algunos se domestican perfectamente; otros siguen siendo malignos y salvajes.

Haeckel turo targo tiempo dos de cstas ares, que cran muy agradables than cobrado, dice Grourcy, afecto à su amo, particularmente el macho, el cual al verle no deja nun. ca de saltar de alegria en su jaula. A una órden sube á su percha; se pasa en el brazo de su dueño; se deja llevar por él y le acaricia la carn con el pico. No le hace êl menor daño aunque le introduzca los dedos en aquel órgano ó le eche de espalda tirándole de las plumas. Juega como un perrito: la hemira no tarço en tener envidia de aquellos halagos, y aho. ra tira de la ropa á su amo hasta que le da de comer; son muy envidiosos uno de otro, y con frecuencia desgarran el vestido de aquel, tirando cada cual por su lado. El macho salta alegremente de un lado á otro como un chiquillo, y con todo retoza. Estos condores difieren de las demás rapaces por lo mucho que se han domesticado, y de los buitres por su alegria.

Los condores viven en buena inteligencia con los otros vultúridos, $y$ se sirven de su pico con tal fuerza y habilidad, que hasta los mismos buitres leonados tienen que cederles el puesto.

\section{EL SARCORAMFO PAPA-SARGORAMPHUS (GYPARCHUS) PAPA}

- Como el condor en el Perú, añade Tschudi, así en Mé xicu y la América del sur llamó la atencion de los primeros viajantes el sarcoramfo papa ó real. Hernandez ya le conoció lédescribió; su plumaje de magníficos y vivos colores, le ha valido el nombre de rey de los buitres (rex auluurum), nom. bre que tiene otra razon de ser; el sarcoramfo papa reina y domina sobre las especies mas pequeñas, y por su fuerza y energia, inspirales el major respeto.

CARACTERES. - Un sarcoramfo real adulto es un ase realmente magnifica: tiene la parte anterior del lomo $y$ las cobijas superiores del ala de un color blanco rojizo vivo; el vientre y las plumas sub-alares de un blanco puro: las pennas de las alas y de la cola negras, las primeras orilladas de gris por fuera; el collarin de un tinte gris; la parte superior de la cabeza y la cara de color rosa de carne, cubiertas ambas de pelos contos y erectiles; la parte posterior $y$ las papilas ver. rugosas, de color rojo oscuro; un sepliegue cutáneo que se dirige hácia el occipucio es del mismo tinte; la cera, el cuello y la cabeza de un amarillo claro; la cresta es alta, lobulada y negrá, el pico negro en la base, de un rojo vivo en el centro y blanco amarillento en la punta; las patas de un gris negro, y el ojo blanco plateado.

Los pequeños tienen el plumaje de color pardo uniforme, mas oscuro en el lomo; la rabadilla y las piernas blancas.

El condor réal mide de $10^{\circ}, 8_{4}$ \& $0^{\circ}, 8_{9}$ de largo, $1^{\prime \prime}, S_{0}$ de ancho en las alas; el largo del ala plegada es de $11 ", 52$; la cola tiene 1$)^{-}, 23$.

La hembra es mas pequeña que el macho: $y$ tambien la cresta carnosa que lleva el pico.

DISTRIBUCION GEOGRÁFICA.-El sarcoramfo papa inabita todas las tierras bajas de América, desde $\operatorname{los} 32^{\circ}$ de la titud austral hasta México y 'Texas; tambien se le ha encon. trado en la Florida; en las montañas no sube at mas de I,600 metros sobre el nivel del mar.

USOS, COSTUMBRES Y REGIMEN.-Segun AZM, Humboldt, el principe de Wied, d'Orbigny, Schomburgk, Bonjan, Tschudi yotros naturatistas, que han hablado de las costumbres de esta rapaz, el sarcoramfo real frecuenta las selvas virgenes y las llanuras cubiertas de árboles; jamás se dO Orbigny, abunda unas ni en las montañas peladas. Segun dien diez veces mas que el urubú y quince mas que el gallinase. El sarcotamfo real pasa la noche en las ramas bajas de los árboles situados en el lindero del bosque; parece preferir ciertos fugares, $y$-se ve a varios de estos vultúridos reunirse en bandadas. Bien csté solo ó en compañia, se pone en mo. vimiento muy temprano por la mañana, $y$ antes qque el con. dor; "isita el bosque y sus alrededores, á fin de ver si ha cazado el jaguar alguna cosa para bl, $y$ si divisa por fin un cadáver, déjase caer ruidosamente, aunque no se acerca in. unediatamente $\{$ su presa: empieza por posarse á cierta dis 
tancia, sobre un árbol ó en el suelo; encoge la cabeza y el cuello entre las espaldillas, $y$ lanza de vez. en cuando sobre el objeto deseado una mirada de codicia, cual si quisicn excitar mas su apetito por la vista. Hasta despues de media hora 120 se prepara a saciar su hamure; jrocede sicm. pre con mucha prudencia, y no se mucre sin asegurarse de que nada le amenaza. A menudo se atraca hasta el punto de no poder andar sin dificultad: cuando tiene el buche lleno de alimentos, el sarcoramfo real exhala un olor insoportable, y si no tiene nada en el cuerpo, despide un fuerte olor de almizcle, como todos los vultúridos. 'l'rminada su comida, emprende el viselo para posarse sobre un alto árbol, con preferencia en uno seco, donde hace la digestion.

Por lo regular, los urubuis son comunmente los primeros en descubrir el cadáver de un animal; pero deben abandonar su banquuete cuando viene su rey á reciamar su parte. \&.tun. que haya rentenares de buitres reunidos alrededor de un resio animal, dice Schomburgk, todos se retimn apenas ap̣a. rece el sarcoramfo real. Posados en un ärbol próximo ó en tierra, espreran, con los ojos brillantes de codicia y de envi. dia, á que el tirano acabe de aplacar su haubre y se retire: tan pronto como concluye precipitanse todos y se disputan la mejor parte de los restos. Con frecuencia he sido testigo del hecho, y puedo asegurar que ante ninguna otra ave se retiran las pequeñas especies de vultúridos ni abandonan su presa sino ante el sarcoramfo real. Cuando le divisan a lo lé jos, retiranse todos, por ocupados que estén, y al acercarse, parece como que le saludan, levantando y bajando alternati ramente las alas y la cola. Cuando la rapaz ha ocupado su puesto, todas las demás permanecen silenciosas y' esperan tranquilamente hasta que le place retinarse.y

Tschudi duda de la exactitud de lo anterior parque no ha observado igual cosa y considera inexactas las noticias de Schomburgk; pero yo he observado precisamente lo mismo en los otogips y los pernópieros africanos; y segun Jerdon, de igual modo procede el otogips calvo.

Algunos indios refrieron al naturalista Azara que fabrica. b.a su nido en los ironcos huecos, hecho que confirma 'Ischudi; el principe de Wied lo pone en duda: Schom burgk 110 sabe nada sobre ef particular: d'Orbigny no ha vis. to nunca el nido del ave; pero le han rontado lo mismo que á Azara; y por último, Burmeister manifiesta que el condor anida en los árboles altos, $y$ hasta en la prunta de las gruesas ramas muertas. Parece que los hueros son blancos: durante varios meses se ve à los pequenos que han emprendido su ruelo, y que permanecen todavia con sus padres.

CAUTIVIDAD. - Los individuos cautiros se dejan do. mesticar fácilmente, pero solo tienen apego of su guardian, mostrándose ariscos a veces can las personas extrañas, y $^{2}$ ma nifestando inclinacion á morder.

\section{LOS CATARTIDOS-CATHARTES}

En toda la América se encuentran estas aves que viltimamente se agruparon en dos géneros. Sin embargo, su carác. ter, usos y costumbres ofrecen tantas analogias en lo esencial, que me limito $\mathfrak{a}$ dar á conocer esa separacion sin tomarla en cuenta

\section{EL CATARTO AURA - CATHARTES AURA}

CARACTERES. - Esta especie se caracteriza por su pico relativaniente corto, pero grueso, y por tener la cera tan prolongada que llega à cubrir las fosas nasales, grandes $y$ de forma oval; el cuello es desnudo en la mitad superior; la cola escalonada y los iarsos relativamente cortos. La cabeza, desnuda por delante, tiene una protuberancia en el occipucio, y otra que se corre désde los ángulos de la boca hasia el centro de la coronilla; su color es rojo de carmin por delan. te, rojo azulado por detrás y rojo pálido alrededor de los ojos; el cuello, desnudo, tiene color de carne; la parte cubierta de plumas, asf cono la superior del lomo y las regiones infe. riores son negras, con un viso verdoso metálico; cada pluma de la parte superior tiene un borde algo mas claro; las rémiges son negras, las secundarias provistas de anchos bordes de un gris pailido; las rectrices un proco mas oscuras que las ré. miges. Fil iris es pardo negro, el pico de un amarillo claro de cuerno, $y$ los piés hanquizcos. Ia longitud del ave es de $0^{*},-, S$, por $I^{m}, 6_{4}$ de anchura de punta a punta de las alas, que miden $t^{\prime \prime}, 49$ y la cola $\|^{\prime \prime}, 26$ (fig. 130 ).

\section{EL URUBÚ-CATHARTES JOTA}

CiRACTÉRES. - Esta especie, propia del este de la América del sur, se parece mucho á la anterior, difiriendo, sin embargo, por tener solo la cabeza yo la garganta ciesnu. das; la nuca y la parte superior del cuello están cubiertas de plumas.

\section{EL GALLINAZO-CATHARTES ATRATUS}

CARACTERES. - Lista ave se distingue por el pico mas prolongado, extendiéndose la cera hasta mas allả de la mi. tad; licne las fosas nasales perquenas, redondeadas y muy proximas a la base del picn; la cola es corta y truncada en íngulo recto; los tarsos relativamente altos.

liene las partes desnudas de la cabeza y la anterior del cucllo de color pizarra oscuro; las prominencias rugosas tras. versales dispuestas con bastante regularidad en el pico, en la coronilia y en la nuca, desde donde bajan hasta la cam, la garganta y los lados del cuello; el cuerpo, las alas y la cola son de un negro mate, con visos de pardo rojo oscuro; la base de los tallos de las rémiges es blanca; el pico pardo negro, bianquizco en la punta, y el ojo pardo oscuro. El ave mide 17",6o de largo total, por $i^{\prime \prime}, 36$ de ala is ala; esta plegada tiene $\left(1^{\circ}, 39\right.$ y la cola $11^{\circ}, 1 S$ (fig. is 1 ).

OBEFRVACIONES GENERALES SOBRE LAS TRES ESPECIES.-El catarto aura, el gallinazo y el urubir se han confundido tamtas vecés uno con otro que es muy dificil reproducir siempre con exactitud los datos recogidos sobre la manera de existir de cada especie; todos los catártidos tienen sin embargo, al menos por lo ţue hasta ahora se sabe, un género de vida tan análogo, que el resúmen de las observaciones mas importantes sobre ellos nos permitira formar una idea exacta de lo que cada especie hace. Consideraré por lo tanto al catarto aura y al urubi como si fuesen una especie; pero debo añadir que no puedo aceptar en todo caso la responsabilidad en cuanto al empleo exacto de los nombres.

DISTRIBUCION GEOGRÁFICA. - Ell catarto aura se extiende desde el Sashatchewan por todo el norte, centro y sur de América hasia el estrecho de Magallanes, y desde la costa del Atlántico hasta la del Pacifico, pero no se encuen. tra en todas partes con igual frecuencia; el gallinazo, por el contrario, es mas propio de la América meridional; falta, por ejemplo, en el norte de la Carolina, mientras que en los paises que rodean el golfo de California, en el centro y sur de América, figura entre las aves mas comunes del pajs.

USOS, COSTUMBRES Y REGIMEN.—Uilloa, Azara, Humboldt, el principe de Wied, d'Orbigny, 'I'schudi, Schom. burgk, Darwin, Burmeister, Gosse, Taylor y Abott nos han proporcionado informes sobre las especies del sur de Amé- 
rica; Wilson, Audubon, Nutall, Gundlach, Ridgway, Ord, Cuiloch, Cones y otros nos hablan de las del norte. Sus usos y costumbres son análogos â los de sus congéneres del anti. guo continente: pero muéstranse mucho mas confiacios, por que en casi todos los paises la autoridad castiga screramente al que mata a uno de estos barrenderos de las calles. Ias dos especies no se encuentran en todas partes juntis; caria cual prefiere ciertos sitios.

Segun 'I'schudi, el aura vive principalmente en las orillas del mar; no se le encuentra casi nunca en el intericr de las tierras. mientras que el gallinnzo se deja ver con mas fre. cuencia en las ciudades y hasea en las montañas; rara vez en la costa. Como quiera que sea, todo el que desembarca en América puede estar seguro de ver una de estas aves tan pronto como pone el pié en el continente a El europeo que llega al Perú, dice 'Tischudi, q̨ueda admirado al ver el gran númern de vulúridos que se hallan en los caminos y en las calles, catusíndole asombro ver su tranquilidad al acercarse cualquiera.

Parece que saben que son en alto grado necesarios para

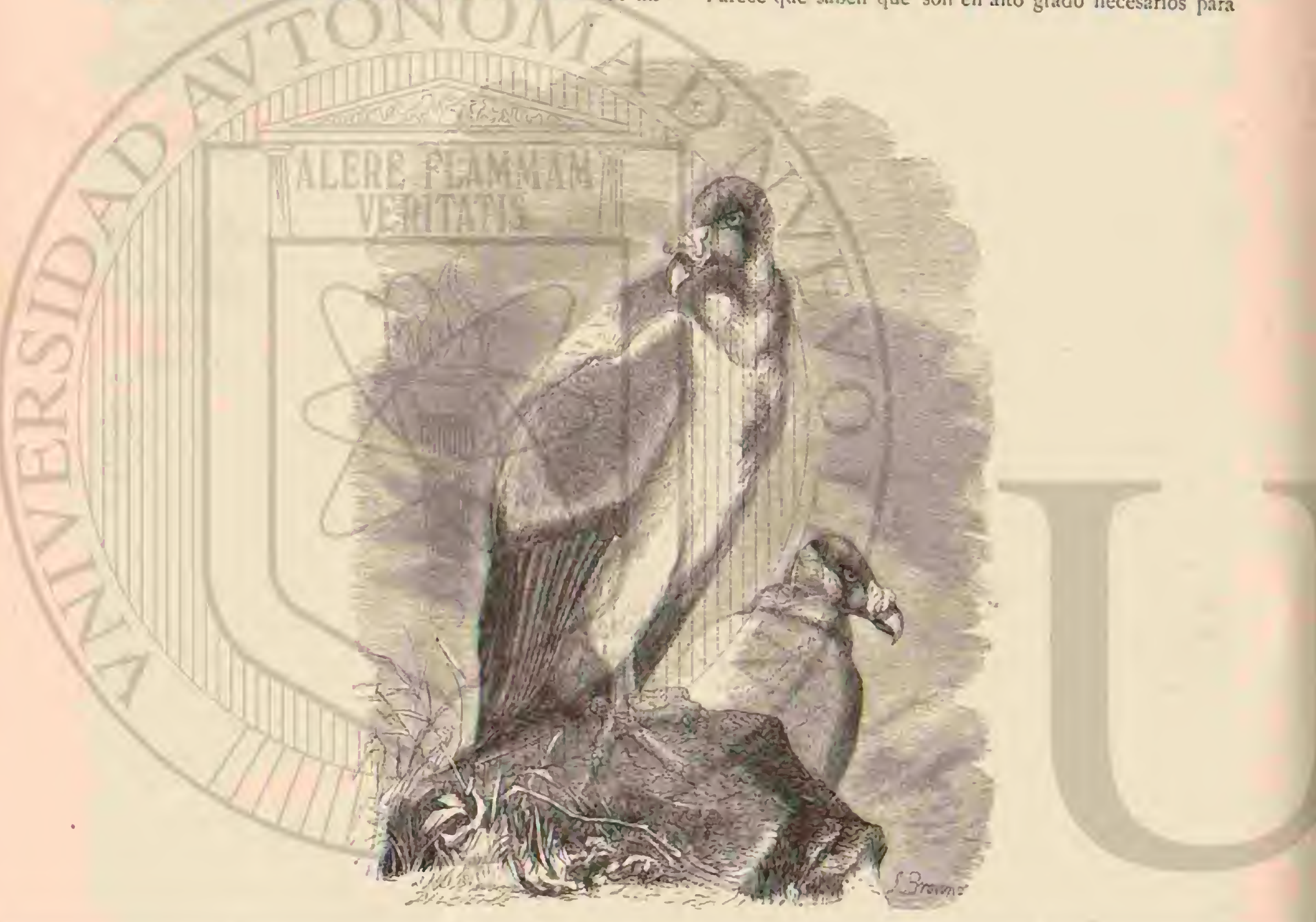

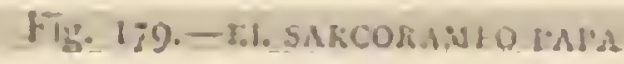

la limpieza pública, y por lo mismo sagrados; en iodas las ciudades de la América meridional desempenan las funciones de nuestra policia urbana.

4Sin ellos, dice Tschudi, la cajital del Perú seria el punto mas malsano de todo el pais; la autoridad no hace alisoluti. mente nada para conservar la limpieza de las calles; pero en cambio millares de gallinazos viven de las inmundicias que se arrojan, y son tan poco timidos que se les ve en el mercado de Lima, correr por en medio de la inultitud mas com. pacta. \$

Lo mismo sucede en todo el resto del sur, y hasta en al. gunos puntos del norte de América; no solo se le, tolera, sino que se le protege por leyes severas.

Muévense como los ctros vultúridos: andan, dice el principe de lried, con el cuerpo recto, y se asemejan bastante á un paro: vuelan con facilidad, ciérnense á menudo, y se remontan á reces a una gran altura; pero no necesitan lucir mucho todas sus cualidades fisicas, porque es muy raro que carczcan de alimento. Cuando descansan encogen cl cuello entre las espaldillas y erizan el plumaje, ofreciendo cntonces un aspecto bastante liediondo. Sus sentidos son muy delicados, pero se guian por la vista sobrc todo para buscar la comida. Audubon, que ha practicado sobre este punto varios experimentos, ha deducido en conclusion que si a estas ropaces se las privara de la vista mo. ririan de hambre. Buscan y encuentran su alimento como las especies que hemos descrito antes.

Los grandes buitres negros, aura y gallinazo, dice Bur. meister, que se encargan en el Brasil de quitar todas las in. mundicias, se encuentran por do quiera. Si un animal caé muerto, precipitanse sobre su cadáver, veinte, treinta, cua. renta ó mas individuos; le arrancan los ojos, y esperan impa. cientes á que los gases que se desarrollan bajo los ardores del sol hagan estallar las paredes abdominales que se descomponen. En aquel momento se promuere un tumulto in. descriptible: cada individuo se apodera de un pedazo de los intestinos, $y$ en un instante quedan hechas pedazos y deroradas las visceras medio descompuestas. Una vez hartas 
las rapaces san a posarse en un árbol próximo, oprimiéndose una contra otra, y alli esperan que la purefaccion cosstinúc su obra y ablande bastante el cuerpo para poder acabar de desorarle. Alguna de cllas, mas impacicnle yque las demós, y cuyo apretito no estri satisfecho, tm?a de arrancas un ratievo pedazo die carne, royendo lus bordes de una abertura; si lo consigue acuden al momento todas las demás, despredaran el cadáver una parte despues de otra, f solo dejan los huesos completamente pelados. Lin dos dias no quedan mas qque algunos restos que sirven de pasto á las moscas.
Por lo dumás comen tambien carne fresca cuando pueden despedazarla; jo pesar de uque muchas veces se ha pretendi. do lo contrario, atacan y matan animales vivos.

coumnte el dia vagan los buitres a lo largo de la ribera, y penetran hasta los caurpamentos de los indios para buscar algo de comida; pero al menudo solo pueden aplacar su ham. bie cogiendo en el agua ó cir las orillas pequeños crocodilos de siete do ocho pulyadas de largo. Fis muy curioso ver cómo estos animales se derienden contra los buitres; apenas divisan เmo, cnderézanse sobre sus jazas delanteras, levantan la cabc-

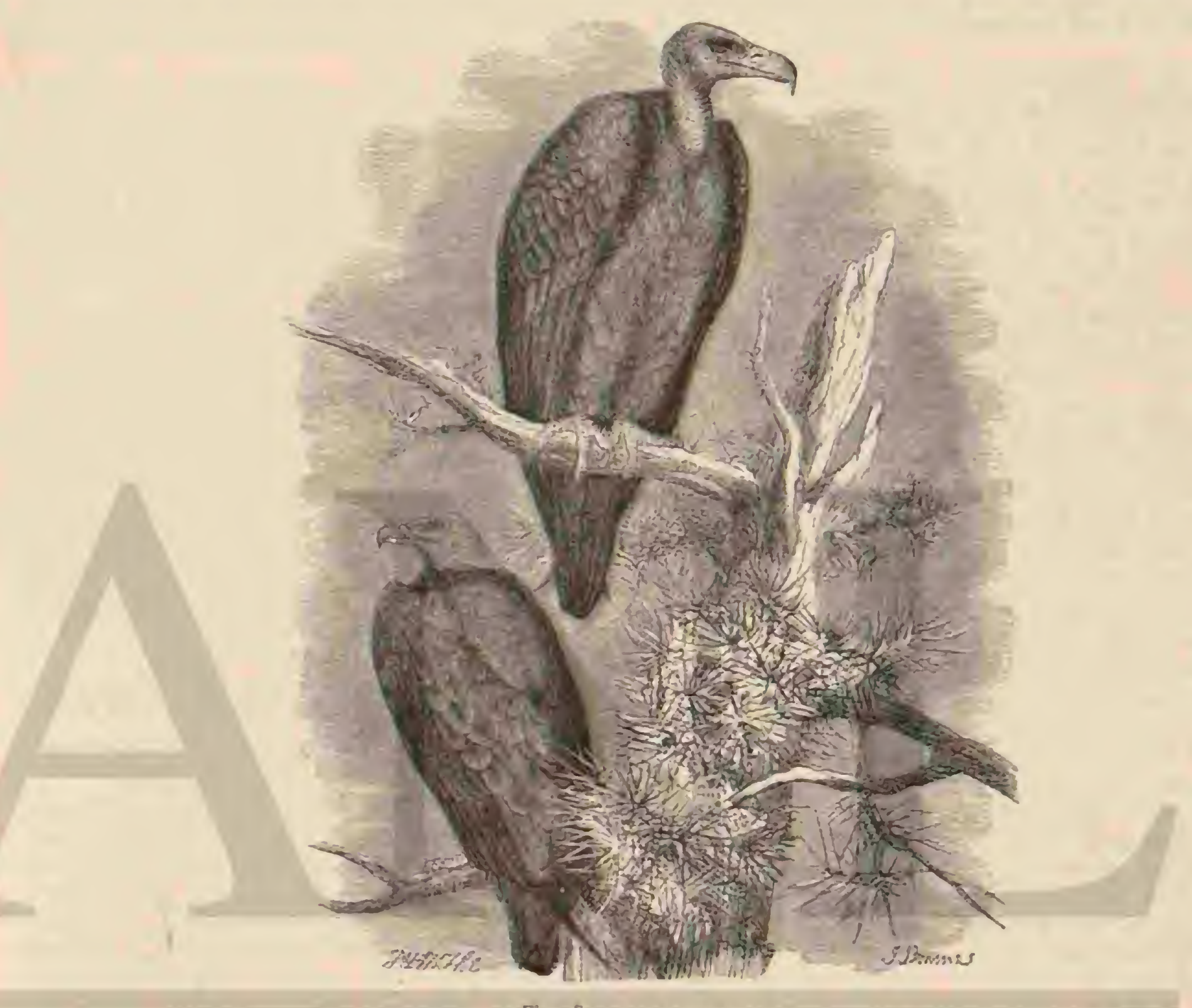

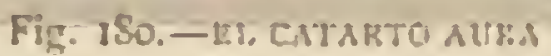

za y abrén nucho la boca: siempre hacen frente to su enemi. go, y le presentan de coninuo sus largos y acerados dicntes. Entonces, mientras que un buitre llama la atencion del pequeño crocodilo, acechá otro una oportunidad para aco. meter al saurio de improviso; cae sobre el, le coge por el cuelio y se remonia llevíndosele por los aires. Hemos observado tal espectáculo mas de una vez

Por su osadia é impudencia son á menudo molestos parn el hombre !́ los carniceros. El príncipe de llied refiere que apenas resuena una detonacion, se les ve aparecer por todos los puntos del horizonic. A spenas habiamos tirado sobre uni pato ó una arecilla, dice, cuando se vecian ya ocho 6 diez buitres, ó mas aun, en los árboles jróximos; y si nos aleja. bamos un irstanie, se les enconeraba devorando la caza." Lo mismo se conducen con el jaguar. aCerca de Joval, réfierc Humboldt, encontramos el mayor jaguar que jamàs habiamos visto: estaba à la sombra de una gran mimosa y acababa de matar a un cappibasa; pero no le habia despedazado aun, y tenia una de sus patas apoyada sobre la presa. Los buitres se habian reunido en gran número jara devorar los restos del animal, y nos divertia mucho observar su osadia mezclada de timidez. Llegaban a dos piés de distancia del carnicero; pero el menor movimiento de este les hacia retroceder al momento; para verlo mejor, pasamos a nuestra canoa, y al ruido de los remos, levantóse el jaguar para ir á ocultarse en las brenas; los buitres quisicron aprovechar la ocasion para devorar al capibara; pero el tigre dió un salto, cogió su presa y lleróscla al bosque.

Los catartos tienen tambien fama de robar los nidos; : hasta se dice que se fijan junto á ciertas ares acúticas para tener mas fácilmente ocasion de comerse sus huevos.

Con el mismo atrevimiento proceden cuando se trata de la bebida donde escasea el agua a grandes distancias. $\mathrm{Mi}$ huésped, dice Tschudi, se quejaba de que los gallinazos ha. cian jadecer sed con frecuencia á su asno; y una mañana me conrenci de la exactizud del hecho. Habióndose llenado de agua in caldero para dar de beber al asno, y como le de. jaran un momento en el patio, bajaron inmediatamente unos 
veinte gallinazos, precipitándose sobre el liquido para apla. car su sed, y apenas se alejaba uno, otro ocupaba su puesto. El pobre borrico observó esta impertinencia al principio mudo de asombro: despues, aranzando hácia el caldero, penetró entre las ares y desvió con la cabeza aquellos huẻs. pedes desagradables; pero estos descargaron picotazos sobre la cabeza de su adversario, obligándole i retirarse. Al cabo de un rato, el cuadrúpedo, volvienco súbitamente, comenzó i cocear contra las roraces aves; esto produjo su efecto al punto; algunas se alejaron del agua, $y$ el asno furioso, pensando solo en vengarse, las persiguió hasta obligarlas á remontarse por el aire Satisfecho de su triunfo y orgulloso de su hazana, dirigióse nuevamente-al caldero, pero otra ver. le vió ocupado El cuadripedo repitió entonces la misina ma. niobra, y esto duró thasta que lós buiares no luvieron ya sed o hasta que el agua se arabó. El pobre asno se vió pues obligado á espemt al dia siguiente para poder disfrutar por ló menos del aspecto del agui. Solo cuando el mozo se co. locaba con un palo junio al caldero érale posiblé ál asno aplacar su sed sin ser estorbado. Como las pocas fuentes de agua dulce de la region están ocupadas dia y noche por la gente que necesita llenar sus cántaros, los gallinazos pade cen sed á menudo y tratan de satisfacerla, ya por astucia ó bien por fuerza, alli donde pueden. ?

Parece que al hombre le complace particularmente turbar el reposo de estos vultúridos: Schomburgk refiere que los oficiales del fuerte Joaquin se dirertian en disparar cañona yos contra las aves que se hallaban reunidas en ulimero de trescientas á cuatrocientas, en el matadero del fuerte; á ve ces quedaban cuarenta ó cincuenta individuos muertos.

QNuestros indios, aniade, ataban un pedazo de carne s. un anzuclo y lo arrojaban a los buitres: el mas voraz lo tragaba y quedaba cogido. Despues le cubrian los indigenas con plu. mas de otras aves, fijåndolas con cera; cortábanle el collar, ponianle una corona sobre la cabeza y le soltaban. La rapaz iba a reunirse con sus compañeros; pero tomándole estos por un monstruo, asusiábansé, huian y no se acercabanlyá hasta que se despojaba de los adornos que le habian puesto.y

Faylor refiere que se entretuvo muchas veccis en arrojar a los gallinazos pieles oé.animales rellenas de algodon, y dice que nada era tan divertido como ver a las rapaces trabajar afanosamente para deshacer aquel maniqui. Burmeister no pudo resistir tampoco á la tentacion de atormentar un poco $d$ las inofensivas aves.

Causforame un singular placer, dice, molestar á estos buitres: acercábame á ellos y disparaba un siro, y cuando huian en todas direcciones, sus alas me arotaban casi el ros. tro. Remontábanse por los aires hasia verse fuera de peligro: describian grandes circulos, sin perderme nunca de vista, y. acababan por volver a concluir su interrumpido banquete. Jamás he oido su roz:parece que siempre están silenciosos. Algunos animales, y particularmente varias rapaces, hosti. lizan tambien al gallinazo y al aura. Ya he hablado de in es. pecie de dominacion que ejerce sobre ellos el sarcoramfo; el caracara y el chimango los persiguen cuando estan hartos de comer, y no los dejan tranquilos hasta que devuelven sus alimentos y se los abandonan.

Segun Tschudi, el gallinazo anida en los tejados de las casas, en los campanarjos de las iglesias, en las ruinas y las paredes altas. Se reproducen en febrero y marzo, y cada juesta se compone de tres huevos de color blanco pardusco.

El urubú, segun el mismo observador, elige las rocas are. nosas de la costa marina, $\delta$ las pequeñas islas inmediatas para construir en cllas su nido, donde la hembra deposita tres ó cuatro huevos mis redondeados y de color mas claro que los del gallinazo.
'Todos los demás naturalistas, excepto Oboss, están con. testes en que estas dos ares no ponen mas que dos huevos en descubierto, ya en la grieta de una roca, ó debajo de un árbol derribado, que los preserva un poco de la intemperie, ó bien, por último, en el hueco de un tronco, ó en una cavidad, en medio de las raices. En el sur de la América del norte, en Texas y en México, anidan preferentemente el gallinazo y el aura, en los pantanos; cligen una eminencia que no pueda ser inundada por las aguas, y practican de. bajo de un matorral una pequeña cavidad donde puedan depositar sus huevos. Con mucha frecuencia se les encuen. tm en medio de las colonias de garzas reales $y$ otras aves de los pantanos.

Segun Audubon, los hijuelos tardan treinta y dos dias en salir á lu\%; el padre y la madre cubren alternativamente y se-alimentan uno á otso; para cllo vomitan cada cual de. lante del nido todo lo que contiene su estómago ó una parte solo. Lo mismo hacen para dar de comer a sus hijue. los pero entonces dejan caer el alimento en el pico. Luego les acostumbran a comer pedazos mas grandes y resis. tentes.

CAUTIVIDAD. - Actualmente se ren catártidos camtiros en todos los grandes jardines zoológicos: Azara dice que se pueden familiarizar en alto grado y hasta convertirse en rerdaderos animales domésticos. Un aınigo de este naturalista ienia uno que entraba y salia libremente; acompanaba á sir amo á los paseos y cacerias, $y$ hasta en sus viajes, obedeciéndole como un perro bien amaestrado cuando se le llamaba para darle alimento. Otro individuo acompañaba a su amo en viájes de mas de cincuenta leguas inglesas, sin sepa. rarse del coche; cuando estaba cansado posábase en el techo de este; y a la vuelta tomaba la delantera para anunciar en casa la llegada del amo.

\section{LOS ESTRIGIDOS_STRI- GID E}

CARACTERES. - Los estrigidos, ó buhos, con los cuales terminaremos la hissoria de las rapaces, se distinguen clara. mente de los vultúridos y de los falcónidos: solo desde léjos ofrecen alguna semcjanza con ciertos buzardos. Su cucrpo parece mus grueso, pero en realidad es delgado, estelio y poco carnoso; tienen la cabeza muy grande, ancha por de. trás y cubierta de un phumaje compacto; los ojos grandes planos, dirigidos hácia adelante y rodeados de un disco de plumas en forma de radios. Iass alas son largas, anchas y cón. cavas; cl pico corto; los tarsos de un largo regular, cubiertos de plumas ó de pelos; el pico sumamente encorrado desde la base, ganchudo, de bordes lisos, sin dientes ni escotadu. ras; la cera, del mismo color del pico, ocuito sicmpre por plumas sedosas, largas y erectiles. Los dedos son bastante cortos, casi iguales, pudiendo dirigirse el externo hácia ade. lante ó hácia atrás; el pulgar es comunmente un poco mas alto que los dedos anteriores; las unas grandes, largas, y muy corvas, puntiagudas y redondeadas.

Las plumas son grandes, largas, anchas, redondeadas en el catremo, finamente divididas, blandas y flexibles, $y$ decrepitan cuando se las oprime I.as de la cara tienen una conformacion muy diferente de las del cuerpo. Las plumas que rodean el ojo, dice Burmeister, asi como las de la linea que se corre entre él y el pico, están muy desordenadas; su tallo se prolonga en forma de seda. El circulo del ojo se une á otro, formado de plumas pequeñas y rigidas, de barbas poco separadas, las cuales constituyen al menos medio circulo al rededor del conducto auditivo externo, y se prolon. 
gan à reces hácia delante has:a la base del pico. Este circulo auricular, que representa el pabéllon, se compone de tres a cinco hileras de plumas; cuanto mas perfecto es, mas se desarrolla tambien el disco ocular, y al mismo tiempo que este último, las plumas de la linea naso-ocular. En este caso, la cerra, y con frecuencia una parte de la porcion córnea del pico, están complctamente ocultas por el plumajc. Estas plunas son las que imprimen â los estrigidos ese aspecto particular que les comunica cierta semejanza con los gatos

Las pennas de las alas son basiante anchas, redondeadas en su cxtremo, y encorvadas hácia el cuerpo, de lo cual re. sulta para el ala una forma cóncava. Las barbas externas de las tres primeras pennas tienen un filete $\delta$ son dentadas; $a$ esta última forma deben los estrigidos su vuclo silencioso, pucs impide el frotamiento; pero no se encuentra en iodos; carecen de ella las especies diurnas. Las barbas internas de las rémiges parecen sedosas ó lanudas, y se adaptan exacta. mente á la penna que se apoya en ellas. La primera témige es corta, la segunda un poco mas larga, la tercera y la cuarta sun las que mas se prolongan. Las rectrices son un poco arqueadas, y tienen casi un largo igual, lo que comunica $a$ la cola una forma cuadrada; solo por excepcion es cónica.

'lodos los estrigidos tienen el plumaje de colores oscuros, poco vistosos, que se coniunden con el de la tierra 6 de los troncos de los árboles. Sin embargo, el plumaje suele presen. tar en su conjunto un dibujo de los mas graciosos; algunas especies ofrecen tambien colores nuuy vivos, y sobre todo muy puros, que constituyen una belleza particular.

La organizacion interna de los estrigidos merece fjar nues tra atencion for algunos instantes: el esqueleto difiere sensiblemente del de los falcónidos: sergun las investigaciones de Nizzsch, el hueso lagrimal está conformado de distinto modo que el de las rapaces diurnas; no forma prominencia sobre el ojo: el hueso cigomático, que en las últimas prolonga dicha saliente, no existe en los estrigidos. El borde superior salien. te de la órbita no esta formado sino por el frontal; il hueso timpánico presenta en su cara interna una articulacion con el esfenóides, que es en un todo independiente de su articulacion anterior. El esternon del mayor ntimero de las especies tiene a cada lado dos expansiones membraniformes que bajan hasta el borde del abdónen: la horquilla es mas delgada y endeble que en los falcónidos. Tienen los estrigidos once vértcbras cervicales, ocho dorsales y ocho caudales; las dorsales no están nunca soldadas entre si. Los luesos son en general menos neumáticos que los de los falcónicios; los fémures no lo son jamis; los espacios á́reos de los huesos del cráneo tienen en cambio mayor desarrollo que en las otras rapaces. En algunos estrigidos tienen aquelios un espesor de mas de un centimetro y parecen esponjosos.

la faringe es muy grande; el esófago carcce de buche; el estómago es membranoso y muy cxtensible; el bazo redon. deado; el higado se divide en dos lóbulos, de la misma forma y volúmen; los ciegos son mas largos y anchos que en ninguna otra rapaz.

Los órganos de los sentidos estín muy desarrollados: estas ares tienen los ojos muy grandes: la córnea es muy convexa, afectando la forma hemisférica. Los lados de la esclerótica, asi como el anillo huesoso esclerótiço, son mus prolongados, de manera que forman una especic de cáliz ó tubo. Los movimientos iniernos del ojo son considerables; á cada uno de los respiratorios, estréchase la pupila ó se dilata.

En ciertas especies presenta la oreja una conformacion particular: en la mayor parte de los estrigidos, la abertura del conducto auditivo cxterno presenta h forma de una gricta que se dirige de arriba abajo al rededor del ojo y está provista de una especie de opérculo movible, y rodeada de un pabellon cubierto de plumas ca forma de nadios, perfectamente dispuesto para recibir y condensar las ondas sonoras.

DISTRIBUCION GEOGRÁFICA. - Los estrigidos, de los cuales se conocen unas igo especies, son cosmopolitas, en la verdadera acepcion de la palabra: labitan en todos los puntos de la tierra; se les encuentra en todas las latitudes. Se les ve desde los helados paises del polo norte hasta el ecua. dor; desde las orillas del mar hasta una altura de 5,000 metros. En el sur son mas numerosas las especies que en el norte; pero aun alli esta ricamente representado este subórden.

USOS, COSTUMBRES Y REGIMEN.-Los bosques constituyen su verdadera pattia; se les encuentra no obstante tambien en las estepas 5 en los desiertos; en las montañas mas peladas como en el interior de las ciudades y pueblos, pues por todas partes encuentran sitios donde albergarse $y$ el alimento necesaria.

Designase s. menudo a los estrigidos con el nombre de rapaces nocturnas, fo cual no es completamente exacto, pues si biun es cierto que las mas no comienzan á cazar hasta la hora del crepúsculo, muchas, asi de las que habitan el polo como de las que viren en los trófuicos, son activas durante el dia.

Ciertos estrigidos de las estepas buscan su alimento à la luz del sol; mientras se ve a otros retozar en el interior de los bosques, y hacer, en una palabra, tanto ejercicio de dia como de noclse. Sir embargo, cuando reinan las tinieblas es cuando mas cazan estas rapaces, y cstán admirablemente conformadas para ello. Tienen una vista excelente para las distancias cortas; su oido es delicado y su plumaje, suave y como des. compuesto, les permite moverse en medio de la oscuridad. Vuelan sin ruido rasando casi la tierra; perciben el mas leve rumor, e] mas ligero frotamiento, y á pesar de las tinieblas divisan los mas pequeños animales. He practicado algunos experimentos, dice mi jadre, en varius buhos domésticos; tenian los ojos completamente cerrados; estaban durmiendo, y obserre siempre con asombro que bastaba el mas ligero ruido para despertarles y hacerles volar. En noches de pro. funda oscuridad vi à los buhos remontarse por el aire y oi su voz tan pronto en un lado como en otro; uno de inis anigos procuró acercarse lenta y cautelosamente-á-un-mochuelo que estaba posado en un árbol, y el ave emprendió el vuelo apenas le hubo divisado. [i] ojo de los estrigicos es muy sensi. ble a la luz: en dias muy claros ciertas esjecies cierran á medias sus pårpados y casi del todo algunas veces; pero es un error creer que no ven durante el dia. ePueden volar en jilena luz, dice mi padre, y pasar por en medio de la mas cernda espesura sin tropezar coritra los árboles. Los estrigi. dos, å los que yo quitaba sus hijuelos, corrian en pleno dia; emprendian el vuelo si les apuntaba; y una vez víal medio dia á un mochuelo que se lanzó desde la torre del castillo de Altemburgo sobre un gorrion que comia en el patio con las gallinas, y al que cogió para llevárselo a su retiro.

Las observaciones siguientes inducen a creer que los buhos intentan enganar al intruso cuando de dia cierran y abren los ojos cual si no pudiemn ver bien. ¿Cuando el mochuelo silvestre, asi me escribe Waiter, se halla bastante seguro en un árbol hueco y asoma la cabuza fuera de la abertura para ver la clara luz del dia, no cierra los ojos á medias, sino que los abre tanto como le es posible para fijarlos en la persona que le inquicta. Si entonces se le tira una piedra con acjerto, obligandole á salir de su escondite, refúgiase cuando puede a una enramada, deja al hombre acercarse y le mira con los ojos entreabierzos. En tl hueco del árbol se cree seguro y no 
jurga necesario enganar; pero fuera, en el follaje, no le pare ce estarlo tanto, mas temiendo los gritos de las aves peque. has no quiere cambiar en seguida de sitio, y por lo tanto recurre á la astucia Los buhos que no cierran los ojos se va. len muy regularmente de otro ardid tomando una posicion que les oculta muchas veces aun á los ojos del mas experto. Con un novimienio verdaderamente brusco oprimen todas las plumas al cuerpo, de modo que este no parece ni ha mi tad tan grueso como de ordinario, prolongan la cara, la es. trechan y la vuelven a un lado; al mismo tiempo cnderczan las orejas y todo el cuerpo tanto como pueden, oprinsen un ala contra el tronco, extendiendo la otra con la articulacion del hombro en forma de ángulo; y en esta posicion, en la cual no quedan visibles las puntas de las alas, los niés y la cola, asenéjanse a un pedazo de rana cubierto de nusge. Pueden permanecer mucho tiempo en esta posicion; pero cuando se les obliga á presentarse tales como son, es decir como buhos, no vuelven fácilinente á tomarla, sino que con tinuan su fuga.y

La forma especial de las alas $y^{\circ}$ la suavidad del plumajo son indicio de que el vuelo debe ofrecer cierras particulari. dades. Es, en cécto, lento y silencioso: los estrigidos vuclan y se ciemen á la vez; las especies diurnas se remonian por los aites tmzando uua curva, y luego se dejan caer poco mas ó menos como las urracas, modo de volar muy penoso y que no se puede sostener largo tienupo. Solo cuando emprenden largos viajes se remontan á la altura de un centenar de metros sobre el suelo, moviéndose á inpulso de fuertes ale tazos.

En tierra son por lo general torpés; los de largas patas, no obstante, pueden alcanzar su presa a la carrera ajudindose de las alas.

En los árboles todos se mueven ágilmente; algunos trepan de una manera singular, saliancio de una rama baja á otra mas alta! I.éjos de ser pesados, son por lo contrario muy vivaces y ligcros; toman las posturas mas diversas; se bajan y se levantan; vuelren la cabeza en todos sentidos, ó la incli nan de una manera muy cómica, y pueden como los perezo sos volver la cara completamente hácia atrás y por lo tanto tambien mirar en opuesta direccion. La $\mathrm{rOz}$ es regularmente fucrte, pero raras veces agradable: un chasquido violento con el pico y un bufido ronco son in expresion ordinaria de su cólera; la voz misma no se oye sino de noche, ó cuando se hallan en gran peligro. Algunas especies chillan de un modo desagradable, oiras producen sonidos claros.

Los estrigidos son seguramente inferiores.en inteligencia \& la mayor parte de las rapaces diurnas, ya que no Algunas especies podrian enganar en tal concepto al obserrador, á causa de su alegria y vivacidad; pero bién pronto se reconoce que á ninguma se la puede considerar como inteli. gente.

Todas cstas arés son tínidas y nada cautelosas, pues no distinguen un peligro imaginario de uno verdadero; rara vez llegan á conocer á las personas qque las aprecian, y ven un enemigo en toda la que les es desconocida. Se puede conse. guir que contraigan cicrtas costumbres; pero no es posible adiestrarlas como a los falconidos: Son maligaas, rabiosas, crucles é indiferentes; en una palabr, no tienen nada de no. ble bajo nuestro punto de vista, ni aun Jiastucia. El halcon, el buro y el milano son en todos concepios superiores á ellas. Se llevan bien con sus semejantes, mientras no les domine alguna pasion ó les acose el hambre; mas no se opone esto \{ que devoren con la mayor complacencia á sus compajieros de rarios anos. Con frecuencia he tenido en una misma jaula de die\% à doce buhos y mochuelos; ninguno pensaba en aco. meter à los demás mientras se conservaban en buena salucl; pero si enfermaba uno de ellos, todos caian sobre el, mata. banle y le devoraban; tambien lie visto a los hijuclos de una misma puesta conerse unos a otros. Seguramente que no dan con esto prucba de ser muy nobles; por lo tanto me creo autorizado a no conceder a los estrigidos un lugar entre los animales superiores.

En libertad solo se alimentan de las presas quue ellos mismos cogen: reconocese lambien que $1: 0$ tocan á los restos pulrefactos. Cazan sobre tudo los pequenios maniferos; las especies mas fuertes se atreven hasta con los pequeños carniceros y las ases de gran tamaño: algunos se alimentan de peces, otros de insectos MIuy pocos, y aun esto indirectamente, son nociros al hombre; los mas le prestan, por el contrario, grandes servicios, pues concienzudas observaciones nos demuestran que los estrigidos de nuestros paises se alimentan casi exclusivamente de ratones, de musgaños y de arvicolas, exterminando un gran número de ellos. Precisa. nente a la hora en que estos roedores emprenden sus correrias, comienzan a cazar aquellos; vuelan silenciosamente so ure el suclo; lo examinan deteridamente, y todo pequeño roédor gue se deja ver nn escapa de su enemigo. Sus dedos, cortos y movibles, cun unias accradas y muy corvas, son sumamentc úciles para los estrigidos; el animal preso entre sus garras muere sin remedio, y espira antes de sospechar el peligro que le amenazaba Despues de habersc apoderado de su presa, dirigese la rapaz a un lugar oculto, y alli la devora.

"Nada mas hediondo, dice mi padre, que un buho cuando cone; triga pedazos enurmes, i costa de grandes esfuerzos, 5. al paso que los demas animales parecen comer con gusto, diriase que el buho se ocupa en una operacion penosa. Yo vi a un individuo tragarse un raton grande de un solo bocado: Ș un mochuelo le di un gorrion; cogióle con una de sus garrass, sc lo llevó a la boca, y comenzó a imgirselo por la cabe. za. lo cual no pudo conseguir sin hacer grandes esfuerzos.

y Reperi el experimento en diversas ocasiones, y unas veces devoraba el mochuelo al ave sin quitarle una sola pluma, otras la desplumaba en parte antes de comérseir. Tragábase los ratones con facilidad: si la yresa es demasiado roluminosa para pasar por el esófago, arrójala el buho, y la oprime con su pico y sus patas hasta reducirla á mas pequeño volúmen. o ponerla mas flexible. Creu que por este concepto podrian compararse con las serpientes: cuando el animal es demasiado grande, conténtanse con devorar ias carnes del pecho y el cerébro, abandonando lo demás.

A esto debo añadir que un estrigido puede tomar su alimento tambien de un modo meros desagradable; un bubó. nido, por ejemplo, cuidado por IValter, solia separar primero la cabeza del raton ọue se le daba, comiéndosela al punto. despues devomba los pulmones, el higado 5 el comron: luego los piés anteriores, uno despries de otro; en seguida sacaba las costillas una por una, y retirando los intestinos, apuraba el resto. Yo no he conocido nunca estrigidos de tan buenos modales, aunque he cuidado centenares de ellos: muy por el contrario, siempre hice las mismas observaciones que mi padre

La mayor parte de los estrigidos pueden privarse de agua dirante varios nueses; parece que la sangre de sus victimas basta para apagar su sed. Sin embargo, behen mucha agua en ciertos monentos, y les complace bañarse.

Su digestion es muy ripida: devuelven los huesos, los pelos y las plumas; para esto abren inucho el pico. bajan la cabeza, saltan con un pié y luego con el otro, cierran los ojos, se sacuden, y acaban por arrojar bolas compuestas de todo lo que no han podido digerir. Altum ha cxaminado varios cen. tenares de ellas, y la visto quue los de Alemania se alimentan sobre todo de pequenos roedores y de musaranias, y con me. 
nos frecuencia de ratns, topos, comadrejas, ares é insectos. En 706 bolas de buho encontró los rêstos de 16 murciélagos, 340 ratones 6 musgairos, 693 arvicolas, 15 So musarañas, 1 topo y 22 aves pequeñas; en 210 bolas del antilo (symium aluce), restos de 1 armiño, $4 S$ ratones 6 musgaños, 2906 arvicolas, 1 ardilla, 33 musarañas, 48 topos, 18 avecillas, $4 \mathrm{~S}$ in. secıos, y además un número considerable de abejorros: en 25 bolas del duque mediano (otus siicestris) se hallaron restos de 6 musgaños, 35 arvicolas y dos aves. En 10 bolas de lechuza, los de 10 arvicolas, I musarana y is insectos. Creo que bastan estas cifras para indicar cuán útiles son estos séres, pues aunque las grandes especies maian de vez en cuando agunas liebres 6 perdices, $y$ las pequerias exterminan tambien animales muy útiles, tales como las musarañas, csias pérdidas están superabundantemente compensadas con los grandes servicios que nos prestan; por lo ianto debemos dispensarles nuestra proteccion.

I.os estrigidos no se molestan mucho para construir su nido: muchos de ellos anidan en los huécos de los tronicos y otros en las grietas de las paredes ó en las rocas; establecen. se varios en madrigueras de mamiferos, y los hay que se al. bergan en nidos abandonados de halcones, de urracas ó de cornejas. A veces reumen algunos materiales; pero con mas frecuencia se limitan a depositar sus huevos en el fondo del nido, sea cualquiera el estado en que se halle. El numero de los de cada puesta variat de dos a siete, y en casos raros ponen uno solo; son de forma redondeada, blancos y de un grano muy fino.

Hasta ahora solo se conoce, al menos nue yon sepa, una cspecie de estrigidos en la que ambos scros incubanalternativamente: ignoro de que manern lo hacen las otras. La actividad de estas aves, como ha dicho muy bien mi padre, se oculta en las tinieblas, y jor eso es muy dificil para el natu. ralista observarla. Io cierto es que en todos los nidos de estrigidos que tuvimos ocasion de cxaminar de dia, la hembra esiaba siempre cubriendo los hueros. Iin cambio no cabe duda que en la alimeniacion de los polluelos tambien Jos machos toman parte. En la coleccion de mi pádre se encontró una pareja adulta del gran duque, cuya hembra fué cogida en una trampa colocada junto a los polluelos atados; el macho cuioó tan celosamente los huérfanos, que dos dias despues le cupo la misma suerte que à su compañera. Mi padre ha hecho la misma observacion en otros estrigidos, sobre todo en el mochuelo silvestre, rictalos, dásipos y surnios. En todas las especies los machos, segun parece, profesan gran carii:o a su cria, la cual defienden en ciertos casos con gran valor Toso III contra sus enemigos. Ios polluelos permanecen nuucho tiem. po en el uido y producen de noche los gritos que se oyen por todos los contornos, haciéndolo en particular cuando abandonan el nido y empiezan á moverse. Yo creo muy fun. dada la opinion de mi padre, quien supone que hacen esto para indicar á los adultos siempre el sitio donde se encuentran. estrigidos tienen muchos enemigos: lodas las ares diurnas los aborrecen, y hasta diriase que desean rengarse de los ataques de las rapaces nocturnas. Cuando se deja ver un estrigido, todas las diurnas manifiestan una gran excitacion; las avecillas dejan oir sus gritos, y' toda la familia alada del bosque se pone en morimiento; una especic da el aviso à la otra; acuden á la vez; aturden al ave nocturna con sus gritos, y hasta las ares mas fuertes le dan repeticos picutazos.

Con demasiada frecuencia figura el hombre en el número de sus enemigos. Solamente los ostiacos y naturales de Hclgoland consideran la carne de los buhos como buen alimento; pero muchos alemanes que pretenden ser instruidos creen hacer una hazaña matando los estrigidos cuando duermen ó al vuelo; rams veces les protegen. El agricultor deberia reunirse con los protcctores de los buhos, cuidándolos cual si fuesen ares sagradas.

CAUTIVIDAD. - Muy pocos estrigidos son susceptibles 
de domesticarse, siquiera algunos sirvan de agradable pasa. tiempo. Los mas se muestmn indiferentes à todo, ó manifies. tan una furia que divierte muchas veces, hecho que se ob serva sobre todo en las grandes especies. Fstas aves parece estar reñidas con todo el mundo, viendo en cada hombre un enemigo; lanzan miradas furiosas; tratan de dar picotazos, bufan y silban á la manera de los gatos. En cuanto à los es. cops, sucede todo lo contrario: son ares muy agradables y de las mas divertidas.

Sc puede conseguir que se reproduzcan aigunos estrígidos cautivos; conozco mas de'un caso de ello.

\section{LOS SURNINOS-SURNINA}

CARACTERES. - LOS surninos 0 estrigidos diumos deben figurar en primer término: constitusen el trínsito cn. tre los falcónidos, por una parte, y los estrigidos nocturnos por otra Tienen la cabeza pequeria; el cuerpo esbelto; las alas y la cola largas, el plumaje compacto y alisado.

\section{EL SURNIO CAPARACOCH - SURNIA FU- NEREA}

CARACTERES. - Esta ave tiene la cabeza ancha, la frente aplanada con cara estrecha, sin circulo de plumas alrededor de los ojos, ni en la cabeza; las ains son bastante largas y obtusas, con la tercera rémige mas larga que las de. mís: la cola prolongada y conica; cl pico fuerte, corto, mas alto que ancho, con el gancho de la mandibula superior muy prominente y que sobresale de la inferior en poco menos de un centimetro; los tarsos y los dedos son cortos.j estån entemmente cubiertos de pluma; los ojos grandes; las orejas se hallan provistas de un pabelion bastante alio, prolongado y de opérculo bastante desarrollado; êl plumaje es abundante, suare y luciente; la primera rémige está en parte dentada en las barbns cxternas.

El caparacoch, vulgarmente llamado mochuelo gavilas, y machuclo de la rga cola de Sitheria, tiene la cara de color blanco, gris, cuando es adulto; a los lados del cuello se vén dos fajas negras semi-circulares, una por delante y li otra por detrás de la oreja; la parte superior de la cabeza es pardo negra; cada pluma tiene una mancha redondeada de color blanco; mas grande en el occipucio. La nuca y otm mancha que hay detrás de la orejn son del mismo tinte; las plumas del lomo blancas tambien, con listas trasversales pardas, y de igual color en su extremo; la garganta es blanca, asi como una faji? que cubre el pecho; el vientre y los costados de igual tinte, con rayas finas pardo negras; las rémiges y las rectrices de un gris raton, con fajas trasversales biancas, cuyo número es de nueve en la cola; el pico es de un amarillo de cera sucio, y negro en la punta; el ojo de ur amarillo de azufre oscuro (figura 182).

Los pequeños difieren muy poco de los adultos, sin contar que estos uitimos presentan en el conjunto de su plumaje notables variaciones, por mas que no se modifique el
tipo.

El caparacoch tiene de $0^{\mathrm{m}}, 39$ a $6^{\mathrm{m}}, 42$ de largo, por anchura de alas de $0^{\circ}, 76 \leq 0^{\circ}, 81$; el ala $p$ legada mide $0^{\circ}, 23 y$ la cola $0^{\circ}, 16$.

\section{EL SURNIO DEL CANADÁ-SURNIA CANA- DENSIS}

CARACTERES. - Esta especie tiene la parte superior del cuerpo inas oscura y las manchas de la inferior mas an. chas, de un color mas ó menos viro. Segun las observacio- nes de Dresser, esta especie es, y no el surnio gavilan, la que hasta ahora se ha cazado d veces en Inglaterra.

DistribUCION GEOGRÁFICA. - El surnio del $\mathrm{Ca}_{\mathrm{a}}$ madá es propio de la América del norte, mientras que el sur. nio gavilan está diseminado en todos los paises seprentrio. nales del antiguo continenie. Esta última especie, a cuya descripcion me limitaré, anida, segun está probado, en el norte de la Escandinavia, en el norte y centro de Rusia y en Siberia, desde el Ural hasta el mar de Ochotsk y desde el limite septentrional de los bosques hasta las estepas situa. das al mediodia de la region salmje. En China no se le ha visto aun. Asi como sucecie con la major parte de los estri. gidos del norte, su mayor ó menor abundancia depende del mayor ó menor número de lemings. Cuando estos se repro. ducen mas que de costumbre, despues de un invierno tem. plado, el surnio gavilan anida por causa de ellos en regiones donde no se suele encontrar otras veces su nido. Por regla general prefiere los bosques de alisos à todos los demás, y de consiguiente, en Escandinavia solo se le ve en aquellos donde estos arboles predominan: el color y los dibujos de su plumaje presentan casi los mismos colores del aliso. Tam. bien anida en los bosques donde hay pinos ó abetos enanos; pero cuando en los primeros encuentra alimento suficiente, segura es que no los abandona. Cuando la nieve cac en abundancia, ó mas bien cuando los lenings escasean, le es forzoso abandonar en invierno sus parajes favoritos, retirán. dose a los valles ó mas hácia el sur. Entonces se presenta (al) vez todos los inviernos en las provincias rusas del Báltico y en Dinamarca, y bastante à menudo tambien en Alemania, donde muchas veces se han muerio indiviouos en la Prusia oriental y occidemial. Con menos frecuencia se le ve en Posen, Silesia, Pomerania y la Marca, y solo algunas veces sc le encuentra en Turingia, Hanover, Westialia y Alsacia. Visita jgualmente la Polonia, Moravia, Galitzia, Hungria, el Austria inferior, el mediodia de Rusia, toda la Siberia meri. dional y las montañas del 'Turkestan meridional. Alguna pa. reja suele permanecer en otros países si las condiciones le son muy propicias.

Es probable que este estrigido haya anidado repetidas ve. ces en la Prusia oriental y occidental I.ceffer hace ya mencion de un caso, sobre otro me escribe Ehmcher lo siguien. te: A principios de julio de 1866 compré en el mercado un buho pequeño cuyo aspecto extrano llamó mi atencion. Gracias a un alimento abundante creció muy pronto, y à mediados de agosto habia alcanzado ya su completo desarrollo. Cuando le compré ignoraba á qué especie pertenecia; mas por mis observaciones reconoci quue era un estrigido diurno; y cuando al fin mudó la pluma vi que era un surnio gavilan. $\$$

Poseemos numerosos datos accrca del género de vida, el régimen y la reproduccion de esta ave; pero debemos lo mas precioso, no i los naiuralistas que le observaron en su pais, sino á los que le han estudiado en Alemania, en especial a mi padre.

Este estrigido no es nada escaso en el alto norte yo mis mo lo he visto repcidas veces, durante nuestro ulltimo viaje Siberia, en las orillas del Obi inferior, pero desgracinda. mente no me fué posible observarle de cerca. Solo puedo decir algo sobre su vue!o, del cual no creo se haya hablado en otra parte. Este estrigido no vuela a la manera de otros buhos que yo conozco, sino como un milano, $y$ hasta es preciso hacer esfuerzos cuando se quiere distinguirle a cierta distancia del milano de las praderas. Basta haberle visto algunas veces para reconocerle, no solo por su cabeza volumi. nosa sino tambien por su vuelo, que á pesar de su gran se. mojanza con el del citado milano, se difurencia sin embaryo 
marcadamente. To se balancen inclinándose de un laco th otro, sino que cleva el vuclo, manteniendo las alas muy a!tas, y aletea a intervalos con mucha suavidad; el vuelo es en su conjunto inas lento que el del milano. Tambien revolotea nuuy á menudo y descansa muchas veces dumante la cara

Los informes de Wallengren, Collet, Wheelwright y Willey dicen en su conjunto poco mas ó menos lo siguiente: en los años en yุue los lemings abundan, el mochuelo gavilan no abandiona el territorio donde anida; solamente los hijuelos emprenden viajes hácia regiones meridionales, y entonces se les ve en sitios poco análogos á los lugares que romunmente habita, asi, por ejemplo en rëgiones desprovisias de bosques, donde por sus usos y costumbres recuerdan mucho à los halcones. Ave diurna como estos, no solo tienen el vielo suave y ripiado del estrigido, sino tambien la viveza y el valor de aquellas rapaces, á las cuales se asemeja tam. bien por su grito. A menudo se le ve posado en la copa seca de un abeto muerto, desde donde busca con la vista alguna presa. Entonces lance poco caso del hombre que se acerca ó apenas se fija én él; sus amarillos ojos lo miran todo tranquilamente con cierta expresion de astucia; pero no hace aprecio de su mayor enernigo; condicese como si le considerase indigno de temerle, $y$ hasta vuelve $l a$ cabeza à otro lado, cual si despreciase al cazador que le amemara. De un modo muy distinto se conduce cuaudo se trata de una presa ó de uno de sus enemigos alados, y aun del hombre que se accrca á su nido: ninguna ave se libra entonces de sus ataques. Wheelwright le vió atacar á un grajo, especie que por lo regular habita los mismos sitios, cuando cruzaba los aires; y le sorprendió tambien mas de una vez devorando una gallinácea de los pantanos, cuyo peso es casi doble. Toda clase de ares, los lemings y raiones del campo asi como los insectos constituyen su alimenio ordi. nario. A semejanza del halcon, precipitase desde el sitio donde descansa sobre uno de los pequeños rocdores, le coge y estrangula con las agudas garras, y llévale á un sitio con. reniente para derorarle. A menudo racila mucho en la elec cion de cste sitio. Cuando las aves salvajes, sobre todo lns grajos, las corncjas y picoparos le provocan, toléralos con frecuencia largo rato; pero de pronto se precipita sobre sus adversarios y atrapa uno de elins. Parece que solo las urracas no temen sus ataques. Cuando se le acosa muy de cerca, por ejemplo cuando se le rompre un ala de un tiro, defién. dese con desesperacion, boca arriba, extendiendo las dos garras hácia su enemigo para herirle.

A principios de majo, en ciertos casos, y a veces en abril, el mochuelo gavilan comienza los preparativos de la repro. diccion: para construir su nido elige ya un hueco de árbol $\checkmark$ una de aquellas caias que en Laponia se colocan cn los árboles para el mérgido merganser, ó bien un nido de cor neja abandonado; a reces tambien fabtica en un árbol alto un nido que principalmente se compone de ramas secas, y cuva cavidad, bastante llana, estí cubierta de hojas secas y musgo. Ia puesta se compone de scis a ocho huevos recondeados, de color blanco y un poco mas pequeños que los del mochuclo arboricola, es decir, de 6,035 a 0 m, 045 de largo, por th, 029 i f $\%, 03$ i de diametro irastersal. El macho vigila cuidadosamente, posado cr la copa de un árbol mucro, tan cerca del nido como le es posible; apenas se acerca sllguien levanta la cabeza y la cola, lanza un grito agudo, semejanic al del rernicalo, y precipitase furiosa mente sobre el intruso. Wheelwright temia tanto al mo chuelo gavilan, que se negó á subir ál los nidos de este, pues en cierta ocasion el macho de una pareja le habia atacado con la mayor furia, arrebatándole no solo la gorra sino tam bien algunos mechones de pelo. Estos estrigidos atacan a los perros de caza intrépidamente en cualquiera época del año.

Segun las obsernaciones del citado naturalista, no deja de ser curioso que el macho tome parte en la incubacion. An. tes que los poltuelos puedan volar, los adultos comienzan mudar la pluma; de modo que cuando aquellos tienen su plumaje completo, tambien estos revisten su plumaje nuevo.

Mi padre, que hace casi 60 airos turo la suerte de obser. var un mochuelo gaviian en Turingia, ha hecho una des. cripcion mucho mas minuciosa que las de todos los natura. listas citados.

r.Tengo el mayor gusto, escribe, en poder decir alguna cosa acerca de las costumbres de un ave tan rara, habienco hecho mis observaciones en una hembra viva que adquiri. Un muchacho la habia visto posarse por la tarde sobre un matormal tiróle una piedra, que le tocó en la cabeza, deján. dala aturdida, y me la present6 luego. Yo deje al ave libre en mi cuarto: todas las rapaces de la misma familia cierran los ojos en tales casos y buscan el rircon mas oscuro para ocultarse: pero aquella, pot el contrario, voló al momento hácia la rentana con los ojos muy abicrtos, y chocó tan violeniamente, que cayó aturdida. Eutonces la puse en una jaula, y léjos de mostrarse timida, se dejó acariciar; le di un raton y lo cogí́ con el pico, sujetíndole luego con una pata. En ticrra estaba con el cuerpo casi horizontal, extendidas las patas y levantada la cola: en la jercha se mantenia con el cuerpo derecho, colgante la cola, las plumas de la espaldilla recogidas sobre las alas, y dobladas las patas de tal modo que solo se veian los jedos. En tal posicion aparecia en toda su belleza: las plumas de los lados de la cabeza estabar continuamente crizadas, y las de la irente recogidas, lo cual comunicaba al ave cierto aspecto análogo al del halcon: todos sus movimientos eran rápidos y ágiles; pero no le gustaba mucho saltar en tierra.

su ror, que se oin sobre todo cuando se trataba de co. gerla, pareciase bastante al grito de angustia del cemicalo, y recordaba á veces el cacareo de la gallina. Cuando estaba furiosa castañcieaba el pico, como lo hacen los otros mo. chuelos, y si no se enojaba mucho, coutentibase con frotar las extrenidades de las dos mandibulas entre si; adelantaba la inferior y la frotaba contra la superior, haciéndola sobre. saiir por encima del gancho de csta, como se obsersa en los loros. Esto producia un chasquido tan particular, que la primera vez que lo oi llegué á creer que el ave se habia roto un hueso. La rapaz estaba mas despierta desde la tarde hasta la caida de la noche.

\Cierto dia se escapó por casualidad y mandé que la bus. casen por todas partes, pero inútilmente. Algunos dias des. pues me dijeron que se hallaba en el matorral mismo donde fué cogricla; distaba una legua de mi casa, y era de creer que rolviese alli el mismo dia de su fuga, pues preferia agnel sitio á todos los demás. La noticia me fué tamto mas agradable cuanto que me hiro concebir esperanzas de récobrar mi ave rara, y felizmente no me engané.

\$unca se veia a la rapaz antes del medio dia; yasaba este tiempo oculta en los pinos y pinabetes mas espesos; presentábase à eso de la una y se posaba en algun árbol poco alto, en una rama baja ó en un matorral. Mimba à tierra, y siempre se volvia de frente á cualq̨uiera que se ncercase; si"se adelantaba álguien parn sorprenderla por detrás, revolvinse inmediatamente, aunque sin mudar de sitio; permitia que se acercase uno ocho ó diez pasos, y no hacia caso de las piedras que le siraban: solo cuando le tocaba una emprendia su vuelo remontándose algunas brazas, jero para volver en seguida al mismo sitio. Vo creo poder deducir de nqui que el ave habita ordinariamente paises desiertos: no 
conoce al hombre, enemigo de todos los animales, ni sabe cuin peligrosa es su proxinidad. Jamás he visto un ave que menos temia i nuestros semejantes.

- Si consigue coger uno ó dos pequeños roedores, des. cansal y no se la ve mas antes del crepúsculo; pero cuando su caceria ha sido infructuosa, permanece por el contrario al acceho aun desjues de anochecer. He hallado sus excre. mentos en diversos sitios, cerca del matorral donde estaba algunas horas del dia; pero nunca en este último.

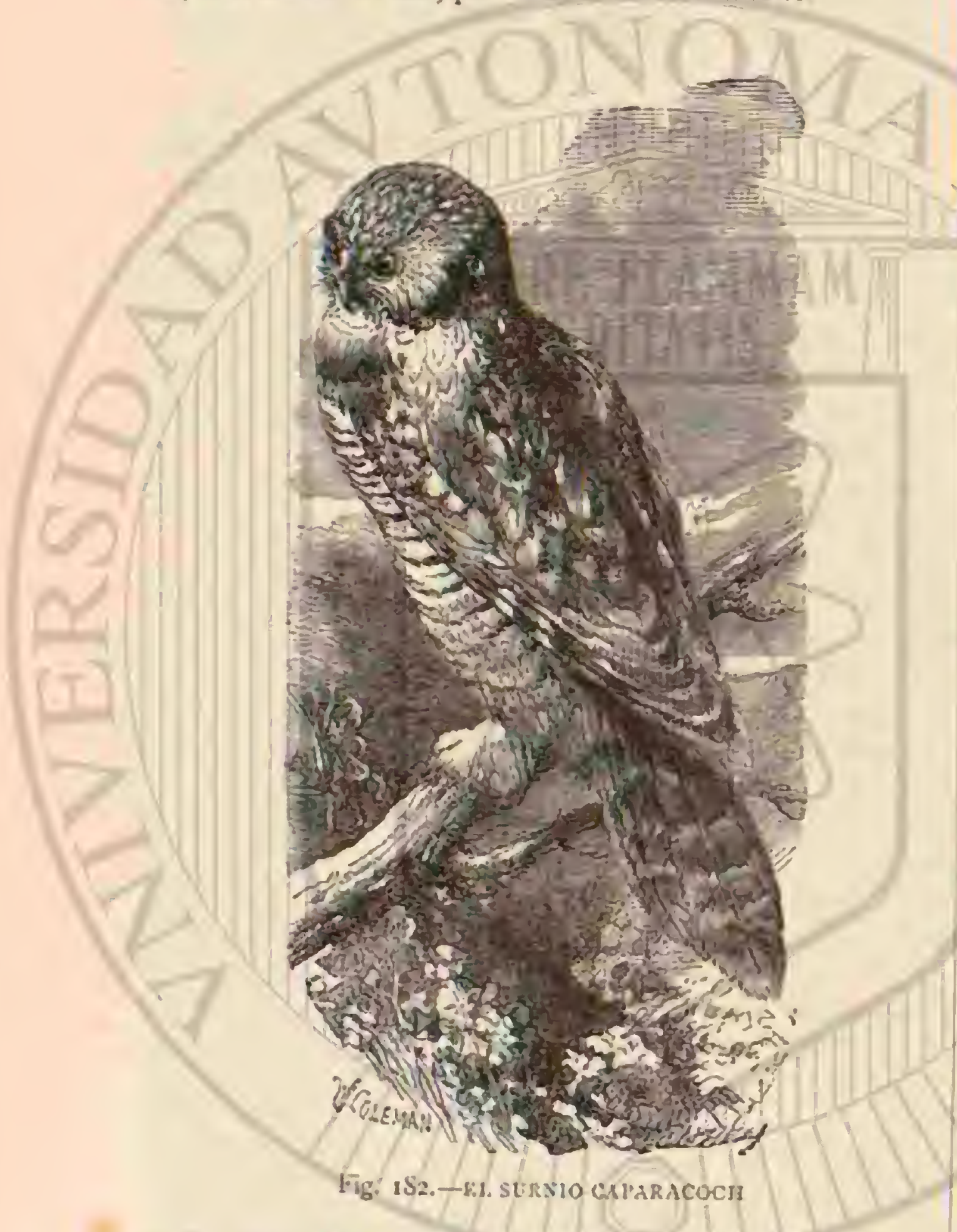

Su vuelo, ligero y rapido, se asemeja al del buitre; como este, aletea un poco precipitadamente y se cierne despues durante algun tiempo. Lleva, sin embargo, las alas como los otros estrigidos, y se reconoce desde luego por su cabeza, que es enorme para semejante ave. No se aleja i gran distancia: solo recorre de cincuenta á cien pasos, y jamas la he visto franquear un trecho de mas de trescientos ó cua. trecientos, sino cuando las cornejas le persiguen de cerca. Entonces dejaba oir una especie de maullido y emprendia la fuga, con un vuelo tan rápido, que las cornejas renunciaban a la persecucion. En el verano debe habitar paises donde no existan las cornejas, porque estas le impedirian completa. menie cazar de dia.

\$El mochuelo gavilan se diferencia de muchos estrigidos en que no sorprende su presa volando junto al suelo, sino que la acecha mas bien, posado en un airbol. Por lo tanto debe elegir parajes donde sean muy comunes los, pequeños roadores, y al efecto le convienen los árboles poco alios, des de donde pueda observat sin obsticulo cuanto pasa i su alrededor.

Yo le vi un dia coger un musgaño: habianle espantado, y abandonó su matorral de costumbre para ir a posarse en la copa de un pino; de repente se lanza átierra, y el grito de un rato: me anunció que su acometida habia sido feliz; casi en el mismo instante apareció llevando en las garras un puñado de yerbas donde se hallaba el pequeño roedor; voló hácia un gran abcto vecino y desapareció de nuestra visia.

> Yo creo que en sus cacerías el oido le es tan uitil como la vista; el musgano que cogió se hallaba á reinticinco pasos, y por el lado opuesto al en que miraba. Es cridente que el rui. do que hacia el pequeno mamifero al correr entre las yerbas secas, bastó para llamar la atencion del ave.

* Esta rapar, anade mi padre, teme las tormentas de nieve: el 14 de diciembre de 1820 nevó inucho, y sopló un fuerte viento; pero todas las aves buscaban sin embargo su alimento; los tordos, los gorriones, los pinzones reales y los paros se movian de un punto a otro, $y$ hasta se dejaba ver alguna alondra. El mochuelo gavilan no apareció hasta el medio dia; se posó en una rama baja; pareció hacerse cargo del mal tiempo y fué á refugiarse en la copa de un pino. Despues de las dos cesó de nerar, y la rapaz y̨uiso comenzar su caza, á cuyo efecto se posó en una rama; en aquel momento disparé con. tra ella; habiala observado suficientemente, y tenia que aban. dunase el pais. Su cabeza estaba cubierta de nieve, y pendian de sus plumas algunos peciacitos de hielo.»

CAUTIVIDAD.- Ia hembra que yo ture cautiva se ali. uientaba de ratones, que devoraba comenzancio por la cabe2a, tragindose luego lo demás del cuerpo; para comer situábase sobre objetos donde pudiese estar pendiente su cola, aunuue. algunas veces cogia su alimento del suelo; por la nochie devolvia los pelos y los huesos.

\section{LOS HARFANGOS - NYCTEA}

CARACTERES. - Las aves de este género se caracterizan por tener la cabeza pequeña y estrecha; la oreja externa pequeña tambien, con circulo auricular poco desarrollado; los tarsos y los dedos cortos, cubiertos de plumas muy compactas; las alas de un largo regular y obtusas, siendo la tercera rémige la mas prolongada: la cola bastante larga y redondeada: el pico fuerte y de gancho corto; el plumaje abundante, mas suave que el de los oiros estrigidos.

\section{EL HARFANGO DE LAS NIEVES-NYCTEA NIVEA}

CARACTERES.-El harfango de las nieves (fig. 183) tiene de $0^{\circ}, 68$ a $0^{\circ}, 7$ I de largo y de $1^{m}{ }^{\prime \prime}, 46$ is $1^{\circ}, 56$ de ala ala; esta plegada mide $0^{\circ}, 45$ y la cola $10^{m}, 26$. El color varia segun la cdad: los vicjos son blancos, con algunas escasas manchas pardas en las alas y la parte anterior de la cabeza; los de edad mediana blancos, con manchas pardas mas ó menos numerosas, dispuestas inasversalmenic en cl cuerpo y ślo largo en la cabeza; en la primera edad son mas abundan. tes aun. El ojo es amarillo y el pico negro.

DISTRIBUCION GEOGRÁFICA.-En rez de enüme. rar todos aquellos países y regiones donde el harfango de las nieves habita, baste decir que es propio de la Tundra, y que se le ha observado en todos los puntos del norte recorridos por los viajeros. No se encuentra con igual frecuencia en diversas partes de la Tundra, jues tambien depende de la ma. yor ó menar abundancia de los lemings; agrádale ademas vivir tranquilo y solitario, y por lo mismo erita las regiones visitadas muchas veces por at hombre, su peor enemigo. Por eso abunda en América, Japonia y el oeste de Rusia mas que en el nordeste de este imperio y en Siberia, donde se le suele dar caza por su carne, al menos en jas regiones que yo visite. En verano habita principalmente las montañas septen. trionales; en invierno desciende á regiones mas bajas, y cuando en su patria son muy frecuentes las nieves y el alimento 
falta, emprende tambien viajes hacia el mediodia. En las es. tepas altas de la Dauria se presentan primero las hembras, segun Radde, á fines de seriembre, y los machos llegan mu. cho mas tarde. En la Escandinavia no visita los valles hasta principios del invierno, y preséntase con mas regularidad quue el mochuelo gavilan en las regiones meridionales, sobre todo en Alemania En la Prusia oriental, parricularniente en Litunnia, se le ve casi todos los inviernos; tambien visita con regularidad ha Prusia occidenial, Posen jo Pomemnia; y no es saro en Dinamarca, aunque solo suele penetrar hasta el me. diodia de Escandinavia, sin franquear los mares que separan ambos paises. Eu las islas Britínicas se le observa igualnuente en invierno, y' es probable que los individuos que se encuen. tran alli procedan tanto de Escandinavia como cie Groenlandis: desde la Tundra de la Siberia penetra hasta el mediodia de Kusia, visitando las estepas de la Siberia uncridional, la Mongolia, China y el Japon.

Desde el norte de América se traslada al mediodia de los Listados-Linidos, á la América central, y aun á la India occi. dental. En ciertos casos permanece duranie el verano en otros paises, pero solo por excepcion. Asi, por cjemuplo, mi amigo Dieper encontró en $1 \$_{43}$ en el campo de Kimcschen (Prusia oriental), hácia la Pascua de Pentecóstes, un nido del harfango de las nieves, cuyos huevos estaban sobre un monton de piedras; y Hume cree tambien gue ol ave anida algunas veces en la India, en las orillas del rio Kabul.

USOS, COSTUMBRES Y REGIMEN. - Un harfango de las nieves ofrece en la Tundra un aspecto magnifico. Durante nuestro viaje á través de la península de los samoyedos tuvimos repetidas veces ocasion de ver esta hermosa ave. El

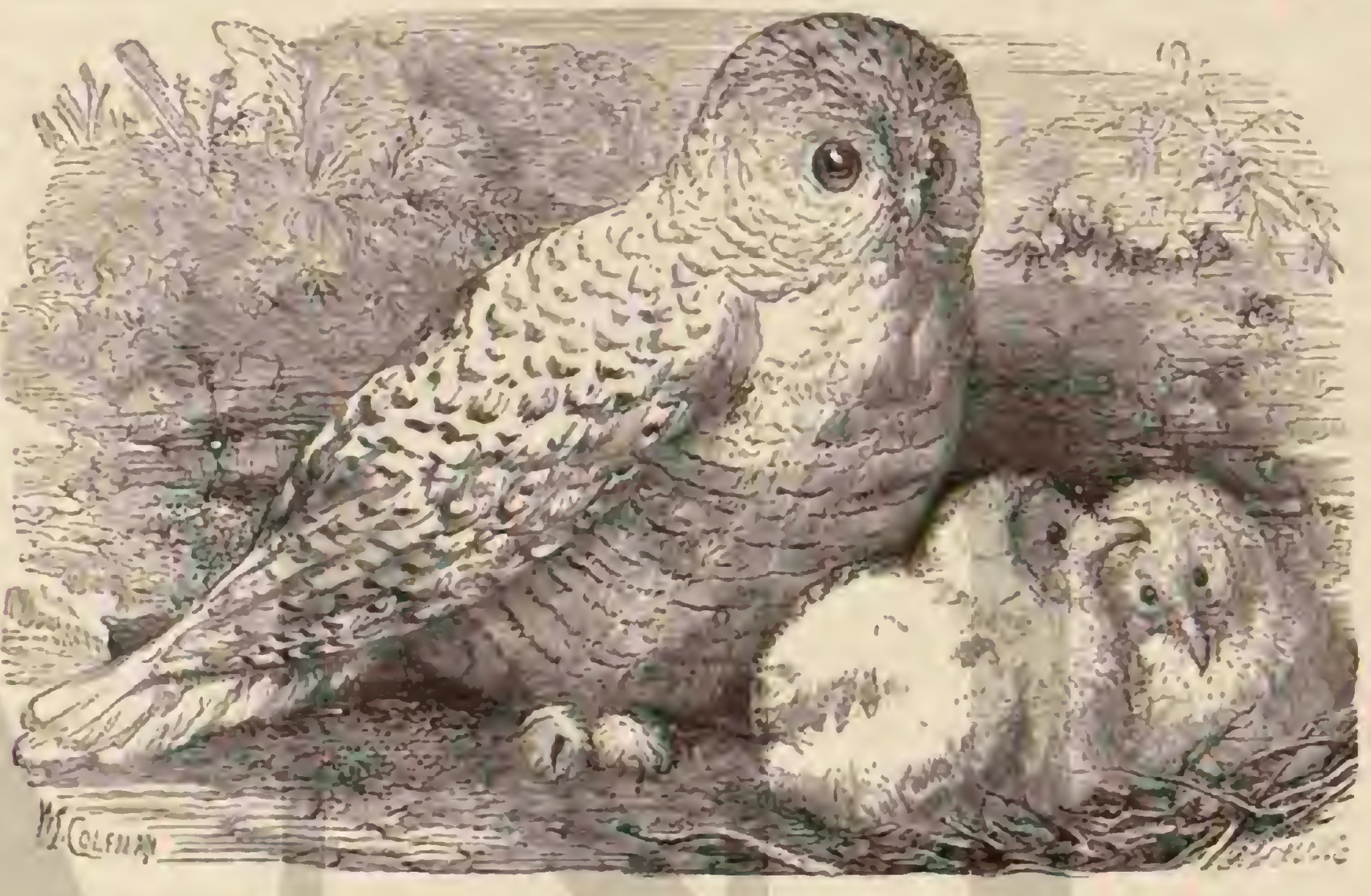

Fig. IS3 - EL HARTASCO IIE WS NIFUES

harfango de las nicves abunda menos de lo que podria suponerse por los restos de plumas encontrados cerca de todos los campamentos de los ostiacos; pero anida en todo el ter. ritorio. Fácilmente se distingue de otros estrigidos, sobre todo del buho de los pantanos, que tambien es muy comun en la Tundra. Por lo regular se ie reconoce a cualqquiera distancia: prescinciiendo del color verdaderamente brillante a la luz del dia, y' de su gran tamaño, reconórese por sus alas cortas, anchas y muy redondeadas, de tal modo que no es posible du. dar. Vuela lo mismo de dia que de noche, y en ciertos casos es mas vivaz por la tarde que durante el crepúsculo vespertino ó maturino. Pósase en rocas salientes 6 colinas para acechar una presa $y^{\circ}$ muchas veces deja oir su von, algo semejante à la del águila marina. A veces se mantiene inmóvil mucho tiempo; clérase despues y se alcja, bien alcteando ơ ya con vuclo sostenido; cuando quiere franquear un gran espacio remóntase trazando espirales hasta la-aitura de una montaña y baja despues á una colina para volver á observar la region. Parece que el dominio que habita y donde caza no es muy extenso, pues pudimos observarle durante un dia entero casi en los mismos sitios. Un individuo que yo maté, era el ina cho de una pareja que vagaba por el mismo territorio. A pesar de que la Tundra de la peninsula de los samoyedos està muy poco poblada y aunque los ostiacos y samoyedos no la cruzan muy á menudo, el harfango de las nieves se muestra sin embargo en extremo timido, of al menos no se pone nun. ca á liro. Vo maté el inaividuo citado aproximindome rânjdamente en un trineo. Fn otros paises conserva tambien la misma limidez, segun me dicen mis compañeros de caza de la Prusia oriental. Aqui evira del todo los bosques y vive con preferencia en los montones de tierra recogidos en los campos 6 en los sauces que bordenn los caminos, pero en todos los casos muéstrase en extremo prudente. Parece ser mas osado que los demás estrigicos: segun ha observado Schrader, ataca con gran vigor álos perros, sobre los cuales se precipita como un balcon. Fil macho muerto por mi cayó cn tierra con el ala herida y preparinndose en seguida al ataque, se defendió desesperadamente cuando quise cogerlo. Produ. ciendo un bufido ronço, hizo chasquear con fuerza el pico apenas alargué la mano para cogerlo, y no solo se defendió con este, sino tambien con las garras, de modo que me vi obligado a ponerle la culata de la escopeta sobre el pecho y aplastarle. Aun asi, no soltó la bota que me habia cogido hasta que le faitó el aliento.

El harfango de las nieves se alimenta de pequeijos roedo. res, principalmente de lemings y además de ardillas, lago. mis, etc.; pero tambien caza varios animales del tamano de una liebre. Una mañana, á principios de abril de 1869 , me escribe Pieper, vi oira vez un harfango de las nieves posado a gran distancia sobre un monion de piedsas; $a$ fin de tenerle $\{$ tiro, procuré acercarme con el mayor sigilo, y cuando avanzaba levanté por casualidad una liebre jơven del tamaño 
de un gato, que se dirigio precisamente hacia el harfango. Aunque solo me hallaba a ciento cincuenta pasos del estrigido, este se precipitó sin embargo sobre la liebre que pasó á unos treinta pasos pror delante del ave; al segundo ataque la hizo rodar por tierra, y arrastrándola á uros cien pasos mas léjos, posóse sobre su cuerpo para devoratla Cuando me hube acercado a unos setenta pasos, la mpaz quiso ale. jarse con su presa, pero la maté al vuelo. La liebre tenia una herida en ambos lados del vientre y ya estaba muerta $\mathrm{Al}$. gunos grupos de estas aves persiguen á las manadas de le. mings, y las parejas que viven solitarias amenazan a toda clase de aves. Ia especie de que hablamos es muy aficionada á las nevatillas, las cuales coge à ln vista del cazador cuando estån heridas $y$ hasta las roba del saco. Tambien acomete af las gallinas silvestres, á los patos y las palo mas salvajes $y$ hasta se apodera de los peces.

Audubon ha visto al hariango de las nieves pescar. tuna mañana, dice, estaba yo al acecho cerca de las cascadas del Ohio, con el objeto de niatar ocas salvajes, pude ver cómo cogia aquella rapaz los peces; estaba oculta en una roca, con la cabeza vuelta hacia el agua, y tan quieta que parecia dormida; pero tan pronto como un per. se dejaba ver en la superficie del agua, avanzaba de pronto el harfango Ia pata y retiróbala con una preśa. Alejłbase entonces algu. nos pasos, le devoraba y volvia á pescar. Cuando cogia un pez grande, sujetábale con las dos garms y se iba a larga distancia, reuniéndose a veces dos harfangos para devomrlo.

Durante su caceria sigue á iodo sér que vuela. ¿Una vez, dice Holboell, oóligué á uno de estos estrigidos á seguirme casi un cuarto de legua à la luz de la lana, arrojando repeti. das veces mi gorra al aire

El harfango de las nieves se reproduce en medio del verano; en junio se encuentran los huevos cuyo mímero es mayor que el de cualquiera otra ave de rapina de regular tama. io. Repetidas veces se han encontrado siete en el mismo nido, pero todos los lapones aseguran que el hariango de lás nieves pone tambien ocho y hasta diez. Collett confirma el informe; añadiendo que tambien la reproduccion de este es. trigido, asi como toda su vida, dependen del majos ó menor número de lemings; de modo que no sola stele anidar alli donde han aumentado mucho estos roedores, sino gue pone tambien mas huevos en los años en que abundan. Parece que la hembra empieza ya a incubar mientras pone, pues en algunos nidos se encuentran polluelos de diferente tamaño. Ios huevos tienen unos (",055 de largo, por $16^{*}, 045$ de grueso y son de color blanco sticio. El nido se reduce $i$ una ligera depresion del terreno cubierta de algunas yerbas secas y de plumas que el ave se arranca. Los padres manifiestan el mas vivo carino a su progenie: la hembra que cubre deja acer. carse mucho al hombre, ó bien trata de alejarle de su nido por astucia; échase en el suelo cual si esturiese herida, y permanece innóvil, como muerta; con las alas extendidas, esforzandose asi en llamar la atencion de su enemigo.

Mientras la hembra cubre, el macho, posado en lugar conveniente y cerca del nido, vigila por su seguridad, dando la señal de alarma con agudos gritos apenas sospecha un peligro; la hembra abandona entonces el nido y a mbos ruelan siempre, dejando oir su voz horas enteras alrededor del nido. En tales casos el macho da prucbas de su atrevimiento; pre. cipitase furiosamente sobre el intruso, y aun con mayor vio. lencia sobre el perro, si alguno le acompaña, y no es muy fácil ahuyentarle, mientras que la hembra raras veces expone de este modo su vida.

En Europa, solamente los naturalistas y los cazadores á quienes gusta perseguir a un are tan grande inquictan á menudo al harfango de las nieves; en la T'undra de ia peninsula de los samojedos, por el contrario, estos últimos y los ostia. cos los cazan sistemáticamente valiéndose de grandes lazos, y' comen con mucho gusto su carne.

CAUTIVIDAD.-Es muy raro ver harfangos cautivos: solo excepcionalmente se consermn cuatro a cinco años.

El harfango de la nieves es vivaz y alegre, aun durante el dia. En su jaula está continuamente en moviniento; no se irrita ante los curiosos: pero si le molestan silba y chasquea el pico como los demás estrígidos.

No he tratado de poner harfangos con otras aves: pero he oido decir que un aficionado encerró uno con un águila, y que vivieron en paz aquellos enemigos naturales.

\section{LAS LECHUZAS - ATHENE}

Fil aic de Mineracra una lechuza: la especie, muy comun en Grecia, se asameja nucho á la de nuestros paises, si es que se diferencia de ella.

CARACTERES. - I Las lechuzas son pequeños estrigidos de cabeza mediana; alas cortas y redondeadas nue cu. bren apenas las dos terceras partes de la cola, la cual es corta y truncada en ángulo recto: tienen las patas bastante altas, con dedos vigorosos y bien armados; el pico corto, comprimido lateralmente, muy encorvado desde la base, de gancho bastante largo y bordes sin diente. El oido externo es pequeño: el circulo auricular poco desarrollado, aunque mas que cn los otros estrigidos diurnos; los tarsos están re. gularmente cubiertos de plumas, y solo de algunas sedas ri. gidas los dedos.

\section{LA LECHUZA COMUN-ATHENE NOCTUA}

CARACTERES. - Ia lechuza comun tiene $\|^{\prime \prime}, 21$ á $0^{\circ}, 22$ de largo por $0^{m}, 52$ a $6,4,55$ de ala 1 ala; esta plegada mide $0^{\circ}$, is y la cola $\left(1^{\mathrm{m}}, 08\right.$. La hembra es algo mayor que el ma. cho. El plumaje de la parte superior del cuerpo es de un cc. lor pardo gris raton con manchas blancas irregulares; la cara gris blanquizca, y la parte inferior del cuerpo blanca tambien con manchas pardas longitudinales. Ins pennas de las rémiges son de un gris pardo con manchas triangulares $y$ fajas trasversales de un blanco rojizo; las rectrices son igualmente pardas y presentan cinco fajas poco distintas de un blanco rojizo; el pico es amarillo verdoso; los piés de un gris ama. rillento y el ojo de un amarillo de azufre. Los individuos pequeños tienen un tinte mas oscuro que los viejos.

En el mediodia de Europa, asi como en Palestina, Arabia, Persia y todo el norte de Africa, esta especie está representada por la lechuza del desierto (Allene slous:), que difiere de la comun por su menor tamaño, su color mas pálido y por tener las manchas poco marcadas, a veces casi imperceptibles: \& esto se debe que algunos naturalistas la conside. ren solo como una variedad.

DISTRIBUCION GEOGRÁFICA. - La lechuza está diseminada desde el mediodia de Escandinavia, la Europa y parte del Asia hasia la Siberia oriental. Habita toda la Alemania, Dinamarca, Holanda, Bélgica, Francia, Fspaña, Austria, Hungria, Rusia meridional, los paises bajos del Danubio y Turquia, asi como la Siberia meridional y el Turkestan; no se encuentra en todas partes con la misna abundancia: pero cuanto mas se avanza por el sur tanto malor es su número; en las ires peninsulas meridionales de Europa se cuenta entre las ares de rapiña mas comunes En las montañas de España sube hasta una altura de 2,000 metros; pero á principios del invierno trasládase ŝ regiones menos elevadas.

La especie no es rara en nuestros paises. 
USOS, COSTUMBRES Y RÉGIMEN, - La lechuza comun evita las grandes selvas; solo le gustan los bosquecillos de poca espesurn; es seguro encontrarla donde los pue. blos están rodeados de verjeles $y$ de árboles añosos. Anida en el interior de las ciudades; se tija en las torres, los tejado5 y las tumbas, y permanece oculta durante el dia. No le inspira temor alguno el hombre, y es mas bien á este á quien le inquieta su vecindad. Es vergonzoso, en eiecto, ver que aun hoy existen pueblos tan supersticiosos como los indios, quienes consideran por lo comun á las lechuzas como séres sobrenaturales. En varios paises de Alemania se cree que esta ave lleva consigo lá desgracia, y que su grito es un pre. sagio de muerte.

Las mujeres han visto con sus propios ojos que la lechuza llegó hasta la rentana de las habitaciones de los enfermos, como para anunciarles que los esperaba en el cementerio. Es muy positivo que esta ave inofensiva, atraida por la luz, se dirige hácia las habitaciones iluminadas y que se posa tambien en las ventanas dejando oir entonces su roz.

Debemos aplaudir á los habitantes del medindia de Europa, donde la lechuza es tan comun, porque no atribuyen í la mpaz funestas cualidades, ni la consideran sino como un sér útil y digno de nuestra proteccion.

Ya en Italia todo el mundo la profésa carino $y$ la cuida; en Crrecia se la considera aun hoy dia como ave dotada de inucha inteligencia y se la honra tanto, que al llegar el rey Oton se le dió una lechuza viva como regalo de bien venida. En el mismo grado es apreciada tambien en Palestina donde se la mira como señal de buena suerte; de inodo que en vez de perseguirla se la cuida y protege.

A decir verdad, la lechuza merece el aprecio del hombre: no se puede decir que sea realunente un ave diuma, pues no despliega actuvidad hasta despues de ponerse el sol; pero no huye de la lu\%, corno lo hacen la mayor parte de los estri. gidos, $y$ desempeha sus funciones á cualquier hora del dia. Nunca duerme tan profundamente que se la pueda sorprender; el mas leve rumor la despierta, y como ve en pleno dia, huye sicmpo.

En su vuclo traza curvas, poco mas ó menos como la ur. raca; avanza rápidamente, y pasa con facilidad a través de la mas enmarañada espesura.

Cuando descansa está como recogida sabre si misma, mas apenas ve algo sosuechoso, endereza el cuerpo, inclinase af derecha é izquierda, y contempla fijamente el objeto que lla. ma su atencion. Su mirada tiene ciertil expresion astuta y burlona, pero nada maligna; se coinprende que los griegos hayan clegido esta ave para favorita de la diosa de la sabiduria. Su inteligencia no es de las mas limitadas, y se puede conside. rar á la rapaz corno uno de los estrigidos mejor dotados por tal concepto.

Vive en buena armonia con sus semejantes: en el mediodia de Europa y en el norte de Africa se encuentran á me. nudo numerosas bandadas de lechuzas, que parecen vivir en la mejor armonia.

Antes de la puesta del sol se oje resonar ya la voz de la lechuza, y a la hom del crepúsculo comienza su caceria. En las noches de luna se la ve en continuo movimiento, aun cuando solo recorre un pequeño dominio; todo le llana la atencion; vuela alrededor del fuego encendido por el caza. dor, acércasc á las ventanas iluminadas, y puede asustar asi á cualquiera persona de espiriu débil y crédulo.

Su alimento consiste sobre todo en pequeños mamiferos, aves 6 insectos: extermina los murciélagos, las musaranas, los ratones, los musgaños, los arvicolas, las alondras, los gorrio. nes, las langostas, los abejorros, eic; pero los pequeños roedores constituyen su alimento principal.
Se reproduce en abril ó maro, en cuya época parece muy excitada, pues grita y se agita mucho. No construye nido: para depositar sus huevos, limitase á elegir una cavidad con veniente en una pared de rocas, debajo de las piedras, en algun muro viejo ó en el hueco de un tronco de írbol. La puesta es de cliatro a seis huevos, los cuales cubre asidua. mente por espacio de catorce ó diez. y seis dias; empolla con tal ardimiento, que Naumann pudo acariciar a una hembra en su nido, y coger un huevo debajo de ella sin que huyese. Alimenta \& sus hijuelos de pequenos rocdores, ares é in. sectos.

Tan luego como los polluelos tienen todo su plumaje y pueden abandonar el nido, los padres se alejan todas las no. ches, segun Robson, á cierta distancia, pósanse en algun sitio alto y producen un grito agudo, á la manera del mirlo, cuan. do quiere advertir a su cria algun peligro. Asi proceden hasta que su progenie deja el nido y rucla hácia ellos. Entonces conduce á sus hijuclos al aire libre $y$ alli donde hay montanass, prefieren estas para acostumbrarlos poco á poco á la independencia; pero por la mañana vuelven siempre al nido hasta que le abandonan del todo.

El azor y el gavilan la matan: la comadreja destroza los huevos; las cornejas, las picazas, fos grajos, y lodas las aves pequeñas la hostigan con sus gritos.

CaUtividad. - La lechuza soporta fácilmente la cautividad, aunque sea en una reducida jaula. Italia es hoy dia el único pais doade se crian todavia muchas cun el objeto de utilizarlas.

- Para no carecer de lechuzas, dice lenz, los italianos se cuidan de formar debajo de los tejados unos espacios conve. nientes, y de fácil acceso, donde puedan anidar estas aves. luego se cogen tantos individuos como se necesitan y se deja à los demás tranqquilos. Ias lechuzas han llegado á ser en Italia verdaderos animales domesticos: despues de cortar. les las alas se las permite correr libremente por las casas ó los patios, donde cazan los pequehos roedores; se las deja principalmente en los jardines, y exterminan las limazas y los pa. rásitos, sin causar el menor daho. Todos los sastres, zapateros y otros artesanos que trabajan en la calle, tienen junto a si dos ó cuatro lechuzas á las cuales dirigen las mas carinosas miradas; y como no pueden darles siempre carne, acos. túmbranlas a nutrirse de polenta.

En Austria se utiliza ya la lechuza para el mismo fin, $y$ segun se asegum, con el mayor éxito. El gran duque es para la caza de halcones lo que la lechuza para la de las aves pe. queñas. - Todas estas, creyendo poder fiarse de su agilidad, jreséntanse sin temor para provocarla; y los grajos y los pricos cruzados maltrátanla á reces de un modo que pudiera costarles caro. I.os últimos, olvidando toda su vimidez cuando ven á una lechuza, acuden uno despues de orro, á menudo desde Jarga distancia, s no abandonan el campo de batalla aunque vean que alguno de sus compañeros perece víctima de su osadía.

Los antiguos halconeros de Holanda se servian de la le. chuza para coger los picos cruzados y cazar los halcones. -

\section{LOS FOLEOPTINX-PHOLEOPTINX}

CARACTERES. - Los folcoptinx son muy análogos à las lechuzas, tienen la misma talla que ellas, poco mas ó nucnos, y difieren esencialmente por los tarsos muy altos y los dedos cortos. Distinguense además por los siguientes camctéres: cabeza redonda y medianamenic voluminosa; ojos grandes; pico prolongado, de gancho regular y mandibula inferior roma, ligeramente escotada por detrás de la punta; alas largas, redonduadas y obtusas, con la cuarta penna mas jro. 
longada; cola corta, truncada en ángulo recto; tarsos altos y delgados, cubiertos de escasas plumas solo en su cara ante rior: dedos revestidos de escamas gruesas y de aigunas plumas en forma de sedas: uñas poco corvas. El plumaje es bastante compacto; las plumas son pequeñas, blandas y se. dosas; el circulo auricular de reducido tamano; las plumas de la linea naso ocular rigidas; y el disco perioftálmico desar. rollado solo por abajo y por detrás.

\section{EL FOLEOPTINXZANCUDO-PHOLEOPTYNX CUNICULARIA}

CARACTERES - Esta mpa Hamadal vulgarmente luho ie los comiejus, nirnge de los brasileños, tiene ellomo gris pardo rojizo, con manchas blancas recondas i ovales; las cejas y la barba son blancas; la parte inferior del cuello de un amarillo rojizo, con manchas de un tinte gris pardo; el pecho de] mismo color, con manchas amarillentas; el vientre blanco amarillento; el ojo amarillento; el pico $y$ las patas de un gris verdoso claro y la cara plantar de los dedos amarillenta (fig. 3 $S_{4}$ ). Esta rapar. mide 1" ,23 de largo por $1,0,58$ de sla á ala; esta plegada $\left(0^{\circ}, 16 \mathrm{y}\right.$ la cola cerca de $(1 \%, 0 \%$

DISTRIBUCION GEOGRÁFICA. - Lista especie es propia de la América del sur.

\section{EL FOLEOPTINX DE LOS HIPOGEOS- PHOLEOPTYNX HYPOGEA}

CARACTERES. - Se asemeja esta especie \& la prece. dente, de modo que una descripcion muy minuciosa joodria

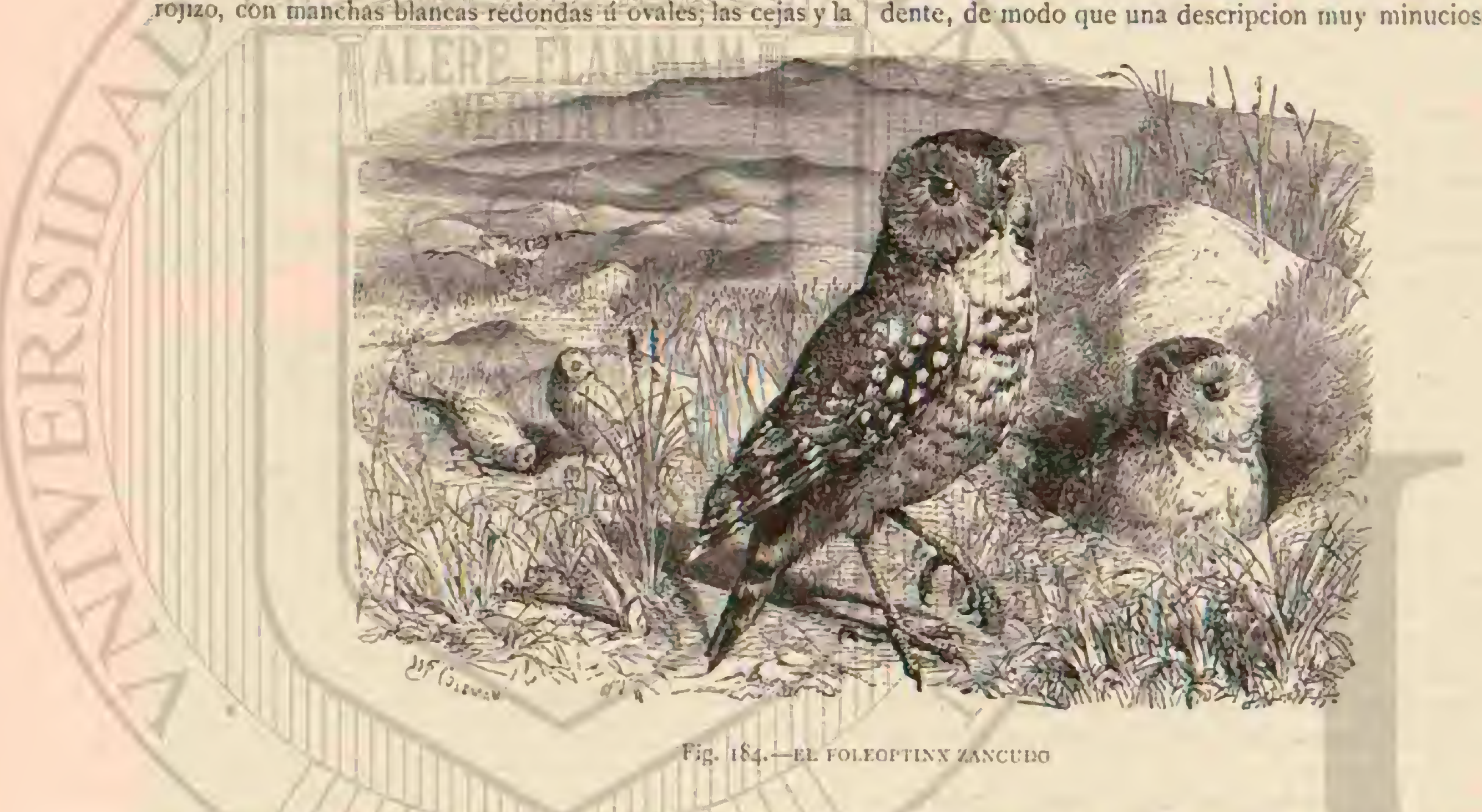

hacer resaltar las diferencias poco importantes que se notan en ambas, pero podemos prescindir de ella, tanto mas cuanto que los naturalistas americanos no estan aun de acuerdo sobre si el foleoptinx zancudo y el de los lipogeos pertene. cen á una misma especie.

USOS, COSTUMBRES Y REGIMEN.-Tambien por este concepio se parecen tanto anibas aves, que los informes de los diversos autores pueden aplicarse lo mismoá una que a otra. Daré por lo tanto la preferencia al foleoptinx yancudo, porque este ha tenido últimamente un observador que lo des. cribe del modo mas minucioso.

Son rapaces caracteristicas de América : habitan en el sur los lianos y las pampas, $y$ en el norte las praderas; son comu. nes en todas partes. El viajero que atraviesa aquellas llanuras desprovistas de árboles, ve á las dos aves en el suelo, ó posadas mas a unenudo en los montecillos que indican la madriguera de un mamifero. En clla se albergan estas rapaces, en compañia del legitimo propictario, y a menudo esián con terribles enemigas, cual son las serpientes venenosas. En los alrededores de Buenos Aires, segun dice Darwin, no se intro. duce esta rapaz siro en las madrigueras de las vizcachas: en el Brasil habita las de los hormigueros y de los armadillos, y en la América del norte vive en las de los cinomis. Obsérvase que las madrigueras habitadas aun por los mamiferos se dis. tirguen por su aseo y buena conservacion; nientras que aquellas donde viren las rapaces se deterioran. Por otra parte, vemos a los cinomis, á los foleoptinx y a las serpientes de cascabel entrar y salir por la misma abertura, y debe deducirse que las dos primeras especies viven en buena armonia. Yo creo que la descripcion de Hudson sobre el folcoptinx zancudo es la mejor de todas. Ein la República argentina, dice, este gracioso estrigido se encuentra en lodos los campos, pues evita los bosques y hasta las regiones donde abundan los árboles. Sufre muy bien la luz del sol, y al parecer no le molestan los rumores del dia. Cuando se acerca alguno mirale fijamente, le sigue con la vista por todas partes, y en caso necesario vuelve la cabeza. Si una persona se acerca á pocos pasos, inclinase como para retozar, produce un cortagrito se. guido de otros tres entrecortados, levántasc y se aleja cuando mas á quince ó veinte meiros de distancia. para volver á po. sarse con la vista fija siempre en el intruso. Apenas se ha vuelto â posar, repite sus inclinaciones y sus gritos: pero des. pues se endereza y muéstrase como asombrado. Duranic el dia aletea de continuo a muy poca altura del suelo, y siempre se eleva verticalmente cuando quicre posarse. Si se le obliga á remontar el vuelo muchas veces seguidas cánsase pronio de tal modo que apela á sus ágiles piés, y por eso es posible alcanarte y cogerle á caballo á los quince ó veinte minutos. Cada parcja vive todo el ano en la mas fiel union: durante el dia suelen posarse en la abertura de una madriguera de vizcacha, colocándose el macho lan cerca de la hembia, que casi se tocan. Si se les asusta entonces, ó cléranse ambos 6 solo el macho, mientras que la hembra desaparece en el intêrior de su refugio. 
En incias las colonias habitadas por europeos, el foleop tinx zancudo abunda nucho, y muéstrase tambien muy faurliar; mientras que en todas las regiones donde los indios cazan, su conducta es del iodo diferente: aqui se remontaal llegar un hombre, con la misma timide\% y preceauciun de todas las demás ares que son perseguidas con regularidad; y aunque la persona esté muy léjos, elévase à considerable al. tura, de tal modo que á veces no le vén los viajeros antes de volver a posarse en tierra. Fste modo de proceder es sin ducia consecuencia de la profunda aversion que todns las tribus de las pampas profesan a este estrigido, objeto de necias supers. ticiones de toda especie; llaman á la graciosa ave chermana del espiritu malo; y cuando pueden perseguirla mátanla sin compasion, jues solo su presencia basta para asustarles: d] indio no establece nunca su campamento alli donde ha visto un buho. Tan luego como las llanuras se colonizan por los europeos, el folcoptinx zancudo pierde su timider, olvida sus precauciones y comienza à ser an familiar como antes cra desconfiado. La trasfornacion del suelo que habita en cam. pos y pastos le importa poco, pues cuando el arado hunde la entrada de sus madrigueras, abre curas nuevas en las inárge nes de los campos, y si anui no encuentra sitio, á orilla de los caminos, tanto solitarios como frecuentados. Aqui llega á ser tan familiar, que un jinete podria matarle sin irabajo con su látigo. Varias parejas viven cerca de mi casa, y cuan. do alguno de nosotros sale á caballo, permanecen posadas en sus agujeros, aunque los cuadrúpedos pasen a tres ó cuatro metros de distancia; cuando mas se limitan a chasuguear el pico, crizan su plunaje y no piensan en huir.

- A veces estos estrigidos cazan tambien de dia, sobre todo cuando ven á su alcance alguna presa que les infunde la esperanza de cogerla fícilmente. Muchns veces me he divertido haciendo rodar pequeños pedazos de tierra cerca de sus agu. jeros, pues al punto persiguen el objeto $y$ solo echan de ver su error cuando ya le han cogido. Durante el periodo de la incubacion $y$ sobre todo cuando crian sus polluclos, son quizás tan actiros de dia como de noche. En los dias mas $2 \mathrm{~cm}$. plados de noviembre déjanse ver à veces grandes escarabajos en un número incalculable, excitando it las ares a la perse cucion, tanio por su tamano como por el zumbido de su vuc. lo. Entonces se ve al foleoptinx zancudo cazar por todas par. tes, pero con frecuencia cae torpemente al suelo, porque asi como todos los estrigidos, tierie la costumbre de coger una presa con ambas garras, viéndose obligado a valerse de sus alas para conservar el equilibrio, el cual pierde muchas veces, cayendo aturdido sobre la jerba. Cuando la presa cogida es pequeña, devórala al poco rato en el mismo sitio; pero si es grande suele remontarse á menudo con gran trabajo, y fran. quea cicrta distancia con su victima, cual si quisicra no perder tiempo en matarla.

Al ponerse el sol, el foleoptinx zancudo deja oir su $\mathrm{rn \%}$, que consiste en un sonido corto seguido de utro mas largo, pero ambos se repiten tantas veces, que el intervalo entre ellos apenas llega à un segundo. Este grito no es ni terribic ni solemne, sino mas bien sunve $y$ triste y recuerda en cierto modo los tonos bajos de la flauta. En la primavera todos gritan, contestíndose unos a otros. Al cerrar la noche remón. tanse sucesivanente por los aires, y entonces se ve a los gra. ciosos estrigidos jor todas partes, revoloteando a una altura de cuarenta metros. Cuando divisan una presa precipitanse verticalmente, hácia el suelo, pero con vuelo iacilante, cual si estuvieran heridos; cuando solo estin a unos diez nietros de altura del suelo fijanse otra vez en su presa, ruelven a revolotear algunos segundos $y$ se dirigen en linea diagonal hácia abajo. Dan caza i todo sér viviente cuando creen poder vencerle. Si las presas son abundanies dejan intactos la cabe- $z a$, cuello y los piés de un raton cogido $y$ tambien desprecian á veces los musios de una rana, ó de un sapo, a pesar de ser las partes mas carnosas y suculentas. Mhatan á picotazos á una serpiente de $0^{*}, 50$ de longitud, precipitändose valerosamente sobre ella hasta que la victima sucumbe; parece que se defien. den de las serpientes renenosas con sus alas. Muchos indivi. duos qque viven cerca de las casas de labmna llegan á ser peligrosos para las peyuenas ares domésticas y roban de dia folluelos. En tiempo de abundancia matan mas de lo que

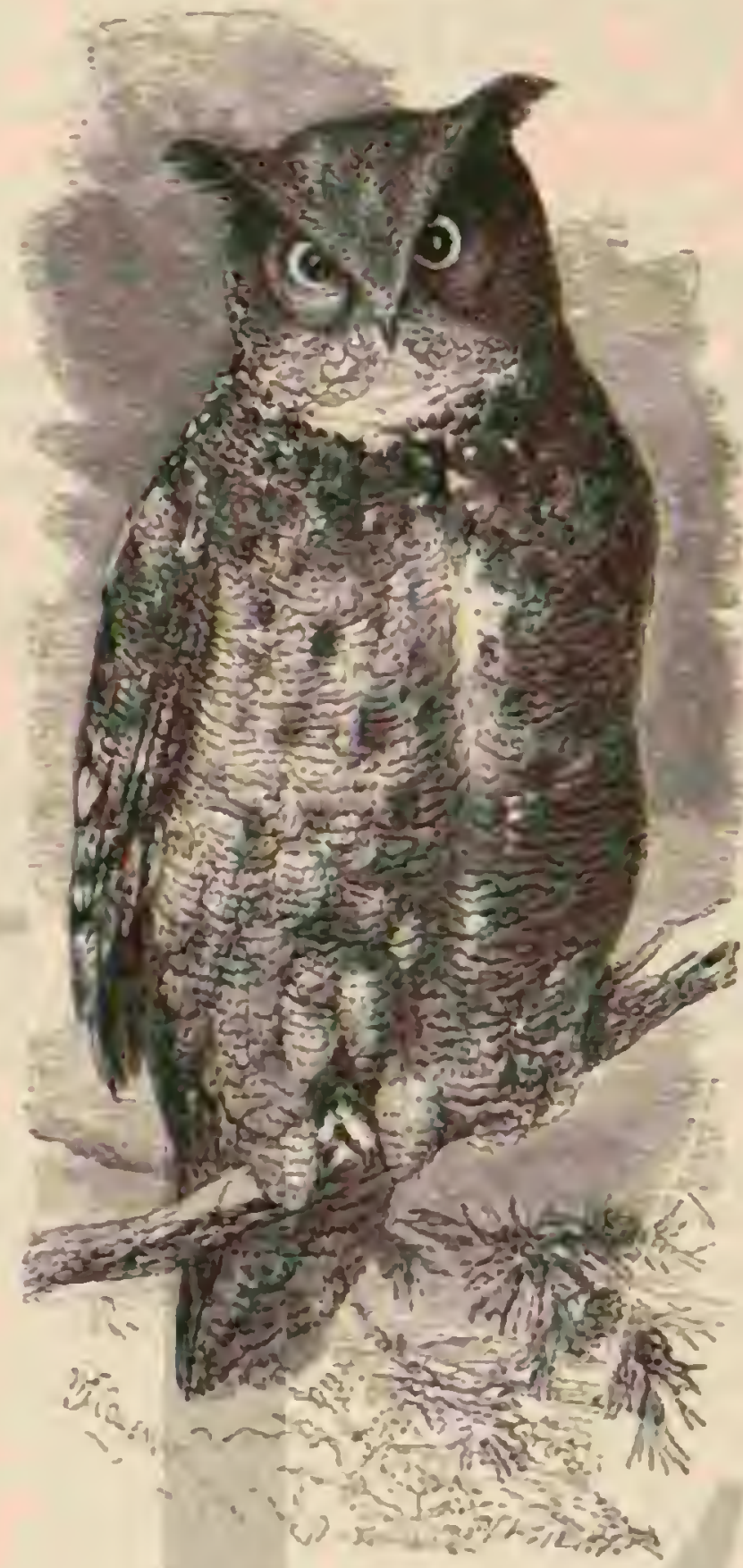

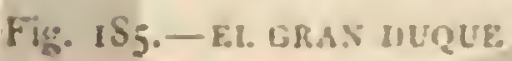

necesitan, pero en invierno sus recursos son á veces muy es. casos; entonces visitan los alrededores de las habitaciones y conténtanse con un pedacito de carne si le cncuentran, aun. que este tan sero como el pergamino.

zi pesar de que estos estrigidos utilizan la mayor parte de las madriguems de las vizcachas, no por eso dejan de cons. truirlas por si mismos cuando las neccsitan. La galeria, cuja longitud varia de uno á cuatro metros, es sinuosa y se ensan. cha en su extremidad posterior, donde se halla el nido, yue se compone de yerbas secas y lana, y a reces tambien de estiércol de caballo. I.os huevos, en nímero de cinco, son casi redondos, de color blanco. Alun despues de haber co. menzado la hembra a poner lleva estiércol al nicjo hasta que todo el suelo queda cubierto de una espesa capa. Al año siguiente, el ave escarba toda la tierra suelta, $y$ la madriguera que sirve de nido por varios anos se arregla otra vez Sin einbargo, siempre esta sumamente sucia, aun en el periodo de la incubacion, ó cuando hay abundancia de alimento. Entonces cubren ol suelo, y casi obstrusen la entrada, no solamente los excrementos y las bolas, sino ambien restos de pieles $y$ huesos, clitros de escarabajo, plumas, ancas de rana en todos los estados de putrefaccion, grandes arañas velludas de la Pampa, restos de serpientes mediu devoradas y de otros varios séres. Todos esos restos en descemposicion 
diseminados dentro ýfuera del nido, indican marcadamente la gran utilidid que reportan estos estrigidos. Los pequeños abandonan el nido antes de poder volar para tomar el sol y recibir el alimento de sus padres. Cuando ailguien se accrca mućstranse sumamente txcitados, castañetean el pico y retiranse al interior de la madriguera; mas al parecer muy contra su voluntad. Cuando pueden volar sirvense de sus alas para ponerse en salvo. Los adultos y pequeños viven á menudo cuatro ó cinco meses juntos

Segun Hudson, es notable la gran diferencia que se observa en la manera de proceder del foleoptinx zancudo al abrir sus madrigueras. Algunas parejas comienzan meses an. tes del periodo de lin incubacion; otras, solimente cuando la hembra se prepara fi poner: en varias macho o hembra es. carban la tierra con ta mayor aficion; otras proceden con sin igual ligereza, trabajando solamente la hembra; no pocas forman su nido con todas las reglas del arte; y algunas abren cincó $\delta$ seis, abandonándolos despues de tres o cuatro sema. nas de irabajo; pero de todos modos, tanto las parejas pere. zosas como las activas terminan en setiembre la construccion dc sus viviendas.

\section{LA LECHUCITA ENANA-MICROPTYNX PASSERINA}

GA RACTERES. Estas rapacestienen el cuerpo prolon. gado; la cabea pequena; los ojos regulares; el pico fuerte, muy corro, escotado y dentado en el borde de la mandibula superior, las ałas son cortas, super-ubusas, con la cuarta y quinta rêmiges mas prolongadas; la co!a cora; el plumaje me. nos suave que en otros buhos; el disco poco pronunciado. Segun mi padre, el macho mide ajoenas $10^{\mathrm{m}}, 17$ de largo por $0^{m}, 41$ de amplitud de alas, la hembra $0^{\circ}, 19$ pror $0^{\circ}, 45$ resizectivanuente; las alas miden $0^{7}, 09$ y la cola $0^{-}, 06$.

El macho adulto ticne el lomo de color gris raton manchado de blanco; el vientre de este último tinte con man. chas longitudinales pardas; la cara gris blanquizca cubierta de pequeños puntos oscuros; el pico amarillo; el iris del mismo color, mas vivo; adornan la cola cuatro fajas blancas.

El color de la hembra es algo mas óscuro que el del macho, y difiere ademas por tener dios lincas curvas oscuras situadas por debajo del ojo.

Lin los jequeños predomina el tinte pardo.

DISTRIBUCION GEOGRÁFICA. - Tambien la lechu cita cnama abunda mas en el norte que en el mediodia, pero su area de dispersion se extiende desde Noruega hasta la Siberia oriental y desde el limite septentrional de los bosques hasta la latitud de la Italia del norte. No escasen en los bos ques de las montañas de Escandinavia y hasta abunda en las selvas de Kusia. Támbien visita continuamente la Alema. nia, y sugun parece con mas frecuencia de lo que se cree; habiendose cazado y cugido muchos individuos en la Prusia oriental yoccidental, Pomerania, Silesia, Sajonia, Turingia, Hannover, Baviera y Wurtemberg. lista especie se ha encontrado además en los Alpes de Suiza, Estiria, Italia, el Cáucaso y las orillas del Amur.

USOS, COSTUMBRES Y REGIMEN.- La lechucita enana abunda mucho á veces en las llanuras de Escandina. vin; pero las fueries revadas ahuyéntanla de los bosques y la obligan á buscar tos alrededores-de-los pueblos. Frademer vió en el invierno de i $\$ \$ 3$ numerosos individuos al mediodia de la isla de Schonen, y Collett la considera despues del mochuelo salvaje como el estrígido mas comun en las cerca. nias de Cristiania. En verano se la encuentra en los bosques fromdosos, sobre todo en los de coniferas, mientras que en invierno le agrnda estar cerca de los pueblos; si el observador pasa entonces por el parque del palacio le Cristiania, podrá oir a menudo su agudo y corto iss, grito algo semejante al del mirlo y que es contestado al punto desde uno de los árboles vecinos. Fn el Gotland oriental habita los extensos bosiques en número tan considerable, que Lundberg vió algunos años mas de cien individuos muertos. Todos los habi. tantes del bosque conocen por lo menos su roz, especie de sibbido que suena como hi ú ho, y que ha dado lugar a que se comparara el de este estrigido con el rumor que producen los remos al moverse en la anilla, $\delta$ las ruedas de un carro cuyo eje no tiene bastante sebo. Además de estos sonidus monótonos la lechucita enana deja oir tambien las silabas $\mathrm{hi,}$, hu, hu, low, que sin embargo solo pueden distinguirse des. de muy cerca; á veces, sobre todo á la hora del crepúsculo matutino, grita tambien $/ i i_{3} h i, h i$, $h i$, pronunciando todas las silabas igualmente sostenidas, al fin produce otro grito que sue

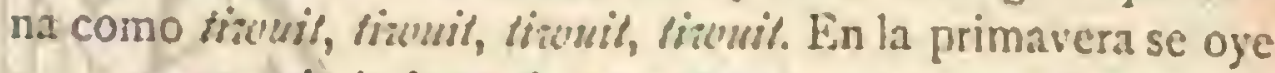
suvoz antes de la hora del crepúsculo, pero no despues de romper el dia. Asi como otros buhos, déjase engañar cuando imitan su voz y' sigue al hombre que la produce en un trecho de mas de mil pasos, pero su vuelo es tan silencioso y el ave se posa tán rópidamente sobre una rama, que a menudo gira a) rededor del viajero mucho tiempo antes de que este pueda notarlo. En medio del verano solo caza de noche, nunca antes de las cuatro de la tarde, con mas afan á la hora del crepúsculo. Atendido su pequeño tamaño, la lechucita çana es una rapaz tan ágil como atrevida; coge ratones, lemings, murcićlagos y otros mamíferos penucinos, pero sobre todo aves, incluso las de igual corpulencia; atrapa su presa tanto al vuclo como cuando corre ó esta posada, y persigue á los gorriones á menudo hasta la inmediacion de edificios habi. tados. No manifiesta timidez ante el hombre, y por lo mismo es fácil accrcarse a ella i tiro o cogerla en toda clase de trampas.

En una carta que recibi de Reichenau, este naturalista me daba datos muy curiosos sobre las costumbres del ave: $₫ \mathrm{En}$ los dias hermosos oigo á reces en los bosques de los contor. nos de Niesbach un grito de ave, muy prolongado, que po. dria reproducirse por la silaba acill. Cuando le escuché por primera vez llamó ya mi atencion, porque no parecia proceder de un ave diurna; y por su semejanza con el conocido limiving de la lechura comun, supuse que cra buho el que le dejó oir; pero pasó mucho tiempo antes de que pudiera ver y observar al ave. En un magnífico dia de noviembre, ha llándome en medio de um claro del bosque, cubierto de maleza, y no léjos de la orilia de una pradera, vi este perjueño estrigido diurno posado en la rama mas alia de una encina. Alli estaba muy crguido, con el plumaje entreabierto para recibir mejor el sol y ocultando ta graciosa cabecita, con sus claros ojos de halcon, cuando se arreglaba el plumaje. Mi instiuto de cazador se antepuso al interés de mi observacion: apunté mi escopeta, cargada con perdigones de mediano tamano, y erré el tiro. Ia lechucita lauró al ruido de la de tonacion, pero solo para dirigirse, con un vuelo parecido al de los halcones, a una haya que apenas distaba unos treinta pasos. Alli se revolvió con grotescas inclinaciones hacia todos lados, elevando y bajancio rápidamente-la corta cola, como pudiera hacerlo un alegre petirojo. Despues de ejecutar los movimientos mas diversos, propios mas bien de un loro guie de un buho, corriendo del modo mas grotesco tan pronto i derecha como à izquierda por una rama horizontal, y demos. trando asi la mayor viveza, alejóse súbitamente y fué á po. sarse en la copa de una encina seca sin ramas, á la altura de unos doce metros. Su aspecto cambió alli del todo; icnia el plumaje en cxtremo alisado y comprimido contra el cuerpo, las plumas del cuello y de la cara estaban tan erizadas, que 
la cabeza pareció casi cuadrangular. Miró con atencion \& sodos lados, irguiendo las plumas de la cabeza, mas sin hacer ningun caso de mi; muj léjos de ello, fijó la vista siem. pre en tierra. De pronto remontóse sin ruido, deslizíndose como un milano por los aires, y un momento desuues oi el chillido de un raton: que ia pequeña rapaz. llevaba en las garras, lanzando verdaderos gritos de triunfo, los cuales po. drian expresarse por las silabas dohill, hill, hill. La lechucita iué á posarse en una encina jóven, à unos tres metros sobre el suclo, donde remató à su victima á picotazos. Tenia las alas inedio extendidas y pendientes, y el plumaje tan crizado, que el ave parecia doble mas grande que antes. Posada sobre su presa, habriala devorado sin duda a mi vista si yo no hubiese muerto a la lechucita de un tiro en aquel momento.

$\Lambda$ causa de sus ataques contra las aves pequenas la lechu. cita enana es perseguida alli donde se deja ver.

Es objeto de aversion; pero tambien de temor y espanto para todas las avecillas, que huyen apenas la ven hacer un movimiento. I a lechuza enana, dice Ciloger, une \& la gracia la agilidad, la rapidez y el valor de los estrigidos diumos, juntamente con el aspecto cómico de las especies noc turnas.

La énoca del regreso de las chochas es para esta rapaz el periodo del celo: forma su nido en los árboles alios de los gmandes bosques. Mi padre pudo examinar un nido, abando. nado por desgracia; estaba situado en el tronco hueco de un haya, y se componia de hojas secas de este árbol y de mus. go, dispuesto con mas órden que en los nidos de otros es. trigidos:

Poco despues del año 1840 una lechucita enana anidó dos vernnos seguidos en un peral muy añoso del jardin que rocieaba la casa paterna de liebe; el nido se hallaba en un pequeĩo agujero en medio del tronco; mientras que al mismo tiempo anidaban dos familias de estorninos en huecos de mayor dimension situados mas arriba. La lechucita enana ha anidado tambicu en Obirloedla, cerca de Aliemburgo, y por consiguienie se conocen tres casos de haberlo hecho en la Turingia oriental, siendo indudable que tambien anida $\mathrm{cn}$ Alemania Los huevos son blancos y tienen $\left(0^{m}, 031\right.$ de dia metro longitudinal, por (1),025 de grueso; su forma es oval, muy ventruda; los poros ínos y la cáscara espesa y lisa.

CAUTIVIDAD. - Mi padre tuvo una lechucita enana cautiva, á la que encerró en una habitacion bastante grande y bien cerrada. a Cuando entraba yo, dice, no la veia, y me era preciso buscar largo tiempo para encontrarla. Por lo re gular estaba oculia en un rincon ó debajo de una tabla cla๖adia en el techo; sus grandes ojos, muy abiertos, dirigian una mirada fija á la persona que entraba; al acercarse cual. quicra crizaba todas sus plumas, castaneteaba el pico, y tomaba unas posturas tan grotescas, que no podia uno menos de reirse Si se trataba de cogerla, daba picotazos, aunque sin hacer daño; permanecia quicta todo el dia; pero despues de ponerse el sol, despertábase y comenzaba á gritar. Su voz puede expresarse por las silabas guils ó fip. es melancólica y poro sonora, pues apenas se oje à treinta $\delta$ cuarenta pasos de distancia.

3. Aquella lechucita no comia sino por la tarde y la norhe, bastábanle dos ratoncilos ó una avecilla del tamaño de un gorrion. Recreabame mucho; pero como la recibi inuy Haca y débil, no tarció en morir á pesar de todos mis cuidados.

Mi amigo el guarda-bosque Purgold conservó durante un año en su alcoba una lechucita enana. Al principio se contiujo como la que yo tuve; durante el dia se ocultaba debajo de la cama huyendo de la lu\% y permanecia muy quicta: mas llegada la noche comenzaba a gritar. Comia ra. incitos gorriones: despues de haber desplumado of estos últimos, despedazábalos y se comia los trozos uno despues de otro, jrincipiando por la cabeza. Durante la noche estaba quieta, sobre todo si habia comido bastante: por la manana antes de amanecer, volvia a gritar, con bastante fucrza para no dejar á su amo dormir. Nunca tuvo este un despertacior mas exacto. Aqquella mpaz arrojaba \& menuro bolas for. madas de pelos, plumas y huesos, exactamente como la mia.s

Gadamer habla tambien de una de estas ares cautivns, y dice lo que sigue: a Siempre está en movimiento, y por esto difiere de todos los demás estrigidos. Se la ve trepar todo el dia por su jaula, ayudándose con el pico y las patas, segun hacen los lores; estí muy donesticada; coge las avecillas en la mano y se las come a mi vista. Cuando ve un perro ó un gato, eriza las plumas.

Un cuarto individuo cuidado por Sivers se domesticó al cabo de quince dias en tan alto grado, que se dejaba acariciar y coger sin tratar de huir. Cuando se le da un ave ó un mton, me escribe Sivers, le coge en la mano, pero llevase la presa tan rápidamente como le es posible á un fragmento de tronco, provisto de un agujero, que le he puesto en la jaula. Muy grotescos son sus ademanes cuando vuelvo este pedazo de tronco para que el agujero se encuentre en direc. cion opuesta al ave ! sobre todo si despues le doy un raton. Haciendo continuas inclinaciones vuclve la cabeza á todos lados para buscar el agujero; cuando al fin le descubre in trodúcese rápidamente, y castaíetea el pico apenas se ve en el interior, peroluego ya no hace caso del que observa y cmpieza à comer. Un quinto individuo del cual me ha. bla Boehm, se conservaba muy bien alimentandosele igualmente con ratones y gorriones; acostumbróse pronio á la jaula, saliaba, aunque algo torpemente por las perchas, y comia bien á presencia de su guardian; pero al acercarse un forastero ocultábase en el rincon mas oscuro de su vivienda, siguiendo desde alli todos los movimientos del desconocido con los ojos muy abiertos. Le gustaba comer mas de un gorrian por dia, y comenzando siempre por la cabeza, dejaba solo las rémiges y rectrices. Cuando Bochm le ponin gorriones vivos en la jaula permanecia al principio quieta, cono. ciendo sin duda que le iaitaba el espacio para maniobrar; los gorrioues perdian poco s poco su timidez y solo cuando pacificamente se posaban al lado de la lechuza sobre la per. cha'ó en el suclo, la rayza se precipilaba súbitanente sobre su victima, cogiala con las garras y la inataba de un pico. lazo en la cabeza.

\section{LOS O'TIDOS- BUBONINA:}

CARACTÉRES. - Los ótidos, conocidos mas vulgar. mente con los nombres de buhos, dusues y ambilos, constivu. yen la segunda sub-familia de la division ó tribu de los estri. giplos, ye distinguen por sus mechones de plumas, en forma de cuernos, sobrepuestos en las orejas. Varian mucho en cuanto a la talla: tienen la rabeza grande; las alas mediana. mente largas y obtusas; la cola corta, truncada casi en àn. gulo recto; los tarsos y Ios dedos de un largo regular, cu. biertos de pluma; las unas muy grandes y ganchudas y cl pico grueso y poco corvo. El plumaje es lacio y abundante, compuesto de plumas grandes, largas y anchas; cl ojo grande y aplanado, de color de amarillo de oro por lo regular.

\section{EL GRAN DUQUE-BUBO MAXIMUS}

CA RACTERES. - El gran duque, liamaco vulgarnente anisto 'fig. 1S5), es de todos los estrigidos el mas perfecto y el mayor a la vez: mide $11^{\circ}, 63$ i $0^{\circ}, 77$ de largo por $1,55^{\circ}$ 
1",77 de ala á ala: esta plegada $0^{\circ}, 45$ y la cola $0^{\circ}, 25$ a $10^{\circ}, 28$. Fil plumaje es rico y abundante: la parte superior del cuerpo es de un amarillo rojo oscuro, manchado de negro, la inferior de un amarillo rojo con manchas longitudinales negras; las plumas de las urejas de este color, orilladas de amarillo por dentro; la garganta blanca: las rémiges y las rectrices sembradas de puntos de un pardo amarillo, alternativamente oscuros y claros. Fn resúmen, no se observan en esta ave sino dos tintes: un gris rojizo mas 6 menos vivo y el negro; cada pluma tiene imanchas trasversales, el tallo y la punta son de color negro sohre fondo rojizo; pero estos tintes son mas $\delta$ inchos pronunciados segun las regiones En el lomo san los puntos negros los mas visibles; en el jrecho los ta. llas, y en el vientre las listas trastersnles. Ii pico es gris arul oscuro: las escamas de los piés del mismo tinte, mas ciaro; el ojo de un hermoso amarillo dorado, con un circulo rojizo.

Fn el norte de Asia y en Fspaña los grandes duques ofrecen un tinte mas patido que el de los nuestros: yo recibi uno de China, mas oscuro que el de nuestros paises, y es por lo tanto probable que existan algunas variedades locales; pero los caractéres que las distinguen son muy poco mar. cados para que podamos describirlas como especies dis. tintas.

DiSTRIBUCION GEOGRÅFICA.-Lil trea de disper. sion del gran duque se extiende por todo el territorio septentrional del antiguo continente; en el norte hasta donde se encuentran bosques y en el sur por las montañas. En Alemania se le ha exterminado en muchas regiones, pero aun se encuentra en Paviera y' en varias montañas, asi como en todos los bosques extensos, con la única excepcion de los de aigunos Estados pequeños. Abunda bastante en la Pru. sia oriental, sobre todo en el bosazue de Ibenhorst, en la Prusia occidental y en Posen, a lo largo de la frontera de Polonia y en Pomerania. Abunda menos en Mecklenisurgo, la Marca, Brunswick y Hannover; encuéntranse algunos in. dividuos en el oeste de Turingia, en Hesse, Baden y IVur. temberg, asi como en viarias partes de la P'rusia Renana y

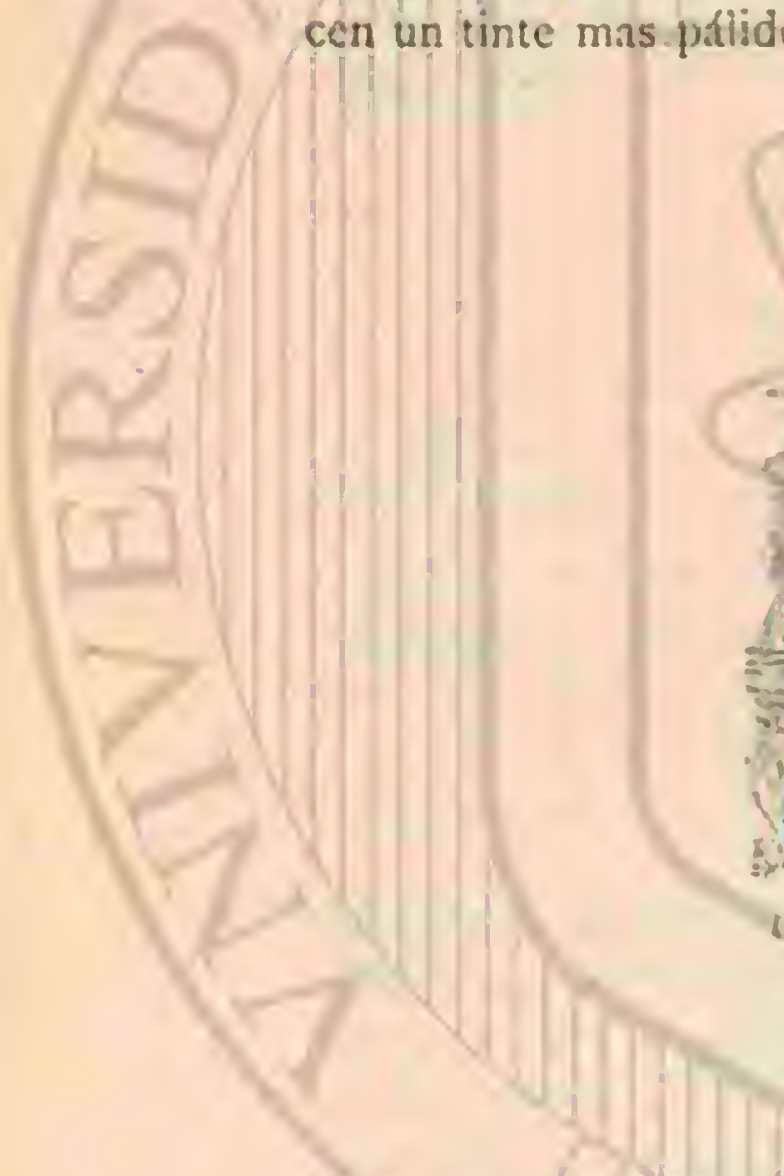

hasta en medio de regiones muy pobladis. Mlucho mayor es su numero cn todos los paises del imperio austriaco, en Es candinavia, toda/la Rusia, los paises bajos del Danubio, 'lurqquia, Grecia, Italia, Espaủa y el sur de Francia, sin que por eso sea un ave comun; escasea en Bélgica y Dinamarca $y$ ha sido casi exterminado en la Gran Bretaña. En Africa se limita su área de dispersion á los paises del Atlas, si bien se le ve algunas veces en Egipto; en Asia, por el contrario, esta diseminado hasta Persia y la Clina, y cuando faita re preséntale el gran duque pálido (Bubo sibiricus), que anenas podrá separarse como especie inciependiente. Desde el limite septentrional de los bosques hasta el Himalaya, se le encuentra en indos los paises y regiones, incluso las cstepas, de cuja fauna animal tenemos noticias exactas. No cmprende viajes; permanece todos los años en el territorio donde anida, ó cuando mas vinga por el pais, mientras no esté apareado.

Fn América está representado por el gran duque de Vir ginia (Bubo rimginiamus) (fig. 186).

\section{EL GRAN DUQUE DE LOS FARAONES - BUHO ASCALAPHUS}

CARACTERES. - Esta especie es mucho mas pequeña que el duque comun, pues solo mide $i^{m}, j^{1}$ á $1 l^{2 n}, 55$ de largo; las alas tienen $\theta^{\prime \prime}, 35$ i $0^{\circ}, 38$ y ia cola $\|^{\prime \prime}$, is de longitud. la parte superior del plunaje es de un pardo amarillento, con mancinas y lineas de un pardo oscuro y blanquuizcas; la barba y el pecho son blancos, y el resto de la parte inferior de un amarillo pardusco. En la region del buche se ven lineas lon. gitudinales anchas y trasversales mas estrechas, de color pardo oscuro: cl pecho y el vientre presentan lineas finas.y rojizas; las rémiges y las rectrices tienen anchas iajas tras. versales pardas; los tarsos son de un color pardo amarilento; el iris de un amarillo de oro intenso y el pico negro.

USOS, COSTUMBRES Y REGIMEN. - Jil gran du. que propiamente dicho, a cuya descripcion me limito, pre. fiere las regiones montañosas que pueden oirecerle retiros seguros y tranquilos: en el llano no se le encuentra sino en los grandes bosques, sobre todo cerca de las rocas escarpa. das; hay parajes que son conocidos desde hace siglos por servir de albergue a los grandes duques. Cuancio se extermina una pareja de estas aves en cualquiera localidad, su. cede con frecuencia que no se vuelve a ver un solo individuo durante varios años; luego llega un dia en que se presenta una nueva pareja y ocupa el mismo sitio habitado por la antigua Permanece alli hasta que la externinan á su vez. Estas ares no evitan del todo la vecindad del hombre: yo cncontré una parcja nuuy cerca de las murallas de Jativa; y Lenz cogió individuos que anidaban en el tejado de una fis. brica construida en medio de un bosque. Sin embargo, al gran duque no le agrada mucho la compaina del hombre, a quien reconoce pror su principal enemigo.

Esta rapaz se deja ver menos de dia que de noche, y no nianifiesta esa gran indiferencia hicia todo, que se nota en los otros cstrigidos. Permanece oculta mientras el sol ilumina 
el horizonte, y aunque no lo hiciese asi, armonizase de tal modo su color con los tintes de las rocas y de los troncos de arbol, que escapa fácilmente a las miradas. Sucede, no obstanie, de vez en cuando, que alguna avecilla descubre su presencia; lo indica al momento 1 sus semejantes, y los gritos de todos los séres alados dan ś conocer dónde se halla cles. condite de la rapaz. Por la roche le descubre su voz sonoral, sobre tudo en la primavera y en el periodo del celo.

Durante el dia suele estar el gran duque en el hueco de una roca ó sobre un årbol; tiene las plumas oprimidas contra el cuerpo; cchadas hácia atrís las de las orejas, y los ojos apenas entreabiertos; diriase que se halla sumido en i:na especie de soñolencia, pero el menor ruido basta para sacarle de este estado. Levanta las plumas de las orejas; vuelve la caleza á tocios lados; inclimase hacia donde se percibe of ru. mor, y mira guiliando los ojos: si cl peligro le parece inminen. te, huye hícia un escondite mejor. Al ponerse el sol se des. pierta; agitase sobre la ranı; alisa cuidadosamente su plumaje, y vuela luego en silencio hácia una roca ỏ un elevindo árbol. En aquel momento es cuancio comienza á dejar oir su voz, que consiste en un grito sordo y prolongado, el cual se podria expresar por las silabas malui. En las noches de luna, y sobre todo en la Epoca de la reproduccion, es cuando grita mas á menudo: su grito tiene algo de fantástico y siniestro en sne. dio del silencio de la noche, y podrin inspirar temor á una persona supersticiosa; el ha servido de origen at la leyenda del cazador infernal, y el vulgo cree que es el ladrido de la trailla del diablo. Bste grito no significa en realidad sino que la no. che es para el gran duque el momento de mostrarse activo; es su señal de llamada y su canto de amor: cuando esta furioso, produce una especie de rechimamiento. En la época del celo sucede a menudo que dos machos se disputan la posesion de una hembra; y entonces se oyen todos estos gritos juntos.

El gran duque caza todos los vertebrados, grandes y pe. queños; los sorprende astutamente y los acomete con valor. Su vuclo, que parece torpe de dia, no lo es por la noche; el ave va rasando el suelo; pero en ciertas ocasiones clérase à gran alturn; muévese \& la vez. con tanta ligereza y silencio, que se apodera de un ave dornicia antes de que haya tenido tiempo de despertarse. Dicese que acomete á los ciervos, is los icmeros y a todos los pequenos mamiferos, y que se atreve á luchar hasta con el águila y el zorro; pero nos faitan pruebas para asegumrio. Snbido es que devoran las liebres, los conejos, las ocas, los patos, las perdices y las ortegas, que no perdona $a$ los buzos, $i$ los cuervos, a las corncjas $y$ i los inochuelos, y que no le imponen las puías del crizo. Es pro. bable que al chasquear el pico ó al agiar has alas espante à las aves dormidas, y que al tratar estas de huir se apodere de ellas al vuelo. A menudo persigue largo tiempo an su pre. sa: caza tambien los animales acuáticos, y acaso pesque de ver en cuando algun pez, aunque constituyan su alimento principal las ratas, los musgaños y las ardillas: extermina además un gran nuimero de reptiles é insectos.

Hácia el mes de marzo es cuando se reprroduce el gran duque, en cuja época se disputan los machos las hembras, segun hemos dicho ya. Una vez formadas las parejas, los individuos que las componen se guardan mutuamente fraelidad, ýsacríican la vida pos salvar á su progenie.

El nido varia segun las localidades: unas veces se halla en alguna madriguera, en la grieta de una roca ó en un edificio antiguo, ra en un árbol, en la tierra desnuda $\delta$ en algun cañaveral; una pareja de gran duques cuyo nido visitó el principe imperial Rodolfo de Austria en la primavera de $1 S ; S$, hasta habia elegido para anidar el hucco, aun cubierto por arriba, de una gruesa rama !putrefacta de encina. Cuando el gran duque puede apoderarse de! nido abandonado de un buro, del cucrio, de la cigüeña, ctc, toma deste luego pose. sion de él, y' apenas le repara; si le es preciso construirle por si uismo, recoge algunas ramas y las cubre toscamente con ramitas y yerbas secas, o bien se contenia con poner en la tierra desnuda. Deposita de dos is tres huevos de forma re. dondeada, blancos y de cascara rugosa; la hembra los cubre atanosamente, y el macho la mantiene entre tanto; los padres llevan á su progenie mucho mas alimento del que necesita.

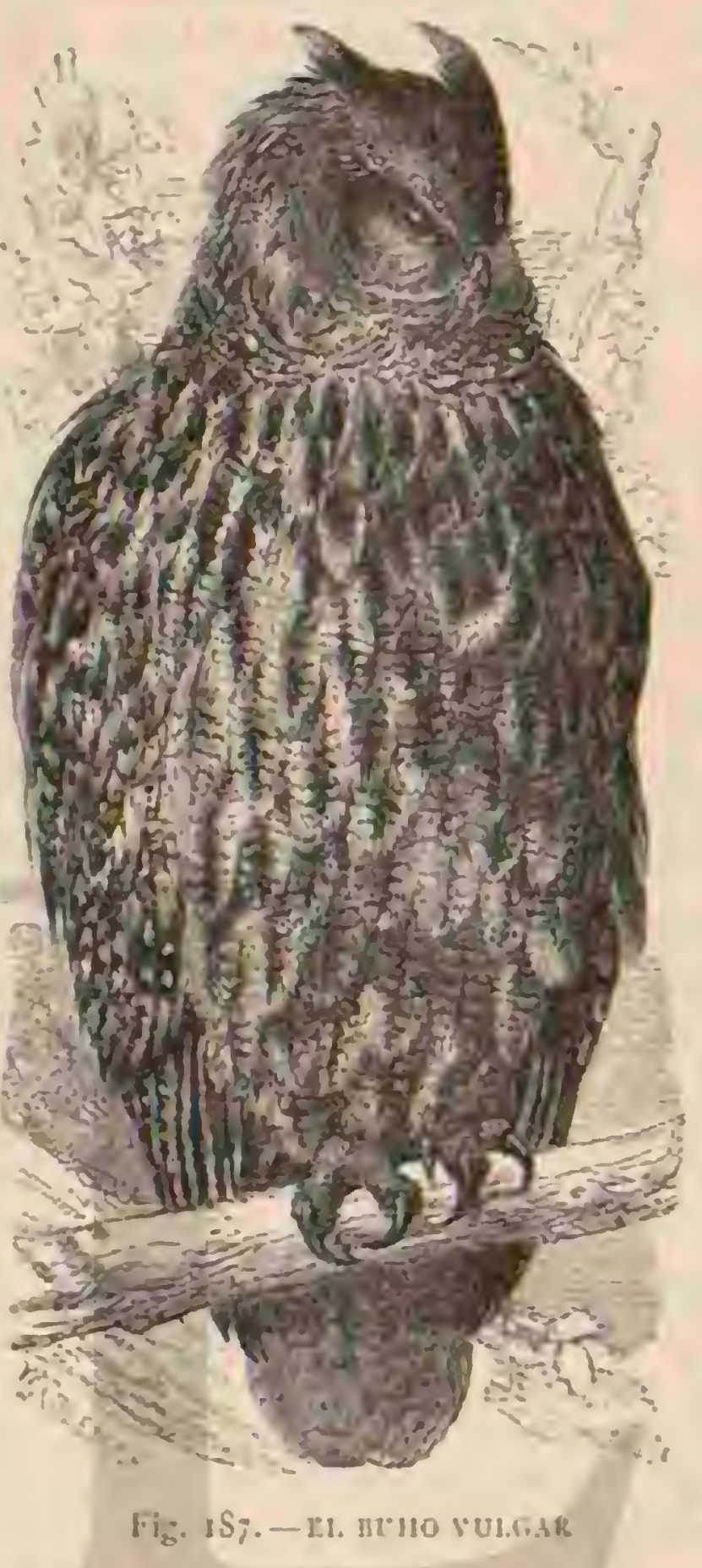

Un nido de gran durue que vió llodzicki, estaba situado entre las cahlas de un pantano, y á él iba diariamente la fami. lia de un campesino para hacer su provision de carne, pues abundaban a su alrededor-los restos de liebres, patos, pollas de agua, ratas, ratones y crizos: el campesino aseguró qque habia tomado durante varias semanas lo necesario para ali. mentarse con atrundancia En caso de peligro defienden los padres â su progenic con valor; acometen á todas las rapaces, y aun al mismo hombre. Se ha observado además que cuan. do sospechan que sus hijuelos no essan ya seguros, los tras. Iadan á otro sitio. Un guardabosque de la Pomerania, reficre Wiesc, tenia hacia mucho tiempo un gran duque en su patio: en la primavera, época del celo, se oyó en los alrededores de la casa, aislada en medio del bosque, el grito de un individuo tibre, y entonces el guarda-bosque aió á su cautivo por la plata í un arbol. No tardó en llegar la rapar. salvaje: cada noche lleyba de comer al prisionero, y cstuvo alimentándole por espacio de cuatro semanas. Si durante el dia se acercaba álguien al gran duque cautivo, oianse resonar al momento los gritos del otro, los cuales no cesaban hasta que desaparecia la persona lin las cuatro semanas llevó la mpaz salvaje i su companera tres liebres, un arvicola anfibio, una infinidad de ratas y ratones, una urraca, dos tordos, una abubilla, dos perdices, un are-fria, dos pollas de agua y una oca salvaje. 
Se ha visto varias reces que los grandes duques seguian alimentando à sus hijuclos cuando estaban encerrados en una jaula. El conde Wodzicki dice haber visto uno al que alimen. taron sus padres durante dos meses, habiéndoles ayudado en su tarea á las pocas semanas el hijuclo que habia quedado libre, y que comenzaba á rolar. Uno de los cazadores del conde Schimmelmann de Ahrenburg tuvo durante varios años una pareja de estas rapaces, que criaron hijuelos varias ve. ces; á fines del otoño las sacaba de su jaula para ponerlas en un grancro, donde les servia un rincon de nido; por Navidad ponian sus buevos. La persona giue me ha referido este hecho, y de cuya veracidad respondo, observo a los padres cuando cubrian, y mas tarde a los hijuelos, desperes de salir à luz; el macho y lá hembra los cuidában con la navor soli. citud, y los defendian valerosamente contra iodos los que se acercaban. En Suiza y Bélgica se han visto hechos seme. jantes.

En el Jardin zoológico de Carlsruhe una hembra de gran duque puso seis años seguidos cada vez cuatro huevos, co. menzando la incubacion apenas hubo depositado el primero y cubriénciolos despues con mucho afan. Neumeier, à quien debemos esta noticia, fuć quien primero turo la ocurrencia de cambiar los huevos por otros de pato. Ia hembra les cu. brió veintiocho dias con buen éxito; pero tan luego comolos cuatro patitos comenzaban $\{$ moverse, cogiólos uno tras otro para devorarlos. 'Todas las ientativas para aparearla con un macho no tuvieron resultado, á causa de su carácter penden. ciero.

Nínguno de los estrigidos de nuestros países es tan univer. salmente aborrecido como el gran duque: casi todas las aves diurnas, y hasta varias de las nocturnas pequeñas, le persiguen y acoson apenas le ven. Las rapaces olvidan toda su prudencia cuando encuentran un gran duque, y los cuervos las imitan. Sin embargo, exceptuando el hombre, los grandes carniceros y el asuila leonada, nada tiene que temer el ave de que hablamos de los demás animales, porque está muy bien armada y sabe defenderse perfectamente.

CAUTIVIDAD. - Si se tiene cuidado del gran duque, se le puede conseryar cautivo varios anos; pero es raro q̧ue se le domestinue completamente: muéstrase tan rabioso con quien le alimenta como con las personas extrañas que se acercan a su jaula. Seria posible, no obstante, que se consiguiera domesticar á estas rapaces cogíndolas péqueñas en el nido y cuidándolas mucho.

Yo tengo uno que puedo llevar en el puño, acariciarle y cogerle por el pico sin temor de que me haga daño. Tam. poco es indomesticable del todo el gran duque de Europa: yo vi uno en casa de mi amigo Merés de Estokolmo; se de. jaba coger y acariciar; acudia cuando se le llamaba por su nombre, y hasta se le podia dejar libre; pues aunque empren. dia pequeñas excursiones volvia con regularidad. El gran du que cautivo vive en buena armonia con sus semejantes; pero mata y devora con el mayor gusto á las rapaces nocturnas mas débiles.

\section{LOS QUETUPAS-KETUPA}

CARACTERES. - Son aves de gran tamaño, cuya cabeza adornan dos grandes mechones de plumas dirigidas hícia atrás. El pico es fuerte, vigoroso y medianamente largo. recto en la base, corvo despues regularmente, comprimido en los lados y terminado en un ganclio grande; los tarsos y los dedos están desnudos; el plumaje es poco abun. dante; las alas, algo cortas, no alcanzan el extremo de la cola: la cuarta rémige es la mas larga. y las orejas relatimmente pequuerias.
DISTRIBUCION GEOGRÁFICA.-IOS quetupas son propios de la India y del pais de los malayos.

USOS, COSTUMBRES Y REGIMEN.-Difieren mucho por este conceplo de los demás ótidos.

\section{EL QUETUPA DE CEILAN-KETUPA CEYLA- NENSIS}

CARACTERES - El quetupa de Ceilan, el bubo fescudor pardo, como le llaman los ingleses, $\delta$ ufum de los habitanies de Bengala, tiene $0^{\prime \prime}, 60$ de largo y $1^{\circ}, 20$ de ala á ala; la cola mide $0^{\circ}, 21$ y el ala plegada $00^{\circ}, 42$. El lomo es de un color de heces de vino; las plumas de la cabera y de la nuca y las $d e l$ mechon que hay sobre las orejas tienen ravas longitudinales de un pardo oscuro; las plumas del lomo y las cobijas supériores del ala ofrecen una mezcla de pardo y leonado, siendo el fondo del primero de estos colores aunque mas ṕślido, recorrido por una linea pardo oscura cortada por pequenàs fajas claras. Las rémiges son pardas, con fajas leo. liadas: las barbas externas de color de vino ó amarillentas; las internas tienen un tinte pálido y manchas blancas: la cola es parda, con cuatro ó cinco fajas mas claras, una de las cuales ocupa la extremidad; la cara parda, cruzada por una lista de igual color, pero mas oscura; la garganta y el pecho de un tinte blanco, con mezcla de negro; el resto del plumaje pardo vinoso; las plumas son negras á lo largo del talla con varias fajas oscuras. El ojo es de un amarillo do. rado ó de naranja; los párpados de un pardo púrpura; el pico aniarillo claro $y$ las patas de un amarillo sucio.

Distribucion GEOGRAFICA. - El quetupa de Ceilan existe en todas las Indias, pero mas particularmente en aquiel pais, donde es bastante comun. Se le encuentra tambien probablemente en el Burmah, y acaso en China: en las islas de los malayos le representa una especie afine.

USOS, COSTUMBRES Y RÉGIMEN. - Esta rapaz habita los pequeños bosques cerca de los pueblos y permanece oculta durante el dia en la copa de un espeso árbol.

Tickell le encontró con mas frecuencia en los cainaverales espesos, entre las rocas escarpadas ó en valles de paredes muy verticales; Holdsworth le vio en los árlooles añosos de las orillas de las aguas estancadas de Ceilan, posado todos los dias en la misma rama. Aunque busca de dia la sombra, agrádale sin embargo tomat à veces el sol, y si entonces se le ahuyenta, vuela ligera $y$ directamente sobre la maleza sin que la luz le moleste, precipitíndose al cabo de algun tiempo hácia la espesura. Por la noche sale fucra de su escondite y dirigese hicia un sitio elevado tal como la cumbre de una colina ó la copa de un árbol para buscar su presa.

Segun Bernstein, la especie malnya se encuentra casi exclusivamente en los bosquecillos de palmeras, cujas enormes hojas entrecruzadas le ofrecen un excelente asilo. Esta ave no se introduce en las casas.

Cuando se espanta al baho pescador, huye hácia un árbol poco elevado, y desde alli examina con detencion of su enemigo. Si no se le obliga, no abandona su retiro antes del crepúsculo, aunçue parece que re bastante bien á la luz del sul. Algunos individuos que yo ture cautivos caraban de dia, y con mucha destreza, los lagartos, las serpientes yilas satas que se acercaban á su jaula, à pesar de no hallarse esta en un lugar oscuro. Cuando viven libres, devoran las gallinas y otras aves, a juzgar por lo que dicen los indios Jerdon ascgura, por el conimrio, gue el quetupa se dirige siempre hácia las corrientes de agua y los estanques: se le ve posado sobre un árbol ó en un cinto de roca, acechando à los peces. Hodgson fué el primero en observar que se alimentaba de estos ani. males, y los prefiere en mucho a los cangrejos, segun dice 
Jerdon. Los indigenas aseguran que acomete á los gatos y los mata.

Su roz ronca suena muchas reces como una carcajada histérica, que podria expresarse por las silabas hu, han, ham, ho; infunde pavor á las almas miedosas que la oyen, impre. sionadas quizsis tambien por la naturaleza de los sitios que el ave prefiere. Tin la época del celo se le oye gritar á menudo repetidamente.

eSolo una rez, dice Bernstein, encontré un nido de quetupa; hallábase á bastante elevacion, en la cina de un viejo dareng, en el sitio en q̨ue se destacaba del tronco una gruesa rama cubierta de musgo, de helechos y de orquideas. En medio de todias estas plantas habia practicado el quetupa una excava cion, en cuyo fondo se hallaba un huevo de color blanco mate, de forma redondeada. En otro nido encontró uno de mis cazadores un hijuelo dispuesto á volar, deduciéndose del hecho que esta rapaz no pone mas que un huevo cada vez.

CA UTIVIDA D. - Los cingaleses ticnen á menudo al quetupa cautivo, merced á lo cual llega algun individuo á nues. tras jaulas; mas á pesar de esto el are escasea bastante en nuestros jardines zoológicos.

\section{EL BUHO VULGAR - OTUS VULGARIS}

CARACTÉRES.-El buho vulgar, que se llama tambien huho de los bosques y duque mediono, representa con bastante exactitud un gran duqque pequeño. Los mechones de pluma que ocupan los lados de la cabeza por encima de las orejas, están bien desarrollados; tiene el lomo amarillo rojo sucio, con manchas, puntos $y$ listas de un gris pardo oscuro: el vientra es de un amarillo rojo mas claro, semibrado de man. chas pardas trasversales ó longitudinales; el pabellon de la oreja negro en su extremidad y por fuera, y blanqquizco intefiormente; la cera de un amarillo rojo agrisado; el pico negruzco y el ojo amarillo vivo (fig. $18 \%$ ).

Ias hembras presentan colores mas oscuros; en los lijjuelos son menos vivos que en los machos adultos.

El buho vulgar tiene $0^{m}, 34$ á $0^{m}, 35$ de largo $y$ de $6^{\circ}, 91$ a $0^{\prime \prime}, 95$ para las alas desplegadas. Estas miden $0^{\circ}, 29$ y la cola $0^{\circ}, 15$ de largo.

DISTRIBUCION GEOGRÁFICA, - EI buho vulgar es tá diseminado desde los $64^{\circ}$ de latitud norte por toda la Eu. ropa; se le encuentra desde el limite septentrional de la zona de los bosques por el centro de Asia, y desde el Ural hasta el Japon. Escasea mas hácia el sur; y tal vez visite solo de paso el Africa, las Canarias y el norocste de la India; mieniras que anida todavia, segun parece, en la isla de Madern Estas indicaciones parecen suficientes, porque se le encuentra en todas partes dentro de los limites citados.

USOS, COSTUMBRES Y REGIMEN. - El buho COmun ó de los bosques merece muy bien este último nombre, porqque solo en ellos se le encuentra, pues si bien es cierto que por la noche recorre algunas veces las inmediaciones de los pueblos, y que durante sus viajes se refugia, si es necesa rio, en un jardin, todo esto no pasa de ser una excepcion. No se puede decir que tenga preferencia por los bosques de tales $\delta$ cuales árboles, pues se le encuentra igualmente en todos.

El buho vulgar se diferencia mucho del gran duque por suls usos y costumbres: verdad es que pasa el dia descansan. do como ś, y que caza á las mismas horas; pero es inucho mas sociable, menos feroz y raras veces timido; cuando de dia está posado en un árbol permite al hombre acercarse sin pensar en la fuga; $y$ hasta se ha dado el caso de no poder obligarle \& levantarse sacudiendo el àrhol.

Solo en el periodo del celo viven apareados los buhos, y apenas comienzar los hijuelos at volar, forman bandadas, muy numerosas a veces. En el otoño recorren el pais sin emigrar; yo he visto algunas de veinte individuos $\delta$ mas, que estaban posadas en un árbol.

Mas al sur se reunen en bandadas mucho mas numerosas aun, por cjemplo en Austria y Hungria. E En los canpos del Austria inferior, me escribe el archiduque Rodolfo, cuando iba a cazar liebres, por el mes de noviembre, pude ver bandadas enteras de buhos comunes que estaban en medio de los campos, inmóviles como patos, y que solo se alejaban lentamente cuando los cazadores estaban ya muy cerca; despues rolvian a bajar, pero al fin, cuando se les habia ahuyentacio varias veces, remontábansc, trazando ępirales, siempre mas grandes, i una altura considerable y pasando por la linea de los cazadores volvian al punto de partida. En Hungria encontré en la misma estacion bandadas de esta especie en extremo numerosas, tanto en la ma. leza de los abetos cnanos como en los bosques frondosos. No vuelan como una bandada dé perdices ó estorninos opri. miendose uno contra otro, y solo demuestran que pertenecen al mismo grupo, por el hecho de reunirse siempre en un espacio relativamente reducido. Cuando en un bosque de abetos enanos, situado entre campos y montones de arena, se hace una batida, presentanse primero por lo regular cinco ó seis de estos buhos delante de la linea de los ca. zadores, pero despues acuden hasta cuarenta ó cincuenta individuos, al principio aisladamente, y luego en tropel; mas no pasan todos por el mismo sitio, sino que se distribuyen igualminte, formando una linea. Muy curioso me parecio el hecho de encontrar bandadas verdaderas de estos estrigidos en los claros de un gran encinar situado cerca de Goedoelloc. Aqui hallé á menudo, cuando iba á caza de ciervos, un número considerable de estos buhos, posados unos junto â otros y muy crguidos. Casi siempre conté de treinta á cunrenta árboles del todo ocupados por estos bu. hos. Mirándome con curiosidad, solian dejarme acercar á pocos pasos antes de emprender la fuga; pero cuando el primero se habia remontado, todos los demás le seguian a cortos intervalos, lo cual no impedia que los encontrase otra vez reunidos a la distancia de algunos centenares de pasos. En bosques frondosos que apenas tenian la altura de un hombre vi á menudo tales bandadas, pero nunca antes de noviembre ni despues de pasada la mitad del invierno.

Para mi no cabe duda de que no solamente la sociabilidad sino tambien la abundancia de alimento en ciertas regiones son la causa de que estos estrigidos se reunan en bandadas tan numerosas. Lin los lugares donde anidan se presentan algunas veces muchos individuos juntos, y otras solo parejas, segun la abundancia de los ratones en ciertos años.

Lsta rapaz se alimenta casi exclusiramente de mamiferos pequeños, sobre todo de musgaños, arvicolas y musaranas. No queremos decir con esto que no acometa a uni perdiz. herida y cansada, ó a otra avecilla cuando se le presenta la ocasion; pero esto sucede tan pocas veces, que no se debe tomar en cuenta.

Walter duda de que coma musarainas, porque un buho vulgar cuidado por èl, si bien las cogin, arrojábalas apenas las tocaba con la lengua A pesar de esto, no puede dudarse del hecho, toda vez que Altum ha encontrado restos de mu. sarnnas en las bolas. Persigue principalmente á los ratones en los linderos o claros de los bosques, pero á reces em. prende tambien expediciones á los campos vecinos.

Cuando se ve al buho vulgar de dia en la sombra mas espesa del bosque, apoyado en el tronco, ó posado en una rama, erguido como un hombre que está de pié, oprimidas 
las plumas contra cl cuerpo, y con los ojos entreabiertos para ver si sa acerca un cnemigo; y cuando entonces se observa que solo caza despues del crepúsculo, podria creerse que este estrígido teme la lur del dia ó que el sol le impide ver bien. Esta opinion es sin embargo crrónea: por mas que parezca têmer la luz, neccsita el calor del sol, pues en la cautividad perece, cuando se le priva completamente de él. Rpenas llega la tarde $y$ los rayos del sol tocan su jaula, me escribe Walter, mira con los ojos muy abiertos, la cabeza erguida $y$ el pecho salienie, txponiéndose todo lo posible it la luz del astro del dia; despues entreabre lás alas y la cola, para que todas las partes sientan la benéfica intuencia del calor, Cuan. do hacia mal sicmpó algunos dias seguidos y el ciclo estaba nublado bajaba if la arena, permanecienjo acurrucarlo mucho tiempo en el sitio donde antes tocaba el sol Muy curioso era el espectáculo que ofrecia este buho al encenderse di árbol de Navidad: lanzábase dusde su perchá ála arena; se recogia como de costumbre y quedaba inmóvil, con la cabeja reclinada sobre los hombros y velto el tóstro hácia el árbol res. plandeciente. Sin duda confundia la luz artificial con la del sol. Cuando trabajo por la noche mi limpara esta muy cerca de la jaula del buho, y este se acerca entonces tanto í la rejilla, que entre el ave y la lláma apenas quedan $00^{m}, 15$ de distancia; asi yermanece a menudo horas enteras en el mismo sitio. En otra ocasion me demostró cuản excelente es su vista con la luz naiural: i la una cic la tarde de cierto dia, cuan. do los rayos del sol penctraban pos la yentana, observis que el buho tenia la vista fija en un punto del techo que se ha. llaba verticalmente sobre mi, expresando el interés que le inspiraba este punto par sus movimientos de cabeza. Siguiendo la direccion con la vista, reconocluna anña mas pequeña que una mosca, inmóvil en el techo sobre mi. E! buho mira. ba algunas veces con indiferencia hácia otra parte, pero de pronto volvia á fijar la mayor atencion en la amina. Impulsa do por la curiosidad subi i una silla para observar al insecto - reconoci entonces que este, sin cambiar de posicion, traba jaba con sus piés en'la tela, descansando á intervalos. Cuan. do hacia esto îltimo el buino volvia los ojos á otro lado; rnas apenas la araña empezala á tejer de nievo, cl ave $J_{3}$ ob. servaba atentamente- A pesar de que yo tengo muy buena vista no me fué posible reconocer los movimicntos de la araña desde mi asiento; mientras que el buho. hallirdose á mayor distancia, los distinguia perfectamente. Yo creo, por Io tanto, que estos buhos no cierran los ojos porçue les moleste la lur del sol, sino para fingir que no hacen el menor caso de un sér peligroso

La hembra deposita sus huevos en el nido abandonado de alguna corneja, de una paloma zurita, de una rapaz diurna ó de una ardilla, y ni aun se toma el trabajo de repararle. La puesta se verifica en el mes de marno, y se compone de cuatro huevos de forma redondeada y rolor blanco, que cubre la hemira por espacio de tres semanas. Mientras dura la incu. bacion el macho alimenta á su compañera y se fija en un sirbol próximo al nido, manifestando su amor con gritos que se parecen á las sílabas huihui y aumn py movimicntos de ala.

Vigila por la seguridad de su compañera y adviértela tan luego como un sér viviente se acerca al nido. 2 Yo he admirado muchisimas veces el valor de este estrigido cuando anuncia. ba con su cinu, ieru, la proximidad de un peligro, y cuando exponiendo su vida, revoloteaba al rededor del intruso. Apenas mataba 2 las hembras, los machos hacian lodos los es. fuerzos posibles para sustituirlas, y entonces los cazaba fácilmente, mientras que antes no se habian puesto jamís á tiro. Los pequeiros chillan de continuo, cual si nunca se hartaran de comer, $y^{\circ}$ obligan á sus padres á cazar pan ellos sin descanso. El hombre inteligente sabe reconocer los servi- cios que le presta esta avey no le hace el menor dano; mientras que el ignorante, por el contrario, mata á todo buho que encuentra, ya sea jóven ó viejo, y para que sea comocida su hazaña, clarn i su victima con las alas exiendidas á la puerua de la casa.

A este ultimo debo decirle que el buho comun es útil mientras vive; cierto que necesita poco alimento; pero aun. que no tenga lambre, apenas divisa un raton precipitase sobre él, y por consiguiente mata mas de estos roedores de los que come. Tambien se los lieva á un escondite para el caso de que no haya encontrado caza. Solo cuando le aflige mucho el hambre coge un raton despues de matarle. Por lo re. gular separa la cabeza y lleva el resto ó un agujero, aunque sola sea jor poco tiemuo; pero cuando una pareja tiene cria caza tantos ratones como puede guardándolos en clase de provision aunque los polluelos estén satisfechos;y por lo tanto, los servicios que presta son muy grandes, atendido su tamaño.

Li buho vulgar es tan antipático a todas las ares pequeñas comollos demás estrigidos, y siempre que se deja ver, es per. seguido yacosido.

CAUTIVIDAD.-Si se cogen buhos pequenos, cuando aun essin cubiertos de su plumon, y se les cuida bien, domesticanse nuy ñonto y son agradables.

\section{EL BUHO BRAQUIOTO-OTUS BRACHYOTOS}

CARACTERES.-El buho braquioto, llamado tambien baho de bus furlanus (fig. 188), se ascmeja mucho á la espe cie anterior, con la que se le ha confundido con frecuencia. Tiene'la cabeza mas pequeña; las orejilas se componen de dos ó cuntro plumas bastante cortas; las alas son mas largas que la cola, el plumaje de un amarillo pálido bastante agradahle; las plumás de la cabeza y del tronco tienen los tallos negros: las cobijas supreriores del ala son amarillas por fuera yegras interiormente y en su extremo las rémiges y las rec. trices están listadas de gris pardo. El circulo auricular es gris b!anq̨uizco; el pico negro j el ojo amarillo claro.

I.os pequeños son mas oscuros que los adultos.

Este buho tiene de $0^{n}, 36$ de largo, $y$ de $0^{n}, 98$ de ala at ala, esta mide $0^{\circ}, 28$ y la cola $0^{\circ}, 15$.

DISTRIBUCION GEOGRÁFICA. - El huho braquioto es propio de la Tundra, pero desde alli se trasiada todos los otonos á los tres continentes sepientrionales; entonces pasa por toda Europa y el Asia, desde donde extiende sus expediciones hasta el Africa, y probablenente lassta las islas de Sandwich; tambien se le encuentra en toda la América, desde el cxtremo norte hasta la punta meridional. Dentro de estos limites no se la ve, sin embargo, en todas partes; falta, por ejemplo, en Australia y en el Africa ineridional, aunque podemos suponer que tambier se la enconirará alguna vez. Burmeister vió uno de estos buhos en plena mar al oeste de las islas de Cabo Verde. Yo he visto muchos en las estepas del valle superior del Nilo, y Jerdon refiere que llega s las Indias todos los inviernos; varios observadores dicen que se presenta en los paises mas meridionales de América en octubre y desaparece en marzo.

USOS, COST UMBRES Y RÉGIMEN.-En la Tundra se encuentra algun buho braquioto tambien de dia, mas por lo regular no aparece antes de las primeras horas de la noche. No teme la luz del sol, pero muy rara vez se le ve cuando este ilumina la tierra, mientras que siempre caza en la oscuridad. En el alto norte, las noches del verano son muy cla. ras y por eso el buho braquioio no caza lo mismo que la major parte de los otros estrigidos: clévase a mucha mas al. tura dicl suelo, casi tanto como nuestro buzo, sulo que revo- 
lotea con mas frecuencil, $y$ de distinto modo aleteando vigorosamentc. Algunas veces tranquea con rapidez cierta distancia; revolutea despues algun tiempo sobre el mismo sitio, examiuando su dominio de la manera mas minuciosa y precipitase a grondes interalos hácia el suelo para coger un leming, su presa urdinaria. Ln Alemania sucle presen. tarse a mediados de setiembre, su paso dura hasta fines de octubre y en narzo cmprende lentamente la vuelta i su patria. Durante su viaje reposa en todas las llanums descubier. tas ó que tienen escasos bosques, pero prefiere las regiones pantanosas, donde permanece de dia oculto en la jerbay en los canaverales: cuando le amenaza un peligro acurrúrase como una perdiz en el suelo y deja llegar al enemigo hasta muy cerca; pero levántase á tiempo y rucla entonces bastante lentamente á la manera del milano á poca distancia del suelo, si bien se renronta en ciertos casos à grandes altu. ras. Persigue principalmente á los ratones y solo por excep cion ataca it uı animal mas grande; no desprecia las avecillas jóvenes y coge tambien topos cuando estos trabajan en la superticie del suelo; á veces acomete á las licores ó conejos pequeños, y en caso de necésidad conténtase con insectos ó ranas.

Fi buho braquioto no vuelve siempre a su patria, pues se ducido algunas veces por la gran abundancia de alimento, pasa el verano en regiones que no se hallan en su área de dispersion. Cuando en la Fiscandinavia, por ejemplo, abun. dan mucho los lemings en los fieldis meridionales como suce dió, segun Colleit, en i $\$ ; 2$, el ave acude alli y aun se queda para anidar. Lo mismo sucede en Alemania todos los años en que abundan los mtones, tal como el de $185 \%$, durante e cual, segun Blasius y Baldamus, anidaron nada menos que doscientas parcjas en los pantanos situados en la confuencia del Elba y el Saale. Altuns encontró en 1872 algunas que anidaron en el Crarbe cerca de Wittenberg, y yo mismo he

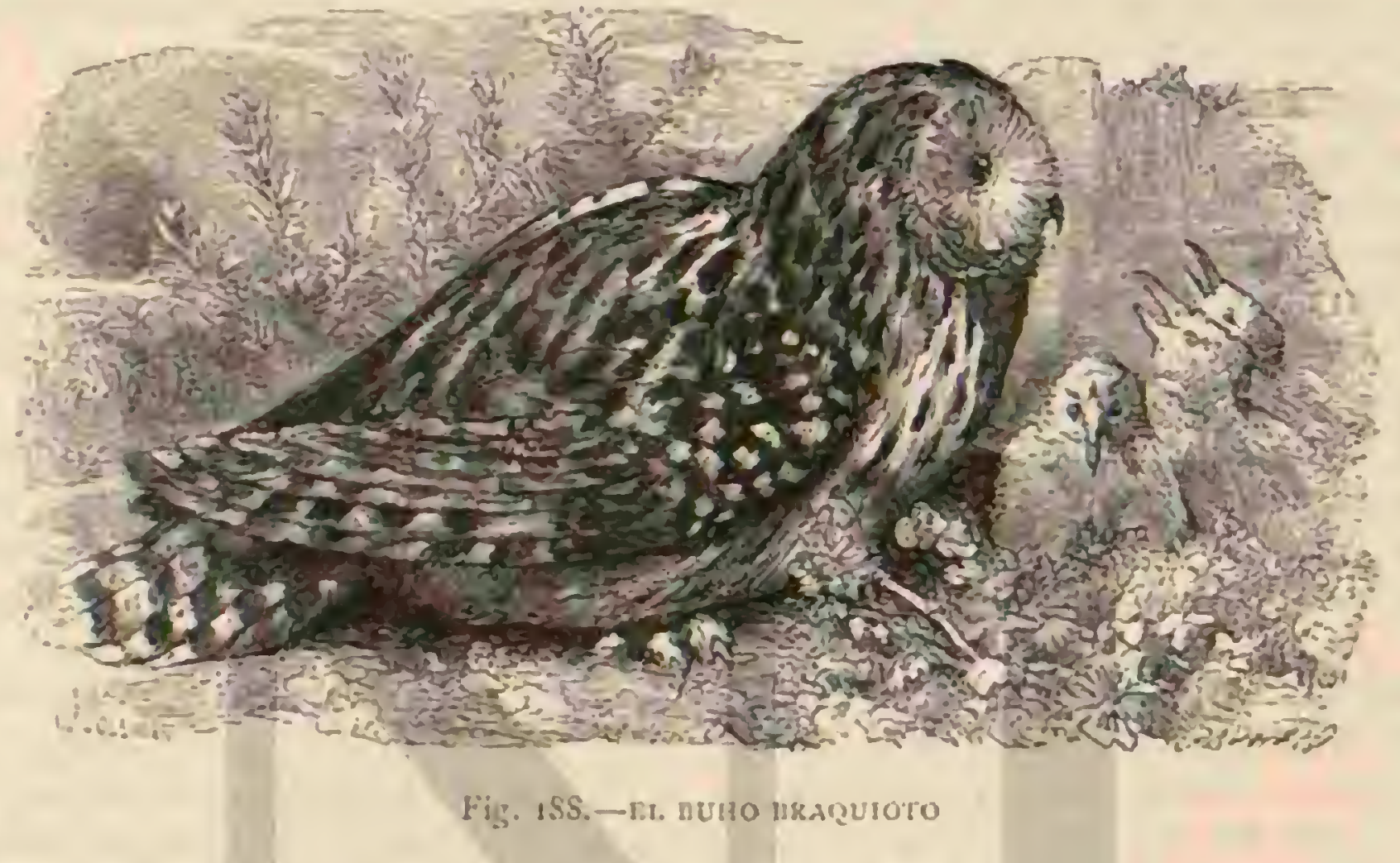

observado que muchos veranos abunda bastante en la selva del Sprec. El nido suelc estar en el suelo, tan escondido como es posible entre las yerbas, y su construccion es en cxtre mo ligera. En mayo se encuentran en el de seis á diez huevos blancos de $0^{m}, 040$ a $10^{n}, 0,47$ de largu por $0^{\circ}, 024$ \{ $\left\{0^{\circ}, 026\right.$ de grueso, que se distinguen de los del buho vulgar por ser mas enjutos y pequenos, asi como por tener la cáscara mas lisa $y$ fina y los poros mas menudos y no ian hondos. No puedo decir si ambos scios incuban $\delta$ si solo la hembra cumple con este deber; pero sabenos que tambien ese buho es en exiremo atrevidoy valeroso cuando se trata de defender su cria. Toda ave de rapina que se acerca se expone tanto de dia como de noche á lós juriosos ataques del macho ó la hembra, sobre sodo del primero, que la obliga, to misnso que á las comejas, à emprender presurosa la fuga; y hasta parece que un halcon grande se atemoriza virdaderamente ante este buho. Lo mismo le sucede al hombre yque le quicre robar su cria: en la selva de Spree, un buho braquioto atacó ś uno de mis conoridos que inteniaba robar los polluelos, acosándole con tal furia, que el hombre.. se vió obligado al defenderse enérgicannente para salvar su cara y sus ojos, pues el ave se precipitaba valcrosamente sobre éi.

A pesar de que el buha braquioto sa hace culpable í veces de alguna fuchoria, debe considerársela sin embargo como un ave en estremo útil y el hombre deberia protegerla en vez de perseguirla. Tal vez su aparicion inesperada induce a muchos caradores a matar á la rapaz desconocida solo para examinarla; pero en general esto no disculpa á los que inmolan centemares de estos séres tan útiles. Schacht ha visto que al. gunos cazadores organizan verdacieras batidas cuando se pre. senta el buho braquioto; cáanle con perros 6 le matan al vuelo, como i los patos y perdices, ranagloríndose despues de sus hazañas.

CA UTIVIDAD. - lambien el buho braquioto se re algu. nas reces cautivo, pero siempre es mas raro que el buho vul. gar; yo he tenido mrios individuos, y nunca observe ninguna paricularidad notable en su manera de proceder.

\section{LOS ESCOPS - SCOPS}

CARACTÉRES. - Un cuerpo esbelto, cabeza bastante grande, alas largas, con la segunda rémige mas prolongada que las otras; cola larga y redondeada; tarsos altos, cubicrtos de plumas por delante y de escamas por detrás; dedos des. nudos; pico fuerte y curvo; plumaje liso y abigarrado, oreji. tas pobladas y cortas, y circulo auricular poco marcado, taies son los caractéres que distinguen al género escops, el cual comprende las mas pequeñas especies de la familia de los estrigidos.

\section{EL ESCOPS DE LA CARNIOLA-SCOPS CAR- NIOLICA}

CARACTÉRES. - Fste estrigido tiene una longitud de $0^{\circ \prime}, 15$ is $11^{m}, 18$ por $\left(1^{m}, 46\right.$ a $11^{m}, 51$ de anchum de punta á punta de las alas; estas miden $0^{n}$, iof $y$ la cola $10^{\circ}, 07$. El lomo es pardo rojo con mezcla de gris ceniciento y listas negruzcas longitudinales; las alas están manchadas de blanco, las espal- 
dillas de un tinte rojizo, cl vientre presenta una mezcla de pardo rojo amarillento y gris blanquizco : el pico es gris azul; los piés de un gris plomo oscuro; los ojos de color amarillo de azuire claro, y el circulo auricular poco marcado (figu. ra $18 n)$.

El macho y la hembra tienen casi el mismo plumaje; en los individuos jorenes los colores son mas opacos y menos abigartados que en los aduitos.

DISTRIBUCION GEOGRÁICA. - El escons habita regularmente en el mediodia de Eurropa; en el norte y centro de Alemania, y en Tnglaterra, solo se encuentran individuos errantes. Anida aisladamente en ins paises. Jel Rhin y en el territario de los Alyes, subre todo en listria, Carintia, Carniola, Tirol y Croacia mas a menudo en el modiodiz de Francia, y con frecucincia en todo el sur de Furopa. Tambien se encuentra con mas ó menos regularidad en el $A s j a$ cen tral, donde se discrnina por el este hasta el lurhestan. Fil escopse de Carniala es para Europa un ave de raso, que se presenta muy pronto, es decir en los últitios dias de marzo ó primeros de abril; vuelve por lo regular hácia el sur en setiembre, of a mas tardar à primerós de octubre, y desde alli extiende sus viajes al centro de Africa. En los paises supe. riores del Nilo no encontré nunca parejas, pero si numerosas bandadas de esta especie que sin duda iban de viaje.

USOS, cOSTUMBRES Y REGIMEN. - Fin España suele estar cl escops en las llanuras cubiertas de úrboles ais. lados, en los campos, en los viñedos, en los paseos y jardines; jarmás le ví en el interior de los bosqques, sin atreverme a àsegurar que no se encuentre en ellos. Léjos de huir la proximidad del homirc, parece que la busca; en el mediodia de trancia y en Fspaña se fja en los pueblos $y$ hasta en las cinciades: en .Iadrid, por ejemplo, abunda en los árboles de los paseos mas frecuentados, y si nó se deja ver con frecuen cia, percibese por lo menos su voz, pues no hay noche en que no se deje oir, sobre todo en la época de la reproduc. cion. Hermanece todo al dia inmóvil, apoyado contra el iron. co de un f́rbol, pegado al suelo ú oculto en una cepa; 'y de tal modo se armoniza su color con el de la corteza y el follaje, que escayna a las miradas, y solo se la ve por casualidad. Hasta despucs de pronerse el sol no comienza su caceria: su vuclo se asemeja al del hálcon mas que al de oiros estrigidos; pero como estos, no se remonta murho sobre la tierr.

Parece que su 10\% se oje \& mucha distancia; los nombres populares que el ave tiene en Italia, Crin, Ciu y Cioni, puc. den servir para expresar los sonidos que produce. Los po lluelos silban de un modo extraño. A pesar de su pequeño tamaño, el escops de la Carniola es una buena rapar; caza principalmente vertebrados pequenos, y no insectos como pociria crecrse: en el estómago de los q̨ue jo mate, hallé $50-$ bre todo mones, y los que ture cautivos acometian à las arecillas; uno de ellós al que dejé yolar libremente por la habitacion, atrapé y mató á mi vista con la mayor destreza un murciélago que andaba por alli.

Segun aseguran los españolés que podian darme noticias sobre el particular, el nido sucle estar en huecos de árboles, y en él se cncuentran á fines de mayo, lo mas fronto, unos huevos pequenos, redondeados y blancos, de $0 \%, 031$ de lon gitud por 0\%,026 de grueso. A principios de julio recibimos un pequeño que tenia los ojos cermdos aun, y jocos dias despues tres mas, los cuales cuicianos tan bien que al poco tiempo de cautividad se familiarizaron mucho.

Podia tocarlos y llevarlos en el puño sin que tratasen de luir; comian en mi mano y me divertian mucho con sus gratescos movinientos Jamís les oi lanzar sibidos de cólem: en los primeros dias de su cautividad no hicicron mas que chasyecar el pico algunas veces: y bien pronto equisicron re cobrar su independencia y se escaparon uno detrás de otro. Mi hermano me ha dicho que tiene un escops jóven, el cual se ha domesticado tanto que juega con su niño.

Los individuos cautivos de esta especie se posan de dia en las posiciones mas diferentes en los sitios mas farorables de su jaula; uno tiene el plumaje alisado, otro le eriza tanto que parece una bola: este incliua una orcja hácia atrás, le. vantando la otra; aquel endereza sus mechones y mira del modo nas grotesco al observador, que puede llegar hasta muy cerca del ave sin que esta se mueva En la jaula elige cada uno su sitio y saben ocultarse tan perfectamente que \{ menudo se les debe buscar mucho tiempo antes de encon. trarlos. Su plumaje se confunde verdaderamente con los ob. jetos çue les rodean; varias veces se ha dado el caso de tener un individuo delante de mí y no verle. No es dificil conservarlos cautivos y no dudo que se conseguirá obtener cria del escops de Carniola en ial estado. Dos de mis cautiros se ha. bian apareado; la hembra puso tres huevos y los cubrió con mucho afan; pero desgraciadamente murió antes de que sa. lieran los polluelos del cascaron.

\section{LOS.ANTILOS-SYRNIINE}

CARACTÉRES. - Los antilos ó mochuelos nocturnos son unos estrigidos de cabeza grande, redondeada y sin orejas; pero que tienen en cambin el conducto auditivo externo muy ábierto y el círculo auricular muy pronunciado. El jico es relativamente largo; las piernas mas ó menos largas; los pies se hallan revestidos de un plumaje tan jronto espeso como ercaso; las alas son generalnente redondeadas; in cola corta 6 larga, redondeada ó cortada en rectíngulo.

\section{EL ANTILO ZUMACAYA-SYRNIUM ALUCO}

CARACTÉRES. - Esta ave tiene la cabeza enorme; los discos perioftálmicos bien pronunciados y anchos; la aber. tura externa del conducto auditivo menos gránde que en los otros estrigidos; el cucllo grueso; el cuerpo recogido; la cola corta; los tarsos y los dedos de un largo regular, cubiertos de espeso plumon; las alas obtusas, con la cuarta rémige mas larga: la cola prolongada y redondeada en el extremo. El plumaje (fig. 190) varia mucho; su color dominante es el pardo gris ó pardo rojo claro, mas oscuro en el lomo que en cl vientre, y sembrado en las alas de manchas pálidas regularmente dispuestas.

En una sariedad de color rojo de orin, cada pluma, que es de un gris amarillento en la base y de un pardo rojo claro en cl extremo, esta cruzada por listas longitudinales de un pardo oscuro; la parte parda terminal es mas extensa en las plumas del lomo que en las del vientre, $y$ por eso tiene un tinte mas oscuro la primera de estas régiones. Las remiges son de un pardo oscuro, con listas rojas; en las rec. trices, excepto las medias, hay varias fajas pardas: la nuca, la region de las orejas y la cara son de un gris ceniciento: el pico y las uñas de un gris ylomo, el ojo pardo oscuro y el borde de los páruados color de carne.

- Su.longitud es de \|\|$^{\prime \prime}, 10$ \& $\theta^{\prime \prime}, 48$ jor un metro de ancho de punta a punta de las alas; estas miden $0 *, 29$ y la cola $00^{\circ}, 1$.

DISTRIBUCION GEOGRÁfICA. - El área de disper. sion del antilo zumacaya se cxtiende desde el $67^{\circ}$ de latirud norte hasta Palestina. Fs inas numeroso en el centro y me. nus en el este, sur y oeste de Europa. Abunda aum en lta lia, sobre todo en la parte occidental y centro del pais, mies. tras que en Grecia y Espana solo se le ve muy aisladamente; en Siberia falta del todo, 6 por lo menos asi parece; 
Tristram le rió en Palestina, en los cedros del Libano, con bastaute regularidad.

USOS, COSTUMBRES Y RÉGIMEN. - El antilo rumacaya de Alemania habita principalmente los bosques, pero tambien en los cdificios. En verano se posa en las copas frondosas de los árboles oprimiéndose contra el tronco; en invicrno le agradan mas los huecos de los árboles, y por lo mismo evita los bosqques jórenes, donde no podria encontrarlos Es tan aficionado á un árbol alto y conreniente para th, que segun Altum se le puede hacer saiir de él muclas veces seguicias dando golpes contra el tronco; $y$ hasta aigu. nos de estos érboles son tan preferidos, que cuando se mata al estrigido que le habita, al poco tiempo le elige otro antilo zumacaja para su vivienda. Esos árboles se encuentran tanto en el bosque mismo como en sus linderus, y hasta en la crilla de los caminos mug frecuentados. La abundancia de estas aves deuende además de la mayor ó menor cantidad de alimento: alli donde hay ratones, seguro es que el antilo zumacnya acudirá, si las demás condiciones se lo permiten; pero en los parajes donde faltan ó escasean, este estrigido no anidia $\delta$ emigra. No teme al hombre, por lo cual se al. berga hasta en edificios habitados, $y$ cuanco una pareja ha elegido este sitio para su morada, otras imitan sin duda el ejemp!o. De noche se le ve posado en las aristas de los te. jados, en las chimencas, en las cercas de los jardines y en otros sitios elevados, desde donde puede observar dónde hay caza.

El antilo zumacaya es al parecer una do las aves que mas temen la luz; pero sabe arreg!arse tan bien aun en medio del dia, que nos vernos obligados a combiar de parecer tan luego como conocemos mejor al ave. xMas de una vez, refiere mi padre, le sorprendi de dia en alguna espesura, y en tales ocasiones desaparecia tan diestramente en medio del ramaje, que aunca le pude matar.s Es pesado y iento en todos sus movimientos; no tiene mada de la gracia cómica de los pequenos estrigidos; su vuelo es ligero, pero vacilante y nada rápido; aletea coll mucha fuerza; cuando caza va rasando el suelo, ó apenas se remonta á varios piés de altura. Su voz es fuerte y sonora; cunite un grito equivalente á fouhuhur, repe tido varias veces, parecido en cierto modo á แna carcajada histérica $\delta$ á un aullido; otras veces prodice un sonido on extremo desagradable, que se podria expresar por raj, al quie añade en ciertus ocasiones otro mas suave, semejante á knwill of kincilt.

No cabe duda de que tambien esta are la dado osigen al cuento aleman del cazador infernal; y el hombre á quien le orurra lo que una vez ocurrió a Schache podrá creer que este mismo cazador fué quien le atacó. \&Cierto dia, dice el citado observador, un antilo zumacaya me asustó de un modo poco agradable. Ėra una roche de enero cuando, hailhándome al acecho en medio de un campo nevado, senti de pronio una corriente de aire producida por los suares aletazos de un sér que en tales circunstancias debia parecerme como un fan tasma; pero en el mismo momento vi un ave bastante gran de qque se posaba sobre mi sombrero. Era el artilo zumacaya, que habia clegido la cabeza de un hombre como observato rio para csperar su presa. Permaneci inmóvil cual una estatua y pude reconocer muy bien que el fantasma nocturno cam. biala varias reces de posicion; no emprendió la fuga hasta que intenté cogerle por las garras, para recompensar el exiraño carino que parccia profesar a mi persona.?

El antilo es uno de los estrigidos mas útiles, pues se ali menta casi exclusivamente de pequecios roedores. Naumann vió ấ cierto individuo acometer de noche á un buzo, de tal modo, que este hubo de buscar su salvacion en la fuga; á la vista de mi padre, otro antilo arrebató á un piccotero de Bo. hemia (bumbycilla grarrula), que estaba cogido $\mathrm{cn}$ un lazo. Sabemos que se apodera de las aves qque anidan ó duermen en tierra, aunqque constituyen su jrincipal alimento los rato. nes, y particularmente los arvicolas, los musganios y las musarañas, por lo cual inerece la rapaz nuestra proteccion. Li. termina tambien muchos insectos nocivos: en el estónsago de un antilo encontró Martin setenta y cinco grandes orugas que devoró en una sola comida.

هCierta noche, dice Altum, lallabame cerca del castillo de Wienburg, situado á media hora de distancin de Muns. ter; esa un ediñcio rodeado en parte de jardines, plazas y varios edificios dependientes; $;$ en el granero habia un nido del antilo zumacaya que contenia polluelos. Los últimos ra. yos del sol ponicnte iluminaban aun el horizonte cuando vi aparecer un antilo adulto en la arista del tejado: poco des. pues llegó otro, quue fué á posarse en la chimenea, y ambos prermanecieron inmóviles, haciendo solo algunus movimientos con la cabeza. De repente elévase el uno, passa por encima del granero y precipitase por el otro lado sasi vertical mente hácia el suelo, volviendo á poco con su presa, que cra un raton de cola harga, y por fo tanto caupesino. Apenas hubo desaparecido con su victima por debajo del lecho, alejóse tambien el segundo y volvio en seguida cargado con otra presa. Desde entonces estaban tan ocuppados en su caza, que por término medio apenas pasaban dos minutos sin que uno ú utro trajera un pequeño mamifero. Mluchas veces no habiau ruelto ás subir apenas cuando ya tomenzaban a perseguir otra victima, y observé ųue nunca era infructunsa su caza. Al fin itupielió la oscuriclad mi observacion. Segun dice Liebe, y como yo he observado, es muy curioso que el antilo runnacaya elija siempre ciertos sitios determinados para arrojar sus bolas. Estos parajes se encuentran mas á menudo cerca de las praderas que extendiéndose for el interior del bosque comunican con el canpo libre, que el ave no deja nunca cie visitar por la noche; pero tamuicen se hallan en medio de bosques jórenes, léjos de todo sitio descubicrto, asi como debajo de árboles aislados 5 distantes del bosque. Es probable que el antilo zumacaya arroje las bolas sobre todo de noche, cuando descansa un rato de las fatigas de la caza en un sitio solitario que le agrade.

En la primavera apenas vuelven las chochas, es decir, a mediados de marzo, ofense en el bosque, segun dice Nau. mann, las careajadas diabulicas y chillonas del antilo zumacaya El bosq̨ue rebosa vida en dicha época, porquue el antilo manifiesta, aun en medio del dia, la mayor excitacion. Segun la temperatura y la abundancia del alimento, la pareja co. mienza nas ó menos pronto sus preparativos para la repro. duccion; en los paises del Rhin principia á veces en febrero; en el centro de Afemania casi siempre en marro: solo cuando el tiempo es algo desfavorable el periodo del celo no conienza ni en Alemanin ni en Hungria, laasta el mes de abril ó primeros de mayo.

El antilu se reproduce is fines de abril 6 principios de mayo, en cuya estacion resuenan sus gritos en todo el bosque. Para depositar sus huevos busca un tronco hueço donde se halle al abrigo de la lluria; en casos raros anida en las grietas de las paredes, debajo de las tejas ó en nidos abandonados de rapaces, de cuervos ó de urracas. El fonda del nido esta cubierto de algunos pelos, lana y musgo; pero con mas freciencia básiale al antilo el agujero que le sirve de réfugio, 5 quie deja en el mismo estado en quue lu encontró. La puesta es de dos ó tses huevos, algo prolongados ú ovales, de cáscara blanca y rugosa : parece que solo cubre la hembra: cl macho le ayuda á criar los hijuelos.

A penas los polluelos se declaran del todo independientes romienzan a recorrer el pais, y cuando hay procos ratones 
emigran en masa, lo cual se puede observar mejor, segun Licbe, en los sitios donde arrojan las bolas, porque despues de marchar los polluelos encuéntranse mucinas de aquellas recien arrojadas en todos los sitios que primeramente ocupa. ban las aves, mientms que en los recien arreglados no se ve ninguna.

Ningun oiro buho se ve tan acosado por las ares pequeñas como el antilo zumacay: Todos los séres alados le provocan donde le encuentran; cuanios pueden cantar y gritar dejan oir su voz para gue acudan sus semejantes, y todos juntos le atomentan hasta ọue se aleja.

CAUTIVIDÁD. - Los cautivos sedonsestican a veces en alto grado, y segun las obseriaciunes de-Liebe, el antiln z.1macaya es entre 10das lás especies de estrfigios la mas pro pia para la joula. Teme tim poco ta luz que al mecion dia elige

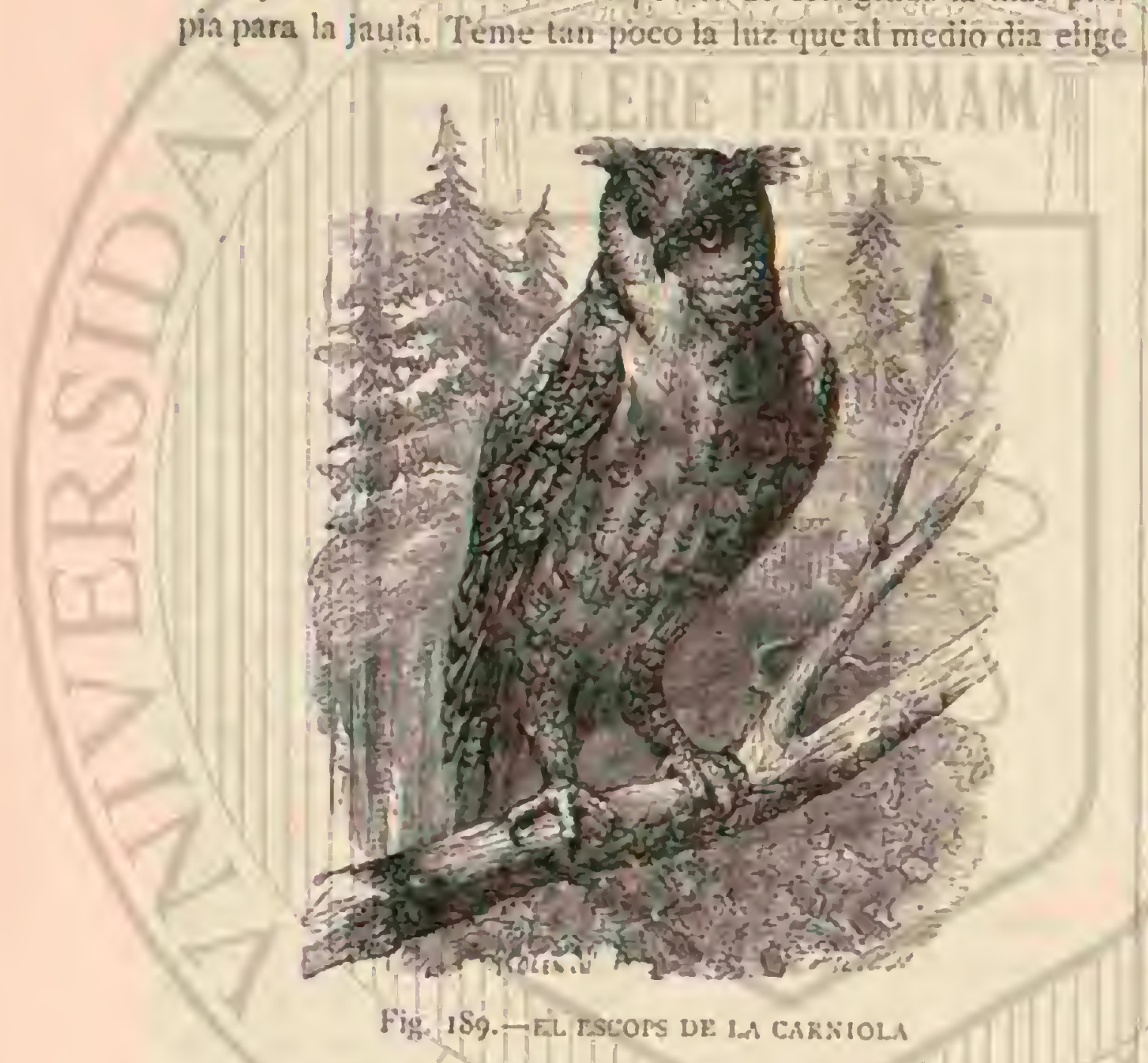

un sitio donde toquen los rayos del sol, de cuyo calor dis. fruta haciendo mil ademanes groiescos. Cuando vive cerca del hombre jermanece todo el dia despierto, sobre todo cuando este se esfuerza para entreienerle, a lo cual se muesira muy agradecido en los primeros años de su vida. Cuando se le coge peq̨ueño en el nido y se le da de comer dos veces al dia en la nano, obligándole a tomar en csta el alimento, acostimbrase tan pronto á su amo, que le prodiga las mis. mas caricias que á sus semejantes: entreabre los ojos haciendo varias muecas y produce un ligero silbido. Liebe ha domes ticado tanto algunos antilos, que acudian cuancu los llamaba posábanse sobre el puño y le rascaban con su corvo pico en la cabeza. cGracias \& los pequeños músculos que hay un la raiz de las plumas, me escribe el citado excelente obsurvador, estas pequenas aves tienen por lo regular una gran mo. vilidad en el rostro, la cual se manifiesta mas aun en la época del celo. Algunas llegan a ser verdaderamente notables en la mimica. La expresion de la cara varia tambien mucho en este estrigidn, segun esté de buen ó mal humor; el antilo zumacaya sabe comuricar á sil rostro una expresion que ape nas se le podria reconocer. Cuando está enojado eriza las plumas superiores del rostro por arriba y ab́ajo, y acercando las i los ojos ofrece tal asprecto, que hasta la persona que no le conoce no puede dudar de su significacion. Si le dominan sentimientos cariñosos dirige las plumas del centro y las de lado del cuello hácia el rostro, con lo cual adquiere este una expresion que en concepto del buho podrá expresar el ca. riño, pero que es en extremo grotesca, por el modo de en treabrir y cerrar la membrana nictitante. El antilo zumacara vive en la mejor armania con sus semejantes, y los hermanos que se han criado juntos no rin̉en aunque hayan cogido á la par un raton. Fntonces el uno deja la presa por aqui, el otro por alli, hasta que uno puede apoderarse de ella; pero no se maltratan con el pico ni con las unas. La buena inieligencia en que viven llega á sı colmo, y son de ver las caricias que se prodigan entre si mscandose con el pico la nuca y la region de las orejas. Yo he hecho observaciones semejantes en mis cautivos. Una rez ture sieie individuos en la misma jaula, donde vivicron dos años en la mejor armonía, y tamproco entre ellos se notó ninguna envidia por el alimento, a pesar de no haber hecho yo nada para enseñarlos. Cuando el uno comia los otros miraban con atercion, pero tranquilamente, sin que nunca se promoviesen pendencias formales por el alimenio. De muy distinto modo se conducian con un individuo muerto ó enfermo de su especie: en el primer caso se lo comian sin vacilar, y en el segundo ie mataban de la ma. nera mas crucl. Una pareja de mis cautivos puso cuatro huc. vos y los cubrió mucho tiempo con ajuda de dos de sus compañeros de jaula.

\section{EL ANTILO DEL URAL-STRNIUM URALENSE}

CARACTÉR ES. - Esta especie es una de las mas grandes de todos los estrigidos; su longitud varia de 11 m. 05 a 0,68, por un metro de ancho de punta á punta de las alas; estas miden $11^{n}, 40$ y la cola $0^{n}, 32$. El color predominante es un blanco gris sombrio; en el lomo se observan fajas longitudinales de un pario oscuro, presentando todas las plumas en el centro manchas longiiudinales pardas que se ensan. chan hácia abajo y que resa!tan mas aun por las lineas pardo oscuras de los tallos. Estas manchas se estrechan en la re. gion de los hombiros, son mayores en las rectrices de las alas, y en las mayores de estas últimas se ven dibujos de un pardo mas claro; las rémiges tienen la punta de un biar:co pardusen y ostentan fajas trasversales compuestas de marchas de un pardo claro, nıs pálido exteriormente; las tectrices superio. rés de la cola son de un pardo pálido, con manchas y li. neas irregulares de color gris; las rectrices, de un pardo os. curo, presentan seis anchas fajas trasversales de color gris pardusco. la cara, rodeada del disco, es de un color blan. quizco, con unas lineas en extremo finas y negruacas gue so. bresalen como radios de los ojos; el disco se compone de plumas blancas con punta negra. La region inferior es de co. lor blanco amarillento con manchas angostas pardas en los tallos y el plumaje de los piés es de un blanco sucio. No se observa gran diferencia entre el macho y la hembra; pero en cambio hay variedades mas oscuras; otras son de un pardo claro ú oscuro: micntras gue los individuos de la Siberia suelen iener un tinte mucho mas pílido. Los ojos, relativa. mente grandes, son de un pardo muy oscuro, los párpados de un rojo intenso de cereza, y el pico amarillo de cera.

DISTRIBUCION GEOGHÁFICA. - Pallas descubrió este antilo en el liral: los natumlistas postcriores le encontrason en casi iodo el este de Europa y tambien en el Asia central desde cl Ural hasta el Pacificu. En Alemania se han cazado varios indivicuos, y el + de abril de iS $7 S$ se mató uno en el distrito de Kranichbruch, en la Prusia oriental; faltábanle las flumas del pecho, como suele suceder \& las que empollan y por lo mismo es probable que el citado in. dividuo anidara en dicho distrito. Fsto parece tanto mas posible cuanto que consta que el antilo del Ural anida en todos los paises del imperio austriaco, como por ejemplo en la selia de Hohemia y en los Carpatos, encontrándose mas ó 
menos regularmente tambien en P'olonia y en Rusia Ade. mís de esto se cazan ó por lo menos vénse todos los invier. nos individuos de la especie en la Prusia oriental. Es pro. bable que no escasce tanto como por lo regular se cree y tal vez viva oculto en los vastos bosques de los territorios cita. dos sino se confunde con cl anito zumacaya. No es raro en todos los sitios farorables de Austria, Hungria, Polonia, Rusia y Finlandia, y tambien en 'Transilvania se presenta con tanta regularidad que los cazadores expertos le encuen. tran muy a menudo en los bosques de aquel pais

USOS, COSTUMBRES Y REGIMEN.-Hasta ahom no se conoce lo suficiente este estrigido para que podamos trazar una descripcion minuciosa de sus usos y costumbres. Se sabe que habita tanto en las rocas como en los árboles altos, y que su género de vida es bastante nisterioso aunque su voz se oiga á mucha distancia. En los últimos meses del otono se le ve a menudo en las llanuras 6 en pequeños bosques $y$ hasta en el campo libre; se sabe además que ve perfectamente de dia y que á veces cana á la luz del sol, dis. ringuiéndose por este concepto de su congéncre el antilo zumacaja; se ha reconocido tambien que no le gusta sêr molestado y que abanciona al punto su morada cuando le amenaza un peligro. Una observacion, en fin, del hermano de Naumaun, nos conduce á creer que es casi ann osado como los estrigidos diurnos, segun lo demostró de un modo notable el individuo visto en $1 \mathrm{~S}$ r $\mathrm{en}$ Anhalt por dicho ob. servacoor. Fil citado antilo persiguió á un buzo, atacándole hasta que ambos se perdieron en el bosque. l'oco despues Naumann le vió volver al campo libre y precipitarse sobre uma garza real que emprendió la fuga lauzando gritos lastimeros y defendiéndose contra los reperidos ataques de su perseguidor. El antilo acometia siempre desde una altura de tres metros sobre la garza, y al ín cayó sobre ella en direccion diagonal, persiguiéndola al menos un cuarto de hora. Su modo de proceder se asemeja por algunos conceptos al del buzo, al que se parece tambien por el ruidoso y à veces sostenido vuelo. La lucha con la garza real conenzó poco despues de ponerse el sol, $y$ las dos aves se perdieron al fin à mucha distancia; pero el observacor pudo oir despucs los gritos lastimeros de la garza real. Esto nos hace suponer que el antilo del Ural no se limita á cazar ratones y otros roedores pequeños, sino que acomete tambien á los mamife ros y aves mas grandes, liebres, concjos, gallos silvestres ! galápagos.

Su nido se encucatra en rocas escarpadas ó en altos bosques de hayas, y segun Tschusi, el ave se presenta cuando mas tarde en abril para dar principio á la reproduccion. En tonces se oye a mucha distancia su grito, que algunos com paran con cl balido de una cabra; otros, sobre todo Wodrichi, dícen que es una mezcla de la roz del gran duque $y$ la del buho vulgar, que á veces recuerda tambien el arrullo de la tórtola. Jiste último natumalista encontró en la primavera dos nidos, uno de los cuales contenia dos nuevos biancos y ova. les y el otro dos mas pequeños, cubiertos de plumon gris. Cuando uno de los guarda.bosques del conde, el cual habia descubierto los polluelos en un profundo hueco de árbol, empezó $a$ cortar el tronco con el liacha para llegar hasta la cria, antes de lograr su intento se alejo algunos pasos, dejan. do en su Jugar un perrito que le acominamaba. Entonces uno de los antilos adulios se precipitó sobre el cánido, cogióle y le clevó is la altura de unos seis metros: sin duda se le hu biera llevado á no inpedirlo el cazador.

CAUTIVIDAD.--Solo una rez he visto el antilo del Ural, cautivo en el Jardin zoológico de Berlin; pero no he podido hacer ninguna obscracion de interés en los dos in. dividuos que alli se hallaban. Nordmann, que ha cuidado alguno, dice que toma en cautividad posiciones tan grotescas como las de la lechucita enama; que coge el alimento saltando con impetu: y que demuestra en todos sus movinientos mas vigor que un harfango de las nieves que dicho observador tenia al mismo tiempo.

\section{EL ANTILO BARBUDO-SYRNIUM BAR- BATUM}

CARACTÉRES. - Esta esperie figura como la mayor de todos los estrigidos; su longitud es de $0^{\circ}, 70$, por $t^{\circ}, 40$ de anchura de punta a punta de las alas; estas miden $0^{\prime \prime}, 4 \delta$, y la cola $0^{\circ}, 2 S$. Su estructurn se asemeja $i$ la de nuestro buho vulgar, pero tiene las formas mas enjutas y la cola reiativa. mente mas larga; su plumaje es muy abundante, el circulo

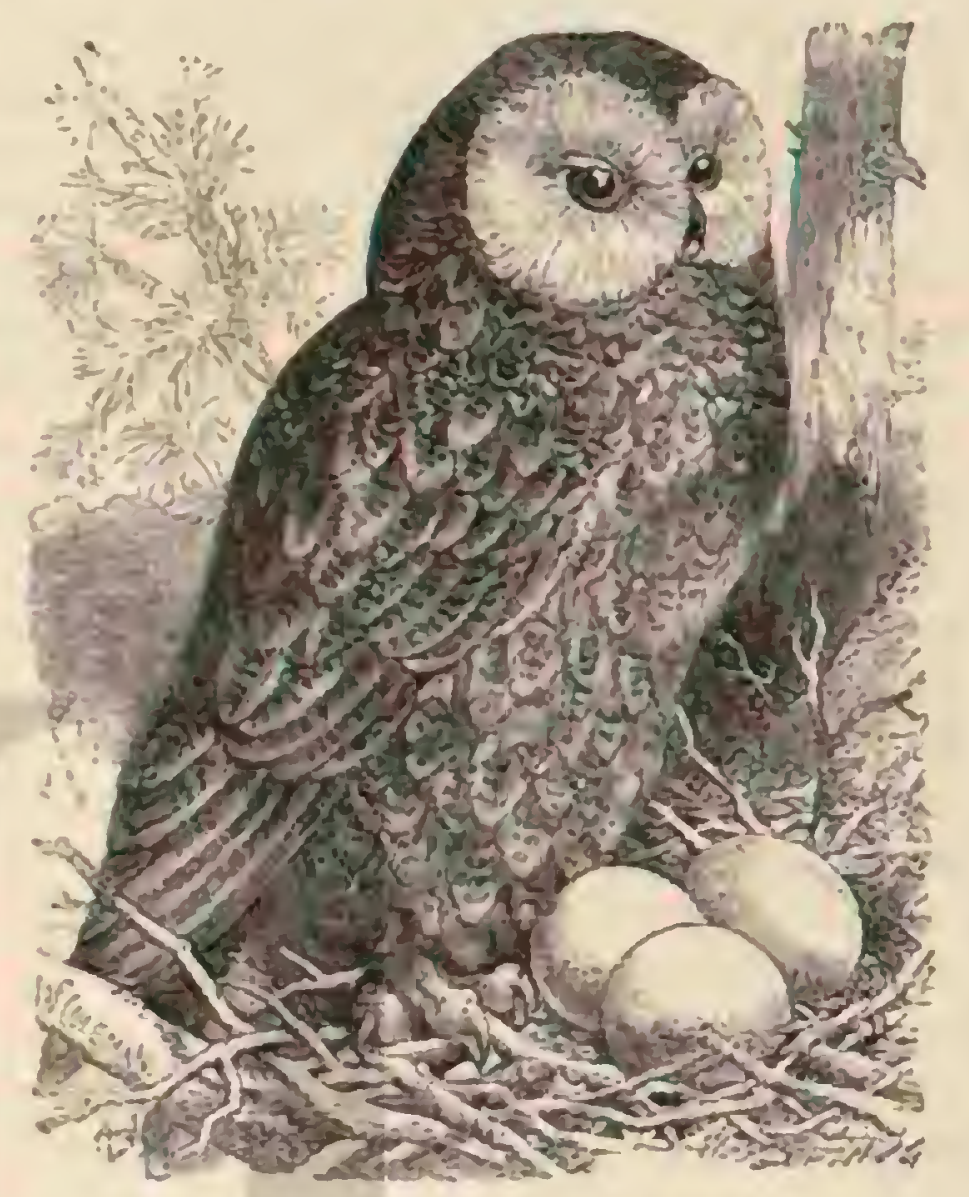

Fig. 190.-R. A.itu.o r.umenta

auricular grande, redondo y con dibujos regulares. En el dorso predomina un pardo gris opaco; cada pluma tiene en su tallo una mancha angular de color pardo oscuro y fajas blanquizeas, recias i onduladas; el color de la region inferior es gris mas ó menos claro, con un ligero viso rojizo; en la region del buche hay manchas longitudinales de un gris oscure, y en los lados del precho y en los piés otras mas an. gostas y trastersales. El disco se compone de plumas cerdosas de color gris blanco, q̨ue algunas veces tienen un lustre ama. rillo de orin y fajas negruzcas, presentando sobre un fondo gris blanco ocho $\delta$ dier circulos muy regulares de un negro pálido quue se enlazan entre si y rodcan los ojos. La region de la garganta tiene una mancha negra en forma de perilla, bordeada en ambos lados por una angosta linea blanca. Las rémiges primarias presentan sobre un fondo pardo oscuro fajas trasversales de un color pardo blanyuirco; sus barbas interiores son de un pardusco pálido, con lineas onduladas ó angulosas; las rémiges secundarias tienen dibujos semejantes; las recirices son de un color pardo gris, mas oscuro en la punta y cruzadas por cinco fajas poco marcadas de color mas claro. Los ojos son relacivamente pequeños; el iris de un color amarillo de fuego muy vivo; los párpados de un pardo rojizo, y el pico es amarillo de cera. los polluclos se parecen á los adultos.

DISTRIBUCION GEOGRÁFICA.-El área de dispersion del antilo barbudo se extiende por el norte del antiguo continente, comprende sobre todo la Laponia, Finlandia, el norte de Rusia, y la Siberia hasta el mar de Ochotsk; pero 
no el norta de Amírica como anies se decia. Aqui se ha obscrvado últimamente el antilo gris, que se ha confundido á menudo con el antilo barbudo. En Alemania solo se ha ca. zado esta ave. segun parece, en la Prusia oriental y en Silesia; pero en el mediodia de la Escandinavia se cncuentra mas á menudo; anida en Laponia, Finlandia, el norte de Rusia y io:1a la Siberia septentriunal.

USOS, COSTUMBRES Y REGIMEN.-Carecennos aUn de observaciones sobre el género de vida de esta ave; casi todas las noticias que se encuentran en las obras zoológicas se refieren à sus congéneres norteamericanos. So:o Wallengren, Nilsson, Locivenhjelm y Volley nos dan algunos breves informes. En liscandinavia, el antilo barbudo sigue anm. bien a las manadas de lemings; y entonces prolunga sus viajes is menudo hasta el ceniro det pais: stl antmero lepende de la major ómenor frecuencia de la caza farorita. No st sabe nada snbre su género de vida ni su mocio de cazar, y la manerá de conducirse con otros mimalos. Ún individuo fue muerto cn Dalckarlia, segun Lundborg, con circunstancias extranas: acometio á un trabajador ocupado en casar la tierra en un gran pantano scco é intentó herirle cn la espalda. Eil hombré judo librarse del ave, y como esta permnecia tran. quila, dejole tiempo parn ir a buscar la escopera Despnes de volver le aisparó un tiro, pero sin tocarle; volvió a cosa para 'catgar otra vez, y mató al ave. El antilo era una hembra muy fiaca, yrobablemenic en extrenin hambrienta, lo cual explica su extraño proceder. Ulienius encontró ś primeros de junio en la Marca de Laponia un nido, y pudo matar la hembra, que cstaba cubricido los huevos, Fil nido se hallaba en un bosque de pinos lisos, y en el tronen de un árbol de tres metros de airum, donde se hasia formado un hueco con la patrefaccion. Hallóse en él un fituevo blanco del tamano de los del gran duque, y otro junto al árbol. Wolley encon tró varios nidos situados, ja en altos árboles of en sus huecosi contenian tres ó cuatro huevos sumamente prequeños en proporcion al tamaño dei ave y mucho mas reducidos qute las del gran dique y los del harlango de las nieves. Nosotros unismos vimos, durante nuestro viaje á Siburia en la parte inferior del Obi, dos antilos barbudos cautivos, propiedad de algunos ostiacos, quic: segun dijeron, los habian hallado cir un nido descubierto en cl irbol de un bosque de sauces: aseguraronne que los alimentaban con peces. Listas aves me recordaron por todo, muestro buho vulgar; jrescindiendo de sus ojos amarillos, tenian la misma expresion benévola: eran igualmente mansas y dóciles y tambien sus movimientos y ademanes no diferian de los de aquel. Con gran pesar mio no pude hacer observaciones minuciosas, porque ambos se destinaban a la coleccion y los mataron al poco tiernyro.

\section{EL NICTALO CALZADO-NYCTAI.E DASYPUS}

CARACTERES. - Los nictalos ticnen la cabeza muy grande; la conclia auditiva en extremo abierta, y provista de un opérculn smmamente desarrollado: el disco facial es ancho y completo; las alas obtusas, largas y redondeadas; la cola bastante larga; los tarsos cortos, cubiertos de plumas sedosas, largas y nuy compacias; el plumaje es biando y secioso.

El nictalo calzado (fig. ig1), conocido generalmente con el nombre de nistabo ó morimelu Tengymalm, se asemeja mucho a la lechuza vulgar por su plumaje. Tiene el lomo de color gris de raton, con grandes manchas blanqunizcas; el vientre blanco con manchas pardas, dispuestas trasversalmente; las rémiges $y$ ias rectrices del rinte gris ritado, con fajas biancas rortadas, de las que hay cinco ó seis en las pennas caudales: el circulo auricular es blanquirco con motas negras; d pico amarillo y el ojo de color de oro.
Los individuos jóvenes tienen el plumaje de color pardc café, con manchas blanquizcas en la coia y las alas.

Eil largo de esta ave es de $0^{\prime \prime}, 23$; sus alas desplegadas de $v^{\circ}, 56$; la cola mide $0^{\circ}$, is $y$ las alas $\left(0^{\prime \prime}, 18\right.$.

DISTRIBUCION GEOGRAFICA.-El área de disper. sion del nictaló calzado comprende el norte y centro de Eu. ropa, el nordeste de Asia y el norte de América, desde el lago de los Esclaros hasta la frontera septentriomal de los Estados.Unidos; pero como se le ha encontrado además en Nepal, puede suponerse que se extiende por el Asia muclio mas de lo que hasta ahora se ha creido, y que probablemente se encuentra en todos los grandes bostues situados entre la Europa central y la América del norte.

USOS, COSTUMARES Y KEGIMEN. - Esta especic no abandona los bosques sino crcepciomalmente; el tronco de un árbol hueco le sirve de albergue y forma el centro de su dominio, al que se conserva fiel.

Lil nictalo calkado es un ave solitaria y timida, que huye de la laz, porque ofericle su vista.

Mi padre ha podido obserwar a una pareja de nictalos li. bres gue anidaron en un lugar oscuro del bosque, y cuyos hijuelos habian abandonado ya su retiro. Hé aqui lo que dice: 4. Apenas llegaba la tarde comenzaban a gritar los hijuelos; callábarise al acercarme, y no se oia yn su voz hasta que, ce. sando el riido, les parccia que habia pasado el riesgo. Apenas volvièron ti gritar, tícé contra uno que se habia posacio cn uni rama seca inuy ceren del tronco; la madre acudió al mo. mérito, lanłando gritos de angustia y iodos emprendieron la fuga. Duraute largo rato reinó un profundo silencio; pero al fin, dejóse oir un grito, y de un segundo tiro maté otro pe. queno sin que me inese posible tocar it un tarcero, pues se habian alujado tanto y era tan entrada la nuche, que hube de abandonar forzosamente la caceria. La conducia de ia madre fué muy singular: cuando vió el peligro, agacluose sobre una rama, de tal modo que apenas la podia ver, y mucho menos tirar; de ves en cuando lanzaba gritos lastinero5, que parecian gemidos tumanos; di varias vuelias por el mismo sitio; pero no divisé a la hembra ni a su progenie, yesde aquelia época no se ha vuelto a ver ningun individuo de la especie en esia localidat.s

Este nictalo anida en los troncos de árboles huecos, y po. ne por abril $\delta$ mayo tres $\delta$ cuntro hueros blancos, de cáscara bastante delgada.

Conte sobre todo pequeños roedores; cara tambien musarañas é insectos, y de vez en cuando avecillas ó murciélagos. A juzgar por lo que observé en los escops, es probable que se apodere de ellos al vuelo, en vez de sacarlos de los agujeros donde se refugian, como lo cree Naumann.

Richarason dice que la luz deslumbsa de tal modo al nictalo, que se le puede coger con la mano; Gadmer asegura que cuando se sorprende $a$ uno de dia es fácil matasle á pa. los. Ignoro si debemos aceptar tales ascrtes al pié de ta letra, y me limitaré á decir que no es muy fácil apoderarse de un nictalo. \& veces no se consigue ni aun poniendo á la entrada de su nido varetas con liga: lo mas seguro es un ziro, dado caso de que se consiga ver al ave.

No solo debe temer el nictalo al hombre, sino tambien á las comadrejas, a los pequeños maniferos que roban los nidos y a las grandes especies de buhos. Las aves pequenas se conducen con esta rapa\% to mismo que con los otros estrigi: dos; la persiguen con sus gritos apenas la ven $\delta$ la descu. bren.

CAUTIVIDAD.-Fi nictalo la sop̣orta fácilmente y se familiariza bastanie: ini padre conservó un individuo varios anos, y judo hacer en él algunas observaciones. Aunque se domesticó bastante pronto, buscaba de dia los rincones mas 
oscuros de la habitacion, y apenas abria los ojos: si le ponian á la luz los cerraba, y tan pronio como le volvian a dejar, corria presuroso á su rincon. Si le gritaban demasiado chasqqueaba el pico, como los otros estrigidos, aunque sin manifestar mucho enojo. No se dejaba ver sino por la tarde, yera entonces muy vivaz: en el primer tiempo de su cautividad solo comia por la noche; pero mas rarde se acosiumbró ś la luz y acabó por no retirarse ya mas a su jaula. Comia en la mano de mi padre; tomaba el alimento con la pata, rara se\% con el pico; llevá balo á un rincon y lo cubria con el cuerpo, erizando el plumaje. Bebia poco; pero cuando hacia calor, baríbase casi todos los dias; estremeciase en los dias frios, y recogia en tonces las patas debajo del cuerpo. Asemejabase su roz á un ligero ladrido, que podria expresarse por iuc, au, zua, que dejaba oir sobre todo al medio dia, por la tarde y por la ma. กิลกล.

Un amigo de mi padre tuvo tambien un nictalo calzado vivo: era muy gracioso, y se domesticó asimismo rápidamen. tc. Cuando se le irritaba chasqueaba el pico, erizaba las plu. mas y abria las alas sin bajarse, como lo hace el gran duque. 'l'ragábase los ratoncitos enteros; desiedazaba los grandes y se comia hasta la piel, devolviendo despunes los huesos. Dos ratones diarios le bastaban para su alimento.

\section{LAS ZUMAYAS - STRIX}

CARACTERES.- Este género es uno de los mas carac. terizados de la familia; y a causa de las particularidades de su estructura se ha considerado tambien como tipo de una sub.familia independiente. Las zumayas tienen el cuerpo prolongado; el cuelio largo; la cabeza grande y ancha; ia cola mediana; los tarsos altos, completamente revestidos de plu. mas sedosas, y solo cubiertos los dedos de algunos pelos diseminados; las uñas largas, finas y aceradas; el plumaje sedoso; el pico recto en la base y corvo en la punta úricamente; el ojo mas pequeño y convcio que en los otros estrigidos; la concha auditisa muy ancha y provista de un opérculo; los discos perioftálmicos compleros y en forma de corazon; las alas subagudas, con la tercena rémige mas larga.

\section{LA ZUMAYA COMUN - STRIX FLAMEA}

CARACTERES. - Esta especie tiene por representantes en otros continentes, sobre todo en Asia y en $A$ mérica, unas especies tan afines, que algunos ornitúlogos-se-inclinan of considerar todas las zuniayas del glabo como pertenecientes a una sola especie. Fil ave que se observa en . llemania tient (1) 32 de largo $50^{\circ}, 90$ de ala 1 ala; esta plegada mide $0^{\circ}, 2 S$ y la cola 0m, 12. El macho viejo riene el lomo gris ceniciento oscuro: los lados de in cabeza y del cuello de un amarillo rojo, con manchas longitudinales muy pequeñas, blancas y negras; las cubijas superiores del ala de un tinte ceniciento oscuro con motas claras y manchas longitudinales blancas y negras; la cara inferior del cuerpo de un amarillo rojo oscu. ro, con manchas pardas s blancas; el circulo perioftálmico rojo en su mitad superior y de un blanco rojo en la inferior. las rémiges-son rojizas en las barbas externas, sembradas de manchas oscuras y blanquizcas en las internas: las rectrices de un amarillo rojo con tres ó cuatro rayas negruzcas, y ler minadas por una faja de un gris ceniciento oscuro; el pico y la membrana que cubre la base es de un blanco rojizo; los piés cie un gris azul sucio y el ojo pardo oscuro.

Los matices de la hembra son mas oscuros.

DISTRIBUCION GEOGRÁFICA.-Ia zumaya comun habita en nucsiros paises los campanarios y castillos, las rui. nas y las casas viejas: en el extremo norte de Europa no se la encuentra sino en los grandes bosques: en las montañas no se eleva sobre la zona de los árboles.

USOS, COSTUMBRES Y REGIMEN.-La especie es mas bien sedemaria que viajera; donde en la actualidad existen zumayas se las ha enconirado en las épocas mas remotas; pero los individuos jóvenes deben andiar errantes algun tiempo, pues han de buscar un donsinio para fijarse, hecho que confirma Bailly con las siguieniés palabras: 4 Debo observar que desde fires de uctubre hasta principios de diciembre llegan casi todos los años algunas reducidas bandadas de zumayas, procedentes del norte; compónense principalmente de hembras y de individuos jóvenes, y nos abandonan por lo regular, para dirigirse al mediodia, tan pronto como alcan. za el frio el grado de intensidad que les lizo huir antes de los paises septentrionales. $\%$

Las zumayas permanecen todo el dia inmóviles en el paraje mas oscuro que pueden encontrar. Ni el repiqque de las campanas que resuenen a su lado, ni las idas y venidas de las palomas que han fijado en el mismo sitio su morada, es bas. tante para obligarlas a cambiar de sitio, ni aun de posicion. Cuando descansan se parecen a los otros estrigidos, aunque difieren á primera vista por sus formas esbeltas y por su cara en forma de cornzon.

Por lo que hemos podido observar en las zunayas cauti. vas, sabemos que su sueño es por demás ligero, tanto que el hombre no las puede sorprender, pues las despicrta el mas leve rumor. Si llega algun curioso, enderézanse, se balancean y apoyan alternativamente sobre una y otra pata, haviendo muchas muecas, pero moviéndose con mas lentitud y torpeza que los demás estrigidos. Cuando les amenaza un peligro, emprenden el ruelo, dando i conocer asi que ven tambien de dia.

1)espues de ponerse el sol abandona la zumaya su retiroy se aleja rasando el suclo: anuncia su presencia un grito ronco, el mas desagradable que haya producido nunca ninguna de nuestras aves indigenas, segun dice Naumann; al mirnr atentamente en la direccion de que parte, es seguro divisar al ave.

I.a zumaya se acerca al hombre sin iemor y viela como una sombra al rededor de su cabeza: cuando hay lu\% de luna anda crrante toda la noche, descansando ta ratos para volver s. su caceria con nuevo ardimiento; cunndo las noclies son imuy oscuras no caza sino pror la tarde y la mañana.

La zumaya comun se alimenta de ratones, ratas, musara. has, topos, avecillas y grandes insectos. Dicese que á menudo hace destrozos en los palomares; pero esto no conviene mucho con la indiferencia que manifiestan las palomas hácia el ave. Mluchas reces, dice Naumann, le he visto volar en nee. dio de mis palomas, que se acostumbraron bien pronio at su presencia, y no perdieron nunca uno solo de sus huevos ó de sus hijuelos, ni fué tampoco acometido ningun pichon adulto. En la primavera se vicron en mi pario dos zumayas que llegaban casi todas las tardes y acabaron por establecerse en el palonar. Apenas llegaba la noche, volaban al rededor, y entraban y salian sin que se moviese una sola paloma. Sidu. mnte el dia se acercaba uno con precaucion, podia verlas en un rincon del palomar, durmiendo tranquilamente entre las palomas y un monton de ratones. Cuando su caza habia sido feliz, tmsportábanla á su morada, y acaso almacenaban alli provisiones para alimentarse cuando el tiempo no eta bieno, como por ejemplo en las noches sombrias y tempestuosas, en que es dificil la caza.

Mi padre cogió cierto dia una de estas zumayas, y era su sueño tan profundo, que el ruido de las palomas ique volaban no bastó para despertarla. No creo, aunque sea opinion muy 
generalizada, que esta are se alimenic de huevos, si bien me aseguró cierta persona haber visto á una zumaja con un huevo de gallina entre las garras. Sin embargo, existen tantas

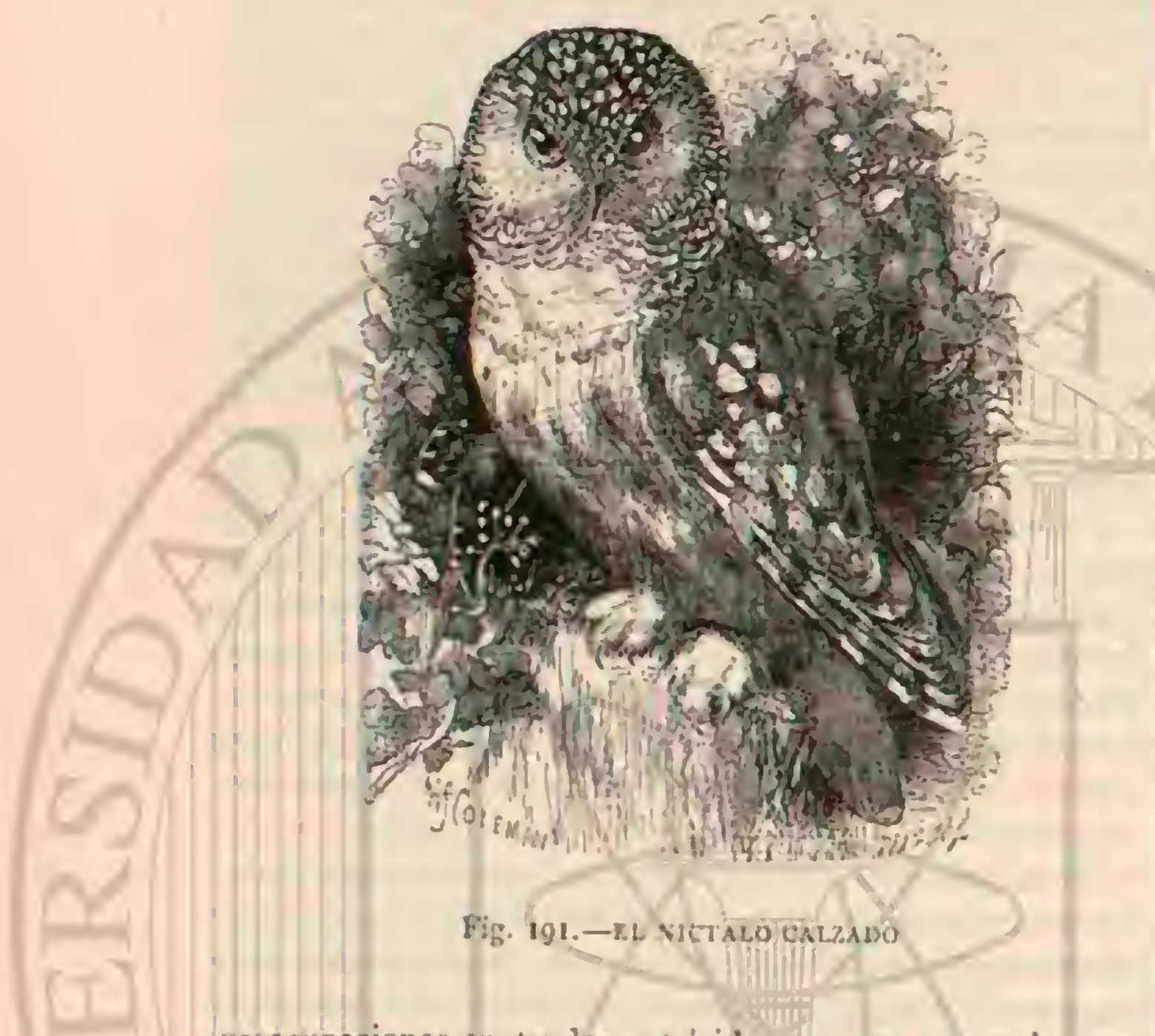

précupaciones contra los estrigidos, que no se puede creer en todos los daños que les imp̧utan: repito que no cometieron el menor desperfecto en mi palomar: puse delante de algunas zumayas hueros de gallina enteros y rotos, y no los tocaron; pero en cambio, sorprendian a las avecillas en su sueno. Muchas de estas rapaces son muy mansas y otras yo. races: un amigo mio adquirió una que fue cogida ocho dias anies, la puso en una habitacion completamente oscura y corrió á buscar una luz lin menos de un minuto, habíase apoderado del pájaro favorito del amo, que era una curruca, la cual habia devorado a medias. Esta zumaya se comia quince ratones en una noche. En caso de necesidad no des. precian los restos putrefactos 8

En España tiene fama esta rapaz de beberse el aceite de las lámparas que arden continuamente en los templos.

Daehne dice que en invierno, y cuando nieva, se deslumbra de tal modo el ave, qque se la puede coger con la mano: yo no hice nunca esta observacion; para coserla he cerrado la entrada de su nido, apoderándome de ella despues por medio de un lazo.

La zumaya es una de las aves mas vítiles. «En todas partes, dice Lenz, se deberian preparar sitios donde anidasen las zumayas y las lechuzas: en las paredes de mi casa se han practicado varias aberturas del tamaño de las de un palomar, las cuales conducen a una especie de cajon que tiene á derc. cha é irquierda sitios conrenicntes para formar nidos. Allí no puede penctrar la luz: al entrar el ave recorre un pasadizo de un pié de largo; y luego debe volverse al derecha ó izquier. da para entrar en sú nido. En el interior de la casa cestá el cajon sólidamente cerrado, de modo que no se pueda moles. tar á las avés.

xEn Holstein hay en la pared de cada granja una abertu. ra por la que puede entrar una zunara: segun el doctor W. Claudio, los campesinos del pais se guardan muy bien de molestar a las rapaces nocturnas, y gracias a ellos entran y salen libremente, cazan los ratones dentro y fuera de tä granja, viven en buena inteligencia con los gatos yanidan en los rincones oscuros.

En estos últimos aios se han hecho observaciones asaz interesantes sobre la reproduccion de la zumaya comun. Los antiguos autores dicen que se reproduce en abril y. majo; pero se cuentan algunas excepcioncs, pues se han encontrado varias reces individuos jovenes en octuture y noviembre, y hasta huevos que cubrian las hembras afanosamente El amor excita á las zumayas, y macho y hembra se persiguen lanzan. do gritos penetrantes: estas aves no fabrican nido; limitanse a depositar sus huevos en un rincon. Los recien nacidos son tan hediondos como los de todos los estrígidos; pero no les aman menos sis padres y les dan abundantes ratones para su alimento.

CAUTIVIDAD. - Ias rumayas sors aves agradables cunn do cstán cautivas y se domestican bien: si se cogen pequeñas y no quicre uno molestarse en criarlas, basta ponerlas en una jaula de varillas bastante espaciadas, dejándolas al cuidado de sus padres, los cuales se encargan de-proporcionarles cuanto necesiten. Si uno las cuida por si mismo, domesticanse muy pronto; se las puede coger 5 acariciar, llevarlas en ef puno y hasta dejarlas volar libremente. Son en fin unos de los estrigidos mas agradables para la jaula; sus muecas divierten a todo el mundo ${ }^{\circ}$ á menudo contraen su disco de tal modo, que segun dice mi padre, parecen verdaderas caricaturas del hombre. 


\section{PÁJAROS Ó PASERINOS-PASSERIN㤅}

I.a gran mayoria de los natumlistas comprende aun loy dia mas de la mitad de todas las ares en un solo órden, formado por unas cinco mil seterientas especies, sin que haya tenico exito ninguna de las rarias tentativas hechas con el proposito de subdividir tan numeroso órden en grupos defi. nidos. El llamado sistema natural resulta ser en este lo mis. mo que en otros casos un sistema artificial por no decir artificioso, no siendo en resúmen sino un modo de presentar nuestros conocimienios actuales.

CARACTERES. - En vista de la multiplicidad de espe. cies $y$ de la diversidad de formas de los pájaros, es dificilisimo asignar a este órden caractéres generales. En ningun otro oscila entre tan extensos limites como en este el tamano de las aves, cuyos extremos opuestos representan el cuerio corax y el revezuelo; y no es menor la diversidad que ofrecen el pico, la pata, las alas, la cola, la clase y coloracion del plu. maje. El pico apenas tiene en los pajaros otro carácter comun sino su longitud regular y la carencia de cera; las piernas están cubiertas de plunias hasta el iarso, y este por delante de placas gruesas, por lo comun en número de siete; la pata es esbelta, con el dedo interior generalmente mas grande que el segundo, dirigido hácia atrás. El distintivo mas importante de la mayor parte, pero no de todos los pajaros, consiste en el desarrollo especial de la laringe inferior provista de dos á cinco pares de músculos repartidos en sus caras anterior y posterior.

las plumas, que suelen ser poco abundantes, se distinguen por un pequeño tallo falso cubierto de plumon y por estar dispuestas en capas bastantc fijas, de las cuales la del dorso y la abdominal presentan un carácter murgeneral. La primera forma invariablemente, segun Carus, una lista no interruns. pida por la espaldilla, detrás de la cual se ensancha formando una superficie cuadrangular ú ovalada, en cuyo centro hay a veces un espacio longitudinal u oval que carece de plumas. En algunos casos sale de ambos lados de esta parte ensan. chada de la capa dorsal una hilera de una pluma hasta la capa caudal. La abdominal ó inferior se divide cerca de la mitad del cuello en dos ramas divergentes, de cada una de las cuales parte a su vez otra bastante ancha liácia fucra, llegando ambas hasta $\mathrm{el} \mathrm{ano.} \mathrm{Las} \mathrm{rémiges} \mathrm{primarias} \mathrm{son} \mathrm{por}$ lo regular en número de diez ó de nueve; en el segundo caso falta la primera, que aunque exista no pasa de ser rudimen. taria. El número de las secundarias oscila entre nueve y ca. iorce, siendo el primero el comun. Las tectrices del antebra20 son por lo regular cortas y dejan casi siempre la mitad de las pennas sin cubrir; las majores forman solo una hilera á la cual se juntan las menores de la muneca $y$ del borde de la membrana del vuelo. Ia cola se compone de doce, rara vez de diez rectrices. No suele liaber plumon entre las plumas, y cuando por casualidad lo hay, es muy escaso.

En el esquelcto orrece el cráneo notable variedad, si bien presenta en cambio grandes analogias en el desarrollo igual del rómer, en las prolongaciones paladiales de la mandibula

томо III superior y en los huesos palatinos. El rómer es escotado en la parte anterior y profundamente hendido en la posterior, tanto que abraza las alas del esfenoides. Las prolongaciones de la mandibula superior son delgadas, largas, á reces muy anchas, y se doblan hácia dentro y atrós sobre los palatinos para rematar debajo del vómer en una extremidad ó ala ensanchada y cóncava á manera de concha, pero que falta en algunas familias; los huesos palatinos finalmente son casi siempre anchos y aplanados hácia atrás. Segun Nitzsch, ca. racteriza \& los pajaros un tubo huesoso particular que condu. ce el aire de la cavidad timpánica á los depósitos de aire de la mandibula inf́crior. Ja columna vertebral consta de diez.á catorce vértebras cervicales, de seis á ocho dorsales, seis á trece sacras $y$ de seis á ocho coxigeas. La quilla del estemon es escotada en el borde anterior y casi siempre ambien en el posterior. En cl extremo anterior de la clavicula hay una robusta apófisis en forma de cono comprimido. El antebrazo es un poco mas largo que el húmero, sin ser excesiva la lon. gitud, como tampoco lo es la de la mano. Las picrnas presen. tan una estructura regular. In forma y el tamaño de la len. gua corresponden siempre al pico. Ia cubierta cónea de la lengua es en muchos casos desligada á bien dentada en el borde y en el extremo. El esófago no forma buche; el esto. mago es carnoso y el cicgo existe siempre.

DISTRIBUCION GEOGRÁFICA.-Ël área de disper. sion de los pájaros corresponde al número extraordinario de estos. Viven en todas partes y forman la parte mas esencial de la poblacion alada de todas las zomas, lavitudes, alturas, comareas y locnlidades. Se los encuentra en todos los paises, en toda region, en las superficies heladas de las altas cordilleras ó del norte lo mismo que en los llanos abrasados por el sol ecuatorial; en las regiones elevadas como en las bajas, en el bosiue como en el campo, en los cañizales de los pantanos como en los paramos desprovistos de vegetacion; en la capi. tal populosa como en el desicrio y la soledad; en todas par. tes, en fin, por poco que encuentren medios de existencia, y los saben encontrar hasta en los islotes solitarios del mar Glacial. Fuera de este órden solo el de las aves de rapina ocupa un área aproximadamente de igual extension y varie. dad; pero siendo los pảjaros mas numerosos en individuos y en especies que aqquellas, resulia que están tambien mas extendidos. Tan solo faltan en un continente, en el del polo antártico que viene b́ ser la sexta parte de nuestro mundo, porque alli ni aun estos séres tan poco exigentes encueniran con qué vivir. Tambien se alcjan del mar, porque son animales terrestres. Su ára de dispersion se extiende por donde quiera que haya el nicnor asomo de regetacion. Son mas numcrosos en los bosques que en campo raso, mas en la zona tórrida qute en las iempladas y frias, salvo algunas excepciones. Muchas especies viven exclusivamente en el suelo, otras casi; y mas $\delta$ menos, la inmensa mayoria. Son pocas las que se abstienen de acercarse a los iugares poblados, $y^{\circ}$ muchas las que residen alrededor de las viviendas del señor de la 
tierra, entrando confiadamente en su labitacion, corral, huerto $y$ jardin, no habiendo ninguna que se alejara de la morada del hombre, si este no se mostrase enemigo suyo, aunque solo sea por el hecho de trasformar a su antojo las condicio. nes de habitabilidad que el pais ó sitio les ofrece.

INTELIGENCIA. - LOS que consideran á los pájaros como los miembros mejor dotados de toda la clase, no les hacen sino justicia. Muchos son los ornitólogos que siguen el cjemplo de Cabanis y tienen al ruiseñor por el ave mas perfecta de todas; Ovien dijo en una ocasion que el cuervo merecia igual distincion, y no puede aducirse gran cosa en contrn de esta, ni de la otra opinion; porque las dotes de los pajaros son efectivamente casi extraordinarias, tanto respecto $a$ inteligencia como is ventajas corporales. Son diestros en toda clase de movimientos y se distinguen tambien ventajo. samente en los demás conceptos. No todos son grandes voladores, si bien algunas especies compiten en este punto con cualquieta otra ave, y la gran mayoria de cllos supera á todas lás de algunos órdenes. En sú mayoria se inueven en tierra con gran soltura y destreza, los unos andando y los otros saltando; muchos atraviesan el ramaje mas espeso con la pres. teza del raton, otros trepan por troncos y ramas ó liacen habilidiades acrobśticas, y algunos dan numerosas pruebas de destreza en sus juegos. A la mayor-parte les desagrada el agua, pero algunas especics la dominan de una manera admirable porque cazan corriendo por el fondo ó atraviesan volando la cascada espumosa que se precipita con estruendo desde las rocas al fondo del precipicio.

Todos sus sentidos están bien desarrollados, figurando en primera linea la vista, y despures el oido y el tacto. El gusto existe, pero no debe ser notable, y en cuanto al olfato, si bien lo tienen bastante desarrollado algunas especies, puede cónsiderarse, al igual del gusto, solo como rudimentario. Corresponde á su cerebro, relativamente grande, una inteligencia extraordinaria, una sensibiliciad delicada $y$ una viveza grande, cualidades todas que no pueden negarse á la gran mayoría de los pájaros. El que los conozca no los calificará de limitacios, á no ser que se niegue á admitir como pruebas las que dan diariamente de lo contrario. Verdad es que en su mayor parte son aves bonachonas y contiadas que en cierta manera justifican una falsa apreciacion, pero todos se muestran, cuando se presenta la ocasion, f́la alura de las circunstancias. Aprenden á conocer à sus enemigos y â apre. ciarlos en lo que valen; saben esquivar peligros, disfrutar de la compania de sus amigos, y agradecer su cariño; por ma. nera que varian de comportamicnio segun las circunstancias, tiempo, localidad y el carácter de las personas y demás séres que tratan. Son grandes por sus cualidades y pasiones; sociables, pacificos $\mathrm{y}$ cariñosos, aunque tambien huraños, pendencieros $\dot{0}$ indiferelites hácia los séres a quienes manifiestan carino en otras ocasiones; son fogosos y ardientes en la estacion de sus amores, $y$ celosos, tercos y llenos de ambicion; combaten cuando es menester sirviéndose de pico y garras, 6 desatianse cantando, volando ó posados, acaso con los de su propia especic, no obstante de vivir generalmente con ellos en apacible intimidad, profesándose mutuo carino y hasta sacrificancose por ellos en cualquier otra ocnsion. Tan grande es su sensibilidad, que muchas veces se sobrepo. ne da la reflexion, les embarga a algunos los senticios y hasta les quita la vida. Esto no podrá negarlo el que los haya ob. servado, pues los pájaros nos dan frecuentes pruebas de esta sensibilidad, ya asistiendo solicitos a alguno de sus semcjan. tes enfermo, débil y necesitado, ya manifestando á su amo, cuando esián domesticados, todo el afecto que le profesan, callando tristes si se halla ausente, $\delta$ saludándole con regocijo tan pronto como le ven llegar, ó ya en fin prorumpiendo en uno de sus admirables cantos que debemos escuchar con la comprension necesaria y con los cuales cabalmente nos em. belesan estas especies. I a mayor parte de ellas poseen una excelente memoria que contribuye poderosamente à jerfeccionar y elevar su inteligencia.

je comprenderá fícilmente que, para animales tan vivos y apasionados, el movimiento casi continuo sea una necesidad. Enemigos de un q̨uietismo soñoliento, agitanse, trabajan y̆ se afanan sin descanso desde el amanecer hasta muy tarde. No hay cualidad suya que no ejerciten; únicamente cuando duermen no se ocupan de nada; despiertos han de hacer una cosa ú orra, aunque no sea mas que arreglarse el plumaje. Invierten una gran parte del dia en procurarse el alimento que necesitan, y dedican un espacio de tiempo no menor al entretenimiento que tanto nos gusta, al canto; pues la inmensa mayoria de ellos es cantora. De algunas especies de loros puede decirse que en cierto modo cantan, aunquue en el fon. do su pretendido canto no es mas que una bulliciosa garrulerla; los pájaros empero cuentan en su seno con todas las ares verdaderamente cantoras, las maestras en este notabilisimo arte, que saben entusiasmar à las personas conocedoras lo mismo que nuestros cantores y cantatrices de profesion a su auditorió. Los pajaros cantores cantan con entusiasmo perseverancia, no solo para divertir a su hembra, 6 si están cautivos, â la persona que los cuida, sino para su deleitcy recreo propios, 6 bien se cjercitan en el canto para que les sirva de arma con la cual vencen ó sucumben en ciertas luchas. El que haya oido y comprendido el canto de un ruisenor 6 tordo no dudará de la alegria y excitabilidad de su espiritu, de su carácter apasionado, sin cuyas cualidades les fuera impósible producirse con tanta maestria. Se han com. parado lás aves cantoras a los poetas, y esta comparacion, algo inexacta como todas, es sin embargo racional, aunque excite la sontisa y mofa de muchos, pues dichas aves son en cierta manera entre los pájaros lo que los poetas entre los lombres.

USOS, COSTUMBRES Y REGTMEN, - A las múlt: ples doies de los pájaros corresponde su modo de ser, su comportamiento, régimen, reproduccion y demás manifestaciones de'su vida; pero muy poco puede decirse respecto \{ estos diferentes puntos que sea general i todo el órden, ya que tratíndose de estas aves todo parece posible: y asi como su configuracion, sus cualidades, su morada y su comportamiento, asi tambien varia su modo de vivir y hasta varian ellos mismos. En su mayoria son en extrémo sociables; es una casualidad cuando se los encuentra sueltos, y por pare. jas únicamente en la época de su reproduccion; mientras que en el resto del año se reunen las parejas \& las familias jara formar grupos, los grupos bandadas y estas verdaderos cjércitos, compuestos no solamente de individuos de una misma especie, sino de varias congenéricas y afines, que con. tinuan unidos meses enteros segun sean las circunstancias, obrando todo este tiempo siempre de comun acuerdo. Vense reuniones de esta especic á últimos de otoño, despues de concluidas las crias y la muda, cerca de nuestras moradas y en nuestros campos; en invierno en los corrales, carreteras y ciudades donde mendigan su sustento, $y$ hasta se conservan y mantienen unidas en la emigracion. El individuo mas ca. paz cuida del bienestar general y los demás prestan obedicn. cia a sus disposiciones é imitan su cjemplo. En algunas especies de pajaros, sociables tambien, rigen otras costumbres; los individuos que forman la bandada conservan su inde. pendencia, lo que no obsta para que mutuamente se auxilien en momentos de peligro y de necesidad, para que las parejas se manifiesten un afecto entrañable, y para qque amen á sus hijuelos con roda la vehemencia de que pueda ser capaz otra 
ave cualquiera: pero en todo lo demás obra cada individuo como mejor le parece, $y$ si se reunen en numerosisimos gru. pos es por el convencimiento que tienen de las ventajas que ofrece al individuo la union con otros muchos de indole y disposiciones semejantes, la proteccion, el goce que resulta de Ia sociedad, y la ocupacion que anhela todo genio activo. Hasta hay especies que celcbran reuniones en ciertos sitios y horas determinados, al parecer para comunicarse lo que á cada cual le ha acontecido durante el dia. Otros pajaros hay que son tan solitarios cumo es posible serlo a un are: se reti. ran á un distrito rigurosamente limitado, dentro del cual no consienten otra pareja ni sus propios hijos, a los que despiden de su lado tan luego como pueden bastarse a sí mismos.

En rigor deberian considerarse todos los miembros de este órden como aves de rapina, aunque choque este nombre al oido, puesto que la gran mayoria se alimenta con preferencia, aunque no exclusivamente, de otros animales, como in sectos, moluscos y toda clase de gusanos, y las especies de mayor talla figuran positivamente entre las rapaces mas ac tivas, puesto que no se limitan á cazar sabandijas, sino qৃue compiten con las aves de rapina verdaderas, empleando en sus cacerias iodo el vigor, destreza, mlor y astucia posibles pero casi rodas las especies que viven preferentemente de otros animales, consumen tambien frutas, bayas y granos, y las que, por el contrario, se mantienen principalmente de estos últimos, cazan tambien, y casi sin excepcion a tempo. radas insectos; de modo que será quizís mas acertado lla. marios omniroros, aunque los menos lo sean de un modo tan general como ciertas especies determinadas que al parecer toman todo lo que es comestible y nunca vacilan cuando se trata de comer.

Segun sea su regrimen principalmente animal 6 regetal, puede el ptjaro permanecer ó no en invicrno en su patria. Los pajaros de todas las especies que habitan en paises cálidos no emigran á la manera de las aves de paso, sino que á lo mas cambian de residencia, ragando de una comarca $f$ otra, como suelen hacerlo tambien algunas de nuestras especies del norte. En nuestro pais despuebla el otoño montes y cam. pos, pucs son pocas las especies de este órden que pueden pasar el invierno septentrional, y no son solamente las in. sectivoras que emigran al sur, sino tambien muchas granivo. ras y hasta una parte de las omnivoras obedecen á esta necesidad fatal 6 ineludible.

Ia primavera, que en algunos paises viene a ser la estacion de las lluvias, es la época del amor para la mayoria de los pajaros; pero entre cllos existen cabalmente algunas especies que no hacen el menor caso del despertar de la naturalezs á nueva vida; que respecto á su reproduccion no tienen en cuenta las estaciones, y que arrostran lo mismo el helado imvierno del norte que los ardores sofocantes del verano tropical; -si bien la gran majoria rinde culto á la primavera como la mejor estacion del ano. Al liegar esta época, se lan disuelto ya todas las grandés agrupaciones que creó el o:ono, y las virtudes sociales han cedido el puesto d una pa. sion amorosa tan fuerte como no se observa sino en algunas pocas especies distintas. Ya no se abre el picosolo para can- tar las glorias, sino que se afila tambien para el combate pro. vocado por los celos, hasta tal punto que podria creerse entonces que enire cantar y luchar pasa el pojjaro el dia. In todas sus acciones se nota una excitacion singúlar; come de prisa, canta, se extasia, practica toda clase de juegos de vuclo que en otras épocas jamás sele ven hacer, y se entrega con gran ardor, por lo comun muchisimas veces al dia, al goce conyu. gal. Aquellas especies que figuran entre las ares solitarias, persiguen en esta epoca a sus semejantes con mas furor que antes, $y$ las que no disuelven sus sociedades, forman colonias en las que no reina tampoco el mejor concierto durante el primer tiempo del celo, disputándose unos à otros los sitios y los materiales para la construccion del nido: pero poco a poco cesa la luchay vielve a reinar la paz cuando los sitios estan ocupados definitivamente, cuando se ha concluido cl nido ó terminado la puesta.

La variedad que ofrecen entre si las diferentes especies de prajaros se vuelve ł encontrar en sus nidos, y bajo este concepto conviene aqui decir que este órden encierra las aves mas artistas. Ia puesta se compone de cuatro a doce y mas huevos, casi siempre abigarrados. Macho y hembra compar. ten el trabajo de incubacion $y^{\circ}$ de alimentacion de la cria, y concluida la primera suelen hacer otra y aun una tercera en el trascurso del verano.

USOS Y PRODUCTOS. - Hablando en tesis general, debemos considerar álos pájaros como animales mas útiles que perjudiciales. Hay entre ellos algunas especies que causan quizás mas daino que provecho, pero son tan pocas que toda su actividad merece ajpenas ser tomada en considera. cion si se compara con la de las demàs. Ina inmensa mayoria es utilisima para nuestros cultivos por la destruccion de insectos, caracoles y gusanos daninos, mientras que no pocas amenizan con su precioso canto bosques y campos, tanto que sin ellos la primavera apenas seria primavera para nos. otros, y que aunque fuesen perjudiciales no quisiéramos vernos privados de ellos. Sucede empero que cabalmente los mejores cantores constiuyen ins especies mas útiles, y que los chapuceros en el arte de cantar forman las mas dañinas, entre las cuales hay que contar ciertos córvidas, algunos fringilidos $;$ ploceidos, que si bien se hacen algo útiles comiendo semillas de jerbas perjudiciales, 5 cazando á reces algunos insectos, pueden en cambio ser muy molestos cuando reunidos en numerosas bandadas inva. den los campos de cereales en la época de la madurez ó las plantaciones de frutales. No es solo el labracior aleman el que mira \& estos huéspedes de reojo, sino que tambien se lamentan en otros paises del daño que causan estos pe. queños graniroros, tan terribles por su número; pues á nadic puede serle indiferente el que se mantengan a costa sura tantos cientos de miles de pequeños hambrientos, y el ver cómo los mas codiciosos de ellos destruỵen doble de lo que devoran. Ia guerra que se les hace es tanto mas justificada cuanto que su carne se considera con mzon como un exce. lente bocado; ni es tan imperdonable como se quiere ahora creer, el coger pájaros de especies no daninas, pero que se presentan en gran número, como por ejemplo los tordos; ni tienen los cazadores de pájaros tóda la culpa de la disminu. cion de estas aves, suponiendo que sca cicrta: con todo bueno es proteger á estas ares y tomar su defensa, ya que todos los pájaros en general, d cxcepcion de pocas especies fuertes y muy listas, tienen que sufrir las persecuciones de muchisimos enemigos de toda clase.

Fi numero de płjaros que se cogen para tenerlos en jaula es por lo menos tạn grande como el que se sacrifica á las exigencias de nuestro estómago. Ningun otro óden suminis. tra tantos inquilinos á las jaulas como este; â él pertenece el único animal doméstico que realmente couservamos encerrado y que tiene el privilegio de trasportar nuestra imaginacion en medio del invierno a la primavera y al verde follaje. No han faltado almas sentimentalisimas que se han lamentado $y$ han gemido de la triste suerte de las pobres avecillas enjauladas; pero sin tener presente en medio de sus lamentos que el pájaro enjaulado es un animal doméstico como cual. quier otro, destinado se servir al hombre. Todo el muncio cree muy puesto en el órden que se crie, se cebe, se mate y se coma un mamifero; pero coger un pájaro, cuidarlo cariñosa- 
mente, indenınizarle en cuanto es posible de la pérdida de su libertad para recibir de él en pago, y á modo de muestra de gratitud, la alegria de poder oir su canto, esto lo califican muchos de encarcelamiento injustificado de un sér archi-nobi. lisimo. Mientras haya en nuestro planeta mas necios que sa. bios, y predomine la necedad hasta en el seno de las mismas sociedades protectoras de animales, donde para decirlo mas claramente no solo impera sino que se fomenta, no puede esperarse que se disipen conceptos tan equivocados. Pero nosotros que conocemos mejor las aves y su género de vida que esas gentes aieminadas que, autorizadas ó no, llenan el mun. do con sus quejas, no nos privareinos ni nos dejaremos amenguar la alegria que nos causan nuestros compañeros alados domésticos; cogeremos y cuidaremos como antes pá. jaros, $y$ compadeceremos en nuestro interior y con todo nues? tro corazon $\{$ aquellas personas que no pueden $\delta$ no quieren comprender nuestro recreo.

Hay tanta divergencia de opiniones respecto á la mejor subdivision de este órden, el mas rico de todos en especies, y cuya descripcion habré de condensar mas que la de los otros, que puede decirse que cada naturalista algo independiente en sus trabajos sigue su sisterna propio y particular. Todas las tentativas hechas pam Ulegar á la adopcion de un sistema comun han quedado sin resultado, y es que todavia nos hallamos muy léjos de conocer los paserinos ó pájaros to bastante para hacer desaparecer todas las dudas respecto á sus afinidades. Algunos autores admiten la division del órden en dos sub-órdenes, los paserinos ó pájaros cantores y los grita. dores, segun que tienen desarrollados ó no los músculos de canto de la laringe inferior. A pesar de no cstar convencido, ni mucho menos, de la necesidad de tal separacion, adoptaré tatnbien este método cn mi descripcion.

\section{LOS PÁJAROS CANTORES- OSCINES}

CARACTÉRES. - Este șub-órden, que comprende la ma yoria de los paserinos, se caracteriza por el completu desarroilo de la laringe, provista casi siempre de cinco pares de músculos repartidos entre la parte anterior y la posterior. Las especies de este grupo se reconocen exteriormente por tener la primera de las diez rémiges de la mano corta, ó atrofiada, ó suprimida del todo; despues por el tarso cubierto por delante de grandes placas completamente confundidas, $y$ lateralmente por una placa en una sola pieza.

\section{LOS TURDIFORMES- RHACNEMIDID压}

CARACTÉRES.-Siguiendo el método de Cabanis, colocaré esta familia de paserinos en primera linea Se distinguen por su cuerpo vigoroso y cabeza grande; el pico regular, recto, un tanto comprimido lateralmente, suavemente encorvado en la parte superior, sin que pase de la punta de la mandibula inferior, y con una escotadura insignificante hácia la punta; cl tarso alto con dedos medianos y uñas visi. blemente corvas; alas de regular longitud, de cuyas diez rémiges primarias ta tercera es la mas larga, y la primera nota. ble por lo corta; y por el plumaje abundante, que por lo regular se compone de plumas relativamente grandes, blandas $y$ de color oscuro en la mayor parte de los casos.

USOS, COSTUMBRES Y REGIMEN. - LOS paseri. nos turdiformes, de los cuales se conocen á poca diferencia unas trescientas setenta y cinco especies, se encuentran dise-
Ininados por todo nuestro planeta; habitan todas las zonas, altitudes y latitudes asi como las localidades mas distintas, si bien en su gran mayoría son silvicolas. Como carácter distintivo de ellos diré que la mayor parte pasan mucho tiempo en tierra, tanto si está cubierta de vegetacion como de guijarros $\delta$ peñas, expuesta á los rayos ardientes del sol ó umbrosa. Adnirablemente dotados por la naturaleza, se cap. tan nuestras simpatias principalmente por su magnifico canto, sin contar su utilidad manifiesta, que los hace merecedores de la benevolencia con que se los mira por lo general. Su alimento consiste en insectos, particularmente larvas, gusanos y lombrices de tierra ó animalillos acuáticos en la mayor extension de la palabra, y de bayas de diferentes clases en el tiempo de la madurez de la fruta, por cuya razon son casi todas las especies que habitan latitudes elevadas aves de paso que desaparecen mas ó menos pronto en otoño, y que vuelven en la primavera para dedicarse a la reproduccion tan luego como se han insialado en sus cuarteles de verano. El nido y los huevos difieren tanto que es dificil decir algo comun á todos, sucediendo lo propio respecto á su manera de criar.

ENEMigOS. - Todas las rapaces que habitan las mismas localidades que ellos son sus enemigos, agregándose á ellas el hombre que es sin disputa el mas perjudicial de todos, no precisamente porque los coge grandes ó pequeños pasa tenerlos en jaula, $\delta$ para comerlos, ni porąue roba sus hue. vos, sino porque reduce sin cesar los sitios donde pueden habitar. No es el naturalista ni el aficionado inteligente que mata ó coge túrdidos para el fin que se propone, quienes disminuyen su número, sino el agricultor y silviculior que arrancan cada mata, vallado, cerca y matorral para roturar el terreno, cambiar el monte en tierra labrantia, $\delta$ en el caso mas favorable en monte cultivado sistemáticamente. No es ningún delito tener túrdidos cautivos con tal q̨ue se sepa cuidarlós convenientemente; antes al contrario esta costumbre sejustifica porquec estas aves son los compañeros mas agrada. b!es que puede adquirir el hombre condenado á vivir en su habitacion. Cogidos en tiempo oportuno y cuidados con esmero, se habitúan pronto à la pérdida de su libertad, cobran gran carino á su amo y se lo demuestran por todos estilos, en to. das las ocasiones; manifiestan tristeza cuando le echan de menos, jübilo cuando le ven venir, en una palabra, entran en relaciones verdaderamente intimas con el hombre; mas para que se conserven en la cautividad hay que cuidarlos, observarlos y entenderlos, y gor esta razon la persona que quiera robar un túrdido 6 un ruiseñor al monte y al público, deberia aprender antes de un pajarero experimentado a cuidarlos y poseer el verdadero amor y paciencia indispensables para tener aves, porque sin estas condiciones no solamente quita. rá la libertad sino la vida a un sér tan noble. Én este caso quien peca es tambien el ignorante $;$ no el alicionado inte. ligente.

\section{LOS HUMICOLINOS - HUMICOLINA}

CaraCtéres.--Para facilitar el estudio de los turdi. formes se divide la familia en grupos que merecen cl nombre de sub-íamilias, siendo la presente una de ellas. Las especies. que á ella pertenecen se distinguen por su estructura compa. rativamente esbelta, su pico en forma de lezna, tarsos altos, alas bastante cortas, cola casi siempre mediana, y el plumaje liso y segun el sexo ó muy poco ó extraordinariamente va. riable.

DISTRIBUCION GEOGRÁFICA. - Los humicolinos habitan con preferencia el antiguo continente, especialmente la parte situada al norte.

USOS, COSTUMBRES Y RÉGIMEN.-Establecense 
cstas aves en el monte bajo y en los matorrales. Bien dotadas por todos conceptos, son sobre todo excelentes cantoras. Se alimentan principalmente de insectos, establecen su nido en e! suelo ó i poca altura, y ponen huevos blancos ó mas con manchas muy tenues.

\section{LOS RUISEÑORES-LUSCINIA}

CARACTÉRES.-El primer lugar en la sub.familia hum cola corresponde a los ruisenores. Se caracterizan por su forma esbelta; pico casi recto, bastante oblongo, un tanto ensanchado en la base, puntiagudo y en forma de lezna; tarsos altos y robustos; alas de mediana longitud; cola reguiar y redondeada y plumaje relativamente escaso y de coloracion igual en ambos sexos.

\section{EL RUISEÑOR COMUN-LUSCINIA VERA}

CARACTERES. - Nuesiro ruiseñor, cuya celebridad remonta á los tiempos mas remotos, se describe en pocas palabras.

Tiene la parte superior del cuerpo de un gris rojo, con la coronilla y el lomo algo mas oscuros quue lo demás; la parte inferior es de un gris amarillento claro: la garganta y el cen. tro del pecho es de un tinte mas pálido; las barbas externas de las rémiges de un pardo oscuro; las rectrices de un pardo rojo orin.

El ojo es pardo rojizo, y el pico y las patas del mismo color algo agrisado. Los pequeños presentan manchas sobre

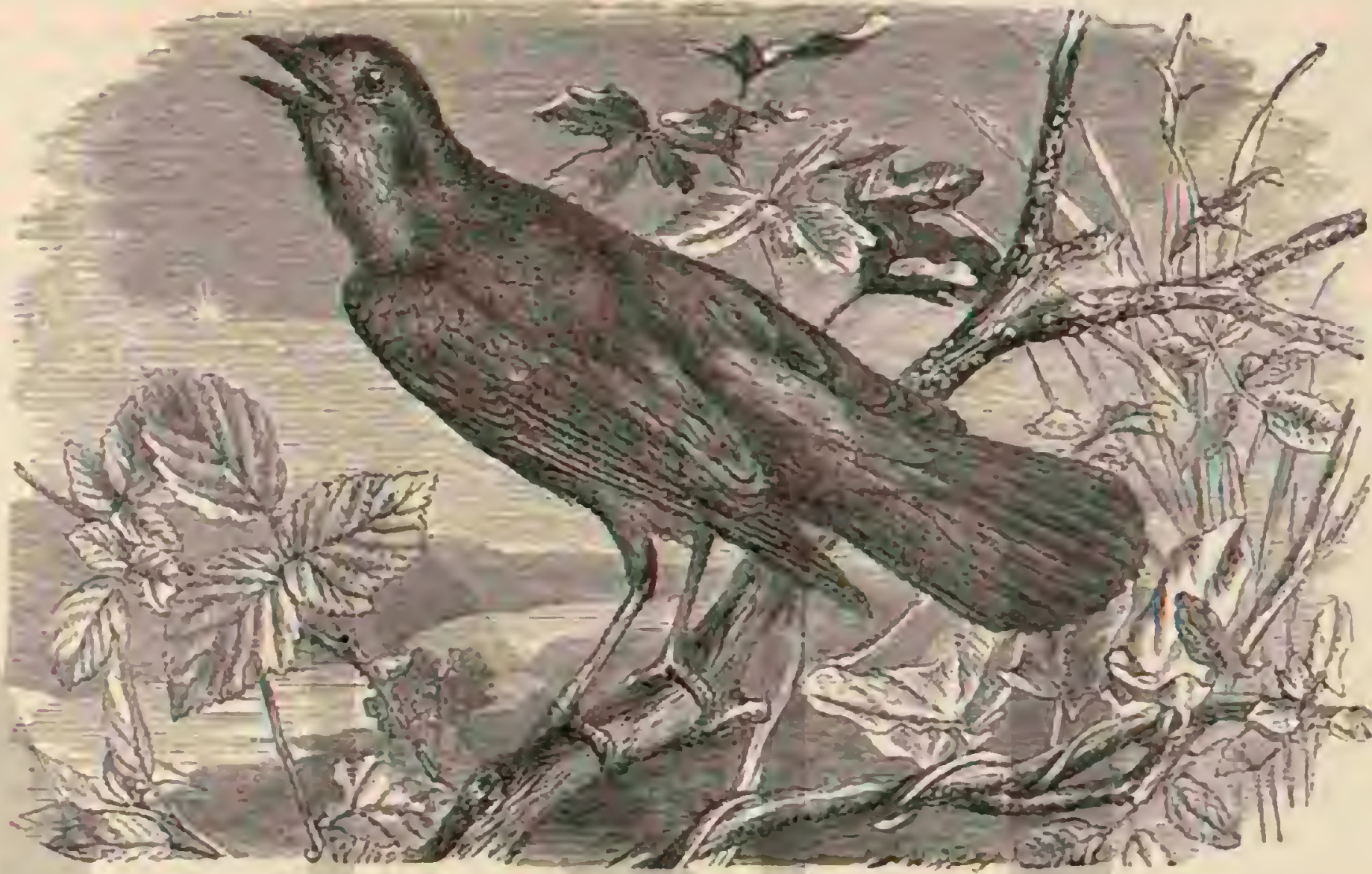

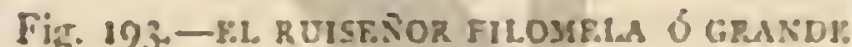

fondo gris pardusco tirando á rojizo á causa de las manchas amarillas claras de los tallos de las plumas y de los filetes negruzcos de la cara superior de las barbas. Miden ()$^{n}, 1 ;$ de largo; $11^{\circ}, 25$ de punta á punta de ala; esta plegada $11^{\circ}, 08$ y la cola 11",07. La hembra es aigo mas pequeria que el macho.

\section{EL RUISEÑOR GRANDE - LUSCINIA PHILO-} MELA

CARACTÉRES. - Es mayor, y sobre todo mas fornida que la especie anterior, aunque en lo demás muy semejante. Sus caractéres mas notables se hallan en la primera rémige que es mucho mas corta que la otra, y en la parte superior del pecho, que tiene manchas escamosas. Su longitud es de $11^{\circ}, 19$, el ancho de punta í punta de ala mide unos $\left(1^{21}, 28\right.$, el ala plegada $11^{\circ}, 09$ y la cola $11^{\prime \prime}, 08$.

Fucra de estas dos especies se han cstablecido recientemente alyunas otras.

\section{EL RUISEÑOR HIBRIDO-LUSCINIA HX- BRIDA}

CARACTÉRES. - Tiene el tamaño de la especie anterior, y como ella la primera réarige corta y la colomcion de la parte superior parda. La inferior es casi idéntica á la espe. cie comun. Vive en Polonia.

\section{EL RUISEŃOR DE LAS ESTEPAS-LUSCINIA GOLTZII}

CARACTERES, - Difiere de nuestro ruiseñor comun en su mayor talla y en tener la segunda rémige relativatuente corta. La parte superiar presenta un tinte pardo rojizo bien marcado, y las plumas carecen del fileic exterior pardo rojizo.

\section{EL RUISEÑOR DE HÁFIZ Ó DE PERSIA- LUSCINIA HAFIZII}

CARACTERES. - Dicen que se caracteriza por su cola mas larga y coloracion mas pálida.

DISTRIBUCION GEOGRÁFICA DE LOS RUISEÑORES. - Haciendo caso orniso de las tres últimas especies mas ó menus dudosas, puede decirsc lo siguiente respecto d́ la dispersion de las especies comun y grande. La primera anida desde Inglaterra (exceptuando la Liscocia é Irlanda) en toda la Europa occidental, central y meridional. Es rara en Suecia, pero comun en la Alemania septenirional al oeste del Peene $y$ en la central y meridional, pero en las localidades á propósito. Es numcrosa en Hungria, Eslavonia, Croacia, Austria alta y baja, Moravia, Bohemia, y comun en las tres peninsulas meridionales. No parece extenderse mucho mas como ave anidadora ni hácia el este ni hảcia el sur; si bicn se encuentra todavia con bastante frecuencia en la primera 
direccion, en la Rusia meridional, Crimea, Cáucaso, Asia Menor y Palestina, mientras que en el sur no pasa de la cordillera del Atlas. Prefiere la llanum, si bien no se aleja enteramente de las montañas con tal que no carezcan de monte alto ó bajo algo frondoso. En la Suiza no es ave excesivamente rara, segun Tschudi, à los mil metros sobre el nivel del mar: y en España es comun hasta á esta misma altura y aun á mil seiscientos metros, segun yo mismo he observado. Busca los tallares bajos, las brenas inmediatas á los estanques ó corrientes de agua, y los jardines: alli es donde viven estas aves, una pareja junto à otra, pero conservando cada cual su dominio, donde no permite la permanencia á ningun intruso. Son muy numerosos los ruiseñores en las 10. calidades donde cncientmi suficiente alimento; abundan en Alemania, y mas aun en el mediodia de Europa, dondé me admirb́ ver cuântos habitan un mismo iardin. No exagera. mos, por ejemplo, al decir que en Espana se encuentra una pareja en cada matorral j en cada vallado. Una mañana de primasera en el Monserrat, ó un paseo por la tarde en los jardines de la Alhambra, son cosas que no puede olvidar nunca aquel que tenga oidos; percibese á la vez el canto de centenares de ruiseñoses, y se ose resonar su voz por doquiema roda la Sierra Morena tan dilatada y cubierta de verdor puede considerarse como un solo jardin poblado de aquellas aves, y no se comprende cómo en el reducido espacio que tiene cada pareja encuentran estos roraces séres con qué ali. mentarse â sil y \& su progenie.

1.o mismo pucdo decir, por mis propias obsernciones, de la Hungria meridional, donde parece ir suplantancio al rui señor 'grande, y no sulamente en' ha sierra, como ya era sabido, sino tambien en el valle del Danubio.

El area de dispersion de la especie mayor es limitrofe \& la anterior por el lado del norte y del este. Es el ruiseñor mas frecuente en Dinamarca y el ínico que se encuentra en İs. candinavia, Ia Pomerania oriental y en toda la Rusia sep tentrional y central; reemplaza aे su congénere en Polonia y acaso tambien en la Falitzia austriaca; se encuentra todavia, aunque muy aisladamente, en el centro del salle del Danubio desde Viéna abajo, presentándose tambien al otro lado del Ural en todos los valles de los rios que atraviesan las estepas de la Siberia occidental, donde cabalmente ha conservado toda la purca, plenitudy variedad de su canto, deleitando el oido del viajero con las mismas estrofas que entusiasmaron á nuestros mas remotos antepasados.

Ambas especies emigran en invierno al Africa central y occidental, $y$ el ruiseñor grande probablemente tambien a los paises meridionales de Asia.

USOS, COSTUMBRES Y REGIMEN.-El ruiseñor comun y el grande concuerdan tanto en los rasgos principales de su género de vida, que la descripcion de las cos. tumbres del uno puede aplicarse casi en un todo al otro: y por esta razon hablaré en lo que sigue principalmente de la especic comun.

All donde el ruiseñor no tiene nada que temer del hom bre, se fija hasta cerca de las casas y no se muestra timido, sino atrevido mas bien, ! por esto se le puede observar mas fícilmente.

Segun Naumann, cuya acabada descripcion tomare por guia, se mueve siempre con cierta dignidad y su aspecto es altivo, distinguiéndose por esto de todas nuestras demás aves cantoras indigenas. Diriase que comprende su mérito; es con. fiada con el hombre; establécese cerca de su morada, y se distingue por sus costumbres tranquilas y pacificas. Vive en perfecta armonia con las otras aves, y rara vez pelea con sus semejantes. Por lo regular se le ve posado en una rama con el cuerpo-derecho, levantada la cola y las alas colganies, cuyas puntas vienen á caer debajo de la cola; rara vez salta cntre el ramaje, pero en tierra lo hace ligeramente, y hasta podria decirse que brinca, dándose atonos como dice Nau. mann, descansando \& cada momento. Si alguna cosa llama su atencion levanta bruscamente la cola, movimiento que repite continuamente: su ruelo es ligero, rípido, ondulado, vacilante por momentos y no muy sostenido. El ave pasa volando de un matorml á otro, $y$ durante el dia no franquea jamás un gran espacio descubierto. Cuando dos machos se persiguen, es cuando mejor se puede juzgar de la ligereza de su vuelo.

El grito de llamada del ruisenoor es un wiid claro, seguido comunmente de un sonido áspero que puede expresarse por korr; cuando se espanta repite el siid varias veces seguidas, y solo una grita karr; si está enojado produce la frase tí, y si contento deja oir una nota sonora que se traduce por tak. Los pequeños gritan al principio fiid y mas tarde kruek: estos sonidos, pronunciados con entonaciones diversas, que a menudo no podemos percibir, tiene cada cual su significado.

El canto del ruiseñor que ha valido á csta ave el afecto del hombre, y que excede en armonia y variedad al de to. das las demás aves exceptuando sus congéneres, es como dice acertadamente Naumann, tan extraordinario y particular, tiene una plenitud de tonos y una armonia tan $\mathrm{cm}$ belesadora junto con una diversidad tan agradable de fra. ses, que no hay ave alguna que pueda imitarlo. Las irases son dulces: los trinos y las notas plañideras y alegres alter. nan con una gracia indescriptible. El ave comienza suave. mente, y poco \& poco se robustece su roz para extinguirse despues de una manera insensible; otra lanza notas fuertes y llenas con singular ardimiento; una tercera combina agra. dablemente los sonidos tiernos y melancólicos con las notas alegres y de triunfo; las pausas y la medida contribuyen a realzar mas la belleza del canto. Nunca se admirará lo bas. tante su fuerza y plenitud; no se comprende cómo un ave tan pequeña puede emitir notas tan sonoras, ni cómo los músculos laringeos están dotndos de tal vigor; y en efecto la sonoridad es tal algunas reces, que hace daño al oido.

Para que un ruiseñor cante bien, debe emitir de veinte s veinticuatro frases; pero muchas tienen un círculo de varia. ciones menos extenso, sienỏo de advertir que la localidad influye tambien mucho. I.os ruiseñores jóvenes no aprenden sino con los viejos que habitan los mismos parajes, $y$ de aqui resulta que en un canton habrả excelentes cantores, mientras que en otro serin medianos. I.os machos viejos cantan mejor que los jóvenes, pues aun en las aves necesita el arte práctica para desarroliarse. Cuando está en celo, son mas ricos los sonidos que producc el ruiseñor, $y$ hace de su canto un arma con la que procuna cclipsar a sus rivales, A los unos se les oye principalmente de noche; álos otros solo de dia. Durante la primera embriaguez del amor, antes de la postura de los huevos, se oye su canto delicioso á todas las horas de la noche; luego guarda silencio el ave; parece haber encontrado el reposo y vuclve á comenzar su vida or. dinaria.

El ruisefior comun difiere del filomela por su roz: su grito de llaniada puede expresarse por sinek-arir, en vez de aubiobkacr. Las notas de su canto son mas bajas, mas lentas y sostenidas, y las pausas mas largas; el canto es mas robusto y clangoroso, pero menos variado que el de la segunda especie, aunque vale tanto como él, y hasta es preferido por al. gúnos aficionados que con mucha razon tienen por incomparables esos sonidos semejantes á un campanilleo. Mc parece que Graessner pinta mejor que nadie la diferencia que hay entre el canto del ruiseñor comun y el del mayor. 
-Fn cuanto he podido deducir del canto de una yo oira es. pecie, considero como principio fijo que el ruiseñor comun, aunque fuese el primer artista de toda su especie, canta repitiendo siempre un numero de frases fijas si bien variando su órden y compás, segun su disposicion del momento y se. gun la hora mas $\delta$ menos adelantada del dia $\delta$ de la noche, mientras que un buen ruiserior grande introduce tantas variaciones en sus frases que es imposible fijar una sucesion determinada de tonos.

* Si se compara el canto de la especie comun con un morivo determinado lleno de intercalaciones y cambios de tonos, se parccerá el de la especie mayor a un recitado en el cual el compositor ha dejado al cantor en completa libertad de in. terpretarlo, libertad de que hace el ave todo el uso posible; cambiando el pequeño artista tan maravillosamente una misma pieza á cada repeticion, que a menudo es imposible reconocerla si el are se halla en disposicion favorable. Claro es que la impresion es siempre mayor cuando uno oje subi. tamente tonos, compases y frases enteramente diferentes de los que esperaba. Por esta razon prefiero la especie grande at la comun, porque el primero no es solamente cantor, sino tambien compositor que sabe variar â voluntad, segun la disposicion en que se encuentra, los tonos que posee.

Los ruiseñores se alimentan de lombrices de tierra de toda especie, larvas de insectos, hormigas y orugas: en el otono comen bayas: recogen su alimento en el suelo, y acuden tan pronto como se socava ó se escarba: rara vez se les ve cazar insectus al ruelo; cada vez que cogen una presa levantan bruscamente la cola.

Estas aves llegan á nuestros países en la segunda mitad del mes de abril, un poco antes 6 mas tarde, segun la temperatura. Aparecen poco á poco, cuando el ogiacanto comienza á cubrirse de hojaj viajan aisladamente y de noche; los machos preceden a las hembras. Algunas veces se ve â primera hora de la manana algun individuo en el aire, á gran altura: de repente baja, se posa sobre un arbolito ó mata § perma. nece oculio todo el dia: por lo regular se le oje antes de verle. Cinda cual busca el sitio del bosque, el matorral ó el jardin donde vivió el año anterior; los machos jóvenes eligen en el canton donde nacieron un lugar conveniente para ijjarse.

Apenas llegan comienzan á cantar, y durante las primeras noches no cesan, sin duda con el objeto de indicar a la hem bra el camino que debe seguir para encontrarlos; 0 acaso tambien procedan así a fin de adquirir una companera. Por último, se verifica el apareamiento, mas no sin percances y sin luchas; los machos célibes hacen todos sus esluerzos para robar á los demás sus hembras; a menudo pelean dos rivales furiosamente; persiguense encarnizados en usedio del ramaje; en la copa de los árbotes ó en tierra, y caen uno sobre otro hasta que alguno de ellos queda duerio del campo de batalla y de la hembra. La nuche, la tarde y la mañana son las ho. ras que el macho consagra al canto, mientras que su compa. hern le escucha con placer: destinan el resto del tiempo á buscar de comer, y bien pronto comienzan á fabricar la cuna de sus hijuelos.

- Su nido no es en rigor una obra artistica: constituye ef fondo una capa de hojarasca, con preferencia de hojas de roble; las paredes se componen de rastrojo seco, tallos de jerbas y hojas de cana; la cavidad está cubierta de raices finas, crines de caballo y pelusilla de ciertas plantas: rara vez se compone el armazon de ramas fucrtes, ni tiene tampoco las paredes de paja. Dice Paessler que el nido del gran ruiseñor es mas grueso, y que la cavidad está tapizada de una capa de pelos mas abundante; pero las dos especies anidan sobre el suelo ó a poca altura, en algun agujero, en medio de las ra- mas tiernas de un tronco, en un matorral ó en una mata, si bien se han observado algunas excepciones Naumann vió un ruiseñor que habia formado su nido en un monton de yerbas secas, en el interior de un pabellon de jardin; y Du. bois encontró otro que habia construido el sujo sobre un nido de reyezuelo, en la rama de un abeto, a la altura de metro $y$ medio de la tierra.

La hembra pone de cuatro à seis huevos que tienen en la especie comun $6^{\circ}, 02$ I de largo y $\left(1^{\circ}, 015\right.$ en su major grueso y en la major respectivarnentc $0^{\circ}, 023 y^{\circ} \|^{\circ}, 016$; en lo demás se parecen mucho; la cáscara es muy fina y lisa, de un brillo mate $y$ de un color entre gris, pardo y verdoso por lo regular uniforme, y á veces con manchas confusas algo mas oscurns.

Cuando la hembra los ha puesto todos, cambia el macho de género de vida: comparte los cuidados de la incubacion; reemplaza á su hembra durante algunas horas hácia el medio dia, y no se le oje cantar sino de dia; vela cuidadosainente sobre su nido yobliga a su compañera á cubrir. Paessler ahuyentó un dia á cierta hembra que cubria sus huevos; el macho interrumpió al instante su canto, precipitóse sobre ella, lanzando gritos de cólera, y la picoteó hasta obligarla á volver á su nido. Cuando un enemigo se acerca se ve à los ruiseñores inquietos y agitados; pero dan pruebas de valor y abnegacion, exponiéndose ellos mismos por salvar à su progenie.

Los pequeños se alimentan de gusanos de toda especie, crecen muy pronto y abandonan cl nido cuando apenas pueden revolotear de mma en rama, permaneciendo con sus padres hasta la primera muda. La hembra solo pone dos reces cuando se pierde la primera pollada la ensenianza de los péquerios ocupa á los padres hasta fines de la estacion, y no los abandonan aunque se los arrebaten, pudiéndose por lo tanto ponerlos en una jaula, que se coloca cerca del nido, con la seguridad de que macho y hembra les darán de comer.

Poco tiempo despues de haber comenzado á volar, comienzan a ensayar su voz los machos jỏvenes, $\delta$ a componer, segun dicen los inteligerites; pero su primer canto no se parece en nada al del padre, si bien es verdad que este último se calla cuando los hijuelos comienzan á dejar oir su voz: sabido es, en efecto, que hácia el dia de San Juan no cantan ya los ruiseñores. A la primavera siguiente no han aprendido todavia los jóvenes cantores: producen sonidos cortos, y pronunciados en cierto modo a la sordina: es preciso que el amor se despierte en ellos y les embriague con sus trasplortes para que desplieguen todas las riquezas de su roz.

En el mes de julio se verifica la muda de los ruisenores y luego se dispersa la familia; en setiembre se reunen de nuevo vicjos y jovenes, algunas veces por bandadas muy numerosas, á fin de emprender sus viajes. Caminan con ligereza y van léjos; peto en el extranjero se les ve poco; jo no encontré mas que algunos, y siempre aislados, en los bosques del sur y del Sudan oriental.

Los ruiseñores, sobre todo los jóvenes, se hallan expurestos á las asechanzas de numerosos enemigos, y por eso el hombie inteligente hace bien al crear condiciones con las que pucdan vivir y cantar seguros. En los grandes jardines es conveniente, como aconseja Lenz, plantar espesas cercas de frambuescros, por ejemplo, dejando que se amontonen las hojas secas, pues bien pronto llegarản los ruisenoores á fijarse; los tallares les pro. tegen, pues en la hojarasca que cae se reunen los gusanos y los insectos de que se alimenta cl ave, siendo además dificil que se deslice alli un enemigo silenciosamente.

CAUTIVIDAD. - Las gentes ignorantes ó malignas son mas temibles aun para el ruiseñor quc los carniceros y las rapaces. A pesar de su natural prudencia, estas aves quedan cogidas en las trampas y los lazos mas toscos, y entonces 
deben sufrir todas las miserias de la cautividad. Por muchos cuidados que se prodiguen á los ruiseñores viejos que se han apareado ya, perecen seguraniente cuanco se les enjaula; los jóvenes solo resisten el cautiverio si se les atiende mucho. Quiero pasar por alto los principios que han de seguirse para conservar ruisenores en jaula: pues aquellos de mis lectores que tengan rocacion para cllo encontrarán en mi obra Aies coutizas todo lo que les interesa, y mas detallado y exacto que en ninguna otra parte. En aquellos puntos dondellegada la primavera se puede oir cantar a los ruiscnores desde la puerta ó la ventana, es incitil tenerlos en jaula; pero dejemos quue cuiden su ruiseñor, sin criticarlo, a las personas á quie. nes su carrera y destino condenan $\$$ vivir entre paredes ó que no tienen resolucion ni tiempo para ir a escuchar at aire libre el canto incomparable de filoniena.

\section{LOS CUELLOS AZULES - CYANE-} CULA

CARACTERES. - Este género, muy afine del anterior, se distingue por el cuerpo prolongado; las alas cortas y muy obtusas, con la tercera y cuarta rémiges de igual longitud; la cola de mediana extension iguai y de dos colores; los tarsos altos, raquiticos, y casi del todo cúbiertos en su cara anterior por una gran escama; el pico mediano, comprimido delante de las fosas nasales, con la arista alta y bastante viva, la pun. ta it mancra de lezna; el plumaje es lacio, sus colores varian segun la edad y el sexo.

Mi padre fué el primero en dejar sentado que todos los diversos cuellos azules que se ven en Alemania eran otras tantas esnecies distintas. Verdad es que las diferencias son insignincantes, pero acompañadas además de determinadas ireas de dispersion, justifican as mi modo de ver la separacion hecha por ni padre.

Para la mejor comprension de este género empezaré por describir la coloracion de todas sus especies. En todas cllas tiene el macho el loma de color pardo ocre oscuro; el vientre blanco sucio, con manchas de un gris pardo en los lados y parte trascra; la garganta de un hermoso azul celeste con sin espejuelo, de diverso color en el centro, limitada inferiormente por una faja negra qué csta separada de una mancha pectoral semi-circular por un angosto filete de color claro. Sobre el ojo tiene una ceja blanquizca unida en el centro de la frente; la linca maso-ocular es negruzca; las rémiges de un gris pardo; las rectrices, excepto las del medio, de un pardo negro, de un rojo vivo en su mitad basilar y de un pardo oscuro hácia la punta; el ojo tiene este último color; el pico es negro; las patas de un gris verdoso por delante $y$ de un gris amarillento por detrús.

En las hembras todos los matices son mas pálidos, y apenas esta indicado el color de la garganta.

Los perzueños ienen el lomo de color oscuro, con manchas de un amarillo rojo; el vientre es listado longitudinalmente y la garganta blanquizca.

La longitud es foco mas 6 menos de ()$^{m}, 15 ;$ el ancho de punta á punta de ala $0^{m}, 22$; el ala plegada mide $t^{*}, 07$ y la cola $1^{\circ}, 06$.

Hé aqui la coloracion de la garganta, en las diferentes es. pecies, conso el mejor medio de distinguirlas:

\section{EL CUELLO AZUL SUECO-CYANECULA SUECICA}

CARACTÉRES. - Tiene en el centro del campo azul de la garganta una estrella color de canela rojizo.

\section{EL CUELLO AZUL DE ESPEJUELO BLANCO - CYANECULA LEUCOCYANA}

CARACTÉRES. - Tiene la estrella blanca en el azul de la garganta (fig. 194).

\section{EL CUELLO AZUL SENCILLO - CYANECULA WOLFII}

CARACTERES. - No tiene estrella ninguna.

Esias especies difieren tambien por la talla: la de garganta azul con espejuelo blanco es la mayor y mas fuerte, y la de Wolf la mas pequeña.

Las hembras se asemejan de tal modo á los machos, que es muy dificil distinguirlas.

Algunos autores han creido observar en individuos cautivos que en los de la especie de espejuelo blanco llegaba a ser ia garganta completamente azul, formándose despues una estre. lla blanca; y han creido poder deducir que dos especies, por lo merros, no formaban sino una. Sin embargo, aun admitiendo comó exacta esta observacion, no por eso será el cuello azul de espejuelo blanco menos distinto del sueco; en todo el norte de Europa y de Asia existe esta especie sola, y no se ha encontrado todavia ningun individuo que forme iránsito entre ella a la de garganta enteramente azul ó de mancha blanca.

Inútil es, por otra parte, insistir mas sobre la existencia de estas aves, como especies 6 variedades, pues todas tienen los mismos usos 6 idénticas costumbres.

DISTRIBUCION GEOGRÁ FICA:- Los cuellos azules son propios del norte del antiguo continente, y se extienden desde alli hasta el sur del Asia y el norte de Africa.

El cuello azul sueco habita dentro del área indicada du. rante la época de su reproduccion, con preferencia, cuando no exclusivamente, en Suecia, por cuya razon le he dado el calificativo de aquel pais; no cria por lo tanto en Alemania, pero si y en grandisimo número en el norte de Escandinavia, Rusia, Finlandia y Siberia En cambio pertenece mas al mediodia y al occidente la especie de espejuelo blanco que no anida en los paises que acabo de citar, pero si en toda la Alemania septentrional, especialmente en Pomerania, la Mar. ca, Sajonia, Anhait, Brunsvick, Meklemburgo, Hannover y Holanda. El cuello azul sencillo habita al parecer comarcas mas elevidas, no anida en Alemania, ni se le ha visto anidar en ninguna parte á lo que yo sepa. Todas las especies atraviesan en su emigracion la Alemania, la Europa meridional, el Africa septentrional y central, $y$ las de manchita rojiza además el Asia central y meridional, lo que les obliga a pasar cordilleras de cinco mil metros de elevacion at fin de estable. cer sus cuarteles de invierno en la India y otros paises meridionales. I legan á nuestro pais á principios de abril, rara vez anies, y mas comunmente a mediados de dicho mes, y parten para el mediodia en setiembre.

USOS, COSTUMBRES Y REGIMEN. - LoS cuellos azules viven en nuestro pais a orillas de los arroyos, de los rios, de los lagos y de los estanques cubiertos de matorral, yerba 6 cañas; en el norte-frecuentan los pantanos y las turberas conociòs con el nombre de furdirn; llegado cl inviemo se albergan en jardines, matormles, campos, praderas cubiertas de altas yerbas y pantanos de mucha agua. En sus emigraciones no recorren tanto espacio como las demás aves cantoras: pasan el invierno en el Egipto bajo y central, en el centro de la China y en el norte de la India; pero hay algunas que llegan hasta las partes mas meridionales de este líltimo pais, ó a los bosques de la corriente superior del Nilo. En sus viajes siguen ciertas rutas que parecen como trazadas 
de antemano; costean los valles y se detienen en puntos da. dos donde hacen alto para descansar. Por la primavera llegan los machos antes que has hembras; en el o:onio van en com. pania jóvenes y adultos: viajan á lo largo de las corrientes de agua en la primera de dichas estaciones, y en la segunda cruzan el pais sin seguir estas sendas naturales, descansando de dia en los campos no segados aun, y encontrándose, aun. q̧ue aisladamente, hasta en el desierto.

Durante el verano no buscan esias ares mas que una cosa, á saber, un espeso matorral cerca del agua; asi es quıe en Alemania evitan los de mancha blanca las montañas, mientras que en Noruega se encuentra la especie sueca en ellas principalmente; frecuentan los Fjelds, ó sea las altas mesetas del pais, donde encuentran lagos y estanques, unos junto a oiros, enlazados por numerosos arroyos, todo lo cual consti. tuye para aquellas aves un rerdadero paraiso. En Alemania no las remos reproducirse sino en localidades que ofrecen condiciones anślogas, las cuales no escasean en los valles del país.

Los cuellos azules son unas bonitas aves que con frecuencia llaman la aiencion del observador; su belleza, y mas aun su manera de vivir, sus usos, costumbres y movimientos, nos seducen y cautivan. A la manera de ia mayor parte de los humicolas, están admirablemente dotados por todos conceptos: en tierra se distinguen por su agilicad; no andan, sino que saltan: pero tan precipitadamente, que se crecria verlos correr. Poco les importa estar en un terreno seco ó cenagoso, en un lugar descubierto, en el mas espeso matorral, $\delta$ en medio de las mas enmarañadas jerbas, pues do quiera que se hallen se mueren con riveza. Saltan poco por las ramas;

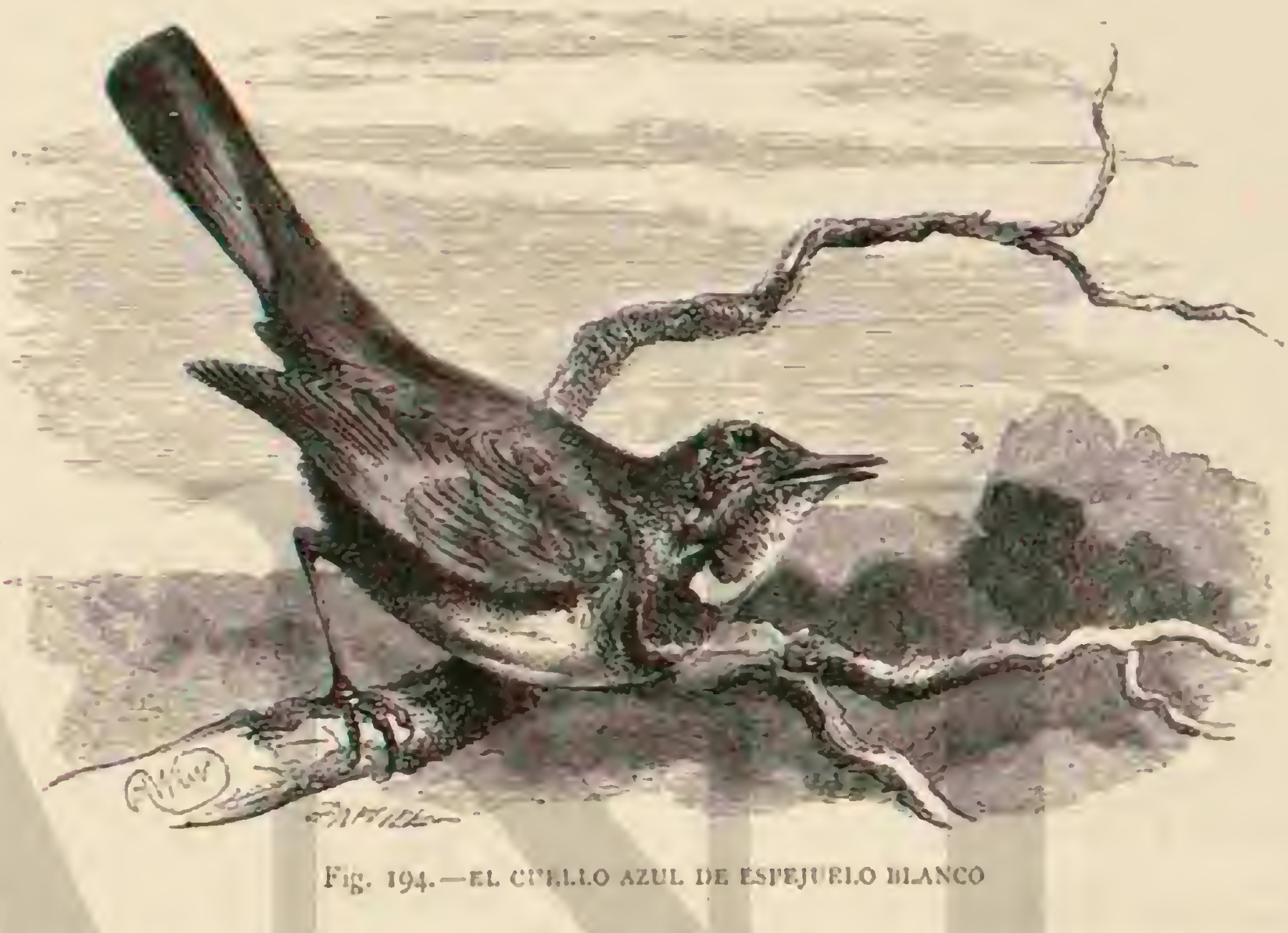

vuelan comunmente para pasar de una a otra, jescansan algun tiempo cuando se posan. En tierra están con el çuerpo derecho y la cola levantada, lo cual les comunica cicrto aire de osadia y altivez; posados sobre una rama no producen tan agraciable impresion. Vuelan rápidanente trazando arcos de circulo mas ó menos extensos; pero no suelen tecorrer de una vez gran espacio. No se remontan comuninente mas que a varios inctros sobre el suelo; apenas divisan un sitio oculto, bajan sa tierra para continuar su camino corricndo.

Sus sentidos alcanzan poco mas ó menos el mismo desarrollo que los del ruiseñor; su inteligencia no es menos perfecta. Conummente se muestran poco tímidos y recelosos con el hombre: pero cuando se les ha jerseguido cobran micdo y son prudentes: si no se les inquieta, distinguense por su viveza, alegria y locuacidad. Se llevan bien con las demás ares: son cariinosos con las de su especie; mas a veces degeneran sus juegos en sérins contiendas, sobre todo si entra por algo el anur ó la pasion de los celos. Dos machos se acometen, hichan con encamizamiento, y la pelea no acaba muchas veces sino con la muerte de uno de los rivales, lo que sucle suceder cuando habitan dos curllos azulès un mismo cuarto of jaula.

Tak tak es el grito de llamada de los cuellos azules, to mismo que el de otras aves cantoras; fred fied es el de ternura; una especie de chirrido indescriprible indica el de cólera. Segun las obserraciones hechas por mi padre, Naumann, Paesslery otres naturalistas, cada especie tiene un canto distinto: el cuello azul sencillo es la que canta mejor: la especie sueca es la que lo hace peor. «Su canto, dice Naumann, se comprore de algunas frases breves, emitidas á cortos intervalos: varias de ellas se reducen á unos sonidos agucios, suaves y muy agradables; pero desgraciadamente, el ave los repite demasiado antes de comenzar otro tema. Lo que ofrece de mas particular este canto, son los trinos, solo percepibles desde muy cerca y que se intercalan entre las otras notas, pareciendo que el are tiene dos roces Casi todos los ma. chos añaden a sus cantos varios sonidos $\delta$ frases enteras, propias de otras aves y hasta imitan gritos de animales que no tienen nada de cantores. Naumann, por ejemplo, ha oido a varios cuellos azules imitar el grito de la golondrina $y$ el de la calandria; el gorjeo del gortion y del finzon: frases enteras del ruisenor y' de ha curruca; el grito de la garra teal y. el canro de la rana. Esta facultad de imitar no pasó desapercibida para los lapones, quienes designaron al ave de sus paises con el nombre de asulor de las cien anees. Cuando el mácho canta está posado comuninente sobre un punto cleva. do, aunque á veces se deja oir timbien en tierra $;$ hasta cuando corre, $y$ desde el alba hasta entrada la noche; pero no acompaña entonces cada frase con un morimiento de cola, segun to hace al producir su grito de llamada.

Estas aves se alimentan de gusanos é insectos que encuen tran en los parajes acuáticos; en otono comen bayns. En las Tundras se alimenta la especie que las habita ciertas tempo. radas casi exclusivamente de mosquitos y de sus larvas. 
Siu nido está uculto ! no se descuhre fícilmente; siempre se halla cerca del agua, à orillas de un foso ó de un riachue lo. Segun Hinz el ave le sitúa constantemente al este $\delta$ al sur, en tierra, medio escondido en algun agujero, entre raices ó matas. Es basiante grande, siempre abierto plor arriba; consta exteriormente de hojas secas de sauce, de rastrojo y tallos de yerbas; en el interior hay o:ras mas finas, 6 peios $\mathrm{y}$ plumas. La hembra pone en mayo seis $\delta$ siete hueros de color azul verdoso pálido, cubiertos de puntos rojos pardos ó con manchas de este linte en la punta gruesa; son de cís. cara muy fira $y$ tiencr $0^{\circ}, 0: 0$ de largo por $0^{\circ}, 0,6$ de ancha. La incubacion dura quince dias macho y hembra cubren alternativamente, nlinentando despries sus hijuelos con insectos 5 gusanos. I.os que abandomn el nido antes de po. der voine corren por el sueto con tanta ligereza como los ra tones, guiados y conducidos por sus padres. Si es favorable el rerano pone la hembra dos veces, segun parece.

La agilidad de esias aves y la maturaleza de los parajes que habitan las ponen a cubierto dé los ataques de los enemigos que amenazan a todas las demás aves cantoras. Los adultos, y con mucha mas frecuericia los hijuclas y los hue. ros, suden ser presa del zorro, de lus pequeños carnicuros que rastrean, y tambien de las ratas; estc viene a ser el único peligro a que se hallan expuestas las nves de que se trata.

CAzA.-Dificil es cazar los cuellos axules, pues saben ocultarse perfectamente: apenas reconacen el peligro, refigianse en los vallados ó en espesos matorrales, donde no los puede desculurir la vista del cazador; pero su glotoneria es a peces causa de su pérdida, y quedan presos en los mas toscos lazos que tienen por cebo gusanos de harina.

CAUTIVIDAD. - En toda pajarera constituyen estas aues un precioso idorno: bien cuidadas se domestican per. fectumente y pronto; por timidas y sálvajes que se inuestren al principio, cantan á porfia Solo pueden conservarse prodi gándolas los mas atentos cuidados.

\section{LOS CALIOPES-CALLIOPE}

CARACTERES. - I Ló caliopes son muy afines álas aves anteriores. Son cantores humicolas del Asia, de pico niedia namente largo y iverte, patas bastante altas: dedos grandes; alas medianas con la primera penna muy corta; cola corta tambien, ligeramente redondeada, de color uniforme y de rec trices laterales puntiagudas, mientras que las medins son re condeadas: el plumaje es liso y compacto.

\section{EL CALIOPE DEL KAMTSCHATKA-CA-} LLIOPE KAMTSCHATKENSIS

CARACTRRES. - De las dos especies que se conocen de este género, es la presente la mas importante, porque se la ha cogido repeidas veces en Europa, y pornque segun toda pro. babilidad habita al occidente del Lral, como tambien en el Cáracaso.

El caliope del Kamtschatha tiene el lomo pardo aceitunado; la cabeza y la frente del mismo matiz, pero mas oscuro; la cara inferior del cuerpo es de un blanco sucio, manchado en los lados de un tinte pardo accirunado; el centro del pecho blanco: por encima del ojo hay una fuja del mismo color; la linea que va del pico al ojo es negra; la garganta de un rojo rubf, rodeada de una faja gris pardo ó cie un gris ceniciento.

Los colores de la hembra son mas pálidos, y solo está in. dicada la mancha de la garganta.

Los pequeños se parecen á la madre. La longitud es de $\left(0^{\prime \prime}\right.$, I6, el ala plegada de $0^{\circ}$, oS y la cola de $0^{\circ}, 06$.
DISTRIBUCION GEOGRÁFiCA.-- El caliopetienesu residencia predilecta en las selvas claras del Asia septentrional, en los saucedales a lo largo de los rios, y en vallados y matorrales en terrenos húmedos. Tambien se presenta aisladamente, aunque tal vez en major número de lo que en el dia se supone, en el lado de acá del Ural, siendo asimismo posible que anide en distritos propicios de la Siberia occidental, á pesar de que mis esfuerzos por descubrirla alli hayan dado un resuliado negativo. Con todo, la patria verdadera del caliope principia al este del Obi, y solo en el Yenisci empiez.s esta ave graciosa á ser comun y frectiente Algunos individuos atraviesan tambien la Europj occidental en sus emigraciones primaverales y autumnales; dos que se han matado en Francia debian forzosamente haber atravesado la Alemania. En los distritos donde tiene costumbre de anidar, aparece en la se gunda mitad de mayo, rara vez antes, y permanece, segun Kittlitz, hasta principios de octubre, si bien algunos se ponen en viaje ya a fines de agosto. Su ruta pasa por la Mongolia, China uneridional, Japon, etc., hasta la India, á donde llega, segui dice Ierson, hácia noviembre. Swinhoc, que observó los caliopes en los alrededores de Pekin, donde son frecuen. tes, cree que pasan el invierno en China; pero lo mismo cuando los observó este naturalista que cuando los vió Kittlitz en Kamtschatka, fué en octubre.

Por su género de vida se asemejan los caliopes á los cue. llos azules y á los calamolérpidos, segun dicen los naturalis. tas que han podido observarlos vivos: Radde y Kitilitz los comparan con los primeros, y Swinhoe con los segundos. Buscan su alimento en el suelo, y segun parece, á la hora del crepúsculo, pues durante el dia salen de su retiro lo me. nos posibie. Corren con tanta o mayor agilidad que los cue. llos azules, y acaso son mas listos aun corriendo por los carricos que crecen junto á pantanos y en prados hámedos. Jerdon dice que son timidos, poco sociables y taciturnos: pero ia descripcion de Radde y la de Middendorf no confirman mas que la primera de estas cualidades. L.05 machos se van antes que las hembras, pero les gusta viajar juntos; y en sus paradas, en la primavera, ocultos en el follaje de los abedules, entonan su canto, lo mismo de dia que de noche, bastante agradable, y de timbre armonioso, segun Kittlitr; pero no muy rico de melodia. El caliope no pucde rivalizar con el ruisenor; mas á pesar de esto es entre las ares canto. res de la Siberia oriental indisputablemente una de las primeras. No empieza su canto con aquel chirrido seguido de algunas notas mas profundas; pues no produce, dice Radde, mas que notas de garganta semejantes at una ligera queja. A semejanza del ruiseñor, comienza por lanzar trés ó cuatro veces un grito que se puede traducit dim, fluego sigue un gorjeo bastante largo;, algo parecido al canto de la alondra; el caliope sabe chirriar, jero poco. Iin el mes de junio, cs decir, cuando estí en celo, ol macho cania mucho, sobre todo por la noche. Dybowsky dice: $x^{\circ}$ Thn pronto como des. aparece el sol del horizonte empiezan estas aves a caniar; al principio son pocas, pero su número crece, y aun dura el crepúsculo cuando llega á oidos del hombre que pernocia en los valles habitados por caliopes, i veces al lado mismo de las tiendas de campaña, y en todas las cercanías, el cauto agradable de estas aves, que dura, segun el éstado del tiém. po, hasta la mañana, jorque si llucre es muy raro oir cantar un caliope y lo mismo sucede cuando el cielo está nubla. do. Kittlitz dice que cuando el macho canta sucle prosarse en la copa de un abedul ó alamo pequeño. Dilata su gar ganta al cantar lo mismo que el ruiseñot, entreabriendo sus alas y levantando la cola en ángulo recto, como el cuello arul, aunque sin moverla: la hembra penmanece entre tanio oculta en la breira y no se deja ver jamás. 
Middendorf halló varios nidos en los alrededores del rio de 'laimyr: estaban todos en tierra, entre algunos troncos de sauces contrahechos, muy cerca del agua, $y$ siempre en sitios inundados en la primavera y cubictos despues de are ma y leña flotante. Fil nido del caliope es de construccion muy artistica: está descubierto por arriba y provisto de una galeria de entrada, abierta horizontalmente en la arena 1) bowsky dice que el nido tiene forma de choza con su abertura lateral, y que se compone en la parte exterior de yerbas secas y paludicas, y en el interior de otras mas finas, pero que todo es de una trabazon tan floja, que no puede levantarse ni guardarse sin perder su forma original. La puesta consiste en cinco huevos cura longitud varia de $U^{*}, 019$ i $0^{ \pm}, 021$, siendo el grueso de $6^{4,}, 015$ á ()$^{\circ}, 016$. La forma de estos huevos es tan variable como el tamaño, pudiendo ser oblunga, recogida $\delta$ abolagada; son un tanto brillantes y pre. sentan sobre fondo azul verdoso manchas pálidas, apenas visibles, de color de ladrillo, mas numerosas en un extremo que en el otro.

A fines de junio vió Middendorf caliopes que cubrian: Al acercarse cualquiera al nido, salia la hembra, pero no volando; corria å saltitos, y agachảndose hasta llegar al mon. ton de maderas floiantes mas próximo, desaparecia de la vis. ta. En agosto mató Kittlitz dos pequeños, cubicrtos aun con su primer plumaje.

CAUTIVIDAD. - El hung-po (petirojo) ó crins-po (cuello de oro), segun Jlaman al caliope en China, es el ave favorita de todos los aficionados. Con la red se coge con la misma facilidad que el cuello azul durante su época de paso, prin. cipalmente en mayo y setiembre que es cuando se venden en los mercados de la capital en gran numero. Se la conserva cautiva, mas no enjaulada, sino atada por el cuello a un lazo, cuyo extremo se sujeta à una rama; sigun Swinhoe, asi cs como se tienen todas las aves en el norte del celeste imperio.

CAZA.- El caliope es demasiado cauto prara exponerse á los tiros del cazador. Algunos machos capturados por Rad. de en una cerca no se dejaron sorprender sino durante el crevúsculo; de dia no era posible acercarse á ellos. eSi para tirarles me ponia á la izquierda del vallado, dice, introducian. se diestramente por las mas angostas aberturas y se inclina. ban por la derecha, é inversamente. Los cuellos azules proceden del mismo modo.

\section{LOS PETIROJOS - RUBECULA}

CARACTERES. - Los rasgos caracteristicos de este género, pobre en especies, son: pico de arista un ianto corva, y con una ligera escotadura cerca de la punta que parece querer formar gancho; patas débiles $y$ medianamente altas; alas bastante cortas y eridebles con la cuarta y quinta rémi. ges mas largas que las demás: las pennas de la cola, ligera. mentc escotadas en medio, son puntiagudas; el plumaje lacio, de barbas largas, y de igual coloracion en ambos sexos, pero manchado en los pequeños.

Es representante de este género el conocidisimo

\section{PETIROJO O PARDILLO - ERITHACUS} RUBECULA

CARACTERES.-Tiene el lomo de color gris aceituna do oscuro; el vientre de un blanco gris: la frente, la garganta y la parti superior del pecho de un rojo amarillo (fig. 195).

Los colores de la hembra son algo mas claros que los del macho.

Los pequeños tienen las plumas de la parte superior del cucrpo de un gris aceitunado, con el tallo color de orin ama rillento; las de las partes injeriores de un anarillo rojo orin mate, con los tallos y los bordes grises. El ojo es grande y pardo, el pico pardo negruzco y las patas color de asta rojizo. El petirojo mide $11^{\prime \prime}, 15$ de largo por $11^{\circ}: 22$ de punta i punta de ala, la cola $10^{\circ}, 06$ y el ala plegada $0^{\circ}, 0 \%$

DistRIBUCION GEOGRÁFICA.-Parece įuce el peti. rojo es propio de Europa, pues apenas traspasa los limites de esta parte del unundo. Su árca de reproduccion comprende desde los $67^{\circ}$ latitud norte hasta el Asia Menor, y desde e] Atlantico hasta el Obi. En su emigracion sisita el Africa sep. centrional, Siria, Palestina y Persia; jero la mayor parte de los petirojos pasan el invierno en el mediodia de Europa y alguno yque otro individuo hasia en Alemania.

USOS, COSTUMBRES Y REGIMEN. - En nuestros paises abunda esta are por todas partes: en los bosques donde hay tallares : parajes húmedos encuentra sitio conveniente para vivir. Frecuenta en sus vinjes los matorrales y vallados; recorre la llanura lo mismo que la montaña, asi los campos como los jardines, $y$ hasta se acerca â las viviendas humanas.

El petirojo es una bonita are de carácter alegre y vivara. cha: en tierra se le ve con el cucrpo levantado, las alas un poco colgantes y la cola horizontal, algo caida cuando esta posado. Salza ripidamente en tierra ó por las ramas: revolo. tea de una en otra; vuela con agilidad; cunndo debe franquear un corto espacio le atraviesa tan pronto á saltitos como volando, y si la distancia es mayor, traza um linea muy on. dulada; deslizase á través de los jarales mas espesos, y da repetidas fruebas de su ligereza. Le gusta estar sobre una rama elevada ó en el suelo; no es aficionado a remontarse por los aires, y por atrevido que parezca, vela continuamente por su seguridad. No eeme al hombre: en cambio conoce sus enemigos naturales ; le inqquieta mucho el verlos. Con los séres mas débiles o con sus semejantes, muéstrase nalicioso y hasta pendenciero, por lo cual vive solo; pero tam. bien se le han reconocido rasgos gencrosos, y se ha obser. rado que en citrtas ocasiones era bueno y comprasivo. I.05 pajarillos huérfanos, incapaces aun de bastarse á si mismos, encuentran en el petirojo un protector, y sus semejantes eniermos un auxiliar: dos petirojos encerrados en la misma jaula peleaban continuamente; revian por cada grano de alimento, y disputábanse, si asi puede decirse, hasta el aire que rèspiraban; acometianse furiosos y menudeaban los picotazos. Cierto dia se rompió uno de ellos una pata, y con esto ier. minaron las luchas: el compañero olvidó al momento su cólera; acercóse al herido, dióle de comer : le cuidó con ternura Curóse la pata; el petirojo recobró la salud y no volvió á turbarse la paz entre las dos aves.

Snell da cuenta de un hecho no menos interesante: un petirojo macho fué cogido con sus hijuelos y le encerraron en una habitacion: alli se consagró á cuidarlos; alimentóles, les comunicó calor y pudo asi criarlos telizmente. Unos ocho dias despues puso el pajarero en la misma habitacion ura cria de jetirojos, los cuales comenzaron bien pronto a jiar, aguijoneados por el hambre; el macho vicjo llego al instunte; muróles largo tiempo; corrió despues al comedero y cogiendo larvas de hormigas se las llevo presuroso, encargándose de criar á las tiernas avecillas cual si fuera su padre.

Naumann cita una historia aniloga: quiso criar un jardillo peqúeño, que hambriento siempre, no dejaba de piar, y lı. biendo en el cuarto un petirojo, accreóse este, pidióle la avecilla de comer y corriendo el otro al comedero, volvio con umas miguitas de pan que puso en el pico del pardillo: repetia la misma openacion siempre que aquel pecia ali mento.

En estado libre contrac á icciss el petirojo amistad con 
otras aves. rlin un bosque de los alrededores de Koethen, refiere Paessler, un petirojo puso en el mismo nido que una curruca, íabricado por esta: una y otra ave dejpositaron seis huevos, y las dos los cubrieron simultáneamente en la mejor armonia.

El petirojo tiene además otras cualidades: es una de nuestras aves cantoras, y su canto se compone de varios trinos que alternan con sonidos de flauta bastante prolongados, emitidos con fuerza, lo que le da un carácter solemne. Bl canto es tan agradable en una habitacion como al aire libre.

En julio ó agosto mudan la pluma estas aves y emprenden luego sus emigracione's.

8.n aquel momento, dice Naumann, se ofe durante el crepussculo en tocos los jarales su canto; yrimero en tierra y despues á una elcuacion rada-vez-major; hasta yue el ave alcanza la copa del abol. Llegada in noche queda el bosque silencioso, y entonces se oye resonar por los ajres la vor del

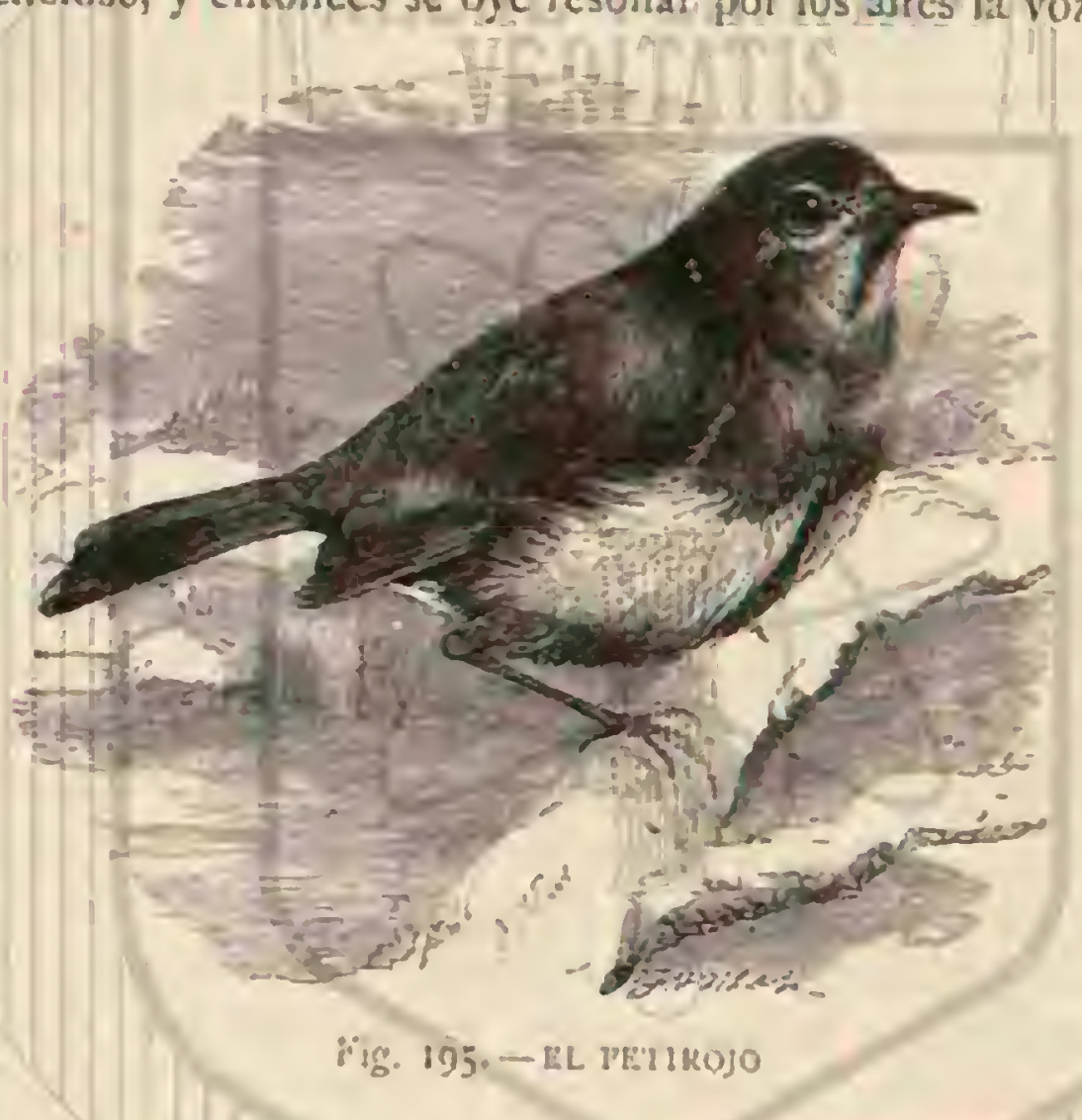

ave y en ella se conoce si van de levante a poniente, ó como sucede en la primavera, niceversa.

No tardan los petirojos en animar los sitios donde deben pasar el invierno: en todos los parajes en que no se reia un solo individuo durante el verano, aparecen estas aves, ocupando todas las breñas. Se les encuentra igualmente en todo el sur y centro de Espana: tambien alli cada pareja tiene su dominio y sabe defenderle y conservarle; pero en este pais no es tan exigente el petirojo como en su patria; bástale un matorral aishdo para albergarse, y parece que no forman entonces todos mas que una sola fanilia.

Al principio de su estancia en el nuevo clima, son pacif cos y silenciosos, como si se resintieran de la mudanza del pais; pero no tardan en recobrar su natural alegria: cantan, retozan, disputan y adqquieren, en una palabra, su acostum. brado buen humor antes de la llegada de la prinavera. Apenas cantan al principio, despues empiezan á ensayarse como si conversasen, pero cada dia crece su entusiasmo, y mucho antes de empezar la primavera en su patria, se ha introducido en su corazon; lo conocen, y entonces cantan como antes; y esto es la señal de que van a volver luego alli donde anidan.

El petirojo suele aparcecr en Alemania a principios de mar8.0, si la icmperatura es demasiado baja; pero en esta epoca padece ś menudo frio y hambre. Viaja solitario por la woche, produciencio peneirantes gritos y rolando á bastante altura; por la mañana se posa en el matorral de algun bos. que, ó en un jardin, para tonar su alimento y descansar un poco. Luego que se ha establecido definitiramente resuena por do quiera su grito de llamada chrickerik, repetido con frecuencia, y pronunciacio a veces como un trino. El primer rayo de sol es para el petirojo la señal de comenzar su canto: en aquel momento se ve al macho posado sobre una de las mas altas ramas de un àrbol, con las alas colgantes, dilatada la garganta, y en actitud altiva y grave, cual si llenase uno de los deberes mas importantes de su vida. Canta mucho, sobre todo por mañana y tarde y á la hora dèl crepúsculo; en la primavera es cuando sc deja oir principalmente; á veces gorjea tambien por el otoño.

Tiene su penueño dominio, el cual defiende con valor, sin tolerar la presencia de vtro de sus semejantes; las diversas parejas viven cada una para si, pero una al lado de otra. En el centro de aquel se encuentra el nido, que esta siempre en tierra, a orillas de un foso, en un agujero, debajo de un tron. co, en medio de las raices, en el musgo, en una mata de yerbas ó en el albergue abandomado de algun cuadrúpedo. La parte exterior del nido se compone de ramitas $y$ in inte. rior de raíces, rastrojo, pelos y plumas; si no está natural. mente protegido por arriba, forma el ave una especie de tejadillo, y pracrica la abertura por el hado. La hembra pone 2i lines de abril 6 principios de maro de cinco a siete huevos de color blanco amarillento, sembrados completamente de puntos de un amarillo rojo oscuro: los padres cubren alterna. tivamente por espacio de quince dias; crian ambos a sus hijuclos; lós alimentan y los llevan consigo duranie unos bcho dias desjues de haber aprendido su vuelo; luego los abandonan, y la hembra vuclie á poner, si el verano lo per. mite. Ciuando álguien se acerca al nido ó á los hijuelos, los pacres lanzan su grito de llamada y de aviso que suena si, manifestando una gran agitacion; los pequeños cuyo piar se oia antes, se calian al propio tiempo y desaparecen por las ramas, mas bien trepando que volando.

Los hijuelos se alimentan al principio de gusanos, y mas tarde les dan los padres de todo lo que les sirve a ellos mis. nos déalimento, tal como insecios de varias clases, arañas, carácoles pequenos, lombrices de tierra, y otros. En el otono sc regalan jovenes y vicjos con las bayas que producen el bosque y el jardin.

CAUTIVIDAD.- - Fil pelirojo es are que se conservá menudo cautiva, anto por su canto como por su gracia: acostúmbrase fácilmente á su nuevo estado; no tarda en perder todo temor y se manifiesta confiada con el hombre; fami. liarizase en muy poco tiempoy reconoce as su amo. Cada vez que le ve le saluda con un alegre gorjeo y dilata el buche y hace toda clase de movimientos para demostrar su satisfaccion. Si se le cuida bien, soporta la cautividad largo tiempo y parece acostumbrarse muy bien á su nueva vida. Se han visto individuos á los que se puso en libertad por la primavera, des. pues de haber pasado un invierno en jaula, y que volvieron en el otolio á la casa de su antiguo amo. Se les puede ensciar

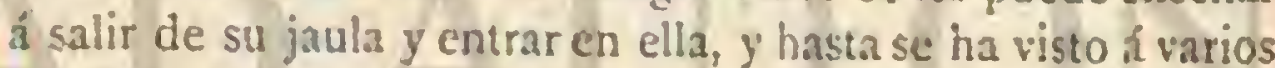
de ellos reproducirse.

- El petirojo cautivo se acostumbra al alimento del hombre.

\section{LOS MONTECOLINOS - MONTI- COIINA}

CARACTÉRES.-Los miembros de esta sub-familia muY numerosa son muy afines á los humicolinos, y en su mayor parte multicolores, de rariable tamano, pero muy semcjantes en cuanto i las costumbres y al genern de vida. Los autores no están de acuerdo respecto á los limites que deben asig. narse á esia familia; unos clasifican á ciertos montecolinos con los túrdidos, yotros los agrupan con los humicolinos; pero si solo se liene en cuenta el género de vida, veremos que no se pueden separar estas aves, y que en rigor no es dado 
aceptar sino como caractéres genéricos las diferencias que presentan.

Los montecolinos tienen el cuerpo esbclto, alas medianas, sub-agudas, con la tercera rémige mas larga; cola corta trun. cada en ángulo recto ó ligeramente escotada; tarsos media. namente aitos y esbeltos: pico puntiagudo á manera de lezna, con mandibula superior terminada por un gancho corto $y$ cndeble. El plumaje es abundante, lacio y por lo comun de distinta coloracion segun el sexo $y$ la edad.

USOS, COSTUMBRES Y REGIMEN.-La mayor parte de los montecolinos habitan rocas y sitios pedregosos, $5 \mathrm{C}$ alejan siempre del bosquue; y se establecen con preferencia en las montanas ó en superficies despejadas, donde cons truyen su nido grande pero sencillo, por lo regular en cuevas $\delta$ agujeros. Se encuentran los huevos, comunnente unicolo. ins, al concluir casi la primavera.

\section{LOS COLIROIOS-RUTICILLA}

CARACTÉRES. - Los colirojostienen el cuerpo esbelio: el pico puniagudo en forma de lezna, terminado por un pequeño gancho, pero sin escotadura; los tarsos altos y del. gados; las alas bastante largas y subagudas, con la tercera rémige mas larga que las otras; la cola mediana casi trunca. da en s.ngulo recio; el plumaje lacio, variable segun la ednd $y$ el sexo.

DISTRIBUCION GEOGRÁFICA.-Habitan el antiguo continente y soll en particulat numerosos en Asia.

\section{EL COLIROJO TITIS - RUTICILLA TITYS}

CARACTERES.-Eil colirojo titis es negro: la cabera, el lomo y el pecho tienen un color gris ceniciento: el vientre

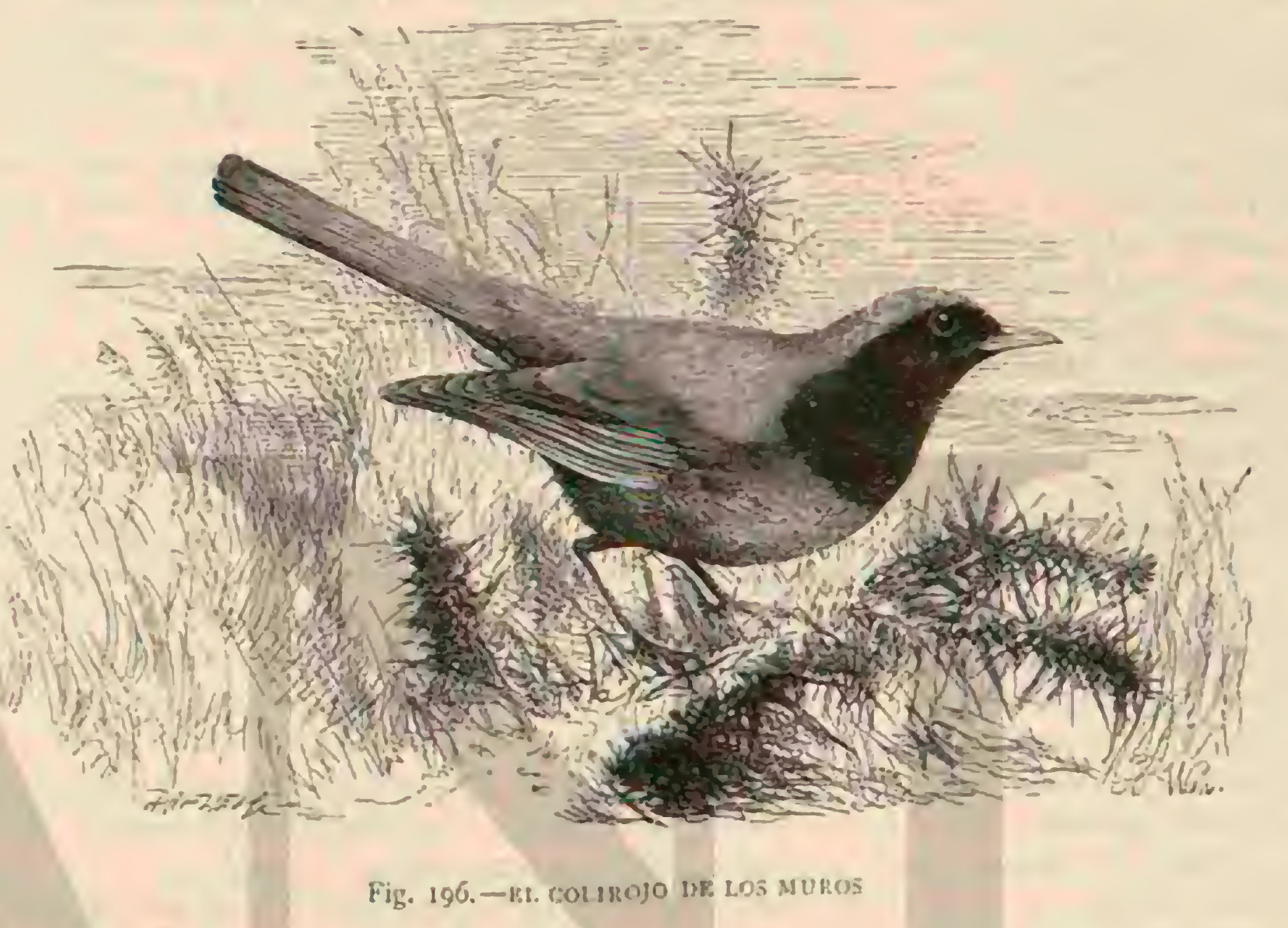

blanquizco; las alas manchadas de blanco; la cola y las plu mas de la rabadilla de un rojo amarillento, excepto las dos rectrices medias, que son de un pardo oscuro.

Las hembras y los machos jórenes de un año tienen el plumaje de un tinte unido gris bien pronunciado, que en los pegqueños estri ondulado de negro. Miden $0^{\mathrm{m}}, 16$ de largo; $0^{\circ}, 26$ de punta á punta de ala; esta plegada $0^{\circ}, 0$ y y la cola $0^{\circ}, 0 \%$.

DISTRIBUCION GEOGRÅ FICA.-EI área que habitan los colirojos se extiende por toda la Europa central y meri. dional y además por el Asia Menor y Persia. Es ave perenne an el sur de nuestro continente, pero en el norte le obliga el invicrno a abandonar el sitio donde anida para retirarse al mediodia, al Asia Menor, Siria, Palestina y al norte de Africa. Hija de las montañas $y$ habitante de las perias en un princi. pio, se ha hecho despues ave doméstica y acostumbrado á vivir en la morada del hombre, ya se halle en populosa ciu. dad, ya en caserío solitario, $\bar{y}$ al propio tiempo ha ido avan. zando mas y mas hácia el norte. Hoy como antes vive en lá Europa meridional y. en Suiza, y tambien en algunos putstos montanosos de la Alemania central, anidando en peñas cortadas á pico; pero es rarisima en la parte septentrional. Junto al Rhin dicen que vive solamente desde el año $1 S_{17}$; asimis. mo ha pasado en tiempos recientes á Inglaterra, esto es, desde el ano i $\$ 29$ y a Irlanda desde i $S_{1} S$, y parece que sigue aun peuctrando mas hácia el nortc, porque se le hai cuconirado últimamente en las islas Feroé y en el mediodia de la Escan- dinavia Siempre es mas comun en la sierra que en el llano, y anida, si no hay otro junto mas á prop̣ósito, hasta cn los tcjados de iabli.

USOS, COSTUMBRES Y REGIMEN. - A nuestro pais llegan á fines de marzo, algo antes á la Alemania meridional; viajan de noche aisladamente, los machos se presentan algunos dias antes que las hembras. Apenas vuelve á su pais, el macho toma posesion del mismo punto que habitaba el año anterior, $y$ desde aquel momento comienra su agradable vida de verano.

El colirojo titis es alegre y vivaz, como todas las ares de la familia y está siempre en movimiento: apenas comienza a despuntar el alba, despiértase ya, y no se entrega al descanso hasta mucho despues de ponerse el sol. Es una de las aves cugo canto se ore primero por la maiana, y de las últimas que se callan por la tarde. Por sus movimientos se parece mas á los montecolinos que a los humicolinos: es vivaz y muy ágil; salıa y vuela con ligereza; mueve graciosamente la cola; avanza dado grandes saltos, unas veces hácia adelanze y otras de lado, indicando todo su aspecto cierta osadia y altivez. Q.Al volar, dice Naumann, corta el aire en linea recta como una Mecha, ó bien traza una linea extensamente ondulada; sabe cambiar de direccion muy bien, volverse y dejarse caer desde arriba para subir de nuevo dejando oir el zumbido de sus aletazos. Coge al vuclo los insectos de que se alimen. เn, como lo hacen los papamoscas. 
Sus sentidos son excelentes, sobre todo la vista; su inteligencia no es en manera alguna limitada: distinguese por lo prudente; conoce d sus enemigos y los teme, siendo hasta receloso con sus amigos. No le inspiran siempre confianza los habitantes del lugar donde se fija; apirtase convenientemente del hombre y prefiere posarse en los tejados; alli le parece estar seguro y se muestra indiferente á todo cuanto pasa á su alrededor, sin que el tumulto de una ciudad populosa le in. quiete en lo mas minimo.

A la manera de las demás aves de la familia, no es nada sociable; vive solo con su hembra, y se aleja poco de su dominio, en el cual no permite la presencia de otro de sus semejantes, y donde disputa casi de continuo con las de. más ares pequeñas.

Su gritó de llamada, bastante agridable, se prede expresar por fol lik lek, sonidos que repite varjas veces seguidas cuando le aménaza un péligro. Su canto es poco notable; consiste en dos 6 tres frases, compuestas de notas, roncas las unas, agudas las otras, y nada armoniosas; pero el colirojo posee en cambio in facultad de initar la voz de las demśs aves. Jaec. kel le ha oido reproducir el canto de la silvia y de la curruca; el grito de llamada del paro, del mirlo y del canario, y el gorjeó de los estorninos; mi padre obsertó hechos análogos; pero debe advertirse que al imitar asi cl canto de otras aves, mezcla el colirojo los roncos sanidos que le son propios, y por esto no se le aprecia como cantor.

Hil colirojo se alimenta casi cxclusivamente de insectos, y sobre todo de moscas y de mariposas. Rara vez baja á tierra; solo por excepcion permanece en ella algun tiempo; pero nunca escarba, como hacen los humicolinos. Apenas madu. ran los frutos se le ve con bastante frectiencia en el liano, pero comunmente caza en las alturas. Las mariposas que otros pájaros desprecian, son para el un bocado agradable; y asi se hace nuy util como destructor de especies nocivas.

Esta ave se reproduce en el mes de mayo. Antes y durante este ticmpo se muestra el macho excitadisimo; sigue des. atentado álix liembra, conforme dice Círlos Mueller con mucha verdad, al traves de corrales, jardines f calles, chillando y cantando alternitivamente; precipitase desde puntos elevados, se aplana contra el suclo moviendo las alas delante de la hembra, ó apoyándose en el tejadó sobre su cola enté. ramente abierta, suplica, se regocija y toca con su pico el de su companera. Esta no se manifiesta menos exaltada yersi. gue con indecible furor á todas las aves de su especie que se aproximan a su macho $\delta$ al sitio que ha escogido para hacer su puesta Si la parcja havita la montaña construye su nido en las grietas de las rocas; en la llanura anida casi exclusivamente en las casas, en los agujeros de las paredes, en las vi. gas, en los puntos salientes, y un poco al abrigo de un árbol hueco. Fn los sitios de la montana donde los pinos y abetos rodean masas de rocas, forma su nido algunas veces en el suelo, debajo de un matorral ó de una piedra, haciéndose tenporalmente silvicola, ú olvidando todo temor se establece hasta en el interior de una habitacion, construyendo su nido en la misma estufa de una cscuela y hasta en un buzon. El nido es muy tosco: cuando el ave le forma en un agujero, limitase a reunir varios materiales casi sin órden; pero le hace un poco mejor cuando estí en sitio descubicrto. La parte exterior se compone de una masa de raices, rastrojo y tallos de yerbas, rellena por dentro de plumas y jelos. Cada puesta consta de cinco á siete huevos de un blanco brillante, de $11^{\prime \prime}, 019$ de largo por $0^{\circ}, 01$; de grueso. Macho $y$ hembra cubren alternativamente $y$ alimentan despues á la cria; demuestran en momentos de peligro un valor heróico, $y$ procu. ran por todos los medios posibies ajartar al enemigo de sus queridos hijuelos. Los pequeños abandonan por lo comun el nido antes del tiempo necesario, lo que fes hace à menudo caer en las garras de animales mapaces, pero en pocos dias adquieren la destrean é independencia necesarias. Luego qui los viejos los jutgan bastante instruidos, empiczan oira cria y aun despues de esta a veces una tercera.

Sucede a veces que durante la época del celo contraen ciertos colirojos amistades extraordinarias. En mi leñera, dice Paessler, se habia establecido una pareja de colirojos en un nido de golondrina, y cuando regresó de su vinje de invierno, hizo otro al lado del primero, $y$ aun no le habia concluido, cuanio el colirojo hembra comenzó á cubrir. Con frecuencia le molestaba con la cola su atareada vecina, y empujảbale muchas veces, pero nunca le inquictó. Mas tarde, locóle cuivir á la golondrina, y las dos hembras perma. necicron una al lado de otra, viviendo en la mejor armonia. Cuanón el macho de la segunda llegaba para distraer á su compañera, hablindole en su lenguaje del cielo y de los insectos, dirigiase a veces a su vecina; por su parte la golondrina no llevaba a mal que la tocara el colirojo macho cuando daba de comer st sus hijuclos. Apenas hubieron crecido estos lo bastante, se ditigió ayucl a una cuadra vecina para cons. truir su nuevo nido; la golondrina le siguió, apropióse un nido viejo que alli encontró, lo recompuso y ambas parejas continuaron siendo vecinas y viviendo en la mejor inteli. gencial

\section{EL COLIROJO ARBORÍCOLA Ó DE LOS MUROS-RUTICILLA PHENICURUS}

CARACTÉres. - Esta especie, que se presenta tam. biun en Alemania, merece su calificacion de arboricola, por. quevive casi cxclusivamente en los àrboles tanto en el monte como en los jardines y huertas. El macho adulto tiene la frenté negra, lo mismo que los lados de la cabeza y la garganta; el lomo de un gris ceniciento; el pecho, los costados y la cola de un rojo de orin vivo; la parte superior de la ca. beza y el centro del vientre blancos; el ojo pardo; el pico y las patas negros (fig. 196).

Ia hembra tiene el lomo gris oscuro; el vientre gris, y li. geramente negra la garganta ålgunas reces.

En los pequeños el lomo es gris, manchado de amarillo roja y de pardo; las plumas del vientre grises y con un fileic amarillo rojo.

Mide $0^{\mathrm{m}}, 1+4$ de largo; $0^{\circ}, 23$ de punta á punta de ala; esta plegada $0^{m}, 08$, y la cola $0^{\circ}, 06$.

\section{DISTRIBUCION GEOGRÁFICA.-El colirojo arbori-} cola labita un área mas dilatada que su congénere, pues no falta en ningun pais de Europa; prefiere la llanura solo á causa de los bosques, por cuya razon no rehuye las monta. inas por principio, y cuando encuentra reunidas las circuns. iancias locales que le convienen se esiablece en cualquier punto. Hácia el este sc cxticnde el area que habita hasta Persia, estando representado mas alli por otro congénere. I dega en abril á nuestro pais y vuelve à emigrar en setiembre hasta el interior del Africa y la India

USOS, COSTUMBRES Y RÉGIMEN. - Tanto por su género de vida como por sus costumbres apenas diliere el colirojo de los muros de la esjecic anterior: díferénciase solo porque prefiere estar en los árboles. Su roz es mas rica Y armoniosa; emite dos $\delta$ tres sonidos compuestos de notas dulces, parecidas a las de la flauta; el canto tienc algo de melancólico, pero es muy agradable, y tambien imita el de otras aves.

Bil colirojo de los muros se alimenta de insectos, los cuales recoge en los árboles y en tierra.

Anida casi invariablemente en un tronen hueco, en casos 
cxcepcionales en la gricta de un muro ó en una anfractuo. sidad, y siempre en excavaciones, sobre todo en aquellas de abertura estrecha; pero Walter encontró uno en tierra arrimado al tronco de un grueso pino, y esio en una locali dad doncie no faltaban huecos en los árboles. El nido, de tosea construccion, se compone de raices y rastrojo seco, entrelazadas sin orden alguno: el interior está cubierto de plu. mas. La hembra pone, en la segunda mitad de abril, de cinco a ocho huevos de cáscarn lisa y color azul rerdoso; la segunda puesta se verifica en junio, pero en un nido diterente, si bien sienupre en un árbol hueco; en la primavera vuelve el colirojo du tomar posesion del primero.

CAUTIVIDAD. - Mas frecuente es ver á esta ave cau. tiva que at su congénere: canta bien y todo el año: pero tiene el defecto de producir con demasiada frecuencia su grito de llamada, triste y monótono, que se expresa por wit, sit, tak, bnk, y por esto calisa fastidio al aficionado.

\section{LOS PETROCINCLOS-PETROCINCLA}

CARACTERES, - Fste género comprende aves de re. gular tamaio, y por esta unica razon ias clasinican muchos naturalistas con los túrdidos. Ilienen el cuerpo esbelto; el pico puntiagudo, fuerte y prolongado, ancho en la base, ligeramente convexo, y con los bordes de la mandibela inferior cortados hácia la punta en el sentido de la curvatura de la superior; los tarsos son de un largo regular y gruesus; las unas largas y' muy corvas; las alas bastante prolongadas y sub-agudas, con la tercera penra quee sobresale de las de más; la cola es corta $y$ el plumaje liso, abigarrado $\delta$ uni. forme.

\section{EL PETROCINCLO SAXÁTIL-PETROCINCLA SAXATILIS}

CARACTERES. - Esta nre no és oira cosa que un co lirojo de gran tamaño. Ia cabeza, el cuello, la nuca y la ra. badilla son de color azul ceniciento; la paste inferior del lowo de un blanco azulado ó blanca; el vientre y el pecho de un rojo vivo; las plumas de la espaldilla de un gris ceni ciento oscuro ó negro pizarra; las rémiges pardo negms, con la punta mas clara: la extremidad de las grandes cobijas de las alas orillada de un blanco matizado de amarillento; las rectrices del mismo color que el vientre, excepto las dos inedias que son de un gris oscuro. In el otono, despues de la muda, todas las plumas tienen un filete claro; cl ojo es pardo rojo; el pico de un negro mate y las patas de un gris rojizo.

La hembra tiene el lomo de un pardo mate, con manchas claras, el cuello blanco, y el vientre rojo claro, sicndo los fileres de las barbas mas oscuros. Los pequenos tienen el plumaje manchado. Miden estas aves $0^{52}, 23$ de largo; $11^{n}, 3 i$ de punta a punta de ala; $\|^{\infty}, 13$ esta última plegada y $0^{*}, 07$ la cola.

DISTRIBUCION GEOGRÁFICA. - El purocinclo sa xátil pertenece a la region del Mcditerránco y se encuentra en casi todas las sierras y cordilleras alias de la Europa meridional. Mas al norte anida aisladamente, con bastante re gularidad, en Fistiria, Carintia, Austria alta, Tirol, en las perias de Kotuch cerca de Stmmberg, en Moravia y f lo largo del Rhin; rara vez en Bohenuia, Jusacia y en el Harz. Hácia el este llega su área de dispersion hasta la Siberia me ridional: es comun en las localidades a propósito de la Esla. vonia, Croacia, Dalmacia, Turquia y Crecia; no es raro en Italia, Crimea, Asia Menor y Siria. En España solo habita las sierras elevadas. En sus emigraciones atraviesa una gran parte del Africa septentrional; yo le he hallado todavia en los bosques inmediatos al Nilo Azul. Iin su patria se le ve ya a mediados de marzo, lo mas tarde en abril, y permanece hasta fin de setiembre ó principios de octubre. Filige por morada sobre codo viñas, o valles anchos yedregosos donde crecen algunos árboles viejos.

USOS, COSTUMBRES Y REGIMEN.-I,as costum bres de esta ave se asemejan mucho á las del colirojo titis: es prudente, vivaz y ágil como él; rara vez pasa todo el dia en el mismo punto; recorre continuamente su dominio y no se posa nunca sino algunos instantes: corre con rapidez por el suelo; salta y hace sus reverencias como ol titis ó cl saxicola moteado; vuela con ligereza y facilidad, siguiendo la linea recta; se cierne, traza círculos antes de posarse y puede coger los inscctos al vuelo. Su grito ordinario es fac, fac, tan semejante al del mirlo como al del saxicola moteado, el de angustia se puede expresar por uit, uil, muy parecido al grito del colirojo en circunstancias análogas, y lo repite varias veces seguidas. Fl canto es rico y variado; las notas llenas y armoniosas, y se distingue al propio tiempo por frases ente. ras sacadas del canto de otras aves, que intercala el petro. cinclo segun la localidad que habita y el talento que tiene. Asi copia y mezcla trozos del canto del ruisenoor, del mirlo, del tordo músico, del pinzon, de la alondra y de la codorniz, del petirojo, del rencejo, de la oropéndola, de la perdiz y hasia del canto del gallo.

El petrocinclo saxátil se alimenta de insectos; en el otoño come además bayas, uvas y frutas de toda especie. Recoge los primeros en el suelo, aunque sin escarbar con su pico, y 6. la manera del colirojo titis atrapa otros insectos al ruelo, persiguiéndolos á mènudo largo rato.

Poco despues de llegar el petrocinclo saxátil comienza la reproduccion: el macho canta entonces á porfia; danza con cl cuerpo levantado, conforme pudo ver Alejandro de Ho meyer, rozando las alas y la cola contra el suelo, erizadas las plumas del lomo, la cabeza echada hícia atrás, el pico muy abierto y los ojos medio cerrados. Por tlltimo, se levanta á la manera de la alondra revoloteando, cerniéndose y cantando mas fuertemente que antes, y vuclve al puesto dunde estaba posado. El nido, sicmpre muy oculto, está situado en un sitio inaccesible, en alguna grieta de nuro ó de roca, en un monton de piedras, debajo de las raices 6 en un espeso ma. torral. La parte exterior esti cubierta de raices, ramas de brezo, astillas, briznas de paja, hojas de yerbas y nusgo, en. trelazado el todo sin órden; el interior forma una excavacion bien reclondeada y cubierta de materiales elegidos con cuidado. Los huevos, cuyo número es de cuatro á seis, tienen cáscara delgada y color azul yercoso; se asemejan \& los del colirojo arboricola, aunque son bastante majores. Miden $0^{4}, 28$ de largo por $0^{m}, 19$ de grueso. Wacho y liembra com parten el trabajo de incubacion y de la cria de los pequeños rasi en proporciones iguales. Cuando amenaza algun peligı avisa el macho con un grito especial que podrá represen. tarse con la onomatopeya frichikinakchak frishisefiatictiok, acompanado de grandes inclinaciones y meneando la cola.

CAUTIVIDAD. - Se sacan con irecuencia los pequeños del nido f se crian con el alimento que se da allos ruiscrnores y tordos, pero 'Talsky dice que los tratantes en pajjaros los suclen confiar al cuidado de una parcja de colirojos tivis, y aun los colocan en un nido de aguzanieves si se encuentra cerca de la casa. Si se les cuida bien se domestican jerfectaniente, segun nos dice el conde Gourcy, y castan apenas divisan a su amo. Wo he visto alguncs, dice el citado autor, que comenzaban a silbar á cualquier hora del dia $\delta$ de la noche an pronto como su amo entraba en la habitacion donde se hallaban; y no querian callarse hasta que se apaga. 
ba la luz. En tales casos no hacen sino repetir algunas frases que se les han enseñado, $y$ no entonan su propio canto. Li. riase que quieren hablar al hombre $y$ hacerse comprender de el. Si están solos cantan como de costumbre.

Con un régimen á propósito y minuciosos cuidados llegan S criar en la jaula, o adoptan pajaros de otras especies, y muestran en general cualidades an excelentes y múltiples que bien pueden citarse como las ares cantoras domésticas mas notables de Europa.

\section{EL PETROCINCLO AZUL - MONTICOLA CYANA}

CARACTERES. - Hosta especie, representante del sub. género de los petrocosifos, es nlgo mas grande que el petro-

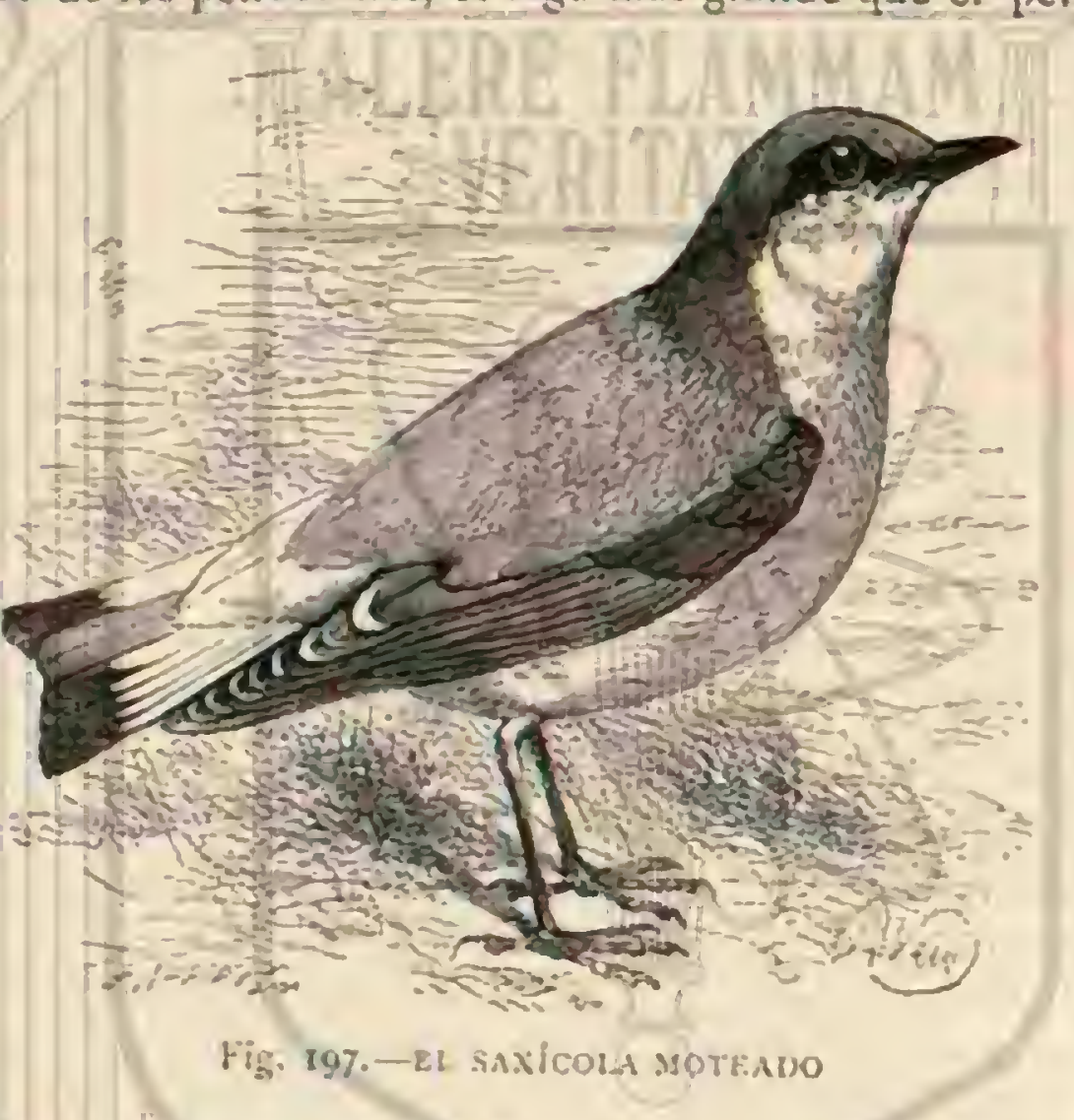

cinclo saxátil. pues mide de $0 \$, 23$ a $0^{n}, 25$ de largo; $0^{m}: 37$ de "punta a punta de ala; esta plegada $0^{\circ}, 12$ y la cola $0^{\circ}, \mathrm{col}$. El plumaje del macho es de un color azul pizarra; las pennas de las alas $y$ de la cola negras, orilladas de azul.

I a hembra es de un gris azulado; la garganta ticne manchas de un pardo rojo claro orladas de pardo negro: adornan el vientre unas medias lunas de color pardo oscuro con filetes blanco parduscos en las plamas; las pennas de las alas $y$ de la cola son del mismo inte.

Los pequecios se parecen a las hembras, diferenciándose tan solo por las imanchas pardo claras, que salpican el lomo. Todas las plunas del macho tienen filetes grises despues de la muda; pero no tardan en desgastarse, $y$ entonces aparece el plumaje en toda su belleza. El ojo es pardo, y el pico negro to mismo que las patas.

DISTRIBUGION GEOGRÁFICA.- La patria del pe. trocinclo azul abraza roda la Europa meridional, el norte de Africa y una gran parte del Asia central hasta la China cen. iral é Himalaya occidental. Tschusi dice que es frecuente en Austria-Hungria, particularmente en Dalmacia, Istria, Croa. cia y Tirol meridional, especialmente en la ermita del Etsch y junto al lago de Garda; pero mas raro como are anidadora en la Transilvania y Carniola, y como ave errante en Carin. tia; segun me participa Tschusi. cria tambien, aunque muy' rara vez, en compañia del petrocinclo saxátil, en el Kotusch, peña caliza de quinientos metros de altura cerca de Stramberg en la parte nordeste de Moravia. Si alguna vez se le ha observado en Alemania no ha podido ser mas que como are errante en las montañas de la Baviera alta. Abunda en Grecia, Italia, Francia meridional y España, como tambien en Palestina y Egipto hasta Abisinia y los paises del Atlas. En invierno se encuentra siempre en la India, á pesar de que no es en rigor ave de paso, puesto que vive perennemente en las localidades à propósito de la Europn meridional, solo que en invierno se traslada ia laderas orientadas al sol.

USOS, COSTUMBRES Y RÉGIMEN،-Por su gẻnero de vida se ascmeja bastante este petrocinclo á la especie anterior; pero le gusta mas el desierto, las paredes de las rocas y los estrechos valles sin árboles ni breñas; evita los bosques, y por otra parte penetra en los lugares habilados. Se le ve posarse en las torres, en las murallas, en los tejados allos y en los monumentos ruinosos, segun lo hace en Egipto. Con razon se le ha dado algunas veces el nombre de rmifaño 6 solitario, porque es insociable por demás: aunque se fija cerca del hombre, muéstrase poco confiado con el y conserva siempre su independencia. Parece que no vive en buena ar. monia con ninguna otra are; es receloso con todas, y ni aun sè reune con sus semejantes. Solo en el periodo del celo se ve álos petrocinclos apareados y con sus hijuelos; mas tarde, hácia el otoño, sepáranse todos y cada cual vive para sí. Fisto no obstante, en Egipto vi algunas reces reducidas ban. dadas de estas insociables aves.

Fil petrocinclo era ya nuy conocido de los antiguos: Ges. ner, reproduciendo lo que han dicho los autores de verda. dero y de falso, se expresa en los términos siguientes: «Esta ave, que llaman gronss, aborrece al hombre instintivamente: crita la sociedad hasta en los lugares salvajes que habita; guis. tanle los parajes desiertos y las cimas de las inontañas; por esto le desagrada el Epiro y otras islas habitadas, y prefiere Es. cim y demás sitios estériles y solitarios, parecidos á esta isia. Ell petrocinclo azul tiene tambien cualidades apreciables: es extraódinariamente vivaz, activo, movedizo j cantor incan. sable. No iguala su canto al del petrocinclo saxátil, pero no deja por esto de valer mucho y se le oye en todas las esta. ciones del año. En sus movimientos se asemeja tambien á lós saxicolas, pero no à los turdinos, con los cuales no puede compararse por poco que se mire con alguma atencion. Es la especie mas vivaracha de todos los montecolinos, tanto al correr como al volar; ninguna de las otras especies sostience tanto tiempo el vuelo ni avanza tanto, al menos que yo sepa. A reces atraviesa de una tirada distancias de un kilómetro cuando deja uno de sus sitios favoritos situados en las alturas, para encaminarse directamente d otra montaña sin bajar á tierra. El vuelo se parece al de los turdinos mas diestros, solo que el petrocinclo se cierne mas que estos, particular. mente antes de posarse, y cuando canta se remonta á los aires, en lo cual dificre de aquellos lil canto viene a ser una mezcla de tonos de otros pájaros: se oyen por ejernplo las notas sostenidas de garganta, propias del petrocinclo saxicola, con la diferencia de que en el azul son mas fuertes y ásperas; despues los tiples agudos de caramillo del tordo zorzal, mezclados con los del ruiseñor, y ademís con algunas. frases del mirlo, pero no tienceste canto la tlexibilidad, suavidad, variedad y dulzura que distinguen al de la especic saxicola, que por esta razon es mas propia para tenerla en la habitacion. El petrocinclo azul repite las diferentes frases por lo regular dos, ires hasta cinco y aun diez veces, y esto hace que su canto parezca menos variado de lo que es en realidad. A veces cmplero se le oyen tonos tan bajitos y trémulos que el péjaro mas diminuto no podria haceriosi mas ienues. l.e gusta cantar mucho durante el crepisculo vespertino y aun á la lur. artificial en las habitaciones. Uno de estos pe. trocinclos tenia la costumbre de cantar bajito de un modo muy agradable cuando la estancia se hallaba muy alumbra. da, 6 bien cuando las personas alli reunidas hablaban mucho y en roz muy alta. Tambien tiene, al igual de orras aves cantoras, su frase favorita que emitc cuando quicre saludar á un conocido, pero como es capar de repetirla entonces de 
seis is reinte reces, llega á aburrir à cualquiern. No ignoraba todo esto el viejo Gessner cuando dicc: Canta muy bien, mucho y variado; además es inteligente, aprende, lo observa todo é indica con su vor diferentes cesas. Cuando se le des. pierta en las noches desapacibles se pore a cantar alto como si asi se le mandase y como si tuviese conciencia de que tal es su obligacion.) Su grito de llamada suena lak, fak, y cuando tiene micdo canta como su congénere saxátil, uit, wit. En la época del celo cjecuta varios cjercicios parecidos ś los bailes á que se entrega en igual circunstancia el petro. cinclo saxátil; solo que entonces el macho, segun dice Homeyer, se pone horizontal; se hincha, lo que le hace aparecer mas grande y abotagado, baja la cabeza, y azota el aire con la cola plegada y levantada a la manera del mirlo. El nido que construye en grietas de roca, campanarios, ruinas de vetustos castillos y en otros edificios elevados, es grande pero sencillo, compuesto exteriormente de brianas de yerba basta y fina, y tapizado interiormente de raicillas torcidas.

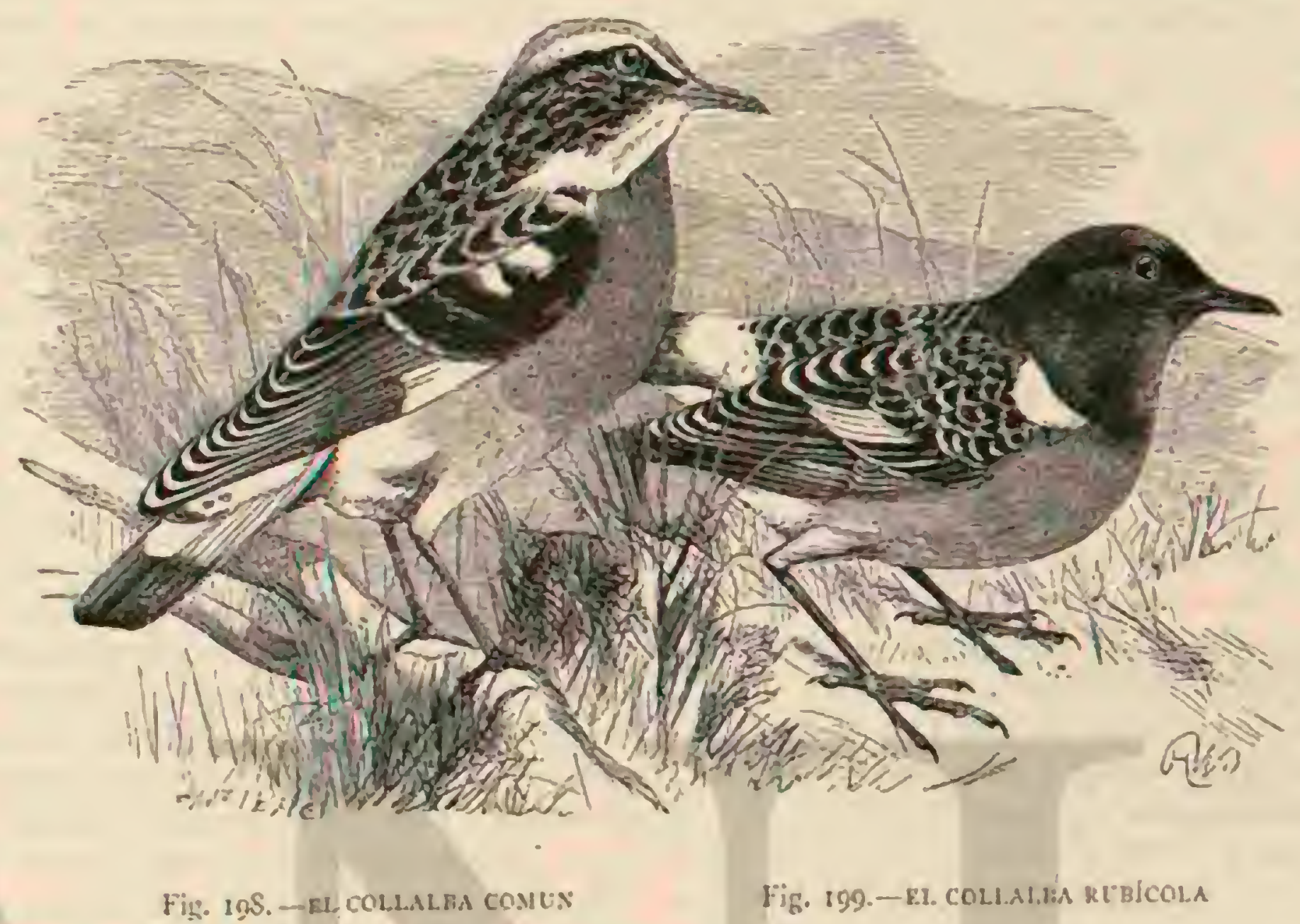

A principios de majo queda terminada la puesta, que consiste en cuatro hasta seis huevos ovalados, relucientes y de color azul verdoso uniforme, ó bien salpicados escasamente, sobre todo hácia el extremo grueso, de manchas de un gris violeta muy tenue. sobre las cuales hay otras rojizas ó pardo rojizas; su longitud es de $0^{*}, 02 \$$ y el major grueso de (,", 0 ig. Irby pudo observar en Gibraltar perfectamente una pareja de petrocinclos azules durante su trabajo de incubacion, pues habian establecido su nido en un hueco de la pared del esta. blo. Habia cinco huevos, y el 20 de junio salieron \& luz. las penuerios, que los padres criaban con la mayor solicitud. Para observaslos mejor mandó practicar Irby un agujero en la pared, delante del cual colocó dentro del cstablo una jaula, en la que metió los pequeñuelos, cubriéndola con un paño que solo dejaba libre un pequeño agujero para poder observar las ares desde el interior del establo. Los padres iban trayendo casi cada cinco minutos por lo régular gusanos, alguna vez. tambien arañas y moscardones Fué imposible averiguar de dónde sacaban los viejos tantos cienpiés, ya que estos animales viven debajo de las picdras. Los traian sicmpre sin la cabeza, que tiene pinzas venenosas, y todos los animales por lo gencral muertos. Dos de los pequenos murieron en la jaula, porqque sus padres no podian llegar á ellos sino con mucho trabajo: pero los tres restantes medraron, y por último, se los crió artificialmente.

CA UTIVIDAD. - Es dificilisimo coger petrocinclos nzu. les vicjos; por esto no se encuentran para la jaula sino peque. nos sacados del nido; cuidándolos bien viven muchos años, pero cobran tanto afecto à su local, que rara vez resisten una mudanza.

Cuando se abrió el nuevo mercado de Ia Vialette, reficre Wright, varios traficantes pusieron sus petrocinclos azules en las nuevas tiendas, pero todas aquellas aves enfermaron una Towo III despues de otra, y al cabo de algunas semanas no quedaba una sola.

En Italia, en Malta y Grecia, son muy buscados los petrocinclos para conservarlos en habitacion. Lindermayer dice que todos los años se exportan muchos ś. Grecia y Turquia;

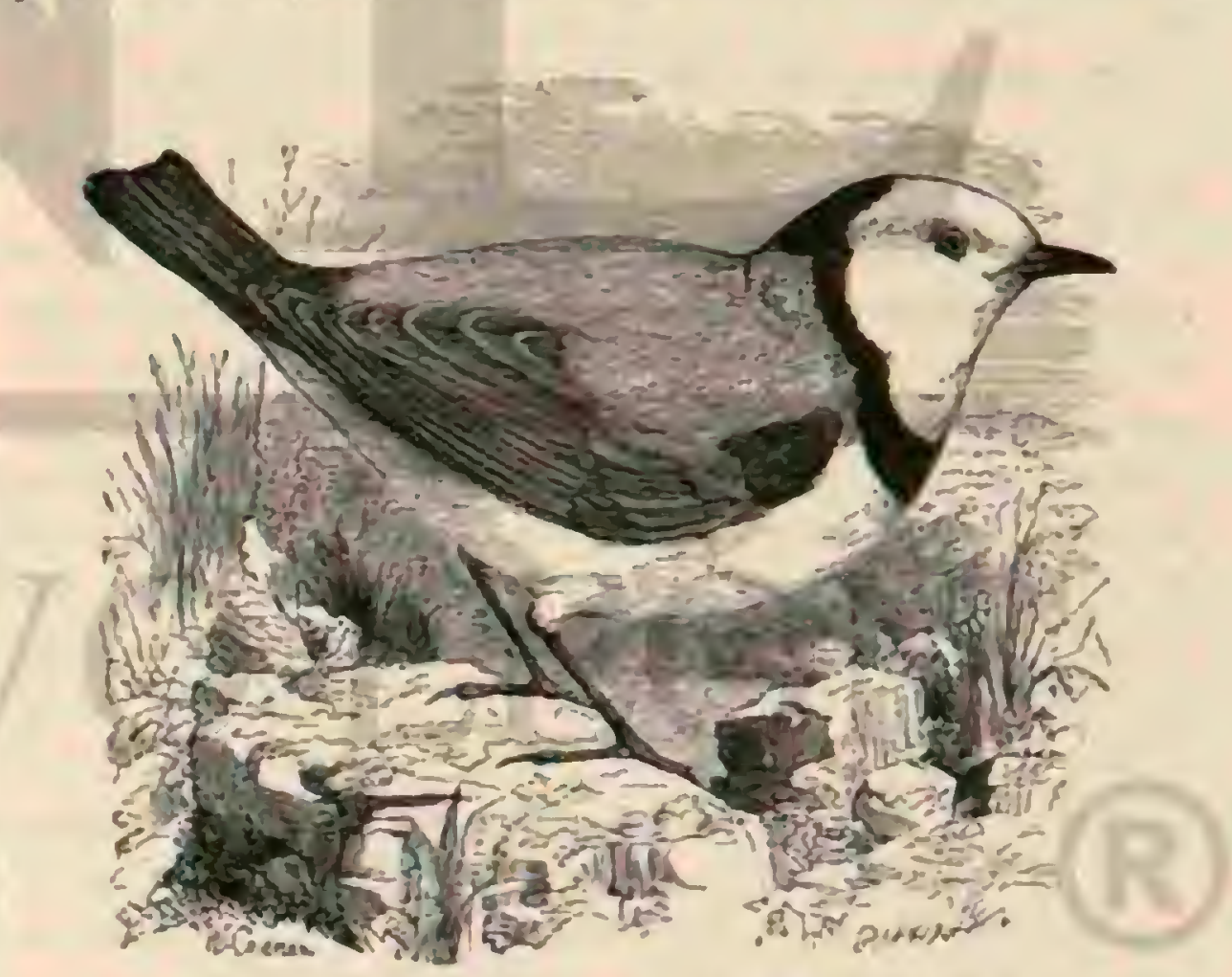

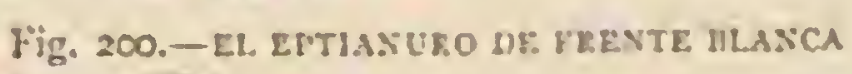

en Maitason muy apreciados, y por uno que cante bien se pagan de 60 \& So pesetas. Reficte Wright que una schora maltesa rica se dió por contenta con adquirir un petrocinclo azul, muy buen cantor, por 180 pesetas, siendo de notar que no le vendió $s u$ amo sin vacilar anies mucho. Los malteses acostumbran a colgar de la jaula donde ponen esta are un pedazo de tela roja, dispuesto de cierta manera, porque creen que esto preservará à sus cautivos del mal de ojo.

ENEMIGOS.-El petrocinclo azul no debe temer tanto 
\$. los carniceros como su congénere, pues los individuos vie. jos escapan merced a su prudencia, y los jórenes por la cir. cunstancia de hallarse el nido en un sitio inaccesible. De vez. en cuando, no obstante, algunas de estas aves perecen entre las garras del halcon, por rápido que sea su vuelo.

\section{LOS SAXÍCOLAS-SAXICOLA}

CARACTERES, - Estas aves se pueden considerar como el tipo de la familia: tienen formas esbeltas; pico en forma de leana; estrechado por delante de las fosas nasales, mas ancho que also en li basc, punta algo curva, apenas escotada y de arista angulosa; los tarsos son altos y endebles; los dedos de ún largo regular; la cola corta, bastante ancha, truncada en ingulo recto. Las alas son aigo truncadas, con la tercera y cuarta rémiges mas largns que las demás. El plumaje es lacio, peroabundante; su coloracion guarda en las diferentes especies cierta igualdad á pesar de su variedad.

\section{EL TORDO COLA-BLANCA-SAXICOLA LEUCURUS}

CARACtéres. - Fintre las especies europeas del géne. ro saxicola ocupa esta, una dé las de mayor talla, Jlamada tambien collalho, el primer puesto. Cabanis la toma por tipo de un sisb-géncro (Dromolees, Turdos curredores). Mide $11=20$ de largo; $11^{m}$. 3 I de punta ś punta de alä; esta plegada $0^{\circ}, 10, y$ 6 (o o la cola. El plumaje es negrisimoy algo reluciente, excep to la cola y sus cobijas superiores é inferiores que son de un blanco deslumbrador con una faja negra en el extremo. Las rémiges son en la raiz de color gris ceniciento claro y negro hácia la punta; la faja negra del extremo de la cola ocupa en las dos rectrices del medio las dos quintas partes y se va angostando hácia fuera, por manera que en las exteriores se reduce su anchura å ocho milimetros. La hembra se asemeja at macho, solo que la parte oscura de su plumaje es negro parciusca comó de hollin. Los pequenos se asemeján á los viejos, segun su sexo respectiro, siendo la coloracion mas clara.

DISTRIBUCION GEOGRAFICA. - Esta bonita ave habita la mayor parte de España y ademås Francia é Italia meridionales, Grecia y el/noroeste de Africa.

USOS, COSTUMBRES Y REGIMEN. - En cUal. quicra parte que se le encuentre, habita el collaba las sicrras desde su falda hasta 2,500 metros de altura sobre el nivel del max,y es muy posible que en el rigor del verano suba aun nucho mas. Fin las regiones bajas no se le ve sino en invierno, como pude observar en las sierras principales de España. Sus sitios faroritos son las peñas mas-ásperas, quebradas y solitarias; cuanto mas oscuras y negrurcas sean, mas fácil es encontrar á esta ave, sin que por csto falte en otras mas claras como son las calizas.

Quien no haya salido de la verde Alemania, dificilmente podrá formarse una idea de las montañas españolas: son bellas y majestuosas hasta cierto punto; pero no comparables con las del noric; rara vez están cubiertas de bosque jamás tapiza sus tiancos una verde pradera; solo les prestan algun colorido las lejanas tintas del horizonte, $y$ sobre el azul del cielo solo se destacar los colores, de las rocas (i).

Cuando se sale de la verde y firril tlanura, donde un lito de agua, que serpentea con caprichosos giros hace brotar

(1) Fisza pintura que el Dr. Brehm hace de La parte mas importante de la orografia de la l'enlnsula es con cécto cierta en muchas comarcas. pero ed otras es eragerald, comn prser!e conseacerse cualquicra que viaje por Galicia, Aturias, montaras de Suatander, provincias vascon. Gadas, serranla de Cvenca y Altarracin yotras machas regiones. una espléndida regetacion, y se interna uno en la montaña, encuéntrase de repente, como sucede en Eigipto, en me. dio del desierto. Verdad es que aun se atraviesa el can. po, donde crecen, plantados en linea recta, numerosos olivos seculares, y que se pisa una alfombra de siempre-vivas; pero aquellos árboles no son los mas á propúsito para comunicar animacion al desierto. Mas adelante se encuentra un terreno duro y siliceo en el que aparece todavia alguna planta, que será abiasada pronto por los ardores del sol: el viajero no ve ya sino la mo:stada en toda su salvaje belleza; peirascos arrastrados por las aguas interceptan la entrada de los valles, enire los cuales crecen y se ostentan adelfas y muchas otms. Ea la falda de la montaña crecen el romero é innu. merables cardos, reemplazando el bosque donde falta. De vez en cuando se divisa un buitre $\delta$ un águila que se cierne en las alturas; tambien suelen verse algunas golondrinas de las rocas ó varias nevatillas, el petrocincio azul y gorriones de roca; luera de esto, diriase que alli no existe la vida, que todo está muerto. De repente, no obstante, hieren el oido del viajero alegres sonidos: es el macho del collalba, que entonal su canto alegre.

El collalba es un ave vivaz y prudente; su macho divierte mucho a menudo. Danza sobre una meseta de rocas, o bien trota a lo largo de una pared de aquellas; extiende su cola y sus alas como el gallo silvestre; baja la cabeza; se vuclve - se revuelve; remóntase cantando, y acaba por bajar len. tamente, con las alas y la cola tendidas, para que oiga mejor la hembia las útimas notas de su canto. De vez en cuando se posa en la copa de un árbol solitario ó sobre una claumbera, y con mas frecuencia en la prominencia de las rocas. No tenie descender de las alturas que habita para llegar hásta los pueblos de las montañas, $\delta$ bien sube á las ernitas solitarias situadas en los picos mas altos.

Cuando esta ave se halla ocupada cerca de su nido da mas gusto observarla; cntonces es realmente encantadora.

la construccion del nido no empieza hasta fines de abril ó los priuneros dias de mayo; yo fe que no le faltan sitios convenientes donde fijarlo, pues por todas partes encuentra, a lo largo de las paredes de roca, numerosas excavaciones 6 grietas a propósiro. Su nido es grande; se compone de rastrojo y raices entrelazadas; el interior está relleno de pelo de cabra. Cada puesta suele ser de cuatro ó cinco huevos, no siendo raro encontrar hasta seis $\delta$ siete; son de un color verde azulado claro, con tuanchas moradas y pardo rojizas. Miden $0^{\prime \prime}, 023$ de largo y $11^{\prime \prime}, 017$ de mayor grueso.

A principios de julio de 1857 encontré un nicio en la Sierra de los Anches, cerca de Murcia. Hallibase en el fondo de una caverna bastante grande, en medio de unos des. prendimientos; cra un sitio admirablemente clegido, pornue es raro que un hombre se aventure en lugar tan desierto; mas a pesar de su prevision, no comprendio sin duda el ave que se podia alcanzar alti fácilmente su nido. Encontré cinco hijuelos, que aun no habian echado la pluma, $y$ antes de que acabase de examinarlos, llegaron el macho $y$ ha hembra Nunca tuve mejor ocasion de acercarme a cstas aves, pues parecian haber depuesto todo temor, y solo estiban a quince pasos de mi, uno à la derecha, la orra i la izquierda. Ia hembra volaba ansiosa de roca en roca, mientras ol macho permanecia en su puesto cantando, como para rogarme que no hiciese daño á su progenie; danzaba, trotaba de un lado a oiro, agachábase, cantaba de nuevo y volvia otra vez à su baile. La situacion era interesante: por un lado la hembra, siempre inquieta, ๖ mostrándose cada rez mas atrevida; por el otro el macho, sin saber qué hacer en medio de su angus. tia, para alejar al enenigo. No podia ser la ocasion mas pro. picia para matarlos; pero no quise hacerlo y me aleje: los 
padres entonaron entonces un alegre canto, como para darme las gracias.

Un poco nas léjos vi un macho y su hembra que guiaban á sus hijuelos, y seguidos de ellos, volaban de piedra en piedra y de roca en roca, como para ensefiarles. Uno de los padres daba la serial de ariso, y en un momento desapare. cia toda la pequeña familia en una grieta ó en medio de los neñascos, apareciendo algunos minutos despues, al oir el grito de llamada, para reunirse en la punta de alguna roca. Los pacires comienzan luego á cazar; cogen aqui un pequeño insecto, alla un gusano; persiguen por los aires á las moscas y las mariposas, y rara vez se les escapa la presa que codician. Los hijuelos han sido testigos de su destreza, $y$ quieren á su rez obtener una parte del botin; al efecto corren, se empujan y pian; pero casi siempre son los machos, mas vivaces, agiles y fuertes que las hembras, los que reciben antes su alimento en el pico. De repente vuclve a levantar cl enemigo la cabeza detrás de la piedra que le oculta; es la cabeza de Medusa para la familia entretenida en alegre juego; pero basta una sola llamada del macho para que io. dos desaparezcan con asombrosa mpidez.

De este modo siguen los polluelos bajo la egida fiel de sus padres, hasta que han mudado su primer plumaje, el cual cae en los meses de julio, agosto y setiembre; entonces se separnn, y á fines de octubre y principios de noviembre se ven las nuevas parejas, separadas ya de su familia, si bien les gusta la compania de otras de su especie. En enero ya ensa. yan su vor y en febrero resuena el canto animado y comple. to que se asemeja hasta confundirse con ell del petrocincio azul, aunque no es tan penetrante ni estridente, y acaba con un sonido especial que tiene cierta analogia con el que emite el colirojo vulgar.

\section{EL SAXÍCOLA SACRISTAN Ó MOTEADO- SAXICOLA CENANTHE}

CARACTERES. - El saxicola motendo tiene el lomo gris ceniciento claro: la rabadilla, la garganta y el vientre de color blanco; el pecho amarillo rojizo; la frente y una linea que hay por encima del ojo blancas; una mancha que se corre entre este último $y$ el pico, las nalgas $y$ las dos rectrices medias negras; las demás son blancas con la punta negra; el ojo pardo; el pico y las patas de un tinte negro (fig. 197). En el otonio, despues de la muda, adquiere el lomo un color rojizo y el vientre es amarillo rojo.

La hembra es de un gris ceniciento rojizo; la frente $y$ la linea sub-ocular de un blanco sucio; la mancha del ojo de un negro de hollin, con filete amarillo claro. El macho mide $0^{\circ}, 16$ de largo por $0^{m}, 29$ de punta á punta de ala, la cola $10^{\circ}, 06 \mathrm{y} \mathrm{cl} \mathrm{ala} \mathrm{plegada}\left(1^{\prime \prime}, 09\right.$. La hembra es algunos tilime tros mas corta y menos ancha.

DISTRIBUCION GEOGRÁFICA. - Mas fácil es citar los paises del antiguo continente donde no se encuentra esta ave, que cnumerar aquellos en que habita. Anida durante el verano desde los Pirineos y el Parnaso hasta la Iaponia y en tocios los paises del Asia de igual latitud poco mas 6 menos, mientras que en América su área se reduce al alto norte; al sur de Nueva-York no se lc ha visto nunca. En su emigracion invernal atraviesa mas de la mitad del Africa: jo le he observado en el Sudan, y otros naturalistas le han en. contrado en el Africa occidental. Lo inismo puede decirse respecio al Asia: Jerdon asegura que visita en invierno, si bien en corto número, las provincias septentrionales.

Represcntan á esta especic cn el sudoeste de Europa otras dos muy alines $y$ que tambien se han cogido en Ale. mania.

\section{EL SAXÍCOLA ROJIZO-SAXICOLA RU- FESCENS}

CARACTÉRES, - Este snxicola es unos cuanios milimetros mas pequeño que el anterior; tiene el lomo gris blan. quizco y la parte inferior del cuerpo enire gris y blanco rojizo; una lista estrecha que va desde el borde del pico al ojo y 1 uma mancha oblonga en la mejilla que abraza parte del ojo son negras, como tambien la rectriz del medio y la extremidad de las otras. El plumaje de la hembra es mas oscaro y tira mas a orin rojizo.

\section{EL SAXÍCOLA STAPAZINO - SAXICOLA STAPAZINA}

CARACTÉRES. - Is aun mas pequeño que el saxicola anterior. Tiene el lomo, el pecho y el vientre color de orin; la gargania y las alas negras; las cobijas menores llesan un filete orin. En los pequeños la cabeza es gris amarillenia, lo mismo que la nuca y el cuello, tenicndo cada pluma el tallo blanco y un filete gris; el vientre es de un blanco sucio; el pecho agrisado; las plumas de esta parte presentan un ligero filete gris pardio; las rémiges y las rectrices son de un negro yálido; las cobijas superiores del ala con filetc gris rojo.

\section{EL SAXICOLA LEONADO-SAXICOLA ISA- BELIINA}

CARACTERES.- Esta especie, muy parecida á la de cola blanca, peroalgo mayor, habita el sudeste de Europa: su color es, en el lomo entre leonado, orin y pardusco, mas subido en la rabadilla y en la parte inferior del cuerpo, lea nado orin amarillo.

\section{EL. SAXÍCOLA LEUCOMELA - SAXYCOLA LEUCOMELA}

CARACTERES,-Es originario del Asia, pero se presen. ta alguna que otra rez en la Europa oriental. Tiene la cabe7n, cuello, nuca, lomo y las dos rectrices medias negros, y todo el resto del plumaje blanco.

USOS, COSTUMBRES Yं REGIMEN DE LOS SAXICOLAS.- Jos parajes donde predomiman los peñas. cos son los preferidos por estas aves, que escasean mucho en los lugares cultivados, si bien se las encuentra tambien donde hay montones de piedras, masas de rocas $\delta$ muros. En Sue. cia, en el sur de Alemania y en Suiza, abunda el saxicola en las alturas, asi como en los valles, á lo largo de las pare. des de roca y en la llanura. En Isscandinavia es uno de los últimos séres animados que se encuentran: yo le vi en todas partes en Iaponia, y en los glaciares de Galdinoepigyen; en los Alpes se remonta sobre la zona de los bosques, hasia los glaciares del Furca y Grossglockner. Las demás especies viven de un modo analogo; habitan las comarcas mas desiertas y de hecho se las ve en el desierto mismo, a los rayos de un sol abrasador, donde solo reina el silencio y la muerte.

El sacristan, al que puedo limitarme en esta descripcion, es un ave alegre, vivaz $y$ hgil, insociable, prudente, $y$ que siempre está en movimiento: inspirale ienor el hombre; le gusta el aislamiento, y no vive en paz con ninguna otra ave, ni aun con sus semejantes. Solo en la Epoca de las emignaciones se le ve reunirse con otras de sus congéneres; pero aun entonces vive cada una para si sin contract realmente amistad con ninguna de sus compañeras de viaje. Si se fijan dos parejas una cerca de otra, cosa que sucede aigunas reces, empénase entre las dos una interminable contienda. 
La persona qque desee observarle no tardará en conseguirlo; pues para descansar escoge siempre el punto mas elevado de su dominio, $y$ no permanece tranquilo un solo instante. Se posa sobre una piedra 6 una eminencia, con el cuerpo derecho; pero a cada instante muere la cola; se baja y se levanta, sobre todo si le llama la atencion alguna cosa desusada; y à esto se debe que los españoles le den el nombre de sacris. fan. En tierra salta con tanta rapidez, que no parece sino que rueda, segun ha observado Naumann; pero en medio de su mas precipitada carrera, detićnese bruscamente; si ha encontrado una piedra se posa encima al momento, encoge las patas varias veces y sigue corriendo despues. Cuando vuela rasa casi siempre el suelo, aunque solo sea para pasar de una montaña á otra: aletea precipitadamente; avanza trazando una ligera curva hácia un objeto elevado, $y$ tan pronto como llega al pié, elévase casi perpendicularmente hácia la cima.

En el acto de volar es cuandio mejor se ve el color blanco de su rabadilla; Naumann ha comparado muy bien en aquel momento al ave con una pluma de oca arrebatada por el viento. Los movimientos cambian en el período del celo, durante el cual se remonta este saxicola cantando å una altura de S á ro metros; luego levanta las alas, déjase caer oblicua-

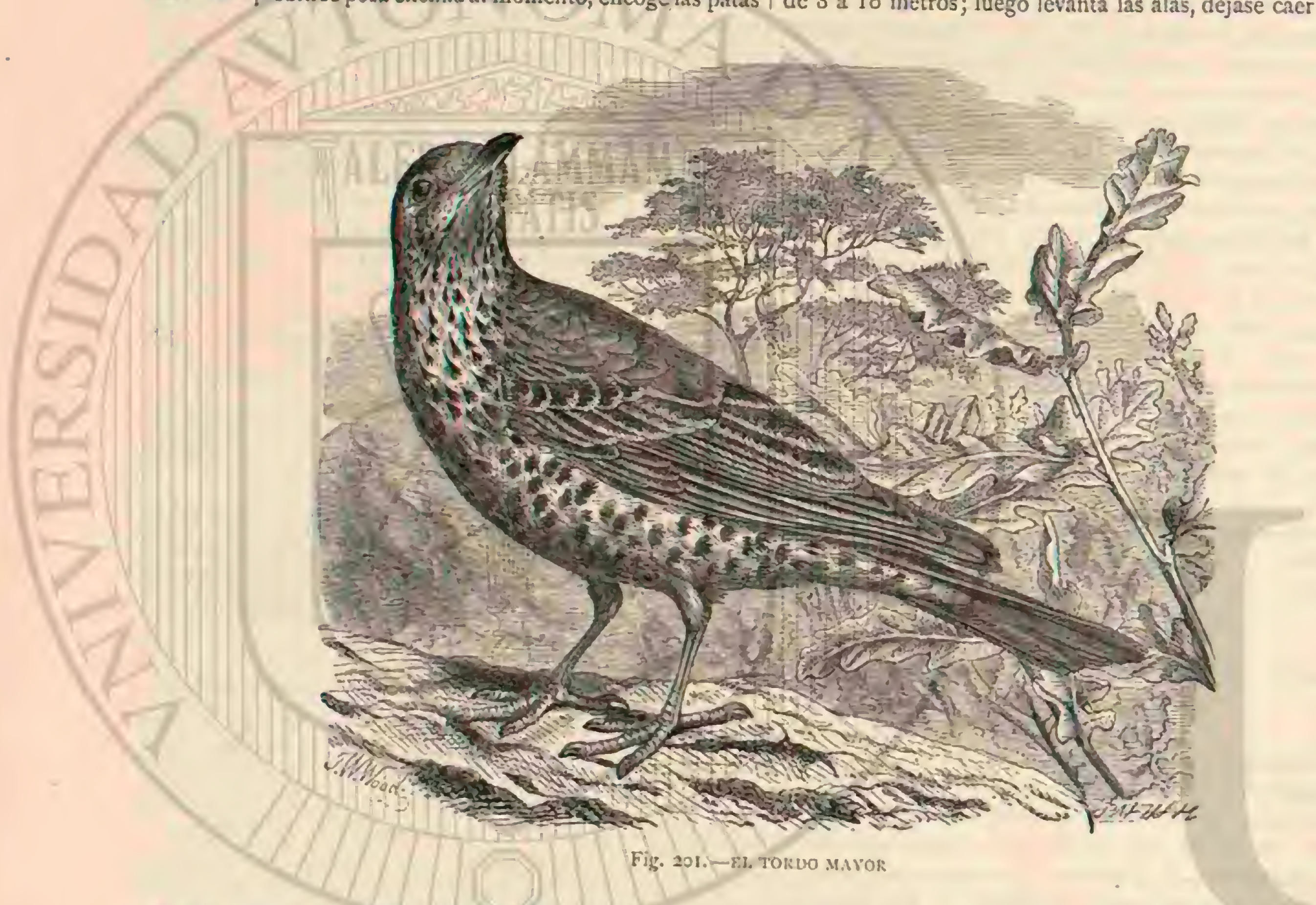

mente y termina su cancion en el momento de posarse en tierra.

Su grito de llamada se puede iraducir por griuff, gruiuf; y cuando esta excitado anade el sonido tar, tac. Su canto es singular y poco agradable: consiste en frases cortas, en las que alterna el grito de llamada con varios sonidos roncos, pareciendo que el ave trata de suplit con su ardimiento la disposicion que no le concedió la naturaleza; hay sin enibar go entre ellos tambien maestros en el canto que imitan el de otras aves con mucha perfeccion. Canta desde la mañana hasta por la tarde, y con frecuencia se oje su voz durante la noche.

El saxicola moteado se alimenta de pequeños coleúpieros, de mariposas, moscas, larvas y orugas. Desde su punto de observacion inspecciona todo su dominio, y no escapa a su penetrante vista ninguno de los séres que se arrastran por el suelo ó cruzan los aires. Atrapa los insectos a la carrera ó al vuclo, lo mismo que los colirojos.

Anida en las grietas de las rocas, en los agujeros de los muros, en los montones de piedras, y menos frecuentemente en los de leña, debajo de los troncos viejos de árbol, en ca vidades practicadas en tierra, $\delta$ bajo la prominencia de una roca; pero siempre en un sitio bien oculto $y$ protegido por arriba. En muchas partes de Alemania no encuentra ya don. de establecerse, y si entonces no prefiere emigrar, se contenta con cualquicra cavidad donde pueda tener cabida su nido. Este es de tosca construccion y paredes gruesas, formadas de raices, hojas y iallos de yerbas, con el interior relleno de lana, pelusilla, pelos y plumas. Los huevos, cuyo número varia en. tre cinco y sicte, son de color azul pálido, ó blanco verdoso uniforme, y rara vez manchados de puntos de un pardo rojizo amarillento. Miden $\|^{*}, 021$ de largo por $\|^{\prime \prime}, 015$ de díme. tro. Solo culbre in hembra; pero ayudala el macho a criar sus hijuelos; mientras aquella esta ocupada en la incubacion, su compañero permanece en los alrededores, velando por la se. guridad del nido. Apenas amenaza algun riesgo lanza gritos de espanto, mientras que la hembra suele recurrir il la astucia a fin de alejar al enemigo de sus hijuelos.

La puesta se verifica en el mes de mayo; el saxicola motea. do no empolla mas que una vez anualmente, y solo por excepcion dos. Los hijuclos pasan todo el verano con sus padres para emigrar con ellos; se van á fines de setiembre $y$ vuelven por marzo.

CAUTIVIDAD. - Los sacristanes adultos soportan con dificultad la pérdida de su libertad; pero si se les coge peq̧uenos del nido, acostưmbranse pronio a la cautividad; aun cuando solo se captan las simpatías del obserrador inteli. gente. 


\section{LOS EPTIANUROS-EPHTHIANURA}

CARACTÉRES. - Estas aves tienen el pico mas corto que la cabeza, bastante recto, comprimido lateralmente y es. cotado por delante de la punta; las alas son largas y muy obtusas, con la tercera y cuarta pennas mas grandes; la cola corta y cónica; los tarsos medianamente altos y delgados, y sus dedos largos.

DISTRIBUCION GEOGRÁFICA.-Todas las especies pertenecientes á este género son propias de la Nueva Holanda

\section{EL EPTIANURO DE FRENTE BLANCA- EPHTHIANURA ALBIFRONS}

CARACTERES. - Es conocida tambien esta ave con el nombre de effiumuro nciatilla: tiene el lomo gris oscuro, presentando cada pluma en su centro una mancha parda; las rémiges y las rectrices medias son de un pardo oscuro, y del mismo tinte las laterales, con una larga mancha bianca en las barbas iniernas, cerca de la punta; la parte anterior de la cabeza, la cara, la garganta, el pecho y el vientre son de un blanco puro; el occipucio negro, asi como una iaja que desciende por los lados del cuello y atraviesa el pecho; el ojo es de un leonado rojizo; el pico y las patas de color negro (fig. 200).

La hembra tiene el lomo gris pardo; la garganta y el vien. tre de un blanco leonado; cl collar negro se marca ligerarnen. te, y apenas está indicada la mancha de las rectrices laterales. Esta are mide (1), II de largo.

DISTRIBUCION GEOGRAFICA.-Gould, el primero que trazó la descripcion del eprianuro de frente blanca, le descubrió en las pequenas islas del estrecho de Bass: mas tarde se le encontró en todo el sur de Australia.

USOS, COSTUMBRES Y REGIMEN.-ES Un ave Ian

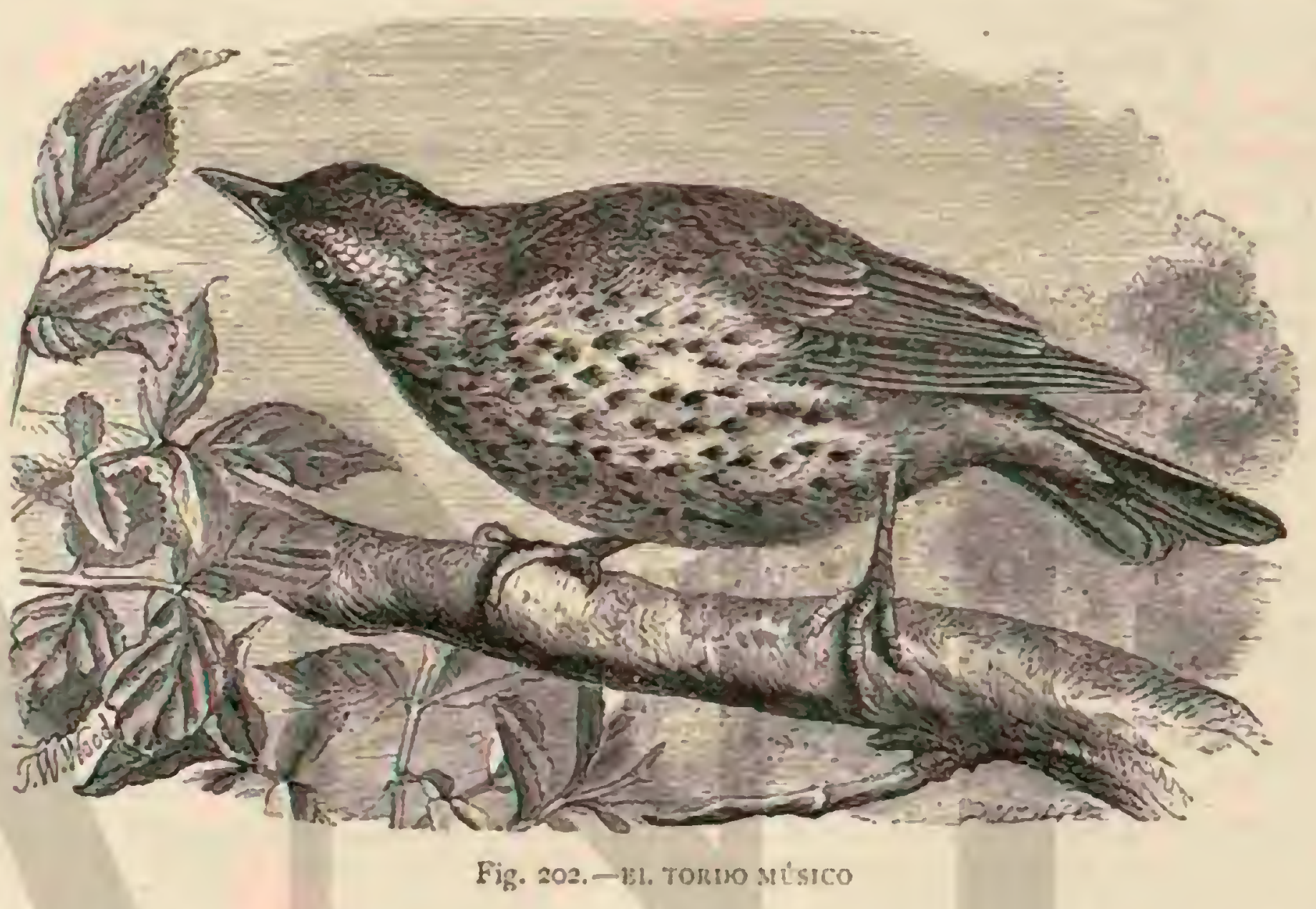

singular por su género de vida como por su plumaje A se. mejanza de todos los montecolinos, distinguese por su vivaci dad, su prudencia y timidez; como ellos permanece á menudo posada en el extremo de una rama seca $\delta$ sobre una piedm, Y si le espanta alguna cosa, vuela para ir a posarse á ciento ó doscientos metros mas léjos En tierra brinca con mucha agilidad, sin que pueda decirse que anda $\delta$ da saltitos; su movimiento, muy particular, es en cierto modo un término medio entre el salto y el paso; al propio tiempo que avanza el awe muere la cola con frecuencia.

Lara vez se ven reunidos mas de cinco ó seis eptianuros durante el periodo del celo no se encuentran siro parcjas aisladas. Son tan poco sociables como las especics examina. das hasta aqui.

Ia reproduccion se verifica en seticmbre ú octubre: el ave fija su nido en un pequeño matorral á poca distancia del sue. to; el armazon se compone de ramas secas; luego sigue una capa de yerbas, y por úttimo otra de hojas tiernas, pelos $y$ diversós inatcriales semejantes. Rasay, el primero que dió a conocer la manera de reproducirse el ave, encontró en su nido tres huevos, rara rę cuatro, que eran de color blanco, con manchas de un rojo pardo oscuro, mas numerosas en la punta gruesa. Los padres manifiestan tal inquietud por su progenie, que muchas veces se descubre por esto mismo dón de se halla; tratan de alejar de clla al enemigo, y le atraen simulando una especie de parálisis, como hacen otras aves. 1)espues de poner por segunda vez se reune la hembra con el macho y todos sus hijuelos, y desde aquel momento forman reducidas familias.

\section{LOS COLLALBAS-PRATINCOLA}

CARACTERES. - Los collalbas son pequeñas ares, un poco pesadas, de pico corto, grueso y redonaeado, ancho en la base y solo encorvado en la punta; las alas son mediana. mente largas y muy obtusas, con la tercera y cuarta rémiges mas prolongadas; la cola es corta con pennas estrechas, $y$ los tarsos altos y delgados: el plumaje es abigarrado.

\section{EL COLLALBA COMUN-PRATINCOLA RU- BETRA}

CARACTÉRES. - Es la especie mas comun del género en nuestro pais; tiene la parte superior del cuerpo de color pardo negruzco con manchas que resultan de los filetes gris orin de las plumas; la inferior es blanco amarillenta tirando a orin; la barba, los costados del cuello, la region superior del ojo y una placa en el centro del ala son blancos. El ojo es pardo oscuro: el pico 5 las patas de un sinte negro. La longi. tud de esta ave es de $0^{\circ}, 14$ y el ancho de punta á punta de ala de $1^{\circ}, 21$; esta última plegada mide $0^{\circ}, 09$ y la cola $0^{\circ}, 05$.

Lin la heubra todos los colores son menos vivos; la linea 
que hay sobre el ojo es amarillenta, y la placa del ala menos marcada.

Los hijuclos tienen el lomo rojo y gris negro, con listas longitudinales de un amarillo rojo; el vientre rojo claro, cubierto de manchas de un amarillo rojizo; las extremidades de las plumas negruzcas.

\section{EL COLLALBA RUBICOLA-PRATINCOLA RUBICOLA}

CARACTERES. - Ej collalba rubicola (fig. 199) es un poco mas grande que el anterior $y$ tiene colores mas vivos. El lomo y la garganta son negros; el vientre rojo bayo; la rabadilla, una mancha gue hay d los lidos del cuello y otra en cl ala son de un blanco puro.

J.a hembra tiene el lomo 5 la garganta de un gris negro: el vieatre amarillo rojo, ! las plumas del lomo llevan un filete amarilla de orin.

DISTRIBUCION GEOGRÁFICA.-EI collalba cómun es muy frecuente en todas las tierras llanas de Alemania y paises limitrofes; además se encuentra en la Europa septen. trional y meridional, asi como en el Asia occidental. En in. vierno emigna a Africa y a la India. Llega a Alemania á ultimos de abril y permanece hasta in de setiembre; en España se lle ve todo el año; y en Inglaterra soporta el invierno. La especie rubicola por lo general menos frecuente en Alemania que la anterior, y mas propia de la jurte occidental, habita los paises templados de Europa y de Asia, hácia el norte hastá la hatitud de la Suecia meridional. En invierno emigra al interior del Airica y a la India.

USOS, COSTUMBRES Y REGIMEN. - LaS prade. ras haindas por arroyos $\delta$ inmediatas a las corrientes de agua, que confinan con los campos $\delta$ los bosques y, están sembradas de algunos matorrales, són los sitios que busca siempre el collalba comun; huye de los lugares desier'tos y' no suele esiar sino en los cultivados. Cuanto mas fétil es. un pais, mas seguro es hallar á esta ave: abundá mucho en las vegas de España; cn la estacion del celo vive en las praderas; y lúcgo se traslada a los campos, sobre todo álos que estan planiados de patatas y coles. Donde se halla no suele pasar desapercibido, pues elige siempre puntos elevados para entregarsc al descanso y accchar su presa. '2

No puede negarse que el collalba comun es la especie me nos agradable de la familia, por mas que figure entre las ares mas alegres, vivaces $y$ ágiles de nuestro pais. Salta rápidamente en tierra, y. siempre que se posa, ó cuando descansa, inclinase bruscamente haicia adelante, moviendo la cola. Al volar traza líneas onduladas, rasando casi la tierra; puede cambiar súbitamente de direccion y atrapar los insectos al ruelo. Se le ve todo el dia posado en la copa de un arbusto, en los tailos mas alios de las plantas herbáceas ó de un ma torral de poca altura, descie donde examina todo cuanto pasa á su alrededor. De repente se precipita á tierra, recoge la presa que acaba de descubrir y vuelve á su sirio ó à orro mas alio.

El collalba comun no es en rigor sociable, aunque si menos pendenciero que otras especies de la misma familia; es afi. cionado á reunirse con sus congineres ó con otras ayes; rara vez traba disputas con cllas.

Su grito de llamada es gangoso y puede expresarse por teu ó lioniceli: su canto, muy agradable, se compone de diversos temas cortos, pero repetidos con diversas variaciones. Las notas son puras y llenas: el collaiba rubicola mezcla con sul canto los de otras ares que viven en las localidades fre cuentadas por ́́l, como por ejemplo, los del verderon, del jilguero, del pardillo, del pinzon real, de la curruca, del pin- zon vulgar, etc. Canta con ardimiento hasta principios de julio: comienza á dejarse oir temprano por la mañana; rara vez guarda silencio durante el dia, y a menudo se le oye aun despues de cerrar la noche.

Fistas aves se alimentan de insectos, particularmente de coleópteros: comen además langostas, larvas, orugas, hormigas $y$ moscas que recogen por ierra, $\delta$ atrapan al vuelo.

El collalba comun construye su nido en los prados al pié de una mata de yerba, debajo de un pequeiro matorral, y comunmente en una ligera depresion del terreno, donde le oculta tan bien que es dificil descubrirlo. llos segadores, dice Naumann, le encuentran menos á menudo que los en. cargados de recoger despues el heno con rastrillos, y hasta he visto nidos que no habiendo sido descubiertos por unos ni por otros, pudieron el macho y la hembra criarielizmente à sus pequeños á pesar de la siega. Las paredes del nido se componen de raices, flojamente entrelazadas, tallos secos, rastrojos, hojas, yerbas y musgo; en el interior hay una carja de materiales mas delicados, cubiertos de crines de caballo. Cada puesta consia de cinco à siete hueros voluminosos, lisos, de color verde azulado claro, con puntos muy pequerios de un tince amarillo rojo, y apenas visible, en la punta mas gruesa. Miden 0 , 019 de largo, por $10 \%$, or 4 en su mayor grueso.

A fines de mayo, of a principios de junio, acaba la hembra de poner, y segun parce, ella sola cubre. La incubacion dura de trece á catorce dias, macho y hembra alimentan á sus hijuelos con insectos, tratándolos carinosamente, $y \mathrm{~cm}$. plean todas las astucias imaginables para alejar de ellos á sus encmigos. Mientras se halle un hombre cerca, dice Naumann, no san $\mathbf{l}$ su nido, aun cuando tengan huevos, nj Innzan un grito que les pueda descubrir. Cuando no se mo. lesta á una pareja de collalbas comunes, solo pone la hembra una rez. al año.

Ĺstas aves deben temer á muchos enemigos, y principal. mente á lodos los pequeños carniceros; las ratas y los ratones devoran las crias, y los adultos son á menudo presa de las rapaces. El hombre no los persigue, antes por el conirario, les dispensa su proieccion en ciertos paises. En Suiza existe una creencia popular, y es que si se mata un collalba rubicola, todas las vacas de aquella parte de los. Alpes dan la leche roja.

CAUTividAD. - No se puede conservar as estas aves cautivas, pues aunque se las deje volar por la habitacion, estån silenciosas, son ariscas y aburren.

\section{LOS TURDINOS - TURDINAE}

CARACTERES - Los miembros de esta sub familia, nu. merosa y diseminada por lodo el globo, pertenecen á las mayores aves cantoras, y se asemejan entre si extraordina. riamente en cuanto á su forma y modo de ser. Su cuerpo es mas ó menos esbelto, el pico mediano, casi recto, suave. mente arqueado en la arista superior, y ligeramente escotado hácia la punta; el tarso es recto y medianamente alto: las alas no se distinguen por su gran longitud, pero son relativarnente puntiagudas con la tercera y cuarta rémiges mas largas que las demás; la cola rara vez pasa de una longitud regular, y esta por lo comun cortada en linea recta, 6 cuando no un poco redondeada en los costados; finaimente, el plu. maje es suave y blando sin ser de barbas notablemente lar. gas. La coloracion varia; por lo general es muy semejante en ambos sexos, aunque en bastantes especies sucede lo contrario. El plumaje de los pequeños tiene manchas.

En cuanto á los usos y costumbres de casi todos los tur. dinos verdaderos, pueden estudiarse perfectamente en nuestras especies indigenas. 
EL TORDO MAYOR Ó DRANA -- TURDUS MAJOR

CARACTÉRES. - Entre las especies de turdinos que anidan en Alemania es esta la mas grande. Mide $10^{\circ}, 26$ de largo; $0^{2}, 44$ de punta a punta de ala; $0^{\circ}, 14 \mathrm{el}$ ala plegada, y $11 \%$, i la cola. El plumaje es en el dorso de un gris oscuro liso 5 sin manchas; los costados de la cabeza tienen un color leonado tirando $\dot{a}$ orin amarillento, con manchas en los tallos de las plumas que forman una lista oscura que baja del extremo de la boca; la parte inferior del cuerpo es de color de orin amarillento pálido con manchas negro parduscas triangulares en la garganta, y ovales en el pecho. Las rémiges, las tectrices mayores de las alas y las rectrices son de un gris pardusco orladas de gris amarillento pálido. El ojo es pardo, el pico oscuro, la pata color de cuerno claro (fig. 201). La hernbra ditiere del macho únicamente por su menor talla, $y$ los pequenos tienen en la parte inferior del cuerpo manchas amarillas longitudinales, y otras negruzcas en las puntas de las barbas, mientras que las cobijas de las alas tienen un filete amarillo.

DISTRIBUCION GEOGRÁFICA. - Son la patria de esta especie todos los paises de Europa desde los mas sep. tentrionales hasta los situados mas al sur, asi como el Hi. malaya. Para morada escoge el monte alto de diferentes especies de árboles, pero con preferencia de coniferas. Los individuos que habitan las regiones mas septentrionales eni. gran en invierno al mediodia y oeste, llegando hasta el nord este de Africa.

\section{EL TORDO MENOR Ó MÚSICO-TURDUS MUSICUS}

CARACTERES. - Este tordo, ave farorita en los pue blos de montaña, se asemeja mucho al anterior, solo que es mas pequeño, pues mide $\left(", 22\right.$ de largo; $11^{\prime \prime}, 34$ de punta á punta de ala; esta plegada $11^{\prime \prime}, 11$, y la cola ()$^{m}, 08$. Eil plumaje es de un color gris aceitunado en la parte superior, $y$ blanco amarillento con manchas pardas triangulares ú ova les en la inferior, siquiera en esta region no sean tan nume rosas como en la análoga del tordo mayor, que tambien tiene las cobijas inferiores de las alas color de orin amari llento pálido, mientras que el músico tiene además las cobijas superiores de las alas manchadas en la punta de color ama rillo de orin sucio (fig. 202). Los dos sexos solo difieren en tamaño, y el plunaje de los pequeños presenta en el dorso manchas longitudinales amarillentas y otras pardas en los cxisemos de las plumas.

DISTRIBUCION GEÓGRÁFICA._El músico habita is mayor parte de Europa asi como tambien el Asia septentrio nal y meridional. En Nlemania es ave de cria en todos los bosques.

\section{EL TORDO ZORZAL - TURDUS PYLARIS}

CARACTÉRES. - Esta especic (fig. 203) es mas abigarrada 1,a cabeza, la parte posterior del cuello y la rabadilla son de un gris ceniciento; el lomo, las cobijas superiores de las alas $y$ las espaldillas de un pardo castańo oscuro; tas rec. trices negras, con las dos medias orilladas de blanco en la punia; las rémiges pardas, con un filete ceniciento exterior las primarias. y maizadas las secundarias de castano claro; la parte exterior del cuello es de un amarillo rojo oscuro, con rayas longitudinales negras; los lados del pecho pardos, ori lladas de blanco las plumas; el vientre de este úlkimo color; el ojo pardo, el pico amarillo $y$ las patas de un pardo oscuro.
Los colores de la hembra son algo mas claros que los del macho. Su longitud es de $1^{\circ}, 26$, el ancho de punts á punta de ala $0^{\circ}, 43$; la largura del ala plegada es de $11^{\circ}, 14 \%$ la de la cola de $1,0,10$.

DISTRIBUCION GEOGRÁFICA. - Su patria era en un principio el norte de Europa y de Asia donde anida prin. cipalmente en los montes de abedules, pero de unos ochenta años ać se ha fijado tambien en Alemania donde establece sus nidos en los bosques y plantaciones de árboles irutaies y aun en huertas $y$ jardines. A menudo pasa el invierno donde anida, y ernigra lo mas hasta el norte de Airica, Palestina y Cachemira.

\section{EL TORDO MALVIS - TURDUS ILIACUS}

CARACTÉRES. - El lomo es de color pardo aceituna; el vientre blanquizco; los lados del pecho y la parte interior de las alas de un rojo vivo, el cuello amarillento; la cara in. ferior del cuerpo está en parte cubierta de manchas prolon. gadas, redondeadas ó triangulares de color pardo oscuro; el ojo es de un pardo caíé; el pico neuro, con la base de la mandibula inferior amarilla; las patas rojizas. Los colores de la hembra son algo mas opacos q̨ue los del macho.

Los pequeños tienen el lomo pardo amarillento, con manchas amarillas; las cobijas inferiores de las alas son de un rojo de orin. Mide 1$)^{\prime}, 22$ de largo; $11^{m}, 35$ de punta á punta de ala; esta plegada $11^{m}$, it y la cola $11^{\circ}, 08$ (fig. 204).

DISTRIBUCION GEOGRÁFICA. - lis are de cria en los paises mas septentrionales de Europa, en el norte y este de Asia y en la parte noroeste del Himalaya; y por excepcion tambien en latitudes mas meridionales. Por lo comun liega sa nuestro pais junto con el tordo conun, y emigra hasta el norte de Africa, bien que la gran majoria pasa el invierno en el mediodia de Europa.

\section{EL MIRLO DE COLLAR - MERULA AUT TURDUS TORQUATUS}

CARACTERES. - Mide esta especie $4^{\prime \prime}, 26$ de largo, $11^{*}, 4^{2}$ de ancho zotal, $11^{\circ}, 14 \mathrm{cl}$ ala plegada y $10^{m}, 11$ la cola. El plumaje del macho tiene manchas claras en forma dé media luna formadas por los filetes de las plumas sobre fondo negro mate, excepto un peto ancho y blanco. Las rémiges y sus cobijas tienen un mati\% gris con orla de color gris pardus. co: las rectrices son uniformemente negras como de hollin, las dos extremas embellecidas por un filete fino, estrecho, de color blanco agrisado. La coloracion de la hernbra es mas ostura a causa de los filcies mas grises y oscuros de las plu. mas; el peto solo está indicado y es de color gris sucio en lugar de blanco. El plumaje de las perqueños se parece algo al del tordo, solo que es como de humo: las plumas del dorso son pardo oscuras con filete mas claro $y^{\circ}$ adomadas parcinlonente de manchas color de orin blanquizco en el tallo. La garganta es de un color orin claro con manchas oscuras longirudinales hicia los costados; el pecho tiene sobre fondo orin manchas en forma de media luna, que ostenta tambien el resio de la parte inferior del cuerpo sobie fondo amarillo gris claro. Vil ojo es pardo, el pico negro, pero la mandibula inferior en la raiz amarillo rojiza; fa pata es de color pardo negruzco (fig. 206).

DISTRIBUCION GEOGRÁFICA. - El mirlo de collar es ave de montana, por cuja razon se encuentra mas comun. mente en las sicras alias que en las medianas. Es ave tan comun en Escandinavia como en Suiza; no es rara en los Alpes de Baviera, en los Vosgos, en la Selva Negra y en el Riesengebirge; anida en los Alpes de Austria y de 'Iransilvania, en los Carpatos, en el Cáucaso, en el Unal, en los Pirineos 
y en la Sierra Nevada. En su cmigracion atravicsa tcdos los larga y en el extremo un tanto redondeada, por cuya razon paises europeos al sur de la Escardinavia hasta el Atlas.

\section{EL MIRLO VULGAR - TURDUS MERULA} se considera â esta ave como representante de un género ó subgénero particular. El plumaje del macho adulio es uniformemente negro, el ojo pardo, el borde del párpado ama. rillo viro, el pico anaranjado y la pata pardo oscura (fig. 207).

CARACTERES.-El mirlo no se distingue de sus conge. neres â primera vista, pero tienc alas obtusas y relativamente cortas con las remiges tercera, cuarta y quinta, iguales entre si, f mas largas que las demás; la coia es proporcionalmente

En la hembra adulta es cl dorso negro mate, y clabdómen, de color gris negruzco, presenta manchas de un gris claro formadas por las orlas de las plumas; la garganta y parte superior del pecho tienen manchas color de orin. En los pequeños se
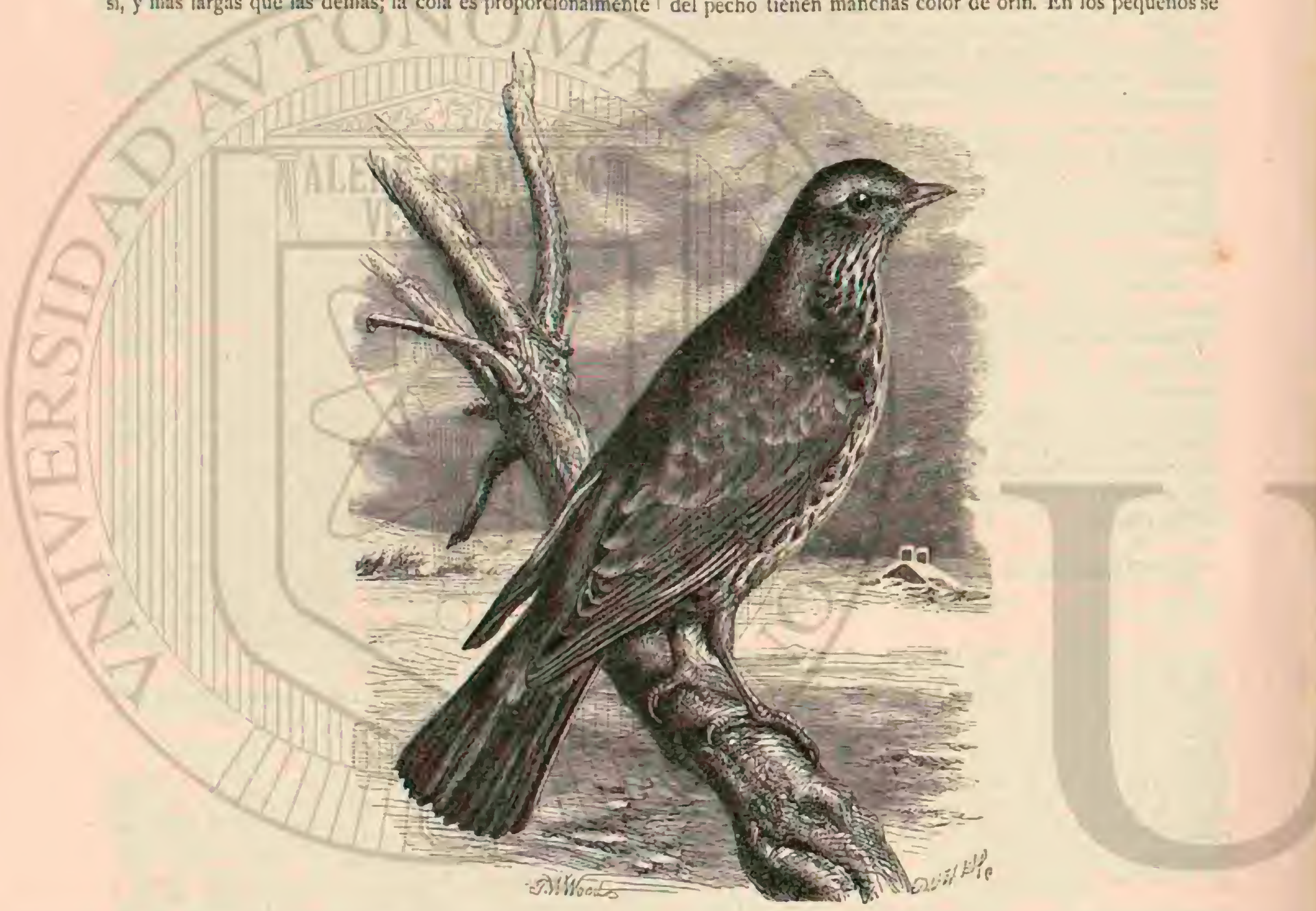

Fig. 203. - 81. TORI20 zORzsi.

ven en la parte superior, que es pardo negra, manchas de amarillo de orin en tos tallos, y en la inferior, de color orin, manchas pardas trasversales.

DISTRIBUCION GEOGRÁFICA.-Vive el mirlo regularmente en todas las localidades á propósito, desde los $66^{\circ}$ latitud norte hasta el cxtremo sur de Europa: y además en el Asia occidental y noroeste de Africa. Elige con preferencia bosoutes húmedos y en general mohedales con mucho monte bajo. Permanece todo el ano en los sitios donde se establece por poca que pueda soportar el clima. Pocos mirlos vicjos que se hayan criado en cl norte emigran, pero muchos pasan el invierno ya en el mediodia de Suecia.

- Además de las especics citadas que pueden designarse como naturales de Alemania se han visto en este pais otras venicas no solamente de Siberia y de la América del norte, sino tambien procedentes de la India y del Japon. Del pri mer pais llegan el tordo de garganta negra (Turdus alrogula ris), el tordo oscuro ( $T$. fuscatus), el tordo de Naumann ('T: Aasnianni), el cordo de cuello rojo (T. ruficollis), el tordo pílido ( $T$. pallens) y el tordo de Siberia ( $T$. sibivinus).
De las especies que habitan la América del norte nos han visitado: el tordo viajero ( $T$. misgraforius) el tordo solitatio (2. I'allasii) (fig. 205), y el tordo canior ( $T$. Sicninsonii); del Asia meridional han venido: el tordo serrano ( $T$. dauma) y finalmente el tordo de plumaje blando ( $T$ : mollissimus). Fáltame espacio para tratar detenidamente de todas estas espe. cies, pero las personas que desecn mas detalles los encontra. rán en mi obra sobre las Aars curutions.

USOS, COSTUMBRES Y REGIMEN DE LOS TORDOS Y DE LOS MIRLOS.--Los tordos viven en las paises mas diversos, en medio de las mas variadas condiciones; pero en todas partes buscan los bosques. Menos delicados. que los humicolinos, todo paraje les agrada, no sierdo los espesos bosques de las llanuras, o las giganiescas selvas virgenes de los trópicos, los que principalmente les atraen, sino que se fjan tambien en los de coniferas, 6 en los matorrales de las estepas de poca espesura. Encuentma un abrigo suficiente mas allá de la zona superior de los árboles, en medio de los glaciares.

Pocos hay que permanezcan todo el año en el mismo pun. 
to: los mas de los que habitan el norte, como los que viven en las regiones templadas, son viajeros y franquean considerables distancjas; los que se han visto á veces en nuestro pais, segun hemos indicado antes, debieron recorrer la mitad del globo para llegar, pues saliendo del exiremo oriente de la Siberia, del Kamtschatka, habian franqueado el mar de Behring, atravesando toda el Asia, antes de penetrar en Europa. - Algunos de ellos, dice Naumann, llegaron á nuestro pais en reducido número, y pareció que ya no se atrevian á rol. ver al punto de partida, pues se reprodujeron y criaron sus hijuelos en ticrra extrana. Nos adniramos al pensar en las enormes distancias que han debido recorrer $y$ en el poco tiempo empleado para ello, venciendo todos los obstáculos que se oponian á su paso. No sabemos á punto fijo cliål es la causa de estas emigraciones; pero se puede creer, con
Naumann, que entran por mucho los instintos sociables de estas aves, y tambien los vientos contrarios, las tormentas y los huracanes, que las apartan de su acostumbrada ruta. Es rerdad que estos rodcos son raros; pero no lo es menos ciue en tiempo normal recorren los tordos inmensos es. nacios.

Tndas estas aves, perfectamente dotadas, son ágiles y pru. dentes; sus sentidos delicados; cantan bien; les gusia la so cicdad, por mas que sean algo pendencieras; en una palabm, reunen mil buenas cualidades, aunque tienen tambien sus defecios. Desde la mañana á la tarde se las ve en continuo movimiento, y ínicamente los ardores del sol de medio dia disminuren algun tanto su actividad. Por su manera de moverse se asemejan mucho á los humicolinos: en tierra brincan ágilmente, dando grandes saltos; si observan algo ratraordi.

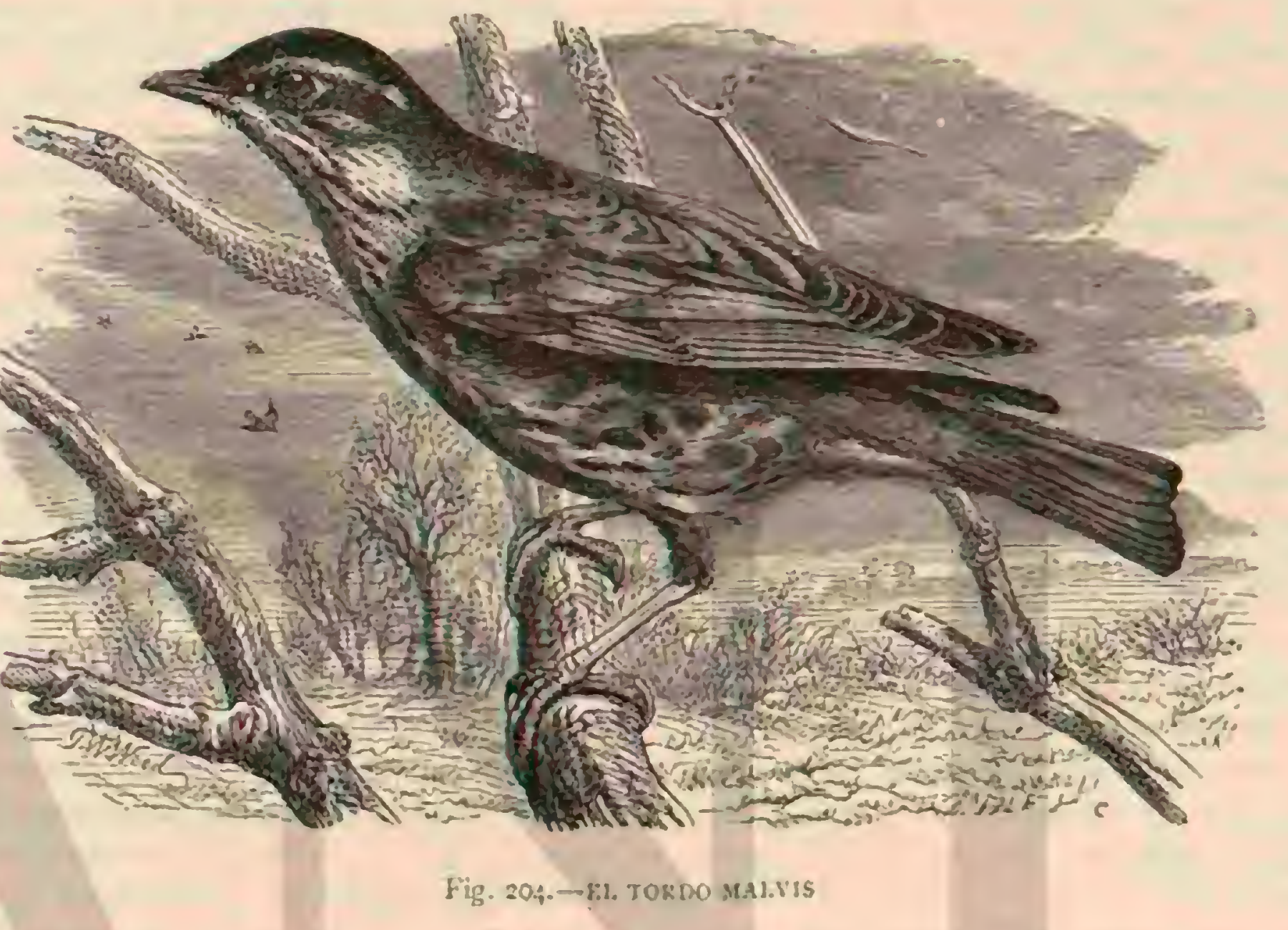

nario, levantan la cola y agitan las alas; no es menor su des treza para recorrer los árboles y saltar de rama en rama, ayu dándose con sus alas. Cuando se asustan los tordos no hacen mas que revolotear con bastante torpeza, rasando el suelo y dirigiéndose de un matorral \& otro; pero una vez que se han remontado a cierta altura cortan los aires con notable rapidez. El zordo músico, el zoryal y el maivis son entre nuestras especies indigenas las que ruelan mejor; el major ó drana y el mirlo, que tienen las alas mucho mas corras, son muy inferiores en este concepto. El vuelo del drana es pesado y oblicuo, lo cual no impide al ave franquuear grandes espacios con cieria rapidez; en cuanto al mirlo, ruela hotizontalmente y por tiempos, y mueve pocu las alas; pern está perfectamente dotado para cambiar fácil y bruscamente de direccion.

los sentidos de los tordos aicanzan un desarrollo baśtante igual: ven perfectamente y divisan á larga distancia el mas pequeño insecto. Fn cuanto al oido, es muy delicado, y sa. ben distinguir los sonidos, como se cieduce yn de su canto. Son golosos, lo cual tieride á probar que tienen gusto; pero por lo que hace á los demás sentidos, no nos atreveremos à ascgurar nada. El que los conozca no puede negarles cieria inteligencia, pues son astutos, prudentes aunque no timidos: y atrevidos y recelosos a la vez, comprenden al momento, aciertan en sus juicios y utilizan todos los medios para esণ̧uivar los peligros. En el bosque hacen las veces de vigilantes o avisadores, que escuchan, no solo à sus semcjanies, simo Томо III lambien is las demás areș, y aun á los mamifcros. Todo cuanto es nuevo ó desusado despierta su atencion: acércanse con curiosidad para rer mejor lo que les chocó, mas no por eso dejan de estar alerta. Los que se han rriado en los bos. ques desiertos del norte son fáciles de sorprender ó de atra par con lazos; pero una vez que les alecciona la experiencia, para lo cual necesitan muy poco, no se dejan ya coger de la misma manera.

Lus tordos son-aves sociables; con raras excepciones; no pueden vivir unos sin otros, y rara ver. lanza ălguno su grito de llamada sin que los demás contesten y acudan presurosos. A pesar de sus instintos de sociabiliciad, no son pacificos, antes por el contrario, disputan casi continuamente. A me nudo se reunen algunas especies distintas y viajan de concierto; agrcgåndose â veces a oiras aves, aunque sin contraer amistad con ellas. Eil hombre no les inspira mucha confianza; aun aquellos que van a establecerse cerca de su morada, están siempre alerta; por otra parte saben distinguir entre los que pueden tener malas intenciones y los que son inofensi. ros. Los individuos que se cogen viros son al principio muy salvajes: pero a los pocos dias de cautividad, y prodigándoles muchos cuidados, se suaviza su carricter y acaban por cobrar afecto a la persona encargada de su conservacion.

Los gritos de los diversos tordos ofrecen entre si mucha analogia, lo cual no impide que se reconozca el de cada es. pecie. El drana usa para su grito de llamada la silaba chsarr. que pruede imitarse perfectamente frotando con una varilla 
las puas de un peine; cuando el are se irrita añade las sila. bas $r a, t a, t a ;$ el sonido que produce en los momentos de angustia es muy dificil, si no imposible de reproducir. El grito de llamada del músicose reduce a un silbido ronco, equivalente \& tzip, al que sigue por lo regular la silaba tack ó tock: cuando el animal se excita puede cxpresarse por sty.a. styr sty:x. El grito del tordo zorzal es clack ihack chaik, repetido varias veces seguidas con mucha rapidez; cuando llama á sus semejantes añade gri gri. El grito del tordo malvis es una nota muy alta y lenta, que se traduce por tsi, á la cual sigue otra mas baja, gack; su grito de angustin es cherr ciserr. El mirlo de collar emite el sonido foce locis, merclando la silaba tack pronunciadal en tono mucho mas bajo. El mirlo negro produce un trino equivalente a sri ó trenk: sillama su atencion algun objeto sospechoso, grita con fuerza dir dix, y cuando huje anade las sílabas gri gris gui. Todos esios gritoś, que solo podemos anotar de un modo muy imper fecto, son muy viriados entre sí pero todos los tordos los comprenden, y se les ve prestar la mayos atencion á los de las otras especies, sobre todo si es el de aviso.

Los tordos pueden figurar entre las buenas aves cantoras: el primer lugar corresponde al músico; luego sigue el mirlo, y despues el drana y el zorzal. Los noruegos llaman al primero ruiseñordel norte; el poeta Welker le dio el nombre de rriseñor de las bosunes. Con sus notas, gue recucrdan los sonidos de la Pauta, se mezclan por desgracia otras chillonas y poco agra. dables; mas no alteran micho la gracia del conjunto.

El canto del mirlo es apenas inferior al del tordo comun: se compone de varias notas adminblemente bellas, aunque mas rnelancólicas que las de aquel: el drana emite solo cinco ó scis frases, cuando mas, poco distintas unas de otras, pero compuestas casi cxclusivamente de notas llenas y aflautadas. Lo mismo sucede con el tordo malvis y el de collar. eVer dad es que su canto no tiene, dice Tschudi, toda la profundidad del que produce el ruisenor; pero como resuena en el bosque el de centenares de individuos, forman un coro me! lodioso, que anima los desiertos paisajes de las altas mon taถ๊ละ. \&

Micmtras que la mayor parte de las, aves mueven las alas, la cola y todo el cuerpo cuando cantan, los tordos permane. cen tranquilos y solemnes al dejar oir su voz. Las frases son redondas y pronunciadas con claridad; el canto es en un todo apropiado para los bosques; pero demasiado fucrte para una habitacion. Los tordos comienzan a cantar pronto y no cesan hasta fines del verano; el mirlo da principio en el mes de febrero, cuando todo el bosque está todavia cubierto de hiclo y nieve El tordo músicn, refugiado en tierra extraira, piensa en su pais, y parece que le consagra sus cantos; lo unismo sucede con el tordo viajero de la América del norte, $f$ pro bablemente con léjos. Imitando en ello á las demás aves cantoras, los machos rivalizan entre si: tan pronto como uno de ellos se posa en la copa de un árboi y deja oir su voz, apresúranse todos los demás a contestarle; diriase que aquel ave comprende la excelencia de su canto, y que siente por ello cierta vanidad, pues al paso que está muy oculto cuando no se le oye, dé. jase ver todo lo posible al entonar su canto, colocindose para ello en un alto trbol, en la extremidad de una rama, y lanza sus notas argentinas, que resuenan en medio dél bosque.

Los tordos se alimentan de insectos, de caracoles y gusa nos; en el otorio conien bayas: recogen su alimento en el suclo, $y$ dedican diariamente varias horas a buscarle. Se les ve salir del bosque $y$ dirigirse á los campos, â las praderas y ílas orillas de las corrientes; corren de un lado á otro, re cogiendo lo que encuentran en tierra, 6 escarban con su pico los montones de hojarasca. Apenas cazan insectos al vielo; los mas de ellos son muy aficionados, los unos a los frutos, los otros á las bayas. No en rano se designa al drana con el nombre de tirdo del muirdago, pues le gustan mucho las ba. yas de esta planta, y empeña furiosas luchas con sus seme. jantes para disputarles aquel alimento. Los antiguos creian que los tordos eran los que propagaban el muérdago, y la opinion parece fundada: despues del periodo del celo se dirige el mirlo de collar a los brezos, y come tal cantidad de bayas de mirtilo que, segun Schaner, su carne adquiere un color azul, se enrojecen sus músculos, y aparecen manchas en las plumas. En invierno busca el zorzal los encbros; alimén. tase de sus frutos, y su carne toma un gusto particular. Los cordos comen adems grosellas, serbas, mosas, frambuesas, bayas de saúco negro y blanco, ciruelas, cerezas y uvas. Todas las especies americanas son tambien unuy aficionadas it los frutos.

Poco despues de llegar á su pais se reproducen los tordos; pero los que liabitan al extremo norte no suelen verificarlo antes del mes de junio. Varios de ellos, particularmente los 7.oreales y los mirlos de collar, siguen reunidos aun en el período del celo, al paso que otros forman parejas que habitan cietlo dominio. Los nidos de las diversas especies se aseme. jan mucho; pero ocupan posiciones distintas: el dranat anida en marzo sobre una conifera ó una encina á 10 o 15 metros sobre el suelo; su nido se compone de briznas secas, tallos de yerba, liguenes, musgo y mices. Las puestas constan de cuatro á cinco huevos, lisos, de un blanco agrisado ó rojizo, cu. biertos de puntos mas ó menos grandes, de un tinte rojo pardo y gris violeta, $y^{\circ}$ largos de $0^{*}, 0,0$ por $0^{\infty}, 022$ de grueso. Si el año se presenta bien, anida cada pareja dos veces du. rante el verano.

El tordo músico forma su nido en un arbolillo ó un mator. ral, empleando los mismos materiales que la especic prece. dente: pero rellena el interior con muggo y madera podrida desmenuzada, reuniendo el todo por medio de salim. En los primeros dias de abril deposita la hembra cuatro ó seis huc. vos lisos, de color azul verdoso mas ó menos intenso, con puntos negros ó de un pardo negro, largos de 0 ", $02 j$ por $0^{*}, 018$ de grueso; a principios del verano anida este tordo por segunda ve\%

De un siglo á esta parte se ha visto al tordo zorzal anidar en Alemania: por mas que los bosques de abedules dal norte constituyan su verdadera residencia. Se fija indistintamente en aquellos que estín próximos á las viviendas humanas y en los que se hallan lejanos. Alli se encuentran nidos casi en todos los árboles, los nuevos al lado de los antiguos; yo he visto a menudo de cinco á diez en una misma copa, pero por lo general solo habia uno habitado. Estor persundido de que eligen para anidar un punto determinado del bosque; si se jenetra en él cuando tienen huevos ó crias, cncuéntrase por todas partes la vida y la animacion; y un todo el bosque re. suenan sus gritos y sus cantos, pues asciende a varios centenares el número de parejas que cubren unas cerca de otras. Sus nidos se hallan en lo alto de los abedules, y rara vez á menos de dos metros del suelo; cada pareja ticne su domi. nio; pero tan poco extenso, que se puede considerar que cada arbol iorma el centro de uno de ellos. El nido se compone de ramilas, rastrojo y briznas de yerba; el interior está relleno de algunas jerbas finas, y la base se forma a menudo con una capa de tierra bastante gruesa La hembra prone de cinco a seis huevos de color verde mas ó menos viro, sembrados de puntos de un pardo rojo, mejor marcados unas reces que otras, reunidos alrededor de la punta gruesa trazando como una corona; su longitud es de $4^{\circ}, 026$ y el grueso de $10^{\circ}, 020$. Se ha observado que los zorzales que anidan en Alemania forman tambien reducidas banciadas. 
Eil tordo malvis habita las mismas localidades que la especie anterior, con corta diferencia, solo que busca mas los bos. ques pantanosos. 'lambien se le ha visto anidar algunas veces en Alemania: su nido se asemeja al del tordo zorzal, y está relleno interiormente de residuos de madera, de tierra y de arcilla, bien agluinacio todo: los huevos son algo mas pe. queños que los del sordo zorzal.

Fil mirlo de collar no anida en la Luropa central á menos altitud que la de 1,000 metros sobre el nivel del mar; en liscandinavia se le encuentra desde las costas hasta la cle. racion de unos 1,500 metros; en las montanas de Suiza se establece en los árboles achaparrados que constitujen los busques en aquella altura. Ciloger encontró nidos en el Kie. sengebirge, ì una altitud de 1,500 metros, y en los pinos a uno de elevacion ciel suelo, asi cerca de las casas como en los parajes desiertos. Cada pareja ticne su pequeño dominio y vive pacificamente con las recinas; los nidos se hallan en medio de los liquenes que penden de las ramas, formando parte de la construccion algunas de las que estín secas. El armazon se compone de tallos de yerbas, ramas pequenas, rastrojo y musgo, reunicio todo con un poco de tierm humedecida 6 de turba: la cavidad esta cubierta de rastrojo y yerbas finas. La liembra deposita en el mes de mayo cuatro ó cinco hue. vos de color verde púlido, sembrados de puntos, manchas y rayas de un tinte violeta y pardo rojo. En la Europa centrol anidan los aduitos dos veces al ano: pero en Escandinavia no sucede lo mismo: en el mes de junio he visto adulios que comenzaban à mudar.

El mirlo negro anida en la espesura, sobre todo en la de coniferas jóvenes, a poca elevacion del suclo $y$ a veces en la tierra misma. El nido varia mucho segun las localidades: á veces se halla en el tronco muy abicrto de un tróol, en cuyo caso se reduce a una masa de musgo y mastrojo seco. Cuando está situado en un arbusto, un matorral, etc., se compone exteriormente de raices y briznas, tapizado intcriormente jor una capa de yerba perfectamente lișa, meachada con tierra húmeda Si la estacion es muy lavorable pone la hombra en marzo: los huevos, cuyo número varia entre cuatro yeis, son de un zinte verde azul palido, con puntos y manchas de un rojo de orin, azuladas ó accitunadas y cenicientas, poco aparenies á veces: la hembra pone por segunda vez á principios de mayo.

Entre los tordos se observa que el macho solo reemplaza a la hembra cuando cubre hácia el medio dia; en las demás horas no cesa un momento de distraeria con sus cantos. Los padres manifiestan a sus hijuelos ol mas vivo amor ye se inquietan mucho cuando álguien se acerca al nido que los oculta, contribuyendo sus gritos de angustia is que se les. descubra antes. Se ha dicho que el zorzal trataba de alejar ¿su enemigo dejando caer sobre él sus excrementos; pero yo no he visto semejante cosa: aunque si es cierto que los tordos acometen á su adversario, se precipitan sobre él y le rozan casi con las alas, procurando asustarle. Si con esto no consiguen nada, apelan á la astucia; revolotean y se salvan pe. nosamente, cual si estuviesen heridos ó paralizados: atraen á su enemigo, como brindándole con una fácil presa; alệanle de la cria y ruelven luego alcgres sa su lado.

Los hijuelos salen a luz: los catorce ó diez y seis dias; los padres los alimentan con insectos; su crecimiento es-muy rápido, pudiendo ya rolar à las tres semanas: permanecen aun algunos dias con aquellos, que no los abandonan hasta que se acerca el otorio; pocas semanas despues de haber em. prendido su vuelo comienza la muda; en el momento de su emigracion, todos tienen el segundo plumaje.

Exceptuando el mirlo, todos los tordos dejan el pais en el otono y se dirigen hacia el sur: las especies originarias del extremo norte pueden pasar muy bien el invierno en el cen. tro de Europa; pero las mas no se detienen sino en el me. diodia, donde cada especie se fịa en las localidades que le convienen. Los mirlos de collar se establecen en bandadas mas ó menos numerosas en las rertientes que baña el sol de las altas montanas de la Fspana meridional. I.os tordos mú. sicos, los malvis y los zorzales pululan a miles en bosques, brênas y vinedos; tambien se ve el drana; pero escasea algun tanto. 1.0 mismo sucede en Grecia é Italia.

lodos los tordos viajan por bandadas sumamente nume. rosas. En el otoño de $S_{52}$, dice Gadamer, tuse que recorrer el hosque: de repente oi sobre mi cabeza un rumor espanta. ble, acompañado de un silbido extraordinario; tuve miedo, y temí iba sa ser derribado por la caida de un meteoro; pero bien pronto supe á qué aenerme. Hallábame debajo de una bandacia de unos diez mil tordos malvis, por lo menos, que dejandose caer desde una altura prodigiosa, fueron á posarse sobre todos los árboles inmedintos. Su descenso fué tan rápido, que no pude observarlos hasta que se hallaron en el ramaje.

Durante su viaje se dividen las bandadas en otras mas ye. quenas; pero no independientes unas de otras, y se las ve cubrir espacios de sarias leguas cuadradas, ocupando todos los matorrales.

CAZA. - Se comprende que diesde hace siglos haya dado caza el hombre a estas bandadas de aves. Marcial clogió en unos versos la carne delicada de los turdos, y otros autores de la antigüedad aseguran que es un soberano remedio para combatir diversas enfermedades, indicando al propio tiempo de que modo se debe preparar. Nosorros podemos suponer que en todo tiempo se han cogido los tordos como hoy dia, es decir, con trampas y lazos en que se ponen por cebo las bayas y los frutos de st gusto. Por fortuna va disminuyendo el número de pajareros. En lirancia, en Italia, España y Grecia persiguen todos a estas aves, y es incalculable el número de las que se matan.

CAUTIVIDAD. - No se queden conservar los tordos cautivos si no se les pone en una gran pajarera al aire libre, pues su voz es demasiado fuerte y sonora para una habitacion, jurescindiendo de que su voracidad ocasiona inconve. nientes que no pueden evitarse ni aun con la mayor limpieza. Cuando es posible proporcionarles una pajarera conveniente los tordos son muy agradables; su viracidad y continuo movimiento distraen umcho, y su canto recrea al aficionado, en una época en que todas las dernas aves guardan silencio, pues tanto cautivos como libres, comienzan a dejar oir su voz. desde el mes de feurero.

\section{LOS BURLONES-MMMNE}

CARACTERES. - las aves que forman este grupo bien circunscrito se asemejan muclio a los turdinos, de los quese distinguen por su cuerpo muy prolongado; pico medianamente largo que si bien se asemeja al de sus afmes, es tmpero mas alto y mas corvo en la arisia supcrior; las patas y los dicios son tambien relativamente mas robustos y los tarsos mas altos; las uñas son débiles; las alas muy redondendas sobresalen muj poco del nacimiento de la cola y tienen la tercera, cuara y quinta rémiges mas largas que las demàs pennas: Ia cola es muy larga pero de poca anchura con las ocho rectrices del centro de igual longitud, mientras que las dos extremias de cada lado son con frecuencia mas cortas oue las del medio, y la extrema mas que la del lado. El plumaje es mas blando y lacio.

DISTRIBUCION GEOGRÁFICA.-Fsta sub familia es propia de América. 
EL SINSONTE - MIMUS POLYGLOTTUS

CARACTERES.-Es el tipo fundamental y la especie mas conocida del grupo. El lomo es pardo gris, y algo mas rscura la region de la linea naso ocular y del oido; la parte inierior del cuerpo es de color pardo leonadu, algo mas claro, casi blanco, en el vientre y barba; las rémiges, rectrices y cobijas de las alas son pardo oscuras, las primeras orladas de color leonado; la quinta, sexta, séptima y octara son blancas en la mitad correspondiente à la raiz; igual color tienen las

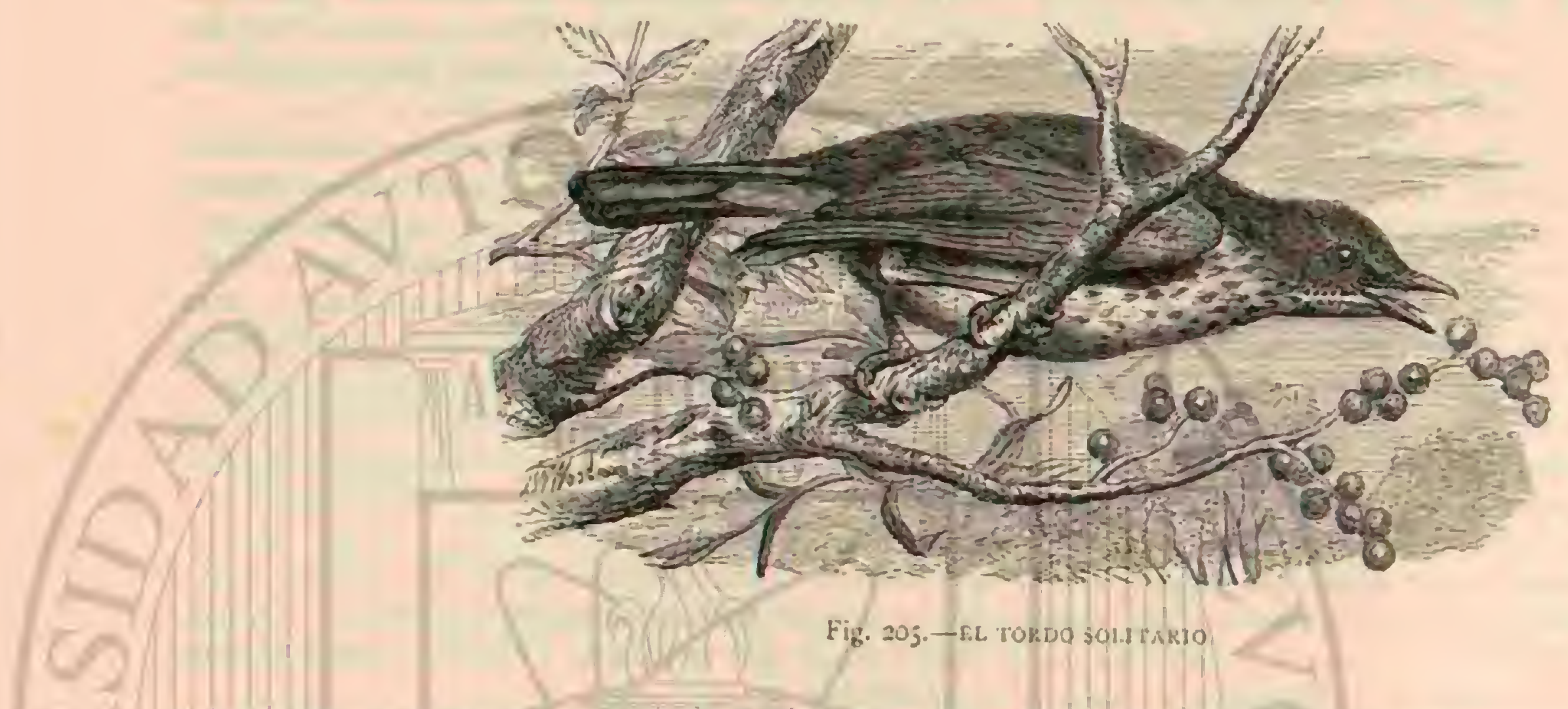

extrenidades de las rémiges secundarias y las grandes cobi- da de un tinte algo mis claro que el resto, pero poco cieterjas, la jrimera toda ella, la segunda en la cara inferior, la minada. En la henbra, cuyo tamaño es apenas menor, no tercera en el extremo, y las demás solo tienen la punta orla- tiene tanta extension como en el macho el color blanco de
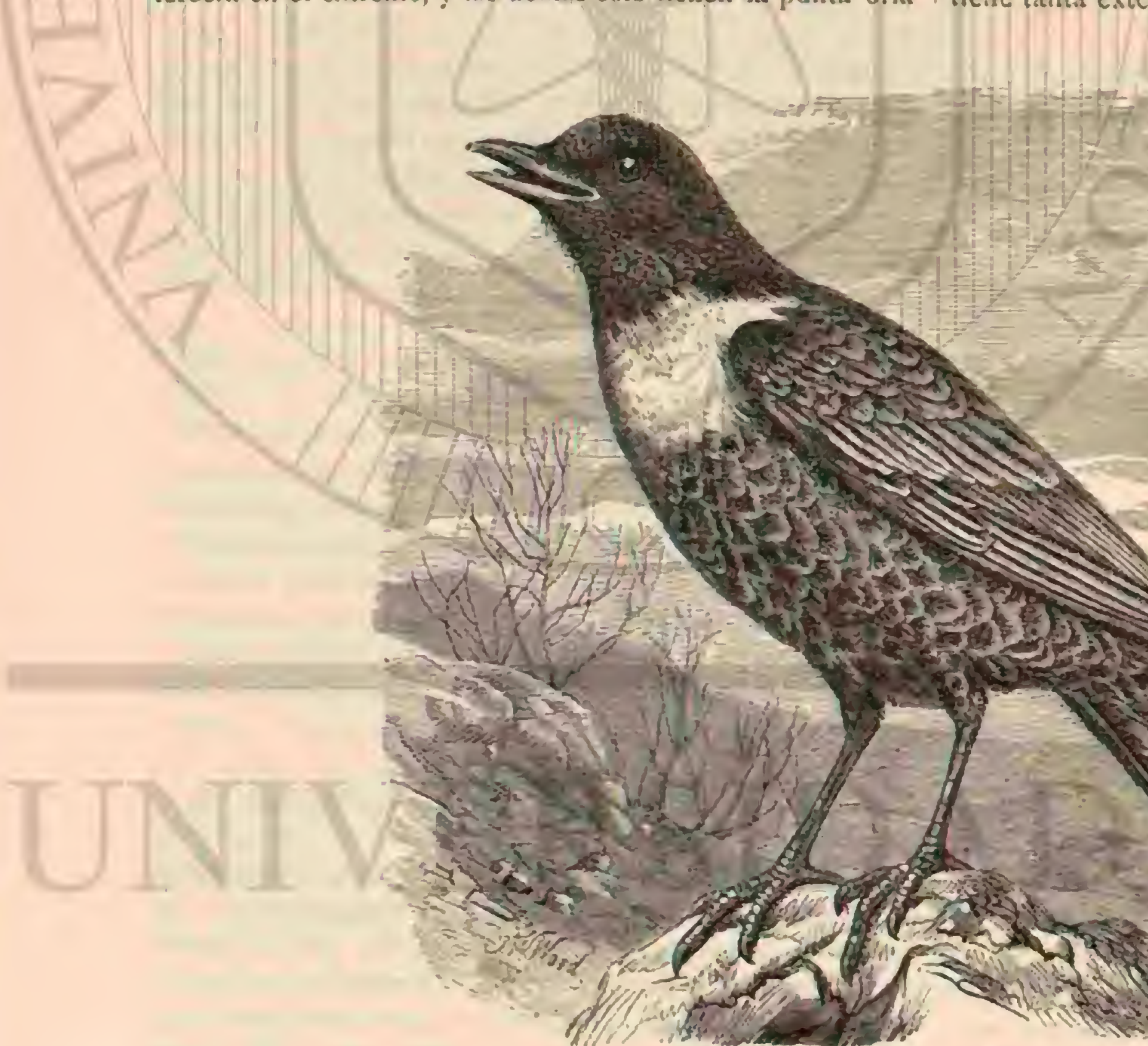

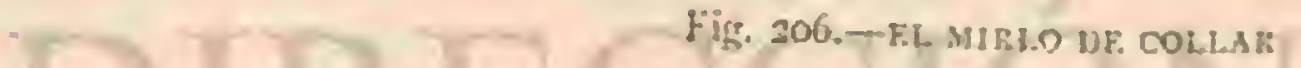

la cara inferior de las pennas primarias El ojo es amarillo pálido, el pico negro pardúsco y la jata pardo oscura. Las dimensiones son: $0^{\circ}, 25$ de largo, $0^{\circ}, 35$ de punta a punta de ala; $11 ", 11$ esta Lilima y $11^{\prime \prime}, 13$ la cola (fig. 208).

DISTRIBUCION GEOGRÁFICA. - La patria de esta ave son los Estados Unidos desde los $40^{\circ}$ latitud norte hácia México, siendo mas frecuente en el sur que en cl norte. Desde alli emigra puntuainsente en otono hácia latitudes mas bajas; on Luisiana es ya constante, por lo menos en su comarca respectiva cuando no en su localidad.

USOS, COSTUMBRES Y REGIMEN.-EI burlon po. ligloto ó sinsonte habita en las breiras de todo género, en los bosques de poca espesura, y en las plantaciones y jardines; anida cerca de la morada del hombre, y en invierno, sobre todo, no se aleja mucho de ella. Busca principalmente las llanuras arenosas, la orilla de los rios y las costas, eligiendo 
los sitios donde crecen arbustos ó árboles poco elerados y aislados $\delta$ en grupos; no se le sucle ver en los grandesbosques á no ser cuando viaja. Esta ave salta en tierra como los tor dos, y á menudo ensancha su cola y la cierra bruscamente. Cuando ruela de un matorral à otro describe una linea ondulada de curvas cortas, abriendo tambien y cerrando la cola En sus viajes recorre grandes espacios, pero jamás iranquea de una vez largas distancias: siempre vucla de árbol en ìrbol.

Audubon asegura que esta ave, tan amiga del hoobre, es en la emigracion muy cauta y recelosa al princjpio, y que hasta que trascurre algun tiempo no se vuelre mas conirada Por lo demás lo que la ha hecho célebre no es su canto propio, sino su don de imitacion, que ha inspirado \& los naturalistas americanos las descripciones mas entusiastas. Wilson y Auciu. hon dicen a una que el burlon poligloto es la primera de todas las aves cantoras, y que ninguna otra tiene una vor. tan extensa y variada.

No son los dulces sonidos de la flauta 6 de cualquier otro instrumento música los que entonces se oyen, dice Au dubon, sino la yoz, mucho mas melodiosa, de la naturaleza misma. Imposible es figurarse notas tan llenas, sonidos tan variados y de tal extension; no existe ninguna otra ase en el mundo que pueda rivalizar con este rey del canto. Algu. nos curopeos han dicho que el del ruisenor vale tanto como el del burlon; yo he oido a las dos aves, tanto en libertad como cautivas, y convengo en que las notas del primero consideradas aisladamenie, son tan bellas como las del se. gundo, pero si se comprende el conjunto, no es comparable el del ruiseñor con el de nuestra especie., Wilson no va tan

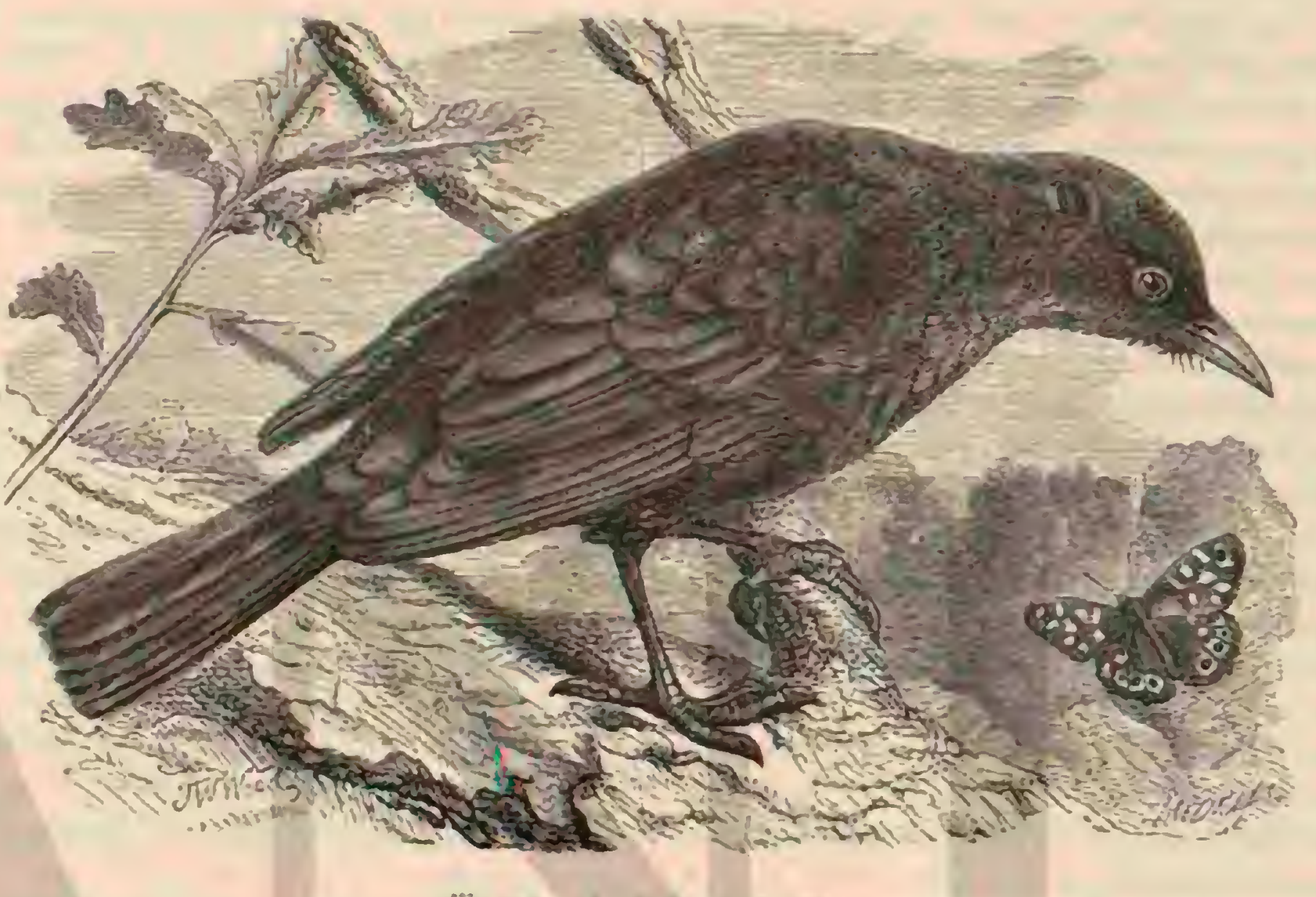

Fัg. :07. H. MHRLO VHI.GAR

Iéjos, y los inteligentes europeos son tambien de un parecer diametralmente opuesto. El burlon poligloto, dice Gerhardi, debe su fama á la admirable facilidad con que imita el canto de otras ares. Las buenas cantoras son inuy rams en el nuevo continente, y basta que haya una mediana que sea pasadera para que se la ponga en las nubes. Gerhardt confirma luego plenamente todo cuanto dicen los naturalistas americanos respecto i la facultad de imitacion de esta ave. Elil 29 de junio, añade, observe un burlon poligioto macho, que dejaba oir su roz no léjos de mi; como siempre, formaban la cuarta parte de su canto el grito de llamaja del re. yezuelo de América, $y$ las notas de esta ave. Comenzó por ellas; continuó con el canto de la golondrina purpứca; gritó de repente como el rhynchudor sparizrius, y dejando la rama donde se habia posado, initó el grito del paro tricolor y el del tordo vinjero. Luego comenzó à correr al rededo: de un seto, con las alas colgantes y la cola lerantada, y reprodujo los cantos del papamoscas, del algarrobero, del tángara, $\mathrm{y} \mathrm{cl}$ grito de llamacia del paro carbonero. Al poco rato rolo a un matorral de irambuesas, picosé algunos irctos, y-lanzó gritos semejantes á los del pico dorado y de la calandria de Virginia. Al ver un gato que se deslizaba por un tronco de árbol, cajó soore él gritando, y cuando este hubo empren. dido la fuga, fué a posarse en una rama y volvió á cantar de nuevo.s

\&l burlon, dice liilson, tiene una roz llena, sonora y muy variada: desde las notas suaves y claras del tordo de los boscques, pasa al ronco grito de los buitres, recorriendo todos los tonos intermedios. Esta ave repite fielmente la entonacion y hasta el compás del canto que imita; pero le exjresa aun con mas gracia y vigor. En los bosques de su pais, ningun ave puede rivalizar con ella; sus cantos son á cual mas variados; se componen de reducidos temas de dos a seis notas, las cuales produce con fuerza y rapidez. durante varias horas seguidas; con frecuencia cree el viajeru oir un gran número de aves que se hubiesen reunido para cantar en el mismo punto; y hasta los demis alados habi. tantes del bosque se equivocan á menudo.y

Los cantos del burion poligioto varian segun las localidades: en los bosques imita el de las aves silvicolas, yerca de las casas repite fielmente todos los sonidos que se oren en las granjas, el canto del gallo, el cacarco de las gallinas, el grito de la nca y del pato, el maullido del gato, el ladrido del perro, el grunido del cerdo, el rechinamiento de una puerta, el chirrido de la lima y el tic fac del molino. A veces alarma a los animales domésticos: silba cuando está el perro dormido, y levantúndose este bruscamente, corre y busca á su amo, crejendo que le ha llamado; desespera á las galli. nas imitando el quejido de angustia del pollito; espanta á todas las aves de un corral remedando el grito de la rapaz; y engana al gato repitiendo el maullido de la gata en celo. Cuando el burlon está cautivo no pierde nada de su admi. rable facultad, antes por el contrario, aprende otros mil so. nidos y los mezcla à menudo de la manera mas cómica 
Yo he cuidado y oido muchos sinsontes, pero ninguno cuyos variados cantos igualaran á ni modo de ver, al del ruisenor comun $\delta$ al del mayor; sin embargo, personas conocedoras đistinguidas aseguran que realmente hay machos cuyo canto incomparable es superior al de todn otra ave.

El sinsonte anida antes ó despues, segun los paises donde se encuentra; en el sur de los Estados.Unidos comienza a construir su nido en abril; en el norte no suele hacerlo antes del mes de mayo: en cl primero de dichos puntos pone la hembra tres veces al año; en el segundo solo dos. El macho se vale de todos los medios para cautivar á su companera: extiende la cola, deja pendientes sus alas, y se pasea grave y altivo en el suclo $\delta$ en el ramaje, d. bien revolotea alrededor de su hembra, batiendo las alas como una mariposa; danza realmente en el aire y expresa sus. sentimientos de mil modus.

El burlon forma su nido en la espesa copa de un árbol ó en un matorral, unas veces muy cerca de las casas, y oiras en los liggares desiertos y retirados, El armazon se compone de ramias secas y las paredes de briznas, rastrojo y copos de lana, estopa y algodon; el interior esti ocupado por una capa bastante espesa de raices tiernas, entrelazadas unas con otras. La primera puesta es de cuatro ä seis huevos, la segunda de cinco cuando mas, y la tercera no suele pasar de tres. Son de forma redondeada, de color verde claro, con puntos y manchas de un pardo oscuro y miden 07,026 de largo por iv, ozo de grueso; la incubacion dura catorce dias, y parece que solo cubre la hembra. Los hijuelos de las dos primeras jolla. das crecen rofidamente, $y$ los de la última tardan mucho en desarrollarse.

Dumnte la incubacion se muestran muy afanosos macho y hembra, y si esta nota que alguicn ha tocado sus huevos, lanza gritos de angustia, llamando fi su companero. Los americanos creen que en tal caso abandonan los padres la pues. ta; pero Audubon afirna, por el contrario, que redobla su amor yno abandonan el nido.

El régimen de estas aves es variable: en veranosealimentan principalmente de insectos; en el otono comen bayns de toda especie jóvenes y viejos. A semejanza de los tordos, el burlon persigue por los aires á has mariposas, los coleópteros, las moscas y mosquitos, 6 bien los coge en la superficic de las ramas y de las hojas.

Todos los carniceros y las rapaces de América exterminan á los burlones, los pequeños deben temer tambien à las ser. pientes. En cuanto á los americanos han cobrado tal afecto á esta ave, que nadie la persigue para comer su carne; léjos dé esto, todos la protegen por todos los medios pasibles, y lo mas que se hace es coger algunos hijuelos en el nido para enjaularlos.

CAUTIVIDAD. - Cuando se cuida bien \& los burlones no tardan en domesticarse perfectamente, $y$ hasta se les pue de acostumbrar á salir de la jaula y á entrar otra vez Los individuos cnjaulados se contentan con el alimento que se da á los tordos; pero son mas delicados que ellos, $y$ es preciso que no les falten huevos de hormiga y gusanos de harina, en gran cantidad. Algunos de los que yo he cuidado, se han reproducido en la jaula

\section{LOS GALEOSCOPTOS - GALEOSCOPTES}

\section{EL AVE GATO-GALEOSCOPTES CAROLINENSIS}

CARACTERES.-Fsta especie de la sub familia de los burlones figura en la fauna alemana porque un individuo llegó una ver à Heligoland, extraviado sin duda. La caracte rizan el pico débil, mas alto q̨ue ancho, ligeramente corvo en su mitad extrema y algo mas en la punta; el tarso mediano cubierto por delante de placas confundidas; decios cortos; ala corta tambien y adenas muy redondeada, $y$ las rectrices de anchura casi igual, algo mas anchas cerca del extremo que es redondeado como lo es tambien toda la cola. La lon. gitud es de $11^{\prime \prime}, 22$, el ancho total de $0^{n}, 30$; el ala plegada mide $11^{\circ}, 09 \mathrm{y}$ la cola $\left(1^{\circ}, 10\right.$. El color dominante es un gris de pizarra algo mas claro en la region abdominal; la coronilla y el occipucio son negros; las cobijas inferiores de la cola castaño rojizo oscuro; las rémiges son negro parduscas con filete leonado en la parte interior; las rectrices negras y las dos externas con una orla gris en la punta. El iris es pardo, el pico negro, y la pata color pardo sombra de Venecia.

DISTRIBUCION GEOGRÁFICA. - Esta ave habita toda la prarte oriental de los Esstados-Unidos desde el lago Winnipeg hasta la Florida, y visita en invierno además la A mérica central, las Indias occidentales $y$ las. islas de Baha. ina En febrero empieza su viaje de regreso y entonces se la ve en lá Florida, Georgia y Carolina; sigue su ruta con cal. ma y aparece en abril en la Virginia y Pensilvania, para llegar finalmentey establecerse en los matorrales, montes bajos y huertas de la Nueva Inglaterra entre el $10^{\circ}$ y 10 de mayo, y alli pása el verano.

USOS, COSTUMBRES Y REGIMEN.-El are gato Se parece en sus costumbres a los burlones y como ellos es de carascter vivaz, inquieto, curioso y pendenciero; pero no los iguala de mucho en ei canto, bien que el de algunos machos se distingue en alto grado por su variedad. Posee un notable don de insitacion que segun se dice es verdaceramente de. licioso en algtnas ncasiones cuando remeda y varia el canto de las aves cantoras buenas 6 malas de la comarca en que habita. Las hay que imitan estrofas enteras de las cantoras mas melodiosas, y otras se contentan con imitar la voz de las gallinas de monte, el cacareo de la de corral, el piar de los polluelos, ó cualquier otro sonido, graznidos, chirridos, etc., mezclándolos con otras frases, y logrando cuando no los aplausos de los conocedorcs, por lo menos divertiry entretener á las personas que las escuchan.

Segun la localidad, empieza esta ave a construir el nido mas ó menos tarde, escogiendo para ello un sitio oscuro en alguna mata apartada. Fl nido suele estar á dos ó tres metros del suelo, es de conseruccion rística, compuesto de ramitas, yerbas y hojas secas, pedacitos de corteza, de piel de culebra, papel, cintas y trapos, y tapizado interiormente de raicillas finas. Componen la puesta cuatro ó cinco huevos relucientes, color verde esmieralda, de $11^{\prime \prime}, 024$ de larga y $0^{\circ}, 017$ de grueso. Macho y hembra comparten el trabajo de incubacion con extranodinaria soliciud; y lo mismo sucede despues con la cria de los pequeñuelos. Al divisar algun sér hostil ó simplemente molesto se precipitan sobre él con el mayor arrojo, aunque sean rapaces peligrosas ó personas; y cuando no les vale el arrojo, gritan lastimeramente y logran asi no poras veces ahuyentar á los intrusos. Hecha la primera cria proce. den á otra, y si cl año es bueno hasta a una tercera.

CA UTIVida D. - Como el régimen de esta ave es igual al de la especie anterior, es fácil mantenerla en la jaula, y si se la ha sacado pequeña del nido y se la alimenta y cuida con carino, se domestica bien $y$ se liace muy agradable con sus graciosos movimientos.

\section{EL ARPORINCO Ó BURLON ROJO-HAR- PORHYNCHUS RUFUS}

CARACTÉRES, - Se caracteriza pror su plico, tan largo ó mas que la cabeza, mas ó menos corro y desprovisto de escotadura; pata robusta, cuyo tarso tiene poco mas ó menos 
la longitud del dedo medio; alas cortas $y$ muy redondeadas, con la cuarta y quinta témiges mas largas que las demás; la cola es larga, estrecha y inuy puntiaguda. İ! ave mide $10^{\circ}, 27$ de largo; $\left(1^{\circ}, 3^{2}\right.$ de punta á punta de ala; esta plegada $0^{\circ}, 11$ y la cola $0^{\mathrm{m}}, 13$. 'loda la parte superior, las alas y la cola son de un color rojo de orin muy vivo; la linea naso-ocular y una línea al través del ojo, los lados de la cabeza y del cuello, as como las partes inferiores, son blancos con un matiz amarillento de orin; las plumas del vientre, de la cabeza, del necho y de los costados tienen en el tallo manchas triangulares par. do oscuras; las remiges llevan en la parte cubierta un filcte pardo oscuro que tira a leonado; las grandes cobijas superio. res de las alas y las del antebrazo tienen en la extremidad un filete blanco, y antes del filete una haja trasversal oscura; las rectrices externas tienen el extremo de color de orin amari. llento inedio borradio. El iris es de color de azufre, el pico pardo oscuro, por debajo pardo claro y la pata amarilla pardusca.

DISTRIBUCION GEOGRÁFICA.-El burlon rojo se presenta en todas partes, pero segun los sitios es mas ó me. nos frecuente, desde las costas del Atlántico lasta las Montañas Peciregosas, y descle la América inglesa hasta Texas, iabiéndose extraviado hasta Heligoland. En algunos punios es muy comun, mientms que en otros ni le conocen siquiern.

USOS, COSTUMBRES Y RÉGIMEN. - En la Nues: Inglaterra, y en general en el norte de su área de dispersion, se presenta en majo, permanece todo el rerano y cmigra en setiembre para pasar el invierno en el mediodia, a partir des. de la Virginia. En su patria no sale cada pareja de un espacio perfectamente limitado, que defiende animosamente contra todos sus vecinos, lo cual no obsta prara que acudan todos cuando uno de ellos los llama en momentos de peligro a fin de perseguir juntos a algun enemigo. Dentro de su distrito no tarda el burlon rojo en llamar la atencion, pues tiene la viveza de todos los tordos burlones Como no es gran volador, prefiere pasar el tiempo en tierra donde registra con su pico largo y corvo todos los escondrijos y revuelve la hoja. rasca en busca de su alimento, volando al próximo matorral cuando quiere descansar 6 cuando amenaza algun riesgo. Desde léjos se le distingue por los muchos morimientos que hace con las alas $y$ la cola, alzando, bajando, extendiendo $y$ piegando unas y otra. Los americanos alaban muchisimo su voz, que en efecto es vibrante, sonora y variada, pero que no puede competir ni con el canto de nuestro tordo, si con el del sinsonte; y dicen que no imita las voces de otros animales.

El burlon rojo hace la primera cris en marzo en los Fistados meridionales, en mayo en Pensilvania, y á últimos de estc mismo unes en la Nueva Inglatern. El nido se encuentra en sitios semejantes al del ave gato y à igual altura; es muy vo. luminoso $y$ rústico, pero bien tapizido interiormente. Ina puesta se compone por lo regular de cuatro huevos, a veces de cinco, en casos rarisimos de seis; estos hueros tienen $10^{\circ}, 02 j$ de longitud por $11^{\infty}, 021$ de diámetro, y sobre fondo blanco of verde claro presentan pequerias manchas pardo rojizas que hácia el extremo grueso se van confundicndo y acaban por formar un aro. E! macho y la hembra cubren alternativamente; ambos cuidan de los pequentuelos y se comportan cerca del nido de un modo análogo al del are gato. Uno de los padres, por lo regular el macho, esta al parecer continuamente de vigilante, para descubrir ctalquier enemigo á tiempo, y ambos unen sus esfuerzos para apartar todo peligro, empleando todos los recursos, lamentos, súpli. cas y avisos que conmueven hasta a personas rudas y las detienen si llevan el intento de danar ă su cria. Los peque. nos abandonan el nido antes de poder volar enienmente: pero guiados y protegidos fielmente por los vicjos, pasan el tiempo que faita hasta su completo desarrollo en algun ma. torral enmarañado y protector.

CAUTIVIDAD.-Cogidos en el nido y bien cuidadosse domestican tan bien que puede dejarse su jaula abierta para que entren $y$ salgan à su gusto, $y$ hasta llegan á acompariar à su amo en sus paseos por el jardin ó campo sin escaparse.

\section{LOS AEDONINOS-AEDONINEF}

Componen esta sub-familia unas aves cuya afinidad con los turdinos es innegable, pero que no son cantoras ni pueden agregarse á ningun otro grupo. Sus caractéres son los del gé. nero siguiente.

\section{LOS ACRÓBATAS-AEDON}

CARACTERES. - Las nueve especies de este género que viven en la Europa meridional, Asia Menor, Palestina y Afri. ca, son todas turdinos pequerios y esbeltos, de pico robusto con la arista superior bastante corva; tarso regular, alas cor. tas, cuya tercera y cuarta rémiges, de igual longitud, forman la punta; la cola es larga, ancha y muy redondeada; el plu. maje blando y sedoso, igual en ambos sexos, y en los pe. (quenos semejante al de los adultos del sexo respectiva.

\section{EL ALZARABO Ó ACRÓBATA MOHOSO- AEDON GALACTODES}

CARACTERES.-Tiene el dorso de un color entre gris rojiro y orin, algo nass oscuro en la coronilla, y tirando inas a gris en la nuca; la parte inferior del cuerpo es gris amari. llenta ó blanca sucia con viso rojizo en los costados del cuello, y amarillenta con mair de orin en las ingles; las inejillas son de un pardo blanquizco, y la linea naso ocular blanca, prolongándose nucho hácia atrás; las rémiges y sus cobijas son pardas, las primarias orladas de pardo claro, y las secun. darias de amarillo de orin mas ancho que en aquellas; las rec. trices son de un hermoso rojo de orin, excepto las del medio, que son mas oscuras, la extremidad es blanca precedida de una mancha redonda de color pardo negruzco. El ojo es pardo oscuro, el pico f las patas rojizos. Los polluclos se asemejan a los padres. Ia longitud es $0^{\circ}, 18$, el ancho de punta à punta de ala $\theta^{\circ}, 2 \%$ esta tiltima plegada mide $\theta^{\circ}, 0 S$ \% la cola $0^{\circ}, 0 \%$. Macho $y$ hembra son del mismo iamaño.

DISTRIBUCION GEOGRÁFICA.-Esta ave habita en España go noroeste de Africa, desde donde visita st veces Iralia, Alemania ja la Gan Bretaina.

\section{EL ACRÓBATA FAMILIAR-AEDON FAMI- LIARIS}

CARACTÉRES. - Se distingue de la especie anterior por su menor talla y el color gris tirando sorin de la parte superior del cuerpo y de las cobijas superiores de las alas; la rabadilla es de color rojo de orin muy vivo, y la barba in. terior de las dos rectrices del medio, parda.

DISTRIBUCION GEOGRÁFICA.-Habita la Grecia, el Asia Menor y al Egipto.

USOS, COSTUMBRES Y REGIMEN. - Ambas especies eligen para morada aquellos sirios secanos que no reciben otra agua que la pluvial, y están escasamente cubiertos de matas pequenas, sin que por esto rehuyan las ierms de cultivo ni por consiguiente la proximidad de las moradas humanas, segun se ve tanto en España como en Grecia, y asi en Egipto como en el páramo Sambara del interior del Airica mencionado ya otras veces. En Espana y Grecia prefieren 
los olivares y las vinas, y en el Asia Méenor se los encuentra en los matorrales diseninados á manera de parque hasta al. turas de 2,000 metros. En el nordeste de Africa vive una es. pecie afine en las hucrtas, montes de unimosas, algodonales, canaverales y aun entre las chozas de las aldeas tnientras haya matas bien espesas.

En las selvas virgenes jamás he visto el acróbata mohoso; en cambio es irecuente en los montes claros de los púramos; tambien parece que se aleja de los bosques elevados de las altas cordilleras, pero no de los de las laderas bajas.

En el Africa central, el acróiata mohoso es un ave seden. taria; de paso en el morte de Africa y el nicdiadia de Europa. Llega á Grecia y Ligipto á mediados ó a rin de abril; á cste úlimo pais un poco mas pronto, y abandona los dos ál fines de seriembre. Los macios aparcen yrimero, las hembras al- gunos dias despues; durante sus viajes se les encuentra por do quiera; luego es preciso buscarlos en sus parajes favoritos, donde se les puede observar con iacilidad. En España conocen todos el rosarcio ó alscrela tan bien como se conoce en otros paises el petirojo.

El ave de que hablamos justifica el nombre de acróbata con que se le designa: gústale correr sobre el extremo de las ramas: el tallo mas alto del matorral que habita, la punta del rodrigon alrededor del cual serpentea la viña, la copa del árbol ó un hilo del telégrafo, son los sitios donde el acróbata se posa con preferencia. Se le ve apoyado sobre la cola, pren. dientes las alas y un poco dobladas las patas, entonando su cancion y acechando la presa. Si divisa un gusano ó un in. secto, precipitase á tierr, se agacha, mueve la cola y la cxtiende, da varios pasos con rapider, coge su presa, lanza un

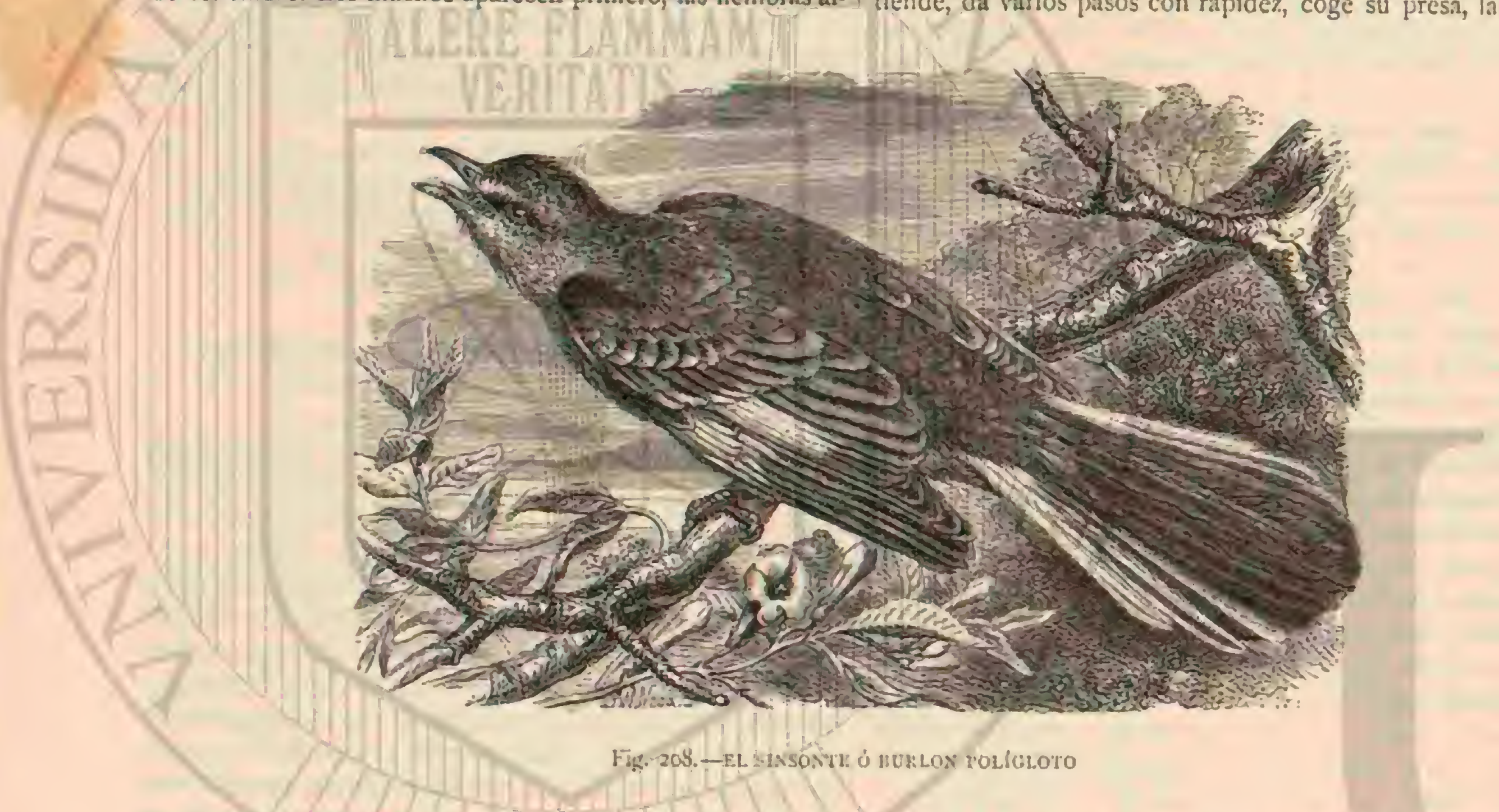

ligero grito de contento que suena bak, the, y vuelve a su sitio. Tambier. le ocupa de nuero cuando se le ha perseguido, y por lo nismo es fácil tirarle; basta gaue el cazador permanezca junto al sitio, encargando á un companero que persiga al ave A la manera del ruiseñor, solo recoge su alimento en cl suclo, busca todos los parajes Jlanos y recorre las sendas y caminos.

- Es la alegria de los habitantes del campo y anima los jardines principaimente por su vivacidad y costumbres nada esquivas, dice Heuglin, por lo cual se asemeja algo al mirlo. A ratos revolotea inquicto de rama en rama, hasta á las mas altas, moviendo constantemente la cola que tan pronto extiende como pliega; otras veces corre afanoso sobre la tierra desnuda ó entre inatas de yerba y zarzales, cazando gusanos y orugas; pero de repente lanza un grito de espanto como los tordos y se refugia nurmurando en la espesura.

El acróbata es prudente y circunspecto cuando las circuns. tancias lo exigen; pero confiado donde sabe que nada debe temer. En España se observa que es en todas partes timido y receloso, porque no hay punto donde ho se le persiga; en el Africa central permite que se acerquen los indigenas y huye de los europeos. Vive pacificamente con las demás aves; pero disputa á menudo con sus semejantes. A veces se ve á dos machos perseguirse encarnizadamente, cogerse por el pico, revolotear en el aire, caer juntos y pasar como una saeta sa través del ramaje y de los zarzales dando pruebas de gran destreza y sin olvidarse de dilatar y de plegar alternati- vamente la cola; pero en muchos casos no es aqquello mas que un juego ó un pasaticmpo.

E, una cosa, sin embargo, no puede el acróbata competir con el ruiseñor: esto es en el canto. El conde von der Muhle dice que el de la primera de estas aves es monótuno, y le compara con el del jilguero jóven, pero en cuanto á mi, juedo decir que a pesar de su sencillez me ha complacido mucho. El acróbata habira los cantones donde no existe el ruiseñor, y por su ardimicnto en el canto, procura sujplir las facultades de que carece. Durante el periodo del celo se uye su roz casi de continuo, bien esté posado, ya corra ó vuele, siendo siempre armoniosos y dulces los sonidos que emite.

La época del celo comienza hácia la segunda semana de mayo y dura mucho tiempo, siendo probable que cada pa. reja empolle varias veces al año. El acróbata hace su nido en un tronco de árbol, entre fuertes ramas $\delta$ en un espeso matorral; se compone exteriornente de briznas, musgo, hojas y taltos, y relleno de plumas, lana y pelusilla. Tristram crec que la hembra no pone antes de haber hallado un pedazo de piel de serpiente, con el cual termina su nido, y que en efecto se encuentra en la mayor parte de cllos. Los cuatro $\delta$ cinco huevos de la puesta varian mucho en tamaño, forma y colomacion: tienen por término medio $(1 \%, 022$ de largo por $0^{\circ}, 015$ de diametro. Su color es un blanco sucio ó bien gris atzulado con manchas mas oscuras apenas visibles, $y$ otras pardas mezcladas de juntitos del mismo color.

Los huevos del acróbata mohoso no se asemcjan en ma- 
nera alguna a los de los otros humicolas: son de un color blanco sucio ó gris azulado, cubiertos de manchas oscuras, poco pronunciadas y de puntos parduscos. En cuanto al desarrollo de los hijuelos, lo unico que sé y puedo decir es, que i principios de setiembre, cuando casi todos los individuos viejos mudaban, encontré todavia pequeños con su primer plumaje.

Tristram dice que los huevos y las crias de esta ave son muy a menudo presa de los reptiles, mas yo no sé hasta qué punto será fundada esta opinion. Lo cierto es que los marni feros carniceros y las rapaces no los perdonan, y que los adiultos cstán expuestos a los mismos peligros que las demás aves pequenas. Solo en España se cazan como rodos los pá jaros cantores para comerlos.

\section{LOS TIMALIDOS- TIMALIID屃}

CA R A CTER ES. - I os timalidos, vulgarmente llamados lordos rovidosos, tienen el cuerpo recogido, alas muy cortas y redondeadas, con la cuarta ó quinta rémige mas larga que las demás; cola mediana, mas ó menos redondeada tambien; pennas anchas; patas vigorosas; pico fuerte, comprimido lateralmente, con la punta de la mandibula superior algo encorvada: plumaje lacio y colores oscuros.

DISTRIEUCION GE.OGRÁFICA.-T.Os timalidos, de los cuales se conocen unas doscientas cuarenta especies, ha. bitan ol Africa y el sur de Asia, siendo especialmente numerosos en la India.

USOS, COSTUMBRES Y REGIMEN.-Por algunos conceptos se asemejan \& los tordos, y por otros á los grajos, á las pegas.rebordas 6 a las currucas. Frecuentan las breñas, los tallares y las espesuras de cañas. Son muy sociables, mas no hasta el punto de formar numerosas bandadas; su vivacidad es notable, gritan casi de continuo, y algunos son buenos cantores. Casi tocios se deslizan con la mayor ligereza entre los mas espesos jarales; no vuelan con perfeccion, y procos hay que se remonten hasta la cona de los mas altos árboiles. Alinéntanse de insectos, moluscos, gusanos, frutos, y principalmente de bayas, tan abundantes en los bosques que ha. bitan.

\section{LOS TIMALIAS-TIMALIA}

CARACTÉRES. - Se ha dado á estas aves el nombre vulgar de fordes chaslatares: tienen el pico corto, fuerte, com. primido lateralmente, de ansta dorsal redondeada, quue avan. za. entre las plumas de la frente; los tarsos y los dedos son gruesos, sobre todo el pulgar; - las unas tucrtes; las alas cortas, muy redondeadas y obtusas, con la quinta y sexta pennas mas largas; la cola mediana y redondenda; rodean la base del pico varias sedas que forman un bigote.

EL TIMALIA DE TOCA - TIMALIA PILEATA

CARACTERES.- El timalia de loca, ó de cabeza roja, tiene el lomn de color pardo accituna; los lados del cuello de un gris ceniciento; las alas y la cola rayadas de pardo rojo; la parte anterior de la cabeza y la region auricular hlancas; la coronilla de un color canela brillanic; la garganta, el cuello y el pecho de un blanco puro; en la segunda de estas partes hay unas rayas muy finas longitudinales; el vicntre es pardo pálido, con viso gris en los lados; el ojo de un tinie rojizo sucio; el pico negro y las patas de color de carre. Fl ase mide $0^{\circ}$, is de largo, el ala $0^{\infty}, 062$ y la cola ()$^{\circ}, 072$ (fig. 2 ro).

DISTRIBUCION GEOGRAFICA.-Esta ave fué descu. bierta por Horsficld en Java; mas tarde la observaron otros naturalistas en el continente indio.

USOS, COSTUMBRES Y REGIMEN.-Horsfield tra26 una cora descripcion del género de vida del ave, ob. servando que el ranto del macho se compone solo de las cinco notas $\left.d^{\prime}\right), r e . m i, j a$, sol, repetidas muy regularmente $y$ con cortos intervalos. Bernstein, aigo mas explícito, dice: $1 \mathrm{El}$ ti malia de toca vive apareado en las espesas brenas que rodean los bosques ó que crecen en el sitio ocupado antes por aquellos; es mucho mas comun en las montanas que en el llano. y rara ver abandona la espesura. Solo por la maíana se le puede ver en alguna rama diesnuda de hoja, alisando y se. cando su plumajc, humedecido por el rocio; el mismo sitio ocupa el macho mientras que la hembra cubre; alli entona tambien su canta. in aquel monento tiene pendientes las alas, y parece insensible á todo cuanto le rodea. Cuando esta excitado ó llama su atencion algo sosprechoso, criza las plú. mas de la cabeza, Icranta la cola y la ensancha: su grito se parcece hasta ciesto punto al del gorrion. 
ail nido se halla situado en un espeso matornal, á muy poca aitura del suclo y no léjos del sitio donde se coloca el macho para cantar; se parece al del hortclano, y su excara. cion es igualmente profunda; está abicrto comunmente por arriba; a veces tiene una abertura oblicua y lateral. Todos los nidos que yo encontré se componian tan solo de hojas de alangalang, solo que las del interior eran mas finasy estaban mejor entrelazadas que las del exterior. Ia construccion es endeble: carece completamente de solidez, y por lo mismo es necesario levantar el nido con precaucion si se quiere evitar que se deshaga 6 se altere su forma. Cada uno contiene dos ó tres huevos blancos, sembrados de puntos de un rojo pardo, mas 6 menos intenso, mayores y mas compacios en la punta gruesa, donde forman una especie de corona. A yeces presentan tambien puntos de un gris ceniciento, mucho menos numerosos, péro mas prolundos, es decir, que parecen estar en el interiur de lá cáscara

\section{LOS CRATEROPOS-CRATEROPUS}

CARACTÉRES. Estas aves tienen el cuerpo grueso; el pico fuerte, largo, comprimido laterahnente y algo encorva. do las patas robustas $y$ de un largo regular; las uñas corvas y aceradas; las alas cortas y obuusas, con la cuarta penna mas desarrollada; la cola bastante larga, ligeramente cónica y de plumas anchas; el plumaje abundante pero recio.

\section{ELCRATEROPO DE RABADILLA BLANCA -CRATEROPUS LEUCOPYGIUS}

CARACTÉRES.-E! color gencral de esta especic es pardo oscuro (sombra de Venecia); las rémiges y la cola son aun mas oscuras, pero algo mas claras en la cara inferior. Cada pluma tiene una orlita blanca angosta en su extremi: dad; la cabeza hasta la mitad de la garganta, la rabadilla, el ano y las cobijas de la cola son blancos; el bordillo interior de todas las rémiges y todo el plumaje tectriz inferior de las alas es color de orin. El ojo carmin oscuro, el jica negro y la pata gris, Su longitud es de $f^{n}, 26$, el ancho de punta a

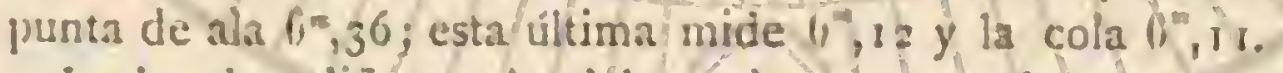

La hembra ditiere solo dél mácho por ser algo mas pequeña

Los hijuelos tienen la cabeza gris azul con un filete claro en las plumas del lomo.

DISTRIBUCION GEOGRAFICA. - Esta ave habita las tzpesums de matormles de Abisinia; otra especie muy arine las brenas del Sudan oriental: pero esta uiltima frecuenta la llanura, mientras que la otra vive en la montana en las regiones comprendidas entre 1,000 y 2,600 metros de altitud.

USOS, COSTUMBRES Y RÉGIMEN. - I.AS dos espe: cies observan el nismo género de vida; ambas son notables y prestan animacion a los bosques que habitan. No es po sible figurarse otras mas chillonas: jamis se las encuentra solitarias, sino en bandadas, compuestas por lo regular de ocho a doce individuos, los cuales hacen siempre la misma cosa y al mismo ticmpo. Juntos vuelan de un matorral à otro, oprimiéndose entre si; all se dividen, le atraviesan, le recorren en todas direcciones; reunense despues de nuevo, gritan y vuelven á rolar. No están ả su gusto sino en los ta. llares mas espesos 6 impenctrables; únicamente se posan en los grandes árboles, aunque solo por un instante; y' de cste modo descubren todo lo que hay en el bosque, bastando la menor cosa para que comiencen à gritar. Cuando lo hace una todas las demás la imitan y contestan; de modo que no se sabe si se debe considerar á estas aves como agradables $\delta$ molestas. Espantan la cazn, y por esto excitan la cólerra del que persigue una pieza; pero por otra parte son tan graciosas alegres, que no se puede menos de cobrarles afecto. Su grito, nada armonioso, es en extremo variado y muy dificil de imi. tar: yo he tratado de hacerlo, sin encontrat nunca una forma satisfactoria; pero los sonidos se pueden expresar aproxima. damente por gurgara, garne gugraek; gara, gara, gaerac; gaerae, gaerae, gagak, pronunciados sordamente; y lara taar tarut, con fuerza. Si se ovese is un individuo solo prodria quj. zás comprenderse él sonido; pero como todos gritan à la vez, el uno con mas vigor que el atro, resulta una algarabia y confusion yue no permiten sacar nada en limpio.

Estas aves vuelan mal; no se remontan jamás á grande al. tura, y aun en caso de peligro no franquean nunca un largo espacio. Procumn refugiarse en los matorrales; al volar agitan con frecuencia las alas; luego las extienden, juntarnente con la cola, y continuan su trayecto cerniéndose.

En el estómago de las que yo mate vi restos de insectos, de hojas, de tallos y de flores.

Nada sé acerca de su manera de reproducirse.

\section{LOS GARRULAXOS-GARRULAX}

Iistas aves constituyen un gérero muy afine al anterior, tanto que ciertos naturalistas le confunden con di. Distingue. se por tener ei pico robusto, triangular en la base, delgado y comprimido á los lados, muy hendido, rodeado en la base de la mandibula supetior de sedas erectiles; ins alas son muy obtusaş, can la tercera y cuaria rémiges mas largas; la cola redonderda; los tarsos y los dedos prolongados, y las plumas occipitales muy largas a menudo y erectiles.

\section{EL GARRULAXO DE CAREZA BLANCA- GARRULAX LEUCOLDPHUS}

CARACTERES.-Tiene $0^{m}, 33$ de largo por $0^{m}, 43$ de punta á punta de ala, la cola $11^{\circ}, 14$ y el ala plegada la misma di. nension. Toda la cabeza, excepto una lista negra que va del pico al ojo, la nuca, el pecho y el cuello son de color blanco, con visos grises a los lados; el resto del cucrpo de un pardo aceituna rojizo; las pennas de las alas y de la cola tienen sus barbas internas mas oscuras que las exiernas

DISTRIBUCION GEOGRÁFICA.-Es comun en todos los espesos bosques del Himalaya.

USOS, COSTUMBRES Y RÉGIMEN. - Esta especie forma bandadas de veinte ó mas individuos, que de vez $\mathrm{cn}$ cuancio dejan oir una especie de carcajada, muy propia para causar admiracion al que la oye por primera vez Comen in. sectos, moluscos y gusanos, y en otoño bayas; recogen los primeros en ticrn, escarbando en las hojas secas, ó los atra pan sobre las ramas, de las q̨ue quitan tambien las bayas.

El nido es una masa de raices, musgo y yerba, y le sitúan en un espeso matorral; los huevos son blancos y poco nume. rosus.

CAUTIVIDAD. - Frith ha descrito las costumbres de un individuo cautivo, perteneciente a una especie afine, cual es el garrulaxo de China (grormalax chinensis) (fig. 211). Era un aye muj agradable y confiada; gustábanle las caricias; cntreabria las alas y tomaba las posturas mas singulares cuando le rascaban el plumajc; cantaba bien y sabia imitar admirablemente $\{$ las otras aves.

Tomaba sus alimentos de una manera muy singular: si le daban carne ó un pedazo grueso de otra cosa cualquiera co. menzaba siempre por fijarle entre las varillas de su jaula; cuando le presentaban una avispa $\delta$ una abeja, cogiala, $y$ hacia de modo que le picase la cola antes de comérsela. Fun 
cuanto a los insectos grandes, golpeábalos vigorosamente con su pico contra el suelo; y de este mocio mató una culebra de cerca de un pié de largo, a la cual atravesó la cabeza, devo. rándola casi por mitad; para ello la sujetó con una pata y la desgarró con el pico.

\section{LOS CÍNCLIDOS - CIN- CLID压}

Algunos auiores clasifican estas aves entre los turdinos; nosotros empero las consideramos como una fanilia aparte á pesar de reducirse á un solo género.

CARAGT2́RES. - El cuerpo es cshelto, pero grueso en apariencia à causa del plumaje espeso que lo cubre; el pico es relativamente débil, recto, encorvado un poco hácia arriba en el dorso, pero hácia abajo en la punta; comprimicio ade más lateralmente y yendo en diminucion hasta la punta; las fosas nasales pueden cerrarse pror medio de un opérculo membranoso; la pata es alta śla par que robusta, de dedos largos con uñas muy encorradas, fuertes, estrechas y de doble corte; las alas son cortisimas, muy redondeadas, de ancho casi igual, con la tercera rémige mas larga que las demás, y la cuarta poco menos; la primera es tan corta que no viene a ser mas que un muñon de pluma; cl plumaje finalmente puede compararse solo con el de las aves acuáticas y de pan. tano, no teniendo ninguna analogia con el de las terrestres; es blando y espeso y estí formado de plumas por fuera, é interiormente de plumazon.

La estruciura interna de los cinclidos recuerda por sus caracteres esenciales la de las otras aves cantoras: los músculos de la laringe están desarrollados: pero todos los huesos, excepto algunas partes del cránco, contienen médula en rez de aire. La lengua es angosta, escotada en su exiremidad, y ligeramente dentada á Ios lados, y pordelante deshilachada; el esófago muy estrecho; el ventriculo subcenturiado largo y cilindrico; cl estómago pequeño y bastante carnoso. Las glándulas coxigeas tienen mucho desarrolloy segregan la materia grasienta destinada a untar las plumas; las masales son bastante voluminosas, al paso que apenas se distinguen en las otras aves cantoras.

DISTRIBUCYON GEOGR X́FICA.-Los cinclidos están diseminados en una gran parte del globo: habitan el antiguo y el nuevo continente, son principalmente numerosos en las regiones septentrionales de ambos. Tambien se encuentran en las montañas del sur, lo mismo en el Himalaya quıe en las Indias.

USOS, COSTUMBRES Y RÉGIMEN.-Bajo este concepto se parecen tanto las pocas especies conocidas actual. mente que bastari para todas el cuadro de la especie alema. na que sigue mas abajo.

\section{EL CINCLO ACUÁTICO-CINCLUS AQUA- TICUS}

CARACTÉRES.-Este cinclo mide $1, \%, 20$ de largo, $y$ 0 ;o de punta a punta de ala; esta plegada (1),02 y la co. fa $1,0,06$. Los individuos aduitos tienen la cabeza, la nucn $y$ la parte postcrior del cuello de color pardo lconado; las plumas del lomo de un tinte pizarra con bordes negros; la gar. ganta y el cuello de un blanco de leche; la parte inferior del pecho y del vientre de un pardo ferruginoso, mas oscuro en los costados; la superior del pecho es pardo rojiza (fig. 212). La hembra es algo mas pequeña que el nuacho, pero el plumaje igual en ambos sexos.

En los individuos jóvenes las plumas del lomo son de un tinte pizarra claro, con filetes negruzcos; las del vientre de un blanco de leche sucio, orilladias y listadas de pardo.

\section{EL CINCLO DE CUELLO BLANCO Ó ALPI- NO-CINCLUS ALBICOLLIS}

CARACTER:S.-Tiene la coloracion del dorso mas clara que la especie anterior; las orias pardas de las plumas son mas marcadas, la parte inferior del cuerpo es de un rojo mas claro y los costados pardos.

Distribucion GEOGRÁl一A. - Vive en los Alpes de Suizn, en las cordilleras de la liuropa meridional y en el Libano.

\section{EL CINCLO DE VIENTRE NEGRO-CINCLUS MELANOGASTER}

CARACTERES. - Tiene la cabeza y el cuello mas claros que la especie acuática, y la parte inferior, sobre toco el medio del vientre, de un negro bien pronunciaco.

DISTRIBUCION GEOGRÁFICA. - Habita en la ES. candinavia y el Asia Menor, dejándose ver accidentalmente en Alemania é Inglaterra.

Los ornitólogos no están acordes acerca de si las tres es. pecies citadas no forman mas que una sola ó realmente son tres. Vieillot quiere que el cinclo alpino forme una especie aparte y mi padre considera el de vientre negro como otr.

USOS, COSTUMBRES Y REGIMEN DEL CINCLO ACUÁTICO. - En los sitios á propósito de todas las sierras de la Europa central es esta are comun, aunque no mucho.

Busca los arroyos de aguas clarns y cubiertos de sombra, que bajan de las montanias, particularmente acpuellos donde viven las truchas; los remonta hasta su origen 6 liasta el glaciar mismo de donde provienen, y los sigue á la llanura. Se. guro es encontrar en l.25 orillas á estas aves, en cunlquier punto, menos donde los residuos de alguna fibrica no envenenen ó revuelvan las aguas. Se ve al cinclo acuático en toda estacion: apártase poco del paraje que una ve\% eligió, y no le abandona ni aun en medio de los rigores del invierno; bien es rerdad, segun me participa el principe imperial de Aus. tria, Rodalro, que solo se fija en verano en los Alpres mas ele. vados, exclusimmente junto hi las pequeñas torrenteras, cuyin corriente sigue en invierno en busca de riachuelos mas abun. dantes en los valles muy bajos, y se establece junto á algun trecho de arroyo que no invade el hielo, puesto que la mis. ma corriente y no sus alrededores, constituye el verdadero terreno de caza del ave. Necesita sumergirse hasta en la es. tacion mas fria, y por eso busca las corrientes vivas, las cataratas $y$ las cascadas, y todos los sitjos, en fin, donde el agua, sea por su propia tempern:ura, por su movimienio continuo $\sigma$ su impetuosidad, no se hiela nunca. Cuanto mas rípido es un arroyo, y mas violenta una corriente, mas se aficionn á ella el cinclo acuático; pero prefiere á la caida de agua pal torbellino que forma en su precipitado curso, la parte tranquila que hay en sus alrededores, porque el rcmolino le lleva alli suficiente alimento. Cada pareja elige para su dominio el espacio de un cuarto de legua poco mas ó menos, á lo largo ciel arroyo, que recorre continuamente sin alejarse nunca del agua Donde acaba el dominio de una pareja comienza el de otra; asi es que á menudo está ocupada una corriente desde su origen hasta el sitio donde desemboca en un rio.

El cinclo acuático es un are de las mas curiosas é intere. santes. Lo mismo que la neratilla, corre con ligereza y rapidez sobre las picòras; mueve continuamente la cabeza como ella; se sumerge en el agua hasta el pecho y los ojos, y aun 
mas; corre por debajo del agua 6 del hielo donde aguanta de quince á veinte segundos, y remonta 6 desciende la corriente cual si anduviese por el suelo. El cinclo acuático se precipita en el mas impetuoso torbellino, en la mas rápida cascada; nada tan bien como las palmipedas, haciendo sus alas las veces de remos, y por decirlo asi vuela debajo del agua. Ningun otra ave se complace tanto en estar bajo la li. quida superficie; á veces baja con lentitud, de una manera insensible, yotras brinca to mismo que la rana

Su vuelo se asemeja bastante al del rejezuelo: cuando se le asusta huye aleteando precipitadamente, siempre á la mis. ma aleura, y sigue todas las sinuosidades del arroyo para detenerse de pronto apenas encuentra in refugio seguro. Muchas veces se deja caer bruscamente al agua, atraido por una presa: si se le persigue, recorre asi volando uin espa. cio de cuatrocientos a quinientos pasos, pero si no se le in. quicta, limitase á irevolotear de piedra en piedra. En el caso de verse acosado de cerca, remóntase al momento á los aires sobre la copa de los árboles, abandona la corriente de agua, y despues de dar un largo rodeo, viclve a su terreno de caza. En los puntos donde no se le persigue, sucede á menudo, segun Homeyer, que se detiene de pronto en medio de su vuelo, permanece en un mismo sitio cemién. dose, estim luego las patas, déjase caer y desaparece en las ondas.

En el cinclo acuático son bastante perfectos la vista y el oido, y tenemos motivo para creer que sus demas sentidos alcanzan tambien un gran desarrollo. Su inteligencia no es en manera alguna limitada: distinguese el ave por su pru. dencia y cautela: conoce à sus amigos y cnemigos, y sin ser recelosa, presta atencion á todo cuanto pasa cerca de ella Huye del hombre que turba su soledad, ya pase con indife. rencia, $\sigma$ bien haga ademan de perseguirla. Está siempre prevenida contra los animales carniceros, sean cuales fue-

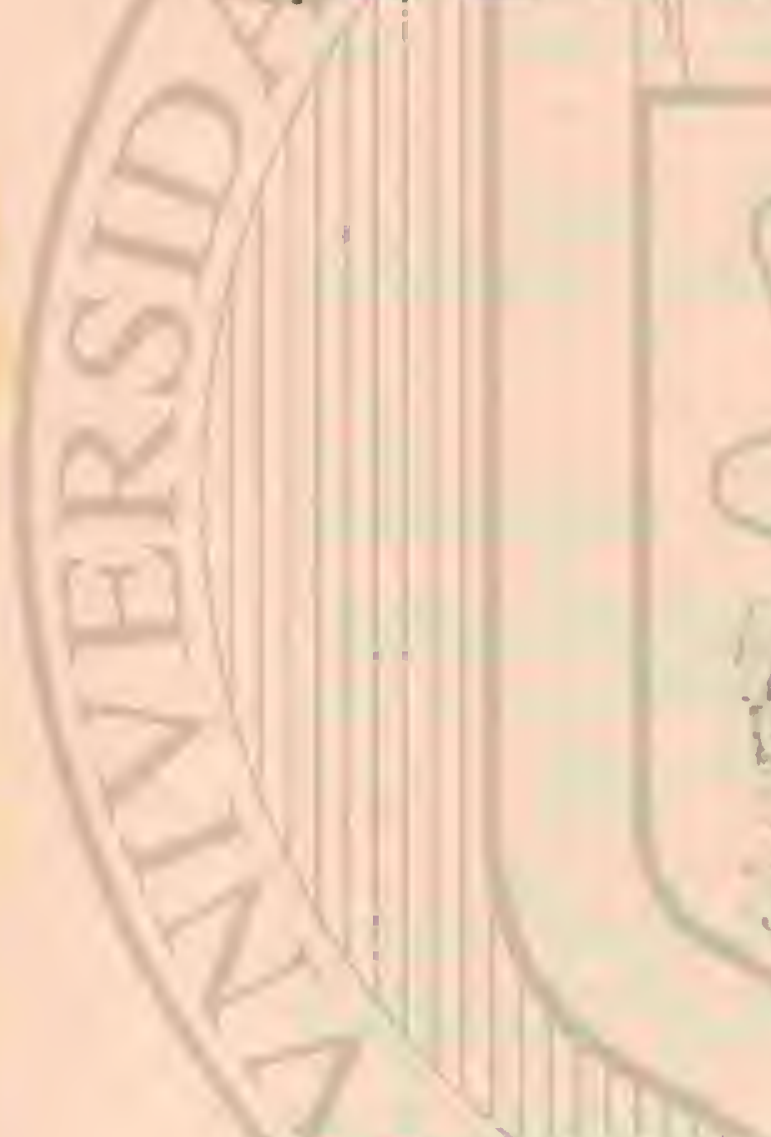

ren; pero es de advertir que esta misma ave, tan rccelosa en la Sierra-Nevada, como al pié de los glaciares de los Alpes y en las montañas de la Iaponia, se acostumbn t vivir cerca del hombre, y se muestra confiada donde sabe que no debe temer peligro alguro. Fijase con frecuencia cerca de los molinos, donde parece considerar al molinero y sus criados como otros tantos amigos si tal pucde decirse; $y$ hasta se la encuentra algunas reces en el interior de las ciudades ó puebios. Honejer, por ejemplo, observó una pareja de cinclos acuáticos en medio de Baden-liaden, a la pucta de las fondas mas frecuentadas, y los vio correr $y$ sumergirse delante de los bañistas.

Lo mismo que otras aves pescadoras, el cinclo acuático no busca nunca la sociedad de sus semejantes.

Solo en la époce del celo se ven mạcho y hembra juntos, pero no se encuentran familias sino mientras los hijuelos necesitan ser conducidos y guiados por sus padres; durante el resto del año vive cada uno para sí, lo cual no obsta para que macho y hembra, que antes formaban una pareja, se vi. siten de vez en cuando. Si un cinclo acuático traspasa sus limites ye aventura en el dominio de su vecino, este cae sobre el $y$ le ahuyenta: hasta con stús pequeños es esta especie inexorable cuando viven ya independientes; y apenas se coinprende cómo consiguen los individuos jórenes en. contrar su dominio. El cinclo acuático no se cuida de las demis aves; vive en buenas relaciones con ellas, pero por pura indiferencia, y permite á las nevatillas y martines ha. bitar cerca dé él.

El grito de esta ave, que se oye cuando se la persigue, puede cxpresarse por ficrr ó faerb: el canto del macho es un gorjeo debil, pero muy agradable; se compone de notas ron. cas, semejantes á ciertos sonidos del cuello azul, á las que siguen otras mas fuertes, como las dei saxicola moteado. Snell compara muy bien estos sonidos con el susurro de un arroyuelo cuando pasa sobre un fondo pedregoso. In las hermosas mañanas de la primavera es principalmente cuando el cinclo canta con ardor; mas no permanece tam. poco mudo si arrecia el frio, sicmpre y cuando brille el sol. \&Bella aparicion es, dice Schinz, la de esta ave en el mes de enero; cuando el frio se deja sentir con mas inten. sidad, cuando toda la naturaleza parece entorpecida, el cinclo acuático, posado sobre una piedm, estaca $\delta$ un témpano de hielo, lanza al aire sus armoniosas notus. Y yo añadiria que la escena ofrece mas atractivo aun, cuando se ve al ave, concluido su canto, precipitarse en el agua helada, bañarse, sumergirse y correr, como si para clla no existiese el invierno con todos sus rigores.

EI cinclo acuàtico, escribe Girtanner, es quizas una de nuestras ares mas cantadoras, puesto que todo lo hace can. tancio. Cuando come canta, y cuando pasea dentro del agua tambien; canta, cuando se arroja valerosamente sobre un cin. clo vecino que invade su territorio; cuando se alisa el plumaje tampoco calla y finalmente muere cantando. Los sonidos varian segun la causa que los provoca. Los gritos de llamada vivos, vibmntes y retadores en que prorumpe cuando va luchar con otro. indican el belicoso ánimo de esie cantor por lo comun tan pacífico; por otra parte, iqué alegre y vivar resuena el canto que entona para su propia distraccion cuando se solaza en su sitio favorito posado sobre una pata con el lomo encorrado y las alas colgantes! Cuando se compone el 
plumaje, suena el canto como suave monólogo; pero cuando en los últimos instantes de su vida le va faltando el aliento $y$ la fuerza, entonces parece su canto fúnebre y doloroso, triste y conmovedor.s

El cinclo acuático se alimenta casi exclusivamente de in sectos y de larvas: en cl estómago de los que abrio mi padre, habia moscas, diversos coleópteros acuáticos, restos vegetales, que tragaria por casualidad el ave con los insectos, $y$ granos de arena que comen tantas ares para ayudar á su digestion. Gloger asegura que en invierno come tambien mo. luscos pequeños y pececillos, lo cual le comunica un olor aceitoso. Posteriormente supe que los chicos de escuela de un pueblo próximo al mio habian cogido dos cinclos peque iros en el nido, que los alimentaban con pececillos rque habian de procurarse con mucho trabajo, y que las aves medraban perfectamente con este régimen.

Girtanner ha puesto este punto en claro; hé aqui lo que escri. be: Los datos inciertos y contralictorios que sc tenian res. pecto al régimen del cinclo acuático en libertad hábian cxcitado hacia tiempo en mí el desco de aclarar este punto con la mayor perseverancia, bien que á pesar de esto j de haber observado dichas ares cien veces y con toda conodidad en su cstaco libre no pude averiguar lo que hubiera de cierto en su aficion a los peces. Las veia correr por el fondo del agua poco profunda, con sus alas ahuecadas, coger insectos, revol. ver masas de musgo acuático; las veia engordar, y tambien comer sin reparo huevos de ranas $y$ de peces, pero nunca noté que atraparan alguno de estos aunque á veces me pare. cia que los perseguian. No quedaba otro medio de saber la verdad sino domesticar esta ave. Hícia el año nuevo adquiri dos viejos quue acepté con ha condicion expresa de que el vendedor me habia de traer diariamente el número de pere. cillos necesarios pam alimentarlos, y asi descubri el misterio, quedando probado en numerosos experimentos que el cinclo acuático se precipita sobre todos los peces que columbra en el agıa, y que despues de haberlos cogido de algunos brincos y empujones, los arroja $\{$ la orilla, y se pone á contemplarlos con detencion. Si el pez cra demasiado grande, se limitaban los mios à dejarle abandonado y dejaban que se corrompiese, y en seguida volvian a zambullirse en uusca de otro: cuando era de su gusto, le golpeaban con fuerza d derecha $e$ irquier. da contra las piedras hasta que saltaba en juedazos, comiéndoselos despues uno tras otro, y repitiendo al poco rato la misma maniobra. Cada dia habia de dar de veinte a treinta pececillos de un dedo de longitud á cada un de las aves: pero tan pronto como cmpezú la primavera no querian ya de ninguna mancra peces, sino la carne que se da à los ruiseño. res Un molinero vió muchas veces, durante los frios mas ri gurosos, un cinclo actuftico que venia para comerse delante de ál la grasa con que se untaba el árbol de la rucda del molino.

Véase ahora cuál es el género de vida de esta arc, segun Homeyer: kientras que el agua del torrente continía clara y limpida, el ave sigue su costumbre ordinaria: despiertase apenas aparceen por oriente los primeros albores del dia y no deja de moverse hasta que cierra la noche. Por ia mañana canta con ardor $y$ caza su presa; pelea con algun recino que invade su dominio; inas para esto no necesita sino algunos minutas, pues muy pronto obliga al intruso at emprender la fuga. Cuando el sol brilla con roda su fuerza, el cinclo acuático busca un refugio contra sus abrasadores rayos en medio de las rocas que bordcan los artoyos, ó cntre algunas raices; pero con la cabeza vuelta hácia el agua, pues no deja pasar una presa sin procurar cogerla. Por la tarde caza de nuevo, bura y canta; despues se dirige al sitio donde acos tumbra á pasar la noche, el cuai se reconoce facilmente por la cantidad de excremento que cubre el suelo.
*. El cinclo acuático, vivaz, nctivo y siempre alegre, esta todo el dia en continuo movimiento: mas no lo hace asi cuando cae la lluvia durante marios dias, y se enturbian las aguas del arroyo donde vive, pues ya no encuentra alli su alimento con iaciliỏnd. Dirigese entonces hácia las orillas de las corrientes donde penden las yerbas de la orilla, inclinándose sobre la superficie del agua, y en las que flotan plantas acufticas; alli jesca á la manera de los jatos, anciando ó madando en medio de las yerbas, y revolviendo con su jico

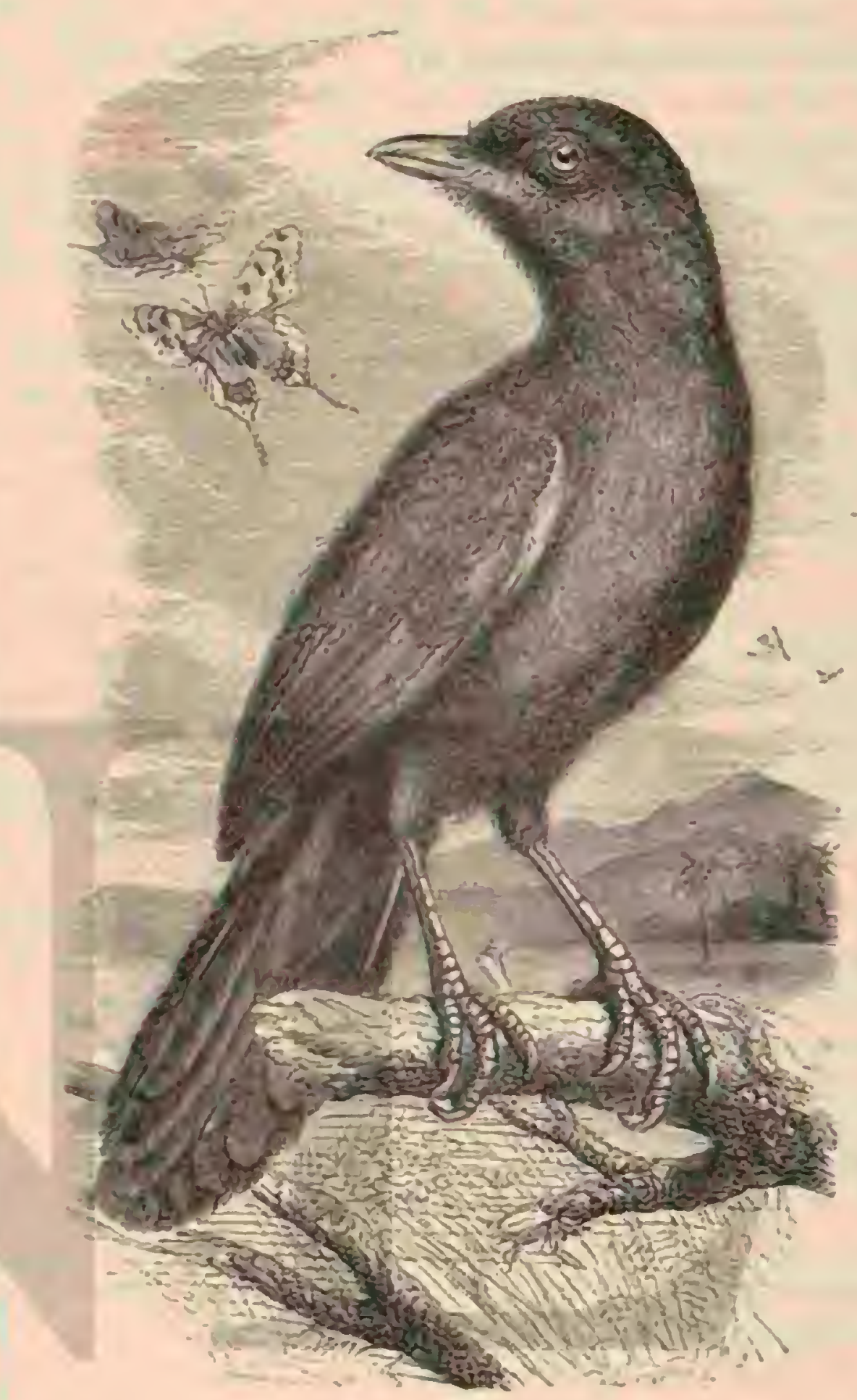

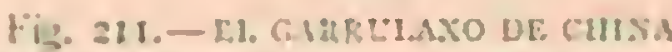

todas las hojas y las briznas parn coger los séres acuaticos g̨ue se fijan en cllas. Si dura mucho la lluvia padece el cinclo hambre, y entonces no canta, ni corre de un lado å otro jugueteando; aventúrase por los matorrales, no léjos de la cor. riente, y busca otra presa; pern cuando el agua vuelve à estar cristalina y rasga tas nubes el primer rayo de sol, recobra su viracidad y alegria de antes.

Hace casi sesenta años que mi padre dió á conocer de qué modo se reproduce el cinclo acuático esta ave, dice, no anida mas que una vez al año, rara vez dos; a principios de abril comienza á construir su nido que sitún cerca del agua, sobre una roca, en el hueco de un tronco de aliso, debajo de un puente, en un dique, en los muros que forman las paredes de los canales, $y$ hasta en conductos de las rue. das cie molino, cuando no funcionan durante algun tiempo. Busca principalmente los sirios por los cuales se precipita alguna corriente de agua, pues alli se halla libre de los gatos, de las martas, de los vesos y de las comadrejas, sin que pue da temer mas que á las ratas. Hace algun tiempo vi un nicio en la pared de la rueda de un molino, y no pude acercarme hasta que se hubo retirado toda el agua: cl nido de este 
cinclo se compone exteriormente de briznas, rastrojo, raices, yerbas y musgo, y esta relleno interiormente con hojas de árboles: la construccion es floja, pero las paredes gruesas, y la cavidad representa mas de media esfera. La entrada suele ser estrecha, y cuando el nido no llena del todo el espacio que ocupa, aquella está prorista de una cubierta, como el del reyezuelo. Si se halla situado en una pala de una rueda de molino, lo llena en parte y lo construye tan ingeniosa. mente en una que se abre hácia abajo, que á pesar de esto no puede caer, aunque le haya de das el ave una longitud de 60 centímetros. La hembra pone de cuatro is seis huevos de

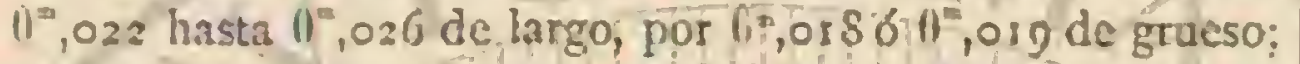
su ctscarz es deigada, con poros muy visibles, y su color blanco brillante. La madre los cubic con tânto afan, que se la podria coger con la mano; no suele criar, sin embargo, mas que dos hijuelos, rára ve\% tres, sin duda porque se echan à perder los huevos a causa de la continua humeand que se hallan expuestos.

Cuando no se molesta a los padres cerca del nido, depo. nen sus recelos y cobran tanta confianza que el hombre no les causa temor alguno. Es digno de ver cuando atraviesan volando una cascada para llegar al nido Añadiré á esta relacion pam completarla que el cincio acuático construye tam. bien á veces su nido al descubierto sobre una piedra plana junto al arroso, y que á pesar de esto no debe temer por su cria, gracins al color de los materiales que se confunde con el del sitio. Tschusi, que es el autor i quien debemos estos datos, refiere que cuando espantaba 1 los pollnclos de uno de cstos nidos, se arrojabar inmediatarnente al agua, donde en seguida se sumergian para nadar por debajo de la superficie con mucha destreza hasta que encontraban en la orilla un agujero donde ocultarse. Tschusi cogió algunos de cstos pequeños y los volvió á poner en el agua, y entonces se su. mergian al instante, alargaban el cuello y avanzaban empu. juindose con las patas y remando con las alas medin abierins con tanta rajider que llegaban à su esconórijo i los cinco ó seis impulsos.

Estas aves deben temer á los carniccros nocturnos que no vacilan en saltar al agua para coger una presa los pequeños son ả menudo víctimas de los gatosi los viejos no se liallan tan expuestos, y rara vez/sirven de pasto a una comadreja, a un reso ó una nutria. Las rapaces no persiguen á los cin. clos, porque estos se refugian en el agua apenas las ven. Al. gunos piscicultores, particularmente los que se ocupan en la cria de truchas, incluyen los cinclos en la lista de las aves que deben exterminarse, $y$ en efecto abonan este modo de ver las observaciones de Girtanner: pero bien mirndo se reducirá á muy poca cosa el perjucio que estas ares causan à la piscicultura, y cuando Girtanner pregunta: ac Deben exterminarse? hay que contestar: iNo! conviene protegerias: primero porque el cinclo acuático no come peces sino durante un tiempo muy corto del año, y aun entonces los tiene que pescar, lo que no parece cosa muy fácil cuando ha de hacerlo en estado libre; $y$ en el resto del año destrupe una multitud de insectos acuśticos y terrestres \& $\forall$ aqui debo añadir que esta ave es un adorno de nuestras corrientes, adomo que conviene salvar de la mano destructora de nues tro tiempo. Por fortuna no son la caza y la pesca cjercicios 3. que puede dedicarse todo el mundo aquellá requiere en el caso de que me ocupo un tindor hábil, y por medio de armadijo solo pueden cogerse cinclos extendiendo debaio del puente po: cionde suelen pasar una red untada de liga. Otro mérodo singular es el siguiente: Un aficionado á pá jaros, me escribió Homeyer, ha descubierto el medio de coger cinclos acuáticos, casi con seguridad. Observa al ave por la tarde, en cl momento de peneirar en el agujero que le sirve de aiberrue, y cuando cierra la noche comienza su caceria. Anda por el agua, deslizándose silenciosamente por la orilla, y llevando en la mano una linterna sorda; pteesto de. lante del agujero que ha reconocido, le ilumina de pronto y deslumbra al ave, pudiendo entonces apoderarse de ella fácilmente. De este modo fué cogido el único cinclo acuktico que yo vi en cautividad; mas por desgracia, no pudo resignarse con su suerte. Siempre salvaje, retiróse al rincon mas oscuro de su jaula, é inútilmente se trató de hacerle co. mer por fuerza huevos de hormiga y gusanos de harina, pues al cabo de seis dias murió. Su fín recordó la fábula del canto del cisne; yo le tenia en la mano para hacerle comer; entonó su canto por última rez y cayó sin vidia.

Cirtanner ha sido mas felic que Alejandro de Homever, pues bà podido criar cinclos pequenos sacados de! nido, y lo que es mas, ha acostumbrado a los viejos a comer en la cautividad. Cedióme algunas parejas que he cuidado algun tiempo, y puerio decir que pocas son las aves indigenas de nuestro pais que me hayan dejado mas satisfecho que estas.

\section{LOS TPOGLODÍTIDOS- TROGLODYTIDE}

CARACTÉRES. - Al oDservar la configuracion, modo de vivit y comportamiento de los trogloditidos, se ic desde luego in afinidad que tienen con los cinclidos; solo que estos son respectó del agua lo que aquellos respecto de la tierra

Las norenta y tantas especies que se conocen de csta fa. milia son aves cantoms pequeñas, fornidas, de pico conto ó médiano, endeble, en forma de lemna, comprimido lateral. menie y con el dorso cncorvado; la pata es medianamente alta, bastante endeble y de dedos cortos; el ala es además de corta, redondeada y ahuccada con la cuarta ó quinta rémige mas larga que las otras; la cola es muy corta en for. ma de cuma 6 cuando menos redondeada. El color funda. mental es un pardo rojizo, y el dibujo consiste en lineas ó fajitas trasversales.

DISTRIBUCION GEOGR ÁFICA. - LOS trogloditidos están diseninados por todo el globo, pero sobre todo por Europa, Asia y América.

USOS, COSTUMBRES Y REGIMEN.-Psefieren eS. tablecerse en comarcas donde abundan los matorrales, so. bre todo cuando hay corrientes y buenos escondrijos. F.n las montañas suben hasta donde llega la region arbórea y hácia el norte se los halla todavía en la zona fria. En realidad no son descontentadizos, pues en todas partes saben encontrar un sitio á propúsito, y por esto se los ve lo mismo en medio del bosque que en los huertos de las aldeas y ciudades, en las orillas de las corrientes como en las pendientes escarpadas de las montañas. Solo se alejan tenazmente del campo raso. Todas las especies son vivas, movedizas y por demás alegres. Son malos voladoses, por cuya razon no cruzan nunca grandes distancias, pero saltan muy de prisa, y para atravesar breỉas $y$ jarales enmarañados, y penctrar en hue. cos, no hay pajaro entre los cantores que los aventaje. Al. gunas especiés figuran en su patria entre las mejores canto. ms, y una de ellas, el caramillo (Cypsorhimus musious) pasa por ser la primera ave cantora de todos los paises ecuatoria. les de América. Alli comparan su canto con el sonido de unas campanillas de cristal perfectamente afinadas $y$ formando acordes cxactos, y aseguran que en ninguma parte es posible oir sonidos mas delicados y suaves a la par que mas armoniosos y vibrantes, y tanto que parecen celestiales mas bien que terrestres. In indole nada esquiva de estas aves da mucho mayor realce á sus excelentes cualidades, pues en lu. 
gar de huir del hombre, acuden sin temor à los sitios donde este vive, $y$ penetran hasta en su morada; verdad es que estc corresponde ś tal confianza otorgando 1 algunas especies su decidida proteccion, como aquella de la América del sur para la cual los habitantes cueigan hasta cacharros va. cios debajo de los tejados y que no tardan en ocupar estas aves, mostrándose tan agradecidas y mansas que, segun Schomburgk, hasta entran en la habitacion por la veniana abierta, y posindose en el antepecho, recrean á los morado. res con su canto agradable. No todas las especies reciben iguales muestras de proteccion, pero siempre son bien vistas 6 cuando menos no se las persigue. Bien puede decirse que estos amables séres tienen para el hombre un atractivo irresistible, pues no de otro modo se explican a mi modo de ver los muchos y graciosisimos cuentos con que la poesia de muchos pueblos ha amenizado la historia de su vida.

Siento que la falta de espacio no me permita hablar de esta numerosa familia como se merece, y tener que reducir. me at la descripcion de una sola especie.

\section{EL TROGLODITA PEQUEÑO-TROGLODYTES PARVULUS}

CARACTKRES. - El troglodita pequeno (fig. 213 ), im. propiamente llamado por el vulgo reycasule, tiene $11^{24}, 10$ de largo y $11^{\circ}, 16$ de punta a punta de ala, la cola $0^{n}, 035$ y el ala plegada $10^{\prime \prime}, 045$. En el macho el lomo es pardo rojo de orin ú orin gris, con rayas trasversales negruzcas; el vientre pardo rojo claro ó gris rojo, con lineas onduladas de un par. do oscurn. Del pico parte una linea parda que cruza el ojo, y otra mis angusta, de color blanco rojizo, corte tambien por encima de aujuel. Las cobijas medias del ala presentan en su cxtremo puntos redondos $\delta$ prolongados, blancos, limitados dè negro por detrás; las rémiges son pardas tirando á gris oscuro en las barbas cubiertas y manchadas alternativanente de negro y rojizo en las barbas externas; las rectrices de un pardo rojo hácia los bordes, con listas trasversales onduladas de un pardo oscuro; el ojo es pardo, y el pico y las patas de un gris rojizo. Ia hembra tiene el color un poco mas claro que el macho; en los pequeños el dorso no presenta tantas manchas; las del vientre son mas numerosas, pero menos marcadas que en los adultos.

DISTRIBUCION GEOGRÁFICA.-Encuéntrase el tro. glodita pequerio en todos los paises de Europa, desde el norte de Rusia y de la Escandinavia, hasta el sur de Fspaña y de Grecia, y además en el centro y noroeste de Asia. Fn las islas de Feroé existe una especie distinta (trigrodyges ho. realis), que difiere probablemente del nuestro por ser de mayores dimensioncs; en la Alemania central parece que hay otra especie, caracterizada por su plumajé salpicado, y á la que ció mi padre el nomure de troglodyles . Vummanu. En tre nosotros apenas hay comarca donde no se vea esta ave, $y$ hasta es muy comur en ciertos puntos.

USOS, COSTUMBRES Y REGIMEN. - Habita en los parajes mas diversos; pero prefiere los valles cuyos flancos están cubiertos de espesura, y en cuyo fondo se desliza algu. na pequena corriente. Penetra hasta en los pueblos, en los jardines, un el interior de las ciudades; y se ija cerca de la morada del hombre, siempre que encuentre un espeso matorral, 6 en su defecto un monton de ramas secas para albergarse.

El troglodita pequeño no suele posarse en los arboles altos comunmente corre por el suelo y avanza á saltitos; va regis trando todos los agujeros, matas y rincones y volando de un matorral it otro. Hay momentos en que se posa en algun punto clesado, y parece que le gusta dejarse ver.
4Por su alegria y buen humor, dice Naumann, por la des. treza y rapidez con que se desliza á través de las ramas, y por cierta osadia en sus movimientos, arentaja el troglodita i casi todas las demás aves de nuestro pais. Su atrevimiento, sin embargo, es de una naturaleza particular: a la menor se. rial de peligro se desvanece, experimentando el ave un exagerado terror; pero no tarda en reponerse, y rara vez pierde su alegria. Se la ve siempre contenta y juguetenndo como si rodo le sobrara, y lo mismo se conduce hasta en medio del invierno, al menos mientras no ruge in tormenta y con tal que las nubes dejen pasar de cuando en cuando un rayo de sol. I.os gorriones, las mas fieles de nuestras aves sedentarias, se resienten del frio, crizan sus plumas y su tristeza indica lo que padecen; pero el troglodita conserva toda su alegria y canta como en la primavera.

'Iodos sus movimientos son â cual mas graciosos; salta por el suelo con el cuerpo tan agachado, que mas bien se cree ver pasar un raton que un pajaro; deslizase con sorpren. dente agilidad por aberturas y agujeros donde no podria peneirar ninguna otra ave; pasa continuamente de un seto ó de un matorral a otro, y los registra con sumo cuidado. En algunos momentos suspende su inspeccion, detiénese sobre un punto descubierto, y toma una postura altiva, con el pe. cho inclinado y la cola levantada verticalmente; si alguna cosa llama su atencion, inclinase varias veces seguidas y levanta con fuerzá la cola Cuancio se cree seguro utiliza todos los momentos de descanso para cantar, o por lo menos para llamar: solo durante la muda parece mas silencioso. Terninado su canto, vielve d correr y a registrar todos los alrededores; y solo se decide a rolar cuando no puede prescindir de hacerlo. 'Ian diestro y ligero es en rodos sus demás mo. vimientos como torpe y pesado para el vuclo: comunnente sigue la linea recta, rasando el suelo y agitando precipitadamente las alas; cuahdo quiere franquear un gran espacio traza una linea ondulada; pero sin elevarse nunca demasiado: bas. ta perseguirle por un campro descubierto para reconocer cuán dificil le es volar. Naumann asegura que un hombre puede cansar á esta ave a la carrera para cogerla luego con la mano, a menos de encontrar un reiugio en un agujero de raton. El troglodita enano conoce que no es diestro parn volar; por eso, sin duda, no abandona la brehia que le oírece un asilo como no le sen preciso hacerlo; si se alejat, refugiase en un agujero antes que buscar su salvacion remontándose por los aires.

Su grito de llamada, que se oje á menudo, se puede expresar por feer ó tere, pronuncindo en distintas entonacio. nes: á veces prociuce un sonido equivalente \& terek, tseck. Su canto es muy agradable: se compone de notas numerosas, variadas y claras, que forman hacia el medio de aquel un trino armonioso, que va bajando de tono hasta el fín. Con frecuencia se reprite este tiltimo al terminar el canto: las notas son llenas y sonoras, y admira que pueda producirlas un ale tan pequeña. En iuvierno produce su canto una impresion de las mas agradables: con eiecto, cuando la naturaleza se halla como muerta, reinando por do quiera el silencio, los árboles privados de su verde follaje, cubierta la tierra por un sudario de rieve y de hielo, y cuando todos los séres enmu. decen mohinos, causa admiracion ver al troglodita, el mas pequeño de todos los pajaros, siempre vivar. y alegre, y entonando su canto como para decir: "ya volverá la primavera.

Hé aqui los pensamientos que esta avecilla Torzosamente suscita hasta en las almas mas prosaicas y miscrables, que no pueden comprender el lado poético de la naturaleza. iQué pobre y triste es la persona que no siente ensancharse el corazon cuando ope el canto del trogiodita en invierno!

lit troglodita pequeno se alimenta de toda clase de insec. 
tos, de amnas y otras sabandijas; en el otoño come bayas de diversas especies; en verano se procura abundante alimento donde las demás aves apenas encuentran qué comer. En el invierno seguramente padece algunas veces hambre, y en. tonces caza insectos y sus huevos. Cuéntase que en Islandia penetra en las chimeneas $y$ se come las carnes que se ponen a secar; esto lo dice Olatisen; pero me parece que el hecho necesita confirmarse, pues si bien es cierto que en esta estacion penetra en las casas, mas bién es para comer moscas que carne fresca ó ahumadis Si descubre un agujero por donde pueda introducirse en una habilacion, seguro es que penetrará en ella; tiene muy boena memoria para reconocer las localidades, de tal modo que siempre encuentra su ca. mino.

La construccion del nido varla como el sitio notabienente segun las localidades. Se han visto algunos en árboles cleva. dos, otros en el suelo, en agujeros, en troncos huecos, en las grietas de un muro ó de una roca, en chozas de carbonero ó debajo de los tejados, en los matorrales, debajo de las raices, en montones de leña, en galerias de mina; pero siempre en lugares perfectamente elegidos y ocultos, sobre todo en la primavera, cuando el ave anida por primera rez antes que los árboles ostenten todo su follaje. Algunos nidos se componen solo de musgo verde y otros de seco, pero tan estrechamente entrelazado, que no parece sino que el ave lo pega y aglutina. Estas construcciones son esféricas, y la abertura de entrada está hecha con mucha perfeccion; otras solo ofrecen un con. junto desordenado de hojas, forrado de una capa de plumas. Sucede tanbien á veces que el troglodita se limita a compo. ner $y$ adaptar a sus necesidades un nido que encuentra ya hecho.

A pesar de todas estas variaciones, la construccion se ar-

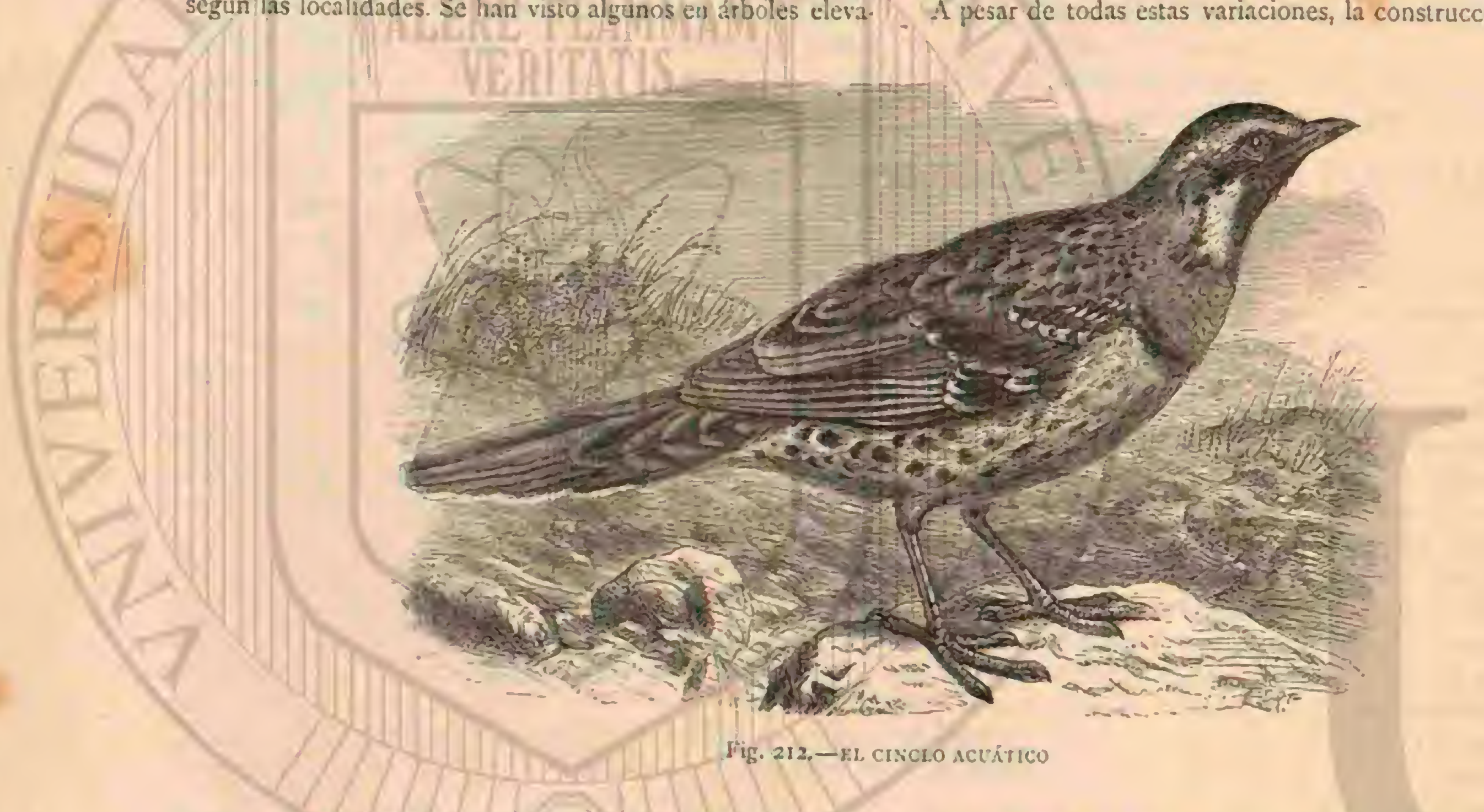

moniza siempre perfectaniente con todo cuanto la rodea, hasta el punto de ser nuy cificil distinguirla, no obstante su tamano colosal en proporcion al del ave. Algunas reces ma. nifiesta una predileccion particular por ciertas localidades: Trinthammer habla de un troglodita que viajaba con los. carboneros, gente que saca per y resina de los árboles por combustion lenta, en una sierra que habitaba; alojábase en su cabain $y$ construin en elia el nido, bien se hallase situada en el mismo paraje que el año anterior ó en otro lugar: los carboneros le conocian perfectamente y sabian quie era su ave.

El troglodita pequeño construye á menudu mas nidos de los que necesita parn sus puestas y que solo le sirven para dormir, pero suclen ser mas pequeños que los nidos de cria, no estando tampoco tapizados de plumas.

Banigk observó un troglodita pequeño desde abril hasta agosto, y refiere en pocas palabras las particularidades siguientes: El macho concluyó casi del todo cuatro nidós antes de encontrar una hembra: despues del celo, y a causa de la persecucion que sufrió la pareja ${ }_{2}$ hubo de construir trés nidos mas antes de poner; la hembra, cansada ya de tantos contratiempos, abandonó á su compañero, sin duda para ir á buscar otro. İl primer macho no dejó por eso de continuar sus tra. bajos durante algunas semanas, y fabricó aun otros dos nidos que no le sirvieron.

Otras costumbres del troglodita me parecen estar en rela. cion con esta mancra de proceder: Orilby ha visto que estas aves van muy á menudo á pasar la noche à una de sus anti. guas moradas, y no solo el macho ó la hembra, sino toda la familia: segun Paessler, un campesino de Anhalt hizo una observacion andloga.

Aquel hombre entró una tarde de invierno en su cuadra jara coger un gorrion, en un nicio de golondrina pegado contra la pared; pero sacó un punado de avecillas, y vió, no sin sorpresa, que cran cinco trogloditas, los cuales se habian apoderado del nido para pasar la noche. A Schacht le pasó lo mismo.

En condiciones normales anida el troglodira pequeno dos veces al año, la primera en abril, la segunda en junio. Cada puesta consta de seis a ocho huevos, redondeados, de tamaño variable y color blanco ó blanco amarillento, sembrados de pequeños puntos rojo pardos ó rojo de sangre, dispuestos á menudo en corona al rededor de la punta gruesa. Macho y hembra cubren alternativamente por espacio de trece dias: ambos alimentan is su progenie y la cuidan con ternura. Los hijuelos no abandonan el nido pronto, y aun despues de cm. prender su ruelo, pasan mucho tiempo sin separarse: es pro. bable que vayan a pasar las noches al sitio donde nacicron.

Ignoramos si son inuchos los peligros que amenazau á los trogloditas; y no sabemos tampoco cuales son todos sus enc. migos; pero deben figurar en gran número, pues de lo contrario abundarian mucho mas los representantes de la es. pecie. Se cogen accidentalmente en redes ó con liga. 
CaUtrividAD. - Fs bastante dificil conservar trogloditas cautivos; pero si se consigue, encuéntranse én ellos unos séres muj agradables. Crourcy turo uno que comenzaba a cantar desde el mes de noviembre para no dejarlo basta fines del verano, en la época de la muda. I.os quue yo he senido y visto en casa de otras personas me han embelesado verchade. mmente.

\section{LOS SILVIDOS - SYLVIIDE}

CARACTERES.-ESta familia, una de las mas ricas en especies, comprende pájaros cantores pequeños y esbelios de pico fino, delgado, en forma de lerna, y dorso corvo hasta la punta ligeramente racinda; patas cortas $\delta$ a lo mas media. nas, cuyos tarsos están cubiertos por delante de placas divididas; alas medianas, casi siempre redondeadas y provistas invariablemente de diez rémiges primarias; cola costa $\delta$ lat. ga, y plumaje sedoso.

DISTRIBUCION GEOGRÁFICA.-I Las cuatrocientas cincuenta especies que à poca diferencia componen esta familia se hallan diseminadas por todos los paises del hemisferio oriental de la tiersa y faitan únicamente en América.

USOS, COSTUMBRES Y REGIMEN.-Habitan todas las comarcas, zonas, datitudes y alturas sicmpre que hay'a ve. getacion. Moran en las selvas lo mismo que en los matormles aislados, en los mohedales como en los cañizares, y entre los juncus y espadañas, animando por consiguiente y á la verdad de un modo bastante agradable los sitios mas variados, conforme a sus muchas excelentes cualidades. Vivaces, acti. vos, movedizos $\&$ inquietos, deslizanse con sorprendente $y$ sin par agilidad por las matas $y$ breñas mas enmaranadas y tupidas, y con la misma facilidad se los ve moverec en el ramaje de los árboles quue en el jaral ó espadañal mas com. pactos é impenctrables. No son menos diestros en correr, al paso que no vucian mal, y si en este último respecto no pueden competir con otras aves, no dejan de entretenerse á me. nudo en hacer muchas habilidades de vuelo. Figuran en su inmensa mayoria entre las aves cantorns mas perfectas y al. gunos son verdaderas maestras en este arte, pudiendo decirse otro tanto por lo que respecta a sus facultades inteleciliales; sus sentidos están asimismo muy desarrollados, y todo el que los conozca les concederí una gran inteligencia. Son saga. ces, saben adaptarse á las circunstarcias, distinguen entre amigos y enemigos mostrándose confiados donde hay motivos prara serlo, y recelosos y esquivos donde se les ha perseguido; si en ocasiones se muesiran desconfiados y astutos, dan prueba en otras de irnncos, leales y afectuosos. Con otras aves viven en bucna amonia, yen paz con las de su esprecic mientras no les excite cl amor ó los celos Fieles á sus deberes conyugales, no reparan en sacrificarse por su cria, dando pruebas verdaderamenic admirables y conmove. doras de su caririo. En una palabra, los sílvidos presentan un conjunto de cualidades tan numerosas como excelentes.

las especies que viren en nucstro pais scptentrional son ares de paso, que en su major parte no se aparean sino en plena primavera. Enionces raóa pareja se reira á su domi. nio bien circunscrito mas 6 menos grande y deñro del cual tolera mus rara vez otra pareja de su especie. Luego de elé gico y bien-señalado ch terrerio, pasa la pareja a ocuparse en la construccion del nido que segun ia especie se construye $y$ coloca de distinta manera. Macho y hembra suclen alternar con mucho celo en el trabajo de cubiir la puesta que puede consistir en cuatro hasta seis 0 á lo mas ocho huevos. Ali. menian á los polluelos exclusivamente con insectos que tambien constituyen el alimento principal de los padres sin que estos rehuynn en absoluto y particularnente en otoño las difurentes bayas y otras frutas que pueden encontrar. Ningun silvido causa ai hombre perjucios de imporiancia, pero si le son de utilidad manifiesta, aunque muchas perso. nas se niegan á reconocerlo asi; y por esta razon todas sus especies merecen en igual grado nuestras simpatias y preteccion de que, gracias a su excelente canto, gozan feliz. mente $y$ casi $\sin$ excepcion en tedas las clases y edades.

Cautividad.- Todos los sílvicos son propios para conservarlos en jaula, y bajo este concepto serán siempre acreedores á la mas alıa eslima, i pesar de los gustos bas. tardos que en los tiltimos tiempos se han apoderado de los aficionados.

\section{LAS CURRUCAS-SYLVIINA}

CARACTÉRES. - Entre todos los silvidos pertenece el prime lugar á los miembros de esta sub-familia que se ca-

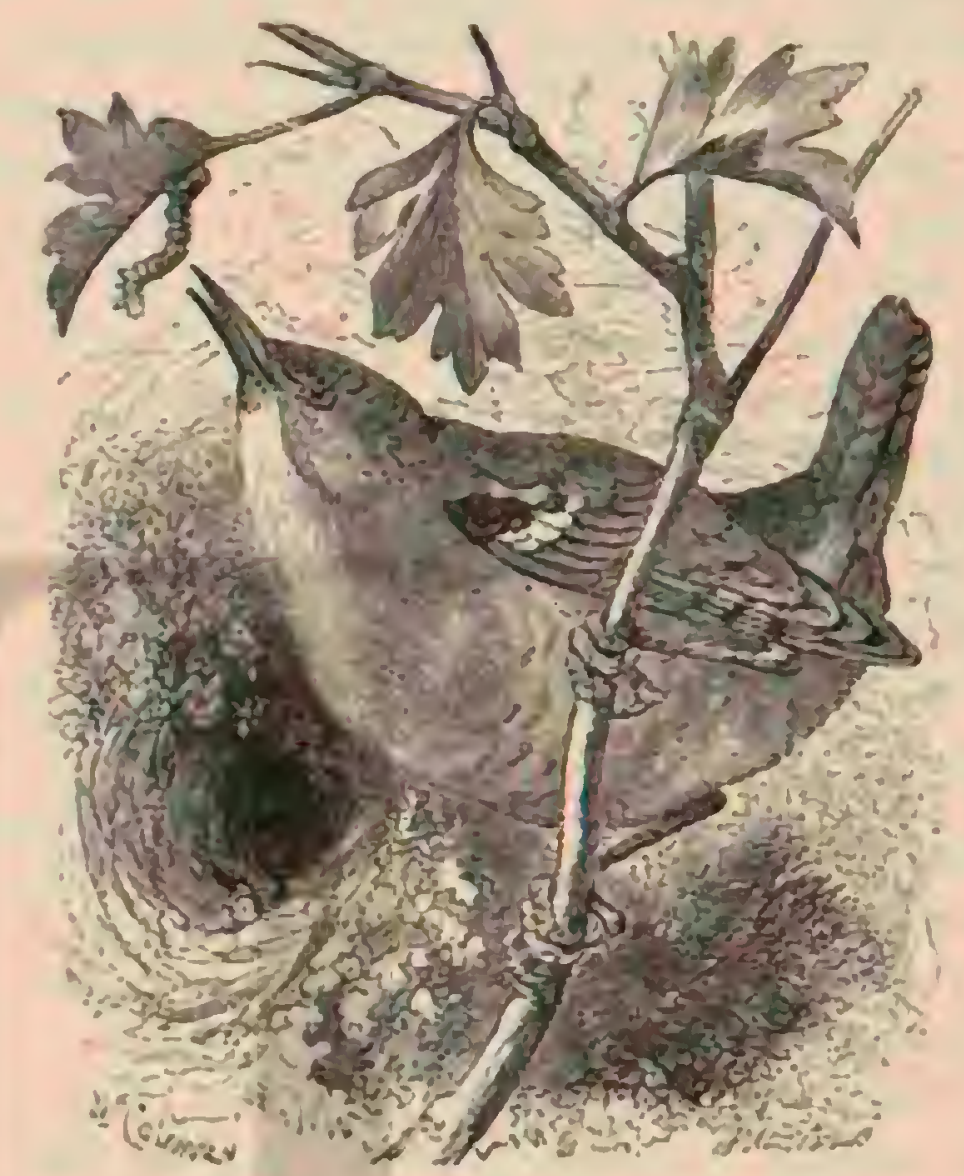

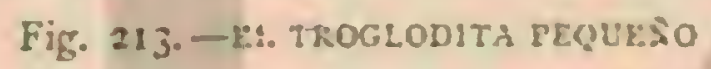

racterizan por su cuerpo esbelto, pico en forma de lezna, muy cónico, robusto en la base y en la punta encorvado ha. cia abajo con una pequecia escotadura cerca de ella; patas robustas y bastante cortas; alas medianas ligaramente redon. deacias con la tercera y cuarta rémiges mas largas que las demás; la cola corta, compuesta invariablemente de doce rectrices, y finalmentc, for su plumaje abundante, sedoso y de una colaracion generalmente pocu vistosa

DISTRIBUCION GFOGRÁFICA.-Las curricas, que comprenden apenas veinticinco especies, tienell por fatria el hemisferio oriental de la tierra, siendo mas numcrosas en la zona septentrional del antiguo continente.

USOS, COSTUMBRES Y REGIMEN. - Eiligen para morada los bosnues, tanto los de follaje como los de conife. ras, asi los montes altos como los bajos y los huertos, sin cenirse d determinadas alturas ni al llano. Reunen casi todas Jas buenas cualidades que distingren á la familia; son excelentes cantoras; alimémanse de insectos, aranas, frutas y ba. yas, y consiruyen nidos sencillos colocados a poca altura en medio de alguna maia.

\section{LA CURRUCA GAVILAN-SYLVIA NISORIA}

CARACTERES. - Esta especie, la nayor de lodas las de esta inmilia que viven en Alemania, mide $1^{\circ}, 1 \mathrm{~S}$ de largo: $6^{*}, 29$ de punta a punta de ala; esta plegada $0^{\circ}, 09$ y la cola 
$0^{\circ}$,oS. El color del dorso es un gris pardusco aceitunado, algo mas oscuro en la coronilla; las plumas de la rabadilla $\checkmark$ las cobijas caudales superiores están en su extremo orladas de blanco con un filete negro interior; las de la frente $y$ de las cejas presentan en el extremo una punta exigua blanquizca; la linea naso ocular es gris, la parte inferior del cuerpo es blanca; las plumas de los costados del cuerpo y de la caibeza, de la barba y garganta tienen en el catremo un filete estrecho y oscuro, con manchas cuneiformes oscuras en todas las cobijas inferiores; las pennas son todas jardo oscuras, con filete estrecho lconado blanco en la barba cxterior, y blan. quizco y mas ancho en la interior; los extromos de las rémi. ges secundarias, sus cojijas y las grandes cobijas superiores de las alas ienen una orka. b!anguecina; y las tres rectrices externas de cada ládo el extremo interior blanco. Iil iris es amarilio limon, el pico de color pardo de asta. pror debajo amarillo, y la pata de un amarillo claro (fig. 24.4). Is hem. bra dinere del macho por lener los colores menos vivos.

DISTRIBUCION GEOGRÁFICA.-Fsta curruca habita y recorrć todas las regiones curopeas situadas al sur de Suecia'y de Inglatern; el Asia occidental y la China sep. tentronal, 8 emigra en invierno hasta el interior de Africa. lis frectrente en determinadas comarcas de Alemania, sobre todo en molicdas y matorrales á orillas de las corrientes, inientras que falta completamente en otras, ó es cuando me. nos ave sumamente rara.

CARACTÉRES. - Jamás llega á nuestro pais antes de fin de abril, sino casi sicmpre á principios de mayo, permaneciendo a lo mas hasta agosto. Para moracja de rerano elige monte bajo y con preferencia espesuras, que abandona á me. dida que crece el ramaje, para establecerse en otros mas nue. vos En los árboles solo descansal durante sus viajes. Rara ver se posa en el suelo, donde se mueve pesadamente; no le gusta volar; pero salta con agilidad entre las ramas, deslizán. dose á través de los mas espesos matorrales. Su grito de lla. mada se expresa por ithch, I el de aviso, mas ronco, por err; su canto difiere segur los parajes que habita; pero siempre. es bello, armonioso y ricamente variado, si bien jarece componerse de los sonidos que produren la curruca de los jardi. nes y la cenicienta, sin poderse empero comparar ni al de la primera, ni al del capirote pot grancie que sea la analogia, Con írecuencia mercla los cantos de la oropéndola, del pin. zon, de la curruca de cabera negra y de otms aves que sucle oir; pero desgraciadamente produce de vez en cuando notas corridas y roncas que le son farticulares y que hieren desagra.

dablemente el oido. Del mismo modo que las demás curru. cas, canta con afan, y por lo mismo es muy buscada como ave de habitacion y una joya del monte.

Ifegada la primavera, cada pareja busca una comarca, y ahujenta a todas las demás currucas de la nisma especie que jeneiran en su dominio. Si una de sus semejantes se atreve á entrar, dice Naumann, el macho no descansa un momento hasta que ha conseguido ponerla en fuga, lo que origina contiendas muy sérias. Mientras que la hembra se ocupa en hacer su nido en un matorral ó en cubrir sus hue. vos ó deslizandose por la espesura, el macho permanece en los árboles altos mas yruximos, donde canta y grita inquieto, vigilando continuamentc pasa impedir que se acerque un rival que si acaso aparece es niacado y perseguido hasta que apela á la fugr.

El nido situado en una espesura $\delta$ en una gran breña es. pinosa, está por lo regular bien oculto $y$ ś una clevacion de un metro y mas sobre el suclo, y no difiere del de las otras cur. rucas. A fines de mayo ó principios de junio se encuentran en él de cuatro á seis huevos prolongados de cáscara delgada, color gris blanco por lo comun con manchas cenicientas y pardas muy claras, estas últimas con matizaceitunado: poco relucientes y de $0^{\circ}, 020$ de largo por $10^{\circ}$, or a de grueso. Los padres se muestran muy recelosos, y aléjanse siempre cuando divisan un sér que temen; en caso de peligro simula la hem. bra una parálisis para salvar of su progenic. Si alguien se acerca al nido antes de estar terminado, abandónanlo macho y hembra para construir otro; lo mismo hacen con los huevos si el hombre los toca. Los hijuelos se declaran muy pronto independientes, aun antes de poder volar bien; pero debe tenerse en cuenta que nacen casi con la facultad de poder deslizarse il traves del ramaje mas espeso. Cuando no se in. quieta a una pareja de currucas, no emąolla mas que una fiž al año, pues le seria imposible hacerlo dos en el poco ticmpo que pasa en nuestro pais.

Jóvenes y viejos se alimentan de insectos que viven en las hojas y en las corolas de las flores, sobre iodo de orugas je. queñas ! larvas, mariposas por lo general dañinas, escaraba. jos, arañas y toda la cafila de sabandijas y gusanos; en otono empero buscan mas las bayas comestibles de cualquiera clase, y guindas cuando es la época.

CAUTIVIDAD. - Ciridandola bien se acostumbra esta curruca a la jaula con igual prontitud que sus congeneres propias de Alemania, siendo tán poco descontentadiza como ellas; canta mucho se domestica al fin $y$ al cabo extraordi. nariamente

\section{LA CURRUCA ORFEO - SYLVIA ORPHEA}

CARACTERES, - Por su tamaño ocupa esta curruca el segundo lugar entrelas especies curopeas. Fol macho mide $11^{*}, 1$; de largo y la liembra $0^{\circ}, 16$; el ancho de punta $a$ pun. ta de ala es de $\left(1 \%, 25\right.$; el ala plegada tiene $11^{\circ}, 0 \$$; la cola $11^{\circ}, 07$.

La coloracion es en el lomo gris ceniciento con visos parduscos; la nuca y la parte superior de la cabera de color pardusco ónegro mate; el vicutre bianco; los lados del pe. cho de un tinte rojo claro; las rémiges $y$ las rectrices de un negro mate pardusco, las barbas externas y extremas de la rectriz mas exterior son blancas, las internas, muy anchas, presentan hícia su extremo una gran mancha cuneiforme de este ultimo color y la segunda rectriz la punta blanca. El ojoes amarillo claro; la mandibula superior negra y la inferior de un negro azulado; las patas de un gris rojizo; rodea el ojo un circulo desnudo gris azul.

Los colores de la hembra son un poco mas pálidos que los del macho, en particular el del occipucio.

DISTRIBUCION GEOGRAFICA. - Esta curruca es propia del mediodia de Europa; su patria enjpieza en los distritos situados en las costas septentrionales del Mediterri. neo, siendo los puntos mas cercanos para nosotros los ale manes la Istria y la Suiza meridional. En las comarcas de Espana donde crece el alto pino y extiende a inanera de quitasol su verde copa, donde los algarrobos cubren los flancus de las montanas de la costa, y los olivares las llanu. ras, no hay que buscar mucho jara encontrar a esta ave, pudiendo decirse oiro tamto respecto de Grecia y en general de la peninsula del Balkan, del mediodia de Francia, de Italia y de Rusia Iin todos estos paises no aparece sino en verano: en Rusia á fines de marzo 6 principios de abril, permaneciendo alli hasta setienibre: pero en España no se pre. senta antes de fin de abril y á veces á principios de majo, marchándose yu en agosto.

Tambien se la encuentra en el Asia occidental y Menor, donde, al igual de Persia y Turkes!an, es ave comun y anida aun en alturas de 2,000 metros sobre el nivel del mar. En Alemania é Inglaterra se dice haberla visto difurentes veces. En su cmigracion invernal llega hasta el centro del Africa y 
at la India, puesto que la he matado junto al rio Azul, y lerdon la ha observado en invierno como huésped frecuente de toda la India meridional.

USOS, COSTUMBRES Y REGIMEN. - $A$ contmrio de las otras currucas, la de que hablamos busca los f́rboles altos: jamás la he visto en los tallares. Abunda mucho mas en la llanura que en las montañas; agrádanle particularmente los terrenos en cultivo y bien bañados; le gusta fijarse en los bosques de piros, donde resuenan sus canios; $y$ alli se la ve posada en la copa de un alto árbol. El orfeo es prudente y receloso, y por lo misno dificil de observar; al acercarse el cazador se refugia en medio del ramaje mas espeso y desaparece de la vista para mucho tiempo.

lista especie merece su nombre de Orfeo. Se la querido rebajar el mérito de su canto, pero nadie puede negar que ocupa un puesto muy preeminente en su familia misma. Tiene algo del canto de nuestro mirlo sin ser tan alto ni tan sostenido. Alejandro de Homeyer que ha tenido una de es. tas currucas mucho tiempo en jaula, dice que canta mejor que todas sus rongéneres: Es un canto particular, dice, que desde luego ofrece el carácter del de una curruca y nada mas, pero que de paso trae a la memoria el de un cinclido por sus frases armoniosamente coordinadas y ejecutadas con pausa, porque k pesar del carícter cadencioso de estribillo propio del canto de todas las currucas, tiene el de esta los puntos secos y estridentes de las silvias de jardin ó falsos ruiscnores (Hjpolais). Por su plenitud y manera de ejectcion se parece muchisimo este canto al de la curruca de huerto, pero es mas sonoro, mas variado y mas espléndido. Sonidos como de grirgaras, chasquidos y cacareos alternan con otros naturales y claros de extraordinario vigor y pleni. tud, que dejan sorprendido al que los escucha, tanto mas cuanto que el canto de las currucas se distingue precisamen. te por su monotonia y la repeticion eterna de sus gargarismos y rechinamientos continuos. A esto se agrega que la curruca orfeo pronuncia las frases con tanta claridad que pueden escribirse á medida que las canta sin necesidad de apresu. rarse. Su grito de llamada suena como yed, cher á manera de chasquido y tru's rarnit; la vou de espanto suena como rivik, if-sk repetido muchas veces. Algunos individuos adoptan tambien voces del canto de otras ares.

Se alimentan de pequeños animalejos, frutas y bayas.

El periodo del celo comprende desde mediados de mayo a la primera mitad de julio, y despues se verifica la muda. Cuando ocurre el apareamiento son muy pendencieros los machos, y se persiguen mutuamente, excitados por los celos Hacen su nido en la copa de un árbol. Por lo regular no estí oculto y-se apoya en la bilurcacion de una rama, difiriendo del de las otras currucas en nue sus paredes son mas sólidas y gruesas El interior está cubierto muchas veces de corteza de vid. 'Thienemann vió uno tapjizado de escamas de peces. Cada puesta consta de cinco huevos, de cascara del. mada, lustrosa y de poros finos; son de color blanco ó blanco verduso $y$ están cubicrtos de puntos gris violeta y pardo amarillos que tambien pueden faltar. Dice Kruper que solo cubre la heinbra: entre tanto se posa el macho bastante léjos de ella y procura entretenerla con sus cantos. Despues de haber comenzado á volar permanecen los hijuelos con los padres algun ticmpo; pero en el momento de la muda scpa. ranse las familias y cada cual se cuida solo de si.

\section{LA CURRUCA DE CABEZA NEGRA Ó CAPI- ROTE-SILVIA ATRICAPILLA}

"De todas las ares de las islas Canarias, la mejor cantora. el copiru'e, no es conocida en Europa, y le gusta tanto su li- bertad, que no se la puede domesticar. He admirado su canto dulce y melodioso en un jardin de los alrededores de Orota. va; pero no la pude ver bastante de cerca para averiguar á qué género pertenecia Tales son las palabras de Humbold al hablar de esta ave: y debe advertirse que años despues de haber pasado por Canarias el ilustre geólogo ignorábamos todavia á que animal se referia.

Sabemos ahorn, en efecto, que el famoso capirote, al que llaman orgullosamente los indigenas su ruiseñor, no es ni mas ni menos que la curruca de cabeza negra, una de las canioras de nuestros bosques y jardines, la mas bonita, mejor dotada y mas celcbrada.

CARACTERES. - Tiene el lomo gris negro; el vientre gris claro; la garganta gris blanquizca: la parte superior de la cabeza de un negro intenso en el macho adulto, y de un pardo rojo en la hembra y el pequeño. El ojo es pardo; el pico negro $y$ las patas de un gris plomo. Fil ave mide $0^{\text {th }}, 15$ de largo por $1^{\prime \prime}, 2$ I de punta a punta de ala, la rola $0^{\prime \prime}, 06$ y cl ala plegada $(1 ", 065$ (fig. $21 \%$ ): la hembra es tan grande como cl macho.

DISTRIBUCION GEOGRÁFICA. - El capirote habita toda la Europa, inclusas las islas de Madera, Canarias y Azores; hácia el norte hasta la Iaponia; en lispania y Grecia se presenta durante su emignacion yo para pasar el inviemo, bien que extiende su viaje entonces tambien hasta el centro del Africa. Llega \& Alemania hácia mediados de abril, alojándose en los bosques, matorrales y jardines, y ros abandona en setiembre. En nuestro país no falta en ninguna comarca, en cuanto yo sepa, bien que en algunas se ha ido laaciendo mur raro de algun tiempo á esta parte, como sucede en la l'uringiá.

USOS, COSTUMBRES Y RÉGIMEN. - RL curruca de cabeza negra, dice mi padre, al que se debe la primera descripcion detallada de su modo de vivir, es un ave agil, prudente y de carácter alegre; se la ve recorrer sin descanso los mas espesos matorrales; lleva el cuerpo horizontal, las patas un poca encogidas, y las plumas apretadas contra el cuerpo, por lo cual parecen sus formas mas elegantes: rara vez baja á tierra; si alguno se accera, procura ocultarse en la espesura, $\delta$ bien se aleja volando; es muy diestra para es. capar, y se necesita perseguir mucho tiempo \& las currucas viejas antes de poderlas tener á tiro: los individuos jóvenes son menos prudentes.

Ni) ruelo de esta are es rápido y directo; al cruzar los aires agita con fuerza las alas, y en casos raros franquea una gran distancia de una sola ve\%. Solo cuando se la persigue largo tiempo se remonta $\delta$ gran altura ó abandona definitivamente la localidad. Durante el periodo ciel celo, cada cur. ruca habita un terreno bastante exienso, y cuprende tam. bien excursiones mas alla de sus limites. En tiempo frio y lluvioso he oido con frecuencia en los jardines situados cerca de las casas $\{$ las currucas acantonadas en los bosques. Su grito de llamada, cquivalente á fack fack tack, es bastante agradable $y$ va seguido de una nota muy dulce, que no es fácil de coniar; ese tack se asemeja al del ruiscnoor y de la curruca parlera, y se necesita un oido muj ejercitado para distinguirie. Segun la entonacion, indica diversos sentimiencos: las hembras viejas que conducen a su progenie son las que le producen con mas frecuencia. El macho canta muy bien, y por tal concepto puede figurar al lado del ruiseñor. Algunas personas prefieren su canto al de la curruca de los jardines y otras le aprecian menos. Las notas son llenas, sonoras $y$ armoniosas; pero las frases tienen poca extension, falta que queda suficientemente compensada por las otras cualidades: algunos machos cantan mejor que otros, y todos dejan oir su voz desde la maijana a la tarde. 
La curruca de cabeza negra anida dos veces al año, en mayo y julio: su nido se encuentra en los bosques de coniferas, en los matorraies de pinos, en los espinosos y en los de otras esencias; $y$ su construccion es mas sólida que la del de las demás currucas. Cada puesta es de cuatro á seis hue. vos ovales, de ciscara lisa y reluciente, y color de carne con manclias, punios $y$ salpicaduras irregulares pardo rojos, teniendo ()$^{n}, 0$ is de largo ${ }^{10}, 014$ de grueso. Macho $y$ hembra cubren alternativamente; crian á sus pequenos con la mayor solicitud, y hasta se sacrifican por ellos. Si perece la madre, encárgase el macho de $\mathrm{M}$ cria

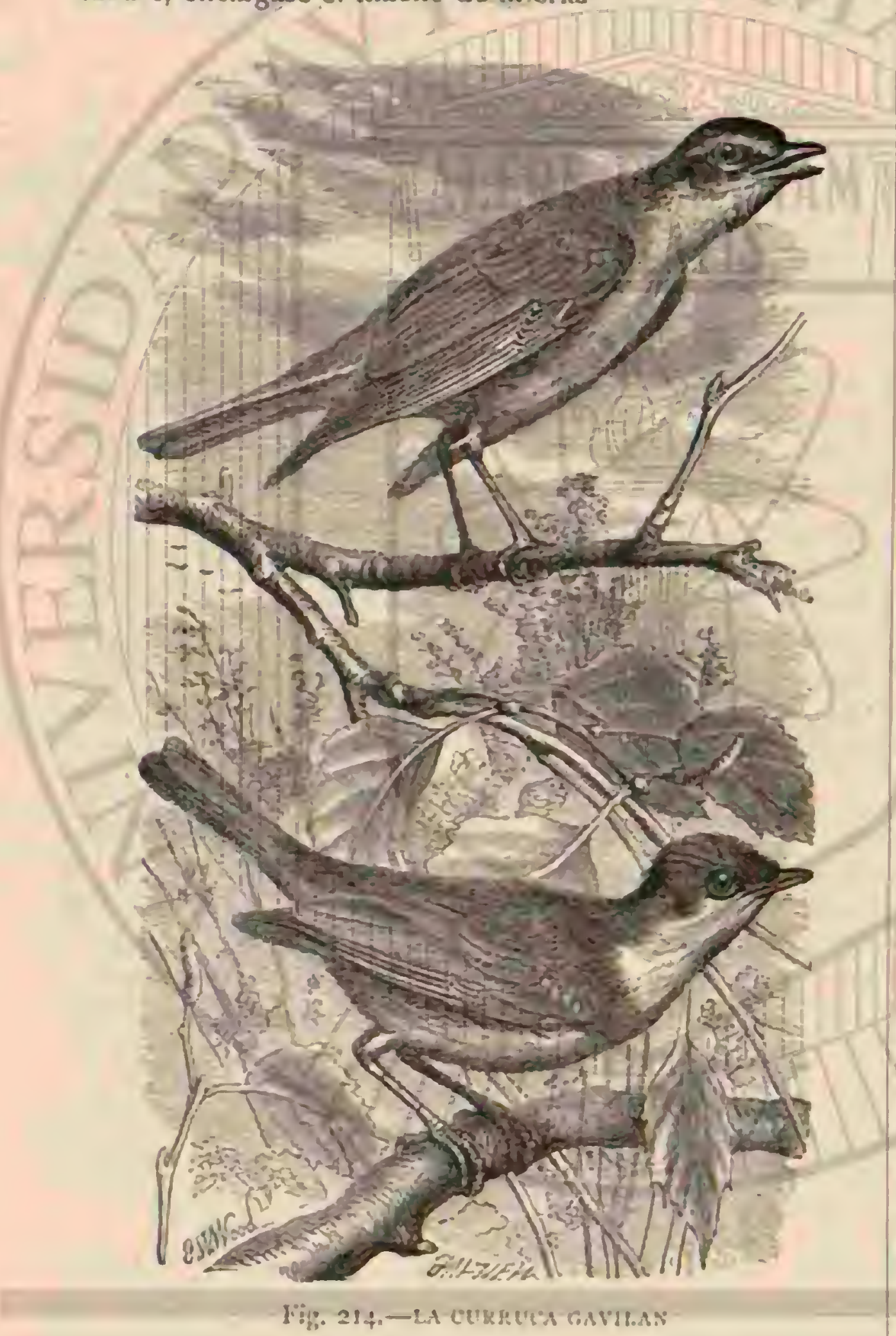

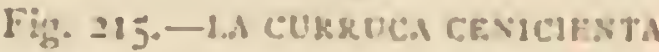

CautrVidad. - He todas las especies del género, la curruca de cabeza negra es la quue se ve mas à menudo cautiva, solo por su bonito canto. Dice mi padre que las que cantan mejor son las que habitan los bosques de abetos de montaña, aunçue las mas de las que viven en otros pueden rivalizar con cllias por tal concepto. \&La curruca de cabeza negra, escribe ef conde de (iourcy, es una de las mejores cantoras y en mi concepto se debe anteponer al ruiseivor como ave de recreo. Su canto, bastante urolongado, tienc notas mas aflautadas, de mayor variacion y menos penetrantes que las del ruiscinor, del cual ha tomado esta curnuca ciertos aires.

Muchas currucas cantan todo el ano, otras solo ocho ó nueve meses: las que se han criado en cautividad no valen nada, pero se las puede enscỉar á que silben cualquier aire sencillo: se ha oido alguna que imitaba la bocina del pos. tillon.

2Tocias las currucas de cabeza negra, aun las mas silves- tres, se domestican perfectamente; reconocen â su dueno y le saludar con sus alegres cantos apenas le divisan. lo lie conservado una mas de once anos y otra nueve. Son ríciles de mantener y no necesitan un alimento tan escogido como los ruiseñores y las demás currucas. Conorco aficionados que no dan á las suyas mas que pan y rábanos, conserván. dolas asi en buena salud: estín muy contentas cuando se les pueden proporcionar bayas

Bolle refier la siguiente anécdota: (En la capital de la Gran Canaria se conserva todavía memoria del capirote de una religiosa: todos los dias, al darle de comer, pronunciaba las frases, mi miño chiquirrilito; y bien pronto aprendió el ave i repetir estas palabras. i Un ave cantora habiar! El pueblo se entusiasmó y durante algunos años fué el capirote cl idolo de todos, llegríndose ả of́recer por êl á su ama grandes sumas. La religiosa no quiso separarse de su querida ave, que era su único recreo, la única felicidad de su vida; mas lo q̨ue no pudieron conseguir brillantes ofertas, lo alcanzó un envidioso, envenenancio al capirote. Sin embargo, se ha conservado su recuerdo, y aun se hablará mucho tiempo de! caso en la ciudad de las Palmas.

\section{LA CURRUCA DE LOS JARDINES - SYLVIA HORTENSIS}

CARACTÉRES. - Como cantom cede proco la curtuca de los jardines á la orfeo. Su longitud es de (1)" 16 ; el ancho total de punta á punta de ala $0^{m}, 25$; esta plegada mide 0 , os de largo y la oola $(1 ; 06$. La hembra es mucho mas pequena que el macha. $\mathrm{Fi}$ plumaje es color gris aceitunado en th dorso y gris claro en la parte inferior del cuerpo; blanquizco en la garganta y vientre; pardo aceitunado en las rémiges y en la cola qué hácia fuera es de un gris leonado; aquellas están orladas en la parte interior de blanco leonado. Un circu. lo de plumas gue rodea el ojo es blanco, el ojo es pardo gris claro, el pico y la pata de color gris aplomado sucio (fig. 21(1).

DISTRIBUCION GEOGRÁFICA. - la patria de la curruca de los jardines es la Europa central. Hicia cil norte se extiende hasta los $69^{\circ}$ de latitud; hácia el sur disminuye con mucha rapider, y en direccion este no pasa de los mon. tes Urales. Fis comun en el mediodia de lirancia y en Italia; anida todaria en Lispana y Portugal, pero por ('recia y el Asia Menor no pasa sino en sus emigraciones que extiende hasta la parte occidental del Africa.

USOS, COSTUMBRES X REGIMEN. - No llega á nuestro pais antes de fin de abril 6 a primeros de mayo pasa abandonarnos en setiembre. Vive en el bosque, ya sea de árboles frondosos 6 ya de coniferas, sin ylue per esto desmienta su nombre, puesto que el jardin y el huerto con sus árboles la arraen principalmente. Vive tanto un los tallares bajos comb en las copas de árboles de regular aliura, que son los que prefiere para posarse cuando quiere cantar.

"La curruca de los jardints, dice Naumann, es un ave solitaria y silenciosa; pero actira á la vez, pues siempre está en movimiento. Completamente inofensiva, jantás molesta ni acomete a las demás ares; inuéstrase confiada con el hombre, y es prudente, aunque no timida A semejanza de las otras currucas, cs tan diestra y ligera para saltar entre el ramaje, como pesada y torpe para andar por el suclo. Vive mas en los árboles que en las brenas; se la re recorrerlos mas á menudo que las otras especies; iranquea volando grandes distancias, y entonces sigue la linea recta, mientras que en sus emigraciones traza en los aires lineas onduladas.

Su grito de llamada es heik, allech; el de aviso, rrah, pronunciado con roz ronca; el de angustia es dificil de anotar: el de coniento se expresa por lizeaziwarien. emitido con dul. 
zura y débilmente: esta are es una de nuestras mejores can. toras. \& Ha la primavera, apenas llega el macho, continúa Naumann, se oye resonar su canto, de notas dulces, aflauta. das y muy dirersas, cuyas largas melojias se siguen lenta. mente 5 sin in:errupcion: esta curruca canta desde su llegada hasta pasado el dia de San Juan, poco mas ó menoș. Solo se calla al medio dia, cuando reemplaza á su hembra en el nido para cubrir los huevos; en todas las demás horas re. suena su vor en el bosque Por la mañana, al rayar el dia, canta sobre un seto $\delta$ un árbal, manteníndose inmóvil; el resto del dia se ocupa en eraminar los árboles, saltando de rama en rama para buscar su alimento, sin dejar por eso de seguir su canto. El de csta curruca tiene una tonada mas proloniada que el de las otras; ofrece alguna sencjanza con el canto de la curruca de cabeza negra, y mas aun con el de la curruca gavilan, del cual difiere solo por alyunas notas mas dulces y melodiosas.

De mis observaciones resulta que varia el canto segun el individuo y la localidad. Las currucas de jardin que cantan mejor de cuantas he tenido ocasion de oir son las de la "luringia superior. Jamás he oido una curruca gavilan que las igualara, pero si currucas de jardin que podian competir con capirotes; una de ellas, que vivió mas de diez años y entonó al morir mi difunto padre un cántico lastimero que á todos nos conmovió, era el ave cantora mas soberbia que en mi vida he oido, $y$ sus descendientes, si bien no alcanzans s!s perfeccion, me alegran y aun me extasian todavia cada verano.

En cuanto à su réginen se asemeja mucho la curruca de los jardines al capirote.

El nido se halla colocado indistintamente à poca 6 á mucha altura; unas veces en breñas y otras en arbolillos, y cuando unas y otros escasean hasta en agujeros en el suclo con en. trada angosta, de lo cual pudo cerciorarse plenamente lugenio de Homeyer en la isla de Hiddeoo. Ls el nido mas ligeramente hecho de todos los de curruca, y a veces de un fondo tan delgado que no se comprence cómo no caen los huevos stravés de el. A esto se ha de agregar que lo fijan por lo comun con tanta dejadez entre ramas delgadisimas que apenas puede resistir, segun asegura Naumann, las repetidas entradas y salidas de los viejos, y que el viento lo vuclca à reces.

\&Las currucas de los jardines, sinade Naumann, son su. mamente caprichosas en la eleccion del paraje que debe ocu. par su nido; comienzan en un punto; abandónanle despues para trabajar en otro mas lejano, y por último prosiguelt su tarea donde se hallaban primero, acabanio la construccion que, en nuestro concepro, está peor situada. Muchas veces se puede atribuir esto á su acostumbrada prudencia: si ven a un hombre cerca del lugar donde hacen el nido, aléjanse de el inmediatamente, aunque tambien debe advertirse que en sitios donde no habia ido nadie hacia largo iempo, he lrallado mucinos nidos sin concluir, compuestos de algunas briznas de yerba en forma de cruz, antes de dar con el verdadero. Los muchos nidos empezados, compuestos de pocas briznas a manera de primer trazado, que suelen encontrarse cuando se va en busca de nidos por los matorrales, son por lo regular abra de una sola pareja.

I fines de mayo termina la incubacion: los huevos que tienen 1 ", org de largo por $0^{\circ}, 01$ \& de grueso y cuyo número varia entre cinco y seis, presentan dibujos y colores suy va. riados; por lo regular son de color blanco agrisado, con viso amarillo $y$ manchas de un tinte cafe con leche, rojas y pardas, y algunas veces puntos de un pardo negro $\delta$ gris ceni. ciento. El macho cubre á medio dia y la hembra en las de más horas. Ios hijuelos abandonan el cascaron al cabo de una quincena, y pasada orra dejan el nido cuancio ven acer- carse algun sér que les inquiete; aun no pueden volar, pero saltan y trepan en medio del ramaje con una destrcza sufi. ciente para perderse de vista. Cuando no se malogra su primera puesta, la especie empolia solo una vez al año.

CaUtrVIDAD.-Se conserva cautiva esta ave por su agradable canto, y se habitua con la misma lacilidad que sus congéneres à la jaula; se domestica sin trabajo, canta mucho y cuando se la cuida bien vive de diez á quince años.

\section{LA CURRUCA GÁRRULA-SYLVIA GARRULA}

CARACTERES. - La colocacion de esta especie es muy análoga a la de la anterior, de la que difiere por su

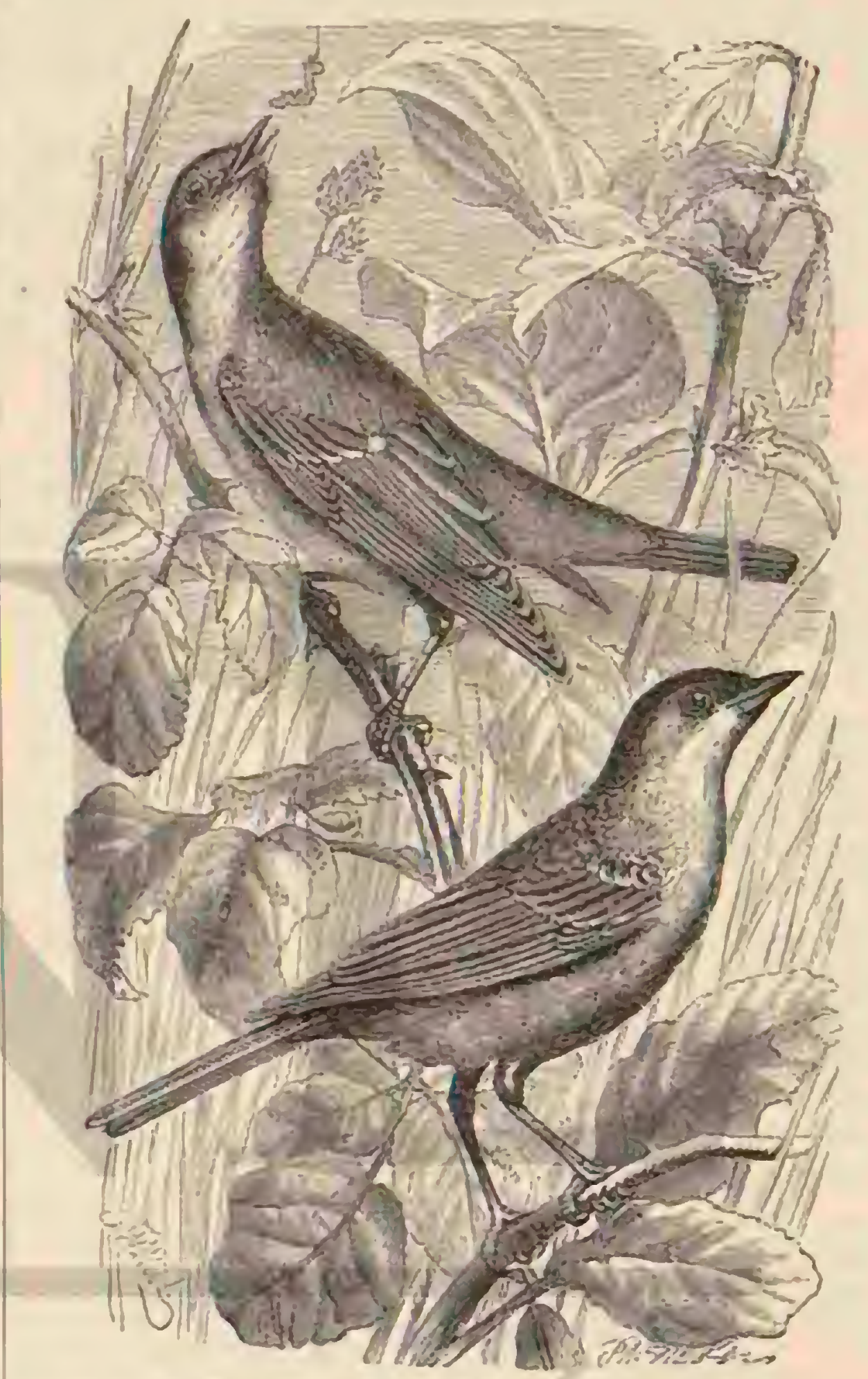

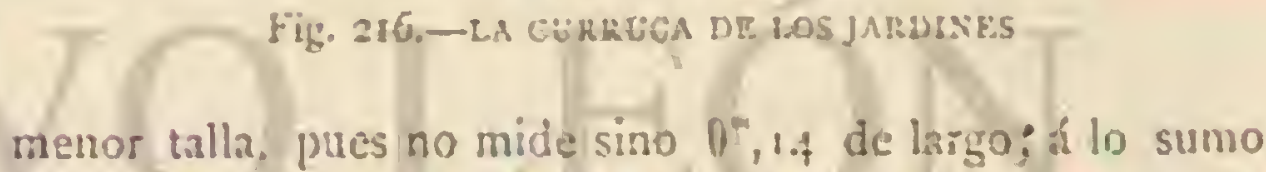
$0^{2}, 21$ de ancho total; el ala plegada ticne $1^{\prime \prime}, 065$ y la cola $11^{\circ}, 05 \mathrm{~S}$ de largo. El plumaje es ceniciento en la coronilla, y gris pardusco en el lomo; la linea naso-ocular es gris ne. gruzca, cl abdómen blanco con viso rojizo amarillento en los Iados del pecho; todas las pennas son de colot pardo aceitu. nado orladas por fuera de pardo leonado, $y$ las de las alas interiormente de color blanquizco: las rectrices extremas son blancas por fuera, j por dentro en su initad extrema tam. bien. Fil ojo es pardo, el pico es gris oscuro y la para gris azulada.

DISTRIBUCION GEOGRÁFICA. - lol curruca gárrula se halla dispersada por toda la parte semplada de Europa y Asia; hricia el norte lasta la Laponia; hácia levante hasta China, y hácia el mediodia hasta Grecia, y en sus emi. graciones llega hasta el africa central y la India Llega a nuestro pais a principios de mayo y se marcha en sctienibre. 
USOS, COSTUMBRES Y REGIMEN. - Durante sU breve residencia en las comarcas curopeas, se establece esta especie con preferencia en jardines, matorrales y setos viros cerca de los pueblos, entre las casas y hasta en grandes ciudades, sin rehuir á pesar de esto el bosque en cuyos linderos $y$ claros se la encuentra tambien.

Rista curruca, dice Naumann, es un ave alegre y muy agradable: jamais permanece en el mismo sitio mucho tiem. po; siempre moviéndose, vivaz y airosa, complacese en jugue. tear con las otras ares y con las de su especic Ia presencia del hombre no la espanta Cuando hace mal iempo y hay humedad, eriza su plumaje, el cual suele tuner sicmare muy liso: salta con ligereza cutre cl ramaje I desaparece rópida. mente de la vista del observador En ticra, por el contratio, es pesadia y corfo y por lo mismo no sucle bajar a ella. Vucla con mpidez cuando debe atraresar un gran espacio pero no siendo asi, tiene el vuelo vacilonte é inseguro.

Su grito de llamada se reduce a una nota vibrante como un chasquido dado con la lengua; el de angustia a una espe cie de fyuejido semejante $l_{1}$ voz de la rana: su canto se comprne de una inezcla de gorjeos y notas igudas y prolon. gadas, que terminan por otras penetrantes y mas breves; es un trino araioninso ó seco y vivaz, por el que se diferencia este canto del de todas las demils cumicas.

Só régimen es igual al de las otras especies del género. Anida en los matorrales de mucha espesura, cerca de iierra: en los bósqques busca las breñas de espina blanca ónegra en los campos, los vallados espinosos, y en los jardines los gro. selleros. Hil nido es de muy ligera construccion; se apoya en la rama siniestar fijo en ella y' se asemeja en un todo al de las viras currucas. Cada puesta consta de cuntro a scis huevos ovales, de 1$)^{2}$, or $\left(6\right.$ de largo por $10^{\circ}, 012$ de grueso, de cóscara delgada, color blanco puro ó verde azulado, y puntos de un gris ceniciento, gris violeta ó pardo amarillo. Macho y hem. bra los cubren alternativamente por espacio de trece dias, manifestando inuchí ternura a su progenie; se valen de la nstucia; se ingen heridos cuando les amenaza algun riesgo, ¿ indican con sus gritos Jastimeros que se acerca algun ene. migo. I'or lo regular son inuy recelosas las currucas parleras en el periodo del celo: dejan de trabajar en su nido cuando observaı que un hombre las ve, y abandonan los huevos si reconocen que la mano del hombre los in tocado; aqueilas empero que se han convencido de que nada tienén que te. mer, picrden poco \& poco su esquivey y permiten que se las observe cuando están cubriendo, con tal de no acercarse ellas fruscamente Tamas abandonan a sus pequenos, ni siyuiera á los cuclillos que han de adoptar con mucha frecuencia despues de haberlos incubado, y á los que crian sacrif. candose por cllos.

CAUTI.vidad.- Como casi todas las currucas, es fáci tambien conger a la especie garrula, accstumbrarla at la ali. mentacion arificial y conscrvarla largo tiempo en la jaula. Jonesticanse inucho por poco que se las trate bien y saben captarse con esto las simpatias del pajarista aficionado.

\section{LA CURRUCA CENICIENTA - SYLVIA} CINEREA

CARACTERES. - Con esta curruca termina la lista de las especies que anidan on Alemania. Se distingue por su csbelter y mide $10^{\prime \prime}, 15$ de largo, $10^{\circ}, 22$ de ancho total $y^{\circ} 6^{\circ}, 07$ de cola y del ala plegada. Ei dorso es pardo terroso tirando á rojo; la parte superior de la caber.s, in posterior del cuello $y$ la region de la oreja son de color gris pardusco, y la linea nasc-ocular, la region temporal y los costados del cuello mar. cadarnentc agrisados; la baiba, la garganta y la region maxi- lar inferior son blancas, $y$ las demás partes inferiores de un matiz delicado rojo de carne tirando a orin pardusco hácia los lados: las rémiges son pardo aceitunadas con orla estrecha por fuera de color de orin leonado, y con orla ancha parda de orin las del antebrazo y sus tertrices; las rectrices son pardo oscu. ras, pero las dos extremas en la parte exterior blancas, $t_{i}$ interiormente en la mitad del extremo gris blanquiacas; la segunda reciriz tiene además en la parte extrema una orla blanca. Eil iris es pardo, al pico pardusco y por debajo ama. rillento, la pata amarilla (fig. 215 ). Ia hembra tiene la parte superior de la cabeza y la posterior del cuello color de tierra con matiz leonado: la region inferior blanca y las orlas blancas de las rémiges mas estrechas y mas pálidas.

DISTRIBUCION GEOGRÁFICA.-I.a curruca gris es la especic que avanza mas al norte, puesto que se la cncuen. tra todavia en la Fscandinavia septentrional; hácia el estese extiende su área hasta el Asia occidental. En invierno emigra hasta el centro del Africa y visita entonces las Canarias.

USOS, COSTUMBRES Y REGIMEN.-En nuestro pais elige para noenda los zarzales y breñas bajas espinosas con preferencia i todo otro monte; en España vive junto con las otras especies pequenas de la familia en el monte bajo especial del cual hablaté mas adelante. Fin una y otra parte se alcja del bosque alto, a pesar de que le gusta posarse en los áboles álios de su comarca para cantar en las ramas mas bajas de lá copa, ó para dejarse caer en la ́fpoca del celo encima de ellas desde otms mas elevadas. En sus viajes se mete por entré las mieses, en Alemania por los campos de centeno y de irigo, y por los maizales en el mediodia de Europa. I.lega bastante tarde, nunca anies de lin de abril, mas bien siem. pre á principios de mayo. Apenas llegada se insiala en su comarca donde cria y permanece hasta agosto; entonces empieza á llevar uma vida errante, y emigra en sctiembre ó en octubre à lo mas.

«la curruca cenicienta, dice mi padre, es inuy vivaz y ágil: se la ve continuamente en movimiento, saltando de rana en rama; deslizase en medio de las espesas breñas, y desaparece por un tiempo mas ó menos larco; luegro sale de pronto, se posa sobre una rama saliente, mira al rededor de si $y$ vuelve a ocultarse: repite esta maniobra durante todo el dia

* Su vuclo es rápido, y agita con frecuencia las alas; por lo regular no se remonta apenas sobre el sucio, ni recorre mas que pequeños espacios. Su grito de llamada se traduce por Ell get che the ef indica diversos sentimientos: el canto del macho, muy variado, pero poco sonoro, se compone de no. las desordenadas, y no vale lo que el de las otras ares indi. genas buenas cantorns. Contribuye, no obstante, a prestar animacion á un pais, yo mezclado con el de la curruca de los jardines, del paro, etc, realza el agradable conciesto de los alados habitanies del bosque.

Naumann dice que desde léjos parece corto el canto de la curruca cenicienia; pero que no lo es en ralidad, pues se compone de un largo fiant) terminado por un forli corto. \& El primero comprende marias notas alternadas, agudas! suaves, que se suceden rópidamente; el forle final consta de sonidos afiautados, pronunciacos por el ave á cuello tendida.

Cla curruca cenicicata, añaric mi padre, canta no solo cuando esra quicia, sino ambien al cruzar los aires. Se posa sobre un matorral, remuniase luego a la altura de unos quince hasta treinta netros, baja despues en linea oblicusa, oj se deja caer con las alas recogidas casi vericalmente, y rnien. tras hace todo esto, no deja un nomento de cantar. por estas evoluciones particulares se puede reconocer de lejos al ave. 
Está prevenida contra el hombre, y se muestra prudente, sin ser timida: si observa que la persiguen, ocúltase cuidado. samente en medio de las breñas 6 de las altas yerbas, de tal modo que con dificultad se la descubre: Naumann dice que procura rastrear por los inatorrales.

En España se mostraba tan timida cuando la vi, que du. rante varias semanas no me pude acercar á ninguna.

Estas currucas son de carácter muy alegre. «No recuerdo, dice Naumann, haber visto ninguna en libertad que estuvie. se triste; juguetean, por el contrario, continunmente con las demás aves; las persiguen y las excitan; pero no se aven. turan en los lugares descubiertos, y están casi siempre es. condidas en la espesura de los matorrales. en el sur, segun lo que yo he visto: en todas partes es una misma la curruca cenicienta, siempre se muestra recelosa y astuta.

Se reproduce poco despues de su llegada, y hace su nido en un espeso matorral ó entre las altas yerbas, rara vezámas de un metro de altura sobre el suclo. Algunas veces toca en tierra, y se compone de rastrojos mezclados con un poco de lana; las paredes son muy delgadas, $y$ el interior está relleno de pelusilla de ciertas plantas.

Ien la segunda quincena de abril se encuentran en el nido de cuatro as seis huevos, muy variables, en cuanto al volú. men, la forma y los colores; miden por término medio $11^{\circ}, 017$ de largo por $11^{2}, 013$ de grueso; son de un blanco de marfil, amarillos, grises, de un amarillo agrisado, de un blanco verdoso ó blanco azulado, con puntos mas ó menos distintos, manchas y rayas de un gris ceniciento ó de pizarra, ó bien pardo aceituna, amarillo verdoso, etc. Los padres se condu. cen con sus hijuelos to mismo que las demás currucas: la segunda puesta sigue inmediatamente á la primera.

Cautivida D. - Pocas veces se ve a esta curruca cauti. va, pues su canto no gusta á todos los aficionados; pero no merece el desprecio tan general con que la miran los pajaristas, y que ha sido causa de que tan injustamente se haya relegado esta ave al olvido, como cantora.

\section{LA CURRUCA DE ANTEOJOS-SYLVIA CONSPICILLATA}

CARACTÉRES. - Esta especie es la imågen reducida y embellecida de la cenicienta. Mide (", $12 ;$ de largo, 6 ", 175 de punta a punta de ala, 10"',056 esta plegada y 11",052 la cola. Le cabeza us gris oscura, la region parotidea ceniciento-clara, la línea naso-ocular negra, el dorso pardo claro con viso rojizo de orin, la rabadilla gris rojiza tirando á orin, la gar. ganta y las cobijas sub-caudales blancas; el resto de la parte inferior del cuerpo ticne un tinte delicado rojizo de carne, mas claro en medio del vientre. Las pennas son de un color gris, las rémiges del antebrazo y las cobijas superiores de las alas llevan una orla ancha rojiza de orin en la barba exterior; la rectriz extrema de cada lado es en la cara exterior de la barba, blanca hasta cerca de la rair, y lleva en la cara interior una mancha cuneiforme que llega hasta el centro y que se repite en las demis recirices disminuyendo en cada una gradualmente. Un circulo blanco rodea el ojo, que es de color pardo rojizo claro; el pico es color de carne rojizo en la base y negro en la punta; la pati es del mismo color ama. rillento ó gris rojizo. Los pequeños difieren de los viejos por su coloracion gris uniforme sin el viso rojizo. Además se distingue esta especie de la cenicienta por su menor talla y coloracion mas vistosa, $y$ por tener la cuarta $y$ no la tercera rémige mas larga que las dernảs.

DISTRIBUCION GEOGRAFICA. - Se puede considerar esta especie como caracteristica de los paises ribereños del Mediterráneo. Habita el mediodia de Francia, España, Portugal, el noroeste de Africa, Palestina hasta la Persia, el Asia Menor, Grecia y el sur de Italia, y las islas de Cabo Verde.

USOS, COSTUMBRES Y REGIMEN. - En España como en Grecia, en la isla de Cerdeña como en Malta, pue. bla los flancos áridos de las montañas que solo producen cardus, romero y otras matas bajas por el estilo, y donde parece ser esta curruca ave sedentaria ó por lo menos errante. El conde ron der Mulhe vió en Grecia reducidas familias durante el invierno; y en la misma estacion observó mi hermano esta ave en los jardines de los alrededores de Murcia. Segun Wright, es la única ave sedentaria de la isla de Malta: Caro asegura que no sale nunca de Cerdeña: mientras que Salvatori opina que solo algunos individuos pasan el invierno en dicha isla, afirmando que á principios de abril se ven llegar muchos á los alrededores de Cagliari. Las primeras que yo observé se hallaban en la vertiente desicrta de una montana donde crecian aisladas algunas cepas; mas tarde encontramos muchas en las espesuras de cardos. Hausmann las halló en Cerdeña, en medio de los matorrales, situados no léjos de la costa; pero no en las montañas.

No he tenido ocasion de estudiar bastante las costumbres de esta hermosa especie: los primeros individuos que ví no eran nada tímidos, y parecian, por el contrario, atrevidos y confindos, pues léjos de permanecer ocultos en los jarales, dejábanse ver con frecuencia, y los machos sobre todo, se posaban en las ramas mas altas para cantar. En el otojio, despues de la muda, procedian de distinia manera las currucas de anteojos: escondianse en medio de los cardos y del romero; se deslizaban en lo mas espeso de los zarzales, y desaparecian de la vista. Si se las espantaba alejábanse con rápido vuelo, pasando de una montaña á otra, y se mante. nian á bastante distancia del suelo. Sin embargo, parecian obrar asi menos por su temor al hombre que por su afan de moverse.

Wright dice que en la isla de Malta, cuando la estaciones favorable, comienzan á cantar las currucas de anteojos desde el mes de enero, y que en la primavera se oge por todas partes su sonora voz.

Por lo comun canta esta ave posada en la copa de un ár. bol, en el extremo de alguna ramita o sobre alguna piedra ó roca grande.

La curruca de anteojos, dice Hausmann, tiene costumbres unuy semejantes á las de la cenicienta: menos timicia que sus congéneres, se la vé posarse sobre las breñas cspinosas para cantar; remóntase como un cohete por los aires y se deja caer con el plumaje erizado sobre una rama antes de terminar el canto. Aseméjase este bastante al de la curruca cenicienta, con la diferencia de ser mas ronco, y rio tan pro. longado ni melodioso. La curruca de anteojos no produce sino el breve grito de sus congéneres, seguido á veces de algunas notas melancólicas; su grito de llamada, fuerte y duro, ofrece analogia con el de la pega reborda. Por fortuna se encuentran ambas especies siempre en los mismos sitios, de modo que no se tarda en conocer la diferencia entre una y otra, á pesar de su analogia. Mi hermano dice que la ob. setracion de Hausmann no es cxacta, y que la especie de antcojos deja oir un canto muy grato y prolongado, bien que poco alto.

La estacion del celo da principio en febrero $y$ dura hasta junio; desde marzo hasta este último mes encontró Wright pequeños, y supone con razon, que cada pareja anida dos veces al año.

(a) fines de abril encontré nidos acabados, continin diciendo Hausmann, pero estaban aun vacios: la cavidad cen. 
tral es profunda $y$ las paredes delgadas; por fuera aparecen algunos copos de lana, que se hallan comprendidos en el armazon; y no se puede ver el nido sino apartando el rama. je, en medio del cual se hal!a: pero estos pảjaros son tan sensibles que to abandonaron en el acto.3 Jos huevos miden unos (1",ory de largo por (1",orr en su mayor diámetro. lil color es verde pálido tisando á gris, con puntitos diminutos parduscos.

LA CURRUCA ALONDRILLA Ó SUBALPINA -SYLVIA SUBALPINA

CARACTÉRES. - Es Un ave encantaciora. In los ma chos adultos, la cara superior del cuerpo es de hermoso co. lor cericiento y la inferior de un blanco agrisado; Ia garganta. de un rojo orin vivo, encuadrada por una faja blanca y angosta, que partiendo de la rois del pico baja hácia lás espaldillas; el ojo está rodeado de un circulo de plumás de colior de ladrillo pálido; las plumas de la oreja son par. das y las rémiges de un pardo oscuro. Las rectrices son tambien de este color, excepto las dos laierales, cuyas barbas externas tienen un finte blanco en los tres cunrtos de su longitud, ofreciendo las internas una mancha triangular mas clara; las demás están orladas de blanco. Lil iris es gris rojizo, el párpado color de ladrillo claro, el pico negro mate; la punta de la mandibula inferior de un rojizo opaco y las patas de un gris rojizo.

Las hembras y los pequeños tienen un plumaje mucho mas sencillo, y su garganta no tiene la mancha roja.

Esta currucia mide de $\theta^{\circ}, 125$ hasta $0^{\circ}, 1,30$ de largo, $0^{\circ}$, is de ancho total, $10^{\prime \prime}, 057 \mathrm{el} \mathrm{ala} \mathrm{y} 1^{m}, 054$ la cola. La hembra es unos cuantos milimetros mas pequeija que el macho.

DISTRIBUCION GEOGRÁFICA. - Habita y cria á poca difurencia en los mismos paises que la especie anierior, es decir en Istria, Dalmacia y Circcia, toda la Italia, la Francia meridional, España, Portugal, las Cannrias y en los paises del Atlas, err ina palabra en todos los paises costaneros del Medicerráneo y mar Negro; y hácia levante llega lasta la

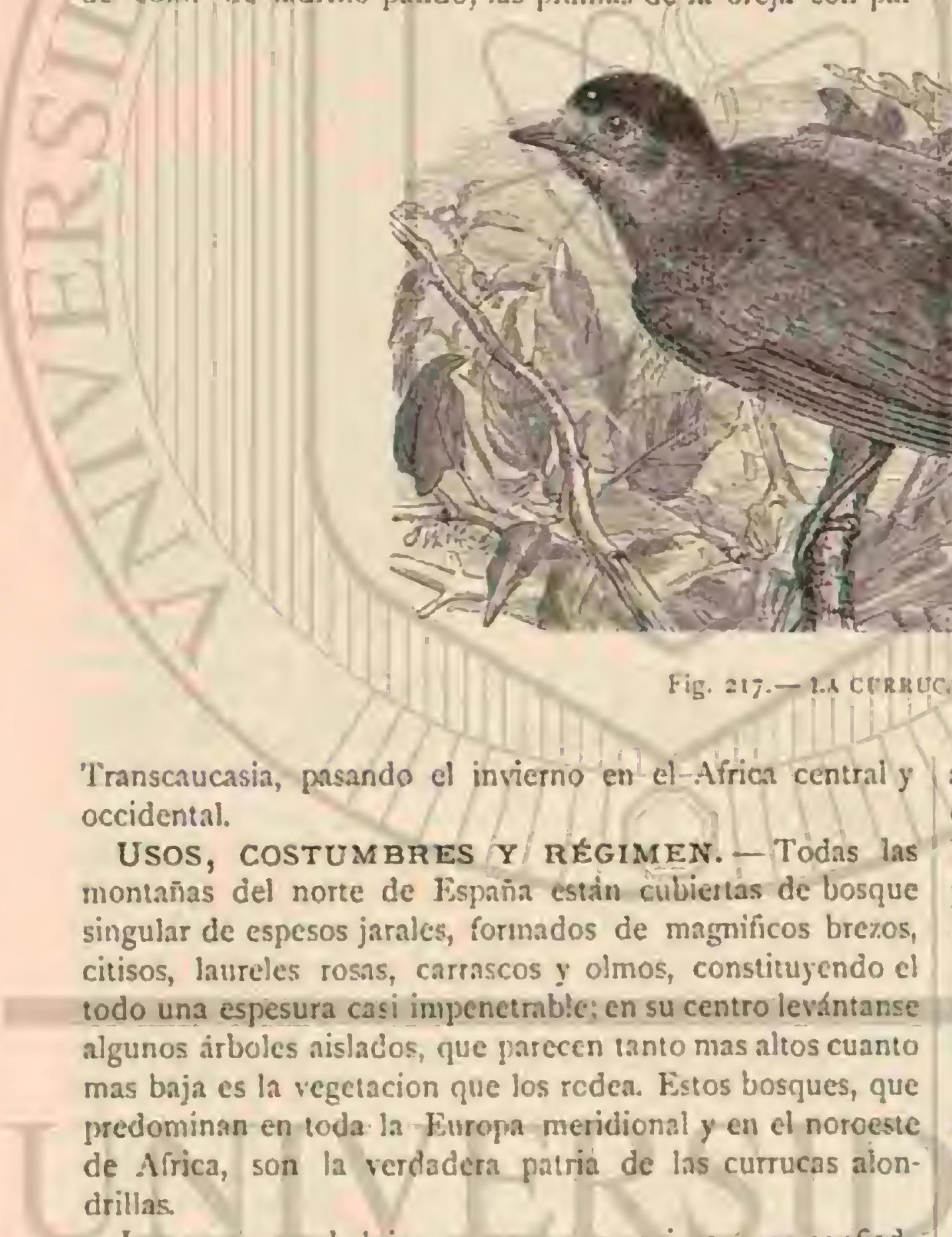
drillas.

La curruca subalpina es un ave preciosa: mas confiada que sus congéneres, déjnse observar de cerca, y lanza al aire sus alegres noiss sin inquietarse por la aproximacion del hombre, el enemigo nato de todos los animales, en quien no ve un sér peligroso mientras ro se la persiga.

Sus usos y costumbres ofrecen mucha analogia con los de La curruca parlera, y mas aun con los de la de cabeza negra: como esta lílima, recorre en todos sentíos y domina per. fectamente los matorrales que le sirven de morada; pero se la ve con mas frecuencia sobre ellos que en el interior. Las parcjas se fjjan unas al lado de otras: casi en cada brejia aparece un macho posado, que canta e inspecciona los alrededores Cuando no se asusta el ave, se la ve saltat alegremenie de rama en rama, volar de un arbusto \& otro, cogien. do aq̨ui una orug̣a, aliá un colébtero; persiguiendo á veces un insecto al vuclo: á remontándose à la copa de los mas altos árboles á seis hasta diez metros sobre el nivel del bos. que sin dejar de cantar. Cuando se le da caza desaparece en la espesura con increible rapidez, y casi es imposible verla ya; solo su grito prolongado de aviso, tser, indica su presencia yermite en cierto modo medir la distancia que ha recorrido. Su grito de llamada, bastante armónico, se puede expresar por tse 6 teck lect; su canto es melodioso, pero emitido $\sin$ mucho vigor.

Empieza por un preludio bastante largo y muy variado, a menudo muy bien coordinado y enlazado, y despues sigue la frase final cantada con voz.iresca y sonora, mas semejante al canto de nuestra curruca de jardin que al final del canto de la especic cenicienta.

La curruca subalpina anida muy cerca del suclo: yo no en. contré su nido hasta fin de mayo; pero quizás seria de la se. gunda pollada; difiere del de las otras currucas por su esiructura mas graciosa y sus paredes relativamente gruesas. La hembra pone cuatro ó cinco huevos cada rez. de $U^{n}, 016$ de largo $1^{1 / 7}, 013$ de grueso poco mas 6 mencs, de color blanco sucio y sembrados de manchas y puntos color pardo aceituna y verde del inismo fruto, que forman fa veces un circulo hácja la punta gruesa Los padres manifiestan à su progenic el mas vivo carino, muéstrarase llenos de angustia cuando ven que la amenaza un peligro, y para evitarlo emplean todos los recursos propios de la familia de los sílvidos, es decir, fingen estar enfermos, cojos, etc.

Fn el norte de Fspana parece scr la alondrilla un ave de paso: en el mes de abril la vi en sitios donde no se la en. 
cuentra en ninguna otra estacion; y á mediados de sctiembre halle reducidas familias, que iban seguramente de viaje. Segun Lindermayer y Krueper, esta curruca aparece en Grecia hàcia fin de marzo; habita primero los lechos secos de los torrentes, y remóntase despues á las montañas para anidar. Dire Salvatori que abandona la Cerdelia á fines del verano: este observador no la vió ya en invierno. Las currucas subal. pinas que se encontraron en Egipto parecian haber emigrado del sudeste de Europa; en cuanto i mi, no la he visto jamás en el verano. Mi licrmano dice haberla oido cantar en invierno en los alrededores de Mlurcia, lo cual probaria que algunas currucas, por lo menos, pasan el invierno cerca del punto donde anidaron.

\section{LA CURRUCA DE RUEPPELL-SYLVIA RUEPPELLII}

CARACTERES.-A la anterior se agrega en el sudeste de Europa la especie pequeña que ha recibido el nombre de su descubridor Rueppell. Su coloracion es tan semejante al de nuestro aguzanieves, que la descripcion de la una podria servir casi palabra por palabra para el otra. La cabeza, la linea nasoocular, la barba y la garganta hasta el pecho son negras; la parte superior del cuerpo es gris oscura; una lista blanca em. pieza en la mandibula inferior y se pierde débajo de la oreja; la parte inferior del cuerpo es tambien blanca con viso rojizo, y gris en las ingles; las rémiges $y$ las pequenas tectrices de las alas son negro parduscas, estas últimas orladas de blan. co; las rectrices medias son negras; las exteriores blancas: la segunda, tercera y cuarta de cadia lado son mas 0 menos blancas en el extremo y cara inferior de la barba. Ia coloracion de la hembra es mas pálida y su talla menor que la del macho. El ojo es pardo claro, el pico color de cuerno $y$ la pata rojiza. El macho mide de largo $\left(0^{\circ}, 83\right.$, de punta á punta de ala $0^{\circ}, 21$, esta última plegada $1^{\circ}, 0$; y la cola $0^{\circ}, 06 \overline{5}$.

DISTRIBUCION GEOGRÁfICA.-La patria de esta curruca es Grecia, Asia Menor, Siria, Palestina. En su emigracion visita la Arabia, Eginto y la Nubia.

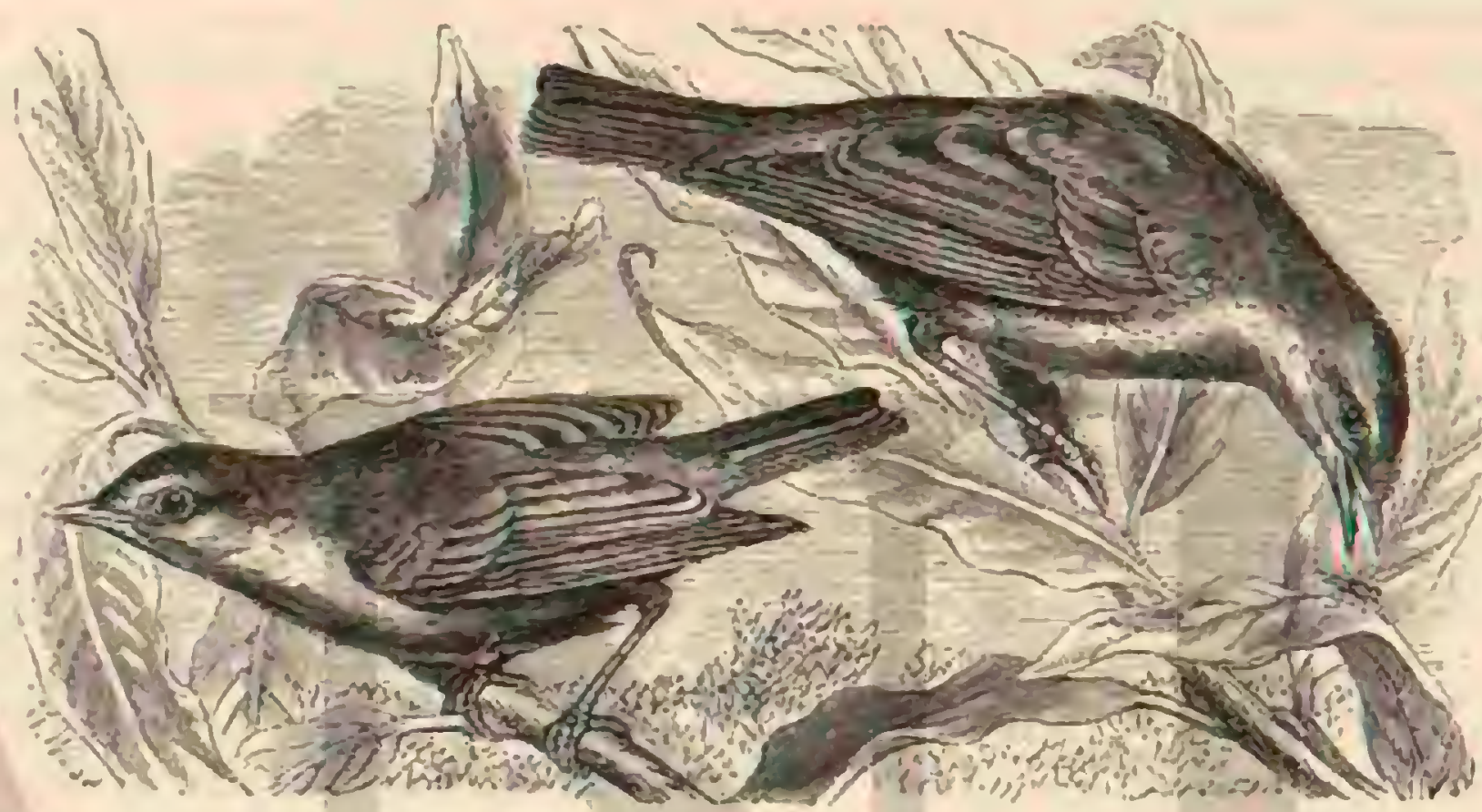

fัI. 21S.-LA CURRUCA DE: CAMEZA ROJTZA

USOS, COSTUMBRES Y REGIMEN.-Faitan datos exactos y detallados respecto \& su modo de vivir; solo Heuglin y Krueper dan algunas noticias, pero escasas. Sabemos que habita en los valles lienos de matorrales en comarcas de. siertas 6 islas de escasa regetacion. Es rara en Grecia, pero algo mas frecuente en Palestina, Asia Menor $y$ en has islas del mar Rojo: en los alrededores de Esmirna es la especie mas comun de la familia Segun Krueper aparece en Jonia hácia fines de marzo, empieza á cubrir á mediados de abril y se marcha en agosto. Una sola rez la he visto y muerto junto al lago de Mensalch, pero sin poder observar su modo de vivir y por esto me he de limitar a reproducir las noticias de los naturalistas que acabo de citar.

Durante su paso se la suele encontrar casi siempre en las breñas ó en espadañales, muy afanada en buscar insectos, asi la vi yo tambien. En su patria se la ve luego que haya llegado á cerros y vertientes cubiertos de bréhas a su gusto hasta gran altura. En general solo se sen los machos, porque las hembras viven mas ocultas. Aquellos prorumpen en su canto posados en la extremidad de una mata, desapa. recen én el jaral, y vuelven á colocárse en la uiltima ramita de otra mata, para repectir la misma maniobra. Cantan mu. cho en la época del celo, se remontan al aire como si baila. ran y vuelven sajar con las alas y la cola extendidas Se las distingue desde luego por su canto de todas las aves que ha. bitan la misma localidad.

Krueper encontró en 7 de abril un nido de esta ave, cons. juesto de yerba seca, sin tapizar y a la altura de quince cen-

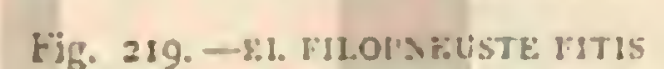

timetros sobre el suelo, con cinco huevos reteados semejontes á los de la curruca cenicienta; hácia últimos de niayo le trajeran tres huevos mas; uno de estos que remirió á Dres. ser tenia $0^{*}, 019$ de largo por 11,015 de grueso y sobre fondo blanco gris puntitos pardo cenicientos que se confundian unos con los otros.

\section{LOS MELIZÓFILOS - MELIZOPHILUS}

CARACTERES. - Mientras que las currucas enumera. das hasta aqui, se parccen tanto que toda separacion y sub. division seria supérflua, existen otras que difieren mas, ya porque en sus alas, muy cortas y muy redondeadas, son de igual longitud y mayores que las demás las rémiges tércera, cuarta y quinta; ya porque su cola larga está marcadamente escalonada, ó ya en in porque su plumaje es mas suelta ! cerdoso. He aqui las leves diferencias que han inducido: Leach à formar con estos pájaros un géncro aparte, que mas bien merece ser considerado como sulgénero.

\section{LA CURRUCA MELANOCÉFALA-SYIVIA MELANOCEPHALA}

CARACTERES. - Es la especie mas conocida del grupo melicophilus y mide $0^{\circ}$, if de largo, $11^{\circ}$, is de ancho total, el ala plegada tiene $10^{\circ}, 055 \mathrm{y}$ la cola $0^{\circ}, 06$. El lomo es gris ne. gro, el vientre y el pecho blancos, con visos rojizos; la ca. beza de un negro de terciopelo: la garganta blanca; las alas 
y la cola negras, con las tres rectrices exiernas y las barbas de las primeras blancas; el ojo anarillo pardo; el párpado desnudo y grueso, de color rojo ladrillo; $\mathrm{el}$ pico azul $y$ las patas de un gris rojizo.

DISTRIBUCION GEOGRÁFICA.--Se halla extendida esta especie desde la Francia y la Italia meridionales por todo el mediodia de Europa, el norte de Africa y el Asia occidental. Es ave comun en los montes bajos y en todos los jardines de Grecia, Italin y Jispana, sin faltar en las islitas mas pequeñas con tal que tengan algunos zarzales y matas espesas.

USOS, COSTUMBRES Y REGIMEN. - La especie es sedentaria en los países que habita: dizrante mas de un año pude observarla diariamente; pero me parece oportuno ceder la palabra a Hausmann, que dió uma descripcion muy cxacta de las costumbres del ave Solo en un punto no pucdo convenir con êl: despues de haber dicho, con justa razon, que la curruca melanocéfala comparte if menudo el habitat de la curruca de anteojos y de la de Cerderia, pone en duda el ascrto del conde von der Mulsle. respecto á que anida con frecuencia en las claumberas, Alrora bien, yo garnntizo la óbservacion de von der Muhle, y debo decir que siempre me pareció que la curruca melanocéfala busca con afan cstos cfctus paral fijarse en ellos, pasticularmente en el invierno. Yor toco lo demás, la descripcion de Hausmann cuadra perfectamente con mis propias observaciones.

«Si se acerca uno al sitio donde se halla oculto cl nido of los hijuelos de una curruca melanocéfala, óyese resonar su grito de aviso, tret, trel, tret, tan de prisa que se cree oir un rechinamiento continuo, repitiendolo el ave con un acento de cóléra ó de angustia. Al mismo ticmpo se le ve erizar las plumas de la cabeza y sus párpados audquieren un tinte rojo de fuego.

- Su grito de llamada es tree, trec, trec, y con él sucle co menzar su canto, que se compone de notas estridentes y agudas, terminándose comunmente con una melodía muy armoniosa. A menudo le entona volando de un punto á otro, $\delta$ como la curruca de anteojos al remontarse por los aires para volver à posarse en sú rama Al cantar el macho suele posarse en un punto elevado; mueve la cola, criza las plumas del cuello, se agacha $y$ hace varias inclinacio. nes. LLa hembra, mucho menos activa que el macho, y de carícter menos alegre, no sueie dejarse ver; manifiesta el mismo cariño 2 sus hijuelos, pero no los defiende con tanto valor.

i. $\mathrm{t}$ macho, siempre inquieto, es parlero con las demás aves y en todo quiere inmiscuirse; si aparece una rapaz en el horizonte, anuncia su llegada i gritos, y si otra ave lanza alguno de angustia al ver á su progenie amenazada, ruela en su auxilio, y ayúdala \& poner en fuga al enemigo, sin que los desagradables percances á que esto la expone por parte de algun cazador sirvan de saludable aviso ì las demás de su especic.

"lodos los nidos de esta ave, que yo he visto, se hallaban en lis brenas espesas y bajas de espino blanco ó de lycium, ó ya en medio de las ramas de un zarzal, cuyo follaje los ocultaba á la vista de sus cremigos.

nEsta ave debe aniciar muy pronto, pues á principios de abril encontré hijuelos que habian comenzado ya à volar. En el mes de agosto descubiri cierto dia un nido con cuatro hue vos recien depositados por la hembra: cada puesta se compone de cuatro 6 cinco, de color blanco sucio 6 de un gris aceitunado, con pequeños puntos oscuros muy numerosos, que forman en la punta gruesa uma pequeña corona de manchas de un tinte pardo aceitunado: estos huevos tienen $i^{\prime \prime, 020}$ de largo por $0^{\circ}, 015$ de grueso: yo no observé nunca grandes diferencias entre los de las diversas polladas. Las paredes del nido son mas gruesas quue las del que bacen las demás currucas.s Despues del periodo del celo, viejos y jóvenes recorren juntos una buena temporada el pais, $y$ aun en los meses de invierno hemos observado algunas familias de estas.

\section{LA CURRUCA DE CERDEÑA-SYLVIA SARDA}

CARACTERES. - Esta curruca mide poco mas ó me. nos $0^{\circ}, r_{3}$ de largo, el ala $0^{\circ}, 055$ y la cola $0^{\circ}, 06$. "liene cl lonio de color ceniciento negruzco, con visos rojos; la cara inferior del cuerpo de un pardo leonado tirando a orin; la garganta blanquizca; cl vicntre de un blanco sucio; las rectri. ces $y$ las remiges de un pardo negro, orilladas de rojo; las rectrices cxternas con un filete blanco extcrior con viso de orin; el ojo pardo; los párpados desnudos, de color de carne amarillento; el pico negro; la base de la mandibula inferior amarillenta; las patas de un tinte de cuerno claro.

Los colores de la hembra son algo mas pálidos que los del macho.

DISTRIBUCION GEOGRÁFICA. - Habita las islas de Sicilia, Cerdenan, Córcega, Malta, Balcares; en Cirecia y sus islas y en Portugal.

USOS, COSTUMBRES Y RÉGIMEN. - Esta curruca, dice Salvatori, es acaso el ave mas comun de toda Cerdena. Habita las montanas y llanuras; pero únicamente los sitios cubiertos de brezos y retama; fijase con preferencia en las co. linas sembradas de estas plantas Parece que sucede lo mismo cn las Haleares, segun Homever, y por lo mismo es mas raro que esta ave falte en Espania, ó sea por lo menos sumamerte cscasa.

《En medio de los tallares donde habita, dice Homeyer, la curruca se conduce mas bien como un raton que como un ave. Abandona un matorral revolotennco ó saltando; introdúcese en otro, desaparece para salir al momento, se posa en alguma piedra ó en una roca, ó se pasea al rededor, y se oculta un poco despues en los jarales. Practica todos estos movimientos con mucha mas agilidad aun que el reyezuelo; corre por el suelo con la gentileza de la nevatilla ó el paso cortado del cuello azul, y lleva la cola levantada casi verticalmente. Posado en una piedra y mirando al rededor de si, ofrece un aspecio realmente cómico.\$

«Siempre en movimiento, dice Hausmann, va de un jaral a otro, coge un insecto en la corola de una Hor, ó bien persigue á la cirrera á una mariposa que vuela rasando el suelo. De ve\% en cuando resuena en los aires su canto armonioso, bastante parecido al de un canario jóven, con la diferencia de que en aquel acaba en un tono menor, como el canto del petirojo: algunas de sus notas son vibrantes, y diriase que las produce una campanilla.

- El grito de llamada de la curruca de Cerdeña es casi el mismo que el de la pega reborda roja: solo difiere en que no lo emite con tanta fuerza. El ave le repite varias veces precipitadamente al avisar á sus compañeras.

Esta curruca es la ultima ave que se oye al cerrar la noclie, cuando ya resuenan los gritos del mochuelo; pero entonces su canto viene a ser como una llamarada que se repite $i$ intervalos largos y desiguales, como si fuese la expresion de la inquietud que siente el animal al ver llegar la noche y no poder cerrar los ojos.

$\$$ Es bastante dificil matar á esta ave en los matorrales donde se ocuita: apenas se ve perseguida, se sumerge, por decirlo asi, en medio de las ramas, y huye rasando el suelo, lo cual le es tanto mas fácil, cuanto que açuellas son menos compactas qque a cicrta altura En ciertos instantes sube por 
una rama, aunque de modo que la cubre siempre el follaje; si pernanece uno quieto se la ve aparecer cantando sobre una de las mas altas, y entonces se puede tirar. Sin embargo, un movimiento algo brusco basta para espantarla; lanza en el momento el sonido breve dek y desaparece de nuevo en medio del follaje. En el caso de estar herida en el ala, corre rápidamente por el suelo, y es preciso andar listo si se quiere cogerla, antes que haya tenido tiempo de ocultarse á las miradas, agachándose detrás de una piedra $\delta$ de una mata.

$\$$ Prefiere anidar en un espeso jaral de mirtos $\delta$ de espinas, pues los de brezo son demasiado claros. Fil nido se compone de rastrojos viejos, $y$ le cubren interiormente algunas crines de caballo mercladas con algunas plumas; es bastante profun do, pero de construccion endeble y paredes delgadas, aseme jándose al de la curruca de los jardines. La hembra deposita cuarro $\delta$ cinco huevos de color verdoso sucio, con manchas irregulares mas $\delta$ menos marcadas, de un verde accituna, azul agrisado, negruzcas, clc, que a veces forman un arabesco negro.

Los hijuelos se parecen a sus padres; pero los machos jóvenes tienen la cibeza y la linea naso-ocular de un color negro menos oscuro que el de los aduitos, y en los párpados no hay mas que un ligero tinte rojo.

Cuando emprenden su vuelo tienen todas las costumbres de los padres; y hasta es dificil apoderarse de la curruca sar. da jóven que ha saltado de su nido sin poder volar aun, pues se desliza en inedio del ramaje con una agilidad que la salva.

La curruca de Cerciena no abandona nunca esta isla, donde pasa el invierno: anida por primera vez en el mes de abril, $y$ tiene por lo menos tres crias al año.

\section{LA CURRUCA DE PROVENZA - SYLVIA} PROVINCIALYS

CARACTRERES.-Esta curruca, que he observado con grán frecuencia en España, debe considerarse como la especie-mas afine de la anierior, conforme resulta de su descrip. cion. lil lomo es gris oscuro; el vientre rojo vinoso oscuro; la garganta rayada de blanco; las recirices y las rémiges de un gris pardusco; las cuatro rectrices externas orilladas de blanco hácia la mandibula superior, que es un poco roma; las alas muy obtusas, con la tercera y cuarta rémiges mas largas que las otras; la cola regular, con una ligera escotadu. ra y dilatada en su extremidad; los tarsos y los dedos raquí. ticos; el plumaje lacio.

DISTRIBUCION GEOGRAFICA.-Debe tenerse en tendido que el area de dispersion de esta especie no se limia de ningun modo al pais que indica su nombre, ni á la Fran. cia occidental, ni á todo el mediodia de Europa, Asia Menor y al norte de Africa, sino que es tambien sedentaria en el sur de Inglaterra.

USOS, COSTUMBRES Y REGIMEN. - En-Inglaterra vive la curruca de Provenza en las laderas solitarias de los cerros cubiertos de ginesta, pero en Espaina frecuenta los pinares, las vertientes de las montanas de la Cataluia sep. tentrional cubiertas de brezos, magnificos retamares, las es. pesuras de encinas cnanas y de romero, los collados aridos solitarios del reino de Valencia donde no crecen mas que algunos matorrales, las ticrras de labor de Castilla que for man como un páramo en ciertas épocas del aìo, los bosques de encinas verdes, los setos y las breñas. Apenas sellega á los lugares que habita, óyese ya su roz: su canto poco varia. do, pero muy armonioso, se parece, segun Hausmann, com pictamente al de la curruca de Cerdeña. Para cantar acos. tumbra í salir de la espesura y á posarse en el cxtremo de una rama, donde se revuelve á derecha é izquierda; sủ pecho está mas bajo ó al nivel del cuarto trascro; levanta la cola, la mueve de adclante atrảs y criza las plumas de la garganta. Apenas divisa al cazador, desaparece en el jaral y ya no se la ve; pero no tarda en presentarse en la copa de un pino ó en la mas alta rama de una breña; mira un instante a codos lados, línzase a tierra, y salta y corre con toda la agilidad de un raton. En los sitios donde la espesura es inenos compacta se la ve pasar como una sombra que se mueve. Cuando re. suena un tiro salta al extremo de una rama para ver de dónde procede el rumor, pero desaparece al momento. Su compor. tamiento me ha hecho recordar muchas veces nuestro accen. tor, pero la curruca de Provenza es muchisimo mas lista y ágil que êl.

La curruca de Provenza no parece nunca tan bonita como cuando conduce á su jóven familia. En los primeros meses del año fabrica su nido $y$ tiene dos ó tres crias al año, de cuatro á cinco hijuelos cada una. Apenas son estos un poco fuertes, y antes de que puedan hacer uso de sus alns, aban. donan el nido: pero saben evitar el riesgo deslizándose como los ratones en medio de los brezos mas enmarañados; sin contar que los padres velan sobre ellos continuamente. Macho s hembra están siempre revoloteando junto a sus hijos y lanzan á cada instanie su grito de llamada. Una ve\% que los pequeños se lann desarrollado un poco mas, siguen á sus padres, y se les ve llegar con el macho, posarse en la copa de las breñas y desaparecer en la espesura á la primera señal. l'an pronto como se oye el grito de aviso, 15 er, 1 ser, todas se callan, hasta el momento en que el macho reconoce que ha pasado el peligro.

Fil rido se parece al de sus congéneres; los huevos miden por término medio ()$^{\prime \prime}, 018$ de largo por (1)",or 4 de diámetro, y tienen sobre fondo blanco verdoso manchas pardas de diferente gradacion de matiz.

\section{LOS FILOSCÓPINOS- PHYLLOSCOPIN.TE}

CARACTERES. - Las cicuto cincuenta especies que aproximadamente forman csta sub.familia se caracterizan por su estructura esbelta, pico en forma de lezna, aplanado en la base; pata endeble, alas medianas, cola casi siempre ligeramenie escotada y plumaic de color de hoja de árbol.

DISTRXBUCION GEOGRÁFICA. - En casi todas las partes del unundu lay miembros de esta sub familia.

USOS, COSTUMBRES Y RÉGIMEN.-Son los filoscópinos las aves arboricolas por esencia de la familia, pues viven y cazan ci las copas de los árboles. En cuanto â sus cualidades, en poco ceden á las currucas, pues tambien son activos, vivaces, listos y buenos cantores, aunque no tanto como aquellas. En lo que difieren estos dos grupos es en la construccion del rido, puesto ique los filoscópịnos trabajar. con mas arte que las curricas.

\section{LOS HIPOLAIS - HYPOLAIS}

CARACTERES. - Merece este género, que tambien se conoce con el nombre de ruiseñores falsos, el primer puesto. Se distingue por su talla relativamente grande y el pico tambicn grande, robusto, ancho, con bordes cortantes y apenas combado; patas robustas, alas medianas con la tercera $\delta$ cuarta rémige mas larga que las demís y la cola mediana 6 corta, ligeramente escotada.

DISTRIBUCION GFOGRÁFICA.- Puchla los paises septentrionales del antiguo continente, la liriopia y la India. 


\section{EL HIPOLAIS DE LOS SAUCES-HYPOLAIS} ICTERINA

CARACTÉRES. - Tiene el dorso gris con matir. verde accitunado, la linea naso ocular y la parte inferior del cuerpo amarillo de azufre pálido, pasando á gris aceitunado en la re gion de la oreja y los costados del cuello y vientre; las rémiges son de color pardo accitunado, con orla verdosa en la parte exterior de la barba, y blanca sucia en la interior; las

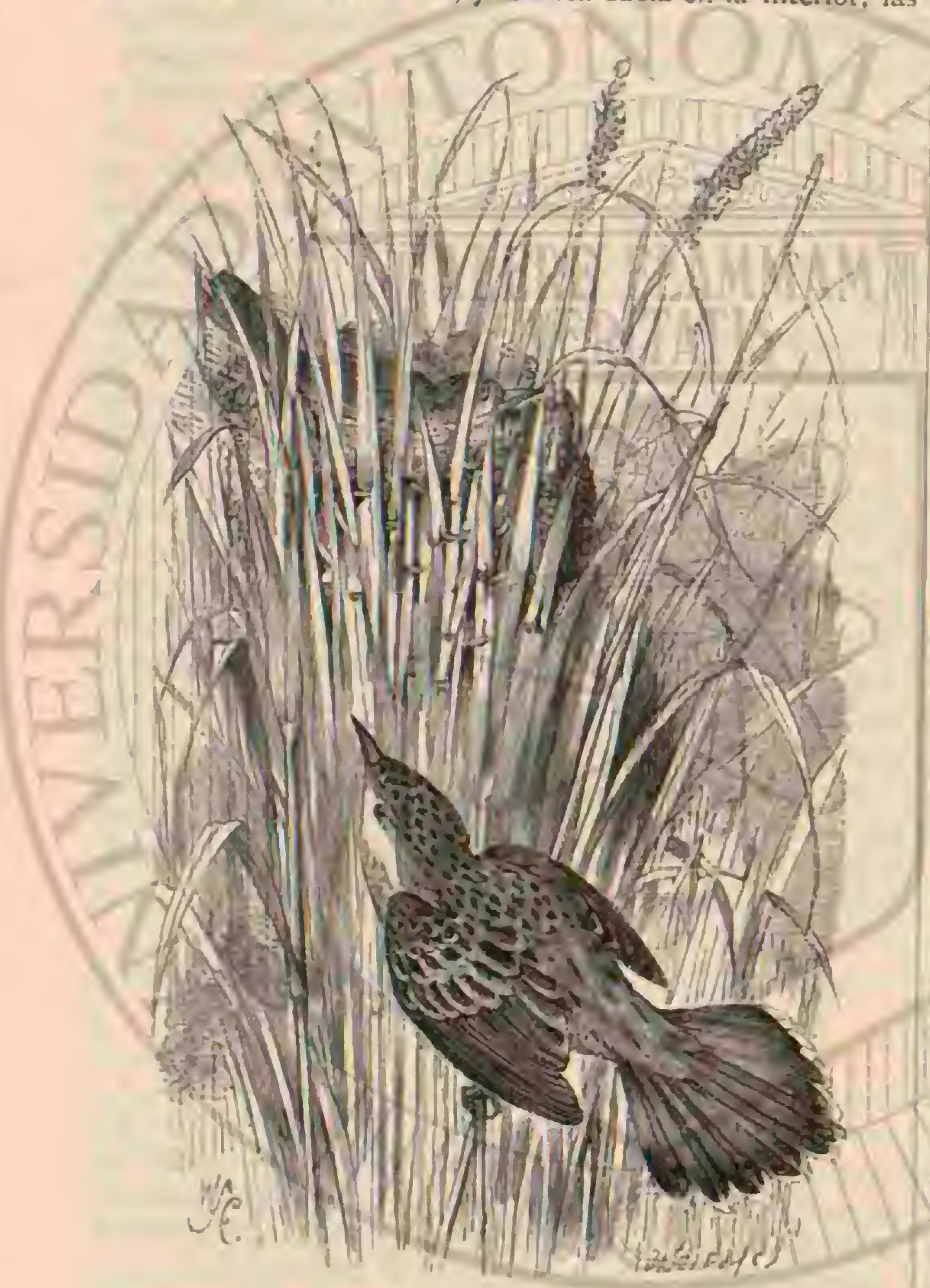

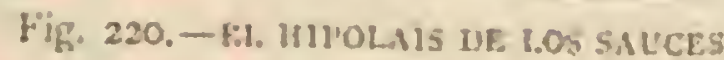

rectrices son mas claras que las rémiges, pero por fuera orla das del mismo modo. El ojo es pardo oscuro, el pico pardo ceniciento y amarillo rojizo en la base de la mandibula infe. rior; la pata es de color azul pálido. Kista especie tiene ft $1: 1 ; 5$ de largo, $1 ", 25$ de ancho rotal, el ala plegada mide $10 ", 00$ y la cola $11,05 \hat{3}$.

DISTRIBUCION GEOGRÁFICA.-La patria de esta especie es la liuropa central, desde donde se extiende al norte hasta la Liscandinavia, mientras que la reemplazan en el medio dia especies afines. No existe en la Gran Bretaña, ni zampoco la hemos obserindo en España. En Cirecia se la ve solo en la Énocar del paso.

\section{EL HIPOLAIS POLÍGLOTO-HYPOLAIS POLYGLOTTA}

CÁRACTERES. - Difiere de la especie anterior solo por su talla algo menor y porque tiene la tercera y cuarta rémi ges, en lugar de la tercera sola, mas largas que las demas. Mlice $0^{\circ}, 137$ de largo, $11^{\prime \prime}, 20$ de ancho total; el ala alcanza $10^{n}, 065$ y la cola $10^{\circ}, 055$.
DISTRIBUCION GEOGRÁFICA.-Esta especie reem. plaza á la anterior en la Europa meridional, desde Portugal hasta la Dalmacia, asi como en el noroeste de Africa.

USOS, COSTUMBRES X REGIMEN.-LS el ave mas delicada y débil de toda la sub familia: aparece en nuestros paises cuando todos los árboles revisten su follaje, y por con. siguiente no llega nunca antes de fines de abril, abandonán. donos á fines de agosto, a mas tardar, para pasar el invierno en Africa.

Esta ave es una de las que viven cerca del hombre, y que parece preferir los jardines y verjeles á los bosques. En rigor, se la encuentra en estos últimos, pero mas bien en el lindero que en el interior: no se la ve en todos los de abetos ni cn las montantas; pero se tiene la seguridad de hallarla en los jardi. nés, donde crecen numerosos saúcos y ligustro, asi como en los verjeles rodeados de seios. Elige con cuidado su dominio; mas una ver. que ha tomado posesion de él, ya no le abandona, y vuclve todos los veranos. Durante sicte años consecutiros he visto áumna de estas aves, que llamábamos á causa de su canto poco notable cel chapucero, regresar al mismo jardin. El hipoiais vaga todo el dia de un punto áotro, cuan. do no cubre su hembra ni necesita cuidar de su familia. Por lo regular vn de un árbol á otro, y se orulta tan bien, que ś reces se tarda mucho en verle, aun cuando se oye continua. mente su $10 \%$. Prefiure ciertos árboles, los mas altos y espesos, y se dirige a ellos varias veces al dia. Cuando se posa tiene el pechó levantado, y si observa algo sospechoso eriza las plumis de la cabeza. Al saltar lleva su cuerpo horizontal. mente con el cuello tendido y nícia adelanie: su vuclo es rápido y ifícil, y al ejecutarle traza el ave los mas bruscos recortes.

Rara ver baja a tierra, el hipolais de los sauces; parece que salta con pesadez, y solo cuando canta permarjece largo tiempo én un mismo sitio. Su grito de llamada comienza por unas silabas bastante dulces, equivalentes á lcck deck, á las que sigue otro grito armonioso; cuando quiere expresar un sentimiento de cólera ó de celos, o anunciar algun peligro, emitc cl sonido teput: las silabas lestedlett indican que el hipolais está dispuesto $a$ la lucha. Su canto no agrada á todos, asi es que va. rian los pareceres acerca de su valor: nosotros debemos añadit que no hay dos individuos que canten lo mismo: uno es imitador, adrnirablemente dotado, que mercla con sus cantos los de las otras aves; el otro no pasa de ser un pobre igno. rante, que solo emite algumas notas armoniosas, las cuales no sabe variar. En cuanto i mi, oigo siempre con gusto el canto del hipolais de los sauces; sus notas aflautadas me hacen olvidar sus sonidos cortados; canta con el mayor ardimiento desde la salicla del sol hasta que se pone, y solo se interrumpe algunas horas hácia la milad de] dia para descansar. Fsta ave es muy ardicnte, sobre todo durante la incubacion, ó cuando algur rival la provoca al combate. Cuando cl hipolais icterino cania no se asusia fácimenic, y hasta lo hace con mas fuerza en caso de peligro, como por ejenuplo cuando se le dispara un tiro y no se le toca. Diriase, como lo ha observado Nau. mann, que quiere poner al mundo entero por testigo de la infructuosa tentatisa de muerte de que ha sido objeto, y que quiere burlarse del torne cazador y ridiculizarle.

1)os machos que viven uno cerca de otro están en conti nua contienda, $y$ se excitan mutuamente en el canto, pero is reces no les basta este por armas. (Cuando un hipolais se presenta en el canton habitado por otro, dice Naumann, precipltase el segundo sobre su contrario $y$ d picotazos le obliga a huir; pero comunmente se resiste el intruso, ye aqui re sultan luchas violentas en las que se ve á menudo á los dos adversarios caer á ierra, cogido uno de otro; pero entonces se espantan, se separan, y cada uno vuelve á su puesto favori. 
to. A los hipolais les gusta juguetear con las demás aves ve cinas. 2

La especie se alimenta principalmente de coleópteros y otros insectos alados, que coge sobre las hojas 6 atrapja al vuelo, y por esto remos al ave con frecuencia revolotear al rededor de la cima de las copas. Cuando maduran las cere. zas, el hipolais de los sauces visita los guindos y se alimenta de esta fruta; lo mismo hace con los groselleros, sin que sea notable el daño que causa

Si se deja tranquuila á una pareja, solo empolla una rezal ano, á fines de mayo ó principios de junio. El nido se halla en el mas espeso matorral de su dominio, comunmente en uno de saúco, de arellano ó de ligustro, y jamás en una breña espinosa. Esta cubierto por un follaje, que le oculta mas ó menos: la estructura es graciosa, y en forma de bolsa; las paredes se componen de hojas y yerbas secas, de fibras cortica. les, de la pelusilla de las plantas ó de pelos, de cortezas de abeto, telas de araña y papel, todo unido con mucha solide\%; el interior está relleno de plumas, yerbas tiernas y crines de caballo.

Los huevos, cuyo número varia entre cuatro y seis, son de forma prolongada, "' de color rojo sontosado $\delta$ de un rosa gris, con puntos y vetas negruzcas $\delta$ de un rojo pardo. Miden 11", 017 de largo por $10^{\circ}, 013$ de diámetro. El macho y la hembra cubren alternativamente por espacio de trece dias: alimentan á sus hijuclos con insectos de toda especie.

CA Z.A.-No se persigue en nuestro pais a esta ave tan vivaz como útil; mas bien se la protege decididamente en al. gunas comarcas, lo que no ha dejado de contribuir a su aumento. Es probable que el gato doméstico sea uno de sus enemigos mas peligrosos por robarle la cria, ya que a los adultos les salva su género de vida de casi todas las asechan. zas de los enemigos de los pajaros, aunque no de las redes que les tienden en Italia.

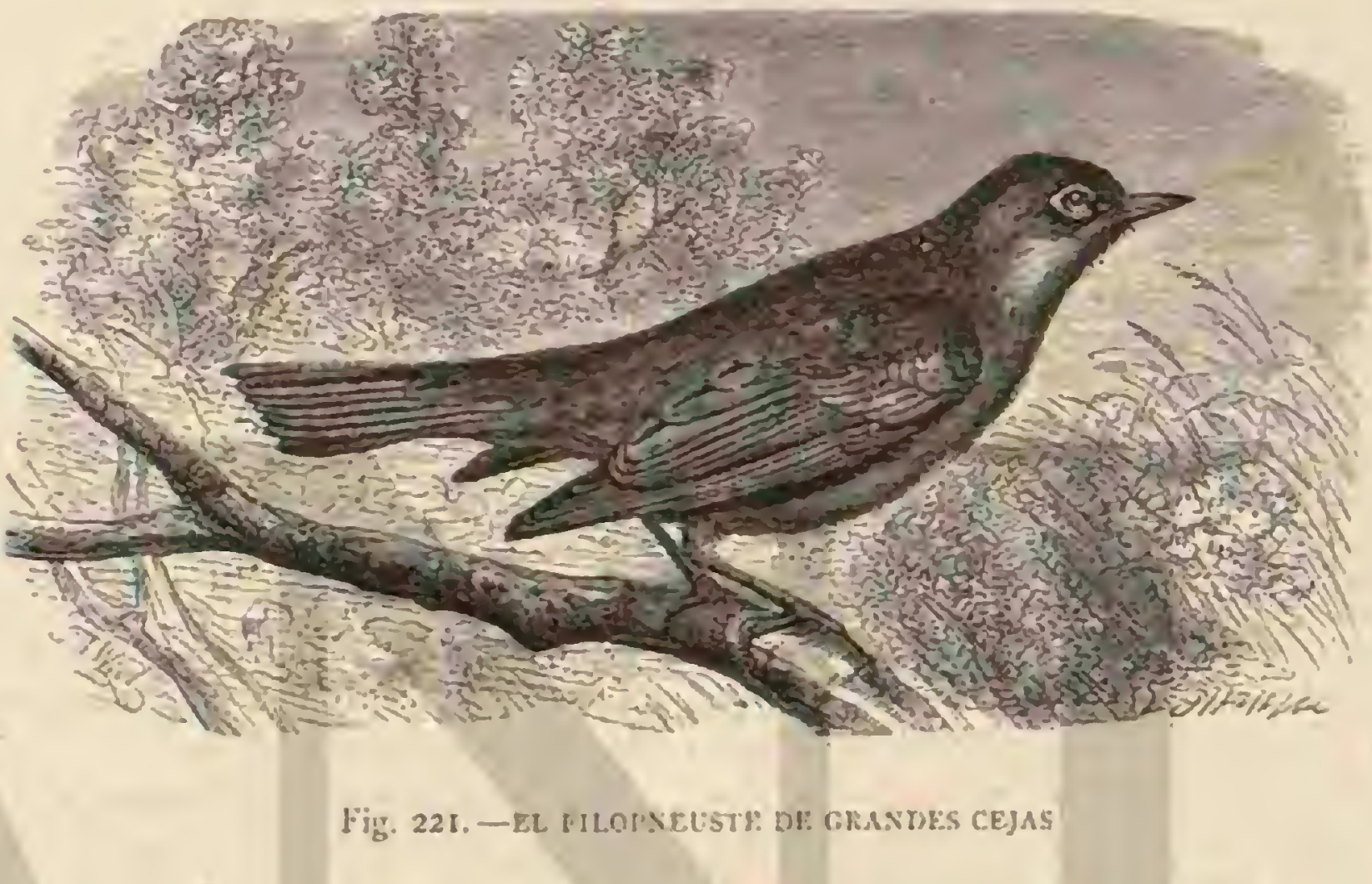

Ca UTIVIDAD. - Es una de las aves mas delicadas de nuestros paises Es necesario cuidarla rauchisimo, darle el alimenio mas escogido, y a pesar de tocjo, $y$ con gran sentiniento de los aficionados, rara vez vive largo tiempo cautiva; conozco, empero, casos en que han vivido arios, cantando mucho, $y$ haciendo la muda sin dificultad. Estos se vuelven muy mansos y son una verdadera joya de la habitacion.

\section{EL HIPOLAIS GRIS-HYPOLAIS OPACA}

En los floridos jardines de los altededores de Valencia fuédonde oi por primera vez el canio de esta ave; su voz no me era desconocida, $y$ aunque no dudase acerca del género i que pertenecia aquuella, no tenia la menor idea de la especie. Nespertada mi curiosidad no me fué dificil descubrir á la cantora tambien extramuros de la ciudad y luego supe que en todas las localidiades del sudeste de España, donde existe, es muy comun esta are, mas que todos sus congéneres.

CARACTERES. - I a parte superior es de color pardusco aceitunado, $y$ la inferior blanca sucia; la linea naso ocular $y$ un circulo estrecho al rededor del ojo son blanquizcos: la. region de la oreja y los costados del cuello y del tronco son de un color pardusco medio borrado; las cobijas sub-alares y sub-caudales son blancas amarillentas; las rémiges y las rectrices pardas con orlas mas claras y casi blancas en las tres rectrices externas. El iris es pardo oscuro; la mandibula superior gris de asta, la inferior gris amarillenta; la pata gris aplomada La longitud es $\|^{\pi}, 15$, el ancho total $10^{\prime \prime}, 20$; el ala plegada mide $1 ", 065$ ! la cola $1 ", 03$.
EL HIPOLAIS PALIDO-HYPOLAIS PALLIDA

CARACTERES. - IS bastante mas pequeiro que el an. terior, de coloracion idéntica, pero difiere por su pico nota. blemente mas estrecho.

\section{EL HIPOLAIS RAMA-HYPOLAIS CALIGATA Ó RAMA}

CARACTERES.-Probablemente es la misma especie que la anterior.

\section{EL HIPOLAIS DE LOS OLIVOS-HYPOLAIS OLIVETORUM.}

CARACTÉRES. - Fs de mayor talla y de color mas os. curo que los anteriores. Difiere además por el tono entre gris y pardo aceitunado de la parte superior, y el viso orin pálido de la parte inferior, del cuello $y$ de los costados que son parduscos, y además por las orlas exteriores é interiores de color blanco leonado de las rémiges.

DISTRIBUCION GEOGRÁFICA.-Estas tres últimas especies representan á la cenicienta $\delta$ gris en Grecia.

USOS, COSTUMBRES Y REGIMEN DEL HIPOLAIS GRIS.-Parece que se aleja de las montanas y prefiere las llanuras cubiertas de árboles: gústanle sobre todo las huertas, ese paraiso de España, regado aun hoy por los canales que abrieron los moros, huertas de cuya fertilidad no es fácil formarse una idea. El hipolais gris vive en los jar- 
dincs, en los paseos de las ciudades, en los olivares $y$ en las vinas, donde abunda tanto, que en una fila de unos veinte álamos, pude tirar contra doce machos, uno despues de otro.

Este hipolais habita los mismos lugares que el icterino de los sauces; pero difiere de sus congéneres por su carácter mas pacifico y su canto. Jamás he visto á dos machos en celo perseguirse y luchar; en canbio he observado dos parejas que hacian su nido en el mismo ärbol. Esto es una prueba de la buena armonia que reina entre los individuos de la especic, que contrasta con las costumbres pendencieras de sus congeneres.

No difiere menos el hipolais gris por su canto de las especies recinas: su grito de llamada es fac lof,y aunque tiene un canto sencillo, un tanto parecido al de algunos calamohérpidos, no desagrada, siquicra carezca de la facultad de imitar que distingue á la especie anterior.

Sus movimientos vienen à ser los del hipolais icterino; peto acaso menos vivaces. Se fija cerca del hombre, á quien no parece temer, pues le deja acercarse mucho, y hasta penetra en los jardines discminados entre las casas. Vive en los árboles de los paseos mas freciéntados, aun de aquellos que, como la glorieta de Valencia, están iluminados perfectamente hasta media noche.

La estacion del celo comienza con el mes de junio y dura hasta fines de julio. El hipolais gris hace su nido en un árbol alto, y en lo mas espeso del follaje, fijándole con ramas verticales que van comprendidas en sus paredes, por el estilo del de los calamohérpidos. Es muy grueso y se compone de sustancias diversas: algunos hay formados de rastrojos $y$ briznas de yerbas entrelazadas, con el interior relleno de pelusilla de cardo; otros se componen eási del todo de esta última, de algodon y trozos de corteza. La cavidad del nido liene un diámetro de $6^{\mathrm{\mu}}, 05$ y una profundidad de $0^{\mathrm{m}}, 04$. Cada puesta consta de tres á cuatro huevos de color gris nálido ó rojizo claro sembrados de puntos irregulares pardo oscuros 6 negros; macho $;$ hembra los cubren alternativa. mente, y se manifiestan en extremo cariûosos con sus hi. juelos. Ignoro si estas aves ponen una ódos veces al aỉo: á fines de julio vil por primera vez pequeños que iban á $\mathrm{cm}$. prender su vuelo, observando que los adultos no mudaban aun. Es probable que la especie na pase en España inas que el verano; pero no sé cuándo llega ni cuándo se va

\section{LOS FILOPNEUSTES -PHYLLOPNEUSTE}

CARACTE.RES. - Este grupo es el que tiene mas afinidad con el de los hipolais, y se compone de especies pequenas con pico débil, algo ensanchado en la rair, comprinido por delante y por lo demás en forma de lezna; patas media. nas, endebles y de dedos cortos; alas regulares con la ter. cera y cuarta rémiges mas largas que las otras; cola mediana. mente larga, recta ó ligeranente escotada, y plumaje lacio casi igual en ambos sexos.

Cuatro especies de este género habitan en Alemania y concucrdan tan bien en su modo de vivir qute podré conden sar esta parte de su historia en una sola.

\section{EL FILOPNEUSTE SILBADOR-PHFLLOP- NEUSTE SIBILATRIX}

CARACTERES.- Is la especie mayor y la mas hermosa del género. Mide $\left.0^{\circ}, 13\right\}^{\circ}$ de largo, $1^{\circ}, 225$ de ancho total; $(1)^{m}, 077$ el ala plegada y 1$)^{n}, 056$ la cola. Ja parte superior es verde accituna claro; una linea entre los ojos que liega hasta la region temporal, los costados de la cabeza, la barba y la garganta, el buche y los cobijas sub.alares son de un amarillo pálido, y las demás partes inferiores blancas; los costados son color de accituna borrado; las rémiges y las rectrices tienen por fuera un filete estrecho verde $y$ por dentro otro mas ancho blanquizco; las rectrices estan orladas en la punta de un matiz mas claro, y las rémiges por fuera de un amarillo verdoso. El circulo ocular es pardo oscuro, la mandi. bula superior parda, la inferior parda con matia de carne; ia pata es parda y en los bordes de las placas amarillenta.

DISTRIBUCION GEOGRAFICA. - Se extiende esta especie desde la mitad de Suecia por toda la Europa central y el Asia occiclental, y visita en su emigracion invernal el norte del Africa hasta Abisinia.

\section{EL FILOPNEUSTE FITIS-PHYLLOPNEUSTE TROCHILUS}

CARACTERES. - Mide esta ave $\theta^{\prime \prime}, 121$ de largo $y$ $\left(1^{\prime \prime}\right.$, I 85 de punta á punta de ala; esta plegada $10^{\prime \prime}, 062$ y la cola $6 ;, 050$. La coloracion es un verde pardusco de aceituna en la parte superior, que pasa a verde en la rabadilla; la parte inferior es de un amarillo pálido, mas subido en el bu che y la garganta; la region de la oreja y los costados de la cabera y del cuello son parduscos amarillentos aceitunatios; la parte inferior del pecho y el vientre son blancos, y en este último tienen las plumas una orla estrecha de un tono ama. rillo pálido semi-borrádo; una linea que pasa por el ojo es anarilla pálida, la linea naso.ocular es pardusca, todas las pennas son aceitunadas y orladas por fuera de color verde par. dusco, \& por dentro de blanquizco mas ancho que por la parte exterion. Ll circulo que rodea el ojo es pardo oscuro; el pico pardo negro, pero amarillo en la base, y la pata par. dusca pmarilienta (fig. 219).

DISTRIBUCION GEOGRÁFICA. - Se extiende la especie fitis desde la mitad de Suecia y' desde Liscocia por torla la Europa y la mayor parte del Asia, encontrándose en in. vierno en la Inciia y casi en toda el Africa.

\section{EL FILOPNEUSTE ROJO - PHYLLOPNEUSTE RUEA}

CARACTERES, - Esta especie es en algunas partes de Alemania mas comun que la fitis. Mide $\left(0^{\prime \prime}\right.$, is de largo, por ()$^{\circ \prime}$, is de ancho total; $\left(11^{\circ}, 060 \text { el ala plegada y } 1\right)^{\prime \prime}, 049$ la cola.

El dorso es de color pardo verdoso aceitunado muy viro; la cabeza y los costados del cucllo y tronco son pardo ama. rillos accitunados; la garganta y el buche mas pálidos; el color en los lados de algunas plumas aparece como borrado, y donde no, están orladas de amarillo pálido; la parte inferior del pecho y el vientre son blancos; una linea al traves de los ojos es amarilla pálida; la linea naso ocular, poco pronuncia. da, es parda; las cobijas sub-alares amarillas; todas las pernnas pardo aceitunadas, teniendo por fuera una estrecha orla de color pardusco verdoso, $y$ por dentro otra mas ancha y blan. co-leonada. El ojo es pardo oscuro, el pico pardo de cuerno, en la base de la mandibula amarillento, y la pata parda gris.

DISTRIBUCION GEOGR ÁFICA. -Esta cspecic penctra tambien hasta el norte de Succin y el Asia occidental, y extiende su viaje de emigracion hasta el centro del Africa.

\section{EL FILOPNEUSTE SERIO-PHYLLOPNFUSTE TRISTIS}

CARACTERES. - Se caracteriza esta especie, que reemplaza as la anterior en el noroeste de Europa, particularmente 
en el Ural del norte, por la coloracion pardo aceitunada mate del dorso y la linea del ojo entre rojiza leonada y orin, que es tambien el color de la cabera, de los costados; de la gar. ganta y del buche.

\section{EL FILOPNEUSTE DE BONELLI-PHYLLOP- NEUSTES BONELLIY}

CARACTÉRES. - Tiene la misma talla de la especic fitis; el color del dorso es pardo aceitunado oscuro con viso amarillo verdoso pálido; amarillo aceitunado viro en la raba. dilla; la linea del ojo y la naso-ocular son blanquiracas, otra linea mas corta detrás del ojo es oscura; la region de la oreja entre pardusco orin y lconado; la parte inferior del cuerpo blanquizca en los costados, con matiz leonado de orin medio borrado; las cobijas sub alares son amarillas de azufre; todas las pennas pardo aceitunadas, orladas por fuera de verde aceitunado, y por dentro de verde blanquizco; las del ante brazo con orlas mas anchas de amarillo aceitunado, y las co. bijas super-alares pardas con un filete verde aceitunado en el extremo. El ojo es pardo oscuro, el pico color pardo de cuer no, y amarillo de cuerno en los bordes y en la base de la mandibula inferior; la pata es parda.

DISTRIBUCION GEOGRAEICA.- la patria de esta especie es el mediodia de Luropa, el Asia occidental y el norte del Africa. En su emigracion visita la Nubia meridional y el Senegal.

\section{EL FILOPNEUSTE ASIÁTICO-PHYLLOP- NEUSTES MAGNIROSTRIS}

CARACTÉRES. - Fn la isla de Heligoland se ha cazado un incividuo de esta especic. Su plumaje es en la parte supe rior verde aceitunado oscuro, la linea del ojo, las mejillas la region de la oreja son blanco amarillentas, la última listada de color oscuro é incierto; la parie superior es blanca con viso amarillento sucio que pasa á gris pardusco borrado; las cobijas sub alares son blanco amarillentas; todas las pernnas, de color pardo oscuro, tienen orlas exteriores estrechas de color verde aceituna, y las primarias orlas interiores mas an chas blanco leonadas; las primeras cobijas del antebrazo tie nen filetes verde-leonados, to que produce una especie de estrella.

USOS, COSTUMBIRES Y REGIMEN.-De los filop. neustes propios de Alemania, el que llega prinzero, esto es, casi siempre a mediados de marzo, es el rojo; siguele hácia fin del mismo mes el fitis, $y$ despues de estos viene la especie sitbadora que llega en la segunda mitad de abril y permanece en nuestros bosques hasta agosto, mientras que la es. pecie ritis no se marclıa antes de fin de setiembre, y la roja solamente en octubrc. Mas tarde que todas estas llega el filopireuste de Bonelli, pájaro alpino, que en Alemania solo labita la Suabia y Baviera, y que vuelve à marcharse ya en agosto. Probablemente no hay provincia en Alemania donde no se encueniren filopneustes rojos, pero solo habitan en cada una determinadas localidades, porque el árbol que prefieren á todos para establecer en él su nido és el haya, y solo. donde este airbol forma bosque se encucntra el ave con notable irecuencia; pero en número limitado donde solo se ven bayas sueltas, diseminadas ó acaso reducidas á un solo cjemplar en algun bosque de pinos 6 abetos. En el mediodía de Hungria no he encontrado al rojo sino en saucedales ó po. bedas, siendo probable que entonces estuviese de paso, puesto que la única especie que aili es sedentaria, solamente vive en las hayas de la Fruscagora y del scinorio de Belye. Es tan grande su predileccion por este árbol que le busca aunque haya de subir hasta el último límite de la region de los bosques, bien que en general parece preferir la montaña al llano.

La especie fitis no es tan cxclusiva, puesto que se la en cuentra positivamente donde quiera que halle albergue y alimento, á pesar de lo cual manifiesta alguna preferencia por ciertos bosques altos con mucho tallar bajo. Lo mismo hay que decir de la especie roja, á la que por esto se le llama tambien salicaria ó de los sauces. Ambas especies viven en muchos distritos pacificamente una al lado de la otra. El filopneuste de Bonelli elige con preferencia para estable. cerse vertientes situadas hảcia mediodia ó levante y cubiertas de lórices y tallares con algunos claros, pero sin desdenar por esto los bosques de follaje con mucho montc bajo y suelo cubierto de vegetacion. Para posarse prefiere cl filop. neuste silbador las ramas inferiores de hayas grandes y allus, mientras que el rojo suele descansar en la punta mas elevada de la copa, y el fitis no hace apenas diferencia entre alto ni bajo. Cada pareja se apropia un distrito bien circunscrito dentro del cual no tolera ninguna otra pareja congénere, $y$ persigue yol molesta a los demás pájaros que se acerquen demasiado, lo cual unido á su genio inquieto y á su canto sen. cillo pero no desagradable, contribuye no poco á animar la solediad de los bosçues.

Con mucha razon dice Naumann que el carácter alegre de los filopneustes se revela en todos sus movimientos y acciones. Dificil es para estas aves estar tranquilas y fijas en-un puesto. Como las currucas, muevense sin cesar, ora desli. zándose hábilmente por entre las ramas, ora volando hácia el extremo de una y sosteniéndose delante de ella con continuos aleteos, quizis para coger un insecto, ora cantando mientras cambian de árbol; y cuando renimente llegan á $\mathrm{pc}$ sarse un rato, han de mover la cola alzåndola y bajándola con rapidez. Su vuelo es incierto y de mucho aletco; saltan como dice Naumann, y aun cuando atraviesan grandes dis. tancias, describen una línea ondulada irregular compuesta de curvas grandes y pequeñas. La especie silbadora merece bien su no:nbré, pues su canto no viene á ser en rigor otra cosa que un pitido continuo que podria representarse por la combinacion sisisisirrrrivirr. Cuando el ave $\mathrm{cm}$ pieza á cantar $\delta \mathrm{sca}$ a chirriar parece que le cuesta trabajo y entonces suele dejarse caer de la rama donde estaba, y sosteniéndose en el aire con precipitado aletco, se dirige â otra rama que segun su cálculo pueda alcanzar al concluir su frase, que entonces remata con un sonido delicadisimo y repetido dos $\delta$ tres veces consecutivas, $y$ que puedc expre. sarse con la onomatopeya: nit. El canto de la especie fitis no consiste en otra cosa; esto es, en una serie de sonidos suaves que suenan como ist, $i-i t$, oit, ofl, oit, ofl, y tan dulces y allautados que junto con las subidas y bajadas de tono tic. nen algo tan singular y simpático que pueden preferirse al canto de otros muchos pájaros, como dice mi padre. Ia es. pecie roja empieza su canto con las silabas trip, trif, trip, it seguido de: dilr, delr, dill, delr, a manera de pito: final. mente puede representarse el canto del filopneuste de Bo. nelli por sece.e.e frrre.ce-da-da, dw-uit,-vit-uit, segun Land. beck Todos los filopneustes cantan, durante la época del celo, con un afan extraordinario, con la garganta hinchada, las plumas de la coronilla erizadas, las alas caidas y haciéndolas temblar; con el alba empiezan y no acaban sino cuando el sol se ha puesto ya.

'lodos los filopneustes construyen sus nidos con mas 6 menos arte en forma de horno de pan, ya cn el suelo, ya cerca de el. Los de las especies silbadora, fitis y Bonelli son de los primeros, y el de la roja iambien pero no siempre, pues á veces se los encuenira en alguna mata á medio ó un 
metro de altum, con preferencia en enebros si los hay. El silbador clige el pié de un tronco grande ó pequeño ó de una cepa entre retamas, brezos, musgo y ycuba; el nido mis. mo se compone de rastrojos fuertes, astillas, tallos de musgo, escamas de pirias y otros materiales por el estilo, formando un hueco de unos $1^{\circ}, 13$ de diametro con un agujero de entrada de $\|^{\circ}, 04$ de anchura, $y$ tapizado interiormente de briz. nas finas de yerba. El fitis y el rojo conseruren su nido con yerba y hojas, lo revisten por fisera de musgo y lo tapizan interiormente con plumas, que por lo comun son de perdiz. La especic Bonclli, finalmente, hace el nido mas voluminoso entre los de sus congéneres Componen la parte exterior rai. ces, jerba y ramitas, fla intcrior materiales mas finos y hasta a beces pelos de mamícros Conforme pudo obstrvat mi padre en una parcja de fitis, empieza la fembra at abrir la excavacion que ha de recibir el nido, arrancando f́ menudo con gran trabajo y esfícrzo las yerbas y el musgo, hasta que con ayuda del pico ha logrado harer un inueco hemisférico. Fintonces acarrea y disponc los materialts, y tanto es su afan y asiduidad, que en muy pocos dias estr lodo listo á pesar de que solo irabaja en las horas de la mañana. Duranie su trabajo emplea las mayores precaucionts para ocultar no solo el nido sino á si mismo, arranca de musgo y la serba a mucha distancia y se va con cllos á posarse primero en algun árbol alto que este cerca, y de alli baja al nido. El filop neuste silbador no hace mas que una cria al año, esto es, fo fines de mayo ó principios de junio; el fits pone antes, casi siempre en la primern mitad de inarzo; d rojo poco mas 6 inenos en igual tiempo, y el lBonclli comienea apenas a me. diaclos de junio, como correspronde a los tilios mas frios que habita; la puesta del silbador se compone de cinco a seis huevos, la del fitis de cinco á siete, is del rojo de cinco á ocho y la del de Bonelli de cuatro d cinco; su tamano varía entre $0^{\circ}, 015$ y $\left(1^{\circ}, 017\right.$ de largo por $11^{\circ}, 011$ hasta $11^{m}, 013$ de diámetró. Su contiguracion es asimismo varia, pero la cás. cara siempre delgadita, Jisa, reluciente y moicada. los del silbador presentan muchas manchas pardo rojizas y otras en tre azuladas y cenicientas semi-borradas sobre fondo blanco, y repartidas mas 6 mellos prufusamiente por toda la sajerfí cie ó acumuladas hácia el exrremo. I as del fitis son de color rojo claso, color de barró rojiso, pardo rojizo claro ó entre rojizo y azul, sobre fondo blanco de leches dispuestas como las anteriores. En la especie roja presentan los huevos man. chas pardo rojizas, rojo parduscas, mas ó menos oscuras y aun cenicientas sobre fondo blanco de yeso. Finalmentc, los de la especic de Bonelli tienen manchas azuladis 6 pardus. cas, ya repartidas sobre toda la cáscara, ya acumuladas hicia el extremo grueso, donde a veces se conianden mas o me nos para formar como un aro.

Macho y hembra comparten el trabajo de incubacion, pero aquel solo sustituye á la segunda en las horas de medio din, sin demustrar tanto celo como la hembra, pues esta casi permite que se la coja con la mano, y literalntenic se deja aplastar antes que abandonar los huevos; cuando acaso huye lo hace rasando el sucto, en lérminos de que mas bien parece que va a rastras que volando; si hay pequeñuclos en el nido huye gritando lastimeramente y a relancio á toda clase de asiucias y tretas. Los pequeños-salen a luz lo mas tarde a los trece dias de incubacion, orros inntos dias des. pues ya son adulios, y á los pocos dias mas independien. ies, que es cuando el fitis y el rojo á veces se determinan 1 hacer una segunda cris.

EN EMIGOS. - A las rapaces tanto de pelo como de pluma, que suelen vivir principalmente de pajaritos, se agregan tambien para hostilizar a los filopneustes los ratones de bos. que, y quizás las culebras y lagartos; pero mas peligrosa que todas estas alimañas es para ellos la lluvia fuerte cuando dura algunos dias. En cuanto al hombre, solo persigue á estas aves alegres y amables en Italia, Espana y Francia meridional para comerlas.

CAUTIVIDAD. - Apenas se ven filopneustes en jaula, $\dot{a}$ pesar de que se acostumbran, aunque no siempre y no sin mucho cuidado, al régimen artificial, se vuelven mansos y compensan con creces el trabajo empleado.

\section{EL FILOPNEUSTE DE GRANDES CEJAS- PHYLLOPNEUSTES SUPERCILIOSA}

CARACTERES. - Ignorada hasta hace poco esta especie, natural del Asia oriental, atraviesa cada año nuestro pais para buscar sus cuarteles de invierno en el Africa occidental, dis. tante muchos miles de kilómetros de su patria. Como quiera que se distingue de las demás especies del género por el pico $y$ las patas relativamente cortas, $y$ alas un tanto mas largas y puntiagudas, se la considera como representante de un sub. género especial, el de los Regulvidens (I'iyllohasileus).

El color del dorso es verde aceitunado claro; una lista bastaute ancha que arranca de la fosa nasal y pasando por encima del ojo, termina en el occipucio, es amarilla pálida orlada en ambos lados de negro mate; otra menos pronunciada y inas clara que el fondo pasa por la coronilla; el cos. tado desde el buche hasta los muslos tiene un viso delicado amarillo verdoso, $y$ amarillento blanquizco en el resto de la parte inferior. Tadas las pennas son de color pardo negruzco con estrechas orlas de verde aceitunado por fuem, y las ré. miges solamenté por dentro de blanco; las rémiges secundarias y las gmades cobijns de las alas tienen en el extremo un filete amarillo pálido que forma dos fajas trasversales en las alas. El ojo es pardo amarillo, el pico color de cuerno oscuro, en la parte inferior de la base maranja claro; la paia es parda rojiza clara. Mide esta ave de $0^{\circ}, 09$ \& $0^{\circ}, 10$ de largo, $1^{\circ}, 16$ de total anchura, $0^{\circ}, 052 \mathrm{cl}$ ala plegada y $0^{n}, 0,39$ la cola (figu1.2 221).

DISTRIBUCION GEOGRAFICA.--lin el dia se igrora lodavia el frea de dispersion de este pájaro y solo se sabe que habita y anida en el 'lurkestan desde el Tianchan; en la Siberia ariental desde el lago Baical; en China jen el Himalaya en una zona entre 1,000 y 2,500 metros de elevacion sobre el nivel del mar, y que emigra cada invierno al sur de la India, mientras que otra partida menos numerosa, pero casi con la misma regularidad, cmprende su ruta en direccion oeste, pasando asi por el norte y occidente de Europa Se observa esta ave, segun me dijo Gactke, casi cada año en la pequena isla de Heliguland, y no cabe duda que este obser. vador sagaz tiene razon cuando le parece indudable que e! nilopneuste de grandes cejas ha de atravesar cada ano la Alę. mania; y en cfecto se lé ha matado en partes inuy distintas de Europa, como cerca de Berlin, strhalt, Viena y Milan; en Inglaterra, Holanda y en Palestina.

USOS, COSTUMBRES Y RÉGIMEN.-Carcemos de datos detallados respecto á este punto, bien que no faltan noticias mas ó menos reridicas suministradas por coleccionis. tas ingleses de huevos. Gactle, de cuyas observaciones so?o se han publicado fragmentos, dice que dichas aves tienen costumbres y género de vida análogos a los demás filonneus. tes; Radde observa que esta ave aparece en el sudeste de Siberia a mediados de mayo y que permanece hasta fin de sctiembre, y que durante su paso en otono hace largas paradas en algunos puntos ó que viaja cuando menos con gran lentiud, pudiérdosela ver meses enteros en los saucedales de las orillas. Swinhoc escribe que raras veces se la ve en compañia de otras aves; que es vivaz y movediza, que nunca 
para y que anuncia su presencia con un grito de llamada que suena como suit. Dybowski es mas explicito, siquiera mas lacónico. Dice que este filopneuste es mas raro en la Siberia oriental que todos sus afines, que aparece alli en la primera mitad de junio yo que anida en las montanas cerca del limite de la region arbóra y mas alla si el terreno está cubierto de rosas alpinas rastreras pero abundantes. Permanece alli hasta mediados de seticmbre. Fil nido, situado por lo regular en una de aquellas matas que crecen entre espeso musgo y yerba, esta construido con gran arte, $y$ abovedado con un techo de yerba seca y fina, de tal forma que mirado de lado tiene toda la apariencia de una choza. Para la construccion principal emplean yerbas secas, y para tapirar el interior pelos de cervatillo ó de rengifero. No puede descubrirse sino obser. vando á los padres cuando llevan el alimenio álos pequeños. Dybowski encontró uno en agosto con seis pequeños, pero cuando fué á cogerlos con la mano se desliaron ligeros entre el musgo a pesar de no volar todavía; á últimos del mismo mes vió jóvenes ya adultos, pero no encontró huevos. En
Cachemira, en una zona entre 1,500 y 2,000 metros dealtura sobre el nivel del mar, es tan frecuente esta ave que cada pareja no dispone por todo distrito mas que de un ierseno de pocos metros de diámetro. Los machos son muy vivaces y despiden continuamente su grito sonoro y doble que casi no nerece el nombre de canto. Brook encontró en los últimos dias de mayo varios nidos con cuatro y cinco huevos apenas incubados que median $0^{\circ}, 014$ de largo por $0^{\circ}, 011$ de ciáme. tro; su color era blanco puro con manclas y puntos rojos parduscos ó pardos purpúreos repartidos por toda la superfi. cie y reunidos y condensados en el extremo grueso en una especie de faja.

\section{LOS RÉGULOS-REGULUS}

CARACTÉRES. - Despues de haber sido trasladados muchas veces de una inmilia a otra, lan encontrado los te. gulos finalmente un puesto definitivo en la sub-familia de los filopneustes. Se caracteriaan por su pico recto, delgado,

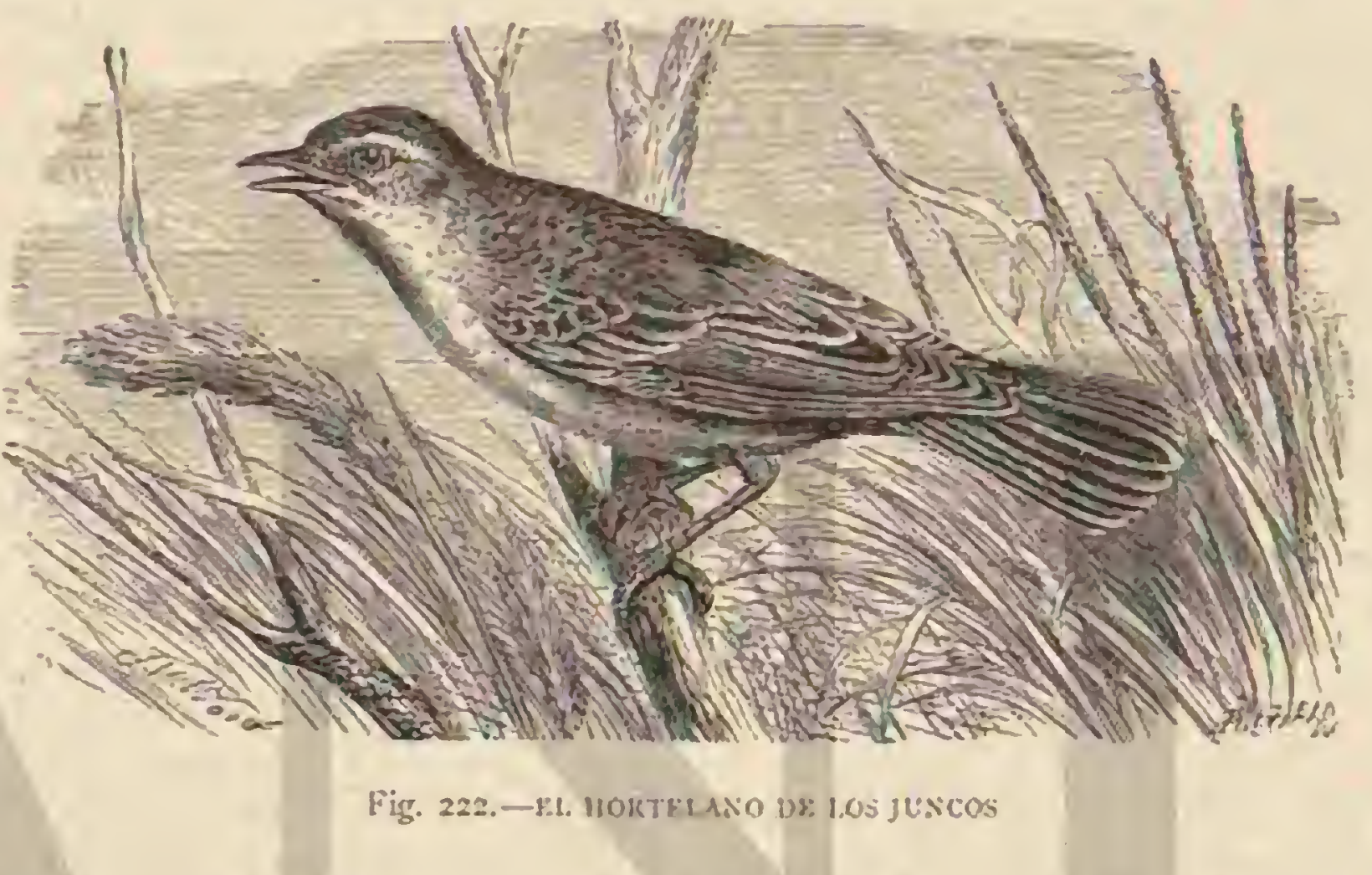

de punta de aguja, algo ensanchado en la base, de dorso alto, y cuya mandibula superior presenta una ligera escoia. dura cerca de la punta, que es algo corva hácia abajo; patas esbeltas de tarso alto con dedos medianos y uñas muy corras; alas cortas, anchas y muy redondeadas con la cuarta y quinta rémiges mas largas que las demás; cola algo escotada y plumaje abundanic compucsto de plumas largas de ancha barba. Plumitas penuenas, deshilachadas y recias, cubren las fosas nasales; en los extremos de la boca hay algunas cer. das; todas las pennas son muy encebles y llexibles; las plunas de la coronilla son mas largas que las oiras del lado y notables por su coloracion viva.

DISTRIBUCION GEOGRÁfICA.-Este géneto se ex. tiende por Europa, Asia y la América del norte. Mi padre fué el primero que disinguió las dos especies q̧ue viven en Europa.

\section{EL ABADEJO Ó RÉGULO DE MOÑO- REGULUS CRISTATUS}

CARACIÉRES. - La parte superior es verde de acejtuna tirando un tanto a lconado, y con matiz pardusco en la region temporal y en los costados del cuello: el borde de la frente y una lista encima de los ojos son de color mas claro; la linea naso ocular $y$ el circulo al rededor del ojo son blanquizcos; las plumas de la coronilla amarillas y color de naranja viro las que forman su jrolongacion, circunscritas lateralmente por una linea negra; la parte inferior del cuerTosso III po es blanca con matiz amarillento de orin, tirando á pardo en los costados; todas las pennas son de color pardo aceitunado con filete verde aceitunado claro en la parte exterior, y además las del antebrazo con filete blanco interior, y una faja negra cerca del principio blanco amarillento de la barba; las últimas rémiges secundarias tienen una mancha blanca en el extreno, y las cobijas de las pennas secunda. rias asi cono las mayores de las primarias llevan un filete ancho blanco amarillento en el extremo, lo que produce dos fajas trasversales. El ojo es pardo oscuro, el pico-negro de asta y la pata pardusca. Ia hembra difiere del macho por tener la curonilla amarilla sin la continuacion de color naranja. Esta especie mide $0^{\circ}, 096$ de largo, $\theta^{\circ}, 154$ de ancho total, $0^{\circ}, 0.48$ el ala plegada, y $11^{\circ}, 03 \$$ la cola

DisTRIBUCION GEOGRAFICA.-El régulo ó aba:dejo de moño se extiencie por tocia la Europa hasta la region mas septentrional; por el norte del Asia hasta el pais del Amur, $y$ en Alemania anida en todos los bosques de conife. ras, en especial en los pinares. Dumnte el verano habita tambien las cordilleras mas clevadas del mediodia, y visita las llanuras durante su época de paso, para desaparecer al principio de la primavera.

\section{EL ABADEJO COMUN - REGULUS IGNICA- PILLUS}

CARACTERES. - Sellama tambien reyezuelo, nombre que se da igualmente á otra especie. El tamaño es igual al 
de la especie anterior y el color en el dorso de un verde aceitunado muy vivo, en los lados del cuello amarillo ano. ranjado y pardusco con matiz de orin en el borde de la freniej una lista estrecha trasversal en la parte anterior de la ca beza y otra longitudinal encima de la línea blanca del ojo son negras; el espacio entre las dos, ocupado por la coro nilla y el occipucio, es naranja oscuro; la linea al través del ojo como tambien el círculo estrecho que lo rodea son gris negruzcos; otra linea estrecha limitada por la lista mas os. cura de la barba débjo del ojo es blanca; la region de la oreja es gris accitunada; la parte inferior del cuerpo blanca cenicienta, y entre pardusca con viso de oriij y leonado en la barba y garganta. Jas pennas, todas de color pardó acei tunado, tienen por fucra una orka estrecha verde amarilla aceitunada, $y$ las rémiges ademís una orla blanca mis ancha en la cara intefior; las secandarias tienen una faja trasversal ancha y negra inmediata a la raiz. que es de color claro; las cobijas del antebrazo asícomo las mayores superiores tienen un filete inal blanco, lo que produce dos lineas trasversales claras pero mal limitadas sobre cl ala. El ojo es pardo os. curo; el pico negro y la pata pardisca I ta hembra divere del machio por su coronilla amarilla anaranjada.

DISTRIBUGION GEOGRÁfICA. - Además de Alc. mania se ha encontrado esta ave en Francia, Italia, (Frecia y Esparia; en este último pais particularmente como huésped de invierno.

USOS; GOSTUMBRES Y REGIMXN. - Ambas es. pecies se asemejan en cxtremo en su modo de ser y cos. tumbres; habitan muchas veces las mismas. localidades, tienen régimen idéntico y anidan del mismo modo. La primera des. cripcion detallada de estas aves y de su género de vida se debe á nu padre, y ella me servirá de base en lo que sigue, ya que las observaciones posteriores apenas han cambiado ni añadidu nada á ella.

En Alemania habisa cl régulo de invierno todo el aho en la misma localidad, o es un ave errante; á menudo esta los doce meses en un pequeño distrito de menos de media le gua cuadmda; sin embargo, en octubre se ven inuchos que llegan del norte para fijarse en los jardines, los bosques de coniferas $y$ de follaje y las comarcas abundantes en matot. rales. Unos pasan el invicrno en nuestros países; los otros continuan su camino hacia el sur y vuelven á los mismos sitios en marzo y abril.

El abadejo comun no pasa nunca el invierno en Alemania, pues necesita un clima mas cólido: se presenta en este pais á fines de marzo ó en los primeros dias de abril, y se va à los últimos de setiembre ó a principios de octubre. Apenas llega fijase en los setos y en los matorrales; pero bien pronto los abandona para dirigirse a los bosques de abcios, donde se establece de hecho $y$ en parejas aisladas. Muchos prosiguen su marcha hácia el norte, mientrás un gran numero se queda en el pais. Viajan de noche y dedican el dia á buscar su ali. mento.

Durante el verano están casi siempre en altos ảrboles, y rara rez se posan en las espesums y los tallares bajos: en el mes de seticmbre andan crantes.

Ambos régulos prefieren los bosques de coniferas á cualesquiera otros; sitúanse en los árboles $y$ en las breias, no siendo raro tampoco verlos en el suelo; el primero prefiere los pinos y el segundo los abetos; y ambos los bosques pequenos de cincuenta á cien hectáreas á los de mayor extension. "La predileccion que manifiestan estas aves por las coniferas, dice Naumann, es muy notable: cuando en otono ó invierno llega una familia de régulos a un jardin donde no hay mas que un pino ó un abeto, se puede tener la seguridad de que le ocu. parán en seguida, permaneciendo all mas tiempo q̨ue en otro punto donde no haya ninguno de estos árboles; pero en sus viajes recorren tambien los bosques de follaje.

La residencia de los régulos en el invierno, $y$ la extension de sus viajes, varian segun la temperatura; si in estacion es buena, seca, y no demasiado fria, viven con jreferencia en las grandes coníeras; pero por el contrario, si el tiempo se pre. senta lluvioso, ventolero ó muy írio, bajan á los matorrales, y hasta se quedan en tierra. En el invierno habitan siempre la parte del bosque mas expuesta á los rayos del sol.

Sorprendente es la inquietud extraordinaria de los régulos; nunca están iranquilos. El régulo 6 abadejo de invierno salta continuamente de rama en rama, sin detenerse nas que un instante para coger algun insecto \& la manera de los filopneustes; esta con el cuerpo horizontal, ins patas encogidas y ahuecadas las plumas. $A$ veces se cuelga de la cana inferior de una rama, aunque no con tanta frecuencia como los pa. ros: su vuelo es ligero y silencioso. Dominale un instinto de sociabilidad extraordinariamente desarrollado: fuera de la estacion del celo es por demás raro encontrar á un régulo solo; por lo regular está en compañia de sus semejantes ó de otras aves. Mi lladre le ha visto principalmente con paros moñudos 'ó pequenos paros carboneros, y' mas rara vez con sireles, trepadores, paros azules, ó grandes paros carboneros.

El grito de llamiada de este régulo es si, si; ó lsil; los individuos de ambos sexos le producen cuando están posa. dos. Su canio no es desagradable: comienza por si, si; ofrece sariaciones en dos notas y tonos diferentes, terminándose con un final armonioso. Los individuos viejos canian en primavera $y$ en verano; los jóvenes en agosto, setiembre y oc. tubre, aunque se hallen en pleno perjodo de muda. En los hermosos dias de invierno produce una grata impresion el canto del régulo ó abadejo de invierno: en el otono, desde principios de setiembre á fin de noviembre, suele tomar esta ave una costumbre particular, y es que comienza por emitir cl sonido si, si y se revuelve agitando las alas. Al oir este grito llegan otros individuos, ejecutan los mismos movimientos, y se lés ve á todos entonces perseguirse por via de diversion, erizando las plumas del noño. 1.0 mismo sucede al verificarse el apareamiento, cuando el macho excita á su hombra; á menudo pelean dos furiosamente cuando se trata de adquuirir una compañera.

El abadejo comun es aun mas ágil y vivaz que su congé nere, y tambien menos sociable que el, pues siempre se le ve solo 6 con su hembra, mientras que el otro forma bandadas mas $\delta$ menos numerosas. En el otoño principalmente, no suelen encontrarse sino parejas; si se da mucric á un individuo, el otro lanza gritos lastimeros, y pasa mucho tiempo sin que se determine s. dejar el sitio donde estaba Su grito de lla madi difiere tambien del de la especie anterior; las silabas si, si, si, son emitidas con mas fuerza y en tono muy diferente, de ral manera que por el grito solo podria reconocer al ave una persona de oido ejercitado. El canto de ambos régulos ofrece desemejanzas mas notables aun: segun he dicho ya, el cel regulo de invierno comprende dos notas principales y termina por un final armonioso; en el del abadejo comun, se continuan los si, si en el mismo tono y no hay final, por manera que este canto parece ser mas breve, sencillo y monotono. li macho produce á veces algunas notas que recuerdan las del paro moñudo. En la primavera y en medio del verano canta muchas reces el abadejo comun, pero muy pocas en el otoino.

Durante el periodo del celo es sumamenic graciosa esta are; el macho eriza el moño, que forma como una brillante corona de los mas vivos colores; grita sin cesar : con las alas un poco separadas del cuerpo, salta al rededor de su hembra, tomando las mas singulares posturas, prodigándola mil halagos hasta que al fin se rinde $a$ sus deseos. 
Ambos régulos se alimentan cie insectes y de pequeños granos: en rerano comen principalmente insectos y orugas de escasa talla, en invierno huevos y larvas. Los recogen en las ramas, entre las hojas ó en las agujas de los pinos: á me nudo se les re revolotear acechando una presa, y á veces atrapan un insecto al vuelo.

La hembra de ambas especies pone dos reces al año, una en majo y la otra en julio: los nidos son dificiles de hallar; están situados cn la extremidad de una larga rama de pino ó de abeto, ocultos entre las ramas y el follaje, y sólidamente sujetos á las briznas que constituyen el armazon, las cuales atravicsan á veces basia el fondo. Tienen la forma esférica y paredes gruesas; su diámetro exterior es de $0^{\circ}, 09\left\{1^{\circ}, 1\right\}$, el interior de $0^{\circ}, 06$ y la profundidad de $0^{\circ}, 04$. La hembra construje sola su nido necesitando para ello de 12 a 20 dias; acompánala el macho, pero sin ayudarla; á veces entrelaza volando las ramas, con mucha destreza, y rellena los huecos que van quedando entre ellas. La primera capa se compone de musgos y de liqueres, sujetos con telas de araira 6 de oru. ga, que el ave cnlaza sólidamente con las ramillas que sostienen la construccion. Algunas veces se ven sobresalir a la superficie algunos pelos de corzo; el interior estri cubicrto de plumas, sobre trodo de paloma, que en to alto del nido se dirigen todas de afuera adentro y obstruyen uma parte de la abertur. Mi padre encontró dos nicios de abadejo comun, en cuya superficie sobresalian pelos de corzo y de ardilla, $y$ el interior estaba cubierto de pelos del primero de dichos animales; en uno de cllos aparecisn mezcladas algunas plu. mas, que ocupaban la parte superior del nido, tapando casi por completo la entrada La primera puesta consta de ocho á diez huevos y' la segunda de seis á nuere: son muj pequenos, solo de $\left\{, 083\right.$ de largo por $11^{\prime \prime}, 010$ de gruese, de un gris amarillento ó color de came pálido, cubiertos de puntos grises, agrupados principalmente hácia la punia gruesa. Algunos presentan vetas $\dot{0}$ manchas; son en extremo frágiles, y sc deben coger con muchas precauciones para que no se rom. pan entre los dedos. Los padres alinentan á su progenie di costa de mil trabajos, pues solo les dan insectos muy péquehoos ó sus huevos. I.os hijuelos están en el nido muy oprimi. dos unos contra otros, y i medida que van creciendo, es jreciso que los padres ensanchen su albergue para que pue. dan caber todos. In familia no se conserva reunida largo tiempo; macho y hembra abandonan pronto la primera cria para empollar de nuevo ó marcharse con sus semejantes.

CAUTIVIDAD. - Raro es ver régulos cautivos, pues son muy delicados, tanto rye mueren nuchas veces al cogerlos, $y$ ofrece gran dificultad acostumbrarlos a un nuevo régi. men. Una ver. acostumbrados soportan años cnteros su exis. tencia en la jaula, dispensándoles por supuesto los cuidados necesarios, y entonces son unos compañeros muy agrada. bles. Si se les deja volar libremente por el cuarto se hacen tan útiles destruyendo las moscas, como fuera en el bosque con la persecucion de insectos daninos.

\section{LOS CALAMOHERPINOS}

CARACTERES.-Las setenta y cinco especies que forman esta sub-familia se caracterizan por su estructurn esbelta, frente achatada, pico relativamente robusto, esbelto, cónico 6 en forma de lezna, patas de tarso alto $y$ fuertes, de dedos gruesos provistos de uñas grandes y muy corvas, alas cortas y redondeadas con la segunda, ó esta y la tercera réniges mas largas que las otras, cola redondeada, escalonada à ahusada, y piumaje liso $y$ algo recio, de color verde $\delta$ amarillo verdoso semejante al del junco.
DISTRIBUCION GEOGRÁFICA.-Habitan principalmente el norte del antiguo contineste, hallandose además representados por ciertas especies en la India, Etiopia y Oceaniz.

USOS, COSTUMBRES Y REGIMEN.-El modo de ser de estos prijaros cantores corresponde i los sitios que frecuentan y que sirven a Brehm para dividirlos en cantores de canareral, de espadanal, de juncal y de prado; todos em. pero viven cerca del suelo y presentan las cualidades que este género de vida requiere. Perfectamente dotados bajo todos conceptos, distinguense tambien por su canto, acuśtico si se quiere. Buscan y encuentran su alimento en el suclo, en la superficie del agua y sobre las plantas donde viven y donde establecen tambien su nido, casi siempre construido con arte.

\section{LOS ACROCÉFALOS Ú HORTE- LANOS - ACROCEPHALUS}

CARACTERES.-Distinguense las especies de este gé. nern por su pico recto, poco combado y de punta apenas encorvada; patas robustas; alas medianas con la tercera $y$ cuarta rémiges mas largas que las demás; cola escalonada y mediana, y coloracion uniforme.

\section{EL HORTELANO TURDOIDEO-ACROCE- PHALUS TURDOIDES}

CARACTERES,-ES la especie mayor y mas conocicia de su género, llamada iambien rordo de rio. Mide $v^{\circ}$, at de largo, $0 \%, 29$ de ancho total, to $^{\circ}, 09$ de ala cuando plegada, y la cola $0^{\mathrm{m}}, 0 \mathrm{~S}_{5}$. El plumaje en la parte superior del cucrpo es pardo oscuro, y en la inferior blanco rojizo amarillcrito, mas claro en la garganta y en medio del pecho; las rémiges, de color pardo oscuro, tienen orla lconada tirnndo á orin en la cara interior, y las rectrices en el extremo orla blanquizca con matiz leonado y mal determinada. El ojo es pardo oscuro, el pico tambien con matiz de asta, C inferiomente amarillo de asta. y la pata pardusca.

DISTRIBUCION GEOGRAFICA. - A excepcion de Inglaterra habita este hortelano ios Hanos de la Europa ten. plada y meridional á contar desde el sur de Suecia, y el Asia occidental. En invierno recorre casi toda el Africa hasta cl pais del Cabo.

USOS, COSTUMBRES Y REGIMEN.-Nunca aban. ciona los cañavemles, y aun en sus viajes no deja las aguas. En su patria ó localidad donde anida aparece a fines de abril y permanece à lo mas hasta fin de scticmbre.

Apenas se presenta en nuestros paises, por la primavern, óyese resonar el canto del macho descie que brilla ia aurora hasta la puesta del sol, y durante el primer tiempo toda la noche. Su canto comprende varias frases muy rariadas, compuestas de notas llenas y fuertes: ol hortelano turdoideo debe apropiarse seguramente el grito de la rana, pues los sonidos que produce ofrecen tanta semejanza con su canto, como con el de otras aves. No sabe emitir una ruta dulce $y$ aflau. tada; todo su canto se reduce á una especie de rechinos y se podria expresar por las silabas darre, darre darre, karri karri, kerr keor kerr, kej kei kei, kerrre karre, kit; y sin embargo, estos sonidos, que se repiten, no son demasia. do desagradables; tienen algo de alegre $y$ bonachon, y parece que el ave esta contenta cuando los emite. Por otra parte, alli donde se ofen no canta ninguna otra ave; solo el des. agradable grito de las especies acuáticas viene a herir algunas veces el oido, circunstancia que inclina al observador a juz. 
garia mas favorablemente. En cuanto á mí, me place mucho oir al hortelano; su canto no me admira, pero siempre me agrada; à otros obșervadores les sucede lo mismo.

Los movimientos del hortelano turdoideo no tienen menos atractivo: el macho canta afanosamente, cual si quisiera risalizar con el ruisenor: tiene el cuerpo derecho, colgantes las alas, la cola extendida, dilatada la garganta, y el pico al aire; se posa sobre una caña balanceada por el riento, y eriza de tal modo sus plumas, que parece mayor de lo que realmen. te es.

Procediendo lo mismo qque los otros calamoherpinos, el hortelano surdoideo no anida hasta que las cañas alcanzan el desarrollo suficiente para ocultarle, lo cual se verifica hácia fin de inajo ó meàiados de junio. Le gusta la sociedad de sus semejantes, y comunmente se encuentran ranas parejas re unidas en una misma localidad, al borde de un pequeno estanque. El nido se talla siempre sobre ia superficie del agua, entre dos canas cuyos tallos están conprendidos en sus paredes.

\&Está colgado, dice Naumann, entre cinco ó seis colum. nas salientes, á cosa de un metro sobre ha superficie del agua; jamås se nalla hácia la periferia del grupo de juncos, sino á menudo muy despejado y por lo comun encima del agua.\$ Observadores concienzudos han visto que en ciertos años hacian estas ares su nido á mayor elevacion que de costumbre; y mucho tiempo despues de terminar su trabajo, llovió copiosamente; subió el nivel de las aguas mucho mas qque de costumbre, y los nidos quedaron encima, mientras que de otro modo habrian quedado sumergidos. Alguna que otra vez, y no precisado siempre por las circunstancias, establece el hortelano surdoideo su nido fucra de los cañaverales, en un matorral $\delta$ evitre los juncos de algun estanque, y se habitúa hasta al ruido de los trenes de ferro-carril que pasan junto á su nido.

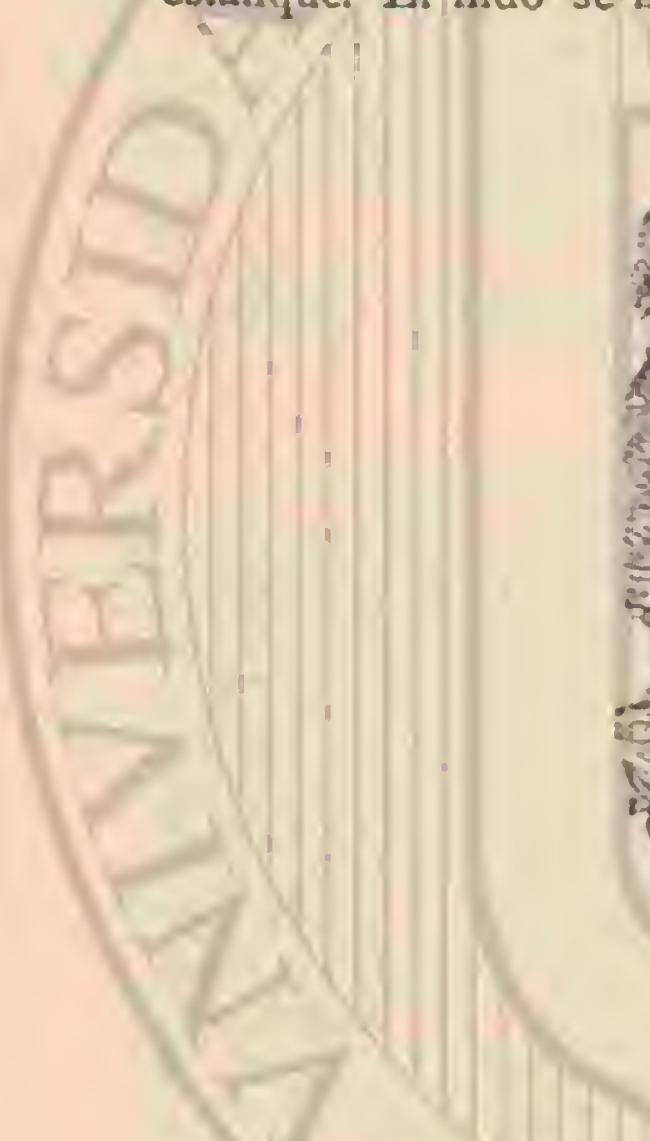

El nido del hortelano turdoideo es mas alto que ancho; sus paredes gruesas, yel borde de la cavidad doblado hacia adentro; las paredes se componen de capas de hojas, y de tallos de yerbas secas, tanto mas finas cuanto mas interiores: el interior está cubierto de pequenas raices. Segun la locali. dad, emplea el ave diversas hojas; las cintrelaza con filamen. tos de corteza de ortiga, pelusilla de ciertos granos, telas de araña, hilos de lana y de ciñamo; $y$ forma algunas reces una capa de briznas de yerba seca, flores de romero y crines de caballo. La puesta se verifica hácia mediados de junio: la hernbra pone de cuatro $\left\{\right.$ cinco huevos de $10^{\circ}, 022$ de largo por $\left(1^{\circ}, 015\right.$ de difmetro, de color azulado ó de un gris verdoso, sembrados de puntos, manchas $y$ salpicaduras de un gris pizarra $\delta$ de color pardo aceitunado. 1.os padres cubren afanosantente por espacio de catorce $\delta$ quince dias; pero no se les ha de inçuietar, pues abandonan la pollada cuando se visita demasiado pronto su nido. Al salir los pequeños á luz, macho $\mathrm{y}$ hembra los alimentan de insectos, manifestándose muy cariñosos con ellos; les advierten los peligros que les amenazan, $y$ los guian mucho tiempo despues de haber em. prendido su vuelo. Los hijuelos abancionan el nido, cuando solo pueden trepar; á fines de julio se declaran independien. tes y prepáranse á emprender sus emigraciones.

CAUTIVIDAD. - Los hortelanos turdoideos son aves muy agradables en jaula, bien que delicadisimos: una vez 'acostumbradas al nuero régimen se distinguen por su aseo y gustan a todo el mundo por su agilidad, viveza y canto, que repiten con ardimiento. Los hay que se vuelven muy mansos. Para cogerlos se fijan palos con travesaños y lazos entre las canas.

\section{EL HORTELANO DE CAÑIZAL - AGROCE- PHALUS ARUNDINACEUS}

CARACTÉRES. - Es el retrato en pequeño del hortelano de rio 6 curdoideo; mide $11^{\circ}$, it de largo, $11^{\circ}$, 2o de punta a punta de ala, esta plegada $11 \%, 065$ y la cola $\left(0^{\circ}, 058\right.$. El dorso y las orlas exteriores de las rémiges y rectrices, de color pardo, son de un pardo rojizo de orin aceitunado; en la rabadilla y las tectrices caudales superiores es cl color mas subido; la parte inferior del cuerpo es blanco-amarillenta tirando a orin; la barba y la garganta tienen un matiz mas claro y mas blanco; la linea naso ocular, el loino, los costa. dos del cuello y del tronco asi como las cobijas sub alares s sub-caudales; son de un amarillo orin muy viro. El circulo que rodea el ojo es parúo oscuro, el pico pardo de cuerno, y rojo anaranjado en el borde de la boca; finalmente la pata es pardusca, color de asta.

DISTRIBUCION GEOGRAFICA. - Desde el sur de Suecia y del mar Blanco se extiende esta especie por ioda la Europa y el Asia occidental y anida hasta en los paises del Atas. En su emigracion atraviesa toda el Africa basta el cabo de Buena Esperanza. En Alemania habita localidades análogas $\{$ las de su congenere major pero se extiende mas j sigue aumentando en número $\because$ dilatando su área de dispersion.

USOS, COSTUMBRES Y REGIMEN.--Cuando aban. dona sus cuarteles de invierno á mediados de abril se di. rige poco á poco al norte, de suerte que á fines de mayo yaun a principios de junio se te puede ver todavia viajando. Vive siempre cerca del agua, por lo reguiar entre las 
cains, pero tambien se establece en los matorrales y aun en los árboles proximios con mas frecuencia que el hortelano turdoideo. Sus cualidades é indole se parecen mucho á los de la especie afine, lo mismo que su canto, solo que los to. nos son mas altos. Un sonido semejante i un chasquido dado con la lengua y que puede imitarse por checke, es su grito de llamada, y otro seco como de cigarra, que suena charr, indica inquieiud $\delta$ disgusto. Pero el canto que se oje mas, es decir, todo el dia, desde el amanecer hasta entrada la noche sin interrupcion, puede cxpresarse con las silabas: firi, tiri, lirr, tir, lir, tseh, tsek, Isek, Isek, Iser, Iser, \$ser, liri, liri, cherk, sherk, shers, wit, ait, it, tret, lrel, lrel.

El nido se halla por lo comun, como el de su congẻnere mayor, entre calas; se compone poco mas ó menos de los inismos materiales, y tiene igual forma, solo que el tejido es mas flojo, y el interior está tapizado mas á menudo de lana vegetal, y alguna que otra vez de musgo verde $\sigma$ hilacha de orugas. Los tres ó cinco huevos que se encuentran a mediados de junio miden por término medio 1$)^{\prime \prime}, 019$ de largo por $0^{\circ}, 01+$ de diámetro, yo presentan sobre fondo verdoso ó blan. co ceniciento, manchas mas o menos numerosas de color gris ó pardo aceitunado ó ceniciento. Macho y hembra alternan en el trabajo de incubacion que cumplen con exquisita solicitud. A los trece ó catorce dias nacen los pequenos ¿ los que alimentan sus padies y no abandonan el nido antes de poder desplegar el vuelo; por manera que desde el primer dia viven ya como los viejos con los cuales vagan errantes por la comarca i fines de julio ó en agosto hasta em. prender su viaje al sur.

\section{EL HORTELANO PALUDICOLA Ó DE ES- PADAÑAL-ACROCEPHALUS PALUSTRIS}

CARACTERES. - Es mas grande que la especie ante. rior de la cual se distingue con la mayor facilidad por sus alas mas largas. Su longitud es la misma, de $11^{\circ}, 14$, pero el ancho total es cuando menos 11,21 ; el ala plegada mide ()$^{m}, 06$; y la cola $11^{m}, 060$. I.a linica diferencia que ofrece. 12 coloracion consiste en que el plumaje de la parte superior tiene un viso diáfano gris accitunado en lugar de pardusco de orin como en la especic anterior, y además en que la rabadilla tiene el mismo color que el resto del dorso. Difiere tambien en el pico algo mas corio y mas robusto, y en la pata quue es unos $0^{\circ}, 00 . \mathrm{p}$ mas corta.

DISTRIBUCION GEOGRAFICA. - El irer de dispersion de este hortelano no llega al norte tanto como la del otro, ni el ave extiende su emigracion al sur tanto como cste.

EL HORTELANO PODENA-AGROCEPHALUS DUMETORUM

CARACTÉRES.-Difiere este hortelano del anterior por la coloracion oscura, de matiz pardo accitunado amarillento, por su pico algo mas largo y por la difurenie estructura del ala.

DISTRIBUCION GEOGRÁFICA.-Kcemplazaal anterior en el noroeste de Rusia y desde alli en los diferentes patses del Asia, en Nepal y Asam hasta la India.

\section{EL HORTELANO ENANO - ACROCEPHALUS SALICARIUS}

CARACTERES. - Esta especic poco conocida todavia, puede pasar como la anterior por muy afine del hortelano paludicola ó de espadanal; tiene fama de excelente cantora y mide $0^{*}, 124$ de largo; el ala plegada $6^{\circ}, 065$ y la cola $0^{40}, 053$. El color es gris amarillento tirando á orin en la parte supe. rior del cuerpo, pero algo mas oscuro en la coronilla, $y$ un poco mas claro en la region coxigea; la parte inferior es de un blanco amarillento de orin, lo mismo que una linea bien determinada sobre el ojo; la barba y la garganta son blanquizcas, y los costados del cuello y del ironco de un anarillo orin palido; las rémiges tienen color pardo gris, con orla exterior amarilla de orin; $y$ las rectrices son pardas con inte de orin, llevando en el extremo un filete estrecho de color pardo de orin claro.

DISTRIBUCION GEOGRÁFICA.-Fista ave, que se ha cogido una vez en Heligoland, habita en el este de Europa y en la Siberia hasta China.

USOS, COSTUMBRES Y REGIMEN DEL HORTELANO PALUDICOLA.- No son solo los caractéres enumerados los que dan śt tata ave el sello de especie indepen. diente; la confrman tambien el sitio que habita y su canto precioso. Bien diferente de las demás especies de la sub. familia, se establece apenas ha llegado,- 10 que nunca sucede antes de principios de inajo, en algun matorral bajo y pa. lustre á orillas de un rio, arroyo, acequia, estanque ó lagu, donde crecen juncos, espadarias y otras plantas acuáticas, 6 bien ortigas, ó donde abunden pastos, prados y campos de cereales. En es:os matorrales pasa los cuatro meses que estí entre nosotros sin preocuparse gran cosa de los cariizales. Fl árbol donde suele habiar es el sauce coronado para aprove. char sus flexibles ramas y las enredaderas de toda clase que cubren el tronco en medio de otras plantas lozanas y espigadas. Desde alli hace sus excursiones á otros árboles y a los campos vecinos, particularmente á los canamares ó sembrados de nabina oleosa; rarisima rez se mele entre jun. cos y espadanas á no ser que crezcan junto á su matorral. Es ave sumamente sociable como la mayor parte de los hortela. nos, y le gusta tener otras parejas de su especie por vecinas inmediatas, de modo que en el trecho de cuatrocientos pasos, dice Altum, es facil encontrar hasta siete ú ocho nidos. Naumann le describe como pajaro muy lindo, alegre, inquie. to, pronto en sus movimientos, ora ande d saltos, ora pase volando por las breñas y matas mas espesas ć intrincadas; cs arrojado y valiente cuando se bate con sus congéneres, sien. do sus costumbres, y en esto están acordes con Naumann otros naturalistas, una mezcla de las que son propias a los hipolais y'a los calamoherpinos. 'Trepa y se agarra, dice este autor, con la destréza de estos y vuela mejor. A menudo hicnde el aire en linea oblicua saliendo de entre las ramas de algun árbol bastante alto para meterse entre las matas bajas, y otras reces se eleva del suelo à gran altura, ó. viela de un arbol á otro bastante distanic en linea recta con la mayor soliura y sin vacilacion, no ya cerca del suelo sino á cualquiera altum. Siempre esti en movimiento, saltando de una parté â otra, ó trepando hasta la punta de la última ramita de su mata ú ocultándose en lo mas espeso del follaje. Con el hombre se muestra muy cauto, calla apenas le ve venir, aunque esté en lo mejor de su canto, y se desliza con tanta habilidad y precaucion, que desaparece sin que sea posible atisbarle ya en ninguna parte. El canto que mas se parece al suyo es el del hipolais, pero a pesar de su sonoridad y fuerza es extraordinariamente suare y delicado; sin desmentir a pesar de esto el carácter del hortelano que al punto se distingue, segun dice Altum, porque no se descuida de interpo. lar de una manera ú otra el caracteristico ter, ler, /sir, firr, firi. "La base de su canto se compone de una docena de roces y.notas de otras aves, mezclados sin órden; siguense los fragmentos de los cantos y llamadas del tordo cantor, de la curruca de jardin, de la golondrina ahumada, de la codor- 
nir, de la pizpita y aguzanicves, del paro de huerto, de los gorriones de campo y de poblacion, del jilguero $y$ de los fringilidos, de la alondra y del sita, y hasta incluye á veces el canto de la rana acuática; pero no enlaza todas estas roces sin concierto y con dureza, sino como quien las posee en propiedad; todas refinadas por su precioso órgano, forman un conjunto nuevo, que constituje un canto propio y que sale de su giarganta con la mayor naturalidad, sin pausas, sin incertidurnbre ni vacilacion y mientras $\mathrm{el}$ ave se halla ocupadisima en la persecucion de algun otro objeto, dealgun rival $\delta$ de un insecto, irepándo ó deslizándose cntre el ramaje. No conozco ave mas maestra en-el canto entre todas las de nuestro pals. Verdad es que este no extasia como el de la alonda de campo, ni se oje ₹ tan gran distancia, ni jgualará jamas al del ruiseños comun ó al de su congénere mayor: pero th́mpoco alcanzara ningun ave la maestria en li imitacion unida al colorido armónico, a la fierza ysonoridad llena de dulkun del hortelano paitudicola. Empieza este a cantar en las noches que no hay luna, cuando las demás aves cantoras djurnas callan; luego à las diez sucede una pausa que dura hasta las once, y entonces continua cantando duminte lo/que queda de noche, bien que las frases no tienen el filego ni la rápida sucesion de las de la maüana. De dia solo calla cuando el sol se acerca al zenit:

El nido no se halla siempre en 10 mas denso de la espresu. ra que ha elegitio por morada, sino con mas frecuencia en el lindera del matorral, à menudo en breñas ó matas que bordean algun scndero, y nunca sobre el agua, pero si á poca altura del welo. En su construccion se asemeja al de sus congéneres, y tambien se halla fijado entre dos vastagos verticales ó tallos de yerba que ofrezcan la resistencia necesaria: ran vez se encuentra colgado de una sola nama. El cuerpo principal se compone de hojas secas, brimas y tallos finos de yerba, fibras corticales de ortigas, acaso nezcladas con hila. cha de orugas $\dot{u}$ otras materias filamentosas animales, todo bien enlazado y amasado. Crines y yerbitas finas forman el interior. Ioss cuatro, hasia cinco, $y$ á lo mas seis huevos de la puesta, que son de cáscara lisa y delicada, miden ll ; o is de largo mor 1$)^{m}$, or \& de dímetro, y presentin sobre rondo gris azulado of blanco arulado manchas bastante grandes, of veces meclio borradas, de color ceniciento, aceitunado ó par. do oscuro, y acaso puntitos y lineas negras parduscas, dis. puestas de un modo itregulary variable. La incubacion se verifica del modo que he descrito al hablar del hortelano de canizal, quighs con la diferencia de que los polluelos abando. nan el nido mas pronio, pero sin salis al principio de la espe. sura, limitándose á andar á saltitos y deslizarse por entre las breñas. No les faltan enemigos que los persigan, y entre ellos figura el hombre, que destruye sus moradas.

CAUTIVIDAD. - Se domestican con facilidad y extasian con su canto incomparable á cualnguier anicionado que busca aigo mas que entretenerse en descubrir en su pinzon de espe. cie exótica algun movimiento nuero of graznido no notado aแก.

\section{EL HORTELANO DE LOS JUNCOS-ACROCE- PHALUS PHRAGMITIS}

CARACTÉRES. - Sucle considerarse esta especie, corno representante de un subgénero especial llamado Calamodus. Su longitud llega á $0^{\circ}, 1$, el ancho total à $0^{\mathrm{\prime}}, 20$; la del ala plegada á $10^{\circ}, 0 \sigma_{3} y$ la de ?a coln $\left\{0^{\circ}, 05\right.$. Ia parte superior del cuerpo es de un color pardusco leonado, lo mismo que las orlas estrechas de la parte exterior de las rémiges; las co. bijas alares y las rectrices son de color pardo oscuro; la raba. dilla $y$ las cobijas caudales superiores de un pardusco de orin: la espaldilla y el lomo tienen manchas lineales en el tallo de las plumas; la parte superior de la cabeza presenta en el cen. tro sobre fondo pardo negruzco una lista longitudinal pardusca leonada y listada de un tinte mas oscuro, $y$ otra lista ancha sobre los ojos, y la linea naso-ocular tiene tambien una lista angosta que pasa por el ojo. Los costados de la cabeza y la parte inferior del cuerpo son de un color delicado amarillento de orin, que es rnas claro y mas blanquuizco en la gargantr, vientre y cobijas caudales superiores. El circulo del ojo es pardo claro: el pico en la parte superior negro de cuerno, $y$ la inferior, como iguslmente el pié, gris (fig. 222).

DISTRIBUCION GEOGRÁFICA.- Esta especic ocupa un área de dispersion muy grande, puesto g̨ue se extiende deșde los $68^{\circ}$ de latitud norte por toda la Europa, y desde la misma latitud á poca diferencia por la Siberia y Asia occi. dental.

\section{EL HORTELANO DE LOS TARAYES-ACRO- CEPHALUS MELANOPOGON}

CARACTÉRES. - Tiene el dorso pardo rojizo, con manchas longitudinales oscuras en las plumas de la espaldilla y nanto; oira longitudinal tambien producida por las orlas la. terales claras, pero mal determinadas, en la parte media de in cabeza, y una linea ancha que pasa desde las fosas nasales a la region tempóml, de color negro pardusco en el sitio de Ia linea naso-ocular, y amarillenta con matiz de orin en el resto; la region subj-orbital es pardusca oscura; la barba, gar. ganta y cobijas alares inferiores son blancas; el resto de la parte inferior del cuerpo tiene un tinte amarillento de orin, mas oscuro en los costados. Las rémiges y rectrices son de color pardo oscuro con oria estrecha leonada con matiz de orin en la caral exterior, orla que se va ensanchando y pasando á pardo rojizo en las rémiges secundarias.

DISTRIBUCION GEOGRAFICA.-Vive en el mediodia de Europa y en el sudeste de Asia; empieza a verse ais. ladamente en la Hungria meridional y norte de Francia, pero es ya frecuente en Italia.

USOS, COSTUMBRES Y RÉGIMEN.-El hortelano de los tarayes habita con preferencia los pantanos, las orillas de las corrientes de agua y mas á gusto todavía los sitios donde crecen con abundancia los juncos y otras plantas pa. lustres de hojas delgadas y angostas. Se le ve asimismo en los campos cruzados por fosos de desagíc que crian espadanas, y en una palabra en terrenos de juncos $y$ no de cañas. Solo en invierno busca las brenas y los estannques cubiertos de cañas en una gran parte de su extension en las llanuras del Africa donde crece la halfa.

Se presenta en nuestros paises hácia fines de abril $y$ nos abandona en octuhre, si bien se encuentran todavia en no. vicinbre algunos individuos rezagados. Pasa el invierno en el centro de Africa; mas no se sabe hasta dónde penctra en el interior de este continente; á veces se ven algunos que se extravian hasta el alta mar: Burmeister vió cierto individuo que se posó en el palo de un buque á la altura de Buenavista.

El hortelano de los taraýes arentaja a las especies de ca. lamoherpinos citadas hasta ahora por su destreza en deslizarse por las breñas mas espesas é intrincádas, éiguala bajo este concepto á las locustelas. Con la agilidad del raton se mueve en la espesura mas densa y enmarañada ó corre debajo de clla por el suelo, y no es menos diestro en cl ruelo que eje. cuta tan pronto revoloteando suavemente como produciendo un fuerte zumbido con las alas; ó bien volando cual si diera saltitos, siempre haciendo $S \mathrm{~S}$, airaresando raras reces grandes distancias y precipitándose casi siempre sobre los juncos 
en linea recta. Alli se siente tan saguro que desecha todo temor, sin hacer caso alguno de la persona que se acerca; de modo que cuando esta se halla ya à diez pasos de él, cs capaz de subir $\{$ la punta de una mata para cantar alli sin el menor cuidado; asi sucede que al momento reaparece cuando un poco antes habia desaparecido por algun motivo entre las breñas. Su grito de liamada es una especie de chasquido, y otro sonido ronco como char representa su disgusto. Un graznido, especie de cui suá, expresa su angustia; su canto, que es agradable, se distingue por un trino largo, aflautado y alto que repite muchas veces. Sa parece en general al canto de otros calamoherpinos, pero por otra parte tambien al del aguzanieves y de la golondrina ahumada, y tan grande es su variedad que bien puede comparársele con el de algunas cur. rucass.

Por lo general vive oculto y retirado el hortelano de los juncos; solo en el periodo del celo se pone i descubierto: entonces se le ve posado en la exiremidad de una rama, lan. zando al aire su canto, como para provocar a sus rivales.

La curiosidad le impele tambien a salir de su retiro algu. nas veces: si se obliga a un perro de muestra á registrar el zarzal donde se halla el ave, esta sube hasta la copa, se para un instante para examinar los alrededores, y desaparece luego con la rapidez del relímpago en la espesura. Cuando la espantan vuela, mas no por mucho tiempo; para dirigirse de un punto á otro, que esté algo lejano, lo hace rasando la superficie del agua 6 de la tierra: solo cuando emigra se re. monta a bastante altura.

El hortelano de los juncos está todo el dia en movimien. 10; el macho solo permanece tranquilo cuando canta; elige una rama para posarse, y a clla vuelve sienapre. Acomete con violencia á las demás ares, y no tolen que ninguna se pose en la misma rama que él.

Cuando la hembra cubre, el inacho canta todo el dia, sobre todo á la hora del crepúsculo matutino; se oye tambien su voz en las hermosas noches de luna, y anima de este modo muy agradablemente sitios donde generalmente no resuena el canto de ninguna otra ave. Cuando está en celo, todos sus movimientos se inodifican, yo ya no se la reconoce. lilévase entonces, particularmente cuando el tiempo es hermoso, oblicuamente por los aires, dando algunos alerazos á largos intervalos se cierne con las alas tan alzadas qque sus puntas se tocan; luego se deja caer súbitamente, cantando á cuello tendido, y erizando sus plumas de tal modo, que pa. rece una bola: si el tiempo es bueno, repite la misma manio. bra varias veces seguidas.

Se alimenta de insectos, como sus congeneres; j: tambien come diversas bayas.

Construye su nido en sitios muy diversos y por lo regular poco accesibles entre las alias yerbas y los juncos, siempre en alguna espesura, léjos de la orilla, dentro de los pantanos, y à menudo tambien en terreno muy secano y á la distancia de ciento á doscientos pasos del agua y en terreno arenoso con tal que crezcan matas y yerbas alli á una altura de medio metro, cuando mas, entre mimbres ó tallos robustos de ortigas yotros En la segunda semana del mes de majo empieza a construir empleando extcriormente yerbas secas, hojas verdes, rastrojos, raices y musgo, y para el interior crines y plumas. La puesta consta de cuatro à seis huevos, de forma y tamaio variable, largos de $\left(1,8,7\right.$ por $0^{\circ}, 12$ de grue. so, con un extremo romo y el otro puntiagudo; son por lo regular de color gris blanquizco, sembrados de manchas, juntos y lineas mas ó menos marcadas, de un tinte gris ó gris pardo, dispuestas a menudo con bastante regularidad. Macho y hembra cubren alternativamente con la solicitud exquisita particular a todos los hortelanos. Entonces son menos esquivos que en otms épocas; vuelan cuando dan de comer a los pequerios trayendo en el pico mariposas y libelulas sin cuidarse de si álguien esta cerca y los observa; y en general si abandonan el nido es solo en los primeros dias de incubacion.

Si se acerca álguien con prudencia al rido mientras la hembra cubre, permanece esta inınóvil, y no huye sino en el último extremo. F! macho no manifiesta tanta inquietud. «Por mas que un peligro amenace a su cria, dice Naumann, y aunque muera la hembra, no por eso deja de cantar y juguetear. Sus movimientos varian, no obstante, cuando salen i2 luz los hijuelos: entonces vuela inquicto por los rastrojos, trazando algunos circulos de escaso radio; su canio es corto, y de vez en cuando lanza un errr mas expresivo.s

En cuanto á la hembra, pierde por completo su timidez natural, y no le importa ponerse á descubierto en la punta de una caña los hijuelos dejan el nido cuando pueden volar bien, pero no se sirven de las alas durante algun tiempo, sino que se les ve correr por medio de las yerbas i la manera de los ratones.

CAUTIVIDAD. - Raro es encontrar un hortelano de los juncos cautivo, no porque ofrezca dificultad acostumbrarlos a la cautividad, sino por lo dificil que es cogerlos. Cuando se consigue conservarlos, pierden pronto su matural salvajis. mo: no son tan delicados ni aleminados como sus congéneres; y apreciadisimos por su carácter alegre, su gentileza y la suavidad de su canto.

\section{EL HORTELANO ACUÁTICO-ACROCE- PHALUS AQUATICUS}

CARACTÉRES. - Es la especie mas afine à la anterior. Mide $11^{\circ}, 13$ de largo, $U^{\circ}, 19$ de punta á punta de ala, esta plegada $0 \div, 058$ y la cola $\left(0^{\circ}, 047\right.$. El color general es el del hortelano de los juncos con la diferencia de que el manto y las espaldillas ostentan en los tallos de sus plumas una linea longizudinal oscura bien determinada, y la lista mas clara en la parte superior de la cabeza no es confusa, sino bien visi. ble y décolor parcio leonado; las partes inferiores son de un amarillo de orin mas vivo, y en las plumas del buche $y$ de los costados, la linea del tallo es muy fina y oscura.

DISTRIBUCION GEOGRÁFICA.- Eil área donde esta especie anida comprende la Europa meridional y central, el Asia occidenial y el noroeste de Africa, inclusas las Canarias. En Alemania vive en las mismas comarcas que su congénere de los juncos, pero en núinero menor que este, como sucede en toda la Alemania del norte en los puntos que responden mas á sus necesidades.

USOS, COSTUMBRES Y RÉGIMEN.-Habita esta ave las llanuras dilatadas, húmedas, cubicrtas de yerba y atravesadas por acequias, zanjas y otras corrientes, con ma. torrales aislados de trecho en trecho. Tierras turbosas y jantanosas y balsas, son los puntos que busca para anidar. Blega y se marcha junto con su congenere citado, al que se aseme. ja muchisimo no solo en la coloracion sino tambien en índole y género de vida. Como êl, vive oculto, se desliza con la mis. ma destreza al través de la vegetacion mas enmaranada; cor. re, trepa, vuela, se precipita al final de sus vuelos cortos verticalmente en tierra, y por último en su grito de llamada y en casi todo se parece al hortelano citado; únicamente di. fiere de él algo en su canto; pero es dificil representar esta diferencia con palabras. Paessler dice que se puede encontrar el nido de este hortelano hŕcia fin de majo con cinco ó seis huevos, muy oculto entre juncos, en la yerba, detrås de algun monton de cualquier cosa como tierra, rastrojos, etc., $\delta$ colgado de algunos tallos al borde de una zanja cerca del agua 
Es bastante mas pequeño quue el de su congénere, pero hecho con los mismos matcriales, $y$ á veces tambien con raicillas pardo-negruzcas y blandas, pero mas comunmente con tallos de yerba $\delta$ de grazmilla de carrizo mezcladas acaso con algunas crines. Los huevos son algo mas pequeíos, mas claros y mas- lisos y relucientes que los de su afine mencionado repetidas veces, $y$ á menudo cubiertos de línens pardas tan finas y poco marcadas, que todo compone. á primera vista un color uniforme. Fl macho ayuda poco a la hembra en la incubacion, supliendo ella este defecto con su celo y solicitud y aferrándose tanto sa la puesta que no huse siro en el uiltimo momento de peligro.

Los hijuelos nacen a los trece dias y al cabo de tres senianas mas abanconan el nido la familia continu entonces por mucho tiempo unicta, aunçue no muy intimamente, re. corriendo la comarca hasta que for fin emprende á principios de agostó su viaje hácia sus cuarteles de invierno. Altum cita á un tal Bolsmann, curá párroco en los alrededores de Muns ter (en Westralia) que ha observado durante muchos años hortelános de esta especie en su paso hácia el sur, el cual efectuabian casi siempre el dia 9 de abril, alguna ver por excepeion el $S$ b el 10 del propio mes, pero pror el mismo sitio.

\section{LAS LOCUSTELAS - LOCUSTELLA}

CARACTERES. - Ias aves que componen este grupo díferen de las otras especies de la fimilia lo suficiente para justificat su reunion en un género especial. Fl cuerpo es es. belto, el pico ancho pero hácia la punta en forma de lezna, la pata es bastante alta y los dedos largos; el ala es corta y redondeada con la segunda y tercera résniges mas largas que las otras; la cola mediana, ancha y escalónada; las cohijas inferiores son muy largas y el plumaje restante es fino y blan. do. Ta coloracion presenta un verde pardusco con manchas mas oscuras en ell lomo y parte anterior del pecho.

\section{LA LOCUSTELA MANCHADA - LOCUSTELIAA NAETA}

CARACTÉRES. - Esth especie viene 1: ser el tipo del grupro. Mide $\left(-, 135\right.$ de largo por ()$^{*}, 1, y$ de junta a punta de ala: esta plegada $n, 063 \mathrm{y}$ la cola $n^{*}, 048$. El color es en el dorso pardo aceitunado con manchas négras parduscas, pe. queñas $y$ redondas en la caheza, $y$ otras anchas en forma de flecha en el manto y espaldilla; la parte inferior del cuerpo es de un tinte anarillo de orin pálido, mas claro tirando á hlanco en la barba, garganta, parte inferior del pecho y en medio del vientre. En el buche se ven lineas finas y oscuras en los tallos de las plumas; las cobiias sub.caudales tienen en los tallos otras manchas anchas y un tanto borradas. Las rérniges son pardo negruzcas con filetes estrechos en los bordes de un gris accitoso que se cnsanchan hácia la raizi el tinte de las rectrices es un gris pardo rerdoso con bordes mas claros y por lo regular con listas trasversales mas oscu. ras. El ojo es de un color pardo ceniciento, el pico color de cuerno y la pata de un rojizo claro (fig. 223). Fn otoño tira la parte inferior mas à amarillo, y los pequeños tienen manchas en el pecho.

DISTRIBUCION GEOGRÁFYCA. - Ia locustela man chada se extiende desde Suecia y Rusia por toda la Europa central y visia durante su paso el mediodia de nuestro con tinente ó el roroeste de Africa.

\section{LA LOCUSTELA LANCEOLADA-LOCUS- TELLA LANCEOLATA}

CARACTÉRES. - Se pareceesta especie mucho a la an terior, si bien ofrece tambien diferencias bastante notables que consisten en su menor talia, color fino amarillento de orin en la patte inferior, y manchas mas marcadas y mas densas que se extienden tambien á la barba y garganta.

DISTRIBUCION GEOGRÅFICA.-Esta ave habita la Siberia media y segun dicen tambien la Rusia meridional.

\section{LA LOCUSTELA LISTADA-LOCUSTELLA CERTHIOLA}

CARACTERES. - Mide $0^{\prime \prime}, 016$ de largo, $0^{\circ}, 075$ el ala plegada y (1) $^{m}, 06$ la cola. El dorso es pardo aceitunado con matiz gris, $y$ manchas anchas $y$ oscuras en los tallos que forman en la parte superior de la cabeza seis lineas longitudinales é irregulares, $y$ otras ocho en el lomo. La parte in. ferior del cuerpo es amarillenta tirando \& orin, blanyuizca en la gargania y'en medio del vientre; las cobijas sub-caudales tienen un tinte entre pardo, leonado $y$ orin con filetes biancos; encima del ojo hay una lista blanquizca; las rémiges $y$ recrices son pardo oscuras, aquellas con orla estrecha de color pardo leonado, inientras que estas están adornadas de siete fajas trasversales oscuras pero apenas perceptibles, $y$ además de un filete ancho $y$ mas claro en el extremo.

DISTRIBUCION GEOGRÁFICA. - Esta especie vive en la parte oriental clel Asia central. Háse muerto tambien un individuo en la isla de Heligoland.

USOS, COSTUMBRES Y REGIMEN. - Vive princi. palmente en terreno llano; pero prefiere ciertos sitios, $y$ asi, por ejemplo, jamís sê la ve en algunos puntos, al paso que es muy comun en otros: no se la encuentra en las montañas. En Alemania aparece hácia mediados de abril y se marcha á fines de seriembre Los parajes que elige para anichar son los pantanos, las praderas donde crecen matorrales de sauce, los rampos y los bosques. En unos sitios no se aleja del agua; ea otros le gusta un terreno seco; en aquellos prefiere verse rodeatio de juncos, en estos de maleza y espinares; lo primero que busca es donde ocultarse. Cuando viaja no se para tanto para escoger; se halla bien alli donde encuentre el terreno cubierto de vegetacion porque le of́rece innumerables escondrijos.

kCon su cuerpo recogido, su plumaje manchado y su rápida carsera, dice Wodzicki, representa esta ave á ios rasco. nes entre las cantoras. Se la ve correr por el suclo con agilidad, atravesar las charcas poco profundas, coger insectos acuáticos para llevarlos á sus hijuelos, saltar por las yerbas y gritar: un momento despues se aleja cantando, con el cuello tencido y la garganta dilatada, asemejándose entonces í un rascon acuático.

(No es fácil, dice Naumann, encontrar un are más aficionada al movimiento ni que viva al propio tiempo mas oculta; itene algo del hortelano, del troglodita y del pipi; corre sin cesar por lás mas enmarañadas espesuras, pasarido de un matorral a otro, y ocultándose siempre en medio de las altas yerbas pantanosas. Fs preciso q̨ue la sorprendan bruscamente para que se decida á salir de su retiro, $y$ aun asi no se aleja nunca mucho y vuela siempre rasando el suelo. Es tan ligera y vivaz como recelosa y astuta; por tierta anda con la misma gracia y ligereza que el pipi, y si la persiguen corre con la mpider del raton. En caso de amenazarlo un peligto, deslízase a través de las ramas y desaparece instantáneamente; anda con el cuerpo horizontal y el cuello tendido, ya menudo corre hácia atrás, agitanco la cola y toda la parte posterior del cuerpo. Si ve algo sospechoso se detiene, agita las alas, las levanta y baja alternativamente $y$ abre y cierra la cola. Cuando está tranquila ejecura todos los movimientos del hortclano, $y$ lo misno en el vuelo; no va por lo regular muy léjos, y traza en los aires una linea recta ligeramente ondula. 
da. Su vuelo parece vacilante é irregular, mas no deja de ser rápido; para posarse precipitase en una breña, y se deja caer antes de saltar al suelo.b

A pesar de esto, dicha ave, tan poro voladora en apariencia, atraviesa á veces distancjas de algunos miles de pasos de un solo vuclo, y como dice Hausmann, alternativamente á uno y otro lado, como un hombre que nada de costado. Su vuelo se parece al de la curruca de los espinares, solo que es mas apresurado y a cada impulso pliega el ave las alas contra la cola.

La locustela y sus afines se distinguen sobre todo pror su canto singular, que consiste en un trino único, prolongado, sin variacion y silbador, semejante al chirrido que producen los saitamontes con el movimiento de sus elitros. Si se quiere expresarlo por medio de letras puede admitirse que suena como sirrrrr ó cono sirrilirrilirril.

\&Es singular, dice Naumann, que este ruido, muy débil cuando se escucha de.cerca, se perciba desde léjos. En una tarde serena, una persona de buen oido le reconoce á mas de mil pasos.

M.Muchas veces, $y$ á todas horas, continúa Naumann, traté de sorprender á esta ave; he grasado noches enteras en el

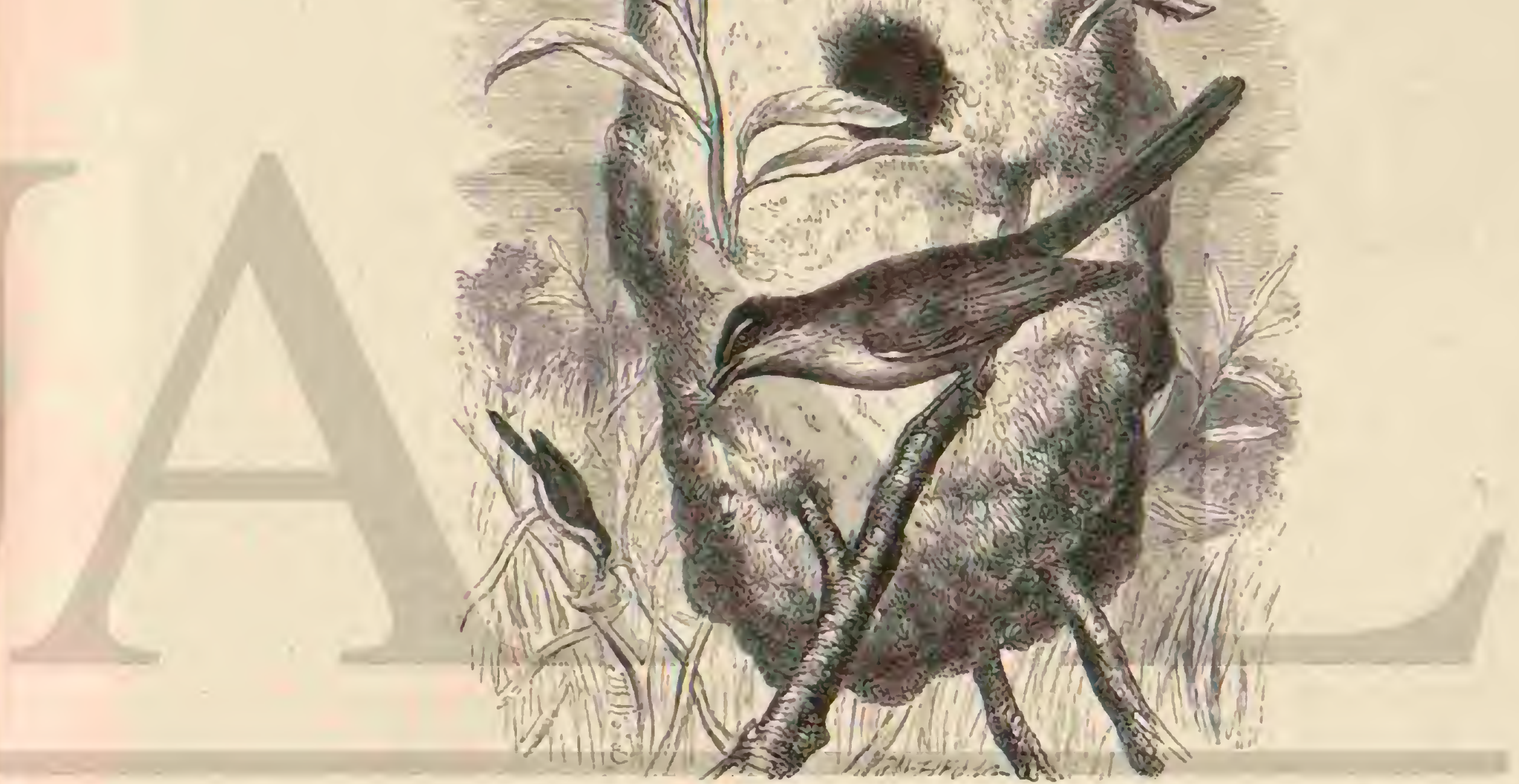

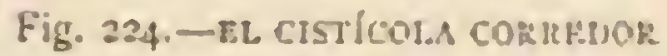

bosque, y siempre me causaba su canto una profunda im- cincuenta ó sesenta pasos del sitio donde le comenzó. Lue. presion: varias horas despues de haber abandonado uni ob- go permancee horas enteras en el mismo sitio, y lo mas que sermatorio, creja oirlo aun; una rama que se rompina, el céfiro que acariciaba las hojas, todo en fin me lo recordaba.s

Por lo regular pronuncia el macho su trino de una sola ver, y por espacio de un minuto. $\delta$ de dos y medio si está muy ardiente, segun lo he podido observar, escuchándole reloj en mano. Detienese algunos segundos, vuelve fi comen. rat, $y$ asi sucesivamente dumnte algunas horas. Cerca del. sitio donde se haila su nido, rara rez se le oye de dia, y solo por algunos instantes: tio canta hasta despues de ponerse el sol, y con un ardor que va en aumento hasta media noche; luego se calla, $y$ una hora despues da principio de nuevo, continuando hasta el amanecer. Cuando la hembra ha pues to permanece ol macho mudo todo el dia; no canta hasta eso de la media noche y apenas comienza á rayar el dia. Mientras que el nido no esté terminado, deslizase el ave á través de las ramas, y al concluit su canto, suele hallarse if hace es subir y bajar à lo largo de un talio ó de una rama. Este canto que nunca he tenido ocasion de oir descubre la locustela al observador atento, pues cuando ella cstá mas afanosa en chirriar no se oyen todavia las langostas, por lo cual no hay mas que seguir la direccion de donde viene el ruido para encontrar el ave. Hausmann dice lo que sigue: eEste pájaro no existe para nosotros sino cuando se le oye, atendido su modo de vivir oculto; y por lo que toca a la hembra, que siempre esta en el suelo entre las altas yerbas, no se la ve nunca i no ser que por una casualidad se pre. sente a la vista; no asi el macho, que por lo regular canta en sitios despejados y siempre llega un momento en que se le atisba.

El mismo autor, apojado en observaciones continuadas por espacio de muchos años, dice que cuando no se molesta al macho canta horas enteras posado en un mismo jumto 
con la cola caida verticalmente, el pico dirigido haicia arriba, la mandibula inferior batiente sin cesar y la garganta dilata. da. Este cantor singular domina y regrula á voluntad la potencia de su roz. Calla de repente cuando uno se acerca ála mata aislada en que está posado; y si el intruso aguarda cinco $\delta$ diez minutos, cmpjieza otra vez a chirriar, pero entonces parece proceder el sonido de una direccion muy distinta $\delta$ es tan bajito y amortiguacio, que es imposible averiguar dónde se halla el cantor. Hay veces on que el ave calla obstiuadamente durante muchos dias y casi semanas enteras; despues se la vuelve a oir solo por la-mañana, ó al medio dia ó à la caida de la tarde; pero por lo comun canta de no. che. Calka cuando hace sol y chirria cuando Jivere $y$ aun durante la tormenta deshechas es, en una palabra, cajurichosa á manera de artista céicbre, y eso que es dificil estar dotado de facultades mas pobres que las suyas.

Su régimen es anślogo al de sus congéneres y varia acaso solo segunl las circunstancias de la localidad que habita.

E! nido de la locustela manchada se parece mas que todos los de cualquier acrocéfalo al de la curruci, pero se halla invariablemente colocido en el suelo tanto si es seco como hứmedo, aunque lo fuese hasta el punto de que se sintiera la humedad inmediatamente debajo de los huevos. A veces está debajo de una pequeña mata, pero mas generalmente en la yerba cerca de una mata 6 de un tronco de arbol y admirablemente oculio. La forma es plana, la construcción muy sencilla s el único material de que se compone consiste en yerbas secas: la sola diferencia que ofrece, comparado con el de la curnica, esta en que la locustela emplea hojas mas anchas que aquella anto para el exterior como para el interior. Alguna que otra vez pone un paco de musgo en la base 1. a puestá se compone de cinco á siete huevos de $0^{\circ}, 017$ de largo por $10^{\circ}, 0.13$ de diámetro, de extremos desiguales, de cascara frágil y un poco reluciente, $y$ que presentan sobre fondo rojizo con viso ya amarillo, ya pálido, ya pardusco, manchas de color de violeta muy claro que provienen de la misma cascara y forman en ambos extremos una especie de aro mas 6 menos bien dispuesto y además puntitos pequenos de color rojizo azulado. Los pequeños salen â luz à los cr. torce dias de incubacion a poca diferencia, se desarrollan rápidamente, y abandonan el nido, por lo menos aquellos a quicries se ha inquietado, antes de saber rolar. Entonces desaparecen corriendo como rarones entre la espesura. Haus. mann dice que la locustela no hace mas que una cria al año si no se la molesta, pero Baldamus y Paessler dicen que se encuentra una cria hảcia mediados de majo, y otra hácia mediados ó fín de julio. En favor de esta última observacion habla el hecho de que cntonces se oye todavia el canto del macho. En la primera quincena de agosto abandonan los padres y las crias la localidad donde estaban pana dirigirse á tierras pantanosas donde abunda mas la regetacion, y de alli poco a poco a los cuarteles de invicrno.

\section{LA LOCUSTELA FLUVIAL - LOCUSTELLA FIUVIATILIS}

CARACTERES.- Tosta especie nide $\theta^{\circ}, 4+7$ de largo, $0^{\circ}, 235$ de amplitud de alas; $10^{\circ}, 073$ el ala plegada $0^{\circ}, 062$ la cola Ia parte superior del cucrpo y cara evterior de las barbas de las rémiges y rectrices son pardas aceitunadas con mati\% leonado; la inferior es mas clara, la garganta y el cen tro del vientre casi blancos; las orlas anchas, pero mal cefi. nidas, de las cobijas sub-caudales, que tienen un tinte pardo de orin, son de un blanco incierto: en la garganta y cabeza se notan manchas longitudinales de color parcio aceitunado muy bormdas. Eil circulo del ojo es pardo, la mandibula su. perior de color pardo de cuerno, y la inferior asi como la pata son de un amarillo de cuerno.

DISTRIBUCION GEOGRÁFICA.-Esta ave, muy ma en Alemania, habita el sudeste de Europa, el Asia occidental y el Africa oriental.

USOS, COSTUMBRES Y REGIMEN.-ES probable que la locustela fluvial sea en Alemania mas frecuente de lo que suele suponerse en el dia, porque es fácil que se la con. funda á menudo con sus afines, y no cabe duda de que se la ha encontrado á orillas del Elba, del Oder, del Memel, asi como recientemente por mi amign liebe junto $\{$ un afluenie del Eiba, el Goelisch. Mas comun es á orillas del Danubio inferiory medio, en Galizzia (Austria), Polonia y en toda la Rusia. I as noticias mas detalladas sobre el género de vida en libertad de esta ave las debemos a Wodzicki y Schauer, que la han obsèrvado en Galitzia Alli habita tambien en sitios bajos, como prados cubiertos de mimbreras formando claros en dilntados bosques de pinabetos, en olmedas de tierras huimedas circuidas de prados y otros sitios análogos, pero con mucha mas frecuencia en los talados de hayas, en las sierras donde crece exuberante un monte bajo entre cepas, raices y troncos viejos y podridos, y que forma junto con la alta yerba, plantas umbeliferas y zaraales, una espesura intrincada. No aparece antes de mediados de mayo en los sitios donde ani. da, hasta que la vegetacion esté bastante adelantada para ocultarla, ni cuando llega se establece en seguida en el punto donde piensa criar, sino que vaga primero por el pais jresen. tándose en sitios donde menos se la buscaria, como en jardines pequeños donde hay matas y setos de grosellas, y aun en vallados muertos y cercas hechas de nimbres; en estos sitios tan pocóá propósito para ocultarse lo logra sin embargo dicha ave, cuyo carácter principal consiste en su vida misteriosa y oculta. Hasta en el sitio donde tiene el nido, como por ejemplo en un prado cubierto á trechos de mimbreras, á duras penas se puede ver al macho en los momentos en que se cree perfectamente seguro, y aun entonces solo en ciertas ramas, sus sitios favoritos, donde mas le gusta cantar, a los que vuelve puntualmente cuando por alguna causa se ha ale. jado de ellos; por lo demás vive siempre escondido, vuela lo menos posible, y cuando lo hace atraviesa solo trechos cortos, dando alciazos iguales y con su rumbido correspondiente, siempre en linea recta, con objeto fijoy sin distractse. Es una verdadera esfinge. Cuando se le inquicta huye en seguicia, $y$ si álguien se acerca á él mieniras está posado, como es su costum. bre, en una rama seca y saliente de sauce, se deja caer inerte como una bala sin mover las alas, verticalmente, y sc oculta en la yerba donde se salva en pocos instantes, metiéndose entre lo mas denso, intrincado y enmarañado del matorral: una ve\% alli ya no hay medio de hacerle salir, ni aun con perro. Solo a) guna rer, cuando tiene toda su atencion fija en el canto, suele olvidar su seguridad y prevision caracteristicas, y permitir à la persona oculta que le observe y estudie su género de vida. Cuando cania hace los mismos movimientos que sus afines, sube á una rama que sobresale de las demás ó alza la cabeza con el pico dirigido verticalmente al aire abriéndole mucho, erizando las plumas de la garganta, y moviendo la lenguia de un modo especinl; lanza su trino, que consiste en dos tonos prolongados, uno bajo y fuerte, y otio mas alto y. débil que el animal produce, segun opinion de Schauer, tanto á la inspiracion como á la espiracion. Comparado con el trino de la locustela manchada, es el de la tluvial mas vigoroso, menos susurrador y mas seco, como el ruido que se produce al afilar un cuchillo en una piedra seca, y que podria repre. sentarse por la silaba iser, repetida sin interrupcion cincuenta ó sesenta reces, bien que el sonido es mas corto todavia y mas semejante al ruido que producen los saltamontes De 
cuando en cuando intercala el ave sugrito de llamada brusco a manera de chicharra y con cierto aire que tiene algo del canio del emberiza. Mientras está cantando, vuelve mas ó menos la cabeza de un lado á otro, con lo cual logra aumen. tar $y$ disminuir a voluntad la fuerza de vibracion de su canto. Cuando se traslada de un sicio á otro ó varia de puesto, ó solo cuando da un brinco, no canta. Si se cree seguro $y$ hace buen tiempo, se posa siempre en una rama seca y saliente de al. guna mata, nunca en la copa de unárbol; y si sorprendido se habia ocultado, vuelve á entonar desde el centro de la maia su canto, primero en frases cortas, interrumpiendose inuchas reces, saltando despues de cada trino y de cada pausa a una rama mas alta hasta que vuelve à hallarse poco á poco en su puesto favorito, donde si ve desaparecido todo peligro vuelve á cantar a cuello tendido. Tambien se le oye cuando hace mucho viento, $\delta$ cuando llueve poco, pero no desde su rama, sino en el interior de la mata, que entonces nu abandona. Como sus afines, hace la locustela preceder su chirrido de una especie de hipo particular, sobre todo despues de haber sido inter. rumpida; y otras veces no acierta á dar con la tonada, porque farece que tose y gargariza, se para y calla 6 solo prueba á emitir un trino suelto. Cada vez que el macho se para responde la hembra con un chic, chic; que expresa indudable. mente su satisfaccion, ya que manifiesta la ingujetud con otro sonido gutural que puede expresarse por $\mathrm{Cr}_{3} \mathrm{cr}$.

El nido se halla construido en el suelo, pero en sitio muy variable, ya en un matorral, ya entre el césped, ya entre las raices de afgun árbol. Fs de estructura muy desigual, tan pronto consistente en hojas bastas de espadaña unidas sin órden alguno y tapizacio interiormente de musgo y raicillas finas, como algo mejor trenzado y tejido, y tapizado con mas esmero, ó bien hecho de musgo y de jerbas finas y pe. quechas, y en medio de un monton confuso de los mismos materiales, de modo que el verdadero nicho se puede sacar de dentro independiente cel forro exterior. A mediados de mayo, y á menudo a ziltimos de este mes, empieza la hembra á poner sus cuatro 6 cinco huevos, y á incubar el $10^{\circ}$ de ju. nio. I.os huevos tienen $1^{m}, 02.4$ de largo por $0^{\mathrm{m}}, 018$ de diame. tro; son de forma variable y de color blanco, algo relucien. tes, con puntitos diminutos pardos ó anarillentos sucios que hăcia el extremo grueso se condensan en una especie de aro mal definido. El amor que la hembra muestra a su cria es tan grande que Wodzicki pudo dispararle tres veces sin to. carla y observar que a pesar de ello volvia al nido y conti. nuaba cubriendo; y eso que estas ares no son de ningun modo indiferentes al peligro, pues al menor ruido se oye el aviso: $r, o r$, chic tanto del macho como de la hembra, grito que repiten hasta que vuctien á estar tranquilos. Los peque. nos abardonan el nido cuando apenas les cubren las plumas y las rectrices empiezan $i$ salir; entonces corren como rato. nes entre la yerba gritando continuamente trif, rif, sin ca. llar aunque los padres les avisen algun peligro; nor fortuna engaña su voz tambien y de un modo extraurdinario al ob. servador mas práctico, y por esto se salvan.

\section{LA LOCUSTELA DE CARRIZAL-LOCUS-- TELLA LUSCINIOIDES}

CARACTERES.-Fsia especie, la tercen de este grupo interesante, mide $U^{\infty}, 14$ de largo, $11^{\circ}, 21$ de amplitud de alas, $0^{\text {"n }}, 067$ el ala plegada, y $0^{-}, 059$ la cola. La parte superio: del cuerpo es de un color pardo de orin accitunado; las ré. miges y rectrices son un poco mas oscuras; la parte inferior del cuerpo y una linea que pasa por el ojo, de un matiz. nuchisimo mas claro, son de un orin rojizo aceitunado; la barba, el centro del vientre $y$ las orlas confusas de los extre. mos de las cohijas sub-caudales son blanqquizcas con matiz de orin, y un la parte inferior de la gargania se obsurvan al. gunas manchas inciertas de color pardo de orin en los tallos de las plumas. El círculo del ojo es pardo oscuro; la mandibula superior negra pardusca, la inferior amarillenta $y$ la membrana de la base del pico color de carne.

DISTRIBUCION GEOGRAFICA.-- Esia ave, propia del mediodia de Europa, se encuentra tambien en la Galitzia austriaca, à orillas del Danubio, en la Rusia meridional, en Holanda, como igualmente en el Asia occidental y el Africa septentrional; en todas partes cmpero limitase á co. marcas especiales, y por lo que roca á Galitzia, en ciertos ahos se presenta en los sitios donde anida en paquisimo nú. mero, mientras que en otros sucede todo lo contrario.

USOS, COSTUMBRES Y RÉGIMEN.-Es, segun Wodzicki, un ave que tiene una preferencia decidida por los canizares de los que no se sejara nunca. Siempre en movimiento como sus afines, corre por el suelo y salta entre canas y carrizos sin parar. Jamás se la vera posada y quieta. En la primavera se divierte dando vuelos de reclano, y re. voloteando por el aire as la manera de las currucas y pipis, pero sin cantar, para echarse otra vez con las alas plegadas entre las canias. Mas confiada y sobre todo mas curiosa que la especie fluvial, se levanta del suclo y se posa sobre una caira apenas oye ruido, y desde alli contempla al parecer muy admirada al cazador y al perro, si eran ellos la causa. Lo que la caracteriza muy especialmente es su inclinacion realmente cxtraordinaria á la riña y pelea. In la época del celo se persiguen macho y hembra, ó dos rivales hasta a los mismos piés del cazador, sin hacer caso de los tiros; y cuando cantan no basta para hacerlas callar el peligro mas inmi. nente. Su canto es aun mas dificil de describir que el de sus congéneres, dificultad tanto mayor cuanto que es imposible oirlo con claridad por el susurro continuo de las canhas, y además porque su voz, con todo y ser la mas agradable, es tambien la mas débil de las tres especies de locustelas, tanto que s alguna distancia podria figurarse el que la oye que le zumban los oidos. La persona que ha oido subir y reventar las burbujas en la superficie de las aguas pantanosas, dice Wodzicki, podrá figurarse fácilnente el canto de la locus. tela de carrizal, que suena ora mas alto ora mas bajo como si se pronunciasen rápidamente las letras $\mathrm{gl} \mathrm{gl} \mathrm{gl} \mathrm{gl} \mathrm{gl} / \mathrm{sin}$ la $r$ que predomina por lo general en los otros. Pista ave canta posada á mayor ó menor altura, muy quieta, con la ca. beza echada hacia atrás, el cucllo estirado y el buche hinchado. Durante toda la época de la cria canta esta locustela todo el dia hasta la puesta del sol, y segun ha obscrvado Schauer toda la noche tambien, y su canto engana absoluta. mente como el de sus congéneres.

Macho y hembra toman parte en la construccion del nido, acarreando trabajosamente los materiales. Al principio hacen los dos lo mismo, pero mas tarde dividen el trabajo; el macho acarrea y la hembra le toms lo que trae y lo coloca en sir puesto. El macho trabaja con tanta alegria como afan, dejando oir sin cesar su monótono er, er. Para emplazamiento del nido buscan un sitio á propósito en medio de espadañas altas y vicjas 6 de yerba espesa, pero raras veces alta; alli cnipiezan la construccion sobre sallos doblados como base y a $11^{\circ}$, I5 y aun á veces $\left\{0^{\circ}, 60\right.$ y $10^{\circ}, 90$ sobre el nivel del agua. El nido mismo se compone de hojas anchas de espadaña bien entrelazadas é interiormente nuy a planadas, produciendo un hueco tan liso que los hucros ruedan al menor impulso. Cualquicra que los conozca, tomarn estos nidos mas bien por los de la gallina enana de cañaveral que por los de un calamoherpino, tan grande es la semejanza, solo qque el del último difiere por su menor lamario. la mayor parte de los nidos que examinó 
Wodzichi tenian la figura de un cono invertido; y median $11^{\prime \prime}, 10$ de alto, $0^{\circ}$, on de diámetro y como $10^{\circ}, 06$ de prolundidad. La puesta consiste en cinco, raras veces en cuatro hue vos y queda terminada ó á últimos de mago ó a principios de junio. La forma y el color de los huevos varian muchísimo asi como el tamano que oscila entre $\left(0^{\circ}, 02\right.$ y y $0^{\prime \prime}, 025$ de largo por un diámetro de $0^{\circ}, 015$ s $10^{\circ}, 020$. Sobre fondo blanquizco ó blanco de cal, estŕn salpicados de puntitos en extremo di. minutos que cubren el extremo grueso casi en su totalidad, y de otros mas gruesos de color amarillo ó negro-parduscos con matiz violeta. En este caso se parecen mucho á los hue vos de la curruca gárrula, pero otros hay que se parecen mas á los del pipi ó à los de la alondra de nionte. Macho y hembra se relevan para cubrir, dedicándose con tanio ardor á este trabajo que se les puede observar muy bien, y si se espantan vuelven sin vacilar, ya de un solo vuelo, ya acercándose is saltitos de rama en rama. Cuando los pequeños pueden volar abandonan todos el carrizal y pasan á las espadañas 6 a las altas yerbas, donde permanecen hasta setiembre corriendo por el suelo inimedo.
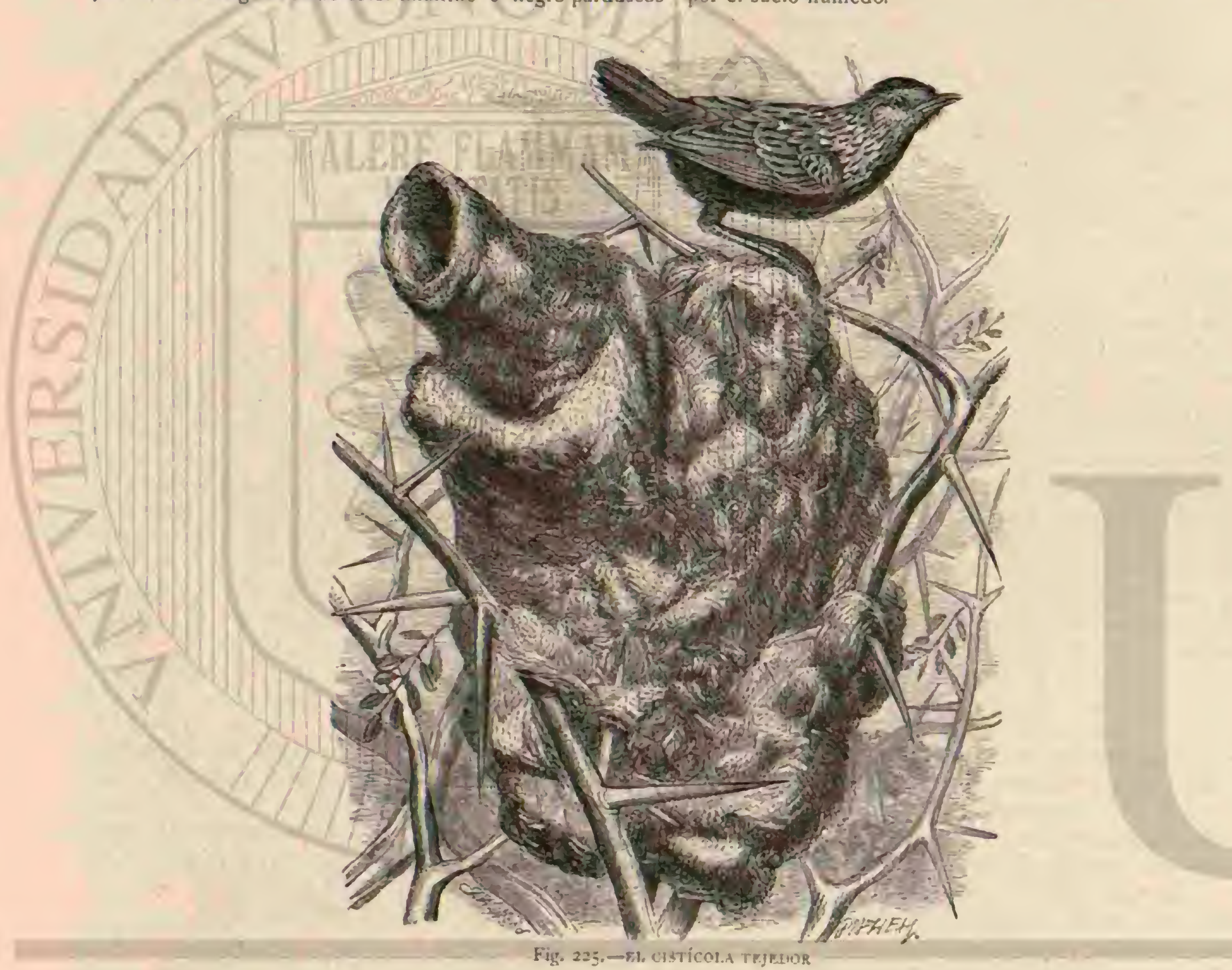

\section{LOS BRADIPTEROS} TERUS

CARACTÉRES. - Se caracterizan pot su pico cono y estrecho, alas muy redondeadas con la tercera y cuarta rémiges mas largas que las demás, y las plumas sub caudales muy anchas, largas y pobladas.

\section{EL BRADIPTERO SEDOSO-BRADYPTERUS} CETTII $\rightarrow$ FH

CARACTÉRES. - Ir.cluyu esia esplecie como represen. tante de un género aparte, para completar este grupa. La parte superior del cuerpo es pardu rojiza, color algo mas subiỏo en la rabadilla y en las cobijas caudales superiores; las rectrices y los filetes exteriores de las rérniges nardo oscuras son mas oscuros; corre una linea mas clara apenas visible al través del ojo; cl circulo que rodea este es mas claro por tirar mas á blanco; la parte inferior del cuerpo y las cobijas sub-caudales son parduscas con matiz de orin, y las mas har. gas cle estas ultimas tienen una orla blanca indeicrminaria etr el extremo. Lil ojo es pardo oscuro, el pico pardo de orin, in base de la mandibula inferior de un amarillo de cuerno y ia para amarilla rojiva La longitud es aproximadamente de $11^{\circ}, 3$, la del ala $11^{\circ}, 06$ y la de la cola $10^{\circ}, 065$. La hembra es bastante mas pẹqueña. El plumaje de los polluelos, además de ser cxtraordinariamente lacio, no es tan rojizo como el del macho y la linea del ojo aperas está indicada.

DISTRIBUCION GEOGRAFICA. - El bradiptero se. coso habita el mediodia de Europa desde España hasta el mar Caspio, el Asia occidental y el Africa septentrional, siendo serientario en todos los puntos donde se le ha observado.

USOS, COSTUMBRES Y REGIMEN. - Busca sitios donde haya aguas, prefiriendo las corrientes, ya sean arrojos, acequias $\delta$ zanjas de desagüe, á las encharcadas siempre que sus orillas se hallen polbladas de juncos, matorrales y zarza. les. Alli pasa su vida oculta. Alejandro de Homejer dice que es are en extremo vivaz y que está siempre en movimiento; 
no se deja ver nucho, péro su canto repentino y alio la delata en seguica. El terreno que habita no pasa de un centenar de pasos de diámetro, pero el ave le recorre sin cesar con una actividad pasmosa; el observador no sabe dónde mirar ni cómo explicarse su rapidez. cuando la oye cantar tan pronto is la derecha como á la izquiercia, y esta sorpresa crece, por. que no se la ve volar; no se tarda empero en convencerse de que no solamente se desliza con gran ligereza por las matas, sino que cruza volando grandes distancias á poca altura de la tierra, oculta entre las matas. lis animal en extremo previsor, huye al menor asomo de peligro, y si es dificil verle, mas lo es tirarle. Su canio y grito de llamada son tan caracteristicos que basta haber oido al bradiptero sedoso una vez para no confundirlo ya jamás con otra ave. El grito de llamada sue. na como clsck, chek, chck, y el canto se asemeja al principio al del ruisenoor, á veces hasta tal punto nque eıgañaria á cualquicra si fuese mas largo y no conclujese con la primera y única estrofa. Hausmann la traduce con la cumbinacion

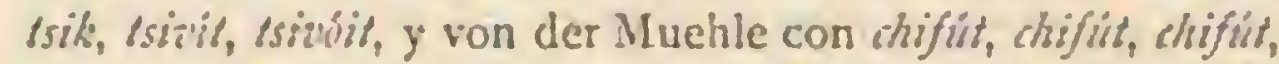
que por casualidad viene á ser una palabra turca, un apodo despreciativo que aplican en Turquia i los judios, circuns. tancia que excita conira estas ares el odio de los pastores griegos, los cuales creen que se mofa de ellos y los quiere insultar llamándolos judios.

Construge siempre el nido en lo mas enmárañado de algun jaral impenetrable a poca altura del suelo, y lo forma con desechos y restos vegetales como tallos y hojas medio descompuestos, tapizando el interior die yerba fina, pelo de cabra, lana de carnero y algodon. A últimos de abril se halla com. pleta la puesta que consiste en cuatro ó cinco huevos de $0 \%, 020$ de largo por $11^{m}, 015$ de grueso, de color uniforme rojo. Sobre su modo de educar la cria no poseo datos; Krue. per dice que los inviernos rigorosos suelen causar grandes destrozos entre estas aves.

\section{LOS DRIMOICINOS-IRYMOICINA}

CARACTÉRES.-Las doscientas especies que à poca diferencia componen este grupo se agregan naturalmente al anterior, y se cancterizan por su pico mediano, comprimido lateraimentey por lo comun un poco corvo: patas relativa. mente muy robustas; alas cortas y redondeadas: cola de lar. gura variable y casi siempre escalonada, y finalmente su plumaje por lo comun unicolor, salvo alguna especic que lo tiene muy variado.

DISTRIBUCION GEOGRÁFICA.-SU área de disper. sion se limira al antiguo continente y á la Oceania.

USOS, COSTUMBRES Y REGIMEN.-Concuerdan en general con los calamoherpinos respecto \& los sitios que apetecen, y si alguma diferencia hay estriba acaso en que los drimoicinos tienen una preferencia aun mas marcada que aquellos por las matas bajas, juncos y yerbas. Keunen la destreza de aquellos y de los silvinos porqzue corren, tre. pan y se deslizan con la misma agilidad sorprendente; pero vuelan mal, con ploca seguridad y vacilantes, lo que no obsta para que se cleven, cuando los excita el amor, á saltos, revo. loteando a fuerza de alcteos hasta por cima de las plantas que les dan albergue, para hacer resonat su canto sencilloy reducido i una sola irase, y precipitarse otra vez en la espe. sura. Sus nidos artisticos y en cierto modo incomparables, formados de hojas cosidas entre si por el ave, se hallan casi en el suelo: alli crian, alli encuentran su alimento y pasan la mayor parte de su vida.

\section{LOS CISTÍCOLAS - CISTICOLA}

CARACTERES.-Distinguese este género por su pico corto, delicado, ligeramente encorvado; tarscs altos s dedos grandes; alas cortas y redondeadas con la cuarta rémige mas larga que las otras y la cola imperceptiblemente redondenda y corta.

\section{EL TINTIN Ó CISTICOLA CORREDOR-CIS- TICOLA CURSITANS}

CARACTÉRES. - la parte superior del cuerpo es de un pardo aceitunado con manchas pardo oscuras, d excep-

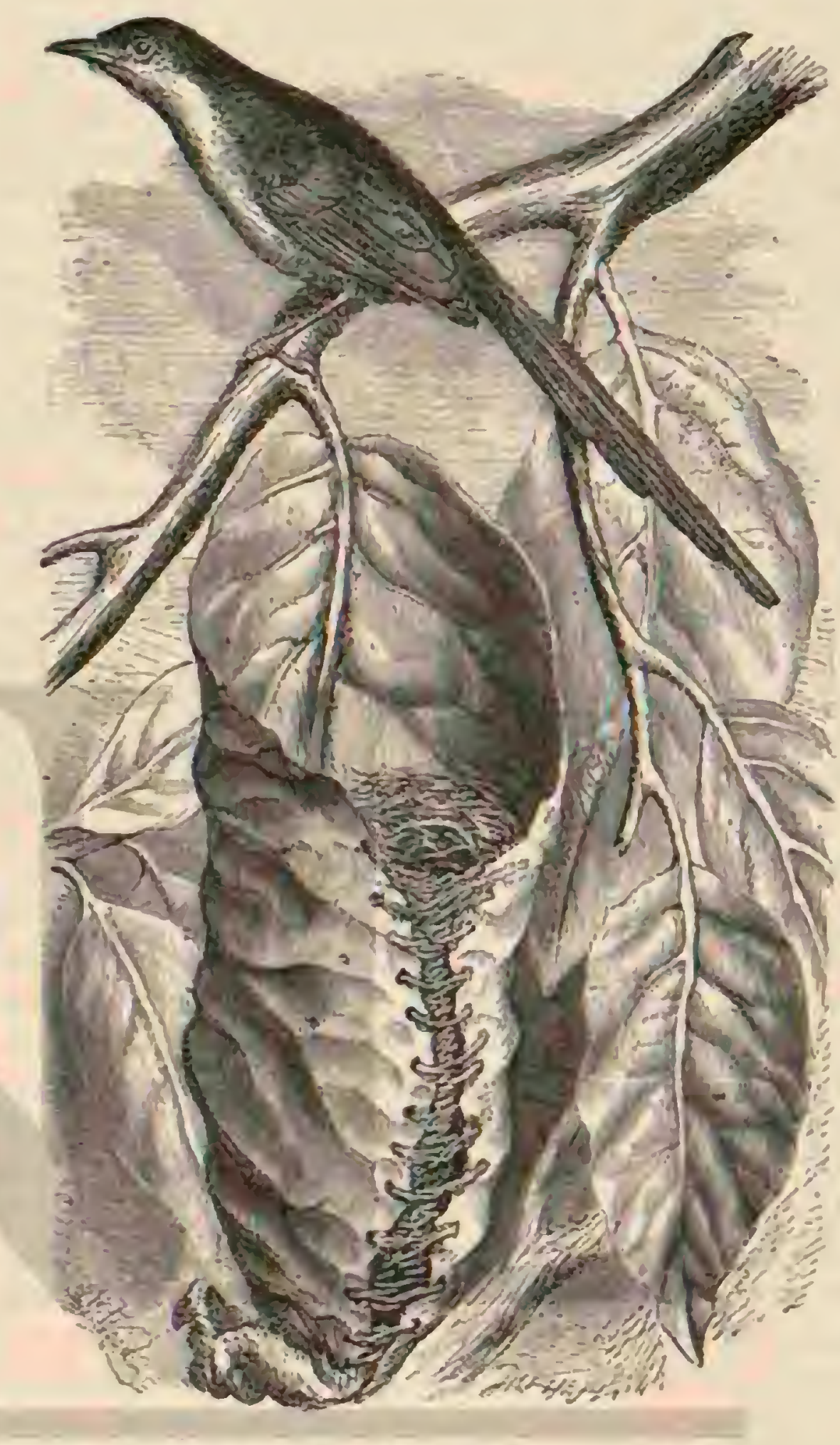

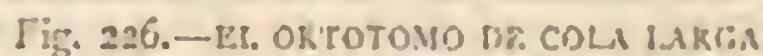

cion de la nuca que es parciusca y de la rabadilla, simplemente parda; el centro de las plumas es pardo negruzco, pero el borde pardo amarillento tirando á orin. En la cabeza laay tres listitas nugruacias y dos de color amarillo claro; la region de la nuca, la garganta y el ceniro del vientre son en. teramente blancos; el pecho, los costados y las cobijas sub caudales son amarillos con matiz de orin; las rémiges de color negro gris orladas por luera de amarillo orin; las reetrices medias son pardas con matiz de orin, y las demús parduscas cenicientas con filete blanco en el extremo, $y$ antes de este hay una mancha negruzca en forma de corazon. Eil ojo es gris claro'y pardusco; el pico color de cucrno $y$ la pata rojiza. Los pequenos difieren de los viejos por su colo. racion algo mas clara. La longitud es de $0^{\circ}, 0 \mathrm{r}$, el ancho de ala os ala de l,",016, la del ala plegada de $0 ", 05, y$ la de la cola de 1$)^{\circ}, 0.4$ (ig. 22.4). la hembra es un poco mas pequelia.

DISTRIBUCiON GEOGRÁFICA. - Ia España central y meridional, la Italia meridional, la isia de Cerdeña, Gre. cia, el norte del Africa y el Asia central, oriental y meridio. 
nal son las regiones y paises donde se encuentra el cisticola corredor, $y$ donde es a la vea frecuente, y en muchas partes comun. Es ave sedentaria hasta en los mismos sitios donde ha racido y donde anida tambien.

USOS, COSTUMBRES Y RFGIMEN. - En España se la encuentra en todas las llanuras bajas, por poco que respondan á sus necesidades: en los diques cubiertos de carias, que separan los arrozales, en los juncales, en las praderas, y en los campos de maiz, de alfalfa y de cánamo. Dice Haus. mann que en Cerdeàa vive a orillas del inar, donde la playa es pantanosa y solo crecen yerbas y juncos espinosos; pero visita tambien los campos de cercales. En las'Bateares in observó Homeyer, asi en, los sembrados y la llanura como en la montana, mientras existan algunos juntos liúnedos, por manera que tambien alli resulta exacto lo que dice Hausmann, i saber, eque una penuera corriente, escasa" mas bien que abundante, y un área de terreno cubicrta de yerba es todo cuanto necesita 7 lin el nordesic de Africa donde se la encuentra desde las costas del .ícdicerrínco hasta /2 Abisinia y a la altura de 2,000 metros, se establece esta are no solo en campos y cañaverales sino tambien en bosques de acacias y palineras y en el noroeste de Aírica en las praderas; Jerdon dice que en las Indias habita en los si. tios donde crecen altas yerbas, en los campos de trigo y en los arrozales. (Luedé pasmado cuando supe que los ornitó. logus eșpanotes no habian observado hasta entunces al cis. ticola corredor, ya que csta ave parcce que hace todo lo po. sible por llamar la atencion del observador.

Durante el periodo del celo, particularmente. se distingue el macho por sus movimicntos, renóntase en ciertos instan. tes por los aires, lanzando siempre en el mismo tono, el grito penetrante test lit tis; vuela largo tiempo de un lado as otro, siempre grimndo; revoloten a cierta altura sobre el homb:e que invade su dominio, y corre por la yerba con la agilidad del raton. Si le disjaran un tiro, se oculta tan bien que no es posible hallaric. Hausmann tiene razon al decir que en el cisticola hay alga de las cosiumbres del troglo. dita, que se esconde en las yerbas $\delta$ en los juncos, y permanece alli con tal tenacidád, que es jreciso dar uria patada en la mata para obligarle s. salir. Trepa como los hortclanos por los tallos de las canins; y á semejanza suyà, solo se mue. re en un espacio muy reducido, 'y no vucla mas léjos qué algunos metros.

En Murcia se da al macho el nombre de fin $\sin$ por la es. pecialidad de su cantar; en Argel le llaman firkfink. Cuan. do tiene miedo produce un vago murmullo; su grito de ternura consiste en una risa mal comprimida; $y$ si le domina la cólera 6 pelea con sus semcjantes grita strus 6 sivil wi

Eil cisticola se alimenta de pequenóos insectos, de dipteros, orugas y moluscos de escaso tamaño; recoge su presa en las hojas y algumas veces en tierra, y aun en el fondo de los charcos.

Sari fué el primero en describir el nido del cisticola: dice que esta are tiene una manera muy especial de recoger las hojas que rodean su nido y de consolidar su trabajo. En el borde de cada una de aquellas practica agujeros, á través

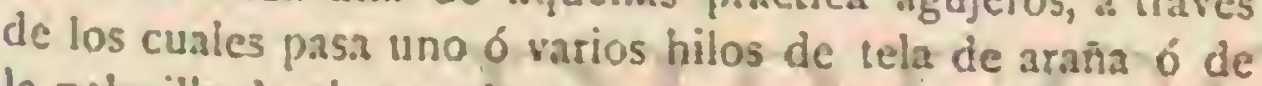
In pelusilla de ciertas plantas; como no son largos, solo pa. san dos ó tres veces de una hoja á otra; tienen/además un espesor variable, y algunas se birurcan. En el interior predomina lana vegetal meaclada con algunas telarañas çue sirven para dar consistencia al lecho.

En la parte lateral y superior del nido se unen las dos paredes interna y externa; pero separanse debajo por una capa mas 6 menos gruesa de hojitas secas y finas, que forman un lecho blando $y$ mas $\delta$ menos grueso, donde depo- sita sus huevos el ave. En el tercio superior de la pared existe una abertura de entrada circular; cl nido afecta en su conjunto la forma de una bolsa ovalada y se halla en me. dio de una inata de yerbas, de cañas $\delta$ de juncos con el fondo distante del suclo \{ lo mas quince centimetros, y se halla cosido á las hojas de la planta con otras hojas intercaladas para acolcharlo. De esta manera ofrecen los tallos, aunque se balanceen, suficiente resistencia para aguantar las tormentas mas recias. Todos los nidos que encontramos correspondian i esta descripcion, pero Heuglin vió otros en Figipio en matas de espinas y plantios de jalmas inceidos en vainas de hojas, tejidos entre espinas, ramitas y yer. ba, y otros mal cerrados, y tapizados por dentro con lana, pelos y plumas.

Creiase que era la hembra la que construia el nido, pero las observaciones de Tristram, confirmadas por las de Jer. don, nos han dado à conocer que el inacho ejecuta la mayor parte del tribajo: cuando la base está concluida comienza á poner la hernbra y cubro cuando ha depositado el último huevo; entré tanto continua el macho levaniando las paredes y cosiendo las hojas. (He tenido la suerte de encontrar, dice Tristran, un nido en vias de construccion, y durante mas de un mes estuve observando diariamente el trabajo del cistico. la. Cuando la hembra puso el primer huevo, la obra era to. davia trasparente, y sus paredes no tenian una pulgada de altura Mientras / duró la-incubacion continuo el macho su tarea; cuardo los pequeños nacicron tenia el nido tres pul. gadas de alto y cra bastante sólido.»

I.os huevos del cisticola varian de una manera notable. lin Fspana encontre una puesta de cinco, todos de color azul ciaro; otros naturalistas los han visto verdes azulados, cubiertos de manchas irregulares de un rojo ladrillo, pardo negras y'de este último tinte; tambien los han hallado blanco verdosos, con manchas pardo rojas $\delta$ de claro de carne; se han visto, for fin, blancos, inanchados de rojo claro.

Los padres profesan mucho amor á sus hijuelos: el macho no conoce entonces el peligro; olvida su timidez natural, y cuando un hombre se acerca a su nido, vuela al rededor de el lanzando gritos de angustia.

Cuando los pequeños comicnzan a volar, ofrecen el mas curioso espectículo: cada individuo de la familia salta, ire. pa, ruela y corre por la yerba. Si uno de los padres trae algun insecto, la jóren bandada se precipita hácia él, todos con la cola levantada y procurando cada cual adelantarse a los otros a lin de Hegar primero para coger la codiciada presa Si amenaza un peligro, desaparece la madre con sus hijuelos; mientras que el macho se remonta por los aires.

Segun Savi, los cisticolas ponen tres veces al año, en abril, julio y agusio. Yo encontre nidos en mayo, junio y julio; entonces comicuza la muda y acaba el periodo del celo.

He trabajado mucho para coger un cisticola vivo: como las trampas para ruiseñor no podian servir, me ocurrió poner lazos a la entrada de los nidos; pero las aves antes de pene. trar en el nido quitaban cuidadosamente los lazos é inutilizaban asf mis esfuer\%os.

Hay otra especie de cisticola ( Drymoica tex $/$ rix ) , que solo difiere de la precedente por tener la cola basiante mas cor. ta, y gue asi como el cisticola corredor construye su nido muy artisticamente (fig. 225). No se diferencia de la otra especie por sus costumbres y género de vida.

\section{LOS ORTOTOMOS-ORTHOTOMUS}

CARACTERES. - licnen el cuerpo esbelto, el pico lat. go, endeble, recto, ancho en la base, y por delante pruntiagu. 
do; la pata es robusta, el tarso alto y los dedos cortos; el ala es corta, endeble, muy redondeada, con la quinta ó sexta ré. miges mas largas que las otras; la cola corta, muy redondeada, tiene las rectrices estrechas. Iil plumaje, que en la base del pico toma la forma de cerdas, tiene una colonacion bastante viva, por lo comun verde en la parte superior, y casi siempre rojiz con matiz de orin en la coronilla.

\section{EL ORTOTOMO DE COLA LARGA - ORTHO- TOMUS BENNETTII}

CARACTÉRES. - El ortotomo de cola larga (fig. 226) tiene el lomo de color verde aceituna, que pasa al amarillento: la parte superior de la cabeza roja; la nuca de un gris rojo; el vientre blanco, en los lados mas borrado y con matiz gris; las rémiges pardas y orilladas de verde; las rectrices de aquel color con visos verdosos, y las externas con la punta blanca. En el macho sobresalen mucho las dos rectrices me. dias, al paso que en la hembra la cola es redondeada. Esta ave mide $0^{m}, 17$ de largo, el ala plegacia $0^{m}, 05$ y la cola $0^{m}, 09$. La hembra apenas llega a $\left(0^{\circ}, 13\right.$ en la primera de estas di. mensiones, su cola no excede de $0^{\circ}, 05$.

DISTRIBUCION GEOGRÁFICA. - Desde el Hima. laya hasta el cabo Comorin, en Ceilan, Java, Burma, etc, se halla esta ave en todas partes donde hay árboles.

USOS, COSTUMBRES Y RÉGIMEN، - Habita los jardines y verjeles, los setos $y$ las espesuras de cañas y los bosques de árboles poco altos. Vive comunmente empareja. do, y algunas veces en reducidas familias. Salta continuamente de una rama á otra, y lanza de vez en cuando un grito estridente, que se puede traducir por tuat 6 stelti fretti. Es muy confiado, y le gusta fijarse cerca de las casas; pero mués. trase prudente si nota que le observan, y cobm miedo cuando se le lia perseguido.

Se alimenia de diversos insectos, y principalmente de hor. migas, grillos, orugas y larvas, que atrapa en la corteza 6 las hojas de los ảrboles, 6 recoge en tierra. Cunndo salta 6 come tiene la costumbre de mover la cola y erizar las plumas de la coronilla.

Los nidos qque encontró Hutton eran de construccion bas. iante graciosa, tenian las paredes formadis de canas, algodon y hebras de lana, sólidamente entrelazadas: la cavidad estaba cubierta de crines de caballo, y suspendido el todo entre dos hojas de una rama de amaltea. Estas dos hojas habian sido unidas primero en el sentido de su longitud, y cosidas luego hasta un poco mas de su mitad inferior, con una fuerte he. bra de algodon que el ave hil6 por si misma. De este modo quedaba una abertura en la parte superior del nido; al nivel de los dos pediculos, tocando inmediatanuente la rama, y por aquella podia penetrar el ave en su albergue.

Otro nido se hallaba en el extremo de una rama, is cosa de $\left(0^{\circ}, 60\right.$ del suelo, y se componia de los mismos materiales que el primero; las hojas aparecian igualmente cosidas por medio de hilos que el ave encontró y con otros que hiló por sí misma.

lodos los.demás nidos que Hutton examinó se parecian á los que se acaban de describir: estaban formados de algo. don, de lana, crines ! fibras vegetales de las clases mas diversas, tenian forma de bolsa y llenaban siempre el interior de las hojas reunidas por una costura Nicholson que encon. tró en huertas de regadio nidos de estas ares con huevos en todas las estaciones del año, cree que el ave prefiere las hojas de berengena (Solanum esrulentum) ó las de una especie de calabaza (Cucurbila oslangrularis). Con el auxilio del pico y de las patas junta el ave los bordes de las hojas, canto con canto ó bien sobrepuestos; entonces las agujerea con el pico en el cual tiene ya el hilo que ella misma ha retorcido 6 que ha encontrado ya hecho, hasta que quedan unidas y en la posicion que çuiere, y entonces arregla el interior.

Cada puesta es de tres ó cuatro huevos, de color blanco, sembrados de manchas de un pardo rojizo, sobre todo en el extrémo delgado.

\section{LOS ESTIPITUROS - STIPITURUS}

\section{EL EMU Ó ESTIPITURO DE COLA DE GASA -STIPITURUS MALACHURUS}

CARACTERES. - El cmu, representante del género es. tipituru, se distingue principalmente por su cola que consiste solo en seis rectrices de barba deshilachada y muy desarro. lladas en el macho. La parte superior del cuerpo es parda con rayas longitudinales negras; la superior de la cabeza es de color rojo de orin, la region de la garganta gris pálido, y el resto de la parte inferior es de un rojo vivo; las rémiges son pardo oscuras con orla pardo roja; las rectrices son pardo oscuras tambien. El ojo es pardo rojizo; el pico y las patas pardos. la hembra tiene la coronilla listada de negro, y la region de la garganta es roja en lugar de gris. La longicud es de $0^{\prime}, 17$, el ala mide $0^{\circ}, 06 \mathrm{y}$ la cola (1)",on (fig. 227).

DISTRIBUCION GEOGRÁFICA.-Se deben a Gould y á Ramsay los datos bastante detallados que tenemos sobre esta ave tan conocida de todos los colonos de Australia, en cuya parte meridional habita las comarcas pantanosas desde la bahia de Moriton en la costa oriental hasta el rio de los Cisnes en la costa occidental, como igualmente en la Tas. mania, siendo frecuente en todas partes donde habita.

USOS, COSTUMBRES Y REGIMEN.-Se encuentra comunmente emparejada ó por reducidas familias: sucle estar oculta, muy cerca del suelo, en medio de las altas yerbas, y rara ver se la ve

El estipituro tiene las alas tan cortas y redondeadas, que no puede volar fácilmente, y mucho menos cuando está mojado por la lluvia ó el rocio. En cambio corre con agilidad por el suelo, lo mismo yque entre las yerbas; es ligero, vivaz, se mueve con rapidez y escapa por lo regular cuando se le persigue. Si un enemigo le acosa muy de cerca, desaparece al momento de la vista, porque sabe ocultarse muy bicn, y no se resuelve a volar sino en el caso de no poder pasar por otro punto. Si está posado y tranquilo tiene la cola levantada, y ś reces la inclina hảcia adelante; en el acto de correr la lleva horizontal hảcia atrás; si le asustan vucla rasando las puntas de las yerbas, y luego se esconde súbitamente en ellas. De vez en cuancio se situia en lo alto de una rama para examinar desde alli los alrededores: en el periodo del celo produce el macho un breve gorjeo; su grito de llamada con. siste en un ligero canto como el del grillo.

Ramisay descubrió un nido de la especie á fines de setiom bre, hallazgo debido of la casualidad: la construccion ern oroidea, la abertura de cntrada muy grande y la cavidad bastante profunda; la parte exterior se componia de raices y la interior de rastrojo y de una capa de musgo; las paredes cran muy endubles. Los huevos, en número de tres, eran blancos sembrados de puntos de un rojo claro, sobre todo hácia la punta gruesa: uno de aquellos era completamente unicolor. La liembra los cubria con afan, y á pesar de ha. berla ahuyentado, volvió inmediatamente al sitio donde es. taba el nido.

\section{LOS ACENTORINOS-ACCENTORINAE}

CARACTERES. - Las aves de este grupo que suele agre. 
garse a la familia de los pájaros cantores y de las que por esta razon trataré aqui, distinguense por los caractéres si. guientes: cuerpo rubusto; pico mediano, cónico y en forma de leina, muy contraido en los bordes que son cortantes, y provisto de una membrana unue cubre las fosas nasales, oblon. gas a manera de rendija; patas de tarso mediano y bastante fucrte; dedos robustos y unas muy corvas; alas médianas ó algo largas cuya tercera ó cuarta rémige suele ser la mas larga; cola corta y de anchura mediana y plumaje lacio. Los los sexos difieren poco, pero si los pequenos de los adultos.

DISTRIBUCION GEOGRAFICA. - Este grupo com. prende doce 't 10 mas veinte especies, segun la manera como se las considere. Fin ol primer caso se limita si wirea de dispersion a la parte del anigúo continente comprendida en ul hemisferio boreal y la India, correspondiendo a furoma solo dos espuecies.

USOS, COSTUMBRES Y REGIMEN. IA mayor par. te son selváticos y prefieren la vida terrestre; saltan mas 6 menos velozmente, pero tomando una posicion inclinada muy particular; cuando vuelan Ic hacen casi siempre rasando casi el suelo y las matitas bajas donde buscan su alimento que consiste en insectos, bayas y semillas pequeñas. Al acercarse el invierno abandonan algunas especies el norte para dirigirse a comarcas meridionales: otras bajan de las regiones clevadas de las sierras a otros sitios mas bajos $\delta$ se trasladan á las vertientes que miran al sur. Empiezan la puesta en época temprana; sus nidos son bastante artísicos y el núme. to de huevos oscila entre tres y seis de color verdoso.

\section{EL ACENTOR DE BOSQUE-ACCENTOR MO- DULARIS}

CARACTERES:-Esta ave, que representa el sub-género de los urmicos, se caracteriza por su estructura esbelta, pico

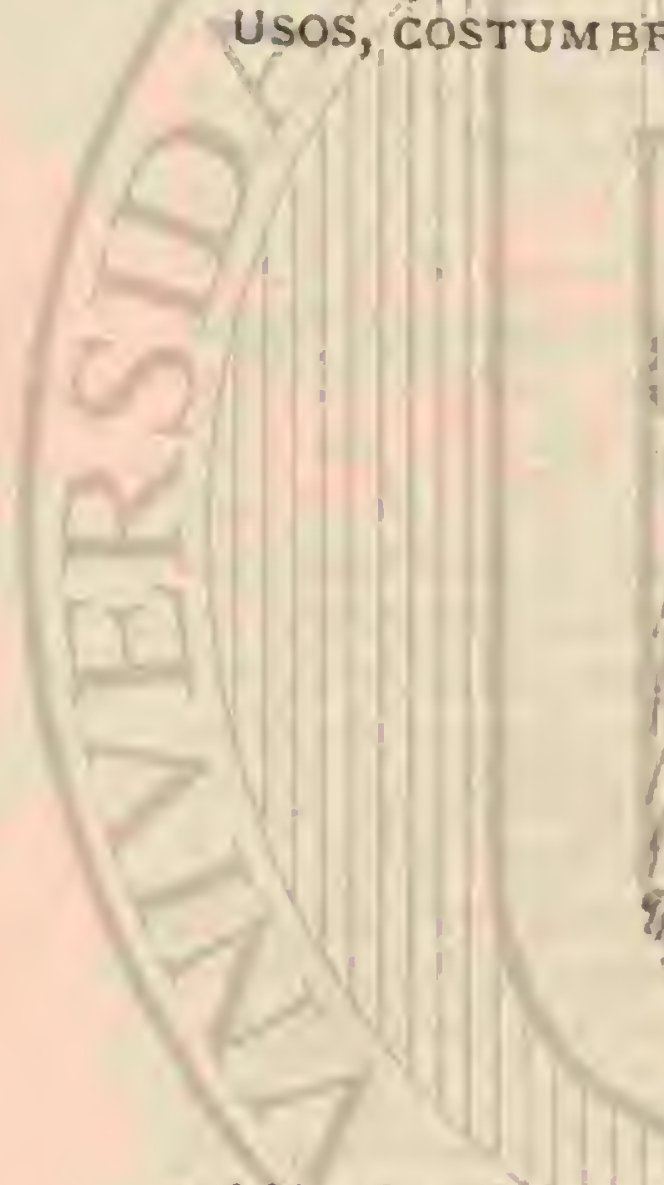

endeble, alas medianas con la cuarta rémige mas larga que las demás, y cola bastante lárgi. lit color es ceniciento en la cabera, cuello, garganta y buche; blanco con mativ gris en la barba; las plumas de lá coronilla presentanen el ceniro man. chas de tallo sin limite determinado: la reginn de la oreja es pardusca y listada con un tinte inas claro; d pecho y cl vien. tre son blannuizcos, hacia los costados parduscos con lincas oscuras en los tallos; las cobijas sub-caudales son pardas y orilladas de un tinte blanquizco; las rémiges y rectrices son de un negro parciusco, algo mas charo en estas que en aquellas, y orladas de color pardo de orin. El ojo es pardo claro, el pico pardo y la pata rojiza los pequenos tienen plumaje arnarillo de orin con manchas pardo negruzcas en la parte superior, y otras de color negro ceniciento en la parte infe. rior menos amarilla, y blanquizca en el centro del vientre. la longitud es de $\left(0^{\prime \prime}, 15\right.$, el ancho total de $10 " 214$, el ala plegada mide $\theta^{\circ}, 071$ y la cola $\|^{\circ}, 06$ (iig. 22\$).

\section{EL ACENTOR DE MONTAN̈A - ACCENTOR MONTANELLUS}

CARACTÉRES. - La parte superior de la cabeza y una lista ancha encima de la linea naso ocular son pardo negruz. cas; la parte inferior del cuerpo amarilla de orin claro, $y$ mas claro todavia en medio del vientre y en las cobijas sub cauda. les; en los costados hay manchas longiturinales de color pardo rojizo, y otras producidas por las mices oscuras de las plumas del vientre y del pecho; la nuca, el manto y la es. paldilla son pardo rojizas con manchas mas oscuras en los tallos de las plumas, y orlas de un tinte mas claro pero mal determinadas en los lados de las barbas; los costados del cuello sun renicientos; la rabadilla y las cobijas caudales superiores de un pardo lconado; las rémiges y sus cobijas son negro parduscas con orlas pardo rojizas difundidas; las secundarias y la cobija stuperior inas grande son blancas en el extremo y forman dos fajas trasversales sobre las alas; las rectrices son de un pardo terroso con orlas mas leonadas, y las tres externas con orlas estrechas en los crtremos. El ojo es pardo, el pico pardo negruzco y la pata de un rojo jas. dusco. La hembra difiere por su coloncion menos viva Iil tamaño es aproximadamente como el del acentor de bosqut.

DISTRIBUCION GEOGRÁFICA.- Esta especie reem. plaza á la anterior en la Siberia uriental. El area de dispersion de aquella comprende los paises situndos entre los $60^{\circ}$ de latitud norte hasia los Pirincos, los Alpes y ul Balcin. Alli anida; pero á fuer de ave errante se presenta tambien masal norte, ! en invierno ron gran regularidad en el mediodia de Europa, pasando hasta el norte del Africa y parte occidental del Asia.

USOS, COSTUMBRES Y RE̊GIMEN. - El acentor de bosque aparece en la Alemania ceritral durante la primera 6 segunda quincena de marzo, segun-que la estacion sea mas 6 menos farorable; permanece algun tiempo en los setos y matomales y luego se dirige a los bosques para reproducirse. Busca con preferencia los de pinos y abetos, y le agrada mas la montaña que la llanura.

4 Lin todos sus movimientos, dice mi padre, ofrece alguna cosa tan particular, que no podria desconocerle el inieligente ni aun desde léjos. Salta en ierra tan bien como en medio de los mas espesos matorrales, con admirable agilidad; desli- 
zase á través de todas las aberturas; se mueve en las yerbas altas y secas; escarba los montones de hojarasca; on una palabra, es muy ligera y diestra en todos sus movimientos. Al verla correr, diriase que es un raton: toma diversas pos. turas; comunmente tiene el cuerpo horizontal, la cola algo levantada y los tarsos un poco encogidos; otras veces endereza el cuerpo, alarga el cuello y baja la cola. Cuando se la persigue emprende el vuelo para posarse en alguna rama, y no la deja hasta que el peligro es inminente. Vuela con rapi dez, batiendo con precipitacion las alas, y sigue la linea recta. Para ir de un matorral a otro msa la tierra; pero cuando quiere abandonar un punto, remóntase á cierta alum por los aires. Mientras busca su alimento está siempre oculta: $y$ se deja ver del todo para cantar. Se posa en la copa de un pino, ó en la extremidad de una rama aislada próxima a la punta; pero rara rez a mas de 20 metros de tierra. Su canto se compone de pocas notas, mezcladas unas cun otras, $y$ es poco agradable

El grito de llamada se reduce à dí doui dii ó sri sri: el de angustia se traduce por dida, pronunciado con fuerza; otro grito que deja oir cuando vuela suena como bibibil: su canto se compone esencialmente de las silabas didi deride. Todos los individuos cantan lo mismo, reconociéndose solo algunas ligeras variaciones entre unas y otras aves. No sucle gritar sino cuando está posada, y con mas frecuencia mientras vuela, cual si quisiera invitar asi á sus compañeras á seguirla. En tales momentos se remonta á menudo á tal altura, que no se la puede percibir \& la simple vista. En el caso de amenazarla un peligro, déjase caer casi verticalmente desde lo alto de un árbol á un matorral, en cuyo interior desaparece.

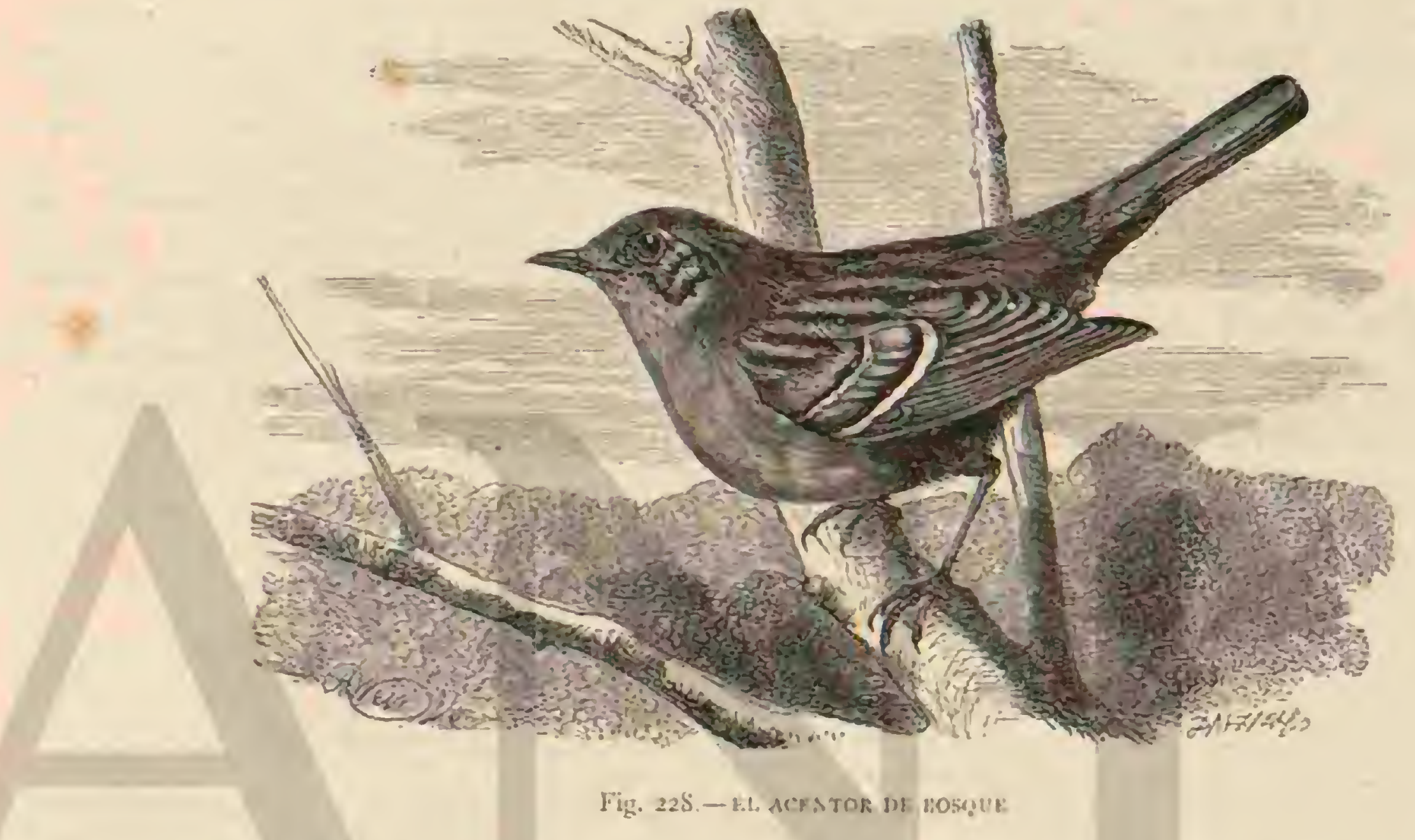

No es, sin embargo, muy timida, sino confiada y mansa, $y$ permite al hombre acercarse bastante.

En verano se alimenta de insectos, sobre todo de peque. nos coleópteros y de sus larvas; cn su viaje apenas come sino granos, y juntamente con cllos, algunas piedrecillas para fa. cilitar la digestion.

A fines de abril entra en celo la especic: el macho canta entonces de continuo, pelea con sus rivales, $y$ mas iarde ayuda á la hembra en la construccion de su nido artistico. Le sitúan en un espeso matorml de pinos, y comunmente á una altura de un metro por término medio del suelo. El fon. do se compone de alginas briznas secas en las que reposa una capa de musgo verde que á veces sirve tamibien para tapizarlo interiormente, 10 que lo embellece mucho, pero por lo comun sucle el interior estar formado de puntas rojas de musgo, pareciendo asi que se halla cubierto de pelos de ardi. Ila; debajo de aquellas hay á menudo un lecho de liquenes y tallitos de retama, $y$ d veces consta la cána mas interna de ha. jas y yerbas secas, lana y plumas. La prinera pucsta se rerifica en mayo, y la segunda en julio; la primera es de cuatro hucvos, que son de un verde azulado uniforne y miden $l i \neq, 020$ de largo por $11^{m}, 0: 4$ de dímetro. La incubacion dura de trece á catorce dias, y es probable que el macho y la hembra cubran aliernativamente; pero como quiera que sea, ambos cuidan de su progenic con el mas tierno cariño. Cuando le anienaza algun riesgo, la hembra se vale de su astucia y de fingimientos, segun lo hacen por lo general las currucas.

Ton: III
CAUTIVIDAD. - Los acentores de bosque se acostumbran pronto á la cautividad y se domestican mucho. Por su dulzura y su confianza son-apreciados de los aficionados, por insignificante que su canto sea.

\section{EL ACENTOR ALPINO-ACCENTOR ALPINUS}

CARACTÉRES. - Esta especie, que representa el sub-género de los acentores propiamente dichos, se asemeja mucho a la alondra. El pico es relativamente fiserte, un tanto corvo arriba y abajo, puntiagudo, muy contraido lateralmentc, es. trecho hácia la punta, pero en la base mas ancho que alto; la pata es robusta, los dedos gruesos y las uñas muy corvas, pero romas; las alas son largas y la tercera rémige pasa de las otras; la cola es corta, escotada en el centro; el plumaje es abundante. La coloracion es en la parte superior de un pardo gris; la nuca y costados del cuello tienen el matiz gris mas marcado; el manto y las espaldillas presentan manchas anchas y oscuras en los tallos; las plumas de la barba y de la garganta son blancas con orlas negras en los extremos; las demás par. tes inferiores son de un gris pardusco, hácia los costados rojo de orin con orlas laterales blanquizcas mal limitadas en los lados de las barbas; las cobijas sub-caudales son negro par. duscas, orladas por fuera de un tinte pardusco con matiz de orin, $y$ blancas en el extremo; las cobijas caudales superiores mayores tienen tambien el extremo blanco; las rectrices son de color pardo negruzco orkadas por fuera de pardo leonado 
y en el extremo inferior de la basba blanquizcas con maziz, de orin. El ojo es pardo, el pico de un tinte negro de cuerno, en la mandibula inferior amarillo de cuerno, y la pata pardusca amarillenta. La coloracion de la hembra es menos viva, y los pequenos tienen sobre fondo gris manchas que en la parte superior son amarillas de orin y negruzcas, y en la in. ferior ambien amarillas de orin, grises y de un negro ceni. ciento. Las réniges primarias tienen filete de color de orin, las alas dos fajas amarillas con tinte de orin, y las rectrices pardas con las puntas del colur de las fajas de las alas. El ojo es pardo claro, la lase del pico amarilia, y la punta negra; la pata es pardusca lil ave adulta mide $0^{\circ}$; is de largo, $0^{\circ}, 30$ de punta a punta de ala; éśa plegada 0,10, y la cola $(1 ; 0 \%$

DISTRIBUCION GEOGHAEICA.-EI neentot alpine se encuentra en todas las cadenas de montanas altas de la Europa central y meridional. En los Alpes es frecuente en todas partes, y raro, bien que constante, en cl Riesengebirge. A lo que parece habita en Suiza en todas las ramificaciones de las montañas, con tal quue presenicn las condiciones necesarias a su existencia, ó por lo menos alli lé encontró Girtan. ner siempre. Tocante al Riesengebirge, limitase esta are a contados sitios, como las cumbres de la kiesenkoppe y del Hohe Rad, donde se la pucde ver todos lós veranos aproxi. madamente en el mismo sitio en que se ta ha visto antes, puesto quéle basta una superficie de pocas hecireas.

USOS, COSTUMBRES Y REGIMEN. - En las neva. dis muntarbas del sur de Lispaña, y â una granaltura, observé por primera vez un ave que no me era collocida aun sino por In quic habia leido. Tan pronto la veia correr sobre las rocas coing ocullarse entre los tomillos y romeros; en oiros mo. mentos rolaba hácia una masa de piedras, y alli entonaba su alegre canto á pesar de la tormenta y de las ráfagas de nieve que nos mortificaban á menudo, puesto que estábamos en noviembre. Aq̣údlla ave cautivó soda mi atencion; mostrália. sealegre, vivazy precovida, poco timida, ágil y graciosa cn todos sus movimientos. Encontramos algunos individuos y pequeñas familias hasta el limice de las nieves, y vimosiun número mucho magor ea las vertientes meridionales bainadas por el sol.

A veces bajan hasta los valles, aunque tengan su verdadero dominio en las altas regiones: puro los que se arenturan asi en las tierras bajas vuelven hácia la montaña a la caida de la tarde. Se reunen para pasar la noche en ásperas rocas, agrietadas $\delta$ cubiertas de algunos escasos matorrales, y com. parten à menudo su albergue con las chovas y las palomas torcaces. Alli busca largo tiempo cada acentor antes de hallar un sitio conveniente en alguna grieta, detajo de una piedra ó en una rendija, mata de yerba ó de otra plantita. Por la mariana á primeratiora enprende su vuelo toda la bandada, $y$ se dispersan los individuos para ir cada cual su canton.

Posteriormente he encontrado tan gracioso pujaro muchas Véces tanto en los Alpres como en el Riescngebirge, sin contar los Alpes de Baviem, única comarca de Alemania donde cria.

En Suiza se le ve, segun Girtanner, casi siempre en peque nas bandadas que parecen preferir la proximidad de las cho zas de los pastores y establos de los ganados en las solanas elevadas de los Alpes; por lo menus no fatean en açucllos puestos cuando el tiempo es tempestuoso 6 las regiones su. periores se cubren de nieve. No suben tanto como el pinzon de las nieves, sino que prefieren sitios pedregosos con alguna regetacion protegidos por paredes de roca vira, y alli, en los puntos resguardados de la lluvia, construyen tambien su nido. Para cantar escoge el macho ó bien una piecira alta ó una punta saliente de la peña. No ofrece nada de notable este canto, pero no cansa y corresponde bien a la indole en general amable y pacifica del ave.
Cuando un grupo de estos acentores sabe que nacie les observa ó por lo menos çue nada tiene que temer, saltan to. dos entre las piedras cubiertas de musgo, dejando oir continuamente sus agradables llamadas, y á medida que avanzan van picando ya un insecio, ya una semilla, un gusanito 6 una baja, pues todo lo que no sea demasiado duro $\delta$ se de. fienda les viene bien. Mientras que les sea posible perma. necer en la alta montaña, csto es, mientras la nieve no cubra el suelo de una capa demasiado espesa, no abandonan su conarca; pero cuando la mano iria del invicrno les tiende una sábana glacial sobre su mesa, han de bajar a sitios me. nos exputestos, tanto que en lo mas crudo de aquella estacion lkgan hasta á las aldeas de montaña siguiendo en com. pania de la corncja y del pinzon de las nieves los rastros de las cathallerias por los caminos ó se presentan hasta junto á las chozas de los habitantes solitarios de los Alpes.

El acentor alpino hace dos crias cuando el verano es benigno, puesto que se encuentran hlievos en estacion muy temprana ýá fin de julio. El nido se halla en las grietas de roca ó en agujeros debajo de algun peñasco, ó bien en es. pesas matas de rosas alpinas, pero siempre en sitio bien abrigadá y oculto. Compónese de musgo y briznas de jerba tapizado interiormente del musgo mas fino ó de lana, crines y pelo de vaca la puesta se compone de cuatro á seis hue. vos de forma prolongada, ciscara lisa y color verde azulado y que difieren solo por su tamaño de los del acentor de bos. que, pies iniden $11^{\mathrm{m}}, 034$ de largo por $11^{\mathrm{m}}, 017$ de diametro.

CAUTIVIDAD. - Los acentores alpinos se acostumbran pronto a la pérdidá de su libertad, se vuelvén muy mansos, se conservan con un régimen y cuidados adecuados algunos años, y recrean h súamo tanto con su canto suave y angradable como con el afan incansable con que lo dejan oir.

\section{LOS MOTACÍLIDOS - MO- TACILLIDE}

CARACTER RE. - Distinguense estas aves por su cuerpo esbeltisimo, pico delgado, recto, en forma de lezna, angu. loso en el dorso, escotado ligeramente en la mandibula su. perior cerca de la junta: alas medianas con la tercera renige mas larga que las otras, y las del antebrazo casi ian largas como las de la mano; cola larga, de rectrices estre. chas y en muy pocas especies bifurcada; patas de tarso bastante aito y esbelto y dedos largos con unas largas tambien, particularmente la dul pulgar yue a veces es un verdadero espolon, y finalmente plumaje abigarrado y algo diferente segun el sexo.

\section{LOS MOTACILINOS - MOTACH.LINAE}

GENERALIDADES. - LOS motacilinos propiamente dichos ascienden a unas treinta especies, que pertenecen casi en su totalidad al antiguo continente donde viven en todas sus latitudes y alturas. Algunas especies no se separan de las corrientes sino en sus viajes, $y$ otras recorren tambien sitios secanos en busca de nimeritus. Las especies septentrionales san aves de paso, las meridionales errantes y algunas positivamente sedentarias. En el nurte aparecen temprano y continuan alli hasta fin de otono sin penctrar muclio hácia el sur. Sus movimientos son donosos y agradables; por lo regular andan con gravedad, inclinan à cada paso la cabeza y tienen la cola horizontal 6 un poco levantada, pero, segun indica su nombre ciensífico, noviéndola continuarnente de arriba abajo. En su vuclo rápido y ágil trazan curvas grandes que resultan de su aleieo violento al. 
ternado con fuertes contracciones de las alas. No puede decirse que su voz sea armoniosa, pero su canto á pesar de ser tambien sencillo, es agradable. Su alimento consiste en toda clase de insectos 6 de sus larvas y sabandijas acúticas pequeñas. El nido, que es tosco, se compone de briznitas de yerba y de paja, ramitas, raicillas, musgo, hojas secas y cosas por el estilo, tapizado interiormente de lana y otras materias blandas. Sienupre se halla cerca del agua en cavi. dades ; agujeros. Los huevos son de cáscara fina y están salpicados de manchitas sobre fondo blanco ó ceniciento.

La mayor parte de los motacilinos saben cautivar s la per. sona mas malhumorada con su gracia y su carácter nada receloso, por cuya razon tienen poco que temer del hombre, pero mucho de las rapaces, las que les preparan no pocas asechanzas durante su estancia veraniega, pero como se mul. tiplican mucho, vuclven a llenar luego los claros que sus enemigos causan en sus filas. Rara vez se les guarda en jaula, pero cuando se hace recrean mucho con su gracia y donairc.

\section{LOS ENICUROS-ENICURUS}

CARACTÉRES. - Algunos naturalisias consideran las aves de este grupo como esplecies de tránsito entre los cinclidos y motacilidos. Son especies grandes, originarias del Asia meridional, que se caracterizan por el pico rélativaniente largo y dorso recto, tarsos altos y robustos, alas cortas entre cuyas remiges primarias, la cuarta, quinta y sexta exceden á las otras en longitud, mientras que las secundarias son cortas, y cola larga y profundamente bifurcada.

\section{EL ENICURO DE LESCHENAULT - ENICU- RUS LESCHENAULTX}

CARACTERES. - Esta ave, el meninling de los malayos, tiene la parte superior del clerpo, la anterior del cuello, las alas y el pecho de un negrofucte aterciopelado; la coronilla; donde las plumas se prolongan formando una especie de moño, la raiz de las rémiges secundarias y de sus cobijas, que forman reunidas una faja trasversal semicircular por el lomo, la parte inferior de este y la del cuerpo son blancas; las rémiges negras, y las rectrices, exceptuando las dos extremas que son enteramente blancas, negras tambien con el extremo blanco. El pico es negro y ia pata amarilla I a longitud es de $0^{m}, 26$ is $\left(0^{m}, 2 \mathrm{~S}\right.$.

DISTRIBUCION GEOGRÁFICA. - Esta ac, dice Bernstein, á quien debenos lo que sabemos sobre su género de vida, se encuentra exclusivamente junto 4 los manantiales y arroyos tan abundantes en las montañas de Java.

USOS, COSTUMBRES Y RÉGIMEN. - SU verdadero habitat es la zona comprendida entre las altitudes de $500 \mathrm{a}$ 1,200 metros. Se la encuentra cerca de los arroyos. Iamás se aleja mucho del agua; pero remontando su curso, avanza con frecuencia larga distancia por el interior de las selvas virgenes, $y$ sorprende á veces encontrarla en sitios donde nunca se podria creer verla. Cierto dia hallé yo un individuo cerca de una corriente, en el Pangesango, à una altura de $\hat{\jmath}, 000$ neiros.

* Por su amor al agua se asemeja este enicuro al calobato amarillo, mientras que por su plumaje recuerda is todo eu. ropeo que desembarca en lava, it la aguzanieve. Cuando corre lleva la cola horizontal, pero si está excitado ú observa algo sospechoso, levanta al momento las plumas blancas de su cabeza y mueve la cola de una manera muy particular; á veces la endereza bruscamente, ensancha las rectrices en forma de abanico, las inclina poco a poco y vuelve a repetir la misma operacion.
Su grito de llamada, and́logo al de la motacila, parece expresarse por tairiff, fsinuill; cuando el ave está inquieta $\delta$ le admira alguna cosa, produce un grito ronco que se puede traducir por rekict.

- Fl enicuro de que hablamos es un ave pacifica 6 ino. fensiva; permite al hombre acercarse i pocos pasos, $y$ huye á corta distancia corriendo ó volando à la manera de la ne. vatilla.

Se alimenta de insectos y de gusanos, que busca alrededor de las piedras ó sobre las plantas, siguiendo siempre la cor. riente; á veces persigue su presa en el agua misma.

Construye siempresu nido en tierra, nuy cerca del agua, y aunque el ave lo ciescubra por su inquietud ó sus mo. vimientos, es dificil hallarlo. Le sitúa en una depresion natural del suelo, en alguna grieta 6 mata de musgo, detrás de las yerbas ó de una piedra, ó debajo de un árbol derriba. do; pero siempre en sitio perfectamente oculto. Enconirada la depresion natural, el ave comienza á rellenarla con una porcion de musgo seco, à la que comunica una forma esférica; y luego cubre el interior con hojarasca, sobre todo con la que está impregnada de humedad, de modo qque no quede de ella sino la nervadura: esta hojarasca, blanda y flexible, constituye un lecho muy á propósito para depositar los hue. ros. Su número no cicede nunca de dos; son de forma pro. longada, redondeados en un extremo y puntiagudos en el otro; su color dominante es blanco mate, que tira mas ó menos al amarillento verdoso, con pequeñas y numerosas manchas de un pardo claro que tiende al amarillo ó al rojo, y cuyos bordes se confundèn insensiblemerte con el matiz. general de la ciscara. Estas manchas forman una corona en la punta gruesa del huevo. los padres se manifiestan muy carinosos con su progenie, y muchas veces, cuando álguien se acerca demasiado al nido, descubren su presencia con un grito duice, prolongado y allautado, equivalente á aiurdh, al que sigue un grito breve $k \xi$, lanzado con fuerza.

\section{LA AGUZANIEVE-MOTACILLA ALBA}

CáRACTÉRES. - Esta especie (fig. 229), que ha recibido los diversos nombres de seiratilla de los arroyes, searstilla hanca, senatilla nzul, molacila laiandera, pajarila de las nie zres, presita, ó simplemente nemwlilla, es la mas conocida del género $s$ puede considerarse como el tipo de la familia. Tie. ne ellomo gris: la nuca de un negro de terciopelo; la garganta y la parte superior del pecho negras; cl vientre, la frente, la línca naso-ocular, las mejillas y los lados del cuello, de color blanco: las rémiges negruzcas, orilladas de gris blanco; las grandes y medianas cobijas superiores del ala, blancas en el extremo, lo cual produce una doble faja trasversal; las rectrices medias son negras, las otras blancas.

I. hembra difiere solo del macho por ser mas pequena la mancha negra quue ocupa la garganta.

El plumaje de otono difiere del de verano para ambos sexos, en que la garganta es blanca y rodeada por una faja negra en forma de herradura.

Los pequerios tienen el lomo de color gris ceniciento sucio; la cara inferior del cuerpo gris ó de un blanco sucio, excepto la garganta, que es negra; el ojo pardo oscuro, y el pico y las patas negras.

Esta are mide $0^{\infty}, 20$ de largo por $0^{\circ}, 28$ de punta á punta de ala, la cola $\left(1^{\prime \prime}, 098\right.$ y el ala plegada $0^{\circ}, 05_{5}$.

En la Gran Bretaña se encuentra con ella una especie afine, que unos consideran como tal y otros como variedad con. forme la consideramos tambien en esta obra; su nombre cientifico es: Mohncilla higulire, larellit y algira. Difiere de la anterior únicamente por su plumaje de primavera que 
ticre el manto, la rabadilla y las espaldillas tambien negras (figura 230).

DISTRIBUCION GEOGRAFICA.-La aguzanicre ha. bita toda la Firopa, la Islandia inclusive; el Asia central y occidental y la Groenlandia. En el invierno emigra hasta el interior del Africa, bièn que algunas quedan ya en el sur de Europa y aun en Alemania.

USOS, COSTUMBRES Y REGIMEN. - Llega i nues. tro pais a principios de maszo, y hasta à fines de fcbrero, cuando la estacion es farorable, para marchar en el ures de oceubre $y$ algunas veces despues.

Donde existe la nevatilla, evita tos altos bosques y no se remonta por las montanas mas alia del limite de los árboles: fuera de estos sitios se la cncuentra por todas partes, no léjos del agua. Parece profesar afecto al hombre, pues se fija cerca de su morada y aumenta con los terrenos roturados: se adap. ia á todas las circunstancias, viéndosela hasta en el interior delas cindades.

Esta ave, á imitacion de sus congeneres, está en continuo movimiento desde la mañana á la tarde: es vivaz, alegre y ágil; solo cuando canta permanece inmóvil en el mismo sitio con la cola colganic y el cuerpo levantado; fuera de este momento corre sin cesar de un lado à otro, ó cuando menos agita la cola Su carrera es ligera y rápida, avanzando paso å paso: $\mathrm{cl}$ ave lleva entonces el cuerpo y la cola horizontales, y algo encogido el cuello. Vuela iácilmente y con mucha rapidez, trazando curvas ascendentes $y$ descendentes, de manera que forman una larga linea sinuosa, sin elevarse mucho sobre el suclo ó la superficie del agua y airavesando trechos cortos; pero á veces franquea sin detenerse distancias gran. des. En el momento de ir á posarse se deja caer bruscamen. te, pero artes de llegar á lierra extiende la cola para dismi. nuir la violencia.

El grito de llamada de esta mutacila es asaz penctrante y se puede expresar por seioni\}, seguido con frecuencia de teisis ó lisicris, el de ternura es cwiriri. Su canto, muy sencillo, no deja de agradar: el ave lo repite varias reces seguidas, lo mismo cuando está posada que en el acto de correr ó volar.
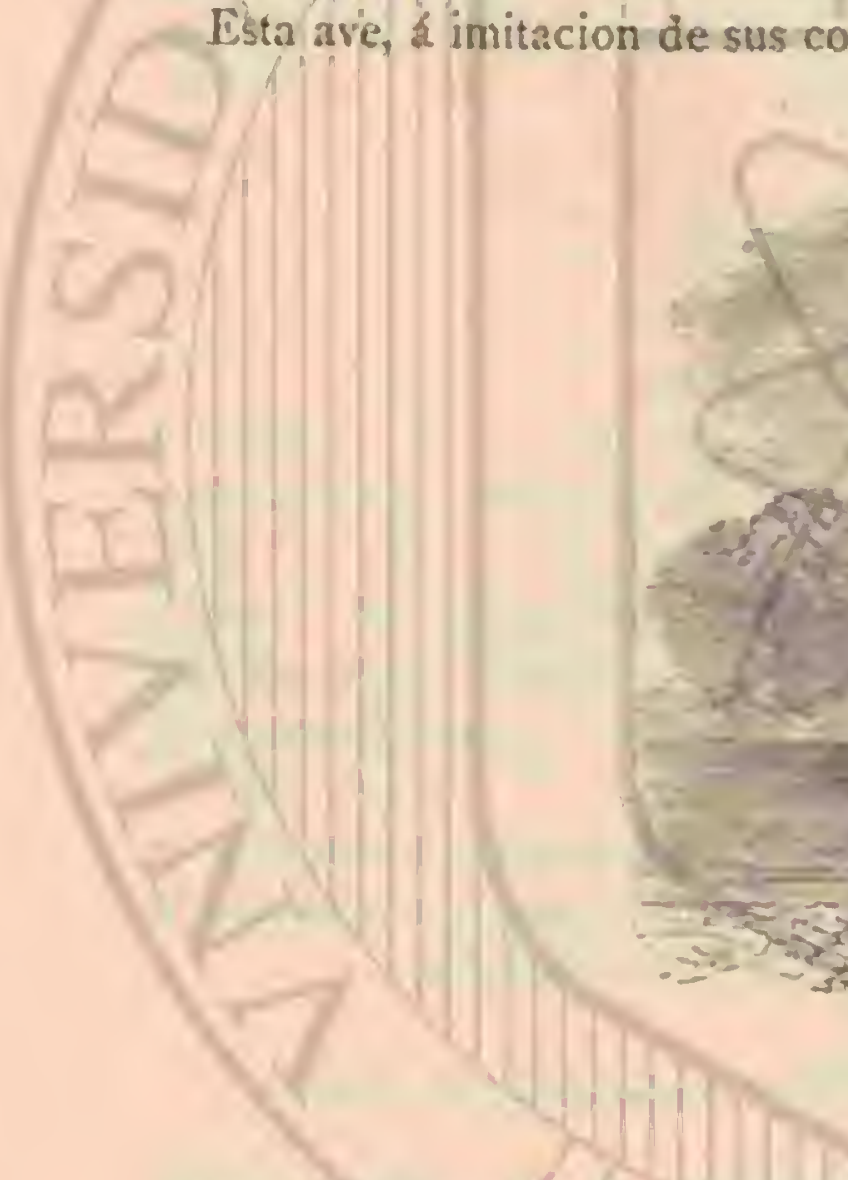

La nevatilla blanca se complace con la comparifía de sus semejantes; pero tambien lo gusta disputar ujuguetear con ellas, aunque algunas veces degeneran sus jasaticmpos ch contienda formal. Con las demás aves se muestra hostil: aco mete $\$$ los pinzones, $\mathbf{a}$ las emberizas, â la's alondras y aun a las rapaces. "Cuando las nevatillas distinguen a un ave de rapina, dice mi padre, la persiguen largo tiempo, lanzando agudos gritos: advierten asi el peligro $\boldsymbol{a}$ los dénás -séres ala. dos, $y$ de este modo obligan a mas de un gavilan a que abandone su caceria. Yo he admirado con frecuencia su valor y agilidad, y estor completamente conrencido de que solo el halcon mas veloz puede llegar á cogerias. Cuando una bandada de estas aves ahuyenia i una mpaz resuena en los aires un canto de triunfo, yespues se discminan todas. Abor recen igualmeute al buho, y acuden al rededor de ćl, lanzan do fueries gritos; pero pronto se alejan si la rapaz, no huye.

I a aguzanicre se alimenta de insectos de toda especie, de larvas y crisálidas: busca su presa á lo largo de has corrientes de agua, en el rango, sobre las piedras, en los momones de estiércol y en los rejados de las casas. Si divisa un insecio cae sobre el y le coge, sin que se le escape nunca, sigue al labrador y devora los insectos y gusanos que descubre el arado; se la encuentra tambien cerca de tocios los rebaios de bueves, y permanece a menudo dias enteros junto á los rediles. Caza igualmente los insectos al vuelo: corre à lo largo de un arroyo; pero sus ojos miran por todas partes, y si pasa un insecto, lánzase por los aires, le prersiguc, y casi siempre acaba por atraparle.
Eon la primavera, cuando todas regresan, cada parcja elige su dominio, lo cual no se verifica sin luchas ni jendencias, pues los machos que no tienen companera tratan de quitäsela á oiro mas afortunado. Los dos rivales se precipitan uno se. bre otro, lanzando el grito de guerra con que persiguen a las rapaces; de ve\% en cuando se manienen a pié firme en una aclisud a la ve\% of ensiva y defensira, como dos gallos furio. sos que se-preparan-a la pelé; despues cac uno sobre oiro y no cesa la lucha hasta que huy'c el menos fuerte de los dos. El rencedor se contonea junto a su hembra; entreabre las alas, mueve la cola con viveza, yo descansa hasta conseguir sus deseos,

In aguzanieve construye su nido donde encuentra un agujero conveniente: le situa en una grieta de roca ó de un muro, en algun hojo, bajo las raices de un árbol, en las vigas de un icjado, en un monton de leña, en el hueco de un tronco, en alguna lancha, etc, etc. El fondo se compone de raices, briznas, tallos de yerba, hoias secas, nusgos, pequenos trozos de madera, cánamo y paja Ia segunda capa esta formada de rastrojos mas delicados, largas jerbas y raicillas; el inie. rior relleno de pelos, crines de caballo, lino, liquenes, lana y otros materialés análogos. La primera puesta consta de sêis i ocho huevos y la segunda de cuatro o scis de (1), org de longitud por 10, 015 de dif́metro; son grises o de un blanco azulado, con punios y lineas mas ó menos pronunciadas, de un tinte gris ceniciento oscuro 6 claro. Ia hembra cubre sola; pero ayidala el maciso á enseb̉ar á los hijuelos, á los (jué en ningun caso abandonan aunque hayan de viajar rio arriba 
abajo con la barca en la cual establecieron su nido, cuando la creian fija: la primera pliesta se completa en el mes de abril y la segunda en junio. Los hijuelos crecen rápidamente. y luego son abandonados; algun tiempo despues se reunen los individuos mayores con sus hermanos mas pequeños $y$ sus padres, y todos viven juntos hasta la época de los viajes. En el otoño se dirigen por las tardes estas familias a los es. tanques cubiertos de cañas, donde buscan un sitio para pasar la noche, en compania de las golondrinas y de los estor. ninos

A fines del otoño forman las aguzanieves numerosas bandadas que en las orillas de los rios pueden llegar á miles de individuos que emprenden juntas su viaje. Vagan todo el dia desde el prado ó un campo sembrado á oiro; pero siguiendo siempre la direccion de su viaje. Por último, á la llegada de la noche, remóntase toda la bandada por los airés, lanzando gritos, y continúa su ruta hácia el sudoeste.

\section{LOS CALOBATOS - CALOBATES}

CARACTERES, - Sc funda la admision de este subgénero únicamente en la mayor longitud de la cola de sus individuos.

\section{EL. CALOBATO AMARILLO-MOTACILLA SULFUREA}

CARACTERrS. - Esta ave linciisimn es el representante del sub-género y se conoce tambien con el nombre de nera. tilla de las montañas y nerutilla amarilla. En la primavera el lomo es gris ceniciento en el macho; el vientre amarillo de azufre; la garganta negra, orillada de blanco á los lados; por encima del ojo hay una linca de este último tinte: cruzan las alas dos fajas de un gris claro, poco marcadas. En el otoño los colores son mas opacos, y la garganta blanquizca: el ojo

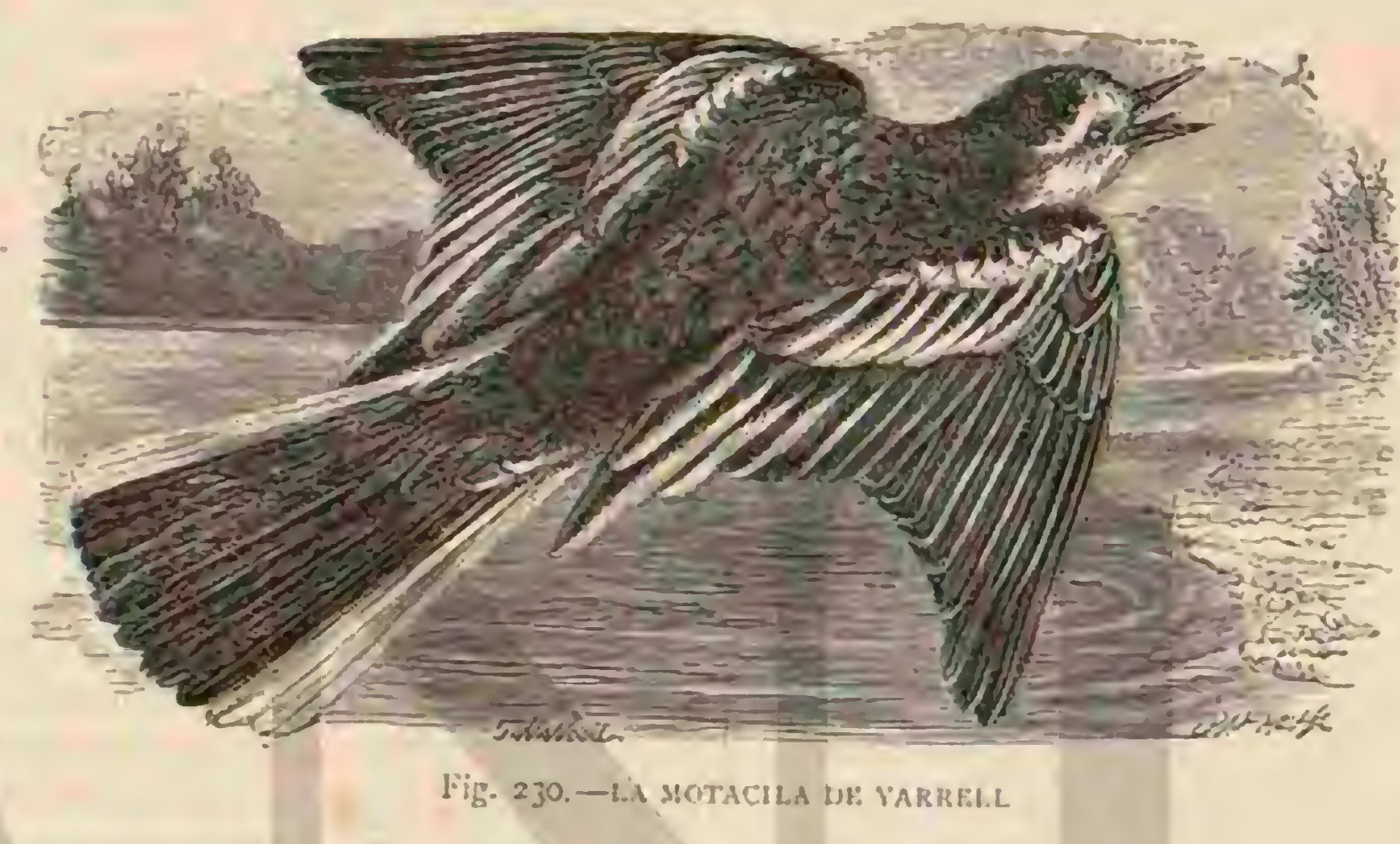

es de un mardo oscuro, el pico negro y las patas de color de cuerno. Esta ave mide $1^{\circ}, 21$ de largo por $\left(1^{m} 255\right.$ de ancho total; el ala plegada tiene $11^{\circ}, 0.55 y$ la cola $10^{\circ}, 105$ (fig. 231 ).

Ias hembras muy viejas se asemejan 1 los machos, aunque su garganta es de un color negro mas sucio y el vientre de un amarillo menos brillante En los pequeños el lomo es gris ceniciento sucio: el vientre gris amarillo y la garganta blanquirca, rodeada de un circulo de puntos negrur.cos.

DISTRIBUCION GEOGRÁFICA.- Eil hrea de disper. sion del calobato amarillo abarca toda ha Furopa desde el sur de Suecia, la mayor parte del Asia y algunas cordilleras del Africa septentrional, oriental y occidental, particular. mente el Atlas, la alta $\mathrm{Abisinia} y$ las tierras altas de la costa occidental. Es raro en el norre de Furopa, pero á contar desde la Alemania central hacia el sur no falta casi en nin. guna sierra; en nuestro pais se encuentra ya junto á cada arroỵo claro en las últimas ramificaciones de las sicrras, y hasta aisladamente en la llanura; en el Mediodia, empero, solo habita las montañas de elevacion regular. Es ave comun en las Canarias.

USOS, COSTUMBRES Y REGIMEN. - Alrededor de la charca, dice I3olle, en la que, se ha condensado el arro yo que baja de la montana, bajo los ardores de un sol abra. sador, y sobre la arena silicca, salta alegremente una pareja de calobatos amarillos; reconozco á los alegres vecinos de la trucha; supe ya lo que eran cuando, nisio aun, recorria los bosques del Harz y las montañas de la Silesia. Volaba esta ave entonces de una á otra piedra cubierta de musgo, y la imigen de los abeios se retrataba en la onda rápida sobre in cual deslizábase ligero el calobato. Aqui, en las Canarias, es la palmera la que se reflcja tambien; ahora pasa el ave sobre el follaje verde claro de las batatas y de las canas, cuya talla gigantesca anuncia la proxinidad de los trópicos. Déjase ver sobre todo a lo largo de los arrojos, aunque no necesita del agua viva; una charca o un canal de riego es lo suficiente para que se fije; y hasta junto á las cisternas tapadas le gusta establecerse: tambien acude â la inmediacion de los depósitos que están continuamente cerrados; le atrae la mayor frescura del aire y la presencia de insecios mas numerosos. No evita la proximidad del hombre; ni tampoco hay utra ave que se pose mas á menudo sobre los tejados de las casas, hasta en cl interior de las ciudades. $\$$

Jerdon dice que pasa el invierno en las Indias, donde llega a finès de setiembre para marchar à principios de mayo; pero que abunda sobre todo en el norte de la Peninsula.

Dificil es hallar un ave mas airosa $y$ de mas gracia: corre con prudencia à lo largo del arroyo, dando pequeños pasos, como una bailarina, $y$ hasta se introduce en el agua; si bien cuida siempre de no ensuciarse el plumaje corre rápida. mente, dice mi padre, no solo por la orilia del agua sino por dentro, con tal que no se moje mas que los tarsos; da saltitos sobre las cxclusas \& los tejados y por las humedas praderas, con el cuerpo horizontal y la cola levantada por lo regular, por temor de mojársela. Si se posa sobre una rama, una piedra ó cualquier punto elevado, endereza el cuerpo y deja la cola pendiente. Su vuelo es fácil, rapido, ondulado é interrumpido; is menudo franquea de una vez un espacio bastante extenso; yo la he visto volar a lo largo de un arrojo por espacio de un cuarto de hora y hasta media hora sin posarse. Lo hace asi principalmente en invierno, pues como 
el alimento no abunda tanto, necesita recorser una distancia mayor para encontrar lo que necesita: en verano no sucle volar léjos cuando se la espanta. Es muy confiada y anida cerca de las casas á menudo en los agujeros de las paredes: deja pasar i su lado, sin huir, al hombre que parece no haberla visto; pero si observa que se trata de perseguirla, procede con mucha prudencia, y no se pone nunca á tiro de escopeta.

Produce su grito de llamada mientras vuela, rara rez cuando se posa; el sonido se ascmeja mucho al de la aguzanieve y para distinguir una especie de oira es necesario co. nocerlas muy bien; se podria expresur por firiti pero es imposible traducirlo bien con exactitud.

El calobato amarillo anida por primera ves en abril, y por segunda en julio, á mas tardar. En el periodo del celo, ofre. ce ef macho un aspecto singular. eSe posa, dice mi padre, en una rama, sobre una picdra on $^{-}$en lo-alto de un tejado, mayor ó menar altura del suelo, s produce, sobre, todo por la mañana, una especie de gorjeo que se podria traducir por fuerli. Vuela agitando las alas precipiladamente y no tarda luego en posarse. 'Tiene ya sus lugares escogiados, un árbol, una presa de agua 6 un tejado, donde llega 2 pasarse todas las mainanas. Fin la primasera entona, aunque rara vez, un canto más agradable y variado que el de la aguzanieve, con la que ofrece, por otra parte, nias de un punto de seme janz...

Hace su nido en la grieta de una roca, de un muro, en un ąujero practicado en tierra, debajo de un sibazo pendiente, en la canal de una rueda de molino, entre ruinas $y$ siempite cerca del agua: el volúmen varia segun la localidad: los ma. teriales aparecen unas reces compactos yotras nuy sueltos; la capa exterior se compone de raices, de briznas, hojas secas, musgo, etc.; la segunda estí formadá de las misnas sustancias, aunque mas finas, y cubren el interior raices pequeñas, pelos, lana y crines de caballo. Ios hueros, en nú. mero de cuntro 1 seis, son de un gris sucio ó blanco azulado, con puntos y manchas amarillas ó de un gris ceniciento y miden 1$)^{*}, 0$ I $\$$ de largo por. $10^{*}, 0: 3$ de grueso. Ial hembra cubre sola, si bien la reemplaza ol macho algunas veces: Jo hace con tanto afan, que se la podria coger entonces con la mano: los padres llevar á sus hijos nbundante alimento, ma. nifestandoles mucha ternura, y permanecen con ellos algun ciempo despues de haber comenzado \& volar.

CAUTIVIDAD. - En la jaula aventajan los calobatos amarillos â todos sus congéneres en gracia y en el recreo que proporcionan, lo que les constituse en uno de los mas bellos adornos de la pajarera, $y$ si se les cuida como corresponde consérvanse musy bien.

\section{LA NEVATILLA CITRINA-MOTACILLA CI- TREOLA}

CARACTÉRES. - Fs una de las especies mas hermosas de nevatillas cuando no la mas hermosa de todas. Es notablemente mas pequeria y sobre todo menos larga que el calobato amarillo, pues mide $0^{\mathrm{m}}, 1 \mathrm{~s}$ de largo, el ala plègada

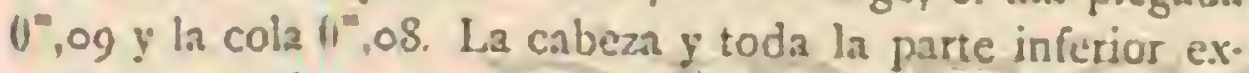
cepto las cobijas sub-caudales blancas son de un amarillo limon muy riro; la nuca y parte anterior del dorso son ni. gras pasando imperceptiblemente a un gris pizarra en la in. ferior; las cobijas superiores son negro parduscas con viso dífano verde amarillento al igual del durso; las rémiges son de un pardo gris oscuro con filete crterior angosto blanquiz. co, que aparece mas ancho en la barba exterior de las cobi. jas del antebrazo, y en el exiremo de las cobijas mayores de las alas, lo yue produce una mancha blanca muy visible so- bre las alas; las ocho rectrices medias son negro-parduscas, y las extremas blancas con filete negro y ancho en el canto interior. El ojo es de un pardo muy oscuro, el pico negro y la pata negra pardusca. La hemora difiere por el color ama. rillo mas claro de la parte inferior del cuerpo; el occipucio es verdoso, y el dorso ceniciento.

DISTRIBUCION GEOGRÁFICA. - Esta especie es originaria de la Tundra, pero en Europa solo se encuentra en el último rincon nordeste, en el distrito del Petchora inferior, desde donde se ha extraviado repetidas veces hasta el oeste de Europa y de consiguiente tambien hasta Alemania. Desde el Petchora extiéndese su área de dispersion por todo el norte de Asia hasta donde llega la 'Tundra, yasa el in vierno, segun parece, en las estejas mas meridionales de 2quel continente; bien que respecto de esto faltan datos. Llega a las comarcas donde hace sus crias junto con la ne. vatilla budites en la segunda quincena de abril y permanece hasta fin de agosto. Dicen que pasa por el Asia oriental cn grandes bandadas; pero nosotros no encontramos en la Sibe. ria occidental sino algumas jrequeñas que iban de viaje; y des. pues en la Tundra de la peninsula de los samojedos muchas parejas que cubrian y que habitan en dicla comarca locali. dades nuy, determinadas, á saber: mimbrerales cnmarañados hasta ser impenciraules, que cubren tiersas fangosas y pan. tanosas atravesadas por zanjas de desagiie, 6 charcos, y con claros cubiertos de espesas y lozsnas yerbas. En estos sitios no falta estalave nunca, micntras que alli donde no concurren estas circunstancias, puede uno viajar dias enteros por la Tundra sin éncontrar una sola pareja.

USOS, COSTUMBRES Y RÉGIMEN, I I nevatilla ci. trina no desmienté su cualidad de especie de tránsito entre el calobato amárillo y la nevatilla budites, y asi se echa de ver en su forma y plumaje como en su indole, bien que bajo este concepto se, paréce mas que á la primera, á la lílima, de la cual es tambien mas arine $y$ d la que se asemeja adcmás tanto en el modó de comer y andar como en el ruelo, puesto que lós arcós que describe suclen ser a poca altura. J.e gusta po. sarse en los extremos de las matas, donde el macho entona su canto breve, que si bien se aseneja al de la especie budi. tes, se distingue de el por la construccion de la frase y algu. nos tonos mas agudos y muy bien pronunciados, ápesar de ser imposible presentarlos gráficamente. Otra cualidad de que participa con la nevatilla budites es su genio pacifico; porque cuando las circunstancias de la localidad lo consienten viven las parejas tan cerca una de otra que los machos se oven mutua y distintamente, y con todo no los he visto reñir run. ca. El nido se halla emplazado, segun nos dijo Dybowski, y posteriormente Secbohm, en sitio muy oculto debajo de inatas de césped añosas 6 en jarales bajitos, eritre el musgo que cubre el suelo turboso; alli está cada dia mas disimulado por. la yerba que en la época de cria crece con la mayor rapidez. "Tallos de musgo mezclados con otros de graminens forman la capa exterior, y musgos, plumas y pulos de rengifero el interior del nido, macizo y bien hecho. Ia hembra empieza à poner á principios de junio, puesto que hasta entonces la nieve no desaparece en la lundra. lorman la puesta cinco, rara vez seis huevos de $11^{\circ}, 019$ a $0^{\circ}, 020$ de largo, por $11^{\circ}, 014$ de grueso, con manchitns muy pálidas y poco perceptibles de color de orin sobre fondo amarillo blanquizco. Macho yem. bra cubren alternativamente y con mucho celo; mientras que uno u otra vigilan y avisan si amenaza algun peligro. Cuando esto sucede el ave que está cubriendo baja del nido ś tierra, para volar luego los dos juntos y atraer al enemigo. Pasado el susto, no vuelven sino al cabo de un rato con gran caute la, à fin de no descubrir el nido. Esto hace dificilisimo encontrarlo y el naturalista casi no juede lograr su objeto sino 
cuando llueve, porque entonces la hembra no quiere aban. donar los huevos y no se levanta sino cuando el intruso casi toca el nida con los pies.

A fines de julio han abandonado los pequenos el nicio, á principios de agosto mudan los padres, y concluida la muda, es decir lo mas tarde á últinos del mismo mes, abandonan el pais.

\section{LOS BUDITES - BUDYTES}

CARACTERES.-Difieren de las otras nevatillas por su cola corta y la uña del pulgar en forma de espolon.

\section{LA NEVATILLA BUDITES Ó DE REDIL - motacilla flava}

CARACTÉRES.-Mide por término medio $0^{m}$, i 7 de largo y $\left(1^{m}, 25\right.$ de punta á punta de ala; esta plegada $00^{\circ}, 08 \mathrm{y}$ la cola $0^{\text {m" }}, 07$. I a parte superior de la cabeza, la linea naso-ocular, la region de la oreja $y$ la nuca, menos una faja estrecha blanca que acaba en la region temporal, son cenicicntas, verdes acei. tunadas las demás partes superiores, y del mismo tinte, pero algo mas oscuras, las cobijas caudales superiores. Los costa. dos de la cabeza y del cuello, como igualmente toda la parte inferior, excepto la barba que es blanca, son de color amari. llo de azufre. Las rémiges son pardo negruzcas, orilladas en la parte exterior de un tinte blanquizco con matiz leonado, como tambien lo son en el extremo las grandes cobijas supe. riores, que producen con esto una faja trastersal mas clara que el fondo; las rectrices son negras, excepto las dos extremas que son blancas con filete negroen la mitad que corres. ponde al la raiz. El iris es negro pardusco; el pico $y$ las patas negros. La hembra tiene la parte superior de lá cabeza y los costados de color verde aceitunado; las plumas de la rabadilla son marcadamente verdes, y la parte inferior del cuerpo amarillo pálido; a los dos lados del buche se ren algunas manchas oscuras poco marcadas, y finalmente la ceja es inas ancha, menos clara y tirando mas a orin. Los pequeños tienell la parte superior del cuerpo de un gris pardusco oscuro, con los extremos de las plumas gris amarillentos y mal defi. nidos, con manchas blancas sucias en la barba y garganta, amarillas de orin sucias en el abdónen y pardo oscuras en el buche; y ademis una linea de manchas que baja de los extremos de la boca.

Hay algunas otras variedades, de formas bien fjas y que algunos naturalistas consideran como especies, y otros como simples variedades de la nevatilla de los rediles. Verdaderas especies son las dos siguientes.

\section{LA NEVATILLA DE CABEZA NEGRA-MO-} TACILLA MELANOCEPHALA

CARACTERES. - liene la parte superior y los costados de la cabeza, asi como la nuca, de un negro interso y ater. ciopelado.

DISTRIBUCION GEOGRÁ FICA.-Anida en el sudeste de Europa y en el 'Turkestan.

\section{LA NEVATILLA DE RAY Ó DE CABEZA AMARILLA-MOTACILLA RAYII}

CARACTERES. - Tiene la parte superior y los costados de la cabeza del mismo color amarillo que la parte inferior del cuerpo.

DISTRIBUCION GEOGRÅFICA. - Anida en Inglaterra, China y en la isla de Formosa.
Pasaré por alto las otras especies ó variedades de este gru. po, y haciendo caso omiso de las separaciones indicadas, re. sultare que la distribucion geográfica de la nevatilla de redil viene á abrazar la Europa, Asia central y noroeste de América como regiones donde cria, y el Asia meridional y el cen. tro y sur de Africa como sus cuarteles de invierno.

USOS, COSTUMBRES Y REGIMEN.-Las nevatillas son en nuestro pais aves emigrantes; pero llegan mas tarde que las aguzanieves, rara vez antes de principios de abril, y á menudo solo a fines de este mes 6 en los primeros dias de mayo, emprendiendo su marcha en agosto ó setiembre.

Durante su paso sc las ve tambien en comarcas donde no construyen nido, porque habrá rebaños que las atraen y las retienen a menudo un dia entero. En general anidan en comarcas húmedas ó inundadas temporalmente, además de la rundra, donde habitan cientos de millares de estas aves tan aficionadas á regiones pantanosas.

Donde anidan nevatillas, dice Naumann, no se encuentra un campo de colza, de habas, de guisantes $\delta$ de trébol, de alguna extension, ni una pradera ó pantano cubierto de yerbas, en que deje de rerse alguna pareja de estas aves. En ciertos puntos se las ve en prodigioso número: $\mathrm{en}$ las tierras turbosas, particularmente, punto donde abundan los campos fértiles en cereales, alternados con yantanos, cañas y pastos, donde pacen ganados, alli encuentra la nevatilla todas las condiciones favorables á su existencia y es de consiguiente comun. Menos graciosas que el calobato amarillo, lo son sin embargo mas que la aguzanieve á la đ̧ue se asemeja tambien mas en sus movinientos.

Corren con agilidady vuelan muy bien; cuando solo han de franquear un corto espacio, su melo se reduce casi á sal. tar, mientras que en sus viajes avanzan con una rapider. sorprendente. A inenudo permanecen largo tiempo en los aires, cerniéndose en un mismo sitio; luego cierran brusca. mente las alas y se dejan cacr casi verticalmente. Su grito de llamada consiste en un silbido traducible por lisiub bilil ó sil sili; otras veces producen el sonido sri: su grito de amor es teirr; el canto se asemeja al de la aguzanicre pero es menos rico que este.

Tan sociables son las nevatillas despues del periodo del cela como pendencieras mientras dum; acometen á casi todas las aves mas péqueinas que ellas; pero al fin parecen acostumbrarse s. su presencia, ó se desaniman al ver que resisten. - Nanifiéstase su caricter belicoso, dice Naumann, cuando un ave extraña penctra en su dominio; debiendo confesar que a menudo me han indicado de este modo la presencia de pequeñas especies raras.

Persiguen á los hortelanos y a las efarbatas con tal ardor, que con frecuencia ne han impedido cazarlas: si algun are extrana se presenta fuera de las altas yerbas, al momento caen sobre ella varias nevatillas furiosas y no le permiten posarse cerca; pero luego acaban por tolerarla, anidando pa. cificamente junto à ella.

El nido se halla situado en el suelo, en medio de las yer. bas, de los trigos $\delta$ de las plantas pantanosas, comunmente en una ligera depresion, $y$ á veces debajo de las raíces: varias raices, rastrojos, hojas secas, yerbas y musgo son los mate. riales que el ave emplea para fabricar un tejido endeble $y$ tosco; cubren el interior yerbas delicadas, espinas de carco, lana, pelos y plumas.

Los huevos, cuyo número varia entre cuatro y seis, tienen la cóscara muy delgada, y son de color blanco sucio, amari. llentos, rojizos 6 agrisados, cubiertos de puntos, manchas $y$ lineas de un tinte gris amarillento, gris pardo, violeta 6 rojo. Miden por término medio $0^{\circ}$, or $S$ de largo, por $0^{\circ}, 013$ de
diámetro. 
El macho cuando trata de cautivar á su hembra, se hin. cha, eriza las plumas, extiende la cola y revolotea ś su alre. dedor. Esta ave no anida mas que una vez al año, á fines de mayo ó principios de junio: solo cubre la hembra, por espacio de trece dias: los padres manifiestan à su progenie el mas vivo amor; pero la descubren á menudo por sus gritos de angustia y la temeridad con que procuran defenderla. Los pequeños se ocultan diestramente en la yerba, y no tardan en llegar á ser tan ágiles como sus padres. Toda la familia vive reunida entonces hasta el momento de la marcha; al llegar un hermoso dia de otono, emprenden su vuelo jóvenes y viejos, dirigiendose hácia los paises meridionales.

Ahora se ven y se ojen estas nevarillas en todas partes, aun en las montañas, a donde acuden atraidas por los numerosos ganados. Parece que realizan su viaje con gran rapidez, atendido que yo las observé en Africa en el mismo tiempo que se considera en Alemania como la época de su paso: y las encontré á menudo alli á principios de mayo, casi en los mismos dias en que nas tarde las observé tambien en Noruega. Muchas sé quedan en Egipto para pasar el invierno; pero la mayor parte avanza hasta el interior del Africa. Alli se las ve en los meses de invierno rodear todos los rebaños ya bovinos, ya lanares, y aun cada camello, caballo, mula ó asno, tanto, que los pastos hormiguean de estas lindas aves. Siguen al ganado maỵor â las estepas y de alli a los abrevaderos, acompañan rolando á sus cuadrúpedos predilectos
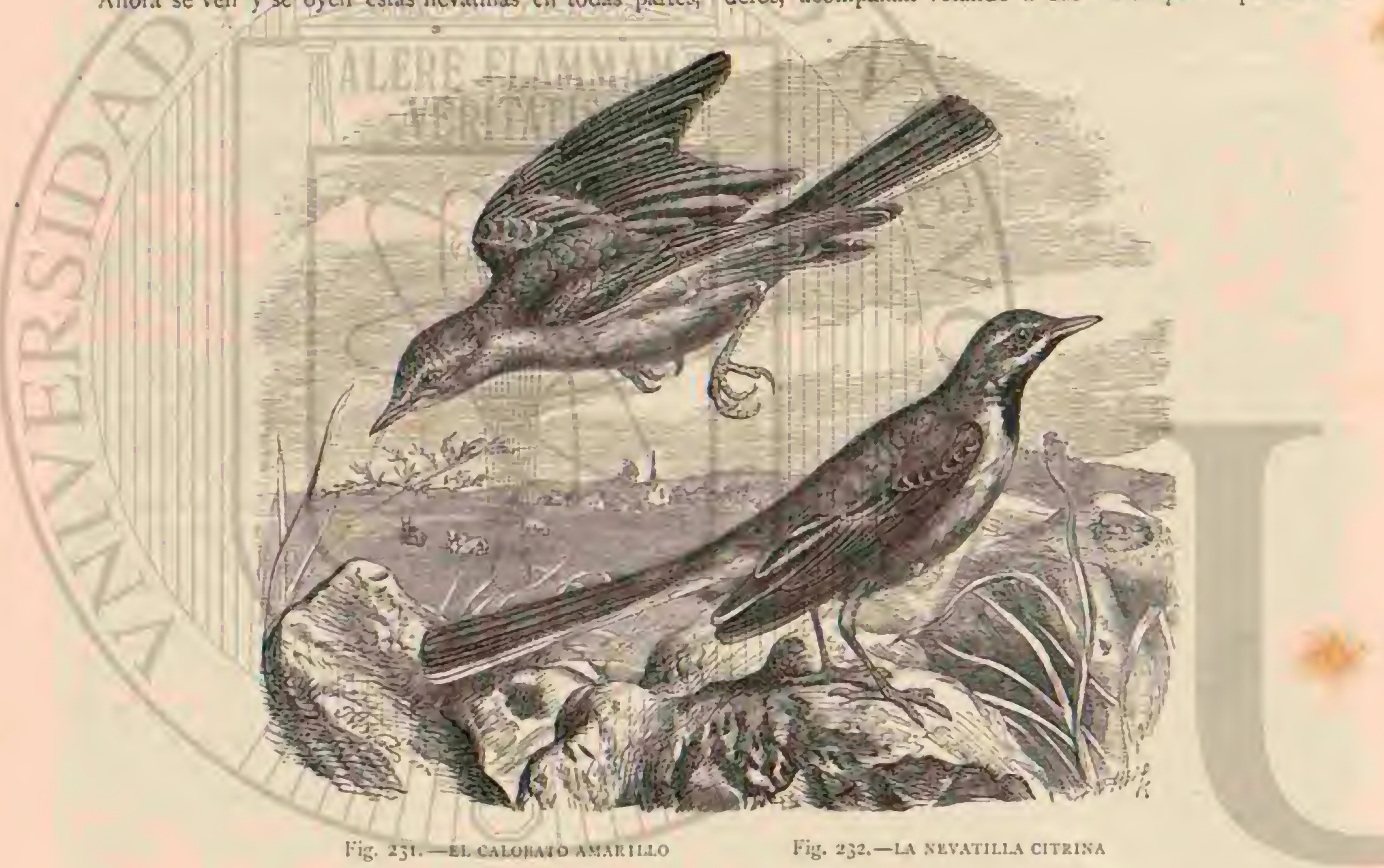

cuando no pueden correr, y donde el suclo lo permite desafian á los bueyes á la carreta; acaso un macho aprovecha una mata para cantar un momento y descansar, apresurándose luego á alcanzar el rebaño rodeado de enjambres de estas aves.

\section{LOS ANTINOS-ANTHINE}

Se pucde considerar à los antinos, que forman la seguncia sub familia, como un tránsito entre las aves cantoras y las alondras, con las cuales se les confundia en otro tiempo.

CARACTÉRES. - Tienen el cuerpo prolongado; la ma. yor parte de las rémiges secundarias de las alas son escota. das en su extremidad, $y$ la mas larga de las cubitales apenas llega á la punta de las mayores remiges primarias; la cola es mediana; los tarsos y los dedos raquiticos $y$ prolongados, las uñas grandes, prolongándose la del dedo posterior en forma de espolon, como en los alaúdidos. El pico es recto, de bordes cortantes, con mandibula superior terminada en punta ligeramente encorvada y precedida de una pequeña escota. dura. El plumaje tiene por lo general colores opacos: varia segun los sexos, $y$ solo por excepcion difiere en los jórenes y los adultos
DisTRIBUCION GEOGRAFICA. - Esta sub-familia, que cuenta unas cincuenta especies, tiene representantes en toda la superficie de la tierra.

USOS, COSTUMBRES Y REGIMEN. - Todos los antinos pasan la mayor parte de su existencia en tierra, y-va. rios de ellos no se posan en los árboles sino por un instante. Son aves alegres, vivaces $y$ ágiles que corren con rapidez y sin saitar. Su andar es fácil y gracioso; llevan el cuerpo horizontal y hacen ligeros movimientos con la cola. Vuclan bien y con viveza, trazando una linea ondulada cuando de. ben franquear un largo espacio; revolotean y, se ciernen en el acto de remontarse por los aires para cantar.

Son ares bien dotadis, que se distinguen por su prudencia y cuyos sentidos alcanzan bastante desarollo. Su grito de llamada es una especie de pio, pio, y su canto agradable, aunque no-variado.

Se alimentan, sobre todo, si no exclusivamente, de insectos, y en particular de coleópteros, de moscas, mosquitos, cínifes y pulgones; algunos comen arañas, gusanos y pequeños animales acuíticos; otros, en fin, varian este régimen con pequeños granos: recogen su presa en el suelo y rara vez la persiguen al ruelo.

Anidan en tierra: el fondo de su nido se compone de ras- 
trojo y raices secas, con las cuales mezclan hojas y oiras sus. tancias vegetales: el interior está cubierto de lana y pelos. Los huevos son de colores oscuros, con puntos, manchas y lineas que forman un dihujo poco marcado. Solo cubre la hembra; pero los dos sexos manifiestan mucho carino hàcia su progenie. Ias mas de estas aves ponen mas de una vez. al año.

\section{EL PIPI DE LAS PRADERAS-ANTHUS PRATENSIS}

CARACTERES.-Esta especie es la mas conocida de la familia. Las plumas del lomo, de un pardo aceituna, presen. tan un ligero viso verde, con manchas de un pardo oscuro, joco marcado en los tallos; las de la rabadilla son de color mas vivo, pero mas uniforme; una faja que se corre sobre los ojos, las mejillas y las partes inferiores son de un amarillo de orin muy delicado, mas ascuro en los costados; en el buche y el pecho se ven anchas lineas de un pardo oscuro; otra que hay debajo de los ojos y una faja en forma de barba, que llega hasta los lados del cuello, son negras; las rémiges y rectrices, de un pardo aceituna oscuro, están orilladas de amarillo en las barbas exteriores; las extremidades de las tec. trices secundarias y las grandes tectrices del ala tienen un borde mas claro, por lo cual se forman dos fajas trasversales poco marcadas; las rectrices son blancas por fucra, y del mismo tintê, mas sucio, en las extremidades; la última mitad de sus barbas inferiores es blanca hasta cerca del canon; en la segunda rectriz, de ambos lados el color blanco se limita en la extremidad de las barbas exteriores. Los círculos oculares son pardo oscuros; los muslos de un pardo de cuerno en su parte superior, y mas claro en la inferior; y los piés parduscos. Ia longitud del ave es de 1$)^{m}, 15$ por $11^{\mathrm{m}}, 24$ de ancho de punta a punta de las alas; estas miden 1$)^{\text {e }}, 07$ y la cola $0^{\circ}, 06$ (fig. 23.3).

Fn el extremo norte de Europa y Asia y desde Iaponia hasta el Kamischatkia, el Himalaya, y además en el norte de Africa, el antino de las praderns está representado por el fipi scrino(Authus seriuus). Esta especie, muy congenérica de la anterior, tiene el mismo tamano, distinguiéndose por las fajas oculares, los lados de la cabeza y del cuello, la barba, la garganta y el buche que son de un bonito color rojizo de carne; las manchas oscuras de los tallos y del vientre y las de los lados del muslo son mucho mas pequeñas; las dos fajas trasucrsales de las alas mas claras y marcadas.

DISTRIBUCION GEOGIR AFICA.- Habita todo el nortc de Europa, desde el circulo polar hasta la luropa central; en Asia otro tanto. Durante el invierno existe en todo el sur de Europa, en el sudoeste de Asia y en el norte de Africa.

USOS, COSTUMBRES Y REGIMEN.-El pipi de los prados llega a nuestros paisés en la epoca del deshiclo, á menudo á principios de marzo, ó à mas tardar á mediados de abril; permanece hasta noviembre y diciembre: á la ma nera de las alondras, emigra en numerosas bandadas, que se reunen a menudo con las de aquelias aves: viajan dia y noche.

Es un ave casi palúdica, que habiala tanio en su patria como en los paises donde pasa el invierno y en las regiones en que abunda el agua, prefiriendo siempre sitios hume. dos y pantanosos. Solo cuando viaja se la ve alguna vez en lugares secos. Ja Tundra es para esta ave un parajso.

El pipi de los pracios es viraz y activo, siempre esta en movimiento, y corre alegremente por todos lados, en medio de las yerbas. Si se le espanta, elévase con rápido vuelo por los aires, lanzando su grito de llamada, y se refugia en otro punto; rara vez se posa sobre un árbol, y cuando lo hace nunca por largo tiempo; diriase que le fatiga permanecer en una rama. Su vuelo cortado parece violento, pero r.o lo es en realidad.

Su grito de llamada consiste en un isst algo ronco, que repite varias veces seguidas; el de ternura se traduce por dwi ó zeri. Segun Naumann, se compone su canto de diversas frases, cuyas notas se repiten con irecuencia: parece que el tema principal es á menudio abittge suiblge aitilge, will sic sic, suic ivic, furrr. Fl macho no suele cantar sino volando; cle vase oblicuamence á una gran alturn, se cierne un instante con las alas levantadas, baja luego poco á poco, 6 bien se deja caer con rapidez cerrándolas a partir del mes de abril hasta julio se oye casi continuamente su voz desde la manana i la tarde.

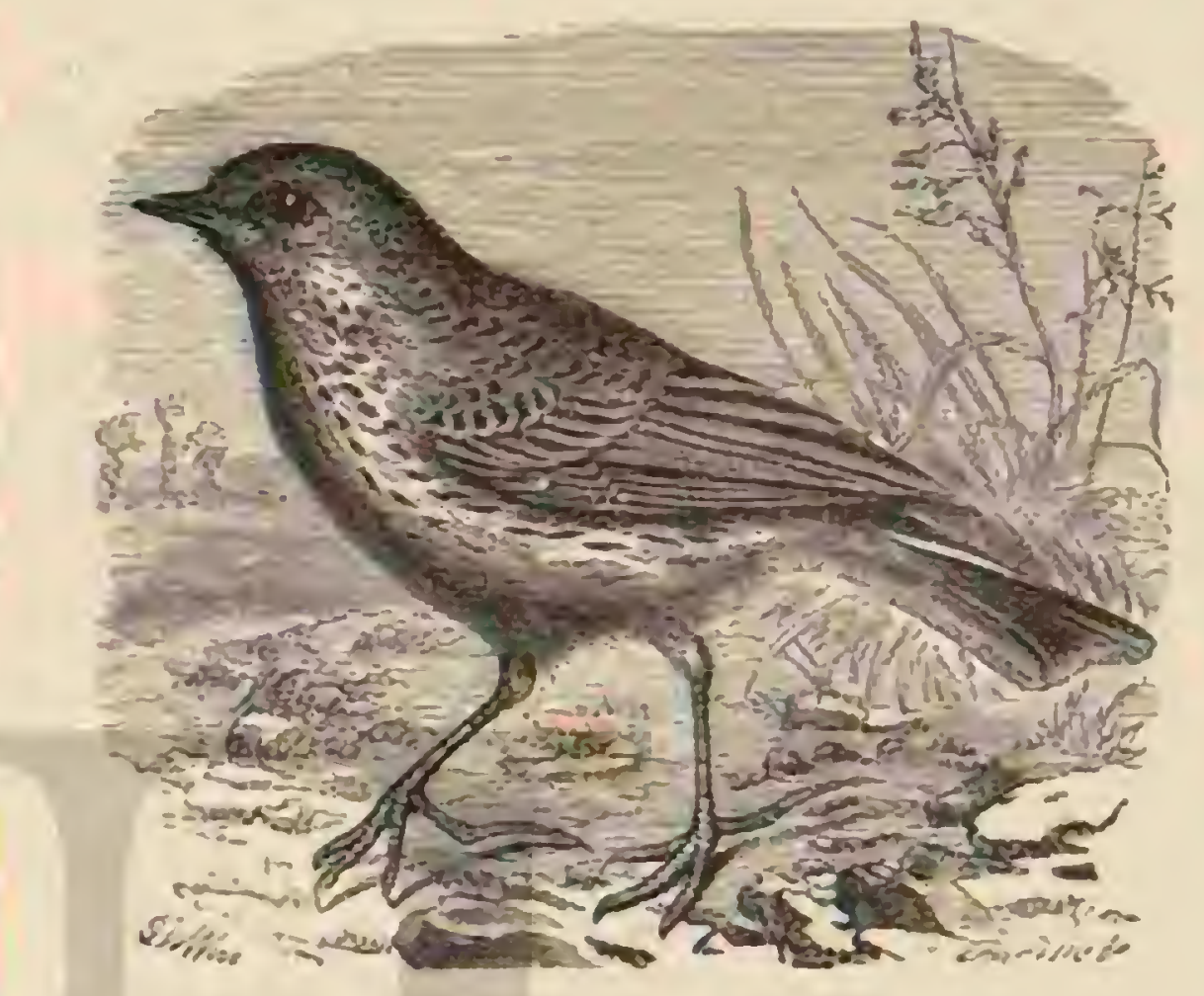

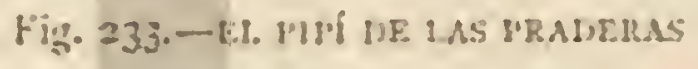

Ll pipi de los prados es muy pacifico con sus semejantes, aunque también gusta armar pendencia con las otras aves que habitan la misma localidad, tal como las nevatillas y los cincramos de los cañaverales. En el periodo del celo sucede a veces que dos machos pelean por una hembra, mientras que los pipis de los prados viven en esta época juntos. Durante sus emigraciones forman bandadas nuly numerosas en ciertas ocasiones.

Esta ave construye su nido entre cañs, juncos ó yerbas, en alguna depresion del terreno, $y$ le oculta siempre tan bien, que es muy dificil encontrarle. Las paredes se componen de tallos secos, raices y rastrojos, encre los cuales hay un poco de musgo; la cavidad es profuncia y esta cubierta de yerbas tiemas y crines de caballo. Caca puesta se compone de cinco ó seis huevos de $10^{m}, 018$ de largo por $11^{m}, 014$ de grueso, de color blanco agrisado ó rojizo sucio, cubicrtos de puntos, estrias y manchas de un tinte gris ó amarillo pardo. La incubacion dura quince dias. Los hijuelos abandonan el nido antes de poder volar; pero saben ocultarse perfectamente en medio de las yerbas, y asi escapan de muchos enemigos. Los padres sc exponen al peligro por salvar á su progenie del riesgo que amenaza. Ctando las circunstancias son javorables, los hijuelos de la primera puesta comienzan a volar á principios de majo, y los de la segunda á fines de julio; pero aun se encuentran en el mes de agosto pequeños que acaban apenas de.dejar el nido.

CAUTIVIDAD. - Si se cuida bien à esta are y se la pone en una espaciosa jaula, soporta la cautividad durante varios años: se domestica muy pronto y carta con afan. No se la puede dejar correr libremente por una habitacion, pues cuan. do se adhieren á sus patas hilos, pelos ó polvo, enferma en seguida. 


\section{EL PIPÍ DE LOS ÁRBOLES-ANTHUS AR- BOREUS}

El pipí de los árboles, llamado vulgarmente alondra de los bosques, se asemeja mucho al pipi de los prados, con el cual se le ha confundido á menudo. Es mayor, liene el pico mas fuerte, los tarsos mas vigorosos, $y$ la uña del dedo interno mas corta y encorvada.

CARACTERES. - El lomo es pardo amarillento ó de color verde aceituna sucio, con mezcla de manchas oscuras dispuestas longitudinalmente; la rabadilla y la parte inierior del lomo son casi de un color; uma raya que se observa sobre el ojo, la garganta, los lados del pecho, las nalgas y las co. bijas inferiores de la cola son de color ámarillo rojo putido; el buche, la parte superior del pecho y los costados presentan manchas negras, dispuestas longitudinalmente; el ojo es pardo, el pico negro y las patas tojizas. Esta ave mide $\theta^{2}, 17$ de largo por 10",29 de punta á punta de ala, la cola 10,065 $y$ el ala $11^{2}, 05_{5}$. La hembra es mucho mas peqquetra que el macho (tig. 234 ).

DISTRIBUCION GEOGRAFICA.-El pipi de los árboles habita en vernno los bosques de Furopar y de la Siberia, y en invierno los de las estepas del Airrica y de la falda del Mimalayia Solo durante sus viajes se deja ver en los sitios desprovistos de airboles.

USOS, COSTUMBRES Y REGIMEN. - IJUSCA los claros del bosque, las copas de poco follaje, los arbotados, y en una palabra, los parajes de mert espesura, pero en cuya in. mediacion haya algunos árboles altos.

Por su género de vida se asemeja mucho el pipi de los árboles al de los prados, aunque anda menos por el suclo. Cuando teme un peligro se reiugia sobre un árbol, mientras que el pipil de los prados no suele hacerlo; corre tambien á lo largo de las ramas; es menos sociable y vive por lo regu. lar solitario. Solo en el otoño se le ve en reducidas familias; pero aun asi, los individuos que las componen suelen estar uno lejos de otro.

Su grito de llamada se puede traducir por sri y el de ter nura por sil sill sit. Canta micjor que los otros pipis; los so. nidos que produce son muy armoniosos y se parecen bas. tante a los del camario; las notas, llenas y claras ofrecen bastante variacion. ๔Su canto, dice Naumánn, se comp̨one de varios trinos claros y agudos, que se suceden con rapider, confündense armoniosamente y terminan por la frase sia sia sia, que se extingue con mucha dulzura. El macho canta con ardor, sobre todo durante la época del celo, y desde que sale el sol hasta que se pone, pero á pastir de fines de junio permanece silencioso. Para cantar se posa en el extremo de una rama, y siempre dejândose oir, remóntase oblicuamente por los aires, se cierne y vuelve á bajar con lentitud á la copa de un arbol vecino, donde termina su canto.

El nido del pipi de los árboles se halla en una depresion del terreno, en medio de las yerbas ó de los brezos; es de tosca construccion, y solo el interior estí hecho con algun mayor esmero. La hembra deposita en él cuatro ó cinco huevos de $11^{\circ}, 020$ de largo por $11^{\circ}$, or 5 de grueso, que varian notablemente, tanto por la forma como por el color; son de un gris rojizo, blanco sucio, blanco agrisado ó azulado, cu. biertos de vetas, manchas, motas 5 puntos de un tinte mas oscuro. La hembra cubre con afan yo solo abandona la pucs. ta cuando álguien se acerca mucho al nido. Los padres se manifiestan muy cariñosos con su progenie; los hijuelos abandonan el nido antes de poder volar.

CAUTIVIDAD. - Los antinos arboricolas se conservan fícilmente en cautividad; domesticanse en alto grado $y$ di. vierten á su dueño tanto por la gracia de sus movimientos como por su excelente canto; el de los individuos ạue se cogen neçueños en el nido iguala al de los que visen libres.

\section{EL PIPÍ ACUÁTICO-ANTHUS AQUATICUS}

CARACTERES. - El pipi acuático tiene el lomo de co. lor gris aceitunado oscuro, con manchas longitudinales de un gris negro; el vientre blanco sucio ó agrisado; los costa. dos con manchas de un tinte pardo aceituna oscuro; por Cetrás del ojo hay una lista gris clara, y dos fajas del mismo color atraviesan el ala. El ojo es pardo oscuro; el pico negro, con la punta de la mandibula inferior amarillenta; las patas de un pardo oscuro. El ave tiene $61^{m}$, is de largo, y $\left(t^{2}, 30\right.$ de punta $a$ punta de ala, la cola $1, ", 07$ y el ala plegada $(1), 09$. La uña del dedo posterior es larga y muy corva. La cola es de un pardo oscuro; las rectrices exteriores blancas por fuera y en la extremidad de las barbas interiores; la segunda y tercera de ambos lados tienen una mancha blanca en la punta del tallo.

DISTRIBUCION GEOGRAFICA.-El árez de dispersion del antino acuático se extiende por el centro y mediodia de Europa, asi como por el oeste y este del Asia hasta la China; en su riaje de invierno ol ave llega hasta el Asia Menor, Palestina y el norte de Africa.

En Escardinavia, Dinaunarca é Inglaterra, esta especie se halla representada por el antino de las rocas (Ansinus niscrurus), que sé distingue por el dorso un poco oscuro con lustre pardo verdoso accituna; las regiones inferiores son de un color rojizo de carne menos vivo, y la mancha de la extremidad de las rectrices exteriores presenta un brillo par. dusco. Vin el norte de América se encuentra el antino pardo (Anthus ludosicianus) que tambien se ha visto en Heligoland. Esta ave tiene el dorso de un pardo aceituna oscuro, con numerosas manchas en las partes inferiores; las rectrices son blancas casi hasta la base.

USOS, COSTUMBRES Y RÉGIMEN.-Mientras los demás pipis habitan la llanura y solo se encuentran aislada raccidentalmente en las montañas, el pipi acuático solo vive en estas. Puebla los Alpes suizos y los del Harm, debajo de la zona de los pinos: únicamenic en sus viajes aparece en la llanura

Aqui se presenta ya cuando comienza el deshielo, y avanza poco á poco hícia el norte; de modo que en la uil. tima mitad de abril llega á los parajes donde anidar Casi to mismo sucede en Suiza.

4Desde el mes de abril, dice Tschudi, busca este pipi los parajes donde se ha derretido la nieve, y se fija en cllos para no dejarlos ya. Fin el verano, cuando hnce demasiacio viento, 5e reune la especie en los lugares puestos al abrigo de la tempestad; llegado el otoño se la encuentra en la inmedia. cion de los pantanos, de las corrientes de agua, de los lagos de la llanura, y hasta cerca de los pueblos. Algunos individuos pasan el invierno alli; pero los mas emigran hàcia Italin; los que se quedan frecuentan las pendientes bañadas por las aguas, los viñedos y las praderas, y pasan la noche en a espesura de encinas cubiertas de hojas secas. Cuando el frio es demasiado riguroso, se dirigen á su vez no otros paises mas cálidos, x Preséntanse por ejemplo en Grecia, España y hasta en Egipto.

4El pipi acuático, dice Gloger, que ha observado perfecta. mente su género de vida, se encuentra à una gran altura en las montañas, donde la vegetacion arborescente solo está re. presentada por algunos pinos achaparrados; 占 reces alcanza mayor altura. Se le ve en todos los puntos donde crecen estos árboles, y se remonta hácia el límite de las nieves eter. 
nas. En Suiza se le observa todavia sobre las rocas desnudas que bordean los arrojos formados por el deshieio; habita las cimas mas áridas y desiertas, asi como los pinares de terreno turboso, surcados por innumerables arroyos; encuéntrase asimismo en las rocas cubiertas tan solo de una ligera capa de verdura, en los lugares donde abundan los pinos achaparrados, en las vertientes de los mas escarpados barrancos, y en las altas mesetas de las montañas.

$\$$ Durante la época del celo, y'solo entonces, le gusta po. sarse en los pinos, y menos a menudo en las piedras y las rocas. Cuando un individuo descansa y se acerca otro, el primero le cede el puesto, lo cual prueba que reina entre ellos buena armonia. Despues del periodo citado, reúnense estas aves en los pastos por centenares de individuos, aun. que sin formar sociedades muy unidas. Por la mañana se ve á los padres conducir á sus hijuelos hacia los arroyos, y acompañarlos á las rocas mas cxpuestas à los rayos del sol, en los dias cálidos y hermosos. Los pipis acuáticos viven so. litarios hasta la llegada de la mala estacion: son en todo tiempo muy tímidos; pero cuando tienen hijuelos, el amor que les profesan les hace perder su temor natural; revoloteau y saltan al rededor de su enemigo y gritan continuamente stici spicb y en sumo terror gelicik, gcicik, levantando y bajando la cola y erizando su plumaje. Su grito ordinario se puede expresar por zsipp agisp: el canto, que se oje hasta fines de julio, es muy agradable, aunque inferior al del pipi rle los árboles. Comienzan por una serie de notas, cada ver. mas precipitadas; al mismo tiempo se remontan por los ai. res, se ciernen un poco, y vuelven á posarse sobre alguna rama, en una piedra 6 en el suelo, para concluir alli su can. to. Rara vez dejan oir su voz mientras estan posados, y solo cuando observan que oscurecen el horizonte negras nu. bes. Fl niclo del pipi acuático está menos oculto que el de sus congéneres: hállase situado en una gricta de roca poco profunda, entre las piedras, en una mata de yerba debajo de algunas raices $y$ de las ramas de pino, y siempre dispuesto de manera que le cubra un tejadillo natural para preservarle de la lluvia y de la nieve. Fil número de los luevos varín en. tre cuatro y siete; son azulados ó de un bianco sucio, cubier. tos de puntos, manchas y rayas de un inte pardo oscuro, pardo, pardo negro ó gris negruzco: con frecuencia se ase. niejan bastante á los del gorrion doméstico.

En las montanas medianns donde esta especic anida, las parejas incuban dos veces cuando el tiempo lo permite, una a primeros de mayo y otra á fines de junio; en las montañas altas solo pone una vez à mediados de mayo. En los Alpes, segun Tschudi, estas aves suelen padecer mucho por el rigor del tiempo en la primavera \& Muchos años, dice, una nevada rardia cubre el nido con los huevos, ahuyenta i la hembra, la sepulta à menudo ú obligala á anidar oira vez mas tarde. Tambien los polluclos sucumben muchas veces bajo la nicve y el hielo antes de poder salir del nido.

\section{EL PIPÍ CAMPESTRE-AGRODROMA CAMPESTRIS}

CARACTERES. - El pipi campestre ó de los camjos, que algunos consideran como tipo de un subgénero independiente (.tgredsema), es la especie indigena mas grande de toda la familia. Tiene 1$)^{\prime \prime}, 18$ de largo $y\left(1^{\prime \prime}, 2 S\right.$ de punta a punta de ala, la cola $0^{*}, 066$ y el ala plegada $0^{\prime \prime}, 0 \$_{3}$. El lomo es de color gris anmrillento claro, con manchns diseninadas que se marcan poco; el vientre de un blanco amarillento sucio, con algunas manchas negras en el buche; sobre el ojo hay una faja de un tinte amarillo claro, $y$ en las alas dos lisias de un blanco amarillento.
Los pequeños tienen el lomo oscuro, con filetes amarillentos en cada pluma, y su garganta presenta numerosas man. chas.

DISTRIBUCION GEOGRÁFICA.-El área de dispersion del pipi campestre comprende, exceptuando el extremo norte de la Tundra y la Gran Bretaña, toda la Europa, el centro y el sur del Asia y el norte del Africa, incluso las islas Canarias.

USOS, COSTUMBRES Y RÉGIMEN.-El pipi de los campos busca con preferencia los sitios estériles y desiertos, debiéndose á ello que abunde mas la especie en el sur que en el norte de Europa. En Alemania no escasea en ciertos puntos; mientras que solo aparece excepcionalmente en otros. No remonta en direccion al norte sino hasta el sur de Succia, antes por el contrario, desciende bastanic hácia el sur. Parece preferir particularmente ciertas islas: Bolle encontró muchas de estas aves en Canarias.

En Espana, Italia, Grecia y Alemania se le encuentra solo en ciertas regiones. Al volver del mediodia preséntase en el sur de Europa un poco antes que en Alemania Aqui apa. rece hácia mediados de abril, para marchar â fin de agosto, poco mas ó menos; en mayo llegan los últimos rezagados, y todos se van en setiembre. Anies de emprender su marcha se reunen en bandadas. Cuando hace buen siempo viajan dia y noche siempre que el viento les favorece.

El pipí campestre recuerda tanto las alondras como las nevatillas por todos sus movimientos; corre en posicion casi horizontal, levantando y bajando á menudo la cola; anda por el suelo tan ocultamente como le es posible; pósase de ver. en cuando en cualquier objeto elevado, para descansar algunos momentos 6 examinar los alrededores, y continisa des. pues su carrera. Al volar mucve las alas rápidamente, recógelas a intervalos y traza lincas onduladas muy curras; antes de posarse su vuelo suele ser sostenido, pero a veces se precipita tambien con las alas recogidas casi verticalmente desde la altura En Alemania, esta ave es casi siempre en extremo timida; mientras que en algunas regiones del sur parece mas familiar, si bien conserva siempre su prudencia. Su voz no es tan agradable como la de otros antinos: su grito de lla. mada suena como dillem ó dlcmsm; con las silabas krillir, Eirlui y sivir expresa su carino; estas silabas forman tambien las partes esenciales de su canto, en cxtremo sencillo y algo semejante á los sonidos que sucle producir la alondra. Su alimento consiste en toda clase de animales pequeios, y tambien come simientes.

Durante el periodo del celo, cada pareja ocupa un dominio bastante exienso, de donde ahuyenta átodos sus semejantes. En aquel momento guistale al macho dejarse ver, posándose sobre un matorral, en una piedra, en un nuro, y reces en un árbol. Elévase oblicuamente por los aires y llega á una altura de 30 á 50 metros; comienza á gorjear, volando irre. gularmente de derecha a izquicrda, y produce sin cesar su sirlui sirlui para recrear a su compañera

El nido es bastante grande: se compone exteriormente de musgos, raices y hojas secas, y su interior està relleno de rastrojo, brianas de yerba y pelos: es tan dificil encontrarle como el de todos los demras pipis, pues el macho y la hem. bra toman iodas las precauciones necesarias para que no se descubra, y si se creen observados no se dejan ver en los alrededores.

Cada puesta consta de cuatro a seis huevos de $\theta^{\circ}, 022$ de largo por $0^{=1} 015$ de grueso, de color blanco sucio, cubiertos de puntos, rayas, vetas y manchitas de un pardo rojizo opaco, mas compactas hácia la punta gruesa. La hembra cubre sola, y entre tanto la entretiene el macho con sus cantos y ejercicios de alto ruelo. Si se acerca cualquiera despacio al nido, 
recorre la hembra algunos pasos antes de volar, segun lo ha obscrvado Naumann: á veces se deja sorprender y solo vuela cuando está uno casi sobre ella.

Los padres manifiestan a ș progenie el mas vivo amor, y se inquisetan mucho cuando les amenaza algun peligro.

Si se cogen los húevos de la primera puesta, anida la hem. bra por segunda vez, y si no hay entorpecimiento, encuéniranse a fines de majo $\delta$ á principios de junio, y èn julio, hijuelos g̨ue han comenzado á yolar.

\section{EL ANTINO DE ESPUELAS-ANTHUS} LONGIPES

CaraCtÉRES. - Estz especie, tipo del subgénero de Ins coridalas ( Cerydalda), es la mas grande entre todos los

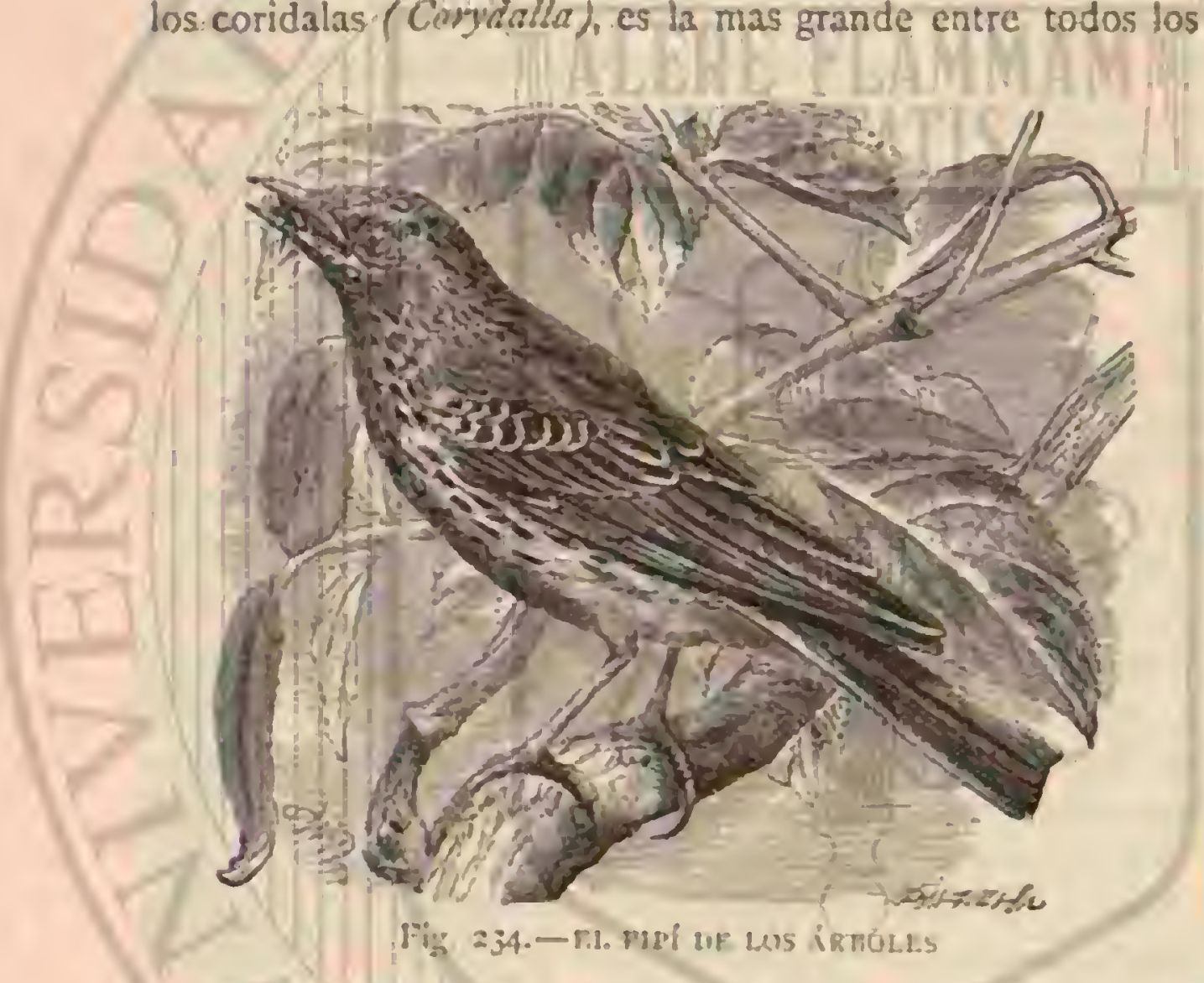

amtinos que existen en Nemania, y se distingue de la precedente por tener muyl larga y casi recta la una del dedo pos. terior. I a longitud de este antino es de $11^{\prime \prime}, 20$ por $11^{-1}, 3 x$ de anchura de punta á punta de las alas; estas miden $11^{\circ}, 10$ y la cola $10^{\circ}, 08$. Las partes súperiores son de un pardo intenso; todas las plumas están orilladas de un pardusco amarillo, que se cxtiende mas en las plumas del manto y en las de los hombros; la rabadilla $y$ las tectrices superiores de la cola son de un solo color pardo amarillo; la linea naso-ocular y una ancha lista que se corre sobre los ojos y las sienes, de un blanco amarillento de orin;-la-region de las orejas y una faja en forma de barba, que parte de los ángulos de la boca, tie. nen manchas pardas; en el buche y los lados del cucllo hay otras mas oscuras; en los lados de los inuslos, se ren lineas estrechas de color oscurn; las rémiges son de un pardo acei tuna intenso; las barbas exteriores de las primarias presentan un borde muy angosto de color pardusco amarillo; las secun. darias le tienen bastante ancho, del mismo color, asi como las tectrices secundarias; estas últimas y las mas graudes de las alas están orilladas de blanquizco en la extremidad, formándose asi dos fajas trasversales de color claro en las alas; las rectrices son de un pardo aceituna oscuro con un estrecho borde color de orin pílido en las barbas exteriores. La pri: mera rectriz. de ambos lados presenta un tinte mas oscuro en la mitad de la base de sus barbas interiores, asi como tá segunda de ambos lados en su extremidad. Los circulos ocu. lares son de un pardo oscuro; la mandibula superior de un blanco de cuerno; la inferior de un pardo ciaro, y los piés de color de carne. Los polluelos se distinguen por los bordes mas marcados de las plumas del dorso y por las manchas mas señaladas del buche.

DistrIBUCION GEOGRÁFICA.- Las estepas del
Asia oriental, incluso el norte de la China, son la patria del antino de espuelas; desde estos puntos el ave cmprende todos los inviernos viajes hácia el sur, presentaindose entonces en la China meridional y en toda la India, sobre todo en Ben. gala, donde abunda mucho en los meses frios, y donde se caza en gran número, vendiéndose bajo el nombre de ormliz. no en el mercado de Calcuta. La misma are extiende sus viajes tambien hácia occidente, llegando quizśs todos los anos ¿ las islas alemanas del mar. del norte, Dinamarca, el medio. dia de Suecia, la Gran Bretaña, Holanda, la Francia occidental, Espana, Portugal y el nordeste de Africa; hasta se asegur que algunos individuos han anidado en Holanda. De las observaciones minuciosas hechas por Gactke en la pe. queña isla de Heligoland, punto muy frecuentado por las aves de paso, resulta que los viajes de este antino se verifican con mas regularidad de la que hasta ahora se suponia y que pro. bablemente estos antinos, baszante escasos en los citados paises de Europa, pasan todins los años mas ó menos yor el mismo carnino. De aqui se desprende que no es exacta la noticia de haber anidado antinos de espuelas en Holanda. Cierto que en este pais y en Bülgica se han cazado individuos jóvenes de esta especie, revestidos con su primer plumaje; pero segun nos demuestran las incomparables observaciones de Craetke, las aves jórenes emprenden sus viajes mucho antes que las adultas, franqueando en pocos dias la inmensa distancia entre el este de Asia y el oesteide Furopa.

USOS, COSTUMBRES Y REGIMEN.- Darece que el antino de espuelas difiere poco de sus congéneres por la manera de vivir. Segun las observaciones de Dybowski, pre. séntase en la siberia oriental á primeros de mayo ó un poco mas tarde; hatsita tanto en las praderas de las estepas y las mesetas situadas á 1.500 metros de altura como en las regrio. nes menos elevadas, y alli donde se le encuentra su número es tan considerable, que figum entre las aves mas abundantes del pais. El nido se halla casi siempre en las cavidades for. madas por las perunas de los animales de los ganados, y con. tiene en la prímera nitad de junio cuatro ó seis liuevos muy brillantes de $6 "$ ",023 de largo por (1"017 de grueso, algo sumejantes á los de la nevatilla; su color es sontosado ó de un accituna pálido, con muchas lineas de forma y longitud muy diversa, que se cruzan y mezclan del modo mas difurente. Mientras la hembra empolla el macho vigila a cierta distan. cia y la advierte cuando la anenaza un peligro; un este easo la liembra se aleja primero á la carrera, remúntase despues, y juntamente con el macho procura ahuyentar al enemigo pro: duciendo gritos desagradables. Cuando ambos han seguido al intruso a cicrta distancia, vuclven síbitamente; la hembra baja al suelo y vuclve á la carrera al nido, aunque este es dificil de encontrar. No escaja, sin embargo, á la penetranic vista del cuclillo, pues precisamente en el nido de este antino se en. cuentran muy á menudo huevos y polluelos del citado jara. sito. En la última mitad de julio la hembra empolla por segunda ves, y despues emigra con el macho $y$ sus hijuelos.

\section{LOS ALAÚDIDOS - ALAU- DIDE}

- CARACTERES. - Los alaudidos son pajaros fornidos, de cabeza roluminosa, alas largas y ancías, con las mas de las rémiges secundarias ciscotadas en el extremo en iorma de corazon. Ia cola es coria: la uina del pulgar recta ó poco menos, y tan larga o mas que el dedo. El plumaje es por lo general opaco y difiere poco en ambos sexos; el de los pequenos se diferencia marcadamente del de los padres antes de la primera muda. 
Los órganos internos presentan la misma disposicion que en los otros pájaros: el esqueleto es vigoroso: los huesos que le componen carecen en gran parte de la médula, y están pro. vistos de células aéreas; tienen músculos laríngeos, propios para el canto; los pulmones son anchos y el estómago mus. culoso: carecen de buche.

DISTRIBUCION GEOGRÁFICA.-LOS alaúdidos, re. presentados lasta ahora por ciento diez especies conocidas, se encuentran en todos los continentes; pero son mas bien propios del antiguo mundo, pues el territorio sepientrional y ul meridional de América y el de Australia solo posecn una especie.

USOS, COSTUMBRES Y REGIMEN. - Fstas ares habitan en las regiones descubiertas, tanto tos campos culti. vados como los incultos, el desicro y la estepa; son las que dan vida con su canto a las inmensas llanuras del Asia Ia parcja de una especie vive junta á la de otra y asi entretienen en la primavera d todas horas del dia á los viajeros. Siempre
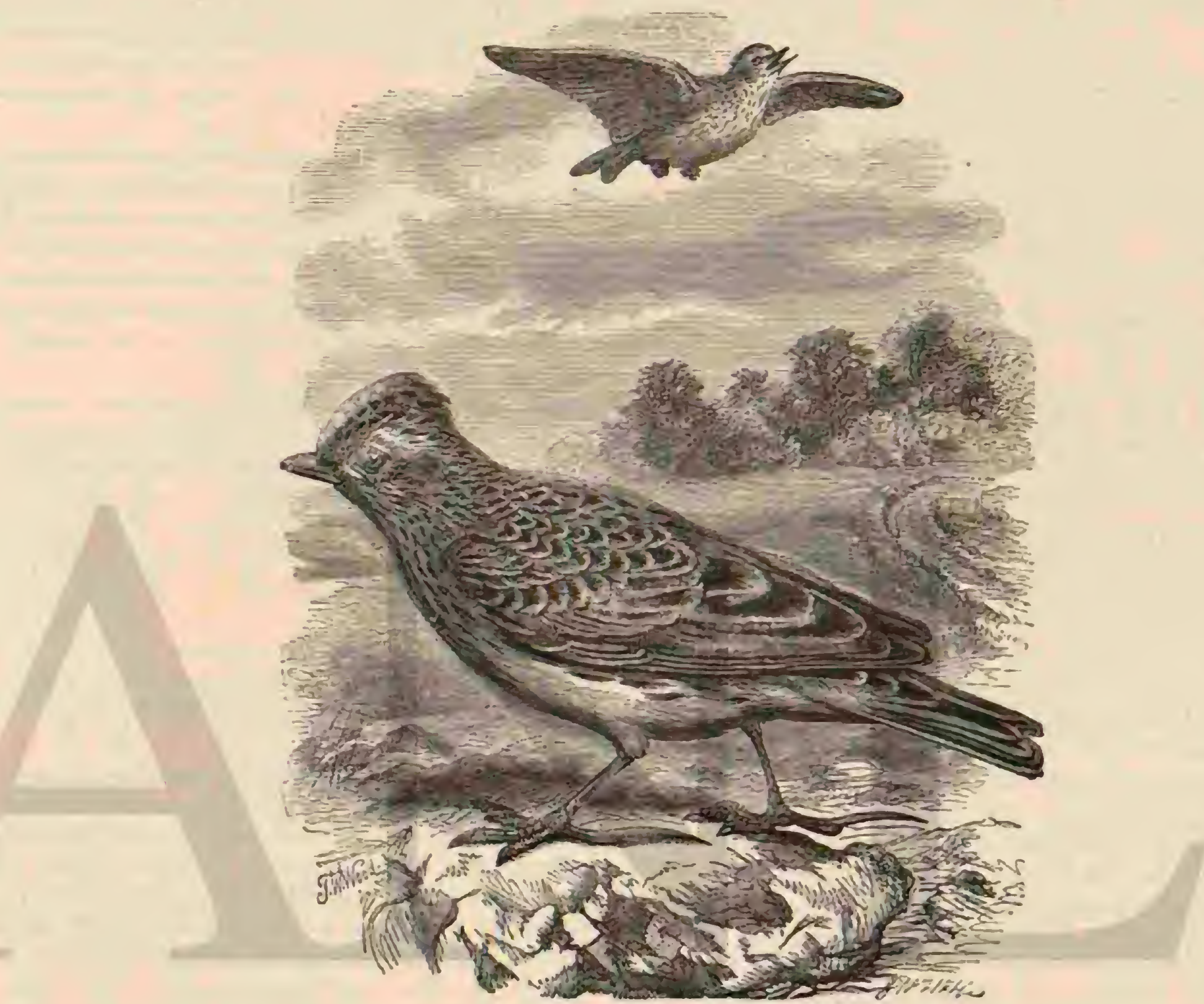

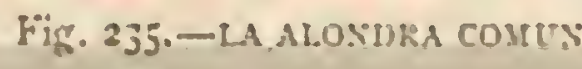

Se ve inna de estas ares en los aires, aunque solo sea porque el coche ó el jinete que pasa la obliga á remontarse.

Todos los alaúdidos del norte son pájaros viajeros; los del sur lienen por el contrario residencia fija: aquellos son los primeros yue llegan en la primavera a nuestros países, y no los abandonan hasta fin de otoño.

Los alavididos son entre los pájaros los que corren mejor. Su vuelo es muy variable: si se les obliga a emprenderle, se remontan al momento trazando lincas extensamente ondula. das, y ensanchan las alas con rapidez para recogerlas en se. guida. Coando cantan, clévanse verticalmente, ó describiendo espirales; vuelven a bajar con lentitud al principio, luego replegan las alas y se dejan caer bruscamente á tierra. Parece que sus sentidos están muy desarrollados, pero medianamente su inteligencia: son viraces, y se mueven de continuo; hasta ņue entran en celo viven en buena armonia entre si; pero llegada la énoca del apareamiento, luchan sin cesar. No lacen aprecio alguno de los otros pájaros, si bien se les encuenira á menudo entre las bandadas de pinzones ó emberizas; solo temen a las aves de rapina; el hombre no les inspira la menor desconfianza, mientras no hayan sido ovjeto de su persecucion. Los mas de cllos son buenos cantores, y hasta hay algunos muy bien dotados en este concepto: su canto, aunnue pobre en motiros, es muy rico en variaciones, y como las pocas notas de que se compone se emiten de mil maneras, parece qque cada vez entona el prajaro un nuevo airé. Todas las especies tienen la facultad de imitar los sonidos que perciben.

Los alaúdidos son á la vez insectivoros y granivoros: en ve. rano comen pequeños insectos, mariposas, langostas, arains y larvas; en invierno se nutren de granos de diversas plantas; en la primavera de scmillas, insectos, retonos, y principalmente de trigo verde. Devoran los granos enteros, y con ellos algunns piedrecitas, que puestas en movimiento por las contracciones del estómago, contribuyen i triturar al alimento. Beben el rocio de las hojas y pueden pasar mucho tiempo sin agua; para limpiarse se revuelcan en la arena, y en invierno en la nieve.

Los alaúdidos forman un nido en una pequeña cavidad del terreno, practicada por ellos mismos: cste nido es un conjunto bastante informe de hojarnsca, rastrojo yerbas, te. niendo siempre la precaucion de elegir maicriales cuyo color 
se confunda con el del centro donde se hallan. Ia primera pucsta es de cuatro a seis, $y$ la segunda de tres á cinco hueros manchados.

Todos los animales rapaces, tanto mamiferos como aves y serpicntes, y tambien cl hombre, persiguen de continuo á los alaúdidos: pero su reproduccion es tan abundante, que por ella se indemnizan todas las pérdidas, sin contar que su número aumenta continuamente á medida que se extiende la agricultura.

\section{LA ALONDRA COMUN-ALAUDA VULGARIS}

CARACTERES - Iista cspecie se caracteriza por su es tructura algo ranuitica el pico, hastante corto, afecta la for. ma cónica: las alas son de longitud regular y puntiagudas. Ia tercera rémige es la mas larga: la cola regular y sesgada; los vies, algu endebles, tienen los dedos bastante cortos. In longitud del ave es de $0^{\circ}$, is por $6^{\circ}, 3^{2}$ de anchura de punta á puntá de alas; estas miden $0^{m}, 10$ y la cola $0^{\circ}, 07$ de largo. Las plimass de las partes superiores son de un pardo de tier$\mathrm{ra}$ orilladas del mismo tinte mas pálido en los lados y con tallos pardo uscuros: la línea naso-ocular, las f́ajas que hay sobre los ojos y la barba son de un blanco pálido: las meji. Has y la region de las orejas de un pardusco de orin con linens mas oscuras, lo mismo que ia garganta, la cabeza, la parte superior del pecho $y$ los costados, que tienen lineas mas anchas en los tallos; el resto de las regiones inferiores es de un blanco púlido; las rémiges de un pardo oscuro, la primera orillada de blanco $y$ las otras de rojizo en las barbas exteriores; estos tintes, se extienden mas en las rémiges se. cundarins posteriores y en las tectrices, formindose asi dos fajas trasyersales de color claro; las rémiges secundarias pos. teriores fas jrimarias anteriores tienen la extremidad blan. quizca; las tectrices inferiores de las alas son de un pardo oscuro: las rectrices de un negro pardo orilladas de un pardo pálido en las barbas exteriores: la primera rectriz de ambos lados es blanca, con un ancho borde negro en las barbas interiores; en la segunda rectriz de cada lado este bordellega hasta el iallo; los ojos son de un pardo oscuro; el pico de un pardo de cuerno; y los pís de un pardusco amarillento.

DISTRIBUCION GEOGRÁFICA. - In patria de la alondra comun se cxtiende en toda Europa desde cl norte de Noruega $y^{*}$ Rusia y en el centro de Asia desde el limite meridional de los bosques hasta las montañas que separan el Asia central de la meridional. Ia aloncira visita rambien el norte de Africa y el mediodia de la India.

\section{LA ALONDRA DE SIBERIA - ALAUDA} SIBIRICR

CARACTERES. - Esta especie es un poco mas grande que la anterior. Ias partes superiores, las rémiges secunda. rias posteriores y sus tectrices son de un pardo oscuro, ori. lladas en sus barbas exteriores de un pardo pailido; la parte superior de la cabeza, la region de las orejas, los ángulos de las alas, las rémiges priniarias, las tectrices de las alas y las superiores de la cola son de un rojo canela; la linea nasoocular, una faja poco marcada que se corre sobre los ojos: los lados de la cabeza, las regiones inferiores, las tectrices inferiores de las alas y la extremidad de las remiges secundarins son blancas; la parte inferior de las mejillas y la region del buche presentan puntos oscuros poco marcados; los lados del pecho san de color rojo cancla, que hácia el vientre tira al pardusco y tienen lineas ascuras en los tallos; las rémiges secundarias son de un tinte pardo intenso, mas claro en las barbas exteriores, y con la extremidad blanca; las rectrices son negras, orilladas de un matiz mas pálido; las exteriores blancas del todo, $y$ la segunda de ambos lados blanca en las barbas exteriores. I.os ojos son pardos; el pico de un gris amarillento mas oscuro, y los piés de un pardo rojizo.

DISTRIBUCION GEOGRÁFICA.-Ia alondra de Si. beria representa $d$ ia especie comun en las estepas de la Europa oriental y en el norte de Asia.

USOS, COSTUMBRES Y REGIMEN, - La alondrn es para nosotros el precursor de la primavera; preséntase en la época del deshiclo, algunas veces á principios de iebrero; y' a fines de este mes, casi todos los individuos han tomado ya posesion de su dominio, donde permanecen durante el vera. no. Hasta los últimos meses del otoño no emprenden su viaje de invierno, yentonces llegan al sur de Europa, ó cuando mas al norte de Africa.

Siempre está en movimiento; se la re correr sin descanso, volas de un punto á otro, reñir con sus semejantes, gritar y cantar. Anda meciendose un poco, corre con rapidez y vucha admirablemente: si su vuelo es precipitado, traza largas lincas onduladas, alcteando con ruido; cuando canta se remonta cernieridose, y agita las alas con regularidad. En tierra se deja ver á menudo en descubierto, posada sobre un pedazo de tierra, una piedra, un matorral ó una estaca.

Su grito de llamada puede expresarse por gerr ó gerrel, seguido de una nota scmejante á un silbido, que hace frit ó tie: cuando anida se cambia este sonico por firri, y por scherritererr, si el pájaro está enojado.

Tocio el mundo conoce el agradable canto de la alondra, que se oye en los campos y praderas de los países donde abundan las colinas y aun de las regiones pantanosas no de. masiado húmedas. Apenas llega el ave comienzan á oirse ya sus alegres melodias que no cesan mientras dura la incuba. cion; canta desde que raya la aurora hasta el crepúsculo respertino, remontándose á intervalos por los aires, revolo:ca mas y mas port las alturas, donde á veces se pierde de vista en el éter; canta sin interrupcion $y$ sin descanso mas que ninguna otra ave; describe ancluas espirales en el aire; vuelve poco á poco hácia el sitio de donde ha salido, baja despacio, precipitase hácia el suelo con las alas recogidas, como una pièdra, y llegada à poca distancia de tierra entreabre de nue. vo aquellas para posarse cerca de su nido. Algunas notas, claras, puras y sonoras componen el canto, pero son tan nu. merosas y diversas las variaciones que algunos de estos pequenos artistas introducen, enriqueciéndolas con las que imitan del canto de otras ares, que el hombre no se cansa nunca de escuchar sus agradables melodias. Las hembras cantan de cierto modo; y los machos jórenes que pocas semanas antes salieron del nicio cjercitan su roz.

Ias alondras solo viven pacificamente entre si en el inviet. no y cuando comienzan sus emigraciones. En el periodo del celo pelean los machos á menudo encarnizadamente; los dos adversarios se cogen y ruedan; con frecuencia interviene un tercero en la lucha, y entonces caen los tres á tierra y se interrumpe el combate; pero solo por breves momentos, pues el canto de uno excita al momento la cólera y la envidia del otro. A veces pelean en tierra los dos rivales á la manera de los gallos, jo dan pruebas de su valor; aunque no hay gran ixcligro para el uno ni para el otro. El vencido se alcja, y su antagonista vuelve triunfante al lado de su hembra, que segun dice Naumann, en ciertas ocasiones toma tambien parte en la lucha.

A causa de estas riīas, el dominio donde cada pareja ani. da es mas grande de lo que seria necesario, pues mientras en Europa se cuentan apenas dos parejas de alondras en una hectárea de terreno, en la estepa viven al menos tres veces mas en igual espacio; pero aqui son siempre de especies dis- 
sintas, y aunque los machos no evitan del todo las rinas, viven por lo regular en bastante buena inteligencia.

A menudo se encuentra el nido de la alondra comun á principios de marzo: está situado por lo regular en un campo de trigo; á veces en una pradera, y hasta en un pantano, en algun pequeño isloie cubierto de yerbas $y$ de juncos. Cada pareja habita un canton, que tiene cuando mas trescientos pasos de díámetro; mas allá comienza el dominio de otra pareja, y asi se puebla todo el pais. El pájaro construye su nido en una pequeña depresion del terreno, formada por el mismo, y redondeada en caso de necesidad; ayudada la hembra por el macho, lleva raices, yerbas y tallos secus, para formar la parte exterior; por dentro suele estar el nido relleno de crines. La primera puesta se verifica comunmente ra media. dos de marzo, y consta de cinco a seis huevos verde amari. llentos ó de un blanco rojizo, sembrados con regularidad de puntos y manchas de un gris pardo ó grists. El macho y la hemora cubren alternativamente, pero mas la segunda que el primero. Cuando los pequeños pueden correr abandonan el nido; apenas se bastan a si mismos, aparćanse los padres por segunda vez, y por tercera, si el año es bueno.

Todos los pequeños cuadrúpedos carniceros, desde el gato doméstico hasta la comadreja y la musaraina, asi como los milanos, cuervos, avutardas y cigüeñas amenazan de continuo la cria de las alondras, y el aguilucho y el gavilan la vida de los adultos. En otro lugar he dicho ya cómo se conducen cstos cuando ven á su enemigo mas encarnizado, el aguilucho. Aunque el hombre coge muchisimas de estas aves, no acora tanto su núncro como los citados enemigos del reino aninal. La alondra comun aumenta â medida que se desarrolla la agricultura, en vez de disminuir.

\section{LA ALONDRA ARBORÍCOLA Ó LULÚ DE LOS BOSQUES - ALAUDA ARBOREA}

CARACTÉRES. - Esta especie se considera á veces tam. bien como tipo de un subgénero independiente (Chorys), cuyos caractéres esenciales consisten en tener el pico endeble, piés pequeños, alas grandes, redondcadas y anchas, y nono corto. Es la mas pequeña de las especies que anidan en Alemania Su longitud varia de $11^{n}, 153$ a $0^{m}, 185$, por $0^{m}, 29$ de anchura de punta i punta de las alas; estas miden $0^{\circ}, 09 \mathrm{y}$ la cola $0^{\circ}, 054$. Las partes superiores $y$ las alas son de un pardo pálido de orin; las plumas de la rabadilla de un pardo gris; la parte superior de la cabeza, el manio y los hombros tienen grandes manchas pardas en los tallos; las regiones in. feriores son blanquizcas, y parduscas en los lados, con lineas estrechas en el buche y el pecho, $y$ otras poco marcadas, en los costados; las plumas de la garganta presentan manchas oscuras en forma de puntos; la linea nasc-ocular y la de las śenes son de un blanquizco de orin; las rémiges de un pardo oscuro; las primarias están orilladas en sus barbas exteriores de un color rojizo; las secundarias tienen anchos bordes del mismo tinte, pero inas oscuro; en las tectrices de la mano la extremidad es blanquizca, con manchas de un pardo oscuro; las dos rectrices del centro son pardas, con un ancho borde pardo rojizo; las otras negras con punia blanca, cuyo color tira a pardusco púlido en las exteriores. Los ojos son de un pardo oscuro; el pico de un pardo de cuèrnoy rojo por de bajo; los piés de un pardo mas claro.

DISTRIBUCION GEOGRAFICA.-Esta graciosa ave es propia de coda Europa, desde la mitad de Succia, y tam. bien del occidente de Asia; los territorios que habita son sin embargo mas limitados que los de otros alaúdidos, pues busca las regiones mas solitarias cubiertas de maleza y de bosque.

USOS, COSTUMBRES Y RÉGIMEN.-EInútil seria, decia mi padre, buscar el lulú de los bosques en las grandes y fértiles llanuras, ó en los bosques de mas rica regetacion; busca las landas, los sitios áridos y las mesetas de las mon. tainas.

Pasada la época del celo, llega con su progenie a las praderas segadas; durante sus emigraciones visita los terrenos baldios y de barbecho; viaja á pequenas jornadas y se alimenta de insectos y granos.

Apenas se derrite la nicte de las montañas, á fines de febrero, vuelve el lulú á nuestros países desde Africa, y roma entonces posesion de su antigua morada.

- Tiene el privilegio de presentir los cambios de tempera. tura: con irecuencia le oi cantar alegremente por la mañana en nuestras montanas, cubiertas aun de nieve, cual si comprendicra que la blanca alfombra comenzaria á desaparecer al medio dia. No se desconsolaba si la nieve le impedia buscar á primera hora la comida; sabia que iba á derretirse, y que hallaria entonces suficiente alimento.

\or todos estilos es un agmiable pajaro el lulú de los bosques: todos sus movimientos son vivos y graciosos, y alli donde no se le molesta, no se muestra esquivo ni desconfindo; pero si se le persigue es timido y salvaje: corre rápidamente á pasitos, con el pecho un poco levantado.

-Si se presenta un gavilan ó un halcon, se aplana contra el suelo ó se acurruca en un pequeño hueco, siendo entorces sumamente dificil divisarle; á menudo se posa en las ramas de los árboles.

*En la primavera viven los lulús de los bosques aparca. dos; pero habiendo mas machos que hembras, como suceda con los mas de los animales, traban reñidas peleas, que obligan a los mas débiles a emprender la fuga. Cuando no estan en celo despliega el macho toda su gentileza: corre alrededor de la hembra, moviendo la cola $y$ levantando su pe. queno mono, y hace graciosas reverencias, como para mani festar todo su amor.

- Si la estacion es favorable, se encuentra ya el nido de este pajjaro a fines de marzo: está situado comunmente de. bajo de una espesura de pinos $\delta$ de enebros, ó en medio de las jerbas, y oculio en un hueco que forma el mismo pajaro; se compone de tallos y hojas de yerbas secas, y contiene cuatro ó cinco huevos blanquircos, sembrados de puntitos de un gris pardo ó pardo claro. Solo cubre la hembra, pero el macho se encarga de darle su alimento.

Bespues de la primera incubacion nu están los padres largo tiempo con sus hijuelos; ni tardan tampoco en apa. rearse por segunda rez. Luego se reunen con toda su progenie y comienza la emigracion, viajando cada familia aisladainente ó varias juntas. La marcha se verifica en la última mitad de octubre ó á principios de noviembre.

4 lil delicioso canto del lulu de los bosques es seguramente su mayor mérito: el viajero atraviesa a pié un desierto pás, donde no hay un solo punto de vista para fijar la mirada: no se divisa for do quiera mas que una miserable regetacion; parece haberse extinguido toda vida animal; pero de pronto se remonta un lulu, dejando oir su grito de llamada lulls. Elivase por los aires, se cierne largo tiempo cantando, $\delta$ se posa en una rama para acabar alli su camto. Por la noche es aun mas agradable este: al pasar por aquellas soiedndes, y cuan. do solo oia á lo léjos cl canto del inochuelo ó del chotocabras, ó bien el vuelo pesado de algun coleóptero, y me parecia estar aislado en medio del desiesto, alegrábame oir al lulú de los bosques, que se remoniaba por el aire lanzando sus trinos armoniosos. Entonces permanecia inmóvil para escuchar aquellas notas argentinas que parecian bajar del cielo; recobraba ánimo, empunaba mi baston de viaje y seguia mi camino. Harto sabia que el pajjaro cantaba solo para distraer 
á su companera; mas pareciane que solo por complacerme animaba con sus sonidos aquella soledad.

No se puede comparar el canto del lulú de los bosques con el del ruiseñor; y sin embargo, le sustituye en cierto modo. Fste últino pájaro no canta mas que dos meses, al paso quue el otro deja oir su voz desde marzo hasia agosto: despues de la muda, produce aun sus notas a fines de setiembre y á principios de octubre, y canta en los parajes mas pobres, en las montanas donde no habiea ningun otro pájaro cantor. El lulú es el favorito de todos los montañeses, el orgullo del afi: cionado, la alegria del artesano yue trabaja todo el dia en su havitacion; inerece en alio grado todo el carino que se le pro. fesa: toda la gloria que le rodea. Desgnciadamente no se reproduce tanto como la alondra comun y in cogujada de mono; muy por el conirario disminuze de una manera las. timosa, sin que se conozca una razon fundada para ello.

\section{LAS COGUJADAS-GALERITA}

CARACTERES. - Los de este género consisten en la estructura del tronco; el pico es fuertc; los tarsos de una al. tura regular, con espolones casi recios en los dedos posterio. res; las alas son grandes, anchas y obtusas; y el plumaje muy ligern: la cabeza esta provista de un mono.

\section{LA COGUJADA DE MOÑO-GALERITA CRISTATA}

CARACTERES. - Poco puede decirse sobre el color del pluniaje, pues la cogujada de moño varia mucho, y aun hoy dia no sabemos si en estas diferencias debemos fundar especies independientes ó si solo se han de considerar como va. riedades. los individuos de esta especie propios de Alema-

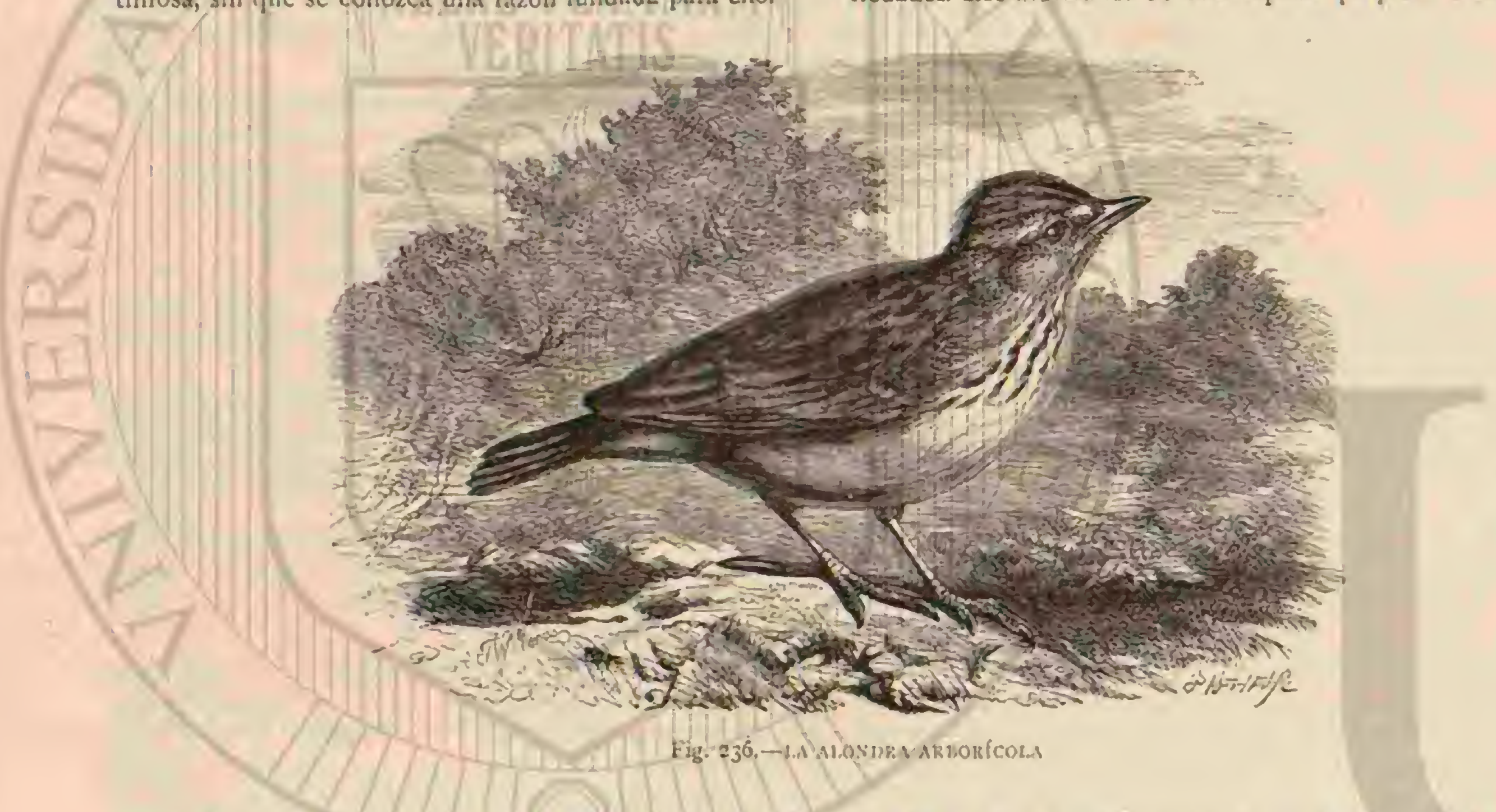

nia se distinguen por tener las partes supperiores de un color pardo rojizo de barro; los tallos de las plumas ciel moño son negros; la línea naso-ocular y una faja poco marcadn, de color de isabela; los lados de la cabeza de un pardo de barro; las partes inferiores de un color blanquizco isabela, que en el pecho y los costados tira al rojizo; en el buche y el pecho se ven grandes manchas poco marcadas, de color oscuro; en las tectrices de la cola hay otras que lo están menos; las rémiges son de un pardo oscuro, con un borde angosto rojizo en la extremidad de las barbas extcriores, mas ancho y del mis mo color en las interiores; las últimas secundarias y las tec trices de las alas están orilladas de un tinte pardusco en las barbas exteriores y en la extremidad; las rectrices, de un tinte pardo intenso, presentan un estrecho borde en la extremidad de las barbas exteriores; las dos últimas tienen toda la barba exterior de un rojizo de orin. Los ojos son de un pardo oscuro el pico pardusco; la mitad de la base de la mandibula infe rior y los piés de un tinte amarillento. Tas longitud del ave es de $0^{\circ}$, is pos $10^{\circ} .33$ de anchura de punta a púnta de las alas; estas miden $0^{\circ}, 095$ y la cola $0^{\circ}, 065$.

DISTRIBUCION GEOGRÁFICA.-La cogujada demo no habita en casi toda la Europa excepio el cxtremo norte, y en una gran parte del Africa; es mas comun en el mediodia; en Esparia y en el norte de Africa la especie parece ser la mas abundante de toda la familia; pero en Alemania se propaga tambien todos los años mas y mas. En el sur de Furopa se la encuentra en los pueblos y en sus contornos, y tambien en las llanums solitarias ó en las monianas; on Alemania pre. fiere vivir cerca del hombre; llega hasta el interior de los pueblos y ciudades y mendiga delante de los graneros y cocinas.

Fn ol medindia de Espania, nuestra cogujada estár represen. tada por la de dicho pais (Gulerila Theilie), que difiere de aquella por tener el pico mas corto, el mono mas largo, Jas lineas del pecho muy marcadas, varias manchas uscuras en la parte superior de las mejillas, y la títima mitad de las barbas interiores, asi como la primera rectriz de ambos lados, de un rojizo de orin.

Cuando no estån en celo las cogujadas moñudas son pảjaros silenciosos. Si difieren de la alondra de los campos por sus formas mas robustas, y yor su mono, que mantienen siempre recto cuando se hallan en tierra, aseméjanse mucho 1 ellas, en cambio, por su manera de andar, su carrera y su vuelo. la roz se reduce á un ligero linid, hosil, seguido co. munmente de cur, cus; su canto nóo es desagradable, aunq̨ue no se pueda comparar con el de la alondra de los campos y mucho menos con el del lulú de los árboles. Alejandro de Homeyer, cuyo oido cjercitado reconoce perfectamente los diversos tonos de la voz de los pájaros, elogia por esie con. cepto â la cogujada moñuda de España 8 Su canto, dice, es tan dulce y plañidero como el del lulú de los árboles, pero mas melancólico aun; no conozco nada tan agradable como 
el canto expresivo de este pájaro, sobre todo si se le compara con las notas chillonas y sonidos discordantes de los de Alemania Al oirle por la primera vez, no podia creer que fuese tal pájaro.» Ia cogujada del desierto no está menos bien do. tada, y aun tiene mas mérito que en España, porque en aque. llas soledades se oje con gusto todo rumor, y cualquier canto de pajjaro parece hermoso.

Estos pájaros se alimentan indistintamente de granos $c$ in. sectos. Desde el otono á funes del invierno comen toda espe. cie de granos, y en la primavera retonos y yerbas.

Estos pájaros anidan en el suclo, en los campos, las pra. deras secas, las virias y jardines: y á menudo muy cerca de las casas: su nido, siempre oculto y dificil de encontrar, ape. nas difiere del de los otros alaúdidos. Los cuatro ó seis, raras veces tres, huevos son amarillentos ó de un blanco rojizo, sembrados de pequeños puntos de color gris ceniciento $0^{\circ}$ pardo amarillo: su longitud es de $0^{\circ}, 022$ por $0^{\circ}, 015$ de grueso.

Liebe ha hecho observaciones en una pareja de cogujadas cuidadas por él, y merced á ellas explicase la historia de la reproduccion de estas aves, y quizás de todos los alaúdidos. la hembra cubre sola los hucros, pero cuandio el tiempo no es demasiado frio abandónalos yor interralos de casi media hora, para limpiarse y buscar alimento, porque el macho no se le lleva. Los polluelos salen á los trece dias del cascaron; y aunquue solo están revestidos entonces de un escaso plu. mon, que permite ver su piel de color negruzco violeta, la hembra los abriga muy poco. Solo de noche ó cuando hace mal tiempo la hembra pcrmanece en el nicio. El macho jiresta su auxilio en la alimentacion de los pollos, pero indirecta-

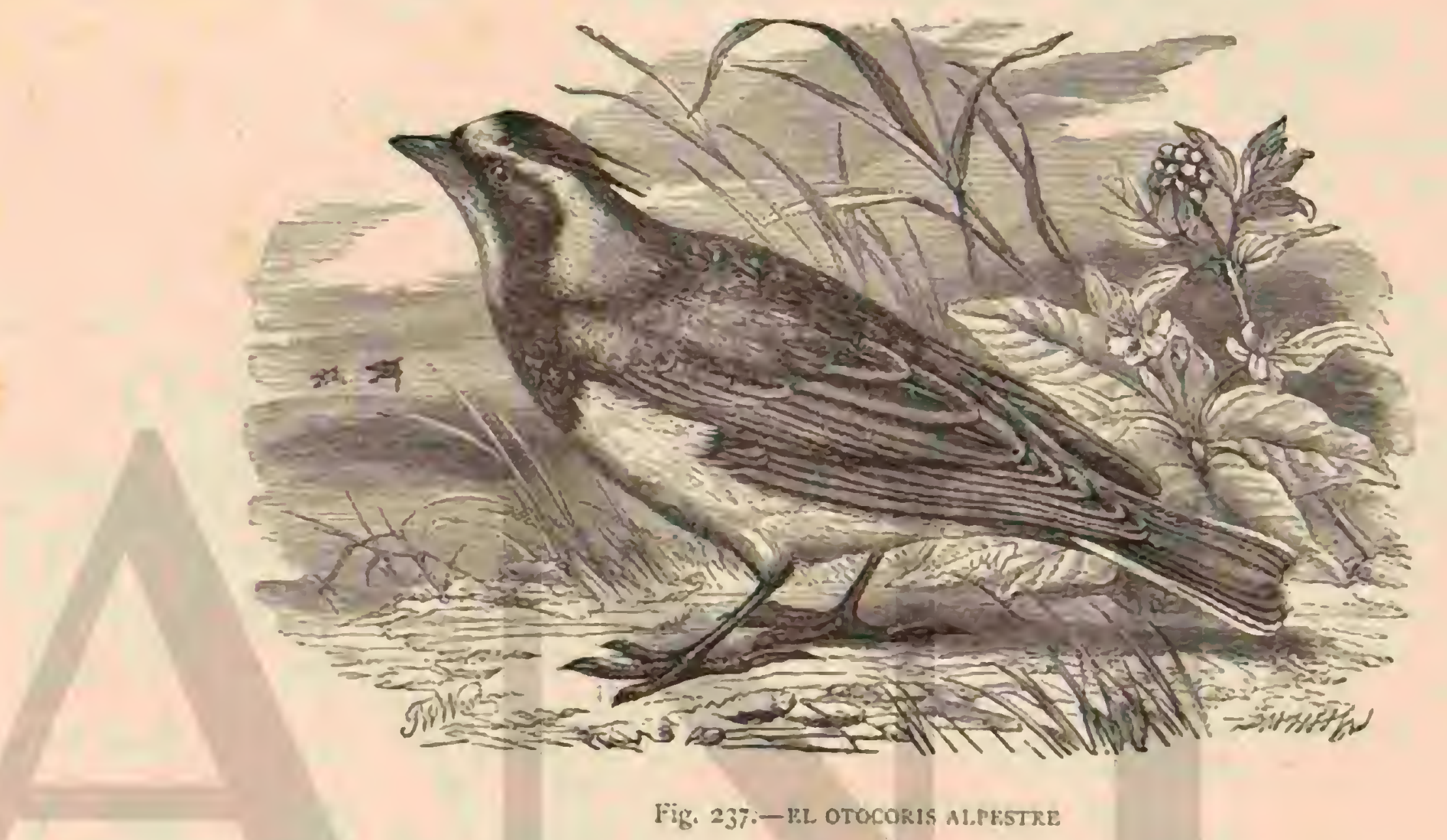

mente; recoge los insectos, los prepara con el pico y ofrécelos. á la hembra para que esta los dé á sus hijuclos. Estos últimos abandonan el nido à los nueve dias ý no vuelven ya á él. Al principio andan saltando torpemente, y solo desde el dia duodécimo aprenden á correr como sus jadres. De noche se ocultan en una cavidad del suelo, pero la hembra no los abriga; solo el macho los cubte con algunos tailos y hojas secas; pero rasas veces los nutre él mismo; linitase á ofrecer a la hembra los alimentos destinados a los polluelos, si bien. la ayuda tambien de otro modo. Cuando la madre llega con el pico lleno y busca en vano a sus hijuclos, el macho los lla. ma en alta voz y al fin le contestan en voz baja, pero bas. tanie marcada para que la madre los oiga. A los catorce dias de su nacimiento, los polluclos empiezan á ejercitar sus alas, y dos dias despues pueden ya volar a bastante distancia. Tan luego como se declaran independientes, los padres incuban por segunda, y mas tarde por tercera rez.

Las cogujadas moñudas son mas afortunadas que la alondra de los campos, en el concepto de que no se las persigue tanto, porque su carne es coriácen; pero tienen los mismos cnemigos que los otros pájaros que anidan en el suelo.

CA UTIVIDAD.-Rara vez se las conserva cautivas.

\section{LOS SIRLÍS-ALAEMON}

CARACTERES. - Estos alaúdidos difieren esencialmente de los que nosotros conoccmos. Su estructura es mquitica;

el pico largo, relativamente delgado y mas ó menos corvo; los tarsos altos; los dedos de longitud regular; el posterior tiene un espolon bastanie corto y ligeramente corvo; las alas son muy largas y anchas; las rémiges icrcera, cuarta y quinta son las mas largas; la cola de longitud regular 6 bastante larga; el plumaje abundante $y$ fino.

\section{EL SIRLI DE DUPONT-ALAEMON}

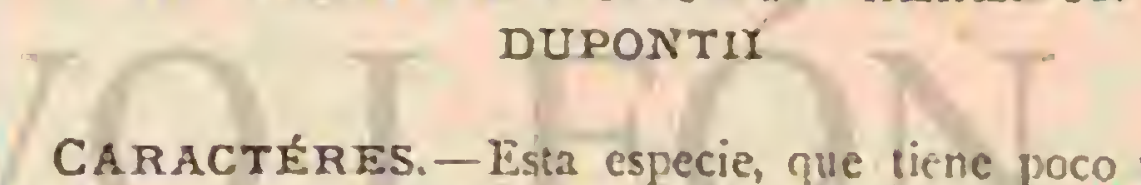
menos el mismo tamano de nuestra cogujada pl pico bastan te corto, puede considerarse como un tránsito entre lasalon. dras campestres y las especies siguientes. Ias plumas de la parte superior son de un pardo de tierra, con horde blan. quizco, pálido de orin por fuera y tallos oscuros; la linea na. so ocular y otra menos marcada q̨ue se corre sobre los ojos, los lados de la cabeza y del cucllo y las partes inferiores son bianquizcas; la garganta, el buche y los lacos del cuello ticnen en los tallos lineas pardas que se ensanchan mas abajo; las rémiges y rectrices son de un pardo oscuro; las primeras cstan orilladas en sus barbas exteriores de un borde blanquizco; las rectrices tienen otro en su extremidad; las dos rectrices del centro están orilladas de color pardusco de orin; la primera rectrir de ambos lados es blanca con un ancho borde pardo oscuro; la segunda blanca solo en las barbas exte. riores. 
DISTRIBUCION GEOGRÁFICA. - El sirli de Dupont habira en el Sahara y se ha encontrado tambien alguna vez en el sur de lirancia.

\section{EL SIRLÍ DEL DESIERTO- ALAEMON DE- SERTORUM}

CARACTERES. - Esta ave tiene el lomo de color rojo isabeir; las rémiges secundarias superiores de un tinte ro. jizo; la linea naso-ocular, los lados de la cabeza y las partes inferines blaneas; la region del buence de un delicado tinte de isabela pálido, con finas lineas oscuras en los tallos; las rémigos primarias son negras; las posteriotes blancas en la extrencidad, las anteriores, desde la tercera, del misumn color en la luse; las tectrices dul brzzo blancas en la extremidad; las remiges secundarias están orilladas de blanco en forma de una ancha fija trasversal; las recirices, de color pardo os. curo, jenen en las barbas exteriores y en la extremidad un borde rojizo isabela; las exteriores son blancas del todo por fuera ins dos del centro de un rojizo cancla con una linea pa:da en los tallos. Ia longitud del ave es de 1,122, la de las aly de 11,12 y la de la cola de 6,09 .

DISTRIBUCION GEOGRÁFICA. - El área de dispersion dal sirll del desierio, que se ha cazado varias veces en el mediodia de Europa, comprende zodo el nordeste de Africa \& oeste del Asia, Palestina, Persin $y$ Sindh. No es ritr esta especie en tado el desierto del nordeste de Africa poo so no la vi nunca en las estepas; únicamente la en. contrd con frecuencia entre Sliez y el Cairo.

USOS, COSTUMBRES Y REGIMEN, - Iil sirli del desierto no forma mas que reducidas familias de cuatro a scis individuos, cuando mas; nunca he visto grandes bandadas ni parcjas solitarias; habitan unas cerca de otras y pareceque viven juntas en la mas periecta inteligencia.

Por sus usos y costumbres el sirli del desierto forma tránsito entre las alonaras y las taquidromos. Corre con mucharspider, pero d la manera cie la tringa, o de otras aves zancutas mas bien que como la alondra. Vuela con facilidad; se cierne y elévase $\leq$ menudo por los aires rértical. mente aunque con mucha rapidez, y no como los alaúdi. dos; se cierne un instante, recoge lúrego las alas, se deja crer a iderra, y repite esta maniobra variás veces seguidas. Yo cro que solo el macho hace $(s t 0, y$ me parece que lo ejecuts para divertir a su hembra. Las parejas permanecen ficlmon:e unas junto á otras, corren y vuclan en compañia; la vointad de una parece ser.ley para las demas.

Estrs pajaros no iemen al hombre: acércanse a las chozas y casas con tanta confianza como la que manifiesta la cogujada aonuda en todo el camino que siguen las caravanas entre el Cairo y Suez. Muchas veces he visto individuos en el interior de las habitaciones: el cazador puede acercarse a ello: fícilmente; pero cuando se les ha cirado una vez, no tardas en hacerse desconfiados.

Su roz es un silbido triste y planidero; su canto se reduce en rigar ś una repericion de su grito de llamada, al que si. gue ut trino.

Nole podido hacer yo mismo observaciones sobre la re. producion. Tristram habla del huevo, pero no del nido; dicc cye el primero tiene $6^{\circ}, 025$ de largo por $0^{\circ}, 015$ de gruesa asemejándose al de cicrtas variedades de nuestro pico rurado. Debo añadir que esta ave, segur parece, y oiras ?̦oplias del desierto, pueden prescindir completamente del ag-a, pues a menudo se las encuentra a muchos kilómetros d: distancia de las corrientes, en los sitios mas secos del desierto.

En el estómago de los sirlis que yo mate solo habia insec. tos; pero no dedurco de aqui que dejen de comer granos. Su canto es asaz penetrante y consiste en una especie de gorjeo.

\section{LAS CALANDRIAS - MELANOCO- RYPHA}

CARACTÉRES. - Las especies de este género son de estructura sólida y recogida; ticnen el pico muy grueso y grande; los tarsos altos y fuertes; los dedos relativamente largos; los posteriores están provistos de espolones: las alas son grandes y anchas; las rémiges segunda y tercera son las mas largas; la cola, casi recta y corta, apenas tiene sés. gradura.

\section{LA CALANDRIA COMUN-MELANOCORYPHA CALANDRA}

CARACTERES. - Ia longitud de esta especie es de $11^{\circ}, 2$ ípor $0^{\circ}, 44$ de anchura de punsa á punta de las alas; estas tienen $11 \%, 1, y^{\circ}$ la cola $6 \%, 07$ de largo. Las plunas de la parte superior son de color pardusco palido, orilladas de un burde isabela claro con tallos oscuros; la linea naso-ocu. lar, una laja poco marcada sobre los ojos, la barba, la garganta, la cabeza y el pecho son de un delicado ansarillento de orin; las plumias del pecho presentan lineas muy finas de color oscuro; el resto de las partes inferiores es blanco; los costados de un pardusco isabela; la region de las orcjas, y unas fajas poco marcadas en forma de barbas son pardus. cas; en los liados del cuello hay dos grandes manchas negras, que a veces se tocan casi; las rémiges primarias son de un pardo oscuro; las secundarias de un pardo de tierra; las primeras tienen en las barbas exteriores un angosto borde pardusco isabela; Tas litumas presentan otro inas ancho del mişmo cólor; las posteriores, tanto de las rúmiges primarias como de las secundarias, están orilladas de blanco en 54 extremidad; las rectrices son de un pardo oscuro, orilladas en las basbas exteriores de un ancho borde pálicio; la pri. mera pluma de cada lado $y$ las puntas de la segunda $y$ ter. cera son blancas, con viso amarillento de orin. Eil iris es de un pardo oscuro; la mandibula superior de un pardo de cuerno; la inierior amarillenta, y los piés rojizos.

DISTRIBUCION GEOGRÁFICAA. - El mediodia de Luropa, sobre todo las costas del Mediterránco, Istria, Dal. macia, Grecia, el sur de Italia y España, asi como el nord. este del Africa y las estepas del Turkestan, son la patria de la calandria comun, que desde los paises indicados pasa tambien al nordeste de Alrica, pero raras veces Jlega has. ta las regiones superiores del Nilo. Tanto en estas como en Paiestina, Persia, todo el centro de Asia y las provincias sud-occidentales de Ia Rusia, esta especie se halla repre. sentada por la calandria de collar (Helanocorypho b́siacacalala) muy congenérica, y que tal vez sea solo uma variedad. Distinguese por ser un poco mas pequena; las hajas longitudinales del dorso parecen mas marcadias; las rémiges ile. nen la punta blanca, y las tectrices, excepto las dos del cen. tro, estån orilladas en su extremidad de un borde blan. quizco de orin.

USOS, COSTUMBRES Y RÉIMEN. - la calan. dria comun habita con preferencia los campos sccos ó los extensos pastos: en el Asia frecuenta las estepas, juntamente con otras cinco especies, por lo menos, à las cuales se impone por todos conceptos.

Por sus usos y costumbres difiere muy poco esta especic de la alondra de los campos: durante la estacion del celo vive apareada en un àistrito determinado, conde busca el 
alimento con sus semejantes; mas terminada la reproduc. cion forma bandadas, muy numerosas á veces. Yo vi una de ellas, compuesta de varios miles de individuos, en un bosque de las estepas, en las márgenes del Nilo Azul.

Se distingue marcadamente de nuestra alondra y de todos los demís alaúdidos que yo conozco por su modo de andar en linea recta y por los movimientos, algo cacharudos, pero muy vigorosos de las ancias alas; cstas últimas forman contraste con el borde mas claro en la cara inferior de las rémiges, y son tan caracteristicas cuando el ave viela, que no se la podria confundir con otros congéneres Ademós se distingive por su agradable canto.

Quien la oye caniar por primera vez queda primero sorprendido, despues admirado; su canto difiere del de los otros alaúdidos por su riqueza, amplitud y vigor. 1 No solo aventaja la calandria ordinaria por su talla á todus los demás representantes de la familia, dice Cetti, sino tambien por su canto, $y^{\circ}$ en tal concepto, puede competir con cuniquier otro pájaro. Su voz es un gorjeo poco agradable; pero su memoria le permite reproducir todo lo que oye, mejorándolo despues. Es, por decirlo asi, el eco de todos los pájaros; oirla equivale à oir á todos los demás; 10 mismo se apropia el grito de las aves de rapiña que los sonidos del pájaro cantor. Al remon. tarse por el aire cmite mil frases musicales, mil trinos mezclados unos con otros; aprende los aires que se tocan delante de ella, é imita con perfeccion los sonidos del clarinete. Su reconocida superioridad en este punto no la enorgullece, pies canta desde la mañana hasta la tarde: una sola calan. dria, pues:a en una ventana, basta para distraer soda ia vecindad; es la alegria y el orgullo del artesano, y encanto del transeunte. Todos los observadores son del parecer de Cetti.

«l grito de llamada de la calandria ordinaria, escribia á mi padre el conde Gourcy, se asemeja bastante al de la alon. dra moñuda, y su canto es delicioso y sorprendente por lo variado. Tiene este pajaro tanta disposicion para imitar, que puede cambiar la voz \& su antojo, lanzando tan pronto un grito agudo y penetranie, como una nota armoniosa. Despues de repetir algun tiempo su grito de ilamada, deja oir ciertos aires de una cancion: luego emire el sonido profundo y prolongado del mirlo; á este siguen varias notas, $y$ hasta cl canto completo de la golondrina de chinenea, del tordo cantor, de la codorniz, del paro, del verderon, de la alondra de los campos y de la de moño, del pinzon y del gorrion. Tambien prodisce el grito de la marica y de la garza; y á cada una de estas notas le da el pájarola entonacion conveniente. Ronca como un hombre que duerme; repite los sonidos mas singulares, los cuales oyó sin duda a otros séres, é imita los cantos con tanta precision que el inteligente lo reconoce en seguida. Tengo una calandria que no conocia el canto de la alondra cuando me la dieron, ni el grito del paro de larga cola; pero bien pronto los aprendió, y los repetia admirablemente. A menudo canta de una manera muy curiosa, que consiste en no mover la garganta, y producir los sonidos como con el pico.

2Por desgracia su rozes demasiado penetrante para que se pueda tener mucho tiempo el pájaro en una habitacion, por cuyo motiva me he visto precisado a desbacerme de la que poseia. El pajarero la vendió varias veces, sin que nadie pudiese conservarla, sicmpre por la misma causa.

Su nido, nculto yenenalmente debajo de algun pedazo de tierra, en un peqqueno matorral ó en los trigos, aunque siem pre en un hueco, está toscamente construido con tallos y rafees secas Los huevos tienen $11^{\prime \prime}, 024$ de largo por $0^{\circ} \mathrm{O}: \mathrm{S}$ de grueso, y su numero varia de cuatro á cinco; son bastante voluminosos, y abultados en el centro; tienen 'color blanco ó blanco amarillento, con pantos y manchas muy diseminadas, de un tinte pardo amarillo gris.
CAzA.- En España se cogen muchas calandrias, y al efecto se usa un procedimiento particular. Los cazadores se dirigen por la noche al campo donde descansan estos pajaros: unos llevan campanillas, los otros linternas y algunos redes. Deslumbradas las calandrias por la luz, y enganiadas por el sonido de aquellas, creen hallarse cerca de un rebano de buejes ó carneros; esperan tranquilamente la llegada de los cazadores, aplanándose contra el suelo, y entonces se las coge con la red, y hasta con la mano. Mi hermano ha asistido à la caza.

\section{LA CALANDRIA NEGRA Ó DE TARTARIA - MELANOCORYPHA TARTARICA}

CaraCterES. - Esta ave es poco mas ó menos del mismo iamaño que la calandria comun, con la cual habita las estepas asiáticas, habiéndose hallado tambien en el oeste de Europa algunos individuos errntes Su plunaje es de un negro muy oscuro; el manto, las rémiges secundarias posteriores y las rectrices están orilladas en su crtremidad de un tinte blanquizco isabela, y las plumas de los lados del pe. cho del mismo color, pero mas pálido. Estos tintes desapare. cen hícia la primavera, y entonces el ave parece casi del to. do negra J.os ojos son de un pardo oscuro; el pico de color gris de cuerno y los pies negros. I a hembra tiene el dorso pardusco pálido, con manchas oscums en los tallos; las regio. nes inferiores, de un pardo pálido, tienen lineas negruzcas, qque en los lados del cuello sé reunen formando una mancha grande; los lados del vientre son parduscos, con lineas negras en los tallos; las rémiges y rectrices de un pardo oscuro, oriIladas en las barbas exteriores de un negro pardo: la primera rémige y la primera rectriz de ambos iados son blancas en las barbas extcriores. I/a longitud del ave es de $0^{\circ}, 30$, la de las alas $0^{n "}, 4$ I la de la cola 1$)^{m}$, oS.

DISTRIBUCION GEOGRAFICA. - Dista especic ha. bita en gran número, y durante todo el año, las estepas sala. das del Asia central.

USOS, COSTUMBRES Y REGIMEN. - I a calandria negra no emigra; lo mas que hace es irasladarse á corta distancia del punto donde no hay nieve. Eversmann y Radde vieron durante el invierno innumerables bandadas.

En nuestro waje por las estepas de la Siberia meridional y del Turkestan la hemos cncontrado a menudo y por mis propias observaciones lie podido formar una idea, aumque incompleta, de su género de vida en -remuo. No busca exclu. sivamente los terrenos cuyo color se confunde con el de su plumaje; frecuenta al contrario las regiones mas diversas, aunque no en todas partes. En mi opinion debe considerár scla como uno de los súres mas graciosos que pueden verso en la estepa. Alli donde habita se ve siempre una pareja bas tante cerca de otra, $f$ la grande ave negra que en un terreno claro se ve \& mucha distancia, es un adorno del paisaje tanto en el suelo como en las regriones aćreas. Es un alaúdido nerfecto cuando corre apresuradamente, revolviendose de continuo, ó cuando vucla cjecutando diversas evoluciones y ale. teando rájridamente á poca distancia de ticra, pero su vuelo en la altura es, por el contrario, muy caracteristico. Aunque se parece mucho al de la calandria comun, distinguese sin embargo, por el extrano revoloteo del are al descender de las regiones aŕreas, revoloteo que le es propio. I as anchas alas carncterizan sobre todo á esta especic en su vuelo sos icnido, y este basta para reconocerla. Sin embargo, mas sc distingue aun por la circunstancia de que cuando ha subido a las alturas inclina las alas diagonalmente, manteniéndolas. algunos segundos tendidas; elévase otra vez sosteniéndose en el mismo sitio con algunos aletaros que se siguen á interva. 
los basiante largos; y entonces, no solo se asemeja da un gran murciélago, sino que parece serlo efectivamente. Al bajar vuela al principio en sentido horizontal; desciende poco à poco y se precipita al fin, no verticalmente, como una piedra. sino tmzando un ángulo obtuso hácia el suclo, ó con preferencia hácia un objeto elevado, como las ramas superiores de un arbusio ob un poste del telégrafo. No teme al viajero, pero huse del coche que se acerca tanto como es necesario, sin alejarse rnucho mientras no se le dispare un tiro. Cuando canta, rara vez se cleva á mucha altura. Su canto me ha recordado mas el de la calandria comen, pern no sé si he oido el siy a propio, o solo melodias aprendidas de otras aves. No hernos hallado ningun aido: pero yz el q de majo recibimos polluelos que le habian abandonado, de lo cual resulta que por lo menos en el sadoeste de la Siberia su reproduccion empicza muy pronto. Lil nido es de construccion, sumannente ligera, y segun Pallas está siempre tan oculto cn el sueló seco apenas cubierto de plantas; uque es muy dificil encuntrarle. La puesta se componc de cuatro huevos de color aulado, con manchas grises por debajo de un gris pardo en/al parte superior; inicien $10^{\circ}, 02 S$ de largo, por $11^{\circ}, 018$ de grueso. Sugun creo, los demis naturalistas no saben nada inas sobire este particular.

Duranie el periodo de la incubacion la calandria de lar. taria Ise nutre principalmente de toda clase de insectos; mas tarde, las simitentes de las plantas alcalinas constitujen suralimento casi exciusivo, asi como el de sus hijuelos. Há cis el otoño abandona el territorio donde anida, por lo regu. lar en union de otras calandrias, para dirigirse hicia el medio. dia; pero no extiende sus viajes it mucha distancia; pasa el invierno en las estepas de la Rusia meridional, en las orillas del Nieper inferior y del Don, con frecuencia tambien en los alrededores de Odessa. Algunos individuós extienden sus vinjes mas hicia al oeste, pero muy rara vez se les se aqui, sobre tixdo en Alemania.

CAUTIVIDAD.-Los caurivos que yo recibi de la Ru. sia meridional se conducian lo mismo yue las calandrias conunes.

\section{LA CALANDRIA BRAQUIDÁCTILA-MELA- NOCORYPHA BRACHYDACTYLA}

CARACTERES. - Lista especie es una calandria en miniatura, que solo se distingue por tener el pico mas endeble y los dedos mas cortos. I as partes sutreriores son de un pardusco pálido de tierm, con los tallos oscuros; la linea naso. ozular y la de las sienes blanquizcas, esta última orillada por debajo de un borde oscuro; la region de las orcjas y las me. jillas son de un rojizo pailido con lineas oscunas; las partes inferiores b!ancas, excepto una mancia negruzca que hay en los lados del cuello; los cos:ados de un rojizo pálido; las té miges de un pardo oscuro, con un borde rojizo pálido de cancla en las barbas exteriores; ias tectrices de las rémiges secundarias tienen las puntas blanquizcas; las tectrices superiores de las alas presentan en la cxircmidad un rojizo pailido de canela: las rectrices son de un pardo oscuro, orilladas en las barbas exteriores de rojizo pailido; la primera de ambos lados es de un blanquizco, rojizo, y tanto esta como la segunda de ambos lados-tienen la última mitad de las barbas interiores blanca. Ios circulos oculares son de un pardo oscuro; el pico amarillento, mas oscuro en le punta; y los piés amarillos. En la hembra la mancina del cuello es mas pequeis.

Varins caianciritirios que se distinguieron como especies diferentes (Colurdrilis lisholsth, C. minor) y otros, deben agruparse probab!emente con la calardria brą̧uidáctila.
DISTRIBUCION GEOGRÁFICA. - La calandía bra. quidáctila 6 calandrina, tiene un area de dispersion mas extensa que la especie anterior: habita en gran numero todas has llanuras del mediodia de Europa, del Asia central y del Africa occidental.

USOS, COSTUMBRES Y REGIMEN. - Busct los parajes mas áridos, aunque sin evitar los mmpos cultivados: todos los paises desiertos del sur y las estepas del isia cons. tituyen su verdadera patria. Ia tierra tiene un color tan análogo al de su plumaje, que no necesita yerbas para escon. derse. A mi me ha saltado a diez pasos de distancia una calandria que no habia visto, y me pasó desapercibida sin mas que aplanarse contra el sueln.

A norte de España llegan graudes bandadas de calandrias braquidíctilas á principios de la primavera; mas no tardan en formar parcjas, cada una de las cuales habita un pequeño distrito.

Iista especie ofrece rarias particularidades propias de los alaúdidos yor lo que hace á sus costumbres. Al volar traza en el aire lineas onduladas irregulares; remóntase oblicuamente; para bajar no hace mas que dejarse caer. Lo mismo cania en tierra que cuando vucla; su canto, como ha dicho Homejer, no es continuado, y se parece al de la alondra de los campos. kis un conjunto de notas prolongadas, seguidas de sonidos brevis de una entonacion muy variada; los soni. dos allautados son languidos y chillones, y las frases finales carecen de brio. El prijaro repite la misma frase diez y veinte reces seguidas, sin variarla apenas; de tal modo que recuerda el munótiono y fastidioso canto de la cosrujada. A pesar de todo, la calandrina puede imitar perfeciamente el canto de otros pdjaros, lo mismo que la calandria comun.

Su hido es tan tosco como el de los otros alaúdidos, y se halla igisaluente oculto: los huevos son de color amarillento claro $\delta$ gris, con puntos de un pardo rojizo, bien marcados, dibujo ņue varia tuucho; su longitud es de 1$)^{\prime \prime}, 020$ por $11^{\prime \prime}, 016$ de grueso.

A principios de setiembre forman bandadas los individuos de un pais y emigran hácia el sur. En las estepas del interior de Africa, cubientas de bosque, se deja ver la especie en tan inmenso numero, que ocupa literalmente todo el terreno en espacios de media legua. Al emprender su vuelo estas ban. dadas forman en cierto modo una verdadera nube.

Segun Jerdon, lo mismo sucede en las Indias: las calan. drinas procedentes dal Asia central llegan en octubre y no. viembre para marcharse en el mes de abril. Dicho autor asegura haber matado de dos tiros reinicuatro, lo cual no creo inverosimil, pues yo he visto un número prodigioso de calandrinas en Africa. En España das cogen á miles; pero su reproduccion es tan raipida, que las perdidas se compensan bien pronto.

\section{LOS AMOMANES-AMMOMANES}

CARACTERES. - Fi desierto tiene sus alondras; pero esias son de color de arena y forman un género caracterizado por su pico mediano y fuerte; sus alas muy desarrolladas, largas, puntiagudas y anchas; su cola relativamenie grande, mas ó zilenos escorada en el centro, r su plunaje de color de arena ó isabela.

\section{EL AMOMANE DEL DESIERTO-AMMOMA- NES DESERTI}

CARACTERES. - Este alaúdido tiene la parte superior de un pardusco de canela gris; la rabadilla rojizo de orin; las partes inieriores blanquizcas; la region do las orejas, cl bu. 
che, los costados, las tectrices interiores de la cola $y$ las inferiores de las alas de un tinte isabela delicado, con lineas oscuras longitudinales poco marcadas en el buche; las rémiges $y$ las rectrices son de un pardo aceituna; las primeras de un rojizo de cancla en las barbas exteriores; la primera rectriz. de cada lado de un isabela de orin hácia la punta. Los ojos son pardos; el pico pardusco; los piés de un pardo intenso. La longitud de esia are es de 10,16 , la anchura de punta a punta de las alas, de $14 ", 23$; estas miden $11^{*}, 095$ y la cola $0^{\circ}, 065$ de largo.

DISTRIBUCION GEOGRÁRICA. - El área de disnersion del amomane del desierto comprende la mayor parte del norte $y$ nordeste de Africa, el Asia occidental $y$ la India central; muy raras veces visita ambien la Europa meridional. Erhard comprende esta especie entre las aves que pasan el vemno en las Cirladas.

En algunas partes del Africa septentrional y en las islas de
Cabo Verde, esta ave tiene por representante al amonane de las arenas (Ammomanes cenctura), que tambien se ha ca. zado alguna vez en Malta. Esta especie, muy congenérica de la anterior y un poco mas pequeina, tiene el dorso rojizo de canela y de color isabela blanco en las partes inferiores; reconócese además fácilmente por sus extremidades de un pardo pálido, sus rémiges de un rojizo canela y las manchas negras en las extremidades de las rectrices, que en el resto son del mismo color que las rémiges.

USOS, COSTUMBRES Y REGIMEN.--Durante mi permanencia en Africa he visto estas dos especies por todas partes, en los desiertos de Egipto y de la Nubia, $y$ hasta en medio de aguellos grandes espacios arenosos que los árabes llaman hammadias (los abrasados). Evita los parajes en que ha: cultivo, y no se encuentra bien sino donde domina la arena: pertenece exclusivamente al desierto, y es alli muy comun.

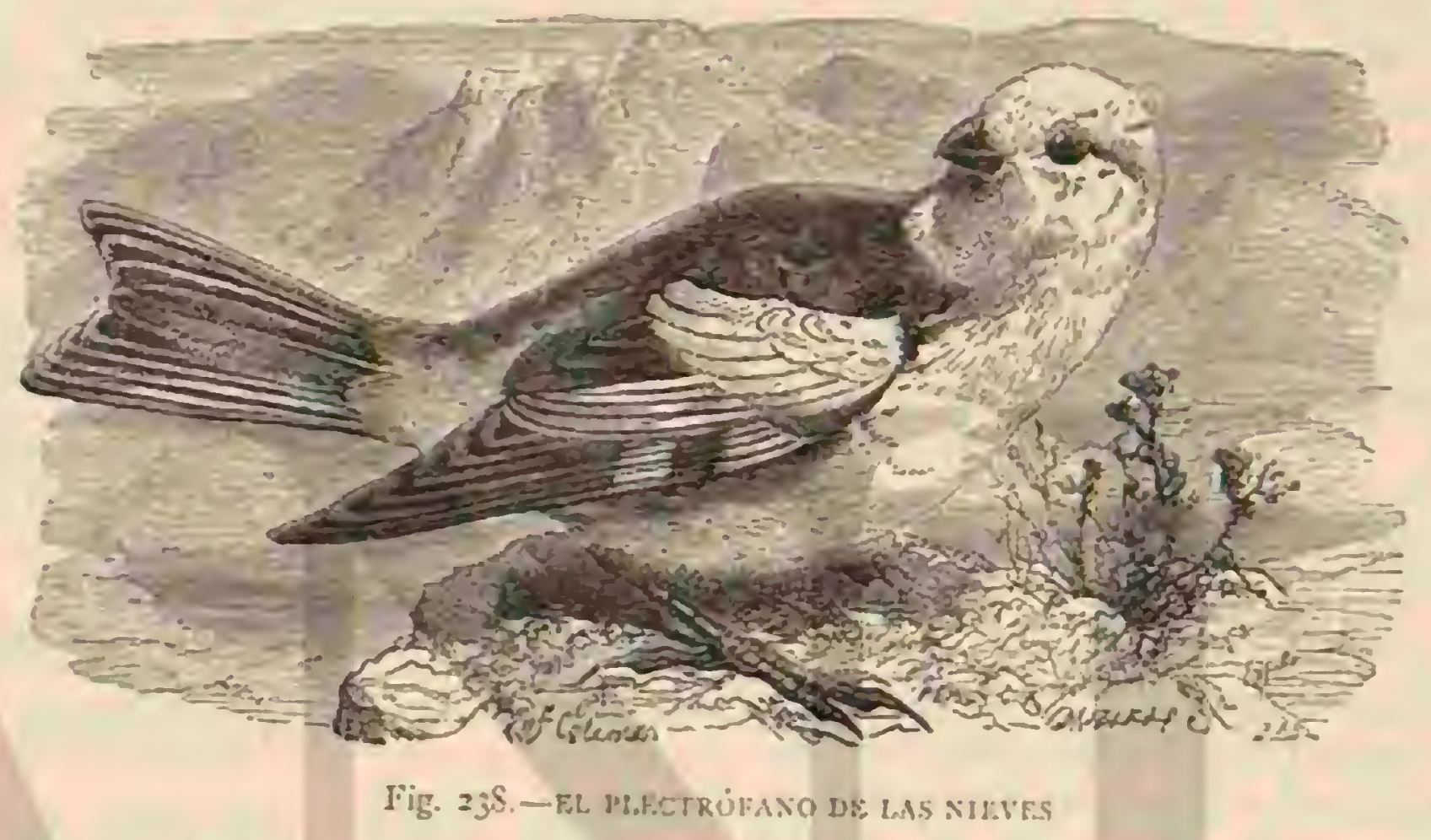

Se oye su grito en el Alto Egipto apenas se pone el pié en el último dique que preserma de la invasion de las arenas movedizas a los paises iertilizados por las aguas bienhecho. ras del Nilo; este pajaro es tambien el que se encuentra en las ruinas de los templos, en medio de los restos majestuo. sos de la civilizacion de los Faraones. Permanece en aquellos parajes desiertos, cual otro sacerdote de Isis metanorfosea do; pero como verdadero pjjaro doméstico, recorre tambien los alrededores de las tiendas de los-nómadas.

Iil amomane del desierto es un pảjaro taciturno, que corre y vucla admirablemente: y á fe que bien necesita de estos dos medios de accion para vivir en el desierto donde se halla: su voz no tiene nada de armoniosa.

Por lo regular se encuentran estos pájaros por parejas, si bien forman a veces bandadas numerosas. Son los séres nias comtentadizos que conozco; pocos metros cuadrados de arena y tres ó cuatro piedras, entre las cuales crecen algunas miseras yerbas, es todo cuanto necesitan; $y$ al ver esto se pregunta uno cómo pueden alimentarse aquellos pajaros en tan ingrato país Sin embargo, el hecho es positivo; cada parcja perma. nece frel å la residencia ǫue eligió; si se vuelve varias veces al sitio donde se la ha visto, se la encontrará siempre en el mismo lugar y en la propia piedra.

En los primeros meses del año el amomane del desierto da principio á la reproduccion. Su nido esta muy oculro debajo de alguna piecrm, en una cavidad ó en la yerba; es de construccion bastante graciosa y contiene en la primavera tres 6 cuatro huevos amarillos, con manchas pardas y rojas, sobre sodo en la extremidad gruesa: miden $10^{n}, 022$ de largo, por (1), 016 de grueso.
Lil macho expresa su pasion por un canto en voz. baja, agradable, aunque pobre, en el cual se repite con frecuencia el grito de llamada; despues da vueltas alredecior de su companiera, con las alas un poco entreabiertas; lucgo vuelan macho $y$ hembra al punto mas alto de su distrito, y el primero continúa su canto.

El amomane del desierto no tene al hombre; he conse guido acercarnıe mucho al pájaro, y aduiré la confíanza con que penetraba en la tienda de un nómada que residio algun tienıpo cerca de una fuente del Bahionda. Al ảrabe no le ocurria siquiera hacer daño al pájaro, y al curopeo, al natu. ralista, hubo de avergonzarle la idea de matarle.

\section{LOS OTOCORIS - PHILEREMUS}

CARACTÉRES. - Este género sc distingue por tener el pico recto, bastante endeble y de longitud regular; los iarsos son fuertes, con dedos regulares y espolones cortos, poco encorvados en el dedo pulgar; las rémiges tercera y cuarta son casi de igual longitud, $y$ las mas largas son anchas; el plumaje es muy abundante; un los lados del occipucio se ven dos pequeiros mechones de plumas; la distribucion de los colores es muy caracteristica.

\section{EL OTOCORI DE LOS ALPES - PHILEREMUS ALPESTRIS}

CARACTERES. - Esta especic, tipo del género que nos ocupa, tiene $0^{\circ}, 17$ de largo por $15^{\circ}: 3^{2}$ de ancho de punta a punta de las alas; estas miden $11^{\prime \prime}, 31$ y la cola $1, \infty, 0 \%$. La frente 
y las fajas que hay sobre los ojos, la barba y la garganta son de un amarillo pálido; una faja trasversal del occipucio, que termina en punta en los lados cie las sienes, la linea nasoocular, la region de las orejas y una gran mancha del buche en forma de media luna son megras; la parte superior de la cabcza, la posterior del cuello y las tectrices superiores de las alas, de un delicado tinte rojizo de vino; el resto de las regiones superiores se distingue por su color pardo de rierra con manchas oscuras en los tallos; las inferiores son blancas; los costados de un rojizo de vino; los muslos presentan lineas longirudinales oscuras; las rémiges, de color pardo, tienen en las barbas cxteriores un borde pardnsco pálido, y la pri. mera está orillada de blanco: las tectrices de las rúmiges secunciarias y las mas grandes de las alas jresentan igualmente en la extrcmidad un borde blanco; las rectrices son negras, excepto las dos del centro, que contrastan for su color pardo oscuro, orilladas de pardo palido; la primera de amluos lindos es blanca en las barbas exteriores. Los circulos oculares son de un pardo oscuro; el pico, gris azulado, y los jiés de un pardo de cuerno. En la hembra, el amarillo del rostro y de la garganta es mas pálido: la faja trasrersal de la cabeza no existe; las manchas nemas de los lacos de la cabera y del buche son menos grandes y un poco mas pálidas, por tener mas claras las puntas de las plumas; en el pecho se ven lineas oscuras poco marcadas en los tallos.

DISTRIBUCION GEOGRÁICA. Vil otocori de los Aixes no toma su nombre de los de Suiza, sino de los del nurtc. Fis propio de la Tundra, donde anida ahora en todas partes de este territorio; de modo yuce innto pertencec al mucro continente como al antiguo mundo.

En otro ticmpo escascaba muchisimo en el noroeste de Europa; pero desde hace unos cincuenta años se ha extendido mas, y habita hoy el norte de la liscandinavia.

USOS, cOST UMBRES Y REGIMEN. - En Finnmark, o sea la Laponia nortega, no habita el otocori alpestre mas que en las altas montaias; scgun mis obserraciones no pasa de una altitud de 100 á 160 metros sobre el nivel del mar, y se le encuentra lo mismo en los parajes mas desiertos qute cercn de has viviendas humanas. A pocos pasos rie la casa de Nordvy, conercianté y naturalista a ta vez, vi una pareja que se disponia á cubrir su segundia puesta. Nordyy me aseguró que cuando el era joven escascaban muchisimo estos pajaros, y que ahora se les veia por todas partes durante el verano.

A fines de octubre abandona la Tundra de Laponia, y a mediados de setiembre los territorios de la Siberia septentrional donde anida; no vuche a cstos antes de principios de mayo, y a la Tundra a mediados deabril. A fines de esic mes las parejas que anidan en Iaponia han construido ya su nido, que por lo regular tiene tambien huevos. Durante su viaje de inviemo visita con regularidad la Alemania, sobre todo las costas del Báltico, y parcece que esto sucede con mucha mas frecuencia que antes desde que el ave ha emigrado of la la. ponia noruega. Segun informes de Schilling, hijo, se presenta ahora todos los inviernos en Ruegen y en las islas vecinas, sobre todo en Hididensoe. Al decir de algunas personas en tendidas, pasa todos los añps por la Prusia oriental y occiủental; Cactie ha observado esta especie en los últimos airos con mucha freruencia en el Helgoland, donde se presenta por bandadas de sesenta, ochenta y hasta cien individuos. No cabe duda que estas bandadas viajeras pasan todos los años por el sur de Escandinavia, aunque se las rea poco, $y^{\circ}$ se presentan en el interior de Alemania con mucha mas fre. cuencia de lo que se cree: pero quizás pasan de montaña en montaña sustraýéndose asi à la observacion. En las cercanias del Obi encontramos en el otono del año $18 \% 6$, desde el 20 de setiembre, numerosas bandadas que en las orillas del rio y en los pueblos buscaban su alimento. No se sabe aun hasta dónde llega en invierno por el sur ó el sudoeste. Radde la en. contró en este tiempo en las altas estepas de la Dauria, en la provincia de Cherson y en Besarabia; Bartheleny-Lapommeraye dice haberla visto varias veces en Provenza, y segun Salvadori, se ha observado repetidas veces en Italia.

El oiocori alpestre se asemeja mucho á nuestra alondra comun; corre y vuela como ella, y para cantar se posa sobre una piedra ó una rama: segun Colles canta tambien volancio. Aliméntase de granos é insectos, y sobre tocio de moscas, que tan abundantes son en todo el pais de Tundra.

Su nido es de construccion muy artistica, relativamente, y esta en una depresion del suelo. El pajaro rellena el interior con rastrojo, yerbas, pelusa de ciertas plantas y cascaras de granos. Cada puesta es de cinco huevos, de $0^{\circ}, 022$ de largo por $6^{n}, 0: 7$ de grueso; tienen un color amarillento, con rayas muy finas y mas oscuras, que forman a veces una especie de corona en el extremo grueso. Algunos presentan manchas de un gris pizarra, ó rasgo's muy finos de un pardo oscuro. Por lo reguiar es muy dificil encontrar los nidos.

No sé si solo la hemiora incuba ó si alterna con el macho en esta ocupacion; pero es cierto que el otocori de los Alpes abandona en seguida el nido, y hasta los huevos cuando se le inquieta.

Cautividán.-Los otocoris de los Alpes cautivos son graciosos en un espracio pequeño, pero mucho mas aun en la pajarera; no solo viven en perfecta armonia con oiras aves, sino que hasta parece agradarles su compaina, y tambien soportan la cautividad muchos anos.

\section{LOS FRINGÍLIDOS-FRIN- GILLID㾁}

CARACTERES.-Esta familia, que esti diseminada en todos los continentes, excepto el de Australia, se compone de unas quinientas especies. Todas ellas rienen el pico de forma cónica, inas ó inenos grueso, rodeado en la base de una prominencia: la mandibula superior es muchas veces un poco mas larga que la inferior y ligeramente ganchuda: alguna vez se cruzan las dos, y sus cortes llegan hasta los áugulos de la boca; los piés son de longitud regular; los dedos casi sicmpre bastante cortos; las unas endebles; los tarsos están cubiertos por detrás de una esjuecie de placas; las rémiges primarias se cuentan siempre en número de nueve; las alas son de longitud rariable; la cola siempre corta, ó de un largo regular; el plumaje liso, sumanente variable por el color, seguri los seros y la edad; pero á veces tambien del todo igual. DISTRIBUCION GEOGRÁFICA. - Dentro de los li. mites indicados, los fringilidos habitan todas las zonas de ta. titud y longitud, todos los parajes desde la costa del mar hasta la cima mas alta de las montañas, asi las islas solitarias como las ciudades pobladas, el desierto y el bosque, las ro. cas desnudas y toda clase de sitios cubiertos por la vegetacion nias diversa. Muchas de las especies septentrionales son aves de paso; mientras que las que viven en el stir de lazona templada, en el sur de los paises ccuatoriales, permanecer sin ctcepcion en sus dorninios; pero tambien muchas de las que anidan y encuentran su alimento durante el rerano en las regiones heladas no las abandonan, por riguroso yue sea el invicrno. Las especies pasajeras se presentan con el des. hielo y solo abandonan su patria à la llegada del invierno.

USOS, COSTUMBRES Y REGIMEN. - Todos los fringilidos son cntre los pájaros las aves mejor dotadas, aun. que algunas veces se pretende lo contrario respecto á ciertas 
especies. Corren ó mas bien saltan con destieza; su vuelo es fácil; la mayor parte de ellos tienen un canto agradable y hasta algunos se distinguen por este concepro; sus sentidos estan bien desarrollados, y sus facultades intelectuales igua. lan î las de la mayor parte de los demás pájaros, siendo por lo tanio capaces de habitar las localidades mas diversas. Casi todos los fringilidos son sociables; pero à pesar de ello, mu. chus no viven en buena armonia sino en el otoño y el invierno, mientras que en la época de la incubacion nunca se aca. ban las luchas. Estas reconocen siempre por causa los culos, y tambien la envidia por el alimento. Aliméntanse de simientes de las plantas mas diversas, y en medio del verano tambien de insectos, que sirven con preferencia para la cria de los pequelios; rara vez dejan de encontrar las unas ó los otros;y solo cuando faltan, la necesidad comun induce á estas aves á unirse.

Casi todas las especies construyen con mucho cuidado sus nidos, cuyas paredes son bastante gruesas; son de formas graciosas, tanto por fuera como por dentro, y están rellenados con mucho esmero, componiéndose de diferentes sustancias vegetales y animales. Los fringilidos incuban dos reces al aijo, algunos tres; las hembras ponen de cinco à ocho hue. vos, de color claro con manchas y lineas mas oscuras, y su reproduccion es por consiguiente inmensa, bastando para resarcir las muchas pérdidas causadas por toda clase de rapa. ces. Tambien el hombre las persigue á veces para evitar que causen destrozos en sus plantaciones; pero en general las protege, porque en rigor no causan daño sino alguna vez y en ciertas temporadas; en cambio compensan los perjuicios por su gran utilidad y recrean al señor de la creacion con su viveza y sus cantos agradables.

CAUTIVIDAD. - Los fringilidos son poco exigentes y se domestican sin dificultad, siendo por lo tanto muy propios para la jaula, mucho mas que la mayor parte de las otras es. pecies de su órden. Desçe la antigüedad son companeros dẹ hombre, cuya vivienda comparten y animan. Algunos de ellos, por lo menos en algunos paises, han merecido mayor consideracion que el ruiseñor, pues seles venera y hasta se les idolatra. Una especie, la única entre los pajjaros, ha llegado a ser verdadera ave doméstica, conquistándose como tal toda In tierra, pues con su canto agradable alegra hasta la choza mas solitaria que el colono construye en la selva virgen recien cultivada, y anima la habitacion del irabajador. Mas de un fringílido pertenece en Alemania á la casa, á la fanilia, a la cual hace olvidar su pobreza, divirtiendo al hombre, cuando acaba sus rudas tareas diarias, con las hermosas melodias que hace resonar de continuo.

Inútil me parece insistir mas en demostrar su importan. cia: son útiles porque se comen los granos de las malas yerbas, y destruyen los insccios nociros; su carne es un manjar delicado; su canto, que restiena en medio de los campos y cuando están cautivos, sobre todo, constituye un agradable pasatiempo para el hombre. Por todos estos conceptos son verdaderamente dignos de nuzstra estimacion.

tun hoy dia los naturalistas no están de acuerdo soure la clasificacion de los fringilidos, pues tambien esta familia está ฮun poco desarregłada, segun dice Wallace; pero poco ả pocn predomina la opinion por la cual se reconocen las subfamilias que a coninuncion enumeráré

\section{LOS EMBERÍCIDOS-EMBERIZINA:}

CARACTERES.-Esta sub-familia forma un grupo rico en generos y comprende unas cincuenta y cinco especies. los emberícidos son pajjaros de tronco fuerte, con pico pequeno, cónico, puntiagudo, grueso en la base, comprimido hateralmente en su parte anterior, mas estrecho arriba gue abajo, muy encorvado hácia adentio en los burdes y deprimido en los ángulos de la boca; la mandibula superior tiene en el paladar una prominencia huesosa que encaja en una cavidad correspondiente de la inferior; los piess son cortos; los dedos largos; la una del dedo posterior afecia muchas veces la forma de espolon; las alas son de tamaño regular; las rémiges segunda y tercera suelen ser las mas largas; la cola, bastante prolongada, se compone de plumas un poco anchas y tiene una ligera sesgadura en su extremidad: el plumaje varia casi siempre segun el sexo y la edad.

DISTRIBUCION GEOGRAFICA. - La mayor parte de los embericidos pertenecen al hemisferio septentrional iel globo.

USOS, COSTUMBRES Y REGIMEN. - Las especies pertenecientes a esta sub-familia viven con prelerencia en la maleza $o$ en cañaverales; no se cuentan entre los fringilidos mas vivaces y mejor dotados, pero no carecen de gracia en su conjunto; son muy sociables y pacificos. En verano se alimentan principalmente de inscctos; en otoño é invierno de simientes harinosas, las cuales buscan en el suelo. Su nido es siempre sencillo y hallase en una pequeña cavidad del suelo, 6 cuando mas un poco elevado. In hembra pone de cuatro as scis huevos de color oscuro, con motas y lineas entrelazadas, y el macho la presta su ajucia para cubrirlos. Algunas especies sufren persecucion desde las épocas mas remoias por ser su carne sabrosa en el otoño; otras, por el contrario, no se hallan expuestas a los ataques del hombre que rara vez las tiene enjauladas.

\section{LOS PLECTRÓFANOS - PLECTRO- PHANES}

CARACTÉRES. - Este género p̧uede considerarse como eslabon que enlaza los alaúdidos con los fringilidos. Las es. pecies que le forman tienen el pico pequeno; la prominencia del paladar poco visible; los jiés robustos; el dedo posterior provisto de una espuela que le iguala en longitud; las alas puntiagudas; las dos primeras rémiges son las mas largas; la cola corta y sesgada en la extremidad, y el plumaje abun. dante.

\section{EL PLECTRÓFANO DE LAPONIA - PLEC- TROPHANES LAPPONICUS}

CARACTÉRES: - En esta especic la cabeza, la cara y la garganta son negras; una ancha faja sobre los ojos y las sicnes de un blanquizco rojizo; la nuca y la parte posterior del cuello de un rojo de cancla; las otras partes superiores de un pardo de orin, con manchas negras en los tallos; los lados del cuello y las regiones inferiores blancas; los custa dos tienen lineas negras en los allos, las cuales se reunen en los lados del pecho formando una gran mancha; las re. miges son de un pardo oscuro, orilladas en las barbas exteriores de un estrecho borde pardo pálido; las rémiges secun. darias posteriores y las tectrices presentan en las barbas exteriores un ancho borde pardo de orin; las tectrices supe. riores de las alas están orladas en su extremidad de un borde leonado, mas ancho y claro en las mayores, en las cuales forma una faja trasversal; las rectrices son negras, con bor. des pálidos; las dos cxteriores blancas en la base por fuera y en la mayor parte de la extremidad de las barbas interio. res. Los círculos oculares son de un pardo oscuro y el pico de un amarillo de paja, negro cerca de la punta y de un negro azulado en la arista: y los piés de un gris azulado. En la hembra, la parte superior es de un pardusco de orin, con 
lineas parduscas en los tallos; In nuca rojiza; la faja de las sienes de un amarillo rojizo; las partes inferiores de un pardo de arin, con manchas oscuras poco marcadas en los tallos; en la region de las orejas se ven lineas de un pardusco os. curo, y tambien tiene una faja poco marcada en forma de barba. La longitud de esta especie es de $11=, 16$, por $11^{\mathrm{m}}$, 2a de ancho de punta a punta de las alas; estas miden $0^{\circ}, 09$ ! la cola $1 \|^{\prime \prime}, 06$.

DISTRIBUCION GEOGRÁFICA. - El piectrófano de Iaponia es propio de la l'undra; de modo que su área de dispersion se extiende por el norte de ambos nundos. Desde aqui enuprende en inviemo sus viajes hácia el mediodiaipero solo hasta donde le obliga la necesidad. Kara vez sc presen. ta ca - lemania; y mas al sur soto se ien algunos individuos crranies. Vuelvé à su patria tan fuego como puede, y entor: ces abunda en todas partes, tarito en las llanuras como en las montañs, siempre, y cuandu haya alisos enanos.

USOS, costumares Y REGIMEN.-Por sus cos. tumbres constituje un iránsito el plectrótano lapon entre los alaúdidos y los embericidos: corre como los primeros y se posa y vuela como los segundos; cuando está en celo se cier. ne el maclio largo tiempo, lo mismo que ba alondra. Se ha dicho que este pájaro no se pasaba en los árboles; pero yo puedo afirmar lo contrario, si bien debo anduir que se te ve con mas frecuencia sobre una piedra que, en el vacilante ramo de un abedul. Su grio de liamada ziene algo de lifgubre, y está en armonia con el desierto dondebusca el virjero las nidos del pájaro; este grito, prociucido $2 a m b i e n$ por la hembra, podria expresarse por fjusi, jusia, y el de aviso por Per, eire. El canto es muy sencillo; se reduce ff un sonido que repite con frecuencia el de llamada: el macho no canta sino cuando vuela; mas entonces lo hace con muclio ardor. Naumann le compara en este punto con la alondra.

Segun Schrader, el plectrófaso lapon-no llega i Iapionia hasta mediados de abril, que es cuando comienaa el periodo del celo. Hállase el nido de esta especie en los parajes húmedos, entre las raices de los abedules, 0 debajo de las fllantas que forman intrincadalespesura; la parle exterior se compone de rastrojos mas ó menos toscos, yel interior está relleno de plumas de lagónedo. 1.a puesta, que ocurre en junio, consta de cinco ó seis huevos prolongados de $1^{\circ}, 0 \geq 0$ de largo por f" ", or 5 de grueso; son de color gris amarillento $\delta$ de un pardo claro, con pequenos puntos y lineas oscuras, mas ó menos marcadas; pero á menudo ialta este dibujo. Yo he visto in fines de julio peqqueños que acababan de em. prender sur ruclo.

Hácia la misma época enconiré parejas de plectrófanos 6 reducidas bandadas, compuestas sin duda de aquellos individuos que habian acabado de criar a su proyenie. No cran icinerosos y parecian no conocer al hombre: pern despiertase su descontianza apenas se les da caza, y despues de oir las primeras detonaciones, se hace muy dificil acercarse a ellos, aun en los parajes mas desiertos. Una vez conocido el peligro que les amenaza, emprenden su vuelo antes que el cazador pueda tenerlos a tiro, y desaparecen al momento.

Durante el periodo del celo no se alimenta el plectrófano lapon mas que de insectos, principalmente de moscas, que habitan en la Tundra á millares, formando espesos enjambres en la supernicie del suclo. Todos Ins individuas quue yo maté tenian el buche y el estómago llenos de ellas: en invicmo comen granos.

Fl plectrófano de espuelas sucle reunirse con las alondras en los ulltimos meses de otorio, y con cllas se le coge á ve. ces en gran número, sobre iodo en China, donde en ciertas temporadas se llevan centenares de individuos \& los mercados.

\section{EL PLECTRÓFANO DE LAS NIEVES-PLEC- TROPHANES NIVALIS}

CARACTERES.-Esta cspecie es en verano de un color ran blanco como la nieve, negra en el manto, en los hombros, las rémiges primarias y las cuatro rectrices de la cola; las plumas del manto y de los hombros tienen bordes blan. cos en su extremidad, y blanca es tambien la basede las rémiges primarias; en invierno, la parte superior de la cabeza, el occipucio 5 la region de las orcjas son de un pardo rojizo de canela; los hombros y el manto negros, con bordes de un pardo rojizo de canela en la extremidad de las plumas; una faja trasversal que se corre sobre el buche y los costados es de color amarillento de orin: las rectrices exteriores de la cala tienen en la parte descubierta una mancha negra en la extremidad; las hembras ostentan en invierno un color pardo rojizo de canela mas intenso aun que en los machos: las tec. trices superiores de las alas son de un pardo de orim, orilla. das de blanco en la extremidad; las manchas negras de las puntas de las rectrices son mas grandes; los circulos oculares de un pardo oscuro; el pico negro en verano y amarillo de naranja en invierno; los piés negros (5ig. 238).

DISTRIBUCION GEOGRAFICA. - El trea de disper. sion del plectróblano de las nieves comprende casi los mis. mos paises habitados por el plectrófano de espuelas, y aunque podria decirse que su patria es mas extensa. el territorio donde inida es no obstante mas limitado que el de su con. gériere, Habita in alta Tundra, y por el norte hasta alli donde desaparece el hiclo; pero aunq̨ue solo sea por algunas semanas, siempre se le encuentra en las inmediaciones de las nieves etcrnas. Es tel ave terrestre mas comun en Islandia y aun anida, segun se asceun, en el Spitzberg, Nueva 7.em. bla y el norte de Groenlandia. En verano solo le he visto en las montah̆as mas aitas de Dovréjeld, en Escancinavia, y en el norte de Laponin, al sur del limite de las nieves; en esta última region solo le hallé aislado y nunca le encontré en la tundra de la peninsula de los samojedos. En su viaje de in. vierno llega hasta el mediodia de Alemania, y a reces se ade. lania mas al sur; en Asia avanza hasta la Siberia meridional fel centro de China; en América hasta el centro de los Es. tados. Unidos.

USOS, COSTUMBRES Y RFGIMEN.-Habita este pájaro las vertientes pedregosas de las montanas: alli es donde pasa su corto verano, y donde ama j se reproduce. Su nido se encuentra siempre en las grietas de las rocas ó debajo de una gran piedra. El exterior está formado de yerba, musgos y liquenes, y cl interior relleno de plumas y de bozo; la entrada es lo mas estrecha posible, y solo permite el paso al pajaro que alli habita.

L.a puesta se compone de cinco à seis huevos, de $10^{n}, 022$ de largo por (1", 016 de grueso: estos varian mucho de color, mas por lo regular son de un blanco azulado con manchas, motas y lineas de un pardo oscuro de orin, que laácia la extremicind gruesa son mas numerosas y forman una especic de corona.

$A$ fines de abril se ore al macho, que posado en una pie. dra, repite su cancion, sumamente agradable y armoniosa; poco despues del periodo del celo se reunen los padres con su progenie, formándose asi grandes bandadas, gue no tardan en cmprender sus viajes.

Durante la época de la reproduccion, los pleciróínos de las nieves se alimentan casi exclusivamente de insertos, sobre todo de moscas: en invierno comen toda clase de granos.

Hay pocos pájaros que viajen en bandndas tan considera. bles; todos los inviernos se presentan en Alemania; pero rara vez en tanto número como en los paises mas septentrionales. 
En Rusia se les llama cofos de nicic; y \& decir verdad, se les ve caer del cielo como tales, cubriendo todos aquellos sitios donde pueden encontrar que comer.

A reces caen tambien sobre los buques en inmenso nú. mero, para descansar un iristante $\& \mathrm{El} 17$ de mayo, dice Malmgrem, explorador del Spitzberg, se posó en los palos y jarcias de nuestro buque una bandada de plectrófanos de las nieves que parccian muy fatigados; permaneció alli poco iempo, y emprendió luego su vuelo hảcia el Spizzberg, luchando penosamente con el viento que era contrario.) Otros viajeros, particularmente Holboell, han sido testigos de hechos semejanies; y por lo tanto vemos que estos pájaros no temen emprender largos viajes, aunque sea á través del mar.

Los plectrófanos de que hablamos se asemejan por sus costumbres, asi \& los emberizas como à las alondras; corren lo mismo que estas; vuclan fácilmente sin aletear mucho, y describen largas lineas onduladas. En sus emigraciones se re. montan a bastante altura por los aires, y en sus viajes ordinarios vuelan rasando la tierra. "Cuando una bandada busca su alimento, dice Naumann, rueda por el suelo, y mientras que una parte de ella se posa, revolotea la otra a escasa altura. Los plectrólanos de las nieves son pajjaros ágiles, siem. pre en movimiento; los frios nass rigurosos no les hacen perder nada de su vivacidad, y aun cuando reine la mayor escaser, encuentran siempre suficiente alimento. Muy pocas veces permanecen largo tiempo en el nismo canton, pues prefieren recorrer cierta parte del pais. Cuando todo está cubierto de una espesa capa de nieve, buscan la comida en los caminos y llegan hasta el interior de las ciudades: si en. clientran alguna casa abandonada en los campos, pasan alli el invierno.

Sus gritos de llamada consisten en un silbido asaz pene. trante, que puede expresarse por $f i s$ y en un sonido fuerte, equivalente a sirr, los cuales emiten soble todo cuando vue. lan. El canto del macho es un gorjeo bastante parecido al de la alondra, aunque dificre por ser los sonidos mas fuertes: en el período del celo se posa el pájaro sobre la nieve ó so. bre la cresta de una roca para cantar.

CAUTIVIDAD.-Los individuos cautivos se conservan raras veces mucho tiempo en la jaula, porque nuestro clima es demasiado cálido para ellos.

\section{LOS EMBERIZAS-EMBERIZA}

CARACTERES. - Iiste gémero se caracteriza por teror pico mas ó menos largo y fuerte, has mandibulas son de diferente longitud y la prominencia del paladar siempre visible; los piés son endebles; el dedo posterior está provisto de una uña muy cora y muy; corva; las alas son de longitud regular; la segunda rénige ó la tercera son las mas largas; y la cola, bastante pro!ongada, tiene una escotadura.

\section{EL EMBERIZA DE LOS JUNCOS-EMBERIZA SCHCENICIUS}

CARACTERES. - Ia cabeza, la barba y la garganta hasta la mitad del buche son negras; una faji en forma de barba, un collar $y$ las partes inferiores, blancos; los costados de color gris con lincas longitudinales oscuras; en el manio y en los hombros, el color gris pasa al pardo oscuro; las plumas de esta region están orilladas en los lados de un rojo pardo de orin; la rabadilla y las tectrices suneriores de la cola son de un pardo gris; las sémiges de un negro pardo, orilladas en las barbas exteriores de un borde pardo de orin, mas ancho en las rémiges secundarias y en las tectrices superiores; estas últimas son de un rojo de orin; las mayores negras en la base, por lo cual se forma una faja trasvereal oscura; las rectrices son negras, las dos del centro orilladas de rojo de orin; las dos exteriores de ambos lados blancas en la nitad extrema de las barbas interiores, la primera de ambos lados blanca ambien en las barbas exteriores. I.os circulos oculares son de un pardo oscuro; el pico del mismo color y los pies parduscos. La hembra tiene la cabeza de un pardo rojizo, con lineas longitudinales negras; la faja de los ojos de un pardusco de orin; la barba, y una ancha faja en

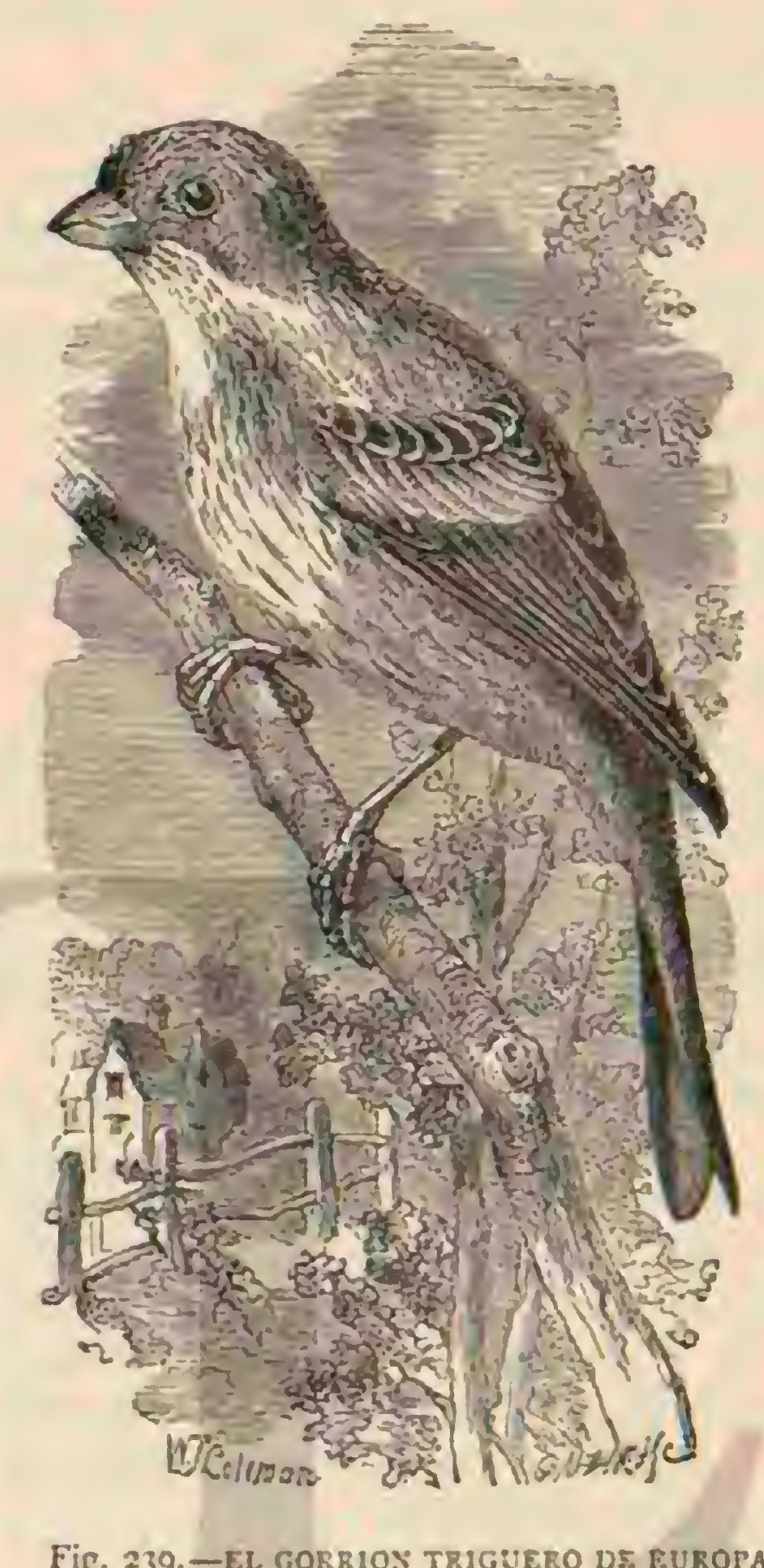

Fig. 239. -EL GORRIOX TRIGUETO DE FUROPA

forma de bigote, de un blanco rojo; en la garganta hay una mancha negra poco marcada, con borde pardo rojo; la parte posterior del cuello, el buche $y$ los costados son parduscos, con lineas longitudinales oscuras. Esta especic mide $11^{ \pm}, 16$ de largo por 0,23 de ancho de punta á punia de las alas: estas tienen $6^{\circ}, 07.5$ y la cola $0^{\circ}, 055$ de longitud.

DISTRIBUCION GEOGRAFICA.-El ảren de dispersion de esta ave comprende toda la Europa y el Asia occi. dental.

En la Europa meridional está representada por el emberiza pirrula (Enderian pyrrimbides), que se distingue por tener el pico fuerte, grueso $e$ igualmente encorvado on la arisia.

USOS, COSTUMBRES Y REGIMEN.-Dentro de su extensa área de dispersion cl emberiza de los juncos solo falta en las moutanias. Habita exclusimmente en sitios pantanosos cubiestos de altas plantas acuáticas, cañas, juncos, maleza de sauce y otras; en una palabra, las orillas de los estanques, rios y lagos, los pantanos y praderas húmedas. Anida en todos estos parajes.

Forma este pajjaro su niclo en el suelo de pequeñas islas en medio de las raíces y de las jerbas, en un sitio bien oculto y fuera del alcance de las aguas; se compone de tallos, de yerbas y hojarasca, y el interior está lleno de crines, pelusa de sauce y de caña; pero la construccion es muy tosca. En 
mayo y á principios de julio, se encuentran de cuatro â seis huevos pequeños de $0^{\infty}, 019$ de largo por $0^{\circ}, 014$ de grueso, de color muy variable, por lo regular gris blanquizco, que tira al pardo o rojo, y con manchas, punias y vetas de un gris ceniciento ó de un pardo sojizo, mas ó menos tmarcadas y confluentes.

Este ptjaro no es timido, soj:e todo cuando se halla cubriendo los huevos en su nido, pues el amor á su progenie le hace olvidar toda su prudencia, hasta el punto de poderse coger a la hembra con la mano. Si álguien se acerca al nido, acude el inacho presuroso, lanzando gritos lastimeros. I.os pequeños se crian del modo ordinario.

Este emberiza es mas alegre, viray ághil que sus congéne. res: trepa habilmente a 10 largo de los tallos de las cañas, por muy delgadas que sean; saita con mucha rapidez y soltura por tierra; víla ligernmente; complácese en remontarse á cierta aliura, cerrando luego las alas, pam dejarse caer en cierto modo; con frecuencia se divierte en revolotear al rededor de los natorraies Cuando le afecta alguna cosa, 6 se dispone á emprender su vuelo, 6 acaba de posarse, imprime a la parie posterior de su cuespo movimicatos bruscos y re petidos, como lo hacen los gorriones de nogal. Su grito de llamada es tzic, pronunciado con fuerza, $y$ mas prolongado que é de los oiros cmbericidos: su canto es iartaleado. Este pajaro, como dice Naurnann. (ahoga todas las notas.? Fin címbio se le oje desde por la mahana hasta la tarde: debo declarar que su continuado gorjeo me agradaba nucho.

Durante el rerano se alimenta este jajjaro casi exclusiva. mente de insectos acuáticos; en otono é invierno come los granos de las cañas, de los juncos, de las yerbas y de diversas plantas jantanosas.

Poco despues del periodo dei celo se reunen estos pájaros en reducidas bandadas para recorrer los campos. A la entrada de la mala estacion abandonan los paísés del norte y van ¿ buscar un asio en la espesura de cañas $y$ en los pantanos cubiertos de altas jerbas, situados en el mediodia de Europa. En invierno vi muchos cerca de Toledo, en las orillns del Tajo, donde babitan las breñas de cardos mas espinosos: to. dos los años abundan estos pajiros en las orillas del lago de ia Albuicra, cerca de valencia.

\section{EL EMBERIZA ENANO-EMBERIZA PU- SILLA}

Caractéres. - La longitud de esta especic es de (1), 15 ; las alas miden $0^{*}, 08$ s la cola $4 \%, 065$. I a parte su. perior de la cabeza, la linea naso-ocular y los lados de la cabeza son de color pardo rojo de canela muy vivo; dos anchas fajas longitudinales que se corren desde las fosas nasales hasta la nuca son negras, y dod mismo color otra mas ancha que cmpiezando detrás de los ojos se reune con una que li. mita la parte posterior de la region auricular; una faja tras versal en los lados del cuello es de color rojizo de orin; las regiones superiores son pardas $y$ las inferiores blanquizcas; las primeras tienen en el manio y los hombros grandes man chas de un color negro pardo, orilladas de pardo rojo en los tallos; en el buche jo el pecho hay numerosas lineas negras en los tallos; las alas y las rectrices, de un pardo oscuro, es tán orilladas en las barbas exterioies de un tinte pardo páli do; las rémiges secundarias inferiures y sus tectrices presentan un borde imas ancho de color gardo de orin; las tectrices mayores de las alas tienen la punia de este mismo tinte, que forma una eaja trasversal; la primera rectriz de ambos lados es blanca en toda la barba exterior y en la extremidad de la interior, mientras que la segunda de cada lado solo presenta una archa faja blanca en las barbas interiores. Los ojos son de un pardo oscuro; el pico del mismo color, y los piés parduscos. El color de la hembra es menos vivo; la coronilla presenta una faja pálida en el centro y dos mas oscuras en Ins lados; la linea naso ocular $y$ las fajas que hay sobre los ojos son de un color de orin pailido; las plumas que rodean las orejas de un rojo de orin.

DISTRIBUCION GEOGRÁFICA.-Fl emberiza enano es propio de Europa y de todo el norte de Asia.

\section{EL EMBERIZA SILVESTRE-EMBERIZA RUSTICA}

CARACTÉRES. - Esta ave, mự congenérica del cm. beriza enano, tiene la parte superior y los lados de la cabeza negros; una ancha línea de las sienes, la barba y la garganta son blancas; las regiones superiores y una ancha faja trasversal que se corre sobre la cabeza, de un pardo rojo oscuro; las tectrices inferiores de las alas son blancas; las plumas del manto y de los hombros tienen en sus tallos grandes man. chas negras; las plunans pardo rojas de los costados están orilladas de blanco; las rémiges primarias, de un color pardo oscuro, están orilladas exteriormente de un pardo pálido; las secundarias son de un negro pardo, asi como las mayores de las tectrices superiores, que tienen bordes pardos en las barbas exteriores y blancos en la extremidad; estos últimos for. man dos fajas trasversales blancas; las pequeñas tectrices su. periores son de un pardo rojizo; las rectrices negras, y las dos del centro orilladas de pardo; las dos exteriores de ambos lados tienen en las barbas interiores una mancha longitudi. nal blanca; la primera es blanca casi hasta la extremidad de las barbas exteriores. Los ojos son pardos; el pico pardo ro. jizo, mas oscuro en la arista, y los piés de un amarillo de cuerno. Ia hembra tience la parte anterior y posterior de la cabeza de color pardo rojizo, con tallos rojizos; una línea que cruza las sienes de un amarillo de orin; la barba y la garganta de un blanguirco rojo; la nuca y una faja trasiersal del buche rojas de orin; cada pluma está orillada de amarillento en la extrcuidad; en los costados hay manchas longitudina. les de un pardo rojo. Esta especie mide $0^{\circ}, 17$ de largo, por 1)" 27 de ancho de punta a punta de las alas; estas tienen $0^{\prime \prime}, 08$ \& y la cola $l=, 064$ de longitud.

DISTRIBUCION GEOGRÁEICA. - El área de disper. sion del emberiza silvestre es casi igual á la del emberiza enano; pero como se extiende mas hácia el oeste, llega desde Kamtscbatka hasta Laponia. Ambas aves visitan en invierno las regiones meridionales, solo que mientras la primera sucle prolongar sus excursiones hasta el mediodia de la China y centro de la India, la segunda no se aleja nuuca tanto de su patria.

Ambas viajan tambien hicia el sudoeste, visitando en tonces la Alemania, por donde pasan desapercibidas con mucha mas frecuencia de lo que hasta ahora creinmos, fundándonos en las observaciones hasta aqui conocidas.

USOS, COSTUMBRES Y RÉGIMEN. - Poco hay que decir sobre el género de vida y el carácter de estas dos especies tan congenéricas. Ambas habitan los bosques de su patria y sobre todo las espesuras de sauces en las orillas y ch las islas de los grandes rios, las cuales uo frecuentan, sir. embargo, mas que para anidar, alejandose tan lentamente como llegaron apenas acaban de criar à sus hijuelos. Radde dice que el emberiza silvestre de la Siberia oriental es entre todos sus congéncres el que mas pronto pasa por el sudocste de acguel pais llegando y'a el 26 de maso á las orillas de Tarainor; pero tan cansado por el viaje á través de la solitaria es. repa, que se le puede coger con la mano. A lines de abril, 6 en mayo, llegan por fin à su patria Lo mismo podemos de. 
cir respecto al emberiza emno de curo género de vida en verano puedo dar algunas noticias, segun mis propias obser. vaciones. Como su color es anślogo al del ierreno y vive siempre tan oculta, el ave pasa facilmente desapercibida, y en rigor solo se la ve cuando el macho se posa en la copa de un airbol para dejar oir su pobre y breve canto, que se reduce $\{$ tres 6 cuatro sonidos. Tan luego como la nieve desaparece de los bosques, ó sea a mediados de junio, la pareja hace sus preparativos para la reproduccion. El i de julio, despues de buscar mucho tiempo, enconiré un nido, que el mismo macho descubrio por haber fingido que cojeaba; este nido estaba en el suelo muy oculto en la yerba seca; bastante pequeno, atendido el tamaño del are, y de forma plana, consistia tan solo en tallos de granineas muy unidos entre si. Los adultos manifestaron gran temor, fingiendo del modo acostumbrado; advertida por el macho, la hembra abandonó por fin el nido, al principio a saltitos, sin que yo In viese, $y$ luego con rapider, hasta que esturo muy léjos. Macho y hembra permanecieron inmóviles mientras yo bus. caba cerca del nido, pero luego se acercaron á tres pasos de mi, produciendo continuamente su grito de llamada que es un agudo, pero débil ziph, sipp, siph. No quise tocar los po. Iluelos, y quizás hubicra obrado del mismo modo si en vez de ellos hubiera encontrado los hueros. Baldamus, que reci. bió algunos de estos por conducto de Middendorfi, dice que son de forma muy variable; miden de $0^{\circ}, 01 ;\left\{10^{\circ}, 027\right.$ de largo por $\|^{\text {mo }}$ or 4 de grueso: la cáscari es amarillenta, con puntos, lineas y manchas poco marcadas, de color pardo violcta, sobre todo en la extremidad gruesa; parécense mucho á los del emberiza hortelano, distinguiéndose no obstan. te por su reducido tamaño, tanto de estos como de todos los de emberiza. Secbohn, que encontró en junio á orillas del Petschora inferior, varios nidos, hace una descripcion análo. ga de los huevos.

\section{EL EMBERIZA GRIS Ó GORRION TRIGUE- RO-EMBERIZA MILIARIA}

CARACTÉRES, - Esta especie se distingue por sus pe. sadas formas; su longitud es de $f_{1}^{*}, 19$, por ( $)=20$ de anchura de punta a punta de las alas; estas miden $0^{\circ}, 09$ y la cola $0^{\mathrm{n}}, 07$ (fig. 239).

Las partes superiores, excepto las plumas de la rabadilla y las tecirices de la cola, son de un color pardusco de tierra. con lineas oscuras en los tallos, que forman descle la mandi. bula inferior algunas fajas poco marcadas en forma de barba, y por su reunion en el centro del buche una gran mancha oscura; la línea naso-ocular y una faja poco-marcada en las sienes son de un blanco palido; la region de las orejas y de las mejillas es de color pardusco, con lineas longitudinales mas oscuras, limitadas en su parte inferior por una faja de un blanco pálido, que tambien presenta linens oscuras; las remi. ges y rectrices son de un pardo oscuro, orilladas de blanq̨uiz. co pailido en las barbas exteriores; las rémiges secundarias y las mayores tectrices superiores de las alas están orilladas del mismo modo, y tambien en la extremidad; de modo que estos bordes forman dos fajas trasversales de color claro. Los ojos son de un pardo oscuro; el pico amarillo de cuerno, y los piés de un amaritlo pálido.

DISTRIBUCION GEOGRAFICA.-Desde el mediodia de Noruega se encuentra esta ave en toda Europa fe igual. mente en los parajes convenientes del Asia occidental, donde suele anidar, cmprendiendo solo cortas expediciones. Fn su emigracion de invicrno llega aisladamente ó en bandadas hasta el norte del Africa, y entonces abunda bastante en Egipto y hasta en las islas Canarias. En verano prefiere las vastas y fértiles llanuras cubiertas de trigo, pero mas le agradan aun las regiones donde alternan las praderas con los campos en que no falian f́rboles y arbustos aislados: siempre se aleia de los grandes bosques y de las montañas. No es raro en ninguna paric de la Alemania septentrional; en el centro de este pais se extiende mas y mas. En los ricos campos de trigo de Austria y Hungría es, si no la mas comun de todas las aves, por lo menos el emberiza que mas abunda.

Por el aspecto general de este prjaro, por su cuerpo grueso y recogido y sus alas cortas, se deduce ya que es pesado: salta con lentitud, encorvando cl cuerpo y moviendo la cola; vuela con trabajo y ruidosamente, aunque no sin cierta rapi. der, y cambia de direccion con mas iacilidad de lo que pudiem esperarse. Su grito de llamada sik, que lanza al em. prender su vuelo, es bastante sonoro; su selial de aviso es un sonido equivalente is sich, muy prolongado; $j \mathrm{en}$ sus momentos de ternura parece pronunciar las silabas tik tik. Su canto no es vigoroso ni agradable; aseméjase al ruido que produce un telar de tejer medias, y por esto se le aplicó en ciertos paises de Europa el nombre de bonetero. El pajjaro, no obstante, parece muy satisfecho de si mismo; al cantar toma las posturas mas extraordinarias, y trata de reemplazar con sus gestos las notas que no puede emitir. El gorrion triguero de Europa no tiene ninguna cualidad buena; es fastidioso, y á mayor abundamiento pendenciero.

Anida por el mes de abril, en medio de las yerbas y muy cerca del suclo: las paredes de su nido se componen de ras. trojos, hojas secas y pajas; y el interior está relleno de pelos 6 verbas muy finas. La hembra pone de cuatro a seis luveros de $0^{\circ}, 024$ de largo por $11^{\circ}$, ors de grueso, de cáscara fina, mate, y color gris empanado, $\delta$ amarillento sucio, cubierta de puntos, pequerias manchas $y$ rajas de un gris rojizo $\delta$ azula. do, principalmente en el extreno grueso. Jos hijuelos se ali. mentan de insectos y comienzan à volar à fines de mayo, Epoca en la que los padres anidan por segunda vez, forman. do despues baudadas, jórenes y viejos, para comenzar sus emigraciones.

CAzA. - Persigueseles activamente para obiener su carne, que es muy delicada: se cazan con escopeta ó los cogen con lazos, redes, etc. No se les coge para la jaula.

\section{EL EMBERIZA AMARILLO-EMBERIZA CITRINELLA}

CARACTERES. - Esta especic abunda mas, pero no tiene un área de dispersion tan extensa como la de la prece. dente. Su longitud es de $\left(7^{m}, 1 \%\right.$ por $10^{m}, 27$ de ancho de punta á punta de las alas; estas tienen $t^{\prime \prime}, 085$ y la cola $l_{1}=, 07$ de largo. Ia cabeza; el cuello $y$ las partes inferiores son de un bonito amarillo vivo; ia frente, una faja longitudinal que se corre sobre los ojos hasta la nuca, y otm que pasa desde el borde posterior de aquellos hasta las sienes, asi como la parte posterior del cuello, son de un verde gris aceituna, con escasas lineas oscuras; la cabeza y sus lados presentan en los tallos lineas de color pardo rojo cancla; la muadilla y las tectrices superiores de la cola tienen otras iguales mas oscu. ras; en el manto y en los hombros estas lineas son de un pardo de orin pálido, $y$ en las partes inferiores del tronco del mismó tinte, mas oscuro: las partes superiores del tronco tienen estas lineas mas anchas y de color negro; las rémiges son de un pardo oscuro; las primarias presentan en sus par. tes interiores un borde amarillo pálido; las secundarias y sus tectrices están orilladas en su extremidad de un pardo rojo, cuyos bordes forman una fajn trasversal: las rectrices de un pardo oscuro con un borde angosto de color mas claro en las barbas exteriores; las dos primeras de ambos lados pro. 
vistas en la extremidad de las barbas interiores de grandes manchas blancas. Los ojos son de un pardo oscuro; el pico de un arul mas claro ell los cortes; los piés de un amarillo rojizo (fig. 2ap). La hembra tiene todos los colores mas pi. lidos; una mancha en la coronilla, las cejas, la barba y la gar. ganta marcadamente amarillas; el buche y el pecho de un pardusco rojizo pálido.

Distribucion GEOGRÁFICA. - La patria del emberiza amarillo cumpreade el norte y centro de Europa y

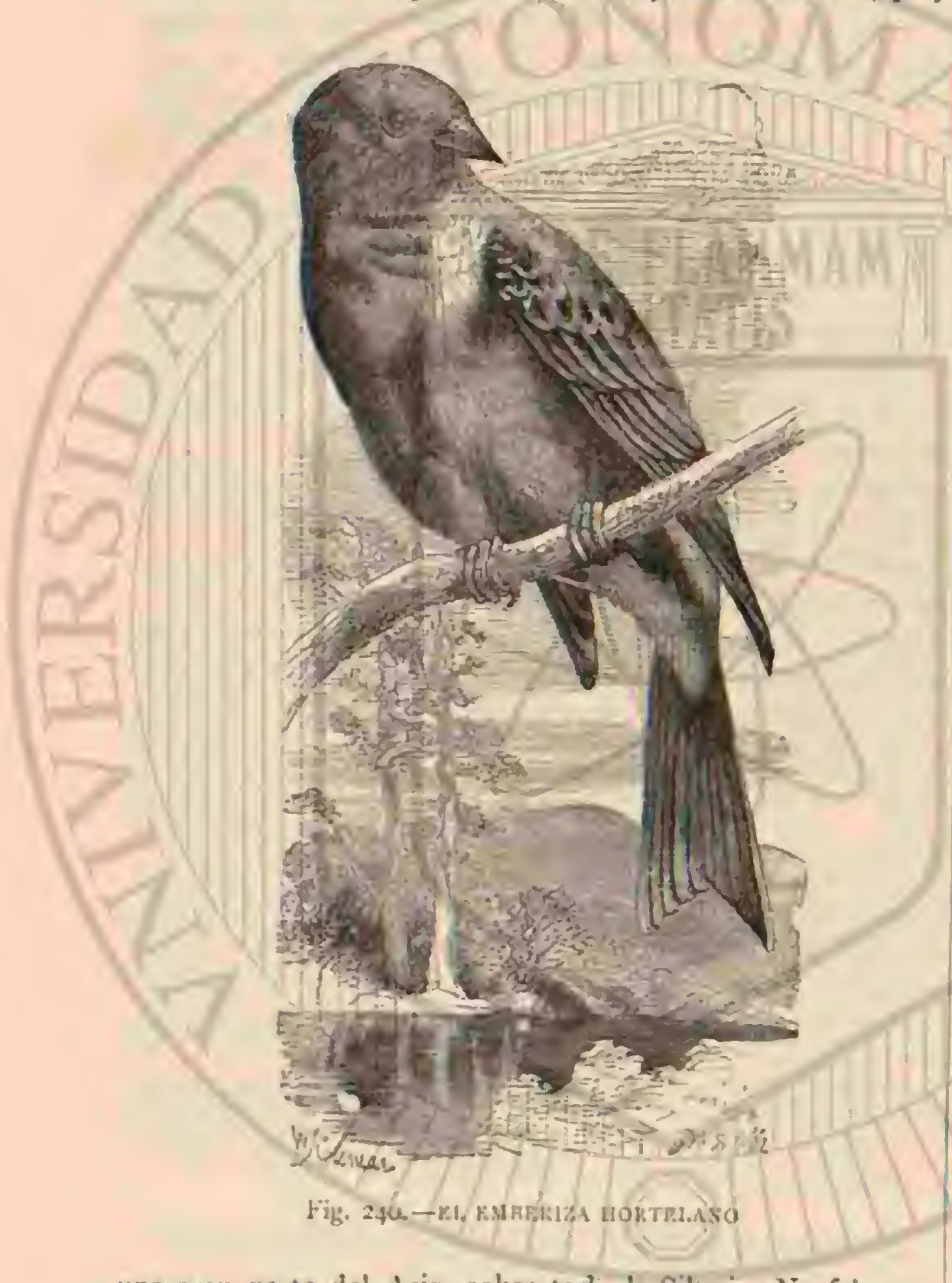

una gran parte del Asia, sobre todo la Siberia. No falta en ninguna region de Alemania; en la montaña se elera hasta el limite de los bosques y habita con preferencia los sitios donde los arbustos alternan con campos, praderas y árboles fru. tales.

\section{EL EMBERIZA DE LAS CERCAS EFMBERIZA GIRLUS}

CARACTÉRES, - Elemberiza de las cercas tiene 1,158 de largo, por $\theta^{m}, 24$ de punta a punta de las alas; estas miden $11^{\circ}, 07 j$ y la cola $11^{m}, 0 \%$. Ia cabeza, la partc posterior, los lados del cuello y una ancha faja trastersal del bucheson de un verde gris: en la coronilla hay lineas negms; las cejas, una faja que hay debajo de los ojos; y una ancha placa en forma de media lura, situnda entre la garganta y el buche son amarillas; la barba, la parte superior del cuello 5 otra faja que desde esta parte se corre hasta por deirás de la re. gion de las orejas son negras; las regiones inferiores de un amarillo claro; los costados rojos de canela; el vientre y los lados de los muslos tienen en sus tallos liness oscuras; el manto y los hombros son de un rojo cancla; las plumas están orilladas de gris en la extremidad y son de un tinte uscuro; la rabadilla y las ectrices superiores de la cula son de un pardus. co verdoso; las rémiges de un pardo oscuro, orilladas en sus barbas exteriores de un borde yálido; las tectrices del braz.o y las rémiges secundarias ostentan en sus barbas exteriores un ancho borde pilido de canela; las tectrices superiorc's de las alas son de un pardo verde $y$ las mas grandes presentan un borde rojizo pálido en la exiscmidad, formando una faja trasversal; las rectricts son de un pardo oscuro, con borde pálido en las barbas exteriores: las dos primems de cada lado tienen manchas longitudinales de color blanco, que en la primera rectriz de cada lado cubren casi todas las barbas exteriores. Los ojos son de un pardo oscuro; el pico negro por arriba y pardusco claro por debajo; los piés de un rojizo claro. La hembra no tiene el color negro de la garganta ni las dos fajas amarillas en la cabeza; las plumas de las partes imfiriores son amarillentas, con tallos oscuros; ia mancha rojo canclis del lado del pecho es mas pálid:

USOS, coSTUMBRES Y REGIMEN.-Todo el verano se le ve en compañia de su hemora 6 de sus pequeños: a principios de la primavera se verifica el apareamiento; en el mes de marno se ven los nidos, que difieren del que fabrica el anterior en que son menos bastos los materiales empleados en la construccion. Lste nido estí situado en los jarales ó las cercas, yuy cerca del suelo: á principios de abril se encuentran siempre huevos; entonces está el macho muy contento, y canta todo el dia, posacio en una rama aislada.

Cada puesta es de cuatro á cinco huevos de cisscara muy delgnda, color blanro sucio ó gris rojizo, y cubierta de man. chas y vemas oscuras. Macho $y^{\circ}$ hemura cubren alternation. unente, y alimentan a lus hijuelos con insectos: si el año es favarable, las hembras jưvenes ponen dos, y hasta ires veces.

I espucs del periodo del celo se reunen los pequerios de diversós nidos del mismo canton, y forman con lus pajjaros de mas edad $y$ de la misma especie numerosas bandadas que recorren el pais. Los cmberizas forman entunces sociedad con las alondras, con los pinzones y los zozzales (turdus pi. laris.

Cuando el invierno es muy riguroso, el emberiza amarillo ticne gute pedir su alimento al hombre, y entonces se le ve llegar à las granjas, donde es recibido comumuente con gus. to. En la prinavera vuelve cada pareja á su amtiguo retiro.

Pari cogerle se emplean trampas ó lazos, pero las rapaces le son mucho mas peligrosas que el hombre.

\section{EL EMBERIZA HORTELANO-EMBERIZA HORTULANA}

CARACTERES.- - Ia longitud de esta ave es de $11^{-}, 16$, por 1$)^{\infty}, 26$ de ancho de punta a punta de las alas; estas uniden 11" 08 y la cola $11,0 \%$. Ja cabeza, el cucllo y el buche son de color verdoso gris pálido; un angosto circulo qus hay alre. dedor de los ojos, la barba, la garganta y una faja tue se cor. re por debajo de la mandibula inferior, limirada por otra mas oscura ten forma de barba, son amarillentas; el resto de las regiones inferiores de un rojizo cancia, mas claro en las tectrices inferiores de la cola; las partes superiores son de un pardo rojizo pálido; el manio y los hornbros presentan anchas tineas oscuras en los tallos; hạ rémiges gon de un pardo os. curo, con bordes angostos de un pardo pítido en las barbas exteriores, excepto la primera que le tiene blanco; las rémiges secundarias posteriores, y sus tectrices en los bordes exterio. ies, son de un pardo de orin: las tectrices superiores de las alas presentan además en su extremidad un borde pardo de orin que forma una faja trasversal; las rectrices son de un pardo oscuro, orilladas de un tinte pálido por fuera; las dos primeras de cada lado son blancas en la última mitad inte. rior; y la primera blanca tambien en el centro de las barbas 
erteriores. Tos ojos son de un pardo oscuro; el pico y los piés de un rojiro de cuerno. La hembia tiene la cabeza y la parte posterior del cuello de color gris pardusco; la garganta y el buche rojizos; y en todas estas partes cruzan lineas negras en los tallos; la baroa, la garganta y una faja que haj por debajo de las mejillas, limitada en su parte inferior por otra mas angosta, de un tinte amarillo, soun de color rojizo de orin; las mejiltas pardas.

DISTRIBUCION GEOGRÁFICA.-Tambien el embe. riza hortelano eștá discminado por una gran parte de Europa; pero falta en algunas regiones $\delta$ al menos es muy raro. lin Alemania tabita continuamente las regiones inferiores del Elba, la Marca y Lausicia, Silesia, Westfalia y ha Prusia Rc. nana Abunda en el sur de Noruega y en Suecia, y es comun en el mediodia de Europa Tambien anida en Holanda,
Inglaterra, Francia, Rusia, en el centro de Asia hasta el Ala. tau, y en las montañas del Asia Menor y de Palestina. En invierno prolonga sus viajes hasta el oeste y este de Africa; habita con preferencia las montañas donde se eleva it la altura de 3.000 matros sobre el nivel del mar.

USOS, COSTUMBRES Y REGIMEN. - Las del horte lano apenas difieren de las de los otros embericidos: habita las inismas localidades que el emberiza amarillo y obscrva ef propio género de vida. Tiene un canto mas dulce, agradable y variado: su grito de llamada es sif gerr, y el de ternura s' $\delta$ pile, pronunciado con suavidad y muy bajo; cuando se le excita lanza un grito asaz pencirante y duro.

Su nido se asemeja al del emberiza amarillo: anida cerca del suelo, en el ramaje mas espeso de las breñas, en las cer. cas y los campos de colza. Ia hembra pone de cuatro of seis huevos cada rez, cuyo colòr es rojizo pálido, blanco ó gris rojizo, con puntos y lineas de un tinte negro y gris azulado. USOS Y PRODUCTOS.--Los romanos, que apreciaban nucho comer su carne, le conservaban en jaulas, é iluminabanlas por la noche con lámparas para que el hortelano, enganado con aquella luz artificial, comiese entonces $y^{\circ}$ engordira mas pronto. En Italia, en el mediodia de lirancia, y sobre todo en las islas de Grecia, existe todavía esta costumbre: alli se cogen dichos pajaros en masa, y cuando han engordado bastante, seinatan y despluman, introduciéndolos en agua hirviendo; luego se colocan en barrilitos por partidas de doscientos 06 cuatrocientos, con vinagre $y$ especias. Ist preparados se venden á subido precio.

\section{EL EMBERIZA ROJIZO - EMBEAIZA CAESIA}

CARACTERES. - Esta especie difiete del emberiza hortelano, su congénere mas afine, por tener la cabeza y una iaja irasversal en el buche de color gris; la garganta es de un rojo de cancla; las partes inferiotes del mismo color, tasas us. curo; las manchas blancas de la extremidad de las rectrices exteriores son mas pequeñas, y el pico de color rojo de conal.

DISTRIBUCION GEOGRAFICA.-Esta especie hab:ia, junta con la anterior, el suceste de Europa, sobre todo la Grecia, y tambien el Asia . Menor, Palestina, el Asia occidental y el noric de Africa: algunos individuos han sido cazados en el sur de dlemania y en Helgoland.

\section{EL EMBERIZA LOCO- EMBERIZA CIA}

CARACTÉRES.-Esta ave es una delas mas bonitas de la sub-familia; tiene $\left.1 \|^{m}, 1\right\}$ de largo, por 11,24 de ancho de punta a punta de las alas; estas miden $\left(1^{m}, 075 \mathrm{y} \text { la cola } 1\right)^{\circ}, 076$. La cabeza y la parte posterior del cucilo son de un gris ce. niciento; la garganta y el buche un poco mas claros; una ancha faja que hay sobre los ojos, las mejillas y la barba, de un gris blanujuizco; otras dos fajas que limitan por arriba y por abajo las cejas, y una de las cuales se corre desde las fosas nasales hasta la nuca, mientras la otra $5 e$ prolonga sobre la linea naso ocular hasta las siencs, soil negris, asi como una tercera faja que partiendo de los ángulos de la boca se reune con las dos anteriores en la extremidad; el manto y los hom. bros son de un pardo rojo de orin, y todias las plumas tieneu tallos oscuros; la rabadilla, las tectrices superiores de la cola y las partes inferiores son de un rojo cancla, mas claro en el centro del vientre; las rémiges, de un pardo oscuro, presentan en las barbas exteriores un ancino borde pardo rojizo; las secundarias exteriores y sus tectrices tienen otro análo. go que se exriende tambien sobre la extremidad mas ancha; las tectrices superiores de las alas sun de un gris oscuro, y las mas grandes negras, con puntas de un rojizo pálido que forman una faja trasversal; las rectrices, excepto las dos del centro, son de un pardo oscuro; los dos exteriores de ambos lados blancas en la mitad interior: la primera de cada lado blanca tambien en las bartas exteriores. Los ojos son de un 
pardo oscuro, como el de la mandibula superior; la inferior del nuismo tinte mas claro; los piés de un color claro de cuerno. El color de la hembra es en general mas pálido $y$ tiene las fajas longiudinales de la cabez? menos marcadas, siendo la region supurior de esta parte de color pardo, con lineas longitudinales mas oscums; ia faja central es gris y las oculares de un blanco pálido; el gris de la garganta y la cabeza tienen puntos poco marcados.

DISTRIBUCION GEOGRÁFICA.- Hi emberiza loco no habita hoy en Alemania mas que la Prusia Kenama, sobre todo el centro del Rhin entre Irlich y Lins, y tambien el sudcste de Bacen, limitándose aqui h los villes altos de las montanas, y alli í los vinedos de la orilla derecha del Rhin. En Austria escasen basiante; pero abunda en el sur de Europa, sobre todó én España, Italia y Grecia y además en el oeste de Asia; desde aqui se disemina por la mayor marte de aquel pais hasta el Himalay'a, donde se encuentra con regu. laridad en la parte occidental.

USOS, COSTUMBRES Y REGIMEN.- Es Un aVe de las montanas que segun mis obscruaciones en España evita siempre las llanuras. Prefiere los Rancos escapados cubiertos de rocas y escombros. Vésele alli corricndo entre las piedras y periascos, sin posarse apenas en lós árboles ó jaraies; por lo demás, sus movimientos se asemejan en un todo a los de los ntros cmberizas. Su grito pucde traducirse por siph, sipp, aipf y su, repetido vatias veces; parécese su canto al del emberiza amarillo, con la unica diferencia de ser mas breve y puro Beclastein le expresa bastante bien con de sonido aizi. sisirt.

Encuéntrasc el nido de este płjaro d orillas del Rhin en las grieins de Tas rocas; en los agujeros de los muros, y en las vinas. La hambra pone de tres í cuatro huevos de (1), or I de largo por (1), 010 de gruesoy de color gris blanquizco, con rasgos negruzcos y grises, que irazan of reces como una co. rona alrededor del huevo, principalmente håcia el extremo mas grueso. Este ditiujo no está formado por lineas cortas interrumpidas, sino continuadas, y por tal carácter se dife: rencian los huevos de este pajjaro de los del emberiza amarillo. Is probable que la hembra ponga dos veces al año, aunque a decir verdad, yo no he visto en Espana pequer̃os antes del mes de julio, debiendo advertir que ia muda se ve. rificaba hícia mediados de agosto. A las nárgenes del Rhin llega el emberiza loco a principios de abril, y se va en noviembre: en Espana vi en invierno con frecuencia bandadas considerables en todas las vertientes de Sierra Nevada cunn do las bañaba el sol.

EL EMBERIZA DE SIBERIA-EMBERIZA SIBIRICA

CARACTERES. - Fsta bonita ave viene lis is de largo, por $l ., 2 \delta$ de ancho de punta á punta de las alas; estas mi. den $\left(0^{\circ}, 0 S 8 \text { y la cola } 1\right)^{\infty}, 0.45$. Las partes superiores, una faja trasversal que pasa por debajo de la garganta y los lados del buche son de un pardo rojizo oscuro; cl cuello amarillo; las plumas del manio y los hombros tienen manchas poco marcadas en los tallos y angostos bördes blanquizcos en las tar. bas exteriores; la linea naso.ocular, los lados de la cabeza y la cara son negros, las partes inferiores amarillas, con lineas mardo rojizas en los costados; las tectrices inferiores de la cola blancas: las remiges cie un pardo oscuro, orilladas de un borde pálido en las barbas exteriores; las secundarias posteriores tienen tambien anchos bordes pardos; las tectrices de las rémiges primarias son de pardo rojo, con anchos bordes de un blanco pálido en la extremidad, gue forman una faja irasiersal; las tectrices inferiores de las alas y una gran placa de las superiores son blancas: la rectriz exterior de cada lado blanca en la base de las barbas interiores, y en la extremidad, de color oscuro; la segunda rectriz de ambos lados presenta en las barbas exteriores una faja longitudinal blanca; las otras son del color de las rémiges primarias. Los ojos son de color pardo rojizo; el pico amarillento; la mandibula inferior rojiza: los piés de un rojizo de cuerno. La hembra tiene las regiones superiores de color pardusco de orin, con tallos oscuros; las plumas de la rabadilla de un pardo rojo; una faja que hay en el centro de la cabera, otra en las cejas, y una tercera que cruza por la parte inferior de las mejillas son ama. rillentas, asi como las partes inferiores; los costados del mismo color, mas oscuro, con lineas en los tallos.

DISTRIBUCION GEOGRÁFICA.-Esta are es propia del Asia septentrional, pero abunda tambien mucho en il nordeste de Europa de donde se traslada á menudo á la Eu. ropa occidental; aunque el mayor número se dirige en invier. no hảcia el sur de la China, Cochinchina, Assam, Burma y los otros palses del Hinalaya occidental.

USOS, COSTUMBRES Y REGIMEN.-En toda la Siberia central, tanto en las llanuras como en las montañas, liasta la aliura de dos mil metros, el emberiza de Siberia se encuentra entre las especies mas conunes de su sub-\{amilia. Con igual frecuencia se presenta tambien en la Europa oriental, sobre todo en el centro y sur del Unal, desde donde se extiende hasta el Dwina y el sudoeste del lago Onega. Durante nuestro viaje la encontramos solo en algunos puntos, es decir en las posesiones de la Corona del Altai. Habita las regiones donde abunda el agua, cubicrtas de espesura de sauces; tambien frecuenta los bosques de alisos bien ba. iados por el sol. prero nunca los de coniferas. Cunndo vuelve de su viaje de invierno no se presenta hasta muj entrada la primavera, ráras veces antes de principios de mayo; llegado a los sitios donde anida, vaga por los alrededores como el cmberiza amarillo, dejando oir su grito de llanıada, que es un agudo zish. sips, comun á nuschas especies de su familia; su canto, el cual citona al posarse en las altas ramas, es mas agradable que el de la mayor parte de los emberizas, distinguiéndose por tres notas breves diferentes, cuvos sonidos se parecen a los de la flauta. Los nidos que Henke encontró el 16 de junio en la isla del Dwina, al norte de Archangel, se hallaban a poca altura del suelo, en la verba, la maleza ó los arbustos; el fondo estaba formado con tallos secos, y has paredes con follaje, raices muy finas, fibras de corteza, briznas de yerba, y \& veces tambien pelos y plumas. Los cinco ó seis huevos que la hembra deposita miden $0^{\circ}, 023$ de largo por $0^{m}, 017$ de grueso; su tallo es verdoso ó de un blanco gris pardusco, con manchas pequeñas y grandes de color verdoso ó gris pardusco, sobre las cuales se ven puntos, manchas irregulares, lineas finas y arabescos de color pardo y negro. Despues del periodo de la incubacion, aduttos y jóvenes se reunen formando numetosas bandadas, que emprenden poco á poco su viaje. Eintonces se cogen muchos en los alrededores de Moscou, desde donde llegan vi. ros á nuestras jaulas.

\section{EL EMBERIZA AMERICANO-EMBERIZA AMERICANUS}

CARACTÉRES.-Tiene la parte superioz de la cabeza de color verdoso amarillento; el cuello de un gris oscuro y el lomo rojizo manchado de blanco, extendiéndose esie co. lor í las alas y la cola, pero sin las manchas; la barba es blanca, y en la gargania hay otra mancha en forma de cora. zon, de color negro intenso y orillacia de blanco; cl pecho es amarillo sobre los ojos hay una linea del mismo tinte; las 
cobijas inferiores del ala son de color castano y el abdómen de un gris blanquizco. Esta ave es un poco mas pequeña que la anterior (ing. 242).

DISTRIBUCION GEOGRAFICA.-Esta are es propia de América y escasea mas que la especie anterior.

USOS, COSTUMBRES Y REGIMEN.-VEASE lo que dice Wilson acerca de las costumbres del emberiza americano: Afarece en Pensilvania a mediados de majo, proce. dente del sur, y recorre las cercanias de Filadelfia, parecien. do que prefiera los campos sembrados de centeno, donde fabrica en tierra su nido, compuesto de hojarasca fina, y on el cual deposita la henbra de cuatro á cinco huevos cubicrtos de manchas y lineas negras. Asi como la mayor parte de las aves de su género, no está dotada de facultades vocales: su canto se compone de cinco notas, ó mas bien de dos, la primera repetida dos veces con lentitud y la segunda tres rá. pidamente, produciendo un sonido que se puede expresar por chip-chip-che-che-che. En el mes de agosto dejan de caniar, y en los primeros dias de seticmbre abandonan el pais.

\section{LOS EUSPIZAS-EUSPIZA}

CARACTERES. - I Las especies de este género se distinguen por su pico robusto, de forma cónica y puntiaguda, con mandibulas casi iguales y una prominencia pequeña longitudinal junto al paladar; los tarsos son fuertes; las alas largas; la primera rémige sobresale de las demás; la cola es de longitud regular, cortada en la punta en rectángulo.

\section{EL EUSPIZA DE CABEZA NEGRA-EUSPIZA MELANOCEPHALA}

CARACTÉRES. - La longitud de esta ave es de $0^{\mathrm{B}}$, I $\mathrm{S}_{3}$ por $11^{m}, 29$ de anchura de punta a punta de las alas; estas tienen (i)" ogs y la cola $\left(r^{m}\right.$, os de largo. La cabeza es negra; las plumas de la parte superior de un pardo rojo de canela vivo, orilladas en su extremidad de un color gris poco marcado; toda la parte inierior es de un amarillo vivo; las réniges $y$ rectrices tienen un color pardo oscuro y ostentan en las barbas exteriores bordes de un pardo pálido, mas anchas en las rémiges secundarias posteriores y en sus tectrices; las pequeñas tectrices de color pardo canela, presentan en su extremidad un borde gris amarillo; las majores tectrices de las alas son parduscas, con la extremidad blanca; este últi. mo color forma una faja trasversal. Los ojos son de un pardo oscuro; el pico azul de cuerno, y los piés de un amarillo par. dusco. I a hembra no tiene el color negro de la cabeza; la parte superior es de un rojo de orin pardusco; la garganta blanca y el resto de las partes inferiores de un color de orin blanquizco.

DISTRIBUCION GEOGRÁFICA.-El euspiza de ca. beza negra habita cl sudeste de Europa desde la Istria, sobre todo Dalmacia y Grecia, muchas islas del mar Adriático, el levante y gran parte del sudoeste de $A$ sia hasta las provincias septentrionales y occidentales de la India, sobre todo P'ersia.

USOS, COSTUMBRES Y RÉGIMEN.-El cuspiza de cabeza negra llega a fines de abril á Grecia y al unismo tiempo tambien á Istria En una hermosa mañana de prima rera, en Grecia, todas las espesuras de la orilla del mar, donde el dia antes se buscaban en vano estas aves, esian verdaderamente cuajadas de euspizas llegados durante la no. che. Anidan en las vinas de la llanura ó en colinas incultas cubiertas de salvias y de azufaifos; desplies de criar sus hi. juelos abandonan la patria á uiltimos de julio ó en agosto para dirigirse a sus cuarteles de invierno; pero no marchan hácia el sudoeste sino al sudeste. Es probable que sean ori. ginarias de la Persia, que forma el centro de su área de dis. persion; desde alli han llegado mas tarde al Asia Menor y la peninsula del Balkan; y al dirigirse hácia su residencia de invierno pasan por el primero de dichos paises, donde abun. dan en todas partes, hasta una altura de casi tres mil metros. Pocas semanas despues de su salida de Europa aparecen en el Dekhan y en las provincias del norte del Indostan, donde forman bandadas innumerables que ocasionan grandes des. trozos en los campos de trigo y vuelven á desaparecer en marzo.

IIl género de vida de este pájaro difiere muy poco del de los otros embericidos: el conde Von der Muhle dice que es estúpicio y confiado, y que con frecuencia se puede matar de un bastonazo al macho cuando canta.

En la éproca del celo se retiran á las colinas incultas cu. biertas de salvias y de azúaifos, a los viñedos y i los jardi. nes poco frecuentados. El macho se posa en la rama mas alta de un árbol ó de un jaral, y deja oir continuamente su canto sencillo, un poco affautado, mientras que la hembra se oculta todo lo posible. El nido, formado en tierra, ó en un espinoso matorral, no suele estar a la vista; su construccion es muy tosca; algunos tallos y hojas, entrelazadas sin órden, forman la pared exterior, y por dentro está relleno de perque ñas raices, rastrojos y crines. A principios ó mediados de junio se encuentran de cinco a siete huevos de $11^{\prime \prime}, 0$ a a de largo por $11^{\prime \prime}, 018$ de grueso, de color verde azulado pálido, cubicrtos de manchas mas 6 menos confluentes, de un gris ceni. ciento, verdosas ó de un gris rojizo.

En Persia se reunen despues de la época de la incubacion miles y miles de euspizas de cabcza negra, que mucho mas temibles aun que las langostas, vagan por todas. partes y co. mienzan à saquear los campos mucho antes de emprender su viaje.

Además de los embericidos descritos, varias especies de la sub-ramilia han visitado la Alemania, ó al menos la Europa; estas especies son las siguientes.

\section{EL EMBERIZA DE LOS PINOS-EMBERIZA LEUCOCEPHALA}

Esta especie es mas grande que el emberiza amarillo: la cabeza, excepto una faja blanca, es de color negro gris, con inezcla de pardo rojo de canela; la linea naso-ocular es blanca; el cuello gris en su parte posterior y blanco en la anterior; la parte superior del tronco y el buche de un rojo canela; las regiones inferiores blancas; ias plumas del lomo tienen los tallos oscuros y bordes pálidos. El emberiza de los pinos es propio de la Siberia oriental, asi como el de cejas amarillas (Limherier chirgsophrys): esta especic, mas pequeria que el emberiza amarillo, ticne la cabeza negra, con tna haja blan. quizca en el centro y otras de color amarillo de oro en las cejas, el dorso es de un pardo rojizo con grandes manchas negras en los tallos, mas estrechas en la garganta, que es blanca; de este mismo color son las partes inferiores, cuyos tallos tienen lineas pardas y otras análogas en los costados. El cmberiza rayado (Emberiza striolata), propio del desierto, se distingue por su plumaje, en el que predomina el color pardo rojo de cancla; la cabeza es de un gris ceniciento, y en su partc superior se ven seis fajas longitudinales paralelas, formadas por las líneas oscuras en los tallos.

\section{LOS ZONOTRIQUUIDOS-PASSERELLAF}

CARACTÉRES. - En Anérica existen unas 120 espe. cies de pájaros cujo plumaje se asenuja al de los emberici. 
dos, $y$ que se caracterizan por su pico raquitico, prolongado, cónico, recto, y de arista ligeramente convexa; las alas son de un largo regular; los tarsos altos; los dedos largos y pro. vistos de uaias fuertes, formando la del pulgar una especie de espolon.

USOS, COSTUMBRES Y X\}E̊GIMEN. - Estos pájaros viven mucho en tierra, como los emberícidos: unos habitan en los bosques, evitando los lugares descubierios; otros bus. can los lugares húmedos, y las orillas de las corrientes; y al.

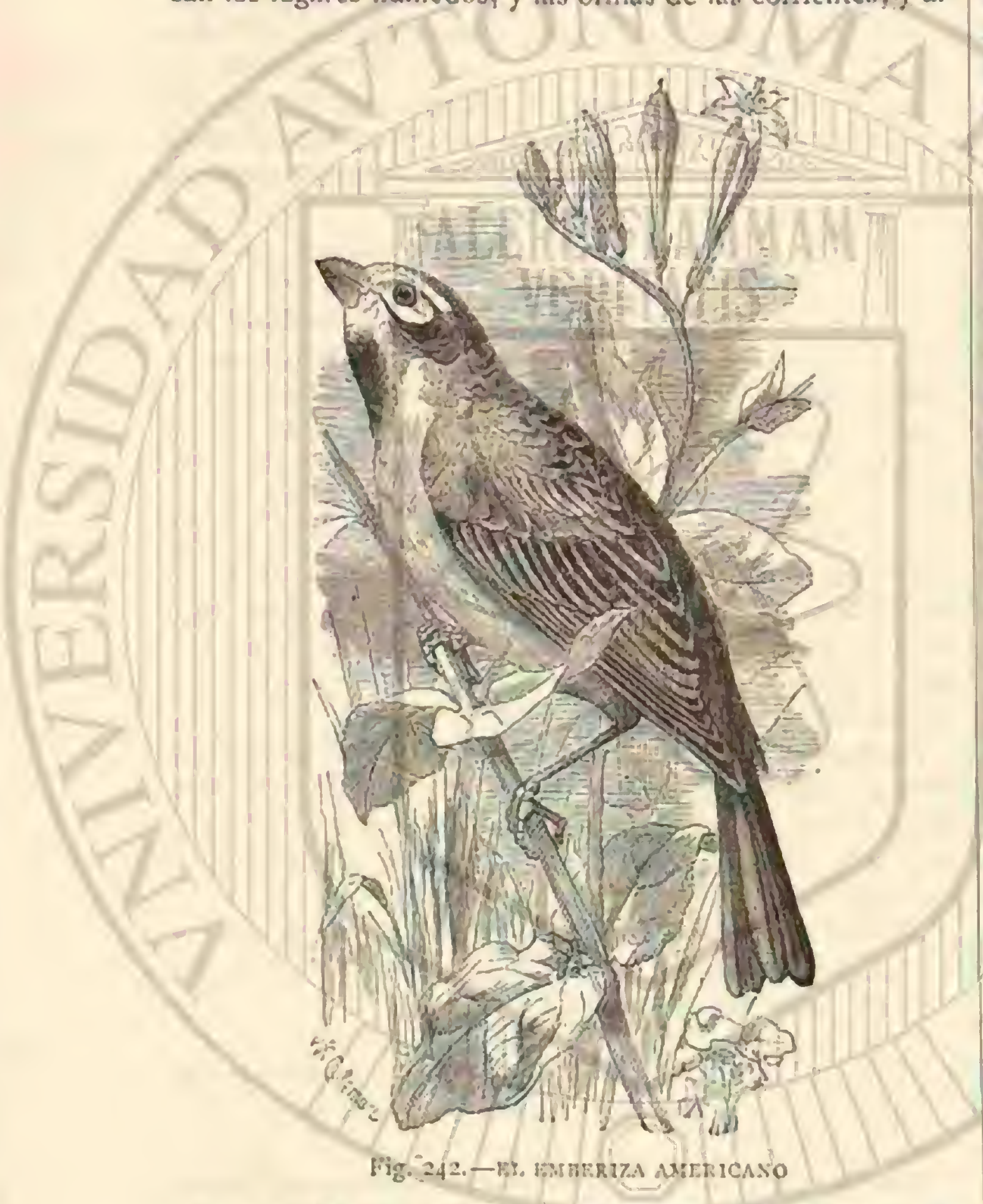

gunos, en fin, los campos, las praderns $y$ las playas; varios de ellos remplazan á nuestros gorriones en el Nuevo Mun. do. Nos limitaremos a estudiar aqui las especies mas cono cidas y comunes.

\section{LOS CHINGOLOS-ZONOTRICHIA}

CARACTERES. - Las especies que pertenecen à este género tienen el pico delgado, de forma cónica, puntiagudo y con tos bordes deprimidos en los ángulos de la boca; los piés son fisertes; los tarsos altos; los dedos largos y provistos de unas grandes, poco corvas; las alas cortas; las rémiges segunda y tercera son las mas largas; la cola, bastante prolongadn, se redondea ligeramente y tiene una sesgadura en su cxtremidad.

\section{EL CHINGOLO DE GARGANTA LARGA- ZONO'TRICHIA AIBICOLLIS}

CARACTERES, - La longitud de esta ave es de $0^{n}, 1 \%$, su anchura de punta á punta de las alas de (1)" 23 ; estas tíltimas miden $0^{\prime \prime}, 075$ y la cola $\|^{\infty}, 07 \mathrm{~S}$. I a parte superior de la cabeza y el occipucio son de color negro, con una angosta línea central blanquizca y una faja ancha amarilla en la línea naso ocular, oriilada de negro por detrás y debajo de los ojos; Ins mejillas y la region de las orejas son de un gris ce. niciento; la barba y la garganta de color blanco, limitado cn su parte inferior por una angosta linea oscura proco marcada; las partes inferiores son blamcas tambien; cl buche de un gris pardusco y los costados cie un pardusco de orin, con lineas longitudinales oscturas; las partes superiores $y$ las tectrices de las alas son pardas; las plumas del manto y de los hombros tienen manchas negras en los tallos y bordes amarillentos en las barbas exteriores; las plumas de la rabadilla son de un pardo pálido; las témiges y rectrices de un pardo aceituna con angostos bordes de color rojizo pálido en las barbas exteriores; las rémiges secundarias posteriores y sus tectrices ticnen anchos bordes de un color pardo de orin. Los ojos son pardos; la manóibula superior banca; la infe. rior de un azul claro, y los piés de color de carne. I.as hem. bras difieren por su tinte mas pálido. En el plumaje de in. vierno de los hijuelos $y$ de los machos, las fajas de las cejas y la del centro de la cabeza son de un pardo de orin, y el blanco de la garganta meros pronunciado. La longitud del ave es de $0^{n}, 1,7$ por $4^{\prime}, 23$ de ancho de punta á punta de las alas; estas miden $0^{\prime \prime}, 08$ y la cola igualmente $0^{\prime \prime}, 08$ (fig. 243).

DYSTRIBUCION GEOGRhFICA. - Esta ave cstá disetminada por todos los Estados orientales de la América del horte; Jero angu no es mas que ave de paso; diurante $\mathrm{el}$ in. vierno permanece en el sur.

Este bonito jájaro, segun asegura Aldubon, no es en la Luisiana mas que un ave de paso, y lo mismo sucede en otros paises del sur. Llega á principios de setiembre, y se marcha en marro: reside mas tiempo en los Estados del Centro.

USOS, COSTUMBRES Y RÉGIMEN.-EI Mismo alltor nos ha dado tambien algunos detalles acerca de las costumbres de la especie; véase lo qque dice: «De repente se ven todas lás cercas y jarales cubiertos de açuellos preciosos pájăos; aparecen en bandadas de treinta á cincuenta indivi. âuos, y conservan entre si la mayor armonia; saltan á tierra para buscar los granos que constituyen su alimento; prero ála menor alarma se refugian todos en el mas espeso matorral. Un momento despues aparece un pajaro en las altas ramas; sigucle un segundo y un tercero; $y$ entonces dan principio á un agradable concierto. Su voz es de una dulzura tan agra. dable que inuchas veces me extasiaba oyéndolos. Por la ma. nana, sin embargo, lanzan gritos estridentes, que podrian traducirse por forit; tambien los oi por la noche.

* En las dias de mucino calor se dirige toda la bandada hácia el bosque á fin de comer las bayas de la vid silvestre, pero nunca se aleja 'mucio del matorral que le sirse de albergue.

Ml principio de la primavera abandonan estos pájaros los paises del sur para trasladarse al norte.s

El nido se halia reguharmente en el suelo, pero en sitios muy diversos; tan pronto se encuentra en un pegueỉoarbusto como en una espesura pantanosa, al pié de un árbol viejo, en una cavidad $\delta$ en medio de las raices; es muy grande, profundo y espacioso en el interior; se compone de musgo ó de gruesos tallos de gramineas, y está relleno de raices y pelos, ó bien á veces de algunas plunias $\delta$ fibras vegetales. Los himeros, en número de cuatıo á siete, tienen (",022 de largo por $11^{\prime \prime}, 015$ de grueso, $y$ son de color blanco verdoso con manchas rojizas ó pardo rojizas, discminadas en iodos sentidos. El periodo del celo comienza en junio, y entonces el macho es en extremo vivaz; entona con aficion su sencillo canto, compuesto de doce tonos diferentes, que el pueblo reproduce á reces de un modo muy divertido; este canto carrece de toda variacion, y por lo mismo cansa muy pronto.

En algunas regiones se da caza al chingolo de garganta 
blanca jara comer su sabrosa carne $\delta$ tenerle en la jaula, donde sirve de recreo, poroue en primavera canta tambien de noche, como sucle hacerlo en su patria.

\section{LOS AMODROMOS-AMMODROMUS}

CA R ACTERES. - Ios pájaros que forman este género tienen el picofino, prolongado, puntiagudo, y con los bordes de la mandibula entrantes; las alas son cortas, la cola media. na y las rectrices puntiagudas.

\section{EL AMODROMO MARÍTIMO-AMMODROMUS MARITIMUS}

CARACTEHES. - El amodromo maritimo (fig. 245) tiene de $0^{m}, 16$ \& $0^{\circ}, 18$ de largo, por $0^{\infty}, 2720^{\circ}, 30$ de punta á punta de alas. El lomo es de un pardo accituna; la garganta y el vientre blancos, el pecho, las mejillas, y una faja longitudinal que hay sobre la cabeza, de un gris ceniciento. Por encima de los ojos existe una faja amarilla; las alas son de este tinte, con otra lista ancha trasversal, de color pardo; el pico y las patas son pardos tambien y el ojo del mismo tinte mas oscuro.

USOS, COSTUMBRES Y REGIMEN. - Lste prijaro singular no tiene las costumbres de los otros; a semejanza del rringa maritimo, corre á lo largo de las playas, rasando la orilla del agua; trepa por las canas con tanta destreza como la curruca ó el hortelano; aliméntase principalnente de crustáceos, cangrejos pequeños y pececillos, y su carne adquiere un gusto aceitoso, como el de las verdaderns aves marinas.

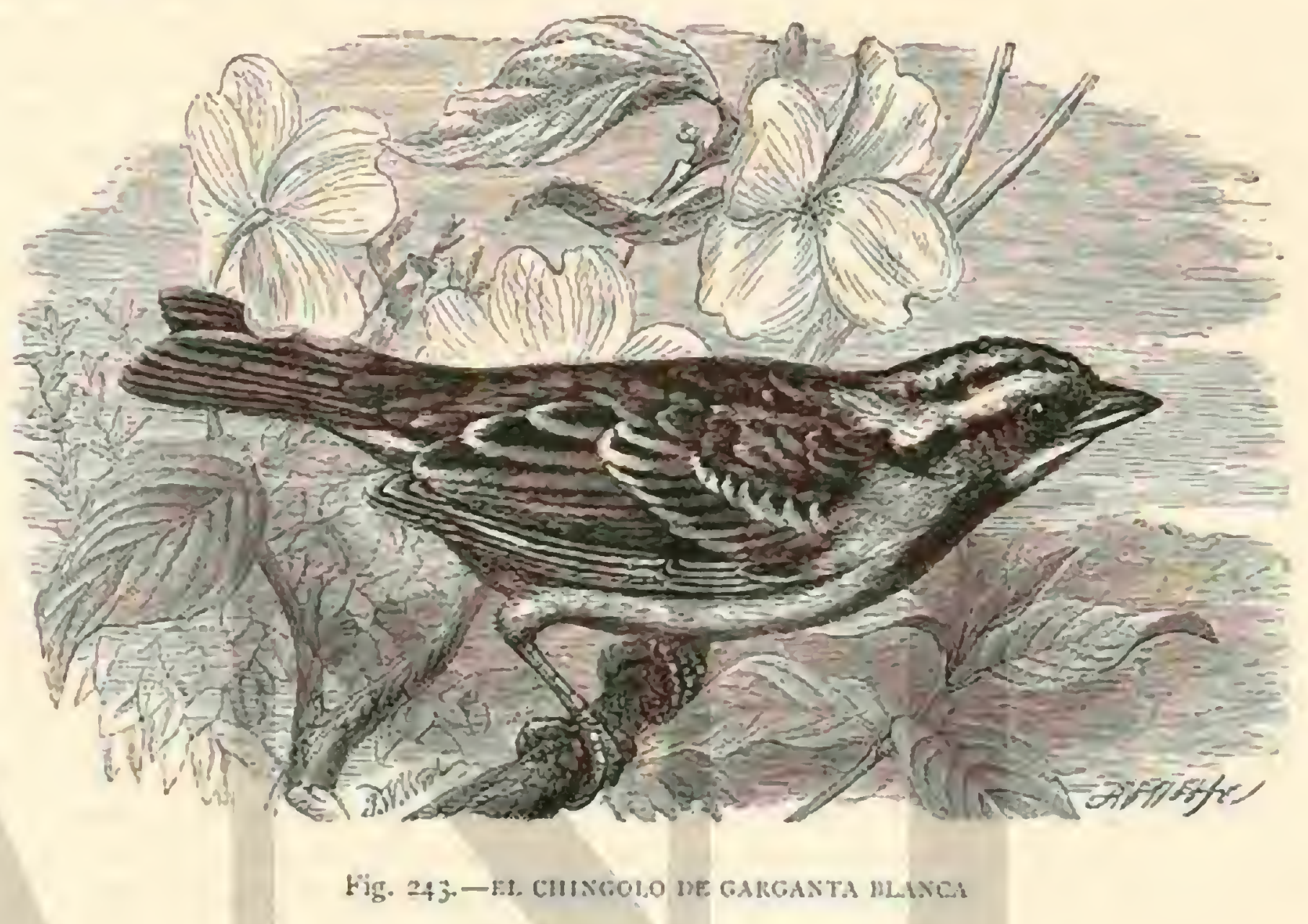

El amcdromo maritimo prefice vivir en los pamianos cu. bierirs de juncos y de altas yerbas, sumergidas á veces en las ondas. Forma su nido en tierra, en medio de una masa de vegetales; pero léjos del alcance de la marea; se compone de jerbas ordinarias por fuera y finas por dentro. El numero de sus huevos varia entre cuatro y seis; son de color gris blanco, con manchas pardas: pone probablemente dos veces al año.

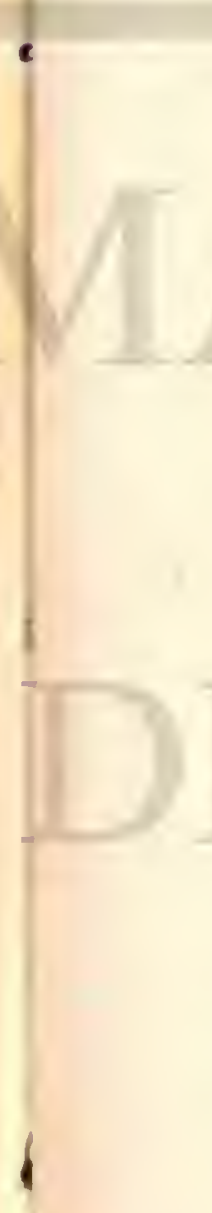

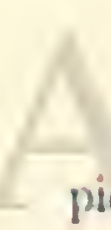

CARACTERES. - las especies de este género tienen el pico pequeno, casi cónico y solo encorvado en la punta; los tarsos son bastante altos; los dedos cortos, provistos de unias de longitud regular, pero iuertes; las alas son cortas, con la segunda rémige mas larga; la cola es de longiud regular, us. trecha, redordeada lateralmente y algo escotada en su extre. midad; el culor del plumaje es opaco.

\section{EL NÍFEO DE INVIERNO-IUNCO HYEMALIS}

CARACTERES. - La longitud de esta ave, tipo del genero, es de $6^{\circ}, 16$ por $0^{4}, 22$ de ancho de punta 1 punta de las alas; cstas miden $0^{\mathrm{m}}, 079$ y la cola ()$^{\mathrm{m}}, 075$. La cabeza $y$ las partes superiores son de un gris de pizarra opaco; las in. feriores, desde el pecho, blancas; las rémiges y sus tectrices de un pardo oscuro, con un borde pardusco poco marcado en ias barbas exteriores; las rectrices son de un negro parde; las dos exteriores blancas; la tercera de cada lado tierie unat mancia longitudinal blanca en el tallo. Los ojos son de un pardo oscuro; el pico de un blanco rojizo, y los piés de color de rarne (fig. 2 a. 4 ).

DISTRIBUCION GEOGRÁFICA.-El nifeo de invierno habita el norte de los Festadós-Lnidos hasta el círculo pular. Abunda bastante, y aparece en gran número, al menos en ciertas épocas, un casi toda la América del norte.

USOS, COS'TUMBRES Y REGIMEN. - "Yo he recorrido unas $1,8=0$ millas, dice Wilson, desde el norte dul Maine hasta Creorgia, y no recuerdo haber franqueado una sola sin ver bandadas de nifeos, comptiestas de miles de individuos algunas veces. "Todos los viajcros á quuienes interrogué habian hecho la misma observacion

El nifeo habita las montanas y el norte y llega a los Estados. Unidos a fines de octubre y los abandona en abril, viajando siempre de noche. Por la manana se ven a veces mu. chos donde no liábia ninguno la vispera: al principio forman reducidas bandadas de veinte á treinta individuos, que recorren el linderó de los bosques, las cercas y las breñas; $y$ luego se reunen en bandadas inmensas, compuestas de varios miles de individuos.

Mientras la ticra no esté cubierta de nieve, alimcintase este pajaro de granos, baỵas é insectos; y á menudo come en compania de las perdices, de los anades, y hasta de las ardi. llas. Cuando cubre la tierra una blanca alrombra, déjase ver 
en los patios de las granjas y por los caminos, llegando al interior de las ciudades; busca sin duda la proteccion del hombre; pero se castiga cruelmente su confianza, pues cada dia se cazan centenares de individuos. Sin embargo, tiene este pajjaro mas amigos que adversarios, y es tan apreciado de los americanos como el petirojo de los europeos; algunas buenas gentes le dan de comer. No huje aunque pasen jinetes y peones a su lado, y solo vuela cuando corre peligro de ser aplastado. Scmejante confianz, no obstante, solo se revela durante el invierno; al principio de la primavera abandona el nifeo los puetblos y ciudades, y se retira hácia el norte 6 las montañas. Rara ve\% se asocia el nifeo de imycrno con otros pájaros: cuando mas se reune er los pueblos con algunos gorriones, y en los corrales con las gallinas: pasa la noche posado en un árbol, ó en una cavidad, que forma el mismo ai. gunas veces en el centro de las gavillās de trigo.

Audubon asegura que los nifeos gunrdan cierta reserva con los ntros pśjaros, y que no se familiarizan con ningun indivi. duo que no sea de su especie Si se le acerca algun extraño, el nifeo abre al momento el pico, extiende las alas, brillan sus ojos y lanza un ligero grio. Por sus movimientos se asemeja al gorrion; salta graciosaniente cuando está en tierra y vucla con rapidez: los celos le inducen á pelear con sus seme. jantes encarnizadamente.

Poco despues de volver á su verdadera patria se reproduce el nifeo de invierno: pelean los machos, persiguense entre si, y vuelan por uno y otro lado, extendicido muclio las alas y la cola. Fn aquel momento es cuando mejor se oye su canto, que se distingue por algunas notas sonoras y corridas: Gerhardt le compara con el de los canarios jóvenes.

Cada pareja busca un sitio convéniente para establecer su nido; elige por lo regular el flanco de una montana cubierto de espesos jarales, y le forma en tierra. La parte exterior se compone de filamentos de corteza y de yerbas, y está relleno interiormente de musgo, crines y pelos; los huevos, en núme. ro de cuatro, tienen unos ()$^{\circ}, 02$ de largo por $\left(1^{\circ}, 01 \%\right.$ en e! máximum de suanchura; su color es blanco amarillento con puntos compactos de color pardo rojizo. No he visto indicado en parte alguna cómo se conduce el macho mientras la hem. bra cubre: pero codos los autores dicen que cuando los pequeños abandunan el nido siguen a sus padres, los cuales velan atentamente por su seguridad, anunciándoles con sus señales el peligro.

CAUTIVIDAD. - Ios cautivos de esta especie que à ve. ces llegan á nuestras jaulas excitan inuy poco el interés.

\section{LOS FRINGILINOS - FRINGILILINAE}

CARACTÉRES. - Esta sub familia, la de los fringilidos propiamente dichos, se compone de unas doscientas treinta especies, cuyos caractéres son los siguientes: pico de forma variable, pero casi siempre delgado, cónico, algunas veces muy fucrte, con la arista casi siempre recta y sin escotadura; las fosas nisales estan situadas en los lados; los tarsos son de altura regular; las alas largas, con las rémiges segunda y icrcera mas largas; la cola de longitud regular; el plumaje mas $\delta$ menos-abundante y casi siempre variable segun el sexo y la edad.

DISTRIBUCION GEOGRÁFICA. - I,OS fringilinus ha. bitan el antiguo contincente sin faltar del todo en el nuevo; están diseminados por tudos los territorios, y ofrecen casi to. das las particularidades de toda la familia.

\section{LOS PINZONES - FRINGILLA}

CARACTERES. - Los pin\%ones, que consideramos romo los tipos mas desarrollados de toda la familia, se distinguen por su estructura prolongada; tienen el pico de longitud regular, cónico ó grueso en la base; la mandibula superior se deprime un poco hácia la punta y los bordes parecen algo recogidos; los tarsos son cortos, los dedos endebles, provis. tos de uñas délgadas, estrechas y puntiagudas; las alas son relativamente largas; las rémiges tercera y cuarta forman la punta; la cola, de un largo regular, es un poco sesgrada.

\section{EL PINZON VULGAR - FRINGILLA CCELEBS}

CARACTERES. - El pinzon vulgar, llamado tambien finzon noble, sibiestre, tiene la frente de color negro muy os. curo; la coronilla y la nuca de un azul pizarra; el manto pardo roji\%o; la parte superior del dorso y la rabadilla verdes: la linea naso.ocular, los círculos oculares, las mejillas y la garganta, de un pardo de orin claro, color que en el buche y los lados dél pecho se convierte en rojizo de carne; el cen. tro del pecho es blanco rojizo; el vientre y las tectrices su. periores de la cola blancas; las rémiges primarias negras, excepto las tres primeras, que tienen la base blanca; las ré. miges secundarias posteriores presentan en sus barbas extc. riores un angosto borde amarillo claro, con ángulos de un amarillo pardo; las tectrices mas pequeias son de un azul pizarra oscuro; las grandes negras, con un ancho borde blanco on la extremidad, el cual forma con el anterior una faja ancha y otra mas estrecha en las alas; las rémiges son de un gris billante en su carn inferior y cestín orilladas de blanco plateado en las barbas interiores; las tectrices inferiores de las alas son blancas, con escamas negras en el borde de las alas; las rectrices del centro son de un gris pizarra oscuro, con ángulos amarillentos; las otras negras; las dos exteriores de ambos lados tienen en las barbas interiores una gran manchá blanca en forma de cuna, que en la prinera rectri\% de cada lado ocupa tambien las barbas extcriores; todas las rectrices son negras por debajo, excepto la última de cada lado, que tiene el color blanco. Los ojos son de un pardo claro; el pico, azul en la primavera, y de un blanco rojizo en oroño é invierno; los piés de color de carne sucio. En la hembra la cabeza y la nuca son de un gris verdoso; una faja que ocupa el lugar de las cejas, la línea naso-ocular, la barba y la garganta de un blanco pardusco; el resto de las partes superiores de un pardo gris aceituna; $y$ las inferiores de un gris claro. Ia longitud del ave es de $0^{\circ}, 165$, por $0^{\circ}, 278$ de ancho de punta a punta de las alas; ustas tienen $0^{\alpha^{\circ}}, 5 S$ y la cola $0^{\star}, 075$ de largo (fig. 246).

DisTribuCion GEOGRÁ FiCA. - Excepto los paises mas septentrionales, el pinzon vulgar abunda en toda la Eu. ropa, pero en el mediodia solo habita la montana durante el verano. Tambien existe en algunas partes del Asia, y en invierno se ven varios individuos en el norte de sfrica.

En los paises del Atlas le representa el pinzon de la Mauritania (Fringilla spothirenys), ulue alguna ve\% se ha cazosdo tambien en el mediodia de Francia. Esta ave se parece mu. cho al pinzon vulgar, pero es un poco mas grande: la cabeza, la region de los ojos y la de los hombros son de un cenicientes azulado; las regiones superiores de un verde accituna; las inferiores de un rojo de vino pálido; las costados grises; las rémiges primarias negras, con un angosto borde llanco en el centro de la base, mas ancho en la ultima mitad de las barbas exteriores; las primeras rémiges secundarias son blan. cas en la base y las posteriores del mismo color en casi toda su extension, asi como en las tectrices pequeñas de las alas; las grandes son blancas, con una faja negra en el centro; las otras pardas, poco mas ó menos del mismo color que en el pinzon vulgar. 
USOS, COSTUMBRES Y REGYMEN.-POCas son las localidades de Alemania donde el pinzon ordinario no apa. rezca en gran nímero; habita los grandes bosques, los tallares aislados, los parques y los jardines: solo evita los lugares pantanosos y demasiado húmedos. Una pareja vive al lado de otra, pero cada cual tiene su dominio propio y no permite la entrada á los intrusos.

Hasta que sacan sus pollos no se reunen los pinzones en grandes bandadas; entonces se merclan con otros pájaros y con los mirlos, recorriendo en su compania el pais.

Fin Alemania, el pinzon es un pájaro de verano: pues aun. que algunos machos pasan tambien el invierno, los mas nos abandonan para trasladarse a otras regiones mas cálidas. Retínense á principios de setiembre; en octubre se organizan las bandadas y desaparecen hácia fin de mes, dirigiéndose al mediodia de Europa para establecerse en el sudoeste de Africa; solo algunas llegan á Egipto. En todas partes se encuentran los pinzones; 10 mismo en los valles que en las montañas, asi en los campos como en los jardines, las brenas $y$ las cercas, y siempre en bandadas, lo cual indica que comprenden que son extraños. A la entrada de la primavera vuelven á marchar, dirigiéndose hácia el norte: en aquel mo. mento se oye resonar todavia en las montaías españolas e canto repetido $y$ vibrante de los machos, mas á poco vuelve a reinar la tranquilidad y el silencio; en los primeros dias de marzo, todos aquellos pájaros han desaparecido, los machos antes, $y$ las hembras unos quince dias mas tarde, pues nunca suclen viajar juntos los dos sexos. Cuando la estacion es buena, déjanse ver los primeros pinzones entre nosotros á fines de febrero; pero en el mes de marzo es principalmente cuando llegan en gran número: los rezagados no aparecen hasta abril.

Cada macho busca su antiguo retiro y espera alli a su compaincra; apenas llega, comicnzan á construir su nicio, y con frecuencia lo concluyen antes que los árboles ostenten todo su follaje. Macho y hembra recorren entonces las copas de aqquellos; la segunda uuscando cuidadosamente; el primero inquieto y agitado y olvidando la natural prudencia de todos los pójaros. Su companera no se ocupa sino en buscar un sitio seguro para su nido; el macho está poseido del sentimiento amoroso y la pasion de los celos. Por fin descubren un lugar conveniente, una bifurcacion en lo alto de un árbol, alguna vieja rama nudosa que debe cubrirse de follaje muy pronto, 6 bien el tejadillo de paja de una cabaia.

De todos los nidos que conocemos en nuestros paises, el del pinzon es el que está construido mas artísticamente, y el mas bonito: tiene la forma de una esfera truncada por arriba; las paredes son gruesas y se componen de musgo, raices y rastrojo, cubiertas por fuera de liquenes del árbol donde se halla situado el nido. Todos estos materiales se enlazan entre si por medio de telas de araña y otros insectos; el conjunto del nido se asemeja de tal modo á un nudo de la rama que le sirve de apoyo, que á primera vista se confunde con él. Interiormente es bastante profundo y está relleno de pelos, plumas, lana y pelusilla de diversas plantas.

Durante la construccion del nido, y mientras que la hembra cubre sus huevos, apenas deja el macho de cantar en todo el dia; sus vecinos le contestan, inuy sobrexcitados por los celos y mas aun por su, amor propio. A semejanza de todos los pdjaros cantores, los pinzones comienzan sus con tiendas por una competencia en el canto; pero enardécense bien pronto, $y$ no conviniéndoles ya tan pacifico torneo, se persiguen furiosos en medio del ramaje hasta que, cogiéndo. se uno á otro por el pico y las patas, se impiden mutuamente volar y caen alcteando al suelo. Su encarnizamiento es tal, que oividan su propia seguridad y no ven ya el peligro; cuando se cansan de luchar, vuelven a cantar de nuevo para pelear oira vey El periodo del celo es para el pinzon la épo. ca de las contiendas, porque siempre tiene vecinos que al buscar tambien una hembra, excitan en el la pasion que le domina.

I.a hembra pone cinco o seis huevos pequeños, de $11^{*}, 018$ de largo por (1"), or 4 de grueso; son de cáscara delgada y co. lor azul verdoso claro, con ondulaciones de pardo rojo páli. do, y puntos de un tinte pardo negro. La incubacion dura quince dias, reemplazando el macho $\{$ la hembra cuando esta abrandona el nido en busca de consida Los padres alimentan principalmente á sus hijuclos con insectos, y los cuidan aun despues de haber eniprendido su vuelo: mas no tardan en buscar por si mismos de comer, y se declaran indepen. dientes. Al salir del nido pian, y mas tarde jroducen el grito de llamada de los padres.

Pocos dias despues de terminar la educacion de los po. lluelos, aparéanse los vicjos de nuevo.

El macho $y$ la hembra aman tiernamente a su progenic: lanzan gritos planideros cuando algun enemigo se acerca al nido, y manifiestan gran temor. Naumann asegura que el macho se ocupa mas de los huevos, y la hembra de los jollos; pero jo no he observado tal diferencia. $A$ pesar de ia ternura que demuestran por su progenie, los pinzones no se condu. cen como los otros pájaros: si de un nido de pardillos se quitan los pequeỉos para ponerlos en una jaula, se puede tener la seguridad de que los padres seguiran alimentaindolos; mas los pinzones no lo hacen así. \& Esta prueba, dice Nau. mann, la hicieron con perjuicio suyo muchos aficionados poco instruidos que quisieron evitarse la molestia de criar á los hijuelos, crejendo que los padres lo harian. La desconfianza y el sentiniento de su propia seguridad domina en estos pájaros sobre el amor paterno... lista regla no carece, sin embargo, de excepciones.

lil pinzon es alegre, vivaz, ågil y prudente, pero de carácter violento y pendenciero: siempre en movimiento, solo descansa en las horas de fuerte calor. En las ramas se mantiene recto; en iierra toma la posicion horizontal; cuando busca su alimento avanza tan pronto a saltitos como andando; en el ramaje adclanta por lo regular de lado; vuela con gracia j rapidez, trazando una linea ondulada, y separa un poco las alas antes de posarse. Cuando debe franquear una larga distancia, elevase a bastante altura, pero en los demás casos rucla rasando casi el suelo.

Su grito de llamada es una especic de pink ó fink: el pájaro lo produce con entunaciones distintas, cada una de las cuales tiene su significacion propin.

Cuando vucla emite un ligero grito que podria expresarse por guips, guisp: en caso de peligro, produce el de aviso, que se traduce por siih, al que están atentos los demás pảjaros. El pinzon pia en el periodo del celo: cuando hace mal tiempo, deja oir una especie de sonido ronco, que los naturales de Turingia traducen por la palabra regen (lluvia). Su canto consta de dos estrofas, las cuales repite con rapidez: los so. nidos que produce son los que mas excitan el interés de los aficionados.

Los verdaderamente apasionados describen una infinidad de especies dé canto, dando á cada una su nombre, hasta el punto de que el conocerlas todas ha llegado á ser una verda. dera ciencia, oscura siempre para los que no son inteligentes en la materia.

En ciertas localidades de las montanas se cultiva particularmente dicha ciencia, y en ella han adquirido una gran reputacion los aficionados de luringin, del Hary y del Austria Superior, que les dan a cada uno un nombre especial, cuyos nombres parecen singulares á los profanos aunque estån 
rasi todos bicu elegidos, sicndo en parte reproducciones del canto mismo. En otros tiempos las mejores cantoras entre esias aves eran muy apreciadas, y pagabanse por ellas sumas casi fabulosas; pero hoy dia la aficion va desapareciendo.

Lil pinzon vulgar solo causa dairo en los plantíos de legum. bres y en los campos recien sembrados. donde come las simientes que se hallan en la superficie Tambien se le culpa de ocasionar perjuicios en el bosque al recoger las simientes de las hayas y de las coniferas, pero dudo que las mismas jersonas que le acusan crean en la veracidad de su aserto. Come las simientes de varias plantas y principalmente las de la yerba: jero durante el periodo de la incubacion se alt unenta exclusivamente de insectos, en su mayor parte muy daibinos para nuestros árboles frutnles. Así compensa los da. nos que pueda causar con la utilidad que reporta, y que na. die podrá negarle.

Los aficionados que cogen pinzones para la jaula no son los que disminuyen el numero, sino los pajareros, que en un solo dia exterminan miles de individuos.

\section{EL PINZON DE LAS MONTANAAS-FRINGI- LLA MONTIFRINGIYLA}

CARACTERES. - Ia longitud de esta especie, la mas afine del pin\%on vulgar, es de $0^{m}, 16$, por $0^{m}, 26$ de ancho de punta a punta de las alas; estas miden $0^{\circ}, 09$ y la cola
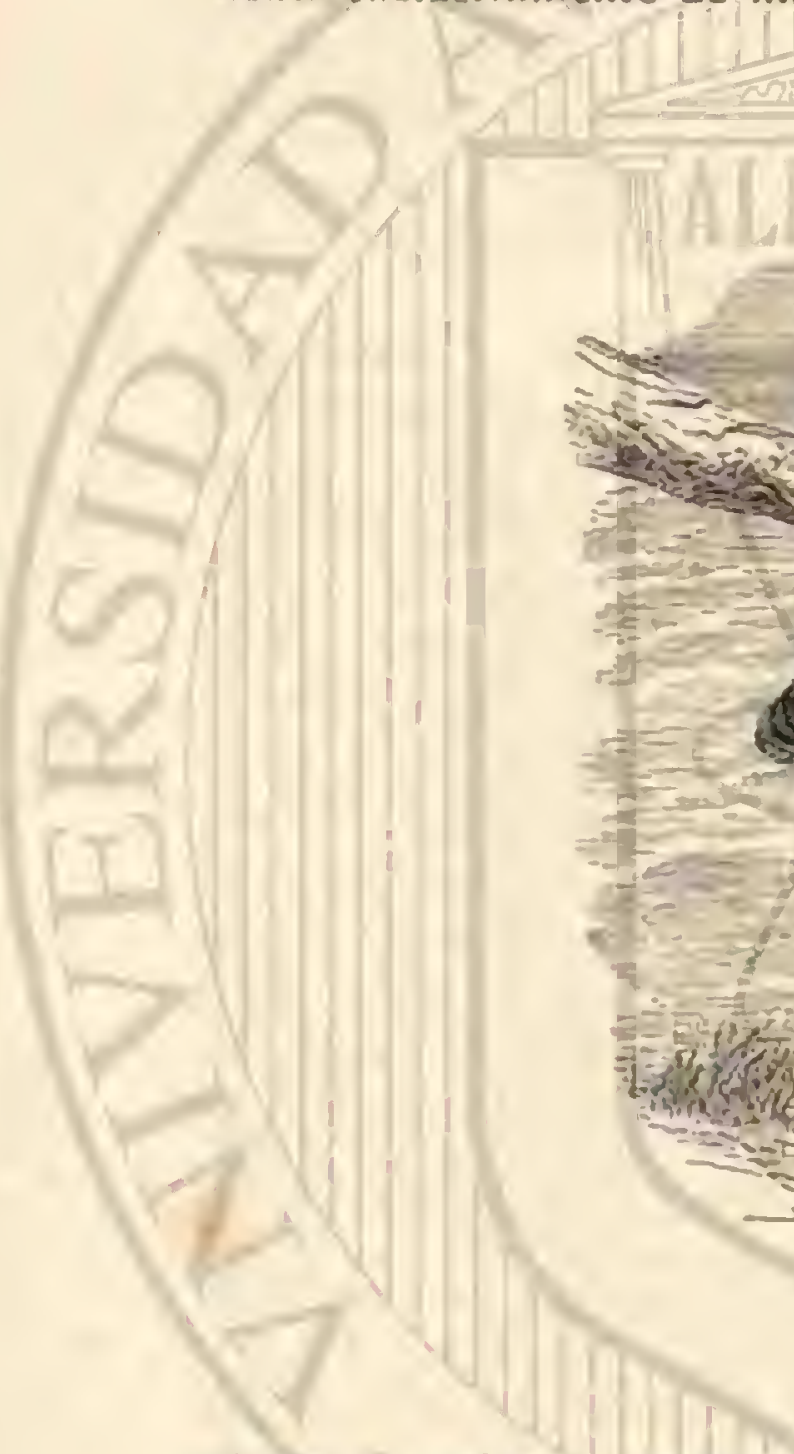

0,066. La cabera, la nuca, el manto, las mejillas y la jparte superior de los lados del cuello son de un negro oscuro con lustre azulado; las plumas de la rabadilla blancas en el cen. tro ; negras en los lados; la garganta y el pecho tienen un viso amarillento; la linéa naso-ocular, la barba y los lados del vientre de un blanco amarillento, los tiltimos con man chas negras; las tectrices inferiores de la cola son de un amarillo de orin; las térniges, de un negro pardusco, están orilla. das de un estrecho borde blanco amarillento en las barbas exteriores, excepto las cuatro primeras, presentando en la basc una mancha nuy blanca; las plumas de los hombros tienen un color amarillento de orin, mas claro en las peque nas tectrices de las alas; las del centro son negras y de un blanco amarillento en las puntas; las grandes tectrices, negras tambien, presentan grandes manchas de color rojo annarillo en los ángulos y en la punta; las rectrices, blancas en la uilui una unitad, están orilladas de amarillento con manchas blan cas en forma de cuña en las barbas interiores. Los ojos son de un pardo oscuro; el pico negro azulado claro, y en otoño amarillo de cera, con la punta negruzca, y los piés de un pardo rojo. En la hembra, la cabeza y la nuca son de un gris verdoso; las regiones supetiores de un pardo gris aceituna, $y$ las inferiores de un gris claro. Despues de la mudá, los colo. res vivos quecian cubiertos por bordes de un pardo ama rillo.

DISTRIBUCION GEOGRÁ FICA.-El área de dispetsion de esta especie se extiende por las altas montañas del antiguo continente, desde los $59^{\circ}$ de latitud norte, en direccion al polo, hasta donde alcanza la vegetacion arboricola. En invierno pasa por coda la Europa, llegando a Espana y Gre cia; en Asia se disemina hasta el Himalaya, y durante su viaje visita á menudo la Alcmania.

USOS, COSTUMBRES Y REGIMEN.-Lin cl mes de agosto se reunen estos pájaros en bandadas y vagan por los paises que se hallan al sur de su patria, apareciendo en Es. paina un poco despues de setiembre. La direccion de las ca. denas de montañas y de los grandes bosques determina la marcha de las bandadas, las cuales cambian á veces de di reccion á causa de reunirse con olros pájaros. En Alemania se encuentran siempre pinzones de las monianss retuidos con los ordinarios, y con pardillos, mirlos, garriones y ver derones. Un bosquecillo, ó un árbol aislado en medio de los campos, les sirve de punto de reunion: jiasan la noche en el bosque mas próximo, y desde alli se dirigen à la canzina en busca de alimento. Las nicves abundantes, que culsren la tierra y los granos con que se nutren, les obligan a marchar ¿ otro pais: sus emigraciones no son regulares; dependen por completo de las circunstancias y de la casualidod.

El pinzon de las montanas ofrece mucha analogia con su congénere: es pendenciero, colérico y celoso, por mas que parezca muy sociable

Tiene tanta agilidad comô el pinzon contun; peró dista mucho de cantar tan bien: su grito de llamada es línguido; es una especie de isseck, diseck ó cunck, seguido con frecuencia de un seliruig chillon; en su canto no hay armonia, ni Srden, ni método; es un conjunto de las diversas notas.

Considérasele como paijaro estripido, pero esro es un error: lo mismo que todos los del norte, muéstrase al principio 
confiado; mas la persecucion de que es objeto le vuelve ti. mido.

Ei pinzon de las montañas habita en su patria los bosques de conifcras, sobre todo aquellos donde hay alisos, pero no es a mido tan aislado, que se necesita mucho tiempo para encontrarle. Cada parcja tiene su dominio separado para anidar, pero los machos se reunen en la época del celo pacificamen. te. En algunos bosques observé que cran en extremo desconfiados, y en otros, por el contrario, muy timidos. En cuanto a su manera de proceder, es la misma que durante el in. vierno; y en el periodo del celo no ofrecen tampoco mucho de interesante. El nido se parece al del pinzon vulgar, pero sus paredes mas gruesas, y están cubiertas por fuera, no solo de musgo sino tambien de corteza de aliso, y rellenos en su interior de lana fina y de algun plumaje entrelazado que á veces cubre la mitad del nido. Los cinco as ocho huevos que la hembra deposita tienen un diámetro longitudinal de $\left(1^{\mathrm{m}}, 087\left\{10^{\mathrm{m}}, 025\right.\right.$, por $0^{\mathrm{m}}, 013$ \& $0^{\mathrm{m}}, 014$ de diámetro trasversal, distinguiéndose de los de sus congéneres por tener el color algo mas verdoso en el fondo.

Aliméntase de diversos granos oleaginosos y en verano tambien de insectos.

CAzA.-Se persigue al pinzon de las montañas para co. mer su carne, que es suculenta, aunque un poco amarga. Con las redes se cogen muchos individuos, pues son tan inexpertos, que caell en todas las trampas.

\section{LOS MONTIFRINGILIDOS -MONTIFRINGILLA}

CARACTÉRES.-I Las especies de este género difieren de las ya descritas por tener la uña del dedo posterior larga y corva en forma de espolon; las alas largas y el plumaje igual en ambos sexos.

\section{EL PINZON DE LAS NIEVES-MONTI- FRINGILLA NIVALIS}

CARACTÉRES. - Ia longitud del pinzon de las nicves, tipo del génere que nos ocupa, es de $0^{\circ}, 20$, por $\left(0^{\circ 1}, 36\right.$ de ancho de punta á punta de las alas; estas tienen $0^{\prime \prime}, 11$ y la cola $0^{\prime \prime}$, oS. I a region superior de la cabeza, las mejillas, la parte posterior y los lados del cuello son de un ceniciento claro; las plumas del.manio de un pardo de café con ángulos mas claros; las plumas del centro de la rabadilla negras, onduladas de blanquizco ó pardusco, las de los lados blancas; la garganta negra; los lados del pecho y los costados de un ceniciento amarillento claro; la barba, el pecho y el centro del vientre de un hlanco sucio; las plumas de lós muslos de un gris claro; el ano g las tectrices inferiores de la cola, blancas; las últimas tienen pequenas manchas de un pardo oscuro en la extremidad; las siete primeras rémiges prima. rias son negras, orilladas en las barbas cxteriores y en la extremidad de un borde pardusco; la octava es negra en la base y en las barbas exteriores; la títima, de un pardo café; el borde de las alas, las tectrices pequeñas, las centrales, y casi todas las grancies de las alas son Blancas; las posteriores - las plumas de los hombros de un pardo oscuro, con los angulos del mismo tinte, pero mas claro; las rectrices del cen. tro negras, orilladas de blanco en las barbas exteriores; y todas las demás blancas. Los ojos son de un pardo oscuro; el pico de un negro pizarra en otoño, amarillento de cera en verano, con la punta siempre negra; los piés son de este color. En la hembra, el blanco de las alas está menos cxtendido. Despues de la muda de otono todos los colores oscuros quedan cubiertos en parte por los bordes mas claros de las plumas.

DISTRIBUCION GEOGRÁfICA.- El pinzon de las nieves es propio de los Alpes del antiguo continente, desde los Pirineos hasta la Siberia;y en verano vive siempre mas arriba de la vegetacion arbórea. Fn nuestros Alpes habita los Cárpatos, el Cáucaso, las montanas altas de Persia y el Himalaya.

USOS, COSTUMBRES Y REGIMEN. - Casi tan TE.

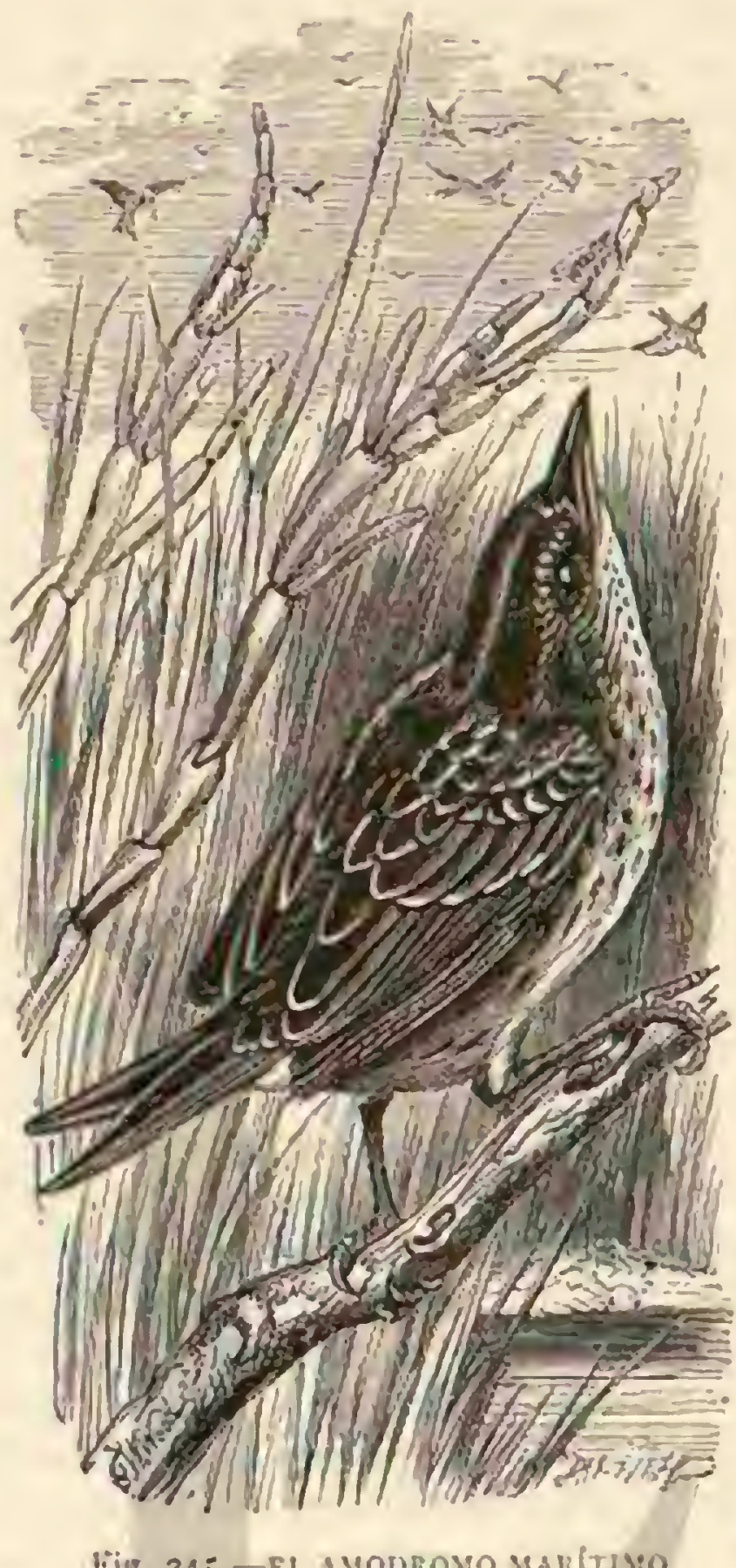

Hig. 245.-Fol. AMOUROMO MAMPTrs:O

sistente como el lagopo de los Alpes, segun dice Stoel. ker, prefiere las reginnes altas de las montains; soln las fuertes nevadas y el frio mas riguroso pueden obligarle a visitar los valles bajos. A principios del invierno no desciende a estos tan a menudo como al fin de dicha estacion, porque la nieve y el frio no incomodan á esta ave mientras hay suficiente alimento. \&El acentor, dice Giranner, baja con mas frecuencia a los valles; solo recuerdo de un pinzon de las nieves que fué muerto en Saint-Gall. Unicamente la extrema necesidad puede inducirle á bajar. En los inviernos mas rigurosos, cuando en las alturas solo reinan las nicves, los hiclos y las tempestades, cuando hasta el acentor, el gi paeto barbudo, el lagopo abandonan su patria, tal ve\% el pinzon de las nieves permanerca todavia en su verdadera área de dispersion; pero no lo cren, porque no puedn figurarme que aun encuentre alli alimento. lin lo mas riguroso del invierno apenas se aleja tampoco de la montaña, y por lo mismo son muy raros los casos en que efectivamente ha je. netrado en Alemania. En verano solo vive en la zona mas alta de los Alpes, tocando casi con las nieves ctcrmas; en la época del celo se le ve primero por parejas, y despues en grupos y bandadas, casi siempre al borde de los precipicios, donde corre apresuradamente por las rocas, elevíndosi de ve\% en cuando con sus compañeros para volar a cicrta distancia, producicn. 
do un ligero ywip, yusp: pero pronto vuclve à bajar á tierra en busca de alimento. Cunndo se le asusta deja oir un silbido planidero, y si le amenaza un peligro advierte a sus compa. heros con un agudo groco. Su canto, que cuando el ave vive libre solo se oye durante la época del celo, se compone de todos los sonidos citados, y segun los inteligentes, ningun pinzon le tiene tan desagradable: es corto, áspero, estridento y en extremo chillon. Esta ave recuerda por sus movimien. tos mas bien al plectrófano de las nieves y la alondra que al pinzon vulgar, pues tiene el vuelo ligero $y$ sostenido como esas especies. Cuarido se le ahuyenta suele elerarse a mucha altura, pero ámenudo vuelve al inismo sitio ce đonde partió, despues de hacer un gran rodeo. Noleme al hombre; si huye de $\mathrm{Cl}$, hácela tan-zolo poraue su aparicion imprevista le es. panta. En los caminos montaiosos suele pasar durante el invierno por delante de las casas; y alli donde se le protege entra yale sin temor en las habiaciones Lin los valles se nuestra al principio tan confiado, que con demasiada fre. cuencia es víctima de la malignidad del hombre: pero nuy pronto aprende por la experiencia á-recelar de él.

La rejroduccion ocurre á principios de mayo, $y$ algunas veces en abril: el pajaro anida en las grietas de las paredes verticales de las rocas, en las resquebrajaduras de los muros b debajo de las tejas de las viviendas aishadas. Su nido es grande: se compone de rastrojo, yestá relleno interiormente de lana, crines, plumas, etc: los huevos, un poco mayores que los del piuzon, son de color blanco de nieve.

los padres cuidan \& la vez de su progenic, alimentándola con larvas de insectos, lombrices y araias; y velan sobre ella con la mas tierna solicitud. Si anidan en la falda de la mon. taria no tardan en llevar à sus hijuelosá las nieves eternas apenas pueden volar. En el invierno se alimentan de granos de toda chase, y no parece que sufran privaciones en aquella estacion. Iin los hospicios les dan de comer, y con frecuencia șe ven bandadas sumamente numerosas a la puerta de dichos establecimientos.

CA UTIVIDAD. - Esta especic se acostumbra fáciimente á la jaula; conténtase con toda clase de alimento convenien. te, y cautiva por su carácter traniuuilo y pacifico, su gracia, sus pocas exigencias y la racilidad con que soparta su prision.

\section{LOS VERDERONES - CHLORIS}

CARACTÉRES, - Este género comprende especies de estructura robusta, que tienen el pico corto y cónico, con mandibulas recogidas y bordes afilados; los dedos son cortos, las alas de longitud regular; las tres primeras rémiges son las mas largas; la cola, bastante cotta, ticne una ligera escotadu ra en el centro.

\section{EL VERDERON COMUN - LIGURINUS CHLORIS}

CARACTERES. - La longitud de esta ave es de $6^{\prime \prime}, 125$, por $11 \%, 26$ de ancho de punta a punta de las alas; estas mi. den $11^{\prime \prime}, 08_{3}$ y la cola $0^{\circ}, 06$. El color predominante es un verde amarillo aceitunn; el borde de la frente, las fajas ocu. lares, la parte posterior de las mejillas y la superior de la garganta, asi como la barba, tienen un color mas vivo y mas amarillo; la region de las orcjas, la nuca, la rabadilla, las tectrices superiores de la coln y la parte inierior de los costa. dos son de un matiz ceniciento poco marcado; la parte inferior del pecho, el vientre, las tectrices inferiores de la cola y el borde de las alas de un verde amarillo de limon; las plumas que rodean el ano blancas; las rémiges primarias negras, con angostos bordes grises en las puntas; las seis primeras de un color vivo de limon en las dos ierceras partes de la base de las barbas; las rémiges sccundarias y sus tectrices negras, y de un gris ceniciento en las barbas exteriores; el resto de las tectrices superiores de las alas de un verde amarillo aceituna; todas las rémiges están orilladas de blanco en la base de las barbas interiores; las rectrices, excepto las dos del centro, son de un amarillo de limon en la mitad de la base y negras en el resto de su extension. Los ojos son de un pardo oscuro; el pico y los piés de un gris rojizo. La hembra tiene los colo. res menos vivos; el dorso de un gris pardo poco pronunciaco; el centro. y la parte inferior del pecho y del vientre blancos: las rémiges secundarias y sus tectrices rienen en sus barbas exteriores un borde pardo rojizo. Los individuos jóvenes se distinguen por su dorso de un pardo amarillo aceituna, con fajas masioscuras; los lados de la cabeza, la rabadilla y ioda la parte inferior son de un amarillento pálido, con angostas lineas longitudinales de un pardusco de orin (fig. 24S).

DISTRIBUCION GEOGRÁFICA.--Habita el verderon tocia la Furopa, excepto los paises mas septentrionales, y tambien se extiende sobre el noroeste del Africa y el Asia Menor hasta el Cáucaso; es muy comun en el mediodín de Eu. ropa, particularmente en España, y aun en Alemania no escasea.

USOS, COSTUMBRES Y REGIMEN.-Busca principalmente los lugares fétiles, los bosquecillos que alternan con los campos, las praderas y los jardines; se le ve tambien cerca de las casas, y evita las grandes selvas. Entre nosorros el verderón es un pájaro viajero, ó por lo menos emigran en invierno los mas de los que pasan el verano en nuestros paí. ses; en Espaùa no sucede asi, pues permanecen todo el ano: es probable que los que se encuentran en inviemo en ciertas latitudes vivan en verano mas al norte.

Hasta el momento de emprender sus viajes no forman estos prjaros grandes bandadas, las cuales se reunen con los pinzo. nés, los gorriones de los nogales y los pardillos. Fucra de esta epoca, viven por parejas 6 en reducidas familias; establecen. se en un pequerio bosque 6 en algun jardin; eligen un espeso árbol para pasar la noche $y$ vagan por los alrededores. Se les ve tedo el dia buscando por tierra los granos.de diversas es. peciés, mas al menor peligro vuelan á un árbol próximo y se ocultan en el follaje.

Por pesado quue parezea á purimera vista el verderon comun, es un pájaro vivaz y ágil en todos sus movimientos. Cuando descansa toma su cuerpo la posicion horizontal, entreabriendo las plumas, $y$ a menudo se pone derecho, y las recoge, hasta el punto de ser dificil reconocerle. Anda á saltitos; su vuelo es bastante facil y ondulado; tan pronto separa lasalas como las recoge, y antes de posarse parece vacilar. No le gusta mudar de sitio cuando no es necesario, mas aun asi, recorre de una vez grandes distancias. En el momento de emprender su vuelo produce un grito de llamada muy breve, cusa equivalencia viene á ser tschick ó fscheck: en sus momentos de ternura parece pronunciar ewivi ó schumusch, con tanta suavidad como fuerza: este mismo grito, acompañado de un ligero silbido, es la scinal de aviso.

En los puntos donde el ferderon se cree seguro, es confiado; pero cuando forma bandada demuestra siempre mucha prudencia, y no parece sino que cada individuo rivaliza en celo para velar por la seguridad comun. "Al acercarse un hombre, dice mi padre, los individuos que se hallan en tierra emprenden su ruelo, $y$ les siguen los otros, mas no tardan en posarse. Muchas veces se les persigue durante un cuarro de hora antes de conseguir tenerios á tiro. . El verderon nunca es muy confiado, y aunque la necesidad le apure, no penctra en las granjas. 
Se alinenta de granos aunque sean venenosos, pero particularmente de los oleaginosos, de colza, lino y cánamo, los cuales recoge por ticra, como el pinzon; cuando cubre el suclo la nieve, come bayas de saúco y de serbal, abriendo las cubiertas para sacar la semilla. El verderon ocasiona con frecuencia perjuicios en los campos de cátiamo, pues no es fácil alejarle de ellos, porque alli encuentra su alinento faro. rito. Tambien es dañoso muchas veces en los huertos; pero el servicio que presta comiéndose los granos de las malas rerbas, compensa con creces el mal que hace.

La hembra pone dos veces al ano, y tres si este es bueno: antes de aparearse el macho, deja oir continuamente su voz: al cantar, remóntase oblicuamente por el aire, agita sus alas, las levanta hasta tocarse casi sus puntas, se balancea de un lado a otro, describe circulos y vuelve lentamente al árbol de donde partió. Si se acerca un rival, persiguele con ardor y lucha mas ó menos tenazmente.

El pájaro construye su nido en una cerca, en la bifurca. cion de una gruesa rama, y emplea al efecto diversos materiales: las ramitas secas, las raices y el rastrojo, constituyen el armazon, y cubren este materias semejantes, aunque mas finas, mezcladas con musgo, liquenes y redijas de lana. La construccion no es tan artistica como la de los pimzones, ni el nido muy sólido y grueso; su forma es poco mas 6 menos la de una media esfera. A fines de abril pone la hembra por primera ver; la segunda en los últimos dias de junio, y si hay una tercera, a principios de agosto. Cada puesta es de cuatro á seis huevos, de $(1), 020$ de largo por $(1), 015$ de grueso, muy abultados, de cáscara lisa y delgada y color azulado ó plateado, con puntos y manchas mas ó menos distintos de color rojo pdlido; ocupan principalmente el extremo grueso, donde se reunen formando circulo.

la hembra cubre los huevos por espacio de catorce dias, sin el auxilio del macho, que se cuida de llevarle siempre su alimento. Ios padres comparten el trabajo de criar los hijuelos: les dan al principio granos, despojados de sus cubiertas y humedecidos en el buche; mas tarde se los dan enteros; algunos dias despues de volar los pequeños, abandónanlos sus padres para ocuparse de una nueva cria Los individuos de la primera forman con otras bandadas, que vagan de un punto á otro. Los padres se agregan á cilas cuando termina la reproduccion.

I.os carniceros pequeños, las aves de rapiña, las ardillas, los lirones, los cuervos, los picos y los grajos, destruren mu chos nidos de verderones, apoderándose tambien de los adultos cuando pueden.

A pesar de eso su número aumenta mas bien que dismi. nuje.

\section{LAS CITRINELAS - CITRINELLA}

CARACTÉRES. - Este género se distingue de los crisomitridos por tener el pico un poco mas corto y grueso: constituye el trínsito entre estos y los verderones.

\section{LA CITRINELA DE LOS ALPES-CITRINE- LLA ALPINA}

CARACTÉRES. - En esta especie, tipo del género, la frente, la parte anterior de la cabeza, la region ocular, la barba y la garganta son de un bonito amarillo; las partes in feriores del mismo tinte, pero mas vivo; el occipucio, la nuca, la parte posterior del cuello, la region de las orejas y los la dos del cuello grises; el manto y los hombros de un verde acciruna opaco, con lineas oscuras poco marcadas en los talios; las plumas de la rabadilia son de un bonito verde limon; las tećtrices superiores de las alas y las de la cola de un verde aceituna; los lados de la parte inferior del vientre de un gris verdoso; las tectrices inferinres de la cola de un amarillo pálido; las rémiges de un pardo oscuro, orilladas en las barbas exicriores de un angosto borde, con las puntas de un gris pálido; en las últimas rémiges secundarias este borde se corre por los lados y es de un verde amarillo, con manchas grises en la extremidad; las tectrices de las rémiges secundarias son de un verde amarillo, y negras en la base, de modo que se forma una estrecha faja oscura en las alas; las rectrices son negras orilladas en las barbas exteriores de un estrecho borda blanquuizco. Los ojos son de un pardo oscuro; el pico pardusco, y los piés pardusco amarillos. Ia hembra, mas pequeina, tiene colores menos viros y mas grises. La longitud de esta especic es de $0^{\prime \prime} 12$, por $0^{\prime \prime}, 23$ de ancho de punta a punta de las alas; estas miden $0^{\circ}, 08$ y la co. la $0^{m}, 055$.

DISTRIBUCION GEOGRÁFICA.- la citrincla de los Alpes es un ave de las montañas, que habita los Alpes occi. dentales yel Asia Menor, y en Alemania la Selva Negra; pero solo en algunos sitios se presenta en número considerable. Segun parece, se ha diseminado descle Italia, donde se la en. cuentra mas á menudo, por el 'lirol y la Suiza; desde agui se ha trasladado últimamente à la Selva Negra de Baden, mien. tras que aun falta por completo en los Alpes orientales. En los de Suiza solo habita los bosques altos; en la Selva Negra busca siempre las cumbres de las montanas mas elevadas, y en ellas los linderos de los bosques y los pastos, evitando no obstante los montes aislados, asi como el interior de los bos. ques. lin Suiza, las tempestades la obligan pronto à buscar los valles bajos, por mas que le agraden las alturas; alli per. manece hasta que en los otros desaparece la nicve y mientras encuentra alimento. En la Selva Negra abandona en invier. no tambien sus morádas y baja a los desfiladeros bañados por el sol en las desembocaduras de los valles; pero no hace esto sino cuando el tiempo es verdaderamente desfarorable, y á primeros de mayo ruelve á presentarse ya en los sitios donde anida, aunque alli esté el suelo cubierto de nieve. Es posible que desde los Alpes emprenda viajes; en la Selva Negra es mas bien un ave crrnnte.

USOS, COSTUMBRES Y REGIMEN.-.Todos los na. turalistas que han podido observar esta especie con deten. cion describen la citrincla de los Alpes como ave alegre vivay, que esti en continuo inovimiento y canta sin interrup. cion. Cuando el tiempo es desfavorable apenas se oye su vo\%; pero en los dias de sol, segun Schultz, y si no sopla el viento, resuena su lastimero grito de llamada, guire, grirc, bill, hill, y tan á menudo, que nunca pasa desapercibido. Sir embargo, es por lo regular bastante imida, y por lo tanto dificil de observar. Segun Alejandro de Homever, el canto se compone de tres partes; la una recuerda el canto del jilguero; la otra el del canario meridional y la tercera es poco mas ó menos un término medio entre los dos. ¿El canario canta; el jilyue. ro silba ligeramente, produciendo un zumbido, pero la citri nela de los Alpes canta con voz sonora. La voz del princru es clara, alta y dura; la del segundo chillona, pero la del úl. timo llena, dulce y agradable Sus gritos de llamada, difae, ditac, wibl, of ditaitatcti, son suaves y bajos; su voz sivit purn y melodiosa la citrinela tiene por consiguiente un cantu ex traño en el que alternan y se confunden los del jilguero y del canario; mas a pesar de esto, el ave figura entre las cantoras de segundo órden de la familia de los fringilidos.

Segun la situacion del territorio donde anida, y segun el tiempo, la pareja comienza en abril, ó cuando mas tarde en mayo, la construccion del nido, que se encuentra siempre en 
árboles, á mas ó menos aluura del suelo. Fin la Selva Negra, segun Schuett, hâllase en los pinos de unos seis metros de elevacion, en el ramaje mas espeso de la copa y cerca del tronco: compónese de pequeñas raices, musgo y fibras de plantas, y esti relleno en su interior de lana y plumas. Los cuniro ó cinco huevos que la hembra pone se parecen a los del jilguero, pero son mas pequeirus y' su cáscara mas fina; miden unos $11 \%, 015$ de largo por $10^{\circ}, 012$ de grueso, $y$ tienen un color vercie claro, con punntos pardo oscuros ó de un rojizo pardo violeta, que en la extremidad gruesa forman a veces una especie de corona. Madia r hembra se cuidan de la ali. mentacion de los polluclos; estos llaman á sus padres con un prolongado ai be, si-be. Permanecen inucho tiempo en el nido, mas apenas se toca este huyen como pequeños reyezuelos, buscando su salvacion en el musgo y en la maleza. Hăcia el otoño se reunen con sus padres y otros individuos de su especie, formando entonces bandadas de cuarenia á cincuenta, que casi siempre buscan las semillas en el suelo de los bosques, siendo dificil ahuyentarlos del paraje donde abunda el alimento. Asi, por ejemplo, una bandada de mas de cien individuos permaneció todo un invierno cerca de la estacion de Chur, alimentándose durante todo este tiempo de simientes.

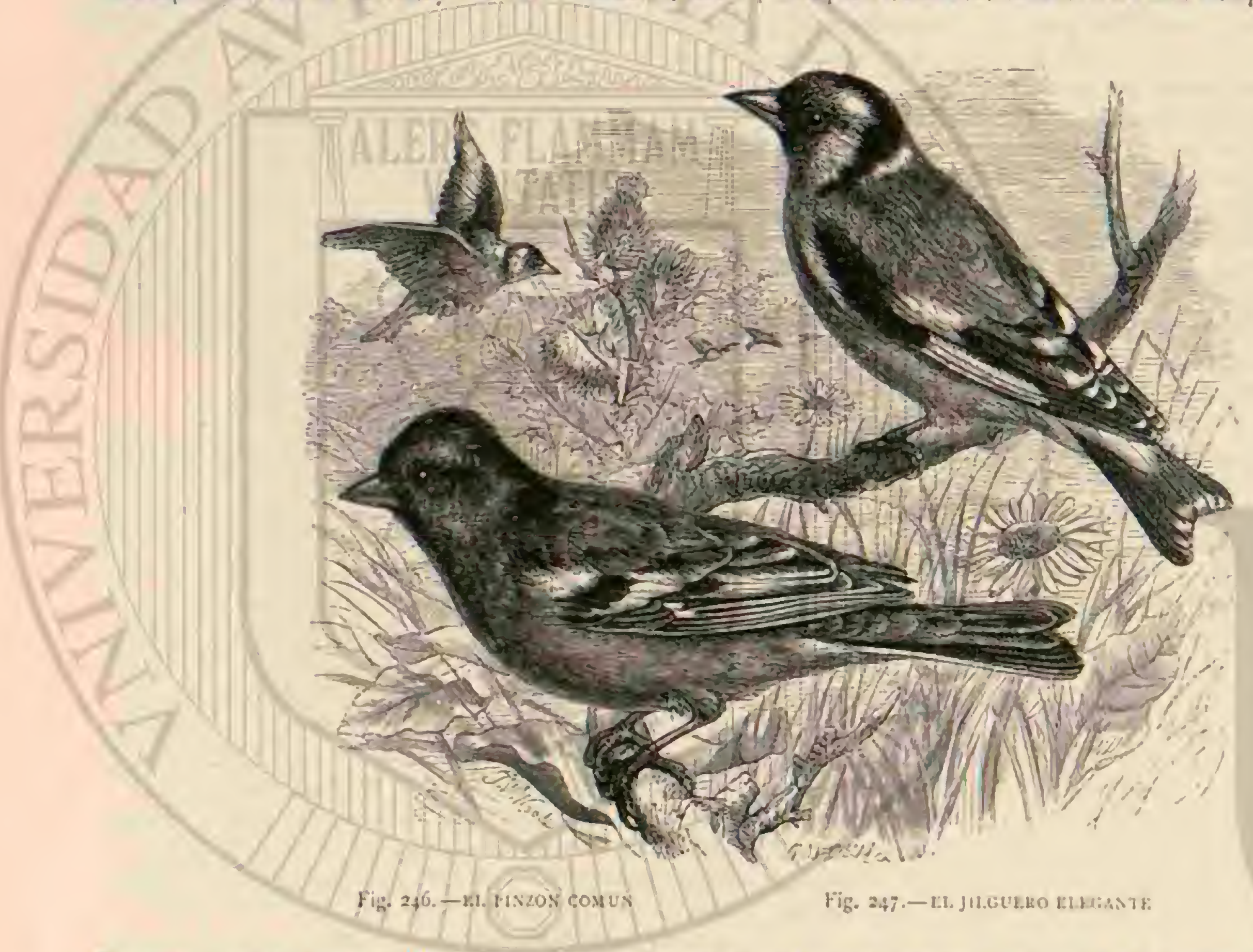

En verano las de la planta llamada diente de leon, las cuales recoge colgándose a la manera del jilguero; tambien busca otras por el sucto; y asimismo le agradan los retonos y tallos tiernos.

CAUTIVIDAD. - No es dificil alimentar al este pảjaro en la jaula; mas á pesar de esto no se conscrva muy bien, y es por lo tanto inferior al verderon y al jilguero como ave ca. sera.

\section{LOS CRISOMÍTRIDOS-CHRY- SOMITRIS}

CARACTERES. - LO; crisomitridos ó verderones se caracterizan por su pico largo, con punta muy fina y aboveda do ligeramente en la arista; las unas son cortas $y$ lis alas re. lativamente largas.

\section{EL VERDERON DE LOS ALISOS- CHRYSOMITRIS SPINUS}

CARACTERES. - Este pajjaro tiene toda la parte superior de la cabeza y de la garganta negras, asi como tambien la nuca y la barba; la parte posterior del cuello, el manto y los homuro de un verde amarillo, con fajas lon. gitudinales oscuras; una faja de la region de las cejas, la parte anterior de las mejillas, el resto de la garganta, los la. dos del cuello, el buche y la parte superior del pecho son de un bonito amarillo accituna; la parte inferior del pecto, el vientre y los costados, casi blancos; las tectrices inferiores de la cola, de un tinte amarillo, presentan, asi como los lados de los muslos, unas lineas longitudinales negras; las plu. mas de la rabadilla son de un amarillo aceiruma: las tectrices superiores de la cola, verdes; las rémiges de un negro fardo, y desde la cuarta amarillas en la base de las barbas exteriores, presentando un estrecho borde verde amarillento; las tiltimas rémiges secundarias tienen las barbas exteriores orilladas de amarillo verdoso, con la punta blanquixca; las tecirices de las alas son de un verde aceituna; las de las ré. miges secundarias de un amarillo. verdoso y negras en la base, de modo que se forma una faja trastersal negra; las rectrices son amarillas, con la puntá negra; las dos del cen. tro de un negro pardo orilladas de verde en las barbas exte. riores. Los ojos son de un pardo oscura; el pico de color de carne y negruzco én la punta, y los piés pardos La hembra tiene la parte superior de la cabeza y la del tronco de un color pardo verdoso, las regiones inferiores de un blanco sucio, con mancias oscuras, que á su vez presentan lineas negruzcas en los tallos; las alas y la cola son de un color 
mucho mas pálido que en el macho: las tectrices superiores de las alas blanq̨uizcas en la extremidad, de manera que se forman dos rajas tmasversales claras en las alas. La longitud de esta especie es de $\left(1^{\circ}, 12\right.$ por $11^{\circ}, 22$ de ancho con las alas desplegadas; estas últimas miden $11^{\circ}, 055 \mathrm{y}$ la cola 11" 0.45 (iig. 250).

DISTRIBUCION GEOGRÁFICA.-El àrea de disper sion del verderon de los alisos comprende casi toda iz Europa y el Asia hasta donde llegan los bosques, extendién. dose por el norte hasta la latitud de la Noruega central.

USOS, COSTUMBRES Y RÉGIMEN. - El verderon. de los alisos es un pajaro de paso: cuando no está en celo vaga por lodas partes; pero rara ver abandona nuestros paises. En invierno le vernos llegar con frecuencia de los mas sep. tentrionales, en busca de un abrigo conira los frios dema. siado rigurosos.

Dumnte el verano habita este verderon las montanas, los bosques de verdes úrboles, y sobre todo aquellos en que han madurado bien los irutos. Alli es donde se reproduce y de donde sale para emprender sus peregrinaciones. En ciertos inviernos aparecen los verderones á miles en los alrededores de los pucblos, y hasta en el interior, al paso que hay años

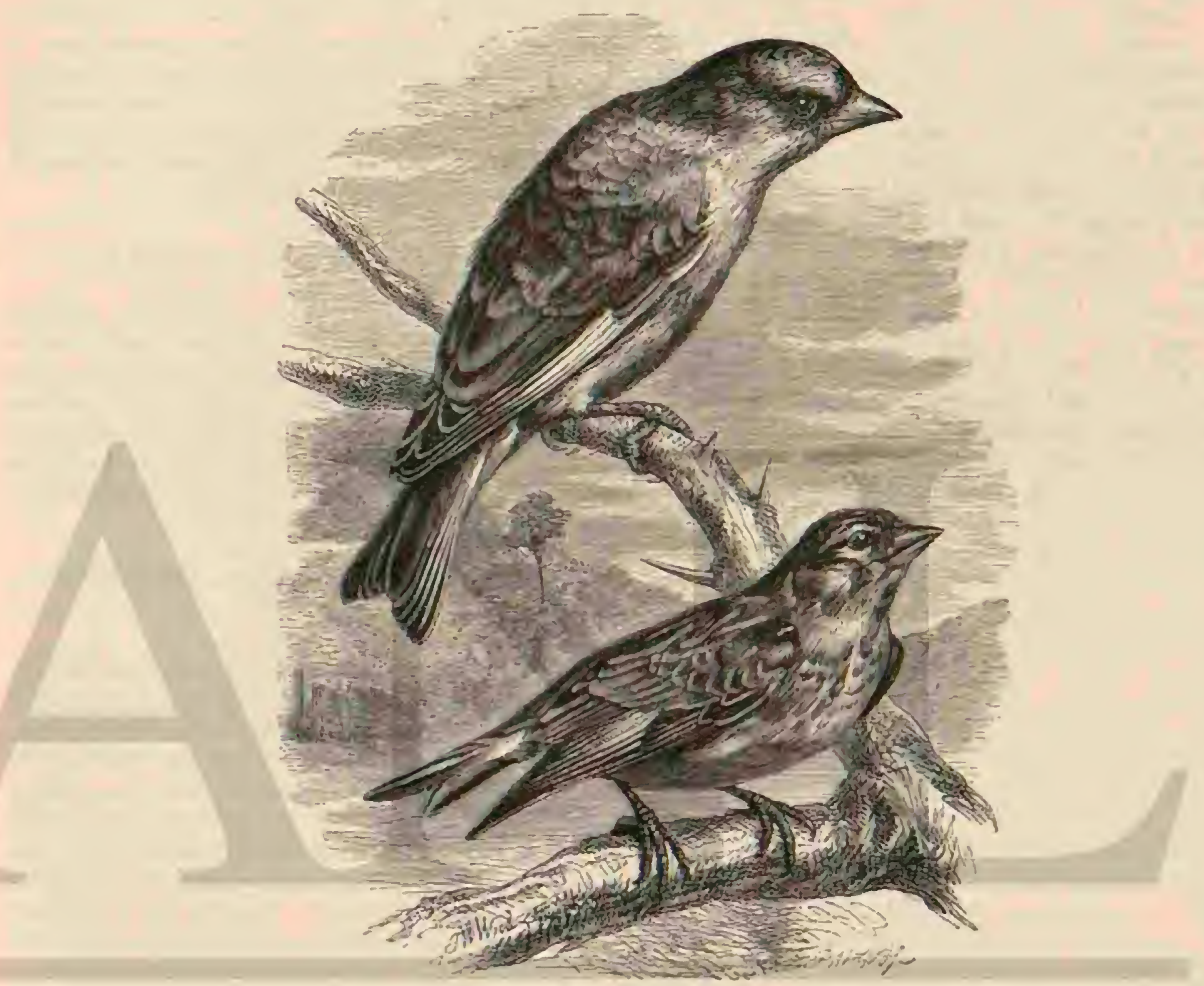

Fig. 24S. - ER, VERHRON COMUN

rig. 249.-TL BARIMLLO COAUX

en que no se ve ninguno. Evitan los paises sin arboleda, y se posan con preferencia en las ramas mas altas.

El verderon de los alisos es uno de los mas bonitos fringilidos. Siempre está contento y alegre y se muestra nuy vivaz, dice Naumann; siempre se ve limpio su plumaje; vuela de un lado at otro; se vuelve y revuelye; canta casi de continuo; salta y trepa muy bien; suspéndese de las ramas mas vacilan. tes; corre 1 lo largo de una delgada y vertical, y no cede ś los paros en agilidad. En el arbol no descansa un momento, y en tierra salia ligeramente, aunque no parece gustarle este movimiento. Su vuclo es rápido, y por lo mismo no teme atravesar vastos espacios, ni remontarse á grandes alturas por los aires. Su grito de llamada se traduce por tretlet ó tettertifte y di di 6 didtlei: por este último sonido comienza el canto del macho, que consiste en un gorjco bastante agra. dable, el cual tcrmina por algunas notas línguidas cuyo equivalente parece ser una especie de dididideidec.

El verderon es jugueton, conisado, sociable, timido, paci- firo y aturdido hasta cierto punto, ó por lo menos, ningun pá. jaro olvida tan pronto su libertad.

El verderon come granos de diversas plantas, sobre todo de los árboles, retoños, hojitas ó insectos, principalinente cuando está cn celo. Con estos úlimos alimenta cxclusiva. mente å sus hijuelos, dándoles sobre todo orugas, pulgones, etc. Se ve siempre á los padres, acompañados de su progenie, cuando apenas acaba de emprender su vuelo, dirigirse i los jardines y verjeles, donde los insectos abundan mas que en el bosque.

Mi padre fué el primero que dió à conocer en detalle todo cuanto se refiere á la reproduccion de cste płjaro, y me pa. rece lo mejor citar aqui sus observaciones; dice asi:

- Los verderones aparecen en abril: el macho tiene una voz fuerte, la cual se oye cuando vuela, como sucede con cl pico cruzado: agita las alas, ladea la cola, y se remonta por los aires à bastante altura, trazando circulos. Con frecuencia se conduce del mismo modo cuando se halla léjos de su 
nido: los que no están apareacios continúan asi hasta media. dos del verano. La hembra permanece tranquila, no se aleja mucho del macho, le picotea y vaga con él por los alrededo. res. Se suelen encontrar varias parejas reunidas que viven en la mejor inteligencia y buscan juntas su alimento.

Poco despues de aparearse comienza la construccion del nido: la hembre busca un sitio faromble, $y$ no se cansa uno de admirar con queé urudencia sabe elegir. Nunca he visto nido de verderon sino en los pinos ó abetos; todos se halla. ban cerca del extremo de las ramas, y tan bien escondidos, que se comprende que la creencia popular los haya inchado de invisibles Aigunos aparecen sobre una rama de pino cu. bierta de liquenes, y solo desde arriba se podria reconocet el nido por su cavidad, á pesar de gue le cubre an menudo una péqueña rama; mirando desde abajo ó de lado, se confunde completamente con los liquenes; dros están construidos en la punta de las ramas, y de tal modo enlazados con ellas, que cierto dia no vió mi pajarero un nido que yo le indicaba, hasta que se acercó á distancin de dos piés, siéndole para ello necesario entreabrir el ramaje. Por lo tanto puede suceder muy bien que despues de haber visto una persona á varios verderones construir su nido, suba a irbol nue los orulta : no lós encuentre. El hecho ha daco márgen s la fábula de que contienen piedrecias que los hacen invisibles. Además de esto, estan situados a diez ó veinte brazas del suclo, muy léjos del tronco, y por lo tanto son mas dificiles de ver que de alcanzar; hasta cierto punto pueden considemrse como invisibles, $y$ si no se ve á los płjaros cuardo los colsstrujen ó dan de comer à sus hijuelos, dificilmente se descubren. Se ha dicho que los verderones anidan en los alisos; esto me parece un error, que solo sostendrán aquel!os que jamás han tenido a la vista nidos de dichos pájaros; con la particulari. dad de que muchos naturalistas han incurrido en él.

sEl niedo queda ieminado muy pronto: en las dos parejas observadas por mi, urabajaba el macho tambien; ambos lle gaban juntos ó scesperaban uno d otro para volar de nuevo. Romuian ramitas sccas parn formar el armazon, arancaban el musgo de los ironcos fie los árboles, y volvian cada viez con el pico lleno de estos materiales. I Era muy curioso verlos arreglar la lana: sujetábamla con una de sus patitas, y tiraban con el pico hasta entreabrirln toda: yo les he visto muy afa. rados en semejante trabajo por la mnniana y al meỏio dia.

nAlgunas reces no se ocupaba en tal operacion mas que la hembra; pero el macho rolaba siempre à su alrededor. Llenos de confianza, no temen que se les observe muy de cerca, si bien sucede á menudồ que abandonan el nido co. menzado para fabricar otro. El ano último sorprendi á un par de verderones que construian el suyo en un abeto: volvi a los dos dias al mismo sitio, y noté, no sin extrañera, que la hembra hacia un segundo nidio en el misno árbol. Tista particularidad, propia del verderon y de la curruca, contribuye a yue sea maș dificil descubrir sus construcciones. lin is ig encontre tres nidos, todos elios abandonados: y mi desnichador hallo por su parte orro sin pajaros. Al verderon le gusta mucho el agua, lo cual se reconoce por el sitio que siempre elige para fijorse: de los tres nidos citados, dos se hallaban cerca de una charca y cl tercero próxinn a un es. tanque: ótro encontré á porn distancia de un arroyo.

sla época de la reproduccion vatía: una vez vi ts principios de mayo hijuelos cubiertos de roda su pluma; pero en el mes de julio es cuando mas se encuentran, de donde se deduce que la puesta debe ocurrir en los primeros dias de junio.»

I a forma del nido es bastante variable: en general se compone el interior de ramitas secas, musgo, liquenes y lana, enlazado todo por medio de filamentos del capullo del gu- sano de seda: las paredes son gruesas y la cavidad bastante profunda.

Los huevos varian de forma, de volúmen $y$ de color; tie. nen generalmente $11^{12}, 016$ de largo por $10^{\circ}, 0 r_{3}$ de grueso $y$ son de un blanco azulado ó verde azul muy claro, con puntos, manchas y lineas mas 6 menos acentuadas.

Ia hembra cubre sola los hucros, y el macho la alimenta. La incubacion dura trece dias, y ambos padres se ocupan en criar a los hijuelos.

CAzA.-Ios verderones tienen muchos enemigos: su in. diferencia y el cariño que profesan $a$ sus semejantes les pierden muchas veces.

CAUTIVIDAD.-El verieron comun es un excelente pajaro para conservar en una habitacion: aprende pronto y ficilmente mil habilidades; come muy poco; vive en perfecta armonia con los otros pajjaros y se le puede enseriar á que salga de su jaula y acuda al llamamiento de su amo: cuando se le cuida bien se reproduce tambien con tanta ia. cilidad como cualquier otro pájaro cautivo.

\section{LOS IILGUEROS-CARDUELIS}

CARACTERES. - El género de los jilgueros comprende pocas especies propias del antiguo continente, que se distinguen por su pico nuy prolongado y puntiagudo, algo encorvido en la punta y recogido en los bordes; los piés son cortos y fueries: los dedos largos, provistos de unas poco corvas; las alas puntingudas, con las cinco primeras rémiges mas largas; la cola, de longitud regular, está ligeramente sesgada; el plumaje es lacio y muy abigarrado.

\section{EL JILGUERO ELEGANTE-CARDUELIS ELEGANS}

CARACTERES. - Una estrecha faja quUe hay alrededor del pico, la linea naso.ocular, el centro de la coronilla y el occipucio son de un negro intenso; la frente, la parte poste. rior de las incjillas y la garganta de un rojo carmin muy vive; las sienes y las mejillas blancas; la nuca, los hombros y el dorso de un pardo amarillento; el buche y los lados del pecho de un parcio rojizo claro; la parte superior de la garganta, la rabadilia y el resto de las partes inferiores blan. cas; las rémiges de un negro oscuro en el tercio de la base, excepto la primera, que tiene un tinte amarillo vivo en las barlas exteriores, presentando junto of la extremidad una especic de placa blanquizea que se ensancha laicia atrás; la cara inferior es de un gris oscuro, con ángulos de un-blanco plateado: las pequeñas tectrices del ala son de un negro os. curo; las centrales y las grandes de un amarillo claro; las rectrices de un pardo oscuro; las exteriores tienen una mancha longitudinal blanca; las otras jresentan como unas pla. cas blancas en la punta. I os ojos son de un pardo de nuez; el pico blanco rojizo y negro en la punta; los picis de color de carne azulado. Ambos sexos se asemejan mucho y solo un conocedor muy experto reconocerá al macho por su tamaño un poco mayor que el de la hembra; aquel tiene ade. mas el color rojo de la cam mas extendido, el negro de la cabear mas intenso y el blanco mas puro. Los polluelós ca recen del rojo s negro en la cabeza; la parte superior de su cuerpo es pardusca, con manchas mas oscuras; la inferior blanca con manchas pardas. La longitud del ave es de $\left(1^{n}, 1,3\right.$, por fi", 22 de ancho de punta a punta de las alas; estas mi. den $0^{\prime \prime}, 0 ;$ y la cola $0^{\circ}, 05$ (ing. 24j).

DISTRIBUCION GEOGRAFICA.- Fl limite septentrional de su área de dispersion se halla en el centro de Suecia, $y$ á partir de alli encuéntrase en toda fiuropa, en las islas 
de Madera, Canarias, el noroeste de Africa y una gran parte del Asia, desde la Siria hasta Siberia: en Cuba ha vuelto al estado salvaje.

E.l jilguero no falta, segun parece, en ningun punto de tan inmenso circulo de dispersion: pero no es en todos del mismo modo abundante, escasenndo en unos, al paso que aparece uumeroso en otros. Bolle le vió muy comun en Canarias: yo encontré bandadas numerosas en Andalucia y Castilla; algunos observadores las han hallado cu Cirecia.

USOS, COSTUMRRES Y RÉGIMEN. - Por todas partes se reunen los jilgueros á centenares en él otoh̆o, para recorrer el pais, y se dividen en reducidas bandadas apenas llega el invierno.

A estos pájaros les gustan principalmente los lugares cu. biertos de bosque, si bien no son silvicolas en tocia la extension de la palabra, puesto que inbitan los jardines, los parques, los caminos, la proxinidad de los campos y las praderas, con preferencia a los grandes bosques; aqui suelen tambicn anidar.

T.l jilguero elegante es un precioso pajjaro: es vivaz, ágil, prudente, astuto y buen cantor; rara vez anda por el suelo, que no parece gustarle mucho; pero en cambio trepa por el ramaje lo mismo que los paros. A semejanza del verderon, se suspende de las ramas mas endebles con la cabeza hácia abajo: su vuelo es ligero, rípido, ondulado como el de la nanyor parte de los fringilidos y solo vacilante en el momento de ir í posarse. Cuando está en la rama parece el jilgnero muy eshelto, porque recoge todas sus plumas. Busca con preferencia la copa de los árboles ó de las breñas, y nunca estå largo tiempo en el mismo sitio, cual si le fuera necesario el movimiento. Inspirale desconfranza el hombre, aunque solo es realmente timido cunndo se le ha cazado. Vive en buena inteligencia con los demás pájaros; pero conscriando cierta indegendencia, y se le encuentra sobre iodo con los paros.

Su grito de llamada le ha valido el nombre aloman de stigglita. que en mi concepto no es simo una onomatopeya de las silabas sliglit, fickeluit, pickelnick ki klcior, las cuales deja oir asi cuando vucla como cuando descansa. Hai es una serial de aviso, y racracracrac indica su cnojo: los pequeños gritan laif liswioi. El canto del macho is claro y agradab!e, por mas que las notas sean menos llenas y brillantes que las del pardillo comun: pero es tan variado este canto, y lo ejecuta el pájaro con tal ardor, que el aficionado aprecia en mucho al jilguero. Cuando esta cautivo canta casi todo el año; si vive libre, solo calla en la época de la muda y durante el mal tiempo.

El jilguero se alimenta de granos de toda especie, principialmente de los del cardo, lo cual le ha ralido su nombre. iNada mas bonito, dice Bolle, que una bandada de eștos prjaros cuando se ba?ancean en los tallos espinosos de los cardos, hundiendo sus cabozas en medio de los hlancos agui. jones de estas plantas. Diriase que han florecido de nuevo, produciendo flores mucho mas hermosas que la primera vez. Posario sobre un tallo de cardo, el jilguero se vale de su largo y puntiagudo pico para extrace activamenic los granos.

En verano come el jilguero insectos, y alimenta con ellos á su progenie; el pájaro es por consiguiente útil para la agricultura en todas las estaciones, toda ver que contribuye a destruir las malas yerbas.

Hay, sin embargo, observadores que le acusan de contri buir a la dispersion de los cardos; pero la simiente de esta planta se extiende ja por el viento, sin el concurso del jilguero, y por eso no se puede hacer responsable al ave.

Su nido se halla de ordinario á seis ú ocho metros de aliura, y le sitúa generalmente en una de las bifurcaciones de la copa del árbol, ocultindole tan bien, que apenas se ve hasta despues de caer la hoja. No deja de estar construido con mucho arte: la parte exterior se compone de liquenes verdes, musgo, pequeñas raices, rastrojo, yerbas y plumas, enlaradas unas con otras con filamentos del capullo de seda; el interior está cubierto con una capa de borm y espinas de cardo, con las que aparecen mezcladas crines y cerdas de puerco. Solo la hembra construye el nido; el macho la distrae ron sus cantos, pero rara rez le presta ayuda.

Cada puesta consta de cuatro á cinco huevos de $0^{\text {" }}$, or 6 de largo por ()$^{m}, 012$ cie grueso, de criscara delgada, biancos ó de un azul verdoso, y cubiertos de puntos grises violeta, dis. puestos en forma de corona en la punta mas gruesa. Rara ver se encuentran huevos antes del mes de mayo, y es de creer que la hembra no hace mas que una puesta anualmen. ie, ó cuando mas dos; cubre ella sola, por espacio de trece ó ratorce dias, y jamás abandona el nido sino algunos instantes, pues el macho se encarga de darle su alimento. Los pa. dres nutren á sus hijuelos al principio con pequeras larvas; luego con insectos y granos: y continúan cuidando de ellos mucho tiempo, aun despues de haber emprendido su vuelo. A la manera que el pardillo, el jilguero elegante no abando. na à su progenie cuando se la quitan del nido í fin de enjau. larla

\section{LOS PARDILLOS - CANNABINA}

CARACTRRES.-Con mucha razon se ha separado á los pardillos de los pinzones pam formar un género que se caracteriza por su pico cónico, redondiado, corto y muy puntiagudo; alas bastante largas, angostas y agudas, y cola cscotada.

DISTRIBUCION GEOGRßFICA.-LOS pardillos habi. tan solo el norte del antiguo continente.

\section{EL PARDILLO VULGAR-CANNABINA LINOTA}

CARACTÉRES. - Fste pardillo tiene la frente y la re. gion ocular de un blanco amarillento pardo; la coronilla de un magnifico rojo de carmin; la partc posterior de los lados de la cabeza y el cucllo de un gris ceniciento, con lineas de un amarillo rojizo: la region posterior del dorso y los hom. bros de un pardo de cancla, siendo los tallos de las plumas mas oscuros; la inferior es de un pardusco blanco; la rabadilla de un blanco sucio; la garganta y la barbilla de un blanco pardusco, con lineas y manchas de un gris oscuro; el centro del pecho, el vientre y las tectrices inferiores de la cola son blancos; los lados del jecho de un rojo de carmin muy vivo; los costados de color canela claro; las rémiges primarias negras, orilladas en anbos lados de un bolanco de nieve y en la punia de un pardusco claro; las secundarias de un negro pardo, con un ancho borde de color claro de canela; Ias plumas de los hombros y las tectrices superiores de las alas tienen los ángulos de un amarillento de orin; las rectrices son negras, orilladas de pardo claro con ingulos blancos en ambos lados, excepto las dos del centro; las tee. tricas superiores de la cola son negras, bordeadns de blanco, y las inferiores de cste último color. Los ojos son de un pardo oscuro; el pico de un gris de plomo, mas oscuro en la base; los piés de un gris rojizo. La longitud de esta especie es de $f^{\circ}, 13$, por $0^{-}, 23$ de ancho de punta a punta de las alas: estas miden $0 \%, 073$ ! la cola $11^{5}, 055$ (fig. 2.99).

DISTRIBUCION GEOGRÁFICA. - Eil pardilio vuigar habita toda la Europa, el Asia Menor y la Asiria, yen invierno visita el noroeste de Africa, pero raras veces el ligipto. En Alemania abunda en todas partes, sobre todo en las re. giones donde hay colinas, alejándose de las altas montañas y los extensos bosques. 
EL PARDILLO DE LAS MONTAÑAS-CANNABINA FLAVIROSTRIS

CARACTERES. - Esta especie tiene la parte superior de la cabeza, los hombros y el dorso de color pardo amarillo, con manchas y fajas de un pardo oscuro; la nuca y los lados del cuello presentan un tinte algo mas claro; las plumas de la rabadilla son de un rojo purpúreo sucio; las cejas y el es. pacio que hay debajo de los ojos de un rejizo oscuro con viso amarillento; la líne? naso-ocular nardusca; la parte supe. rior de las mejillas presenta manchas dei mismo color; la garganta es de un anarillento rojizo óccuro; los lados del buche y del pecho del mismo tinte, mas elaro, con manchas negras longitudinales; ci cuntro del pecho y el vitutre de in blanco amarillento 6 blanco dè todo; los inuslos de un amarillento de orin; las barbas exteriores de las remiges son deun pardo rojo; las cuatro yrimeras tienen estrechos bordes de un blanco pardusco, $y$ las siguientes mas anchos $y$ blancos, siendo en todas los ángulos de este color; las tectrices superiores de las alas, de un pardo oscuro, presentan ángulos de un pardo amarillento de orin; las mayores tienen ademis un borde blanco amarillento de orin en la extremidad; las rectrices son de un pardo oscuro; las del centra están orilladas de pardo claro, $y$ las otras tienen bordes blancos. Los ojos son pardos; el pico de un amarillo claro, y en la primavera amarillo de limon; los piés de un gris de cuerno. En la hem. bra falta el rojo de la rabadilla. La longitud del ave es de $0^{\circ}, 1,3$ por $0^{\circ}, 225$ de ancho de punta í punta de las alas; estas tienen $0^{\circ}, 073$ y la cola $11^{\prime \prime}, 065$.

USOS, COSTUMBRES Y REGIMEN. - El pardillo es uno de nuestros pájaros mas bonitos, y de los mas buscados para las habitaciones joor su canto. \& El pardillo, dice mi padre, es socinble, alegre, vivaz y bastante tímido: fuern del tiempo de la reproduccion vive con sus semejantes en ban.

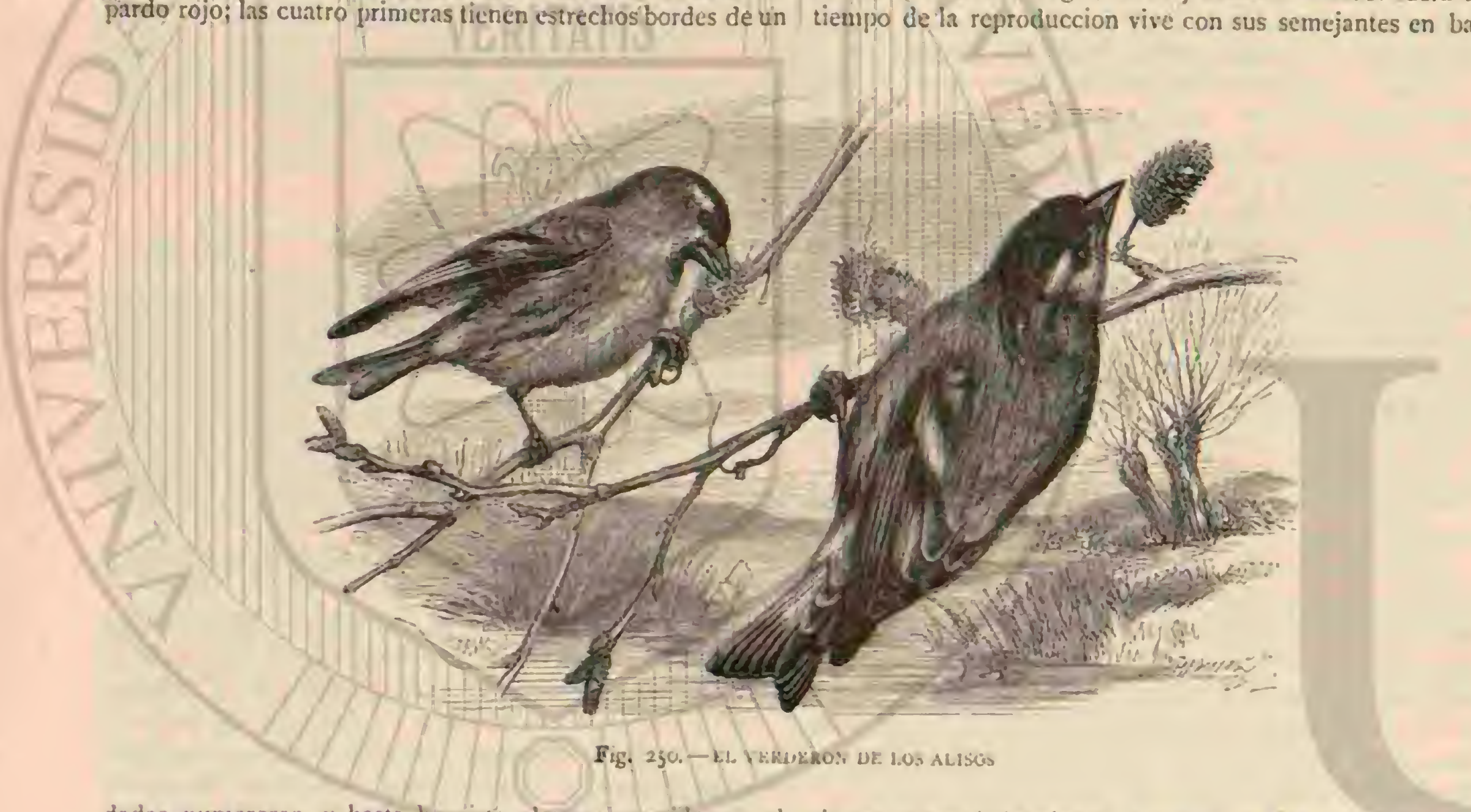

dadas numerosas, y hasta he visto alguncs reunidos en el alguna que sé halle aislada; tambien se sitúa en las breñas, periodo del celo. Llegado el otoho, y con frecuencia ya en y con preferencia en los pinos y abetos mas altos. el mes de agosto, se reunen por cenienares; en el invicrno se merclan con los verderones, tos pinzanes comunes, los de las montanas, y los gorriones; sepáranse en la primarera y se aparean, pero continuan viviendo unos cerca de otros en buena armonia

- Duranie el periodo del celo vaga el pardillo de un lado á otro: todas las primaveras veo llegar a mi jardin una hem. bra cuyo nido está situado á un cuarto de legua de distancin. Cuando la pardilla no cubre los hucros, acompañala el macho en sus peregrinaciones; $y$ asi es que se les ve casi siempre juntos.

- He observado á menudo con sentimiento el tierno anor que se profesan; cuando matan á uno, vueha el otro mucho tiempo á su alrededor, llamandole sin querer alejarse, y pro. curando llevarle consigo. Manifiestan el mismo amor á su progenie, y caen fácilmente en los lnzos donde ven $a$ sus hi-juelos.

\$Su vuelo es bastante rápido, y vacilante cuando el pájaro quiere posarse: muchas veces vuela el pardillo describiendo circulos; otras va rasando el suclo como para posarse, y ele. vándose de pronto, recorre todavia un gran espacio.

- En tierra salta con bastante ligereza: para cantar legusta posarse en la rama nas alta de un airbol ó en el cxtremo de

Supne mi padre que el canto del pardillo es bien conocido: limitase á decir que canta, ya esté posado óvolando, des. de el nes de marzo al de agosto, y que los pequeños se dejan oir despues de su primera muda, 6 sea en los meses de no. riembre y dicicmbre. El grito de llamada del pardillo es un sonido equivalenie á gack ó graesker, lanzado con fuerza y re. petido varias veces: si observa algo sospechoso, sigue á este sonido un ir sonoro. El canto es de los mas notables, com. parado con el de los demás pájaros; comienza de ordinario por un gocskgacek mezclado con notas a plautadas, emitidas con brio. Por el mes de abril es cunndo comienza ia pardilla á fa. bricar su nido, y pone dos ó tres reces al año. Está situado en un bosquecillo aislado ó en el lindero del bosque, muy cerca del suelo, y se compone de ramitas, raices, yerbas, etc., mas finas por dentro que por fuera; el interior está relleno principnimente de crines. Cada puesta es de cuatro ó cinco huevos, de color blanco arulado, con algunos puntos y rayas de un rojo pálido, rojo oscuro 6 pardo cancla la hembra, única que los cubre, está sobre ellos trece ó catorce dias; los padres alimentan á su progenie y permanecen largo tiempo con ella, particularmente con la uiltima pollada. Mientras la hembra cirbre, visitala el macho con frecuencia, se posa so. bre un árbol próximo y canta á cuello tendido. 
Al contrario de los pinzones, los pardillos se llevan bien: durante la estacion del celo: los machos cuyas hembras estain cubriendo los huevos vuelan \& menudo juntos y se reunen para cantar, sin pelear nunca.

Mi padre refierte el hecho siguiente: cDescubri un nido donde piaban los pequeños, y pude observar a mi gusto las costumbres de estos pájaros; estuvieron en aquel mientras carecieron de plumas, y solo se les oia cuando los padres les lievaban de comer. Apenas les salió la pluma no dejaron ya oir su vor, y adquirieron pronto bastante fuerza para volar. Cierto dia comenzaron todos à batir las alas, repitiendo estos movimientos hasta por la tarde; $y$ à la maủana siguiente, appenas rayó e! alba, habian emprendido todos su vuelo. Mante. nianse ocultos en el follaje, cerca del nido, revoloteando de un lado å otro, hasta que por fin se alejaron en compañia de sus padres.

- Fistaban estos bastante domesticados para no asustarse al verme, aun cuando fuesen conmigo algunas personas.

- Llevaban de comer à su progenie á cada doce ó diez y" seis minutos: iban juntos siempre; posábanse en un manzano vecino; lanzaban ligeros gritos de liamada, y se dirigian des. pues al nido por el mismo lado invariablemente, secibicndo

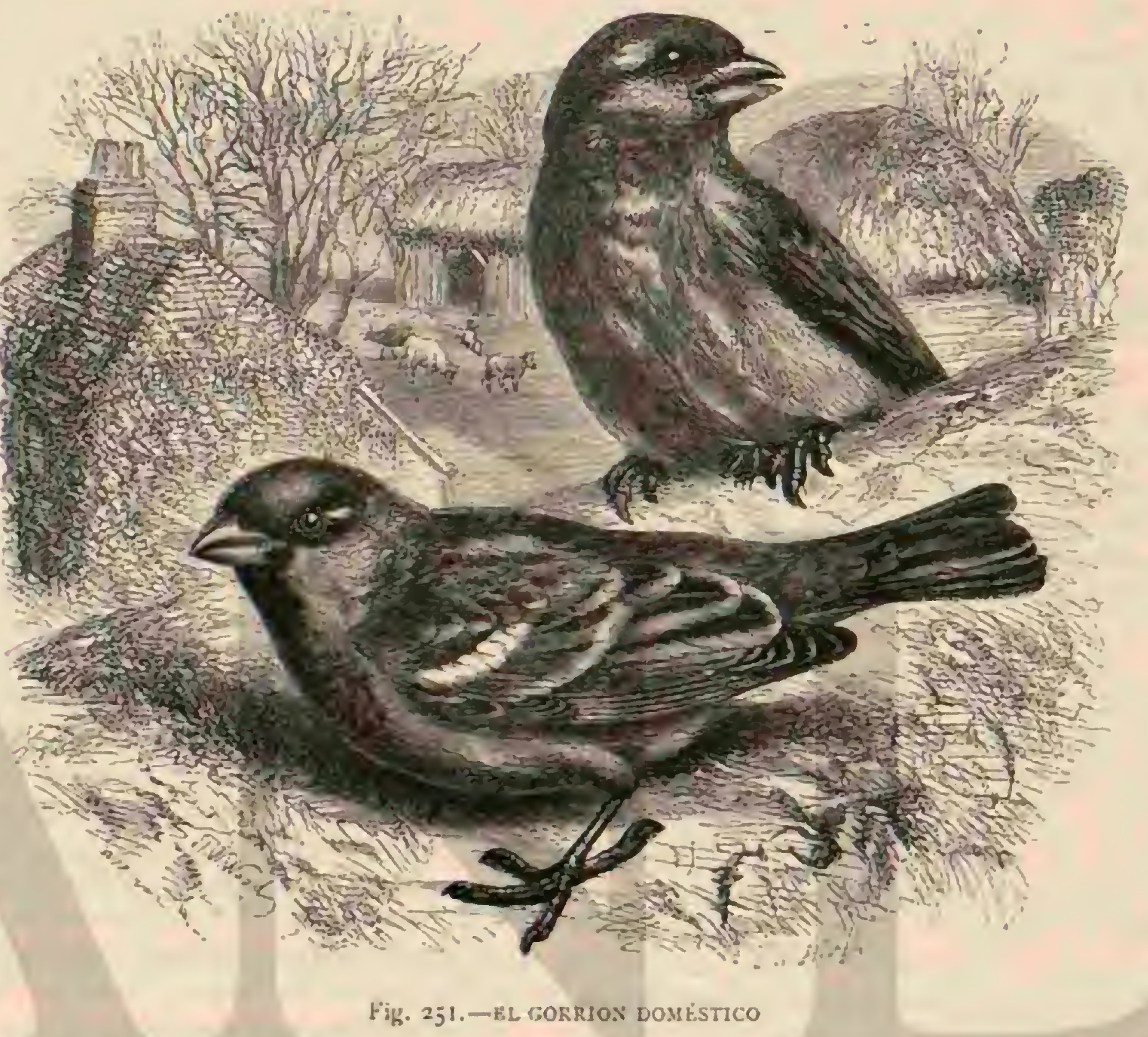

entonces cada hijuelo en el pico su parte de alimento. Ei macho era siempre el primero en hacer la distribucion; esperaba luego à que la hembra yracticase lo mismo, jon seguida emprendian los dos su vuelo, piando en sental de llamada: una sola vex llegó la hembra sin su companero, y solo enton. ces dió de comer á su progenie primero que êl.

- Antes de abandonar el nido quitaba la pardilia todos los excrenentos; pero no los tiraba al suclo, sino que se los tra. gaba é iba á expelerlos despues mas léjos: el macho nó se cuidaba tanio del aseo; solo una vez le ví imitar en esto á su compañern. I.a pardilla procede asi para que los excrementos no indiquen dónde se halla su nido; otros pájaros hay que bacen lo mismo.

* Despues de haber comenzado á volar, los pequeños estuvieron largo tiempo con sus padres, que los conducian y ali. mentaban.

Rara vez abandonan las pardillas sus huevos, y jamás su cria, a la que continuan alimentando aunque se halle en jaula. Los aficionados se aprovechan a menudo de tal cir. cunstancia para evitarse la molestia de cuidar \& los pequeños: y yo no sé de ningun caso en que los pardillos hayan rehusado cumplir con los deberes paternos Se puede atraer á los padres á larga distancia de su antiguo nido alejando poco a poco la jaula donde se halla la cria; pero esto tiene un inconveniente: criados asi los hijuelos, contintian siendo salvajes y timidos; mientras que se domestican muy pronto los que alimenta uno mismo.

Ll pardillo se alimenta casi exclusiramente de simientes; pero no se le considera en ninguna parte como muy dañno, à no ser que se le haga responsable de las fechorins que al parecer comete al comer las simientes de col, zanahoria, lechuga y otras plantas de nuestros jardines. Sin embargo, alinréntase sobre todo de las semillas de las malas yerbas, tal como las del llanten y diente del leon; agradanle en parti. cular las simientes de toda clase de col, cánamo y zanaho. rias, y sobre todo de gramineas.

CaUTIVIDAD. - El pardillo es con justo motivo uno de los pajaros mas buscados para las habitaciones: al cabo de poco tiempo profesa al hombre un cariño poco comun en los demás pájaros, y canta la mayor parte del año. Todos los verdaderos aficionados tienen pardillos: se mantienen fácilmente con grnnos de colza, y les gustan mucho las hojas de lechuga ó escarola.

Los machos que se cogen cuando son pequeños, apren. den con facilidad a repetir diversos aires $y$ las canciones de otros pajjaros; pero con la misina se acostumbran á emitir sonidos desagradables y se malcan muy pronto. Mi padre tenia un pardillo macho, el cual imitaba el canto del pirron tan admirablemente, que se le hubiera romado por uno de estos pájaros: tambien poseyó otro que cantaba como el ca. 
nario. Naumana habla de pardillos que aprendicron el canto del jilguero, de la alondra y del ruiseñor.

\section{LOS SICERINOS-LINARIA}

CARACTERES. - Ios sicerinos recuerdan los pardillos $y$ se asemejan at los verderones: tienen el pico muy prolongado, cónico, comprimido lateralmente y de punta delgada; la mandibula superior es un poco inas larga que in inferior; las fosas nasales, yequenas y redondas, se hallan en la base del pico y están rodeadas de flumas cerdosas bastante largas y espesas; los piés son fuentes y contos, con deàns pro. vistos de uñas grandes, muy corvas y afiladins jas alas, de longitud regular, tienen las tres primeras rémíges mas largas: las rectrices son de mediana longitud, pero las del centro mucho mas cortas, de modo que la cola presenta unal sesgadura bastante profunda. En el plumaje, mur abundante, predomina el color pardo pálido; la cabcza de los machoos tiene siémprc, sin embargo, un color rojo mas $\delta$ menos vivo.

\section{EL SICERINO VULGAR-LINARIA VULGARIS}

CARACTÉRES. - Esta especie es la mas comun del grupo. El borde de la frente y las plunitas cerdosis de las fosas, nasales son de un gris pardo oscuro; la linea naso. ocular, una mancha oval de la batba y la parte superior de la garganta de un pardo intenso; la frente y la coronilla de un rojo de carmin muy vivo; las plumas de esta region de un negro gris en la base; el occipucio y el resio de las regio. nes superiores de un pardo de orin pílido con fajas longitudinales de un pardo oscuro; las plumas de la rabadilla son de un rojo de carmin pálido, con bordes blanquizcos en los lados y tallos de un pardo claro; las tectrices superiores de la coln, de color pardo oscuro, tienen bordes blancos amarillentos en los lados; las mejillas $y$ la region de las orejas son de un paroo de orin con lineas mas oscuras; la garganta, el buche y los lados del pecho de un rojo de carmin; las plumas del centro de la garganta estan orilhadas de blanquizco; el resto de las partes inferiores és blanco, los costados de un pardusco de orin pálidó con anchas fajas lonnizudina. les oscuras, poco marendas: las fémiges, de un parco oscuro, tienen en sus barbas exteriores un angosto borde pardo, mas ancho y claro en las últimas rémiges secundarias; las tectrices pequeñas y las mas grandes presentan en la cxtremidad un ancho borde bianco rojizn, que forma dos fajas de color claro en las alas; las rectrices son de un pardo oscuro, con un estrecho borde rojizo de orin en las barbas exteriores $y$ uno ancho mas extenso en las interiores - bos ojos son de un pardo oscuro; Ia inandibula superior de un azul de cuerno; la inferior amarilla, y los, piés de un pardo gris. Las hembras $y$ los polluelos tienen inus poco color de carmin en el pecho $y$ en la rabadilla; cl buche $y$ cl pecho son de un pardusco de orin, con tallos oscuros; la placa roja de la cabeza es mas pequeñay de color menos vivo. La longitud del ave es de $0^{\circ}, 13$, por $0^{\infty}, 22$ de ancho de punta á punta de las alas; estas miden $11^{\prime \prime}, 07 \mathrm{y}$ la cola $0^{\circ}, 06$.

DISTRIBUCION GEOGRAFICA. - El frea de disper. sion de esta ave comprende la zona fria de ambos mundos, hasta donde llega la vegetacion arbórea; desde agui se tras. lada todos los años á las regiones mieridionales, presentán. dose á veces por bandadas innumerables en Alemania.

\section{EL SICERINO DE LAS MONTAÑAS - LINA- RIA RUFESCENS}

CARACTÉRES. - Lista especie se caracteriza por tener el occipucio, los ladus del cuello, el dorso, la rabadilla y los costados de un pardo de orin amarillento con manchas lon. girudinales de un pardo oscuro; la línea naso-ocular y una mancha de la ganganta son de un negro pardo; la frente y la parte anterior de la coronilla de un rojo de carmin oscuro; la barbilla y la region superior del pecho de un color sonro. sado prálido, con bordes blancos en las plumas; el resto de las partes inferiores blanquizco, con viso sonrosado; las tectrices inferiores de la cola tienen manchas longitudinales negruzcas; las alas y las rectrices, de un pardo negruzco, están orilladas en sus barbas extcriores de una estrecha faja de color blanco sucio; las últinas rémiges secundarias, las plu. mas de los hombros y las grandes tectrices de las alas pre. sentan anchos bordes de color de barro, cuyos bordes forunan dos fajas bien marcadas en las alas. Los ojos son de un pardo óscuro, el pico amariilento, mas oscuro en la punta y en lós bordes, y los piés negros. Ia longitud de esta especie

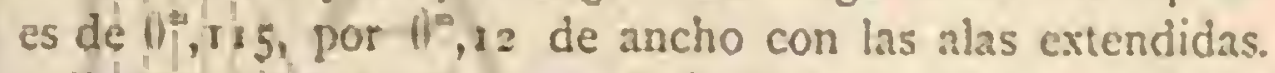

DISTRIBUCION GEOGRÁFICA. - El sicerino de las montañas anicla en Fscocia y en los Alpes orientales, sobre todo en los de Salzburigo, donde es muy frecuente, por ejenipla cerca de 'Tamsweg y I.ungau; 'Tschusi fué el primero en darnos noticias sobre esta especie, que, segun dice, habita de continuo en los Alpes.

\section{EL SICERINO DE PICO LARGO-LINARIA HOLBOELLI}

CARACTERES. - El sicerino de pico largo se asemeja por su color y tamaño a la especie conuun, pero distinguese por su pico mucho mas grande, y sobre todo mas largo, de color rivo de naranja con arista negra, cubierto en una tercera jarte por las plumitas de las fosas nasales.

DISTRIBUCION GFOGRÁ FICA. - La patria de esta especie, que algunos ornitólogos no consideran ni siqquicra como variedad, es la Groenlandia; desde aqui el ave emigra â reces por bandadas á Europa

\section{EL SICERINO BOREAL-LINARIA BOREALIS}

CARACTERES. - Fil sicerino boreal, llamado tambien sicerino gris, tiene el mismo tamaño del pardillo y su color en general se asemeja al del sicerino vuigar, pero siempre mucho mas claro, porque los bordes parduscos de orin de las plumas de este tiran en aquel mas á un blanco pálido. La rabadilla y las partes inferiores son casi de un solo color blanco; las últimas tienen en sus lados algunas linens finas de color oscuro en los tallos; la garganta, el buche y el pe. cho del macho presentan en invierno $y$ la primavera un ligero lustre rojo de carmin; las plumitas de las fosas masalcs cubrén mas de la mitad de la base del pico, álo cual se debe que este parezca en extremo corto y mas alto que iargo. los ojos son de un pardo oscuro; la mandibula superior de un negro de cuerno; la inferior-amarilla en invierno, y los piés de un pardusco oscuro.

DISTRIBUGION GEOGRÁFICA. - Eł área de dispersion del sicerino boreal se exticnde desde el Petschora por todo el norte de Asia y América hasta Grocnlandia, pero tambien esta ave visita la Alemania en inviernos rigurosos, a veces por bandadas mas ó menos numerosas.

USOS, COSTUMBRES Y REGIMEN. - Al recorret los inmensos bosques de abcaules de los paises del norte, se comprende porqué estos pajaros no llegan regularmente y en el mismo nuimero á nuestros países todos los inviernos. No necesitan emigrar mientras encuentran abundantes tos frutos de dichos árboles, que constituyen su alimento prin. 
cijal; solo cuando carecen de cllos se ven precisados a di. rigirse hácia otros palses. Por numerosas que senn las ban. dadas que a reces se ven entre nosotros, no se las juede comparar con las que pasan todo el año en su patria, puesto que en el norte encuentran estos pajaros inucho mejor to. das las condiciones necesarias para su existencia Los bos. ques de abedules cubren extensiones de varios centenares y hasta miles de miriametros cuadrados, $y$ ha de ser el verano muy malo para que aquellos súres no encuentren lo bastante para su alimento.

Necesita este pajaro dichos bosques pam vivir, como e! pico cruzado las coniferas: en el invierno encuentra granos y en verano insectos, principalmente moscas. Yo vi muchos al norte de 'Tromsoe; vivian en familias con sus pequeiros, que hacia poco habian dejado el nido, y los alimentaban con in. sectos sus padres; no cran fáciles de observar, ni consegui adquirir una cria. Los mosquitos llenaban de tal modo el bosque, que no se podia cazar sin sufrir grandes molestias y tormentos de que no es fácil formarse uma idea. En el lugar mismo donde se hallaban aquellos pájaros, todos los árboles y matorrales estaban materialmente rodeados de una nube de moscas; el que se aventuraba a cazar alli, era acometido al momento, y sufria picaduras an dolorosas, que no podia seguir adelante. En cuanto á los pájaros, encuentran alli fácilmente de qué alimentarse en verano, y se necesitan circunstancias muy excepcionales para que jadezcan hambre en el invierno: aquellos insectos y los frutos del abedul son wuy suficientes en ambas estaciones para suministrarles cuanto les pueda hacer falta.

Lo que hemos dicho basta para explicar que hasta ahora sean tan escasos uuestros informes sobre la vida de este pá. jaro en libertad. Poco despues de llegar por bandadas á los sitios donde anida, disuélvense estas mas o menos para dar principio ála consiruccion del nido. En el centro de la Escandinavia elige los bosques elerados de las montanas; en el norte anida tanto en las alturas como en las tierras ba. jas, con tal que los abedules constituyan la mayoria de los árboles. El nido se halla casi siempre á poca altura del sućlo, en alguno de los abedules que tienen forma de arbustos, y por su construccion se parece mas al de nuestro pardillo; liene la forma de una cacerola, cuyo fondo se compone de ramitas y las paredes de tallos; musgo y pelos, mientras que el interior está relleno de plumas. Ia puesta se compone cuando mas de siete huevos, de $\left(1^{m}, 017\right.$ de largo, por $1 ;, 01 . ;$ de grueso, de color verde claro con manchas y puntas de un rojo opaco y pardo claro. El macho canta, segun Collet, con mucha aficion durante el periodo del cclo, pero casi siempre volando. Es probable alterne con la hembra para cubrir los huevos, ayudándole en la cria de los polluelos, a los que. ali. merta solo con toda clase de insectos. Digno de notar es que aun durante la incubacion el ave demuestra su incons. tancin, presentándose muchos aỉos en gran múmero y por bandadas, mientras que en otros escasea y solo se la ve aislada.

No se sabe aun por qué conceptos difiere su reproduccion de las de otras especies. Luebbert; que en verano vió aun sicerinos en la montana de Cilatz y en el Ricsengebirge, y crevó haber recibido los hucros de una parcja, habla sin duda del sicerino cie las montainas. Détsemos comprender a este tambien entre las aves que anidan en Alemania, pues Yocher encontró sus nidos en los Alpes de Salzburgo. En las regiones llanas y formadas de colinas en Alemania, el sicerino vulgar se presenta a principios de noviembre para pasar alli el invierno, a veces jor grandes bandadas, y no siempre en los anos que tambien entre nosotros comienzan con un invierno riguroso. Reinese regularmente con el verderon y recorre con este el pais, albergándose de noche en las espesuras espinosas. Wagner asegura haber visto varios individuos de una bandada que se precipitaron de noche sobre la nieve para reposar en ella, y asegura además haber cogido algunos en aquella ocasion.

Mientras se halla entre nosotros el sicerino boreal se alimenta prejerentemente del fruto del aliso y del abedul, y de granos oleaginosos.

En los primeros dias de su llegada no parecen conocer estos pajjaros la malignidad del hombre, pues avanzan hasta los pueblos, buscan su alimento, y no les intinida la proximidad de su enemigo: cuando se les ha dado caza algunas veces, proceden con mas prudencia, sin ser por ello tínidos.

Este pájaro se distingue por lo alegre, lo vivaz y aigil; siempre está en morimiento; trepa mejor que los otros frin. gilidos y rivaliza por tal concepto con el pico cruzado, y hasta con los paros. Curioso de ver es el ramaje filiforme de un abedul cubierto por una bandada de tan bonitos pájaros: se suspenden tomando las mas rariadas posiciones, y pican los frutos con verdadero frenesi; no es la tierra extraña para ellos; bajan mas á menudo que sus congéneres y saltan con mucha ligereza. En su rápido vuelo trazan lineas onduladas: para franquear espacios sin árboles, remóntanse por los aires a bastante altura; mientras que en los sitios cubiertos de bosçue, permanecen cerca del suelo. Su grito de llamada podria traducirse por fschellschek: le lanzan en el monento de emprender su vuelo, y a menudo ra seguido de una es. pecie de miss muy suave: el canto se compone de cstos dos sonidos, enlazados por un silbido fuerte.

Es muy sociable este pájaro con sus semejantes y otras especies afines: cuando se ha formado una bandada no se separan ya; todos los individuos que la componen llaman a gritos a los que se alejan un poco ó pasan cerca. Asócianse con los verderones, y si no los encuentran, con los pardillos vulgares y los gorriones, viviendo todos en muy buena inte. ligencia, sin pelear nunca.

CAZA. - No son dificiles de coger estos pajaros en un laro bien dispuesto: su instinto de snciabilidad les pierde, pues cuando uno de ellos queda preso atrae á los demás, que sufren la misma suerte. Para apoderarse del primero se fjan en el extremo de una pértiga larga y flexible unas varitas de liga, con las que se tocan las alas del animal mientras come; para manejar aquella se necesita alguna destrear; pero como el pajiaro es bastante estupido, se deja coger por tan sencillo medio. Con las redes quedan presos muchos in. dividuos, y se da el caso de que vuelvan á buscar a sus com. pañeros cautivos los que cscaparon, déslizándose debajo de cllas: en varios puntós se les caza solo para comer su carnc.

CAUTIVIDAD.-Ios individuos que se enjaulan se do. mestican muy pronto y se contentan con el régimen mas sencillo. Seducen \& la vista por su agilidad y sus movimicntos; no tardan en trabar amistad con los orros pajarillos, y los acarician continuamente.

\section{LOS GORRIONES - PASSER}

CARACTERE.S. - L LOS gorriones son fringilidos de estruCtura sólida, rronco corto, pico de longitud regular y grueso; piés fuertes y uñas cortas y endebles; las alas son obtusas; las réniges segunda, tercera y cuarta forman la punta; la cola es corta, ó cuando mas de longitud regular ! apenas sesgada en su extremidad: el plumaje es abundante.

\section{EL GORRION COMUN - PASSER DOMESTICUS}

CARACTERES. - Esta especie es la mas conocida del 
genero. la parte anterior de la cabeza y el centro de la coronilla son de un gris pardusco; las plumas están orilladas de pardo rojo, mas pélido en la punta; una ancha faja que se corre desde los ojos por las sienes y los lados del cuello hasta la nuca, son de un pardo castano; cl manto y los hombros del mismo color, mas claro, con anchas fajas longitudinales negras; las plumas del manto tienen en las barbas exicriores un borde rojo canela; las plumas de la rabadilla y las tectrices de la cola son de color gris pardusco, con puntas rojizas; una manchita en cl bordé posterior de los ojos, las mejillas, la region de las orejas y la parte superior de los lacios del cuello son blanoos: la linea naso-ocular, el borde de los ojos, la region de los ingutos de la boca, una gran mancha en forma de escado que cubre la barba, la garganta y la region de la cabeza son de color negro: el resto de las partes inferiores blanco; los costados de un gris ceniciento; lis rémiges de un pardo oscuro, orillndas on sus barbas ex. teriores de pardo de orin, y en las interiores de un borde mas claro poco marcado; las tectrices de las rémiges secundarias, de un negro pardo, presentan anchos bordes pardo canela en las barbas cexteriores; las tectrices superiores de las alas son de un plardo castano; las mayores negras en la base y blancas en la extremidad, formándose así una faja trassersal en las alas: las rectrices de un pardo oscuro. Los ojos son pardos; el pico negro, y en invierno gris claro con la punta mas oscira: los piés de un parciusco amarillo. La hembra tiene las partes superiores de un pardo pullido de orin, con lineas negras longitudinales en el manto; una faja que se corte desde el borde de los ojos sobre las sienes es de un blanco amarillento de orin; las mejillas, los lados del cuello y las partes inferiores de un pardusco gris; la barba, el pecho, el centró del vientre $y$ la region del ano, de un color blanco sucio? las tectrices inferiores de la cola son de un pardusco claro de orini las tectrices de las rémiges están orilladas de un pardo pálido de orin en las barbas exteriores, y las gue forman la faja trastersal de las alas tienen las puntas de un blanco sucio; el jico es pardusco de cuerno. Ios polluélos se parecen á la hembra La longitud de esta especie es de $11^{*}, 016$, por $0^{*}, 025$ de ancho de ala a ala; esta mide $1^{m}, 075$ y la cola $B=, c_{3 j}$ (fig. 258 ).

DISTRIBUCION GEOGR AFICA. - Dil área de disper. sion del gorrion comun se extiende por casi toda la liuropa y la mayor parte de Asia; en el norte hasta donde llegan las colonins, y en el sur hasta el norte del Africa, Palestina, el Asia Menor, India y Ceilan. Tambien ha penetrado en Aus. tralia y el norte de América, en Java y la Nueva Zelanda.

En el sudeste de Europa, Asia Menor, Palestina, Siriay los paises del mar Rojo le representa el gorrion de cabeza roja (J'asser ilalic), que se le asemeja portamaño y color en general, difiriendo sin embargo por los siguientes caractéres distintivos: la parte superior de la cabeza y la nuca son de un solo color rojo; en el buche se ve una placa negra, cuyas plumas tienen los bordes grises mas anchos; la línea naso ocular tiene una angosta línea blanca y las plumas de la rabadilla y tectrices superiores de la cola son de color par. do gris

USOS, COSTUMBRES Y RFGIMEN.-ES condicion caracteristica de esta especie vivir en intima relacion con el hombre alli donde se la encuentra. Habita tanto en la gran ciudad como en el pueblecillo solitario, siempre que esté rotieado de campos de trigo, faltando solo en algunos pue. blos inmediatos a los bosques; sigue al colono en todos los paises del Asia donde antes no se le veia; descie los bosques se traslada á las islas donde antes no cra conocicio; y perma. nece en las ruinas de las poblaciones destruidas, como testigo viviente de otros dias mas felices. Apenas se aleja de los recintos de la ciudad ó de los limites de los pucblos, pero se posesiona muy pronto de las nuevas construcciones, 6 de una casa recientementa edificada. Algunas reces cmprencie viajes para explorar paises que se hallan fuera de su área de dispersion. Asi, por ejemplo, se presenta por parcjas en las orillas del Varanger-lijord casi todos los años; examina el pais y visita todas las habitaciones, pero desaparece otra vez sin dejar vestigio, cuando no le agrada la localidad. Sociable en exiremo, solo durante la época del celo sep̧rárase en parcjas, aunque sin evitar por eso la compania de las otras.

Con frecuencia anida una al lado de otra, y por celosos que sean los machos, sc buscan continuamente mientras cu. bren las hembras. Aprenas emprenden los pequeños su vuelo, forman grandes bandadas, y cuando los padres terminan la educacion de la progenie, se reunen con cllas para seguir su suerte. En tanto ciue los campos estén cubiertos de sus co. sechas, todos los dias se ve a los gorriones abandonar en masa el pueblo, diseminarse por la campina y volver mas tarde á su retiro. Descansan al medio dia en espesos ảrboles y con preferencia en cercas; por la tarde se reunen con gran algazara, y alli pasan la noche 6 van a buscar un refugio en las granjas, en los cobertizos y otros sitios semejantes. En invierno construyen verdaderos lechos, que consisten en blandos nidos, muy bien rellenos, propios para resguardarse del frio. Cón este objeto se albergan asimismo en las chi. meneas.

Por torpe quise parezca el gorrion a primera vista, no deja de estar bien dotado. Salta pesadamente, pero no sin cierta rapidez; vucla con grandes esfuerzos, y aleteando aceleradamente, franquea grandes distancias describiendo lineas algo arqueadas al principio y luego rectas, $y$ antes cle posarse en un árbol extiende un proco sus alas. Por mas que le agraden las casas altas, rara vez se eleva mucho; mas á pesar de su torpeza aparente sabe muy bien arreglarse en todo; estábien dótado resprecto á la inteligencia, y gracias á ella ha logrado conocer poco á poco el hombre y sus costumbres, tanto que verdaderamente asombra y divierte al observador minucioso. En todas partes y en todas las circunstancias el gorrion se muestra mas 6 menos activo segun el carácier del hombre, $y$ de consiguiente no se conduce del mismo modo en la ciudad que en cl pucblo. Alli donde se le protege familiarizase mu. cho, llegando á ser casi molesto; pero muéstrase timido donde se le persigue, cauto y astuto. Nada de lo que puede serle útil ó hacetle daño pasa desapercibido à su penetrante vista: su experiencia sumenta de ano en ano, y se reconoce entre adultos y jórenes la misma diferencia que entre un sabio y un estúpido. Tambien con otros séres se reune mas $\delta$ menos amistosamente: tan pronto se fia como desconfia del prerro; manifiesta al caballo simpatia; advierte á sus semejantes y a otras aves para que teman al gato; robat la gallina los granos por delante del pico sin hacer caso de sus amenazas; y come de la misma cazuela con los mas diversos animaies si estos se lo permiten. A pesar de su sociabilidad rine continuamente con otros pájaros cuando estos tienen la misma intencion que él, por cjemplo, cuando se trata de saquear un àrbol frutal; y cuando le donina el amor, que en êl despierta los mas violentos celos, lucha con sus rivales tan furiosamente que podria creerse que se trata de un duelo mortal, aun cuando todo se reduce a la pérdida de algunas plumas. Solo por un concepto no puede este pájaro interesarnos en manera algu. na: pia del modo mas insoportable y su canto no merece el nombre de tal. Schill, schilm! y fich son sus gritos de llamacia, los cuales repite con tania frecuencia que puede aburrit al observador mas indulgente; y cuando se ha reunido una mu. merosa bandada, su tell tell, silh, dell, diel, schilk llega á ser 
verdaderamente insoportable. El gorrion produce sin embargo unos sonidos mas suaves para manifestar su carijo i la hembra, sonidos que podrian traducirse por duirr y dif; pero su canto, en el que todos estos sonidos constituyen la parte principal, no puede ser de nuestro agrado, $y$ las voces terr ó tell, terer, tell, tell, tell de que se sirve para advertir á sus compañeros, $\delta$ cuando súbitamente les amenaza un riesgo, ofenden verdaderamente nuestro oido. A pesar de cllo, el gorrion grita, canta y produce ruido, cual si estuviera dotado de una vor. de ruiscricr: los polluelos hacen ya en el nido sus estudios.
Merced a las condiciones favorables en que se halla el gorrion por su contacto familiar con el hombre, que fácilmente le proporciona su alimento, comienza muy pronto à construir su nido é incuba durante el verano al menos tres, y aun cua. tro veces «Deshonesto en extremo, sirviéndome de las mismas palabras de Gessner, el macho expresa sus deseos piando de continuo, $y$ la hembra le demuestra su buena voluntad tomando toda clase de posiciones; agita las alas y produce un dic, die die en extremo cariinoso. Despues sigue el aparea. miento, $\delta$ al menos una tentativa para efectuarle; poco despues vuelven as declararse el amor $y$ realizan el acto.

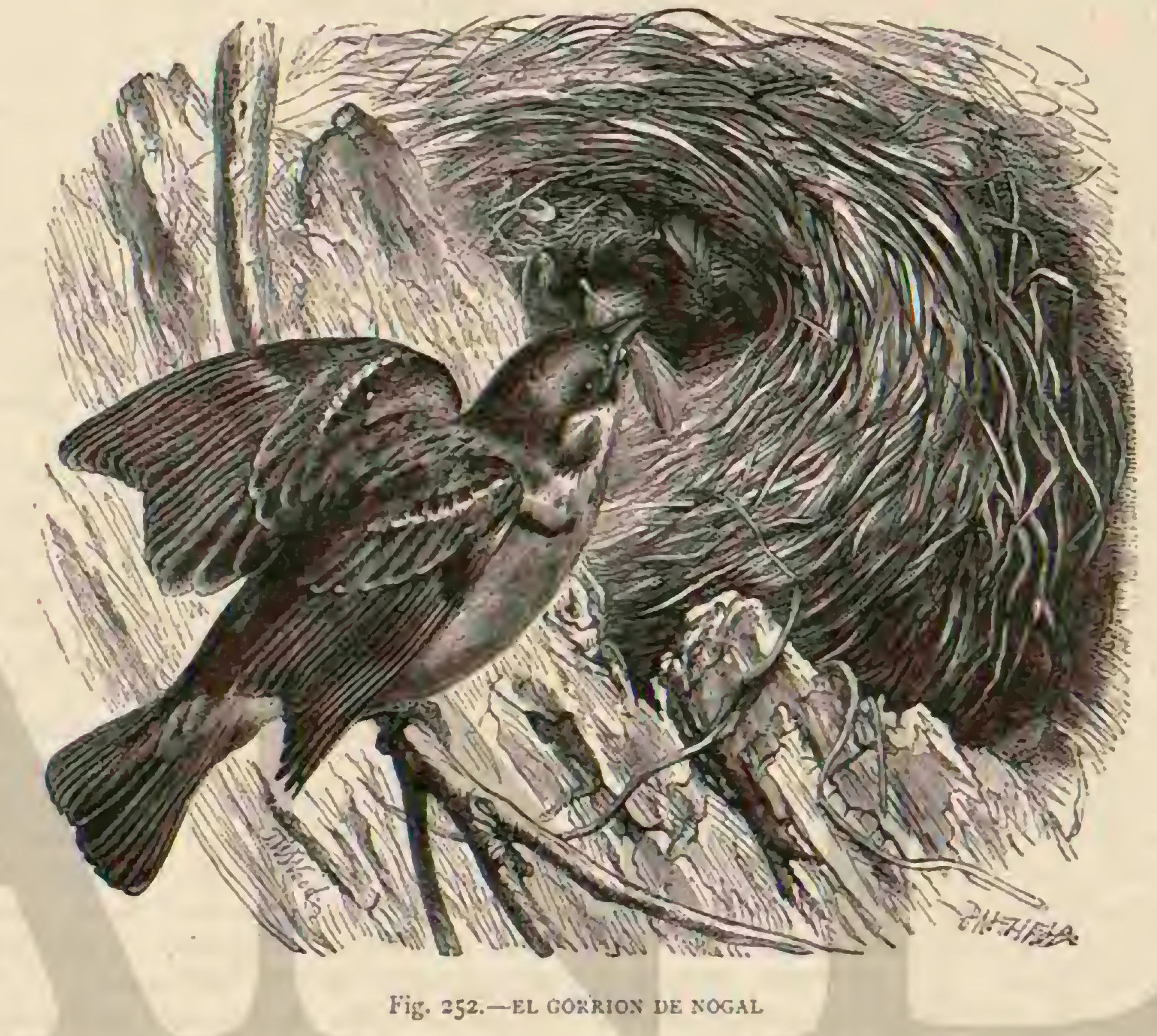

El nido varia segun la localidad: por lo comun està situado en el agujero de una tapia 6 en cl hueco de un árbol; otras veces se alberga este pajaro on algun nido de estornino 6 golondrina, $\delta$ en el fondo del de una cigūcna: nótase por úl. timo que anida entre las ramas de un árbol, cuando no en alguna breria. Como hemos dicho ya, varia el nido, segun ef sitio donde se construye: pero nunca pasa de ser una masa mas ó menos informe de paja, heno, ramitas, lanas, pelos, trapos y pedazos de papel cubièto todo interiormente por una capa de plumas. Los nidos que se halian en los árboles tienen por encina un tejadillo, del cual carecen á menudo los que hay en las cavidades.

Cuando el año se presenta bien, la hembra pone en marzo pos primera rez, comunmente de cinco á seis huevos, y solo

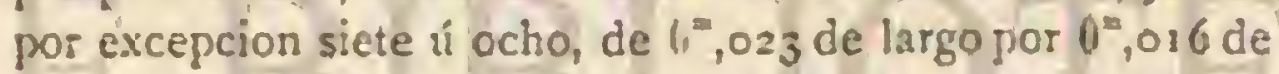
grueso; la cåscara es tenue, poco brillante, azulada ó de un blanco rojizo, con diversas manchas de pardo y gris. Los padres cubren alternativamente por espacio de trece ó catorce dias; comienzan por dar insectos à sus pequeños, despues granos medio digeridos en el buche, y por último cereales y frutos. A los ocho dias de haber volado los hijuelos, apa. réanse de nuevo los padres, reforman el nido, y quince dias despues vuclve á poner la hembra, continuando asi hasta el mes de seticmbre.
El padre y la madre cuidan de su progenie con la mayor ternura, olvidando entonces su acostumbrada prudencia, y si cualquicra de ellos muere, el que sobrevive despliega mayor actividad para dar de comer á los hambrientos hijuelos, y cuando uno de estos no puede salir del nido, le alimentan los padres mientras carece de la libertad.

USOS Y PRODUCTOS. - Las opiniones sobre la utilidad y el daño que causa el gorrion son muy diversas; pero últimamente predomina mas y mas la opinion de que este parssito, que vive à expensas del hombre, no merece nuestra proteccion. Ciento que no causa dano en las calles de las ciudades y de los pueblos, porquıe aqui se alimenta principalmente de despojos; pero en cambio puede ocasionar perjuicios muy sensib!es en las grandes casas de labranza, en los graneros, campos de trigo y jardines, pues roba á las aves domésticas su alimento, come y ensucin el irigo, destruye los retoños en los árboles frutales, y no desprecia tampoco la fruta. No debemos tolerarle por lo tanto en los jardines ni en las vinas. El daño mas considerable que el gorrion ocasiona consistc, sin embargo, como dice muy bien Eugenio de Homeyer, en que ahuyenta á las aves mas útiles, sobre todo á los estorninos y los picoparos, molestando tambien á las aves cantoras en los jardines que ocupa. No trataré de averiguar si el daño causado por cada pareja de gorriones con sus polluelos cuan. 
do invernan en una region puede evaluarse en dos francos cincuenta céntimos ó en cuatro francos, segun lo asegura Eugenio de Homeyer; pero en vista de las observaciones de este excelente naturalista, de grado $\delta$ por fuerza me veo obligado á declararme en favor de los que opinan que el gorrion no es digno de la indulgencia que antes he pedido para él.

CAUTIVIDAD. - El gorrion no es propio para la jaula, aunque puede domesticarse mucho. La criada de uno de mis amigos de Carintia me enseñó con orgullo "su favorito, un gorrion que no solamente salia y entmba libremente, sino que descansaba y dormia tambien en el seno de su ama.

\section{EL GORRION DE COLLAR - RASSER HISPA- NIOLENSIS}

CARACTERES. - Algunos naturalistas consideran á esta especie, llamada tambien gorrion de los pankanus, cono úuica variedad de nuestro gorrion comun, pero se distingue no solo por el color, sino tambien por su género de vida, de tal modo que no puede dudarse de su independencia como especie Su longitud es de $0^{m}, 16$, por $1,, 25$ de ancho de punta a punta de las alas; esta tiene 1), 065 y la cola (1), 06 de largo.

La parte superior de la cabeza, las sienes y la nuca son de un pardo rojo castaño; la linea naso-ocular; una estrecha linea que hay debajo de los ojos, el mantos los hombros son negros; las plumas de estos ưltimos tienen anchos bordes de un amarillento de orin, pero casi sienupre están cubiertos; las plumas de la rabadilla son negras, con bordes leonados; una angosta linea que desde las fosas nasales se corre hasta las cejas, Las mejillas, la region auricular $y$ lis partes superiores de los lados del cuello, blancas; la barba, la garganta y el buche, hasta la region inferior del cuello, negras con angostos bordes grises en las plumas, que forman una especie de collar; cl resto de las partes inferiores y las tectrices inferio res de las alas son de un blanco pálido amarillento; los cos. tados tienen anchas líneas negras en los tallos; las rémiges, de un pardo oscuro, presentan en sus barbas exteriores un angosto borde pardo leonado de orin, mas ancho en las rémi. ges secundarias; las tectrices superiores de las alas son de un pardo rojo vivo; las mayores negras en la base y blancas en el resto de su extension, por lo cual se forma una raja tras. versal de brillo metálico; y las rectrices, de un pardo oscuro, estån bordeadas de leonado en las barbas exteriores. Los ojos son de un pardo de vierra; el pico negro de cuerno, y en in. vierno de color claro de cuerno; los piés parduscos la hem. bra se parece á la del gorrion doméstico, pero su plumaje es muclio mas claro; las partes inferiores son de un blanco amarillento; en la garganta hay una mancha gris negruzca, poco marcada; $y$ en cl pecho y los costados angostas lineas longitudinales de color oscuro.

Distribucion GEOGRÁrcA.- Hi gorrion de los pantanos se encuentra en Espana, en Grecia, en el norte de Africa, en las islas situadas al noroeste de aquel continente Y tambien en ciertas partes del Asia.

USOS, COSTUMBRES Y REGIMEN.-Busca con pre ferencia, al menos en España y Egipto, los parajes donde hay mucha agua: es un verdadero pajaro del campo, que solo se acerca accidentalmente a las moradas del hombre; y si bien es verdad que no las evita, no es menos cierto que tampocó las busca. En Espana y en Egipto es donde se pueden ob. servar principalmente las diferencias en la manera de ser de este gorrion y de su congénerc doméstico: este es cl fiel com. pañero del hombre; el otro no se cuida de él. Frecuenta sobre todo las orillas de los rios y canales, los pantanos y arrozales, apareciendo en bandadas sumamente numerosas. En España vi muchos en el valle del Tajo, pero siempre muy cerca del rio; en Egipto cra el pajaro que hallaba con mas frecuencia en el Delta y en las márgenes del Nilo. Savi, Bolle, Haus. mann, el conde von der Muhle y Homeyer, han hecho las mismas observaciones en Cerdeña, las Canarias, Grecia y los paises del Atlas.

Sin embargo, Bolle nos dice que las palmeras atraen tambien al gorrion de que se trata, hasta el punto de que abandona los pantanos y observa el género de vida del gorrion domés. tico. Seguro es encontrar este pájaro alli donde los pueblos estén rodeados de palmeras, sobre todo cuando es el único representante de la familia de los paserinos, como sucede en las Canarias. Busca las copas de las pralmeras, dice Bolle, pan establecer su nido; ’ estos árboles, que planta el hom. bre alrededor de su morada, le han familiarizado con el rey de la creacion. Lo mismo sucede en Egipto: el gorrion de los pantanos habita las palmeras situadas cerca de los pue. blos, y se aleja de estos cuidadosamente cuando no encuentra dichos árboles. Sin embargo, no se crea que le bastan para su existencia, toda vez que no se ve al gorrion en todo el alto Egipto y la Nubia, donde los bosques de datileras cubren espacios inmensos. En las Canarias, añade Bolle, ni uno solo de aquellos árboles, que elevan al aire su majestuo sa copa, deja de tener nidos de gorriones en las hojas mas bajas; alli donde las palıneras forman bosquecillos abundan aquellos pajaros en número considerable. Como se necesita mucha destreza y paciencia para trepar à lo alto de los troncos, anidan alli los gorriones con toda seguridad, y esto explica su asonibrosa multiplicacion. Miran sin temor al terrible halcon (Timmursulus aloudarius), que se posa cerca de ellos; sus gritos y continuo piar se mezclan con los silbidos del viento, que ązota con violencia el espeso follaje de las palmeras. En aq̣uellos juntos en que sopla una húmeda brisa, como por ejenulo, en la Vega de Canaria, la naturaleza ro dea los nidos de gorriones de jardines aéreos, mas hermosos, mas ricos que los de Serniramis: el viento arrastra por entre los huecos de las hojas tierra y arena, que luego es regada por las lluvias, y bien pronio se ve a una vertiginosa altura, cómo reverdece y se presenta todo un pensil de rosas cinerarias, de helechos primorosamente labrados, y de azufaifos arborescentes, etc. Esto solo se encuentra, sin embargo, en ciertas localidades privilegiadas; la morada de estos pájaros es por lo general mas sencilla, $y^{\circ}$ hasta dos veces les he visto dejar sus árboles favoritos, con el objeto de hallar su alimen. 10 con mas facilidad. En la rica y hermosa hacienda de Maspamolas, al sur de Canaria, no hay palmeras, pero si ininen. sos campos de trigo y eras vastisimas, donde se llevan las cosechas, que por el método antiguo se hacen trillar por los buejes, los caballos y los nutos, que trotan en circulo. Estas cras son para los pájaros granivoros ún punto de rcunion; llegan en masa a fin de buscar los granos que han quedado en la paja; y los gorriones que forman parte de aquella, como lo hacen en nuestros paises, han fjado su domicilio en los naranjos $\delta$ en los agujeros de las tapias. \& En otro punto vió Bolle gorriones de los pantanos que anidaban a centenares debajo del tejado de una iglesia.

Por todas sus costumbres se parece mucho este pájaro al gorrion doméstico; pero opino con Homeyer, que su vuelo es anas rápido, y que cuando va con sus semejantes, constituye lineas compactas, lo cual no lacen las otras especies. Ml ver las bandadas que forma en Egipto, diriase que son verdade. ras nubes que cubren los arrozales; los individuos se oprimen de tal modo unos contra orros, que se pueden matar muchos de un solo tiro.

Por la vor. se diferencia el gorrion de los pantanos del do méstico; pero no me es posible especificar bien en qué difie re. Homeyer, que tiene el oido mas fino, dice que la roz del 
primero es mas fuerte, mas pura y sariada que la del segun. do; si bien produce este ciertos sonidos que le son propios. aNo es de esperar, dice, una gran diferencia entre los dos; pero creo que solo por la voz se puede distinguir el gorrion doméstico del de los pantanos, y con mas seguridad que en otras especies, como por ejemplo ciertos picos crurados, los cuales difieren mucho por otros conceptos Me hallo en el caso de resolver sobre este punto, porque tengo en jaula dos gorriones de los pantanos de Argel, uno de los campos y otro doméstico.

Bajo el punto de vista de la inteligencia iguala el gorrion de los pantanos \& su congénere: es mas timido, mas receloso, $y$ se ha familiarizado menos con la sociedad del hombre.

En Canarias y en Egip:o comienza el periudo del celo para este pajjaro en el mes de febrero, $\delta$ en los primeros dias de marzo a mas tardar; en dicha época estan llenas de nidos todas las palmeras del Delta, y tambien todos los huecos de los troncos. El nido es como el del gorrion doméstico, y solo consiste en una masa irregular de diversos materiales: los huevos se parecen tanto álos de nuestrogorrion, que los mas expertos inteligentes no pueden distinguirlos. En el mes de mayo, cuando los hijuelos de la primera cria han emprendido su ruelo, los padres anidan de nuevo, y mas tarde lo hacen por tercera vez.

El gorrion de collar no tiene amigos en ninguna parte $y$ bastante razon hay para juzgnrle desfavorablemente. En los arrozales de Egipto ocasiona graves perjuicios por su asombrosa multitud; en Palestina, donde tambien abunda en ex: tremo, se le persigue con encarnizamiento; en los parques y paseos frondosos de las Canarias hácese tambien necesario rechazarle enérgicamente.

Los individuos cautivos, que en general se conducen como los gorriones domésticos, no son muy agradables; solamente los aficionados suelen tenerlos alguna vez en jaula.

\section{EL GORRION DE LAS MONTAÑAS -PASSER MONTANUS}

CARACTÉRES. - Fsta ave, llamáda tambien con frécuencia gorrion de nogal, mide $0^{\circ}$, is de largo por $0^{\prime \prime}, 205$ de ancho de punta a punta de las alas; estas miden $0^{2}, 065 \mathrm{y}$ la cola $0^{m}, 055$. I a parte superior de la cabeza, las sienes $y$ la nuca son de un pardo rojo pálido; la linea naso.ocular, una mancha que hay en la parte posterior de la region auricular, otra en los ángulos de la boca y una tercera en la barba, asi como la garganta, son negras: las mejillas y la parte superior de los lados del cuello blancas; las regiones inferiores de un blanco pardusco, mas claro en el centro; los costados de un pardusco leonado; del mismo color son las rectrices inie. riores de la cola, que están orilladas de bianquizco; la parte posterior del cucllo, el manto y los hombros son rojos, con anchas lineas longitudinales negras; la rabadilla y las tectri. ces superiores de la cola de un pardo leonado; las rémiges de un pardo oscuro, con un angosto borde amarillento en las barbas extriores, mas ancho y de color mas vivo en las rémiges secundarias; las tectrices de estas últimas tienen casi todas las barbas exteriores rojas, con la punta blanquizca; las tectrices de las alas son de un pardo oscuro; las mayores negras en la base y blancas en el resto de su exiension, formando una faja trasversal; las rectrices, de color pardo, tienen bordes leonados en las barbas exteriores. Los ojos son dé un pardo oscuro; el pico negro y los piés rojizos (figu. ra 252). La hembra tiene la mancha negra de las orejas un poco mas pequeña.

DISTRIBUCION GEOGRAFICA.-El gorrion de las montañas abunda en todos los paises de la Europa central; pero escasea en el sudoeste Es mus comun en el centro del Asia; se le encuentra en Malaca y Java y penetra en el norte hasta mas allá del círculo polar. En las orillas de la parte inferior del Obi, en China, el Japon. Formosa é India representa al gorrion doméstico; en Australia y en la Nueva Lelanda se ha localizado con buen éxito.

USOS, COSTUMBRES Y RÉGIMEN. - Este pajaro prefiere el bosque y el campo à los pueblos y ciudades, en lo cual se diferencia de su congénere. Solo en invierno se acerca $a$ las casas; durante el verano permanece donde los prados alternan con los campos, y anida en los árboles hue. cos 6 en las canteras. Forma bandadas numerosas una parte del año, y vive por parejas en el periodo del celo. Aquellas recorren el pais en cierto radio; se mezclan con los zorzales, las alondras, los pinzones, los verderones y los pardillos; vi. sitan los campos en verano y las granjas en invierno; en la primarera se forman las parejas.

El gorrion de nogal ofrece en su modo de ser mas de un punto de contacto con su congénere el doméstico: es menos prudente, $y$ tan solo acaso porque le falta la compañia continua del hombre, y no le han enseỉado las lecciones de la experiencia. Su aspecio is mas airoso que el del doméstico; tiene el plumaje mas comprimido; es osado y ágil, y siempre esta en movimiento. Vuela mejor; anda con mas soltura por tierra, y aunque su grito de llamada conserva el tipo del que produce nuestro gorrion, es mas breve y sonoro.

Desde el otoño d la primavera se alimenta de granos; en verano come orugas, pulgones y otros parásitos, y por lo tanio es muj útil col los huertos y jardines. A reces causa algun daño en los campos de trigo; pero no toca á los frutos ni á las hortalizas: devora los pequenos insectos y los granos lechosos.

Para esta especie comienza el periodo del celo en el mes de abril y se prolonga hasta el de agosto: la hembra pone dos $\delta$ tres huevos al ano y forma su nido en una cavidad, con preferencia en algun tronco hueco, mas bien que en las grietas de las rocas ó en las tapias: no está mejor construido que los de sus congéneres. Los huevos, cuyo número varia de cinco á sicte en cada puesta, se asemejan mucho á los del gorrion doméstico, con la única diferencia de tener mas estrias, siendo, por consiguiente, mas oscuros y de menor tamano. El macho y la hembra cubren alternativamente duranic trece ó catorce dias.

Este gorrion se aparea con el doméstico y produce hijuelos fecundos, cuyo plumaje se parece al de los individuos domésticos jóvenes, con la díferencia de tener la cabeza mas oscura y una mancha gris negra en la garganta Por lo ge. neral cl padre es un gorrion de nogal y la madre de la es. pecic doméstica.

C.AZA.-Mas fácil es de coger este gorrion que el otro: empléase la liga, trampas y lazos de diversa clase: tiene los mismos enemigos que el doméstico.

\section{LAS PETRONIAS-PETRONIA}

CARACTERES. - Son gorriones de formas recogidas, de pico vigoroso, redondo, un poco deprimido en los bordes, abovedado por delante y puntiagudo; los tarsos son fuertes; las alas-relativamente angosias -y puntiagudas; las rémiges segunda y tercera son las mas largas, y las posteriores sesgadas en la extremidad; la cola es corta, cortada casi en ánguio recto en su punta; el plumaje es igual en ambos sexos.

LA PETRONIA DE LAS ROCAS-PETRONIA STULTA

CARACTERES. - Ia parte superior es de un pardo 
claro de tierra; una ancha faja que se corre desde las fosas nasales, soure los ojos, hasta la nuca, es de un pardo oscuro; otra que hay en el centro de la rabeza, de un pardo claro, color que en la nuca pasa al pardusco leonado; una tercera, que comenzando detrás de los ojos se corre por las sienes, limitándose al fin por otra de color pardo oscuro, es de un gris leonado claro; el manto de un pardo oscuro, con grandes manchas longitudinales de un blanco pardusco que se reunen en forma de faja; las tectrices superiores de la cola

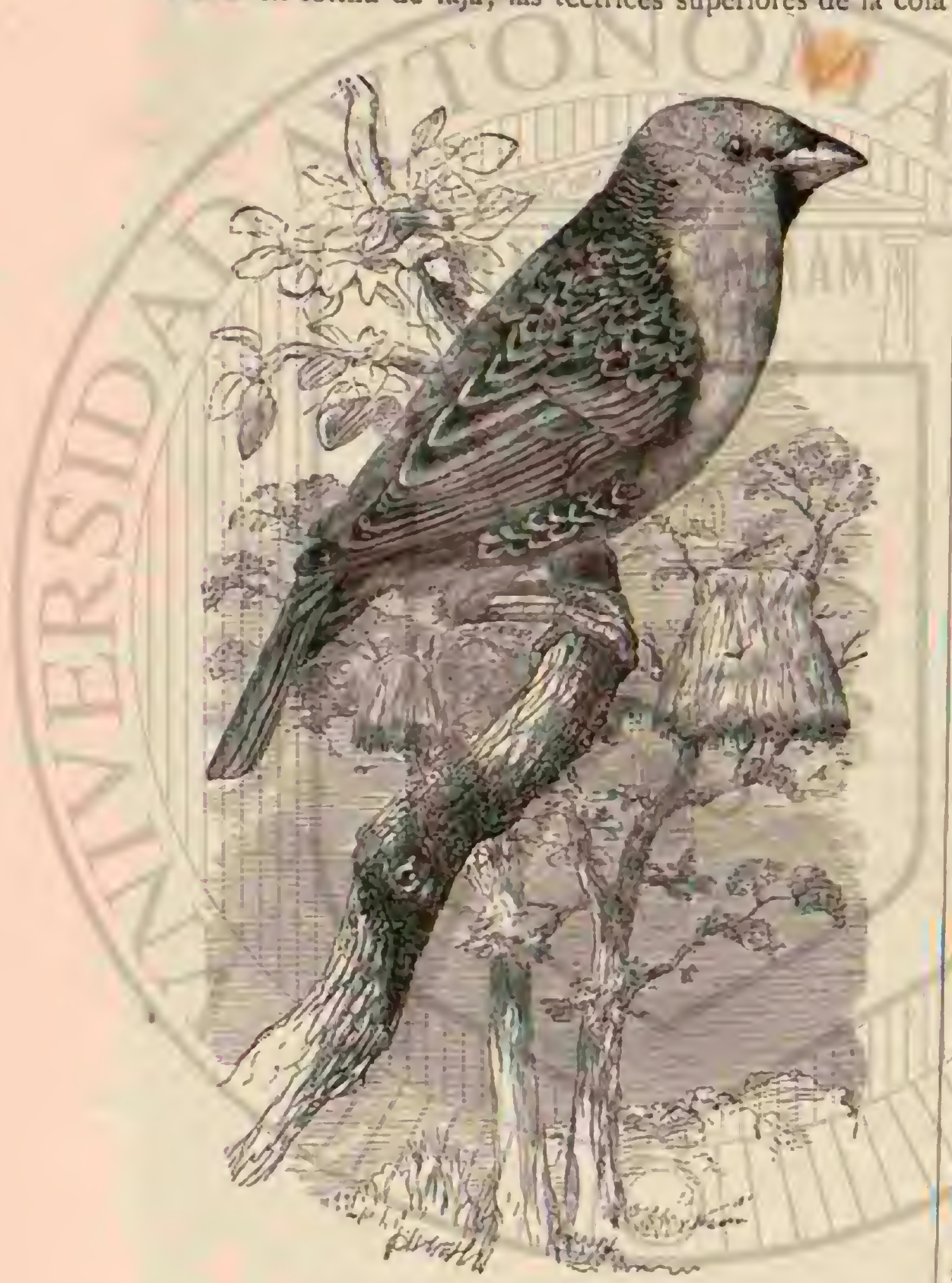

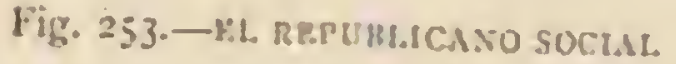

tienen la punta de un blanco leonado; las mejillas y los lados del cuello son de un solo color pardusco de tierra; las plumas de la parte inferior de un blanco amarillento con bordes de un pardo pálido, que en el buche, el pecho y la region inferior de los costados forman fajas longitudinales pardas: una mancha trasversal y osalada en el centro de la garganta es de un amarillo claro; las tectrices inferiores de la cola, pardas, con anchos bordes de un blanco amarillento en extremidad; las rémiges, de un pardo oscuro, estån orilladas en las barbas exteriores y en la punta de un tinte pardusco, que se ensancha en las primeras rémiges primarias aumentando mas aun en las secundarias; las últimas de estas tiemen una gran mancha puntiaguda de color blanco leonado; las tecirices de las rémiges son de un parda oscuro, con un an gosto borde blanco en las barbas extcriores; las grandes tec trices de las alas, que son igualmente de color pardo oscuro, tienen un ancho borde blanco leonado en la extremidad, el cual forma una faja trasrersal; todas las rémiges tienen el borde de las barbas interiores pardusco leonado; las rectri ces, de un pardo oscuro, mas claro hácia la base, presentan en la punta de las barbas inferiores una gran mancha blanca; las úitimas rectrices de ambos lados tienen en sus barbas exteriores un borde blanco leonado; las otras están orilladas de color amarillento aceituna. Los ojos son de un pardo os. curo; el pico amarillo de aceite, nas oscuro en la mandibula superior, y los pies de un rojizo de cuerno. La hembra tiene poco mas 6 menos el mismo color, y solo se distingue por la mancha mas pequeña en la garganta. La longitud del ave es de $0^{\circ}, 16$ por $0^{\prime \prime}, 29$ de anchura de punta a punta de las alas; estas miden $0^{\prime \prime}, 09$ y la cola $l^{m}, 056$.

DISTRIBUCION GEOGRAFICA.-El área de dispersion de la petronia de las rocas comprende todo el centro $y$ mediodia de Europa, incluso la isla de Madera, el noroeste de Africa; las Canarias, el sudoeste y oeste del Asia, la Siberia oriental y el Aighanistan. En Alemania, donde no se cưenta entre las aves comunes, hállase aislada en regiones pedregosas, donde busca las ruinas de los castillos, como por ejemplo, el de Lobedaburgo, cerca de Jena, asi como las rocas de los alrededores de esta ciudad; en algunas partes del Harz visita las orillas del Mosela y del Rhin. Con mas regularidad se le ve hácia el sur de la Irrancia meridional; en España, Argelia, islas Canarias, Italia meridional, Grecia, Dalmacia, Montenegro, Palestina y el Asia menor, figura entre las aves comunes del pais.

USOS, COSTUMBRES Y FÉGIMEN. - Habita en los pirises últimamente citados todos los sitios propios, tanto los pueblos y ciudades, cono los valles pedregosos mas soli. tarios, y hasta forma, como sus congéneres, verdaderas co. lonins.

En Esparia le encontré con seguridad en las pendientes escarpadas de las montañas y en las ruinas de los castillos: en Canarias busca, segun Bolle, Jas torres y los edificios elevados que hay en medio de las ciudades. No huye de la ve. cindad dal hombre; pero sabe conservar su libertad. Rara vez se arentura por las calles, y tiene costumbre de it al campo para buscar su alimento. Difiere de los otros paserinos por hallarse dominado continuamente de un temor $y$ desconfianza đৃue rayan en la exageracion.

Distinguese por sus movimientos de los restantes de la fa milia: su vuclo es rápido y ruidoso; antes de posarse se cier. ne un instante con las alas muy tendidas, y se parece mas bien á los piquituertos que á los verdaderos gorriones. F: ticrra salta con bastante ligereza; cuando se posa toma una actitud altiva y menea con frecuencia la cola. Su grito de llamada podria espresarse por gruivioh, siendo mas acentuada la ültima silaba; su scinal de aviso, crrr, se asemeja bastante 1. La de los otros pascrinos; su canto es un gorjeo bastante sencillo y entrecortado, que recuerda un poco el del pinzon real, aunque no pureda decirse que sea agradable.

Se reproduce este prjaro á fines de in primavera ó en los primeros dias de verano: el periodo del celo comienza para él en España en el mes de abril pero de ordinario no se en. cuentran los ridos laasta majo, junio y julio. En Alemania es dificil observar la reproduccion de la peironia de las ro. cas, mas no sucede lo mismo en el mediodia: alli anida, por lo regular, con varios de sus sernejantes, en las grietas de las rocas, en los agujeros de las tapias, en los troncos huecos y debajo de las tejas de los edificios elevados. Sin embargo, es bastante dificil adquirir un nido, aun en aquellas locali. dades donde el pajaro es comun, pues siempre elige el sitio con mucho cuidado, $y$ en los desfiladeros halla lugares favo. rables para escoger. Eil nido, que mi padre fue el primero en describir, ofrece alguna semejanza con el de los otros pase. rinos: se compone de chinamo, cortezas de árbol y trapos toscamente entrelazados, y por dentro relleno de plumas, pelos, copos de lana, restos de capullo de seda y otros ma. teriales semejantes. Una vez hecho el nido, sirve varios años, 
y lo mas que hace la pareja es componerlo un poco cada primavera. El número de huevos es de cinco ó seis, un poco majores que los del gorrion doméstico; son grises ó de un blanco sucio, manchados de gris ceniciento y de gris oscuro, sobre todo en el extremo grueso. No se sabe si los padres cubren alternativamente, pero si que alimentan los dos á sus pequeños.

Cuando estos pueden ya volar, se reunen con sus semejantes $y$ forman grandes bandadas; vagan sin rumbo fjjo por los campos, y entre tanto cubren los padres por segunda ó tercera rez. Hasta que han terminado su obra de reproduccion, no vuelven á reunirse los riejos con las bandadas.

Observa este pajjaro el mismo régimer que los demís de
In familia: en verano come principalmente insectos, $y \mathrm{en}$ invierno granos, bayas, etc. En Espana se le encuentra á menudo en los caminos, registrando el estiércol, como lo hace el gorrion domestico y el de nogal.

Ciza. - Solo donde abunda es fácil apoderarse de él. En España se llevan mucho á los mercados, y se cogen con redes, con un reclamo ó por medio de liga. Es dificil tirar. les, porque estos prudentes påjaros, â los que cierto natura. lista que solo estudiaba los pajaros por las pieles, pudo apli. car el calificativo de stultus, observan muy pronto si se les persiguc, y aumenta su innata desconfianza Mi padre ob. serva, y con razon, que están muy alerta sobre todo donde pasan la noche, y que para cogerlos es preciso esperarlos al

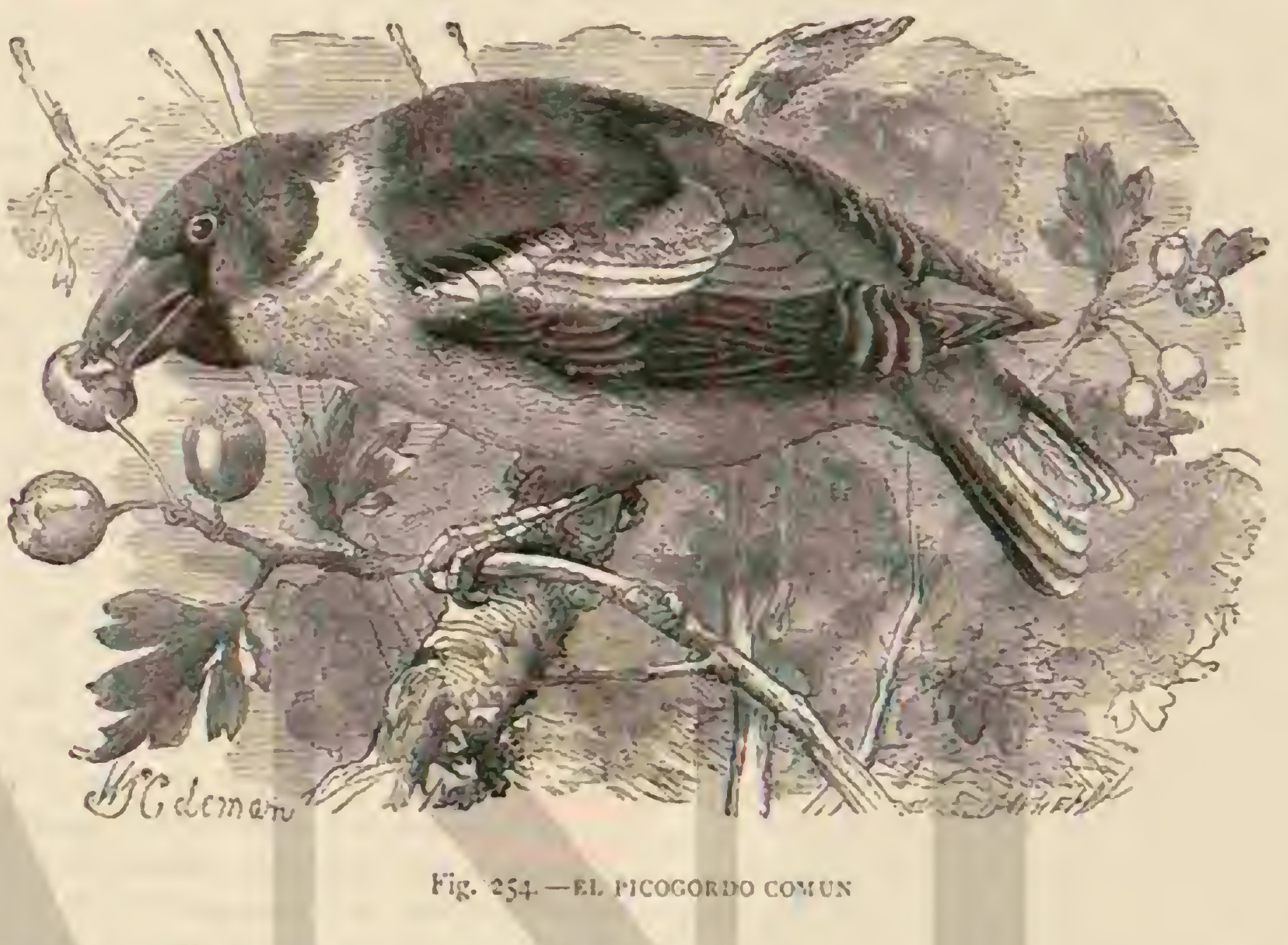

acecho. Lo misno sucede en España: muchas veces hicimos lo posible por sorprenderlos, pero inútilmente, y á pesar de ser cazadores, fué forzoso volvernos con las manos vacias.

Ca UTIVIDAD. - Este pajaro da poco que hacer y es muy agradable cuando estí cautivo: pronto adquiere con. fianza; vive en buena armonia con sus semejantes, y gusta mucho su docilidad. Tambien se reproduce en cautividad cuando se le cuida bien.

\section{LOS REPUBLICANOS-PHI- LET ERUS}

CARACTERES.-Estas aves han sido consideradas como ploceidos, pero pertenecen al grupo de los gorriones: tie. nen el pico prolongado, cónico, comprimido lateralmente, algo corvo en la arista y escotado en los bordes superiores; los piés son vigorosos; los tarsos cortos; los dedos largos y cubiertos de gruesas escamas; las alas bastante prolongadas f: puntiagudas; la segunda-rémige es la mas larga; la cola corta, ancha y cortada en rectángulo en su extremidad.

\section{ELREPUBLICANO SOCIAL-PHILETARUS SOCIUS}

CARACTÉRES.-Las plumas de la parte superior de la cabeza son pardas; las del resto de la region superior un poco mas oscuras, con un angosto borde pardo leonado; las de la nuca y de los costados del cuello, mas oscuras aun, tienen la extremidad mucho mas clara; la linea naso-ocular, la region de los angulos de la boca, la baroa y la garganta, son negras; los lados del buche y el resto de las partes inferiores de un pardusco amarillento pálido; algunas plumas de los lados de los muslos son negras, con bordes de color pardo leonado; las rémiges, las tectrices, las tectrices de las alas, las superiores de la cola, y en fin, las plumas de la rabadilla, son de un pardo oscuro; las réniges están oriliadas en las barbas exteriores de un color-pardo leonado, asi como las tectrices de la cola. Los ojos son de un pardo oscuro; el pico y los piés de un pardo pálicio. La longitud de esta especic es de $0^{\circ}, 13$, la de las alas de $U^{\circ}, 05$ y la de la cola de $0^{\circ}, 05$ (fig. $=53$ ).

DISTRIBUCION GEOGKÁkiCA. - ill republicano so. cial es propio del centro del Afrien meridiunal, donde el pais de los namaguas forma el centro de su área de dispersion.

USOS, COSTUMBRES Y REGIMEN.-Los antiguos viajeros hacen ya mencion de este pájaro. \& En el pás de los namaguas, dice W. Parterson, hay bosques de mimosas que producen mucha goina, y cuyas ramas oirecen abundante pasto a las giráas. Su cxtenso ramaje y su tronco aplanado sirven de albergue a una especie de pájaros, que viven como en familia para defenderse contra las serpientes, las cuales se comen sus huevos. La estructura de los nidos es muy no. table: ochocientos ó mil individuos habitan bajo un mismo techo, que en forma de tejado de paja cubre una gran rama y sus accesorias mas pequeias; de ellas parecen desbordarse los nidos, que quedan pendientes de tal inanera, que ninguna serpiente ni animal carnicero podria alcanzarlos. Estos pảja. ros rivalizan en industria con las abejas: todo el dia están ocupados en buscar la yerba que forma la parte esencial de su 
construccion, la cual agrandan y perfeccionan; y como todos los años fabrican nuevos nidos, doblégase el ramaje bajo el peso de aquella ciudad aérea. Debajo del tejado hay muchas aberturas, cada una de las cuales conduce à una galeria en cuyos lados estin dispucsios los nidos, a unos $\left(0^{m}, 05\right.$ de distancia unos de otros. Esios pájaros se alimentan sin duda de los granos de las yerbas con que construyen el nido.

A. Smith confirma tan cxacta descripcion, añadiendo algunos detalles: La particularidad mas ctriosa que ofrecen los republicanos, dice, es la disposicion de sus nidos, situados todos debajo de un tejado: cuando hallan un sitio conve. niente y comienzan a ciomiciliarse, trabajan de consuro para construir aquel armazon:

- Cada parcjá bace su nido particular; pero fan cerca del de otra, que cuando se conclufe el trabajo, crecrisc ver uno solo, cubierto de un tejado inmenso, que solo presenta en su cara inferior una infinidad de agujeros redondos. listos nidos no sirven para poner Gos veces; asi es qure los pijaros cons. truyen ptros nuevos debajo de los primeros, de tal manera que vengan a quedar cubiertos por ellos y por cl secho. La construccion aumenta. pues. de volumen todos los anios, linsta que su peso ocasiona la caicia de la rama.

Se cncuentran comunmente las colonias del republicano social en árboles muy elevados y fuertes, y a falta de ellos, albérgansé los pájaros en áloes arborescentes.

Cada puesta es de tres $\delta$ cuatro huevos de un color blanco arulado, cubiertos de puntitos pardos en el extremo mas grueso. No se sabe si la hembra cubre sola ó si le presta su auxilio el macho: los pequeños se alizuentan de insectos. Se. gun la opinion de Ayres, los nidos sirven tambien de dormi. torios

No figuran republicanos en nuestros mercados de pájaros exóticos: de modo que nada puede decirse de sus costumbres en el estadó de cautividad.

\section{LOS COCOTRÁUSTIDOS - COCCO- THRAUSTES}

CARACTÉRES.- las éspecies de esté género se distinguen por su estruchura robusta y recogida; el pico, en extremo grande, grueso, completamente cónico, corvo, con bardes afilados y un poco recogidos, tiene junto s la punta de la mandibula superior una escotadura poco marcada; las fosas nasales, pequenas y redondeadas, hállanse en la base del pico y están cubiertas de cerdas, plumitas y pelos muy cortos: los piés son cortos, pero gruesos y robustos; las unas de longitud regular y muy puntiagudas; las alas son relativamente anchas; la tercera rémige es la mas larga y la última tiene una cscotadura en forma de gancho, cerca de la cxtrenidad obsusa de las barbas exteriores; otra escotadura se observa en las barbas interiores; la cola es muj" corta, sesgada marcadamente en el centro: el plumaje espeso y suave.

\section{EL PICOGORDO COMUN-COCCOTHRAUSTES VULGARIS}

CARACTERES. - La longitud de esta are es de ()$^{*}$, I por $11^{m}, 3$ d de ancho de punta á punta de las alas: estas tienen $11^{*}, 10$ y la cola $11^{5}, 06$ de largo. La frente $y^{y}$ la parte anterior de la coronilla son de un pardo amarillo; la region superior ¥ los lados de la cabeza de un amarillo pardo; una estrecha faja de la frente, la linea naso-ocular y la garganta son ne. gras; la nuca y la parte posterior del cuello de un gris ceniciento; la superioz del lomo de un pardo chocolate y la inferior de un castaño claro; el buche y el pecho tienen un color rojo gris sucio; el vientre es gris blanco; la region del ano y las tectrices inferiores de la cola del mismo tinte, las rémi. ges azules, con brillo mctálico, excepto las dos últimas que son de un negro pardo, con una mancha blanca en la base de las barbas interiores; las secundarias tienen un borde gris; las pequelias tectrices de la parte superior del ala son de un pardo oscuro de chocolate; las centrales blancas, las anteriores mas grandes, negras; las posteriores de un bonito fondo amarillo; las rectrices del centro tienen la base negra, l. última mitad de las barbas exteriores presenta un color pardo amarillo, con la punta blanca; las otras son negras en la base y blancas en la úlima mitad de las barbas interiores; las dos últimas de cada lado, negras en las barbas exteriores, y todas están orilladas de blanco en la extremidad. Los ojos son de un rojizo gris; el pico azul en primavera y amarillo de cuerno en otoño: los piés de color de carne. Ia hembra tiene Ia parte superior de la cabeza de un gris amarillento claro; las regiones inferiores del tronco de color gris, y la mayor parte superior de las alas amarillenta. Los polluelos difieren por tener la garganta y la linea naso ocular de un pardo gris oscuro; el buche y el cuello de un amarillo claro; la coroniIla, las mejillas y el occipucio de un amarillo de orin oscuro; la nuca, los lados del cuello y la barbilla de un amarillo de tiern, con borde gris amarillento en las plumas; las del man. to son de un pardo amarillo pálido; las de la garganta y del cuello de un gris amarillento, $y$ las del resto de las regiones inferiores de un pardo sucio, que en los coslados tira al roji20; Lodas estas partes tienen manchas en forma de media luna, de color pardo oscuro (fig. 254).

DISTRIBUCION GLOGRÁFICA.-Los países iemplados de Europa y firica son la parria del picogordo comun; el limite septentrional de su area de dispersion es Suecia y las provincins occidentales y meridionales de la Rusia europea: En Alemaniá se le ve tambien á menudo en invierno, pero probablemente solo como are pasnjera que liega de la Europa septentrional. los individuos que anidan en Alemania emprenden con regularidad viajes hácia el sur. En la Europa meridional solo se presenta de paso, como por ejem. plo en lispana desde donde se traslada al noroeste del Africa. In Siberia se le encuentra desde las fuentes del Amur hasta las fronteras europeas, pero solo como ave de verano.

USOS, COSTUMBRES Y REGIMEN.-En Alcmania abunda el picogordo en ciertas localidades, al paso que es raro en otras, si bien se conoce en todas partes, porque vaga de un punto \& otro. Elige como residencia de verano las montarias $y$ las colinas cubiertas de bosque; pero evita los puntos en que hay coníferas. Segun Kadde, no hace lo mismo en la Rusia meridional, donde invade las estepas, segun parece, á medida que las van despejando. Como quiera que sea, solo habita los bosques durante el periodo del celo; pa. sada esta época vaga con sus pequeĩos por el campo y frecuenta los jardines y huertos.

El picogordo vulgar comienza sus viajes á fines de ociubre 6 en noviembre, y regresa en marzo, aun cuando algunos individuos no vuelven hasta mayo: en este mes vi yo en Madrid una reducida bandada de picogordos.

Atendida la organizacion del picogordo, es fácil comprender que ser pesado y perezoso: permanece largo tiempo en el mismo sitio, sin alejarse de a por su voluntad; vacila al. gun tiempo antes de emprender su vuelo; no recorre larga distancia de una ven, y acaba sicmpre por volver al sitio de donde se le ahuyentó. Se anueve con bastante ligereza en el ramaje; pero en tierra es torpe, porque sus patas son dema. siado cortas para su grueso cuerpo; el vuelo es pesado, aun. que rápido y ruidoso; aletea con iuerza y traza en el espacio lineas onduladas; antes de posarse acostumbra á cernerse por un momento. 
No porque sea pesado el aspecto de este píjaro se debe tacharle de estúpido; léjos de esto, el picogordo es astuto y prudente; conoce á sus enemigos y sabe prevenirse contra ellos. No le gusta mudar de sitio, dice mi padre; pero aun. que coma está siempre atento, ve el peligro, $y$ irata de escapar ocultándose en el follaje 6 emprendiendo la fuga, sin dejarse ver hasta que ya no teme nada. Cuando los árboles están cubicrtos de su follaje, se le oye mucho tiempo antes de percibirle, y se esconde tan bien, que muchas veces tiré yo piedras á varios árboles menos al en que se hallaba, pues no le veia: cuando se asusta se posa en la rama mas alia para poder mirar a lo léjos. A su astucia reune una gran pru. dencia: en mi jurentud aceché una vé por espacio de ocho dias a un picogordo que se ponia delante de mi ventana para comer los granos de col en el jardin: su presencia y astucia le sirvió para escapar muchas reces, y parecia conocer las armas de fuego.

Cuando un grupo de picogordos ocupa un cerezo, es mas fáril acercarse á ellos, aunque tambien alli se muestran muy circunspectos los individuos viejos, y no se oye su voz hasta el instante de emprender su vuelo. No es menos prudente este pajjaro en ticrra extraina: tan poco se fia de los árabes como de los habitantes de la Europa central.

Al picogordo le gustan principalmente los granos encerra. dos en una gruesa cáscara. \& Parece preferir á todo, dice mi padre, los granos de las hayas y de las cerezas; parte las cerezas, tira el pulpejo, abre el huesoy' se come la almendra; esto lo hace en menos de un minuto, y con tal fuerza, que se ofe a treinta pasos de distancia: lo mismo hace con el fruto del ojaranzo. Los granos que se iraga pasan directa. mente il su estómago, y solo cuando este se llena se detienen en el buclic. Cuando los ärboles quedan desnudos, busca el picogordo los granos que han caido á tierra, y por esto se le ve saltar por el suclo á fines del otoño $y$ en el invierno. Tambien le gustan los cereales, y ocrsiona con frecuencia graves daños en los campos y jardines, pues uno solo de es. tos pájaros puede destrozar muchas plantas.

En invierno come los granos del serbal; alimentase ademis de tallos é insectos, sobre todo de coleópteros y sus latvas. Muchas veces, dice Naumann, coge los saltones al vielo, y se posa en un árbol para devorarlos, despues de haberles quitado las alas y las patas. Yo los he visto bajar a los campos acabados de labrar, y coger insectos para llevár. selos \& su progenie.

Segun que la estación sea mas ó mienos favorable, anida el picogordo una $\delta$ dos veces, en el mes de majo y a princi. pios de julio: cada pareja se acantona, y no permite que pernuanczca ninguno de sus semejantes en las limites del dominio que eligió. El macho está en continuo movimiento; va de un árbiol a viro, $y$ se posa en las ramas altas, descie donde deja oit continuamente su voz.

Su canto se compone de sonidos agudos, parecidos a su roz de llamada zi 6 sick. El macho mismo parece compla. cerse en su propio canto, pues toma todas las posturas inaginables para manifestar su satisfaccion.

Construyén estos pájaros su nido en pequeñas ramas, á mayor ó nuenor altura del suelo; por lo regular está muy aculto; el fondo se compone de ramaje seco, tallos de yerba, de raices, etc.; sigue luego una capa de musgo y de liquenes, y cl interio está tapizado de pelos, crines y copos de lana; las paredes no son gruesas, pero revela cierio arte su cons. truccion. Esie nido, fácil de reconocer por su gran anchura, contiene de tres á cinco huevos de $6^{\prime \prime}, 0_{3}$ de largo, y gruesos a proporcion, de color gris verdoso ó amarillento, 5 con manchas y rayas mas ó menos distintas, de un tinte pardo, pardo negro, gris oscuro ó pardo claro.
La hembra cubre siempre: no abandona sus huevos sino al medio dia, para ir a comer; durante su ausencia, ocupa el macho su lugar. Ios padres alimenian a los pequeños y los cuidan largo tiempo despues de haber comenzado á volar, pues hasia que pasan algunas semanas no pueden triturar por si mismos los huesos de las cerezas.

Una iamilia de estos pajaros, dice Naumann, despoja bien pronto un cerezo: cuando los picogordos han visitado una huerta, vuelven á ella micntras encuentran su fruta favo.

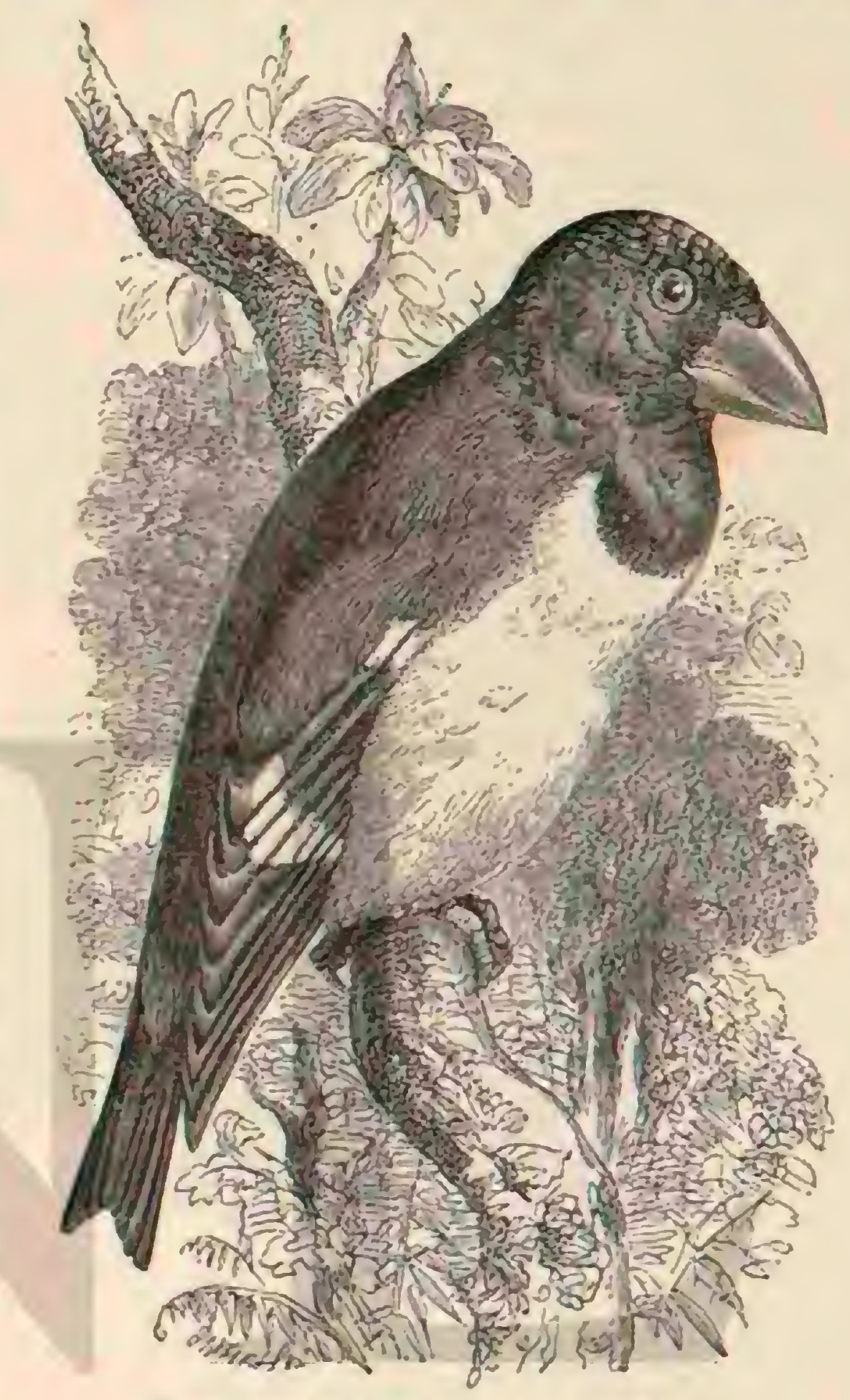

Fig. 255. - 8.1 PICOCORUO NF.GRO Y AMArLLLO

rita, sin que basten para alejarlos todos los ruidos yritos que puedan producirse; los espantajos :ampoco los asustan; el medio mas eficaz es la escopeta. Son aficionados particu. larmente a las guindas ágrias; tambien hacen mucho daño en los huertos cuando se comen los granos y los guisantes. Despojan los serbales, quitando asi al cazador las bayas que le sirven para sus lazos; no se sacian nunca, y además tienen la costumbre de volver siempre al mismo sitio, hasta que lo han devorado todo.

CAZA. - Teniendo en cuenta lo dicho, no es de extraìar que el hombre trate de externinar á los picogordos por todos los medios posibles: lazos, trampas, varetas de liga, nada se omite para cogerlos, y se tira sobre cllos sin compasion.

CAUTIVIDAD. - Los cautiros se acostumbran pronio á la jaula; conténtanse con toda clase de alimento y se domes. tican fácilmente; pero siempre son peligrosos, porque dan fuertes picotazos á todo cuanto se pune di su alcance cuando se les irrita.

Un estudiante de la Universidad de Jena tenia un pico. gordo al que embriagaban por diversion sus camaradas. Mi padre, que vió este pajaro, dice que nada era mas fảcil: lle. nábase de cerveza el cañon de una pluma, y se la presentaba 
por su extremo abierio; el pajaro la cogia entre sus mandibulas, y tragaba el liquido, bastando repetir la operacion algunas reces para que el animal se emborrachase: su marcha vacilante excitaba la risa de cuantos le veian.

\section{EL PICOGORDO NEGRO Y AMARILLO- COCCOTHRAUSTES MELANOXANTHUS}

CARACTERES. - Esta-segunda especie (fig. 255), no menos noiable gue la anterior, tiene ci plumaje de la cara

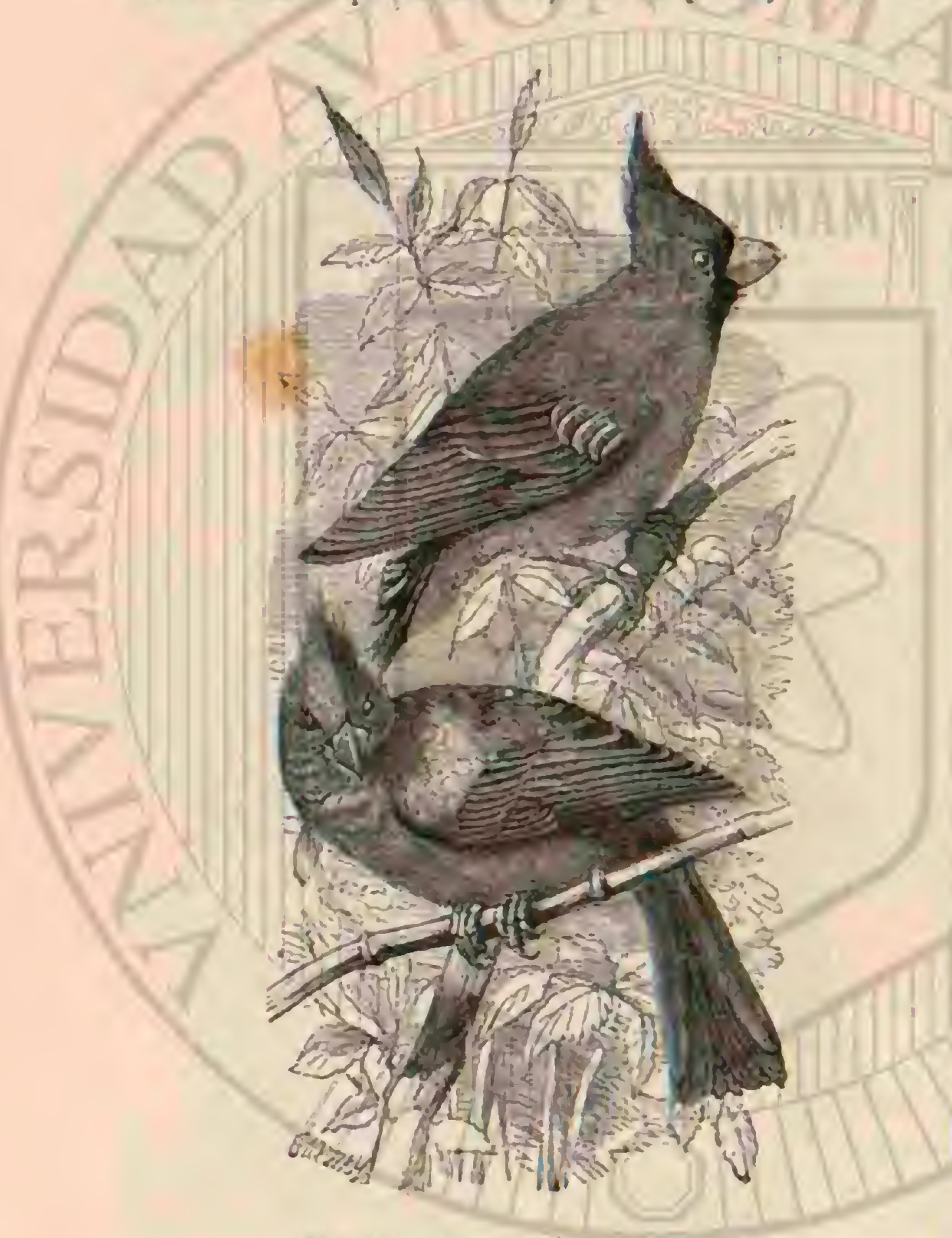

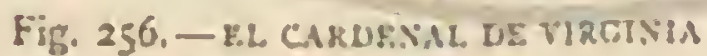

superior del cuerpo y del pecho de rolor negro denso, con algunas manchas blancas en las cuatro rémiges primarias del ala; algunas de las denuas y las secundarias están ornacias de un filete del mismo tinte, formanto asi un marcado contraste con las plumas del lomo. Ia parte inferior del pecho y el abdómen son de un amarillo de oro, de modo que los tres colores citados son los dominantes, sin ningun tinte intermediario, como se observa generalmente en las demas ares de plumaje brillante.

La hembra se distingue fácilmente del macho por tener granỏes manchas amarillas en el lomo, la cabeza y el cuello; el pecho y el abdómen son de un gris amarillento, con motas negras.

Fin los hijuelos es el tinte negro menos puro y el amasillo casi blanco.

Ias dimensiones de esta ave son poco mas ó menos las mismas que las de la especie anterior.

DISTRIBUCION GEOGRÁFICA.-Habita esta are el norte de la India: pero en sus excursiones llega hasta el centro del sur en busca de alimento.

USOS, COSTUMBRES Y REGIMEN. - Observa en un todo el mismo género de vida de la especie anterior.

\section{LOS PITILINOS-PITYLIN.F}

CARACTERES.-Los pitilinos ó Arjoros.loros son cocotráustidos de pico muy fuerte, grueso, convexo y cónico; la mandibula superior en forma de gancho, y con una escota. dura, sobresale de la inferior, cuyos bordes se encorvan mas 6 menos; las alas son cortas; la tercera y cuarta plumas mas largas; la cola larga y redondeada $\delta$ puntiaguda, y rara vez truncada. Las patas son vigorosas; los tarsos bastante altos, y los dedos de un largo regular. El plumaje, abundante y suave, carece comunmente de brillo metálico; su color es por lo regular gris ó gris verde aceituna, y en muy pocos individuos amarillo, rojo ó negro, y menos aun variado.

DISTRIBUCION GEOGRÁFICA. - La America del sur es la verdadera patria de estos pajaros; solo algunas ra. ras especies habitan en la del norte.

USOS, COSTUMBRES Y REGIMEN.-Los pitilinos riencn las mismas costumbres que los picogordos y pinzones: habitan con preferencia las breñas y el lindero del bosque, y se alimentan de granos duros, bayas é insectos. Ia voz de los mas se reduce a un grito de llamada muy breve; algunos son verdaderos pájaros cantores, y por esto los buscan mucho los aficionados.

\section{LOS GUIRACAS - HEDYMELES}

CARACTERES. - Las especies de este genero tienen el pico corto, mas's menos grueso, y alguna rez muy fuerte, con los bordes superiores deprimidos en el śngulo de la boca; los piés son relativamente pequeios y endebles; las alas largas; las rémiges segunda, tercera y cuarta las gute for. man la punta; la cola es corta y cortada en ángulo recto; el plumaje es aburdante y recio.

\section{EL GUIRACA DE LA LUISIANA - HEDYME- LES LUDOVICIANUS}

CARACTERES. - La longitud de esta ave es de $0^{\circ}, 18$, por $6 \%, 29$ de punta a punta de las alas: estas miden $0^{\circ}, 09$ y la cola 11,07 . La region superior de la garganta, las alas, la cola y la barba son negras; las demas partes inferiores blancas, excepto una ancha placa que llega hasta el centro del pecho y cuyo color es rojo de escarlata; el vientre y los la. dos de los muslos tienen algunas lineas negras; las rémiges primarins son blancas en la mitad de la base; las secun. darias y sus recrices, incluso las superiores de las alas, son del mismo color en la extremidad; los hombros y las tectri. ces inferiores de la cola de un rojo de escarlata; las últimas rectrices blancas, en la última mitad de las barbas interiores. Jos ojos son de un pardo de nuez; el pico amarillo pálido, y los piés de un pardo gris. La hembra tiene las regiones superiores de un pardo de tierra, con lineas mas oscuras en los tallos; la cabeza y el pecho de un pardusco amarillo, cruzado por lineas longitudinales mas oscuras; una faja de la coronilla, otra mas ancha, que ocupa el lugar de las cejas, y la linea naso-ocular son blancas; los lados de la cabeza, las rémiges y rectrices de color pardo; las rémiges secundarias, las tectrices pequenas y las superiores de las alas son blancas en la extre. midad; las inferiores de la cola de color de naranja.

DISTRIBUCION GEOGRÁFICA.-El área de dispersicn de esta are comprende el este de los Esiados-Unidos, en el norte hasia el Saskatchewan y en el oeste hasta el Ne. braska. Tambien extiende sus viajes por la América central hasta Nueva Granada. Dentro de los paises indicados el are se presenta con regularidad, pero siempre aisladamente. Abunda en el sur de Indiana, en el norte del Illinois y en el 
oeste de Iowa; parece que su numero aumenta yoco is poco en Massachusetts.

Q Un dia del mes de agosto, refiere Audubon, avanzaba yo penosamente à lo largo del rio Mohawk, cuando me sorpren. dió la noche, y como conocia poco el pais, resolvi esperar la mañana en el sitio donde me hallaba. Era el tiempo cálido y sereno; reflejábase en las aguas el pálido fulgor de las estrellas, y á lo léjos percibiase el rumor de una cascada: encendi fuego debajo de una roca, $y$ alli me eché tranquilamente. Con los ojos cerrados, daba libre curso á mis idens, $y$ cuando me hallaba en lo mejor de mi sueño, despertóme de repente el canto nocturno de un pájaro, tan armonioso y so. noro en medio del silencio de la noche, que huyó el sueño de mis párpados, pues nunca hasta entonces me habia cautirado tanto música alguna. Aquellos sonicios me hacian feliz, y hasta podria decir que a la misma alondra le causaron impresion, porque enmudeció al momento al oir tan dulce armonia Mlucho tiénipo despues de haber callado el pájaro, hallábane dominado aun por el eíecto que me produjo, has. ta çue al fin volvi á quedar dormido

G Con frecuencia, continua Audubon, he observado este magnifico pajaro en la parte inferior de la Luisiana, en el Kentucky, y en los alrededores de Cincimnati; sienupre desde el mes de marzo, en cura época se dirige hácia el este le he visto durante sus viajes por Pensylsania, en Nueva-York y en los demás Estados del este; en las posesiones Británicas, desde Nueva lirunswick jueva Escocia hasta lerranova, donde anida con frecuencia; jamás le hallé ni en el Labrador, ni en las costas de Cieorgia y de la Carolina; pero existe, no obstante, en las montañas de dichos Estados. A fines de

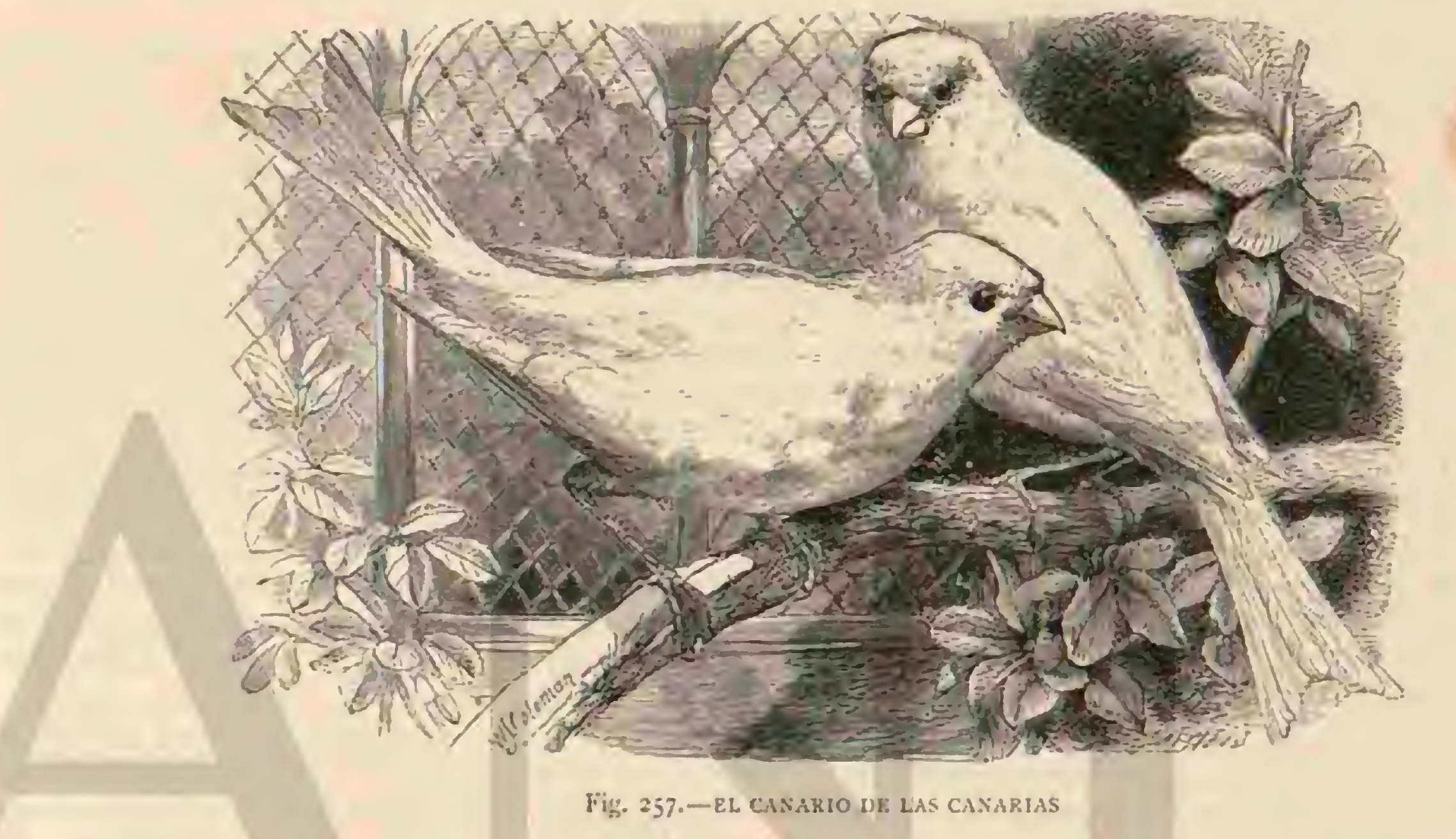

majo encontré un gran número de estos pảjaros en las márgenes del rio Schuzlkil, à 20 ó 30 millas de Filadelfra; observé muchos en los grandes pinares de Pensylvania; pero mas aun en el Estado de Nueva-York, sobre todo á lo largo de los rios: este påjaro es muy comun tambien en las orillas de los lagos Eric y Ontario.

USOS, COSTUMBRES Y REGIMEN. - EI pico grueso de pecho rosa vuela en línca recta y con cierta gracia: en sus emigraciones se remonta a gran altura sobre los bosques, dejando oir a intersalos un grito penetrante; pero una vez posado se calla. Hácia la caida de la tarde se sirúa en la cima de uno de los átboles mas altos, y alli fyermanece algun tiempo, con el cuerpo recto y rigido; luego se meie en la espesura y desaparece en medio del follaje para pasar la noche.

El guiraca de la Luisiana se alimenta de granos de toda especie, particularmente de las gramíneas, de bayas, retoños y florecillas tiernas: caza los insectos, $y$ los coge á menudo al vuelo.

Desde el fin de mayo á julio encontró Audubon nidos de esta especie en las ramas superiores de los pequeños jarales; muchas veces en árboles altos, y por lo regular cerca del agua.

El nido del guiraca de la Luisiana se compone de ramas secas, entrelazadas con hojas y pedazos de corteza de la vid silvestre; por dentro está tapizado de peequeñas rajces y crines. Cada puesta es de cuatro hucros, si bien parece que solo tic. nen una al año: los padres cubren alternativamente, $y$ hasta los tres anoos no ostentan los hijuelos su mas bello plumaje. Apenas nacen, los alimentan los padres con insectos, y mas tarde con granos humedecidos en el buche. Solo al tercer año llegan á tener el plumaje de los adultos.

CAUTIVIDA D. - Los americanos consideran ả esta ave como uno de los pájaros cantores mas sobresalientes é iniatigables; su canto es variado y armonioso, las notas lienas y bien mareadas, y cuando hace buen tiempo se le ofe por la noche. Produce los sonidos variados y melodiosos del ruiseñor, dice Neuttall, y parece extasiarse con su mistno carto, excitándose hasta cierto punto. lan pronto enite notas dé. biles y temblonas, comollenas y sonoras; planideras en un principio, son luego animadas $\delta$ de tiernisima dulzura. 2

Dicho observador crce que ninguna de las demás aves cantoras de América, excepto el burlon, le aventaja por este concepto; pero sin duda esta opinion es exngerada. Jil con. junto del canto es un quejido, casi la expresion de la tristezs, este canto puede desesperar al fin al que le oye A presas de eso el guiraca de la Luisiana figura entre las buenas cantoras y se conserva además muy bien en la jaula

\section{LOS CARDENALES - CARDINALIS}

CARACTERES. - Las especies pertenecientes á este gé nero tienen el cuerpo un poco prolongado, el pico corto, fuerte, puntiagudo, muy ancho en su base, con arista encur- 
vada y una escotadura en cl centro de la mandibula superior; las alas son cortas, la cola larga y sesgada en el centro, la cabera está provista de un mono erectil.

\section{EL CARDENAL DE LA VIRGINIA-CARDI- NALIS VIRGINIANUS}

CARACTÉRES. - La longirud de esta especie, bien conocida tambien en Furopa, es de $\eta^{*}, 20$, por $\AA^{*}, 26$ de ancho de punta á punta de las alas; estastienen $10 ", 0$ y y la cola V",08 de largo. El color predominante del plumaje es un rojo de escarlata muy vivo; las plunias del manto, de los hombros $y$ de la rabadilla son mas opacas, con un angosto borde gris leonado en su mitad: la línea naso ocular, una estrecha faja que hay alrevedor de los ojos, la barixa y la parte superior de la garganta son regras; las rémiges de un rojo oscuro de escarlaza y pardas en el tercio de la extenuidad; las últimns rémiges secundarias están orilladas de pardo leonado en las barbas extcriores; las rectrices tienen un color escariaia os. curo, muy brillante en la parte inferior. Los ojos son de un pardo rojizo; el pico rojo, 5 negro en li base de la mandibula inferior; los piés pardos. In la hembra, la parte anterior de la cabeza y el lomo son de un pardo de corzo; las partes inferiores de un pardo amarillo, mas vivo en la cabeza, en el pecho y én el vientre; el moño, las barbas exteriores de las réniges, las tectrices y la cola, de un rojo de escarlata opaco; la burbia y la garganta de un gris negruaco (ñg. 256).

DISTRIBUCION GEOGRÁFICA. II área de disper. sion del cardenal de la Virginia comyirende el sur de los Estados-Linidos, México y California!

USOS, COSTUMBRES Y REGIMEN.-En los invicr. nos templados permanece en los parajes donde anida, pero cuando el úempo es mas riguroso emigra. A causa de su magnifico plumaje llama ya desde lejos la atencion y consti. tuye verdadero adorno del bosque.

Segun el principe de lWied, pasa el dia en medio de las ramas entrelazadas de las lianas, y de alli parte para empren. der sıs excursiones por campos y jardines cuando el bosque no le proporciona lo necesario para su alimento; lo mismo se. le encuentra cerca de las ciludades que en la espesura de los bosques.

«e le ve, dice Audubon, en los campos y alamedas de árboles, en los jardines, y hasta en el interior de las ciudades y jueblos. Raro es entrar en un jardin sin percibir desde luego al rojo płjaro que salta entre el ramaje; pero en todas paries se le mira con gusto y se le aprecia, no solo por su brillante plumaje, si que tambien por su armonioso mnto.s

En verano se aparean los carcienales, y en el invierno for. man reducidas bandadas; viven en buena inteligencia con los otros pijaros, mas no con sus semejantes, sobre todo en el periodo del celo. En invierno suelen frecuentar las granjas, y juntamente con las palomas, los gorriones y verderones, recogen los granos que alli encuentran; penetran en los esta. blos y las cuadras y buscan en los jardines toda clase de frutos.

Con el auxilio de su grueso pico puede abrir muy bien el cardenal de Virginia los granos duros del maiz, mondar la avena y triturar el rrigo, debiendo d esta circunstancia el no paciecer nunca hambre: se oculta por la noche en una gavilla de heno ó en la copa de un árbol, y soporta fácilmente asf los rigores del invierno.

Sicmpre alcgre, retozon ! sctivo, apenas permanece un instante quieto en el mismo sitio; nuévese continuamente; revoloica y. salta de un lado á oiro; cuando está posado toma la posicion horizontal, y deja pendiente la cola agitandola con frecuencia. Para andar por tierra salta con bastante rapi. dez; en el mmaje se mueve con mucha agilidad: su vueloes rápido y ruidoso, pero mra vez sostenido; levanta $\delta$ baja con. tinuamente la cola, y la ensancha ó la recoge.

Cunndo el cardenal viaja recorre á pié una parte del cami. no; aranza á saltitos, deslizandose de jaral en jaral y volando de un bosque a otro. En el periodo del celo traban frecuen. tes peleas los inachos que se hollan establecidos en el canton con los que van llegando; precipitanse furiosos sobre los in. trusos que penetran en su dominio: les persiguen lanzando agudos gritos; les acometen por el aire, y nodescansan hasta que los ahuyentan de los alrededores. Conseguido esto, vuel. ve el cardenal; manifiesta su alegria con un canto de triunfo, y se reme con su companera, á la que profesa tanto cariño como ella à él. Una tarde del mes de febrero, dice Audu. bon, cogi un cardenal macho; á la mañana siguiente estaba la hembra cerca de la jaula de su compañero, y se dejó cogerá su ver.s

Arida este pajaro en un jaral ó un árbol, cerca de una granja ó en medio de los campos; lo mismo en el lindero del bosque que en la uas intrincara espesura Parecen gustarle sobre todo las orillas de las corrientes; suele encontrarse su nido nariy cerca de alguna casa, y á menudo á pocos metros de distancia del sitio donde se halla el del pajaro burlon. Se compone de hojas secas y ramas, particularmente de las espinosas, enlazadas con rastrojo y pámpanos de la vid silvesire; el interior está relleno de yerbas. Los huevos, cuyo número varíalentre cuatro y seis, son de un blanco sucio, con man. chas de un tinte pardo aceitunado, y' se parecen por el color a los de ln calandria o del gorrion doméstico. Gerhardt dice no haber hallado nunca una puesta cuyos huevos fuesen todos del mismolcolor.

En los Lstados diel norte no suele poner el cardenal mas de una re\% al ano; mas en los del sur tres con frecuencia. l.os padres no permanecen con su progenic mas que algunos dias despues de haber dejado el rido.

El cardenal de Virginia se alimenta de granos, cereales y bayas: en la primavera come las flores del arce azucarado, en verano las bayas del serbal; tambien caza actimmente los co. leópteros, las mariposas, las langostas, las orugas y otros in. sectos. Dice Wilson que se alimenta principalmenie de naiz, y que come tambien los huesos de las cerczas, las pepitas de las manzanas y los granos de diversas bayas.

Los naturalistas americanos estan bastanie conformes en elogiar el canto de esta ave, mientras que nosotros no podemos entusiasmarnos por el.

Los sonidos que produce el cardenal, dice Wilson, son completamente iguales á los del ruiscrior; se le ha llamado muchas veces aruiscñor de la Virginia, y merece este nom. bre por la pureza y variedad de su canto.s

Este canto, dice Audubon, es claro al principio, seme. jante al sonido del clarinete: ra disminurendo poco á proco hasta cxtinguirse; en el periodo del celo es cuando el pajaro se entusiasma mas. Parece que comprende su fuerza; hincha su pecho: extiende las rosadas plumas de su cola, agita las alas y' se vuelve a derecha ei izquierda, cual si le admirase i él mismo la dulzura extraordinaria de su voz. Siempre emite nuevas melodias, y solo se calla para respirar; se le oje mu. cho antes que haya dorado el sol el horizonie, $y$ hasta el ins. tante en que los ardores del astro abrasador obligan á toda la creacion á entregarse algun tiempo al descanso; mas ape. nas se despicrta la naturaleza, vuelie el pájaro á entonar sus dulcisimos cantos, y ya no se calla hasta que le rodean las densas sombras de la noche. lodos los dias procura el carderal distraer con nuevas melodias a su compañera durnnte la incubacion; pocos habré entre nosotros que no admiren siempre a este pajjaro cantor. Cuando se oscurece el cielo, 6 
invaden has tinieblas el bosque y se cree liegada la noche, ¿puede darse cosa mas grata que oir resonar de repente la roz melodiosa del cardenal? ¿Cuántas veces me ha extasiado su canto en medio del silencio que me rodeaba!ł

Tambien yo reconozco que el canto de un buen cardenal es uno de los mas agradables que puedan oirse de un pájaro granivoro, pues se distingue por la pureza y variedad de los sonidos; pero debo añadir que este mismo pájaro puede llegar á ser muy desagradable por su grito de llamada zill, producido continuamente, $y$ que en algo recuerda tel del mirlo. Como cantor en la selva libre, el ruiscrior de la Virgissin po. drá merecer todos los elogios; pero como ave de jaula solo ocupa un rango inferior, á pesar de que á veces ambien se propaga en cautividad.

\section{LOS PIRRULINOS-PYRRHULINA:}

CARACTÉRES.-Las especies de esta sub-familia tienen el pico corto, grueso, abovedado en todos sus lados y provisto de un pequeño gancho en la mandibula superior; los piss son cortos y bastante fuertes; las alas de longitud regular, con la punta obtusa; la cola corta en la mayor parte de las especies, y poco sesgada; el plumaje mas ó menos suave y blando, con colores muy finos por lo regular.

DISTRIBUCION GEOGRAFICA. - Excepto la Aus. tralia, los pirrulinos están discminados por todos los continentes, pero son propios en particular de la zona templada $y$ fria.

USOS, COSTUMBRES Y REGIMEN.-Habitan los bosques y espesuras, los jardines y árboles aislados, las ro. cas y desiertos, y aliméntanse de simientes, tallos y retonos. Los mas de ellos son bastanie torpes in sus movimientos, y salvo algunas cxcepciones, no se distinguen tampoco como buenas aves cantoras; son inferiores a otros fringilidos por término medio, sin que pueda decirse, sin embargo, que sus facultades carecen de cierto desarrollo.

\section{LOS CANARIOS-SERINUS}

CARACTF.RES. - Aigunos naturalistas comprenden los canarios entre los fringilidos, y otros enire los pirrulinos, de lo cual resulta que podemos consideratlos como tránsito de una af otra sub familia. Su pico es pequeño, corto, grueso y de punta obiusa, poco corvo por arriba, recogido en los bor. des, y con una ligera escotadura junto a la extremidad; los tarsos son bastante cortos, y los dedos no muy largos, pro. visios de uilas pequeñas, ligeramente corvas y puntiagudas; las alas, de longitud regular, rematan en punta; ia segunda y tercera rémiges son las mas largas, la cola, de mediana lar gura, es bastante sesgada en la extremidad.

\section{EL CANARIO MERIDIONAL-SERINUS ME- RIDIONALIS}

CARACTÉRES. - La longitud de este canario es de $\left(1^{\circ}, 125\right.$, por $(0), 21$ de punta $a$ junta de las-alas, que miden $0^{n}, 67$ y la cola $11^{m}, 05$. Fil color predominante del plumaje es in bonito verdc; el occipucio, el dorso y los hombros son de, un verde amarillo, con manchas longitudinales negruzcas poco marcadas; la frente, una faja que hay sob:e los ojos, un anillo de la nuca, In rabadilla $y$ las partes inieriores son de un amarillo de oro pálido, mas claro hácia el vientre y blan co en las tectrices inferiores de la cola; el pecho y los lados del vientre presentan grandes manchas longitudinales de un negro oscuro: las rémiges primarias, de un pardo oscuro, es. tán orilladas de amarillo verdoso en las barbas cxteriores y de blanquizco en la extremidad; las rémiges secundarias son del mismo color, solo que tienen los bordes inas anchos; las plumas de los hombros presentan otro muy extenso en las harbas exteriores y en la extremidad; las pequenas tectri. ces superiores de las alas son de un bonito verde; las mayo. res están orilladas de blanquirco y tienen un ancho borde amarillo blanquizco en la punta, el cual forma una faja trasversal de color claro en las alas; las rectrices son de un ne. gro pardo, orilladas de blanquizco en las barbas inieriores y de amarillo verdoso en las exteriores. I.os ojos son de un pardo claro; el pico gris de cuerno, con tinte rojizo en su parte inferior; y los piés de un color de carne amarillento. la hembra es mas pequeña; en su plumaje predomina el amarillo verdoso, $y$ en todas partes tiene manchas longitudi. nales negras. Los poliuelos se parecen á la hembra; pero el color predominante es tan claro, que parece blanqquizco.

DISTRIBUCION GEOGRÁFICA. - El canario meridional es realmente propio del sur de Furopa, del Asia Menor, desde donde se ha extendido poco à poco hácia el norte, y aun se disemina mas y mas en territorios donde hace cuarenta años taltaba del tolo. En los veinte años úlimos se ha propagado en casi todo el imperio austriaco, la Silesia, Franconia y luringia; en $187 j$ se ha presentado tambien en ln Marca, donde sin duda se aclimatara.

\section{EL CANARIO DE FRENTE AMARILLA- SERINUS PUSILLUS}

CARACTERES. - Esta especie considerada por algunos naruralistas como tipo de un subgénero independiente, del de los camarios verderones (Oraepiehus), tiene (1), 11 de largo; las alas miden $0^{\circ}, 07$ y la cola $0^{\circ}, 05$. La parte anterior de la cabeza es de un rojo de naranja oscuro: el resto de la rabe. za, el cuello y la parte superior del pecho de un negro par. dusco opaco; el dorso, los lados del pecho y del vientre del mismo color, pero cada pluma tiene un ancho borde amarillo claro; la rabadilla es de un tinte anaranjado: el vieutre ama. rillo; los costados presentan líneas negras longitudinales; las rémiges primarias son de un pardo gris, con un estrecho borde amarillo de limon en las barbas exteriores; las plumas de los hombros, de un parda oscuro, están orilladas de un tinte blanco amarillento en los lados y tienen la extremidad blancjuizca; las tectrices superiores de las alas son de un pardusco dorado: las mayores están orilliadas de blanco en su extremidad, formando una faja en las alas; las rectrices, de un pardo oscuro, tienen borde de color amarillento limon en las barbas exteriores y blanco en la extremidad; las tec: trices superiores de la cola son de un matiz mas oscuro, con Ia junta igualmente blanca; las tectrices inferiores ofrecen este íltimo tinte. El iris pardo; el pico negro, y los piés de un pardo oscuro. La hembra ticne lós colores menos viros y le falta el negro en la cabeza.

DISTRIBUCION GEOGRÁFICA. - En Alemania, el canario meridional es un pájaro de paso, que llega en los ü. limos dias de marzo, 6 a principios de abril, para marcharsc a la entrada del invierno. En todo el mediodia de Europa anda erraric en dicha estacion de un punto à otro, sin emi. gras realmente.

Aquil se le re en todas partes con mas frecuencia que en Alemania y no falta ni aun en las cumbres de montañas bas. tante altas.

USOS; COSTUMBRES Y REGIMEN. - Iil canario meridional prefiere ciertas condiciones, y por lo mismo no es raro en algunas localidades, al paso que falta del todo en otras muy cercanas: busca los jardines donde hay árboles, siruados cerca de las huertas. 
Este canario es un bonito pájaro, vivaz, activo y de melo dioso canto: sus costumbres nos ofrecen varias particulari dades curiosas, sobre todo en el periodo del celo. I.os pri meros que llegan son siempre machos: luego aparecen las hembras; aquellos se distinguen en seguida por su canto y su continua agitacion. Posados en las cimas mas altas, dejan pendientes sus alas, levantan un poco la cola, sé vuelven de todos lados y cantan con ardor; pero si hace frio, sopla el vienio ó llueve, presentan un aspecto muy distinto, segun dice Alejandro de Homeyer. Se sitúan á poca distancia del sueln para resguardarse del aire: pian de re\% en cunndo ligeramente, pican el árbol donde se han posado y permanecen luego silenciosos. Kesulta de aqui que cuardo el mal liempo se prolónga, pucden existir muchos ganarios en el pais sin que se note su prescncia; pero al primer rayo de sol, cubren lodos los árboles y resuenan por los aires sus trinos. A medida que se acerca el periodo del celo, cantan los canarios con mas viveza; sabida es que los mas de los pajaros han de conquistar asi el amor de su compantera, y en este punto sostienc el canario meridional una verdacera lucha, Implora a su hembra con los mas dulces sonidos; á semejanza del cuclillo, se agracha sobrela rama, ó se aplana én ciertd modo, eriza las plumas del cuello, cusancha la cola, se vuelve y revuclve, enderćase de pronto, se remonta par los aires revóloteando de una manera singular y desordena. da, como lel murciélago inclinase \& derecha \& izquierda y vuelice al mismo sitio para continuar su canto. los otros machos excitan sus celos; precipitase furioso contra un ad. versario; te persigue cuando huye; recorren ambos el follaje largo tiempo, y expresan su colera piarido repecidas veces, Hasta que la hembra cubre no cesan aquellas luchas; pasado el periodo del celo, reúnense todos los individuos de un can. ton y viven en paz En Espaija se les ve formar bandadas mu; numerosas; pero solo desde el otono se reunen con los jilgueros, los pinzones y otros pájaros de los campos, aunque no contraen intimas relaciones.

El canto de este canario es particular: Hoffmann le icon para, y con razon, con el de $\hat{l}_{2}$ cursuca de invierno, y explica la diferencia entre úno y otro por la estructura del pico, que es mas grueso en el primeto de dichos pajaros, lo cual cam. bia un poco el timbre de las notas. No se puede decir que el canto sea excelente, porque guarda denasiada uniformidad y es en extremo plañidero si tiene algo de agradable lil nombre de himigritlel, con que se conoce vulgarmente este pajjaro en Baviera, es una onomatopeja de su canto.

El nido del canario de que hablamos se asemeja al del pinzon: unas veces se compone tan solo de perquenas raices, y otras lo fabrica con rastrojo, yerba y heno, taj)izado inte. rormente de pelos y plumas. Hállase situacio en una rama mas ó menos alta y en lo mas espeso del follaje: segun Hoff mann, prefierc este pajarn marcadamente los perales, y en ellos establece su nido cuando le es posible; pero tambien lo hace en los manzanos, los guindos, y hasta en otros árbo. les verdes. En Espana prefiere los limoneros, aunque sin fijarse en ellos exclusivamente. El nido contiene cuatrn ó cinco huevecillos, de extremos obtusos y color blanco 6 verdoso sucio, con puntos y manchas de un pardo mate, rojo, gris rojizo y negro púrpura, principalmente en el extremo mas grueso. En dicho pais he hallado sicmpre huevos de ca nario desde el mes de abril al de julio: en Nlemania comien7.a el periodo del celo á mediados del primero de cstos me. ses: la especie pone probablemente dos veces al ano.

No es fácil descubrir el nido del canario; pero encuén. trase al fin porque la misma hembra revela su presencia. eSi tiene hambre, dice Hoffmann, llama a su macho con el mismo sonido que cste produce en su amorosa contienda.
Cuando oia yo a una canaria llamar así, situábame cerca, y esperaba la llegada del macho para descubrir el nido. Ia hembra cubre siempre; y no se levanta aunque haya trabaja. dores debajo de ella.

A los trece dias, poco mas ó menos, salen los hijuelos: y mientras se hallan en el nido piden su alimento repitiendo continuamente unos sonidos que podrian traducirse por sio sik ó sill sill. Cuando se halla próximo á terminar su creci. miento, despliegan mucha actividad y emprenden su vuelo, demasiado pronto alguras veces. Los padres continuan alimentíndolos, aunque se les haya puesto en una jaula sus. pendida cerca del nido.

Despues del periodo de la incubacion las parejas y sus po. lluclos se reunen con los que salieron antes del nido, y á veces tambien con verderones, gorriones y otros congéneres, consermandose sin embargo siempre entre ellos cierta independencim listas bandadas recorren entonces el pais y buscan su alimento, q̧ue consistc casi exclusivamente en simientes finas y tallos vegetales; de modo que no molestan al hombre por ningin concepto.

En Alemania no se persigue al canario meridional, que tiene sin embargo por enemigos \& varias pequeñas rapaces $y$ 1 ciertos ancionados En España, por el contrario, se cogen miles de individuas en los llamados árboles de gorriones, para comer su carrie: á este electo se usa un procedimiento parti. cular. Consiste en untar con liga varias ramitas de esparto, que tanto abunda en ciertas comarcas meridionales: tambien se prone dicha sustancia en los árboles, cuidando de elegir los que se hallan aistados en medio de los campos, porque son los que freculentan los pajaros para descansar. Semejante medio produce nuy buen resultado, pues apenas se escapa la cuarta parte de los individuos que se posan, y no solamente canarios, sino tambien otros fringilidos y hasta figuilas se co. gen de este modo.

CAUTIVIDAD. - El canario meridional es un ave bas. tante agradable para la jaula, pero no se conserva tan bien como podria creerse á primera vista.

\section{EL CANARIO DE LAS CANARIAS-SERINUS CANARIUS}

QTrescientos anos hace, dice Bolle, que el canario domes ticado abandonó su patria, pasando a ser cosmopolita El hombre civilizado se apoderó de la especic para llevarla muy léjos; asocióla à su suerte, y llegó a modificarla de tal modo, que linneo ${ }^{-}$Bufion pudieron engainarse hasta el punto de tornar por tipo de la especie el pájaro de color amarillo de oro que todos conocemos, sin ujjarse en la especie madre de plumaje verdoso, que se, ha conserndo invariable.

\Conocemos demasiado bien el canario doméstico; sabe. mos cuáles son sus costumbres y particularidades, y esta cir. cunstancia, con el alejaniento, nos ha permitido adquirir los pocos conocimientos que poseemos acerca de la vida del ca. nario silvestre.

Ahora se necesitaria seguramente un Bolle para describir las costumbres de este pájaro en su estado libre. l'odos los naturalistas anteriores, excepto Alejandro de Humboldt, nos dicen alguna cosa sobre esa especie; pero en los informes que nos dan, lo falso se halla tan mezclado con lo verdadero, que es dificil separar lo uno de lo oiro. Solo la descripcion de Bolle, de la cual haré un extracto, nos permite formar idea exacta de este pájaro tan apreciable. El citado naturalista le encontró en las cinco islas cubiertas de bosques del grupo de las Canarias, la Gran Canaria, Tenerife, Gomera, Palma y Hierro, pero cree que en tiempos anieriores habitaba tam. bien otras varins que hoy dia carecen de bosquees, asi como 
ahora es propio de las de Madera y del Cabo Verde. En las citadas islas se halla en todos los puntos donde los árboles frondosos alternan con la maleza; parece preferir los linderos en que hay sauces y una espesa vegetacion: los que bordean csas islas quedan sumergidos en las aguas durante la estacion lluviosa, secándose cuando comienza el rerano; además se encuentra el ave en los jardines, alrededor de las viviendas humanas. Su área de dispersion se extiende desde la costa maritima hasta la montaña, donde se eleva a 1,500 metros. Abunda en todos los puntos en que la naturaleza reune las condiciones necesarias para su bienestar; es comun en las vinas de las islas, $\mathrm{g}$ tampoco escasea en los pinares que cil. bren las pendientes de las montañas; solo parece que evita el interior de los bosques altos, en cuyos linderos se le encuentra todavia.
CARACTERES.-El canario silvestre, cavario de las Ci:uarias ó canurio (fig. 257), como le llaman los españoles portugueses en su patrin, es mas pequeño y esbeito que el doméstico de Europa; tiene $0^{\circ}, 12$ \& $0^{m}, 13$ de longitud, las alas miden $0^{m}, 07^{\circ}$ " la cola $0^{\circ}, 06$. Los machos viejos tienen el lomo verde amarillo, listado de negro, $r$ las plumas orilla. das en gran parte de un tinte gris ceniciento claro, que casi llega a ser el color dominante. La rabadilla es de un verde amarillo; las cobijas superiores de la cola, verdes, con filete gris ceniciento; la cabeza y la nuca de un verde amarillo, con festones grises muy angostos; la frente de un amarillo de oro verdoso, lo mismo que la garganta, la parte superior del pecho y una ancha faja, que partiendo del ojo, se dirige en. corvándose à la nuca: los lados del cuello son de un gris ce. niciento. La parte inferior del pecho es amarillenta; el vien. tre $y$ las plumas inferiores de la rabadilla blanquizcos; la espaldilla verde, bordeada de negro y verde pálido; las pen. nas de las alas negras, con un estrecho filete verde, $y$ las de la cola de un gris negro, orilladas de blanco. Fil iris es par do oscuro, yel pico $y$ las patas de un color pardusco de carne. Segun Bollc, no aparecen estos tintes hasta el segun do año.

Is hembra tiene el lomo gris pardo, muy listado de negro; las plumas de la nuca y de la parte superior de la cabeza, del unismo matiz y verde claro en la base; la frente verde; la faja que corre desde el pico al ojo, gris; las mejillas son en parte de un amarillo verde y lo demás gris ceniciento. Los lados del cuello presentan un collar poco pronunciado, verde amarillo por delante y gris ceniciento por detrás; la espaldilla r las pequeñas tectrices superiores del ala son de un vercic amarillo claro, $y$ las grandes tectrices y las rémiges, de un pardo oscuro, orilladas de verde; las plumas del pecho y de la garganta de un amarillo de oro verdoso, orilladas de blan co; la parte superior del pecho y el vientre, de este uiltimo cólor; y los costados pardos con rayas mas oscuras.

Los hijuelos tienen el tinte pardusco, que tira en el pecho al amarillo de ocre; en las mejillas y la garganta hay ligeras manchas de amarillo limon.

USOS, COSTUMBRES Y REGIMEN. - El canario silvestre se alimenta sobre todo, si no exclusinmenie, de sustancias vegutales, de granos pequeños, de hojillas tiernas, irutos jugosos, y particularmente higos.
No pueden privarse del agua, $y$ con frecuencia se les ve volar juntos hácia los arroyos para beber yañarse.

Bolle describe cxtensamente la reproduccion del canario silvestre en los términos siguientes: đEstos pájaros se aparean y fabrican su nido en la primern mitad de marzo: nunca los he visto situarse-á menos de a-metros y' medio del 'suelo, y con frecuencia a mucha mas aleura; parece que prefieren los arbolitos entrelazados, y entre ellos los mas verdes $\delta$ que echan hoja pronto. Anidan á menudo en los ciruelos y los granados, de ramas numerosas y diseminadas; no suclen fijarse tanto en los naranjos, cuya copa es demasiado som. bria, y nunca se ponen en las higueras, a lo que parece. Iil nido esta siempre oculto: pero las continuas idas y venidas de los padres, que no se alejan mucho, dan a conocer donde se halia. A fines de marzo de $1 \$ 56$, y en un jardin de la villa de Orotava, convertido ya en una especie de selva, vi yo el primer nido de canarios: hallabase en la bifurcacion de un boj de 4 metros de altura, que se elevaba en medio de un bosque de mirtos, y unicamente su fondo tocaba las ramas; ancho por la base, estrechábase por arriba, se redondeaba lucgo y su construccion cra irregular. Componiase de la pe. lusa blanca de varias plantas, y estaba sostenido por algunos rastrojos secos. El primer huevo fue depositado el 30 de marzo, y otro mas en cada uno de los cuatro dias siguientes: algunas reces he hallado tres ó cuatro de un mismo dia; pero nunca mas de cinco, pareciendo ser este, por lo tanto, el nú. mero ordinario de cada puesta. 
Los huevos tienen un tinte verde mas pálido, sembrado de manchas de un pardo rojizo, y rara rez son incoloros, ase. mejándose en un todo á los del canerio doméstico. La cautividad no ejerce influencia alguna en la duracion de la incubacion; en el canario silvestre es tambien de unos trece dias.

\Los hijuelos están en el nido hasta tener todas sus plumas, y cuando han emprendido su vuelo, les alimentan todavia sus padres, principalmente el inacho. En general pone la liembra cuatro veces al año, y if veces solo tres.

Lin tocios los nidos que observó Bolle, la pelusilla de las plantas constituia el elenento dominante; cu algunos no ha bia ni rastrojo ni yerba. Alientras la liemira rubre, perma. nece el macho cerca de clia, y preferentemente en un úrbol que no haya revestica aun su foliajc, como par ejemplo, en una acacia, un plátano \& un castano, árboles todos cuyos bo. tones tardan mas en abrirse; a veces se coloca en las ramas secas, como las que tienen en abunciancis los maranjos dise. minados al rededor de las viviendas. Desde aquel punto canta mas tiempo y con mas gusto.

SSe ba discutido mucho acerca del valor del canto de este pilaro: úógianle unos con exceso. y le juzgan orros demasiado severamente: no se alejan de lo cierto los que dicen que jos canarios silvestres cantan como los domésticos. Hon los úl. timos no es semejante facultad un resultado de la educacion; es que el canto se ha conservado tal como autes era: con la enseñanza se han podido desarollar ciertas notas, adqqui riendo otras mas seguridad y brillo; pero el tipo no ha varia. do; y pruébanos que si un pueblo putede olvidar su lengua, una especie de pájaros guarda constantemente la suya en medio de las circunstancias mas diversas. Los mil atractivos del paisaje jel encanto de lo desconocido contribuyen tam. bien al úrito de este canto: es mas bello, mas dulce y armo. nioso, no cuando suena en una reducida y empolvada habita. cion, sino cunndo se oye al aire libre, bajo la celeste bóveda; alli donde las rosas y jazmines trepan al rededor de los ci. preses, y cortandolas ondas sonoras, hacen perder a los irinos esa durcza de pue adolece el canto del canario dóméstico. Pero escuchar no basta; entra por mucho la inaginacion: y se forma un juicio que pudieran otros tachar de exigerado: entre los pardillos, los ruiseñores y los canarios domésticos, sucede que los silvestres no están todos igualmente dotados: hay entre ellos buenos y malos cantores; pero puedo asegurar que nunca oi mas preciosos gorjeos, notas de perho mas penetrantes y cxpresivas que las que producen estos pájaros en Canarias, y aun algunos de los domésticos que habitan todavia su pais. Iamás olvidare el de un magnifico macho de la Gran Canaria que me regaló un amigo mis; no se debe juzgar del canto de los canarios silvestres por el de algunos individuos cogiáos muy jórenes y enseñados sin el auxilio de un maestro innejorable.

Dil ruclo de estos pájaros es como el del pardillo; describun lineas onduladas; no se elevan a gran altura y van de árbol en frbol. Cuando vuelan en bandada, los individuos no se oprimen unos contra otros, sino que guardan siempre entre sí cierta distancia, y lanzan sonidos de llamada muy breves y repetidos. Cuando no están en celo los camarios de que hablamos, forman bandadas muy numerosas, las cuales se dividen con frecuencia en reducidos grupos, ţue se dir. gen cada cual por su lado para ir á explotar los campos que pueden proporcionarles alimento; pero antes de ponerse el sol se vuelven a reunir todos para pasar la noche juntos.

CA 7.A. - L lis muy fácil apgoderarse de los canarios: los jó venes, sobre indo, quedan cogidos en todos los lazos, siempre que uno de sus semejantes sirva de reclamo: aqui te nemos otra prueba de su extremada socinbilidad. He visto coger algunos en redes donde se habia puesto como reclamo un pardillo ó un jilguero.

*n las Canarias se suele emplear una jaula de dos com. partimientos: el exterior provisto de una trampa y el interior destinado a poner el reclamo. Colócase este aparato en los bosques, cerca del agua, y por la maisana es cuando se cogen mas individuos. Oculto el pajarero en un jaral, puede observar cómodamenie las interesantes costumbres de los canarios: yo he visto coger asi de diez y scis a veinte en pocas horas, y eran la mayor parte jóvenes que no habian mudado aun la pluma.

CAUTIVIDAD. - He observado detenidamente í estos pajaros cautivos, y he tenido hasta diez y ocho a la vez En Santa Cruz se pueden obtener a razon de 30 céntimos cuan. do se eligen jóvenes y se han comprado ya otros; los machos vicjos cogidos úlkimamente valen una peseta y 20 céntimos; en la Gran Canaria los precios son mas altos, aunque todo es géneralmente barato alli.

- Estos pájaros son de suyo inquietos, tardan mucho en perder su timidez innata; cuando se ponen varios en una jaula algo pequeña se desgastan fácilmente las plumas. Mucho les gusta enlazar sus picos y pronto se reconocen los machos por su canto penctrante y agudo. Cren que no hay pájaro granivaro mas delicado que este: muchos son victimas de las convulsiones, y sucumben al segundo y tercer aiaque.

pos machos silvestres se unen fácilmente con las hembras doinésticas muestranse muy carinosos y fieles con ellas; nunca se olvidan de darles su alimento, y pasan toda la noche posados en el nicio. En tales casos amenazan con su pico á todo pája:o que se acerca; yo vi á un macho luchar en semejante circunstancia con un serderon, $y$ aunque herido de gravedad en una pata, no dejó de oponer resistencia, provo. cando á su encmigo, que era mas iuerte. Iué necesario sa. carle al momento de la jaula para salvar su vida.

- Én Tenerife llaman ierdegcis á los mestizos de los cana. rios silvestres y dontésticos, y son inuy apretciados: algunos he visto cuya nadre era de color amarillo vivo, y que se distin. guian yor su belleza y los cxtraños dibujos del plumaje. Te. nian el lomo verde oscuro, y la parte inferior del cuerpo, á partir de la garganta, de un amarillo de oro: considerábanlos como pajaros sumamente raros. Cuando se practican en Canarias estos cruzamientos, se tiene siempre cuidado de dar al macho silvestre dos hembras domésticas, porquue es muy ardiente..

Debo abstenerme de hacer aqui una descripcion minuciosa del canario dom estico, tanto mas cuanto que en los úl. timos años se ha ėcrito tanto sobre cstas avecillas, su cria y comercio, que molestaria as mis lectores al tocar un asunto en demasia tratado.

\section{LOS ERITRÓSPICES -ERYTHROSPIZA}

CARACTERES. - A estegénero pertenecen solo algunas especies, que se caracterizan por tener el pico corvo, corto, grueso, abovedado por arriba y por abajo, s recogido en los bordes; los piés son cortos y endebies; los dedos bastante largos, como tambien las alas, cuyia punia esta formada por la primera-rémige; la cola es cortn y sesgada en el centro.

\section{EL ERITRÓSPICE GITAGINO-ERYTHROS- PIZA GITHAGINFA}

CARACTERES.-Esta especie, llamada tambien pinson del desicrib, cormeta del iesievfo y moro, tiene un plumaje magnifico, de color gris sedoso mezclado con rojo sonrosa. 
do; este último tinte se extiende y oscurece mas à medida que el ave avanza en años; en la primavera, cuando el plumaje ostenta todos sus brillantes colores, el rojo llega it su estado mas perfecto, de modo que es muy superior al es malte purpúreo de la amapola de nuestros campos, por lo cual ha merecido el ave su nombre cientifico. Hacia el o:ono, cse color palidece mucho, y entonces el macho se asemeja mas a la hembra, cuyo color predominanic es un rojo amarillo muy intenso. Obsérvanse, sin embargo, muchas variacio. nes en el color: algunos machos parecen estar bañados en sangre, y otros tienen un color gris como la arena del desierto. La sustancia colorante roja no se limita solo al plumaje, sino que se extiende tambien ś la epidermis; de modo que un eritróspice gitagino sin plumas parece un verdadero piel roja pequeio. La coronilla y la nuca adquieren tambien en la primavera un tinte gris sedoso; los hombros y el dorso son de un color ceniciento mas $\delta$ menos pardusco, con viso rojizo; las tectrices mas grandes de las alas son de un pardusco púlido, con un ancho borde sonrosado; las rémiges y las rectrices de un gris pardo oscuro, orilladas de rojo de carmin en las barbas exteriores y de blanquizco en las interiores; las puntas tienen bordes de color claro. Toda la parte superior del cuerpo de la hembra es de un gris pardusco; las regiones inferiores de un gris claro con viso rojizo, y el vientre de un blanco sucio. Ia longitud del ave es de $\theta=13$ por (1) ${ }^{\prime}, 23$ de ancho de punta á punta de las alas; estas iniden (1)",0g y la cola $0^{\prime \prime}, 05$.

DistRIBUCION GEOGRÁFICA.-Prra conocer el pais de este pájaro es preciso recorrer el désierto, tomando esta palabra en su acepcion mas lata, pues vive alli exclusi. vamente: Bolle le halló muy abundante en Canarias, principalmente en las islas orientales, en Ianzarote, fuerteventura y la Gran Canaria. Yo vi muchos en casi todo el alto Egipto y en la Nubia, hasta cerca de la region de las estepas, donde desaparece, aunque tambien encontré algunos individuos en los desiertos de Arabia. Este pájaro visita durante sus emigraciones las islas del Archipiélago, la Provenza y la Tosca. na; en Malta se le ve todos los inviemos.

\&os parajes, dice Bolle, que busca el critróspice son siempre los que están desprovistos de árboles y caldeados por el sol: parece que aquel timido pájaro necesita pascar libre. mente sus miradas por la llanura y las colinas. Prefiere los lugares mas pedregosos y áridos donde la reflexion de la luz sobre las rocas, y las vibraciones del aire que se eleva, ca. lentado por los rayos perpendiculares del sol, deslumbran y ciegan al viajero. Acá ó allí crece entre las piedms una mata de yerba agostada por los ardores del sol, ó bien se en. cuentra una escusilida breña alimentada por un poco de tiern vegetal; y esto basta para que se nutra el pajjaro. Alli vive el conirostro, observando todas las costumbres de los saxicolas, y se reune con otros de sus semejantes cuando no está en celo; alli es donde salta de piedra en piedra, y donde vuela rasando el suclo, de tal modo que apenas le puede se guir la vista. El plumaje gris de rojo de los individuos viejos se confunde con el tinte de las piedras y de los troncos des. nudos de las euforbiáceas; el color isabela de los jórenes se pierde sobre el amarillo leonado de la arena, de las inatas y de las rocas calcáreas; y la vibracion particular de las capas inferiores de la atmósfera, causa dé tantos espejismós é ilu. siones, contribuye aun mas a ocultar á estos pajjaros. El naturalista perderia bien pronto sus huellas si la voz no le guiasc: un sonido atraviesa el aire, semejante al de una trompeta; es vibrante y estridente, $y$ si se tiene el oido fino, percibese que ra seguido de algunas notas dulces, argenti. nas, que parecen los últimos acordes de una lira pulsada por invisibles manos. Otras reces se ojen sonidos singulares, profundas, semejantes al canto de la rana de las Canarias; estos sonidos se repiten a intervalos cortos, y el mismo pł. jaro se contesta con algunas notas casi iguales, aunque mas débiles, de tal modo, que no parece sino que el animal es ventrilocuo. Nada mas dificil que tratar de describir el canto de los pajaros, pero seria imposible hacerlo tratíndose del eritróspice. Produce este sonidos del tocio especiales, pro. pios de un mundo idea!, y que se deben haber oido para formar una idea. Seguramente que ninguno espera encontrar un verdadero pájaro cantor en paises tan desolados; pero aquellos trinos singulares y románticos, si así puedo expre sarme, seguidos de algunas notas particularment: roncas, constituyen una cancion del prjaro. Conviene perfectamente con la fisonomia del paisaje: escúchase con placer; se entristece uno cuando vuelve \& reinar el silencio: y echa de menos aquellos sonidos, que son como la roz melancólica del desierto, como un misterioso dialogo de los espiritus de la soledad.

\$ El moro desaparece de los puntos donde el terreno esta solo descubierto de arenas volndoras, pues no esta organi. zado para correr por la superficie como el chorlito. Parece que tambien evita las montañas empinadas y pedregosas; pero le gusta estar al lado de las negras corrientes de lava, pues aunque solo encuentre alli alguna pobre graminea, le ofrecen en cambio las grietas de las rocas un refugio seguro. Nunca se le ve posado en un árbol ó êl un jaral.

D En los paises habitados son estos pájaros bastante timidos; pero donde les rodea por todas partes la calma y la so. ledad, no tienen desconfianza; con frecuencia llegan los mas jóvenes ś posarse junto al viajero y le miran con sus ojitos negros y brillantes que revelan la curiosidad

Lo mismo sucede en el valle del Nilo: el critróspice del desierto habita las orillas pedregosas del rio, por encima del Liout; donde cl desierto llega hasta las márgenes del Nilose puede tener la seguridad de encontrarle.

lin el norte y el centro de la Nubia se ven bandadas de cincuenta a sesenta individuos que descienden sobre los campos 6 vuelan por la montaña: cuanto mas salvajes son las rocas y mayor es el numero de sus grietas, mas abundantes aparecen los pájaros en cllas; pero en el desierto propia. mente dicho no suelen estar sino cerca de las fuentes. Son alli los mas numerosos; las alondms y las caberizas del de. sierto son las únicas que habitan con él tan misera pais.

Los individuos cautivos cuidados por Bolle eran dóciles, pacificos, sociables, atrevidos y graciosos; llamábanse sin cesar unos a otros y se contestaban, emitiendo unas veces so. nidos claros y sonoros, aunque breves, y otras sostenidos, como los de una trompeta; a menudo producian notas bajas y línguidas, g̨ue recordaban el sonido de una campanilla de plata, 6 bien roncas, conso las de los emberizas. Al kne, kne, kae que repiten con mas trecuencia, sucéderse casi siempre una nota mas baja y muj breve. Estos sonidos, roncos umas veces y armoniosos otras, pero siempre sumamente expresi. vos, traducen muy bien todos los sentimientos del pájaro. En algunos casos, aunųue muy raros, se oje una especie de gorjeo prolongado, pero sin trabazon, semejante al de los loros pequeibs, y a veces cacarean como los polluelos, repiticndo tres ó cuatro veces seguidas un kackink, kirekiaks. Un sonoro schak schal: indica la sorpresa $\delta$ desconfianza, al ver cosas inusitadias. En la primavera es cuando los machos producen con mas fuerza el sonido semejante al de la trompeta, que las hembras no pueden emitir: para esto echan la cabeza há. cia atris, abren mucho el pico y colócanle verticalmente; las notas mas dulces se producen con la boca cerrada. Cuando estas aves cantan, $\delta$ se hallan en el periodo del celo, ejecu. tan los movimientos mas grotescos; bailan dando rucltas unas 
al rededor de otras; y si están excitadas se acosan con suma vivacidad. Si el macho persigue a la hembra endereza á me. nudo el cuerpo verticalmente, afectando entonces, con las alas muy abiertas, la figura de un escudo; diriase que quiere estrechar entre sus brazos al objeto de su amor.

Cuando está en libertad el eritróspice se alimenta casi exclusivamente de granos de toda especie, y acaso tambien de hojas y retoños; parece que desprecia los insectos y necesita de todo punto el agua. Ror escasa, turbia y salobre que sea la corriente, es preciso que el pajaro vaya por lo menos una vez al dia; la presencia de los eritróspices es siempre una buena senal para la caravana sofocada por la sed.s Por la mañana $y$ al medio dia llegan estos pajatos en bandadas a la corricnte, beben mucho y se bañan en los sitios poco profundos.

En el unes de marzo comienza el periodo del celo, y el plumaje del macho se ostenta entonces en toda su hermosura; aléjanse las parejas, aunque sin separarse comple:amente de la bandada, y se las ve posarse sobre las piedras ó las rocas. Ojense tambien los sonidos de trómpera del macho, ả los cuales responde la roz de la hembra, que, mucho mas dulce, se asemeja al canto de la alondra. In las márgenes del Nilo vi á estos pajaros recoget materiales jara construir su nido mas no pude descubrir uno solo, pues las rocas donde los depositan son inaccesibles para el naturalista.

Bolle no fué mas aiortunado que yo i pero los pastores de Canarias le dijeron que los eritróspices forman sus nidos en las grietas de las corrientes de lava, ó sobre el suclo, al abri go de una roca saliente.

Sola liristram dice que el nido está fabricado exclusiva mente con pequeñas raices finas y tallos Rexibles. Los tres ó cuatro hucvos que la hembra deprosita tienen unos $0^{\circ}, 018 \mathrm{de}$ largo, por 11,012 de grueso y son de color verde mar con puntos y manchas de un pardo rojo, muy aislados en la ex tremidad ěstrechia, mientras que en la otra forman una especie de corona compuesta de arabescos finos, lincas angulosits y grandes manchas de un pardo rojo claro, mas pálido on los. bordes.

CA UTIVIDAD. - Jos pirizones del desierto ciutivos son muy raros entre nosotros, porque no se les persigue en su patria; su manera de proceder entretiene uuscho; conténtan. se con poca cosa y se domestican fácilmente. Los individuos cuidados por Bolle se reprodujeron varias veces produciendo robustos polluelos.

\section{LOS ACANTAS-CARPODACUS}

CARACTERES. - Mientmas que los critróspices solo ha. bitan los desicrios áridos, los acanias buscan por el contrario los sitios donde abunda el agua. Las procas especies de este género se-caracterizan por su pico relativanente delgado, bastante corvo hasta en la arista, abovedado lateralmente, y recorido en los bordes arquendos, cuya punta superior sobre sale de la mandibula infurior; los piés son robustos; los de dos, de longitud regular, estản provistos de uñas muy corvas, puntiagudas y comprimidas lateralmente; las alas son de lon gitud regular; las tres primeras rémiges, poco mas ó menos iguales entre si, son las mas largas; la cola, de mediana lon giud, tienc una ligera sesgadura en el centro; el macho se distingue por el magnífico color rojo purpúreo en su plumaje.

\section{EL ACANTA CAARMSÍ-CARPODACUS ERY- THRINUS}

CARACTERES. - En esta ave predomina el color rojo de carmin; la parte posterior del cuello y cl dorso son de un gris pardo, con manchas mas oscuras de un viso carmesi; el vientre, los muslos y las tectrices inferiores de la cola de un blanco sucio; las rémiges de un pardo intenso, orilladas en las barbas exteriores de blanco amarillenio de orin; las plu. mas de los hombros tienen berdes de color pardusco claro, con viso carmesi; las rectrices son de un pardo gris, orilladas de un tinte mas claro; las tectrices superiores de la cola tienen bordes rojos de carmin. En la hembra predomina en vez. del carmesi un color pardo gris leonado, con manchas longitudinales mas oscuras. Los ojos son pardos; el pico de un color claro; los piés de un tinte oscuro de cuerno. la longitud del are es de $0^{10}, 86$, por $0^{\circ}, 26$ de ancho de punta $a$ punta de las alas; estas tienen $0^{*}, 08$ y la cola $6^{\circ}, 06$ de largo.

DISTRIBUCION GEOGRÁFICA,-El acanta carmesi no habita en Europa con regularidad mas que en orierte, sobre todo en Galitzia, Polonia, las provincias del Báltico, el centro y sur de Rusia, y ademąs toda el Asia central desde el Liral hasta ol Kamtschatka. De aqui emigra regularmente hácia el sur, pasando por la China llega lasta la India, asi como por el Turkestan á la Persin. Visita bastante á menudo la Alemania oriental donde ha anidado en Silesia y en el Schleswig; con frecuencia se le ha observado en el centro, occidente y sur de Alemania, en Holanda, Bélgica, Francia, Ingluterna é Italit

USOS, COSTU MBRES Y RÉGIMEN. - El acanta car mesi se presenta á mediados de mayo, ó cuando mas pronto á principios de abril, en los sicios donde anida, los ruales abandona de nuevo en setiembre. Prefiere las espesuras próximas ó las aguas ó los pantanos cubiertos de cañaverales y de maleza; pero no se limita á las llanuras, sino que tambien visila los parajes donde abundan las colinas, elevinuo. se if mas de 2,000 metros de altura en las inontarias. No abunda en ninguna parte; sicmpre se le ve aislado; y nunca forma numerosas bandadas en verano.

Inmediatamente despues de su llegada ójese ya su canto, cn extremo variado y sunoro, y que si bien recuerda el del jilguero, pardillo y canario, es sin cmbargo tan especial qua no se le puede confundir con el de ningun otro fringilido. Este canto es tan rico como agradable, tan suave como armonioso, y se considera como uno de los mejores que pueda producir el pico de un pajaro. In el Kamischatlia sc ha interpretato este canto, segun dice lititlitz, por un texto ruso: escherivischa nividel (jo he visto la tschewitscha). T'schewischa se llama, segun Kittliz, la mayor especie de los salmones que alli se encuentran; este es el pez-mas apreciado en el pais; constituye el alinento principal de los indigenas, y llega al Kamtschatia poco mas ó menos al mismo tiempo que el pajaro. El canto del acanta se considera como la señal que indica la llegada del salmon; y en un pais cuyos habitantes se alimentan principalmente de peces, el acaria carmesi no es solo el precursor de la estacion mas hermosa, sino tambien de una abundante cosecha. En efecto, à menudo se oyen en las notas del canto, sonidos semejantes a las palabras rusas y que el ave pronuncia con marcada entonacion. Cuando el macho canta suele posarse en el arbusto donde se halla el nido $\delta$ en uno inmediato; entonces eriza las plumas de la coronilla y del pecho, cual si quisiera ostentar todo el esplendor de su plumaje: desaparece despues, produciendo aun algunas notas que casi resucnan como un murmulio en el interior del arbusto, $y$ al poco rato vuelve á presentarse para cantar de nuevo. Sus movimientos recuerdan los del pardillo, al que tambien se parece por su viracidad.

El alimento de este pajjaro consiste en simientes de toda clase, que recoge tanto en plantas altas como en cl suclo; tambien come retonos y tallos tiernos, y además se nutre, por lo menos en la jaula, de larvas de hormiga y otras sustancias 
animales. En los paises donde inverna vive de las simientes del bambú, de los juncos y cañas, permaneciendo casi exclusivamente alli dónde crecen estas plantas, por lo cual se le llama en la India grorrion de los cariaicerales. I.o mismo aqui que en su patria invade tambien los campos, pero en ningu. na parte causa graves perjuicios á las plantas cultivadas.

El nido se encuentra por lo regular en los espinos negros y' siempre en arbustos espesos y espinosos cuancio mas á dos. metros del suelo, y se asemeja, segun Taczanowski, al de la curruca de los espinos; compónese de tallos finos y flexibles de ralces; está muy bien relleno interiormente de sustancias mas tiermas aun, de la misma clase, tal como restos de flores y algunos pelos; pero el conjunto de la construccion es muy ligero y flojo. La puesta se compone de cinco huevos, raras veces de seis, que por término merio miden $11^{n}, 020$ de largo por $\left(0^{m}, 015\right.$ de grueso; $y$ la cáscara es muy fina y de un magnifico color verde azulado con aigunas masichas y lineas de un color pardo amarillo, pardo oscuro, 6 rojizo, que solo en la extremidad gruesa son mas numerosas; en los úitimos dias de mayo la hembra suele completar su puesta. Mientras agueila cubre, el macho canta con tamto afan como antes, pero á menudo á bastante distancia del nido, al que sin $\mathrm{cm}$. bargo vuelve con frecuencia. Cuando les amenaza un riesgo advierte of la hembra con un sonido semejante a la voz de aviso del canario, y que es comun à los dos sexos. Cuando los polluclos salen del nido el aracho deja de cantar y cam.

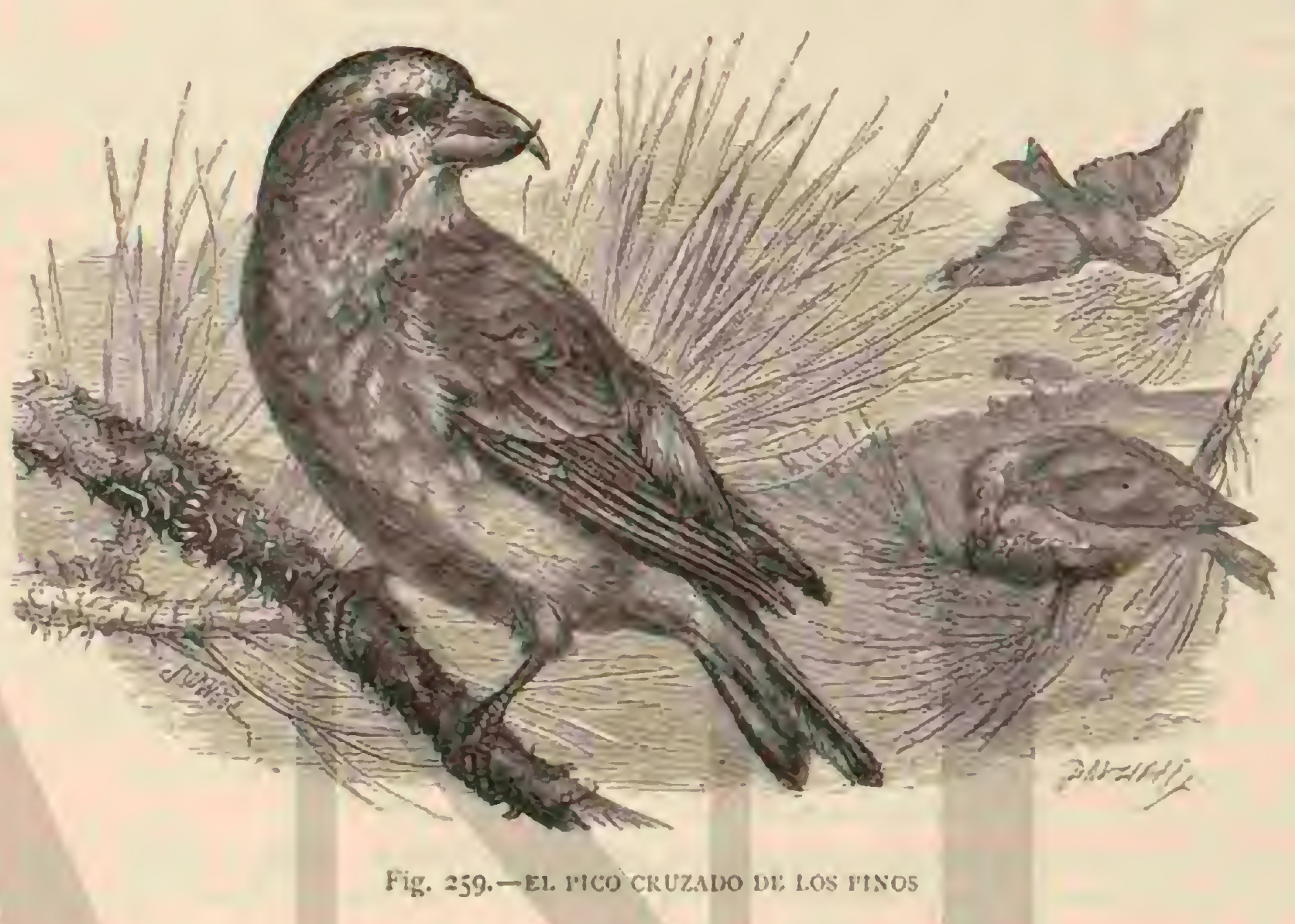

bia completamente de conducta: silenciosos y ocultos, evi. tando con prudencia al hombre que se acerca, as! los adultos como los pequenos vagan por la espesura hasta que llega el tiempo de emprender su vinje, y entonces desaparece una familia tras otra.

CAUTIVIDAD. - Los acantas carmesis cautivos son aves en extremo agradables, pero tienen un color mas delicado que el de ningun otro płjaro de igual hermosura, color que pierde su esplendor é intensidad al solo contacto de la mano. Despues de la muda su plumaje adquiere unos colores ver. dadcramente desagradables, y raras veces se conservan estas aves aigunos años en la jaula.

\section{EL ACANTA ROSADO-ERYTHROTHORAX ROSEUS}

CARACTERES.-El acanta rosado tiene unos $0^{\circ}, 20 \mathrm{de}$ largo y $0^{m}, 30$ sus alas desplegadias: la frente es de un blanco brillante, y todo el lomo de un rojo carmin vivo, con las alas del mismo color, cruzadas por dos fajas claras: cl vientre es tambien de un tinie carmin. Los machos jórenes tienen el plumaje pardo rojizo, con fajas longitudinales oscuras, y otras dos rojo amarillas en las alas.

Ia hembra se parece à la del pardillo vulgar.

Dice Radde que la faja blanca de la frente es mas cxtensa en todos los machos viejos, y menos pronunciado el rojo; en los jorenes se mezcla de pardo el rojo de la cabeza; la parte anterior parece gris rojiza. A medida que el pajjaro envejece, invade el color rosa las anchas fajas blancas de las Toso III pequerias y medianas cobijas superiores del ala: en las hem. bras son siempre rojas la parte sujuerior de la cabeza y la rabadilla; las de aranzada edad tienen el vientre de carmin claro.

DISTRIBUCION GEOGRAFICA.-Radde ha observa. do con frecuencia el acanta rosado en los montes de Bureja: en la Epoca de las emigraciones se deja ver accidentalmente en Rusia, Hungría y Alemania.

USOS, COSTUMBRES Y RÉGIMEN.-Por setiembre forma el acanta rosado reduciojas bandadas de seis a doce individuos; en invierno se le encuentra solo con su hembr, y desaparece hacia la primarer.

Este pajaro busca las selvas de poca espesura, sobre todo aquellas donde predominan las enciras y los abcdules ne. gros; tambien se le halla en los valles donde hay bosque. Reúnese á menudo con el pinzon de moniaña 6 de los Ar. denes, y con el canario enano de la Siberia. En pleno dia se dividen las bandadas de estos pajaros; cada individuo reposa perezosamente en una rama, separado de los demís é indi. ferente á todo: cuando buscan su alimento, por la mañana, parceen $\tan$ timidos como viraces.

\section{LOS URAGOS-URAGUS}

CARACTERES.-De los acantas se ha separado últimamente una especie propia del Asia, dándole el rango de gé. nero independiente. Se caracteriza por iener el pico endeble; la mandibula supcrior poco saliente; los piés débiles; las alas obtusas, formando la cuarta rémige la punta; la cola tan larga 
como el cuerpo, escalonada, con una sesgadura en el centro; y el plumaje sedoso: estos son los caractéres distintivos del género que nos ocupa.

\section{EL URAGO DE SIBERIA-URAGUS SIBIRICUS}

CARACTERES. - El macho adulto tiene un magnifico color de rosa, con viso gris de plata; una faja de la frente es de un sonrosado muy vivo; el dorso del mismo color mas oscuro, porque en esta paste las lineas de los tallos son mas marcadas y solo dejan un borde rojo en las barbas; la rabadilla resalta por su color carmesi vivo; la cabeza y li garganta son blanquircas, con lustre sedoso, sobre todo despues de la muda, que en general reviste al pájaro de un plumaje inas claro, porque todas las plumas nucras están orilladas de un color blanco que poco á poco se desgasta. Cada pluma tiene la base de un gris oscuro, $y$ el resto de un curmesi pálido con borde claro. Las penquenas tectrices superiores y las plumas de los hómbros son blancas en las barbas exteriores y en la extremidad, $\delta$ cuando menos están orilladas de blanco; las tres últirnas rectrices de cada lado son igualmente blancas, excepto los tallos, que tienen un tinte oscuro, como lo es el borde de la base de las barbas interiores, el cual se ensancha hácia el centro de la cola en cada una de las rectrices: las del centro estin orilladas solo de blanco. La hembra tiene un color aceituna claro ó verảe gris. Ta longitud del pájaro és de ()$^{\circ}, 8$, la de las alas de ()$^{\prime \prime}, 08$ y la de la cola de ()$^{\prime \prime}, 09$. "Distribucion GEOGRÁFICA. - El urago de Siberia habita las regiones pantanosas cubiertas de canaverales del Asia oriental, y sobre todo el este de la Siberia y de la China, asi como la Nandchuria y el oriente del Turkestan. Seigun dicen, se han observado individuos errantes en el sudeste de Europa $y$ hasta en Hungria. Radde los vió durante todo el año en las regiones centrales del Amur.

USOS, COSTUMBRES Y RÉGIMEN. - Hácia fines de otoño reúnense lás parejas en bandadas de diez á treinta individuos $y$ vagan por el pais dejando oir silbidos monosj. lábicos.

«Cerca de Irkutsk, dice Radde, no son numerosas hasta fines de setiembre, en cuga época cogen los pasajeros un gran número de urazos, paros, picos cruzados, pinzones rea. les $y$ plectrófanos de las nieves; pero los primeros no resisten largo tiempo la cautividad, y pierden su viveza acostumbrada.

\$ Hasta el mes de noviembre se les ve tan solo pasar: mas tarde las parejas son sedentarias y habitan los espesos jarales que bordean las corrientes, en compañia del pinzon comun. Son bastante aficionados śla proximidad de los cam. pos, principaimente de aquellos donde se dejan las cosechas en gavillas. Cerca del Ocon se deja ver el urago de Siberia al mismo tiempo que los picoteros, y puebla con ellos las islas; en las montañas de Bureja no se ven grandes bandadas hasta fines de setiembre. En todas partes despliegan muchn actividad estos pajjaros: nunca vuclan juntos, sino aisladamente, y se llaman sin cesar unos á otros: al volar trazan una curva poco eleracia, y producen sus alas un pe. queño murmullo:

Fista are abunda mucho en la Dauria. Segun Dybowski, á quien debemos los informes mas minuciosos sobre su género de vida, durante el verano se la ve en las pendientes meridionales de las montanas y solo hácia fines de la primavera baja â las llanuras, donde visita con preferencia los bosques que rodean los rios, riachuelos y fuentes de la es. tepa.

En la primera mitad de junio, el urago de Siberia comien. za la construccion de su nido, que se suele encontrar en abedules enanos, rams veces en pequenos sauces y alerces; por lo regular se halla á metro y medio $\delta$ dos metros sobre el suelo, y siempre tan cerca del tronco como es posible. Su construccion es tan ligera como podria esperarse de un pájato de pico grueso, y se compone de varias clases de tallos secos de ramaje blanņueados por el sol, y entreiazados con fibras de sauce, y de varias plantas; el interior está relleno de gramineas finas, crin de caballo, pelos de corzo y liebre y \& veces tambien plumas. La puesta se compone de cuatro huevos, rara vez de tres ó cinco, que miden (I",010 de largo por $0^{n}$, or 4 de grueso, ascmejándose á los del acanta carme. si; son muy bonitos, de color verde azulado muy intenso, con escasas manchas y lineas parduscas, que solo en la extremidad gruesa son mas numerosas. Durante la construccion del nido el niacho deja oir su canto, bajo, pero agradable. Cuando se acerca un hombre advierte á la hembra con un silbido y esta se alcja entonces al punto. Si el intruso permanece en la inmediacion del nido vuelve al cabo de mucho tiempo, pero sin perder su tinidez. Cuando el cuclilto pone un huevo en su nido abandónale en seguida y se sirve del material para la construccion de ntro; $y$ si se le quita la puesta 6 la cria, aléjase inmediatamente de la region.

\section{LOS PINZONES - PYRRHULA}

CARACTERES. - Estos pájaros, tipos de la sub.familia, tienen estructura robusta, con pico grande, corto, grueso, muy abovedado lateralmente, algo comprimido hácia la pun. ta j un poco ganchudo; los piés son cortos; los declos de longiud regular; Ias alas bastantc obtusas; las remiges segun. da, tercera y cuarta forman la punta; la cola es bastante larga y sesgada ligeramente en el centro; el plumaje espeso, suave y de diferénte color segun el sexo.

\section{EL PINZON REAL COMUN - PYRRHULA VULGARIS}

CARACTÉRES. - El pinzon teal comun (fig. 258 ), lla mado vulgarmente frailecillo, tiene ()$^{n}, 17$ de largo y $11^{n}, 28$ de ala a ala; el ala plegada mide casi $\|^{\prime \prime}, 09$ y la cola $0^{n}, 06$.

El macho viejo tiene la parte superior de la cabeza de co. lor negro oscuro brillante, lo mismo que la garganta, las alas y la cola; el lomo es de un gris ceniciento; la rabadilla $y$ el bajo vientre de un tinte blanco, y el resto de esta última parte y el pecho de un rojo vivo.

En la hembra la parte inferior del cuerpo es de color gris ceniciento con matices menos vivos.

Los pequerios no tienen la cabeza negra: las alas pre. sentan en todos dos fajas de un blanco agrisado al nivel del carpo.

Hay pinzones blancos, negros y de colores mezclados.

DISTRIBUCION GEOGRÁFICA.-El pinzon real habita tocia la Europa excepto el norte y el esté; en el sur de nuestro continente solo se presenta en invierno. Fin el este $y$ norte de Europa y en toda el Asia central represéntale el pinzon grande (Pyrrinula major) que solo se distingue por su mayor tamnno; pero esta diferencia es tan constante, que debemos reconocer la separacion de ambas especies, introducida por mi padre. El pinzon grande anida todavía en Prusia y Pomerania, pero no en el oeste cie Alemania, donde solo se presenta de paso; el pinzon real no se encuentra ya en Pomerania.

USOS, COSTUMBRES Y RÉGIMEN.-Tanto la una como la otra especie, de cuya separacion prescincio en la descripcion siguiente, son en un todo pájaros selváticos que no abandonan nunca el bosque mientras encuentran alimen. 
to. Solo cuando el invierno obliga al pinzon real a salir de su dominio llega en bandadas a las plantaciones de árboles frutales ó a las huertas de los pueblos, ó bien s los bosques que lindan con los campos, donde busca las pocas bayas que otros congéneres le han dejado. Al principio de la temporada, cuando vagan por el país, se ven á menudo solo machos, que mas tarde se mezclan con las hembras. Mientras no les obligan circunstancias especiales a emprender largos viajes permanecen en su territorio; pero á veces cxtiunden sus expediciones hasta el sur de España 6 Grecia. Casi siempre viajan de dia, rolando si es posible, de un bosqque á otro.

¿Fil nombre del pinzon, dice mi padre, es en aleman sinó. nimo de tonto y ancerico: no se prede negar que el jinzon es un pájaro sin malicia y sin recurso contra las astucias del hombre; se le puede cozar fícilmente con escopeta y cogerle; pero su estupidez no igtala á la de los picos cruzados. Cierto es que al sonar el tiro que da muerte a uno de los suyos, toda la bandada quiere posarse de nuevo sobre la rama donde cayó la victima, mas nunca permanece uno solo in. móvit, y sin volar, como to hacen los picos cruzados. Si cl pinzon fuera tan estúpido como se dice, iseria posible que aprendiese á silbar ciertos aires? Lo que domina a este pajaro es el amor á sus semejantes: si nuere uno se lamentan los otros; no pueden resolverse a dejar el sitio donde su. cumbió su compañero, y quieren llevársclo consigo. Seme. jante abnegacion ocasiona con frecuencia escenas conno. redoras: cierto dia tiré contra un pinzon macho que se hallaba posado en una cerca con uno de sus compañeros; este huyó. y le perdi de vista, mas volvió á poco y fué á co. locarse en el mismo sitio donde habia caido el otro: podria cizar otros muchos ejemiplos, mas no lo creo nccesario.

- El pinzon asanza a saltitos, y es bastante torpe en tierm: pero en los árboles no sucede asi: se posa con el cuerpo ho. rizontal y los tarsos encogidos, 6 bien se mantiene derecho, extendiendo las patas: algunas veces se cuelga de las ramas con la cabcza hácia abajo. No suele oụrimir las plumnas contra el cuerpo, y por esto parece mas grueso de lo que real. mente es. En el momento de emprender su vuclo, 6 cuando se posa, enderéase altivamente. Un airbol cubicrto de pin. zones es cosa muy agradable; el color rojo de los machos se destaca admirablemente sobre el rerde follaje, en verano, y sobre la blanca-nieve en-invierno.

\$.os pinzones parecen insensibles al frio; hasta en el ri. gor del invierno son vivaces y estain alegres, si bien $\mathbf{a}$ condi. cion de que se les dé bastante de comer. Su espeso plumaje les preserva del frio, $c$ influye asimismo en el ruelo, que aunque lento, es fácil, y traza una linea ondulada, aseme. jándose al del halcon. Lo mismo en el uno que en el otro, obsérvase que las alas se abren mucho y se repliegan des. pues: Con frecuencia se balancean los pinzones en el aire antes de posarse, y á veces se precipitan casi rericalmente, recogiendo pronto las alas.

* El grito de llamada del macho, idéntico al de la hembra, es un sonido planidero que podria expresarse por ing 6 lus: le produce el pájaro cuando cruza los aires, en el momento de emprender su vuele $y$ al posarse. Segun la entonacion, puede ser un grito de llamada, de aviso ó de dolor, y cxpre se lo yue quiera, le comprenden los otros; de donde es fácil deducir la delicadeza y finura del oido de estos fuajaros, los cuales llegan á percibir diferencias que con dificultad nota. ria el hombre. El canto del macho no tiene nada de particular; distinguense algumas notas corridas, dificiles de tra. ducir. Cuando vive en libertad cania principalmente en la Época del celo; si está cautivo se le oye todo el año.

El pinzon se alimenta de granos, y come tambien las semillas encerndas en las bayas; en verano devora muchos insectos. Cuéstale trabajo extraer los granos de las piñas, y por eso los recoge en tierra cuando se han desprendico por si solos.

En invierno es fácil reconocer la presencia de los pin\%ones en los árboles de bayas, por los restos que cubren el suelo, aunque el pájaro no toma este alimento sino cuando le apura el hambre, toda vez que prefiere los granos secos. Tiene la costumbre de tragar arena para facilitar la trituracion de los alimentos.

Este pinzon puede ser nocivo porque destruza los retonos de nuestros árboles frutales, pero como nunca se presenta en gran número, los perjuicios causados por él apenas son considerables, salvo el caso de que alguna bandada ocupe una pequeña huerta, sin que nadie la moleste en mucho tiempo. Eil pinzon real anida con regularidad en las regiones monta. nosas donde hay grandes extensiones cubiertas de bosq̨ue y donde este ofrece espesuras proco frecuentadas y ocultas.

Raros son los casos en que se fija en los parques j jardines, y solo cuando sabe por experiencia que no se le ha de molestar. Asi, por ejemplo, conócese una pareja que anida todos los años en la hiedra que tapiza la chozas de un parque de Anhall.

E.l nido está situado siempre en un lugar bien oculto, 'á media altura de un árbol, bien sea en alguna bifurcacion, 6 en una rama gruesa, á poca distancia del tronco. Nunca se ha visto nido de pinzon en las ramas muy altas.

Fste niclo se asemeja al del verderon ordinario: exteriormente se compone de ramitas secas de los pinos, abetos y abedules; luego sigue una capa de líquenes, j por dentro está relleno de pelos de corzo y crines de caballo, 6 solo de yerbas y musgo, y tambicn lana algunas veces. Fn el mes de mayo contiene cuatro ó cinco hueros pequeños, redondos y de cáscara lisa; su color es verde claro ó azulado, con man. chas violeta sin lustre ó de un negro mate, y puntos y lineas de un rojo pardo, diversamente contorneadas.

La hembra cubre los huevos por espacio de quince dias, y durante este tiempo es alimentada por el macho: los padres comparten despues el trabajo de enseñar á sus pequeños; manifiéstanles mucha ternura y los defienden hasta con peli gro de su vida. Al principio les dan de comer insectos; luego granos, humedecidos préviamente en cl buche, y por último secos: aun cuando les haya salido toda-su pluma siguen los padres alimentíndoles si no tienen una segunda puesta.

CAUTIVIDAD. - Se cogen los pinzones pequeiros en el nido para criarlos en casa y enscriarlos, y cuanto antes se comience mejor resultado se obtiene; inutil parece decir que el maestro debe ser bueno, pues con uno malo no se conse. guiria el objeto. Todos los años se crian asi en Turingia centenares de pin\%ones pequeños, que se remiten en seguida a Berlin, Varsovia, San Petersburgo, Amsterdarn, Lóndres, Viena y hasta América.

Desde el primer dia de su cautiverio comienza la educa. cion, es decir, se silba delante de ellos el nire que deben aprender, sin hacer falsas notas, $y$ cada vez en el mismo tono. Se la querido hacer uso de las canarias, pero esto no dió buenos resultados; y ni aun in flauta vale lo que un buen silbador. Algunos pinzones aprenden asi fácilmente dos ó tres aires; otros están siempre mudos; los unos conservan sienjre el sonido en la memoria; los demás los olvidan a cada muda.

Tambien aprenden á cantar las hembras, mas no tan bien como los machos, aunque hay algunas que llegan á ser ver. daderas artistas Yo he oido silbar ciertos aires, dice mi padre, á muchos jilgueros y mirlos; pero ningun pájaro de nuestro país puede completir con el pinzon por la pureza, la suavidad y el timbre de notas: es increible que pueda llegar 
a tal punto. Aprende á menudo varics aires, y los repitecon un tono tan armonioso, que no se cansa uno de oirle.

Además de su facultad de imitar, el pirzon real se distingue de todos los otros pájaros por la facilidad con que se domestica y por el afecto incomparable que llega á profesar á su amo, con el cual se encariña de tal modo, que siempre está alegre cuando le re, $y$ triste si se ausenta; hasta podria morir por el exceso de alegria $\delta$ de pena que le causara su amo. No cuesta mucho acostumbrarle a entrar y salir libre. mente en la habitacion: anida fácilmente en la jaula y reune por lo tanto muchas excelentes cualidades.

\section{LOS PICOS-DUROS-PINICOLA}

CARACTERES.-1.as picos duros constituyen el último género de la sub-farnilia de que podemos ocuparnos. Estos. jåjaros tienen cuerpo robusto; pico abovedndo, con una ligera escotadura en los bordes; la mandibula superior sobre: sale en forma de gancho; los piés son relativamente cortos, pero fuertes; los dedos robustos, provistós de uñas grandes; las alas plegadas cubren el primer tercio de la cola; las rémiges segunda y tercera forman la panta; la cola es bastante larga y sesgada en el centro; el plumaje, en fin, espeso y notable por la belleza de sus colores.

\section{EL PICO-DURO VULGAR-MINICOLA ENU- CLËATOR}

CARACTERES.-En el macho adulto predomina un bonito color rojo, mientras que en los de un año $y$ en las hembras este color tira mas al amarillento; la garganta es do un tinte mas claro y en las alas hay dos fajas trasversales blancas; las plumas son de un gris ceniciento en la base, negruzcas á lo largo del tallo y rojas 6 de un amarillo rojo en la purita, presentando \& veces manchas mas oscuras en el centro; los bordes son por lo reguiar de un color menos in. tenso; las rémiges y rectrices negruzcas, con bordes mas claros. los njos son de un pardo oscuro; cl pico de un pardo sucio, negruzco en la punta; la marrdibula inferior es mas clara que la superior; los piés de un pardongris. Ia longitud de esta especie es de $\left(0^{m}, 2\right.$ por $0^{*}, 35$ de ancho de punta punta de las alas; estas miden $6=, 12$ y la collt 0 , 08 de largo.

DISTRIBUCION GEOGRAFICA. - Todos los paises árticos sun la patria de este bonito y extraio pajaro. Por to que hasta ahora se sabe, el pico duro vulgar no abunda en ninguna parte: en verano vive apareado y aisladamente en un extenso dominio y solo se reune por bandadas en otoño, las cuales mgan durante toda el invierno por los bosques del norte; acércanse tambien á veces i las casas de labranza solitarias, y vuelven á principios de primavera á los sitios donde anidan. Algunos picos duros vulgares se presentan casi todos los inviernos rigurosos, mientras viajan, en el noroeste de Alemania, así como en las provincias del Bảltico, en la Rusia septentrional y en las regiones correspondientes de Asia y de América. Estos picos llegan a veces en gran número hasta nosotros; pero solo cuando median circunstancias especiales, sobre todo cuando las fucttes nevaojas les obligan a dirigirse lrácia el sur, los grupas dispersos se reunen y forman enionces bandadas muj considerables. Fn los anos 1790, 1995. $179 \mathrm{~S}$ y $1 \mathrm{SO}_{3}$ los picos duros se presentaron en número tan ininenso en los praises del Báltico, que solo en la region de Riga se pudieron coger todas las semanas, durante algun ticmpo, mas de mil parejas; en $1821,1832,1844$ y 1878 llegaron a Prusia bandadas innumerables, y en $3 \$ 45,1856,1863$ y $18 ; 0$ observáronse en Pomerania en menor número. Mas hácia el norte se les ve todos los inviernos en regiones donde no se encuentran en verano; en el centro y sur de Alemania, en Holanda, Bélgica, Francia é Inglaterru, figuran, por cl con. trario, entre los pájaros mas raros.

A estas emigraciones forzosas hácia las regiones menos frias debemos la mayor parte de nuestros conocimientos acerca de las costumbres de los picos duros vulgares.

Vemos, pues, que son pajaros nuuy sociables: no acostum. bran ś separarse; van siempre reunidos, juntos buscan su alimento y pasan todos la noche en el mismo sitio. Prefieren estar en los bosques de coniferas, sobre todo en donde abun. dan los caebros; en los demás escasean y atraviesan apresu. radaniente las llanuras descubiertas, sin detenerse un mo. mento.

Cuando visitan por primera vez paises extraños no nıanifiestan malicia ni desconfianza, porque no conocen aun la perversidad del hombre: léjos de inquictarse al acercarse el cazador, miran con curiosidad la escopeta que les apunta, y permanecen en su sirio sin pensar en huir, aunque agobiados de tristeza cuando cae uno de ellos herido mortalmente. Cuando comien es muy fácil cogerlos por medio de lazos co. locados en una pértiga, en los cuales quedan sujetos por la cabeza; tambien se dejan atrapar con las trampas mas toscas. Todos los que han observado á estos pajjaros libres dicen que son muy carinosos cntre si: de cuatro individuos se cogicron una vez tres, y se vió al otro deslizarse bajo la red para com partir|la suerte de sus compañeros. No se debe tachar sin embargo el hecho de estupidez, pues vemos que la experien. cia les enseña por fin á ser tan desconfiados, timidos y pru. dentes, como lo son, segun Collet, en los sitios donde anidan.

El pico duro vulgar tiene muchas de las costumbres de los picos cruzados: es un verdadero pájaro arboricola, jara el y̧ue parece extraña la tierra; trepa hábilmente entre el ramaje y franquea saltarido espacios bastante considerables: su vuelo es rajpido $y$ un poco oscilante en el momento de posarse; pero cuando baja al suelo avanza a saltitos bastante torpes.

Tiene una voz muy agradable: su grito de llanada consiste en un silbido scmejante al del pinzon real; su canto, que se oye hasta en cl invierno, es tan variado como armonioso; pero en dicha estacion no se puede formar exacta idea de él, pues el pájaro solo emite entonces sonidos cortos yó media roz. En la primarera, cuando le domina el sentimiento del amor, canta con entusiasmo y cautiva a sus oycntes, aun \& los que han escuchado \& otros mejor dotados que él. Los naturalistas suecos nos dicen que canta principalmente en las hermosas noches de verano, yo por eso le llaman s'igilanue noe. incrio.

Su carácter es dócil y pacifico; y la hembra muéstráse siem pre sumamente curiüosa con el macho.

E! pico duro libre se alimenta de simientes de las conife. ras, las cuales extrae por las escamas abiertas de la piña, las recoge en las ramas ó en el suclo; no desprecia las de otras clases ni tampoco las bayas, y considera en general los retoños 6 la verdura como una golosina. En verano se alimenta quizis tamien de insectos, sobre todo de moscas, muy frecuentes en su pais y con ellas nutre probablemente : sus hijuelos. Sin embargo, no ienemos observaciones exactas sobre este particular.

Pocos datos tenemos acerca de la manera de reproducirse los picos duros, pues en verano no se les encuentra nunca al sur del Vainland y del Dalarna. Solo una vez, por un caso raro, se les vió anidar en Alemania, y por fortuna cerca de la casa de Naumann, cujo padre publicó una descripcion del nido. Hallábase este situado en una pequeña rama de li gustro, á I "',30 de altura sobre el suelo, poco mas ó menos, y tenia el aspecto de un nido de curruca. Componiase la 
parte exterior de vilos de ramas y de rastrojo, y el interior estaba relleno delrin. Contenia cuatro huevos, que Naumann describio, rero incompletamente, segun resulto mas tarde. Tienen $0^{\circ}, x: 5$ de largo por $0^{\circ} 020$ de grueso y son de un hermoso colo: azul pálido, salpicados de rojo pardo en el extremo mas grusso, y con algunas manchas de un tinte pardo castaño.

Segun las obseraciones de Wolley, los nidos que hay en I aponia se suelen hallar en pinos bajos a una altura de cua.

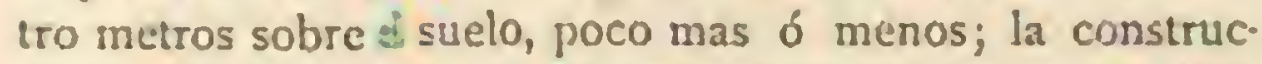
cion exterior se cmpone de ramas largas, delgadas y flexibles, y es á vecesun extremo lacia : el interior está relleno de raices finas, musgo y tallos mucho mejor entrelazados que en el exterior. Ia puesta se compone por lo regular de cuatro huevos, que solo cubre la hembra, segun la observa. cion de Naumanr mientras que el macho la entretiene con su agradable cant.

CAUTIVIDAa.-Los picos duros cautivos se acostum. bran en pocas hors ś la jaula; toman al punto el alimento y se domestican tronto, lo mismo que cualquier otro pirru. lino; pero raras reces se conservan mucho tiempo en la jaula, sin contar çe en la primera muda pierden para siempre sus magnificos colores.

\section{LOS LOXINOS-I.OXIINA}

CARACTÉRES. - Esta última sub-familia comprende un solo género, clue los picos cruzados, pájaros de estruc. tura recogida, de cabera grande y formas un poco pesadas; tienen el pico mur fuerte, grueso, comprimido lateralmente y escotado en los cordes; la mandibula superior, redondeada en la angrosta arista, se prolonga en larga punta, encorván. dose ligeramente hiricia abajo en figura de gancho; la inferior, mas fuerte que la superior, se arquea cruzándose con aquella, bien por el lado derecho ó ya por el izquicrdo; el pie es corto y fuere, con dedos largos y robustos; las uñas, encorvadas en forma de arco y puntiagudas, presentan dos cortes; las alas, bastante largas y estrechas, tienen la pri. mera rémige mas prolongada que las demás; las rémiges primarias son angostas y redondeadas longitudinalmente; las secundarias, mas anchas, se cortan casi en ángulo recto; la cola es corta y bifurcada; las-plumas peñueisas, espesas, suaves y muy variadas, segun la edad y el sexo.

\section{EL PICO CRUZADO DE LOS ABETOS-} LOXIA PITYOPSITTRCUS

CARACTERES. - Este pájaro, el mas grande y fuerte del género, tiene una longitud de $\|^{*} \cdot 20$, por $11^{\prime \prime}, 30$ de ancho de punta a punta de las alas; estas miden $10^{m}, 11$ ! Ia cola ()$^{*}, 0 \%$. El pico es en extremo fuerte, grueso y alto; las dos man dibulas se encorvan casi en semicirculo completo. La cabeza, la garganta, la barbilla, el pecho y' el vientre son de un rojo mas ó menos viro, mas claro por delante, con lustre gris en las mejillas y ceniciento en la garganta; las plumas del dorso son de un gris rojo, grises en la base y orilladas de rojo en la punta; las de la rabadilla de este mismo color negro, pero mas vivo que el de las ótras plumas pequenas; las de la parte inferior del vientre de un rojo ceniciento claro ó blanquiz. cas, con viso rojizo gris; las iectrices inferiores de la cola, de color gris blanco, con lineas mas oscuras y lustre rojizo. La hembra tiene las plumas de la coronilla y del dorso de un gris oscuro, las primeras orilladas de amarillento verde y las segundas de verde gris: la linea naso-ocular y la parte ante. rior de las mejillas son de un gris claro; la posterior de estas de un gris oscuro; la nuca y la parte posterior del cuello de un amarillo verde gris; la garganta de un gris claro; ti pecho y centro del vientre de un gris blanquizco; el resto de las regiones inferiores gris pálido, presentando las plumas an. chos bordes de color amarillo verdoso; las rémiges y las rectrices son de un negro gris orilladas de verde, y de gris os. curo en la carn inferior; las tectrices inferiores de la cola de un negro gris con puntas blancas.

I.os individuos jóvenes tienen la cabeza y la nuca de color negro gris, con lineas de un gris blanco; la linea naso.ocular y las mejillas de un gris oscuro; las plumas del dorso de un negro gris, rayadas de gris verdoso; las de la rabadilla son de un amarillo verde con lineas longitudinales oscuras; las de las regiones inferiores de un gris blanco con fajas longitudinales claras y oscuras de color gris muy intenso; las ré. miges $y$ rectrices tienen un color verdoso gris oscuro ó gris claro en los bordes; las tectrices superiores de las alas son de un gris claro en la punta y forman dos estrechas fajas en las alas.

\section{EL PICO CRUZADO DE LOS PINOS-LOXIA CURVIROSTRA}

CARACTÉRES. - Fista especie, mas pequeña que la anterior, tiene el pico mas prolongado y menos corro con la punta mas larga y mas baja que en el pico cruzado de los aberos. La longitud de esta especic es de $11^{m}$, is por $1 ", 28$ de anchura de punta a punta de las alas; estas miden $11^{\text {" }}$,og y la cola $11^{\circ}, 06$ de largo. Is cabeza, la nuca y la parte inferior del tronco son del mismo color que en su congénere; la parte posterior de las mejillas de un pardo gris oscuro; las plumas de la parte inferior del vientre de un gris blanco; las rémiges y rectrices, con sus tectrices superiores, de un negro gris, orilladas de gris rojizo; las tectrices inferiotes de la cola, de un gris oscuro, tienen las puntas blancas con viso rojizo En la hembra, las regiones superiores solz de un gris oscuro, y las inferiores de un gris claro; cada pluma está orillada de verde amarillo; la rabadilla tiene este mismo color. El plumaje de los polluelos es de un gris oscuro en el dorso, con ángulos verdosos blançuizcos en las regiones inferiores, viso verdoso mas ó menos marcado y manchas longitudinales de color gris oscuro.

\section{EL PICO CRUZADO DE FAJAS ROJAS- LOXIA RUBRIFASCIATA}

CAR ACTERES. - Ėste pảjaro mide $6, " 175$ de largo, por $\left(0^{*}, 30\right.$ de ancho con las alas extendidas, $y$ difiere del pico cruzado de los pinos por tener un circuk de color gris en la nuca; los hombros son de un pardo oscuro, con puntos rojos $y$ dos anchas fajas en las alas, de color sonrosado en el ma. cho, gris en la hembra y gris amarillo en lós polluclos, cu. yas fajas estin formadas por las punias de las iccirices superiores.

\section{EL PICO CRUZADO DE FAJAS BLANCAS- LOXIA BIFASCIATA}

CARACTERES - El pico cruzado de hajas blancas es mas pequeiro que todas las especies anteriores. Tiene una longitud de $6^{\circ}, 16$, por $11^{\circ}, 27$ de ancho de punta à punta de las alas; estas miden $(4,09 \mathrm{y} \text { la cola } 1)^{\circ,}, 06$ de largo. El color predominante del plumaje es un magnifico rojo, que en la nuca y centro de la parte inferior tira al gris. Las grandes y pequeñas tectrices superiores de las alas forman en estas dos anchas fajas; las tectrices de los hombros tienen igualmente la extremidad blanca. La hembra y los polluelos se parecen á 
los del pico cruzado de los pinos, pero tambien tienen las fajas blancas en las alas.

DISTRIBUCION GEOGRÁFICA.-LOS picos cruzados pertenecen à las especies de su clase que mi padre ha liamaclo con mucha razon gijoros gifonos. Asi como el extraño pueblo cuyo nombre se les aplica, preséntanse súbitamente en cierta region, donde permanecen bastante tiempo, acos. tumbrándose desde el primer dia á las condiciones del pais; reprodúcense tambien \& veces y desapparecen de pronto. Sus viajes parecen tener cierta relacion con la abundancia de simientes en los bosques de coniferas, sin que esto se pueda fijar como una regha segura, pues se da el caso de qute ralten muchos años en nuestros bosques de coniferas y villvan despues á cllos en gran numero. Solo se conncen con certeza los sitios gue habitan; pero su patria no tiene límites fo. das las esprecies citadas anidan on el norte de Europa, asi como tambien en todo el norte del Asia hasta la region de los bosques: tal ve\% deberiamos considerar este último continénte como la patria prinuitiva de esas aves.

USOS, COSTUMBRES Y RÉGIMEN DE. LOS PICOS CRUZADOS.-Cuando se cruza un bosque de coniferas en años en que estos arboles tienen muchas pin̉as, se oyen veces sus gritos de liamada que podrian traducirse por goes,

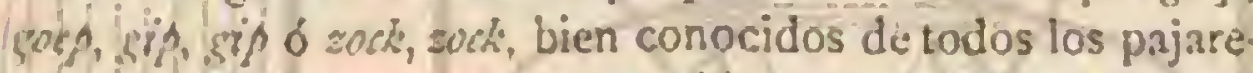
ros y de muchos cazadores; tambien se percibe en algunas ocasiones eanto del macho. Llegan a la selra los picos cru. zados y se instalan alli: si la localidad tes agrada se reprodu cen, y si no, 3 se trasladan al cabo de cierto tiempo á un punto mas conveniente. Pronto eligen el mejor sitio del bosque, y despues de volar todo el dia, se dirigen à thl por la tarde.

Todos los picos cruzados son sociables, y no acostumbran at separarse, estando apareados, ni aun en el periodo del celo. Sus costumbres ofrecen particularidades muy curiosns: son esencialmente arboricolas, 5 solo en caso de necesidad bajan á tierra para npagar la sed $\delta$ comerse los piñones que se desprenden del árbol. la copa de los pinos es su morada: trepan àgilmente por el majaje, ayudándose del pico, lcomo los loros; suspéndense con el auxilio de este brgano 6 de las patas, con la cabeza hácia arrióa ó hácia abajo, y permanecen algunos minutas en esta posicion, ian incómoda al pa. recer. Vuelan con facilidad y ligerear; pero rara vez recorren una larga distancia; extienden mucho las alas; recógenlas luego súbitamente sobre los costados, y describen asi en el aire una linea ondulada.

Fin la época del celo se remontan revoloteando sobre los árboles; permanecen suspendidos en el mismo punto, cantan, y viselven despues al sitio acostumbrado. Excepto al medio dir, siempre están en cuntinuo mosimiento.

Durante la primasera, el verano y otono comienzan á vagar por el bosque desde uque raya al dia, rasladandose de una arboleda a otra y de colina en colina; los pajareros que ponen sus trampas en junio y julio, se ven por lo tanto pre. cisados a ocupar su puesto a las dos de la madrugada. En el invierno, cuando el frio es riguroso, permanecen largo tiempo estos pájaros en el sitio donde han pasado la noche; dejan oir, no obstante, su voz a primers hora; pero no ensprenden el vuclo hasta que el sol ilumina todo el horizonte. In dicha estacion se les ve muy afanados a las diez de la mañana, hora en que comienzari á tomar su silimento; á las dos horas se trançuilizan; pero continuan comiendo hasta las cuatro, y luego se entregan al descanso: beben al medio dia, y en ve. rano à cso cie las diez ó las once.

los picos cruzados se cuidan muy poco de los demás habitantes de la selva, yasta del hombre, aunque desde los primeros dias reconocen en êl a un enemigo. En este hecho se han fundado algunos para sostencr que los picos cruzados son séres estupidos: y apoyan su opinion en otros datos que probarian, en efecto, una completa halta de facultades intelectuales; pero si se estudian con mas atencion estos pájaros, se observa que saben aprovecharse de las lecciones de la ex. periencia, j que son en realidad menos tontos de lo que pa. recen. Fácil es cogerlos 6 matarlos: $y^{\circ}$ son tan fieles entre si, que su carino les cuesta \&́ menudo la vida ó la libertad; pero esto no es, en mi concepto, una prucba de estupidez, sino de buen natural. El macho, cuya hembra acaba de morir, permanece en la rama agobiado de dolor, ó vuelve á buscarla al sitio donde la perdió: pero cuando estos pájaros lle. gan á conocer la malignidad humana se vuclien muy des. confiados.

Segun dice mi padre, â quien debemos la descripcion mas exacta de las costumbres de esios pajaros, eel grito de llama. da del pico cruzado de los abetos es un sonido que podria traducirse por las silabas gmef, goep, $\delta$ gif, gip, 6 soc, soc. Pro. ducen el primero cuando ruelan ó están posados; es la scñal de marcha, un llamamiento, un grito destinado ś reunir ślos individuos de la bandada; ; por lo mismo es fuerte siempre. Gip. sip es el grito de ternura con que se comunican el ma. cho $Y$ la hembr cuando descansan; pronúncianlo á media Yoz, de tal modo que se necesita estar al pié del árbol para oirla Diriase muchas veces, que el pájaro que produce este sonido esti muy léjos, y de pronto se ve asomar su cabeza. Zoces el grito de que se vale el pájaro, cuando está posado, para llamar á los que pasan cerca de él, invitándoles 1 dete. nerse; algunas veces, no obstante, lo produce un pájaro que vuela; es un grito sonoro y fuerte, y debe ser el principal que emplean para la llanada.

- Los hijuelos pian casi lo mismo que el pardillo jóven. pero bien pronto adquieren la voz de los padres y ejecutan los mismos gorjeos.

* Eil pico cruzado de los pinos lanza su grito de llamada cuando se posa 6 vuela; es un giṕ gip mas débil que el del pico de los abetos, y cuando se ban oido una ve\% los dos, no se pueden confundir: yo los reconozco en el bosque desde léjos. Fiste gí̧ es á la vez una senal de particia, de aviso y de llamamiento: cuando los pảjaros están posados y lanza este sonido fuertemente alguno de ellos, todos los demás prestan atencion y emprenden su vuelo apenas da uno la seval. Si están comiendo y pasan cerca varios de sus semejantes produciendo tal grito, no se inquictan; y contestan á veces con un soc, zof, como invitíndoles a tomar parte en su banquéte. Este sonicio es mas fuerte y claro nque el del pico cruzado de los abetos: y si uno de los individuos se aleja mucho, los otros le pronuncian continuamente para evitar que su com. pancro se extravie; tambien se vale del mismo grito el pajaro que colocado en la copa de un arbol, quiere invitar á toda una bandada á que se pose alli: es entonces muy sonoro, y rara vez se oje cuando los picos vuelan. Cuando los picos cruzados se posan, dejan oir un ligero grito muy bajo, que se parece bastante al pio, fio de los polluelos; los pequeños que le producen, emiten además casi los mismos sonidos que los picos cruzados jorrenes de los abetos.

El canto del macho es delicioso: el del pico cruzado de los abetos es aun mejor que el del de los pinos, siquiera se ase. mejen nucho. Son sonidos pronunciados con voz fuerte, $y$ a los que siguen algunas notas senicjantes á silbidos débiles. Si están libres cantan sobre todo cuando el tiempo es hermoso y sereno y no hace mucho frio; pero callan en los dias veniosos y de tempestad. Para cantar se posan siempre en las ramas mas altas; solo en el periodo del celo trinan cuando vuelan. In hembra les imita, pero su vor es mas baja y me. nos sostenida que la del macho. Si están enjaulados cantan tocio el ario, excepto en la época de la muda. Los picos cru. 
2ados se alimentan casi cxclusivamente de piñones; necesitan de todo punto su fuerte y encorvado pico para comerlos, y tanta iuerza como destreza para abrir las piñas a fin de sacar su contenido. El pájaro llega volando, se suspende del fruto cónico, con la cabeza hácia abajo, ó bien le coloca sobre una rama y le sujeta con sus vigorosas uñas, largas y puntiagudas. Es muy curioso ver a un pájaro tan pę̧ueño, dice mi padre, cuando se traslada de un árbol à otro, llevan. do una piña de regular tamaño; la coge con sus pico, manteniendo la punta, por lo regular, hácia adelante, y vuela á oiro árbol situado â unos veinte pasos, â fin de poder abrir el fruto, pues no encuentra en tocias partes ramas donde le sea posible practicar semejante operacion cómodamente. He aņuí cómo procede: con la punta de su mandibula superior arranca las anchas escamas del centro: hace un agujero en el cual introduce su pico, un poco abierto, y luego levanta el capillo con un movimiento de cabeza. Fntonces puede intro. ducir fácilmente con su lengua el piñon en la boca; rompe luego la cubierta y se traga la almendm: no abre nunca los grandes conos.

\$Su pico en cruz le es muy útil para esto; no necesita abrirle mucho para darle una gran extension, y le basta un ligero movimiento de cabeza para levantar una escama.

\$Semeiante maniobra produsce cierto ruido, una esperie de castanteteo suticientemente sonoro para que se oiga desde el pié ciel árbol. El pico cruzado de los pinos no suele sacar todos los granos de un cono, segun lo hacen sus otros con. géneres; abandona el fruto cuandio está picoieado cn sus tres cuartas partes, y a menudo antes de haberlo abierto. No tie nen únicamente esta costumbre los individuos jóvenes, como creia Bechstein, sino tambien los viejos: asi es, que donde ha residido por algun tiempo uno de estos pájaros, el suelo aparece cubierto de pinas abiertas.

Cuando los árboles no contienen ya sus frutos, este pâja. ro recoge y abre los que han caido.

Rara vez toca el pico cruzado de los pinos los conos apretados de sus árboles favoritos, pues no tiene suficiente fuerza para romperlos; pero devora muchos de los abetos cuyas escamas lévanta de una sola vez por el punto por donde in. troduce su pico. Ias dos especies abren siempre el fruto con su mandibula superior, y apoyando la inferior contra la pina; observándose que en los individuos en que el cruzamiento de las mandíbulas se verifica hácia la derecha, siempre es la mitad de este lado la superior; en los otros es la mitad iz. quierda.

En dos 6 tres minutos acaban con una piina; el pájaro la deja caer $y$ busca otra, $y$ asi sucesivamente hasta que se llena el buche.

Por los frutos que cubren el suelo se reconoce que hay picos cruzados en el pais. Cuando nada les molesta, perma. necen estos pajiaros horas enteras en el mismo árbol, y habi. tan varias semanas en un punto, sin buscar nunca otro alimento mientras encuentren pirias. Si estas llegan á faltar, comen granos oleaginosos, de cánamo, cardo, ctc, y tambien insectos, principalmente pulgones, que cazan en los jardines $y$ huertos.

La operacion que practican los picos cruzados con los conos resinosos es causa de que marichen su plumaje, siquiera tengan tanto aseo como los otros pájaros; despues de cada comida emplean varios minutos para limpiarse, y frotan su pico con. tra las ramas. No pueden, sin embargo, tener siempre sus plumas tan limpias como quisieran, y ś veces quedan cubier tas de la sustancia resinosa. Su régimen produce además otro efecto, á saber: el de comunicar à su carne cualidades particulares: cuando se alimentan exclusivamente de pinones, se impregnan de tal modo de resina, que su cadáver resiste largo tiempo à la putrefaccion. " Ia carne, dice mi padre, tiene un olor muy desagradable, sin ser en realidad repugnante; se debe preservarla de las moscas, pues ponen sobre ella sus huevos, y las larvas penetran en el interior $y$ se la comen. He practicado varios experimenios, y siempre con el mismo resultado: tengo á la vista uno de estos pảjaros, que fue muerto el verano último, cuando mas fuerte era el calor, y aun conserva todas sus plumas: ambien he visto uno que se conservó momificado naturalmente por espacio de veinte años. La causa de semejante estado de conservacion reside evidentemente en el alimento resinoso que toman estos pa. jaros, pues cuando comen durante algun tiempo insectos, sc corrompe su cuerpo tan pronto como el de las demás aves.

Un grupo de picos cruzados es uno de los mas bonitos ormamentos del bosque, sobre todo en medio del invierno, cuando todo está cubierto de una blanca alfombra: el plumaje de aquellos pajarillos se destaca graciosamente sobre el verde sombrio de las ramas y la desiumbrante blancura de la nieve.

Por otra parte, su alegria y caracter retozon, su continua actividad, su gorjeo f su canto, contribuyen poderosamente á prestar animacion al paisaje. El espectáculo interesa toda. via mas cuando media la circunstancia de ser tambien el invierno el periodo del celo.

Sabida es que los picos cruzados anidan en toda estacion, lo mismo en los mas fuertes calores que en los frios mas ri. gurosos, cuando cubre la tierra espesa capa de nieve y parece cxtinguirse la vida en la naturaleza. El páijaro no se inquieta por esto, pues lleva en si la primavera con todas sus alegrias: la bandada se divide en parejas, las cuales eligen los mejores árboles del bosque para que sirvan de cuna á su progenie; pero nunca se alejan mucho unas de otras. Lil macho se posa sobre la rama mas alta; canta, llama, se vuelve y revuelve, como deseoso de que le admire la hembra en zodas sus íases. Si aquella no acude, dirigese á otro punto para llanarla de nuevo; si se acerca corre detrás, jugueteando y picando, $y$ la persigue de rama en rama.

El pico cruzado de los abetos acostumbra tambien a eje. cutar varias habilidades en el aire: elévase con repetidos ale. tazos y se cierne cantando; pero siempre vuelve despues al árbol de donde partió, como lo hace el juico cruzzado de los pinos. El nido se halla situado unas veces a bastante altura, y otras en una bifurcacion ó en una rama gruesa cerca del tronco; alguno aparece en la copa ó en medio del árbol, pero sicmpre de modo que los ocultc el ramaje, preserván. doles de la niere. El nido esta formado exteriormente de ramitas de pino, de brezo, de rastrojo seco, liquenes y musgo, y relleno interiormente de plumas, yerba $y$ agujas 6 tallos de coníferas.

Las paredes tienen unos $0^{*}, 0_{3}$ de espesor y estain artisti. camente tejidas; el fondo es relativamente profundo.

Tuve ocasion, dice mi padre, de observar una hembra que formaba su nido: tmjo primero ramas secas, y despues recorrió el árbol para coger liquenes; llenaba su picu y al llegar al nido los entrelazaba. Terminado el armazon, cmplcó mucho tiempo para ponerlo todo en órden, y aplastaba ias ramas salientes con el pecho ó las comprimia revolviéndose en todos sentidos.

Cogió casi todos sus materiales en un árbol próximo, y tenia tanta prisa, que trabajaba basta en la hora del medio dia, bastándole dos 6 tres minutos pam arreglar iodo el ma. terial que traia de una vez. El macho permaneció cerca de la hembra para hacerle companía, posado en una rama ó sobre el nido; cuando comenzó á cubrir, llevóla el alimento, y trató de distraerla con sus canciones, pues apenas habia puesto el primer huero no se movió ga del nido: hubiérase 
dicho que el macho procuraba hacer menos penosa su inmo. vilidad.

Cada piresta es de tres ó cuatro huevos pequeños de $l^{m}, 028$ de largo por $11^{*}, 022$ de grueso cuando mas, de un color blanco agrisado $\delta$ amulado, $y$ cubiertos de manchas y rayas de un pardo rojo 'ó negro, dispuestas ora en círculo alrede. dor del extremo mas grueso, ora diseminadas en toda la su. perficie del huevo.

Al salir los hijuelos del cascaron los alimentan los padres con granos de pino 6 abeto, convenientemente remojados al principio y unedio digeridos, en el buche; crecen muy pronto, y muéstranse vivaces y activos; pero necesitan mas que los otros pájaros, que les cuiden largo tietupo los padres. Hasta que abancionan el nido ro crece su pico, y por lo tamto 110 pueden abrir por si misrios las jiñas; suelen situarsc en los espesos árboles, principalmente en los abetos, y siempre cerca de sus padres. Cuando estus recogen los granos, los pequeños gritan sin cesar, cual otros ninos mimados, y si abardonar el árbol, les siguen llariándoles con voz plañidera hasta que ruelven. Poco á poco aprenden á comer por si solos: los padres comienzan por presentarles conos medio abiertos para que aprendan ślevantar las escamas; y mas tarde les enseñan á partirlos enteros. Aun despues de poder comer ya solos, siguen los padres alimentándoles.

CAZA. 一No cs dificil coger á estos pájaros: los que aca.

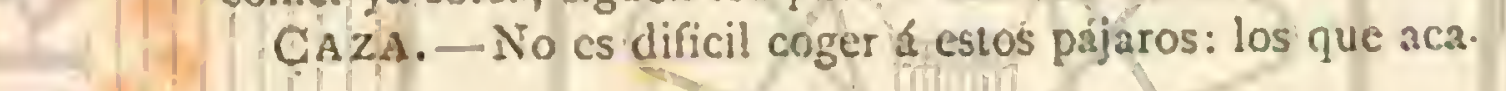

ban de llegar á un pais permiten que el cazador se acerque, y no emprenden su vuelo hasta caer alguno herido de muer. te. Acaso sea mas fícil cogerlos vivos: en luringia se usan al efecto grandes pértigas, al extremo de las cuales se coloca un manojo de ramas de pino cubiertas de liga; se dejan en un claro del bosque antes de rayar el dia, y se pone al lado una jaula que contiene un pico cruzado, el cual sirve de re. clamo. Cuantos pájaros pasan por alli se accercan al momen. to, atraidos por el canto de su semejante cautivo; y muchos de ellos nquedan pegados at la liga al posarse en las ramas.

Bien puede asegurarse que la utilidad que nos reportan los picos cruzados compensa con creces los pocos perjuicios que puedan causarnos. Sin contar el recreo que proporcionan á todo aficionado à los animales, constituyendo á la vez en invierno un adorno para las coniferas, son uítiles porque en los años en que abundan las simientes desprenden las piñas que en demasía sobrecargan las copas de los árboles, conservando así estos últimos. Recientemente se ha querido considerar á estos pájaros como perjudiciales, al menos para los bosques, pero los que lo han hecho solo ha. brán pensado que estos escasean en la Marca y en otras regiones pobres de Alemania, sin recordar las hermosas scl. vas de nuestras montañas medias. Acquí hallan esas aves tal abundancia de alimento que á ningun selvicultor pesan las piñas que abren.
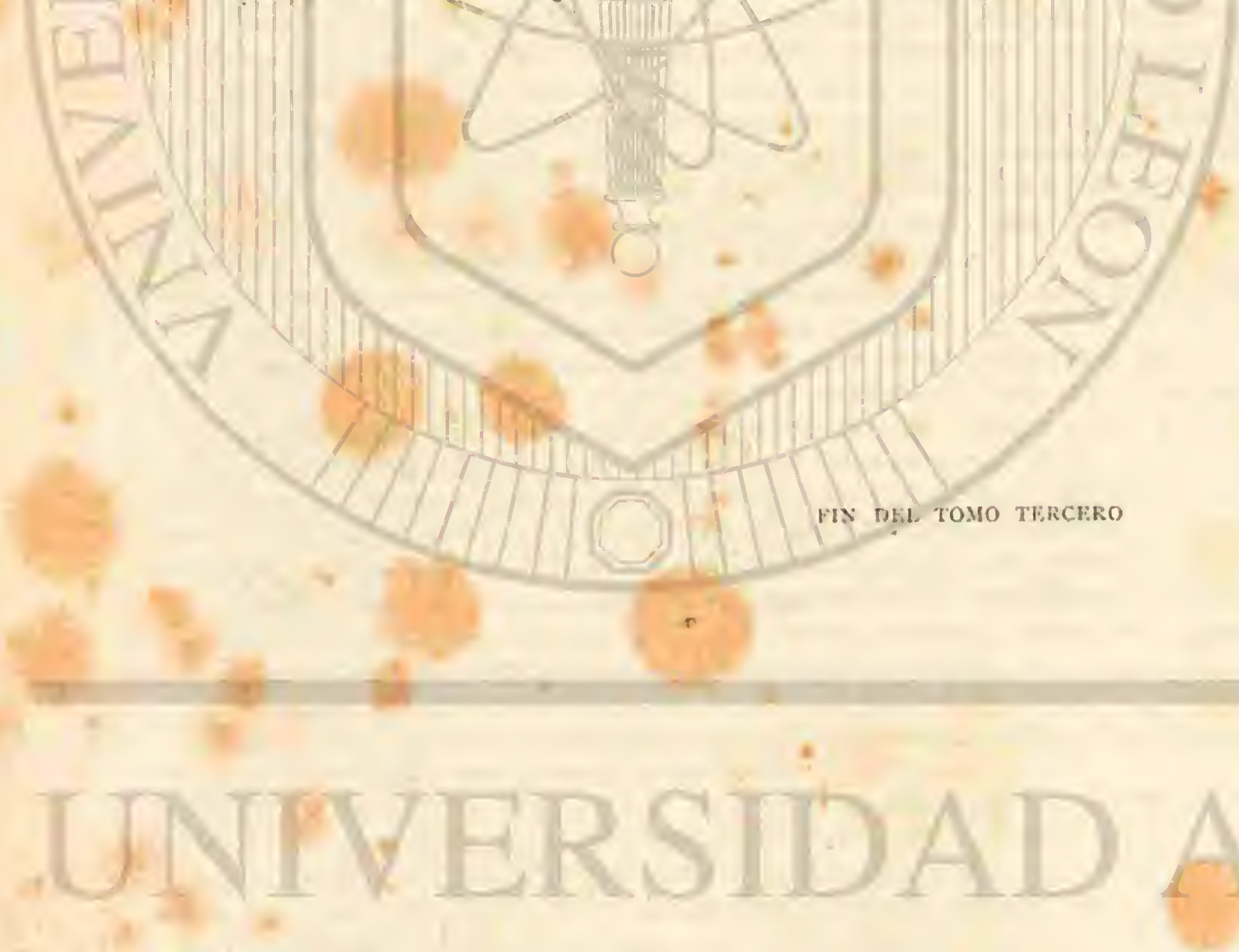

HW DEL TOMO THRCFRO

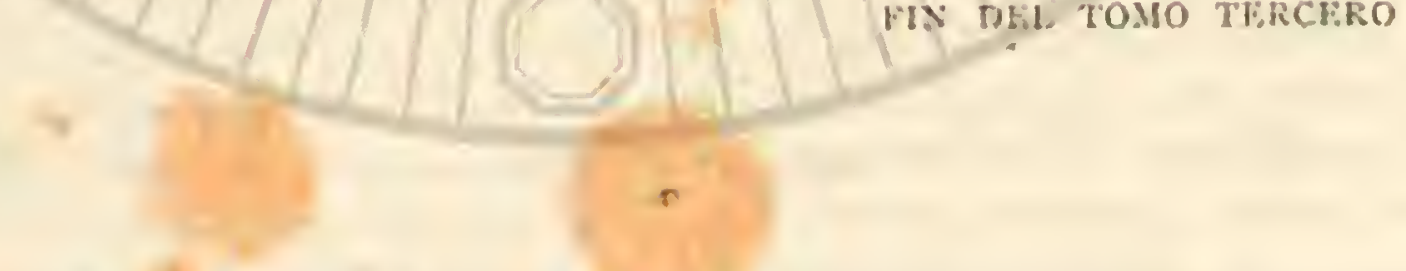

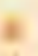
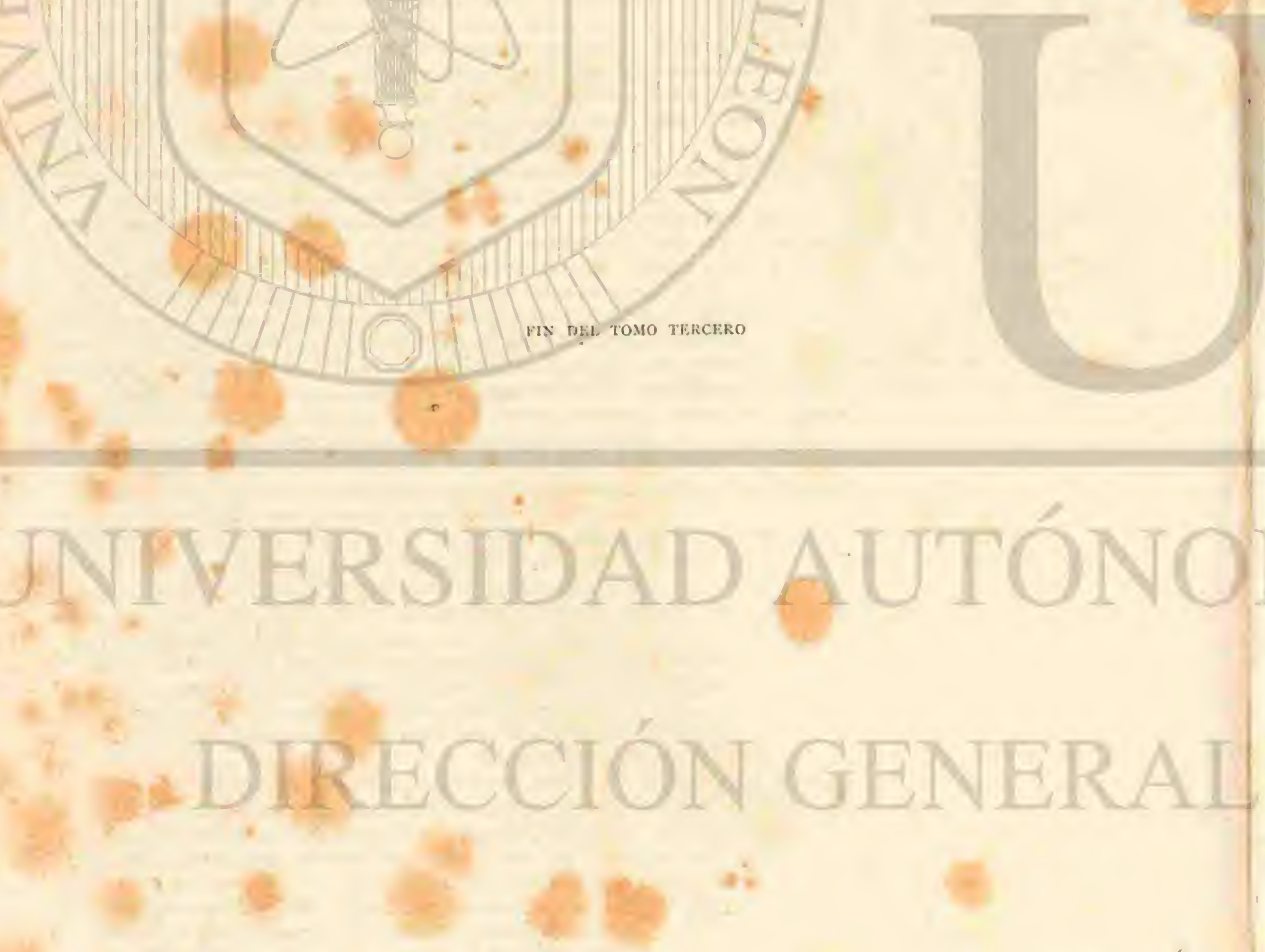


\section{INDICE ALFABÉTICO}

DE: TAS CLASES, FAMLIAS, TRIBUS, GENEROS Y FSPECIES CONTI:AIDOS FN EL TOMO TERCERO

Abadcjo 499

Abejarucos 155

Abejaruco adornado 160

Idem comun 156

Idem egipcio 157

Idem nubio 159

Acantas 578

Acantá carmesi idem

Idem rosado 579

Acantilus 209

Acantilo espinoso idern

Acentores 514

Acentor alpino 515

Idem de bosque $5 \mathrm{x}_{4}$

Idem de montaña idem

Acentorinos $5^{1} 3$

Acróbatas $47 \hat{3}$

Acróbata familiar idem

Idem mohoso idem

Acrocéfalos $50 \mathrm{I}$

Aedoninos 473

Aguilas 316

Ayuila Adalberto 323

Idem auday, 331

Idem azor $3 j 2$

Idem calzada 328

Idem canadense 316

Idem clanga 320

Idem chillowa $\hat{3} 24$

Idem de las estepas 326

Idem de penacho 334

Idem dorada 316

Idem enana 328

Idem itnperial 322

Idem leonada 316

Idem moñuda 333

Idem belicosa idem

iguiluchos 286

Aguilacho comun idem

Aguzanicve $5 \mathrm{IT}$

Aituros 215

Aiture de capucha idem

Alaudidos 526

Alcedinidos 138

Alcedininos 139

Alciones 148

Alcion 140

Idem de vientre rojo 148

Idem enano idem

Alcioninos 147

Alondra arboricola 520

Idem comun 528

Idem de Siberia idem

Amodromos 547

Amodromo maritimo idem

Amomanes 534

Amomane del desierto idem

Antilos 436

Antilo barbudo 439

Idem del Ural 438

Idem zumacaya $43^{6}$

Antinos 522

Antino de espuclas 526

Antrostomo vocinglero 18

Tosso 111
Aquilidos 314

Arakanga 42

Araras 41

Arara de alas verdes 42

Idem jacinto idem

Ararauna idem

Arporinco 472

Astúridos 300

Azores 306

Azor de las zoritas idem

Azulejo 163

Balbusardo pescador 347

Batracostomos 172

Batracostomo cornudo idem

Belatrix 217

Idem real idem

Bolborincos 53

Bolborinco calita 54

Bradipictos 510

Bradiptero sedoso idern

Brotoquéridos 53

Brotoquerido tirika idem

Buceroridos 126

Buconicios \$2

Bucorax de mono blanco ${ }_{13} \mathrm{~S}$

Budites 520

Buho vulgar 433

Idem braquioto 43

Buitres 405

Buitre monje 6 ceniciento idem

Burlones 469

Burlon roju 472

Buteónidos 370

Buzos 375

Idem chillones $3^{8} \mathrm{r}$

Buzo chilion austral idem

Idem vulgar 376

Buzos diguilas 378

Buzo-íguila calzado idem

\section{Cacatúas 29}

Cacatúa arara 24

Idem blanco $\hat{3}^{\mathrm{I}}$

Idem corella 36

Idem de Banks $3 \hat{3}$

Idem de casco 32

Idem de las Molucas 29

Idem de mono amarillo 30

Idem incr idem

Cacatuidos 26

Calamoherpinos 501

Calandrias $53^{2}$

Calandria braquidactila 534 Idem comun 532

Idem negra 533

Calaos 126

Calno de prominencia asurcada 133

Caliopes 452

Caliope del Kamtschatka idem

Calipsitacos $3^{6}$

Caliptorincos 32

Calobatos 5 in

Calobato amarillo idem
Calotorax 216

Idem de Mulsant idem

Caluros 9 r

Caluro magnifico idem

Idem resplandeciente idem

Campefilos 242

Campefilo imperial idem Idem principal $2,4 \hat{j}$

Campilopterinos 213

Canarios 573

Canario de las Canarias 57.4

Idem de frente amarilla $5 i 3$

Idem meridional idem

Caprimúlgidos 167

Caracaras ${ }_{3} \delta_{3}$

Caracara del Brasil idem

Cardenales $57 \mathrm{t}$

Cardenal de la Virginia 57

Cartacuba 153

Catarinos 410

Catártidos $4 r_{3}$

Catarto aura idem

Cefalcpis 217

Idem de Delalande idem

Ceix 144

Idem iridáctilo 145

Centropodidos 1 is

Centropo de Egipto idem

Cerilos 145

Cerilo pico idem

Idem moteado $14 i$

Cernicalos 293

Cernicalo comun 294

Idem crecerina 297

Cianalciones $x+9$

Cianalcion de Míac Leag idem

Cimindis 354 .

Idem de pico ganchudo idem

Cinclidos 477

Cinclo acuático idem

Idem de cucllo blanco idem

Iuem de vientre negro idem

Cipsélidos 192

Circactos 370

Circaeto Juan-le Blanc idem

Circidos $36_{2}$

Circido azulado idem

Idcm de las estepas 363

Idem ceniciento 365

Idem de los pantanos 367

Cirtostomos 468

Cirtostomo de Australia idem

Cisticolas 511

Cisticola corredor idem

Idem esyuenicola idem

Citrinelas 553

Citrinela de los Alpes iden

Coccilidos is

Coccistidos 105

Coccistes grajo idem

Cocizos 112

Cocizo americano II $_{3}$

Cocotráustidos 568

Cogujadas $53^{\circ}$ 
Cogujada de moño $53^{\circ}$

Colaptos 258

Colapto de México 260

Idem dorado 258

Colibris 210

Colibri 216

Idem propiamente dicho idem

Colirojos $\$ 55$

Colirojo arboricola ó de los muros 456

Iden titis 455

Colidos 120

Colius 121

Coliu de cola larga idem

Collalbas 403

Collalba rubicola 464

Idem común 463

Condor 410

Coracias 163

Coraciá de Madagascar 160

Coracidos 16 r

Cordeilos r 190

Cordéilo de Virginia idem

Corilis 24

Idem de coronilla azul idem

Cosmetornis 183

Cosmetornis porta-estandarte ident

Cotorras 46

Cotorra de la Carolina idem

Crateropos 476

Crateropo de rabadilla blanca idem

Crisocoxis 109

Idem dorado idem

Crisolampos 213

Crisolampo ninfa idem

Crisomitridos 554

Crisotis 17

Idem de las amazonas 18

Cuellos-azules 450

Cuello azul de espejuelo blanco idem

Idem sencillo idem

Idem suecoidem

Currucas $48_{3}$

Idem alondrilla 490

Curruca cenicient2 488

Idem de anteojos 489

Idem de cabeza negra 485

Idem de Cerdeña 492

Idem de los jardines 486

Idem de Provenza 493

Idem de Ruppell 49 !

Idem gárrula ó parlera 487

Idem gavilan 483

Idem melanocéfala 491

Idem orfeo 484

Cuclillos on

Cuclillo propiamente dicho idem

Cuculidos 92

Cuculinos 95

Curucús 88

Curucu de Massena 89

Crotofagidos 115

Crotofagido ani idem

Crotofagos idem

Chingolos 546

Chingolo de garganta larga idem

Chotacabras I 80 ,

Idem de collar rojo 181

Idem europeo 180

Chupafiores 315

Idem enano 216

Idem negro idem
Dasiptilos 72

Dasiptilo de Pesquet idem

Desudroquelidones 193

Dendroquelidon Klecho idem

Dicoceros 129

Dicocero bicornio idem

Diodontes 301

Diodonte bidentado 302

Docimastes 210

Docimaste portaespada 220

Domicellas 6.

Drimoicinos 511

Driocopidos 239

Driocopos 240

Driocopo negro idem

Duque (Gran) 429 .

Idem idem de los Farzones 430

Egotelos 172

Egotelo de Nueva Holanda 173

Elanios 352

Elanio melanóptero idem

Electidos 16

Electido rojo i?

Idem verde idem

Embericidos 537

Emberizas 539

Emberiza amarillo 541

Idem americano 544

Idem de las cercas 542

Idem de los juncos 539

Idem de los pinos 545

Idem de Siberia 544

Idem entenco 540

Idem gris 6 gorrion triguero 541

Idem hortelano $54^{2}$

Idem loco 543

Idem rojizo 543

Idem silvestre 540

Emu 513

Enicognato leptorinco 45

Enicuros 517

Fnicuro de Leschenant idem

Eptianuros 463

Eptianuro de frente blanca idem

Eritróspices 576

Eritróspice gitagino idem

Escitropes I10 Idem gigante idem

F.scops 435

Idem de la Carniola idem

Escotornis $\mathrm{I} 8 \mathrm{x}$

Idem climacuro idem

Esparganuros 218

$$
\text { Idem de Dupont } 219
$$

Idem Safoidem

Espilocireos 370 Idem de Jardine idem

Esqquizoris 125 Idem de fajas idem

Estcatórnidos 176

Esteganuros 218

Esteganuro del paraíso idem Idem de Hunderwood idem Idem de vientre cobrizo idem

Estipituros $5^{13}$ Idem de cola de gasa idem

Estrigidos 416

Estrigópidos 37

Eudinamis 108

Idem oriental idem

Eufemidos 61

Eufemido hermoso idem
Eurilaimidos 167

Eurilaimio de Java idem

Euristomos 166

Euristomo de Oriente idem

Euspiras 545

Eutoxeres águila 212

Faetones 213

Faeton de cejas idem

Faetornitidos idem

Faleónidos 27I

Falconinos idem

Fenicofeidos $11 \mathrm{I}$

Fenicofeido asiático idem

Idem triste idem

lienicofeinos idem

Filopneustes 496 Idem de Bonelli 497

Idem de grandes cejas 298

Idem fitis 496

Idem rojo idem

Idem silbador idem

Idem serio idem

Filoscópidos 493

Foleoptin 425

Idem de los hipogeos 426

Idem zancuda idem

Fringilidos 536

Fringilinos 548

Friorques 372

Idem apivoro idiem

Galbulidos 84

Galeoscoptos $47^{2}$

Galeoscopto de la Carolina

Gallinazo 4 I 3

Garrulaxos 476

Garrulaxo de cabeza blanca idem

Gavilanes 302

Gavilan comun 302

Gecinos 254

Gecino gris 257

Idem verde 254

Georoccites 114

Idem de California idem

Gcocolaptos 262

Geocolapto campestre idem

Gerifaltes 276

Gerifalte ártico idem

Idem de Noruega 37.7

Gipaćtidos 388

Gipaeto barbudo idem

Gipogeranio serpentario 312

Gips 403

Idem leonada idem

Idem de Ruppell idem

Gorriones 561

Gorrion comun idem

Idem de collar 564

Idem de Italia $56_{2}$

Idem de las montañas 565

Guacharo de Caripe $1 ; 6$

Guiracas 570

Guiraca de la Luisiana idem

Halcones 272

Halcon $2 S x$

Idem comun idem

Idem chiquera 285

Idem de Feldegg 279

Idem enano 290

Idem lanario 279

Hapalodermos 87 
Hapalodermo marina 87

Harfangos 422

Harfango de las nieves idem

Harpactos 86

Harpacto listado idem

Harpia fero\% 336

Heliactinos 217

Idem cora 2 IS

Idem cornudo idem

Heliotricinos 215

Heliotris idem

Idem orejudo idem

Helotarsos $35^{\circ}$

Helotarso batelero $35 \mathrm{I}$

Hidropsalis 182 Idem lira idem

Hipermetros 219 Idem gigante idem

Hipolais 493

Idem de Ins olivos 495

Idem de los sauces 494

Idem gris 495

Idem pálido idem

Idem poligloto 494

Idem rama 495

Hortelanos $50 \mathrm{r}$

Hortelano acuático 505

Idem de cañizal 502

Idein de espadanal 503

Idem de los juncos 504

Idem de los tarayes idem

Idem de rio jol

Idem enano 503

Idem paludicula idem

Idem podena idem

Idem turdoideo idem

Humicolinos 446

Hutu 154

Ibijos 173

Ibijo gigante idem

Ictinidos 353

Ictínido del Mississippi idem

Ieracidos 292

Idem berigora idem

Ierax 293

Idem azulado idem

Idem berigora 292

Indicadores 92

Indicador de Sparmann 93

Jacamaras $S_{4}$

Jacamara (gran) 85

Idem del paraíso idem

Idem tridáctilo idem

Idem verde $S_{4}$

Jaco 13

Jacobinos 215

Jilgueros 556

Jilguero elegante idem

Kakapo $3^{8}$

Kea 69

Kobez vespertino 298

Kural 120

Lampornitidos $\geq 13$

Lampornis idem

Idem mango idem

Lechucita enana 428

Lechuzas $\$ 2.4$

Lechuza comun idem

Leprosomidos IIg
Levirostros 73

Licméridos 31

Licmérido de nariz idem

Locustelas 506

Locustela de carrizal 509

Idem nuvial 508

Idem lanceolada 506

Idem listada iden

Idem manchada idem

Lofornis 217

Idem espléndido idem

Lóridos 64

Lori de las damas 64

Idem omnicoloro 66

Loros I

Idem grises 12

l.oxinos $5^{8} 3$

Luciferos 216

Lulí de los bosques 520

Macaguas 301

Macagua burlon idem

Macrocércidos

Macrodipterix $\mathbf{1} 8_{3}$

Idem longipeno idem

MLartines cazadores 149

Martin pescador 140

Megalemas $8 \mathrm{I}$

Megalema indio idem

Megalénidos 80

Melancrpos 245

Melanerpo de cabeza roja idem

Idem - hormiguero 246

Melierax 309

Idem cantor 310

Idem listado idem

Melizófilos 491

Mclopsitacos 56

Melopsitaco ondulado idem

Meropidos 155

Milanos 356

Milano govindia 362

Idem negro $35^{8}$

Idem parásito 361

Idem real 356

Milvagos 380

Milvago chimachima idem

Milvidos 349

Mirlo de collar $\$ 65$

Idem vulgar 46 i

Momótidos 154

Montecolinos 454

Montifringilidos 55

Motacilidos 516

Motacilinos idem

Musofigidos 122

Músofagos 123

Musofago violeta idem

Nasiternos 36

Nasiterno enano idem

Naucleros 354

Nauclero martinete iden

Neofrome pernóptero 400

Neofron monje 402

Nestures 68

Nestor de pico largo 69

Idem meridional $6 \$$

Nevatilla budites 521

Idem citrina 520

Idem de cabera negra 531

Idem de Ray idem

Nictalo calzado 440
Nictiornitinos 160

Nictiornis de Atherton idem

Nisaetos 3.32

Nistalos 82

Nistalo chacuru idem

Nifeos 547

Nifto de invierno idem

Oreotroguilidios 214

Orcotroquilo del Chimborazo iden

Ortotomos 512

Ortotomo de cola larga 513

Otidos 429

Otocoris 535

Idem de los Alpes idem

Otogips 408

Idem calvo idem

Idem nuricular idem

Oxipogones 220

Oxipogon de linden idem

Pijjaros 443

Idem cantores $44^{6}$

Paleornitidos 49

Paleórnido de collar 50

Paralciones 149

Paralcion gigante idem

Pardillos 557

Pardillo de las montañas $55^{8}$

Idem rulgar 55 i

Pasćridos 443

Pétirrojos 453

Petirrojo pardillo idem

Petrocinclos 457

Petrocinclo azul $45 \delta$

Idem * saxitil $45 i$

Petronias 565

Petronia de las rocas idem

Peroporos 60

Pezoporo vivaz idem

Picidos 235

Picos 239

Idem 246

Pico blanco 253

Idem de la Mauritania $24 \%$

Idem mayor idem

Idem medio 249

Idem menor 251

Pico cruzado de fajas rojas $5^{8} 3$

Idem idem de fajas blancas idem

Idem de los abetos idem

Idem de los pinos idem

Picos duros 582

Pico duro vulgar idem

Idem gordo comun 568

Idem idem negro 570

Picoideos $2 \mathrm{G}_{3}$

Picoideo tridáctilo idem

Picumnidos 264

Picumnos 265

Picumno enano idem

Pigargos $33^{\delta}$

Pigargo buitre 346

Idem de cola blanca 3.38

Idem de cabera blanca 330

Idem marino 345

Idem rocinglero idem

Idem vulgar 338

Pinzones 5.48

Pinzon vulgar iden

Pinzones 580

Idem real comun idem

Pinzon de las montañas $55^{\circ}$ 
Piones so

Pione accipitrino idem

Pivi acuritico 524

Idem campestre 525

Idem de los arboles 524

1 den de las praderas 5:3

Pirrodos 68

Pirrodo de los papues idem.

Pierrulinos 573

Pitilinos 570

Platicercidos 63

Platicerco de vientre amarillo $6_{3}$ ] T Sarcoramfo condor idem

Idem omnicoloto idem Idem papa 4 I2

Platisillopteros 114 Sauroteros III3

Platistitoptero rnjo idem

Plectróños 537

Plectrónanos 537
Plectrófano de las nicres $53^{\mathrm{S}}$

1 Idem de Laponia 537

Podigeros isi

Podagero nacunca idem

Poúráridos 170

Podargos idem

Podario humeral idem

Polibóridos 380

Poliboroides sil

Poliboroide ripo idem

Politoninidos 212

Polonilos 119

Polofilo faisan idem

Predatoras 268

Prioniles vulgar 154

Priotelos 90

Priotelo temnuro idem

Quivelitopteros $\$$;

Qúlidóptero tencbroso idem

Quetupas $43^{2}$

Queturar de Ceilan idem

Ramfastidos 74

Ramfodones/2:3

Ramfodon manchado idem

Ramfornicrones 2 In

Ramtornicron pico de espins idem

Rancacas 382

Rancaca aguileño idem

Rapaces 268

Régulos 499

Régulo de moño idem

Reguloideo de grandes cejas idem

Republicanos $56 \%$

Republicano social idem

Rincaceros 128

Rincacero de pico rojo idem

Riticeros I $3 \hat{3}$

Sirli de Dupont idem

Timalea de toca idem
Ruiseñores 447

Ruiseñor comun idem

Idein de las estepas idem

Idem de Persia idem

Idem grande 447

Idem hibrido idem

Sagitarinidos $3^{12}$

Saiknganas 205

Salingana propiamente dicha idem

Sarcoramfos 410

Snuroteros in 3

Item leonado idem

Idem leucomela idem

Idem rojizo idem

Idern stapazino idern

Sicerinos $5^{\text {too }}$

Sicerino boreal 560

Idem de las montañas idem

ldem de picn largo idein

Idem rulgar idem

Silvias

Silvidos 483

Sinsonte 470

Sirlis $53^{1}$

Sirli del desierto $5 \hat{3}^{2}$ ?

Sitácidos 12

Siracinos +1

Sitáculos 21

Sitáculo de Swinder 24

Idem sonrosaido 2?

Surninos 420

Surnio caparacoc 420

Surucús 88

Surucil de Massena 89

Idem mexicano 90

Idem pompeo 58

Idem surucua idem

Tanisipteros 15:

Tanisiptero silvia idem

Teroglosos 79

Terogloso aracari idem

Timalidos 475

limalias idem

Tintin 511

Todiranifos 149

Todiramfo de cabeza verde idem
Todidos $15^{2}$

Todis idem

Todi ó platirostro verde idem

Tok $1: 8$

Torcecuellos 265

Torcecuello verticilo idem

Tordo cola blanca 460

Idem malvis $46_{5}$

Idem mayor idem

Idem músico idem

Idem zorzal idem

Torquilinos 265

Tragopan 136

Trapistas 83

Trapista pardo idem

Traquifonos 8I

Traquifono aljorarndo idem

Tricoglosos 65

Trogloditidos ${ }_{4} 80$

Troglodita pequẽno $\& \delta 1$

Trogonidos 86

Troquilinos 216

Tucanes 76

Tucan de pico rojo idem

Idem de Temminck idem

Idem toco idem

Turacos 124

Turaco de mejillas blancas 124

Turdiformes 446

I'urdinos 464

Uractos $33^{\mathrm{I}}$

Uracto audaz. idem

Uragos 579

Urago de Siberia 580

Urubitingas 336

Urubitinga de la Guajana idem

Urubú 413

Vencejos 195

Vencejo alpino idem

Idem comun 202

Idem enano 205

Verderones $55^{2}$

Verderon comun idem

Idem de los alisos 554

Volucridos I

Vulturidos $\hat{3}^{S_{4}}$

Vulturinos 399

Zonotriquidos 545

Zumayas 44 I

Zumaya comun idem

Zumbones 210 